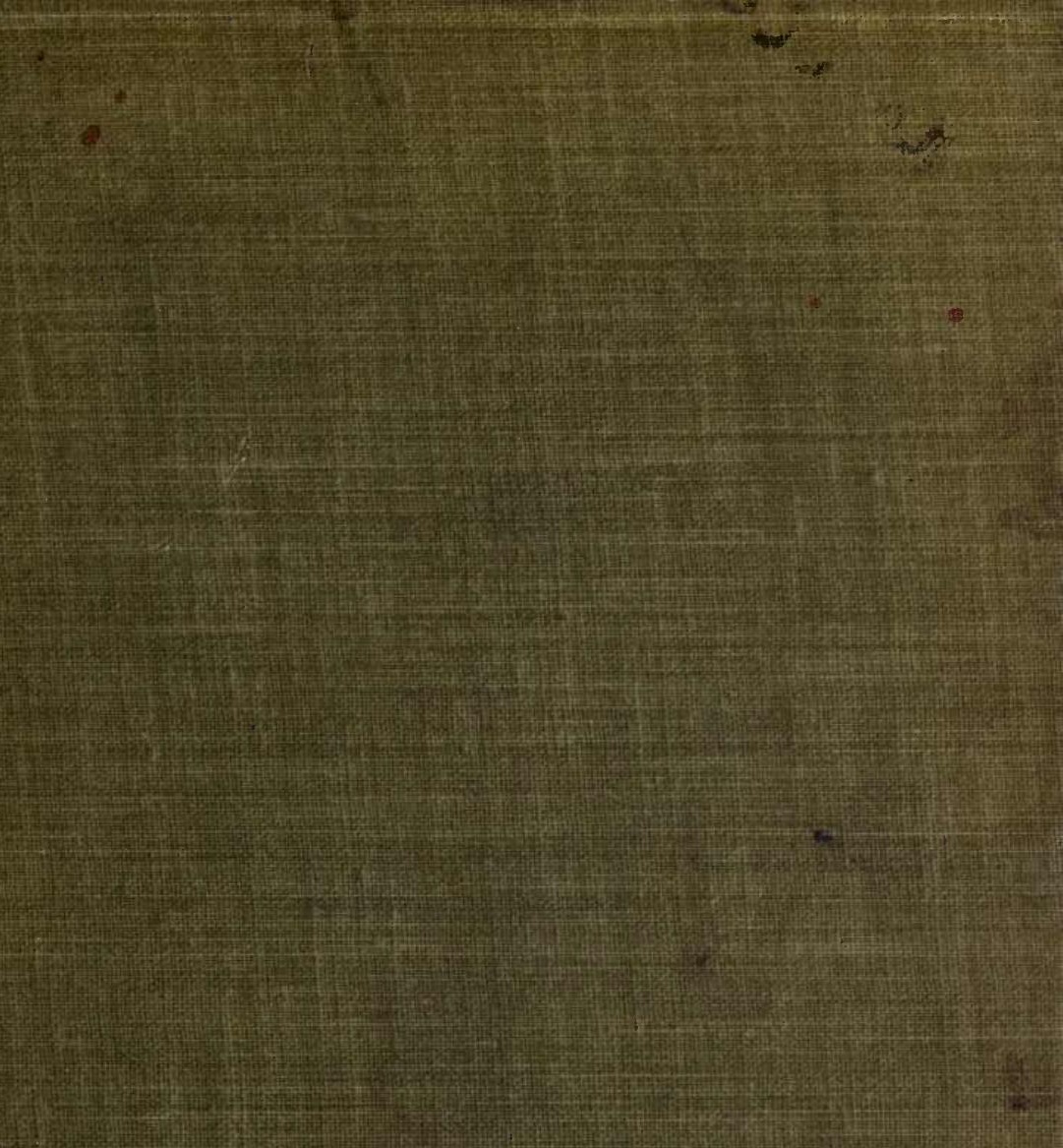




\section{F. C. H. Jones}

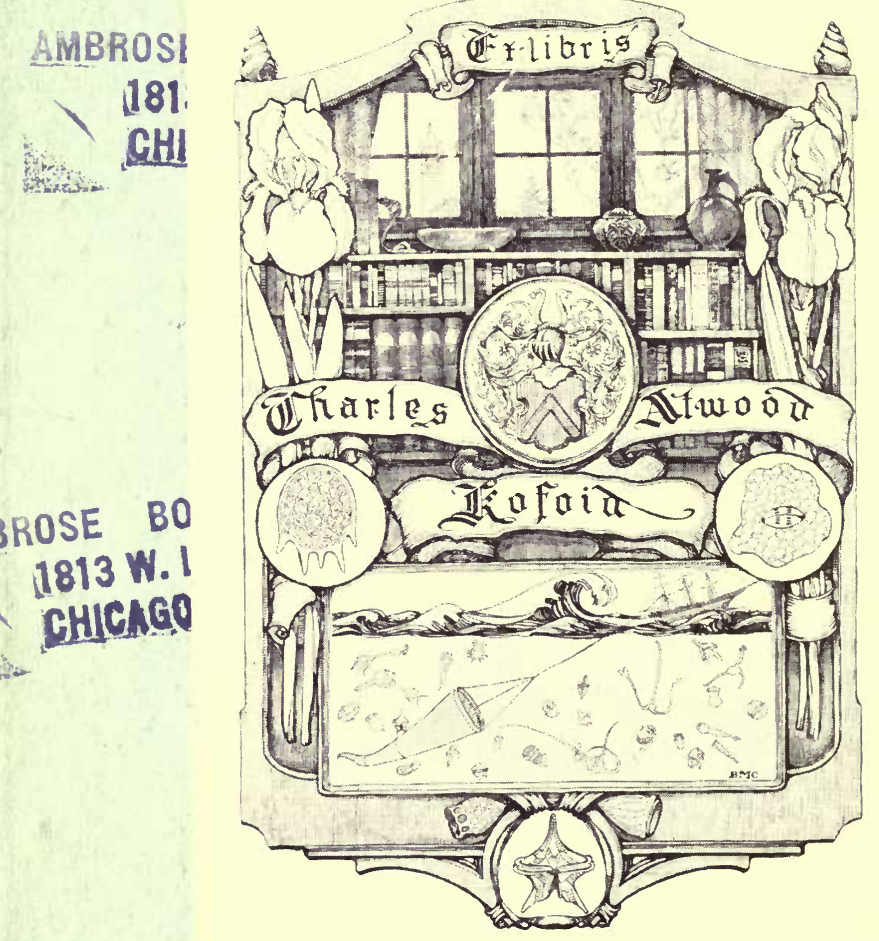




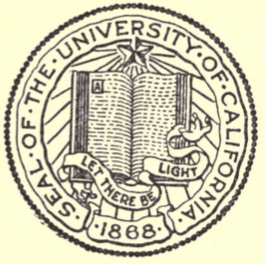

\title{
THE LIBRARY OF
} THE UNIVERSITY OF CALIFORNIA

\author{
PRESENTED BY \\ PROF. CHARLES A. KOFOID AND \\ MRS. PRUDENCE W. KOFOID
}







\title{
MANUAL
}

OF

THE FLORA

OF THE

\section{NORTHERN STATES AND CANADA.}

\author{
BY \\ NATHANIEL LORD BRITTON, Pн.D. \\ Director-in-Chief of the New York Botanical Garden \\ Emeritus Professor of Botany in Columbia University
}

THIRD EDITION, REVISED AND ENLARGED

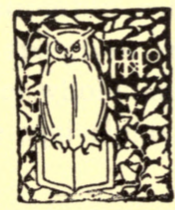

NEW YORK

HENRY HOLT AND COMPANY

1907 


\section{AЯOIA HHT}

- AOHKAO W\%A 2JTATS VAHHTYOИ

Copyright, rgor,

BY

HENRY HOLT \& CO. 
The arrangement of orders and families adopted is essentially that of Engler \& Prantl's “ Natürlichen Pflanzenfamilien,” Berlin, r89oI90I, an arrangement which seeks to bring out something of the developmental relationships of the groups by proceeding from the more simple to the more complex. Order and family are not here regarded as synonymous terms, but are used, as by zoologists, in the sense of the former being composed of the latter; thus the order Liliales is composed in our territory of the families Juncaceae, Melanthaceae, Liliaceae, Convallariaceae, Smilaceae, Haemodoraceae, Amaryllidaceae, Dioscoreaceae, and Iridaceae.

In the scientific nomenclature the principles adopted by the botanists of the American Association for the Advancement of Science at a meeting held in Rochester, N. Y., in 1892 , and in Madison, Wis., in 1893, supplementary to the Code of Nomenclature adopted by the International Congress of Botanists held in Paris, France, in 1867 , have been followed; these principles are essentially the same as those followed by American zoologists. An English name has also been associated with each species, accepted either from popular usage or chosen in reference to some more or less distinctive feature of the piant.

Keys formed by the grouping of contrasting features have been prefixed to the descriptions of species, genera and families, and a general key to the orders follows this preface.

The collections on which the descriptions are based are nearly all at the New York Botanical Garden.

I take much pleasure in acknowledging important assistance in the preparation of the work by my associates, Prof. L. M. Underwood, Dr. John K. Sma'l, Dr. P. A. Rydberg, Mr. G. V. Nash, and Mr. E. P. Bicknell.

N. L. B.

New York Botanical Garden, August 24, 1901 . 


\section{PREFACE TO THE SECOND EDITION.}

THE second edition of this Manual has been revised by the correction of the stereotyped plates, where practicable, and by the insertion of descriptions of over one hundred aaditional species in the Appendix, in order to attempt to present the greater part of the results reached by students of our flora during the past three years. A large number of synonyms have been added in the text, in order to make the book more readily comparable with previously published works of a similar character. To facilitate the more rapid determination of genera and species, artificial keys to the families, prepared by Dr. Karl M. Wiegand of Cornell University, have been added to the preliminary matter, and an artificial key to the genera of Composites, also written by him, has been inserted immediately before the Appendix.

In order to bring the species described in the Appendix into consideration more readily, the words "See Appendix" have been added after the generic name whenever a species is there described.

N. L. B.

New York Botanical GaRden, November, I904.

\section{NOTE TO THE THIRD EDITION.}

An Analytical Key to the Genera of the Grasses, prepared by Dr. Karl M. Wiegand, has been added to this edition.

N. L. B.

February, I907. 


\section{TABLE OF CONTENTS.}

General Key to the Orders................ vii

Analytical Key to the Families of Angiosperms...... xi

Key to the Families of Angiosperms Containing

Diøcious SpEcies..................... xxii

Descriptive Flora .................. I-IO 36

Analytical Key to the Genera of the Composite.... 1037

Analytical Key to the Genera of the Family GraMINEÆ......................... 1045

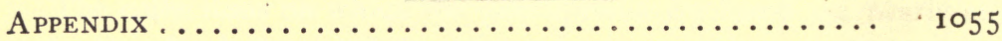

Glossary of Special Terms................ 1095

Abbreviations of the Names of Authors........... Iic 3

Index of Latin NAMES ................... 1107

English Index of Plant Names............... I II5 


\section{GENERAL KEY TO THE ORDERS.}

Subkingdom PTERIDOPHYTA.............

Spores developing intia fand archegonia); flowers and seeds none.

Sporanges (spore-cases) borne on the back of a leaf, or in spikes or panicles.

Sporanges contained in sporocarps.

Order I. FILICALES.... I

Sporanges clustered underneath the scales of a terminal cone-like spike; stems I9

jointed, rush-like.

Sporanges borne in the axils of scale-like or tubular leaves.

Order 3. Equisetales... 21

Order 4. LyCopodiales..

Subkingdom SPERMATOPHYTA............

Microspores (pollen-grains) developing into a tubular prothallium (pollentube); macrospores (embryo-sac) developing into a minute prothallium, and, together with it, remaining enclosed in the macrosporange (ovule) which ripens into a seed; flowering plants.

1. Ovules not enclosed in an ovary.

Class I. GYMNOSPERMAE.

2. Ovules enclosed in an ovary.

Class 2. ANGIOSPERMAE...

30

$3^{8}$

* Embryo with r cotyledon ; stem with no distinction into pith, wood and bark; leaves mostly parallel-veined. Subclass I. MONOCOTYLEDONES..

† CARPELS I OR MORE DISTINCT (united, at least partially in family Scheuchzeriaceae of the order Naiadales. in which they are mostly united until maturity, and in family Vallisneriaceae, also of the Naiadales, which are aquatic herbs with imperfect flowers); parts of the flowers mostly unequal in number.

Inflorescence various, not a true spadix.

Flowers not in the axils of dry chaffy scales; our species aquatic or marsh plants.

Endosperm mealy or fleshy; perianth of bristles or chaffy scales; flowers monœecious, spicate or capitate. Order I. PANDANALES...

Endosperm none, or very little; perianth corolla-like or herbaceous, or none.

Order 2. NaIADALES.... 40

Flowers in the axils of dry chaffy scales, arranged in spikes or spikelets.

Order 3. GRaminales..

Inflorescence a fleshy spadix, with or without a spathe; or plants minute, floating free, the flowers few or solitary on the margin or back of the thallus.

Order 6. ARALES...... 228

† CARPELS UNITED INTO A COMPOUND OVARY; parts of the usually complete flowers mostly in 3's or 6's.

Seeds with endosperm.

Flowers regular, or nearly so (corolla irregular in Commelina).

Endosperm mealy; ovary superior.

Endosperm fleshy or horny; ovary superior or inferior.

Flowers very irregu'ar; ovary inferior. Order 9. Sc
Seeds without endosperm, very numerous and minute; ovary inferior.

Order 8. Liliales...... 244

Order ro. ORCHIDALES.. 
** Embryo normally with 2 cotyledons; stems differentiated into pith, wood and bark; leaves mostly net-veined. Subclass 2. DICOTYLEDONES. 306

† Petals distinct to the base, or wanting (the two lower petals more or less united in family Papilionaceae; two inner petals or all four of them coherent in family Fumariaceae; three petals united with each other in family Polygalaceae; five petals sometimes slightly united in Oxalis, and in the family Ilicaceae).

Series 1. Choripetalae. 306

$\$$ Petals none (except in family Portulacaceae and in most Caryophyllaceae, which are herbs with the leaves nearly always opposite, the seeds with endosperm, and in the pistillate flowers of the walnuts) (Juglans).

Calyx none (except in the family Juglandaceae, trees with odd-pinnate leaves).

Marsh herbs with small perfect flowers, in nodding spikes in our species.

Order 2. PiPERALES....... 307

Trees or shrubs ; staminate flowers, and sometimes also the pistillate, in aments.

Leaves simple.

Fruit many-seeded; seeds with a tuft of hairs at one end.

Fruit I-seeded.

Order 3. Salicales ....... 307

Stigmas 2; ovule orthotropous; endosperm none

Order 4. MYRICALES....... 320

Style stigmatic above; ovule amphitropous; endosperm thin.

Order 5. LEITNERIALES... 32I

Leaves odd-pinnate; fruit a nut enclosed in a husk.

Order 7. JUGlandales.... 322

Calyx present.

Flowers, at least the staminate ones, in aments. Order 8. FAgales. ....... 326

Flowers not in aments (in ament-like spikes in Morus); but variously clustered, or rarely solitary.

Flowers monœcious, diœcious or polygamous (sometimes perfect in Ulmus) ; ovary superior, I-celled. Order 9. UkT.CAles.......

Flowers diœcious or perfect; ovary inferior, at least in part.

Ovary I-celled.
Ovary several-celled (usually 6-celled flowers perfect).

Order I2. ARISTOLOchiales. 346

Flowers mostly perfect in our genera (diœecious in some species of Rumex in the family Polygonaceae : monocious or dicecious in some Chenopodiaceae and Amaranthaceae); ovary superior.

Embryo straight or nearly so; fruit an achene.

Order 13. POLygonales.....

Embryo coiled, curved or annular; fruit not an achene.

Order 14. Chenopodiales.. 36y

華 Petals present (wanting in Ceratophyllaceae, aquatic herbs with whorled dissected leaves; in many Ranunculaceae; in Calycocarpum, a diœcious vine of the Menispermaceae; in Lauraceae, alternate-leaved aromatic trees and shrubs; in Podostemaceae, aquatic herbs with the simple flowers irvolucrate; in Liquidambar, a tree of the Hamamelidaceae with palmately lobed leaves and capitate flowers; in Sanguisorba, pinnate-leaved herbs of the Rosaceae; in Xanthoxylum, pinnate-leaved trees of the Rutaceae; in Euphorbiaceae; in Callitrichaceae, Empetraceae and Buxaceae; in some of the Aceraceae and Rhamnaceae; in Thymeleaceae, Elaeagnaceae and in some species of Ludwigia in Onagraceae: in Hippuris and Proserpinaca of the Haloragidaceae, and in Nyssa of the Cornaceae).

A. Ovary superior, free from the calyx (partly or wholly inferior in some Saxifragaceae, in Hydrangeaceae, Grossulariaceae, Hamamelidaceae, Pomaceae, and Loasaceae).

Carpels solitary, or several and distinct (united in some Nymphaeaceae): stamens mostly hypogynous and more numerous than the sepais; sepals mostly distinct.

Order 15. RANALES. ...... 403

Carpels 2 or more, united into a compound ovary; stamens hypogynous; sepals mostly distinct.

Plants not insectivorous.

Order 16. Papaverales. . 437 
Insectivorous plants, secreting a viscid liquid, with basal leaves and scapose flowers.

Order 17. SARRACEN1ALES. 469

Carpels solitary, or several and distinct, or sometimes united; stamens mostly perigynous or epigynous; sepals mainly united or confluent with the concave receptacle (hypanthium).

Order 18. ROSALES. ..... 47I

Carpets united into a compound ovary; sepals nostly distinct (united more or less in some Rhamnaceae).

Stamens few, rarely more than twice as many as the petals.

Stamens as nany as the sepals or fewer and opposite them, or more numerous.

Ovules pendulous, the raphe toward the axis of the ovary.

Order 19. Geraniales..... 572

Ovules pendulous, the raphe away from the axis of the ovary, or erect, or ascending.

Order 20. SAPINDALES..... 597

Stamens as many as the sepals and alternate with them, opposite the petals when these are present; ovules erect.

Order 21. Rhamnales. ... 6ir

Stamens usually very numerous (except in some Hypericaceae, in Elatinaceae, Violaceae and Passifloraceae); disc inconspicuous, or none.

Sepals valvate; placentæ united in the axis of the capsule.

Order 22. Malvales......6 616

Sepals or calyx-segments imbricated or convolute (except in Loasaceae, in which the calyx-tube is adnate to the ovary; placentæ mainly parietal, sometimes united in the axis.

Order 23. Parietales....

B Ovary inferior, adnate to the calyx, wholly or in part (except in Lythraceae and our Melastomaceae, where it is usually merely enclosed by it, and in Thymeleaceae and Elaeagnaceae, which are shrubs or trees with no corolla).

Fleshy spiny plants, with jointed stems, the leaves very small or none in our genera; calyx-segments and petals very numerous.

Order 24. Opuntiales..... 642

Herbs, shrubs or trees, not fleshy nor spiny; calyx-segments rarely more than 5 .

Petals none in our species; ovary 1-ovuled. Order 25. 'THYMELEales... 645

. Petals present (except in some Haloragidaceae, small aquatic herbs).

Ovules several or numerous in each cavity of the ovary (except in Haloragidaceae and ' $T$ rapaceae, aquatic herbs).

Ovule $I$ in each cavity of the ovary.

Order 26. MYRTALES..... 647

Order 27. UmBELlaLEs.... 667

$\dagger+$ PETALS MORE OR LESS UNITED (nearly or quite separate in Clethraceae, Pyrolaceae, some Ericaceae, Primulaceae, Styracaceae, Asclepiadaceae, Oleaceae, Cucurbitaceae and Galıx of the Diapensiaceae).

Series 2. Gamopetalae... 69 I

$\ddagger$ Ovary superior (except in Vacciniaceae and Symplocaceae, in which it is partly or wholly inferior).

Stamens mostly free from the corolla, or adnate merely to its base (at the sinuses of the corolla in Diapensia and Pyxidanthera of the Diapesiaceae), as many as the lobes and alternate with them, or twice as many. Order I. ERICALES....... Stamens borne on the corolla, as many as its lobes and opposite them, or twice as many, or more.

Herbs.

Shrubs or trees.

Order 2. Primulales... $7 \mathbf{r} 3$

Or.ler 3. EBENaLES.. ... 720

Stamens borne on the corolla, as many as its lobes or fewer, and alternate with them (in our species of Fraxinus and Adelia of the Oleaceae there is no corolla). Corolla not scarious, nerved.

Qvaries 2, distinct (except in some I.oganiaceae, and in Gentianaceae and Menyanthaceae, in which the ovary is compound with 2 cavities or rarely more, or with I cavity and 2 placentæ; flowers regular; stanıens mostly adnate to only the lower part of the corolla; leaves mostly opposite.

Order 4. Gentianales...

Ovary I, compound (2-divided in Dichondra of the Convolvulaceae; in Boraginaceae and Labiatae mostly deeply 4-lobed around the style): flowers regular or irregular; stamens mostly adnate to the middle of the corolla-tube or beyond; leaves opposite or alternate. 
ł Ovary inferior.

Anthers distinct.

Stamens as many as the corolla-lobes and alternate with them (one fewer in Linnaea of the Caprifoliaceae), or twice as many; ovary compound, with $\mathrm{I}$ ovule or more in each cavity; leaves opposite or verticillate.

Order 7. Rubiales...... 860

Stamens mostly fewer than the corolla-lobes; ovary I-celled with I pendulous ovule, or 3 -celled with 2 of the cavities without ovules.

Order 8. VAlerianales. 877

Anthers united (except in Campanula and Specularia of the Campanulaceae, in Ambrosiaceae and in Kuhnia of the Compositae).

Order 9. Campanulales. 88I. 


\title{
ANALYTICAL KEY TO THE FAMILIES OF ANGIOSPERMS.*
}

\author{
PREPARED BY
}

\section{DR. KARL M. WIEGAND.}

Note.-To observe the structure of the ovary, make several thin sections with a sharp instrument, mount in water, and view with a lens by transmitted light, as follows:

I. Vertical medial section to show inferior or superior ovary and number of ovules.

2. Cross-section to show number of cells and placentæ.

The older ovaries, being larger, are preferable for the study of cross-sections.

The family names in parenthesis are those of Gray's Manual.

\section{A. Ovary inferior.}

b HERBS (RARELY SLIGHTLY WOODY AT THE BASE).

\section{c. LEAVES OPPOSITE OR VERTICILLATE.}

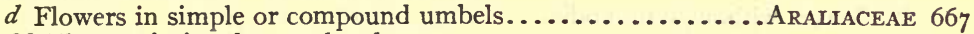
$d d$ Flowers in involucrate heads.

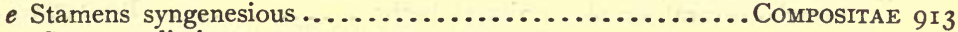

ee Stamens distinct.

$f$ Leaves punctate with resinous dots; heads white or purple

ff Leaves not punctate.

Kuhnia in Compositae 924

$g$ Heads greenish or yellowish, monœcious or diœcious.

Ambrosiaceae (in Compositae) 908 gg Heads white, purple or blue; flowers perfect...... DIPSACACEAE 880 ddd Flowers in neither umbels nor involucrate heads.

$e$ Corolla gamopetalous; limb of calyx often minute.

$f$ Stamens twice the number of the corolla lobes.

ff Stamens as many as the corolla lobes.

Adoxaceae (in Caprifoliaceae) 877

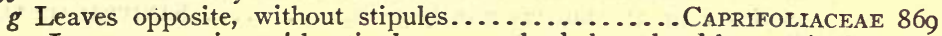

gg Leaves opposite, with stipules; or whorled and without stipules.

fff Stamens fewer than the corolla lobes.

RUBIACEAE 860

$g$ Flowers $1-2$; creeping plants........... Linnaea in CAPRIFoldaCEAE 873

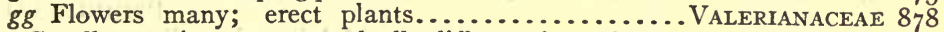

$e e$ Corolla wanting, or not markedly different from the calyx, or of separate petals.

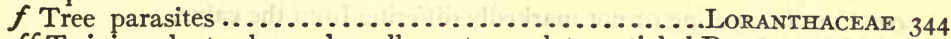
$f f$ Twining plants; leaves broadly ovate, cordate, petioled.DIOSCOREACEAE $28 \mathrm{I}$ fff Neither twining nor parasitic.

$\boldsymbol{g}$ Floating aquatics.

* On page xxii will be found a key to the families containing dicecious species for con venience in determination when only one sex is at hand. 
$h$ Perianth-parts 6; leaves whorled, elliptic-linear, sessile.

$h h$ Perianth-parts 4 ; rarely with $2-4$ more petals.

VALIISNERIACEAE (HYDROCHARIDACEAE)

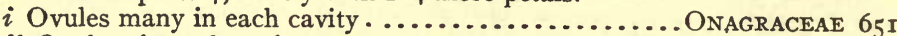

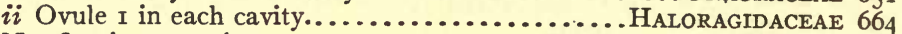

gg Not floating aquatics.

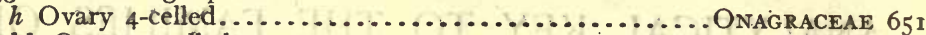

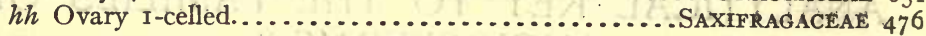

cc LEAVES ALTERNATE OR BASAL.

d Flowers in simple, compound or paniculate umbels; leaves mostly compound, rarely simple.

e Fruit dry, splitting into 2 parts; ovary 2-celled; styles 2 . UMBELLIFERAE 669 $e e$ Fruit fleshy; ovary 3-5-celled (rarely 2-celled); styles 2-5.ARALIACEAE 667 $d d$ Flowers in involucrate heads.

$e$ Flowers all with ligulate corollas; juice milky.

$$
\text { Cichoriaceae (in Compositae) }
$$

$e e$ Flowers all tubular or the outer ligulate; juice very rarely milky.

$f$ Stamens distinct or nearly so; flowers greenish, monœcious or dide-

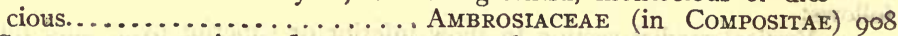

$f f$ Stamens syngenesious; flowers green or showy, perfect, monœcious

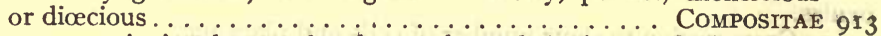

ddd Flowers not in involucrate heads nor in umbels (or rarely in simple umbels, then also the leaves simple).

$e$ Corolla of separate petals.

$f$ Flowers with 5 or more conspicuous staminodia.

$g$ Staminodia petal-like; fertile stamen $\mathrm{I}$; monocotyledons.

gg Staminodia stamen-like; fertile stamens 5; dicotyledons.

MARANTACEAE 288

Parnassiaceae (in Saxifragaceae) 475

ff Flowers without staminodia.

$g$ Stamens more than 12.

$h$ Ovaries several, simple; ordinary herbs..............ROSACEAE 490

$h h$ Ovaries compound, I-celled with several parietal placentæ.

$i$ Plants covered with tuberculate or spinulose-roughened, often

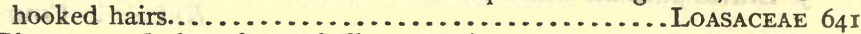

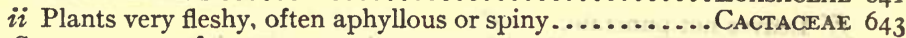
gg Stamens 12 or fewer.

$h$ Vines, usually with tendrils.

$h h$ Not vines.

$i$ Ovule I in each cell; aquatic plants or in muddy places.

Haloragidaceae 664

ii Ovules many in each cell, or if $\mathrm{r}$, then plants neither aquatic nor in mud.

j. Style $\mathrm{I}$; stamens mostly $4-8 \ldots \ldots \ldots \ldots \ldots \ldots . \ldots . \ldots$ ONAGRACEAE $65 \mathrm{I}$

jj Styles 2 or 3 ; stamens mostly 5 ro............SAXIFragACEAE 476 ee Corolla gamopetalous.

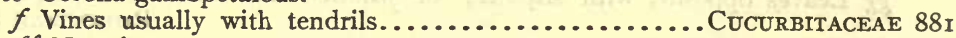

ff Not vines.

$g$ Ovary I-celled with central placenta; stamens opposite lobes of corolla.

gg Ovary 2-5-celled; stamens alternate with lobes of corolla.

Primulaceae 7 I 3

Campanulaceae 883

eee Corolla wanting or not markedly differing from the calyx.

$f$ Flowers irregular.

$g$ Fertile stamens $\mathrm{I}-2$; monocotyledonous............ ORCHIDACEAE 289

gg Fertile stamens 6-many, dicotyledonous......... ARISTOLOCHIACEAE 347

ff Flowers regular.

$\boldsymbol{g}$ Leaves linear, parallel-veined; monocotyledonous.

$h$ Aquatic plants; stamens $3-12$; ovary I-celled (6-9-celled). 
hh Terrestrial plants.

i Stamens 6 .

ii Stamens 3 .

j Stamens opposite outer perianth-lobes; flowers showy.. IRIDACEAE 28 I if Stamens opposite inner perianth-lobes

$k$ Flowers numerous, small, yellowish; plant stout.

PAGB

HAEMODORACEAE 278

$k k$ Flowers $\mathrm{I}-3$, blue; plant very slender......... BuRMANNIACEAE 289

gg Leaves, if linear, not parallel-veined and with a midrib.

$h$ Ovary I-celled.

i Flowers borne on a fleshy spike inclosed in a spathe...... ARACEAE 229

$i i$ Flowers cymose, umbellate or solitary; no spathe... SANTALACEAE 345

hh Ovary 3-4-celled.

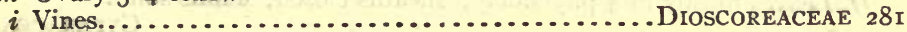

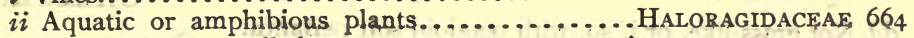

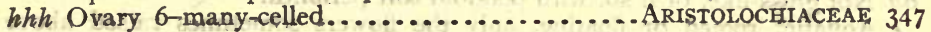

$\iota b$ WOODY PLANTS.

c Staminate Flowers in Catkins, pistmlate not; moncecious.

d Ovary I-celled or incompletely $2-4$-celled............ JUGLANDACEAE 322

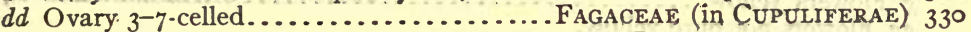
cc Both Staminate and pistmilate Flowers in Catkins; moncecious;

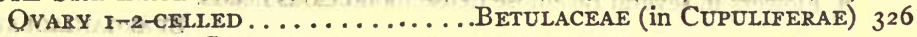

ccc Flowers not in Catkins.

$d$ Leaves opposite or whorled.

e Flowers umbellate................................................ 667

$e e$ Flowers not umbellate, though first divisions sometimes clustered.

$f$ Corrolla wanting.

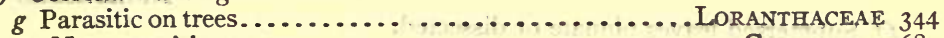

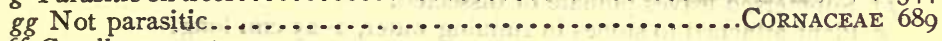

ff Corolla present.

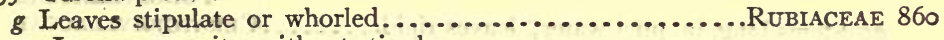

gg Leaves opposite, without stipules.

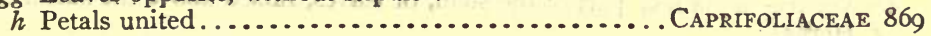

$h h$ Petals distinct.

$i$ Stamens 8 or more. ........ Hydrangeaceae (in Saxifragaceae) 484

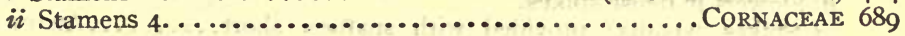

dd Leaves alternate.

e Flowers umbellate, minute, greenish.................................... 667

ee Flowers not umbellate.

$f$ Corolla absent.

$g$ Ovary I-celled.

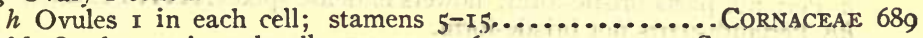

$h h$ Ovules $2-4$ in each cell; stamens $3-6 . . . \ldots \ldots \ldots . . . .$. Santalaceae 345

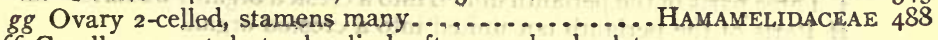

ff Corolla present, but calyx-limb often nearly obsolete.

$g$ Corolla perigynous.

$h$ Stamens 4-5.

i Flowering in early summer.GrossularIaceae (in SAXIFragaceaE) 486

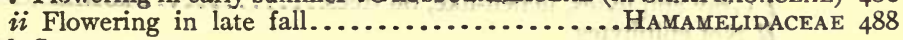

$h h$ Stamens many.

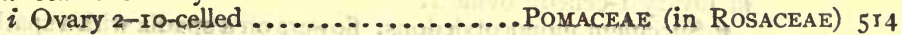

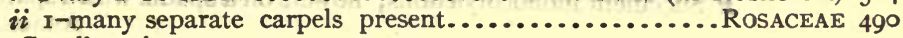
rg Corolla epigynous.

$h$ Filaments more or less united below................. STrRaceaE 722

$h h$ Filaments distinct.

i. Petals distinct; ovary $1-2$-celled............................ 689 ii Petals distinct; ovary $4-5$-celled.

iii Petals united; ovary 2-ro-celled.. VACCINIACEAE (in ERICACEAE) 707 


\section{$A A$. Ovary superior.}

$b$ COROLLA ABSENT, OR NOT MARKEDLY DIFFERING FROM THE CALYX.

c Scarcely any Differentiation into Stem and Leaves; floating

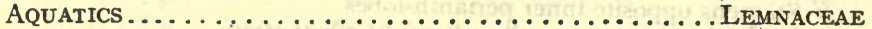

cc ORDiNARY LEAFY Plants.

$d$ Grass-like plants with very small green or brown flowers; perianth when present rigid; bracts rigid.

e Perianth present, 6 -parted..................... Juncaceae

ee Perianth absent or of bristles or irregular scales.

$f$ Leaves mostly in $\frac{1}{2}$ phyllotaxy, and mostly with open sheaths; culms

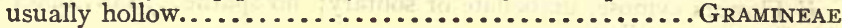

ff Leaves mostly in $\frac{1}{3}$ phyllotaxy; sheaths closed; culms solid.

$d d$ Not grass-like, or if so, with petaloid soft perianth.

Cyperaceae 158

e Aquatic; rooted or floating, only the flowers sometimes raised above the surface.

$f$ Submersed leaves entire or denticulate.

$g$ Flowers yellow. PONTEDERIACEAE 242 gg Flowers not pure yellow.

$h$ Flowers in several racemose dense monœcious heads.

hh Flowers not in heads or if so, then perfect.

Spargantaceae

$i$ Flowers axillary, solitary, with a 2-lobed, truncate or retuse ovary.

Callitrichaceae (in Halorageae) 596

ii Flowers spicate, or if axillary, then ovary not as above.

NAIADACEAE 40

ff Submersed leaves pinnate or dissected.

$g$ Plant attached to stones in running water, $2-25 \mathrm{~cm}$. long.

Podostemaceae 472

gg Stems long, in quiet water; leaves rigid......... CERATCPHYLLACEAE 408 $e e$ Not true aquatics; part of the stem, or leaves, raised above the surface.

$f$ Herbs.

$g$ Perianth none.

$h$ Flowers in dense spikes.

$i$ Spikes (spadix) provided with spathes, short...........ARACEAE 2.29

ii Spikes long-cylindric, nodding, naked..SAURURACEAE (PIPERACEAE) 307

$h h$ Flowers not in spikes but in special, often calyx-like, involucres.

gg Perianth-parts several.

EUPHORBIACEAE 585

$h$ Perianth-parts bristle-form; flowers in dense spikes......TYPHACEAE $3^{8}$

hh Perianth-parts not bristle-form.

$i$ Three parts of the perianth united into a crested organ.Pol ygaLACEAF $5^{82}$.

ii Parts of the perianth not united into a crested organ.

j Perianth-parts 6-20.

$k$ Plants with tendrils; flowers in umbels. .Smilaceae (in LILIACEAE) 275

kk Plants without tendrils.

$l$ Gray epiphytes, lichen-like, on trees............ BROMELIACEAE 238

u Not epiphytes.

$m$ Ovary I-celled: ovule I.

$n$ Succulent monocotyledons; flowers on a spadix with a spathe.

ARACEAE 229

$n n$ Not succulent, dicotyledons; flowers not as above; leaves with stipular sheaths ................ PolygonACEAE $35^{\circ}$

$m m$ Ovaries 3 -many, separate.

$n$ Stamens $3-6 \ldots$...... ScHEUCHZERIACEAE (in NATADACEAE) 52

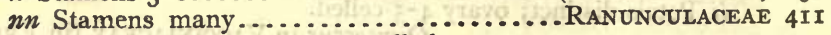
mmm Ovary single, 2-4-many-celled.

$n$ Rigid-stemmed dicotyledons; leaves netted; ovules $\mathrm{r}-2$ in each cavity. 
nn Mostly succulent monocotyledons; ovules mostly many (rarely I or 2).

o Flowers in dense spikes, greenish, usually with spathes.

oo Flowers, if in dense spikes, with showy perianth.

ARACEAE 229

$p$ Fruit a berry......... Convallariaceat (in Lillaceae) 269 $p p$ Fruit a capsule

$q$. Leaves pinnately parallel-veined; flowers blue or white;

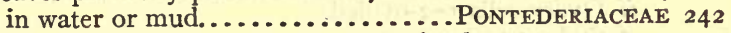

$q q$ Leaves mostly palmately parallel-veined.

r Capsule mostly septicidal; plants rarely bulbous.

Melanthaceae (in Lillaceae) 254

rr Capsule loculicidal; plants mostly bulbous.. LiLIACEAE 260 ji Perianth-parts 2-5, or 2-5-parted.

$k$ Ovaries $2-$ many, distinct.

$\zeta$ Leaves linear, basal; bog plants.

Il Leaves not both linear and basal

Scheuchzeriaceae (in NaIAdaceae) 52

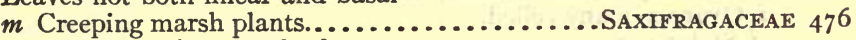

$m m$ Not creeping marsh plants.

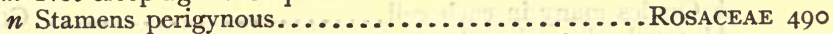

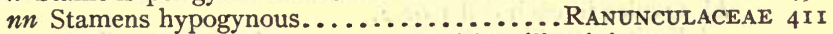

$k k$ Ovary I-celled, many-ovuled; plants with milky juice.

$k k k$ Ovary I-celled, I-ovuled.

Papaveraceae 437

$l$ Flowers in dense fleshy spikes, usually with spathes..ARACEAE 229

ll Flowers not in dense fleshy spikes.

$m$ Perianth medium-sized, and colored, or small and leaves with sheath-like stipules.

$\boldsymbol{n}$ Ovary permanently invested by the perianth-tube; fruit not an achene; no sheath-like stipules....... NyCTAGINACEAE 382

nn Ovary plainly free; fruit an achene; sheath-like stipules

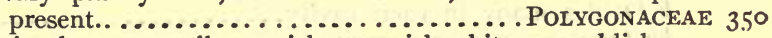

$m m$ Perianth very small greenish, greenish-white or reddish; no sheath-like stipules.

$n$ Leaves parallel-veined; monœcious monocotyledons.

nn Leaves netted-veined; dicotyledons.

SParganiaceaE (in TyPhaceaE)

o Styles or stigmas I

oo Styles or stigmas $2(3)$.

$p$ Leaves deeply palmately cleft or compound.

MORACEAE (in URTICACEAE) 339

$p p$ Leaves pinnately lobed, serrate or entire.

$q$ Inflorescence scarious-bracted; stipules none.

$q q$ Inflorescence not scarious-bracted; stipules none.

AMARANTACEAE 377

$q q q$ Stipules scarious or none; leaves opposite.

Chenopodiaceae 368

CARYophyllaceaE 387

$k k k k$ Ovary 2-many-celled.

$l$ Flowers in involucrate heads.............. ERIOCAULACEAE 236

Il Flowers not in involucrate heads.

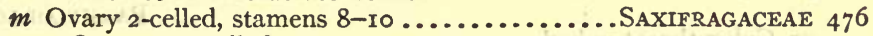

$m m$ Ovary 3-4-celled, stamens $I-I 5$.

$n$ Ovules many in each cell...........Arzoaceat (FrcotomaE) $3^{8} 3$

$n n$ Ovules $\mathrm{I}-2$ in each cell.

- Plants procumbent; leaves alternate.

BUXACEAE (in EUPHORBIACEAE) 598

oo Plants erect, or if procumbent, then leaves opposite. 
mmm Ovary 5-celled; stamens Io.

Penthoraceae (in Crassulaceae) 475 ff Woody plants.

mmmm Ovary to-celled; stamens ro......... PHYTOLACCACEAE $38 \mathrm{I}$ $g$ Flowers in aments.

$h$ Perianth present, 4-5-lobed............MoRAcEAE (in URTICACEA $) 339$ $h h$ Perianth wanting or a glandular disk.

i Ovary-cells many-ovuled. SALICACEAE 307

ii Ovary-cells $\mathrm{I}-2$-ovuled.

$j$ Styles or stigmas 2.

$k$ Pistillate flowers solitary behind each bract.........MYRICACEAE 320 $k k$ Pistillate flowers $2-3$ behind each bract.

Betulaceae (in Cupuliferae) 326

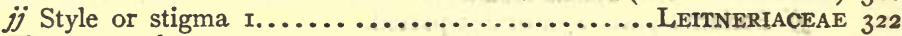
gg Flowers not in aments.

$h$ Recurved or twining brier-like monocotyledons.

hh Ordinary shrubs or trees; dicotyledons.

SMILACEAE (in LIIIACEAE) 275

i Ovary 2-many-celled.

$j$ Styles $\mathrm{I}-2$.

$k$ Ovules many in each cell................................... 630

$k k$ Ovules in each cell $\mathrm{I}$ or 2 .

$l$ Fruit a double samara...........AceraceaE (in SAPINDACEAE) 607

Ul Fruit a single samara or drupe................ OleaceaE 723 ji Styles 3-4.

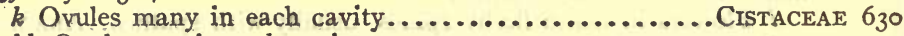

$k k$ Ovules $\mathrm{I}-2$ in each cavity.

$l$ Flowers perfect, rarely polygamous............. RHAMNACEAE 6I I

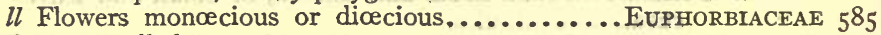

ii Ovary I-celled.

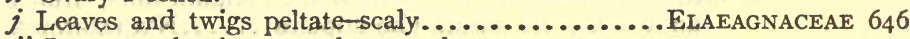

jj Leaves and twigs not peltate-scaly.

$k$ Ovules many in each cavity................................... 630

$k k$ Ovules $\mathrm{x}-2$ in each cavity.

$l$ Calyx-tube cylindric or urn-shaped, large.......THYMELEACEAE 645

$l$ Calyx-tube short or none, small.

$m$ Flowers yellowish, often showy.

$m m$ Flowers green.

n Plants usually with milky juice; flowers in pedunculate spikes or heads.................. MORACEAE (in URTICACEAE) 3.39 $n n$ No milky juice; flowers in sessile heads or racemes.

bb COROLLA POLYPETALOUS.

ULMACEAE (in URTICACEAE)

c HERBS.

d Saprophytes, without chlorophyll... MONOTropaceae (in ErICACEAE) 695

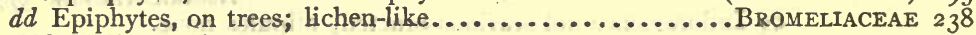
ddd Ordinary plants.

e Stamens perigynous.

$f$ Anthers usually long and curved, opening by terminal pores.

ff Anthers opening longitudinally.

MEI.ASTOMACEAE $65^{\circ}$

$g$ Calyx with a fringed crown in the throat; vines; stamens 5 .

gg Calyx-throat naked.

Passifloraceae 641

$h$ Plants fleshy; ovules many; scale at base of each carpel.

hh Plants not fleshy; no scales on the receptacle.

Crassulaceae 473

i Sepals

PORTULACACEAE 384

ii Sepals 5 , or calyx 5 -lobed.

i Ovules many. 

ij Ovules $I-4$, or if many, then carpels more than 2.

$k$ Style $\mathrm{I}$.

$l$ Pistils $\mathrm{r}$-many, separate, $\mathrm{I}$-celled............................... 490

ll Pistil $\mathrm{x}, 2-5$-celled........................

$k k$ Styles 2 ; pistil $1 . . . \ldots \ldots \ldots \ldots \ldots \ldots \ldots . . \ldots$ CARYOPHYLLACEAE 387 ee Stamens hypogynous.

$f$ Stamens monodelphous or diadelphous, at least below.

$g$ Flowers irregular.

$h$ Corolla papilionaceous..........PApilionaceat (in Leguminosae) 532 $h h$ Corclla not papilionaceous.

$i$ Corolla spurred.

j Ovary r-celled.

Papaveraceae 437

jj Ovary 5-celled.............Balsaminaceae (in Geraniaceae) 610

ii Corolla not spurred.

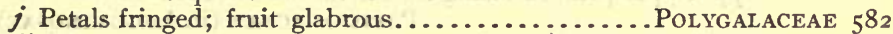

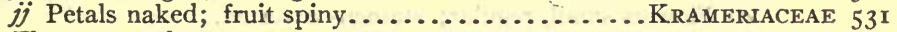

gg Flowers regular

$h$ Ovary I-celled; placenta free-central; stamens opposite the petals.

hh Ovary 4-many-celled; stamens alternate with the petals.

Primulaceae 7 I 3

$i$ Stamens united throughout, forming a central column around the pistil............................................... 6 r 7

ii Stamens uniter only at the base.

$j$ Stamens Io; leaves 3 -foliolate. Oxalidaceat (in Geraniaceat) 575

jj Stamens 5 ; leaves simple................................. 578

ff Stamens separate.

$g$ Pistils 2-many, distinct.

$h$ Leaves conspicuously sheathing; pinnately or palmately parallel-

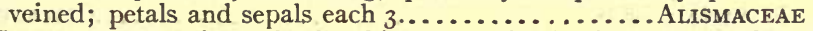

$h h$ Leaves not conspicuously sheathing; netted-veined; petals rarely 3 .

$i$ Aquatic or in muddy places; leaves peltate or deeply cordate.

NyMPHAEACEAE 406

ii Rarely aquatic; when so, with dissected leaves... RANUNCULACEAE 4 I I gg Pistil solitary.

$h$ Ovary I-celled.

$i$ Insectivorous plants; leaves covered with glandular tentacies.

ii Not insectivorous; no tentacles.

DroseracFae 470

$j$ Styles $2-9$ or $2-9$-parted.

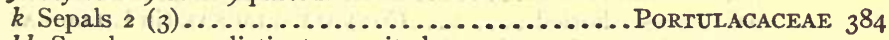

$k k$ Sepals 4 or 5 , distinct or united.

$l$ A fleshy cup-shaped glandular disk at base of ovary..RESEDACEAE 469

$\eta l$ No disk.

$m$ Ovules many.

$n$ Placenta parietal; foliage punctate...........HYPERICACEAE 624

nn Placenta central; foliage not punctate... CARYOPHYLLACEAE 387

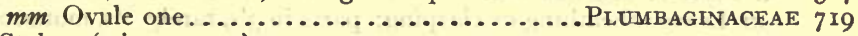

ij Style I (stigmas I-4).

$k$ Petals 3 , moss-like herbs.

Mayacaceae 234

$k k$ Petals 4-12, rarely fewer; not moss-like.

$l$ Placentæ 2-5; stamens alternate with petals.

$m$ Calyx deciduous.

$n$ Sepals 2, or united; falling very early. Papaveraceae 437 $n n$ Sepals $4-8$, falling while in flower.

o Ovary stipitate or stamens 8 or more....... CAPPARIDACEAE 467

oo Ovary sessile, stamens $6 \ldots \ldots \ldots \ldots \ldots \ldots \ldots$...................... 443

$m m$ Calyx persistent.

$n$ Flowers regular. 
o No sterile stamens ..................... Cistaceae 630

oo Sterile stamens present. PARNASSIACEAE (in SAXIFragaceaE) 475

$n n$ Flowers irregular ..................... VIOLACEAE 633

ll Placenta I, parietal; stamens alternate with or opposite to the petals.

$m$ Anthers opening by uplifting valves, or leaves peltate; stamens opposite to the petals..................BERBERIDACEAE 432

$m m$ Anthers not opening by uplifting valves; leaves not peltate; stamens alternate with the petals.

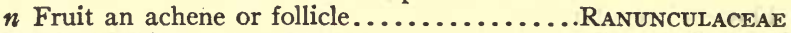

$n n$ Fruit a legume.

o Flowers medium, regular or irregular; stamens mostly included.

$p$ Upper petal inclosed by the lateral ones in the bud.

CaEsalpinaceae (in Leguminosae) 528

$p p$ Upper petal inclosing the lateral ones in the bud.

Papilionaceae (in Leguminosae) 532

oo Flowers small, regular; stamens exserted.

Mrmosaceae (in Leguminosae) 527

IIl Placenta I, free-central; stamens opposite the petals.

Primulaceae 7 I3

hh Ovary 2-many-celled.

$i$ Stamens 5 -many; mostly aquatic plants with peltate or deeply cor-

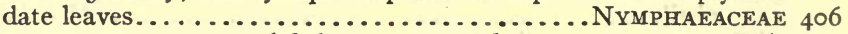

ii Stamens many; terrestrial; leaves not as above.

$j$ Style dilated, umbrella-like; leaves tubular......SARRACENIACEAE 470

jj Style ordinary; leaves not tubular.

$k$ Styles 2-7.

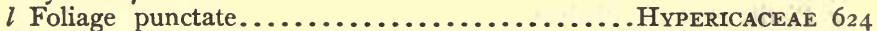

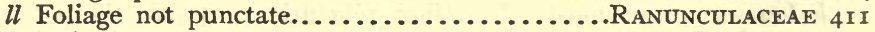

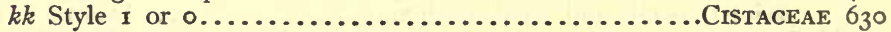

iii Stamens 2-I5; plants not as in $i$.

$j$ Anthers opening by terminal pores, inverted.

jj Anthers opening longitudinally.....PyrolaceAe (in ErICACEAE) 692

$k$ Stamens tetradynamous...........................

$k k$ Stamens not tetradynamous.

$l$ Styles 2-5, or stigmas 5 .

$m$ Aquatics or mud-creepers; ovules many....... ElatinaceaE 629 $m m$ Terrestrial, or if in mud, erect.

$n$ Ovules numerous in each cell.

o Leaves alternate........PenthoraceaE (in CRAssulaceaE) 475

oo Leaves whorled......... Convallariaceae (in LILIACEAE) 269 $n n$ Ovules $\mathrm{I}-2$ in each cell.

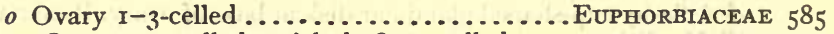

oo Ovary 4-5-celled or falsely 8-ro-celled.

p Ovary 4-5-celled, deeply 4-5-lobed.........GeraniaceaE 573

$p p$ Ovary falsely 8-ro-celled, not deeply lobed...... LinaceaE 578

$u$ Style $\mathrm{I}$; stigmas $\mathrm{I}-3$.

$m$ Leaves sheathing or clasping; parts in 3's, rarely 2's, monocotyledons.

$n$ Petals deliquescent, blue or white; fertile stamens $3^{-6 .}$

nn Petals not deliquescent; fertile stamens 6, rarely 4.

COMMELINACEAE 239

CONVAllariaceae (in Liliaceae) 269

$m m$ Leaves not sheathing nor clasping; parts in 2's or 5's.

$n$ Leaves simple.

o Stamens 2 ; petals $4 \ldots \ldots . . . . . . . . .$. CRUCIFERAE 443

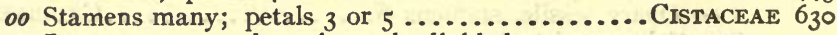

nn Leaves compound or pinnately divided.

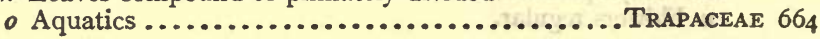


oo Vines. ooo Not vines.

p Petals and sepals 2-3 . LImnanthaceae (in Geraniaceae) 599 cc Woodx Plants.

$p p$ Petals and sepals $5 \ldots \ldots \ldots \ldots \ldots \ldots . .$. . ZygOPHYLLACEAE $5^{80}$

d Stamens 15 or more.

e Stamens monadelphous, at least at base.

$f$ Calyx valvate in the bud.

ff Calyx imbricated in the bud; stamens united only at base.

Malvaceae 6r7

Theaceae (TERnStroemiaceae) 623

ee Stamens distinct.

$f$ Pistils several.

$g$ Stamens perigynous............................................. 490

gg Stamens hypogynous.

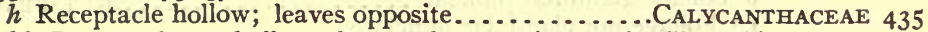

$h h$ Receptacle not hollow; leaves alternate (except in Clematis).

$i$ Fruit aggregate; trees; sepals and petals in several series of 3 's.

ii Fruit separate.

Magnoliaceae 409

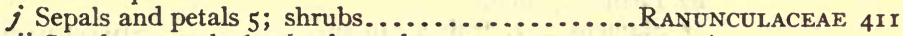
ff Pistil $\mathrm{r}$.

jj Sepals 3 , petals 6 ; shrubs and trees............... ANonACEAE 4 ro

$g$ Stamens perigynous.............. DRUPACEAE (in RosaceAE) 523

g $g$ Stamens hypogynous.

$h$ Leaves compound..............Mimosaceae (in Leguminosae) 527

hh Leaves simple.

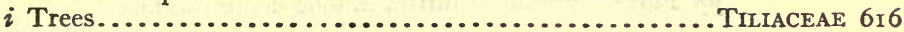

ii Shrubs.

j Leaves opposite; dehiscence of capsule mostly septicidal.

HYPERICACEAE 624

jj Leaves alternate above; dehiscence loculicidal........ CISTACEAE 630 dd Stamens fewer than r $_{5}$.

e Stamens perigynous.

$f$ Calyx-tube almost none; flowers small, greenish....... RHAMNACEAE 6 I $\mathrm{r}$ $f f$ Calyx-tube crowned with a double or triple fringe... PASSIFLORACEAE $64 \mathrm{I}$ fff Calyx-tube cylindric, naked................... LYTHRACEAE 648 ee Stamens hypogynous.

$f$ Flowers very irregular.

$g$ Ovary I-celled.

$h$ Upper petal inclosed by lower in bud.

Caesalpinaceae (in Leguminosae) 528

hh Lower petals inclosed by upper ..PAPILIONACEAE (in LEGUMINOSAE) 532 $g g$ Ovary 3 -celled .............. HippocastanaceaE (in SapindaceaE) 608

ff Flowers regular or nearly so.

$g$ Vines.

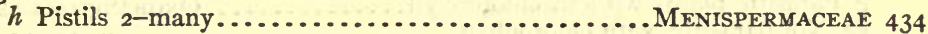
hh Pistil r.

$i$ Leaves crenulate, pointed, lanceolate.............. CELASTRACEAE 605

ii Leaves sharply dentate, lobed, compound or broad......VITACEAE 6 I 3 gg Not vines.

$h$ Pistils several.

$i$ Flowers in pedunculate heads.

Platanaceae 490

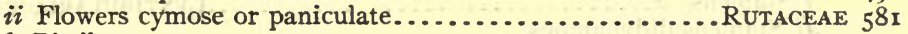

hh Pistil one.

$i$ Style I (often several stigmas or branches) or none.

$j$ Leaves very small, $4-7 \mathrm{~mm}$. long; evergreen low shrubs.

EMPETRACEAE 598

ij Leaves larger.

$k$ Anthers opening by apical valves; leaves or twigs usually somewhat spiny. 
$k k$ Anthers ordinary, or opening by terminal valveless pores.

$l$ Ovary I-celled.

$m$ Placentæ 2 ; petals 4 ; stamens distinct........ CAPPARIDAceAe 467 $m m$ Placenta I; petals 4-5; stamens distinct or united.

$n$ Petals valvate................ $n n$ Upper petal inclosed by the others.

Il Ovary 2-5-celled.

Caesalpinaceae (in Leguminosae) 528

$m$ Ovules many in each cell.

$n$ Leaves tomentose beneath; flowers in umbel-like corymbs.

$n n$ Leaves not tomentose beneath; flowers racemose.

ERICACEAE $6 g 6$

$m m$ Ovules $\mathrm{I}-3$ in each cell.

Clethraceae (in Ericaceae) 692

$n$ A disk or ring-like growth between petals and ovary.

o Foliage glandular punctate...................RUTACEAE 58 I oo Foliage not glandular punctate.

$p$ Leaves simple. Celastraceae 605 $p p$ Leaves compound.

$q$ Leaflets 3 , rarely $5 \ldots$.... Staphyleaceae (in Sapindaceae) 606 $q q$ Leaflets $7-$ many.

r Stamens $2-3$; fruit a samara.............. SimARUBACEAE 582

rr Stamens 8-10; fruit a berry............. SAPINDACEAE 609

$n n$ Disk or ring absent.

o Stamens 2, rarely 4; sepals and petals 2 or $4 \ldots$. OLEACEAE 723 oo Stamens, sepals and petals 4 or more.

$p$ Flowers minute, greenish, axillary............. IllCACEAE 602 $p p$ Flowers minute, whitish, in long dense racemes.

Cyrillaceae 602

$p p p$ Flowers medium or large, showy; racemes few-flowered.

StYRACACEAE 722

ii Styles 2-5.

$j$ Leaves opposite...............AcERACEAE (in SAPINDACEAE) 607

jj Leaves alternate.

$k$ Ovary I-celled; ovule I; sap resinous or milky...ANACARDIACEAE 599 $k k$ Ovary 2-celled; ovules several in each cell; flower white.

ITEACEAE (in SAXIFRAGACEAE) 485 $k k k$ Ovary 3 -celled; ovules $\mathrm{I}-2$ in each cell; flowers greenish.

EUPHORBIACEAE 585

$3 b b$ COROLLA GAMOPETALOUS.

$c$ Stamens (Fertile) 2-4.

$d$ Herbs.

e Ovary 4-celled, deeply 4-lobed; stems 4-angled. .LABIATAE 779 ee Ovary I-celled

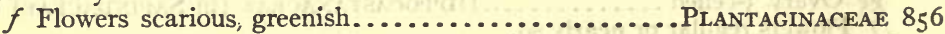

ff Flowers ordinary, petaloid.

$g$ Parasitic plants without chlorophyll............. OROBANCHACEAE 848

$g g$ Not parasitic, with chlorophyll.

$\stackrel{n}{ }$ Flowers regular or nearly so.

$i$ Stamens 3; grass-like plants; flowers yellow.......... XYRIDACEAE 235 ii Stamens 4-12; plants not grass-like; flowers rarely yellow.

GentianaceaE 728

hh Flowers conspicuously irregular.

LENTIBULARIACEAE 845

$i$ Stamens $2 \ldots \ldots \ldots$........

$j$ Flowers small; plant puberulent.. Phrymaceae (in Verbenaceae) 855

jj Flowers large; plant clammy-pubescent.

eee Ovary 2-4-celled; not deeply 4-lobed.

Martyniaceae (in Pedaliaceae) 852 
ff Flowers ordinary, petaloid.

PAGE

$g$ Grass-like monocots; flowers in involucrate heads.... ERIOCAULACEAE 236 $\mathrm{g} g$ Not grass-like; flowers not as above.

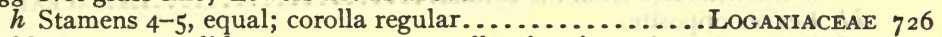

$h$ Stamens 4 , didynamous or 2 ; corolla often irregular.

$i$ Ovules $\mathrm{I}$ in each of the 4 cavities................. VERBENACEAE 776

ii Ovules 2-many in each of the 2 cavities.

$j$ Capsule with elastic valves............................................ 853

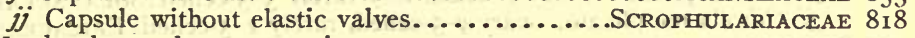
$d d$ Woody plants; leaves opposite.

$e$ Ovules $\mathrm{I}-2$ in each cell.

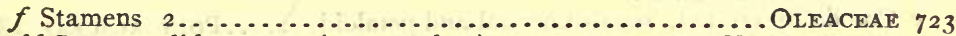

$f f$ Stamens didynamous (very rarely 2 )............. VERBENACEAE 776 $e e$ Ovules many in each cell.

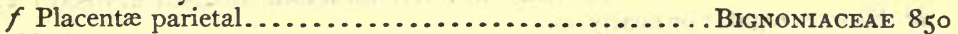

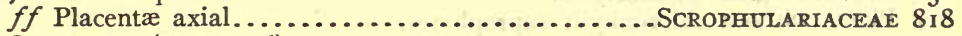

cc STAMENS 5 (RARELY 6)

d Ovaries 2, distinct or nearly so; juice usually milky; seeds frequently with hairy appendages.

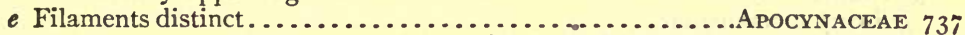

$e e$ Filaments monadelphous; corolla with a crown...... AscLEPIADACEAE 740

$d d$ Ovary one; seeds not appendaged.

e Ovary deeply 4 -lobed...

ee Ovary not 4-lobed.

$f$ Ovary I-celled.

$g$ Leaves 3 -foliolate, or floating and otbicular.

Menyanthaceae (in Gentianaceae) 7.36

gg Leaves dentate, cleft, or pinnately compound.... HYDROPHYLLACEAE 762 ggg Leaves entire or nearly so, not as above.

$h$ Stamens opposite the lobes of the corolla; placenta free-axial.

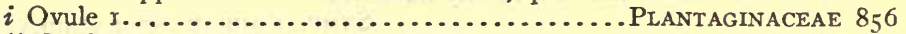

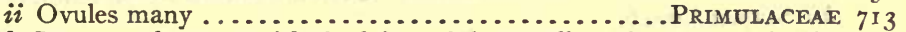

$h h$ Stamens alternate with the lobes of the corolla; placentæ parietai.

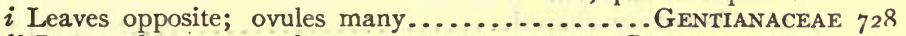

ii Leaves alternate; ovules $3-5 \ldots \ldots \ldots \ldots \ldots \ldots$. ConvolvUlaceAE 749

ff Ovary 2-5 celled.

$g$ Parasitic climbers, without chlorophyll

gg Not parasitic, green.

Cuscutaceae (in Convolvulaceae) 754

$h$ Leaves alternate.

$i$ Herbs.

$j$ Ovary 3-celled; styles or stigmas 3 .

$k$ Stamens inserted in sinuses of the corolla; or monadelphous.

$k k$ Stamens inserted on the corolla-tube, free

ij Ovary 2-celled or 4 stigmas I or 2.

$k$ Corolla plicate; stamens often centrally connivent.. SolanaCEAE 808 .

$k k$ Corolla not plicate; stamens not conspicuously connivent.

$l$ Ovules numerous.

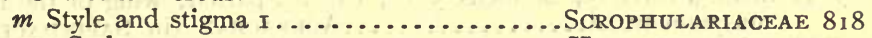
$m m$ Styles $2 . \ldots \ldots \ldots \ldots \ldots \ldots \ldots \ldots \ldots \ldots$ HydropHyLLACEAE 762

Il Ovules $\mathrm{I}$ or 2 in each cell.

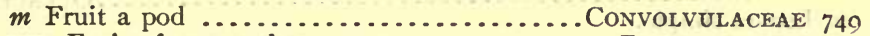

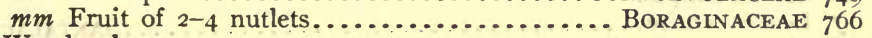

ii Woody plants.

i Stamens opposite the lobes of the corolla; ovules I in each cell;

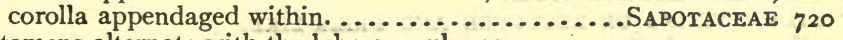

jj Stamens alternate with the lobes; ovules many.

k. Stamens on the corolla. 
$l$ Plants small or scapose; corolla not plicate..... DIAPENSIACEAE $7 \mathbf{I 2}$

ll Plants tall, twining; corolla plicate.............. SolANACEAE 808

$k k$ Stamens free from the corolla................. ERICACEAE 696 $h h$ Leaves opposite.

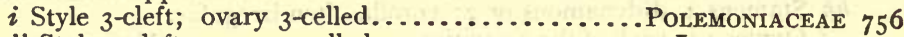

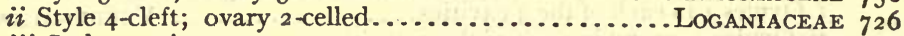
iii Style or stigma 1 .

$j$ Corolla plicate; ovary 2-celled, very rarely 3-5-celled.SolanACEAE 808

jj Corolla not plicate; ovary 4-5-celled, rarely 2-5-celled. ERICACEAE 696 ccc STAMENS 6-MANY.

$d$ Flowers very irregular.

e Corolla lip crested; sepals unequal and petaloid.......PolygalaceaE $5^{82}$ ee Corolla lip naked; sepals equal, united, not petaloid.

dd Flowers regular or nearly so.

Trifolium in Papilionaceae (in Leguminosae) 539

e Plants without chlorophyll; saprophytes.

ee Plants with chlorophyll.

Monotropaceae (in Ericaceae) 695

$f$ Herbs.

$g$ Leafy dicotyledons.

$h$ Stamens alternate with the lobes of the corolla; placentæ 2, parietal.

$h h$ Stamens opposite the lobes of the corolla; placenta free-axial.

GENTIANACEAE 728

gg Grass-like monocotyledons; flowers minute in heads.

Primulaceae 713

ff Woody plants.

Eriocaulaceae 236

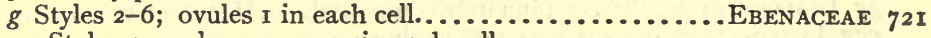
gg Style I; ovules I or more in each cell.

$h$ Stamens more than 16 , mostly numerous.

hh Stamens 6-16.

Symplocaceae (Styracaceae) 721

$i$ Ovules $\mathrm{I}$ in each cell.

$j$ Corolla not urn-shaped......................... StrraceaE 722

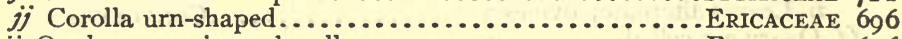

ii Ovules many in each cell ..................... ERICACEAE 696

\section{A KEY TO THE FAMILIES OF ANGIOSPERMS CONTAINING DIECIOUS SPECIES.}

\section{A. Woody plants.}

\section{$b$ LEAVES OPPOSITE.}

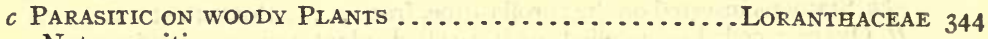
cc Not parasitic.

$d$ Scurfy plants covered with silvery or brown peltate scales.ElaEAGNACEAE 646 dd Not peltate-scurfy.

$e$ Leaves compound.

$f$ Leaflets 3 , rarely 5 ; stamens 5 -ro; calyx 5-parted; wing of the fruit

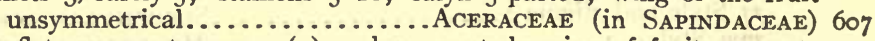

ff Leaflets $5^{-I I}$; stamens 2 (4); calyx 4-parted; wing of fruit symmetrical..................................................... 723

ee Leaves simple.

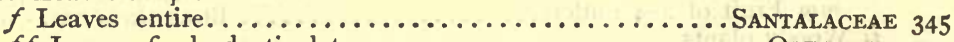

ff Leaves finely denticulate....................................... 723

$b b$ LEAVES ALTERNATE.

c STEM TWINING OR RECURVED AND BRIER-LIKE.

$d$ Flowers umbellate; monocotyledons .........SMILACEAE (in LILIACEAE) 275

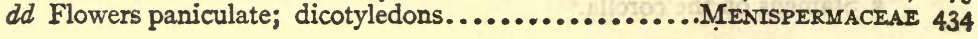


ec STEM NOT TWINING NOR BRIER-LIKE.

PAGB

$d$ Flowers in catkins.

e Perianth 4-5-parted.................Moraceae (in URTICACEAE) 339

ee Perianth none, or cup-like and not parted.

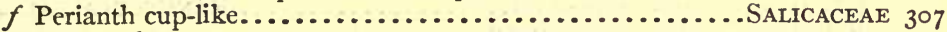

ff Perianth none.

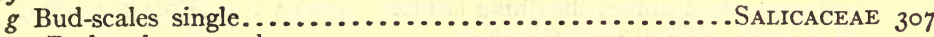

gg Bud-scales several.

$h$ Leaves rugose-reticulated beneath, entire ...........LITNERIACEAE 322

$h h$ Leaves not as above...................... MYRICACEAE 320

dd Flowers not in catkins.

e Leaves minute, $4-7 \mathrm{~mm}$. long .............................. ee Leaves much larger.

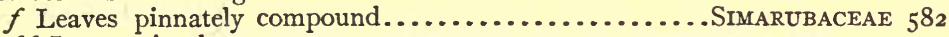
$f f$ Leaves simple.

$g$ Leaves serrate-dentate.

$g g$ Leaves entire or lobed.

$h$ Flowers appearing before or with the leaves, or leaves evergreen.

hh Flowers appearing after the leaves.

LAURACEAE 435

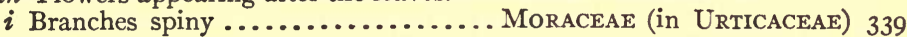

ii Branches not spiny.

$j$ Flowers racemose, umbellate, or clustered, small and numerous.

$k$ Flowers densely spicate or capitate; hypogynous disk absent.

Chenopodiaceae 368

$k k$ Flowers racemose; disk present and lobed, or of separate scales.

SANTALACEAE 345

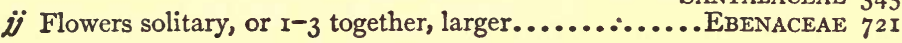

\section{$A A$. Herbs.}

$b$ FLOWERS IN INVOLUCRATE HEADS.

c STAMENS Distinct.

$d$ Plants scapose; leaves grass-like.................. EriocaUt.acEaE 236 $d d$ Plant not scapose; leaves not grass-like; pistillate involucre woody.

Ambrosiaceae (in Compositae) 908

cc Stamens syngenesious; pistLllate InVOLUCRE NOT WOOdy.

$b b$ FLOWERS NOT IN INVOLUCRATE HEADS.

Compositae 9i3

$c$ Leaves verticillate.

$d$ Aquatic plants.

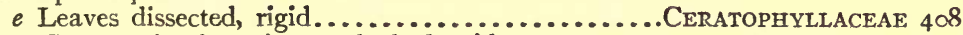

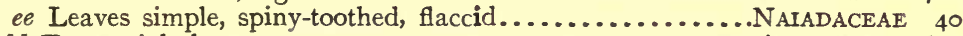

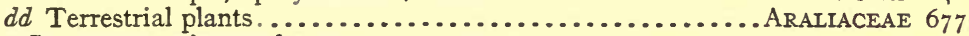

cc Leaves opposite or alternate.

$d$ Grass-like plants with linear parallel-veined leaves and greenish or

- brownish flowers.

e Leaves usually in the $\frac{1}{2}$ phyllotaxy; mostly with open sheaths; and usually with hollow culms......................................

ee Leaves usually in the $\frac{1}{3}$ phyllotaxy, with closed sheaths; culms solid.

dd Not grass-like.

CyPeraceae 158

$e$ Aquatic, not rising above the surface of the water.......... NAIADACEAE 40 ee Not strictly aquatic.

$f$ Flowers with both calyx and corolla.

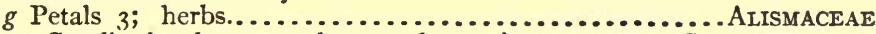

gg Corolla deeply 5 -parted or petals 5 ; vines........... CucurbitacEAE 881

$f$ Flowers apetalous, or perianth-parts all similar. 
g Flowers umbellate. gg Flowers not umbellate

$h$ Flowers on a spadix inclosed in a spathe...............ARACEAE 229 hh Flowers not as above.

$i$ Leaves ternately compound................RANUNCULACEAE 4 II ii Leaves simple or once pinnate.

$j$ Leaves with united sheathing lacerate stipules.......POLYGONACEAE $35^{\circ}$ jj Leaves without such stipules.

$k$ Leaves 3 -many-lobed or parted.......MORACEAE (in URTICACEAE) 339 $k k$ Leaves not lobed, rarely lacerate-toothed.

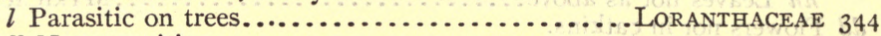
$l l$ Not parasitic.

$m$ Inflorescence bracted; bracts and sepals mostly scarious.

AMARANTHACEAE 377 $m m$ Inflorescence not conspicuously scarious-bracted.

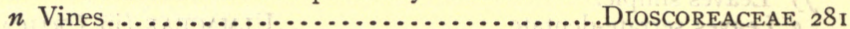
$n n$ Not vines.

o Plants more or less scurfy; leaves sinuate-dentate or entire.

CheNOPODIACEAE 368 oo Plants not scurfy; leaves sharply dentate...... URTICACEAE $34 \mathrm{I}$ 


\section{FLORA.}

\section{Subkingdom PTERIDÓPHYTA.}

\section{Ferns and Fern-Allies.*}

Plants containing woody and vascular tissues producing spores asexually, which, on germination, develop small flat mostly green prothallia (gametophyte). On these are borne the reproductive organs, the female known as archegones, the male as antherids. From the fertilization of the egg in the archegone by spermatozoids produced in the antherid, the asexual phase (sporophyte) of the plant is developed; this phase is represented by an ordinary fern, lycopod or horsetail. Comprising about 4000 living species, of which more than three-fourths are confined to tropical regions.

\section{Order I. FILICÀLES.}

Spores, all of one kind and size, produced in sporanges, which are borne on the back of a leaf, in spikes or panicles.

Vernation erect, or inclined; sporanges in spikes, or panicles, opening by a transverse slit.

Fam. r. Ophioglossacea.

Vernation coiled; sporanges reticulated, usually provided with a ring (annulus).

Sporanges opening vertically.

Sporanges panicled, with a rudimentary ring; marsh ferns.

Fam. 2. Osmundacea.

Sporanges sessile on a filiform receptacle: leaves filmy, translucent.

Sporanges ovoid, in panicles, or spikes, with a vertical ring.

Fam. 4. Schizacacea.

Sporanges opening transversely, provided with a vertical ring, borne in sori on the back or margin of a leaf.

Fam. 5. Polypodiacea.

\section{Family I. OPHIOGLOSSÀCE E Presl.}

\section{- Adder's-Tongue Family.}

More or less succulent plants consisting of a stem and leaf growing from a fleshy root. Sporophyll in the form of a spike or panicle, the sporanges formed from the interior tissues, naked, opening at maturity by a transverse slit. Spores yellow. Prothalli subterranean, devoid of chlorophyll. Contains five genera, three of which are American.

Veins reticulate; sporanges cohering in a distichous spike. Veins free; sporanges distinct, borne in spikes or panicles.

r. Ophioglossum.

2. Botrychium.

\section{OPHIOGLÓSSUM L.}

Low plants from a small fleshy rootstock, with slender fleshy roots, the bud for the following year formed at the side of the base of the stem. Leaves simple, solitary, borne on the stem. Sporophyll terminal, formed of two rows of large coales. 
cent sporanges. Veins reticulate. Spores sulphur-yellow. [Name from the Greek, signifying the tongue of a snake, in allusion to the narrow spike of spo. ranges.] About 30 species of wide geographic distribution.

Leaf ovate to elliptic, large; basal veins, $9^{-1} 3$ or more.

Areolæ with few veinlets; apex obtuse.

Areolæ broad, with many veinlets; apex mucronate. Leaf lanceolate, small; basal veins 5-7.

1. O. vulgatum.

2. O. Engelmanni.

3. O. arenarium.

I. Ophioglossum vulgàtum L. ADDER's-Tonguz. (I. F. f. I.) Rootstock short, oblique; stem slender, erect, simple, glabrous, I-4 dm. high, bearing the sessile thin ovate or elliptic-oblong leaf, $3-12 \mathrm{~cm}$. long, near its middle ; leaf I-5 $\mathrm{cm}$. wide, rather firm in texture, distinctly reticulated, with few veinlets within the areolæ; basal veins 9-13; spike solitary, $1-2.5 \mathrm{~cm}$. long, erect, the axis extending beyond the sporanges into a point. In moist meadows and thickets, Pr. Edw. Isl. to Alaska, south to Fla. Also in Europe and Asia. May-Aug.

2. Ophioglossum Engelmánni Prantl. (I. F. f. Ia.) Rootstock cylindric ; stem 8-22 cm. high, bearing an elliptic or lanceolate-elliptic leaf which is $3-9$ $\mathrm{cm}$. long, 1.5-5 cm. wide, obtuse but sharply apiculate, fleshy but becoming pellucid; basal veins 13 or more, the transverse veinlets oblique, forming broad oblong-hexagonal a reolæ with numerous included veinlets; spike $1.5-2.5 \mathrm{~cm}$. long, apiculate. In moist ground, Va. and Ind. to Mo., Tex. and Ariz.

3. Ophioglossum arenàrium E. G. Britton. (I. F. f. rb.) Rootstock slightly thickened; stem 5-18 cm. high, bearing a lanceolate leaf $2-5 \mathrm{~cm}$. long, 5-12 mm. wide, with a long tapering base and an obtuse or rarely somewhat acute apex; basal veins $5-7$, the central nearly parallel with short oblique veinlets, forming long narrow areolæ with few faint included veinlets near the middle of the leat and much shorter irregular ones toward the margin; spikes $\mathbf{I - 3} \mathrm{cm}$. long, often twisted, apiculate. Gregarious in a single colony near the seashore, Holly Beach, N. J.

\section{BOTRÝCHIUM Sw.}

Fleshy plants with short erect rootstocks, and clustered fleshy roots, the bud for the succeeding year imbedded in the base of the stem. Leaf pinnately or ternately divided or compound, the sporophyll pinnate or tripinnate with sessile distinct sporanges in rows on either side of its branches, forming large panicles in some species. Veins free. Spores of various shades of yellow. [Greek, in allusion to the grape-like clusters of sporanges.] About 20 species, mostly natives of the northern hemisphere.

Bud for the following year enclosed in the base of the stem.

Leaf rising above the middle of the stem, small plants maturing in early summer.

Vernation partly inclined in one or both portions.

Leaf entire, or with $1-3$ pairs of distant lunate decurrent segments.

1. B. tenebrosum.

Leaf with fan-shaped segments; sporophyll not bent in vernation. 2. B. Lunaria.

Leaf pinnatifid or 2-pinnatifid with narrow segments; both leaf and sporophylls bent in vernation.

3. B. neglectum.

Vernation wholly inclined, recurved in the fertile portion; leái triangular. sessile.

Leaf rising from little above the rootstock.

4. B. lanceolatum.

Vernation wholly straight ; bud smooth; leaf entire, or 2-6-lobed.

Vernation inclined; bud pilose; leaf ample ternate.

5. B. simplex.

Leaf segments obliquely ovate or oblong, large, $1-2 \mathrm{~cm}$. long.

Leaf segments laciniate, narrow, $1 \mathrm{~mm}$. or less wide.

6. B. obliquum.

Leaf segments small, $3-6 \mathrm{~mm}$. wide, rounded or ovate.

7. B. dissectum.

8. B. matricaria.

Bud enclosed in a cavity at one side of the base of the stem; leaf ternate, decompound, sessile at the middle of the stem.

9. B. Virginianum.

I. Botrychium tenebròsum A. A. Eaton. Plant $3-20 \mathrm{~cm}$. high, averaging 10-12 cm., one-third of which is below ground; slender, fleshy, light green or 
yellowish after fruiting, transparent when dry; leaf above the middle of the stem, often immediately under the sporophyll, short-petioled, entire, lobed, or usually with I-3 pairs of distant alternate lunate decurrent entire segnents; the apex emarginate or with a triangular elongation; sporophyll usually short-stalked, simple, or rarely with one or two short, somewhat dilated branches, bearing alternate or nearly opposite clusters of sporanges ; spores very large, verrucose ; sporophyll not bent in vernation. Rich shady situations, usually among maples at the border of swamps; Mass. and N. H. to Cent. N. Y.

2. Botrychium Lunària (L.) Sw. Moonwort. (I. F. f. 3.) Plant very fleshy, 5-30 cm. high. Leaf usually sessile, borne at or above the middle of the stem, pinnate with 2-8 pairs of lunate or fan-shaped lobes which vary from crenate to entire and are either close and imbricated or somewhat distant; sporophyll 2-3-pinnate, often dense, 3-5 cm. long, often about the height of the sterile; apex only of the leaf bent over the nearly straight sporophyll in vernation. Greenland to Alaska, south to Conn., Cent. N. Y., Mich., Br. Col., and in the Rocky Mts. to Colo., mostly in fields. Also in N. Europe and Asia. June-July.

3. Botrychium negléctum A. Wood. (I. F. f. 4.) Plant $5-30 \mathrm{~cm}$, high, often very fleshy. Sterile portion borne above the middle of the stem, short-stalked, ovate or oblong, I-2-pinnatifid or rarely 2-pinnate, with obtuse divisions and narrow toothed segments; midveins disappearing by continued branching : sporophyll 2-3-pinnate, often much branched; spores tulberculate; apex of both leaf and sporophyll turned downward in vernation. In grassy woods and swamps, N. S. to $\mathrm{Md}$, west to $\mathrm{O}$. and Wash. (B. matricariafolium Dav., not A. Br.). May-June.

4. Botrychium lanceolatum (S. G. Gmel.) Angs. (I. F. f. 6.) Plant 7-20 $\mathrm{cm}$. high, somewhat fleshy. Leaf closely sessile near the summit of the stem, $2 \mathrm{~cm}$. or more wide, 3 -lobed or broadly triangular and 2-pinnatifid, the ultimate segments lanceolate, acute, oblique, entire or dentate ; midvein continuous, with forking veinlets; sporophyll slightly overtopping the leaf, short-stalked, 2-3pinnate ; sporophyll recurved its whole length with the shorter leaf reclined upon it in vernation. In meadows, woods, and swamps, N. S. to Alaska, south to N. J., O., and in the Rocky Mts. to Colo. Also in Europe and Asia. June-July.

5. Botrychium símplex E. Hitchcock. (I. F. f. 2.) Plant 5-16 cm. high, slender, very variable. Leaf ovate, obovate, or oblong, entire, lobed, or pinnately parted, borne near the base of the stem; sporophyll a simple or slightly compound spike, sometimes reduced to only a few sporanges; spores large for the genus, minutely tuberculate; apex of leaf and sporophyll erect in vernation. In moist woods or meadows, Pr. Edw. Isl. to Md., west to Wyo. and Cal. Also in N. Europe. May-June.

6. Botrychium obliquum Muhl. (I. F. f. 5, as B. ternatum.) Plant robust, $15 \mathrm{~cm} .-5 \mathrm{dm}$. high. Leaf rising from near the base on a stalk $2-10 \mathrm{~cm}$. or more long, termate with the three divisions nearly equal, bipinnate or somewhat tripinnatifid in larger forms, the ultimate segments obliquely ovate or oblong-lanceolate, the terminal of each division elongate, I-2 cm. long, 5-8 mm. wide, the margins crenate or serrate ; sporophyll long-stalked, triquadripinnate ; bud densely pilose, both portions bent in vernation. Low woods and open places widely distributed from N. B. to Fla. and Mex. and westward to Minn.

Botrychium obliquum intermedium (D. C. Eaton) Underw. Plant larger, the leaf on a shorter stalk $2-5 \mathrm{~cm}$. long, the leaf sometimes reaching $15 \mathrm{~cm}$. each way; lateral divisions smaller than the terminal: ultimate segments similar to the type, but mostly shorter. In low ground, N. N. Y. and N. E.

7. Botrychium dissectum Spreng. (I. F. f. 5a.) Plant 5-IO dm. high with slender fleshy stems. Leaf long-stalked from near the base of the stem, with broadly deltoid basal divisions, decompound; secondary pinnæ lanceolate from a broader base, pinnate with laciniate and deeply cut pinnules, the ultimate divisions divergent, often 2 -toothed at their apices, usually less than I $\mathrm{mm}$. wide; sporophyll long-stalked 2-3-pinnate; bud pilose, enclosed in the base of the stem, both portions bent in vernation. Rare in E. Mass. and common from S. N. E. southward to $\mathrm{Va}$., inland to Ind. and $\mathrm{Ky}$.

8. Botrychium matricariæ (Schrank) Spreng. Plant $10-15 \mathrm{~cm}$. high, with sloinder fleshy stems. Leaf moderately short-stalked, ternate, small, $3-5 \mathrm{~cm}$. wide and high, the three divisions similar, bipinnatifid or bipinnate; ultimate segments 
small, 3-6 mm. wide, rounded or somewhat obliquely ovate, the margins undulate or crenate ; sporophylls rather long-stalked for the size of the plant, 2-3-pinnate with large sporanges; bud pilose. . In old meadows, N. N. E. and N. Y. and nortliward; also in Europe.

9. Botrychium Virginiànum (L.) Sw. (I. F. f. 7.) Plant 2-6 dm. high, the stem slender but fleshy. Leaf nearly or quite sessile above the middle of the stem, spreading, thin, ternate with the primary divisions pinnate to 2-pinnate and the segments I-2-pinnatifid; ultimate segments oblong, more or less toothed near the apex; epidermal cells flexuous; sporophyll long-stalked, 2-3-pinnate; bud for the following year pilose, enclosed in a glabrous cavity at one side of the lower part of the stem ; sporophyll recurved its whole length, the leaf reclined upon it in vernation. In rich woods, N. S. to Fla., west to Br. Col, and Ariz. Also in Europe and Asia. June-July.

\section{Family 2. OSMUNDÀCEAE R. Br.}

Large ferns with stout often erect rootstocks, $I-2$ pinnate leaves which are coiled in vernation, the veins free, mostly forked, running to the margins of the pinnules or lobes. Sporanges large, globose, with mere traces of an elastic ring of cells or none, borne on modified contracted pinnæ or in clusters (sori) on the lower surfaces of the pinnules. Three genera; only one American.

\section{OSMÚNDA L.}

Tall swamp ferns, growing in large crowns, with the fertile (spore-bearing) portions very much contracted, the short-pedicelled naked sporanges on the margins of their rachis-like divisions, which are destitute of chlorophyll. Veins forked, regular and prominent. Sporanges thin, reticulated, opening by a longitudinal cleft into two halves, a few parallel thickened cells near the apex representing the rudimentary transverse ring. Spores green. [From Osmunder, a name for the god Thor.] Six species, mostly of the north temperate zone.

Leaves bipinnate, fertile at the apex.

Sterile leaves bipinnatifid.

I. O. spectabilis,

Pinnæ of sterile leaf with a tuft of tomentum at base; fertile leaf distinct from sterile. 2 2. O. cinnamomea.

Pinnæ of sterile leaf without a tuft of tomentum at base: leaves fertile in the middle.

3. O. Claytoniana.

I. Osmunda spectábilis Willd. Royal FerN. (I. F. f. 8.) Rootstock bearing a cluster of several tall bipinnate leaves, $6 \mathrm{dm} .-2 \mathrm{~m}$. high, and $3 \mathrm{dm}$. or more wide. Pinnæ 1.5-3 dm. long, 5-10 cm. wide, the pinnules oblong-ovate or lanceolate-oblong, sessile or slightly stalked, glabrous, finely serrulate, especially near the apex and occasionally crenate towards the truncate, oblique or cordate base; sporophylls linear-cylindric, panicled at the summit, withering and shrivelling with age, greenish before maturity, but becoming dark brown after the spores have fallen. In swamps and marshes, N. B. to Fla., N. W. Terr., Neb. and Miss. Also in Mexico. Has been confused with $O$. regalis L. May-July.

2. Osmunda cinnamòmea L. Cinnamon FerN. (I. F. f. 9.) Rootstock very large, widely creeping, bearing a circular cluster of sterile leaves with one or more fertile ones within. Stipes $3 \mathrm{dm}$. or more long, clothed with ferruginous tomentum when young, glabrous when old; sterile leaves $3 \mathrm{dm},-\mathrm{I} \mathrm{m}$. long, glabrous when mature, except a small tuft of tomentum at the base of each pinna; pinnæ linear-lanceolate, deeply pinnatifid into oblong obtuse segments; sporophyll contracted, bipinnate, soon withering; sporanges cinnamon-colored after the copious green spores have been discharged. In wet places, N. S. to Minn., to Fla. and Mex. Forms occur with leaves variously intermediate between the fertile and sterile; some being sterile at the apex, others in the middle, others on one side only. May-June.

3. Osmunda Claytoniàna L. Clayton's Fern. (I. F. f. ro.) Rootstock stout, bearing a circle of 2-pinnatifid leaves $6 \mathrm{dm} .-2 \mathrm{~m}$. high, 1.5-2.5 dm. wide ; sterile pinnæ without tufts of tomentum at the base, linear-lanceolate, deeply 
cleft into oblong obtuse segments, some of the leaves contracted in the middle and bearing 2-5 pairs of sporophylls with dense, cylindric divisions which are greenish at first, afterwards dark brown, finally withering ; leaves clothed with tomentum when young, glabrous when mature, the fertile ones taller than the sterile, and finally widely recurving. In moist places. Newf. to Minn., N. C. and Mo. Also in India. May-July.

\section{Family 3. HYMENOPHYLLÀCEAE Gaud.}

Membranous, mostly small ferns with filiform or slender creeping rootstocks. Leaves usually much divided. Sporanges sessile on a filiform, usually elongated receptacle, surrounded by a transverse ring which opens vertically. Several genera, comprising some 200 species, very abundant in tropical regions.

\section{TRICHÓMANES L.}

Delicate filmy ferns, the leaves usually much divided. Sporanges flattened, surrounded by a broad entire transverse ring opening vertically, sessile on the lower part of the slender filiform receptacle. Receptacle surrounded by a tubular or funnel-shaped indusium which is truncate or slightly 2-lipped. [Greek, in allusion to the thin hair-like segments of some species.] About roo species, mostly of tropical regions.

I. Trichomanes Boschiànum Sturm. Bristle Fern. (I. F. f. II.) Rootstock filiform, wiry, tomentose, creeping. Stipes (petioles) ascending, $2.5-7.5 \mathrm{~cm}$. long, naked or nearly so; leaves $5-20 \mathrm{~cm}$. long, $1.5-3.3 \mathrm{~cm}$. wide, membranaceous, lanceolate or ovate-lanceolate, 2-3-pinnatifid ; pinnæ ovate, obtuse, the upper side of the cuneate base parallel with or appressed to the narrowly winged rachis; segments toothed or cut into linear divisions; indusia terminal on short lobes, I-4 on a pinnule, the mouth slightly 2 -lipped, receptacle more or less exserted. On wet rocks. $\mathrm{Ky}$. to Fla, and Ala. Has been confused with the West Indian T: radicans Sw.

\section{Family 4. SCHIZAEÀCEAE Reichenb.}

Ferns of various habit, with simple or pinnate leaves. Sporanges borne in spikes or panicles, ovoid, sessile, provided with an apical ring, opening vertically by a longitudinal slit. Several genera and about roo species, mainly tropical.

Sporanges in close 2-ranked spikes; leaves filiform or linear. Sporanges in ample panicles; pinnules palmate.

1. Schizaea.

2. Lygodium.

\section{SCHIZAEA J. E. Smith.}

Small slender ferns with filiform or linear leaves, the fertile distinct from the sterile. Sporanges sessile in close distichous spikes along the single vein of the narrow divisions of the sporophylls, provided with a complete apical ring. [Greek, in allusion to the cleft leaves of some species.] A genus of 19 species, of wide distribution, mostly tropical.

I. Schizaea pusílla Pursh. Curly-grass. (I. F. f. I2.) Sterile leaves linear, slender and tortuous. Sporophylls longer, 7-12 cm. high, the fertile portion terminal, consisting of about 5 pairs of crowded pinnæ, forming a distichous spike; sporanges ovoid or pyriform, sessile in two rows along the single vein of the narrow incurved linear divisions of the fertile leaf, partially concealed by its incurved margins, which are hooded at the apex and ciliate; ring apical, the sporanges opening by a vertical slit. In wet soil, pine-barrens of N. J. and in N. S. and Newf. Rare and local. Aug.-Sept.

\section{LYGÒDIUM Sw.}

Twining or climbing ferns, the lower divisions sterile, variously stalked and lobed, the fertile terminal, panicled. Sporanges ovoid, solitary or in twos in the axils of imbricated scale-like indusia, provided with an apical ring, opening verti- 
cally. Indusia fixed by their broad bases to short oblique veinlets. [Greek, in al. lusion to the flexible stipes. 1 About 20 species, mostly tropical.

I. Lygodium palmàtum (Bernh.) Sw. Climbing liern. Hartford Fern. (I. F. f. I3.) Rootstock slender, creeping. Stipes slender, flexible and twining; leaves 4-10 $\mathrm{dm}$. long, their short alternate branches 2 -forked, each fork bearing a nearly orbicular 4-7-lobed pinnule which is more or less cordate at the base with a narrow sinus; surfaces naked ; fertile pinnules contracted, several times forked, forming a terminal panicle ; sporanges solitary, each covered by a scale-like indusium. In moist thickets and open woods, N. H. and Mass. to Penn., Fla. and Tenn.; rare. Summer.

\section{Family 5. POLYPODIÀCEAE R. Br.}

\section{Fern Family.}

Ferns of various habit, the rootstocks horizontal and often elongate, or short and erect, the leaves entire, pinnate, pinnatifid or decompound, coiled in vernation. Sporanges borne in clusters (sori) on the lower side or margins of the leaves or their segments, stalked, provided with a vertical ring, opening transversely. Sori with or without a membranous covering (indusium). Prothallium green. About 200 genera and 3000 species of wide distribution.

Leaves all flat, or their edges only slightly revolute.

Sori without indusia.

Sori roundish or not more than twice as long as broad.

Stipes articulated to the rootstocks ; leaves in our species pinnatifid.

I. Polypodium.

Stipes not articulated to the rootstocks; leaves in our species 2-3-pinnatifid or ternate.

Sori linear and marginal.

14. Phegopteris.

2. Notholaena.

Sori with marginal indusia formed of the more or less altered edge of the leaf.

Sporanges at the ends of veins, borne on a reflexed portion of the leaf.

3. Adiantum.

Sporanges borne on a continuous vein-like receptacle which connects the apices of the veins.

Sporanges at or near the ends of unconnected veins.

Leaves of two forms; stipes pale.

Leaves uniform; stipes usually dark-colored.

4. Pteridium.

Sori mostly forming a continuous indusium around the segment.

5. Cryptogramma.

6. Pellaea.

Sori minute ; indusium usually interrupted, if continuous the segments small and bead-like.

Sori dorsal or marginal, provided with special indusia.

7. Cheilanthes.

Sori linear or oblong; indusia more than twice as long as broad.

Sori in chain-like rows parallel to the midribs or rachises.

Leaves dimorphous.

Leaves uniform.

8. Lorinseria.

8a. Anchistea.

Sori all oblique to the midrib or rachises; veins free.

Sori single on the upper side of a veinlet or rarely crossing it.

9. Asplenium.

Sori confluent in pairs with an apparently double indusium opening in the middle; leaf simple.

10. Phyllitis.

Sori partly parallel to the midrib, partly oblique; veins united.

Sori roundish, indusia less than twice as long as broad.

II. Camptosorus.

Indusium superior.

Indusium orbicular, peltate, fixed by the centre.

12. Polystichum.

Indusium reniform or orbicular with a narrow sinus by which it is attached to the leaf.

r3. Dryopteris.

Indusium delicate, partly inferior, fixed by a broad base and enclosing the sorus like a hood.

Indusium wholly inferior.

Indusium roundish or stellate.

Indusium cup-shaped or somewhat 2-valved.

15. Filix.

aves closely rolled together with necklace-like segments.

16. Woodsia.

17. Dennstaedtia.

Leaves with anastomosing veins; rootstock creeping with scattered leaves.

I9. Onoclea. 


\section{POLYPÒDIUM L.}

Pinnate or simple ferns with stipes articulated to the creeping rootstocks. Sori hemispheric, dorsal, in one or more rows on either side of the midribs. Indusium none. Sporanges pedicelled, provided with a vertical ring which bursts transversely. Veins free in the northern species. [Greek, in allusion to the branched rootstocks of some species.] About 350 species, of wide distribution, mostly tropical.

Lower surface of the leaf glabrous ; plant green. Lower surface of the leaf densely scaly; plant grayish.
I. P. vulgare.

2. P. polypodioides.

r. Polypodium vulgàre L. Polypody. (I. F. f. 71.) Rootstock widely creeping, densely covered with cinnamon-colored scales. Stipes light-colored, glabrous, 5-15 cm. long ; leaves ovate-oblong or narrowly oblong in outline, subcoriaceous, evergreen, glabrous on both surfaces, 7-25 cm. long, $2.5-4.5 \mathrm{~cm}$. wide, cut nearly to the rachis into entire or slightly toothed, obtuse or subacute, linear or linear-oblong segments; sori large, borne about midway between the midrib and the margins of the segments; veins free. On rocks or rocky banks, almost throughout N. Am., Asia and Europe. Forms with the ends of the segments enlarged, somewhat palmately lobed, and the upper crested are known as var. cristatum. Forms with the segments broad and deeply pinnatifid are called var. Cambricum.

2. Polypodium polypodioides (L.) A. S. Hitchcock. (I. F. f. 72.) Rootstock widely creeping, woody, covered with small brown scales. Stipes densely scaly, 2.5$4.5 \mathrm{~cm}$. long ; leaves oblong-lanceolate in outline, acute, coriaceous, evergreen, 3-I5 $\mathrm{cm}$. long, $2.5-4 \mathrm{~cm}$. wide, cut very nearly or quite to the rachis into entire oblong or linear-oblong obtuse segments, glabrous or nearly so on the upper surface, the lower densely covered with gray peltate scales with darker centres, as are also the rachises; veins indistinct, unconnected, and usually once forked. On trees or rarely on rocks, $\mathrm{Pa}$. to Va. and Fla., west to Ill., Mo. and Tex., and throughout tropical America. (Polypodium incanum Sw.)

\section{NOTHOLAÈNA R. Br.}

Mostly small rock-loving ferns, with I-3-pinnate or pinnatifid leaves and marginal roundish or oblong sori, which are at first distinct but soon confluent into a narrow band. Indusium none, but the sporanges are sometimes at first covered by the inflexed margin of the leaf. Veins free. Sporanges pedicelled, provided with a vertical transversely bursting ring. Lower surface of the leaf often covered with a white or yellow waxy powder, or in some species with a dense tomentum. [Greek in allusion to the woolly lower surfaces.] About 40 species, of wide distribution, most numerous in America. Besides the following, some 13 others are found in the mountainous portions of the southwestern U. S.

I. Notholaena dealbata (Pursh) Kunze. (I. F. f. 70.) Rootstock short, chaffy with narrow brown scales. Stipes tufted, wiry, very slender, shining; dark brown, $\mathbf{2 . 5}-4.5 \mathrm{~cm}$. long; leaves triangular-ovate in outline, acute, broadest at the base, 2.5-10 cm. long, 3-pinnate, the rachis black and shining; pinnæ ovate, the lower slender-stalked ; ultimate pinnules ovate or obovate, obtuse, lobed, crenate or entire, small, scarcely $2 \mathrm{~mm}$. long, white and powdery on the lower surface. On calcare. ous rocks, Mo. and Kan. to Ariz. and Tex.

\section{ADIÁNTUM L.}

Graceful ferns of rocky hillsides, woods, and ravines, with much divided leaves and short marginal sori borne on the under side of the reflexed and altered portion of the pinnule, which serves as an indusium. Stipes and branches of the leaves very slender or filiform, polished and shining. [Name ancient.] A genus of 80 or 90 species, mostly of tropical America.

Leaves 2-pinnate, ovate-lanceolate in outline.

Leaves dichotomously forked with pinnate branches.
I. A. Capillus-Veneris. 2. A. pedatum.

I. Adiantum Capillus-Véneris L. Venus-hair Fern. (I. F. f. 59.) Rootstock creeping, rather slender, chaffy with light-brown scales. Stipes very slender, black or nearly so, shining, 7-22 cm. long; leaves ovate-lanceolate in outline, bi- 
pinnate below, simply pinnate above, membranous, commonly drooping, r.5-6 dm. long, I-3 dm. wide at the base; pinnules and upper pinnæ wedge-obovate or rhomboid, rather long-stalked, glabrous, the upper margin rounded and more or less incised, crenate or dentate-serrate, except where it is recurved to form the in. dusia. In ravines, Va. to Fla., west to Mo., S. Dak. and Cal. Widely distributed.

2. Adiantum pedàtum L. MAIDEN-HAIR FERN. (I. F. f. 60.) Rootstock slender, creeping, chaffy, rooting along its whole length. Stipes 2-4.5 dm. long, dark chestnut-brown, polished and shining, dichotomously forked at the summit; leaves obliquely orbicular in outline, $2-4.5 \mathrm{dm}$. broad, the pinnæ arising from the upper sides of the two branches of the stipe, somewhat radiately arranged, the larger ones $1.5-2.5 \mathrm{dm}$. long, 2.5-5 cm. wide; pinnules oblong, triangularoblong, or the terminal one fan-shaped, short-stalked, the lower margin entire and slightly curved, the upper margin cleft, lobed or dentate, bearing the lincar-oblong, often short sori. In woods, N. S. to Br. Col., south to Ga., Ark., Utah and Cal., in Alaska and W. Asia.

\section{PTERÍDium Scop.}

Large, mostly coarse ferns, growing in open sunny places, with variously divided leaves, and marginal linear continuous sori which occupy a slender or filiform receptacle, connecting the tips of free veins. Indusium membranous, formed of the reflexed margin of the leaf. Stipes continuous with the rootstock. [Greek name for ferns, from the fancied resemblance of their leaves to the wings of birds.] About 100 species of wide distribution, mostly of warm and tropical regions.

I. P. aquilinum (L.) Kuhn. BRAKE. BRACKen. (I. F. f. 6I.) Rootstock stout, woody, horizontal. Stipes 3-6 dm. long, straw-colored or brownish; leaves 6-I2 dm. long, 3-9 dm. wide, usually glabrous, ternate, the three branches ear.h bipinnate; upper pinnules undivided, the lower more or less pinnatifid. In sunny places, distributed over nearly the whole of N. Am. [Pteris aquilina L.]

P. aquillnum latiúsculum (Desv:) Underw. Pinnules linear and entire, or with the segments less crowded and the terminal lobe attenuate, narrow and entire. In sandy soil, N. J. to Fla. and Tex. (P. aquilinum pseudocaudatum Clute.)

\section{CRYPTOGRÁMMA R. Br. ROCK-BRAKE.}

Light green, alpine and arctic ferns with leaves of two kinds, the segments of the sterile much broader than those of the fertile, the sporanges in oblong or roundish sori, which are at length confluent and cover the backs of the fertile pin. nules. Indusium formed of the somewhat altered margin of the pinnule, at first reflexed to the midrib, so that the segments appear pod-like, at length opening out flat. Sporanges borne at or near the ends of unconnected veins. [Greek, in allusion to the hidden sporanges.] Two species.

I. Cryptogramma acrostichordes R. Br. (I. F. f. 62.) Rootstock stout, short, chaffy. Stipes slender, densely tufted, straw-colored, $5-15 \mathrm{~cm}$. long, chaffy below; leaves ovate or ovate-lanceolate in outline, thin, glabrous, 2-3-pinnate, the sterile shorter than the fertile, their ultimate segments and pinnules crowded, ovate, oblong or obovate, obtuse, crenate or slightly incised; fertile leaves with linear or linear-oblong segments $6-12 \mathrm{~mm}$. long, $2 \mathrm{~mm}$. or less wide, the margins involute to the midrib at first, expanded at maturity and exposing the light brown sporanges. Forming dense patches among rocks, Lab. and Hudson Bay to Alaska, south to Iakes Huron and Superior, Colo., and Cal.

2. Cryptogramma Stélleri (Gmel.) Prantl. (I. F. f. 63.) Rootstock slender, creeping, threadlike, somewhat scaly. Stipes scattered, $5-8 \mathrm{~cm}$. long, straw-colored or pale brown, slightly chaffy below; leaves thin-membranous, ovate in outline, 5-13 cm. long, 2.5-5 cm. wide, 2-3-pinnate or pinnatifid above, the fertile taller than the sterile and with narrower pinnules and segments; pinnæ lanceolatedeltoid, cut to the rachis into a few blunt or subacute slightly lobed or entire seg. ments; indusium broad, continuous; veins of the fertile leaves mostly only one. forked, everywhere apparent and conspicuous. On rocks, preferring limestone, Lab. to Br. Col., south to Mass., Penn., Iowa and Colo. Also in Asia. SPellaea Stelleri Watt.] 


\section{Pellatea link. Cliff-brake.}

Rock-loving ferns of small or medium size with pinnate or pinnatifid leaves and intramarginal sori borne on the ends of unconnected veins, at length confluent and forming a marginal line. Indusium commonly broad and membranous, formed of the reflexed margins of fertile segments which are more or less modified and mem. branous. Fertile and sterile leaves similar. Stipes usually dark-colored. [Greek, in allusion to the dark-colored stipes.] About 55 species, of wide distribution.

I.eaves pinnate or 2-pinnate with large pinnules.

Leaves small, 3-pinnate, the pinnuies narrow.

I. Pellaea atropurpùrea (L.) Link. (I. F. f. 64.) Rootstock short, densely (lothed with rusty hair-like scales. Stipes tufted, 5-15 cm. long, dark purple or nearly black; leaves coriaceous, lanceolate or ovate-lanceolate in outline, $\mathbf{I}-3 \mathrm{dm}$. long, 5-15 cm. wide, simply pinnate or 2-pinnate below; rachis dark-brown or purple, glabrous or pubescent; pinnules and upper pinnæ $2.5-5 \mathrm{~cm}$. long, glabrous, $6 \mathrm{~mm}$. or less wide, short-stalked or sessile; indusium formed of the slightly altered incurved margin of the pinnules; veins obscure, commonly twice forked. On rocks, preferring limestone, Ont. to Br. Col., south to Conn., Ga., Ariz. and N. Mex.

2. Pellaea dénsa (Brack.) Hook. (I. F. f. 65.) Rootstock rather slender, chaffy with blackish scales. Stipes densely tufted, wiry, slender, light brown, 7-22 $\mathrm{cm}$. long; leaves ovate or triangular-oblong in outline, $2.5-4.5 \mathrm{~cm}$. long, densely 3-pinnate, the segments 6-12 $\mathrm{mm}$. long, linear, nearly sessile, acuminate or mucronate, those of the fertile leaves tapering at each end, with narrowly recurved margins; apices of the rare sterile leaves sharply serrate, otherwise similar to the fertile ones. Mt. Albert, Gaspé, P. Q. Also from Br. Col. to Wyo. and Cal.

\section{CHEILÁNTHES Sw. LiP-FERN.}

Mostly pubescent or tomentose rock-loving and small ferns with much divided leaves, the sori terminal on the veins, ultimately more or less confluent. Indusium formed of the reflexed margin of the leaf, roundish and distinct or more or less confluent. Sporanges often much concealed in the scales or tomentum which covers the segments in many species. [Greek, in allusion to the lipped indusia of some species.] About 65 species, of temperate and tropical regions.

Leaves nearly glabrous, 2-pinnate.

Leaves hirsute and glandular, not tomentose ; indusia not continuous.

Leaves more or less tomentose; indusia mostly continuous.

1. C. Alabamensis.

2. C. lanosa.

Leaves 5-10 cm. long; stipes slender, at length nearly glabrous. 3. C. Féei.

Leaves I.5-4.5 dm. long; stipes stout, densely brown-tomentose. 4. C. tomentosa.

I. Cheilanthes Alabaménsis (Buckl.) Kunze. (I. F. f. 66.) Rootstock creeping, rather stout and short, with slender brown scales. Stipes black, 7-18 cm. long, slender, wiry, villous at least towards the base with rusty wool; leaves lanceo. late in outline, glabrous, 5-25 cm. long, 2-pinnate; pinnæ numerous, ovate-lanceolate, acuminate, very short-stalked, the lowest usually smaller than those above; pinnules oblong or triangular-oblong, mostly acute, often auriculate on the upper side of the base, more or less toothed or incised; indusia pale, membranous, interrupted by the incising of the pinnæ. On rocks, Va. to Ala., west to Ark. and Ariz.

2. Cheilanthes lanòsa (Michx.) Watt. (I. F. f. 67.) Rootstock short, creeping, with pale rusty-brown scales. Stipes tufted, wiry, chestnut-brown, 5-10 cm. long, hirsute; leaves herbaceous, oblong-lanceolate in outline, Io-22 cm. long, 2.5-5 $\mathbf{c m}$. wide, gradually attenuate to the apex, 2-pinnate; pinnules somewhat distant, lanceolate-deltoid, acute, deeply pinnatifid or incised, more or less covered with almost bristly hairs and usually somewhat glandular, obtuse or subacute; sori numerous, covered by the infolded ends of the rounded or oblong lobes. On rocks, West Rock, New Haven, and southern New York to Ga., west to Mo., Ark. and Tex.

3. Cheilanthes Féei Moore. (I. F. f. 68.) Rootstock short, covered with narrow brown scales lined with black. Stipes densely tufted, slender, about as long as the leaves, at first covered with woolly hairs, at length nearly glabrous; leaves 
ovate-lanceolate in outline, 5-10 cm. long, 2.5-5 cm. wide, 3-pinnate or 2-pinnate with the pinnules pinnatifid, the upper surface slightly tomentose, the lower densely matted with whitish-brown woolly hairs; upper pinnæ oblong-ovate, the lower deltoid, the lowest distant; ultimate segments or lobes minute, the terminal ones slightly larger than the others, all roundish or obovate and much crowded; indusium narrow. On rocks, Ill.. to Br. Col., Tex. and Ariz. (C. gracilis Mett.)

4. Cheilanthes tomentòsa Link. (I. F. f. 69.) Rootstock stout, short, densely chaffy with light brown scales. Stipes tufted, $\mathrm{x}-2 \mathrm{dm}$. long, rather stout, densely brown-tomentose even when mature; leaves oblong-lanceolate in outline, 3-pinnate, I.5-4.5 dm. long, densely tomentose, especially beneath, with slender brownish-white obscurely articulated hairs; pinnæ and pinnules ovate-oblong or oblong-lanceolate, the ultimate pinnules about $\mathbf{I}$. mm. long, the terminai ones sometimes twice as large as the others; indusium pale, membranous, continuous. On rocks, Va. to $\mathrm{Ga}_{\text {., }}$ west to Mo., Tex., Ariz. and Mex.

\section{Lorinsèria Presl. Chatn-frRn.}

Medium-sized ferns of swamps with dimorplous pinnate leaves, and linear sori sunk in cavities of the leaf, arranged parallel to the midribs. Indusia subcoriaceous, fixed by their outer margins to a veinlet and covering the cavity like a lid. Veins copiously reticulated. Only the following species. [Named in honor of Dr. Gustav Lorinser, a Bohemian physician and naturalist.]

I. Lorinsèria areolàta (L.) Underw. (I. F. f. 43.) Rootstock slender, creeping, chaffy. Leaves of two kinds, the fertile taller than the sterile and borne on longer stipes, 3-6 cm. high, their pinnæ narrowly linear; sterile leaves deltoidovate, membranous, the segments lanceolate or oblong-lanceolate, minutely serrulate or undulate, their bases connected by a rather broad rachis-wing. In swamps, Me. to Fla., La. and Ark. ; also in Mich. (Woodzvardia areolata (L.) Moore.)

\section{8a. ANChistè A Presl. Chain-fern.}

Large coarse ferns of swamps or wet woods, with uniform nearly bipinnate leaves and oblong sori arranged in chain-like rows parallel to the midribs. Indusia fixed by their outer margins to a veinlet. Veins forming a single row of areolæ next the midrib, then free to the margin. Two species of the northern hemisphere, the following and one of eastern Asia. [Greek, referring to its relationship to Woodrvardia.]

I. Anchistèa Virgínica (L.) Presl. (I. F. f. 42.) Rootstock stout, subterranean, creeping, chaffy. Stipes stout, 3-4.5 dm. long, nearly or quite naked; leaves oblong-lanceolate, acute at the apex, narrowed at the base, 3-6 din. long, 15-22 cm. wide; pinnæ linear-lanceolate, glabrous, acuminate at the apex, sessile, deeply pinnatifid into oblong obtuse segments with minutely serrulate margins; sori $4 \mathrm{~mm}$. long. In swamps, N. S. to Ont. and Mich., south to Fla., La. and Ark. (Woodwardia Virginica (L.) J. E. Smith.)

\section{Asplènium l. Spleenwort.}

Large or small ferns with entire, lobed, pinnate, 2-3-pinnate, or pinnatifid leaves, and linear or oblong sori oblique to the midribs or rachises. Leaves mostly uniform. Veins free. Indusia straight or curved, opening towards the midribs when single. Sporanges pedicelled, provided with an elastic ring, bursting transversely. [Ancient Greek name; some species were supposed to be remedies for diseases of the spleen.] A genus of some 200 species, of very wide geographic distribution.

Sori straight or rarely slightly curved, attached to the upper side of a vein; mostly small (except in No. 7).

Leaves pinnatifid or pinnate below, tapering to a point.

Stipes blackish below; lobes rounded or the lowest acuminate.

Stipes blackish throughout; lobes acute or acuminate.

I. A. pinnatifidum.

2. A. ebenoides. 
Leaves once pinnate.

Pinnæ $7 \mathrm{~mm} .-8 \mathrm{~cm}$. long, mostly blunt.

Rachis chestnut-brown or blackish.

Pinnæ auricled at the upper side of the base.

Pinnæ opposite, oblong; rachis dark brown or black.

3. A. resiliens.

Pinnæ partly alternate, lanceolate; rachis chestnut-brown.

Pinnæ not auricled, partly alternate, partly opposite.

4. A. platyneuron.

5. A. Trichomanes.

Rachis green; pinnæ not auricled.

5. A. Triride.

Pinnæ 5-12 cm. long, acute or acuminate.

7. A. angustifolium.

Leaves 2-3-pinnatifid.

Stipes green; leaves ovate-deltoid; pinnules fan-shaped, veins flabellate.

Stipes dark at the base, green above.

Leaves ovate-lanceolate, broadest near the base.

Leaves lanceolate, broadest above the middle. Io. $A$. fontan
Stipes chestuut-brown throughout, as also the lower part of the rachis.

8. A. Ruta-muraria.

II. A. Bradleyi.

Sori usually more or less curved, sometimes horseshoe-shaped, often crossing to the outer or lower side of the veinlet; large ferns.

Leaves 2-pinnatifid; segments blunt, scarcely crenate.

Leaves 2-pinnate; pinnules acute, toothed or pinnatifid.

12. A. acrostichoides.

13. A. Filix-famina.

I. Asplenium pinnatífidum Nutt. (I. F. f. 46.) Rootstock short, creeping, chaffy. Stipes tufted, polished, blackish below, green above, 5-I2 cm. long, somewhat chaffy helow, at least when young; leaves broadly lanceolate in outline. 7-25 cm. long, firm, tapering upward to a long narrow tip, pinnatifid or the lower parts pinnate; lowest pinnæe or occasionally several pairs sometimes tapering to a point like that of the apex of the leaf; lobes or pinnæ rounded or the lowest acuminate. On rocks, N. J. and Pa. to Ill., south to Ga. and Ark.

2. Asplenium ebenoides R. R. Scott. (I. F. f. 47.) Rootstock short, chaffy. Stipes blackish tufted, 4-10 cm. long; leaves lanceolate in outline, variable in size and length, $8-25 \mathrm{~cm}$. long, $2.5-5 \mathrm{~cm}$. wide at the base, firm, tapering into a very long narrow acuminate apex, pinnatifid, or commonly pinnate below, the segments or pinnæ lanceolate from a broad base, acute or acuminate, irregular in length, the lower sometimes shorter than those just above; sori several on each segment, straight or slightly curved. On limestone, Vt. to Ind., south to Ala. Local; rare except in the last-named locality.

3. Asplenium resìliens Kunze. (I. F. f. 48.) Rootstock short, chafty with black stiff scales. Stipes tufted, blackish and shining, 2.5-5 cm. long; leaves rather firm, linear-oblong or linear-oblanceolate, 7-25 cm. long, 10-25 $\mathrm{mm}$. wide, once pinnate; pinnæ 4-12 mm. long, mostly opposite, oblong, obtuse, entire or crenulate, auricled on the upper side and nearly sessile, the middle ones the longest, the lower gradually shorter and reflexed; rachis dark brown or black; sori oblong, short, borne about midway between the midrib and the margin of the pinnæ, nearly or quite straight. On limestone, Va. to Fla., west to Mo., Tex., and N. Mex.

4. Asp'enium platyneùron (L.) Oakes. (I. F. f. 49.) Rootstock short. Stipes tufted, purplish-brown and shining, $2.5-10 \mathrm{~cm}$. long ; leaves linear, $2-4 \mathrm{~cm}$. long, $1.2-3.5 \mathrm{~cm}$. wide, firm, once pinnate, the rachis chestnut-brown; pinnæ 20-40 pairs, lanceolate, subfalcate, alternate or partly so, sessile, crenate, serrate or incised, auricled on the upper side at the base and occasionally also on the lower; lower pinnæ gradually smaller and oblong or triangular; sori 8-12 on each side of the midrib of the pinnæ, becoming crowded at maturity. On rocks and banks, preferring limestone soil, Me. and Ont. to Fla., Colo. and Tex. (A. ebeneum Ait.)

5. Asplenium Trichómanes L. (I. F. f. 50.) Rootstock short, nearly erect, chaffy with blackish scales. Stipes densely tufted, numerous, $2.5-12 \mathrm{~cm}$. long, purplish-brown and shining; leaves linear in outline, 7-20 cm. long, 12-20 $\mathrm{mm}$. wide, rather rigid, once pinnate, evergreen ; pinnæ oval or roundish-oblong, inequilateral, partly opposite, partly alternate, or nearly all opposite, cuneate at the base, the point of attachment to the dark brown rachis narrow, their margins slightly crenate; sori $3^{-6}$ on each side of the forking and evanescent midrib, short, 
narrowed at either end. On rocks, preferring limestone, throughout nearly the whole of N. Am. Also in Europe and Asia.

6. Asplenium víride Huds. (I. F. f. 5 I.) Rootstock stout, creeping, with brown nerveless scales. Stipes numerous, densely tufted, brownish below, green above; leaves linear-lanceolate. 5-20 cm. long, 8-20 cm. wide, once pinnate, pale green, soft, herbaceous or almost membranous; rachis green ; pinnæ 12-20 pairs, ovate or rhomboid, deeply crenate, obtuse, unequal sided, their upper edges narrowed suddenly at the base, the lower obliquely truncate; sori oblong and numerous or scattered and fewer. On rocks, N. B. and Vt. to Br. Col. Also in northern Europe and Asia.

7. Asplenium angustifòlium Michx. (I. F. f. 52.) Rootstock stout, creeping, rooting throughout. Stipes growing in a crown, brownish or green above, chaffless, 2-3 dm. long, sometimes slightly scaly toward the base; leaves lanceolate in outline, 3-6 dm. long, once pinnate, glabrous ; pinnæ $20-30$ pairs, linear-lanceolate, or those of the sterile leaves lanceolate, acuminate at the apex, obtuse or truncate at the base, 5-12 cm. long flaccid, the margins entire or slightly crenulate; fertile leaves commonly taller than the sterile, narrower, their pinnæ generally much narrower, often falcate; sori $20-30$ on each side of the midrib, linear, crowded. In moist woods $\mathrm{P}$. Q. to Wis. south to Va. and $\mathrm{Ky}$.

8. Asplenium Rùta-murària L. (I. F. f. 53.) Rootstock short, ascending. Stipes tufted, naked, green, 5-7 cm. long; leaves ovate or deltoid-ovate in outline, 5-12 cm. long, glabrous, evergreen, 2-3-pinnate or pinnatifid above ; pinnæ and pinnules stalked ; pinnules rhombic or obovate, mostly obtuse, dentate or incised, cuneate at the base ; veins flabellate ; sori few, linear-oblong, confluent when mature and covering nearly the whole pinnule, the indusium membranaceous and delicate. On limestone, Vt. to Mich., Conn., Ala. and Mo. Also in Europe, Asia and N. Africa.

9. Asplenium montànum Willd. (I. F. f. 54.) Rootstock short, chaffy at the summit. Stipes tufted, naked, slender, blackish at the base, 5-7 cm. long; leaves $5-20 \mathrm{~cm}$. long, ovate-lanceolate in outline, acuminate at the apex, rather firm, I-2 pinnate; lower pinnæ longest, pinnate or pinnatifid, the lobes or segments ovate or oblong; upper pinnæ less divided, merely toothed or incised; veins obscure ; sori linear-oblong, short, the lower ones sometimes double, usually abundant, often confluent at maturity and concealing the narrow membranous indusia. On rocks, Conn. and N. Y. to Ga., west to O. and Ark.

10. Asplenium fontànum (L.) Bernh. (I. F. f. 55.) Rootstock short, ascending, with narrow dark scales at the apex. Stipes tufted, $2.5-7 \mathrm{~cm}$. long, somewhat blackish at the base especially on the inner side, usually glabrous; leaves lanceolate, broadest above the middle, thin, 2-3 pinnate, $7-15 \mathrm{~cm}$. long, I-3 cm. wide, acuminate at the apex, narrowed to the base; pinnæ ro-I 5 pairs, the segments deeply dentate with spinulose teeth ; sori only I to 4 on each segment, covered with a membranous subentire indusium, rarely confluent. On rocks, Lycoming Co., Pa., and Springfield, O. Also in Europe.

I I. Asplenium Brádleyi D. C. Eaton. (I. F. f. 56.) Rootstock short, chaffy with brown scales. Stipes tufted, slender, 5-7 cm. long, chestnut-brown; leaves oblong-lanceolate or oblong, acuminate at the apex, not narrowed at the base, pinnate with 8-12 pairs of short-stalked or sessile, oblong-ovate pinnæ, the lower again pinnatifid or pinnate with oblong obtuse lobes or pinnules, which are toothed at the apex, the upper pinnatifid with dentate or nearly entire lobes; rachis brown; sori short, borne near the midrib, covered with the narrow indusium until maturity. On rocks, often preferring limestone, N. Y. to Ga. and Ala., west to Ark. Local. July-Sept.

12. Asplenium acrostichordes Sw. (I. F. f. 57.) Rootstock sinuous, creeping. Stipes 2-3 dm. long, straw-colored, somewhat chaffy below at least when young; leaves lanceolate in outline, 3-9 dm. long, I.5-3 dm. wide, acute or acuminate at the apex, narrowed to the base, pinnate-pinnatifid; pinnæ linearlanceolate, sessile, acuminate, deeply pinnatifid into numerous oblong obtuse or subacute, slightly crenate segments; sori crowded, slightly curved or straight, the lower ones often double; indusium light-colored and somewhat shining when young. In rich moist woods, N. S. to Minn., south to Ga. and Ala. Also in E. Asia.

13. Asplenium Fìlix-foémina (L.) Bernh. (I. F. f. 58.) Rootstock creeping, rather slender for the size of the plant. Stipes tufted, 1.5-2.5 dm. long, 
straw-colored, brownish or reddish; leaves wroadly oblong-ovate or oblong-lanceolate, acuminate at the apex, 3-9 dm. long, bipinnate; pinnæ lanceolate, acuminate, short-stalked or the upper ones sessile, I-2 dm. long; pinnules oblong-lanceolate, incised or serrate, their lobes or teeth often again toothed, those toward the ends of the pinnæ confluent by a very narrow margin to the secondary rachis ; sori short, the indusia straight or variously curved, sometimes horseshoe-shaped. In woods, thickets, and by walls and fences, N. S. to Alaska, south to Fla., La., and Ariz. Also in Europe and Asia.

\section{PHYLLITIS Hill, 1756. [Scolopendrium Adans. 1763.]}

Large ferns with oblong or strap-shaped mostly entire leaves, and linear elongated sori which are almost at right angles to the midrib and contiguous in pairs, one on the upper side of a veinlet, the other on the lower side of the next contiguous veinlet, thus appearing to have a double indusium opening longitudinally along its middle. Five species, mainly of temperate regions. Only the following is known to occur in N. Am. [Greek name of the Harts-tongue.]

I. Phyllitis Scolopéndrium (L.) Newman. Harts-Tongue. (I. F. f. 441 Rootstock short, chaffy with light brown scales. Stipes 5-15 cm. long, fibrillose chaffy below or sometimes up to the base of the leaf; leaves entire, bright green, firm, 2-4.5 dm. long, $2.5-6 \mathrm{~cm}$. wide, cordate at the base, the margins entire or undulate, the lower surface of the midrib sometimes chaffy; pairs of sori distinct, 4-I5 mm. long; conspicuous on the lower surface, the sporanges dark brown at maturity; veins free, usually once forked near the midrib. On shaded cliffs of the corniferous limestone, Chittenango Falls and Jamesville, N. Y.; near South Pittsburg, Tenn.; Owen Sound, Ont., N. B. and Mex. Widely distributed in Europe, Asia and Africa.

\section{CAMPTOSòrus Link.}

Slender ferns with tapering simple entire or undulate leaves, bearing linear or oblong sori several times longer than broad, irregularly scattered on either side of the reticulate veins or sometimes crossing them, partly parallel to the midrib and partiy oblique to it, the outer ones more or less approximate in pairs. Indusium inembranous. [Greek, referring to the bent or curved sori.] Two species.

I. Camptosorus rhizophýllus (L.) Link. WALking-FerN. (I. F. f. 45.) Rootstock short, usually creeping, chaffy. Stipes light green, 2.5-15 cm. long, tufted, spreading; leaves rather thin, lanceolate, simple, long-acuminate at the apex, cordate, hastate or rarely narrowed at the base, $10-25 \mathrm{~cm}$. long, sometimes with a more or less elongated pair of basal auricles; tip of the leaf and sometimes the tip of one or both of the basal auricles rooting and forming a new plant by the ultimate withering away of its tissue, but commonly two or sometimes as many as four plants are found connected; sori usually numerous, irregularly scattered on the lower surface. On rocks, preferring limestone, P. Q. to Ont. and Minn., south to N. Car. and Kan.

\section{POLÝSTICHUM Roth.}

Coarse pinnate or bipinnate ferns growing from an erect rootstock, with round sori usually borne on the backs of the veins, the sterile and fertile leaves similar in outline. Indusium superior, centrally peltate, orbicular. Stipe continuous, not jointed with the rootstock. Veins free. [Greek, signifying many rows, without obvious application.] Some 45 species of wide distribution.

Leaves once pinnate.

Stipes short; lower pinnæ much reduced.

Stipes longer; lower pinnæ usually little reduced. Leaves 2-pinnate.

r. P. Lonchitis.

2. P. acrostichoides.

3. P. Braunii.

I. Polystichum Lonchitis (L.) Roth. Holly-FERN. (I. F. f. 26.) Rootstock short, stout, densely chaffy. Stipes $2.5-12.5 \mathrm{~cm}$. long, bearing large dark brown scales with some smaller ones; leayes rigid, evergreen, narrowly lanceolate in vutline, once pinnate; pinnæ broadly lanceolate-falcate, $2.5-5 \mathrm{~cm}$. long, acute or acuminate at the apex, strongly auricled $m$ the upper side at the base and obliquely truncate on the lower, densely spinulose-dentate, the lowest commonly triangular 
and shorter; sori large, at length contiguous, borne nearer the margin than the midrib. On rocks, Lab. to Alaska, south to Ont. and Br. Col., and in the Rocky Mts. to Utah. Also in N. Europe and Asia.

2. Polystichum acrostichoides (Michx.) Schott. Christmas Fern. (I. F. f. 27.) Rootstock stout, creeping. Stipes $12-16 \mathrm{~cm}$. long, densely chaffy; leaves linceolate, 1.5-6 dm. long, 7-12 cm. wide, rigid, evergreen, subcoriaceous, once pinnate ; pinnæ linear-lanceolate, somewhat falcate, $2.5-7 \mathrm{~cm}$. long, acutish at the apex, half halberd-shaped at the base, bristly with appressed teeth, the lower scarcely smaller; fertile fronds contracted at the summit, bearing the large contiguous sori near the middle, which soon cover the whole lower surface. In woods and rocky places, N. B. and N. S. to Fla., west to Ont., Wis., and Miss. JulyAug. Forms with cut-lobed or incised pinnæ are known as var. Schweinitzii; occasional forms are 2-pinnatifid.

3. Polystichum Braùnii (Spenner) Fée. (I. F. f. 28.) Rootstock stout. Stipes 10-12 cm. long, chaffy with both broad and narrow brown scales; leaves oblong-lanceolate, not coriaceous, 2-pinnate, the rachis chaffy, at least below ; pinuæ numerous, close together, lanceolate or linear-lanceolate, broadest at the base, cut to the midvein into ovate or oblong pinnules; middle pinnæ 6 -ro $\mathrm{cm}$. long, the lower gradually shorter; pinnules truncate and nearly rectangular at the base, acute or obtuse, sharply toothed and beset with long soft hairs and scales; sori small, mostly nearer the midvein than the margin. In rocky woods, Quebec to Alaska, south to Me., the mountains of Penn., Mich. and Br. Col. Aug.

\section{DRYÓPTERIS Adans. [ASPIDIUM Sw.] SHIRLd-FerN.}

Ferns with 2-3-pinnate or pinnatifid leaves and round sori usually borne on the backs of the veins, the fertile and sterile leaves similar in ortline. Indusium flattish, cordate reniform, superior, fixed by its sinus. Stipe continuous, not jointed with the rootstock. Veins free. [Greek, signifying oak-fern, in allusion to the forest habitat of most species.] About I 50 species, of wide distribution.

Texture thin-membranous; veins simple or once forked; leaves pinnatifid.

Lower pinuæ very much reduced.

I. D. Noveboracensis.

Lower pinnæ little smaller than the middle ones.

Veins I-2-forked; sori crowded, IO-I2 to a segment.

Veins simple; sori larger, distant, 4-1o to a segment.

Texture firmer, sometimes subcoriaceous; veins forking freely.

2. D. Thelypteris.

3. D. simulata.

Leaves 2-pinnatifid or 2-pinnate; segments not spinulose.

Leaves small, narrowly lanceolate.

Leaves larger, mostly $0.4-1.6 \mathrm{~m}$. high.

Indusia large, thinnish and flat.

Pinnæ widest at the base.

Pinnæ widest at the middle.

Indusia convex, without marginal glands.

Sori near the margin.

Sori near the midvein.

Leaves 2-pinnate or 3-pinnatifid; segments spinulose-toothed.

4. D. fragrans.

5. D. cristata.

6. D. Goldieana.

7. D. marginalis.

8. D. Filix-mas.

Leaves ovate-lanceolate, usually not narrowed below; scales of stipes usually with a dark centre.

9. D. spinulosa.

Leaves elongated-lanceolate, usually narrowed at the base; scales of the stipes pale brown. Iо. D. Boottii.

I. Dryopteris Noveboracénsis (L.) A. Gray. (I. F. f. 29.) Rootstock slender, creeping. Leaves lanceolate, tapering both ways from the middle, 3-6 dm. long, $10-15 \mathrm{~cm}$. wide, membranous, long-acuminate at the a pex, once pinnate; pinnæe lanceolate, sessile, long-acuminate, deeply pinnatifid, ciliate and finely pubescent beneath, 3-7 cm. long, the two or more lower pairs gradually shorter and deflexed, commonly distant; segments flat, oblong, obtuse, the basal ones often enlarged; veins simple or those of the basal lobes forked; sori not confluent, borne near the margin; indusium minute, reniform, delicate, glandular. In moist woods, Newf. to Ont. and Minn., south to Ga., Ala. and Ark.

2. Dryopteris Thelýpteris (L.) A. Gray. (I. F. f. 30.) Rootstock slender, creeping. Leaves lanceolate or oblong-lanceo'ate, scarcely narrower at the base than at the middle, $3-8 \mathrm{dm}$. long, $10-15 \mathrm{~cm}$. wide, short-acuminate, membranous, once 
pinnate; pinnæ linear-lanceolate, short-stalked or sessile, mostly horizontal, acuminate at the apex, nearly truncate at the base, 3-7 cm. long, slightly pubescent beneath, deeply pinnatifid; segments oblong, obtuse or a ppearing acute from the strongly revolute margins; veins regularly once or twice orked; sori crowded, 10-12 to each segment ; indusia reniform, slightly glandular or glabrous. In marshes, N. B. to Manitoba, south to Fla. and Tex. Also in Europe and Asia.

3. Dryopteris simulàta Davenp. (I. F. f. 3I.) Rootstock wide-creeping, brownish; stipes I.5-5 dm. long, straw-colored, dark brown at base, with deciduous scales; leaves 2-5 dm. long, 5-I6 cm. wide, oblong-lanceolate, tapering to an acuminate apex (abruptly tapering in the fertile leaf), little or not at all narrowed at the base; pinnæ I2-2O pairs, lanceolate, pinnatifid, the segments obliquely oblong, obtuse, entire, slightly revolute in the fertile leaf; surfaces finely pubescent, especially near the midribs; texture rather thin; veins simple, nearly straight; sori rather large, somewhat distant, 4-Io to each segment; indusia finely giandular at the margins, withering-persistent. In woodland swamps, Me. to Conn. and Md.

4. Dryopteris fràgrans (L.) Schott. (I. F. f. 32.) Rootstock stout, with brown shining scales. Stipes 5-10 cm. long, chaffy; leaves lanceolate, firm, glandular, and aromatic, pinnate or nearly bipinnate, acuminate at apex, narrowed to the base, 7-30 cm. long; pinnæ deeply pinnatifid, numerous, lanceolate, acute, $\mathbf{1} .2-3 \mathrm{~cm}$. long; segments oblong, obtuse, dentate or nearly entire, nearly covered by the large sori; indusium thin, nearly orbicular, persistent long after the sporanges have matured, its margin ragged and sparingly gland-bearing. On rocks, Labrador to Alaska, south to Vt. and Wis. Also in Greenland, Europe, and Asia.

5. Dryopteris cristàta (L.) A. Gray. (I. F.f. 33.) Rootstock stout, densely chaffy. Stipes of the sterile leaves 5-12 cm. long, those of the fertile $1.5-2.5 \mathrm{dm}$. long; leaves linear-oblong or lanceolate, acuminate, gradually and slightly narrowed to the base, rather firm, 3-8 dm. long, 10-1 $5 \mathrm{~cm}$. wide, pinnate; pinnæ lanceolate or triangular-ovate, acuminate, deeply pinnatifid or the lower pinnate, the segments 6-10 pairs, serrate or incised; sori about midway between the margin and midrib; indusium thin, glabrous. In wet woods and swamps, Newf. to Manitoba, south to $\mathrm{Ky}$. and Ark. Also in Europe and Asia.

Dryopteris cristata Clintoniana (D. C. Eaton) Underw. Leaves 8-12 dm. long, with oblong-lanceolate pinnæ which are broadest at the base and ro- $15 \mathrm{~cm}$. long; segments 8-16 pairs, linear-oblong, obscurely serrate; veins pinnately forking, bearing the sori near the midvein. Me. and Ont. to N. J., Penn. and Wis.

6. Dryopteris Goldieàna (Hook.) A. Gray. (I. F. f. 34.) Rootstock stout, chaffy. Stipes $2.5-4.5 \mathrm{dm}$. long, chaffy at least below ; leaves broadly ovate, rather firm, 6-I $2 \mathrm{dm}$. long, usually $3 \mathrm{dm}$. or more wide, glabrous or nearly so, dark green above, pinnate or nearly 2-pinnate; lower pinnæ broadly lanceolate, widest at about the middle, $1.5-2.5 \mathrm{dm}$. long, $2.5-5 \mathrm{~cm}$. wide, parted into about 20 pairs of oblong-linear subfalcate segments which are serrate with appressed teeth ; sori very near the midrib, close together but distinct, large ; indusium orbicular, glabrous, persistent. In rich woods, N. B. to Minn., south to N. Car. and Tenn.

7. Dryopteris marginàlis (L.) A. Gray. (I. F. f. 35.) Rootstock stout, ascending, chaffy with dark brown shining scales. Stipes $7-20 \mathrm{~cm}$. long, chaffy below ; leaves borne in a crown, ovate-oblong or ovate-lanceolate in outline, subcoriaceous, I.5-7.5 dm. long, pinnate or 2-pinnate, acuminate at the apex, slightly narrowed at the base; pinnæ numerous, lanceolate, nearly sessile, glabrous, $5-12.5 \mathrm{~cm}$. long, the lower broader and shorter than the middle ones, the upper pinnatifid, the lower pinnately parted into oblong, sometimes slightly falcate obtuse entire dentate or pirnately lobed pinnules; sori distinct, close to the margin, covered by the glabrous indusium. In rocky woods, Pr. Edw. Isl. to Minn. south to Ga., Ala. and Ark. A hybrid with $D$. cristata has been described.

8 Dryopteris Filix-más (L.) Schott. MALE Fern. (I. F. f. 36.) Rootstock stout, ascending or erect, chaffy. Stipes Io- $15 \mathrm{~cm}$. long, very chaffy below ; leaves oblong-lanceolate, acute, or acuminate at the apex, slightly narrowed to the base, 3-9 dm. long, rather firm, half evergreen, pinnate or partly 2-pinnate; pinnæ lanceolate, broadest at the base, gradually acuminate to the apex, 7-I5 cm. long, pinnatifid almost to the rachis or pinnately divided into oblong glabrous lobes or pinnules; pinnules slightly dentate, incised or nearly entire ; sori large, borne near the midvein, more numerous on the lowcr halves of the segments; indusium firm, 
convex, glabrous. In rocky wsods, Lab. to Alaska, south to $\mathrm{N}$. Mich. and $\mathrm{Br}$. Col. Also in Greenland, Europe and Asia, and in the Andes of S. Am.

9. Dryopteris spinulòsa (Retz) Kuntze. (I. F. f. 37.) Rootstock chaffy. Stipes 1.5-4.5 dm. long, bearing a few pale brown deciduous scales; leaves ovate-lanceolate, 2-pinnate, the pinnæoblique to the rachis, elongated-triangular, rather thin, the lower pairs broadly triangular, slightly shorter than the middle ones; pinnules oblique to the midrib, connected by a very narrow wing, oblong, incised or pinnatifid with spinulose-toothed lobes; indusium glabrous. In rich woods, Newf. to Alaska and Wash., south to Ky. and Mich.

Dryopteris spinulosa intermedia (Muhl.) Underw. Scales of the stipes few, brown with a darker centre ; leaves oblong-ovate, 2-3-pinnate, the pinnæ oblong-lanceolate, spreading, the lowest unequally triangular-ovate; pinnules crowded, pinnately divided; indusium delicate, beset with stalked glands. Lab. to Alaska, south to N. Car. and Mo.

Dryopteris spinulosa dilatata (Hoffm.) Underw. Scales of the stipe large, brown with a darker centre; leaves broadly ovate or triangular-ovate, commonly 3-pinnate; pinnules lanceolate-oblong, the lowest of ten much elongated; indusium glabrous. Newf. to Wash. and Alaska, south along the Alleghenies to Ga. and Tenn. and to O. and Neb. Also in Europe and Asia.

Io. Dryopteris Boòttii (Tuckerm.) Underw. (I. F. f. 38.) Rootstock, ascend. ing. Stipes 2-3 dm. long, covered, at least below, with thin pale-brown scales; leaves elongated-oblong or lanceolate in outline, thin, acuminate at the apex, slightly narrowed at the base, nearly or quite 2-pinnate, 3-7.5 dm. long, $7.5-12.5 \mathrm{~cm}$. wide ; pinnæ lanceolate, long-acuminate, broadest at the nearly sessile base; pinnules broadly oblong, very obtuse, the lower pinnatifid ; sori distinct, borne about halfway between the midvein and margin ; indusium minutely glandular. In woods, N. S. to Minn., south to Del. and W. Va. Also in N. Eu. and Asia.

\section{x4. PHEGÓPTERIS Fée.}

Medium-sized or small ferns with 2-3-pinnatifid or ternate leaves and small round sori borne on the backs of the veins below the apex. Stipe not jointed with the rootstock. Indusium wanting. Fertile (spore-bearing) and sterile leaves similar. Sporanges pedicelled, provided with a vertical ring, bursting transversely. [Greek, signifying beech-fern.] About 75 species of wide geographic distribution.

Leaves triangular, 2-pinnatifid; pinnæ sessile, adnate to the winged rachis.

Leaves longer than broad, usually dark green.

Leaves as broad as long, or broader, usually light green.

Leaves ternate, with the three divisions petioled ; rachis wingless.

Divisions subequal, often deflexed at right angles to the stipe.

Terminal division largest erect, the leaves thus appearing pinnate.

I. P. Phegopteris.

2. P. hexagonoptera.

3. P. Dryopteris.

4. P. Robertiana.

r. Phegopteris Phegópteris (L.) Underw. (I. F. f. 39.) Rootstock slender, creeping, somewhat chaffy at least when young. Stipes $15-22 \mathrm{~cm}$. long; leaves triangular, thin, mostly longer than wide, $10-25 \mathrm{~cm}$. long, $7-15 \mathrm{~cm}$. wide, acuminate at the apex, pubescent, especially on the veins beneath; pinnælanceolate or linear-lanceolate, acuminate at the apex. sessile, broadest above the base, pinnately parted very nearly to the rachis into oblong obtuse entire segments, the lower pair deflexed and standing forward; basal segments, at least those of the upper pinnæ, decurrent and adnate to the winged rachis. In moist woods, Newf. to Alaska, south to the mountains of Va., Mich. and Wash. Also in Europe and Asia. Aug. ( $P$. polypodioides Fée.)

2. Phegopteris hexagonóptera (Michx.) Fée. (I. F. f. 40.) Rootstock creeping, chaffy, somewhat fleshy. Stipes $2-4.5 \mathrm{dm}$. long, straw-co'ored, naked ; leaves triangular, as broad as or broader than long, 2-3 dm. wide, slightly pubescent and often slightly glandular beneath, acuminate at the apex ; uppermost pinnæoblong, obtuse, dentate or entire, small, the middle ones lanceolate, acuminate, the very large lowest pair broadest near the middle, pinnately parted nearly to the midvein into linear-oblong obtuse segments; sori mostly near the margin. In dry woods, Quebec to Minn., south to Fla. and La: 
3. Phegopteris Dryópteris (L.) Fée. OAK-FERn. (I. F. f. 4I.) Rootstock creeping. Stipes slender, I-3 dm. long, chaffy at least near the base; leaves thin, broadly triangular, almost glabrous, $\mathbf{I}-2 \mathrm{dm}$. wide, ternate, the three primary divisions stalked, pinnate or partly bipinnate, the terminal one slightly larger, all spreading more or less at right angles to the stipe ; pinnules lanceolate or oblong-lanceolate, obtuse to subacute, sessile; segments oblong, obtuse, entire or crenate, close together. In moist woods and swamps, Newf. to Alaska, south to Va., Minn., Or., and in the Rocky Mts. to Colo. Also in Europe and Asia.

4. Phegopteris Robertiàna (Hoffm.) A. Braun. Stipes $15-25 \mathrm{~cm}$. long, straw-colored when dry; leaves 8-20 cm. long, mostly erect, $12-18 \mathrm{~cm}$. wide, deltoid-ovate, bipinnate, the lowest pinnæ much the largest, pinnatifid or again pinnate; upper pinnæe smaller, pinnatifid, lobed or entire; sori numerous. Lab. to Ia. and Idaho. Also in Europe. (Phegopteris Dryopteris Robertiana Davenp.)

\section{FflliX Adans, ${ }_{776}$. [Cystopteris Bernh. 1806.]}

Delicate rock ferns with slender stipes, 2-4-pinnate leaves, and roundish sori borne on the backs of the veins. Indusium membranous, hood-like, attached by a broad base on its inner side and partly under the sorus, early opening and somewhat evanescent. Veins free. Sporanges pedicelled, provided with a transversely bursting vertical ring. [Ancient name of the fern plant.] Five species, natives of the north temperate zone.

\section{Leaves ovate-lanceolate or lanceolate, 2-3-pinnate. \\ Leaves broadest at base, long-tapering, bearing bulblets beneath. \\ Leaves scarcely broader at base, short-pointed; no bulblets. Leaves deltoid-ovate, 3-4-pinnate.}

I. F. bulbifera. 2. F. fragilis. 3. F. montana.

I. Filix bulbifera (L.) Underw. (I. F. f. 23.) Rootstock short, rooting. Stipes Io-1 $5 \mathrm{~cm}$. long, light-colored; leaves elongated, lanceolate from a broad base, 3-8 dm. long, 2-3-pinnatifid or pinnate ; pinnules crowded, toothed or pinnatifid; rachis wingless, commonly bearing underneath, in the axils of the pinnæ and segments, large fleshy bulblets which fall away and propagate the plant; indusia short, truncate on the free side, early thrown back and withering. On moist rocks, especially limestone, Quebec to Wis., south to Tenn. and Ark.

2. Filix frágilis (L.) Underw. (I. F. f. 24.) Rootstock short. Stipes Io-20 $\mathrm{cm}$. long; leaves thin, oblong-lanceolate, slightly tapering below, I-3 dm. long, 2-3. pinnatifid or pinnate; pinnæ lanceolate-ovate, irregularly pinnatifid, with a broad central space and bluntly or sharply toothed segments decurrent along the margined or winged rachis, without bulblets; indusia narrow or acute at the free end, early withering; texture membranous. On rocks and in moist grassy woods, Newf. to Alaska, south to Ga. and Ariz. Almost cosmopolitan.

3. Filix montàna (Lam.) Underw. (I. F. f. 25.) Rootstock widely creeping. Stipes 15-22 cm. long, slender; leaves deltoid-ovate, 3-4-pinnate, about $15 \mathrm{~cm}$. long and broad, the lowest pinnæ deltoid-lanceolate and much larger than the upper, their inferior pinnules $2.5-3 \mathrm{~cm}$. long ; segments deeply divided into oblong lobes, deeply toothed; sori numerous; indusia acute, soon withering. On rocks, Lab. and Quebec to Br. Col., south to the north shore of L. Superior, and Colo. Also in N. Europe and Asia.

\section{WOZ̈DSIA R. Br.}

Small or medium-sized ferns, growing in rocky places, with I-2-pinnate or pinnatifid leaves and round sori borne on the backs of simply forked free veins. Indusia inferior, thin and often evanescent, roundish or stellate, either small and open or early bursting at the top into irregular lobes or segments. Stipes often jointed above the base and separating at the joint. [Name in honor of Joseph Woods, 1776-1864, English architect and botanist.] About 15 species, natives of temperate and cold regions. 
Stipes obscurely jointed near the base; cilia of the indusium inflexed over the sporanges.

Leaves with more or less rusty chaff underneath.

Leaves glabrous or nearly so.

I. W. Ilvensis.

Leaf lanceolate, not tapering below; pinnæ cordate-ovate, 5 - 7 -lobed.

2. W. alpina.

Leaf linear or linear-oblong, often tapering•both ways; pinnæ deltoid.

3. W. glabella.

Stipes not jointed; cilia of the indusium very short, hidden by the sporanges.

Puberulent; indusium deeply cleft, ending in hairs with cylindric cells.

Leaves and stipes glabrous; indusium divided to centre into beaded hairs.

5. W. Oregana.

Indusium distinct, at first enclosing the sporanges, splitting into jagged lobes.

\section{W. obtusa.}

I. Woodsia Ilvénsis (L.) R. Br. (I. F. f. I6.) Rootstock short, cæspitose. Leaves lanceolate, IO- $25 \mathrm{~cm}$. long, glabrous above, more or less covered with rusty chaff beneath, as are also the slender stipes; pinnæ crowded, sessile, pinnately parted, the crowded segments oblong, obscurely crenate; stipes jointed near the base; sori borne near the margins of the segments, somewhat confluent when old; indusium minute, concealed beneath the sorus, its margin cleft into filiform segments, which are inflexed over the sporanges and inconspicuous, especially when mature. On exposed rocks, Lab. and Greenland to Minn., south to N. Car. and Ky. Also in Europe and Asia.

2. Woodsia alpìna (Bolton) S. F. Gray. (I. F. f. I7.) Rootstock short, cæespitose. Leaves narrowly oblong-lanceolate, 5-15 cm. long, I5-25 cm. wide, scarcely narrower below; pinnæ cordate-ovate or triangular-ovate; pinnately 5-7-lobed, glabrous or very nearly so on both surfaces; stipes jointed near the base; sori somewhat scattered on the segments; indusium as in the preceding species. On moist rocks, Lab. to Alaska, south to N. B., N. N. Y. and W. Ont.

3. Woodsia glabélla R. Br. (I. F. f. I8.) Rootstock small, cæspitose. Stipes obscurely jointed at the base; leaves linear or lanceolate, 5-12 cm. long, 8-15 mm. wide; pinnæ deltoid to ovate, the lower remote, obtuse, crenately lobed, often somewhat smaller than the middle ones, glabrous or nearly so; sori scattered on the segments; indusium minute, membranous, with 6-1o radiating segments, covered by the sporanges, its filamentous segments only inflexed over them when young. On moist rocks, Lab. to Alaska, south to N. H., Vt., N. N. Y. and the north shore of L. Superior. Also in arctic and alpine Europe and Asia.

4. Woodsia scopulina D. C. Eaton. (I. F. f. I9.) Rootstock short, densely chaffy. Stipes 5-10 cm. long, not jointed, puberulent like the rachis and lower surface of the leaf with minute flattened hairs and stalked glands; leaves lanceolate, I2-25 cm. long, tapering from about the middle to both ends; pinnæ numerous, oblong-ovate, pinnatifid into IO-16 oblong toothed segments; indusium hidden beneath the sporanges, very deeply cleft into short cilia with cylindric cells. In crevices of rocks, N. Minn. and W. Ont. to Or., south in the Rocky Mts. to Ariz., and in the Sierra Nevada to Cal. Summer.

5. Woodsia Oregàna D. C. Eaton. (I. F. f. 20.) Rootstock short. Stipes and leaves glabrous; stipes not jointed, brownish below; leaves $5^{-25} \mathrm{~cm}$. long, elliptic-lanceolate, the sterile shorter than the fertile; pinnæ triangular-oblor.g, obtuse, pinnatifid; lower pinnæ reduced in size and somewhat remote from the others; rachis straw-colored; segments oblong or ovate, dentate or crenate, the teeth often reflexed and covering the submarginal sori; indusia minute, concealed by the sporanges, divided almost to the centre into a few beaded hairs. On rocks, N. Mich., Minn. and Manitoba to Br. Col., south in the Rocky Mts. to Ariz., and in the Sierra Nevada to Cal. July-Aug.

6. Woodsia obtùsa (Spreng.) Torr. (I. F. f. 21.) Rootstock short. Stipes not jointed, pale green, 7-15 cm. long; leaves broadly lanceolate, 15-40 cm. long, minutely glandular-pubescent, nearly 2-pinnate; pinnæ rather remote, triangularovate, or oblong, pinnately parted into obtuse oblong crenate-dentate segments; veins forked and bearing the sori on or near the minutely toothed lobes; indusia conspicuous, at first enclosing the sporanges, at length splitting into several jagged lobes, which are much wider than those in any of the preceding species, On 
rocks, N. S. to N. N. Y., Wis. and Br. Col., south to Ga., Ala., the Ind. Terr. and Ariz. Ascends to $670 \mathrm{~m}$. in Va. July-Aug.

\section{I7. DENNSTAÉDTIA Bernh.}

Large ferns with 2 3-pinnatifid leaves, and creeping or erect rootstocks. Sori small, globular, marginal or submarginal. Sporanges borne in an elevated globular receptacle, enclosed in the membranous cup-shaped inferior indusium, which is open at the top and on the outer side adherent to a reflexed toothlet of the leaf. Sporanges pedicelled, provided with a vertical ring which bursts transversely. Veins always free. [Named in honor of August Wilhelm Dennstedt, a student of the Flora of Weimar.] About 30 species of wide distribution.

I. Dennstaedtia punctilobula (Michx.) Moore. (I. F. f. 22.) Rootstock creeping, not chaffy. Stipes stout, chaffless, pale green and sweet-scented ; leaves 3Io dm. long, $\mathbf{I} 2-20 \mathrm{~cm}$. wide, ovate-lanceolate, acute or acuminate, frequently longattenuate, usually 3-pinnatifid, thin and delicate ; rachis and under surface minutely glandular and pubescent; sori minute, each on a recurved toothlet, usually one at the upper margin of each lobe ; sporanges few ; indusium cup-shaped with a delicate membranous irregular margin. In various situations, most abundant on open hillsides, N. B. and Ont. to Ind. and Minn. (according to Upham), south to Ala. and Tenn. Ascends to $1680 \mathrm{~m}$. in Va. Aug. (Dicksonia punctilobula A. Gray.)

18. MATTEÚCCIA Todaro, 1866. [Struthiopteris Willd, 1809. Not Scop. 1760.]

Coarse ferns griwing in a crown from an erect rootstock, with the sporophylls closely rolled tugether into necklace-like segments entirely unlike the broad bipinnatifid sterile leaves. Veins free.-Three species of the northern hemisphere.

I. Matteúccia Struthićpteris (I.) Todaro. Ostrich Fern. (I. F. f. I5.) Rootstock stout, ascending, bearing a circle of sterile leaves with one or more fertile ones within. Fertile leaves 3-5 dm. high, simply pinnate with necklaceshaped pinnæ which are formed of the closely revolute margins; sori crowded and confluent ; sterile leaves $6 \mathrm{dm} .-2 \mathrm{~m}$. high, 1.5-4 dm. wide, broadly lanceolate, bipinnatifid, much the broadest above the middle and gradually tapering below, the lower pinnæ being gradually much reduced; veins pinnate, free and simple; texture firm ; rootstocks stoloniferous. In moist thickets, especially along streams, N. S. to Md., west to Ill. and Br. Col. Also in Europe and Asia.

\section{ONOCLÈA L.}

Coarse ferns, with leaves growing separately from a wide creeping slender rootstock, with the sporophylls closely rolled up into berry-like segments, and entirely unlike the broad pinnatifid foliage leaves. Sori round, borne on the back of the veins. Indusium very thin and membranous, hemispheric or hood-shaped, fixed at the inferior side of the sorus. Sporophylls unrolling at maturity, allowing the spores to escape, and remaining long after the sterile leaves have been killed by frost. Veins forming small areolæ. [Name ancient, not originally applied to these plants.] A single species.

I. Onoclea sensibilis L. Sensitive FerN. (I. F. f. I4.) Rootstock rather slender, rooting ; sporophylls 3-7 dm. high, persistent over winter, much contracted, and with short pinnules rolled up into berry-like closed involucres forming a narrow panicle; foliage leaves $3^{-1} 3 \mathrm{dm}$. high, broadly triangular, deeply pinnatifid, the segments lancéolate-oblong, entire, undulate, or the lower pairs sinnuate-pinnatifid; veins freely anastomosing; lowest segments tapering both ways from the middle. In moist soil, Newf. and Ont. to Minn. and south to the Gulf. Ascends to $900 \mathrm{~m}$. in Va. Various forms intermediate between sporophylls and foliage leaves occur. Sensitive to early frosts. Aug.-Nov.

\section{Order 2. SALVINIÀLES.}

Aquatic or uliginous herbs with entire or 2-lobed, filiform, or 4-foliolate leaves. Spores of two kinds and sizes (microspores and macrospores) contained in sporocarps. 


\section{Family r. MARSILEACEAE R. Br.}

Perennial herbaceous plants rooting in mud, with slender creeping rootstocks and 4 -foliolate or filiform leaves. Asexual propagation consisting of sporocarps borne on peduncles which rise from the rootstock near the leaf-stalk or are consoiidated with it, containing both macrospores and microspores. The macrospores germirate into prothallia which bear archegonia, while the microspores grow into prothallia bearing antheridia. Two genera and some 45 species of wide distribution.

\section{MARSíLEA L.}

Marsh or aquatic plants, the leaves commonly floating on the surface of shallow water, slender-petioled, 4-foliolate. Peduncles shorter than the petioles, arising from their bases or more or less adnate to them. Sporocarps ovoid or beanshaped, composed of two vertical valves with several transverse compartments (sori) in each valve. [Name in honor of Giovanni Marsigli, an Italian botanist, who died about $\mathrm{r} 804$.] About 40 species, widely distributed.

Sporocarps glabrous and purple when mature.

Sporocarps dense, y covered with hair-like scales.

r. M. quadrifolia.

2. M. vestita.

I. Marsilea quadrifòlia L. European Marsilea. (I. F. f. 73.) Rootstock slender, buried in the muddy bottoms of shallow lakes or streams. Petioles usually slender, $5^{-\mathrm{I}} 3 \mathrm{~cm}$. high, or when submerged sometimes elongated to 3-6 $\mathrm{dm}$. Leaflets mostly triangular-obovate, variable in outline, 6-16 mm. long, 4-12 $\mathrm{mm}$. wide, glabrous or rarely with scattered hairs when young, the margins entire; sporocarps 2 or rarely 3 on a branching peduncle, which is attached to the petiole at its base, covered with short yellowish-brown hairs when young, becoming glabrous and dark purple when mature; sori 8 or 9 in each valve. Along the shores of Bantam Lake, Litchfie'd Co., Conn., whence it has been introduced into various parts of the country, notably into $\mathrm{E}$ Mass. Also in Europe and Asia.

2. Marsilea vestıta Hook \& Grev. (I. F. f. 74.) Rootstock slender. Petioles slender, 5-13 cm. high; leaflets similar to those of the preceding species, entire or toothed; sporocarps 4-8 $\mathrm{mm}$. long, 4-6 $\mathrm{mm}$. wide, with a short raphe, a short and blunt lower tooth and an acute and sometimes curved upper one, densely covered with soft spreading narrow hair-like scales, or (in the forms known as $\dot{M}$. mucronata) these are short and appressed or almost wanting; sori 6-II in each valve. In wet sand or in shallow ditches, Kan. to Ariz. and Mex., north to Br. Col. Also found in Fla.

\section{Family 2. SALVINIÀCEAE Reichenb.}

Small floating plants with a more or less elongated and sometimes branching axis bearing apparently 2-ranked leaves. Sporocarps soft, thin-walled, borne 2 or more on a common stalk, I-celled, with a central often branched receptacle, which bears macrosporanges containing a single macrospore or microsporanges containing numerous microspores. The macrospores germinate into prothallia which bear archegones, the microspores into prothallia which bear antherids. The family consists of two genera.

Leaves 12-18 mm. long, 2-ranked, on mostly simple stems.

Leaves minute, closely imbricated on pinnately branching stems.

1. Salvinia.

2. Azolla.

\section{SALVínia Adans.}

Floating annual plants with slender stems bearing rather broad 2-ranked leaves. Sporocarps globose, depressed, 9-14-sulcate, membranous, arranged in clusters, I or 2 of each cluster containing ro or more sessile macrosporanges, each containing few macrospores, the others containing numerous smaller globose pedicelled microsporanges with very numerous microspores, Leaves rather dark 
green, finely papillose on the upper surface. [Name in honor of Antonio Maria Salvini, I633-1729, Italian scientist.] About 13 species of wide distribution.

I. Salvinia nàtans (L.) Hoffm. (I. F. f. 75.) Leaves oblong, rather thick, obtuse or emarginate at the apex, rounded or cordate at the base, entire, 15-30 $\mathrm{cm}$. long, pinnately veined, bright green and papillose above, the lower surface densely matted with brown pellucid hairs; sporocarps $4-8$ in a cluster, the upper ones containing about Io macrosporanges, each containing a few macrospores, the remainder containing numerous microsporanges each with numerous microspores; macrosporcs marked with 3 obtuse lobes which meet at the apex. Bois Brulé Bottoms, Pcrry Co., Mo., and near Minneapolis, Minn. Introduced into ponds in S. E. N. Y. Reported by Pursh in 1814 from Cent. N. Y., but his exact station is unknown. Also in Europe and Asia.

\section{Azólla Lam.}

Minute moss-like reddish or green floating plants, with pinnately branched stems covered with minute imbricated 2 -lobed leaves, and emitting rootlets beneath. Sporocarps of two kinds borne in the axils of the leaves, the smaller ovoid or acornshaped, containing a single macrospore at the base and a few corpuscles above it whose character is not fully known, the larger globose, producing many pedicelled sporanges, each containing several masses of microspores which are often beset with a series of anchor-like processes of unknown function. [Greek, signifying killed by drought.] About 5 species of wide geographic distribution.

I. Azolla Caroliniàna Willd. (I. F. f. 76.) Plants greenish or reddish, 2-4 $\mathrm{mm}$. each way, deltoid or triangular-ovate, pinnately branching, sometimes covering large surfaces of water. Macrospores minutely granulate, with three accessory corpuscles ; masses of microspores armed with rigid septate processes; leaves with ovate lobes, their color varying somewhat with the amount of direct sunlight, the lower usually reddish, the upper green with a reddish border. Floating on still water, Ont. and W. N. Y. to Br. Col., south to Fla., Ariz. and Mex.

\section{Order 3. EQUISETÀLES.}

Rush-like perennial plants, with mostly hollow jointed simple or often much-branched grooved stems, provided with a double series of cavities and usually with a large central one, the branches verticillate, the nodes provided with diaphragms. Rootstocks subterranean. Leaves reduced to sheaths at the joints, the sheaths toothed. Sporanges Icelled, clustered underneath the scales of terminal cone-like spikes. Spores all of the same size and shape, furnished with 2 narrow strap-like appendages attached at the middle, coiling around the spore when moist and spreading, when dry and mature, in the form of a cross (elaters). Epidermis impregnated with silica, rough. Prothallium on the surface of the ground, green, usually diœecious.

\section{Family 1. EQUISETÀCEAE Michx. \\ Horsetail Family.}

The family consists of the following genus :

\section{EQUisètum L. Horsetails. Scouring Rushes.}

Characters of the order. [Name ancient, signifying horsetail, in allusion to the copious branching of several species.] About 25 species, of very wide geographic distribution.

Stems annual ; stomata scattered.

Stems of two kinds, the fertile appearing in early spring before the sterile.

Fertile stems simple, soon withering; sheaths of branches of sterile stems 4-toothed.

Fertile stems branched when old, only the apex withering.

Branches of the stem simple, their sheaths 3 -toothed.

Branches compound

I. E. arvense.

2. E. pratenso.

3. E. sylvaticum. 
Stems all alike; spores mature in summer; branches simple or none.

Sheaths rather loose; branches usually long; stems bushy below, attenuate upwards.

Central cavity fery small; spike long.

4. E. palustre.

4. E. palustre.
short.

Sheaths appressed; branches usually short.

5. E. littorale.

6. E. fuviatile.

Stems perennial, evergreen; spikes tipped with a rigid point; stomata in regular rows. Stems tall, usually many-grooved.

Stems rough and tuberculate, prominently ridged.

Ridges with I line of tubercles; ridges of sheath tricarinate; stem stout.

7. E. robustum.

Ridges of the stem with 2 indistinct lines of tubercles; ridges of sheath obscurely 4-carinate; stem slender.

Stems not tuberculate; sheaths enlarged upward.

Stems low, slender, tufted, usually 5-10-grooved.

Central cavity small; sheaths 5 -ro-toothed.

Central cavity none; sheaths 3 -toothed.

8. E. hyemale.

9. E. laevigatum.

10. E. variegatum.

II. E. scirpoides.

I. Equisetum arvénse L. Field HorsetaIl. (I. F. f. 77.) Stems annual, with scattered stomata, the fertile appearing in early spring before the sterile. Fertile stems $\mathbf{I}-\mathbf{2 . 5} \mathrm{dm}$. high, not branched, soon withering, light brown, their loose scarious sheaths mostly distant, whitish, ending in about $\mathbf{2} 2$ brown acuminate teeth ; sterile stems green, rather slender, $5 \mathrm{~cm},-6 \mathrm{dm}$. high, 6-19-furrowed, with numerous long mostly simple verticillate 4 -angled or rarely 3 -angled solid branches, the sheaths of the branches 4 -toothed, the stomata in 2 rows in the furrows; central cavity one-fifth to one-fourth the diameter of the stem. In sandy soil, especially along roadsides and railways, Newf. and Creenland to Alaska, south to Va. and Cal. Also in Europe and Asia. An occasional form in which the sterile stem bears a terminal spike is known as var. serotinum.

2. Equisetum praténse Ehrl. (I. F. f. 78.) Stems annual, 2-4 dm. high, with scattered stomata, the fertile appearing in spring before the sterile, branched when old, only its apex withering, the two becoming similar; stems rough, $8-20$ ridged with narrow furrows and cylindric or cup-shaped sheaths ; branches straight, rather short, simple, densely whorled, 3-angled or rarely 4-5-angled, solid; sheaths of the stem with about II short ovate-lanceolate teeth, those of the branches 3-toothed; rootstocks solid, acutely angled. In sandy places, N. S. and Rupert R. to Minn., and Alaska, south to N. J. and Colo. Also in Europe and Asia.

3. Equisetum sylváticum. L. (I. F. f. 79.) Stems annual, with scattered stumata, the fertile appearing in early spring before the sterile, at first simple, at length much branched and resembling the sterile, only its naked apex withering. Stems 2-5 dm. high, usually 12-furrowed, producing verticillate compound branches, the branchlets curved downward; sheaths loose, cylindric or campanulate, those of the stem with 8-14 bluntish teeth, those of the branches with 4 or 5 teeth, those of the branchlets with 3 divergent teeth; central cavity nearly one-lialf the diameter of the stem; branches and branchlets solid. In moist sandy woods and thickets, Newf. and Greenland to Alaska, south to Va. and Mich. Also in Europe and Asia.

4. Equisetum palústre L. (I. F. f. 8o.) Stems annual, slender, all alike, 2.5-4.5 dm. long, deeply 5-9-grooved, the grooves separated by narrow roughish winglike ridges, the central canal small; sheaths rather loose, bearing about 8 subulatelanceolate whitish-margined teeth ; branches simple, few in the whorls, 4-7-angled. always hollow, barely sulcate, more abundant below than above, their sheaths mostly 5-toothed; spike rather long; stomata abundant in the furrows. In wet places, N. S. to Alaska, south to Me., W. N. Y., Minn. and Ariz. Also in Europe.

5. Equisetum littoràle Kuehl. (I. F.f. 81.) Stems annual, very slender, all alike, $2-4.5 \mathrm{dm}$. high, slightly roughened. $6-19$-grooved, the ridges rounded, the central canal one-half to two-thirds the diameter; sheaths dilated above, the uppermost inversely campanulate, their teeth herbaceous, membranous at the margins, narrow, lanceolate; branches of two kinds, simple, some 4-angled and hollow, some 3 -angled and solid, the first joint shorter or a trifle longer than the sheath of the stem; spike short with abortive-spores, these commonly with no elaters. On sandy river and lake shores, Me, and Ont. to N. J. and Penn., west to Br. Col. Also in Europe. 
6. Equisetum fluviátile L. (I. F. f. 82.) Stems annual, all alike, 6-12 dm. high, 10-30-furrowed, very smooth, usually producing upright branches after the spores are formed, the stomata scattered. Sheaths appressed with about I8 dark brown short acute rigid teeth, air cavities wanting under the grooves, small under the ridges; central cavity very large ; branches hollow, slender, smaller but otherwise much like the stems, short or elongated; rootstocks hollow. In swamps and along the borders of ponds, N. S. to Alaska, south to Va., Neb. and Wash. Also in Europe and Asia.

7. Equisetum robústum A. Br. (I. F. f. 83.) Stems perennial, stout, tall, evergreen, $1-2.5 \mathrm{~m}$. high, sometimes $2 \mathrm{~cm}$. in diameter, 20-48-turrowed, simple or little branched. Ridges roughened with a single series of transversely oblong siliceous tubercles; sheaths short, cylindric, appressed, marked with black girdles at the base, and at the bases of the dark caducous teeth; ridges of the sheath 3-carinate; branches when present occasionally fertile; spikes tipped with a rigid point. In wet places, $\mathrm{O}$ to La. and Mex., west to $\mathrm{Br}$. Col. and Cal. Also in Asia. May-June.

8. Equisetum hyemàle L. Scouring-Rush. (I. F. f. 84.) Stems slender, rather stiff, evergreen, 6-12 dm. high, with the stomata arranged in rows, rough, 8-34-furrowed, the ridges with two indistinct lines of tubercles, the central cavity large, from one-half to two-thirds t'e diameter; sheaths rather long, cylindric, marked with one or two black girdes, their ridges obscurely 4-carinate; teeth brown, membranous, soon deciduous; spikes pointed; stem rarely producing branches which are usually short and occasionally fertile; forms are sometimes found with longer sterile branches. In wet places and on banks, especially along rivers and lakes, throughout nearly the whole of N. Am., Europe and Asia.

9. Equisetum laevigàtum A. Br. (I. F. f. 85.) Stems $3-15 \mathrm{dm}$. high, simple or little branched, pale green, persistent, 14-30 furrowed, the ridges almost smooth. Slieaths elongated and enlarged upward, with a black girdle at the base of the mostly deciduous, white-margined teeth and rarely also at their bases; ridges of the sheath with a faint central carina and sometimes with faint short lateral ones; stomata arranged in single series; central cavity very large, the wall of the stem very thin ; spikes pointed. Along streams and rivers, especially in clay soil, valiey of the Delaware R. in N. J. and E. Penn. to N. Car. and La., west to Br. Col. and the Mexican border.

10. Equisetum variegàtum Schleich. (I. F. f. 86.) Stems slender, perennial, evergreen, $1.5-4.5 \mathrm{dm}$. long, usually simple from a branched base, tufted, 5-Io-furrowed, the stomata borne in regular rows. Sheaths companulate, distinctly 4-carinate, variegated with black above, the median furrow deep and excurrent to the teeth and downward to the ridges of the stem, the teeth 5-10, each tipped with a deciduous bristle; central cavity small, rarely wanting. Lab. and Greenland to N. Terr., south to N. H., W. N. Y., Neb. and Nev. Also in Europe and Asia. May-June.

II. Equisetum scirpoldes Michx. (I. F. f. 87.) Stems perennial, evergreen, filiform, 4-15 cm. long, somewhat rough, flexuous and curving, growing in s'ender tufts, mostly 6-furrowed with acute ridges, simple or branching from near the base. Sheaths 3-toothed, distinctly 4-carinate, the central furrow broad, the lateral narrow, the bristly teeth rather persistent ; central cavity entirely wanting. On moist or wet wooded banks. Lab. to Alaska, south to Penn., Ill. and Br. Col. Also in Europe and Asia.

\section{Order 4. LYCOPODIÀLES.}

Spores produced in sporanges, which are borne in the axils of scalelike or elongated leaves.

Spores all of one sort and size.

Fam. I. Lvcosodiaceae.

Spores of two sizes,

Leaves scale-like, 4-many-ranked, on branching stems.

Fam. 2 . Selag
Leaves elongated, clustered on a corm-like trunk ; aquatic or mud plants.

Fam. 3. Iscetaceae, 


\section{Family I. LYCOPODIÀCEAE Mỉchx.}

\section{Club-moss Family.}

Somewhat moss-like, erect or trailing terrestrial herbs with numerous small lanceolate or subulate simple leaves, sometimes oblong or roundish, arranged in 2-many ranks, the stems often elongated, usually freely branching. Sporanges I-3-celled, solitary in the axils of the leaves or on their upper surfaces. Spores uniform, minute. Prothallia (as far as known) mostly subterranean, with or without chlorophyll, monœcious. Four genera and about I Io species.

\section{LYCOPòdIUM L. Club-mosses. (See Appendix.)}

Perennial plants with evergreen I-nerved leaves arranged in 4-16 ranks. Sporanges coriaceous, flattened, reniform, I-celled, situated in the axils of ordinary leaves or in those of the upper modified, bract-like ones, which are imbricated in sessile or peduncled spikes, opening transversely into 2 valves, usually by a line around the margin. Spores all of one kind, copious, sulphur-yellow, readily inflammable from the abundant oil they contain. [Greek, meaning wolf's foot, perhaps in allusion to the branching roots of some species.] About 100 species of wide distribution.

Sporanges borne in the axils of leaves which are similar to those of the stem.

Sporanges mostly wanting in the axils of the upper, mostly 8-ranked leaves.

Stems mostly erect, rigid; leaves uniform, ascending. $\quad$ 1. L. Selago.

Stems somewhat lax, spreading; leaves spreading or deflexed, alternately longer and shorter.

2. L. lucidulum.

Sporanges only in the axils of the upper leaves forming terminal spikes; leaves many-ranked.

Plant slender; leaves acute, soft, mostly entire.

3. L. inundatum.

Plant stout; leaves narrow, spinulose-pointed, bristle-toothed below the middle. 4. L. alopecuroides.

Sporanges borne in the axils of yellowish ovate or cordate scale-like leaves, which are very unlike those of the sterile stems.

Stems leafy up to the base of the spike or nearly so.

Spikes erect, closely sessile.

Stems erect, tree-like.
Stems creeping with ascending branches.

Leaves uniform, spreading, 5-ranked.

Leaves of 2 forms, erect-imbricate, 4-ranked.

\section{L. obscurum.}

6. L. annotinum.

7. L. alpinum.

Spikes erect, short-peduncled; leaves small, appressed, 4-ranked.

8. L. sabinaefolium.

Fertile branches with minute leaves so that the spikes appear long-peduncled.

Leaves uniform, many-ranked; stems terete.

Leaves of 2 forms, few-ranked; stems flattened.

9. L. clavatum.

Sterile stems entirely creeping; spikes solitary.

Sterile stems with fan-like ascending branches; spikes clustered.

10. L Carolinianum.

II. L complanatum.

I. Lycopodium Selàgo L. (I. F. f. 88.) Stems 7-I5 cm. high, thick, rigid, erect, 2-5 times forked, the branches forming a level-topped cluster. Leaves crowded, uniform, ascending, elongated-lanceolate, mucronulate, entire or spinulose-denticulate, nerved below, convex above, the upper mostly 8-ranked, steri'e, those below bearing the small sporanges in their axils, those of the lower half of the stem again sterile; plant propagated also by bud-like organs which have a lower pointed bract and 2 or 3 upper fleshy and obovate ones. On rocks, Lab. and Greenland to Alaska, south to the mountains of Me., N. H., Vt. and N. N. Y., on the summits of the higher Alleghenies to N. Car., and to Mich. and Wash. Also in Europe and Asia.

2. Lycopodium lucídulum Michx. (I. F. f. 89.) Stems lax, ascending or spreading, thick, 2-3 times forked, the branches I.5-3 dm. high. Leaves widely spreading or reflexed, dark green, shining, r-nerved, acute, minutely toothed, a series of longer ones alternating with a series of shorter, the latter more frequently bearing the sporanges at a short distance below the summit of the stem; sporanges 
of preceding years often persistent; plant also propagated like the preceding species by gemmae, which fall to the ground and become new plants. In cold, damp woods, Newf. to Br. Col. south to N. Car. and Ia.

3. Lycopodium inundàtum L. (I. F. f. 90.) Plants, $2.5-13 \mathrm{~cm}$. long, with creeping flaccid forking brittle sterile stems closely appressed to the earth. Fertile stems erect, solitary, $2.5-15 \mathrm{~cm}$. high, terminated by a short spike ; leaves lanceolate or lanceolate-subulate with hyaline margins, those of the spike similar to those below, acute, soft, spreading, mostly entire, those of the sterile stems curved upward; spikes rarely two together, $1.5-3.5 \mathrm{~cm}$. long, yellowish; sporanges transversely oval, splitting nearly to the base; spores large, reticulated. In sandy bogs, Newf. to W. Ont. and Mich., south to Fla. Also in Europe and Asia. Larger forms with fertile stems $12-17 \mathrm{~cm}$. high and more pointed serrate leaves have been separated as var. Bigelovii.

4. Lycopodium alopecuroides I. (I. F. f. 9I.) Plant stout, leafy, the sterile branches flaccid, recurved and creeping, sometimes $25 \mathrm{~cm}$. long. Fertile stems stout, rigid, erect, I5-50 cm. high, terminated by a spike $1.8-3.5 \mathrm{~cm}$. long, and, including its leaves, 8-10 mm. thick; leaves narrowly linear-subulate, those of the spike similar to those below, spinulose-pointed, spreading, conspicuously bristletoothed below the middle, those of the spike with long setaceous tips; sporanges transversely oval, splitting to near the base. In pine-barren swamps, N. J. to Fla., near the coast, west to Miss.

5 Lycopodium obscùrum L. Ground Pine. (I. F. f. 92.) Stems erect, I.5-3 $\mathrm{dm}$. high, bushy, the branches fan-like, the rootstocks subterranean, nearly horizontal. Leaves lanceolate-linear, acute, entire, 8-ranked on the main stem, those of the branches 6-ranked, with the two upper and the two lower ranks shorter and appressed, or all alike and equally incurved-spreading, densely clothing the stems up to the bases of the spikes; spikes I-IO on each plant, I2-35 cm. long, composed of many-ranked ovate scarious-margined bracts (scale-like leaves), each with a transversely oval sporange in its axil. In moist woods, Newf. and Lab. to Alaska, south to N. Car. and Ind. Also in Asia. (L. dendroideum Michx.)

6. Lycopodium annótinum L. (I. F. f. 93 ) Stems much branched, slender, creeping, rather stiff, 3-12. dm. long, the branches similar, ascending, $12-20 \mathrm{~cm}$. high, sparingly forked. Leaves uniform, sprealing, 5-ranked, rigid, linear. lanceolate, minutely serrulate, nerved below; spikes solitary or several at the ends of the branches, oblong-cylindric, $2.5-6 \mathrm{~cm}$. long, composed of ovate or ovatecordate, short-acuminate and denticulate bracts, each with a sporange in its axil; spores smooth or spinulose-reticulated on the basal surface. In woods and thickets, commonly in dry soil, Lab. to Alaska, sonth to N. J., W. Va., Mich., Colo. and Wash. Also in Europe and Asia. Mountain forms with more rigid pointed leaves have been separated as var. pungens.

7. Lycopodium alpınum L. (I. F. f. 94.) Stems elongated, creeping, with ascending densely crowded dichotomous branches. Leaves 4-ranked, erect-imbricate, adnate-decurrent, of two forms; those of the lateral rows lanceolate, falcate, acute, carinate, concave within, those of the intermediate rows scarcely one-third as large, lanceolate-subulate, the upper and lower rows alike; spikes solitary at the apices of slightly elongated branches, erect, closely sessile, the stems leafy to their bases; bracts broadly ovate, acuminate, dentate; spores reticulated. In woods, Lab. to L. Superior, Wash. and Alaska. Sometimes united with L. com. planalum. Also in Europe and Asia.

8. Lycopodium sabinaefòlium Willd. (I. F. f. 95.) Stems elongated, creeping, or subterranean with short erect dichotomous clustered ascending branches, 5-8 cm. long. Leaves 4-ranked, small, appressed or slightly curved outward, lanceolate, mucronate, entire, apparently terete ; spikes short-peduncled, solitary, cylindric, with cordate acuminate erose-denticulate or entire bracts; sporanges transversely oval or somewhat reniform, deeply splitting. In cold woods, Lab. to N. J. and $\mathrm{Br}$. Col.

9. Lycopodium clavàtum L. Running Pine. (I. F. f. 96.) Stems creeping, 3-20 dm. long, with similar short irregular ascending or decumbent densely leafy branches. Leaves much crowded, many-ranked, incurved, linear-subulate, bristle-tipped, the lower denticulate, the upper nearly entire and slightly decurrent on either side ; spikes I-4 on long 8-striate peduncles; bracts membranous, round. 
ish, erose-denticulate below, bearing in the axil a transversely oval sporange which splits nearly to the base ; spores narrowly reticulate. In woods, Lab. to Alaska, south to N. Car., Mich and Wash. Also in Europe, Asia and Cent. Am.

ro. Lycopodium Caroliniànum L. (I. F. f. 97.) Sterile stems and their few short branches creeping, closely appressed to the earth, $2.5-8 \mathrm{~cm}$. long, emitting numerous roots on the lower side. Leave of fertile stems of two forms, the lateral ones broadly lanceolate, acute, and somewhat oblique, I-nerved, widely spreading, in 2 ranks with a shorter, intermediate row appressed on the upper side; peduncles simple, slender, $5^{-15} \mathrm{~cm}$. high, clothed with small oract-like leaves and bearing a single cylindric spike; bracts cordate, short-acuminate, mostly entire with trans. versely oval sporanges in the upper axils. In moist pine-barrens, N. J. to Fla. and La. near the coast.

II. Lycopodium complanàtum L. (I. F. f. 98.) Stems extensively creeping, with erect or ascending fan-shaped branches several times forked above, with crowded flattened branchlets. Leaves minute, imbricate-appressed, 4-ranked, the lateral rows with somewhat spreading tips, the intermediate smaller, narrower and wholly appressed, forming a flat surface; peduncle slender, 5-I5 cm. high, dichotomous, bearing 2-4 linear-cylindric spikes; bracts broadly ovate, acuminate, the margins pale and erose : sporanges transversely oval, deeply splitting. In woods and thickets, Newf. to Alaska, south to N. Car., Mich. and Br. Col. Also in Europe and Asia. Forms with less distinctly dimorphous leaves and narrower, more erect and bushy branches have been separated as var. Chamaecyparissus.

\section{Family 2. SELAGINELLÀCEAE Underw.}

Terrestrial, annual or perennial, moss-like plants with branching stems and scale-like leaves, which are many-ranked and uniform, or 4ranked and of two types spreading in two planes. Sporanges I-celled, solitary in the axils of leaves which are so arranged as to form more or less quadrangular spikes, some containing 4 macrospores (macrosporanges), others containing numerous microspores (microsporanges), which develop into small prothallia, those from the macrospores bearing archegones, those from the microspores antherids. The family consists of the following genus:

\section{SELAGINÉLLA Beauv.}

Characters of family. [Name diminutive of Selago, ancient name of a Lyco. podium.] About 340 species, widely distributed, most abundant in tropical regions.

Stem-leaves all alike, many-ranked.

Stems compact with rigid leaves; spikes quadrangular.

Stems slender; leaves lax, spreading; spikes enlarged, scarcely quadrangular.

Stem-leaves of 2 kinds; 4 -ranked, spreading in 2 planes.

I. S. rupestris.

2. S. selaginoides.

3. S. apus

I. Selaginella rupéstris (L.) Spring. (I. F. f. 99.) Stems tufted, with occa. sional sterile runners and sub-pinnate branches, $2.5-8 \mathrm{~cm}$. high, commonly curved when dry. Leaves rigid, appressed-imbricated, $2 \mathrm{~mm}$. or less long, linear or linearlanceolate, convex on the back, more or less ciliate, many-ranked, tipped with a distinct transparent awn; spikes sessile at the ends of the stem or branches, strongly quadrangular, $12-25 \mathrm{~mm}$. long, about $2 \mathrm{~mm}$. thick; bracts ovate-lanceolate, acute or acuminate, broader than the leaves of the stem ; macrosporanges and microsporanges borne in the same spikes, the former more abundant. On dry rocks, Me. to Ont. and $\mathrm{Br}$. Col., south to Ga., Mo. and Cal.

2. Selaginella selaginoides (L.) Link. (I. F. f. I00.) Sterile branches creeping, slender, $12-50 \mathrm{~cm}$. long, the fertile erect or ascending, thicker, $2.5-8 \mathrm{~cm}$. high, simple; leaves lanceolate, acute, lax and spreading, sparsely spinulose-ciliate, 2-4 mm. long ; spikes solitary at the ends of the fertile branches, enlarged, oblonglinear, subacute, $2.5 \mathrm{~cm}$. or less long, 4-5 mm. thick; bracts of the spike lax, ascending, lanceolate or ovate-lanceolate, strongly ciliate. On wet rocks, Lab. to Alaska. south to N. H., Mich. and Colo. Also in N. Europe and Asia. 
3. Selaginella apus (L.) Spring. (I. F. f. ror.) Annual, light green, stems creeping, $2.5-10 \mathrm{~cm}$. long, much branched, flaccid, angled on the face. Leaves minute, membranous, of 2 kinds, 4-ranked, spreading in 2 planes : upper leaves of the lower plane spreading, the lower reflexed, ovate, acute, serrulate, not distinctly ciliate; leaves of the upper plane ovate, short-cuspidate; spikes $6-16 \mathrm{~mm}$. long, obscurely quadrangular; bracts ovate, acute, sometimes serrulate, acutely keeled in the upper half; macrosporanges more abundant toward the base of the spike. In moist shaded places, often among grass, Me. and Ont. to the N. W. Terr., south to Fla., La. and Tex.

\section{Family 3. ISOETÀCEAE Underw. Quillwort Family.}

Aquatic or marsh plants rooting in the mud, with a short buried 2lobed or 3-lobed trunk (stem) sending out abundant roots and sending up a compact tuft of rush-like leaves. Sporanges sessile in the axils of the leaves, some containing macrospores (macrosporanges), others microspores (microsporanges); the former germinate into prothallia bearing only archegones, the latter into prothallia bearing usually only a single antherid. The family consists of the following genus only.

\section{ISÒETES L. Quillworts. (See Appendix.)}

Submerged, amphibious or uliginous plants with a cluster of elongated awlshaped leaves rising from a more or less 2-3-lobed fleshy short stem, the leaves with or without peripheral bast-bundles, with or without stomata, bearing a small membranous organ (ligule) above the base. Sporanges sessile in the excavated bases of the leaves, orbicular or ovoid, the sides more or less covered with a fold of the inner side of the leaf-base (velum). The sporanges of the outer leaves usually contain spherical, mostly sculptured macrospores, those of the inner ones contain minute powdery usually oblong microspores. [Name Greek, taken from Pliny, apparently referring to the persistent green leaves.] About 50 species, widely distributed. Owing to their aquatic habitat and apparently local distribution, these plants are popularly little known.

Submerged or rarely emersed in very dry seasons; leaves quadrangular, without peripheral bast-bundles.

Stomata wanting; macrospores crested.

Leaves stout, rigid, scarcely tapering. $\quad$ 2. I. lacustris.

Leaves slender, tapering.

Stomata present ; macrospores echinate.

2. I. lacustris.

3. I. echinospora.

Amphibious or submerged only in earlier stages; stomata always present on the quadrangular leaves.

Peripheral bast-bundles wanting.

Microspores papillose or tuberculate, not reticulate, white.

Leaves 5-8 cm. long; macrospores with minute warts. 4. I. saccharata.

Leaves Io-20 cm. long: macrospores with jagged crests. 5. I. riparia.

Microspores densely reticulate and often slightly papillose, dark brown : macrospores with thick-walled reticulations.

6. I. foveolata.

Peripheral bast-bundles irregular or wanting ; submersed leaves very long ; macrospores with convolute labyrinthine ridges.

Peripheral bast-bundles present.

Macrospores sparsely covered with irregular crests. $\quad 8$. . Canadensis.

Macrospores with honeycomb-like reticulations. $\quad$ 9. I. Engelmanni.

Terrestrial; stomata abundant on the triangular leaves.

Leaves $r_{5}-60$, usually black at the base.

Leaves 8-12, bright green, paler at the base.

Io. I. melanopoda.

I1. I. Butleri.

I. Isoetes iacústris L. (I. F. f. I02.) Submerged or rarely above water; leaves ro-25, rigid, rather thick, scarcely tapering, dark or olive green, obtusely quadrangular, $5^{-15} \mathrm{~cm}$. long ; stomata none; peripheral bast-bundles wanting; sporange orbicular or broadly elliptic, unspotted; velum rather narrow ; ligule triangular, short or. somewhat elongated; macrospores 500-800 $\mu$ in diameter, marked all over with distinct or somewhat confluent crests, and bearing three con- 
verging ridges ; microspores 35-46 $\mu$ long, smooth. In water $0.3^{-1.6} \mathrm{~m}$. deep, Lab. to the N. W. Terr., south to E. Mass. and N. J. Also in Europe and Asia.

2. Isoetes Tuckermáni A. Br. (I. F. f. IO3.) Submerged or rarely partly or wholly emersed in dry seasons ; leaves 10-30, very slender, tapering, olivegreen, quadrangular, 5-8 cm. long, without peripleral bast-bundles, the outer recurved ; sporange oblong, mostly white, its upper one-third covered by the velum; macrospores $440-560 \mu$ in diameter, with wavy somewhat parallel and branching ridges on the upper half, separated by the three converging ridges, the lower covered with an irregular network; microspores 26-32 $\mu$ long, nearly smooth. In ponds, Newf. to Middlesex County, Mass., clustered in shallow water.

3. Isoetes echinóspora Braùnii (Durieu) Engelm. (I. F. f. I04.) Submerged or rarely emersed ; leaves $\mathbf{1 2 - 2 5}$, tapering, soft, reddish-green, 7-20 cm. long, without peripheral bast-bundles, bearing stomata only toward the tip ; sporange orbicular or broadly elliptic, spotted, one-half to three-fourths covered with the velum; macrospores $400-500 \mu$ in diameter, covered with broad spinules which are often slightly confluent and incised at the tips ; microspores 26-39 $\mu$ long, smooth. Lab. and Greenland to Alaska, south to N. J., Penn. and Utah.

Isoetes echinospora robústa Engelm. Much larger than the prececiing, leaves 25-70 or even more $12-30 \mathrm{~cm}$. long, with abundant stomata throughout. With the preceding.

Isoetes echinospora Boóttii Engelm. Leaves 12-20, soft, erect, bright green, ro.-13 cm. long, with a few stomata near their tips ; sporange nearly orbicular, with pale spots, two thirds or more covered by the velum; macrospores $390-500 \mu$ in diameter, with longer and more slender simple spinules ; microspores 26-30 $\mu$ long. In ponds, Middlesex County, Mass., usually submerged.

Isoetes echinospora muricata (Durieu) Engelm. Leaves 15-20, flaccid, bright green, I5-30 cm. long, bearing few stomata ; sporange broadly oval, with pale-spots, about one- half covered by the velum ; macrospores $400-580 \mu$ in diameter, with shorter and more confluent, almost crest-like spinules; microspores $28-32 \mu$, slightly rough on the edges. Submerged in running water in tributaries of Mystic Pond, Middlesex County, Mass.

4. Isoetes saccharàta Engelm. (I. F. f. I05.) Amphibious or uliginous with a flat depressed trunk. Leaves 10-20, olive-green, pale at the base, spreading, 5-8 cm. long, quadrangular; stomata numerous ; sporange oblong, unspotted, with a narrow velum covering only one-fourth or one-third of its surface ; peripheral bastbundles wanting; ligule triangular, rather short; macrospores $400-470 \mu$ in diameter, with very minute distinct or rarely confluent warts as if sprinkled with grains of sugar ; microspores papillose, 24-28 $\mu$ long. In mud overflowed by the tides, Wicomico and Nanticoke rivers, E. Md. and near Washington, D. C.

5. isoetes riparia Engelm. (I. F. f. I06.) Ampbibious or uliginous, usually emersed; leaves 15-30, deep green, rather rigid, I0-20 $\mathrm{cm}$. long, quadrangular, bearing numerous stomata; peripheral bast-bundles wanting; ligule rather short, triangular; sporange mostly oblong, distinctly spotted with groups of brown cells, one-fourth or rarely one-half covered with the velum ; macrospores $450-650 \mu$ in diameter, marked with distinct or anastomosing jagged crests or somewhat reticulate on the lower side ; microspores 28-32 $\mu$ long, more or less turberculate. Bor. ders of the lower Delaware R. to Me.

6. Isoetes foveolàta A. A. Eaton. (I. F. f. I06c.) Amphibious from a bilobed or rarely trilobed base ; leaves $15-70$, stout $5-15 \mathrm{~cm}$. long, pinkish even when dry or rarely dark green; stomata scattered found only near the tips ; no peripheral bast-bundles; monoicous or becoming dioicous ; velum covering onefourth or one-third of the sporange; ligule round-ovate; sporanges thickly sprinkled with dark cells which are often collected in groups ; macrospores $380-560 \mu$ in diameter, covered beneath with very thick-walled reticulations, the openings appearing like little pits; reticulations elongate on the upper surface of the spore; microspores dark brown, 22-35 $\mu$ long, densely reticulate and usually slightly papillose. In muddy banks of the Pautuckaway River, Epping and E. Kingston, N. H.

7. Isoetes Eátoni Dolge. (I. F. f. Io6b.) Amphibious from a large trunk $2.5^{-10} \mathrm{~cm}$. in diameter. Leaves of the submerged plant 20-200, varying in length up to $7 \mathrm{dm}$., marked with an elevated ridge on the ventral side; leaves of the emersed plant shorter, $7 \cdot 5-15 \mathrm{~cm}$. long, stomata abundant ; peripheral bastbundles irregular in occurrence or often wanting; velum covering one-fourth of the 
sporange ; polygamous; sporanges large, Io by $4 \mathrm{~mm}$., pale, spotted ; macrospores small, $300-400 \mu$ in diameter, marked with convolute labyrinthine ridges and cristate on the angles of the inner face; microspores $25-30 \mu$ in diameter, smooth or slightly papillose. In mud flats. E. Kingston and Epping, N. H.

8. Isoetes Canadénsis (Engelm.) A. Br. Plant amphibious from a 2-lobed trunk. Leaves 10-75, 2-4.5 dm lcng, when submersed, erect or spirally ascending when scattered ; emersed leaves $10-15 \mathrm{~cm}$. long, tortuous and often interlaced, with numerous stomata and usually four bast-bundles; velum narrow, covering from one-fifth to one-fourth of the sporange ; sporanges thickly sprinkled with dark brown cells; macrospores more numerous on submersed plants, globose $500-675 \mu$ in diameter, sparsely covered with irregular crests which at maturity separate into irregular groups leaving bare spaces, serrate or spinulose at the top ; microspores more numerous on emersed plants, 22-40 $\iota$ in diameter, ashy, papillose. In mud, Me. and Ont. to Mass. and Pa., and in Br. Col. (I. F. f. Io6a.)

9. Isoetes Engelmánni A. Br. (I. F. f. I07.) Amphibious, usually partly immersed when mature. Leaves 25-100, light green, quadrangular, tapering, 22-50 cm. long, bearing abundant stomata; peripheral bast-bundles present; sporange oblong or linear-oblong, unspotted; velum narrow ; macrospores $400-520 \mu$ in diameter, covered with honeycomb-like reticulations; microspores 24-28 $\mu$ long, mostly smooth. In ponds and ditches, rooting in mud, Me. to Del. and Penn., III. and Mo.

Isoetes Engelmanni vallida Engelm. Leaves 50-200, keeled on the upper side, 4.5-6 $\mathrm{dm}$. long ; sporange linear oblong, $\mathrm{I}-2 \mathrm{~cm}$. long, one-third to two-thirds covered by the velum ; microspores $320-480 \mu$ in diameter ; microspores $24-27 \mu$ long, spinulose. Warriorsmark, Cornwall and Smithville, Pa., and Wilmington, Del.

Isoetes Engelmanni grácilis Engelm. Leaves 8-12, slender, 22-30 cm. long; bastbundles often quite small or only two present; spores as in the typical form. S. New Eng. to N. J.

I0. Isoetes melanópoda J. Gay. (I. F. f. I08.) Terrestrial with a subglobose deeply 2-lobed trunk. Leaves $15-60$, slender, erect, bright green, with a blackish shining base, $12-15 \mathrm{~cm}$. long, triangular, bearing stomata throughout, well developed peripheral bast-bundles, thick dissepiments and small air-cavities within; ligule triangular, awl-shaped; sporange mostly oblong, spotted with a narrow velum; polygamous ; macrospores $250-400 \mu$ in diameter with low more or less confluent tubercles, often united into worm-like wrinkles, or almost smooth ; microspores 23$28 \mu$ long spinulose. In moist prairies and overflowed fields, Ill. to Ia., Mo. and Tex.

I I. Isoetes Bútleri Engelm. (I. F. f. rog.) Terrestrial from a subglobose trunk. Leaves 8-15, bright green, paler at the base, triangular, 4.5-18 cm. long, bearing numerous stomata, and with well developed peripheral bast-bundles, thick dissepiments and small air cavities within; sporange usually oblong, spotted; velum very narrow or none; ligule small, triangular; diœcious ; macrospores 500-630 $\mu$ in diameter, with distinct or confluent tubercles ; microspores 28-34 $\mu$ long, dark brown, papillose. On rocky hillsides, St. Louis, Mo., and on saline flats, Ind. Terr. 


\title{
Subkingdom SPERMATÓPHYTA.
}

\author{
Seed-bearing Plants.
}

Plants producing seeds which contain an embryo formed of one or more rudimentary leaves (cotyledons), a stem (hypocotyl, radicle), and a terminal bud (plumule), or these parts sometimes indifferentiated before germination. Microspores (pollen-grains) are borne in microsporanges (anther-sacs) on the apex or side of a modified leaf (filament). The macrosporanges (ovules) are borne on the face of a flat or inrolled much modified leaf (carpel) and contain one macrospore (embryo-sac); this develops the minute female prothallium, an archegone of which is fertilized by means of a tube (pollen-tube), a portion of the male prothallium sprouting from the pollen-grain.

There are two classes which differ from each other as follows:

Ovules and seeds borne on the face of a scale; stigmas none. Class r. Gyms spermaE. Ovules and seeds contained in a closed cavity (ovary); stigmas 1 or more.

Class 2. ANgiospermaE.

\section{Class I. GYMNOSPÈRMAE.}

Ovules (macrosporanges) naked, not enclosed in an ovary, this represented by a scale or apparently wanting. Pollen-grains (microspores) dividing at maturity into two or more cells, one of which gives rise to the pollen-tube (male prothallium), which directly fertilizes an archegone of the nutritive endosperm (female prothallium) in the ovule.

The Gymnosperms are an ancient group, first known in Silurian time. They became most numerous in the Triassic age. They are now represented by not more than 450 species of trees and shrubs.

There are three orders, Pinales, Cycadales and Gnetales, the first of which is represented in our area by the Pine and Yew Families.

\section{Family I. PINÀCEAE Lindl.}

$$
\text { Pine Fanily. Conifers. }
$$

Resinous trees or shrubs, mostly with evergreen narrow entire or scalslike leaves, the wood uniform in texture, without tracheae, the tracheids marked by large depressed disks, the pollen-sacs and ovules borne in separate sfixi: (aments). Perianth none. Stamens several together, subtended by a scale; filaments more or less united; pollen-sacs (anthers) 2-several-celled, variously dehiscent; pollen-grains often provided with two lateral inflated sacs. Ovules with two integuments, orthotropous or amphitropous, borne solitary or several together on the surface of a scale, which is subtended by a bract in most genera. Fruit a cone with numerous, several or few, woody, papery or fleshy scales; sometimes berry-like. Seeds wingless or winged. Endosperm fleshy or starchy, copious. Embryo straight, slender. Cotyledons 2 or several. About 25 genera and 240 species of wide distribution, most abundant in temperate regions. 
Scales of the cone numerous (except in Larix); leaf-buds scaly.

Cone-scales woody ; leaves needle-shaped, 2-5 in a sheath.

I. Pinus.

Leaves fascicled on very short branchlets, deciduous. 2 . Larix.

Leaves scattered, persistent.

Cones pendulous; leaves jointed to short persistent sterigmata.

Leaves tetragonal, sessile.

Leaves flat, short-petioled.

Cones erect; sterigmata inconspicuous or noze.

Scales of the cone few ( $3-12)$; leaf-buds naked.

Cone-scales spiral, thick; leaves deciduous.

Cone-scales opposite ; leaves persistent.

Cone oblong, its scales not peltate.

Cone globose, its scales peltate.

Fruit fleshy, berry-like, a modified cone.
3. Picea.

4. Tsuga.

5. Abies.

6. Taxodium.

7. Thuja.

8. Chamaecyparis.

9. Juniperus.

\section{PÌNUS L. (See Appendix.)}

Evergreen trees with two kinds of leaves, the primary ones linear or scale-like, deciduous, the secondary ones forming the ordinary foliage, narrowly linear, arising from the axils of the former in fascicles of 2-5 (rarely solitary in some western species), subtended by the bud-scales, some of which are united to form a sheath. Staminate aments borne at the bases of shoots of the season, the clusters of stamens spirally arranged, each in the axil of a minute scale; filaments very short; anthers 2-celled, the sacs longitudinally dehiscent. Ovule-bearing aments solitary or clustered, borne on the twigs of the preceding season, composed of numerous imbricated minute bracts, each with an ovule-bearing scale in its axil, ripening into a large cone, which matures the following autumn, its scales elongating and becoming woody. Seeds 2 on the base of each scale, winged above, the testa crustaceous. [Name Celtic.] About 75 species, of the northern hemisphere.

Leaves 5 in a sheath; cone-scales little thickened at the tip.

heaves $2-3$ in a sheath; cone-scales much thickened at the tip.

r. P. Strobus.

Cones terminal or subterminal.

Leaves 2 in a sheath; cones $3-6 \mathrm{~cm}$. long, their scales pointless.

Leaves 3 in a sheath; cones $1-2.5 \mathrm{dm}$. long, their scales prickle-tipped.

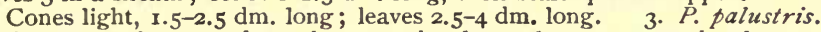
Cones very heavy and woody, I-I.5 dm. long; leaves $1.2-2.5 \mathrm{dm}$. long.

4. P. ponderosa.

Cones lateral.

Cone-scales with neither spine nor prickle; leaves in 2's.

5. P. divaricata.

Cone-scales tipped with a spine or prickle.

Leaves some or all of them in 2's.

Cones $3-7 \mathrm{~cm}$. long, their scales tipped with prickles.

Leaves stout, $3^{-6} \mathrm{~cm}$. long.

Leaves slender, $7^{-1} 3 \mathrm{~cm}$. long.

6. P. Virginiana.

7. P. echinata.

Cones 8--12 cm. long, their scales tipped with very stout short spines.

Leaves in 3's (very rarely some in 2's or 4's).

8. P. pungens.

Leaves $1.5-2.5 \mathrm{dm}$. long ; old sheaths $1-2.5 \mathrm{~cm}$. long ; cones oblong-conic. 9. P. Taeda.

Leaves $7-13 \mathrm{~cm}$. long; old sheaths $0.6-1.2 \mathrm{~cm}$. long; cones ovoid. 1o. $P$. rigida.

r. Pinus Stròbus L. White Pine. Weymouth Pine. (I. F. f. I Io.) A large forest tree, the bark nearly smooth except when old, the branches horizontal, verticillate. Leaves 5 in a sheath, very slender, pale green and glaucous, 7-12 cm. long, with a single fibro-vascular bundle, the dorsal side devoid of stomata; sheaths loose, deciduous; ovule-bearing aments terminal, peduncled; cones subterminal, drooping, cylindric, often slightly curved, $10-15 \mathrm{~cm}$. long, about $2.5 \mathrm{~cm}$. thick when the scales are closed, resinous; scales slightly thickened at the apex, obtuse and rounded or nearly truncate, without a terminal spine or prickle. In woods, often forming dense forests, Newf. to Man., south along the Allegh. to Ga. and to Ill. and Ia. June.

2. Pinus resiòsa Ait. Canadian Pine. Red Pine. (I. F. f. III.) A tall forest tree, the bark reddish, rather smooth, flaky when old. Leaves 2 in each sheath, slender, dark green, $10-15 \mathrm{~cm}$. long, with 2 fibro-vascular bundles; sheaths 
12-25 mm. long when young; staminate aments $12-18 \mathrm{~mm}$. long; cones subterminal, oval-conic, 3-6 cm. long, usually less than $2 \mathrm{~cm}$. thick while the scales are closed; scales thickened at the apex, obtuse, rounded and devoid of spine or prickle. In woods, Newf. to Man., Mass., Penn., Wisc. and Minn. May-June.

3. Pinus palústris Mill. Long-Leaved Pine. Georgia Pine。 (I. F. f. II2.) A large tree, sometimes attaining a height of $30 \mathrm{~m}$., the bark nearly smooth. Leaves in 3's, slender, dark green, clustered at the ends of the branches, 2.5-4 dm. long, with 2 fibro-vascular bundles; sheaths $1.5-3 \mathrm{~cm}$. long; buds long; staminate aments rose-purple, $5-9 \mathrm{~cm}$. long, very conspicuous ; cones terminal, spreading or erect, conic-cylindric, I-2.5 dm. long, 5-8 cm. thick before the scales open; scales thickened at the apex, with a transverse ridge bearing a short central recurved prickle. In sandy, mostly dry soil, Va. to Fla and Tex., mostly near the coast. March-April.

4. Pinus ponderòsa Dougl. Western Yellow Pine. (I. F. f. II3.) One of the largest trees, attaining a maximum height of nearly $80 \mathrm{~m}$. and a trunk diameter of $5 \mathrm{~m}$. Branches widely spreading or somewhat drooping ; bark light red, scaly ; leaves in 3's (rarely some of them in 2's), rather stout, 1-2.5 dm. long, slightly scabrous; cones subterminal, very dense, heavy, ovoid-conic, I-I.5 dm. long, 3-4.5 $\mathrm{cm}$. thick; scales much thickened at the apex, the transverse ridge prominent, with a triangular subulate short stout recurved prickle. Mont. to Br. Col., Neb., Tex., Mex. and Cal.; the shorter-leaved eastern form which reaches our area has been distinguished from the western type as var. scopulorum. April-May.

5. Pinus divaricàta (Ait.) Gord. Labrador Pine. Gray Pine. (I. F. f. i I4.) A slender tree, usually $12-20 \mathrm{~m}$. high, but sometimes reaching $30 \mathrm{~m}$., and a trunk diameter of I m., the branches spreading, the bark becoming flaky. Leaves in 2's, stout, stiff, more or less curved, spreading or oblique, crowded along the branches, seldom over $3 \mathrm{~cm}$. long; fibro-vascular bundles 2 ; cones commonly very numerous, lateral, oblong-conic, usually upwardly curved, $2.5-5 \mathrm{~cm}$. long, 18-30 $\mathrm{mm}$. thick when mature; scales thickened at the end, the transverse ridge a mere line with a minute central point in place of spine or prickle at maturity; young scales spiny tipped. In sandy soil, N. B. to Hudson Bay and the N. W. Terr., south to Me., N. N. Y., N. Ill. and Minn. May-June. (P. Banksiana Lamb.)

6. Pinus Virginiàna Mill. Jersey Pine. Scrub Pine. (I. F. f. II5.) A slender tree, usually small, the old bark dark-colored, flaky, the branches spreading or drooping. Leaves in 2's, dark green, rather stout and stiff, spreading when old, 3-7 cm. long, with 2 fibro-vascular bundles; young sheaths rarely more than $5 \mathrm{~mm}$. long ; cones commonly few, lateral, recurved when young, spreading when old, oblong-conic, 3-6 cm. long, their scales somewhat thickened at the apex, the low transverse ridge with a short central more or less recurved prickle. In sandy soil, L. I. to S. C., Ala., S. Ind. and Tenn. April-May. (P. inops Ait.)

7. Pinus echinàta Mill. Yellow Pine. Spruce Pine. (I. F. f. II6.) A forest tree, reaching a maximum height of about $30 \mathrm{~m}$. and a trunk diameter of I.5 m., the branches spreading, the old bark rough in plates. Leaves some in 2's, some in 3's, slender, not stiff, dark green, 7-13 cm. long, spreading when mature; fibro-vascular bundles 2 ; young sheaths $10-16 \mathrm{~mm}$. long; cones lateral, oblongconic, about $5 \mathrm{~cm}$. long, usually less than $2.5 \mathrm{~cm}$. thick when the scales are closed; scales thickened at the apex, marked with a prominent transverse ridge and armed with a slender, nearly straight, deciduous prickle. In sandy soil, S. N. Y. to Fla., Ill., Kans. and Tex. Produces shoots from stumps. May-June. (P. mitis Michx.)

8. Pinus pùngens Michx.f. Table-Mountain Pine. Hickory Pine. (I. F. f. II7.) A tree with a maximum height of about $20 \mathrm{~m}$. and trunk diameter of $\mathbf{~ m}$., the branches spreading, the old rough bark in flakes. Leaves mostly in 2's, some in 3's, stout and stiff, light green, 6-10 $\mathrm{cm}$. long, crowded on the twigs ; fibro-vascular bundles 2 ; young sheaths ro-16 $\mathrm{mm}$. long; cones lateral, usually clustered, long-persistent, ovoid, 8-12 cm. long, 5-7 cm. thick, while the scales are closed, nearly globular when these are expanded; scales thick, woody, their ends with a large elevated transverse ridge, centrally tipped by a stout reflexed or spreading spine 4-5 mm. long. In woods, sometimes forming forests, W. N. J. and Cent. $\mathrm{Pa}$. to $\mathrm{Ga}$. and Tenn. May.

9. Pinus Taèda L. Loblolly Pine. Old-field Pine. (I. F. f. I18.) A forest tree, reaching a height of $50 \mathrm{~m}$. and a trunk diameter of $1.6 \mathrm{~m}$., the 
branches spreading, the bark thick and rugged, flaky in age. Leaves in 3's, (rarely some of them in 2's), slender, not stiff, light green, ascending or at length spreading, I5-25 cm. long; fibro-viscular bundles 2 ; sheaths $16-25 \mathrm{~mm}$. long when young; cones lateral, spreading, oblong-conic, 7-12 cm. long, thick before the scales open; scales thickened at the apex, the transverse ridge prominent, acute, tipped with a central short triangular reflexed-spreading spine. S. N. J. to Fla., Tex. and Ark. April-May.

io. Pinus rígida Mill. Pirch-pine. Torch-pine. (I. F. f. IIg.) A tree reaching a maximum height of about $27 \mathrm{~m}$., and a trunk diameter of $\mathrm{I} \mathrm{m}$., the branches spreading, the old bark rough, furrowed, flaky in strips. Leaves in 3's (very rarely some in 4's), stout, stiff, rather dark green, 7-13 cm. long, spreading; fibro-vascular bundles 2 ; sheaths $8-13 \mathrm{~mm}$. long when young; cones lateral, ovoid, 3.5-7 cm. long. becoming nearly globular when the scales open, commonly numerous and clusterel; scales thickened at the apex, the transverse ridge acute, with a stout central triangular recurved-spreading prickle. In dry, sandy or rocky soil, N. B. to Unt., W. Va., Ga. and Tenn. Develops shoots from stumps. AprilMay.

\section{LÀRIX Adans.}

Tall trees with horizontal or ascending branches and small narrowly linear deciduous leaves, without sheaths, in fascicles on short lateral scaly bud-like branchlets. Aments short, lateral, moncecious, the staminate from leafless buds; the ovule-bearing buds commonly leafy at the base and the aments red. Anther-sacs 2-celied, the sacs transversely or obiiquely dehiscent. Pollen-grains simple. Conez ovoid or cylindric, sinall, erect, their scales thin, spirally arranged, obtuse, persistent. Ovules 2 on the base of each scale, ripening into 2 reflexed somewhat winged seeds. [Name ancient, probably Celtic.] About 9 species, natives of the north temperate and subarctic zones. Besides the following 2 others occur in the western parts of N. Am.

I. Larix larícina (Du Roi) Ko'h. American Larch. Tamarack. HackMATACK (I. F. f. r 20 .) A slender tree, attaining a maximum height of about $35 \mathrm{~m}$. and a trunk diameter of $\mathrm{I}$ m., the branches spreading, the bark close or at length slightly scaly. Leaves pale green, numerous in the fascicles, $1-2.5 \mathrm{~cm}$. long. about $0.5 \mathrm{~mm}$. wide, deciduous in late autumn; fascicles borne on short lateral branchlets about $4 \mathrm{~mm}$. long; cones short-peduncled at the ends of similar branchlets, ovoid, obtuse, $12-17 \mathrm{~mm}$. long, composed of about 12 suborbicular thin scales, their margins entire or slightly la cerate. In swampy woods and about margins of lakes, Newf. to the N. W. Terr., south to N. J., Penn., Ind. and Minn. March-April. (L. Americana Michx.)

\section{PİCEA Link.}

Evergreen conic trees, with linear short 4-sided leaves spreading in all directions, jointed at the base to short persistent sterigmata, on which they are sessile, falling away in dring, the bare twigs appearing covered with low truncate projections. Leaf-buds scaly. Staminate aments axillary, nearly sessile; anthers 2celled, the sacs longitudinally dehiscent, the connestive prolonged into an appendage; pollen-grains compound; ovule-bearing aments, terminal, ovoid or ob'ong; ovules 2 on the base of each scale, reflexed, ripening into 2 more or less winged seeds. Cones ovoid or oblong, obtuse. pendulous, their scales numerous, spirally arran re 1, thin, obtuse, persistent. [Name ancient.] About 14 species, natives of the north te.nperate and subarctic zones. Besides the following, 3 others occur in the northwestern parts of N. Am.

Twigs and sterigmata glabrous, glaucous; cones oblong-cylindric. Twigs pubescent, brown: cones ovoid or oval.

Leaves not glaucous.

Leaves glaucous.

I. P. Canadensis.

2. P. Mariana.

3. P. Urevifolia.

I. Picez Canadónsis (Mill.) B.S. P. White Spruce. (I. F. f. I2r.) A slender tree, attaining a maximum height of about $50 \mathrm{~m}$. and a trunk diameter of I m., but usually much smaller. Twigs and sterigmata glabrous, pale and glau. cous; leaves light green, siender, $12-16 \mathrm{~mm}$. long, very acute; cones cylindric or 
oblong-cylindric, pale, 3.5-5 $\mathrm{cm}$. long, $12-17 \mathrm{~mm}$. thick before the scales open; scales almost membranous, their margins usually quite entire; bracts incised. Newf. to Huds. Bay and Alaska, south to Me., N. N. Y., Mich., the Black Hills, Mont. and Br. Col. Sometimes with a strong, skunk-like odor. AprilMay. (P. alba Link.)

2. Picea Mariàna (Mill.) B.S. P. Black Spruce. Red Spruce. (I. F. f. 122 and I23.) A tree, sometimes $35 \mathrm{~m}$. high, the trunk sometimes reaching a diameter of $3.3 \mathrm{~m}$., the branches spreading, the bark smooth or only slightly roughened. Twigs pubescent; sterigmata pubescent or glabrate; leaves thickly covering the twigs, green, stout, straight or curved, rarely more than $16 \mathrm{~mm}$. long, obtuse or acuminate or merely mucronate at the apex; cones oval or ovoid, 2-5 cm. long, mostly persistent on the twigs for two or more seasons, their scales with entire, lacerate or erose margins. Newf. to Huds. Bay and the N. W. Terr., south to N. J., N. C., Mich. and Minn. Tree very variable in the size of cones and in the thickness of its leaves; the leaves of the lower branches often very sharppointed, while those of the upper are blunt or mucronate. May-June. (P. nigra.)

3. Picea brevifòlia Peck. Swamp Spruce. (I. F. f. 122a.) A small slender tree, or on mountains reduced to a shrub. Twigs pubescent; sterigmata glabrous, or slightly pubescent; leaves nearly straight, mostly glaucous, obtuse, or merely mucronate, stout, 4-12 mm. long; cones oval, persistent for two seasons or more, 1.5-3 cm. long, the scales with eroded margins. In swamps and bogs, Vt. to Ont., N. N. Y. and Mich. June.

\section{TSÜGA Carr.}

Evergreen trees with slender horizontal or drooping branches, flat narrowly linear scattered short-petioled leaves, spreading and appearing 2-ranked, jointed to very short sterigmata and falling away in drying. Leaf-buds scaly. Staminate aments axillary, short or subglobose; anthers 2 -celled, the sacs transversely dehiscent, the connective slightly produced beyond them; pollen-grains simple. Ovulebearing aments terminal, the scales about as long as the bracts, each bearing 2 reflexed ovules on its base. Cones small, ovoid or oblong, pendulous, their scales scarcely woody, obtuse, persistent. Seeds somewhat winged. [Name Japanese.] About 7 species, the following of E. N. Am., 2 in N. W. N. Am., 2 or 3 Asiatic.

Cones $\mathrm{r}-2 \mathrm{~cm}$. long, their scales remaining appressed.

Cones $2.5-3 \mathrm{~cm}$. long, their scales widely spreading at maturity.
1. T. Canadensis.

2. T. Caroliniana.

I. Tsuga Canadénsis (L.) Carr. Hemlock. (I. F. f. 124.) A tall forest tree, sometimes $35 \mathrm{~m}$. high, the trunk reaching $1.6 \mathrm{~m}$. in diameter, the lower branches somewhat drooping, the old bark flaky in scales. Foliage dense; leaves obtuse, flat, 12-1 $8 \mathrm{~mm}$. long, less than $2 \mathrm{~mm}$. wide, dark green above, pale beneath, the petiole less than one-half as long as the width of the blade; cones oblong, obtuse, as long as or slightly longer than the leaves, their scales suborbicular, obtuse, minutely lacerate or entire, not widely spreading at maturity. N. S. to Minn., south to Del., along the Alleghenies to Ga. and Ala. and to Mich. and Wis. April-May.

2. Tsuga Caroliniàna Engelm. Carolina Hemlock. (I. F. f. 125.) A forest. tree attaining a maximum height of about $27 \mathrm{~m}$. and a trunk diameter of 1.3 m., the lower branches drooping. Leaves narrowly linear, obtuse, ratlier light green above, nearly white beneath, 14-22 $\mathrm{mm}$. long, the petiole nearly as long as the width of the blade; cones $2.5-3 \mathrm{~cm}$. long, the scales firm but scarcely woody, oblong, obtuse, widely spreading at maturity. S. W. Va. to S. Car. and Ga. in the mountains. April.

\section{5. À BIES Juss.}

Evergreen trees with linear flat scattered sessile leaves, spreading so as to appear 2-ranked, but in reality spirally arranged, not jointed to sterigmata, and commonly quite persistent in drying, the naked twigs marked by the flat scars of their bases. Staminate aments axillary; anthers 2 -celled, the sacs transversely 
dehiscent, the connective prolonged into a short knob or point; pollen-grains compound. Ovule-bearing aments lateral, erect; ovules 2 on the base of each scale, reflexed, the scale shorter than or exceeding the thin or papery, mucronate or aristate bract. Cones erect, subcylindric or ovoid, their scales deciduous from the persistent axis, orbicular or broader, obtuse. [Ancient name of the firs.] About 20 species, natives of the north temperate zone, chiefly in boreal and mountainous regions. Besides the following, some 7 others occur in the western parts of N. Am. and $\mathrm{I}$ in Mex.

Bracts serrulate, mucronate, shorter than the scales; leaves obtuse. Bracts aristate, reflexed, longer than the scales; leaves mostly emarginate.

I. A. balsamea. 2. A. Fraseri.

I. Abies balsàmea (L.) Mill. Balsam Fir. (I. F. f. I26.) A slender forest tree attaining a maximum height of about $30 \mathrm{~m}$. and a trunk diameter of $\mathrm{I} \mathrm{m}$., usually much smaller and on mountain tops and in high arctic regions reduced to a low shrub. Bark smooth, warty with resin "blisters." Leaves fragrant in drying, less than $2 \mathrm{~mm}$. wide, $12-20 \mathrm{~mm}$. long, obtuse, dark green above, paler beneath or the youngest conspicuously whitened on the lower surface; cones cylindric, 5-10 cm. long, 2-3 cm. thick, upright, arranged in rows on the upper side of the branches, violet or purplish when young: bracts obovate, serrulate, mucronate, shorter than the broad rounded scales. Newf. and Lab. to Hud. Bay and the N. W. Terr., south to Mass., Penn., along the Alleghenies to Va. and to Mich. and Minn. Canada balsam is derived from the resinous exudations of the trunk. May-June.

2. Abies Fràseri (Pursh) Lindl. Fraser's Balsam Fir. (I. F. f. 127.) A forest tree, similar to the preceding species. Leaves, especially the younger, conspicuously whitened beneath, I-2 cm. long, nearly $2 \mathrm{~mm}$. wide, emarginate or some of them obtuse at the apex; cones oblong-cylindric or ovoid-cylindric, $5-8 \mathrm{~cm}$. high, about $2.5 \mathrm{~cm}$. thick, their scales rhomboid, much broader than high, rounded at the apex, much shorter than the papery bracts, which are reflexed, their summits emarginate, serrulate and aristate. On the high Alleghenies of S. W. Va., N. Car., and Tenn. May.

\section{TAXÒDIUM L. C. Rich.}

Tall trees with horizontal or drooping branches, and alternate spirally arranged sessile linear or scale-like leaves, deciduous in our species, spreading so as to appear 2-ranked, some of the twigs commonly deciduous in autumn. Leaf-buds naked. Staminate aments very numerous, globose, in long terminal drooping panicled spikes, appearing before the leaves; anthers $2-5$ celled, the sacs 2 -valved. Ovule-bearing aments ovoid, in small terminal clusters, their scales few, bractless, each bearing a pair of ovules on its base. Cones globose or nearly so, the scales thick and woody, rhomboid, fitting close together by their margins, each marked with a triangular scar at its base. Seeds large, sharply triangular-pyramidal. [Name Greek, referring to the yew-like leaves.] Three known species, the following of S. E. N. Am., I Mexican, I Chinese.

I. Taxodium distichum (L.) L. C. Rich. BALD Cypress. (I. F. f. I28.) A large forest tree, attaining a maximum height of about $50 \mathrm{~m}$. and a trunk diameter of nearly $3 \mathrm{~m}$., the old bark flaky in thin strips. Jeaves narrowly linear, flat, thin, I-2 cm. long, I mm. wide, or less, rather light green, acute, those on some of the flowering branches smaller, scale-like; cones globose or slightly longer than thick, pendent at the ends of the branches, very compact, $2-3 \mathrm{~cm}$. in diameter; surfaces of the scales irregularly rugose above the inversely triangular scar; seeds 8-10 mm. long. In swamps and along rivers, Del. to Fla., west to Tex., north in the Miss. Valley region to S. Ind., Mo. and Ark. The roots develop upright conic "knees" sometimes $1.5 \mathrm{~m}$. high and .4 m. thick. MarchApril.

\section{THÙJA L.}

Evergreen trees or shrubs with frond-like foliage, the leaves small or minute, scale-like, appressed, imbricated, opposite, 4-ranked, those of the ultimate branchlets mostly obtuse, those of some of the larger twigs acute or subulate. Aments 
monœcious, both kinds terminal, the staminate globose; anthers opposite, 2-4 celled, the sacs globose, 2-valved. Ovule-bearing aments ovoid or oblong, small, their scales opposite, each bearing 2 (rarely 2-5) erect ovules. Cones ovoid or ob. long, mostly spreading or recurved, their scales 6-10, coriaceous, opposite, not peltate, dry, spreadin s when mature. Seeds oblong, broadly or narrowly winged or wingless. [Name ancient.] About 15 species, natives of North America and eastern Asia. Besides the following, another occurs from Idaho and Or. to Alaska.

I. Thuja occidentalis L. White Cedar. Arbor Vite. (I. F. f. I29.) A conical tree, reaching a height of $22 \mathrm{~m}$. and a trunk diameter of $1.6 \mathrm{~m}$., the old burk deciduous in ragged strips. Scale-like leaves of the ultimate branches nearly obicular, obtuse, $2-3 \mathrm{~mm}$. broad, the two lateral rows keeled, the two other rows flat, causing the twigs to appear much flattened; leaves of the older twigs narrower and longer, acute or acuminate; mature cones, 8-1o long, their scales obtuse; seeds broadly winged. In wet soil and along the banks of streams, forming almost impenetrable forests northward, N. B. to James Bay and Man., south to N. J., along the Alleghenies to N. C. and to Ill. and Minn. May-June.

\section{CHAMAECÝPARIS Spach.}

Evergreen trees, similar to the Thujas, with minute opposite appressed 4-ranked scale-like leaves, or those of older twigs subulate, and small monœcious terminal aments. Staminate aments as in Thuja, but the filaments broader and shieldshaped. Ovule-bearing aments globose, their scales opposite, peltate, each bearing 2-5 erect ovules. Cones globose, the scales thick, peltate, each bearing 2-5 erect seeds, closed until mature, each with a central point or knob. Seeds winged. [Greek, meaning a low cypress.] About 7 species, the following of the eastern U. S., 2 in western N. Am., 3 or 4 Japanese.

I. Chamaecyparis thyoides (L.) B.S P. Southern White Cedar. (I. F. f. 130.) A forest tree, reaching a maximum height of about $30 \mathrm{~m}$. and a trunk diameter of $1.5 \mathrm{~m}$. Leaves of the ultimate branchlets ovate, acute, scarcely $\mathbf{I} \mathrm{mm}$. wide, those of the lateral rows keeled, those of the vertical rows slightly convex, each with a minute round discoid marking on the centre of the back, those of the o'der twigs narrower and longer, subulate: cones about $6 \mathrm{~mm}$. in diameter, blue, each of their closely fitting scales with a small central point: seeds narrowly winged. In swamps, Mass, and N. H. to N. N. J, Fla. and Miss., mostly near the coast. April-May. (C. spharoidea Spach.)

\section{JUNIPERUS L. (See Appendix.)}

Evergreen trees or shrubs with opposite or verticillate, subulate or scale-like, sessile leaves, commonly of 2 kinds, and diœcious or sometimes monœcious, small globose axillary or terminal aments. Leaf-buds naked. Staminate aments oblong or ovoid; anthers 2-6-celled, each sac 2-valved. Ovule-bearing aments of a few opposite somewhat fleshy scales, or these rarely verticillate in 3 's, each bearing a single erect ovule or rarely 2 . Cones globose, berry-like by the coalescence of the fleshy scales, containing $\mathbf{I}-6$ wingless bony seeds. [Name Celtic.] About 30 species, natives of the northern hemisphere, some of them extending into tropical regions. Besides the following, 4 or 5 others occur in the western parts of North America.

Leaves all subulate, prickly pointed, verticillate; aments axillary.

Small erect tree or shrub; leaves slender, mostly straight.

Low depressed shrub; leaves stouter, mostly curved.

2. J. nana.

Tree; fruit on short straight branches.

Depressed shrub; fruit on short recurved branches.

r. J. communis.

2. J. nan

3. J. Virginiana.

4. J. Sabina.

I. Juniperus commùnis L. JUNIPER. (I. F. f. I31.) A low tree or erect shrub, sometimes attaining a height of $8 \mathrm{~m}$ and a trunk diameter of $25 \mathrm{~cm}$., usually smaller, the branches spreading or drooping, the bark shreddy. Leaves subulate, rigid, spreading, or some of the lower reflexed, mostly straight, prickly pointed, verticillate in 3 's, often with smaller ones fascicled in their axils, $1-2 \mathrm{~cm}$. long, less than $2 \mathrm{~mm}$. wide, channeled and commonly whitened on the upper surface; aments 
axillary; berry-like cones sessile or very nearly so, dark blue, 6-8 mm. diameter. On dry hills, N. S to Br. Col., south to N. J., Penn., Mich., Neb. and in the Rocky Mts. to N. Mex. Also in Europe and Asia. The fruit is used for flavoring gin. April-May. Fruit ripe Oct.

2. Juniperus nana Willd. Low JonipER. (I. F. f. 132.) A depressed rigid shrub, seldom over $0.5 \mathrm{~m}$. high, forming circular patclies often $3-4 \mathrm{~m}$. in diameter. Leaves similar to those of the preceding, but stouter, similarly channeled and often whitened above, appressed-ascending, rather rigid, spiny-tipped, 8-12 mm. long; mostly incurved, densely clothing the twigs, verticillate in 3's; aments axillary: berry-like cones blue, 8-1o mm. in diameter. In dry, open places, Lab. to Br. Col., south to Mass, N. Y., Mich. and in the Rocky Mts. to Col. and Utah. Also in Europe and Asia. The characteristic growth in a depressed circular patch gives the plant a very different aspect from the true Juniper. April-May.

3. Juniperus Virginiàna L. RED Cedar. Savin. (I. F. f. I33.) A tree, reaching a maximum height of about $32 \mathrm{~m}$. and a trunk diameter of $1.6 \mathrm{~m}$., conic when young, but the branches spreading in age. Leaves mostly opposite, all those of young plants and commonly some of those on the older twigs of older trees subulate, spiny-tipped, 4-8 mm. long, those of the mature foliage scale-like, acute or subacute, closely appressed and imbricated, 4-ranked, causing the twigs to appear quadrangular; aments terminal; berry-like cones light blue, glaucous, about $6 \mathrm{~mm}$. in diameter, on straight peduncle-like branchlets of less than their own length, I-2 seeded. In dry soil, N. B. to Br. Col., Fla., Tex., N. Mex. and Ariz. Also in the W. I. Wood used in large quantities in the manufacture of lead pencils. April-May. Fruit ripe Sept.-Oct.

4. Juniperus Sabina L. Shrubby Red Cedar. (I. F. f. 134.) A depressed shrub, seldom more than $\mathbf{1 . 3} \mathrm{m}$. high. Leaves similar to those of the preceding species, those of young plants and the older twigs of older plants subulate, spiny-tipped, those of the mature foliage scale-like, appressed, 4-ranked, acute or acuminate; aments terminal; berry-like cones light blue, somewhat glacuous, 8-ro $\mathrm{mm}$. in diameter, borne on recurved peduncle-like branchlets of less than their own length, I-4 seeded. On banks, N. S. to Br. Col., south to Mass, N. N. Y., Minn. and Mont. Also in Europe and Asia. April-May.

\section{Family 2. TAXÀCEAE Lindl.}

Trees or shrubs, resin-bearing except Taxus. Leaves evergreen or deciduous, linear, or in several exotic genera broad or sometimes fan-shaped, the pollen-sacs and ovules borne in separate clusters or solitary. Perianth wanting. Stamens much as ir the Pinaceae. Ovules with either one or two integuments; when two, the outer one fleshy; when only one, its outer part fleshy. Fruit drupe-like or rarely a cone. About 8 genera and 75 species, of wide geographic distribution, most numerous in the southern hemisphere. The Maiden-hair Tree, Ginkso biloba, of China and Japan, with fan-shaped leaves, is an interesting tree, formerly included in the group, much planted for ornament, now regarded as forming a distinct natural family.

\section{TÁXUS L.}

Evergreen trees or shrubs, with spirally arranged short-petioled linear flat mucronate leaves, spreading so as to appear 2-ranked, and axillary and sclitary, sessile or subsessile very small aments; staminate aments consisting of a few scaly bracts and 5-8 stamens, tlieir filaments united to the middle; anthers 4-6-celled. Ovules solitary, axillary, erect, subtended by a fleshy, annular disk which is bracted at the base. Fruit consisting of the fleshy disk which becomes cupshaped, red, and nearly encloses the bony seed. [Name ancient.] About 6 species, natives of the north temperate zone. Besides the following, another occurs in Fla., one in Mex. and one on the Pacific coast.

I. Taxus Canadénsis Marsh. American Yew. Ground Hemlock. (I. F. f I35.) A low shrub, seldom over $1.5 \mathrm{~m}$. high. Leaves dark green on both sides. narrowly linear, mucronate, narrowed at the base, 12-20 $\mathrm{mm}$. long, nearly $2 \mathrm{~mm}$. wide, persistent on the twigs in drying; staminate aments globose, $2 \mathrm{~mm}$. long, usually numerous; ovules usually few; fruit red and pulpy, resinous, oblong, 
nearly $6 \mathrm{~mm}$. hig, the top of the seed not covered by the fleshy integument. In woods, Newf. to Man., N. J., in the Alleghenies to Va., and to Ia. April-May.

\section{Class II. ANGIOSPËRMAE.}

Ovules (macrosporanges) enclosed in a cavity (the ovary) formed by the infolding and uniting of the margins of a modified rudimentary leaf (carpel), or of several such leaves joined together, in which the seeds are ripened. The pollen-grains (microspores) on alighting upon the summit of the carpel (stignia) germinate, sending out a pollen-tube which penetrates its tissues and reaching an ovule enters the orifice of the latter (micropyle), and its tip coming in contact with a germ-cell in the embryosac, fertilization is effected. In a few cases the pollen-tube enters the ovule at the chalaza, not at the micropyle.

There are two sub-classes, distinguished as follows :

Cotyledon one; stem endogenous.

Sub-class x. MONOCOTYLEDONES.

Cotyledons two; stem (with rare exceptions) exogenous.

Sub-class 2. DicotrLEDONES.

\section{Sub-class I. MONOCOTYLÉDONES.}

Embryo with a single cotyledon and the first leaves of the germinating plantlet alternate. Stem composed of a ground-mass of soft tissue (parenchyma) in which bundles of wood-cells are irregularly imbedded; no distinction into wood, pith and bark. Leaves usually parallel-veined, mostly alternate and entire, commonly sheathing the stem at the base and often with no distinction of blade and petiole. Flowers mostly 3merous or 6-merous.

\section{Order I. PANDANÀLES.}

Our species aquatic or marsh plants, with narrow elongated leaves and very small, imperfect and incomplete flowers in spikes or heads. Perianth of bristles, or of chaffy scales. Ovary 1, 1-2-celled. Endosperm mealy or fleshy.

The order takes its name from the tropical genus Pandanus, the socalled Screw-Pine.

Flowers in terminal spikes.

Flowers capitate, the heads axillary to leaf-like bracts.

Fam. x. Typhaceae.

Fam. 2. Sparganiaceae.

\section{Family I. TYPHÀCEAE J. St. Hil.} Cat-tail Family.*

Marsh or aquatic plants with creeping rootstocks, fibrous roots and glabrous erect, terete stems. Leaves linear, flat, ensiform, striate, sheathing at the base. Flowers monœcious, densely crowded in terminal spikes, which are subtended by spathaceous, usually fugacious bracts, and divided at intervals by smaller bracts, which are caducous, the staminate spikes uppermost. Perianth of bristles. Stameñs 2-7, the filaments connate. Ovary I, stipitate, I-2-celled. Ovules anatropous. Styles as many as the cells of the ovary. Mingled among the stamens and pistils are bristly hairs, and among the pistillate flowers many sterile flowers with clavate tips. Fruit nutlike. ' Endosperm copious. The family comprises only the following genus:

\section{TYेPHA L.}

Characters of the family. [Name ancient] About Io species, widely dis. tributed in temperate and tropical regions. Besides those here described, another occurs in Cal. 
Spikes dark brown or black, the pistillate and staminate usually contiguous, the former without bractlets; stigmas spatulate or rhomboid; pollen 4-grained. x. T. latifolia.

Spikes light brown, the pistillate and staminate usually distant, the former with bractlets; stigmas linear; pollen in simple grains.

2. T: angustifolia.

I. Typha latifòlia L. Broad-Leaved Cat-TaIl. (I. F. f. I36.) Stems stout, I-2.7 m. high. Leaves 6-25 mm. broad; spikes dark brown or black, the staminate and pistillate portions usually contiguous, each $7 \cdot 5-30 \mathrm{~cm}$. long and often $2 \mathrm{~cm}$. or more in diameter, the pistillate without bractlets; stigmas rhomboid or spatulate; pollen-grains in 4's; fruit furrowed, bursting in water; seeds with a separable outer coat. In marshes, throughout N. Am., except the extreme north. Also in Europe and Asia. June-July. Fruit, Aug.-Sept.

2. Typha angustifòlia L. NARrow-Leaved CAT-TaIL. (I. F. f. 137.) Stems slender, 1.5-3.5 m. high. Leaves mostly narrower than those of the preceding species, 4-12 mm. wide; spikes light brown, the staminate and pistillate portions usually distant, the two together sometimes $0.5 \mathrm{~m}$. long, the pistillate, when mature, 6-16 mm. in diameter, and provided with bractlets; stigmas linear or linear-oblong; pollen-grains simple; fruit not furrowed, not bursting in water; outer coat of the seed not separable. Abundant in marshes along the Atlantic Coast from N. S. to Fla. and Cuba, but also occurring rather rarely inland. Also in Europe and Asia. June-July. Fruit, Aug.-Sept.

\section{Family 2. SPARGANIÀCEAE Agardh. 1858. Bur-reed Family.*}

Marsh or pond plants with creeping rootstocks and fibrous roots, erect or floating simple or branched stems, and linear alternate leaves, sheathing at the base. Flowers monœcious, densely crowded in globose heads at the upper part of the stem and branches, the staminate heads uppermost, sessile or peduncled. Spathes linear, immediately beneath or at a distance below the head. Perianth of a few irregular chaffy scales. Stamens commonly 5, their filaments distinct; anthers oblong or cuneate. Ovary sessile, mostly I-celled. Ovules anatropous. Fruit mostly I-celled, nutlike. Embryo nearly straight, in copious endosperm. The family comprises only the following genus :

\section{SPARGÀnIUM L. (See Appendix.)}

Characters of the family. [Greek, referring to the ribbon-like leaves.]

About ro species, of temperate and cold regions. Besides the following, one occurs in Cal.

Fruit sessile.

Fruit stalked.

Inflorescence branching.

1. S. eurycarpum.

Inflorescence simple.

2. S. androcladum.

Staminate heads $4-6$, pistillate $2-6$, 10-16 mm. in diameter. 3. $S$. simplex.

Staminate heads $\mathrm{I}-2$, pistillate $\mathrm{I}-3,4-10 \mathrm{~mm}$. in diameter. 4. S. minimum.

I. Sparganium eurycárpum Engelm. Broad-Fruited BUR-REed. (I. F. f. I38.) Stems stout, I-2.8 m. high, branching. Leaves flat, slightly keeled beneath, the lowest $\mathrm{I}-2 \mathrm{~m}$. long; staminate heads numerous; pistillate heads $2-4$ on the stem or branch, sessile or peduncled, hard, compact and $2-3 \mathrm{~cm}$. in diameter when mature; style I; stigmas I-2; nutlets 6-10 mm. long, obtusely 4-5-angled, narrowed at the base, the top rounded, flattened or depressed, abruptly tipped with the style; scales as long or nearly as long as the fruit and as many as its angles, often with 2 or 3 other exterior ones, somewhat spatulate, the apex roundea, denticulate or eroded In marshes and along streams, Newf. to $\mathrm{Br}$. Col., south to Va., Mo., Utah and Cal.

2. Sparganium andrócladum (Engelm.) Morong. Branching BuR-Reed. (1. F. f. 139, Stem slender, more or less branching, $2.5^{-6} \mathrm{~cm}$. high. Pistillate 
heads $3-7$, sessile or the lowest peduncled, axillary or the peduncles and branohes axillary ; style I ; stigma I (rarely 2 ); fruiting heads $\mathbf{I} 2-25 \mathrm{~mm}$. in diameter ; nutlets fusiform, 4-6 $\mathrm{mm}$. long, $3 \mathrm{~mm}$. thick, often strongly contracted at the middle, tapering into the style; scales oblong, as long as the nutlets or shorter, the exterior ones narrower; stalk of fruit $2 \mathrm{~mm}$. long or more. In bogs or shallow water, N. S. to Ont. and Br. Col., south to Fla. and La. June-Aug.

Sparganium andrócladum flúctuans Morong. Floating in deep water with long slender stems and thin leaves $2-7 \mathrm{~mm}$. wide; inflorescence usually sparingly branched; fruiting heads 8-12 mm. in diameter. In cold ponds, N. B. to Penn.

3. Sparganium símplex Huds. Simple-stemmed BuR-Reed. (I. F. f. I40.) Stem slender, 3-60 $\mathrm{cm}$. high, simple. Leaves more or less triquetrous, 4-8 $\mathrm{mm}$. wide; inflorescence $2-20 \mathrm{~cm}$. long ; staminate heads $4-6$; pistillate $2-6$, sessile or the lowest peduncled; fruiting heads 10-16 mm. in diameter; nutlets fusiform or narrowly oblong, obtusely angled at the apex, more or less contracted in the middle, smaller than those of the preceding species and more tapering at the summit; scales denticulate, about one-half as long as the nutlets ; stigma linear, as long as the style or shorter, rarely 2 ; stalk of fruit about $2 \mathrm{~mm}$. long. Borders of ponds and streams, Newf. to Br. Col., Penn., Mont. and Cal. June--Aug.

Sparganium simplex angustifoilum (Michx.) Engelm. Floating in deep water. Leaves very long, $1-3 \mathrm{~mm}$. wide, their sheaths of ten inflated at the base; staminate and pistillate heads $\mathrm{I}-4$; fruiting heads $6-15 \mathrm{~mm}$. in diameter. In mountain lakes and slow streams, Newf. to Ore., N. Y. and Cal.

4. Sparganium mínimum Fries. Small BUR-ReEd. (I. F. f. I4I.) Floating, stems very slender, $0.1-1 \mathrm{~m}$. long. Leaves thin and lax, $\mathrm{I}-5 \mathrm{~mm}$. wide ; inflorescence $2 \mathrm{~cm}$. or more long; staminate heads I-2; pistillate, I-3, sessile, axillary, supra-axillary or the lowest on an axillary peduncle; ripe fruiting heads 4-10 $\mathrm{mm}$. in diameter; nutlets ovoid, slightly triangular, tapering abruptly into the style, 2-4 mm. long, twice as long as the denticulate scales; stigma ovai, often oblique, about as long as the style; stalk of the nutlet $0.5-1 \mathrm{~mm}$. long, often apparently none. In ponds and streams, N. B. to Man. and Ore., south to N. J., Mich. and Utah. Also in northern Europe. Dwarf forms, growing out of water, sometimes occur with stems $3^{\prime}-6^{\prime}$ high. June-Aug.

\section{Order 2. NAIADÀLES.}

Aquatic or marsh herbs, the leaves various in form. Flowers perfect, monœcious or diœcious. Perianth present, or wanting. Parts of the flower mostly unequal in number. Carpels I or more, mostly distinct and separate (united in Vallisneriaceae; united at least until maturity in Scheuchzeriaceae); endosperm none, or very little.

Perianth, if present, inferior ; carpels mostly distinct.

Perianth-segments, when present, herbaceous.

Carpels distinct ; aquatic herbs.

Carpels united until maturity; bog plants; flowers racemed or spiked.

Fam. 2. Sicheuchzeriaceae.

Perianth of 2 series of segments, the outer green, the inner mostly white.

Perianth superior; carpels united.

Fam. 3. Alismaceae.

Fam. 4. Vallisneriaceae.

\section{Family I. NAIADÀCEAE Lindl.*}

Immersed aquatic plants with slender, often branching, leafy stems, the leaves flat or filiform, and perfect, monœcious or diœcious, spicate axil- 
lary or spadiceous flowers. Perianth of 4 segments, or a hyaline envelope, or wanting. Stamens I-4 or occasionally more, distinct and hypogynous in the perfect flowers, solitary or connate in the sterile. Anthers extrorse, I-2-celled. Ovaries $\mathrm{I}-9$, mostly distinct, I-celled, mostly $\mathrm{I}$-ovuled. Carpels rarely dehiscent. Seeds straight or curved. Endosperm none. About 10 genera and 100 species of wide geographical distribution, most abundant in temperate regions. The months noted in the descriptions indicate the fruiting period.

Flowers perfect.

Perianth of 4 distinct segments.

Perianth none; flowers naked.

I. Potamogeton.

2. Ruppia.

Flowers monœecious or diøecious.

Leaves entire.

Leaves I-nerved, 2-8 cm. long, $0.5 \mathrm{~mm}$. or less wide.

Leaves many-nerved, $0.3^{-1.6} \mathrm{~m}$. long, $2-8 \mathrm{~mm}$. wide.

Leaves spiny-toothed on the margins.

3. Zannichellia.

4. Zostera.

5. Naias.

\section{POTAMOGÉTON L.}

Leaves alternate or the uppermost opposite, often of 2 kinds, submerged and floating, the submerged mostly linear, the floating coriaceous, lanceolate, ovate or oval. Spathes stipular, often ligulate, free or connate with the base of the leaf or petiole, enclosing the young buds and usually soon perishing after expanding. Peduncles axillary, usually emersed. Flowers small, spicate, green or red. Perianth-segments 4 , short-clawed, concave, valvate. Stamens 4 , inserted on the claws of the perianthsegments. Anthers sessile. Ovaries 4, sessile, distinct, I-celled, I-ovuled, attenuated into a short style, or with a sessile stigma. Fruit of 4 drupelets, the pericarp usually thin and hard or spongy. Seeds crustaceous, campylotropous, with an uncinate embryo thickened at the radicular end. [Greek, in allusion to the aquatic habitat.] About 65 well-defined species, natives of temperate regions. Besides the following, 3 others occur in the southern parts of N. Am.

Stipules axillary and free from the leaf.

With floating and submerged leaves.

Submerged leaves bladeless.

Nutlets more or less pitted.

Nutlets not pitted.

Submerged leaves with a proper blade.

1. P. natans.

2. P. Oakesianus.

Submerged leaves of 2 kinds, lanceolate and oval or oblong.

Uppermost broadly oval or elliptic, lowest lanceolate.

3. P. amplifolius.

Uppermost lanceolate and pellucid, lowest oblong and opaque.

Submerged leaves all alike, capillary or linear-setaceous.

4. $P$. pulcher.

$x$-nerved or nerveless.

3 -nerved

25. P. Vaseyi.

26. P. lateralis.

Submerged leaves all alike, linear.

Nearly the same breadth throughout, obtusely pointed, coarsely cellularreticulated in the middle.

Broader at base, acute, without cellular-reticulation.

Submerged leaves all alike, lanceolate.

5. P. Nuttallii.

Uppermost leaves petioled, lowest sessile.

All the leaves petioled.

9. $P$. heterophyllus.

6. P. alpinus.

base.

loating leaves large, broadly elliptic, rounded or subcordate at

Floating leaves narrowly elliptic, tapering at base.

7. $P$. lonchites.

Floating leaves mostly obovate or oblanceolate, tapering at base.

All the leaves sessile or subsessile.

8. P. Faxoni.

Fruit only $2 \mathrm{~mm}$. long, obscurely 3 -keeled.

Fruit $3 \mathrm{~mm}$. long, distinctly 3 -keeled.

1o. P. spathulaeformis.

12. P. Zizii. 
With submerged leaves only.

Without propagating buds and without glands.

Leaves with broad blades, mostly lanceolate or ovate, many-nerved.

Leaves subsessile or short-petioled, mostly acute or cuspidate.

13. P. Iucens.

Leaves semi-amplexicaul, obtuse and cucullate at the apex.

14. P. praelongus.

Leaves meeting around the stem, very obtuse at the apex, not cucullate.

15. P. perfoliatus.

Leaves with narrow blades, linear or oblong-linear, several-nerved.

Leaves oblong-linear, 5-7-nerved, obtuse at the apex.

Leaves narrowly linear, 3-nerved, acute at the apex.

I6. P. Mysticus.

$2 \mathrm{r}$. $P$. foliosus.
Leaves with narrow blades, capillary or setaceous, 1 -nerved or nerveless.

With propagating buds or glands, or both.

17. P. confervoides.

With buds, but without glands.

Leaves serrulate, 3-7-nerved.

Leaves entire, with 3 principal and many fine nerves.

Commonly with glands, but no buds.

18. P. crispus.

19. P. zosteraefolius.

Stems long-branching from the base ; leaves lax, flat, 3-nerved, abruptly acute or cuspidate.

20. P. Hillii.

Stems simple; leaves strict, revolute, 3-5-nerved, acuminate.

With both buds and glands.

Glands large and translucent ; buds rare.

Glands small, often dull; buds common.

Leaves linear, 5-7-nerved.

Leaves linear, 3-nerved.

Leaves capillary, $\mathbf{I}$-nerved or nerveless.

Stipules adnate to the leaves or petioles.

24. P. rutilus.

22. P. obtusifolius.

23. P. Friesii.

27. P. pusillus.

28. P. gemmiparus.

With both floating and submerged leaves.

Submerged peduncles as long as the spikes, clavate, often recurved.

Submerged peduncles none, or at most hardly $2 \mathrm{~mm}$. long.

29. $P$. diversifolius.

With submerged leaves only.

Stigma broad and sessile.

Style apparent ; stigma capitate.

Fruit without keels or obscurely keeled.

Fruit strongly 3 -keeled.

Leaves entire, 3-5-nerved.

Leaves minutely serrulate, finely many-nerved.

3o. P. Spirillus.

31. P. filiformis.

32. P. pectinatus.

33. P. interruptus.

34. P. Robbinsii.

I. Potamogeton nàtans L. Common Floating Pondweed. (I. F. f. I42.) Stems 0.6-1.3 m. long, simple or sparingly branched. Floating leaves thick, the blade ovate, oval or elliptic, 5-10 $\mathrm{cm}$. long, 2-5 cm. wide, usually with a thort abrupt tip, rounded or subcordate at the base, many-nerved; submerged leaves reduced to phyllodes which commonly perish early; stipules sometimes in $\mathrm{cm}$. long, acute, 2-keeled; peduncles as thick as the stem, 5-10 $\mathrm{cm}$. long; spikes very dense, about $5 \mathrm{~cm}$. long; fruit turgid, 4-4.5 $\mathrm{mm}$. long, about $2.5 \mathrm{~mm}$. thick, scarcely keeled, narrowly obovoid, slightly curved on the face; style broad; nutlet hard, pitted or impressed on the sides, 2-grooved on the back; embryo forming an incomplete circle, the apex pointing toward the base. In ponds and streams, throughout N. Am. except the extreme north, extending into iffex. Also in Europe and Asia. July-Aug.

2. Potamogeton Oakesiànus Robbins, OAkes' Pondweed. (I. F. f. I43.) Stems very slender, often much branched from below. Floating leaves elliptic, mostly obtuse, rounded or subcordate at the base, $2-5 \mathrm{~cm}$. long, $10-20 \mathrm{~mm}$. wide, 12-:O-nervèd; petioles 5-15 cm. long; submerged leaves mere capillary phyllodes, often persistent; peduncles $2-8 \mathrm{~cm}$. long, commonly thicker than the stem; spikes cylindric, I2-25 cm. long; stipules acute, hardly keeled; fruit obovoid, about $3 \mathrm{~mm}$. long, $2 \mathrm{~mm}$. thick, nearly straight on the face, 3 -keeled, the middle keel sharp; style apical or subapical; sides of the nutlet not pitted, but sometimes 
slightly impressed; embryo circle incomplete, the apex pointing toward the base. In still water, Anticosti to N. Penn. and N. J. Summer.

3. Potamogeton amplifòlius Tuckerm. Large-Leaved Pondween). (I. F. f. I44.) Stems long, simple or occasionally branched. Floating leaves oval or orate, abruptly pointed at the apex, rounded at the base, 5-10 $\mathrm{cm}$. long, 3-5 cm. wide, many-nerved; submerged leaves mostly petioled, large, the uppermost often elliptic or oval, 7-I5 cm. long, 2-5 cm. wide, the lowest lanceolate, often $20 \mathrm{~cm}$. long, with about 25 nerves, often with the sides closed and assuming a falcate shape; stipules tapering to a long sharp point, sometimes ro $\mathrm{cm}$. long; peduncles thickened upward, 5-20 cm. long; spikes $2-5 \mathrm{~cm}$. long; fruit 4-5 mm. long, $2.5 \mathrm{~mm}$. thick, turgid, the pericarp hard, obliquely obovoid, 3-keeled; face more or less angled; style subapical; embryo slightly incurved. In lakes, Ont. to Br. Col., south to Conn., Ky. and Neb. July-Sept.

4. Potamogeton púlcher Tuckerm. Sported Pondweed. (I. F. f. I $\div 5$.) Stems simple, terete, black-spotted, $0.3-0.7 \mathrm{~mm}$. long. Floating leaves usually massed at the top on short lateral branches, alternate, ovate or round-ovate. subcordate, 2-8 cm. long, 5-II cm. wide, many-nerved; peduncles about as thick as the stem, 5-10 $\mathrm{cm}$. long, spotted; submerged leaves of $2 \mathrm{kinds}$, the uppermost pellucid, lanceolate, long-acuminate, undulate, 7-20 cm. long, $1-3.5 \mathrm{~cm}$. wide, tapering at the base into a short petiole, 10-20-nerved; the lowest much thicker, opaque, spatulate, long; stipules 2-carinate; fruit 4-4.5 nm. long, $3 \mathrm{~mm}$. thick, turgid, tapering into a stout apical style, the back sharply $3 \cdot k e e l e d ;$ face angled near the middle, with a sinus below; embryo coiled. In ponds and pools, Me. to Ga. and Mo. July.

5. Potamogeton Nuttállii Cham. \& Sch. Nuttall's Ponnweed. (I. F. f. 146.) Stems slender, compressed, mostly simple, $0.3^{-2} \mathrm{~m}$. long. Floating leaves opposite, elliptic, to obovate, obtuse, short-petioled, 3-8 cm. long, 8-24 mm. wide, many-nerved; submerged leaves linear, 2-ranked, 5-17 cm. long, 2-6 mm. wide, 5 -nerved, the 2 outer nerves nearly marginal, the space between the 2 inner and the midrib reticulated; stipules obtuse, hyaline, not keeled; peduncles $2-13 \mathrm{~cm}$. long; spikes $\mathbf{I}-2.5 \mathrm{~cm}$. long; fruit round-obovoid $2.5-4 \mathrm{~mm}$. long, 2-3 mm. thick, 3-keeled, the sides flat and indistinctly impressed; style short, apical; embryo coiled one and one-third times. In ponds and streams, N. S. to Penn. and S. C. June-Aug. (P. Claytonii Tuckerm.)

6. Potamogeton alpinus Balbis. Northern Pondweed. (I. F. f. I47.) Plant of a ruddy tinge; stems simple or branched, somewhat compressed. Floating leaves spatulate or oblanceolate, obtuse, many-nerved, tapering into petioles 2-r2 cm. long; submerged leaves semi-pellucid, the lowest sessile, the uppermost petioled, oblong-linear or linear-lanceolate, obtuse or rarely acute, narrowed at the base, 7-30 cm. long, 4-20 mm. wide, 7-17-nerved; stipules broad, faintly 2-carinate, obtuse or rarely acute; spikes $2-3 \mathrm{~cm}$. long; fruit obovoid, lenticular, reddish, $25 \mathrm{~mm}$. long, $2 \mathrm{~mm}$. thick, 3-keeled, the middle keel sharp, the face arched, beaked by the short recurved style; apex of the embryo pointing directly to the basal end. In ponds, N. S. to Br. Col., N. J. and Cal. Also in Europe. July-Aug. (P. rufescens Schrad.)

7. Potamogeton lonchites Tuckerm. Long-Leaved Pondweed. (I. F. f. I48.) Stem terete, much branched, $\mathbf{r}-2 \mathrm{~m}$. long. Floating leaves rather thin, elliptic, pointed at both ends, $5-15 \mathrm{~cm}$. long, $\mathrm{r}-3 \mathrm{~cm}$. wide, many-nerved, petioled; submerged leaves pellucid, ro-32 cm. long, 4-24 mm. wide, rounded at the base or tapering into a petiole; stipules acuminate, strongly or faintly 2carinate; peduncles thickening upward, 5-8 cm. long; spikes cylindric, $2-5 \mathrm{~cm}$. long; fruit about $4 \mathrm{~mm}$. long, 2-3 mm. thick, obliquely obovoid, the face nearly straight, the back 3 -keeled, the middle keel rounded or often with a projecting wing under the style, not impressed on the sides; embryo slightly incurved, apex pointing slightly inside of the base. In ponds and slow streams, N. Br. to Wash., Fla. and Cal. July-Oct.

F'ot amogeton lonchites Noveboracénsis Morong. Floating leaves thicker, $7-14 \mathrm{~cm}$. long, about $5 \mathrm{~cm}$. wide, $20-24$-nerved, abruptly pointed or obtuse at the apex; peduncles sometimes Io-12 cm. and spikes $7.5 \mathrm{~cm}$. long. Lakes of Cent. N. Y.

8. Potamogeton Fáxoni Morong. Faxon's Pondweed. (I. F. f. I49.) Floating leaves numerous, mostly obovate or oblanceolate, blunt-pointed or obtuse 
at the apex, narrowed at the base, often strikingly like those of $P$. spathucaeformis, 5-9 cm. long, 15-25 mm. wide, 13-17-nerved, petioled; submerged leaves oblonglanceolate, acute or sometimes obtuse, $7-13 \mathrm{~cm}$. long, $\mathbf{r}-25 \mathrm{~cm}$. wide, 5-13-nerved, often with an irregular areolation on each side of the midrib; petioles $1.2-2.5 \mathrm{~cm}$. in length; peduncles slightly thicker than the stem; spikes dense, 2-5 cm. long; fruit not collected. Little Otter Creek and Lake Champlain, Ferrisburg, Vt.

9. Potamogeton heterophyllus Schreb. VArious-leaved PONDweEd. (I. F. f. I50.) Stems slender, compressed, much branched, sometimes $4 \mathrm{~m}$. long. Floating leaves pointed at the apex, mostly rounded or subcordate at the base, 1.5ro $\mathrm{cm}$. long, 8-30 mm. wide, ro-18-nerved, on petioles $2-10 \mathrm{~cm}$. long ; submerged leaves pellucid, sessile, linear-lanceolate, acuminate, cuspidate, rather stiff, 2-15 $\mathrm{cm}$. long, 2-16 $\mathrm{mm}$. wide, 3-9-nerved, the uppermost often petioled; peduncles often thickened upward, sometimes clustered; stipules spreading, obtuse 1.5-2.5 $\mathrm{cm}$. long; spikes 1.8-25 cm. long; fruit roundish or obliquely obovoid, $2-3 \mathrm{~mm}$. long, 1-2 mm. thick, indistinctly 3 -keeled; style short, obtuse, apical; apex of the embryo nearly touching the base, pointing slightly inside of it. A very variable species, occurring in different forms throughout almost all N. Am. except the extreme north. Also in Europe. July-Sept.

Potamogeton heterophýllus graminifolius (Fries) Morong. Submerged leaves delicate, flaccid, linear, 4-12 cm. long, 2-6 nim. wide With the type.

Potamogeton heterophýllus myriophýllus (Robbins) Morong. Stems dichotomously branching, very leafy; submerged leaves delicate, about $2.5 \mathrm{~cm}$. long and $4 \mathrm{~mm}$. wide, 3-5nerved, linear or the upper oblanceolate; floating leaves elliptic or lanceolate-oblong; rootstock tuberous. Mass., R. I. and Conn.

Potamogeton heterophýllus minimus Morong. Stems long and almost capillary, the internodes $7-10 \mathrm{~cm}$. long, densely clustered on short lateral branches, $1-2.5 \mathrm{~cm}$. long, scarcely $0.5 \mathrm{~mm}$. wide, acuminate, $\mathrm{x}$-nerved; floating leaves $\mathrm{I}-3.5 \mathrm{~cm}$. long, $6-18 \mathrm{~mm}$. wide, lanceolate, oval or ovate, usually clustered at the summit of the stem. Mass. and N. H.

Io. Potamogeton spathulaefórmis (Robbins) Morong. Spatulate-leaved Pondweed. (I. F. f. I5I.) Stems many, branched, o.6-1 m. long. Floating leaves obovate or elliptic, abruptly acute at the apex, rather thin, 13-23-nerved, 2-6 cm. long, $1.5^{-2} 5 \mathrm{~cm}$. wide, borne on slender petioles; submerged leaves pellucid, spatulateoblong or linear-lanceolate, 5-10 $\mathrm{cm}$. long, 6-18 mm. wide, 5-13-nerved, cuspidate or spinescent, sessile or subsessile, often reduced to phyllodes with a very narrow blade and a long acumination at the base and apex; peduncles often thickening upward, 2-5 cm. long; stipules obtuse, faintly keeled, the apex slightly hooded; spikes large; fruit about $2 \mathrm{~mm}$. long, roundish or obliquely ovoid, obscurely 3 -keeled, with a curved or slightly angled face; embryo with the apex pointing slightly inside of the base. In Mystic Pond, Medford, Mass. Also in Europe. Summer.

II. Potamogeton Illinoénsis Morong. Illinois PondweEd. (I. F. f. 152.) Stem stout, much branched above. Floating leaves opposite, numerous, thick, IO-I4 cm. long, 5-9 cm. wide, many-nerved' oval or broadly elliptic, shortpointed, petioled; submerged leaves numerous, IO-20 $\mathrm{cm}$. long, $2-5 \mathrm{~cm}$. wide, 13-I9-nerved, acuminate or the uppermost acute, mostly tapering at the base into a short, broad, flat petiole, rarely reduced to phyllodes; stipules $5-8 \mathrm{~cm}$. long, obtuse, strongly 2-carinate; peduncles 5-10 cm. long; spikes $2-5 \mathrm{~cm}$. long; fruit roundish or obovoid, 3-4 mm. long, 2-3 mm. thick, dorsally 3-keeled; style short, blunt. In ponds, Ill. to Ia. and Minn. Aug.

I Potamogeton Zízii Roth. Zız's Pondweed. (I. F. f. I53.) Stems slender, branching. Floating leaves elliptic, 4-10 cm. long, $\mathbf{I}-2.5 \mathrm{~cm}$. wide, manynerved; petioles mostly short ; submerged leaves mostly lanceolate or oblanceolate, thin, acute or cuspidate, 5-15 cm. long, 6-30 mm. wide, 7-17-nerved; stipules obtuse, 2-keeled; peduncles thicker than the $\mathrm{s}^{\cdot} \mathrm{em}, 6-15 \mathrm{~cm}$. long; spikes $2-5 \mathrm{~cm}$. long ; fruit obliquely obovoid, $2.5-4 \mathrm{~mm}$. long, about $2 \mathrm{~mm}$. thick, the face dorsally 3-keeled; style short. blunt, facial; apex of the embryo pointing directly to the base. In lakes and streams, Que. to Mont., Fla. and Wyo. Also in Europe. July-Aug.

Potamogeton Zizii Methyénsis (A. Benn.) Morong. Middle leaves narrow; upper leaves oval; stipules long ; fruit small. Methy Lake, Can. 
13. Potamogeton lùcens L. Shining Pondweed. (I. F. f. 154.) Stera thick, branching below and often with masses of short leafy branches at the summit. Leaves all submerged, elliptic, lanceolate or the uppermost oval, shining, sessile or shortpetioled, $6-20 \mathrm{~cm}$. long, $1.5-4 \mathrm{~cm}$. wide, the tips often serrulate ; stipules 2 -carinate, sometimes very broad; peduncles 7-15 cm. long; spikes 5-6 $\mathrm{cm}$ long, very thick; fruit about $3 \mathrm{~mm}$. long and $2.5 \mathrm{~mm}$. thick, roundish, the face usually with a slight inward curve at the base; apex of the embryo pointing transversely inward. In ponds, N. S. to Fla., west to Cal. and Mex. Local. Also in Europe. Sept.-Oct.

Potamogeton lùcens Connecticuténsis Robbins. Stems flexuous; leaves acuminate; fruit larger than that of the type (about $4 \mathrm{~mm}$. long), distinctly 3 -carinate and with a facial style. Saltonstall's l'ond, Conn., and White Plains, N. Y.

14. Potamogeton prælóngus Wulf. White-stemmed Pondweed. (I. F. f. 155.) Stems white, flexuous, flattened, much branched, growing in deep water, sometimes $2.6 \mathrm{~m}$. long. Leaves all submerged, oblong or oblong-lanceolate, semiamplexicaul, bright green, $\mathbf{I}-3.5 \mathrm{~cm}$. long, 5-30 cm. wide, with 3-5 main nerves; stipules white, scarious, obtuse and commonly closely embracing the stem; peduncles 7-50 cm. long, erect, straight, about as thick as the stem; spikes 2-5 $\mathrm{cm}$. long, thick, cylinđric; fruit dark green, obliquely obovoid, 4-5 mm. long, 3-4 $\mathrm{mm}$. thick, the back much rounded, often with the upper curve nearly as high as the style; the middle keel sharp; style short, obtuse, facial. N. S. to Br. Col., N. J., Minn. and Cal. Also in Europe. June-July.

ij Potamogeton perf liàtus L. Clasping-leaved Pondweed. (I. F. $f$. 156.) Stems slendler, much branched. Leaves all submerged, orbicular or ovate, so netimes lanceolate, usually obtuse and minutely serrulate at the apex, cordateperfoliate at the base, $3-5 \mathrm{~cm}$. long, $0.5-2.5 \mathrm{~cm}$. wide; peduncles $3.5 \mathrm{~cm}$. long, usually erect or slightly spreading; spikes $1.5-2.5 \mathrm{~cm}$. long; fruit obliquely obuvoid, $2.5-3 \mathrm{~mm}$. long, $2 \mathrm{~mm}$. thick, obscurely 3 -carinate on the back, the face s'ightly curved outwardly toward the top, the sides with a shallow indentation which runs into the face; style nearly facial; embryo slightly incurved or with its apex pointing cirectly toward the base. In ponds and streams, Newf. to Br. Col., Fla., and Cal. Also in Europe and Asia. July-Sept.

Potamogeton perfoliàtus Richardsònii A. Bennett. Leaves 2-12 cm. long, 8-r6 $\mathrm{mm}$. wide at the broadened amplexicaul base, often curving inward at the apex, $13-23$ nerved. Fruit somewhat larger than that of the type, about $4 \mathrm{~mm}$. long and $2.5 \mathrm{~mm}$. thick. N. N. E. to Or., Del., Neb., and Cal.

16. Potamogeton Mýsticus Morong. Mystic Pond Pondweed. (I. F. f. 157.) Whole plant very slender and delicate, stems irregularly branching above, nearly filiform, terete, $0.3-3.3 \mathrm{~m}$. long. Leaves all submerged, scattered oblonglinear, $2-4 \mathrm{~cm}$. long, $2-6 \mathrm{~mm}$. wide, 5-7-nerved, obtuse and rarely with minute serrulations near the apex, abruptly narrowed at the base and sessile or partly clasping; stipules obtuse, about $12 \mathrm{~mm}$. long, hyaline and with many fine nerves, mostly deciduous, but sometimes persistent and closely sheathing the stem; spikes few, capitate, 4-6-flowered, borne on erect peduncles 2-5 cm. long: immature fruit obovoid, less than $2 \mathrm{~mm}$. long, about $\mathrm{I} \mathrm{mm}$. wide, obscurely 3 -keeled on the back, slightly beaked by the slender, recurved style. Mystic Pond, Medford, and Miacount Pond, Nantucket, Mass. Aug.-Sept.

I7. Potamogeton confervordes Reichb. Alga-like Pondweed. (I. F. f. 158.) Stems slender, terete, I5-45 cm. long, the upper branches repeatedly forking. Leaves very delicate, flat, setaceous, $2-6 \mathrm{~cm}$. long, the broadest scarcely $0.5 \mathrm{~mm}$. wide, tapering to a long hair-like point, $\mathrm{I}-3$-nerved and often with a few cross-veins; stipules delicate, obtuse, 4-6 mm. long; peduncles 5-20 cm. long, erect, somewhat thickened upward; spikes $6-8 \mathrm{~mm}$. long; fruit roundish-obovoid, $2-3 \mathrm{~mm}$. long and about as thick, the back sometimes a little angular or sinuate, 3 -keeled, the middle keel sharp, the face notehed near the base, the sides impressed with a shallow indentation which runs into the notch of the face; apex of the embryo nearly touching the base a little to one side. In cold or mountain ponds, Me. and N. H. to N. J. and Pein. Slso i.r Lurop: Aug.-Sept. (P. Tuckermani Robbins.) 
18. Potamogeton críspus L. Curled-leaved Pondweed. (I. F. f. 159.) Stems branching, compressed. I, eaves 2-ranked, linear-oblong or. linear-oblanceolate, sessile or semi-amplexicauı, obtuse, serrulate, crisped, I-IO cm. long, 6-I4 mm. wide, 3-7-nerved, the midrib often compound and the outer nerves very near the margin; stipules small, scarious, obtuse, early perishing; peduncles $2-5 \mathrm{~cm}$. long, frequently recurved in fruit, sometimes very numerous; spikes about $\mathrm{I} \mathrm{cm}$. long, appearing very bristly with the long-beaked drupelets when in fruit ; fruit ovoid, about $3 \mathrm{~mm}$. long, $2 \mathrm{~mm}$. or more wide, 3 -keeled on the back, the middle keel with a small projecting tooth near the base, the face slightly curved, the style facial and nearly as long as the drupelet; embryo small, its apex pointing directly toward its base. The plant is mainly propagated by peculiar winter buds. In fresh, brackish or even salt water, Mass., Penn., and Va. Also in Europe. Aug.

19. Potamogeton zosteraefòlius Schum. Eel-Grass Pondweed. (I. F. f. I60.) Stems much flattened, sometimes winged, widely branching. Leaves linear, obtuse and mucronate or sharp-pointed at the apex, 5-30 cm. long, 2-5 mm. wide, with 3 princip 1 lnerves and many fine ones; stipules scarious, obtuse, finely nerved, soon perishing; peduncles 3-10 $\mathrm{cm}$. long; spikes cylindric, about $\mathbf{I} \mathrm{cm}$. long, 12-15-flowered; fruit obovoid with a broad base, about $4 \mathrm{~mm}$. long, 2.5-3 mm. thick, 3-kee'ed on the back, the lateral keels rather obscure; face arched, beaked with a short recurved style; embryo slightly incurved. The plant is propagated by the terminal leaf-buds, which sink to the bottom, and rest during the winter. In still or running water, N. B. to N. J., west to Or. Also in Europe. July-Aug.

20. Potamogeton Híllii Morong. Hill's PondweEd. (I. F.f. I6r.) Stems slightly compressed, slender, widely branching, $0.3-0.6 \mathrm{~m}$. long. Lenves linear, acute, cuspidate, or often almost aristate, $2-6 \mathrm{~cm}$. long, $0.5 .-2.5 \mathrm{~mm}$. wide, 3nerved, the lateral nerves delicate and nearer the margins than the midrib; stip. ules whitish, many-nerved, obtuse, 6-10 $\mathrm{mm}$. long; peduncles about $\mathrm{I} \mathrm{cm}$. long, erect or slightly recurved; spikes capitate, 3-6-fruited; fruit obliquely obovoid, obtuse at the base, about $4 \mathrm{~mm}$. long, 2-2.5 mm. thick, 3-carinate on the back, the middle keel sharp and more or less undulate, flat on the sides, face slightly arched; style nearly facial, short; embryo coiled. In ponds, E. N. Y. to Mich. There are two forms of the species, the one 2-glandular at the base of the leaves, the other glandless. July-Sept.

21. Potamogeton foliosus Raf. Leafy Pondweed. (I. F. f. 162.) Stems flattened, much branched, $0.3^{-1} \mathrm{~m}$. long. Leaves $2-5 \mathrm{~cm}$. long, I-2 mm. wide, acute, 3-nerved; stipules white, hyaline, obtuse or sometimes acute, I-2 cm. long; peduncles more or less clavate, erect; spikes about 4-flowered; fruit lenticular or nearly orbicular, about $2 \mathrm{~mm}$. in diameter, 3 -keeled on the back, the middle keel winged, sinuate-dentate, often with projecting shoulders or teeth at each end, the face strongly angled or arched, sharp, often with a projecting tooth at the base; style apical. In ponds and streams, N. B. to Br. Col., Fla., N. Mex. and Cal. July-Aug. (P. pauciflorus Pursh.)

Potamogeton foliòsus Niagarénsis (Tuckerm.) Morong. $\mathrm{m}$. long, leaves sometimes over $7.5 \mathrm{~cm}$. in length and $2 \mathrm{~mm}$. wide, $3-5$-nerved; stipules larger and occasionally acute; spikes 8-12-flowered. Niagara Falls to Mich. and Cal.

22. Potamogeton obtusifòlius Mert. \& Koch. Blunt-Leaven Pondweed. (I. F. f. 163.) Stems usually slender, compressed, widely branching. Leaves linear, 5-8 cm. long, I-4 mm. wide, obtuse, often mucronate, usually 3-nerved with a broad midrib, sometimes 5-7 nerved, 2-glandular at the base, the glands large and translucent; stipules white or scarious, many-nerved, obtuse, $1-2 \mathrm{~cm}$. long, often as long as or longer than the internodes; peduncles numerous, slender, erect; spikes $68 \mathrm{~mm}$. long, ovoid, 5-8-flowered; fruit obliquely obovoid, about 3 $\mathrm{mm}$. long and $2 \mathrm{~mm}$. thick, 3 -keeled; style short, blunt, nearly facial. In sti!l water, Que. to Penn., Minn., and Wyo. Also in Europe. July-Aug.

23. Potamogeton Frièsii Ruprecht. Fries' PondweEd. (I. F. f. 164.)

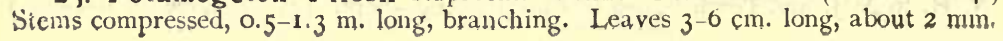


wide, acute, obtuse ur cuspidate at the apex, mostly 5-nerved, rarely 7 -nerved, 2-glandular at the base, the glands small; stipules white, hyaline, finely nerved, obtuse or acute, $1-2 \mathrm{~cm}$. long; peduncles often thicker than the stem and sometimes thickening upward; spikes, when developed, interrupted; fruit quite similar to that of $P$. pusillus, but with a recurved style, usually with a shallow pit on the sides, and with the apex of the embryo pointing toward the basal end. In still water, N. B. to N. Y., west to Br. Cul. Also in Europe. Propagating buds occasional. July-Aug.

24. Potamogeton rìtilus Wolfg. Slender Pondweed. (I. F. f. I65.) Stems very slender, $0.2-0.6 \mathrm{~m}$. long, compressed, simple or nearly so. Leaves 2-3.5 cm. long, $0.5-1 \mathrm{~mm}$. wide, acute or acuminate, strict. nearly erect, 3-5nerved, revolute, often 2-glandular at base and bright green, the nerves prominent beneath; stipules acute, $\mathbf{I - 2} \mathrm{cm}$. long, often longer than the internodes and hiding the bases of the leaves above, persistent, becoming white and fibrous with age; peduncles $\mathrm{I}-3.5 \mathrm{~cm}$. long; spikes 6-10 $\mathrm{mm}$. long, usually dense, but sometimes interrupted; fruit obliquely obovoid, alsout $2 \mathrm{~mm}$. long and I mm. thick, obscurely keeled or the back showing only 2 small grooves; apex of the drupelet tapering into a short facial nearly straight recurved style; embryo circle not complete, the apex pointing a little inside of the base. Anticosti and James Bay to Mich. and Minn. Also in Europe.

25. Potamogeton Vàseyi Robbins. Vasey's Pondweed. (I. F. f. I66.) Stems filiform, widely branching below, and with many short lateral branches above, $0.3-0.5$ long, the emersed fertile forms in shallow water, and the more common sterile submerged forms in water from 2-3 m. in depth. Floating leaves on the fertile stems only, coriaceous, in 1-4 opposite pairs, oval, oblong or obovate, 8-10 mm. long, 4-6 mm. wide, with 5-9 nerves deeply impressed beneath, tapering at the base into petioles $6-8 \mathrm{~mm}$. long; submerged leaves capillary, 2-4 cm. long; stipules white, delicate, many-nerved, acute or obtuse, $4-6 \mathrm{~mm}$. long; peduncles 6-12 mm. long, thickening in fruit; spikes 4-6 mm. long, 2-6 fruited; fruit roundish-obovoid, about $2 \mathrm{~mm}$. long and nearly as thick, 3-keeled, the middle keel rounded, tipped with a straight or recurved style. E. Mass. to S. Ont. and $\mathrm{O}$. The plant is furnished with propagative buds. July-Aug.

26. Potamogeton lateràlis Morong. Opposite-Leaved Ponnweed. (I. F. f. 167.) Stems filiform, much branched. Floating leaves on sterile shoots only, coriaceous, elliptic, obtuse, 8-10 $\mathrm{mm}$. long, 2-4 mm. wide, 5-7-nerved, the nerves deeply impressed beneath, usually in $\mathbf{I}-3$ opposite pairs which stand at right angles to the stem on petioles $6-20 \mathrm{~mm}$. long; submerged leaves linear, acute, 2-8 cm. long, 0.5-1 mm. wide, 1-3-nerved, 2-glandular at the base, but the glands small and often obsolete; stipules small, hyaline, many-nerved, obtuse, deciduous; peduncles and floating leaves lateral, widely spreading at maturity, sometimes recurved, spikes capitate or often interrupted, 3-4-flowered; fruit obliquely obovoid, about $2 \mathrm{~mm}$. long, lenticular, the back much curved and 2 -grooved, the face arched and surmounted by the nearly sessile stigma; curve of the embryo oval, its apex nearly touching its base. In lakes and slow streams, E. Mass. to Mich. Proliferous shoots at the summit of the stem and on the upper branches appear late in the season, as the plants a re beginning to decay. July-Aug.

27. Potamogeton pusíllus L. SMall Pondweed. (I. F. f. 168.) Stems filiform, branching, 0.I-0.6 m. long. Leaves all submerged, linear, obtuse and mucronate or acute at the apex. 2-glandular at the base, $2.8 \mathrm{~cm}$. long, about $\mathbf{I ~} \mathrm{mm}$. wide, I-3-nerved, the lateral nerves oiten obscure; stipules short, hyaline, obtuse;

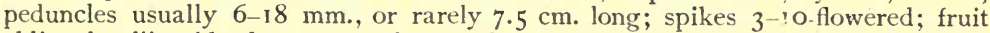
obliquely ellipsoid, about $2 \mathrm{~mm}$. long and I mm. thick, curved and 2 -grooved on the back or sometimes with 3 distinct keels, the face slightly arched, beaked by a straight or recurved style; apex of the embryo slightly incurved and pointing ob. liquely downward. Propagative buds occur in greater or less abundance. In ponds and slow streams, N. B. to Br. Col., south to Va., Tex., and Cal. Also in Europe. July-Aug.

Potamogeton pusíllus Panormitànus (Biv.) Morong. Uppermost leaves subcoriaceous, spatulate, opposite, divaricate, 3-5-nerved, 8-10 $\mathrm{mm}$. long, tapering into a broad putiolẹ as long as the blade, Ottawa, Onț. Also in Europe. 
Potamogeton pusillus polyphýllus Morong. Stem 7-14 cm. long, divaricately branching from the base and very leafy throughout ; leaves very obtuse, 3-nerved. Plant not known to flower, but abundantly provided with propagating buds which are thickened, hardened and closely invested with imbricated leaves. E. Mass.

Potamogeton pusíllus Sturróckii A. Bennett. A rare form with delicate bright green pellucid leaves, $2-8 \mathrm{~cm}$. long, obtuse or often apiculate at the apex, less than $2 \mathrm{~mm}$. wide, sometimes 5-nerved; fruit much smaller than that of the type, short-beaked. E. Mass. A'so in Europe.

28. Potamogeton genmíparus (Robbins) Morong. Capillary Pondween. (I. F. f. I69.) Stems filiform, terete, branching, 0.I-1.3 m. long. Leaves capillary, sometimes not as wide as the stem, often with no perceptible midrib, tapering to the finest tip, $2-8 \mathrm{~cm}$. long, 2-glandular at the base; stipules $1-2.5 \mathrm{~cm}$. long, mostly deciduous; spikes interrupted, 3-6-flowered; peduncles filiform, or sometimes slightly thickened, $\mathbf{I}-5 \mathrm{~cm}$. long; fruit seldom formed, similar to that of $P$. pusillus, except that it is flatter and somewhat impressed on the sides. In ponds, E. Mass. and R. I. It is commonly propagated by its abundant buds; the leaves and stems are often alike in thickness, so that the plant seems to consist of threads. Aug.-Sept. (P. pusillus var. (?) gemmiparus Robbins.)

29 Potamogeton diversifolius Raf. Rafinesque's Pondweed. (I. F. f. 170.) Stems flattened or sometimes terete, much branched. Floating leaves coriaceous, the largest $2.5 \mathrm{~cm}$. long by $1.2 \mathrm{~cm}$. wide, oval or elliptic and obtuse, or lanceolate-oblong and acute; petioles filiform or dilated; submerged leaves setaceous, seldom over $0.5 \mathrm{~mm}$. wide, $2-8 \mathrm{~cm}$. long; stipules obtuse or truncate, 6 - $10 \mathrm{~mm}$. long, those of the floating leaves free, those of the submerged leaves sometimes adnate; emersed peduncles 6-14 $\mathrm{mm}$. long; submerged peduncles 4-6 mm. long, clavate, as long as the spikes; emersed spikes 6-10 mm. long, occasionally interrupted; fruit cochleate, rarely over I mm. long, 3-keeled, the middle keel narrowly winged and usually with 7 or 8 knob-like teeth on the margin, the lateral keels sharp or rounded; embryo coiled $11 / 2$ times. In still water, Me. to Fla., west to Neb. and Tex. June-Sept. (P. hybridis Nichx.)

Pomategon diversifolius multidenticulatus Morong. Differs from the type in the numerous teeth of the fruit, as many as 12 being sometimes found on the middle keel, and each lateral keel with 6-8 more, the teeth often bristle-like and sometimes 2-pronged. Conn. to E. Penn. and Del.

Potamogeton diversifolius trichophýllus Morong. Plant about $15 \mathrm{~cm}$. long, without floating leaves, the submerged leaves as fine as floss silk and entirely nerveless. Lake Marcia, N. J.

30. Potamogeton Spiríllus Tuckerm. SpIral Pondweed. (I. F. f. ry r.) Stems compressed, branched, I $5-50 \mathrm{~cm}$. long, the branches often short and recurved. Floating leaves oval or elliptic, obtuse, the largest about $2.5 \mathrm{~cm}$. long and I. $2 \mathrm{~cm}$. wide, with $5^{-1} 3$ nerves deeply impressed beneath, their petioles often $2.5 \mathrm{~cm}$. long; submerged leaves linear, 3-4 mm. long, about I mm. wide, mostly 5-nerved; stipules of the upper floating leaves free; those of the submerged leaves adnate to the blade or petiole; spikes above water 6-ro $\mathrm{mm}$. long, continuous, the lower mostly sessile, capitate and I-IO-fruited; fruit cochleate, roundish, less than $2 \mathrm{~mm}$. long, flat and deeply impressed on the sides, 3-keeled on the back, the middle keel winged and sometimes 4-5-toothed; style deciduous; embryo spiral, about $\mathrm{I} \frac{1}{2}$ turns. In ponds and ditches, N. S. and Ont. to Minn., south to Va., Mo., and Neb. June-Aug.

3r. Potamogeton filifòrmis Pers. Fillform Pondweed. (I. F. f. 172.) Stems from a running rootstock, slender, $1-7 \mathrm{~m}$. long, filiform above, stout and thick toward the base. Leaves numerous, 5-30 $\mathrm{cm}$. long, $0.5^{-1} \mathrm{~mm}$. wide, I-nerved with a few cross veins; sheaths about $2 \mathrm{~mm}$. long and the free part of the stipule $12 \mathrm{~mm}$. long, scarious on the ed res; flowers on long, often recurved peduncles, 2-12 in each whorl; fruit 2-3 $\mathrm{mm}$. long, slightly less than $2 \mathrm{~mm}$. wide, the sides even, the back not keeled, the face nearly straight or obtusely angled near the top; stigma nearly or quite sessile, remaining on the fruit as a broad truncate projection. In ponds and lakes, Anticosti to W. N. Y. and Mich. August. 
Potamogeton fillformis Macdunii Morong. Leaves $2-7.5 \mathrm{~cm}$. long, the largest $\mathrm{I} \mathrm{mm}$. or more wide, obtuse, stiff, with a strong nidrib and raised or slightly revolute margins; fruit rarely more than $2 \mathrm{~mm}$. long; peduncles only $1.5^{-2} \mathrm{~cm}$. long; plant commonly with a compact bushy habit. In brackish or salt water lakes, prairie region of Can.

32. Potamo eton pectinàtus L. Fennel-leaved Pondweed. (I. F. f173.) Stems slender, much branched, $0.3-1 \mathrm{~mm}$. long, the branches repeatedly forking. Leaves setaceous, attenuate to the apex, I-nerved, $2.5-15 \mathrm{~cm}$. long, often capillary and nerveless; stipules half free, $1.2-2.5 \mathrm{~cm}$. long, their sheaths scarious on the margins; peduncles filiform; the flowers in verticils; fruit obliquely obovoid, with a hard thick shell, 3-4 mm. long, $2-2.5 \mathrm{~mm}$. wide, without a middle keel, but with obscure lateral ridges on the back, plump on the sides and curved or occasionally a little angled on the face; style straight or recurved, facial; embryo apex pointing almost directly toward the basal end. In fresh, brackish, or salt water, Cape Breton to Br. Col., south to Fla., Tex., and Cal. Also in Europe. July-Aug.

3. Potamogeton interrúptus Kitaibel. InTERruP'Ted PondweEd. (I. F. f. I74.) Stems arising from a running rootstock which often springs from a small tuber, 0.6-I.3 m. long, the branches spreading like a fan. Leaves linear, 7-I5 $\mathrm{cm}$. lons, 2-25 mm. wide, 3-5-nerved, with many transverse veins; narrow, Inerved leaves occur on some plants and these are acuminate, much like those of $P$. pectinatus; stipules partially adnate to the leaf-blade, sometimes with narrowly scarious margins, the free part shorter and scarious, obtuse; spikes interrupted; fruit broadly, obliquely obovoid, obtuse at the base, the largest $4 \mathrm{~mm}$. long and nearly as broad, prominently keeled and with rounded lateral ridges on the back, the face nearly or quite straight; style facial, erect. In ponds and streams, Pr. Edw. Isl. to N. Ind., Mich., and Neb. Also in Europe. Aug.

34. Potamogeton Robbínsii Oakes. Robbins' Pondweed. (I. F. f. 175.) Stems stout, widely branching, 0.6-I.3 m. long, from running rootstocks sometimes $0.3 \mathrm{~m}$. long. Leaves linear, 7-13 cm. long, 4-6 mm. wide, acute, finely manynerved, crowded in 2 ranks, minutely serrulate, auriculate at the point of attachment with the stipule; stipules adnate, the free part $1.2-2.5 \mathrm{~cm}$. long, acute, persistent, white, membranous, mostly lacerate; peduncles $2-7 \mathrm{~cm}$. long, the inflorescence frequently much branched and bearing from 5-20 peduncles; spikes interrupted, flowering under water; fruit obovoid, about $4 \mathrm{~mm}$. broad and $3 \mathrm{~mm}$ wide, 3 -keeled on the back, the midalle keel sharp, the lateral ones rounded, the face arched, the sides with a shallow depression which runs into the face below the arch; style subapical, thick, slightly recurved; apex of the embryo pointing a little inside the basal end. In ponds and lakes, N. B. to Or., south to Del., Penn., and Mich. The plant is freely propagated by fragments of the stems which throw out rootlets from each joint, but this is the rarest of our species to form fruit. Aug.-Sept.

\section{RÚPPIA L.}

Slender, widely branched aquatics with capillary stems, slender alternate I-nerved leaves tapering to an acuminate apex, and with membranous sheaths. Flowers on a capillary spadix-like peduncle, naked, consisting of 2 sessile anthers, each with 2 large separate sacs attached by their backs to the peduncle, having between them several pistillate flowers in 2 sets on opposite sides of the rachis, the whole cluster at first enclosed in the sheathing base of the leaf. Stigmas sessile, piltate. Fruit a small obliquely-pointed drupe, several in each cluster and pedicelled; embryo oval, the cotyledonary end inflexed, and both that and the hypocotyl immersed. [Name in honor of Heinrich Bernhard Rupp, a German botanist.] In the development of the plants the staminate flowers drop off and the peduncle elongates, bearing the pistillate flowers in 2 clusters at the end, but after fertilization it coils up and the fruit is drawn below the surface of the water.

Three or four species, occurring in salt and brackish waters all over the world. The following are the only ones known to occur in N. Am. 
I. Ruppia maritima L. MARitime Ruppia. (I. F. f. I76.) Stems usually whitish, often I $\mathrm{m}$. long, the internodes irregular, naked. Leaves $2-8 \mathrm{~cm}$. long, I.5 mm. or less wide; sheaths with a short free tip; peduncles in fruit sometimes $0.3 \mathrm{~m}$. long; pedicels $4-6$ in a cluster, $1-3.5 \mathrm{~cm}$. long; drupes with a dark hard shell, ovoid, about $2 \mathrm{~mm}$. long, often oblique or giblous at the base, pointed with the long style, but varying much in shape; t forms with very short peduncles and pedicels, and with bioad, stiongly marked sheaths occur. Common in brackish or salt water along the At'antic and Pacific Coasts of N. Am. and in the saline districts in the interior. Widely distributed in I. F. Old World and in S. Am. July-Aug.

(1. F. Ruppia occidentàlis S. Wats. Western Ruppia. (I. F. f. 177.) Stems lary, ivuter, the branching fan-like. Leaves $7-20 \mathrm{~cm}$. long, with large branches and leaves often thickly clustered at the nodes, the sheaths overlapping each other; drupes larger, ovoid or pyriform, lorne on pedicels atout $2 \mathrm{~mm}$. long, the peduncles. bright red when fresh and sometimes ncarly $0.7 \mathrm{~m}$. in length. In saline ponds, Neb. to Br. Col. Summer.

\section{ZANNICHÉLLIA L.}

Stems, flowers and leaf-buds all at first enclosed in a hyaline envelope, corresponding to the stipule in Potamogeton. Staminate and pistillate flowers in the same axil; the staminate solitary, consisting of a single 2-celled anther, borne on a short pedicel-like filament; the pistillate $2-5$. Ovary flask-shaped, tapering into a short style; stigma broad, hyaline, somewhat cup-shaped, its margins angled or dentate. Fruit a flattish falcate nutlet, ribbed or sometimes toothed on the back. Embryo bent and coiled at the cotyledonary erd. [In horor of J. H. Zannichelli, 1662-1729, Italian physician and botanist.] Two or three species of very wide geographical distribution in fresh-water ponds and streams.

I. Zannichellia palústris L. ZaNnichellia. (I. F. f. I78.) Stems capillary, sparsely branched, the rhizome creeping; roots fibrous. Leaves $2-7 \mathrm{~cm}$. long, 0.5 $\mathrm{mm}$. or less wide, acute, thin, I-nerved with a few delicate cross-veins; spathe-like envelope separate from the leaves and fruits at maturity; fruits $2-6$ in a cluster, 2-4 mm. long, sometimes sessile, sometimes pedicelled, sometimes the whole cluster peduncled; style persistent, straight or curved, I-2 mm. long; plant flowering and ripening its fruit under water. In fresh or brackish ponds, pools or ditches, nearly throughout N. Am., except the extreme north, and widely distributed in the Old World. July-Sept.

\section{NÀIAS L.}

Slender, branching aquatics, wholly submerged, with tibrous roots. Leaves opposite, alternate or verticillate, sheathing at the base. Flowers monœcious or diœcious, axillary, solitary, sessile or pedicelled. Sterile flower with a double perianth, the exterior one entire or 4-horned at the apex, the interior one hyaline, adhering to the anther; stamen sessile or stalked, I-4-celled, apiculate or 2-lobed at the summit. Fertile flowers of a single ovary which tapers into a short style; stigmas 2-4, subulate. Mature carpel solitary, sessile, ellipsoid, its pericarp crustaceous. Seed conformed to the pericarp and embryo to the seed, the raphe distinctly marked. [Greek, a water-nymph.] About Io species, occurring in fresh water all over the world. The following are the only ones known in N. Am.:

Sheaths broadly rounded, their margins entire or with a few large teeth.

I. N. marina.

Sheaths narrowly and obliquely rounded, each margin with 5-10 minute teeth; leaves linear.

Seeds shining, with $30-50$ rows of faint reticulations.

2. N. flexilis.

Seeds dull, with 16-20 rows of strongly marked reticulations. 3. N. Guadalupensis. Sheaths auriculate; leavts delicately filiform.

4. $N$. gracillima.

I. Naias marina L. LARgE NaIAS. (I. F. f. I79.) Diœcious; stem stout, compressed, commonly armed with teeth twice as long as their breadth. Leaves opposite or verticillate, $1-2.5 \mathrm{~cm}$. long, about $2 \mathrm{~mm}$. wide, with 6-1o spine-pointerl teeth on each margin and frequently several along the back; sheaths with rounded lateral edges; fruit large, 4-5 mm. long the pericarp tipped with a long persistent 
style and 3 thread-like stigmas; seed not shining, rugose. In lakes, Cent. N. Y. to Fla., west to Cal. Also in Europe. Summer.

Naias marìna grácilis Morong. Internodes $2-8 \mathrm{~cm}$. long, with a few teeth on the upper part; leaves scarcoly $0.5 \mathrm{~mm}$. wide, with $15-24$ large teeth on the margins and a few on the back; sheaths with 2 or 3 teeth on each margin; seed sculptured with about 25 rows of nearly square or irregularly oblong reticulations. Cent. $\mathrm{N}$. Y. and Fla.

Naias marina recurvàta Dudley. Branches and leaves recurved; leaves 6-12 mm. long, narrow, with 2-4 large teeth on each margin and none on the back; internodes short, naked, or with I or 2 teeth; sheaths I-toothed on each side. Cayuga Marshes, N. Y.

2. Naias fléxilis (Willd.) Rost. \& Schmidt. Slexder Naias. (I. F. f. i8o. aStem slender, forking. Leaves linear, pellucid, acuminate or abruptly acute, $\mathbf{I}-2.5$ $\mathrm{cm}$. long. I-2 mm. wide. numerous and crowded on the upper parts of the branches, with 25-30 minute teeth on each edge; sheaths obliquely rounded with 5-1o teeth on each margin ; fruit ellipsoid with very thin pericarp, 2-4 $\mathrm{mm}$. long, $0.5^{-1} \mathrm{~mm}$. in diameter; style long, persistent; stigmas short ; seed smooth, shining, strawcolored, sculptured, though sometimes quite faintly, with 30-40 rows of nearly square or hexagonal reticulations which are scarcely seen through the dark pericarp. In ponds and streams throughout nearly all N. Am. Also in Europe. Summer.

Naias fléxilis robústa Morong. Stem stout, few-leaved, I-2 m. long; internodes elongated. Mass. to Mich. and Tex.

3. Naias Guadalupénsis (Spreng.) Morong. Guadaloupe Naias. (I. F. f. 18r.) Stems nearly capillary, $0.3-0.7 \mathrm{~m}$. long, widely branched from the base. Leaves numerous, 12-18 mm. long, $0.5^{-1} \mathrm{~mm}$. wide, acute. opposite or in fascicles of 2-5, frequently recurved, with sheaths and teeth like those of $N$. Alexilis but generally with 40-50 teeth on each margin of the leaf: fruit about $2 \mathrm{~mm}$. long; pericarp dark and strongly marked by $16-20$ rows of hexagonal or rectangular reticulations which are transversely oblong; seed straw-colored, not shining. In ponds and lakes, Neb. to Or. and Tex., east to Fla. Also in tropical America. July-Sept.

4. Naias gracíllima (A Br.) Morrng. Thread-Like NaIAs. (I. F. f. I82.) Diœcious; stem capillary, I5-40 cm. ling, much branched, the branches alternate. Leaves numerous, opposite or often fascicled in 3's-5's or more, setaceous, $2-5 \mathrm{~cm}$. long, usually with about 20 minute teeth on each margin ; sheaths auricled, with 6 or 7 teeth on each auricle, the teeth standing upon setaceous divisions of the sheath; stigmas very short; fruit oblong-cylindric, I mm. long, $0.5 \mathrm{~mm}$. in diameter, slightly curved inwardly or straight, the pericarp straw-colored or purplish, marked by about 25 rows of irregularly oblong reticulations; seed not shining. In pools and ponds, E. Mass. to Del. and Mo. July-Sept.

\section{ZOSTÉRA L.}

Marine plants with slender rootstocks and branching compressed stems. Leaves 2-ranked, sheathing at the base, the sheaths with inflexed margins. Spadix linear, contained in a spathe. Flowers monœcius, arranged alternately in 2 rows on the spadix. Staminate flower merely an anther attached to the spadix near its apex, I-celled, opening irregularly on the ventral side; pollen thread-like. Pistillate flower fixed on its bick near the middle ; ovary I ; style elongated ; stigmas 2, capillary; mature carpels flask-shaped, membranous, rupturing irregularly, beaked by the persistent style ; seeds ribbed; embryo ellipsoid. [Greek, referring to the ribbon-like leaves.] About 6 species of marine distribution. Besides the following one occurs in Fla. and one on the Pacific Coast.

I. Zostera mariua E. EEI.-Grass. GRASS-WRACK. (I. F. f. I83.) Leaves ribbon-like, obtuse at the apex, $0.3^{-2} \mathrm{~m}$. long, $2-8 \mathrm{~mm}$. wide, with $3-7$ principal nerves. Spadix $2.5-6 \mathrm{~cm}$. long ; flowers about $6 \mathrm{~mm}$. long, crowded, usually from 10-;0 of each kind on the spadix ; ovary somewhat vermiform: at anthesis the stigmas are thrust through the opening of the spathe and drop off before the anthers of the same spadix open : the anthers at anthesis work themselves out of the spathe and discharge the glutinous stringy pollen into the water ; secds cylindric, strongly 
about 20-ribbed, about $3 \mathrm{~mm}$. long, and $1 \mathrm{~mm}$. in diameter, truncate at both ends, the ribs showing very clearly on the pericarp. In bays, streams, and ditches along the Atlantic Coast from Greenland to Fla., and on the Pacific from Alaska to Cal. Also on the coasts of Europe and Asia. Summer.

\section{Family 2. SCHEUCHZERIÀCEAE Agardh.*}

\section{Arrow-grass Family.}

Marsh herbs with rush-like leaves and small spicate or racemose perfect flowers. Perianth 4-6 parted, its segments in two series, persistent or deciduous." Stamens 3-6. Filaments very short or elongated. Anthers mostly 2-celled and extrorse. Carpels 3-6, I-2-ovuled, more or less united until maturity, dehiscent or indehiscent. Seeds anatropous. Embryo straight. Four genera and about ro species of wide geographic distribution.

Leaves all basal ; flowers numerous on naked scapes, spicate or in spike-like racemes.

Stem leafy; flowers few in a loose raceme.

x. Triglochin.

2. Scheuchzeria.

\section{TRIGLÒCHIN L.}

Marsh herbs with basal half-rounded ligulate leaves with membranous slieaths. Flowers in terminal spikes or racemes on long naked scapes. Perianth-segments 3-6, concave, the 3 inner ones inserted higher up than the outer. Stamens 3-6; anthers 2-celled, sessile or nearly so, inserted at the base of the perianth-segments and attached by their backs. Ovaries 3-6, x-celled, sometimes abortive; ovules solitary, basal, erect, anatropous. Style short or none. Stigmas as many as the ovaries, p'umose. Fruit of 3-6 cylindraceous oblong or obovoid carpels, which a re distinct or connate, coriaceous, costate, when ripe separating from the base upward from a persistent central axis, their tips straight or recurved, deliscing by a ventral suture. Seeds erect, cylindraceous or ovoid-oblong, compressed or angular. [Greek, in allusion to the three-pointed fruit of some species.] About 9 species, natives of the temperate and subarctic zones of both hemispheres. Only the following are known to occur in N. Am.:

Carpels 3 .

Fruit linear or clarate, tapering to a subulate base.

Fruit nearly globose.

I. T. palustris,

2. T. striata.

Carpels 6; fruit oblong or ovoid, obtuse at the base.

3. 7: maritima.

I. Triglochin palústris L. Marsh Arrow-grass. (I. F. f. r84.) Rootstock short, oblique, with slender fugacious stolons. Leaves linear, shorter than the scapes, 12-30 cm. long, tapering to a sharp tip ; ligule very short ; scapes $\mathbf{I}$ or 2 , slender, striate, $0.2-0.6 \mathrm{~m}$. high; racemes $12-30 \mathrm{~cm}$. long; pedicels capillary, in fruit erect-appressed and 5-7 mm. long; perianth-segments 6 , greenish-yellow ; anthers 6 , sessile; pistil of 3 united carpels, 3-celled, 3-ovuled; stigmas sessile; fruit 6-7 $\mathrm{mm}$. long, linear or clavate; ripe carpels separating from the axis and hanging suspended from its apex, the axis 3-winged. In bogs, N. B. to Alaska, south to N. Y., Ind. and Mont. Also in Europe and Asia. July-Sept.

2. Triglochin striàta R. \& P. THREE-RIBBED ARROW-GRAss. (I. F. f. 185.) Roatstocks upright or oblique. Scapes I or 2, more or less angular, usually not over $0.3 \mathrm{~m}$. high; leaves slender, slightly fleshy, nearly or quite as long as the scapes, $0.5^{-2} \mathrm{~mm}$. wide; flowers very small, light yellow or greenish, in narrow racemes; pedicels I-2 $\mathrm{mm}$. long, not elongating in fruit; perianth-segments 3 , stamens 3 ; anthers oval, large; pistil of 3 united carpels; fruit subglobose or somewhat obovoid, about $2 \mathrm{~mm}$. in diameter, appearing 3-winged when dry by the contracting of the carpels; carpels coriaceous, rounded and 3 -ribbed on the back; 
axis broadly 3-winged. In saline marshes, Md. to Fla. and La. Also in tropical America. June-Sept.

3. Triglochin marítima L. SEASIDE ARROW-GRASS. (I. F. f. I86.) Rootstock without stolons, often subligneous, the caudex thick, mostly covered with the sheaths of old leaves. Scape stout, nearly terete, $0.1-0.7 \mathrm{~m}$. high; leaves halfcylindric, usually about $2 \mathrm{~mm}$. wide; raceme elongated, often $0.4 \mathrm{~m}$. long or more; pedicels decurrent, 2-3 mm. long, slightly longer in fruit; perianth-segments 6 , each subtending a large sessile anther; pistil of 6 united carpels; fruit oblong or ovoid, 5-6 mm. long, 3-4 mm. thick, obtuse at the base, with 6 recurved points at the summit; carpels 3-angled, flat or slightly grooved on the back, or the dorsal edges curving upward and winged, separating at maturity from the hexagonal axis. In salt marshes, along the Atlantic seaboard from Lab. to N. J., and in fresh or saline marshes across the continent to Alaska and Cal. Also in Europe and Asia. July-Sept.

\section{SCHEUCHZÈRIA L.}

Rush-like bog perennials with creeping rootstocks, and erect leafy stems, the leaves elongated, half-rounded below and flat above, striate, furnished with a pore at the apex and a membranous ligulate sheath at the base. Flowers small, racemose. Perianth 6-parted, regularly 2-serial, persistent. Stzmens 6, inserted at the base of the perianth-segments ; filaments elongated ; anthers linear, basifixed, extrorse. Ovaries 3 or rarely $4-6$, distinct or connate at the base, I-celled, each cell with 1 or 2 collateral ovules. Stigmas sessile, papillose or slightly fimbriate. Carpels divergent, inflated, coriaceous, I-2-seeded, follicle-like, laterally dehiscent. Seeds straight or slightly curved, without endosperm. [Name in honor of Johann Jacob Scheuchzer, 1672-1733, Swiss scientist.] A monotypic genus of the nortl temperate zone.

I. Scheuchzeria palústris L. (I. F. f. I87.) Leaves IO-40 $\mathrm{cm}$. long, the upper ones reduced to bracts; stems solitary or several, usually clothed at the base with the remains of old leaves, $10-40 \mathrm{~cm}$. tall; sheaths of the basal leaves often 10 $\mathrm{cm}$. long with a ligule $12 \mathrm{~mm}$. long; pedicels spreading in fruit; flowers white, few, in a lax raceme; perianth-segments membranous, I-nerved, $3 \mathrm{~mm}$. long, the inner ones the narrower; follicles $4-8 \mathrm{~mm}$. long, slightly if at all united at the base ; seeds oval, brown, with a very hard coat. In bogs, Lab. to Hudson Bay and Br. Col., south to N. J., Penn., Wis. and Cal. Also in Europe and Asia. Summer.

\section{Family 3. ALISMÀCEAE DC.*}

\section{Water-Plantain Family.}

Aquatic or marsh herbs, mostly glabrous, with fibrous roots, scapose stems and basal long-petioled sheathing leaves. Inflorescence racemose or paniculate. Flowers regular, perfect, monœecious or diœecious, pedicelled, the pedicels verticillate and subtended by bracts. Receptacle flat or convex. Sepals 3, persistent. Petals 3, larger, deciduous, imbricated in the bud. Stamens 6 or more; anthers 2-celled, extrorse or dehiscing by lateral slits. Ovaries numerous or rarely few, I-celled, usually with a single ovule in each cell. Carpels becoming achenes in fruit in our species. Seeds uncinate-curved. Embryo horseshoe-shaped. Endosperm none. Latex-tubes are found in all the species, according to Micheli. About 13 genera and 70 species, of wide distribution in fresh water swamps and streams.

Carpels in a ring upon a small flat receptacle.

1. Alisma.

Carpels crowded in many series upon a large convex receptacle.

Flowers perfect, staminate or polygamous.

Pedicels not recurved; calyx spreading.

Pedicels recurved in fruit ; calyx appressed to the carpels.

Flowers monœcious or diœcious.

2. Echinodorus.

3. Lophotocarpus.

4. Sagittaria. 


\section{ALISMA L.}

Perennial or rarely annual herbs with erect or floating leaves, the blades severalribbed, the ribs connected by transverse veinlets, or seemingly pinnately veined. Scapes short or elongated. Inflorescence paniculate or umbellate-paniculate. Flowers small, numerous on unequal 3-bracteolate pedicels, the petals white or rose tinted. Stamens 6, subperigynous. Ovaries few or many, in one whorl on the receptacle, ripening into flattened achenes which are 2-3-ribbed on the curved back and 1-2-ribbed on the sides. [Greek, said to be in reference to the occur. rence of the typical species in saline situations.] About ro species, widely distributed in temperate and tropical regions.

I. Alisma Plantàgo-aquática L. Water Plantain. (I. F. f. I88.) Leaves ovate to linear, acute, cordate, rounded or narrowed at the base, the blades 3-ro-ribbed; petioles $2-25 \mathrm{~cm}$. long; scapes occasionally 2 from the same root, usually solitary, $0.2-1.3 \mathrm{~m}$. high; inflorescence a large loose panicle ; pediceis verticillate in 3's-10's, subtended by 3 striate acuminate bracts; petals $1-2 \mathrm{~mm}$. long; styles deciduous, the base remaining as a small point or short beak on the inner curve of the achene; stigma small, terminal; achenes obliquely obovate, nearly $2 \mathrm{~mm}$. long, arranged in a circle, forming an obtusely triangular truncate head. In shallow water or mud throughout N. Am. Also in Europe and Asia. June-Sept.

\section{1a. HELIANTHIUM Engelm.}

A low perennial uliginous herb with narrow basal leaves and white flowers umbelled at the summits of slender scapes. Sepals 3, ovate, obtuse; petals 3 , obovate, emaryinate. Stamens 9, with thick filaments, 3 opposite each sepal ; carpels several or. numerous, spirally arranged in a head; style very sliort; carpels turgid, glandless, beakless. A monotypic genus.

r. Helianthium tenéllum (Mart.) Britton. Dwarf Water Plantain. Plant delicate, stoloniferous, $2-12 \mathrm{~cm}$. high. Leaves lanceolate or linear-lance()late, the blades acute at both ends, 6-30 $\mathrm{mm}$. long, 2-6 $\mathrm{mm}$. wide; petioles longer or shorter than the blades, narrowly dilated at the base; scape solitary, often surpassing the leaves, commonly reclined; umbel 2-8-flowered; pedicels very unequal, often recurved in fruit; bracts lanceolate, more or less connate at the base. In mud, Mass. to W. Ont. and Minn., south to Fla., Mo., Tex., Mex. and in S. A. April-Aug. [Alisma tenellum Mart.; Echinodorus parvulus Engelm.]

\section{ECHINÓDORUS Rich.}

Perennial or annual herbs with long-petioled elliptic, ovate or lanceolate, often cordate or sagittate leaves, 3-9-ribbed and mostly punctuate with dots or lines. Scapes often longer than the leaves; inflorescence racemose or paniculate, the flowers verticillate, each verticil with 3 outer bracts and numerous inner bracteoles: flowers perfect; sepals 3 , distinct, persistent; petals white, deciduous: receptacle large, convex or globose; stamens 12-30; ovaries numerous; style obliquely apical, persistent; stigma simple; fruit achenes, more or less compressed, coriaceous, ribbed and beaked, forming spinose heads. [Greek, in allusion to the spinose heads of fruit.] About 14 species, mostly natives of America. Only the following are known in N. Am. :

Scapes reclining or prostrate; style shorter than the ovary; beak of achene short.

Scapes erect; style longer than the ovary; beak of achene long.

I. E. radicans.

2. E. cordifolius.

I. Echinodorus radicans (Nutt.) Engelm. CREEPING BUR-HEAD. (I. F. f. 190.) Leaves coarse, ovate, obtuse, cordate, 5-20 cm. long, 3-18 cm. wide, marked with short pellucid lines, the nerves $5-9$, connected by netted cross-veins. Petioles sometimes $0.5 \mathrm{~m}$. long; sca pes creeping, $0.6-1.4 \mathrm{~m}$. long, slightly scabrous, often rooting at the nodes; verticils distant; pedicels 3-12, unequal, slender or filiform; sepals persistent, much shorter than the lieads; petals larger, obovate, about $6 \mathrm{~mm}$. long; stamens about $: 0$; style shorter than the ovary; achenes numerous, about $4 \mathrm{~mm}$. long, 6-ro-ribbed, with 2-several oval glands on each side and beaks about one. 
fourth their length; fruiting heads $8 \mathrm{~mm}$. in diameter. In swamps, Ill. to N. C. and Fla., west to Mo. and Tex. June-July.

2. Echinodorus cordifolius (L.) Griseb. UPRIGHT BUR-HEad. (I. F. f. I9I.) Leaves variable in form, often broadly ovate, obtuse, cordate at the base, 15-20 $\mathrm{cm}$. long and wide, but in smaller plants sometimes nearly lanceolate, acute at each end and but 2-5 cm. long; petioles angular, striate; scapes I or more, erect, 12-40 cm. tall; flowers 3-6 in the verticils; pedicels erect after flowering; sepals shorter than the heads; petals 4-6 mm. long; stamens often I2; styles longer than the ovary; fruiting heads very bur-like, $4-6 \mathrm{~mm}$. in diameter; achenes about $3 \mathrm{~mm}$. long, narrowly obovate or falcate, 6-8-ribbed; beak apical, oblique, about one-halt the length of the achene. In swamps and ditches, Ill. to Fla., Mo. and Tex. Alse in tropical America. June-July. (E. rostratus Engelm.)

\section{LOPHOTOCÀRPUS T. Durand.}

Annual, bog or aquatic herbs with basal leaves, and simple erect or rarely branching scapes bearing flowers in verticils of 2-3 ai the top. Sepals 3, distinct, persistent, erect after flow ring and enclosing or enwrapping the fruit. Petals white, deciduous. Receptacle strongly convex. Bracts membranous, those of the lower verticils orbicular or ovate and obtuse, connaie at the base, those of the stam. inate flowers lanceolate and acute, free, or connate. Stamens 9-15, hypogynous, inserted at the base of the receptacle. Filaments flattened. Pistils numerous; ovule solitary, erect, anatropous; style elongated, oblique, persistent. Achenes winged or crested. Embryo horseshoe-shaped. [Greek, signifying crested fruit.] About 9 species, the following of E. N. Am., 2 in W. N. Am., the others of tropical America.

Leaves with sagittate or hastate blades, seldom bladeless. Plants growing in fresh-water ponds and marshes.

Basal lobes of the leaves widely divergent; large plants, 2-4 dm. high: petioles spongy, thick.

r. L. calycinus.

Basal lobes not widely divergent; low plants, I-I.5 dm. high; petioles slender.

2. L. depauperatus.

Leaves mostly bladeless phyllodes. Submersed seashore and tidal-flat aquatics.

Phyllodes thick, spongy, nodose, I-3 dm. long.

Phyllodes flat, spatulate, not nodose, 3-7 cm. high.

3. L. spongiosus.

4. L. spathulatus.

I. Lophotocarpus calycinus (Engelm.) J. G. Smith. Leaves floating or ascending, entire, hastate, sagittate, or triangular crescent-shaped, the basal lobes spreading, ovate, acute or acuminate, the apex acute or obtuse, the blade varying from $10-20 \mathrm{~cm}$. long, sometimes $30 \mathrm{~cm}$. wide at the base. Scape simple, weak and at length decumbent, shorter than the leaves ; verticils of flowers $2-5$; fertile pedicels very thick, recurved in fruit, equalling or longer than the slender sterile ones; petals 6-10 mm. long; filaments papillose, about as long as the anthers; achene cuneate, $2 \mathrm{~mm}$. long, narrowly winged on the margins, tipped with a short lorizontal triangular beak. In swamps, N. B. to Va. and La., Okla. and S. Dak. July-Sept. (Sagittaria calylina Engelm.)

2. Lophotocarpus depauperàtus (Engelm.) J. G. Smith. Sagittaria caly. cina depauperata Engelm. in herb. Low, $10-15 \mathrm{~cm}$. high; petioles slender, ascending; blades elliptic, hastate or sagittate, acute, 3-nerved, $1.8-3.3 \mathrm{~cm}$. long, the basal lobes divergent; scape half as long as the leaves; fertile pedicels slender, 8-25 mm. long; fruiting head depressed-globose, $6.5-8 \mathrm{~mm}$. in diameter; achenes broadly cuneate, $1.5 \mathrm{~mm}$. long, $2 \mathrm{~mm}$. wide, the slender horizontal beak one-third the width of the body. Margins of ponds, Wis. to the Ind. Terr. June-Sept.

3. Lophotocarpus spongiòsus (Engelm.) J. G. Smith. Sagittaria calycina spongiosa Engelm. Submersed aquatic, with thick, spongy nodose phyllodes and scapes 10-30 cm. high; blades 5-10 $\mathrm{cm}$. long, spatulate and obtuse, or elliptic and truncate, or hastate or sagittate with narrow, falcately-divergent, acute lobes 2-10 $\mathrm{mm}$. wide, often half as long as the blade; scape simple, terete, spongy, half the length of the petioles, at length decumbent, bearing 2 or 3 verticils of $1-3$ flowers each ; fertile pedicels $3^{-6} \mathrm{~mm}$. thick, Io-35 $\mathrm{cm}$. long; fruiting head 
depressed-globose, 7-ro $\mathrm{mm}$. in diameter; achenes 2-2.5 mm. long, cuneate, with a narrow dorsal wing and a very short ascending or horizontal beak. Margins of brackish ponds and tide-water marshes, N. B. to Va. July-Aug.

4. Lophotocarpus spathulàtus J. G. Smith. Low aquatic, $3-7 \mathrm{~cm}$. high ; phyllodes bladeless or sometimes spatulate at the tip, ascending, with the edges vertical through a twist in the base, $30 \mathrm{~mm}$. wide, obtuse or rounded at the apex. Scape simple, usually shorter than the phyllodes, 3-4 cm long, one- or two-flowered, thickened, reflexed after flowering; bracts scarious, broadly ovate, obtuse ; stamen; 6-9, the filament; flattened, incurved, broadest at the base, I.5-2 mm. long, glabrous; anthers I mm. long, oblong; sepals oblong-orbicular, $3 \mathrm{~mm}$. long, nerveless, thin, scarious on the margins, and papery in fruit; petals ovateorbicular, obtuse, shorter than the sepals; achenes I-5 mm. long, obovate, obtuse, narrowly winged on the back to about the level of the beak and sometimes with a transverse lateral ridge near the tip; beak slender, oblique or horizontal. Sandy beaches above salt-water but within the influence of tides. Newburyport, Mass. Type collected by A. A. Eaton, 1898 .

\section{SAGITTÀRIA L.}

Perennials, mostly with tuber-bearing or nodose rootstocks, basal long-petioled nerved leaves, the nerves connected by numerous veinlets, and erect, decumbent or floating scapes, or the leaves reduced to bladeless phyllodes. Flowers monœeious or diœcious, borne near the summits of the scapes in verticils of 3 's, pedicelled, the staminate usually uppermost. Verticils 3 bracted. Sepals persistent, those of the pistillate flowers reflexed or spreading in our species. Petals 3 , white, decid. uous. Stamens inserted on the convex receptacle ; staminate flowers sometimes with imperfect ovaries. Pistillate flowers with numerous distinct ovaries, sometimes with imperfect stamens; ovule solitary; stigmas small, persistent. Achenes num. erous, densely aggregated in globose or subglobose heads, compressed. Seed erect, curved. [Latin, referring to the arrow-shaped leaves of some species.] About $3^{\circ}$ species, natives of temperate and tropical regions. Besides the following, some Io others occur in the southern and western parts of N. Am.

Fertile pedicels slender, ascending, not reflexed in fruit.

Leaf-blades sagittate; filaments glabrous.

Basal lobes one-fourth to one-half the length of the blade.

Beak of the achene more than on $\theta$-fourth its length.

Beak of the achene erect.

Fruiting pedicels shorter than the bracts; leaves broad.

I. S. longirostra.

Fruiting pedicels longer than the bracts; leaves narrow.

Beak of the achene horizontal or oblique.

2. S. Engelmanniana.

3. S. latifolia.

Beak of the achene less than one-fourth its length.

Petioles rather short, curving; bracts long; bog species.

Petioles elongated; bracts short; aquati- species.

4. S. arifolia.

5. S. cuneata.

Basal lobes two-thirds to three-fourths the length of the blade.

Leaf-blades entire, or rarely hastate or cordate.

6. S. longiloba.

Filaments slender, tapering upward; leaves seemingly pinnately veined.

Filaments glabrous; bracts connate. $\quad 7 . S$. ambigua.

Filaments cobwebby-pubescent; bracts mostly distinct.

8. S. lancifolia.

Filaments abruptly dilated, pubescent; veins distinct to the base of the blade.

Fruiting heads sessile or very nearly so.

Both staminate and pistillate flowers pedicelled.

9. S. rigida.

Leaves reduced to terete nodose phyllodes, rarely blade-bearing.

ro. S. teres.

Leaves reduced to flat nodeless phyllodes, rarely blade-bearing; petals with a rose-colored spot at base.

Leaves rigid; blades elliptic-linear. II. S. Eatoni.

Leaves not rigid; blades lanceolate or linear-oblong, phyllodes flat, nodose; petals white. 
Fertile pedicels stout, reflexed in fruit; filaments dilated.

Filaments pubescent; leaf-blades ovate or ovate-elliptic. I4. S. platyphylla.

Filaments glabrous; leaf-blades linear-lanceolate or reduced to phyllodes.

15. S. subulata.

I. Sagittaria longiróstra (Micheli) J. G. Smith. Long-BEAkEd ArrowHEAD. (I. F. f. 193.) Monœcious, glabrous, scapes erect, rather stout, 0.4-I m. tall. Leaves broad, sagittate, $10-30 \mathrm{~cm}$. long, abruptly acute at the apex, the basal lobes ovate or ovate-lanceolate, acute, one-third to one-half the length of the blade; scape usually longer than the leaves, 6-angled below; bracts triangularlanceolate, acuminate, $1.5-3 \mathrm{~cm}$. long, longer than the fertile pedicels; petals $16-28$ $\mathrm{mm}$. long; styles curved, twice as long as theovaries; achene obovate, about $4 \mathrm{~mm}$. long, winged on both margins, the ventral margin entire or undulate, the dorsal eroded, its sides with a short crest, its beak stout, erect, or somewhat recurved. In swamps and along ponds, N. J. and Penn. to Ala. July-Sept.

2. Sagittaria Engelmanniàna J. G. Smith. Engelmann's Arrow-head. (I. F. f. I 194.) Monœcious, glabrous; scape erect or ascending, slender, $20-50 \mathrm{~cm}$. high. Leaves narrow, $4-20 \mathrm{~cm}$. long, $2-8 \mathrm{~mm}$. wide, acute or obtuse at the apex, the basal lobes narrowly linear, acuminate, one-third to one-half the length of the blade; scape striate, about as long as the leaves; bracts lanceolate, acute, shorter than the slender fertile pedicels, $8-12 \mathrm{~mm}$. long; flowers $\mathbf{I} .5^{-2.5} \mathrm{~cm}$. broad; style about twice as long as the ovaries; achene obovate, $4 \mathrm{~mm}$. long, winged on both margins, and with I-3 lateral wing-like crests on each face, the beak short, stout, erect, about I mm. long. In shallow water, N. H. and Mass. to Del., near the coast. Aug.-Sept. (S. variabilis var. (?) gracilis Engelm.)

3. Sagittaria latifòlia Willd. Broad-Leaved ArRow-Head. (I. F. f. I95.) Monœcious or sometimes diœcious, glabrous or nearly so; scape stout or slender, 0.I-1.2 m. tall, simple or branched. Leaves exceedingly variable in form and size, sometimes linear-lanceolate and acuminate at the apex, sometimes wider than long and obtuse; basal lobes from $\frac{1}{4}$ to $\frac{1}{2}$ as long as the blade; bracts acute, acuminate or obtuse, the upper ones sometimes united; flowers $2.5-4 \mathrm{~cm}$. wide; achene 2-4 $\mathrm{mm}$. long, broadly winged on both margins, its sides even or I-ribbed, the beak about one-third its length, horizontal or nearly so. In shallow water, throughout N. Am., except the extreme north, extending to Mex. July-Sept. (S. variabilis Engelm.)

Sagittaria latifòlia pubéscens Muhl. Whole plant pubescent, varying from merely puberulent to densely hirsute. Ont. to N. J., Fla, and Ala.

4. Sagittaria arifolia Nutt. Arum-leaved Arrow-head. (I. F. f. 196.) Glabrous or nearly so, terrestrial or partially submerged; scape weak, ascending, $0.2-0.5 \mathrm{~m}$. long. Leaves sagittate, broad, acute at the apex, about as long as the scape, their margins slightly curved, their basal lobes acute or acuminate, onefourth to one-third the length of the blade; petioles usually curving outwardly; bracts lanceolate, acute, usually equalling or longer than the fertile pedicels, often reflexed; petals 6-10 $\mathrm{mm}$. long; achene cuneate-obovate, about $2 \mathrm{~mm}$. long, winged on both margins, the sides smooth, the beak short, erect. Quebec to Minn. and Br. Col., south to Me., Miclı., Kans., N. Mex., and Cal.

5. Sagittaria cuneàta Sheldon. Floating ARRow-head, (I. F. f. I97.) Aquatic, submerged, rooting in sand; scape very slender, simple, terete, $0.3-0.6$ $\mathrm{m}$. long, bearing the flowers at the surface of the water. Leaves long-petioled, the blade floating, sagittate, linear-lanceolate, acuminate, 5-10 cm. long, the basal lobes acuminate, about one-fourth its length; phyllodes of two kinds. one petiolelike and as long as the leaves, the other lanceolate, and clustered at the base of the plant; bracts ovate-lanceolate, acute, 4-6 mm. long, much shorter than the slender fertile pedicels; flowers $1.2-1.6 \mathrm{~cm}$. broad: achene only $1 \mathrm{~mm}$. long, obovate-cuneate, its beak very short, erect. In shallow water, Minn. to Wash. and Br. Col. Aug.-Sept.

6. Sagittaria longíloba Engelm. LONG-LObEd Arrow-HEad. (I. F. f. I98.) Monœcious; glabrous; scape slender, simple or rarely branched, 0.3-0.6 m. tall. Leaves long-petioled, the apex acute, the basal lobes linear-lanceolate, acuminate, about three-fourths the length of the blade: bracts lanceolate, acuminate, $6-8 \mathrm{~mm}$. long, much shorter than the very slender fertile pedicels which are longer than the 
sterile ones; stamens numerous, the filaments longer than the anthers; achene about $2 \mathrm{~mm}$. long, quadrate-obovate, somewhat broader above than below, winged on both margins, its beak exceedingly short. In shallow water, Neb. to Colo., south to Tex. and Mex.

7. Sagittaria ambígua J. G. Smith. Kansas Sagittaria. (I. F. f. I99.) Monœcious; glabrous; scape erect or ascending, $0.3-0.6 \mathrm{~m}$. high. Leaves lanceolate, entire, long-petioled, acute or acuminate at both ends, seemingly pinnately veined, really 5-7-nerved, $12-20 \mathrm{~cm}$. long, equalling or shorter than the scape; bracts lanceolate, acuminate, $\mathbf{I}-\mathbf{I} .6 \mathrm{~cm}$. long, much shorter than the slender fruiting pedicels, connate at the base, papillose; stamens 20-25; filaments glabrous, longer than the anthers; achene about $2 \mathrm{~mm}$. long, oblong, curved, narrowly winged on both margins, its sides smooth and even, its beak short, oblique. In ponds, Kan. and the Ind. Terr.

8. Sagittaria lancifòlia L. Lanced-leaved Sagittaria. (I. F. f. 200.) Monœecious, glabrous; scape rigid, erect, stout or rather slender, striate, branched or simple, longer than the leaves. Leaves lanceolate or oblong-lanceolate, acute or acuminate at both ends, firm, entire, the blades 5-9-nerved, 0.2-0.4 m. long, gradually narrowed into the long petioles, apparently pinnately veined; flowers numerous, $1-2.5 \mathrm{~cm}$. broad; bracts ovate or ovate-lanceolate, usually not united at the base, glabrous or nearly so, equalling or shorter than the fruiting pedicels; stamens numerous; filaments cobwebby-pubescent, equalling or longer than the anthers; achene narrowly obovate-cuneate, $2-3 \mathrm{~mm}$. long, winged on both margins, its sides smooth, its beak tapering, oblique. In swamps and shallow water, Del. to Fla. and Tex., near the coast. Widely distributed in tropical America.

9. Sagittaria rígida Pursh. Sessile-fruited Arrow-head. (I. F. f. 201.) Monœecious, glabrous; scape simple, weak, curving, ascending or decumbent, shorter than the leaves. Leaves very variable, linear, lanceolate, elliptic or broadly ovate, acute or obtuse at the apex, entire or with I or 2 short or slender basal lobes; bracts ovate, obtuse, 4-8 $\mathrm{mm}$. long, united at the base or sometimes distinct; heads of fruit sessile or very nearly so; pedicels of the sterile flowers $I-2.5 \mathrm{~cm}$. long; filaments dilated, mostly longer than the anthers, pubescent; achene narrowly obovate, 3-4 $\mathrm{mm}$. long, winged on both margins, crested above, tipped with a stout nearly erect, beak of about one-fourth its length. In swamps and shallow water, Quebec to Minn., N. J., Tenn., Mo. and Neb. July-Sept. (S. heterophylla Pursh.)

ro. Sagittaria tères S. Wats. Slender Sagittaria. (I. F. f. 202.) Monœcious; glabrous; scape slender, erect, simple, I.5-4.5 dm. long, bearing only I-3 verticils of flowers. Leaves usually reduced to elongated terete nodose phyllodes or some of them short and bract-like, one or two of the longer ones occasionally bearing a linear blade; bracts ovate, obtuse, about $3 \mathrm{~mm}$. long, much shorter than the filiform fruiting pedicels, which are longer than the sterile ones; flowers I2-16 mm. broad; stamens about I2, their dilated filaments pubescent, shorter than the anthers; achene broadly obovate, $2 \mathrm{~mm}$. long, the ventral margin winged, the dorsal 7-II-crested, the sides bearing several crenate crests, the beak short, erect. In ponds, Mass. to S. Car. Aug.-Sept.

II. Sagittaria Éatoni J. G. Smith. Eaton's SagitTaria. Monœcious, 0. I-0.2 m. high, glabrous; scape simple, slender, ascending, weak, bearing I, 2, or rarely 3 verticils of flowers. Leaves mostly bladeless phyllodes, rarely with linear-lanceolate, acute or acuminate blades r.8-3 cm. long, 2-4 mm. wide; the phyllodes fiat, nodeless; lowest verticil with two fertile flowers, and one staminate; fertile pedicels 4-8 $\mathrm{mm}$. long, shorter than the sterile ones, very slender; sepals ovate-lanceolate, obtuse, $4 \mathrm{~mm}$. long; petals white, with a rose-colored spot at the base, obovate-cuneiform, emarginate; stamens I2; mature achenes not known; pistils very minute, 80-100. Ripple-swept, sandy shores, between high and low tide, above the influence of salt water, Newburyport, Mass.

I2 Sagittaria cristàta Engelm. CRested SagitTaria. (I. F. f. 203.) Monocious; scape slender, erect, $0.3-0.8 \mathrm{~m}$. high, simple, bearing 4 or 5 verticils of flowers at or above the surface of the water. Leaves long-petioled, spongy and rigid, reduced to slender phyllodes or bearing linear-lanceolate or elliptic blades 5-10 $\mathrm{cm}$. long, and 6-25 $\mathrm{mm}$. wide; bracts acute, 4-8 $\mathrm{mm}$. long, much shorter than the slender fertile pedicels; flowers 1.6-2 cm. broad; stamens about 24; filaments dilated, pubescent, at least at the middle, longer than the anthers; achene obliquely 
obovate, the dorsal margin with a broad crenate wing, the ventral straight-winged, each side bearing 2 crenate crests, the beak short, oblique. In shallow water, Ia. and Minn. Phyllodes are commonly developed from the nodes of the rootstuck. July-Aug.

13. Sagittaria gramínea Michx. Grass-leaved Sagittaria. (I. F. f. 204.) Monœcious or diœecious; glabrous; scape simple, erect, 0. I-0.6 m. tall. Leaves long-petioled, the blades linear, lanceolate or elliptic, acute at both ends, 5-15 cm. long, $x-6 \mathrm{~cm}$. wide, 3-5-nerved, with nerves distinct to the base, or some of them occasionally reduced to flattened phyllodes; bracts ovate, acute, 3-6 mm. long, much shorter than the slender or filiform fruiting pedicels, connate to the middle or beyond; flowers 8-12 mm. broad; stamens about 18; filaments dilated, pubescent, longer than or equalling the anthers; achene obovate, I-2 mm. long, slightly wing-crested on the margins and ribbed on the sides, the beak very short. In mud or shallow water, Newf. to Ont. and S. Dak., south to Fla. and Tex. Early leaves often purplish. July-Sept.

I4. Sagittaria platy phýlla (Engelm.) J. G. Smith. Ovate-Leaved SagitTAR1A. (I. F. f. 205.) Nonœcious; glabrous; scape erect, simple, rather weak, mostly shorter than the leaves. Leaves rigid, the blades ovate, ovate-lanceolate or ovate-elliptic, short-acuminate or acute at the apex, rounded, gradually narrowed or rarely cordate or hastate at the base, seemingly pinnately-veined, 5-I 5 $\mathrm{cm}$. long; bracts broadly ovate, acute, connate at the base, 4-8 $\mathrm{mm}$. long; flowers I. $6-3 \mathrm{~cm}$. broad; fertile pedicels stout, divergent in flower, reflexed in fruit, I-6 $\mathrm{cm}$. long; filaments dilated, pubescent, rather longer than the anthers; achene obliquely obovate, winged on both margins, the dorsal margins somewhat crested, the sides with a sharp wing-like ridge. In swamps and shallow water, S. Mo. to Miss. and Tex. Phyllodes, when present, oblong or oblanceolate. July-Sept.

I5. Sagittaria subulàta (L.) Buchenau. Subulate Sagittaria. (I. F. f. 206.) Monœcious or rarely diœcious; scape very slender, 5-I5 cm. high, few. flowered, about equalling the leaves. Leaves all reduced to rigid phyllodes or sometimes bearing linear or linear-lanceolate blades $2-4 \mathrm{~cm}$. long; bracts united to the apex or becoming partly separated; flowers I. $1.6 \mathrm{~cm}$. broad; fertile pedicels reflexed and much longer than the bracts in fruit; stamens about 8 ; filaments about equalling the anthers, dilated, glabrous; achenes rather less than $2 \mathrm{~mm}$. long, obovate, narrowly winged, with two or three crests on each side, the wings and crests sometimes crenite; beak short. In tide-water mud, S. N. Y. and Penn. to Fla. and Ala. July--'iept. (S. pusilla Nutt.)

Sagittaria subulata gracillima (S. Wats.) J. G. Smith. Submerged; leaves o.6-1.3 dm. long, bladeless or bearing small 3-nerved lanceolate blades $2-5 \mathrm{~cm}$. long. $6-8 \mathrm{~mm}$. wide; scape simple, terete or compressed, about as long as the leaves; flowers few, $1.6-2 \mathrm{~cm}$. broad. E. Mass. and R. I. Perhaps a distinct species. Fruit not seen.

\section{Family 6. VALLISNERIÀCEAE Dumort.}

\section{Tape-Grass Family.}

Submerged or.floating aquatic herbs, the leaves various. Flowers regular, mostly diœecious, appearing from an involucre or spathe of $\mathrm{I}-3$ bracts or leaves. Perianth 3-6-parted, the segments either all petaloid or the 3 outer ones small and herbaceous, the tube adherent to the ovary at its base in the pistillate flowers. Stamens 3-12, disti or monadelphous. Anthers 2-celled. Ovary I-celled with 3 parietal placentæ or 6-9-celled. Styles 3-9, with entire or 2-cleft stigmas. Ovules anatropous or orthotropous. Fruit ripening under water, indehiscent. Seeds numerous, without endosperm. About 14 genera and 40 species of wide distribution in warm and temperate regions. Besides the following, another genus, Halophila, occurs on the coast of Fla. 


\section{x. PHILÒtRIA Raf. [ELODEA Michx.]}

Stems submerged, elongated, branching, leafy. I eaves opposite or whorled, crowded, I-nerved, pellucid, minutely serrulate or entire. Flowers diœcious or polygamous, arising from an ovoid or tubular 2-cleft spathe. I'erianth 6-parted, at least the 3 inmer segments petaloid. Staminate flowers with 9 stamens, the anthers oblong, erect. Ovary $\mathrm{I}$-celled with 3 parietal placentæ. Stigmas 3. nearly sessi.e, 2-lobed. Fruit oblong, coriaceous, few-seeded. [Name from the Greek, refering to the leaves, which are often whorled in threes.] About ro species, inhabitants of fresh-water ponds and streams in temperate and tropical America.

I. Philotria Canadénsis (Michx.) Britton. Water-weed. Ditch-Moss. WATER Thyme. Stems O.I-I m. long. Leaves linear or elliptic, acute or sbtuse, serrulate or entire, verticillate in 3's or 4's or the lower opposite, 4-15 mm. long, I-4 mm. wide; flowers axillary, white, the staminate minute, sessile, break. ing off at the time of flowering and rising to the surface where they shed their pollen around the pistillate ones; pistillate flowers expanding on the surface, which they reach by means of the slender calyx-tube, which varies in length from $5^{-25}$ c:n., their spathes ro-15 $\mathrm{mm}$. long; stigmas spreading, papillose or pubescent. Nearly throughout N. Am., except the extreme north. Naturalized in Europe. It has been maintained that there are four N. Am. species. May-Aug.

The p'ant of the northern lakes and rivers, with ovate or oval leaves, is apparently the type of the species. The plant of the Atlantic States with lanceolate or linear-lanceolate leaves is the Serpicula verticillata angustifolia Muhl. (I. F. f. 207); that of the Central States from Minn. to Ky. and Mo., with leaves similar to this, but pellucid, and the stems shorter, is Udora Canadensis minor Engelm. These three appear to be distinct, but for lack of flowers and fruit in the material at my command, I am at present unable to characterize them further.

\section{VALLISNËRIA L.}

Aquatic diœcious submerged perennials, with long grass-like floating leaves. Staminate fluwers with a 2-3-parted spathe on a short scape, numerous, nearly sessile on a conic receptacle; perianth 3 parted; stamens generally $2(\mathbf{I}-3)$. Pistillate flowers on a very long flexuous or spiral scape, with a tubular, 2-cleft, I-flowered spathe; perianth-tube adnate to the ovary, 3-lobed and with 3 small petals; ovary $\mathbf{r}$-celled with 3 parietal placentæ; stigmas 3 , nearly sessile, short, broad, 2-toothed with a minute process just below each sinus; ovules numerous, borne all over the ovary-wall, orthotropous. Fruit elongated, cylindric, crowned with the perianth. [Named for Antonio Vallisneri, $166 \mathbf{I}-1730$, Italian naturalist.] A monotypic genus of wide distribution both in the Old World and the New.

I. Vallisneria spiràlis L. TAPE-GRASS. EEL-GRASS. (I. F. f. 208.) Plant roting in the mud or sand, stoloniferous. Leaves thin, narrowly linear, 5-nerved, obtuse, sometimes serrate near the apex, $0.2-2 \mathrm{~m}$. long, 4-18 $\mathrm{mm}$. wide, the 2 marginal nerves faint; the staminate bud separates from the scape at the time of flowering and expands upon the surface of the water; pistillate flowers upon a long thread like scape, the spathe 12-25 mm. long, enclosing a single white flower; ov.ıry as long as the spathe; after receiving the pollen from the staminate flowers the scape of the pistillate contracts spirally; ripe fruit $5-17 \mathrm{~cm}$. long. In quiet waters, N. B. to Fla., Mınn., Iowa and Tex. The "wild celery" of Chesapeake Bay, and a favorite food of the canvas-back duck. Aug.-Sept.

\section{LIMNÒBIUM L. C. Richard.}

Aquatic, stoloniferous herbs, the leaves fascicled at the nodes, petioled, broad, often cordate. Flowers monœecious, white, from sessile or stipitate, 2-leaved, membranous spathes. Perianth 6-parted, the segments petaloid, the 3 outer oblong-oval, the 3 inner oblong-linear. Staminate flowers $2-4$ in a spathe, longpeduncled, the stamens united in a column bearing 6-12 anthers at different heights, sometimes producing only 9-12 staminodia, the filaments tipped with abortive anthers. Pistillate flowers sessile or short-peduncled with 3-6 vestigial stamens; ovary 6-9-celled with as many central placentæ; stigmas as many as the 
cells, each 2-parted. Fruit a many-seeded berry. [Greek, referring to the aquatic habitat.] Three or four species, natives of America.

I. Limuobium Spóngia (Bosc.) L. C. Richard. Frog's.BIT. (I. F. f. 209.) Blades of the leaves orbicular or broadly ovate, cordate or renifurm, faintly 5-7nerved and cross-veined, purplish and spongy beneath, $2-5 \mathrm{~cm}$. broad, on petioles $2-25 \mathrm{~cm}$. in length. Stolons rooting and sending up flowers and leaves at the nodes; peduncles of the staminate flowers, 7-10 $\mathrm{cm}$. long, those of the pistillate flowers stouter, $2.5-5 \mathrm{~cm}$. long, nodding in fruit. In shallow, stagnant water, Lake Ont. to Fla., Ill., Mo. and La. July-Aug.

\section{Order 3. GRAMINÀLES.}

Grasses and sedges. Monocotyledonous plants, mostly herbaceous, with leafy or leafless, usually simple, stems (culms), the leaves usually narrow and elongated, entire or minutely serrulate. Flowers mostly perfect, small, incomplete, in the axils of dry, chaffy scales (glumes) arranged in spikes or spikelets.

Fruit a caryopsis (grain); culm mostly hollow. Fruit an achene; culm solid.

Fam. I. Gramineae. Fam. 2. Cyperaceae.

\section{Family I. GRAMínEAE Juss.*}

\section{Grass Family.}

Annual or perennial herbs, of various habit, rarely shrubs or trees Culms (stems) generally hollow, but occasionally solid, the nodes closed Leaves sheathing, the sheaths usually split to the base on the side opposite the blade; a scarious or cartilaginous ring, naked or hairy, rarely wanting, called the ligule, is borne at the orifice of the sheath. Inflorescence spicate, racemose or paniculate, consisting of spikelets composed of two to many 2 -ranked imbricated bracts, called scales (glumes), the two towest in the complete spikelet always empty, one or both of these sometimes wanting. One or more of the upper scales, except sometimes the terminal ones, contains in the axil a flower, which is usually enclosed by a bract-like awnless organ called the palet, placed opposite the scale and with its back toward the axis (rachilla) of the spikelet, generally 2keeled; sometimes the palet is present without the flower, and vice versa. Flowers perfect or staminate, sometimes monœcious or diœcious, subtended by I-3 minute hyaline scales called the lodicules. Stamens I-6, usually 3. Anthers 2-celled, versatile. Ovary I-celled, I-ovuled. Styles $1-3$, commonly 2 and lateral. Stigmas hairy or plumose. Fruit a seed-like grain (caryopsis). Endosperm starchy. About 3500 species widely distributed throughout the world, growing in water and on all kinds of soil. Those yielding food-grains are called cereals. The species are more numerous in tropical countries, while the number of individuals is much greater in temperate regions, often forming extended areas of turf. The time of year noted is that of ripening seed.

\section{KEY TO THE TRIBES AND GENERA. $\dagger$}

$A$. Spikelets I or 2-flowered, when 2-flowered the upper fertile, lower staminate; rachilla articulated below the scales or the subtending involucre, and not extending beyond the flowers.

Spikelets not flattened laterally.

Flowering scale and palet hyaline; none of the scales spiny.

Spikelets monœcious; staminate and pistillate in the same panicle.

I. Maydeae.

Spikelets in pairs, perfect, or the pedicellate one staminate, empty, rudimentary or wanting.

il. Andropogoneae.

* Contributed by Mr. Geo. V. Nasi.

t See p. 1045 for additional analytical key. 
Flowering scale and palet membranous; second scale spiny (in ours).

III. Zoysieae.

Flowering scale and palet of the perfect flower coriaceous or chartaceous; spikelets involucrate in Nos. 18 and 19 ; scales 3 or 4 .

Spikelets flattened laterally, I-flowered; scalés 2.

IV. Paniceae.

V. Oryzeae.

$B$. Spikelets I-many-flowered; rachilla generally articulated above the two lower scales (below them in Nos. 38, 46, 54 and 6r) and frequently extending beyond the flower in I-flowered spikelets.

Culms herbaceous.

Spikelets upon pedicels in panicles, spike-like panicles or racemes, not in rows.

Spikelets with but I perfect flower, which is terminal except in Nos. 42 and 43 .

Fifth scale enclosing a perfect flower; palet I-nerved.

Third scale enclosing a perfect flower; palet 2-nerved.

VII. Agrostideae.

Spikelets with 2 or more perfect flowers (or one staminate in Nos. 46 and $5 \mathrm{I}$ ).

Flowering scales generally shorter than the empty lower ones, usually with a bent awn on the back. VIII. Aveneae.

Flowering scales generally longer than the empty lower ones, unawned or with a straight awn from the apex. X. Festuceae.

Spikelets in two rows, forming a one-sided spike or raceme.

IX. Chlorideae.

Spikelets in two opposite rows, forming an equilateral spike (unilateral in Nardus).

Culms woody, at least at the base; tall reeds.

XI. Hordeae.

XII. Bambuseae.

\section{Tribe I. MAYDEAE.}

Ferile spikelets imbedded in the joints of the thick rachis.

1. Tripsacum.

\section{Tribe II. ANDROPOGONEAE.}

Joints of the rachis not much thickened nor excavated for the reception of the spikelets. Spikelets alike, perfect.

2. Erianthus.

Spikelets not alike, the sessile perfect, the pedicelled staminate, empty or wanting.

Inflorescence composed of spike-like silky racemes.

Racemes usually in pairs, rarely in 3 's -5 's and digitate, the rachis internodes and pedicels opaque; fourth scale of the spikelet with a blade.

4. Andropogon.

Racemes panicled, the rachis internodes and pedicels thickened on the margins and with the intervening portion thin and translucent; fourth scale Inflorescence paniculate.

of the spikelet pedicel-like, without a blade. 5 . Amphilophis.

Pedicelled spikelet wanting (in our species).

Pedicelled spikelet present and usually staminate.

6. Sorghastrum.

7. Sorghum.

Joints of the rachis greatly thickened and excavated for the reception of the spikelets.

3. Manisuris.

\section{Tribe III. ZoysieaE.}

Spikelets in a terminal spike; second scale spiny.

8. Nazia.

\section{Tribe IV. Paniceae.}

Spikelets without a subtending involucre of bristles or valves.

Spikelets all alike.

Second scale of the spikelet not enlarged nor saccate at the base.

Spikelets arranged in one-sided racemes.

Spikelets with a swollen ring-like callus at the base.

Spikelets without a callus.

12. Eriochloa.

Racemes alternate or scattered, rarely in a terminal pair, or sometimes single and slender, in the latter case the spikelets broadly oval and obtuse.

Spikelet of 3 scales. 
Opening in the flowering scale turned away from the rachis of the raceme; spikelets usually oval or orbicular and obtuse, rarely narrower and acute.

9. Paspalum.

Opening in the flowering scale turned toward the rachis of the raceme; spikelets lanceolate to ovate, acute.

Spikelets of 4 scales. 10. Anastrophus.

Spikelets awnless, the scales glabrous.

14. Brachiaria.

Spikelets with the second and third scales hispid on the nerves and usually long-awned, or in one species the third scale only awn-pointed. 15 . Echinochloa.

Racemes long and slender, digitate or whorled, sometimes single or in pairs; spikelets lanceolate and acute. I3. Syntherisma.

Spikelets arranged in a true panicle, either open or contracted. 16. Panicum.

Second scale of the spikelet much enlarged, many-nerved, deeply saccate at the base.

17. Sacciolepis.

Spikelets of two kinds, one borne on terminal panicles, the other solitary on subterranean peduncles and maturing seed.

Spikelets subtended by an involucre consisting of :

I1. Amplicarpon.

I-many persistent bristles; spikelets in dense spikes or spike-like panicles, deciduous. 18. Chatochloa.

2 spine-bearing valves forming a bur enclosing the spikelets and deciduous with them.

I9. Cenchrus.

\section{Tribe V. ORYzEAE.}

Spikelets monœcious; tall aquatic grasses.

Pistillate spikelets ovate, borne at the apex of each branch of the panicle.

Pistillate spikelets linear, borne on the upper branches of the panicle.

20. Zizaniopsis.

21. Zizania.

Spikelets not monœcious; grasses of swamps or wet grounds.

22. Homalocenchrus.

\section{Tribe VI. Phalarideae.}

Third and fourth scales

small and empty or rudimentary, not awned; stamens 3.

empty, awned upon the back; stamens 2.
subtending staminate flowers with 3 stamens; fertile flowers with 2 stamens.

23. Phalaris.

25. Savastana.

\section{Tribe VII. Agrostideae.}

Flowering scale indurated at maturity, of firmer texture than the empty scales, and closely enveloping the grain.

Rachilla not prolonged beyond the palet.

Flowering scale with a three-branched awn; stamens mostly 3 .

Flowering scale with a simple awn.

26. Aristida.

Flowering scale narrow; awn persistent.

Awn tortuous or twisted, stout; callus evident. 27. Stipa.

Awn straight, very slender; callus minute. 31. Muhlenbergia.

Flowering scale broad; awn slender, straight, deciduous : callus obtuse.

Flowering scale grlabrous, or pubescent with short hairs.

28. Oryzopsis,

Flowering scale pubescent with copious long silky hairs extending much beyond the scale.

Flowering scale awnless.

29. Eriocoma.

3o. Milium.

Rachilla with a pedicel-like extension beyond the palet; stamens 2.

32. Brachyelytrum.

Flowering scale hyaline or membranous at maturity; empty scales coarser; grain loose.

Spikelets in a dense spilie-iike panicle. (Some species of No. 37 may be looked for here.) 
Spikelets $6 \mathrm{~mm}$. or less long.

Spikelets readily deciduous at maturity. Empty scales not awned. Empty scales awned.

Spikelets not deciduous; empty scales persistent. Flowering scales slightly exceeding the empty ones.

Flowering scales much shorter than the empty ones.

35. Alopecurus.

38. Polypogon.

33. Heleochloa.

34. Phleum.

Spikelets 10-12 mm. long; tall seashore grasses.

43. Ammophila. Spikelets variously panicled; panicle not spike-like, except in a few species of No. 37.

Seed loosely enclosed in the pericarp, which opens readily at maturity.

Empty scales minute; low arctic grass. 36 . Phippsia.

Empty scales not minute; no callus, awns or hairs. 37. Sporobolus.

Seed adherent to the pericarp.

Palet I-nerved; stamen I; flower plainly stalked: scales not hairy.

Palet 2-nerved; stamens 3 ; flower not plainly stalked. 40. Cinna.

Flowering scale bifid, with a delicate awn on its back ; rachilla prolonged into a short bristle.

45. Apera.

Flowering scale entire; rachilla not prolonged into a bristle.

Callus with a tuft of long hairs at the base (except in some species of genus 42.)

Rachilla extended beyond the palet.

Rachilla not extended beyond the palet. 44. Calamovilfa.

Callus naked or with very short hairs.

Empty scales somewhat shorter than the flowering ones; arctic grass.

39. Arctagrostis.

Empty scales longer than the flowering ones; panicle open; spikelets small.

41. Agrostis.

\section{Tribe VIII. Aveneae.}

Spikelets deciduous ; lower flower perfect, upper staminate, awned ; plant velvety.

Spikelets not deciduous; empty scales persistent, flowering ones deciduous.

Spikelets of 2 perfect flowers; rachilla not prolonged beyond the upper one.

Spikelets 2-many-flowered; rachilla prolonged beyond the upper flower.

Awn of flowering scale upon the back, inserted below the teeth.

Flowers all perfect, or the upper ones staminate or wanting.

Spikelets less than $12 \mathrm{~mm}$. long; grain free, unfurrowed. Flowering scale finely erose-dentate or 2-lobed.

Flowering scale cleft or 2 -toothed, with the teeth sometimes produced into awns.

Spikelets over $12 \mathrm{~mm}$. long; grain furrowed, usually adherent to the scales.

Upper flower perfect, lower staminate, its scale strongly awned.

51. Arrhenatherum.

Awn from between the lobes or teeth of the flowering scale, generally twisted.

52. Danthonia.

\section{Tribe IX. ChlorideaE.}

Flowers perfect or some of them rudimentary.

I perfect flower in each spikelet; sometimes 2 in Nos. 59 and 6r.

No empty scales above the flower.

Spikelets deciduous.

Rachis produced beyond the upper spikelet; spikelets narrow.

54. Spartina.

Rachis not so produced; spikelets globose, sometimes 2 -flowered.

6r. Beckmannia.

Spikelets not deciduous; empty scales persistent; low slender grasses.

Spikes 2-6, slender, digitate, $2.5-5 \mathrm{~cm}$. long. 53. Capriola.

Spikes many along a common axis, $5-10 \mathrm{~cm}$. long.

58. Sikedonnardus. 
One-several empty scales above the flower.

Lower empty scales 4 ; spike solitary, dense.

55. Campulosus.

Lower empty scales 2 .

Spikes in false whorls or closely approximate; scales long-awned.

Spikes remote, or the lowest only approximate.

56. Chloris.

Spikelets scattered or remote on filiform spikes.

Spikelets crowded, sometimes 2- flowered.

57. Gymnopogon.

Spikes 4 or less; spikelets numerous, 25 or more.

Spikes numerous, 12 or more; spikelets few, 12 or less.

6n. Atheropogon.

2-3 perfect flowers in each spikelet.

Spikelets densely crowded; spikes usually digitate.

Spikes with terninal spikelets.

62. Eleusine.

Spikes without terminal spikelets, the rachis extending beyond them into a point.

Spikelets distinctly alternating; spikes remote.

63. Dactyloctenium.

64. Leptochloa.

Spikelets diœecious, very unlike; spikes short ; low prairie grass. 65. Bulbilis.

\section{Tribe X. Festuceae.}

Rachilla with long hairs enveloping the flowering scale; tall aquatic grass.

67. Phragmites.

Rachilla and flowering scales naked or hairy, hairs much shorter than the scales.

Stigmas barbellate; spikelets in clusters of $3-6$ in the axils of stiff spinescent leaves. 66. Munroa.

Stigmas plumose ; spikelets not in the axils of leaves ; inflorescence various.

Spikelets of two forms, the fertile $1-3$-flowered, surrounded by the sterile, consisting of many empty pectinate scales.

86. Cynosurus.

Spikelets all alike.

Flowering scale I-3-nerved, or rarely with faint additional intermediate nerves.

Flowering scales membranous; seed not beaked nor exserted from the scales.

Lateral nerves of flowering scale pilose.

Internodes of the rachilla long, the deeply 2-lobed flowering scale attached by a long-pointed callus, which is copiously pilose on the outer surface. 70 . Triplasis.

Internodes of the rachilla and the callus of the flowering scale short, blunt.

Panicle simple or compound, contracted or open, the spikelets on pedicels of varying length.

$$
\text { 69. Tricuspis. }
$$

Panicle composed of long branches along which the appressed spikelets are arranged on short pedicels.

72. Diplachne.

Lateral nerves of the flowering scale glabrous.

Callus of the flowering scale conspicuously pubescent with long hairs.

Panicle contracted; flowering scale broadly oval, rounded at the apex.

74. Rhombolytrum.

Panicle open and diffuse; flowering scales lanceolate and acute.

Callus of the flowering scale glabrous.

71. Redfieldia.

Second empty scale similar to the first.

Panicle narrow, the branches appressed.

Panicle dull, interrupted; rachilla articulated.

73. Molinia.

Panicle shining, dense and spike-like; rachilla continuous. 77 . Koeleria.

Panicle open, the branches more or less spreading.

Rachilla continuous; flowering scales deciduous in fruit, the palet persistent.

75. Eragrostis.

Rachilla articulated ; flowering scales and palets both deciduous with the rachilla internodes. 
Second empty scale very dissimilar to the first, broad and rounded at the summit.

76. Eatonia.

Flowering scales coriaceous in fruit; seed beaked and exserted from the scales.

Flowering scales 5-many-nerved.

Flowering scales 3 -toothed at the apex.

Flowering scales not 3 -toothed at the apex.

8o. Korycarpus.

Spikelets with 2 or more of the upper scales empty, broad and enfolding each other.

79. Melica.

Spikelets with the upper scales flower-bearing, or narrow and abortive.

Keel of the palet winged or with a linear appendage.

Keel of the palet not appendaged.

8r. Pleuropogon.

Stigmas placed at or near the apex of the ovary ; flowering scales awned only in Nos. 85 and 93.

Scales more or less strongly compressed and keeled. Empty basal scales 3-6; spikelets flat, 2-edged. 82. Uniola.

Empty basal scales 2; spikelets flattened. Panicle contracted; spikelets diøecious. 83. Distichlis.

Panicle open; spikelets perfect.

Flowering scales herbaceous, awnpointed; spikelets collected in onesided clusters.

85. Dactylis.

Flowering scales scarious-margined; rachis glabrous or with webby hairs.

Spikelets large, cordate.

84. Briza.

Spikelets mostly smaller, not cordate.

Empty scales projecting beyond the uppermost flowering ones; arctic grass.

88. Dupontia.

Uppermost scales exceeding the empty ones; flowering scales 2-10, mostly webby at base.

87. Poa.

Flowering scales membranous; rachis hirsute with stiff hairs, extended into a hairy appendage.

90. Graphephorum.

Scales rounded on the back, at least below.

Flowering scales with a basal ring of hairs, toothed at apex; water grass. 89. Scolochloa.

Flowering scales naked at the base:

Obtuse or subacute and scarious at the apex, usually trothed.

Plainly 5-7-nerved; styles present. 9r. Panicularia.

Obscurely 5 -nerved; no style. 92. Puccinellia.

Acute, pointed or awned at apex. 93. Festuca.

Stigmas plainly arising below the apex of the ovary; scales mostly awned.

94. Bromus.

\section{Tribe XI. HORDEAE.}

Stigma I; spike unilateral; spikelets I-flowered, narrow.

95. Nardus.

Stigmas 2; spike symmetrical.

Fpikelets solitary at the notches of the rachis.

Flowering scales with their backs turned to the rachis. 
Flowering scales with their sides turned to the rachis.

Spikelets I-2-flowered in slender articulate spikes.

Spikelets 2-many-flowered in stout inarticulate spikes (articulated in one species).

Spikelets 2-6 at each joint of the rachis ; scales mostly long-awned.

98. Agropyron.

Spikelets $\mathrm{r}$-flowered or with the rudiment of a second flower.

Spikelets 2-many-flowered.

99. Hordeum.

Rachis of the spike articulated, readily breaking up into joints. roo. Sitanion.

Rachis of the spike continuous, not breaking up into joints.

Empty scales a little smaller than the flowering ones.

Empty scales very small or none.

IOI. Elymus,

102. Hystrix.

\section{Tribe XII. BambuseaE.}

Tall canes with large flat spikelets in panicles or racemes.

103. Arundinaria.

\section{TRÍPSACUM L.}

Tall perennial grasses with thick rootstocks, rather broad, flat leaves and monœ. cious flowers. Spikelets I-2-flowered, in terminal or axillary, solitary or clustered, elongated spikes. Staminate spikelets in 2's at each node of the upper part of the axis. 2 -flowered zusisting of four scales, the two outer coriaceous, the two inner thinner, the palet hyaline; stamens 3. Pistillate spikelets in excavations at the lower joints of the spilie, I-flowered; stigmas exserted; style slender. Grain partly enclosed in the excavations of the spikes, covered in front by the horny exterior lower scale. [Name from the Greek, in allusion to the polished outer scales.] About 3 species, natives of tropical and temperate America. Besides the following, another occurs in the southern United States.

I. Tripsacum dactyloides L. Gama-grass. (I. F. f. 210.) Rootstock I.25-2.5 cm. thick, culms stout, erect. I-2 m. tall. Leaves smooth and glabrous, $3 \mathrm{dm}$. or more long, $1.25-3.75 \mathrm{~cm}$. wide; spikes terminal, and in the upper axils, solitary or 2-3 together, I-I.25 dm. long; outer scales of the staminate spikelets linear and obtuse, $8 \mathrm{~mm}$. long, about $2 \mathrm{~mm}$. wide, faintly many-nerved; exterior scale of the pistillate spikelets horny, shining. In swamps or along streams, Conn. to Kansas, south to Fla. and Tex. June-Sept.

\section{ERIÁNTHUS Michx. (See Appendix.)}

Tall, generally robust, perennial grasses, with thick creeping rootstocks, long flat leaves, and perfect flowers in terminal panicles. Spikelets generally with a ring of hairs at the base, 2 at each node of the jointed rachis, one sessile, the other with a pedicel, generally I-flowered. Scales 4, the two outer indurated, the inner liyaline, the fourth bearing a terminal straight or contorted awn; palet small, hyitline; stamens 3. Grain oblong, free, enclosed in the scales. [Greek, referring to the woolly spikelets.] About 17 species, natives of the temperate and tropical regions of both hemispheres. Besides the following, four others occur in the Southern States.

Awn spiral.

Awn straight.

I. E. alofecuroides.

Panicle lax; branches long and spreading; basal hairs longer than the outer scale of the spikelet. 2. E. saccharoides.

Panicle compact or strict; branches short and erect or appressed; basal hairs equalling or shorter than the outer scale of the spikelet.

Outer scale about $5 \mathrm{~mm}$. long.

Outer scale about $8 \mathrm{~mm}$. long.

3. E. compactus.

4. E. brezibarbis.

I. Erianthus alopecuroides (L.) Ell. SpIRal-Awned Plume-grass. (I. F. f. 2 II.) Culms stout, erect, r.5-3 m. tall, the summit and the axis of the panicle densely pubescent. Sheaths glabrous; leaves $1.5^{-6} \mathrm{dm}$. long, $1.25^{-2.5} \mathrm{~cm}$. wide; panicle oblong, I.5-3 dm. long, $5-7.5 \mathrm{~cm}$. wide, branches spreading, $7.5-12.5$ 
cm. long, slender, loose; awn 12-16 mm. long, the portion included in the outer scales tightly spiral, bent at point of exsertion, and thence loosely spiral. In damp soil, N. J. to Ky. and Mo., south to Ga. and Ala. Sept.

2. Erianthus saccharoides Michx. Plume-Grass. (I. F. f. 212.) Culms robust, erect, $1.4-3 \mathrm{~m}$. tall, the summit and the axis of the panicle densely pubescent, with appressed long rigid silky hairs. Sheaths densely pubescent at the throat; leaves $0.6-2.5 \mathrm{~cm}$. wide; panicle lax, broadly oblong, I.25--3.75 dm. long, 5-10 cm wide, its branches spreading, 5-10 $\mathrm{cm}$. long, internodes about $4 \mathrm{~mm}$. long; outer scales of the spikelet a little exceeding the pedicel and about one-half as long as the basal hairs; awn $2-2.5 \mathrm{~cm}$. long, scabrous. In moist sandy soil, S. E. Va. to Fla. and La. Aug.-Sept.

3. Erialthus compáctus Nash. Contracted Plume-grass. (I. F. f. 213.) Culms $\mathrm{I}-3 \mathrm{~m}$. tall, the summit and axis of the panicle densely pubescent with ap. pressed long rigid silky hairs. Sheaths glabrous, or pubescent at the top; leaves 6-12 mm. wide; panicle narrowly oblong, I-1.5 dm. long, about $3.75 \mathrm{~cm}$. wide; branches erect, $2.5-5 \mathrm{~cm}$. long; internodes about $2 \mathrm{~mm}$. long; outer scales of the spikelet exceeding the pedicels and about equalling the basal hairs; awn $\mathbf{I - 2} \mathrm{cm}$. long, scabrous. In moist soil, N. J. to N. C. and Tenn. Aug.-Sept.

4. Erianthus brevibàrbis Michx. Short-BEarded Plume-Grass. (I. F. f. 214.) Culms stout, erect, I-2 m. tall, nodes naked or scantily barbed, the summit and axis of the panicle smooth or scabrous. Sheaths glabrous; leaves rough, 34.5 dm. long, 6-10 mm. wide, acuminate; panicle linear-oblong, 2-2.5 dm. in length, $2.5-3.75 \mathrm{~cm}$. wide, branches erect, $5-12.5 \mathrm{~cm}$. long, internodes about $5 \mathrm{~mm}$. long; outer scales of the spikelet about $8 \mathrm{~mm}$. long, twice the length of the pedicel and equalling or twice as long as the basal hairs, lanceolate, long-acuminate; inner scales shorter; awn 1.8-2.5 cm. long, straight, scabrous. In moist soil, Del. to N. C. and La. Autumn.

\section{MANISÜRIS L. [ROTTBOELLIA L. f.]}

Mostly tall perennials, with running rootstocks, narrow flat leaves and cylindrical jointed spikes, terminal and from the upper axils. Spikelets in pairs at each node of the excavated rachis, one sessile and perfect, the other with a pedicel and either staminate or empty. Scales of the perfect spikelet 4, the outermost thick and coriaceous, covering, together with the pedicel of the sterile spikelet, the excavation in the rachis; second scale chartaceous; third and fourth hyaline, the latter subtending a palet and perfect flower. Stamens three. Styles distinct. Grain free. [Greek, in allusion to the tail-like spikes.] About 25 species, widely distributed in tropical and temperate countries.

Culms from a creeping rootstock, round; sheaths round, narrow.

Culms tufted, no rootstocks, much flattened, at least below; sheaths much compressed, broad, keeled.

I. M. cylindrica. 2. M. rugosa.

1. Manisuris cylíndrica (Mx.) Kuntze. Creeping Mansuris. Culms 3-ro $\mathrm{dm}$. tall, slender; leaves $3 \mathrm{dm}$. or less long, $\mathbf{I}-3 \mathrm{~mm}$. wide; racemes $\mathbf{I}-2 \mathrm{dm}$. long; sessile spikelets $4.5-5 \mathrm{~mm}$. long, about equalling the internodes, the first scale more or less pitted in longitudinal lines, or rarely unpitted, the the pits often containing a subulate hair; pedicellate spikelets reduced to $I$ or 2 scales, the pedicel linear, shorter than the sessile spikelet and curved around its margin. In sandy soil, Ga. and Fla. to Tex.; also in Mo., Ark. and Ind. Terr. June-Aug.

2. Manisuris rugòsa (Nutt.) Kuntze. Wrinkled Manisuris. (I. F. f. 215.) Culms 6-12 dm. tall, compressed, much branched above. Sheaths compressed; leaves flat, 1.5-6 dm. long, 2-6 mm. wide; spikes partially included in the sheath or more or less exserted, 3-5 cm. long; outermost scale of the spikelets about 4 $\mathrm{mm}$. long, strongly transverse-rugose. In wet soil along the coast, Del. to Fla., west to Tex. June-Sept.

\section{ANDROPÒgON L. (See Appendix.)}

Perennial grasses with usually long narrow leaves, and terminal and axillary racemes. Spikelets in pairs at each node of the jointed hairy rachis, one sessile and perfect, the other with a pedicel and either staminate, empty or reduced to a 
single scale. Perfect spikelet consisting of 4 scales, the outer 2 coriaceous, the second keeled and acute, the two inner hyaline, the fourth more or less awned and subtending a palet and perfect flower. Stamens 1-3. Grain free. [Greek, in allusion to the bearded rachis.] About 150 species, widely distributed in tropical and temperate regions. Besides the following, some 25 others occur in the southern and western parts of N. Am.

Racemes singly disposed; apex of the rachilla internodes with a translucent cup-shaped entire or irregularly-toothed appendage.

Spikelets 5-7 mm. long; sheaths of the innovations green. I. A. scoparius.

Spikelets 8-10 mm. long; sheets of the innovations strongly compressed, glaucous.

2. A. littoralis.

Racemes disposed in pairs or more; apex of the rachis internodes unappendaged.

Pedicellate spikelet sterile, of $\mathrm{I}$ or 2 scales, much smaller than the sessile one.

Racemes usually protruding from the lateral fissure of the spathe, sometimes more or less exserted from the apex, the peduncle never long-exserted.

Branches of the inflorescence crowded at the summit of the culm in a dense corymbiform panicle. $\quad$ 3. A. corymbosus.

Branches of the inflorescence scattered along the culm in a long linear panicle.

Racemes much exserted on long peduncles.

Stamen I; upper sheaths much enlarged. 5 5. Alliottii.

Stamens 3 ; sheaths not enlarged.

First scale of the spikelet nerveless between the keels; terminal hairs of the internodes about twice their length. $\quad 6 . A$. argyraeus.

First scale of the spikelet with 2 or 3 nerves between the keels; terminal hairs of the internodes about equalling them.

7. A. Cabanisii.

Pedicellate spikelet as large as or larger than the sessile, of 4 scales and a stamin.te or rarely perfect flower.

Fourth scale of sessile spikelet with a long geniculate awn, more or less spiral at the base.

Outer two scales of the sessile spikelet more or less hispidulous all over; hairs on the rachis internodes usually $2 \mathrm{~mm}$. or less long.

8. A. furcatus.

Outer 2 scales of the sessile spikelet smooth or nearly so, except on the nerves; hairs of the rachis internodes 3-4 $\mathrm{mm}$. long, usually yellow.

9. A. chrysocomus.

Fourth scale of the sessile spikelet awnless or with a short, straight, untwisted awn.

Marginal hairs on the pedicels and rachis internodes copious, stiff. 10. A. Hallii.

Marginal hairs on the pedicels and rachis internodes scant or almost wanting, lax, crisped.

II. A. paucipilus.

I. Andropogon scopàrius Michx. Broom BeARD-GRass. (I. F. f. 216.) Culms tufted, 6-12 dm. tall. Sheaths sometimes glaucous; leaves 1.5-3 dm. long, scabrous ; spikes $2.5-5 \mathrm{~cm}$. long, loose, solitary, on long-exserted slender peduncles; rachis slender, flexuous, joints and pedicels ciliate with long, spreading hairs; outermost scale of sessile spikelet about $6 \mathrm{~mm}$. long; a wn spiral, IO-I $2 \mathrm{~mm}$. long; pedicelled spikelet a single awn-pointed scale. In dry sandy fields, N. B. to Alb. south to Fla. and Tex. Aug.-Oct.

2. Andropogon littoràlis Nash. SEaside Beard-grass. Culms densely tufted, 8-10 dm. tall, the innovations with the leaves and strongly compressed sheaths glaucous; leaves $2 \mathrm{dm}$. long or less, rough; racemes $3-4 \mathrm{~cm}$. long, rarely longer; sessile spikelets $8-10 \mathrm{~mm}$. long, the awn of the fourth scale geniculate, spiral, Io-1 $5 \mathrm{~mm}$. long; pedicellate spikelet a single-awned scale. In sand along the seashore, N. Y. and N. J. Aug.-Oct.

3. Andropogon corymbòsus (Chapm.) Nash. Bushy Beard-grass. (I. F. f. 221.) Culms 4-10 dm. tall, from a little exceeding to twice as long as the basal leaves; sheaths keeled, those at the base much compressed and equitant, rough, more or less papillose-hirsute; culm leaves rough; spathes very rough, tightly enrolled around the common peduncle, which is usually as long as the spathe and hispidulous toward the summit; racemes in pairs, more or less exserted, $2-3 \mathrm{~cm}$. 
long; sessile spikelet $4-5 \mathrm{~mm}$. long, the awn I-I.8 cm. long. Wet soil, D. C. to Fla. and Miss. Sept.-Oct. [A. glomeratus (Walt.) B. S. P. in part.]

Andropogon corymbosus abbreviàtus (Hack.) Nash. Differs from the type in having the spathes generally about equalling the racemes, and few if any of them narrow and enrolled on the peduncles. Similar situations, Long Island to Fla. Sept.-Oct.

\section{Andropogon Virgínicus L. Virginia Beard-grass. (I. F. f. 220.)} Culms tufted, 5-10 dm. tall, many times longer than the basal leaves; sheaths, at least the lower ones, more or less tuberculate-hirsute on the margins; leaves $4 \mathrm{dm}$. long or less, more or less hirsute on the upper surface near the base; spathes 3-5 $\mathrm{cm}$. long, broad; racemes generally in pairs, $2-3 \mathrm{~cm}$. long; sessile spikelets 3-4 $\mathrm{mm}$. long; the awn IO-I 5 long; pedicellate spikelet wanting or rarely present as a minute scale. Dry or moist fields, Mass. to Ill., south to Fla. and Tex. Aug.Sept.

5. Andropogon Ellióttii Chapm. Elliott's Beard-Grass. (I. F. f. 222.) Culms tufted, 5-8 dm. tall; lower sheaths and those of the innovations densely appressed-hirsute, those of the inflorescence much enlarged and much crowded at the summit, 8-II cm. long; leaves $2 \mathrm{dm}$. or less long, rough above and hirsute near the base; racemes in pairs, slender, 3-4 cm. long, those on the longer branch at each node exserted, the rest concealed in the sheaths; sessile spikelets 4.5-5 mm. long, the awn geniculate, $1.5-2.3 \mathrm{~cm}$. long, usually spiral at the base; the column much exserted. Dry sandy soil, $\mathrm{Pa}$. (according to S. Watson), south to Fla. and Miss. Sept.-Oct.

6. Andropogon argyraèus Schultes. Silvery Beard-grass.

(I. F. f. 2I 7.) Culms 6-12 dm. tall, simple at base, generally much branched above. Sheaths somewhat compressed; basal leaves I.5-3 dm. long; upper 5-20 $\mathrm{cm}$. by $2 \mathrm{~mm}$. wide; spikes in pairs, $2.5-5 \mathrm{~cm}$. long, on exserted slender peduncles; joints of the rachis and pedicels pubescent with long, silky-white, spreading hairs; outermost scale of sessile spikelet about $5 \mathrm{~mm}$. long, acuminate, hispidulous; awn loosely spiral, $12-18 \mathrm{~mm}$. long, scabrous; pedicelled spikelet a minute deciduous scale. In dry sandy soil, Del. to Mo., south to Fla. and Tex. Sept. [A. argenteus Ell.]

7. Andropogon Cabanísii Hack. Cabanis' Beard-grass. Culms 6-ro $\mathrm{dm}$. tall. Sheaths smooth or a little roughened; leaves $2.5 \mathrm{dm}$. or less long, smooth beneath, rough above; racemes in pairs, 4-7 cm. long, grayish; sessile spikelets 6-7 mm. long, broadly lanceolate, the first scale strongly hispidulous and 2-3-nerved between the keels; pedicellate spikelet of a single hispidulous scale 3-3.5 mm. long. Dry soil, Pa. (according to Hackel) and Fla. June-Aug.

8. Andropogon furcàtus Muhl. Forked BEARD-Grass. (I. F. f. 219.) Culms stout, 9-18 dm. tall. Sheaths smooth and glabrous; leaves $1.5-4.5 \mathrm{dm}$. long; spikes $2-5$, in pairs or approximate, 5-10 $\mathrm{cm}$. long; joints of rachis and pedicels ciliate with short hairs; outermost scale of sessile spikelet $6-8 \mathrm{~mm}$. long; awn IO-I $4 \mathrm{~mm}$. long; loosely spiral, geniculate; pedicelled spikelet of 4 scales. In dry or moist soil, Me. to Man., south to Fla. and Tex. Aug.-Sept.

9. Andropogon chrysocòmus Nash. Yellow.haired Beard-grass. Culms 7-I5 dm. tall; sheaths smooth and glabrous; leaves $3 \mathrm{dm}$. long or less, smooth beneath, a little roughened above; racemes in 2 's -4 's, 5-9 cm. long, stout, long-exserted; sessile spikelets about I cm. long, the outer 2 scales hispid on the nerves, the awn of the fourth seale twisted at the base, geniculate, 10-1 $2 \mathrm{~mm}$. long; pedicellate spikelet awnless. Dry soil, Kans. to Tex. July-Sept.

Io. Andropogon Hàllii Hack. Hall's Beard-Grass. (I. F. f. 2I8.) Culms robust, 9-18 dm. tall, more or less glaucous. Sheaths somewhat glaucous; leaves $3 \mathrm{dm}$. long or less; spikes 2-5, 5-10 cm. long; outermost scale of sessile spikelet about $8 \mathrm{~mm}$. long, acuminate, glabrous at base, from sparingly to copiously silkypubescent toward the apex; awn straight, 4-10 $\mathrm{mm}$. long, or sometimes wanting: pedicelled spikelet consisting of 4 scales, generally larger than the sessile spikelet and enclosing three stamens. Dry sandy soil, Kans. and Mont. to Mex. Aug.Sept.

Ix. Andropogon paucípilus Nash. Scant-hatred Beard-grass. Culms IO-I2 dm. tall, rather stout. Sheaths smooth and glabrous, as are the leaves which are erect and $3 \mathrm{dm}$. long or less; racemes in 2 's -3 's, 5-7 cm. long, exserted; 
sessile spikelets 9-10 $\mathrm{mm}$. long, the outer 2 scales hispid on the nerves toward the apex, pubescent toward the summit with long loose-crisped hairs; pedicellate spikelet similar to the sessile one, staminate. In dry soil, Mont. and Neb. July.

\section{AMPHILÒPHIS Nash.}

Perennial grasses with usually flat leaves and showy, often silvery-white, pan. icles, the axis short, making the panicle appear fan-like, or elongated with the branclies more scattered. Racemes usually numerous, the internodes with manifestly thickened margins, the median portion thin and translucent, the pedicels of the same structure, the margins ciliate with usually long hairs. Sessile spikelets of 4 scales, the first one 2 -keeled, the second I-keeled, the third and fourth scales hyaline, the latter very narrow, stipe-like, somewhat thickened, gradually merging into a usually geniculate, contorted or spiral awn, or the awn rarely wanting. Pedicellate spikelets staminate and similar to the sessile, or sterile and smaller than them. Stamens 3. Styles distinct. Stignas plumose. Grain free, enclosed in the scales. [Greek, in reference to the hairs surrounding the spikelets.] About 30 species, in temperate and tropical countries.

I. Amphilophis Torreyànus (Steud.) Nash. TORREy's BEARD-Grass. (I. F. f. 223.) Culms erect, 4.5-io.5 dm. tall, the nodes naked. Sheaths more or less glaucous; leaves $7 \cdot 5-17.5 \mathrm{~cm}$. long, glaucous; spikes $2.5-3.75 \mathrm{~cm}$. long in a terminal long-exserted panicle 4 -Io $\mathrm{cm}$. long; outermost scale of sessile spikelet 3-4 mm. long, about equalling the terminal hairs of the rachis-joints, lanceolate, acute; awn 8-16 mm. long, spiral; pedicelled spikelet rudimentary. In dry soil, Kans. to Ariz. and Mex. Aug.-Sept. (Andropogon Torreyanus Steud.)

\section{SORGHÁSTRUM Nash.}

Generally tall grasses, ours perennials, with long, narrow, flat leaves and terminal panicles. Spikelets in pairs, or 3's at the end of the branches, one sessile and perfect, the lateral pedicelled, empty, or reduced to the pedicel only. Perfect spikelet consisting of 4 scales, the two outer indurated and shining, the inner hyaline, the fourth awned and subtending a palet and perfect flower, or the palet sometimes wanting. Stamens 3. Styles distinct. Stigmas plumose. Grain free. [Named in reference to its resemblance to sorghum.] Ahout 15 species, in temperate and tropical countries. (Chrysopogon Benth. Not Trin.)

I. Sorghastrum avenàceum (Michx.) Nash. INdian Grass. (I. F. f. 224.) Culms 9-24 dm. tall. Lower leaves $3 \mathrm{~d}$. or more in length; panicle $\mathbf{I}-3 \mathrm{dm}$. long, brownish-yellow; branches $5^{-10} \mathrm{~cm}$. long, erect-spreading; spikelets erect or somewhat spreading ; first scale of sessile spikelet $6-8 \mathrm{~mm}$. long, pubescent with long hairs; second scale glabrous; awn I-2 cm. long, the column having but a single bend; lateral spikelets wanting. In dry fields, Ont. to Man., south to N. H., Fla. and Ariz. Aug.-Sept. (Chrysopogon az'enaceus Benth.)

\section{SÓRGHUM Pers.}

Annual or perennial grasses, with long, broad, flat leaves and terminal ample panicles. Spikelets in pairs at the nodes, or in 3's at the ends of the branches, one sessile and perfect, the lateral pedicelled, staminate or empty. Sessile spikelet consisting of 4 scales, the outer indurated and shining, obscurely-nerved, inner hyaline, the fourth awned and subtending a small palet and perfect flower, or palet - sometimes wanting. Stamens 3. Styles distinct. Grain free. [Name Iudian.] About 13 species, of wide distribution in tropical and warm-temperate regions.

I. Sorghum Halepénse (L.) Pers. Johnson-Grass. (I. F. f. 225.) Culms 9-20 dm. tall; sheaths smooth; leaves $3 \mathrm{dm}$. or more long, 6-25 $\mathrm{mm}$. wide; panicle from I.5-4.5 dm. long; outer scales of sessile spikelet 4-6 mm. long, usually purplish, pubescent with long appressed hairs; awn when present $8-16 \mathrm{~mm}$. long. In fields and waste places, southern $\mathrm{Pa}$. to Mo. and Kans., south to Fla. and Tex. Native of southern Europe and Asia. July-Sept.

\section{NÀZIA Adans.}

An annual grass, diffusely branched, with flat leaves and I-flowered decid ous spikelets, either solitary or in clusters of 3-5 in a terminal spike. Scales of spikelet 2 or 3 , the outermost small or wanting, the second rigid and covered with hooked prickles, the third membranous, subtending a palet and perfect flower.

[Name 
unexplained.] A monotypic genus, native of tropical and temperate regions of the Old World.

I. Nazia racemòsa (L.) Kuntze. Prickle-Grass. (I. F. f. 226.) Culms 5-35 cm. tall, pubescent above. Leaves $2 \cdot 5-7 \cdot 5 \mathrm{~cm}$. long, rather strongly ciliate; spike $2.5^{-10} \mathrm{~cm}$. long, sometimes partially included in the somewhat inflated upper sheath; second scale coriaceous, $3 \mathrm{~mm}$. long, 5-nerved; third scale $2 \mathrm{~mm}$. long, I-nerved. Occasional in ballast and waste places about the seaports. July-Sept.

\section{PÁspalum L. (See Appendix.)}

Perennial grasses, various in habit, with generally flat leaves and I-flowered spikelets, borne singly or in pairs in 2 rows on 1 -sided spikes, which are single, in pairs or panicled. Spikelets oblong to orbicular, flat on the outer surface, convex on the inner. Scales 3, the outer ones membranous, the inner one indurated and subtending a palet and perfect flower. Stamens 3. Styles separate. Stigmas plumose. Grain ovoid or oblong, free. [An ancient Greek name for some grass, used by Hippocrates.] About 160 species, of wide distribution in tropical and temperate regions, most abundant in America.

Rachis of the racemes very broad, twice the width of the spikelets, or nearly so, which are partially concealed by its in rolled margins.

Rachis extending beyond the spikelets, long-acuminate; spikelets about I mm. long.

Rachis not extending beyond the spikelets, acute; spikelets $2 \mathrm{~mm}$. long.

1. P. mucronatum.

2. P. membranaceum.

Rachis of the racemes narrower than the spikelets, not inrolled on the margins.

Racemes 2, approximately in a pair at the summit of the culm; rootstocks exten. sively creeping; culms not tufted.

Racemes I-several, alternate; culms tufted.

3. P. distichum.

Culms simple, no branches from the upper sheath; racemes stout.

Spikelets obtuse, glabrous.

Spikelets $3 \mathrm{~mm}$. or less long.

Leaves very hirsute on both surfaces; the hairs on the sheaths very dense and long.

Leaves glabrous beneath, or nearly so.

Spikelets elliptic, hence longer than broad, decidedly convex on the inner side; sheaths glabrous or nearly so.

5. P. laeve.

Spikelets orbicular, or nearly so, hence as broad as long, but little convex on the inner side; sheaths hirsute.

Spikelets $4 \mathrm{~mm}$. or more long.

Spikelets acute, long villous-ciliate on the margins.

6. P. circulare.

7. P. glabratum.

8. P. dilatatum.

Culms branched, the upper sheath containing from $\mathrm{I}-3$ branches; racemes slender.

Leaves glabrous on both surfaces, or the midnerve sometimes pubescent beneath.

Sheath margins glabrous.

Sheath margins pubescent.

9. P. ciliatifolium.

Spikelets orbicular, hence as broad as long, straw-color, $2 \mathrm{~mm}$. in diameter.

10. P. stramineum.

Spikelets broadly obovate to oval, longer than broad, green, $1.5 \mathrm{~mm}$. long.

Leaves pubescent on both surfaces.

II. P. longipedunculatum.

Pubescence of copious soft short-appressed liairs.

Culms prostrate, the lower leaves $\mathrm{I} \mathrm{dm}$. or less long.

12. P. prostratum.

Culms erect, the lower leaves $\mathbf{r} .5 \mathrm{dm}$. or more long.

13. P. Bushii.

Pubescence of more or less spreading and usually rather long stout hairs.

Culm densely pilose below the racemes; lower sheaths usually glabrous or nearly so.

Culm glabrous; lower sheaths generally hirsute.

Spikelets I-I.5 mm. long.

Spikelets $2-2.25 \mathrm{~mm}$. long.

15. P. setaceum.

Racemes on the main culm $r$, or sometimes 2 ; spikelets glabrous; leaves rather thin. 16. P. Muhlenbergii.

Racemes on the main culm 2 or 3 ; spikelets pubescent; leaves thick.

17. P. dasyphyllum. 
I. Paspalum mucronàtum Muhl. Water Paspalum. (I. F. f. 227.) Culms ascending, 1.5-9 dm. long, from a floating or creeping base, branched. Sheaths very loose or inflated, smooth or scabrous, glabrous or pubescent; leaves 7.5-30 $\mathrm{cm}$. long, 6-25 mm. wide, acuminate, scabrous; spikes $20-100,1.25-7.5 \mathrm{~cm}$. long, alternate or sometimes approximately whorled, slender ; rachis flat, thin, exceeding the spikelets, long-acuminate, scabrous, its margins nearly enclosing the spikelets: spikelets in two rows, about I mm. long, elliptic, pubescent; outer scales very thin, 2 -nerved, the first one usually a little the longer. In water, Va. to southern Ill. and Karıs., south to Fla. and Tex. Also in tropical America. Sept. ( $P$. fluitans Kunth.)

2. Paspalum membranàceum Walt. Walter's Paspalum. (I. F. f. 228.) Culms erect or ascending, much branched, smooth, creeping at the base. Sheaths a little inflated, smooth; leaves $3 \cdot 75-8.75 \mathrm{~cm}$. long, 4-6 mm. wide; spikes 3-7, alternate, about $2.5 \mathrm{~cm}$. long, the lower ones usually included in the upper sheath; rachis not exceeding the spikelets, flat, thin, 2-3 mm. wide, acute, smooth, its inrolled margins partly enclosing the spikelets; spikelets about $2 \mathrm{~mm}$. long, crowded in 2 rows, oval, obtuse, smooth; outer scales 5 -nerved; third scale lenticular, slightly shorter than the outer ones. Moist or wet grounds, N. J. and Del. to southern Ohio, south to Fla. and Tex. Sept. (P. Walterianum Schultes.)

3. Paspzlum dístichum L. JoinT-Grass. (I. F. f. 229.) Culms erect, 1.5-6 dm. tall, extensively creeping at base. Sheaths smooth, sometimes ciliate on the margins, or sparsely pubescent; leaves flat, $3.75-12.5 \mathrm{~cm}$. long, $2-4 \mathrm{~mm}$. wide, acuminate, smooth; spikes $2.5-6.25 \mathrm{~cm}$. long, in pairs, or occasionally with a third, exserted; rachis flat, I-2 mm. wide, smooth; spikelets $2.5-3 \mathrm{~mm}$. long, elliptic, somewhat pubescent or glabrous, acute, nearly sessile in 2 rows; outer scales 3-5-nerved, slightly exceeding the acute third one, which is sparingly bearded at the apex. Va. to Mo. and Cal., south to Fla., Tex. and Mex. Also in the West Indies, Central and South America. Aug.-Sept.

4. Paspalum plenípilum Nasl. Long-haired Paspalum. Culms tufted, erect, rather slender, 3-8 $\mathrm{dm}$. tall. Sheaths little compressed, very dersely pubescent with long spreading white hairs; leaves erect or nearly so, $2.5 \mathrm{dm}$. or less long, 4-6 mm. wide, densely pubescent on both surfaces with stift hairs, those toward the base on the upper surface very long; racemes $2-4$, ascending, 3-6 cm. long; spikelets singly arranged, oval, 2.5-2.75 min. long and about $2 \mathrm{~mm}$. broad, prominently convex on the inner side, the empty scales glabrous, 3 -nerved. In dry places, N. J. Aug.

5. Paspalum laeve Michx. Field Paspalum. (I. F. f. 234.) Bright green. culms rather stout, erect or ascending, 3-9 dm. tall, glabrous. Sheaths compressed, glabrous or somewhat pubescent; leaves $7.5-30 \mathrm{~cm}$. long, 4-8 mm. wide, acuminate, glabrous beneath, hirsute above near the base; spikes $2-6,3.5-7.5 \mathrm{~cm}$. long, more or less spreading, alternate, about $2-5 \mathrm{~cm}$. apart on the single stout peduncle, pilose in the axils; spikelets $2.5-3 \mathrm{~mm}$. long, oval, close, crowded $\mathrm{i}$. 2 rows, glabrous. In moist fields, R. I. to $\mathrm{Ky}$. and Mo., south to Fla. and Tex. Ascends to $1700 \mathrm{ft}$. in N. C. Aug.-Sept.

6. Paspalum circulàre Nash. Round-Flowered Paspalum. Culms erect or nearly so, 3-8 dm. tall. Sheaths compressed, at least the lower ones hirsute; leaves erect or ascending, $3 \mathrm{dm}$. or less long, 5-8 mm. wide, glabrous beneath, hirsute above toward the base; racemes usually in pairs, sometimes in 3 's, rarely in 4's, 4-9 cm. long; spikelets sirgly arranged, orbicular, about $3 \mathrm{~mm}$. in diameter, the inner side but slightly convex, the empty scales glabrous, very thin, bright green, 3-nerved. In moist or dry fields, N. Y. to N. C.; also in Mo. JulySept.

7. Paspalum glabràtum (Engelm.) Mohr. Engelmann's Paspalum. (I. F. f. 235.) Culms stout, erect, 9-18 dm. tall, from a creeping rootstock, glabrous. Sheaths glabrous, sometimes glaucous; leaves $2-4 \mathrm{dm}$. long, 6-I4 $\mathrm{mm}$. wide, acuminate, glabrous beneath, hirsute above; spikes $2-5$, on the single stout peduncle, 5-12 cm. long, erect or ascending, bearded in the axils; rachis about $2 \mathrm{~mm}$. wide, flat on the back, scabrous on the margins; spikelets $4 \mathrm{~mm}$. long, broadly oval, glabrous, glaucous, singly disposed and crowded in 2 rows; outer scales 5-nerved; third scale striate. Moist places, Del. to Ky. and Kans., south to Fla. and Tex. Sept. (Paspalum Floridanum Michx. in part.) 
8. Paspalum dilatàtum Poir. Tali Paspalum. (I. F. f. 230.). Culms erect, 9-18 dm. tall. Sheaths compressed, smooth and glabrous; leaves $3 \mathrm{dm}$. or more long, 4-IO mm. wide, sometimes with a tuft of hairs at the base; spikes 4-I2, 5-12.5 cm. long, spreading, alternate; rachis of the spikes narrow, less than $2 \mathrm{~mm}$. wide, somewhat flexuous, scabrous; spikelets about $3 \mathrm{~mm}$. long, in 3 or 4 rows, acute; outer scales 5 -nerved, the first villous on the margins, the second glabrous or sparsely pubescent, the third nearly orbicular, minutely punctate-striate. In moist soil, Va. to Fla., west to Tex. Aug.-Sept.

9. Paspalum ciliatifòlium Michx. Ciliate-leaved Paspalum. Culms tufted, erect, 4-8 dm. tall. Sheaths smooth and glabrous; leaves $5^{-25} \mathrm{~cm}$. long, 6-15 mm. wide, smooth and glabrous on both surfaces, the margins conspicuously ciliate with long hairs; racemes single or sometimes in 2's, $5-11 \mathrm{~cm}$. long; spikelets in pairs, I.8-2.I mm. long and I.5-I.8 mm. broad, oval to broadly obovate, the empty scales 3 -nerved, or the midnerve rarely lacking in the second, glabrous, In sandy or rocky soil, D. C. and Va. to Fla. and Miss. June-Sept.

xo. Paspalum stramíneum Nash. STRaw-COlored Paspalum. Foliage yellowish-green, the spikelets, and sometimes also the sheaths, pale straw.color. Culms tufted, 2-8 dm. tall; sheaths, all but the lower ones, glabrous except on the margins; leaves erect or nearly so, firm, long-ciliate on the margins, otherwise glabrous, 5-25 cm. long, 5-10 mm. wide; racemes 4-10 cm. long, usually in pairs, rarely I or 3 ; spikelets in pairs, orbicular, $2 \mathrm{~mm}$. in diameter, the first scale 3 nerved, pubescent, the second scale 2-nerved, glabrous or nearly so. In sandy places and fields, Neb., Kans. and Ind. Terr. July-Sept. (Paspalum ciliatifolium Michx. in part.)

I I. Paspalum longipedunculàtum Le Conte. Long-Stalked Paspalum. (I. F. f. 233.) Culms reclining or decumbent, 3-4.5 dm. long, smooth, leafy at base. Sheaths glabrous or ciliate on the margins, pilose at the throat; leaves 2.5$8.75 \mathrm{~cm}$. long, 4-6 $\mathrm{mm}$. wide, ciliate on the margins and along the midnerve; peduncles $I-2$ from the upper sheath; spikes $I-2,2.5-6.25 \mathrm{~cm}$. long, more or less curved; rachis very narrow, more or less flexuous; spikelets about $1.5 \mathrm{~mm}$. long; outer scales 3-nerved, the first one glabrous or sometimes sparsely pubescent; third scale slightly exceeding the outer ones. Sandy soil, N. C. to Fla., Ky. and Tenn. Aug.-Sept.

I2. Paspalum prostràtum Nash. Prostrate Paspalum. Culms prostrate, tufted, forming large, dense masses, 5-8 dm. long. Sheaths, as well as both surfaces of the leaves, softly and densely pubescent with short hairs; leaves erect or nearly so, ciliate on the margins, 3.5-10 $\mathrm{cm}$. long, 5-8 mm. wide; racemes 5$7.5 \mathrm{~cm}$. long, usually in pairs on the main culm; spikelets in pairs, about $2 \mathrm{~mm}$. long and $1.8 \mathrm{~mm}$. wide, oval, the outer scales densely pubescent, the first scale 3-nerved, the second scale usually 2-nerved by the suppression of the midnerve. In dry sandy soil, southeastern N. Y. to-Del. Aug.-Sept.

13. Paspalum Búshii Nash. Bush's Paspalum. Culms erect, 8-1o dm. tall, rather stout, lower sheaths pubescent, the others pilose on the margins; leaves erect or ascending, 5-20 cm. long, 5-15 mm. broad, ciliate on the margins, softly and densely pubescent on both surfaces with very short hairs; racemes IO-I 2 $\mathrm{cm}$. long, in 2's or 3's on the main culm; spikelets in pairs, $2-2.2 \mathrm{~mm}$. long and about $1.8 \mathrm{~mm}$. broad, oval, the empty scales densely pubescent, 3-nerved, or the second scale sometimes 2-nerved by the suppression of the midnerve. In dry soil, Mo. Aug.

14. Paspalum pubéscens Muhl. Pubescent Paspalum. Culms erect, 4$8 \mathrm{dm}$. tall, pilose at the summit. Sheaths glabrous or nearly so; leaves 4-23 cm. l.ng, 3-6 $\mathrm{mm}$. wide, rarely broader, densely long-pubescent on both surfaces; racemes usually 1 , rarely $2,6-12 \mathrm{~cm}$. long; spike'ets in pairs, glabrous, about 2 $\mathrm{mm}$. long, oval, 1.5-1.8 mm. wide, the empty scales 3-nerved, or the second 2nerved by the suppression of the midnerve. In dry soil, N. J. and Pa. to Kans., south to Fla. and Tex. Aug.-Sept. (Paspalum ciliatifolium Michx. in part.)

15. Paspalum setàceum Michx. Slender Paspalum. (I. F. f. 23I.) Culms mostly erect, 3-6 dm. tall, slender, smooth. Sheaths and leaves generally very pubescent, the latter $7 \cdot 5-20 \mathrm{~cm}$. long, $2-6 \mathrm{~mm}$. wide, erect, acuminate; spikes $3.75-8.75 \mathrm{~cm}$. long, more or less curved, generally solitary, occasionally $\mathbf{2}$, on a long-exserted slender peduncle, with usually I or $\mathbf{2}$ additional shorter pe- 
duncles from the same upper sheath; spikelets about $1.5 \mathrm{~mm}$. long, in 2 narrow rows, broadly obovate, very obtuse; empty scales 3-nerved, glabrous or pubescent; third scale obovate, shining. In dry fields, N. H. and Mass. to Ill., south to Fla. and Tex. Aug.-Sept.

16. Paspa um Muhlenbérgii Nash. Muhlenberg's Paspalum. (I. F. f. 232.) Culms tufted, at first erect, at length reclining, 4-8 dm. long. Sheaths usually hirsute all over; leaves 5-20 cm. long, usually 7-II $\mathrm{mm}$. wide, sometimes narrower, ciliate on the margins with generally long hairs, more or less pubescent on both surfaces with similar hairs; racemes solitary or in 2's, 5-10 cm. long; spikelets in pairs, glabrous, about $2 \mathrm{~mm}$. long and $1.8 \mathrm{~mm}$. wide, oval or broadly cbovate, the empty scales 3-nerved, or the second rarely 2 -nerved by the suppression of the midnerve. In fields or in sandy or stony ground, Mass. to Mo. and Ind. Terr., south to S. Car., Ga. and Miss. Aug.-Oct. (Paspalum ciliatifoizum Michx. in part.)

17. Paspalum dasyphýllum Ell. Hairy-Leaved Paspalum. Plant yellowish green. Culms tufted, 2-6 dm. tall; sheaths, as well as both surfaces of the leaves, densely pubescent, with long, yellowish, spreading hairs; leaves erect i $\mathrm{r}$ ascending, thick, $2 \mathrm{dm}$. or less long, usually $1-2 \mathrm{~cm}$. broad; racemes on the main culm in 2's or 3's, 4-10 cm. long; spikelets in pairs, $2-2.2 \mathrm{~mm}$. long and about $1.8 \mathrm{~mm}$. wide, broadly obovate, the first scale generally pubescent, 3 -nerved, the second scale glabrous, usually 2 -nerved or sometimes 3 -nerved. In dry, usually sandy, places, S. Car. to Fla.; also in Mo. June-Sept. (Paspalum ciliatifolium Michx. in part.)

\section{זo. ANÁSTROPHUS Schlecht.}

Perennial grasses, with the culms usually rooting at the lower nodes, with flat leaves and $\mathrm{r}$-flowered spikelets, borne singly in 2 rows in one-sided spikes which (in our species) are disposed in a single pair at the summit of the culm, or some. times with an additional one a short distance below. Spikelets oblong to lanceolate, convex on the outer surfice, flat on the inner. Scales 3 , the outer 2 membranous, the inner one firm and with its opening turned toward the rachis, subtending a perfect flower. Stamens 3. Styles separate. Stigmas plumose. Grain free. [Greek, signifying turned around, referring to the spikelets.]

Spikelets less than $2 \mathrm{~mm}$. long, oblong.

Spikelets about $4 \mathrm{~mm}$. Iong, broadly lanceolate.
I. A. compressus.

2. A. paspaloides.

I. Anastrophus compréssus (Sw.) Schlecht. (I. F. f. 236.) Stolons numerous, leafy, sometimes $6 \mathrm{dm}$. long. Culms I.5-6 dm. tall, slender, compressed, glabrous; sheaths loose; leaves glabrous, sometimes sparsely ciliate, obtuse, those of the culm 5-10 cm. long, 4-6 mm. wide, those of the stolons about $2.5 \mathrm{~cm}$. lon $\mathrm{g}$, 2-4 mm. wide; spikes $2-5,2.5-5 \mathrm{~cm}$. long, approximate at the summit of the long and slender stalk; spikelets not crowded nor secund, about $2 \mathrm{~mm}$. long, acute. Va. to Fla. and west to La. Widely distributed in tropical America. Probably not native in the U.S. Aug.-Sept. (Paspalum compressum Nees.)

2. Anastrophus paspaloides (Michx.) Nash. (I. F. f. 237.) Culms 3-7.5 $\mathrm{dm}$. tall, from an extensively creeping base. Sheaths and leaves glabrous or pubescent, the latter 5-22 cm. long, 6-12 mm. wide, obtuse: spikes $3 \cdot 75-8.75 \mathrm{~cm}$. long, in pairs, or sometimes with an additional one; rachis flat, about $1 \mathrm{~mm}$. wile; spikelets about $4 \mathrm{~mm}$. long, broadly lanceolate, acute, not crowded; outer scales 5-nerved, glabrous. Moist ground, Md. to Fla., west to Tex. July-Aug. (Paspalum paspaloides Scribn. P. Elliottii S. Watson.)

\section{AMPHICÀRPON Raf.}

Erect perennial grasses, with flat leaves and spikelets of two kinds; one kind borne in terminal panicles, deciduous without perfecting fruit; the other solitary, terminating subterranean peduncles, and maturing seed. Scales 3, membranous, the innermost subtending a palet and a perfect flower; the scales of the subterranean spikelets become indurated and enclose the grain. Stamens 3. Stigmas plumose. [Greek, in allusion to the two kinds of spikelets.] Species 2, inhabiting the southeastern U. S., one of them restricted to Fla. 
I. Amphicarpon Amphicàrpon (Pursh) Nash. (I. F. f. 238.) Culms 3-4.5 $\mathrm{dm}$. tall, slender, glabrous. Sheaths papillose-hirsute; leaves $2.5-15 \mathrm{~cm}$. long, 4-I2 $\mathrm{mm}$. wide, erect, hirsute and ciliate; panicle linear, I-I.5 dm. long, branches erect; spikelets about $4 \mathrm{~mm}$. long, elliptic; outer scales 5-nerved, glabrous; subterranean spikelets ovoid in fruit, about $6 \mathrm{~mm}$. long. In moist pine barrens, N. J. to Fla. near the coast. Aug.-Sept. [A. Purshii Kunth.]

\author{
12. ERIÓCHLOA. H. B. K.
}

Annual or perennial grasses, with flat leaves and short-pedicelled spikelets horne in secund spikes, which form a terminal panicle. Spikelets with an annular callus at the base and articulated to the pedicel. Scales 3, the two outer membranous, acute, the inner one shorter, indurated and subtending a palet and a perfect flower. Stamens 3. Styles distinct. Stigmas plumose. Grain free. [Greek, signifying wool-grass.]

I. Eriochloa punctàta (L.) W. Hamilt. DotTed Millet. (I. F. f. 239.) Culms 3-9 dm. tall. Sheaths sometimes pubescent ; leaves $5-25 \mathrm{~cm}$. long ; spikes $4-25,2.5-5 \mathrm{~cm}$. long, sessile or nearly so; rachis pubescent; spikelets about $4 \mathrm{~mm}$. long, ovate-lanceolate, acuminate; outer scales pubescent with appressed silky hairs, the third about $2 \mathrm{~mm}$. long, rounded at the apex and bearing a pubescent awn about $1 \mathrm{~mm}$. long. Neb. to Tex. and Mex. Widely distributed in trop. Am.

\title{
13. SYNTHERÍSMA Walt.
}

Annual grasses, with flat leaves and spikelets borne in pairs or sometimes in 3's, in secund spikes which are digitate or approximate at the summit of the culm. Spikes often purplish. Scales of the spikelet 4 , sometimes 3 by the suppression of the lowest one; the fourth or innermost scale chartaceous, subtending a palet of similar texture and a perfect flower. Stamens 3. Stigmas plumose. [Greek, cropmaking, in allusion to its abundance.] Species about 25, widely distributed in temperate and tropical regions.

Rachis of the racemes with the angles wingless; first scale of the spikelet wanting, or sometimes present as an inconspicuous rudiment.

Racemes usually short, 2-10 cm. long; spikelets less than $2 \mathrm{~mm}$. long.

Racemes usually exceeding to $\mathrm{cm}$, long, rarely shorter; 1 . S. fliformis. long.

2. $S$. villosa.

Rachis of the racemes with the lateral angles broadly winged; first scale of the spikelet usually present, generally wanting in Nos. 3 and 4 .

Pedicels terete or nearly so, sparingly if at all hispidulous.

Sheaths and leaves strongly pubescent; second scale one-half or less as long as the spikelet.

Sheaths and leaves glabrous; second scale nearly as long as the spikelet.

Pedicels sharply 3 -angled, the angles strongly hispiduious.

4. S. linearis.

Spikelets usually less than $3 \mathrm{~mm}$. long; third scale with the first and second nerves on each side hispid above the middle.

Spikelets more than $3 \mathrm{~mm}$. long; third scale with the nerves smooth.

6. S. fimbriata.

I. Syntherisma filifórmis (L.) Nash. Slender Finger-GRass. (I. F. f. 242.) Culms I.5-7 dm. tall. Sheaths hirsute, at least the lower ones; leaves 3-20 cm. long, I-4 mm. wide; racemes 2-5, 2-10 cm. long, erect or ascending; spikelets about $1.8 \mathrm{~mm}$. long, $0.75 \mathrm{~mm}$. wide, elliptic, acute, in pairs, the first scale wanting, the second 3 -nerved, the third 7 -nerved, the fourth scale deep chestnut-brown at maturity. Dry sandy soil, N. H. to Mich., south to Del., N. C. and the Ind. Terr. July-Sept. [Panicum filiforme L.]

2. Syntherisma villòsa Walt. Southern Slender Finger-grass. Culms densely tufted, 6-I4 dm. tall. Sheaths, at least the lower ones, hirsute; leaves o.7-2.5 dm. long, 3-6 mm. wide; racemes 2-8, commonly more than $5,4--0 \mathrm{~cm}$. long, generally $12-15 \mathrm{~cm}$., erect or ascending; spikelets $2.5 \mathrm{~mm}$. long, about 0.8 $\mathrm{mm}$. wi.le, elliptic, acute, usually in 3 's, the first scale wanting, the second scale 3-nerved, the third scale 7 -nerved, the fourth scale deep chestnut-brown at maturity. Sandy soil, principally along the coast, from Ga. and Fla. to Tex.; also in the Ind. Terr. and Ill. June-Oct. 
3. Syntherisma serótina Walt. LATE-FLOWERING Finger-GRass. (I. F. f. 24Ia.) Culms 2-5 dm. long, tufted, at length much branched and prostrate and rooting at the lower nodes. Sheaths, at least the lower ones, densely papillosehirsute with spreading hairs; leaves $1.5^{-10} \mathrm{~cm}$. long, usually less than $5 \mathrm{~cm}$., 3-10 $\mathrm{mm}$. wide, lanceolate, pubescent on both surfaces; racemes 2-6, 2.5-10 $\mathrm{cm}$. long; spikelets about $1.5 \mathrm{~mm}$. long and $0.6 \mathrm{~mm}$. wide, elliptic, acute, usually in pairs, the first scale wanting, the second 3-nerved, the fourth scale white. Low, open grounds, Del. to Fla. and Miss. June-Oct.

4. Syntherisma lireàris (Krock.) Nash. Small Crab-Grass. (I. F. f. 24I.) Culms 2-5 dm. tall, finally prostrate, and forming large mats. Sheaths smooth and giabrous; leaves $1.5-13 \mathrm{~cm}$. long, 2.5-6 mm. wide, smooth and glibrous on both surfaces; racemes $2-5,2-8 \mathrm{~cm}$. long, finally widely spreading; :p:kelets slightly exceeding $2 \mathrm{~mm}$. long and about I $\mathrm{mm}$. wide, elliptic, acutish, usually in pairs, the first scale wanting or sometimes present as a mere rudiment. the second scale 3 -nerved, the third scale 7 -nerved, the fourth scale deep chestnutbrown when mature. Introduced into waste places and fields and along roadsides. N. S. to S. Dak., south to Fla. and Kans. July-Sept. [Panicum glabrum Gaud.]

5. Syntherisma sanguinàlis (L.) Dulac. LARGE CRAB-GRASS. (I. F. f. 240.) Culms I m. or less long, finally prostrate at the base and rooting at the lower nodes. Lower sheaths densely papillose-hirsute; leaves 4-20 cm. long, 4-10 $\mathrm{mm}$. wide, more or less papillose-hirsute on both surfaces; racenes $3-10,5-18 \mathrm{~cm}$. long; spikelets $2.5-3 \mathrm{~mm}$. long and about $0.8 \mathrm{~mm}$. wide, elliptic-lanceolate, acute, in pairs, the first scale minute, triangular, the second scale 3-nerved, about one-half as long as the spikelet, the third scale 7-nerved, the fourth scale yellowish white, acutely apiculate. Cultivated places, fields, roadsides, etc., throughout N. Am., principally in the north. July-Aug. [Panicum sanguinale L.]

6. Syntherisma fimb:iàia (Link) Nash. Fimbriate Crab-grass. Culms $8 \mathrm{dm}$. long or less, finally prostrate at the base and rooting at the lower nodes. Iower sheaths densely papillose-hirsute with spreading hairs; leaves $2-8 \mathrm{~cm}$. long, 5-10 $\mathrm{mm}$. wide, both surfaces glabrous or more or less pubescent; racemes 2-9. 2-12 cm. long; spikelets $3-3.5 \mathrm{~mm}$. long and about $0.8 \mathrm{~mm}$. wide, lanceolate, very acute, in pairs, the first scale minute, the second scale 3 -nerved, more than onehalf as long as the spikelet, the third scale 7 -nerved, the fourth scale lanceolate, very acute, yellowish-white. Dry sandy soil, D. C. to Fla., west to Tex., also in Kans. June-Sept.

\section{BRACHIÁRIA Ledeb.}

Usually perennial grasses, with flat leaves and a panicle composed of alternate scattered one-sided racemes with the spikelets borne in 2 rows. Spikelets 1 -flowered, articulated to the pedicel below the empty scales. Scales 4 , the outer 3 membranous; fourth scale chartaceous, enclosing a palet of similar texture and a perfect flower. Stamens 3. Styles distinct. Stigmas plumose. Grain free. Species about IOo, natives of temperate and tropical regions.

Spikelets ovate, acute, about $2.5 \mathrm{~mm}$. long. spikelets oval or obovoid, obtuse, turgid, about $3 \mathrm{~mm}$. long. r. B. digitarioides, 2. B. obtusa.

I. Brachiaria digitarioides (Carpenter) Nash. Narrow Panicum. (I. F. f. 245.) Glabrous, culms erect from a long and stout creeping rootstock, 9-1 $5 \mathrm{dm}$. tall, simple, stout, smooth. Sheaths smooth; leaves $\mathrm{I}-2.5 \mathrm{dm}$. long, 8-16 mm. wide, long-acuminate; panicle linear, 1.5-3 dm. long, its branches $2.5-7.5 \mathrm{~cm}$. long, erect; spikelets about $2.5 \mathrm{~mm}$. long, ovate, acute; first scale about one-half as long as the spikelet, acute, 3-nerved; second about $2 \mathrm{~mm}$. long, 5-nerved and a little exceeded by the 3-nerved third one; the fourth 3-nerved, slightly shorter than the third. In water, Del. to Fla. and Tex. July-Aug. (Panicum digitarioides Carpenter.)

2. Brachiaria obtùsa (H. B. K.) Nash. Blunt Panicum. (I. F. f. 246.) Glabrous, culms erect, 3-6 dm. tall, simple or branching at base, smooth. Sheaths smooth; leaves $6.25^{-22} \mathrm{~cm}$. long, 2-6 mm. wide, usually erect, long-acuminate; panicle linear, 5-15 cm. long; branches $1.8-3.7 \mathrm{~cm}$. long, appressed; spikelets about $3 \mathrm{~mm}$. long, crowdel, oval or obovoid, obtuse, turgid; first scale shorter 
than the rest, obtuse, 5-nerved; second, third and fourth scales about equal, the second and third 5-nerved, the fourth chartaceous. Kans. to Ariz., south to Tex. and Mex. July-Sept. (Panicum obtusum H. B. K.)

\section{ECHiNÓCHLOA Beauv.}

Usually táll grasses, commonly annuals, with broad leaves and a terminal in. florescence consisting of one-sided racemes racemosely or paniculately arranged. Spikelets I-flowcred, singly disposed, or in smaller racemes or clusters on the ultimate divisions of the inflorescence. Scales 4, the outer 3 membranous, hispid on the nerves, the third and usually also the second scale awned, or sometimes merely awn-pointed, the awn often very long; fourth scale indurated, shining, frequently pointed, enclosing a palet of similar texture and a perfect flower. Stamens 3. Styles distinct. Stigmas plumose. Grain free. [Greek, in reference to the stout hispid hairs of the spikelets.] Species about 12, mostly in warm and tropical countries.

Sheaths glabrous.

Spikelets $3 \mathrm{~mm}$. long, the second and third scales more or less awned.

Spikelets $2 \mathrm{~mm}$. long, the second and third scales merely awn-pointed.

I. E. Crus-galli.

Sheaths, at least the lower ones, densely papillose-hirsute.

2. E. colona.

3. E. Walteri.

I. Echinochloa Crús-gálli (L.) Beauv. BARnyard-Grass. Cockspur-Grass. (I. F. f. 243.) Culms $6-12$ dm. tall, often branching at base. Sheaths smooth and glabrous; leives I.5 $6 \mathrm{dm}$. long, 6-25 mm. wide, glabrous, smooth or scabrous ; panicle composed of $5^{-1} 5$ sessile, erect or ascending branches, or the lower branches spreading or reflexed; spikelets ovate, green or purple, densely crowded in 2-4 rows on one side of the rachis; second and third scales about $3 \mathrm{~mm}$. long, scabrous or hispid, the third sale more or less awned, empty, the fourth ovate, abruptly pointed. In cultivated and waste places, throughout N. Am. except the extreme north. Widely distributed as a weed in all cultivated regions. Naturalized from Europe. Aug.-Ost. (Panicum Crus-galli L.)

2. Echinochlox colòna (L.) Link. Jungle Rice. (I. F. f. 243a.) Culms tufted, smooth and glabrous, 1.5-7.5 dm. tall, often decumbent and rooting at the lower nodes Sheaths compressed, usually crowded ; leaves flat, $2.5-17 \mathrm{~cm}$. long, 2-8 mm. wide; inflorescence composed of 3-1 8 r-sided more or less spreading dense racemes, 6-30 $\mathrm{mm}$. long, disposed a!ong a 3 -angled rachis and generally somewhat exceeding the length of the internodes; spikelets single, in pairs, or in 3 's in 2 rows on one side of the hispidulous, triangu!ar rachis, obovate, pointed, the first scale about one-haif as long as the spikelet, 3 -nerved, the second and third scales a little more than $2 \mathrm{~mm}$. long, awnless, 5-nerved, hispid on the nerves, the fourth scale cuspidate. Fields and roadsides, Va. to Fia., Tex. and Mex. Common in all tropical countries. March-Sept. (Panicum colonum L.)

3 Echinochloa Wàlteri (Pursh) Nash. Salt-marsh Cockspur-grass. (I. F. f. 244.) Culms 9-18 dm. tall, robust, smooth. Sheaths, at least the lower ones. papillose-hispid; leaves $3 \mathrm{dm}$. or more long, $1.25-2.5 \mathrm{~cm}$. wide, strongly scabrous above; panicle 1.5-4.5 dm. long, consisting of 10-40 ascending or spreading branches; spikelets ovate-lanceolate, densely crowded in 2-4 rows on one side if the scabrous and hispid rachis, brownish-purple; second and third scales about 3 $\mathrm{mm}$. long, scabrous and hispid, tipped with upwardly barbed awns, sometimes ro-20 times their length; fourth scale ovate-lanceolate, acuminate. In marshes and ditches, principally within the influence of salt-water, Ont. to N. H. and R. I., Fla. and La. Aug.--Oct. (Panicum Walteri Pursh.)

\section{PÁNICUM L. (See Appendix.)}

Annuals or perennials, various in habit, with open or contracted panicles. Spikelets 1 -2-flowered, when 2 -flowered the lower one staminate only. Scales 4 , the 3 lower membranous, empty, or the third with a staminate flower, varying in the same species; the inner or fourth scale chartaceous, shining, enclosing a palet of sinnilar texture and a perfect flower. Awns none. Stamens 3. Styles distinct. Stigmas plumose. Grain free, enclosed in the liardened fruiting scale and palet. 
[Old Latin name for some grass, probably the cultivated Sorghum, referring to its panicle, taken from Pliny.] About 300 species, in temperate and tropical regions. The geographic distribution of many of our species is not well ascertained. The old English name Panic or Panic-grass is often applied to any of the species.

Palet of the fourth scale much enlarged at maturity, forcing the spikelet open and making it gape.

Palet of the fourth scale not enlarged, smaller than the scale.

Spikelets roughened with numerous tubercles, glabrous. Spikelets not tuberculate, or if so, the tubercles bearing hairs.

I. P. lians.

2. P. verrucosum.

(A) Basal and culm leaves similar, usually elongated; spikelets lanceolate to ovate, commonly the former, acute to acuminate.

Lower sheaths round or but little flattened, not keeled.

Culms branched, at least at maturity; no scaly rootstocks nor stolons. Sheaths very pubescent.

Spikelets lanceolate, $3 \mathrm{~mm}$. long or less.

Annuals; pedicels not usually more than 2-3 times as long as the spikelets.

Culms stout; panicle usually included at the base, its many branches repeatedly divided and bearing numerous spikelets.

3. P. capillare.

Culms slender; panicle exserted, its few branches but little divided, and bearing comparatively few spikelets.

Spikelets $2 \mathrm{~mm}$. long, acute.

Spikelets $3 \mathrm{~mm}$. long, acuminate.

4. P. Philadelphicum.

5. P. flexile.

Perennial; pedicels commonly many times as long as the spikelets.

Spikelets ovate, $5 \mathrm{~mm}$. long. $\quad$ 7. P. miliaceum.

Sheaths glabrous.

Culms simple, from stout, of ten scaly, rootstocks.

Culms tufted; rootstocks scaly.
Culms not tufted; rootstocks not scaly; leaves glaucous and very thick.

Io. P. amarum.

Lower sheaths much compressed, broad, keeled, often equitant.

Fourth scale of the spikelet sessile.

Spikelets 3-3.5 mm. long, the apex curved. 13. P. rostratum.

Spikelets less than $3 \mathrm{~mm}$. long, the apex not curved.

Ligule naked; culms finally much branched.

Ligule ciliate; culms simple or nearly so.

II. P. agrostoides.

12. P. longifolium.

Fourth scale of the spikelet distinctly stalked. 14. P. stipitatum.

(B) Basal and culm leaves dissimilar, the former generally much shorter and broader than the latter; rosulate tufts of leaves often present in the fall; spikelets oval to obovate or globose, obtuse, or rarely acutish (acute in No. 15$)$.

(A) Middle leaves of the main culm less than $1.5 \mathrm{~cm}$. wide, usually less than I $\mathrm{cm}$. in width, the base rounded or truncate, rarely subcordate, sometimes narrowed toward the base.

(a) Leaves elongated, erect, narrow, distinctly narrowed toward the base, especially the lower ones.

Secondary panicles borne on short basal branches, which are nearly concealed in the dense tufts.

Spikelets less than $3 \mathrm{~mm}$. long, obtuse or acutish, pubescent.

Spikelets 3-4 mm. long, acute, glabrous. 16. $P$. linearifolium.

No concealed basal panicles.

15. P. depauperatum.

Sheaths glabrous, or merely ciliate on the margins.

Leaves linear, less than $5 \mathrm{~mm}$. wide.

Leaves linear-lanceolate, 6 -10 $\mathrm{mm}$. wide.

7. $P$. Werneri.

Sheaths densely pubescent.

18. P. Bicknellii.

19. P. laxiflorum.

(b) Leaves not elongated, lanceolate, not manifestly narrowed toward the base, 
1. Culms, leaves, and sheaths glabrous or the latter two merely ciliate on the margins.

Spikelets glabrous.

Nodes of the culm naked.

Leaves divaricate; culms erect, short, the later branches bunched.

23. P. dichotomum.

Leaves erect; culms accumbent, weak, finally elongated, and the later branches scattered.

Nodes of the culm densely barbed.

$$
\text { 24. P. sphagnicola. }
$$

Spikelets pubescent.

25. P. barbulatum.

Culms very slender, less than $2 \mathrm{dm}$. tall, densely tufted, simple.

22. P. Brittoni.

Culms not slender, $3 \mathrm{dm}$. or more tall, at length branched.

Spikelets elliptic; leaves smooth above or nearly so, naked at the base.

Panicle dense, the branches erect or nearly so; spikelets $1.5 \mathrm{~mm}$. long. 27. P. Eatoni.

Panicle lonse and open, the branches spreading; spikelets $2 \mathrm{~mm}$. long. 28. P. boreale.

Spikelets globose or nearly so; leaves very rough above, thick, ciliate at the base.

46. P. spharocarpon.

2. Culms, sheaths or leaves, or all of them, pubescent.

* Spikelets $2.5 \mathrm{~mm}$. or less long.

t Leaves glabrous, or if pubescent beneath, the hairs short and soft.

Primary leaves long and narrow, erect, thick, the numerous secondary leaves very narrow, $1.5 \mathrm{~mm}$. or less wide, usually involute when dry.

Spikelets broadly obovoid, barely $2 \mathrm{~mm}$. long.

Spikelets elliptic, $3 \mathrm{~mm}$. long.

20. P. neuranthum.

21. P. angustifolium.

Primary leaves lanceolate. the secondary leaves flat, lanceolate, exceeding $2 \mathrm{~mm}$. broad.

Culms villous with short hairs, at least below.

Leaves minutely villous beneath.

Culms erect, rigid. 3 I. P. Columbianum.

Culms weak, finally decumbent and forming mats.

Leaves glabrous beneath.

32. P.tsugetorum.

Spikelets obovoid, $1.5 \mathrm{~mm}$. long.

Spikelets elliptic, $2.5 \mathrm{~mm}$. long.

3o. P. Nashianum.

Culms not villous.

49. P. Ashei.

Culms glabrous; spikelets about $1.25 \mathrm{~mm}$. long.

29. ". nitidum.

Culms at base densely pubescent with long stiff, appressed hairs; spikelets $2-2.5 \mathrm{~mm}$. long.

Panicle $3-4 \mathrm{~cm}$. long, oblong, dense; spikelets 2 $\mathrm{mm}$. long; leaves naked on the margins. 39. P. Addisonit.

Panicle 5-7 cm. long, broadly ovoid, open; spikelets $2.5 \mathrm{~mm}$. long; leaves ciliate at the base.

40. P'. Commonsianum.

tf Leaves pubescent on both surfaces, especially beneath.

Hairs on the lower surface short, soft, and copious.

Hairs on the upper surface of the leaves long and stiff; spike. lets about $1.5 \mathrm{~mm}$. long. $\quad 37$. P. lanuginosum.

Hairs on the upper surface of the leaves short, soft, and copious.

Spikelets nearly $2 \mathrm{~mm}$. long; panicle dense, oblong; culms. slender, glabrous.

26. P. annulum.

Spikelets $2.5 \mathrm{~nm}$. long; panicle open, ovoid ; culms stout, densely pubescent.

38. P. viscidum.

Hairs on the lower, as well as the upper, surface stiff and long, sometimes scattered.

Spikelets $1.5 \mathrm{~mm}$, long. 
Culms slender; hairs on the upper surface of the leaves extremely long and copious.

Panicle 2-3 cn. long; culms minutely pubescent above. 34. P. filiculme.

Panicle 4-6 cm. long; culms hirsute above, especially in the panicle.

Culms rather stout; hairs on the upper surface of the leaves shorter and more scattered, sometimes nearly wanting.

Spikelets a little more than $2 \mathrm{~mm}$. long.

35. P. pubescens.

36. P. Atlanticum.

** Spikelets more than $3 \mathrm{~mm}$. long.

Leaves glabrous, or sometimes pubescent beneath.

l'anicle narrow, its branches appressed. 44. P.xanthophysum.

Panicle open, its branches spreading.

Sheaths glabrous, except the ciliate margins; spikelets elliptic. 45. P. calliphyllum.

Sheaths papillose-hirsute; spikelets broadly ovoid, turgid.

Leaves pubescent on both surfaces.

43. P. Scribnerianum.

Leaves erect, rigid, thick, 3-4 $\mathrm{mm}$. wide; spikelets pubescent with short hairs.

41. P. Wilcoxianum.

Leaves often spreading, not thick, 5-10 mm. wide; spikelets longlirsute.

42. P. Liebergii.

(B) Middle leaves of the main culm more than $1.5 \mathrm{~cm}$. wide, often $3 \mathrm{~cm}$. in width, the base cordate and clasping.

Spikelets $2.5 \mathrm{~mm}$. long or less.

Leaves glabrous on both surfaces.

Spikelets about $1.5 \mathrm{~mm}$. long; panicle oblong and dense; culms simple.

47. P. polyanthes.

Spikelets $2.5 \mathrm{~mm}$. long; panicle ovoid and open; culms branched.

Sheaths papillose-hispid, especially the short terminal ones on the branches.

Sheaths glabrous.

Leaves densely villous.

52. P. clandestinum.

48. P. commutatum.

38. P. viscidum.

Spikelets $3 \mathrm{~mm}$. long or more.

Nodes manifestly and copiously barbed; spikelets $4-5 \mathrm{~mm}$. long.

Nodes naked.

51. P. Porterianum

Sheaths glabrous, or merely pubescent on the margins; panicle open, its branches spreading.

50. P. macrocarpon.

Sheaths hispid; panicle contracted, its branches appressed.

44. P. xanthophysum.

r. Panicum hians Ell. Gaping Panicum. (I. F. f. 247.) Glabrous; culms erect, 3-7.5 dm. tall, generally simple, sometimes creeping at base, smooth. Leaves $7 \cdot 5-12.5 \mathrm{~cm}$. long, 2-6 mm. wide, acuminate, generally erect; panicle $7 \cdot 5-20$ $\mathrm{cm}$. long; branches few, generally spreading, the longer ones often drooping, the lower naked below the middle; spikelets about $2 \mathrm{~mm}$. long; fourth scale exceeded by the third and its usually empty palet which is much enlarged, generally forcing the spikelet wide open. In moist ground, N. Car. to Mo., south to Fla. and Tex. Aug.-Sept.

2. Panicum verrucòsum Muhl. Warty Panicum. (I. F. 1. 278.) Culms erect or decumbent, slender, generally much branched at base. Sheaths glabrous, much shorter than the internodes: leaves $5-17.5 \mathrm{~cm}$. long, 2-8 mm. wide, erect or ascending, glabrous, rough on the margins; panicle $7 \cdot 5-30 \mathrm{~cm}$. long, its lower branches 5-15 cm. long, naked below, strict and ascending, or lax and spreading; spikelets about I.5 mm. long, elliptic, acutish, borne in pairs along the branches, the first scale about one-quarter as long as the warty second and third, the fourth scale apiculate. Moist soil, Mass. to Fla., west to La., mostly near the coast. July-Sept.

3. Panicum capillàre L. Witchigrass. Tumble Weed. (I. F. f. 274.) Culms erect or decumbent, 3-6 dm. tall, simple or sometimes sparingly branched. Sheaths papillose-hirsute; leaves 1.5-3 dm. long, 6-16 mm. wide, pubescent; terminal panicle $2-3.5 \mathrm{dm}$. long, lower branches $\mathbf{1} .5^{-2.5} \mathrm{dm}$. long; lateral pani- 
cles, when present, smaller; spikelets $2-2.5 \mathrm{~mm}$. long, acuminate; first scale onefourth to one-half as long as the spikelet; second and third scales nearly equal, very acute, the fourth $1.5 \mathrm{~mm}$. long. In dry soil, common as a weed in cultivated fields, N. S. to Br. Col., south to Fla., Tex. and Nev. July-Sept.

Panicum capillàre Gattingìri Nash. Culms more slender than in the type; terminai panicle rarely over $\mathbf{1 . 5} \mathrm{dm}$. long, the lateral ones very numerous. Noist places, N. j. to Tenn., Mo. and southward.

4. Panicum Philadélphicum Bernh. Wood Panicun. (I. F. f. 277 .) Culms erect, or occasionally decuinbent, 2-6 dm. long, slender, somewhat branched at base. Sheaths hirsute; leaves 5-10 $\mathrm{cm}$. long, 2-6 $\mathrm{mm}$. widle, erect, more or less pubescent; panicle $10-22.5 \mathrm{~cm}$. long, its lower branches 7.5-10 $\mathrm{cm}$. long, spreading or ascending; spike'ets about $1.5 \mathrm{~mm}$. long, elliptic, acute, smooth, borne in pairs at the extremities of the ultimate divisions of the panicle; first scale about one-third as long as the equal acute second and third ones, the fourth sonc what shorter than the third. In dry woods and thickets, N. B. to Ga., west to Mo. Aug.-Sept. (P. minus (Muhl.) Nash, nct P. pubescens minus Poir.)

5. Panicum fléxile (Gattinger) Scribn. Wiry Panicum. (I. F. f. 275.) Culms erect, I.5-4.5 dm. tall, slender, bearded at the nodes. Sheaths papillosehirsute; leaves 10-22.5 cm. long, 4-6 mm. wide, ercct, long-acuminate, more or less pubescent; panicle $\mathbf{I}-2.25 \mathrm{dm}$. long, narrowly ovoid to oblong in outline, its branches ascending, the lower ones 5-8.5 cm. long; spikelets $3 \mathrm{~mm}$. long, much shorter than the pedicels, acuminate; first scale about one-fourth as long as the spikelet; second and third scales about equal, 5-7-nerved; fourth scale elliptic, somewhat shorter than the third. In moist or dry soil, Penn. to Tenn. and Mo. Aug.-Oct.

6. Panicum cognàtum Schultes. Diffuse Panicum. (I. F. f. 276.) Culms erect or decumbent, 3-6 dm. tall, generally much branched at the base, slender. Lower sheaths sometimes densely pubescent; leaves $3.75^{-10} \mathrm{~cm}$. long, 2-6 mm. wide, ascending, acuminate, glabrous; panicle 1.25-3 dm. long, bearded in the axils, the lower branches $\mathrm{I}-2 \mathrm{dm}$. long, finally exserted and widely spreading at maturity; spikelets lanceclate, about $3 \mathrm{~mm}$. long, acuminate, glabrous or pubescent, on capillary pedicels of many times their length; first scale minute; second and third equal, acute, glabrous or sometimes villous, the fourth lanceolate, $2.5 \mathrm{~mm}$. long. In dry soil, Ill. to Ga. and Fla., west to Minn., Mo. and Ariz. July-Sept. (P. autumnale Bosc.)

7. Panicum miliàceum L. Mrllet. (I. F. f. 272.) Culmse rect or decumbent, rather stout, $3 \mathrm{dm}$. tall or more, glabrous or hirsute. Sheaths papillose-hirsute; leaves $1.25-2.5 \mathrm{dm}$. long, 8-25 $\mathrm{mm}$. wide, more or less pubescent; panicle rather dense, I-2.5 dm. long; branches erect or ascending; spikelets $5 \mathrm{~mm}$. long, acuminate; first scale about two-thirds as long as the spikelet, acuminate, 5-7nerved; second scale acuminate, I3-nerved, somewhat exceeding the 7-13-nerved acuminate third one, which subtends an empty palet; fourth scale shorter than the third, becoming indurated, obtuse. In waste places, Me. to Del. and Penn., west to Neb. Adventive from the Old World. July-Sept.

8. Panicum proliferum Lam. SPREAding Panicum. (I. F. f. 273.) Culms at first erect, 3-6 dm. tall, simple, later decumbent and geniculate, I-I.5 m. long, branched at all the upper nodes. Sheaths loose, glabrous, somewhat flattened; leaves 1.5-6 dm. long, 4-20 mm. wide, long-acuminate, scabrous on the margins and occasionally on the nerves; panicle pyramidal, I-4 dm. long; spikelets $2-3 \mathrm{~mm}$. long, crowded, lanceolate, acute, glabrous, sometimes purplish; first scale about one-fourth as long as the spikelet, enclosing its base; second and third scales about equal, acute, 5-7-nerved; fourth scale elliptic, shining. In wet soil, Me. to Penn. and Neb., south to Fla. and Tex. July-Sept.

9. Panicum virgàtum L. TALL Sмоотн Panicum. (I. F. f. 270.) Culms erect from a creeping rootstock, 9-15 dm. tall, glabrous. Sheaths smooth and glabrous; leaves elongated, $3 \mathrm{dm}$. long or more, 6-12 mm. wide, flat, long-acuminate, narrowed toward the base, glabrous, rough on the margins; panicle 1.5 .5 $\mathrm{dm}$. long, the lower branches $\mathbf{I}-\mathbf{2 . 5} \mathrm{dm}$. long, more or less widely spreading or sometimes nearly erect; spikelets ovate, acuminate, $4-4.5 \mathrm{~mm}$. long; first scale 
acuminate, about one-half as long as the spikelet, 3-5-nerved; second scale generally longer than the others, 5-7-nerved, the third similar and usually subtending a palet and staminate flower. In moist or dry soil, Me. and Ont. to Minn., south to Fla., Kans. and Tex. Aug.-Sept.

10. Panicum amàrum Ell. Sea-BEACH Panicum. (I. F. f. 271.) A tufted tall grass with glaucous foliage and large panicle. Culms 8-12 dm. tall; sheaths overlapping; blades thick and leathery, involute on the margins, generally 3-6 dm. long or more, 8-12 mm. wide; panicle large, narrow, much branched, usually 3-7 dm. long, sometimes smaller; spikelets numerous, 4-5 mm. long. usually rather narrow, the first scale about one-half as long as the spikelet or a little longer, the second and third scales about equal in length, all the scales very acute or acuminate. In sands, along the coast, Va. to Fla. Aug.-Oct.

i. Panicum agrostoides Spreng. Agrostis-like Panicum. (I. F. f. 24).) Culms erect, 4.5-6 dm. tall, much branched, compressed, smooth. Sleaths cimpressed, glabrous, or sometimes hairy at the throat; ligule very short, naked; leaves $3 \mathrm{dm}$. long or more, $4-8 \mathrm{~mm}$. wide, acuminate; panicles pyramidal, I- 3 $\mathrm{dm}$. long, terminating the culm and branches; primary branches of the panicle sprearling, secondary generally appressed; spikelets $1.5 \mathrm{~mm}$. long, acute, straight; first scale 3-nerved, acute; second and third scales 5-nerved, about twice as long as the first and longer than the oval fourth scale. Wet ground, Me. to Minn., south to Fla., Kans. and Tex. July-Sept.

I2. Panicum longifolium Torr. Long-Leaved Panicur. (I. F. f. 25I.) Culms erect, 3-6 dm. tall, slender, simple, or occasionally with a single lateral panisle. Leaves 2-3 dm. long, 2-4 mm. wicle, acuminate into a long, slender point, rough, glabrous; ligule short, pilose; panicles I. $55^{-2.25} \mathrm{dm}$. long; primary branches long and slender, spreading, secondary very short, appressed, generally bearing I-3 spikelets; spikclets $2 \mathrm{~mm}$. long, acuminate; first scale acute, about one-half as long as the acuminate second one; third scale equalling the second, acuminate, one-third longer than the elliptic obtuse fourth one. Moist soil, Conn. to Penn. and D. C. Aug-Sept.

13. Panicum rostràtum Muhl. Beaked Panicuil. (I. F. f. 248.) Culms erect from a creeping scaly branched rootstock, 4.5-15 dm tall, much branched. Sheaths glabrous, or the lower ones pubescent; leaves $3 \mathrm{dm}$. long or more, 4-Io mm. wide, acuminate; panicles pyramidal, I.5-3 dm. long; axis and ascencling branches scabrous; spikelets $3 \mathrm{~mm}$. long, crowded, lanceolate, acuminate; first scale less than one-half as long as the spikelet; second scale curved at the apex, scabrous above on the middle nerve; third scale usually subtending a small empty palet. Moist soil, N. J. to Ill. and Kans., south to Fla. and Tex. July-Sept.

14. Panicum stipitatum Nash. Loxg Panicum. (I. F. f. 250.) Culms erect, 9-I $5 \mathrm{dm}$. tall, much branched. Leaves $3 \mathrm{dm}$. long or more, 4-8 mm. wide, acuminate, scabrous; panicles pyramidal, I-3 dm. long: primary branches spreading or ascending, the secondary usually divaricate; spikelets about $2.5 \mathrm{~mm}$. long, crowded, acuminate; first scale acute or acuminate, one-third the length of the equal and acuminate second and third; fourth scale narrowly elliptic, about onehalf as long as the third and raised on a delicate stalk about $0.5 \mathrm{~mm}$. long. Muist soil, N. J. and Penn. to Ky., Tenn. and N. Car. July-Sept. (P. elongatum Pursh. Not Salisb. I 796.)

I5. Panicum depauperàtum Muhl. Starved Panicun. (I. F. f. z68.) Culms erect, $3 \mathrm{dm}$. tall or less, simple or branched at base. Sheaths glalrous to hirsute; leaves erect, elongated, I-4 mm. wide, mostly cruwded at base and equalling cr one-half as long as the culm, the upper culm-leaf ofien much exceeding the pani le; primary panicle generally much exserted from the upper sheath, 2.5-7.5 $\mathrm{cm}$. long, usually linear, its branches mostly erect; secondary panicles on very short basal branclies and often concealed by the lower leaves; spikelets 3-4 mm. long, glabrous, acute. In dry places N. S. to Manitoba, south to Fla. and Tex. June-Sept.

I6. Panicum linearifolium Scribn. Linear-Leaved Panicum. (I. F. f. 268a.) Culms tufted, very slender, erect, smooth and glabrous, simple, I.5-4 dm. tall. Sheaths glabrous or pilose with long white hairs; leaves elongated, glabrous or more or less pilose, especially upon the lower surface, $7 \cdot 5^{-25} \mathrm{~cm}$. long, $2-4 \mathrm{~mm}$. 
wide, the uppermost leaf the longest, and often extending beyond the panicle; primary panicle loose and open, 3.75-10 cm. long, its branches ascending; spikelets $2-2.5 \mathrm{~mm}$. long, obtuse or acutish, pubescent with spreading hairs. Dry soil, especially hillsides, N. Y. and N. J. to Mo. (P. Enslini Nash, not Trin.)

I7. Panicum Wérneri Scribn. Werner's Panicum. (I. F. f. 268b.) Smooth and glabrous, light green. Culms tufted, erect, slender, simple or later sparingly branched, 2.5-4.5 dm. tall; leaves erect, elongated, linear, acuminate, 5-10 cm. long, 3-5 $\mathrm{mm}$. wide, panicle loose and open, $6.2-8.7 \mathrm{~cm}$. long, its branches ascending; spikelets about $2 \mathrm{~mm}$. long on longer hispidulous pedicels, oval, minutely and sparsely pubescent, the first scale orbicular, about one-quarter as leng as the spikelet, I-nerved, the second and third scales 7-nerved, the fourth scale oval, slightly apiculate. Dry knolls in swamps, N. Y. and Ohio. June-July.

18. Panicum Bicknóllii Nash. Bicknell's Panicum. (I. F. f. 268c) Culms erect or decumbent at the base, slender, 2-4 dm. tall, the lower internodes puberulent. Sheaths ciliate on the margins, the lowermost pubescent; leaves e.ongated, erect, linear-lanceolate, acuminate, narrowed toward the ciliate base, primary leaves $7.5-17.5 \mathrm{~cm}$. long, 5-10 $\mathrm{mm}$. wide; primary panicle $6-7.5 \mathrm{~cm}$. long, its branches ascending, secondary panicles smaller, with appressed branches; spikelets obovate or oval, $2.5-3 \mathrm{~mm}$. long, pubescent with short, spreading hairs, the first scale I-nerved, the second and third scales 9-nerved. Dry wooded hills, N. Y. and Penn. July-Aug.

19. Panicum laxiflòrum Lam. LaX-Flowered Panicum. (I. F. f. 262.) Culms erect, 2-4 dm. tall, simple, pubescent, or glabrate. Sheaths shorter than the internodes, hirsute; leaves $6.25-12.5 \mathrm{~cm}$. long, 4-10 mm.wide, erect, generally narrowed at base, long-acuminate, pubescent or glabrate; panicle 5-10 $\mathrm{cm}$. long, its axis and erect or spreading branches sometimes hirsute; spikelets about $2 \mathrm{~mm}$. long, ellipsoid or narrowly obovoid, strongly pubescent; first scale minute, I-nerved; second and third about equal, 9-nerved, very pubescent, as long as the shining, obtuse, minutely apiculate fourth one; third scale usually with an empty palet. Moist soil, Va. to Ky., south to Fla. June-Aug.

20. Panicum neurátt um Griseb. Nerved Panicum. (I. F. f. =69a.) Culms tufted, slender, at length much branched, 3-7.5 dm. tall. Sheaths glabrous, or the lower pulescent; leaves smooth and glabrous, the primary erect, acuminate, $2.5-10 \mathrm{~cm}$. long, $2-5 \mathrm{~mm}$. wide, those on the branches shorter, erect or ascending, usually involute when dry, concealing the small secondary panicles; primary panicle $2.5-10 \mathrm{~cm}$. long, its branches at first erect, at length widely spreadiny; spikclets numerous, broadly obovate, about $2 \mathrm{~mm}$. long, densely pubescent with short, spreading hairs, the second and third scales 7-nerved. Dry or moist soil along the coast, Va. to Fla. and La. Also in Cuba. June-Oct.

21. Panicum angustif jlium Ell. NarRow-Leaved Panicum. (I. F. f. 269.) Culms erect, 3-6 dm. tall, glabrous, at first simple, later profusely branched above. Leaves elongated, 2-6 min. wide, narrowed to the base, firm, glabrous, those of the culm distant, those of the branches shorter and crowded; primary panicle long-exserted, $2.5-7.5 \mathrm{~cm}$. long, its branches ascending or erect; lateral panicles smaller, shorter than the leaves; spikelets few, about $2.5 \mathrm{~mm}$. long, elliptic to obovoid; first scale one-fourth to one-third as long as the spikelet; second and third oval, 9-nerved, pubescent; fourth oval, minutely pubescent at the apex. Dry soil, N. Car. to Mo., south to Flı. and Tex. June-Aug.

22. Panicum Brittoni Nash. Britton's Panicum. (I. F. f. 263a.) Smooth and glabrous. Culms coarsely striate, not branched, tufted, slender, erect, rigid, I-2 $\mathrm{dm}$. tall; leaves longer than the sheaths, those on the culm three in number, the middle one the longest, $1.25-3.1 \mathrm{~cm}$. long, $1.5-3 \mathrm{~mm}$. wide, erect, acuminate, 5-7-nerved; panicle $1.8-3.1 \mathrm{~cm}$. long, its branches spreading or ascending; spikelets one-half as long as the pedicels or less, obovoid, obtuse, $1.5 \mathrm{~mm}$. long, the first scale one-third as long as the spikelet, the second and third scales 7-nerved, densely pubescent with spreading hairs. Moist sand in the pine barrens of southern N. J. May-June.

22. Panicum dichótomum L. Forken Panicum. (I. F. f. 264.) Smooth and glabrous, or the lower nodes barbed. Culms erect, I.5-6 dm. tall, at first simple, later profusely dichotomously branched at about the middle. Leaves light green, widely spreading, generally much narrowed toward the base, the primary 
ones distant, 5-7.5 cm. long, 4-6 mm. wide, those of the branches $2.5 \mathrm{~cm}$. long or less, I $-2 \mathrm{~mm}$. wide, sometimes involute; primary panicle usually long-exserted, 2.5-5 cm. long; branches lax, spreading, bearing few spikelets; secondary panicles smaller, not exceeding the leaves, their branches with very few spikelets; spikelets about $2 \mathrm{~mm}$. long, ellipsoid, glabrous. In woodlands and thickets, N. Y. to Ky., Mo. and southward. June-July.

24. Panicum sphagnícola Nash. Sphagnum Panicum. (I. F. f. 264b.) Culms slender, 4.5-9 dm. long, at length much elongated, dichotomously much branched and declining. Leaves erect, smooth and glabrous on both surfaces, lanceolate, the primary leaves $2.5-6.25 \mathrm{~cm}$. long, 2-IO $\mathrm{mm}$. wide, those on the branches $3.75 \mathrm{~cm}$. or less long: primary panicle loose and open, $3.75-7.5 \mathrm{~cm}$. long, its branches spreading or ascending; spikelets on elongated filiform pedicels, I.75-2.5 mm. long, oval to obovoid, the scales glabrous or sparsely pubescent, the first less than one-half as long as the spikelet, I-nerved, the second and third scales 7-nerved. Sphagnum bogs, D. C. and southern N. J. to Fla., west to Tex. JuneSept.

25. Panicum barbulàtum Michx. Barbed Panicum. (I. F. f. 265.) Culms at first simple, erect, 6-9 dm. tall, later profusely branched for their whole length, 9-12 dm. long, prostrate or leaning, the nodes strongly barbed. Leaves smooth and glabrous, the primary ones $7.5-12.5 \mathrm{~cm}$. long, about $1.25 \mathrm{~cm}$. wide, widely spreading, the lower ones usually reflexed, those of the branches $1.25-5 \mathrm{~cm}$. long, 2-4 $\mathrm{mm}$. wide; primary panicle $7 \cdot 5-12.5 \mathrm{~cm}$. long, ovoid, its branches ascending, rigid; secondary panicles smaller, lax, the branches bearing few spikelets; spikelets about $1.5 \mathrm{~mm}$. long, ellipsoid, purple, glabrous. Moist soil, Conn. and N. Y. to Tenn., south to Fla. and Tex. June-Aug.

26. Panicum ánnulum Ashe. Culms single, sometimes somewhat tufted, slender, 4-8 dm. tall, glabrous, the nodes densely barbed with long hairs. Sheaths, especially the lower ones, pubescent; leaves suftly and densely pubescent on both surfaces, spreading: panicle oblong, dense, 5-II cm. long: spikelets nearly $2 \mathrm{~mm}$. long, elliptic, pubescent. In dry rocky woods, Md. (according to Ashe) to Ga. June-July.

27. Panicum Èatoni Nash. Eaton's Panicum. (I. F. f. z67c) Smooth and glabrous. Culms 4.5-10.5 dm. tall, erect, at length dichotomously branched and swollen at the nodes; leaves erect, lanceolate, acuminate, 3.75-10 cm. long, 3-10 $\mathrm{mm}$. wide; panicle finally long-exserted, dense and contracted, $75-12.5 \mathrm{~cm}$. long, $3.2 \mathrm{~cm}$. or less broad, its branches erect-ascending; spikelets oval, about $\mathbf{1} .5 \mathrm{~mm}$. long, acutish, the first scale I-nerved, the second and third scales 7 -nerved, densely pubescent with spreading hairs. Along the coast, in damp or wet places, Me. to N. J. May-Aug.

28. Panicum boreàle Nash. Northern Panicum. (I. F. f. 26I.) Culms at first erect and simple, 3-6 dm. tall, later decumbent and somewhat branched, smooth and glabrous. Leaves 7.5-12.5 cm. long, 6-13 mm. wide, erect, sparsely ciliate at the base, acuminate; panicle 5-10 $\mathrm{cm}$. long, ovoid, its branches 2.5-5 $\mathrm{cm}$. long, spreading or ascending: spikelets $2 \mathrm{~mm}$. long, about equalling the pedicels, ellipsoid, somewhat pubescent; first scale ovate, obtuse; second and third scales oblong-ovate, 7-nerved, pubescent, equalling the fourth, which is oval, acute, and slightly more than $1.5 \mathrm{~mm}$. long. Moist soil, Newf. and Ont. to N. Y., Vt. and Minn. June-Aug.

29. Panicum nítidum Lam. Shining Panicum. (I. F. f. 263.) Culms at first simple, 3-4.5 dm. tall, later profusely dichotomously branched, 6-9 dm. long. Sheaths glabrous to pubescent; leaves glabrous, the primary ones $2.5-7.5 \mathrm{~cm}$. long, 3-6 mm. wide, erect, those of the branches $1.25-2.5 \mathrm{~cm}$. long, $2 \mathrm{~mm}$. wide or less; primary panicle long-exserted, $2.5-5 \mathrm{~cm}$. long, ovoid, those of the branches smaller; spikelets about I mm. long, obovoid, pubescent, usually purple; second and third scales broadly oval or orbicular, 7-nerved. Common in dry sandy soil, N. E, to N. Car. June-Aug.

30. Panicum Nashiànum Scribn. Nash's Panicum. (I. F. f. 264a.) Culms tufted, glabrous or puberulent, slender, 1.5-3.75 dm. tall, at length much branched. Leaves erect or ascending, lanceolate, acuminate, smooth and glabrous, ciliate, at least at the base, $1.8-5 \mathrm{~cm}$. long, 2-5 mm. wide, the leaves of the branches smaller; primary panicle $2.5-5 \mathrm{~cm}$. long, the branches widely spreading; spikelets about 2 
mm. long, obovate, the second and third scales 7-nerved, densely pubescent with short, spreading hairs. Pine lands, Va. to Fla. March-July.

31. Panicum Columbiànum Scribn. (I. F. f. $\approx 67$ b.) Culms tufted, erect, softly pubescent, 2-6 dm. tall, at length dichotomously branched, the branches erect. Lower sheaths pubescent, the upper glabrous; leaves lanceolate, erect, thickish and firm, glabrous above, the lower ones more or less pubescent beneath, the primary $3 \cdot 75-5 \mathrm{~cm}$. long, 4-6 mm. wide, those on the laranches smaller; panicle small, ovate, $2.5-3.75 \mathrm{~cm}$. long, its branches ascending; spikelets broadly obovoid, a little more than $1.5 \mathrm{~mm}$. long. the outer 3 scales densely pubescent with spreading hairs. Fields and open woods, Mass. to N. Car., west to Tenn. and Ala. June-Sept.

32. Panicum tsugetòrum Nash. Hemlock Panicum. (I. F. f. 267d.) Culms and sheaths pubescent with short appressed or ascending hairs intermixed toward the base with longer ones. Culms tufted, $4.5 \mathrm{dm}$. or less tall, at length much branched and decumbent or prostrate; leaves erect or ascending, firm, lanceolate, minutely appressed-pubescent beneath, smooth and glabrous above, the primary leaves $3 \cdot 75-7.5 \mathrm{~cm}$. long, 5-8 mm. wide, those on the branches smaller; primary panicles broadly ovoid, $3 \cdot 75-6.25 \mathrm{~cm}$. long, the branches spreading-ascending; spikelets broadly obovoid, about $1.75 \mathrm{~mm}$. long, the outer 3 scales pubescent, with short spreading hairs. Dry soil in hemlock woods, Conn. and N. Y. to Ohio.

33. Panicum implicàtum Scribn. Hairy-Panicled Panicum. (I. F. f. 267a.) Culms tufted, erect, 2.5-4.5 dm. tall, very slender, more or less pubescent, at length much branched. Sheaths densely papillose-hirsute, at least the lower ones; leaves erect, lanceolate, 1.25-5 cm. long, 2-6 mm. wide, at least the lower ones papillose-hirsute on both surfaces, especially beneath; panicle open, ovate, $2.5-6.25 \mathrm{~cm}$. long, its branches widely spreading; spikelets broadly obovoid, obtuse, purplish, about I.5 $\mathrm{mm}$. long, the outer 3 scales pubescent with short, spreading hairs, the first scale nearly one-half as long as the spikelet, broadly ovate, obtuse. Dry soil, Me. to Conn., N. Y. and N. J.

34. Panicum filicùlme Ashe. Culms densely tufted, slender, finally much branched, 2-3 dm. tall, minutely pubescent above. Sheaths hirsute with strongly very long hairs; leaves erect, the primary ones $1.5-3 \mathrm{~cm}$. long, 2-4 $\mathrm{mm}$. wide, papillose-pubescent on both surfaces or sometimes glabrous beneath, the hairs on the upper surface exceedingly long and copious; primary panicle long-exserted, 2-3 cm. long; spikelets broadly obovoid, I.5 mm. long, pubescent. In dry soil, N. J. to Ga. June-Aug.

35. Panicum pubéscens Lam. Hairy Panicum. (I. F. f. 267.) Culms at first erect and simple, later profusely branched and leaning or ascending, glabrous or pubescent. Sheaths hirsute, often papillose; leaves more or less hirsute, especially beneath, generally more or less spreading, those of the culm $5-7.5 \mathrm{~cm}$. long, those of the branches much shorter; primary panicles less than $7.5 \mathrm{~cm}$. long, ovoid, their branches ascending; lateral panicles much smaller; spikelets hardly $2 \mathrm{~mm}$. long, pubescent. In dry soil, common, Me. and Quebec to $\mathrm{Br}$. Col., south to Ga., Ind. Terr. and Ariz. June-Aug.

36. Panicum Atlánticum Nash. Atlantic Panicum. (I. F. f. 267f.) Papillose-hirsute with long, white, spreading hairs. Culms tufted, at length branched. 3-5 dm. tall, erect or ascending, a smooth ring below the nodes which are barbed with spreading hairs; leaves erect, rigid, thickish, linear-lanceolate, 3.75-10 c.n. long, 4-7 mm. wide, middle leaves the longest; panicle $3 \cdot 75^{-6.25}$ $\mathrm{cm}$. long, 3-6 cm. wide; spikelets numerous, obovoid, a little over $2 \mathrm{~mm}$. long, I. $5 \mathrm{~mm}$. wide, obtuse, the outer 3 scales densely pubescent with short spreading hairs. Dry soil, N. Y. to Ohio and Va. June-Aug.

37. Panicum lunuginòsum Ell. Woolly Panicum. (I. F. f. 266a.) Culms, sheaths and leaves villous with spreading hairs, those on the leaves and the upper part of the culm shorter. Culms leafy, tufted, 3-7.5 dm. tall," erect, at length branched, a smooth ring below each barbed node: leaves erect, lanceolate, $3 \cdot 75-12.5 \mathrm{~cm}$. long, 4-9 mm. broad; panicle ovoid, $3 \cdot 75^{-10} \mathrm{~cm}$. long, the axis pubescent, the branches ascending, the larger $2.5-5 \mathrm{~cm}$. long; spikelets numerous, broadly obovoid, about $1.75 \mathrm{~mm}$. long, the first scale orbicular, the second and third scales nearly orbicular, densely pubescent with spreading hairs. Dry sandy soil, south. ern N. J. to Fla, and Ala. 
38. Panicum víscidum Ell. Velvety Panicum. (T. F. f. 266.) Culms erect, 6-12 dm. tall, simple, or at length much branched above, villous. Sheaths villous; leaves softly pubescent, those of the culm ro-r $7.5 \mathrm{~cm}$. long, 10-16 mm. wide, distant, those of the branches $2.5-6.25 \mathrm{~cm}$. long, 4-10 $\mathrm{mm}$. wide, crowded; primary panicles $7 \cdot 5^{-1} 5 \mathrm{~cm}$. long, ovoid, branches ascending; secondary panicles much smaller; spikelets ovoid to oval, about $2.5 \mathrm{~mm}$. long, pubescent; fourth scale oval, apiculate, $2 \mathrm{~mm}$. long. Moist soil, N. J. to Ind. and the Ind. Terr., south to Fla. and Tex. Not viscid. June-Aug.

39. Panicum Addisònii Nash. Rigid Panicum. (I. F. f. 267e.) Culms 2.5-3.75 dm. tall, rigid, tufted, erect, or decumbent at the base, at length much branched, the branches erect, pubescent with long, nearly appressed hairs. Sheaths appressed-pubescent, at least the lower ones; leaves erect, lanceolate, thickish, smooth and glabrous on both surfaces, acuminate, $2.5-7.5 \mathrm{~cm}$. long, 3-6 mm. wide; panicle ovoid to oblong, $1.8-5.6 \mathrm{~cm}$. long, its branches spreading or ascending; spikelets obovoid, $2 \mathrm{~mm}$. long; second and third scales densely pubescent with long, spreading hairs. Sandy soil, southern N. J. May-June.

40. Panicum Commonsiànum Ashe, Commons' Panicum. Culms tufted, erect, 2 5-5 dm. tall, densely appressed-hirsute below and puberulent above, or rarely somewhat hirsute. Sheaths, especially the lower ones, appressed-hirsute; leaves erect or nearly so, firm, glabrous on both surfaces, ciliate toward the base, 4-10 $\mathrm{cm}$. long, 3-6 mm. wide; panicle open, 5-7 cm. long, broadly ovate, its branches spreading; spikelets $2.5 \mathrm{~mm}$. long, obovate, pubescent. On dry, sandy ridges along the coast, Del. to N. Car. June-July.

41. Panicum Wilcoxiànum Vasey. Wilcox's Panicum. (I. F. f. 260.) Culms erect, I.5-2.5 dm. tall, sparingly pubescent. Sheaths papillose-pubescent; leaves $3.75-7.5 \mathrm{~cm}$. long, less than $4 \mathrm{~mm}$. wide, long-acuminate, strongly pubescent with long hairs; panicle about $3.75 \mathrm{~cm}$. long, oblong to ovoid, compact; branches less than $2.5 \mathrm{~cm}$. long, ascending, flexuous; spikelets about $2.5 \mathrm{~mm}$. long, ellipsoid; first scale about one-quarter as long as the spikelet; second and third scales about equal, pubescent; fourth scale about as long as the third, obtuse. In dry soil, Neb. (and Kans.?). July-Aug.

42. Panicum Liebérgii (Vasey) Scribn. Lieberg's Panicum. (I. F. f. 259a.) Culms erect, slender, glabrous, roughish, especially near the nodes, 3-6 dm. tall, at length branched. Sheaths papillose-hirsute with spreading hairs: leaves erect or ascending, lanceolate, 5-10 $\mathrm{cm}$. long, 6-12 mm. wide, acuminate at the apex, papillose-hispid beneath and sometimes sparingly so on the rough upper surface; panicle oblong, 5-10 cm. long, its branches erect or ascending; spikelets $3-4 \mathrm{~mm}$. long, oval, the outer three scales papillose-hirsute with long, spreading hairs. Dry soil, Ohio to Minn. and S. Dak., south to Mo. and Neb. June-July.

43. Panicum Scribneriànum Nash. SCRIBneR's Panicum. (I. F. f. 259.) Culms erect, 1.5-6 dm. tall, simple, or late in the season dichotomously branched above, sparingly pubescent. Sheaths strongly papillose-hispid; leaves 5-10 cm. long, 6-12 mm. wide, more or less spreading, smooth above, scabrous beneath: panicles small, the primary one ovoid, $3 \cdot 75-7.5 \mathrm{~cm}$. long, the secondary ones much smaller and more or less included; branches of the primary panicle spreading, 1.6-3.7 cm. long, often flexuous; spikelets turgid, obovoid, about $3 \mathrm{~mm}$. long. In dry or moist soil, Me. and Ont. to Minn., south to Va., Kans. and Ariz. June-Aug.

44. Panicum xanthóphysum A. Gray. Slenver Panicum. (I. F. f. 258.) Culms erect, 3-6 dm. tall, simple. Sheaths sparingly papillose-hirsute; leaves $7.5^{-1} 5 \mathrm{~cm}$. long, 8-1 $8 \mathrm{~mm}$. wide, long-acuminate, erect, smooth and glabrous; panicle long-exserted, linear, 3.75-ro cm. long, its branches appressed; spikelets few, about $3 \mathrm{~mm}$. long, obovoid, pubescent or glabrate; first scale about one-half as long as the nearly equal obtuse second and third; fourth scale indurated and shining, elliptic or oval. Dry soil, Me. and Ont. to Manitoba, south to N. J. and Penn. Plant light green, becoming yellowish in drying. June-Aug.

45. Panicum calliphýllum Ashe. Plant yellowish-green. Culms single or a little tufted, simple, 4-5 dm. tall, minutely pubescent; sheaths glabrous, excepting the ciliate margins; leaves ascending, 9-II cm. long, 9-12 $\mathrm{mm}$. wide, lanceolate, smooth and glabrous, ciliate at the base; panicle $6-9 \mathrm{~cm}$. long, its ascending scabrous branches $3-4 \mathrm{~cm}$. long; spikelets few, $3 \mathrm{~mm}$. long, elliptic, pubescent. In dry soil, central N. Y. June-Aug. 
46. Panicum sphaerocàrpon Ell. Round-Fruited Panicum.

(I. F. f. 252.) Culms generally erect, simple or somewhat branched at base, 2.5-6 dm. tall, smooth, or the nodes sometimes pubescent. Sheaths usually shorter than the inter. nodes, glabrous, the margins ciliate; leaves 5-10 $\mathrm{cm}$. long, 4-14 $\mathrm{mm}$. wide, acuminate, scabrous above, smooth beneath, the margins cartillaginous and minutely serrulate, ciliate towards the base; panicle ovoid, 5-10 $\mathrm{cm}$. long; spikelets less than $2 \mathrm{~mm}$. long, nearly spherical or somewhat longer than thick, obtuse, purple; first sca!e broadly ovate, obtuse. Dry soil, southern Ont., N. Y. and Mo. to Fla., Tex. and Mex. July-Sept.

47. Panicum polyánthes Schult. Small-fruited Panicum. (I. F. f. 253.) Culms generally erect, 6-9 dm. tall, simple, smooth. Sheaths smooth, glabrous, longer than the internodes; ligule none; leaves $1.25^{-2} \mathrm{dm}$. long, $1.25^{-2.5} \mathrm{~cm}$. wide, lo:ig-acuminate, smooth, cordate-clasping and sparingly ciliate at the base; panicle $7 \cdot 5^{-20} \mathrm{~cm}$. long, ovoid to oblong in outline; branches slender, ascending; spikelets 1.5 mm. long, obovoid to nearly spherical, numerous; first scale minute, second and third about equal, 7-nerved, puberulent, the fourth white and shining. Woods and along thickets, southern N. Y. to Penn. and Mich., south to Fla., La., Neb. and Tex. July-Sept. (P. microcarpon Muhl.)

48. Panicum commutàtum Schultes. Variable Panicum. (I. F. f. 255.) Culms erect, 3-8 dm. tall, glabrous or nearly so, simple, finally dichotomously brancled above. Sheaths glabrous or puberulent, generally ciliate on the margins; primary leaves $7-11 \mathrm{~cm}$. long, I.5-2.5 cm. wide, sparingly ciliate at the base, glabrous, those of the branches generally broader and more crowded than those of the main stem; panicle 7-12.5 cm. long, the branches spreading; spikelets 2.5 mm. long, elliptic; second and third scales equal, 7-nerved, pubescent. In dry woods and thickets, N. Y. to Ky., south to Fla. and Tex. June-Aug.

49 Panicum Áshei G. Pearson. Ashe's Panicum. Culms tufted, 2-4 dm. tall, finally sparingly branched, minutely pubescent. Sheaths glabrous or minutely pubescent, ciliate on the margins; leaves distant on the main culm, in the branched state crowded at the end of the few branches, spreading or ascending, lanceolate to ovate-lanceolate, glabrous on both surfaces, ciliate at the base, those on the main culm 4-7 cm. long, 6-10 mm. wide, those on the branches smaller; panicle 4-6 cm. long, open, its branches ascending; spikelets about $2.5 \mathrm{~mm}$. long and about I mm. broad, elliptic, obtusish, more or less pubescent with spreading hairs. In dry woods, N. Y. to Tenn. and Ga.; also in Mo. July-Sept.

50. Panicum macrocàrpon Le Conte. Large-Fruited Panicum. (I. F. f. 256.) Culms 3-9 dm. tall, erect, simple or somewhat branched above, smooth, the nodes, at least the upper ones, naked. Sheaths smooth and glabrous, ciliate; leaves 7.5-17.5 cm. long, 1.8-3.7 cm. wide, cordate-clasping at base, acuminate, smooth and glabrous or nearly so on both surfaces, ciliate; panicles $7.5-15 \mathrm{~cm}$. long, generally long-exserted, rarely included, its branches more or less ascending; spikelets 3-4 mm. long, turgid, oval to obovoid; second and third scales broadly oval, obtuse, 9-nerved, pubescent. Usually on dry hillsides, N. H. to N. Car., west to Iowa and Kans. July-Aug.

51. Panicum Porteriànum Nash. Porter's Panicum. (I. F. f. 254.) Culms erect, 3-6 dm. tall, simple or somewhat dichotomously branched above, the nodes densely barbed. Sheaths generally softly pubescent; leaves ovate to broadly lanceolate, 5-10 cm. long, 1.25-3.7 cm. wide, cordate-clasping at base, acute, glabrous, at least below; panicle included or somewhat exserted, the branches spreading or ascending, bearing few elliptic short-pedicelled appressed spikelets $4-5 \mathrm{~mm}$. long; first scale one-third to one-half as long as the pubescent and equal second and third ones; fourth scale about as long as the third. In woods, Me. and Ont. to Minn., south to Fla. and Tex. June-Aug.

52. Panicum clandestinum L. Hispid Panicum. (I. F. f. 257.) Culms erect or ascending, $4 \cdot 5^{-12} \mathrm{dm}$. tall, rather stout, simple at first, much branched later in the season. Sheaths longer than the internodes, much crowded on the branches, papillose-hispid, especially the upper ones; leaves $5-20 \mathrm{~cm}$. long, 1.2-3.7 $\mathrm{cm}$. wide, cordate-clasping at base, acuminate, smooth and glabrous, the margins ciliate at base; primary panicle sometimes long-exserted; panicles of the branches included in the sheaths, rarely slightly exserted; spikelets $2-2.5 \mathrm{~mm}$. long, ellip. soid. In thickets, Quebec to Mich., south to Ga., Mo, and Tex. June-July. 


\section{SACCÓLEPIS Nash.}

A perennial grass with flat leaves and a terminal contracted panicle. Spikelets numerous, readily deciduous when mature, I-flowered, articulated to the pedicel below the empty scales. Scales 4 , the outer 3 membranous, the first scale small, the second one much larger than the rest, many-nerved, strongly saccate at the base; fourth scale much shorter than the third, chartaceous, enclosing a palet of similar texture and a perfect flower. Stamens 3. Styles distinct. Stigmas plumose. Grain free. [Greek, in reference to the large saccate second scale of the spikelet.] Species I, native of the southern U. S. Also in Cuba.

I. Saccólepis gíbba (EIl.) Nash. (I. F. f. 279.) Culms erect from a creeping base, 6-1 $8 \mathrm{dm}$. long, dichotomously branched below. Lower sheaths densely hirsute, the upper generally glabrous; leaves $7.5-17.5 \mathrm{~cm}$. long, 4-20 $\mathrm{mm}$. wide, usually spreading, more or less pubescent; panicle $7.5^{-22.5} \mathrm{~cm}$. long, dense and contracted; branches $1.2-2.5 \mathrm{~cm}$. long, erect; spikelets 3-4 mm. long, elliptic, somewhat acute; first scale about one-quarter as long as the spikelet; second scale gibbous at base II-nerved; third scale about equalling the second, 7 -nerved, empty, the fourth one shorter than the second. Swamps, Va. to Tenn., south to Fla. and La. Also in Cuba. July-Sept. (Panicum gibbum Ell.)

18. CHAETÓCHI O.: Scribn. (Setaria Beauv. 1812. Not Ach., 1798.) (See Ap..)

Mostly annual grasses with erect culns and flat leaves, the inflorescence in spike-like clusters. Spikelets I-flowered, or rarely with a second staminate flower, the basal bristles single or in clusters below the articulation of the rachilla, and therefore persistent. Scales of the spikelet 4, the three outer membranous, the third often subtending a palet and rarely a staminate flower; the inner or fourth scale chartaceous, subtending a palet of similar texture and a perfect flower. Stamens 3 . Styles distinct, elongated. Stigmas plumose. Grain free, enclosed in the scales. [Greek, in reference to the bristles of the inflorescence.] Species about 20, in tem. perate and tropical regions.

Bristles downwardly barbed. Bristles upwardly barbed.

x. C. verticillata.

Spike-like inflorescence racemose; second scale much shorter than the spikelet.

Annual; spikelets exceeding $3 \mathrm{~mm}$. long; upper surface of the lower leaves hirsute.

Perennials; spikelets less than $3 \mathrm{~mm}$. long; leaves glabrous.

Culms tufted; spikelets nearly $3 \mathrm{~mm}$. long, the second scale usually 5nerved.

2. C. glauca.

Culms not tufted; spikelets $2.5 \mathrm{~mm}$. long the second scal 3. C. occidentalis. the fourth scale purple, at least at the tip. $\quad$ 4. C. versicolor.

Spike-like inflorescence paniculate, sometimes nearly racemose in some forms of

No. 5 ; second scale as long as the spikelet or nearly so.

Flowering scales dull, faintly rugose, obtuse, rather thin in fruit.

Inflorescence $2.5-8.5 \mathrm{~cm}$. long, $1.25 \mathrm{~cm}$. or less thick; spikelets about $2 \mathrm{~mm}$. long ; bristles green.

5. C. viridis.

Inflorescence $1-2 \mathrm{dm}$. long, $1.25-5 \mathrm{~cm}$. thick; spikelets about $3 \mathrm{~mm}$. long; $\begin{array}{ll}\text { bristles usually purple. } & \text { 6. C. Italica. }\end{array}$

Flowering scales shining, perfectly smooth, very acute, hard in fruit.

7. C. magna.

I. Chaetóchloa verticillàta (L.) Scribn. Fox-tail Grass. (I. F. f. 280.) Culms erect or decumbent, 3-6 dm. tall. Sheaths glabrous; leaves 5-20 cm. long, scabrous above; spikes $5-7.5 \mathrm{~cm}$. long; spikelets about $2 \mathrm{~mm}$. long, equalled or exceeded by the downwardly barbed bristles; first scale less than one-half as lon as the spikelet, I-nerved; second and third scales 5-7-nerved, equalling the oval fourth one. About dwellings and in waste places, N. S. and Ont. to N. J., Ky. and Neb. Naturalized from Europe. July-Sept.

2. Chaetochloa glaùca (L.) Scribn. Yellow Fox-tail. Pigeon Grass. (I. F. f. 28I.) Culms 3-I2 dm. tall. Sheaths glabrous: leaves 5-I $5 \mathrm{~cm}$. long, pilose above near the base; spikes 2.5-10 cm. long; spikelets $3 \mathrm{~mm}$. long, much shorter than the bristles; first scale I-3-nerved, somewhat shorter than the 5-nerved second; third scale 5-nerved, equalling the fourth, which is V-shaped in cross-sec tion, about twice as long as the second. In waste places and cultivated grounds, 
- throughout N. Am., except the extreme north. Often a troublesome weed. $\mathrm{Na}$. turalized from Europe. July-Sept.

5. Chaetochloa occidentalis Nash.

Western Fox-tail Grass. Culms tufted, from a branching rootstock, 3-8 dm. tall. Sheaths compressed, keeled, smooth and glabrous; leaves erect, firm, $1.6 \mathrm{dm}$. or less long, 5-7 mm. wide, gla. brous; spike-like racemes 3-5 cm. long, I. $-2 \mathrm{~cm}$. thick, the bristles green; spikelets a little less than $3 \mathrm{~mm}$. long, the first scale about one-half as long as the spikelet, 3-nerved, the second scale a little longer, 3-5-nerved, the fourth scale strongly transverse-rugose, elliptic. In meadows, Kans. and Ind. Terr. July.

4. Chaetochloa versícolor Bicknell. SEacoast Fox-Tail Grass. Perennial. Culms 6-12 dm. long, ascending; sheaths smooth and glabrous, compressed and keeled; leaves long and narrow, I-3.5 dm. long, $2-6 \mathrm{~mm}$. wide, pale green or glaucous, snooth or nearly so; spike-like panicle long-exserted, rather slender, 2.5-7 $\mathrm{cm}$. long, about $1.5 \mathrm{~cm}$. thick; spikelets usually single, about $2.5 \mathrm{~mm}$. long and I. $25 \mathrm{~mm}$. wide, the first scale ovate, 3 -nerved, about one-half as long as the spikelet, the second scale acute, 3 -nerved, the third scale 5 -nerved, the fourth scale rather pointed, purple-tipped; bristles in two nearly equal clusters of 5 each, very slender, 6-10 mm. long. Borders of salt and brackish marshes, Conn. to Fla.

5. Chaetochloa viridiz (L.) Scribn. Green Fox-Tall Grass. (I. F. f. 282.) Culms 3-9 dm. tall. Sheaths glabrous; leaves $7.5-25 \mathrm{~cm}$. long, 4-12 mm. wide; spikes compound, $2.5-10 \mathrm{~cm}$. long; spikelets about $2 \mathrm{~mm}$. long, elliptic, much shorter than the green, or sometimes yellowish, bristles; first scale less than one-half as long as the spikelet, I-3-nerved; second and third scales 5 -nerved; fourth scale equalling or slightly exceeding the second. In waste places and cultivated grounds throughout N. Am., except the extreme north, and often a troublesome weed. Naturalized from Europe. July-Sept.

6. Chaetochloa Itálica (L.) Scribn. Italian Millet. Hungarian Grass. (I. F. f. 283 .) Culms 6-I8 dm. tall. Sheaths smooth or scabrous; leaves I. 5-3 dm. or more in length, $6-36 \mathrm{~mm}$. wide, generally scabrous; spikes $\mathbf{1}-2.25$ dm. long, r.25-5 cm. thick, usually very compound; spikelets about $3 \mathrm{~mm}$. long, elliptic, equalled or exceeded by the purplish bristles; first scale less than one-half as long as the spikelet, I-3-nerved; second and third 5-7-nerved, fourth scale equalling or somewhat exceeding the second. In waste places, escaped from cultivation, Quebec to Minn., south to Fla: and Tex. Native of the Old World. July-Sept.

7. Chaetochloa màgna (Griseb.) Scribn. Giant Fox-Tail Grass. Culms I. 5-5 m. tall, stout. Sheaths densely hirsute on the margins, otherwise glabrous: leaves $8 \mathrm{dm}$. or less long, 2-4 cm. wide, very rough on both surfaces; panicle 2-6 $\mathrm{dm}$. long, 3-6 cm. thick, nodding above; spikelets $2 \mathrm{~mm}$. long, the first scale about one-half as long as the spikelet, 3-nerved, the second scale as long as the spikelet, 7-nerved, the fourth scale oval, very acute, smooth and shining. In swamps, Del (according to Scribner) to Fla. and Tex. July-Aug.

\section{I9. CÉNCHRUS L. (See Appendix.)}

Annual or perennial grasses, with usually flat leaves. Inflorescence spikelike. Spikelets subtended by a spiny involucre which is deciduous with them at maturity. Scales 4; the first hyaline; the second and third membranous, the latter sometimes having a palet and staminate flower in its axil; the fourth chartaceous, subtending a palet of similar structure which encloses a perfect flower. Stamens 3. Styles united below. Stigmas plumose. Grain free, enclosed in the scales. [Ancient Greek name for some grass, probably Millet.] About 12 species, in tropical and temperate regions. Besides the following, some 4 others occur in the southern parts of N. Am.

I. Cenchrus tribuloides L. Bur Grass. Hedgehog Grass. (I. F. f. 284.) Culms erect or decumbent from an annual root, 2-9 dm. long. Sheaths usually loose, compressed, smooth; leaves $6.25-12.5 \mathrm{~cm}$. long; spikes $2.5-6.25 \mathrm{~cm}$. long, sometimes partially included in the upper sheath; involucres crowded on the scabrous rachis, 2 -flowered, globose, pubescent except at the base, forming spiny burs, the spines stout; spikelets about $6 \mathrm{~mm}$. long. On sandy shores and in waste places, Me. and Ont. to Minn., south to Fla. and Tex. Sometimes a noxious weed. Apparently perennial in the Southern States. Aug.-Sept. 


\section{ZIZANı́ÓPSIS. Doell and Aschers.}

Tall aquatic monœcious grasses, with long flat leaves and paniculate inflor. escence. Spikelets I-flowered, the pistillate borne at the top of the branches, the staminate at the base. Scales 2, nearly equal, membranous, the outer one in the pistillate spikelets broad, acute, and bearing an awn. Stamens 6 . Styles united. Grain nearly globose, the pericarp readily separable. [Name in allusion to the resemblance of this grass to Zizania.] A monotypic genus, of temperate and tropical America.

I. Zizaniopsis miliàcea (Michx.) Doell. and Aschers. Zizaniopsis. (I. F. f. 285 .) Culms I-4.5 mm. tall, from a long rootstock. Sheaths loose, glabrous; ligule 8-14 mm. long, thin-membranous; leaves $3 \mathrm{dm}$. long or more, $1.25-2.5 \mathrm{~cm}$. wide; panicle 3-4.5 dm. long, narrow; branches erect; staminate spikelets 6-8 $\mathrm{mm}$. long, the outer scale 5 -nerved, the inner 3-nerved; pistillate spikelets about $6 \mathrm{~mm}$. long, the outer scale bearing an awn 2-6 mm. long, 5-nerved; inner scale 3-nerved. Swamps, Ga. to Ohio (according to Riddell), south to Fla. and Tex. June-July. (Zizania miliacea Michx.)

$$
\text { 21. ZIZÀNIA L. }
$$

A tall, aquatic monœcious grass, with long flat leaves and an ample panicle. Spikelets I-flowered, the pistillate borne on the upper branches of the panicle, the staminate on the lower. Scales 2 , mentbranous, the outer somewhat longer, acute in the stamirate, long-awned in the pistillate spikelets. Stamens 6. Styles nearly distinct. Grain linear. [From an ancient Greek name for Darnel.] A monotypic genus of N. Am. and Asia.

I. Zizania aquática L. Wild Rice. Indian Rice. Water Oats. Reed. (I. F. f. 286.) Culms erect from an annual root, 9-30 dm. tall. Sheaths loose, glabrous; ligule about $6 \mathrm{~mm}$. long, thin-membranous; leaves $3 \mathrm{dm}$. or more long; panicle $3-6 \mathrm{dm}$. long, the upper branches erect, the lower widely spreading; staminate spikelets 6-12 mm. long, outer 5-nerved, the inner 3-nerved; scales of the pistillate spikelets $8-24 \mathrm{~mm}$. long, the outer one 5-nerved, with an awn $2.5-5$ $\mathrm{cm}$. long, the inner narrower, 3-nerved, awn-pointed; grain I-3 cm. long. In swamps, N. B. to Manitoba, south to Fla. and Tex. June-Oct.

\section{HOMALOCÉNCHRUS Mieg. [LEERSIA Sw.]}

Marsh grasses with flat narrow, generally rough leaves and paniculate inflorescence. Spikelets I-flowered, perfect, strongly flattened laterilly, and usually more or less imbricated. Scales 2, chartaceous, the outer one b"oad and strongly conduplicate, the inner much narrower. Stamens I-6. Styles short, distinct. Stigmas plumose. Grain ovoid, free. [Greek, in reference to the supposed resemblance of these grasses to Millet.] About 5 species, natives of temperate and tropical counfries. Besides the following, 2 others occur in the southern U. S.

Spikelets oblong, their width less than one-half their length, somewhat imbricated.

Spikelets 2.5-3 mm. long; panicle-branches usually rigid. $\quad$ I. H. Virginicus.

Spikelets 4-5 mm. long; panicle-branches generally lax. Spikelets oval, their width more than one-half their length, much imbricated.

3. H. lenticularis.

I. Homalocenchrus Virginicus (Willd.) Britton. White Grass. (I. F. f. 287.) Culms 3-9 dm. long, much branched, slender. Leaves $5-15 \mathrm{~cm}$. long, 2-16 mm. wide, scabrous; terminal panicle finally open and long-exserted, $7 \cdot 5-=0$ $\mathrm{cm}$. long; lateral panicles smaller and usually included; spike'ets $2.5-3 \mathrm{~mm}$. long, about I mm. wide; outer scale hispid on the keel and margins; stamens I or 2. Swamps or wet woods, Me. to Ont. and Minn., south to Fla. and Tex. Aug.-Sept.

2. Homalocenchrus oryzoides (L.) Poll. Rice Cut-Grass. (I. F. f. 283) Culms 3-12 dm. long, much branched, rather stout. Leaves $7 \cdot 5-25 \mathrm{~cm}$. long, 4-IO $\mathrm{mm}$. wide ; terminal panicle $1.25-2.25 \mathrm{dm}$. long, finally long-exserted, its branches lax, and later widely spreading : lateral panicles generally included; spikelets 4-5 mm. long, about $1.5 \mathrm{~mm}$. wide, elliptic; scales pubescent, the outer one hispid on the kcel and on the margins; stamens 3. In swamps and along streams, often forming dense tangled masses, N. S. to western Ont., south to Fla. and Tex. Also in the temperate parts of Europe and Asia. Aug.-Sept. 
3. Homalocenchrus lenticulàris (Michx.) Scribn. CAtch fly Grass. (I. F. f. 289.) Culms 6-I 2 dm. tall, usually simple. Leaves $\mathrm{I}-3 \mathrm{dm}$. long, 8-20 mm. wide; panicle I. I2-2.25 dm. long, finally exserted, its branches lax, and later spreading; spikelets much imbricated, 4-5 mm. long, 2-3.5 mm. wide; scales smonth or sparingly hispid-scabrous, the outer one strongly 3-nerved, hispid on the keel and margins, the inner much narrower, strongly $\mathbf{r}$-nerved, hispid on the keel; stamens 2. Wet grounds, Va. to Minn. and Mo., south to Fla. and Tex. July-Sept.

\section{PHÁLARIS L.}

Annual or perennial grasses with flat leaves, the inflorescence spike-like, capitate or a narrow panicle. Spikelets crowded, I-flowered. Scales 5, the first and second about equal in length, strongly compressed laterally, usually wing-keeled; third and fourth scales much smaller or reduced to mere rudiments; fifth scale subtending a palet similar to itself and a perfect flower. Stamens 3. Styles distinct. Stigmas plumose. Grain oblong, free, smooth, enclosed in the indurated scales. [Greek, alluding to the shining grain.] About ro species, mostly natives of southern Europe. Besides the following, 3 others occur in the U. S.

Outer scales not winged; inflorescence a narrow panicle.

Outer scales broadly winged; inflorescence a spike or spike-like panicle.

Spikelets narrow; third and fourth scales much reduced, rigid, subulate, hairy. 2. P. Caroliniana.

Spikelets broad; third and fourth scales thin-membranous, broadly lanceolate, glabrous or sparingly hairy.

3. P. Canariensis.

I. Phalaris arundinàcea L. Reed Canary-grass. (I. F. f. 290.) Glabrous, $6-15 \mathrm{dm}$. tall. Leaves $8.75-25 \mathrm{~cm}$. long, 6-16 mm. wide; panicle $7 \cdot 5-z 0$ $\mathrm{cm}$. long, dense and contracted; spikelets $5-6 \mathrm{~mm}$. long; outer scales 3-nerved; third and fourth scales less than one-half as long as the fifth; fifth scale about three-fourths as long as the spikelet, pubescent with long appres secl silky hairs. In moist or wet soil, N. S. to Br. Col., south to N. J., Ky., Kans, and Nev. A!so in Europe and Asia. July-Aug. The Ribbon-grass or Painted-grass of cultivation, the so-called variety picta, has leaves variegated with green and white stripes, is a derivative of this species, and sometimes escapes from gardens.

2. Phalaris Caroliniàna Walt. Carolina Canary-grass. (I. F. f. 29r.) Culms 3-10.5 dm. tall. Leaves 5-15 cm. long, 4-10 mm. wide; spike-like panicle oblong, 2.5-10 $\mathrm{cm}$. long; spikelets $5 \mathrm{~mm}$. long, 3-nerved; third and fourth scales less than one-half as long as the fifth; fifth scale about two-thirds as long as the spikelet, acuminate, pubescent with long appressed hairs. In moist soil, S. Car. to Mo. and Cal., south to Fla. and Tex. June-Aug.

3. Phalaris Canariénsis L. Canary-grass. (I. F. f. 292.) Culms 3-9 dm. tall. Leaves 5-30 cm. long, 4-12 mm. wide, strongly scabrous; spikes I.25$3.75 \mathrm{~cm}$. long, ovoid; spikelets $6-8 \mathrm{~mm}$. long; outer scales whitish with green nerves; third and fourth scales about half the length of the fifth, broadly lanceolate, thin-membranous, sparingly hairy; fifth scale about two-thirds as long as the spikelet, pubescent with appressed hairs. In waste places, N. S. to Ont., Va. and Neb. Naturalized from Europe. The grain is the common food of canary birds. JulyAug.

\section{ANTHOXÁNTHUM I.}

Fragrant annual or perennial grasses, with flat leaves and spike-like panicles. Spikelets I-flowered, narrow, somewhat compressed. Scales 5; the two outer acute or produced into a short awn, the first shorter than the second; third and fourth szales much shorter, 2-lobed, awned on the back; the fifth scale shorter than the others, obtuse. Stamens 2. Styles distinct. Stigmas elongated, plumose. Grain free, enclosed in the scales. [Greek, referring to the yellow hue of the spikelets in some species.] A genus of 4 or 5 species, natives of Europe.

I. Anthoxanthum odoràtum L. SweEt Vernal-grass. (I. F. f. 293.) Culms 3-6 dm. tall. I eaves $1.25-15 \mathrm{~cm}$. long, 2-6 mm. wide, glabrous or nearly so: panicles $2.5-6.25 \mathrm{~cm}$. long; spikelets $8 \mathrm{~mm}$. long, crowded; outer scales glabrous or pubescent; the third and fourth very hairy, the former with an awn nearly twice 
its length inserted about the middle, the fourth scale bearing near the base an awn more than twice its length. In fields and meadows throughout nearly the whole of N. An. Very fragrant in drying. Naturalized from Europe. June-July.

\section{SAVASTÀNA Schrank. [HIEROCHLOË Gmel.]}

Aromatic perennial grasses, with flat leaves and contracted or open panicles. Spikelets 3-flowered, the terminal flower perfect, the others staminate. Scales 5; the first and second nearly equal, acute, glabrous; the third and fourth somewhat shorter, obtuse, entire, emarginate, 2 -toothed or 2-lobed, with or without an awn, enclosing a palet and stamens; fifth scale often produced into a short awn, enclosing a palet and perfect flower. Stamens in the staminate flowers 3, in the perfect 2. Styles distinct. Stigmas plumose. Grain free, enclosed in the scales. [Name unexplained.] About 8 species, natives of temperate and cold regions.

Third and fourth scales unawned;

Entire; culms 3-1o dm. tall.

Panicle $\mathrm{I} \mathrm{dm}$. long or less, its branches short, $5 \mathrm{~cm}$. long or less; leaves short and broad.

Panicle $1.5-5 \mathrm{dm}$. long, its branches capillary, drooping, $\mathrm{x}-2 \mathrm{dm}$. long; leaves long and narrow.

Erose-trincate; culms 1.5 dm. tall or less.

Third and fourth scales awned.

2. S. Nashii.

3. S. pauciflora.

4. S. alpina.

I. Savastana odoràta (L.) Scribn. Holy-grass. Seneca Grass. (I. F. f. 294.) Sheaths smooth; lower leaves elongated, I-2 dm. long, 2-6 mm. wide, the upp 2 r ones $1.25-5 \mathrm{~cm}$. long; panicle 5-10 $\mathrm{cm}$. long, its branches $2.5-5 \mathrm{~cm}$. long, usually spreading; spikelets yellowish-brown and purple, 4-6 mm. long; first and second scales acute; third and fourth villous and strongly ciliate, awn-pointed. Newf. to Alaska, south to N. J., Wis. and Colo. Also in northern Europe and Asia. June-July. This and other sweet-scented grasses are strewn before the churches in northern Europe, whence the name Holy-grass. Also known as Vanilla-grass.

2. Savastaiz Náshii Bicknell. Nodding Vanilla-grass. (I. F. f. 294a.) Plant smooth, glabrous and shining. Culms erect, slender, 6-9 dm. tall. Sheaths overlapping, striate; leaves erect or ascending, elongated, the culm leaves 5 or 6 , 5-20 cm. long, 4-6 mm wide, acuminate; punicle long-exserted, loose and open, I.7$4.5 \mathrm{dm}$. long, its apex nolding, the capillary branches drcoping, the larger $7 \cdot 5-17.5$ $\mathrm{cm}$. long, in puirs; spikelets $5-8 \mathrm{~mm}$. long, on capillary pedicels; scales 5 , the outer 2 abrupily long-acuminate; the third and fourth scales atout $5 \mathrm{~mm}$. long, rough, ciliate on the margins with ascending hairs. Along brackish marshes, N. Y. City. July-Aug.

3. Savastanz pauciflòra (R. Br.) Scribn. ArCtic Holy-grass. (I. F.f. 295.) Glabrous; culms I.5 dm. high or less, erect, simple, smooth, sheaths mostly at the base of the culm, overlapping; leaves smooth, the basal ones $2.5-5 \mathrm{~cm}$. long, I $\mathrm{mm}$. wide, involute at least when dry; culm leaves $1.25 \mathrm{~cm}$. long or less, $2 \mathrm{~mm}$. wide, flit; p inicle less than $2.5 \mathrm{~cm}$. long, contracted; spikelets few, 3-4 mm. lorg; first and second siales $3-4 \mathrm{~mm}$. long, smooth and glabrous; third and fourth shorter. scabrous. Arctic America. Summer.

4. Savastaiz alpina (Sw.) Scribn. Alpine Holy-grass.

(I. F.f. 296.) Culms 1.5-4.5 dm. tall. Lower leaves elongated, $7 \cdot 5^{-1} 5 \mathrm{~cm}$. long, about $2 \mathrm{~mm}$. wide, the upper much shorter, $1.25-5 \mathrm{~cm}$. long, 2-4 mm. wide: panicle $1.8-3.7 \mathrm{~cm}$. long, contracted; spikelets 5-7 mm. long. crowded; third and fourth shorter, cili. ate on the margins, the former bearing an awn about $2 \mathrm{~mm}$. long, the latter with a more or less bent awn about $6 \mathrm{~mm}$. long; fifth scale acute, usually awn-pointed. Greenland to Alaska, south to the high mountains of N. E. and N. Y. Also in northern Europe and Asia. July-Aug.

\section{ARÍSTIDA L. (See Appendix.)}

Grasses varying greatly in habit and inflorescence. Leaves narrow, often in. volute-seticeous. Spikelets narrow, I-flowered. Scales 3, narrow, the two outer carinate; the third rigid and convolute, bearing three awns occasionally united at the base, the lateral awns rarely wanting or reduced to rudiments. Palet 2-nerved. 
Stamens 3. Styles distinct. Stigmas plumose. Grain free, tightly enclosed in the scale. [Latin, from arista, an awn.] About 100 species, in the warmer regions of both hemispheres. Besides the following, some 25 others occur in the southern and western parts of N. Am. The English name Three-awned Grass is applied to all the species.

Awns not articulated to the scale.

Central awn coiled at the base.

First scale usually equalling or sometimes slightly shorter than the second scale, which is generally $7-9 \mathrm{~mm}$. long.

x. A. dichotoma.

First scale much shorter than the second (often but little more than one-half as long), which is ro-r $5 \mathrm{~mm}$. long.

Lateral awns short, straight and erect, I-2 $\mathrm{mm}$. long, the central awr. usually more than five times their length, its straight portion 5-8 mm. long.

2. A. Curtissii.

Lateral awns more or less spreading, usually a little spiral at the base, the central awn from one-half again to twice their length, its straight portion $10-15 \mathrm{~mm}$. long.

Central awn not coiled at the base.

3. A. basiramea.

Panicle narrow, linear to oblong, the branches short (sometimes long in No. I2), erect or ascending.

Central awn and sometimes the lateral ones also strongly reflexed, the bend semicircular.

4. A. ramosissima.

Central awn from erect to spreading with no semicircular bend at the base. First scale much shorter than the second, usually about one-half as long.

Spikelets crowded, $4-6$ on the short branches, which are spikeletbearing to the base or nearly so.

5. A. fasciculata.

Spikelets not crowded, usually $1-3$ on branches naked at the base.

Second scale of the spikelet $1.5 \mathrm{~cm}$. or less long, usually equalling or slightly exceeding the flowering scale.

6. A. Fendleriana.

Second scale of the spikelet $2 \mathrm{~cm}$. or more long, from one-half again as long as to nearly twice the length of the flowering scale.

7. A. longiseta.

First scale from a little shorter than to exceeding the second.

Spikelets exceeding $2 \mathrm{~cm}$. long; first scale $5-7$-nerved.

Spikelets less than $1.5 \mathrm{~cm}$. long; first scale $1-3$-nerved.

8. A. oligantha.

Sheaths glabrous, or pubescent only at the apex.

Leaves strongly involute, densely villous at the base

Leaves flat, at least not villous at the base.

First scale generally shorter than or equalling the second.

First scale usually exceeding the second.

Sheaths, at least the lower ones, densely woolly. II. A. purpurascens. 12. A. lanosa.

Panicle diffuse and open, the branches very long and widely spreading. 13. A. divaricata.

Awns articulated to the scale, united at the base into a spiral column.

Column conspicuous, $6 \mathrm{~mm}$. long or more.

Column inconspicuous, $2 \mathrm{~mm}$. long or less.
14. A. tuberculosa. 15. A. desmantha.

r. Aristida dichótoma Michx. Poverty-grass. (I. F. f. 297.) Culms 1.5-6 dm. tall, dichotomously branched. Leaves $2.5-7.5 \mathrm{~cm}$. long, less than $2 \mathrm{~mm}$. wide, involute, usually scabrous; spike-like racemes or panicles $5-12.5 \mathrm{~cm}$. long, slender; spikelets about $6 \mathrm{~mm}$. long; outer scales nearly equal, usually awnpointed; third scale shorter than the second, the middle awn horizontal, the terminal straight portion 4-6 mm. long, the lateral awns $2 \mathrm{~mm}$. long or less, erect. Dry sandy soil, Me. to Ont., Neb. and the Ind. Terr., south to Ga. and Tex. Aug.Sept.

2. Aristida Curtíssii (A. Gray) Nash. Curtiss' Aristida. Culms tufted, 2-5 dm. tall, branching. Leaves $4-16 \mathrm{~cm}$. long, $1-2 \mathrm{~mm}$. wide; panicle $5-9 \mathrm{~cm}$. long, the branches erect; spikelets generally 10-12 $\mathrm{mm}$. long, rarely longer, the first scale much shorter than the second, which usually about equals the flowering scale; the flowering scale 7-II $\mathrm{mm}$. long; the lateral awns very short, $1-2 \mathrm{~mm}$. 
long, straight and erect. In dry soil, Mo. and Kans, to the Ind. Terr.; also in Va. Sept.-Oct.

3. Aristida basiràmea Engelm. Forked Aristida. (I. F. f. 299.) Cuims tufted, rather slender, 2-6 dm. tall, branching. Leaves $3-15 \mathrm{~cm}$. long, $1.5 \mathrm{~mm}$. wid: or less; panicle 3-9 cm. long, the branches erect; spikelets $10-15 \mathrm{~mm}$. long, the first scale much shorter than the second; the flowering scale 7-I I $\mathrm{mm}$. long, considerably shorter than the second scale; the lateral awns more or less spreading, usually a little spiral at the base, one-half to two-thirds as long as the central awn, which is strongly spiral at the base. In dry places, Minn. to Neb., south to Ill. and Kans.

4. Aristida ramosíssima Engelm. Branchen Aristida. (I. F. f. 300.) Culms I.5-6 dm. tall, branched. Leaves $3.5-7.5 \mathrm{~cm}$. long, $2 \mathrm{~mm}$. wide or less, flat, smooth beneath, scabrous above; spikelets few, borne in loose spikes, 5-10 cm. in length; first scale awn-pointed; second scale $1.6-2 \mathrm{~cm}$. in length, exceeding the first, terminated with an awn 2-6 $\mathrm{mm}$. long; third scale as long as the second; middle awn about $2.5 \mathrm{~cm}$. long, forming a hook, the lateral awns erect. In dry soil, Ill. to Ky. and Mo. July-Sept.

5. Aristida fasciculàta Torr. Bushy Aristida. (I. F. f. 306.) Culms 3-6 dm. tall, branched. Leaves $5^{-1} 5 \mathrm{~cm}$. long, $2 \mathrm{~mm}$. wide or less, flat; panicle 7.5$17.5 \mathrm{~cm}$. long, at first strict, the branches finally more or less spreading; first scale of spikelet I-nerved, shorter than the second scale; third scale equalling or longer than the second; awns divergent, the midclie one $8-16 \mathrm{~mm}$. long, the lateral ones shorter. Dry soil, Kans. to Cal., south to Mex. Aug.-Sept. (Aristida dispersa Trin. and Rupr.)

6. Aristida Fendleriàna Steud. Fendler's Aristida. (I. F. f. 304.) Culms densely tufted, I.5-2.5 dm. tall, erect, rigid, simple. Sheaths smooth, confined to the base of the culm ; leaves involute, at least when dry, often curved, $0.5 \mathrm{~mm}$. in diameter; panicle 7-IO cm. long, strict, its branches short and appressed and usually bearing a sing.'e spikelet; spikelets $1.2-1.5 \mathrm{~cm}$. long, the flowering scale 9-12 $\mathrm{mm}$. long, the central awn $2-3.5 \mathrm{~cm}$. long, the lateral ones a little shorter. In dry sandy soil, Black Hills to Neb. and Utah, south to Tex. and N. Mex. (Aristida purpurca Nutt. in part.)

7. Aristida longisèta Steud. Long-Awned Aristida. Culms tufted, 2-4 dm. tall, simple. Leaves 3-ro cm. long, involute, at least when dry; panicle I-2 $\mathrm{dm}$. long, its branches usually bearing but a single spikelet; spikelets $2-2.5 \mathrm{~cm}$. long, the flowering scale $1.2-1.6 \mathrm{~cm}$. long, from a little over one-half to two-thirds as long as the second scale, the central awn 6-I I cm. long, the lateral ones equalsing it or a little shorter. In dry sandy soil, Neb. to Mont. and Wash., south to Tex. and Mex. (Aristida purpurea Nutt. in part.)

8. Aristida oligántha Michx. FEw-Flowered Aristida. (I. F. f. 303.) Culms 3-6 dm. tall, dichotomously branched. Leaves $2.5^{-1} 5 \mathrm{~cm}$. long, I-2 mm. wile, smooth; spikelets few, in a lax spike-like raceme or panicle; first scale 5 . lierved, occasionally 7 -nerved at base, equalling or somewhat shorter than the stiond, which bears an awn 4-8 mm. long; third scale shorter than the first, awns Givergent or spreading, the middle one $3 \cdot 7-6.2 \mathrm{~cm}$. long, the lateral somewhat s:orter. Dry soil, N. J. to Neb., south to La. and Tex. Aug.-Sept.

9. Aristida siríta Michx. Erect Aristida. (I. F. f. 305.) Culms 0 . I2 $\mathrm{dm}$. tall. Leaves involute-filiform, the basal $3 \mathrm{dm}$. or more in length, those of the culm 2-3 dm. long, or the upper shorter; panicle spike-like, strict, or the top sometimes nodding, I.5-6 dm. long; outer scales of the spikelet awn-pointed, the first I-nerved, shorter than the second; thir 1 scale equalling the first or a little shorter: middle a wn I-2 cm. long, horizontal when old, the lateral ones shorter, erect or divergent. Dry soil, Va. ( 1 cording to S. Watson), south to Fla. July-Sept.

ro. Aristida grácilis Ill. Slender Aristida. (I. F. f. 298.) Culms I. 5-6 dm. tall. Leavcs $2.5-10 \mathrm{~cm}$. long, $2 \mathrm{~mm}$. wide or less, flat, or involute when dry; panicle spike-like, 7.5-17.5 $\mathrm{cm}$. long, slender; spikelets about $6 \mathrm{~mm}$. long; ()uter scales about equal; third scale about equalling the second, generally mottled, middle awn horizontal, the lateral awns $2-6 \mathrm{~mm}$. long, erect. Dry soil, N. H. and Mass. to Ill. and Neb., south to Fla. and Tex. Aug.-Sept.

II. Ari-tida purpuráccens Poir. Purplish ARIstida. (I. F. f. 3or.) Culms 3-7.5 dm. tall. Leaves :-2 dm. long, about $2 \mathrm{~mm}$. wide, flat, or becoming invo- 
lute in drying; spike-like panicles $1.25-4.5 \mathrm{dm}$. long, strict, or sometimes nodding: outer scales of spikelet awn-pointed, the first longer than the second; third scale from two-thirds to three-quarters as long as the first, middle awn $1.8-2.4 \mathrm{~cm}$. long, horizontal, the lateral awns somewhat shorter, erect or divergent. In dry soil, Mass. to Minn., south to Fla. and Tex. Sept.-Oct.

12. Aristida lanòsa Muhl. Woolly Aristida. (I. F. f. 3O2.) Culms 6-I2 $\mathrm{dm}$. tall. Leaves $3 \mathrm{dm}$. long or more, about $4 \mathrm{~mm}$. wide, attenuate into a long, slender point; panicle 3-6 dm. long, strict; outer scales of the spikelet awn-pointed, the first I-I.4 cm. long, exceeding the second; third scale slightly shorter than the second, middle awn $1.6-2.4 \mathrm{~cm}$. long, usually horizontal, the lateral awns about two-thirds as long, erect or divergent. Dry sandy soil, Del. to Fla. west to Tex. Aug.-Sept. (Aristida lanala Poir.)

I3. Aristida divaricàta H. \& B. Spreading Aristida. (I. F. f. 306a.) Culms 4.5-9 dm. tall, tufted, erect. Sheaths overlapping, rough; culm leaves, 1.5-3 dm. long, 2-4 $\mathrm{mm}$. wide; the sterile shoots from one-third to one-half as long as the culm, the leaves narrower; panicle comprising one-half of the plant, or more, often inclucled at the base, its branches rigid, at length widely spreading; spikelets, exclusive of the awns, about $1.25 \mathrm{~cm}$. long; empty scales acuminate, usually awn-pointed; flowering scale commonly slightly shorter than the empty ones, firm; the lateral awns shorter than the central, which is $1.2-2 \mathrm{~cm}$. long. Dry sandy soil, Kans. to Ariz. and N. Mex., south to Mex.

I4. Aristida tuberculòsa Nutt. SEA-BEACH ARIstida. (I. F. f. 307.) Culms 1.5-6 dm. tall, dichotomously branched. Leaves $1.25-2.25 \mathrm{dm}$. long, about $2 \mathrm{~mm}$. wide, smooth beneath, scabrous above; panicle 1.25-2 $\mathrm{dm}$. long, branches slender, ascending; outer scales of the spikelet about equal, awned, the third scale shorter; awns divergent or reflexed, more or less coiled. Sandy soil, especially on seabeaches, N. H. to Minn., south to Ga. Also in the interior in Ill., Wis., Minn. and Neb. Aug.-Sept.

15. Aristida desmàntha Trin. \& Rupr. Western Aristida. (I. F. f. 308.) Culms 3-6 dm. tall, branched. Leaves 1.5-3 dm. long, less than $2 \mathrm{~mm}$. wide, smooth beneath, scabrous above; panicle about $\mathbf{1 . 5} \mathrm{dm}$. long, the branches slender, ascending; outer scales of the spikelet about equal, the third one shorter; awns spreading or reflexed, somewhat coiled. In dry soil, Kans. (?), the Ind. Terr. and Tex. Aug.-Sept.

\section{STIPA L.}

Generally tall grasses, the leaves usually convolute, rarely flat, the inflorescence paniculate. Spikelets I-flowered, narrow. Scales 3; the two outer narrow, acute or rarely bearing an awn, the third rigid, convolute, with a hairy callus at the base, and bearing a more or less bent awn, which is spiral at the base, and articulated to the scale. Palet 2-nerved. Stamens 3, rarely fewer. Styles short, distinct. Stigmas plumose. Grain narrow, free, tightly enclosed in the scale. [Greek, in allusion to the tow-like plumes of some species.] A genus of about roo species; distributed throughout the temperate and tropical zones. Besides the following, some 20 others occur in the southern and western parts of N. Am.

Outer scales of the spikelet 4-12 $\mathrm{mm}$. long :

Obtuse or blunt-pointed, $4 \mathrm{~mm}$. in length.

Acute, 8-12 mm. in length.

Awn less than five times the length of the scale.

Awn more than seven times the length of the scale.

Outer scales of the spikelet $2 \mathrm{~cm}$. long or more.

Base of panicle usually included in the upper sheath; third scale 8-12 mm. long; awn slender, curled.

4. S. comata.

Panicle exserted from the upper sheath; third scale $1.4-2.4 \mathrm{~cm}$. long, awn bent.

5. S. spartea.

I. Stipa Macoùnii Scribn. Macoun's Strpa. (I. F. f. 309.) Culms 3-6 dm. tall. Leaves 5-12.5 cm. long, $1-2 \mathrm{~mm}$. wide, flat, becoming involutesetaceous in drying, scabrous; panicle $5-12.5 \mathrm{~cm}$. long, contracted, the branches $2.5-5$ $\mathrm{cm}$. long; spikelets borne at the ends of the branclies; third scale pubescent with long, appressed silky hairs, callus obtuse; awn 8-10 mm. long, contorted. N. B. w) the N. W. Terr., Me., N. II., Lake Superior, and Mont. July. [S. Richardsoni A. Gray. $]$ 
2. Stipa virídula Trin. Green Stipa. (I. F. f. 310.) Culms 4.5-9 dm. tall. Leaves smooth or scabrous, the basal ones involute-filiform, one-third to one-half as long as the culm, those of the culm $7 \cdot 5^{-22} \mathrm{~cm}$. long, broader; panicle spike-like, strict and erect; outer scales of spikelet 6-8 mm. long, long-acuminate; third scale shorter, more or less pubescent with long appressed silky hairs, callus acute; awn 1.8-3.2 cm. long, bent, loosely spiral at base. Minn. to Br. Col., south to Kans., N. Mex. and Cal. July-Aug.

3. Stipa avenàcea L. Black OAT-GRass. (I. F. f. 3II.) Culms 3-7.5 dm. tall. Leaves involute-filiform, smooth beneath, scabrous above, the basal one-third to one-half the length of the culm, those of the culm $7 \cdot 5-12.5 \mathrm{~cm}$. long; panicle I.25-2 dm. long, loose, the branches lax, finally spreading; outer scales of the spikelet 8-10 mm. long; third scale a litt!e shorter, black, pilose at base, and with a ring of short hairs at the top; callus hard, acute; awn $3 \cdot 75-6.25 \mathrm{~cm}$. long, bent, loosely spiral below. In dry woods, R. I. to Fla., mostly near the coast; also in western Ont. and Wis. May-June.

4 Stipa comàta Trin. and Rupr. IVestern Stipa. (I. F. f. 312.) Culms 3-6 dm. tall. Uppermost sheaths very long and inflated, enclosing the base of the panicle; basal leaves involute-filiform, one-quarter to one-half as long as the culm, the culm leaves $7 \cdot 5-1.5 \mathrm{~cm}$. long, a little broader than the basal ones, involute; panicle 1.5-2.25 dm. long, loose, the branches erect-ascending; outer scales of the spikelet $1.8-2.4 \mathrm{~cm}$. long, acuminate into an awn $4-8 \mathrm{~mm}$. in length; callus acute; awn I-2 dm. in length, spiral and pubescent below. On prairies, Alberta to Br. Col., south to Neb., N. Mex. and Cal. June-July.

5. Stipa spàrtea Trin. Porcupine-grass. (I. F. f. 3I3.) Culms 6-I $2 \mathrm{dm}$. tall. Basal leatves one-third to one-half as long as the culm, $2 \mathrm{~mm}$. wide or less, usually involute, those of the culm I.5-3 dm. long, about $4 \mathrm{~mm}$. wide, generally flat; panicle I-2.5 dm. in length, its branches erect; outer scales of spikelet 2.5$3.6 \mathrm{~cm}$. long, acuminate into a long slender point; callus acute; awn I-2 dm. long, stout, usually twice bent, tightly spiral and pubescent below, doubly spiral about the middle. On prairies, Manitoba to Br. Col., south to Ill. and Kans. June-July.

\section{ORYZÓPSIS Michx.}

Usually tufted grasses, with flat or convolute leaves and paniculate inflorescence. Spikelets I-flowered, broad. Scales 3; the two lower about equal, obtuse or acuminate; the third scale shorter or a litt'e longer, broad, bearing a terminal awn which is early deciduous, the callus at the base of the scale short and obtuse, or a mere scar. Stamens 3. Styles distinct. Stigmas plumose. Grain oblong, free, tightly enclosed in the convolute scale. [Greek, in allusion to the supposed resemblance of these grasses to rice.] About 24 species, distributed through temperate and subtropical regions, rarely extending into the tropics. Besides the following, some 7 others occur in the western parts of N. Am.

Spikelet, exclusive of awn, 2.5-4 mm. long.

A wn less than $2 \mathrm{~mm}$. long, much shorter than the scale; outer scales $3-4 \mathrm{~mm}$. in length.

I. O. juncea.

Awn 6-8 mm. long, more than twice as long as the scale; outer scales about 2.5 $\mathrm{mm}$. in length.

Spikelet, exclusive of awn, 6-8 mm. long.

Culms nearly naked, leaves all crowded at the base; panicle $5-7.5 \mathrm{~cm}$. long, its branches $2.5 \mathrm{~cm}$. in length or less, erect.

Culms leafy to the top; panicle $\mathrm{r} .5-3 \mathrm{dm}$. long; branches $5-10 \mathrm{~cm}$. in lengthi, more or less spreading.

4. O. melanocarfa.

I. Oryzopsis júncea (Michx.) B. S. P. Slender Mountain Rice. (I. F. f. 314.) Culms glabrous, 1.5-6 dm. tall, erect. Sheaths usually crowded at the bise of the culm; leaves smroth or scabrous, erect, involute, the basal about onehalf the length of the culm, occasionally equalling it, filiform, those of the culm 2.5-IO cm. long: panicle $2.5-6.25 \mathrm{~cm}$. long, the branches $1.25^{-2.5} \mathrm{~cm}$. in len $\mathrm{t}^{1} .1$, e.e $t$ or aszending, the lower half naked; spikelets 3-4 $\mathrm{mm}$. long, the third sca!e pubescent with short appressed silky hairs, the awn less than $2 \mathrm{~mm}$. long. In dry places, Quebec to Br. Col., Mass, Penn. and Wis. May-June. (O. Canadensis Torr.)

2. Oryzopsis micrántha (Trin. and Rupr.) Thurb. SMali. Flowered MounTAIN Rice. (I. F. f. 3I5.) Culms glabrous, 3-7.5 dm. till, erect, slender. 
Leaves erect, scabrous, the basal one-half the length of the culm, less than I mm. wide, usually more or less involute, the culm leaves 5-20 cm. long, $1-2 \mathrm{~mm}$. broad; panicle $7.5^{-1} 5 \mathrm{~cm}$. long, the branches finally spreading, the lower ones $2.5-5 \mathrm{~cm}$. long, naked for about two-thirds their length; spikelets $2-2.5 \mathrm{~mm}$. long, the third scale glabrous, bearing an awn $6-8 \mathrm{~mm}$. long. S. Dak. to Neb., N. Mex. and Ariz. June-July.

3. Oryzopsis asperifòlia Michx. White-grained Mountain Rice. (I. F. f. 316.) Culms $2.5-5 \mathrm{dm}$. tall, erect, smooth or s sabrous. Sheaths crowded at base ; leaves erect, rough, especially above, the basal ones elongated, often equalling or exceeding the culm, 4-8 $\mathrm{mm}$. wide, the I or $2 \mathrm{culm}$ leaves much reduced, less than $1.25 \mathrm{~cm}$. long; panicle $5-7.5 \mathrm{~cm}$. long, contracted, the branches $2.5 \mathrm{~cm}$. in length or less, erect; spikelets, exclusive of awn, $6-8 \mathrm{~mm}$. long ; third scale whitish, equalling the second or a little shorter, sparingly pubescent, the awn 7-10 $\mathrm{mm}$. long. In woods, N. S. to Br. Col., south to N. J., Penn., Minn., and in the Rocky Mts. to N. Mex. May-June.

4. Oryzopsis melanocàrpa Muhl. Black-Fruited Mountain Rice. (I. F. f. 3I7.) Glabrous; culms 4.5-9 dm. tall, erect, simple, roughish. Sheaths smooth or scabrous, the lower ones usual y longer, the upper slightly shorter than the internodes; leaves 1.25-3 dm. long, 4-14 mm. wide, narrowed toward the base, acuminate at apex into a long slender point, scabrous, especially above ; panicle branched or nearly simple, 7.5-30 $\mathrm{cm}$. long, its branches 5-10 $\mathrm{cm}$. long, spreading or ascending, the lower half naked; outer scales of the spikelet about equal, $6-8 \mathrm{~mm}$. in length, acute ; third scale shorter, acute, dark colored, sparingly pubescent, the awn $1.6-2.4 \mathrm{~cm}$. long. Rocky woods, Vt. and Ont. to Minn., south to Mass., N. J., Ky. and Mo. July-Aug.

\section{ERIOCÒMA Nutt.}

Perennial tufted grasses, with usually involute leaves and a contracted or open panicle. Spikelets I-flowered. Scales 3; outer two membranous, glabrous; third scale firmer, becoming hard in fruit, densely pubescent with long silky hairs, and bearing a terminal readily deciduous awn, the callus at the base of the scale short and obtuse. Stamens 3. Styles distinct. Stigmas plumose. Grain free, enclosed in the scale. [Greek, referring to the copious silky hairs of the flowering scale.] A small genus of 2 or possibly more species, natives of western N. Am.

r. Eriocoma cuspidàta Nutt. Silky Oryzorsis. (I. F. f. 318.) Culms 3-6 $\mathrm{dm}$. tall, erect, rigid, simple, smooth. Leaves I.5-3 dm. long, less than $2 \mathrm{~mm}$. wide, involute, stiff, smooth or somewhat scabrous; panicle $1.5-3 \mathrm{dm}$. long, diffuse, generally partially included in the upper sheath, its branches widely spreading and many times forked, the ultimate divisions flexuous; outer scales of the spikelet 6-8 mm. in length, long-acuminate, glabrous; third scale about one-half as long, acute, densely pubescent with long silky erect hairs nearly twice its own length, the awn 4-6 mm. long. On prairies, Alberta to Wash., south to Kans., Ariz. and Mex. May-July. (Oryzopsis cuspidata Vasey.)

\section{3о. MíLIUM L.}

Annual or perennial grasses, with flat leaves and terminal lax panicles. Spike. lets I-flowered. Scales 3, obtuse, not awned; the outer about equal; the third thinmembranous, at length rigid, glabrous or pubescent; palet scarcely shorter. St:mens 3. Styles short, distinct. Stigmas plumose. Grain ovoid or oblong, free, tightly enclosed in the rigid and shining scale and palet. [Latin name for Millet.] Species 5 or 6, chiefly in Europe and Asia.

I. Milium effùsum L. TAll Millet-Grass. (I. F. f. 3I9.) Glabrous throughout; culms 6-18 dm. tall, erect, simple, smooth. Leaves $7 \cdot 5-22.5 \mathrm{~cm}$. long, 6-16 mm. wide, narrowed toward the base, acuminate, smooth or scabrous: panicle $7.5-25 \mathrm{~cm}$. in length, lax, its branches $5-7.5 \mathrm{~cm}$. long, slencler, somewhat flexuous, naked at base and dividing above the middle, at length widely spreading; spikelets 2.5-3 mm. long; outer scales equal, smooth or scabrous, the third scale shorter, smooth, white. In woods, Cape Breton Isl. and Quebec to western Ontario, south to Mass., Penn. and Mich. Also in Northern Europe and Asia. June-July. 


\section{MUHLENBÉRGIA Schreb.}

Mostly perennial grasses, with flat or convolute leaves and paniculate inflorescence. Rootstocks often scaly. Spikelets $\mathbf{I}$-flowered, very rarely 2 -flowered. Scales 3 , very rarely 4 ; the outer ones empty, membranous or hyaline, acute and sometimes awned; third scale 3-5-nerved, subtending a palet and perfect flower, obtuse, acute, or very often produced into a capillary awn; palet 2-keeled. Stamens often 3. Styles distinct. Stigmas plumose. Callus minute. Grain narrow, free, tightly enclosed in the scale. [In honor of Henry Muhlenberg, 1756-1817, North American botanist.] About 60 species, chiefly natives of America, a few Asiatic.

Panicle cuntracted, narrow, spike-like, the short branches rarely spreading.

Flowering scales not awned but sometimes awn-pointed.

Outer scales not awned, about half as long as the flowering scale, acute.

Outer scales long-acuminate, awn-pointed or awned.

I. M. sobolifera.

Outer scales about equal in length to the flowering scale, sharp-pointed, about $3 \mathrm{~mm}$. long.

2. M. Mexicana.

Outer scales exceeding the flowering scale, generally twice its length, awned, about $5 \mathrm{~mm}$. long.

Flowering scale long awned; awn usually twice the length of the scale, sometimes shorter.

Outer scales about equalling the flowering scale.

Basal hairs not more than one-half the length of the flowering scale.

Spikelets consisting of 3 scales and I perfect flower. 4. M. sylvatica.

Spikelets consisting of 4 scales, the third with a perfect flower, the fourth empty and awned.

Basal hairs as long as the flowering scale.

Outer scales one-half to two-thirds as long as the flowering scale.

5. M. ambigua.

6. M. comata.

Outer scales less than one-third the length of the flowering scale.

7. M. tenuiflora.

First scale minute, often wanting; flowering scale with an awn less than twice its length.

First scale about two-thirds as long as the second.

8. M. diffusa.

Panicle contracted, its branches closely appressed; awn about three times as long as the flowering scale. $\quad 9 . M$. palustris.

Panicle open, its branches finally spreading; awn four times or more as long as the flowering scale.

Panicle open, its branches long and spreading.

ro. M. microsperma.

Culms $4.5 \mathrm{dm}$. tall or more; panicle diffuse; leaves elongated, not rigid.

Culms $3 \mathrm{dm}$. tall or less; leaves $5 \mathrm{~cm}$. long or less, rigid.

I1. M. capillaris.

Secondary branches of the panicle single; basal leaves short, numerous, strongly recurved.

12. M. gracillima.

Secondary branches of the panicle fascicled; basal leaves few, not recurved.

13. M. pungens.

I. Muhlenbergia sobolifera (Muhl.) Trin. Rock Muhlenbergia. (I. F. f. 320.) Glabrous; culms 3-9 dm. tall, erect, slender, simple, or sparingly branched above, smooth. Leaves rough, those of the culm I-I.5 dm. long, $2-6 \mathrm{~mm}$. wide, those of the branches $2.5-7.5 \mathrm{~cm}$. long, about $2 \mathrm{~mm}$. wide; panicle $75-15 \mathrm{~cm}$. in length, slender, its branches $1.8-2.5 \mathrm{~cm}$. long; outer scales about I mm. long, half to two-thirds the length of the spikelet; the third scale scabrous, obtuse, 3-nerved, the middle nerve usually excurrent as a short tip. Rocky woods, N. H. and Mass. to Minn., south to Va., Tenn. and the Ind. Terr. Sept.-Oct.

2. Muhlenbergia Mexicàna (L.) Trin. Meadow Muhlenbergia. (I. F. f. 321.) Glabrous; culms 6-12 dm. long, erect, or often prostrate, much branched, smooth. Leaves scabrous, those of the culm I-I.5 dm. long, $2-6 \mathrm{~mm}$. wide, the branch leaves smaller; panicle 5-15 cm. long, contracted, its branches spike-like, 2.5-5 cm. long, erect or appressed; spikelets $2.5-3 \mathrm{~mm}$. long; outer scales somewhat unequal, exceeding the flowering one, or slightly shorter, acuminate or shortawned, scabrous, especially on the keel ; third scale acuminate, scabrous, particularly toward the apex. In swamps and borders of fields, N. B. to western Ont., south to N. Car., Tenn., Neb. and the Ind. Terr. Aug.-Sept. F. f. $3^{2-.}$ ) Culms $3-9 \mathrm{dm}$. tall, erect, usually mich branched, smooth and 
glabrous. Leaves 5-12.5 cm. long, 2-6 mm. wide, scabrous; panicle $5-\mathbf{I I} .25 \mathrm{~cm}$. in length, usually dense and interrupted, the branches $1.25^{-2.5} \mathrm{~cm}$. long, erect or appressed, the spikelets much crowded; outer scales of the spikelet acuminate, 4-6 mm. long, including the awn, smooth, or scabrous, especially on the keel; third scale one-half to two-thirds as long, acuminate, the strongly scabrous midrib excurrent in a short point. In wet places, Newf. to Br. Col., south to N. J., Mo. and N. Mex. Aug.-Sept. (M. glomerata Trin.)

4. Muhlenbergia sylvática Torr. Wood Muhlenbergia. (I. F. f. 323.) Culms 3-9 dm. tall, erect, branched. Leaves 5-17.5 cm. long, 2-6 mm. wide, rough; panicle $7.5-17.5 \mathrm{~cm}$. in length, somewhat lax, the branches $2.5-7.5 \mathrm{~cm}$. long, erect or ascending; outer scales of the spikelet 2.5-3 mm. long, awn-pointed, scabrous ; third scale equalling or somewhat exceeding the outer ones, strongly scabrous, attenuate into a slender awn 2-4 times its length. In moist woods and along streams, N. B. to Ont. and Minu., south to N. Car., Tenn., Neb. and the Ind. Terr. Aug.-Sept.

5. Muhlenbergia ambígua Torr. Minnesota Muhlenbergia. (I. F. f. 324.) Glabrous; culms $3 \mathrm{dm}$. tall or lower, erect, branched, smooth. Sheaths shorter than the internodes; leaves $2.5-7.5 \mathrm{~cm}$. long, 2-4 mm. wide, scabrous; panicle $2.5-7.5 \mathrm{~cm}$. long, rigid, its branches $1.25-2.5 \mathrm{~cm}$. long, dense, appressed; outer scales of the spikelet awn-pointed, unequal, the longer about $4 \mathrm{~mm}$. in length and exceeding the body of the third scale, which is scabrous, villous, and attenuate into an awn 2-3 times its length; a fourth narrow awned scale is nearly always present. Along a lake shore in Minn.

6. Muhlenbergia comata (Thurb.) Benth. Hairy Muhlenbergia. (I. F. f. 325.) Culms 3-7.5 dm. tall, erect, slender, smooth and glabrous. Sheaths shorter than the internodes, smooth or slightly scabrous; leaves $6.2-12.5 \mathrm{~cm}$. long, 2-4 mm. wide, erect, flat, rough; panicle often tinged with purple, 5-10 cm. in length, dense, branches 1.25-3.75 cm. long, erect; outer scales of the spikelet equal, or the second a little the longer, smooth, scabrous on the keel; third scale shorter, smooth and glabrous, bearing an awn 2-3 times its length, the basal hairs silky, erect, fully as long as the scale. On prairies, Kans. (?) and Colo. to Cal. Aug.-Sept.

7. Muhlenbergia tenuifiòra (Willd.) B. S. P. Slender Muhlenbergia. (I. F. f. 326.) Culms 6-9 dm. tall, erect, slender, simple or sparingly branched, smooth. Sheaths usually shorter thin the internodes; leaves $6.25-17.5 \mathrm{~cm}$. long, 2-8 mm. wide, narrowed toward the base, acuminate, scabrous; panicle $1.25^{-2.25}$ $\mathrm{dm}$. long, slender, its branches $2.5-8.75 \mathrm{~cm}$. long, appressed; outer scales of the spikelet unequal. half to two-thirds the length of the third one, awn-pointed, scabrous; third scale 2.5-3 mm. long, scabrous, bearing an awn 2-4 times its length. In rocky woods, Mass. to southern Ont. and Minn., south to Ala. and Tex. Aug.Sept.

8. Muhlenbergia diffùsa Willd. Nimble Will. Dropseed-Grass. (I. F. f. 327.) Culms 3-9 dm. long, decumbent, or often prostrate or creeping and ascending, very slender, diffusely branched. Sheaths shorter than the internodes, loose; leaves 3.75-8.75 cm. long, I-4 mm. wide, scabrous; panicle 5-20 cm. long, slender, somewhat lax, its branches $2.5-5 \mathrm{~cm}$. long, erect, outer scales of the spikelet minute, the lower one often wanting; the third scale, exclusive of the awn, about $2 \mathrm{~mm}$. long, strongly scabrous, particularly upon the nerves; the awn $\mathrm{I}-4 \mathrm{~mm}$. in length. On dry hills and in woods, Me. and southern Ont. to Minn., south to Fla., Kans. and Tex. Aug.--Sept.

9. Muhlenbergia palùstris Scribn. Swamp Muhlenbergia. Culms slender, weak, 6-1o dm. long. Sheaths smooth and glabrous; leaves erect, 3-5 cm. long, about $2 \mathrm{~mm}$. wide, smooth beneath and rough above; panicle slender, contracted, I-I.5 dm. long, its branches appressed; spikelets, exclusive of the awn, 2.5-2.8 mm. long, the first scale shorter than the second, which is about one-third as long as the spikelet; the flowering scale $2.3-2.5 \mathrm{~mm}$. long, shortly 2-toothed at the apex, bearing an awn between the teeth $5.5-8 \mathrm{~mm}$. long, the callus hairy. In a swamp at Washington, D. C. Sept.

I O. Muhlenbergia microspérma (DC.) Trin. Small-seeded MuhlfnberGIA. (I. F f. 328.) Culms I.5-4.5 dm. tall, erect, finally decumbent or somewhat prostrate at base, slender, diffusely branched. Leaves $1.25-6.25 \mathrm{~cm}$. long, $2 \mathrm{~mm}$. wide or less, scabrous; panicle 5-10 $\mathrm{cm}$. in length, slender, open, the branches 2.5 
$\mathrm{cm}$. long or less, ascending or erect; outer scales of the spikelet unequal, obtuse or rounded at apex, about one-third the length of the third scale, which is $2.5-3 \mathrm{~mm}$. long, exclusive of the awn, and strongly scabrous; awn $1.2-2.4 \mathrm{~cm}$. in length. In dry soil, Kans. to Cal., south to Mex.

II. Muhlenbergia capillàris (Lam.) Trin. Long-Awned HaIR-Grass. (I. F. f. 329.) Culms 4.5-12 dm. tall, erect, simple, smooth or nearly so. Sheaths smooth, the lower short and overlapping, the upper ones much longer; leaves I.5-3 $\mathrm{dm}$. long, 2-4 mm. wide, scabrous; panicle $1.75-3 \mathrm{dm}$. in length or more, diffuse, the capillary branches $\mathrm{I}-2 \mathrm{dm}$. long, at length widely spreading; spikelets on long hair-like pedicels which are clavate-thickened at the apex; outer scales unequal, acute or short-awned, slightly scabrous; third scale, exclusive of the awn, 4 $\mathrm{mm}$. long, about twice as long as the first one, scabrous, the awn 6-18 mm. in length. In dry sandy or rocky soil, Mass. to N. J. and Mo., south to Fla. and Tex. Panicle usually light purple. Sept.-Oct.

I2. Muhlenbergia gracíllima Torr. Filiform Muhlenbergia. (I. F. f. 33o.) Culms $1-3.5 \mathrm{dm}$. tall, from a slender creeping rootstock, erect, slender, simple, rigid. Leaves $2.5-5 \mathrm{~cm}$. long, involute-setaceous, smooth or somewhat scabrous, rigid, the basal numerous, usually strongly recurved, the $\mathbf{I}-3 \mathrm{culm}$ leaves ereci or ascending; panicle $5 \mathbf{- 2 2 . 5} \mathrm{cm}$. in length, open, the branches finally widely spreading, $2.5-7.5 \mathrm{~cm}$. long, filiform; spikelets about as long as the filiform pedicels, which are clavate-thickened at the apex; outer scales unequal, usually awnpointed or short-awned, slightly scabrous; third scale $2.5-3 \mathrm{~mm}$. long, longer than the outer ones, sometimes twice as long, scabrous; awn $2-4 \mathrm{~mm}$. long. On prairies, Kans. to Colo., south to Tex. and N. Mex. Sept.-Oct.

I Muhlenbergia pángens Thurb. Prairie Muhlenbergia. (I. F. f. 331.) Culms $1.5-3.75 \mathrm{dm}$. tall, from a creeping rootstock, erect from a decumbent branching base, rigid, minutely pubescent. Sheaths crowded at the base of the culm, scabrous; leaves $2.5-5 \mathrm{~cm}$. long, involute-setaceous, rigid, scabrous; panicle $7.5^{-1} 5 \mathrm{~cm}$. in length, open, the branches $5-6.25 \mathrm{~cm}$. long, single, distant, much divided from near the base, the divisions apparently fascicled; spikelets on long pedicels, which are clavate-thickened at the apex; outer scales, when mature, equalling or often shorter than the body of the third one, scabrous, especially on the keel; third scale, when mature, 1.5-2 mm. long, scabrous, the awn shorter than its body. On prairies, Neb. to Utah, south to Tex. and Ariz. Aug.-Sept.

\section{BRACHYÉLYTRUM Beauv.}

A tall grass with flat leaves and a narrow panicle. Spikelets I-flowered, narrow, the rachilla produced beyond the flower, and sometimes bearing a minute scale at the summit. Scales 3; the outer small and inconspicuous, the lower often wanting; the third much longer, rigid, 5-nerved, acuminate into a long awn; palet scarcely shorter, rigid, sulcate on the back, 2-nerved. Stamens 2. Styles short, distinct. Stigmas plumose, elongated. Grain ob!ong, free, enclosed in the scale and palet. [Greek, in allusion to the minute outer scales.] A monotypic genus of eastern N. Am.

I. Brachyelytrum eréctum (Schreb.) Beauv. Brachyelytrum. (I. F. f. 332.) Culms 3-9 dm. tall, pubescent at and near the nodes. Sheaths more or less villous, especially at the throat: leaves $5-12.5 \mathrm{~cm}$. long, 6-18 mm. wide, scabrous; panicle 5-15 cm. in length, slender, branches $2.5-7.5 \mathrm{~cm}$. long, erect or appressed; outer scales of the spikelet unequal, the upper less than one-third as long as the flowering scale. the lower minute or wanting; third scale, exclusive of the awn, 9-12 $\mathrm{mm}$. long. scabrous, especially on the midnerve, the awn erect, $1.8-2.4 \mathrm{~cm}$. long. Moist places. Newf to western Ont. and Minn., south to N. Car., Tenn. and Kans. July-Aug.

\section{HELEÓCHLOA Host.}

Perennial tufted grasses with flat leaves and spicate or paniculate inflorescence. Spikelets I-flowered. Scales 3 ; the 2 outer empty, somewhat unequal, membranous, acute, ciliate-keeled ; the third scale similar, a little longer; palet shorter, hyaline, 2-nerved. Stamens 3. Styles distinct. Stigmas plumose. Grain oblong, free, loosely enclosed in the scale. [Greek, signifying meadow-grass.] 
About 8 species, chiefly natives of the Mediterranean region, one or two also widely distributed through middle Europe and Asia.

I. Heleochloa schoenoides (L.) Host. Rush Cat-tall Grass. (I. F. f. 333.) Glabrous. Culms $1-4.5$ dn. tall, branched, smooth; sheaths abont half the length of the internodes, the upper loose, the one immediately below the spike inflated and usually partially enclosing it ; leaves $2.5-7.5 \mathrm{~cm}$. long, $2-4 \mathrm{~mm}$. wide, flat, acuninate, smooth beneath, scabrous above; spikelets $2.5 \mathrm{~mm}$. long, the empty scales acute, compresserl, ciliate-keeled, I-nerved; third scale equalling or longer than the second, acute, compressed, ciliate-keeled, otherwise glabrous, I-nerved. In waste places, southem N. Y. to Del. Naturalized from Europe. July-Aug.

\section{PHLÈUM L.}

Annual or perennial grasses with flat leaves and spicate inflorescence. Spikelets I-flowered. Scales 3 ; the 2 outer empty, membranous, compressed, keeled, the apex obliquely truncate, the nidnerve produced into an awn; the third scale much shorter, broader, hyaline, truncate, denticulate at the summit ; palet narrow, hyaline. Stamens 3. Styles distinct, somewhat elongated. Stigmas plumose. Grain ovoid, free, enclosed in the scale and palet. [Name Greek, taken from Pliny ; originally applied to some very different plant.] About Io species, inhabiting the temperate zones of both hemispheres. The following only are natives of N. Am. The English name Cat-tail Grass is applied to all the species.

Spikes usually elongated, cylindric; awns less than one-half the length of the outer scales; upper sheath not inflated. I. P. pratense.

Spikes not elongated, ovoid to oblong and cylindric ; awns about one-half the length of the outer scales; upper sheath inflated.

2. P. alpinum.

I. Phleum praténse L. Timothy. Herd-grass. (I. F.f. 334.) Glabrous and smooth or very nearly so throughout. Culms 3-I2 dm. tall, erect, simple; sheaths usually exceeding the internodes, sometimes shorter, the upper one long and not inflated, or very slightly so ; leaves $7.5-22.5 \mathrm{~cm}$. long, 4-6 mm. wide, smooth or scabrous; spike usually elongated, cylindric, $3.75^{-17.5} \mathrm{~cm}$. in length, $5-8 \mathrm{~mm}$. in diameter; outer scales of the spikelet, exclusive of the awn, 2-5 $\mathrm{mm}$. long, ciliate on the keel, the awn less than half their length. In fields and mead. ows nearly throughout N. Am. Also in Europe and Asia. Widely cultivated for hay. The scales are sometimes modified into small leaves. July-Aug.

2. Phleum alpinum L. Mountain Phleum. (I. F. f. 335.) Glabrous. Culms I.5-4.5 dm. tall, erect or sometimes decumbent at the base, simple, smooth; sheaths often much shorter than the internodes, sometimes longer, the upper one usually much inflated; leaves smooth beneath, scabrous above, the lower 5-7.5 $\mathrm{cm}$. long, 2-8 mm. wide ; upper leaf generally very short, less than $2.5 \mathrm{~cm}$. long ; spike short, ovoid to oblong and cylindric, $1.25-5 \mathrm{~cm}$. in length, 6-12 $\mathrm{mm}$. in diameter; outer scales of the spikelet, exclusive of the awn, $3 \mathrm{~mm}$. long, strongly ciliate on the keel, the awn about one-half their length. Lab. to Alaska, south to the mountains of N. H., Vt., Ariz. and Cal. Also in northern Europe and Asia and in Patagonia. Summer.

\section{ALOPECÙRUS L.}

Annual or perennial grasses with erect or decumbent culms, usually flat leaves and spicate inflorescence. Spikelets I-flowered, flattened: scales 3, the 2 lower empty, acute, sometimes short-awned, more or less united below, compressedkeeled; keel ciliate or somewhat winged ; third scale truncate or obtuse, hyaline, 3-nerved, awner on the back, subtending a perfect flower and usually a palet ; palet hyaline, acute, sometimes wanting. Stamens 3. Styles distinct or rarely united at the base. Stigmas elongated, hairy. [Greek, signifying Fox-tail Grass, in allusion to the spikes.] About 20 species, principally natives of the north temperate zone. Besides the following, some 4 others occur in western N. Am.

Outer scales of the spikelet united for one-half their length, smooth to hispid on the keel. r. A. agrestis.

Outer scales of the spikelet united for one-quarter their length or less, long-ciliate on the keel. 
Scales $2-2.5 \mathrm{~mm}$. in length.

Scales $4-6 \mathrm{~mm}$. in length.

2. A. geniculatus.

Spike $3.75-6.25 \mathrm{~cm}$. long ; outer scales glabrous or sparingly pubescent on the lateral nerves.

Spike $3.75 \mathrm{~cm}$. long or less; outer scales villous.

3. A. pratensis.

4. A. alpinus.

I. Alopecurus agréstis L. Slender Foxtail. (I. F. f. 336.) Smooth or slightly scabrous; culms $3-6 \mathrm{dm}$. tall, erect, simple. Sheaths shorter than the internodes ; leaves $3 \cdot 75-17.5 \mathrm{~cm}$. long, 2-6 mm. wide, scabrous, especially above; spike $3 \cdot 75^{-10} \mathrm{~cm}$. long, 4-8 mm. thick; outer scales of the spikelet united at the base for about half their length, narrowly wing-keeled, 4-5 $\mathrm{mm}$. long, the nerves smooth or scabrous, sometimes hispid below, especially on the keel; third scale equalling or sliglatly exceeding the outer ones, smooth and glabrous, the awn inserted near the base, about twice its length, bent. In waste places and ballast, southern N. Y. and N. J. Adventive trom Europe. Native also of Asia. JulyAug.

2. Alopecurus geniculàtus L. Marsh FoxtaIL. (I. F. f. 337.) Glabrous or very nearly so. Culms $1.5-4.5 \mathrm{dm}$. tall, erect, or sometimes decumbent at the base; sheaths usually shorter than the internodes, loose or somewhat inflated; leaves $2.5^{-15} \mathrm{~cm}$. long, I-4 mm. wide, scabrous, especially above; $2.5-7.5 \mathrm{~cm}$. in length, 4-8 $\mathrm{mm}$. thick; outer scales of the spikelet slightly united at the base, 2-2.5 mm. long, obtuse or subacute, smooth, glabrous except on the pubescent lateral nerves and strongly ciliate keel; third scale somewhat shorter, obtuse, smooth and glabrous, the awn inserted at or below the middle, equalling or exceeding it. In wet soil, Newf. to Br. Col., south to Fla., Tenn., Ariz. and Cal. Also in Europe and Asia. July-Sept.

3. Alopecurus praténsis L. MEadow Foxtall. (I. F. f. 338.) Nearly or quite glabrous. Culms $3-6.25 \mathrm{dm}$. tall, erect, simple; sheaths usually much shorter than the internodes, loose or somewhat inflated; leaves $3 \cdot 75-8.75 \mathrm{~cm}$. long, $2-6 \mathrm{~mm}$. wide, scabrous, at least above; spikes $3.75-6.25 \mathrm{~cm}$. in length, 8-12 mm. thick; outer scales of the spikelet uniting at the base for about one-quarter their length, 4-6 mm. long, acute, glabrous except the sparingly pubescent lateral nerves and the strongly ciliate keel; third scale slightly shorter, obtuse, smooth and glabrous, the awn inserted about quarter way up the scale and exceeding it. In meadows, N. S. to southern N. Y. and Ohio. Naturalized from Europe. June-July.

4. Alopecurus alpinus J. E. Smith. Alpine Foxtall. (I. F. f. 339.) Culms glabrous and smooth or nearly so, 1.25-6 dm. tall, erect, sometimes decumbent at the base, simple. Sheaths generally shorter than the internodes, loose, often inflated; leaves $2.5^{-17.5} \mathrm{~cm}$. long, 2-6 mm. wide, smooth beneath, slightly scabrous above; spike $3.75 \mathrm{~cm}$. in length or less, 6-12 $\mathrm{mm}$. thick; outer scales of the spikelet united only at the base, $4 \mathrm{~mm}$. long, obtuse, villous and ciliate: third scale about equalling the outer ones, obtuse, glabrous except at the villous apex, the awn inserted about one-third the way up, a little exceeding the scale. Greenland and Lab. to Alaska. Also in arctic and alpine Europe and Asia. Summer.

\section{PHÍPPSIA R. Br.}

A low annual tufted grass, with flat leaves and spike-like panicles. Spikelets I-flowered ; scales 3 ; the 2 outer empty, minute, the first often wanting; the third scale thin-membranous, keeled. Palet somewhat shorter, 2-keeled. Stamen I, rarely 2 or 3. Styles short, distinct. Stigmas plumose. Grain oblong, enclosed in the scale and palet, which readily split and allow it to drop out. [In honor of John Constantine Phipps, 1744-1792, arctic navigator.] A monotypic genus of the arctic regions.

I. Phippsia álgida (Soland.) R. Br. Phippsia. (I. F. f. 340.) Smooth and glabrous throughout. Culms $2.5-12.5 \mathrm{~cm}$. tall, erect, simple; leaves $2.5 \mathrm{~cm}$. in length or less, $0.5^{-2} \mathrm{~mm}$. wide, obtuse ; panicle $6-35 \mathrm{~mm}$. in length, contracted; branches 6-18 mm. long, erect or appressed; spikelets I-1.5 mm. long; outer scales minute, unequal, acutish, the first often wanting ; third scale broad, I-nerved, obtuse, or subtruncate and somewhat erose, the palet about two-thirds as long, broad, 2-keeled, erose-truncate. Arctic regions of both the Old World and the New. Summer. 


\section{SPORÓBOLUS R. Br. (See Appendix.)}

Perennial or rarely annual grasses, with flat or convolute leaves and open or contracted panicles. Spikelets generally small, I-flowered, occasionally 2-3. flowered. Scales in the I-flowered spikelets 3, membranous; the 2 outer empty, the first somewhat shorter ; the third scale equalling or longer than the empty ones; palet 2-nerved. Stamens 2-3. Styles very short, distinct. Stigmas plumose. Grain free, and often early deciduous. [Greek, referring to the deciduous grain.] About 80 species, in tropical and temperate regions, very numerous in America. Besides the following, 4 or 5 others occur in the southern and western U. S.

Panicle contracted, spike-like.

Spikelets more than $3.5 \mathrm{~mm}$. in length.

Panicle terminal; upper sheaths $7.5 \mathrm{~cm}$. long or more.

Leaves glabrous or very nearly so.

Third scale of the spikelet acuminate, much longer than the second and usually greatly exceeded by the palet.

1. S. asper.

Third scale of the spikelet acutish or obtuse, somewhat exceeding the secund and equalling or a little shorter than the palet.

Leaves, at least the lower, papillose-hirsute.

Panicles terminal and lateral; sheaths $3.75 \mathrm{~cm}$. long or less.

2. S. longifolius.

3. S. pilosus.

Spikelets $3 \mathrm{~mm}$. long or less.

4. S. vaginaeflorus.

Sheaths inflated, the uppermost usually enclosing the base of the panicle.

Sheaths not inflated; panicle exserted.

5. S. neglectus.

Branches of the panicle not crowded; third scale acuminate.

Outer scales of the spikelet obtuse or abruptly acute, less than half as long as the third scale; ligule about $2 \mathrm{~mm}$. long, acutish.

\section{S. brevifolius.}

Outer scales of the spikelet acuminate and awn-pointed, more than half as long as the third scale; ligule less than $0.5 \mathrm{~mm}$. long, erosetruncate.

7. S. cuspidatus.

Branches of the panicle densely crowded; third scale acute.

Culms decumbent and branched at the base, from a stout horizontal rootstock; panicle short.

Culms erect, simple, tufted; panicle usually elongated.

8. S. Virginicus.

9. S. Indicus.

Panicle open, its branches more or less spreading, at least at maturity.

First scale one-half as long as the second or less.

Branches of the panicle verticillate.

Spikelets $1.5 \mathrm{~mm}$. long, green. $\quad$ ro. S. argutus.

Spikelets $2.5-3 \mathrm{~mm}$. long, purple. $\quad$ iा. S. gracilis.

Branches of the panicle alternate or sometimes subverticillate.

Spikelets about $2 \mathrm{~mm}$. long; first scale lanceolate.

Pedicels equalling or shorter than the spikelets; first scale acute.

Sheaths naked or sparingly ciliate at the throat; panicle usually exserted.

12. S. airoides.

Sheaths densely pilose at the throat; base of the panicle generally included.

13. S. cryptandrus.

Pedicels much longer than the spikelets; first scale narrow, acuminate. I. S. Texanus.

Spikelets 4-5.5 mm. long; first scale subulate, usually awned.

First scale about equalling the second.

14. S, heterolepis.

Perennials; culnıs from long rootstocks.

Culms erect, simple; leaves elongated.

Culms decumbent and branched below ; leaves short.

15. S. Torreyanus.

16. S. asperifolius.

Annuals ; roots fibrous, no rootstocks.

Empty scales but little shorter than the flowering scale, usually pubescent. 18. S. confusus.

Empty scales one-half as long as the flowering scale, glabrous.

19. S. serotinus.

I. Sporobolus ásper (Michx.) Kunth. Rough Rush-Grass. (I. F. f. 341.) Culms 6-1 $5 \mathrm{dm}$. tall, erect. Leaves $7 \cdot 5-35 \mathrm{~cm}$. long, 2-4 mm. wide at the base, 
attenuate into a long slender involute tip, smooth and glabrous beneath, scabrous above, or somewhat hairy at the base; panicle 5-12.5 $\mathrm{cm}$. in length, linear, strict, its branches $2.5-5 \mathrm{~cm}$. long, appressed; spikelets $6-8 \mathrm{~mm}$. long, the outer scales unequal, acute; third scale pubescent at the base, much longer than the second and greatly exceeded by the long-acuminate almost awned palet. In dry soil, Del. to Ill., south to Fla. and Tex. Aug.-Sept.

2. Sporobolus longifòlius (Torr.) Wood. Long-Leaved Rush-grass. (I. F. f. 342.) Culms 4.5-10 dm. tall, erect, occasionally branched. Leaves I$4.5 \mathrm{dm}$. long, 2-4 $\mathrm{mm}$. wide at the base, attenuate into a long slender involute tip, smooth and glabrous beneath, scabrous and hairy at the base above; panicle more or less included in the upper sheath, $7 \cdot 5^{-25} \mathrm{~cm}$. in length, linear, strict, the branches 2.5-5 cm. long, erect; spikelets 4-5 mm. long; outer scales unequal, acutish, glabrous, the lower shorter; third scale glabrous, acutish or obtuse, exceeding the second and equalling or a little shorter than the obtuse palet. In dry soil, Me. to Penn., Neb. and Kans., south to Fla. and Tex. Aug.-Sept.

3. Sporobolus pilosus Vasey. HaIRY Rush-grass. (I. F. f. 343.) Culms 3-4.5 dm. tall, erect, rigid, stout. Ieaves $7.5-15 \mathrm{~cm}$. long, 2-4 mm. wide at base, erect, rigid, attenuate into a slender involute tip, the lower papillose-hirsute on both sides, the upper usually glabrous beneath, scabrous above and somewhat hairy near the base; panicle $5-7.5 \mathrm{~cm}$. in length, included at the base, erect, strict, its branches $1.25-2.5 \mathrm{~cm}$. long, erect; spikelets $5 \mathrm{~mm}$. long, the outer scales unequal, glabrous, obtuse, the lower shorter; third scale obtuse, glabrous, somewhat exceeding the second and equalling or a little longer than the obtuse palet. In dry soil, Kans. and Mo. Aug.-Sept.

4. Sporobolus vaginaeflòrus (Torr.) Wood. Sheathed Rush-Grass. (I. F. f. 344.) Culms 2-4.5 dm. tall, erect, slender. Sheaths usually inflated; leaves $2 \mathrm{~mm}$. wide or less, smooth and glabrous beneath, scabrous and hairy near the base above, attenuate into a slender involute point, the lower elongated, the upper $2.5-7.5 \mathrm{~cm}$. long, setaceous; panicles $1.8-5 \mathrm{~cm}$. in length, the terminal one exserted or sometimes partially included, strict, the branches $1.25 \mathrm{~cm}$. long or less, erect, the lateral ones enclosed in the sheaths; spikelets $3.5-4.5 \mathrm{~mm}$. long, the outer scales unequal, acuminate, the third scale scabrous, sparingly appressed-pubescent, about as long as the second and equalling or slightly exceeded by the very acute palet. In dry soil, N. H. to N. Y., Ill. and Neb., south to Ga. and Tex. Aug.Sept.

5. Sporobolus negléctus Nash. Small Rush-grass. (I. F. f. 345.) Culms 1.5-3 dm. tall, erect from a usually decumbent base, slender. Sheaths inflated; leaves $2 \mathrm{~mm}$. wide or less at the base, smooth and glabrous beneath, scabrous and hairy near the base above, attenuate into a slender point, the lower elongated, the upper $2.5-7.5 \mathrm{~cm}$. long, setaceous; terminal panicle $2.5-6.25 \mathrm{~cm}$. in length, usually more or less included in the upper sheath, strict; lateral panicles enclosed in the sheaths; spikelets about $3 \mathrm{~mm}$. long, the outer scales acute, the third scale acute, glabrous, a little longer than the second and about equalling the acute palet. In dry soil, Mass. to Ky., Neb. and Kans. Aug.-Sept.

6. Sporobolus brevifòlius (Nutt.) Nash. Short-leaved Rush-Grass. I. F. f. 346.) Smooth and glabrous; culms I.5-4.5 dm. tall, arising from a horizontal rootstock, erect, slender, decumbent and branching at the base. Leaves 1.25-5 cm. long, involute-setaceous; panicle $1.25-7.5 \mathrm{~cm}$. in length, usually about $3.75 \mathrm{~cm}$., linear, its branches 6-1 $2 \mathrm{~mm}$. long, erect or appressed; spikelets $2.5-3$ $\mathrm{mm}$. long, the outer scales unequal, less than half as long as the third, obtuse or abruptly acute, scabrous on the keel and at the apex; third scale long-acuminate, sometimes cuspidate, scabrous toward the apex. Anticosti Isl. and Me. to Br. Col., south in the mountains to N. Mex. and Cal. Summer.

7. Sporobolus cuspidàtus (Torr.) Wood. Prairie Rush-grass. (I. F. f. 347.) Smooth and glabrous; culms 3-6 dm. tall, erect, simple or somewhat branched. Leaves $2.5-10 \mathrm{~cm}$. long, less than $2 \mathrm{~mm}$. wide at the base, erect, involute-setaceous, at least when dry; panicle $3.75-12.5 \mathrm{~cm}$. in length, slender, its branches 6-25 $\mathrm{mm}$. long, appressed; spikelets $2.5-3 \mathrm{~mm}$. long, the outer scales half to three-quarters as long, acuminate or cuspidate, scabrous on the keel; third scale long-acuminate and cuspidate, sparingly scabrous. In dry soil, Manitoba to the N. W. Terr., south to Mo. and Kans. Aug.-Sept. 
8. Sporobolus Virginicus (L.) Kunth. Seashore Rush-grass. (I. F. f. 348.) Culms I.5-6 dm. tall, erect or sometimes decumbent, from a stout rootstoci. Sheaths numerous, short, overlapping and crowded at the lower part of the culm, smooth, glabrous or sometimes pilose on the margins and at the throat; leaves 2.5$20 \mathrm{~cm}$. long, $4 \mathrm{~mm}$. wide or less at the base, distichous, acuminate into a long point, involute on the margins and at the apex, smooth beneath, scabrous above or sometimes sparingly hairy; panicle $2.5-7.5 \mathrm{~cm}$. long, 4-10 $\mathrm{mm}$. thick, dense and spikelike, usually exserted; spikelets $2-2.5 \mathrm{~mm}$. long, the outer scales about equal, acute, smoth and glabrous; third scale smooth and glabrous, acute, slightly shorter than the second and about equalling the obtuse palet. On sandy shores, Va. to Fla., west to Tex. and Mex., Also in Cuba. Aug.-Sept.

\section{Sporobolus Indicus (L.) R. Br. India Rush-grass. Smut-grass.} (I. F f. 349.) Glabrous and smooth throughout. Culms 3-12 dm. tall, erect, tufted; leaves 2-6 $\mathrm{mm}$. wide, attenuate into a long slender point, the lower 2-3 dm. long, the upper shorter; panicle I-4 dm. in length, usually elongated, narrow, spike-like; spikelets $1.5-2 \mathrm{~mm}$. long, the outer scales unequal, about half as long as the third, obtuse, smooth and glabrous, the lower one shorter, and often erose-truncate; third scale acute, somewhat exceeding the obtuse or acutish palet. In meadows and waste places, Va. to Fla, west to Ark. and Cal. Naturalized from tropical regions; very abundant in Cent. and S. Am. July-Sept.

Io. Sporobolus argùtus (Nees) Kunth. Pointed Dropseed-Grass. (I. F. f. $35^{\circ}$.) Culms $3 \mathrm{dm}$. tall or less, erect, or somewhat decumbent at the base. Sheaths shorter than the internodes, their margins sometimes hirsute at the top; leaves $2.5-5 \mathrm{~cm}$. long, 2-4 $\mathrm{mm}$. wide at the hase, acuminate, smooth and glabrous beneath, scabrous, and often sparingly hairy at the base above; panicle $3.75-7.5$ $\mathrm{cm}$. in length, the branches $1.25-2.5 \mathrm{~cm}$. long, verticillate, at first appressed, finally widely sprealing; spikelets $1.5 \mathrm{~mm}$. long; outer scales smooth and glab. rous, the first rounded or obtuse, one-quarter the length of the acute second one; third scale about equalling the second, acute. Kans., the Ind. Terr. and Colo., south to Tex. and Mex. Also in the West Indies. July-Sept.

I I. Sporobolus gracilis (Trin.) Merr. Purple Dropseed-grass. WireGRASS. (I. F. f. 35I.) Glabrous and smooth throughout. Culms 3-6 dm. tall, tufted, erect, slender. simple; leaves filiform or setaceous, the basal $1.5-3 \mathrm{dm}$. long, numerous, those of the culm few, $2.5-7.5 \mathrm{~cm}$. long; panicle $7.517 .5 \mathrm{~cm}$. in length, open, the branches verticillate, the lower $2.5-5 \mathrm{~cm}$. long, widely spreading; spikelets $2.5-3 \mathrm{~mm}$. long, purple, the outer scales very unequal, tle first cbtuse or acutish, one-fourth to one-third the length of the acute second one; third scale subacute or blunt, equalling the second and the obtuse palet. Dry sandy soil, Vat. to Fla., west to Tex. Aug.-Sept. (Sporobolus junceus (Mx.) Kth.; not Agrostis juncea Lam.; S. ejuncidus Nash.)

12. Sporobolus airoìdes Torr. Hair grass Dropsefd. (I. F. f. 352.) Culms 4.5-9 dm. tall, erect, simple. Leaves smooth beneath, scabrous above and sometimes sparingly hairy near the Jase, $\mathrm{I}-3 \mathrm{~mm}$. wide at the base, attenuate into a long slender involute point, the basal about one-half as long as the culm, the upper culm leaves $5-12.5 \mathrm{~cm}$. in length; panicle $1.25-4 \mathrm{dm}$. long, usually exserted, the branches alternate or the upper verticillate, at length widely spreading, the lower $75^{-17.5} \mathrm{~cm}$. long; spikelets $1.5-2 \mathrm{~mm}$. long, the scales acute, glabrous, the outer unequal, the lower one about half as long as the upper; third scale equalling the second and the palet. Prairies, Neb. to Cal., south to Tex. and Ariz. Aug.Sept.

13. Sporobolus cryptándrus (Torr.) A. Tray. SAND Dropseed. (I. F. f. 353.) Culms 4.5-10.5 dm. tall, erect. Sheaths with a dense pilose ring at the summit, the lower short, crowded and overlapping, the upper much longer, generally enclosing the base of the panicle; leaves $7 \cdot 5-15 \mathrm{~cm}$. long, 2-4 mm. wide, flat, glabrous beneath, scabrous above, long-acuminate; panicle $1.5-2.5 \mathrm{dm}$. in length, the branches spreading or ascending, alternate, the lower $3.75-7.5 \mathrm{~cm}$. long; spikelets $2-2.5 \mathrm{~mm}$. long, the scales acute, glabrous, the outer scabrous on the keel, the lower one-third as long as the upper; third scale somewhat longer or shorter than the second. In sandy soil, coast of N. E., along all the Great Lakes, west to Dak., south in the interior to Mo., Tex. and Mex. Aug.-Oct. 
Culms 3-9 dm. tall, erect. Leaves involute-setaceous, glabrous, the margins and upper part of the midrib very rough, the basal about three-fourths the length of the culm, occasionally equalling it, those of the culm shorter; panicle $7.5-25 \mathrm{~cm}$. in length, its branches erect or ascending, alternate or subverticillate, the lower 3.75$8.75 \mathrm{~cm}$. long; spikelets $4-5.5 \mathrm{~mm}$. long, the scales smooth and glabrous, the outer unequal, acuminate, the lower subulate, about half the length of the broad second one, often awn-pointed; third scale obtuse or acute, shorter than the second or occasionally equalling it. In dry soil, Quebec to Assiniboia, south to Penn., Ill., Neb. and Ark. Aug.-Sept.

I 5. Sporobolus Torreyànus (R. \& S.) Nash. Flat-Stemmed Dropseed. (I. F. f. 356.) Culms 3-6 dm. tall, from a horizontal rootstock, stout, simple, much compressed, smooth and glabrous. Sheaths compressed, overlapping, some-

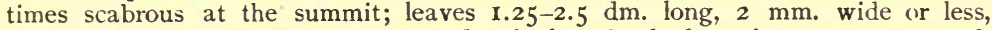
folded. slightly rough; panicle $\mathbf{I}-2.5 \mathrm{dm}$. in length, the branches erect or ascending, the lower $5-7.5 \mathrm{~cm}$. long; spikelets about $\mathbf{1} .75 \mathrm{~mm}$. long; outer scales subequal, obtuse or somewhat acute, smooth and glabrous; third scale obtuse and apiculate, strongly scabrous, slightly exceeding the outer ones. In bogs, L. I. and in the pine barrens of N. J. Sept.-Oct. (Sporobolus compressus (Torr.) Kth. Not Agrostis compressa Willd.)

16. Sporobolus asperifòlius Nees \& Meyen. Rovgh-Leaved Dropseed. (I. F. f. 357.) Culms 1.5-4.5 dm. tall, erect from a decumbent and branched base. Sheaths short, crowded and overlapping; leaves numerous, $2.5-8.75 \mathrm{~cm}$. long, 2-3 mm. wide at the base, acuminate, strict, often erect, flat, glabrous, smooth beneath, very rough above; panicle $7 \cdot 5-20 \mathrm{~cm}$. in length, included at the base, rarely entirely exserted, the capillary branches spreading or ascending, the lower $5-10 \mathrm{~cm}$. long; spikelets occasionally 2-3-flowered, $1.5 \mathrm{~mm}$. long; outer scales subequal, acute, glabrous, sparingly scabrous; third scale obtuse or acute, glabrous, somewhat exceeding the second. Dry soil, Assiniboia to Br. Col., south to Mo., Neb., Cal. and Mex. Aug.-Sept.

17. Sporobolus Texànus Vasey. Texas Dropseed. Culms 3-6 dm. tall, branching below. Sheaths crowded, the lower ones papillose-hirsute; leaves erect, firm, 4-15 $\mathrm{cm}$. long, 3-5 $\mathrm{mm}$. wide, smooth beneath, very rough above; panicle included at the base, the upper branches finally widely spreading, $5-10 \mathrm{~cm}$. long; spikelets a little exceeding $2 \mathrm{~mm}$. long, on long slender pedicels; scales smooth and glabrous, the first scale narrow, acuminate, less than one-half as long as the second. which equals the third scale. Kans. (according to B. B. Smyth) to Tex. and N. Mex. Aug.

I8. Sporobolus confùsus Vasey. Culms tufted, I-3 dm. tall, slender, from an anrial root. Leaves $\mathrm{I}-4 \mathrm{~cm}$. long, $1.5 \mathrm{~mm}$. or less wide ; panicle open, 3-20 cın. long, its slender branches spreading or ascending, the longer $1.5-4 \mathrm{~cm}$. long; spikelets $1.25-1.5 \mathrm{~mm}$. long, on capillary pedicels which are abruptly thickened at the apex, the empty scales shorter than the flowering scale, glabrous or pubescent, the flowering scale usually pubescent, sometimes glabrous. Neb. (according to Rydberg) and Colo. to Tex., Ariz. and Mex. July-Sept.

19. Sporobolus serótinus (Torr.) A. Gray. Late-flowering Dropseed. (I. F. f, 355.) Glabrous and smooth or very nearly so. Culms $1.5-4.5 \mathrm{dm}$. tall, from an annual root, erect, slender; sheaths short, confined to the lower part of the culm; leaves I mm. wide or less, slightly scabrous above, flat, the basal one-third to half the length of the culm, those of the culm $5^{-10} \mathrm{~cm}$. long ; panicle $7.5^{-22.5} \mathrm{~cm}$. in length, the branches capillary, erect or ascending, the lower $2.5-6.25 \mathrm{~cm}$. long; spikelets about $1.25 \mathrm{~mm}$. long, the outer scales subequal, obtuse, smooth or sometimes sparingly scabrous; third scale twice the length of the outer ones, acuminate. In wet sandy soil, Maine to Mich., south to N. J. Sept.-Oct.

\section{POLYPÒGON Desf.}

Mostly annual grasses, with decumbent or rarely erect culms, flat leaves and spike-like panicles. Spikelets I-flowered; scales 3 ; the 2 outer empty, each extended into an awn; third scale smaller, generally hyaline, short-awned from below the apex, subtending a palet and perfect flower; palet shorter than the scale. Stamens I-3. Styles short, distinct. Stigmas plumose. Grain free, enclosed in 
the scale and palet. [Greek, in allusion to the many long awns which resemble a beard.] About Io species, widely distributed in temperate and warm regions, rare in the tropics.

I. Polypogon Monspeliénsis (L.) Desf. Beard-grass. (I. F. f. $35^{8}$.) Culms $6 \mathrm{dm}$. tall or less, erect from a usually decumbent base. Leaves 3.75-15 $\mathrm{cm}$. long, 3-6 mm. wide, scabrous, especially above; panicle $2.5-10 \mathrm{~cm}$. in length, dense and spike-like, the branches $1.25 \mathrm{~cm}$. in length, ascending; spikelets crowded; outer scales about $2 \mathrm{~mm}$. long, obtuse, slightly bifid, scabrous, bearing a more or less bent awn 4-6 $\mathrm{mm}$. long; third scale much shorter, erose-truncate, hyaline, bearing a delicate awn about $0.5 \mathrm{~mm}$. long, inserted below the apex. In waste places, N. H. to S. Car., mostly near the coast. Very abundant in western N. Am., from Br. Col. to Mex. Naturalized from Europe. Native also of Asia. July-Sept.

\section{ARCTAGRÓSTIS Griseb.}

A perennial grass with flat leaves and contracted panicle. Spikelets I-flowered. Scales 3 ; the 2 outer empty, unequal, somewhat acute, membranous; the third scale exceeding the second, subtending a palet and perfect flower, obtuse; palet obtuse, 2-nerved. Stamens 2 or 3. Styles distinct, short. Stigmas plumose. Grain oblong, free, enclosed in the scale and palet. Seed adherent to the pericarp. [Latin, signifying an arctic Agrostis-like grass.] A monotypic genus of arctic and subarctic regions.

r. Arctagrostis latifòlia (R. Br.) Griseb. Arctagrostis. (I. F. f. 359.) Culms 1.5-6 dm. tall, erect, or sometimes decumbent at the base, simple, smooth and glabrous. Sheaths shorter than the internodes; leaves $2.5-17.5 \mathrm{~cm}$. long, $2-8$ $\mathrm{mm}$. wide, usually erect, scabrous: panicle $3.75-20 \mathrm{~cm}$. long, narrow, its branches I. 25-5 cm. in length, ascending or erect; spikelets 3-4 mm. long; outer scales unequal, acutish, the lower about two-thirds to three-fourths the length of the upper; third scale obtuse, exceeding the second, hispid on the keel. Greenland to Hudson Bay and Alaska. Also in arctic Europe and Asia. Summer.

\section{CÍNNA L.}

Tall grasses with flat leaves and panicled spikelets. Spikelets I-flowered. Scales 3 ; the 2 outer empty, keeled, acute; the third scale similar, but usually shortawned on the back, subtending a palet and a stalked perfect flower; palet a little shorter, I-nerved. Stamen I. Styles short, distinct. Stigmas plumose. Grain narrow, free, enclosed in the scale and palet. Seed adherent to the pericarp. [Greek, taken from Dioscorides.] Four known species, inhabiting the temperate regions of Europe and N. Am. Besides the following, another occurs in the western U.S.

Panicle narrow at maturity, its filiform branches erect or drooping; spikelets 4-5 mm. long; first scale much shorter than the second. I. C. arundinacea. Panicle open, its capillary branches flexuous and drooping; spikelets $3 \mathrm{~mm}$. long; first scale about equalling the second.

2. C. latifolia.

I. Cinna arundinàcea L. Wood ReED-Grass. (I. F. f. 360.) Culms 6-15 $\mathrm{r} \mathrm{m}$. tall, erect. Leaves $\mathrm{I}$.5-3 dm. long, 4-14 mm. wide, scabrous; panicle $1.5-3 \mathrm{dm}$. in length, usually contracted, sometimes purple, the filiform branches erect or drooping, the lower $3.75-11.25 \mathrm{~cm}$. long; spikelets $4-5 \mathrm{~mm}$. in length, the scale; acute, scabrous, especially on the keel, the first one shorter than the second; third scale slightly exceeded or equalled by the second, usually bearing an awn about 0.5 $\mathrm{mm}$. long from the 2 -toothed apex. In moist woods and swamps, Newf. to the N. W. Terr., south to N. Car., La., Mo. and Tex. Aug.-Sept.

2. Cinna latifòlia (Trev.) Griseb. Slender WoOD ReEd-grass. (I. F. f. 36r.) Culms 6-12 dm. tall, erect. Leaves $\mathbf{r}-2.5 \mathrm{dm}$. long, 4-12 mm. wide, scabrous; panicle $1.25-2.5 \mathrm{dm}$. in length, open, the capillary branches generally spreading, flexuous and often drooping, the lower $3.75-12.5 \mathrm{~cm}$. in length; spikelets $3 \mathrm{~mm}$. long; scales scabrous, the outer acute, strongly hispid on the keel, the first about equalling the second; third scale usually exceeded by the second and bear. 
ing a rough awn $\mathbf{I}-2 \mathrm{~mm}$. long from the 2-tıothed apex. In damp woods, Newf. to Br. Col., south to N. J., in the Alleghanies to N. Car., to Wis., and in the Rocky Mts. to Colo. and Utah. Also in Northern Europe. Aug.-Sept. [C. pendula Trin.]

\section{4r. AGRÓSTIS L.}

Annual or perennial tufted grasses with flat or bristle-like leaves and paniculate inflorescence. Spikelets I-flowered. Scales 3; the 2 outer empty, membranous, keeled, acute; the third shorter, obtuse, hyaline, sometimes bearing a dorsal awn, subtending a perfect flower; palet shorter than the scale, sometimes minute or wanting. Stamens usually 3. Styles distinct, short. Stigmas plumose. Grain free, enclosed in the scale. Seed adherent to the pericarp. [Name Greek, ruferring to the field habitat of many species.] A genus of about 100 species, widely distributed throughout the world, particularly numerous in temperate regions. Besides the following, some 15 others are found in western N. Am.

Palet conspicuous, at least one-third as long as the scale.

Panicle open, its branches long and usually spreading.

Panicle dense and contracted, spike-like, its branches short and appressed.

2. A. coarctata.

Palet inconspicuous, minute or wanting.

Branches of the contracted panicle short, spikelet-bearing to the base; third scale awnless.

3. A. asperifolia.

Branches of the panicle slender, naked below, spikelet-bearing from about the middle to the end.

Third scale awned.

Awn very finely filiform, barbellate, at least twice the length of the spikelet. 4. A. Elliottiana.

Awn stouter, glabrous, rigid, usually bent, less than twice the length of the spikelet.

Branches of the panicle generally ascending; spikelets $2 \mathrm{~mm}$. long.

Culms $1.5 \mathrm{dm}$. or less tall; panicle $2.5 \mathrm{~cm}$. or less long; a tufted alpine grass.

Culms 3-6 dm. tall; panicle exceeding $5 \mathrm{~cm}$. long.

5. A. rupestris.

6. A. canina.

Branches of the panicle usually spreading; spikelets $2.5-3 \mathrm{~mm}$. long. 7. A. rubra.

Third scale not awned, or very rarely bearing a short awn.

Culms weak, usually decumbent and often prostrate at base; leaves lax; spikelets $1.5 \mathrm{~mm}$. long.

Culms and leaves erect.

8. A. perennans.

Branches of the panicle capillary, elongated, usually dividing above the middle, the spikelets crowded at the extremities.

Spikelets 1.5-2 mm. long; leaves short. 9. A. hyemalis.

Spikelets $2.5-3 \mathrm{~mm}$. long; leaves elongated.

Io. A. altissima.

Branches of the panicle not elongated, dividing at or below the middle. Spikelets about $2 \mathrm{~mm}$. long; a grass of low elevations.

Spikelets 2.5-3 mm. long; a high-mountain gra.s.

Ix. A. intermedia.

I2. A. Novae-Angliat.

I. Agrostis álba L. Red-Top. Fiorin. Herd-grass. (I. F. f. 362.) Culms 2-7.5 dm. tall, erect or decumbent at the base, often stoloniferous, simple, smooth and glabrous. Leaves 5-20 $\mathrm{cm}$. long, 2-6 mm. wide, scabrous; panicle 5-22.5 cm. in length, usually open, or sometimes contracted after flowering, green or purplish, the branclies ascending or erect, the lower $2.5-7.5 \mathrm{~cm}$. long; spikelets 2-2.5 mm. long; outer scales about equal, acute, smooth and glabrous, except on the hispid or scabrous keel; third scale shorter, obtuse or acute, the palet at least one-third its length. A most variable species, occurring in fields and meadows nearly throughout N. Am., extensively cultivated for fodder. Naturalized from Europe, and perhaps also native northward. July-Sept.

2. Agrostis coarctàta Ehrh. DENSE-Flowered Bent-grass. (I. F. $f$. 362a.) Glabrous. Culms tufted, erect, or decumbent at the base and often rooting at the lower nodes, 3-5 dm. tall, at len-rtil branching; leaves erect, rough on 
both surfaces, $3 \cdot 75-8.75 \mathrm{~cm}$. long, $3 \mathrm{~mm}$. or less wide; panicle dense and contracted, 3.75-10 cm. long, 6-12 mm. thick, its branches erect, the longer $3.1 \mathrm{~cm}$. long or less; spikelets $2-2.5 \mathrm{~mm}$. long; empty scales acute, the flowering scale about three-quarters as long as the spikelet, denticulate at the truncate or rounded apex; palet about one-half as long as the scale. Me. to N. J. Also in Europe. July-Sept.

3. Agrostis asperifollia Trin. Rovgh-Leaved Bent-Grass. (I. F. f. 363.) Culms 3-9 dm. tall, erect, or sometimes decumbent at the base. Leaves $2.5-20 \mathrm{~cm}$. long, $2-8 \mathrm{~mm}$. wide, generally erect, flat, very rough; panicle contracted, $6.25-25 \mathrm{~cm}$. in length, often interrupted or glomerate, the branches $3.75-7.5 \mathrm{~cm}$. in length, erect, spikelet-bearing to the base; spikelets crowded, 2-2.5 $\mathrm{mm}$. long, the outer scales scabrous, especially on the keel; third scale about three-fourths the length of the second; palet minute. Manitoba to Wash., south to Wis., Neb., Tex. and Cal. Aug.-Sept. (A. exarata Trin. in part.)

4. Agrostis Ellicttiana Schultes. ElliotT's Bent-Grass. (I. F. f. 364 .) Culms I.25-3.5 dm. tall, erect, slender. Leaves rough, $1.25-5 \mathrm{~cm}$. long, $2 \mathrm{~mm}$. wide or less; panicle 5-12.5 $\mathrm{cm}$. in length, usually narrow, sometimes open, the branches slender, naked below, erect or ascending, the lower $2.5-3.75 \mathrm{~cm}$. long; spikelets $1.5 \mathrm{~mm}$. long; outer scales subequal, scabrous on the keel, acute; third scale about three-quarters as long as the first, erose-truncate, acute or 2-toothed, bearing a very finely filiform flexuous barbellate awn, 2-4 times its length, inserted just below the apex; palet short. In dry soil, S. Car. to Ky. and Kans., south to Fla. and Tex. May-July.

5. Agrostis rupéstris Allioni. Rock Bent-Grass. (I. F. f. 365a.) Culms tufted, I. $5 \mathrm{dm}$. tall or less, slender, erect, or decumbent at the base. Leaves smooth and glabrous, those on the culm $2.5 \mathrm{~cm}$. or less long, the basal leaves from one-third to one-half as long as the culms; panicle contracted, $2.5 \mathrm{~cm}$. or less long, its axis and branches smooth, the latter erect or nearly so, spikelet-bearing above the midlde; spikelets about $2 \mathrm{~mm}$. long; flowering scale hyaline, denticulate at the obtuse or truncate apex, bearing about the niddle a dorsal scabrous awn a little over $2 \mathrm{~mm}$. long; palet wanting. Lab. and the high mountains of Nev. Also in Europe. Summer.

6. Agrostis canina -.. Brown Bent-grass. (I. F. f. 365 .) Culms 3-6 dm. tall, erect, slender, simple. Leaves $2.5-7.5 \mathrm{~cm}$. in length, $2 \mathrm{~mm}$. wide or less, scabrous; panicle 5-17.5 cm. in length, contracted in fruit, the branches slender, naked below, ascending or spreading in flower, the lower $2.5-6.25 \mathrm{~cm}$. long; spikelets $2 \mathrm{~mm}$. long, on appressed pedicels, the outer scales subequal, acute, strongly scabrous on the keel; third scale alsout two-thirds the length of the first, obtuse, smooth and glabrous, bearing a straight or somewhat bent dorsal awn 2-4 $\mathrm{mm}$. long, inserted just above the middle; palet minute or none. In meadows, Newf. to Alaska, south to Penn. and Tenn. Native northward; naturalized from Europe southward. A variable species. July.-Sept.

7. Agrostis rùbra L. Red Bent-grass. (I. F. f. 366.) Smooth or very nearly so, glabrous. Culms I.5-6 dm. tall, erect or sometimes decumbent at the base, simple ; leaves 5-10 $\mathrm{cm}$. long, I-3 mm. wide ; panicle $6.25^{-12.5} \mathrm{~cm}$. in length, open, the branches generally widely spreading and more or less flexuous, rarely erect, the lower $2.5-6.25 \mathrm{~cm}$. long; spikelets $2.5-3 \mathrm{~mm}$. long, the outer scales acute, scabrous on the keel; third scale shorter than the first, obtuse, bearing a usually bent dorsal awn 4-5 mm. long, inserted helow the middle. Summits of the highest mountains of N. E., N. Y. and N. Car. The American plant may be specifically different from the European. Summer.

8. Agrostis perénnans (Walt.) Tuckerm. Thin-Gr.Ass. (I. F. f. 367.) Culms 3-7.5 dm. long from a decumbent or prostrate base, weak, slender, simple or sparingly branched above, smooth and glabrous. Leaves 5-15 cm. long, 2-4 $\mathrm{mm}$. wide, lax. scabrous; panicle $\mathrm{I}-2 \mathrm{dm}$. in length, open, the branches $2.5-5 \mathrm{~cm}$. long, widely spreading, the branchlets and pedicels divergent; spikelets 1.5-2 $\mathrm{mm}$. long, the outer scales acute, scabrous on the keel; third scale about threequarters the length of the first, smooth and glabrous, not awned; palet small or wanting. In shaded, damp places, Quebec and Ont. to Wis., south to S. Car. and Kıns. Panicle usually light gresn, sometimes purplish. July-Sept.

9. Agrostis hyemàlis (Walt.) L. S. P. ROUGH HaIR-GRASS. (I. F. f. 368.) 
Culms 3-6 dm. tall, erect, slender. Leaves $5-12.5 \mathrm{~cm}$. long, $\mathbf{r}-3 \mathrm{~mm}$. wide, usually erect, roughish; panicle $\mathbf{1} \cdot 5^{-6} \mathrm{~d}$.. long, usually purplish, the capillary scabrous branches ascending, sometimes widely spreading, or often drooping, the lower $7 \cdot 5-15 \mathrm{~cm}$. long, dividing above the middle, the divisions spikelet-bearing at the extremities; spikelets $1.5^{-2} \mathrm{~mm}$. long, the outer scales acute, scabrous toward the apex and on the keel; third scale two-thirds the length of the first or equalling it. obtuse, rarely bearing a short awn; pilet usually very small. In dry or moist soil throughout nearly the whole of $\mathrm{N}$. Am. except the extreme north. July-Aug.

ro Agrostis altíssima (Walt.) Tuckerm. TAll Bent-grass. (I. F. f. 369. ? Culms 6-12 dm. tall, erect. Leaves elongated, 1.5-3 dm. in length, 2-3 mm. wide. scabrous; panicle $\mathbf{1} \cdot 75^{-2.25} \mathrm{dm}$. long, the branches ascending or erect, somewhat scabrous, the lower 5-10 cm. in length, spikelet-bearing at the extremities; spikelets 2.5-3 mm. long, the outer scales acute, scabrous on the keel; third scale shorter. obtuse, scabrous, occasionally bearing a short awn; palet small or wanting. In sandy swamps, N. J. to Fla. and Ala. Panicle usually purplish. Aug.-Oct.

I I. Agrostis intermèdia Scribn. Upland BeNT-GRass. (I. F. f. 37o.) Culms 3-9 dm. tall, erect. Sheaths smooth, those at the base of the culm often crowded and overlapping; leaves $\mathbf{I}-2.25 \mathrm{dm}$. long, 2-6 mm. wide, scabrous; panicle $I-2.25 \mathrm{dm}$. in length, the branches $3.75-7.5 \mathrm{~cm}$. long, ascending, dividing at the middle or below, the divisions divergent, the pedicels appressed; spikelets about 2 $\mathrm{mm}$. long, the outer scales acute or acuminate, scabrous on the keel; third scale about three-fourths the length of the first, smooth; palet small or wanting. In dry soil, Mass. to N. Y., Tenn. and Mo. Aug.-Oct.

12. Agrostis Nòvae-Ángliae Tuckerm. New England Bent-grass. (I. F. f. 37I.) Culms $2-4 \mathrm{dm}$. tall, erect. Sheaths longer than the intcrnodes, generally overlapping; leaves $2.5 \cdot 8.75 \mathrm{~cm}$. long, $2 \mathrm{~mm}$. wide or less, erect, usually involute, scabrous; panicle $1-2 \mathrm{dm}$. in iength, open, the branches spreading or ascending, dividing at or below the middle, the divisions divergent, the pedicels often appressed; spikelets $2.5-3 \mathrm{~mm}$. long, the outer scales acute, strongly scabrous on the keel; third scale somewhat shorter, obtuse. Newf., south to the high mountains of N. E., N. Y. and N. Car.

\section{CALAMAGRÓsi is Adans.}

Generally perennial grasses, various in habit, with flat leaves and paniculate inflorescence. Spikelets I-flowered, the rachilla usually prolonged beyond the flower and pubescent. Scales 3 ; the 2 outer empty, carinate, membranous; the third scale hyaline, shorter than the outer, obtuse, usually copiously long-hairy at the base, or rarely the hairs scanty or short, and bearing a straight, bent, or twisted dorsal awn; palet shorter, 2-nerved. Stamens 3. Styles short, distinct. Stigmas plumose. Grain free, enclosed in the scale. Seed adherent to the pericarp. [Greek, signifying Reed-grass.] A genus of about I30 species, widely distributed throughout temperate and mountainous regions, and particularly numerous in the Andes. Besides the following, some 20 others occur in the western parts of N. Am. The English name Small-reed is applied to any of the species.

Prolongation of the rachilla hairy its whole length.

Awn strongly bent, manifestly exserted, the hairs of the callus much shorter than the scale.

Sheaths usually naked at the summit, rarely bearded; panicle tinged with purple; empty scales rather thick.

Sheaths bearded at the summit; panicle pale; empty scales thin.

Spikelets 4-6 mm. long; callus-hairs sparse; palet equalling the scale or nearly so.

2. C: lorteri.

Spikelets 3.5-4 mm. long; callus-hairs rather copious; palet considerably shorter than the scale.

3. C. nemoralis.

Awn straight or nearly so, included, the hairs of the callus equalling or but little shorter than the scale.

Panicle open, the lower rays widely spreading.

Spikelets 4-6 mm. long, very acuminate.

Spikelets 3-4 $\mathrm{mm}$. long; panicle usually loosely flowered.

Spikelets $2-2.5 \mathrm{~mm}$. long; panicle rather densely flowered.

4. C. Langsdorfii.

5. C. Canadensis.

6. C. Macouniana, 
Panicle more or less contracted,

Culms and almost filiform leaves $\_i t$, not rigid.

Culms and wider leaves hard, more or less rigid.

7. C. neglecta.

Panicle elongated, rather loosely flowered; culms not tufted or but little so.

Panicle short, dense and spike-like; culms strongly tufted.

Panicle narrow, much interrupted below; awn much shorter than the scale.

9. C. Labradorica.

Panicle thick, continuous or but little interrupted; awn about equalling the scale.

Prolongation of the rachilla hairy only at the summit.

ro. C. hyperborea.

I1. C. cinnoides.

I. Calamagrostis brevisèta (A. Gray) Scribn. Pickering's Reed-Grass. (I. F. f. 376.) Culms 3-4.5 dm. tall, erect, rigid, simple, scabrous below the panicle. Sheaths smooth and glabrous, the lowcr overlapping, the upper one elongated; leaves $3.75^{-10} \mathrm{~cm}$. long, $4 \mathrm{~mm}$. wide, erect, smooth bencath, rough above; panicle $7.5-11.25 \mathrm{~cm}$. in length, the branches ascending or crect, the lower $2.5-3.75 \mathrm{~cm}$. long; spikelets 3-4 mm. long, purple tinged, the outer scales acute, scabrous on the keel; third scale shorter than the second, obtuse, scabrous, the basal hairs very short; awn bent, not twisted, equalling or slightly exceeding the scale. In wet places, Cape Breton Isl. to N. H. and Mass. Occurs in the alpine regions of the White Mts. Aug.-Sept.

Calamagrostis breviseta débilis Kearney. Differs from the above in its softer texture, usually lower and more slender culms, thinner leaves, smaller panicles and the narrower and thinner empty scales. Newf. to Mass.

Calamagrostis breviseta lacústris Kearney. Differs from the species in its stouter rootstock and taller culms, which are usually $5^{-10} \mathrm{dm}$. tall, in its often longer panicle, its shorter palet and the copious and longer callus hairs of the flowering scale. Mountains of N. E.; also along the Great Lakes from Ont. to Minn.

2. Calamagrostis Pòrteri A. Gray. Porter's Reed-grass. (I. F. f. 375.) Culms 6-I2 dm. tall, erect, simple, smooth and glabrous. Sheaths slightly sca. brous, with a villous ring at the summit; leaves $1.5-3 \mathrm{dm}$. long, 4-8 mm. wide, rough; panicle I-2 dm. in length, the branches erect, the lower $2.5-5 \mathrm{~cm}$. long; spikelets $4-6 \mathrm{~mm}$. long, the outer scales strongly scabrous, acute; third scale shorter than or equalling the second, obtuse, scabrous, the basal hairs less than one-half the length of the scale, sparse; awn bent, about equalling the scale, the lower part much twisted. In dry woods, Penn. and southern N. Y. Aug.-Sept.

3. Calamagrostis nemoràlis Kearney. Wood ReEd-Grass. Slightly glaucous. Culms 1O-I5 dm. tall, rather slender; sheaths loosely embracing the culm, usually tomentose at the apex, glabrous; leaves 3-6 mm. wide, flat, very rough on both surfaces, the lower ones and those on the innovations 2-3.5 dm. long; panicle I-I.5 dm. long, contracted; spikelets numerous, 3.5-4 mm. long, the empty scales acuminate, the awn of the flowering scale attached about one-fifth above the base, slightly exceeding the scale, stout, bent near the middle, the palet about three. fifths as long as the scale. Woods, Me. and western N. Y.

4. Calamagrostis Langsdórfii (Link) Trin. Langsdorf's- ReEd-GRass. (I. F. f. 374.) Culms 3-6 dm. tall, erect, simple, smooth or roughish. Sheaths shorter than the internodes; leaves I-3 dm. long, 4-8 mm. wide, scabrous; panicle $5^{-15} \mathrm{~cm}$. in length, the branches ascending or sometimes erect, the lower $2.5-5 \mathrm{~cm}$. long, naked at the base; spikelets $4-6 \mathrm{~mm}$. long, the outer scales acuminate, strongly scabrous; the third scale equalling or shorter than the second, scabrous, the stout awn as long as or a little exceeding the copious basal hairs which are usually somewhat shorter than the scale. Newf. to Alaska, south to the mountains of N. E. and N. Y., and to Manitoba and Wash. Also in northern Europe and Asia. Summer.

5. Calamagrostis Canadénsis (Michx.) Beauv. Blue Jornt-Grass. (I. F. f. 373.) Culms 6-15 dm. tall, erect, simple, smooth or somewhat scabrous. Sheaths shorter than the internodes; leaves $\mathbf{I} .5-3 \mathrm{dm}$. long or more, $2-8 \mathrm{~mm}$. wide, rough; panicle $\mathrm{I}-2 \mathrm{dm}$. in length, open, usually purplish, the branches spreading or ascending, the lower $3.75-7.5 \mathrm{~cm}$. long, naked at the base; spikelets $3 \mathrm{~mm}$. long, the outer scales equal or subequal, acute, strongly scabrous; the third scale equalling 
or slightly shorter than the second, scabrous, the awn delicate and equalling the copious basal hairs which are about as long as the scale or some of them shorter. In swamps and wet soil, Newf. to Alaska, south to N. Car., N. Mex. and Cal. Ascends to $1500 \mathrm{~m}$. in the Adirondacks. July-Sept.

Calamagrostis Canadensis acuminata Vasey. Differs from the species in its usually smaller panicle, larger (3.5-4 mm. long) spikelets with the empty scales sharply acuminate, and more scabrous and longer awn of the flowering scale. Lab. and Newf. to Alaska, south in the Mountains to N. Car., N. Mex. and Cal.

\section{Calamagrostis Macouniàna Vasey. Macoun's Reed-Grass. (I. F, f.} 372.) Culms 6-9 dm. tall, erect, simple, smooth and glabrous. Sheaths shorter than the internodes; leaves $7 \cdot 5-17.5 \mathrm{~cm}$. long, 2-5 mm. wide, erect, acuminate, scabrous; panicle open, $7.5^{-11.25} \mathrm{~cm}$. in length, the branclies ascending, or sometimes erect, the lower $2.5-3.75 \mathrm{~cm}$. long, naked at the base; spikelets $2 \mathrm{~mm}$. long, the outer scales acute, scabrous, the first shorter than the second; third scale equalling the second, the awn a little exceeding it; basal hairs about as long as the scale. Manituba and Mont. to Wash., south to Mo. Summer.

7. Calamagrostis neglècta (Ehrh.) Gaertn. Narrow ReEd-Grass. (I. F. f. 378.) Glabrous and smooth throughout. Culms 4.5-6.25 dm. tall, erect, simple, s!ender. Sheaths shorter than the internodes; leaves narrow, involute in drying, the basal one-third as long as the culm, those of the culm $5-12.5 \mathrm{~cm}$. long, erect; panicle contracted, $6.25-10 \mathrm{~cm}$. in length, the branches $2.5 \mathrm{~cm}$. long or less, erect; spikelets $4 \mathrm{~mm}$. long, the scales scabrous, the outer acute; third scale obtuse, about three-fourths as long as the second, the awn exceeding the scale. Lab. to Alaska, south to northern Me., Wis., Mont., Colo., and Ore. Also in Europe and Asia. Summer.

Calamagrostis neglecta borealis. Differs from the species in its shorter culms (2-3 $\mathrm{dm}$. tall) and leaves, smaller and denser panicle $(3-5 \mathrm{~cm}$. long), and the spikelets but 3 $\mathrm{mm}$. long. Lab. and Hudson Bay. Also in northern Europe.

8. Calamagrostis inexpánsa A. Gray. Bog ReEd-Grass. Culms but little tufted, 8-12 dm. tall. Sheaths smooth and glabrous; leaves rough, 2-3 dm. long, $4 \mathrm{~mm}$. wide or less; panicle I.5-2 dm. long, usually nodding at the summit, its branches rather long, nearly erect; spikelets 4-4.5 mm. long, numerous, the empty scales scabrous, hispid on the keel, acute, the flowering scale scabrous, the callushairs from three-fourths as long to equalling the scale, the awn from shorter to exceeding the scale. Bogs and sandy banks, N. J. and western N. Y. to S. Dak. and Colo.

9. Calamagrostis Labradòrica Kearney. LABRADOR REed-GRASS. Culms 3.5-5 dm. tall, rigid. Sheaths tightly embracing the culm; leaves $5-20 \mathrm{~cm}$. long, $2.5 \mathrm{~mm}$. or less wide, strongly involute, thick, scrabrous above, smooth beneath; panicle spike. like and dense, $6-9 \mathrm{~cm}$. long, strict; spikelets about $4 \mathrm{~mm}$. long, the empty scales acute, nearly glabrous excepting on the hispidulous keels, firm, thick, dark purple, the flowering scales about $3.5 \mathrm{~mm}$. long, scabrous, the awn much shorter than the scale, usually slender, the callus-hairs from somewhat shorter to nearly equalling the scale. Among rocks on the seashore, Lab. July.

Io. Calamagrostis hyperbòrea Lange. Northern ReED-Grass. Culms densely tufted, rigid, stout, 4-1o dm. tall. Sheaths smooth and glabrous; leaves very rough on both surfaces, flat, or often involute toward the apex, stiff, I-3 dm. long, $5 \mathrm{~mm}$. or less wide; panicle contracted, 7-14 cm. long, its branches short, usually erect, sometimes ascending; spikelets 3-4 $\mathrm{mm}$. long, the empty scales scabrous, acute, the flowering scale with the callus-hairs from a little shorter than to nearly equalling it, the awn shorter than or longer than the scale. Meadows and swamps, Greenland to Alaska, south to Penn., Colo. and Cal. June-Aug. Very variab!e. The var. Elongata Kearney has the panicle very long and ratiner loose, with usually longer branches, and the spikelets 3-4 $\mathrm{mm}$. long; the var. AMERICANA (Vasey) Kearney has the panicle usually very dense and the spikelets about $3 \mathrm{~mm}$. long.

II. Calamagrostis cinnoides (Muhl.) Scribn. NutTall's Reed-grass. (I. F. f. 379.) Culms 9-15 dm. tall, erect. Sheaths smooth or rough, the lower 
sometimes sparingly hirsute, and rarely with a villous ring at the summit; leaves I-3 dm. long or more, 4-10 $\mathrm{mm}$. wide, scabrous, occasionally sparingly hirsute; panicle $7.5-17.5 \mathrm{~cm}$. in length, contracted, the branches erect, the lower $2.5-5 \mathrm{~cm}$. long; spikelets 6-8 $\mathrm{mm}$. long; scales strongly scabrous, the outer about equal, acuminate and awn-pointed; third scale shorter, obtuse, the basal hairs one-half to two-thirds its length; awn stout, exceeding or equalling the scale. In moist soil, N. H. and Mass. to Penn., south to Ga. July-Aug.

\section{AMMÓPHILA Host.}

Tall perennial grasses with flat leaves, convolute above, and dense spike-like panicles. Spikelets I-flowered, the rachilla prolonged beyond the flower and hairy. Scales 3, rigid, chartaceous, acute, keeled; the 2 outer empty, the lower I-nerved, the upper 3-nerved; third scale 5 -nerved, with a ring of short hairs at the base, subtending a chartaceous 2-nerved palet and a perfect flower. Stamens 3. Styles distinct. Stigmas plumose. Grain free, loosely enclosed in the scale and palet. [Greek, signifying sand-loving, in allusion to the habitat of these grasses.] Two species, the following widely distributed along the fresh and salt-water shores of the northern hemisphere, the other European.

r. Ammophila arenària (L.) Link. Sea Sand-Reed. Sea Mat-weed. MARAm. (I. F.f. 380 .) Glabrous ; culms 6-I 2 dm. tall, erect, rigid, stout, arising from a long horizontal hranching rootstock. Sheaths smooth, the lower short, crowded and overlapping, the upper longer; leaves $\mathbf{1} .5-3 \mathrm{dm}$. long or more, rigid, attenuate into a long slender involute point, smooth beneath, scabrous above; spikelike panicle dense, I-3 dm. in length, $1.2-1.6 \mathrm{~cm}$. thick, its branches $3.75 \mathrm{~cm}$. long or hess, appressed; spikelets $\mathbf{I}-\mathbf{I} .2 \mathrm{~cm}$. long. the scales scabrous, about equal in length, the third usually with the rudiment of an awn just below the apex; basal hairs 2-4 mm. long. In sands of the seacoast from N. B. to Va., and inland along the shores of the Great Lakes. Also on the coasts of northern Europe. Aug.-Sept.

\section{CALAMOVÍLFA Hack.}

Tall grasses with stout horizontal rootstocks, elongated leaves, which are involute at the apex, and paniculate inflorescence. Spikelets I-flowered, the rachilla not prolonged beyond the flower. Scales 3, I-nerved, acute, the 2 outer unequal, empty; third scale longer or shorter than the second, with a ring of hairs at the base; palet strongly 2-keeled. Stamens 3. Styles distinct. Stigmas plumose. Grain free. Seed adherent to the pericarp. [Greek, signifying a reed-like grass.] Three known species, natives of the temperate and subtropical regions of $\mathrm{N}$. Am.

Spikelets 4-5 mm. long, the basal hairs less than half the length of the third scale.

Spikelets 6-8 mm. long, the basal hairs more than half the length of the third scale.

2. C. longifolia.

I. Calamovilfa brevípilis (Torr.) Hack. Short-haired ReEd-Grass. (I. F.f. 38 I.) Glabrous and smooth or very nearly so. Culms 6-I2 dm. tall, erect, simple ; leaves 1.5-3 dm. long, $3 \mathrm{~mm}$. wide or less, attenuate into a long slender invo!ute tip, smooth beneath, slightly scabrous above; panicle open, $1.25-2.5 \mathrm{~cm}$. in length, the branches ascending, the lower 5-10 $\mathrm{cm}$. long; spikelets 4-5 mm. long; scales acute, scabrous toward the apex, the outer unequal, the first one-half as long as the second; third scale exceeding the second, pubescent on the lower half of the keel; basal hairs one-third the length of the scale; palet nearly equalling the scale, pubescent on the lower half of the keel. In swamps, pine barrens of N. J. Local. Aug.-Sept.

2. Calamovilfa longifòlia (Hook.) Hack. LoNg-LEAVEn REED-Grass. (I. F. f. 382.) Culms 3-9 dm. tall, erect, simple, stout, smooth and glabrous. Sheaths crowded and overlapping, glabrous or rarely pilose; leaves $2-3 \mathrm{dm}$. long or more, panicle narrow, often $3 \mathrm{dm}$. long or more, pale, the branches erect or ascending, the lower I-2.5 dm. long; spikelets 6-8 $\mathrm{mm}$. long; scales acute, smooth, the first shorter than the second; the third a little longer or slightly shorter than the second, and nearly twice the length of the copious basal hairs; palet slightly 
shorter than the third scale. On sandy shores, western Ont. and Manitoba to the Rocky Mts., south to Ind., Kans. and Colo. July-Sept.

\section{APÈrA Adans.}

Annual grasses, with narrow flat leaves, and ample open or contracted panicles. Spikelets I-flowered, small, the rachilla prolonged beyond the flower into a bristle. Scales 3 ; the 2 outer empty, unequal, thin, membranous, keeled, acute: the third scale a little shorter, membranous, bearing a long slender awn inserted just below the shortly 2-toothed apex; palet a little shorter than the scale, 2-keeled, 2-toothed. Stamens 3. Styles distinct, short. Stigmas plumose. Grain narrow, free, included in the scale. Seed adherent to the pericarp. [Greek, signifying not mutilated, whole or entire; application uncertain.] Two species, natives of Europe and western Asia.

I. Apera Spica-vénti (L.) Beauv. Silky Bent-grass. Windlestraw. (I. F. f. 383.) Culms 3-6 dm. tall, erect, simple, slender, smooth and glabrous. Sheaths usually longer than the internodes, the upper one generally including the base of the panicle; leaves $2.5^{-17.5} \mathrm{~cm}$. long, $\mathrm{r}-4 \mathrm{~mm}$. wide, scabrous; panicle $7.5-22.5 \mathrm{~cm}$. in length, the branches erect or ascending, capillary, $3.75-7.5 \mathrm{~cm}$. long; outer scales of the spikelet $2-2.5 \mathrm{~mm}$. long, acute, smooth and sinining; third s aale hairy or nearly smooth, bearing a dorsal scabrous awn 6-8 mm. long; rudiment at the end of the rachilla less than $0.5 \mathrm{~mm}$. long. In waste places and on ballast, Me. to southern N. Y. and Penn. Adventive from Europe. June-July.

\section{HÓLCUS L.}

Annual or perennial grasses with flat leaves and spike-like or open panicles. Spikelets deciduous, 2 -flowered; lower flower perfect, upper staminate. Scales 4; the 2 lower empty, membranous, keeled, the first I-nerved, the second 3 -nerved and often short-awned; tlowering scales chartaceous, that of the upper flower bearing a bent awn. Palet narrow, 2-keeled. Stamens 3. Styles distinct. Stigmas plumose. Grain oblong, free, enclosed in the scale. [Greek, taken from Pliny.] About 8 species, natives of the Old World.

I. Holcus lanàtus L. Velvet-grass, Meadow Soft-grass. (I. F. f. 384 .) Softly and densely pubescent, light green. Culms $4 \cdot 5^{-9} \mathrm{dm}$. tall, erect, often decumbent at the base, simple; sheaths shorter than the internodes; leaves $2.5^{-1} 5 \mathrm{~cm}$. long, 4-12 $\mathrm{mm}$. wide; spikelets $4 \mathrm{~mm}$. long, the empty scales whitevillous, the upper awn-pointed; flowering scales $2 \mathrm{~mm}$. long, smooth, glabrous and shining, the lower sparsely ciliate or the keel, somewhat obtuse, the upper 2-toothed and bearing a hooked awn just below the apex. In fields, meadows and waste places, N. S. to Ont. and IIl.; south to N. Car. and Tenn. Also on the Pacific Coast. Naturalized from Europe. June-Aug.

\section{AIRA L.}

Mostly annual grasses with narrow leaves and contracted or open panicles. Spikelets small, 2 -flowered, both flowers perfect. Scales 4 ; the 2 lower empty, thin-membranous, acute, subequal, persistent ; the flowering scales usually con.. tiguous, hyaline, mucronate or 2-toothed, deciduous, bearing a delicate dorsal awn inserted below the middle; palet a little shorter than the scale, hyaline, 2-nerved. Stamens 3. Stigmas plumose. Grain enclosed in the scale and palet, and often adhering to them. [Greek name for Lolium temulentum.] Four or five species, natives of Europe.

Panicle open ; flowering scales about $2 \mathrm{~mm}$. long; plants 1.25-2.5 dm. tall. I. A. caryophyllea. Panicle contracted; flowering scales about $3 \mathrm{~mm}$. long ; plants $5-10 \mathrm{~cm}$. tall. 2. A praecox.

I. Aira caryophýllea L. Silvery Hair-grass. (I. F. f. 385.) Smooth and glabrous throughout. Culms $1.25^{-2.5} \mathrm{dm}$. tall, erect from an annual root, simple, slender; sheaths mostly basal; leaves $1.25-5 \mathrm{~cm}$. long, involute-setaceous ; panicle 2.5 -10 $\mathrm{cm}$. in length, open, the branches spreading or ascending, the lower $2.5 \mathrm{~cm}$. long or less; spikelets $2-2.5 \mathrm{~mm}$. long, the empty scales acute ; flowering 
scales very acute, 2-toothed, $2 \mathrm{~mm}$. long, bearing an awn 3-4 mm. long. In fieids and waste places, eastern Mass. to Va. Also on the Pacific Coast. Local. Natural. ized from Europe. Panicle silvery, shining. May-July.

2. Aira praècox L. Early Hair-grass. (I. F. f. 386.) Glabrous and smooth throughout. Culms $5^{-10} \mathrm{~cm}$. tall, erect, from an annual root, simple, rigid; sheaths clothing the whole culm, the upper one often enclosing the base of the panicle ; leaves $2.5 \mathrm{~cm}$. long or less, involute-setaceous : panicle contracted, strict, $1.25-2.5 \mathrm{~cm}$. in length; spikelets about $3 \mathrm{~mm}$. long, the empty scales acute; the flowering scales acuminate, 2 -toothed, about $3 \mathrm{~mm}$. long, bearing an awn 3-4 $\mathrm{mm}$. long. In dry fields, southern N. J. and Penn. to Va. Naturalized from Europe. May-Ju'y.

\section{DESCHÁMPSIA Beauv.}

Perennial grasses with flat or involute leaves, and contracted or open panicles. Spikelets 2-flowered, both flowers perfect, the hairy rachilla extended beyond the flowers or rarely terminated by a staminate one. Scales 4 (rarely more), the 2 lower empiy, keeled, acute, membranous, shining, persistent; the flowering scales of about the same texture, deciduous, bearing a dorsal awn, the apex toothed. Palet narrow, 2-nerved. Stamens 3. Styles distinct. Stigmas plumose. Grain oblong, free, enclosed in the scale. [In honor of J. C. A. Loiseleur-Deslong. champs, 1774-1849, French physician and botanist.] About 20 species, inhabiting cold and temperate regions, a few occurring in the high mountains of the tropics. Besides the following, some 6 others occur in the western parts of N. Am.

Upper flowering scales reaching or extending beyond the apex of the empty scales.

Flowering scales about $2.5 \mathrm{~mm}$. long, erose-truncate; leaves flat.

Flowering scales about $4 \mathrm{~mm}$. long, acute or obtuse ; leaves involute.

I. D. caespitosa

2. D. flexuosa.

Empty scales extending much beyond the upper flowering scale.

3. D. atropurpurea.

I. Deschampsia caespitòsa (L.) Beauv. TuFred HaIr-grass. (I. F. f. 387.) Culms 6-12 dm. tall, erect, simple, smooth and glabrous. Leaves flat, 2-3 mm. wide, smooth beneath, strongly scabrous above, the basal ones numerous, - one-quarter to one-half as long as the culm, those of the culm $5^{-15} \mathrm{~cm}$. long ; panicle open, $7.5-22.5 \mathrm{~cm}$. in length, the branches widely spreading or ascending, often somewhat flexuous, naked at the base, the lower 5-12.5 cm. long; spikelets $3.5^{-}$ $4 \mathrm{~mm}$. long; flowering scales about $2.5 \mathrm{~mm}$. long, erose-truncate at the apex, the awns somewhat shorter or a little longer, the upper scale reaching to or extending beyond the apices of the empty ones. Newf. to Alaska, south to N. J., Ill., Minn. and in the Rocky Mts. and Sierra Nevada to N. Mex. and Cal., mostly in wet soil. Also in Europe and Asia. July-Aug.

2. Deschampsia flexuòsa (L.) Trin. Wavy HaIr-grass. (I. F. f. 388.) Glabrous throughout. Culms 3-7.5 dm. tall, erect, slender, simple, smooth ; leaves involute-setaceous, smouth beneath, scabrous above, the basal very numerous, onefifth the length of the culm or less, those of the culm $2.5-7.5 \mathrm{~cm}$. long; panicle open, 5-20 cm. in length, the branches ascending or erect, sometimes widely speading, naked at the base, flexuous, the lower $3.75-12.5 \mathrm{~cm}$. long; spikelets $4.5-5 \mathrm{~mm}$. long; flowering scales about $4 \mathrm{~mm}$. long, acutely toothed at the apex; awns bent and twisted, much exceeding the scale. In dry soil, Greenland and Newf, to Ont. and Mich., south to N. Car. and Tenn. Ascends to $1500 \mathrm{~m}$. in the Adirondacks. Also in Europe. July-Aug.

3. Deschampsia atropurpùrea (Wahl.) Scheele. Mountain HaIR-grass. (I. F. f. 389.) Glabrous and smooth or very nearly so. Culms 1.5-4.5 dm. tall, erect, simple, rigid; leaves $2-4 \mathrm{~mm}$. wide, erect, sometimes slightly scabrous above, the basal $6.25^{-12.5} \mathrm{~cm}$. long, those of the culm shorter; panicle contracted, usually purple or purplish, $2.5-5 \mathrm{~cm}$. in length, the branches erect, or sometimes ascending, the lower $1.25-3.75 \mathrm{~cm}$. long; spikelets $5 \mathrm{~mm}$. long; flowering scales about $2.5 \mathrm{~mm}$. long, erose-truncate at the apex: awus bent and much longer than the scales; upper scale much exceeded by the very acute outer ones. On alpine 
summits of N. Y., N. E., Mont., Ore. and Wash., north to Lab. and Alaska. Also in Europe. July-Aug.

\section{TRISÈTUM Pers.}

Mostly perennial tufted grasses, with flat leaves and spike-like or open panicles. Spikelets 2-4-flowered, the flowers all perfect, or the uppermost staminate; rachilla glabrous or pilose, extended beyond the flowers. Scales 4-6, membranous, the 2 lower empty, unequal, acute, persistent; flowering scales usually shorter than the empty ones, deciduous, 2-toothed, bearing a dorsal awn below the apex, or the lower one sometimes awnless. Palet narrow, hyaline, 2-toothed. Stamens 3. Styles distinct. Stigmas plumose. Grain free, enclosed in the scale. [Latin, referring to the three bristles (one awn and two sharp teeth) of the flowering scales in some species.] About 50 species, widely distributed in temperate or mountainous regions. Besides the following, about 8 others occur in the western parts of N. Am.

Flowering scales all bearing long dorsal awns.

Panicle contracted, dense; flowering scales $5 \mathrm{~mm}$. long or less.

I. T. subspicatum.

Panicle open, loose; flowering scales $5 \mathrm{~mm}$. long or more. 2. T. flavescens. Lower flowering scale not bearing a long dorsal awn, a rudiment sometimes present.

3. 7. Pennsylvanicum.

I. Trisetum suspicàtum (L.) Beauv. Narrow False-oat. (I. F. f. 390.) Softly pubescent or glabrous. Culms I.5-6 dm. tall, erect, simple ; leaves $2.5^{-10}$ $\mathrm{cm}$. long, I-4 mm. wide; panicle spike-like, 2.5-12.5 cm. in length, often interrupted below, its branches $3.75 \mathrm{~cm}$. or less long, erect; spikelets $2-3$-flowered, the empty scales hispid on the keel, shining, the second about $5 \mathrm{~mm}$. long, the first shorter; flowering scales 4-5 $\mathrm{mm}$. long, acuminate, scabrous, each bearing a long bent and somewhat twisted awn. In rocky places, Lab. to Alaska, south on the mountains to N. Car., N. Mex. and Cal. Also in Europe and Asia. Aug.-Sept.

2. Trisetum flavéscens (L.) R. \& S. Yellow False-oat. (I. F. f. 391.) Culms $4 \cdot 5-7.5 \mathrm{dm}$. tall, erect, simple, smooth, glabrous. Sheaths more or less pubescent; leaves $3.75-12.5 \mathrm{~cm}$. long, 2-6 mm. wide, scabrous, sometimes sparingly hairy; panicle open, $5-12.5 \mathrm{~cm}$. in length, the branches ascending or erect, somewhat flexuous, naked below, the lower 2 5-5 cm. long; spikelets 3-4-flowered; empty scales smooth and glabrous, the second acute, $5 \mathrm{~mm}$. long, the first about half as long, narrower, acuminate; flowering scales $5-6 \mathrm{~mm}$. long, scabrous, bearing a long bent and twisted awn. Introduced into Mo. and Kans. Native of Europe and Asia. Panicle yellow, turning dull brown. July-Aug.

3. Trisetum Pennsylvánicum (L.) Beauv. MARsh False-oat. (I. F. f. 392.) Culms 3-9 dm. tall, erect, simple, slender and often weak, smooth and glabrous. Sheaths shorter than the internodes, sometimes scabrous; leaves $2.5-15$ $\mathrm{cm}$. long, 2-6 mm. wide, rough; panicle $5-20 \mathrm{~cm}$. in length, yellowish, narrow, the branches ascending, the lower $2.5-5 \mathrm{~cm}$. long; spikelets 2 -flowered; outer scales smooth, shining, subequal, the second 4-5 mm. long; flowering scales 4-5 mm. long, scabrous, the lower not long-awned, but a rudimentary awn sometimes present, the upper with a long bent and twisted awn. In swamps and wet meadows, N. Y. to Ill., south to Fla. and La. Ascends to 1050 m. in Va. Panicle sometimes loose and nodding. June-July.

\section{AVENA L.}

Annual or perennial grasses, with usually flat leaves and panicled spikelets. Spikelets 2-many-flowered, or rarely I-flowered; lower flowers perfect, the upper often staminate or imperfect. Scales 4-many (rarely 3); the two lower empty, somewhat unequal, membranous, persistent; flowering scales deciduous, rounded on the back, acute, generally bearing a dorsal awn, the apex often 2-toothed. Palet narrow, 2-toothed. Stamens 3. Styles short, distinct. Stigmas plumose. Grain oblong, deeply furrowed, enclosed in the scale and palet, free or sometimes adherent to the latter. [Old Latin name for the oat.] About 50 species, widely distributed in temperate regions, chiefly in the Old World. Oats (Avena sativa L.) sometimes appear in waste places or in fields where it has been cultivated. 
Empty scales of the spikelet $1.2 \mathrm{~cm}$. in length or less, shorter than the flowering scales.

Flowering scales with a ring of short hairs at the base; awn nearly as long as the scale.

I. A. striata.

Flowering scales naked at the base; awn not over one-half as long as the scale.

Empty scales $1.2-1.8 \mathrm{~cm}$. in length, enclosing the flowering scales.

2. A. Smithii. 3. A. fatua.

I. Avena striàta Michx. Purple OAt. (I. F. f. 393.) Culms 3-6 dm. tall, erect, simple, slender, smooth and glabrous. Leaves erect, $2.5-15 \mathrm{~cm}$. long, 2-6 $\mathrm{mm}$. wide, smooth heneath, usually scabrous above; panicle $6.25-12.5 \mathrm{~cm}$. in length, lax, the branches erect or ascending, naked below, the lower $2.5-6.25 \mathrm{~cm}$. long; spikelets 3-6-flowered. the empty scales smooth, the second 6-7 $\mathrm{mm}$. in length, 3nerved, the first two-thirds to three-quarters as long, I-nerved; flowering scales 6-8 $\mathrm{mm}$. long, with a ring of short hairs at the base, strongly nerved, scabrous; awns as long as the scales or longer. In woods, N. B. to Br. Col., south to northern Penn., Minn. and Neb. Spikelets reddish purple. July-Aug.

2. Avena Smíthii Porter. Smith's OAt. (I. F. f. 394.) Culms 7.5-15 dm. tall, erect, simple, scabrous. Sheaths shorter than the internodes, very rough; leaves I--2 dm. long, 6-1 $2 \mathrm{~mm}$. wide, scabrous; panicle $1.5-3 \mathrm{dm}$. in length, the branches finally spreading; spikelets 3-6-flowered; empty scales smooth, the second 6-8 $\mathrm{mm}$. in length, 5-nerved, the first shorter, obscurely 3-nerved; flowering scales $\mathbf{I} \mathrm{cm}$. long, naked at the base, strongly nerved, scabrous, bearing an awn one-fourth to one-half their length. Northern Mich. and Isle Royal. Summer.

3. Avena fátua L. Wild OAT. (I. F. f. 395.) Culms 3-12 dm. tall, erect, simple, stout, smooth and glabrous. Sheaths smooth, or scabrous at the summit, sometimes sparingly hirsute, the lower often overlapping; leaves $7.5^{-20} \mathrm{~cm}$. long, 2-8 $\mathrm{mm}$. wide; panicle open, $\mathrm{I}-3 \mathrm{dm}$. in length, the branches ascending; spikelets 2-4-flowered, drooping; outer scales $1.8-2.5 \mathrm{~cm}$. in length, smooth, enclosing the flowering scales; flowering scales $1.2-1.8 \mathrm{~cm}$. long, with a ring of stiff brown hairs at the base, pubescent with long rigid brown hairs, bearing a long bent and twisted awn. In fields and waste places, N. Dak. and Minn.; abundant on the Pacific Coast. Naturalized from Europe or Asia. July-Sept.

\section{ARRHENATHÈRUM Beauv.}

Tall perennial grasses with flat leaves and contracted or open panicles. Spikelets 2-flowered; lower flower staminate, upper perfect; rachilla extended beyond the flowers. Scales 4, the 2 lower empty, thin-membranous, keeled, very acute or awn-pointed, unequal, persistent; flowering scales rigid, 5-7-nerved, deciduous, the first bearing a long bent and twisted dorsal awn, inserted below the middle, the second unawned; palet hyaline, 2-keeled. Stamens 3. Styles short, distinct. Stigmas.plumose. Grain ovoid, free. [Greek, referring to the awn of the staminate scale.] Six species, natives of the O'd World.

I. Arrhenatherum elàtius (L.) Beauv. OAT-Grass. (I. F. f. 396.) Glabrous. Culms 6-1 $2 \mathrm{dm}$. tall, erect, simp'e; lower sheaths longer than the internodes; leaves $6.25-30 \mathrm{~cm}$. long, 2-8 $\mathrm{mm}$. wide, scabrous: panicle $\mathrm{I}-3 \mathrm{dm}$. in length, contracted, the branches erect, the lower $2.5-5 \mathrm{~cm}$. long; empty scales finely rough. ened, the second $8 \mathrm{~mm}$. long, the first shorter; flowering scales about $8 \mathrm{~mm}$. long. In fields and waste places, Me. and Ont. to Ga., Tenn. and Neb. Also on the Pacific Coast. Naturalized from Europe. June-Aug. [A. avenaceum Beauv.]

\section{DANTHÒNIA DC.}

Mostly perennial grasses, with flat or convolute leaves and contracted or open panicles. Spikelets 3-many-flowered, the flowers all perfect, or the upper staminate; rachilla pubescent, extending beyond the flowers. Scales 5-many, the 2 lower empty, keeled, accte, subequal, persistent, generally extending beyond the uppermost flowering one; flowering scales rounded on the back, 2 -toothed, deciduous, the awn arising from between the acute or awned teeth, flat and twisted at base, bent; palet hyaline, 2 -keeled near the margins, obtuse or 2-toothed. Stamens 3. Styles distinct. Stigmas plumose. Grain free, enclosed in the scale. [Name in honor of Etienne Danthoine, a Marseilles botanist of the last century.] A genus of about IoO species, widely distributed, chiefly in South Africa. 
Empty scales $125 \mathrm{~cm}$. long or less; sheaths glabrous or sometimes sparingly pubescent at the base.

Teeth of the flowering scale about $1 \mathrm{~mm}$. long, acute; culm leaves short; panicle contracted.

I. D. spicata.

Teeth of the flowering scale $2-3 \mathrm{~mm}$. long, awned; culm leaves elongated; panicle usually open.

Empty scales more than $1.25 \mathrm{~cm}$. long.

Sheaths and flowering scales villous.

Sheaths glabrous; flowering scales pilose on the margins.

2. D. compressa.

3. D. sericea.

4. D. epilis.

I. Danthonia spicàta (L.) Beazv. Common Wild OAT-grass. (I. F. f. 397.) Culms 3-7.5 dm. tall, erect, nearly terete. Sheaths glabrous or often sparingly pubescent below; leaves rough, $2 \mathrm{~mm}$. wide or less, usually involute, the lower $\mathbf{I}-1.5 \mathrm{dm}$. long, the upper $2.5-5 \mathrm{~cm}$. long; inflorescence racemose or paniculate, $2.5-5 \mathrm{~cm}$. in length, the pedicels and branches erect or ascending; spikelets 5-8-flowered; empty scales 8-10 $\mathrm{mm}$. long, glabrous; flowering scales broadly oblong, sparingly pubescent with appressed silky hairs, the teeth about I mm. long, acute or short-pointed, the bent and widely spreading awn closely twisted at the base. loosely so above. In dry soil, Newf. to Quebec and N. Dak., south to N. Car., Kans., and La. Ascends to $900 \mathrm{~m}$. in Va. July-Sept.

2. Danthonia compréssa Austin. Flattened Wild Oat-grass. (I. F. f. 398.) Culms 4.5-9 dm. tall, erect, flattened. Leaves $2 \mathrm{~mm}$. wide or less, rough, lax, the basal from one-third to one-half the length of the culm; lower culm leaves I.5-2 dm. long, the upper 7.5-15 cm.; panicle open, $6.25^{-10} \mathrm{~cm}$. in length, the lower branches generally spreading; spikelets 5-1O flowered; empty scales I-1.2 $\mathrm{cm}$. long, glabrous; flowering scales oblong, with a ring of short hairs at base, pubescent with appressed silky hairs, the awn erect or somewhat bent, strongly twisted below, slightly so aDove, the teeth $2-3 \mathrm{~mm}$. long, acuminate, awned. In woods, Me. and Vt. to N. Car. and Tenn. Ascends to $1800 \mathrm{~m}$. in N. Car. JulySept.

3. Danthonia serícea Nutt. Silky Wild OAT-Grass. (I. F. f. 399.) Culms 4.5-9 dm. tall, simple, glabrous. Sheaths shorter than the internodes, villous; leaves rough and more or less villous, $2-3 \mathrm{~mm}$. wide, the basal one-quarter to onehalf the length of the culm, usually flexuous, those of the culm $2.5-10 \mathrm{~cm}$. long, erect; panicle $6.25-1 \mathrm{I} .25 \mathrm{~cm}$. in length, contracted, the branches erect or ascending; spikelets 4-IO-flowered; empty scales $1.4-1.6 \mathrm{~cm}$. long, glabrous; flowering scales oblong, strongly pubescent with long silky hairs, the awn erect or somewhat bent, closely twisted below, loosely so above, the teeth $2-3 \mathrm{~mm}$. long, acuminate, awned. $I_{i i}$ dry sandy soil, Mass. to N. J., south to Fla. May-July.

4. Danthonia epilis Scribn. Sмоотн Wild OAT-GRASS. (I. F. f. 398a.) Glabrous. Culms erect, tufted, $4-7 \mathrm{dm}$. tall, slightly roughened just below the panicle and puberulent below the brown noles; leaves smonth excepting at the apex, 2-4 $\mathrm{mm}$. wide, erect, those on the sterile shoots $1.5 \mathrm{dm}$. or more long, the culm leaves 5-IO cm. long; panicle 5-7.5 cm. long, contracted; spikelets, including awns, I.8-2 $\mathrm{cm}$. long, 5-IO-flowered; empty scales acuminate; flowering scales 5-6 mm. long to the base of the teeth, pilose on the margins below and sometimes sparingly so on the midnerve at the base, the teeth, including the awns, 2-3 $\mathrm{mm}$. long, the central awn 9-12 mm. long, more or less spreading. In swamps, southern N. J. to (ia. May-July.

\section{CAPRIOLA Adans. [CYNODON Rich.]}

Perennial grasses with short flat leaves and spicate inflorescence, the spikes digitate. Spikelets I-flowered, secund. Scales 3; the 2 lower empty, keeled; flowering scale broader, membranous, compressed; palet a little shorter than the scale, hyaline, 2-keeled. Stamens 3. Styles distinct. Stigmas short, plumose. Grain free. [Name mediæval Latin for the wild goat, that feeds on this grass in waste rocky places.] Four known species, of which three are Australian, the following widely distributed.

I. Capriola Dáctylon (L.) Kuntze. Bermuda-grass. Scutch-Grass. Dog'sTOo'Th Grass. (I. F. f. 400.) Culms I-3 dm. tall, erect, from long creeping and branching stolons, smooth and glabrous. Sheaths glabrous or somewhat hairy, crowded at the bases of the culms and along the stolons; leaves $2.5-5 \mathrm{~cm}$. 
long, 2-4 mm. wide, flat, rigid, smooth beneath, scabrous above; spikes 4-5, 1.25-5 $\mathrm{cm}$. in length, digitate; rachis flat; spikelets $2 \mathrm{~mm}$. long; outer scales hispid on the keel, narrow, the first shorter than the second, about two-thirds as long as the broad and strongly compressed third one. In fields and waste places, southern N. Y. to Penn. and Tenn, south to Fla. and Tex. Abundant in the Southern States. Cultivated for pasture. Naturalized from Europe. July-Sept.

\section{SPARTINA Schreb.}

Perennial glabrous grasses, with long horizontal rootstocks, flat or involute leaves, and an inforescence of one-sided spreading or erect alternate spikes. Spike. lets I-flowered, narrow, deciduous, borne in two rows on the rachis, articulated with the very short pedicels below the scales. Scales 3 ; the two outer empty, keeled, very unequal; the third subtending a perfect flower, keeled, equalling or shorter than the second; palet often longer than its scale, 2-nerved. Stamens 3. Styles filiform, elongated. Stigmas filiform, papillose or shortly plumose. Grain free. [Greek, referring to the corl-like leaves of some species.] About 7 species, widely distributed in saline soil, a few in fresh-water marshes.

First scale awn-pointed, equalling the third; second long-awned. First scale acute, shorter than the third, usually one-half as long.

First scale strongly scabrous-hispid on the keel.

Leaves $1.25 \mathrm{~cm}$. wide or more, flat.

Leaves $6 \mathrm{~mm}$. wide or less.

I. S. cynosuroides.

Spikes ascending or erect; leaves narrow, involute; coast plant.

3. S. patens.

Spikes appressed; leaves usually flat at the base; western species.

First scale smooth on the keel or occasionally slightly scabrous. 4. 5. S. strictis.

I. Spartina cynosuroides (L.) Willd. TALL Marsh-grass (I. F. f. 40I.) Culms 6-1 $8 \mathrm{dm}$., tall, erect, simple, smooth. Leaves $3 \mathrm{dm}$. long or more, 6-14 $\mathrm{mm}$. wide, scabrous on the margins, becoming involute in drying, attenuate into a long slender tip; spikes 5-30, 5-12.5 cm. long, often on peduncles $1.25-2.5 \mathrm{~cm}$. in length, ascending or erect; rachis rough on the margins; spikelets much imbricated, 1.2-1.4 cm. long; outer scales awn-pointed or awned, strongly hispid-scabrous on the keel; third scale as long as the first, the scabrous midrib terminating just below the emarginate or 2-toothed apex; palet sometimes exceeding the scale. In swamps and streams of fresh or brackish water, N. S. to Assiniboia, N. J. and Tex. Sometimes glaucous. Called also Fresh-water Cord-grass. Aug.-Oct.

2. Spartina po:ystàchya (Michx.) Ell. SAlt ReED-Grass. (I. F. f. 402.) Culms I-3 m. tall, erect, stout, simple, smooth. Leaves $3 \mathrm{dm}$. long or more, I.25$2.5 \mathrm{~cm}$. wide, flat, scabrous at least on the margins, attenuate into a long slender tip; spikes 20-50, ascending, often long-peduncled, 5-10 cm. in length, the rachis rough on the margins; spikelets much imbricated, 8-10 $\mathrm{mm}$. long, the outer scales acute, strongly scabrous-hispid on the keel, the first half the length of the second; third scale scabrous on the upper part of the keel, obtuse, longer than the first and exceeded by the palet. In salt and brackish marshes, Me. to N. J. and Fla. Called also creek-thatch. Aug.-Oct.

3. Spartina pàtens (Ait.) Muhl. Salt-meadow grass. (I. F. f. 403.) Culms 3-9 dm. tall, erect, or decumbent at base, smooth. Leaves 1.5-3 dm. long, 2-4 $\mathrm{mm}$. broad, involute, attenuate into a long tip, smooth and glabrous beneath; spikes 2-10, 2.5-5 cm. long, usually ascending, more or less peduncled, the rachis slightly scabrous; spikelets $6.8 \mathrm{~mm}$. long; outer scales acute, scabrous-hispid on the keel, the first usually rather less than one-half as long as the second; third scale somewhat scabrous on the upper part of the keel, emaryinate or 2-toothed at the apex, longer than the first and exceeded by the palet. On salt meadows, Newf. and N. S. to Fla., west to Tex. This and Juncus Gerardi, the "Black-grass," furnish most of the salt-meadow hay of the Atlantic Coast. Aug.-Oct.

4. Spartina gracilis Trin. INLAND CORD-GRass. (I. F. f. 404.) Culms 3-9 dm. tall, erect, simple, smooth. Sheaths overlapping, those at the base of the culm short and crowded; leaves $3 \mathrm{dm}$. long or less, $2-6 \mathrm{~mm}$. wide, flat or involute, attenuate into a long tip; spikes 4-8, 2.5-5 cm. long, appressed, more or less pe- 
duncled; spikelets $6-8 \mathrm{~mm}$. long; outer scales acute, scabrous-hispid on the keel, the first half the length of the second; third scale obtuse, slightly shorter than the second and about equalling the obtuse palet. In saline soil, Assiniboia and Br. Col. to Neb. and Nev. Aug.-Sept.

5. Spartina strícta (Ait.) Roth. Smooth Marsh-grass. (I. F. f. 405.) Culms 3-9 dm. tall, erect, simple, smooth. Sheaths overlapping, those at the base shorter and looser, much crowded; leaves $7 \cdot 5-30 \mathrm{~cm}$. long, 4-8 mm. wide at the base, involute, at least when dry ; spikes $3-5$, erect or nearly so, $2.5-5 \mathrm{~cm}$. long ; spikelets 1.2-1.6 cm. long, loosely imbricated; empty scales acute or acutish, I-nerved, the first shorter than the second, which exceeds or equals the third; palet longer than the third scale.

Spartina stricta maritima (Walt.) Scribn. Culms taller, sometimes $3 \mathrm{~m}$. high, and leaves longer; spikes more numerous, usually appressed.

Spartina stricta alternifiora (Lois.) A. Gray. Culms r2-18 dm. tall; spikes slender, appressed, $7 \cdot 5^{-12.5} \mathrm{~cm}$. long, the spikelets barely overlapping.

Very variable. Common in some one of its forms, along the coast from Me. to Fla. and Tex. Also on the coast of Europe. Our plant does not appear to be satisfactorily identified with the European. Aug.-Oct.

\section{Campulòsus Desv.}

Tall pungent-tasted grasses, with flat or convolute narrow leaves and a curved spicate inflorescence. Spikelets borne pectinately in two rows on one side of the flat curved rachis, I-flowered. Lower 4 scales empty, the first very short, hyaline; the second, third, fourth and fiftl awned on the back, the latter subtending a perfect flower and palet, the uppermost scales empty. Stamens 3. Styles distinct. Stigmas plumose. Grain oblong, free, loosely enclosed in the scale. [Greek, in allusion to the curved spike.] Seven known species, four of them American, the others in the eastern hemisphere.

I. Campulosus aromáticus (Walt.) Scribn. Toотнache-Grass. (I. F. f. 406.) Culms 9-12 dm. tall, erect, simple, smooth or somewhat scabrous. Leaves $2.5^{-1} 5 \mathrm{~cm}$. long, 2-4 $\mathrm{mm}$. wide, flat or involute, smooth ; spike terminal, solitary, curved, 5-10 $\mathrm{cm}$. long, the rachis extended into a point; spikelets about $6 \mathrm{~mm}$. long; second scale thick and rigid, awn-pointed, bearing just above the middle a stout horizontal or recurved awn : third fourth and fifth scales membranous, scabrous, awned from below the 2 -toothed apex, the fifth subtending a perfect flower, the others empty. In wet soil, especially in pine barrens, Va. to Fla. July-Sept.

\section{CHLÒRIS Sw.}

Mostly perennial grasses with flat leaves and spicate inflorescence, the spikes few or numerous, verticillate or approximate. Spikelets I-flowered, arranged in two rows on one side of the rachis. Scales 4 ; the 2 lower empty, unequal, keeled, acute; third and fourth usually awned, the former subtending a perfect flower; palet folded and 2 -keeled. Stamens 3. Styles distinct. Stigmas plumose. Grain free, enclosed in the scale. [Greek, greenish-yellow, referring to the color of the herbage.] About fifty species, mostly natives of warm and tropical regions. Be. sides the following some ro others occur in the southern U. S.

Spikes slender, naked at the base; nerves of the third scale all pilose with short appressed hairs. I. C. verticillata. Spikes stout, spikelets crowded to the very base; lateral nerves of the third scale with a tuft of very long hairs at the summit.

r. Chloris verticillàta Nutt. Prairie Chloris. (I. F. f. 407.) Culms I.5-4.5 dm. tall, erect, or decumbent and rooting at the lower nodes. Leaves 2.5$7.5 \mathrm{~cm}$. long, 2-4 mm. wide, obtuse, often apiculate, scabrous; spikes sle der, usually spreading, 5-11.25 cm. long, in one or two whorls, or the upper ones approximate; spikelets, exclusive of the awns, about $3 \mathrm{~mm}$. long, the third scale $2 \mathrm{~mm}$. long, obtuse, ciliate on the nerves, especially on the lateral ones, bearing just below the apex a scabrous awn about $5 \mathrm{~mm}$. long; fourth scale as long as or shorter than the third, awned noar 30 usually truncate apex. On prairies, Kans. to Tex. May-July. 
2. Chloris elegans I. B. K. Culms 1.5-9 dm. tall, finally branched. Sheaths compressed, keeled; leaves usually less than I dm. long, sometimes longer, 2-6 mm. wide, smooth beneath, generally very rough above; inflorescence silvery-white, often tinged with purple, consisting of 3-12 erect spikes $2-8 \mathrm{~cm}$. long; spikelets, exclusive of the awns, about $4 \mathrm{~mm}$. long, usually 2 -flowered, the third scale with the midnerve abruptly contracted a short distance below the awn, the awn 5-Io mm. long. Sandy soil, Kans. (according to Hitchcock) to Ariz., south to Mex.

\section{GYMNOPÒgON Beauv.}

Perennial grasses with flat and usually short rigid leaves, and numerous slender alternate spikes. Spikelets I-flowered, almost sessile, the rachilla extended and bearing a small scale which is usually awned. Scales 3 or 4; the 2 lower empty, unequal, narrow, acute; third broader, fertile, 3-nerved, slightly 2 -toothed at the apex, bearing an erect awn; the fourth empty, small, awned; palet 2 -keeled. Stamens 3. Styles distinct. Stigmas plumose. Grain linear, free, enclosed in the rigid scale. [Greek, naked-beard, referring to the prolongation of the rachilla.] Six known species, all but one of them natives of America.

Spikes bearing spikelets their whole length ; awn longer than flowering scale.

Spikes bearing spikelets above the middle; awn shorter than flowering scale. I. G. ambiguus.

2. G. brevifolius.

I. Gymnopogon ambíguus (Michx.) B.S.P. BROAd-LEAved Gymnopogon. (I. F. f. 408.) Culms 3-4.5 dm. tall, erect, or decumbent at the base, simple or sometimes sparingly branched. Sheaths short, with a villous ring at the summit, crowded at the base of the culm; leaves $2.5-10 \mathrm{~cm}$. long, 4-12 $\mathrm{mm}$. wide, lanceolate, acute, cordate at the base, spreading, smooth or a little scabrous above; spikes slender, spikelet-bearing throughout thcir entire length, at first erect, the lower I-2 dm. long, at length widely spreading; spikelets, exclusive of awns, 4-5 mm. long; first scale shorter than the second; third scale exceeded by the second, the callus at the base hairy, the awn 4-6 mm. long. In dry sandy soil, southern N. J. to Kans., south to Fla. and Tex. Aug.-Oct. [G. racemosus Beauv.]

2. Gymnopogon brevifolius Trin. Short-LEaved Gymnopogon. (I. F. f. 409.) Culms 3-6 dm. long, from a decumbent base, simple, slender. Sheaths sometimes crowded near the middle of the culm; leaves $2.5-5 \mathrm{~cm}$. long, 2-8 mm. wide, usually spreading, lanceolate, acute, cordate at the base; spikes very slender, spikelet-bearing above the middle, the lower $1.5 \mathrm{dm}$. long, at first erect, finally widely spreading; spikelets, exclusive of the awns, $3 \mathrm{~mm}$. long; first scale shorter than the second; third scale equalling or exceeded by the second, short-awned, sparingly villous or glabrous, the callus hairy. In dry soil, N. J. to Fla., west to Miss. Aug.-Oct.

\section{SCHEDONNÀRDUS Steud.}

An annual grass with branching culms, narrow leaves and slender spikes arranged along a common axis. Spikelets $\mathbf{I}$-flowered, sessile and alternate on the rachis. Scales 3 ; the 2 lower empty, narrow, membranous, acuminate; the flowering scale longer, of similar texture; palet narrow, shorter. Stamens 3: Styles cistinct. Stigmas plumose. Grain linear, free, enclosed in the rigid scale. [Greek, in allusion to the resemblance of this grass to the genus Nardus.] A monotypic genus of central N. Am.

I. Schedonnardus paniculitus (Nutt.) Trelease. Schedonnardus. (I. F. f. 4 Io.) Culms $2-4.5 \mathrm{dm}$. tall, erect, slender, rigid, branching at the base, scabrous. Sheaths crowded at the base of the culm, compressed, smooth and glabrous; leaves $2.5-5 \mathrm{~cm}$. long, $2 \mathrm{~mm}$. wide or less, flat, usually erect ; spikes numerous, rigid, widely spreading, alternate, the lower $5-10 \mathrm{~cm}$. long, the axis and branches triangular; spikelets $2.5-3 \mathrm{~mm}$. long, sessile and appressed, alternate; scales hispid on the keel, the second longer than the first and exceeded by the acute third one. Manitoba and Assiniboia, south to Ill., Tex. and N. Mex. July-Sept. [S. Teranus Steud.] 


\section{BoUteloùa Lag.}

Annual or perennial grasses with flat or convolute leaves and numerous spikelets in few one-sided spikes. Spikelets I-2-flowered, arranged in two rows on one side of a flat rachis, the rachilla extended beyond the base of the flowers, bearing I-3 awns and I-3 rudimentary scales. Two lower scales empty, acute, keeled; flowering scale broader, 3-toothed, the teeth awn-pointed or awned; palet hyaline, entire or 2-toothed. Stamens 3. Styles distinct. Stigmas plumose. Grain oblong, free. [In honor of Claudius Boutelou, a Spanish botanist.] About 30 species, particularly numerous in Mexico and in the southwestern U. S.

Rachilla bearing the rudimentary scales and awns glabrous; second scale strongly papillose-hispid on the keel.

I. B. hirsuta.

Rachilla bearing the rudimentary scales and awns with a tuft of long hairs at the apex; second scale scabrous and sparingly long-ciliate on the keel.

2. B. oligostachya.

I. Bouteloua hirsùta Lag. Hairy Mesquite-Grass. (I. F. f. 4II.) Culms I.5-5 dm. tall, erect, simple or sometimes sparingly branched at the base. Sheaths mostly at the base of the culm; leaves $2.5-12.5 \mathrm{~cm}$. long, $2 \mathrm{~mm}$. wide or less, erect or ascending, flat, scabrous, sparingly papillose-hirsute near the base, especially on the margins; spikes I-4, I.25-5 cm. long, usually erect or ascending, the rachis extending beyond the spikelets into a conspicuous point; spikelets numerous, 5-6 mm. long, pectinately arranged; second scale strongly papillose-hirsute on the keel; third scale pubescent, 3-cleft to the middle, the nerves terminating in awns; rachilla without a tuft of hairs under the rudimentary scales and awns. In dry soil, especially on prairies, Ill. to Dak., Tex. and Ariz. July-Sept.

2. Bouteloua oligostàchya (Nutt.) Torr. Grama-Grass. Mesquite-Grass. (I. F. f. 412.) Culms I.5-4.5 dm. tall, erect, simple. Leaves $2.5-10 \mathrm{~cm}$. long, 2 mm. wide or less, involute, at least at the long slender tip, smooth or scabrous; spikes $\mathrm{I}-3,2.5-5 \mathrm{~cm}$. long, often strongly curved, the rachis terminating in a short inconspicuous point; spikelets numerous, pectinately arranged, about $6 \mathrm{~mm}$. long; second scale scabrous and sometimes long-ciliate on the keel, sometimes with a few papillae; third scale pubescent, 3-cleft, the nerves terminating in awns; rachilla with a tuft of long hairs under the rudimentary scales and awns. On prairies, Manitoba to Alberta, south to Wis., Tex. and Mex. July-Sept.

\section{6o. ATHEROPÒGON Muhl.}

Perennial grasses with narrow flat leaves and an inflorescence composed of numerous short scattered few-flowered one-sided spreading or frequently reflexed spikes. Spikelets I-flowered, crowded in 2 rows, sessile, imbricated, the rachilla articulated above the empty scales and extending beyond the flower, its sumn 't bearing scales or awns. Scales 3 or more, the lower 2 empty, unequal, acute. nar. row, keeled, the third scale thicker and broader, enclosing a narrow 2-toothed hya. line palet and a perfect flower, 3-toothed at the apex, the teeth more or less awned; the small upper scales minute, awned. Stamens 3. Styles distinct. Stigmas plumose. Grain free, enclosed in the scale. [Grcek, in reference to the awns of the flowering scales.] Species about 15, natives of temperate and tropical regions.

I. Atheropogon curtipéndulus (Michx.), Fourn. Racemed Bouteloua. (I. F. f. 4I3.) Culms 3-9 dm. tall, erect, simple, smooth and glabrous. Leaves 5-30 cm. long, $4 \mathrm{~mm}$. wide or less, flat or involute, rough, especially above; spikes numerous, 6-16 $\mathrm{mm}$. long, widely spreading or reflexed; spikelets 4-12, divergent from the rachis, 7-12 $\mathrm{mm}$. long; scales scabrous, especially on the keel, the first shorter than or equalling the second; the third 3-toothed, the nerves extended into short awns; rachilla bearing at the summit a small awned scale, or sometimes a larger 3-nerved scale, the nerves extended into awns; anthers vermillion or cinnabar-red. In dry soil, Ont. to Manitoba, south to N. J., Ky., Tex. a..c? Mex. JulySept. (Bouteloua curtipendula (Michx.) Torr.)

\section{6r. BECKMÁNNIA Host.}

A tall erect grass with flat leaves and erect spikes borne in a terminal panicle. Spikelets I-2-flowered, globose, compressed. Scales 3 or 4 ; the 2 lower cmpty, membranous, saccate, obtuse or abruptly acute: the flowering scales narrow, thin- 
membranous; palet hyaline, 2-keeled. Stamens 3. Styles distinct. Stigmas plu. mose. Grain oblong, free, enclosed in the scale and palet. [In honor of Johann Beckmann, I739-I81 I, teacher of Natural History at St. Petersburg.] A monotypic genus of the north tenuperate zone.

r. Beckmannia erucaefórmis (L.) Host. Beckmannia. (I. F. f. 4I4.) Glabrous. Culms 4.5-9 dm. tall, erect, simple, smooth; sheaths longer than the internodes, loose; leaves $7 \cdot 5^{-22.5} \mathrm{~cm}$. long, $4-8 \mathrm{~mm}$. wide, rough; panicle $\mathbf{I}-2.5 \mathrm{~d}$. in length, simple or compound, the spikes about $1.25 \mathrm{~cm}$. long; spikelets $2-3 \mathrm{~mm}$. long, I-2-flowered, closely imbricated in two rows on one side of the rachis; scales smooth, the outer saccate, obtuse or abruptly acute; flowering scales acute, the lower generally awn-pointed, the upper rarely present. In wet places, western Ont. to Br. Col., south to Iowa, Colo. and Cal. July-Sept.

\section{ELEUSiNE Gaertn.}

Tufted annual or perennial grasses, with flat leaves and spicate inflorescence, the spikes digitate or close together at the summit of the culm. Spikelets several-flow ered, sessile, closely imbricated in two rows on one side of the rachis, which is not extended beyond them; flowers perfect or the upper staminate. Scales compressed, keeled; the 2 lower empty; the others subtending flowers, or the upper empty. Stamens 3. Styles distinct. Stigmas plumose. Grain loosely enclosed in the scale and palet. [From the Greek name of the town where Ceres was worshipped.] Species 6, natives of the Old World. Besides the following, two others have been found in ballast fillings about the eastern seaports.

I. Eleusine Índica (L.) Gaertn. Wire-Grass. Crab-Grass. YARD-Grass. (I. F. f. 4I5.) Culms I.5-6 dm. tall, tufted, erect, or decumbent at the base. Sheaths loose, overlapping and often short and crowded at the base of the culm, glabrous or sometimes sparingly villous; leaves $7.5-30 \mathrm{~cm}$. long, 2-6 mm. wide, smooth or scabrous; spikes 2-10, $2.5-7.5 \mathrm{~cm}$. long, whorled or approximate at the summit of the culm or one or two sometimes distant; spikelets 3-6-flowered, 3-4 mm. long: scales acute, minutely scabrous on the keel, the first I-nerved, the second 3-7nerved, the others 3-5-nerved. In fields, dooryards and waste places all over N. Am. except the extreme north. Naturalized from the warmer regions of the Old World. June-Sept.

\section{DACTYLOCTÈNIUM Willd.}

An annual grass, with flat leaves and spicate inflorescence, the spikes in pairs or digitate. Spikelets several-flowered, sessile, closely imbricated in two rows on one side of the rachis, which is extended beyond them into a sharp point. Scales compressed, keeled, the 2 lower and the uppermost ones empty, the others subtending flowers. Stamens 3. Styles distinct, short. Stigmas plumose. Grain free, rugose, loosely enclosed in the scale. [Greek, referring to the digitately spreading spikes.] A monotypic genus of the warmer parts of the Old World.

I. Dactyloctenium Aegýptium (L.) Willd. Egyptian Grass. (I. F. f. 4I6.) Culms I.5-6 dm. long, usually decumbent and extensively creeping at the base. Sheaths loose, overlapping and often crowded, smooth and glabrous; leaves r. $5 \mathrm{dm}$. in length or less, $2-6 \mathrm{~mm}$. wide, smooth or rough, sometimes pubescent, ciliate toward the base; spikes in pairs, or 3-5 and digitate, $1.25-5 \mathrm{~cm}$. long; spikelets 3-5-flowered; scales compressed, scabrous on the keel, the second awned, the flowering ones broader and pointed. In waste places and cultivated ground, southern N. Y., Penn. and Va. to Ill. and Cal., south to Fla. and Mex. Widely distributed in tropical America. Naturalized from Asia or Africa. July-Oct.

\section{LEPTóchloA Beauv.}

Usually tall annual grasses, with flat leaves and numerous spikes forming a simple panicle. Spikelets usually 2-many-flowered, fiattened, alternating in two rows on one side of the rachis. Scales 4 to many; the 2 lower empty, keeled, shorter than the spikelet; the flowering scales keeled, 3-nerved. Palet 2-nerved. Stamens 3. Styles distinct. Stigmas plumose. Grain free, enclosed in the scale and palet. [Greek, in allusion to the slender spikes.] About I2 species, natives of the warmer regions of both hemispheres. Besides the following, 3 others occur in the southern U. S. 
Flowering scales $1.5 \mathrm{~mm}$. long, the pubescence on the nerves long and copious.

Flowering scales less than $1 \mathrm{~mm}$. long, the pubescence on the nerves short and scant.

2. L. attenuata.

I. Leptochloa mucronata (Michx.) Kunth. Northern LeptochloA. (I. F. f. 4I7.) Culms 3-12 dm. tall, finally branching. Sheaths, at least the lower ones, commonly more or less hirsute ; leaves $6-25 \mathrm{~cm}$. long, I cm. or less wide, rough ; inflorescence $1.5-5 \mathrm{dm}$. long; spikes generally elongated, ascending, $5^{-1} 5 \mathrm{~cm}$. long; spikelets $2.5-3 \mathrm{~mm}$. long; scales usually 5 , the outer empty 2 acute, equal, or the first somewhat shorter than the second, the first scale usually a little shorter than the first flowering scale. In fields, Va. to Fla., west to Cal. June-Aug.

2. Leptochloa attenuata Nutt. Sharp-Scaled Leptochloa. Culms tufted, branching at the base, 2-4 dm. tall, rarely taller. Lower sheaths sparingly pilose ; leaves 4-8 cm. long, sometimes longer, 3-5 mm. wide, sparingly pilose beneath; inflorescence I.5-2 dm. long; spikes numerous, finally spreading, $2-5 \mathrm{~cm}$. long, rarely longer; spikelets $1.6-2 \mathrm{~mm}$. long; scales 5 or 6 , the outer 2 subulate, acuminate, awn-pointed, usually about equal, or the first shorter than the second, which reaches or extends beyond the apex of the second flowering scale. In sandy river bottoms, Ill. to Ind. Terr. Sept.-Oct.

\section{BÚLBILIS Raf. [BUCHLÖ̈ Engelm.]}

A perennial stoloniferous monœcious or apparently diœcious grass with flat leaves and spicate inflorescence. Staminate spikelets borne in two rows on one side of the rachis, the spikes at the summit of the long and exserted culms. Pistillate spikelets in spike-like clusters of 2 or 3 , on very short culms, scarcely exserted from the sheath. Stamens 3. Styles distinct, long. Stigmas elongated, short-plumose. Grain ovate, free, enclosed in the scale. [Name apparently from the supposed bulb-like base of old plants.] A monotypic genus of central N. Am.

I. Bulbilis dactyloides (Nutt.) Rat. Buffalo-grass. (I. F. f. 418.) Culms bearing staminate flowers $\mathbf{I}-3 \mathrm{dm}$. tall, erect, slender, naked above; those bearing pistillate flowers $1.25-7.5 \mathrm{~cm}$. long, much exceeded by the leaves; leaves $2 \mathrm{~mm}$. wide or less, more or less papillose, those of the staminate culms $2.5-10 \mathrm{~cm}$. long, erect, those of the stolons and pistillate culms $2.5 \mathrm{~cm}$. long or less, spreading; staminate spikes 2 or 3, approximate; spikelets 4-5 mm. long, flattened, 2-3-flowered, the empty scales I-nerved, the flowering 3-nerved ; pistillate spikelets ovoid, the outer scales indurated. On plains and prairies, Minn. to Dak., south to Ark., Tex. and Mex. A valuable fodder-grass. June-July.

\section{MUNRÒA Torr.}

A low diffusely branched grass, with flat pungently pointed leaves crowded at the nodes and the ends of the branches. Spikelets in clusters of $3-6$, nearly sessile in the axils of the floral leaves, 2-5-flowered, the flowers perfect. Two lower scales empty, lanceolate, acute, I-nerved, hyaline ; flowering sca!es larger, 3-nerved ; I or 2 empty scales sometimes present above the flowering ones; palet hyaline. Stamens 3. Styles distinct, elongated. Stigmas barbellate or short-plumose. Grain free, enclosed in the scale and palet. [In honor of Gen. William Munro, English agrostologist.] Three known species, the following of the plains of $\mathrm{N}$. Am., the others in S. Am.

I. Munroa squarròsa (Nutt.) Torr. Munro's Grass. (I. F. f. 4I9.) Culms 5-20 dm. long, tufted, erect, decumbent or prostrate, much branched, smooth or rough. Sheaths short, crowded at the nodes and ends of the branches, smooth, pilose at the base and throat, sometimes ciliate on the margins; leaves $2.5 \mathrm{~cm}$. long or less, I-2 mm. wide, rigid, spreading, scabrous, pungently pointed; spikelets 2-5 flowered, the flowers perfect; empty scales I-nerved, shorter than the flowering scales, which are about $5 \mathrm{~mm}$. long, 3-toothed, the nerves excurrent as short points or awns, with tufts of hair near the middle ; palets obtuse. On dry plains, S. Dak. to Alberta, south to Neb., Tex. and Ariz. 'Aug.-Oct.

\section{PHRAGMİtES Trin.}

Tall perennial reed-like grasses, with broad flat leaves and ample panicles. Spikelets 3-several-flowered, the first flower often staminate, the others perfect; 
rachilla articulated between the flowering scales, long-pilose. Two lower scales empty, unequal, membranous, lanceolate, acute, shorter than the spikelet; the third scale empty or subtending a staminate flower; flowering scales glabrous, narrow, long-acuminate, much exceeding the short palets. Stamens 3. Styles distinct, short. Stigmas plumose. Grain free, loosely enclosed in the scale and palet. [Greek, referring to its hedge-like growth along ditches.] Three known species, the following of the north temperate zone, one in Asia, the third in S. Am.

I. Phragmites Phragmites (L.) Karst. ReED. (I. F. f. 420.) Culms 1.5-5 m. tall, erect, stout, from long horizontal rootstocks, smooth and glabrous. Sheaths overlapping, loose ; leaves $1.5-3 \mathrm{dm}$. long or more, 8-50 mm. wide, flat, smonth, glabrous; panicle I.5-3 dm. long or more, ample; spikelets crowded on the ascending branches; first scale I-nerved, half to two-thirds as long as the $3^{-}$ nerved second one; flowering scales I-I.2 cm. long, 3-nerved, long-acuminate, equalling the hairs of the rachilla. In swamps and wet places nearly throughout the U. S., extending north to N. S., Manitoba and Br. Col. Also in Europe and Asia. Rarely ripening seed. Aug.-Oct. [P. communis Trin.]

68. SIEGLINGIA Bernh.

A perennial tufted grass with flat leaves and a narrow simple panicle. Spikelets few, 3-5-flowered, the rachiila internodes short. Scales 5-7, the lower 2 empty, equalling or nearly as long as the spikelet, the flowering scales very firm, rounded on the back, obscurely 9-nerved, the nerves more prominent at the shortly 3 -toothed summit, pilose near the margins, the callus short and obtuse, pilose; palet 2-keeled, ciliate on the keels. Stamens 3. Styles short, distinct. Stigmas plumose. Grain free, enclosed in the scale. [Named in honor of Prof. Siegling, German botanist.] A monotypic genus of the Old World.

I. Sieglingia decúmbens (L.) Kuntze. Heather-grass. (I. F. f. 423.) Culms $1.5-4.5 \mathrm{dm}$. tall, erect, often decumbent at the base, simple, smooth and glabrous. Sheaths villous at the summit; leaves smooth beneath, usually scabrous above, I-3 mm. wide, the basal $7 \cdot 5-15 \mathrm{~cm}$. long, those of the culm $2.5-7.5 \mathrm{~cm}$. long: panicle $2.5-5 \mathrm{~cm}$. long, contracted, the branches $2.5 \mathrm{~cm}$. long or less, erect; spikelets 3-5-flowered, 6-1o $\mathrm{mm}$. long, the joints of the rachilla very short; lower scales equalling the spikelet, acute; flowering scales broadly oval, clliate on the margins below, obtusely 3 -toothed, with two tufts of hair on the callus. Introduced into Newf. Native of Europe and Asia. Summer.

\section{TRICÚSPIS Beauv.}

Usually perennial grasses with flat or involute leaves and an open or contracted sometimes spike-like panicle. Spikelets 3-many-flowered, the flowers perfect or the upper ones staminate, the rachilla articulated above the empty scales and between the flowers. Scales 5-many, membranous, sometimes firmer, the lower 2 empty, keeled, obtuse to acuminate, usually shorter than the rest, sometimes longer, the flowering scales 3-nerved, the midnerve or all the nerves excurrent, the midnerve and the lateral nerves or the margins pilose, the apex shortly 2 -toothed, rarcly entire, the teeth obtuse or acute, the callus shcrt and obtuse; palet shorter than the scale, compressed, 2-keeled. Stamens 3. Styles short, distinct. Stigmas plumose. Grain free, enclosed in the scale. [Named in reference to the teeth of the flowering scale of most of the species.] Species about 30, natives chiefly of temperate regions. (Sieglingia Bernh. in part.)

Panicle open, the branches long and more or less spreading, often drooping at the apex.

Panicle contracted, the branches short and erect or appressed.

I. T. seslerioides.

Panicle spike-like, I-3 dm. long; spikelets numerous; leaves long and flat.

Second empty scale $\mathrm{I}$-nerved; flowering scales $3.5-4 \mathrm{~mm}$. long.

2. T. stricta.

Second empty scale 3-5-nerved; flowering scales $5^{-6} \mathrm{~mm}$. long.

3. T. elongata.

Panicle $\mathrm{I}-3 \mathrm{~cm}$. long, almost raceme-like; spikelets few ; leaves thick, folded.

4. T: pilosa.

I. Tricuspis ses!erioides (Michx.) Torr. TALL RED-TOP.

Culms 6-15. dm. tall, erect, somewhat flattened, often viscid above. Sheaths some- 
times villous at the summit, the lower short, overlapping and crowded, the upper longer, equalling or shorter than the internodes; leaves $\mathbf{I}-3 \mathrm{dm}$. long or more, 6-I2 mm. wide, flat, attenuate into a long tip, smooth beneath, scabrous above; panicle $\mathbf{1} .5-4.5 \mathrm{dm}$. long, the branches finally ascending or spreading, the lower $\mathbf{1}-2.5 \mathrm{dm}$. long, usually dividing above the middle; spikelets 4-8-flowered, 6-8 mm. long, purple; empty scales glabrous, obtuse, generally slightly 2-toothed; flowering scales oval, the nerves pilose, excurrent as short tips. In fields, Conn to Kans., south to Fla. and Tex. July-Sept. (Sieglingia seslerioides (Michx.) Scribn.)

2. Tricuspis strícta (Nutt.) A. Gray. NARrow Tricuspis. (I. F. f. 422.) Culms 4.5-12 dm. tall, erect, a little compressed. Leaves I.5-3 dm. long or more, flat, long-acuminate, smooth beneath, scabrous above; spike-like panicle 1.25-3 $\mathrm{dm}$. in length, the branches appressed, the lower $2.5-5 \mathrm{~cm}$. long; spikelets 4-IOflowered, 4-6 mm. long; lower scales usually about two-thirds as long as the spikelet, rarely extending beyond the flowering scales, acute, glabrous; flowering scales ovate, the nerves pilose for more than half their length, the middle and often the lateral excurrent as short tips. Moist soil, Miss. to Kans. and Tex. July-Oct. (Sieglingia stricta (Nutt.) Kuntze.)

3. Tricuspis elongà̇a (Buckley) Nash. Long-Panicled Tricuspis. (I. F. f. 422b.) Culms 3-9 dm. tall, tufted, erect, rough, the sterile shoots about onehalf as long as the culms. Sheaths rough, a ring of hairs at the apex; leaves rough, usually involute when dry, $7 \cdot 5^{-2} 5 \mathrm{~cm}$. long, 2-4 mm. wide; panicle narrow, 1.25-2.5 dm. long, $\mathbf{1} .25 \mathrm{~cm}$. wide, its branches erect, $3.75 \mathrm{~cm}$. long or less; spikelets 10-12-flowered, 9-12 mm. long, the empty scales scabrous, the first Inerved, the second 3-nerved; flowering scales about $6 \mathrm{~mm}$. long, obtuse at the scabrous apex, 3-nerved, the lateral nerves vanishing at or below the apex, the midnerve usually excurrent as a short tip. Prairies, Kans. to Ariz. and Tex. June-Aug. (Sieglingia elongata (Buckley) Nash.)

4. Tricuspis pilòsa (Buckley) Nash. Sharp-scaled Tricuspis. (I. F. f. 422c.) Culms tufted, $6.25-30 \mathrm{~cm}$. tall, the sterile shoots I dm. tall or less. Sheaths smooth, a tuft of hairs on each side of the apex, much shorter than the internodes; leaves strict or curved, thick, linear, obtuse, I-nerved, the margins white, serrulate, $3.75 \mathrm{~cm}$. long, or less, less than $2 \mathrm{~mm}$. wide, folded, at least when dry, pubescent with long hairs, especially beneath; panicle almost raceme-like, long-exserted, I.25-3.75 cm. long; spikelets 3-IO, crowded, 8-12-flowered; empty scales, acuminate, I-nerved; flowering scales 6-6.5 mm. long, acuminate, 3 -nerved, the midnerve generally excurrent as a short tip, all the nerves pilose (the lateral at the top and bottom, the midnerve below the middle). Dry soil, Kans. to Colo., Tex, and N. Mex. April-Sept. (Sieglingia pilosa (Buckley) Nash.)

\section{TRIPLÀsIS Beauv.}

Perennial (?) grasses, with narrow flat or involute leaves and contracted or open somewhat branched panicles. Spikelets shortly pedicelled, 2-6-flowered, the glabrous rachilla articulated between the flowers, the internodes very long. Scales 4-8, membranous, the lower 2 empty, keeled, the flowering scales dorsally rounded at the base, 3-nerved, the lateral nerves pilose, deeply 2 -lobed at the apex, longawned between the lobes, the callus long and subulate, pubescent on the outer surface; palet 2-keeled, the keels long-ciliate. Stamens 3. Styles short, distinct. Stigmas plumose Grain free, enclosed in the scale. [Greek, referring to the 3 divisions of the flowering scales.] Species 3, natives of the eastern and southern parts of N. Am. Besides the following, two others occur in the southern U.S.

I. Triplasis purpùrea (Walt.) Chapm. SAND-GRASS. (I. F. f. 424.) Culms 3-9 dm. tall, erect, prostrate or decumbent. Leaves $1.25-6.25 \mathrm{~cm}$. long, $2 \mathrm{~mm}$. wide or less. rigid, scabrous, sometimes sparsely ciliate; panicle $2.5-7.5 \mathrm{~cm}$. long, the branches rigid, finally widely spreading, the lower $1.8-3.75 \mathrm{~cm}$. long; spikelets 2-5-flowered, 5-8 mm. long, the jomts of the rachilla half as long as the flowering scale; flowering scales oblong, 2-loled at the apex, the lobes erose-truncate, the nerves strongly ciliate, the middle one excurrent as a short point. In sand, especially on sea-beaches, Me. to 'Tex. and along the Great Lakes. Also from Neb. to N. Mex. Plant acid. Aug.-Sept. 


\section{7r. REDFIÈLDIA Vasey.}

A tall perennial grass, with long narrow leaves and an ample panicle. Spikelets I-3-flowered, the flowers all perfect. Empty scales 2, about equal, shorter than the spikelet, I-nerved; flowering scales membranous, 3-nerved, with a ring of hairs at the base. Palet 2-nerved, shorter than the scale. Stamens 3. Styles long, distinct. Stigmas sliort, plumose. Grain oblong, free. [In honor of John H. Redfield, 1815-1895, American naturalist.] A monotypic genus of the western U. S.

r. Redfieldia flexuòsa (Thurb.) Vasey. Redfieldia. (I. F. f. 425.) Culms 4.5-12 dm. tall, erect from a long horizontal rootstock. Sheaths smooth, the lower short and overlapping, often crowded, the upper much longer; leaves 3-6 $\mathrm{dm}$. long, 2-4 mm. wide, involute; panicle ample and diffuse, 2-5.5 dm. in length, the branches finally widely spreading, flexuous, the lower $7 \cdot 5-20 \mathrm{~cm}$. long: spikelets about $6 \mathrm{~mm}$. long, I-3-flowered, the empty scales acute, glabrous; flowering scales with a ring of hairs at the base, minutely scabrous, twice the length of the empty ones, acute, the middle nerve usually excurrent as a short tip. On prairies, Neb. and Wyo. to Colo. and the Ind. Terr. Aug.-Sept.

\section{DIPLÁCHNE Beauv.}

Tufted grasses, with narrow flat leaves and long slender spikes arranged in an open panicle, or rarely only one terminal spike. Spikelets several-flowered, narrow, sessile or shortly pedicelled, erect. Two lower scales empty, membranous, keeled, acute, unequal; flowering scales 1-3-nerved, 2 -toothed and mucronate or short-awned between the teeth. Palet hyaline, 2-nerved. Stamens 3. Styles distinct. Stigmas plumose. Grain free, loosely enclosed in the scale and palet. [Greek, referring to the 2-toothed flowering scales.] About 15 species, natives of the warmer regions of both hemispheres. Besides the following species, about 6 others occur in the southern and western parts of N. Am.

Awn less than one-third as long as the flowering scale.

Spikelets 4-8 mm. long, the flowering scales acute or obtuse at the 2-toothed apex, lateral nerves often excurrent.

x. D. fascicularis.

Spikelets ro-12 $\mathrm{mm}$. long, the flowering scales acuminate at the usually entire apex, the lateral nerves rarely excurrent.

Awn one-half as long as the flowering scale or more.

2. D. acuminata.

3. D. procumbens.

I. Diplachne fasciculàris (Lam.) Beauv. Salt-meadow Diplachne. (I. F. f. 426.) Culms tufted, finally branching, 3-8 dm. tall. Leaves erect, I-2 $\mathrm{dm}$. long, $3 \mathrm{~mm}$. or less wide, involute when dry, rough; racemes 8 or more, erect or ascending, the larger oncs 4-8 cm. long; spikelets 4-8 $\mathrm{mm}$. long; scales Io-12, the flowering scales, exclusive of the awn, 3-4 mm. long, the midnerve extending into an awn I mm. long or less. Along the coast. Fla. to Tex., and extending up the Miss. Valley to III. and Mo. July-Sept.

2. Diplachne acuminàta Nash. Sharp-scaled Diplachne. Culms tufted, 3-6 dm. tall, finally branching. Leaves erect, I-3 dm. long, $4.5 \mathrm{~mm}$. or less wide, usually involute when dry, very rough; racemes numerous, erect or ascending, the larger 7-I5 cm. long; spikelets IO-I2 mm. long; scales 8-II, the flowering scales 6-7 mm. long, acuminate at the entire or occasionally slightly 2toothed apex, the lateral nerves rarely slightly excurrent, the midnerve extending into an awn 0.75-1.3 mm. long. Wet or moist soil, Ark. to Neb. and Colo. JuneAug.

3. Diplachne procúmbens (Muhl.) Nash. Long-Awned Diplachne. Culms tufted, finally branching, $2-4 \mathrm{dm}$. tall. Leaves erect, $8-20 \mathrm{~cm}$. long, $4 \mathrm{~mm}$. or less wide, involute when dry; racemes numerous, erect, the larger $5-7 \mathrm{~cm}$. long; spikelets about I cm. long; scales 8-10, the empty ones usually awned or awn-pointed, the flowering scales, exclusive of the awn, 4.5-5 mm. long, acuminate at the slightly 2 toothed apex, the midnerve extending into an awn one-half or more as long as the scale. Brackish marshes, N. Y. to S. Car. Aug.-Oct. 
qual, shorter than the spikelet; flowering scales membranous, rounded on the back, 3-nerved; palets scarcely shorter than the scales, obtuse, 2-keeled. Stamens 3. Styles short. Stigmas short, plumose. Grain oblong, free, enclosed in the scale and palet. [Name in honor of Joh. Ignaz Molina, Chilian missionary and naturalist.] A monotypic genus of Europe and Asia.

I. Molinia coerùlea (L.) Moench. Molinia. (I. F. f. 427.) Culms 3-Io dm. tall, erect, simple, smooth and glabrous. Sheaths overlapping, and confined to the lower part of the culm, smooth and glabrous; leaves $\mathbf{I}-3 \mathrm{dm}$. long or more, 2-6 mm. wide, erect, acuminate, smooth beneath, slightly scabrous above; panicle $7.5-25 \mathrm{~cm}$. in length, green or purple, the branches usually erect, $2.5-10 \mathrm{~cm}$. long; spikelets 2-4-flowered, 5-8 $\mathrm{mm}$. long; empty scales acute, unequal; flowering scales about $4 \mathrm{~mm}$. long, 3 -nerved, obtuse. Introduced on ballast and into waste places, Me. to N. Y. Adventive from Europe. Aug.-Sept.

\section{RHOMBOLỲTRUM Link.}

Perennial grasses, with usually flat leaves, and a narrow contracted spike-like panicle. Spikelets numerous. Scales several, the outer two empty ones I-nerved, the flowering scales broad, rounded at the apex, 3-nerved, the nerves glabrous, the lateral ones vanishing below the margin, the midnerve at the margin or sometimes excurrent as a short tip, the callus pilose; palet 2-keeled. Stamens 3 . Styles short, distinct. Stigmas plumose. Grain free, enclosed in the scale. [Greek, in reference to the round flowering scales.] Species 4 or 5, natives of warm or tropical countries. (Sieglingia Bernh. in part.)

I. Rhombolytrum albéscens (Vasey) Nash. (I. F. f. 422a.) Culms tufted, 3-5 dm. tall, the sterile shoots one-half as long as the culm or more. Leaves smocth beneath, roughish above, acuminate, $6.25-27.5 \mathrm{~cm}$. long, 2-4 mm. wide; panicle dense and contracted, white, $6.25-12.5 \mathrm{~cm}$. long, 6-18 mm. broad, its branches erect or ascending, $2.5 \mathrm{~cm}$. or less long; spikelets 7-I I-flowered, 4-5 mm. long, the empty scales white, I-nerved, about equal; flowering scales about $3 \mathrm{~mm}$. long, 3-nerved, the lateral nerves vanislsing below the apex, the midnerve excurrent in a short scabrous point. Prairies, Kans. to Tex. Aug.-Sept. (Sieglingia albescens (Vasey) Kuntze.)

\section{ERAGRóstis Beauv. (See Appendix.)}

Annual or perennial grasses, rarely diœcious, from a few inches to several feet in height, the spikelets in contracted or open panicles. Spikelets 2-many-flowered, more or less flattened. Two lower scales empty, unequal, shorter than the flowering ones, keeled, I-nerved, or the second 3-nerved ; flowering scales membranous, keeled, 3-nerved ; palets shorter than the scales, prominently 2 -nerved or 2 -keeled, usually persisting on the rachilla after the fruiting scale has fallen. Stamens 2 or 3. Styles distinct, short. Stigmas plumose. Grain free, loosely enclosed in the scale and palet. [Greek etymology doubtful, perhaps signifying a low grass, or Love-grass, an occasional English name.] A genus of about Ioo species, widely distributed throughout all warm and temperate countries. Besides the following, some 15 others occur in the southern and western parts of $\mathrm{N}$. Am.

Culms often decumbent at the base and generally much branched, $4.5 \mathrm{dm}$. tall or less ; usually annuals.

Spikelets 2-5-flowered, 2-3 $\mathrm{mm}$. long.

Culms branched only at the very base; pedicels and branches of the panicle long and capillary. $\quad$ I. E. capillaris.

Culms branched above the base; pedicels and branches of the panicle short.

Spikelets 5-many-flowered, 3-16 mm. long.

$$
\text { 2. E. Frankii. }
$$

Spikelets $1.5 \mathrm{~mm}$. wide or less.

Flowering scales thin, usually bright purplish, the lateral nerves faint or wanting; spikelets about $\mathrm{I} \mathrm{mm}$. wide. 3 3. E. pilosa.

Flowering scales firm, usually dull purple or green, the lateral nerves very prominent; spikelets about $1.5 \mathrm{~mm}$. wide. 4. E. Purshii.

Spikelets $2 \mathrm{~mm}$. wide or more.

Lower flowering scales about $1.5 \mathrm{~mm}$. long; spikelets $2 \mathrm{~mm}$. wide.

Lower flowering scales $2-2.5 \mathrm{~mm}$. long; spikelets $2.5-3 \mathrm{~mm}$. wide. 
Culms erect or ascending, simple, rigid, 4.5-16 dm. tall ; ususlly perennials. Spikelets not clustered.

Hranches of the open panicle widely spreading, at le:st when old.

Spikelets closely sessile.

Spikelets more or less pedicelled.

7. E. sessilispica.

Pedicels long, commonly at lcast the length of the spikelets.

Pedicels commonly much shorter than the spikelets.

9. E. pectinacea.

Leaves elongated; branches of the panicle long and slender; spike. lets scattered, 6-25-ीlowered.

Io. E. refracta.

Leaves not clongated; branches of the panicle short and stout, rigid, spikelets crowded, 5-12-flowered. 8. E. curtipedicellata.

Branches of the elongated paniclc erect or ascending, capillary, somewhat flexuous.

Spikelets clustered on the very shori erect or ascending branches. Ix. E. trichodes.

Culms extensively creeping; flowers diœecious.

12. E. secundiflora. 13. E. hypnoides.

I. Eragrostis capillàris (L.) Nees. Capillary Eragrostis. (I. F. f. 428.) Culms 2-4.5 dm. tall, erect, slender, sparingly branched at the base. Sheaths glabrous or sparingly hairy, the upper enclosing the base of the panicle; leaves 7.5-25 cm. long, 2-4 mm. wide, long-acuminate, smooth beneath, scabrous above and sparingly hirsute near the base; panicle diffuse, $\mathbf{I}-4 \mathrm{dm}$. in length, the branches capillary, spreading or ascending, 3.75-12.5 cm. long; spikelets ovate, 2-4-flowered, little flattened, 2-3 mm. long; empty scales about equal, acute; flowering scales acute, the lower $1.5 \mathrm{~mm}$. long. In dry places, N. H. and R. I. to N. Y. and Mo., south to Ga. and Tex. Aug.-Sept.

2. Eragrostis Fránkii Steud. Frank's Eragrostis. (I. F. f. 429.) Culms I.5-4 dm. tall, tufted, erect, or often decumbent at the base. Sheaths loose, shorter than the internodes: leaves $5-12.5 \mathrm{~cm}$. long, 2-4 $\mathrm{mm}$. wide, smooth beneath, scabrous above; panicle $5^{-1} 5 \mathrm{~cm}$. in length, open, the branches ascending, the lower 2.5-3.75 cm. long; spikelets ovate, 3-5-flowered, 2-3 mm. long; empty scales acute, the first shorter than the second; flowering scales acute, the lower I. 5 mm. long. In moist places, southeastern N. Y. and northern N. J. to Minn., south to Miss., La. and Kans. Sept.-Oct.

3. Eragrostis pilòsa (L.) Beauv. Tufted Eragrostis. (I. F. f. 430.) Culms I.5-4.5 dm. tall, tufted, erect, slender, branched. Sheaths sometimes pilose at the throat; leaves $2.5-12.5 \mathrm{~cm}$. long, $2 \mathrm{~mm}$. wide or less, smooth beneath, scabrous above; panicle $5^{-15} \mathrm{~cm}$. in length, the branches at first erect, finally widely spreading, $2.5-3.75 \mathrm{~cm}$. long, often hairy in the axils; spikelets 5-12-flowered, 3-6 mm. long, about I $\mathrm{mm}$. wide; lower scales acute, the first one-half as long as the second; flowering scales acute, the lower $1.5 \mathrm{~mm}$. long, thin, usually purplish. Waste places or cultivated ground, southern N. E. to Ill. and Kans., south to Fla. and Tex. Naturalized from Europe. Aug.-Sept.

4. Eragrostis Púrshii Schrad. Pursh's Eragrostis. (I. F. f. 43I.) Culms I.5-4.5 dm. tall, tufted, usually decumbent at the base and much branched, smooth. Leaves $3.75-8.75 \mathrm{~cm}$. long, $2 \mathrm{~mm}$. wide or less, smooth beneath, rough above; panicle open, 7.5-20 cm. long, the branches spreading, $2.5-6.25 \mathrm{~cm}$. long, naked in the axils; spikelets 5-15-flowered, dull purple or green, 3-8 $\mathrm{mm}$. long, about $\mathbf{1 . 5} \mathrm{mm}$. wide; empty scales acute, the lower about two-thirds as long as the upper, scabrous on the keel; flowering scales acute, firm, the lower ones $1.5 \mathrm{~mm}$. long. In dry places, apparently throughout the U. S., extending into Ont. Aug.-Sept.

5. Eragrostis Eragróstis (L.) Karst. Low ERAgrostis. (I. F. f. 432.) Culms seldom over $4 \mathrm{dm}$. tall, tufted, usually decumbent and much branched. Sheaths sparingly pilose at the throat; leaves $2.5-6.25 \mathrm{~cm}$. long, $\mathrm{r}-4 \mathrm{~mm}$. wide, smooth beneath, rough above and somewhat pilose near the base; panicle 5-11.25 $\mathrm{cm}$. in length, the branches spreading or ascending, $1.8-3.75 \mathrm{~cm}$. long; spike?ets 8-r8-flowered, 6-10 mm. long, about $2 \mathrm{~mm}$. wille; empty scales acute, the first twothirds as long as the second: flowering scales obtuse, $1.5 \mathrm{~mm}$. long, thie lateral nerves prominent. In waste places or cultivated ground, Ont. to N. E., N. Y. and Penn. Locally naturalized from Europe. July-Sept. [E. minor Host.]

6. Eragrostis màjor Host. STRong-Scknted ERAgrostis. (I. F. f. 433.) Culms 1.5-6 dm. tall, erect, or decumbent at the base, usually branched. Sheiths 
sparingly pilose at the throat; leaves $5-\mathbf{I} 7.5 \mathrm{~cm}$. long, 2-6 mm. wide, flat, smocth beneath, scabrous above; panicle $5^{-1} 5 \mathrm{~cm}$. in length, the branches spreading or ascending, 2.5-5 cm. long; spikelets 8-35-flowered, 5-16 mm. long, about $3 \mathrm{~mm}$. wide, very flat; empty scales acute, the first slightly shorter than the second; flowering scales obtuse, 2-2.5 $\mathrm{mm}$. long, the lateral nerves prominent. In waste and cultivated places nearly throughout the U. S., and in Ont. Naturalized from Europe. Unpleasantly scented, handsome. Aug.-Sept.

7. Eragrostis sessilispica Buckley. Prairie Eragrostis. (I. F. f. 434.) Culms 2-10.5 dm. tall, erect, simple. Sheaths crowded at the base of the culm, pilose at the summit; leaves 5-15 cm. long, $1.5-3 \mathrm{~mm}$. wide, rough above, glabrous or sparingly pilose beneath; panicle $2-4 \mathrm{dm}$. in length, the branches stout, rigid, widely diverging; spikelets scattered, closely sessile, appressed, 5-12-flowered, 8-I4 $\mathrm{mm}$. long; empty scales about equal in length, acute; flowering scales very acute, about $4 \mathrm{~mm}$. long, the lateral nerves very prominent. Prairies, Kans. to Tex. Aug.-Sept.

8. Eragrostis curtipedicellàta Buckley. SHort-STAlked Eragrostis. (I. F. f. 435.) Culms 1.5-9 dm. tall, erect, rigid, simple. Sheaths overlapping, pilose at the summit; leaves $5-20 \mathrm{~cm}$. long, 2-4 $\mathrm{mm}$. wide, smooth beneath, scabrous above; panicle I-3 dm. in length, the branches widely spreading, 3.75-I I.25 $\mathrm{cm}$. long; spikelets 5-12-flowered, 3-6 mm. long, on pedicels of less than their own length; scales acute, the empty ones somewhat unequal, the flowering ones about I. $75 \mathrm{~mm}$. long, scabrous on the midnerve, their lateral nerves prominent. Prairies, Kans. to Tex. Aug.-Sept.

9. Eragrostis pectinàcea (Michx.) Steud. Purple Eragrostis. (I. F. f. 436.) Culms $3-7 \cdot 5 \mathrm{dm}$. tall, erect or ascending, rigid, simple. Sheaths overlapping, glabrous or villous, the upper one often enclosing the base of the panicle; leaves $1.25-3 \mathrm{dm}$. long, 4-8 $\mathrm{mm}$. wide, smooth beneath, scabrous above and sparingly villous at the base; panicle $1.5-6 \mathrm{dm}$. in length, purple or purplish, the branches $7.5-25 \mathrm{~cm}$. long, strongly bearded in the axils, widely spreading or the lower often reflexed; spikelets 5-I5-flowered, 3-8 $\mathrm{mm}$. long, on pedicels of at least their own length; scales acute, the empty ones about equal, the flowering ones about I.75 mm. long, their lateral nerves very prominent. In dry soil, N. H. to Ill. and S. Dak., south to Fla. and Tex. Aug.-Sept.

Io. Eragrostis refrácta (Muhl.) Scribn. MEadow Eragrostis. (I. F. f. 437.) Culms 3-9 dm. tall, erect, slender, simple. Sheaths overlapping, smooth and glabrous; leaves $1.25-3 \mathrm{dm}$. long, 2-4 mm. wide, smonth beneath, rough above, and villous toward the base; panicle $2-5 \mathrm{dm}$. long; branches slender, $\mathrm{I}-2.5 \mathrm{dm}$. long, at length widely spreading, the axils often bearded; spikelets 6-25-flowered, 5-12 mm. long, longer than their pedicels; empty scales acute, the first somewhat shorter than the second; flowering scales very acute, $1.5^{-2} \mathrm{~mm}$. long, the lateral nerves prominent. In moist soil, Del. and Md. to Fla., west to Tex. Aug.Sept.

II. Eragrostis trichòdes (Nutt.) Nash. HAIR-LIkE Eragrostis. (I. F. f. 438.) Culms 6-12 dm. tall, erect, simple. Sheaths overlapping, pilose at the throat; leaves I.5-6.5 dm. long, 2-4 mm. wide, smooth beneath, slightly scabrous above, attenuate into a long slender tip; panicle 2.25-6.5 dm. in length, narrow and elongated, the branches erect or ascending, capillary, subdividing, somewhat flcxuous, 7.5-I7.5 $\mathrm{cm}$. long; lower axils sometimes bearded; spikelets usually pale, 3-Io-flowered, 5-9 mm. long; lower scales very acute, about equal; flowering scales acute, the lower ones $2.5-3 \mathrm{~mm}$. long, their lateral nerves manifest. In dry sandy soil, Ohio and Ill. to Neb., south to Ark. and Tex. Aug.-Sept.

12. Eragrostis secundiflòra Presl. Clustered Eragrostis. (I. F. f. 439.) Smooth and glabrous. Culms I.5-9 dm. tall, erect, simple; leaves 5-30 $\mathrm{cm}$. long, 2-4 mm. wide; panicle $3.75-15 \mathrm{~cm}$. in length, the branches $1.25-3.75$ $\mathrm{cm}$. long, erect or ascending; spikelets crowded or clustered, sessile or nearly so, strongly flattened, 8-40-flowered, 6-20 mm. long, 2-5 $\mathrm{mm}$. wide; lower scales acute, about equal; flowering scales $3-3.5 \mathrm{~mm}$. long, acute, usually purple-bordered, the lateral nerves prominent. In dry soil, Kans. and Mo., south to Tex. and La. Aug.-Sept.

13. Eragrostis hypnoides (Lam.) B.S.P. Creeping Eragrostis. (I. F. f. 440.) Culms 2.5-45 cm. long, extensively creeping, branched, the branches erect 
or ascending, $2.5^{-1} 5 \mathrm{~cm}$. high. Sheatlıs villous at the summit; leaves $5 \mathrm{~cm}$, long or less, I-2 mm. wide, flat, smooth beneath, rough abuve; spikelets diœcious, Io 35 -flowered, 4-16 mm. long; lower scales unequal, the first one-half to two-thirds as long as the second; flowering scales about $2.5 \mathrm{~mm}$. long, the lateral nerves prominent; scales of the pistillate flowers more acute than those of the staminate. On sandy or gravelly shores, Vt. and Ont. to Ore., south to Fla. and Mex. Also in the West Indies. Aug.-Sept. [E. reptans Nees.]

\section{EATÒNIA Raf. (See Appendix.)}

Tufted perennial grasses, with flat or involute leaves and usually contracted panicles. Spikelets 2-3-flowered; the rachilla extended beyond the flowers. Two lower scales empty, shorter than the spikelet, the first linear, acute, I-nerved, the second much broader, 3-nerved, obtuse or rounded at the apex, or sometimes acute, the margins scarious; flowering scales narrower, generally cbtusc. Palet narrow, 2-nerved. Stamens 3. Styles distinct, short. Stigmas plimose. Grain free, loosely enclosed in the scale and palet. [In honor of Amos Eaton, I 776-1842, American botanist.] A genus of 4 or 5 species, confined to N. Am.

Empty scales unequal, the first shorter and about one-sixth as wide as the second.

Second scale obovate, of ter almost truncate.

Second scale oblanceolate, obtuse or abruptly acute.

Empty scales equal, the first not less than one-third as wide as the second.

I. E. obtusata.

2. E. Pennsylvanica.

3. E. nitida.

I. Eatonia obtusàta (Michx.) A. Gray. Blunt-scaled Eatonia. (I. F. f. 441.) Culms 3-7.5 dm. tall, erect, simple, often stout. Sheaths usually more or less rough, sometimes pubescent; leaves $2.5-22.5 \mathrm{~cm}$. long, I-8 mm. wide, scabrous; panicle $5^{-15} \mathrm{~cm}$. in length, dense and generally spike-like, strict, the branches $3.75 \mathrm{~cm}$. long or less, erect; spikelets crowded, $2.5-3 \mathrm{~mm}$. long; empty scales unequal, often purplish, the first narrow, shorter than and about one-sixth as wide as the obtuse or almost truncate second one; flowering scales narrow, obtuse, $1 \cdot 5^{-2}$ mm. long. In dry soil, Mass. and Ont. to Assiniboia, Fla. and Ariz. June-Aug.

2. Eatonia Pennsylvànica (DC.) A. Gray. Pennsylvania Eatonia. (I. F. f. 442.) Culms 3-9 dm. tall, erect, simple, slender. Leaves $6.25-17.5 \mathrm{~cm}$. long, $2-6 \mathrm{~mm}$. wide, rough; panicle $7 \cdot 5-17 \cdot 5 \mathrm{~cm}$. in length, contracted, often nodding, lax, its branches $2.5-6.5 \mathrm{~cm}$. long; spikelets $3-3.5 \mathrm{~mm}$. long, usually numerous, somewhat crowded and appressed to the branches; empty scales unequal, the first narrow, shorter than and about one-sixth as broad as the obtuse or abruptly acute second one, which is smooth, or somewhat rough on the keel; flowering scales narrow, acute, $2.5 \mathrm{~mm}$. long. In hilly woods or moist soil, N. B. to $\mathrm{Br}$. Colo., south to Ga., La. and Tex. June-July.

Eatonia Pennsylvanica màjor Torr. Culms taller; panicle longer and more compound; leaves longer and broader. Range apparently nearly that of the typical form.

3. Eatonia nítida (Spreng.) Nash. Slender Eatonia. (I. F. f. 443.) Culms 3-6 dm. tall, erect, very slender. Sheaths pubescent; leaves $1.25-7.5 \mathrm{~cm}$. long, $2 \mathrm{~mm}$. wide or less, often pubescent, the uppermost very short; panicle $5^{-15}$ $\mathrm{cm}$. in length, lax, the branches spreading at flowering time, afterwards erect, $2.5-$ $6.25 \mathrm{~cm}$. long; spikelets not crowded, $3 \mathrm{~mm}$. long; empty scales smooth, the nirst about one-third as wide as and equalling the second, which is obtuse or almost truncate, often apiculate; flowering scales narrow, $2-2.5 \mathrm{~mm}$. long, obtuse or acutish, smooth. In dry woods, Conn. to southern N. Y., N. J., Ga. and Ala. MayJune.

\section{KOELÈrIA Pers.}

Tufted annual or perennial grasses, with flat or setaceous leaves and mostly spike-like panicles. Spikelets 2-5-flowered. Tws lower scales empty, narrow, acute, unequal, keeled, scarious on the margins; the flowering scales 3-5-nerved. Palet hyaline, acute, 2-keeled. Stamens 3. Styles very short. Stigmas plumose. Grain free, enclosed in the scale and palet. [In honor of Georg Ludwig Koeler, German hotanist.] About 15 species of wide geographic distribution. The following, which may contain two forms, occurs in N. Am. 
I. Koeleria cristàta (L.) Pers. Koeleria. (I. F. f. 444.) Culms 3-7.5 $\mathrm{dm}$. tall, often pubescent just below the panicle. Leaves $2.5-30 \mathrm{~cm}$. long, $1-3 \mathrm{~mm}$. wide, erect, flat or involute, smooth or rough, often more or less hirsute; panicle $2.5^{-17.5} \mathrm{~cm}$. in length, pale green, usually contracted or spike-like, the branches erect or rarely ascending, $2.5 \mathrm{~cm}$. long or less; spikelets 2-5-flowered, 4-6 mm. long, the scales rough, acute, the empty ones unequal; flowering scales $3-4 \mathrm{~mm}$. long, shining. In dry sandy soil, especially on prairies, Ont. to Br. Col., south to Penn., Neb., 'Tex. and Cal. Also in Europe and Asia. Very variable. JulySept.

\section{CATABRòsA Beauv.}

A perennial grass, with soft flat leaves and an open panicle. Spikelets usually 2-flowered. Two lower scales empty, thin-membranous, much slorter than the flowering ones, unequal, rounded or obtuse at the apex; flowering seales membranous, erose-truncate. Palet barely shorter than the scale. Stamens 3. Styles distinct. Stigmas plumose. [Greek, in allusion to the erose top of the flowering scales.] A monotypic genus of arctic and mountainous regions of the northern hemisphere.

I. Catabrosa aquática (L.) Beauv. Water Whorl-Grass. (I. F. f. 445.) Smooth and glabrous. Culms I-6 dm. tall, erect, from a creeping base, bright green, flaccid; sheaths usually overlapping, loose; leaves $3.75-12.5 \mathrm{~cm}$. long, $2-6 \mathrm{~mm}$. wide, flat, obtuse; panicle $2.5-20 \mathrm{~cm}$. in length, open, the branches whorled, spreading or ascending, very slender, I.25-5 cm. long; spikelets $2.5-3.5$ $\mathrm{mm}$. long, the empty scales rounded or obtuse, the first about half as long as the second, which is crenulate on the margins; flowering scales $2-2.5 \mathrm{~mm}$. long, 3-nerved, erose-truncate at the apex. In water or wet soil, Lab. and Quebec to Alaska, south to Neb., Colo. and Utah. Also in Europe and Asia. Summer.

\section{MÉLICA L.}

Perennial grasses, with usually soft flat leaves and contracted or open panicles. Spikelets I-several-flowered, often secund, the rachilla extended beyond the flowers and usually bearing 2-3 empty club-shaped or hooded scales, convolute around each other. Two lower scales empty, membranous, 3-5-nerved; flowering scales larger, rounded on the back, 7-13-nerved, sometimes bearing an awn, the margins more or less scarious; palets broad, shorter than the scales, two-keeled. Stamens three. Styles distinct. Stigmas plumose. Grain free, enclosed in the scale and palet. [Name used by Theophrastus for sorghum; said to be in allusion to the sweet culms of some species.] About 30 species, inhabiting temperate regions. Besides the following, some ${ }_{5}$ others occur in the Rocky Mts. and on the Pacific Coast.

Second scale much shorter than the 3-5-flowered spikelet.

Spikelets few ; branches of the panicle spreading or ascending.

Spikelets usually numerous ; branches of the panicle erect. Second scale nearly equalling the 2 -flowered spikelet.

I. M. diffusa.

2. M. parviflora. 3. M. mutica.

I. Melica diffùsa Pursh. Tall Melic-grass. (I. F. f. 446.) Culms 4.5$12 \mathrm{dm}$. tall. Leaves I- $2 \mathrm{dm}$. long, 4-8 mm. wile, rough; panicle $1.5-2 \mathrm{dm}$. in length, open, the branches spreading or ascending, the lower $3.75-7.5 \mathrm{~cm}$. long; spikelets usually numerous, about 3-flowered, 9-I I mm. long, nodding, on slender, more or less flexuous, pubescent pedicels; empty basal scales very broad, obtuse or acutish, the second generally much exceeded by the spikelet: flowering scales 7-9 mm. long, acute or obtuse, scabrous. Penn. to Minn., south to Va., Ky. and Tex. May-June.

2. Melica parvifiòra (Porter) Scribn. Small Melic-grass. (I. F. f. 447.) Culms 4.5-7.5 dm. tall. Sheaths more or less rough; leaves $1.25-2.25 \mathrm{dm}$. long, 2-4 mm. wide, rough; panicle $1.25^{-1.75} \mathrm{dm}$. in length, contracted, the branches erect, the lower $2.5-5 \mathrm{~cm}$. long: spikelets few, 4-5-flowered, I-I.3 cm. long, nodding, on somewhat flexuous strongly pubescent pedicels; lower scales obtuse or acutish, the second much exceeded by the spikelet; flowering scales 7-8 $\mathrm{mm}$. long, acutish, scabrous. Prairies, Kans. and Colo. to Ariz. and Tex.
3. Melica mùtica Walt.
NARI OW MELIC-GRASS.
(I. F. f. 448.)
Culms 
3-9 dm. tall, erect, usually slender. Sheaths rough; leaves rough, $\mathbf{I}-\mathbf{2 . 2 5} \mathrm{dm}$. long, 2-10 $\mathrm{mm}$. wide; panicle $8-26 \mathrm{~cm}$. in length, narrow, the branches spreading or ascending, $2.5-5 \mathrm{~cm}$. long; spikelets about 2-flowered, 7-9 mm. long, nodding, on more or less flexuous pubescent pedicels; empty scales very broad, acutish to obtuse, the second nearly as long as the spikelet or sometimes equalling it; flowering scales 6 $-8 \mathrm{~mm}$. long, generally very obtuse, scabrous. In rich soil, Penn. to Wis., south to Fla. and Tex. June-July.

\section{KORYCÀRPUS Zea.}

Erect grasses, with long flat leaves and narrow paniculate or racemose inflorescence. Spikelets 3-5-flowered, the rachilla readily disarticulating between the flowers. Upper scales empty, convolute. Two lower scales empty, the first narrow, 3-nerved, acute, the second broader, 5-nerved; flowering scales broader than the lower ones, acuminate or mucronate, rounded on the back, finally coriaceous and shining, 3-nerved. Palet 2-keeled. Stamens 2, rarely I. Styles short, distinct. Stigmas plumose. Grain beaked, free. [Greek, in allusion to the beaked grain.] Two known species, the following North American, the other Japanese.

r. Korycarpus diándrus (Michx.) Kuntze. American Korycarpus. (I. F. f. 449.) Culms 4.5-12 dm. tall, very rough below the panicle. Sheaths overlapping, confined to the lower part of the culm; leaves $2-6 \mathrm{dm}$. long, I-I. $8 \mathrm{~cm}$. wide, long-acuminate at the apex, usually scabrous; panicie often reduced to a raceme, 5-18 cm. in length, the branches erect, 2.5-5 cm. long; spikelets 3-5-flowered, I.21. $6 \mathrm{~cm}$. long, the lower scales unequal, the second much exceeded by the spikelet; flowering scales somewhat abruptly acuminate; palets shorter than the scales and exceeded by the beaked grain. In rich woods, Ohio to Neb., south to Ga., Tenn. and the Ind. Terr. Aug.-Sept. [Diarrhena Americana Beauv.]

\section{PLEUROPÒGON R. Br.}

Erect grasses with flat leares and racemose inflorescence. Spikelets 5-14-flowered; flowers perfect, or the upper staminate. Two lower scales empty, unequal, thin-membranous, I-nerved, or the second imperfectly 3-nerved; flowering scales longer, membranous, 7-nerved, the middle nerve excurrent as a short point or awn. Palet scarcely shorter than the scale, 2-keeled, the keels winged or appendaged. Stamens 3. Styles short. Stigmas plumose. Grain free, enclosed in the scale and palet. [Greek, side-beard, from the appendages to the palets.] Three known species, the following arctic, the others Californian.

T. Pleuropogon Sabínii R. Br. Sabine's Pleuropogon. (I. F. f. 45o.) Smooth. Culms I.5 dm. or less tall; sheaths one or two; leaves 6-25 mm. Iong, erect, glabrous; raceme $2.5-5 \mathrm{~cm}$. in length; spikelets $3-6,5-8$-flowered, about I $\mathrm{cm}$. long, on spreading or reflexed pedicels $2 \mathrm{~mm}$. in length or less; lower scales smooth, the first acute, shorter than the obtuse second; flowering scales oblong, 4-5 $\mathrm{mm}$. long, erose-truncate at the scarious summit, scabrous, the midnerve sometimes excurrent as a short point; palet bearing an awn-like appendage on each keel near the middle. Arctic regions of both th $=$ Old World and the New. Summer.

\section{UNìOLA L. (See Appendix.)}

Erect and often tall grasses with flat or convolute leaves and paniculate inflorescence. Spikelets 3-many-flowered, flat, 2-edged, the flowers perfect, or the upper staminate. Scales flattened, keeled, sometimes winged, rigid, usually acute; the lower 3-6 empty, unequal; the flowering scales many-nerved, the uppermost scales often smaller and empty; palets rigid, 2-keeled. Stamens I-3. Styles distinct. Stigmas plumose. Grain compressed, free, loosely enclosed in the scale and palet. [Name diminutive of unus, one, of no obvious application.] About 8 species, natives of America. Besides the following, 2 others occur in the southeastern U. S.

Spikelets about $6 \mathrm{~mm}$. in length; panicle spike-like.

Spikelets exceeding $1.25 \mathrm{~cm}$. in length; panicle open.

I. U. Iaxa.

Panicle lax, the branches pendulous; spikelets on long thread-like pedicels.

Panicle strict, the branches erect, rigid; spikelets on short stout pedicels. 
I. Uniola láxa (L.) B.S.P. Slender SpIke-grass. (I. F. f. 45 I.) Culms 4.5-12 dm. tall; leaves I.25-4 dm. long, 2-6 mm. wide, usually erect, flat, attenuate into a long tip, smooth or slightly rough; panicle spike-like, $\mathbf{I}-\mathbf{3} \mathrm{dm}$. in length, erect, strict, or nodding at the summit, the branches erect, $2.5-5 \mathrm{~cm}$. long ; spikelets short-stalked or nearly sessile, 3-6-flowered, about $6 \mathrm{~mm}$. long; flowering scales 3-4 mm. long, acuminate, spreading in fruit; palet arched, about two-thirds as long as the scale; stamen I. Sandy soil, L. I. to Penn. and Ky.. south to Fla. and Tex., mostly near the coast. Aug.-Sept. [U. gracilis Michx.]

2. Uniola latitòlia Michx. BROAd-Leaved SpIke-Grass. (I. F. f. 452.) Culms 6-I5 dm. tall; leaves $\mathbf{I}-2.25 \mathrm{dm}$. long, 6-25 mm. wide, flat, narrowed into a somewhat rounded, often ciliate base, acuminate at the apex, smooth, excepting the margins; panicle lax, 1.25-2.5 dm. in length, its branches fliform and pendulous, the lower 5-12.5 cm. long; spikelets many-flowered, oblong to ovate, r.8-3 $\mathrm{cm}$. long, on long capillary pendulous pedicels; flowering scales 9-12 mm. long, ciliate-hispid on the winged keel; stamen I. In moist places, Penn. to Ill. and Kans., south to Fla. and Tex. Ascends to $600 \mathrm{~m}$. in N. Car. Aug.-Sept.

3. Uniola paniculàta L. SEA OATs. (I. F. f. 453.) Culms 9-24 dm. tall. Leaves $3 \mathrm{dm}$. long or more, about $6 \mathrm{~mm}$. wide, involute when dry, attenuate into a long slender tip; panicle 2.25-3 dm. in length or more, the branches erect or ascending, strict, rigid, the lower 6-12.5 cm. long; spikelets many-flowered, shortpedicelled, ovate to oval when mature, $1.25-2.5 \mathrm{~cm}$. long; flowering scales 8-10 mm. long and scabrous on the keels; stamens 3. In sands of the seacoast, Va. to Fla. and west to Tex. Also in the West Indies and S. Am. Spikelets persistent into the winter. Oct.-Nov.

\section{DISTICHLIS Raf.}

Diœcious grasses, with rig;d culms creeping or decumbent at the base, flat or convolute leaves and spike-like paniculate inflorescence. Spikelets flattened, more numerous on the staminate plants than on the pistillate, 6-16-flowered; rachilla continuous in the staminate spikelets, articulated in the pistillate. Two lower scales empty, narrow, keeled, acute, shorter than the flowering ones; flowering scales broader, many-nerved, acute, rigid; palets 2-keeled. Stamens 3. Styles thickened at the base, rather long, distinct. Stigmas long-plumose. Grain free. enclosed in the scale and palet. [Greek, signifying two-ranked, probably in reference to the spikelets.] Four known species, natives of America, inhabiting the seacoast or alkaline soil; one of them is also found in Australia.

I. Distichlis spicàta (L.) Greene. Marsh SpIKe-grass. (I. F. f. 454.) Culms $7 \cdot 5-60 \mathrm{~cm}$. tall, erect from a horizontal rootstock, or often decumbent at the base. Sheaths overlapping and often crowded ; leaves $1.25-15 \mathrm{~cm}$. long, 2-4 mm. wide, flat or involute; panicle dense and spike-like, $1.8-6 \mathrm{~cm}$. in length, the branches $2.5 \mathrm{~cm}$. long or less, erect; spikelets 6-16.flowered, 8-18 mm. long. pale green; empty scales acute, the first 1 -3-nerved, two-thirds as long as the 3-5-nerved second one: flowering scales 3-5 $\mathrm{mm}$. long, acute or acuminate. On salt meadows along the Atlantic coast from Me. to Fla., in saline soil throughout the interior, and on the Pacific Coast north to Br. Col. June-Aug. [D. maritima Raf.]

\section{BRİZA L.}

Annual or perennial grasses, with flat or convolute leaves and open or rarely contracted panicles. Spikelets large, flattened, tumid, many-flowered, nodding, the flowers perfect. Scales thin-membranous, strongly concave, the 2 lower empty, 3-5-nerved, somewhat unequal; flowering scales imbricated, broader than the empty ones, 5-many-nerved; uppermost scales often empty; palets much shorter than the scales, hyaline, 2-keeled or 2-nerved. Stamens 3. Styles distinct. Stigmas plumose. Grain usually free, enclosed in the scale and palet. [Greek name for some grain, perhaps rye.] About 12 species, natives of the Old World and temperate S. Am.

Perennial; ligule $\mathrm{x} \mathrm{mm}$. long or less, truncate; spikelets 5-12-flowered, 4-5 mm. long.

Annual; ligule $2 \mathrm{~mm}$. long or more, acute; spikelets 3-6-flowered, 2-3 mm. long. 
1. Briza mèdia L. Quake-grass. Quaking-grass. (I. F. f. 455.) Culms 1.5-6 dm. tall, erect, from a perenrial root, simple. Ligule I mm. long or less, truncate; leaves $2.5-7.5 \mathrm{~cm}$. long, 2-5 mm. wide; panicle $3.75-12.5 \mathrm{~cm}$. in length, the capillary branches spreading or ascending, $2.5-6 \mathrm{~cm}$. long; spikelets 4-5 mm. long, orbicular to deltoid-ovate, 5-12-flowered; scales scarious-margined, the lower ones about $2 \mathrm{~mm}$. long; flowering scales $2-3 \mathrm{~mm}$. long, broader than the lower ones, widely spreading. In fields and waste places, Ont. to Mass. and R. I. Naturalized from Europe. Native also of Asia. June-July.

2. Briza minor L. Lesser QUaking-Grass. (I. F. f. 456.) Culms I-4 dm. tall, erect from an annual root, simple. Ligule $2-6 \mathrm{~mm}$. long, acute; leaves 2.5-12.5 cm. long, 2-8 mm. wide, sometimes scabrous; panicle 5-12.5 cm. in length, open, the capillary branches spreading or ascending, $2.5-6 \mathrm{~cm}$. long; spikelets 3-6-flowered, $2-3 \mathrm{~mm}$. long, about $4 \mathrm{~mm}$. broad, truncate at the base; scales scarious-margined, the lower ones about $2 \mathrm{~mm}$. long; flowering scales much broader and deeply saccate, about $1.5 \mathrm{~mm}$. long. In ballast and waste places about Camden, N. J. ; common in Cal., and widely distributed in tropical America. Adventive or naturalized from Europe. June-July.

\section{DÁCTYLIS L.}

A tall perennial grass, with flat leaves and paniculate inflorescence. Spikelets 3-5-flowered, short-pedicelled, in dense capitate clusters, the flowers perfect or the upper staminate. Two lower scales empty, thin-membranous, keeled, unequal, mucronate; flowering scales larger than the empty ones, rigid, 5-nerved, keeled, the midnerve extended into a point or short awn; palets shorter than the scales; 2-keeled. Stamens 3. Styles distinct. Stigmas plumose. Grain free, enclosed in the scale and palet. [Name used by Pliny for some grass with finger-like spikes.] A monotypic genus of Europe and Asia.

I. Dactylis glomeràta L. ORChARD Grass. (I. F. f. 457.) Culms 6-I2 dm. tall, tufted. Leaves $7.5-22.5 \mathrm{~cm}$. long, 2-6 mm. wide, flat, scabrous; panicle $7.5-20 \mathrm{~cm}$. in length, the branches spreading or ascending in flower, erect in fruit, the lower 2.5-6 cm. long, spikelet-bearing from above or below the middle : spikelets in dense capitate clusters, 3-5-flowered ; lower scales I-3-nerved, the flowering scales 4-6 mm. long, rough, pointed or short-awned, ciliate on the keel. In fields and waste places, N. B. to Manitoba, south to S. Car. and Kans. Naturalized from Europe and cultivated for fodder. June-July.

\section{CYNOSÙRUS L.}

Annual or perennial tufted grasses, with flat leaves and dense spike-like inflorescence. Spikelets of two kinds, in small clusters; lower spikelets of the clusters consisting of narrow empty scales, with a continuous rachilla, the terminal spikelets of 2-4 broader scales, with an articulated rachilla and subtending perfect flowers. Two lower scales in the fertile spikelets empty, I-nerved, the flowering scales broader, I-3-nerved, pointed or short-awned ; upper scales narrower, usually empty. Siales of the sterile spikelets pectinate, spreading, all empty, linear-subulate, I-nerved. Stamens 3. Styles distinct, short. Stigmas loosely plumose. Grain finally adherent to the palet. [Greek, signifying dog's-tail, referring to the spike.] About 5 species, natives of the Old World.

I. Cynosurus cristàtus L. Dog's-Tall Grass. (I. F. f. 458.) Culms 3-7.5 dm. tall. Leaves $3.75-12.5 \mathrm{~cm}$. long, I-4 mm. wide, smooth, glabrous; spike-like panicle 5-10 cm. in length, 5-12 mm. wide, long-exserted ; spikelets arranged in clusters, the terminal fertile, the lower larger and sterile; scales of the former about $3 \mathrm{~mm}$. long, pointed or short-awned, the scales of the sterile spikelets very narrow, pointed, strongly scabrous on the keel. In fields and waste places, Quebec and Ont. to southern N. Y. and N. J. Adventive from Europe. June-Aug.

\section{PÒA I.}

Annual or perennial grasses, with flat or convolute leaves and contracted or open panicles. Spikelets 2-6-flowered, compressed, the rachilla usually glabrous; flowers perfect, or rarely diœcious. Scales membranous, keeled; the 2 lower empty, I-3nerved; the flowering scales longer than the empty ones, generally with a tuft of cobwebby hairs at the base, 5-nerved, the marginal nerves usually pubescent, often 
also the dorsal one; palets a little shorter than the scales, 2 -nerved or 2-keeled. Stamens 3. Styles short, distinct. Stigmas plumose. Grain free, or sometimes adherent to the palet. [Name Greek, for grass or herbage.] A genus of about I50 species, widely distributed in all temperate and cold regions. The English name Meadow-grass is often applied to most of the species. Besides the following, some 75 others occur in the western parts of N. Am.:

Annuals or biennials; culms low and densely tufted, commonly less than $2 \mathrm{dm}$. long.

Flowering scale distinctly 5-nerved, not webby at the base. I. P. annua.

Flowering scale 3 -nerved, or obscurely 5 -nerved, webby at the base.

2. P. Chapmaniana.

Perennials; culms tall, usually exceeding $2 \mathrm{dm}$. long (shorter in Nos. 3 and 4 ).

$A$. Culms tufted, usually densely so.

a. Panicle open, loose.

I. Rootstocks slender; often stoloniferous.

Culms less than $2 \mathrm{dm}$. tall; low arctic or alpine grasses.

Flowering scales pubescent all over.

Flowering scales glabrous or slightly pubescent.

Culms exceeding $2 \mathrm{dm}$. in height.

3. P. abbreviata.

4. P. laxa.

Basal leaves much shorter than the culms.

Flowering scales not webby at the base.

Panicle with short stiff branches; flowering scales glabrous below between the nerves. 8 . P. glauca.

Panicle with long slender flexuous branches; flowering scales pubescent below between the nerves.

Flowering scales webby at the base.

12. P. autumnalis.

Flowering scales glabrous; culms manifestly compressed.

10. P. debilis.

Flowering scales pubescent on one or more of the nerves; culnıs round or but little compressed.

Lateral nerves of the flowering scale glabrous.

Plant yellowish green; flowering scales $2.5 \mathrm{~mm}$. long.

9. P.trivialis.

Plant green; flowering scales $3.5 \mathrm{~mm}$. long.

13. P. alsodes.

Lateral nerves of the flowering scales pubescent.

Lower half of the flowering scale densely villous between the nerves; arctic grass.

16. P. cenisia.

Lower half of the flowering scale glabrous between the nerves; sometimes somewhat pubescent in No. II.

Panicle-branches dividing and spikelet-bearing usually at and above the middle; spikelets $4 \mathrm{~mm}$. long or less.

Intermediate nerves of the flowering scale obscure.

Culms usually rigid and $4 \mathrm{dm}$. or less tall, the panicle generally less than $\mathbf{I . 5} \mathrm{dm}$. long.

\section{P. nemoralis.}

Culms usually 6-io dm. tall, the panicle commonly $2-4 \mathrm{dm}$. long.

6. P. flava.

Intermediate nerves prominent.

Spikelets crowded on the spreading or ascending branches; midnerve of the flowering scale pubescent only below. 7. P. praten sis.

Spikelets scattered on the spreading often reflexed branches; midnerve pubescent its whole length.

II. P. sylvestris.

Panicle-branches very long, dividing and spikelet-bearing only at the end; spikelets $\mathbf{S}$ mm. long. 
Basal leaves very long, the early ones frequently as long as the culms.

2. Rootstocks short and stout; no stolons. 15. P. brevifolia.

Ligule acute, $4 \mathrm{~mm}$. long; flowering scales lanceolate, $3 \mathrm{~mm}$. long. 17. P. pseudopratensis. Ligule truncate, $2 \mathrm{~mm}$. long; flowering scales ovate, $4 \mathrm{~mm}$. long.

ठ. Panicle contracted or spike-like. I8. P. alpina.

Internerves of the flowering scale very pubescent below with long appressed hairs, the remainder appressed-hispidulous.

Flowering scale erose-truncate at the apex, the nerves strongly silky pubescent below.

22. P. arida.

Flowering scale obtuse or acute at the apex, the nerves not silky pubescent.

Innovations short, usually less than $6 \mathrm{~cm}$. long; culms generally 4 dm. or less tall. 23. P. Buckleyana.

Innovations long, usually exceeding $2 \mathrm{dm}$. long; culns commonly 6 $\mathrm{dm}$. or more tall.

24. P. lucida.

Internerves of the flowering scale appressed-hispidulous all over.

$B$. Culms not tufted; rootstocks long, creeping. 25. P. laevigata.

Flowering scales naked or with short hairs at the base.

Culnis compressed, slender; plant bluish green; spikelets $3-6 \mathrm{~mm}$. long.

Culms not compressed, stout; spikelets about $1 \mathrm{~cm}$. long. I9. P. compressa. 21. P. glumaris.

Flowering scales with webby hairs at the base longer than the scale. 20. P. arachnifera.

1. Poa ánnua L. Annual Meadow-grass. Low Spear-grass. (I. F. f. 459.) Culms 5-30 cm. tall, from an annual root, erect or decumbent at the base, somewhat flattened, smooth. Sheaths loose, usually overlapping; leaves $1.25-10 \mathrm{~cm}$. long, 1.5-3 mm. wide, smooth; panicle 1.25-10 cm. in length, open, branches spreading, 6-35 mm. long, naked at the base; spikelets $3-5$-fluwered, $3-5 \mathrm{~mm}$. long; lower scales smooth, the first narrow, acute, I-nerved, about two thirds as long as the broad and obtuse 3-nerved secund one; flowering scales $2.5-3 \mathrm{~mm}$. long, distinctly 5 -nerved, the nerves pilose below. In waste and cultivated places nearly throughout N. Am. Naturalized from Europe. Native also of Asia. MayOct.

2. Poa Chapmaniàna Scribn. Chapman's Spear-grass. (I. F. f. 460.) Culms $7 \cdot 5^{-1} 5 \mathrm{~cm}$. tall, erect, from an annual root, simple, rigid, smooth and glabrous. Sheaths tight, mostly at the base of the culm; leaves $1.25-2.5 \mathrm{~cm}$. long, $2 \mathrm{~mm}$. wide or less, smooth; panicle $2.5-5 \mathrm{~cm}$. in length, the branches usually erect, sometimes spreading or ascending, $1.8 \mathrm{~cm}$. long or less, naked at the base; spikelets 3-7-flowered, 2.5-3 mm. long; lower scales about equal, 3-nerved, acute; flowering scales webbed at the base, obtuse, 3-nerved, sometimes with two additional obscure nerves, the prominent ones sometimes pilose for three-fourths their length. In dry soil, Ky. and Tenn. to Fla. and Ala. April-May.

3. Poa abbreriàta R. Br. Low Spear-Grass. (I. F. f. 462.) Culms I-5 dm. tall or less. Sheaths and leaves crowded at the base of the culm ; leaves I.25$2.5 \mathrm{~cm}$. long, I mm. wide; panicle contracted, $\mathbf{I} .25^{-2.5} \mathrm{~cm}$. long, branches very short and erect; spikelets 3-5-flowered, $5 \mathrm{~mm}$. long; lower sca!es acute, smooth and glabrous; flowering scales about $3 \mathrm{~mm}$. long, obtuse, strongly pubescent all over, the intermediate nerves very obscure. Arctic America from Greenland and Lab. to the Pacific. Summer.

4. Poa láxa Haenke. Wavy Meadow-grass. Mountain Spear-grass. (I. F. f. 463.) Culms $3 \mathrm{dm}$. tall or less, erect, simple. Leaves $2.5-7.5 \mathrm{~cm}$. long, I-2 $\mathrm{mm}$. wide, acuminate; panicle $2.5-7.5 \mathrm{~cm}$. in length, the branches usually erect, sometimes ascending, $2.5 \mathrm{~cm}$. long or less; spikelets $3-5$-flowered, 4-5 mm. long; lower scales usually 3-nerved, acute, glabrous, rough on the keel at its apex; flowering scales 3-3.5 mm. long, obtuse, 3-nerved, or sometimes with an additional pair of obscure nerves, the midnerve pilose on the lower half, rough above, the lateral ones pilose for one-third their length. Greenland to Alaska, south to the mountains of N. E., to Manitoba and in the Rocky Mts. to Colo. Also in Europe and Asia. Summer. 
5. Poa nemoràlis L. Wood Meadow-grass. Northern Spear-grass. (I. F. f. 470.) Culms I.5-6 dm. tall, erect, slender, sometimes rigid. Leaves $2.5^{-}$ Io $\mathrm{cm}$. long, $2 \mathrm{~mm}$. wide or less, erect, smooth or rough; panicle $5-12.5 \mathrm{~cm}$. in length, open, the branches erect or ascending, rarely spreading, $2.5-5 \mathrm{~cm}$. long; spikelets 2-5-flowered, 3-5 mm. long; lower scales acute or acuminate, I-3-nerved; flowering scales obtuse or acute, $2-2.5 \mathrm{~mm}$. long, faintly 5 -nerved, somewhat webby at base, the midnerve and the marginal nerves silky-pubescent on the lower half. Anticosti Isl. to Br. Col., south to Me., Minn., S. Dak., and in the Rocky Mts. to Colo. Also in Europe and Asia. Summer.

6. Poa flàva L. False Red-Top. Fowl Meadow-grass. (I. F. f. 47I.) Culms 4.6-15 dm. tall. Leaves 5-15 cm. long, 2-4 mm. wide, smooth or rough ; panicle $1.5-3 \mathrm{dm}$. in length, open, the branches spreading or ascending, $5-12.5$ $\mathrm{cm}$. long, divided and spikelet-bearing above the middle; spikelets 3 -5-flowercd, 3-4 mm. long, exceeding their pedicels; lower scales acute, the flowering sciles obtuse, somewhat webly at the base, $2-3 \mathrm{~mm}$. long, silky-pubescent on the lewer half of the marginal nerves and the midnerve, the intermediate nerves olsscure or wanting. In swampy places, N. S. and N. B. to Vancouver Isl., south to N. J., IIl. and Neb. Also in Europe and Asia. July-Aug.

7. Poa praténsis L. Kentucky Blue-grass. June-grass. (I. F. f. 466.) Culms $3^{-12} \mathrm{dm}$. tall, from long running rootstocks ; leaves smooth or rough, I-6 $\mathrm{mm}$. wide, those of the culm $5-15 \mathrm{~cm}$. in length, the basal mucl longer; panicle $6-20 \mathrm{~cm}$. in length, usually pyramidal, the branches spreading or ascending, sometimes flexuous, $2.5-7.5 \mathrm{~cm}$. long, divided and spikelet-bearing above the middle; spikelets 3-5-flowered, 4-5 mm. long, exceeding their pedicels; scales acute; flowering scales $3 \mathrm{~mm}$. long, webbed at the base, 5 -nerved, the marginal nerves and mid. nerve silky-pubescent below, the intermediate ones naked. In meadows, fields, and woods, almost throughout N. Am. Widely cultivated for hay and pasture. Also in Europe and Asia. In N. Am. probably indigenous only in the northern and mountainous regions. Variable. June-Aug.

8. Poa glaùca Vahl. Glaccous SPeAr-Grass. (I. F. f. 469.) Culms I.5-6 dm. tall, rigid, somewhat glaucous. Sheaths overlapping, confined to the lower half of the culm ; leaves $2.5-5 \mathrm{~cm}$. long, $2 \mathrm{~mm}$. wide or less, smooth beneath, scabrous above; panicle $2.5-7.5 \mathrm{~cm}$. in length, open, the branches erect or ascending, I. 25-3.75 cm. long; spikelets 2-4-flowered, 5-6 mm. long; empty basal scales acute, 3 -nerved, glabrous, rough on the upper part of the keel; flowering scales $3-3.5 \mathrm{~mm}$. long, obtuse or acutish, rough, not webbed at the base, the lower half of the midnerve and marginal nerves silky-pubescent, the intermediate nerves obscure and occasionally sparingly pubescent at the base. White Mts. of N. H. Also in Europe. Summer.

9. Poa triviàlis L. Roughish Meadow-grass. (I. F. f. 468.) Culms 3-9 $\mathrm{dm}$. tall, usually more or less decumbent at the base. Sheaths rough; leaves 5-17.5 cm. in length, 2-4 mm. wide, generally very rough; panicle $\mathbf{I}-\mathbf{1} .5 \mathrm{dm}$. long, open, the branches usually spreading or ascending, $2.5-5 \mathrm{~cm}$. long; spikelets 2- or sometimes 3 -flowered, $3 \mathrm{~mm}$. long, exceeding their pedicels; scales acute; flowering scales $2-3 \mathrm{~mm}$. long, webbed at the base, 5-nerved, the midnerve silkypubescent below, the lateral nerves naked, the intermediate ones prominent. In meadows and waste places, N. B. to Mich. and Va. Naturalized from Europe. June-Aug.

ro. Poa débilis Torr. Weak Spear-grass. (I. F. f. 472.) Culms 3-7.5 $\mathrm{dm}$. tall, slender, flattened. Sheaths compressed; leaves $2.5-1 \mathrm{I} \mathrm{cm}$. long, $2 \mathrm{~mm}$. wide or less, erect, smooth beneath, rough above; panicle $5-15 \mathrm{~cm}$. in length, open, often nodding at the top, the branches erect or ascending, sometimes spreading, 3.75-7.5 cm. long; spikelets 2-4-flowered, 3-4 $\mathrm{mm}$. long, their pedicels longer; flowering scales $3 \mathrm{~mm}$. long, obtuse, sparingly webbed at the base, 5-nerved, the nerves naked. In woods, N. S. and N. B. to Ont. and Minn., south to R. I., Penn. and Wis. June-Aug.

I r. Poa sylvéstris A. Gray. Sylvan Spear-grass. (I. F. f. 474.) Culms 3-9 dm. tall, slender, slightly Hattened. Leaves smooth beneath, rough above, 2-6 $\mathrm{mm}$. wide, those of the culm $3 \cdot 75^{-15} \mathrm{~cm}$. in length, the basal much longer; panicle $7.5-17.5 \mathrm{~cm}$. in length, the branches spreading or ascending, sometimes reflexed when old, $3.75-7.5 \mathrm{~cm}$. long, spikelet-bearing at the extremities; spikelets 
2-4-flowered, 2-4 mm. long; flowering scales about $2.5 \mathrm{~mm}$. long, webbed at the base, obtuse, often pubescent bslow, 5-nerved, the midnerve pubescent nearly its entire length and the marginal nerves below the middle. In thickets and meadows, N. Y. to Wis. and Neb., south to N. Car., La. and Kans. June-July.

12. Poa autumnàlis Muhl. Flexuous Spear-grass. (I. F. f. 473.) Culms 3-9 dm. tall. Leaves $2 \mathrm{~mm}$. wide or less, smooth beneath, rough above, those of the culm $3 \cdot 75^{-1} 5 \mathrm{~cm}$. long, the basal much longer; panicle $7.5-22 \mathrm{~cm}$. in length, the branches long and slender, spikelet-bearing at the extremities, 5-12.5 cm. long; spikelets 3-5-flowered, 5-6 mm. long; empty basal scales acute, the first I-nerved, narrow, shorter than the broad 3-nerved second; flowering scales rounded or retuse at the apex, 3-4 $\mathrm{mm}$. long, not webbed at the base, pubescent on the lower part, 5-nerved, the midnerve silky-pubescent for three-fourths its length. In woods, N. J. and Penn. to Ky., south to Fla. and Tex. March-May.

13. Poa alsòdes A. Gray. Grove MÉadow-Grass. (I. F. f. 475.) Culms $2-7.5 \mathrm{dm}$. tall. Leaves usually rough, 2-4 mm. wide, those of the culm $5-20 \mathrm{~cm}$. in length, the basal longer; panicle $8-20 \mathrm{~cm}$. in length, the branches spreading or ascending, 3.5-7.5 cm. long, spikelet-bearing at the ends; spikelets $2-3$-flowered, about $5 \mathrm{~mm}$. long; flowering scales acute, about $4 \mathrm{~mm}$. long, webbed at the base, the midnerve pubescent near the base, the marginal nerves naked, the intermediate ones very faint. In woods and thickets, N. S. to Ont. and Minn., south to N. Car. and Tenn. May-June.

r 4. Poa Wòlfii Scribn. Wolf's Spear-grass. (I. F. f. 476.) Culms 3-9 dm. tall. Leaves $2 \mathrm{~mm}$. wide or less, smooth beneath, rough above, those of the culm 5-10 $\mathrm{cm}$. in length, the basal much longer; panicle $7.5^{-15} \mathrm{~cm}$. in length, lax, its branches erect or ascending, flexuous, 3.75-6 cm. long; spikelets 2-4flowered, 5-6 mm. long; scales acute; flowering scales about $4 \mathrm{~mm}$. long, copiously webbed at the base, 5-nerved, the marginal and midnerves silky-pubescent for more than half their length, the intermediate nerves prcminent, naked. Ill., Temn., Minn., Kans.

15. Poa brevifòlia Muhl. Short-Leaved Spear-grass. (I. F. f. 477.) Culms 3-9 dm. tall, erect. Leaves smooth beneath, rough above, $2-4 \mathrm{~mm}$. wide, abruptly acute, those of the culm r.25-10 cm. long, the uppermost sometimes almost wanting; basal leaves usually equalling or nearly as long as the culm; panicle 6-12.5 cm. in length, open, the branches ascending, widely spreading or often reflexed, $3 \cdot 75-7.5 \mathrm{~cm}$. long, spikelet-bearing at the ends; spikelets $3-6$-flowered, 5-7 $\mathrm{mm}$. long; flowering scales slightly webbed at the base, 4-5 $\mathrm{mm}$. long, obtuse, 5-nerved, the keel and marginal nerves sparingly pubescent, the intermediate nerves prominent, naked. In rocky woods, N. J. and Penn, to Ill., south to N. Car. and Tenn. April-June.

I6. Poa cenisia All. Arctic Spear-grass. (I. F. f. 465.) Smooth and glabrous. Culms I-4 dm. tall, erect, slender; leaves $2.5^{-10} \mathrm{~cm}$. long, I-2 mm. wide; panicle $2.5-10 \mathrm{~cm}$. in length, open, the branches generally widely spreading and more or less flexuous, 2.5-6 cm. Inng ; spikelets 3-5-flowered, 5-7 mm. long ; lower scales acute or acuminate, I-3-nerved; flowering scales about $4 \mathrm{~mm}$. long, faintly 5 -nerved, the nerves short-pilose on the lower half, minutely pubescent between the nerves, somewhat webbed at the base. Greenland and Lab. to Alaska. Also in Europe. Summer.

I 7. Poa pseudopraténsis Scribn. and Rydb. Prairie Meadow-Grass. (I. F. f. 467.) Culms 3-6.5 dm. tall. Ligule $4 \mathrm{~mm}$. long, acute, decurrent; leaves 2-6 min. wide, smooth beneath, a little rough above and on the margins, those of the culm 2.5-8 cm. long, the basal 1.5-2.5 dm. in length; panicle $5-12.5 \mathrm{~cm}$. long, open, the branches spreading or ascending, $2.5-5 \mathrm{~cm}$. long; spikelets 3-5-flowered, 6-8 mm. long, exceeding their pedicels; lower scales nearly equal, acute, 3-nerved; flowering scales acutish, about $3 \mathrm{~mm}$. long, rough above, 5 -nerved, pubescent between the nerves below, the marginal nerves and midnerve silky-pubescent about half their length. Manitoba and Assiniboia to Neb. and Colo.

18. Poa alpina L. Alpine Spear-grass. (I. F. f. 464.) Smooth and glabrous. Culms I-4.5 dm. tall; ligule $2 \mathrm{~mm}$. long, truncate; leaves $2.5-7.5$ cm. long, 2-4 mm. wide, abruptly acute; panicle $2.5-7.5 \mathrm{~cm}$. in length, the branches generally widely spreading, $2.5 \mathrm{~cm}$. long or less; spikelets 3-5-flowered, 5-6 mm. long; lower scales broad, glabrous, rough on the keel, acute; flowering 
scales about $4 \mathrm{~mm}$. long, obtuse, pilose for half their length, pubescent between the nerves toward the base. Lab. to Alaska, south to Quebec, Lake Superior, and in the Rocky Mts. to Colo. Also in Europe and Asia. Summer.

19. Poa comspréssa L. Wire-grass. Flat-stemmed Meadow-grass. ENglish Blue-Grass. (I. F. f. 46r.) Pale bluish green, glabrous. Culms 1.5-6 dm. tall, decumbent at the base, from long horizontal rootstocks, much flattened; sheaths loose, flattened, shorter than the internodes; leaves $2.5-10 \mathrm{~cm}$. long, about $2 \mathrm{~mm}$. wide, smooth beneath, rough above; panicle usually contracted, the branches erect or ascending, $2.5 \mathrm{~cm}$. long or less, spikelet-bearing nearly to the base; spikelets 3-9-flowered, 3-6 nm. long; lower scales acute, 3 nerved; flowering scales $2-2.5 \mathrm{~mm}$. long, obscurely 3 -nerved, the nerves sparingly pubescent toward the base. Waste places and cultivated grounds and woods almost throughout N. Am. Ascends to $630 \mathrm{~m}$. in Va. Naturalized from Europe. Native also of Asia. Varies from weak and slender to quite stiff. June-Aug.

20. Poa arachnífera Torr. Texas Blue-grass. (I. F. f. 479a.) Culms tufted, 3-9 dm. tall, from running rootstocks; sterile shoots from one-half as long as the culms to equalling them. Leaves linear, erect, usually folded when dry, smooth beneath, rough above, 3.5-22.5 $\mathrm{cm}$. long, 3-6 mm. broad, abruptly acute; panicle dense and contracted, sometimes interrupted below, 7.5-16 cm. long, 1.25-3.75 cm. broad, its branches ascending or erect; spikelets numerous, 4-7flowered, the scales acuminate; flowering scales $4-5 \mathrm{~mm}$. long, often pointed, pubescent at the base with copious long cohwebby hairs, 5-nerved, the midnerve and lateral nt:rves pilose below the middle. Prairies, Kans. to N. Mex., south to La. and Tex. Also introduced in Fla. April-May.

21. Poa glumàris Trin. Large-flowerei Spear-grass. (I. F. f. 480.) Cu'ms I.5-9 dm. tall, erect or assurgent. Sheaths loose; leaves $\mathbf{I}-2.5 \mathrm{dm}$. long, $28 \mathrm{~mm}$. wide; panicle $\mathbf{I}-\mathbf{2 . 5} \mathrm{dm}$. in length, the branches erect or ascending,

5-5 cm. long; spikelets 3-5-flowered, 8-12 mm. long; flowering scales 6-8 mm. long, usually acutish, scabrous, 5-7-nerved, pubescent at base and on the lower part of the midnerve and lateral nerves, not webbed. Anticosti Isl. and N. S. to Quebec and Alaska. Summer.

22. Poa àrida Vasey. Prairie Spear-grass. (I. F. f. 478). Culms 3-6 $1 \mathrm{~m}$. tall, erect, rigid. Sheaths usually overlapping; ligule $2-4 \mathrm{~mm}$. long, acute; leaves smooth beneath, rough above, I-2 $\mathrm{mm}$. wide, flit or folded, pungently pointed, those of the culm $1.25-2.5 \mathrm{~cm}$. long, erect, the basal leaves $7 \cdot 5^{-15} \mathrm{~cm}$. long; panicle contracted, 5-12.5 cm. in length, the branches erect, spikelet-bearing nearly to the base, $3.75 \mathrm{~cm}$. long or less; spikelets $4-7$-flowered, 5-7 mm. long; flowering scales 3-4 mm. long, erose-truncate at apex, strongly silky-pubescent on the nerves for half their length, the lower part very pubescent between the nerves; intermediate nerves very obscure. Meadows and low grounds, N. W. Terr. to Kans. and Ariz. April-Aug.

23. Poa Buckleyàna Nash. Buckley's Spear-grass. (I. F. f. 479.) Culms I.5-4 dm. tall, rarely taller, erect, rigid. Ligule 4-6 mm. long, acute; leaves $2.5-10 \mathrm{~cm}$. long, about $2 \mathrm{~mm}$. wide, erect, flat, or becoming involute, smooth or rough; panicle $2.5^{-10} \mathrm{~cm}$. in length, contracted, the branches erect, $3.75 \mathrm{~cm}$. long or less, spikelet-bearing nearly to the base; spikelets $2-5$-flowered, $4-6 \mathrm{~mm}$. long: flowering scales about $4 \mathrm{~mm}$. long, obtuse or acutisl, appressed-pubescent below, with long hairs. Usually in dry soil on mountain slopes or elevated prairies, S. Dak. to Br. Col., Colo. and Cal. May-Sept.

24. Poa lùcida Vasey. Culms 6-8 dm. tall, erect, the innovations $2-3 \mathrm{dm}$. long; sheaths smooth and glabrous; leaves of the culm I dm. or less long, those on the innovations much longer; panicle I-2 dm. long, its larger branches 3-5 cm. long; spikelets 6-10 mm. long, 4-6-flowered, the flowering scales about $4.5 \mathrm{~mm}$. long, appressed-pubescent below with long hairs, obtuse or acutish. Moist hillsides and meadcws, Mont. to Neb. and Colo. June-Aug.

25. Poa laevigàta Scribn. Culms densely tufted, 6-8 dm. tall, erect, slender, the innovations I-2 dm. long; sheaths snooth and glabrous; leaves I $\mathrm{dm}$. or less long; panicle very slender, $8-14 \mathrm{~cm}$. long, its larger branches $3-5 \mathrm{~cm}$. long; spike. lets 5-7 mm. long, 3-4-flowered, the flowering scales 3-4 $\mathrm{mm}$. long, hispidulous all over, obtuse to acutish. On dry hills, Mont. to Neb, and Colo. June-Aug. 


\section{DUPÓNTIA R. Br.}

Low grasses, with flat leaves and generally narrow panicles. Spikelets 2-4. flowered, the flowers all perfect. Two lower scales empty, extending beyond the flowering scales, membranous; flowering scales entire, membranous, with a tuft of hairs at the base. Stamens 3. Styles distinct. Stigmas plumose. [Name in honor of J. D. Dupont, French botanist.] Two arctic species, both circumboreal.

I. Dupontia Físheri R. Br. Fisher's Dupontia. (I. F. f. 48I.) Smooth and glabrous. Culms $1.25-3 \mathrm{dm}$. tall; leaves $2.5-15 \mathrm{~cm}$. long, 2-4 mm. wide, flat; panicle usually contracted, $3 \cdot 75-8.5 \mathrm{~cm}$. long, the branches less than $3.75 \mathrm{~cm}$. long, erect, or sometimes ascending; spikelets few, about 2 -flowered, $6-8 \mathrm{~mm}$. long; empty basal scales thin, generally acute, the first I-nerved, somewhat shorter than the second, which is usually 3 -nerved, the lateral nerves often vanishing at about the middle; flowering scales 5 -6 $\mathrm{mm}$. long, I-nerved or obscurely 3-nerved; basal hairs about $\mathbf{m m}$. long. Arctic regions of northeastern America. Also in arctic Europe and Asia. Summer.

\section{SCOLÓCHLOA Link.}

Tall aquatic or marsh grasses, with flat leaves and ample panicles. Spikelets 2-4-flowered, the fowers perfect. Two lower scales empty, thin-membranous, 3-5-nerved; flowering scales rigid, with a tuft of hairs at the base, rounded on the back, 5-7-nerved, some of the nerves usually excurrent as short points; palets about equalling the scales, 2-nerved. Stamens 3. Styles very short. Stigmas plumose. Grain hairy at the apex. [Greek, referring to the prickle-like projecting nerves of the flowering scales.] Species 2, in the north temperate zones of both continents.

1. Scolochloa festucàcea (Willd.) Link. Fescue ScolochloA. (I. F. f. 482.) Culns 9-15 dm. tall. Sheaths often overlapping; leaves 2-3 dm. long or more, 4-8 mm. wille, flat, scabrous on the margins; panicle $2-3 \mathrm{dm}$. in length, usually open, the branches ascending, naked at the base, the lower $7 \cdot 5-10 \mathrm{~cm}$. long; spikelets 6-8 mm. long; empty basal scales acute, the first shorter than the second; flowering scales scabrous, 7-nerved. Iowa and Neb., north to Manitoba and Assiniboia. July-Aug. [Graphephorum festucaceum A. Gray.]

\section{9o. GRAPHÉPHORIJM Desv.}

Slender erect grasses, with flat leaves and a usually contracted nodding panicle. Spikelets 2-4-flowered, flattened, the rachilla hirsute and extending beyond the flowers. Two lower scales empty, somewhat shorter than the flowering scales, thin-membranous, acute, keeled; flowering scales membranous, olscurely nerved, entire, sometimes short-awned just below the apex. Stamens 3. Styles distinct. Stigmas plumose. Grain glabrous. [Greek, pencil-bearing, referring to the tuft of hairs at the end of the rachilla.] Three known species, natives of northern $N$. Am.

I. Graphephorum melicoìdeum (Michx.) Beauv. Graphephorum. (I. F. f. 483.) Culms $3-7.5 \mathrm{dm}$. tall. Sheaths glabrous, or the lower often villous; leaves $3.75-22.5 \mathrm{~cm}$. long, 2-4 mm. wide, long-acuminate, rough; panicle 5 -I 5 $\mathrm{cm}$. in length, the top usually nodding, the branches erect, $2.5-5 \mathrm{~cm}$. long; spikelets 2-4-flowered, 5-6 mm. long; scales scabrous on the keel, the empty ones unequal, the first I-nerved or obscurely 3 -nerved, shorter than the 3 -nerved second; flowering scales 3-5-nerved, acute. In wet soil, Anticosti Isl. to Ont., south to Me. and Mich. Aug.-Sept.

\section{PANiculària Fabr. [GLYCERia R. Br.]}

Mostly perennial grasses, often tall, with flat leaves and paniculate inflorescence. Spikelets few-many-flowered, terete or somewhat flattened. Two lower scales empty, obtuse or acute, I-3-nerved; flowering scales membranous, rounded on the back, 5-9-nerved, the nerves disappearing in the hyaline apex. Palets scarcely shorter than the scales, rarely longer, 2-keeled. Stamens 2 or 3. Styles distinct. Stigmas plumose. Grain smooth, enclosed in the scale and palet, free, or when dry s'ightly adhering to the latter. [l,atil, referring to the panicled spikelets.] About 20 species, widely distrıbuted in N. Am., a few in Europe and Asia, 
Srikelets ovate or oblong, $8 \mathrm{~mm}$. long or less.

Flowering scales very broad, obscurely or at least not sharply nerved.

Panicle open, the branches ascending or spreading, often drooping.

Spikelets 3-5-flowered; lowest flowering scale about $2 \mathrm{~mm}$. long.

1. P. laxa.

Spikelets 5-12-flowered; lowest flowering scale about $3 \mathrm{~mm}$. long.

Panicle contracted, the branches erect.

Flowering scales narrow, sharply and distinctly 7 -nerved.

Panicle elongated, its branches erect or appressed.

2. P. Canadensis.

3. P. obtusa.

Panicle not elongated, 4. P. Torreyana.

Scales about $2 \mathrm{~mm}$. long, obtuse or rounded at the apex.

Spikelets $3 \mathrm{~mm}$. long or less; branches of the panicle often drooping.

5. P. nervata.

Spikelets $4-6 \mathrm{~mm}$. long; branches of the panicle ascending or spreading.

Scales 2.5-3 $\mathrm{mm}$.' long, truncate and denticulate at the apex.

6. P. Americana.

7. P. pallida.

Spikelets linear, $12 \mathrm{~mm}$. long or more.

Flowering scales 4-5 $\mathrm{mm}$. long, obtuse, equalling or exceeding the obtuse palet.

Flowering scales firm, hispidulous all over, truncate at the apex.

8. P. fuitans.

Flowering scales thin, hispidulous on the nerves only, obtuse at the apex.

Flowering scales $6-8 \mathrm{~mm}$. long, shorter than the acuminate palet.

9. P. borealis.

Flowering scales obtuse, about $6 \mathrm{~mm}$. long, a little exceeded by the palet.

Io. P. brachyphylla.

Flowering scales acute, about $8 \mathrm{~mm}$. long, much exceeded by the palet.

1. P. acutiflora.

I. Panicularia láxa Scribn. Northern Manna-grass. (I. F. f. 484.) Culms 6-12 dm. tall, smooth or slightly scabrous. Sheaths overlapping, rough; leaves $2-4 \mathrm{dm}$. long, $4-8 \mathrm{~mm}$. wide, very rough; panicle $17.5-22.5 \mathrm{~cm}$. in length, tlie branches spreading or ascending, the lower 7.5-15 cm. long; spikelets 3-5-flowered, about $4 \mathrm{~mm}$. long; empty scales unequal, scarious, acute, I-nerved, the first one-half to two-thirds the length of the second; flowering scales broad, about $2 \mathrm{~mm}$. long, twice the length of the second scale, obtuse, obscurely 7 -nerved. In water or vet soil, Me. to Penn. Aug.

2. Panicularia Canadénsis (Michx.) Kuntze. RatTlesnake-Grass. (I. F. f. 485.) Culms 6-9 dm. tall, smooth or slightly scabrous. Sheaths shorter than the internodes, those at the base of the culm overlapping; leaves 1.5-3 dm. long or more, 4-8 mm. wide, rough; panicle $1.25-2.5 \mathrm{dm}$. in length, the branches spreading, ascending or often drooping, $6.25-12.5 \mathrm{~cm}$. long; spikelets 5-12-flowered, 5-8 mm. long, flattened, turgid; empty scales unequal, acute, I-nerved; flowering scales broad, 3-4 mm. long, obtuse or acutish, obscurely 7-nerved. In swamps and marshes, Newf. and N. B. to Ont. and Minn., south to N. J., Ohio and Kans. The handsomest species of the genus. Ascends to $1500 \mathrm{~m}$. in the Adirondacks. July-Aug.

3. Panicularia obtùsa (Muhl.) Kuntze. Blunt Manna-grass. (I. F. f. 486.) Culms 3-9 dm. tall, erect. Sheaths sometimes rough, strongly striate, the lower overlapping; leaves $1.5-4 \mathrm{dm}$. long, 4-8 mm. wide, usually stiff, erect or ascending, smooth beneath, more or less scabrous above; panicle $7.5-20 \mathrm{~cm}$. in length, contracted, dense, the branches erect; spikelets 3-7-flowered, 4-6 mm. long; empty scales acute, scarious, I-nerved; flowering scales about $3 \mathrm{~mm}$. long, broad, obtuse, obscurely 7-nerved. In swamps, N. B. to N. Y. and central Penn., south to Del. and Md. Ascends to $690 \mathrm{~m}$. in the Catskill Mts. July-Aug.

4. Panicularia Torreyàna (Spreng.) Merr. Long Manna-grass. (I. F. f. 487.) Culms 6-9 dm. tall. Leaves lax, 1.5-3 dm. long, 3-6 mm. wide, lon.5acuminate, smooth beneath, rough above; panicle elongated, contracted, narrow, usually nodding at the summit, 1.5-3 lm. in length, the branches erect or appressed, $2.5-6 \mathrm{~cm}$. long; spikelets 3-4-flowered, 3-4 mm. long; empty scales unequal, acute, r-nerved; flowering scales narrow, about $2 \mathrm{~mm}$. long, obtuse or acutish, distinctly 7-nerved. In wet woods, Newf. to Qucbec and Minn., south to N. Car. and Ky. Ascends to $1200 \mathrm{~m}$, in the Adirondaclis. Aug.-Sept. (I'. clongata Kuntze.) 
5. Panicularia nervàta (Willd.) Kuntze. Nerved Manna-grass. (I. F. f. 488.) Culms 3-9 dm. tall. Sheaths usually more or less rough; leaves $1.5-3 \mathrm{dm}$. long, 4-10 min. wide, a cute, smooth beneath, rough above; panicle $7.5-20 \mathrm{~cm}$. in length, often purple, open, the branches filiform, spreading, ascending or often drooping, rarely erect, 5-12.5 cm. long; spikelets 3-7-flowered, 2-3 mm. long; empty scales obtuse, I-nerved; flowering scales about $1.5 \mathrm{~mm}$. long, obtuse or rounded, with 7 sharp distinct nerves and evident furrows between. In wet places, Newf. to Br. Col., south to Fla. and Mex. Ascends to $1200 \mathrm{~m}$. in Va. June-Sept.

6. Panicularia Americàna (Torr.) MacM. Reed Meadow-Grass. Tall ManNa-GRAss. (I. F. f. 489.) Culms 9-I5 dm. tall. Sheaths loose, smooth, or sometimes rough; leaves $2-3 \mathrm{dm}$. long or more, 6-16 mm. wide, usually smooth beneath, rough above; panicle $2-4 \mathrm{dm}$. in length, its branches spreading, ascending or rarely erect, I-2 dm. long; spikelets 4-7-flowered, 4-6 $\mathrm{mm}$. long; empty scales acute, I-nerved; flowering scales about $2 \mathrm{~mm}$. long, obtuse or rounded at the apex, sharply and distinctly 7-nerved, the furrows between the nerves evident. In wet soil, N. B. to Alaska, south to Tenn., Colo. and Nev. Ascends to $630 \mathrm{~m}$. in Penn. June-Aug.

7. Panicularia pállida (Torr.) Kuntze. Pale Manna-grass. (I. F. f. 49o.) Pale green. Culms 3-9 dm. long, assurgent; leaves 5-15 cm. long, 2-4 mm. wide, smooth beneath, rough above; panicle $3.75-17.5 \mathrm{~cm}$. in length, the branches spreading, ascending or rarely erect, often flexuous, $2.5-5 \mathrm{~cm}$. long; spikelets 4-8-flowered, 5-7 mm. long; empty scales unequal, the first 1 -nerved, obtuse, shorter than the 3nerved and truncate second ; flowering scales $2.5-3 \mathrm{~mm}$. long, truncate and denticulate at the apex, sharply and distinctly 7 -nerved, with plain furrows between the nerves. In shallow water, N. B. to Ont., south to Va., Tenn. and Ind. Ascends to $600 \mathrm{~m}$. in Penn. July-Aug.

8. Panicularia flùitans (L.) Kuntze. Floating Manna-grass. (I. F. f. 49I.) Culms 1O-I $5 \mathrm{dm}$. long, flattened, erect or decumbent, usually stout, often rooting from the lower nodes. Sheaths loose, generally overlapping, smooth or rough; leaves $1.25-3 \mathrm{dm}$. long or more, 4-I2 mm. wide, scabrous, often floating; panicle $2.25-4.5 \mathrm{dm}$. long, the branches, at least the lower ones, at first appressed, later ascending, and 7.5-15 cm. long; spikelets linear, 7-I 3 -flowered, $2-2.5 \mathrm{~cm}$. long ; empty scales unequal, I-nerved, the lower acute or obtuse, the upper obtuse or truncate ; flowering scales $4-4.5 \mathrm{~mm}$. long, thick, oblong, rounded or truncate at the erose apex, scabrous, sharply 7 -nerved. In wet places or in water, Newf. to $\mathrm{Br}$. Col., south to N. Car., Ky., Iowa and Cal. Also in Europe. July-Sept.

9. Panicularia borealis Nash. Slender Manna-grass. (I. F. f. 49Ia.) Glabrous. Culms erect from a creeping base, 4.5-15 dm. tall; sheaths overlapping, smooth or roughish, the uppermost one enclosing the base of the panicle; leaves linear, abruptly acuminate, I-5 dm. long, 2-10 $\mathrm{mm}$. wide; panicle slender, the exserted portion I.5-5 dm. long, its branches appressed or nearly so ; spikelets I-I.8 cm. long, 7-13-flowered, appressed; outer two scales I-nerved, unequal; flowering scales thin, 4-5 mm. long, 7-nerved, the nerves only scabrous; paltt slightly shorter than the scale. In shallow water, Me. to N. Y., Idaho, Cal., Wash., and northward.

Io. Panicularia brachyphflla Nash. Short-Leaved Manna-grass. (I. F. f. 492a.) Glabrous. Culms erect from a creeping base, 6-9 dm. tall; sheaths generally longer than the internodes, almost closed, the uppermost one enclosing the base of the panicle; leaves linear, acuminate, 6-12.5 cm. long, 4-5 mm. wide; panicle slender, the exserted portion 3-4 dm. long, its branches appressed or nearly so; spikelets compressed-cylindric, $2-2.8 \mathrm{~cm}$. long, 7-12-flowered; empty scales I-nerved; flowering scales scabrous all over, 7 -nerved, about $5 \mathrm{~mm}$. long, the obtuse apex obscurely and irregularly few-toothed; palet about $6 \mathrm{~mm}$. long, acuminate, a little exceeding the scale. In shallow water, Me. to N. Y. June-July.

I I. Panicularia acutiflòra (Torr.) Kuntze. Sharp-scaled Manna-grass. (I. F. f. 492.) Culms 3-6 dm. tall, flattened, erect from a decumbent base, simple. Sheaths loose, generally a little exceeding the internodes, smooth and glabrous; leaves 7.5-15 cm. long, 4-6 mm. wide, smooth beneath, rough above; panicle I.5$3 \mathrm{dm}$. in length, the branches erect or appressed, 5-10 $\mathrm{cm}$. long; spikelets linear, 5-12-flowered, $2.5-4.5 \mathrm{~cm}$. long; empty scales acute, smooth; flowering scales 
about $8 \mathrm{~mm}$. long, lanceolate, acute, scabrous, exceeded by the long-acuminate palets. In wet places, Me. to southern N. Y., Ohio and Tenn. Local. June-Aug.

\section{Puccinéllia Parl.}

Perennial grasses, with flat or involute leaves and contracted or open panicles. Spikelets 3-several-flowered. Lower scales empty, obtuse or acute, unequal; flowering scales obtuse or acute, rounded on the back, 5-nerved, the nerves very obscure or almost wanting. Palet about equalling the scale. Stamens 3. Styles wanting. Stigmas sessile, simply plumose. Grain compressed, usually adhering to the palet. [Name in honor of Benedetto Puccinelli, Italian botanist.] About I4 species, in all temperate regions.

Panicle open, its branches spreading or ascending, rarely erect.

Lower flowering scales 3-4 mm. long; plant stoloniferous.

Lower flowering scales $2.5 \mathrm{~mm}$. long or less; plants not stoloniferous.

Second empty scale less than half the length of the flowering scales, broad, obtuse or truncate; spikelets crowded.

2. P. distans.

Second empty scale more than half the length of the flowering scales, narrow, obtuse or acute; spikelets not crowded.

I anicle contracted, its branches erect, rarely ascending; northern species.

3. P. airoides.

4. P. angustata.

I. Puccinellia maritima (Huds.) Parl. Goose-grass. Sea Spear-grass. (I. F. f. 493.) Stoloniferous, smooth, glabrous. Culms I.5-6 dm. tall, erect, or decumbent at the base; leaves $1.25-12.5 \mathrm{~cm}$. long, $2 \mathrm{~mm}$. wide or less, flat to involute; panicle $5^{-15} \mathrm{~cm}$. in length, open, the branches ascending, or rarely erect, $2.5-5 \mathrm{~cm}$. long; spikelets 3-10-flowered, 6-12 mm. long; empty scales unequal, the first usually I-nerved, the second 3-nerved; flowering scales 3-4 mm. long, broad, obtuse or truncate. In salt marshes and on sea beaches, N. S. to R. I. Also on the Pacific coast, and on the coasts of Europe and Asia. July-Aug.

2. Puccinellia distans (L.) Parl. Sireading Meadow-Grass. (I. F. f. 494.) Culms 3-6 dm. tall, erect, or sometimes decumbent at the base, tufted. Leaves $1.25-15 \mathrm{~cm}$. long, 2-4 $\mathrm{mm}$. wide, flat or folded, usually stiff and erect, smonth beneath; panicle $5-17.5 \mathrm{~cm}$. in length, open, rarely contracted, the branches spreading or ascending, whorled, the lower $2.5-11.5 \mathrm{~cm}$. long, sometimes reflexed; spikelets crowded, 3-6-flowered, 3-5 mm. long; empty scales obtuse or acute, I-nerved, the second exceeding the first and less than half the length of the obscurely nerved and obtuse flowering scales, which are $1-2 \mathrm{~mm}$. long. On salt meadows, sea beaches and in waste places, N. S. to N. J. Probably naturalized from Europe. July-Aug.

3. Puccinellia airoides (Nutt.) Wats. \& Coult. Slender Meadow-Grass. (I. F. f. 495.) Culms 3-12 dm. tall, erect. Leaves 5-10 cm. long, $3 \mathrm{~mm}$. wide or less, flat or involute, usually erect, smooth beneath, rough above; panicle open, its branches slender, spreading or ascending, rarely erect, the lower $5-8.5 \mathrm{~cm}$. long and often reflexed; spikelets scattered, I-7-flowered, 3-6 $\mathrm{mm}$. long; empty scales unequal, the first acute, I-nerved, the second obtuse or acute, 3-nerved, more than half the length of the obtuse flowering scales, which are $2-2.5 \mathrm{~mm}$. long. In saline soil, Manitoba to the N. W. Terr., Wash., Neb. and Nev. July-Aug.

4. Puccinellia angustàta (R. Br.) Scribn. Arctic Meadow-Grass. (I. F. f. 496.) Smooth and glabrous. Culms I-3 dm. tall, erect, simple; leaves $1.25-6.5$ $\mathrm{cm}$. long, $2 \mathrm{~mm}$. wide or less: panicle $2.5-5 \mathrm{~cm}$. in length, contracted, the branches short and erect or appressed; spikelets $2-7$-flowered, $6-8 \mathrm{~mm}$. long; empty scales obtuse or rounded at the apex, the first I-nerved, the second 3 -nerved; flowering scales $2.5-3 \mathrm{~mm}$. long, usually purplish, rounded at the apex. Greenland and Hudson Bay to Alaska, south to Me. Also in Europe and Asia. Summer.

\section{FESTÙCA L.}

Mostly tufted perennial grasses, with flat or convolute leaves and paniculate inflorescence. Spikelets 2-several-flowered. Two lower scales empty, more or less unequal, acute, keeled; flowering scales membranous, narrow, rounded on the back, 5-nerved, usually acute, and generally awned at the apex. Palet scarcely shorter than the scale. Stamens I-3. Styles very short, distinct. Stigmas plumose. Grain 
glabrous, elongated, often adherent to the scale or palet. [Latin, stalk or straw.] A genus of about 80 species, widely distributed, particularly numerous in temperate regions. Besides the following, some 15 others occur in the western parts of N. Am.

Empty scales membranous, firm, the second one 3-5-nerved.

Leaves $2 \mathrm{mim}$. wide or less, usually involute or folded.

Annuals; flowering scales long-awned.

First scale more than one-half as long as the second; awn not exceeding the length of the flowering scale.

I. F. octofiora.

First scale less that one-half as long as the second; awn much longer than the flowering scale.

Perennials; flowering scales awnless or short-awned.

Culms from a rootstock or with stolons.

Culms densely tufted, no rootstocks.

2. F. Myuros.

Flowering scales short-awned; leaves setaceous.

Culms 2-4 dm. tall; culm-leaves long.

3. F. rubra.

Culms $1.5 \mathrm{dm}$. or less tall; culm-leaves very short, usually about $x$ $\mathrm{cm}$.; an alpine grass.

Flowering scales awnless; leaves filiform.

5. F. brachyphylla.

Leaves $4 \mathrm{~mm}$. wide or more, flat.

6. F. capillata.

Flowering scales awnless or short-awned.

Flowering scales 5-7 mm. long; spikelets 5-ro-flowered.

7. F. elatior.

Flowering scales $4 \mathrm{~mm}$. long or less; spikelets 3-6-flowered.

Spikelets very broad; branches of the panicle spikelet-bearing from the middle or below.

8. F. Shortii.

Spikelets lanceolate; branches of the panicle elongated, spikelet-bearing at the end.

Flowering scales long-awned.

9. F. nutans.

ro. F. gigantea.

Empty scales broad, scarious, with broad hyaline margins, thin, $x$-nerved; base of the culms clothed with dry leafless sheaths.

Panicle loose and open, usually purple, its branches often widely spreading.

Panicle narrow, strict, rigid, green, its branches appressed.

II. Fi. scabrella.

12. F. Watsoni.

I. Festuca octoflòra Walt. Slender Fescue-grass. (I. F. f. 497.) Culms I-4.5 dm. tall, erect, from an annual root, slender, rigid. Leaves $3.75-7.5 \mathrm{~cm}$. long, involute, bristle-form; raceme or simple panicle often one-sided, $2.5-15 \mathrm{~cm}$. i: length, contracted, its branches erect, or rarely ascending; spikelets 6-13-flowered, 6-Io $\mathrm{mm}$. long; empty scales acute, smooth, the first I-nerved, more than hilf the length of the 3-nerved second one; flowering scales, exclusive of awn, 3-5 $\mathrm{mm}$. long, usually very scabrous, acuminate into an awn nearly as long as the body or shorter, or sometimes awnless; stamens 2. Dry sandy soil, Quebec to Br. Col., south to Fla., Tex. and Cal. June-Aug.

2. Festuca Myùros L. Rat's-TAIL Fescue-Grass. (I. F. f. 498.) Culms 3-6 dm. tall, erect from an annual root; leaves $5-12.5 \mathrm{~cm}$. long, subulate, involute, erect; panicle usually one-sided, I-3 dm. in length, contracted, sometimes curved, its branches appressed; spikelets 3-6-flowered; empty scales very unequal, acute, smooth, the first I-nerved, less than half as long as the 3-nerved second one; flowering scales, exclusive of the awn, 4-6 mm. long, narrow, acuminate into an awn much longer than the body; stamen I. In waste places and fields, N. H. to N. J. and Fla. Also on the Pacific coast. Naturalized from Europe. June-July.

3. Festuca rùbra L. Red Fescue-grass. (I. F. f. 499.) Culms 4.5-7.5 dm. tall, from running rootstocks, erect, simple; basal leaves involute-filiform, $7 \cdot 5^{-15}$ $\mathrm{cm}$. long; culm leaves shorter, erect, flat, or involute in drying, minutely pubescent above; panicle 5-12.5 cm. in length, sometimes red, open at flowering time, contracted in fruit; spikelets 3-10-flowered, 8-12 mm. long; lower scales acute, unequal, the first I-nerved, shorter than the 3 -nerved second; flowering scales about $6 \mathrm{~mm}$. long, obscurely 5-nerved, sometimes scabrous, bearing awns of less than their own length. Lab. to Alaska, south, especially on the mountains, to Va., Tenn. and Colo. Also in Europe and Asia. Summer.

4. Festuca ovina L. Sheep's Fescue-grass. (I. F. f. 500.) Culms I.5$3.5 \mathrm{dm}$. tall, erect, tufted, slender, rigid; sheaths usually crowded at the base of the culm; ligule auriculate, short; leaves filiform or setaceous, those of the culm few, $2.5-7.5 \mathrm{~cm}$. long, erect, the basal ones numerous; panicle $3.75-7.5$ 
cm. long, often one-sided, narrow, its branches short, usually erect or appressed; spikelets 3-5-flowered; empty scales unequal, acute, the first I-nerved, the second 3-nerved; flowering scales 3-4 mm. long, smooth, acute, usually short-awned. In fields and waste places, Lab. to Br. Col., south to N. J., Colo. and Cal. Variable. Probably indigenous r.orthward, but mostly naturalized from Europe. Native also of Asia. The so-called var. vivipara, a state of this grass with the scales wholly or partly transformed into small leaves, is found on the mountains of N. E. and in arctic America.

Festuca ovina duriúscula (L.) Hack. Culms taller and stouter, the panicle usually more open and the flowering scales about $6 \mathrm{~mm}$. long. Newf, to the Rocky Mts., south to Va. and Colo. Naturalized from Europe.

5. Festuca brachyphylla Schultes. Short-leaved Fescue-grass. (I. F. f. 500a.) Smooth and glabrous. Culms densely tufted, $2 \mathrm{dm}$. tall or less, slender, erect, much exceeding the short basal leaves; sheaths coarsely striate; leaves very narrow, involute, at least when dry, those on the culm $1.25 \mathrm{~cm}$. or less long, erect or ascending; panicle $2.5 \mathrm{~cm}$. or less long, nearly simple, its branches appressed; spikelets 2-4-flowered, the empty scales acuminate, the first I-nerved, the second 3-nerved; flowering scales acute or acuminate, rough toward the apex, 4-5 mm. long, exclusive of the scabrous awn, which is $\mathbf{I}-2.5 \mathrm{~mm}$. long. Newf. to Br. Col., the higher mountains of Vt. and the Rocky Mts. to Colo. Summer.

o. Festuca capillàta Lam. Filiform Fescue-grass. (I. F. f. 50ob.) Densely tufted. Culms erect from a decumbent base, I.5-4 dm. tall, slender, smooth and glaucous, shining; sheaths confined to the base of the culm; leaves filiform, smooth or rough, the basal ones from one-third to one-half as long as the culm, the culm leaves $2.5-3.75 \mathrm{~cm}$. long; panicle contracted, $1.25-5 \mathrm{~cm}$. long, its branches erect, $1.25 \mathrm{~cm}$. or less long; spikelets 4-5 mm. long, 4-5-flowered; outer scales empty, unequal, the first acuminate, the second acute; flowering scales about $2.5 \mathrm{~mm}$. long, unawned, acute. Fields and roadsides, Me. and N. Y. Also in Miss. Introduced from Europe. June-July.

7. Festuca elàtior L. TAll or Meadow Fescue-grass. (I. F. f. 502.) Culns 6-I $5 \mathrm{dm}$. tall, erect, simple; leaves I-4 dm. long, 4-8 mm. wide, flat, smooth beneath, more or less rough al ove; panicle $\mathrm{I}-3.5 \mathrm{dm}$. in length, often nodding at the top, simple to very compound, the branches ascending or erect, $5-20$ cm. long; spikelets 5-9-flowered, 9-12 mm. long; empty scales acute, the first I -3nerved, the second 3-5-nerved; flowering scales acute or short-pointed, smooth and glabrous, 5-6 mm. long, indistinctly 5-nerved. In fields and waste places, N. S. to Ont., south to N. Car., Tenn. and Kans. Naturalized from Europe and culti.. vated for hay. Variable. July-Aug.

8. Festuca Shórtii Kunth. SHort's Fescue-grass. (I. F. f. 503.) Culms 6-12 dm. tall, erect. Leaves $1.25-2.5 \mathrm{dm}$. long, 2-6 mm. wide, flat, smooth beneath, rough above: panicle $7 \cdot 5-17.5 \mathrm{~cm}$. in length, open, the branches spreading or ascending, rarely erect, spikelet-bearing from the middle or below, the lower $3.75-8.75 \mathrm{~cm}$. long; spikelets broadiy obovate when mature, 3-6-flowerer, 5-6 mm. long; empty scales acute, unequal, scabrous on the nerves, the first 1-3-nerved, the second 3-nerved; flowering scales about $4 \mathrm{~mm}$. long, smooth, obtuse or acutish, fatintly nerved. In woods and thickets, Penn. (according to Porter) and Ill. to Kans., south to Miss. and Tex. July-Aug.

9. Festuca nutans Willd. Nodding Fescue-Grass. (I. F. f. 504.) Culms 6-9 dm. tall, slender, glabrous or sometimes pubescent; leaves I-3 dm. long, 4-6 mm. wide, rather lark green, flat, smooth beneath, rough above; panicle $\mathbf{I}-2.25$ $\mathrm{dm}$. in length, its branches at first erect, the lower $6.25-12.5 \mathrm{~cm}$. long, finally spreading and nodding, spikelet-bearing only at the ends; spikelets lanceolate, 3-5flowered, 5-6 mm. long, empty scales acute, scabrous on the keel, the first I-nerved, shorter than the 3 -nerved second; flowering scales about $4 \mathrm{~mm}$. long, smooth, acute, very faintly nerved. In rocky woods, N. S. to Ont. and Neb., south to Fla. and Tex. Ascends to $690 \mathrm{~m}$. in Va. June-Aug.

ro. Festuca gigantèa (L.) Vill. Great Fescue-grass. (I. F. f. 505.) Culms 6-12 dm. tall, erect, simple. Sheaths usually overlapping; 1.25-3 dm. long or more, bright green, 4-12 mm. wide, flat, rough; panicle $1.75-3 \mathrm{dm}$. in length, loose, narrow, the branches erect or ascending, the lower $5-10 \mathrm{~cm}$. long; spikelets 
3-7-flowered ; empty scales acuminate, smooth and glabrous, the first I-3-nerved, shorter than the 3-5-nerved second; flowering scales, exclusive of awn, about 6 $\mathrm{mm}$. long, faintly 5 -nerved, slightly scabrous, minutely 2 -tonthed at the apex, bearing an awn 1.2-1.6 cm. long. In waste places, Me. to southern N. Y. Adventive from Europe. July-Aug.

11. Festuca scabrélla Torr. Rovgh Fescue grass. (I. F. f. 50I.) Culms 3-6 dm. tall, erect, usually rough below the panicle. Sheaths overlapping, smooth ; leaves rough, $2 \mathrm{~mm}$. wide or less, those of the culın $2.5-7.5 \mathrm{~cm}$. long, erect, the basal flat, much longer and readily deciduous from the sheaths, involute in drying; panicle $7.5-10 \mathrm{~cm}$. in length, opcn, its branches ascending or the lower widely spreading; spikelets 3-5-flowered, about $8 \mathrm{~mm}$. long; empty scales scarious, unequal, smooth, the first I-nerved, the second longer, 3-nerved; flowering scales about $6 \mathrm{~mm}$. long, scabrous, often bearing a short awn $2 \mathrm{~mm}$. long or less. Lab. and Quebec to Manitoba and Br. Col. Summer.

12. Festuca Wátsoni Nash. Watson's Fescue-grass. Culms tufted, erect, rigid, the base clothed with dry leafless sheaths. Sheaths smooth and glabrous; leaves erect, stiff, smooth beneath, rough above, $2.5 \mathrm{dm}$. long or less, 2-4 mm. wide, those on the culm much shorter than those of the innovations; panicle strict, narrow, IO-I2 $\mathrm{cm}$. long, its branches erect or appressed; spikelets usually 3-flowered, 7-8 $\mathrm{mm}$. long, the scales acute, the flowering scales strongly scabrous. Meadows, Mont. to Neb. and Colo. June-July. (Festuca Kingii (S. Wats.) Scribn. Not $F$. Kingiana Endl.)

\section{BROMUS L.}

Annual or perennial grasses, with flat leaves and terminal panicles, the pedicels thickened at the summit. Sheaths sometimes not split. Spikelets few-many-flowered. Two lower scales empty, unequal, acute; flowering scales rounded on the back, or sometimes compressed-keeled, 5-9-nerved, the apex usually 2-toothed, generally bearing an awn just below the summit; palet shorter than the scale, 2-keeled. Stamens usually 3. Stigmas sessile, plumose, inserted below a hairy cushion-like appendage at the top of the ovary. Grain adherent to the palet. [Greek name for a kind of oats.] About 40 species, most numerous in the north temperate zone. Besides the following, some 14 others occur in the western part: of N. Am.

Lower empty scale I-nerved, the upper 3 -nerved.

Awn shorter than the flowering scale or wanting; perennials 6-12 dm. tall.

Flowering scales awnless, or merely awn-pointed. $\quad$ I. B. inermis.

Flowering scales awned.

Sheaths glabrous or softly pubescent, the lower sometimes sparingly hirsute. Leaves 4-12 mm. wide; culms stout; branches of the panicle more or less spreading or drooping.

2. B. ciliatus.

Leaves less than $4 \mathrm{~mm}$. wide; culms slender; branches of the panicle erect.

Sheaths strongly retrorse-hirsute.

Awn longer than the flowering scale; low annuals 3-6 dm. tall.

Flowering scales appressed-hirsute, 8-12 $\mathrm{mm}$. long.

Flowering scales sparsely appressed-hispidulous.

3. B. erectus.

4. B. asper.

Spikelets usually single on the long naked spreading branches.

6. B. sterilis.

Spikelets several on the branches which are divided and spikelet-bearing above the middle.

7. B. Madritensis.

Lower empty scale 3 -nerved, the upper 5-9-nerved (3-nerved in No. 8).

a. Flowering scales rounded on the back, at least below.

r. Flowering scales awned.

Flowering scales pubescent.

Pubescence dense, consisting of long silky hairs.

Second empty scale 3 -nerved; flowering scales $1-1.2 \mathrm{~cm}$. long.

8. B. Porteri.

Second empty scale 5-7-nerved; flowering scales about $8 \mathrm{~mm}$. long.

Pubescence of short soft appressed hairs, not dense.

9. B. Kalmii. 
Flowering scales glabrous or minutely roughened.

Awns straight.

Nerves of the turgid fruiting flowering scales obscure; sheaths glabrous.

11. B. secalinus.

Nerves of the flowering scale prominent; sheaths softly and densely pubescent with reflexed hairs.

Spikelets broadly lanceolate, usually 1 , or sometimes 2 , on the longer branches.

12. B. racemosus.

Spikelets lanceolate, several on the longer branches.

Awns strongly bent near the base, divergent.

2. Flowering scales awnless, nearly as broad as long.

13. B. arvensis.

b. Flowering scales compressed-keeled.

Flowering scales pubescent; awn $4-6 \mathrm{~mm}$. long.

14. B. squarrosus.

I4. B. brizaformis. Flowering scales minutely roughened; awn less than $2 \mathrm{~mm}$. long, or none.

17. B. unioloides.

I. Bromus inérmis Leyss. Hungarian Brome-grass. Culms tufted, 8-r2 dm. tall; sheaths smooth and glabrous; leaves r.5-2.5 dm. long, 4-6 mm. wide, smooth and glabrous; panicle 1.5-2.5 dm. long, oblong, the axis scabrous, its scabrous branches a:cending, in clusters; spikelets $2-2.5 \mathrm{~cm}$. long, about $5 \mathrm{~mm}$. wide, oblong, erect, the first scale I-nerved, the second scale 3 -nerved, the flowering scales 10-1 $2 \mathrm{~mm}$. long, 5-7-nerved, awnless, or 1arely awn-pointed. In fields and waste places, S. Dak. and Ohio. Introduced from Europe. June-July.

2. Bromus ciliàtus L. Fringed Brome-grass. Wood Chess. (I. F. f. 506.) Culms 6-12 dm. tall, glabrous or pubescent. Sheaths often softly pubescent, or the lower sometimes sparingly hirsute; leaves $\mathrm{r}-3 \mathrm{dm}$. long, 4-r2 $\mathrm{mm}$. wide, smooth beneath, scabrous and often pubescent above; panicle open, $1-2.5$ dm. in length, its branches widely spreading or often drooping; spikelets 5-10. flowered, $2.5 \mathrm{~cm}$. long or less; first scale r-nerved, the second longer, 3-nerved; flowering scales 8-12 $\mathrm{mm}$. long, obtuse or acute, 5-7-nerved, appressed-pubescent on the margins or over the entire surface; awn $4-8 \mathrm{~mm}$. long. In woods and thickets, Newf. to Manitoba and Br. Col., south to Fla. and Tex. Variable. The form known as var. purgans ( $B$. pubescens Muhl.) with the flowering scales pubescent all over, may be distinct. July-Aug.

3. Bromus eréctus Huds. Upright Brome-grass. (I. F. f. 507.) Culms 6-9 dm. tall. Sheaths glabrous or slightly pubescent; leaves sparingly pubescent, 2-4 mm. wide, those of the culm $1-2 \mathrm{dm}$. long, the basal about $3 \mathrm{dm}$. long, very narrow; panicle $7 \cdot 5-17.5 \mathrm{~cm}$. in length, the branches erect or ascending, the lower 2.5-7.5 cm. long; spikelets I.25-3.75 cm. long, sometimes purplish, 5-10-flowered; empty scales acuminate, the first $\mathbf{I}$-nerved, the second longer, 3 -nerved; flowering scales $\mathbf{I}-\mathbf{I} .2 \mathrm{~cm}$. long, acuminate, very rough-pubescent, 5 -nerved, the intermediate nerves faint; awn 4-6 mm. long. In waste places about N. Y. Adventive from Europe. July-Aug.

4. Bromus ásper Murr. Hairy Brome-grass. (I. F. f. 508.) Culms 6-i 8 dm. tall, rough. Sheaths strongly retrorse-hirsute, especially the lower; leaves 2-3 dm. long or more, 6-12 mm. wide, rough or often hirsute; panicle $1.5-3 \mathrm{dm}$. in length, open, the branches usually drooping; spikelets 5-ro-flowered, $2.5-3.75 \mathrm{~cm}$. long; empty scales acute, scabrous on the nerves, the first I-nerved, the second longer, 3-nerved; flowering scales about $1.2 \mathrm{~cm}$. long, acute, hispid near the margins and on the lower part of the keel; awn 6-8 mm. long. In waste places, N. B. to Mich. and $\mathrm{Ky}$. Naturalized from Europe. July-Aug.

5. Bromus tectòrum L. Downy Brome-grass. (I. F. f. 509.) Culms 1. 5-6 dm. tall, erect from an annual root. Sheaths, at least the lower ones, softly pubescent; leaves $2.5-10 \mathrm{~cm}$. long, 2-4 mm. wide, softly pubescent; panicle 5$15 \mathrm{~cm}$. in length, open, the branches slender and drooping, somewhat one-sided; spikelets numerous, 5-8-flowered, on capillary recurved slender pedicels: empty scales acuminate, usually rough or hirsute, the first I-nerved, the second longer, 3. nerved; flowering scales 8-12 mm. long, acuminate. 7-nerved, usually rough or hirsute; awn 1.2-1.6 cm. long. In fields and waste places, Mass. and R. I. to Ont., south to Md. and Ohio. Naturalized from Europe. Sometimes a troublesome weed. May-July. 
6. Bromus stérilis L. Barren Brome-grass. (I. F. f. 5 IO.) Culms 3-6 dm. tall; sheaths smooth or rough, the lower sometimes pubescent; leaves 7.5-22.5 cm. long, 2-6 mm. wide, usually more or less pubescent; panicle 1.25 $2.5 \mathrm{dm}$. in length, the branches ascending or often widely spreading, not one-sided, stiff; spikelets few, 5-10-flowered, spreading or pendulous ; empty scales acuminate, glabrous, the first I-nerved, the second longer, 3-nerved; flowering scales I.2r. $6 \mathrm{~cm}$. long, acuminate, 7 -nerved, scabrous on the nerves, the awn $1.4-2.4 \mathrm{~cm}$. long. In waste places and ballast, eastern Mass. to Penn. and Ohio. Locally iaturalized or adventive from Europe. Native also of Asia. June-July.

7. Bromus Madriténsis L. Compact Chess. (I. F. f. 509a.) Culms 3-6 dm. tall, tufted; sheaths glabrous, or the lower ones pubescent; leaves 6.25$20 \mathrm{~cm}$. long, 3-6 $\mathrm{mm}$. wide, rough above, often pubescent on both surfaces; panicle dense, $7.5-15 \mathrm{~cm}$. long, its rough branches erect or ascending, the longer $5-7.5 \mathrm{~cm}$. long; spikelets numerous. $3 \cdot 75-5 \mathrm{~cm}$. long, including the awns scales acuminate, scarious on the margins, the first scale I-nerved, the second 3-nerved; flowering scales, exclusive of the awn, $\mathbf{r} .2-\mathbf{I} .4 \mathrm{~cm}$. long, sparsely and minutely appressedpubescent, 5 -nerved, the apex acuminately 2 -toothed, bearing an erect or divergent a wn 1.2-1.8 cm. long. Waste places, Mich. and Va.; also in Cal. Locally adventive from Europe. Summer.

8. Bromus Pòrteri (Coulter) Nash. Porter's Chess. (I. F. f. 5IIr.) Culms 4.5-9 dm. tall, pubescent below the nodes. Sheaths glabrous or sometimes softly pubescent ; leaves $2-6 \mathrm{~mm}$. wide, rough, those of the culm $\mathrm{I}-2.25 \mathrm{dm}$. long, the basal narrow and about one-half the length of the culm; panicle $7.5-15 \mathrm{~cm}$. in length, its branches drooping and flexuous, at least when old, the nodes of the axis pubescent; spikelets 5-IO-flowered, r.8-3 cm. long, on slender flexuous pedicels; empty scales pubescent, 3-nerved: flowering scales $1-1.2 \mathrm{~cm}$. long, obtuse, 5-7nerved, densely pubescent with long silky hairs; awn 2-4 mm. long. In dry soil, S. Dak. to Mont., south to western Neb., N. Mex. and Ariz. July-Aug.

9. Bromus Kàlmii A. Gray. Kalm's Chess. (I. F. f. $5^{\text {I2.) }}$ Culms 4.5-9 $\mathrm{dm}$. tall. Sheaths more or less pubescent ; leaves $6-17.5 \mathrm{~cm}$. long, $2-8 \mathrm{~mm}$. wide, sparingly pubescent ; panicle $5-15 \mathrm{~cm}$. in length, open, its branches usually flexuous; spikelets 6-ro-flowered, r.2-2.4 cm. long, on slender flexuous pedicels; empty scales pubescent, the first acute, 3-nerved, the second obtuse or mucronate, 5-7nerved; flowering scales about $8 \mathrm{~mm}$. long, 7-9-nerved, densely silky pubescent, the awn 2-3 $\mathrm{mm}$. in length. In woods and thickets, Quebec to Manitoba, south to Mass., Penn., Ill. and Iowa. July-Aug.

I0. Bromus hordeàceus L. SofT Chess. (I. F. f. 513.) Culms 2-9 dm. tall, usually pubescent below the panicle. Sheaths mostly pubescent; leaves 2.5$17.5 \mathrm{~cm}$. long, $2-6 \mathrm{~mm}$. wide, pubescent; panicle generally contracted, its branches erect or ascending, $2.5-5 \mathrm{~cm}$. long; spikelets appressed-pubescent, on short pedicels; empty scales acute, the first 3-nerved, the second longer, 5-7-nerved; flowering scales broad, obtuse, 7-9 mm. long, 7-9-nerved, bearing an awn $68 \mathrm{~mm}$. in length between the obtuse or acute teeth. In fields and waste places, Conn. and N. Y. to Va. and Neb. Locally adventive from Europe. July-Aug.

I I. Bromus secálinus L. Cheat. C'Hess. (I. F. f. 5 I4.) Culms 3-9 dm. tall; sheaths generally glabrous; leaves $5-22.5 \mathrm{~cm}$. long, $2-6 \mathrm{~mm}$. wide, smooth or rough, sometimes hairy; panicle 5-20 $\mathrm{cm}$. in length, open, its branches ascending or drooping; spikelets turgid, glabrous, erect or somewhat pendulous, 6-10flowered; empty scales scabrous toward the apex, the first 3 -nerved, acute, the second longer and broader, 7-nerved, obtuse; flowering scales $6-8 \mathrm{~mm}$. long, broad, turgid, obtuse, rough toward the apex, the nerves obscure, awnless or bearing a straight awn $8 \mathrm{~mm}$. long or less between the obtuse short teeth. In fields and waste places almost throughout temperate N. Am., often a pernicious weed in grain fields. Naturalized from Europe. Native also of Asia. June-Aug.

12. Bromus racemòsus $L$. Upright Chess. Smooth Brome-grass. (I. F. f. 515.) Culms 3-9 dm. tall, glabrous or sparingly pubescent below the panicle. Sheaths pubescent; leaves $2.5-22.5 \mathrm{~cm}$. long, $1-8 \mathrm{~mm}$. wide, pubescent; panicle $2.5-25 \mathrm{~cm}$. in length, the branches erect or ascending, the lower sometimes $6 \mathrm{~cm}$. long; spikelets erect, 5-II-flowered; empty scales acute, the first 3 -nerved, the second longer and broader, 5-9-nerved; flowering scales broad, 7-9 mm. long, obtuse, smooth and shining, the nerves prominent; a wn straight, $6-8 \mathrm{~mm}$. in length. In 
felds and waste places all over the eastern U. S. and Br. Am.; also on the Pacific Coast. Naturalized from Europe. Native also of Asia. June-Aug.

13. Bromus arvénsis L. Field Chess or Brome. (I. F. f. 5I5a.) Culms erect, 3-9 dm. tall, glabrous except at or near the brown nodes. Sheaths softly and densely pubescent with short reflexed hairs; leaves erect or ascending, more or less hirsute on both surfaces, 7-5-15 cm. long, 4-6 mm. wide; panicle ample, 1.25-2.25 $\mathrm{dm}$. long, its rough branches erect or ascending, rarely spreading, the longer $7 \cdot 5-$ $15 \mathrm{~cm}$. long; spikelets, including the awns, $1.8-2.4 \mathrm{~cm}$. long, lanceolate, the scales minutely and sparsely appressed-pubescent toward the acute apex, papillose along the nerves, the first scale 3-nerred, the second 5-nerved; flowering scales broadest at the middle, 5-nerved, $7-8 \mathrm{~mm}$. long, bearing an erect awn of about the same length. Fields and waste places, N. Y., N. J. and Mich. Locally adventive from Europe. Summer.

14. Bromus squarròsus L. CoRn Brome. (I. F. f. 5 I6.) Culms 2-4.5 dm. tall. Sheaths softly pubescent; leaves $2.5-12.5 \mathrm{~cm}$. long, 2-4 $\mathrm{mm}$. wide, softly pubescent; panicle 5-15 cm. in length, open, the branches ascending or drooping, often flexuous; spikelets nodding, 6-12-flowered, on slender pedicels; empty scales obtuse or acutish, the first 5-nerved, the second longer, 7-9-nerved; flowering scales 9-II mm. long, obtuse, shining, minutely scabrous; awn inserted below the apex, about as long as the scale, bent at the base and divergent. In bal. last and waste places about the eastern seaports. Fugitive or adventive from Europe. July-Aug.

15. Bromus brizaefórmis Fisch. \& Mey. Quake-grass Brome. (I. F. f. 517.) Culms 2-6 dm. tall; sheaths, at least the lower, pubescent with soft villous hairs; leaves $2.5^{-17.5} \mathrm{~cm}$. long, 2-6 mm. wide, pubescent; panicle $3.75-20 \mathrm{~cm}$. in length, open, the branches ascending or often drooping, flexuous; spikelets few, I. $5-2.5 \mathrm{~cm}$. long, laterally much compressed; empty scales very obtuse, often purplish, glabrous or minutely pubescent, the first 3-5-nerved, the second larger, 5-9-nerved; flowering scales $6-8 \mathrm{~mm}$. long, very broad, obtuse, 9-nerved, shining, glabrous or sometimes minutely pubescent, awnless. Introduced into Penn. and Del.; also from Mont. to Cal. Native of northern Europe and Asia. July-Aug.

I6. Bromus breviaristàtus (Hook.) Buckl. SHORT-Awned Chess. (I. F. f. 518.) Culms 3-12 dm. tall, sometimes pubescent below the panicle. Sheaths pubescent, at least the lower ones; leaves I.5-3 dm. long or more, 4-12 mm. wide, rough and often pubescent; panicle $\mathrm{I}-4 \mathrm{dm}$. in length, its branches erect or ascending, the lower $5^{-15} \mathrm{~cm}$. long; spikelets 5-10-flowered; empty scales acute, pubescent, the first 3-5-nerved, the second longer, 5-9-nerved; flowering scales compressed, keeled, I.2-1.4 cm. long, acute, 7-9-nerved, appressed-pubescent; awn 4-6 mm. long. In dry soil, Manitoba to Br. Col., south to Neb., Ariz. and Cal. July-Aug.

I7. Bromus unioloìdes (Willd.) H.B.K. Schrader's Brome-Grass. Southern Chess. (I. F. f. 5 I9.) Culms I.5-9 dm. tall; sheaths glabrous or frequently pubescent; leaves $7 \cdot 5-32 \mathrm{~cm}$. long, $2-8 \mathrm{~mm}$. wide, usually rough, at least above; panicle 5-25 cm. in length, the branches erect or ascending, or the lower branches of the larger panicles widely spreading; spikelets much compressed, 6-Io-flowered; empty scales acute, the first 3-5-nerved, the second longer, 5-9nerved; flowering scales $1.2-1.6 \mathrm{~cm}$. long, very acute, minutely scabrous, bearing an awn less than $2 \mathrm{~mm}$. long or awnless. Kans. (?) to the Ind. Terr., Tex. and Mex. Widely distributed in S. Am. May-July.

\section{NÀRDUS L.}

A low perennial tufted grass, with setaceous rigid leaves and a terminai onesided slender spike. Spikelets I-flowered, narrow, sessile and single in each notch of the rachis. Scales 2, the lower empty, adnate to the rachis, or almost wanting, the upper flower-bearing, narrow, with involute and hyaline margins; palet narrow, 2-nerved. Stamens 3. Style elongated, undivided. Stigma elongated, shortpapillose. Grain linear, glabrous, enclosed in the scale, usually free. [Name Greek, of uncertain application.] A monotypic genus of the Old World.
I. Nardus strícta L.
WIREBENT.
MAT-GRASS.
NARD.
(I. F. f. 520.)

Culms I-4 dm. tall, rigid, roughish. Sheaths usually at the base of the culm; 
leaves setaceous, stiff, rough, the I or 2 culm leaves about $2.5 \mathrm{~cm}$. long, erect, the basal ones numerous, $5^{-12.5} \mathrm{~cm}$. long; spike $2.5-7.5 \mathrm{~cm}$. in length, strict; spikelets I-flowered, 6-8 mm. long, arranged alternately in 2 rows on one side of the erect slender rachis, often purplish; lower scale empty, very short, adnate to the rachis, sometimes almost wanting; flowering scale $6-8 \mathrm{~mm}$. long, scabrous, longacuminate or short-awned. Introduced into Newf. and at Amherst, Mass. Adventive irom Europe. July-Aug.

\section{LòliUM L.}

Annual or perennial grasses, with flat leaves and terminal spikes. Spikelets several-flowered, solitary, sessile and alternate in the notches of the usually continuous rachis, compressed, the edge of the spikelet (backs of the scales) turned toward the rachis. Scales rigid; lower scale empty in the lateral spikelets, and the 2 lower empty in the terminal; flowering scales rounded on the back, 5-7-nerved; palets 2-keeled. Stamens 3. Styles distinct, very short. Stigmas 2, plumose. Grain adherent to the palet. [Latin name for Darnel.] About 6 species, natives of the Old World.

Empty scale shorter than the spikelet.

Flowering scales awnless.

Flowering scales awned.

Empty scale equalling or extending beyond the flowering scales.

1. L. perenne.

2. L. Italicum.

3. L. temulentum.

r. Lolium perénne L. RAY-gRass. Rye-gRass. (I. F. f. 521.) Smooth and glabrous. Culms I.5-7.5 dm. tall; leaves 5-12.5 cm. long, 2-4 mm. wide; spike 7.5-20 cm. in length; spikelets 5-10-flowered, 8-12 mm. long, the empty scale shorter than the spikelet, strongly nerved; flowering scales 4-6 mm. long, obscurely nerved, acuminate, awnless. In waste places and cultivated grounds al$\mathrm{m}$ sst throughout the northern U. S. and southern Br. Am. Naturalized from Europe. Native also of Asia. Erroneously called Darnel, this name belonging to L. temulentum. July-Aug.

2. Lolium Itálicum A. Br. Awned Ray-grass. Culms tufted, 6-10 dm. tall. Sheaths smooth and glabrous; leaves I-2 dm. long, 3-7 mm. wide; spikes 2-3 dm. long; spikelets 20-30, 1.5-2 cm. long, the flowering scales bearing an awn equalling or a little shorter than themselves. In fields and waste places, N. Y., N. J. and Iowa. June-Aug.

3. Lolium temuléntum L. DARnel. Ivray. (I. F. f. 522.) Glabrous. Culms 6-12 dm. tall; leaves $\mathrm{I}-2.5 \mathrm{dm}$. in length, 2-6 mm. wide, smooth beneath, rough above; spike I-3 dm. in length; spikelets 4-8-flowered, I-I.8 cm. long, the strongly nerved empty scale equalling or extending beyond the obscurely nerved flowering scales, which are awned or awnless. In waste places and cultivated grounds, locally naturalized or adventive from Europe, N. B. to Mich., Ga. and Kans. Abundant on the Pacific Coast. Locally a troublesome weed. June-Aug.

\section{LEPTÙRUS R. Br.}

Usually low annual grasses, with narrow leaves and strict or curved elongated slender spikes. Spikelets I-2-flowered, sessile and single in alternate notches of the jointed rachis. Empty scales 2, rarely I, narrow, rigid, acute, 5-nerveci; flowering scales much shorter, hyaline, keeled, one side turned to the rachis. Palets hyaline, 2-nerved. Stamens 3, or fewer. Styles short, distinct. Stigmas 2, plumose. Grain narrow, glabrous, free, enclosed in the scale. [Greek, referring to the narrow spikes.]. Species 5 or 6 , natives of the Old World.

I. Lepturus filiförmis (Roth) Trin. Slender Hardgrass. (I. F. f. 523.) Culms 7.5-30 cm. long, decumbent, much branched. Sheaths loose, shorter than the internodes; leaves $1.25-5 \mathrm{~cm}$. long, $2 \mathrm{~mm}$. wide or less, usually involute, smooth beneath, rough above; spikes $2.5-15 \mathrm{~cm}$. in length, slender, strict or curved; spikelets 4-5 mm. long; empty scales acute; flowering scales about $3.5 \mathrm{~mm}$. long, I-nerved. In waste places, southern Penn. to Va., near or along the coast. Adventive from Europe. Summer. 


\section{AGROPY̌RON J. Gaertn.}

Annual or perennial grasses, with flat or involute leaves and terminal spikes. Spikelets 3-many-flowered, sessile, single and alternate at each notch of the usually continuous rachis, the side of the spikelet turned toward the rachis. Two lower scales empty; flowering scales rigid, rounded on the back, 5-7-nerved, usually acute or awned at the apex; palets 2 -keeled, the keels often ciliate. Stamens 3 . Styles very short, distinct. Stigmas plumose. Grain pubescent at the apex, usually adherent to the palet. [Greek, referring to the growth of these grasses in wheat-fields.] About 40 species, in all temperate regions. Besides the following, some twelve others occur in the western parts of N. Am.

Culms tufted, no creeping rootstocks or stolons.

Basal culm-leaves longer than the upper; empty scales awnless.

Flowering scales long-awned.

Culms stout, erect; spikes erect, often one-sided.

Culms geniculate, ascending; spikes nodding.

Flowering scales with a short awn or awnless.

Spikes slender, 5-12 cm. long; ensty and flowering scales broadest below the middle.

1. A. Richardsonii.

2. A. caninum.

Spikes $2.5-7 \mathrm{~cm}$. long; empty and flowering scales broadest above the mid-

Basal culm-leaves shorter than the upper; empty scales short-awned 4. A. violaceum.

Culms from creeping rootstocks.

5. A. Gmelini.

Rachis articulated, finally breaking up; spikes 4-angled.

Rachis continuous; spikes more or less flattened.

Spikelets compressed, lanceolate to ovate, ascending.

Spikelets nearly round or but little compressed, linear, erect.

Flowering scales densely pubescent.

Flowering scales glabrous or merely hispidulous.

Leaves very rough throughout.

Leaves smooth beneath, more or less hirsute above.

6. A. tetrastachys.

7. A. spicatum.

8. A. dasystachyum.

9. A. pseudorepens.

Io. A. repens.

I. Agropyron Richardsònii Schrad. Culms 6-ro dm. tall; sheaths smooth and glabrous; leaves erect, $8-20 \mathrm{~cm}$. long, $4-8 \mathrm{~mm}$. wide, very rough; spike stout, strict, often one-sided, 9-I5 cm. long, 8-10 mm. thick; spikelets crowded, 3-5flowered, the empty scales firm, rough on the nerves, short-awned, the flowering scales glabrous, with an awn usually 2-3 times as long as themselves. From Minn. to the Saskatchewan, south to Neb. and Colo. July-Aug.

2. Agropyron caninum (L.) R. \& S. Awned Wheat-grass. FibrousROOTED WhEAT-GRASS. (I. F. f. 528.) Culms 3-9 dm. tall; sheaths glabrous or the lower sometimes pubescent; leaves $7 \cdot 5-22.5 \mathrm{~cm}$. long, 2-6 mm. wide, smooth beneath, rough above; spike $7.5-20 \mathrm{~cm}$. in length, nodding at the top; spikelets 3-6-flowered; empty scales 9-12 mm. long, 3-5-nerved, acuminate, awn-pointed or bearing an awn 2-6 mm. long; flowering scales 8 -10 $\mathrm{mm}$. long, usually scabrous toward the apex, acuminate into an awn sometimes twice their own length. N. B. to Br. Col., south to N. Car., Tenn. and Colo. Also in Europe and Asia. Native northward; southward locally naturalized from Europe. July-Aug.

3. Agropyron ténerum Vasey. Slender Wheat-grass. (I. F. f. 527.) Glabrous; culms 6-9 dm. tall. Sheaths glabrous; leaves $7 \cdot 5-25 \mathrm{~cm}$. long, 2-4 mm. wide, flat or involute, rough; spike $7 \cdot 5-17.5 \mathrm{~cm}$. in length, usually narrow and slender; spikelets 3-5-flowered; empty scales 8-12 mm. long, acuminate or shortawned, 3-5-nerved, scarious on the margins; flowering scales $10-12 \mathrm{~mm}$. long, 5 -nerved, awn-pointed or short-awned, scarious on the margins, often rough toward the apex. In dry soil, Lab. to Br. Col., south to N. H., Vt., Kans., Colo. and Cal. July-Aug.

4. Agropyron violàceum (Hornem.) Vasey. Purplish Wheat-grass. (I. F. f. 526.) Culms I.5-6 dm. tall; leaves 5-15 cm. long, 2-6 mm. wide, flat or involute, rough or sometimes smooth beneath; spike $2.5^{-10} \mathrm{~cm}$. in length, occasionally longer, 4-6 mm. broad; spikelets 3-6-flowered; empty scales broad, usually purplish, scarious on the margins, 5-7-nerved, 8-12 $\mathrm{mm}$. long, acute or acuminate, sometimes awn-pointed, rarely long-awned; flowering scales often purplish, 5-7-nerved, scarious on the margins, 8-12 mm. long, acuminate or short. 
awned, the awn rarely as long as the body. Lab. to Br. Col. and Alaska, south to the mountains of N. E., N. Y., Penn. and Neb., and in the Rocky Mts. to Colo. Ascends to $1650 \mathrm{~m}$. in the White Mts. Also in northern Europe and Asia. Summer.

5. Agropyron Gmélini Scribn. \& Sm. Gmelin's Wheat-Grass. (I. F. f. 528a.) Culms 4.5-12 dm. tall, tufted; leaves erect, I-2.5 dm. long, 2-6 mm. wide, acuminate, smooth beneath, scabrous on the margins and sometimes also sparsely so above; spike slendcr, long-exserted, 5-20 cm. long; spikelets 6-20, somewhat crowded, appressed to the rachis, more or less compressed, 5-9-flowered ; empty scales I-I.4 cm. long, shorter than the spikelet, acuminate into a shorter awn; flowering scales 8-12 $\mathrm{mm}$. long, acuminate, bearing at or just below the apex a slender scabrous awn 1.4-3 cm. long. Bottom lands, Wash. to western Neb.

6. Agropyron tetrástachys Scribn. \& Sm. COAST Wheat-Grass. (I. F. f. 524c.) Glaucous. Culms rigid, 4.5-9 dm. tall, from a running rootstock; leaves erect, acuminate, $1.25-20 \mathrm{~cm}$. long, $4 \mathrm{~mm}$. or less wide, smooth beneath, glaucous above, scabrous on the margins; spikes long-exserted, 7.5-12.5 cm. long, 4-sided; spikelets crowded, I.2-2 cm. long, 6-I I-flowered, appressed to the 4 angled articulated rachis, the angles hispidulous; empty scales lanceolate, $1 \mathrm{~cm}$. long, 5-7nerved; flowering scales lanceolate; keeled, rough toward the apex, acute, awn. pointed or short-awned. Sandy beaches, coast of Me. July-Aug.

7. Agropyron spicàtum (Pursh) Scribn. \& Sm. Western Wheat-grass. (I. F. f. 524b.) Pale green, glaucous. Culms 4.5-12 dm. tall, from a slender creeping rootstock; leaves erect, 5-20 cm. long, 4-8 mm. wide, acuminate, very scabrous above, smooth beneath, becoming involute when dry; spike strict, I-2 $\mathrm{dm}$. long; spikelets crowded, divergent from the rachis, compressed, lanceolate when closed, 1.25-2.5 cm. long, 6-12-flowered; empty scales acuminate, awnpointed, shorter than the spikelet, hispidulous on the keel; flowering scales $\mathbf{I}-\mathbf{I} .2$ $\mathrm{cm}$. long, acute or a wn-pointed, glabrous or sparsely pubescent. Prairies and high plains, Manitoba and Minn. to Ore., south to Mo. and Tex.

8. Agropyron dasystàchyum (Hook.) Vasey. Northern Wheat-Grass. (I. F. f. 525.) Glaucous. Culms 3-9 dm. tall, from long running rootstocks; leaves 5-22.5 $\mathrm{cm}$. long, 2-6 $\mathrm{mm}$. wide, flat, or becoming involute in drying, smooth beneath, rough above; spike $6.25-17.5 \mathrm{~cm}$. in length; spikelets 4-8-flowered; empty scales 3-5-nerved, lanceolate, acuminate or short-awned, 6-9 $\mathrm{mm}$. long; flowering scales broadly lanceolate, 5-nerved, 9-12 mm. long, acute, or short-awned, densely villous. Sand-hills and dunes, Hudson Bay to the N. W. Terr. and Wyo., and on the shores of Lakes Huron and Superior. Summer.

9. Agropyron pseudorèpens Scribn. \& Sm. False Couch-grass. (I. F. f. 524a.) Light green. Culms 3-9 dm. tall, from a running rootstock; leaves erect, prominently nerved, rough on both surfaces, acuminate, the culm leaves 7.5-20 $\mathrm{cm}$. long, 4-6 mm. wide, the basal leaves about one-half as long as the culms; spikes 7.5-20 cm. long, strict; spikelets I-I. $6 \mathrm{~cm}$. long, 3-7-flowered, a little compressed, appressed to the rachis; empty scales lanceolate, equalling or somewhat shorter than the spikelet, acuminate and often awn-pointed, 5-7-nerved, the nerves hispidulous; flowering scales 5-nerved, roughish toward the apex, usually awnpointed. Rich river-bottoms, Mont. to Br. Col., south to Neb., Ariz. and Tex. July-Aug.

I0. Agropyron rèpens (L.) Beauv. Couch-grass. Quitch-Grass. (I. F. f. 524.) Culms 3-12 dm. tall, from a long jointed running rootstock. Leaves 7.5$30 \mathrm{~cm}$. long, 2-10 $\mathrm{mm}$. wide, smooth beneath, hirsute above; spike $5-20 \mathrm{~cm}$. in length, strict; spikelets 3-7-flowered; empty scales strongly 5-7-nerved, usually acute or awn-pointed, sometimes obtuse; flowering scales smooth and glabrous, acute or short-awned at the apex. In fields and waste places, almost throughout $\mathrm{N}$. Am. except the extreme north. Naturalized from Europe, and often a troublesome weed. Very variable. Native also of Asia. July-Sept.

\section{HÓRDEUM L.}

Annual or perennial grasses, with flat leaves and terminal cylindric spikes. Spiklets I-flowered, usually in 3 's at each joint of the rachis, the lateral generally short-stalked and imperfect; rachilla prorluced beyond the flower, the lower empty scales often reduced to awns and forming an apparent involucre around the spike- 
lets. Empty scales rigid; flowering scales rounded on the back, 5-nerved at the apex, awned; palet scarcely shorter than the scale, 2-keeled. Stamens 3. Styles very short, distinct. Grain usually adherent to the scale, hairy at the summit. [Latin name for barley.] About zo species, widely distributed in both hemispheres.

Flowering scales, exclusive of awn, 6-8 mm. long.

Awn of the flowering scale $1.25 \mathrm{~cm}$. long or less.

All the empty scales of each cluster bristle-like.

Four of the empty scales of each cluster dilated above the base.

A wn of the flowering scale $2.5 \mathrm{~cm}$. long or more.

Flowering scales, exclusive of awn, about $1.2 \mathrm{~cm}$. long.

I. H. nodosum.

2. H. pusillum.

3. H. jubatum.

4. H. murinum.

I. Hordeum nodòsum L. Meadow Barley. (I. F. f. 529.) Culms I.5-6 Im. tall, erect, or sometimes decumbent; leaves $3.75-12.5 \mathrm{~cm}$. long, 2-6 mm. wide, flat, rough; spike $2.5-8.5 \mathrm{~cm}$. in length; spikelets usually in 3 's, the central one containing a palet and perfect flower, the lateral enclosing a staminate or rudimentary flower, or a palet only; empty scales of each cluster awn-like; flowering scale of the central spikelet $6-8 \mathrm{~mm}$. long exclusive of the awn, which is $6-12 \mathrm{~mm}$. long, the corresponding scale in the lateral spikelets much smaller and short-stalked. In meadows and waste places, Ind. to Minn., Br. Col. and Alaska, south to Tex. and Cal. Also in Europe and Asia. June-July.

2. Hordeum pusíllum Nutt. LitTle Barley. (I. F. f. 530.) Culms I-4 dm. tall, erect, or decumbent at the base; leaves $1.25-7.5 \mathrm{~cm}$. long, I-4 mm. wide, erect, smooth beneath, rough above; spike $2.5-7.5 \mathrm{~cm}$. in length; spikelets usually in 3 's, the central one containing a palet and perfect flower, the lateral imperfect; scales awned, the empty ones scabrous, those of the central spikelet and the lower ones of the lateral spikelets dilated above the base; flowering scales smooth, that of the central spikelet 6-8 $\mathrm{mm}$. long, short-awned, the corresponding scale in the lateral spikelets smaller and very short stalked. In dry soil, Ont. to Br. Col., south to Neb., Ark., Tex. and Cal.; also sparingly introduced along the coast from Va. to Fla. June-July.

3. Hordeum jubàtum L. Squirrel-tail Grass. (I. F. f. 531.) Culms 2.5-7.5 dm. tall; leaves $2.5-12.5 \mathrm{~cm}$. long, 2-4 mm. wide, erect, rough; spike 5-IO $\mathrm{cm}$. in length; spikelets usually in 3 's, the central one containing a palet and perfect flower, the lateral imperfect; empty scales consisting of slender rough awns 2.5-6.25 cm. long; flowering scale of the central spikelet $6-8 \mathrm{~mm}$. long, scabrous at the apex, bearing a slender rough awn 2.5-6.25 $\mathrm{cm}$. long; the corresponding scale in the lateral spikelets short-awned, about $6 \mathrm{~mm}$. long including its pedicel, sometimes reduced to a rudiment. In dry soil, Ont. to Alaska, south to Kans., Colo. and Cal. Naturalized in the east from Lab. and Quebec to N. J. and Penn. July-Aug.

4. Hordeum murinum L. Wall Barley. (I. F. f. 532.) Cuims I.5-6 $\mathrm{dm}$. tail, erect, or decumbent at the base; leaves $2.5^{-1} 5 \mathrm{~cm}$. long, 2-6 $\mathrm{mm}$. wide, rough; spikes 5-10 $\mathrm{cm}$. in length; spikelets usually in 3's; scales awned, the empty ones awn-like, scabrous, those of the central spikelet broader and ciliate on the margins, bearing awns $1.8-2.4 \mathrm{~cm}$. long, those of the lateral spikelets similar, with the exception of the second scale, which is not ciliate; flowering scales scabrous at the apex, bearing an awn about $2.5 \mathrm{~cm}$. long, those of the lateral spikelets about $1.2 \mathrm{~cm}$. long, the corresponding scale in the central spikelet somewhat smaller. On ballast and sparingly in waste places, southern N. Y. and N. J. to D. C. Also from Ariz. to Cal. Adventive or naturalized from Europe. JuneJuly.

\section{SITÀNION Raf.}

'Tufted grasses with flat or involute leaves and a termınal dense spike with the rachis articulated and readily breaking up. Spikelets numerous, in 2's or 3's at each joint, I-5-flowered; empty scales entire or divided, the divisions extending often to the base, the scales or their divisions bearing long slender awns; palet 2keeled. Stamens 3. Styles distinct, short. Stigmas plumose. Grain adherent to the palet. [Greek, the meaning obscure.] Usually considered a monotypic genus, but probably divisible into a number of species. 
I. Sitanion elymoìdes Raf. (I. F. f. 540.) Culms 1.5-6 dm. tall; sheaths sometimes hirsute; leaves $5-17.5 \mathrm{~cm}$. long, I-4 mm. wide, often stiff and erect, usually rough, sometimes hirsute, flat or involute; spike $5^{-15} \mathrm{~cm}$. in length; spikelets I-5-flowered; empty scales entire or divided, often to the base, the divisions awl-shaped and bearing long unequal slender awns $2.5-8.5 \mathrm{~cm}$. in length; flowering scales 6-10 $\mathrm{mm}$. long, 5-nerved, scabrous, at least toward the apex, bearing a long slender divergent awn $2.5-8.5 \mathrm{~cm}$. in length, the apex of the scale sometimes 2-toothed, the teeth often produced into short awns. In dry soil, S. Dak. to Ore., south to Kans., Tex., Ariz., and Cal. July-Aug. [Elymus Sitanion Schultes.]

\section{ror. ÉLYMUS L. (See Appendix.)}

Tall grasses, with usually flat leaves and dense terminal spikes. Spikelets 2several-flowered (rarely I-flowered) sessile, usually in pairs, occasionally in 3's or more, in alternate notches of the continuous or jointed rachis, the empty scales forming an apparent involucre to the cluster. Two lower scales empty, narrow, acute, sometimes awned, entire; flowering scales shorter, rounded on the back, 5-nerved, usually bearing an awn. Palet a little shorter than the scale, 2keeled. Stamens 3. Styles very short, distinct. Stigmas plumose. Grain sparsely hairy at the summit, adherent to the palet. [Greek, to roll up, referring to the involute palet.] About 40 species, natives of temperate regions. Besides the following, some 15 others occur in the western parts of $\mathrm{N}$. Am.

Flowering scales conspicuously awned (rarely awnless in No. 2).

Spikelets divergent from the rachis of the broad spike.

Empty scales narrowly awl-shaped; spike slender.

Empty scales linear-lanceolate to linear; spike stout.

Flowering scales glabrous.

I. E. striatus.

2. E. Virginicus.

Empty scales linear, thick, firm, bearing generally a much shorter awn.

3. E. hirsutiglumis.

Empty scales narrowly lanceolate, rather thin, bearing commenly an awn equalling or exceeding themselves.

Spike rather loosely flowered, nodding at the summit, usually longexserted.

4. E. Canadensis.

Spike densely flowered, compact, strict, usually included at the base.

Spikelets appressed to the rachis of the narrow spike.

5. E. robustus.

Empty scales narrowly lanceolate, acuminate or awn-pointed.

6. E. glaucus.

Empty scales awl-shaped, bearing àn awn equalling or exceeding themselves.

Flowering scales awnless or awn-pointed.

Flowering scales glabrous.

Flowering scales villous.

7. E. Macouniï.

8. E. condensatus.

9. E. arenarius.

I. Elymus striàtus Willd. Slender Wild Rye. (I. F. f. 533.) Culms 3-9 dm. tall; sheaths glabrous or hirsute; leaves I.25-2.25 din. long, 4-10 mm. wide, smooth or slightly rough beneath, pubescent above; spike $6-12 \mathrm{~cm}$. in length, often nodding, broad, slender, dense: spikelets divergent from the rachis, I-3flowered; empty scales awl-shaped, $1.8-2.4 \mathrm{~cm}$. long, including the slender rough awn, I-3-nerved, the nerves, and often the whole scale, rough, hispid or lirsute ; flowering scales about $6 \mathrm{~mm}$. long, smooth, scabrous or hispid, bearing a slender rough awn $1.6-3 \mathrm{~cm}$. in length. In woods and on banks, Me. and Ont. to Tenn., Neb. and Kans. June-July.

2. Elymus Virgínicus L. Terrell-grass. Virginia Wild Rie. (I. F. f. 534.) Culms 6-9 dm. tall: sheaths sometimes pubescent, the uppermost often inflated and enclosing the peduncle and the base of the spike; leaves I.25-3.5 dm. long, 4-16 mm. wide, rough; spike 5-17.5 cm. in length, broad, stout, upright; spikelets divergent from the rachis, 2-3-flowered; empty scales thick and rigid, lanceolate, 1.6-2.4 cm. long, including the short awn, 5-7-nerved; flowering scales 6-8 mm. long, glabrous, bearing a rough awn 4-18 $\mathrm{mm}$. in length, or rarely awnless. In moist soil, especially rlong streams, N. S. and N. B. to Manitoba, south to Fla. and Tex. Ascends tc $600 \mathrm{~m}$. in N. Car. July-Aug. 
3. Elymus hirsutiglumis Scribn. \& Sm. STRICT WILd-Rve. (I. F. f. 535a.) Culms erect from a perennial root, 3-9 dm. tall; sheaths longer than the internodes, the uppermost often inflated and enclosing the base of the spike; leaves $2-3 \mathrm{dm}$. long, 8-18 mm. wide, acuminate, very rough on both surfaces; spikes $6-15 \mathrm{~cm}$. long, stout, the rachis pubescent; spikelets crowded, in pairs, 2-5-flowered; empty scales linear, I-I.2 cm. long, thick, 3-5-nerved, the nerves hirsute, acuminate into a scabrous awn as lony as or shorter than the scale; flowering scales lanceolate, 5-nerved, appressed-hirsute, 8-10 $\mathrm{mm}$. long, acuminate into a rough awn i.2-I.6 $\mathrm{cm}$. long. River banks, Me. to Va., west to Ill. and Neb. July-Aug.

4. Elymus Canadénsis L. Nodding Wild-Rye. (I. F. f. 535.) Culms 6-I $5 \mathrm{dm}$. tall; leaves $\mathrm{I}-3 \mathrm{dm}$. long or more, 4-20 mm. wide, rough, sometimes glaucous; spike 1-3 dm. in length, rather slender, nodding, its peduncle much exserted; spikelets divergent from the rachis, 3-5-flowered; empty scales awl-shaped, rigid, 3-5-nerved, 1.6-3.2 cm. long, including the long slender rough awns; flowering scales $8-14 \mathrm{~mm}$. long, nearly smooth to hirsute, bearing a slender scabrous straight or divergent awn 2-5 cm. in length. On river banks, N. S. and N. B. to Alberta, south to Ga., Tex. and N. Mex. Ascends to $630 \mathrm{~m}$. in Va. July-Aug.

5. Elymus robústus Scribn. \& Sm. Stout Wild-Rye. (I. F. f. 535b.) Culms erect, stout, 9-I2 $\mathrm{dm}$. tall; sheaths smooth or slightly roughened; leaves firm, very rough on both surfaces, $\mathrm{I}-4 \mathrm{dm}$. long, 8-20 mm. wide, acuminate; spike usually partially included at the base, stout, strict, I-2 $5 \mathrm{dm}$. long, compact, the rachis usually glabrous except on the angles; spikelets numerous. crowded, in 2's4's, 3-4-flowered; empty scales subulate, I-r.2 cm. long, bearing an awn about twice as long; flowering scales lanceolate, I-I.2 cm. long, 2-toothed at the apex, from sparsely to densely appressed-pubescent, bearing a straight or curving awn 3-4.5 cm. long. River banks, Ill. to Mont.. south to Kans.

6. Elymus glaùcus Buckl. Sмоотн Wild-RYE. (I. F. f. 536.) Culms 6-I5 $\mathrm{dm}$. tall; sheaths rarely pubescent; leaves $\mathrm{I}-3 \mathrm{dm}$. long, 4-16 mm. wide, smooth beneath, sometimes rough above; spike $7 \cdot 5-20 \mathrm{~cm}$. in length, narrow, slender; spikelets appressed to the rachis. 3-6-flowered: empty scales narrowly lanceolate, 8-12 mm. long, acuminate or awn-pointed, rigid, 3-5-nerved; flowering scales smooth or slightly rough, I-I.2 cm. long, bearing a slender straight rough awn I.2-I. $8 \mathrm{~cm}$. in length. In moist soil, Ont. to Br. Col., south to Mich., Ariz. and Cal. June-Aug.

7. Elymus Macoùnii Vasey. Macoun's Wild-Rye. (I.F. f. 537.) Culms 3-9 dm. tall: leaves 5-I $5 \mathrm{~cm}$. long, 2-5 $\mathrm{mm}$. wide, rough, especially above; spike 5-12.5 cm. in length, narrow, slender, often somewhat flexuous; spikelets appressed to the rachis, single at each node, or the lower sometimes in pairs, I-3-flowered; empty scales (occasionally 3) awl-shaped, 3-nerved, rough, 6-8 $\mathrm{mm}$. long, bearing a slender straight rough awn, 6-10 $\mathrm{mm}$. in length; flowering scales 7-10 $\mathrm{mm}$. long, rough toward the apex, bearing a slender straight awn 6-10 mm. long. Prairies, Manitoba and Assiniboia, south to Neb. and N. Mex. July-Aug.

8. Elymus condensàtus Presl. Smooti Lyme-grass. (I. F. f. 538.) Culms 6-30 dm. tall; leaves I.5-3 dm. long or more, 6-24 mm. wide, scabrous, at least above; spike $1-4 \mathrm{dm}$. in length, usually stout, strict, often inter rupted below, sometimes compound at the base; spikelets 3-6-flowered, 2-several at each node of the rachis; empty scales awl-shape 1, 9-I $2 \mathrm{~mm}$. long, I-nerved, usually rough; flowering scales 8-10 mm. long, generally awn-pointed, usually rough, sometimes smooth. In wet saline situations, Alberta to Br. Col., south to Neb., Ariz. and Cal. July-Aug.

9. Elymus arenàrius L. Downy Lyme-Grass. Sea Lyme-grass. (I. I. f. 539.) Culms I-2.5 m. tall, usually softly pubescent at the summit. Sheaths often glaucous; leaves $7 \cdot 5-30 \mathrm{~cm}$. long or more, 3-10 $\mathrm{mm}$. wide, flat, or becoming involute, smooth beneath, rough above; spike $7 \cdot 5^{-25} \mathrm{~cm}$. in length, usually strict; spikelets 3-6-flowered, frequently glaucous; empty scales 1.6-2.8 cm. long, 3-5nerved, acuminate, more or less villous; flowering scales $1.6-2 \mathrm{~cm}$. long, acute or awn-pointed, 5-7-nerved, usually very villous. On shores, Greenland and Lab. to the N. W. Terr. and Alaska, south to N. H., Lake Superior and Wash. A!so in Europe and Asia. Summer. 


\section{HÝSTRIX Moench. [ASPRELLA Willd.]}

Usually tall grasses, with flat leaves and terminal spikes. Spikelets 2-several. flowered, in pairs, rarely in 3's, at each node of the rachis. Empty scales wanting, or sometimes appearing as mere rudiments; flowering scales narrow, convolute, rigid, rounded on the back, 5-nerved above, terminating in an awn; palet scarcely shorter than the scale, 2-keeled. Stamens 3. Styles very short, distinct. Stigmas plumose. Grain oblong, adhering to the palet when dry. [Greek name of the Porcupine, referring to the long awns.] Four known species, the following and a Californian one occurring in N. Am.

1. Hystrix Hystrix (L.) Millsp. BotTle-Brush Grass. (I. F. f. 54I.) Culms 6-I2 dm. tall; leaves I-2.5 dm. long, 6-I2 mm. wide, smooth beneath, rough above; spike $7.5-17.5 \mathrm{~cm}$. in length; spikelets at length widely spreading, 8-12 mm. long, exclusive of the awns, readily deciduous, even when young; empty scales awn-like, usually present in the lowest spikelet; flowering scales 8-12 mm. long, acuminate into an awn about $2.5 \mathrm{~cm}$. in length. In rocky woods, $\mathrm{N}$. B. to Ont. and Minn. south to Ga., Ill. and Neb. Ascends to $630 \mathrm{~m}$. in Va. June-July.

\section{ARUNDINÀRIA Michx.}

Arborescent or shrubby grasses, with simple or branched culms and flat short. petioled leaves which are articulated with the sheath. Spikelets borne in panicles or racemes, 2-many-flowered, large, compressed. Empty scales I or 2, the first sometimes wanting; flowering scales longer, not keeled, many nerved; palets scarcely shorter than the scales, prominently 2-keeled. Lodicules 3. Stamens 3 . Styles 2 or 3. Stigmas plumose. Grain furrowed, free, enclosed in the scale and palet. [From Arundo, the Latin name of the Reed.] About 24 species, natives of Asia and America. Two are found in the southern U. S.

Spikelets borne on radical shoots of the year ; culms $4 \mathrm{~m}$. tall or less.

Spikelets borne on the old stems; culms $5 \mathrm{~m}$. tall or more.

r. A. tecta.

2. A. macrosperma.

r. Arundinaria técta (Walt.) Muhl. Scutch Cane. Small Cane. (I. F. f. 542.) Culms I-4 m. tall, erect, shrubby, branching at the summit. Sheaths longer than the internodes, smooth or rough, ciliate on the margins; ligules bristly; leaves lanceolate, $8.5-20 \mathrm{~cm}$. long, 8-24 mm. wide, flat, more or less pubescent beneath, glabrous above; racemes on short leafless culms; spikelets 7-ro-flowered, $2.5-3.75 \mathrm{~cm}$. long, on pedicels $2.5 \mathrm{~cm}$. in length or less, which are sometimes pubescent; empty scales unequal, the first usually very small, sometimes wanting; flowering scales $\mathbf{1 . 2 - 2} \mathrm{cm}$. long, acute or acuminate, smooth, glabrous or pubescent. In swamps and moist soil, Md. to Ind. Mo., Fla. and Tex. MayJuly.

2. Arundinaria mácrosperma Michx. Giant Cane. Culms woody, 6-9 m. tall, finally branched above; sheaths ciliate on the margins, otherwise glabrous; leaves lanceolate, smooth or roughish, $3 \mathrm{dm}$. or less long, the larger $2-3 \mathrm{~cm}$. wide, those on the ultimate divisions smaller and crowded at the summit of the branches; inflorescence on the old wood, the spikelets $3 \cdot 5^{-6} \mathrm{~cm}$. long, on slender more or less leafy branches, the flowering scales glabrous or hirsute, acuminate. Forming "cane brakes" along river banks and swamps, Va. to Fla., west to La.; along the Miss. R. and its tributaries as far north as Ky., Tenn. and Mo. May-July.

\section{Family 2. CYPERÀCEAE J. St. Hil.}

$$
\text { Sedge Family. }
$$

Grass-like or rush-like herbs. Stems (culms) slender, solid (rarely hollow), triangular, quadrangular, terete or flattened. Roots fibrous (many species perennial by long rootstocks). Leaves narrow, with closed sheaths. Flowers perfect or imperfect, arranged in spikelets, one (rarely 2) in the axil of each scale (glume, bract), the spikelets solitary 
or clustered, I-many-flowered. Scales 2-ranked or spirally imbricated, persistent or deciduous. Perianth hypogynous, composed of bristles, or interior scales, rarely calyx-like, or entirely wanting. Stamens $1-3$, rarely more. Filaments slender or filiform. Anthers 2-celled. Ovary I-celled. Ovule I, anatropous, erect. Style 2-3.cleft or rarely simple or minutely 2 toothed. Fruit a lenticular, plano-convex, or trigonous achene. Endosperm mealy. Embryo minute.

About 65 genera and 3000 species, of very wide geographic distribution. The dates given below indicate the time of perfecting fruit.

Flowers of the spikelet all, or at least one of them, perfect ; spikelets all similar.

Scales of the spikelets 2-ranked.

Perianth none; spikelets in solitary or umbelled terminal heads.

Spikelets with 2-many perfect flowers; scales several to numerous.

Spikelets with but I perfect flower; scales 2-4.

Perianth of 6-9 bristles; inflorescence axillary.

Scales of the spikelets spirally imbricated all around.

I. Cyperus.

2. Kyllinga.

3. Dulichium.

Spikelets with several to many perfect flowers.

Base of the style swollen, persistent as a tubercle on the achene.

Leaves reduced to basal sheaths; bristles of the perianth usually present ; spikelet solitary.

Culm leafy; perianth-bristles none; spikelets I-numerous.

Spikelets capitate, involucrate.

Spikelets umbellate or cymose.

\section{Dichromena.}

Spikelets in terminal and axillary compound cymes; most of the style persistent.

6. Psilocarya.

Spikelets in a terminal umbel, base of style persistent.

Base of the style enlarged or narrow, deciduous.

7. Stenophyllus.

Flowers with no rond sepals nor interior perianth-scales.

Style swollen at the base; bristles none. 8 . Fimbristylis.

Style not swollen at the base; bristles usually present.

Spikelets solitary to many; bristles $I-6$, rarely none.

9. Scirpus.

Spikelets solitary or few; bristles 6-many, soft, smooth, very long, slender, much exserted. Io. Eriophorum.

Flowers with a perianth of 3 stalked sepals or of 1 or 2 interior hyaline scales.

Perianth of 3 broad stalked sepals, usually alternating with as many bristles.

11. Fuirena.

Perianth of 1 or 2 hyaline scales (sepals ?); bristles none.

Perianth of a single minute posterior scale. I2. Hemicarpha.

Perianth of 2 scales, convolute around the ovary.

13. Lipocarpha.

Spikelets I-4-flowered, some of the flowers imperfect.

Style, or its base, persistent as a tubercle on the achene. 14. Rynchospora.

Style wholly deciduous.

15. Cladium.

Flowers all monoecious or dioecious, usually borne in separate small spikelets.

Achene not enclosed in a utricle (perigynium).

Spikelets clustered or solitary, not in a terminal spike; achene bony.

Spikelets forming a terminal spike; arctic genera.

Scales 2-flowered, androgynous.

Scales I-flowered, monoecious.

16. Scleria.

Achene enclosed in a utricle (perigynium).
Axis of the pistillate flower conspicuou

17. Elyna.

18. Kobresia.
perigynium.
19. Uncinia.

Axis of the pistillate flower rudimentary or none, not exserted.

20. Carex.

\section{CYPÈRUS L. (See Appendix.)}

Annual or perennial sedges. Culms in our species simple, triangular, leafy near the base, and with $\mathbf{I}$ or more leaves at the summit forming an involucre to the simple or compound, umbellate or capitate inflorescence. Rays of the umbel sheathed at the base, usually very unequal, one or more of the heads or spikes 
commonly sessile. Spikelets flat or subterete, the scales falling away from the rachis as they mature (nos. I-I9), or persistent and the spikelets falling away from the axis of the head or spike with the scales attached (nos. 20-32). Scales concave, conduplicate or keeled, 2-ranked, all flower-bearing or the lower ones empty. Flowers perfect. Perianth none. Stamens I-3. Style 2-3-cleft, deciduous from the summit of the achene. [Ancient Grcek name for these sedges.] About 650 species, of wide distribution in tropical and temperate regions. Besides the following, some 40 others occur in the southern U. S.

Style 2-cleft; achene lenticular, not 3 -angled; scales falling from the rachis; spikelets flat.

Achene one-half as long as the scale; umbel nearly or quite simple.

Spikelets yellow; superficial cells of the achene oblong. I. C. flavescens.

Spikelets green or brown; superficial cells of the achen quadrate.

Scales obtuse or obtusish, appressed.

Scales membranous, dull; style much exserted. 2. C. diandrus.

Scales subcoriaceous, shining; style scarcely exserted.

Scales acute, somewhat spreading at maturity.

3. C. rivularis.

Achene narrowly obovate; spikelets $\mathrm{I}-3 \mathrm{~cm}$. long. 4. C. Nuttallii.

Achene linear-oblong; spikelets $0.5^{-2} \mathrm{~cm}$. long. 5. C. microdontus.

Achene nearly as long as the scale; umbel sometimes much compound.

Style 3-cleft; achene 3-angled.

6. C. flavicomus.

A. Scales falling away from the persistent rachis of the flattened spikelets.

Wings of the rachis, if present, permanently adnate to it.

Scales tipped with recurved awns; low annual, $2-15 \mathrm{~cm}$. tall.

Scales acute or obtuse, not awned.

7. C. inflexus.

Wings of the rachis none or very narrow.

Stamens 3 ; spikelets linear-oblong, 8-25 mm. long; scales acute. Annual; culms smooth, 5-25 cm. long. 8. C: compressus.

Perennial; culms rough, $30-85 \mathrm{~cm}$. tall. 9. C. Schweinitzii.

Stamen I; spikelets ovate, 4-8 mm. long.

Tall perennial; achene linear; scales acutish.

Low annual; achene oblong; scale-tips recurved.

ro. C. pseudovegetus

II. C. acuminatus.

Wings of the rachis evident.

Low annual, adventive from Europe; scales brown.

Tall indigenous perennials (no 13 sometimes annual ?).

Lower leaves reduced to pointed sheaths.

Leaves all elongated-linear.

13. C. Haspan.

Scales mucronate, reddish brown or green.

Scales acute or obtuse, not mucronate.

I4. $C$. dentatus.

Scales wholly or partly purple-brown; achene linear.

Scales tightly appressed. I5. C. rotundus.

Tips of the scales free. I6. C. Halliz.

Scales straw-colored; achene obovoid.

I7. C. esculentus.

Wings of the rachis separating from it as interior scales; annuals.
Spikes loose; spikelets $620 \mathrm{~mm}$. long.
Spikes dense, cylindric ; spikelets $3-5 \mathrm{~mm}$. long.
18. C. erythrorhizos.
I9. C. Halei.

B. Spikelets falling away from the axis of the spikes, the lower pair of scales com monly persistent.

Annuals; spikelets elongated, nearly terete.

Scales imbricated; achene obovoid.

Scales thin, dull brown; spikelets very slender. 20. C. speciosus.

Scales rigid, yellow-brown; spikelets stout.

Scales distant, achene linear-oblong.

21. C. ferax.

22. C. Englemanni.

Perennial by hard, tuber-like basal corms; spikelets more or less flattened.

Achene narrowly linear-oblong, 3-4 times as long as thick.

Spikelets flat, several-many-flowered.

23. C. strigosus.

Spikelets subterete, few-flowered.

Spikelets $12-25 \mathrm{~mm}$. long, loosely spicate; lower reflexed. 
Spikelets 3-12 mm. long, densely capitate or spicate. Spikelets all reflexed; culms rough. 25. C. retrofractus. Spikelets spreading or only the lower reflexed; culms smooth. Heads oblong or cylindric.

Spikelets 6-10 $\mathrm{mm}$. long, the lower reflexed.

26. C. Lancastriensis. Spikelets 3-4 mm. long, the lower spreading.

Heads globose.

27. C. cylindricus.

28. C. mularis.

Achene oblong or obovoid, about twice as long as thick.

Rachis wingless or very narrowly winged.

Scales pale green, niembranous, dull.

Scales chestnut-brown, shining.

Rachis-wings membranous, broad.

29. C. filiculmis.

3o. C. Houghtoni.

Scales firm, not appressed; spikelets loosely capitate.

3r. C. Grayi.

Scales thin, closely appressed; spikelets densely capitate.

32. C. echinatus.

I. Cyperus flavéscens L. Yelrow Cyperus. (I. F. f. 543.) Annual; culms very slender, tufted, leafy below, $7-30 \mathrm{~cm}$. tall, mostly longer than the leaves. Leaves 2-3 $\mathrm{mm}$. wide, smooth, the longer usually exceeding the inflorescence: clusters terminal and sessile, or on I-4 short rays; spikelets in 3's-6's, linear, subacute, yellow, many-flowered, flat, 8-1 $8 \mathrm{~mm}$. long, 3-4 mm. broad; scales ovate, obtuse, I-nerved, appressed, twice as long as the orbicular-obovate black obtuse lenticular shining achene ; stamens 3; style deeply 2-cleft ; superficial cells of the achene oblong. In marshy ground, Me. to Mich., Fla. and Mex. Also in the Old World. Aug.-Oct.

2. Cyperus diándrus Torr. Low Cyperus. (I. F. f. 544.) Annual; culms tufted, slender, 5-40 $\mathrm{cm}$. tall. Leaves about $2 \mathrm{~mm}$. wide, those of the involucre usually 3 ; clusters sessile and terminal, or at the ends of $\mathbf{I}-3$ rays; spikelets $8-18$ $\mathrm{mm}$. long, linear-oblong, acute, flat, many-flowered; scales ovate, green, brown. or with brown margins, obtuse, I-nerved, appressed, membranous, dull; stamens 2 or 3 ; style 2 -cleft, its branches much exserted; achene lenticular, oblong, gray, not shining, one-half as long as the scale, its superficial cells quadrate, about as long as wide. In marshy places, N. B. to Minn., S. Car. and Kans. Aug.-Oct.

3. Cyperus rivulàris Kunth. Shining Cyperus. (I. F. f. 545.) Similar to the preceding species, culns slender, tufted. Umbel usually simple; spikelets linear or linear-oblong, acutish, 3-20 mm. long; scales green or dark brown, or with brown margins, appressed, firm, subcoriaceous, shining, obtuse; stamens mostly 3 ; style 2-cleft, scarcely exserted; achene oblong or oblong-obovate, lenticular, somewhat pointed, dull, its superficial cells quadrate. In wet soil, especially along streams and ponds, Me. to S. Ont., Mich. and Neb., Va., N. C. and Mo. Aug.-Oct.

4. Cyperus Nuttàllii Eddy. Nuttall's Cyperus. (I. F. f. 546.) Annual; culms slender, tufted, equalling or longer than the leaves. Leaves of the involucre $3-5$, spreading, the larger often $12 \mathrm{~cm}$. long; umbel 3-7-rayed; spikelets rather lonsely clustered, linear, very acute, flat, spreading, I-3 cm. long, 2-3 mm. wide; scales yellowish-brown with a green keel, oblong, acute; stamens 2; style 2-cleft, its branches somewhat exserted; achene lenticular, narrowly obovate, obtuse or truncate, dull, light brown, one-third to one-half as long as the scale, its superficial cells quadrate. Salt marshes, Me. to Miss. Aug.-Oct.

5. Cyperus microdóntus Torr. Coast Cyperus. (I. F. f. 547.) Annual; similar to the preceding species; culms very slender, tufted, sometimes $0.5 \mathrm{~m}$. high. Leaves about $2 \mathrm{~mm}$. wide, those of the involucre much elongated; umbel commonly simple, sessile, capitate, or I-6-rayed; spikelets linear, acute, 6-18 mm. long, less than $2 \mathrm{~mm}$. wide, yellowish-brown; scales ovate, acute, thin; style 2 -cleft, its branches much exserted; achene lenticular, linear-oblong, short-pointed, light hrown, one-half as long as the scale, its superficial cells quadrate. In wet soil, on or near the coast, Va. to Fla. and Tex. Aug.-Oct.

6. Cyperus flavícomus Michix. Eleciant Cyperus. (I. F. f. 548.) Annual; culms $0.3^{-1} \mathrm{~m}$. tall, leafy below. Le:ives $4-6 \mathrm{~mm}$. wide, those of the involucre $3^{-3}$, the longer ones much exceeding the inflorescence; umbels few-several-rayed; 
often compound; primary rays $1-6 \mathrm{~cm}$. long; spikelets numerous, usually densely clustered, linear, acute, 8-20 cm. long, 2-3 mm. wide, flat, many-flowered, spread. ing; scales oblong, obtuse, thin, dull, yellowish-brown; stamens 3 ; style 2-cleft, little exserted; achene obovate, lenticular, black, mucronate, not shining, nearly as long as the scales and often persistent on the rachis after these have fallen away. In wet or moist sandy soil, Va. to Fla. and La. Aug.-Oct.

7. Cyperus infléxus Muhl. Awned Cyperus. (I. F. f. 549.) Annual; culms slender or almost filiform, tufted, about equalled by the leaves. Leaves $2 \mathrm{~mm}$. wide or less, those of the involucre 2-3, exceeding the umbel; umbel sessile, capitate, or I-3-rayed; spikelets linear-oblong, 6-Io-flowered, 4-6 mm. long; scales light brown, lanceolate, rather firm, strongly several-nerved, tapering into a long, recurved awn, falling from the rachis at maturity; stamen I; style 3-cleft; rachis winged, the wings persistent; achene 3-angled, brown, dull, narrowly obovoid or oblong, obtuse, mucronulate. In wet, sandy soil, Vt. to the N. W. Terr. and Ore., south to Fla., Tex., Cal. and Mex. Fragrant in drying. July-Sept.

8. Cyperus compréssus L. Fl.at Cyperus. (I. F. f. 550.) Annual; culms slender, erect or reclining, smooth, 7-25 cm. long. Leaves light green, about $2 \mathrm{~mm}$. wide, those of the involucre $2-3$, the longer exceeding the spikelets; umbel capitate or with $2-3$ short rays; spikelets narrowly lanceolate, acute, $8-20 \mathrm{~mm}$. long, 3-4 mm. wide, very flat, many-flowered; scales light green with a yellow band on each side, ovate, acuminate, firm, keeled, several-nerved, falling away from the narrowly-winged rachis at maturity; stamens 3; style 3-cleft; achene sharply 3-angled, obovoid, obtuse, dull, brown, about one-third as long as the scale. In fields, Md. to Fla., west to Mo. and Tex. Also in trop. Amer. and the Old World. Aug.-Oct.

9. Cyperus Schweinítzii Torr. Schwernitz's Cyperus. (I. F. f. 551.) Perennial by the thickened corm-like bases of the culms; culms rather slender, rough, at least above, $0.3-0.8 \mathrm{~m}$. tall. Leaves $2-5 \mathrm{~mm}$. wide, rough-margined, those of the involucre 3-7, erect: umb I simple, 3-9-rayed, the rays erect, sometimes ro $\mathrm{cm}$. long; spikelets flat, in rather loose ovoid spikes, linear oblong, 6-12-flowered, 8-16 mm. long; scales convex, light green, ovate, acute or acuminate, 9-I3-nerved, falling away from the rachis at maturity; stamens 3; style 3-cleft; achene 3-angled, oblong, brown, acute at each end, nearly as long as the scale. In sandy soil, especially along lakes and streams, W. N. Y. and S. Ont. to the N. W. Terr., Minn., Iowa and Kans. Aug.-Oct.

ro. Cyperus pseudovégetus Steud. Marsh Cyperus. (I. F. f. 552.) Perennial by thickened tuber-like joints of the rootstocks, culm rather stout, 0.3-I.3 m. high, often equalled by the leaves. Leaves 3-4 mm. wide, smooth, nodulose, the midvein prominent; leaves of the involucre 4-6, spreading: umbel severalrayed, compound; spikelets ovate, flat, many-flowered, light green, densely capitate, 4-6 mm. long; scales keeled, conduplicate, I-nerved, curved, acute, longer than the linear 3-angled slightly stalked achene; stamen I; style 3-cleft. In marshes, Del. to Fla., west to Kans. and Tex. July-Sept.

I I. Cyperus acuminàtus Torr.\& Hook. Short-Pointed Cyperus. (I. F. f. 553.) Annual; culms very slender, tufted, 7-40 cm. tall. Leaves light green, usually less than $2 \mathrm{~mm}$. wide, those of the involucre much elongated; umbel I-4rayed, simple; rays short; spikelets flat, ovate-oblong, obtuse, 4-8 mm. long, manyflowered, densely capitate; scales oblong, palc-green, 3-nerved, coarsely cellular, conduplicate, with a short sharp more or less recurved tip; stamen I: style 3-cleft; achene sharply 3-angled, gray, oblong, narrowed at each end, about onc-half as long as the scale. In moist soil, Ill. to La., west to Iowa, Kans., Ore., Tex., and Cal. July-Oct.

12. Cyperus fúscus L. Brown Cyperus. (I. F. f. 554.) Annual; culms tufted, $15-40 \mathrm{~cm}$. high, longer than or equalled by the leaves. Leaves rather dark green, about $2 \mathrm{~mm}$. wide, those of the involucre 4-6; umbel several-rayed; spikelets linear, 4-14 $\mathrm{mm}$. long, less than $2 \mathrm{~mm}$. wide, many-flowered, acute; scales ovate, subacute, becoming dark brown, faintly about 3 -nerved, separating from the narrowly winged rachis as they mature; stamens 2 or 3 ; style 3 -clc.ft; achene 3-angled, oblong, pointed at each end, nearly as long as the scale. Revere Beach, Mass., and New London, Comn. Adventive or fugitive from Europe. Also in ballast about the eastern seaports. July-Sept. 
13. Cyperus Háspan L. Sheathed Cyperus. (I. F. f. 555.) Perennial by short rootstocks (sometimes annual?), roots fibrous; culms weak, tufted, $0.3^{-I}$ $\mathrm{m}$. high. Lower leaves reduced to membranous acuminate sheaths; leaves of the involucre about 2 , usually less than $2 \mathrm{~mm}$. wide; umbel simple or compound, the longer rays $2-5 \mathrm{~cm}$. long; spikelets few, capitate, linear, acute, many-flowered, 6I $2 \mathrm{~mm}$. long, about I mm. wide; scales oblong or oblong-lanceolate, reddish-brown, acute, mucronulate, keeled, 3-nerved; rachis winged; stamens 3; style 3-cleft; achene 3-angled, broadly obovoid, obtuse, nearly white, much shorter than the scale. In swamps, Va. to Fla. and Tex., mostly near the coast. Also in tropical Anerica and in the warmer parts of Europe, Asia, and Australia. July-Sept.

14. Cyperus dentàtus Torr. Toothed Cyperus. (I. F. 556.) Perennial by scaly rootstocks which sometimes bear small tubers; culms rather stiff, $0.2-0.5$ m. tall. Leaves keeled, 2-4 mm. wide, those of the involucre umbel, somewhat compound; longer rays $2.5-7.5 \mathrm{~cm}$. long; spikelets linear, very flat, many-flowered, mostly blunt, IO-20 $\mathrm{mm}$. long, nearly $4 \mathrm{~mm}$. wide; scales light reddishbrown, ovate-lanceolate, thin, keeled, 5-7-nerved, mucronate, separating from the rachis when mature, their tips spreading; causing the spikelet to appear toothed; stamens 3; style 3-cleft, the branches exserted; achene 3-angled, obtuse, mucronate, light brown, much shorter than the scale. In sandy swamps and on river shores, Me. to N. N. Y., south to W. Va. and S. Car. Scales often modified into tufts of small leaves. Aug.-Oct.

15. Cyperus rotúndus L. Nut-grass. (I. F. f. 557.) Perennial by scaly tuber-bearing rootstocks; culm rather stout, $0.1-0.5 \mathrm{~m}$. high, usually longer than the leaves. Leaves 3-6 mm. wide, those of the involucre 3-5; umbel 3-8-rayed, the longer rays 5-II cm. long; spikelets linear, clustered, few in each cluster, acute, 8-20 mm. long, 2-3 mm. wide; scales dark purple-brown or with green margins and centre, ovate, acute, appressed when mature, about 3 -nerved on the keel; stamens 3 ; style 3 -cleft, its branches exserted; achene 3 -angled, about onehalf as long as the scale. In fields, Va. to Fla., west to Kans. and Tex. Also in tropical Am., and widely distributed in the Old World. July-Sept.

r6. Cyperus Hallii Britton. Hall's Cyperus. (I. F. f. 558.) Perennial by scaly rootstocks; culm rather stout, $0.6-0.9 \mathrm{~m}$. tall, about equalled by the leaves. Basal leaves about 4-6 mm. wide; involucral leaves 3-6, the longer much exceeding the inflorescence; umbel compound, its longer rays 7-10 $\mathrm{cm}$. long, the raylets sometimes $2.5 \mathrm{~cm}$. long; spikelets numerous, loosely clustered, linear, 7-15flowered, 10-16 mm. long, 2-3 mm. wide; involucels setaceous; scales ovate, acute, strongly 7-9-nerved, dark reddish-brown or with lighter margins, their tips not appressed; stamens 3 ; style 3-cleft, its branches much exserted; achene linearoblong, 3-angled, about one-half as long as the scale. Kans. and the Ind. Terr. to Tex. July-Sept.

17. Cyperus esculéntus L. Yellow Nut-grass. (I. F. f. 559.) Perennial by scaly tuber-bearing rootstocks; culm usually stout, $0.3-0.8 \mathrm{~m}$. tall, commonly shorter than the leaves. Leaves light green, 4-8 $\mathrm{mm}$. wide, the midvein prominent; those of the involucre 3-6, the longer much exceeding the inflorescence; umbel 4-IO-rayed, often compound; spikelets numerous in loose spikes, straw-color or yellowish-brown, flat, spreading, $1-2.5 \mathrm{~cm}$. long, about $3 \mathrm{~mm}$. wide, manyflowered; scales ovate-oblong, subacute, 3-5-nerved; rachis narrowly winged; stamens 3 ; style 3-cleft; achene obovoid, obtuse, 3-angled. In moist fields, N. B. to Minn. and Neb., south to Fla. and 'Tex. Also on the Pacific Coast from Cal. to Alaska, in tropical America, and widely distributed in the Old World. Sometimes a troublesome weed. Aug.-Oct.

Cyperus esculéntus angustispicatus Britton. Spikelets very slender, $2 \mathrm{~mm}$. wide or less. Mass, to S. Car. and Mo.

18. Cyperus erythrorhizos Muhl. Red-Rooted Cyperus. (I. F. f. 560.) Annual; culms tufted, stout or slender, 7-50 cm. tall. Leaves 3-8 $\mathrm{mm}$. wide, rough-margined, those of the involucre 3-7, some of them 3-5 times as long as the inflorescence: umbel mostly compound; spikelets linear, subacute, 6-25 mm. long, less than $2 \mathrm{~mm}$. wide, compressed, many-flowered, clustered in oblong, nearly or quitc scile spikes; scales bright chestnut brown, oblong-lanceolate, mucronulate, appressed, separating from the rachis at maturity, the membranous wings of the 
rachis separating as a pair of hyaline interior scales; stamens 3; style 3-cleft; achene sharply 3-angled, oblong, pointed at both ends, pale, one-half as long as the scale. In wet soil, S. Ont. to Mass. and Fla., west to Neb., Kans., Tex. and Cal. Aug.-Oct.

I9. Cyperus Hàlei Torr. Hale's Cyperus. (I. F. f. 56r.) Annual; culm stout, $0.6-1 \mathrm{~m}$. tall, about equalled by the leaves. Leaves $6-8 \mathrm{~mm}$. wide, very rough-margined, those of the involucre 5-8, much elongated; umbel compound, several-rayed; spikes cylindric, sessile or very nearly so, exceedingly dense, I-2.5 $\mathrm{cm}$. long; spikelets very numerous, linear, 3-5 mm. long, $1 \mathrm{~mm}$. wide, spreading; scales brown, keeled, indistinctly 5-nerved, oblong, mucronulate, separating from the rachis at maturity, the wings of the rachis separating as a pair of hyaline scales, as in the preceding species; stamens 3; style 3-cleft; achene 3-angled, minute. In swamps, S. Mo. to Tenn., La. and Fla. July-Sept.

20. Cyperus speciòsus Vahl. Michaux's Cyperus. (I. F. f. 562.) Annual; culms usually tufted, I0-40 $\mathrm{cm}$. tall, reddish toward the base. Leaves rough-margined, 3-5 $\mathrm{mm}$. wide, the midvein prominent; leaves of the involucre much exceeding the umbel; umbel 3-7-rayed, the primary rays $2-15 \mathrm{~cm}$. long; involucels narrow; spikelets subterete, very narrowly linear, 8-25 mm. long, less than $2 \mathrm{~mm}$. thick, Io-30-flowered, falling away from the axis at maturity; scales dull brown, thin, appressed, ovate, obtuse, faintly 3-5-nerved on the back; rachiswings broad, clasping the achene, persistent; stamens 3 ; style 3 -cleft, slightly exserted; achene pale, 3 -angled, about one-half as long as the scale. In marshes, E. Mass. and R. I. to Ohio and Minn., Fla., Tex. and Cal. July-Sept.

Cyperus speciosus ferruginéscens (Boeckl.) Britton. Scales spreading or slightly recurved, reddish. Mo. to Tex. and N. Mex.

Cyperus speciosus parvus (Boeckl.) Britton. Culm 2-7 cm. high; umbel very simple, generally of but a single cluster of short spikelets. Mo. to N. Mex.

21. Cyperus fèrax Rich. Coarse Cyperus. (I. F. f. 563.) Annual, closely related to the preceding species, but with smooth-margined, shorter and broader leaves, those of the involucre sometimes but little exceeding the inflorescence. Umbel often compact, the rays mostly short; spikelets linear, subterete, IO-20flowered, I6-25 $\mathrm{mm}$. long, about $2 \mathrm{~mm}$. thick, falling away from the axis at maturity; scales ovate-oblong, appressed, imbricated, obtuse, rather firm, green and 7-9-nerved on the back, yellowish on the sides; stamens 3; style 3-cleft; rachis broadly winged; achene 3 -angled, narrowly obovoid, obtuse. In wet soil, Mo. to Cal. and widely distributed in tropical America. Aug.-Oct.

22. Cyperus Engelmánni Steud. Engelmann's Cyperus. (I. F. f. 564.) Annual; culms slender, $15-75 \mathrm{~cm}$. tall. Leaves elongated, 4-6 mm. wide, flaccid, roughish on the margins, those of the involucre $4-6$, the longer exceeding the umbel; umbel often compound, the spikelets often densely crowded, very narrowly linear, subterete, I-2.5 cm. long, 5-15-flowered; rachis narrowly winged; scales greenish-brown, oblong, obtuse, thin, faintly 3-5-nerved on the back, distant, the successive ones on each side of the spikelet separated by a space of about one-half their length; stamens 3; style 3-cleft; achene linear-oblong, 3-angled, two-thirds as long as the scale. In wet soil, Mass. to S. Ont. and Wisc., south to N. J. and Mo. Aug.-Oct.

23. Cyperus strigòsus L. Straw-colored Cyperus. (I. F. f. 565.) Perennial by basal tuber-like corms; culm rather stout, $0.3-0.9 \mathrm{~m}$. tall. Leaves rough-margined, 4-6 $\mathrm{mm}$. wide, the longer ones of the involucre much exceeding the umbel; umbel several-rayed, some of the primary rays often $10-15 \mathrm{~cm}$. long, their sheaths terminating in 2 bristles; involucels setaceous; heads oblong or ovoid; spikelets flat, linear, 8-19 mm. long, $2 \mathrm{~mm}$. wide or less, 7-15-flowered, separating from the axis at maturity; scales straw-colored, oblong-lanceolate, subacute, strongly several-nerved; stamens 3; style 3-cleft; achene linear-oblong, 3-angled, acute, about one-third as long as the scale. In moist meadows, swamps or along streams, Me. and Ont. to Minn. and Neb., south to Fla. and Tex. Aug.Oct.

Cyperus strigòsus capitatus Boeckl. Umbel simple or nearly so; spikelets 8-14 mm. long, densely capitate in subglobose heads. Range of the type. 
Cyperus strigdsus compósitus Britton. Umbel very compound; heads cylindric; spikelets 6-12 mm. long, 4-6-flowered. S. N. Y. and Penn. to Ala. and Iowa.

Cyperus strigòsus robústior Kunth. Umbel compound; spikelets $16-25 \mathrm{~mm}$. long, ro-25-flowered. Range of the type.

24. Cyperus refráctus Engelm. Reflexed Cyperus. (I. F. f. 566.) Perennial by tuber-like corms; culm stout, smooth, $0.3-0.9 \mathrm{~m}$. tall. Leaves $5-8 \mathrm{~mm}$. wide, rough-margined, elongated; umbel 6-13-rayed, usually compound, the longer rays sometimes $20 \mathrm{~cm}$. long, their sheaths terminating in $\mathbf{I}$ or 2 short teeth; involucels setaceous; raylets filiform; spikelets very narrowly linear, loosely spicate, acute, flattish, 1-2.5 cm. long, I mm. thick, 3-6-flowered, the upper spreading, the lower reflexed; scales yellowish-green, oblong-lanceolate, obtuse, closely appressed, 9-I I-nerved, thin; stamens 3; style 3-cleft, its branches much exserted ; achene narrowly linear, obtuse, apiculate, about 5 times as long as thick, and onehalf as long as the scale. In dry fields, N. J. to N. Car. and Mo. July-Sept.

25. Cyperus retrofráctus (L.) Torr. Rough Cyperus. (I. F. f. 567.) Perennial by tuber-like corms; culm rough-puberulent, at least above, mostly longer than the puberulent leaves. Leaves 3-5 $\mathrm{mm}$. wide, those of the involucre $4-7$, the longer not greatly exceeding the umbel, sometimes shorter; umbel simple; rays 5-15 cm. long, their sheaths 2-toothed; heads oblong or obovoid; spikelets linearsubulate, 6-12 mm. long, about I mm. thick, I-2-flowered, all soon strongly reflexed, separating from the axis at maturity; flowering scales lanceolate, acute, the upper one subulate, all strongly several-nerved; stamens 3 ; style 3 -cleft ; achene linear, 3-angled, obtuse, apiculate, two-thirds as long as the scale. In dry sandy soil, S. N. J. to Fla., west to Ky., Ark. and Tex. July-Sept.

26. Cyperus Lancastriénsis Porter. Lancaster Cyperus. (I. F. f. 568.) Perennial by ovoid or oblong corms; culm slender, smooth, mostly longer than the leaves, $0.3-0.8 \mathrm{~m}$. tall. Leaves 4-6 mm. wide, those of the involucre $4-7$, the longer much exceeding the inflorescence; umbel simple, 5-9-rayed, the longer rays 5-Io $\mathrm{cm}$. long, their sheaths nearly truncate; heads oval, obtuse, $\mathbf{I}-2.5 \mathrm{~cm}$. long; spikelets densely clustered, 8-10 $\mathrm{mm}$. long, linear, subterete, 2-4-flowered, the lower reflexed, the middle ones spreading, all separating from the axis at maturity; scales green, strongly several-nerved, the flowering ones lanceolate, subacute; stamens 3 ; style 3-cleft; achene linear, obtuse, apiculate, 2-3 times as long as thick, two-thirds as long as the scale. In dry fields, N. J. and Penn. to Va. and Ala. July-Sept.

27. Cyperus cylíndricus (Ell.) Britton. Pine-Barren Cyperus. (I. F. f. 569.) Perennial by small hard corms; culms smooth, usually tufted, I-5 dm. tall, longer than the leaves. Leaves $2-3 \mathrm{~mm}$. wide, the longer ones of the involucre much exceeding the umbel; umbel simple, the rays short, or the longer $2-7 \mathrm{~cm}$. long, the sheaths 2-toothed; heads very dense, cylindric, 6-12 mm. long, 4-8 mm. in diameter; spikelets 3-4 mm. long, flattish, I-2-flowered, spreading or the lower reflexed; scales green, oblong; rachis winged; stamens 3 ; style 3 -cleft; achene linear-oblong, 3-angled, apiculate, slightly more than one-half as long as the scale. In sandy pine barrens and on the sea shore, S. N. Y. to Fla., west to Tex., mostly near the coast. July-Sept.

28. Cyperus ovulàris (Michx.) Torr. Globose Cyperus. (I. F. f. 570.) Perennial by hard tuber-like corms; culm usually strict, smooth, $0.2-0.8 \mathrm{~m}$. tall, longer than the leaves. Leaves smooth, 4-6 mm. wide, the longer ones of the involucre much exceeding the umbel; umbel simple, few-rayed; sheath of the rays truncate or slightly toothed; heads globose or sometimes a little longer than thick, $8-14 \mathrm{~mm}$. in diameter, very dense, the spikelets radiating in all directions ; spikelets 4-7 mm. long, usually 3 -flowered, separating from the axis at maturity; rachis winged; scales ovate or ovate-lanceolate, obtuse or subacute, green, strongly severa!nerved; stamens 3; style 3-cleft; achene linear-oblong, 3-angled, 2-3 times as long as thick. In dry fields and on hills, S. N. Y. to Fla., west to Ill., Kans. and Tex. July-Sept.

29. Cyperus filicúlmis Vahl. Slender Cyperus. (I. F. f. 57I.) Perennial by hard oblong corms; culm smooth, slender or almost filiform, ascending or reclined, I.5-4.5 dm. long, usually longer than the rough-margined leaves. Leaves 2-4 mm. wide, keeled; spikelets densely clustered in I-7 globose heads, linear, acute, 5-II-flowered, subterete or compressed, 5-12 mm. long, $2 \mathrm{~mm}$. wide or less, 
tardily falling from the axis at maturity ; rachis wingless; scales ovate, acute or obtuse, pale green, strongly 7-II-nerved, appressed; stamens 3; style 3-cleft ; achene oblong or obovoid, 3-angled, obtuse, apiculate, dull gray, two-thirds as long as the scale, about twice as long as thick. In dry fields and on hills, N. H. to Ont., Minn. and Neb. south to Fla., Kans., Tex. and No. Mex. June-Aug.

30. Cyperus Hoùghtoni Torr. Houghton's Cyperus. (I. F. f. 572.) Perennial by tuber-like corms; culms very slender, smooth, $0.3-0.6 \mathrm{~m}$. tall. Leaves shorter than the culm, $2 \mathrm{~mm}$. wide or less, smooth, those of involucre $3-5$, the longer much exceeding the umbel; umbel simple, I-5-rayed, the rays mostly short, their sheaths 2-toothed; spikelets loosely capitate, linear, compressed, acute, 8-16 $\mathrm{mm}$. long, about $2 \mathrm{~mm}$. wide, II-I5-flowered, falling away from the axis when mature; scales chestnut-brown, firm, shining, oblong; obtuse, truncate, or apiculate, strongly about II-nerved; rachis very narrowly winged; stamens 3; style 3-cleft; achene broadly oblong, less than twice as long as thick, 3-angled, brown, apiculate, nearly as long as the scale. In sandy soil, Mass. to Minn., Kans. and Ore. July-Aug.

31. Cyperus Gràyi Torr. Gray's Cyperus. (I. F. f. 573.) Perennial by thick hard oblong or ovoid corms; culms tufted, ascending or reclined, stiff, smooth, very slender, $15-50 \mathrm{~cm}$. long. Leaves shorter than the culm, bright green, $2 \mathrm{~mm}$. wide or less, those of the involucre 4-8; umbel 4-10-rayed, simple, the longer rays 7-Io $\mathrm{cm}$. long; sheaths of the rays truncate or nearly so; spikelets 5-10 mm. long, loosely capitate, compressed, linear, rigid, spreading ; scales green, ovate, obtuse or subacute, strongly 13-15-nerved, rather widely spreading wherf old; joints of the rachis broadly winged; stamens 3; style 3-cleft; achene oblong or oblong-obovoid, obtuse, apiculate, about two-thirds as long as the scale. In sands of the sea shore and in pine barrens, N. H. to Fla. July-Sept.

32. Cyperus echinàtus (Ell.) Wood. BALdwin's Cyperus. (I. F. f. 574.) Perennial by tuber-like corms; culms slender, smooth, erect, mostly longer than the leaves. Leaves pale green, 3-4 mm. wide, those of the involucre 5-10, the longer usually much exceeding the umbel; umbel, 6-13-rayed; the rays filiform, their sheaths short, mucronate; spikelets $4-6 \mathrm{~mm}$. long, linear, flat, capitate in globose lieads; scales thin, pale green, appressed, ovate-lanceolate, acute, 9-13-nerved, with narrow scarious margins: joints of the rachis broadly winged; stamens 3 ; style 3-cleft; achene oblong-obovoid, obtuse, one-half as long as the scale, about twice as long as thick. In dry soil, N. Car. to Fla., west to Mo. and Tex. July-Aug.

\section{KÝLLINGA Rottb.}

Annual or perennial sedges, with slender triangular culms, leafy below, and with 2 or more leaves at the summit forming an involucre to the strictly sessile, simple or compound, dense head of spikelets. Spikelets numerous, compressed, falling away from the axis of the head at maturity, consisting of only 3 or 4 scales, the I or 2 lower ones small and empty, the middle one fertile, the upper empty or staminate. Joints of the rachis wingless or narrowly winged. Scales 2-ranked, keeled. Perianth none. Stamens I-3. Style 2-3-cleft, deciduous from the summit of the achene. Achene lenticular or 3-angled. [In honor of Peter Kylling, a Danish botanist of the seventeenth century.] About 20 species, natives of tropical and temperate regions. Besides the following, 2 others occur in the So. U. S.

r. Kyllinga pùmila Michx. Low KyllingA. (I. F. f. 575.) Anuual; culms densely tufted, filiform, erect or reclined, 3-40 $\mathrm{cm}$. long, mostly longer than the leaves. Leaves light green, roughish on the margins, usually less than $2 \mathrm{~mm}$. wide, those of the involucre 3-5, elongated, spreading or reflexed; head oblong or ovoid-oblong, 6-8 mm. iong, simple or commonly with 1 or 2 smaller ones at the base; spikelets about $3 \mathrm{~mm}$. Song, flat, I-flowered, the 2 empty lower scales more or less persistent on the rachis aiter the fall of the rest of the spikelet; scales ovate, acuminate or acute, thin, about 7-nerved; stamens 2; style 2-cleft; achene lenticular, obtuse. In moist or wet soil, Va. to Fla., west to Ill., Mo., Tex. and Mex. Aug.-Sept.

\section{DULÍCHIUM i. C. Richard.}

A tall perennial sedge, with terete hollow jointed culms, leafy to the top, the lower leaves reduced to sheaths. Spikes axillary, peduncled, simple or compound. 
Spikelets 2-ranked, flat, linear, falling away from the axis at maturity (?) manyflowered. Scales 2-ranked, rarinate, conduplicate, decurrent on the ioint below. Flowers perfect. Perianth of $\sigma_{1-9}$ retrorsely liarbed bristles. Stamens 3. Style 2-cleft at the summit, persistent as a beak on the summit of the achene. Achene linear-oblong. [Name said to be from Dulcichimum, a Latin name for some sedge.] A monotypic genus of E. N. Amer.

1. Dulichium arundinàceum (L.) Britton. Dulichium. (I. F. f. 576.) Culm stout, $0.3^{-1} \mathrm{~m}$. tall, erect. Leaves numerous, flat, $2-8=\mathrm{m}$. long, $4-8 \mathrm{~mm}$. wide, spreading or ascending, the lower sheaths bladeless, brown toward their summits; peduncles 4-25 mm. long; spikelets narrowly linear, spreading, $1-2.5 \mathrm{~cm}$. long, about $2 \mathrm{~mm}$. wide, 6-12-flowered; scales lanceolate, acuminate, strongly several-nerved, appressed, brownish: bristles of the perianth rigid, longer than ihe achene; style long-exserted, persistent. In wet places, N. S. to Ont., Minn. and Neb., south to Fla. and Tex. Aug.-Oct. [D. spathaceum Pers.]

\section{ELEÓcharis R. Br. (See Appendix.)}

Annual or perennial sedges. Culms simple, triangular, quadrangular, terete, flattened or grooved, the leaves reduced to sheaths or the lowest very rarely bladebearing. Spikelets solitary, terminal, erect, several-many-flowered, not subtended by an involucre. Scales concave, spirally imbricated all around. Perianths of I-12 bristles, usually retrorsely barbed, wanting in some species. Stamens 2-3. Style 2-cleft and achene lenticular or biconvex, or 3-cleft and achene 3-angled, but sometimes with very obtuse angles and appearing turgid. Base of the style persistent on the summit of the achene, forming a terminal tubercle. [Greek, referring to the growth of most of the species in marshy ground.] About Ioo species, widely distributed. Besides the following, some $\mathbf{1 7}$ others occur in the southern and western parts of N. Am.

Spikelet scarcely or not at all thicker than the culm.

Culm stout; spikelet many-flowered.

Culm terete, nodose.

Culm quadrangular, continuous.

Culm slender, triangular, continuous

Spikelet manifestly thicker than the culm.

Style mostly 2-cleft; achene lenticular or biconvex.

Upper sheath scarious, hyaline; plants perennial by slender rootstocks.

Scales pale green or nearly white; achene $0.5 \mathrm{~mm}$. long.

Scales dark reddish brown; achene I $\mathrm{mm}$. long.

4. F. ochreata.

5. E. olivacea.

Upper sheath truncate, oblique, or toothed, not scarious.

Annual, with fibrous roots.

Achene jet black.

Culms 2-8 cm. tall; achene $0.5 \mathrm{~mm}$. long; bristles 2-4.

6. E. atropurpurea.

Culms 7-25 cm. tall; achene $\mathrm{I} \mathrm{mm}$. long; bristles 5-8.

Achene pale brown.

7. E. capitata.

Spikelet ovoid or oblong; tubercle deltoid, acute.

Spikelet oblong-cylindric; tubercle broad, low.

8. E. ovata.

9. E. Engelmanni.

Perennial by horizontal rootstocks.

ro. E. palustris.

Style 3-cleft; achene 3-angled or turgid.

Achene reticulated or cancellate.

Spikelet compressed; culm filiform.

Spikelet terete; culm slender.

Achene transversely cancellate; bristles none.

Achene reticulated; bristles present, stout.

Tubercle conic, smaller than the achene.

Tubercle cap-like, as large as the achene or larger.

II. E. acicularis.

12. E. Wolfii:

13. E. tortilis.

I4. E. tuberculosa.

Achene smooth or papillose.

Achene smooth, white; culms capillary.

Achene papillose or smooth, brown, black or yellow.

15. E. Torreyana. 


\section{Achene smooth.}

Tubercle flat, covering the top of the black achene.

Tubercle ovoid-conic, acute, contracted at the base.

Achene papillose.

Achene 3 -ribbed on the angles.

Achene obtuse-angled, not ribbed. Culm filiform; scales obtuse. Culm flat; scales acute.

Tubercle subulate or narrowly pyramidal.

Culms filiform, wiry, densely tufted, $1-2.5 \mathrm{dm}$. long.

Culms flattened, slender, 3-6 dm. long.
17. E. albida.

18. E. tricostata.

19. E. tenuis.

20. E. acuminata.

21. L. intermedia.

22. E. rostellata.

1. Eleocharis interstíncta (Vahl) R. \& S. KNotted SpIKe-Rush. (I. F. f. 577.) Perennial by stout rootstocks; culms terete, hollow, nodose, papillose, $0.4-0.9 \mathrm{~m}$. tall, the sterile ones sharp-pointed. Sheaths membranous, the lower sometimes bearing short blades; spikelet terete, cylindric, many-flowered, subacute, 2.5-4 cm. long, $4 \mathrm{~mm}$. in diameter, not thicker than the culm; scales ovate, orbicular or obovate, obtuse or the upper acute, narrowly scarious-margined, faintly many-nerved, persistent; bristles about 6 , rigid, retrorsely barbed, as long as the body of the achene or shorter; stamens 3; style 3-cleft, exserted; achene obovoid, brown, shining, with minute transverse ridges, convex on one side, very obtusely angled on the other, 2 or 3 times as long as the conic acute black broadbased tubercle. In water, Mass. to Mich., the IV. I. and Mex. July-Sept.

2. Eleocharis mutàta (L.) R. \& S. Quadrangular SPIKE-RUsh. (I. F.f. 578.) Perennial by stout rootstocks; culms sharply 4-angled, stout, not nodose, papillose, $0.6-1.2 \mathrm{~m}$. tall. Sheaths purplish-brown or green, sometimes bearing short blades; spikelet terete, cylindric, 2-5 cm. long, $4 \mathrm{~mm}$. in diameter, manyflowered, about as thick as the culm; scales coriaceous, broadly ovate or obovate, obtuse or the upper subacute, scarious-margined, faintly many-nerved, persistent; bristles about 6 , rigid, retrorsely barbed, about as long as the achene ; stamens 3 ; style 3-cleft; achene obovoid, biconvex or slightly angled on the back, minutely cancellate, about twice as long as the conic acute tubercle, which is truncate or con. tracted at the base. In ponds, streams and swamps, N. N. J. to S. Ont. Mich. south to Ala., Mo., Tex. and Guatemala. Also in the W. I. and S. Am. July-Sept.

2. Eleocharis Robbínsii Oakes. Robins' SPIke-RUSH. (I. F. f. 579.) Perennial by slender rootstocks; culms slender, 3-angled, 0.I-5 m. long, sometimes producing numerous ñliform flaccid sterile branches from the base. Sheaths apf-essed, obliquely-truncate; spikelet subulate, few-flowered, not thicker than the culm, I-2 cm. long, $2 \mathrm{~mm}$. in diameter; sca!es lanceolate or oblong-lanceolate, strongly concave, faintly several-nerved, persistently clasping the rachis, narrowly scarious-margined; style 3-cleft; bristles 6, equalling the achene and tubercle, retrorsely barbed; achene obovoid, light brown, biconvex or obtusely angled on the back, longer than the coric-subulate flattened tubercle, which has a raised ring around its base. In shallow water, N. B. to Mich., south to Fla. Aug-Sept.

4. Eleocharis ochreàta (Nees) Steud. PALE SPIKE-RUSH. (I. F. f. 580.) Perennial by slender rootstocks; culms very slender, or filiform, pale green, 3-angled, 5-25 cm. tall. Upper sheath with a white, hyaline, scarious limb; spikelet subacute, 2-3 times as thick as the culm, about $4 \mathrm{~mm}$. long, 2-3 $\mathrm{mm}$. in diameter, several-flowered; scales pale green, oblong-lanceolate, obtuse or the upper acute, thin, hyaline with a faint midvein; style 2 -cleft; bristles about 6 , slender, retrorsely barbed, somewhat longer than the achene; $0.5 \mathrm{~mm}$. long, lenticular, obovate, smooth, brown, 2-4 times as long as the conic acute tubercle, which is often constricted at the base. In wet soil, S. Va. to Fla. and Miss. Alsc in trop. Amer. Aug.-Sept.

5. Eleochai is oiivàcea Torr. Bright Green SPIKe-Rush. (I. F. f. 58I.) Perennial by running rootstocks, often tufted and matted; culms very slender, bright green, erect or reclining, flattened, 2-ro $\mathrm{cm}$. long. Upper sheath with a white hyaline limb; spikelet ovoid, much thicker than the culm, several-many-flowered, about $4 \mathrm{~mm}$. long, $2 \mathrm{~mm}$. in diameter; scales ovate, thin, acute, reddish brown. with a green midvein and narrow, scarious margins; stamens 3 ; style 2 -cleft; bris- 
tles 6-8, slender, retrorsely barbed, longer than the achene and tubercle; achene obovoid, similar to that of the preceding species but twice as large, 3-4 times the length of the conic acute tubercle. In wet soil, Me. to S. Ont. and Penn., south to S. Car., mostly near the coast. Aug.-Sept.

6. Eleocharis atropurpùrea (Retz) Kunth. PURPLE SPIKe-RUsh. (I. F. f. 582.) Annual ; roots fibrous; culms tufted, very slender, 2-9 cm. high. Upper sheath I-toothed; spikelet ovoid, many-flowered, subacute, 3-4 mm. long, $2 \mathrm{~mm}$. in diameter or less; scales minute, ovate-oblong, persistent, purple-brown with green midvein and very narrow scarious margins; stamens 2 or 3 style 2 -3-cleft ; bristles 2-4, fragile, white, minutely downwardly hispid, about as long as the achene; achene jet black, shining, $0.5 \mathrm{~mm}$. long, smooth, lenticular; tubercle conic, minute, depressed but rather acute, constricted at the base. In moist soil, Iowa, Neb. and E. Colo. to Cent. Am., east to Fla.; widely distributed in tropical America. July-Sept.

7. Eleocharis capitàta (L.) R. Br. Capitate Spike-Rush. (I. F. f. 583.) Annual; roots fibrous; culms densely tufted, nearly terete, almost filiform, $5-25 \mathrm{~cm}$. tall. Upper sheath I-toothed; spikelet ovoid, obtuse, much thicker than the culm, 3-5 mm. long, 2-3 mm. thick, many-flowered; scales broadly ovate, obtuse, firm, pale or dark brown with a greenish midvein, narrowly scarious-margined, persistent ; stamens mostly 2 ; style 2 -cleft ; bristles $5-8$, slender, downwardly hispid, as long as the achene; achene obovate, jet black, smooth, shining, nearly $\mathbf{I}$ mm. long; tubercle depressed, apiculate, constricted at the base, very much shorter than the achene. In moist soil, Md. to Fla., west to Ind. and Tex. Widely distributed in tropical regions. July-Sept.

8. Eleocharis ovàta (Roth) R. \& S. Ovold SpIke-RUsh. (I. F. f. 584.) Annual ; roots fibrous; culms tufted, slender.or filiform, rather deep green, nearly terete, mostly erect, 5-40 $\mathrm{cm}$. tall. Upper sheath I-toothed; spikelet ovoid or oblong, obtuse, many-flowered, 4-Io mm. long, 2-3 $\mathrm{mm}$. in diameter ; scales thin, oblong-orbicular, very obtuse, brown with a green midvein and scarious margins; bristles 6-8 (sometimes fewer or wanting), deciduous, usually longer than the achene ; stamens 2 or 3 ; style 2-3-cleft; achene pale brown, shining, lenticular, obovate-oblong, smooth, I mm. long or more ; tubercle deltoid, acute, compressed, scarcely constricted at the base, about one-fourth as long as the achene and narrower. In wet soil. N. B. to Ont. and Br. Col. south to Fla., Ore., Neb. and Tex. Also in Europe. Variable. July-Sept.

9. Eleocharis Engelmánni Steud. Engelmann's Spike-Rusil. (I. F. f. 585.) Annual, similar to the preceding species, but culms commonly taller, sometimes $0.5 \mathrm{~m}$. high. Upper sheath obliquely truncate or I-toothed; spikelet oblong-cylindric or ovoid-cylindric, obtuse or subacute, 4-16 mm. long, 2-3 mm. in diameter, many-flowered; scales pale brown with a green midvein and narrow scarious margins, ovate, obtuse, deciduous; style 2 -cleft; bristles about 6 , not longer than the achene; achene broadly obovate, brown, smooth, lenticular; tubercle broad, low, covering the top of the achene, less than one-fourth its length. In wet soil, Mass. to Va., west to Ind., Ark., Tex. and Cal. July-Sept.

ro. Eleocharis palústris (L.) R. \& S. CREePING SPIke-RUsh. (I. F. f. 586.) Perennial by horizontal rootstocks; culms stout, terete or somewhat compressed, striate, $0.3-1.6 \mathrm{~m}$. tall. Basal sheaths brown, rarely bearing a short blade, the upper one obliquely truncate; spikelet ovoid-cylindric, 6-25 mm. long, 3-4 mm. in diameter, many-flowered, thicker than the culm; scales ovate-oblong or ovate-lanceolate, purplish brown with scarious margin and a green midvein, or pale green all over; bristles usually 4, slender, retrorsely barbed, longer than the achene and tubercle, or sometimes wanting ; stamens $2-3$; style 2-3-cleft; achene lenticular, smooth, yellow, over I $\mathrm{mm}$. long; tubercle conic-trianguiar, constricted at the base, flattened, one-fourth to one-half as long as the achene. In ponds, swamps and marshes, Lab. to Br. Col., south to Fla., Tex. and Cal. Also in Europe and Asia. Aug.-Sept.

Eleocharis palústris glaucéscens (Willd.) A. Gray. Culms slender or nearly filiform, $0.2-0.5 \mathrm{~m}$. tall ; spikelet oblong, 4-10 mm. long; achene smaller; tubercle narrower. In wet meadows and marshes; range nearly of the type in N. Am. Perhaps a distinct species.

The so-called variety calva is a form without bristles. 
Eleocharis palústris Wátsoni Clarke. Culms stout, $15^{-25} \mathrm{~cm}$. tall ; spike ovoid ; scales dark purple-brown. Lab. and Pr. Edw. Isl. to Hudson Bay.

Ir. Eleocharis aciculàris (L.) R. \& S. Nefole Sirike-Rush. (I. F. f. 587.) Perennial by filiform stolons or rootstocks; culms tufted, finely filiform or setaceous, obscurely 4-angled and grooved, weak, erect or reclining, 5-20 cm. long. Slieaths truncate; spikelet compressed, narrowly ovate or linear-oblong, acute, broader than the culm, 3-IO-flowered, 3-6 $\mathrm{mm}$. long, I $\mathrm{mm}$. wide; scales oblong, obtuse or the upper subacute, thin, pale green, usually with a narrow brown band on each side of the midvein, deciduous, many of them commonly sterile; bristles $3-4$, fragile, fugacious, shorter than the achene; stamens 3 ; style 3-cleft; achene obovoid-oblong, pale, obscurely 3-angled with a rib on each angle and 6-9 lower intermediate ribs connected by fine ridges; tubercle conic, acute, one-fourth as long as the achene. In wet soil, throughout N. Am., except the extreme north. Also in Europe and Asia. July-Sept.

12. Eleocharis Wòlfii A. Gray. Wolf's SPIKE-Rush. (I. F. f. 588.) Perennial by short rootstocks; culms slender, erect, tlattened and 2-edged, $0.2-0.5 \mathrm{~m}$. tall. Upper sheath oblique, scarious, hyaline-tipped; spikelet oblong or ovoid-oblong, terete, acute, thicker than the culm, 4-6 mm. lcng, nearly $2 \mathrm{~mm}$. in diameter; scales ovate, obtuse or the upper acute, thin, pale green with purplish brown bands, tardily deciduous; bristles none (or perhaps early deciduous); style 3 -cleft; achene obovoid, obscurely 3 -angled, longitudinally 9-ribbed, the ribs transversely connected by minute ridges; tubercle depressed-conic, much sliorter than the achene. In wet meadows, Ill., Minn. and Iowa. June-Aug.

13. Eleocharis tórtilis (Link) Schultes. Twisted SPIKE-RUsh. (I. F. f. 589.) Annual; roots fibrous; culms tufted, filiform, sharply 3 -angled, pale green, erect or reclining, twisting when old, $0.3-0.4 \mathrm{~m}$. long. Sheaths obliquely truncate, $\mathbf{1}$-toothed; spikelet ovoid or oblong, subacute, several-flowered, 4-6 mm. long, about $2 \mathrm{~mm}$. thick, much thicker than the culm; scales firm, pale, ovate, mostly obtuse; bristles 4-6, rigid, retrorsely barbed, about equalling the achene and tubercle; stamens 3 ; style 3 -cleft ; achene obovoid, obscurely 3 -angled, strongly reticulated, longitudinally about I8-ribbed; tubercle cap-like or conic, truncate at the base, one-fourth to one-half as long as the achene. In wet soil, near the coast, N. J. to Fla. and Tex. July-Sept.

I4. Eleocharis tuberculòsa (Michx.) R. \& S. LARGE-Tubercled SpikeRUSH. (I. F. f. 590.) Annual; culms tufted, slightly compressed, very slender, rather stiff, striate, bright green, $0.2-0.5 \mathrm{~m}$. tall. Upper sheath obliquely truncate or I-toothed; spikelet ovoid, many-flowered, 6-12 $\mathrm{mm}$. long, nearly $4 \mathrm{~mm}$. in diameter; scales broadly ovate, obtuse, pale greenish brown with a darker midvein, broadly scarious-margined, firm, tardily deciduous; bristles 6, rigid, downwardly or rarely upwardly barbed, about as long as the achene and tubercle; stamens 3; style 3-cleft; achene obovoid, pale, trigonous, strongly reticulated, longitudinally about I8-ribbed; tubercle cap-like or conic, nearly or quite as large as the achene. In wet soil, near the coast, Mass. to Penn., Fla. and Tex. July-Sept.

15. Eleocharis Torreyana Boeckl. TORREY's SPIKE-RUSH.

(I. F. f. 59r.) Annual; culms finely filiform, densely tufted, somewhat 4-sided, erect or reclining, often proliferous by developing secondary culms in the axils of the spikelet, sometimes rooting at the summit, $5-20 \mathrm{~cm}$. long. Upper sheath obliquely trun. cate; spikelet oblong, subacute, terete or nearly so, much thicker than the culm, many-flowered, 3-5 mm. long; scales ovate, acute, brownish-red with a green midvein and lighter margins, early deciduous except the lowest, which is commonly larger than the others, persistent and bract-like; bristles 3-6, slender, shorter than or equalling the achene; stamens 3 ; style 3 -cleft; achene white, 3 -angled, obovoid, smooth, minute; tubercle conic-pyramidal, much shorter than the achene. In wet sandy soil, S. N. J. to Fla. and Tex., mostly near the coast. June-Aug. The similar E. microcarpa Torr. occurs only in the Gulf States and West Indies.

I6. Eleocharis melanocà pa Torr. BLACK-Fruited SpIkE-RUSir. (I. F. f. 592.) Perennial by short rootstocks; culms flattened, striate, tufted, slender, erect, 0.2-0.5 m. tall. Upper sheath truncate, I-toothed; spikelet oblong or cylindricoblong, obtuse, 6-12 mm. long, 3-4 mm. in diameter, many-flowered, thicker than the culm; scales ovate, obtuse, brown, with a lighter midvein and scarious mar. 
gins; bristles 3 or 4 , -wagile, downwardly hispid, equalling or longer than the achene, fugacious or perhaps sometimes wanting; stamens 3; style 3-cleft; achene 3-angled, obpyramidal, black, smowih; tubercle depressed, covering the summit of the achene, light brown, pointed in the middle. In wet sandy soil, E. Mass. and R. I. to Fla., near the coast. Also in W. Ind. July-Sept.

I7. Eleocharis álbida Torr. White SpIkE-RUsh. (I. F. f. 593.) Annual; roots fibrous; culms very slender, tufted, nearly terete, striate, erect, $0.1-0.2 \mathrm{~m}$. tall. Upper sheath very oblique and toothed on one side; spikelet ovoid-globose or oblong, obtuse, 4-8 mm. long, 3-4 $\mathrm{mm}$. in diameter, many-flowered, thicker than the culm; scales pale green or nearly white, rather firm, ovate, obtuse, deciduous; bristles about 6 , downwardly barbed, persistent, as long as the achene: stamens 3 ; style 3-cleft; achene broadly obovoid, nearly black when ripe, 3-angled, smooth; tubercle ovoid-conic, contracted or truncate at the base, about one-fourth as long as the achene. In wet soil, Md. to Fla., Tex. and Mex., near the coast. June-Aug.

18. Eleocharis tricostàta Torr. Three-RIBbed SpIKe-RUsh. (I. F. f. 594.) Perennial by short rootstocks; culms very slender, erect, compressed, striate, $0.3-0.6 \mathrm{~m}$. tall. Upper sheath obliquely truncate, toothed on one side; spikelet oblong, becoming oblong-cylindric, obtuse, many-flowered, ro-18 mm. long, 2$3 \mathrm{~mm}$. in diameter; scales ovate, thin, deciduous, obtuse, brown with a green midvein and scarious margins; bristles none; stamens 3; style 3-cleft; achene obovoid, 3-angled, brown, dull, papillose, strongly ribbed on each of its angles; tubercle conic, acute, light brown, constricted at the base, minute, very much shorter than the achene. In wet soil, S. N. Y. to Fla. July-Sept.

I9. Eleocharis ténuis (Willd.) Schultes. Slender Spike-rush. (I. F. f. 595.) Perennial by rootstocks; culms tufted, filiform, mostly erect, 4-angled with concave sides, $0.2-0.4 \mathrm{~m}$. tall. Upper sheath ob.iquely truncate, toothed on one side; spikelet narrowly oblong, mostly acute, many-flowered, thicker than the culm, 6-Io mm. long, about $2 \mathrm{~mm}$. in diameter; scales thin, obovate or ovateoblong, obtuse, the midvein greenish, the margins scarious; bristles 2-4, shorter than the achene, fugacious or wanting; achene obovoid, obtusely 3-angled, yellowish brown, papillose; stamens 3; style 3-cleft; tubercle conic, short, acute. In wet soil, Cape Breton Isl. to Ont. and Manitoba, south to Fla. and Tex. The achenes are more or less persistent on the rachis of the spikelet after the fall of the scales. May-July.

20. Eleocharis acuminàta (Muhl.) Nees. Flat-stemmed Spike-Rush. (I. F. f. 596.) Perennial by stout rootstocks, similar to the preceding species but stouter; culms flattened, striate, slender but rather stiff, tufted, $0.2-0.5 \mathrm{~m}$. tall. Upper sheath truncate, sometimes slightly I-toothed; spikelet ovoid or oblong, obtuse, thicker than the culm, many-flowered, 6-12 $\mathrm{mm}$. long; scales oblong or ovate-lanceolate, acute or the lower obtusish, purple-brown with a greenish midvein and hyaline white margins, deciduous; bristles I-5, shorter than or equalling the acliene, fugacious, or wanting; stamens 3; style 3-cleft, exserted; achene obovoid, obtusely 3 -angled, light yellowish brown, papillose, much longer than the depressed-conic acute tubercle. In wet soil, Anticosti to Manitoba, south to Ga., La., Mo. and Neb. Achenes persistent on the rachis as in E. tenuis. June-Aug.

21. Eleocharis intermèdia (Muhl.) Schultes. Matten SPIKE-RUsh. (I. F.f. 597.) Annual; roots fibrous; culms filiform, densely tufted, diffusely reclining or ascending, usually matted, grooved, I0-30 cm. long. Upper sheath obliquely truncate, toothed on one side; spikelet ovoid-oblong, acute, 8-20-flowered, thicker than the culm; scales oblong-lanceolate, obtuse or the upper subacute, light purplebrown with a green midvein, tardily deciduous or the lower one persistent; bristles persistent, downwardly barbed, longer than the achene and tubercle: stamens 3 ; style 3-cleft; achene 3-angled, obovoid, light brown, finely reticulated; tubercle conic-subulate, very acute, slightly constricted at the base, one-fourth to one-half as long as the achene. In marshes, Ont. to Minn., south to N. J., Ohio, Ill. and Iowa. July-Sept.

22. Eleocharis rostellàta Torr. Beaked SpIKe-Rush. (I. F. f. 598.) Pereunial by a short caudex; culms slender, wiry, the fertile erect or ascending, the sterile reclining and rooting at the summit, grooved, $0.3^{-1.5} \mathrm{~m}$. long. Upper sheath truncate; spikelet oblong, narrowed at both ends, thicker than the culm, 
10-20-flowered, 6-12 mm. long, about $2 \mathrm{~mm}$. in diameter; scales ovate, obtuse or the upper acute, green with a somewhat darker midvein; bristles 4-8, retrorsely barbed, longer than the achene and tubercle; stamens 3; style 3-cleft; achene oblong-obovoid, obtusely 3 -angled, its surface finely reticulated; tubercle conicsubulate, about one-half as long as the achene or shorter, capping its summit, partly or entirely falling away at maturity. In marshes and wet meadows, N. H. to Vt. and W. N. Y., Br. Col., Fla., Tex., Mex. and Cal. Also in Cuba. Aug-Sept.

\section{DICHRÓMENA Michx.}

Leafy-stemmed sedges, perennial by rootstocks, the spikelets crowded in a terminal head involucrate by the upper leaves, which are often white at the base. Spikelets compressed, several-many-flowered. Scales spirally imbricated all around, several of them with imperfect flowers, or empty. Perianth none. Stamens 3. Style 2-cleft, its branches subulate. Achene lenticular, transversely rugose, crowned with the broad persistent base of the style (tubercle). [Greek, alluding to the two-colored involucral leaves.] About 8 species, natives of America. Besides the following, another occurs in the southwestern United States.

Leaves of the involucre linear; tubercle truncate at the base.

L. D. colorata. Leaves of the involucre lanceolate, long-acuminate ; tubercle decurrent on the edges of

the achene.

2. D. latifolia.

I. Dichromena coloràta (L.) A. S. Hitchcock. NarRow-Leaved DichroMENA. (I. F. f. 599.) Glabrous; culm slender, erect, rather sharply triangular, $0.3-0.6 \mathrm{~m}$. tall. Leaves distant, narrowly linear, about $2 \mathrm{~mm}$. wide, much shorter than the culm, those of the involucre 4-6, reflexed when mature, yellowish white at the base ; head globose, I-2 cm. in diameter; spikelets narrowly oblong, acute; scales membranous, lanceolate, nearly white, x-nerved, subacute at the apex; achene obovate, brown, nearly truncate at the summit, compressed, covered by the tubercle which is not decurrent on its edges. In moist sandy soil, pine barrens of N. J. to Fla. and Tex. Also in tropical America. June-Sept.

2. Dichromena latifòlia Baldw. Broad-Leaved Dichromena (I. F. f. 600.) Similar to the preceding species but the culm stouter, obtusely triangular or nearly terete, the leaves lanceolate or linear-lanceolate, tapering gradually to a long-acuminate apex from a broad base, 3-8 mm. wide, sometimes overtopping the culm, but the lowest much shorter, those of the involucre 7-10, strongly reflexed when old. Head globose, I-2 cm. in diameter; spikelets oblong, subacute; scales ovatelanceolate, nearly white, rather obtuse; achene nearly orbicular in outline, pale brown, faintly wrinkled transversely and longitudinally, so as to appear reticulated; the tubercle decurrent on its margins. In wet pine barrens, Va. to Fla. and Tex. June-Aug.

\section{PSILOCÀRYA Torr.}

Annual sedges, with fibrous roots, slender leafy stems and ovoid or oblong, many-flowered terete spikelets in terminal and axillary, mostly compound umbels, the rays and raylets bracted at the base. Scales of the spikelets spirally imbricated all around, all fertile, deciduous. Flowers perfect. Perianth none. Stamens I or 2. Style 2-cleft, enlarged at the base. Achene lenticular or biconvex, smooth or transversely wrinkled, capped by the persistent base of the style (tubercle), or nearly the whole style persistent as a beak. [Greek, referring to the absence of perianth-bristles.] About Io species, natives of temperate and tropical America. Besides the following, another occurs in the southeastern United States.

Achene strongly wrinkled, much longer than the subacute tubercle

Achene smooth or but little wrinkled; tubercle subulate.

I. P. nitens

2. P. scirpoides.

I. Psilocarya nitens (Vahl) Wood. Short-Beaked Bald-Rush. (I. F. f. 6or.) Glabrous; culms tufted, slightly angled, 7-36 cm. tall. Leaves narrowly linear, about $2 \mathrm{~mm}$ wide, smooth, sometimes overtopping the culm, sheathing at the base the midvein prominent; umbels mostly loose; spikelets ovoid; 4-6 mm. long, rather less than $2 \mathrm{~mm}$. in diameter; scales brown, broadly ovate, thin, I-nerved, obtuse, acute or apiculate; achene lenticular, nearly orbicular, light brown, strongly wrinkled transversely; tubercle shorter than the achene, subacute, 2-lobed at the base. In wet soil. L. I. and Del. to Fla. and Tex., near the coast. July-Oct. 
2. Psilocarya scirpoides (Torr.) LoNG-BEAKED BALD-RUSH. (I. F. f. 602.) Similar to the preceding species. Umbels commonly more numerous; spikelets oblong or ovoid-oblong; achene $\mu_{\star} \times$,rly orbicular in outline, biconvex, not as flat as that of $P$. nitens, dark brown, fair. ly transversely wrinkled or smooth, sometimes k)ngitudinally striate, slightly contracted at the base into a short stipe ; tubercle subulate, as long as the achene or sometimes longer, its base decurrent on the edges. In wet soil. E. Mass. and R. I. July-Sept.

\section{STENOPHÝLLUS Raf.}

Mostly annual sedges, with slender erect culms, leafy below, the leaves narrowly linear or filiform, with ciliate or pubescent sheaths. Spikelets umbellate, capitate or solitary, subtended by a I-several-leaved involucre, their scales spirally imbricated all around, mostly deciduous. Flowers perfect. Perianth none. Stamens 2 or 3. Style 2-3-cleft, glabrous, its base much swollen and persistent as a tubercle on the achene as in Eleocharis. Achene 3-angled, turgid or lenticular. [Greek, referring to the narrow leaves.] A genus of some 20 species, natives of temperate and warm regions. Besides the following, 5 others occur in the southern United States.

1. Stenophyllus capillàris (L.) Britton. HAIR-LIke Stenopiryllus. (I. F. f. 603.) Annual; roots fibrous; culms filiform, densely tufted, erect, grooved, smooth, 5-25 cm. tall. Leaves roughish, much shorter than the culm, their sheaths more or less pubescent with long hairs; involucral leaves I-3, setaceous; spikelets narrowly oblong, somewhat 4-sided, 5-8 mm. long, less than $2 \mathrm{~mm}$. thick, several in a terminal umbel, or in depauperate forms solitary; scales oblong, obtuse or emarginate, puberulent, dark brown with a green keel; stamens 2; style 3-cleft; achene yellow-brown, narrowed at the base, very obtuse or truncate at the summit, $0.5 \mathrm{~mm}$. long, transversely wrinkled; tubercle minute, depressed. In dry or moist soil, throughout $\mathrm{N}$. Am. except the extreme north. Also in tropical America. July-Sept. [Fimbristylis capillaris A. Gray.]

\section{FIMBRÍSTYLIS Vahl.}

Annual or perennial sedges. Culms leafy below. Spikelets umbellate or capitate, terete, several to many-flowered, subtended by a I-many-leaved involucre, their scales spirally imbricated all around, mostly deciduous, all fertile. Perianth none. Stamens I-3. Style 2-3-cleft, pubescent or glabrous, its base much enlarged, falling away from the summit of the achene at maturity. Achene lenticular, biconvex, or 3-angled, reticulated, cancellate, or longitudinally ribbed or striate in our species. [Greek, in allusion to the fringed style of some species.] A large genus, the species widely aistributed in temperate and tropical regions. $\mathrm{Be}$ sides the following, some 4 others occur in the southern and western parts of North America.

Style 2-cleft; achene lenticular or biconvex.

Culms $0.2-0.9 \mathrm{~m}$. tall; spikelets umbellate; style mostly pubescent. Perennial ; leaves involute.

Scales coriaceous, shining, glabrous.

Scales membranous, dull, puberulent. Annual; roots fibrous; leaves flat.

Culms 2-10 cm. tall, very slender; spikelets capitate; style glabrous below.

r. F. spadicea.

2. F. castanea.

3. F. laxa.

4. F. Vahlii.

Style 3-cleft; achene 3-angled.

Umbel mostly compound; spikelets narrow, acute, mostly peduncled; achene $\mathrm{n}$ :arly or quite smooth.

5. F. autumnalis.

Umbel mostly simple; spikelets plump, obtuse, mostly capitate and sessile; achene distinctly reticulated.

6. F. Frankii.

I. Fimbristylis spadícea (L.) Vahl. Stiff Fimbristrylis. (I. F. f. 604.) Perennial by a thickened base, glabrous; culms slender, 3-angled, wiry, 3-9 dm. tall, usually longer than the strongly involute rigid leaves. Leaves about $2 \mathrm{~mm}$. wide when unrolled. their sheaths dark brown; leaves of the involucre 3-6, erect; umbel several-rayed, the rays nearly erect. 5-15 cm. long: central spikelets of the umbels and umbellets scssile, the etlers pedicelled; plikelets ovoid or ovoid. 
cylindric, acute, 5-12 $\mathrm{mm}$. long, about $2 \mathrm{~mm}$. in diameter; scales oval obovate, or orbicular, obtuse or subacute, coriaceous, glabrous, shining, dark brown with a green midvein; stamens 2; style 2-cleft; achene lenticular, obovate, brown. In marshes and shallow water, Va. to Fla., near the coast. Widely distributer in tropical America. July-Sept.

2. Fimbristylis castànea (Miclix.) Vahl. Marsil Fimbristylis. (1. F. f. 605.) Perennial by a thick base; culms slender, 3 -angled, $0.2-0.5 \mathrm{~m}$. tall, usually exceeding the leaves. Leaves involute, less than $2 \mathrm{~mm}$. wide, their sheatss green and more or less pubescent; leaves of the involucre 2-4, short; umbel simple or compound, the rays $\mathrm{I}-5 \mathrm{~cm}$. long; central spikelets sessile; spikelets oblong, 6-10 $\mathrm{mm}$. long, 2-3 mm. in diameter; scales thin, brown with a lighter midvein, broadly oblong or nearly orbicular, dull, puberulent, obtuse or mucronate; stamens 2-3; style 2-cleft; achene obovate or oblong, biconvex, pale brown. On salt meadows, southern N. Y. to Fla. and La. Also in wet soil in the interior from Ont., Mich. and Ill. to Kans. and Tex., and in tropical America. The achene in the prairie plant is shorter and less tapering to the base than in the coast form. July-Sept.

3. Fimbristylis láxa Vahl. Weak Fimbristylis. (I. F. f. 606.) Annual; roots fibrous ; culms slender, flattened, striate, densely tufted, erect or ascending, 5-40 $\mathrm{cm}$. long, usually longer than the leaves. Leaves flat, about I mm. wide, glabrous or sparingly ciliate, pale green, those of the involucre $3-5$; umbel simple or slightly compound, the central spikelet sessile ; spikelets ovoid or ovoid-oblong, 6-12 mm. long, about $2 \mathrm{~mm}$. in diameter; scales ovate, thin, pale greenish brown, subacute or mucronulate; stamen I ; style 2 -cleft, pubescent; achene biconvex, obovoid, light brown, longitudinally ribbed, the ribs tubercled and connected by very fine cross-lines. In moist soil, S. Penn. to Fla., west to Ill., Mo. and Tex. Also in trop. Am. July-Sept.

4. Fimbristylis Vàhlii (Lam.) Link. VAhL's Fimbristylis. (I. F. f. 6o7.) Annual ; culms very slender, densely tufted, compressed, striate, 2-ro cm. high, longer than or equalling the leaves. Leaves setaceous or almost filiform, rough, those of the involucre 3-5, erect, much exceeding the simple capitate cluster of 3-8 spikelets ; spikelets oblong-cylindric, obtuse, 4-8 $\mathrm{mm}$. long, about I $\mathrm{mm}$. thick, many-flowered; scales lanceolate, pale greenish-brown, acuminate; stamen $\mathbf{I}$; style 2-cleft, glabrous below; achene minute, biconvex, yellowish-white, cancellate. In moist soil, Mo. to Tex., east to N. Car. and Fla. July-Oct.

5. Fimbristylis autumnàlis (L.) R. \& S. SLender Fimbristylis. (I. F. f. 608.) Annual ; roots fibrous ; culms very slender, densely tufted, flat, 7-40 cm. long, usually much exceeding the leaves. Leaves narrowly linear, flat, $1-2 \mathrm{~mm}$. wide, glabrous, those of the involucre 2-3, usually all shorter than the umbel; umbel compound or decompound, the primary rays 4-10 $\mathrm{mm}$. long, the secondary filiform; spikelets linear-oblong, acute, 6-40 mm. long, I mm. thick or less; scales ovate-lanceolate, subacute, strongly mucronate, greenish-brown, the midvein prominent; stamens I-3; style 3-cleft; achene obovoid, nearly white, 3-angled with a ridge on each angle, smooth or indistinctly reticulated, sometimes roughened. In moist soil, Me. to Mich., south to Fla. and La. Also in trop. Am. Depauperate forms occur with culms not over $2 \mathrm{~cm}$. high bearing solitary spikelets. June-Sept.

6. Fimbristylis Frànkii Steud. Annual, lower than the preceding species, the leaves often shorter. Uimbel mostly simple, the spikelets, or most of them, capitate and sessile, ovoid or oval, blunt, the heads sometimes appearing almost sessile at the base; achenes rather larger, distinctly reticulated. In mud or wet sand, N. II. to Mo., Tenu. and La. Jume-Sept.

\section{SCÍRPUS L. (See Appendix.)}

Annual or perennial very small or very large sedges, with leafy culms or the leaves reduced to basal sheaths. Spiktlets terete or somewhat flattened, solitary, capitate, spicate or umbellate, subtended by a I-several-leaved involucre or the involucre wanting in some species. Scales spirally imbricated all around, usually all fertile, the I-3 lower sometimes empty. Flowers perfect. Perianth of I-6, slender or rigid, short or elongated, barbed, pulsescent or smooth bristles, or none in some species. Stamens 2-3. Style 2-3-cleft, not swollen at the base, wholly 
deciduous from the achene, or its base persistent as a subulate tip. Achene triangular, lenticular or plano-convex. [Latin name of the Bulrush, said to be from sirs, the Celtic word for rushes.] About 200 species of very wide geographic distribution. Besides the following, some 6 others occur in the southern and western parts of North America.

Spikelet solitary, terminal, bractless or subtended by a single bract or short leaf.

No involucral bract.

Culms $2-5 \mathrm{~cm}$. high; achene smooth; plant of saline soil. I. S. nanus.

Culms 7-25 $\mathrm{cm}$. high; achene reticulated; plant of fresh-water marshes.

Involucral bract present, erect.

2. S. pauciflorus.

Bract shorter than or but little exceeding the spikelet; plants not aquatic.

Culm terete; leaf of upper sheath subulate; bristles smooth.

3. S. caespitosus.

Culns triangular; leaf of upper sheath linear; bristles upwardly barbed. Leaves shorter than the culm; scales acute. 4. S. Clintoni.

Leaves about as long as the culm; scales cuspidate.

Bract at least twice as long as the spikelet; plant aquatic.

5. S. planifolius.

6. S. subterminalis.

Spikelets normally more than I, usually several or numerous, often appearing lateral; involucral bract only $x$.

Spikelets few, I-I2, appearing lateral.

Culms not sharply 3 -angled; achene plano-convex; annuals.

Achene strongly transversely rugose.

Achene smooth or very slightly roughened.

7. S. Hallii.

Bristles downwardly barbed, about equalling the achene.

Bristles minute or wanting.

8. S. debilis.

9. S. Smithii.

Culms sharply 3 -angled; plants perennial by rootstocks.

Achene plano-convex, bristles shorter than or equalling the achene.

Spikelets acute, much overtopped by the slender involucral leaf; scales awned.

ro. S. Americanus.

Spikelets obtuse; involucral leaf short, stout; scales mucronulate.

Achene 3-angled, ridged on the back.

II. S. Olneyi.

Bristles longer than the achene; involucral leaf erect.

Bristles as long as the achene; involucral leaf abruptly bent.

12. S. Torreyi:

13. S. mucronatus.

Spikelets several or numerous, umbelled; tall sedges.

Culm sharply triangular, equalled by the long leaves. I4. S. cylindricus.

Culm terete; leaves reduced to sheaths.

Bristles downwardly barbed; achene gray, abruptly mucronate.

I5. S. validus.

Bristles short-plumose below; achene nearly white, narrowed above.

Spikelets several, spicate.

16. S. Californicus.

I7. S. rufus.

Spikelets several, capitate or umbellate, larce ; involucral leaves 2 or more.

Achene lenticular or plano-convex; spikelets capitate.

Capitate cluster simple; achene obovate-oblong, pale brown.

18. S. interior.

Capitate cluster often compound; achene orbicular-obovate, dark brown.

Achene sharply 3 -angled; spikelets umbellate.

19. S. robustus.

Spikelets oblong-cylindric, $1.5-2.5 \mathrm{~cm}$. long; bristles 6.

Spikelets narrowly cylindric, $2-5 \mathrm{~cm}$. long; bristles 2-4. 2I. S. Vorae-Angliae.

Spikelets very numerous in compound umbels or umbelled heads, snall; involucral leaves several; tall sedges.

Bristles downwardly barbed; spikelets in umbelled heads.

Spikelets ovoid or oblong, 3-5 mm. long.

Bristles equalling or slightly exceeding the achene; leaves $6-16 \mathrm{~mm}$. wide. Style 3-cleft ; achene 3-angled; bristles 6.

Spikelets $3^{-8}$ in each head; bristles barbed throughout; scales obtuse. 22. S. sylvaticus.

Spikelets 3-20 in each head; bristles not barbed below; scales acute.

Style 2-cleft; achene plano-convex; bristles 4. 24. S. microcarpus. 
Bristles flexuous, twice as long as the a hene; leaves $4-6 \mathrm{~mm}$. wide.

Spikelets cylindric, 6-ro mm. long.

Bristles smooth or slightly pubescent; umbel mostly decompound.

25. S. polyphyllus.

26. S. Peckii.

Bristles shorter than or scarcely exceeding the scales.

Bristles about as long as the achene; scales subacute.

Bristles much longer than the achene; scales mucronate.

27. S. divaricatus.

28. S. lineatus.

Bristles much exserted beyond the scales when mature.

29. S. cyperinus。

I. Scirpus nànus Spreng. Dwarf Club-Rush. (I. F. f. 6og.) Annual; roots fibrous; culms filiform, flattened, grooved, tufted, erect or ascending, $2-5 \mathrm{~cm}$. high, bearing a scarious bladeless sheath near the base. Spikelet solitary, terminal, ovoid-oblong, rather acute, 3-8 flowered, 2-3 $\mathrm{mm}$. long, not subtended by a bract; scales ovate or lanceolate, pale green, the lower obtuse, the upper subacute; bristles about 6, downwardly barbed, longer than the achene; stamens 3; style 3-cleft; achene oblong, 3-angled, pale, pointed at each end, smooth. Muddy places in salt marshes, Cape Breton Id. to Fla. and Tex., and about salt springs in N. Y. and Mich. Also on the Pacific Coast of N. Am. and on the coasts of Europe. July-Sept.

2. Scirpus pauciflòrus Lightf. Few-Flowered Club-Rush. (I. F. f. 6IO.) Perennial by filiform rootstocks; culms very slender, little tufted, 3 -angled, grooved, leafless, 7-25 cm. tall, the upper sheath truncate. Spikelet terminal, solitary, not subtended by an involucral bract, oblong, compressed, 4-Io flowered, 4-6 mm. long, nearly $2 \mathrm{~mm}$. wide; scales brown with lighter margins and midvein, lanceolate, acuminate; bristles 2-6, hispid, as long as the achene or longer; stamens 3 ; style 3-cleft; achene obovoid-oblong, gray, rather abruptly beaked, its surface finely reticulated. In wet soil, Anticosti and Ont. to Me., W. N. Y., Minn. and Br. Col., south in the Rocky Mountains to Colo. Also in northern Europe. July-Oct.

3. Scirpus caespitòsus L. Tufted Club-Rush. (I. F. f. 6rir) Perennial; culms smooth, terete, densely tufted, light green, erect or ascending, almost filiform, wiry, $10-40 \mathrm{~cm}$. long. Basal sheaths numerous, membranous, imbricated, acuminate, the upper one bearing a short very narrow blade; spikelet solitary, terminal, few-flowered, ovoid-oblong, about $4 \mathrm{~mm}$. long, subtended by a subulate involucral leaf of about its own length; scales yellowish-brown, ovate, obtuse or subacute, deciduous; bristles 6 , smooth, longer than the achene; stamens 3 ; style 3 -cleft; achene oblong, smooth, 3-angled, brown, acute. In bogs and on moist rocks, Greenl. to Alaska, south to the mountains of N. E., the Adirondacks, W. N. Y., I!I., Minn. and Br. Col., in the Rocky Mountains to Colo., and on the higher summits of the southern Alleghenies. Also in Europe and Asia. June-Aug.

4. Scirpus Clíntoni A. Gray. Clinton's Club-Rush. (I. F. f. 612). Perennial; culms tufted, triangular, very slender, erect, $10-40 \mathrm{~cm}$. tall, roughish on the angles. Lower sheaths imbricated, one or more of them bearing short subulate blades, the upper one bearing a flat, narrowly linear blade shorter than the culm; spikelet solitary, terminal, ovoid, few-flowered, 3-4 $\mathrm{mm}$. long, subtended by a subulate involucral bract; scales ovate, pale brown, acute; bristles $3-6$, filiform, upwardly barbed, as long as the achene or longer; style 3-cleft; achene oblong, lirown, sharply 3-angled, smooth, obtuse. In dry fields and thickets, N. B. to W. N. Y. and Mich., south to N. C. Local. June-Aug.

5. Scirpus planifòlius Muhl. Woon Club-Rush. (I. F. f. 6r3.) Perennial; culms triangular, slender, tufted, rather weak, roughish on the angles, $15-40 \mathrm{~cm}$. tall. Lower sheaths bearing short subulate blades, the upper with a flat narrowly linear rough-margined leaf about as long as the culm; spikelet solitary, terminal, ovoid-oblong, acute, several-flowered, subtended by a short involucral bract; scales ovate-lanceolate, yellowish-brown with a green midvein, which is extended beyond the acute apex into a sharp cusp; bristles 4-6, upwardly barbed, about equalling the achene; stamens 3; style 3-cleft, pubescent; achene oblong, 3-angled, smootl, light brown, rather obtuse. In woods and thickets, Mass. to Del., W. N. Y. and Mo. May-July.

6. Scirpus subterminàlis Torr. Water Club-Rush. (I. F. f. 614.) Perenniai (?), aquatic, culms slender, terete, nodulose, $0.3^{-1} \mathrm{~m}$. long. Leaves slender, channeled, $15^{-50} \mathrm{~cm}$. long, $0.5^{-1} \mathrm{~mm}$. wide; spikelet solitary, terminal, 
oblong cylindric, narrowed at each end, several-flowered, 6-10 $\mathrm{mm}$. long, subtended by a subulate erect involucral leaf $\mathbf{I}-3 \mathrm{~cm}$. long, thus appearing lateral; scales ovate-lanceolate, acute, membranous, light brown with a green midvein; bristles about 6 , downwardly barbed, as long as the achene or shorter; stamens 3; style 3-cleft to about the middle; achene obovoid, 3-angled, dark brown, smooth, rather more than $2 \mathrm{~mm}$. long, obtuse. abruptly beaked by the slender hase of the style. In ponds and streams or sometimes on their borders, N. B. to the N. W. Terr. and Wash., south to N. J., Penn. and Mich. The so-called variety terrestris is an emersed form with erect culms and shorter spikelets. July-Aug.

7. Scirpus Hàllii A. Gray. Hall's Club-Rush. (I. F. f. 6I5.) Annual; culms very siender, smooth, tufted, obtusely triangular, erect, striate, I-3 dm. tall. Lower sheaths oblique, and acuminate or mucronate, the upper one commonly bearing a filiform blade $\mathbf{I}-6 \mathrm{~cm}$. long; spikelets capitate in clusters of $\mathbf{I}-7$, oblongcylindric, obtuse, many-flowered, 6-12 $\mathrm{mm}$. long, about $2 \mathrm{~mm}$. thick, appearing lateral by the extension of the solitary involucral leaf; scales ovate-lanceolate, light greenish brown, acuminate, keeled, cuspidate; bristles wanting; stamens mostly 2; achene obovate-orbicular or slightly broader than high, black, plano-convex, mucronulate, wrinkled transversely, about $\mathbf{~ m m}$. in diameter. In wet soil, Mass. to Fla., west to Ill., Col., Tex. and Mex. The lowest sheaths occasionally subtend a flower with very long styles. July-Sept.

8. Scirpus débilis Pursh. Weak-stalked Club-Rush. (I. F.f. 6Ib.) Annual, smooth; culms slender, terete or nearly so, tufted, I.5-5 dm. high. Sheaths obliquely truncate, the upper one rarely bearing a short subulate blade; spikelets capitate in clusters of $\mathbf{I}-\mathbf{1 2}$, ovoid-oblong, subacute, many-flowered, appearing laterd, the involucral leaf narrowly linear, 3-10 cm. long, erect or divergent; scales light yellowish brown with a green midvein, broadly ovate, obtuse or acute; bristles 4-6, downwardly barbed, about as long as the achene; stamens 2-3; style 2-cleft or rarely 3-cleft; achene plano-convex, broadly obovate or orbicular, smooth or slightly roughened, dark brown, shining, obtuse, mucronulate. In wet soil, Me. to Ont. and Minn., south to Ga., Ala. and Neb. July-Sept.

9. Scirpus Smíthii A. Gray. Smith's Club-RUSH. (I.F.f. 6I7.) Annual, similar to the preceding species; culms usually lower and more slender or nearly filiform; sheaths oblique and acuminate or the upper one bearing a subulate blade. Spikelets 1-4, ovoid, acute, 4-6 mm. long, the involucral leaf narrow, elongated, erect; scales oblong, obtuse, mucronulate, pale brown with a green midvein; bristles usually wanting, sometimes I-3, and very much shorter than the achene; style 2-cleft; achene plano-convex, obovate or orbicular, brown, rather dull, smooth or minutely roughened, obtuse, mucronulate. In wet muddy places, Vt. to Ont. and Minn., Del., Penn. and Mich. July-Sept.

ro. Scirpus Americànus Pers. Three-square. Chair-maker's Rush. (I. F. f. 6I8.) Perennial by long rootstocks: culms sharply triangular, erect, stiff, 0.3-1.I m. tall. Leaves I-3, narrowly linear, keeled, shorter than the culm; spikelets oblong-ovoid, acute, $8-12 \mathrm{~mm}$. long, capitate in clusters of $1-7$, appearing as if lateral; involucral leaf slender, 3 -10 $\mathrm{cm}$. long; scales broadly ovate, brown, often emarginate or sharply 2 -cleft at the apex, the midvein extended into a subulate awn sometimes $2 \mathrm{~mm}$. long, the margins scarious; bristles 2-6, downwardly barbed, shorter than or equalling the achene; stamens 3 ; achene obovate, planoconvex, smonth, dark brown, mucronate. In fresh water and brackish swamps throughout N. Am. Also in Chile. June-Sept. [S. pungens Vahl.]

Scirpus Americànus longispicàtus Britton. Spikelets linear-cylindric, $\mathbf{x - 2 . 5} \mathrm{cm}$. long; bristles as long as the broadly obovate achene. S. shore of Lake Ont., Col. and N. Mex.

I I. Scirpus Ólneyi A. Gray. Olney's Bulrush. (I. F. f. 6I9.) Similar to the preceding species; culms stout, sharply 3-angled with concave sides, $0.5^{-2} \mathrm{~m}$. tall. Leaves $\mathrm{I}-3,2-13 \mathrm{~cm}$. long, or sheaths sometimes leafless; spikelets capitate in dense clusters of 5-12, oblong or ovoid-oblong, obtuse, 5-8 mm. long, the involucral leaf short, stout, erect, I-3 cm. long; "scales oval or orbicular, dark brown with a green midvein, emarginate or mucronulate, glabrous; bristles usually 6, slightly shorter than or equalling the achene, downwardly barbed; stamens 2-3; style 2 cleft; achene obovate, plano-convex, bruwn, mucronate. In salt marshes, Mass. 
to Fla., Tex., Mex. and Cal., extending north along the Pacific Coast to Ore.

in Ark. June-Sept.

12. Scirpus Tórreyi Olney. Torrey's Bulrush. (I. F. f. 620.) Perennial by rootstocks; culms sharply 3-angled, rather slender, nodulose, $0.5-1.1 \mathrm{~m}$. tall. Leaves narrowly linear, elongated, nodulose, light green; spikelets $\mathbf{I - 4}$, in an apparently lateral capitate cluster, oblong, narrowed at each end, IO-16 mm. long; involucral leaf $5^{-15} \mathrm{~cm}$. long, erect; scales ovate or lanceolate, shining, chestnutbrown, glabrous, mucronulate; bristles about 6, downwardly barbed, longer than the achene; stamens 3; style 3-cleft: achene obovoid, smooth, slining, light brown, 3-angled, one of its sides broader and flatter than the others. In swamps, Vt. to R. I. and Penn., west to Minn. and Manitolsa. July-Sept.

13. Scirpus mucronàtus L. Bog Bulrush. (I. F. f. 621.) Perennial : culms stout, tufted, 3-angled, smooth, $0.3^{-1} \mathrm{~m}$. tall. Spikelets 5-12 in a capitate cluster, oblong, obtuse, $8-18 \mathrm{~mm}$. long, rather more than $2 \mathrm{~mm}$. in diameter, subtended by a linear abruptly spreading involucral leaf; scales broadly ovate, obtuse, light brown with a narrow green midvein, mucronate; bristles 6 , stout, rigid, downwardly barbed, as long as the achene; stamens 3 ; style 3 -cleft; achene obovoid, smooth, shining, dark brown, 3 -angled, two of the sides narrower and more convex than the third. In a swamp in Del. Co., Penn. Probally adventive or fugitive from Europe. Widely distributed in the Old World. July--Sept.

I4. Scirpus cylindricus (Torr.) Britton. Canby's Bulrush. (I. F. f. 622.) Perennial by stout rootstocks : culm stout, 3 -angled above, $\mathrm{x}-2 \mathrm{~m}$. high, the linear nodulose keeled dark green leaves nearly or quite as long. Involucral leaf I-2.5 $\mathrm{dm}$. long, erect; spikelets in an apparently lateril umbel, drooping, oblong-cylindric, acutish, $\mathbf{I}-2 \mathrm{~cm}$. long, primary rays of the umbel bracted by $\mathbf{I}$ or more subulate-linear leaves; scales ovate or ovate-lanceolate; pale brown, acute, mucronulate ; bristles 6 , stout, rigid, about as long as the achene, serrate; stamens 3 ; style 3-cleft; achene ohovoid, 3-angled, light brown, smooth, abruptly subulate-pointed. In ponds and swamps. Md. to Fla. and La. July-Sept. [S. Canbyi A. Gray.]

15. Scirpus validus Vahl. Great Bulrushr. Mat-RUsh. (I. F. f. 623.) Perennial by rootstocks ; culm stout, terete, smooth, erect, $x-3 \mathrm{~m}$. tall, sometimes $2 \mathrm{~cm}$. in diameter, sheathed below. Involucral leaf solitary, erect, shorter than the umbel ; umbel compound, appearing lateral, its primary rays $2-10 \mathrm{~cm}$. long ; bracts linear-lanceolate; spikelets becoming ollong-cylindric, sessile or some of tiem peduncled, in capitate clusters of $\mathrm{I}-5,5-16 \mathrm{~mm}$. long, 3-4 mm. in diameter ; scales ovate or oblong, with a strong midvein which is sometimes excurrent ; bristles, 4-6, downwardly barbed, equalling or longer than the achene; stamens 3 ; style 2-cleft : achene plano-convex, obovate, gray, abruptly mucronate, dull. In ponds and swamps throughout N. Am. June-Sept.

i6. Scirpus Califórnicus (C. A. Meyer) Britton. California Bulrusir. (I. F. f. 624.) Perennial, similar to the preceding species, the leaves reduced to basal sheaths. Involucral leaf short, stoutly subulate; umbel compound; spikelets 6-ro mm. long, acute, peduncled or some of them sessile; scales brown, ovate, awnpointed; bristles shorter than or equalling the achene, short plumose below; stamens 2-3; style 2-cleft; achene obovate, plano-convex, nearly white, narrowed above into a short point, contracted at the base. In swamps, Fla. to La., N. Mex. and Cal., and widely distributed in tropical America. Not certainly known within our area. June-Aug.

17. Scirpus rùfus (Huds.) Schrad. Red Club-Rush. (I. F. f. 625.) Per. ennial; culms smooth, slender, somewhat compressed, 7-40 cm. tall. Leaves half. terete, smooth, shorter than the culm, channeled, $1-8 \mathrm{~cm}$. long, less than $2 \mathrm{~mm}$ wide, the lowest reduced to sheaths; spikelets red-brown, few-flowered, narrowly ovoid-oblong, subacute, about $6 \mathrm{~mm}$. long, in a terminal 2-ranked spike; involu. cral leaf solitary, erect, equalling or longer than the spike; scales lanceolate, acute, I-nerved; bristles 3-6, upwardly barbed, shorter than the achene, deciduous; stamens 3; style 2-cleft; achene oblong, pointed at both ends, light brown, plano. convex or slightly angled, 3-4 mm. long. In marshes, N. B. and Que. to the N. W. Terr. Also in northern Europe. Summer.

18. Scirpus interior Britton. Prairie Butrush. (I. F. f. 626.) Perennial, culm smooth, sharply triangular, $0.3-0.5 \mathrm{~m}$. tall. Leaves usually pale green, smouth, $2-4 \mathrm{~mm}$. wide, those of the involucre 2 or 3 , the longer much exceeding 
the inflorescence; spikelets 3 -10 in a dense terminal simple head, oblong cylindric, r.5-2.5 cm. long, 5-8 mm. in diameter; scales ovate, pale brown, 2-toothed at the apex, the midvein excurrent into an ascending or spreading awn; bristles I-3, much shorter than the achene or none; style 2-cleft; achene lenticular, obovate or oblong-ovi te, mucronulate, yellow-brown, its surface strongly cellularreticulated. On wet prairies and plains, Man. and Minn. to Neb., Kans, and Mex., west to Nev. May-Aug. (S. campestris Britton, not Willd.)

19. Scirpus robústus Pursh. Salt Marsh Bulrush. (I. F. f. 627.) Perennial by rootstocks; culm stout, stiff, 3-angled with flat sides, smooth, $0.5-\mathbf{I} .4$ m. tall. Leaves dark green, smooth, 5-10 mm. wide; involucral leaves 2-4, elongated, similar; spikelets ovoid-oblong, stout, 1.5-2.5 cm. long, 8-10 mm. in diameter, 6-20 together in a dense terminal cluster; scales ovate, brown, fuberulent, thin, the midvein excurrent into an, at length, reflexed awn 3-5 znn. long; bristles I-6, fragile, shorter than the achene, or none; style 3-cleft; achene compressed, flat on the face, convex or with a low ridge on the back, obovate-orbicular, dark brown, shining, $3 \mathrm{~mm}$. long. In salt marshes, N. S. to Tex. July-Oct.

20. Scirpus fluviátilis (Torr.) A. Gray. River Bulresh. (I. F. f. 628.) Perennial by rootstocks; culm stout, smooth, triangular with nearly flat sides, $0.9-2$ m. tall. Leaves 8-16 mm. wide, smooth, attenuate to a very long tip; those of the involucre $3-5$, erect or spreading, often $20 \mathrm{~cm}$. long; spikelets in a terminal umbel, solitary or 2-3 together at the ends of its long spreading or drooping rays, or the central spikelets sessile, oblong-cylindric, acute, $1.6-2.5 \mathrm{~cm}$. long, about $7 \mathrm{~mm}$. in diameter; scales ovate, scarious, puberulent, the midvein excurrent into a curved awn 3-4 mm. long; bristles 6 , downwardly barbed, about as long as the achene; style 3-cleft; achene sharply 3-angled, obovoid, rather dull, short-pointed, $4 \mathrm{~mm}$. long. In shallow water, Que. to Minn., N. J., Neb. and Kans. June-Sept.

2I. Scirpus Nòvae-Angliae Britton. New England Coast Sedge. (I. F. f. 627a.) Perennial by rootstocks; culm stout, I-2 m. tall, sharply 3-angled. Leaves long, 8-12 $\mathrm{mm}$. wide, roughish on the margins when dry, the lowest reduced to pointed sheaths, those of the involucre $2-5$, the longer of them nuch exceeding the inflorescence; spikelets narrowly cylindric, acute, $1.8-5 \mathrm{~cm}$. long, less than $8 \mathrm{~mm}$. thick, solitary or $2-5$ together at the ends of the rays; rays 2-10 $\mathrm{cm}$. long; scales awned; bristles 2-4, shorter than the grayish-white dull obovate achene, which is distinctly 3 -angled; style 3 -cleft. In fresh water and brackish marshes, Conn. and S. N. Y.

22. Scirpus sylváticus L. Wood Bulrush. (I. F. f. 629.) Perennial by long rootstocks; culm triangular, stout, smooth, I-2 m. tall, often overtopped by the upper leaves. Leaves $1-1.6 \mathrm{~cm}$. wide, rough on the margins, those of the involucre $5-8$, the larger often $0.3 \mathrm{~m}$. long or more; umbel terminal, very large, sometimes $2 \mathrm{dm}$. broad, about 3 times compound, the spikelets ovoid or ovoidoblong, 3-5 mm. long, in capitate clusters at the ends of the raylets; bractlets of the involucels small, linear or lanceolate; scales ovate-oblong, obtuse, brown with a green centre; bristles 6 , downwardly barbed, slightly exceeding the achene; stamens 3; style 3-cleft; achene oblong, 3-angled, obtuse, nearly white, mucronulate. In swamps, N. H. to N. Car. Also in Europe. June-Aug.

23. Scirpus atróvirens Muhl. Dark-green Buirush. (I. F. f. 6jo.) Perennial by rootstocks; culms triangular, rather slender, leafy, $0.5-1.2 \mathrm{~m}$. high. Leaves elongated, nodulose, dark green, 6-12 $\mathrm{mm}$. wide, one or two of them usually exceeding the inflorescence; spikelets ovoid-oblong, acute, densely capitate at the ends of the rays or raylets; involucels short; scales greenish-brown, oblong, acute, the midvein excurrent; bristles usually 6 , downwardly barbed above, nakeil below, about as long as the achene; stameıs 3 ; style 3-cleft; achene oblongobovoid, 3-angled, pale brown, dull. In swamps, N. S. to Manitoba, Ga. and LaJune-Aug.

Scirpus atróvirens pállidus Britton. Whole plant pale green; scales awned; spikelets oblong-cylindric, very numerous in the capitate clusters. Minn. to the N.W. Terr. and Colo.

24. Scirpus microcàrpus Presl. Small-fruiten Bulrush. (I. F. f. 63r.) Perennial; culms $0.9-1.6 \mathrm{~m}$. tall, often stout, overtopped by the leaves. Longer leaves of the involucre usually exceeding the inflorescence; spikelets ovoid-oblong, acute, 3-4 mm. long, in capitate clusters at the ends of the usually spreading ray. 
lets; scales brown with a green midvein, bristles 4, barbed downwardly nearly or quite to the base, somewhat longer than the achene; stamens 2; style 2-cleft; achene oblong-obovate, nearly white, plano-convex or with a low ridge on the back, pointed. In swamps and wet woods, N. S. to Quebec and Alaska, Mass., N. Y., Minn. and Cal. July-Sept.

25. Scirpus polyphyllus Vahl. Leafy Bulrush. (I. F. f. 632.) Perennial by rootstocks; culms slender, sharply triangular, $0.3-1.1 \mathrm{~m}$. tall, very leafy, the leaves 4-6 mm. wide, 3-ranked, rough-margined, those of the involucre 3-6, the longer commonly somewhat exceeding the inflorescence; spikelets ovoid, about $3 \mathrm{~mm}$. long, capitate at the ends of the raylets; scales ovate, bright brown, mostly obtuse, mucronulate; bristles 6 , downwardly barbed above the middle, twice as long as the achene; stamens 3: style 3-cleft; achene obovoid, 3-angled with a broad face and narrower sides, short-pointed, dull. In swamps, wet woods and meadows, Mass. to Minn., Ala. and Ark. Some of the scales of the spikelets occasionally develop into linear leaves. July-Sept.

26. Scirpus Péckii Britton. Peck's Bulrush. (I. F. f. 633.) Perennial by rootstocks; culms slender, triangular, 0.4-1 m. tall, leafy. Leaves elongated, 4-Io $\mathrm{mm}$. wide, rough-margined, the upper overtopping the culm, those of the involucre $3-5$, the longer exceeding the inflorescence; umbel compound, large; spikelets cylindric, obtusish, 6-10 $\mathrm{mm}$. long, in capitate clusters at the ends of the raylets or some of them peduncled; scales dark brown, keeled, mucronate, falling early; bristles 4-6, downwardly barbed from below the middle to the summit, longer than the achene; style 3-cleft; achene 3-arigled, $0.5 \mathrm{~mm}$. long, oblong, narrowed at each end, slender-beaked. In swamps, Conn. and N. Y. July-Sept.

27. Scirpus divaricàtus Ell. SpReading Bulkush. (I. F. f. 634.) Roots fibrous; culms obtusely triangular, smooth, rather slender, $0.6-1.1 \mathrm{~m}$. tall. Leaves 4-8 mm. wide, rough-margined, not exceeding the inflorescence; umbel decompound, the primary rays very slender, sometimes $1.5 \mathrm{dm}$. long, spreading or drooping: involucels setaceous. spikelets mostly solitary at the ends of the raylets, linear-oblong, obtuse, 6-12 mm. long, I mm. thick; scales ovate, greenish-brown, subacute or obtuse, bristles 6, flexuous, longer than the achene, somewhat pubescent, not barbed, sh irter tian the scales; stamens 3; style 3-cleft; achene 3-angled, oblong, narrowed at buth ends, apiculate, nearly white, not shining. In swamps, Va. and $\mathrm{Ky}$. to Mo., Fla. and La. The spikelets sometimes partially develop into tufts of leaves. June-Aug.

28. Scirpus lineàtus Michx. Kendish Bulrush. (I. F. f. 635.) Perennial by stout rootstonks; culms triangular, erect, $0.3-1 \mathrm{~m}$. high, leafy. Leaves $4-8 \mathrm{~mm}$. wide, not exceeding the inflorescence; light green, flat, rough-margined; umbels decompound, the rays very slender, becoming pendulous; spikelets mostly solitary at the ends of the raylets, oblong, obtuse, 6-10 $\mathrm{mm}$. long, about $2 \mathrm{~mm}$. in diameter; scales ovate or oblong, reddish-brown with a green midvein; bristles 6 , weak, smooth, entangled, much longer than the achene, equalling the scales or longer; stamens 3; style 3-cleft; achene oblong or oblong-obovoid, pale brown, narrowed at both ends, 3-angled, short-beaked. In swamps and wet meadows, N. H. to Ont., Ore., Ga. and Tex. June-Sept.

29. Scirpus cypérinus (L.) Kunth. Wool-grass. (I. F. f. 636.) Perennial; cu'ms smooth, obtusely triangular or nearly terete, stiff, leafy, o.6-2m. tall. Leaves elongated, 3-6 mm. wide, rough-margined, those of the involucre $3^{-6}$, the longer much exceeding the inflorescence; umbel terminal, compound, the rays at length somewhat drooping; spikelets ovoid-oblong, obtuse, 3-5 $\mathrm{mm}$. long, in capitate clusters of $3^{-15}$ at the ends of the raylets; scales ovate or lanceolate, acute or subacute; bristles 6 , entangled, smooth, much longer than the achene, much exserted beyond the scales and grayish brown at maturity; stamens 3 ; style 3 -cleft; achene 3-angled, oblong, slender-beaked, nearly white. In swamps, Newf. to Ont., Va. and Ky. Aug.-Sept.

Scirpus cypérinus Erióphorum (Michx.) Britton. Range of the type, but extending to Fla. and La.

Spikelets mostly peduncled.

\section{ERIÓPHORUM L.}

Bog sedges, perennial by rootstocks, the culms erect, triangular or nearly terete, the leaves linear, or 1 or 2 of the upper ones reduced to bladeless sheaths. Spike. 
lets terminal, solitary, capitate or umbelled, suitended by a I-several-leaved involucre, or naked. Scales spirally imbricated, usually all fertile. Flowers perfect. Perianth of 6 or numerous filiform smooth soft bristles, which are white or brown, straight or crisped, and exserted much beyond the scales at maturity. Stamens 1-3. Style 3-cleft. Achene 3-angled, oblong, ellipsoid or obovoid. [Greek, signifying wool-bearing, referring to the soft bristles.] About ro species, in the northern hemisphere. Besides the following, one occurs in Alaska.

Spikelet solitary ; involucral leaf short or none.

Bristles only 6 , white, crisped, very long.

Bristles numerous, straight or slightly crisped.

I. E. alpinum.

Bristles bright white.

Culm with 2 inflated bladeless sheaths; achene obovoid, obtuse.

2. E. vaginatum.

Only the upper sheath bladeless, or all blade-bearing; achene linear-oblong, acute.

Bristles reddish-brown

Spikelets several, umbellate or capitate ; involucre I-4-leaved.

Achene obovoid, obtuse; spikelets umbellate.

Achene linear-oblong, acute ; spikelets capitate or some of them peduncled.

3. E. Scheuchzeri.

4. E. russeolum.

Leaves channeled or 3-sided; bristles $4^{-6}$ times as long as the scale, bright white.

Upper part of culm and the peduncles rough ; bristles $2-2.5 \mathrm{~cm}$. long.

Plant smooth or nearly so throughout ; bristles I-I. $5 \mathrm{~cm}$. long.

6. E. paucinervium.

Leaves flat; bristles 3 times as long as the scale, brown (rarely white).

8. E. Virginicum.

I. Eriophorum alpinum L. Alpine Cotton-grass. (I. F. f. 637.) Peren. nial by short rootstocks, sending up numerous filiform triangular roughish culms, I. 5-2.5 dm. high. Leaves subulate, 6-20 mm. long, triangular, channeled, borne near the base of the culm, the lower sheaths often bladeless; spikelet terminal, small, erect; involucral bract subulate, mostly shorter than the spikelet, sometimes wanting; scales oblong-lanceolate, yellowish brown, firm, the midvein slender; bristles 6, white, crisped, 4-7 times as long as the scale; achene narrowly obovoidoblong, brown, apiculate, dull. In bogs and on high mountains, Newf. to Hudson Bay and the N. W. Terr., south to Vt., N. N. Y. and Minn. Also in Europe and Asia. Summer.

2. Eriophorum vaginàtum L. Sheathed Cotton-grass. (I. F. f. 638.) Culms stiff, obtusely triangular, smooth, slender, 2-4 dm. tall, bearing two distant inflated sheaths, the upper one usually above the middle. Leaves stiff, filiform, triangular, channeled, shorter than or sometimes overtopping the culm; involucral leaf wanting; spikelet solitary; scales ovate-lanceolate or the lowest lanceolate, acuminate, purple-brown, thin; bristles numerous, white, straight, glossy, 4-5 times as long as the scale; anthers linear; achene obovoid, obtuse, brown, dull, minutely apiculate. In bogs, Newf. to Alaska, Mass., Penn. and Minn. Also in N. Europe and Asia. June-Aug.

3. Eriophorum Scheuchzèri Hoppe. Scheuchzer's CotTon-grass. (I. F. f. 639.) Similar to the preceding, but the sheaths all blade-bearing or only the upper one bladeless; culms slender, smooth, nearly terete. Leaves usually much shorter than the culm; scales ovate-lanceolate, long-acuminate, purplebrown; bristles white or slightly yellowish, weak, nearly straight; " anthers cordate-ovate;" achene narrowly oblong, acute, brown, dull, subulate-beaked. In bogs, Newf. and Lab. to Manitoba, Alaska and Ore. Also in Europe. Summer.

4. Eriophorum russèolum Fries. RUSSET CotTon-GRAss. (I. F. f. 640.) Culms triangular, erect, smooth, longer than the leaves. Upper sheath inflated, bladeless, mucronate, or rarely with a short subulate blade usually borne below the middle of the culm; leaves filiform, triangular-channeled, mucronate, $2-10 \mathrm{~cm}$ long; spikelet erect; involucre none; scales ovate-lanceolate, acuminate, thin, purplish brown with nearly white margins; bristles numerous, bright reddish brown, 3-5 times as long as the scale; achene oblong, narrowed at each end, apiculate. Searcely differs from the preceding species except in the color of the bristles and the shorter-pointed achene. In bogs, Newf. to Quebec. June-Aug. 
5. Eriophorum polystàchyon L. TALl CotTon-GRAss. (I. F. f. 64I.) Culm stiff, smooth, obtusely triangular above, $0.4-0.9 \mathrm{~m}$. tall, all the sheaths bladebearing. Leaves flat, $38 \mathrm{~mm}$. wide, tapering to a channeled rigid tip, those of the involucre 2-4, the longer commonly equalling or exceeding the inflorescence; spikelets 3-12, drooping, in a terminal umbel; rays filiform, smooth or rough ; scales ovate-lanceolate, acute or acuminate, purple-green or brown ; bristles numerous, bright white, about $2.5 \mathrm{~cm}$. long, $4-5$ times as long as the scale; achene obovoid, obtuse, light brown. In bogs, Newf. to Alaska, south to N. J., Ga. and Neb. Also in Europe and Asia. June-Aug.

6. Eriophorum paucinérvium (Engelm.) A. A. Eaton. Few-Nerved Cot TON-GRASS. (I. F. f. 642, as E.gracile.) Culm slender, obtusely triangular, rough above on the angles, $0.4-1 \mathrm{~m}$. tall, the sheaths all blade-bearing. Leaves narrowly linear, 2-4 mm. wide, triangular-channeled, rough-margined; involucral leaf commonly only I, stiff, erect ; spikelets $3-8$, capitate or subumbellate, the longerpeduncled ones drooping; peduncles scabrous; scales ovate or oblong, obtuse or subacute, yellowish brown, the midvein rather strong, often with a weaker nerve on each side ; bristles numerous, bright white, $2-2.5 \mathrm{~cm}$. long, 4-6 times as long as the scale; achene linear-oblong, acute, pointed. In bogs, N. B. to N. J. and Ill. May-Aug.

7. Eriophorum grácile Koch. Slender Cotton-Grass. Culms slender, 3-7 dm. tall, terete or nearly so, smooth, with I or 2 triquetrous leaves $1.5-2.5$ $\mathrm{cm}$. long. Involucral leaves I or 2, short; spikelets usually 3 or 4 , sessile, or on smooth peduncles; scales ovate, or the inner lanceolate, obtuse, dark lead. colored ; bristles numerous, I-I.5 $\mathrm{cm}$. long. In bogs, Newf. to Wash., south to S. N. Y., Pa., Neb. and Cal. July-Sept.

8. Eriophorum Virgínicum L. Virginia Cotton-grass. (I. F. f. 643.) Culm stiff, obtusely triangular above, smooth, o.4-I. I m. tall, rather leafy. Leaves narrowly linear, flat, $2-5 \mathrm{~mm}$. wide, channeled toward the apex, those of the involucre 2-4, spreading or deflexed, 5-15 cm. long ; spikelets several or numerous in a dense terminal capitate cluster, erect or the outer spreading; scales ovate, acute, brown with a green centre, about 5 -nerved; bristles numerous, dingy brown, about 3 times as long as the scale; achene linear-oblong, acute, apiculate, light brown. In bogs, Newf. to Manitoba, Fla. and Neb. June-Sept.

\section{Eriophorum Virginicum álbum A. Gray. Bristles white. N. N. Y.}

\section{FUIRÈNA Rottb.}

Perennial sedges, with leafy triangular culms (in a southern species the leaves reduced to inflated sheaths), and many-flowered terete spikelets in terminal and axillary clusters, or rarely solitary. Scales spirally imbricated, awned, the I or 2 lower commonly empty. Flowers perfect. Perianth of 3 ovate oblong or cordate-ovate, stalked, often awned sepals, usually alternating with as many downwardly barbed bristles. Stamens 3. Style 3-cleft, not swollen at the base, deciduous. Achene stalked or nearly sessile, sharply 3-angled, acute or mucronate, smooth. (In honor of Georg Fuiren, 158I-1628, Danish physician.) About 20 species, natives of warm-temperate and tropical regions. Besides the following, I or 2 others occur in the southern United States.

Sepals awned from the apex or awnless. Sepals awned on the back below the apex.

x. F. squarrosa. 2. F. simplex.

I. Fuirena squarròsa Michx. Squarrose Fuirena. (I. F. f. 644.) Rootstock short, sometimes tuber-bearing; culms tufted, glabrous or nearly so, 5-50 $\mathrm{cm}$. tall. Leaves flat, nearly or quite glabrous or the lower sheaths pubescent; spikelets sessile and $\mathbf{I}$-1o together, capitate clusters, ovoid or ovoid-oblong, 6-12 $\mathrm{mm}$. long, about $5 \mathrm{~mm}$. in diameter; scales ovate or oblong, brown, pubescent, mostly obtuse, 3-nerved, tipped with a stout spreading or recurved awn of nearly their cwn length; sepals oblong, long-stalked, usually narrowed at both ends, the awn downwardly barbed or sometimes smooth; bristles mostly longer than the achene. In wet meadows and marshes, Mass. to.Fla. and La. near the coast. Also in Micl. and Neb. July-Sept. 
Fuirena squarrosa híspida (Ell.) Chapm. Sheaths and leaves hirsute; sepals ovate, cordate at the base or abruptly narrowed into the stalk, awnless or very short-awned at the apex; bristles usually shorter than or equalling the achene; plant usually taller. $\mathrm{N}$. Y. to Fla., Ala. and Tex.

2. Fuirena símplex Vahl. Western Fuirena. (I. F. f. 645.) Similar to the preceding species; culms I-5 dm. tall, glabrous. Leaves flat, glabrous or ciliate; scales tipped with a spreading or reflexed awn; sepals ovate-oblong, obtuse and usually notched at the apex, obtuse, truncate or subcordate at the base; awned on the back from below the apex, the awn smooth or downwardly barbed; bristles retrorsely hispid, equalling or exceeding the sessile or short-stalked achene. In moist soil, Neb. to Tex. and Mex. June-Sept.

\section{HEMICÀRPHA Nees \& Arn.}

Low tufted mostly annual sedges, with erect or spreading, almost filiform culms and leaves, and terete small terminal capitate or solitary spikelets subtended by a I-3-leaved involucre. Scales spirally imbricated, deciduous, all subtending perfect flowers. Perianth of a single hyaline sepal (bract?) between the flower and the rachis of the spikelet; bristles none. Stamens $\mathrm{x}-3$. Style 2-cleft, deciduous, not swollen at the base. Achene oblong, turgid or lenticular. [Greek, in allusion to the single sepal.] About 3 species, natives of temperate and tropical regions. Besides the following, another occurs in the southwestern U.S.

I. Hemicarpha micrántha (Vahl) Pax. Hemicarpha. (I. F. f. 646. Annual; glabrous; culms compressed, grooved, 2-10 cm. long, mostly longer than the setaceous smouth leaves. Spikelets ovoid, many-flowered, obtuse, about $2 \mathrm{~mm}$. long; involucral leaves usually much exceeding the spikelets; scales brown, obovate, with a short blunt spreading or recurved tip; stamen $\mathbf{I}$; achene obovateoblong, obtuse, mucronulate, little compressed, light brown. In moist, sandy soil, R. I to Penn., Neb, Fla., Tex. and Mex. July-Sept. [H. subsquarrosa Nees.]

Hemicarpha micrántha aristulàta Coville. Scales pale, cuneate-obovate, tapering into squarrose awns about their own length. Kans. to Tex.

\section{LIPOCÀRPHA R. Br.}

Low annual sedges, with slender tufted culms leafy at the base, and terete many-flowered spikelets in a terminal head, subtended by a 1 -several-leaved involucre. Scales firm, spirally imbricated, all fertile or several of the lower ones empty, at length deciduous. Flowers perfect. Perianth of two small sepals (bracts?) one on each side of the flower; bristles none. Stamens 1-2. Style 2-3-cleft, deciduous, its base not swollen. Achene plano-convex or 3-angled. (Greek, alluding to the thick sepals in some species.) About 7 species, widely distributed in warm and tropical regions.

I. Lipocarpha maculàta (Michx.) Torr. AMerican Lipocárpha. (I. F. f. 647.) Glabrous; culms grooved, compressed, smooth, longer than the narrowly linear somewhat channeled leaves, $7-25 \mathrm{~cm}$. tall. Leaves of the involucre 2-4; spikelets ovoid-oblong, obtuse, 5-6 mm. long, $2 \mathrm{~mm}$. in diameter, in a terminal capitate cluster; scales rhombic or lanceolate, acute, curved, the sides nearly white, or flecked with reddish-brown spots; exterior sepal convolute around the achene, nerved, hyaline: stamen I; achene oblong, yellowish, contracted at the base. In wet or moist soil, E. Va. to Fla. Also near Philadelphia, where it is probably adventive. July-Sept.

\section{RYNCHósPora Vahl. (See Appendix.).}

Leafy sedges, mostly perennial by rootstocks, with erect 3 -angled or terete culms, narrow flat or involute leaves, and ovoid oblong or fusiform, variously clustered spikelets. Scales thin, r-nerved, imbricated all around, usually mucronate by the excurrent midvein, the lower empty. Upper flowers imperfect, the lower perfect. Perianth of I-20 (mostly 6) upwardly or downwardly barbed or scabrous bristles, wanting in some species (no. 2). Stamens commonly 3. Style 2-cleft, 2-toothed or rarely entire. Achene lenticular or swollen, not 3-angled, smooth or transversely wrinkled, capped by the persistent base of the style (tubercle), or in 
some species by the whole style. [Greek, referring to the beak-like tubercle.] About 200 species, of wide geographic distribution, most abundant in warm regions. Besides the following, some .7 others occur in the southern U.S.

Style entire or 2-toothed, persistent as a long-exserted subulate beak.

Style deeply 2-cleft, only its base persistent as a tubercle.

Bristles minute or wanting.

Bristles plumose.

Bristles downwardly barbed or rarely smooth.

Scales white or nearly so; bristles 9-15.

Scales brown; bristles 6 .

Leaves filiform; achene oblong.

Leaves narrowly linear, flat; achene obovate.

1. R. corniculata.

Bristles equalling the achene; tubercle one-half as long or less.

6. R. Knieskernii.

Bristles reaching or exceeding the end of the tubercle, which is as long as the achene.

Spikelets few-several in numerous rather loose clusters.

Spikelets very numerous in 2-6 very dense globose heads.

7. R. glomerata.

8. R. axillaris.

Bristles upwardly barbed.

Spikelets very numerous in $2-6$ very dense globose heads.

Spikelets few-several in rather loose clusters.

Achene smooth.

Leaves setaceous; achene obovate, shining.

Leaves narrowly linear, flat; achene broadly oval, dull.

Achene transverse'y wrinkled.

8. R. axillaris.

Spikelets ovoid, in erect cymose clusters; achene longer than the bristles.

Leaves flat; spikelets nearly or quite sessile. Ir. R. cymosa.

Leaves involute; spikelets distinctly pedicelled.

12. R. Torreyana.

Spikelets spindle-shaped, in drooping panicles; achene shorter than the bristles.

13. $R$. inexpansa.

I. Rynchospora corniculàta (Lam.) A. Gray. HoRnen Rush. (I. F. f. 648.) Culm triangular, smooth, I-2 m. tall. Leaves flat, I.5-4.5 dm. long, 6$16 \mathrm{~mm}$. wide, rough-margined; umbels sometimes $2.5 \mathrm{dm}$. broad; spikelets spindleshaped, 8-12 $\mathrm{mm}$. long in flower, capitate at the ends of the rays and raylets; primary rays sometimes $15 \mathrm{~cm}$. long; scales lanceolate, thin, acute, light brown; bristles about 6, rigid, upwardly scabrous; style subulate, entire or minutely 2-toothed at the apex, 2-4 times longer than the achene, upwardly scabrous, I-2.5 cm. long, much exserted beyond the scales when mature; achene obovate, flat, $4 \mathrm{~mm}$. long, dark brown, smooth. In swamps, Del. to Fla., Ohio, Mo. and Tex. July-Sept.

Rynchospora corniculata macrostàchya (Torr.) Britton. Bristles about twice as long as the achene. Range of the type, but extending north to Mass.

2. Rynchospora pállida M. A. Curtis. Pale Beaked-Rush. (I. F. f. 649.) Rootstocks slender; culms triangular, $0.3-0.6 \mathrm{~m}$. tall. Leaves $\mathbf{I}-2 \mathrm{~mm}$. wide, nearly smooth, the lowest reduced to scales; spikelets numerous, spindle-shaped, 4-6 mm. long, aggregated in a compound terminal head, or occasionally also in a cluster from the upper axil; uppermost leaves subulate; scales pale greenish brown, lanceolate, acuminate ; bristles minute and early deciduous, or wanting; style 2cleft; achene lenticular, obovate-oblong, smooth, brown, shining, I mm. long, tipped by a short tubercle. In pine-barren bogs, N. J. to N. Car. Aug.-Sept.

3. Rynchospora oligántha A. Gray. FEW-FLOWERED BEAKED-RUSH. (I. F. f. 650.) Rootstocks short; culms almost thread-like, leafy toward the base, r.5-4 dm. tall. Leaves filiform; spikelets I-4, terminal, narrowly oblong, acute, 6-8 mm. long, subtended by I or 2 filiform bracts; scales ovate, pale brown, acute, cuspidate ; bristles usually 6 , densely plumose below the middle; style 2-cleft ; achene obovoid-oblong, obtuse, pale brown, dull, transversely wrinkled; tubercle 
with a flat depressed border and a flattened conic acute projection. In wet sandy soil, Del. to Fla. and Tex. June-Aug.

4. Rynchospora álba (L.) Vahl. White Beaked-Rush. (I. F. f. 651.) Pale green; rootstocks short; culms slender or filiform, glabrous, 1.5-5 dm. tall. Leaves bristle-like, $0.5-1 \mathrm{~mm}$. wide, shorter than the culm; spikelets in $\mathbf{1}-4$ dense corymbose clusters, narrowly oblong, acute at both ends, 4-6 mm. long; scales ovate or ovate-lanceolate, white, acute; bristles 9-15, downwardly barbed, slender, about as long as the achene and tubercle; style 2-cleft; achene obovate-oblong, smooth, pale brown, lenticular ; tubercle triangular-subulate, flat, one-half as long as the achene. In bogs, Newf. to Alaska, south to Fla., Ky., Minn. and Ore. Alsa in N. Europe and Asia. June-Aug.

5. Rynchospora capillàcea Torr. Capillary Beaked-Rush. (I. F. f. 652.) Culms filiform, glabrous. 1.5-5 dm. tall. Leaves filiform, less than $0.5 \mathrm{~mm}$. wide, much shorter than the culm; spikelets few, in I-3 loose clusters oblong, acute at both ends, 4-6 mm. long ; scales ovate-oblong, chestnut-brown, heeled, mucronate; bristles 6, slender, downwardly barbed; achene narrowly oblong, short-stalked, light brown, minutely wrinkled, lenticular ; style 2-cleft ; tubercle compressed, triangular-subulate, dark brown, about one-half as long as the achene. In bogs, Me. to Ont. and Minn., south to N. J., Penn. and Mich. July-Aug.

Rynchospora capillàcea laevisèta E. J. Hill. Bristles smooth. N. Ind. and Mich.

6. Rynchospora Knieskérnii Carey. Knieskern's Beaked-Rush. (I. F. f. 653.) Culms slender, smooth, 2-3.5 dm. tall. Leaves narrowly linear, flat, about I $\mathrm{mm}$. wide, much shorter than the culm; spikelets numerous, in several distant compact clusters, oblong, acute, about $2 \mathrm{~mm}$. long ; scales chestnut-brown, ovate ; bristles 6 , downwardly barbed, equalling the achene; achene obovate, lenticular, brown, minutely wrinkled; style 2 -cleft; tubercle triangular-subulate, pale, one-half as long as the achene or less. Pine barrens, N. J. to Va. July-Aug.

7. Rynchospora glomeràta (L.) Vahl. Clustered BEAKed-Rush. (I. F. f. 654.) Rootstocks slender; culms smooth, triangular, $0.3^{-1} \mathrm{~m}$. high. Leaves flat, $2-4 \mathrm{~mm}$. wide, rough-margined, shorter than the culm; spikelets, in 3-7 corymbose-capitate axillary clusters, oblong, narrowed at both ends, 3-4 mm. long; scales lanceolate, dark brown; bristles 6 , downwardly barbed; achene obovate, lenticular, smooth, dark brown; tubercle subulate, about as long as the achene. In moist soil, Me. to Ont., Mich., Fla. and Tex. July-Sept.

Rynchospora glomeràta paniculàta (A. Gray) Chapm. Culm stouter, sometimes I-I.I m. tall; leaves usually wider; spikelets numerous in compound clusters. Md. to Fla. and La.

Rynchospora glomeràta minor Britton. Culms very slender, $1.2-2.5 \mathrm{dm}$. tall ; leaves $0.5 \mathrm{~mm}$. wide or less; clusters 2 or 3 , small, with 3 -10 spikelets. Mass. and N. H.

Rynchospora glomerdta discùtiens Clarke. Bristles smooth, or barbed at the apex only. N. J. to N. Car.

8. Rynchospora axillàris (Lam.) Britton. (I. F. f. 655.) Culms stout, 3-angled, $0.5-1 \mathrm{~m}$. tall. Leaves flat, keeled, 2-3 mm. wide; spikelets spindle-shaped, 5-6 nım. long, numerous, in several short-peduncled axillary and terminal dense globose heads sumetimes $2 \mathrm{~cm}$. in diameter; scales dark brown, ovate-oblong, acute; bristles usually 6, downwardly or upwardly barbed; achene broadly obovate, brown, smooth, lenticular; tubercle subulate, about as long as the achene. In swamps, L. I. to Fla. and La. July-Sept.

Rynchospora axillàris microcéphala Britton. Heads 8-1o mm. in diameter : spikelets $3 \mathrm{~mm}$. long; achene one-half as large as that of the type. N. J. to Fla. and La.

9. Rynchospora fúsca (L.) R. \& S. Brown Beaked-Rush. (I. F. f. 656.) Rootstocks short; culms 3-angled, smooth, I.5-4.5 dm. tall. Leaves setaceous, channeled, scarcely $1 \mathrm{~mm}$. wide, much shorter than the culm; spikelets spindleshaped, acute, about $5 \mathrm{~mm}$. long, in 1-4 loose clusters; scales oblong-lanceolate, brown, shining, concave; bristles 6, upwardly barbed, often unequal; achene narrowly obovate, turgid-lenticular, smooth, shining; tubercle triangular-subulate, nearly as long as the achene. In bogs, N. B. to Del., west to Mich. Also in Europe. July-Aug. 
Io. Rynchospora gracilénta A. Gray. Slender Beaked-Rush. (I. F. 657.) Culms slender or filiform, smouth, $0.3-0.5 \mathrm{~m}$. tall. Leaves flat or becoming involute in drying, rather less than $2 \mathrm{~mm}$. wide, shorter than the culm; spikelets nasrowly ovoid, acute, $4 \mathrm{~mm}$. long, few, in I-4 loose clusters, the lower clusters filiform stalked; scales ovate, brown, mucronate; bristles 6 , upwardly barbed, equalling the achene and tubercle; achene broadly oval or nearly orbicular, dark brown, lenticular, dull, smooth; tubercle narrowly subulate, flat, widened at the base, pale, about as long as the achene. In pine-barren swamps, N. J. to Fla. and Tex. June-Aug.

I I. Rynchospora cymòsa Ell. Grass-Like Beaked-Rush. (I. F. f. ó58.) Light green; culms tufted, 3-angled, smooth, $0.3-0.5 \mathrm{~m}$ tall. Leaves flat, narrowly linear, grass-like, 3-4 $\mathrm{mm}$. wide or the basal ones broader; spikelets ovoidoblong, acute, $3 \mathrm{~mm}$. long, sessile or nearly so, capitate in 2's-7's on the ultimate branches of the axillary and terminal clusters; bracts setaceous; scales dark brown, broadly ovate; bristles 6, upwardly barbed, shorter than the achene; achene broadly obovate or oblong, lenticular, transversely wrinkled; style 2-cleft; tubercle conic, one-fourth to one-third as long as the achene. In moist soil, N. J. to Ky., Mo., Fla. and Tex. Also in Cuba. June Aug.

12. Rynchospora Torreyàna A. Gray. Torrey's BeAked-RUSH. (I. F. f. 659.) Culms terete or obscurely 3-angled, smooth, slender, 0.4-0.9 m. tall. Leaves involute, the lower 3-4 $\mathrm{mm}$. wide at the base, elongated, the upper bristlelike, distant; spikelets ovoid, $3 \mathrm{~mm}$. long, peduncled, numerous in r-4 loose dist.ınt clusters; scales brown, ovate, mucronate; bristles 6 , upwardly barbed, shorter than the oblong-obovate transversely wrinkled lenticular achene; style 2-cleft; tulercle flat, conic, one-fourth to one-third as long as the achene. In wet pine barrens, N. J. to S. Car. July-Aug.

13. Rynchospora inexpànsa (Michx.) Vahl. Noding Beakei)-Rush. (I. F. f. 660.) Rootstocks slender; culms smooth, slender. 3-angled, 0.5-0.9 m. tall. Leaves smooth, $2 \mathrm{~mm}$. wide or less, flat, the lower elongated, the upper bristle-like, remote; spikelets spindle-shaped, acute at both ends, about $6 \mathrm{~mm}$. long, numcrous in 1-4 narrow finally drooping panicles; scales brown, lanceolate, acuminate; bristles 6, upwardly hispid, very slender, about twice as long as the achene; achene narrowly oblong, transversely wrinkled; style 2-cleft; tubercle flat, trimgular-subulate, one-half as long as the achene. In moist soil, Va. to La. june-itug.

\section{CLÀDIUM P. Br.}

Perenniai leafy sedges, similar to the liynchosporas the spikelets oblong or fusiform, few-flowered, variously clustered. Scales imbricated all around, the lower empty, the middle ones mostly subtending imperfect flowers, the upper usually fertile. Perianth none. Stamens 2 or sometimes 3. Style 2-3-cleft, deciduous from the summit of the achene, its branches sometimes 2-3-parted. Achene ovoid to globose, smooth or longitudinally striate. Tubercle none. [Greek, referring to the branched inflorescence of some species.] About 30 species, natives of tropical and temperate regions. Besides the following, another occurs in C'alifornia.

Leaves about $2 \mathrm{~nm}$. wide; umbels small ; achene truncate at the base.

I. C. mariscoides. Leaves 6-20 mm. wide; umbels large, panicled; achene narrowed to the base.

2. C. effusum.

J. Cladium mariscoides (Mull.) Torr. Twig-Rush. (I. F. f. 661.) Culm slender, rather stiff, obscurely 3-angled, smooth, 0.3-0.9 m. tall. Leaves about 2 mm. wide, concave, with a long compressed tip, nearly smooth; umbels 2 or 3 , compound, small; spikelets oblong, narrowed at both ends, acute, $5 \mathrm{~mm}$. long, capitate on the raylets; scales chestnut-brown, ovate or ovate-lanceolate, acute; upper scale subtending a perfect flower with 2 stamens and a filiform 3-cleft style, the next lower one with 2 stamens and an abortive ovary; achene ovoid, acute, finely longitudinally striate, about $2 \mathrm{~mm}$. long. In marshes, N. S. to Ont and Minn.! south to Fla. and $\mathrm{Ky}$. July-Sept. 
2. Cladium effúsum (Sw.) Torr. Saw-grass. Culm stout, $1.5-3 \mathrm{~m}$. high, obtusely 3-angled. Leaves very long, glabrous, 6-20 $\mathrm{mm}$. wide, the margins spinulose-serrulate; umbels several or numerous, decompound, forming a large panicle; spikelets mostly 2-5 together at the ends of the raylets, narrowly ovoid, acute, 4-5 mm. long; uppermost scale subtending a perfect flower; stamens 2; achene ovoid, abruptly sharp-pointed, wrinkled, narrowed to the base, $2 \mathrm{~mm}$. long. In fresh water, southern Va. to Fla. and Tex. Also in the W. I. Aug.-Sept.

\section{SCLÈRIA Berg. (See Appendix.)}

Leafy sedges, mostly perennial, the spikelets small, clustered in terminal, or terminal and axillary fascicles, or sometimes interruptedly spicate. Flowers monoecious. Fertile spikelets I-flowered. Staminate spikelets many-flowered. Scales imbricated, the I-3 lower and sometimes also the upper ones of the fertile spikelets empty. Perianth none. Style 3-cleft, slender or sometimes swollen at the base, deciduous. Ovary supported on a disk (liypogynium), or this wanting. Stamens I-3. Achene globose or ovoid, obtuse, crustaceous or bony, white in our species. [Greek, in allusion to the hard fruit.] Alout roo species, natives of tropical and temperate regions. Besides the following, some 4 others occur in the southern U. S.

Spikelets in terminal, or terminal and lateral clusters; achene supported on a hypogynium.

Achene smooth.

Hypogynium supporting 8 or 9 small tubercles under the achene.

Hypogynium covered with a rough white crust.

I. S. oligantha.

Achene reticulated or irregularly rugose.

Culms erect or ascending; achene reticulated; leaves $2-3 \mathrm{~mm}$. wide.

Culms spreading; achene irregularly rugose ; leaves 4-8 $\mathrm{mm}$. wide.

3. S. reticularis.

4. S. Torreyana.

Achene papillose.

Spikelets interruptedly glomerate-spicate; no hypogynium.

5. S. pauciflora.

6. S. verticillata.

r. Scleria oligántha Michx. FEw-flowered Nut-Rush. (I. F. f. 662.) Rootstocks thick, hard, clustered. Culms slender, erect, sharply 3-angled, nearly smooth, $0.4-0.6 \mathrm{~m}$. tall. Leaves smootl or slightly rough at the apex, 4-6 mm. wide, the lower short, acute, the upper elongated; clusters terminal, usually also I or 2 axillary and filiform-stalked; bracts slightly ciliate or glabrous; achene ovoid, obtuse but sometimes pointed, bright white, smooth, shining; hypogynium a narrow obtusely triangular border supporting 8 or 9 small tubercles under the achene. In moist soil, Va. to Fla. and Tex., near the coast. June-Aug.

2. Scleria triglomerata Michx. TAll Nut-RUSH. (I. F. f. 663.) Rootstocks hard, clustered; culms 3-angled, 0.4-0.9 m. tall. Leaves flat, glabrous or nearly so, 3-5 mm. wide, the upper tapering to a long tip, rarely exceeding the culm; flower-clusters terminal, and usually also 1 or 2 smaller ones from the axils; achene ovoid or ovoid-globose, obtuse, bony. obscurely 3-angled, smooth, bri ht white, shining, about $2 \mathrm{~mm}$. high, supported on a low obtusely triangular, papillose-crustaceous hypogynium. In meadows and thickets, Vt. to Wis., Fla. and Tex. July-Sept.

Scleria triglomerata minor Britton. Culms very slender, $0.2-0.3 \mathrm{~m}$, long; flowerclusters smaller; achene ovoid, subacute, one-half as large as that of the type. S. N. J.

3. Scleria reticulàris Michx. Reticulated Nut-Rush. (I. F. f. 664.) Rootstocks small; culms slender, erect, 3-angled, 0.3-0.6 m. tall. Leaves narrowly linear, glabrous or nearly so, 2-3 mm. wide, not overtupping the culm; spikelets in a terminal cluster and I-3 remote axillary rather loose ones; bracts glabrous; achene globose, crustaceous, dull white when mature, reticulated, I $\mathrm{mm}$. in diameter, glabrous; hypogynium 3-lobed, its lobes appressed to the base of the achene. In moist meadows, E. Mass. to Fla., west to Mo. Also in Cuba. JulySept. 
Scleria reticularis pubéscens Britton. Reticulations on the achene pubescent; lateral clusters usually longer stalked. Conn. to Fla. and Cuba.

Scleria reticularis obscura Britton. Reticulations very obscure, the top of the achene almost smooth. K. I. to N. Car.

4. Scleria Torreyàna Walp. Torrey's Nut-Rush. (I. F. f. 665.) Culms weak, spreading or diffuse, 3-angled, nearly or quite smooth, $0.3-0.6 \mathrm{~m}$. long. Leaves linear, nearly flat, glabrous, 3-8 mm. wide, not exceeding the culm; spikelets in a loose terminal cluster, and I-3 filiform-stalked axillary ones; bracts glabrous; achene globose, somewhat pointed, nearly $2 \mathrm{~mm}$. in diameter, irregularly rugose with low ridges, the ridges usually pubescent, and connected by shorter longitudinal ones; hypogynium 3-lobed, the lobes appressed to the base of the achene. In moist soil, S. N. J. to Fla., Tex. and Mex. Also in Cuba. June-Aug.

5. Scleria paucifiòra Muhl. Papillose Nut-RUsh. (I. F. f. 666.) Rootstocks hard, clustered ; culms slender, erect, usually tufted, 3-angled, 2-5 dm. tall. Leaves narrowly linear, less than $2 \mathrm{~mm}$. wide, the upper elongated and often overtopping the culm, their sheaths often densely puberulent ; spikelets in a small terminal cluster and sometimes also in I or 2 axillary ones; achene oblong or globular, I mm. in diameter or rather more, crustaceous, papillose, the lower papillae elongated and reflexed; hypogynium a narrow obtusely triangular border supporting 6 small tubercles. In dry soil, N. H. to Ohio, Mo., Fla, and Tex. Also in Cuba. June-Sept.

6. Scleria verticillàta Muhl. Low Nut-RusH. (I. F. f. 667.) Roots fibrous ; culms very slender or filiform, 3 -angled, smooth or nearly so, erect, I-5 dm. tall. Leaves very narrowly linear, $0.5-1 \mathrm{~mm}$. wide, erect, shorter than the culm ; spikelets in several separated clusters; bracts bristle-like; scales glabrous; achene globose, I mm. in diameter, crustaceous, marked by sharp distinct transverse ridges, or somewhat reticulated; hypogynium none. In moist meadows, E. Mass. to Ont. and Mich., south to Fla., Tex. and Mex., and in the W. I. Plant, especially the roots, fragrant in drying. July-Sept.

\section{ELỲNA Schrad.}

Low tufted artic and mountain sedges, with erect slender mostly leafless culms, the narrowly linear leaves clustered at the base, and small 2 -flowered spikelets in a narrow terminal cylindric spike. Scales of the spikelet 3 or 4 , distinct, usually only one of them flower-bearing; the staminate flower of 3 stamens, the pistillate of a single pistil. Bristles or perianth wanting. Style slender, 3-cleft, not jointerl to the oblong ovary. Achene obtusely 3-angled, sessile. [Greek, signifying covering, perhaps in allusion to the overlapping scales.] Four or five species of the arctic and alpine regions of the northern hemisphere.

I. Elyna Bellàrdi (All.) C. Koch. (I. F. f. 668.) Culms very slender, 1-4.5 dm. tall, longer than the very narrow leaves. Old sheaths fibrillose, brown; margins of the leaves more or less revolute; spike subtented by a short bract, or bractless, densely flowered or sometimes interrupted below, $1.5-3 \mathrm{~cm}$. long, 3-4 $\mathrm{mm}$. in diameter; achenes rather less than $2 \mathrm{~mm}$. long, $1 \mathrm{~mm}$. thick, appressed. In arctic America from Greenl. to Bering Sea, south in the Rocky Mountains to Cols. Also in Europe and Asia. Summer.

\section{KOBRESIA Willd. (See Appendix.)}

Slender arctic and mountain sedges, with erect culms leafy below, and few-several. flowered spikelets clustered in a terminal spike. Scales of the spikelets I-flowered. the lower usually pistillate, and the upper staminate. Stamens 2-3. Perianthbristles or perigynium wanting. Ovary oblong, narrowed into a short style: stigmas 2-3 linear. Achene obtusely angled, sessile. [In honor of Von Kobres, a naturalist of Augsburg.] Three or four species, widely distributed in arctic and mountainous regions.

I. Kobresia bipartita (All.) Britton. (I. F. f. 669.) Culms solitary or tufted, smooth or very nearly so, $\mathbf{I}-3 \mathrm{dm}$. tall. Leaves about $\mathbf{I} \mathrm{mm}$. wide, infolded at least in drying, the old sheaths becoming fibrillose; spike $3 \mathrm{~cm}$. long or less, cor.posed of several or numerous linear appressed or ascending spikelets; scales somewhat serrulate on the keel, rather more than I mm. long; mature achenes slightly 
longer than the scales. Greenland to the Canadian Rocky Mountains. Also in Europe and Asia. Summer. [K. caricina Willd.]

\section{UNCÍNIA Pers.}

Culms erect, leafy, or the leaves all basal. Spike simple, erect, terminal, the scales imbricated, I-flowered, the lower pistillate, the upper staminate. Scales ovate or oblong, concave, not keeled, obtuse or the lower acute. Stamens 3, rarely I or 2. Pistil enclosed in a utricle (perigynium), borne at the base of a slender axis, which is usually exserted beyond the orifice of the perigynium, at least in fruit, and sometimes hooked. Stigmas mostly 3. Achene 3-angled. [Latin, referring to the hooked axis of the southern species.] About 30 species, all but the following natives of the southern hemisphere.

I. Uncinia microglòchin (Wahl.) Spreng. Northern Uncinia. (I. F. f. 670.) Perennial by short stolons; culms very slender, weak, I-3 dm. long. Leaves I-2 mm. wide, much shorter than the culm; spike 8-16 mm. long, usually pistillate for more than one-half its length; scales oblong-lanceolate, I-nerved, deciduous; perigynia narrowly lanceolate, $6-8 \mathrm{~mm}$. long, less than $1 \mathrm{~mm}$. thick, reflexed in fruit; achene oblong, obtusely 3 -angled, much shorter than the perigynium; axis of the pistillate flower bristle-like, long-exserted beyond the orifice of the perigynium. Greenland to James Bay and Br. Col. Also in the arctic and mountainous parts of Europe and Asia and at the Strait of Magellan. Summer.

\section{CÀREX L. (See Appendix )}

Grass-like sedges, perennial by rootstocks. Culms mostly 3-angled. Leaves 3ranked, the upper elongated or very short (bracts) and subtending the spikes of flowers, or wanting. Flowers monoecious or dioecious, solitary in the axils of bracts (scales). Spikes either wholly pistillate, wholly staminate, or bearing both staminate and pistillate flowers (androgynous). Perianth none. Staminate flowers of 3 stamens, the filaments filiform. Pistillate flowers of a single pistil with a style and 2 or 3 stignas, borne on a very short axis in the axil of a sac-like bractlet or second bract called the perigynium (utricle), which completely encloses the achene. Achene 3-angled, lenticular or plano-convex. A vast genus, of more than 1000 species, widely distributed, most abundant in the temperate zones. Besides the following about an equal number occur in the western and southern parts of N. A. Specimens can only be satisfactorily determined when nearly or quite mature.

I. Staminate flowers numerous, in onc or more terminal spikes, which are some. times pistillate at the base or summit; or the spike solitary and the staminate flowers uppermost or basal, rarely diccious; stigmas mostly 3 and the achene 3 -angled or swollen (stigmas 2 and the achene lenticular or compressed in nos. 12-16; 49-59; 67-72); pistillate spikes stalked or sessile, the lower commonly stalked. Nos. I-142. EUCAREX.

A. Perigynia mostly long-beaked, 3-20 mm. long, often inflated, the beak usually as long as the body or longer (short-benked in Nos. I1-I6, 34 and 35); pistillate spikes mostly large (small in nos. I, 13 and 14), globose, ovoid, oblong or cylindric. Nos. $\mathrm{r}-35$.

Perigynia membranous or papery. Nos. I-3I.

Spike solitary, few-flowered, staminate above; perigynia strongly reflexed, subulate. PAUCIFLORAE. [p. 19o.]

I. C. paucifora.

Spikes normally several, the staminate uppermost ; if solitary, staminate at the base. (See no. 30.) Nos. 2-31.

Perigynia ovoid, conic with a narrowed base, or subulate, tapering into the beak. Nos. 2-28.

Teeth of the perigynium-beak slender, short or none, not stiff nor awned. Nos. 2-24.

Teeth of the perigynium-beak lanceolate or subulate. Nos. 2-10. LUPULINAE. [p. I9I.]

Teeth of the perigynium-beak short or almost wanting (long in No. I 7) nos. II-24. VESICARIAE. [P. 192.]

Teeth of the perigynium-beak stiff, setaceous or awned. Nos. 25-28. PSEUDOCYPERAE. [p. 195.]

Perigynia obovoid, very abruptly contracted into the beak; spikes exceedingly dense. Nos. 29-3i. SQuarrosae. [p. rg6.]

Perigynia firm, hard or leathery. Nos. 32-35. PaludosaE. [p. Ig6.] 
B. Perigynia short-beaked or beakless, little or not at all inflated, $x-5 \mathrm{~mm}$. long, the beak coinmonly not more than one-half as long as the body (long-beaked in Nos. 43, 82, $83.96)$; spikes small and oblong or globose; or elongated, linear or narrowly cylindric. Nos. 36-142.

Spikes 2 or more, the staminate one always uppermost, sometimes partly pistillate. (No. 140 may be looked for here.) Nos. 36-132.

Pistillate spike or spikes many-flowered, mostly $2.5 \mathrm{~cm}$. long or more (or shorter in Nos. $44,48,53-55,61,63-65,73,75,76,85,89-92)$, linear, narrowly cylindric or oblong. Nos. $36-92$.

Perigynia with a straight short beak (long-beaked in No. 43 ; nearly beakless in No. 36 ), firm or leathery in texture; pistillate spikes erect (or nodding in No. 37) ; stigmas 3. Nos. 36-43. [p. 197.]

Perigynia beakless or very short-beaked (see No. 36 ), and with orifices nearly or quite entire, thin in texture, not inflated, closely investing the achene; pistillate spikes erect or drooping, often brown or purple; stigmas often 2 . Nos. 44-72.

Pistillate spikes erect or somewhat spreading (drooping when mature in No. 45). Nos. 44-58. [p. 199.]

Pistillate spikes drooping, mostly on slender or filiform stalks (erect in Nos. 66 and 71). Nos. 59-72. [p. 201.]

Perigynia tapering to a distinct beak (nearly or quite beakless in Nos. 73-77), menibranous in texture (firm in No. 88), inflated or lonsely investing the achene; pistillate spikes mostly drooping, often narrowly linear. Nos. $73-92$.

Terminal spike staminate below, pistillate above; beak of the perigynium short or none. Nos. 73-8r.

Spikes all erect or nearly so. Nos. 73-76. Virescentes. [p. 204.]

Pistillate spikes drooping or spreading (erect or little spreading in No. 78). Nos. 77-8I. Gracillimae. [p. 205.]

Terminal spike entirely staminate, or sometimes pistillate at the base. Nos. 82-92. [p. 206.] (See No. 140.)

Pistillate spikes small, few-many-flowered, mostly 6-25 mm. long (sometimes longer in Nos. 103, 104, 116). Nos. 93-132. (See also Nos. 44, 48, 53-55, 61, 63-65, $68,73,75,80,84,85$ and $89-92$.

Perigynia glabrous. Nos. 93-120. [p. 208.] (See No. 123.)

Pistillate spikes many-flowered, 6-25 mm. long, usually dense. Nos. 93-99.

Pistillate spikes few-several-flowered, often loose. Nos. I00-120; $136-138$.

Perigynia more or less pubescent (becoming glabrous in No. 123). Nos. 121132. [p. 213.]

Spike solitary (except in No. 140), sometimes diœcious. Nos. 133-142. [p. 215.]

11. Staminate flowers few, at the summits or bases of the always sessile spiles, or sometimes forming whole spikes, or variously intermixed with the pistillate: stigmas always 2; achene lenticular, compressed, ellipsoid or plano-convex. Nos. 143-205. VIGNEA.

Staminate flowers at the summits of the spikes. Nos. 143-1 73 .

Spike solitary, termtnal, mostly brown, plants often diœcious. Nos. 143-146. DiolCaE. [p. 217.$]$

Spikes several or many, clustered, separated or sometimes panicled. Nos. $147-15$.

Spikes densely aggregated into a globose or ovoid head, often appearing like a solitary terminal spike. Nos. 147-15I [p. 218.]

Clusters of spikes looser, often compound or the spikes distinctly separated (mo:e or less aggregated in Nos. 170-173). Nos. $15^{2-1} 73$.

Spikes yellowish or brown at maturity, often in compound or panicled clusters. Nos. 152-163. [p. 218.]

Spikes green or greenish when mature, aggregated or separated, in simple clusters. Nos. 164-173. MuhlenbergianaE. [p. 220.]

Staminate flowers variously mingled with the pistillate in the spikes or occasionally forming whole spikes. (See Nos. 143-146.)

Perigynia radiately spreading or reflexed.

Perigynia erect or appressed.

Perigynia wingless, the inner face flat.

Perigynia winged, the inner face concave.

174. C. sterilis.

187. C. bromoides. 190. C. siccata.

Staminate flowers at the bases of the spikes. Nos. 174-205.

Perigynia without a marginal wing. Nos. 174-187. Elongatae. [p. 222.]

Perigynia with a narrow or broad marginal wing. Nos. 188-205. Ovales. [p. 225.]

I. Carex pauciflòra Lightf. Few-Flowered Sedge. (I. F. f. 671.) Glabrous; culms slender, $0.7-5 \mathrm{dm}$. high. Leaves very narrow, shorter than the culm, spike 
androgynous, the staminate and pistillate flowers each 2-5; perigynium green, narrow, scarcely inflated, 6-8 mm. long, about I mm. in diameter, several-nerved, tapering into a slender or almost subulate beak, strongly reflexed and readily detachable when mature, 2-3 times longer than the deciduous lanceolate or ovate scale; stigmas 3. In bogs, Newf. to Alaska, Mass., Penn., Mich. and Wash. June-Aug.

Pistillate spikes ovoid or globose, few-many-flowered.

Perigynia subulate, reflexed when mature.

2. C. Collinsii.

Perigynia conic or ovoid, not reflexed.

Plants yellow or yellowish; perigynia little inflated.

Leaves 2-4 mm. wide; staninate spikes sessile.

3. C. abacta.

Leaves 4-12 mm. wide; staminate spike mostly stalked. 4. C. folliculata.

Plants green; perigynia much inflated; staminate spike stalked.

Leaves $4-6 \mathrm{~mm}$. wide; heads loosely flowered.

Leaves 6-1o mm. wide; heads globose, dense.

5. C. intumescens.

6. C. Asa-Grayi.

Pistillate spikes oblong or cylindric, densely many-flowered.

Pistillate spikes oblong; achene longer than thick.

Perigynia several-nerved, shining; leaves 2-4 mm. wide.

Perigynia many-nerved, dull ; leaves 4-10 $\mathrm{mm}$. wide.

Pistillate spikes cylindric ; achene not longer than thick.

.Yerigynia yellowish, tapering into a beak twice as long as the body.

7. C. Louisianica.

8. C. Iupulina.

9. C. lupuliformis.

Perigynia greenish-brown, abruptly narrowed into a beak 2-3 times as long as the body.

Io. C. grandis.

2. Carex Collínsii Nutt. Collins' Sedge. (I. F. f. 672.) Glabrous; culms slender, erect or reclining, $1.5-5 \mathrm{dn}$. long. Leaves narrow, the broadest about $5 \mathrm{~mm}$. wide; staminate spike stalked; pistillate spikes 2-4, distant, 2-8-flowered; bracts similar to the leaves; perigyriia light green, scarcely inflated, subulate, $\mathbf{I}-\mathbf{I} .4 \mathrm{~cm}$. Inng, tapering into an almost filiform beak, faintly many-nerved, strongly reflexed when mature, about 3 times as long as the lanceolate-acuminate persistent scale; stigmas 3. In bogs, R. I. to E. Penn. and Ga. June-Aug.

3. Carex abácta Bailey. Yellowish SEDGE. (I. F. f. 673.) Glabrous, yellowish; culm rather stiff, slender, $0.2-0.5 \mathrm{~m}$. high. Leaves narrow, the broadest about $4 \mathrm{~mm}$. wide, the uppermost often exceeding the culm; staminate spike sessile; pistillate spikes 2 or 3, several-flowered, the upper sessile or very nearly so; bracts similar to the leaves; perigynia slender, narrow, scarcely inflated, tapering into a subulate 2 -toothed beak, I-I.5 $\mathrm{cm}$. long, less than $2 \mathrm{~mm}$. thick, strongly manynerved, about twice as long as the acute or acuminate scale. In bogs and wet meadows, Newf. to N. H., N. Y. and Mich. Also in Japan. July-Sept.

4. Carex folliculàta L. Loxg Sedge. (I. F. f. 674.) Glabrous; light green or yellowish; culm erect or reclining, $0.4-1 \mathrm{~m}$. long. Leaves elongated, often $12 \mathrm{~mm}$. wide; pistillate spikes 2-4, usually distant, all except the uppermost slender-stalked, the lower often nodding; bracts commonly overtopping the spikes; perigynia ovoid, somewhat inflated, green, rather prominently many-veined, I2 $16 \mathrm{~mm}$. long, about $2 \mathrm{~mm}$. in diameter near the base, tapering from below the middle into a slender 2 -toothed beak, longer than the awned scarious-margined persistent scale; teeth of the perigynium nearly erect; stigmas 3 . In swamps and wet woods, Newf. to Md., Mich. and IV. Va. Probably extends further south, but there mostly represented by the var. Australis Bailey. May-Sept.

5. Carex intuméscens Rudge. Bladder Sedae. (I. F. f. 675.) Glabrous; culms slender, commonly tufted, $0.4-0.9 \mathrm{~m}$. high. Leaves elongated, dark green, roughish, 3-6 $\mathrm{mm}$. wide; bracts similar, overtopping the culm; staminate spike mostly long-stalked; pistillate spikes I-3, sessile or short-stalked, globose or ovoid; perigynia I-30, spreading or the upper erect, $12-20 \mathrm{~mm}$. long, much inflated, about $6 \mathrm{~mm}$. in diameter above the base, many-nerved, tapering into a subulate 2 -toothed beak, the teeth somewhat spreading; scales narrowly lanceolate, acuminate or aristate, about one-half as long as the perigynia; stigmas 3 . In swamps, bogs and wet woods, Newf. to Manitoba, Fla. and La. May-Oct.

Carex intuméscens Fernáldi failey. Perigynia narrower, I-5 in each spike, all erect or slightly spreading. Me. to X. I'. and Mass.

6. Carex Asa-Gràyi Bailey. Gray's Sedge. 
similar to the upper leaves, usually mucl overtopping the culm; staminate spike mostly long-stalked; pistillate spikes I or 2, dense, about $2.5 \mathrm{~cm}$. in diameter: perigynia 10-30, ovoid, glabrous or pulescent. much inflated, nıany-nerved, about $8 \mathrm{~mm}$. in diameter, tapering to a sharp 2-toothed beak; scales ovate or lanceolate, acuminate or cuspidate, scarious, about one-third as long as the perigynia; stigmas 3. In swamps and wet meadows, Vt. to Mich., Ga. and Mo. June-Sept.

7. Carex Louisiánica Bailey. Louisiana Sedge. (I. F. f. 677.) Culms slender, smooth or nearly so, $0.2-0.5 \mathrm{~m}$. tall. Leaves $2-4 \mathrm{~mm}$. wide, roughish, the upper overtopping the spikes; pistillate spikes I-3, oblong, about $2.5 \mathrm{~cm}$. long, I. 5-2 cm. thick, erect, the lower slender-stalked, the upper nearly sessile; staminate spike long-stalked; perigynia ovoid, much inflated, smooth, strongly severalnerved, shining, 10-12 $\mathrm{mm}$. long, alout $5 \mathrm{~mm}$. in diameter at the rounded base, tapering into the long 2-toothed beak, the small teeth slightly spreading; scales oblong-lanceolate, acuminate, about one-half as long as the perigynia; stigmas 3 . Swamps, Mo. to Tex. and Fla. June-Aug.

8. Carex lupulina Muhl. Hop SEDGE. (I. F. f. 678.) Glabrous; culms stout, 0.3-1 m. tall. Leaves elongated, nodulose, 5-12 mm. wide, the upper ones and the similar bracts much overtopping the culm; staminate spike solitary or rarely several; pistillate spikes 2-5, densely many-flowered, oblong, $2.5 \mathrm{~cm}$. long, often 3-6 cm. in diameter; perigynia often short-stalked, much inflated, many-nerved, 12-15 $\mathrm{mm}$. long, about $3 \mathrm{~mm}$. in diameter above the base, tapering from below the middle into a subulate 2-toothed beak; achene longer than thick; scales acuminate or aristate, one-third as long as the perigynia; stigmas 3. In swamps and ditches, Hudson Bay to W. Ont., Iowa, Fla. and 'Tex. June-Aug.

Carex lupullna Bélla villa (Dewey) Bailey. Culm slender; pistillate spikes remote, slender-stalked, sometimes staminate at the summit, the perigynia widely spreading, the staminate spike sometimes branched and with $\mathrm{I}$ or 2 perigynia at its base. E. N. Y. to S. Ont.

A hybrid with $C$. retrorsa is described.

9. Carex lupulifórmis Sartwell. Hop-Like Sedge. (I. F. f. 679.) Glabrous; culm stout, erect, $0.3^{-1} \mathrm{~m}$. tall. Leaves and bracts similar to those of the preceding species; staminate spike stalked or nearly sessile, sometimes $10 \mathrm{~cm}$. long; pistillate spikes $3-6$, densely many-flowered, $5-8 \mathrm{~cm}$. long, $\mathbf{I}-2 \mathrm{~cm}$. in diameter, often staminate at the top; perigynia yellowish, sessile, much inflated, severalnerved, I-I.6 cin. long, about $4 \mathrm{~mm}$. in diameter above the base, tapering from below the middle to a subulate 2-toothed beak; achene as long as thick, its angles mamillate; scales lanceolate, awned, shorter than or equalling the perigyria. Swamps, Mass. to Del., Ont. and Minn. June-Aug.

Ic. Carex grándis Bailey. LARge Sedge. (I. F. f. 680.) Glabrous; culms slender, $0.5-0.9 \mathrm{~m}$. high. Leaves rather dark green, elongated, 8-12 $\mathrm{mm}$. wide; bracts similar to the leaves, much overtopping the culm; staminate spike sometimes bearing perigynia at its base; pistillate spikes 3-5, all stalked or the upper sessile, cylindric, $2-7.5 \mathrm{~cm}$. long; perigynia much swollen at the base, about $4 \mathrm{~mm}$. in diameter, 10-12 mm. long, many-nerved, spreading at maturity, 3-4 times as long as the scarious lanceolate acuminate or aristate scale, abruptly contracted into a subulate 2-toothed beak 2-3 times as long as the inflated portion; stigmas 3 . In swamps, Del. to Ky. and Mo., Fla., La. and Tex. June-Aug.

Spikes small, $2.5 \mathrm{~cm}$. long or less, oblong or subglobose; stigmas often 2.

Spikes green or greenish yellow.

Leaves involute; perigynia ovoid; pistillate spikes few-several-flowered. II. $C$. oligosperma.

Leaves flat; perigynia oblong-elliptic; pistillate spikes many-flowered.

Spikes dark brown or purple; arctic species. 12. C. Mainensis.

Leaves flat.

Perigynia little inflated, papery.

Beak of perigynium nearly or quite entire. I3. C. miliaris. Beak of perigynium sharply and minutely 2-toothed.

Perigynia much inflated, very fragile. Leaves involute when dry.

I4. C. saxatilis. I5. C. membranopacta. I6. C. ambusta. 
Spikes large, 2-15 cm. long, cylindric or oblong-cylindric; stigmas 3 .

Scales acute, acuminate or smooth-awned, or the lower slightly roughened.

Perigynia ascending or spreading, not reflexed.

Spikes narrowly cylindric, $2-15 \mathrm{~cm}$. long, 6-8 mm. thick.

Leaves 4-12 mm. wide; culm stout.

Leaves $2-5 \mathrm{~mm}$. wide; culm slender.

17. C. utriculata.

18. C. monile.

Spikes cylindric or oblong-cylindric, $2-5 \mathrm{~cm}$. long, $12 \mathrm{~mm}$. thick.

Scales smooth-awned.

Scales acute, acuminate or the upper obtuse. 20. C. bullata.

Perigynia, at least the lower ones, reflexed when mature.

Spikes all clustered at the summit or the lower 1 or 2 separated; perigynia all reflexed when old.

21. C. retrorsa.

Spikes scattered; only the lower perigynia reflexed. 22. C. Hartii.

Scales tapering into rough awns, or subulate and scabrous.

Spikes cylindric, about $12 \mathrm{~mm}$. thick; perigynia tapering into the beak. 23. C. lurida.

Spikes narrowly cylindric, $6-8 \mathrm{~mm}$. thick; perigynia abruptly narrowed into the beak.

24. C. Baileyi.

I I. Carex oligospérma Michx. Few-Seeded Sedge. (I. F. f. 68I.) Glabrous; culms slender, $0.4-0.9 \mathrm{~m}$. tall. Leaves about $3 \mathrm{~mm}$. wide, involute when old: bracts similar, overtopping the culm; staminate spike stalked; pistillate spikes I or 2, I-2 cm. long, sessile or the lower short-stalked, the upper sometimes reduced to I or 2 perigynia and with a staminate summit; perigynia ovoid, erect. inflated, strongly few-nerved, yellowish green, 4-5 $\mathrm{mm}$. long, tapering into a minutely 2 -toothed beak; scales acute or mucronate, shorter than the perigynia; stigmas 3. In bogs, Newf. to the N. W. Terr., Mass., Penn. and Mich. June-Sept.

I2. Carex Mainénsis Porter. Marne SeDGe. (I. F. f. 682.) Culm stouter than that of $C$. miliaris, rough above, $0.4-0.9 \mathrm{~m}$. tall. Leaves $2-3 \mathrm{~mm}$. wide, flat, shorter than the culm, the lower bracts narrower, staminate spikes I-4, slenderstalked; pistillate spikes I-3, erect, cylindric or oblong, I-2.5 cm. long, sessile or the lower short-stalked; perigynia oblong-ellıptic, yellowish green, few-nerved, acute, narrowed into a 2 -tonthed beak; scales lanceolate, acute or acuminate, yellowish or brownish margined, slightly shorter than the perigynia; stigmas 2 or 3. On lake and river shores, Me. to Lab. Summer. (C. Raeana of Ill. Fl. not of Boott.) Perhaps a hybrid of the following with $C$. monile.

13. Carex miliaris Michx. Northeastern Sedge. (I. F.f. 683.) Glabrous; culm slender, roughish above. $0.2-0.5 \mathrm{~m}$. tall. Leaves, flat, about $2 \mathrm{~mm}$. wide, elongated, nodulose; bracts similar to the leaves, often overtopping the culm; staminate spikes I or 2, stalked, narrowly linear; pistillate spikes I-3, oblong or linearoblong, many-flowered, 8-25 mm. long, the upper sessile, the lowest, when three, stalked; perigynia ovoid, faintly few-nerved, 2-3 mm. long, dark brown or browntipped, tapering into a short, nearly entire beak, slightly longer than the wholly or partly brown scale; stigmas 2. Borders of lakes and streams, Lab. to Me. Reported from N. Minn. Summer.

The var. major Bailey is perhaps distinct.

I4. Carex saxatilis L. Russet SEDGE. (I. F. f. 684.) Glabrous; culms slender, 7-25 cm. tall. Leaves flat, $2-3 \mathrm{~mm}$. broad; bracts short; staminate spike short-stalked; pistillate spikes I-4, all stalked or the upper nearly or quite sessile, oblong, densely many-flowered; perigynia dark purple-brown, ovoid, nerveless or faintly few-nerved, tipped with a short minutely 2-toothed beak; scales oblong, subacute, greenish purple, about as long as the perigynia; stigmas usually 2 . Greenland to James Bay and Alaska. Also in arctic Europe and Asia. Summer.

I5. Carex membranopácta Bailey. Fragir.e SEDGE. (I. F. f. 685.) Similar to $C$. saxatilis but stouter and taller, $1.5-4.5 \mathrm{dm}$. high. Leaves flat, not exceeding the culm, $3 \mathrm{~mm}$. wide; bracts short; staminate spikes I-3, short-stalked; pistillate spikes commonly 2, sessile or the lower short-peduncled, narrowly oblong, obtuse, about $2.5 \mathrm{~cm}$. long and $8 \mathrm{~mm}$. in diameter; perigynia spreading, brown-purple, ovoid, fragile, much inflated, about $3 \mathrm{~mm}$. long, tipped with a short nearly entire beak, about as long as the ovate-oblong greenish-purple or white-margined scales. Greenland, through arctic America to Kamptchatka. Summer.

I6. Carex ambústa Bortt. Blackened Skdie. (I. F. f. 686.) Similar to C. saxatilis; culms $2-4.5 \mathrm{dm}$. tall. Leaves mostly less than $2 \mathrm{~mm}$. wide, involute 
in drying; bracts similar to the upper leaves; staminate spike stalked; pistillate spikes I or 2, erect, obtuse, I2-18 mm. long, about $7 \mathrm{~mm}$. in dianeter; perigynia oblong-lanceolate, $3 \mathrm{~mm}$. long, biconvex, smorth, firm, not inflated, dull, few-nerved at the base, green below, dark brown at the sumnit, tapering into a short minutely 2-toothed beak; stigmas 2. Lab., Br. Col. to Alaska. Summer.

I7. Carex utriculàta Boott. BotTle SedGe. (I. F. f. 687.) Glabrous; culms erect, 0.4-I m. tall. Leaves elongated, nodulose, 4-12 mm. wide; bracts overtopping the culm; staminate spikes 2-4, linear, stalked; pistillate spikes 3 or 4, nearly erect, cylindric, usually densely many-flowered, $5-15 \mathrm{~cm}$. long, the lower short-stalked, the upper sessile; perigynia ovoid, light green, somewhat inflated, few-nerved, 4-5 mm. long, narrowed into a sharp 2-toothed beak; scales lanceolate, the lower awued and slightly longer than the perigynia. Marshes, Anticosti to Br. Col., Del., Ohio, Minn., Nev. and Cal. June-Sept.

I8. Carex monile Tuckerm. Necklace Sedge. (I. F. f. 688.) Glabrous; culm slender, o.3-I m. tall. Leaves elongated, rather light green, 3-5 mm. wide, little or not at all nodulose; staminate spikes I-4, slender-stalked; pistillate spikes I-3, erect-spreading, cylindric, 2-8 cm. long, 5-8 $\mathrm{mm}$. in diameter, rather loose at maturity, the upper sessile, the lower one, when 3 , slender-stalked; perigynia yellowish green, ovoid, inflated, about $5 \mathrm{~mm}$. long, rather strongly 8-10nerved, tapering into a sharp 2 -toothed beak; scales lanceolate, acuminate or awned, shorter than the perigynia. In marshes and wet meadows, N. S. to Br. Col., N. J., Mo., Colo. and Cal. June-Aug.

19. Carex Tuckermàni Dewey. Tuckerman's Sedge. (I. F. f. 689.) Glabrous: culm slender, usually roughish above, erect or reclining, $0.5^{-1} \mathrm{~m}$. long. Leaves and bracts much elongated, 3-5 mm. wide; staminate spikes 2 or 3 ; pistillate spikes cylindric, 2-5 cm. long, about $1.2 \mathrm{~cm}$. in diameter; the upper sessile or nearly so, the lower stalked; perigynia very much inflated, yellowish green, ovoid, few-nerved, abruptly contracted into a subulate 2 -toothed beak; scales lanceolate, awned, about half as long as the perigynia. In bogs and meadows, N. B. to Ont., Minn., N. J. and Iowa. June-Aug.

20. Carex bullàta Schk. ButTon SedGe. (I. F. f. 69o.) Glabrous; stoloniferous; culms slender, $0.3-0.6 \mathrm{~m}$. high, roughish. Leaves and bracts very narrow and elongated, rarely more than $4 \mathrm{~mm}$. wide, rough-margined; staminate spikes mostly 2, long-stalked; pistillate spikes 1-3, light green, oblong or oblongcylindric, 2-4 cm. long, 9-12 mm. in diameter; perigynia much inflated, ovoid, 5-6 mm. long, tapering into a subulate rough 2 -toothed beak, shining, strongly nerved, 2-3 times longer than the scale. In swamps, Me. to N. C. June-Aug.

2I. Carex retrórsa Schwein. Retrorse SedGe. (I. F.f. 69r.) Glabrous; culm stout, $0.3^{-1} \mathrm{~m}$. tall. Leaves elongated, thin, rongh-margined, 5-7 mm. wide, the upper commonly exceeding the culm, the bracts similar; staminate spikes I-3, short-stalked; pistillate spikes 3-6, all close together at the summit and sessile of very nearly so or the lowest distant and stalked, cylindric, $2-5 \mathrm{~cm}$. long; perigynia ovoid, membranous, strongly few-nervel, yellowish green, about $6 \mathrm{~mm}$. long, reflexed at maturity, tapering into a subulate 2 -toothed beak; scales lanceolate, acute, one-third to one-half as long as the perigynia. In swamps and wet mearlows, Newf. to Manitoba, Idaho, Wash., Mass., Penn., Mich. and Fowa, Aug.-Sept.

22. Carex Hàrtii Dewey. HART Wright's Sedre. (I. F. f. 692.) Glabrous; culms nearly smooth, $0.3-0.8 \mathrm{~m}$. long. Leaves elongaterl, rough on the margins and midvein, 4-6 mm. wide; staminate spikes I or 2, the lower sometimes pistillate at the b.ıse, stalked; pistillate spikes $2-4$, scattered, rather loosely manyflowered, the upper sessile, the lower slender-stalked, 2-5 cm. long, all erect or ascending; perigynia inflated, ovoid-conic, spreading or the lower slightly reft:xed, few-nerved, about $6 \mathrm{~mm}$. long, grarlually tapering into the long 2 -torthed beak, 2-3 times as long as the scale. In marshes, Ont. and N. H. to Mich. June-Aug.

23. Carex lùrida Wahl. Sallow SeDge. (I. F. f. 693.) Glabrous; culm slender, $0.3^{-1} \mathrm{~m}$. tall. Leaves elongated, rough, rarely more than $4 \mathrm{~mm}$. wide ; staminate spike short-stalked; pistillate spikes, I-4, cylindric, 2-5 cm. long, the upper sessile, the lower peduncled; perigynia inflated, ovoid, tapering into a long subulate beak, ascending or the lower spreading, $8 \mathrm{~mm}$. long, thin, yellowish green, rather conspicuously nerved, longer than the rough-awned scale. In swamps and 
wet meadows, N. S. to Minn., Neb., Fla. and Tex. June-Oct. C. tentaculata altior Boott is a hybrid with C. lupulina.

Carex lùrida fláceida Bailey. P'istillate spikes $\mathrm{I}-2.5 \mathrm{~cm}$. long, brown, all sessile or very nearly so, clustered at the summit, rather more loosely flowered. Me., N. H. and N. Y. to N. Car. and Tenn.

Carex lùrida párvula (Paine) Bailey. Culm I-3.5 dm. high; pistillate spikes only I or 2 , scarcely more than $\mathbf{I} \mathrm{cm}$. long, globose or oblong, sessile or very nearly so; perigynia $6 \mathrm{~mm}$. long. N. H. to Penn, and Iowa.

Carex lùrida exúndans Bailey. Culms long and spreading; pistillate spikes $3-6 \mathrm{~cm}$. long. on very long stalks; scales subulate, the lower often much longer than the perigynia. Occasional with the typical form.

24. Carex Bàileyi Britton. Bailey's Sedge. (I. F. f. 694.) Glabrous; culms erect or reclining, slender, minutely scabrous above, $0.2-0.5 \mathrm{~m}$. long. Leaves roughish, elongated, 3-4 $\mathrm{mm}$. wide; staminate spike short-peduncled; pistillate spikes I-3, narrowly cylindric, very densely erect or ascending, $1.5-2.5 \mathrm{~cm}$. long, about $8 \mathrm{~mm}$. in diameter; perigyria inflated, ovoid, 5-6 mm. long, ascending, ab. ruptly contracted into the subulate 2 -toothed beak, prominently several-nerved. Bogs, Vt. to Va. and Tenn. June-Aug.

Spikes all erect or ascending.

Spikes, at least the lower ones, slender-stalked and drooping.

\section{C. Schweinitzii.}

Pistillate spikes oblong-cylindric, 1.2-5 $\mathrm{cm}$. long: perigynia ascending. 26. C. hystricina.

Pistillate spikes narrowly cylindric, $2.5-6 \mathrm{~cm}$. long ; perigynia reflexed. Teeth of the beak erect or little spreading.

Teeth of the beak recurved-spreading.

27. C. Pseudo-cyperus. 28. C. comosa.

25. Carex Schweinítzii Dewey. Schwernitz's Sedge. (I. F. f. 695.) Glabrous; light green; culm roughish above, $0.3-0.8 \mathrm{~m}$. tall. Leaves elongated, 5-8 mm. wide, those of the culm mostly short; staminate spike solitary or sometimes 2, often pistillate at the base or in the middle; pistillate spikes $3-5$, ascending, linear-cylindric, $3-8 \mathrm{~cm}$. long, about $8 \mathrm{~mm}$. thick, the upper usually sessile, the lower stalked; perigynia thin, somewhat inflated, ovoid-conic or oblong, tapering into the subulate, 2 -toothed beak, about $5 \mathrm{~mm}$. long and $2 \mathrm{~mm}$. in diameter, ascending, few-nerved, equalling, or the upper lusger than the lanceolate or linear scale; stigmas 3. In swamps and bogs, Mass. to Ont., Mich., N. J. and Mo. June-Aug.

26. Carex hystricina Muhl. Porcupine Sedge. (I. F. f. 696.) Glabrous, light green; culms $0.3-0.5 \mathrm{~m}$. tall. Leaves 3-5 mm. wide; staminate-spike slender-stalked; pistillate spikes, I-4, oblong-cylindric, dense, I-3 cm. long, about 9 $\mathrm{mm}$. in diameter, the lower slender-stalked and drooping; perigynia ascending. somewhat inflated, ovoid-conic, 5-6 mm. long, strongly many-nerved, tapering into the subulate 2-toothed beak, equalling or the upper longer than the narrow rough scales; stigmas 3 . In swamps and low meadows, N. S. to N. WV. Terr., Ga. and Neb. June-Aug. Said to hybridize with $C$. comosa.

Carex hystricina Dúdleyi Bailey. Culms often reclining, $0.5-0.9 \mathrm{~m}$. Jong; leaves 5-8 mm. wide ; staminate spike long-stalked ; pistillate spikes $3-6 \mathrm{~cm}$. long, $1 \mathrm{~cm}$. in diameter, filiform-stalked. Me. to Conn., Penn. and Mich.

27. Carex Pseùdo-Cypèrus L. Cyperus-like Sedge. (I. F. f. 697.) Glabrous; culms stout, rough on the angles, at least above, $0.5^{-1} \mathrm{~m}$. high. Leaves nodulose, 5-IO mm. wide; staminate spike short-stalked; pistillate spikes 2-5, linear-cylindric, dense, slender-stalked, spreading or drooping, 2-7 cm. long, 6-8 $\mathrm{mm}$. in diameter; perigynia light green, slightly inflated, conic, prominently many-ribbed, somewhat flattened, at length reflexed, tapering into a short 2 -toothed beak, the short teeth slightly spreading; scales linear with a broad base, ciliatescabrous, about equalling the perigynia; stigmas 3 . In bogs, N. S. to Manitoba, Me., N. Y., and Mich. Also in Europe and Asia. June-Aug.

28. Carex comòsa Boott. BRistly SEDGE. (I. F. f. 698.) Similar to the preceding species; culms commonly stouter, the leaves sumetimes $12 \mathrm{~mm}$. wide. Staminate spike sometimes pistillate at the summit; pistillate spikes 2-6, all spreading or drooping, stouter and bristly, about $12 \mathrm{~mm}$. in diameter; perigynia 
more slender, little inflated, strongly reflexed when mature, tapering into a slender prominently 2 -toothed beak, the teeth subulate and recurved-spreading; scales mostly shorter than the perigynia, very rough; stigmas 3 . In swamps, N. S. to Ont. and Wash., south to Ga., La. and Cal. May-Oct.

Scales linear-subulate, longer than the perigynia.

Scales lanceolate, about one-half as long as the perigynia.

Spikes I-3, subglobose or oval, staminate below; achene linear-oblong.

29. C. Frankii.

30. C. squarrosa.

Spikes 2-6, oblong-cylindric, usually staminate at both ends; achene ovoid.

31. C. typhinoides.

29. Carex Fránkii Kunth. Frank's Sedge. (I. F. f. 699.) Glabrous; tufted; culms stout, smooth, leafy, $0.3-0.7 \mathrm{~m}$. tall. Leaves elongated, roughish, $5-8 \mathrm{~mm}$. wide; staminate spike stalked; pistillate spikes $3-6$, exceedingly dense, cylindric, erect, $1-4 \mathrm{~cm}$. long, about $8 \mathrm{~mm}$. in diameter, the upper nearly or quite sessile, the lower slender-stalked; perigynia green, slightly inflated, about $2 \mathrm{~mm}$. in diameter, few-nerved, obovoid with a depressed summit from which arises the subulate 2 . toothed beak; scales linear-subulate, longer than the perigynia ; stigmas 3 . In swamps and wet meadows, E. Penn. to Va. and Ga., Mo., La. and Tex. JuneSept. [C. stenolepis Torr., not Less.]

30. Carex squarròsa L. Squarrose Sedge. (I. F. f. 700.) Glabrous; culms slender, rough above on the angles, $0.6-0.9 \mathrm{~m}$. tall. Leaves elongated, rarely more than $4 \mathrm{~mm}$. wide, rough-margined; spikes $\mathrm{I}-3$, erect, stalked, oblong or globose, exceedingly dense, rarely over $2.5 \mathrm{~cm}$. long, I-2 cm. in diameter, the upper one club-shaped, staminate at the base or sometimes for one-half its length or more; perigynia yellowish green, becoming tawny, the lowest reflexed, some. what inflated but firm, obovoid, 2-3 mm. in diameter, few-nerved, abruptly narrowed into the subulate minutely 2 -toothed beak, twice as long as the lanceolate acuminate or awn-tipped scale; achene linear-oblong, tapering into the stout style; stigmas 3. In swamps and bogs, Conn. to Mich. and Neb., south to Ga., La. and Ark. June-Sept.

3I. Carex typhinoides Schwein. Cat-Tail Sedge. (I.F.f. 7or.) Similar to the preceding, but darker green; leaves often 8-10 mm. wide; spikes 2-6, cylindric, 2-5 cm. long, 8-I4 mm. in diameter, often staminate at both ends, the terminal one commonly tapering to a conic summit; basal staminate flowers much less numerous; perigynia dull straw color, ascending or the lowest spreading or reflexed, inflated, abruptly contracted into the slender 2 -toothed beak, which is often upwardly bent; scales oblong-lanceolate, obtusish; achene ovoid-elliptic, sharply 3-angled, tipped with the subulate style. In swamps, Quebec to Iowa, Va., La. and Mo. July-Aug.

Leaves bright green, not glaucous; teeth of the perigynium-beak slender, conspicuaus. Scales lanceolate, acute or acuminate; leaves glabrous.

Scales ovate-lanceolate, rough-awned; leaves often pubescent.

Leaves pale green, glaucous; teeth of the perigynium-beak short.

Pistillate spikes about $8 \mathrm{~mm}$. thick, teeth of the perigynium-beak manifest.

C. trichocarpa.

33. C. aristata.

34. C. riparia.

Pistillate spikes about $4 \mathrm{~mm}$. thick, teeth of the perigynium-beak minute.

35. C. acutiformis.

32. Carex trichocàrpa Muhl. Hairy-fruited SedGe. (I. F. f. 702.) Culm usually stout and tall, smooth below, very rough above. Leaves elongated, glabrous, rough-margined, 4-6 mm. wide; staminate spikes 2-6, long-stalked; pistillate spikes cylindric, densely flowered except at the base, 2-10 $\mathrm{cm}$. long, I-I. $6 \mathrm{~cm}$. in diameter, the upper sessile or nearly so and erect, the lower slenderstalked; perigynia ovoid-conic, pubescent or glabrous, many-ribbed, 8-10 mm. long, tapering into the stout conspicuously 2 -toothed beak, the teeth somewhat spreading; scale hyaline, acute or acuminate. In marshes and wet meadows, Quebec to Mich., Iowa, Ga. and Kans. June-Aug.

33. Carex aristàta R, Br. Awned Sedge. (I. F. f. 703.) Culms erect, smooth or roughish above, sharp-angled, $0.5^{-1.2} \mathrm{~m}$. tall. Leaves elongated, 5-10 $\mathrm{mm}$. wide, often pubescent beneath and on the sheaths; staminate spikes as in the preceding; pistillate spikes $3-5$, remote, cylindric, sessile or the lower short. 
stalked, 2-10 cm. long, perigynia ascending, conic, glabrous, many-ribbed, $8-12 \mathrm{~mm}$. long, tapering into the conspicuously 2-toothed beak, the teeth divergent; scales oblong-lanceolate, rough-awned, one-half to two-thirds as long as the perigynia. In bogs, Ont. to the N. W. Terr., N. Y., Iowa, Utah and Ore. June-Aug.

34. Carex ripària Curtis. RIVER-BANK SEDGE. (I. F. f. 704.) Glabrous, pale green; culms smooth, or roughish above, $0.5-1 \mathrm{~m}$. tall. Leaves elongated, 6-12 mm. wide, about equalling the culm; staminate spikes I-5; pistillate spikes 2-5, cylindric, 3-10 $\mathrm{cm}$. long, about $8 \mathrm{~mm}$. in diameter, the upper erect, sessile or nearly so, the lower stalked; perigynia narrowly ovoid, firm, scarcely inflated, ascending, tapering into a short 2 -toothed beak, the teeth divergent; scales lanceolate or oblanceolate, long-aristate or acute, the lower longer, the upper equalling or shorter than the perigynia. In swamps, Newf. to James' Bay and Manitoba, south to Fla., La., Tex. and Idaho. Also in Europe. May-Aug.

35. Carex acutifórmis Ehrh. Swamp Sedge. (I. F. f. 705.) Culms stout, sharp-angled, $0.5-0.9 \mathrm{~m}$. tall, often rough above. Leaves $5^{-12} \mathrm{~mm}$. wide, flat, pale green; lower bracts similar to the leaves, the upper short and narrow; staminate spikes I-3, stalked; pistillate spikes 3-5, linear-cylindric, 3-8 cm. long, 4-5 mm. thick, the upper sessilc or nearly so and erect, the others slender-stalked, spreading or drooping; perigynia ovoid, $3 \mathrm{~mm}$. long, not inflated, many-nerved, tapering into a short and minutely 2-toothed beak; scales awn-tipped, longer than the perigynia or the upper equalling them. In swamps and wet meadows, E. Mass. Naturalized from Europe. June-Aug.

Uppermost spike staminate from the base to about the middle. Shortianak. 36. C. Shortiana.

Upper one or more spikes entirely staminate, or occasionally pistillate at the base.

Perigynia papillose; beak very short, nearly or quite entire. ANOMALAE.

37. C. scabrata.

Perigynia pubescent (sometimes glabrous in no. 39), the beak sharply 2 -toothed. HIRTAE.

Staminate spike or spikes sessile or nearly so.

Staminate spike or spikes distinctly stalked.

38. C. vestita.

Leaves glabrous; native species.

Leaves flat or their margins slightly revolute.

Scales only half as long as the perigynia; southern coast species.

39. C. Walteriana.

Scales equalling or but slightly shorter than the perigynia; northern species.

Leaves 4-7 $\mathrm{mm}$. wide; perigynia $3 \mathrm{~mm}$. thick, the nerves $\begin{array}{ll}\text { prominent. } & \text { 40. C. Houghtonii. }\end{array}$

Leaves $2-4 \mathrm{~mm}$. wide: perigynia $2 \mathrm{~mm}$. thick, the nerves obscured by the dense pubescence. $4 \mathrm{I}$. C. lanuginosa.

Leaves strongly involute, $2 \mathrm{~mm}$. wide or less. $\quad 42$. C. filiformis.

Leaves or their sheaths pubescent; introduced species; beak long.

43. C. hirta.

36. Carex Shortiàna Dewey. Short's SedGe. (I. F. f. 706.) Glabrous; culms slender, rough above, $0.3-1 \mathrm{~m}$. tall, usually overtopped by the upper leaves. Leaves elongated, roughish, 4-5 $\mathrm{mm}$. wide; bracts short, narrow, rarely much exceeding the spikes; spikes 3-7, linear-cylindric, densely many-flowered, $\mathbf{J}-3$ $\mathrm{cm}$. long, 3-4 $\mathrm{mm}$. in diameter, erect, the lower sfalked; perigynia dark brown, compressed, 2-edged, orbicular or obovate, nerveless, abruptly minutely beaked, equalling or shorter than the scales, which are hyaline, scarious-margined, ovate or oblong-lanceolate, persistent; orifice of the perigynium entire or very nearly so; stigmas 3. In moist meadows and thickets, Penn. to Va. and Tenn., west to Iowa and the Ind. Terr. May-July.

37. Carex scabràta Schwein. Rough Sedge. (I. F. f. 707.) Glabrous; culms rough above, leafy, $0.3-0.9 \mathrm{~m}$. long. Leaves rough, much elongated, 5-7 mm. wide, the bracts similar but narrower; staminate spike short-stalked; pistillate spikes 3-6, erect, the upper short-stalked, the lower sometimes spreading or drooping, all linear-cylindric, dens ly many-flowered, $2-5 \mathrm{~cm}$. long, $5-8 \mathrm{~mm}$. in diameter; perigynia greenish brown, ovoid, somewhat inflated, strongly nerved, papillose, tipped with a short minutely 2-toothed or entire beak; scales lanceolate, acute or 
short-awned, prominently I-nerved, shorter than the perigynia. In moist woods and thickets, Me. to Ont., Mich., S. Car. and Tenn. May-Aug.

38. Carex vestita Willd. Velvet Sedge. (I. F. f. 708.) Culms strict and slender, $0.4-0.8 \mathrm{~m}$. tall, rough above. Leaves $3-5 \mathrm{~mm}$. wide, not overtopping the culm; bracts similar, but narrower, short, rough-ciliate; staminate spike solitary, rarely 2, almost sessile ; pistillate spikes I-5, oblong, I-2 cm. long, $6-8 \mathrm{~mm}$. in diameter, erect, commonly staminate at the summit, sessile or the lower shortstalked; perigynia ovoid, densely pubescent, less than $2 \mathrm{~mm}$. in diameter, prominently few-ribbed, tapering gradually into a short conic 2 -toothed whitish beak, slightly shorter than or equalling the ovate acute membranous scales. In sandy woods, N. H. to Penn., south to Ga. June-July.

39. Carex Wailteriàna Bailey. Walter's SEDGe. (I. F. f. 709.) Culms slender, strict, usually rough above, $0.3-0.8 \mathrm{~m}$. tall. Leaves narrow, elongated, 2-4 $\mathrm{mm}$. wide, nodulose, not overtopping the culm; lowest bract similar, the upper smailer, often almost filiform; staminate spikes $2-5$, long-stalked; pistillate spikes I or 2 , when 2 the lower remote from the upper, sessile or short-stalked, oblongcylindric, erect, 2-4 cm. long, about $8 \mathrm{~mm}$. in diameter, rather loosely, many. flowered; perigynia ovoid, purple-brown, many-nerved, slightly inflated, glabrous, or pubescent, $3 \mathrm{~mm}$. in diameter, tapering into a short 2-toothed beak; scales ovate, acute, short-aristate or obtuse, membranous, one-half the length of the perigynia. In pine-barren bogs, southern N. J. to Fla. May-July.

40. Carex Houghtònii Torr. Houghton's Sedge. (I. F. f. 7 Io.) Culms rough above, erect, $0.3-0.8 \mathrm{~m}$. tall, exceeding the leaves. Leaves and lowest bract 4-7 mm. wide, rough, their margins revolute; upper bracts much shorter; staminate spikes I-3, stalked, sometimes pistillate at the base; pistillate spikes 2 or 3 , nblong-cylindric, I-4 cm. long, 6-8 $\mathrm{mm}$. in diameter, erect, rather loosely flowered, the upper sessile, the lower stalked; perigynia broadly ovoid, $3 \mathrm{~mm}$. in diameter, light green, densely pubescent, many-ribbed, narrowed into a short conspicuously 2-toothed beak; scales lanceolate, short-awned, hyaline-margined, strongly Inerved, somewhat shorter than the perigynia. In sandy or rocky soil, N. S. to the N. W. Terr., Me., Mich. and Minn. June-Sept.

4I. Carex lanuginòsa Michx. Woolly Sedge. (I. F. f. 7II.) Culm slender, but usually rather stouter than that of $C$. filiformis, sharp-angled and rough above. Leaves and lower bracts elongated, not involute, 2-4 mm. wide, sometimes overtopping the culm; staminate spikes I-3, long-stalked, sometimes pistillate at the base; pistillate spikes $\mathbf{x}-3$, usually distant, sessile or the lower slender-stalked, cylindric; 5-6 mm. in diameter; scales acuminate or aristate. In swamps and wet meadows, N. S. to Br. Col., south to N. J., Kans., N. Mex. and Cal. June-Aug.

Carex lanuginòsa Kansàna Britton. Plant pale; leaves $\mathrm{x}-2 \mathrm{~mm}$. wide, very rough; perigynia $1 \mathrm{~mm}$. in diameter, the ribs conspicuous. Mo. and Kans.

42. Carex filifórmis L. Slender Sedge. (I. F. f. 7I2.) Culms very slender, erect or reclining, smooth, obtusely angled, $0.5-0.9 \mathrm{~m}$. long. Leaves very narrow, involute, about $2 \mathrm{~mm}$. wide, rough-margined, not overtopping the culm; lower bract similar, upper bracts filiform; staminate spikes 1-3, commonly 2, stalked; pistillate spikes I-3, cylindric, $1.5-2 \mathrm{~cm}$. long, about $6 \mathrm{~mm}$. in diameter. erect, sessile, or the lower distant and short-peduncled; perigynia green, ascending, oval, densely pubescent, faintly nervel, about $2 \mathrm{~mm}$. in diameter, tapering into a short 2-toothed beak; scales ovate, membranous, acute or short-awned, shorter than or equalling the perigynia. In wet meadows and swamps, Newf. to Br. Col., N. J., Penn., Mich. and Iowa. Occasionally diœcious. Also in Europe. June-Aug.

43. Carex hírta L. HaIRY SEDGE. (I. F. f. 713.) Rootstocks creeping: culms rather slender, nearly smooth, I.5-4 dm. tall. Leaves flat, pubescent, especially on the sheaths, 3-5 mm. wide, the basal ones much elongated, the upper and the similar bracts shorter; staminate spikes 2 or 3 , stalked; pistillate spikes 2 i. 3 , remote, erect, oblong-cylindric, $2-3 \mathrm{~cm}$. long, about $6 \mathrm{~mm}$. in diameter; perigynia ovoid-oblong, green, densely pubescent, $2 \mathrm{~mm}$. in diameter, $4 \mathrm{~mm}$. long, fewribbed, tapering into a prominently 2 -toothed beak; teeth often as long as the beak; scales lanceolate, aristate, 3-nerved, shorter than the perigynia. In fields and waste places, Mass. to E. N. Y. and Penn. Nat. or adv. from Europe. June-Sept. 
Terminal spike staminate below, pistillate above (rarely all staminate in No. 47); stigmas 3. ATRATAE.

Scales shorter than or equalling the perigynia; arctic and alpine species.

Orifice of the perigynium minutely 2 -toothed; scales obtuse or acutish.

Pistillate spikes 4-10 $\mathrm{mm}$. long, erect.

44. C. alpina.

Pistillate spikes $8-25 \mathrm{~mm}$. long, drooping when old.

Orifice of the perigynium entire; scales acute or awned.

Perigynium ovate, the style usually protruding.

Perigynium obovate, the style not protruding.

Scales manifestly longer than the perigynia ; bog species.

45. C. atratiformis.

46. C. stylosa.

47. C. Parryana.

48. C. Buxbaumii.

Terminal spike staminate throughout (occasionally pistillate at the top in No. 53); stigmas 2, rarely 3 in No. 55. RIGIDAE.

Lower sheaths becoming very fibrillose; tufted bog species.

Lower sheaths not at all fibrillose, or slightly so.

Scales shorter than or equalling the perigynia (or longer in No. 50).

Culms $0.3-0.6 \mathrm{~m}$. tall; scales acute or acuminate.

Pistillate spikes linear-cylindric.

Pistillate spikes oblong-cylindric.

Culms 0.2-1.I m. tall; scales obtuse or the lower acute.

Scales green.

Leaves 4-6 $\mathrm{mm}$. wide; pistillate spikes $4-6 \mathrm{~mm}$. thick; perigynia nerveless.

52. C. aquatilis.

Leaves $2 \mathrm{~mm}$. wide; pistillate spikes $2-4 \mathrm{~mm}$. thick; perigynia faintly few-nerved.

Scales purple or brown.

53. C. lenticularis.

Scales shorter than the perigynia; marsh and meadow species.

54. C. Goodenovii.

Scales equalling or longer than the perigynia; arctic and alpine species.

Culms only $2-17 \mathrm{~cm}$. tall ; arctic species.

55. C. Bigelovit.

56. C. subspathacea.

Scales distinctly longer than the perigynia; northern salt marsh species.

Basal leaves $2 \mathrm{~mm}$. wide or less; scales little longer than the perigynia.

57. C. salina.

Basal leaves 2-6 nim. wide; scales much longer than the perigynia.

58. C. cuspidata.

44. Carex alpina Sw. Alpine Sedge. (I. F. f. y 14.) Culms slender, rough above, leafy below the middle, I.5-5 dm. tall. Leaves roughish, I-3 mm. wide, shorter than or equalling the culm; spikes $2-4$, clustered, the terminal I or 2 staminate below, oblong or globose, 4-10 mm. long, sessile, or the lower peduncled; perigynia oval, orbicular or obovoid, light green, about $2 \mathrm{~mm}$. long, tipped with a very short and minutely 2 -toothed beak, nerveless or with a few faint nerves, equalling or slightly shorter than the ovate black or purple-brown scales. In rocky places, Quebec to James' Bay and Athabasca, western Ont. and Isle Royale, Lake Superior, south in the Rocky Mts. to Colo. Also in Europe. Summer.

45. Carex atratifórmis Britton. BLACK SEDGE. (I. F. f. 7I 5.) Glabrous; culms slender, sharp-angled, rough above, 2-5 dm. tall, usually leafy only below. Leaves $2-4 \mathrm{~mm}$. wide, rarely over $\mathrm{I} .5 \mathrm{dm}$. long, much shorter than the culm; spikes $2-5$, dense, oblong-cylindric, $8-25 \mathrm{~mm}$. long, about $5 \mathrm{~mm}$. in diameter, the terminal one usually staminate at the base and sessile, or nearly so, the others slendt:stalked; lower bracts $\mathrm{I}-3.5 \mathrm{~cm}$. long, very narrow, the upper subulate; perigynia flattened, ovate or nearly orbicular, puncticulate, about $2 \mathrm{~mm}$. long, tipped with a short, 2-toothed beak; scales black or reddish-brown, oblong, slightly narrower than the perigynia and about equalling them. Newf. to the mountains of N. E., west to the N. W. Terr. Summer.

46. Carex stylòsa C. A. Meyer. Variegated Sedge. (I. F. f. 716.$)$ Culms slender, 3-4 dm. tall, rough and leafless above. Leaves $3 \mathrm{~mm}$. wide; staminate spike solitary, nearly sessile, often pistillate for one-half its length or more; pistillate spikes 2 or 3 , oblong-cylindric, erect, $8-12 \mathrm{~mm}$. long, about $3 \mathrm{~mm}$. in diameter, the lower slender-stalked and subtended by a subulate bract; perigynia ovate, slightly inflated, brown, minutely granulate, less than $2 \mathrm{~mm}$. long, nerveless, beakless, the orifice entire and closed by the usually protruding style; scales black with white veins, obtusish, shorter than the perigynia. Lab. and Greenland to Alaska. Summer. 
47. Carex Parryàna Dewey. Parry's Sedge. (I. F. f. 717.) Glabrous, culms very slender, smootl, stiff, $2-5 \mathrm{dm}$. tall, leafless above. Leaves about $2 \mathrm{~mm}$. wide, much shorter than the culm, their margins somewhat involute; spikes I-4, dense, erect, linear-cylindric, $1-2.5 \mathrm{dm}$. long, $3 \mathrm{~mm}$. in diameter, the upper sessile, staminate below or throughout, the lower stalked and subtended by an almost filiform bract; perigynia plano-convex, obovate, pale, less than $2 \mathrm{~mm}$. long, minutely papillose, faintly few-nerved, minutely beaked, the orifice entire: scales ovate, acute or mucronulate, dark brown with lighter margins, about as long as the perigynia. Hudson Bay to N. W. Terr., south in the Rocky Mts. to Colo. Summer.

48. Carex Buxbaùmii Wahl. Brown SedGe. (I. F. f. 7 I8.) Glabrous; culms slender, stiff, sharp-angled, rough above, 3-9 dm. till. Leaves rough, erect, $\approx-4$ $\mathrm{mm}$. wide; spikes 2-4, oblong or cylindric, erect, all sessile and close together, ( $\mathrm{r}$ the lowest sometimes distant and short-stalked, $8-37 \mathrm{~mm}$. long, about $8 \mathrm{~mm}$. in diameter, the terminal one staminate at the base or rarely throughout; perigy ni: elliptic or obovate, flat, ascending, $2 \mathrm{~mm}$. long, light green, faintly few-nerved. beakless, the apex minutely 2 -toothed; scales ovate, awn-tipped, black or dark brown with a green midvein, longer than the perigynia. In bogs, Newf. to Alaska, Ga., Ky., Utah and Cal. Also in Europe. (C. fusca Bailey, not All.)

49. Carex strícta Lam. Tussock SEDGE. (I. F. f. 719.) Glabrous, rather dark green; culms slender, stiff, usually in dense clumps, sharply 3-angled, rough above, $0.3-1.1 \mathrm{~m}$. tall. Leaves rarely overtopping the culm, very rough margined, 2-4 mm. wide, their sheaths becoming fibrillose; lower bract similar; staminate spikes solitary or sometimes 2, stalked; pistillate spikes 2-5, linear-cylindric, often staminate at the top, densely flowered, or loose at the base, $2-5 \mathrm{~cm}$. long, about $4 \mathrm{~mm}$. thick, sessile or the lower stalked; perigynia ovate-elliptic, acute, faintly few-nerved, $2 \mathrm{~mm}$. long or less, minutely beaked, the orifice entire or nearly so; scales brown-purple with green margins and midvein, oblong or lanceolate, appressed; stigmas 2. In swamps, Newt. to Ont., Neb., Ga. and Tex. Hybridizes with C. filiformis. July-Sept.

Carex stricta angustàta (Boott) Bailey. Pistillate spikes longer, 5-1o cm. long, erect; scales lanceolate, acute, often longer than the perigynia. Range apparently nearly that of the type.

Carex stricta xerocarpa (S. H. Wright, Britton). Pistillate spikes almost filiform, about $2 \mathrm{~mm}$. in diameter, erect. N. Y. to Ill.

50. Carex Hàydeni Dewey. Hayden's Sedge. (I. F. f. 720.) Glabrous, similar to $C$. stricla but smaller; culm slender, seldom over $0.5 \mathrm{~m}$. high. Leaves $2-3 \mathrm{~mm}$. wide, their sheaths slightly fibrillose or not at all; lower hract foliaceous, about equalling the culm; pistillate spikes $\mathrm{I}-3 \mathrm{~cm}$. long, about $4 \mathrm{~mm}$. in dianieter, erect or somewhat spreading, sessile or nearly so ; perigynia orbicular, obtuse, about $\mathbf{I m m}$. broad, faintly 2-4-nerved, minutely beaked, the orifice entire; scales lanceolate, purplish, spreading, very acute, alout twice as long as the perigynia; stigmas 2. Swamps, N. B. to R. I., Iowa and Neb.

51. Carex Nebraskénsis Dewey. Nebraska Sedge. (I. F. f. 721.) Glabrous; culms stout, sharp-angled, $0.3-0.6 \mathrm{~m}$. tall. Leaves pale green, $3-5 \mathrm{~mm}$. wide, rough-margined, their sheaths more or less nodulose; lower bract sometimes equalling the culm, the upper much shorter and narrower: staminate spikes commonly 2, stalked; pistillate spikes 2-4. dense, oblong-cylindric, erect, $2-3 \mathrm{~cm}$. long, about $6 \mathrm{~mm}$. in diameter, sessile or the lower short-stalked; perigynia elliptic or obovate, prominently several-ribbed, short-beaked, the beak 2 -toothed; scales ovate or lanceolate, acute or mucronate, brown with a green midvein or green all over, the upper shorter than the perigynia; stigmas 2. Neb. to Ore. and N. Mex. May-Aug.

52. Carex aquátilis Wahl. Water Sedge. (I. F. f. 722.) Glatrous, glaucous, pale green; culms sharp-angled above, smooth or nearly so, 0.5-I.I m. tall. Leaves elongated, 4-7 $\mathrm{mm}$. wide, their sheaths nodulose; bracts similar, the lower much overtopping the culm; staminate spikes I-3, stalked; pistillate spikes linear-cylindric, often staminate at the summit, $2-6 \mathrm{~cm}$. long, 4-6 mm. in diameter, sessile and dense, or the lower loosely flowered at the base and short-stalked; perigynia elliptic, green, nerveless, minutely beaked, the orifice entire; scales oblong, 
shorter than or equalling the perigynia and much narrower, stigmas 2. In swamps and along streams, Newf. to Alaska, Mass., Penn., Ohio, Minn. and Br. Col. Also in Europe. Hybridizes with $C$. stricta. June-Aug.

53. Carex lenticulàris Michx. Lenticular Sedge. (I. F. f. 723.) Glabrous, pale green; culms slender, sharp-angled, roughish above, $0.3-0.6 \mathrm{~m}$. tall. Leaves elongated, rarely over $2 \mathrm{~mm}$. wide, slightly rough-margined, their sheaths not fibrillose; lower bracts similar, usually much overtopping the spikes; staminate spike solitary or rarely 2 , sessile or short-stalked, often pistillate above; pistillate spikes 2-5, clustered or the lower distant, sessile or the lower short-stalked, erect, linear-cylindric, 8-25 mm. long, 3-4 mm. in diameter; perigynia ovate or elliptic, acute, minutely granulate, faintly few-nerved, tipped with a minute entire beak; scales green, appressed, shorter than the perigynia; stigmas 2. On shores, Lab. to the N. W. Terr., Me., Vt., Ont. and Minn. June-Aug.

54. Carex Goodenòvii J. Gay. Goodenovgh's SedGe. (I. F. f. 724.) Glabrous; culms stiff, sharp-angled, sometimes rough above, $0.3-0.6 \mathrm{~m}$. tall. Leaves elongated, smooth, glaucous, $2-4 \mathrm{~mm}$. wide, not exceeding the culm, their sheaths not fibrillose; lower bracts usually foliaceous; staminate spike sessile or stalked; pistillate spikes $2-4$, sessile or nearly so, erect, many-flowered, narrowly cylindric, 4-5 mm. in diameter, $1-2.5 \mathrm{~cm}$. long; perigynia flattened, broadly oval or ovate, faintly few-nerved, green, less than $2 \mathrm{~mm}$. long, minutely beaked, the orifice nearly entire; scales purple-brown to black with a green midvein, very obtuse, shorter than the perigynia; stigmas 2. In wet grounds, Newf. to Mass. and Penn. June-Aug.

55. Carex Bigelòvii Torr. Bigelow's SEDGE. (I. F. f. 725.) Glabrous and smooth throughout or nearly so; culms sharp-angled, $2-5 \mathrm{dm}$. tall. Leaves 3-4 nm. wide, not exceeding the culm, the lower bracts similar, but shorter; sheaths slightly or not fibrillose; staminate spike stalked, sometimes pistillate at the base, pistillate spikes 2-4, linear-cylindric, loosely flowered at the base, dense above, I-2.5 cm. long, 3-4 mm. thick, the upper sessile, the lower often slenderstalked; perigynia oval, about $2 \mathrm{~mm}$. long, f intly nerved, scarcely beaked, the orifice entire: scales purple-brown with a narrow green midvein, often with green margins, obtuse or the lower acute, equalling or a little exceeding the perigynia; stigmas 2, rarely 3. Greenland and Lab. to the mountains of New England and N. Y. Also in Europe. Summer.

56. Carex subspathàcea Worm:k. Hoppren's Sedge. (I. F. f. 726.) Glabrous; culm smooth, $2-13 \mathrm{~cm}$. tall. Leaves rigid, smooth, about $2 \mathrm{~mm}$. wide; lower bracts foliaceous; staminate spike stalked; pistillate spikes I-3, erect, sessile or very short-stalked, 6-12 $\mathrm{mm}$. long, about $3 \mathrm{~mm}$. in diameter; perigynia oval or ovoid, very short beaked, pale green, faintly few-nerved, about $2 \mathrm{~mm}$. long; scales ovate or ovate-oblong, shorter than or equalling the perigynia; stigmas 2. Greenland to Hudson Bay. Summer.

57. Carex salina Wahl. Salt-Marsh Sedge. (I. F. f. 727.) Glabrous; culm smooth, I.5-5 dm. tall. Leaves narrowly linear, I-2 mm. wide, the lower bract similar; staminate spikes I or 2, stalked; pistillate spikes I-3, slender-stalked or the upper sessile, erect, loosely fe.--everal-flowered, $1-2.5 \mathrm{~cm}$. long, 3-4 mm. thick: perigynia ovate-elliptic, ale, f.intly iew-nerved, ascending, $3 \mathrm{~mm}$. long, tapering into a short entire be... or cuspidate, somewhat longer than the perigynia; stigmas 2. In salt marshes, Greenland to Hudson Bay. Also in arctic Europe. Summer.

58. Carex cuspidàta Wahl. Cuspidate SEDGE. (I. F. f. 728.) Glabrous; culms erect, 3-7 dm. tall. Basal 1:aves often equalling the culm, 3-6 mm. wide, smooth; leaves of the culm similar to the lower bracts, which usually overtop the spikes; staminate spikes I-3, stalked; pistillate spikes $2-4$, cylindric, often staminate at the summit, erect, the lower stalked; perigynia -lliptic, green, 2-4-nerved, with a short entire beak; scales lanceolate, pale, acuminate or contracted into a serrate awn, much longer than the perigynia; stigmas 2. In marshes, Newf. and Lab. to Mass. Also in Europe. Summer.

Culms slender ; pistillate spikes $0.6-6.5 \mathrm{~cm}$. long: stigmas 3 ( 2 in No. 59 ).

Pistillate spikes linear; scales shorter than the perigynia. PRASinaE. Perigynia twisted toward the top; scales purple-brown. Perigynia straight; scales green.

59. C. torta.

60. C. prasina. 

Pistillate spikes oblong, globose or cylindric; scales equalling the perigynia of
longer.

Bracts manifestly sheathing; arctic species. FerRugineaE. 6r. C. misandru. Bracts sheathless; scales mostly dark. PENDulinae.

Pistillate spikes narrowly cylindric; southern coast species.

Pistillate spikes oblong or globose; northern species.

62. C. littoralis.

Scales not longer than the perigynia.

Pistillate spikes 6-12 mm. long, few-flowered; scales obtuse.

Pistillate spikes $\mathrm{I}-2 \mathrm{~cm}$. long, several-flowered; scales acute.

Scales distinctly longer than the perigynia.

64. C. limosa.

Perigynia oval or suborbicular.

Perigynia elliptic-lanceolate.

65. C. Magellanica.

66. C. podocarpa.

Culms tall, usually stout; pistillate spikes 2-10 cm. long: scales I-8 times as long as the perigynia; stigmas 2 (or 3 in Nos. 70 and 71 ). CRYPTOCARPAE.

Perigynia smooth.

Scales purple-brown; arctic species.

Scales green; plants not arctic.

67. C. cryptocarpa.

Perigynia nerveless or faintly nerved, much shorter than the scales. Perigynia nearly orbicular, biconvex.

Perigynia obovoid, obtuse.

Perigynia oblong or elliptic, acute.
Perigynia strongly several-nerved, about equalling the scales.

Spikes erect; leaves very rough-margined.

Spikes drooping, filifornı stalked.

Perigynia granular or papillose.

68. C. maritima.

69. C. crinita.

7o. C. gynandra.

71. C. macrokolea. 7ra.C. verrucosa.

72. C. glauca.

59. Carex tórta Boott. Twisted Sedge, (I. F. f. 729.) Glabrous; culm slender, smooth or slightly scabrous above, $0.4-1 \mathrm{~m}$. long. Leaves about $4 \mathrm{~mm}$. wide, those of the culm very short; sheaths not fibrillose; lower bract commonly foliaceous; staminate spikes I-3, stalked; pistillate spikes 3-5, all but the upper spreading or drooping, linear, $2-7.5 \mathrm{~cm}$. long, about $4 \mathrm{~mm}$. in diameter; often loosely flowered toward the base; perigynia oblong or narrowly ovate, green, nerveless, narrowed and more or less twisted above, $2-3 \mathrm{~mm}$. long; scales ovate, purplebrown with a green midvein, shorter and mostly narrower than the perigynia; stigmas 2. In marshes and wet thickets, Me. and Vt. to N. Car. and Mo. June-July.

60. Carex prásina Wahl. Drooping Sedge. (I. F. f. 730.) Glabrous; rather light green; culm slender, smooth or nearly so, reclining, 3-angled, 0.3$0.7 \mathrm{~m}$. long. Leaves flaccid, roughish, 3-5 mm. wide; lower bract similar, commonly overtopping the spikes; staminate spike short-stalked, often pistillate ai the summit; pistillate spikes 2 or 3 , linear-cylindric, drooping, the lower filiformstalked, 2-6 cm. long, $4 \mathrm{~mm}$. in diameter, rather loosely many-flowered; perigynia light green, lanceolate, obscurely nerved, tapering into a slender minutely 2 -toothed beak; scales ovate, acute, acuminate, or short-awned, pale green, shorter than the perigynia; stigmas 3. In meadows and moist thickets, Me. to Ont., N. J. and Penn., south in the Alleghanies to Ga. May-July.

61. Carex misándra R. Br. Short-leaved Sedge. (I. F. f. 731.) Glabrous; culms $2-40 \mathrm{~cm}$. tall. Leaves $2-3 \mathrm{~mm}$. wide, clustered, seldom over $6 \mathrm{~cm}$. long: bracts narrowly linear, sheathing, not overtopping the spikes; terminal spike slender-stalked; pistillate spikes I or 2 , filiform-stalked, $6-15 \mathrm{~mm}$. long, about $4 \mathrm{~mm}$. thick, rather few-flowered, drooping; perigynia narrowly lanceolate, acuminate, narrowed at the base, $3 \mathrm{~mm}$. long, dark brown, denticulate above; scales ob. tuse, purple-black with white margins, somewhat shorter than the perigynia; stigmas 2 or 3. Throughout arctic America, extending south in the Rocky Mts. to the higher summits of Colo. Also in arctic Europe and Asia. Summer.

62. Carex littoràlis Schwein. BARRATt's Senge. (I. F. f. 732.) Glabrous, pale green, somewhat glaucous; culms smooth, $0.2-0.5 \mathrm{~m}$. tall, leafless above. Leaves 3-4 mm. wide, smooth, the lower sheaths fibrillose; bracts not sheathing, the lower usually short and narrow; staminate spikes I-3, usually rather long. stalked; pistillate spikes 2-4, drooping or the upper ascending, slender-stalked, linear-cylindric, $\mathrm{I}-5 \mathrm{~cm}$. long, $6 \mathrm{~mm}$. in diameter, mostly staminate at the summit; 
perigynia oblong, green, faintly few-nerved, 2-3 mm. long, tipped with a minute entire beak: scales brown-purple with lighter margins, obtuse, equalling or shorter than the perigynia; stigmas 3. In pine-barren swamps, Conn. and N. J. to E. Penn. and N. Car. May-July.

63. Carex rarifiòra J. E. Smith. Loose-flowered Alpine Sedge. (I. F. f. 733.) Glabrous, culms very slender, rather stiff, erect, I-3 dm. tall, smooth, or roughish above. Leaves $2 \mathrm{~mm}$. wide or less, the lower very short; bracts subulate, purple at the base; staminate spike solitary, long-stalked; pistillate spikes I or 2 . narrowly oblong, few-flowered, 6-12 $\mathrm{mm}$. long, $4 \mathrm{~mm}$. in diameter, nodding on filiform stalks; perigynia pale, oblong, acute at each end, $3 \mathrm{~mm}$. long, I mm. wide, minutely beaked, few-nerved, the orifice entire; scales oval, purple-brown with a greenish midvein, obtuse or mucronate, equalling or a little longer than the perigynia; stigmas 3. In wet places, Greenland and Lab. to Hudson Bay, south to Me. and to northern Minn. Also in Europe and Asia. Summer.

64. Carex limòsa L. Mun SEDGE. (I. F. f. 734.) Glabrous; culms rough above, 2.5-5 dm. tall. Leaves $2 \mathrm{~mm}$. wide or less, shorter than the culm: bracts linear-filiform; staminate spike long-stalked; pistillate spikes I or 2, filiformstalked, drooping, $1-2 \mathrm{~cm}$. long, about $6 \mathrm{~mm}$. thick; perigynia pale, oval, narrowed at both ends, $3 \mathrm{~mm}$. long, with a minute entire beak, several-nerved, about as long as the oval cuspidate or acute scale; stigmas 3. In boss, Newf. to the N. W. Terr., south to Me., N. J., Iowa and Idaho. Also in Europe. Summer.

65. Carex Magellánica Lam. Magellan Sfidge. (I. F. f. 735.) Glabrous; culms smooth or nearly so, $1.5-5 \mathrm{dm}$. tall. Leaves flat, 2-4 mm. wide, commonly shorter than the culm, the lower bract similar; staminate spike solitary, rarely 2 ; pistillate spikes I-3, filiform-stalked, drooping, 8-16 mm. long, about $6 \mathrm{~mm}$. in diameter; perigynia biconvex, oval, pale, granulate-papillose, few-nerved, $2-3 \mathrm{~mm}$. long, with a very minute entire beak; scales long-acuminate or awned, dark green or purplish brown, longer than the perigynia; stigmas 3 . In bogs, Newf. to Manitoba, Me., Penn. and Mich. Also in Utah, Europe, and in southern S. Am. Summer.

66. Carex podocàrpa R. Br. Long-Awned Arctic Sedge. (I. F. f. 736.) Glabrous; culms slender, rough above, 2.5-5 dm. long. Leaves 3-4 mm. wide, the lowest reduced to sheaths; lower bract similar to the upper leaves; staminate spikes I or 2, stalked; pistillate spikes 2-4, cylindric, dense, I-3.5 cm. long, $6 \mathrm{~mm}$. in diameter, the lower often nodding; perigynia elliptic-lanceolate, flat, about $5 \mathrm{~mm}$. long, acute, faintly nerved, the orifice entire ; scales purple-black, ovate, acuminate, longer than the perigynia, long-awned; stigmas 2 or 3. Arctic America. Summer.

67. Carex cryptocàrpa C. A. Meyer. Hidden-fruited Sedge. (I. F. f. 737.) Glabrous; culm stout, 3-angled, rough above, $0.4-0.9 \mathrm{~m}$. tall. Leaves smooth, 4-6 mm. wide; staminate spikes 2-4, stalked; pistillate spike 2-5, filiform-stalked and drooping, $2-8 \mathrm{~cm}$. long, 6-8 $\mathrm{mm}$. in diameter; perigynia oblong or oval, green, several-nerved, $3 \mathrm{~mm}$. long, with a very short entire beak; scales purplebrown, lanceolate, acuminate, 2 or 3 times longer than the perigynia; sigmas 2. Arctic America from Greenland to Alaska. Summer.

Carex cryptocàrpa variegàta (Derjer) Britton. Seldom over $3 \mathrm{dm}$. tall; pistillate spikes about $2, \mathrm{I}-2 \mathrm{~cm}$. long; scales ovate-lanceolate, acute, little longer than the perigynia. Range of the species.

68. Carex marítima Muller. Seaside Sedge. (I. F. f. 738.) Glabrous, light green: culms 3-angled, smooth, or roughish above, $0.3-0.6 \mathrm{~m}$. tall. Leaves 4-6 mm. wide, the lower bracts similar; staminate spikes I-3, slender-stalked; pis. tiilate spikes 2-4, cylindric, often staminate at the summit, $2-8 \mathrm{~cm}$. long, $8-12 \mathrm{~mm}$. thick, drooping on filiform stalks; perigynia oval to orbicular, pale, biconvex, less than $2 \mathrm{~mm}$. long, nerveless or with a few faint nerves, with a very short and nearly entire beak; scales green. linear-subulate, ciliate, scabrous, 3-8 times as long as the perigynia; stigmas 2 . In salt meadows, Newf. and Lab. to Mass. Also in Europe. June-Aug.

69. Carex crinita Lam. Fringed Sedge. (I. F. f. 739.) Glabrous; culms 3-angled, $0.5^{-1.3} \mathrm{~m}$. tall. Leaves rough-margined, 6-10 mm. wide, the lowest very short and sheathing; staminate spikes I or 2, stalked; pistillate spikes 
3-5, narrowly cylindric, 2-11 cm. long, 6-8 $\mathrm{mm}$. in diameter, stalked, drooping: perigynia obovoid, obtuse, about $2 \mathrm{~mm}$. long and nearly as thick, nerveless, abruptly tipped by the short entire beak; scales green, subulate, ciliate-scabrous, spreading, 2-6 times as long as the perigynia; stigmas 2 . In swamps and wet woods, N. S. and Ont. to Fla. and Tex. June-Aug. A hybrid with C. torta is described.

Carex crinlta minor Boott. Culms slender, lower; leaves $3-5 \mathrm{~mm}$. wide; pistillate spikes $2-3 \mathrm{~cm}$. long, $4 \mathrm{~mm}$. thick, spreading or slightly drooping ; perigynia little more than I mm. in diameter. Me. to S. N. Y.

70. Carex gynándra Schwein. Nodding Sedge. (I. F. f. 740.) Similar to the preceding species. Leaves 6-12 $\mathrm{mm}$. wide, glabrous or their sheaths often finely pubescent; pistillate spikes 2-10 $\mathrm{cm}$. long, narrowly cylindric; perigynia oblong or elliftic, faintly isw-nerved or nerveless, compressed, slightly inflated, 3-4 $\mathrm{mm}$. long, and about one-nalf as broad, tapering to an acute entire orifice; scales subulate, rough, ascending, 2-4 times as long as the perigynia. In swamps, Newf. to northern N. Y., Fla. and La. June-Aug.

Carex gynándra Porterı (Olney) Britton. Smaller, bearing the same relation to the species that minor does to $C$. crini ${ }^{2} a$. Me.

7I. Care:z macrokòlea Steud. Southern Glaucous Sedge., (I. F. f. 741.) Glabrous, light sreun, glaucous; culms stout, $0.5-1.1 \mathrm{~m}$. tall. Leaves rough, 3-6 $\mathrm{mm}$. wide, tap rivg to a very long narrow tip; lower bracts similar; staminate spikes I or s, chort-stalked; pistillate spikes $2-8$, cylindric, $2-5 \mathrm{~cm}$. long, erect, sessile or the lower s. lked; perigynia dark brown, 3-angled, $3 \mathrm{~mm}$. long, several-nerved, abruptly cuntracted into a short sharp beak; scales oblong, roughawned, as $1 \mathrm{~g}$ as the perigynia or longer. In swamps, Mo. to Fla. and Tex. June-Aug.

7ra. Carex ve:rucòsa Muhl. WARTy SEDGe. Glabrous and usually glaucous; cuims slend $r, 1 \mathrm{~m}$. tall $\mathrm{c}$. less. Leaves smooth or very nearly so, 2-6 $\mathrm{mm}$. wide, l...g-atte:uute; staminate spike I, stalked; pistillate spikes I-6, cylindric, $3-5 \mathrm{~cm}$. 1....; filiform-stalked and nodding, or the upper erect; perigynia 3-angled, somewhat swollen, abruptly sharp-beaked, 3-4 mm. long, about as long as the ovate awn 2 ccalss. In wet soil, S. E: Va. to Fla., Mo. and Miss. June-Aug.

72. Care:: glaìca Scop. Glaucous Sedge. (I. F. f. 742.) Glabrous, pale green, glaucc us, culms $0.2-0.5 \mathrm{~m}$. tall. Leaves smooth or nearly so, about $4 \mathrm{~mm}$. wide; lower br.ct similar, narrower; staminate spikes mostly 2, stalked; pistillate spikes 2 or 3 , at length drooping, slcnder-stalked, linear-cylindric, $2-5 \mathrm{~cm}$. long, $6 \mathrm{~mm}$. thick; prrigynia brown, ellipsoid, few-nerved, or nerveless, granulate or papillose, nearly $2 \mathrm{~mm}$. long, minutely beaked, the orifice entire; scales ovate or lanceolate, brown with a green midvein, about as long as the perigynia; stigmas 2. In meadows, N. S. and Ont. Adventive from Europe. June-Aug.

Perigynium densely pubescent.

Pistillate spikes oblong-cylindric, $8-20 \mathrm{~mm}$. long; perigynia oval or ovoid, fewnerved.

Pistillate spikes narrowly cylindric, 12-3 $\mathrm{jm}$. long; perigynia oblong, strongly several-nerved.

Perigynium nearly glabrous, at least $\therefore$ hen mature.

74. C. costellata.

Spikes 5-7 mm. thick; perigynia imbricated, flattened; top of the achene not bent. 75. C. triceps.

Spikes $4 \mathrm{~mm}$. thick; p rigynia not imbricated, swollen; top of the achene bent, or tipped with a bent styl.

76. C. Caroliniana.

73. Carex viréscens Muhl. Downy Green Sedge. (I. F. f. 743.) Culms slender, rough above, I.5 $-5 \mathrm{dm}$. tall. Leaves light green, pubescent, especially on the sheaths; spikes 2-5, short-stalked, erect or nearly so, $8-20 \mathrm{~mm}$. long, about $3 \mathrm{~mm}$. in diameter, the terminal one staminate below; perigynia 3 -sided, rather less than $2 \mathrm{~mm}$. long, green, beakless, the orifice entire; scales oblong-ovate, cuspidate, slightly shorter than the perigynia. In dry woods and thickets, Me. and Ont. to Mich., N. Car. and Mo. June-July.

74. Carex costellàta Britton. Kibbed SEdge. (I. F. f. 744.) Similar to the preceding, but taller and more spreading. Leaves pubescent; spikes 2-5, 
rather bose, $3 \mathrm{~mm}$. in diamet $\epsilon_{\text {, }}$, the terminal one staminate below, the lower one cominonly filiform-stalked; perigynia narrowed at each end, $2 \mathrm{~mm}$. long, rather more than I mm. thick; scales ovate, shorter than the perigynia. In woods, Me. and Ont. to N. Car. June-Aug.

75. Carex tríceps Michx. Hirsute Sedge. (I. F. f. 745.) Light green; culms rough above, 1.5-9 dm. long. Leaves 2-4 mm. wide, pubescent; spikes 2-5, dense, erect, sessile or very nearly so, 6-16 $\mathrm{mm}$. long, usually clustered, the terminal one staminate at the base; perigynia oval or obovoid, flattened, not inflated, green or greenish-brown, few-nerved, usually pubescent when young, when mature I-2 mm. long, the orifice minutely notched or entire; scales ovate, cuspidate or short-awned; achene elliptic-olovoid, its summit not bent. In woods, fields and swamps, Mass. to southern Ont. and Mich., Fla. and Tex. April-Aug.

76. Carex Caroliniàna Schwein. Carolina Sedge. (I. F. f. 746.) Culms slender, rough above, $0.3-0.6 \mathrm{~m}$. tall. Leaves $2-3 \mathrm{~mm}$. wide, rather dark green, glabrous except on the sheaths; spikes 2-4, oblong, dense, sessi'e or nearly so, 8-12 $\mathrm{mm}$. long; clustered; the upper one staminate at the base; perigynia subglobose or obovoid, swollen, about $1 \mathrm{~mm}$. in diameter, nerveless or faintly nerved, brown, beakless; scales brown, ovate, mucronate; achene pyriform, bent at the summit or tipped with the bent style. In meadows, N. J: and Penn. to N. Car. and Ark. May-July.

Perigynia 2-4 mm. long, slightly swollen; spikes linear or linear-cylindric.

llant glabrous; perigynia obtuse.

Sheaths pubescent; perigynia pointed at both ends.

Perigynia $2 \mathrm{~mm}$. long; spikes erect or somewhat spreading. 78. C. aestivalis.

Perigynia $4 \mathrm{~nm}$. long; spikes drooping, at least when old. 79. C. oxylepis.

Perigynia 4-5 mm. long, manifestly swollen; spikes oblong or oblong-cylindric.

Perigynia faintly few-nerved; scales ovate, acute or short-awned. 80. C. formosa.

Perigynia strongly many-nerved; scales lanceolate, long-awned. 81. C. Davisii.

77. Carex gracíllima Schwein. Graceful Sedge. (I. F. f. 747.) Glabrous; culms roughish above, $0.3^{-1} \mathrm{~m}$. long. Leaves dark green, 3-6 $\mathrm{mm}$. wide, shorter than the culm; lower bract foliaceous; spikes $3-5,2-6 \mathrm{~cm}$. long, about $4 \mathrm{~mm}$. thick or sometimes much smaller, filiform-stalked and drooping, the upper one partly or wholly staminate; perigynia ovoil-oblong, obtuse, few-nerved, glabrous, $2 \mathrm{~mm}$. long; scales ovate-oblong, pale, one-half as long as the perigynia. In moist woods and meadows, Newt. to Manitoba, N. Car., Ohio and Mich. MayJuly.

Professor Bailey has described a hybrid with $C$. hirsuta. Carex Sullivantii Boott, is a hybrid of $C$. gracillima with $C$. pubescens.

78. Carex aestivàlis M. A. Curtis. Summer Sedge. (I. F. f. 748.) Culms slender or filiform, $0.2-0.5 \mathrm{~m}$. tall. Leaves flat, $2-3 \mathrm{~mm}$. wide, elongated, their sheaths usually pubescent; spikes $3-5$, narrowly linear, erect or somewhat spreading, 2-5 cm. long, about $3 \mathrm{~mm}$. thick, the terminal staminate at the base or also at the summit; perigynia oblong, 3 -sided, few-nerved, $2 \mathrm{~mm}$. long, beakless, the orifice entire; scales ovate-oblong, the lower cuspidate or short-awned. In mountain woods, Mass. and N. Y. to Ga. June-Aug.

79. Carex oxflepis Torr. \& Hook. Sharp-SCaled Sedge. (I. F. f. 749.) Culms slender, smooth, $0.2-0.5 \mathrm{~m}$. tall. Leaves 3-6 mm. wide, pubescent, especially on the sheaths; spikes 4 or 5 , linear-cylindric, $2-5 \mathrm{~cm}$. long, about $4 \mathrm{~mm}$. in diameter, filiform-stalked, the terminal one staminate at the base or sometimes wholly staminate; perigynia oblong, 3-angled, pointed at both ends, less than 2 $\mathrm{mm}$. thick, several-nerved, the orifice entire; scales ovate-lanceolate; short-awned, shorter than the perigynia. Mo. to Tenn., S. Car., Tex. and Fla. April-May.

8o. Carex formòsa Dewey. Handome SedGe. (I. F. f. 750.) Culms slender, smooth, $0.2-0.6 \mathrm{~m}$. tall. Leaves pubescent, especially on the sheaths, the basal 4-6 mm. wide; spikes 3-5, dense, $\mathrm{I}-3 \mathrm{~cm}$. long, nearly $6 \mathrm{~mm}$. in diameter, filiformstalked, the upper one staminate at the base; perigynia ovoid, glabrous, swollen, $4 \mathrm{~mm}$. long, $2 \mathrm{~mm}$. thick, with a short slightly notched beak; scales lanceolate or ovate, green, acute, or the lower short-awned. In dry woods and thickets, Mass, and Vt, to Ont., $\mathrm{N}, \mathrm{Y}$, and Mich, June-July, 
8r. Carex Davísii Schwein. \& Torr. Davis' Sedge. (I. F. f. 75r.) Similar to the preceding, stouter. Leaves 3-6 $\mathrm{mm}$. wide, pubescent; lower bract foli. aceous; spikes clustered, or the lower one distant, $6 \mathrm{~mm}$. in diameter, at length spreading or drooping, the terminal one staminate at the base; perigynia much swollen, strongly several-nerved, 4-5 mm. long, with a short but conspicuously 2-toothed beak; scales lanceolate or oval, long-awned, equalling or longer than the perigynia. In moist thickets and meadows, Mass. to N. Y., Minn., Ga., Ky., Kans. and the Ind. Terr. May-July.

Perigynia manifestly beaked, nerved or nerveless; pistillate spikes drooping, at least when old.

Beak of the perigynium cylindric or subulate, $1-2$ times as long as the body. SYL, VATICAE.

Perigynia broadly oval, smooth, spreading. $\quad 82$. C. longirostris.

Perigynia narrowly conic, tuberculate-hispid, appressed. 83. C. Assiniboinensis,

Beak of the perigynium not more than one-half as long as the body.

Leaves pubescent. Flexiles. 84. C. castanea.

Leaves glabrous.

Pistillate spikes narrowly oblong, 4-12 $\mathrm{mm}$. long; perigynium $2 \mathrm{~mm}$. long: arctic and alpine species. CAPILlaRes. 85. C. capillaris.

I'istillate spikes linear, $2-8 \mathrm{~cm}$. long ; perigynium 4-6 mm. long. DEBILES. Perigynia membranous, few-nerved; pistillate spikes slender.

Leaves $5^{-10} \mathrm{~mm}$. wide ; scales two thirds as long as the perigynia.

86. C. arctata.

Leaves $2-5 \mathrm{~mm}$. wide; scales one-half as long as the perigynia. 87. C. tenuis.

Perigynia coriaceous, strongly many-nerved; pistillate spikes thicker. 88. C. oblita.

Perigynia beakless or minutely beaked, finely many-striate; spikes erect or nearly so. GRISEAE.

Leaves slightly glaucous or not at all.

Perigynia little longer or shurter than the scales.

Pistillate spikes dense, usually many-flowered; leaves $4-6 \mathrm{~mm}$. wide, spreading, soft.

89. C. grisea.

Pistillate spikes loosely several-flowered ; leaves $2-4 \mathrm{~mm}$. wide, mostly erect and rigid.

Perigynia 2-3 times longer than the scales.

Plant very glaucous all over.

9o. C. amphibola.

91. C. flaccosperma.

92. C. glaucodea.

82. Carex longiróstris Torr. Long-Beaked Sedge. (I. F. f. 752.) Gla. brous, light green; culms slender, roughish above, $0.2-1 \mathrm{~m}$. long. Leaves flat, 2-3 mm. wide, usually not exceeding the culm, the bracts similar; staminate spikes I-3, slender-stalked; pistillate spikes $2-4$, oblong-cylindric, loosely flowered, I-5 $\mathrm{cm}$. long, 6-8 $\mathrm{mm}$. in diameter, all filiform-stalked and nodding or the upper one nearly sessile; perigynia slightly inflated, pale, strongly I-nerved on each side, the body about $2 \mathrm{~mm}$. long, contracted into a very slender beak; scales lanceolate, spreading, acuminate, scarious-margined, $6-8 \mathrm{~mm}$. long. On banks and in moist thickets, N. B. to Ont. and the N. W. Terr., Mass., Penn., Mich. and Neb. JuneSept.

83. Carex Assiniboinénsis W. Boott. Assiniboia Sedge. (1. F. f. 753.) Glabrous; culms filiform, reclining, $0.5-0.6 \mathrm{~m}$. long, longer than the leaves. Leaves and bracts $2 \mathrm{~mm}$. wide or less, the lower reduced to short purplish sheaths; staminate spike long-stalked; pistillate spikes 2 or 3, distant, loosely few-flowered, 1.5-3 cm. long, drooping on filiform stalks; the flowers alternate; perigynia obtusely 3-angled, subulate-beaked, above $6 \mathrm{~mm}$. long and $2 \mathrm{~mm}$. thick above the base; scales lanceolate, awned, about the length of the perigynia. In wet soil, northern Minn. and Manitoba. Summer.

84. Carex castànea Wahl. Chestiut Senge. (I. F. f. 754.) Culms slender or filiform, rough above, $0.3^{-1} \mathrm{~m}$. tall. Leaves 3-5 mm. wide, shorter than the culm; bracts linear-filiform, I-3 cm. long; staminate spike stalked; pistillate spikes I-4, oblong or oblong-cylindric, I-2.5 cm. long, about $6 \mathrm{~mm}$. thick, drooping on filiform stalks; perigynia glabrous, oblong or oblong-lanceolate, 3-angled, few-nerved, tapering into a 2 -toothed leak one-half as long as the body, scales ovate or ovite-lanceolate, acute or cuspiclate, rather shorter than the perigynia. In dry thickets and on banks, Newf, to Conn., Minu. and Kaus. June-July. 
85. Carex capillàris L. HAIR-LIKE SEDGE. (I. F. f. 755.) Glabrous; culms slender or filiform, $5-35 \mathrm{~cm}$. tall. Leaves $\mathrm{I}-2 \mathrm{~mm}$. wide, much shorter than the culm, roughish; lower bract similar, tho upper much narrower; spikes filiformstalked, the terminal one staminate; pistillate spikes I-3, 4-12 mm. long, $2 \mathrm{~mm}$. thick, nodding, 2-12-flowered; perigynia oblong, 3-angled, almost nerveless, about $2 \mathrm{~mm}$. long, the slender beak about one-third as long as the body; scales oval, scarious-margined, shorter than the perigynia. Greenland to Alaska, Me., N. H., N. Y., Mich., and in the Rocky Mts. to Colo. and Utah. Also in Europe and Asia.

86. Carex arctàta Boott. Drooping Wood SEDGe. (I. F. f. 756.) Glabrous, culms 3-6 dm. long. Leaves roughish-margined, much shorter than the culm, 5-10 mm. wide; staminate spike short-stalked; pistillate spikes 2-5, linear, $3 \mathrm{~mm}$. thick, many-flowered, ascending, or at length drooping and filiform-stalked; perigynia oblong, rather strongly few-nerved, about $4 \mathrm{~mm}$. long, less than $2 \mathrm{~mm}$. thick, 3-angled, tapering into a short 2-toothed beak; scales ovate, cuspidate or short-awned, shorter than the perigynia. In dry woods and thickets, N. B. to Minn., Penn. and Mich. May-June.

Carex arctàta Fáxoni Bailey. Spikes nearly erect, 2-4 of. them clustered near the sumnit, usually shorter, the staminate one very short; perigynia 4-5 mm. long. Quebec to N. H., Minn. and Mich.

\section{Carex Kniéskerni Dewey is probably a hybrid of $C$. arctata with $C$. castanea or $C$. formosa.}

87. Carex ténuis Rudge. Slender-stalked Sedge. (I. F. f. 757.) Culms rough above, I-9 dm. long. Leaves $3-5 \mathrm{~mm}$. wide; lower bracts similar; staminate spike short-stalked; pistillate spikes $2-5$, linear, $3 \mathrm{~mm}$. thick, filiform-stalked and spreading or drooping; perigynia spindle-shaped, glabrous or puberulent, faintly few-nerved, obtusely 3 -angled, $6 \mathrm{~mm}$. long, less than $2 \mathrm{~mm}$. thick, tapering into a short 2-toothed beak; scales ovate or oblong, one-half as long as the perigynia. In woods, Newf. to Mich., N. Car. and Ky. May-Aug. A hybrid with C. virescens occurs at Revere, Mass.

Carex ténuis interjécta (Bailey) Britton. Pistillate spikes very slender, often compound at the base, erect or nearly so, filiform-stalked, loosely flowered, the perigynia alternate, only about $4 \mathrm{~mm}$. long. N. Y. and Penn.

Carex ténuis eréctior Britton. Mostly taller and stouter than the type, and erect: leaves about $4 \mathrm{~mm}$. wide; pistillate spikes erect or but slightly spreading; perigynia $5 \mathrm{~mm}$. long, one-third longer than the scales. White Mts.

88. Carex oblita Steud. Dark-green SEDGe. (I. F. f. 758.) Glabrous; culms sharply 3-angled, smooth or nearly so, 3-9 dm. long. Leaves 4-5 mm. wide, shorter than the culm; lower bract similar; staminate spike solitary, filiform. stalked; pistillate spikes $3-5,2-6 \mathrm{~cm}$. long, about $5 \mathrm{~mm}$. thick, loosely flowered, slender-stalked, the lower distant, drooping; perigynia 3-angled, glabrous, $6 \mathrm{~mm}$. long, less than $2 \mathrm{~mm}$. thick, tapering into a short 2 -toothed beak; scales obtuse, about one-third the length of the perigynia. In bogs, central N. Y. and Penn. to N. J. and N. Car. June-Aug.

89. Carex grísea Wahl. Gray Sedge. (I. F. f. 759.) Glabrous; culms smooth or nearly so, 3-6 dm. long. Leaves light green, sometimes slightly gioucous; bracts similar, much overtopping the spikes; staminate spike sessile; pistillate spikes 3-5, oblong, 8-25 mm, long. about $4 \mathrm{~mm}$. thick, the lower slender-stalked and distant; perigynia $5 \mathrm{~mm}$. long, $2 \mathrm{~mm}$. thick; beakless; scales cuspidate or awned. In woods and thickets, Me. to Ont. and Minn., N. Car. and Kans. May-July.

90. Carex amphíbola Steud. Narrow-leaved Sedge. (I. F. f. 760.) Glabrous; culms slender, 3-5 dm. long. Leaves $2-4 \mathrm{~mm}$. wide; bracts similar, erect, not over $2 \mathrm{~mm}$. wide, overtopping the spikes; staminate spike short; pistiliate spikes $2-4, \mathbf{r}-2.5 \mathrm{~cm}$. long, less than $4 \mathrm{~mm}$. thick, loosely several-flowered, the lower on filiform stalks; perigynia oblong or obovoid, firm, pointed, beakless, 3-angled, $4 \mathrm{~mm}$. long, about $2 \mathrm{~mm}$. thick; scales awned, spreading. In dry soil, N. J. and Penn. to Iowa, Fla. and Tex. April-June.

9r. Carex flaccospérma Dewey. Thin-fruited Sedge. (I. F. f. 76r.) Similar to Carex grisea and $C$. glaucodea, slightly glaucous; culms $3^{-6} \mathrm{dm}$. tall. Ie tves thin, the basal ones 6-12 mm. wide, the bracts leafy; staminate spike sessile or nearly so; pistillate spikes $2-4$, oblong, erect, the lower slender-stalked; 
perigynia oblong, 3-angled, $5 \mathrm{~mm}$. long; scales broadly ovate, green, 2-3 times shorter than the perigynia. S. Mo. to Tex., N. Car. and Fla. June-July.

92. Carex glaucòdea Tuckerm. Glaucescent Sedge. (I. F. f. 762.) Similar in habit to Carex grisea, but pale and very glaucous; culms 1.5-5 dm. long. Leaves 4-8 mm. wide; bracts foliaceous; staminate spike sessile; pistillate spikes 3-5, erect, densely flowered, the lower slender-stalked; perigynia oblong, 3-4 mm. long, beakless, nearly twice as long as the scales. In open fields and meadows, Mass. to Penn., Ill., Va. and Ark. May-July.

Fistillate spikes scattered, distant, long-stalked or the 2 upper ones close together and nearly sessile. Granulares.

Bracts elongated, mostly overtopping the spikes ; perigynia strongly many-nerved.

Basal leaves $3-6 \mathrm{~mm}$. wide ; perigynia $2-3 \mathrm{~mm}$. long. 93. C. granularis.

Basal leaves 5-16 mm. wide; perigynia-1.5 mm. long. 93a. C. Shriveri.

Bracts short, rarely overtopping the spikes; perigynia obscurely few-nerved.

94. C. Crawei.

Pistillate spikes close together and nearly sessile at the summit of the culm, or the lowest distant and stalked.

Beak of the perigynium stout, 2-toothed; plants glabrous. EXTENSAE.

Leaves strongly involute; perigynia brown, the beak shorter than the body. 95. C. extensa.

Leaves flat, 2-5 $\mathrm{mm}$. wide; perigynia yellow when mature, $4^{-6} \mathrm{~mm}$. long, the beak about as long as the body.

Leaves flat, $2 \mathrm{~mm}$. wide or less; perigynia dark green, $2 \mathrm{~mm}$. long, the beak one-half as long as the body.

Beak of the perigynium short, entire or none; leaves, or their sheaths, more or less pubescent. Pallescentes.

Perigynia faintly few-nerved, beakless.

Perigynia strongly many-nerved, cylindric-beaked.

98. C. pallescens.

99. C. abbreviata.

93. Carex granulàris Mull. Meanow SedGe. (I. F. f. 763.) Glabrous, slightly glaucous; culms slender, smooth or nearly so, I.5-6 dm. long. Leaves 3-6 mm. wide, the basal shorter than the culm; bracts similar ; staminate spike sessile or short-stalked; pistillate spikes $3-5$, erect or slightly spreading, $1-3 \mathrm{~cm}$. long, $4 \mathrm{~mm}$. thick, many-flowered, stalked or the upper sessile perigynia ovoid, strongly many-nerved, 2-3 mm. long, with a short, bent or nearly straight beak; scales ovate, acute or cuspidate. In moist meadows, N. B. to Ont., Manitoba, Fla. and La. May-July.

93a. Carex Shriveri Britton. Basal leaves broader, 5-16 mm. wide, glaucous; spikes smaller and narrower; perigynia $\mathbf{I}-\mathbf{I} .5 \mathrm{~mm}$. long, narrower, the beak slightly bent. N. Y. and Penn. to Wis. and Va. (C. granularis Shriveri Britton, I. F. I: 322.)

94. Carex Cràwei Dewey. CRAwe's Sedge. (I. F. f. 764.) Glabrous ; culms stiff, 7-40 $\mathrm{cm}$. tall. Leaves rather stiff, 2-4 $\mathrm{mm}$. wide, shorter than the culm; the bracts similar; staminate spikes I-3, long-stalked; pistillate spikes I-4, cylindric, erect, $\mathbf{I}-2.5 \mathrm{~cm}$. long, 4-6 mm. thick, the lowest often borne near the base; perigynia ovoid, usually resinous dotted, $2-3 \mathrm{~mm}$. long, tapering into a short entire beak; scales obovate or oval, acute or cuspidate, shorter than the perigynia. In meadows and on banks, Quebec to Man., Penn., Tenn. and Neb. May-July.

95. Carex exténsa Gooden. Long-Bracted Sedge. (I. F. f. 765.; Glabrous; culms stiff, 2.5-5 dm. tall. Leaves 2-4 mm. wide, involute, erect, shorter than the culm; lower bract similar, much exceeding the spikes; staminate spike sessile; pistillate spikes I-3, erect, oblong, densely many-flowered, IO-I6 mm. long, about $6 \mathrm{~mm}$. thick; perigynia ovoid or ovoid-oblong, brown, $3 \mathrm{~mm}$. long, many-ribbed, tapering into a short 2-tnothed beak; scales ovate, acute, shorter than the perigynia. Borders of salt meadows, Coney Island, N. Y., and near Norfolk, Va. Naturalized from Europe. June-Aug.

96. Carex flàva L. Yellow SedGe. (I. F. f. 766.) Glabrous, yellowgreen; culms slender but stiff, smooth or nearly so, 2-6 dm. tall. Leaves 2-5 mm. wide, flat; lower bract elongated, spreading or ascending; staminate spike ; pistillate spikes $\mathrm{I}-4$, oblong, erect, densely flowered, 6-12 mm. long, about $6 \mathrm{~mm}$. thick; perigynia yellow, spreading or deflexed when mature, 4-6 $\mathrm{mm}$. long, severalnerved, the subulate 2 -toothed beak about as long as the body; scales acute or subacute, shorter and narrower than the perigynia. In swamps and wet mearlows, 
Newf. to the N. W. Terr., R. I., N. J., Ohio and Mont. Also in Europe. JulySept.

97. Carex virídula Michx. Green Sedge. (I. F. f. 767.) Glabrous, bright green; culms slender, smooth, I-4 dm. tall, often exceeded by the basal leaves. Leaves $2 \mathrm{~mm}$. wide or less, the similar bracts much overtopping the spikes; staminate spike sessile; pistillate spikes $2-5$, oblong, 4-12 mm. long, $4 \mathrm{~mm}$. in dia meter or less; perigynia ovoid-oblong, $2 \mathrm{~mm}$. long or less, few-nerved, narrowed at the base, tapering into a 2-toothed beak about one-half as long as the body; scales ovate, shorter than the perigynia. In bogs and on wet rocks, Newf. to Hudson Bay and the N. W. Terr., south to Me., Penn., Minn., Utah and Wash. Summer.

98 Carex palléscens L. PALE Sedge. (I. F. f. 768.) Light green; culms slender, rough above, I-5 dm. tall. Ieaves flat, $2-3 \mathrm{~mm}$. wide, pubescent at least on the sheaths; lower bract similar; staminate spike stalked; pistillate spikes 2-4, oblong, slender-stalked or the upper one sessile, densely many-flowered, 8-18 $\mathrm{mm}$. long, 4-5 $\mathrm{mm}$. in diameter; perigynia short-oblong, pale, $2 \mathrm{~mm}$. long, obtuse, fewnerved, beakless, the orifice entire; scales ovate, cuspidate or short-awned. In fields and meadows, Newf. to Ont., R. I., Penn., Ill. and Wis. Also in Europe. May-July.

99. Carex abbreviàta Prescott. Tokrey's Sedge. (I. F. f. 769.) Pale green; culms rather stiff, $2.5-5 \mathrm{dm}$. tall, finely ciliate-pubescent. Leaves about $2 \mathrm{~mm}$. wide, elongated, usually densely pubescent; lower bract spreading or ascending; staminate spike short-stalked; pistillate spikes I-3, short-oblong, 6-10 $\mathrm{mm}$. long, sessile or the lower one short-stalked, clustered ; perigynia broadly oblong or obovoid, glabrous, about $2 \mathrm{~mm}$. long, many-nerved, obtuse, abruptly tipped by a short cylindric beak; scales cuspidate, shorter than the perigynia. In dry soil, N. Y. to the N. W. Terr., south in the Rocky Mts. to Colo. June-July.

\section{Scales of the spike normal, not elongated and leaf-like. Nos. I00-120.}

Leaves $2-36 \mathrm{~mm}$. wide; bracts leafy, usually large. Nos. I00-1 19.

Periginia green (yellow or purple in no. 116). Nos. 100-117.

Perigynia finely many-striate. OligocarpaE.

Sheaths glabrous.

Perigynia narrowed at both ends, beakless. Ioo. C. conoidea.

Perigynia with a short entire beak. Ior. C. oligocar $\uparrow$ a. Sheaths pubescent.

102. C. Hitchcockiana.

Perigynia with few or many, mostly strong nerves. LAXiflorae.

Plants not at all glaucous, or very slightly so.

Beak of the peregyniunt straight, slender.

Culms slender, spreading; pistillate spikes 2 or 3 , stalked, spreading.

Culms stout, $\epsilon$ rect ; pistillate spikes 1 or 2 , erect.

Beak of the perigynium bent, short or none.

104. C. polymorpha.

Leaves mostly narrow, $2-12 \mathrm{~mm}$. wide.

Scales, at least the upper, obtuse.

Bracts elongated; spikes loosely flowered; culms slender. ro5. C. tetanica.

Bracts short; spikes densely flowered; culms stout. 106. C. Meadii.

Scales acute, cuspidate, acuminate or awned.

Perigynia obtusely 3 -angled.

Perigynia obovoid, $2.5-3 \mathrm{~mm}$. long.

107. C. laxiflora.

Perigynia oblong, narrow, about $4 \mathrm{~mm}$. long.

Perigynia sharply 3 -angled. 108. C. styloflexa.

Spikes drooping or spreading; leaves $2-4 \mathrm{ma}$ wide, or wider in the variety.

I09. C. digitalis.

Spikes erect ; leaves 6-12 $\mathrm{mm}$. wide. I Iо. C. Careyana.

Leaves broad, $12-36 \mathrm{~mm}$. wide.

Bracts leafy, the upper usually overtopping the spikes. II . C. Albursina.

Bracts mostly reduced to purple leafless sheaths. 
Plants distinctly glaucous.

Pistillate spikes drooping on hair-like stalks.

Pistillate spikes erect.

113. C. laxiculmis.

Basal leaves much longer than the culm.

14. C. ptychocarpa.

Basal leaves shorter than the culm or equalling it.

Leaves $12-25 \mathrm{~mm}$, wide.

Leaves 2-4 $\mathrm{mm}$. wide.

15. C. platyphylla.

Scales acute; perigynia yellow, purple or mottled.

16. C. panicea.

Scales obtuse, or the lower acute; perigynia pale green.

Perigynia white, yellow or becoming brown. Bicolores. I17. C. livida.

Perigynia beakless.

II8. C. aurea.

Perigynia with a short cylindric beak; arctic species. I19. C. bicolor.

Leaves and culms almost capillary; bracts reduced to bladeless sheaths. DigitataE.

Scales of the spikes leaf-like, elongated. Phyllostachyae. 120. C. setifolia.

Lower scales $2 \mathrm{~mm}$. wide or less, not concealing the perigynia.

Body of the perigynium oblong; beak flattened.

Body of the perigynium globose; beak subulate.

Lower scales 2-4 mm. wide, concealing the perigynia.

136. C. Willdenovii.

137. C. Jamesii.

138. C. durifolia.

I00. Carex conoidea Schk. Field SEDGE. (I. F. f. 770.) Glabrous; culms rather stiff, 2-5 dm. tall. Leaves $2-3 \mathrm{~mm}$. wide; lower bracts similar; staminate spike long-stalked; pistillate spikes I-3, distant, erect, oblong, $\mathbf{I}-2.5 \mathrm{~cm}$. long, 5 $\mathrm{mm}$. thick, the lower slender-stalked; perigynia oblong, obtusely 3 -angled, acute, beakless, $2-3 \mathrm{~mm}$. long, about I $\mathrm{mm}$. thick, the orifice entire; scales broadly ovate, contracted into a rough awn, the lower longer than the perigynia, the upper shorter than or equalling them. In meadows, N. S. to Ont., south to R. I., N. J., Ohio and Iowa. May-June.

Ior. Carex oligocàrpa Schk. Few-Fruited SEDGe. (I. F. 77I.) Glabrous; culms very slender or almost fili ${ }^{\wedge}$ rm, roughish, 2-5 dm. long. Leaves about 2 $\mathrm{mm}$. wide, soft, the bracts simil $\mathbf{r}$ tamin spike long-stalked or nearly sessile; pistillate spikes 2-4, erect or aly , distant, loosely few-flowered, 8-16 mm. long, less than $4 \mathrm{~mm}$. thick, the 1 e Tiform-stalked; perigynia oblong, pale, 2$2.5 \mathrm{~mm}$. long, narrowed into a sh $\mathrm{rt} \sim \mathrm{n}$.ir beak; scales ovate, with a rough spreading awn. In dry woods and thickets, Vt. and Ont. to Mich., Iowa, N. J., W. Va. Mo., and Kans. May-July.

102. Carex Hitchcockiàna Dewy. Hitchcock's Sedge. (I. F. f. 772.) Culms slender, 3-6 dm. tall ; leaves 3-6 mm. wide, the similar bracts overtopping the spikes, their sheaths pubescent, their blades somewhat so; pistillate spikes 2-4, loosely few-flowered, perigynia ovoid, btusely 3-angled, $3 \mathrm{~mm}$. long, nearly $2 \mathrm{~mm}$. thick, with a short oblique entire beak; cale ovate or ovate-lanceolate, roughawned. In woods and thickets, Vt. and Sni. to Mich., Iowa, N. J., W. Va. and Mo. May-July.

I03. Carex altocaùlis (Dewey) Britton. Sheathed Sedge. (I. F. f. 773.) Glabrous; culms slender, weak, 2-6 dm. long. Leaves 3-4 mm. wide, shorter than the culm, the upper ones and the bracts usually very short; staminate spise long-stalked; pistillate spikes 2 or 3, distant, slender-stalked, less than $2.5 \mathrm{~cm}$. long, loosely several-flowered, their stalks partly enclosed by the long sheaths; perigynia oblong, 3-angled, few-nerved, $4 \mathrm{~mm}$. long, with a beak about one-fourth the length of the body, the orifice 2-tooth, oblique; scales oval or ovate-lanceolate. In swamps. Quebcc and Vt. to Ont., N. Y. and Minn. Summer.

I04. Carex folymórpha Muhl. Variable Sedge. (I. F. f. 774.) Glabrous, rather dark green; culms stiff, 2-6 dm. tall. Leaves 3-4 mm. wide, nearly erect; bracts usually little longer than the pistillate spike; staminate spikes I or 2, long-stalked; pistillate spikes commonly solitary, erect, short-stalked or sessile, 2-4 cm. long, $8 \mathrm{~mm}$. thick; perigynia ovoid-oblong obscurely 3 -angled, fully $4 \mathrm{~mm}$. long and $2 \mathrm{~mm}$. in diameter, the beak more than one-half as long as the body, the orifice oblique; scales red-brown, somewhat shorter than the perigynia. In swamps or wet meadows, Me. to N. J., Penn. and N. Car. June-Aug.

105. Carex tetánica Schk. Wood's SEDGe. (I. F. f. 775.) Light grcen 
and glabrous; culms slender, rough above, 2-5 dm. tall. Leaves 2-4 mm. wide ; bracts narrow, elongated; staminate spike stalked; pistillate spikes 2 or 3, erect, distant, $2.5 \mathrm{~cm}$. long or less, or the lower filiform-stalked and drooping; perigynia oblong, many-nerved, about $3 \mathrm{~mm}$. long, the summit curved outwardly and tapering to an entire orifice, beakless: scales ovate-oblong. In meadows and wet woods, Me. and Ont. to Manitoba, N. Car. and La. June-July.

106. Carex Mèadii Dewey. Mead's SEDGe. (I. F. f. 776.) Similar to the preceding; culm stouter, very rough above, $3-4 \mathrm{dm}$. tall. Bracts short, not overtopping the spikes; staminate spike long-stalked; pistillate spikes I-3, oblongcylindric, dense, $1-2.5 \mathrm{~cm}$. long, about $6 \mathrm{~mm}$. in diameter, erect, stalked or tlie upper one sessile; perigynia broadly oblong, many-nerved, $3 \mathrm{~mm}$. long, tipped with a minute slightly bent beak; scales ovate, green with purple-brown margins. In swamps and wet meadows, R. I. to Penn. and Ga., west to Mich., Assiniboia, Neb. and Ind. Terr. The lowest spike is sometimes borne on a very long stalk arising from the axil of one of the basal leaves. May-July.

107. Carex laxiflòra Lam. Loose-Flowered SEDGE. (I. F. f. 777.) Glabrous; culms slender, roughish above, 1.5-6 dm. long. Leaves $3-6 \mathrm{~mm}$. wide, soft; staminate spike usually stalked; pistillate spikes 2-4, distant, hinear-cylindric, 3-4 min. thick, all slender-stalked and spreading or drooping or the upper one erect and sessile; perigynia obovoid, mor e or less oblique, $2.5-3 \mathrm{~mm}$. long, strongly many-nerved, tapering into a short outwardly bent entire beak; scales ovate with broad white scarious margins acute, cuspidate or awned. In meadows and thickets, Me. and Ont. to Minn., Fla., Ala. and the Ind. Terr. May-July.

Carex laxiflòra blánda (Dewey) Boott. Pistillate spikes cylindric, mostly densely flowered, the upper sessile or nearly so, erect, contiguous to the usually sessile staminate one, the lower slender-stalked. Range of the type. Perhaps specifically distinct.

Carex laxifiòra vàrians Bailey. Stouter and taller than the preceding: leaves 5$7 \mathrm{~mm}$. wide ; pistillate spike sometimes $3 \mathrm{~cm}$. long and $5 \mathrm{~mm}$. thick, dense, often compound at the base, the upper sessile or short-stalked and contiguous to the sessile staminate one, the lower long-stalked. N. H. to N. Y., Mich., Mo. and Neb.

Carex laxifiòra patulifollia (Dewey) Carey. Glaucous or pale green; basal leaves 5-9 mm. wide; staminate spike usually stalked; pistillate spikes $2.5 \mathrm{~cm}$. long or more, loosely flowered, scattered; perigynia oblong or ellipsoid, the beak nearly straight. Halifax, N. S. (according to Macoun); Mass. to Mich., Ala. and Tenn.

Carex laxiflora divaricata Bailey. Perigynia larger than in the other forms, contracted into a stipe one-half as long as the body. Washington, D. C.

ro8. Carex stylofléxa Buckley. Bent Sedge. ' (I. F. f. 778.) Glabrous; culms slender, smooth, 2-5 dm. long. Leaves $3-6 \mathrm{~mm}$. wide, shorter than the culm; bracts short; staminate spike usually long-stalked; pistillate spikes 1-4, distant, loosely flowered, less than $16 \mathrm{~mm}$. long, the lower drooping on filiform stalks; perigynia oblong, triangular, many-nerved, about $4 \mathrm{~mm}$. long, $2 \mathrm{~mm}$. thick, somewhat oblique, slender-beaked; scales ovate or ovate-lanceolate, acute, cuspidate or short-awned, shorter than the perigynia. In woods and thickets, N. Y. and Penn. to Fla., La. and Tex. May-July.

ro9. Carex digitalis Willd. Slender Wood Sedge. (I. F. f. 779.) Glabrous, bright green; culms slender or almost filiform, usually reclining, I-4.5 dm. long. Leaves 2-4 mm. wide; staminate spike stalked; pistillate spikes 2-4, linear; loosely alternately flowered, I-2.5 cm. long, the lower filiform-stalked, spreading or drooping; perigyria oblong, sharply triangular, many-nerved, $2 \mathrm{~mm}$. long, more than I mm. thick, the short beak slightly oblique; scales acute, acuminate or short-awned. In woods and thickets, Me. and Ont. to Minn., Fla. and Tex. MayJuly.

Carex digitàlis copulàta Bailey. Larger in every way, culms sometimes $5 \mathrm{dm}$. long, reclining; leaves $5-8 \mathrm{~mm}$. wide; pistillate spikes shorter and denser; perigynia larger. Mich., S. Ont. and Iowa.

I Io. Carex Careyana Torr. CARey's SEDGE. (I. F. f. 780.) Glabrous, bright green; culms 2-6 dm. tall. Basal leaves, 6-1 $2 \mathrm{~mm}$. wide, short; bracts linearlanceolate with very long sheaths, the blades $2-7.5 \mathrm{~cm}$. long; staminate spike usually large, long-stalked; pistillate spikes I-3, less than $2.5 \mathrm{~cm}$. long, the lower on a long filiform stalk; perigynia ovoid-oblong, sharply 3-angled, many-nerved, fully 
$4 \mathrm{~mm}$. long, the short beak slightly oblique, entire; scales ovate with white hyaline margins, cuspidate or awned, shorter than the perigynia. In woods, N. E. (according to Bailey); N. Y. to Mich. and Va. May-June.

I Ir. Carex Albursina Sheldon. White BeAR Sedge. (I. F. f. 78I). Glabrous, rather deep green; culms flattened, usually spreading, 2-5 dm. long. Basal leaves lanceolate or oblong-lanceolate, acuminate, shorter than the culm, $\mathbf{I}-3 \mathrm{~cm}$. wide; bracts similar to the narrower culm leaves; staminate spike sessile or nearly so; pistillate spikes $2-4, \mathbf{I}-2.5 \mathrm{~cm}$. long, very loosely flowered; perigynia obovoid, obtusely 3 -angled, many-nerved, $4 \mathrm{~mm}$. long, $2 \mathrm{~mm}$. thick, with a short bent entire beak; scales ovate-oblong, scarious-margined, shorter than the perigynia. In woods, Quebec to Mass., N. Y., Minn., Va. and Iowa. June-Aug.

I I 2. Carex plantagínea Lam. Plantain-leaved Sedge. (I. F. f. 782.) Glabrous, rather dark green; culms I.5-5 dm. long. Leaves $\mathbf{I}-2.5 \mathrm{~cm}$. wide, persistent through the winter; bracts short, usually with purplish clasping sheaths; staminate spike long-stalked, purple; pistillate spikes 3 or 4, slender-stalked, 2.5 $\mathrm{cm}$. long or ltss; perigynia oblong, outwardly curved, many-nerved, $3 \mathrm{~mm}$. long; scales ovate, cuspidate. In woods, N. B. and Ont. to Manitoba, Va. and Wis. MayJuly.

I 3. Carex laxicúlmis Schwein. Spreading Sedge. (I. F. f. 783.) Glabrous; blue-green and glaucous; culms filiform, ascending or diffuse 1.5-6 dm. long. Basal leaves elongated, 6-Io $\mathrm{mm}$. wide; bracts usually short; staminate spike long-stalked; pistillate spikes 2-4, oblong, 6-12 $\mathrm{mm}$. long, about $4 \mathrm{~mm}$. thick, drooping on long hair-like stalks or the upper short-stalked; perigynia ovoidoblong, 3-angled, many-nerved, about $2 \mathrm{~mm}$. long, scarcely beaked, longer than the ovate green cuspidate or short-awned scales. In woods and thickets, Me. and N. H. to Ont., Mich., R. I. and Va. May-June.

I 4. Carex ptychocàrpa Steud. Thicket Sedge. (I. F. f. 784.) Glabrous; pale green and glaucous; culms very slender, smooth, $5^{-15} \mathrm{~cm}$. tall ; basal leaves 4-8 $\mathrm{mm}$. wide; bracts foliaceous; staminate spike small, sessile; pistillate spikes 2 or 3 , the lower one often slender-stalked and nearly basal, all erect, 8-16 $\mathrm{mm}$. long; perigynia oblong, pale, 3-angled, many-nerved, $2 \mathrm{~mm}$. long, pointed at both ends, minutely straiglit-beaked, the orifice entire; scales ovate, obtuse, about one-half as long as the perigynia. In moist woods and thickets, Mass. and N. J. to Fla. and La. June-Sept.

I 5. Carex platypállla Carey. Broad-leaved Sedge. (I. F. f. 785.) Glabrous, pale green and glaucous; culms spreading or reclining, I-4 dm. long. Leaves flat, I-2 $5 \mathrm{~cm}$. ide; bracts linear-lanceolate with clasping sheaths; staminate spike stalked; pistillate spikes 2-4, distant, erect, slender-stalked or the upper one nearly sessile, several-flowered, $\mathbf{x}-2 \mathrm{~cm}$. long; perigynia oblong, 3-angled, many-nerved, slightly bent at the summit, 2-3 mm. long; scales acute, cuspidate or short-awned. In woods and thickets, Quebec and Ont. to Micl. N H., Va. and Ill. May-Jurie.

I 16. Carex panícea L. Grass-like Sedge. Carnation-grass. (I. F. f. 786.) Glabrous, pale bluish green and glaucous; culms smooth, stiff, $2.5-6 \mathrm{dm}$. tall. Leaves $2-4 \mathrm{~mm}$. wide, the bracts much shorter and narrower; staminate spikes I or 2, stalked; pistillate spikes 2 or 3 , distant, filiform-stalked or the upper nearly sessile, about $5 \mathrm{~mm}$. thick; perigynia oval, about $3 \mathrm{~mm}$. long, obscurely 3-angled, yellow, purple, or mottled, faintly few-nerved, with a short entire somewhat oblique beak; scales ovate, acute, purple or purple-margined. In fields and meadows, N. S. to Me. and R. I. Nat. from Europe. June-July.

II7. Carex livida (Wahl.) Willd. LIVID SEDGE. (I. F. f. 787.) Glabrous, pale green and very glaucous; culms erect, smooth, 2-4 dm. tall. Leaves 2-4 $\mathrm{mm}$. wide, involute in drying; bracts narrow, usually short; staminate spike shortstalked; pistillate spikes I-3, I $-2.5 \mathrm{~cm}$. long, about $4 \mathrm{~mm}$. thick, clustered at the summit, cylindric, the third, when present, distant, stalked; perigynia oblong, very pale, nearly $4 \mathrm{~mm}$. long, finely nerved, straight, beakless, narrowed to an entire orifice; scales ovate, obtuse or the lower subacute, rather shorter than the perigynia. In bogs, Lab. and Hudson Bay to Alaska, south to Conn., the pine barrens of N. J. , central N. Y. and Mich. Also in Europe. Summer.

I 18. Carex aùrea Nutt. Golden-fruited SedGe. (I. F. f. 788.) Glabrous, light green; culms erect or reclining, 5-40 cm. long. Leaves flat, $2-3 \mathrm{~mm}$. wide; 
bracts similar; terminal spike short-stalked, staminate or androgynous; pistillate spikes 2-4, oblong, clustered near the summit or the lower one distant, filiformstalked, few-flowered, 4-20 mm. long; perigynia obovoid or subglobose, becoming fleshy, yellow or brown and about $2 \mathrm{~mm}$. in diameter when mature, many-nerved, beakless, the orifice entire; scales ovate; stigmas mostly 2. In wet meadows, springs and on wet rocks, Newf. to the N. W. Terr. and Br. Col., south to Mass., Penn., Mich., Utah and Wash. Summer.

ז19. Carex bìcolor All. Parti-Colored Sedge. (I. F. f. 789.) Similar to trie preceding, but with somewhat glaucous culms. Basal leaves 2-4 mm. wide; spikes 2-4, mostly clustered at the summit; perigynia oblong, white, compressed, few-nerved, less than $2 \mathrm{~mm}$. long, not fleshy at maturity, abruptly tipped with a short entire nearly cylindric beak; scales brown-purple with white midvein and margins, oval, shorter than the perigynia. Greenland and Lab. (according to Boott). Also in Europe. Summer.

120. Carex setifòlia (Dewey) Britton. Bristle-leaned Sedge. (I. F. f. 790.) Glabrous, pale green; culms filiform, smooth, weak, I-4 dm. long. Leaves filiform, shorter than the culm, less than $0.5 \mathrm{~mm}$. wide; bracts reduced to bladeless sheaths; staminate spike sessile or nearly so; pistillate spikes 2-4, slenderstalked, 4-8 $\mathrm{mm}$. long, loosely few-flowered, the upper commonly overtopping the staminate; perigynia oblong, 3 -angled, $2 \mathrm{~mm}$. long, polished and nearly olack when mature, faintly few-nerved, tapering into a short entire beak; scales ovate, hyaline, shorter than the perigynia; stigmas 3. In dry sandy or rocky soil, preferring limestone, N. B. to the N. W. Terr, Penn., Ky. and Neb. May-July.

Culm-leaves present, often short; bracts mainly reduced to bladekss purplish sheaths. Penunculatae.

Staminate spike short-stalked or sessile.

Perigynia about twice as long as the scales.

Perigynia not longer than the scales.

121. C. concinna.

122. C. Richardsoni.

Staminate spike long-stalked, commonly with some pistillate flowers at its base.

Leaves all basal; bracts short or long, not sheathing.

123. C. pedunculata.

Neither the culm nor the leaves pubescent; perigynia rounded. MontanaE.

Plant not stoloniferous.

Plants stoloniferous, the stolons sometimes short.

Culms, or some of them, longer than the leaves.

Scales smooth or very nearly so.

Staminate spike conspicuous, 6-r $8 \mathrm{~mm}$. long.

Staminate spike stout, $\mathrm{I}-3 \mathrm{~mm}$. thick.

Plant dark green; staminate spike very prominent; perigynia broadly oval.

125. C. Pennsyluanica.

Plant light green; staminate spike shorter; perigynia oblong.
126. C. varia.

Staminate spike very slender, not over I $\mathrm{mm}$. thick. 127. C. Novae-Angliae.

Staminate spike inconspicuous, rarely over $4 \mathrm{~mm}$. long (longer in the variety).

Scales, at least the lower, rough-awned. 129 . C. praecox.

Culms, or most of them, much shorter than the leaves.

Scales light green with purple margins; perigynia oblong.

130. C. nigromarginata.

Scales green with lighter scarious margins; perigynia oval.

13t. C. umbellata.

Plant pubescent all over; perigynia sharply 3-angled. TRIQUETRAE.

r32. C. pubescens.

I21. Carex concínna R. Br. Low Northern SEdGe. (I. F. f. 79r.) Culms filiform, smooth, 5-15 cm. tall. Leaves about $2 \mathrm{~mm}$. wide, pale green, much shorter than the culm; bracts reduced to green bladeless sheaths, or the lower one with an erect subulate blade 6-12 mm. long; staminate spike sessile; pistillate spikes I-3, erect, 4-8 mm. long. about $2 \mathrm{~mm}$. thick, compactly few-flowered; perigynia oblong-ovoid, 3-angled, pubescent, short-beaked, few-nerved, about twice as long as the ovate green or purplish scales. In rocky places, Quebec and Ont. to Br. Col. Summer.

I 22. Carex Richardsòni R. Br. Richardson's Sedge. (I. F. f. 792.) Culms slender, rough, I-3 dm. tall. Leaves about $2 \mathrm{~mm}$. wide, those of the culm 
vel $f$ snort; bracts bladeless, sheathing, $6-25 \mathrm{~mm}$. long, usually brown-purple with a white hyaline tip; staminate spike short-stalked; pistillate spikes I or 2, erect, short-stalked, 8-18 mm. long, compact, their stalks partly or wholly enclosed in the sheaths; perigynia obovoid, pubescent, about $2 \mathrm{~mm}$. long, minutely beaked; scales mostly longer than the perigynia, purple, conspicuously white-margined. In dry soil, Ont. to the N. W. Terr. and Br. Col., south to western N. Y., Ill., Iowa and S. Dak. Summer.

123. Carex pedunculàta Muhl. Long-STalked Sedge. Densely matted; culms slender, roughish above, $7-25 \mathrm{~cm}$. long. Leaves flat, 2$3 \mathrm{~mm}$. wide; sheaths green, the upper almost bladeless; staminate spike long. stalked; pistillate spikes 2-6, 6-12 mm. long, few-flowered filiform-stalked and spreading or drooping, some of them appearing basal; perigynia obovoid, 3-angled, $4 \mathrm{~mm}$. long, nerveless, narrowed into a stipe, tipped with a minute and somewhat oblique entire beak; scales ovate, abruptly cuspidate or the lower subulate-awned. In dry woods, Anticosti to Manitoba, Va., Penn. and Iowa. May-July.

124. Carex pedicellàta (Dewey) Britton. Firrous-rooted Sedge. (I. F. f. 794.) Light green, not stoloniferous; culms slender, roughish above, r.5-5 dm. long. Leaves 2-4 mm. wide, shorter than the culms; lower bract $0.6-5 \mathrm{~cm}$. long; staminate spike short-stalked, $8-25 \mathrm{~mm}$. long ; pistillate spikes 2-4, short-oblong, few-flowered; perigynia oval or oblong, rather less than $2 \mathrm{~mm}$. long, pale, pubescent, with a subulate 2-toothed beak one-fourth the length of the body; scales green, ovate, acute. In dry soil, N. S. to Minn. Ga., Ohio and Neb. May-July.

Carex pedicellata Wheèleri (Bailey) Britton. Usually lower than the species and the leaves much shorter than the culm; staminate spike only $4^{-6} \mathrm{~mm}$. long; pistillate spikes closer together. N. S. to Conn. and Mich.

125. Carex Pennsylvánica Lam. Pennsyluania Sedge. Dark or dull green, stoloniferous; culms slender, I.5-4 dm. tall. Leaves I-3 mm. wide, the old sheaths persistent and fibrillose; lower bract rarely over $1 \mathrm{~cm}$. long ; staminate spike sessile or very short-stalked, $\mathrm{I}-2.5 \mathrm{~cm}$. long ; pistillate spikes I-3, short-oblong, few-flowered, sessile ; perigynia oval, about $2 \mathrm{~mm}$. long, pubescent, I-ribbed on each side, with a 2-toothed beak about one-fourth the length of the body; scales ovate, purplish, acute or cuspidate. In dry soil, N. B. to Manitoba and the N. W. Terr., south to N. Car., Tenn. and Kans. May-June.

I26. Carex vària Muhl. Emmons' SEdGe. (I. F. f. 796.) Stoloniferous; culms filiform, erect or somewhat spreading, I.5-5 dm. long. Leaves $1-2.5 \mathrm{~mm}$. wide, nearly always shorter than the culms; lower bract scale-like or subulate, rarely $2 \mathrm{~cm}$. long; staminate spike $4-8 \mathrm{~mm}$. long, sessile, usually rather prominent; pistillate spikes 2-4, 4-6 mm. long; perigynia oblong, pubescent, about $2 \mathrm{~mm}$. long, narrowed at the base, with a subulate minutely 2-toothed beak commonly one-half the length of the body; scales ovate, green or purplish-brown, acute. In dry soil, N. S. to Ont., Manitoba, Ga. and Tex. May-July.

127. Carex Nòvae-Ángliae Schwein. New England Sedge. (I. F. f. 797.) Stoloniferous; culms filiform, erect or reclining, I-2 dm. long. Leaves about I $\mathrm{mm}$. wide, soft, elongated, often exceeding the culms; staminate spike short-stalked, very narrow, 6-16 mm. long; pistillate spikes $\mathrm{I}-4$, distant, subglobose; lower bract filiform, sometimes overtopping the spikes; perigynia $2 \mathrm{~mm}$. long, pubescent, tipped by a subulate 2-toothed beak about one-fourth the length of the body; sales ovate. greenish-brown, acute or cuspidate; stigmas 2 or 3 . In wet shaded places. Newf. to Me., Mass. and N. N. Y. Summer.

128. Carex defléxa Hornem. Northern Sedge. (I. F. f. 798.) Culms filiform, diffuse, $2-30 \mathrm{~cm}$. long. Bracts $\mathbf{r}-5 \mathrm{~cm}$. long; staminate spike sessile, 2-6 mm. long, inconspicuous; pistillate spikes I-4, 4-8 mm. long, the upper sessile, the lower slender-stalked; commonly also I or 2 nearly basal filiformstalked spikes from the lowest sheaths; perigynia oblong, pubescent, $2 \mathrm{~mm}$. long or less, with a flat 2-toothed beak about one-fourth the length of the budy; scales green, acute or cuspidate; stigmas 3 or 2 . In open places, N. S. to Ont., Me., Vt. and Penn. Summer.

Carex defléxa Farwéllii Britton. Densely tufted; culms stiff, erect, I.5-4 dm. tall, commonly much longer than the leaves; staminate spike conspicuous, 6-ro $\mathrm{mm}$. long; pistillate spikes 2 or 3 , scattered, the lower slender-stalked and subtended by a foli- 
aceous bract which often overtops the culm; perigynia 2-3 $\mathrm{mm}$. long. N. Mich. to Br. Col. and Ore., south in the Rocky Mts. to Colo.

I28a. Carex álbicans Willd. Whitish Sedge. Stoloniferous, pale green; culms $0.7-5 \mathrm{dm}$. tall. Leaves usually shorter than the culm, 2-3 mm. wide, flat; bracts very short; staminate spike less than $6 \mathrm{~mm}$. long, sessile; pistillate spikes 2 or 3 , clustered, ovoid, about as long as the staminate; perigynia ellipsoid, 3-angled, pubescent, the short beak 2-toothed; scales acute or cuspidate, shorter than the perigynia. In dry soil, N. E. and N. Y. May-June.

129. Carex praécox Jacq. Vernal SedGe. (I. F. f. 799.) Dark green, stoloniferous; culms slender, smooth, 7-30 cm. long. Leaves I-3 mm. wide, almost always much shorter than the culm; lower bract 6-25 mm. long; staminate spike usually large and conspicuous; pistillate spikes I-3, all close together, oblong, 6-12 mm. long; perigynia oblong or olsovoid, sharply 3-angled, pubescent, brown, about $2 \mathrm{~mm}$. long: tipped with a minute beak; scales ovate, purple-brown with a lighter midvein, acute, cuspidate or the lower rough-awned, about equalling the perigynia. E. Mass. to N. Y. Nat. from Europe. Native also of Asia. May-June.

I30. Carex nigro-marginàta Schwein. Black-EDGEd SEDGE. (I. F. f. 800.) Bright green, stoloniferous; culms filiform, 5-20 cm. long. Leaves 2-4 $\mathrm{mm}$. wide, much longer than the culms, rather stiff; bracts short and subulate or wanting; staminate spike sessile, 4-6 mm. long; pistillate spikes I-3, sessile, about $6 \mathrm{~mm}$. long; perigynia oblong, narrowed at the base into a short stipe, pubescent or nearly glabrous, $2-3 \mathrm{~mm}$. long, with a cylindric-subulate 2 -toothed beak onethird to one-half as long the body; scales acute or cuspidate, green with purple margins or variegated, rather longer than the perigynia. Dry soil, N. Y. to N. Car. May-July.

131. Carex umbellàta Schk. Umbel-Like SedGe. (I. F. f. 8or.) Rather ight green, tufted and matted, stoloniferous; culms filiform, $5-15 \mathrm{~cm}$. long. Leaves $\mathbf{I}-3 \mathrm{~mm}$. wide, usually much exceeding the culms, the old sheaths fibrillose; itaminate spike commonly conspicuous; pistillate spikes I-3, filiform-stalked from the basal sheaths or I or 2 of them sessile or very nearly so at the base of the staminate, ovoid-oblong, 4-8 $\mathrm{mm}$. long; perigynia oval, pubescent, 3 -angled, the body rather less than $2 \mathrm{~mm}$. long, tipped with a subulate 2 -toothed beak of nearly its length; scales acuminate or short-awned, about as long as the perigynia. Dry soil, N. S. to the N. WV. Terr., N. J., the Ind. Terr. and Ore. May-July.

132. Carex pubéscens Muhl. Pubescent Sedge. (I. F. f. 802.) Pubescent all over, bright green, stoloniferous; culms $3-6 \mathrm{dm}$. long. Leaves flat, soft, elongated, 4-7 mm. wide; lower bracts $2-8 \mathrm{~cm}$. long; staminate spike sessile or nearly so; pistillate spikes 2-4, oblong-cylindric, 8-20 mm. long, the upper sessile; perigynia 3 -angled, obovoid, narrowed to a stipe-like base, densely pubescent, and, including the subulate minutely 2 -toothed beak, about $4 \mathrm{~mm}$. long; scales ovate, rough-awned or cuspidate, about as long as the perigynia. In woods and thickets, N. S. to N. Dak., N. J., Ky. and Mo. June-Aug.

Leaves $2-5 \mathrm{~cm}$. wide, thick, spreading. PhysocephalaE. Leaves $0.5-6 \mathrm{~mm}$. wide.

Staminate and pistillate spikes on different culms. SCIRPINAE.

Leaves longer than the culm; perigynia obovoid; southern species.

Leaves shorter than the culm; perigynia oval; northern species.

133. C. Fraseri.

134. C. picta.

135. C. scirpoidea.

Staminate and pistillate flowers in the same spike.

Scales of the spike leaf-like, elongated. PHyLlostachyaE.

Lower scales $2 \mathrm{~mm}$. wide or less, not enclosing the perigynia.

Body of the perigynium oblong, its beak flattened. 136 . C. Willdenovii.

Body of the perigynium globose, its beak subulate. 137. C. Jamesii.

Lower scales $2-5 \mathrm{~mm}$. wide enclosing the perigynia. 138. C. durifolia.

Scales of the spike short, normal.

Leaves $\mathrm{I}-2 \mathrm{~mm}$. wide; arctic and western species. RUPESTRES.

Spike solitary, androgynous; perigynium-beak stout, long.

139. C. rupestris.

Spikes $2-4$, the staminate uppermost ; perigynium-beak short. 
Leaves $0.5 \mathrm{~mm}$. wide or less.

Perigynia obtuse, beakless; swamp species. Leptocephalae.

r4r. C. leptalea.

Perigynia obovoid-oval, beaked; prairie species. FilifoliaE.

142. C. filifolia.

133. Carex Fràseri Andr. Fraser's Sedge. (I. F. f. 803.) Glabrous; culms smooth, slender, reclining, 2.5-5 dm. long. Basal leaves 2-4 dm. long, flat, firm, spreading, finely many-nerved, their margins usually finely crumpled in drying; culm leaves reduced to clasping basal sheaths; spike solitary, bractless, terminal, androgynous, $\mathbf{I}-2.5 \mathrm{~cm}$. long, the pistillate portion dense, about $1.2 \mathrm{~cm}$. in diameter in fruit; perigynia ovoid, pale green, faintly many-nerved, fully $4 \mathrm{~mm}$. long, with a short nearly truncate beak; scales ovate, obtuse, much shorter than the perigynia. In rich woods, Va., W. Va., Tenn. and N. Car. Our largest-leaved species. May-July.

I34 Carex pícta Steud. BootT's Sedge. (I. F. f. 804.) Dioecious; foliage glabrous, light green; culm slender, smooth, I.5-3 dm. long. Leaves 3-6 mm. wide; spike usually solitary, densely many-flowered, the staminate about $2.5 \mathrm{~cm}$. long, the pistillate narrowed at the base, $2-6 \mathrm{~cm}$. long, subtended by a short purple sheath; perigynia strongly many-nerved, pubescent at least toward the obtuse summit, about $3 \mathrm{~mm}$. long; scales purple, shining, obovate, acute or cuspidate, longer and wider than the perigynia. In woods, Ind. to Ala. and La. Summer.

13?- Carex scirpoidea Michx. Scrrpus-like Sedge. (I. F. f. 805.) Dioecious ; foliage glabrous, rather bright green; culms erect, stiff, $1.5-4.5 \mathrm{dm}$. tall. Leaves I-2 nm. wide; spike usually solitary, linear-cylindric, $1.5-3 \mathrm{~cm}$. long, 3-4 mm. in diameter, subtended by a short or subulate bract; perigynia few-nerved, densely pubescent, $2 \mathrm{~mm}$. long, with a very short beak; scales ovite-oval, dark purple, acute, about as long as the perigynia. In rocky soil, Greenland to Alaska, south to the higher mountains of N. Eng. and Lake Huron. Also in northern Europe and Asia. Summer.

136. Carex Willdenòvii Schk. Willdenow's Sedge. (I. F. f. 8o6.) Glabrous and pale green; culms 2-10 cm. high. Leaves $2-3 \mathrm{~mm}$. wide, often $3 \mathrm{dm}$. long, much overtopping the spikes, the lowest reduced to sheaths; spikes $1-5$, androgynous, staminate above, pistillate below, or sometimes completely staminate, about $1.2 \mathrm{~cm}$. long, appearing nearly basal, one of them or more on long filiform stalks; body of the perigynium oblong, smooth, 2-3 $\mathrm{mm}$. long, narrowed into a 2 -edged rough beak of about its own length; scales lanceolate, acute, acuminate or awned, finely several-nerved, the lower $\mathbf{I}$ or 2 commonly bract-like. In dry woods and thickets, Me. to Ohio, Mich., Manitoba, Fla., Ky. and Tex. April-July.

137. Carex Jàmesii Schwein. James' SedGE. (I. F. f. 807.) Similar to the preceding species, but the leaves rather narrower, soft, spreading or ascending. Spikes androgynous, the terminal staminate portion slender, the pistillate flowers only $\mathrm{I}-4$ and slightly separated; body of the perigynium subglobose, $2 \mathrm{~mm}$. in diameter, abruptly tipped by a subulate rough beak of more than its own length ; lower scales bract-like, foliaceous, the upper shorter and sometimes not exceeding the perigynia. In dry woods and thickets, S. Ont. and N. Y. to Ind., Iowa, D. C., W. Va. and Mo. April-May.

138. Carex durifòlia Bailey. BAck's Sedge. (I. F. f. 8o8.) Glabrous; culms scarcely $2.5 \mathrm{~cm}$. high. Ieaves $1.5-3 \mathrm{dm}$. long, 3-6 mm. wide, much overtopping the spikes ; spikes $1-3$, nearly basal, androgynous, 1 or 2 of them very slender-stalked, the staminate flowers few, terminal, the pistillate 2-6, subtended by leafy bract-like elongated scales which nearly enclose the inflorescence : perigynia oval, smooth, tapering into a stout subulate beak nearly or quite as long as the body. In woods and thickets, Ont. to Manitoba., Mass., N. Y., Ohio and Neb. Also in Colo. (according to Bailey). May-June. [C. Backii Boott.]

139. Carex rupéstris All. Rock SEDGe. (I. F. f. 809.) Culms rather stout, obtusely 3 -angled, erect, $2-15 \mathrm{~cm}$. tall. Leaves $\mathbf{I}-2 \mathrm{~mm}$. wide, involute in drying, often curved; bract subulate, erect, shorter than the terminal androgynous spike or wanting; spike $\mathbf{I}-2.5 \mathrm{~cm}$. long, the pistillate flowers few, basal ; perigynia smooth, obovoid or elliptic, firm, faintly few-nerver, about $4 \mathrm{~mm}$. long, the beak stout, cylindric, about one-half as long as the body; scales purple-brown. 
Lab. and Greenland to Br. Col., south in the Rocky Mts. to Colo. Also in northern Europe and Asia. Summer.

I 40. Carex supína Willd. Weak Arctic Sedge. (I. F. f. 81o.) Glabrous, tufted; culms nearly filiform, sharply 3-angled, I-2.5 dm. tall. Leaves about I $\mathrm{mm}$. wide, rough-margined, flat, shorter than the culm; lower bract short, subulate; staminate spike sessile or nearly so, 6-12 mm. long; pistillate spikes $\mathrm{I}-3$, sessile near the summit, subglobose or oblong, 4-6 $\mathrm{mm}$. long; perigynia ovoid, smooth, hard, nerveless, about $2 \mathrm{~mm}$. long, 3-angled, with a very short beak; scales ovate, brown-purple or lighter-margined. N. Minn. (according to Bailey) and Manitoba to arctic America and Greenland. Also in northern Europe and Asia. Summer.

i41. Carex leptàlea Wahl. Bristle-STalked Sedge. (I. F. f. 8ri.) Light green and glabrous; culms filiform, smooth, I.5-4.5 dm. long. Leaves not over $0.5 \mathrm{~mm}$. wide; spike solitary, terminal, androgynous, linear, 4-14 mm. long; perigynia few, linear-oblcng, light green, many-nerved, obtuse and beakless, about $3 \mathrm{~mm}$. long; scales membranous, the lowest sometimes attenuated into a subulate awn nearly as longas the spike; stigmas 2 or 3 . In bogs and swamps, Newf. to Br. Col., Fla., La., Tex., Colo. and Ore. June-Aug.

142. Carex filifòlia Nutt. Thread-leaved Sedge. (I. F. f. 812.) Densely tufted, pale green and glabrous; culms slender, smooth, erect, $0.7-3.5 \mathrm{dm}$. tall. Leaves filiform, rather stiff, about $0.5 \mathrm{~mm}$. wide, their sheaths ultimately fibrillose; spike erect, bractless, $0.6-3 \mathrm{~cm}$. long, the pistillate part about $4 \mathrm{~mm}$. in diameter; perigynia obovoid-oval, triangular, few-nerved or nearly nerveless, rough or somewhat pubescent at the summit, $2 \mathrm{~mm}$. long, abruptly tipped by a short cylindric entire beak; scales broadly oval, about as long as the perigynia but much broader. In dry soil, Manitoba to Br. Col., Kans., Colo. and Cal. May-July.

Perigynia nerveless, or faintly few-nerved.

Perigynia with a short nearly entire beak.

Perigynia beakless, the orifice 2-toothed.

Perigynia strongly several-nerved on the outer face.

Beak of the perigynium very short.

Beak slender, rough, about half as long as the body of the perigynium.

143. C. capitata.

144. C. nardina.

145. C. Redowskyana.

I46. C. exilis.

143. Carex capitàta L. Capitate Sedge. (I. F. f. 8I3.) Culms very slender, stiff, $0.5-4.5 \mathrm{dm}$. tall, smooth or nearly so. Leaves filiform, involute, erect, shorter than the culm; spike ovoid, bractless, 4-8 mm. high; perigynia oblong-elliptic, $2 \mathrm{~mm}$. long, I mm. thick, with a nearly entire dark brown beak about one-fourth as long as the body; scales broadly ovate, brown, shorter and rather broader than the perigynia. Greenland and Lab. to the N. W. Terr. and on the White Mts. Also in Europe. Summer.

I44. Carex nàrdina Fries. NARD SEDGE. (I. F. f. 8I4.) Culms filiform, smooth, 4-12 cm. tall, densely tufted. Leaves filiform, erect, about as long as the culms; spike terminal, ovoid-oblong, 6-12 mm. long, bractless; perigynia oblongelliptic, yellowish brown, nerveless, nearly $4 \mathrm{~mm}$. long, somewhat hispid above, beakless, the orifice 2 -toothed; scales ovate, brown, rather longer than the perigynia. Lab. and Hudson Bay to Br. Col. Summer.

I45. Carex Redowskyàna C. A. Meyer. Redowsky's Sedge. (I. F. f. 315.) Culms slender, stiff; 0.7-2 dm. tall. Leaves almost bristle-form, erect; spike oblong, 4-16 $\mathrm{mm}$. long, the pistillate part 4-6 mm. thick, sometimes wholly staminate or pistillate; perigynia ovoid-ellipsoid, stipitate, 2-3 mm. long, spreading or reflexed when mature, strongly several-nerved, little compressed, rougl above, narrowed into a very short 2-toothed beak; scales ovate, acute .or cuspidate, shorter than or equalling the perigynia. In bogs, Lab. to the N. W. Terr., Me., Vt., Penn., Mich. and in the Rocky Mts. to Colo. Also in Europe and Asia. Summer.

I46. Carex exilis Dewey. COAST SEDge. (I. F. f. 8I6.) Culms very olender, stiff, nearly or quite smooth, 2.5-5 dm. tall. Leaves involute-filiform; spike bractless, $0.6-3.6 \mathrm{~cm}$. long, occasionally quite dioecious; perigynia ovoid. ellipsoid, about $3 \mathrm{~mm}$. long, rather strongly several-nerved on the outer face, faintly few-nerved on the inner, spreading or reflexed at maturity, narrowed into a slender rough 2 -toothed beak, about one-half as long as the body; scales ovate, 
acute. In bogs, Newf. and Lab. to S. N. J., mostly near the coast. Reported from Minn. May-July.

Scales ovate or ovate-lanceolate, acute or acuminate, not awned. FoetidaE.

Perigynia strongly many-nerved.

Perigynia faintly several-nerved.

147. C. chordorhiza.

Culms and leaves usually curved; scales shorter than the perigynia.

Culms mostly straight, erect; scales equalling the perigynia.

148. C. incurva.

149. C. stenophylla.

Scales lanceolate, awned, or long-acuminate. ARENARIAE.

Scales 2-4 times longer than the perigynia; western species. 150. C. Douglasii.

Scales about equalling the perigynia; introduced sea-coast species.

I51. C. arenaria.

r 47. Carex chordorhiza L. f. CReeping Sedge. (I. F. f. 8I7.) Rootstocks slender; culms slender, 2-4.5 dm. tall. Leaves 2-3 mm. wide, shorter than the culm, somewhat involute in drying, the lower ones reduced to sheaths; spikes 2-4, aggregated into a head 8-12 $\mathrm{mm}$. long; perigynia ellipsoid, slightly more than $2 \mathrm{~mm}$. long, flat on the inner side, convex on the outer, strongly many-nerved, abruptly tipped by a short entire beak. In bogs and shallow water, Anticosti to Hudson Bay and the N. W. Terr., south to Me., N. Y., Penn., Ill. and Iowa. Also in Europe. Summer.

I48. Carex incúrva Lightf. Curved Sedge. (I. F. f. 8I8.) Densely tufted ; culms smooth, often curved, 2-15 cm. long. Leaves less than $2 \mathrm{~mm}$. wide, usually curved ; spikes 2-5, sessile and aggregated into a dense head 10-16 mm. in diameter; staminate flowers few, borne at the tops of the spikes; perigynia ovate, slightly swollen, compressed, $3 \mathrm{~mm}$. long, narrowed above into a short conic entire beak, faintly several-many-nerved, scales ovate, brown or brownish, acute or subacute, shorter than the perigynia. Greenland and Hudson Bay to Br. Col., south in the Rocky Mts. to Colo. Also in Europe and Asia. Summer.

149. Carex stenophýlla Wahl. Involute-Leaved Sedge. (I. F. f. 8I9.) Densely tufted and strongly stoloniferous, pale green; culms smooth, stiff, 7-20 cm. high. Leaves involute, about $\mathbf{I} \mathrm{mm}$. wide; inflorescense much as in the preceding species; perigynia about $2 \mathrm{~mm}$. long, faintly several-nerved, flat on the inner face, low convex on the outer, narrowed into a short entire beak; scales ovate, brownish, acute or acuminate, about equalling the perigynia. In dry soil, Man. to Br. Col., Iowa, Kans. and Colo. Also in Europe and Asia. June-Aug.

I50. Carex Douglásii Boott. Douglas' SedGe. (I. F. f. 820.) Light green ; rootstock extensively creeping; culms smooth or nearly so, I-3 dm. tall. Leaves $2 \mathrm{~mm}$. wide or less, somewhat involute in drying: spikes oblong, acute, 8-12 mm. long, in a dense oblong or ovoid cluster $2-5 \mathrm{~cm}$. long; staminate flowers terminal or variously distributed; perigynia ovate-lanceolate, about $3 \mathrm{~mm}$. long, faintly several-nerved, the slender beak more than one-half as long as the body; scales pale greenish brown, lanceolate, scarious, smooth-awned, 2-4 times longer than the perigynia. In dry soil, Manitoba to Neb., N. Mex., Br. Col. and Cal. June-Aug.

I5 r. Carex arenària L. SAnd SEDge. SAnd-STAR. (I. F. f. 82I.) Rootstock extensively creeping; culms I-4 dm. high. Leaves $2 \mathrm{~mm}$. wide or less; lower bract subulate : spikes oblong, 6-10 mm. long, in a terminal ovoid cluster $2-5 \mathrm{~cm}$. long ; perigynia lanceolate, 3-4 $\mathrm{mm}$. long, strongly several-nerved on both sides, the flat strongly 2 -toothed beak nearly as long as the body; scales lanceolate, long-acuminate or awned, about equalling the perigynia. On sea beaches near Norfolk, Va. Adventive or naturalized from Europe. June-July.

Perigynia strongly several-nerved, especially on the outer face. Nos. 152-r54. VuLPINAE.

Beak of the perigynium shorter than the body.

Beak of the perigynium equalling or longer than the body.

152. C. conjuncta.

Spikes crowded in an oblong cluster; beak 1-2 lengths of the body.

Spikes in a large branching cluster; beak 3-4 lengths of the body.

153. C. stipata.

154. C. Crus. Corvi. 
Spikes several or many in an oblong or narrow, simple or somewhat compound cluster.

Leaves $2 \mathrm{~mm}$. wide or less.

Beak of the perigynium shorter than the body; western species.

156. C. marcida.

Beak as long as the body ; northern marsh species. $\quad$ 157. C. teretiuscula.

Leaves $2-6 \mathrm{~mm}$. wide.

Scales acuminate, cuspidate or awned.

Perigynia 3-5 mm. long.

Perigynia ovate or ovate-lanceolate, the beak about as long as the body. 158. C. alopecoidea.

Perigynia broadly ovate or obicular, the beak about one-third as long as the body.

Perigynia $3 \mathrm{~mm}$. long or less.

Leaves as long as the culm or longer.

Leaves shorter than the culm. 159. C. gravida.

Perigynia ovate-elliptic, the base narrowed.

Perigynia lanceolate, the base truncate. 162. C. setacea.

Scales blunt, scarious-tipped.

160. C. vulpinoidea.

I6r. C. xanthocarpa.

163. C. Sartwellii.

152. Carex conjúncta Boott. Soft Fox Sedge. (I. F. f. 822.) Light green; culms sharply 3-angled when fresh, soft, 4-9 dm. tall. Leaves soft, roughmargined, 5-7 mm. wide; bracts smáll and bristle-like, or wanting; spikes in a terminal elongated cluster, or the lower separated; perigynia ovate-lanceolate or lanceolate, $3 \mathrm{~mm}$. long, tapering into a roughish 2 -toothed beak; scales oblonglanceolate, cuspidate or short-awned, about as long as the perigynia. In moist meadows and thickets, N. J. (according to Bailey), Penn. to Ky., Iowa and Minn. June-Aug.

153. Carex stipàta Muhl. Awl-fruited Sedge. (I. F. f. 823.) Culms smooth, sharply 3-angled, 2-10 dm. tall. Leaves flat, 4-8 mm. wide; bracts bristleform or wanting; spikes numerous, yellowish brown, in a terminal oblong cluster 3-10 cm. long, the staminate flowers few, always terminal; perigynia lanceolate, 4-5 $\mathrm{mm}$. long, tapering into a rough flattened 2 -tıothed beak $\mathrm{I}-2$ times as long as the body; scales ovate or lanceolate, acuminate, shorter than the perigynia. In swamps and wet meadows, Newf. to Ont. and Br. Col., south to Fla., Tenn., Mo., N. Mex. and Cal. May-July.

154. Carex Crús-Córvi Shuttlw. Raven's-foot Sedge. (I. F. f. 824.) Pale green and glaucous; culms 3-angled, rough above, 0.5-1.I m. tall. Leaves flat, 5-12 mm. wide, rough-margined; usually shorter; spikes yellowish brown, very numerous in a large compound branching cluster I-3 dm. long; perigynia elongated-lanceolate, about $8 \mathrm{~mm}$. long, with a short hard base and a subulate rough 2 -toothed beak; scales ovate or lanceolate, thin, much shorter than the perigynia. In swamps, Ind. to Minn., Fla., La. and Tex. May-July.

155. Carex decompósita Muhl. Large-Panicled Seige. (I. F. f. 825.) Dark green; culms smooth, obtusely angled, or terete below, 4-9 dm. tall. Leaves 4-8 mm. wide, rough, longer than the culm; spikes yellowish brown, very numerous in a decompound cluster $5^{-1} 3 \mathrm{~cm}$. long, the lower branches $2-5 \mathrm{~cm}$. long; bracts subulate, ciliate, or wanting; perigynia short-obovate, less than $2 \mathrm{~mm}$. long, hard, abruptly tipped with a short slightly 2-toothed beak; scales ovate, about equalling the perigynia. In swamps, N. Y. to Ohio, Mich., Fla. and La. MayAug.

I56. Carex màrcida Boott. Clustered Field Sedge.

(I. F. f. 826.) Light green; culms 3-angled, rough, at least above, 3-6 dm. tall. Leaves $2 \mathrm{~mm}$. wide or less, much shorter than the culm; bracts short, subulate, or wanting; spikes several, staminate at the summit or some of them wholly staminate, in an oblong head about $3 \mathrm{~cm}$. long; perigynia ovate, dark brown, about $2 \mathrm{~mm}$. long, faintly nerved, tapering into a flat serrate beak; scales brownish, acute or cuspidate, about equalling the perigynia. In dry soil, Manitoba to $\mathrm{Br}$. Col., Kans., N. Mex. and Nev. June-Sept.

157. Carex teretiúscula Goolen. Lesser Panicled SedGe. (I. F. f. 827.) Rather light green; culms very rough, at least above, 3-7 dm. long. Leaves mostly less than $2 \mathrm{~mm}$. wide; bracts small or none; spikes several or numerous, in a narrowly oblong cluster $2-5 \mathrm{~cm}$. long; perigvnia ovate-oval, smooth, dark brown 
hard, shining, the body slightly more than $1 \mathrm{~mm}$. long, truncate or rounded at the head, short-stalked, tapering into a flat conic beak about its own length; scales thin, ovate, brownish, acute or short-awned, about equalling the perigynia. In swamps and wet meadows, N. S. to Hudson Bay, Br. Col., R. I., Penn. and Neb. Also in Europe. May-July.

Carex teretiúscula pràrea (Dewey) Britton. Cluster of spikes compound, branched, the top commonly nodding. Ont. to Br. Col., Mass., Tenn., Ky., Iowa and Ore.

158. Carex alopecoìdea Tuckerm. Foxtall Sedge. (I. F. f. 828.) Light green; culms soft, sharply 3-angled, 5-9 dm. long, roughish above. Leaves flat, 3-6 mm. wide; bracts almost filiform, commonly short; spikes several or numerous, in a cluster 2-5 cm. long; perigynia ovate or ovate-lanceolate, short-stipitate, 3$4 \mathrm{~mm}$. long, pale brown, the tapering rough 2-toothed beak nearly as long as the body ; scales ovate or oval, light brown, cuspidate or short-awned, ahout as long as the perigynia. In meadows, Vt. to N. Y., Penn., Mich. and Manitoba.

\section{Carex alopecoldea sparsispicàta Dewey. Spikes distinctly separated. S. E. Mich.}

159. Carex grávida Bailey. Heavy Sedge. (I. F. f. 829.) Light green; culms 4-9 dm. tall, 3-angled, rough above. Leaves flat, 3-6 mm. wide; bracts usually very short; spikes several, in a dense heavy head $2-3.5 \mathrm{~cm}$. long, pale, subglobose ; perigynia flat, broadly ovate or suborbicular, 3-4 mm. long, rounded at the base, narrowed into a 2 -toothed beak about one-third as long as the body, several-nerved on the outer face or nerveless; scales, acute, cuspidate or shortawned, about as long as the perigynia. Ill. to S. Dak., Neb. and Ind. Terr. May-July.

160. Carex vulpinoidea Michx. Fox Sedge. (I. F. f. 83o.) Culms stiff, 3-angled, rough above, 3-9 dm. tall. Leaves $2-5 \mathrm{~mm}$. wide, often exceeding the culm ; bracts bristle-like; spikes ovoid-oblong, 4-8 $\mathrm{mm}$. long, very numerous in a cluster $3-13 \mathrm{~cm}$. long; perigynia ovate, less than $2 \mathrm{~mm}$. long, greenish brown, flat, several-nerved on the outer face, nerveless or I-3-nerved on the inner, tipped with a lanceolate 2-toothed beak about haif as long as the body; scales lanceolate, acuminate or awned, about as long as the perigynia, but narrower. In swamps and wet meadows, N. B. to Manitoba, Fla., La., Neb. and Tex. June-Aug.

I6I. Carex xanthocàrpa Bicknell. Yellow-Fruited SEDGE. (I. F. f. 83I.) Culms rather stout, rough above, $0.3-1.4 \mathrm{~m}$. tall, much longer than the leaves. I eaves $3-6 \mathrm{~mm}$. wide ; head usually dense; spikes numerous, ovoid, short ; bracts mostly short and inconspicuous: perigynia bright yellow, plano-convex, ovateelliptic, about $3 \mathrm{~mm}$. long, with a narrowed or cuneate base, and a short minutely 2-toothed beak, nerveless, or obscurely few-nerved on the outer face; scales acuminate, short-awned. In fields, Mass. to N. Y. and Iowa. June-Aug.

Carex xanthocàrpa annéctens Bicknell. Lower and slender; leaves 2-4 mm. wide; head not over $3.5 \mathrm{~cm}$. long; bracts usually numerous and longer than the globose spikes; perigynia ovate or suborbicular. Abundant in the vicinity of N. Y.

162. Carex setàcea Dewey. Bristly-Spiked Sedge. (I. F. f. 832.) Culms $0.4-1.2 \mathrm{~m}$. tall, rough above. Leaves 3-6 dm. long, 2-6 inm. wide, shorter than the culm; head narrowly oblong, 3-6 cm. long; bracts bristle-like; spikes ovoid or ovoid-oblong, 5-8 $\mathrm{mm}$. long, usually close together; perigynia lanceolate or ovate-lanceolate, tapering from a more or less truncate base to a narrow rough 2-toothed beak, few-nerved, 2.5-3 mm. long. N. Y. and Mass. June-Aug.

I63. Carex Sartwéllii Dewey. Sartwell's Sedge. (I. F. f. 833.) Culms stiff, rough above, 3-angled, 3-9 dm. tall. Leaves 2-4 $\mathrm{mm}$. wide; bracts setaceous, usually small; spikes ovoid or oblong, 4-8 mm. long, usually densely aggre. gated in a narrow cluster; perigynia lanceolate, about $2 \mathrm{~mm}$. long, strongly several-nerved on both faces, tapering into a short 2 -toothed beak; scales ovate, pale brovn, about equalling the perigynia. In swamps, Ont. to Br. Col., N. Y., Ill., Mich., Ark. and Utah. May-July.

Perigynia ellipsoid, nearly terete; spikes 1-5-flowered, widely separated, or the uppes close together.

Perigynia lanceolate, ovate or roundish, compressed or plano-convex; spikes severa!many-flowered. 
Spikes separated or the upper close together; perigynia mostly radiating, or reflexed. Leaves $1-3 \mathrm{~mm}$. wide.

Beak of the perigynium one-fourth to one-half as long as the body; native woodland species.

Ferigynia ovate-lanceolate, 2-3 $\mathrm{mm}$. long.

Perigynia stellately radiating.

Perigynia reflexed when mature.

165. C. rosea.

166. C. retrofiexa.

Perigynia narrowly lanceolate, 3-4 mm. long. 167. C. Texensis.

Beak of the perigynium more than half as long as the body; introduced field species.

Leaves $5-9 \mathrm{~mm}$. wide.

168. C. muricata.

169. C. sparganioides.

Spikes all aggregated or the lower separated; perigynia spreading or ascending.

Leaves thin, lax, 4-8 $\mathrm{mm}$. wide; perigynia about $4 \mathrm{~mm}$. long:

Leaves stiffer, $\mathrm{I}-4 \mathrm{~mm}$. wide.

I7o. C. cephaloidea.

Perigynia $2 \mathrm{~mm}$. long or less, nerveless or faintly few-nerved.

Leaves 2-4 $\mathrm{mm}$ wide; perigynia ovate I71. C. cephaiophora.

Leaves I-2 mm. wide; perigynia orbicular-ovate; southern.

I72. C. Leavenuorthii.

Perigynia $3 \mathrm{~mm}$. long, strongly-nerved (except in var. Xalapensis). 173. C. Muhlenbergii.

164. Carex tenélla Schk. Soft-Leaved Sedge. (I. F. f. 834.) Light green; rootstocks slender; culms almost filiform, rough, I.5-5 dm. long. Leaves soft, about I mm. wide, spreading; spikes only I-5-flowered; perigynia ovoidellipsoid, nearly terete, hard, finely many-nerved, about $2 \mathrm{~mm}$. long, with a very minute entire beak; scales ovate, hyaline, acute. In bogs, Newf. to $\mathrm{Br}$. Col., N. J., Penn., Mich., N. Mex. and Cal. Also in Europe. June-July.

Carex Eleócharis Bailey. A very slender erect species, with 2 or 3 small brown I-3-flowered spikes aggregated in a terminal head, 3-4 $\mathrm{mm}$. long, ovoid, slightly swollen marginless plano-convex short-beaked perigynia. Collected by Prof. Macoun on the Saskatchewan Plains; probably occurs within the northwestern limits of our area.

I65. Carex ròsea Schk. Sterlate Sedge. (I. F. f. 835.) Culms slender or filiform, rough above, 3-7 dm. long. Leaves flat, soft, $2 \mathrm{~mm}$. wide or less, shorter than the culm; lower bract I- $6 \mathrm{~cm}$. long; spikes 4-8, subglobose, 4-6 mm. in diameter, 5-15-flowered; perigynia ovate-lanceolate, flat, bright green, stellately diverging, nerveless, shining, 2-3 $\mathrm{mm}$. long, tapering into a stout 2 -toothed beak, about one-fourth the length of the body; scales ovate-oblong, white, half as long as the perigynia. In woods and thickets, Newf. to Ont., Manitoba, N. Car., Mo. and Neb. May-July.

Carex ròsea radiàta Dewey. Culms filiform, spreading; leaves about $\mathbf{I} \mathrm{mm}$. wide; spikes only 2-6-flowered, scattered; perigynia ascending, lanceolate, about I mm. wide. Me, and Ont. to Mich., N. Car. and Ky.

166. Carex retrofléxa Muhl. Reflexed Sedge. (I. F. f. 836.) Culms very slender, 2-5 dm. tall. Leaves about $1 \mathrm{~mm}$. in width, mostly shorter than the culm; lower bract bristle-form; spikes 4-8, subglobose, 4-9-flowered, the upper all close together; staminate flowers terminal or rarely variously intermixed with the pistillate; perigynia oblong-lanceolate or ovate-lanceolate, radiating or reflexed at maturity, about $3 \mathrm{~mm}$. long, smooth, compressed, but not as flat as those of the preceding species, somewhat corky-thickened at the base, tapering upwardly into a 2-toothed beak about one-third the length of the body; scales ovate, about half as long as the perigynia. In woods and thickets, Mass. to Ont., Mich., Ark., Fla. and Tex. May-July.

I67. Carex Texénsis (Torr.) Bailey. Texas Sedge. (I. F. f. 837.) Similar to the preceding; culms very slender. Leaves soft, about I $\mathrm{mm}$. wide, shorter than the culm; lower bract commonly filiform; spikes 4-7, 4-Io flowered; all close together in a narrow head, or the lower separated; perigynia narrowly lanceolate, green, nerveless, smonth, radiating or widely spreading, 3-4 mm. long, the tapering beak about one-half as long as the body; scales lanceolate or ovate, acute or acuminate, less than one-half as long as the perigynia. S. Ill. (according to Bailey), Ala. to Tex. April-May. 
168. Carex muricàta L. Lesser Prickly Sedge. (I. F. f. 838.) Bright green ; culms slender, roughish, at least above, 3-7 dm. long. Leaves $2-3 \mathrm{~mm}$. wide, shorter than the culm; bract short, subulate; spikes 5-Io, 4-IO-flowered, clustered into an oblong head, or the lower I or 2 distant; perigynia ovate or ovate-lanceolate, $4 \mathrm{~mm}$. long, smooth, shining, nerveless, spreading or radiating when mature, not reflexed, tapering into a rough-edged 2 -toothed beak as long as the body; scales ovate or ovate-oblong, acute, shorter than the perigynia. In meadows and fields, Mass. to N. Y., Ohio and Va. Naturalized from Europe. June-Aug.

169. Carex sparganioìdes Muhl. BUR-REed SedGe. (I. F. f. 839.) Rather dark green with nearly white sheaths ; culms rough, 3-angled, 5-9 dm. tall. Leaves flat, 5-9 $\mathrm{mm}$. wide, the lower very short; spikes 6-12, oblong or subglobose, 5-8 $\mathrm{mm}$. in diameter, the upper aggregated, the lower 2-4 commonly separated; perigynia flat, ovate, $3 \mathrm{~mm}$. long, spreading or radiating, pale, narrowly wing-margined, usually few-nerved on the outer face, the rough 2 -toothed beak one-fourth to one-third the length of the body ; scales ovate, acute or cuspidate, about one-halt as long as the perigynia. In woods and thickets, Mass. to Ont., Mich., Va., Ky., Iowa and Mo. June-Aug.

170. Carex cephaloìdea Dewey. Thin.leaved Sedge. (I. F. f. 840.) Similar to the preceding; culms rough above. Leaves flat, 4-8 mm. wide, thin and lax, somewhat shorter than the culm; bracts usually short ; spikes 4-8, subglobose, in an oblong cluster; perigynia ovate or ovate-lanceolate, greenish brown, nearly $4 \mathrm{~mm}$. long, ascending, nerveless or faintly few-nerved, tapering into a rough 2 -toothed beak one-fourth to one-third as long as the body; scales ovate, white, short-cuspidate or awned, about one-half as long as the perigynia. In dry fields and on hills, Mass. to Penn., Ill., Mich. and Wyo. May-July.

I7I. Carex cephalóphora Muhl. Oval-Headed Sedge. (I. F. f. 84I.) Pale green ; culms slender, rough above, $2.5^{-6} \mathrm{dm}$. tall. Leaves $2-4 \mathrm{~mm}$. wide; bracts of the lower spikes bristle-form; spikes few, subglobose, clustered in a shortoblong head 8-16 mm. long; perigynia broadly ovate, $2 \mathrm{~mm}$. long or less, pale, nerveless or very faintly few-nerved, tipped with a 2 -toothed beak about one-fourth the length of the body; scales ovate, rough-cuspidate or awned, equalling or a little shorter than the perigynia. In dry fields and on hills, Me. and Ont. to Man., Fla., Mo. and Tex. May--July.

172. Carex Leavenwórthii Dewey. Leavenworth's Sedge. (I. F. f. 842.) Similar to the preceding, but smaller; culms almost filiform, roughish, I.5-4 dm. tall. Leaves narrower, I-3 mm. wide, mostly shorter than the culm; bracts of the lower spikes bristle-form or wanting; spikes 4-7, densely crowded; perigynia orbicular-ovate, rather less than $2 \mathrm{~mm}$. long and about as wide, tipped with a very short 2-toothed beak; scales ovate, acute or cuspidate, shorter and narrower than the perigynia. In meadows, Iowa to Miss., Ark. and Tex. May-June.

I73. Carex Muhlenbérgii Schk. MUhlenberg's SedGe. (I. F. f. 843.) Light green; culms slender, erect, 3-angled, rough, at least above, 3-6 dm. tall. Leaves $2-4 \mathrm{~mm}$. wide, usually shorter than the culm, somewhat involute in drying; bracts bristle-form, usually short; spikes 4-10, ovoid or subglobose, close together in an oblong head; perigynia broadly ovate-oval, $3 \mathrm{~mm}$. long, strongly nerved on both faces, ascending, with a short 2-toothed beak; scales ovate-lanceolate, rough-cuspidate or short-awned, narrower and mostly longer than the perigynia. In dry fields and on hills, Me. and N. H. to Ont., Minn., Fla. and Tex. May-July.

Carex Muhlenbérgii Xalapénsis (Kunth) Britton. Perigynia nearly or quite nerveless; leaves broader and longer. S. N. Y. to Mo., Tex. and Mex.

Perigynia radiately spreading, or reflexed when old.

Perigynia distinctly nerved on both faces, the beak rough.

Perigynia lanceolate; beak more than half as long as the body.

174. C. sterilis.

Perigynia ovate; beak about one-third as long as the body, abrupt.

175. C. Atlantica.

Perigynia faintly nerved on the outer face, nerveless or nearly so on the inner; beak smoothish.

I76. C. interior. 
Perigynia ascending, appressed or somewhat spreading when old, not radiating.

Perigynia ovate, oval, oblong or elliptic.

Bracts short, scale-like or none, the lowest occasionally longer than its spike.

Spikes distinctly separated or the upper close together.

Heads silvery green or nearly white.

177. C. canescens.

Heads brown or brownish.

Spikes few-flowered, $4.6 \mathrm{~mm}$. long; perigynia less than $2 \mathrm{~mm}$. long, the beak manifest. $\quad$ 178. C. brunnescens.

Spikes dense, many-flowered; perigynia about $2 \mathrm{~mm}$. long, the beak very short. 179. C. Norvegica.

Spikes densely clustered at the top of the culm, or the lower separated. Spikes green or greenish brown.

Spikes several in an ovoid cluster; perigynia ovate, rough-beaked. 180. C. arcta.

Spikes only 2-4; perigynia elliptic, beakless. 181. C. tenuiflora. Spikes dark brown; arctic species.

Culms slender, stiff, erect.

Leaves involute; scales about equalling the perigynia. I82 C. Heleonastes.

Leaves flat; scales shorter than the perigyni?.

Culms weak, spreading or reclining. 183. C. lagopina.

Bracts brictle-form, much elongated, much exceeding the 2-4 oblong nerved perigynia.

Perigynia lanceolate or ovate-lanceolate.

Perigynia nerveless; spikes oblong or subglobose.

185. C. trisperma.

Perigynia strongly several-nerved; spikes narrowly oblong-cylindric.

187. C. bromoides.

174. Carex stérilis Willd. Little Prickly Sedge. (I. F. f. 844.) Culms slender, $2-4.5 \mathrm{dm}$. tall, rough, at least above. Leaves $\mathrm{I}-2 \mathrm{~mm}$. wide, shorter than the culm; spikes 3-5, subglobose or short-oblong, about $5 \mathrm{~mm}$. thick; staminate flowers usually numerous at the bottom of the upper spike, or whole spikes occasionally staminate, or plints rarely quite diœcious; perigynia pale, lanceolate, compressed, spreading or reflexed when old, $3 \mathrm{~mm}$. long, $1 \mathrm{~mm}$. wide, several-nerved on both faces, tapering into a sharp-edged 2 -toothed rough beak more than onehalf as long as the body; scales ovate, shorter than the perigynia. In moist soil, Newf. to Br. Col., Fla., La., Colo. and Cal. Variable. May-July.

Carex stérilis cephalántha Bailey. Stouter, sometimes 5 dm. tall. Spikes 4-8, contiguous or separated; fluwers more numerous; perigynia rather larger; spikes very bristly. Range nearly that of the species; perhaps merely a stout form.

I75. Carex Atlántica Bailey. Eastern Sedge. (I. F. f. 845.) Similar to large forms of the preceding, but stouter; culms rough above, 3-7 dm. tall. Leaves 2-3 mm. wide, stiff, flat, or in drying somewhat involute; spikes $4-7$, subglobose or short-cylindric, nearly $6 \mathrm{~mm}$. in diameter; perigynia broadly ovate, flat, sharpmargined, 2-3 mm. long, strongly several-nerved on the outer face, few-nerved on the inner, spreading or reflexed at maturity, abruptly tipped with a stout rough 2-toothed beak about one-third as long as the body; scales shorter than the perigynia. In swamps, Newf. to Fla. June-July.

I76. Carex intèrior Bailey. Inland SEDGE. (I. F. f. 846.) Similar w C. sterilis; culms slender, wiry, 2-6 dm. tall. Leaves about $\mathbf{I} \mathrm{mm}$. wide, shorter than the culm; spikes 2-4. nearly globular, $4 \mathrm{~mm}$. in diameter; perigynia ovate or ovate-lanceolate, $2 \mathrm{~mm}$. long or less, faintly few-nerved on the outer face, nearly nerveless on the inner, thickened, spreading or reflexed when old, tapering into a nearly smooth 2-toothed beak one-third to one-half as long as the body; scales ovate, shorter than the perigynia. Wet soil, Me. to Minn., Fla. and Kans. May-July.

Carex intèrior capillacea Bailey. Leaves about $0.5 \mathrm{~mm}$. wide; perigynia ovate, cordate, strungly nerved. Mass. to N. J. and Penn.

I77. Carex canéscens L. Silvery Sedge. (I. F. f. 847.) Pale green and somewhat glaucous: culms s!ender, 2.5-6 dm. tall. Leaves flat, I-2 mm. wide, s.iorter than the culm; spikes 4-9, short-oblong or subglobose, sessile, 5-10 mm. lo'ng; perigynia oval or ovate-oval, silvery green or nearly white, faintly fewnerved, blunt-edged, rather less than $2 \mathrm{~mm}$. long, rough above, with a minute 
entire beak; scales ovate. In swamps and bogs, Newf. to Br. Col., Va., Mich., Colo. and Ore. Also in Europe and Asia. May-July.

178. Carex brunnéscens (Pers.) Poir. Brownish Sedge. (I. F. f. 848.) Rather dark green, not glaucous; culms stiff, roughish above, 2-4.5 dm. tall. Leaves $2 \mathrm{~mm}$. wide or less, shorter than the culm ; spikes 4-8, subglobose or shortoblong, few-flowered, rarely over $5 \mathrm{~mm}$. long; perigynia brown, smaller than those of the preceding, less than $2 \mathrm{~mm}$. long, with a manifest beak about one-fourth as long as the body ; scales ovate, membranous, brownish. In wet places mostly at high altitudes, Lab. to Br. Col., N. Y. and N. E., on the southern Alleghenies, and the Rocky Mts. Also in Europe. Summer.

Carex brunnéscens gracílior Britton. Culms nearly filiform, weak, often spreading; spikes 4-8-flowered; perigynia spreading, longer-beaked. Range of type, mostly at lower altitudes.

I79. Carex Norvégica Willd. Norway Sedge. (I. F. f. 849.) Bright green; culms slender but stiff, I.5-4 dm. tall. Leaves $2 \mathrm{~mm}$. wide or less, shorter than the culm; bracts very short or wanting; spikes $3-6$, brown, oblong or subglobose, 6-12 mm. long; perigynia about $2 \mathrm{~mm}$. long, elliptic, blunt-edged, narrowed at both ends, brownish, finely many-nerved, with a very short rough beak; scales ovate or oval, brown, obtuse, rather shorter than the perigynia. Along salt meadows, Me. to Anticosti. Reported from Minn. Also in Europe. Summer.

180. Carex àrcta Boott. Northern Clustered Sedge. (I. F. f. 850.) Rather light green, not glaucous ; culms siender, 3-7 dm. tall, rough above; leaves flat, about $2 \mathrm{~mm}$. wide. Spikes oblong, 6-8 $\mathrm{mm}$. long, aggregated into a cluster about $2.5 \mathrm{~cm}$. long ; perigynia pale, ovate, many-nerved, mostly spreading, tapering into a rough beak about one-half as long as the body; scales pale brown, usually acute, shorter than the perigynia. In swamps and wet woods, Me. and N. B. to Manitoba., Minn. and Br. Col. June-July.

18r. Carex tenuifòra Wahl. Sparse-flowered Sedge. (I. F. f. 851.) Light green ; culms very slender, rough above, $2-5 \mathrm{dm}$. long. Leaves I mm. wide or rather more, flat, usually much shorter than the culm ; spikes only 2-4, clustered, subglobose, few-flowered, about $5 \mathrm{~min}$. in diameter; perigynia pale, elliptic, very obscurely few-nerved, narrowed at both ends, 2-2.5 mm. long, beakless, spreading; scales nearly white, about equalling the perigynia. In bogs, N. B. to Manitoba, south to Me., Vt. and Mich. Also in Europe. Summer.

182. Carex Heleonástes Ehrh. Hudson Bay Seige. (I. F. f. 852.) Culms slender, very rough above, I.5-4.5 dm. high. Leaves rigid, erect, becoming invo'ute, less than $2 \mathrm{~mm}$. wide, shorter than the culm; bracts very sh srt or none ; spikes 3-5, subglobose, brown, about $5 \mathrm{~mm}$. in diameter, clustered; perigynia broadly ovate or ovate-elliptic, blunt-edged, faintly several-nerved, about $2 \mathrm{~mm}$. long, with a short sharp beak; scales ovate, brown with broad hyaline margins, about as long as the perigynia. Hudson Bay to Manitoba and the Canadian Rocky Mts. Also in Europe. Summer.

183. Carex lagopina Wahl. ARCTIC HARE'S-Foot SEDGE. (I. F. f. 853.) Culms rough, stiff, $1.5-4 \mathrm{dm}$. tall. Leaves flat, $2 \mathrm{~mm}$. wide or less, shorter than t' e culm ; bracts very short or wanting ; spikes 3-6, oblong, dark brown, narrowed at the base, 6-8 $\mathrm{mm}$. long; perigynia elliptic or obovate, rather less than $2 \mathrm{~mm}$. long, firm, several-nerved, narrowed at the base, rather abruptly tipped by the beak; scales ovate, brown, hyaline-margined, acute, shorter than the perigynia. Lab. and Greenland to Alaska ; south in the Rocky Mts. to Utal.. Also in northern Europe and Asia. Summer.

I84. Carex glareòsa Wahl. Weak Clustered Sedge. (I. F. f. 854.) Closely resembles the preceding, but has weak spreading or reclining culms 0.5-4.5 dm. long. Leaves narrower, flat, about $1 \mathrm{~mm}$. wide, spikes 2 or 3, oblong or subglobose, several-flowered, 4-8 $\mathrm{mm}$. long, brown, subtended by very small scale-like bracts; perigynia oblong-oval, strongly several-nerved, less than $2 \mathrm{~mm}$. long, short-beaked; scales ovate, rich brown, about as long as the perigynia. Greenland and Hudson Bay to Quebec, west through arctic America to Alaska: Also in northern Europe and Asia. Summer.

Carex glaredsa ursina (Dewey) Bailey. Lower; densely tufted; spikes smaller. Arctic America. 
185. Carex trispérma Dewey. Three-fruited Sedge. (I. F. f. 855.) Bright green ; culms filiform, weak, usually rcclining or spreading, 3-7 dm. long. Leaves flaccid, flat, about $1 \mathrm{~mm}$. wide, shorter than the culm; spikes 2 or 3 , only 2-4-flowered, widely separated, the lowest subtended by a bristle-form bract I $8 \mathrm{~cm}$. long ; perigynia oblong, green, 3-4 $\mathrm{mm}$. long, very finely many-nerved, narruwed at both ends and tipped with a very short nearly entire beak; scales ovate or ovate-lanceolate, acute, somewhat shorter than the perigynia. In swamps and wet woods, Newf. to Manituba, Md., Ohio, Mich. and Neb. June-Aug.

186. Carex Deweyàna Schwein. Dewer's Sedge. (I. F. f. 856.) Pale green ; culms slender, spreading, 2-6 dm. long. Leaves 2-3 mm. wide, that, soft, shorter than the culm; bracts bristle-form, the lower commonly elongated; spikes $3^{-6}$, oblong or subglobose, few-flowered, about $5 \mathrm{~mm}$. in diameter, sessile, separated or the upper contiguous ; perigynia lanceolate or ovate-lanceolate, thin, nerveless, 4-5 $\mathrm{mm}$. long, the inner face flat, the tapering rough strongly 2 -toothed beak at least one-half as long as the body; scales nearly white, cuspidate or acute, equalling the perigynia, or shorter. In dry woods, N. S. to Manitoba, Ore., Conn., Penn., Iowa, N. Mex. and Utah. May-July.

187. Carex bromoides Schk. BRome-Like SeDGe. (I. F. f. 857.) Bright green ; culms slender, roughish above, 2-6 dm. long. Leaves $2 \mathrm{~mm}$. wide or less, flat, soft; bracts subulate or bristle-form, the lowest commonly elongated; spikes 3-7, narrowly oblong-cylindric, 8-16 mm. long, erect or ascending, mostly close together, the staminate flowers either basal, basal and terminal, or forming whole spikes, the plant occasionally quite dioccious; perigynia linear-lanceolate, pale, strongly several-nerved, 4-5 $\mathrm{mm}$. long, the inner face flat, the tapering rough 2-toothed beak at least one-half as long as the body; scales oblong-lanceolate, green, acute or acuminate, shorter than the perigynia. In bogs and swamps, N. S. to Ont., Mich., Fla. and La. June-Aug.

Perigynia lanceolate or ovate-lanceolate, 2-5 times as long as wide.

Top of the culm nodding; arctic and northwestern species. I88. C. pratensis.

Culms strictly erect, mostly stiff.

Perigynia nerveless, broadly winged; northwestern species.

Perigynia several-nerved on both faces.

189. C. xerantica.

Yerigynia broadly winged; staminate flowers intermixed with the pistillate.

Perigynia narrowly winged; staminate flowers all Lasal. Igo. C. siccata.

Spikes $1-2.5 \mathrm{~cm}$. long; perigynia about $8 \mathrm{~mm}$. long.

Spikes $0.4^{-1} .6 \mathrm{~cm}$. long; perigynia $4-6 \mathrm{~mm}$. long.

191. C. Muskingumensis.

Spikes oblong or oval; perigynia ascending or erect.

Spikes greell-brown, blunt. $\quad$ 192. C: tribuloides.

Spikes bright brown, pointed; perigynia lanceolate. 193. C. scoparia.

Spikes rather dark brown, blunt; perigynia ovate-lanceolate 194. C: leporina.

Spikes subglobose; perigynia spreading, at least when old. 195. C. cristatella.

Perigynia ovate, not nore than twice as long as wide (longer in some forms of no. 19 ?).

Yerigynia narrowly winged alove; heads greenish brown. 196. C. adusta.

Perigynia broadly wing-margined.

Perigynia spreading or ascending.

Spikes silvery green.

Spikes yellowish brown or greenish.

Perigynia erect or appressed.

Heads silvery green or nearly white; sea beach species.

Heads brown-green; meadow or marsh species.
200. C. $($. silicea.

Perigynia orbicular, very broadly ovate or somewhat obovate, sometimes wider than long. Heads green-brown.

Perigynia spreading or ascending; achene sessile. 201. C. festucacea.

Perigynia erect, 4-5 mm. broad; achene short-stalked. 202. C. alata.

Heads silvery green, yellowish or whitish.

l'erigynium-wing firm; achene sessile.

Perigynium-wing membranous; achene stalked.

203. C. albolutescens.

204. C. Bicknellit.

Perigynia narrowly linear-lanceolate, tapering into a subulate beak $2-3$ times as long as the body. CYPEROIDEAE. 205. Ci. sychnccephala. 
188. Carex pratícola Rydb. Northern Meadow Sedge. (I. F. f. 858.) Light green; culms erect when young, the summit later nodding, nearly smooth, 3-4 dm. tall. Leaves about $2 \mathrm{~mm}$. wide, shorter than the culm; lower bracts bristle-form; spikes 3-6, oblong or club-shaped, silvery-brown and shining, 6-1o mm. long, about $5 \mathrm{~mm}$. in diameter; perigynia lanceolate, pale, nerveless on the inner face, few-nerved on the outer, $5 \mathrm{~mm}$. long, wing-margined, tapering into a beak nearly as long as the body; scales membranous, lanceolate, acute or acuminate. Lab. to Ont., Mich., Manitoba and Alaska, south in the Rocky Mountains to Colo. Summer. (C. pratensis Drej. not Hose.)

189. Carex xerántica Bailey. White-scaled Sedge. (I. F. f. 859.) Similar to the preceding, but the culms stout, stiff and strictly erect, even when mature. Leaves about $2 \mathrm{~mm}$. wide, involute in drying, shorter than the culm; spikes about 5, oblong, close together, 8-12 mm. long; perigynia lanceolate, pale, $5 \mathrm{~mm}$. long, nerveless, conspicuously wing-margined, the inner face concave, the rough tapering beak about as long as the body; scales silvery white, lanceolate, acute or acuminate. W. Manitoba and adjacent N. W. Terr. May-July.

190. Carex siccata Dewey. Dry-spiked Sedge. Hillside Sedge. (I. F. f. 860.) Rootstocks long and stout; culms slender, rough above, 2-6 dm. tall. Leaves erect, about $2 \mathrm{~mm}$. wide; spikes 3-6, otlong or subglobose, $5-8 \mathrm{~mm}$. long, brownish or brown, the staminate flowers basal, or variously situated, or whole spikes staminate; perigynia ovate-lanceolate, firm, about $5 \mathrm{~mm}$. long, wing-margined, strongly several-nerved on both sides, the inner face concave by the incurved margins, the tapering rough beak nearly as long as the body; scales ovatelanceolate, membranous, acute or acuminate. In dry fields and on hills, Ont. and Manitoba to Br. Col., R. I., N. Y., Mich., Ariz. and Cal. May-July.

19r. Carex Muskinguménsis Schwein. Muskingum Sedge. (I. F. f. 86r.) Culm stout, stiff, very rough above, 5-9 dm. tall. Leaves flat, longpointed, 3-5 $\mathrm{mm}$. wide, shorter than the fertile culms, those of sterile culms crowded near the summit; bracts short and scale-like; spikes 6-12, oblongcylindric, $1.2-2.5 \mathrm{~cm}$. long, erect, close together, pale brown; perigynia narrowly lanceolate, about $8 \mathrm{~mm}$. long and rather less than $1 \mathrm{~mm}$. wide, strongly severalnerved, flat, narrowed to both ends, scarious-margined, rough-ciliate, the tapering 2-toothed beak at least as long as the body; scales lanceolate, acuminate, onethird to one-half as long as the perigynia. In moist woods and thickets, Ohio to Mich., Manitoba and Mo. June-Aug.

192. Carex tribuloìdes Wahl. Blunt Broom Sedge. (I. F. f. 862.) Bright green; culms erect, roughish alove, 2-9 dm. tall. Leaves flat, $2-6 \mathrm{~mm}$. wide; lower bract bristle-form; spikes 6-20, oblong or top-shaped, blunt, 6-12 mm. long: perigynia lanceolate, greenish brown, flat, 4-5 $\mathrm{mm}$. long, I-2 $\mathrm{mm}$. wide, several-nerved on each face, with a sharply 2 -toothed, rough wing-margined beak; scales lanceolate, whitish, acute, about half as long as the perigynia. In meadows, N. B. to Manitoba, Fla. and Ariz. July-Sept.

Carex tribuloldes Bébbii Bailey. More slender, spikes fewer, smaller, about $6 \mathrm{~mm}$. long, commonly bractless, mostly clustered in a dense head; perigynia broader and shorter. Range of the type.

Carex tribuloides moniliformis (Tuckerm.) Britton. Slender, the culm much ex. ceeding the leaves; spikes all or all but the uppermost separated, 5-8 mm. long, the rachis somewhat zigzag. Me. and N. B. to N. Y., Iowa and N. Dak.

193. Carex scopària Schk. Pointen Broom Sedge. (I. F. f. 863.) Culms slender, erect, roughish above, 1.5-7.5 dm. tall. Leaves less than $3 \mathrm{~mm}$. wide; spikes 3-10, oblong, narrowed at both ends, bright brown, 6-16 mm. long, usually aggregated into an ovoid head; perigynia lanceolate, 4-6 $\mathrm{mm}$. long, rather less than $2 \mathrm{~mm}$. wide, narrowly wing-margined, several-nerved on both faces, tapering into the ciliate 2-toothed beak; scales thin, brown, acuminate or cuspidate, shorter than the perigynia. In moist soil, N. S. to Manitoba, Fla. and Colo. July-Sept.

r94. Carex leporina L. Hare's-Foot Sedge. (I. F. f. 864.) Culms slender, roughish above, 3-4 dm. tall. Ieaves about $2 \mathrm{~mm}$. wide, flat, shorter than the culm; bracts very short and scale-like or wanting; spikes $4-7$, oblong, blunt, 8-12 mm. long, dark brown, shining, clustered in a terminal oblong head; 
perigynia ascending or appressed, ovate-lanceolate, $4 \mathrm{~mm}$. long, rather narrowly wing-margined, several-nerved on both faces, the rough tapering 2 -toothed beak nearly as long as the body; scales lanceolate, brown, acute, narrower and shorter than the perigynia. Newf. to Mass. Also in Europe and Asia. June-Aug.

195. Carex cristatélla Britton. Crested SedGe. (I. F. f. 865.) Culms 3-7 ùm. tall, stiff, roughish above, longer than the leaves. Leaves 3-4 mm. wide; lower bracts bristle-form, $0.6-3 \mathrm{~cm}$. long ; heads 6-15, globose or subglobose, 4-6 mm. in diameter, densely aggregated into an oblong head or the lower slightly separated ; perigynia lanceolate or ovate-lanceolate, squarrose when mature, green or greenish brown, 3-4 mm. long, narrowly wing-margined, several-nerved on both faces, tapering into a ciliate 2-toothed beak; scales lanceolate, nearly white, much shorter than the perigynia. In meadows and thickets, N. B. to Manitcba, Mass., Penn., Ill. and Neb. July-Sept. [C. cristata Schwein., not Clairv.]

I96. Carex adústa Boott. Browned SedGe. (I. F. f. 866.) Culms stout, entirely smooth, 3-8 dm. tall, growing in dense tufts. Leaves about $2 \mathrm{~mm}$. wide, shorter than the culm; bracts subulate, tapering from a broad nerved base, the lower I or 2 often exceeding the spikes; spikes 5-12, subglobose or shortoval, several-flowered, apparently confluent, or slightly separated, bright greenish brown ; perigynia broadly ovate, firm, very narrowly wing-margined or wingless, rough above, plano-convex, 4-5 mm. long, tapering into a 2-toothed beak, several-nerved on the outer face, nerveless on the inner; scales lanceolate, acute or cuspidate, about equalling the perigynia. In dry soil, Newf. to the N. W. Terr., N. Y. and Mich. June-July.

I97. Carex foènea Willd. HAY SEDGE. (I. F. f. 867.) Rather light green ; culm smooth, erect or the summit nodding, 3-10 dm. tall. Leaves flat, soft, 2-4 mm. wide, shorter than the culm; bracts very short or wanting, or the lowest occasionally manifest; spikes 4-IO, subglobose or short-oblong, narrowed at the base, 5-6 mm. in diameter, silvery green, all separated on a sometimes zigzag rachis, or the upper contiguous ; perigynia ovate, about $3 \mathrm{~mm}$. long, broadly wingmargined, strongly several-nerved on both faces, tapering into a short rough 2 -toothed beak: scales lanceolate, acuminate, about equalling the perigynia. In dry woods, often on rocks, N. B. to Penn., Iowa, Minn. and Br. Col. June-July.

Carex foènea perpléxa Bailey. Culms stouter, spikes commonly aggregated and larger, less contracted at the base, the summit of the culm erect or nearly so ; perigynia thicker. Me. to Va., Iowa and Minn.

198. Carex stramínea Willd. Straw Sedge. (I. F. f. 868.) Culms slender, roughish above, 3-7.5 dm. long, the top commonly nodding. Leaves $2 \mathrm{~mm}$. wide or less, long-pointed, shorter than the culm; bracts short or the lower bristle-form and exceeding its spike; spikes 3-8, subglobose or slightly obovoid, 4-5 mm. thick, yellowish brown or greenish; perigynia ovate, brown, about $3 \mathrm{~mm}$. long, strongly several-nerved on the outer face, fewer-nerved on the inner, wingmargined, the tapering rough 2-toothed beak about as long as the body; scales lanceolate, acute, about equalling the perigynia, but narrower. In dry fields, N. B. to Manitoba, Penn., Mich. and Iowa. June-July.

Carex straminea mirábilis (Dewey) Tuckerm. Larger; culm slender, o.5-r.3 m. long; leaves $2-5 \mathrm{~mm}$. wide; spikes larger, $6-8 \mathrm{~mm}$. thick, rather greener; perigynia spreading, narrowed, longer than the scales. Range of the type, extending south to N. Car., Mo. and Neb. Perhaps better regarded as a distinct species.

199. Carex silícea Olney. SEA-BEach Sedge. (I. F. f. 869.) Culms slender, rather stiff, roughish above, 3-8 $\mathrm{dm}$. tall, the summit recurved or nodding. Leaves $2 \mathrm{~mm}$. wide or rather less, involute in drying, shorter than the culm ; bracts very short ; spikes 5-8, ovoid-conic or ovoid-oblong, silvery-green, nearly white or becoming brownish, erect, conspicuously contracted at the base, $8-12 \mathrm{~mm}$. long, about $5 \mathrm{~mm}$. thick, separated or the uppermost close together; perigynia ovateoval, short-beaked, finely nerved on both faces, wing-margined, appressed, about $4 \mathrm{~mm}$. long, longer and broader than the lanceolate scales. In sands of the sea coast, Nova Scotia to New Jersey. June-Aug.

2nn. Carex ténera Dewey. Marsh Straw Sedge. (I. F. f. 87o.) Culm slender, erect or the summit nodding, roughish above, 2-6 dm. high. Leaves 
shorter than the culm, usually less than $2 \mathrm{~mm}$. wide, tapering to a very long tip ; spikes 4-6, oval, obtuse, greenish brown, 8-10 $\mathrm{mm}$. long, commonly much contracted at the base ; perigynia ovate to ovate-lanceolate, strongly several-nerved on both faces, wing-margined, the tapering rough beak more than half as long as the body ; scales lanceolate, about as long as the perigynia, but much narrower. In wet soil, common along brackish marshes, Me. and Ont. to Va. and La. Reported from Iowa. May-June.

Carex ténera invisa (W. Boott) Britton. Spikes smaller, subglobose or short-oblong, not more than $6 \mathrm{~mm}$. thick, the lower one usually subtended by a filiform bract $\mathrm{I}-8 \mathrm{~cm}$. long. Me. to Del.

201. Carex festucàcea Willd. Fescue Sedge. (I. F. f. 871.) Culms nearly or quite smooth, erect, $0.3-I_{0} 2 \mathrm{~m}$. tall. Leaves erect, $2-4 \mathrm{~mm}$. wide, shorter than the culm; spikes 3-8, green-brown, oblong or nearly globular, clustered, 4-8 $\mathrm{mm}$. in diameter; perigynia orbicular or very broadly ovate, broadly wing-margined, about $3 \mathrm{~mm}$. in diameter, several-nerved on both faces, the roughish beak about one-third the length of the body; scales acute or obtusish. In dry or moist soil, N. B. to Assiniboia, Neb., Fla. and Kans. May-July.

202. Carex alàta Torr. BROAD-Winged SedGe. (I. F. f. 872.) Culms erect, roughish above, $0.3-1 \mathrm{~m}$. tall. Leaves $2-4 \mathrm{~mm}$. wide, shorter than the culm ; spikes oblong or oblong-conic, green-brown, ro-16 mm. long, 8-10 $\mathrm{mm}$. thick, usually little separated, bractless, or the lower one subtended by a short bract ; perigynia orbicular or obovate-orbicular, very broadly winged, 4-5 $\mathrm{mm}$. in diameter, faintly few-nerved or almost nerveless, the short beak not more than onefourth as long as the body ; scales lanceolate, acuminate, scarcely over $0.5 \mathrm{~mm}$. wide; achene distinctly stipitate. In moist soil, N. H. to Penn. and Fla., mostly near the coast. Reported from Iowa. May-June.

202. Carex albolutéscens Schwein. Greenish-white Sedge. (I. F. f. 873.) Similar to the preceding; culms $0.3-0.5 \mathrm{~m}$. tall, stout. Leaves $2-4 \mathrm{~mm}$. wide, shorter than the culm; bracts filiform or wanting; spikes $3-8$, oblong, usually narrowed at both ends, silvery green when young, becoming brownish, 8-12 $\mathrm{mm}$. long, clustered; perigynia broadly ovate, not twice as long as wide, broadly winged, strongly nerved on both faces, about $4 \mathrm{~mm}$. long, the roughish beak about one-third as long as the body ; scales lanceolate, acuminate ; achene nearly or quite sessile. In wet soil, abundant along salt meadows, N. B. to Penn. and Fla. May-July.

204. Carex Bicknéllii Britton. Bicknell's Sedge. (I. F. f. 874.) Culms 0.5-1 m. high, rough above, much longer than the leaves. Leaves mostly nearly basal, 3-5 mm. wide ; bracts usually very short ; spikes 3-7, ovoid, subglobose, or somewhat obovoid, 8-12 $\mathrm{mm}$. long, silvery green or becoming yellowish; perigynia very broadly ovate, thin, several-nerved on the outer face, 4-6 $\mathrm{mm}$. long, the broad membranous wing I $\mathrm{mm}$. wide, the rough 2 -toothed beak one-fourth to one-half as long as the body; achene stalked. In dry soil, N. Y. to Minn., Mo. and Kans. June-July.

205. Carex sychnocéphala Carey. Dense Long-Beaked Sedge. (I. F. f. 875.) Culms quite smooth, $0.7-5 \mathrm{dm}$. high. Leaves about $2 \mathrm{~mm}$. wide; lower bracts similar, much elongated, o.7-3 dm. long, nearly erect; spikes 4-10, oblong, densely many-flowered, aggregated and contluent into an oblong or ovoid head $3 \mathrm{~cm}$. long or less; perigynia linear-lanceolate, $5-6 \mathrm{~mm}$. long, about $\mathrm{I} \mathrm{mm}$. wide at the base, tapering into a subulate rough 2-toothed beak 2-3 times as long as the few-nerved body; scales linear-lanceolate, long-acuminate, shorter and rather narrower than the perigynia. In meadows and thickets, Ont. and N. Y. to Manitoba, Iowa and Br. Col. July-Aug.

Order 4, PRÍNCIPES, including only the family Palmaceae, Palms, and Order 5, SYNANTHAE, including only the family Cyclanthaceae, are not represented in our territory. 


\section{Order 6. ARÀLES.}

Monocotyledonous herbs, mostly fleshy. Inflorescence in the Araceae a fleshy spadix, subtended by a spathe, or naked. The Lemnaceas are minute floating thalloid plants, with few or solitary flowers on the margin or back of the thallus.

\section{Family I. ARÀCEAE Neck.}

\section{Arum Family.}

Herbs mostly with basal long-petioled leaves, and spathaceous inflorescence, the spathe enclosing or subtending a spadix. Rootstock tuberous or a corm. Spadix densely flowered, the staminate flowers above, the pistillate below, or the plants wholly diœecious, or with perfect flowers in some species. Perianthwanting, or of $4^{-6}$ scale-like segments. Stamens 4-10 in our species; filaments very short; anthers 2-celled, commonly with a thick truncate connective, the sacs opening, by dorsal pores or slits. Ovary I-several-celled; - ovules I-several in each cavity; style short or wanting; stigma terminal, mostly minute and sessile. Fruit a berry or utricle. Seeds various. Endosperm copious, sparse or none. About I05 genera and 900 species, mostly of tropical regions, a few in the temperate zones.

Flowers without a perianth.

Flowers monœcious or diœcious, borne at the base of the spadix.

Flowers monœcious, covering the whole spadix.

Flowers perfect.

Flowers with a perianth.

Spadix enclosed in a shell-like fleshy spathe.

Spadix naked, terminating the scape.

Spadix naked, borne at the base of a leaf-like spathe.

1. Arisaema.

2. Peltandra.

3. Calla.

4. Spathyema.

5. Orontium.

6. Acorus.

\section{ARISAÈmA Mart. (See Appendix.)}

Perennial herbs with acrid corms, simple scapes and I to 3 slender-petioled di. vided leaves unfolding with the flowers. Spadix bearing the flowers near its base. Spathe convolute, open or contracted at the throat. Flowers dioecious or monoe. cious, the staminate of 4 almost sessile 2-4-celled anthers, which open by confluent slits at the apex, the pistillate with a I-celled ovary containing I to many ortho. tropous ovules; style very short or none, tipped with a peltate-capitate stigma. Fruit a globose red berry, the clusters usually large and conspicuous when ripe. Seeds with copious endosperm and an axial embryo. [Greek, in reference to the red-blotched leaves of some species.] About 50 species, mostly natives of temperate and subtropical Asia. Besides the following another occurs in the S. U. S.

Spathe hooded, open at the throat, enclosing the spadix.

Hood of spathe striped; spadix stout, club-shaped. Spathe convolute; summit of the spadix exserted.

r. A. triphyllum

3. A. Dracontium.

I. Arisaema triphýllum (L.) Torr. JACK-IN-THE-PUlPIT. Indian Turnip. (I. F. f. 876.) Leaves nearly erect, 2.5-9 dm. high, usually exceeding the scape, 3-foliolate, the segments ovate, sometimes lobed, 4-8 cm. wide, sessile or very short-stalked; flowers commonly dicecious, yellow; spadix 4-8 cm. long, its naked summit blunt, colored; spathe green, and purple-striped, curving in a broad striped flap over the top of the spadix. acuminate; ovules 5 or 6 ; berries shining, about $I \mathrm{~cm}$. in diameter. forming a dense ovoid head $2-8 \mathrm{~cm}$. long. In moist woods and thickets, N. S. to Fla., Ont., Minn., Kans. and La. April-June.

2. Arisaema pusíllum (Peck) Nash. Similar to the preceding, but smaller and more slender, seldom over $3.5 \mathrm{dm}$. high. Leaf-segments narrowed at the base; spathe striped below, the hood deep brown or nearly black; spadix slender, cylindric. In open sunny bogs, N. Y., flowering about a month later than $A$. triphyllum where the two grow in the same region. (A. triphyllum pusillum Peck, Rep. N. Y. State Mus. 5 I : 297). 
3. Arisaema Dracóntium (L.) Schott. Green Dragon. Dragon-Root. (I. F. f. 877.) Corms clustered. Leave 2-I I dm. long, pedately divided into 5I7 segments, much longer than the scape; segments obovate or oblong, 2-10 cm. wide, abruptly acute at the apex, narrowed to a sessile or nearly sessile base, entire or the lateral ones somewhat lobed; spathe greenish or whitish, acuminate, 2$5 \mathrm{~cm}$. long; spadix ovary turbinate, with 6-8 bottle-shaped ovules; berries reddish. orange in large ovoid heads. Mostly in wet woods and along streams, Me. to Ont, and Minn., south to Fla., Kans. and Tex. May-June.

\section{PELTÁNDRA Raf.}

Bog herbs, with sagittate or hastate leaves, the petioles sheathing the shorter scape. Spathe elongated, convolute, or expanded above. Flowers monocious, covering the spadix. Perianth none. Staminate flowers uppermost, consisting at first of irregularly 4-sided oblong flat-topped shields, from the edges of which appear 6-10 imbedded anthers opening by apical pores, the shields shrivelling and leaving the anthers nearly free. Ovaries ovoid, surrounded at base by 4 or 5 white fleshy scale-like staminodia, I-celled; ovules solitary or few, amphitropous; style erect, thick, tipped with a small stigma. Fruit a green or red berry, I-3seeded, when ripe forming large globose heads and enclosed in the persistent leathery base of the spathe. Seeds surrounded by a tenacious jelly; endosperm none. [Greek, referring to the shield-shaped staminate disks.] The genus consists of the two, following species :

Spathe narrow, convolute its whole length, green. Spathe with a whitish dilated summit.

1. P. Virginica.

2. P. sagittaefolia.

I. Peltandra Virgínica (L.) Kunth. Green Arrow-Arum. (I. F. f. 878.) Leaves bright green, somewhat hastate-sagittate, I-8 dm. long, acute or acuminate, ñrm, strongly veined. Root a tuft of thick fibres; scape recurving and immersing the fruiting spadix at maturity; spathe green, I-2 dm. long, long-conic, closely investing the spadix throughout, the strongly involute margins undulate; spadix shorter than the spathe, the pistillate flowers covering about one-fourth of its length, the rest occupied by staminate flowers; ovaries globose-ovoid; style nearly $2 \mathrm{~mm}$. long; berries greer when ripe. In swamps o: shallow water, Me. and Ont. to Mich., Fla. and La. May-June.

2. Peltandra sagittaefòlia (Michx.) Morong. White Arrow-Arum. (I. F. f. 879.) Leaves sagittate, sometimes wider than those of the preceding, the basal lobes diverging; petioles 2-5 dm. long; spatle 7-10 $\mathrm{cm}$. long, with a whitish expanded acuminate apex; spadix scarcely more than one-half as long as the spathe; ovaries ovcid; style scarcely any; stigma broad, depressed, lobed; ripe berries red. In marshes and springs, southern Va. (according to Gray) to Fla. May-July.

\section{CÁlla L.}

A bog herb with slender acrid rootstocks, broadly ovate or nearly orbicular cordate leaves, and a large white persistent spathe. Spathe ovate-lanceolate or elliptic, acuminate, open. Spadix cylindric, much shorter than the spathe, densely covered with flowers. Flowers perfect or the uppermost staminate; perianth none. Stamens about 6; filaments linear; anther-sacs divaricate, opening by slits. Ovary ovoid, I-celled; style very short; stigma small, flat, circular. Ovules 6-9, anatrapous. Berries obconic, depressed. Seeds hard, smooth, oblong, striate toward the micropyle and pitted at the other end. Endosperm copirus. [An ancient name, taken from Pliny.] A monotypic genus of the cooler portions of the north temperate zone.

I. Calla palústris L. Water Arum. (I. F. f. 880.) Petioles I-2 dm. long. Blades thick, entire, $3^{-10} \mathrm{~cm}$. wide, cuspidate or abruptly acute; scape as long as the petioles, sheathed at the base; rootstocks covered with sheathing scales and with fibrous roots at the nodes; sfathe $2.5-6 \mathrm{~cm}$. long and about $2-5 \mathrm{~cm}$. wide; berries red, distinct, few-seeded, forming a large head when mature. In b rs, N. S. to Minn., Va., Wis. and Iowa. Also in Europe and Asia. May-June. Fruit ripe July-Aug. 


\section{SPATHYÈMA Raf. [SYMPLOCARPUS Salisb.]}

A fetid herb, with large ovate cordate leaves, thick straight rootstocks and a short erect partly underground scape. Spathe swollen, shell-like, thick, pointed, completely enclosing the spadix. Spadix globose or oblong, short-stalked, covered by the perfect flowers. Perianth of 4 hooded sepals. Filaments slightly dilated; anthers 2-celled, short, extrorse, opening longtitudinally. Ovary nearly buried in the tissue of the spadix, I-celled with a solitary suspended anatropous ovule. Style pyramidal, 4-sided, thick, elongated; stigma minute. Berries immersed in the spongy axis of the spadix, becoming adnate to the succulent perianth in ripening, I-seeded, forming large heads. Seeds large. Embryo large, fleshy; endosperm none. [Greek, referring to the spathe.] A monotypic genus of E. North America and N. E. Asia.

I. Spathyema foètida (L.) Raf. Skunk CabbaGe. (I. F. f. 88I.) Leaves numerous, in large crowns, 3-9 dm. long, often $3 \mathrm{dm}$. wide. strongly nerved, abruptly acute at the apex, thin, entire, their petioles deeply channeled. Rootstock thick, terminating in whorls of fleshy fibers; spathe preceding the leaves, erect, $7-15 \mathrm{~cm}$. high, $2-8 \mathrm{~cm}$. in diameter at the base, convolute, firm, purplesrown to greenish yellow, often mottled; spadix about $2.5 \mathrm{~cm}$. in diameter in flower, enlarging and sometimes $15 \mathrm{~cm}$. in diameter in fruit. In swamps and wet soil, N. S. to Ont., Minn., Fla. and Iowa. Feb.-April.

\section{ORÓNTIUM L.}

Aquatic herbs, with thick rootstocks, oblong-elliptic nerved leaves without a distinct midvein, and slender terete scapes terminated by a cylindric spadix. Spathe enclosing the spadix when very young. soon parting and remaining as a sheathing bract at its base, or falling away. Flowers perfect, bright yellow, covering the whole spadix. Sepals 4-6, scale-like, imbricated upon the ovary; stamens as many as the sepals; filaments linear; abruptly narrowed above; anthers small, with two diverging sacs opening by oblique slits. Ovary partly imbedded in the axis of the spadix, depressed, obtusely angled, I-celled; ovule solitary, half-anatropous; stigma sessile. Fruit a green utricle. Endosperm none: embryo long-stalked. [Ancient name of some water plant.] A monotypic genus of eastern N. America.

I. Orontium aquáticum L. Golden-Club. (I. F. f. 882.) Leaves deep dull green above, pale beneath, the blade I-3 dm. long, 4-12 cm. wide, entire, acute or cuspidate at the apex, narrowed at the base into a petiole. Scape 1.5$6 \mathrm{dm}$. long, flattened near the spadix; spadix 2-5 cm. long, 6-8 $\mathrm{mm}$. in diameter, much thickened in fruit; spathe bract-like, 5-10 cm. long, 2-keeled on the back, usually falling away early; utricle roughened on top with 9 or ro tubercles. In swamps and ponds, Mass. to Penn., Fla. and La., mostly near the coast. AprilMay.

\section{6. ÁCORUS L.}

Erect herbs, with long branched rootstocks, sword-shaped leaves, and 3-angled scapes keeled on the back and channeled in front, and a seemingly lateral cylindric spadix, the scape appearing as if extending long beyond it, but this upper part is morphologically a spathe. Flowers perfect, densely covering the spadix. Perianth of 6 membranous concave sepals. Stamens 6; filaments flatted; anthers reniform or sagittate, 2-celled, the cells confluent at maturity. Ovary oblong. 3-4celled with 2-8 anatropous ovules in each cavity; stigma sessile, depressed-capitate. Fruit a 2-3-celled gelatinous berry, few-seeded. Endosperm copious. [Name ancient.] Two known species, the following widely distributed in the north temperate zone, the other Japanese.

I. Acorus Cálamus L. Siveet Flag. Calamus-root. (I. F. f. 883.) Leaves linear, erect, 5-15 dm. tall and $2-5 \mathrm{~cm}$. wide or less, sharp-pointed and sharp-edged, with a ridged midvein, 2-ranked, closely sheathing each other and the scape. Spathe projecting $2-8 \mathrm{dm}$. beyond the spadix; spadix spike-like, 5-9 cm. long, about $\mathbf{I} \mathrm{cm}$. in diameter; flowers minute, greenish-yellow. In swamps and along streams, N. S. to Ont., Minn., La. and Kans. Also in Europe and Asia. May-July. 


\section{Family 2. LEMNÀCEAE Dumort. \\ Duckweed Family.}

Minute perennial floating aquatic plants, without leaves or with only very rudimentary ones. The plant-body consists of a disk-shaped, elongated or irregular thallus, which is loosely cellular, densely chlorophyllous and sometimes bears one or more roots. The vegetative growth is by lateral branching, the branches being but slightly connected by slender stalks and soon separating. The inflorescence consists of one or more naked monœcious flowers borne on a slight lateral prominence on the edge or upper surface of the plant. Each flower commonly consists of but a single stamen or a single flask-shaped pistil. The anther is provided with two to four pollen-sacs, containing spherical minutely barbellate grains. The pistil is narrowed to the funnel-shaped scar-like stigmatic apex, and produces $\mathrm{I}-6$ erect or inverted ovules. The fruit is a $1-6$ seeded utricle. The family comprises the smallest of the flowering plants and contains 4 genera and about 30 species of wide distribution.

Thallus with one root or several.

Roots several.

Root solitary.

1. Spirodela.

Thallus rootless.

Thallus thick, globose to subcylindric.

Thallus thin, ligulate.

2. Lemna.

3. Wolffia.

4. Wolffiella.

\section{SPIRODÈLA Schleid.}

Thallus disk-shaped, 7-12-nerved. The lateral branches subtended by a single bipartite basilar rudimentary leaf. The thinly capped rootlets as well as the nerves are provided with a single bundle of vascular tissue. Spathe sac-like. The ovary produces two anatropous ovules. Fruit unknown. [Greek, in allusion to the cluster of rootlets. Two species, the following, and $S$. oligorhiza, a native of the southern hemisphere.

r. Spirodela polyrhiza (L.) Schleid. Greater Duckweed. (I. F. f. 884.) Thallus 2-10 mm. long, thick, flat and dark green above, slightly convex and purple beneath, palmately 5-15-nerved, bearing a central cluster of from 4-16 elongated roots. Rootcap pointed. In still water, N. S. to Br. Col., S. Car., Tex., northern Mex. and Nev. Widely distributed in the Old World and in tropical America.

\section{LÉMNA L.}

Thallus disk-shaped, usually provided with a central nerve and with or without two or four lateral nerves. Each thallus produces a single root, which is devoid of vascular tissue and is commonly provided with a thin blunt or pointed rootcap. The ovary contains from one to six ovules. Fruit ovoid, more or less ribbed. Endosperm in one or three layers. [Greek, in allusion to the growth of these small plants in swamps.] About ro species, in temperate and tropical regions.

Thalli long-stipitate.

I. L. trisulca.

Thalli short-stipitate or sessile.

Spathe open.

Thalli I-nerved or nerveless.

Thalli thin, without papules; rootcap strongly curved, tapering.

2. L. cyclostasa.

Thalli thick with a row of papules along the nerve; rootcap little curved, cylindric.

Thalli 3 -nerved; rootcap cylindric.

Spathe sac-like.

3. L. minima.

4. L. perpusilla.

Thalli green or purplish beneath; fruit not winged.

Thalli pale beneath, usually strongly gibbous; fruit winged. 6. L. gibba.

I. Lemna trisúlca L. Ivy-Leaved Duckweed. (I. F. f. 885.) Thallus lanceolate, submerged and devoid of stomata in the primary aquatic form, ovate to oblong-lanceolate, 5-15 mm. long, floating and provided with stomata in the later flowering stage. The later and more common form is narrowed at the base to a 
slender stipe, thin, denticulate, with or without rootlets, and slightly 3 -nerved; several individuals often remain connected, so as to form a chain-like series; rootcap pointed; fruit symmetrical; seed deeply 12-I5-ribbed. In water, N. S. to N. J., N. Mex., Br. Col. and Cal. Also in Europe, Asia, Afriea and Australia. July-August.

2. Lemna cyclostàsa (Ell.) Chev. Valdivia Duckweed. (I. F. f. 886.) Thallus oblong-elliptic, $2-4.5 \mathrm{~mm}$. long, thin, subfalcate and shortly stalked at the base, provided with numerous stomata, except on the borders, nerveless; rootcap blunt; spathe reniform; fruit ovoid-oblong, unsymmetrical; seed prominently 12-29-ribbed. In pools and rivers, Mass. to Fla., Ill., Wyo. and Cal. Also in South America. June-July. (L. Valdiviana Phil.)

3. Lemna mínima Philippi. Least Duckweed. (I. F. f. 886a.) Thallus oblong to elliptic, 2-4 mm. long, obscurely I-nerved, or nerveless, with a row of papules along the nerve, the lower surface flat, or slightly convex; the apex rounded, rootcap usually short, a little curved, rarely perfectly straight, cylindric, blunt; spathe open; pistil short-clavate; stigma concave; ovule solitary, obliquely orthotropous; seerl oblong, pointed, about I6-ribbed, with many transverse striations. Ga. and Fla. to Kans., Wyo. and Cal.

4. Lemna perpusílla Torr. Mrnute Duckweed. (I. F. f. 887.) Thallus small, 2-3.5 mm. long, obovate, often purplish tinged beneath, unsymmetrical and abruptly narrowed to a very short stalk, provided throughout with numerous stomata, obscurely 3-nerved; rootcap straight, pointed; fruit ovoid; seed 12-20ribbed. In ponds, rivers, springs and lakes, Mass. to N. Y., Fla., Minn., Neb. and Kan. June-July.

Lemna perpusilla trinèrvis Aust. Thallus oblong to oblong-obvate, less unsymmetrical, thin, prominently 3-nerved. N. J. to Mo., La. and the Ind. Terr.

5 Lemna minor L. Lesser Duckweed. (I. F. f. 888.) Thallus obovate or subcircular, I.5-5 mm. long, thickish, rarely reddish or purplish tinged, shortstalked when young, provided throughout with stomata, nearly symmetrical, obscurely 3-nerved, very rarely 4-5-nerved. Rootcap obtuse or subtruncate; fruit symmetrical, subturbinate; seed with a prominent protruding hilum, deeply and unequally 12-15-ribbed; ovule I. In ponds, lakes and stagnant waters, throughout N. Am., except the extreme north. Also in Europe, Asia, Africa and Australia. Summer.

6. Lemna gíbba L. Gibbous Duckweed. (I. F. f. 889.) Thallus unsymmetrical, obovate or slort-obovate, 2-6 $\mathrm{mm}$. long, thickish or more or less strongly gibbous beneath, short-stalked when young, soon separating, provided with stomata which are sparse beneath, obscurely 3-5-nerved; rootcap mostly short-pointed, cylindric, rarely long-pointed or obtuse; fruit symmetrical; seed thick, deeply and unequally ribbed. In ponds and rivers, Neb. to Tex., Wyo., Ariz. and Cal. Also in Mexico, Europe, Asia, Africa and Australia. June-July.

\section{WÒLFFIA Horkel.}

Thallus small, globose, ovoid-oblong, subcylindric or irregular, rootless, nerve. less and leafless. The vegetative growth is from a cleft near one end of the plant, the branch being mostly sessile and soon detached. The ovary contains one orthotropous ovule. Fruit spherical or short ovate, smooth. Endosperm in a single layer. [Name in honor of Nath. Matth. v. Wolff, 1724-1784, Polish physician and naturalist.] A genus of about 12 species, mostly in tropical and subtronical regions.

Thallus globose to ellipsoid, not punctate.

Thallus flattened above, at least on the margin, brown-punctate. Apex of thallus acute.

A large conic papule on the upper surface.

\section{W. Columbiana.}

2. W. punctata.

3. W. papulifera.

I. Wolffia Columbiàna Karst. Columbia Wolffia. (I. F. f. 8go.) Thallus spherical or subellipsoidal, $0.5^{-1} \mathrm{~mm}$. long, with a limited number of stomata ( $I$ to 6 ), loosely cellular and clear green throughout, not punctate nor gibbous. Floating as minute alga-like grains just beneath the surface of the water in stagnant ponds, pools and shallow lakes, Mass. to Ont., N. J., S. Car., Minn., Mo. and La. Also in Mexico and South America. June-July. 
2. Wolffia punctàta Griseb. Punctate Wolffia. (I. F. f. 89I.) Thallus oblong, smaller than the last, $0.5-0.8 \mathrm{~mm}$. long, flattish, densely cellular, with numerous stomata and dark green above, gibbous, more loosely cellular, with fewer stomata and paler beneath; brown-dotted throughout with minute pigment cells. Floating on the surface of stagnant waters, Ont. to Mich. and Penn. JuneJuly. (W. Brasiliensis Engelm., not Wedd.)

3. Wolffia papulifera Thompson. Pointed Duckweed. (I. F. f. 89ra.) Thallus slightly unsymmetrical, obliquely broadly ovate, about I m. broad, the apex rounded, the upper surface flat at the margin, gradually ascending into a prominent conic papule on the median line, brown-punctate, the under surface strongly gibbous, less punctate; stomata numerous on the upper surface; flower and fruit unknown. Floating, with the entire upper surface exposed to the air. - Kennett and Columbia, Mo.

4. WOLFFIÉLLA Hegelm.

Thallus thin, unsymmetrical, rootless, curved in the form of a segment of a band, punctate on both surfaces with numerous brown pigment-cells. Pouch opening as a cleft in the basal margin of the thallus, a stipe attached to its margins. Flowers and fruit unknown. [Diminutive of $\mathrm{Wolffi}$.] About 7 species, mostly of tropical regions. Besides the following, 2 others are known from western North America.

I. Wolffiella Floridàna (J. D. Smith) Thompson. Florida WolfFiella. (I. F. f. 889a.) Thallus solitary, or commonly coherent for several generations, forming densely interwoven masses, strap-shaped, scythe-shaped, or doubly curved, tapering from the rounded oblique base to a long-attenuate apex, 5-10 $\mathrm{mm}$. long, I4-2I times as long as wide; basal portion of the long stipe persistent, the pouch elongated-triangular, or the upper angle rounded. Ga. and Fla. to Mo., Ark. and Tex.

\section{Order 7. XYRIDÀLES.}

Monocotyledonous herbs, mostly with narrow leaves. Flowers usually complete, their parts mostly in 3's or 6's. Corolla regular or nearly so (except in Commelina). Ovary compound, superior. Endosperm of the seed mealy.

a. Ovary I-celled.

Aquatic moss-like leafy herbs; flowers solitary.

Erect scapose rush-like herbs; flowers in terminal scaly heads or spikes.

Fam. 2. Xyridaceae.

Mud or aquatic herbs, the flowers subtended by spathes (Heteranthera in Pontederiaceae).

6. Ovary 2-3-celled (except in some Pontederiaceae).

Flowers very small, densely capitate, monoecious or dioecious.

Flowers perfect.

Epiphytes; leaves scurfy.

Terrestrial or aquatic herbs; leaves not scurfy.

Fam. 3. Eriocaulaceae.

Perianth of 2 series of parts, the outer (sepals) green, the inner (petals colored.

Perianth 6-parted.

Fam. 4. Bromeliaceae.

\section{Family 1. MAYACÀCEAE Walp.}

\section{Mayaca Family.}

Slender branching aquatic moss-like herbs, with linear sessile I-nerved entire soft leaves, notched at the apex. Flowers solitary, peduncled, white, perfect, and regular, the peduncles bracted at the base. Perianth persistent, consisting of 3 lanceolate green herbaceous sepals and 3 obovate white spreading petals. Stamens 3 , hypogynous, alternate with the petals; filaments filiform; anthers oblong, somewhat 4-sided, 2-celled. Ovary superior, sessile, I-celled with 3 parietal placentae; ovules several or numerous, orthotropous; style filiform; stigmas terminal, entire or with 3 short lobes. Capsule I-celled, 3-valved. Seeds ovoid or globose, 
the testa reticulated; embryo at the apex of the mealy endosperm. The family consists of the following genus :

\author{
1. MAYÀCA Aubl.
}

Characters of the family. [Aboriginal name of these plants in Guiana.] Abou: 7 species, natives of warm and tropical America. Only the following occurs in the United States :

I. Mayaca Aublèti Michx. Mayaca. (I. F. f. 892.) Stems tufted, 7-55 $\mathrm{cm}$. long, little branched. Leaves densely clothing the stem and widely spreading, linear-lanceolate, translucent, 4-6 mm. long, about $0.5 \mathrm{~mm}$. wide; peduncles 4- 1 ? $\mathrm{mm}$. long, very slender, recurved in fruit ; flowers $6-8 \mathrm{~mm}$. broad, lateral, rarely more than one on each branch ; capsule oblong-oval, about as long as the sepals, tipped until dehiscence by the subulate style. In fresh water pools and streams, Va. to Fla. and Tex. May-July.

\title{
Family 2. XYRIDÀCEAE Lindı.
}

Yellow-eyed Grass Family.

Tufted herbs, with basal narrow equitant commonly 2-ranked leaves, and erect simple leafless scapes. Flowers perfect, mostly yellow, nearly or quite regular, solitary and sessile in the axils of coriaceous imbricated bracts (scales), forming terminal heads. St pals 3 , the two lateral ones small, keeled, persistent, the other one larger, membranous (wanting in the South American genus Abolbodal). Corolla inferior, with a narrow tube and 3 spreading lobes. Stamens 3 , inserted on the corolla, usually alternating with as many plumose or bearded staminodia. Ovary sessile, I-celled or incompletely 3-celled; ovules on 3 parietal placentae, orthotropous; style terminal (unappendaged in $X y$ ris, in Aholboda appendaged at the base), 3-branched above; stigmas apical. Fruit an oblong 3-valved capsule. Seed-coat longitudinally striate. Embryo apical. Endosperm mealy or somewhat fleshy. Two genera, comprising some 60 species, mostly of tropical distribution in both the Old World and the New.

\section{XỲRIS L. (See Appendix.)}

Characters of the family as given above. [Greek name for some plant with 2-edged leaves.]

Besides the following species there are some 9 others in the southern United States. Lateral sepals wingless, the keel fringed with short hairs.

Lateral sepals winged, the keel fimbriate or lacerate.

I. X. Alexuosa.

Scapes not bulbous-thickened at the base; leaves flat or but slightly twisted.

Lateral sepals about as long as the bracts, their keels lacerate.

Head oblong, 3-6 mm. long; northern.

Head oval or ovoid, 6-16 mm. long; southern.

2. X. montana.

Keel of lateral sepals lacerate to below the middle. 3. X. macrocephala.

Keel of lateral sepals lacerate only above the middle.

4. X. Caroliniana.

Lateral sepals longer than the bracts, their keels long-fimbriate.
Scapes conspicuously bulbous-thickened at the base; leaves spirally twisted.
6. $X$. arenicola.

I. Xyris flexuòsa Muhl. Slender Yellow-eyed Grass. (I. F. f. 893-) Scapes slender, straight or sometimes slightly twisted, I-4.5 dm. tall, 2-edged above, bulbous-thickened at the base. Leaves flat or becoming twisted when old, 2-1 $5 \mathrm{~cm}$. long, 1-3 mm. wide ; head globose, or short-oblong, obtuse, 6-8 mm. high ; bracts broadly oval or slightly obovate, entire, or somewhat lacerate at the apex; lateral sepals linear, about as long as the bracts, curved, fringed with short hairs on the wingless keel ; flowers 6-8 mm. broad. In bogs, Me. to Minn., Ga. and Tex. July-Sept.

2. Xyris montàna $H$. Ries. Northern Yellow-eyed Grass. (I. F. f. 894.) Scapes very slender, straight or slightly twisted, 2-edged above, $5-30 \mathrm{~cm}$. 
tall, not bulbous-thavened at the base. Leaves narrowly linear, 2-15 cm. long, I-2 $\mathrm{mm}$. wide, not twisted or but slightly so; head oblong or ovoid, subacute, 3-6 $\mathrm{mm}$. long ; bracts rounded and finely lacerate at the apex; lateral sepals linear, irreguıarly serrate-fimbriate on the winged keel above the middle, about as long as the bracts. In bogs, N. S. to Ont., Mich., Penn. and N. J. July-Aug.

3. Xyris macrocéphala Vahl. SOUTHERn Yellow-EYED Grass. (I. F. f. 895.) Scapes slender, slightly twisted, 2 -edged above, I-edged below, not thickened at the base, 1.5-4.5 dm. tall. Leaves linear or linear-lanceolate, flat, 7-25 cm. long, 2-8 $\mathrm{mm}$. wide; head ovoid, or subglobose, blunt or subacute, I-I. $5 \mathrm{~cm}$. long; scales ovate or oval, mostly entire; lateral sepals lanceolate, the winged keel fimbriate from the apex to below the middle ; corolla-lobes obovate, 4-6 $\mathrm{mm}$. long. In bogs, Md. to Fla. and La. Widely distributed in tropical America. June-Aug. (X. communis Kunth.)

4. Xyris Caroliniàna Walt. Carolina Yellow-fyed Grass. (I. F. f. 896.) Scapes mostly slender, straight or somewhat twisted, 2-edged above, 2-5 dm. tall, not thickened at the base. Leaves linear or linear-lanceolate, flat, I-4 $\mathrm{dm}$. long, 2-Io mm. wide; head globosc, ovoid or broadly oval, blunt, 8-16 mm. long; scales oval or slightly obovate, entire somewhat lacerate; lateral sepals linear, about as long as the bracts, the narrowly winged keel lacerate or incisedserrate only above the middle. In swamps and bogs, Mass. to Penn., Fla. and La., mostly near the coast. June-Aug.

5. Xyris fimbriàta Ell. Fringed Yellow-eyed Grass. (I. F. f. 897.) Scapes rather stout, roughish, straight or somewhat twisted, strongly 2-edged above, $0.5-1.2 \mathrm{~m}$. high. Leaves flat, 6-12 mm. wide; head oblong-cylindric, or sometimes globose-ovoid, I-I. $5 \mathrm{~cm}$. in diameter; scales obovate, their margins entire or the apex lacerate; lateral sepals longer than the bracts, exserted, long-fringed on the winged keel above the middle. In wet pine barrens, S. N. J. to Fla. and Miss., mostly near the coast. July-Sept.

6. Xyris arenicola Small. Twisted Yellow-eyed Grass. (I. F. f. 898.) Scapes stout, much spirally twisted, I-edged below, or 2 -edged at the summit, smooth or nearly so, the base conspicuously bulbous-thickened and with the sheathing leaves sometimes $2.5 \mathrm{~cm}$. in diameter. Leaves narrowly linear from a broad shining nearly black base, rigid, rather shorter than the scapes, spiraliy: twisted; head oblong or oblong-cylindric, acute or subacute, $1-2.5 \mathrm{~cm}$. long; bracts oblong-obovate, minutely lacerate-serrulate at the apex or entire; lateral sepals linear, exserted, the winged keel fringed with rather short processes above the middle. In dry pine barrens, S. N. J. to Fla., west to Tex., mostly near the coast, extending north to Ark. (X. torta Kunth, not J. E. Smith.) May-Aug.

\section{Family 3. ERIOCAULÀCEAE Lindl.*}

\section{Pipewort Family.}

Bog or aquatic herbs, perennial or perhaps sometimes annual, with fibrous mostly knotted or spongy roots, tufted grass-like basal leaves, and monœcious (androgynous) or occasionally dioecious very small flowers, in terminal solitary heads, on long slender scapes. Head of flowers involucrate by bracts, each flower borne in the axil of a scarious scale. Perianth of 2 series of segments or rarely of one series. Stamens in the staminate flowers as many or twice as many as the sepals. Ovary 2-3-celled. Ovules 2 or 3. Fruit a 2-3-celled, 2-3-seeded capsule, loculicidally dehiscent. Seeds pendulous, orthotropous; endosperm farinaceous. Six genera and about 340 species, widely distributed in warm and tropical regions, a few extending into the temperate zones.

Perianth of 2 series of segments; sepals and petals 2 or 3 ; stamens distinct; anthers 2 celled.

Stamens twice as many as the inner perianth-segments (petals). I. Exiocaulon.

Stamens as many as the inner perianth-segments. 2 . Dupatya.

Perianth simple, of 3 segments (sepals); stamens 3, monadelphous below; anthers I-celled. 


\section{ERIOCAÙLON L. (See Appenđi. .)}

Acaulescent or very short stemmed herbs, the scapes erect, or when immersed delicate, angular with a long sheathing bract at the base. Leaves mostly short, spreading, acuminate, parallel-nerved. Head of flowers woolly, white, leadcolored or nearly black. Staminate flowers: outer perianth-segments 2 or 3, distinct or sometimes connate, the inner united below into a tube, alternate with the outer ones, each with a minute spot or gland near its middle or apex; stamens mostly 4-6, one opposite each perianth-segment, the filaments of those opposite the inner segments the longer; pistil small, rudimentary or none. Pistillate flowers: outer perianth-segments as in the staminate flowers, the inner indistinct, narrow; stamens wanting; ovary sessile or stalked; style columnar or filiform, stigmas 2 or 3 , filiform. Fruit a thin-walled capsule. Seeds oval, covered with minute processes. [Greek, in allusion to the wool at the base of the scape in some species.] About IIO species, of very wide geographic distribution in tropical and warm regions. Besides the following, 3 others occur in the southern U. S. and 3 in Mexico.

Leaf-blades as long as the sheaths, coarsely 3-8-fenestrate-nerved; scapes 7-angled; heads $4-6 \mathrm{~mm}$. in diameter. $\quad$ 1. E. septangulare. Leaf-blades shorter than the sheaths, finely 6-20-fenestrate-nerved; scapes ro-12-angled; heads 6-12 $\mathrm{mm}$. in diameter.

Leaf-blades much longer than the sheaths, finely ro-5o-nerved; scapes lo-14-angled; heads $8-16 \mathrm{~mm}$. in diameter.

3. E. decangulare.

I. Eriocaulon septangulàre With. Seven-Axgled Pipewort. (I. F. f. 899.) Stem a mere.crown. Leaf-blades pellucid, 3-8-fenestrate-nerved, $1-8 \mathrm{~cm}$. long; scapes weak, twisted, about 7-angled, smooth, 2-20 cm. tall, or when submersed sometimes $\mathbf{I}-3.5 \mathrm{~m}$. long; involucral bracts glabrous, or the innermost bearded at the apex, oblong, usually shorter than the flowers; marginal flowers usually staminate; scales of the receptacle spatulate or obovate, abruptly pointed, brown above; staminate flowers about $2.5 \mathrm{~mm}$. high; pistillate flowers scarcely more than half as large; perianth-segments of both kinds of flowers white-bearded. In sti.l water or on shores, Newf. to Ont., Minn., Fla. and Tex. Also in western Europe. July-Oct.

2. Eriocaulon compréssum Lam. Flattened Pipewort. (I. F. f. 900.) Leaf-blades 6-20-fenestrate-nerved, tapering to a long sharp tip, rigid, or when submerged thin and pellucid. Stem a mere crown ; scapes 1.5-9 dm. tall; smooth, flattened when dry, IO-12-angled; involucral bracts rounded, obtuse, scarious, shining, smooth, imbricated in 3 or 4 series; heads frequently dioecious ; receptacle glabrous ; flowers $3-4 \mathrm{~mm}$. high, otherwise similar to those of the preceding. In still shallow water, S. N. J. to Fla. and Tex. Also in Cuba. At flowering time the styles and stigmas are much exserted, standing above the heads like projecting threads. May-Oct.

3. Eriocaulon decangulàre L. Ten-angled Pipewort. (I. F. f. 901.) Stems short and thick, 2-5 cm. long. Leaf-blades finely many-nerved, tapering to a blunt tip, 1.5-5 dm. long, 4-16 mm. wide: scapes stout, rigid, glabrous, 10-14-angled, 0.3-1 m. tall; heads $8-16 \mathrm{~mm}$. in diameter; involucral bracts ovate, often eroded, denticulate at the apex and pubescent below, imbricated in 4 or 5 series; receptacle pubescent with many-celled hairs; flowers $4 \mathrm{~mm}$. high, densely woolly at the base ; scales longer than the flowers, acute, white-bearded; as are the spatulate perianth-segments. In swamps, S. N. J. and Penn. to Fla. and Tex. Also in Cuba. June-Oct.

\section{DUPÀTYA Vell. [PAEPALANTHUS Mart.]}

Perennial or rarely annual herbs, our species with the habit of Eriocaulon. Stems very short. Leaves awl-shaped, tufted. Scapes slender, several-angled, erect, twisted in growth, sheathed at the base by a long acute bract. Flowers androgynous, in globular or hemispheric heads, each in the axil of a scale, or the scales sometimes obsolete. Involucral bracts imbricated in 3 or 4 series. Perianth of 2 series, each of 2 or 3 segments in the staminate flowers, the outer segments distinct, the inner connate : stamens 2 or 3 , inserted on the inner perianth and opposite its lobes, Pistillate flowers with the outer segments distinct, 
the inner often connate above the 2-celled, 2-3-ovuled ovary; style cleft into 2 or 3 entire or 2-cleft stigmas. Fruit a 2-3-celled, 2-3-seeded capsule, loculicidally dehiscent. [Name in honor of Dupaty.] About 2r 5 species, mostly natives of tropical America. Only the following is known in the U. S.:

I. Dupatya flavídula (Michx.) Kuntze. Dupatya. (I. F. f. 902.) Leaves 3-5-nerved, 2-5 cm. long, awl-shaped, woolly at the base, glabrous or sparingly pubescent above. Scapes usually numerous, 5-angled, pubescent, I-3 dm. high ; sheaths longer than the leaves, slightly inflated above, puhescent ; involucral bracts straw-colored, glabrous, obtuse, oval, shining, somewhat pubescent at the base; scales very thin, scarious-white, linear, slightly pubescent, about as long as the flowers ; flowers about $2.5 \mathrm{~mm}$. high; perianth 6-parted; outer perianth of tie staminate flowers stalked, woolly, the inner a campanulate tube with 3 stamens; pistillate flowers with both sets of perianth-segments distinct, the inner much narrower than the outer; style 3-parted; stigmas 3. In moist pine barrens, S. Va. to Fla. March-July.

\section{LACHNOCAÙLON Kunth.}

Tufted herbs with the habit of Eriocaulon, the leaves linear. Scape several. angled, sheathed at the base by an entire bract about as long as the leaves; heads globose. Receptacle pilose. Flowers androgynous. Perianth of 3 segments. Staminate flowers with 3 stamens united below into a thickened tube which is coalescent with a body, variously regarded as a corolla or as a rudimentary pistil, bearing at its apex 3 fimbriate or entire lobes alternate with the filaments; anthers I-celled, minute. Pistillate flowers with a sessile 3-celled, 3-ovuled ovary surrounded by copious woolly hairs at the base; styles united below, spreading above into 3 divisions which are 2-parted, there being thus 6 stigmas. [Greek, referring to the woolly scapes of some species.] Four known species, natives of the southern U. S.

r. Lachnocaulon ánceps (Walt.) Morong. Hairy Pipewort. (I. F. f. 903). Leaves glabrous or sparingly pubescent, 2-8 $\mathrm{cm}$. long, tapering to an obtuse callous tip. Scapes slender, $0.5-5 \mathrm{dm}$. tall, 2-4-angled, clothed with long soft appressed upwardly pointed hairs; sheaths equalling or shorter than the le +ves; heads globose, $2-6 \mathrm{~mm}$. in diameter; involucral bracts ovate or oblong, shorter than the flowers, usually brown; flowers about $2 \mathrm{~mm}$. high; scales brown, spatulate, white-bearded at the apex; perianth of the staminate flowers shortstalked, pubescent at the base, woolly and fimbriate at the summit; segments of the pistillate perianth white, glabrous, obtuse; ovary densely villous around the base; seeds strongly ribbed. In most pine barrens, Va. to Fla. March-June.

\section{Family 4. BROMELIÀCEAE J. St. Hil.}

\section{Pine-Apple Family.}

Epiphytic herbs (some tropical species terrestrial), mostly scurfy, with elongated, entire or spinulose-serrate leaves. Flowers spiked, panicled, or solitary, regular and perfect, usually conspicuously bracted. Perianth of 3 thin distinct or somewhat united sepals, and 3 clawed distinct or united petals. Stamens 6, usually inserted on the base of the corolla. Ovary inferior or superior, 3-celled; ovules numerous in each cavity, anatropous; style short or elongated; stigmas 3. Capsule 3-valved in our species. Seeds numerous, the testa membranous. Embryo small, situated at the base of the copious endosperm: About 35 genera and 900 speries, all natives of tropical and subtropical America.

\section{TILLÁNDSIA L.}

Epiphytic plants with narrow entire leaves and white, yellow or purple flowers. Sepals distinct and separate or very nearly so. Petals distinct. Stamens hypogynous or the three inner ones inserted on the bases of the petals; filaments filiform; anthers linear or linear-oblong. Ovary superior; style subulate; stigmas short. Capsule sebticidally 3 -valved. Seeds erect, narrow, supported on a long funiculus which splits up into fine threads. [Dedicated to Elias Tillands, Swedish (?) botanist 
of the seventeenth century.] About $35^{\circ}$ species, natives of warm and tropical America. Besides the folluwing some 9 others occur in the southern U. S.

I. Tillanásia usneoides L. LoNg Moss. Florida Moss. (I. F. f. 904.) Stems very slender, thread-like, flexuous, hanging clustered in festoons from the branches of trees, I-8 m. long, gray and, like the filiform leaves, densely silveryscurfy all over. Leaves scattered, $2-8 \mathrm{~cm}$. long, scarcely $1 \mathrm{~mm}$. thick, their bases somewhat dilated; flowers sessile and solitary or rarely 2 together in the axils of the leaves; sepals about $6 \mathrm{~mm}$. long, pale green; petals yellow; stamens ahout as long as the calyx; capsule linear, $2-3 \mathrm{~cm}$. long, at length splitting into 3 linear valves. E. Va. to Fla., Tex. and Mex. Very widely distributed in tropical America.

\section{Family 5. COMMELINÀCEAE Reichenb.}

\section{- Spiderwort Family.}

Perennial or annual leafy herbs with regular or irregular perfect and often showy flowers in cymes, commonly subtended by spathe-like or leafy bracts. Perianth of 2 series; a calyx of mostly 3 persistent sepals and a corolla of mostly 3 membranous and deciduous or fugacious petals. Stamens mostly 6, hypogynous, rarely fewer, all similar and perfect or 2 or 3 of them different from the others and sterile; filaments filiform or somewhat flattened; anthers-z-celled, mostly longitudinally dehiscent. Ovary superior, sessile or very nearly so, 2-3-celled; ovules I or several in each cell, anatropous or half anatropous; style simple ; stigmas terminal, entire or obscurely 2-3-lobed. Seeds solitary or several in each cell of the capsule. Capsule 2-3-celled, loculicidally 2-3-valved. Embryo small. Endosperm copious. About 25 genera and 350 species, mostly natives of tropical regions, a few in the temperate zones.

Perfect stamens 3, rarely 2 ; petals unequal; bracts spathe-like. Perfect stamens 6, rarely 5 ; petals all alike; bracts leaf-like.

1. Commelina.

2. Tradescantia.

\section{COMMELINA L.}

Somewhat succulent, branching herbs, with short-petioled or sessile leaves, and irregular mostly blue flowers in sessile cymes subtended by spathe-like bracts. Sepals unequal, the larger ones sometimes slightly united. Petals unequal, 2 of them larger than the third. Perfect stamens 3, rarely 2, one of them incurved and its anther commonly larger. Sterile stamens usually 3, smaller, their anthers various. Filaments all glabrous. Capsule 3-celled. Seeds I or 2 in each cavity, the testa roughened, smooth or reticulated. [Dedicated to Kaspar Commelin, I667-1731, Dutch botanist.] About 95 species of wide distribution in warm and temperate regions. Besides the following, some 5 others occur in the southern U.S.

Spathes not united at the base.

Spathes acuminate; capsules 3 -celled, 5-seeded.

Spathes acute; capsules 2-celled, 4-seeded.

I. C. nudifiora.

2. C. communis.

Spathes with united bases.

All three cavities of the ovary with 2 ovules.

Sheaths, at least the lower ones, glabrous or nearly so; pubescence, if present, not hirsute.

Sheaths more or less hirsute.

Capsules 2-valved, dorsal cavity indehiscent.

Capsules 3-valved, all cavities dehiscent.

Ventral cavities of the ovary with 2 ovules, dorsal cavity with $x$ ovule.

3. C. crispa.

4. C. Virginica.

5. C. erecta.

6. C. hirtella.

I. Cornmelina nudiflòra L. CReeping DAY-Flower. (I. F. f. 905.) Glabrous or very nearly so; stems procumbent or creeping, 3-8 dm. long. Leaves lanceolate or ovate-lanceolate, $2.5-7.5 \mathrm{~cm}$. long, acute or acuminate at the apex, their sheaths sometimes ciliate; spathe acuminate, $2-4 \mathrm{~cm}$. long; peduncled, the 2 bracts not united by their margins; flowers few in each spathe, 6-12 $\mathrm{mm}$. broad; ventral cavities of the ovary 2 -ovuled, the dorsal I-ovuled; capsule commonly 5 -seeded 
( 2 seeds in each of the ventral cells, $\mathrm{I}$ in the dorsal); seeds oblong, reticulated, about $2 \mathrm{~mm}$. long. Along streams and in waste places, N. J. to Ind. and Mo., south to Fla., Tex. and through tropical America to Paraguay. Widely distributed in Asia and Africa. July-Oct.

2. Commelina commùnis L. Asiatic Day-Flower. (I. F. f. 907.) Glabrous or nearly so; stems ascending or decumbent, sometimes rooting at the nodes, $3-9 \mathrm{dm}$. long. Leaves lanceolate or oblong-lanceolate, 4-12 cm. long, acuminate at the apex, narrowed or rounded at the base, smooth ; sheath white-membranous with green veins, sometimes ciliate, $\mathbf{I} \cdot 5-2.5 \mathrm{~cm}$. long; spathes few, peduncled, their 2 bracts acute, nearly $2.5 \mathrm{~cm}$. long, glabrous or sometimes pubescent, distinct; flowers deep blue, $12 \mathrm{~mm}$. broad or more; ventral cavities of the ovary 2-ovuled, the dorsal I-ovuled; capsule 2-celled, each cavity 2-seeded; seeds dark brown, roughened. In waste places, S. N. Y. and E. Penn., south to Ga. and Ky. Adventive or naturalized from Asia. July-Oct.

3. Commelina crispa Wooton. CUrley-leaved Day-flower. Finely villous or glabrate below; stems commonly branched at the base, the branches 2-9. dm. long. Leaves lanceolate or linear-lanceolate, 3-8 cm. long, acuminate, crisped, slightly contracted at the base; sheaths pale, I2-15 $\mathrm{mm}$. long, ciliate; spathes $2-2.5 \mathrm{~cm}$. long, acute or acuminate, pubescent, united at the base; sepals orbicular-elliptic; petals various, the 2 upper light blue, with slender claws and broadly reniform blades $\mathbf{I}-\mathbf{I} .5 \mathrm{~cm}$. broad, the third white, lanceolate, $2-3 \mathrm{~mm}$. long ; capsules 4-5 mm. long, 3-celled, 2 cavities dehiscent, third cavity indehiscent ; seeds smooth. In sandy and rocky soil, Neb. to Tex. and N. Mex. Summer and fall.

4. Commelina Virgínica L. Virginia Day-flower. (I. F. f. 909.) Similar to the preceding species, somewhat pubescent, or glabrous ; stems diffusely branched, 4-9 dm. high. Leaves lanceolate or linear-lanceolate, 6-12 cm. long, acuminate at the apex; sheaths inflated, often pubescent, the orifice sometimes fringed; spathes several, usually peduncled, the 2 bracts acute or acuminate, 15-25 $\mathrm{mm}$. long, distinct; corollas $2.5 \mathrm{~cm}$. broad or less, showy; capsule 3-celled, each cavity I-seeded, the dorsal one indehiscent and roughened. In moist soil, S. N. Y. to Ill. and Mich., south to Fla., Neb., Tex. and through tropical America to Paraguay. June-Sept.

5. Commelina erécta L. Slender Day-flower. (I. F. f. 908.) Somewhat pubescent, or glabrcus; stems commonly tufted, erect or ascending, 3-7 dm. tall, the roots thickened. Leaves linear-lanceolate, $6-15 \mathrm{~cm}$. long, acuminate at the apex, narrowed at the base; sheaths $12-25 \mathrm{~mm}$. long, often hirsute; spathes peduncled or sessile, acute or acuminate, distinct, 2-4 cm. long ; corollas $12 \mathrm{~mm}$. broad or more; ovary 3-celled, each cavity I-ovuled ; capsule papery, all its cavities dehiscent, each I-seeded; seeds ash-colored, nearly or quite smocth, puberulent. In moist soil, S. Penn. (according to Watson), south to Fla., Tex. and in tropical America. Aug.-Oct.

6. Commelina hirtélla Vahl. Bearded Day-flower. (I. F. f. go6.) Stem stout, erect or ascending, 5-12 dm. high. Leaves lanceolate, acuminate, roughish, IO-18 cm. long, their sheaths $12-25 \mathrm{~mm}$. long, fringed with rather stiff and long lrownish hairs and sometimes pubescent ; spathes sessile or short-peduncled, often clustered at the summits of the stem and branches; bracts acute, united at the base, rather strongly cross-veined; ventral cavities of the ovary 2-ovuled, the other I-ovuled; capsule 5-seeded; seeds brown, somewhat more than $2 \mathrm{~mm}$. long, smooth, minutely puberulent. In moist soil, S. N. J. to Mo., south to Fla. and Tex. Aug.-Oct.

\section{TRADESCÁNTIA L.}

Somewhat mucilaginous herbs, with simplè or branched stems, mostly narrow and elongated leaves, and showy regular flowers in terminal, or terminal and axillary, umbel-like cymes subtended by leaf-like or scarious bracts. Sepals 3, distinct, herbaceous. Petals 3, sessile. Stamens 6, all alike and fertile, or those opposite the petals shorter. Filaments bearded or glabrous. Ovary 3-celled, the cavities usually 2-ovuled. Capsule 3-celled, loculicidally 3-valved, 3-12-seeded. [In honor of John Tradescant, gardener to Charles I, died 1638.] About 35 species, 
natives of tropical and temperate America. Besides the following, some 8 others occur in the southern U. S.

Umbel-like cymes peduncled, subtended by small bracts.

Umbel-like cymes sessile, subtended by leaf-like bracts.

Leaves linear or linear-lanceolate, 12-50 times longer than broad.

Stems I to rarely $8 \mathrm{~cm}$. long; bracts longer than the leaves. 2. T. brevicaulis.

Stems elongated, I-10 dm. long; bracts mostly shorter than the leaves.

Foliage bright green; pedicels, like the sepals, pilose or villous; sepals be coming membranous.

Pedicels and sepals pilose with gland-tipped hairs.

Stems I-3 din. tall; bracts lanceolate, the bases sac-like, whitish, broader than the leaves.

3. T: bracteata.

Stems 3-8 dm. tall; bracts linear, the bases not sac-like, green, narrower than the leaves.

Pedicels and sepals villous with non-glandular hairs.

4. $T$, occidentalis.

5. T. Virginiana.

Foliage glaucous; pedicels glabrous; sepals with a tuft of hairs at the apex.

Leaves lanceolate, 2-10 times longer than broad.

6. 7: reflexa.

Slender; stems strict; cymes solitary and terminal or on corymbed branches; species Alleghenian.

7. T. montana.

Stout ; stems zigzag ; cymes terminal and sessile in the upper axils; species cam. pestrian.

8. T. pilosa.

I. Tradescantia ròsea Vent. Roseate Spinerwort. (I. F. f. 9I4.) Glabrous; stem slender, erect, mostly tufted, $12-30 \mathrm{~cm}$. tall. Leaves narrowly linear, grass-like, nearly erect, channeled, $10-18 \mathrm{~cm}$. long, clasping at the base; bracts very short and scarious; cymes terminal, long-peduncled, few-flowered, subtencled by small pointed bracts; pedicels slender; sepals lanceolate, acute, 4-6 mm. long, shorter than the petals; corolla rose-color, 12-16 mm. broad; filaments hairy; style slender, long-exserted. In dry woods, Md. to Mo., south to Fla. and Tex. April-Aug.

2. Tradescantia brevicaùlis Raf. SHORT-STEmmed SPIDERWort. (I. F. f. 9i2.) Villous with long hairs; stems only $1-8 \mathrm{~cm}$. high, the plant often appearing nearly stemless; leaves mostly basal, I.5-3 dm. long. grass-like, linear-lanceolate, acuminate, ciliate, at least at the base, glabrous, or villous toward the apex; bracts similar to the leaves, but usually more elongated; cymes 4-12-flowered; pedicels slender, $2.5-5 \mathrm{~cm}$. long, villous; sepals oblong; corolla about $2.5 \mathrm{~cm}$. broad, blue or rose-purple. In dry soil, Ill., Ky. and Mo. April--May.

3. Tradescantia bracteàta Small. Long-Bracted Spiderwort. (I. F. f. 9I0a.) Deep green, glabrous to the inflorescence or nearly so; stems erect, I-3 $\mathrm{dm}$. tall, simple or sparingly branched; leaves linear or linear-lanceolate, $\mathbf{I}-\mathbf{2} \mathrm{dm}$. long, long-acuminate; sheaths paler than the leaf-blades, conspicuously ribbed, the upper often ciliate; bracts of the involucre 2, broader than the leaves, saccate at the base, ciliate, often villous on the back; cymes few-flowered; pedicels 1.2-2.5 $\mathrm{cm}$. long, glandular-pubescent like the sepals; sepals ovate-lanceolate or ellipticlanceolate, involute; corolla blue or reddish, about $2.5 \mathrm{~cm}$. broad. In sandy soil, Minn. to S. Dak., south to Kans. Spring and summer.

4. Tradescantia occidentàlis Britton. Western SpIderwort. Mostly glabrous to the inflorescence, bright green. Stems solitary, erect, 3-8 $\mathrm{dm}$. tall, simple; leaves linear, 2-3 dm. long, involutely folded, curved; sheaths $1-4 \mathrm{~cm}$. long, conspicuously ribbed, rarely with a few cilia; bracts of the involucre 2 , linear, slightly unequal; pedicels rather slender, $\mathbf{I}-2 \mathrm{~cm}$. long; sepals oblong or elliptic, apparently lanczolate by the involute edges, 8-10 $\mathrm{mm}$. long, glandular-pilose; petals blue or reddish, almost $\mathbf{1} \mathrm{cm}$. long, orbicular-ovate; capsules obovoid or oblong. 5-6 mm. long, puberulent at the apex; seeds $3 \mathrm{~mm}$. long, pitted and ridged. On sand-hills, Iowa to Tex., west to the Rocky Mts. Summer. (T. Virginiana occidentalis Britton.)

5. Tradescantia Virginiàna L. SPIDERwort. (I. F. f. 9ro.) Glabrous or slightly pubescent, bright green; stems stout, 2-4 dm. tall. Leaves nearly flat, linear or linear-lanceolate, long-acuminate, often more than $3 \mathrm{dm}$. long; bracts leaflike, commonly nearly as wide as the leaves; cymes solitary and terminal, or rarely 
2-4, loosely several-many-flowered; pedicels villous, slender; corolla blue or purplish, rarely white, $2-4 \mathrm{~cm}$. broad, very showy; sepals elliptic, ovate or ovatelanceolate, acute or obtuse, villous, 12-18 $\mathrm{mm}$. long, much longer than the capsule. In rich soil, mostly in woods and thickets, S. N. Y. to Ohio and S. Dak., south to Va., Ky. and Ark. Escaped from cultivation in N. E. May--Aug.

6 Tradescantia refléxa Raf. Reflexed Spiderwort. (I. F. f. 9ila.) Glabrous to the sepals, glaucous; stems erect, 3-9 dm. tall, mostly branched, rather strict; leaves linear, 2-5 dm. long, rather rigid, long-attenuate; sheaths large, I$3 \mathrm{~cm}$. long: bracts of the involucres 2, unequal, reflexed; cymes usually densely fruited; pedicels slender, 2-3 cm. long, recurved; sepals oblong or elliptic, appir. ently lanceolate by the involute edges, $8-10 \mathrm{~mm}$. long, hooded with a tuft of hairs at the apex; corollas blue or red, $2-3 \mathrm{~cm}$. broad; petals suborbicular; capsule ovoid or oblong, 5-6 mm. long, glabrous. In sandy or loamy soil, Minn. to Fla. and Tex. Spring and summer.

7. Tradescantia montàna Shuttlw. Mountain Spiderwort. (I. F. f. 911.) Dark green and glabrous or nearly so; stems slender, simple or sparingly branched, 3-7 dm. tall. Leaves lanceolate or linear-lanceolate, I-3 dm. long, mostly distant, their sheaths enlarged; bracts similar to the leaves but shorter; cymes mostly solitary and terminal, sessile in the bracts, rather densely flowered; pedicels and calyx glabrous or pubescent; corolla less than $2.5 \mathrm{~cm}$. broad; sepals apparently lanceolate by the involute edges, acute, hooded, 5-6 mm. long. In woods and thickets, mountains of southwestern Va. to Ky. and Ga. June-Aug.

8. Tradescantia pilòsa Lehm. Zigzag SpIDerworT. (I. F. f. 913.) More or less puberulent or short-pilose; stem stout, 3-9 dm. high, commonly flexuous, often branched. Leaves broadly lanceolate, acuminate at the apex, mostly narrowed at the base, $15-25 \mathrm{~cm}$. long, dark green above, paler beneath; bracts usually narrower and shorter than the leaves; cymes $3-8$; terminal and axillary or on short axillary branches, densely many-flowered; pedicels and calyx pubescent and more or less glandular, rarely nearly glabrous; corollas lilac-blue, $18-30 \mathrm{~mm}$. broad. In thickets and on shaded hillsides, southern Penn. to Ill. and Mo., south to Fla. JuneAug.

\section{Family 6. PONTEDERIÀCEAE Dumort.*}

\section{Pickerel-zueed Family.}

Perennial aquatic or bog plants, the leaves petioled, with thick blades, or long and grass-like. Flowers perfect, more or less irregular, solitary or spiked, subtended by leaf-like spathes. Perianth free from the ovary, corolla-like, 6-parted. Stamens 3 or 6, inserted on the tube or the base of the perianth; filaments filiform, dilated at the base or thickened at the middle; anthers 2-celled, linear-oblong or rarely ovate. Ovary 3-celled with axile placentae, or I-celled with 3 parietal placentae; style filiform or columnar; stigma terminal, entire or minutely toothed ; ovules anatropous, numerous, sometimes only I of them perfecting. Fruit a many-seeded capsule, or a I-celled, 1-seeded utricle. Endosperm of the seed copious, mealy; embryo central, cylindric. About 5 genera and 25 species, inhabiting fresh water in the warm and temperate regions of America, Asia and Africa.

Flowers 2-lipped, stamens 6 ; fruit a I-seeded utricle.

Flowers regular; stamens 3 ; fruit a many-seeded capsule.

1. Pontederia.

2. Heteranthera.

\section{PONTEDÈRIA L.}

Leaves thick with many parallel veins, the petioles long, sheathing, arising from a horizontal rootstock. Stem erect, I-leaved, with several sheathing bract-like leaves at the base. Flowers blue, ephemeral, numerous, spiked, the spike (or spadix) peduncled and subtended by a thin bract-like spathe. Perianth 2 -lipped, the upper lip of 3 ovate lobes, the middle lobe longest, the lower lip of 3 linear-oblong spreading lobes. Stamens 6, borne at unequal distances upon the 
perianth-tube, 3 of them opposite the lower lip, the others opposite the upper lip ; anthers oblong, subversatile, introrse. Ovary 3 -celled, 2 of the cells abortive and empty. Fruit enclosed in the thickened tuberculate-ribbed base of the perianth. [In honor of Giulio Pontedera, 1688-1757, protessor of botany in Padua.] Seven or eight species, natives of America.

I. Pontederia cordata L. Pickerel-weed. (I. F. f. 915.) Stem rather stout, $0.3^{-I . I} \mathrm{~m}$. tall. Leaves ovate, cordate-sagittate, I-2 dm. long, $5-15 \mathrm{~cm}$. wide at the base, the apex and basal lobes obtuse; basal lobes often with long narrow appendages on the sheathing petiole ; spadix and inflorescence glandularpubescent; perianth about $8 \mathrm{~mm}$. long, it and the filaments, anthers, and style bright blue, its tube curved, slightly longer than the lobes; middle lobe of the upper lip with 2 yellow spots at the base within ; ovary oblong, tapering into the style; stigma minutely 3-6 toothed. Borders of ponds and streams, N. S. to Minn., Fla. and Tex. The flowers are trimorphous. June-Oct.

Pontederia cordàta lancifòlia (Muhl.) Morong. Leaves lanceolate, rounded or narrowed at the base, $5^{-25} \mathrm{~cm}$. long, 6-16 mm. wide. Ont. to N. J., Cuba and Tex.

\section{HETERANTHÈRA R.\& P.}

Herbs with creeping, ascending or floating stems, the leaves petioled, with cordate, ovate, oval or reniform blades, or grass-like. Spathes I-flowered or several-flowered. Flowers small, white, blue or yellow. Lobes of the perianth nearly or quite equal, linear. Stamens 3, equal or unequal. inserted on the throat of the perianth. Ovary fusiform, entirely or incompletely 3-celled by the intrusion of the placentae; ovules numerous; stigmas 3-lobed. Fruit enclosed in the withered perianth tube. Seeds ovoid, many-ribbed. [Greek, referring to the unequal anthers of some species.] About 9 species, 2 in tropical Africa, the others American; only the following in the U.S.

Leaves mostly reniform, sometimes cordate-ovate.

Leaves ovate or oval, sometines slightly cordate.

Leaves linear, grass-like, floating.
1. H. reniformis.

2. H. limosa.

3. H. dubia.

I. Heteranthera renifórmis R. \& P. Mud-Plantain. (I. F. f. 916.) Stems creeping in the mud, rooting at the nodes. Leaves cordate or reniformrarely cordate-ovate and acute, the blades $\mathbf{I}-3 \mathrm{~cm}$. long, $\mathbf{I} .5-3.5 \mathrm{~cm}$. wide; peti, oles sheathing, 2-10 cm. long; spathe 2-5-flowered; tube of the perianth slender, about $8 \mathrm{~mm}$. long, its lobes shorter; flowers white or pale blue; anthers basifixed, the 2 upper oval, the other on a longer filament and linear. In mud or shallow water, Conn. to N. J., Neb. and Kans., south to La. Also in South and Central America.

2. Heteranthera limòsa (Sw.) Willd. Smaller Mud Plantain. (I. F. f. 917.) Stems commonly much branched from the base, I.5-4 dm. long. Leaves obtuse, rounded or slightly cordate at the base, $2.5 \mathrm{~cm}$. long or less; petioles $5-13 \mathrm{~cm}$. long; spathes I-flowered, often on peduncles $2 \mathrm{~cm}$. long or more; flowers white or blue, usually larger than those of the preceding; filaments equal or nearly so; anthers linear, often sagittate. In mud or shallow water, Va. to Ky., Neb., Fla., La., Kans. and throughout tropical America.

3. Heteranthera dùbia (Jacq.) MacM. WATer Star-Grass. (I. F. f. 9I8.) Aquatic; stem slender, forked, often rooting at the nodes, $6-10 \mathrm{dm}$. long. Leaves flat, elongated, acutish, their sheaths thin, with small acute stipule-like appendages; flowers light yellow, the periantlı-segments narrow; stamens nearly equal; tube of the perianth $2-3.5 \mathrm{~cm}$. long; spathe I-2-flowered; filaments dilated below ; anthers linear, $4 \mathrm{~mm}$. long, sagittate; stigma several-lohed; capsule I-celled with 3 parietal placentae, many-seeded. In still water, Ont. to Ore., Fla. and Mex. Also in Cuba. July-Oct. [H. graminea Vahl.] 


\section{Order 8. LILIÀLES.}

Monocotyledonous plants, mostly with well-developed perianth, the flowers usually regular and complete, and their parts in 3's or 6's. Ovary superior or inferior, compound. Endosperm of the seed fleshy or horny.

Ovary superior (except in Aletris of the Liliaceae, and some species of Zygadenus in the Melanthaceae).

Perianth-segments distinct, green or brown, not petal-like; herbs with grass-like leaves and small flowers.

Fam. r. Juncaceae.

Perianth-segments distinct, or partly united, at least the inner petal-like.

Fruit a capsule (except in Yucca baccata, where it is large, fleshy and indehiscent).

Capsule mostly septicidal ; plants rarely bulbous. Fam. 2. Melanthaceae.

Capsule loculicidal (septicidal in Calochortus); plants mostly bulbous.

Fruit a fleshy berry.

Fam. 3. Liliaceae.

Erect herbs ; tendrils none ; flowers perfect.

Vines, climbing by temdrils, or rarely erect umbels.

Ovary inferior, wholly or in part.

Stamens 3, opposite the inner corolla-segments.

Stamens 6 in our species.

Erect perennial herbs; flowers perfect.

Twining vines; flowers diœecious.

Stamens 3, opposite the outer corolla-segments.

Fam. 4. Convallariaceae.

Fam. 5. Smilaceae.

Fam. 6. Haemodoraceae.

Fam. 7. Amaryllidaceae.

Fam. 8. Dioscoreaceae.

Fam. 9. Iridaceae.

\section{Family 17. JUNCÀCEAE Vent.*}

\section{K'ush Family.}

Perennial or sometimes annual, grass-like, usually tufted herbs, commonly growing in moist plares. Inflorescence usually compound or decompound, paniculate, corymbose, cymose, or umbelloid, rarely reduced to a single flower, bearing its flowers singly, or loosely clustered, or aggregated into spikes or heads. Flowers small, regular, with or without bractlets (prophylla). Perianth 6-parted, the parts glumaceous. Stamens 3 or 6 , rarely 4 or 5 , the anthers adnate, introrse, 2-celled, dehiscing by a slit. Pistil superior, tricarpous, I-celled or 3-celled, with 3-many ascending anatropous ovules, and 3 filiform stigmas. Fruit a loculicidal capsule. Seeds 3-many, small, cylindric to subglobose, with loose or close seed-coat, with or without caruncular or tail-like appendages. Seven genera and about 200 species, widely distributed.

Leaf-sheaths open; capsule I- or 3-celled, many-seeded; placentae parietal or axial.

Leaf-sheaths closed; capsule I-celled, 3 -seeded, its placenta basal.

I. Juncus.

2. Juncoides.

\section{x. JÚNCUS L. (See Appendix.)}

Usually perennial plants, principally of swamp habitat, with glabrous herbage: stems leaf-bearing or scapose, leaf-sheaths with free margins, and leaf blades terete, gladiate, grass-like, or channeled. Inflorescence paniculate or corymbose, often unilateral, sometimes congested, bearing its flowers either singly and with 2 bractlets (prophylla), or in heads and without bractlets, but each in the axil of a bract; bractlets almost always entire; stamens 6 to 3 ; ovary 1 -celled or by the intrusion of the placentae 3-celled, the placentae correspondingly parietal or axial: seeds several-many, usually distinctly reticulated or ribbed, often tailed. About $\mathbf{1 5 0}$ species, most abundant in the north temperate zone. The species bloom in sum. mer. [Latin, from jungo, to bind, in allusion to the use of these plants for wither 
A. Lowest leaf of the inflorescence terete, not conspicuously channeled, ere: $t$, appearing like a continuation of the stem, the inflorescence therefore appearing lateral; stem leaves none.

1. Flowers bracteolate, inserted singly on the branches of the inflorescence. GENUINI.

Perianth-parts green, or in age straw-colored.

Perianth-parts equalling or exceeding the capsule, all acute.

Stamens 3; leaf of the inflorescence much shorter than the stem.

Capsule without a distinct apical papilla.

Capsule with a distinct apical papilla.

1. J. effusus.

2. J. conglomeratus.

Stamens 6; leaf of inflorescence about equalling the stem, or longer.

Perianth-parts reaching only the middle of the capsule, inner obtuse.

4. J. gymnocarpus.

Perianth-parts with a chestnut-brown stripe down either side of the midrib.

5. J. Balticus.

2. Flowers not bracteolate, inserted in heads on the branches of the inflorescence. ТнаLASSICI.

Perianth-parts pale brown; seed tailless.

Perianth-parts green, or in age straw-colored; seed tailed.

6. J. Roemerianus.

7. J. maritimus.

B. Lowest leaf of the infloresence not appearing like a continuation of the stem, or if so, conspicuously channeled along the upper side, the inflorescence usually appearing terminal.

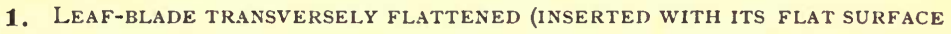
FACING THE STEM), OR TERETE AND CHANNELED, NOT PROVIDED WITH SEPTA.

* Flowers bracteolate, inserted singly on the branches of the inflorescence, sometimes clustered or congested, but never in true heads. PoIOPHYLLI.

Annual; inflorescence, exclusive of its leaves, more than one-third the height of the plant.

8. J. bufonius.

Perennial; inflorescence, excluding leaves, not one-third the height of the plant.

Leaf-blade flat, but sometimes involute in drying.

Inflorescence 1-3-flowered; leaves with fimbriate auricles.

Inflorescence, except in depauperate specimens, several-many-flowered; leaves with entire auricles.

Cauline leaves 1 or 2 , rarely wanting; perianth-parts obtuse.

Cauline leaves none; perianth parts acute or acuminate.

10. J. Gerardi.

Inflorescence usually much exceeded by its lowest leaf; flowers seldom plainly secund; perianth $3.5-5.5 \mathrm{~m} . \mathrm{m}$. long, usually exceeding the capsule; capsule obovoid, broadly rounded at the apex, the placentae intruded half way to the axis.

11. J. tenuis.

Inflorescence rarely exceeded by its lowest leaf; flowers plainly secund on the branches; perianth 2.5-4 $\mathrm{mm}$. long, equalling the capsule; capsule oblong, 3 -sided, truncate at the apex; placentae meeting at the axis. 12 . J. secundus.

Leaf-blade terete, channeled along the upper side.

Lowest leaf of inflorescence not four lengths of the panicle; capsule oblong to obovoid.

Seed tailed. 13. J. Vaseyi.

Seed not tailed.

Perianth 2.5-3 $\mathrm{mm}$. long, plainly exceeded by the capsule.

14. J. Greenei.

Perianth $3.5-4 \mathrm{~mm}$. long, not exceeded by the capsule.

15. J. dichotomus.

Lowest leaf of the inflorescence rarely less than four times as long as the panicle; capsule globose-ovoid.

16. J. setaceus.

* Flowers not bracteolate, in true heads on branches of the inflorescence. GRAMINIFOLIS.

Stem erect; capsule oblong or obovoid, obtuse at the apex.

Stamens 3, with red-brown anthers; capsule not mucronate.

Stamens 6, with yellow anthers; capsule mucronate.

Stem creeping; floating, or ascending; capsule subulate.

17. J. marginatus.

18. $J$. longistylis.

r. J. repens. 
2. LEAF-BLADE NOT TRANSVERSELY FLATTENED, COMMONLY TERETE, HOLLOW, PROVIDED WITH SEPTA.

* Leaf-blade usually channeled along the upper side; septa usually imperfect, not externally evident; inflorescence of $1-4$ heads; plants of arctic or alpine range. ALPINI.

Body of the seed $\mathrm{I} \mathrm{mm}$. in length or more.

Leaf-sheath not auriculate.

Leaf-sheath auriculate.

Body of the seed less than $\mathrm{I} \mathrm{mm}$. in length.

20. J. castaneus.

21. J. stygius.

Lowest leaf of inflorescence foliose, erect; capsule deeply retuse at apex.

22. J. biglumis.

Lowest leaf of inflorescence membranous, spreading; capsule obtuse and mucronate at the apex. 23. J. triglumis.

* * Leaf-blade not channeled along the upper side (except in $J$. bulbosus), the septa perfect (except in $J$. polycephalus), and usually externally evident; infiorescence, except in depauperate specimens, of several to many heads; plants not of arcticalpine range. SEPTATI.

+ Stamens 6, one opposite each perianth-part.

Heads reduced to one, or rarely two flowers.

Heads 2-many-fiowered.

24. J. pelocarpus.

Epidermis not roughened.

Plants with two kinds of leaves, one normal, the other basal, submersed, and capillary.

Plant low, less than $2.5 \mathrm{dm}$. high.

Plant tall, more than $2.5 \mathrm{dm}$. high.

Plants without submerged capillary leaves.

Capsule oblong, either abruptly acuminate or bluntly acute.

Branches widely spreading; capsule sharply acute, tapering into a conspicuous tip. 27. J. articulatus.

Branches usually strict; capsule broadly acute, or obtuse, with a short tip.

Capsule subulate.

28. J. Richardsonianus.

Leaf-blades erect; inner-perianth-parts longer than the outer.

29. J. nodosus.

Leaf-blades abruptly divergent from the stem; outer perianth-parts longer than the inner.

3o. J. Torreyi.

Epidermis of the leaves roughened with minute tubercles. 3r. J. Caesariensis.

$+\dagger$ Stamens 3, none opposite the inner perianth-parts.

Capsule less than three-fourths as long as the perianth.

Capsule more than three-fourths as long as the perianth.

32. J. brachycarpus

Capsule tapering evenly into a prominent subulate beak.

Leaf-blade vertically flattened and with incomplete septa, only rarely compressed and with complete septa.

Leaf-blade terete or nearly so, the septa complete.

Uppermost cauline leaf with a well-developed blade.

34. J. scirpoides.

Uppermost cauline leaf with a rudimentary blade rarely exceeding $3 \mathrm{dm}$. in length.

35. J. megacephalus.

Capsule obtuse to acute at the apex, sometimes mucronate, but not prolonged into a beak.

Seed o.6-2 mm. long.

Perianth about $2 \mathrm{~mm}$. long, the fruiting head not more than $4 \mathrm{~mm}$. high. 36. J. brachycephalus.

Perianth 3-4 mm. long, or if shorter, the fruiting head $4 \mathrm{~mm}$. high or more.

Seed $0.4-0.5 \mathrm{~mm}$. long.

37. J. Canadensis.

Perianth and mature capsule $2-4 \mathrm{~mm}$. long.

Perianth $2.5-4 \mathrm{~mm}$. long, or if less the whole plant not $5 \mathrm{dm}$. high. 38. J. acumitanus.

Perianth $2-2.5 \mathrm{~mm}$. long, the whole plant more than $5 \mathrm{dm}$. high.

Perianth and mature capsules $4^{-6} \mathrm{~mm}$. long.

39. J. robustus.

40. J. diffusissimus.

I. Juncus effùsus L. Common Rush. Bog Rush. Soft Rush. (I. F. f. 9I9.) Plant 0.4-I.2 m. high, tufted, erect. Rootstock branching, proliferous; stem soft, merely striate beneath the inflorescence; basal leaf-blades reduced to filiform rudiments; inflorescence many-flowered, $2-10 \mathrm{~cm}$. high, in one form congested; lowest bract of the inflorescence, 5-25 cm. long; perianth 2-3 mm. long, its parts green, lanceolate, acuminate; anthers shorter than the filaments; capsule oloyoid, 3-celled, muticous, regularly dehiscent; seed $0.4-0.5 \mathrm{~mm}$. in length, reticulate 
in about 16 longitudinal rows. In swamps and moist places, nearly throughout N. A., except the arid and high northern portions. Also in Europe and Asia.

2. Juncus conglomeràtus L. Glomerate Rush. (I. F. f. 920.) Plant 3-6 dm. high, tufted, erect. Rootstock stout, with proliferous branches ; stem distinctly ribbed just beneath the inflorescence; leaf-blades wanting, or minute filiform rudiments ; inflorescence congested, seldom more than $2 \mathrm{~cm}$. high ; lowest bract of the inflorescence $5-15 \mathrm{~cm}$. long; perianth $2.5-4 \mathrm{~mm}$. long, its parts green, lanceolate, acuminate; anthers shorter than the filaments; capsule obovoid, obtuse or retuse at apex, tipped with the base of the style; seed $0.4-0.5 \mathrm{~mm}$. in length, acute or abruptly apiculate at both ends, reticulate in about 16 longitudinal rows. In the sphagnum bogs of Newf. Also in northern Europe and Asia.

3. Juncus filifórmis L. Thread Rush. (I. F. f. 92 I.) Stems I-6 dm. tall, erect, from a creeping rootstock; basal leaves reduced to bladeless sheaths; inflorescence commonly with less than 8 flowers and less than $2 \mathrm{~cm}$. high; perianth 2.5-3.5 mm. long, its parts narrowly lanceolate, acute, or the inner obtuse; stamens 6, about half as long as the perianth ; style very short ; capsule obovoid, green, barely pointed, about three-fourths as long as the perianth, 3-celled; seed about $0.5 \mathrm{~mm}$. long, pointed at either end, with an irregularly wrinkled coat, seldom developing reticulations. Lab. to Br. Col., Penn., Mich., and in the Rocky Mts. to Utah and Colo. Also in Europe and Acia.

4. Juncus gymnocàrpus Coville. Pennsylvania Rush. (I. F. f. 922.) Stems erect, 3-6 dm. higl, about $2 \mathrm{~mm}$. thick, from a creeping proliferous rootstock; basal leaves rejuced to bladeless clasping sheaths; panicle commonly I.5-3 cm. high, spreading, its subtending leaf usually $\mathbf{I}-2.5 \mathrm{dm}$. long ; perianth $2 \mathrm{~mm}$. in length or a little less, its parts with a green midrib, equal, lanceolate, the outer acute, the inner obtuse; capsule almost twice as long as the perianth, broadly ovoid, conspicuously mucronate, brown and shining; barely dehiscent, 3-celled; seed about $0.6 \mathrm{inm}$. long, none with perfect markings seen. In swamps, mountains of Schuylkill and Lebanon counties, Penn.

5. Juncus Bàlticus Willd. Baltic Rush. (I. F. f. 923.) Stems 2-9 dm. high, arising at intervals from a stout creeping rootstock; basal leaves reduced to bladeless sheaths; panicle commonly 2-6 cm. high; perianth $3-4.5 \mathrm{~mm}$. long, its parts nearly equal, brown with a green midrib and hyaline margins; style $\mathbf{1}-2 \mathrm{~mm}$. long; stigmas a little shorter; stamens 6 , about two-thirds the length of the perianth; anthers much longer than the filaments; capsule about as long as the perianth, pale to dark brown, narrowly ovoid, conspicuously mucronate, 3-celled; seeds usually with a loose coat, nearly I $\mathrm{mm}$. long, about 40-striate. On shores, Lab. to Alaska, S. N. Y., Ohio and Neb., and far south in the western mountains. Also in Europe and Asia. Variable.

6. Juncus Roemeriànus Scheele. Roemer's Rush. (I. F. f. 924.) Stems $0.5^{-1.2} \mathrm{~m}$. tall, from a tough scaly rootstock 5-10 $\mathrm{mm}$. thick; inner sheaths bearing erect blades of about the same length as the stem; inflorescence $1-2.5 \mathrm{~cm}$. high, diffuse, its leaf 6-I $5 \mathrm{~cm}$. long; heads 2-6-flowered; perianth pale brown, $2-3.5 \mathrm{~mm}$. long, the parts linear-oblong, the outer acuminate, the inner shorter and bluntly acute; flowers imperfectly dioecious; stamens 6, on fertile plants reduced to sterile staminodia; capsule brown, about as long as the perianth, narrowly obovoid, obtuse or truncate, mucronate, 3-celled; seed dark brown, abruptly apiculate, indistinctly reticulate or distinctly $20-26$-ribbed and the intervening spaces imperfectly cross-lined. In brackish marshes, N. J. to Tex.

7. Juncus marítimus Lam. SEA Rush. (I. F. f. 925.) Stems 0.5-I m. high, from a stout horizontal rootstock. Outer basal leaves reduced to bladeless sheaths, the innermost foliose, with a long terete stout blade about equalling the stem ; leaf of the inflorescence erect, sometimes $3 \mathrm{dm}$. long; panicle $0.7-2 \mathrm{dm}$. high, its branches, stiff, erect; heads 2-6-flowered; perianth 3-3.5 mm. long, its parts green, lanceolate, with hyaline margins; flowers perfect; stamens 6 , two-thirds as long as the pcrianth : filaments about as long as the anthers; capsule $3-3.5 \mathrm{~mm}$. long, narrowly ovoid, acute, mucronate, brown above, 3 -celled; seed brown, the body narrowly and obliquely oblong, 20-30-ribbed, indistinctly reticulate, tailed at either end. Coney Island, N. Y. Common on the coasts of Europe.

8. Juncus bufònius L. Toad Rush. (I. F. f. 926.) Plant branching from the base, annual, erect, seldom exceeding $2 \mathrm{dm}$. in height; leaf-blade flat, $0.5^{-1} \mathrm{~mm}$. 
wide, in low plants often much narrower; inflorescence with blade-bearing leaves at the lower nodes; flowers inserted singly on its branches; perianth-parts 4-7 mm. long, lanceolate, acuminate, equal; stamens usually 6, sometimes 3; anthers shorter than the filaments; capsule about two-thirds as long as the perianth, narrowly oblong, obtuse, mucronate, 3-celled; seed broadly oblong, with straight tips, minutely reticulate in 30-40 longitudinal rows. A cosmopolitan species, occurring throughout $\mathrm{N} . \mathrm{Am}_{2}$, except the extreme north.

9. Juncus trífidus L. Highland Rush. (I. F. f. 927.) Tufted, I-3 dm. high; stems about $0.5 \mathrm{~mm}$. thick; basal leaves almost bladeless sheaths, the uppermost with a rudimentary blade and fimbriate auricles; stem leaf $\mathbf{I}$, near the inflorescence, with a narrower blade; inflorescence a cluster of $\mathbf{I}-3$ flowers, the lowest subtending bract similar to the stem leaf; perianth dark brown, $2.5-3.5 \mathrm{~mm}$. long; stamens 6; capsule equalling the perianth, coriaceous, 3-celled, obovoid, mucronate-aristate; seeds few, narrowly obovoid, acute at the base, irregularly angled, minutely striate both longitudinally and transversely. Greenland and Lab., south on the higher mountains of N. Eng. and N. Y. Also in northern Europe and Asia.

10. Juncus Geràrdi Lois. BlaCk-Grass. (I. F. f. 928.) Tufted, 2-7.5 dm. high, with creeping rootstocks. Basal leaves with rather loosely clasping auriculate sheaths; cauline leaves usually I or 2, similar to the basal; inflorescence paniculate; perianth $2-2.5 \mathrm{~mm}$. long, its parts oblong, obtuse, with green midrib and dark brown margins, straw-colored in age; stamens 6 , barely exceeded by the perianth; anthers much longer than the filaments; capsule longer than the perianth, obovoid, mucronate, shining, 3-celled; seed dark brown, obovate, acute at base, obtuse and often depressed at the summit, marked by 12-16 conspicuous ribs, the intervening spaces cross-lined. On salt meadows, Gulf of St. Lawrence to Fla.; rare in W. N. Y. and the vicinity of the Great Lakes. Occurs also on the northwest coast, and in Europe.

II. Juncus ténuis Willd. Slender RUsh. Yard Rush. (I. F. f. 929.) Tufted, 2-7.5 dm. high; basal leaves with blades $0.5-1.5 \mathrm{~mm}$. wide, sometimes involute in drying; stem leaves none; inflorescence usually much exceeded by its lowest leaf, I dm. high or less; perianth 3.5-5 mm. long, its parts lanceolate, acuminate, widely divergent, touching the capsule for about half their length; stamens 6 , about half as long as the perianth; capsule oblong to obovoid, rounded at the top, imperfectly 3 -celled; seed $0.4-0.5 \mathrm{~mm}$. long, narrowly oblong to obovoid, with oblique ends, reticulated in about 16 rows. In dry or moist soil, almost throughout N. Am., now migrating to all parts of the world. Variable.

12. Juncus secúndus Beauv. SEcund Rush. (I. F. f. 930.) Tufted, I.5$4 \mathrm{dm}$. high; leaves usually less than one-third the height of the plant; inflorescence 2-IO $\mathrm{cm}$. high, the flowers secund on the branches; perianth-parts 2.5$3.5 \mathrm{~mm}$. long, equalling or barely exceeding the capsule and appressed to it for about two-thirds their length; stamens 6 , about one-half as long as the perianth; capsule narrowly ovoid, 3 -sided above the middle with straight sides and a truncate apex, completely 3-celled, the placentæ meeting in the axis; seed $0.3-0.4 \mathrm{~mm}$. long, narrowly oblong to ovoid, obliquely tipped, with 12-16 longitudinal rows of areolæ. In dry soil, Me. (according to Fernald), N. J., Penn. to N. Car., and occasional in the middle Miss. Valley.

13. Juncus Vàseyi Engelm. VAsEY's Rush. (I. F. f. 93I.) Tufted, 3$6 \mathrm{dm}$. high; basal leaves with minutely auriculate sheaths, the uppermost bearing a terete channeled blade; stem leaves none; inflorescence $4 \mathrm{~cm}$. in height or less, 4-40-flowered; perianth 3-4 $\mathrm{mm}$. long, the parts subulate-lanceolate, with hyaline margins; stamens 6; anthers shorter than the filaments; style almost wanting; stigmas short; capsule slightly exceeding the perianth, narrowly oblong, obtuse or truncate, with a short tip, 3-celled; seed long-tailed, with a linear-oblong oblique body about $0.5 \mathrm{~mm}$. long, 20-24-ribbed. Me. and Ont. to Mich., Ill. and Iowa.

I4. Juncus Greènei Oakes \& Tuckerm. Greene's Rush. (I. F. f. 932.) Tufted, 2-6 dm. high. Basal leaves with terete channeled blades one-half to twothirds the length of the stem; panicle $2-4 \mathrm{~cm}$. high, rather compact, much exceeded by its lowest bract; perianth 2.5-3 mm. long, its parts stiff, lanceolate, sharply acute, with brownish red stripes and apex, the inner shorter; stamens 6 ; anthers about as long as the filaments; capsule one-fourth to one-half longer than the perianth, ovate-lanceolate, truncate, 3-celled; seed obliquely oblong, $0.4-0.5 \mathrm{~mm}$. long, 
slightly reticulated in about $20-24$ rows, the areolæ nearly square. N. B. to N. J., near the coast; Mich., Wis., Minn. and Ont.

15. Juncus dichótomus Ell. Forked Rush. (I. F. f. 933.) Tufted, 3-10 $\mathrm{dm}$. high; leaves all basal except those of the inflorescence; blades terete, channeled along the upper side, about one-half the height of the stem; inflorescence paniculate, subsecund; perianth about $4 \mathrm{~mm}$. long, its parts subulate-lanceolate, strawcolored when old; stamens 6 ; capsule slightly shorter than the perianth, oblong, obtuse, mucronate, I-celled; seed oblong, dark brown, obliquely apiculate, less than $0.5 \mathrm{~mm}$. long, reticulate in about 14 longitudinal rows, the smooth areolæ about as long as broad. In dry soil, Me. to Fla. and Tex., near the coast.

I6. Juncus setàceus Rostk. AwL-Leaved Rush. (I. F. f. 934.) Densely tufted. Stems terete, spreading, 4-1o dm. long; leaves all basal except those of the inflorescence, the uppermost sheath usually bearing a long terete blade similar to the stem, but channeled; the other sheaths with filiform blades; involucral leaf appearing like a continuation of the stem, I $-3 \mathrm{dm}$. long; inflorescence appearing lateral, $5 \mathrm{~cm}$. long or less; perianth 2-5 mm. long, its parts lanceolate, acuminate, rigid, widely divergent in fruit; stamens 6 ; capsule globose, shining, mucronate, I-celled, barely dehiscent; seed subglobose, $0.5-0.6 \mathrm{~mm}$. long, reticulate in about 12 longitudinal rows. In marshes, Del. to Fla. and Tex., near the coast, extending north in the Miss. Valley to Mo.

I7. Juncus marginàtus Rostk. Grass-Leaved Rush. (I. F. f. 935.) Tufted, I.5-7.5 dm. high from branching rootstocks. Leaf-sheaths auriculate; blades I-3 mm. Lroad, $2-4$ conspicuous veins in addition to the midrib; inflorescence $\mathrm{I} \mathrm{dm}$. high or less, the panicle composed of 2-20 turbinate to subspherical 5-1o-flowered heads; perianth 2.5-3.5 $\mathrm{mm}$. long, the outer parts ovate, acute, the inner slightly longer, obtuse, with hyaline margins; stamens 3 ; anthers ovate, much shorter than the filaments; capsule equalling the perianth, obovoid, truncate or retuse, almost 3-celled, the placentæ deeply intruded; seed oblong, 0.4-0.5 mm. long, pointed at either end, I2-16-ribbed. Grassy places, Me. to Ont., Fla. and Neb.

Juncus marginàtus aristulatus (Michx.) Coville. Taller, sometimes I.I m. high ; leafblades $2-5 \mathrm{~mm}$. broad; heads usually $20-100$, mostly 2-5-flowered. N.Y. to Fla. and Mex., mostly near the coast; Miss. Valley to Kans. and Mich.

Juncus marginatus setòsus Coville. Inner perianth-parts ovate or lanceolate, acute or acuminate; seeds smaller. Kans. to Mex.

r8. Juncus longístylis Torr. Long-STyied Rush. (I. F. f. 936.) Stems erect, loosely tufted, $2-7.5 \mathrm{dm}$. high, slender, compressed, I-3-leaved. Leaf-blades I. 5-3 $\mathrm{mm}$. wide, the midrib well defined; inflorescence $5 \mathrm{~cm}$. high or less, usually of 2-10 irregular 3-8-flowered heads, or reduced to a single larger one; perianth 5-6 mm. long, the parts equal, brown, lanceolate, acuminate; stamens 6 , the yellow linear anthers longer than the filaments; style about I $\mathrm{mm}$. long; stigmas 2-3 $\mathrm{mm}$. long; capsule shorter than the perianth, oblong, brown, angled above, obtuse or depressed at the summit, mucronate, 3-celled; seed oblong, white-tipped, about 0.5 $\mathrm{mm}$. long, I4-20-ribbed. Neb. and the Rocky Mountain region.

19. Juncus rèpens Michx. Creeping Rush. (I. F. f. 937.) Perennial by prostrate rooting branches; stems compressed, ascending, floating or prostrate, $0.5-5$ $\mathrm{dm}$. long. Leaves with compressed sheaths, auriculate, the blades $2-8 \mathrm{~cm}$. long, I-2 mm. broad, filiform-acuminate; inflorescence of I-8 heads, one or more heads often occurring also at the lower nodes; heads 5-10-flowered; flowers 6-1o mm. long; perianth-parts subulate-lanceolate, the outer keeled, about one-third shorter than the inner; stamens 3; filaments longer than the yellow anthers; capsule subulate, beakless, about as long as the outer perianth-parts, 3-celled; seed oblong, acute at either end, finely reticulate. In swamps and streams, Del. to Fla., Culsa and Tex., and in Lower Cal.

20. Juncus castàneus Smith. Chfstnut Rush. (I. F. f. 938.) Stems erect, I-5 dm. high, terete, leafless, or with a single leaf, arising singly from a slender rootstock. Basal leaves 3-5, the outer sheaths short, loose, the inner clasping, their blades tapering to a slender channeled acutish apex; inflorescence strict, usually exceeded by its lowest bract; heads I-3, 3-I2-flowered; pedicels I-2.5 $\mathrm{mm}$. long; perianth brown or black, 4-7 mm. long, its parts lanceolate, acute; anthers 
about I mm. long; capsule brown, $I_{2}-2$ times as long as the perianth, narrowly oblong, tapering to an acute summit, imperfectly 3-celled; seed 2.5-4 $\mathrm{mm}$. long, contracted into long slender tails. Newf. to Alaska, south along the Rocky Mts. to Colo. In Europe and Asia.

21. Juncus stýgius L. Moor Rush. (I. F. f. 939.) Rootstock none; stems 0.7-3 dm. high, single, or few together, erect, I-3-leaved below; leaf-sheaths I-2 cm. long, clasping, auriculate; blades 2-10 $\mathrm{cm}$. long, slightly compressed, channeled on the upper side, tapering to a blunt point; inflorescence of $I-4$ heads; heads I-4-flowered; perianth 3-5 $\mathrm{mm}$. long, pale, its parts lanceolate, 3-nerved, equal; anthers oblong, shorter than the filaments; capsule 6-8 mm. long, pale brown, spindle-shaped, mucronate, 3-celled below, few-seeded; seed spindle shaped, 2.5-3 mm. long, with a loose coat, narrowed into thick tails. Newf. to Me., N. N. Y., Mich. and Minn.; also in Br. Col. and Europe.

22. Juncus biglùmis L. Two-Flowered Rush. (I. F. f. 940.) Stems $0.2-2 \mathrm{dm}$. high, loosely tufted on a branched rootstock, nearly terete. Leaves $\mathbf{I}-5$, all basal, the outermost sheath usually $8 \mathrm{~mm}$. long or less, the innermost sometimes much longer, the blades nearly terete; inflorescence a capitate cluster of $\mathbf{r}-4$ flowers, its lowest bract erect, foliose; perianth $3-3.5 \mathrm{~mm}$. long, dark brown, its parts oblong, obtuse, nearly equal; anthers linear-oblong; capsule longer than the perianth, cylindric-oblong, 3-sided, retuse at the summit; purplish black, or with purple-margined valves, imperfectly 3-celled; seed $0.5-0.6 \mathrm{~mm}$. long, fusiform, narrowed into short stout tails. Baffin Bay to Alaska and Br. Col. Also in Europe and Asia.

23. Juncus triglùmis L. Three-flowered Rush. (I. F. f. 94I.) Stems 7-I $7 \mathrm{~cm}$. high, loosely tufted on the branched rootstock, erect, terete. Leaves I-5, all basal, with sheaths clasping and conspicuously auriculate, the blades subterete, blunt; inflorescence a capitate cluster of $\mathbf{I}-5$ (usually 3 ) flowers; the lowest 2 or 3 bracts usually brown, obtuse and membranous; perianth 3-4 $\mathrm{mm}$. long, its parts oblong-lanceolate, obtuse; anthers linear, short; capsule about equalling the perianth, oblong, obtuse, mucronate. 3-angled, imperfectly 3-celled; seed about $2 \mathrm{~mm}$. long, oblong, abruptly contracted into slender tails. Lab. and Newf. to Alaska, south in the Rocky Mountains to Col. Also in Europe and Asia.

24. Juncus pelocàrpus E. Meyer. Brownish-Fruited Rush. (I. F. f. 942.) Rootstock slender; stems 0.7-5 dm. high; I-5-leaved; basal leaves 2-4, mostly with slender terete blades seldom exceeding $12 \mathrm{~cm}$. in length; inflorescence $\mathbf{I} \mathrm{cm}$. in height or less; panicle loose, with distant heads of $\mathbf{I}$ or sometimes 2 flowers; perianth $\mathbf{1} .5-3 \mathrm{~mm}$. long, the parts linear-oblong, obtuse or the inner sometimes acute; stamens 6; anthers slightly exceeding the filaments; style commonly $1 \mathrm{~mm}$. long; capsule subulate-linear, I-celled, its slender beak exceeding the perianth; seed oblong to obovoid, $0.4-0.5 \mathrm{~mm}$. long, reticulate in about 24 rows. Newf. to N. J. and Minn.

Juncus pelocarpus subtilis (E. Meyer) Engelm. Much smaller, depressed, $\mathrm{r}-\mathrm{few}$ flowered. N. Me. and adjacent Can.

25. Juncus bulbòsus L. Bulbous Rush. (I. F. f. 943.) Tufted, 5-20 cm. high; usually bulbous. Leaves of two kinds, the basal mostly submersed, filiform, the cauline stouter, all with auriculate sheaths, panicle of I-Io heads; heads 4-15flowered, some of the flowers often transformed into tufts of small leaves; perianth 2.5-3 mm. long, its parts nearly equal, linear-lanceolate, obtuse, brown, or with a green midrib; stamens 3; capsule narrowly oblong, obtuse, mucronate, slightly exceeding the perianth, brown above, I-celled; seed narrowly oblong, about $0.5 \mathrm{~mm}$. long, acute at base, obtuse and apiculate above, 25-30-ribbed. Lab. and Newf. Common in Europe.

26. Juncus militàris Bigel. Bayonet Rush. (I. F. f. 944.) Stems 0.5I. $2 \mathrm{~m}$. high, erect, stout, 3-6 $\mathrm{mm}$. thick below, arising from a stout roctstock. Leaves of two kinds, the submersed borne in fascicles on the rootstock and developing filiform blades sometimes $5 \mathrm{dm}$. long; basal leaves reduced to loose bladeless sheaths; stem leaves $\mathbf{I}$ or 2 , the lower with a long stout terete blade, the upper, when present, reduced to a bladeless sheath; inflorescence 7-I5 $\mathrm{cm}$. high; heads 6-12-flowered; perianth $3-3.5 \mathrm{~mm}$. long, its parts narrowly linear-subulate, the inner longer than the outer; stamens 6; capsule ovoid, acuminate, beaked, I celled, 
few-seeded, about equalling the perianth; seed obovoid, about $0.5 \mathrm{~mm}$. long, reticulated in about 24 rows. Shallow margins of lakes, ponds or streams, N. S. to N. N. Y. and Md.

27. Juncus articulàtus L. Jointed Rush. (I. F. f. 945.) Rootstock branching; stems erect or ascending, 4-6 dm. high, tufted, somewhat compressed, 2-4leaved, basal blade-bearing leaves $\mathrm{I}$ or 2, usually dying early; stem leaves with conspicuously septate blades; inflorescerce rarely exceeding $\mathbf{I} \mathrm{dm}$. in height, its branches spreading; heads 6-12-flowered; perianth 2-3 $\mathrm{mm}$. long, the parts nearly equal, lanceolate, acuminate, reddish brown with a green midrib or green throughout; stamens 6 ; capsule longer than the perianth, brown, 3-angled, tapering into a conspiciuous tip, I-celled; seed oblong-obovoid, about $0.5 \mathrm{~mm}$. long, reticulate in about I6-20 rows. Lab. to Mass., N.Y., Mich. and Br. Col. Also in Europe and Asia.

28. Juncus Richardsoniànus Schult. Richardson's Rush. (I. F. f. 946.) Stems erect, $\mathrm{I} .5-5 \mathrm{dm}$. high in loose tufts, from creeping rootstocks, I-2-leaved; panicle 6-20 cm. high, sparse, its branches strict or slightly spreading; heads 3-12flowered; perianth $2-2.5 \mathrm{~mm}$. long, the inner parts shorter than the outer, obtuse, the outer paler; stamens 6; anthers much shorter than the filaments; capsule ovoidoblong, slightly exceeding the perianth, with a short tip; seed about $0.5 \mathrm{~mm}$. in length, narrowly obovoid to oblong, apiculate, acute or acuminate at the base, lightly reticulate in about 20 rows. N. S. to Br. Col., Penn., Neb. and Wash.

29. Juncus nodòsus L. Knotted Rush. (I. F. f. 947.) Stems I.5-6 dm. high, erect, arising singly frrm thickenings of a slender rootstock; stem leaves 2-4, and like the basal ones with long erect blades; panicle seldom exceeding $6 \mathrm{~cm}$., bearing I-30 heads; heads several-many-flowered, 7-I $2 \mathrm{~mm}$. in diameter; perianth 2.4-3.5 mm. long, its parts lanceolate-subulate, the inner longer than the outer; stamens 6; capsule lanceolate-subulate, 3-sided, I-celled, exceeding the perianth; seed oblong, acute below, apiculate above, rarely more than $0.4 \mathrm{~mm}$. long, reticulate in, 20-30 rows. N. S. to Va., Neb. and Br. Col. Also in Nev.

30. Juncus Tórreyi Coville. TorRey's Rush. (I. F. f. 948.) Stems 2-Io $\mathrm{dm}$. high; rootstock slender, with tuberiform thickenings; leaf-blades stout, terete, abruptly divergent from the stem; inflorescence congested, consisting of $\mathrm{I}-2 \mathrm{O}$ heads; heads IO-16 mm. in diameter; perianth 4-5 $\mathrm{mm}$. long, its parts subulate, the outer longer than the inner; stamens 6; capsule subulate, 3-sided, I-celled, beaked; seed $0.4-0.5 \mathrm{~mm}$. in length, oblong, acute at both ends, reticulate in about 20 longitudinal rows. W. N. Y. to Tex. and the Pacific coast.

3r. Juncus Caesariénsis Coville, New Jersey Rush. (I. F. f. 949.) Stems $0.5^{-1} \mathrm{~m}$. high, stout, erect, slightly roughened; basal leaves few, the uppermost, like the cauline, with long erect terete roughened blades; inflorescence 2 -Io $\mathrm{cm}$. high, with spreading branches, its lowest bract with a small blade; heads 2-5-flowered; perianth 4-5 $\mathrm{mm}$. long, the parts lanceolate-acuminate, stiff, green, striate, the inner longer than the outer; stamens 6; capsule lanceolate-oblong, 3-sided, mucronate-acuminate, incompletely 3-celled; seed tailed at both ends, altogether about $2 \mathrm{~mm}$. long. Sandy swamps of S. N. J. [J. asper Engelm., not Sauzé.]

32. Juncus brachycàrpus Engelm. SHorT-Fruited Rush. (I. F. f. 950.) Stems erect, 2-9 dm. high, terete, I-4-leaved; blades terete, $2 \mathrm{~mm}$. thick or less; inflorescence sometimes I dm. high and with 20 spherical heads; perianth $3-4 \mathrm{~mm}$. long, its parts subulate, the inner about three-fourths as long as the outer; stimens 3; capsule one-half to two-thirds as long as the perianth, oblong, mucronate, I-celled; seed oblong, acute at both ends, about $0.4 \mathrm{~mm}$. long, reticulate in about 18 longitudinal rows. S. Ont., through the Miss. Valley to Okla., Tex. and Miss.; also from N. Car. to Md.

33. Juncus polycéphalus Michx. Many-Headed Rush. (I. F. f. 95I.) Stems stout, about I m. high, compressed, 2-4-leaved. Leaves $0.5 \mathrm{~m}$. in length or less, the upper shorter; blades vertically flattened, $3-8 \mathrm{~mm}$. broad; inflorescence $\mathrm{I}-3.5$ $\mathrm{dm}$. high; heads globose, 7-10 $\mathrm{mm}$. in diameter; perianth $3-4 \mathrm{~mm}$. long, its parts subulate; stamens 3 ; capsule subulate, I-celled, exceeding the perianth; seed narrowly oblong, about $0.5 \mathrm{~mm}$. long, acute at each end, with nearly straight tips, reticulate in about 12 rows. In swamps, Va. (?) to Fla. and Tex.

34. Juncus scirpoìdes Lam. ScIRPus-Like Rush. (I. F. f. 952.) Stems $2-9 \mathrm{dm}$. high, erect, terete, in clusters. Stem leaves I-3; blades terete, $2 \mathrm{~mm}$. 
thick or less, usually less than I dm. long, the septa perfect; basal leaves similar, but with longer blades; inflorescence strict or slightly spreading, sometimes $\mathbf{1} .5 \mathrm{dm}$. in length; heads 2-30, globose, 6-I2 $\mathrm{mm}$. in diameter; perianth $2.5-3.5 \mathrm{~mm}$. long, its parts subulate, the inner somewhat shorter; capsule subulate, I-celled, its long beak exceeding the perianth; seed oblong, abruptly apiculate at either end, reticulate in 14-20 longitudinal rows. Me. (according to Fernald), N. Y. to Fla. and La.

35. Juncus megacéphalus M. A. Curtis. Carolina Rush. (I. F. f. 953.) Stems 3-9 dm. high, tufted from a branching rootstock, stout, 2-3-leaved. Leaves with auricled sheaths, the blades of the basal $2 \mathrm{dm}$. long or less; the uppermost rarely $2 \mathrm{~cm}$. in length; inflorescence $1.5 \mathrm{~cm}$. high or less, its lowest leaf almost bladeless, the others scarious; panicle of I-40 heads; heads spherical, 8-12 $\mathrm{mm}$. in diameter; perianth $3-3.5 \mathrm{~mm}$. long, its parts subulate, the outer longer than the inner; stamens 3; capsule subulate, beaked, equalling the perianth, 3 -sided, I-celled; seed oblong, acute at either end, reticulate in I2-14 rows. Va. (?), N. Car. to Fla.

36. Juncus brachycéphalus (Engelm.) Buch. SMall-HEaded Rush. (I. F. f. 954.) Stems 3-6 dm. high, tufted, 2-4-leaved; leaves all with well developed blades, the lower commonly I-2 dm. long; inflorescence commonly 6-I5 $\mathrm{cm}$. high, with spreading branches; heads top-shaped, 2-5-flowered; perianth 2-2.5 mm. long, its parts lanceolate, the outer shorter than the inner; stamens 3 ; capsule reddish brown, about one-half longer than the perianth, ovoid-oblong, tipped, 3-sided, I-celled; seed with narrowly oblong body, short-tailed at either end, 20-30-ribbed. Me. to Penn., Ill. and Wis.

37. Juncus Canadénsis J. Gay. CanadA Rush. (I. F. f. 955.) Stems 0.3-I.2 m. high, erect, stout, 2-4-leaved, few in a tuft. Basal leaves usually decayed at flowering-time; stem leaves with large loose auriculate sheaths, and a stout erect blade usually I-2.5 din. long; panicle $0.7-2.5 \mathrm{dm}$. in height; heads usually crowled, 5-40-flowered; perianth 3-4 $\mathrm{mm}$. long, the parts narrowly lanceolate, acute, the inner longer than the outer; stamens 3; capsule lanceolate, acute, mucronate, 3-sided, I-celled, reddish brown, exceeding the perianth; seed I-2 mm. long, tailed at either end, the body with a smooth shining coat, about 40-striate. N. B. to Minn., Ga. and La.

Juncus Canadénsis subcaudatus Engelm. Stems 4-7.5 dm. high, slender, frequently waak and reclining; heac's few, scattered; seed with very short tails. R. I. to Penn. and $\mathrm{Ga}$.

Juncus Canadénsis brevicaudatus Engelm. Stems erect, 2-7.5 dm. tall, slender, closely tufted; panicle contracted; heads 2-6-flowered; seed long-tailed N.S. to Minn. and N. J.

38. Juncus acuminàtus Michx. Sharp-Fruited Rush. (I. F. f. 956.) Plant 2.5-9 dm. high; rootstock short. Stems few or several in a tuft. erect, I-3-leaved; blades of the lower leaves I-2 dm. long; inflorescence $0.5-1.5 \mathrm{dm}$. high, and with 5-50 heads, rarely larger, or reduced even to a single head, its branclies usually spreading; heads 3-20-flowered; perianth $2.5-3.5 \mathrm{~mm}$. long, its parts lanceolate-subulate, nearly equal; stamens 3 ; capsule ovate-lanceolate, broadly acute, mucronate, I-celled, equalling the perianth, light brown; seed oblong. about $0.5 \mathrm{~mm}$. in length, tipped at $\epsilon$ ither end, reticulate in $16-20$ longitudinal rows. Me. to S. Ont., Minn., Ga. and Mex. Also on the northwest coast. Heads often proliferous.

Juncus acuminàtus débilis (A. Gray) Engelm. Smaller, densely tufted, 2.5-5 dm. high, the stems often weak and procumbent; perianth shorter, $2-2.5 \mathrm{~mm}$. long; capsule linear oblong, obtuse, about one-third longer than the perianth, short-tipped. N. J. to S. Car.

39. Juncus robústus (Engelm.) Coville. Srour Rush. (I. F. f. 957.) Plant about $9 \mathrm{dm}$. high. Stems single or few in a tuft, stout, nearly terete, I-2-leaved; blades erect, terete, conspicuously many-septate, 2-6 dm. long, usually reaching or exceeding the inflorescence; inflorescence $\mathbf{I}-2.5 \mathrm{dm}$. ligh, with innumerable (commonly 300-500) heads; heads 2-IO-flowered; perianth $2-2.5 \mathrm{~mm}$. long, its parts nearly equal, lanceolate-subulate; stamens 3; capsule equalling or one-third exceeding the perianth, straw-colored, oblong, obtuse with a short tip, 3-sided 
when dry, I-celled; seed mearly as in $\mathcal{F}$. acuminatus. S. Ill. to Kans., Okla., La. and Tex.

40. Juncus diffusissimus Buckley。 Diffuse Rush. (I. F. f. 958.) Plant 3-6 dm. high. Stems few in a tuft, erect, slender, terete or slightly compressed, 2-4-leaved; blades I-2 dm. long; inflorescence diffusely branched, I-2 dm. high and broad; heads 3-12-flowered; perianth $2.5-3.5 \mathrm{~mm}$. long, its parts subulate, equal; capsule linear-lanceolate in outline, 4-5.5 $\mathrm{mm}$. long, with a short tip, 3sided, light brown, I-celled; seed oblong to obovoid, acute at the base, abruptly tipped, reticulate in about 16 rows. S. Kans. to Miss. and Tex.

\section{JUNCOIDES Adans. [LUZULA DC.] (See Appendix.)}

Perennial plants, with herbage either glabrous or sparingly webbed, stems leafbearing, leaf-sheaths with united margins, and leaf-blades grass-like. Inflorescence umbelloid, paniculate, or corymbose, often congested; flowers always bracteolate, the bractlets usually lacerate or denticulate; stamens 6 in our species; ovary I-celled, its 3 ovules with basal insertion; seeds 3 , indistinctly reticulate, sometimes carunculate, not distinctly tailed. [Greek, meaning like Juncus.] About 40 species, widely distributed, mostly flowering in spring.

Inflorescence umbelloid, $\mathbf{x}$ or 2 flowers on each of its branches.

1. J. pilosum.

Inflorescence theoretically paniculate, the flowers often crowded in spike-like clusters.

Outer perianth-parts shorter than the inner; introduced species. 2. J. nemorosum.

Perianth-parts equal or nearly so ; native species.

Flowers $1-3$ together, on the branches of an open panicle. 3. J.parviflorum.

Flowers crowded into one or more thick spikes or spike-like clusters.

Inflorescence nodding.

4. J. spicatum.

Inflorescence erect or spreading, or its individual branches rarely nodding.

Inflorescence of $1-3$ spike-like or capitate flower-clusters, or the leafblades sharp-pointed.

Inflorescence crowded into a single cluster; ieaves flat, usually with a blunt apex.

5. J. nivale.

Inflorescence in $1-4$ clusters; leaves narrowed above, involutechanneled, apex very sharp.

Inflorescence of 2-12 spike-like or capitate clusters. leaf-blades with. blunt points.

7. J. campestre.

I. Juncoides.pilòsum (L.) Kuntze. HAIRy Wood-RUsh. (I. F. f. 959.) Tufted, often stoloniferous. Steins erect, 2-4-leaved, I.5-3 dm. high; leaf-blades 3-8 mm. wide, flat, slightly webbed, acuminate into a blunt tip; inflorescence an umbelloid flower-cluster, the filiform pedicels equal or nearly so, I-flowered or sometimes 2-flowered; perianth 2.5-3 mm. long, its parts triangular-ovate, acuminate, brown with hyaline margins, about twice as long as the toothed bractlets; capsule about one-fourth exceeding the perianth, its valves ovate, acuminate; seed provided at the summit with a conspicuous hooked caruncle. N. B. to Alaska, N. Y., Mich. and Ore., and in the Alleghanies to N. Car. Also in Europe and Asia.

2. Juncoides nemoròsum (Poll.) Kuntze. Forest Wood-RUsh. (I. F. f. 960.) Loosely tufted or somewhat stoloniferous. Stems slender, 3-7 dm. high, I -6-leaved; leaf-blades 3-6 mm. wide, ciliate, flat; inflorescence diffusely paniculite or corymbose, the few lower bracts foliose; flowers in clusters of 3-8, the bractlets ovate, entire or sparingly denticulate above; perianth about $2.5 \mathrm{~mm}$. in length, its parts ovate-lanceolate, acute, the outer about one-fifth shorter than the inner; capsule ovoid, acuminate, barely equalling the perianth; seed obliquely ovoid, about $\mathbf{I} .2 \mathrm{~mm}$. long. A European species, naturalized at Riverdale, N.Y.

3. Juncoides parvifiòrum (Ehrh.) Coville. SMall-flowered Wood-Rush. (I. F. f. 96r.) Stems single or few in a tuft, stoloniferous, 2.5-7.5 dm. high, 2-5leaved; leaves glabrous, their blades $3-10 \mathrm{~mm}$. wide; inflorescence a nodding decompound panicle, its lowest bract foliose; flowers borne singly, or sometimes 2 or 3 together, on slender pedicels; bractlets ovate, entire or rarely somewhat lacerate; perianth I.5-2.5 mm. in length, its parts ovate, acuminate, slightly exceeded by the ovoid capsule; seed narrowly oblong, I-1.5 mm. in length. Lab. to Br. Col., N. H., N. Y. and Minn.; in the mountains to Ariz. and Cal. Also in Europe and Asia. 
4. Juncoides spicàtum (L.) Kuntze. SPIKed Wood-RUSH. (I. F. f. 962.) Closely tufted, without rootstocks. Stems erect, I-4 dm. high, distantly I-3. leaved; leaf-blades $\mathrm{I}-3 \mathrm{~mm}$. broad, often involute, especially above, sparingly webly, especially at the base; inflorescence a nodding, spike-like, often interrupted panicle, commonly $\mathbf{I}-2.5 \mathrm{~cm}$. in length; bractlets ovate-lanceolate, acuminate, sparingly lacerate; perianth brown, 2-3 mm. long, its parts lanceolate, aristate-acuminate; capsule broadly ovoid, bluntly acute, about two-thirds as long as the perianth; seed narrowly and obliquely obovoid, about $3 \mathrm{~mm}$. long. Lab. to Alaska, mountains of N. Eng., N. N. Y., Colo. and Cal. Also in Europe and Asia.

5. Juncoides nivàle (Laest.) Coville. ARCTic Wood-RUSH. (I. F. f. 963.) Stems tufted, 5-10 cm. high, I- or 2-leaved. Leaves with sheaths glabrous at the mouth, their blades $2-4 \mathrm{~mm}$. broad, flat and tapering to a usually blunt and callous tip; inforescence an erect oblong to ovate, spike-like cluster, $\mathbf{I . 3} \mathrm{cm}$. in height or less; bractlet and perianth dark purple, the former ovate and sparingly lacerate at the hyaline apex; perianth-parts $\mathbf{I} \cdot 5^{-2} \mathrm{~mm}$. in length, narrowly oblong; capsule subspheric, exceeding the perianth; seed narrowly oblong, about I $\mathrm{mm}$. long. Baffin Bay to Alaska. Also in arctic and alpine Europe and Asia.

6. Juncoides hyperbòreum (R. Br.) Sheldon. NORTHERN Wood-RUsh. (I. F. f. 964.) Stems tufted, commonly I-2 dm. high, erect, I-2-leaved. Leaves with sheaths sparingly ciliate at the mouth, the blades erect, I- $3 \mathrm{~mm}$. wide at the base, usually involute in age; tapering into a very sharp tip; inflorescence erect, consisting of a single oblong cluster, or its one or two lower divisions on peduncles I $-3 \mathrm{~cm}$. long: bracts and bractlets membranous, fimbriate; perianth-parts brown, paler above, about $2.5 \mathrm{~mm}$. long, ovate-lanceolate, acuminate, denticulate or slightly lacerate at the apex; capsule about three-fourths as long as the perianth, ovoid, obtuse; seed rather narrowly oblong. Arctic America, Lab. and the higher moun. tains of N. Eng. Also in Europe and Asia.

7. Juncoides campéstre (L.) Kuntze. Common Wood-RUsh. (I. F. f. 965.) Stems tufted, I-5 dm. high, 2-4-leaved. Leaf-blades flat, 2-7 mm. broad, tapering to a blunt tip, sparingly webbed when young; inflorescence umbelloid; lower bracts foliose; floral bracts ovate, acuminate; bractlets similar but smaller, fimbriate at the apex; perianth 2-3 mm. long, brown, its parts lanceolate-ovate, acuminate; capsule obovoid or broadly oblong; seed with an oblong body about I $\mathrm{mm}$. in length, supported on a narrower white, loosely cellular, strophiole-like base about one-half as long. In woodlands, almost throughout the U. S. and Br. Am. Also in Europe and Asia. Variable. One of our earliest flowering plants.

\section{Family 2. MELANTHÀCEAE R. Br.}

\section{Bunch-flower Family.}

Leafy-stemmed herbs (some exotic genera scapose), with rootstocks or rarely with bulbs, the leaves parallel-veined. Flowers regular, racemose, panicled or solitary. Perianth of 6 separate or nearly separate, usually persistent segments. Stamens 6, borne on the bases of the perianthsegments. Anthers small, 2-celled, or confluently i-celled and cordate or reniform, mostly versatile and extrorsely dehiscent (introrse in Tofieldia and Abama). Ovary 3-celled, superior or rarely partly inferior; ovules anatropous or amphitropous. Styles 3, distinct, or more or less united. Fruit a capsule with septicidal dehiscence (loculicidal in Abama and Uvularia). Seeds commonly tailed or appendaged. Embryo small, in usually copious endosperm. About 36 genera and 140 species, widely distributed.

Flowers numerous in terminal erect racemes or panicles.

Anthers oblong or ovate, 2-celled.

Anthers introrsely dehiscent.

Capsule septicidal; flowers involucrate by 3 bractlets.

Capsule loculicidal; flowers not involucrate.

x. Tofieldia.

2. Abama. 
Anthers extrorsely dehiscent.

Flowers perfect.

Stem very leafy; leaves linear; seeds few.

Leaves basal, oblanceolate; seeds numerous.

Flowers diœcious; stem leafy.

Anthers cordate or reniform, confluently 1-celled.

3. Xerophyllum.

4. Helonias.

5. Chamaelirium.

Plants glabrous.

Perianth-segments not gland-bearing.

Flowers perfect; perianth-segments obtuse.

6. Chrospermc

Flowers polygamous; perianth-segments acuminate. 7. Stenanthium.

Perianth-segments bearing 1 or 2 glands, or a spot.

Stem and inflorescence pubescent.

Perianth-segments clawed, free from the ovary.

Perianth-segments not clawed, adnate to the base of the ovary.

8. Zygadenus.

9. Melanthium.

10. Veratrum.

Flowers solitary, terminal or opposite the leaves, drooping.

II. Uvularia.

\section{TOF̈IÈLIA Huds.}

Perennial herbs, with short erect or horizontal rootstocks, fibrous roots, slender erect stems leafless above or nearly so, linear leaves clustered at the base, and small perfect white or green flowers in a terminal raceme. Pedicels bracted at the base, solitary or clustered. Flowers usually involucrate by 3 scarious somewhat united bractlets. Perianth-segments oblong or obovate, suljequal, persistent, glandless. Stamens 6; filaments filiform; anthers ovate, sometimes cordate, introrse. Ovary sessile, 3-lobed at the sunmit; styles 3, short, recurved. Capsule 3-lobed, 3beaked, septicidally dehiscent to the base, many-seeded. Seeds tailed or appendaged in most species. [Dedicated to Tofield, an English correspondent of Hudson.] About 15 species, natives of the north temperate zone, $\mathbf{I}$ or 2 in the Andes of South America. Besides the following another occurs in the southeastern States and two in northwestern America.

Stem glabrous: seeds unappendaged.

Stem viscid-pubescent; seeds appendaged.

Capsule oblong, $6 \mathrm{~mm}$. high; perianth-segments thin.

Capsule ovoid, 3-4 mm. high; perianth-segments rigid in fruit.

r. T. palustris.

r. Tofieldia palístris Huds. Scotrish Asphodel. (I. F. f. 966.) Stems slender, leafless or bearing a few leaves near the base, 5-25 cm. tall. Leaves $\mathrm{I}-4 \mathrm{~mm}$. wide; raceme oblong or subglobose in flower, dense, elongating to an inch or less in fruit, the lower flowers first expanding; pedicels usually solitary, minutely involucrate, $\mathbf{I}-2 \mathrm{~mm}$. long in fruit; flowers greenish white, $2 \mathrm{~mm}$. broad; perianthsegments obovate, obtuse, much shorter than the oblong-globose minutely beaked capsule. Greenland and Lab. to Alaska, Quebec, Lake Superior, and the Canadian Rocky Mts. Also in Europe and Asia. Summer.

2. Tofieldia glutinòsa (Michx.) Pers. Glutinous Tofieldia. (I. F. f. 967.) Stem viscid-pubescent with black glands, 1.5-5 dm. tall, bearing 2-4 leaves near the base. Basal leaves $2-6 \mathrm{~mm}$. wide; raceme oblong and $\mathbf{I}-3 \mathrm{~cm}$. long in flower, longer in fruit, the upper flowers first expanding; pedicels commonly clustered in 3's (I's-4's), becoming 4-12 mm. long in fruit; involucral bracts minute, united nearly or quite to their apices, flowers $6-8 \mathrm{~mm}$. broad; perianth-segments oblong. mostly obtuse; capsule oblong, about $6 \mathrm{~mm}$. high, twice as long as the perianth; seeds tailed at each end. In bogs, Newf. to Alaska, Me., Ohio, Mich., Wyo. and Ore., and in the southern Alleghenies. May-June.

2. Tofieldia racemòsa (Walt.) B. S. P. Viscid TofieldiA. (I. F. f. 968.) Similar to the preceding but rather stouter and taller; the glutinous pubescence rougher. Leaves $1.5-4.5 \mathrm{dm}$. long, 3-6 mm. wide; raceme $2-10 \mathrm{~cm}$. long in flower, often loose, the uppermost flowers first expanding; pedicels mostly clustered in 3's, ascending; involucral bractlets about $1 \mathrm{~mm}$. long, united to above the middle: perianth-segrments narrowly obovate, obtuse, rigid; capsule ovoid, $3 \mathrm{~mm}$. long, little longer than the calyx; seeds tailed at each end. In swamps, S. N. J. to Fla. and Ala. June-Sept.

\section{ABÀMA Adans. [NARTHECIUM Juss.]}

Perenrial herbs, with creeping or horizontal rootstocks, fibrous roots, erect simple stems and linear grass-like basal leaves, those of the stem short and distant. 
Flowers small, greenish-yellow, perfect, borne in a terminal raceme. Pedicels bracted at base and usually bearing a small bractlet. Perianth-segments persistent, linear or linear-lanceolate, obscurely 3-5-nerved, glandless. Stamens 6; filaments subulate, woolly; anthers linear-oblong, erect, introrse. Ovary sessile; style very short or none; stigma slightly 3-lobed. Capsule oblong, loculicidally dehiscent, many-seeded, the linear seeds tailed at each end. [Greek, signifying without step, the plants reputed to cause lameness in cattle.] Four known species, natives of the northern hemisphere. Besides the following, another occurs in northwestern America.

I. Abama Americàna (Ker) Morong. American Bog-Asphodel. (I. F. f. 969.) Glabrous; stems wiry, stiff, $2.5-4 \cdot 5 \mathrm{dm}$. tall. Basal leaves $2 \mathrm{~mm}$. wide or less; lower stem leaves $\mathrm{I}-5 \mathrm{~cm}$. long; raceme $2-5 \mathrm{~cm}$. long, dense; perianthsegments 4-6 mm. long, slightly exceeding the stamens; pedicels ascending, 6-8 $\mathrm{mm}$. long in fruit; capsule about I $\mathrm{cm}$. long, tapering to a subulate beak. In pine barren swamps, S. N. J. June-Sept.

\section{XEROPHÝLLUM Michx.}

Tall herbs, with thick short woody rootstocks, simple erect leafy stems, the leaves narrowly linear, rough-margined. Flowers very numerous, white, in a large dense terminal raceme, the lower ones first expanding. Perianth witheringpersistent, its segments oblong or ovate, 5-7-nerved, spreading, glandless. Stamens 6 , rather shorter than the perianth-segments; filaments subulate, glabrous; anthers oblong. Ovary sessile, 3-grooved; styles 3, filiform, reflexed or recurved; ovules only 2-4 in each cavity. Capsule ovoid, 3-grooved, loculicidally and sometimes also septicidally deliiscent. Seeds 5, oblong, not at all appendaged, or only minutely so. [Greek, signifying a dry leaf.] Three species, the following of the southeastern U. S., the others of western America.

I. Xerophyllum asphodeloìdes (L.) Nutt. Turkey-BEard. (I. F. f. 970.) Stem 0.6-1.4 m. tall, densely leafy below, sparsely leafy above. Leaves slightly dilated at the base, the lower 1.5-4.5 dm. long, $2 \mathrm{~mm}$. wide or less, except at the broader base; flowering raceme $5-8 \mathrm{~cm}$. in diameter, its summit conic; flowering pedicels spreading, filiform, I.8-3.5 cm. long, in fruit erect; perianth-segments obtuse, about $6 \mathrm{~mm}$. long; capsule ellipsoid, obtuse, $4 \mathrm{~mm}$. long. In dry pine barrens, S. N. J. to E. Tenn. and Ga. May-July.

\section{HELÒNIAS L.}

A perennial glabrous bog herb, with a stout rootstock, thick fibrous roots, basal oblanceolate persistent leaves and rather large perfect purple flowers, racemed at the summit of an erect hollow bracted scape. Perianth-segments spreading, spatulate, persistent. Stamens 6, hypogynous, longer than the perianth-segments; filaments filiform; anthers ovate. Ovary ovoid, 3-grooved, 3-celled, slightly 3-lobed, many-ovuled; styles 3 , stigmatic along the inner side, deciduous. Capsule obovoid, deeply 3-lobed, the lobes divergent, ventrally dehiscent above. Seeds numerous, linear, white-appendaged at each end. [Name from the Greek, in allusion to its growth in swamps.] A monotypic genus of eastern N. Am.

I. Helonias bullàta L. Swamp Pink. (I. F. f. 971.) Leaves dark green, thin, clustered, 1.5-4 dm. long, I.5-5 cm. wide. Scape stout, its bracts lanceolate, acute or acuminate; raceme dense, becoming $\mathbf{I}-2 \mathrm{dm}$. long in fruit; perianthsegments about $6 \mathrm{~mm}$. long; capsules about $6 \mathrm{~mm}$. long, the valves papery; seeds 3-4 mm. long. In bogs, N. N. J., S. N. Y., and E. Penn. (?) to Va. Local. April-May.

\section{CHAMAELÍRIUM Will.}

Glabrous, slightly fleshy herbs with bitter tuberous rootstocks. Basal leaves spatulate. Flowers small, white, diøecious, in a long bractless spike-like raceme. Perianth of 6 I-nerved segments. Staminate flowers with 6 stamens, the anthers subglobose, 2-celled; pistillate flowers with a 3 -celled oblong ovary, 3 short styles, stigmatic along the inner side, and usually with 6 staminodia. Capsule oblong, slightly 3 -lobed, loculicidally 3 -valved. Seeds 6-12 in each cavity, broadly winged at both ends, narrowly winged on the sides. [Greek, signifying a low lily.] Only t'le following species, natives of easteru N. Am. 
Capsule oblong, pedicels slender, barely club-shaped. Capsule obovoid, pedicels stout, club-shaped.

r. C. Iuteum.

2. C. obovale.

I. Chamaelirium lìteum (L.) A. Gray. Blazing-STAR. (I. F. f. 97 .) Staminate plant 3-7 dm. tall, the pistillate often taller and more leafy. Basal leaves 5- $-0 \mathrm{~cm}$. long, tapering into a long petiole; stem leaves lanceolate, the linear acute or acuminate; staminate raceme finally erect, 7-22 cm. long, the pediceis spreading; pistillate raceme erect; flowers nearly $6 \mathrm{~mm}$. broad; capsules oblong, 7-ro mm. long. In moist meadows and thickets, Mass. to Ont., Mich., Fla. and Ark. Spring.

2. Chamaelirium obovale Small. Similar to the preceding. Pistillate flowers slightly larger; capsules obovoid or oblong-obovoid, 12-14 $\mathrm{mm}$. long, the stout club-shaped pedicels about the same length. In open woods, N. Y. to W. Va. asd N. C. Spring.

\section{CHROSPÉRMA Raf. [AMIANTHIUM A. Gray.]}

An erect glabrous herb, with an ovoid-oblong coated bulb, and numerous long blunt basal leaves, a few short ones on the stem. Flowers perfect, white, in a dense terminal raceme, the lower ones first expanding. Perianth of 6 distinct glandless persistent obtuse segments. Stamens inserted on the bases of the segments; anthers small, reniform. Ovary ovoid, 3-lobed, 3-celled. Capsule 3-celled, dehiscent above the middle, the cavities I-2-seeded, its 3 divergent lobes tipped with the subulate styles. Seeds ovoid, reddish brown. [Greek, referring to the colored seeds.] A monotypic genus of eastern N. Am.

1. Chrosperma muscaetóxicum (Walt.) Kuntze. Fly-poison. (I. F. f. 973.) Bulb nearly $2.5 \mathrm{~cm}$. in diameter. Stem 4-12 dm. tall. Basal leaves shorter than the stem, the upper bract-like; raceme becoming cylindric, $5^{-1} 3 \mathrm{~cm}$. long; pedicels ascending, 8-20 $\mathrm{mm}$. long; bractlets ovate; sepals obtuse, 4-6 mm. long; filaments filiform; capsule 4-6 mm. in diameter, scarcely as long. In dry sandy woods, L. I. to E. Penn., Fla., Tenn. and Ark. May-July.

\section{STENÁNTHIUM Kunth.}

Erect glabrous bulbous herbs, with small white or greenish, polygamous flowers in an ample terminal panicle. Leaves linear, keeled. Perianth-segments lanceolate, acuminate, glandless, spreadling, persistent, adnate to the base of the ovary. Stamens shorter than the perianth-segments; anthers cordate or reniform. Ovary ovoid. Capsule ovoid-oblong, 3-lobed, finally dehiscent to the base, the loles with short beaks. Seeds about 4 in each cavity, oblong. [Greek, in allusion to the narrow perianth-segments.] The genus comprises only the two following species:

Leaves 4-6 mm. wide; capsule reflexed. Leaves 6-20 mm. wide ; capsule erect.

1. S. gramineum. 2. S. robustum.

I. Stenanthium gramíneum (Ker) Morong. Grass-leaved Stenanthium. (I. F. f. 974.) Stem 9-1 2 dm. tall. Leaves grass-like, often $3 \mathrm{dm}$. long; the upper reduced to small linear-lanceolate bracts; panicle open, simple or somewhat compound, 3-6 dm. long, its branches nearly filiform, spreading or drooping; flowers 8-12 mm. broad; capsule ovoid-oblong, with a top-shaped base, 6-8 $\mathrm{mm}$. long. In dry soil, Va. and Ky. to Fla. and Ala. Aug.-Sept.

2. Stenanthium robústum S. Wats. Srout Stenanthium. (I. F. f. 675.) Stem stout, 9-15 dm. tall, usually leafy. Leaves often $3 \mathrm{dm}$. long or more; panicle denser than that of the preceding, commonly longer, usually compound, its branches spreading or ascending; flowers greenish or white, $12-16 \mathrm{~mm}$. broad; capsule ovoid-oblong, 8 I $2 \mathrm{~mm}$. long, erect, the very short beaks recurved-spreading. In moist soil, S. Penn. and Ohio to S. Car. and Tenn. July-Sept.

\section{ZYGADÈNUS Michx.}

Glabrous erect perennial herbs, from bulbs. or rootstocks, with leafy stems. Leaves linear. Flowers greenish, yellowish or white, in a terminal panicle or raceme. Perianth withering-persistent, its segments separate or united below, bearing 1 or 2 glands or a spot just above the narrowed base. Stamens free from the perianth segments; anthers cordate or reniform. Capsule 3-lobed, 3-celled, 
the cavities not diverging, dehiscent to the base. Seeds oblong or linear, angled. [Greek, referring to the two glands of some species.] About Io species, natives of North America and Mexico, $I$ in Siberia.

Plant with a thick rootstock; glands of the perianth segnents 2, orbicular.

Plants bulbous; gland only $\mathbf{r}$, sometimes faint or a mere spot.

Gland distinctly obcordate; perianth-segments 8-10 mm. long. 2. Z. elegans.

Gland not obcordate ; perianth-segments 4-8 $\mathrm{mm}$. long.

Gland with a poorly defined or irregular margin ; perianth free from the ovary; western species.

Leaves 6-16 $\mathrm{mm}$. wide ; flowers mostly perfect.

Leaves $4-6 \mathrm{~mm}$. wide; flowers polygamous.

3. Z. Nuttallii.

4. Z. venenosus.

Gland a mere yellow spot; perianth adnate to the ovary ; eastern coast species.

5. Z. leimanthoides.

r. Zygadenus glabérrimus Michx. Large-Flowered Zygadenus. (I. F. f. 976.) Slightly glaucous; stem stout, 6-I2 dm. tall. Leaves 6-I $2 \mathrm{~mm}$. wide, channeled, often $3 \mathrm{dm}$. long or more, the upper appressed, passing into the bracts of the panicle; panicle $1.5-3 \mathrm{dm}$. long, its branches ascending; pedicels longer than the bractlets ; flowers white, mostly perfect, $2.5-3.5 \mathrm{~cm}$. broad; perianth-segments lanceolate or oblong-lanceolate, narrowed into a short claw ; styles subulate; capsule shorter than the perianth. In swamps, Va. to Fla. July-Sept.

2. Zygadenus élegans Pursh. Glaucous Zygadenus. (I. F. f. 977.) Very glaucous; bulb about $2.5 \mathrm{~cm}$. long. Stem slender, I.5-9 dm. tall; leaves 4-I4 mm. wide, keeled, the lower I-3 dm. long ; bracts green or purplish ; inflorescence sometimes $3 \mathrm{dm}$. long, open, its branches ascending; flowers greenish, r.6$2 \mathrm{~cm}$. broad ; perianth-segments oval or obovate, obtuse, united below and adnate to the base of the ovary ; capsule oblong, exceeding the perianth. In moist places, N. B. to Alaska, Vt., N. Y., Mo., and in the Rocky Mts. to N. Mex. June-Aug.

3. Zygadenus Nuttàlii (A. Gray) S. Wats. NutTall's Zvgadenus. (I. F, f. 978 .) Light green, scarcely glaucous; stem 3-6 dm. high. Leaves 6-16 mm. wide, shorter than the stem, strongly conduplicate; inforescence racemose or paniculate; bracts shorter than the slender pedicels; flowers mostly perfect, about 12 $\mathrm{mm}$. broad; perianth-segments oval or ovate, obtuse, free from the ovary, thin, short-clawed; capsule 8-12 mm. long. On prairies, Kans. and Colo. to Tex. May-June.

4 Zygadenus venenòsus S. Wats. Porsonous Zygadenus. (I. F. f. 979.) Pale green ; stem slender, $1.5-6 \mathrm{dm}$. tâll, from a small coated bulb. Leaves conduplicate, roughish, 4-6 mm. wide, shorter than the stem; inflorescence a raceme. 5-10 cm. long in flower, elongating in fruit, the pedicels longer than the bracts; flowers yellow or yellowish, polygamous, about $8 \mathrm{~mm}$. wide; perianth-segments ovate or elliptic, short-clawed, free from the ovary, bearing a roundish gland with an irregular margin; fruiting pedicels erect; capsule longer than the perianth. S. Dak. and Mont. to Br. Col., Neb., Utah and Cal. May-June.

5. Zygadenus leimanthoìdes (A. Gray) S. Wats. Pine-BARRen ZyGadeNus. (I. F. f. 980.) Stem slender, 3-12 dm. high, from a fibrous-coated bulb. Leaves 4-8 mm. wide, green on both sides, blunt, or the upper acuminate; panicle I-3 dm. long, its branches densely many-flowered, spreading or ascending; bractlets much shorter than the pedicels; flowers mostly perfect, white or greenish, about $8 \mathrm{~mm}$. broad; perianth-segments oblong, obtuse, not clawed, adnate to the base of the ovary, bearing a basal yellowish spot; capsu'e ovoid, much longer than the perianth. In swamps or wet soil, S. L. I. to Ga. July-Aug.

\section{MELÁNTHIUM L.}

Tall leafy herbs, perennual by thick rootstocks, the stem, at least its upper part, pubescent. Leaves oval, oblanceolate or linear. Flowers greenish, white or cream-colored, darker in withering, monœcious or polygamous, in a large terminal panicle. Perianth of 6 separate persistent clawed segments, free from the ovary. Stamens shorter than the segments and adnate to them; anthers cordate or reniform, their sacs confluent. Ovary ovoid; styles 3, subulate. Capsule 3-lobed, 3-celled, the cavities several-seeded. Seeds flat and winged, several in each cavity. [Greek, signifying black flower.] The genus comprises the following species and one in Florida: 
Perianth-segments with 2 glands at the base of the blade.

Blade of the perianth-segments oblong, entire; leaves linear. $\quad$ x. M. Virginicum.

Blade of the perianth-segments nearly orbicular, undulate; leaves oblanceolate.

Perianth-segments oblanceolate, glandless; leaves oval.

2. M. latifolium.

3. $M$. parviflorum.

I. Melanthium Virgínicum L. Bunch-Flower. (I. F. f. 981.) Stems 7-I $5 \mathrm{dm}$. high. Leaves linear, often $3 \mathrm{dm}$. long, 8-25 mm. wide, the lower sheathing, the upper smaller, sessile; panicle 1.5-4.5 dm. long, its branches ascending; pedicels much longer than the bracts; flowers $1.2-2 \mathrm{~cm}$. broad, greenish yellow, turning brown; perianth-segments obtuse, the blade oblong, flat, entire, sometimes obcordate, twice as long as the claw; capsule $\mathbf{I}-\mathbf{I} .5 \mathrm{~cm}$. long, the persistent styles erect; seeds 8-Io in each cavity. In meadows, wet woods and marshes, R. I. to N. Y., Minn., Fla. and Tex. June-Aug.

2. Melanthium latifolium Desr. CRISPed Bunch-Flower. (I. F. f. 982.) Stem 6-12 dm. tall. Leaves oblanceolate, acute, $2.5 \mathrm{~cm}$. wide, the lower clasping; panicle usually $3 \mathrm{dm}$. long or more, its branches ascending or spreading; pedicels 6-16 mm. long; flowers 12-16 mm. broad; greenish white, turning darker; blade of the perianth-segments orbicular or ovate, undulate and crisped, bearing 2 glands at the base; capsule $12-16 \mathrm{~mm}$. long, its cavities 4-8-seeded; flowers fragrant. In dry woods and on hills, Conn. to Penn. and S. Car. July-Aug.

Melanthium latifolium longipedicellatum A. Brown. Lower leaves $\mathrm{I}-2 \mathrm{~cm}$. wide, and upper pedicels $2.5 \mathrm{~cm}$. long. W. Va.

3. Melanthium parviflòrum (Michx.) S. Wats. Small-flowered MelanTHIUм. (I. F. f. 983.) Stem slender, 3-I5 dm. tall. Lower leaves broadly oval or oblanceolate, acute, I-2 dm. long, 4-IO $\mathrm{cm}$. wide, with narrow sheathing bases, the upper narrowly linear-lanceolate; panicle 3-6 dm. long, open, its slender branches divergent or ascending; pedicels filiform, much longer than the bracts, somewhat longer than the perianth-segments; flowers 8-10 $\mathrm{mm}$. broad, greenish ; perianth-segments oblanceolate, glandless, short-clawed or sessile; capsule 10$12 \mathrm{~mm}$. long. In dry woods, mountains of Va. to S. Car. June-Aug.

\section{VERÀTRUM L.}

Tall perennial herbs, with short poisonous rootstocks, the leaves mostly broad, clasping, strongly veined and plaited, the stem and inflorescence pubescent. Flow. ers greenish, yellowish or purple, polygamous or monœcious, on short pedicels in large terminal panicles. Perianth-segments 6, glandless or nearly so, not clawed, adnate to the base of the ovary. Stamens opposite the perianth-segments and free from them, short, mostly curved. Anthers cordate, their sacs confluent. Ovary ovoid; styles 3, persistent. Capsule 3-lobed, 3-celled, the cavities several-seeded. Seeds flat, broadly winged. [Ancient name of the Hellebore.] About 10 species, natives of north temperate zone. Besides the following arother occurs in the southern U. S. and two on the Pacific coast.

Flowers yellowish green; perianth-segments pubescent, ciliate. Flowers purple; perianth-segments glabrous or nearly so.

I. V. viride.

2. $V$. Woodii.

I. Veratrum víride Ait. American White Hellebore. Indian Poke. (I. F. f. 984.) Rootstock erect, 5-8 cm. long, 2-5 cm. thick. Stem stout, 0.6$2.8 \mathrm{~m}$. tall, very leafy; leaves acute, the lower broadly oval or elliptic, 1.5-3 dm. long, 0.7-I.5 dm. wide, short-petioled or sessile, sheathing, the upper successively narrower; panicle 2-6 dm. long, densely many-flowered, its lower branches spreading or drooping; pedicels mostly shorter than the bracts; flowers $1.5^{-2} 5 \mathrm{~cm}$. broad; perianth-segments oblong or oblanceolate, twice as long as the stamens; ovary glabruus; capsule $2-2.5 \mathrm{~cm}$. long. In swamps and wet woods, Quebec to Alaska, Ga., Tenn., Minn. and Br. Col. May-July.

2. Veratrum Woòdii Robbins. Woon's False Hellebore. (I. F. f. 985.) Rootstock short, erect. Stem slender, 0.6-I.5 m. tall; leaves mostly basal, oblong or oblanceolate, 5-10 $\mathrm{cm}$. wide, narrowed into sheathing petioles; upper leaves small and linear-lanceolate; panicle open, 3-6 dm. long, its branches ascending; pedicels shorter than the perianth; flowers $12-16 \mathrm{~mm}$. broad, purple; perianth. secmits otlanceolate, obtuse, entire, little longer than the stamens; ovary pubes. 
cent when young; capsule $12-16 \mathrm{~mm}$. long. In dry woods and on hills, $\mathrm{S}$. Ind. to Mo. June-July.

\section{UVULÀRIA L.}

Erect forked herbs, perennial by rootstocks. Stem leafy above, scale-bearing below, the leaves alternate, sessile or perfoliate. Flowers large, solitary at the ends of the branches or rarely 2 together, peduncled, drooping. Perianth bellshaped or narrower; segments distinct, deciduous, each bearing a nectary at the base. Stamens 6, free, or adnate to the very bases of the perianth-segments; filaments filiform; anthers linear, the sacs longitudinally dehiscent. Ovary 3-lobed, 3-celled, short-stalked or sessile; styles united to about the middle, stigmatic along the inner side above; ovules several in each cavity. Capsule ovoid or obovoid, 3-angled or 3-winged, loculicidally dehiscent. Seeds globose, $1-3$ in each cavity. [Name Latin, from uvula, a palate, in allusion to the hanging flowers.] Five or six species, natives of eastern N. Am.

Capsule obtusely 3 -angled, truncate or rounded; leaves perfoliate.

Glabrous, glaucous ; perianth-segments papillose within.

Leaves pubescent beneath ; perianth-segments smooth.

Capsule acutely 3-angled or 3-winged, acute at each end; leaves sessile.

Leaves thin, slightly rough-nargined, narrowed at both ends. 3. U. sessilifolia.

Leaves firm, manifestly rough-margined, sometimes subcordate. 4. U. puberula.

I. Uvularia perfoliàta L. Perfoliate Bellwort. (I. F. f. 986.) Glabrous and glaucous or pale green. Stems $1.5-5 \mathrm{dm}$. high, slender, usually with I-3 leaves below the fork; leaves oval, oblong or ovate-lanceolate, acute at the apex, rounded or sometimes narrowed at the base, smooth-margined, 5-10 cm. long when mature; flowers $2-2.6 \mathrm{~cm}$. long, pale yellow; perianth-segments granularpapillose within; stamens shorter than the styles or equalling them, the connective sharp-tipped; capsule obovoid, truncate, thicker than long, 8-10 mm. long, obtusely 3 -angled, with concave sides and grooved angles. In moist woods and thickets, Quebec and Ont. to Fla. and Miss. Flowers fragrant. May-June.

2. Uvularia grandifiòra J. E. Smith. LARGE-FLOWERED BELLWORT. (I. F. f. 987.) Stems rather stouter than that of the preceding, naked or with $I$ or 2 leaves below the fork. Leaves perfoliate, oblong, oval or ovate, pubescent beneath, at least when young; flowers lemon-yellow, $2.5-3.4 \mathrm{~cm}$. long; perianth-segments smooth on both sides or slightly granular within; stamens exceeding the styles, the connective blunt; capsule obtusely 3-angled, truncate. In rich woods, Quebec to Minn., Ga., Tenn. and lowa. April-June.

3. Uvularia sessilifòlia L. Sessile-leaved Bellwort. (I. F. f. 988.) Glabrous; stem slender, naked or bearing I or 2 leaves below the fork. Leaves oblong or oblong-lanceolate, $3-8 \mathrm{~cm}$. long when mature, thin, sessile, acute at each end, roughish-margined, pale or glaucous beneath; flowers greenish yellow, I.6$3 \mathrm{~cm}$. long; perianth-segments smooth; styles exceeding stamens; anthers blunt; capsule sharply 3-angled, narrowed at both ends, short-stipitate, about $2.5 \mathrm{~cm}$. long. In moist woods and thickets, N. B. and Ont. to Minn., Ga. and Ark. May-June.

Uvularia sessilifolia nitida (Britton) Morong. Leaves smaller, bright green on both sides; flowers light yellow; capsule scarcely stipitate. I'ine barrens of N. J.

4. Uvularia pubérula Michx. Mountain Bellwort. (I. F. f. 989.) Stem sparingly rough-pubescent with short hairs. Leaves oblong, oval or ovate, roughmargined, firm, sessile, acute at the apex, obtuse, subcordate or sometimes narrowed at the base, shining, green on bo'h sides, the midvein sometimes pubescent; Rowers light yellow, about $2.5 \mathrm{~cm}$. long; styles exceeding the stamens; capsule sharply 3-angled, acute at both ends, sessile or very nearly so on the short pedun. cle. In mountain woods, Va. and W. Va. to S. Car. May-June.

\section{Family 3. LILIÄCEAE Adans.}

Lily Family.

Scapose or leafy-stemmed herbs from bulbs or corms, or rarely with rootstocks or a woody caudex (Yucca), the leaves various. Flowers soli. 
tary or clustered, regular, mostly perfect. Perianth parted into 6 distinct or nearly distinct segments, or these more or less united into a tube inferior or partly superior (Aletris). Stamens 6, hypogynous or borne on the perianth or at the bases of its segments; anthers 2-celled, mostly introrse, sometimes extrorse. Ovary 3-celled; ovules few or numerous in each cavity, anatropous or amphitropous; styles united; stigma 3-lobed or capitate. Fruit a loculicidal capsule (septicidal in Calochortus), or in Yucca sometimes fleshy and indehiscent. Seeds various, winged or wingless. Embryo in copious endosperm. About 125 genera and I 300 species, widely distributed.

* Plants bulbous, or with rootstocks, or fibrous-fleshy roots.

Ovary superior, not adnate to the perianth.

Roots fibrous-fleshy; scape tall : flowers orange or yellow.

Low fleshy herb with a short rootstock; flowers white.

r. Hemerocallis.

Plants with bulbs or corrs.s.

Flowers umbelled.

Perianth 6-parted.

Odor characteristically onion-like ; ovules $\mathbf{I}$ or 2 in each cavity.

3. Allium.

Odor not onion-like; ovules several in each cavity. 4. Nothoscordum.

Perianth funnelform, the tube about as long as the lobes. 5. Andrestephium.

Flowers solitary, racemed, corymbed or panicled.

Anthers not introrse.

Perianth-segments all alike or nearly so; capsule loculicidal.

Anthers versatile; tall herbs.

Anthers not versatile; low herbs.

Stem leafy; flowers leafy-bracted.
Leaves only 2, appearing basal ; flowers bractless.

6. Lilium.

8. Erythronium.

Outer segments narrower than the inner; capsule septicidal.

Anthers introrse.

9. Calochortus.

Perianth of 6 separate segments.

Filaments filiform.

Filaments flattened.

Perianth globose, oblong or urn-shaped.

Ovary half inferior; roots fibrous; flowers racemed.

** Stem a woody caudex; leaves rigid, mostly bearing marginal fibres.

10. Quamasia.

11. Ornithogalum.

12. Muscari.

13. Aletris.

14. Yucca.

\section{HEMEROCÁLLIS L.}

Tall glabrous herbs, with fibrous fleshy roots, basal linear leaves and large oowers clustered at the ends of leafless scapes. Perianth funnelform, its lobes ob. long or spatulate, much longer than the cylindric tube. Stamens 6, inserted at the summit of the perianth-tube, shorter than the lobes, declined; filaments filiform ; anthers linear-oblong, the sacs introrsely dehiscent. Ovary oblong, 3-celled; ovules numerous in each cavity; style slender, declined, tipped with a small capitate stigma. Capsule oblong or ovoid, thick-walled, 3-angled, transversely wrinkled, loculicidally 3-valved. [Greek, signifying beautiful for a day.] About 5 species, natives of Europe and Asia.

1. Hemerocallis fúlva L. DAy Lily. (I. F. f. 990.) Scapes 9-18 dm. high, mostly longer than the leaves. Leaves $8-2 \mathrm{~mm}$. wide, channeled; flowers 6-15, short-pedicelled, tawny orange, 1-1.2 dm. long, opening for a day; tube of the perianth $2.5-4 \mathrm{~cm}$. long, the lobes oblong, netted-veined. In meadows and along streams, N. B. and Ont. to Va. and Tenn. Escaped from cultivation. Native of Europe and Asia. June-Aug.

Hemerocallis flava L., the Yellow Day Lily, with bright yellow flowers, their lobes parallel-veined, is occasionally found near old gardens.

\section{LEUCÓCRINUM Nutt.}

A low acaulescent herb, from a short rootstock, the roots thick, fibrous. Outer leaves membranous, acute, short; - inner leaves linear, elongated, tne innermost reduced to bracts. Flowers large, white, umbellate from the subterranean axiss. 
Pedicels Eliform. Perianth with a very narrow tube and a salverform limb, persistent, the 6 linear-oblong lobes spreading, nerved, shorter than the tube. Stamens borne near the top of the perianth-tube, shorter than the lobes; filaments filiform; anthers linear, their sacs introrsely dehiscent. Ovary ovoid, 3-celled: style filiform; stigma small. Capsule oval or obovoid, 3-angled, sessile, obtuse. loculicidal. Seeds several in each cavity, angled. [Greek, meaning white lily.] A monotypic genus of northwestern N. Am.

I. Leucocrinum montànum Nutt. Leucocrinum. (I. F. f. 991.) Inner leaves 5-25 cm. long, 2-6 mm. wide; lowers 3-8; perianth-limb about $1.2 \mathrm{~cm}$. broad, the lobes acute; perianth-tube $2-5 \mathrm{~cm}$. long, less than $2 \mathrm{~mm}$. in diameter; anthers coiled, at least when dry; capsule 6-8 mm. long, erect, leathery. In sandy soil, S. Dak. and western Net. to ᄂ... Apr?

\section{. Állium l (See Appendix.)}

Bulbous herbs, characteristic "y dorous ailiaceous), the bulbs solitary, or clustered on short rootstocks. Leaves narrowly linear, or rarely lanceolate or oblong, sheathing, basal, or sometimes also on the stem. Stem (usually a scape) simple, erect. Flowers white, purp'e, pink or green, in a terminal simple umbel, subtended by 2 or 3 membranous separate or united bracts. Pedicels slender, not jointed. Perianth persistent, the 6 segments separate, or united by their very bases. Stamens inserted on the bases f the perianth-segments; filiments filiform or dilated, sometimes toothed; anther-sacs introrsely dehiscent. Ovary sessile or nearly so, completely or incompletely 3-celled; style fi:corm, jointed, usually deciduous; stigmas small; ovules $\mathbf{I}-6$ in each cavity. Capsule loculicidal. [Latin for garlic.] About 275 species of wide distribution. Besides the following, some 40 others occur in the western U. S.

Leaves oblong-lanceolate, absent at flowering time.

Leaves linear, present at flowering time.

Bulb-coats membranous, not fibrous-reticulated.

Umbel capitate; pedicels shorter than the flowers.

Umbel loose; pedicels much longer than the flowers.

Flowering umbel nodding.

Perianth campanulate, white or pink; outer segments acute.

3. A. cernuum.

Perianth urn-shaped, purple; outer segments obtuse or notched.

Flowering umbel erect.

4. A. Allegheniense.

Leaves flat or channeled, all nearly basal.

Leaves terete, hollow, several on the stem; flowers often replaced by bulblets.

r. A. tricoccum.

2. A. Sibiricum.

brous-reticulated.

Bulb-coats fibrous-reticulat
Capsule not crested.

Flowers mostly replaced by bulblets; scape $3-6 \mathrm{dm}$. tall. 7. A. Canadense.

Flowers rarely replaced by bulblets.

Scape 3-6 dm. tall; pedicels $16-24 \mathrm{~mm}$. long ; perianth segments thin.

8. A. mutabile.

Scape $\mathrm{I}-2 \mathrm{dm}$. tall; pedicels $8-\mathrm{r} 2 \mathrm{~mm}$. long; perianth-segments rigid in fruit.

Capsule-valves with 2 short crests.

9. A. Nuttallii.

Io. A. reticulatum.

I. Allìm tricóccum Ait. Wild LEek. (I. F. f. 992.) Bulbs ovoid, clustered, their coats fibrous-reticulated. Leaves oblong-lanceolate or elliptic, appearing early in the spring, but withering before flowering time, $1.5-3 \mathrm{dm}$. long, $2-5 \mathrm{~cm}$. wide, tapering into a long petiole; scape $\mathrm{I}-4 \mathrm{dm}$. tall; bracts of the umbel usually 2, membranous, acuminate, deciduous; umbel many-flowered, erect; pedicels I-2 cm. iong; flowers white; perianth-segments obtuse, 4-6 mm. long; ovule $\mathbf{I}$ in each cavity of the ovary; capsule deeply 3-lobed, about $6 \mathrm{~mm}$. broad; seeds globose, black, smooth. In rich woods, N. B. to Minn., N. Car. and Tenn. June-July.

2. Allium Sibíricum L. (I. F. f. 993.) Bulbs narroily ovoid, their coats not fibrous-reticulated. Scape 3-7 dm. high, beạring I or 2 elongated terete hollow Leaves: basal leaf I; bracts of the umbel 2, ovate; umbel many-flowered, capitate, 
the pedicels 2-6 mm. long: \{lowers rose-color, longer than the pedicels; perianth narrowly campanulate, its segments $\delta-12 \mathrm{~mm}$. long, lanceolate, acuminate; stamens much shorter than the perianth; ovules 2 in each cavity; capsule obtusely 3 -lobed. In moist soil, N. B. to Alaska, Me., N. N. Y.. Mich., Wyo. and Wash. Also in Europe and Asia. June-July. (A. Schoenoprasum Ill. Fl., not L.)

A. Schoenóprasum, the Chives of the gardens, a snialler plant, with several narrow basal leaves and openly campanulate perianth, occasionally escapes from cultivation.

3. Allium cérnuum Roth. NodDing Wild Onion. (I. F. f. 994.) Bulbs narrowly ovoid, with a long neck. Scape slightly ridged, 3-6 dm. high; leaves 2-4 mm. wide; umbel many-flowered, nodding in flower; pedicels filiform, I.5-3 $\mathrm{dm}$. long; flowers white, rose or purple; perianth-segments ovate-oblong, 4-6 mm. long; stamens longer than the perianth; ovules 2 in each cavity; capsule 3 -lobed, rather shorter than the perianth, each valve bearing 2 short processes near the summit. On banks and hillsides, N. Y. to Minn. and Br. Col., W. Va., Ky., S. Dak., and in the Rocky Mts. to N. Mex. Variable. July-Aug.

4. Allium Allegheniénse Small. Allegheny Onion. Bulbs ovoid. Leaves few, with narrowly linear blades 2-3 dm. long; scapes 3-5 dm. tall, 2-edged at least at maturity; umbel nodding, 12-40-flowered; pedicels $15-26 \mathrm{~mm}$. long, filiform, becoming thicker in age; perianth purple, mostly urn-shaped, $4-5 \mathrm{~mm}$. high, the segments oval, the outer obtuse or notched, shorter than the inner; capsule 4-5 mm. high, with 2 large processes on each valve. On cliffs or in rocky soil, Va. to N. Car., Tenn. and Ga. Summer and fall.

5. Allium stellàtum Ker. Prairie Wild ONion. (I. F. f. 995.) Bulbs narrowly ovoid, $2-5 \mathrm{~cm}$. long. Scape slender, 2-4.5 dm. tall; leaves r.5-2.5 mm. wide, nearly flat; umbel erect, subtended by 2 lanceolate or ovate bracts; pedicels filiform, I-2 cm. long; flowers rose-color; perianth-segments ovate-oblong, acute, 4-6 mm. long; filaments slightly widened at the base; capsule shorter than the perianth, 3-lobed, about 6-seeded, each valve bearing 2 erect processes below the apex. On rocky banks, Ill. and Minn. to Mo. and Kans. July-Aug.

6. Allium vineàle L. Wild Garlic. Field Garlic. Crow Garlic. (I. F. f. 996.) Bulb ovoid, $2.5 \mathrm{~cm}$. high or less. Stem 3-9 dm. tall, bearing 2-4 terete hollow leaves below the middle at flowering time, the early basal leaves similar; bracts 2 , lanceolate, deciduous; umbel erect, the flowers often wholly or in part replaced by small bulblets which are tipped with a long capillary appendage; pedicels 6-25 mm. long, filiform; flowers green or purple, about $4 \mathrm{~mm}$. long; filaments flattened, broad, the 3 interior ones bearing a tooth on each side just below the anther; capsule 3-lobed. In fields and meadows, Conn. to Ohio, Mo. and Va. Naturalized from Europe, Junc-July.

7. Allium Canadánse L. MEADOW GaRLIC. (I. F. f. 997.) Bulb ovoid, the outer coats fibrous-reticulated. Scape terete, 2-6 dm. tall; leaves basal or nearly so, narrowly linear, slightly convex beneath, $2-3 \mathrm{~mm}$. wide; bracts white, ovate, acuminate; flowers often replaced by ovoid bulblets; flowers pink or white, the perianth-segments oblong-lanceolate, acute. In meadows and thickets, Me. to Minn., Fla., La. and Ark. May-June.

8. Allium mutábile Michx. Wild Onion. (I. F. f. 998.) Bulbs ovoid, their coats prominently fibrous-reticulated. Scape terete, $3-6 \mathrm{dm}$. tall; leaves basal, channeled, 2-4 mm. wide; bracts long-acuminate; umbel rarely bulblet-bearing; pedicels 16-24 mm. long; flowers pink, rose or white, 5-8 $\mathrm{mm}$. long; perianthsegments thin, longer than the stamens; capsule rather shorter than the perianth. In moist soil, N. Car. to Ncb., Fla. and Tex. April-June.

9. Allium Nuttàllii S. Wats. Nuttall's Wild OnIon. (I. F. f. 999.) Bulbs ovoid, their coats fibrous-reticulated. Culm slender, $\mathrm{r}-2 \mathrm{dm}$. tall; leaves basal, I-2 mm. wide; bracts 3 or 2 , acute or acuminate; pedicels slender, 8-I $2 \mathrm{~mm}$. long; flowers rose or white, about $6 \mathrm{~mm}$. long; perianth-segments acute or acuminate, becoming rigid in fruit: capsule shorter than the perianth. On prairies, Neb. and Col. to Tex. and Ariz. April-June.

ro. Allium reticulàtum Don. Fraser's Wild Onion. (I. F. f. IOoc.) Similar to the preceding, the bulb rather larger. Scape slender; leaves usually less than $2 \mathrm{~mm}$. wide; bracts mostly 2, acuminate; pedicels slender, 6-12 mm. 
long; flowers white or pink, 5-6 mm. long; perianth-segments thin; capsule shorter than the perianth, each of its valves learing 2 short crests just below the summit. Assiniboia and S. Dak. to N. Mex. and Ariz. May-July.

\section{NOTHOSCÓRDUM Kunth.}

Scapose herbs, similar to the onions, but without alliaceous odor, with mem. branous-coated bulbs, narrowly linear basal leaves and small yellow or yellowish green flowers in an erect 2 -bracted umbel. Perianth 6-parted, withering-persistent, its segments $\mathbf{I}$-nerved. Stamens 6 , inserted on the bases of the perianth-segments; anther-sacs introrsely dehiscent. Ovary sessile, 3-celled; ovules several in each cavity; style filiform, jointed near the base, but commonly persistent; stigma small, capitate. Capsule 3-lobed, loculicidal. Seeds angled or flattish, black. [Greek, signifying false garlic.] About 10 species, the following in the southern U.S. and Mex., 8 or 9 in tropical and S. Am., 1 Chinese.

I. Nothoscordum biválve (L.) Britton. Yellow False Garlic. (I. F. f. roor.) Bulb globose. Leaves I-5 $\mathrm{mm}$. wide, flat; bracts lanceolate, acuminate, persistent; umbel 6-12-flowered; pedicels filiform, 2-5 cm. long in fruit; flowers IO-I $2 \mathrm{~mm}$. long; perianth-segments thin, oblong-lanceolate, longer than the stamens; capsule obovoid or somewhat depressed, 4-6 mm. high, the style as long or slightly longer. In sandy soil, Va. to Tenn. and Neb., Fla., Tex. and Mex. March-July.

\section{ANDROSTÈPHIUM Torr.}

Scapose herbs from a small membranous-coated corm. Leaves basal, narrowly linear. Flowers rather large, blue, in a terminal several-bracted umbel. Perianth funnelform, withering-persistent, the tube about as long as the 6 oblong lobes. Stamens 6, inserted on the throat of the perianth; filaments dilated, united to the middle or above into an erect crown-like tube with toothed lobes alternating with the linear-oblong anthers. Ovary sessile, 3-celled; ovules several in each cavity; style filiform; stigma 3-grooved. Capsule membranous, 3-angled, loculicidal. Seeds few, large, oval, black. [Greek, referring to the crown.] Two species, natives of the southwestern U. S.

I. Androstephium coerùleum (Scheele) Greene. Androstephium. (I. F. f. 1002.) Corm subglobose. Scape $0.5^{-2} \mathrm{dm}$. tall; leaves $2-4 \mathrm{~mm}$. wide, half terete; bracts 2-4, scarious, acuminate, persistent; umbel 2-7-flowered; pedicels $0.6-3 \mathrm{~cm}$. long; perianth $2-3 \mathrm{~cm}$. long, the lobes about as long as the tube; filament-tube about $1 \mathrm{~cm}$. long; style about as long; capsule $8-12 \mathrm{~mm}$. high; seeds thin, narrowly winged. Prairies, Kans. to Tex. March-April.

\section{LÍLIUM L.}

Tall bulbous herbs, with simple leafy stems, and large erect or drooping showy flowers. Perianth funnelform or campanulate, deciduous, of 6 separate spreading or recurved segments, each with a nectar-bearing groove at its base within. Stamens 6, hypogynous; filaments filiform or subulate; anthers linear, versatile, their sacs longitudinally dehiscent. Ovary 3-celled; ovules numerous; style long, somewhat club-shaped above; stigma 3-lobed. Capsule loculicidally dehiscent. Seeds numerous, flat, horizontal, packed in 2 rows in each cavity. [Latin, from the Greek name of the Lily, said to be from the Celtic li, white.] Ahout 45 species, natives of the north temperate zone. Besides the following, some 8 others occur in western N. Am.

Flower or flowers erect; perianth-segments narrowed into long claws.

Perianth-segments merely acute.

Leaves lanceolate, nearly all verticillate.

Leaves narrowly linear, nearly all alternate.

I. I.. Philadelphicum.

2. L. umbellatum.

Perianth-segments long-acuminate; leaves all alternate, appressed.

Flowers drooping or spreading; perianth-segments not clawed.

3. L. Catesbaei.

- Leaves or most of them verticillate, their axils not bulbiferous : native species. Leaves finely roughened on the veins beneath.

Perianth-segments recurved or spreading. 4. L. Canadense.

Perianth-segments not recurved; mountain species. 5. L. Grayi. 
Leaves perfectly smooth; perianth-segments recurved.

Leaves lanceolate; stem $0.9-3.2 \mathrm{~m}$. tall ; flowers $1-40$.

Leaves oblanceolate; stem 6-9 dm. tall ; flowers $1-3$.

6. L. superbum.

7. L. Carolinianum.

Leaves all alternate, crowded, the upper axils bulb-bearing; escaped from gardens.

8. L. tigrinum.

I. Lilium Philadélphicum L. Ren Lily. Wood Lily. Philadelphia Lily. (I. F. f. IOO3.) Bulb composed of jointed fleshy scales. Stem 3-9 dm. tall, leafy above; leaves acute at both ends or the lower sometimes obtuse, 2-10 $\mathrm{cm}$. long, 6-14 mm. wide; thin, the margins finely roughened; flowers $1-5$, erect, 6-10 cm. high; perianth reddish orange, its segments spatulate, somewhat spreading, purple spotted below; capsule obovoid-oval, 4-5 cm. high. In dry woods and thickets, Me. to Ont., N. Car. and W. Va. June-July.

2. Lilium umbellàtum Pursh. Western Red Lily. (I. F. f. I004.) Similar to the preceding species; stem usually more slender. Leaves linear, blunt, or the upper acute, ascending, or sometimes appressed, 2-8 cm. long, 2-5 mm. wide, all alternate or the uppermost verticillate; flowers I-3, erect, 5-8 cm. high; peri. ianth-segments red, orange or yellow, spotted below, the claw shorter than the blade; capsule oblong, 7-10 $\mathrm{cm}$. long. In dry soil, Ohio to Minn. and the N. W. Terr., Mo., Ark. and Colo. June-July.

3. Lilium Catesbaèi Walt. Southern Red Lily. (I. F. f. IO05.) Bulb composed of leaf-bearing scales, their leaves linear, $5^{-10} \mathrm{~cm}$. long, often falling away before the plant flowers. Stem leaves alternate, acute or acuminate, erect oappressed, 2-8 cm. long, 2-6 mm. wide; flower erect; perianth-segment scarlet with a yellow purple-spotted base and a slender claw, spreading or somewhat re. curved, 7-13 cm. long, long-asuminate, wavy-margined; capsule $2.5 \mathrm{~cm}$. high. In pine barrens, N. Car. to Fla. and Ala. Reported from Ky. and Mo. July-Aug.

4. Lilium Canadénse L. Wild Yellow Iily. Canada Lily. (I. F. f. 1006.) Bulbs subglobose, composed of numerous thick white scales. Stem 6-15 dm. tall; leaves lanceolate, verticillate in 4's-Io's or some of them alternate, acuminate, 5-I5 cm. long, roughened on the margins and on the veins beneath; flowers I-16, nodding on long peduncles; perianth-segments 5-8 cm. long, yellow or red, spotted below, recurved or spreading; capsule erect. In swamps, meadows and fields, N. S. to Ont., Minn., Ga. and Mo. Red-flowered fórms with slightly spreading perianth-segments resemble the following species, and forms with strongly recurved segments, L. superbum. June-July.

5. Lilium Gràyi S. Wats. Asa Gray's LiLY. (I. F. f. I007.) Rootstock bearing small bulbs with thick scales. Stem slender, 6-9 dm. high; leaves oblonglanceolate, acute or acuminate, narrowed at the lase, 5-1o cm. long, verticillate in 3 's-8's or the lowest commonly smaller and scattered, all roughened on the veins beneath; flowers I-3, long-peduncled, spreading or slightly drooping, 5-8 cm. long, red or tinged with yellow at the base; perianth-segments oblong-spatulate, not clawed. acute, spotted; capsule fig-shaped. Peaks of Otter, Va., and on the higher mountain summits in N. Car. July-Aug.

6. Li ium supérbum L. TURK's-Cap Lily. (I. F. f. IOO8.) Bulbs globose on short rootstocks, their scales white, ovate. Stem $0.9-2.5 \mathrm{~m}$. high; leaves lanceolate or linear-lanceolate, smooth, acuminate at both ends, 5-15 cm. long, verticillate in 3's-8's or the upper alternate; flowers orange, orange-yellow or rarely red, 3-4o, nodding, long-peduncled, forming, when numerous, a large panicle; perianth-segments 6-Io cm. long, lanceolate, acuminate, purple-spotted, at length usually strongly recurved from below the middle; capsule obovoid. In meadows and marshes, Me. to Ont., Minn., N. Car. and Tenn. July-Aug.

7. Lilium Caroliniānum Michx. Carolina Lily. (I. F. f. IOog.) Bulbs horne on short rootstocks, globose, composed of fleshy scales. Stem 6-9 dm. high; leaves oblanceolate or obovate, smooth, verticillate, or the upper and lower alternate, narrowed at the base, the veinlets prominently anastomosing; flowers I-3, orange-red, 7-10 cm. long, long-peduncled, nodding; perianth-segments lanceolate, acuminate, purple-spotted below, strongly arched backward with their tips sometimes connivent. In dry woods, Va. to Fla. and La. Aug.

8. Lilium tigrinum Andr. Tiger Lily. (I. F. f. IOIO.) Bulb globose, 
composed of numerous scales. Stem stout, purple, or nearly black, white-pubes. cent above, $6-\mathbf{r} 5 \mathrm{dm}$. tall; leaves lanceolate, all alternate, $\mathbf{I}-\mathbf{I} .5 \mathrm{dm}$. $\operatorname{long}, \mathbf{I}-2 \mathrm{~cm}$. wide, the upper bearing blackish bulblets in their axils; flowers 525 , orange-red, nodding, 7-II cm. long; perianth-segments lanceolate, papillose, recurved, purplespotted. Escaped from gardens, Me. and Mass. Native of China and Japan. Summer.

\section{FRITILLÀria L.}

Bulbous herbs with simple stems, and nodding, leafy-bracted flowers. Perianth mostly campanulate, deciduous, of 6 separate and nearly equal segments, each with a nectar-pit or spot at the base. Stamens 6, liypogynous; anthers linear or oblong. Ovary nearly or quite sessile, 3-celled; ovules numerous in each cavity; style slender or filiform, 3-lobed or 3-cleft ; capsule obovoid or globose, 6-angled, loculicidally dehiscent. Seeds numerous, flat, margined or winged. [Latin, from fritillus, a dice-box or chess-board, in allusion to the form or to the checkered markings of the perianth in some species.] About 50 species, natives of the north temperate zone. Besides the following, about 12 others occur in western N. Am.

I. Fritillaria atropurpùrea Nutt. PURPle Fritillaria. (I. F. f. Iori.) Stem I.5-4 dm. high, slender, leafless below; leaves linear, alternate, sessile, 3-10 cm. long; flowers I-6, purple or purplish green and mottled; perianth-segments narrowly oblong, obtusish, 1.2-2 cm. long; stamens shorter than the perianth; style 3-cleft; capsule erect, acutely angled, ro-12 mm. high. N. Dak. to Neb., Wyo. and Cal. June-July.

\section{ERYTHRÒNIUM L.}

Low herbs, from deep membranous-coated corms, sometimes propagated by offshoots, the stem simple, bearing a pair of unequal leaves, usually below the middle, the leaves thus appearing basal. Flowers large, nodding, bractless, solitary, or several in some western species. Perianth-segments separate, lanceolate, oblong or oblanceolate, deciduous, with nectariferous groove, and sometimes 2 short processes at the base. Stamens 6, hypogynous, shorter than the perianth; anthers not versatile. Ovary sessile, 3-celled; style 3-lobed or 3-cleft. Capsule obovoid or oblong, somewhat 3-angled, loculicidal. [Greek, in allusion to the red flowers of some species.] About 12 species, all but one North American. The species are erroneously called Dog's-tooth Violet.

Stem with no offshoot; flowers $2-5 \mathrm{~cm}$. long.

Offshoots produced at the base of the corm; perianth-segments recurved.

Flowers yellow; stigmas very short.

Flowers white, blue or purple; stigmas 2-3 mm. long, recurved.

No offshoots, propagating by basal corms; perianth-segments not recurved.
2. E. albidum.

3. E. mesochoreum.

Stem with a fleshy offshoot below the leaves; flowers rose, about $1.2 \mathrm{~cm}$. long.

4. E. propullans.

r. Erythronium Americànum Ker. Yellow Adder's-tongue. (I. F. f. Ior2.) Corm ovoid, $1-2 \mathrm{~cm}$. high, producing offshoots from its base. Stem I.5-3 dm. lung; leaves oblong or oblong-lanceolate, $7-20 \mathrm{~cm}$. long, flat, usually mottled with brown, narrowed into clasping petioles; peduncle about as long as the leaves; flower yellow, or rarely purplish tinged; perianth-segments oblong, $2-5 \mathrm{~cm}$. long, recurved, dotted within, the 3 inner auricled at the base; style club-shaped; capsule obovoid; seeds curved, pointed at both ends. In moist woods and thickets, N. S. to Ont., Minn., Fla., Mo. and Ark. March-May.

2. Erythronium álbidum Nutt. White AdDer's-tongue. (I. F. f. Ior3.) Similar to the preceding, the leaves sometimes rather narrower. Flower white, blue or purple; perianth-segments oblong, recurved, none of them auricled at the base; style somewhat thickened upward; stigmas linear, finally recurving, $2-3 \mathrm{~mm}$. long; capsule obovoid or oblong. In moist woods and thickets, Ont. to Minn., Ga., Tenn. and Tex. March-May.

3. E:ythronium mesochòreum Knerr. Minland Adder's-Tongue. (I. F. f. I0r4.) Corm ovoid, not developing offshoots; new corms formed at or within the 
base of the old one. Leaves narrowly oblong, not mottled, I-2.5 cm. long, some. what folded; flower lavender tinted, 2-5 cm. long; perianth-segments not recurved; style slender; stigmas recurved; capsule obovoid, I-3 cm. high. On prairies, Iow a to Mo., Neb. and Kans.

4. Erythronium propúllans A. Gray. Minnesota Adder's-Tongue. (I. F. f. IOI 5.) Corm ovoid, not developing offshoots. Stem I.5-2 dm. long, bearing a fleshy curved offshoot $2-5 \mathrm{~cm}$. long from a slit near the base of the petiolesheath; leaves oblong, acute, $0.5^{-1} \mathrm{dm}$. long, slightly mottled or green; flower rose or pink, about $1.2 \mathrm{~cm}$. long, on a filiform peduncle shorter than the leaves; perianth-segments with a yellow base, apparently not recurved, none of them auricled; stigmas mere ridges. In rich woods, Minn. Also in S. Ont. (according to Macoun) and reported from New York. May.

\section{CALOCHÓRTús Pursh.}

Herbs, with coated corms, linear leaves and large peduncled flowers. Perianthsegments spreading or connivent, yellow, blue, purple, white or variegated; the 3 outer sepal-like, narrow; the 3 inner petaloid, gland-bearing, and barbed or spotted within. Stamens 6, hypogynous; anthers linear or oblong. Ovary 3-celled; ovules numerous; style very short or none; stigmas 3, recurved. Capsule 3-angled, mostly septicidal, the valves sometimes 2-clcft. Seeds flat. [Greek, signifying beautiful herb.] About 35 species, natives of western N. Am. and Mex.

Anthers obtuse; gland of inner perianth-segments orbicular or oval. Anthers acute; gland transverse, curved or reniform.

r. C: Nutfallii.

2. C. Gunnisini.

I. Calochortus Nuttàllii T. \& G. Nuttall's Mariposa Lily. (I. F. f. Ior6.) Corm I-2 cm. high. Stem few-leaved, 0.7-4 dm. tall; leaves $2-8 \mathrm{~cm}$. long, 2-5 mm. wide, the lowest commonly bearing a bulb in its axil; outer perianthsegments lanceolate or ovate-lanceolate, acute or acuminate, shorter than the inner; inner perianth-segments obovate-cuneate, $\mathbf{I}-2.5 \mathrm{~cm}$. wide, white, lilac or yellowish, with a yellow base and a purple or purplish spot, the gland orbicular or oval; filaments 6-8 mm. long; about equalling the oblong sagittate anthers; capsule $6-8 \mathrm{~mm}$. thick, acuminate. S. Dak. to Neb, and Cal. June-July.

2. Calochortus Gunnisòni S. Wats. Gunnison's Mariposa Lily. (I. F. f. 1017.) Stem 1.5-4 dm. high. Leaves usually less than $2 \mathrm{~mm}$. wide, involute, at least when dry; outer perianth-segments lanceolate or oblong-lanceolate, scariousmargined, acuminate; inner perianth-segments similar to those of the preceding, lilac, yellowish below the midclle, purple-lined and banded, the gland transverse, oblong, curved or reniform, pubescent; anthers acute: capsule narrowly oblong, narrowed at both ends. S. Dak. and Neb. to Ariz. and N. Mex. June-July.

\section{ro. QUAMÀsia Raf. [CAMASSIA Lindl.]}

Scapose herbs, with membranous-coated edible bulbs, linear basal leaves, and rather large, blue, purple or white bracted flowers in a terminal raceme. Perianth of 6 separate equal persistent 3-7-nerved segments. Pedicels jointed at the base of the flower. Stamens inserted at the bases of the perianth-segments; filaments filiform; anthers oblong or linear-oblong, versatile, introrse. Ovary 3-celled, sessile; ovules numerous in each cavity; style filiform, its base persistent; stigma 3-lobed. Capsule oval, 3-angled, loculicidal. Sceds black, shining. [From quamash, the Indian name.] About 4 species, natives of N. Am.

I. Quamasia hyacínthina (Raf.) Britton. Wild Hyacinth. (I. F. f. 1018.) Bulb ovoid, its outer coat usually nearly black. Scape slender, 3-6 dm. tall; basal leaves acuminate, shorter than the scape, 3-8 $\mathrm{mm}$. wide; raceme open; flowers several or many; pedicels filiform, about as long as the bracts and the perianth; bracts long-acuminate; perianth-segments narrowly oblong, 3-5-nerved, blue or nearly white, longer than the stamens; capsule about $8 \mathrm{~mm}$. high, the valves transversely veined. In meadows and along streams, Penn. to Minn., Ala. and Tex. April-May.

\section{ORNITHÓGALUM L.}

Scapcse herbs, with coated bulbs, narrow basal fleshy leaves, and large white or yellow flowers in a terminal bracted corymb or raceme. Perianth-segments 
equal or nearly so, separate, white, or sometimes green without, persistent. Stamens hypogynous; filaments flattened, often broad; anthers versatile, introrse. Ovary 3-celled, sessile; ovules several or numerous in each cavity; stigma capitate, 3-lobed or 3-ridged. Capsule subglobose, 3-sided or 3-lobed, loculicidal. Seeds black. [Greek, signifying bird's milk, said to be in allusion to the egg-white color of the flowers in some species.] About 75 species, natives of Europe, Asia and Africa.

Flowers corymbose, erect; pedicels long, slender.

Flowers racemose, drooping; pedicels very short, stout.

r. O. umbellatum.

2. O. nutans.

I. Ornithogalum umbellàtum L. Star-of-Bethlehem. (I. F. f. IoIg.) Tufted; bulbs ovoid. Scape slender, I-3 dm. high; leaves 2-5 mm. wide, dark green with a light midvein, blunt; flowers corymbose, opening in sunshine; bracts linear-lanceolate, mostly shorter than the pedicels; pedicels erect or ascending; perianth-segments oblong-lanceolate, acute, white above, green with white margins beneath, I-2 cm. long, about twice as long as the stamens; filaments not toothed. In fields and meadows, N. H. to Penn. and Va. Naturalized from Europe. MayJune.

2. Ornithogalum nùtans L. Drooping Star-of-Bethlehem. (I. F. f. 1020.) Bulb ovoid, 2-5 cm. long. Scape stout, 3-6 dm. high; leaves blunt, 4-8 $\mathrm{mm}$. wide; flowers racemose, nodding; raceme loose; pedicels stout, 4-12 $\mathrm{mm}$. long; bracts lanceolate, long-acuminate, much longer than the pedicels; perianthsegments oblong-lanceolate, about $2.5 \mathrm{~cm}$. long, nearly twice as long as the stamens; filaments 2-toothed at the apex. Escaped from gardens, Penn. to D. C. Native of Europe. April-May.

\section{MUSĊ̀̃RI Mill.}

Low bulbous scapose herbs, with basal linear fleshy leaves, and nodding bracted racemose flowers, deep blue (rarely white) in the following species. Perianth globose, urn-shaped, or oblong, with 6 teeth or short lobes. Stamens 6 , inserted on the perianth-tube, included; anthers ovate, versatile, introrse. Ovary 3-celled, sessile; ovules 2 in each cavity; style short; stigma 3-lobed. Capsule 3-sided or 3-winged, loculicidal. Seeds black, angled. [From the musk-like odor of the flowers of some species.] About 40 species, natives of Europe, Asia and Africa.

Perianth globose, 2-3 mm. in diameter; leaves erect.

Perianth oblong, urn-shaped, 4-6 mm. long; leaves recurved.
I. $M$. botryoides.

2. M. racemosum.

I. Muscari botryoìdes (L.) Mill. Grape-Hyacinth. (I. F. f. IO2I.) Scape $\mathbf{I}-2.5 \mathrm{dm}$. high; leaves about as long as the scape, $2-8 \mathrm{~mm}$. wide, channelled; raceme oblong-cylindric, 2-3 cm. long, dense, or becoming longer and looser in fruit; pedicels shorter than the faintly odorous flowers; valves of the cap. sule obovate. In meadows and thickets and along roadsides, escaped from gardens, N. H. to Ohio and Va. Naturalized or adventive from southern Europe. Native also of Asia. April-June.

2. Muscari racemòsum (L.) Mill. Starch Grape-Hyacinth. (I. F. f. I022.) Leaves $2-4 \mathrm{~mm}$. wide, recurved or spreading, channelled above; raceme oblong or ovoid, many-flowered, dense; pedicels shorter than the starchy-scented flowers or sometimes equalling them, slender; perianth constricted at the throat, with 6 deltoid recurved white teeth; capsule-valves suborbicular, retuse. Escaped from gardens S. N. Y. to Penn. and Md. Native of southern Europe. AprilMay.

\section{3. ÁLETRIS L.}

Scapose perennial bitter fibrous-rooted herbs, with basal lanceolate leaves, and small, white or yellow, bracted perfect flowers in a terminal spike-like raceme. Perianth oblong or campanulate, roughened without, 6-lobed, its lower part adnate to the ovary. Stamens 6, inserted on the perianth at the bases of the lobes, included; anthers introrse. Ovary 3-celled; ovules numerous, anatropous; style 3-cleft above; stigmas minutely 2 -lobed. Capsule ovoid, enclosed by the persistent perianth, 3-celled, many-seeded, loculicidal. Seeds oblong, ribbed. Embryo small. Endosperm fleshy. [Greek, signifying to grind corn, apparently in allu. 
sion to the rough, mealy flowers.] About 8 species, natives of eastern N. Am. and Asia.

Perianth white, oblong or cylindi...

Perianth yellow, bell-shaped or ovoid-globose.

1. A. farinosa.

2. A. aurea.

I. Aletris farinòsa L. Star-grass. Colic-Root. (1. F. f. IO23.) Roots tough; scape 4-9 dn. tall, slender, terete, striate. Basal leaves lanceolate or linearlanceolate, acuminate at the apex, narrowed to the base, spreading, pale, yellowish green, 5-I5 cm. long, 6-20 min. wide; raceme I-3 dm. long in flower, or longer in fruit, dense, erect; pedicels $2 \mathrm{~mm}$. long or less; bracts subulate; perianth white, or the oblong lobes yellowish, 6-8 mm. long; style subulate, capsule ovoid, about $4 \mathrm{~mm}$. long, loculicidal above. In dry, mostly sandy soil, Me. to Out., Minn., Fla. and Tenn. May-July.

2. Aletris àrea Wait. Yeliow Colic-Root. (I. F. f. IO24.) Basal leaves shorter than those of the preceding, acuminate, narrowed into short petioles. Scape 3-8 dm. tall; raceme 2-6 dm. long, usually loose; pedicels $2 \mathrm{~mm}$. long or less, shorter than the bracts; perianth bell-shaped or ovoid-globose, 4-6 mm. long, its lobes oval; style short; capsule ovoid, about as long as the perianth. S. N. J. (according to Gray and to Rusby); Ya. to Fla. and Tex. June-Aug.

\section{YÚCCA L.}

Large plants, with a short sometimes subterranean caudex, or tall woody and leafy stem, or bracted scape, the leaves linear or lanceolate, usually rigid and sharppointed, bearing long marginal thread-like fibres in our species. Flowers large. nodding in a terminal raceme or panicle. Perianth campanulate, or nearly globular, white in our species, of 6 ovate, or ovate-lanceolate united segments. Stamens hypogynous, shorter than the perianth; filaments thickened above; anthers small, versatile. Ovary sessile, 3-celled, or imperfectly 6-celled; ovules numerous; style columnar, short, with 3 stigmatic lobes. Fruit a capsule, or fleshy, or spongy and indehiscent. Seeds numerous, flattened, horizontal. [The Haytien name.] About I6 species, natives of North and Central America.

Fruit fleshy, indehiscent, drooping.

x. 'Y. baccata.

Fruit an erect capsule.

Leaves 4-10 $\mathrm{mm}$. wide; scape short, bearing a long raceme.

Leaves $2-5 \mathrm{~cm}$. wide; scape $0.6-3 \mathrm{~m}$. high, bearing a large panicle.

2. Y. glauca.

3. Y. filamentosa.

I. Yucca baccàta Torr. Spanish Bayonet. (I. F. f. IO25.) Caudex very short, or sometimes $2.5 \mathrm{~m}$. tall, covered with the reflexed dead leaves. Leaves 4-9 dm. long, 2-5 cm. wide, with a much wider base, and a stout brown tip, concave, the marginal fibres 5-12 cm. long; panicle peduncled; pedicels stout; flowers I-I.2 dm. broad; perianth-segments $1.5-2.5 \mathrm{~cm}$. wide; style slender; fruit oval, dark purple, indehiscent, edible, droopirg 5-8 $\mathrm{cm}$. long, with a 6 -grooved beak. W. Kans. (?), S. Colo. to Tex., Cal. and Mex. April-June.

2. Yucca glaùca Nutt. BEAR-GRass. (I. F. f. ro26.) Caudex very short; leaves basal, narrowly linear, smooth, very stiff, sharp-pointed, 4-Io $\mathrm{mm}$. wide, with a broader base, concave, at least when dry, the marginal fibres filiform; scape short; flowers 3-7 cm. broad, racemose; perianth-segments ovate, $2.5-4 \mathrm{~cm}$. long; style short: pedicels stout, erect ; capsule oblong, about $2.5 \mathrm{~cm}$. thick, 6 -sided. In dry soil, Iowa to S. Dak., Wyo., Mo., Tex. and Ariz. May-June.

3. Yucca filamentòsa L. Adam's Needle. (I. F. f. IO27.) Caudex short. Leaves lanceolate, narrowed above the broad base, acuminate and sharp-pointed, flat, roughish, 3-8 dm. long, I.5-5 cm. wide; scape $0.6-3 \mathrm{~m}$. high; panicle large, its branches divergent or ascending; flowers numerous; perianth-segments $3-6 \mathrm{~cm}$. long, ovate; capsule oblong, about $2 \mathrm{~cm}$. thick. In sandy soil, Md. to Fla., Tenn. and La. Escaped from gardens in Penn. May-July.

\section{Family 4. CONVALLARIÀCEAE. Link. Lily-of-the-Valley Family.}

Scapose or leafy-stemmed herbs, with simple or branched routstocks. Flowers solitary, racemose, paniclid or umbelled, regular and perfect. 
Leaves broad, parallel-veined and sometimes with cross-veinlets, in Asparagus and its allies reduced to scales bearing filiform or flattened branchlets in their axils. Perianth inferior, 4-6-parted with separate segments. or oblong, cylindric or urn-shaped and 6-lobed or 6-toothed. Stamens 6, rarelv 4. hypogynous or borne on the perianth; anthers introrsely. extrorsely or laterally dehiscent. Ovary 2.3-celled, superior; ovules anatropous or amphitropous: style slender or short: stigma mostly 3-lobed. Fruit a fleshy berry. Seeds few or numerous. Embryo small. Endosperm copious. About 23 genera and 215 species, widely distributed.

Leaves reduced to scales; leaf-like branchlets filiform.

Leaves broad; stems simple or somewhat branched.

I. Asparagus.

Leaves alternate or basal.

Leaves basal; flowers umbelled or solitary.

Leaves alternate (solitary in flowerless plants of no. 4).

2. Clintonia.

Perianth-segments separate.

Flowers racemed, umbelled, panicled or solitary, terminal.

Flowers racemed or panicled.

Perianth-segments 6.

Perianth segments 4 .

Flowers umbelled or solitary.

Flowers solitary or two together, axillary.

Perianth cylindric or oblong, 6-toothed.

Leaves nearly basal; flowers racemed; perianth 6-toothed.

Leaves in I or 2 whorls below the flower or flowers.

Leaves in 2 whorls; flowers umbelled.

Leaves in I whorl; flowers solitary.

3. Vagnera.

4. Unifolium.

5. Disporum.

6. Streptopus.

7. Salomonia.

8. Convallaria.

9. Medeola.

10. Trillium.

\section{ASPÁRAGUS L.}

Stem at first simple, fleshy, scaly, at length much branched; the branchlets fili. form and mostly clustered in the axils of the scales in the following species, flattened and linear. Flowers small, solitary, umbelled or racemed. Perianth-segments alike, separate, or slightly united at the base. Stamens inserted at the bases of the perianth-segments; anthers introrse Uvary sessile, 3-celled; ovules 2 in each cavity; style short; stigmas 3, short, recurved. Berry globose. Seeds few, rounded. [Ancient Greek name.] About roo species, natives of the Old World.

I. Asparagus officinalis L. Asp'ARagus. (I. F. f. 1028.) Rootstock much branched. Young stems edible, stout, later branching, and becoming $\mathbf{I}-2 \mathrm{~m}$. tall, the filiform branchlets $6-18 \mathrm{~mm}$. long. Flowers mostly solitary at the nodes, green, drooping on filiform jointed peduncles; perianth campanulate, about $6 \mathrm{~mm}$. long, the segments linear; stamens shorter than the perianth; berry red, about $8 \mathrm{~mm}$. in diameter. Escaped from cultivation and naturalized, especially along salt marshes, N. B. to Va. and locally in waste places in the interior. Native of Europe. May-June.

\section{CLINTÒNIA Raf.}

Somewhat pubescent scapose herbs, with slender rootstocks, erect simple scapes, and few broad petioled sheathing basal leaves, the bractless flowers umbelled at the summit of the scape in our species. Perianth-segments equal or nearly so. Stamens 6 , iisserted at the bases of the perianth segments; filaments filiform; antliers laterally dehiscent. Ovary 2-3-celled; ovules 2-several in each cavity; stigma obscurely 2-3-lobed. Berry globose or oval. [Name in honor of De Witt Clinton, I769-1828, American naturalist, Governor of the State of New York.] Six species, the following of eastern North America, two Asiatic.

Flowers greenish yellow, drooping, $x .6-2 \mathrm{~cm}$. long; berry blue. Flowers white, not drooping, 8-10 mm. long; Lerry black.
I $C$. borealis.

2. C. umbellulata.

r. Clintonia boreàlis (Ait.) Raf. Yellow Clintonia. (I. F. f. IO29.) Scape 1.5-4 dm. high. Leaves 2-5. oval, oblong or obovate, thin, ciliate, shortacuminate or cuspidate : umbel 3-6-flowered; pedicels 6-30 mm. long, slender, erect or ascending in fruit; stamens about as long as the perianth; ovary 2 -celled; 
ovules numerous, in 2 rows in each cavity; style slender, somewhat thickened a bove; berry oval. several-seeded, about $8 \mathrm{~mm}$. in diameter. In moist woods and thickets Newf. to Ont. and Minn., N. Car. and Wis. May-Jure.

2. Clintonia umbellulàta (Michx.) Torr. White Clintonia. (I. F. f. IOzo.) Saape 2-4.5 dm. high. Leaves 2-5, oblong, oblanceolate or obovate, acute or cuspidate, ciliate, umbel several-many-flowered; pedicels ascending or erect, slender, pubescent, becoming $\mathbf{I}-3 \mathrm{~cm}$. long in fruit ; flowers white, odorous, often purplish dotted; perianth-segments obtusish; ovary 2-celled; ovules 2 in each cavity; style slender; berry globose, few-seeded. In woods, N. Y. and N. J. to Ga. and Tenn. May-June.

\section{VÀGNERA Adans. [SMILACINA Desf.]}

Stem scaly below, leafy above, the leaves aiternate, short-petioled or sessile. Inflorescence a terminal raceme or panicle. Flowers white or greenish white, small. Perianth of 6 spreading equal segments. Stamens 6 , inserted at the bases of the perianth-segments; filaments filiform or slightly flattened; anthers introrse. Ovary 3-celled, sessile; ovules 2 in each cavity; style columnar; stigma 3-grooved or 3lobed. Berry globular. Seeds usually 1 or 2, subglobose. [Named in honor of Wagner.] About 25 species, natives of North America, Central America, and Asia. Besides the following, one or two others occur in the western U. S.

Flowers numerous, panicled.

Flowers few-several, racemose.

Plant $2.5-4.5 \mathrm{dm}$. high: leaves numerous.

Plant 0.5-4 dm. high; leaves 2-4.

I. V. racemosa.

2. I. stellata.

3. I. trifolia.

I. Vagnera racemòsa (L.) Morong. Wild Spikenard. (I. F. f. Io3I.) Rootstock fleshy. Stem somewhat angled, leafy, finely pubescent above, or nearly glabrous, 3-9 dm. high. Leaves oblong-lanceolate or oval, sessile or the lower short-petioled, $0.7-1.5 \mathrm{dm}$. long. acuminate, finely pubescent beneath, their margins minutely ciliate; panicle densely many-flowered, 2-10 cm. long, peduncled; flowers about $4 \mathrm{~mm}$. broad; perianth-segments oblong; berry red, aromatic, speckled with purple, 4-6 mm. in diameter. In moist woods and thickets, N. S. to Br. Col., Ga., Mo. and Ariz. May-July.

2. Vagnera stellàta (L.) Morong. Star-flowered Solomon's Seal. (I. F. f. I032.) Rootstock stout, fleshy. Stem glabrous, 2-5 dm. tall, leafy. Leaves ob'ong lanceolate or lanceolate, sessile and somewhat clasping, minutely pubescent beneath, 5-13 cm. long, flator somewhat concave; raceme $2-5$ long cm. long, severalflowered; pedicels $2-8 \mathrm{~mm}$. long; perianth-segments oblong, obtuse; style about as long as the ovary; berry green with 6 black stripes, or black, 6-10 $\mathrm{mm}$. in diameter. In moist soil, Newf. to Br. Col., Va., Ky., Kans. and Cal. Also in northern Europe. May--June.

3. Vagnera trifolia (L.) Morong. Three-leaved Solomon's Seal. (I. F. f. I033.) Glabrous; rootstock slender. Stem slender, $0.5-4 \mathrm{dm}$. ligh, =-4. leaved (usually 3 -leaved); leaves oval, oblong or oblong-lanceolate, sessile, sheathing, $5^{- \text {I } 3}$ $\mathrm{cm}$. long, acute or acuminate at the apex, narrowed at the base; raceme few-flowered, peduncled; perianth segments oblong or oblong-lanceolate, obtuse, finaliy somewhat reflexed; berry dark red, $5-6 \mathrm{~mm}$. in diameter. In bogs and wet woods, Newf. to Br. Col., N. J., Penn. and Mich. Also in northern Asia. May-June.

\section{UNIFÒLIUM Adans. [MAIANTHEMUM Wigg.]}

Low herbs, with slender rootstocks, simple few.leaved stems, and small white flowers in a terminal raceme, the pedicels commonly 2-3 together. Perianth of 4 separate spreading segments. Stamens 4, inserted at the bases of the segments; filaments filiform; anthers introrse. Ovary sessile, 2 -celled; ovules 2 in each cavity; style about as long as the ovary, 2-lobed or 2-cleft. Lerry globular, 1-2seeded. [Many plants bear only a solitary long petioled leaf, arising from the rootstock, whence the I atin name.] Two known species, the following of eastern N. Am., the other of Europe, Asia and N. W. America.

I. Unifolium Canadénse (Desf.) Greene. False Lily-of-tie-valley. TwoLeAvey Solomon's SEAL. (I. F. f. ro34.) Stem slender, I-3-leaved (usually 2- 
leaved), 5-18 cm. high; leaves orate or ovate-lanceolate, $2-8 \mathrm{~cm}$. long, cordate, with a narrow or closed sinus, sessile, short-petioled; solitary leaves of the stemless plants on petioles 2-10 cm. long; raceme many-flowered, $2-5 \mathrm{~cm}$. long; perianthsegments becoming reflexed, about $2 \mathrm{~mm}$. long; berry pale red, speckled, about $4 \mathrm{~mm}$. in diameter. In moist woods and thickets, Newf. to the N. W. Terr., N. Car., Iowa and S. Dak. May-July.

\section{DÍSPORUM Salisb.}

Herbs with slender rootstocks, branching stems, leafy above, and alternate ses. sile or clasping leaves, the flowers terminal, drooping, whitish or greenish yellow, solitary or in simple umbels. Perianths of 6 narrow deciduous segments. Stamens 6, hypogynous; filaments filiform or somewhat flattened; anthers extrorse. Ovary 3-celled; ovules 2 or sometimes several in each cavity; style slender; stigma 3-cleft or entire. Berry ovoid or oval. [Greek, referring to the 2 ovules in each cavity of the ovary, in most species.J About 15 species, natives of N. Am. and Asia. Besides the following, some 5 others occur in western N. Am.

Stamens shorter than the perianth; fruit smooth, 2-6-seeded. Stamens as lor.g as the periantn; fruit roughened, 4-18-seeded.

I. D. lanuginosum.

2. D. trachycarpum.

r. Disporum lanuginòsum (Michx.) Nicholson. Hairy Disporum. (I. F. f. 1035.) Finely and rather densely pubescent, 3-7 dm. high. Leaves ovate-lanceolate, or oblong-lanceolate, 5-II cm. long, long-acuminate at the apex, rounded at the base, 7-15-nerved; flowers solitary or 2-3 together, greenish, 12-18 mm. long; pedicels filiform; perianth narrowly campanulate, its segments linear-lanceolate, acuminate, glabrous; ovary oblong; style slender, 3-cleft; berry oval, red, IO-I $4 \mathrm{~mm}$. long. In woods, Ont. to WV. N. Y. and Tenn. May-June.

2. Disporum trachycàrpum (S. Wats.) B. \& H. Rovgh-Fruited DisPORUM. (I. F. f. 1036.) Puberulent, 3-6 dm. high. Leaves ovate, oval or oblong. lanceolate, 3-9 dm. long, acute or short-acuminate at the apex, rounded or subcordate at the base, 5-II-nerved; flowers yellowish white, 8-14 mm. long: perianth narrowly campanulate, its segments acute, little spreading; style slender, 3-lobed; berry depressed-globose or somewhat obovoid, 8-IO $\mathrm{mm}$. in diameter, 4-I 8-seeded. Manitoba and the N. W. Terr. to S. Dak., Neb., Wash. and Ariz. May-Aug.

\section{STRÉPTOPUS. Michx.}

Branching herbs, with thin sessile or clasping alternate leaves. Flowers solitary or 2 together, extra-axillary, slender-peduncled, greenish, rose or purplish, small, nodding. Peduncles bent or twisted at about the middle. Perianth campanulate, its 6 segments recurved or spreading, deciduous, the outer flat, the inner keeled. Stamens 6, hypogynous; filaments short, flattened; anthers sagittate, extrorse. Ovary 3-celled; ovules numerous in 2 rows in each cavity; style slender. Berry globose or oval, red, many-seeded. [Greek, twisted stalk, in reference to the bent or twisted peduncles.] About 5 species, natives of the north temperate zone. Besides the following, another occurs on the Pacific Coast.

Leaves glaucous beneath, clasping; flowers greenish-white. Leaves green on both sides, sessile; flowers purple or rose.

I. S. amplexifolius. 2. S. roseus.

I. Streptopus amplexifòlius (L.) DC. Clasping-Leaved Twisted-stalK. (I. F. f. IO37.) Rootstock short, stout. Plant 4-9 dm. high; stem usually branching below the middle; leaves $5^{-1} 3 \mathrm{~cm}$. long, acuminate at the apex, cordate-clasping at the base, glabrous; peduncles I-2-flowered; flowers 8-12 $\mathrm{mm}$. long; perianth-segments narrowly lanceolate, acuminate; anthers subulate-pointed; stigma simple, obtuse or truncate; berry oval, Io-16 mm. long. In moist woods, Lab. to Alaska, N. Car., Ohio, Mich. and N. Mex. May-July.

2. Streptopus ròseus Michx. Sessile-Leave1) Twisted-Stalk. (I. F. f. I038.) Plant 3-8 dm. high. Branches sparingly pubescent; leaves 5-II cm. long, acuminate at the apex, sessile, rounded, or slightly clasping at the base, their margins finely ciliate ; peduncles usually pubescent ; flowers purple or rose, 8-I2 $\mathrm{mm}$. long; perianth-segments lanceolate, acuminate; anthers 2-horned; style 3-c'eft, the spreading branches stigmatic along the inner side; berry globose or 
ova:, IO-12 mm. in diameter. In moist woods, Lab. to Alaska, Ga., Mich. and Ore. May-July.

\section{SALOMÒNIA Heist.}

Herbs, with thi_s jointed and scarred rootstocks, simple stems, scaly below, leafy above, the leaves sessile and alternate in our species. Flowers greenish or pinkish, axillary, drooping, peduncled, solitary or 2-10 in an umbel, the pedicels jointed at the base of the flower. Perianth 6-lobed. Stamens 6, included ; filaments adnate to the perianth for half their length or more; anthers sagittate, introrse. Ovary 3-celled ; ovules $2-6$ in each cavity ; style slender ; stigma small, capitate or slightly 3-lobed. Berry globular, dark blue or nearly black, with a bloom, in our species. [Named in honor of Salomon.] About 20 species, natives of the north temperate zone. (Polygonatum Adans.)

Leaves pubescent beneath; filaments filiform, roughened.

1. P. biflorum.

Plant glabrous throughout; filaments smooth, somewhat flattened. 2. P. commutatum.

I. Salomonia biflòra (Walt.) Britton. Hairy Solomon's SEal. (I. F. f. 1039.) Stem slender, glabrous, 2-9 dm. high. Leaves $4-10 \mathrm{~cm}$. long, $1.2-5 \mathrm{~cm}$. wide, acute or acuminate at the apex, sometimes obtuse at the base, pubescent especially on the veins and pale beneath, glabrous above; peduncles I-4-flowered (often 2-flowered); perianth 8-12 mm. long; filaments filiform, adnate to the perianth for about three fourths its length, papillose-roughened; berry $6-8 \mathrm{~mm}$. in diameter. In woods and thickets, N. B. to Ont., Mich., Fla. and W. Va. AprilJuly. (P. biflorum Ell.)

2. Salomonia commutàta (R. \& S.) Britton. Smootir Solomon's Seal. (I. F. f. IO4O.) Glabrous throughout; stem $0.3-2.5 \mathrm{~m}$. high. Leaves $3-15 \mathrm{~cm}$. long, 7-10 cm. wide, narrowed, rounded or somewhat clasping at the base ; peduncles I-8-flowered, glabrous; perianth $12-20 \mathrm{~mm}$. long; filaments somewhat flattened, smooth, adnate to the perianth for half its length or more; berry 8-12 $\mathrm{mm}$. in diameter. In moist woods and along streams, rarely in dry soil, R. I. to Ont., Manitoba, Ga., La., Utah and N. Mex. May-July. (P. commutatum Dietr.)

\section{CONVALLÀRIA L.}

A low glabrous herb, with horizontal rootstocks and 2 or sometimes 3 erect leaves, narrowed into sheathing petioles, the lower part of the stem bearing sheath. ing scales. Flowers white (rarely pink), fragrant, nodding. Raceme I-sided. Perianth globose-campanulate, 6-lobed, deciduous, the short lobes recurved. Stamens 6 , included ; filaments short, adnate to the lower part of the perianth ; anthers introrse. Ovary 3-celled; ovules several in each cavity; style slender, 3 grooved; stigma small, capitate, slightly 3-lobed. Berry globose. [Latin from convallis, valley, and the Greek for lily.] A monotypic genus of Europe, Asia and the higher Alleghenies.

I. Convallaria majàlis L. Lily-of-The-valley. (I. F. f. IO4I.) Stem I-2.3 dm. high. Leaves oblong, or oval, appearing nearly basal, acute at both ends, 1.2-3 dm. long, $2-6 \mathrm{~cm}$. wide; basal scales large, one of them subtending an erect angled scape shorter than the leaves; raceme $2-10 \mathrm{~cm}$. long, loosely several. flowered; pedicels filiform, recurved, 6-12 $\mathrm{mm}$. long; perianth 6-8 $\mathrm{mm}$. long; filaments shorter than the anthers; berry about $6 \mathrm{~mm}$. in diameter. On the higher mountains of Va., N. Car. and S. Car. Common in cultivation. May-June.

\section{MEDĖOLA L.}

A slender erect unbranched herb, loosely provided with deciduous wool. Rootstock thick, white, tuber-like, with somewhat the odor and taste of cucumbers. Leaves of flowering plants in 2 (rarely 3 ) whorls; lower whorl of 4-10 oblonglanceolate or ohovate leaves; upper whorl of 3-5 ovate or oval leaves, subtending the sessile umbel of small greenish yellow declined flowers. Perianth of 6 separate equal recurved segments. Stamens 6, hypogynous; filaments slender, longer than the oblong extrorse anthers. Ovary 3-celled; ovules several in each cavity; styles 3 , recurved. Berry globose. [Name from Medea, a sorceress, referring to the supposed healing properties.] A monotypic genus of eastern N. Am. 
r. Medeola Virginiàna L. Indian CUCUMber-Root. (I. F. f. IO42.) Root. stock 2-8 cm. long. Stem 3-8 dm. tall, bearing the lower whorl of leaves above the middle, or in flowerless plants at the summit; leaves of the lower whori sessile, $5^{-1} 3 \mathrm{~cm}$. long, acuminate, narrowed at the base, 3-5-nerved and reticulate-veined; leaves of the upper whorl 2-5 cm. long; umbel 2-9-flowered; pedicels filiform, 2-5 $\mathrm{cm}$. long or less, declined in flower, erect or ascending in fruit; perianth-segments 6-10 $\mathrm{mm}$. long, obtuse; berry dark purple, 8-1 $5 \mathrm{~mm}$. in diameter. In moist woods and thickets, N. S. to Ont., Minn., Fla. and Tenn. May-June.

\section{ro. TRÍLLIUM L. (See Appendix.)}

Glabrous erect unbranched herbs, with short scarred rootstocks, and 3 leares whorled at the summi ${ }^{+}$of the stem, subtending the bractless flower. Solitary longpetioled leaves are sometimes borne on the rootstock. Perianth of 2 series of segments, the outer 3 (sepals) green, persistent, the inner 3 (petals) white, pink, purple or sometimes greenish, deciduous or withering. Stamens 6, hypogynous; filaments short; anthers linear; ovary sessile, 3-6-angled or lohed, 3-celled; ovules several or numerous in each cavity: styles 3. Berry many-seeded. Seeds horizontal. [Latin, in allusion to the 3-parted flowers and the 3 leaves.] About 20 species, natives of N. Am. and Asia. Besides the following, some 7 others occur in the southern and western parts of N. Am. Phyllody, i. e., the reversion of petals or sepals to leaves, is occasional in the genus, and the floral parts are sometimes in 4's instead of 3's.

Flower sessile.

Leaves sessile; sepals not reflexed.

Flowers purple; petal-blades lanceolate.

Flowers green; petal-blades linear.

Leaves petioled; sepals reflexed.

Flower peduncled.

Leaves oval or ovate, obtuse or obtusish, $2-5 \mathrm{~cm}$. long.

Leaves broadly ovate or rhombic, acuminate, $5^{-1} 7 \mathrm{~cm}$. long.

Leaves sessile, or narrowed at the base and short-petioled.

Petals obovate or oblanceolate, $3-6 \mathrm{~cm}$. long.

Petals ovate or lanceolate, $1-3 \mathrm{~cm}$. long.

Peduncle $3^{-10} \mathrm{~cm}$. long, erect or declined; petals spreading.

Peduncle $3 \mathrm{~cm}$. long or less, recurved beneath the leaves; petals recurved.

Leaves distinctly' petioled, obtuse or rounded at the base.

6. T. erectum.

1. $T$. sessile.
2. $T$. viride.
3. $T$. recurvatum.

4. T. nivale.

5. T. grandiflorum.

7. T. cernuum.

8. T, undulatum.

I. Trillium séssile L. Sessile-flowered Wake-robin. (I. F. f. ro43.) Stem 1-3 dm. tall. Leaves ovate or oval, cuspidate at the apex, 4-15 cm. long, often blotched; sepals lanceolate, spreading, I-5 cm. long; petals lanceolate, some. what longer than the sepals, erect-spreading, purple; anthers longer than the fila. ments, the connective prolonged beyond the sacs; berry globose, 6-angled, about $1.2 \mathrm{~cm}$. in diameter. In moist woods and thickets, Penn. to Ohio, Minn., Fla. and Ark. April-May.

2. Trillium víride Beck. Green Wake-Robin. (I. F. f. I043a.) Light green. Stems $\mathbf{I}-4 \mathrm{dm}$. tall, rough-pubescent near the top, or glabrous in age; leaves oblong to ovate, 5-10 cm. long, usually blotched, more or less pubescent on the nerves beneath; sepals linear or linear-lanceolate, bright green; petals clawed, the blades linear or nearly so, surpassing the sepals, light green or purplish green; filaments flattened. In woods and glades, Mo. and Tenn. to Miss. and Ark.

3. Trillium recurvàtum Beck. PraIRIE WAKe-RoBIN. (I. F. f. IO44.) Stems 1.5-4.5 dm. tall. Leaves ovate, oval or oblong, 4-1o cm. long, acute, narrowed into petioles, sometimes blotched: flower erect; sepals lanceolate, acuminate, 1.2-3 cm. long, reflexed; petals spatulate or oblong, nearly erect, clawed, acute or acuminate, equalling the sepals or somewhat longer; anthers 8-14 mm. long, much longer than the filaments, the connective prolonged beyond the sacs: berry ovoid, 6 -winged above, about $1.8 \mathrm{~cm}$. long. In woods and thickets, Ohio to Minn., Miss. and Ark. April-June.

4. Trillium nivàle Riddell. Early Wake-Robin. (I. F. f. I045.) Stem 5-12 cm. high. Leaves 2-5 cm. long, obtuse; petioles 4-12 mm. long; peduncle 
erect, bent, or recurved; sepals narrowly oblong or oblong-lanceolate, obtuse; petals white, oblong or oval, obtuse, longer than the sepals, erect-spreading; anthers about as long as the filaments, the connective not prolonged beyond the sacs; styles slender; berry globose, 3-lobed. In woods and thickets, Penn. to Ohio, Minn., Ky. and Neb. March-May.

5. Trillium grandiflorum (Michx.) Salisb. LARGe-flowered Wake-Robin. (I. F. f. I046.) Stems usually stout, $2-4.5 \mathrm{dm}$. high. Leaves rhombic-ovate or rhombic-oval, 6-15 cm. long, acuminate, narrowed to the sessile or nearly sessile base; peduncle 3-8 cm. long; sepals acuminate, $2-5 \mathrm{~cm}$. long, spreading; petals erect-spreading, obtuse or cuspidate, strongly veined, white or pink, thin, longer than the sepals; anthers longer than the filaments; styles slender, berry globuse, black, slightly 6-lobed, $1.5-2.5 \mathrm{~cm}$. in diameter. In woods, Quebec to Ont : Mini., Fla. and Mo. May-June.

6. Trillium eréctum L. Ill-Scented WAKE-ROBIN. (I. F. f. IO47.) Stem stout, 2-4 dm. high. Leaves broadly rhombic, 7-18 cm. long, often as wide or wider, acuminate at the apex, narrowed at the base; peduncle erect inclined or declined beneath the leaves; sepals lanceolate, acuminate, spreading; petals acute or acutish, spreading, equalling the sepals or longer, dark purple, pink, yellow, greenish or white; anthers longer than the filaments; styles short; berry ovoili, somewhat 6-lobed, reddish, $1.5-2.5 \mathrm{~cm}$. long. In woods, N. S. to James Bay, Manitoba, N. Car., Tenn. and Mo. Flowers unpleasantly scented. April June.

7. Triilium cérnuum L. NodDing Wake-Robin. (I. F. f. 1048.) Stem 2-5 dm. high. Leaves broadly rhombic, acuminate at the apex, narrowed at the base, sessile, or with the petioles $2-4 \mathrm{~mm}$. long; peduncle recurved beneath the leaves, the flower drooping; sepals acuminate; petals white or pink, rolled bickward, wavy-margined, equalling the sepals, or a little longer; anthers about as long as the filaments; berry ovoid, red-purple. In rich woods, N. S. to Ont. and Minn., Ga. and Mo. April-June.

8. Trillium undulatum Willd. Painted IVAke-Robin. (I. F. f. IO49.) Stem 2-6 dm. high. Leaves ovate, $0.7-2 \mathrm{dm}$. long, petisled, long-acuminate at the apex, obtuse or rounded at the base; flower peduncled, erect or somewhat inclined, 2-6 cm. long; sepals acuminate, $1.8-3 \mathrm{~cm}$. long; petals ovate or ovatelanceolate, acuminate or acute, white, with purple veins or stripes, thin, longer than the sepals, wavy-margined; styles slender; berry ovoid, obtuse, bluntly 3-angled, bright red, shining, $1.2-2 \mathrm{~cm}$. in diameter. In woods, N. S. to Ont. and Wis., Ga. and Mo. May-June. [T. erythrocarpum Michx.]

\section{Family 5. SMILÀCEAE Vent.}

\section{Smilax Family.}

Mostly vines with woody or herbaceous, often prickily stems. Leaves alternate, netted-veined, several-nerved, petioled. Petiole sheathing, bearing a pair of slender tendril-like appendages, persistent, the blade failing away. Flowers small, mostly green, diøecious, in axillary umbels, Perianth-segments 6 . Stamens mostly 6, distinct; filaments ligulate; anthers basifixed, 2-celled, introrse. Ovary 3 celled, the cavities opposite the inner perianth-segments; ovules 1 or 2 in each cavity, orthotropous ; style very short or none; stigmas I-3. Fruit a globose berry containing I-6 brownish seeds. Endosperm horny, copious; embryo small, oblong, remote from the hilum. Genera 3, only the following in N. A.; species about 200 , in warm and temperate regions.

\section{x. SMILAX L.}

Rootstocks usually large and tuberous, stems usually twining, and climbing by means of the coiling appendages of the petiole. Lower leaves reduced to scales. Flowers regular. Perianth-segments distinct, deciduous. Pedicels borne on a globose or conic receptaçle, inserted in small pits, generally among minute bract- 
lets. Filaments inserted on the bases of the perianth-segments. Staminate flowers without an ovary. Pistillate flowers usually smaller than the saminate, usually with I-6 abortive stamens. Berry black, red or purple (rarely white), with 3 strengthening bands of tissue running through the outer part of the pulp, connected at the base and apex. Embryo lying under a tubercle at the upper end of the seed. [Ancient Greek name, perhaps not originally applied to these plants.] About 195 species of wide distribution, most abundant in tropical America and Asia. Besides the following, about five others occur in the southern U. S., and one in Cal. and Ore.

Stem annual, herbaceous, unarmed.

Petioles tendril-bearing; stems climbing.

Leaves usually ovate, thin.

Leaves glabrous.

Leaves pubescent beneath.

Leaves usually hastate, coriaceous.

Petioles without tendrils or nearly so; stems erect.

Stem perennial, woody, usually armed with prickles.

Berries black or bluish-black.

Fruit ripening the first year.

Leaves glaucous.

Leaves green on both sides.

Leaves rounded or lanceolate, 5-nerved. $\quad 6$. S. rotundifolia.

Leaves ovate, 7 -nerved.

I. S. herbacea.

2. S. pulverulenta.

3. S. tamnifolia.

4. S. ecirrhata.

Leaves round-ovate, often narrowed at the middle, 7 -9-nerved.

8. S. Pseudo-China.

Leaves deltoid or deltoid-hastate, 5-7-nerved, often with $\mathrm{I}$ or 2 additional nerves on each side.

Fruit ripening the second year; leaves elliptic or lanceolate, evergreen.

Berries red.

ro. S. laurifolia.

Leaves ovate or ovate-lanceolate, base rounded; berries bright red.

Leaves lanceolate, acute at the base; berries dull red.

Leaves lanceolate, acute at the base; berries dull red. I2. S. lanceolata.

I. Smilax herbàcea L. CARRIOn-flower. (I. F. f. IO5O.) Tubers short, thick, numerous. Stem herbaceous, glabrous, unarmed. Leaves ovate, rounded, or lanceolate, acute, acuminate or cuspidate at the apex, obtuse or cordate at the base, thin, 7-9-nerved, 3-13 cm. long; peduncles usually 6-10 times as long as the petioles, flattened; umbels 15-80-flowered; pedicels 6-16 mm. long; flowers carrion-scented; filaments 2-3 times as long as the anthers; berries bluish black, 2-4-seeded, 6-8 mm. in diameter. In woods and thickets, N. B. to Ont., Dak., Fla., La. and Neb. April-June.

2. Smilax pulverulénta Michx. Hairy Carrion-flower. Similar to the preceding; stems elongated, climbing; leaves ovate to elliptic-ovate, $8-15 \mathrm{~cm}$. long, short-acuminate, usually 9-nerved, pubescent beneath, cordate at the base; petioles often as long as the blades; peduncles as long as the petioles or longer: pedicels 5-12 mm. long; berries subglobose, 8-10 $\mathrm{mm}$. in diameter. In alluvial soil, Ont. to Wis., N. Car. and Mo. Spring.

3. Smilax tamnitòlia Michx. Halberd-leaved Smilax. (I. F. f. ro5 r.) Glabrous, herbaceous; stem and branches unarmed. Leaves coriaceous, mostly ovate-hastate, with broad obtuse lobes at the base, slightly narrowed at about the middle, truncate or subcordate at the base, green on both sides, $2.5-8 \mathrm{~cm}$. long, 5-7-nerved; peduncles I-3 from the same axil, 2-10 cm. long, usually much longer than the leaves; umbels IO-30-flowered; pedicels 4-6 $\mathrm{mm}$. long; filaments I-2 times as long as the anthers; berries black, 4-6 mm. in diameter, $\mathrm{x}$-3-seeded. In dry soil. S. N. J. and Penn. to S. Car. and Tenn. May-July.

4. Smilax ecirrhàta (Engelm.) S. Wats. Upright Smilax. (I. F. f. ro52.) Stem herbaceots, glabrous, simple, erect, 1.5-6 dm. tall. Leaves often whorled at the summit of the stem, ovate, rounded or cordate at the base, thin, 5-9-nerved, more or less pubescent beneath and erose-denticulate on the margins; petioles 2-3.6 $\mathrm{cm}$. long; peduncles long, often pubescent; pedicels 4-10 $\mathrm{mm}$. long. In dry soil, Va. to Minn, and Fla. May-June.

5. Smilax glaùca Walt. Glaucous-leaved Greenbrier. (I. F. f. IO53.) Roptstock deep, knotted and tuberous. Stem terete; branches and twigs angled, 
armed with rather stout prickles, or sometimes unarmed; petioles 6-12 $\mathrm{mm}$. long, tendril-bearing; leaves ovate, acute or cuspidate at the apex, sometimes cordate at the base, entire, mostly 5-nerved, $3^{-15} \mathrm{~cm}$. long; peduncles flattened; umbels 6-12-flowered; pedicels 4-8 mm. long; berries bluish black, about $6 \mathrm{~mm}$. in diameter, 2-3-seeded. In dry sandy soil, E. Mass. to Fla., Kans. and Tex. May-June.

6. Smilax rotundifòlia L. Greenbrier. Catbrier. Horsebrier. (I. F. f. I054.) Rootstocks long, sparingly tuberous. Stem woody, terete, the branches often 4-angled, glabrous; prickles .scattered, sometimes none; petioles 6-12 mm. long; leaves thick and shining when mature, acute or acuminate at the apex, obtuse or cordate at the base, entire or the margins erose-denticulate, 5-nerved, 5-15 cm. long; peduncles flattened; umbels 6-25-flowered; pedicels 2-8 $\mathrm{mm}$. long; perianth-segments pubescent at the tip; filaments $2-3$ times as loing as the antliers; berries black, I-3-seeded, about $6 \mathrm{~mm}$. in diameter. In woods and thickets, Ont. to Minn., Fla. and Tex. April-June.

7. Smilax híspida Muhl. Hispid Greenbrier. (I. F. f. 1055.) Glabrous; stem commonly thickly hispid with numerous slender prickles, the branches more or less angled; petioles 8-18 mm. long, tendril-bearing; leaves thin, ovate, abruptly acute and cuspidate at the apex, obtuse or subcordate at the base, 7-nerved, 5-13 $\mathrm{cm}$. long; peduncles flattened; umbels Io-26-flowered; pedicels 4-6 mm. long; filaments a little longer than the anthers; berries bluish black. In thickets, Ont. to Minn., Neb., Va. and Tex. May-July.

8. Smilax Pseùdo-China L. Long-stalked Greenbrier. (I. F. f. I056.) Glabrous; rootstock often bearing large tubers; stem terete, the branches angled. Lower part of the stem beset with straight prickles, the branches mostly unarmed; petioles 6-25 $\mathrm{mm}$. long; leaves firm, ovate, often narrowed at about the middle or lobed at base, acute or cuspidate at the apex, 7-9-nerved, 6-13 cm. long; peduncles flattened, 2-8 cm. long, umbels I 2-40-flowered ; pedicels 6-8 mm. long ; stamens 6-10; berries black, 4-6 mm. in diameter. In dry or sandy thickets, Md. to Neb., Fla. and Tex. March-Aug.

9. Smilax Bòna-nóx L. Bristly Greenbrier. (I. F. f. 1057.) Rootstocks bearing large tubers; stem terete or slightly angled, the branches often 4-angled. Prickles often wanting on the branches; petioles 6-12 $\mathrm{mm}$. long; leaves thick, ovate or commonly deltoid-hastate, glabrous, green on both sides, often spiny on the margins and the veins beneath, acute or abruptly cuspidate at the apex, obtuse, truncate or cordate at the base, 5-9-nerved, 3-I I cm. long : peduncles slender, flattened, I.4-3 cm. long: umbels 15-45-flowered; pedicels 4-8 mm. long; stigmas I-3; berries $4-6 \mathrm{~mm}$. in diameter, mostly I-seeded. In thickets, Mass. to Kans., Fla. and Tex. April-July.

io. Smilax laurifòlia L. Laurel-leaved Greenbrier. (I. F. f. IO58.) Rootstocks bearing tubers sometimes I.5 dm. thick; stem high-climbing, terete, armed with strong straight prickles, the branches angled, mostly unarmed. Petioles stout, 6-16 mm. long; leaves leathery, evergreen, elliptic or oblong-lanceolate, acute or abruptly cuspidate at the apex, narrowed at the base, entire, 3-nerved, or sometimes with an additional pair of nerves near the margins, 5-II cm. long; peduncles stout, angled, 4-20 mm. long; umbels 6-30-flowered; pedicels 4-6 mm. long; anthers usually about one-third shorter than the filaments; stigma I, sometimes 2 ; berries black, ovoid, 4-6 mm. thick. In moist woods and thickets, S. N. J. to Fla. and Tex., north in the Miss. Valley to Ark. March-Sept.

II. Smilax Walteri Pursh. Walter's Greenbrier. (I. F. f. IO59.) Glabrous; stem angled, prickly below; branches commonly unarmed. Petioles 4-12 nm. long, angled; leaves ovate or ovate-lanceolate, rarely lobed at the base, cordate or subcordate, entire, 5-7-nerved, $5^{-13} \mathrm{~cm}$. long, $2-8 \mathrm{~cm}$. wide; peduncles 4-10 mm. long, flattened; umbels 6-15-flowered; pedicels very slender, 4-6 mm. long; berries globose, coral-red (rarely white), 6-8 mm. in diameter, 2-3-seeded. In wet soil, pine barrens of N. J. to Fla., Tenn. and La. April-June.

12. Smilax lanceolàta L. LANCE-LeAved Greenbrier. (I. F. f. IO6o.) Glabrous, stem terete, usually prickly, the branches slender, long, mostly unarmed. Petioles 2-4 mm. long; leaves rather thin, lanceolate, acute or acuminate at the apex, narrowed at the base, entire, shining above, 5-7-nerved, 5-10 cm. long; peduncles thick, angled, 6-16 mm. long; umbels 8-40-flowered; pedicels 4-14 mm. 
long ; filaments longer than the anthers; berries dark red, globose, 4-6 $\mathrm{mm}$. in diameter, usually 2 -seeded. In thickets, Va. to Ark., Fla. and Tex. March-Aug.

\section{Family 6. HAEMODORÀCEAE R. Br.}

\section{Bloodwort Family.}

Perennial herbs with erect stems, narrowly linear leaves, and regular or somewhat irregular small perfect flowers in terminal cymose panicles. Perianth 6-parted or 6-lobed, adnate to the ovary, persistent. Stamens 3 , opposite the 3 inner perianth-segments. Ovary wholly or partly inferior, 3-celled or rarely I-celled ; ovules usually few in each cavity, half-. anatropous; style mostly slender; stigma small, entire or 3-grooved. Fruit a loculicidally 3 -valved capsule. Seeds few or rarely numerous; embryo small, in fleshy endosperm. About 9 genera and 35 species, mostly natives of South Africa and Australia, a few in tropical America; only the following genus in the north temperate zone.

\section{GYROTHÈcA Salisb.}

A rather stout herb, with a short rootstock, red fibrous roots and equitant leaves, the basal ones longer than those of the stem. Flowers numerous, yellowish, small, in a dense woolly cymose panicle. Perianth 6-parted to the summit of the ovary, the outer segments smaller than the inner. Filaments filiform, longer than the perianth; anthers linear-oblong, versatile. Ovary 3-celled; ovules few in each cavity, borne on fleshy placentæ; style very slender, declined. Capsule enclosed by the withering-persistent perianth, nearly globular, 3-valved. Seeds about 6 in each cavity, flattened, nearly orbicular, peltate. (Greek, referring to the round fruit.) A monotypic genus of southeastern N. Am. and the W. I.

1. Gyrotheca tinctòria (Walt.) Salisb. RED-RoOT. (I. F. f. ro6r.) Stem $48 \mathrm{dm}$. tall, glabrous below, pubescent or woolly above. Leaves 4-ro mm. wide, acuminate, the basal ones shorter than the stem, the upper reduced to bracts; panicle 5-I3 cm. broad, almost capitate when young, white-woolly; flowers 8-io mm. broad, bracteolate, the perianth yellow and glabrous within; style about as long as the stamens; pedicels stout, about as long as the capsule; capsule about $6 \mathrm{~mm}$. in diameter. In swamps, E. Mass. to N. J. and Fla., mostly in pine barrens near the coast. Also in Cuba. July-Sept. (Gyrotheca capitata Morong.)

\section{Family 7. AMARYLLIDÀCEAE Lindl.}

\section{Amaryllis Family.}

Perennial herbs (some tropical species woody or even arboreous), with bulbs or rootstocks, scapose or sometimes leafy stems and usually narrow and entire leaves. Flowers perfect, regular or nearly so. Perianth 6-parted or 6-lobed, the segments or lobes distinct, or united below into a tube which is adnate to the surface of the ovary (adnate only to the lower part of the ovary in Lophiola). Stamens 6 in our genera, inserted on the bases of the perianth-segments or in the throat of the perianth opposite the lobes. Anthers versatile or basifixed, 2-celled, the sacs usually longitudinally dehiscent. Ovary wholly or partly inferior, usually 3-celled. Style filiform, entire, lobed, or cleft into 3 stigmas at the summit. Ovules usually numerous, rarely only I or 2 in each cavity of the ovary, anatropous. Fruit cupsular, rarely fleshy. Seeds mostly black, the embryo small, enclosed in fleshy endosperm. About 70 genera and 800 species, principally natives of tropical and warm regions, some in the temnerate zonos 
Bulbous herbs with flowers on scapes.

Flower solitary (in our species); perianth with a crown.

Flower solitary; perianth without a crown.

Anthers versatile; tube of the perianth not greatly elongated.

\section{Narcissus.}

2. Atamosco.

Anthers erect; tube of the perianth several times the length of its lobes.

3. Cooperia.

Flowers clustered; perianth with a membranous crown connecting the lower parts of the filaments.

Bulbless herbs, with rootstocks or corms.

4. Hymenocallis.

Perianth adnate to the whole surface of the ovary; leaves mostly basal.
Tall, fleshy-leaved; anthers versatile.
5. Agave.

Low, linear-leaved; anthers not versatile.

6. Hypoxis.

Perianth adnate only to the lower part of the ovary; stem leafy; flowers woolly.

7. Lophiola.

\section{NARCÍSSUS L.}

Bulbous herbs, the flowers solitary or several on leafless scapes, the leaves linear, basal. Flowers subtended by a deciduous spathe; perianth 6-parted, bearing a cup-like funnelform or cylindric crown in the throat. Stamens inserted on the tube of the perianth; ovary 3-celled. About 20 species, natives of the Old World.

1. Narcissus Pseudo-Narcíssus L. Daffodil. Scape about $3 \mathrm{dm}$. high, 2-edged. Leaves narrowly linear, about as long as the scape; flower bright yellow, 5-8 cm. broad; crown crenate, rather longer than the perianth-tube. Escaped from cultivation, Penn. and N. J. April-May. Flowers often double.

\section{ATAMósco Adans.}

Glabrous herbs with coated bulbs, narrow leaves, and erect scapes, the flower large, erect, pink, white or purple. Perianth funnelform, naked in the throat, with 6 membranous equal erect-spreading lobes united below into a tube, subtended by an entire or 2-cleft bract. Stamens inserted on the throat of the perianth, equal or nearly so. Ovary 3-celled; style long, filiform, 3-cleft at the summit; ovules numerous, in 2 rows in each cavity. Capsule subglobose or depressed, 3-lobed, loculicidally 3 -valved. Seeds mostly flattened, black or nearly so. [Greek, signifying wind-flower.] About 30 species, natives of America. Besides the following, 4 others occur in the southern U. S. (Zephyranthes Herb.)

1. Atamósco Atamásco (L.) Greene. Atamasco Lily. (I. F. f. ro62.) Bulb ovoid, about $2.5 \mathrm{~cm}$. long. Leaves fleshy, shining, 1.5-4 dm. long, 3-6 mm. wide, blunt, usually shorter than the scape; scape terete, erect; bract 2 -cleft into acuminate lobes, longer than the ovary; flowers 5-9 $\mathrm{cm}$. high, white with a purplish tinge or sometimes light purple; perianth-segments oblong-lanceolate, acute, shorter than the tube; stamens shorter than the tube; style longer than the stamens; capsule depressed, about $1.2 \mathrm{~cm}$. high. In moist places, S. Penn. (?), E. Va. to Fla. and Ala. Perianth rarely 8-lobed. March-June. (Zephyranthes Atamasco Herb.)

\section{COOPÈRIA Herb.}

Low herbs with coated bulbs, grass-like leaves and I-flowered scapes, the flower large, long, erect, subtended by a spathe-like bract. Perianth salverform, with 6 spreading lobes. Stamens inserted on the throat of the perianth; filaments short; anthers linear. Ovary 3-celled; style filiform; stigma slightly 3-lobed; ovules numerous, in 2 rows of each cavity of the ovary. Capsule depressed, 3 lobed, loculicidally 3-valved. Seeds numerous, horizontal, black. [In honor of Daniel Cooper, I8 17 ? -1842 , Curator, Botanical Society of London.] Two known species, natives of the southwestern U. S. and Mex.

I. Cooperia Drummóndii Herb. Drummond's Cooperia. (I. F. f. I063.) Bulb globose, about $2.5 \mathrm{~cm}$. in diameter. Leaves $1.5-3 \mathrm{dm}$. long, 4-6 mm. wide. erect; scape slender, hollow, about as long as the leaves; spathe-like bract $2-5 \mathrm{~cm}$. long, 2-cleft above into acuminate lobes; flower 7-13 cm. high, white or pinkish; tube of the perianth very slender, about $3 \mathrm{~mm}$. in diameter, slightly expanded just below the limb; segments oblong, nearly $2.5 \mathrm{~cm}$. long; ovary sessile; capsule somewhat obovoid, about I cm. in diameter, deeply lobed. On prairies, Kans. to La., Tex., Mex. and N. Mex. April-July. 


\section{HYMENOCÁLLIS Salisb.}

Mostly tall bulbous herbs with usually lanceolate or linear-oblong leaves, and large white umbelled flowers on solid scapes, each flower subtended by 2 mem. branous bracts. Perianth of 6 spreading or recurved narrow equal elongated lobes, united below into a long cylindric tube. Stamens inserted in the top of the perianthtube, the lower parts of the long filaments connected by a membranous crown; anthers linear, versatile. Ovary 3-celled; ovules only $\mathbf{I}$ or 2 in each cavity; style filiform, long-exserted; stigma small, entire or nearly so. Capsule rather fleshy. Seeds usually only I or 2, large, green, fleshy. [Greek, beautiful membrane, referring to the crown.] About 30 species, all American. Besides the following, ro others occur in the Southern States.

I. Hymenocalis occ:dentàlis (Le Conte) Kunth. Hymenocallis. (I. F. f. 1064.) Bulb large. Leaves linear-oblong, narrowed at each end, fleshy, glaucous, 3-6 dm. long, $1.5-5 \mathrm{~cm}$. wide ; scape equalling or longer than the leaves; bracts linear-lanceolate; umbel several-flowered; perianth-tube 3-4 $\mathrm{mm}$. in diameter, $7-13 \mathrm{~cm}$. long, the linear lobes nearly as long; crown funnelform, narrowed below, $2.5-3 \mathrm{~cm}$. long, its margins entire, erose or 2 -toothed between the filaments ; free part of the filaments about $2.5 \mathrm{~cm}$. long, white; anthers $1 \mathrm{~mm}$. wide, yellow; style extending for $5-8 \mathrm{~cm}$. beyond the crown, green; fruit $1.2-2 \mathrm{~cm}$. in diameter. In moist soil, Ga. to S. Ill. and Mo. July-Sept.

\section{AGÀVE L.}

Fleshy herbs, some tropical species very tall, with a short crown-like or erect rootstock (caudex) and tall bracted scapes, the leaves large, thick, sometimes spinytoothed, basal, or clustered at the top of the caudex, and large bracted flowers in terminal spikes or compound clusters. Perianth tubular or funnelform, withering. persistent, of 6 equal or nearly equal lobes, united below into a tube. Stamens inserted on the perianth at the bases of the lobes, exserted. Ovary 3-celled; style slender, exserted, 3 -lobed; ovules numerous, in 2 rows in each cavity of the ovary. Capsule 3-lobed, thick-walled, many-seeded. Seeds compressed, somewhat cuneate, black. [Greek, signifying noble.] About 140 species, all American. Besides the following, some I 2 others occur in the southwestern States.

I. Agave Virgínica L. False Aloe. (I. F. f. 1065.) Glabrous throughout; rootstock a short crown. Scape 6-12 dm. tall, sometimes nearly $1.2 \mathrm{~cm}$. in diameter at the base, its bracts distant, long-acuminate; leaves narrowly oblong, I.5-6 dm. long, acuminate, their margins entire or denticulate; spike 3-6 dm. long, loose ; flowers greenish yellow, odorous, solitary in the axils of short bracts; perianth slightly expanded above, $\mathbf{1} \cdot \mathbf{5 - 2 . 5} \mathrm{cm}$. long, the tube about twice as long as the erect lobes ; capsule $\mathbf{I}-\mathrm{I} .6 \mathrm{~cm}$. in diameter, abruptly contracted into a short stalk. In dry soil, Md. to Ind., Mo., Fla. and Tex. Summer.

\section{HYPO'XIS L.}

Low, mostly villous herbs, with a corm or short rootstock, grass-like leaves and slender few-flowered scapes, the flowers rather' small. Perianth 6-parted, its segments equal or nearly so, separate to the summit of the ovary, witheringpersistent, the 3 outer ones greenish on the lower side in our species. Stamens inserted on the bases of the perianth-segments ; filaments short ; anthers erect, sagittate or entire. Ovary 3-celled; style short ; stigmas 3, erect; ovules numerous, in 2 rows in each cavity. Capsule thin-walled, not dehiscent by valves. Seeds globular, black, laterally short-beaked by their stalks. [Greek, originally given to some plant with sour leaves.] About 50 species, widely distributed. Besides the following, two others occur in the southern States.

I. Hypoxis hirsùta (L.) Coville. Stargrass. (I. F. f. Io66.) Corm 6-I2 mm. in diameter. Leaves basal, narrowly linear, 2-5 mm. wide, more or less villous, mostly longer than the scapes ; scapes slender, erect, villous above, 5-I5 cm. high; flowers I-6, umbellate; bracts subulate, shorter than the pedicels; perianthsegments narrowly oblong, spreading, mostly obtuse, bright yellow within, villous without, 6-10 mm. long; stamens somewhat unequal; style 3 -angled, the stigmas decurrent on the angles; capsule about $3 \mathrm{~mm}$. in diameter. In dry soil, Me. and Ont. to Assiniboia. Fla. and Tex. May-Oct. 


\section{LOPHOLA Ker.}

An erect perennial herb with slender rootstocks, erect sparingly leafy stems, the leaves narrowly linear and mostly basal, and numerous small yellowish flowers in a terminal woolly cymose panicle. Perianth campanulate, persistent, of 6 nearly equal woolly segments, slightly united at the base. Stamens inserted on the bases of the perianth-segments; filaments filiform, short; anthers basifixed. Ovary 3 -celled; style subulate, at length 3 -cleft; ovules numerous, in 2 rows in each cavity. Capsule ovoid, finally loculicidally 3 -valved at the summit. Seeds oblong, numerous, ribbed. [Greek, referring to the tufts of wool on the perianth.] A monotypic genus of southeastern N. A.

I. Lophiola Americàna (Pursh) A. Wood. Lophiola. (I. F. f. I067.) Stem stiff, terete, glabrous below, white-woolly above, 3-6 dm. tall. Leaves equitant, glabrous, much shorter than the stem, the upper ones reduced to scales: panicle densely white-woolly, composed of numerous few-several-flowered cymes; pedicels short, rather stout ; perianth-segments linear-lanceolate, about $4 \mathrm{~mm}$. long, longer than the stamens and with a tuft of wool at the base within; capsule about as long as the persistent style. Pine barren bogs, N. J. to Fla. June-Aug. [L. aurea Ker.]

\section{Family 8. DIOSCOREÀCEAE Lindl.}

\section{Yam Family.}

Herbaceous or slightly woody twining vines with fleshy or woody rootstocks, slender stems, petioled, mostly cordate, several-nerved and reticulate-veined leaves, and small inconspicuous diœcious or monœcious. (in some exotic genera perfect) regular nowers in spikes, racemes or panicles. Perianth 6-parted, that of the pistillate flowers persistent. Staminate flowers with 6 or 3 stamens, sometimes with a rudimentary ovary. Pistillate flowers with an inferior 3 -celled ovary, 3 styles and 3 terminal stigmas, sometimes also with 3 or 6 staminodia; ovules 2 (rarely I) in each cavity of the ovary, pendulous, anatropous or amphitropous. Fruit a 3-valved, 3-angled capsulc in the following genus. Endosperm of the seed fleshy or cartilaginous, enclosing the small embryo. About 9 genera and 175 species, mostly natives of America, a few in the Old World.

\section{DIOSCOREA L.}

Characters of the family as defined above. [Name in honor of the Greek natturalist Dioscorides.] About 160 species, most numerous in tropical regions, a few in the temperate zones.

r. Dioscorea villòsa L. WiLD YAM-Root. (I. F. f. I068.) Rootstock knottedhorizontal, woody, r.5-3 dm. thick. Stem 2-5 m. long, glabrous; leaves ovate, entire, slender-petioled, alternate or the lower opposite or in 4's, acuminate, cordate at the base, 5-15 cm. long, 9-13-nerved, thin, pale and more or less pubescent beneath; flowers greenwish yellow, nearly sessile, the staminate $2-3 \mathrm{~mm}$. broad in drooping panicles, the pistillate about $6 \mathrm{~mm}$. long in drooping spicate racemes; capsules membranous, 1.5-2.5 cm. long, strongly 3-winged. In moist thickets, R. I. to Ont., Minn., Fla. and Tex. June-July. Fruit ripe Sept., persistent on the vines into the winter.

\section{Family 9. IRIDÀCEAE Lindl.}

\section{Iris Family.}

Perennial herbs with narrow equitant 2-ranked leaves and perfect, mostly clustered flowers subtended by bracts. Perianth of 6 segments or 6-lobed, its tube adnate to the ovary, the segments or lobes in two series, convolute in the bud, withering-persistent. Stamens 3, inserted on the perianth opposite its outer series of segments or lobes; filaments 
filiform, distinct or united; anthers 2-ceiled, extrorse. Ovary inferior, mostly 3-celled; ovules mostly numerous in eacli cell, anatropous; style 3-cleft, its branches sometimes divided. Capsule 3-celled, loculicidally dehiscent, 3-angled or 3-lobed (sometimes 6-lobed), many-seeded. Endosperm fleshy or horny; embryo straight, small. About 57 genera and Iooo species, of wide distribution.

Style-branches opposite the anthers, very broad, petal-like.

Style-branches alternate with the anthers, slender or filiform.

Style-branches, 2-cleft; plants bulbous.

Style-branches undivided; plants not bulbous.

Filaments all distinct; seeds fleshy.

Filaments united; seeds dry. x. Iris.

2. Nemastylis.

3. Gemmingia.

4. Sisyrinchum.

\section{IRIS L. (See Appendix.)}

Herbs, with creeping or horizontal, often woody rootstocks, erect stems, erect or ascending equitant leaves, and large regular terminal sometimes panicled flowers. Perianth of 6 clawed segments united below into a tube, the three outer dilated, spreading or reflexed, the 3 inner narrower, smaller, usually erect, or in some species about as large as the outer. Stamens inserted at the base of the outer perianth-segments; anthers linear or oblong. Ovary 3-celled; divisions of the style petal-like, arching over the stamens, bearing the stigmas immediately under their mostly 2-lobed tips; style-base adnate to the perianth-tube. Capsule oblong or oval, 3-6-angled or lobed. Seeds numerous, vertically compressed, in 1 or 2 rows in each cavity. [Greek, rainbow, referring to the variegated flowers.] About roo species, mostly in the north temperate zone. Besides the following, some 8 others occur in the southern and western parts of N. Am.

Stenis tall, usually several-flowered, leafy; outer perianth-segments larger than the inner.

Flowers blue, variegated with yellow, white or green (rarely all white).

None of the perianth-segments crested; native species.

Leaves $\mathrm{I}-2.5 \mathrm{~cm}$. wide.

Leaves somewhat glaucous.

Leaves bright green, not glaucous.

x. I. versicolor.

Outer perianth-segments 7-10 cm. long; flowers sessile.

Outer perianth-segments $6-7 \mathrm{~cm}$. long; flowers pedicelled.

Leaves much narrower, 4-8 $\mathrm{mm}$. wide.

3. I. Caroliniana.

Capsule obtusely angled, 3-6-lobed.

Capsule 3-lobed; northern.

Capsule 6-lobed; western.

Capsule sharply 3 -angled.

Outer perianth-segments strongly crested; introduced.

Flowers reddish or red-brown.

Flowers bright yellow; introduced species.

4. I. Hookeri.

5. I. Missouriensis.

6. I. prismatica.

7. I. Germanica.

8. I. fulva.

9. I. Pseudacorus.

Stems low, seldom over $\mathrm{r} .5 \mathrm{dm}$. tall, $\mathrm{x}-3$-flowered; outer and inner perianth-segments nearly equal.

Outer perianth-segments crested; leaves lanceolate.

Perianth-tube very slender, exceeding the bracts.

Perianth-tube expanded above, not exceeding the bracts. II. I. lacustris

Outer perianth-segments crested, claws slightly pubescent; leaves linear.

12. I. verna.

I. Iris versícolor L. Larger Blue FlaG. (I. F. f. 1069.) Rootstock fleshy. Stem terete or nearly so, 6-1o dm. tall, leafy; leaves erect, shorter than the stem, somewhat glaucous, $12-25 \mathrm{~mm}$. wide; bracts commonly longer than the pedicels; flowers violet-blue, variegated with yellow, green and white; perianth-segments glabrous, crestless, the outer ones spatulate, $5-8 \mathrm{~cm}$. long, longer and wider than the inner; perianth-tube shorter than the ovary; capsule oblong, obscurely 3 -lobed, about $3 \mathrm{~cm}$. long and $1.5 \mathrm{~cm}$. in diameter; seeds $4-6 \mathrm{~mm}$. broad, in 2 rows in each cavity. In marshes, thickets, and wet meadows, Newf. to Manitoba, Fla. and Ark. May-July.

2. Iris hexagòna Walt. Southern Blue FlaG. (I. F. f. rojo.) Roctstock stout, thick. Stems terete, usually simple, leafy, 3-9 dm. tall; leaves 1-3 
$\mathrm{cm}$. wide, green, not glaucous, the lower often 6-9 dm. long; flowers solitary in the upper axils, sessile, similar to those of $I$. versicolor, but larger, the broader outer crestless perianth segments often I dm. long and over $2.5 \mathrm{~cm}$. wide, much wider than the erect inner ones; perianth-tube rather longer than the ovary; capsule oblong-cylindric, 6-angled, about $5 \mathrm{~cm}$. long; seeds in 2 rows in each cavity. In swamps, S. Car. and Fla. to Ky., Mo. and Tex. April-May.

3. Iris Caroliniàna S. Wats. Carolina Blue Flag. (I. F. f. Io7I.) Rootstock stout, fleshy. Stem 6-1o dm. tall ; leaves bright green, $1.5-3 \mathrm{~cm}$. widc; flowers solitary or 2 or 3 together, lilac, variegated with yellow, purple and brown, pedicelled; outer perianth-segments broadly spatulate, $6-8 \mathrm{~cm}$. long, with narrow claws, the inner narrower and nearly erect; perianth-tube about $1.2 \mathrm{~cm}$. long above the ovary ; capsule oblong, obtusely 3-angled, 3-5 cm. long; seeds in I row in each cavity, 8-10 mm. broad. In swamps, S. Va. and E. N. Car. May-Jume.

4. Iris Hóokeri Penny. Hooker's Blue Flag. (I. F. f. Io72.) Rootstock rather slender. Stems slender, terete, 2.5-5 dm. tall. Leaves mostly basal, narrowly linear, bright green, 4-8 $\mathrm{mm}$. wide ; flowers solitary or 2 together, pedicelled, the pedicels shorter than the bracts; perianth-segments glabrous, crestless, the inner ones oblanceolate, much shorter and smaller than the outer; capsule short-oblong, 2-3 cm. long, thin-walled, transversely veined, obtusely 3 -lobed ; seeds in 2 rows in each cavity, about $3 \mathrm{~mm}$. broad. On river shores, Newf. to Quebec and Me. Summer.

5. Iris Missouriénsis Nutt. Western Blue Flag. (I. F. f. IO73.) Rootstock stout. Stem rather slender, terete, I.5-6 dm. tall, I-2-flowered; leaves mostly basal, green, sometimes purplish below, 4-8 mm. wide ; flowers pale blue and variegated, pedicelled; pedicels slender, $1-5 \mathrm{~cm}$. long, usually shorter than the scarious bracts; perianth-segments glabrous, crestless, the outer ones $5-6 \mathrm{~cm}$. long, the inner somewhat shorter, the tube $6-8 \mathrm{~mm}$. long above the ovary; capsule oblong, 2.5-3 cm. long, obtusely 6-angled, faintly veined. In wet soil, S. Dak. to Mont., Nev., Colo. and Ariz. May-July.

6. Iris prismática Pursh. Slender Blue Flag. (I. F. f. Io74.) Rootstock rather slender, tuberous-thickened. Stems slender, often flexuous, 3-9 dm. tall, usually simple, bearing 2 or 3 leaves; leaves almost grass-like, 3-5 mm. wide; flowers solitary or 2 together, blue, veined with yellow, slender-pedicelled; pedicels commonly longer than the bracts; outer perianth-segments $3-5 \mathrm{~cm}$. long. glabrous and crestless, the inner smaller and narrower, the tube 4-6 $\mathrm{mm}$. long above the ovary ; capsule narrowly oblong, acute at each end, sharply 3 -angled, $2.5-3.5 \mathrm{~cm}$. long, 6-8 mm. thick; seeds about $2 \mathrm{~mm}$. broad, thick, borne in $\mathrm{I}$ row in each cavity. In wet grounds, N. B. to Penn. and N. Car. May-June.

7. Iris Germánica L. FleUR-DE-LIS. (I. F. f. IO75.) Rootstock thick. Stems stout, usually branched and several-flowered, 4-9 dm. tall, bearing several leaves. Leaves glaucous, $1.5^{-2.5} \mathrm{~cm}$. wide, the basal ones mostly shorter than the stem; bracts scarious; flowers nearly sessile, large and showy, deep violetblue veined with yellow and brown or sometimes white; outer perianth-segments broadly obovate, 7-10 cm. long, their claws strongly crested; inner perianthsegments narrower, arching. Escaped from gardens to roadsides in $\mathrm{Va}$. Native of Europe. May-June.

8. Iris fúlva Ker. Red-Brown FlaG. (I. F. f. Io76.) Rootstock stout, fleshy. Stems sleıder, 6-9 dm. tall, several-flowered and bearing 2-4 leaves; leaves pale green and somewhat glaucous, $6-16 \mathrm{~mm}$. wide; pedicels $\mathrm{I}-2.5 \mathrm{~cm}$. long, shorter than the bracts; flowers reddish brown, variegated with blue and green ; perianth-segments glabrous, crestless, the outer ones 3-5 cm. long, the inner smaller, spreading; style-branches $4-6 \mathrm{~mm}$. wide. In swamps, S. Ill. to Ga., La., Mo., Ark. and Tex. May-June.

9. Iris Pseudácorus L. Yellow FlaG. (I. F. f. ro77.) Rootstock thick. Stems 3-9 dm. high, usually several-flowered; leaves pa'e green and glaucous, stiff, 8-16 mm. wide; flowers bright yellow, short-pedicelled; perianth-segments glabrous and crest'ess, the outer broadly obovate, 5-6 cm. long, the inner oblong, nearly erect, scarcely longer than the claws of the outer ones; capsule ob.ong, 5-8 cm. long. In marshes, Mass. to N. Y. (Ohio ?) and N. J. Nat. or adv. from Europe. May-July.

10. Iris cristàta Ait. Crested Dwarf IRIS. (I. F. f. IO78.) Ruotstock 
slender, branched, creeping, tt serous-thickened. Stems only 2-8 cm. high, I-2. flowered; leaves lanceolate, bright green, I-2 dm. long, 6-1 $8 \mathrm{~mm}$. wide, much exceeding the stems; stem flattened; flowers blue, pedicelled; perianth-segments obovate, $2.5-3.3 \mathrm{~cm}$. long, the outer crested, little longer than the naked inner ones, the tube very slender, 3-6 cm. long above the ovary, longer than the bracts; capsule oval, sharply triangular, narrowed at each end, 1.2-2 cm. high. 'On hillsides and along streams, Md. to S. Ohio, Ind., Ga., Tenn. and Mo. April-May.

I I. Iris lacústris Nutt. DWarf Lake IRIS. (I. F. f. IO79.) Similar to the preceding in size and foliage, or the leaves rather narrower, sometimes wavymargined. Flowers blue; perianth-tube only $\mathbf{I}-2.5 \mathrm{~cm}$. long, shorter than the bracts and the sometimes yellowish perianth-segments, somewhat expanded up. ward; capsule ovoid, about $1.5 \mathrm{~cm}$. high, borne on a pedicel of about its own length. Shores of Lakes Huron and Superior. Local. May.

12. Iris vérna L. DWARF IRIS. (I. F. f. IO80.) Rootstock slender. Stems 2-8 cm. high, usually I-flowered. Leaves narrowly linear, $0.7-2 \mathrm{dm}$. high, 4-IO $\mathrm{mm}$. wide; flowers violet-blue or rarely white, pedicelled; perianth-segments crestless, the outer about $3 \mathrm{~cm}$. long, obovate, narrowed into slightly pubescent slender yellow claws, the inner somewhat smaller, glabrous; capsule obtusely triangular, short. On shaded hillsides and in woods, S. Penn., Va., Ky. and Ga. AprilMay.

\section{NEMÁSTYLIS Nutt.}

Bulbous herbs, with erect slender terete usually branched stems, and elongated linear folded leaves. Flowers rather large, in our species blue or purple, solitary or several together, fugacious, sultended by 2 herbaceous bracts. Perianth of 6 spreading nearly equal obovate segments, distinct nearly or quite to the summit of the ovary. Filaments more or less united; anthers short; style short, its branches slenderly 2-parted; stigmas small, terminal. Capsule loculicidally dehiscent at the summit. [Greek, referring to the thread-like style-branches.] About Io species, natives of America. Besides the following, some 3 others occur in the southern U. S.

I. Nemastylis acùta (Bart.) Herb. Northern Nemastylis. (I. F. f. IO3̊.) Bulb dark colored, ovoid, scaly, $2.5 \mathrm{~cm}$. long or less. Stem 3-6 dm. tall, bearing 3 or 4 leaves $0.7-2.5 \mathrm{dm}$. long, 3-5 mm. wide; bracts lanceolate, each pair subtending I or 2 flowers; flowers light blue or purple, 2-5 cm. broad, slenderpedicelled; pedicels rather shorter than the bracts; perianth-segments obtuse; stylebranches exserted between the free parts of the filaments, their filiform divisions 4-6 mm. long ; capsule obovoid, ro-12 mm. high. On prairies, Tenn. to Kans., Ark., La. and Tex. April-June.

\section{GEMMINGIA Fabr. [PARDANTHUS Ker.]}

An erect perennial herb, with stout rootstocks and Iris-like leaves. Flowers in terminal bracted clusters, rather large, crimson and purple-mottled. Perianth of 6 oblong spreading nearly equal withering-persistent segments, distinct very nearly to the summit of the ovary. Stamens inserted on the bases of the segments; anthers linear-oblong. Style very slender, enlarged above, the 3 slender undivided branches alternate with the anthers. Capsule fig-shaped, obovoid, thin-walled, loculicidally 3 -valved, the valves recurving, finally falling away, exposing the mass of black fleshy seeds, borne on a central axis. A monotypic genus of eastern Asia.

I. Gemmingia Chinénsis (L.) Kuntze. Blackberry Lily. (I. F. f. IO82.) Stem stout, $0.4-1.2 \mathrm{~m}$. tall, leafy. Leaves equitant, $2-2.5 \mathrm{dm}$. long, $1.6-2.5 \mathrm{~cm}$. wide, the two sides united above the middle; upper bracts scarious; flowers several or numerous, 3-5 cm. broad; perianth-segments obtuse, mottled with crimson and purple, persistent; capsule about $2.5 \mathrm{~cm}$. high, the persistent mass of globose black seeds resembling a blackberry. On hills and along roadsides, S. N. Y. to Ga., Ind. and Mo. Nat. from Asia. June-July.

\section{SISYRÍNCHIUM L.*}

Perennial mostly tufted slender herbs with fibrous roots from contracted rootstocks, simple or branched 2 -winged or 2-edged stems, and linear grass-like leaves. 
Flowers from terminal spathes consisting of mostly one pair of opposite conduplicate herbaceous bracts enclosing membranous scales; perianth blue, violet, or white with a yellow eye, rarely all yellow, the 6 oblong or obovate segments spreading and aristulate; filaments monadelphous; anthers linear or oblong, the sacs distinct at base; style threadform, the branches filiform or obsolete; ovary 3-celled; capsule globose, oval or obovoid, usually trigonous, loculicidally 3 -valved; seeds globose to obovoid, often angled, pitted or smooth. Flowers fugacious, opening successively in sunlight, each usually lasting but a day. Probably not less than 125 species, nearly all American. Besides the following many others occur in the Southern and Western States.

Filaments free above, anthers over $3.5 \mathrm{~mm}$. long; spathes twin, sessile, terminating the subterete wingless stem.

Filaments monadelphous to the top; anthers under $2.5 \mathrm{~mm}$. long.

Spathes twin, sessile, terminating the winged stem.

Spathes single.

Flowers yellow; primary bract long and foliaceous, stem simple.

Flowers blue, violet or white.

I. S. hastile.

2. S. albidum.

\section{S. faviflorum.}

Stems mostly simple with a sessile terminal spathe.

Capsules 4-6 mm. 'ligh, lesvos 2-6 nim. wide.

Capsules 2-4 mm. high, leaves $0.5^{-2} \mathrm{~mm}$. wide.

6. S. angustifolium.

Bracts glabrous, the outer one united-clasping below, flowers deep violet blue, rarely white.

5. S. mucronatum.

Bracts scabrous, puberulent, sometimes glabrous, the outer one not united-clasping at base or scarcely so; flowers pale blue or white. 3. S. campestre.

Stems both simple and branched, broadly winged; spathes mostly purplish. 7. S. intermedium.

Stems mostly branched above, bearing two or more pedunculate spathes.

Tufts fibrose-coated at base.

Plant turning dark when dry ; capsules dark and thick-walled; peduncles mostly over I $\mathrm{mm}$. wide ; coastwise.

Plant not turning dark when dry; capsules pale and thin-walled; peduncles mostly under $0.5 \mathrm{~mm}$. wide. 9. S. Farallii.

Tufts not fibrose-coated at base.

Plant usually turning dark in drying; stem broadly winged; pedicels spreading or recurved.

ro. S. graminoides.

Plant not turning dark when dry; pedicels not recurved; spreading. Capsules dark and thick-walled.

Spathes 13-20 mm. long; capsules longer than broad, not apiculate; inner bract obtuse. II. S. Atlanticum.

Spathes ro-r $3 \mathrm{~mm}$. long; capsules broader than long, apiculate.

12. S. apiculatum.

Capsules pale and thin-walled; peduncles closely erect; inner bract acute.

13. S. strictum.

1. Sisyrinchium hástile Bicknell. Spear-Like Sisyrinchium. Very slender and stiffly erect, dull green, 3-4 dm. high. Stems I mm. wide cr less, compressed-subterete and bluntly two-edged, not at all winged, closely striate, minutely granulose-roughened; leaves similar to the stems, usually shorter, thickedged, obtusely slender-pointed, the conduplicate broadened base smooth and membranous; spathes usually two in a close pair at the top of the stem, each usually 4-bracted, the bracts lanceolate-attenuate, the inner ones $2-2.5 \mathrm{~cm}$. long; primary bract slenderly much prolonged; interior scales ample, sometimes slightly exserted; flowers few, on pedicels not longer than the inner bracts. Fruit and color of flower unknown. Sandy shores of Belle Isle in the Detroit River, Mich. Early June.

2. Sisyrinchium álbidum Raf. White Blue-eyed Grass. Green and glaucescent, the spathes often purplish, 1.5-4.5 dm. high. Leaves half the lieight of the stems or longer, I-3.5 mm. wide, very acute, mostly smooth-edged; stems usually broadly winged, I-3 $\mathrm{mm}$. wide, the edges serrulate to smooth; spathes sessile in a close terminal pair, the prominent outer bract $2.5-7 \mathrm{~cm}$. long, its edges free to the base; inner bracts acuminate, often ciliolate on the keel, mostly 15-20 $\mathrm{mm}$. long; flowers white to pale blue; perianth 8-12 $\mathrm{mm}$. long; capsules pale, depressed-subglobose, $2-3 \mathrm{~mm}$. hign, on erect-spreading pedicels usually shorter 
than the inner bracts; seeds globose, I mm. or less in diameter, umbilicate, dis. tinctly pitted. Mo. to Mich., La., Ala. and N. Car. April-June.

3. Sisyrinchium campéstre Bicknell. Prairie Blue-eyed Grass. Similar to $S$. mucronatum Michx., but often stiffer and more glaucous, with always smoothedged stems and leaves, usually broader, more gibbous spathes, and pale blue or frequently white flowers. Stem usually less than $1 \mathrm{~mm}$. wide, the leaves rather broader; spathes green to dull pink-purple, the bracts commonly scabrous-puberulent all over, but sometimes glabrous, the outer one usually less slenderly prolonged than in $S$. mucronatum, and not united-clasping at base, or but slightly so, 2.5-4.5 cm. long, rarely more than twice longer than the inner bract, which emerges more abruptly from the base of the spathe than in $S$. mucronatum, and has more broadly hyaline edges; capsules pale, trigonous-subglobose, 2-4 mm. high. Wis. to N. Dak., La. and N. Mex., mostly on prairies. May-June.

Sisyrinchium campéstre Kansanum Bicknell. Becoming stouter and broader-leaved than the type with larger, longer-bracted spathes and coarser roots; pale green and glaucous, usually without any purplish tinge, the flowers apparently always white. Stems rather broadly winged, $\mathrm{x}-2 \mathrm{~mm}$. wide, the stiff often falcate leaves becoming $2.5 \mathrm{~mm}$. wide; bracts mostly smooth, sometimes obscurely roughened, the margins conspicuously white-hyaline, the outer one slenderly prolonged often for more than twice the length of the inner one, sometimes $6.5 \mathrm{~cm}$. long; capsules apparently not larger than in the type. Kans. and Oklohoma.

4. Sisyrinchium flaviflòrum Bicknell. Yellow-Flowered Sisyrinchium. About $2.5 \mathrm{dm}$. high, dull green, glaucescent. Leaves sometimes equalling the stems, smooth-edged or nearly so, acute, the larger ones broadened upward, $\mathbf{1}-2.5 \mathrm{~mm}$. wide ; stems rather prominently winged, I-3 mm. wide, broader at the base of the spathe, smooth-edged; bracts of the spathe membranous, smooth, the outer one much prolonged and foliaceous, mostly about $6 \mathrm{~cm}$. long and surpassing the inner bract 3-4 cm., the narrowly hyaline margins free to the base; flowers lemon. yellow, on pedicels IO-I $5 \mathrm{~mm}$. long, sometimes only half the length of the inner bract; perianth about $12 \mathrm{~mm}$. long. Fruit not known. Missouri. June.

5. Sisyrinchium mucronàtum Michx. Michaux's Blue-Eyed Grass. More cæspitose than $S$. angustifolium and decidedly more slender and delicate, with smaller spathes and capsules, sometimes scarcely glaucescent and the spathes often bright red-purple. Stem and leaves from capillaceous to $1.5 \mathrm{~mm}$. wide, rarely wider, the edges very smoth to denticulate-scabrous, the stems narrowly winged or merely margined, sometimes not longer than the leaves; spathes often slightly bent, the bracts thin, glabrous, hyaline-margined, the outer one slenderly prolonged, $1.5-6 \mathrm{~cm}$. long, united-clasping for $\mathbf{I}-6 \mathrm{~mm}$. at base; inner bract scarious, obtuse to attenuate, 10-20 mm. long, gradually emerging from the outer one, flowers deep violet blue, rarely white; perianth 6-14 $\mathrm{mm}$. long; capsules pale and thin-walled, subglobose to obovate-oblong, trigonous, $2 \cdot 4 \mathrm{~mm}$. high, on slender subspreading exserted pedicels. In meadows and fields, southeastern Mich. to N. J. and Va. May-June.

6. Sisyrinchium angustifjlium Miller. Northern Blue-eyed Grass. (I. F. f. I085.) Stiff and erect, pale and glaucous, 8-55 cm. high. Leaves half the height of the stem or longer, I-3.5 mm. wide, acute, the edges minutely serrulate; stem simp'e or rarely branched, I-3 $\mathrm{mm}$. wide, winged, the edges minutely serrulate; spathes green or slightly purplish, the outer bract rarely less than twice the length of the inner one, $2-6.5 \mathrm{~cm}$. long, obscurely hyaline-margined, united-clasping for 2-6 $\mathrm{mm}$. at base; inner bract attenuate, 15-30 $\mathrm{mm}$. long ; flowers deep violetblue; the perianth IO-12 mm. long; capsules broadly oval to globose, 4-6 $\mathrm{mm}$. high, pale, often purplish-tinged, on erect pedicels usually shorter than the inner bract. Fields and hillsides, Newf. to N. J. and on the mountains to Va., west to Saskatchewan and Colo. May-June.

7. Sisyrinchium intermèdium Bicknell. Intermediate Blue-eyed Grass. Dull green and glaucescent, drying dark, the spathes usually purple. Tufts not fibrose at base, IO-40 cm. high; stems either simple or branched above into two peduncles; leaves very tlin and weak-nerved, I.5-2.5 mm. wide, often smoothedged; stems erect but frail, mostly $\mathbf{1 . 5} \mathrm{mm}$. wide, very flat, the thin wings serrulate ; peduncles usually shorter than the subtending reaf, $5-8 \mathrm{~cm}$. long, the outer one 
divergent; bracts of the spathe thin, cuspidate-acute; the outer one attenuately prolonged, $2-6 \mathrm{~cm}$. long, on simple stems sometimes three times the length of the inner one; flowers few, 3-6, pale blue; perianth 8-12 mm. long; capsules dark, subglobose, about $4 \mathrm{~mm}$. high, on slenderly exserted finally spreading pedicels. S. N. J. to N. Car. May-June. Intermediate in appearance between S. angustifolium, or $S$. mucronatum, and $S$. graminoides.

8. Sisyrinchium arenicola Bicknell. Sand Blue-eyed Grass. Deep green or glaucescent, often purplish-tinged, the base of the tufts coarsely fibrous. Leaves stiff, attenuate, cuspidate-acute, $\mathbf{I}-3 \mathrm{~mm}$. wide, closely striate; usually serrulate; stem erect, often curved, $20-40 \mathrm{~cm}$. high, r.5-3 mm. wide, stiff, the firm wings striate, mostly serrulate; node commonly only one, its erect leaf conspicuous, attenuate-acute, the compressed broadened base strongly striate; peduncles 2-4, curved, subequal and approximate, $3-12 \mathrm{~cm}$. long. mostly $1 \mathrm{~mm}$. wide or more; spathes erect, the acute bracts firm and strongly striate, slightly unequal: flowers sometimes as many as I2, deep violet-blue; perianth 8-10 $\mathrm{mm}$. long: capsules dark and thick walled on erect slightly exserted pedicels, broadly oval or obovoid, 3-5 mm. high. L. I., Staten I. and N. J., in sandy soil on or near the coast. June-July.

9. Sisyrinchium Farwèllii Bicknell. Farwell's Blue-eyed Grass. Dull green and glaucescent, not turning dark when dry, the thin tufts fibrous-coated at base. Leaves much shorter than the stems, $\mathbf{r}-3 \mathrm{~mm}$. wide, firm, membranous, attenuate-acute, the edges serrulate to smooth. Stems flexuous-erect, $20-30 \mathrm{~cm}$. high, r-2 mm. wide, winged, the edges usually serrulate; nodes one or two, their leaves shorter than the two or three peduncles, slenderly attenuate; peduncles very slender, 4-II cm. long, mostly less than $0.5 \mathrm{~mm}$. wide; spathes pale, narrow, 17-20 $\mathrm{mm}$. long, the bracts subequal, papery, sometimes only obscurely nerved, slenderpointed or subaristulate. Flowers very small, pale blue. Capsules pale and thinwalled, subglobose, $2-3 \mathrm{~mm}$. high on slender, flexuously erect, much exserted pedicels. Southeastern Mich.

ro. Sisyrinchium graminoides Bicknell. Common Blue-Eyed Grass. (I. F. f. ro83.) Sometimes not at all tufted, bright green, often glaucescent, drying dark. Stem and leaves thin and grass-like, 2-6 mm. wide, the edges minutely serrulate; leaves usually half the height of the stem; stem broadly winged, forking into two winged peduncles $5-20 \mathrm{~cm}$. long, subtended by a conspicuous erect acuminate leaf; nodes sometimes two: spathes mostly green, erect, the bracts subequal or sometimes the outer one foliaceously prolonged, the inner one acute or attenuate, $15-20 \mathrm{~mm}$. long; flowers $3-6$, blue, the perianth 8-ro $\mathrm{mm}$. long; capsules dark and thin-walled, subglobose, 4-5 mm. high, on slender exserted flexuously spreading or finally recurved pedicels. Mass. and N. H. to Minn., Fla. and Tex. May-June.

II. Sisyrinchium Atlánticum Bicknell. Eastern Blue-eyed Grass. (I. F. f. ro84.) Very pale and glaucous, not drying dark, the narrow stems and leaves firm and very smooth, mostly $\mathrm{r}-2 \mathrm{~mm}$. wide, rarely $3 \mathrm{~mm}$. Leaves attenu. ate, commonly about half the height of the stem; stem margined or narrowly winged, often somewhat geniculate at the one or two nodes; peduncles $\mathbf{r}-3$, slender, usually short; spathes often bent sideways, usually slightly purplish, the thin bracts subequal, the outer one usually acute, the incer one scarious-obtuse, mostly 12-15 mm. long: flowers 3-10, violet-blue; perianth 6-12 $\mathrm{mm}$. long; capsules dark and thick-walled, more or less oblong, $2-4.5 \mathrm{~mm}$. high, contiguous on erect little-exserted pedicels. Mass. and Vt., along and near the coast to Fla., usually in or near brackish marshes. May-June.

x2. Sisyrinchium apiculàtum Bicknell. Apiculate Brur.-eyed Grass. Pale green and glaucescent, keeping its color when dry, about $40 \mathrm{~cm}$. high, not fibrous at base. Leaves about half the height of the stems, becoming over $2 \mathrm{~mm}$. wide, acute, firm, withering-persistent, the edges very smooth; stem $\mathrm{I}-2 \mathrm{~mm}$. wide, narrowly winged, the edges smooth; nodes mostly two, supporting I-3 slender peduncles $3-8 \mathrm{~cm}$. long; leaf of upper node very short; spathes green, often deflected, short and rather broad, IO-I $3 \mathrm{~mm}$. long, the subequal bracts convex, strongly striate, acute or the inner one obtuse, the margins rather broadly whitehyaline ; flowers small, violet-blue ; capsules dark, broadly subglobose, distinctly apiculate, $2.5-3.5 \mathrm{~mm}$. high, sparsely puberulent, on loosely erect well-exserted margined pedicels. Muskegon Co., Mich. June. 
13. Sisyrinchium stríctum Bicknell. Strict Blue-EYed Grass. About $30 \mathrm{~cm}$. high in erect tufts not fibrose at base, pale light green and glaucous, not changing color when dry. Stems and leaves I-2 mm. wide, mostly serrulate, the leaves thin, tapering-acute, over half the height of the stems; node only one, its erect leaf closely united-clasping below, subequal with the two short approximate peduncles, 4-7 cm. long; spathes sometimes much tinged with red-purple, erect, narrow, I6-20 $\mathrm{mm}$. long, the bracts subequal, sharp-pointed, the outer one rather abruptly narrowed above ; flowers rather small, deep violet-blue; capsules pale and thin-walled, somewhat obovoid, about $4 \mathrm{~mm}$. high, on suberect, slightly exserted margined pedicels. In sandy soil, Montcalm Co., Mich. June.

\section{Order 9. SCITAMINÀLES.}

Large monocotyledonous herbs with very irregular flowers. Ovary inferior, composed of several united carpels. Seeds with endosperm.

\section{Family r. MARANTÀCEAE Lindl. Arrowroot Family.}

Tall herbs, perennial by rootstocks or tubers, or sometinics annual, with scapose or leafy stems, mostly large entire long-petioled sheathing leaves, often swollen at the base of the blade, the veins pinnate, parallel. Flowers perfect, or sometimes polygamous, in panicles, racemes or spikes. Perianth superior, its segments distinct to the summit of the ovary, or united into a tube, normally in 2 series of 3, the outer (sepals) usually different from the inner (petals). Perfect stamen I; anthers I-2-celled. Staminodia mostly 5, often petal-like, very irregular. Ovary I-3-celled, inferior; ovule I in each cavity, anatropous; style slender, curved, terminal; stigma simple. Fruit capsular or berry-like. Seed solitary in each cavity. Embryo central, in copious endosperm. About 12 genera and I60 species, mostly tropical.

\section{x. THÀLIA L.}

Annual (or perennial?) herbs, with long-petioled basal leaves, erect scapes and terminal panicled spikes of bracted flowers. Sepals 3, membranous, separate, equal. Petals 3, separate or somewhat coherent at the base. Staminodia slightly united below, one of them (labellum) broad, crested. Anther I-celled. Ovary I-celled or with 2 additional small empty cavities. Base of the style adnate to the base of the stamen-tube. Stigma 2-lipped, dorsally appendaged. Capsule globose or ovoid. Seed solitary, erect. Embryo strongly curved. [In honor of Jo. hann Thalius, German naturalist of the sixteenth century.] About 7 species, all American. Besides the following, another occurs in the Southern States.

I. Thalia dealbata Roscoe. Powdery Thalia. (I. F. f. I086.) Plant white-powdery nearly all over. Scapes terete, 9-18 dm. tall ; petioles 3-8 dm. long ; leaves ovate-lanceolate, acute or acuminate, $1.5-3 \mathrm{dm}$. long; panicle 2-4.5 $\mathrm{dm}$. long, its spikes numerous; bracts narrow, deciduous, not longer than the spikes; bractlets ovate, unequal, coriaceous, about $12 \mathrm{~mm}$. long; flowers purple, longer than the bractlets; capsule ovoid, about $8 \mathrm{~mm}$. in diameter. In ponds and swamps, S. Car. to La., Mo. and Tex.

\section{Order IO. ORCHIDÀLES.}

Monocotyledonous herbs, many tropical species epiphytes. Flowers very irregular, or in Burmanniaceae regular, mostly complete and perfect, their parts in 3 s or 6's. Orary inferior, compound. Seeds very rivmerous and minute, without endosperm. 


\section{Family I. BURMANNIÀCEAE Blume.}

Burmannia Family.

Low annual herbs, with filiform stems and fibrous roots. Leaves basal or reduced to cauline scales or bracts. Flowers regular, perfect, the perianth with 6 small thick lobes, its tube adnate to the ovary. Stamens 3 or 6, included, inserted on the tube of the perianth; anthers 2-celled, the sacs transversely dehiscent. Style slender; stigmas 3, dilated; ovary inferior, with 3 central or parietal placentæ. Ovules numerous. Capsule many-seeded. Seeds minute, oblong; endosperm none. Ten genera and about 60 species, widely distributed in tropical regions. The family is represented in $\mathrm{N}$. Am. by the following genus and Apteria of the Gulf States.

\section{BURMÁNNIA L.}

Erect herbs, with simple stems and small alternate scale-like or bract-like leaves. Tube of the perianth strongly 3-angled or 3 -winged, the 3 outer lobes longer than the inner. Stamens 3, opposite the inner perianth-lobes. Filaments very short; connective of the anthers prolonged beyond the sacs into a 2-cleft crest. Ovary 3 -celled, with 3 thick 2-lobed central placentr; stigmas globose or 2-lobed. Capsule crowned by the persistent perianth, opening by irregular lateral ruptures. [In honor of Johann Burmann, Dutch botanist of the eighteenth century.] About 20 species, natives of warm regions. Besides the following another occurs in the southeastern States.

I. Burmannia biflòra L. Northern Burmannia. (I. F. f. I087.) Stems very slender, $5^{-15} \mathrm{~cm}$. high, simple or forked above. Flowers I or several, terminal; angles of the perianth-tube conspicuously winged, the outer lobes ovate, acute, thie inner linear and incurved : seeds very numerous, oblong-linear, sparingly striate. In swamps and bogs, Va. to Fla. and La. Sept.-Nov.

\section{Family 2. ORCHIDÀCEAE Lindl.* Orchid Family.}

Perennial herbs, with corms, bulbs or tuberous roots, sheathing entire leaves, sometimes reduced to scales, the flowers perfect, irregular, bracted, solitary, spiked or racemed. Perianth superior, of 6 segments, the 3 outer (sepals) similar or nearly so, 2 of the inner ones (petals) lateral, alike; the third inner one (lip) dissimilar, often markedly so, usually larger, often spurred, sometimes inferior by torsion of the ovary or pedicel. Stamens variously united with the style into an unsymmetrical column; anther I or in Cypripedium 2, 2-celled; pollen in 2-8 pear-shaped, usually stalked masses (pollinia), united by elastic threads, the masses waxy or powdery, attached at the base to a viscid disk (gland). Style often terminating in a beak (rostellum) at the base of the anther or between its sacs. Stigma a viscid surface, facing the lip beneath the rostellum, or in a cavity between the anther-sacs (clinandrium). Ovary inferior, usually long and twisted, 3 -angled, I-celled; ovules numerous, anatropous, on 3 parietal placentæ. Capsule 3 -valved. Seeds very numerous, minute, mostly spindle shaped, the loose coat hyaline, reticulated ; endosperm none; embryo fleshy. About 4 Io genera and 5000 species, of wide distribution, most abundant in the tropics, many of those of warm regions epiphytes.

Anthers 2; lip a large inflated sac.

1. Cypripedium.

Anther solitary.

Pollinia with a caudicle, which is attached at the base to a viscid disk or gland. Glands enclosed in a pouch.

Sepals free; lip 3 -lobed.

Sepals united above into a hood; lip entire. 
Glands not enclosed in a pouch.

Lip not fringed nor cut-toothed.

Stem leafy; anther-sacs mostly parallel.

Valves of the anthers dilated at the base enclosing the glands below,

Valves not dilated at the base.

4. Perulariat.

Glands surrounded by a thin membrane. 5. Coeloglossum.

Glands naked.

Beak of the stigma with 2 or 3 appendages.

6. Gymnandeniossis.

Beak of the stigma not appendaged. 7. Limnorchis.

Stem scapiform; leaves $\mathrm{I}-2$ basal; anther-sacs divergent.

Basal leaves 2 ; ovary straight.

Basal leaf $I$; ovary arcuate.

Lip fringed or parted and cut-toothed.

8. Lysias.

9. Lysiella.

10. Blephariglottis.

Pollinia not produced into a caudicle (except apparently in No. 23).

Pollinia granulose or powdery.

Flowers comparatively large, solitary or few ; anthers incumbent on a long column.

Leaves not grass-like; lip free.

Flowers terminal; lip crested。

Leaves alternate.

Stem-leaves whorled.

Flowers axillary; lip not crested.

Leaves grass-like.

I. Pogonia.

12. Isotriza.

I3. Triphora.

Flowers solitary, terminal; lip adherent to the base of the column.

Flowers racemose; lip free.

14. Arethusa.

15. Limodorim.

Flowers small, numerous, in spikes or racemes; anthers erect, jointed to a short column.

Anther operculate; leaves broad, alternate. I6. Epipactis.

Anther not operculate.

Leaves green, borne on the stem.

Leaves alternate; spike mostly twisted. 17. Gyrostachys.

Leaves 2, opposite; spike not twisted. I8. Listera.

Leaves white-reticulated, basal.

19. Peramium.

Pollinia smooth and waxy.

Plants with corms or solid bulbs, rarely with coralloid roots; leaves basal or cauline.

Leaves unfolding before or with the flowers.

Leaf cauline; lip ovate, or auricled at the base.

Leaf or leaves basal.

20. Achroanthes.

Leaves 2; lip flat ; flowers racemed. 21. Leptorchis.

Leaf I ; lip saccate ; flower solitary. 22. Calypso.

Leaf $\mathrm{I}$, basal, unfolding after the flowering time.

Flowers long-spurred; lip 3-lobed.

Flowers not spurred; lip 3-ridged.

23. Tipularia.

24. Aplectrum.

Plants with coralloid roots, bulbless; the leaves reduced to scales.

Pollinia 4 , in 2 pairs ; flowers gibbous or spurred.

Pollinia 8, united ; flowers not gibbous nor spurred.

25. Corallorhiza.

r. CYPRIPẼDIUM L.

26. Hexalectris.

Glandular-pubescent herbs, with leafy stems or scapes, and tufted roots of thick fibres. Leaves large, broad, many-nerved. Flowers solitary or several, drooping. large, showy. Sepals spreading, separate, or 2 of them united under the lip. Lip a large inflated sac. Column declined, bearing a sessile or stalked anther on each side and a dilated petaloid sterile stamen above, which covers the summit of the style. Pollinia granular, without a caudicle or glands. Stigma terminal, broud, obscurely 3-lobed. [Name Greek, Venus' sock or buskin.] Alout 40 species, natives of temperate and tropical regions. Besides the following, some 5 others occur in western North America.

Sepals separate; stem leafy, I-flowered.

1. C. arietinum.

Lateral sepals more or less united.

Plant 2-leaved; scape 1 -flowered.

2. C. acaule.

Stem leafy to the top, I-several-flowered.

Sepals and petals not longer than the lip,

3. C. reginae. 
Sepals and petals longer than the lip.

Sterile stamen lanceolate; lip white.

Sterile stamen triangular; lip yellow.

\section{C. candidum.}

Lip 3-5 cm. long, vertically flattened, pale yellow. 5. C. hirsutum. Lip I.5-3 cm. long, laterally flattened, bright yellow. 6. C. parriflorum.

I. Cypripedium arietinum R. Br. Ram's-head Ladies' Slipper. (I. F. f. 1088.) Stem 2-3 dm. high, I-flowered. Leaves 3 or 4, elliptic or lanceolate, 5-10 $\mathrm{cm}$. long, I-7 cm. wide; sepals separate, lanceolate, longer than the lip; petals linear, greenish brown, about as long as the sepals; lip 14-16 mm. long, red and white, veiny, prolonged at the apex into a long blunt spur, somewhat distorted at the upper end which resembles a ram's head. In cold and damp woods, Quebec to Unt., N. Y. and Minn. May-Aug.

2. Cypripedium acaùle Ait. Moccasin Flower. Noah's Ark. StemLESS LAADIES'Slipper. (I. F. f. I089.) Scape 1.5-3 dm. high, I-flowered. Leaves 2 , basal, elliptic, $15-20 \mathrm{~cm}$. long, thick; occasionally a smaller leaf is borne on the scape; sepals greenish purple, spreading, 3-5 cm. long, lanceolate; petals narrower and somewhat longer than the sepals; lip often over $5 \mathrm{~cm}$. long, pink with darker veins or sometimes white, the upper part of its interior surface crested with long white hairs; sterile stamen triangular, acuminate, keeled inside. In sandy or rocky wooks, Newf. to Ont., N. Car., Ky. and Minn. Flower fragrant. May-June.

3. Cypripedium reginae Walt. Showy Ladies' Slipper. (I. F. f. rogo.) Stem stout, 3-6 dm. Ligh, leafy to the top. Leaves elliptic, acute, 7-1 $8 \mathrm{~cm}$. long; flowers 1-3; sepals round-ovate, white, not longer than the lip, the lateral ones united for their whole length; petals somewhat narrower than the sepals, white; lip much inflated, over $2.5 \mathrm{~cm}$. long, variegated with purple and white stripes; stamen cordate-ovate. In swamps and woods, N. S. to Ont. and Minn., south to Ga. June-Sept.

4. Cypripedium cándidum Willd. Small White Ladies'Slipper. (I. F. f. rogi.) Stem 1.5-3 dm. high, leafy. Leaves 3 or 4, elliptic or lanceolate, acute or acuminate, 7-12 cm. long; bracts $3-5 \mathrm{~cm}$. long, lanceolate; flower solitary; sepals lanceolate, longer than the lip, greenish. purple-spotted; petals somewhat longer and narrower than the sepals, wavy, tivisted, greenish; lip white, striped with purple inside, about $2 \mathrm{~cm}$. long; sterile stamen lanceolate. In bogs and meadows, N. Y. and N. J. to Minn., Neb. and Mo. May-July.

5. Cypripedium hirsùtum Mill. Large Y'ellow Ladies' Slipper. (I. F. f. Iog2.) Stems leafy, 3-6 dm. high. Leaves oval or elliptic, 7-12 cm. long, acute or acuminate; sepals ovate-lanceolate, usually longer than the lip, yellowish or greenish, striped with purple; petals narrower, usually twisted; lip much inflated, 2-5 cm. long, pale yellow with purple lines; sterile stamen triangular. In woods and thickets, N. S. to Ont., Minn., Ala. and Neb. May-July.

6. Cypripedium parviforum Salisb. Smali Yellow Ladies' Slipper. (I. F. f. ro93.) Stems 3-6 dm. high, slender, leafy, Leaves oval, elliptic or lanceolate, 5-I5 cm. long; sepals and petals longer than the lip; petals usually twisted; lip 14-30 mm. long, bright yellow, more or less marked with purple stripes, spots or blotches; sterile stamen triangular, yellow and purple spotted like the lip. In woods and thickets, Newf. to Br. Col., Wash., Ga. and Mo. MayJuly.

\section{2. ÓRCHIS L.}

Plants with biennial fleshy tubers, or in our species with a rootstock and numerous fleshy roots; stem in our species scape-like, I-leaved at the base. Flowers in short terminal spikes. Sepals separate, subequal, spreading. Petals similar to the sepals. Lip connate with the base of the column, 3-lobed, produced below into a spur. Column short, scarcely extending beyond the base of the lip. Anther 2-celled, the sacs contiguous and slightly divergent; pollinia granulose, I large mass in each sac, produced into a slender caudicle, the end of which is attached to a small gland. Stigma a hollowed surface between the anther-sacs, the rostellum a knob-like projection under the anther. Glands enclosed in a pouch. Capsule oblong. erect, without a beak. [Name ancient.] Abrout 80 species, natives of the nor.h temperate zone, only two known in N. Am. In habit the following differs somewhat from the typical Old Wurld species. 
I. Orchis rotundifòlia Pursh. Small Round-leaved Orchis. (I. F. f. 1095.) Stem $2-2.5 \mathrm{dm}$. high. Leaf varying from nearly orbicular to oval, $3-7 \mathrm{~cm}$. long, with I or 2 sheathing scales below it; spike 2-6-flowered ; flowers I 2-16 $\mathrm{mm}$. long, subtended by small bracts; sepals and petals oval, rose-color; lip white, purple spotted, longer than the petals, 3-lobed, the middle lobe larger, dilated, 2-lobed or notched at the apex; spur slender, shorter than the lip. In damp woods, Greenland to the Rocky Mts., Me., N. Y. and Minn. June-July.

\section{GALEÓRCHIS Rydb.}

Rootstock very short; root of numerous fleshy fibres. Stem scape-like, with 2 large rounded leaves at the base. Flowers in a short loose spike with large leaflike bracts surpassing them. Sepals united above, forming a kind of galea, or hood. Petals connivent, somewhat adnate to the sepals. Lip entire, wavy, produced below into a spur. Column short, scarcely extending beyond the base of the lip. Anthers 2-celled, the sacs divergent : pollinia granulose, I large mass in each sac, produced into a slender caudicle. Glands enclosed in a pouch. [Compound word of which the first part refers to the hood-like united sepals.]

A monotypic genus, native of North America. It was established by Rafinesque in 1836 , under the name Galearis, which is antedated by Galearia Presl, of 1830 .

I. Galeorchis spectábilis (L.) Rydb. Showy Orchis. (I. F. f. 1094.) Stem 2-3 dm. high, thick, fleshy, 5-angled. Leaves with I or 2 scales below them, obovate, sometimes $2 \mathrm{dm}$. long and I $\mathrm{dm}$. wide, but usually smaller, clammy to the touch ; spike 3-6 flowered; flowers about 2-5 cm. long, violet-purple mixed with lighter purple and white; bracts foliaceous, sheathing the ovaries; lip whitish, divergent, entire, about as long as the petals; spur obtuse, about $1.6 \mathrm{~cm}$. long; colunn violet on the back; capsule about $2-5 \mathrm{~cm}$. long, strongly angled. In rich woods, N. B. to Ont. and Minn., south to Ga., Ky. and Neb. April-June. [Orchis spectabilis $\mathrm{L}$.]

\section{PERULÀria Lindl.}

Leafy-stemmed plants, from a cluster of thick fibrous roots. Flowers small, greenish, in a long open spike with long bracts. Sepals and petals broad, spreading. Lip lanceolate, with a tooth on each side at the base, and a central tubercle at the middle of the base. Spur slerder, straight, longer than the lip, but shorter than the ovary. Valves of the anthers horizontal, opening upward, dilated at the base so as to form an oblong cavity, enclosing the orbicular incurved gland. Polinia granulose, produced at the base into a caudicle. A genus of 2 or 3 boreal, nearly related species, often included in Habenaria. [Latin, a little wallet.]

I. Perularia flàva (L.) Rydb. Tubercled Orchis. Small Pale-green ORCHIS. (I. F. f. 1105.) Stem rather stout, 3-6 dm. high, leafy. Leaves lanceolate or elliptic, acute or obtuse, I-3 dm. long; bracts acuminate, longer than the ovaries ; petals greenish ; sepals and petals ovate or roundish, about $6 \mathrm{~mm}$. long ; sepals greenish yellow; lip a little longer than the petals; capsule about $8 \mathrm{~mm}$. long. In moist soil, N. H. to Minn., south to Fla., La, and Mo. June-July. [Habenaria flava (L.) Gray.]

\section{COELOGLÓSSUM Hartman.}

Leafy plants, with biennial 2-cleft tubers. Flowers greenish in a long leafy. bracted spike. Sepals free, somewhat arcuate, bent together and forming a hood. Petals narrow. Lip oblong, obtuse, 2-3-toothed at the apex. Spur much shorter than the lip, blunt, sac-like. Column short. Pollinia with long caudicles. Glands small, scarcely wider than tiee caudicle, surrounded by a thin membrane. A boreal genus of 2 or 3 species, often included in Habenaria or Platanthera. [Name Latin, compound, heaven-tongue.]

I. Coeloglossum bracteàtum (Willd.) Parl. Long-bracten Orchis. (I. F. f I IO3.) Stem leafy, I. 5-6 dm. high. Leaves lanceolate, ovate or oval, or thie lowest sometimes obovate, 5-12 cm. long, the upper much smaller; bracts longer than the ovaries, the lower ones 2 or 3 times as long; spike $7-12 \mathrm{~cm}$. long, loosely flowered; flowers green or greenish; sepals ovate-lanceolate, dilated or somewhat gibbous at the base, about $6 \mathrm{~mm}$. long ; petals very narrow, sometimes thread-like; lip 6-8 $\mathrm{mm}$. long, oblong-spatulate, 2-3-toothed or lobed at the apex, 
more than twice as long as the white sac-like spur; anther-sacs divergent at the base. In woods and meadows, N. B. to Br. Col., south to N. Car. and Neb. Also in Europe. May-Sept. [Habenaria bracteata (Willd.) R. Br.]

\section{GYMNADENIÒPSIS Rydb.}

Leafy plants, with fleshy fibrous or somewhat tuberous roots, and a short spike of small flowers. Sepals free and spreading. Lip entire or 3 -toothed at the apex, much exceeded by the long filiform or clavate spur. Beak of the stigma with 2-3 oblong or clavate appendages. Anther-sacs parallel and approximate, their glands naked and contiguous. Pollinia granular, with short caudicles. A North American genus, hitherto included in Habenaria. It is closely related to the European genus Gymnadenia, from which it differs in the appendages of the stigma; hence the name.

Spur filiform; lip entire; stem leafy.

Ovary not twisted; spur longer than the ovary; flowers white.

Ovary twisted; spur shorter than the ovary, flowers orange. Spur clavate; lip 3-toothed; stem 1-2-leaved.

I. G. nivea.

2. G. integra.

3. G. clavellata.

I. Gymnadeniopsis nívea (Nutt.) Rydb. Southern Small White Orchis. (I. F. f. IO99.) Stem slender, angled, 3-3.5 dm. high. Leaves linearlanceolate, acuminate, I-2 dm. long, the upper much shorter and passing into the bracts of the spike; spike 5-Io cm. long, loosely many-flowered; flowers small, white; lateral sepals broadly oblong, dilated or slightly eared at the base, spreading, about $6 \mathrm{~mm}$. long; petals and upper sepal smaller; stigma appendaged by 2 small horns affixed to the back of the anther; ovary straight. In pine barren bogs, Del. to Fla. and Ala. Aug. [Habenaria nivea (Nutt.) Spreng.]

2. Gymnadeniopsis integra (Nutt.) Rydb. SMall Southern Yellow OrChis. (I. F. f. I IO2.) Stem 3-6 dm. high, angled, with I-3 linear-lanceolate leaves below, and numerous bract-like ones above. Lower leaves $5-20 \mathrm{~cm}$. long. acute; spike $2-7 \mathrm{~cm}$. long, densely flowered; flowers orange-yellow: upper sepal and petals connivent; lateral sepals longer, oval or obovate, spreading; lip oblong, mostly crenulate or erose, sometimes entire; stigma with 2 lateral fleshy appendages and a narrow beak. In wet pine barrens, N. J. to Fla. and I.a. The upper surface of the leaves is often reticulated with hexagonal cells. July. [Habenaria inte,ra (Nutt.) Spreng.]

3. Gymnadeniopsis clavellata (Michx.) Rydb. SMall Green Wood ORCHIS. (I. F. t. I rO4.) Stem 2-5 dm. ligh, angled, I-leaved near the base, often with several small bract-like leaves above, or one of these larger. Basal leaf oblanceolate, 5-15 cm. long; bracts shorter than the ovaries; spike $\mathbf{I}-2.5 \mathrm{~cm}$. long, loosely flowered; flowers small, greenish or whitish; sepals and petals ovate; lip dilated and 3 -toothed at the apex; the teeth often small and inconspicuous; spur longer than the ovary, incurved, clavate; stigma with 3 club-shaped appendages; capsule ovoid, nearly erect. In wet or moist woods, Newf. to Minn., south to Fla. and La. July-Aug. [Habenaria clavellata (Michx.) Spreng.]

\section{LIMNÓRCHIS Rydb. (See Appendix.)}

Leafy plants with thick fleshy roots and small greenish or whitish flowers in a long spike. Sepals and petals free and spreading. Lip entire. Beak of the stigma without appendages. Anther-sacs nearly parallel, wholly adnate. Glands naked. Pollinia granular. A North American genus of about a dozen species, differing from Lysias in the general habit and the almost parallel anther-sacs. [Greek, Marsh-orchis.]

Lip lanceolate, slightly if at all dilated at the base; flowers greenish or purplish.

Spur shorter than the lip, much thickened at the end, obtuse. r. L. hyperborea.

Spur slightly exceeding the lip, slightly if at all thickened at the end.

Plant stout ; flowers comparatively large ; sepals $4^{-6} \mathrm{~mm}$. long.

Plant slender; flowers smaller; sepals $2.5-4 \mathrm{~mm}$. long.

2. L. media.

3. L. Huronensis.

Lip decidedly rhomboid-dilated at the base ; flowers white.

Flowers not very fragrant; sepals $2-3 \mathrm{~mm}$. wide, not strongly striate.

Flowers very fragrant ; sepals I.5-2 mm. wide, strongly striate.

4. L. dilatata.

5. L. fragrans. 
I. Limnorchis hyperbòrea (L.) Rydb. TAll Leafy Green Orchis. (I. F. f. I roo.) Stem rather stout, 2-6 dm. high. Leaves lanceolate, mostly acute, 5-3o $\mathrm{cm}$. long; spike narrow, 7-20 cm. long; flowers small, divaricate, greenish or greenish yellow; sepals and petals ovate, obtuse, 4-6 mm. long; upper sepal crenulate at the apex; lip lanceolate, entire, obtuse, about $7 \mathrm{~mm}$. long; spur seldom equalling the lip, blunt, slightly incurved, decidedly clavate; glands small; ovary more or less twisted; pod I cm. long, $5 \mathrm{~mm}$. wide. Labrador and Newfoundland. [Hahenaria hyperborea (L.) R. Br.]

2. I.imnorchis média Rydb.

Intermediate Bog Orchis. Stem stout, 4-8 dm. high. Leaves lanceolate, acute, I-2 dm. long; spike long, densely flowered; bracts rather large and with scabrous margins; flowers divaricate, greenish or purplish; sepals ovate-oblong, 4-6 mm. long; petals lanceolate, obtuse; lip lanceolate, entire, obtuse, slightly dilated at the base, 5-7 mm. long ; spur slightly excceding the lip, curved, obtuse, scarcely at all thickened at the apex; ovary somewhat twisted; pod about $\mathrm{x} \mathrm{cm}$. long and $5 \mathrm{~mm}$. in diameter. It has been confused with $L$. hyperborea and $L$. dilatata. In bogs, Can. and N. Y., west to Minn. Type specimen from Quebec. June-Aug.

3. Limnorchis Huronénsis (Nutt.) Rydb. Huron Orchis. Stem slender, 2-3 dm. high. Lower leaves oblanceolate, obtuse; upper lanceolate and acute; spike long, rather lax; bracts lanceolate, the lower often twice as long as the flowers; flowers almost erect, light green; sepals oblong, 1.5-2 $\mathrm{mm}$. long; lip linear-lanceolate, entire; spur generally exceeding the lip, scarcely clavate, curved, often acutish; pod about $\mathbf{I} \mathrm{cm}$. long and $3 \mathrm{~mm}$. in diameter. It resembles a slender $L$. hyperborea, differing in the smaller erect flowers, longer and narrower spur and pod. In swamps, Can. to N. Y.; apparently also in the Black Hills of S. Dak. JuneJuly. [Orchis Huronensis Nutt.]

4. Limnorchis dilatàta (Puısh) Rydb. Tall White Bog Orchis. (I. F. f. I Ior.) Stem slender, leafy, 3-6 dm. high. Leaves lanceolate, 7-20 cm. long, obtuse or acute; spike 5-25 cm. long; bracts acute, the lower longer than the ovary, the upper shorter; flowers small, white; sepals ovate, obtuse, nearly $6 \mathrm{~mm}$. long nd 2-3 mm. wide; lip entire, dilated or obtusely 3 -lobed at the base, obtuse at the apex, shorter than the blunt incurved slightly clavate spur; glands close together, strap-shaped, nearly as long as the pollinia and caudicle; stigma with a trowelshaped beak between the bases of the anther-sacs. In bogs and wet woods, N. S. to Siask., south to Me., N. Y. and Neb. June-Sept. [Habenaria dilatata (Pursh) Hook.]

5. Limnorchis frágrans Rydb.

Fragrant Orchis. Stem very slender, leafy above, 2-3 dm. high. Leaves linear, about I dm. long and 8-ro mm. wide, acute; spike slender and lax ; bracts lanceolate, acuminate, the lower longer than the flowers; flowers small, pure white, very fragrant; sepals lanceolate, often acutish, 1.5-2 $\mathrm{mm}$. wide and strongly striate; lip about $5 \mathrm{~mm}$. long, narrowly linear, dilated at the base, obtuse, shorter than the curved filiform spur; otherwise as the preceding. In bogs, Willoughby Mountains, Vt. July.

\section{LÝSIAS Salisb.}

Plants with tubers or fleshy roots; stem scapose. Leaves 2, basal. Flowers greenish or white; sepals free, large and spreading; petals small and narrow; lip entire, linear or nearly so ; spur long and slender, generally longer than the elongated, straight ovary. - Beak of the stigma without appendages. Anther-sacs widely diverging, their narrow beak-like bases projecting forward; stalk of the pollen-mass laterally affixed to the back of the orbicular gland, whose face is turned inward. Pod cylindric-clavate, distinctly stipitate. A circumboreal genus of about half a dozen species, separated independently by Salisbury in 1812 as Lysias and by Richard in 1818 under the name Platanthera.

Scape bracted.

Scape naked.

I. L. orbiculata.

2. L. Hookeriana.

I. Lysias orbiculàta (Pursh) Rydb. LARGe Round-Leaved OrChis. (I. F. f. rog6.) Scape stout, bracted, 3-6 dm. high, occasionally bearing a small leaf. Leaves orbicular, spreading flat on the ground, shining green above, silvery be- 
neath, I0 $17 \mathrm{~cm}$. in diameter; raceme loosely many-flowered; pedicels about $\mathbf{I ~} \mathrm{cm}$. long, the fruiting ones erect; flowers greenish white; lateral sepals falcate-ovate, obtuse, 8-10 $\mathrm{mm}$. long; lip about $12 \mathrm{~mm}$. long ; spur much longer than the ovary, often $3.5 \mathrm{~cm}$. long; anther-sacs prominent, converging above ; glands small, orbicular, nearly $5 \mathrm{~mm}$. apart, their faces turned toward the axis. In rich woods, Newf. to Br. Col., N. Car. and Minn. July-Aug. [Habenaria orbiculata (Pursh) Torr.]

2. Lysias Hookeriàna (A. Gray) Rydb. Hooker's Orchis. (I. F. f. ro97.) Scape 2-4 dm. high, not bracted. Leaves fleshy, shining, spreading or ascending, oval, orbicular or obovate, $0.7-\mathbf{I} .4 \mathrm{dm}$. long; raceme rather loosely many-flowered, 1-2 dm. long : bracts acute, about as long as the yellowish green flowers; lateral sepals greenish, lanceolate, acute, spreading, about $8 \mathrm{~mm}$. long; petals narrowly linear or awl-shaped; lip linear-lanceolate, acute, 8-10 $\mathrm{mm}$. long; anther-sacs widely diverging below; glands small, their faces turned inward ; spur slender, acute, 16 $\mathrm{mm}$. long or more, as long as the ovary or considerably longer. In woods, $\mathrm{N}$. S. to Minn., N. J., Penn. and Iowa. June-Sept. [Habenaria Hookeriana, A. Gray.]

\section{LYSIÉLLA Rydb.}

Small plant with a short rootstock and thick root-fibers. Stem scapoše, naked, with a single cbovate leaf at the base: flowers greenish yellow. Upper sepal round-ovate, erect, surrounding the broad column; lateral sepals reflexed, spreading; petals lanceolate smaller; lip entire linear-lanceolate, deflexed; spur slightly curved, shorter than the arcuate ovary. Beak of stigma not appendaged. Anther-sacs widely diverging, wholly adnate, arcuate; glands small, their faces turned inward. Pod obovoid. A monotypic genus, mostly of North America. [Name diminutive of Lysias.]

I. Lysiella obtusàta (Pursh) Rydb. Small Northern Bog Orchis. (I. F. f. rog8.) Scape slender, naked, $8-20 \mathrm{~cm}$. high, 4-angled. Leaf solitary, basal, obovate, 4-10 cm. long, 10-24 mm. wi.de; spike 2-5 cm. long, loose; flowers greenish yellow, about $6 \mathrm{~mm}$. long; upper sepal erect, round-ovate, green with whitish margins; lateral sepals spreading-reflexed, oblong, obtuse or acute ; petals shorter, dilated or obtusely 2 -lobed at the base, connate with the base of the column; lip entire, linear-lanceolate, obtuse, deflexed, about $6 \mathrm{~mm}$. long; spur about as long as the lip, slender, curved, blunt. In bogs, N. B. to Br. Col., south to Me., N. Y. and Colo. Also in northern Norway. July-Sept. [Habenaria obtusata (Pursh) Richards.]

\section{BLEPHARIGLÓTTIS Raf.}

Plants with tall and leafy stems and fleshy or tuberous roots. Flowers several or numerous in an open spike with foliaceous bracts; corolla white, yellow or purplish; sepals broad and spreading or reflexed; lip variously fringed or 3-parted and cut-toothed; spur longer than the lip. Anther-sacs widely separated and usually diverging, their narrow beak-like bases supported by the arms of the stigma, strongly projecting forward and upward; gland naked; pollinia granular. A North American genus of perhaps a dozen species. [Name Greek, meaning fringed throat.]

Lip not 3-parted, pectinately fringed.

Spur half as long as the ovary: flowers yellow.

Spur longer than the ovary.

Flowers bright yellow.

Flowers white.

Lip 3-parted.

Segments of the lip deeply fringed.

Segments narrow: fringe of a few threads.

Segments broadly fan-shaped; fringe copious.

I. B. cristata.

2. B. ciliaris.

3. B. blephariglottis.

Segments fringed to the middle or deeper; flowers white.

\section{B. lacera.}

5. B. leucophaea.

Segments not fringed beyond the middle; flowers lilac, rarely white. Raceme 4-5 cm. thick; lip $\mathrm{r}-2 \mathrm{~cm}$. broad. $\quad 6$. B. grandiflora. Raceme $\mathrm{I}-3 \mathrm{~cm}$. thick; lip 8-r2 mm. broad. 7. B. psycodes. Segments of the lip cut-toothed; flowers violet-purple. $\quad$ 8. B. peramoena.

I. Blephariglottis cristàta (Michx.) Raf. CRested Yellow OrChis. (I. F. f. I I06.) Stem slender, angled, 2-6 dm. high. Leaves narrowly lanceolate, 5-20 cm. long, the upper much smaller, similar to the bracts; bracts as long as the 
flowers; spike 5-10 cm. long, dense; flowers orange ; sepals roundish ovate, about $3 \mathrm{~mm}$. long; petals narrower, pectinate-fringed; lip slightly longer than the sepals, deeply fringed to the middle or beyond; spur 4-6 mm. long, about half as long as the ovary. In bogs, N. J. to Fla. and La. July-Aug. [Habenaria cristata (Michx.) R. Br.]

2. Blephariglottis ciliàris (L.) Rydb. Yellow-Fringed Orchis. (I. F. f. I 107.) Stem slender, 3-7 dm. high. Leaves lanceolate, acute, I-2 dm. long, the upper smaller; spike closely many-flowered, 7-I5 cm. long, sometimes $7 \mathrm{~cm}$. thick; flowers orange or yellow, iarge, showy; sepals orbicular or broadly ovate, oblique at the base, $4-8 \mathrm{~mm}$. long; petals much smaller, oblong or cuneate, usually toothed; lip oblong, IO-I $4 \mathrm{~mm}$. long, copiously fringed more than half-way to the middle; spur 25-35 mm. long, very slender. In meadows, Vt. (?) and Ont. to Mich., south to Fla. and Tex. July-Aug. [Habenaria ciliaris (L.) R. Br.]

3. Blephariglottis blephariglóttis (Willd.) Rydb. WHITE-FRINGED ORCHIs. (I. F. f. I I08.) Stems and leaves similar to those of the preceding species. Spikes densely or rather loosely many-flowered; flowers pure white, usually a little smaller than those of $H$. ciliaris; lip narrower, oblong; petals toothed or somewhat fringed at the apex: fringe of the lip copious or sparse. In bogs and swamps, Newf. to Minn. and N. J. Intermediate forms [B. bicolor Raf.] between this and the preceding species, with light yellow flowers, are probably hybrids. Blooms a few days earlier than ciliaris where the two grow together. July-Aug. [H. blephariglottis (Willd) Torr.]

Blephariglottis blephariglóttis holopétala (Lindl.) Rydb. One or both of the petals entire; lip often sparingly fringed. With the type. Probably a mere form.

4. Blephariglottis lácera (Michx.) Rydb. RagGed Orchis. (I. F. f. I Iog.) Stem rather slender, 3-6 dm. high. Leaves firm, lanceolate, $12-20 \mathrm{~cm}$. long, the upper gradually smaller; spike 5-I5 cm. long, loose; flowers greenish yellow; sepals ovate, obtuse, about $6 \mathrm{~mm}$. long, the upper one a little broader than the others; petals linear, entire, obtuse, about as long as the sepals; segments of the lip narrow, deeply fringed, the fringe of a few threads, about $1 \mathrm{~cm}$. long; spur $14-16 \mathrm{~mm}$. long, curved, shorter than the ovary, clavate at the apex; glands oblong-linear, hyaline, as long as the caudicle. In swamps and wet woods, N. S. to Minn., south to Ga. and Mo. June-July. [H. lacera (Michx.) R. Br.]

5. Blephariglottis leucophaèa (Nutt.) Rydb. PRAIRIE White-Fringed OrCHIS. (I. F. f. IIIO.) Stem stout, angled, 5-8 dm. high. Leaves lanceolate, I-2 dm. long; spike 7-I $2 \mathrm{~cm}$. long, very thick, loosely flowered; flowers large, white, fragrant, sometimes tinged with green; sepals broadly ovate; petals obovate, minutely cut-toothed, about $6 \mathrm{~nm}$. long; lip 12-14 mm. long, the segments broadly wedge-shaped and copiously fringed; spur 25-35 $\mathrm{mm}$. long, longer than the ovary; caudicles long and slender; glands transversely oval; ovary often recurved. On moist prairies, western N. Y. to Minn., Ky., Ark. and Neb. July. [11. leucophaca (Nutt.) Gray.]

6. Blephariglottis grandiflòra (Bigel.) Rydb. LARGE PURPLE-Fringed Orchis. (I. F. f. IIII.) Stem 3-I5 dm. high. Leaves oval or lanceolate, I-2.5 $\mathrm{dm}$. long, obtuse, or the upper smaller and acute; raceme 7-35 cm. long, sometimes $6 \mathrm{~cm}$. thick, densely flowered; flowers lilac or purplish, sometimes whitish, fragrant; upper sepal and petals erect, connivent; petals oblong or oblanceolate, more or less toothed, I cm. long; lip $\mathbf{I}-2.5 \mathrm{~cm}$. broad, about $\mathbf{I} \mathrm{cm}$. long, the segments broadly fan-shaped, copiously fringed nearly to the middle; glands orbicular, turned inward; spur filiform, clavate, 25-35 mm. long. In rich woods and meadows, N. B. to Ont. and Mich., south to N. Car. June-Aug. [H. grandiflora (Bigel.) Torr.]

7. Blephariglottis psycòdes (L.) Rydb. Smaller Purple-Fringed Orchis. (I. F. f. II 12.) Stem rather slender, 3-9 dm. high. Leaves oval, elliptic or lanceolate, 5-25 cm. long, the upper smaller; raceme 5-15 cm. long, 2-4 cm. thick, loosely or densely several many-flowered; flowers lilac, rarely white, fragrant; lower sepals ovate, obtuse, about $8 \mathrm{~mm}$. long, the upper one a little narrower; petals oblong or oblanceolate, toothed on the upper margin; lip 8-12 $\mathrm{mm}$. broad, the segments fan-shaped and copiously fringed; spur somewhat clavate at the apex, about $16 \mathrm{~mm}$. long, longer than the ovary. In meadows, swamps and wet woods, Newf. to Minn., south to N. Car. and Ind. July-Aug. [H. psycodes (L.) A. Gray.] 
8. Blephariglottis peramoèna (A. Gray) Rydb. Fringeless Purple Orchis. (I. F. f. III3.) Stem 3-7 dm. high. Leaves elliptic or lanceolate, I-2 dm. long, the upper gradually smaller; spike 5-15 cm. long, 2.5-3.5. cm. thick, densely or rather loosely many flowered; flowers large, showy, violet-purple; lateral sepals round-ovate, $6-8 \mathrm{~mm}$. long, the upper one smaller; petals smaller, roundobovate, clawed, entire, or slightly erose : lip 14-20 mm. long, the segments fanshaped, cut-toothed, not fringed, the middle one 2-lobed; spur about as long as the ovary, curved, clavate: glands orbicular, oblique. In moist meadows, N. J. to Ill., Va. and $\mathrm{Ky}$. July-Aug. [H. peramoena Gray.]

\section{POGÒNIA Juss.}

Mostly low herbs with slender rootstocks and fibrous roots, the flowers terminal, solitary, the leaves alternate. Sepals and petals separate, erect or ascending. Lip erect from the base of the column, spurless, crested. Column elongated, club-shaped at the summit. Anther terminal, stalked, attached to the back of the column, its sacs parallel; pollinia 2, I in each sac, powdery-granular, without a caudicle. Stigma a flattened disk below the anth r. Capsule oblong or ovoid, erect. [Greek, bearded, from the bearded lip of the type species.] Only the following Nortl Americall species are known :

Sepals and petals nearly equal and alike: lip bearded.

Sepals longer and narrower than the petals; lip not bearded.

I. P. ophioglossoides. 2. P. divaricata.

I. Pogonia ophioglossoides (L.) Ker. Rose Pogonia. SNake-mouth. (I. F. f. I II4.) Stem 2-3.8 dm. high, I-3-leaved, not rarely with a long-petioled basal leaf. Stem leaf or leaves 1-4 cm. long, lanceolate or ovate, erect, bluntly acute ; flowers fragrant, pale rose-color, slightly nodding, large, solitary or occasionally in pairs, subtended by a foliaceous bract ; sepals and petals about equal, elliptic or oval, $\mathbf{1 2 - 2 0} \mathrm{mm}$. long ; lip spatulate, free or somewhat appressed to the column below, fringed. Propagates by running rootstocks. In meadows and swamps, Newf. to Ont., Fla. and Kans. June-July.

2. Pogonia divaricata (L.) R. Br. Spreading Pogonia. (I. F. f. ili6.) Stem 2-6 dm. high, bearing a leaf near the middle, and a foliaceous bract near the flower. Leaf lanceolate, or narrowly elliptic, obtuse, clasping, 5-10 cm. long ; flower terminal, solitary; sepals linear, longer and narrower than the petals, diverging, dark-colored; petals flesh-color, lanceolate, narrowed at the apex ; lip as long as the petals, 3-lobed, crenulate or wavy-margined, greenish, veined with purple, not bearded, the upper lobe long. In swamps, southern N. I. to Fla. and Ala. Reported from Wisconsin. July.

\section{ISÒTRIA Raf.}

Low herbs with a rootstock and fibrous roots. Flowers terminal. Leaves 5 in whorl near the top of the plant. Sepals and petals separate, ascending, the former generally longer than the latter. Lip erect from the base of the column, crested, spurless, sessile. Anthers and pollinia as in Pogonia. Capsule oblong, erect. [Greek, in equal threes.] Only the following species are known:

Lip crested along a narrow line down the face; peduncle as long as the capsule or longer.

Lip crested over the whole face and lobes; peduncle shorter than the capsule.

I. verticillata.

2. I. affinis.

I. Isotria verticillàta (Willd.) Raf. Whorled Pogonia. (I. F. f. I1I7.) Stem 2.5-3 dm. high, from long fleshy roots. Leaves obovate, abruptly pointed at the apex, sessile, $2-4 \mathrm{~cm}$. long; flower solitary, erect or declined; peduncle 12-16 $\mathrm{mm}$. long, in fruit usually equalling or exceeding the capsule; sepals linear, 3-5 $\mathrm{cm}$. long, spreading, dark purple; petals linear, erect, obtuse, greenish yellow, about $20 \mathrm{~mm}$. long; lip 3-lobed, crested along a narrow band, the upper part expanded, undulate; capsule erect, $2.5 \mathrm{~cm}$. long or more. In moist woods, E. Mass. to Ont., Wis., Ind. and Fla. May-June. [Pogonia verticillata (Willd.) Nutt.]

2. Isotria affinis (Austin) Rydb. SMaller Whorled Pogonia. (I. F. f. II 8.) Smaller than the preceding species, stem 2-2.5 dm. high. Leaves 2-5 $\mathrm{cm}$. long; flowers 2 or solitary, greenish yellow; peduncle 5-10 $\mathrm{cm}$. long, mưch 
shorter than the ovary and capsule; sepals equalling the petals, or but little ionger, somewhat narrowed at the base; lip crested over nearly the whole face and lobes; capsule erect, about $2 \mathrm{~cm}$. long. In moist woods, Conn. to S. N. Y., Penn., and N. J. Rare and local. June. [Pogonia affinis Austin.]

\section{ז3. TRÍPHORA Nutt.}

Low herbs with fleshy tubers and axillary flowers. Sepals and petals separate, ascending, subequal. Lip erect, slightly clawed, and more or less 3-lobed, not crested, spurless. Column elongated, club-shaped at the summit. Anther terminal, stalked, attached to the back of the column, its sacs parallel; pollinia 2, I in each sac, powdery-granular, without caudicles. Stigma a flattened disk below the anther. Capsule oval, drooping. [Greek, bearing three, in allusion to the usual 3 flowers.] A genus of 8 species of North and tropical America, only the following found in the United States.

I. Triphora trianthóphora (Sw.) Rydb. Nodding Pogonia. (I. F. f. III5.) Stems glabrous, $7-20 \mathrm{~cm}$. high, from a tuberous root, often clustered. Leaves 2-8, alternate, ovate, 6-18 mm. long, clasping; flowers $1-7$, axillary, peduncled, pale purple, at first nearly erect, soon drooping; perianth $12-16 \mathrm{~mm}$. long; sepals and petals about equal, connivent, elliptic, obtuse; lip clawed, somewhat 3-lobed, roughish or crisped above, about as long as the petals; capsule oval, drooping, about $12 \mathrm{~mm}$. long. In rich woods, Can. (?), Vt. to Fla., Wis. and Kans. Aug.Sept. [Pogonia trianthophora (Sw.) B. S. P.]

\section{ARETHÙSA L.}

Low herbs, with small bulbs and mostly solitary flowers on slender scapes, the solitary leaf linear, hidden at first in the upper scale, protruding after flowering. Sepals and petals about equal, connivent and hooded above, coherent below. Lip dilated and recurved-spreading at the apex, crested on the face with straight somewhat fleshy hairs, slightly gibbous at the base. Column adherent to the lip below, linear, narrowly winged and dilated at the summit. Anther operculate, of 2 approximate sacs incumbent upon the column; pollinia 4, 2 in each sac, powderygranular. Capsule erect, ellipsoid, strongly angled. [Dedicated to the nymph Arethusa.] Two known species, the following occurring in North America, the other in Japan.

I. Arethusa bulbòsa L. Arethusa. (I. F. f. III9.) Scape glabrous, I2$25 \mathrm{~cm}$. high, bearing I-3 loose sheathing bracts. Leaf linear, many-nerved, becoming 10-15 cm. long; flower solitary (rarely 2), arising from between a pair of small unequal scales, rose-purple, $2-5 \mathrm{~cm}$. high; sepals and petals linear to elliptic, obtuse, arched over the column; lip usually drooping beneath the sepals and petals, the apex broad, rounded, variegated with purplish blotches; capsule ellipsoid, strongly 6-ribbed, rarely maturing. In bogs, Newf. to Ont. and Minn., south to N. Car. and Ind. May-June.

\section{LIMODÒRUM L. [CALOPOGON R. Br.]}

Scapose herbs, with round solid bulbs which arise from the bulb of the previous year, a leaf appearing the first season, succeeded in the following year by the scape. Flowers several in a loose terminal spike or raceme. Sepals and petals nearly alike, separate, spreading. Column elongated, 2-winged above. Anther terminal, operculate, sessile; pollinia solitary, 1 in each sac, loosely granular. Lip spreading, raised on a narrow stalk, dilated at the apex, bearded on the upper side with long club-shaped hairs. [Greek, a meadow-gift.]

I. Limodorum tuberòsum L. Grass-Pink. Calopogon. (I. F. f. I r45.) Scape slender, naked, 3-5 dm. high. Leaf linear-lanceolate, 2-3 dm. long, 6-20 $\mathrm{mm}$. wide, sheathing, with several scales below it; spike I-4 dm. long, 3-I5-flowered; flowers about $2 \mathrm{~cm}$. long, purplish pink, subtended by small acute bracts; sepals obliquely ovate-lanceolate, acute, about $2 \mathrm{~cm}$. long; petals similar; column incurved; lip as long as the column, broadly triangular at the apex, crested along the face with yellow, orange and rose-colored hairs; capsule oblong, nearly erect. In bogs and meadows, Newf. to Ont. and Minn., south to Fla. and Mo. June-July. 


\section{EPIPÁCTIS R. Br.}

Tall stout herbs with fibrous roots and simple leafy stems. Leaves ovate or lanceolate, plicate, clasping. Flowers leafy-bracted, in terminal racemes. Sepals and petals all separate. Spur none. Lip free, sessile, broad, concave below, constricted near the middle, the upper portion dilated and petal-like. Column short, erect. Anther operculate, borne on the margin of the clinandrium, erect, ovate or semiglobose, its sacs contiguous. Pollinia 2-parted, granulose, becoming attached to the glandular beak of the stigma. Capsule oblong, beakless. [Greek name for Helleborine.] About ro species, widely distributed. Besides the following, another occurs in the western United States.

r. Epipactis viridifiòra (Hoffm.) Reichb. Helleborine. (I. F. f. I Izo.) Stem 3-6 dm. high, glabrous below, pubescent above. Leaves ovate or lanceolate, obtuse or acute, 4-7 cm. long; flowers greenish yellow to purple; pedicels 4-6 $\mathrm{mm}$. long; sepals 8-10 mm. long, lanceolate; petals narrower; lip expanderl into a slightly undulate apex, tapering to a point; bracts lanceolate, longer than the flowers. Ont., Mass. and N. Y.; also in Europe. July-Aug.

\section{GYRÓSTACHYS Pers. [SPIRANTHES Rich.] (See Appendix)}

Erect herbs, with fleshy-fibrous or tuberous rocts and slender stems or scapes, leaf-bearing below or at the base. Flowers small, spurless, spiked, I-3-rowed, the spikes more or less twisted. Sepals free, or more or less colierent, or sometimes united with petals into a galea. Lip sessile or clawed, concave, erect, embracing the column and often adherent to it, spreading and crisped, or rarely lobed or toothed at the apex, bearing minute callosities at the base. Column arched below, obliquely attached to the top of the ovary. Anther without a lid, borne on the back of the column, erect. Stigma ovate, prolonged into an acuminate beak, at length bifid, covering the anther and stigmatic only underneath. Pollinia 2, I in each sac, powdery. Capsule ovoid or oblong, erect. [Greek, referring to the twisted spikes.] About 80 species, widely distributed in tropical and temperate regions. Besides the following, two occur in the Southern States and three or four on the Pacific Coast. The flowers are often fragrant.

Flowers 3-ranked; stems not twisted, or but slightly so.

Sepals and petals more or less connivent into a hood.

Lateral sepals separate, free.

r. G. stricta.

Spike short, about $5 \mathrm{~cm}$. long, 8-1o $\mathrm{mm}$. thick ; callosities none, or mere thickenings of the basal margins of the lip.

Spike 10-1 $5 \mathrm{~cm}$. long, 12-20 mm. thick; callosities nipple-shaped.

Spike I2-I4 mm. thick; callosities hairy, straight.

Flowers yellowish; spike acute; lower bracts longer than the flowers.

3. G. ochroleuca.

Flowers white; spike obtuse; lower bracts shorter than the flowers.

4. G. cernua.

Spike $16-20 \mathrm{~mm}$. thick; callosities glabrous, incurved. 5. G. odorata.

Flowers merely alternate, appearing secund from the spiral twisting of the stem.

Stem leafy; lower leaves elongated, mostly persistent through the flowering season.

Outer sepals lanceolate; bracts lanceolate to ovate, scarcely scarious-maryined.

6. G. praecox.

Outer sepals linear; bracts broadly ovate, scarious-margined. 7. G. linearis.

Stem a scaly scape ; leaves basal, mostly withering before the flowering season.

Root a single tuber; spike about $2.5 \mathrm{~cm}$. long.

Root a cluster of tubers ; spike $2-7 \mathrm{~cm}$. long.

8. G. Grayi.

9. G. gracilis.

I. Gyrostachys strícta Rydb.

Hooded Ladies' Tresses. (I. F. f. I I 2 I.) Stem I.5-3.5 dm. high, glabrous, leafy below, bracted above, the inflorescence rarely puberulent. Lower leaves 7-20 cm. long, linear or linear-oblanceolate; spike 5-10 cm. long, 8-14 mm. thick; bracts shorter than the flowers; flowers white or greenish, ringent, 6-8 mm. long, spreading horizontally, very fragrant; upper sepal broad, obtuse or merely acutish at the apex; lip oblong, broad at the base, contracted below the dilated crisped apex, thin, transparent, veined; callosities mere thickenings of the basal margins of the lip, or none. It has hitherto been confused with the Alaskan $G$. Romanzoffiana, which has a very short spike $\mathbf{I - 2} \mathrm{cm}$. long, upper portion of the scape densely glandular, the sepals united to near the apex, 
and acuminate. G. stricta may be the trise Ophrys cernua L., from the character "petalis superioribus confuentibus." In bogs, Newf. to Idaho, south to Me., Penn., Minn. and Colo. July-Aug.

2. Gyrostachys plantagínea (Raf.) Britton. Wide-Leaved Ladies' Tresses. (I. F. f. I I 22.) Stem I-2.5 dm. high, glabrous or pubescent, bracted above, bearing 4 or 5 lanceolate or oblanceolate leaves below. Leaves 3-12 cm. long; spike 2-5 cm. long, 8-10 mm. thick, dense ; floral bracts mostly much shorter than the flowers; flowers spreading, about $6 \mathrm{~mm}$. long; petals and sepals white; lip pale yellow on the face, oblong, not contracted at the middle, the wavy apex rounded, crisped or fringed, the base short-clawed; callosities none, or mere thickenings of the lip margins. Moist banks and woods, N. B. to Minn., south to Va. and Mich. June-Aug.

3. Gyrostachys ochroleùca Rydb.

Yellow Ladies' Tresses. Stem 3-5 dm. high, densely pubescent above. Basal leaves linear, tapering to both ends, distinctly petioled, I-2 dm. long; lower stem leaves similar but often sessile; upper stem leaves bract-like, lanceolate ; spike $5^{-15} \mathrm{~cm}$. long, $15-20 \mathrm{~mm}$. in diameter, densely flowered, generally acute; flowers ochroleucous or greenish yellow, strongly fragrant, about $\mathbf{I} \mathrm{cm}$. long ; bracts lanceolate or ovate-lanceolate, acuminate, the lower generally longer than the flowers. Otherwise as in G. cermua. Hillsides, N H. to N. Car., and Penn. Type from Mt. Washington, Mass. Aug.-Sept,

4. Gyrostachys cérnua (L.) Kuntze. Nodding Ladies' Tresses. (I. F. f. II23.) Stem 2-6 dm. high (rarely taller), usually pubescent above, mostly bearing 2-6 acuminate bract-like stem leaves. Basal leaves from linear-oblanceolate to linear, 7-35 cm. long, the blade narrow; spike 10-12 cm. long, $12-14 \mathrm{~mm}$. thick; bracts ovate, acute, generally not longer than the flowers; flowers white, fragrant, nodding or spreading, about Io mm. long; lip oblong, or sometimes ovate, the broad apex rounded, crenulate or crisped; callosities nipple-shaped, straight, hairy. In meadows and swamps, N. S. to Ont. and Minn., south to Fla. and La. Aug.-Oct.

5. Gyrostachys odoràta (Nutt.) Kuntze. Fragrant Ladies' Tresses. (I. F. f. I I 24.) Stem stout, 3-6 dm. high, strongly pubescent above. Lower and basal leaves 2-4 dm. long, 15-50 $\mathrm{mm}$. wide, tapering into sheathing petioles, the upper reduced to bracts; spike $12-15 \mathrm{~cm}$. long, $16-20 \mathrm{~mm}$. thick; foral bracts often exceeding the flowers, long-acuminate; flowers yellowish white, fragrant, $10 \mathrm{~mm}$. long; lip as long as the petals, oblong, broad at the base, contracted above the middle, the dilated apex crisped or toothed; callosities nipple-shaped, incurved, glabrous. On river banks, often in water, Va. to Ky., Fla. and La. Sept.-Oct.

6. Gyrostachys praècox (Walt.) Kuntze. Grass-Leaved Ladies' Tresses. (I. F. f. I I 25.) Stem slender, 2.5-6 dm. high, glandular-pubescent above, leafy. Leaves linear, 1-3 dm. long, with narrow grass-like blades and long sheathing petioles, mostly persistent through the flowering season, the upper smaller; spiki usually much twisted, 5-20 cm. long, 8-12 $\mathrm{mm}$. thick; bracts ovate, about as long as the ovaries; flowers white or yellowish, about $8 \mathrm{~mm}$. long, spreading; lip abou $6 \mathrm{~mm}$. long, short-clawed, oblong, contracted above, the dilated apex obtuse, cren ulate, often dark-striped in the middle; callosities small, glabrous. In grass places, S. N. Y. to Fla. and La. July-Aug.

7. Gyrostachys lineàris Rydb.

LiNeAR-Leaved Ladies' TRessel Stem slender, 4-5 dm. high, glandular-pubescent above, leafy. Leaves narrowl p linear, 5-10 cm. long, 2-4 mm. wide, mostly persistent, the upper small and bract like; spike 4-10 cm. long, 8-10 mm. thick; bracts broadly ovate, scarious-marginer, abruptly contracted into a cusp; flowers yellowish, about $8 \mathrm{~mm}$. long, spreadink; lateral sepals free, linear, placed so as to leave an open space between them and th $\mathrm{e}$ upper one, the latter connivent with the petals; lip as in the preceding, but gene ally less curved. In meadows, N. Y. to Va Type from Closter, N. J. July-Auy.

\section{Gyrostachys Gràyi (Ames) Britton. Litrle Ladies' Tresses.} F. f. II26.) Stems very slender, $12-25 \mathrm{~cm}$. high, with small deciduous brac c above. Leaves basal, ovate or oblong, short, abruptly narrowed into a petiol . mostly disappearing at or before the flowering time; spike slender, about $2-3 \mathrm{cr}$. long and $6 \mathrm{~mm}$. thick, glabrous, little twisted; flowers white, $2-3 \mathrm{~mm}$. long; lif . thin, striped, obovate-oblong, crisped at the summit, short-clawed; callosities nippl ". shaped, slender; root a solitary spindle-shaped tuber. In dry sandy soil, Mass. o Md., E. Ky. and Tenn. Aug.-Sept. (Spiranthes simplex A. Gray, not Griseb.) 
9. Gyrostachys grácilis (Bigel.) Kuntze. Slender Ladies' Tresses. (I. F. f. II 27.) Stem slender, 2-6 dm. high, from a cluster of spindle-shaped tuberous roots, glabrous, or rarely pubescent above, bearing small deciduous bracts. Leaves basal, obovate, or ovate-lanceolate, petioled, the blades $I-5 \mathrm{~cm}$. long, 8-20 mm. wide, mostly perishing before the flowering season; spike $2-6 \mathrm{~cm}$. long, 8-12 mm. thick, loose, usually much twisted; flowers white, fragrant, 4-5 mm. long; sepals a little longer than the lip; lip about $4 \mathrm{~mm}$. long, oblong, dilated and crenulate or wavy-crisped at the apex, usually thick and green in the middle, white and hyaline on the margins; callosities small, nipple-shaped. In dry fields and open woods, N. S. to Minn., Fla., La. and Kans. Aug.- Oct.

\section{LISTERA R. Br.}

Small herbs, with fibrous or sometimes rather fleshy-fibrous roots, bearing a pair of opposite green leaves near the middle, and I or 2 small scales at the base of the stem. Flowers in terminal racemes, spurless. Sepals and petals nearly alike, spreading or reflexed, free. Anther without a lid, erect, jointed to the column. Pollinia 2, powdery, united to a minute gland. Capsule ovoid or obovoid. [Name in honor of Martin Lister, I638 (?)-1712, a correspondent of Ray.] About 12 species, natives of the north temperate and arctic zones. Besides the following, another occurs in northwestern North America.

Lip broadly wedge-shaped, retuse or 2 -lobed at the apex.

Leaves oval ; pedicels and ovaries glandular.

Leaves reniform; pedicels and ovaries glabrous.

Lip oblong or linear.

Lip broad, 2-cleft 1/4-1/3 its length; base auricled.

Lip 2-cleft about $1 / 2$ its length.

Lip twice as long as the petals, with lateral teeth.

Lip 4-8 times as long as the petals, with auricles at the base.

1. L. convallarioides.

2. L. Sinallii.

3. L. auriculata.

4. L. cordata.

5. L. australis.

I. Listera convailarioides (Sw.) Torr. Broad-Lipped Twayblade. (I. F. \& II 28.) Stem I-2 dm. high, glandular-pubescent above the leaves. Leaves simooth, round-oval or ovate, obtuse or apiculate at the apex, sometimes slightly wounded at the base, 3-9-nerved. Raceme 3-7 cm. long, loosely 3-12-flowered; fi wers greenish yellow; pedicels filiform, glandular, bracted, 6-8 mm. long; petals and sepals linear-lanceolate, much shorter than the lip; lip wedge-shaped, retuse at the dilated apex, generally with a tooth on each side at base; column elongated, but shorter than the lip, a little incurved, with 2 short projecting wings above the inther. In woods, N. S. to Alaska, south to Vt., Mich., and Cal. June-Aug.

2. Listera Smállii Wiegand. Small's Twayblade. (I. F. f. I I 28a.) Stem lender, I5-20 cm. high. glandular above the leaves. Leaves at or below the midlle of the stem, ovate-reniform, apiculate or short-acuminate; raceme open, rachis frlandular, but pedicels and ovaries glabrous or nearly so; sepals and petals lanreolate, longer than the ovary; lip large, $9 \mathrm{~mm}$. long, broadly obovate or wedgeshaped, broadly 2 -lobed at the apex and with prominent lateral teeth near the base; crlumn rather short and thick. In damp woods, in the mountains from Penn. to N. Car. June-Aug. [Listera reniformis, Small, not G. Don.]

3. Listera auriculata Wiegand. Auricled Twayblade. Stem slender, Io is $\mathrm{cm}$. high, glabrous below, glandular above the leaves. Leaves large, 3.5-5 $\mathrm{cm}$. long, oval or elliptic-ovate, borne above the middle of the stem; raceme many-flowered; rachis pubescent, pedicels and ovaries glabrous; sepals lance-ovate; petals oblong-linear, longer than the ovary, spreading, obtuse; lip slightly ciliate, oblong, broadest at the auricled base. cleft $\frac{1}{4}-\frac{1}{8}$ its length; column rather stout, 2.5 mm. long. In cedar swamps of Quebec, N. H. and Me. July.

4. Listera cordàta (L.) R. Br. Heart-leaved Twayblade. (I. F. f. II 29.) Stem very slender, glabrous or nearly so, 7-25 cm. high. Leaves sessile, cordate or broadly ovate, mucronate, $\mathbf{I}-\mathbf{2 . 5} \mathrm{cm}$. long; raceme rather loose, $\mathbf{I}-5 \mathrm{~cm}$. long, 4-20-flowered; flowers purplish, minute; pedicels glabrous, bracted, about $2 \mathrm{~mm}$. long; sepals ovate and petals oblong. scarcely $2 \mathrm{~mm}$. long; lip narrow, often with a subulate tooth on each side of the base. twice as long as the petals, 2-cleft, the segments linear or setaceous and ciliolate; column very small, the clinandrium just 
appearing above the anther. In moist woods, Lab. to Alaska, N. J. and Ore. Also in Europe and Asia. June-Aug.

5. Listera australlis Lindl. Southern Twayblade. (I. F. f. IIzo.) Stem slender, I-2.5 dm. high, more or less pubescent above. Leaves ovate, acutish, mucronate, glabrous, shining, 14-25 mm. long, 3-7-nerved; raceme 5-7 cm. long, loosely 8-15-flowered; flowers yellowish green with purplish stripes; sepals and petals minute; lip 6-10 mm. long, 2-parted, split halfway to the base or deeper, 4-8 times as long as the petals, its segments linear-setaceous; column very small. In logs, N. Y. and N. J. to Fla., and Ala. and La. Feb.-June. A third leaf is rarely borne below the flowers.

\section{I9. PERÀMIUM Salisb. [GOODYERA R. Br.]}

Herbs with bracted erect scapes, the leaves basal, tufted, often blotched with white, the roots thick fleshy fibres. Flowers in bracted spikes. Lateral sepals free, the upper one united with the petals into a galea. Lip sessile, entire, roundish ovate, concave or saccate, without callosities, its apex reflexed. Anther without a lid, erect or incumbent, attached to the column by a short stalk; pollinia I in each sac, attached to a small disk which coheres with the top of the stigma, composed of angular grains. About 25 species, widely distributed in temperate and tropical regions.

Lip evidently saccate.

Spike loosely flowered; lip with recurved margins.

Spike r-sided; beak shorter than the stigma proper.

Blotches white, mostly along the cross veins; galea stronglv recurved.

Blotches pale, mostly along the ribs; galea not strongly recurved.

Spike spiral; beak as long as the stigma proper or longer.

Spike dense, not 1 -sided; margins of the lip not recurved.

Lip scarcely saccate, with incurved margins.

2. P. repens.

3. P. tessellatum.

4. P. pubescens.

5. P. Menzicsii.

I. Peràmium ophioìdes (Fernald) Rydb. White-blotched Rattlesnake Plaintain. Scape $\mathrm{I}-2 \mathrm{dm}$. high, glandular-pubescent. Leaf-blade $\mathbf{I}-2 \mathrm{~cm}$. long, broadly ovate, abruptly contracted into a short winged petiole, dark green, generally with the white blotches most conspicuous along the cross-veins; flowers greenish white, 4-5 $\mathrm{mm}$. long; galea concave with a short strongly recurved tip; lip deeply saccate, with recurved margins and tip; anthers blunt. In cold, mossy woods from Prince Edward Island to Man. and N. Car. July-Sept. [Goodyera repens ophioides Fernald.]

2. Peramium rèpens (L.) Salisb. Northern Rattlesnake Plaintain. (I. F. f. II3I.) Scape I-2.5 dm. high. Leaves ovate, the blade $\mathrm{I}-3 \mathrm{~cm}$. long, somewhat reticulated with pale blotches, tapering into a sheathing petiole; spike short, I-sided; flowers greenish white, 5-6 mm. long; galea concave, ovate, with a short spreading or slightly recurved tip; lip saccate, with a narrow recurved or spreading apex; column very short; anther 2 -celled, blunt. In woods, N. S. to Alaska (?), south to Mass. and Co'o. Also in Europe and Asia. July-Aug.

3. Peramium tessellàtum (Lodd.) Rydb. Checkered Rattlesnake PlanTAIN. Scape $2 \mathrm{dm}$. high or more. L,eaves from 2 to $7 \mathrm{~mm}$. long, ovate to oblonglanceolate, dark green with pale blotches, or sometimes not blotched; spike about 6 $\mathrm{cm}$. long; flowers $6-8 \mathrm{~mm}$. long; galea with a slightly recurved tip; lip less saccate than in the preceding and with the tip less recurved; anthers acuminate; beak as long as the body of the stigma or longer. In woods, seldom in bogs, from Newf. to Lake Superior, south to N. Y. Aug. [Goodyera tessellata Lodd.]

4. Peramium pubéscens (Willd.) MacM. Downy Rattlesnake Plantain. (I. F. f. I132.) Usually larger than the preceding species, scape $15-60 \mathrm{~cm}$. high, densely glandular-pubescent, bearing 5-Io lanceolate scales. Leaves 2-5 cm. long, I $5-25 \mathrm{~mm}$. wide, strongly white-reticulated, oval or ovate; spike not I-sided; flowers 6-8 mm. high, greenish white; lateral sepals ovate; galea ovate, its short tip usually not recurved; lip strongly saccate with a short broad obtuse recurved or spreading tip. In dry woods, Newf. to Ont. and Minn., south to Fla. and Tenn. July-Aug. 
5. Peramium Menzièsii (Lindl.) Morong. Menzies' Rattlesnake Plan. TAIN. (I. F. f. I I33.) Scape stout, 2-4 dm. ligh, glandilar-pubescent. Leaves ovate-lanceolate, 4-6 cm. long, I 5-30 mm. wide, the blade acute at both ends, often without white blotches or reticulations ; spike not I-sided ; flowers 7-9 $\mathrm{mm}$. long ; gaiea concave, ovate-lanceolate, the tip long, usually recurved; lip swollen at the base : anther ovate, pointed, on the base of the column, which is prolonged above the stigma into a gland-bearing awl-shaped beak. In woods, Quebec to Br. Col., N. H., N. Y., Minn., Ariz., and Cal. Aug.

\section{ACHROÁNTHES Raf. [MICROSTYLIS Nutt.]}

Iow herbs, from a solid bulb, our species I-leaved, and with I-several scales at the base of the stem. Flowers small, white or green, in a terminal raceme. Sepals spreading, separate, the lateral ones equal at the base. Petals filiform or linear, spreading. Lip cordate or eared at the base, embracing the column. Anther erect between the auricles, 2-celled; pollinia 4, smooth and waxy, 2 in each sac, the pairs cohering at the summit, without caudicles or glands. Capsule oval, sometimes nearly globose, beakless. [Greek, in allusion to the green flowers?] About 40 species, widely distributed. Besides the following, about 4 others occur in the southern and western parts of North America.

Leaf sheathing the base of the stem.

Leaf clasping the stem near the middle.

1. A. monophylla.

2. A. unifolia.

I. Achroanthes monophýlla (L.) Greene. White Ander's-moutir. (I. F. f.

II34.) Stem slender, IO-I5 cm. high, smooth, glabrous, striate. Leaf sheathing the stem at its base, the blade $2-5 \mathrm{~cm}$. long, $\mathrm{I}-4 \mathrm{~cm}$. wide; raceme $2-7 \mathrm{~cm}$. long. narrow, 6-10 $\mathrm{mm}$. thick; flowers whitish, ahout $2 \mathrm{~mm}$. long; pedicels nearly erect, bracted, $2-4 \mathrm{~mm}$. long; sepals acute; lip triangular or ovate, acuminate, the lateral lobes obtuse ; capsule oval, about $6 \mathrm{~mm}$. long. In woods, Qucbec to Minn., Penn., and Neb. July.

2. Achroanthes unifòlia (Michx.) Raf. Green Adder's-mouth. (I. F. f. I 135.) Stem glabrous, striate, IO-25 cm. high. Leaf clasping the stem near the middle, oval or nearly orbicular, $2-5 \mathrm{~cm}$. long; raceme $2-7 \mathrm{~cm}$. long, sometimes $2 \mathrm{~cm}$. thick; flowers greenish, about $2 \mathrm{~mm}$. long, the pedicels very slender, spreading, 6-10 $\mathrm{mm}$. long; sepals oblong; lip broad, 2-lobed at the apex, with a small tooth in the sinus; capsule oval or subglobose. In woods and thickets, Newf. to Ont. and Minn., south to Fla., Ala. and Mo. July.

\section{I. LEPTÓRCHIS Thouars. [LIPARIS Rich.]}

Low herbs, with solid bulbs, the base of the stem sheathed by several scales and 2 broad shining leaves. Flowers in terminal racemes. Sepals and petals nearly equal, linear, spreading, petals usually very narrow. Column elongated, incurved, thickened and margined above. Pollinia 2 in each sac of the anther, smooth and waxy, the pairs slightly united, without stalk, threads or glands. Lip nearly flat, often bearing 2 tubercles above the base. [Greek, signifying a slender orchill.] About 100 species, widely distributed in temperate and tropical regions; only the following known to occur in North America:

Raceme many-flowered; lip as long as the petals.

Raceme few-flowered; lip shorter than the petals.

I. L. liliifolia.

2. L. Loeselii.

I. Leptorchis liliifòlia (L.) Kuntze. Large Twayblade. (I. F. f. II36.) Scape I-2.5 dm. high, 5-10-striate. Leaves ovate or oval, 5-12 cm. long, obtuse, keeled below, the sheaths large and loose. Raceme sometimes $15 \mathrm{~cm}$. long; flowers numerous, slowy; petals very narrow or thread-like; lip erect, large, ro-I $2 \mathrm{~mm}$. long, about as long as the petals, wedge-obovate; column $3 \mathrm{~mm}$. long, incurved, dilated at the summit; capsule somewhat club-shaped, about $12 \mathrm{~mm}$. long, the pedicel thickened in fruit. In moist woods and thickets, Me. to Minn., Ga. and Mo. May-July.

2. Leptorchis Loesèlii (L.) MacM. Fen Orchis. Loesel's Twayblade. (‥ F. f. I I37.) Scape 5-20 cm. high, strongly 5-7-ribbed. Leaves elliptic or 
elliptic-lanceolate, 5-15 cm. long, obtuse; raceme few-flowered; flowers greenish. smaller than those of the preceding species, 4-6 $\mathrm{mm}$. long; sepals narrowly lance. olate, spreading; petals linear, somewhat reflexed; lip obovate, pointed, its tip incurved; column half as long as the lip or less; capsule about ro mm. long, wingangled, on a.thickened pedicel. In wet thickets and on springy banks, N. S. to the N. W. Terr., south to Md. and Mo. Also in Europe. May-July.

\section{CALÝPSO Salisb.}

Bog herb, with a solid bulb and coralloid roots, the low $\mathbf{I}$-flowered scape sheathed by 2 or 3 loose scales and a solitary petioled leaf at the base. Flower large, showy, terminal, bracted. Sepals and petals similar, nearly equal. I.ip large, saccate and swollen, 2-parted below. Column dilated, petal-like, bearing the lid-like anther just below the summit. Pollinia 2, waxy, each 2-parted, without caudicles, sessile on a thick gland, the stigma at the base. [Dedicated to the goddess Calypso.] A monotypic genus of the cooler portions of the north temperate zone.

I. Calypso bulbòsa (L.) Oakes. Calypso. (I. F. f. II38.) Bulb I cm. in diameter or less. Scape 7-I5 cm. high; leaf round-ovate, 2-3.5 cm. long, nearly as wide, obtusely pointed at the apex, rounded or subcordate at the base; flowers variegated, purple, pink and yellow, the peduncle jointed; petals and sepals linear, erect or spreading, 1o-14 mm. long, with 3 longitudinal purple lines; lip large, saccate, 2-divided below, spreading and drooping, with a patch of yellow woolly hairs near the point of division; capsule about $\mathbf{r} \mathbf{c m}$. long, many-nerved. Labrador to Alaska, south to Me., Mich., Cal. and Ariz. Also in Europe. Flower some. what resembling that of a small Cypripedium. May-June. [C. borealıs Salisio.]

\section{TIPULÀ RIA Nutt.}

Slender scapose herbs, with solid bulbs, several generations connected by offsets, the flowers in a long loose terminal raceme. Leaf solitary, basal, unfolding long after the flowering season (in autumn), usually after the scape has perished. Scape with several thin sheathing scales at the base. Flowers green, nodding, bractless. Sepals and petals similar, spreading. Lip 3-lobed, produced backwardly into a very long spur. Column erect, wingless or very narrowly winged. Anther terminal, operculate, 2 -celled. Pollinia 4, ovoid, waxy, 2 in each anther-sac, separate, affixed to a short stipe, which is glandular at the base. [Latin, similar to Tipula, a genus of insects, in allusion to the form of the flower.] Two known species, the following of eastern North America, the other Himalayan.

I. Tipularia unifòlia (Muhl.) B.S. P. CRANE-FLy OrCHIS. (I. F. f. I I44.) Scape glabrous, 4-5 dm. high, from a bard, often irregular solid bulb or corm. Leaf arising in autumn from a fresh latcral corm, ovate, $5-7 \mathrm{~cm}$. long, dark green, frequently surviving through the winter; raceme $12-25 \mathrm{~cm}$. long, very loose; flowers green, tinged with purple; sepals and petals 6-8 $\mathrm{mm}$. long, narrow; lip mostly shorter than the petals, the middle lobe narrow, prolonged, dilated at the apex, the lateral lobes short triangular; spur often twice as long as the flower; column shorter than the petals, the beak minutely pubescent; capsule ellipsoid, 6-ribbed. In woods, Vt. to Mich., south to Fla. and La. Local and rare. JulyAug. [T. discolor Nutt.]

\section{APLÉCTRUM Nutt.}

Scapose herbs, from a corm, produced from the one of the previous season by an offset and sometimes with coralloid fibres; the scape clothed with several sheathing scales. Leaf solitary, basal, developed in auturnn or late summer, broad, petioled. Flowers in a terminal raceme, the pedicels subtended by small bracts. Petals and sepals similar, narrow. Lip clawed, somewhat 3-ridged, spur none. Column free, the anther borne a little below its summit. Pollinia 4, lens-shaped, oblique. [Greek, meaning without a spur.] A North American genus of 2 or 3 species. 
I. Aplectrum hyemàle (Mulıl.) Torr. Adam-And-Eve. Putty-Root. (I. F. f. I I 47.) Scape glabrous, 3-6 dm. high, bearing about 3 sheathing scales. Leaf arising from the corm, at the side of the scape, elliptic or oval, 10-15 cm. long, I-5 $\mathrm{cm}$. wide, usually lasting over winter; raceme $5-10 \mathrm{~cm}$. long, loosely several-flowered: bracts lanceolate, 2-6 mm. long; flowers dull yellowish brown mixed with purpre, rnout $2.5 \mathrm{~cm}$. long, short-pedicelled; sepals and petals linear-oblanceolate, about I cm. long, $2-2.5 \mathrm{~mm}$, wide, acute or rarely obtuse; lip shorter than the petals, obtuse, somewhat 3 -lobed and undulate; column slightly curved, shorter than the lip; capsule oblong-ovoid, angled, about $2 \mathrm{~cm}$. long. In woods and swamps, Vt. and Ont. to the N. W. Terr., south to Ga. Several old corms usually remain attached to the latest one. Sipecimens with yellowish green, unspotted flowors have been collected by Prof. Underwood at Jamesville, N. Y. May-June.

2. Aplectrum Shórtii Rydb. Short's Putty-Root. Like the preceding, but stems stouter, the sheaths of the scales of the stem loose. inflated; leaves broadly oval or obovate, often $7 \mathrm{~cm}$. wide; sepals and petals much broader, very obtuse, 3-4 mm. wide, and lip more gibbous at the base; bracts ovate, I-3 mm. long. The only specimens seen were collected by Dr. C. W. Short in Ky.

\section{CORALLORHİZA R. Br.}

Scapose herbs, saprophytes or root-parasites, with large masses of coralloid branching roots, the leaves all reduced to sheathing scales. Flowers in terminal racemes. Sepals nearly equal, the lateral ones united at the base with the foot of the column, forming a short spur or gibbous protuberance, the other one free, the spur adnate to the summit of the ovary. Petals about as long as the sepals, I-3-nerved. Lip I-3-ridged. Column nearly free, slightly incurved, somewhat 2-winged. Anther terminal, operculate. Pollinia 4 , in 2 pairs, oblique, free, soft-waxy. [Greek, from the coral-like roots.] About 15 species, widely distributed in the north temperate zone. Besides the following, some 4 others occur in the southern and western parts of North America.

Spur small or sac-like, adnate to the top of the ovary.

Lip not deeply 3 -lobed.

Lip 2-toothed or 2-lobed above the base.

Lip entire, or merely denticulate.

Flowers about 6-8 nim. long; lip not notched; column narrowly winged.

2. C. odontorhiza.

Flowers $14 \mathrm{~mm}$. long; lip notched; column mánifestly winged.

Lip deeply 3-lobed; flowers $12-18 \mathrm{~mm}$. long.

No spur or sac.

3. C. Wisteriana.

4. C. multiflora.

5. C. striata.

x. Corallorhiza Corallorhiza (L.) Karst. EARly Coral-Root. (I. F. f. II39.) Scape glabrous, I-4 dm. high, clothed with 2-5 closely sheathing scales. Raceme 2-7 cm. long, 3-12-flowered; flowers dull purple, about $1 \mathrm{~cm}$. long; sepals and petals narrow, about $6 \mathrm{~mm}$. long; lip shorter than the petals, oblong, whitish, 2 -toothed or 2-lobed above the base; spur, a sac or small protuberance adnate to the summit of the ovary; capsule 8-12 mm. long, oblong or somewhat obovoid. In woods, N. S. to Alaska, south to N. J., in the mountains to Ga., and to Neb. and Wash. Also in Europe. May-June.

2. Corallorhiza odontorhiza (Willd.) Nutt. Small-flowered CoralRoor. (I. F. f. I I 4O.) Scape slender, purplish, I.5-3.5 dm. high. Raceme 5-10 cm. long, 6-20-flowered; flowers 6-8 mm. long, purplish; sepals and petals lanceolate, $4 \mathrm{~mm}$. long or less, marked with purple lines; lip as long as the petals, broadly oval or obovate, entire or denticulate, narrowed at the base, not notched, whitish; spur, a small sac adnate to the top of the ovary; wings of the column very narrow. In woods, Mass. to Mich., Fla. and Mo. July-Sept.

3. Corallorhiza Wisteriàna Conrad. Wister's Coral-Root. (I. F. f. II4I.) Stem stouter than that of the preceding species, 2-4 dm. high, bearing several sheathing scales. Raceme 5-12 cm. long, loose, 6-15-flowered; flowers about I4 $\mathrm{mm}$. long, slender-pedicelled; lip broadly oval or obovate, 8-1o mm. long and wide, abruptly clawed, white with crimson spots, crenulate, notched at the apex; spur, a somewhat conspicuous protuberançe adnate to the top of the ovary; column 
strongly 2-winged toward the base; capsule about $10 \mathrm{~mm}$. long. In woods, Mass. to Ohio, Fla. and Tex. Feb.-May.

4. Corallorhiza multiflòra Nutt. Large Coral-Root. (I. F. f. II42.) Scape 2-5 dm. high. purplish, clothed with several appressed scales. Raceme 5-20 cm. long, 10-30-flowered; flowers $12-18 \mathrm{~mm}$. long, brownish purple, shortpedicelled; sepals and petals somewhat connivent at the base, linear-lanceolate, about $6 \mathrm{~mm}$. long: lip white, spotted and lined with purple, oval or ovate in out. line, deeply 3-lobed, crenulate, the middle lobe broader than the lateral ones, its apex curved; spur manifest, yellowish; capsule ovoid or oblong, 10-16 mm. long. In woods, N. S. to Br. Col., south to Fla., Mo. and Cal. July-Sept.

Corallorhiza multiflora flávida Peck. Whole plant light yellow; lip white, unspotted. Perhaps distinct. IJ. Y. to Neb. and MId.

5. Corallorhiza striàta Lindl. Striped Coral-Root. (I. F. f. II43.) Scape stout, purplish, 2-5 dm. high. Raceme 5-15 cm. long, ro-25-flowered. Flowers dark purple; sepals and petals narrowly elliptic, striped with deeper purple lines, I2-I4 $\mathrm{nm}$. long, spreading; lip oval or obovate, entire or a little undulate, somewhat narrowed at the base, about as long as the petals; spur none, but the perianth has a gibbous saccate base ; capsule ellipsoid, reflexed, 16-20 mm. long. In woods, Ont. and N. N. Y. to Mich., Ore. and Cal. July.

\section{HEXALÉCTRIS Raf.}

Scapose herbs, from thick scaly rootstocks and fleshy coralloid roots, the leaves reduced to purplish scales, sheathing the scape. Flowers bracted in a loose terminal raceme. Perianth not gibbous or spurred at the base, the petals and sepals similar, nerved, spreading. Lip obovate, with several crested ridges down the middle, somewhat 3-lobed, the middle lobe a little concave. Column free, thick, slightly incurved. Pollinia 8, united in a cluster. Capsule ellipsoid, the fruiting pedicels thick. [Greek, signifying six crests.] A monotypic genus of the southeastern United States and Mexico.

I. Hexalect: is spicàta (Walt.) Barn. CRested Coral-Root. (I. F. f. I I46.) Scape stout, 2-5 dm. high, its upper scales lanceolate, the lower sheathing and truncate or acute. Raceme Io-18 cm. long, 8-12-flowered; flowers large, brownish purple, $25 \mathrm{~mm}$. high or more; pedicels short, stout; sepals and petals narrowly elliptic, obtuse or acutish, spreading, striped with purple veins, 12-18 $\mathrm{mm}$. long, longer than the broad lip; middle lobe of the lip rounded or crenulate, the lateral ones shorter, rounded; column slightly spreading at the summit, shorter than the lip; capsule ellipsoid, about $2 \mathrm{~cm}$. long. In rich woods, N. Car. to Ky. and Mo., south to Fla. and Northern Mexico. Aug. (H. aphyllus Raf.)

\section{Sub-class 2. DICOTYLÉDONES.}

Embryo of the seed with two cotyledons (in a few genera one only, as in Cyclamen, Pinguicula and some species of Capnoides), the first leaves of the germinating plantlet opposite. Stem exogenous, of pith, wood and bark (endogenous in structure in Nymphaeaceae), the wood in one or more layers surrounding the pith, traversed by medullary rays and covered by the bark. Leaves usually pinnately or palmately veined, the veinlets forming a network. Parts of the flower rarely in 3's or 6's.

Dicotyledonous plants are first definitely known in Cretaceous time. They constitute between two-thirds and three-fourths of the living angiospermous flora.

\section{Series I. Choripétalae.}

\section{Petals separate and distinct from each other, or wanting.}

The series is also known as Archichlamideae, and comprises most of the families formerly grouped under Apetalae (without petals) and Polypetalae (with sepa. rate petals). Exceptions to the typical feature of separate petals are found in the 
Papilionaceae, in which the two lower petals are more or less united; in the Fumariaceae, where the two inner petals or all four of them are sometimes coherent; the Polygalaceae, in which the three petals are united with each other, and with the stamens; Oxalis in Geraniaceae; and Ilicaceae, whose five petals are sometimes joined at the ba is.

\section{Order I. CASUARINALES,}

comprising only the family Casuarinaccae, is confined to tropical seacoasts.

\section{Order 2. PIPERÀLES:}

Dicotyledonous herbs, with neither petals nor sepals, the spicate flowers bracteolate.

\section{Family r. SAURURACEAE Lindl. \\ Lizard's-tail Fimily.}

Perennial herbs with broad entire alternate petioled leaves, and small perfect incomplete bracteolate flowers, in peduncled spikes. Perianth none. Stamens 6-8, or sometimes fewer, hypogynous; anthers 2-celled, the sacs longitudinally dehiscent. Ovary 3-4-carpelled, the carpels distinct or united, I-2-ovuled; ovules orthotropous. Fruit capsular or berry-like, composed of 3 or 4 mostly indehiscent carpels. Seeds globose or ovoid, the testa nembranaceous. Endosperm copious, mealy. Embryo minute, cordate, borne in a small sac near the end of the endosperm. Three genera and 4 species, natives of N. Am. and Asia.

\section{SAURÙRUS L.}

Marsh herbs, with slender rootstocks, jointed stems and cordate leaves, their petioles sheathing the stem at the nodes, and small white flowers, in $\mathbf{I}$ or $\mathbf{2}$ dense elongated spikes opposite the leaves. Bractlets adnate to the flowers or to their minute pedicels. Stamens 6-8; filaments filiform, distinct. Carpels united at the base. Styles as many as the carpels, recurved, stigmatic along the inner side. Fruit rugose, depressed-globose, separating into 3 or 4 one-seeded carpels. [Name Greek, meaning the tail of a lizarl, in allusion to the long slender spike.] Two species, the following of eastern N. Am., the other of eastern Asia.

I. Saururus cérnuus L. Lizard's-Tall. (I. F. f. I148.) Somewhat pubescent when young, becoming glabrous; stem erect, sparingly branched, 6-1 $5 \mathrm{dm}$. high. Leaves ovate, thin, palmately 5-9-ribbed and with a pair of strong ribs above, dark green, acuminate, 7-15 cm. long, 5-9 $\mathrm{cm}$. wide; petioles stout, shcrter than the blades; spikes few, very dense, longer than their peduncles, $10-15 \mathrm{~cm}$. long, the apex drooping in flower; flowers fragrant; stamens white, spreading, about $4 \mathrm{~mm}$. long; fruit $3 \mathrm{~mm}$. in diameter, strongly wrinkled when dry. In swamps and shallow water, Conn. to Fla., S. Ont., Mimn. and Tex. June-Aug.

\section{Order 3. SALICÀLES.}

Trees or shrubs, with imperfect small flowers in aments. Sepals and petals none. Leaves simple. Fruit a many-seeded capsule. Seeds with a tuft of hairs at one end.

\section{Family 1. SALICÀCEAE Lindl.* Willow Family.}

Jixecious trees or shrubs with light wood, bitter bark, brittle twigs, and aiternate stipulate leaves, the stipules often minute and caducous.

* Revised by Dr. P. A. RYdBERG. 
Flowers solitary in the axil of each bract. Staminate flowers consisting of from one to numerous stamens inserted on the receptacle, subtended by a gland-like or cup-shaped disk; anthers 2-celled, the sacs longitudinally dehiscent. Pistillate aments sometimes raceme-like; pistillate flowers of a I-celled ovary subtended by a minute disk; placentae 2-4, parietal; ovules usually numerous, anatropous ; stigmas $2-4$, simple or 2-4cleft. Seeds small or minute, provided with a dense coma (, flong, mostly white, silky hairs. Endosperm none. Cotyledons plano-convex. Radicle short. The family includes only the 2 following genera, consisting of 200 species or more, mostly natives of the north temperate and arctic zones.

Rracts fimbriate or incised; stamens numerous.

Bracts entire; stamens 2-10.

x. Populus. 2. Salix.

\section{ז. PÓPULUS L.}

Trees with scaly resinous buds, and usually long-petioled leaves, the stipules minute, fugacious. Disk cup-shaped, oblique. Staminate aments dense, pendulous. Staminate flowers with from 4 to 60 stamens, their filaments distinct. Pistillate aments sometimes raceme-like through the elongation of the pedicels. Ovary sessile; style short; stigmas 2-4, entire or 4-lobed. Capsule 2-4-valved. Coma of the seeds often very long and conspicuous. [Name ancient, used for these trees by Pliny.] About 25 species, natives of the northern hemisphere. Besides the following, some 3 others occur in the western part of N. Am.

Petioles terete or chanelled, scarcely or not at all flattened laterally.

Leaves persistently and densely white-tomentose beneath, lobed or coarsely sinuatedentate.

Leaves glabrous or nearly so when mature, crenate.

Foliage densely tomentose when young; capsule slender-pedicelled.

Foliage not tomentose; capsule short-pedicelled.

2. P. heterophylla.

Leaves broadly ovate, truncate or cordate at the base; petioles and nerves usually puberulent.

3. P. candicans.

Leaves ovate to lanceolate, acute or obtuse at the base; petioles glabrous. Leaves ovate or broadly lanceolate; petiole fully half as long as the blade. Leaves green on both sides, abruptly acuminate.

6. P. acuminata. Leaves pale beneath, acute or somewhat acuminate.

4. P. balsamifera.

Leaves lanceolate; petiole about ohe-third the length of the blade or less. 5. P. angustifolia.

Petioles stron ly flattened laterally.

Leaves broadly deltoid, abruptly acuminate.

Young leitves pubescent; capsule nearly sessile.

Young leaves not pubescent; capsule slender-pedicelled.

Leaves broadly ovate or suborbicular.

Leaves coarsely sinuate-dentate.

Leaves crenulate-denticulate.

7. P. nigra.

8. $P$. deltoides.

9. P. grandidentatu. 10. P. tremuloides.

I. Populus álba L. Abele. White or Silver-leaf Porlar. (I. F. f. 1 164.) A large tree, with smooth light gray bark, attaining a maximum height of about 35 $\mathrm{m}$. and a trunk diameter of $1.5 \mathrm{~m}$. Young foliage densely white-tomentose, the leaves becoming glabrate and dark green above, broadly ovate or nearly orbicular in outline, apex acute, base truncate or subcordate, 3-5-lobed or irregularly dentate, $6-10 \mathrm{~cm}$. lorg; petiole shorter than the blade; staminate aments $3-5 \mathrm{~cm}$. long. In yards and along roadsides, springing up from suckers of older trees, N. B. to Va. Native of Europe and Asia. March-May.

2. Populus heterophýlla L. Swamp or Downy Poplar. (I. F. f. II68.) An irregularly branching tree, sometimes $25 \mathrm{~m}$. high and with a trunk $\mathbf{I} \mathrm{m}$. in diameter, the bark rough. Leaves long-petioled, broadly ovate, obtuse or subacute at the apex, rounded, truncate or subcordate at the base, crenulate-denticulate, 12$15 \mathrm{~cm}$. long, or those of young plants much larger, glabrous or somewhat floccose beneath when mature; bracts glabrous or nearly so; staminate aments stout, 7-10 cm, long, 18-25 mm. in diamęter, drooping; stamens numerous; pistillate aments 
raceme-like, peduncled ; capsules ovoid, acute, 2-valved, 8-12 mm. long, shorter than or equalling their pedicels. In swamps, S. Conn. and N. Y. to Ga., west to La., north in the Miss. Valley to Ind. and Ark. April-May.

3. Populus cándicans Ait. BALM of Gilead. A large tree, reaching a height of $30 \mathrm{~m}$. and a trunk diameter of $2 \mathrm{~m}$., with spreading branches; the buds large and very resinous. Leaves broadly cordate, dark green above, pale beneath, acuminate, more coarsely crenate than in the next with gland-tipped teeth, 6-15 $\mathrm{cm}$. long, 3-12 cm. wide, pubescent when young, generally glabrous in age, with the exception of the ciliate margins and pubescent veins and petioles; otherwise like the following. N. B. to N. J. west to Minn., but mostly escaped from cultivation. (P. balsamifera candicans A: Gray.)

4. Populus balsamífera L. Tacamahac. Balsam Poplar. (I. F. f. I I65.) A large tree, with nearly smooth gray bark, reaching a maximum height of about $25 \mathrm{~m}$. and a trunk diameter of $2 \mathrm{~m}$., the branches stout, ascending. the large buds very resinous, the foliage glabrous. Leaves broadly ovate, dark green and shining above, pale beneath, acute or acuminate at the apex, rounded or acute at the base, crenulate, 7-12 cm. long; aments and bracts somewhat pubescent; stamens $18-30$; lobes of the stigmas broad; capsule ovoid, 2-valved, short-pedicelled. In moist or dry soil, especially along streams and lakes, Newf. to Hudson Bay and Alaska, south to N. Y., Neb. and Nev. April.

5. Populus angustifòlia James. Narrow-leaved or Black Cottonwood. (I. F. f. I I66.) A slender tree, maximum height about $20 \mathrm{~m}$., trunk diameter $6 \mathrm{dm}$.; crown narrowly pyramidal, branches ascending; foliage glabrous. Twigs terete, gray; leaves lanceolate, ovate-lanceolate or ovate, spreading, drying brownish, gradually acuminate or acute at the apex or some of them obtuse, narrowed, rounded or rarely subcordate at the base, $5-12 \mathrm{~cm}$. long, I-3 cm. wide, finely cren. ulate from base to apex; petioles plano-convex, not flattened laterally, 6-1 $2 \mathrm{~mm}$. long; lateral veins 8-15 on each side of the blade; staminate aments oblong-cylindric, 2-6 cm. long; lobes of the stigmas broad; capsules ovoid, short-pedicelled. In moist soil, especially along streams, N. W. Terr. to Neb., N. Mex., and Ariz. April-May.

6. Populus acuminàta Rydberg. Rydberg's Cottonwood. (I. F. f. I167.) A slender tree, with terete twigs, reaching approximately the dimensions of $P$. angustifolia, the crown broadly pyramidal with spreading branches, the foliage glabrous. Leaves rhomboid-lanceolate, spreading or drooping, drying green, abruptly or gradually long-acuminate at the apex, cuneate, obtuse or rounded at the base, 5-15 cm. long, 2-6 cm. wide, crenulate or the base entire; petioles slender, 2-6 cm. long; staminate aments about $3 \mathrm{~cm}$. long; pistillate aments slender, drooping, 7-12 cm. long; capsules ovoid, obtuse, distinctly pedicelled. Black Hills, S. Dak. to Utah, south to N. Mex. April-May.

7. Populus nigra L. Black Poplar. (I. F. f. II7I.) A large tree, sometimes $30 \mathrm{~m}$. tall and the trunk $12 \mathrm{dm}$. in diameter, usually much smaller. Twigs terete; young foliage somewhat pubescent, the mature leaves firm, nearly or quite glabrous; petioles slender, flattened laterally; leaves broadly deltoid, abruptly acuminate at the apex, broadly cuneate or obtuse at the base, crenate, 5 -10 $\mathrm{cm}$. long; staminate aments $3-5 \mathrm{~cm}$. long; stamens about 20 ; pistillate aments 5-I2 $\mathrm{cm}$. long in fruit, spreading; capsules oblong, very obtuse, borne on pedicels of much less than their own length. Valleys of the Hudson and Delaware Rivers, naturalized from Europe. April-May.

The Lombardy Poplar, Populus Italica, commonly planted for ornament, occasionally spreads by sending up shoots from its subterranean parts.

8. Populus deltoides Marsh. Cottonwood. Necklace Poplar. (I. F. f. I 172.) A large tree, the greatest of the poplars, attaining a maximum height of $45 \mathrm{~m}$. and a trunk diameter of $2.2 \mathrm{~m}$., the bark grayish-green, somewhat rough when old. Foliage glabrous; leaves broadly deltoid-ovate, abruptly acuminate at the apex, crenulate, truncate at the base, $10-17 \mathrm{~cm}$. long; petiole flattened iaterally, stout, about as long as the blade; bracts glabrous, deeply fimbriate; staminate aments drooping, 7-12 cm. long, IO-I $2 \mathrm{~mm}$. in diameter; pistillate aments loosely 
flowered, becoming $15-25 \mathrm{~cm}$. long in fruit; capsules ovoid, acute, 8-Io $\mathrm{mm}$. long, 2-4-valved, shorter than or equalling their pedicels. In moist soil, especially along streams and lakes, Quebec to Man., south to Fla. and Tenn. April-May. Alse called Carolina Poplar.

Populus deltoides occidentalis Rydb. Leaves with longer acumination, broader base and coarser teetlı; young branches light yellow and shining. Sask. to Alb., south to Kan., and N. Mex.

9. Populus grandidentàta Michx. Large-toothed Aspen. (I. F. f. II69.) A forest tree with smooth, greenish-gray bark, maximum height about $20 \mathrm{~m}$., and trunk diameter $7 \mathrm{dm}$. Leaves of very young plants densely whitetomentose beneath, sometimes $3 \mathrm{dm}$. long, with irregularly denticulate margins, those of older trees tomentose when young, glabrous when mature, short-acuminate, obtuse or truncate at the base, 6-10 cm. long; petioles slender; bracts silky, irregularly 4-7 cleft; staminate aments 4-10 cm. long, about $\mathrm{I} \mathrm{cm}$. in diameter, drooping; pistillate aments somewhat pubescent, dense, 7-12 cm. long in fruit, also drooping; stigma-lobes narrow; capsule conic, acute, 2 -valved, about $6 \mathrm{~mm}$. long, papillose. In rich woods, N. S. to Ont. and Minn., south to N. J. and in the Alleghanies to N. Car. and Tenn. April.

Io. Populus tremuloides Michx. American Aspen. (I. F. f. II7o.) A slender tree, with smooth, light green bark, reaching a maximum height of about $30 \mathrm{~m}$. and a trunk diameter of $\mathrm{x} \mathrm{m}$., the young foliage glabrous, excepting the ciliate margins of the leaves. Petioles very slender, causing the leaves to quiver in the slightest breeze; leaves usually short-acuminate at the apex, finely crenulate all around, truncate, rounded or subcordate at base, $2-6 \mathrm{~cm}$. broad, or those of very young plants much larger; bracts silky, deeply 3-5-cleft into linear lobes; aments drooping, the staminate $4-6 \mathrm{~cm}$. long, $6-8 \mathrm{~mm}$. in diameter, the pistillate longer, dense; stigma-lobes linear; capsule like that of the preceding species, but somewhat smaller. In dry or moist soil, Newf. to Hudson Bay and Alaska, soutı to N. J., Ky., Neb., in the Rocky Mountains to Mexico and to Lower California. March-May.

\section{SALIX L. (See Appendix.)}

Trees or shrubs, with single-scaled buds, the scales with an adherent membrane within, mostly narrow and short-petioled leaves and persistent or early decidvous broad or minute stipules. Bracts of the aments entire. Disk gland-like, small or minute. Staminate aments dense, erect, spreading or drooping. Staminate flowers with I-IO, mostly 2, stamens, their filaments distinct or sometimes united. Pistillate aments usually erect or spreading. Ovary sessile or short-stipitate. Style short or filiform. Stigmas 2, entire or 2-cleft. Capsule mostly 2-valved. [Name ancient.] About 200 species, of wide geographic distribution throughout the north temperate and arctic zones, a few in the southern hemisphere. Besides the following, many others occur in the northern and western parts of North America. Numerous liybrids between the species have been recorded.

* Capsule glabrous, or slightly silky when young in Nos. 20-22.

I. Trees or larger shrubs with serrate, acute or acuminate leaves.

Stamens 3-7; filaments hairy at the base; bracts caducous, light yellow.

Pedicels slender, 3-5 times as long as the gland.

Petioles and stipules withou: glands.

Leaves green or pale beneath.

Leaves narrowly lanceolate; petioles very short.

Leaves broadly lanceolate; petioles slender. r. S. nigra.

Leaves whitish beneath.

Petioles and stipules with prominent glands. Pedicels about twice as long as the gland. Stamens 2.

Filaments hairy at the base; bracts caducous, yellow.

Pedicels in fruit $\mathrm{I}-3 \mathrm{~mm}$. long.

Stigma sessile; leaves linear or lance-linear-

Leaves finely and almost permanent.y silky.
3. S. amygdaloides.

2. S. longipes.

4. S. lucida.

5. S. fragilis. 
Leaves coarsely silky when young, glabrate in age.

Leaves linear-lanceolate; bracts ovate or obovate, obtuse.

21. S. fuviatilis.

Leaves narrowly linear, bracts lanceolate, acute. 22. S. linearifolia.

Style evident, but short ; leaves lanceolate. 5. S. fragilis.

Pedicels in fruit less than $1 \mathrm{~mm}$. long; stigma sessile.

Branches not drooping; leaves lanceolate. 6. S. alba.

Branches drooping; leaves linear-lanceulate. 7. S. Babylonica.

Filaments glabrous; bracts persistent.

Mature leaves glabrous.

Pedicels in fruit $1-3 \mathrm{~mm}$. long; capsule $5-9 \mathrm{~mm}$. long.

Length of leaf-blade less than three times it breadth.

Mature leaves thin, dull.

8. S. balsamifera.

Mature leaves thick, firm, dark green and shining above.

Length of leaf-blade three times its breadth or more. 9. S. glaucophylla.

Leaves dark green above; young branches not light yellow.

Pedicels 2-4 times as long as the fuscous bracts; mature leaves slightly serrate. Io. S. Mackenziana.

Pedicels not longer than the bracts; mature leaves strongly serrate.

Bracts pale; leaves not whitish beneath.

II. S. cordata.

Bracts fuscous; leaves whitish beneath. 12. S. Missouriensis.

Leaves yellowish green; young branches light yellow. 13. S. lutea.

Pedicels in fruit less than $1 \mathrm{~mm}$. long; capsule 3-5 mm. long. 14. S. acutidens.

Mature leaves densely silky-pubescent; capsule subsessile. I5. S. adenophylla.

2. Very low shrubs with serrate or crenate, obtuse leaves; filaments glabrous. Leaves oblong, obovate or cuneate.

Low shrub with erect branches and closely serrate or crenate leaves.

Depressed shrub with distantly crenate or subentire leaves. 16. S. myrtillifolia.

Leaves nearly orbicular.

17. S. Uva-ursi.

18. $S$. herbacea.

3. Low shrub with entire-margined leaves; filaments glabrous. 19. S. myrtilloides.

I. Filaments distinct.

**Capsule silky or tomentose.

$A$. Capsule distinctly pedicelled, rostrate; style none or short.

a. Mature leav.. not densely hairy beneath.

Leaves linear or linear-lanceolate.

Filan $\epsilon$ nts hairy; capsule slightly silky when young, in age glabrate. Leaves finely and almost permanently silky.

20. S. Iuteosericea.

Leaves coarsely silky when young, glabrate in age.

Leaves linear-lanceolate; bracts ovate or obovate, obtuse. 21. $S$. interzor.

Leaves narrowly linear; bracts lanceolate, acute. 22. S. linearifolia.

Filaments glabrous; capsule permanently hairy.

Leaves oblong, elliptic, or ovate-lanceolate. 23. S. petiolaris.

Bracts fuscous, obovate or cuneate, long-hairy.

Mature leaves rather thin, obovate or oblanceolate, irregularly or indistinctly toothed; young branches glabrous or slightly puberulent.

Mature leaves oblong, firm, dentate.

Young branches densely hairy; aments short ard dense.

Young branches glabrous; aments long, laxer. 25. S. eriocephala. 26. $S$. prinoides.

Bracts yellow, linear oblong or lanceolate.

Pedicel scarcely longer than the elongated gland.

Pedicel much longer than the gland. 
Bracts longer than the pedicels; aments erect. 28. S. squamata.

Bracts much shorter than the pedicels ; aments drooping. Mature leaves thin, glabrous. 29. $S$. perrostrata. Mature leaves firm, pubescent or tomentose beneath.

b. Mature leaves densely white-hairy beneath. 30. S. bebbiana.

Leaves white-tomentose beneath.

Style, if any, less than $1 \mathrm{~mm}$. long.

Leaves ovate-lanceolate, slender-petioled.

Leaves oblanceolate, short-petioled.

Leaves 5-10 cm. long; fruiting aments $2-3 \mathrm{~cm}$. long.

3r. S. humilis.

Leaves $2-5 \mathrm{~cm}$. long ; fruiting aments about $1 \mathrm{~cm}$. long.

32. S. tristis.

Style over I $\mathrm{mm}$. long; leaves linear or lanceolate. 33. S. candida. Leaves silvery silky beneath.

Style shorter than the stigma; leaves serrulate.

Style longer than the stigma; leaves entire-margined.

$B$. Capsule subsessile.

35. S. argyrocarpa.

Style long.

Tree with linear-lanceolate acuminate silvery leaves. $\quad 36$. S. viminalis. Low shıubs.

Leaves glabrous, or when young covered with long white hairs parallel to the midrib.

Bracts fuscous, obovate, densely white-silky.

Aments naked, from lateral buds.

Aments ending short leafy branches.

Leaves and young twigs darkening in drying.

Leaf-blade 10-20 nim. long; aments $10-20 \mathrm{~mm}$.

38. S. Groenlandica.

Leaf-blade 25-50 $\mathrm{mm}$. long; anients $25-80 \mathrm{~mm}$.

Leaves broadly obovate or obcordate, obtuse.

39. S. arctica.

Leaves narrowly obovate or obovate-lanceclate, often acute.

40. S. anglorum.

Leaves and yellowish or light brown twigs not darkening in drying.

Leaves obovate or oblanceolate, acute.

Leaves broadly obovate, obtuse.

Bracts yellow, oblong, white-silky.

41. S. vacciniformis.

42. S. callicarpaea.

Capsule conic, 7-8 $\mathrm{mm}$. long, grayish pubescent.

43. S. glauce.

Leaves broadly obovate, obtuse, not turning black in drying. 44. S. Waghornei.

Leaves broadly oblanceolate, acute, turning black in drying. 45. S. atra.

Leaves permanently hairy.

Leaves silky-pubescent, oblanceolate or lanceolate. 46. S. stricta.

Leaves with scattered villous hairs spreading in all directions, broadly ovate.

Style very short, or generally none.

Mature leaves covered with long silky hairs beneath. 48. S. vestita.

Leaves, at least in age, not silky beneath.

Bracts broadly obovate, fuscous, the upper portion at least glabrous.

Bracts oblong, yellow, densely hairy.

49. S. orbicularis.

5o. S. reticulata.

51. S. purpurea.

2. Filaments united; pedicel and style none.

47. S. Labradorica.

I. Salix nigra Marsh. Black Willow. (I. F. f. II73.) A tree. with rough flaky dark brown bark, attaining a height of $40 \mathrm{~m}$. and a trunk diameter of I $\mathrm{m}$. Leaves narrowed at the base, serrulate, somewhat pubescent when young, glabrous and green above, somewhat paler, and sometimes pubescent on the veins beneath, 6-12 cm. long, 4-18 mm. wide; aments expanding with the leaves, on short lateral branches, the staminate $3-5 \mathrm{~cm}$. long, the pistillate $4-8 \mathrm{~cm}$. long and 
spreading in fruit; stamens 3-7, distinct, their filaments pubescent below; stigmas nearly sessile; capsule ovoid, acute, about twice as long as its pedicel. Along streams and lakes, N. B. to W. Ont., Fla. and Cal. Hybridizes with S. alba. April-May.

Salix nigra falcata (Pursh) Torr. Leaves narrower, 4-6 mm. wide, falcate, green on both sides. Mass. to Ohio and Fla.

2. Salix lóngipes Anders. WARD's Willow. (I. F. f. II74.) A tree, sometimes Io $\mathrm{m}$. high, the trunk reaching $2 \mathrm{dm}$. in diameter, the branches spread. ing or drooping, the bark dark reddish brown, covered with small scales. Leaves lanceolate or oblong-lanceolate, rounded, subcordate, or narrowed at the base, 6-18 $\mathrm{cm}$. long, $\mathbf{I}-4 \mathrm{~cm}$. wide, somewhat pubescent beneath; stipules often large, sometimes persistent; aments expanding with the leaves, terminal, the staminate 5-10 $\mathrm{cm}$. long, the pistillate as long or shorter; capsule conic. Along streams and lakes, Md. to Mo., south to Fla, and Tex. Wood dark brown. March-May. (S. Wardii Bebb.)

3. Salix amygdaloides Anders. Peach-leaved Willow. (I. F. f. I I75.) A small tree, sometimes $20 \mathrm{~m}$. high and the trunk $6 \mathrm{dm}$. in diameter, the brown bark scaly. Leaves pubescent when young, glabrous when old, dark green above, paler and slightly glaucous beneath, narrowed at the base, $8-12 \mathrm{~cm}$. long, about 2 $\mathrm{cm}$. wide, sharply serrulate; petioles 6-I $5 \mathrm{~mm}$. long, glandless; stipules commonly fugacious; aments appearing with the leaves, terminal on short lateral branches, the staminate $3-5 \mathrm{~cm}$. long, the pistillate loose, spreading and $6-10 \mathrm{~cm}$. long in fruit; stigmas nearly sessile; capsule narrowly ovoid, acute, glabrous, at length about as long as its filiform pedicel. On lake and river shores, Quebec to Br. Col., N. Y., Mo. and N. Mex. April-May.

4. Salix lùcida Muhl. Shining Willow. Glossy Willow. (I F. f. I I76.) A tall shrub, or sometimes a tree $6 \mathrm{~m}$. high, the bark smooth or slightly scaly, the twigs yellowish brown, shining. Leaves lanceolate, ovate-lanceolate or ovate, mostly long acuminate, narrowed or rounded at the base, sharply serrulate all around, green and glossy on both sides or bearing a few scattered hairs when very young, $7-12 \mathrm{~cm}$. long, $2-7 \mathrm{~cm}$. wide when mature; stipules small, semi-cordate or oblong, very glandular, commonly persistent; petioles stout, 6-12 $\mathrm{mm}$. long, glandular at the base of the blade; aments on short lateral leafy branches, the staminate stout, 2-5 cm. long, the pistillate dense, 5-7 cm. long in fruit, often long-persistent; stigmas nearly sessile; capsule narrowly ovoid, acute, glabrous, much longer than its pedicel. In swamps and along streams and lakes, Newf. to the N. IV. Terr., N. J., Ky. and Neb. A most beautiful willow. April-May.

5. Salix frágilis L. Crack Willow. Brittle Willow. (I. F. f. i i77.) A tall, slender tree, with ronghish gray bark, attaining a height of about $25 \mathrm{~m}$. and a trunk diameter of $2 \mathrm{~m}$.; twigs reddish green, very brittle at the base. Leaves lancerlate, long-acuminate, narrowed at the base, sharply serrulate, glabrous on buth sides, rather dark green above, paler beneath, 8-15 cm. long, I-3 cm. wide, glandular at the base of the blade; petioles 6-16 $\mathrm{mm}$. long, glandular above; stip. ules semicordate, fugacious; staminate aments 2-5 cm. long; stamens 2, or sometimes 3 or 4 ; pistillate aments $7-12 \mathrm{~cm}$. long in fruit, rather loose; stigmas nearly sessile; capsule long-conic. Escaped from cultivation, Mass. to N. J. and Penn. Native of Europe. Hybridizes with the following species. The twigs break away and grow into new plants. April-May.

Salix frágilis decípiens (Hoffm.) Anders., with yellowish or red twigs and smaller, brighter green leaves, appears to be known only in cultivation within our area.

6. Salix álba L. White Wrllow. Huntingnon Willow. (I. F. f. i I78.) A large tree, sometimes $30 \mathrm{~m}$. tall and a trunk diameter of $2.5 \mathrm{~m}$; ; bark gray, rough; twigs brittle at the base. Leaves narrowed at the base, serrulate, silky. pubescent on both sides when young, less so and pale or glaucous beneath when mature, 5-I3 cm. long, 8-16 mm. wide; stipules ovate-lanceolate, deciduous; petioles 4-8 mm. long, glandless or sparingly glandular; aments on short lateral leafy branches; pistillate aments linear-cylindric, 3-6 cm. long; stigmas nearly sessile; capsule ovoid, acute. In moist soil, especially along streams, N. B. and Ont. to Penn., sparingly escaped from cultivation. Native of Europe. April-May. 
Salix álba coerùlea (J. E. Smith) Koch. Mature leaves bluish green, glabrous, glau. cous beneath. Occasional in the Eastern States.

Salix álba vitellina (L.) Koch. Mature leaves glabrous above; twigs yellowish green. The commonest form in North America.

7. Salix Babylónica L. Weeping Willow. Ring Willow. (I. F. f. I 79.) A large tree, with rough gray bark, sometimes attaining a height of $20 \mathrm{~m}$. and a trunk diameter of $18 \mathrm{dm}$., the twigs slender, green, elongated, drooping. Leaves serrulate all around, narrowed at the base, sparsely pubescent when young, glabrous when mature, green above, paler beneath, 10-18 cm. long, 6-12 mm. wide, sometimes curling into rings; petioles 6-12 $\mathrm{mm}$. long, glandular above; àments appearing on short lateral leafy branches; bracts ovate-lanceolate; style almost none; capsule ovoid-conic. Widely cultivated and sometimes spreading by the distribution of its twigs. Native of Asia. April-May.

8. Salix balsamífera (Hook.) Barratt. Balsam Willow. (I. F. f. r20r.) A shrub, 12-30 dm. high, the twigs glabrous, shining, the youngest foliage pubescent. Mature leaves elliptic, ovate-oval or obovate, thin, glabrous, acute or some of them obtuse at the apex, rounded or subcordate at the base, dark green above, glaucous and prominently reticulate-veined beneath, 5-8 cm. long, $2-4 \mathrm{~cm}$. wide, slightly crenulate-serrulate, the minute teeth glandular; stipules minute or none: petioles slender, 6-12 mm. long; aments expanding with the leaves, leafy-bracted at the base, cylindric, the staminate dense, about $2 \mathrm{~cm}$. long, the pistillate rather loose, 5-7 cm. long in fruit; bracts villous, persistent; style very short; capsules very narrow, acute, 4-5 $\mathrm{mm}$. long. In swamps, Lab. to Man., south to Me. and Minn. May.

9. Salix glaucophylla Bebb. Broad-leaved Willow. (I. F. f. II99.) A shrub, I-3 m. high; foliage glabrous or when young sparingly pubescent. Mature leaves ovate, obovate or oblong-lanceolate, white-glaucous beneath, short-acuminate, the base rounded or acute, serrulate with gland-tipped teeth, $5-10 \mathrm{~cm}$. long, $1-3 \mathrm{~cm}$. wide; stipules large, persistent; petioles stout, 6-12 $\mathrm{mm}$. long; aments expanding before the leaves, leafy-bracted at the base, the staminate $3-5 \mathrm{~cm}$. long, the pistillate 4-7 cm. long in fruit; bracts densely white-villous, persistent: style filiform; capsule beaked from an ovoid base, acute. On sand dunes, Lake Michigan, N. Ill. and Wis. April.

Io. Salix Mackenziàna Barratt. Mackenzie's Wrllow. A small tree, with smooth pale yellowish or grayish bark. Young branches glabrous or slightly puberulent, yellow or often tinged with bright red; mature leaves oblanceolate or lanceolate, cuneate at the base, finely crenulate-serrate or entire; stipules large, oblique, reniform and somewhat persistent; aments on short leafy-bracted branches, the pistillate $4-6 \mathrm{~cm}$. long in fruit; style very short; capsule ovoid, acute, $6-8 \mathrm{~mm}$. long. In damp soil from Man. to N. W. Terr. and N. Cal. April.

Ir. Salix cordàta Muhl. Heart-leaved Willow. (I. F. f. II98.) A shrub, I5-35 dm. high, the twigs puberulent or glabrous; young leaves pubescent; mature leaves oblong-lanceolate, green on both sides or paler beneath, acuminate at the apex, narrowed, obtuse or subcordate at the base, sharply serrulate with glandular teeth; stipules oblique, serrulate, usually large and persistent; petioles 8-I8 $\mathrm{mm}$. long; aments bracted at the base, expanding before the leaves, the staminate about $2 \mathrm{~cm}$. long, the pistillate $4-6 \mathrm{~cm}$. in fruit; style short; capsules narrowly ovoid, acute. In wet soil, N. B. to Br. Col., south to Va., Mo., Colo. and Cal. Hybridizes with $S$. sericea and other species. April-May.

Salix cordàta angustàta (Pursh) Anders. Leaves narrower, linear-lanceolate. Range of the type.

Salix cordata rígida (Muhl.) Carey. Leaves broad, sharper serrate especially at the cordate base, strongly veined; pedicels little if at all longer than the bracts; stigmas subsessile. N. B. to Penn.

12. Salix Missouriénsis Bebb. Missouri Willow. (I. F. f. 1200! A tree, often $15 \mathrm{~m}$. high, the trunk sometimes $4.5 \mathrm{dm}$. in diameter, the thin gray bark with small appressed scales. Twigs of the season pubescent or puberulent; leaves lanceolate, or oblanceolate, acuminate, finely serrate with minute glandtipped teeth, rounued or narrowed at the base, pubescent when young, glabrous or nearly so when mature, green above, pale and usually glaucous beneath, $7-15 \mathrm{~cm}$. 
long, I-3 cm. wide; petioles I cm. long or less; stipules often I cm. long, persistent or deciduous: aments unfolding long before the leaves, the staminate about $3 \mathrm{~cm}$. long, the pistillate $7-10 \mathrm{~cm}$. long; style very short; capsule narrowly ovoid. On river banks, Mo. and Neb. Wood dark brown. March-April.

13. Salix lútea Nutt. Yellow Willow. A shrub, 2-5 m. high, with light gray rough bark; twigs very light yellow, slender and shining, perfectly glabrous; leaves lanceolate, 4-7 cm. long, Io-18 mm. wide, long-acuminate at the apex, cuneate at the base, finely serrate, yellowish green and shining above, glaucous beneath, rather thin; stipules small and generally deciduous: aments on short lateral branches, short; the pistillate $2-3 \mathrm{~cm}$. long in fruit; style very short; capsule ovoid. On river banks and springy grounds from Neb. to Assiniboia and Mont.

14. Salix acútidens Rydb. Sharp-toothed Willow. Shrub, 2-3 m. high, bark green or on the younger branches often purplish; leaves rather thin, 6-12 $\mathrm{cm}$. long, 3-4 cm. wide, oblong, long-acuminate, rounded or acute at the base, shining above, more or less glaucous beneath, very sharply dentate, the teeth tipped with a small gland; stipules obliquely ovate, large, toothed and persistent; aments leafy-bracted below; fertile ones slender, in fruit 3-4 cm. long; bracts yellow, obovate, hairy; style about I $\mathrm{mm}$. long; capsule ovoid. The form of the leaves is intermediate between that of $S$. cordata and $S$. eriocephala with the texture of that of S. balsamifera; but the small glabrous short-pedicelled capsule distinguishes the species. Swamps of Conn., N. Y. and Penn. (S. myricoides Torr. Fl. N. Y. 2: 207 ; not Muhl.)

I5. Salix adenophylla Hook. FurRy Wir.ow. (I. F. f.1203.) A straggling shrub, I-2.5 m. high, the twigs, petioles, stipules and leaves densely silky-tomentose, the silky hairs falling away from the leaves when old. Leaves ovate, acute or short-acuminate, or the lower obtuse at the apex, cordate or rounded at the base, finely serrulate with gland-tipped teeth, 2-5 cm. long, 15-30 mm. wide; petioles stout, 3-6 mm. long, dilated at the base; stipules ovate-cordate, obtuse, serrulate, persistent; aments leafy-bracted at the base, dense, expanding with the leaves, the staminate about $2 \mathrm{~cm}$. long, the pistillate $3-10 \mathrm{~cm}$. long in fruit; style filiform; capsule ovoid-conic, acute, 3-4 mm. long. On lake and river shores, Lab. to Ont., Penn. and Ill. Hybridizes with $S$. cordata. April-May.

I6. Salix myrtillifolia Anders. Bilberry Willow. A shrub generally less than I m. high, with erect branches, much resembling Vaccinium Myrtillus in general habit and form of the leaves. Leaves obovate or oblong, 2-6 cm. long, light green, rather thin, obtuse, seldom acute, closely and finely crenate; stipules small, deciduous; aments on short leafy branches; the staminate $1-2 \mathrm{~cm}$. long, the pistillate $2-3 \mathrm{~cm}$. long in fruit; bracts obovate, fuscous, slightly hairy: capsule subsessile, ovate, tapering into a short style. From Lah. to Lower Mackenzie River and Alberta.

17. Salix Ùva-úrsi Pursh. Bearberry Willow. (I. F. f. I205.) A depressed or prostrate glabrous shrub, the terete brown branches $15-30 \mathrm{~cm}$. long, diffuse from a deep central root. Leaves obovate or elliptic, obtuse or acute at the apex, narrowed at the base, crenulate-denticulate or entire, 8-20 $\mathrm{mm}$. long, 4-10 $\mathrm{mm}$. wide, prominently veined, deep green and shining above, pale beneath; petioles 2-4 mm. long; aments leafy-bracted at the base, dense, about $1 \mathrm{~cm}$. long in flower, the pistillate $2-5 \mathrm{~cm}$. long in fruit; bracts obovate, obtuse, densely silky; stamens usually solitary, rarely 2 ; style short; capsule ovoid-conic, acute, glabrous, very short-pedicelled. Lab. and Hudson Bay, south to the summits of the mountains of N. Y. and N. Eng. May-June.

18. Salix herbàcea L. DwARF Willow. (I. F. f. ז206.) A depressed matted shrub, with very slender angled twigs $2-15 \mathrm{~cm}$. long, the youngest foliage somewhat pubescent. Mature leaves glabrous, suborbicular, rounded or retuse at the apex, cordate or rounded at the base, thin, crenulate-denticulate all around, finely reticulate-veined, bright green and shining on both sides, $\mathbf{I}-2 \mathrm{~cm}$. in diameter; petioles very slender, 4-8 $\mathrm{mm}$. long; aments terminating 2 -leaved branchlets, 7-10-flowered, 4-8 mm. long; bracts obovate, obtuse, persistent, glabrous or nearly so: stamens 2; style rather longer than the 2-cleft stigmas; capsule narrowly conic, glabrous, nearly sessile. Iab. and Quebec, through Arctic America, and on the White Mountains of N. H. and Mt. Katahdin, Me. Also in Europe and Asia. Summer. 
19. Salix myrtillordes L. Bog Willow. (I. F. f. 1204.) An erect slender glabrous shrub, 3-IO dm. high, the twigs light brown, terete. Leaves oblong, elliptic or solnewhat obovate, obtuse or acute at the apex, entire, mostly narrowed at the base, 2-4 cm. long, 8-16 mm. wide, short-petioled, bright green above, pale or glaucous beneath, their margins slightly revolute; aments expanding with the leaves, leafy-bracted at the base, rather dense, $2 \mathrm{~cm}$. long or less, or the pistillate longer in fruit; bracts persistent, obtuse, slightly villous; style shorter than or equalling the stigmas; capsule oblong-conic, obtuse, glabrous, $5 \mathrm{~mm}$. long, 2-3 times as long as the filiform pedicel which slightly exceeds the bract. In bogs, N. B. and Quebec to Br. Col., south to N. J. and Iowa. Also in northern Europe. April-May.

Salix myrtilloides pedicellaris Anders. Leaves narrower, oblong-linear or oblanceolate; pedicels sometimes longer. Range of the type.

20. Salix luteoserıcea Rydb.

Silvery Sandbar Willow. A shrub, with grayish bark, I- $6 \mathrm{~m}$. high, occasionally monœcious; leaves linear-lanceolate or linear, entire, or slightly and remotely denticulate, acute, $2-8 \mathrm{~cm}$. long, 2-6 $\mathrm{mm}$. wide, permanently yellowish silky; aments at the ends of leafy branches, the staminate $2-3 \mathrm{~cm}$. long, pistillate $3-5 \mathrm{~cm}$.; bract of staminate flowers obovate; of the pistillate ones broadly lanceolate; capsule elongated-ovoid, slightly silky when young, soon glabrate, 4-5 $\mathrm{mm}$. long. On sandbars, Saskatch. and $\mathrm{Br}$. Col. to Neb., Ind. Terr., and Ariz. Type from Nebraska.

2r. Salix intérior Rowlee. Sandbar Willow. River-bank Willow. (I. F. f. II8I.) A much.branched shrub, I-4 m. high, forming thickets, or sometimes a slender tree, 6-9 $\mathrm{m}$. tall, and with a trunk $3 \mathrm{dm}$. in diameter; branches brown or grayish. Leaves 6-10 $\mathrm{cm}$. long, 5-10 $\mathrm{mm}$. wide, acuminate, remotely denticulate with somewhat spreading teeth, short-petioled, bright green: petioles not glandular: stipules minute or none; aments on short leafy branches, the staminate dense, $2-4 \mathrm{~cm}$. long, the pistillate looser, about $5 \mathrm{~cm}$. long in fruit; capsule ovoid-conic, finely silky when young, glabrate in age, about $5 \mathrm{~mm}$. long. Along streams and lakes, Quebec to the N. W. Terr., south to Va., Ky. and Tex. AprilMay. [S. furiatilis A. Gray, not Nutt.]

22. Salix linearifòlia Rydb. Linear-leaved Willow. A low shrub, very soon glabrous, with red branches; leaves $4-10 \mathrm{~cm}$. long, $2-4 \mathrm{~mm}$. wide, remotely dentate, narrowly linear; stipules minute, deciduous; aments loosely flowered at the ends of leafy branches, the staminate about $3 \mathrm{~cm}$., the pistillate $3-4 \mathrm{~cm}$. long; capsule almost glabrous from the beginning, conic, 3-4 $\mathrm{mm}$. long; bract nearly as long as the pistil, almost glabrous. Sandbars, from Minn. and Saskatch. to Ind. Terr. and Colo. (S. rubra Richards.; not Smith.)

23. Salix petiolàris J. E. Smith. Slender Willow. (I. F. f. II89.) A shrub, similar to S. sericea, but the young leaves only slightly silky, the branches slender, upright or ascending. Mature leaves lanceolate, acuminate at both ends, serrulate with blunt cartilaginous teeth, remaining green in drying, $8-16 \mathrm{~mm}$. wide; petioles 4-IO $\mathrm{mm}$. long; stipules deciduous; aments expanding before the leaves, the pistillate short-peduncled, usually rather loose, about $2 \mathrm{~cm}$. long in fruit; stigmas nearly sessile; capsule tapering from an ovoid or oblong base, 4-6 mm. long, about twice as long as the filiform pedicel. In swamps, N. B. to the N. W. Terr., south to Tenn. and Wis. May.

Salix petiolàris grácilis Anders. Pedicels nearly as long as the capsules; leaves rather narrower. Range of the type.

24. Salix díscolor Muhl. Glaucous Willow. (I. F. f. 1187.) A shrub or low tree, maximum height $7 \mathrm{~m}$., trunk diameter $3 \mathrm{dm}$.; young leaves sometimes pubescent. Mature leaves rather thin, usually glabrous, bright green above, glaucous and nearly white beneath, oblong-oblanceolate, acute at both ends, irregularly serrulate or nearly entire, slender-petioled, $4-10 \mathrm{~cm}$. long, $1.5-3 \mathrm{~cm}$. wide; petioles 6-24 mm. long: stipules obliquely lanceolate or semicordate, commonly deciduous; aments unfolding much before the leaves, dense, the pistillate $4-7 \mathrm{~cm}$. long in fruit; capsule narrowly conic, tapering to a slender beak, 5-8 $\mathrm{mm}$. long. In swamps or on moist hillsides, N. S. to Man., Del. and Mo. March-April. 
25. Salix eriocéphala Michx. Pussy Willow. A shrub or low tree, much resembling the preceding. Mature leaves rather firm, green and shining above, glaucous and generally hairy beneath, especially on the veins, quite often ferruginıus, 6-10 $\mathrm{cm}$. long, $2-4 \mathrm{~cm}$. wide; stipules semicordate, often deciduous; aments unfolding before the leaves, dense and short, the staminate $1-2 \mathrm{~cm}$. long, yellowish silky-hairy, the pistillate ones $3-4 \mathrm{~cm}$. in fruit; capsule as in the preceding, often ro $\mathrm{mm}$. long. In wet places from N. Eng. to Penn. and Ill. This has been confused with $S$. discolor, as intermediate forms apparently occur.

Salix eriocéphala amplifolia Rydb. Leaves broadly oval, 4-5 cm. wide. Conn. and N. Y.

26. Salix prinoides Pursh. Chestnut-oAk Willow. Shrub resembling the preceding, but branches slender, glabrous; mature leaves lighter colored above and less glaucous beneath, narrower and more tapering at both ends, serrate; aments longer, $4 \mathrm{~cm}$. long or more, rather lax, sparingly silky; capsule conic, finely silky, with a more evident style. N. Y. to Va.

27. Salix latiúscula Anders. Newfoundland Willow. (I. F. f. 1202.) A low shrub, with dark brown glabrous twigs, the young shoots pubescent. Leaves oval or obovate, subcordate at the base, short-pointed at the apex, serrulate, when mature bright green above, pale beneath, about $4 \mathrm{~cm}$. long, $2.5 \mathrm{~cm}$. wide; stipules ovate-cordate, acute; aments unfolding with the leaves, borne at the ends of short branches, dense, spreading or erect, the staminate $2 \mathrm{~cm}$. long, the pistillate $5-8 \mathrm{~cm}$. long in fruit; bracts yellow, obtuse, persistent, slightly villous; capsule ovoid-conic, sparsely tomentose, acute, $6 \mathrm{~mm}$. long; style very short. Summer. Newf. (accord. ing to Andersson). [S. Barkleyi latiuscula Anders.]

28. Salix squamata Rydb. LONG-BRACTed Willow. A shrub or low tree, resembling closely $S$. eriocephala, but young branches only slightly pubescent, Mature leaves firm, green and shining above, glaucous and glabrous beneath, 6-10 $\mathrm{cm}$. long, distinctly dentate-serrate, acute at both ends; aments on more or less leafy branches, erect, the fertile ones in fruit 3-7 cm. long, rather loose; bracts yellowish or reddish, lanceolate, acute, three-fourths as long as the pistil; capsule conic; style short; stigmas short and almost entire. N. J. and Penn. Summer. Type from Sparta Junction, N. J.

29. Salix perrostràta Rydb.

Long-BEaked Willow. A shrub, I-4 m. high with grayish, rough and scaly bark; branches yellow or the youngest tinged with red, at first finely pubescent; leaves obovate-lanceolate or oblanceolate, when young finely silky, in age glabrate, $2-4 \mathrm{~cm}$. long, $\mathbf{I}-\mathbf{1 . 5} \mathrm{cm}$. wide, acute at both ends, and with undulate margins, light green above and paler beneath; petioles $2-6$ $\mathrm{mm}$; stipules minute, deciduous; aments somewhat leafy-bracted, almost sessile; the staminate $1-1.5 \mathrm{~cm}$. long, the pistillate in fruit $2-3 \mathrm{~cm}$.; capsule conic, longrostrate; stigma subsessile. Black Hills of S. Dak., Pine Ridge, Neb. and Wyoming. May-June. (S. Bebbiana Rydb. Cont. U. S. Nat. Herb. 3: 523, mainly, not Sarg.)

30 Salix Bebbiàna Sarg. BeBb's Willow. (I. F. f. Ir84.) A shrub, $2-6$ $\mathrm{m}$. tall, or sometimes a tree $8 \mathrm{~m}$. high, the twigs pubescent or puberulent, terete. Leaves elliptic, oblong or oblong-lanceolate, acute, acuminate or some of them blunt at the apex, rounded or narrowed at the base, sparingly serrate or entire, dull green and puberulent above, pale, reticulate-veined and tomentose beneath or nearly glabrous on both sides when very old; petioles 4-12 $\mathrm{mm}$. long, stipules semicurdate, acute, deciduous; aments sessile, expanding with or before the leaves, dense, the staminate $2-3 \mathrm{~cm}$. long, the pistillate $5 \mathrm{~cm}$. long in fruit; capsule very narrowly long-conic, twice as long as the filiform pedicel. In dry soil and along streams, Anticosti to Hudson Bay and Br. Col., south to N. J., Penn., Neb. and Utah. April-May.

31. Salix hùmilis Marsh. PraIRIE Willow. (I. F. f. II85.) A shrub, I$2.5 \mathrm{~m}$. long, the twigs tomentose or pubescent, terete. Leaves oblanceolate, petioled, 5-10 cm; long, 8-16 mm. wide, acute at both ends or the lower broader and obtuse at the apex, sparingly denticulate, the margins slightly revolute, the upper surface dark green, dull, puberulent or glabrous; petioles 4-6 mm. long; stipules obliquely lanceolate or ovate, acute, commonly persistent; aments unfolding much before the leaves, sessile, ovoid-oblong, short, dense; stignas nearly sessile; capsule narrowly conic. In dry soil, N. S. to western Ont., south to N. Car., Tenn. and Neb. Hybridizes with $S$. dissnlnr. April-May. 
32. Salix trístis Ait. Dwarf Gray Willow. Sage Willow. (I. F. f. I 186.) A tufted, slender shrub, 3-6 dm. tall, the twigs terete, puberulent, the roots long and thick. Leaves oblanceolate or linear-oblong, acute or obtusish, somewhat undulate, green and puberulent or glabrous above, crowded, 2-5 cm. long: their margins revolute; petioles about $2 \mathrm{~mm}$. long; stipules minute, deciduous; aments expanding much before the leaves, dense, very small, sessile; bracts persistent; stigmas sessile or nearly so; capsule ovoid with a long, slender beak, tomentulose, about $6 \mathrm{~mm}$. long. In dry soil, N. S. (?), Me. to Minn., south to Fla. and Tenn. March-April.

33. Salix cándida Fluegge. Hoary Willow. (I. F. f. II93.) An erect shrub, 6-I $5 \mathrm{dm}$. tall, the older twigs red or purple and terete, the younger densely white-tomentose. Leaves green and loosely tomentose or becoming glabrate above when mature, oblong or oblong-lanceolate, thick, sparingly repand-denticulate or entire, acute at both ends or the lower obtuse at the apex, 5-10 $\mathrm{cm}$. long, 6-16 mm. wide, their margins slightly revolute; petioles 3-4 $\mathrm{mm}$. long; stipules lanceolatesubulate, about equalling the petioles, deciduous; aments expanding before the leaves, dense, cylindric, the staminate about $2.5 \mathrm{~cm}$. long, the pistillate $3-5 \mathrm{~cm}$. long in fruit; bracts villous, persistent; capsule ovoid-conic, acute, 5-6 mm. long. In bogs, Lab. to N. W. Terr., south to N. J., Iowa and Mont. Hybridizes with $S$. petiolaris and $S$. cordata. May.

34. Salix serícea Marsh. Silky Willow. (I. F. f. II88.) A shrub, 2-4 m. tall, with slender purplish puberulent twigs, the young leaves densely silky-pubescent. Mature leaves glabrous or nearly so, lanceolate, acuminate, narrowed or obtuse at the base, serrulate all around with gland-tipped teeth, dark green above, paler and somewhat glaucous beneath, turning brown or black in drying, 6-10 $\mathrm{cm}$. long, I-2 cm. wide; stipules narrow, deciduous; petioles 4-14 mm. long, sometimes glandular; aments expanding before the leaves, sessile, usually with a few leafy bracts at the base, dense, the staminate about $2 \mathrm{~cm}$. long, the pistillate $2-4 \mathrm{~cm}$. long in fruit; bracts villous, persistent; capsule ovoid-oblong, obtuse, pubescent, about 4 $\mathrm{mm}$. long. In swamps and along streams, Me. to Mich. and Va. May.

Salix sericea subsericea (Anders.) Rydb. Leaves less silky, more sharply serrate; capsule smaller. N. Y. to Mich. (S. petiolaris subsericea Anders.).

35. Salix argyrocàrpa Anders. Silver Willow. (I. F. f. I Igo.) An erect or diffuse shrub, 1.5-6 dm. high, the twigs dark green, nearly terete, shining. Leaves oblong or oblanceolate, acute at each end or the lower obtuse, short-petioled, entire or crenulate, bright green and glabrous above, persistently silvery-silky beneath, 3-5 cm. long, 6-12 mm. wide, the margins slightly revolute; aments unfolding with the leaves, leafy-bracted at the base, dense, $2.5 \mathrm{~cm}$. or less long; scales persistent, villous; capsule oblong-conic, acute, 2-3 $\mathrm{mm}$. long, about twice as long as its pedicel. Lab. and Quebec to the White Mountains of N. H. Hybridizes with $S$. chlorophylla. June-July.

36. Salix viminàlis L. Osier Willow. (I. F. f. I194.) A small slender tree or shrub, with terete green twigs. Leaves sparingly repand-crenulate or entire, revolute-margined, short-petioled, dark green and glabrous above, persistently silvery-silky beneath, 7-15 $\mathrm{cm}$. long, 4-16 $\mathrm{mm}$. wide; stipules narrow, deciduous; aments expanding before the leaves, dense, the pistillate $5-7 \mathrm{~cm}$. long and $\mathbf{I} \mathrm{cm}$. in diameter in fruit; capsule narrowly ovoid-conic, acute, about $6 \mathrm{~mm}$. long. Cultivated for wickerware and occasionally escaped into wet places in the Eastern and Middle States. Native of Europe and Asia. April-May.

37. Salix chlorophylla Anders. TeA-LeAved Willow. (I. F. f. I 195.) A shrub, 3-30 dm. high, much branched, the twigs glabrous, dark purple-green, sometimes glaucous. Leaves oblong, lanceolate or elliptic, acute. or obtuse at the apex, minutely repand-crenulate or entire, narrowed at the base, bright green and shining above, pale and glaucous beneath, 3-7 cm. long, I-2 cm. wide; petioles 6-16 mm. long; stipules minute, fugacious, or wanting; aments sessile, dense, oblong-cylindric, the staminate $2 \mathrm{~cm}$. or less long, the pistillate $2-5 \mathrm{~cm}$. long in fruit; bracts villous, persistent; capsule conic, acute, $5 \mathrm{~mm}$. long. Swamps, Lab. to Br. Col., and the White Mountains of N. H., and Colo. Summer. [S. phyllicifolia Bebb, not L.]

38. Salix Groenlándica (Anders.) Lundst. GreenlaNd Willow. A low 
cespitose shrub, I-2 dm. high, much branched, with short stout branches and dark brown or purplish bark. Leaves crowded, obovate, when young covered with long white hairs, soon glabrate above, more tardily so below, entire, obtuse, bright green; petioles short, $2-5 \mathrm{~mm}$. long; aments short and very dense, oblong-obovoid; capsule ovoid, densely white-villous. Geeenland, Baffin Bay region, and Labrador.

39. Salix àrctica Pall. Arctic Willow. Ground Willow. (I. F. f. I 197.) A low branching slirub, I-3 dm., seldom I-2 m., high, the twigs terete or nearly so. Leaves glabrous, elliptic or broadly obovate, entire, obtuse and usually rounded at the apex, narrowed or rounded at the base, long-petioled, pale and glaucous beneath; petioles slender, I-3 cm. long; aments dense, oblong; capsule conic, villous. Arctic America and Asia. Summer.

40. Salix anglòrum Cham. Robert Brown's Willow.

(I. F. f. I196.) A low, branched shrub with prostrate branches, the twigs 4-angled, slender. Leaves glabrous, slightly silky when young, acute or the lower obtuse at the apex, entire or wavy, narrowed at the base, the lower surface pale or glaucous, the margins not revolute; petioles only ro- $15 \mathrm{~mm}$. long ; stipules narrow, deciduous; capsule ovoidconic, tomentose, acute, about 5-8 mm. long. Labrador, Greenland and Anticosti to Alaska. Summer. (S. Brownii Bebb.)

41. Salix vacciniformis Rydb. BlueberRy Willow. A small shrub, with numerous ascending, light brown branches, which are glabrous, or very soon glabrate; leaves small, resembling those of Vaccinium uliginosum, about $2 \mathrm{~cm}$. long, dark and shining above, paler beneath; aments $2-3 \mathrm{~cm}$. long, rather loose; capsule 7-8 mm., loosely villous, ovoid. Anticosti, Hudson Bay and Labrador. (S. Macounii Rydb.; not S. Richarilsonii Macouniana Bebb.)

42. Salix callicarpaèa Trautv. TrautvetTeR's Willow. A very low depressed shrub with the habit of $S$. Uva-ursi, with light yellow glabrous twigs; leaves small, about $1.5 \mathrm{~cm}$. long and I $\mathrm{cm}$. wide, bright green above, a little glaucous beneath, strongly reticulated; petioles I-5 mm. long; aments about $2 \mathrm{~cm}$. long, dense; capsule 4-6 mm., grayish tomentose, ovate. Mt. Gaspé, Quebec and Lab. rador.

43. Salix glaùca L. Northern Willow. (I. F. f. II92.) A low arctic shrub, with terete brown twigs, the young shoots and leaves densely silky, becoming glabrate when old, turning black in drying. Leaves elliptic or obovate, entire, obtuse or acute at the apex, narrowed at the base, $3-7 \mathrm{~cm}$. long, $1-2 \mathrm{~cm}$. wide: petioles 1-10 mm. long; stipules deciduous; the staminate aments dense, about $2 \mathrm{~cm}$. long, the pistillate 4-7 cm. long in fruit, rather loose. Arctic America from Labrador to Alaska. Also in arctic and alpine Europe and and Asia. Summer.

44. Salix Wághornei Rydb. Waghorne's Willow. A low shrub, I-3 dm. high, with brown shining bark; branches at first slightly silky, soon glabrate; leaves 2-3 cm. long and $1.5^{-2} \mathrm{~cm}$. wide, at first somewhat silky, soon glabrate, obtuse or rounded at the base, rounded at the apex, light green above, slightly glaucous beneath, thin, entire; petioles I-5 mm. long; aments dense, short; the staminate ones I-2 cm. long; pistillate in fruit $2-2.5 \mathrm{~cm}$. Labrador. August.

45. Salix àtra Rydb. Blackening Willow. A low shrub, with ascending dark brown branches, which are more or less villous when young; leaves small, I. 5-2.5 cm. long, when young covered with long white appressed hairs, dark green above, pale beneath, blackening in drying; aments $1.5-3 \mathrm{~cm}$. long, rather dense; capsule ovoid. Labrador and Hudson Bay.

46. Salix stricta (Anders.) Rydb. Drummond's Willow. (I. F. f. IIgI.) A shrub, 2-5 dm. high, with purplish-green or yellowish twigs. Leaves oblong or oblanceolate, acute at the apex and cuneate at the base or the lower obtuse at both ends, entire or nearly so, short-petioled, tementose on both sides or glabrate above when old, I-5 cm. long, 4-8 $\mathrm{mm}$. wide; stipules fugacious; aments expanding with the leaves, dense, $1-2 \mathrm{~cm}$. or less long, leafy-bracted at the base; capsule ovoid-conic, acute, densely tomentose, about $5 \mathrm{~mm}$. long. Anticosti and Quebec to western arctic America, south along the Rocky Mountains to Colo. Summer. (S. desertorum Bebb; not Richards.)

47. Salix Labradòrica Rydb. Labrador Willow. A low shrub; older hark dark brown and shining; young shoots more or less densely villous; leaves broadly ovate, often obtuse or subcordate at the base, firm, dark and glossy above, more or less glaucous beneath, on both surfaces invested with villous hairs, blacken- 
ing in drying; a ments densely many-flowered, about $3 \mathrm{~cm}$. long; bracts oblong, brown, villous; capsule $6-8 \mathrm{~mm}$. long, ovoid-conic, densely white-villous. Lab. Summer.

48. Salix vestita Pursh. Hairy Willow. (I. F. f. 1183 .) A low shrub, I-2 dm. seldom $5 \mathrm{dm}$. high, the twigs 4 -sided, green. Leaves obovate, thick, mostly retuse or emarginate at the apex, slightly crenulate, narrowed or rounded at the base, dark green and glabrous above, persistently tomentose-silky beneath, shortpetioled, 2-5 cm. long; petioles 4-8 $\mathrm{mm}$. long, channeled, not glandular; aments slender, stalked; pistillate 3-5 cm. long in fruit; capsules narrowly ovoid-conic, sessile, densely silky-tomentose, about $6 \mathrm{~mm}$. long. Lab. and Quebec to the N. W. Terr. and Ore. June.

49. Salix orbiculàris Anders. Round-Leaved Net-veined Willow. A low shrub, closely resembling $S$. reticulata, but stems more purplish; leaves generally more rounded, often subcordate at the base, purple or brown-veined, but most easily distinguished by the broadly obovate bracts. Lab. to Alaska and Br. Col. (S. reticulata of American authors, mostly.)

50. Salix reticulàta L. Net-veined Willow. (I. F. f. in82.) A procumbent shrub, 5-3 dm. high, often sending out roots from the twigs, the young shoots 4-sided, purple-green. Leaves elliptic or obovate, thick, obtuse, narrowed or rounded at the base, obscurely crenulate or entire, slender-petioled, glabrous or somewhat silky-pubescent when young, dark green above, not shining, glaucous and strongly reticulate-veined beneath, $2-4 \mathrm{~cm}$. long; petioles $8-20 \mathrm{~mm}$. long, channeled; stipules oblong, obtuse; aments terminal, long-stalked, dense; filaments pubescent at the base; capsule ovoid-conic, tomentose, about $6 \mathrm{~mm}$. long. Lab. Very rare. Also in northern Europe and Asia. June.

5I. Salix purpùrea L. PURple Willow. (I. F. f. Ii 80.) A slender shrub or small tree, with purplish flexible twigs, maximum height about $3.5 \mathrm{~m}$.; branches often trailing; bark smooth and very bitter. Leaves oblanceolate or spatulate, acute, serrulate, narrowed at the base, short-petioled, glabrous, green above, paler and somewhat glaucous beneath, 4-7 cm. long, 5-8 mm. wide; stipules minute; petioles 2-4 $\mathrm{mm}$. long, not glandular; aments appearing before the leaves, dense, leafy-bracted at the base, the staminate about $2 \mathrm{~cm}$. long, the pistillate $3-5 \mathrm{~cm}$. long, sessile or nearly so; filaments and sometimes also the anthers united, pubescent; bracts purple, persistent; capsules ovoid-conic, obtuse, tomentose, $5 \mathrm{~mm}$. long. Sparingly escaped from cultivation in the Atlantic States. Native of Europe. Also called Bitter, Rose and Whipcord Willow. April-May.

\section{Order 4. MYRICÀLES.}

Shrubs or trees, with simple leaves and small monœcious or diøcious flowers in aments. Perianth none. Ovary I-celled; style short; stigmas 2. Ovule erect, orthotropous. Endosperm none. Only one family.

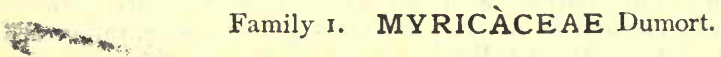

Bayberry Family.

Leaves alternate, mostly coriaceous and aromatic. Flowers solitary in the axils of the bracts Staminate flower with 2-16 (usually 4-8) stamens inserted on the receptacle; filaments short; anthers ovate, 2-celled, the sacs longitudinally dehiscent. Ovary subtended by $2-8$ bractlets; stigmas linear. Fruit a small drupe or nut, the exocarp often waxy. Seed erect. Cotyledons plano-convex. Radicle very short. Two genera and 35 species of wide geographic distribution.

Ovary subtended by 2-4 bractlets; leaves serrate or entire, estipulate. I. Myrica. Ovary subtended by 8 linear persistent bractlets; leaves pinnatifid, stipulate. 


\section{r. MYRICA L.}

Leaves entire, dentate or lobed, mostly resinous-dotted. Staminate aments oblong or narrowly cylindric, expanding before or with the leaves. Stamens 4-8. Pistillate aments ovoid or subglohose; ovary subtended by $2-4$, mostly short, bractlets. Drupe globose or ovoid, its exocarp waxy. [Ancient Greek name of the Tainarisk.] Besides the following species, another occurs in the Southern States and 2 on the Pacific coast.

Bractlets of pistillate aments persistent, clasping the drupes; low bog shrub.

Bractlets of pistillate aments decicuous, the ripe drupes separated.

Slender tree; leaves mostly acute, narrow; drupe less than $2 \mathrm{~mm}$. in diameter.

Shrub; leaves mostly obtuse, broader; drupe $2-3 \mathrm{~mm}$. in diameter.

$$
\text { 2. M. cerifera. }
$$

3. M. Carolinensis.

I. Myrica Gàle L. Sweet Gale. (I. F. f. I I59.) A shrub, the twigs dark brown. Leaves oblanceolate, oltuse and dentate at the apex, narrowed to a cuneate entire base, short-petioled, dark green and glabrous above, pale and puberulent or glabrous beneath, 2-6 cm. long, unfolding after the aments; staminate aments linear-oblong, I-2 cm. long, crowded; pistillate aments ovoid-oblong, obtuse, about $8 \mathrm{~mm}$. long, their bracts imbricated; drupe resinous-waxy, not longer than the 2 ovate persistent bractlets. In wet places, Newf. to Alaska, S. N. Y., Va., Mich. and Wash. Also in Europe and Asia. April-May.

2. Myrica cerífera L. Wax myrtle. (I. F. f. II6o.) A slender diœcious tree, the bark gray, nearly smooth. Leaves narrow, oblong or oblanceolate, mostly acute, entire or sparingly dentate, narrowed at the base, fragrant, shortpetioled, dark green above, paler and sometimes pubescent beneath, golden-resinous, $2-8 \mathrm{~cm}$. long, unfolding with or before the aments; staminate aments cylindric; pistillate aments short, oblong; ripe drupes globose, bluish white, waxy, tipped with the base of the style, long-persistent. In sandy swamps or wet woods, Md. to Fla., Tex., north to Ark. March-April.

3. My: ica Caroliné is Mill. Waxberry. Bayberry. (I. F. f. II6I.) A shrub, $0.5-2.5 \mathrm{~m}$. ligh, with smooth gray bark, the twigs often pubescent. Leaves oblancerlate or obovate, glabrous above, of ten pubescent beneath, resinous, 5-IO $\mathrm{cm}$. long, $\mathbf{I}-3 \mathrm{~cm}$. wide, serrate with a few low teeth above the middle, or entire, obtuse or sometimes acute at the apex, narrowed at the base, short-petioled ; staminate aments cylindric or oblong, 6-18 mm. long; pistillate aments short, oblong ; ripe drupes globose. bluish white, very waxy, long-persistent. In dry or moist sandy soil, N. S. to Fla. and Ala. and on the shores of Lake Erie. Occurs also in bogs in N. N. J. and Penn. April-May.

\section{COMPTÒNIA Barks.}

A low, branching shrub with terete brown branches and narrow, deeply pinnatifid leaves, the young foliage pubescent. Aments expanding with the leaves, the staminate ones and their fluwers as in Myrica. Fertile aments globose-ovoid, on monœcious plants appearing below the staminate, several-flowered. Ovary subtended by 8 linear-subulate persistent bractlets, which form an involucre to the ovoid-oblong bony nut. Fruit bur-like. [Name in honor of R $\cdot v$. Henry Compton, I632-17:3. bishop of Oxford.] A monotypic genus of eastern N. An.

r. Comptonia peregrina (L.) Coulter. Sweet FerN. (I. F. f. I I62.) Leaves linear-oblong or linear-lanceolate, $0.7-1.5 \mathrm{dm}$. long, short-petioled, obtuse or subacute at the apex, deeply pinnatifid into numerous oblique lobes, fragrant ; stipules semi-cordate, mostly deciduous ; staminate aments clustered at the ends of the branches, $2.5 \mathrm{~cm}$. long or less, their bracts reniform, acute ; pistillate aments bur-like in fruit, the subulate bractlets longer than the light brown, shining, striate, obtuse nut. In dry soil, especially on hillsides, N. S. to Man., N. Car., Ind. and Mich. April-May.

\section{Order 5. LEITNERIÀLES.}

Shrubs or trees with diccious small flowers in aments, and simple entire petioled alternate leaves. Staminate flowers with no perianth. 
Pistillate flowers subtended by 3 or 4 bractlets (perianth?). Ovary 1-celled; style slender, stigmatic above; ovule laterally affixed, amphitropous. Endosperm thin. Only one family.

\section{Family I. LEITNERIÀCEAE Drude. Cork-wood Fanily.}

Aments expanding before the leaves. Staminate flowers with 3-12 stamens inserted on the receptacle; filaments distinct; anthers, oblong erect, 2-celled, the sacs longitudinally dehiscent. Style terminal, grooved and flattened, recurved, caducous. Fruit an oblong drupe with thin exocarp and hard endocarp. Testa thin. Cotyledons flat, cordate at the base; radicle short, superior. Comprising only the following genus of the southern U.S.

\section{LEITNÈRIA Chapm.}

Characters of the family. One species, or perhaps two. [In honor of Dr. E. F. Leitner, a German naturalist, killed in Florida during the Seminole war.]

I. Leitneria Floridàna Chapm. Leitneria. Cork-wood. (I. F. f. II63.) Bark gray and rather smooth; young twigs, leaves and aments densely pubescent. Leaves oblong or elliptic-lanceolate, narrowed at the base, bright green, firm, 0.7-1.5 dm. long, finely pubescent, at lcast on the veins, and rugose-reticulated beneath; staminate aments ascending, 2-5 $\mathrm{cm}$. long, their bracts triangular-ovate, acute, tomentose; pistillate aments shorter, borne toward the ends of the twigs; drupe slightly compressed, about $2 \mathrm{~cm}$. long, 6-8 $\mathrm{mm}$. thick, rugose-reticulated. In swamps, S. Mo. to Tex., and in Fla. Wood lighter than cork and probably the lightest wood known, weighing only about $121 / 2 \mathrm{lbs}$. per cubic foot. March.

\section{Order 6. BALANOPSIDÁLES,}

includes only the family Balanopsidaceae, comprising the genus Balanops of Australasia.

\section{Order 7. JUGLANDÀLES.'}

Trees with alternate pinnately compound leaves, and monœcious bracteolate flowers, the staminate in long drooping aments, the pistillate solitary or several together. Staminate flowers consisting of 3-numerous stamens with or without an irregularly lobed perianth adnate to the bractlet, very rarely with a rudimentary ovary. Anthers erect, 2-celled, the sacs longitudinally dehiscent; filaments short. Pistillate flowers bracted and usually 2-bracteolate, with a 3-5-lobed (normally 4-lobed) calyx or with both calyx and petals, and an inferior 1-celled or incompletely 2-4-celled ovary. Ovule solitary, erect, orthotropous ; styles 2, stigmatic on the inner surface. Fruit in our genera a drupe with indehiscent or dehiscent, fibrous or woody exocarp (husk; ripened calyx ; also regarded as an involucre), enclosing the bony endocarp or nut which is incompletely 2-4-celled. Seed large, 2-4-lobed. Endosperm none. Cotyledons corrugated, very oily. Radicle minute, superior. Only one family.

\section{Family 1. JUGLANDÀCEAE Lindl. Walnut Family.}

Characters of the order. Six genera and about 35 species, mostly of the warmer parts of the north temperate zone. The young leaves in the bud are stipulate in at least two species of Hicoria. 


\section{JÜGLANS L.}

Trees, with spreading branches, superposed buds, fragrant bark, and oddpinnate leaves, with nearly or quite sessile leaflets, the terminal one sometimes early perishing. Staminate flowers in drooping cylindric aments, borne on the twigs of the previous year; perianth 3-6-lobed; stamens 8-40 in 2 or more series. Pistillate flowers on a terminal peduncle at the end of shoots of the season, the calyx 4-lobed, with 4 small petals ailnate to the ovary at the sinuses; styles fimbriate, very short. Drupe large, globose or ovoid, the exocarp somewhat fleshy, fibrous, indehiscent, the exdocarp bony, rugose or sculptured, 2-4-celled at the base, indehiscent, or in decay separating into 2 valves. [Name a contraction of the Latin Fovis glans, the nut of Jupiter.] About 8 species, natives of the north temperate zone, $\mathbf{I}$ in the W. I., $\mathbf{I}$ or 2 in the Andes of S. Am. Besides the following $I$ or 2 others occur in the soutliwestern U. S.

Fruit globose, obtuse, not viscid : petioles puberulent. Fruit oblong, pointed, viscid; petioles pubescent.

1. J. nigra.

2. J. cinerea.

I. Juglans nigra L. Black Walnut. (I. F. f. II49.) A large forest tree with rough brown bark, the twigs of the season and petioles puberulent, the older twigs glabrous or very nearly so. Leaflets 13-23, ovate-lanceolate, more or less inequilateral, acuminate at the apex, rounded or subcordate at the base, serrate, pubescent beneath, 7-I3 cm. long; staminate aments 7-14 cm. long; drupes usually solitary or 2 together, globose or a little longer than thick, 3-8 cm. in diameter, papillose; nut corrugated, slightly compressed, 4-celled at the base. In rich woods, Mass. to S. Ont., Minn., Fla., Kans. and Tex. April-May. Fruit ripe Oct.-Nov.

2. Juglans cinèrea L. Butrernut. White Walnut. Onl-nut. (I. F. f. I I50.) A forest tree, resembling the Black Walnut, the bark gray, smoother, the twigs, petioles and leaflets viscid-pubescent, at least when young. Leaflets $\mathbf{I} \mathbf{I}-\mathbf{I} 9$, oblong-lanceolate, acuminate, scarcely inequilateral, obtuse, rounded or truncate at the base, serrate; drupes racemed, $5-8 \mathrm{~cm}$. long and about one-half as thick, pointed; nut 4-ribbed, deeply sculptured, and with sharp longitudinal ridges, firmly adherent to the husk, 2-celled at the base. In rich or rocky woods, N. B. and Ont. to N. Dak., Neb., Del., Ga., Miss. and Ark. April-May. Fruit ripe Oct.-Nov.

\section{HICÒRIA Raf. [CARYA Nutt.]}

Trees, with odd-pinnate leaves and serrate or serrulate leaflets. Staminate flowers in slender drooping aments, borne in 3's on a common peduncle at the base of the shoots of the season, or clustered and sessile or nearly so in the axils of leafscars at the summit of twigs of the preceding year; calyx adnate to the bract, 2-3-lobed or 2-3-cleft; stamens 3-10; filaments short. Pistillate flowers 2-6, together on a terminal peduncle; bract fugacious or none; calyx 4-toothed; petals none; styles 2 or 4, papillose or fimbriate, short. Fruit subglobose, oblong or obovoid, the husk separating more or less completely into 4 valves; nut bony, incompletely 2-4-celled. [From the aboriginal name Hicori.] About I5 species, natives of eastern North America, one in Mexico.

Bud-scales valvate; lateral leaflets lanceolate or oblong-lanceolate, falcate.

Nut not compressed or angled; seed sweet. I. H. Fecan
Nut somewhat compressed or angled; seed intensely bitter.
Leaflets $7-9$; nut smooth.
Leaflets $9-13$; nut angled.
2. H. minima.
3. H. aquatica.

Bud-scales imbricate; lateral leaflets not falcate.

Husk of the fruit freely splitting to the base; middle lobe of the staminate calyx narrow, often at least twice as long as the lateral ones.

Bark shaggy, separating in long plates.

Leaflets $3-5$ (rarely 7 ); nut rounded at the base, $\mathbf{I - 2} \mathrm{cm}$. long.

Leaflets oblong-lanceolate to obovate; twigs puberulent.

Leaflets narrowly lanceolate; twigs glaucous. 4. H. ovata.

5. H. Carolinae-septentrionalis.

Leafets 7-9; nut usually pointed at both ends, $2 \cdot 5-3 \mathrm{~cm}$. long. 
Bark close, rough ; leafiets 7-9.

Foliage persistently stellate-pubescent ; staminate aments stellate-woolly. 7. H. alba.

Mature leaves glabrous, or nearly so ; staminate aments slightly pubescent.

8. H. pallida.

Husk of fruit thin, not freely splitting to the base; lobes of the staminate calyx mostly nearly equal.

Fruit nearly globular; nut thin-shelled; bark, at least that of old trees, separating in strips.

Fruit little flattened; middle lobe of staminate calyx short.

Fruit much flattened; middle lobe of staminate calyx long.

9. H. microcarpa.

Fruit obovoid; nut thick-shelled; bark close.

Foliage nearly or quite glabrous.

Foliage with silvery peltate glands.

ro. $H$. borealis.

II. H. glabra.

12. H. villosa.

I. Hicoria Pecán (Marsh.) Britton. Pecan. (I. F. f. II5I.) A large tree, with rough bark. Young twigs and leaves pubescent; mature foliage nearly glabrous; bud-scales few, small; leaflets II-I5, oblong-lanceolate, short-stalked, inequilateral, acuminate, $\mathbf{I}-\mathbf{I} .8 \mathrm{dm}$. long; staminate aments sessile or nearly so, 1.2-1.5 dm. long; middle lobe of the staminate calyx linear, much longer than the oblong lateral ones; fruit oblong-cylindric, 3-6 cm. long; husk thin, 4-valved; nut smooth, oblong, thin-shelled, pointed, 2-celled at base, dissepiments thin, very astringent; seed delicious. In moist soil, especially along streams, Ind. to Iowa, Mo., Ky. and Tex. April-May. Fruit ripe Sept.-Oct. [C. olivaeformis Nutt.]

2. Hicoria mínima (Marsh.) Britton. BitTer-NUT. Swamp Hickory. (I. F. f. II 52.) A slender tree, the bark close, rough. Bud-scales 6-8, small, caducous; young foliage puberulent; leaflets 7-9, sessile, long-acuminate, $0.7-1.5 \mathrm{dm}$. long, I-3 cm. wide, the lateral ones falcate; staminate aments slightly pubescent; lobes of the staminate calyx about equal, the middle one narrower; fruit subglobose, narrowly 6-ridged, $2-3.5 \mathrm{~cm}$. in diameter; husk thin, tardily and irregularly 4-valved; nut short-pointed, 1.5-2.5 cm. long, thin-shelled. In moist woods and swamps, Quebec to Ont., Minn., Fla. and Tex. May-June. Fruit ripe Sept.-Oct.

3. Hicoria aquatica (Michx. f.) Britton. Water Hickory. (I. F. f. 1153.) A swamp tree, the bark close, the young foliage pubescent. becoming nearly gl tbrous when mature. Leaflets 9-13, lanceolate, or the terminal one oblong, longacuminate at the apex, narrowed at the base, $0.7-1.3 \mathrm{dm}$. long, $\mathbf{I}-2.5 \mathrm{~cm}$. wide, the lateral strongly falcate; staminate aments and calyx as in the preceding species; fruit oblong, ridged, $2-3.5 \mathrm{~cm}$. long, pointed; husk thin, tardily splitting; nut oblong, thin-shelled, angular. In river swamps, Va. to Fla., Ill., Ark. and Tex. MarchApril. Fruit ripe Sept.-Oct.

4. Hicoria ovàta (Mill.) Britton. Shag-Bark. Silell-Bark Hickory. (I. F. f. II54.) A large tree; bark shaggy in narrow plates; young twigs and leaves puberulent. Leaflets 5 , or sometimes 7 , oblong, oblong-lanceolate or the upper obovate, acuminate at the apex, narrowed to the sessile base, I-I. $5 \mathrm{dm}$. long, those of young plants much larger; bud-scales 8-10, the inner becoming very large; fruit subglobose, 2.5-5.5 cm. long; husk thick, soon splitting; nut white, somewhat compressed, 4-celled at the base, 2-celled (rarely 3-celled) above, pointed, slightly angled, thin-shelled. In rich soil, Quebec to Ont., Minn., Fla., Kans. and Tex. May. Fruit ripe Sept.-Nov. [Carya alba Nutt., not Juglans alba L.]

5. Hicoria Carolinae-septentrionàlis Ashe. Southern ShaG-BArk. (I. F. f. I1 54a.) A tree, with gray bark hanging in loose strips. Bud-scales 8-Io, the inner greatly enlarging in leafing; terminal bud ovoid-lanceolate, truncate; twigs slender, glaucous, smooth, purplish brown; staminate aments glabrous; young foliage blackening in drying, glabrous, ciliate, with few resinous globules; leaflets 3-5; fruit subglobose, I. 5-3 cm. long; husk soon falling into 4 pieces; nut white or brownish, much compressed, angled, cordate or subcordate at top, thin-shelled. Sandy or rocky woods, Del. to Ga. and Tenn.

6. Hicoria laciniòsa (Michx. f.) Sarg. Big Shag-bark. King-NUt. (I. F. f. I 155.) A large tree, the bark separating in long narrow plates, the young foliage densely puberulent, the mature leaves somewhat so beneath. Leaflets 7-9 (rarely 5), acute or acuminate, sometimes $2 \mathrm{dm}$. long; middle lobe of the staminate caly $\lambda$ 
linear, twice as long as the lateral ones; fruit oblong, 5-8 cm. long; husk thick, soon splitting to the base; nut oblong, somewhat compressed, thick-shelled, pointed at both ends, yellowish white. In rich soil, N. Y. and Penn. to Ind., Iowa, 'Tenn., Kans. and the Ind. Terr. May. Fruit ripe Sept.-Oct. [Carya sulcata Nutt.]

7 Hicoria álba (L.) Britton. White-heart Hickory. Mocker-nut. (I. F. f. I156.) A large tree, the foliage and twigs persistently tomentose-stellatepubescent, fragrant when crushed; bark close; bud-scales large; leaflets 7-9, oblonglanceolate or the upper oblanceolate or obovate, long-acuminate; middle lobe of the staminate caly $\mathrm{x}$ linear, much longer than the lateral ones; fruit globose or oblongglobose, 3-9 cm. long; husk thick; nut grayish-white, angled, pointed at the summit, little compressed, thick-shelled, 4-celled at the base. In rich soil, Mass. to Ont., Ill., Neb, Fla. and Tex. May-June. Fruit ripe Uct.-Nov. [C. tomentosa Nutt.]

8. Hicoria pállida Ashe. PALE-LEAved HICKORY. A forest tree with very rough gray bark and purple-brown twigs, the buds sharp-pointed, their scales 5-9. Leaflets 7-9, lanceolate or ovate-lanceolate, long-acuminate, glabrous or nearly so when old, pale and with numerous silvery scales beneath, the rachis stellate-pubescent, at least when young; middle lobe of the staminate calyx linear, somewhat longer than the lateral ones; fruit usually subglobose, sometimes oval or pyriform, the husk rather thin, sometimes tardily splitting; nut laterally flattened, 4-celled at the base. In dry soil, S. Va. to Tenn., Ga. and Ala. April-May. (H. villosa pallida Ashe.)

9. Hicoria microcărpa (Nutt.) Britton. Small-Fruited Hickory. (I. F. f. I 157.) A forest tree, the older bark separating in narrow plates, the foliage glabrous. Bud-scales 6-8; leaflets 5-7, oblong, or ovate-lanceolate, acuminate at the apex, 9-13 cm. long; staminate aments glabrous; middle lobe of the staminate calyx equalling or somewhat longer than the lateral ones; fruit globose or globoseoblong, less than $2.5 \mathrm{~cm}$. long, the husk thin, tardily and incompletely splitting to the base; nut subglobose, slightly compressed, thin-shelled, pointed ; seed sweet. In rich woods, Mass. to Mich., Va., Ill. and Mo. May-June. Iruit ripe Sept.-Oct.

ro. Hicoria bo eàlis Ashe. Northern Hickory. (I. F. f. I156b.) A small tree, with rough furrowed bark when young, becoming shaggy in narrow strips with age. Bud-scales 8-10, imbricated, the inner bright-colored and sericeous; terminal bud ovoid-lanceolate; twigs slender, glabrous, bright brownish red; middle lobe of staminate calyx much prolonged; young leaves blackening in drying, ciliate, with few resinous globules on lower surface; leaflets 5 , occasionally 3, lanceolate, the upper $9-\mathbf{1 5} \mathrm{cm}$. long; fruit ovoid, much flattened. $\mathbf{I} .5 \mathrm{~cm}$. long or more; husk very thin, rugose, coriaceous, usually not splitting; shell thin and elastic; seed large, sweet and edible. A small tree of dry uplands, growing with oaks and H. microcarpa. Mich., Detroit river. Probably also in S. Ont.

I I. Hicoria glàbra (Mill.) Britton. Pig-nut Hickory. (I. F. f. I158.) A tree, the bark close, rough; foliage glabrous, or slightly pubescent. Budscales 8-10, imbricated, the inner ones enlarging; leaflets 3-7, rarely 9, oblong, oblong-lanceolate or the upper obovate, sessile, acuminate at the apex, mostly narrowed at the base, $7-15 \mathrm{~cm}$. long, in young plants much larger; staminate aments glabrous, peduncled in 3 's; lobes of the staminate calyx about equal in length, the middle one narrower; fruit obovoid or obovoid-oblong, $3.5-5 \mathrm{~cm}$. long; husk thin, the valves very tardily dehiscent; nut brown, angled, pointed, very thick-shelled; seed astringent and bitter, not edible. In dry or moist woods, Me. to Ont., Minn., Fla., Kans. and Tex. Fruit ripe Oct.-Nov.

Hicoria glabra hirsùta Ashe. Similar to type, but leaves larger, pubescent beneath, thinner, generally destitute of resinous globules on the lower surface; fruit larger. Va. to $\mathrm{Ga}$.

12. Hicoria villòsa (Sarg.) Ashe. Scurfy Hickory. Woolly Pig-nut. I. F. f. I156a.) A small or medium sized tree. with deeply furrowed dark gray bark. Buds of 6-8 imbricated scales, the outer usually thickly dotted with resinous globules; lateral buds mostly short-stiped; staminate aments pubescent, and gland and scurf covered; twigs usually glabrous, bright purple-brown; petiole pubescent; leaflets 5-9, at first thickly covered beneath with silvery peltate glands, mixed with resinous globules, generally pubescent; fruit about $2.5 \mathrm{~cm}$. long, obovoid, the husk partly splitting; nut brown, thick-shelled, angled; seed small, but sweet. Mo. 


\section{Order 8. FAGÀLES.}

Trees or shrubs, with small monœecious or rarely diøecious flowers in aments, or the pistillate ones subtended by an involucre, which becomes a bur or cup in fruit. Calyx usually present. Corolla none. Endosperm none.

Both staminate and pistillate flowers in aments.

Fam. r. Betulaceae.

Pistillate flowers subtended by an involucre, which becomes a bur or a cup in fruit.

Fam. 2. Fagaceae.

\section{Family I. BETULÀCEAE Agardh.}

\section{Birch Family.}

Monœcious or rarely diœcious trees or shrubs, with alternate petioled simple leaves, and small flowers in aments. Stipules mostly fugacious. Staminate aments pendulous. Staminate fowers $I-3$ together in the axil of each bract, consisting of a membranous 2-4-parted calyx or none, and 2-IO stamens inserted on the receptacle, their filaments distinct, their anthers 2-celled, the anther-sacs sometimes distinct and borne on the forks of the 2-cleft filaments. Pistillate aments spike-like or capitate. Pistillate flowers with or without a calyx adnate to the solitary 1-2-celled ovary; style 2 -cleft or 2 -divided; ovules $\mathrm{I}-2$ in each cavity of the ovary, anatropous, pendulous. Fruit a small, mostly I-celled and I-seeded nut or samara. Testa membranous. Endosperm none. Cotyledons fleshy. Radicle short. Six genera and about 75 species, mostly natives of the northern hemisphere.

Staminate flowers solitary in the axil of each bract, destitute of a calyx ; pistillate flowers with a calyx.

Staminate flowers with no bractlets; pistillate aments spike-like; nut small, subtended by or enclosed in a large bractlet.

Fruiting bractlet flat, 3 cleft and incised.

Fruiting bractlet bladder-like, closed, membranous.

1. Carpinus.

2. Ostrya.

Staminate flowers with 2 bractlets; pistillate flowers 2-4, capitate; nut large, enclosed by a leafy involucre. 3 . Corylus.

Staminate flowers $3-6$ together in the axil of each bract, with a calyx ; pistillate flowers without a calyx.

Stamens 2; filaments 2-cleft, each fork bearing an anther-sac; fruiting bracts 3-lobed or entire, deciduous.

Stamens 4 ; anther-sacs adnate; fruiting bracts woody, erose or 5-toothed, persistent.

5. Alnus.

\section{ז. CARPINUS L.}

Trees or shrubs, with smooth gray bark, furrowed and ridged stems, and straight-veined leaves, the primary veins terminating in the larger teeth. Aments expanding before the leaves. Staminate aments linear-cylindric, sessile at the ends of sliort lateral branches of the preceding season, their flowers consisting of 3-12 stamens; filaments short, 2-cleft, each fork bearing an anther-sac. Pistillate flowers in small terminal aments, 2 to each bract, consisting of a 2-celled ovary adnate to a calyx and subtended by a flat persistent bractlet, which becomes much enlarged, folizceous and lobed or incised in fruit, the bracts deciduous; stigmas 2, subulate. Nut small, ovoid, acute, borne at the base of the large bractlet. [The ancient name.] About.I2 species, natives of the northern hemisphere, only the following American.

I. Carpinus Caroliniàna Walt. American Hornbeam. Blue Beech. WATER BEEch. (I. F. f. I207.) A small tree, with slender terete gray twigs. Leaves ovate-oblong, acute or acuminate, sharply and doubly serrate, rounded or subcordate at the base, somewhat inequilateral, o.6-I dm. long, slightly pubescent on the veins beneath; petioles very slender; staminate aments $2-3 \mathrm{~cm}$. long, their bracts triangular-ovate, pulerulent; bractlet of the pistillate flowers 3 -lobed 
at the base, strongly veined and about $2.5 \mathrm{~cm}$. long when mature, its middle lobe lanceolate, 2-4 times as long as the lateral ones, incised-dentate on one side, often nearly entire on the other; nut $4 \mathrm{~mm}$. long. In moist woods and along streams, N. S. to Ont., Minn., Fla. and Tex. April-May.

\section{2. ÓSTRYA Scop.}

Trees similar to the Hornbeams, the aments expanding with or before the leaves. Staminate aments sessile at the ends of branchlets of the preceding season; filaments 2 -cleft. Pistillate a ments small, terminal, erect, the flowers 2 to each bract, subtended by a tubular, persistent bractlet which enlarges into a nerved, bladderlike sac in fruit. Style slender; stigmas 2, subulate. Nut ovoid-oblong, compressed, smooth, sessile in the base of the inflated sac. Mature pistillate ament hop-like. [The ancient name.] Four species, the following, I in the Southwest, I in Europe and Asia, I Japanese.

1. Ostrya Virginià'1a (Mill.) Willd. Hop-mornbeam. Iron-wood. (I. F. f. 1208.) Bark scaly. Twigs pubescent. Leaves ovate or oblong-ovate, acuminate, the base rounded or inequilateral, sharply and doubly serrate, sparingly pubescent above, pubescent or tomentose beneath, $6-15 \mathrm{~cm}$. long; petioles rarely more than $4 \mathrm{~mm}$. long; staminate aments $3-7.5 \mathrm{~cm}$. long, their bracts triangular-ovate, acuminate; bractlet of each fertile flower forming a sac $12-16 \mathrm{~mm}$. long in fruit, cuspidate, pubescent, villous near and at the base with bristly hairs, finely reticulated; nut $5 \mathrm{~mm}$. long, shining; ripe fertile aments $4-7 \mathrm{~cm}$. long. In dry woods, Cape Breton I. to S Dak.. Fla., Neb. and Tex. April-May. Fruit ripe July.-Aug.

\section{CÓRYLUS L.}

Shrubs or small trees, with broad thin serrulate or incised leaves. Staminate aments sessile at the ends of twigs of the previous season, expanding much before the leaves, the flowers with about 4 stamens and 2 bractlets; filaments 2 -cleft or 2 divided, each fork bearing an anther-sac, which is villous at the summit. Calyx none. Pistillate flowers from scaly buds, clustered at the ends of short branches of the season, each in the axil of a bract, consisting of an incompletely 2 -celled ovary adnate to a calyx, a short style and 2 slender stigmas; bractlets 2 , enlarged in fruit, forming a leaf-like involucre to the nut. Nut ovoid or oblong, bony. [Name Greek, from the helmet-like involucre.] Species 7, in the northern hemisphere. Besides the following, another occurs in California.

Involucre of 2 broad laciniate bractlets.

Involucral bractlets united, prolonged into a tubular bristly beak.

I. C. Americana.

2. C. rostrata.

I. Corylus Americàna Walt. HAzel-nut. (I. F. f. 1209.) A shrub, o.8$2.5 \mathrm{~m}$. tall, the young shoots russet-brown, densely hispid-pubescent with pinkish hairs. Leaves ovate or broadly oval, acute or acuminate, serrulate all around, cordate or obtuse at the base, finely tomentose beneath, $0.7-1.5 \mathrm{dm}$. long; petioles 4-8 $\mathrm{mm}$. long: staminate aments mostly solitary, 7-10 $\mathrm{cm}$. long; involucre of the nut compressed, the 2 finely pubescent leaf-like bractlets laciniate on their margins, commonly broader than high; nut compressed, light brown, striate, $1-1.5 \mathrm{~cm}$. high. In thickets, Me. and Ont. to Man., Fla. and Kans. March-April. Nuts ripe JulyAug.

2. Corylus rostràta Ait. Beaked Hazel-nut. (I. F. f. I210.) A shrub, similar to the preceding. Leaves ovate or narrowly oval, incised-serrate and serrulate, glabrous, or with some scattered appressed hairs above, sparingly pubescent at least on the veins beneath; $2-6 \mathrm{~cm}$. wide; involucral bractlets bristly-hairy, united to the summit and prolonged into a tubular beak about twice the length of the nut, laciniate at the summit; not ovoid, scarcely compressed, striate. In thickets, N. S. to Br. Col., Ga., Tenn., Kans. and Ore. April-May. Fruit ripe Aug.-Sept.

\section{BÉtula L. (See Appendix.)}

Aromatic trees or shrubs, with dentate or serrate leaves, scaly buds and flowers of both kinds in aments expanding before or with the leaves. Staminate flowers consisting of a membranous, usually 4-toothed perianth, 2 stamens, and subtended by 2 bractlets; filaments short, deeply 2 -cleft, each fork bearing an anther-sac. Pistillate flowers 2 or 3 (rarely 1 ) in the axil of each bract, the bracts deciduous 
with the fruits; perianth none; ovary sessile, 2-celled; styles 2 , stigmatic at the apex, mostly persistent. Nut small, compressed, membranous-winged on each side (a samara), shorter than the bracts. [The ancient name.] About 35 species, natives of the north temperate and arctic zones.

\section{* Trees.}

Fruiting aments peduncled; bark chalky-white.

Leaves deltoid, acuminate; lateral lobes of fruiting bracts short, divergent.

Leaves ovate or suborbicular; lateral lobes of the fruitic bracts ascending

\section{B. populifolia.}

2. B. papyrifera.

Fruiting aments peduncled; bark greenish-brown or brown.

Western; leaves ovate, often obtuse at the base.

Eastern; leaves rhombic, acute at both ends.

3. B. fontinalis.

4. B. nigra.

Fruiting aments sessile, at the ends of short branches; bark brown or yellowish.

Fruiting bracts $4 \mathrm{~mm}$. long, lobed at the apex; leaves shining above.

Fruiting bracts $8 \mathrm{~mm}$. long, lobed to about the middle; leaves dull above.

6. B. lutea.

\section{** Shrubs.}

Twigs glandular-warty; leaves glabrous.

Twigs not glandular-warty, glabrous or pubescent.

Leaves glabrous; upper fruiting bracts mostly entire.

Young foliage densely pubescent; bracts 3 -lobed.

7. B. glandulosa.

8. B. nana.

9. B. pumila.

I. Betula populifòlia Marsh. American White Bırch. (I. F. f. I2II.) A slender tree, with white smooth bark, tardily separating in thin sheets; twigs russet, warty. Leaves deltoid, pubescent on the veins when young, nearly glabrous when old, minutely glandular, long-acuminate, sharply dentate and commonly somewhat lobed, obtuse or truncate at the base, 3-6 cm. long, slender-petioled; staminate aments $5-8 \mathrm{~cm}$. long; pistillate a ments cylindric, in fruit $1.5-3.6 \mathrm{~cm}$. long, slenderpeduncled; fruiting bracts puberulent, $2-4 \mathrm{~mm}$. long, their lateral lobes larger than the middle one; nut narrower than its wings. In moist or dry soil, N. B. to $\mathrm{S}$. Ont. and Del. Leaves tremulous like those of the Aspens. May.

2. Betula papyrifera Marsh. PAPER or CANoe Birch. (I. F. f. 1212.) A large forest tree. Burk chalky white, peeling in thin layers. Leaves ovate, acute or acuminate, dentate and denticulate, glabrous above, glandular and pubescent on the veins beneath, slender-petioled, 3-I I cm. long: petioles I $-3 \mathrm{dm}$. long: staminate aments $5^{-10} \mathrm{~cm}$. long; pistillate aments cylindric, slender-peduncled, 2-5 $\mathrm{cm}$. long; fruiting bracts 4-6 mm. long, puberulent or ciliate; nut narrower than its wings. Newf. to Alaska, Penn., Mich., Nẹb. and Wash. April-May.

Betula papyrífera minor Tuckerm. A low bushy form, occurring on the higher mountains of N. E. and N. N. Y.

3. Betula fontinàlis Sargent. WeSTERN RED BIRCH. (I. F. f. 1213.) A tree, the bark smooth, dark bronze, the twigs gray-brown, warty. Lcaves broadly ovate or nearly orbicular, sharply serrate, short-petioled, glabrous on both sides or sparingly pubescent beneath, $2-5 \mathrm{~cm}$. long; pistillate aments peduncled, cylindric, $2-3 \mathrm{~cm}$. long, about $1 \mathrm{~cm}$. in diameter in fruit; fruiting bracts ciliolate, about $6 \mathrm{~mm}$. long, their lateral lobes ascending; nut much narrower than its wings. W. Neb. to Br. Col., Cal, and N. Mex. April-May.

4. Betula nigra L. River Birch. Red Birch. (I. F. f. 1214.) A slender tree: bark reddish or greenish-brown, peeling in very thin layers; twigs red. dish. Young shosts, petioles and lower surfaces of the leaves tomentose; leaves rhombic-ovate, irregularly serrate or somewhat lobed, base cuneate, when mature dark green above, pale beneath, 3-8 $\mathrm{cm}$. long; petioles 6-16 $\mathrm{mm}$. long; staminate aments mostly clustered in 2's or 3's, 6-9 cm. long; pistillate aments oblong . cylindric, spreading, peduncled, $2-5 \mathrm{~cm}$. long, $10-12 \mathrm{~mm}$. in diameter in fruit; fruiting bracts tomentose, about equally 3-lobed; nut broadly obovate, wicler than its wings. Along streams and lakes, Mass. and N. H. to Iowa, Kans., Fla. and Tex. April-May.

5. Betula lénta L. Cherry, Black or Sweet Birch. 
separating in layers; twigs smooth, warty; young leaves silky. Mature leaves ovate or ovate-oblong, acute or acuminate, the base cordate or rounded, sharply serrulate, bright green, and shining above, pubescent on the veins beneath, 6-10 $\mathrm{cm}$. long; petioles 6-12 mm. long; staminate aments clustered, 6-10 $\mathrm{cm}$. long; pistillate aments sessile, dense, oblong, about $2.5 \mathrm{~cm}$. long in fruit, nearly erect; bracts appressed, about $4 \mathrm{~mm}$. long, nearly equally 3 -lobed, the lateral lobes somewhat divergent; nut oblong, broader than its wings. Newf. to Ont., Fla. and Tenn. April-May.

6. Betula lùtea Michx. f. Yellow Birch. Gray Birch. (I. F. f. 12I6.) A large forest tree, similar to the preceding, the bark yellowish or gray, separating in thin layers or close, the twigs gray-brown. Leaves ovate or oblong-ovate, mostly acuminate at the apex, rounded, obtuse or rarely subcordate at the base, sharply serrulate, dark green and dull above, pubescent on the veins beneath; staminate aments usually 2-4 together; pistillate aments sessile, oblong or oblongcylindric, rather loose; bracts nearly equally 3 -lobed to the middle, ciliolate, the lateral lobes ascendling. Newf. to Manitoba, N. Car., Ga. and Tenn. April-May.

7. Betula glandulòsa Michx. Glandular or Scrub Birch. (I. F. f. I2I7.) A shrulb, 3-12 dm. high, the twigs brown, glandular-warty, not pubescent. Leaves orbicular, oval or obovate, glabrous, rounded at the apex, crenate-dentate, bright green above, pale and glandular-dotted beneath, short-petioled, $0.6-2.5 \mathrm{~cm}$. long; petioles $2-6 \mathrm{~mm}$. long; staminate aments commonly solitary, $1-1.5 \mathrm{~cm}$. long; pistillate aments cylindric, erect, peduncled, $1-2.5 \mathrm{~cm}$. long and about $4 \mathrm{~mm}$. in diameter in fruit; fruiting bracts glabrous, the lateral lobes divergent, rather shorter than the middle one; nut oblong, usually narrower than its wings. Newf. to Alaska, the higher mountains of Me. and N. N. Y., Mich., Misn., and in the Rocky Mountains to Colo. Also in Asia. June-July.

8. Betula nàna L. Dwarf BIRCH. (I. F. f. I2I8.) A low diffuse shrub, similar to the preceding, but the twigs glandless. Leaves orbicular, obovate, or reniform, bright green, firm, deeply and incisely crenulate, rounded at the apex, 6-20 $\mathrm{mm}$. long; petioles rarely more than $2 \mathrm{~mm}$. long; staminate aments $\mathbf{I}-2.5$ $\mathrm{cm}$. long; pistillate aments oblong, 6-10 $\mathrm{mm}$. long; fruiting bracts glabrous, the lower usually 3 -lobed, the upper ovate or lanceolate, mostly entire; nut oblong, wingless or narrowly winged. Greenland and Lab. to Hudson Bay. Also in northern Europe and Asia. May-June.

Betula nana flabellifolia Hook. Leaves with a cuneate base and more deeply incised-crenulate. Lab. and Newf.

9. Betula pùmila L. Low BiRCH. (I. F. f. I2 I9.) A bog shrub, 0.5-5 m. tall, the twigs brown, becoming glabrous, the young foliage densely brownish tomentose. Leaves obovate, broadly oval or orbicular, rounded at both ends or some of them cuneate-narrowed at the base, rather coarsely dentate, when mature glabrous abrve, pale, persistently tomentose or becoming glabrous beneath and reticulate-veined, $1-3 \mathrm{~cm}$. long; petioles 3-6 $\mathrm{mm}$. long; fruiting aments oblongcylindric, erect, peduncled, $2.5 \mathrm{~cm}$. long or less; bracts puberulent or ciliolate, the lateral lobes spreading at right angles, shorter than the middle one; nut oblong, mostly rather broader than its wings. Newf. to Ont., the N. W. Terr., N. J., Ohio and Minn. May-June.

\section{5. ÁLNUS Gaertn.}

Shrubs or trees, with dentate or serrulate leaves, few-scaled buds, and flowers of both kinds in aments, expanding before, with or after the leaves, making their first appearance during the preceding season, the staminate pendulous, the pistillate erect, clustered. Staminate flowers 3 or sometimes 6 in the axil of each bract, consisting of a mostly 4 -parted perianth, 4 stamens and subtended by I or 2 bractlets; filaments short, simple; anther-sacs adnate. Pistillate flowers 2-3 in the axil of each bract, without a perianth, but subtended by $2-4$ minute bractlets; ovary sessile, 2-celled; styles 2 ; bracts woody, persistent, 5-toothed or erose. Nut small, compressed. [Ancient Latin name derived from the Celtic, in allusion to the growth of these trees along streams.] About 14 species, natives of the northern hemisphere and the Andes of S. Am. Besides the following, some 6 others occur in the western parts of N. Am. 
Nut bordered by a membranous wing on each side.

i. A. Alnobetulu.

Nut acute-margined, wingless.

Leaves obovate, broadly oval or suborbicular, dull; aments expanding long before the leaves.

Leaves finely tomentose or glaucous beneath.

2. A. incana.

Leaves green, glabrous or sparingly pubescent beneath.

Leaves finely serrulate; foliage not glutinous; native.

Leaves dentate serrate; twigs glutinous; introduced tree. 4. A. glutinosa.

Leaves oblong, bright green and shining above; aments expanding in autumn.

5. A. maritima.

I. Alnus Alnobétula (Ehrh.) K. Koch. Green or Mountain Alder. (I. F. f. I220.) A shrub, $0.5-3.5 \mathrm{~m}$. high, the young foliage glutinous and more or less pubescent. Leaves oval or ovate, sharply and irregularly serrulate or incised-serrulate, when mature dark green and glabrous above, usually pubescent on the veins beneath, $5^{-13} \mathrm{~cm}$. long; petioles 8-25 mm. long; aments expanding with the leaves, the staminate slender, naked, $3^{-6} \mathrm{~cm}$. long, the pistillate from scaly buds, oblong or ovoid-oblong, slender-peduncled, becoming 12-14 mm. lorg in fruit, their bracts irregularly 5-toothed; nut oblong, the thin wing about as broad as the body. Lab. to Hudson Bay, south to the higher mountains of N. E. and N. Y. Also in Europe and Asia. June. [A. crispa (Ait.) Pursh.]

2. Alnus incàna (L.) Willd. Speckled or Hoary Alder. (I. F. f. r22r.) A shrub, or rarely a small tree, the young shoots pubescent. Leaves oval or ovate, usually acute, finely serrulate or dentate, dark green above, pale or glaucous and pulsescent, at least on the veins beneath, $5-13 \mathrm{~cm}$. long, the veins prominent on the lower surface; petioles $8-25 \mathrm{~mm}$. long; aments appearing from naked buds, the staminate $3-8 \mathrm{~cm}$. long, the pistillate ovoid, $1-1.5 \mathrm{~cm}$. long in fruit, their bracts 5-toothed; nut orbicular, coriaceous-margined. In wet soil, Newf., N. W. Terr., S. N. Y., Penn. and Neb. Also in Europe and Asia. April-May.

3. Alnus rugòsa (DuRoi) K. Koch. Smooth Aliner. (I. F. f. I222.) A shrub, or sometimes a small tree, the bark smooth, the younger shoots somewhat pubescent. Leaves green on both sides, obovate or oval, mostly obtuse and rounded, sharply and minutely serrulate, when mature glabrous above, usually pubescent on the veins beneath, $7-13 \mathrm{~cm}$. long; aments appearing from naked buds, the staminate 5-10 cm. long, the pistillate ovoid, $I-2 \mathrm{~cm}$. long in fruit; nut ovate, narrowly coriaceous-margined. In wet soil, or on hillsides, Me. to Ohio, Minn., Fla. and Tex. March-April. [A. serrulata Willd.]

4. Alnus glutinòsa (L.) Medic. European Alder. (I. F. f. I223.) A tree, the bark smooth, the foliage glutinous. Leaves broadly oval, orbicular or obovate, thick, dark green, dull, often obtuse at both ends, dentate and the teeth denticulate, glabrous above, pubescent on the veins beneath, 5-13 cm. long; aments, the staminate 7-10 cm. long, the pistillate ovoid-oblong, I-2 cm. long in fruit; nut wingless, coriaceous-margined. In wet places, S. N. Y. and N. J., escaped from cultivation. Native of Europe. April.

5. Alnus marítima (Marsh.) Muhl. Seaside Alder. (I. F. f. 1224.) A small tree, glabrous or nearly so throughout. Leaves oblong, ovate-oblong or obovate, firm, acute at both ends, bright green and shining above, pale green and dull beneath, sharply serrulate, 5-10 cm. long; aments unfolding long after the leaves, the staminate $2.5^{-6} \mathrm{~cm}$. long, the pistillate oblong, $1.5^{-2.5} \mathrm{~cm}$. long; nut oblongobovate, wingless, coriaceous-margined. In wet soil, S. Del. and E. Md.; also in the Ind. Terr. Aug.-Sept.

\section{Family 2. FAGÀCEAE Drude.}

\section{Beech Family.}

Trees or shrubs. Leaves alternate, petioled, pinnately veined, the stipules, if any, deciduous. Flowers small, monœecious, the staminate in aments, or capitate, the pistillate subtended by an involucre of partly or wholly united bracts, which becomes a bur or cup. Petals none. Staminate flowers with a 4-7-lobed perianth and 4-20 stamens; filaments slender, distinct, simple; anther-sacs adnate, longitudinally dehiscent. 
Pistillate flowers with a 4-8-lobed urn-shaped or oblong perianth, adnate to the 3-7-celled ovary; ovules $1-2$ in each cavity, only 1 in each ovary ripening, pendulous, anatropous; styles as many as the cavities of the ovary, linear. Fruit a I-seeded nut, with a coriaceous or somewhat bony exocarp. Testa thin. Endosperm none; cotyledons large, fleshy, often rugose ; radicle short. About 5 genera and 375 species, of very wide geographic distribution.

Staminate flowers capitate; nut sharply triangular.

Staminate flowers in slender aments; nut rounded or plano-convex.

\section{Fagus.}

Pistillate flowers $2-5$ in each involucre; involucre becoming globose and very prickly in fruit, enclosing the nuts.

2. Castanea.

Pistillate flower $\mathrm{t}$ in each involucre; involucre of numerous scales forming a cup in fruit and subtending the acorn.

3. Quercus.

\section{FÀGư $\mathbf{L}$.}

Trees, with smooth light gray bark, and serrate straight-veined leaves. Flowers appearing with the leaves, the staminate in slender-peduncled pendulous heads, the pistillate about 2 together in short-peduncled subutate-bracted involucres in the upper axils. Staminate flowers yellowish-green, subtended by decidlous bracts, consisting of a campanulate 4-8-lobed calyx, and 8-16 stamens with filiform filaments. Pistillate flowers with a 6-lobed perianth adnate to a 3 -celled ovary; ovules 2 in each cavity, usually I only of each ovary maturing; styles 3 , filiform. Nut coriaceous, sharply 3-angled, enclosed in the 4-valved bur. [Name from tne Greek, to eat, referring to the esculent nuts.] About 4 species, natives of the northern hemisphere, only the following native in N. Am.

I. Fagus Americàna Sweet. American BeEcir. (I. F. f. I225.) A large forest tree, the lower branches spreading. Leaves cvate or ovate-oblong, firm, acuminate, 5-12 cm. long, densely silky when young, glabrous or nearly so when mature, green on both sides, not shining; petioles 4-12 $\mathrm{mm}$. long: heads of staminate flowers $12-18 \mathrm{~mm}$. in diameter, hanging on long peduncles; bur $1-2 \mathrm{~cm}$. high, densely tomentose, its soft pricklets recurved or spreading; nut brown; seed sweet. In rich soil, N. S. to Ont. and Wis., Fla. and Tex. April-May. Nut ripe Sept..Oct.

\section{CASTÀnEA Adans.}

Trees or shrubs, with serrate straight-veined leaves, their teeth sharply acuminate. Flowers appearing after the leaves, the staminate in narrowly cylindric interrupted axillary yellowish aments, several in the axil of each bract, the bracts fugacious, the pistillate in prickly involucres at the bases of the staminate aments or in separate axils. Staminate flowers 2-bracteolate, consisting of a mostly 6-lobed campanulate perianth and numerous stamens, sometimes also with an abortive ovary; filaments filiform, long-exserted. Pistillate flowers 2-5 (commonly 3 ) in each involucre, consisting of an urn-shaped 6-lobed perianth adnate to the mostly 6-celled ovary, and usually with 4-12 abortive stamens; ovules 2 in each cavity, I ovule only of each ovary usually maturing: styles as many as the cavities of the ovary, slender, exserted; stigmas minute. Pistillate involucre enlarging and becoming a globose mostly 4-valved very prickly bur in fruit, enclosing I-several nuts. Nut rounded or plano-convex, I-seeded, the shell coriaceous. Seed large, sweet. Style mostly persistent. [Name Greek, from a city in Thessaly.] Four or five species, natives of the northern hemisphere. Besides the following, another occurs in the southeastern United States.

Leaves green on both sides; nuts usually 2-5 in each involucre; large tree.

Leaves densely white-tomentose beneath; nut usually solitary; shrub or small tree.

2. C. pumila.

I. Castanea dentàta (Marsh.) Borkh. American Chestnut. (I. F. f. 1226.) A large tree, with gray bark rough in longitudinal plates. Leaves oblong. lanceolate, glabrous, firm, acuminate, coarsely serrate, with very sharp-pointed ascending teeth, rather dark green above, lighter beneath, $\mathbf{I}-3 \mathrm{dm}$. long, petioles stout, $\mathbf{I}-2.5 \mathrm{~cm}$. long; staminate aments erect, numerous, $\mathbf{1} \cdot 5-3 \mathrm{dm}$. long, 8-1O $\mathrm{mm}$. 
in diameter; burs 3-10 $\mathrm{cm}$. in diameter, enclosing $\mathbf{I - 5}$ nuts; nuts puberulent, dark brown, plano-convex or angled on the face, or when solitary ovoid. In rich soil, Me. and Ont. to Mich., Ga. and Ala. Involucre sometimes suppressed and the nuts naked. June-July. Nuts ripe Sept.-Oct.

2. Castanea pùmila (L.) Mill. Chinquapin. (I. F. f. 1227.) A shrub or small tree, the young shoots puberulent. Leaves oblong, acute at both ends, sharply serrate with ascending or divergent teeth, dark green and glabrous above, densely white-tomentulose beneath, 0.7-1.5 dm. long, 2-6 cin. wide; staminate aments erect or somewhat spreading, 7-12 cm. long, 6-8 $\mathrm{mm}$. in diameter; burs $3 \mathrm{~cm}$. in diameter or less, commonly spicate, enclosing a solitary ovoid brown nut (rarely 2); seed very sweet. In dry soil, N. J. and Penn. to Ind., Fla. and Tex. June. Nuts ripe Sept.

\section{QUÉRCUS L.}

Trees or shrubs, with pinnatifid lobed, dentate, crenate or entire leaves, deciluous, or in some species persistent. Flowers very small, green or yellowish, appearing with or before the leaves, the staminate numerous in slender, mostly drooping aments, the pistillate solitary in many-bracted involucres. Staminate flowers subtended by caducous bracts, consisting of a mostly 6-lobed campanulate perianth and 6-12 stamens with filiform filaments, sometimes also with an abortive pilose ovary. Pistillate flowers with an urn-shaped or oblong calyx, adnate to a mostly 3 -celled ovary; ovules 2 in each cavity of the ovary, rarely more than $I$ in each ovary maturing; styles as many as the ovary-cavities, short. Fruit consisting of the imbricated and more or less united bracts of the involucre (cup), subtending or nearly enclosing the ovoid, oblong or subglobose, I-seeded coriaceous nut (acorn). [The ancient Latin name, probably of Celtic derivation, signifying "beautiful tree."] About 200 species, natives of the northern hemisphere. Besides the following, some 30 others occur in the western and southern secticn; of N. Am.

\section{* Leaves or their lobes bristle-tipped, deciduous; acorns maturing in autumn of second year.}

\section{+ Leaves pinnatifid or pinnately lobed.}

Leaves green on both sides.

Cup of the acorn saucer-shaped, much broader than high.

Cup r6-25 mm. broad; acorn ovoid; leaves dull.

Cup 8-16 mm. broad; leaves shining.

Acorn subglobose or short-ovoid; northern.

Acorn ovoid; southern.

Cup of the acorn turbinate or hemispheric.

I. Q. rubra.

2. Q. palustris.

3. Q. Schneckii.

Inner bark gray to reddish; leaves deeply lobed.

Leaves shining both sides. lobed to near the midrib. Acorn ovoid; cup 15-25 mm. wide.

Acorn narrow'; ellipsoid; cup ro-15 mm. wide

Leaves dull and paler beneath; acorn ovoid.

Inner bark orange.

Leaves white or gray-tomentulose beneath.

Large trees; leaf-lobes lanceolate or linear-lanceolate, long.

Leaves rounded or obtuse at base, 3-5-lobed; lobes linear or lanceolate, often falcate.

Leaves cuneate and acute at base, 5-II-lobed; lobes triangular.

Shrub or low tree; leaf-lobes triangular-ovate, short.

4. Q. coccinea.

5. Q. ellipsoidalis.

6. Q. borealis.

7. Q. velutina.

++ Leaves 3-5-iobed above the middle or entire, obovate or spatalate in outline.

Leaves obovate-cuneate, brown-floccose beneath.

Leaves spatulate, glabrous both sides.
II. Q. Marylandica.

12. Q. nigra.

$+\uparrow+$ Leaves entire, oblong, lanceolate or linear-oblong (sometimes lobed in no. 14).

Leaves linear-oblong, green and glabrous on both sides.

Leaves oblong, glabrous, dark green and shining above.

Leaves oblong or lanceolate, brown-tomentulose beneath.
13. Q. Phellos.

14. Q. laurifolia.

15. Q. imbricaria. 

* Leaves or their lobes not bristle-tipped, deciduous; acorns maturing in autumn
of first year.

+ Leaves pinnatifid or pinnately lobed.

Mature leaves pale, or glaucous and glabrous beneath ; cup shallow. 16. Q. alba.

Mature leaves tomentulose beneath; cup one-third to fully as long as the acorn. Upper scales of the cup not awned.

Leaves yellowish-brown tomentulose beneath; acorn ovoid.

Leaves white-tomentulose beneath; acorn depressed-globose. 17. Q. minor.

18. Q. lyrata.

Upper scales awned, forming a fringe around the acorn:

19. Q. macrocarpa.

\section{++ Leaves crenate or dentate, not lobed.}

Fruit peduncled.

Feduncle much longer than petioles; leaves white-tomentulose beneath.

20. Q. platanoides.

Peduncle equalling or shorter than the petioles; leaves gray-tomentulose beneath.

Bark white, flaky.

Bark close.

21. Q. Michauxii.

22. Q. Prinus.

Fruit sessile or nearly so.

Tall trees.

Leaves mostly oblong to lanceolate; cup deep; bark close. 23. Q. acuminata.

Leaves obovate; cup shallow; bark more or less flaky. 24. Q. Alexanderi.

Shrub or low tree; leaves oval or obovate.

* * * Leaves entire (rarely with a few bristle-tipped lobes), evergreen.

25. Q. prinoides.

26. Q. Virginiana.

I. Quercus rùbra L. Ren OAK. (I. F. f. 1228.) A large forest tree, the bark dark gray, slightly roughened. Leaves oval or somewhat obovate, when mature glabrous, or pubescent in the axils of the veins beneath, $1-2 \mathrm{dm}$. long, dull green above, pater beneath, sinuses rounded, lobes triangular-lanceolate, tapering from a broad base to an acuminate apex; styles spreading; cup saucer-shaped, its base flat or slightly convex, 16-25 mm. broad; bracts ovate or ovate-lanceolate, appressed; acorn ovoid, 2-3 cm. long, 2-4 times as long as the cup. N. S. to Ont., Minn., Fla., Kans, and Tex. May-June. 'Acorns ripe Oct.-Nov.

Quercus rùbra runcinàta $\mathrm{A}$. DC. Leaf-lobes nearly entire; acorn $1.2 \mathrm{~cm}$. high. Near St. Louis. Perhaps a hybrid with Q. digitata.

2. Quercus palústris DuRoi. Swamp OAk. Pin OAK. (I. F. f. 1229.) A torest tree, the lower branches deflexed; bark brown, rough when old. Leaves broadly oblong or obovate, deeply pinnatifid, bright green, glabrous and shining above, duller, glabrous or with tufts of hairs in the axils of the veins beneath, $0.7-$ $1.3 \mathrm{dm}$. long, the lobes oblong, lanceolate or triangular-lanceolate, divergent; styles slender; cup saucer shaped, 8-12 $\mathrm{mm}$. broad, base flat, bracts triangular-ovate, appressed; acorn subglobose or ovoid, 8-14 mm. ligh, often striate, 2-3 times as long as the cup. In moist ground, Mass. to Wis., Del. and Ark. May-June. Acorns ripe Sept.-Oct.

3. Quercus Schnéckii Britton. Schneck's Red OAK. (I. F. f. I23O.) A forest tree, similar to the preceding species. Bark reddish-brown, with broad ridges broken into plates; leaves mostly obovate, bright green and shining above, paler and with tufts of wool in the axils beneath, $0.5-1.5 \mathrm{dm}$. long, truncate or broadly wedge-shaped at the base, deeply pinnatificl into 5-9 oblong or triangular lobes; styles short; cup saucer-shaped, 10-16 $\mathrm{mm}$. broad, its scales appressed; acorn ovoid, $\mathbf{I}-2.5 \mathrm{~cm}$. long, 2-3 times as high as the cup. Ohio and S. Ind. to Iowa, Mo., Fla. and Tex. April-May. Acorns ripe Sept.-Oct. (Q. Texana Sargent, in part, not Buckley.)

4. Quercus coccínea Wang. Scarlet OAK. (I. F. f. I23I; acorns.) A forest tree, inner bark pale reddish or gray; foliage turning scarlet in autumn. Leaves deeply pinnatifid, glabrous, bright green and shining above, paler beneath, I-2 $\mathrm{dm}$. long, rather thin, the lobes oblong or lanceolate, divergent or ascending, fewtoothed; styles slender, recurved-spreading; cup hemispheric or top-shaped, its bracts triangular-lanceslate, mostly glabrous; acorn ovoid, $\mathbf{I}-2 \mathrm{~cm}$. high, about twice as long as the cup. In dry soil. Me, and Ont. to Minn., Fia. and Mo. MayJune. Acorns ripe $S$ Pt - () t. 
5. Quercus ellipsoidàlis E. J. Hill. HILl's OAK. A tall tree, the lowest branches drooping, the bark close, fissured, gray, the innermost layer yellowish. Leaves oval to obovate-orbicular in outline, when mature $6-15 \mathrm{~cm}$. long, deeply 5-7-lobed, the sinuses rounded, shining above, glabrous or nearly so beneath, the base broadly cuneate to truncate; petioles $2.5-5 \mathrm{~cm}$. long; styles spreading or recurved, flattish ; cup turbinate, short-peduncled, its bracts pubescent. appressed; acorn ellipsoid to subglobose, I-2 cm. long, I-I.5 cm. thick, I-2 times as long as the cup. Ill., Mich. and Minn.

6. Quercus boreàlis Michx. f. Gray OAK. A large tree, the leaves similar to those of $Q$. rubra, the acorns similar to those of $Q$. coccinea. Leaves 7-13-lobed to the middle or somewhat beyond, rather lustrous and deep green above, dull and paler and glabrous or nearly so beneath; cup turbinate, peduncled, its bracts appressed; acoin ovoid, i -2 times as long as the cup, about $2.5 \mathrm{~cm}$. long. Quebec to Ont., N. Y. and Penn. (Q. ambigua Michx. f., nct H. \& B.)

7. Quercus velutìna Lam. Black OAK. Quercitron. (I. F. f. 1232.) A large forest tree similar to $Q$. coccinea; outer bark very dark brown, rough in ridges, the inner bright orange. Leaves sometimes lobed to beyond the middle, firm, brown-pubescent or sumetimes stellate-pubescent when young, when mature glabrous and dark dull green ab Jve, pa'e green and usually pubescent on the vcirs beneath, and with tufts of wool in the axils, the broad oblong or triangu'ar-lanceolate lobes and their teeth bristle-tipped; cup hemispleric or top-shaped, commonly narrowel into a short stalk, its brac.s mostly pubescent, the upper somewhat squarrose; acor. ovo:d, I-2.5 $\mathrm{cm}$. ligh, more or less longer than the cup. Me. to Ont., Minn., Fla., Neb. and Tex. May-June. [Q tinctoria Bartr 1

8. Quercus digitata (Marsi.) Sudw. Spanisir OAK. (I. F.f. I233.) Leaves dark green and glabrous above, gray-tomentulose beneatl, deeply pinnatifid inw 3-7 linear or lanceolate lobes, often falcate, acuminate ; terminal lobe commonly elongated; styles slender; cup saucer-shaped with a turbinate base, Io-14 $\mathrm{mm}$. broad, its bracts ovate, obtuse, appressed; acorn subglobose or depressed, abou twice as high as the cup. In dry soil, L. I., N. J. to Fla., Mo., Neb. and Tex. May.-June. Acorns ripe Sept.-Oct. [Q. falcata Michx.]

9. Quercus pagodaefòlia (Ell.) Ashe. A tree sometimes $32 \mathrm{~m}$. high, the branches spreading, the bark dark gray, rough. I eaves oval to oblong in outline, cuneate to truncate at the base, 2-3 dm. long, deeply 5-I I-lobed, persistently white. tomentulose beneath, dark green above, the lobes narrowly triangular, spreading or somewhat ascending, usually entire; twigs tomentose; petioles $3-6 \mathrm{~cm}$. long; cup sessile, shallow, its bracts appressed ; acorn globose, about $1 \mathrm{~cm}$. in diameter, about one-half enclosed in the cup. In wet or moist soil, E. Va. and N. Car. to Ga., Ind. and Mo. April-May.

10. Quercus nàna (Marsh.) Sarg. BeAR OR SHRUb OAK. (I. F. f. 1234.) A shrub or rarely a small tree, often forming dense thickets; bark gray, nearly smooth. Leaves mostly obsvate, $5-13 \mathrm{~cm}$. long, short-petioled, dark green and glabrous above, grayish-whiie tomentulose beneath, 3-7-lobed; lobes triangularovate, acute; styles recurved; cup saucer-shaped, $8-12 \mathrm{~mm}$. broad, with a turbinate or rounded base, its bracts lanceolate, appressed; acorn globose-ovoid, longer thin the cup. In sandy or rocky soil, Me. to Ohio, Del., and the mountains of N. C. and $\mathrm{Ky}$. May. Acorns ripe Oct.-Nov. A hybrid of this, presumably with Q. coccinea, was found by Dr. Robbins of Uxbridge, Mass. [Q. ilicifolia Wang.]

I I. Quercus Marylándica Muench. BLACK-JACK OR BARREN-OAK. (I. F. f. 1235.) Bark nearly black, very rough in ridges. Leaves obovate, stellatepubescent above and brown-tomentose beneath when young, 3-5-lobed toward the broad usually nearly truncate apex, cuneate below, the lobes short; mature leaves dark green, glabrous above, paler and more or less floccose beneath, o.7-1.7 dm. long, styles recurved; cup deep, 10-16 $\mathrm{mm}$. broad, its bracts oblong-lanceolate, appressed, pubescent; acorn ovoid, 2-3 times as high as the cup. In dry soil, L. I. to Ohio, Neb., Fla. and Tex. Acorns ripe Oct.-Nov.

N. Car.

Quercus Rúdkini Britton, a hybrid of this with $Q$. Phellos, occurs from Staten I. to Quercus Brittoni W. T. Davis is a hybrid with Q. nana, Staten I, 
12. Quercus nigra L. WATER OAK. (I. F. f. 1236.) Bark gray, rough in ridges. Leaves spatulate or obovate, I-3-lobed at the apex, or some of them entire and rounded, coriaceous, short-petioled, rather bright green and shining, finely reticulate-veined, glabrous when mature except tufts of hairs in the axils of the veins beneath, $3-8 \mathrm{~cm}$. long, the lobes low, usually obtuse and bristle-tipped; styles recurved: cup saucer-shaped with a rounded base, 10-14 $\mathrm{mm}$. broad, its bracts appressed; acorn globose-ovoid, 2-3 times as high as the cup. Along streams and swamps or sometimes on the upland, Del. to Ky., Mo., Fla. and Tex. April-May. Acorns ripe Sept.-Oct. [Q. aquatica Walt.]

I3. Quercus Phéllos L. Willow OAK. (I. F. f. I237.) A tree, with slightly roughened reddish brown bark. Leaves narrowly oblong or chlonglanceolate, entire, acute at both ends, very short-petioled, bristle-tipped, glabrous or very slightly pubescent in the axils of the veins beneath when mature, $5-10 \mathrm{~cm}$. long, 8-25 $\mathrm{mm}$. wide; styles slender, recurved-spreading; cup saucer-shaped, nearly flat on the base, $8-12 \mathrm{~mm}$. broad; acorn subglobose, $8-12 \mathrm{~mm}$. high. In moist woods, L. I. to Fla., Mo. and Tex. April-May. Acorns ripe Sept.-Oct.

Quercus heterophýlla Michx., the Bartram Oak, probably a hybrid of Q. Phellos with Q. rubra, but perhaps a distinct species, intermediate in leaf and fruit characters between the two, occurs from Staten Island to N. Car. and in Mo. Q. Phellos hybridizes also with Q. nana.

I4. Quercus laurifòlia Michx. Laurel OAK. (I. F. f. I238.) Bark nearly black, with flat ridges. Leaves oblong or oblong-obovate, often somewhat falcate, green and shining alove, paler beneath, glabrous when mature, $0.3^{-1.5}$ $\mathrm{cm}$. long, I-2.5 cm. wide, entire, or those of young shoots unclulate-lobed, the apex bristle tipped; styles rather short, recurving; cup saucer-shaped, $\delta$ - I 2 mm. wide, its base somewhat rounded, its scales ovate, rounded, appressed; acorn $3-4$ times as long as the cup. Along streams and swamps, Va. to Fla. and La., mostly near the coast.

15. Quercus imbricària Michx. Shmgle OAK. (I. F. f. I239.) A forest tree. Leaves oblong or lanceolate, entire, coriaceous, acute at both ends, shortpetioled, bristle tipped, dark green above, persistently gray-tomentulose beneath, 0.7-I.7 dm. long, I.5-5 cm. wide; styles recurved; cup hemispheric or turbinate, ro-I $4 \mathrm{~mm}$. broad, its bracts appressed; acorn subglobose, IO-I4 $\mathrm{mm}$. high. Central Penn. to Mich., Neb., Ga. and Ark. April-May.

Quercus Leana Nutt. is a hybrid of this and Q. velutina, with intermediate characters. Ohio to Mo. and D. C.

Quercus tridentàta Engelm. is a hybrid with Q. Marylandica. Ill. and Penn.

Also hybridizes with Q. palustris and Q. rubra in Mo.

16. Quercus álba L. White OAK. (I. F. f. I240.) A large forest tree, with light gray bark scaling off in thin plates. I,eaves obovate, green above, pale and more or less glaucous beneath, pubescent when young, nearly glabrous when old, thin, pinnatifid into 3-9 oblong obtuse-toothed or entire lobes, I-2 dm. long: styles short, erect; fruit peduncled; cup. depressed-hemispheric, $1.4-2 \mathrm{~cm}$. broad, its bracts thick, warty, obtuse, woolly or at length glabrate, appressed; acorn ovoidoblong, $2.5 \mathrm{~cm}$. high or less, 3-4 times as high as the cup. Me. to Ont., Minn., Fla. and Tex. May-June. Acorns ripe Sept.-Oct.

Hybrids with Q. macrocarpa have been observed in Ill., with Q. minor, from Ill. to Va. and S. Car., with Q. Prinus, near Washington, D. C., and N. Y., and with Q. acuminata in Mo.

I7. Quercus minor (Marsh.) Sarg. Post or IRon OAK. (I. F. f. I24I.) A tree, with rough gray bark, or sometimes a shrub. Leaves broadly obovate, deeply lyrate-pinnatifid into 3-7 broad rounded often deeply undulate or toothed lobes, when mature firm, glabrous, dark green and shining above, brown-tomentulose beneath, I-2 dm. long, I-I.5 dm. wide or smaller; petioles stout; fruit nearly or quite sessile; styles short; cup hemispheric, I2-16 $\mathrm{mm}$. broad, base narrowed, its bracts lanceolate, subacute, slightly squarrose; acorn ovoid, I-2 cm. high, 2-3 times as long as the cup. In dry soil, Mass. to S. N. Y.. Mich., Fla. and Tex. MayJune. Acorns ripe Sept.-Oct. [Q. obtusiloba Michix.] 
18. Quercus 1yràta Walt. Swamp, Overcup or Post OAK. (I. F. f. 1242.) A large tree; bark gray or reddish, in thin plates. Leaves obovate, $\mathbf{r} .5-2 \mathrm{dm}$. long, lyrate-pinnatifid or lobed to beyond the middle, thin, when mature bright green and shining above, densely white-tomentulose beneath, the lobes entire or toothed, the upper pair the larger and usually divergent; fruit peduncled; styles short; cup depressed-globose, $2.5-3.5 \mathrm{~cm}$. in diameter, its bracts broad, thin, cuspidate; acorn depressed-globose, nearly or quite immersed in the cup. In swamps or along streams, N. J. to Ind., Mo., Fla. and Tex. April-May.

19. Quercus macrocàrpa Michx. Mossy-CUP or BUR OAK. (I. F. f. I243.) A large tree, with gray flaky bark. Leaves obovate or oblong-obovate, rather thin, irregularly lobed, pinnatifid, or some coarsely crenate; when mature bright green and shining above, grayish-white tomentulose beneath, I-2 dm. long, the lobes toothed or entire, rounded; fruit short-peduncled or sessile; styles short; cup hemispheric or subglobose, $\mathbf{1} .5^{-2.5} \mathrm{~cm}$. in diameter, its bracts floccose, thick, hard, ovate or lanceolate, the lower acute, the upper subulate-tipped, the tips forming a fringe around the acorn; acorn $1.5-3.5 \mathrm{~cm}$. long, ovoid, $\mathrm{I}-2$ times as high as the cup. In rich soil, N. S. to Manitoba, Mass., Penn., Kans. and Tex. May-June. Hybridizes with Q. acuminata in Kans. and Mo.

20. Quercus platanoides (Lam.) Sudw. Swamp White OAk. (I. F. f. 1244.) A large tree, with flaky gray bark. Leaves obovate, or oblong-obovate, coarsely toothed or sometimes lobed nearly to the middle, firm, when mature I-2 dm. long, dark green, dull and glabrous above, densely white-tomentulose beneath; peduncles $2-5$ times as long as the petioles; cup hemispheric, its bract pubescent, lanceolate, appressed, the lower obtuse, the upper acute or acuminate, acorn oblong-ovoid, about $2.5 \mathrm{~cm}$. high; cup about $1.2 \mathrm{~cm}$. high; seed rather sweet. In moist or swampy soil, Quebec to Mich., Ga. and Ark. May-June. Acorns ripe Sept.-Oct. [Q. bicolor Willd.]

21. Quercus Michauxii Nutt. Cow OAk. Basket OAk. (I. F. f. I245.) A large tree, with white flaky bark. Leaves obovate or broadly oblong, when mature bright green, feebly shining above, pale and gray-tomentulose beneath, crenately toothed, I-2 dm. long, the teeth often mucronulate; fruit short-peduncled or sessile; styles very short; cup depressed-hemispheric, $2.5-3.5 \mathrm{~cm}$. broad, its bracts thick, ovate or lanceolate, appressed; acorns ovoid, about 3 times as high as the cup. In moist soil, Del. to Ind., Mo., Ark., Fla. and Tex. April-May. Acorns ripe Sept.-Oct., sweet and edible.

22. Quercus Prinus L. Rock Chestnut Oak. (I. F. f. I246.) A large tree; bark brown, ridged, close or slightly flaky. Leaves coarsely crenate, oblong, oblong-lanceolate or obovate, when mature dark green, glabrous and feebly shining above, finely gray-tomentulose beneath, 1.2-2 dm. long; petioles slender; peduncles equalling or shorter than the petioles; styles very short: cup hemispheric, $1-3 \mathrm{~cm}$. broad, its bracts tomentose, triangular ovate, acute or cuspidate, appressed; acorn ovoid, 2-3 times as high as the cup; seed edible, but not very sweet. In dry soil, Me. to Ont.. Ala. and Tenn. May-June. Acorns ripe Oct.-Nov.

23. Quercus acuminàta (Michx.) Houda. Chestnut or Yellow OAK. (I. F. f. 1247.) A tree with gray close bark. Leaves oblong, lanceolate or sometimes obovate, acuminate or acute, coarsely toothed, with acute teeth, when mature dark green and shining above, pale, gray-tomentulose and prominently veined beneath, I I.5 cm. long, 2.5-6 cm. wide: fruit sessile or very short peduncled; cup hemispheric, I-1.6 cm. broad, its bracts floccose, ovate, thick, acute or cuspidate, appressed; acorn ovoid, I-2 cm. high, about twice as high as the cup. In dry soil, preferring limestone ridges, Ont. to Minn., Ga., Ala. and Tex. May-June. Acorns ripe Oct.-Nov., edible. [Q. Muhlinbergii Engelm.]

24. Quercus Alexánderi Britton. Alexander's OAK. (I. F. f. 1245; leaves.) A tree similar to the preceding species, but the leaves broadest above the middle, obovate or oblong-obovate; cup cupulate, short-stalked or sessile, shallow; acorn ovoid, I.5-2 cm. long, 2-3 times as high as the cup; bark, especially that of old trees, flaky. Vt. to Mich., Ohio and Ind. Type specimens from Birmingham, Mich.

25. Quercus prinoides Willd. Scrub Chestnut OAK. (I. F. f. r248.) A shrub, o.6-5 m. tall, sometimes tree-like, the bark gray. Leaves obovate, coarsely toothed, when mature bright green and somewhat shining above, gray tomentulose 
beneath, 6-13 cm. long, 5-8 cm. wide, mostly acute or short-acuminate at the apex, narrowed at the base, the teeth short, triangular; petioles slender, 6-18 $\mathrm{mm}$. long; fruit sessile ; cup hemispheric, thin, about $1.2 \mathrm{~cm}$. broad and one-half as high, its bracts floccose, triangular-ovate or oblong-lanceolate, appressed; acorn ovoid, obtuse, 2-3 times as long as the cup; seed sweet. In dry sandy or rocky soil, Me. to Minn., Ala. and Tex. April-May. Acorns ripe Sept.-Oct.

26. Quercus Virginiàna Mill. LIVE OAK. (I. F. f. 1249.) A tree, with rough brown bark; often shrubby, the young shoots puberulent. Leaves evergreen, coriaceous, oblong, elliptic or oblanceolate, obtuse, entire or with a few bristle. tipped teeth, bright green and glabrous above, pale green and puberulent or becoming glabrous beneath, $2-8 \mathrm{~cm}$. long; petioles stout, $2-6 \mathrm{~mm}$. long; fruit peduncled; cup nearly hemisplieric, I-1.6 cm. broad, its bracts closely appressed, ovate or lanceolate; acorn ovoid oblong, about twice as high as the cup; seed not edible. In dry, soil, Va. to Fla., Tex. and Mex., mostly near the cuast. Also in Cuba. March-April. Acorns ripe Sept.-Oct. [Q. virens Ait.]

\section{Order 9. URTICÀLES.}

Trees, shrubs or herbs, the flowers with a calyx but without corolla, small, not borne in aments, monœecious, diœcious or polygamous; ovary I-celled, superior.

Fruit not an achene (except in Humulus and Cannabis of the Moraceae): trees, shrubs or herbs; ovule pendulous.

Trees with alternate leaves, the sap not milky.

Trees with alternate leaves and milky sap; or opposite-leaved herbs or herbaceous vines.

Fam. 1. Ulmaceae.

Fam. 2. Moraceae. Fruit an achene; herbs with small clustered greenish flowers; ovule erect or ascending.

Fam. 3. Urticaceae.

\section{Family I. ULMÀCEAE Mirbel. Elm Fanily.}

Trees or shrubs, with alternate simple serrate petioled pinnately veineo stipulate leaves, the stipules usually fugacious. Flowers small, moncecious, diœcious, perfect or polygamous, clustered, or the pistillate solitary. Perianth 3-9-parted or of 3-9 distinct sepals. Petals none. Stamens in our species as many as the perianth-lobes or sepals and opposite them; filaments straight; anthers ovate or oval, longitudinally dehiscent. Ovary I-celled (rarely 2-celled), mostly superior; ovule solitary, pendulous, anatropous or amphitropous; styles or stigmas 2. Fruit a samara, drupe or nut. Endosperm of the seed little or none. Embryo straight or curved; cotyledons mostly flat. About 13 genera and 140 species, widely distributed in temperate and tropical regions.

Flowers borne in clusters on twigs of the preceding season; fruit a samara or nut-like.

Flowers expanding before the leaves; calyx 4-9-cleft; fruit a samara. 1. Ulmus

Flowers expanding with the leaves; caly $x$ 4-5-cleft; fruit nut-like.

2. Planera.

Flowers borne on twigs of the season, the pistillate mostly solitary; fruit a drupe.

3. Celtis.

\section{ULMUS L.}

Trees, with 2-ranked straight-veined inequilateral leaves. Flowers perfect or polygamous, fascicled or racemose, usually unfolding before the leaves, borne axillary on the twigs of the preceding season. Calyx campanulate, 4-9-lobed, persistent, its lobes imbricated. Filaments erect, slender, exserted. Ovary sessile or stalked, compressed. Styles 2, divergent, stigmatic along the inner margin. Fruit a 1-seeded flat orbicular or oval samara, its membranous wings continuous all around except at the apex, commonly as broad as or broader than the body. Embryo straight. [The ancient Latin name of the elm; Celtic elm.] About I 8 species, 
natives of the northern nemisplere. Besides the following, 3 others occur in tho southern U. S. and one in Mex.

Leaves smonth or slightly rough above; samara densely ciliate.

$\mathrm{N}$ une of the branches corky-winged; samara-faces glabrous.

some or all of the branches corky-winged; samara-faces pubescent.

Leaves $5^{-13} \mathrm{~cm}$. long; flowers racemose; northern.

Leaves $2-8 \mathrm{~cm}$. long; flowers fascicled; southern.
very rough above; samara not ciliate; twigs not corky

I. U. Americana.

Leaves very rough above; samara not ciliate; twigs not corky-winged. 4. U. fulva.

I. Ulmus Americàna L. American White or Water Elm. (I. F. f. 1250.) A large tree, with gray flaky bark, and glabrous or sparingly pubescent twigs and buds, the branches terete. Leaves oval or obovate, apex abruptly acumillate, base obtuse or obtusish, and very inequilateral, sharply and usually doubly serrate, slightly rough above, 5-13 cm. long; flowers fascicled; pedicels filiform, drooping, jointed; calyx 7-9.lobed, oblique, its lobes oblong, rounded; samara ovate-oval, reticulate-veined, IO-12 $\mathrm{mm}$. long, its faces glabrous; styles strongly incurved. In moist soil, especially along streams, Newf. to Manitoba, Fla. and Tex. March-April.

2. Ulmus racemòsa Thomas. CoRK OR Rock ElM. (I. F. f. 125I.) A large tree, the young twigs puberulent; bud-scales ciliate and somewhat pubescent; branches, or some of them, winged by narrow plates of cork. Leaves similar to those of the preceding, but less sharply serrate, smooth above; flcwers racemose ; pedicels filiform, drooping, jointed; calyx-lotes oblong, rounded ; samara oval, 12-16 mm. long, its mägins densely ciliate; persistent styles strongly incurved and overlapping. In rich soil, Quebec to Ont., Mich., N. J., Tenn. and Neb. April.

Uilmus campéstris L., from Europe, distinguished by its nearly or quite glabrous, not ciliate samaras, and wingless branches, rarely escapes from cultuvation.

3. Ulmus alàta Michx. Wingen Elm. Wahoo. (I. F. f. 1252.) A small tree, the branches, or most of them, with corky wing-like ridges. Twigs and buds glabrous or nearly so; leaves oblong, oblong-lanceolate or oblong-ovate, acute, doubly serrate, base obtuse, inequilateral and sometimes subcordate, roughish alove, pubescent beneath, at least on the veins, $2-8 \mathrm{~cm}$. long; flowers fascicled; pedicels filiform; calyx lobes obovate, rounded; samara oblong, 8-10 $\mathrm{mm}$. long, pubescent on the faces: styles very slender. In dry or moist soil, S. Va. to Fla., Ill., Ark. and Tex. March.

4. Ulmus fúlva Michx. Slippery, Red or Moose Elm. (I. F. f. 1253.) A tree, with rough gray fragrant bark, twigs rough-pubescent; bud-scales densely brown tomentose. Leaves ovate, oval or obovate, very rough with short papillæ above, pubescent beneath, sharply doubly serrate, acuminate at the apex, obtuse, inequilateral and commonly cordate at the base, 1-2 dm. long; flowers fascicled; pedicels 4-6 mm. long, spreading, jointed near the base; caly $x$-lobes lanceolate, subicute, samara oval orbicular, 12-18 $\mathrm{mm}$. long, pubescent over the seed. In woods, on hills and along streams, Quebec to N. Dak., Fla. and Tex. MarchApril.

\section{PLÁNERA J. F. Gmel.}

Trees, similar to the elms, the flowers monœecious or polygamous, unfolding with the leaves. Staminate flowers fascicled on twigs of the preceding season, the pistillate or perfect ones in the axils of leaves of the year. Calyx 4-5 cleft, cam. panulate, persistent, the lobes imbricated. Filaments filiform, straight, exserted. Ovary stalked, ovoid, slightly compressed, I-celled. Styles 2, spreading, stigmatic along the inner side. Fruit coriaceous, oblıquely ovoid, compressed, ridged on the back, covered with short fleshy processes. Embryo straight. [Name in honor of Johann Jakob Planer, 1743-1789, Professor of Botany in Erfurt.] A monotypic genus of southeastern N. Am.

I. Planera aquática (Walt.) J. F. Gmel. Planer-tree. Water Elm. (I. F. f. 1254.) A small tree, the foliage nearly glabrous. Leaves ovate or oblong-lanceolate, acute at the apex, obtuse or cordate and usually somewhat inequilateral at the base, serrate, 3-4 mm. long; petioles $2-5 \mathrm{~cm}$. long; stipules lanceolate, about as long as the petioles, decicluous; staminate flowers fascicled and somewliat racemose from scaly buds, perfect or pistullate flowers on short 
branches; fruit 4-6 mm. long, about equalling its stalk, its soft processes I mm. long. In swamps, Mo. to Ind., Ky., N. Car., La. and Fla. April-May.

\section{CÉLTIS L. (See Appendix.)}

Trees or shrubs, wi i serrate or entire pinnately veined or in some species 3-5nerved leaves, and polygamous or monœcious (rarely diœcious?) flowers, borne in the axils of leaves of the season, the staminate clustered, the fertile solitary or 2-3 together. Calyx 4-6-parted or of distinct sepals. Filaments erect, exserted. Ovary sessile. Stigmas 2, recurved or divergent, tomentose or plumose. Fruit an ovoid or globose drupe, with a row of bars at the base, the exocarp pulpy, the endocarp bony. Seed-coat membranous. Embryo curved. [Name ancient, used by Pliny for an African Lotus-tree.] About 60 species, natives of temperate and tropical regions. Besides the following, some 5 others occur in the southern and southwestern parts of N. Am.

Leaves sharply serrate, thin ; ripe drupe 8-10 $\mathrm{mm}$. in diameter.

Leaves smooth above.

Leaves scabrous above.

Leaves entire or nearly so, thick ; drupe $4-6 \mathrm{~mm}$. in diameter.

1. C. occidentalis.

2. C. crassifolia.

3. C. Mississippiensis.

I. Celtis occidentàlis L. American Nettle-tree. Sugar-berky. (I. F.f. 1255.) A tree or shrub, the bark dark and rough, the twigs glabrous. Leaves ovate or ovate-lanceolate, sharply serrate, mostly thin, usually abruptly acuminate, inequilateral, pinnately veined, 0.3-I dm. long, smooth above, pubescent or glabrate beneath; calyx-segments linear-oblong, deciduous; drupe globose and purple, or nearly black when mature, or orange, $8-10 \mathrm{~mm}$. in diameter. In dry soil, Quebec to Manitoba, La., N. Car., Mo. and Kans. April-May. Fruit rip' Sept. Variable.

2. Celtis crassifolia Lam. HACKBERry. A tree or shrub, the young shoots puberulent. Leaves ovate, firm, inequilateral, acute or short-acuminate at the apex, often cordate at base, scabrous above and often so beneath, more or less pubescent, usually serrate quite to the tip, rarely entire, 3-12 cm. long; fruiting pedicels mostly about twice as long as the petioles or more, sometimes short; drupe purple, red or nearly black when mature, globose to oval, 8-10 $\mathrm{mm}$. in diameter. N. Y. to S. Car., Ohio, Ill., Mo. and Tenn.

3 Celtis Mississippiénsis Bosc. Southern Hackberry. (I. F. f. 1256.) A tree, similar to the two preceding, the bark light gray, rough and warty. Leaves lanceolate, firm, entire or with a few low sharp teeth, 3-nerved and prominently pinnately veined, glabrous, long-acuminate at the apex, inequilateral, $2-8 \mathrm{~cm}$. long, drupe purple-black, 5-6 mm. in diameter. In dry soil, N. Car. to Ill., Mo., Kans., Fla. and Tex. April. Fruit ripe July-Aug.

\section{Family 2. MORÀCEAE Lindl. Mulberry Family.}

Trees, shrubs or herbs, mostly with milkv sap, petioled stipulate leaves, and small monocious or diœecious axillary clustered flowers, or the pistillate flowers solitary in some exotic genera. Calyx mostly 4-5parted. Petals none. Staminate flowers panicled, spicate or capitate, the stamens as many as the calyx-segments. Pistillate flowers capitate, spicate or cymose. Ovary superior, I-celled in our genera. Ovule solitary, pendulous, anatropous. Styles 1 or 2 . About 55 genera and 925 species, natives of temperate and tropical regions.

Trees or shrubs; stipules fugacious.

Staminate and pistillate flowers spiked; leaves dentate or lobed.

Staminate flowers racemose or spiked; pistillate capitate.

Pistillate perianth deeply 4 -cleft; leaves entire.

Pistillate perianth $3-4$-toothed; leaves various.

Erect or twining herbs; stipules persistent.

Twining vines; pistillate flowers in ament-like clusters.

Erect herb; pistillate flowers spicate.

1. Morus.

2. Toxylon.

3. Broussonetia.

4. Humulus.

5. Cannabis, 


\section{MÒRUS L.}

Trees or shrubs, with milky sap, alternate dentate and often lobed, 3-nerved leaves, fugacious stipules, the pistillate spikes ripening into a succulent aggregate fruit. Staminate flowers with a 4-parted perianth, its segments somewhat imbricated, and 4 stamens, the filaments inflexed in the bud, straightening and exserted in anthesis. Pistillate flowers with a 4-parted persistent perianth, which becomes fleshy in fruit, a sessile ovary, and 2 linear spreading stigmas. Fruiting perianth enclosing the ripened ovary, the exocarp succulent, the endocarp crustaceous. Albumen scanty; embryo curved. [The ancient name of the mulberry; Celtic $m o^{-}$.] About Io species, natives of the northern hemisphere. Besides the following tress, another occurs in the southwestern U. S.

1, eaves rough above, pubescent beneath; fruit purple; spikes $2-6 \mathrm{~cm}$. long. 1. $M . r u b r a$. Leaves smooth and glabrous, or very nearly so, on both sides; fruit nearly white; spikes $1-1.5 \mathrm{~cm}$. long.

2. M. alba.

I. Morus rùbra L. Red MulberRy. (I. F. f. 1257.) Bark brown and rough. Leaves ovate or nearly orbicular, scabrous above, pubescent beneath, or when young almost tomentose, acuminate at the apex, rounded, truncate or cordate at the base, serrate-dentate or 3-7-lubed, 7-13 cm. long; staminate spikes drooping; pistillate spikes spreading or pendulous in fruit, $8-10 \mathrm{~mm}$. in diameter, slender peduncled, dark purple-red, delicious. In rich soil, Vt. and Ont. to Mich., S. Dak., Fla. and Tex. April-May. Fruit ripe in June.

2. Morus älba L. White Mulberry. (I. F. f. I258.) Bark light gray, rough, the branches spreading. Leaves ovate, thin, smooth, glabrous and somewhat shining on both sides, acute or abruptly acuminate at the apex, rounded, truncate or cordate at the base, viırying from serrate to variously loled, $5-15 \mathrm{~cm}$. long : staminate spikes slender, (1ro sping ; pistillate spikes oblong or subglobose, drooping, $6 \mathrm{~mm}$. in diameter and white or pinkish when mature, not as succulent as those of the preceding. Sprringly escaped from cultivation. Me. and Ont. to Fla. Introduced from the Uld Wor.d for feeding silkworms. May. Fruit ripe July-Aug.

\section{TÓXYLON Raf. [MACLURA Nutt.]}

A tree, with milky sap, thick alternate petioled pinnately veined leaves, stout axillary spines, calucous stipules and diœeious axillary flowers, the staminate racemose, the pistillate capitate. Staminate flowers with a 4 parted calyx, its segments valvate, and 4 stamens, the filaments inflexed in the bull, straightening and somewhat exserted in anthesis. Pistillate flowers with a 4-cleft calyx enclosing the sessile ovary, and a filiform long-exserted style, the calices becoming fleshy and enlarged in fruit, densely aggregated into a large globular head. Endosperm none; embryo curvel. [Greek, signifying bow-wood.] A monotypic genus of the south central U. S.

I. Toxylon pomíferum Raf. Osage Orange. (I. F. f. 1259.) Foliage puberulent when young, glabrous when mature. Leaves ovate, ovate lanceolate or ovate -oblong, glossy, entire, 7-15 cm. long, apex acuminate, base obtuse, truncate or subcordate; axillary spines sometimes $8 \mathrm{~cm}$. long: staminate racemes $\mathbf{I}-2.5 \mathrm{~cm}$. long; flowers about $2 \mathrm{~mm}$. broad; head of pistillate flowers peduncled, pendulous, ripening into a hard yellowish tubercled syncarp 5-15 cm. in diameter. In rich soil, Mo. and Kans. to Tex. Much planted for hedges and occasionally spontaneous in the East. May-June. Fruit ripe Oct.-Nov.

\section{BROUSSONÉTIA L'Her.}

Trees, with milky sap, the leaves alternate, petioled. entire, serrate, or 3-5. lobed, 3-nerved at the base. Flowers diœcious, the staminate in cylindric amentlike spikes, the pistillate capitate. Staminate flowers with a deeply 4-cleft perianth. 4 stamens, and a minute rudimentary ovary. Pistillate flowers with an ovoid or tubular perianth, a stalked ovary and a 2-cleft style. Head of fruit globular, the drupes red, exserted beyond the persistent perianth. [In honor of Broussonet, French naturalist.] About 4 species, natives of eastern Asia.

I. Broussonetia papyrifera (L.) Vent. PAPER Mulberry. 
often deeply 3 -lobed, sometimes with a lobe on one sid $\geq$ only, as in Sassafras, rarely 5 -lobed, rough above, tomentose beneath, $\mathbf{I} \cdot 2 \mathrm{dm}$. long; spikes of staminate flowers peduncled; heads of pistillate flowers $\mathbf{I}-2.5 \mathrm{~cm}$. in diameter. Escaped from cultivation, N. Y. to Ga. and Mo. May-June.

\section{HÙmULUS L. (See Appendix.)}

Herbaceous perennial rough vines, with broad opposite thin petioled palmately veined leaves, lanceolate membranous stipules, and diœcious axillary flowers, the staminate panicled, the pistillate in ament-like drooping clustered spikes. Staminate flowers with a 5-parted calyx, the segments distinct and imbricated, and 5 short erect stamens. Pistillate flowers in 2's in the axil of each bract of the ament. consisting of a membranous entire perianth, clasping the ovary, and 2 filiform caducous stigmas. Fruiting aments cone-like, the persistent bracts subtending the compressed ovate achenes. Endosperm fleshy. Embryo spirally coiled. [Name said to be the diminutive of the Latin humus, earth.] Two species, the following widely distributed through the north temperate zone, the other native of northeastern Asia.

I. Humulus Lùpulus L. Hop. (I. F. f. 1261.) A vine, often $8 \mathrm{~m}$. long, very rough with stiff reflexed hairs. Leaves orbicular or ovate in outline, slenderp tioled, deeply 3-7-cleft or some of the upper ones ovate, acute and merely serrate; stipules reflexed, acuminate, $8-25 \mathrm{~mm}$. long; ripe pistillate clusters (hops) 2.5-6 cm. long; fruiting bracts broadly ovate, concave, thin, glabrous or nearly so, obtuse, much longer than the achenes; fruiting calyx and achene strongly resinous-a romatic. In thickets and on river-banks, N. S. to Manitoba, N. Y., Pisnn., in the Alleghanies to Ga., to Kans., and in the Rocky Mts. to Ariz. and N. Mex. Extensively escaped from cultivation. Native also of Europe and Asia. July-Aug. Fruit ripe Sept._Oct.

\section{CÁNNABIS L.}

A stout, rough and puberulent herb, with petioled digitately 5 -1 I-divided thin leaves, subulate stipules, and greenish diœcious axillary flowers, the staminate panicled, the pistillate spicate. Staminate flowers with a 5-parted calyx, the sepals distinct and imbricated, and 5 short stamens. Pistillate flowers solitary in the axils of foliaceous bracts, consisting of a thin entire calyx clasping the sessile ovary, and 2 filiform caducous stigmas. Fruit a compressed achene. Endosperm fleshy; embryo curved. [The classic name of hemp.] A monotypic genus of central Asia.

I. Cannabis sativa L. Hemp. (I. F. f. 1262.) Annual, branching, 1-3 m. tall, the inner fibrous bark very tough. Leaves divided to the base, the segments lanceolate or linear-lanceolate, acuminate at both ends, sharply and coarsely serrate, $0.7-\mathbf{I} .5 \mathrm{dm}$. long; staminate panicles narrow, loose, peduncled; pedicels filiform, bracteolate, 2-6 mm. long; pistillate spikes erect, leafy-bracted; achene crustaceous, ovoid-oblong, about $4 \mathrm{~mm}$. high. In waste places, N. B. to Ont., Minn., N. Car., Tenn. and Kans. July-Sept.

\section{Family 3. URTICÀCEAE Reichenb.}

\section{Nettle Family.}

Herbs (some tropical species shrubs or trees), with watery sap, mostly stipulate simple leaves, and small greenish diøecious, monœcious or polygamous flowers, variously clustered. Calyx 2-5-cleft, or of distinct sepals. Petals none. Stamens in the staminate flowers as many as the lobes or segments of the calyx (sepals) and opposite tliem, the filaments inflexed and anthers reversed in the bud, straightening at anthesis. Ovary superior, I-celled; style simple; ovule solitary, erect or ascending, orthotropous, or in some genera partly amphitrofous. Fruit an achene. Endosperm oily, usuafly not copious; embryo straight. About 40 genera and 475 species of wide geographic distribution. 
Herbs with stinging hairs.

Leaves opposite; both kinds of flowers 4-parted; achene straight.

Leaves alternate; staminate flowers 5-parted; achene oblique.

1. Urtica.

2. Urticascrum. Herbs without stinging hairs.

Flower-clusters panicled or spiked, not involucrate; leaves mostly opposite.

Pistillate calyx 3 parted or of 3 sepals.

Pistillate calyx 2-4-toothed or entire.

3. Adicea.

Flower-clusters involucrate by leafy bracts; leaves alternate.

4. Boehmeria.

5. Parietaria.

\section{URTİCA L.}

Herbs, with stinging hairs, 3-7-nerved petioled dentate or incised leaves, and distinct or connate stipules. Flowers small and numerous, axillary, cymosepaniculate, or glomerate, diœcious, monœecious or androgynous. Staminate flowers with a deeply 4-parted calyx and 4 stamens. Pistillate calyx 4-parted, the segments unequal; ovary straight; stigma sessile or nearly so; ovule erect, orthotropous. Achene compressed, enclosed by the persistent calyx. Seed-coat thin; endosperm little; cotyledons broad. [The ancient Latin name.] About 30 species of wide distribution.

Perennials, $0.6-2.2 \mathrm{~m}$. tall ; flower-clusters large, compound.

Leaves ovate, cordate at base.

Leaves laciniate, rarely cordate.

Annuals, 1.5-7 dm. tall ; flower-clusters small, mostly glomerate.

Leaves oval, laciniate-dentate; plant leafy at the top. 3. U. urens.

Leaves ovate or lanceolate, crenate; upper leaves very small.

I. U. dioica.

2. U. gracilis.

4. U. chamaedryoides.

I. Urtica dioica L. Stinging or Great Nettle. (I. F. f. I263.) Densely beset with stinging hairs; stem $0.6-1.2 \mathrm{~m}$. tall, puberulent above. Leaves thin, ovate, long-petioled, acute or acuminate at the apex, cordate at the base, sharply serrate with acute teeth, pubescent beneath, 3-5-nerved, 7-I3 cm. long; stipules lanceolate; flower-clusters large, cymose-paniculate; flowers diœcious or androgynous. In waste places, N. S. to Ont., Minn., S. Car. and Mo. Nat. from Europe. Native also of Asia. July-Sept.

2. Urtica grácilis Ait. Slender Nettle. (I. F. f. I264.) Sparingly armed with stinging hairs; stem usually slender, $0.6-2.2 \mathrm{~m}$. tall. Leaves lanceo. late or ovate-lanceolate, slender-petioled, long-acuminate at the apex, narrowed or sometimes rounded at the base (rarely subcordate), sharply serrate, 3-5-nerved, sparingly pubescent, 7-I $5 \mathrm{~cm}$. long; petioles usually bristly; stipules lanceolate; flower-clusters compound, smaller than those of the preceding, but commonly longer than the petioles; flowers diocious or androgynous. In dry soil, N. S. to Br. Col., N. Car., La. and Kans. June-Oct.

3. Urtica ùrens L. Small Netrile. (I. F. f. I265.) Stem I.5-4.5 dm. high, stinging-bristly. Leaves thin, glabrous or very nearly so, elliptic, oval or ovate, deeply incised or sometimes doubly serrate, 3-5-nerved, 2-8 cm. long, slender-petioled; stipules short; flower-clusters oblong, rather dense. In waste places, Newf. to N. Y., N. J. and Fla. Also on the Pacific Coast. Nat. from Europe. May-Sept.

4. Urtica chamaedryoides Pursh. Weak Netrue. (I. F. f. I266.) Sparingly stinging-bristly; stem slender, weak, ascending, I.5-IO dm. long. Leaves slenderpetioled, thin, crenate-dentate, the lower broadly ovate or orbicular, obtuse at the apex and usually cordate at the base, $\mathbf{I}-3 \mathrm{~cm}$. wide, the upper ovate or lanceolate, acute or acuminate at the apex, the uppermost very small; stipules lanceolatesubulate; flower-clusters small, glomerate. In thickets, Ky. to Ark., Ga. and 'Tex. April-Aug.

\section{URTICÁSTRUM Fabr. [LAPORTEA Gaud.]}

Perennial herbs, armed with stinging hairs, the leaves broad, alternate, serrate. petioled, the flowers monocious or dinecious, sessile in loose axillary compound cymes. Staminate flowers in our species with 5 imbricated sepals, 5 stamens and a rudimentary ovary. Pistillate flowers with 4 unequal sepals, the outer I or 2 minute, an oblique or nearly straight compressed ovary and a subulate slender persistent style; ovule erect. Achene very oblique, flat. reflexed. Seed-coat mem. 
branous. Endosperm scanty or wanting. [Latin, star nettle.] About 25 species, mostly of tropical distribution. only the following North-American.

I. Urticastrum divaricàtum (L.) Kuntze. Wood NetTle. (I. F. f. I267.) Stem 3-12 dm. tall. Leaves thin, ovate, long-petioled, acuminate or acute at the apex, sharply serrate. 3-nerved and pinnately veined, glabrous or with some stinging hairs, $5-\mathbf{I} 3 \mathrm{~cm}$. wide; petioles $3-\mathbf{I} 3 \mathrm{~cm}$. long ; stipule solitary, small, lanceolate, 2-cleft, commonly deciduous; flower-clusters often longer than the petioles, the lower staminate, the upper pistillate, divergent, $5^{-15} \mathrm{~cm}$. broad in fruit; ultimate branches of the fruiting clusters flat, cuneate, emarginate; achene twice as long as the calyx, glabrous. In rich woods, N. S. to Ont., Minn., Fla. and Kans. July-Aug.

\section{A DícEa Raf. [PILEA Lindl.]}

Herbs, with opposite petioled mostly 3-nerved leaves, connate stipules, and small monœecious or diœecious flowers in axillary clusters. Staminate flowers mostly 4-parted (sometimes 2 - or 3-parted) and with a rudimentary ovary. Pistillate flowers 3-parted, the segments in most species unequal, each subtending a staminodium in the form of a concave scale; ovary straight; stigna sessile, penicillate. Achene compressed. Seed-coat thin. Endosperm scanty or none. [Name unexplained.] About ${ }^{5}$ O species, chiefly in the tropics, most abundant in tropical America. Besides the following, another occurs in the southern U. S.

I. Adicea pùmila (L.) Raf. Clearweed. Richweed. (I. F. f. 1268.) Annual, stems pellucid, usually branched, glabrous, succulent, I.5-6 dm. high. Leaves membranous, ovate, slender-petioled, acuminate or acute, 3-nerved, coarsely dentate, $2-13 \mathrm{~cm}$. long, sparingly pubescent with scattered hairs; petioles much longer than the pistillate flower-clusters; sepals of the pistillate flowers lanceolate, nearly equal; achene ovate, acute, I mm. long. In swampy, shaded situations, often on old logs. N. B. to Ont., Minn., Fla., La. and Kans. Also in Japan. July-Sept.

\section{BOEHMĖRIA Jacq.}

Perennial stingless herbs (some tropical species shrubs or even trees), with petioled 3-nerved leaves, distinct or connate stipules, and small monœcious or diøecious flowers, glomerate in axillary spikes or heads. Staminate flowers mostly 4-parted, or the calyx of 4 distinct sepals, usually with a rudimentary ovary. Pistillate calyx tubular or urn-shaped, enclosing the ovary; stigma subulate. Achene enclosed by the pistillate calyx. [In honor of Georg Rudolph Boehmer, 1723-1803, Professor in Wittenberg.] About 50 species, mostly natives of tropical regions, the following of eastern N. A.

I. Boehmeria cylíndrica (L.) Willd. False Nettle. (I. F. f. 1269.) A perennial rough erect branching herb, 3-Io dm. tall. Stem stiff; leaves ova'e, ovate-oblong or ovate-lanceolate, thin, slender petic'ed, opposite, or some alternate, coarsely dentate, $\mathbf{I}-3 \mathrm{~cm}$. wide; petioles shorter than the blades; stipules distinct; flowers dinecious or androgynous; staminate spikes usually interrupted, the pistillate mostly continuous, $0.6-3 \mathrm{~cm}$. long; achene ovate-oval, acute, rather less than $2 \mathrm{~mm}$. long. In moist soil, Quebec and Ont. to Minn., Fla., Neb. and Kans. July--Sept.

Boehmeria cylíndrica scábra Porter. Leaves firm, rough above, tomentose beneath, short-petioled or nearly sessile, usually reflexed; fruiting spikes much longer than the petioles. Penn., N.J. and S. N. Y. to Fla., Kans. and Tex.

\section{PARIETÀRIA I.}

Herbs, with alternate entire 3 -nerved petioled leaves, no stipules, and axillary glomerate polygamous flowers, involucrate by leafy bracts. Calyx of the staminate flowers 4-parted or of 4 (rarely 3) distinct sepals. Fertile flowers with a 4-lobed calyx investing the ovary, a short or slender style, and a penicillate stigma. Achene enclosed by the pistillate calyx. [Ancient Latin, referring to the growth of some species on walls.] About 7 species, widely distributed; besides the following, another occurs in the southern U. S.

I. Parietaria Pennsylvánica Muhl. Pennsylvania Pellitory. (I. F. f. 1270.) Annual, pubescent; stem weak, ascending or reclining, slender, I-4 dm. long. Leaves lanceolate or oblong-lanceolate, membranous, dotted, acuminate at 
the apex, narrowed at the base, 3 -nerved and with $1-3$ pairs of weaker veins above, slender-petioled, 6-12 mm. wide; petioles almost filiform; flowers glomerate in all except the lowest axils, the clusters shorter than the petioles; bracts of the involucre linear, 2-3 times as long as the flowers; style almost none; achene abuut I $\mathrm{mm}$. long. On dry rocks and banks, Ont. to Br. Col., Fla., Colo. and Mex. June-Aug.

\section{Order Io. PROTEÀLES,}

includes only the Family Proteaceae, with nearly Iooo species, all natives of the southern hemisphere.

\section{Order II. SANTALÀLES.}

Herbs or shrubs, mostly parasitic, the flowers with a calyx, but without a corolla, perfect or imperfect, clustered or solitary. Ovary 1, inferior, at least in part 1 -celled.

Tree-parasites, with opposite leaves or scales; fruit a berry. Fam. 1. Loranthaceae. Root-parasites, or shrubs; leaves alternate in our genera; fruit a drupe, or nut.

Fam. 2. Santalaceae.

Family I. LORANTHÀCEAE D. Don.

Mistletoe Family.

Parasitic green shrubs or herbs, containing chlorophyll, growing on woody plants and absorbing food from their sap through specialized roots called haustoria (a few tropical species terrestrial). Leaves in the following genera opposite, in Razoumofskya reduced to opposite scales. Flowers regular, terminal or axillary, diœcious or monœcious, and perianth simple, or in some exotic genera perfect, and with perianth of both calyx and corolla. Calyx-tube adnate to the ovary. Stamens 2-6. Ovary solitary, erect; style simple or none; stigma terminal, undivided, obtuse. Fruit a berry. Seed solitary, its testa indistinguishable from the endosperm, which is usually copious and fleshy; embryo terete or angled. About 21 genera and 500 species, widely distributed; most abundant in tropical regions.

Leaves scale-like, united at the base; anthers I-celled; berry peduncled.

Leaves thick, flat; anthers 2-celled; berry sessile.

1. Razoumof skya.

2. Phoradendron.

I. RAZOUMÓFSKYA Hoffm. [ARCEUTHOBIUM Bieb.]

Small or minute fleshy glabrous plants, parasitic on the branches of coniferous trees, their branches 4 -angled, and leaves reduced to connate scales. Flowers diœcious, not bracted, in the axils of the scales. Staminate flowers with a 2 -5parted calyx and usually an equal number of stamens, the anthers sessile on the segments. Pistillate flowers with the ovary adnate to the tuhe of the calyx, the calyx-limb 2-parted. Disk present in both kinds of flowers. Berry fleshy, ovoid, more or less flattened, borne on a short somewhat recurved peduncle. Embryo enclosed in the copious endosperm. [In honor of Alexis Razoumofski, Russian botanist.] About Io species. Besides the following, 7 or 8 others occur in western N. Am. and Mex., 2 in Europe and Asia.

I Razoumofskya pusílla (Peck) Kuntze. Small Mistietof. (I. F. f. 127I.) Plant inconspicuous: stems 4-20 $\mathrm{mm}$. long, nearly terete when fresh, somewhat 4-angled when dry. Scales suborbicular, appressed, obtuse, about I $\mathrm{mm}$. wide; flowers diœcious, solitary in most of the axils, longer than the scales; 
berry ovoid-oblong, acute, about $2 \mathrm{~mm}$. long, nodding on a slightly exserted peduncle; seeds enclosed in a viscid mucus. On twigs of spruces and larch, Me. to Conn., N. Y. and Penn. June.

\section{PHORADENDRON Nutt.}

Shrubs, parasitic on trees, with opposite coriaceous flat faintly nerved leaves, terete twigs, and diœcious axillary spicate bracted small flowers, solitary or several in the axil of each bract. Staminate flowers with a 3-lobed (rarely 2-4-lobed) calyx, bearing a sessile transversely 2-celled anther at the base of each lobe. Pistillate flowers with a similar calyx adnate to the ovoid inferior ovary. Style short, obtuse or capitate. Fruit a sessile fleshy berry. Endosperm copious. [Greek, tree-thief, from its parasitic habit.] About 80 species, all American. Besides the following, 5 or 6 others occur in the Western States.

I. Phoradendron flavéscens (Pursh) Nutt. American Mistletoe. (I. F.f. I272.) A branching glabrous or slightly pubescent shrub, the twigs terete, brittle at the base. Leaves oblong or obovate, rounded at the apex, narrowed into short petioles, 3-5-nerved, entire, I-2 cm. wide, dark green; spikes solitary, or 2 or 3 together in the axils, linear, shorter than the leaves; berry globose, white, about $4 \mathrm{~mm}$. in diameter. Parasitic on deciduous leaved trees, notably on the Tupelo and Red Maple, N. J. to Ohio, Ind., Mo., Fla. and Tex. May-July.

\section{Family 2. SANTALÀCEAE R. Br.}

\section{Sandalwood Family.}

Herbs or shrubs (some exotic genera trees), with entire estipulate leaves. Flowers perfect, monœcious or diœcious, mostly greenish. Calyx adnate to the base of the ovary, or to the disk, 3-6-lobed, the lobes valvate. Petals none. Stamens as many as the calyx-lobes and inserted near their bases, or opposite them upon the disk. Ovary 1celled; ovules $2-4$, pendulous from the summit of the central placenta; style cylindric, conic or sometimes none; stigma capitate. Fruit a drupe or nut. Seed I. Testa none; endosperm copious, fleshy; embryo small, apical. About 26 genera and 250 species, mostly of tropical distribution, a few in the temperate zones.

Perennial herbs; flowers perfect, cymose or solitary.

Shrubs : flowers imperfect, mostly diœcious.

Flowers racemose.

Staminate flowers umbellate, the pistillate solitary.

r. Comandra.

2. Pyrularia.

3. Nestronia.

\section{COMÁNDRA Nutt.}

Glabrous herbs, some (or all?) parasitic on roots of other plants. Leaves alternate, entire, pinnately veined. Flowers perfect, terminal or axillary, rarely solitary, cymose, bractless. Calyx campanulate, the base of its tube adnate to the ovary, its limb 5-lobed (rarely 4-lobed). Stamens 5, or rarely 4, inserted at the bases of the calyx-lobes and between the lobes of the disk, attached to the middle of the lobes by tufts of hairs. Anthers ovate, 2-celled. Fruit drupaceous, crowned by the persistent calyx. [Greek, referring to the hairy attachments of the anthers.] Four known species, the following N. Am., one European.

Cymes mostly corymbose-clustered at the summit of the stem; leaves acute, sessile; style slender.

Leaves oblong, pale green; fruit globose-urn-shaped.

Leaves lanceolate or linear, glaucous; fruit ovoid.

I. C. umbellata.

2. C. pallida.

Peduncles few, axillary; leaves oval, obtuse, short-petioled; style short. 3 . C. livida.

I. Comandra umbellàta (L.) Nutt. BASTaRd Toad-flax. (I. F. f. I273.) Stem slender, leafy, I.5-5 dm. tall. Leaves oblong or oblong-lanceolate, pale green, acute or subacute at both ends, sessile, ascending, I-3 cm. long, the lower smaller; cymes several-flowered, corymbose at the summit of the plant or also axillary; peduncles filiform; pedicels very short; calyx greenish white or purplish, 
about $4 \mathrm{~mm}$. high; drupe globose, 5-6 mm. in diameter. In dry fields and thickets, Cape Breton I. to Ont., Br. Col., Ga., Ariz. and Cal. April-July.

2. Comandra pállida A. I)C. Pale Comandra. (I. F. f. 1274.) Similar to the preceding but paler and glaucous, the leaves narrower, linear or linearlanceolate, acute or the lowest and those of the stem oblong-elliptic; cymes fewseveral-flowered, corymbose-clustered at the summit; peduncles usually short; calyx purplish, about $4 \mathrm{~mm}$. high; fruit ovoid-oblong, 6-8 mm. high. In dry soil, Man. to Br. Col., Minn., Kans., Tex. and Cal. April-July.

3. Comandra lívida Richards. Northern Comandra. (I. F. f. r275.) Stem slender, usually quite simple, I-3 dm. high. Leaves oval, thin, obtuse or rounded at the apex, narrowed at the base, short-petioled, $1-2.5 \mathrm{~cm}$. long, 6-I 2 $\mathrm{mm}$. wide ; petioles $2-4 \mathrm{~mm}$. long; cymes axillary, few (often only $\mathrm{I}$ to each plant), 1-5-flowered; peduncle shorter than its subtending leaf, filiform; flowers sessile ; drupe globose-oblong, about $6 \mathrm{~mm}$. in diameter, red, edible. In moist soil, Newf. to Hudson Bay, the N. W. Terr., Vt., Ont., Mich., and Br. Col. June-July.

\section{PYRULÀRIA Michx.}

A branching shrub (the Asiatic species trees), with thin alternate pinnately veined entire short-petioled deciduous leaves, and diœcious or polygamous small greenish racemose flowers. Staminate flowers with a campanulate 3-5-cleft calyx, the lobes valvate, pubescent at the base within; disk of 3-5 distinct glands or scales; stamens 4 or 5 , inserted between the glands and opposite the calyx-lobes; filaments short; anthers ovate. Pistillate and perfect flowers with a top-shaped calyx adnate to the obovoid ovary; style short, stout; stigma capitate, depressed. Fruit a pear-shaped or oval drupe, the endocarp thin and endosperm of the seed very oily. [Name from Pyrus, the pear, from the similar shape of the fruit.] Three species, the following and two Asiatic.

I. Pyrularia púbera Michx. Oil-nut. Buffalo-nut. (I. F. f. 1276.) A much branched shrub, I-5 m. tall, with terete twigs, the young foliage pubescent. Leaves oblong, oblong-lanceolate or somewhat obovate, nearly glabrous when mature, acute or acuminate at both ends, $1.5-3 \mathrm{~cm}$. wide; racemes terminating short branches, the staminate many-flowered, $2-5 \mathrm{~cm}$. long, the pistillate few-flowered and shorter; pedicels 3-4 mm. long; calyx 3-5-cleft; drupe about $2.5 \mathrm{~cm}$. long, crowned by the ovate acute calyx-lobes. In rich woods, Penn. to Ga. May. Fruit ripe Aug.-Sept.

\section{NESTRÒNIA Raf.}

A low glabrous diœecious shrub, with opposite short-petioled, oblong to ovate entire leaves. Staminate flowers small, in axillary peduncled umbels; calyx topshaped, 4-5-cleft, the lobes spreading, each with a tuft of wool; stamens as many as the calyx-segments and opposite them; disk crenate. Pistillate flowers solitary in the axils, short-peduncled; calyx narrowly top-shaped, 4.lobed; stamens 4; style short, 4-lobed; ovary adnate to the calyx. Fruit an oval I-seeded drupe. [From the Greek name of Daphne.] A monotypic genus of the southeastern U. S.

r. Nestronia umbéllula Raf. Nestronia. (I. F. f. I276a.) Shrub 3-1o dm. high, branching. Leaves thin, $2-5 \mathrm{~cm}$. long, pinnately veined, bright green above; petioles 2-6 $\mathrm{mm}$. long; peduncles of the staminate 3-9-flowered umbels filiform, the pedicels about $4 \mathrm{~mm}$. long, equalling the green calyx; stamens shorter than the oblong-ovate calyx-segments, pistillate calyx glaucescent, about $6 \mathrm{~mm}$. long, the lobes much shorter than the tube; drupe about $1.2 \mathrm{~cm}$. in diameter. In woods and along streams, Va. to Ga. and Ala. April-May.

\section{Order I2. ARISTOLOCHIÀLES.}

Herbs or vines, mostly with cordate or reniform leaves and perfect flowers. Calyx inferior, its tube wholly or partly adnate to the ovary, Corolla none. Ovary several- (mostly 6-) celled. Only the following family. 


\title{
Family I. ARISTOLOCHIÀCEAE Blume.*
}

\author{
Birthwort Family.
}

Acaulescent plants, or with erect or twining stems. Leaves alternate, often basal, exstipulate. Flowers regular or irregular, sometimes clustered. Calyx-limb 3-6-lobed or irregular. Stamens 6-many, adnate to the pistil; anthers 2-celled, their sacs longitudinally dehiscent. Ovules numerous in each cavity, anatropous, horizontal or pendulous. Fruit a many-seeded 6-celled capsule. Seeds angled or compressed, with a crustaceous testa and usually with a fleshy or dilated raphe; endosperm fleshy, copious; embryo minute. Six genera and about 200 species of wide distribution in tropical and temperate regions.

Acauiescent herbs; perianth regular, persistent ; filaments distinct.

Calyx-tube mainly free from the ovary; filaments shorter than the anthers; styles distinct.

1. Hexastylis.

Calyx-tube wholly adnate to the ovary; filaments longer than the anthers: styles united.

Vines or erect leafy-stemmed herbs ; perianth irregular, deciduous; anthers sessile.

3. Aristolochia.

\section{r. HEXÁSTYLIS Raf.}

Perennial evergreen acaulescent herbs with glabrous or nearly glabrous foliage. Rootstocks dichotomously branched; roots fleshy. Leaves usually I every year, the blades leathery, often mottled, petioled. Flowers solitary, on a pedicel arising from a membranous bract. Calyx glabrous without, the tube terete, some. times inflated, the 3 segments shorter than the tube, valvate. Corolla none. Stamens 12; filaments shorter than the anthers or wanting. Ovary mainly free from the calyx-tube. Styles distinct, prolonged beyond the extrorse stigmas into cleft appendages. Capsule free, sometimes distending the calyx-tube. Seeds flattened. [Greek, referring to the six styles.]

Leaf-blades mostly of an ovate or suborbicular type.

Calyx-tube turbinate during anthesis.

1. H. heterophylla.

Calyx-tube campanulate, cylindric-campanulate, sometimes constricted at the throat.

Calyx $2.5-5 \mathrm{~cm}$. long, much longer than thick.

Calyx $1-2 \mathrm{~cm}$. long, slightly longer than thick.

2. H. Shuttleworthit.

Calyx campanulate at maturity, its segments about one-half as long as the tube.

3. H. Virginica.

Calyx urn-shaped at maturity, its segments barely one-third as long as the tube.

4. H. Memmingeri.

Leaf-blades mostly of a hastate type.

Calyx not constricted at the throat; segments erect.

Calyx constricted at the throat ; segments spreading.

5. H. Ruthii.

6. H. arifolia.

I. Hexastylis heterophylla (Ashe) Small. Ashe's Hexastylis. Leafblades ovate to orbicular-reniform or triangular-ovate, $5-10 \mathrm{~cm}$. long, acute or sometimes rounded or retuse at the apex, with a slightly open sinus; petioles as long as the blades or twice as long: calyx $\mathbf{I}-\mathbf{1} .5 \mathrm{~cm}$. long, the tubes turbinate at least during anthesis, the segments $8-12 \mathrm{~mm}$. broad, often nearly as long as the tube, crisped, orange, purple or brown-purple without, brighter within ; prolongations of the styles very stout, barely notched; capsules hardly distending the calyx at maturity ; seeds oval. In mountain woods, Va. to Ga. and Ala. March to May. (Asarum heterophyllum Ashe.)

2. Hexastylis Shúttleworthii (J. Britten) Small. LARge flowered Hexastylis. (I. F. f. 1279.) Leaf-blades ovate to suborbicular or rhombic-orbicular, 5-8 cm. long, apiculate or obtuse ; petioles as long as the blades or longer; calyx 2.5-5 cm. long; the tube cylindric campanulate, the segments $1.5-2 \mathrm{~cm}$. broad, often abruptly acute, mottled within; pedicels shorter than the diameter of the calyx-tube ; prolongations of the styles stout, barely notched ; capsule hardly distending the calyx; seeds triangular in outline. In high-mountain woods, Va. to 
N. C. and Tenn. May to July. [Asarum macranthum (Shuttlw.) Small; not Hook. A. Shuttleworthii J. Britten.]

3. Hexastylis Virgínica (L.) Small. Virginia Hexastylis. (I. F. f. 1278. ) Leaf-blades ovate or rarely orbicular-ovate, $4-9 \mathrm{~cm}$. long, mostly obtuse or retuse, usually with an open sinus; petioles as long as the blades or twice as long; calyx $1.5^{-2} \mathrm{~cm}$. long, the tube campanulate; the segments less than $\mathrm{I} \mathrm{cm}$. broad, rarely half as long as the tube, spreading, usually purplish and sometimes mottled within; pedicel about as long as the calyx; prolongations of the styles stout, barely notched; capsule only slightly distending the calyx; seeds oblong. In woods, Va. and W. Va., south to S. Car. and Tenn. May-June. (Asarum Virginicum L.)

4. Hexastylis Mémmingeri (Ashe) Small. Memminger's Hexastylis. Slender. Leaf-blades suborbicular or ovate, 4-7 cm. long, mostly obtuse or retuse, sometimes mottled, with a slightly open sinus; petioles about as long as the blades or much longer; calyx I-1.5 cm. long, urn-shaped, the tube more or less constricted at the throat; the segments rarely over $3 \mathrm{~mm}$. long, obtuse; pedicel as long as the calyx or shorter; prolongations of the styles slender, usually deeply cleft; capsule conspicuously distending the calyx; seed sharply triangular. In sandy woods, Va. and W. Va., south to Ga. May and June. (Asarum Memmingeri Ashe.)

5. Hexastylis Rúthii (Ashe) Small. Ruth's Hexastylis. Stout. Leafblades hastate to triangular, occasionally slightly rhombic, $8-15 \mathrm{~cm}$. long, obtuse, retuse or abruptly pointed, with a rather narrow sinus; petioles longer than the blades; calyx $2-3 \mathrm{~cm}$. long; the tube narrowed to the mouth but not constricted, usually over ro $\mathrm{mm}$. in diameter at the throat, the segments erect, mostly longer than broud, dull purplish green within; pedicel as long as the calyx or much longer; prolongations of the styles notched to the stigma; capsule barely distending the calyx-tube. In sandy woods, S. W. Va. to Tenn. and Ala. April to July. (Asarum Ruthii Ashe.)

6. Hexastylis arifòlia (Michx.) Small. Halberd-Leaved Hexastylis. (I. F. f. 1280.) Stout. Leaf-blades hastate, triangular or ovate-hastate, $6-12 \mathrm{~cm}$. long, mostly obtuse or retuse, entire, sometinies with a wide-open sinus; petioles usually much longer than the blades; calyx $2-3 \mathrm{~cm}$. long, urn-shaped; the tube less than $8 \mathrm{~mm}$. in diameter at the constricted throat; the segments triangular or rounded, broader than long, spreading, purple-brown within; prolongations of the styles cleft to the top of the stigmas; capsule only slightly distending the calyx-tube. In sandy soil, Va. to Ga. and Ala. May to July. (Asarum arifolium Michx.)

\section{2. ÁSARUM L.}

Perennial acaulescent herbs, with usually manifestly pubescent foliage. Rootstocks elongated; roots fibrous. Leaves in pairs, deciduous, the blades membranous, mostly broader than long, cordate at the base, petioled. Flowers on pedicels arising from between the petioles. Calyx pubescent without, the tube angled, the 3 segments as long as the tube or longer, inflexed in the bud. Corolla none. Stamens 12: filaments longer than the anthers. Ovary adnate to the calyx-tube. Styles united; stigmas terminal. Capsules inferior, angled. Seeds plump. [The ancient name, meaning obscure.]

Calyx-segments lanceolate-acuminate, longer than the tube, not reflexed.

Calyx-segments slightly longer than the tube, the tubular portion $4-8 \mathrm{~mm}$. long; species mainly Alleghenian.

I. A. Canadense.

Calyx-seginents much longer than the tube, the tubular portion 10-20 $\mathrm{mm}$. long; species campestrian.

Calyx-segments triangular, merely acute, about as long as the tube, reflexed.

2. A. acuminatum.

3. A reflexum.

r. Asarum Canadénse L. Wild Ginger. (I. F. f. 1277.) Foliage finely pubescent. Petioles $\mathbf{r}$.5-3 dm. long: blades reniform, I-I.8 dm. broad, often short-pointed, with a usually closed basal sinus : calyx slender, pedicelled, pubescent without, $2-3.8 \mathrm{~cm}$. broad, mainly brownish purple, its tube angled, its segments lanceolate, acuminate, longer than the tube, with tubular tips 4-8 mm. lono, curving upward; style-column 6.lobed: capsule $12-15 \mathrm{~mm}$. in diameter. In rich woods, N. B. to Quebec, Ont. and N. C. April-May.

2. Asarım acuminàtum (Ashe) Bicknell. Long-Tipped Wild Ginger. (I. F. f. I277a.) Quite similar to $A$. Canadense, but more pubescent, at least 
when young. Leaf-blades very thin, reniform-cordate, and acutely short-pointed or broadly reniform and blunt, densely cinereous-tomentulose beneath, less closely so in age, the larger nerves often somewhat bristly, thus giving the lower surfaces a white-reticulated aspect; calyx-segments much longer than those of $A$. Canadense and of a duller brownish purple color, caudate-acuminate or flagellate, the tubular terminations Io-20 mm. long, recurved-spreading. In rich woods, Minn. and Wis. to Manitoba, Ind. and Ohio. May-June.

3. Asarum refléxum Bicknell. Short-lobed Wild Ginger. (I. F. f. 12776.) Similar to the two preceding species in habit, but more loosely pubescent and with more elongated and slender rootstocks; leaf-blades reniform, much broader than long, blunt-tipped, the upper surface and the petioles nearly glabrous in age; calyx much smaller, the tube white within, the segments early reflexed, triangular, purplish brown, about as long as the tube, with a straight obtuse tip 2-4 mm. long. In rich woods, along streams and in river valleys, Conn. to Iowa, N. C., Mo. and Kan. April-May.

Asarum reflexum ambiguum Bicknell. Leaf-blades short and conspicuously broad, wirh a wide and often rectangular sinus; calyx-segments narrower and longer, 12-19 $\mathrm{mm}$. long, the straight tip $4^{-8} \mathrm{mrn}$. long, sometimes extending back to the base of the ovary. Mich., Ill. and Mo.

\section{ARIStolòchia L.:}

Perennial herbs or twining vines. Leaves alternate, mostly petioled and entire (some exotic species 3-7-lobed), cordate, palmately nerved. Flowers irregular. Calyx adnate to the ovary, at least to its base, the tube usually inflated around the style and contracted at the throat, the limb spreading or reflexed, entire, 3-6. lobed or appendaged. Stamens mostly 6 ; anthers adnate to the short style or stigma, 2.celled, the sacs longitudinally dehiscent. Ovary mostly 6.celled with 6 parietal placentæ. Style 3-6-lobed. Capsule naked, septicidally 6-valved. Seeds very numerous, horizontal, compressed. [Named for its supposed medicinal properties.] Alout 180 species, widely distributed in tropical and temperate regions. Besides the following, some 6 others occur in the southern and western United States.

\section{Erect herbs.}

Calyx-tube bent ; flowers solitary, on basal scaly branches.

Leaves hastate at the base ; capsules 5-6 mm. in diameter. I. A. Nashii.

Leaves merely cordate at the base ; capsules about ro mm. in diameter.

Calyx-tube straight ; flowers axillary, clustered.

2. A. Serpentaria. 3. A. Clematitis.

Tall twining vines; flowers axillary; calyx-tube bent.

Leaves minutely pubescent ; calyx-limb flat, spreading.

Leaves tomentose; calyx-limb rugose, reflexed.

4. A. macrophylla. 5. A. tomentosa.

r. Aristolochia Nàshii Kearney. NAsh's Snakeroot. Stems erect or reclining, I-3 dm. long, zigzag, simple or branched below; leaves thin, linear or linear-lanceolate above the hastate base, 2-10 $\mathrm{cm}$. long, acuminate, ciliate, shortpetioled; peduncles slender; bracts $2-4 \mathrm{~mm}$. long; calyx S-shaped, brownish purple, IO-12 mm. long, the limb slightly 3 -lobed, about I cm. broad; capsules subglobose, 5-6 mm. in diameter, sharply angled. In damp woods, Va. to Fla. and La. Summer.

2. Aristolochia Serpentària L. Virginia Snakeroot. Serpentary. (I. F. f. 1281.) Stems erect, 2-5 dm. tall, sometimes branched below, more or less zigzag; leaves rather thin, oblong-lanceolate to ovate or oval-lanceolate, $4-15 \mathrm{~cm}$. long, acuminate, undulate, cordate, short-petioled; peduncles scaly, solitary or clustered; bracts 2-3 mm. long; calyx S-shaped, about $1 \mathrm{~cm}$. long, the limb slightly 3-lobed; capsules subglobose, about $10 \mathrm{~mm}$. in diameter, somewhat ribhed; flowers sometimes cleistogamous. In dry woods, Conn. and N. Y. to Mich., south to Fla. and La. Summer.

3. Aristolochia Clematitis L. Birthwort. (I. F. f. 1282.) Stem erect, glabrous, zigzag, 3-6 dm. tall; leaves dark green, reniform, glabrous, or their margins minutely spinulose-ciliate, strongly reticulate-veined, $5^{-1} 3 \mathrm{~cm}$. wide; petioles shorter than the blades; flowers fascicled in the axils, $2.5-3.5 \mathrm{~cm}$. long; tube 
of the calyx yellowish green, straight, enlarged around the ovary, the lobes appendaged; anthers equidistant. Near Ithaca and Flushing, N. Y., and E. Penn. Escaped from cultivation. Native of southern Europe. Summer.

4. Aristolochia macrophylla Lam. Dutchman's Pipe. (I. F. f. 1283.) A twining vine, the stem sometimes $2.5 \mathrm{~cm}$. in diameter and $10 \mathrm{~m}$. long; leaves thin, broadly reniform or suborbicular, densely pubescent beneath when young, glabrous or nearly so, and 1.5-3.6 dm. broad when mature; petioles $2.5-10 \mathrm{~cm}$. long; peduncles solitary or 2 or 3 together, about as long as the petioles, each with a suborbicular clasping bract at about the middle $12-25 \mathrm{~mm}$. in diameter; calyx-tube strongly curved, $2.5 \mathrm{~cm}$. long or more, contracted at the throat, yellowish green, veiny, the limb flat, spreading, purple-brown, somewhat 3-lobed; anthers contiguous in pairs under the 3 lobes of the stigma; capsule oblong-cylindric, 5-7.5 cm. long. In rich woods, S. Penn. to Minn., Ga., Tenn. and Kans. May-June. Fruit ripe Sept.

5. Aristolochia tomentòsa Sims. Woolly PIPE-VINe. (I. F. f. I284.) Similar to the preceding, but the twigs, petioles, leaves and peduncles persistently tomentose. Leaves suborbicular or broadly ovate, $0.7-1.5 \mathrm{dm}$. broad when mature; petioles rather stout; peduncles mostly solitary, bractless; calyx-tube sharply curved, yellowish green, about $3 \mathrm{~cm}$. long, its throat nearly closed, the limb dark purple, 3-lobed; capsule oblong-cylindric. In woods, Mo., Kans., and S. III. to N. Car., Ala. and Fla. May-June.

\section{Order I3. POLYGONÀLES.}

Characters of the only family, Polygonaceae, as given below.

\section{Family I. POLYGONÀCEAE Lindl.*}

\section{Buckwheat Family.}

Herbs, twining vines, shrubs or trees, with alternate, or sometimes opposite or whorled, simple mostly entire leaves, jointed stems, and usually sheathing united stipules (ocreae). Flowers small, regular, perfect, diœecious, monœcious or polygamous. Petals none. Calyx inferior, 2-6-cleft or 2-6-parted, the segments or sepals more or less imbricated, sometimes petaloid, sometimes developing wings in fruit. Stamens 2-9, inserted near the base of the calyx ; filaments filiform or subulate, often dilated at the base, distinct or united into a ring; anthers 2-celled, the sacs longitudinally dehiscent. Ovary superior, I-celled; ovule solitary, orthotropous, erect or pendulous; style 2-3-cleft or 2-3-parted, sometimes very short; stigmas capitate or tufted, rarely 2 -cleft; fruit a lenticular 3-angled or rarely 4-angled achene, usually invested by the persistent calyx ; endosperm mealy; cotyledons accumbent or incumbent; embryo straight or nearly so. About 30 genera and 800 species, of wide geographic distribution.

Flowers subtended by involucres.

Ocreae present ; calyx 2-4-parted; stamens 3 or fewer.

Ocreae none; calyx 6-cleft or 6 parted ; stamens 9.

1. Macounastrum.

2. Eriogonum.

Flowers not involucrate: stamens $4-8$.

Ocreae present; stigmas tufted.

Calyx 6-parted; style 3-parted; achene 3-angled.

Calyx 4-parted; style 2-parted; achene lenticular.

Ocreae present ; stigmas capitate.

Pedicels mostly several together; achene much surpassing the calyx.

3. Rumex.

4. Oxyria.

5. Fagopyrum.

Pedicels usually fascicled; achene mostly enclosed by the enlarged calyx.

Pedicels solitary; leaves jointed at the base.

Ocreae obscure or wanting; stigmas 2-cleft.

8. Brunnichia. 


\section{MACOUNÁSTRUM Small.}

Low glabrous annual herbs, with fibrous roots, erect or spreading simple or forked stems, alternate or opposite leaves, funnelform membranous ocreae, and minute perfect terminal clustered flowers, subtended by a several-leaved involucre. Calyx 2-4-parted (usually 3-parted), greenish-white, the segments valvate, equal ; pedicels subtended by transparent bracts: stamens 2 or 4 , alternate with and often protruding between the calyx-segments; filaments stout; style 2-3-parted; stigmas capitate; achene ovoid, exceeding the persistent calyx; embryo eccentric, accumbent. Two or three species, the following circumboreal, the others of the higher Hinalayas.

I. Macounastrum Islándicum (L.) Small. Macounastrum. (I. F. f. I2 $\delta_{5}$.) Stems very slender, $2.5^{-10} \mathrm{~cm}$. long, sometimes tufted. Leaves obovate, oblong or almost orbicular, 2-10 mm. long, fleshy, obtuse, sessile or short-petioled; ocreae about I mm. long; involucre consisting of 3-6 obovate or orbicular bracts; flowers fascicled in the involucres, short-pedicelled; calyx I mm. long, the segments ovatelanceolate, rather obtuse; style-branches short; achene less than $2 \mathrm{~mm}$. long, brown, striate, its faces convex. Greenland and Labrador to Hudson Bay and Alaska. Also in arctic Europe and Asia. Summer.

\section{ERIÓGONUM Michx.}

Anıual or peremnial acaulescent or leafy-stemmed herbs, some species very woody at the base, often with tufted stems, and entire alternate opposite or whorled leaves. Flowers small, fascicled, cymose, umbellate or capitate, subtended by 5-8-toothed or cleft involucres. Calyx 6 cleft or 6-parted, usually colored, the segments equal or the outer ones larger. Stamens 9; filaments filiform, often villous. Style 3-parted; stigmas capitate. Achene pyramidal, 3-angled, more or less swollen near the base, invested by the calyx-segments, or winged. Embryo axial or somewhat eccentric. [Greek, referring to the woolly and jointed stems.] About 160 species, natives of America, mostly of the western U. S.

Achenes 3-winged.

I. E. alatum.

Achenes merely angled, never winged.

Calyx contracted into a stipe-like base.

Caulescent ; stems topped by compound cymes.

Sten leaves alternate.

Sten leaves opposite or whorled.

2. E. longifolium.

Calyx yellow; basal leaves rounded at the base ; Alleghenian.

3. E. Allenii.

Calyx white or pink; basal leaves narrowed at the base; campestrian. 4. E. Jamesii.

Scapose ; stems topped by simple umbels.

5. E. flavum.

Calyx jointed to the pedicel without a stipe-like base.

Scapes or peduncles topped by capitate clusters.

Calyx glabrous; achenes over $2 \mathrm{~mm}$. long.

Calyx villous; achenes less than $2 \mathrm{~mm}$. long.
Scapes or peduncles topped by more or less compound cymes.

Involucres erect or at least never drooping.

Ovaries and achenes completely clothed with wool; leaf-blades silky above with silvery hairs.

8. E. lachnogynum.

Ovaries and achenes glabrous or villous at the top; leaf-blades more or less floccose.

Annual; herbaceous throughout and usually simple at the base.

Perennial ; slırubby and much branched at the base.

9. E. annuum.

Calyx yellow.

Calyx white, pink or reddish.

10. E. campanulatum.

Leaf-blades copiously pubescent on both sides.

11. E. corymbosum.

Leaf-blades densely pubescent beneath, inconspicuously so above.

Inflorescence 2-3 times compound; branches spreading.

12. E. microthecum.

Inflorescence 5-7 times compound; branches erect or nearly so.

Involucres on drooping on deflexed peduncles.

13. E. effusum.

14. E. cernuum. 
I. Eriogonum alàtum Torr. Winged Eriogonum. (I. F. f. I 286.) Perennial, strigose. Stems erect, 3-9 dm. tall, paniculately branched; leaves mostly basal, spatulate to oblanceolate, $2.5-7.5 \mathrm{~cm}$. long, or those on the stem nearly linear, obtuse or rather acute, ciliate, with prominent midrib beneath ; panicle open; involucres in cymules, campanulate, 2-3 $\mathrm{mm}$. high, the 5 teeth obtuse, spreading or reflexed; calyx yellowish, $2 \mathrm{~mm}$. long; filaments glabrous; achenes 5-7 mm. long, glabrous, 3-winged its whole length. On plains and prairies, Neb. to Colo., south to Tex. and N. Mex. June-Sept.

2. Eriogonum longifòlium Nutt. LONG-LEAVED ERIOGonum. (I. F. $f$. 1287.) Perennial from a stout root, caulescent. Foliage strigose or somewhat tomeritose; stems erect, 6-13 dm. tall, paniculately or corymbosely branched above; leaves alternate, the blades narrowly oblong or linear-oblong, 5-22 cm. long, the lower ones with broad sheathing petioles, the upper sessile; bracts lanceolate to subulate; involucres turbinate-campanulate, 4-5 mm. long, silky ; calyx herbaceous, 4-5 $\mathrm{mm}$. long; achenes pubescent especially above, 4-5 $\mathrm{mm}$. long including the beak. In dry soil, S. Mo. to Tex. June-Nov.

3. Eriogonum Állenii S. Wats. Allen's Eriogonum. (I. F. f. 1288.) Perennial, floccose-tomentose; stems erect, 2-6 dm. tall, dichotomously branched above; leaves basal and in whorls of 3 's to 5 's at the nodes, the blades oblong or ovate-oblong, 6-8 cm. long, obtuse at both ends or cordate at the base, rather green above, the basal slender-petioled; involucres in clustered cymes, turbinate, 3-6 mm. high, with 5 obtuse teeth; calyx bright yellow, 6-7 mm. long, pubescent, the segments spatulate or obovate-spatulate, rounded, concave; stamens and style-branches exserted; achenes. On dry mountain slopes, Va. and W. Va. July-Aug.

4 Eriogonum Jàmesii Benth. James' Eriogonum. (I. F. f. 1289.) Perennial by woody rootstocks, tomentose with white or whitish hairs; stems short; leaves approximate, the blades oblong to oblong-spatulate, $3-8 \mathrm{~cm}$. long, narrowed into slender petioles which often exceed the blade in length, rarely glabrate above; peduncles erect, or assurgent, sometimes tufted, $\mathbf{r}-3 \mathrm{dm}$. tall, dichotomous and corymbose above; bracts broadened upward or oblong; involucres campanulate, about $5 \mathrm{~mm}$. high, sessile or short-stalked, with rounded teeth; calyx white or pink, $4 \mathrm{~mm}$. becoming 6-7 mm. long, the tube attenuate into a stipe-like base, the inner segments longer and slightly larger than the outer; filaments villous at the base; achene $4 \mathrm{~mm}$. long, pubescent above the swollen base. On plains and prairies, Kans. and Colo. south to N. Mex. and Ariz. June-Nov.

5. Eriogonum flàvum Nutt. Yellow ERIogonum. (I. F. f. 1299.) Perennial from a stout scaly base, scapose, tomentose throughout with white hairs; leaves crowded, linear-oblong to oblong-spatulate, $2.5-8 \mathrm{~cm}$. long, flat or nearly so, narrowed into short petioles with dilated bases; scapes erect, 5-30 cm. long, mostly solitary; involucres in terminal umbels, turbinate 4-5 $\mathrm{mm}$. high, shorter than their stalks, with blunt teeth; bracts subtending the umbel similar to the leaves but smaller; calyx yellow, about $6 \mathrm{~mm}$. long, copiously pubescent, narrowed into a stipe-like base; filaments villous at the base; achenes about $4 \mathrm{~mm}$. long, villous near the top. On dry plains and prairies, N. W. Terr. south to Neb., Kans. and Ariz. Summer.

6. Eriogonum pauciflòrum Pursh. Few-Flowered ERIOGonum. (I. F.f. 1294.) Perennial, sparingly pubescent; stems very short, covered with the persistent leaf-bases; leaves linear or linear-spatulate, $2.5-7.5 \mathrm{~cm}$. long, glabrous or nearly so above, tomentose or cottony beneath, becoming strongly revolute, slenderpetioled; peduncles slender, erect, 5-I5 cm. ligh, simple, sparingly tomentose; involucres 4-10, capitate, about $3 \mathrm{~mm}$. high, turbinate-campanulate, with 5 obtuse teeth ; calyx white, about $3 \mathrm{~mm}$. long, glabrous; achenes $2.5 \mathrm{~mm}$. long, the faces swollen about the middle, inconspicuously striate-reticulated. On dry plains, Neb. and Colo. Summer.

7. Eriogonum múlticeps Nees. Branched Eriogonum. (I. F. f. I293.) Perennial from a more or less matted base, tomentose with white hairs. Leaves spatulate, I.5-5 cm. long, num rous. obtuse; peduncles simple, $2.5^{-1} 5 \mathrm{~cm}$. long, rather slender; involucres $3-12$, in a head terminating the peduncles, about $3 \mathrm{~mm}$. high, with 5-6 acute teeth; bracts spatulate; calyx white or rose, $3 \mathrm{~mm}$. becoming $5 \mathrm{~mm}$. high, somewhat villous, the segments cuneate, obtuse or notched at the 
apex; filaments sparingly villous near the base; achenes I $\mathrm{mm}$. long. On dry plains or hillsides, Neb. and Colo. Summer.

8. Eriogonum lachnogỳnum Torr. LoNG-ROOTED ERIOgonum. (I. F. f. 1296.) Scapose perennial. Stems short, often tufted, clothed with the dilated petiole-bases; leaves numerous, crowded, lanceolate to narrowly oblong, $1.5-3 \mathrm{~cm}$. long: silky above, white tomentose beneath, somewhat revolute; scapes erect, I-3 $\mathrm{dm}$. tall, tomentose, branching into a dichotomous cyme above; involucres broad.y campanulate or nearly hemispheric, 3-4 $\mathrm{mm}$. high, commonly sessile, 5-toothed; bracts scale-like; calyx $3 \mathrm{~mm}$. long, densely silky-villous; filament villous at the base; achenes about $2 \mathrm{~mm}$. long, covered by a mass of cottony hairs. On dry plains and prairies, Kans. to Colo. and Ariz. Spring to fall.

9. Eriogonum ánnuum Nutt. ANNuAl ERIogonum. (I. F. í. I290.) Annual, caulescent white floccose-tomentose. Stems erect, 3-9 dm. tall; leaves narrowly oblong or oblanceolate, $2-7 \mathrm{~cm}$. long, sometimes revolute or crisped; peduncles shorter than the stems, topped by dicliotomous cymes; involucres turbinate or turbinate-campanulate, 2-3 mm. high, secund, short-stalked; calyx white or pink, I-2 $\mathrm{mm}$. long, glabrous, the outer segments obovate, the inner narrower, all truncate or retuse; achenes $\mathbf{1} .5 \mathrm{~mm}$. long, with a globular base and smooth-angled beak about as long as the base. On dry plains and prairies, Neb. to Tex., N. Mex. and Mex. July to Sept.

Io. Eriogonum campanulàtum Nutt. NARrow-Leaved Eriogonum. (I. F. f. 1297.) Perennial from a woody base. Stems branched, more or less tomentose; leaves crowded on short branches, narrowly oblanceolate or linear, 2-8 cm. long, obtuse, sometimes revolute, narrowed into petioles; pedancles erect or nearly so, I-3 dm. tall, glabrous, topped by often trichotomous cymes; involucres oblongturbinate, $2-3 \mathrm{~mm}$. high, with five obtuse teeth: bracts scale-like; calyx yellow, 1.5-2 $\mathrm{mm}$. long, the segments often becoming fiddle-shaped, retuse or emarginate; filaments villous below the middle; achenes $3 \mathrm{~mm}$. long, pitted, enlarged at the hase. In dry soil, Neb. to Ore., south to Utah and N. Mex. Summer and fall.

II. Eriogonum corymbòsum Benth. CRISP-LEAVEd Eriogonum. (I. F. t. 1292.) Perennial, caulescent, densely floccose-tomentose. Stem erect, branched, 3-6 dm. tall; leaves oblong or oval, I-4 cm. long, obtuse, more or less crisped, narrowed at the base; peduncles terminating leafy branches, $\mathbf{I}-10 \mathrm{~cm}$. long, topped by a trichotomous cyme; involucres campanulate, sessile, 2-4 mm. long, 5-toothed; calyx 2-4 $\mathrm{mm}$. long, white or pinkish, glabrous, the outer segments broadened upward, rounded or notched at the apex, broader and longer than the inner; filaments woolly below; achenes about $2 \mathrm{~mm}$. long, with a rounded base and rough angles especially on the beak. In dry soil, Neb. and Kans. to Utah, south to N. Mex. and Ariz. Aug.-Sept.

12. Eriogonum microthècum Nutt. SLender ERIogonim. (I. F. f. I 29I.) Shrubby, more or less floccose-tomentose, 1-3 dm. tall. Stems diflusely branched below, the branches spreading or ascending; leaves oblanceolate, spatulate or narrowly oblong, $1-2 \mathrm{~cm}$. long, flat or revolute, with short petioles; peduncles erect, 3-IO $\mathrm{cm}$. long, topped by small twice or thrice compound corymbose cymes; bracts scale-like; involucres narrowly campanulate, $2 \mathrm{~mm}$. high; the teeth acutish; calyx glabrous, white or pink, sometimes tinged with red, 2.5-3 $\mathrm{mm}$. long, the outer segments obovate or oval-obovate, the inner smaller, inclined to be oblong; filaments villous; achenes $2-2.5 \mathrm{~mm}$. long, swollen at the base. On dry plains or prairies, S. Dak. to Wash., south to Tex. and Calif. Summer and fall.

13. Eriogonum effùsum Nutt. EfFuse Eriogonum. Shrubby, 2-4 dm. tall, white floccose-tomentose. Stems stout, diffusely branched; leaves linear or narrowly oblong, I-4 cm. long, revolute; peduncles $2-10 \mathrm{~cm}$. long, topped by $5-7$ times compound stiff corymbose cymes; bracts scale-like ; involucres narrowly campanulate, $2-2.5 \mathrm{~mm}$. high, the tube slightly angled, the teeth rather obtuse; calyx $2 \mathrm{~mm}$. high, white, glabrous, the outer segments cuneate obovate, rounded at the apex, the inner notched; filaments villous, especially below the middle; achenes 3-angled. On dry plains or prairies, S. Dak. and Neb. to Wyo., south to N. Mex. Summer.

14. Eriogonum cérnuum Nutt. Nodding Eriogonum. (I. F. f. 1298.) Annual, nearly acaulescent, often difluse. Leaves basal, the blades suborbicular to oval, I-2 cm. long, obtuse or slightly apiculate, floccose-tomentose; the petioles 
as long as the blades or shorter; scapes erect, I -4 dm. tall, sometimes branched at the base, topped by trichotomous compound cymes; involticres turbinate-campanulate, I-2 mm. high, solitary on deflexcel peduncles, the teetl olstuse; calyx white or pinkis:1, 1-1.5 mm. long, the outer segments broadly obovate, ofien becoming fidile-shaped, the inner smaller; filments glabrous; achencs about I 1 m. long, with a globose base and rough angles. In dry soil, Neb. to Wyo. and Ore., south to N. Mex. and Arız. Summer and fall.

\section{RÙMEX L.}

Perennial or annual, leafy-stemned herbs, some species slightly woody, the reaves in some mainly hasal. Stem grooved, mostly branched, erect, spreading or creeping. Leives flat or crisped, the ocreate brittle and fugacious, the inflorescence of simp!c or compound, often panicled racemes. Flowers green, perfect, diøcious, or polygamo-monœeious, whorled, on jointed pedicels. Corolla none. Calyx 6-parted, the 3 outer sepals unchanged in fruit, the 3 inner ones mostly developed inte: wings, one or all three of which usually bear a callosity (tubercle); wings entire, dentate, or fringed with bristle-like teeth. Stamens 6, filaments glabrous. Style 3-parted: stigmas peltate, tufted; achene 3-angled. the angles usually margined. Embryo borne in onc of the faces of the 3 -angled seed. [The ancient Latin name.] About 130 species, of wide geo : raphic clistribution. Besides the following anme 6 others occur in the southern and western parts of North America.

\section{"Leaves hastate; flowers dic xions. follage acid; low species.}

Inner sepals not developing wings in fruit; achene granular. I. R. Acetos $34: 0$ Fruiting inner sepals developing wings; achene smooth.

Basal leaves numerous; wings orbicular-cordate.

Rasal leaves few; wings broadly oblong-cordate.

2. R. hastatulus.

3. R. Acetosa.

Leaves not hastate; flowers perfect or polygamo-diœcious; foliage scar $c$ ? ist cis all acid; tali species.

Leaves flat, bright or light green, or graucescent.

Wings, 12-35 $\mathrm{mm}$. broad, reddishi: no tubercles.

$W$ ings small, not red, bearing tubercles.

Tubercles usually 3 .

Pedicels little longer than the wings. 5 5. $R$. salicifolius.

Pedicels several times longer than the wings, $\quad 6$. $R$. verticillat,

Tubercle usually $\mathrm{I}$; pedicels equalling the wings. $\quad 7 . R$. altissin.

I Laves wavy-margined or crisped, dark green, not glaucescent.

'Vings entire, more or less undulate.

Lower leaves narrowed or acuminate at the base.

Tubercle $\mathrm{I}$.

Tubercles 3 .

Lowe1 leaves cordate or roundeci at the base.

Tubercles wanting.

Tubercles mostly 3 .

Inflorescence not leafy: pedicels long.

Inflorescence leafy: pedicels long.

Tubercle $\mathrm{r}$; inforescence not leaf $y$; pedicels short.

Wings toothed or fringed.

4. R. venosu。

8. R. Patientar.

9. R. Britanniza.

Io. R. occidentalns.

II. R. crispus.

12. R. conglomeratus.

13. R. sanguineus.

Lower leaves cordate.

Wings ovate or oblong-ovate; tubercles mostly 2.

Wings hastate or ovate-liastate; tubercle $\mathrm{I}$.

I4. R. pulcher.

15. $R$. obtusifol. $\therefore$

Lower leaves mostly narrowed at base: wings with 4 spreading bristle-like teeth.

16. R. persicarioides.

-. Rumex Acetosélla I. Firid or Sheep Sorrei. (I. F. f. 1299.) t.nnual or perennial, glabrous, diøeious; stem slender, erect or nearly so, the rootstock woody, horizontal or creeping. Leaves narrowly hastate, $5^{-16} \mathrm{~cm}$. long, obtuse or acute at the apex, usually widest above the midcle, petioled, the basal auricles entice or $\mathbf{1}$ - 2 toothed. or the uppermost leaves searly lineas and not auricled, all papillose; ocreate silvery, 2 purted, som lacerate; flowers in erect panicled ractemes; racemes interrupted; ca!: x green, I $\mathrm{mm}$. long, pedicelled; 
stamens exserted; achene less than $2 \mathrm{~mm}$. long, very granular, exceeding the persistent calyx, its angles not margined. In dry fields and on hillsides through out N. Am. except the extreme north. In large part naturalized from Europe. Sometimes a troublesome weed. May-Sept.

2. Rumex hastátulus Muhl. Engelmann's Sorrel. (I. F.f. I300.) Perennial from a woody base, glabrous, diœcious; stem rather strict, erect, $10-40 \mathrm{~cm}$. tall. Leaves hastate, oblong or oblanceolate, $2-10 \mathrm{~cm}$. long. the basal numerous, auricled at the base, subacute, petioled, those of the stem linear, all papillose; ocreae silvery, 2-parted, at length lacerate; racemes ascending, at length interrupted; calyx green, winged in fruit; pedicels equalling or longer than the wings; wings mostly broader than high, cordate, 2-4 mm. long; stamens slightly exserted; achene reddish, smooth, shining, less than $2 \mathrm{~mm}$. long, invested by the calyxwings, its angles margined. On the seacoast, S. N. Y. to Fla. and on the plains from Kans. to Tex. March-Aug.

3. Rumex Acetòsa L. Sorrel. Sour Dock. (I. F. f. 130I.) Perennial, glabrous, diœecious; stem erect, simple, grooved, 30-90 cm. tall. Leaves oblonghastate or ovate-sagittate, $2-12 \mathrm{~cm}$. long, acute, crisped on the margins, the basal few, long-petioled, the upper subsessile, the acute auricles entire or 1 -toothed and more or less reflexed; ocreae lacerate; racemes nearly erect, crowded, at length interrupted; calyx green, $2 \mathrm{~mm}$. long, winged in fruit; pedicels equalling or shorter than the wings, jointed; wings cordate, 4-5 $\mathrm{mm}$. long; achene rather more than $2 \mathrm{~mm}$. long, pointed, smooth, shining, blackish, invested by the calyx-wings. Lab. to Alaska. Naturalized from Europe in Vt., N. Y. and Penn. Summer.

4. Rumex venòsus Pursh. VEINED Dock. (I. F. f. I3O2.) Perennial by a woody rootstock, glabrous, stem rather stout, erect, somewhat flexuous, $15-40 \mathrm{~cm}$. tall, grooved, branched. Leaves ovate to oblong, 2-12 cm. long, acute at both ends, petioled, rather coriaceous; ocreae funnelform, thin, brittle; racemes mostly erect, soon interrupted; calyx red, pedicelled, conspicuously winged in fruit; pedice's at maturity rather stout, slightly shorter than the wings, jointed at about the middle; wings broad, suborbicular, with a deep sinus at the base, veiny, reddish; achene $6 \mathrm{~mm}$. long, smooth, shining, its faces concave, its angles margined. N. W.. Terr. to Ore. and Wash., South to Mo. and Nev. May-Aug.

5. Rumex salicifolius Weinm. White, Pale or Willow-leaved Dock. (I. F. f. I303.) Perennial, glabrous, pale green; stem erect, ascending, or sometimes spreading, flexuous, 3-9 dm. high. Leaves lanceolate, linear-lanceolate or the lower oblong, acute or acuminate at both ends, or rarely obtuse at the apex, petioled; racemes erect, divergent or reflexed, dense, in fruit interrupted below, $2 \mathrm{~mm}$. long, pedicelled; pedicel; slightly longer than the wings, jointed near the base; wings triangular-ovate, $3 \mathrm{~mm}$. long, undulate or subdentate, each bearing a large ovoid tubercle; achene $2 \mathrm{~mm}$. long, dark red, its faces concave, its angles slightly margined. In swamps, Lab. to S. N. Y., Fla., Neb., Tex. and L. Calif. Also in Europe. May-Sept.

6. Rumex verticillàtus L. Swamp Dock. (I. F. f. I304.) Perennial, glabrous, rather bright green; stem erect, ascending or decumbent, 6-15 dm. long, more or less flexuous when old. Leaves narrowly oblong, oblong-lanceolate or lanceolate, $5.30 \mathrm{~cm}$. long, narrowed at both ends or obtusish at the apex, slightly papillose, long-petioled; racemes interrupted below, spreading in fruit; calyx green, $2 \mathrm{~mm}$. long; pedicels stout, thickened above, jointed near the base, 3-5 times as long as the wings, or rarely shorter; wings broadly deltoid, $4 \mathrm{~mm}$. long, more or less decurrent on the pedicel, each bearing a narrowly ovoid tubercle; achere $2.5 \mathrm{~mm}$. long, reddish, pointed, its faces concave. In swamps, Quebec to Ont. and Iowa, south to Fla. and Tex. May-July.

7. Rumex altíssimus Wood. TALL or Peach-Leaved Dock. (I. F. f. 1305.) Perennial, glabrous, rather pale green; stem erect, simple or sparingly branched above, 3-12 dm. tall. Leaves lanceolate, oblong-lanceolate or ovatelanceolate (sometimes oblanceolate), 5-25 cm. long, acute at both ends, papillose; panicle rather open; racemes slightly interrupted in fruit; flowers .densely whorled, $2 \mathrm{~mm}$. long; pedicels slender, jointed near the base, as long as the wings; wings triangular-cordate, 4-5 $\mathrm{mm}$. long, usually one of them only bearing an ovoid tubercle; achene $3 \mathrm{~mm}$. long, dark red, its faces concave. Along streams and in swamps, Mass. to Neb., Md. and Tex. April-June. 
8. Rumex Patiéntia .L. Patience Dock. (I. F. f. I306.) Perennial, glabrous; stem erect, simple or sparingly branched, 6-15 dm. tall. Lower leaves ovate-lanceolate, long-petioled, IO-40 cm. long, the upper oblong-lanceolate or oblong-elliptic, acute or obtușish, the uppermost lanceolate; fruiting panicle dense; racemes erect, somewhat interrupted in fruit; flowers densely whorled; pedicels slender, 2-4 times as long as the calyx-wings, jointed below the middle; wings orbicular-cordate, 4-6 mm. long, one of them bearing a prominent ovoid callosity; achene $3 \mathrm{~mm}$. long, light brown, its faces concave, its angles obscurely margined. In waste places, Me. and Ont. to Wis., south to Conn., Penn. and Kans. Also in the Far West. Naturalized from Europe. May-June.

9. Rumex Británnica L. Great Water-Dock. nial, glabrous, dark green; stem stout, erect, more or less branched, 9-r $8 \mathrm{dm}$. tall. Leaves lanceolate or oblong lanceolate, the lower $3^{-6} \mathrm{dm}$. long, long-petioled, the upper 5-15 cm. long, short-petioled; fruiting panicle dense; racemes nearly erect, more or less interrupted; flowers densely whorled; pedicels slender, conspicuously jointed above the base, $1 / 2-2$ times as long as the calyx wings; wings broadly cordate, $6 \mathrm{~mm}$. long, irregularly denticulate, each bearing a large callosity; achene ovoid-oblong, or oblong, $4 \mathrm{~mm}$. long, pointed at both ends, brown, its faces concave, its angles slightly margined. In swamps and wet soil, N. B. and Ont. to Minn., N. J., Penn., Ill. and Neb. July-Aug.

10. Rumex occidentàlis S. Wats. Western Dock. (I. F. f. 1308.) Perennial. glabrous; stem strict, erect or nearly so, strongly grooved, 6-9 dm. high. Leaves lanceolate or ovate-lanceolate, bluish-green, somewhat crisped and wavy. margined, papillose, the lower $20-30 \mathrm{~cm}$. long, obtuse or subacute at the apex, more or less cordate at the base, long-petioled, the upper smaller and usually lanceolate; panicle rather dense, leafless or nearly so, erect; racemes usually not interrupted; flowers loosely whorled; calyx $2 \mathrm{~mm}$. long; pedicels obscurely jointed below the middle, 2-3 times longer than the calyx-wings; wings triangular-ovate, 5-8 mm. long, somewhat dentate or undulate, bearing no tubercles; achene oblong, 4-5 mm. long, short-pointed, chestnut-brown. In wet places, Lab. to Alaska, Ont., Rocky Mountains to Tex., and to Calif. May-Aug.

I I. Rumex críspus L. Curled Dock. (I. F. f. I309.) Perennial, gla. brous, dark green; stem rather slender, erect, 3-1o dm. tall. Leaves crisped and wavy-margined, the lower oblong or oblong-lanceolate, 15-30 cm. long, longpetioled, the upper narrowly oblong or lanceolate, 7-15 cm. long, short-petioled, all cordate or obtuse at the base, more or less papillose; panicle rather open; racemes simple or compound, by the elongation of the pedicels apparently continuous in fruit; flowers rather loosely whorled; fruiting pedicels $11 / 2-2$ times as long as the calyx-wings, jointed near the base; wings cordate, 3-4 $\mathrm{mm}$. long, truncate or notched at base, erose-dentate, or nearly entire, each bearing a tubercle; achene $2 \mathrm{~mm}$. long, dark brown. In fields and waste places nearly throughout the U. S. and southern British America. Often a troublesome weed. Naturalized from Europe. Native also of Asia. June-Aug. Hybridizes with $R$. obtusifolius.

I2. Rumex conglomeràtus Murr. Clustered or Smaller Green Dock. (I. F. f. I3IO.) Perennial, glabrous, pale green; stem slender, erect, 3-9 dm. tall. Leaves ovate, oblong or lanceolate, $2.5-14 \mathrm{~cm}$. long, some of them slightly fiddleshaped, acute at the apex, obtuse at the base, crenulate and slightly crisped, petioled; panicle loose and open in fruit; racemes leafy, slender, ascending, much interrupted; flowers loosely whorled; pedicels shorter than or equalling the calyxwings, jointed near the base; wings ovate, fiddle-shaped, $3 \mathrm{~mm}$. long, toothed near the base, each bearing a large oblong callosity; achene less than $2 \mathrm{~mm}$. long, pointed, red, its faces convex. In waste places, Va. to S. Car. Also in Calif. Naturalized from Europe. May-July.

13. Rumex sanguíneus L. BLOODY or Red-veined Dock. (I. F. f. I3II.) Perennial, glabrous; stem slender, erect, 3-9 dm. high. Leaves oblong, oblonglanceolate or lanceolate, $2.5^{-15} \mathrm{~cm}$. long, the lower long-petioled, cordate at the base, acute or obtuse at the apex, usually red-veined, the upper short-petioled; panicle loose: racemes slender, spreading, not leafy, interrupted; flowers loosely whorled; pedicels slender, I-I I $/ 2$ times as long as the calyx-wings, jointed at the base; wings oblong, $3 \mathrm{~mm}$. long, one of them bearing a spherical-oblong callosity; achene less than $2 \mathrm{~mm}$. long, sharp-pointed, dark red, its faces convex. In waste 
places and ballast, S. N. Y. to Va. and La. Uncommon. Naturalized or advenive from Europe. May-Aug.

14. Rumex púlcher L. Fiddle Dock. (I. F. f. I3 I2.) Perennial, dark green; stem slender, erect or procumbent, diffusely branched, 3-9 dm. long, the branches spreading. Leaves oblong, or some of the lower fiddle-shaped, 2.5I $5 \mathrm{~cm}$. long, long-petioled, obtuse at the apex, cordate at the base; upper oblong or oblong-lanceolate, $2.5-7.5 \mathrm{~cm}$. long, usually narrowed at both ends; petioles more or less pubescent; panicle loose; racemes long, divergent, sometimes reflexed, much interrupted, rather leafy; flowers few in the whorls; pedicels equalling the calyx-wings, jointed at or below the middle; wings ovate or oblong-ovate, $4 \mathrm{~mm}$. long, truncate at the base, one larger than the others or all three of different sizes, fringed with spine-like teeth, usually two, sometimes one or all three bearing tubercles; achene $2 \mathrm{~mm}$. long, pointed, reddish, its faces concave. In waste places, Va. to Fla. and La. Also on the Pacific Coast and in ballast about the northern seaports. Naturalized from Europe. June-Sept.

15. Rumex obtusifolius L. BROAD-LEAved or Bitter Dock. (I. F. f. I313.) Perennial, glabrous, dark green; stem stout, erect, more or less scurfy above, 6-12 dm. tall. Lower leaves oblong-lanceolate, 15-35 cm. long, long-petioled, all cordate or rounded at the base, obtuse or acute at the apex, the upper lanceolate or oblong-lanceolate, 5-15 cm. long, short-petioled, somewhat undulate or crisped; panicle rather open; racemes nearly erect, continuous or interrupted below; flowers loosely whorled; pedicels slender, somewhat longer than the calyxwings, jointed below the middle; wings hastate, $4-5 \mathrm{~mm}$. long, fringed with a few spreading spiny teeth, one of them bearing an oblong tubercle; achene $2 \mathrm{~mm}$. long, pointed, dark red, its faces concave, its angles slightly margined. In waste places, N. S. and N. B. to Ore., south to Fla. and Tex. Naturalized from Europe. Native also of Asia. June-Aug.

16. Rumex persicarioides L. Golden Dock. (I. F. f. I3I4.) Annual, pubescent, pale green; stem rather stout, erect and simple, or diffusely branched, 3-9 dm. high, sometimes spreading or creeping, very leafy. Leaves lanceolate, or oblong, 2.5-30 cm. long, narrowed at the base, or sometimes cordate, or sagittate, acute at the apex, undulate; panicle simple or compound ; racemes erect, leafybracted, mostly interrupted; flowers densely whorled; pedicels slender, I-I $\frac{1}{\%}$ times as long as the calyx-wings, jointed at the base; wings oblong, $2 \mathrm{~mm}$. long, with $\mathbf{I}-3$ bristles on each margin, each bearing an ovoid or oblong callosity; achene less than $2 \mathrm{~mm}$. long, pointed, reddish, its faces convex, its angles slightly margined. On sandy shores, N. B. to Va., extending across the continent through British America, south in the interior to Kan. and N. Mex. and on the Pacific Coast to Calif. Has been confounded with R. maritimus L. of the Old World. July-Oct.

\section{OXÝRIA Hill.}

Low fleshy glabrous perennial herbs, with erect stems. Leaves mostly basal, long-petioled, reniform or orbicular, cordate, palmately nerved, with cylindric ocreae. Flowers perfect, green, in terminal panicled racemes. Calyx 4-parted, the outer segments smaller than the inner; stamens 6, included; filaments short, subulate, glabrous. Ovary I-celled; ovule solitary; style 2-parted; stigmas fimbriate, persistent on the large wings of the fruiting calyx. Achene lenticular. Embryo straight, borne in the ceintre of the endosperm. [Greek, sour, from the acid leaves.] Two known species, the following, and one in the Himalayas.

1. Oxyria dígyna (L.) Camptdera. Mountain Sorrel. (I. F. f. I3 I5.) Rootstock large, chaffy: stems scape-like, simple or sparingly branched, leafless or nearly so, 5-30 cm. tall. Leaves reniform or orbicular-reniform, $1-3.5 \mathrm{~cm}$. wide, undulate, sometimes emarginate at the apex, the basal long-petioled; ocreae oblique, loose, racemes many-flowered; flowers slender-pedicelled; segments oblong, the inner erect, the outer reflexed in fruit; achene ovoid, smooth, surrounded by a broad membranous wing. Greenland and Lab. to Alaska, south to the White Mts. of N. H. and in the Rocky Mts. to Colo. Also in northern Europe and Asia. July-Sept.

\section{FAGOPỲRUM Gaertn.}

Annual or perennial rather fleshy usually glabrous leafy herbs, with erect, striate or grooved stems. Leaves alternate, petioled, hastate or deltoid, with ob. 
lique, cylindric or funnelform ocreae. Flowers small, white or green, in terminal or axillary usually paniculate racemes, perfect, borne solitary or several together from each ocreola, slender-pedicelled. Calyx about equally 5-parted, persistent and unchanged in fruit, the segments petaloid, shorter than the achene. Stamens 8; filaments filiform, glabrous. Ovary I-celled, I-ovuled; style 3-parted; stigmas capitate. Achene 3-angled. Embryo central, dividing the mealy endosperm into two parts; cotyledons broad. [Greek, beech-wheat, from the similarity of the grain.] About 6 species, native of Europe and Asia.

Racemes panicled or corymbose; angles of the achene not crested. Racemes mostly simple; angles of the achene crested, undulate.

I. F. Fagopyrum. 2. F. Tataricum.

I. Fagopyrum Fagopyrum (L.) Karst. Buckwheat. (I. F. f. I3 I6.) Annual, glabrous except at the nodes, stem 3-9 dm. high. Leaves hastate, $2.5-7.5 \mathrm{~cm}$. long, abruptly narrowed above the middle, acuminate, the nerves on the lower surface slightly scurfy; ocreae brittle and fugacious; racemes mostly panicled, sometimes corymbose, many-flowered, erect or inclined to droop: pedi. cels as long as the calyx; calyx-segments white or whitish; stamens included; style-branches deflexed in fruit; achene acute, $5 \mathrm{~mm}$. long, about twice as long as the calyx, its faces pinnately-striate when mature, the angles acute, not crested. In waste places, and persistent in fields after cultivation. Reported from almost all parts of the northern U.S. and southern British America. Native of eastern Europe or western Asia. June-Sept. [F. esculentum Moench.]

2. Fagopỳrum Tatáricum (L.) Gaertn. Tartary Buckivheat. (I. F. f. I317.) Annual, similar to the preceding species, but the leaves deltoid-hastate, or oblong hastate, often broader than long, $2.5-10 \mathrm{~cm}$. wide, acute or short-acuminate at the apex; racemes terminal and axillary, mostly solitary, simple and fewflowered, long-peduricled; flowers whitish, short-pedicelled; achene subacute, 5 $\mathrm{mm}$. long, its angles crested with three prominent lobes above the middle, its faces pinnately sulcate from a conspicuous groove. In waste places, eastern Canada and New England. Adventive from Asia. Summer.

\section{POLÝGONUM L. (See Appendix.)}

Annual or perennial, terrestrial or aquatic herbs, some species woody, with erect. prostrate, climbing or floating stems, alternate entire leaves, continuous with, or jointed to the cylindric funnelfurm or two-lobed, often lacerate or fringed ocreae, Flowers normally perfect, green, white, pink or purple, variously clustered, the clusters terminal or axillary. Pedicels jointed, subtended by ocreae or ocreolae; calyx 4-5-parted or 4-5-cleft, the outer sepals or segments somewhat larger than the inner: stamens 5-9, included or exserted; filaments filiform, or dilated at the base, glabrous; style 2-3-parted or 2-3-cleft, its branches included or exserted; stigmas capitate: achene lenticular or 3-angled (rarely 4 angled), invested by or exceeding the calyx. Embryo near the end of the seed, in one of its angles. [Greek, manyknees from the swollen joints of some species.] About 200 species, of wide geographic distribution. Besides the following, some 33 others occur in the western and southern parts of North America.

I. Flowers in terminal spike like racemes; calyx 5 -cleft or 5 -parted; stem not twining. Raceme solitary ; alpine species; perennial, not aquatic.

Racemes solitary or 2 ; aquatic or swamp species; perennials.

I. P. viviparum.

Leaves oblong, elliptic, or elliptic-lanceolate, not acuminate. 2. P. amphibium.

Leaves narrowly lanceolate, or oblong-lanceolate, not acuminate.

Leaves ovate-lanceolate, or oblong-lanceolate, usually acuminate.

3. P. Hartwrightii.

4. P. emersum.

Racemes several or numerous; annuals or perennials, mostly terrestrial.

Ocreae naked or ciliolate, their limbs not spreading.

Racemes drooping.

Achene ovoid; style 2.parted to near the base.

Achene broadly oblong-ovoid; style 2 -cleft to-below the middle. 
Racemes erect.

Style-branches scarcely or slightly exserted.

Achene broadly oblong, biconvex.

Achene orbicular, flat.

5. P. Portoricense.

Style-branches long-exserted; achene ovoid, somewhat gibbous.

Ocreae fringed with bristles, their limbs not spreading.

9. P. longistylum.

Racemes not interrupted, erect; achene lenticular or 3-angled.

Ocreae conspicuously fringed; achene broadly ovoid.

Ocreae inconspicuously fringed; achene narrowly ovoid.

10. P. Persicaria.

Racemes not interrupted, erect; achene always 3-angled.

II. P. persicarioides.

Ocreolae conspicuously fringed.

Ocreolae inconspicuously fringed.

14. P. Opelousanum.

Leaves mostly glabrous above; achene pointed at the top.

Leaves strigose above; achene pointed at both ends.

15. P. hydropiperoides,

Racemes not interrupted, drooping.

13. P. setaceum.

Racemes interrupted, erect or drooping.

Achene granular and dull: racemes drooping.

Achene smooth, shining; racemes erect.

Ocreae fringed with bristles, their limbs normally spreading.

12. P. Careyi.

16. P. Hydropiper.

1. P. punctatum.

18. P. orientale.

2. Flowers in long naked much interrupted spike-like racemes; calyx 4-parted.

19. F. Virginianum.

3. Flowers in axillary clusters; stems more or less wiry, not twining.

Plants prostrate; achene invested by the calyx.

Achene pointed at the apex, rounded at the base.

Leaves mostly acute; style 3 -parted to below the middle.

Leaves mostly obtuse; style 3-parted to the base.

Achene pointed at both ends.

20. P. aviculare.

21. P. littorale.

22. P. Bellardi.

Plants prostrate; achene protruding beyond the caly $x$.

Leaves mostly longer than the internodes; sea beach species.

Leaves shorter than the internoles; plant of waste places. 24. $\dot{P}_{\text {. Rayi. }}$ Rartim

Plants erect or ascending, rather stout.

Achene invested by the calyx.

Leaves oval, oblong or obovate, persistent.

25. P. erectum.

Leaves narrowly lanceolate or linear-oblong, persistent. 27. P. ramosissimum.

Leaves oblong-lanceolate or narrowly oblong, fugacious.

Achene much exserted beyond the calyx.

28. P. camporum.

26. P. exsertum.

Plants strictly erect and very slender.

Leaves with a lateral impression on either side of the midvein ; fruiting pedicels stout, erect.

Leaves without lateral impression; fruiting pedicels slender, deflexed.

3o. P. Douglasii.

4. Flowers in axillary and terminal clusters, racemes or panicled racemes; stems mostly twining.

Stems twining; herbaceous vines.

Outer segments of the calyx unchanged, or keeled in fruit. Achene granular and dull; ocreae not bristly.

Achene smooth and shining; ocreae bristly.

Outer segments of the calyx conspicuously winged in fruit. Calyx-wings not incised.

Fruiting calyx 10-12 mm. long, the wings crisped. 33. $P$. scandens.

Fruiting calyx 6-8 $\mathrm{mm}$. long, the wings rather flat. $34 . P$. dumetor $u m$.

Caly $x$-wings incised.

Stems stout, erect, tall; outer calyx-segments winged in fruit. 36. P. Zuccarinii.

35. P. cristatum.

31. P. Convolvulus. 32. P. cilinode.

36. $P$ uccarinii.

37. P. sagittatum.

38. $P$. arifolium.
Leaves sagittate; achene 3-angled.

Leaves halberd-shaped; achene lenticular.
I. F. f. 1318.) Perennial 
or clustered, erect, simple, 5-25 cm. tall. Basal leaves oblong u. anceorate, 2.5-20 $\mathrm{cm}$. long, rather acute at the apex, cordate or subcordate at the base, long-petioled; stem leaves narrowly lanceolate or linear, $2.5-7.5 \mathrm{~cm}$. long, the lower petioled, the upper sessile, their margins often revolute; ocreae clasping below, open above; raceme solitary, terminal, narrow, rather dense, bearing a number of rather darkcolored bulblets about its base; calyx 5-parted, pale rose-color or white; stamens 8 , exserted; style 3-parted, achene oblong, 3-angled. Greenland and Labrador to Alaska, south to the high summits of the mountains of New England, and in the Rocky Mountains to Colo. Also in Arctic and alpine Europe and Asia. JuneAug.

2. Polygonum amphíbium L. Water Persicaria. (I. F. f. I3 I9.) Aquatic, perennial, glabrous when mature; stem floating or submersed, 1-6 m. long. Leaves oblong, elliptic or elliptic-lanceolate, 4-10 cm. long, petioled, obtuse or subacute at the apex, slightly inequilateral, rounded or narrowed at the base, sometimes ciliate; ocreae cylindric, those of the branches often longer than the internodes, their limbs sometimes spreading, usually glabrous; raceme terminal, usually solitary, 12-25 mm. long, dense, erect, oblong or ovoid; calyx rose-color, 5-parted; stamens 5, exserted; style 2-cleft, exserted; achene orbicular-oblong, lenticular, $3 \mathrm{~mm}$. long, biconvex, black, smooth and shining, or granular. In ponds and lakes, Quebec to Alaska, south to northern N. J., Ky., Colo. and Cal. Also in Europe. July-Aug.

3. Polygonum Hartwrightii A. Gray. Hart Wright's Persicaria. (I. F. f. I320.) Perennial by rootstocks, more or less hispid; sten ascending, decumbent or erect, 1.5-6 dm. long, many-jointed, usually rather stout. Leaves lanceolate, oblong-lanceolate or oblong, 7-15 cm. long, obtuse or subacute the apex, short-petioled or sessile; ocreae cylindric, varying from one-half as long to as long as the internodes, the limb abruptly spreading, fringed with short bristles; racemes usually solitary, dense, $\mathbf{I}-2.5 \mathrm{~cm}$. long, oblong; calyx rose-colored, 5-parted; stamens 5, exserted; style exserted, 2-cleft to beyond the middle; achene oblong, biconvex, lenticular, black, smooth, shining. In swamps or moist soil, Hudson Bay to Ore., south to Me., S. Penn., Kans., Nev. and L. Calif. JuneAug.

4. Polygonum emérsum (Michx.) Britton. Swamp Persicaria. (I. F. f. 1321.) Perennial by long creeping or horizontal rootstocks, glabrous or strigosepubescent; stem erect or assurgent, commonly simple, enlarged at the nudes, 3-9 dm. or sometimes $6 \mathrm{~m}$. long. Leaves ovate-lanceolate or oblong-lanceolate, or the upper sometimes narrowly lanceolate. 6-20 cm. long, acute or usually acuminate at the apex, rounded or cordate at the base, petioled, the lateral nerves prominent, sometimes forking; ocreae cylindric, not ciliate; racemes $\mathbf{I}$ or 2 , erect, $2.5-8 \mathrm{~cm}$. long, linear-oblong, c'ense; calyx dark rose-color, 5-parted; stamens 5, exserted; style 2-cleft, exserted; achene broadly obovate or orbicular, $3 \mathrm{~mm}$. long, very convex, lenticular, black and slightly granular, but shining. In swamps and moist soil, Me., Ont. to N. W. Terr. and Br. Col., south to Va., La. and Mex. July-Sept. [P. Muhlenbergii S. Wats.]

5. Polygonum Portoricénse Bertero. Dense-Flowered Persicaria. (I. F. f. 1322.) Perennial, more or less scurfy; stem erect, decumbent or floating, I-1.5 m. long or longer, branched, enlarged at the nodes. Leaves lanceolate or linearlanceolate, 4-30 cm. long, acuminate at both ends, obscurely punctate, shortpetioled, the nerves prominent beneath; ocreae cylindric, sometimes bristly when young, naked when mature, sometimes hispid; racemes narrow, paniculate, often in pairs, $2.5^{-13} \mathrm{~cm}$. long, dense, erect; calyx white or whitish, 5 parted to near the base; stamens 6-8, included; style 2-3.cleft, somewhat exserted; achene lenticular and strongly biconvex or 3-angled, 2-3 $\mathrm{mm}$. long, broadly oblong, orbicular or even broader than high, black, smooth and shining, or minutely granular. In wet soil, Mo. to Fla., Tex., the W. I. and S. Am. May-Nov.

6. Polygonum incarnàtum Ell. Slender Pink Persicaria. (I. F. f. 1323.) Annual, glabrous or nearly so; stem erect, more or less swollen at the nodes, 6-12 dm. tall. Leaves lanceolate, 7-22 cm. long, acuminate at both ends, short-petioled, sparingly punctate and ciliate; ocreae cylindric, loose, brittle, sometimes ciliolate when young, glabrous when mature: racemes panicled, drooping, 3.5-10 cm. long, linear, many-flowered; calyx white or pink, small, 5-parted; 
stamens 6; style 2-parted to near the base; achene ovoid-oblong, lenticular, about $2 \mathrm{~mm}$. long, flat or biconcave, smooth, shining. In wet soil, Vt. to Ill. and Neb., south to Fli. and La. June-Sept.

7. Polygonum lapathifolium L. Dock-leaved or Pale Persicaria. (I. F. f. I324.) Annual, stem erect or ascending, swollen at the nodes, 3-9 dm. high, the peduncles and pedicels glandular. Leaves lanceolate or oblonglanceolate, 5-25 cm. long, usually broader than those of the preceding, attenuate to the apex, acuminate at the base, short-petioled, ciliate, inconspicuously punctate; ocreae cylindric, ribbed or striate; racemes panicled, $2.5-10 \mathrm{~cm}$. long, drooping, narrow, rather dense; calyx pink, greenish or white, 5-parted; stamens 6; style 2 -parted to below the middle; achene broadly oblong or ovoid, lenticular, $2 \mathrm{~mm}$. long, brownish or black, slightly reticulated but shining, its faces concave. In waste places, throughout temperate N. Am. Nat. from Europe. Sometimes a troublesome weed. Native also of Asia. June-Sept.

Polygonum lapathifoliuin nodòsum (Pers.) Small. Generally robust and glabrous; stem stout, reddish, purple spotted and with a purple ring below each ocrea, much thickened at the nodes; leaves conspicuously punctate; racemes $2.5-7.5 \mathrm{~cm}$. long, less drooping, often erect : achene slightly larger. Occasional in the range of the type.

Polygonum lapathifolium incanum (Schmidt) Koch. Low; stem slender, erect, 5-30 cm. high, slightly scurfy; leaves lanceolate, ovate or oblong, usually narrowed at the base, white-tomentose beneath, glabrous above; racemes $1-4 \mathrm{~cm}$. long. In waste places, N. S. to Ont., N. Y., and Br. Col.

8. Polygonum Pennsylvánicum L. Pennsylvania Persicaria. (I. F. f. 1325.) Annual, glabrous below; stem erect, 3-9 dm. tall, the upper parts, the peduncles and pedicels glandular. Leaves lanceolate, acuminate at the apex, petioled, ciliate, 5-30 cm. long, the upper sometimes glandular beneath; ocreae cylindric, naked, glabrous; racemes panicled, erect, thick, oblong or cylindric, dense, 2.5-5 cm. long; calyx dark pink or rose-color, 5-parted; stamens 8 or fewer; style 2 -cleft to about the middle; achene orbicular or mostly broader than high, $3 \mathrm{~mm}$. long, short-pointed, lenticular, smooth, shining. In moist soil, N. S. to Ont., Minn., Fla. and Tex. July-Sept.

9. Poly gonum longístylum Small. Long-Strled Persicaria. (I. F. f. 1326.) Annual or perennial, glabrous except the glandular upper branches and peduncles; stem erect, rather slender, 3-9 dm. tall. Leaves lanceolate or ovatelanceolate, 2.5-15 cm. long, acuminate at both ends, petioled, their margins undulate, slightly crisped, more or less ciliolate; ocreae cylindric, entire, brittle; racemes panicled, sometimes geminate, $2.5-8 \mathrm{~cm}$. long, rather dense, erect; calyx lilac, 5-parted to below the middle, the lobes petaloid; stamens 6-8, included; style 2-parted, slender, conspicuously exserted; stigmas black; achene broadly ovoid, lenticular, slightly gibbous on both sides, long-pointed, black, granular, but somewhat shining, $2.5 \mathrm{~mm}$. long. In moist soil, S. Ill. and Mo. to La. and N. Mex. Aug.-Oct.

ro. Polygonum Persicària L. Lady's Thumb. (I. F. f. 1327.) Annual, glabrous or puberulent; stem erect or ascending, r.5-6 dm. high. Leaves lanceolate or linear-lanceolate, 2-15 cm. long, acuminate at both ends, conspicuously punctate, usually with a dark triangular or lunar blotch near the centre, their margins entire or slightly eroded, often ciliate; ocreae cylindric, nearly glabrous, fringed with short bristles; racemes solitary or panicled, I-5 cm. long, ovoid or oblong, dense, erect; calyx pink or dark purple; stamens mostly 6; style 2-3parted to below the middle; achene broadly ovate and lenticular, often gibbous or 3-angled, 2-2.5 mm. long, smooth and shining. In waste places, throughout N. Am. except the extreme north. Nat. from Europe. Often an abundant weed. JuneOct.

I r. Polygonum persicarioides H. B. K. Southwestern Persicaria. (I. F. f. 1328.) Perennial, glabrous or minutely pubescent; stem erect, decumbent or creeping, 3-9 dm. long. Leaves lanceolate or linear-lanceolate, acuminate at both ends, punctate, 4-25 cm. long; ocreae cylindric, glabrous, or sparingly strigillose, fringed with short bristles; racemes more or less panicled, erect, $2.5-7.5 \mathrm{~cm}$. long, narrowly oblong or linear, loosely flowered; calyx rose-color tinged with green, 5-parted to below the middle; stamens 8 or fewer; style 2-3- 
parted to near the base; achene lenticular and biconvex, or 3-angled, more or less gibbous, $2 \mathrm{~mm}$. long, ovoid or broadly oblong, short-pointed, black, minutely granular, but shining. Neb. to Mex.; widely distributed in tropical Am. JuneSept.

I2. Polygonum Càreyi Olney. Carey's Persicaria. (I. F. f. I329.) Annual, rough-glandular throughout; stem erect, 3-9 dm. tall. Leaves oblonglanceolate or linear-lanceolate, the uppermost nearly linear, 5-27 cm. long, shortpetioled or nearly sessile, acuminate at both ends, hispid on the midrib, ciliate, sparingly punctate; ocreae cylindric, sparsely hispid, fringed with long bristles; racemes several, narrow, loosely fluwered, drooping, $2-7 \mathrm{~cm}$. long; calyx purplish; stamens 5 or sometimes 8 ; style 2 -parted to below the middle; achene lenticular, broadly ovoid or obovoid, $2.5-3 \mathrm{~cm}$. long, short-pointed, thick, smooth and shining. In marshes, Me. and Ont. to Mich., south to R. I., N. J. and Penn. July-Sept.

13. Polygonum setàceum Baldw. Bristly Persicaria. (I. F. f. I33o.) Perennial, strigose; stem 6-12 dm. high, erect, simple or sparingly branched; leaves lanceolate or oblong-lanceolate, 5-23 cm. long, acuminate at both ends, ciliate, inconspicuously punctate; ocreae cylindric, strigose, fringed with very long bristles; racemes few, terminal, 2.5-6.5 cm. long, erect, narrow, sometimes geminate, rather loosely flowered; calyx white or pink; stamens 8; style 3-parted to below the middle; achene 3-angled, oblong or obovoid, thick-pointed, $1-2 \mathrm{~mm}$. long, minutely reticulated and rather dull, or smooth and shining. In swamps, southern Mo. to La., east to N. Car. and Fla. June-Sept.

I4. Polygonum Opelousànum Riddell. Opelousas Persicaria. (I. F. f. 133I.) Perennial, glabrous or nearly so; stem slender, erect or ascending, sparingly or considerably branched, 3-9.dm. tall, becoming woody below. Leaves linear or linear-lanceolate, 4-13 cm. long, ciliate; ocreae cylindric, strigose, fringed with long bristles; spike-like racemes panicled, erect, often geminate, $1.2-5 \mathrm{~cm}$. long, not densely flowered; calyx white, 5-parted to below the middle; stamens 8 or fewer; style deeply 3-parted; achene 3-angled or rarely 4-angled, broadly ovoid or obovoid, I.5 mm. long, black, smooth and shining. Mo. to La., Tex. and Mex. July-Sept.

I5. Polygonum hydropiperoides Michx. Mild Water Pepper. (I. F. f. 1332.) Perennial, strigillose; stem erect, decumbent or prostrate, slender, 3-9 dm. long. Leaves narrowly lanceolate or oblong-lanceolate, varying to linear-lanceolate, 5-I5 cm. long, short petioled, acute at apex, ciliate, pubescent with appressed hairs on the midrib beneath; ocreae cylindric, loose, strigose, fringed with long bristles; racemes panicled, terminal, erect, narrow, more or less interrupted, 3-7.5 cm. long; calyx pink or greenish; stamens 8; style 3-parted to below the middle; achene 3-angled, ovoid or oblong, 2-2.5 $\mathrm{mm}$. long, smooth, shining. In swamps and wet soil, N. B. to Minn. and Calif., south to Fla. and Mex. June-Sept.

Polygonum hydropiperoldes Macouni Small. More robust than the type; stem 3-12 dm. long, clothed with stout appressed hairs; leaves lanceolate, obtuse; ocreolae more or less ciliate; calyx white or whitish, often conspicuous. Quebec to W. Va. and Ind. Also in Calif.

r6. Polygonum Hydrópiper L. Smart-weed. Water Pepper. (I. F. f. 1333.) Annual, glabrous, stem erect, often red or reddish, 2-6 dm. tall. Leaves lanceolate or oblong-lanceolate; $2.5-8 \mathrm{~cm}$. long, short-petioled, acute or acuminate at the apex, undulate or slightly crisped, punctate, ciliate, very acrid; ocreae cylindric, fringed with short bristles, sometimes slightly pubescent, usually swollen at the base by the development of several flowers within; racemes panicled, 2.5-7.5 cm. long, narrow, drooping, interrupted; calyx green, 3-5-parted (usually 4-parted), conspicuously punctate; stamens 4 or sometimes 6 : style short, 2-3-parted; achene lenticular or 3-angled, broadly oblong or ovoid, slightly gibbous, $2.5-3 \mathrm{~mm}$. long, granular, dull. In moist waste places, almost throughout N. Am. Naturalized from Europe in our area, perhaps indigenous in the far Northwest. July-Sept.

17. Polygouum punctàtum Ell. DotTed or Water Smart-WeEd. (I. F. f. 1334.) Annual or perennial, glabrous or very nearly so; stem erect or ascending, rarely prostrate, simple or branched, 3-12 dm. long. Leaves lanceolate or oblonglanceolate, 3-20 cm. long, acuminate at both ends, petioled, ciliate, conspicuously punctate, acrid, the midrib often with a few scattered hairs; ocreae cylindric, 
falling away at maturity, fringe 1 with long bristles; racemes narrow, erect or slightly drooping, loosely-flowered, $2-8 \mathrm{~cm}$. lung; calyx greenish; stamens 8 ; style 2-3-parted to the base; achene oblong, thick, lenticular or 3-angled, $2.5 \mathrm{~mm}$. long, smooth, shining. In swamps and wet places, throughout N. Am. except the extreme north. June-Oct. [P. acre H. B. K., not Lam.]

Polygonum punctàtum leptostàchyum (Meisn.) Small. Rather smaller; stem slender, 3-6 dm. long; leaves narrower; racemes very slender and much interrupted, clustered at the summit; achene about $2 \mathrm{~mm}$. long, oblong, shining. Vt. to Calif., south to Fla. and Mex.

Polygonum punctatum robústior Small. Larger and stouter than the type, leafy : stem 6-12 dm. tall, conspicuously enlarged at the nodes; leaves 5-20 cm. long; racemis thicker, 2.5-10 cm. long, interrupted below; achene $3 \mathrm{~mm}$. long, slightly granular, sonewhat obovoid; calyx-segments white. Mass. to Fla., near the coast.

18. Polygonum orientàle L. Prince's Feather. (I. F. f. 1335.) Annual, more or less hispid; stem erect, 3-25 dm. tall, branched. Leaves ovate or broadly oblong, 7-30 cni. long, petioled, acuminate at the apex, ciliate; petioles slightly winged; ocreae cylindric, loose, mostly with a spreading border, ciliate; racemes panicled, oblong-cylindric, $2.5-10 \mathrm{~cm}$. long, dense, drooping; flowers large for the genus; calyx dark rose-color or crimson; stamens 7, exserted; style 2.cleft to abcve the middle; achene orbicular or broader than long, lenticular, flat, $3 \mathrm{~mm}$. in diameter, finely reticulated and rather dull. In waste places, escaped from gardens throughout eastern N. Am. Native of India. Aug.-Sept.

19. Polygonum Virginiànum L. VIRGinia KNOTWEeD. (I. F. f. I336.) Annual, nearly glabrous, or strigose; stem erect cr arching, simple, or branched above, 3-12 dm. tall. Leaves ovate, elliptic.ovate or cvate-lanceolate. shortpetioled, acuminate at the apex, $5^{-15} \mathrm{~cm} . \mathrm{kng}$, sparingly ciliate; ocreae cylindric, strigose, fringed with short bristles; racemes spike-like, naked, greatly elongated and interrupted, sometimes 4-5 dm. long; calyx curved, greenish or rose-color, 4-cleft; stamens 5; style long, exserted, 2-parted to the base, its branches at length curled; achene $4 \mathrm{~mm}$. long, cvate-oblong. lenticular, strcngly biconvex, dark brown or cream-colored, shining. In wocds, N.S. to Minn., south to Fla. and Tex. July-Nov.

20. Polygonum aviculàre L. KNotgrass. Door-WeEd. (I. F. f. I337.) Annual or commonly perennial, slender, glabrous, dull green or bluish green; stem prostrate or ascending, I-7 dm. long. Leaves oblong, linear or oblanceolate, $0.5-2$ $\mathrm{cm}$. long, jointed to the ocreae, narrowed at the base, usually acute at the apex, not conspicuously veined; ocreae oblique, silvery, 2-parted or at length lacerate; clusters axillary, I-5-flowered; calyx green, 5-parted, the lobes with a white or pink border; stamens 5-8; style short, 3-parted to near the base; achene 3-angled, ovoid, $2 \mathrm{~mm}$. long, acute, reticulated. A weed in cultivated and waste grounds, common almost thrcughout N. Am., Asia and Europe. June-Oct.

21. Polygonum littoràle Link. Shore KNotweed. (I. F. f. 1338.) Annual or perennial, stout, glabrous, bright green or slightly glaucous; stem 3-12 dm. long, prostrate or ascending, diffusely branched from a woody base, striate. Leaves oblong, oblong-lanceolate or oblanceolate, $0.5-2.5 \mathrm{~cm}$. long, obtuse or subacute at the apex, mostly acuminate at the base, prominently veined, often crisped, jointed to the ocreae; ocreae oblique, at length lacerate; flowers axillary, 2- 6 in each cluster ; calyx green, its lobes whitish-margined or carmine; stamens 8; style short, 3-parted to the base; achene broadly ovoid, 3-angled, $3 \mathrm{~mm}$. long, more or less pinched at the apex. On shores and in waste places, N. B. to Minn. and Cal., south to Va., Ill. and Kans. Also in Europe. Aug.-Sept.

22. Polygonum Bellàrdi All. Bellard's Knotweed. (I. F. f. 1339.) Annual, dingy green; stem slender, prostrate or spreading, 3-9 dm. long, often diffusely branched, striate. Leaves oblong-lanceolate or linear-lanceolate, short. petioled, $0.5-4 \mathrm{~cm}$. long, acute at the apex, acuminate at the base, distant, prominently veined beneath, jointed to the ocreae; ocreae oblique, silvery, slightly laccrate when yourig, becoming much incised when old; flowers I-3 together in the axils; calyx grecn, its lobes white-margined; stamens 8 ; style 3 -parted to the base, very short; achene ovoid or oblong-ovoid, 3 -angled, rather pointed at both ends. $2-2.5 \mathrm{~mm}$. long, reticulated and rather dull. In waste grounds, Washington, D. C. Adventive from eastern Europe and western Asia. 
23. Polygonum marítimum L. SE 2 SIDE KNotweED. (I. F. f. 1340.) Perennial or sometimes annual, glaucous, glabrous; root usually deep, woody; stem prostrate or ascending, branched, 2-5 dm. long. Leaves ovate or oblong, mostly equalling or longer than the internodes, $0.5-2.5 \mathrm{~cm}$. long, fleshy, veined beneath, somewhat rugose above, conspicuously jointed to the ocreae, the margins often revolute; ocreae large, silvery, at length lacerate, becoming brown at the base; flowers I-3 together in the axils; calyx white or pinkish; stamens 8; style short, 3 -parted; achene 3 -angled, ovoid or narrowly ovoid, $3 \mathrm{~mm}$. long, acute or acuminate, shining, longer than the calyx. In sands of the seashore, Me. to Fla. Also on the coast of Europe. July-Sept.

24. Polygonum Ràyi Babingt. Ray's Knotweed. (I. F. f. I34I.) Perennial or annual, glabrous, slightly glaucous ; stem I-6 dm. long, prostrate, usually much branched. Leaves ovate-lanceolate or oblong, $0.5-3 \mathrm{~cm}$. long, acute or obtusish at the apex, veined beneath, inconspicuously so above, shorter than the internodes, inconspicuously jointed to the ocreae; ocreae becoming lacerate, silvery, brown and glaucous at the base when old: flowers 2-4 together in the axils; stamens 5 or 6; style short, 3-parted to the base; achene ovoid, 3-angled, 4-6 mm. long, slightly granular but shining, much exceeding the calyx. In waste places, N. B. and Prince Edward's I. to Br. Col., south along the Atlantic coast to Va. Apparently naturalized from Europe. May-Sept.

25. Polygonum eréctum L. ERECT Knotweed. (I. F. f. I342.) Annual, glabrous; stem erect or ascending, 2-6 dm. high, terete, nearly simple or much branched. Leaves oval, oblong or obovate, subsessile or short-petioled, $0.5-4 \mathrm{~cm}$. long, obtuse or subacute at the apex, conspicuously jointed to the ocreae; ocreae oblique, funnelform, soon lacerate, silvery when young; flowers 1 or 2 together in the axils; calyx greenish, enlarged in fruit; stamens 6 (sometimes 5 ); style very short, 3 -parted to near the base; achene ovoid-pyramidal, 3-angled, $3 \mathrm{~mm}$. long, reticulated and dull, invested by the calyx, or the apex slightly protruding. In moist or dry soil, Me. to Ont., the N. W. Terr., Tenn. and Ark. July-Sept.

26. Polygonum exsértum Small. Long-Fruited Knotweed. (I. F f. 1343.) Annual, glabrous, sometimes slightly glaucous; stem slender, brownish, erect or nearly, so, conspicuously striate, branched, 5-10 dm. tall. Leaves lanceo. late, rarely oblanceolate, $\mathbf{I}-4 \mathrm{~cm}$. long, acute or cuspidate at the apex, acuminate at the base, nearly sessile: ocreae soon lacerate, silvery, becoming brownish; calyx greenish or white, 6-parted to near the base; stamens 5 or 6; style 3-cleft or 3parted, very short; achene 3-angled, narrowly pyramidal, 5-6 $\mathrm{mm}$. long, more or less constricted above the midule, chestnut brown, smooth, shining, 2-3 times as lon $r$ as the calyx, at length twisted. N. W. Terr., south to Ill., Mo. and Neb., and on the Atlantic coast, in brackish marshes, from Me. to N. Y. Aug.-Oct.

27. Polygonum ramosíssimum Michx. Bushy Knotweed. (I. F. f. I344.) Annull, bright green or yellowish green, glabrous; stem erect or ascending, u sually very much branched, slender, usually rigid, I-I2 dm. tall. Leaves lanceol.tte or linear oblong, $0.5-4 \mathrm{~cm}$. long, acuminate at both ends, persistent, conspicuously jointed to the ocreae; ocreae oblique, funnelform, few-nerved, becoming deeply lacerate; flowers several together in the axillary clusters; calyx 5-6. part $\mathrm{d}$, greenish-white; stamens 6 or fewer; style very short, 3-parted to the base; achene 3 -angled, acute, sometimes slightly protruding beyond the calyx, $\mathrm{n}$ aarly $3 \mathrm{~mm}$. long, black, reticulated, dull. In saline soil, Minn. to the N. W. Terr., N. Mex. and Cal., and on the Atlantic coast from Me. to N. J. July-Sept.

Polygonum ramosíssimum prolificum Small. Bushy, much branched; stem nearly erect, its internodes short, its nodes giving off 2 or more branches; leaves narrower; flowers and achenes more numerous. Neb. and Kan., also on the coast of Me.

28. Polygonum campòrum Meisn. Prairie Knotweed. (I. F. f. I345.) Annual or perennial, glabrous ; stem mostly erect, slightly striate, much branched, sometimes slightly glaucous, 6-9 $\mathrm{dm}$. tall. Leaves linear-lanceolate or oblong, soon falling away, subsessile, rather obtuse at the apex, veined beneath, $0.5^{-2.5}$ $\mathrm{cm}$. long ; ocreae funnelform, early lacerate and fugacious, dark brown; flowers several together in the axillary clusters; pedicels short; stamens 8 ; style short, 3-parted; achene pyramidal-ovoid, 3-angled, black, nearly $3 \mathrm{~mm}$. long, shining. On prairies, Neb. to La., and N. Mex. Also in S. Am. July-Sept. 
29. Polygonum ténue Michx. Slender Knotweed. (I. F. f. I346.) Annual, glabrous, somewhat rough about the rides; stem very slender or filiform, erect, somewhat 4-angled, I-4 dm. tall. Leaves linear or linear-lanceolate, sessile, acuminate at the apex, o 5-2.5 cm. long, articulated to the ocreae, I-ribbed with a lateral impression on each side of the rib, the margins minutely scabrous or serrulate; ocreae funnelforn, soon lacerate; flowers several in the axillary clusters, green, sub: essile; calyx-lobes whitish ; stamens 8 ; style 3-parted nearly to the base, its branches diverging ; fruit erect ; achene 3 angled, black, $2-2.5 \mathrm{~mm}$. long, reticulated on the angles, the centre of its faces smooth. Dry soil, Me. and Ont. to Mun., Neb., Ga. and Ark. July'-Sept.

30. Polygonum Douglásii Greene. Dorglas' Knotween. (I. F. f. 1347.) Annual, similar to the preceding species, glabrous, somewhat rough at the nodes, sometimes slightly glaucous; stem erect, $2-5 \mathrm{dm}$. tall, simple or usually much branched. Leaves oblong or narrowly lanceolate, $1-5 \mathrm{~cm}$. long, subsessile, rather thin, flat or revolute, with no lateral impressions parallel to the midrib; ocreae oblique, short, soon lacerate ; clusters axillary, several-flowered; the flowers and fruit deflexerl ; calyx green with white or rose-colored margin ; stamens 8; style 3-parted; achene 3-angled, 2.5-4 mm. long, oblong or ovoid-oblong, black, smooth and shining. N. W. Terr. and Br. Col. to N. Mex., Neb. and Ind. Terr., east through Ont. to northern N. Y. and Vt. June-Sept.

31. Polygonum Convólvulus L. Black Binineed. (I. F. f. 1348.) Annual, glabrous, scurfy; stem twining or trailing, 1.5-10 dm. long, mostly branched. Leaves ovate-sagittate or the uppermost lanceolate-sagittate, long-petioled, acuminate at the apex, slightly ciliate, $1-7.5 \mathrm{~cm}$. long; ocreae oblique, short, rough on the margin ; axillary clusters or racemes loosely flowered; flowers greenish, pendulous on slender pedicels; calyx 5-parted or rarely 6-parted, closely investing the achene, the outer lobes slightly or not at all keeled; stamens 8; style nearly entire; stigmas 3 ; achene 3 angled, obovoid.pyramidal, $3 \mathrm{~mm}$. long, thickpointed, black, granular, rather dull. In waste and cultivated grounds, nearly throughout N. Am., except the extreme north. Naturalized from Europe. Native of Asia. Sometimes a troublesome weed. July-Sept.

32. Polygonum cilinòde Miclix. Fringed Black Bindweed. (I. F. f. 1349.) Perennial, sparingly pubescent; stem red or reddish, twining or prostrate, $0.3-3 \mathrm{~m}$. long. Leaves broadly ovate or somewhat hastate, acuminate at the apex, cordate at the base, rather long-petioled, undulate, finely ciliate, $2.5-10 \mathrm{~cm}$. long, or the upper smaller; ocreae small, armed with reflexed bristles near the base; racemes mostly panicled, axillary and terminal, interrupted; calyx whitish; style short, 3 parted to the base; achene 3 angled, oblong-pyramidal or ovoid, nearly $3 \mathrm{~mm}$. long, very smooth and shining. In rocky places, N. S. to Ont., Minn. and Penn., south in the Alleghanies to N. Car. June-Sept.

Polygonum cilinode brévis Peck. Stems erect, about $3 \mathrm{dm}$. tall: inflorescence mostly terminal. Adirondack Mountains, N. Y.

33. Polygonum scándens L. Climbing False Buckwheat. (I. F. f. 1351.) Perennial, glabrous; stem climbing, $0.5^{-6} \mathrm{~m}$. long, rather stout, branched, rough on the ridges. Leaves ovate, acuminate, cordate at the base, $2.5-15 \mathrm{~cm}$. long or the upper smaller, the larger long-petioled, finely punctate, the margins scabrous; ocreae oblique, smooth and glabrous; racemes usually numerous and panicled, interrupted, leafy, 5-20 cm. long; flowers yellowish-green, long-pediceled; calyx 5-parted, the three outer segments very strongly winged and decurrent on the pedicels, especially in fruit; style almost none; stigmas 3 ; fruiting calyx 10-12 $\mathrm{mm}$. long, the wings crisped, not incised; achene 4-5 mm. long, 3-angled, rather blunt at both ends, smooth, shining. In woods and thickets, N. S. to Ont. and the Rocky Mts., south to Fla., Neb. and Tex. Aug.-Sept.

34. Polygonum dumetòrum L. COPSE OR HEDge BuckwheAt. (I. F. f. 1350.) Perennial, glabrous, similar to the preceding species; stem extensively twining, $0.5-3 \mathrm{~m}$. long, much branched. Leaves ovate or somewhat hastate, and sometimes inequilateral, acuminate at the apex, cordate at the base, $2.5-7 \mathrm{~cm}$. long, long-petioled, or the upper smaller or nearly sessile; ocreae oblique, smooth; racemes numerous, much interrupted. leafy hracted, 5-13 cm. long; flowers yellow. ish green, pendulous; caly $\times$ 5-parted, the three outer segments winged or keeled 
and much enlarged in fruit; style short, 3-parted; fruiting calyx 6-8 mm. long, the wings nearly flat, not incised; achene oblong, 3 -angled, $4 \mathrm{~mm}$. long, inclined to be pointed at both ends, black, smooth, shining. Prairies of Ill. and about St. Louis, Mo. Also in the vicinity of Knoxville, Tenn. Naturalized from Europe(?). July-Sept.

35. Polygonum cristàtum Engelm. \& Gray. Crested False Buckwheat. (I. F. f. r352.) Perennial, scurfy; stem slender, twining, $0.7-2.5 \mathrm{~m}$. long, more or less branched. Leaves triangular or ovate, $2.5^{-\mathrm{I}} 3 \mathrm{~cm}$. long, acuminate at the apex, undulate, truncate or cordate at the base, rather long-petioled; ocreae cylindric-funnelform; flowers in simple or compound often naked racemes $2.5^{-1} 3^{\mathrm{cm}}$. long; pedicels about $5 \mathrm{~mm}$. long, jointed near the middle; calyx greenish-white 4-5 $\mathrm{mm}$. long, 5-parted, the three outer segments keeled and at maturity winged; stigmas 3; fruiting calyx 6-8 $\mathrm{mm}$. long, its wings incised; achene 3 -angled, oblong, black, smooth, shining, about $3 \mathrm{~mm}$. long. Sandy woods and rocky banks, Conn. to Ga., the Ind. Terr. and Tex. Aug.-Oct.

36. Polygonum Zuzzarínii Small. Japanese Knotweed. (I. F. f. I353.) Perennial, more or less scurfy; stem stout, erect, woody below, much branched, $\mathrm{r}-2.5 \mathrm{~m}$. tall. Leaves oblong-ovate or ovate-lanceolate, petioled, $5^{-1} 5 \mathrm{~cm}$. long, acuminate cuspidate at the apex, truncate or subcordate at the base, reticulateveined on both surfaces, undulate; ocreae oblique, smooth, fugacious; racemes mostly terminal, panicied, 5-10 $\mathrm{cm}$ long, or axillary, many-flowered, more or less pubescent; flowers greenish-white, long-pedicelled; outer segments of the 5-parted calyx very broadly winged in fruit; style 3 -parted; achene 3 -angled, narrowly oblong or oblong-pyramidal, 2.5-3 mm. long, black, smooth, shining. Escaped from cultivation in Me., near Philadelphia, Pa., Schenectady, N. Y., N. J., and in Ohio. Native of Japan. July-Oct.

37. Polygonum sagittàtum L. Arrow-Lenved Tear-thumb. (I. F. $f$ I354.) Annual, light green; stem slender, weak, decumbent, or climbing over other plants by the abudant recurved prickles which arm its four prominent angles. Leaves lanceolate-sagittate or oblong-sagittate, $1.2-7.5 \mathrm{~cm}$. long, obtuse or acute at the apex, slightly rough on the margins, the lower petioled, the upper subsessile; petioles and lower surface of the midribs prickly; ocreae oblique, not ciliate fringed at the base by a few bristle-like prickles; flowers in rather denee terminal heads or racemes; calyx greenish or rose-colored; style 3-parted to below the mildle; achene 3 -angled, oblong-pyramidal, thick pointed, $3 \mathrm{~mm}$. long, dark red, smooth, shining. I.. wet soil, Newf. and N. S. to the N. W. Terr., south to Fla. and Kans. July-Sept.

38. Polygonum arifjlium L. Halnerd-leaved Tear-thumb. (I. F. f. 1355.) Perennial; stem ridged, reclining, 3-18 dm. long, the ridges armed with recurved prickles. Peduncles and pedicels glandular or pubescent; leaves broadly hastate, long-petioled, $2.5^{-25} \mathrm{~cm}$. long, pubescent or glabrous beneath, the apex and basal lobes acuminate; petioles and stronger nerves prickly; ocreae oblique, fringed at the summit with short bristles and at the base with slender prickles; flowers in terminal and axillary heads or racemes; calyx rose-color or greenish. 4-parted; style 2-parted; achene lenticular, broadly obovate, $4 \mathrm{~mm}$. long, strongly biconvex, dark brown, smooth, shining. In moist or wet soil, N. B. and Ont. to Minn., south to S. Car. July-Sept.

\section{POLYGONÉlLA Michx.}

Annual or perennial glabrous herbs, sometimes slightly woody, with branched, usually conspicuously jointed stems, alternate narrow leaves jointed to the mostly naked ocreae, and small white, pink or greenish flowers in slender panicled racemes. Calyx unequally 5-parted, persistent, its segments petalloid, loosely invest. ing the achene or its base in fruit, the three inner calyx-segments often winged. Stamens 8, included; filaments filiform, or much dilated or auricled at the base. Style 3-parted, short or almost wanting stigmas capitate. Achene 3-angled, smooth. Embryo slender, nearly straight in on of the angles of the seed. [Dimin. utive of Polygonum.] Five or six sprcies, natives of N. Am. 
I. Polygonella articulàta (L.) Meisn. Coast Jointweed. (I. F. f. I356.) Annual, glaucous; stem wiry, erect or sometimes diffusely spreading, simple or branched, I-3 dm. long. Leaves linear or linear-subulate (apparently filiform from the revolute margins), $\mathbf{I}-4 \mathrm{~cm}$. long, cylindric, slightly expanded at the summit; racemes numerous, erect, many-flowered, $2.5-5 \mathrm{~cm}$. long: ocreolae crowded or imbricated; pedicels reflexed; calyx-segments white with a dark mid-rib, loosely investing the achene, not winged in fruit; achene narrowly ovoid-pyramidal, pointed, $2 \mathrm{~mm}$. long, brown. In sands of the seashore and sandy soil along the coast, Me., N. H. to Fla., and on the shores of the Great Lakes. July-Uct.

2. Polygonella Americàna (F. \& M.) Small. Southern Jointweed. (I. F. f. 1357.) Perennial, slightly glaucous; stem erect or ascending, wiry, somewhat flexuous, 5-12 dm. high, simple or slightly branched, covered with a ridged more or less scaly bark. Leaves linear or linear-spatulate, $0.5-2.5 \mathrm{~cm}$. long, often fascicled on short branches, rather fleshy, obtuse and revolute at the apex; ocreae scarious-margined, split on one side; racemes $2.5-7.5 \mathrm{~cm}$. long, dense, divergent; calyx white or pink, its three inner segments developing orbicular cordate wings, the two outer reflexed in fruit: pedicels divergent; achene elliptic-oblong, 2-5 mm. long, chestnut-brown, pointed at both ends. In dry soil, Mo. to Tex., east to Ga. and Ala. Aug.-Oct.

\section{BRUNNÍCHIA Banks.}

Perennial glabrous herbs with elongated grooved much branched stems climbing by tendrils at the ends of the branches, and alternate entire petioled leaves, the ocreae obscure or wanting, and small perfect flowers in panicled terminal and axillary racemes. Pedicels slender, fascicled in the axils of lanceolate-subulate bracts. Calyx 5-parted, much enlarged, coriaceous and winged on one side in fruit, closely investing the achene, the segments spreading when fresh, converging when dry. Stamens 7-10, mostly 8 , filaments filitorm, much dilated at the base. Style 3 parted, the stigmas 2-cleft at the summit; ovary imperfectly 2-celled; ovule pendulous. Achene 3-angled. Seed irregularly 6-grooved, the embryo in one of its angles. [Name in honor of M. T. Brunnich, Norwegian naturalist.] Two known species, the following of southeastern N. Am., the other of tropical Africa.

I. Brunnichia cirrhòsa Banks. BRunnichia. (I. F. f. 1358.) Stem 2-6 m. long, somewhat woody, rather tough. Tendrils numerous, filiform; leaves ovate or ovate-lanceolate, acute or acuminate, $2.5^{-15} \mathrm{~cm}$. long, truncate or subcordate at the base, petioled; ocreae represented by a ring of short bristles, racemes 5-15 cm. long; calyx 6-8 mm. long. greenish, 5-parted, its base strongly winged along one side; achene oblong-ovoid, $6 \mathrm{~mm}$. long, brown, smooth, closely invested by the calyx which becomes $2.5 \mathrm{~cm}$. or more in length. On banks of streams, S. Ill. to Ark., S. Car. and Fla. May-June.

\section{Order I4. CHENOPODIÀLES.}

Herbs, mostly with perfect flowers. Calyx present. Corolla, if present, polypetalous. Ovary superior. Embryo coiled, curved or annular. Fruit not an achene.

Fruit a utricle (see also last genera of Caryophyllaceae).

Flowers bractless, or, if bracted, the bracts not scarious; sepals green, or greenish.

Flowers bracted, the bracts, and also the sepals, mostly scarious.

Fam. 1. Chenopodiaceae.

Fam. 2. Amaranthaceae.

Fruit fleshy, enclosing several carpels; a berry.

Fam. 3. Phytalaccaceae.

Fruit an anthocarp, the persistent base of the corolla-like calyx enclosing a utricle.

Fam. 4. Ayctaginaceae.

Fruit a capsule, dehiscent by valves, or teeth (utricular in Anychia, Paronychia and

Scler anthus of the Caryophyllaceae).

Capsule 2-several-celled; petals none.

Capsule $\mathrm{x}$-celled; petals mostly present.

Sepals 2.

Fam. 5. Aizoaceae.

Sepals 5 or 4 , distinct or united.

Fam. 6. Portulacaceae.

Fam. 7. Caryophyllaceae. 


\section{Family I. CHENOPODIÀCEAE Dumort.}

Goosefoot Fiamily.

Annual or perennial herbs, rarely shrubs, with angled striate or terete stems. Leaves alternate or sometimes opposite, exstipulate, simple, entire, toothed or lobed, mostly petioled (in Salicornia reduced to mere ridges). Flowers small, green or greenish, regular or slightly irregular, variously clustered, occasionally solitary in the axils. Petals none. Calyx persistent, 2-5-lobed, 2-5-parted or rarely reduced to a single sepal, wanting in the pistillate flowers of some genera. Stamens as many as the lobes or divisions of the calyx, or fewer, and opposite them; filaments slender; anthers 2-celled, longitudinally dehiscent. Disk usually none. Ovary I-celled; ovule solitary, amphitropous; styles I-3; stigmas capitate, or 2-3-lobed or divided. Fruit a utricle, with a thin or coriaceous pericarp. Seed vertical or horizontal ; endosperm mealy, fleshy or wanting. About 75 genera and 550 species, of wide geographical distribution.

* Embryo annular or conduplicate, not spirally coiled; endosperm copious (except in Lealy herbs; endosperm copious.

Salicornia).

Fruit enclosed by or not longer than the calyx or bractlets.

Flowers perfect or some of them pistillate ; calyx herbaceous or fleshy.

Calyx 2-5-lobed or 2-5-parted : stamens $1-5$.

Fruiting calyx wingless, its segments often keeled.

Calyx herbaceous or but slightly fleshy in fruit ; flowers in panicled spikes.

I. Chenopodium.

Fruiting calyx dry, strongly reticulated; leaves pinnatifid.

2. Roubieva.

Calyx very fleshy and bright red in fruit ; flowers densely capitate.

Fruiting caly $x$ horizontally winged.

Calyx of I sepal ; stamen I.

Flowers monœcious or diœcious : calyx of pistillate flowers none ; fruit enclosed by 2 bractlets.

Bractlets flat or convex, not silky.

Bractlets silky-pubescent, conduplicate.

Flowers perfect ; calyx membranous; leaves filiform-linear.

Fruit much exserted beyond the calyx.

Leafless fleshy herbs with opposite branches; endosperm none.
6. Atriplex.

7. Eurotia.
8. Kochia.

9. Corispermum.

10. Salicornia.
3. Blitum.

4. Cycloloma.

5. Monolepis.

* Embryo spirally colled; endosperm little or none.

Shrub ; flowers monœcious, not bracteolate.

II. Sarcobatus.

Herbs ; flowers perfect, bracteolate.

Fruiting calyx wingless; leaves fleshy, not spiny.

Fruiting caly $\mathrm{x}$ bordered by a thin horizontal wing : leaves very spiny.

13. Salsola.

\section{CHENOPÒDIUM L. (See Appendix.)}

Annual or perennial herbs, with alternate petioled leaves. Flowers small, green, perfect, sessile, bractless, clustered. Calyx 2-5-parted or 2-5-lobed, embracing or enclosing the utricle, its segments or lobes often keeled or ridged. Stamens I-5; filaments filiform or slender. Styles 2 or 3 ; seed horizontal or vertical, sometimes in both positions in different flowers of the same species ; endosperm mealy; embryo comp!etely or incompletely annular. [Greek, goose-foot, from the shape of the leaves.] About 60 species, mostly weeds, of wide geographic distribution. Besides the following, some 5 others occur in the western parts of N. Am.

* Embryo a complete ring.

Leaves white-mealy on the lower surface.

Leaves or some of them sinuate-toothed or lobed.

Sepals strongly keeled in fruit.

Pericarp firmly attached to the seed ; stem erect, tall. 
Sericarp readily detached from the seed; stem low.

Sepals not keeled in fruit; stem decumbent.

6. C. Fremontii incanum.

2. C. glaucum.

3. C. leptophyllum.

Leaves mostly entire, narrowly linear or oblong.

Leaves green and glabrous or nearly so on both surfaces when mature.

Leaves oblong or ovate-oblong, entire.

Leaves, at least the lower, sinuate, toothed or incised.

4. C. polyspermum.

Stamens 5 ; calyx not fleshy.

Pericarp readily separable from the seed.

Leaves oblong or lanceolate; calyx-lobes scarcely keeled.

Leaves triangular-hastate; calyx lobes keeled. 6. C. Fremontii.

Pericarp firmly attached to the seed.

Flower-clusters, at least the upper, longer than the leaves.

Leaves oblong, rhombic-ovate or lanceolate, narrowed at the base. Leaves obtuse or merely acute. $\quad$ I. C. album viride.

Leaves or some of them cuspidate or brittle tipped.

7. C. Berlandieri.

Leaves triangular-ovate, truncate or subcordate at base.

8. C. urbicum.

Spikes loosely panicled in the axils, the panicles shorter than the leaves.

Stamens only $\mathrm{x}$ or 2 ; calyx slightly fleshy, red. Leaves very coarsely toothed.

9. C. murale.

II. C. rubrum.

10. C. hybridum.

Leaves broadly triangular-hastate, entire or merely undulate. 12. C. Bonus-Henricus.

**Embryo an incomplete ring.

Leaves ovate or oblong, pinnately lobed; flowers in long loose panicles.

Leaves lanceolate; flowers in continuous or interrupted spikes.

Spikes borne in the axils of the numerous small upper leaves. 14. C. ambrosioides.

Spikes in large conmmonly leafless terminal panicles.

13. C. Botrys.

I. Chenopodium álbum L. Lamb's Quarters. White Goosefoot. Pig wEED. (I. F. f. I359.) Annual; stem usually slender, erect, commonly mucl branched, $0.3-3 \mathrm{~m}$. tall. Leaves rhombic-ovate or the upper lanceolate, narrowed at the base, 3-nerved, dentate, sinuate or lobed, or the upper entire, 2-10 cm. long; spikes terminal and axillary, simple or compound, often panicled; calyx about $\mathbf{I} \mathbf{m m}$. broad in fruit, its segments usually completely enclosing the utricle; seed horizontal, black, shining, firmly attached to the pericarp. In waste places. A ccmmon weed throughout N. Am. except the extreme north. Nat. from Europe. Native also of Asia. June-Sept.

Chenopodium álbum viride (L.) Moq. Plant brighter green; leaves green on both sides or but slightly mealy beneath. Range of the type.

2. Chenopodium glaùcum I. OAK-Leaved Goosefoot. (I. F. f. 136o.) Annual, succulent; stem usually much branched, decumbent or prostrate. Leaves oblong, lanceolate or ovate-lanceolate, mostly narrcwed at the base, dark green above, $2-5 \mathrm{~cm}$. long, the lower or all of them sinuate-dentate cr lobed ; flcwers in axillary often branched spikes, or the upper panicled; calyx abcut $1 \mathrm{~mm}$. broad, its segments obtuse, neither fleshy nor keeled in fruit; utricle brcwn, depressed, its summit not completely covered by the calyx; seed of lateral flowers vertical, that of terminal flowers commonly horizontal. A weed in waste places throughout N. Am. except the extreme north. Nat. from Europe. June-Sept.

3. Chenopodium leptophyllum (Moq.) Nutt. Narrow-Leaved Goosefoot. (I. F. f. 136I.) Annual, scarcely succulent; stem slender, usually erect, striate or gronved, at least when dry, branched, I.5-8 dm. tall, mealy above. Leaves linear to oblong, acute or acuminate, or the lower obtuse, entire or the lower rarely toothed, short-petioled, 2-6 mm. wide, I-3-nerved; flowers axillary and terminal simple or branched spikes; calyx about $\mathbf{I} \mathrm{mm}$. broad, its segments strongly keeled and nearly covering the fruit; seed horizontal, readily detached from the pericarp. In dry soil, Manitoba and the N. W. Terr. to Mo., N. Mex. and Ariz. Also on the shores of Lake Erie and on sands of the stashore, Conn. to N. J. July-Sept.

Chenopodium leptophỳllum subglabrum S. Wats. Leaves scarcely mealy or quite green; flowers loosely clustered. W, Nẹb, and Colo, 
4. Chenopodium polyspérmum L. Many-Seeded Goosefoot. (I. F. f. 1362.) Annual, glabrous, not mealy ; stem commonly much branched, striate, 1.5-9 dm. high. Leaves oblong, elliptic or ovate, slender-petioled, entire, thin, obtuse, 2-8 cm. long, flowers in loose axillary and terminal panicles; calyx less than $2 \mathrm{~min}$. wide, its segments oblong, not keeled, not completely covering the fruit; seed firmly attached to the pericarp, horizontal. In waste places and ballast, Mass. to N. J. Adv. from Europe. July-Sept.

5. Chenopodium Bosciànum Moq. Busc's Guoseroot. (I. F. f. 1363.) Annual, light green; stem slender, 3-10 dm. tall, the branches very slender. Leaves thin, lanceolate or oblong-lanceolate, acute or acuminate at the apex, narrowed at the base, slender-petioled, 2-6 cm. long, the lower sinuate-dentate or nearly all of them entire; flowers in slender spikes; calyx-segments broadly oblong, obtuse ; herbaceous, nearly covering the utricle; seed horizontal, readily separating from the pericarp, black, shining. In woods and thickets, N. Y. and N. J. to Ind., Minn., N. Car. and Tex. July-Sept.

6. Chenopodium Fremúntii S. Wats. Fremont's Goosefoot. (I. F. f. 1364.) Annual, light green; stem erect, grooved, branched, 3-10 dm. tall. Leaves thin, broadly triangular-hastate, sinuate-dentate or the upper entire, mostly obtuse at the apex, truncate or abruptly narrowed at the base, slender-petioled, 2-10 $\mathrm{cm}$. long and nearly as wide, the uppermost sometimes very small, oblong or lanceolate and acute; spikes slender; calyx I mm. wide, its segments ntarly enclosing the utricle; pericarp easily separable from the seed; seed horizontal, shining. In woods and thickets, S. Dak. to Mont., Nev. and N. Mex. July-Sept.

Chenopodium Fremóntii incànum S. Wats. Low; stems stout and much branched, the branches and lower surfaces of the leaves densely white-mealy; leaves 6-25 mm. long. Range of the type. Probably a distinct species.

7. Chenopodiu n Berlandièri Moq. Berlandier's Goosefoot. (I. F. f. 1365.) Annual; ste.n erect, commonly much branched, 4-1o dm. tall, the branches ascending. Lives lanceslate, oblong or rhombic-lanceolate, slender-petioled, thin, sone or all of the $n$ cuspidate-acuminate at the apex or bristle-tipped, narrowed at the base, 1-4 cm. long; flowers in rather loose panicled spikes; calyx nearly $2 \mathrm{~mm}$. broad, its segments keeled, enclosing the utricle; pericarp firmly attached to the horizontal seed. In dry soil, suuthern Mo. to Tex. and in Fla. June-Sept.

8. Chenopodiu.n úrbicu.n L. UPRIGHT OR City GoOseroot. (I. F. f. 1366.) Annual; ste.n commonly stout, erect, channeled, 3-9 dm. tall. Leaves hastate or triangular ovate, acute at the apex, truncate subcordate or abruptly narrowed at the base, stout-petioled, coarsely and irregularly dentate or the uppermost entire, the larger $7^{-1} 3 \mathrm{~cm}$. long; spikes in erect panicles, the upper longer than the leaves; calyx I mm. broad, its segments oblong, obtuse, not entirely enclosing the fruit; seed horizontal, firmly attached to the pericarp, its margins rounded. In waste places, N. S. and Ont. to S. N. Y. Adventive from Europe. June-Sept.

9. Chenopodium muràle L. Netrle-leaved Goosefoot. Sowbane. (I. F. f. 1367.) Annual, somewhat scurfy above; stem 3-8 dm. high, leafy to the summit. Leaves rhombic-ovate, thin, bright green, acute or acuminate, sharply and coarsely sinuate dentate, cuneate or subtruncate at the base, slender-petioled, 5-10 cm. long; flowers in loose axillary panicles, often not longer than the petioles; calyx-segments not entirely enclosing the utricle; seed sharp-edged, horizontal, firmly attached to the pericarp. In waste places, Me. to Mich., Br. Col., Fla. and Mex. June-Sept.

10. Chenopodium hybridum L. Maple-leaved Goosefoot. (I. F. f. 1368.) Annual, sometimes more or less scurfy; stem slender, erect, 6-13 dm. tall. Leaves ovate or rhombic-ovate, long-acuminate at the apex, truncate rounded or subcordate at the base, thin, slender-petioled, sharply dentate with $1-4$ large acute teeth on each side, or the upper lanceolate and entire, the lower $\mathbf{I - 2} \mathrm{dm}$. long: flowers in large panicles; calyx about $2 \mathrm{~mm}$. broad, its segments oblong, slightly keeled, incompletely covering the fruit; seed horizontal, sharp edged, firmly at. tached to the pericirp. In woods and thickets, sometimes in waste places, Quebec to the Northwest Terr., Br. Col., N. Y., Ky. and N. Mex. Also in Europe. July-Sept.
I. Chenopodium rùbrum $\mathrm{L}$.
ReD Goosefoot. 
glabrous; stem leafy, 3-8 dm. tall, the branches stricţor ascending. Leaves thick, 3-10 cm. long, rhombic-ovate or rhombic-lanceolate, petioled, narrowed at the base, coarsely sinuate-dentate or the upper entire; flowers in erect compound leafy-bracted spikes; caly x 3-5-parted, its segments slightly fleshy, red, not keeled, obtuse, about as long as the utricle; stamens I or 2; stigmas short; seed horizontal, shining, separating from the pericarp. On the seacoast, Newf. to N. J., and in saline soil in the interior across the continent, south to central N. Y., Neb. and Br. Col. Also in Europe and Asia. July-Sept.

12. Chenopodium Bonus-Henricus L. Good KIng Henry. (I. F. f. 1370.) Perennial by a thick rootstock, glabrous; stem erect, 3-8 dm. tall. Leaves broadly trangular-hastate, palmately veined, entire or undulate, rarely with $\mathbf{I}$ or 2 small teeth, the lower long-petioled, the upper much smaller; flowers simple or panicled, commonly dense spikes sometimes 7-10 cm. long; calyx 4-5-parted; stigmas elongated; seed ver:ical, or that of terminal flowers horizontal, black, shining, blunt edged. In waste places, N. S. to Ont., Mass. and southern N. Y. Naturalized from Europe. June-Sept.

13. Chenopodium Botrys L. Feather Geranium. Jerusalem Oak. (I. F. f. 1371.) Annual, glandular-pubescent and viscid, strong-scented; stem 2-6 dm. tall. Leaves ovate or oblong, deeply pinnately lobed, petioled, $\mathbf{I}-5 \mathrm{~cm}$. long, or the uppermost much smaller, the lobes mostly obtuse and dentate; flowers very small, in numerous loose axillary cymose panicles; calyx 3-5-parted, the segments lanceolate, acute, thin, rather longer than the utricle; seed horizontal or vertical, firmly attached to the pericarp. In waste places, N. S. to Minn., Ore., N. Y., Ky. and Mex. Naturalized from Europe. Native also of Asia. July-Sept.

14. Chenopodium ambrosioides L. MExican TEA. (I. F. f. 1372.) Annual, glabrous or slightly glandular.pubescent, strong-scented; stem leafy, 6-1o dm. high, angular and gruoved. Leaves oblong or oblong-lanceolate, narrowed to a short petiole, repand-dentate, undulate or the upper entire, 2-9 $\mathrm{cm}$. long, the upper numerous and much smaller; flowers in small denee axillary spikes; calyx usually 3-parted, completely enclosing the fruit; pericarp readily separable from the seed; seed horizontal or vertical, shining. In waste places, Me. and Ont. to Fla., wcst to Cal. Naturalized from tropical America. Aug.-Oct.

15. Chenopodium anthelmínticum L. IVORMSEED. (I. F. f. I373.) Annual or sometimes perennial, similar to the preceding species and perhaps intergrading with it; stem somewhat stouter. Leaves lanceolate or ovate-lanceolate, usually acuminate at the apex and narrowed at the base, slender-petioled, coarsely dentate or incised, 5-13 cm. long, the lower $2 \mathrm{~cm}$. or more wide, the upper gradually smaller; flowers in linear usually bractless panicled spikes, or the lower spikes leafy-bracted. In waste places, Mass. to Ont., Wis., Fla. and Mex. Naturalized from Europe. Aug.-Oct.

\section{ROUBIÈVA Moq.}

A perennial herb, glandular-pubescent, strong-scented, prostrate, and diffusely branched, with narrow small short-petioled deeply pinnatifid leaves. Flowers small, green, perfect, or pistillate, solitary, or in small axillary clusters. Calyx urn-shaped, 3-5-toothed, narrowed at the throat, in fruit becoming obovoid, strongly reticulated and closed. Stamens 5. Styles 3, exserted. Wall of the pericarp thin, glandular. Seed vertical. Embryo a complete ring in the mealy* endosperm. [Name in honor of G. J. Roubieu, French botanist.] A monotypic genus of S. Am.

I. Roubieva multifida (L.) Moq. Cut-leaved Goosefoot. Roubieva. (I. F. f. I374.) Very leafy, prostrate, or the branches ascending, I.5-3.5 dm. long. Leaves lanceolate or linear-lanceolate or linear-oblong in outline, $1-3 \mathrm{~cm}$. long ; flowers I-5 together in the axils, sessile, less than I $\mathrm{mm}$. broad, some perfect. some pistillate; fruiting calyx, 3-nerved and strongly veined, I mm. thick ; utricle compressed. In waste places and ballast, S. N. Y. to Va. Naturalized or adventive from tropical America. June-Sept.

\section{BLITUM L.}

Annual succulent branching herbs, with alternate hastate petioled leaves. Flowers small, aggregated in globose axillary sessile heads, or the upper heads forming an interrupted spike. Calyx 2-5-lobed, becoming pulpy and bright red 
in fruit. Stamens $\mathbf{I}-5$. Perigarp separating from the seed. Seed vertical, shining. Embryo a complete ring in the mealy endosperm. [The classical name of orache.] One or perhaps two species, natives of N. Am. and Europe.

I. Blitum capitàtum L. Strawberry Blite. (I. F. f. 1375.) Sten 1.5-6 dm. long, the branches ascending. Leaves usually longer than wide, 3-8 cm. long, sinuate-dentate, or the upper or sometimes all of them entire, cordate or reniform, lower petioles often longer than the blades: heads becoming bright red and $10-16 \mathrm{~mm}$. in diameter in fruit, and then somewhat resembling strawberries; seed compressed, ovate. In dry soil, N. S. to Alask،, N. J., Ill., Minn., in the Rocky Mountains to Colo. and Utah and to Nev. Also in Europe. June-Aug.

\section{CYCLOLÒMA Moq.}

An annual diffusely branched glabrous or cobwebby -pubescent herb, with alternate petioled irregularly toothed leaves, and small sessile bractless flowers in panicled interrupted spikes. Calyx 5-lobed, the lobes keeled in flower, a thin horizontal irregularly dentate wing developing below them in fruit. Stamens 5 . Styles 2-3. Fruit (except its summit) enclosed by the calyx, depressed. Seed horizontal; embryo a complete ring in the mealy endosperm. [Greek, circle border, alluding to the calyx-wing.] A monotypic genus of north central North America.

1. Cycloloma atriplicifòlium (Spreng.) Coult. Cycloloma. (I. F. f. 1376.) Pale green or beconing dark purple, bushy-branched 1.5-5 dm. high. Leaves lanceolate, mostly acuminate, narrowed into slender petioles, sinuate-dentate with acute teeth, 2-8 cm. long or the upper much smaller; spikes numerous, loosely flowered ; slender ; fruit, including the winged calyx, $4 \mathrm{~mm}$. broad ; calyx-lobes not completely covering the summit of the utricle, which appears as a 5-rayed area. Along streams and on sand hills and banks, Manitoba to Ind., Ill., the N. W. Terr., Neb., and Ariz. Summer.

\section{MONÓLEPIS Schrad.}

Low annual branching herbs, with small narrow alternate entire toothed or lobed leaves, and polyganious or perfect flowers in small axillary clusters. Calyx of a single persistent herbaceous sepal. Stamen 1. Styles 2, slender. Utricle flat, the pericarp adherent to the smooth vertical seed. Embryo a very nearly complete ring in the mealy endosperm, its radicle turned downward. [Greek, single.scale, from the solitary sepal.] Three known species, natives of western N. Am., the following one reaching our limits.

I. Monolepis Nuttalliàna (R. \& S.) Greene. Monolepis. (I. F. f. I377.) Slightly mealy when young, glabrous or nearly so when old ; stem 7-30 cm. high ; branches many, ascending. Leaves lanceolate, short-petioled, or the upper sessile, I $6 \mathrm{~cm}$. long, narrowed at the base, 3-lobed, the middle lobe linear or linearoblong, acute or acuminate, 2-4 times as long as the lateral ones; flowers clustered in the axils; sepal oblanceolate or splatulate : pericarp minutely pitted, about $1 \mathrm{~mm}$. broad; margins of the seed acute. In alkaline or dry soil, Manitoba and the N. W. Terr. to Minn., Neb., N. Mex. and S. Cal. June-Sept.

\section{6. ÁTRIPLEX L.}

Herbs oi low shrubs, often scrufy canescent or silvery. Leaves alternate, or some of them opposite. Flowers diœcious or monœcious, small, green, in panicled spikes or capitate-clustered in the axils. Staminate fowers bractless, consisting of a 3-5-parted calyx and an equal number of stamens; filaments separate or united by their bases; d rudimentary ovary sometimes present. Pistillate flowers sub. tended by 2 bractlets which enlarge in fruit and are more or less united, sometimes quite to their summits: perianth none: stigmas 2 . Utricle conpletely or partially enclosed by the fruiting bractlets. Seed vertical or rarely horizontal; embryo annular; endosperm mealy. [From a Greek name of orache.] About 130 species, of very wide geographic distribution. Besides the following, some 45 others occur in the western parts of North America.

Annual herbs ; stems or branches erect, diffuse or ascending.

Leaves hastate, ovate, rhombic-lanceolate or linear lanceolate.

Plants green, glabrous or sparingly scurfy, not silvery; leaves slender-petioled.

Leaves lanceolate, several times longer than wide.

I, A. patula. 
Leaves triangular-hastate, the lower only $\mathrm{I}-2$ times as long as wide.

Plant very scurfy; leaves rhombic-ovate, short-petioled.

2. A. hastata.

Plants densely silvery; leaves hastate, entire or little toothed.

Staminate spikes dense, short; leaves petioled. 4. A. argentea.

Staminate spikes elongated, interrupted; upper leaves sessile.

Leaves oblong, densely silvery, entire; plant of sea beaches.

5. A. expansa.

6. A. arenaria. Perennial herbs or shrubs; leaves oblong or oblanceolate, entire; plants of the western plains.

Fruiting bractlets suborbicular, wingless, their sides crested or tubercled.

Fruiting bractlets appendaged by 4 vertical reticulated wings.

7. A. Nuttallii.

8. A. canescens.

I. Atriplex pátula L. Spreading Orache. (I. F. f. 1378.) Annual, dark green; stem much branched, diffuse, ascending or sometimes erect, 3-10 $\mathrm{dm}$. long. Leaves lanceolate or linear-lanceolate, the uppermost nearly sessile, entire, sparingly toothed, or 3-lobed below the middle, acuminate at the apex, narrowed or cuneat at the base, 4-35 mm. wide; flowers in panicled interrupted slender mostly leafless spikes, and usually also capitate in the upper axils; fruiting bractlets united only at the base, fleshy, triangular or rhombic, $6-8 \mathrm{~mm}$. wide, their sides often tubercled; radicle ascending. In waste places and ballast, N. S. and Ont. to S. N. Y. and N. J. Naturalized from Europe. Native also of Asia. July-Aug.

2. Atriplex hastàta L. Halberd-Leaved Orache. (I. F. f. 1379.) Annual, pale green, or purple, somewhat scurfy, at least when young; stem branched, 3-7 din. tall. Leaves slender-petioled, acuminate, the lower broadly triangularhastate, entire or sparingly toothed, $2-10 \mathrm{~cm}$. long, the basal lobes divergent, acute or acuminate; upper leaves sometimes triangular-lanceolate; inflorescence as in the preceding; the fruiting bractlets sometimes broader. In salt meadows and waste places mostly near the coast, N. B. to S. C., and in saline soil, Manitoba to Br. Col., Neb. and Utah. Also in Europe. Aug.-Oct.

3. Atriplex ròsea L. Red ORache. (I. F. f. I380.) Annual, pale green, very scurfy; stem usually much branched, 3-7 dm. high. Leaves ovate or rhombicovate, short-petioled or the upper sessile, coarsely sinuate-dentate, $\mathbf{r}-9 \mathrm{~cm}$. long; flowers mostly in axillary capitate clusters, or some in terminal spikes; fruiting bractlets broudly ovate or triangular-hastate, strongly veined, mealy-white, dry, about $6 \mathrm{~mm}$. broad, united only at their bases, their margins tonthed or lacerate and sides tubercled. In waste places and ballast, N. S. to N. N. Y. and N. J. Adventive from Europe. Aug. -Oct.

4. Atriplex argéntea Nutt. Silvery Orache. (1. F. f. 1381.) Annual, pale, densely silvery-scurfy or becoming smooth; stem bushy-branched, I.5-5 dm. high, angular. Iseaves firm, triangular-hastate or rhombic-ovate, mostly acute at the apex, petioled or the upper sessile, entire or sparingly dentate, $1-5 \mathrm{~cm}$. long, the basal lobes short; flowers in capitate axillary clusters, or the staminate in short dense spikes; fiuiting bractlets suborbicular, rhombic or broader than high, 4-8 $\mathrm{mm}$. wide, united nearly to their summits, the margins sharply tonthed, the sides sometimes tubercled or crested. In dry or saline soil, Minn. to the N. W. Terr., Mont., Neb., Coio. and Utah. June-Sept.

5. Atriplex expánsa S. Wats. Sessile-Leaved Orache. (I. F. f. I382.) Similar to the preceding but stouter, the stem erect, widely branched, sometimes $2 \mathrm{~m}$. tall. Leaves thin, sessile or the lower very short-petioled, $1-4 \mathrm{~cm}$. long and nearly as wide at the base; fruiting bractlets broad, united nearly to their summits, tubercled, their margins strongly toothed. W. Kans. (according to A. S. Hitchcock) to Chihuahua and N. Mex., west to Cal. July-Oct.

6. Atriplex arenària Nutt. SEA-BEACH ATRIPI.ex. (I. F. f. 1383.) Annual, pale, densely silvery-scurfy; stem bushy-branched, I-4.5 dm. high, the branches ascending or decumbent, angular; leaves oblong, entire, short-petioled or sessile, $\mathbf{I}-4 \mathrm{~cm}$. long, the lateral veins few and obscure; flowers in axillary clusters much shorter than the leaves; fruiting bractlets triangular wedge-shaped, broadest above, 4-6 mm. wide, united nearly to the several-toothed summits, their margins entire, their sides reticulated, or sometimes crested or tubercled. On sandy sea beaches, N. S. (?), Mass. to Fla. July-Sept. 
7. Atriplex Nuttàlii S. Wats. Nuttall's Atriplex. (I. F. f. I384.) f scurfy pale grean shrub, 3-7 $\mathrm{dm}$. tall, the branches rather stiff, leafy, the ba nearly white. Leaves oblong, linear-oblong or oblanceolate, narrowed at the base, sessile, entire, 4-ro $\mathrm{mm}$. wide; flowers in terminal spikes and clustered in the axils, often strictly diœcious ; fruiting bractlets ovate or suborbicular, united to above the middle, 3-5 $\mathrm{mm}$. broad, the margins toothed, the sides crested, tubercled or spiny. In dry or saline soil, Manitoba to the N. W. Terr., Neb., Colo. and Nev. Aug.-Oct.

8. Atriplex canéscens (Pursh) James. Bushy Atriplex. (I. F. f. I38 A pale densely scurfy shrub, resembling the preceding species and with simi foliage. Flowers in short terminal spikes and in axillary clusters; bractlets ov in flower, united nearly to their summits; in fruit appendaged by 4 broad distinct wings, which are $4-8 \mathrm{~mm}$. broad at the middle and usually about twice a high, strongly reticulate-veined, not tubercled nor crested. In dry or saline soil, S. Dak. and Neb. to N. Mex., Mex., Nev. and Cal. July-Sept.

\section{EURÒTIA Adans.}

Pubescent perennial herbs or low shrubs, with alternate entlre narrow leave and monœcious or diœcious flowers, capitate or spicate in the axils. Staminate flowers not bracteolate, consisting of a 4-parted calyx and as many exserted stamens. Pistillate flowers 2-bracteolate, the bractlets united nearly or quite to their summits, densely covered with long silky hairs, 2 -horned; calyx none; ovary ovoid, sessile, pubescent; styles 2, exserted. Seed vertical; embryo nearly annular in the mealy endosperm, its radicle pointing downward. [From the Greek for hoariness or mould.] Two known species, the following of western N. Am., the other of western Asia and eastern Europe.

I. Eurotia lanàta (Pursh) Moq. American Eurotia. White Sage. (I. F. f. 1386.) A stellate-pubescent erect much-branched shrub 3-9 dm. high, the hairs long, white when young, becoming reddish brown, the branches very leafy. Leaves linear or linear-lanceolate, short-petioled or the upper sessile, obtuse at the apex, narrowed at the base, 4-9 $\mathrm{mm}$. wide, their margins revolute, the mid-vein prominent; bractlets lanceolate, $4-8 \mathrm{~mm}$. long in fruit, appendaged by 4 tufts of spreading hairs; utricle loose, the pericarp readily separating from the large seed. In dry soil, N. W. Terr. to Neb., N. Mex., Nev. and Cal. June-Sept.

\section{KÒCHIA Roth.}

Herbs or low shrubs, with alternate sessile narrow entire leaves, and perfect or pistillate flowers in the axils. Calyx 5-lobed, wingless, or sometimes developing a horizontal wing, enclosing the fruit. Stamens 3-5, their filaments linear. Ovary ovoid; stigmas 2. Utricle pear-shaped or oblong, the pericarp membranous, not adherent to the seed. Seed inverted, the testa thin ; embryo annular; endosperm little or none. [Naine in honor of W. D. J. Koch, I771-1849, Director of the Botanical Garden at Erlangen.] About 35 species, mostly natives of the Old World, the following introduced from Europe. An indigenous species, $K$. Americana, occurs in the western U. S.

1. Kochia Scopària (L.) Roth. Kochia. (I. F. f. I387.) Annual, pubescent or becoming glabrate; stem erect, slender, leafy, 3-8 dm. tall. Leaves linearlanceolate or linear, ciliate, acuminate, 2-5 cm. long, 2-4 $\mathrm{mm}$. wide, the upper gradually smaller: flowers sessile in the axils of the upper leaves, forming short dense bracted spikes; fruiting calyx-segments each with a short triangular horizontal wing. In waste places, Ont., Vt. and N. N. Y. Adventive from Europe. Na、 tive also of Asia. July-Sept.

\section{CORISPÉRMUM I.}

Annual herbs, with alternate narrow entire I-nerved leaves, and perfect bract. less small green flowers, solitary in the upper axils, forming terminal narrow leafy spikes, the upper leaves shorter and broader than the lower. Calyx of a solitary thin broad sep 1 , or rarely 2. Stamens I-3, rarely more, and one of them longer. Ovary ovoid: styles 2. Utricle ellipsoid, mostly plano-convex, the pericarp firmly adherent to the vertical seed, its margins acute or winged. Embryo annular in the somewhat fleshy endosperm, its radicle pointing downward. [Greek, bug-seed.] 
Abont Io species, natives of the north temperate and subarctic zones. Only the following is known to occur in N. Am.

Upper leaves imbricated; fruit $3.5-5 \mathrm{~mm}$. long.

Upper leaves not imbricated; fruit $2 \mathrm{~mm}$. long.

1. C. hyssopifolium.

2. C. nitidum.

I. Corispermum hyssopifòlium L. Bug-seed. (I. F. f. I388.) Rather pale green, somewhat pubescent when young, fleshy; stem erect, 1.5-4 dm. tall, the branches slender, ascending or divergent. Leaves narrowly linear, sessile, I-5 cm. long, 2-4 mm. wide, cuspidate, the upper ovate or lanceolate, imbricated, appressed-ascending, or at length spreading, acute or acuminate, 6-12 mm. long, scarious-margined; utricle 3.5-5 $\mathrm{mm}$. long, winged. In sandy soil, shores of the Great Lakes to the N. W. 'Terr., Arctic America and Br. Col., south to Kans., Tex. and Ariz. Also in Europe and Asia. July-Sept.

2. Corispermum nitidum Kit. SMAll-Fruited Bug-SeEd. Like the pre ceding, but taller, 3-6 dm. high, glabrous, with ascending branches, narrower leaves and lax spikes, the leaves of which are not imbricated, 3-4 mm. long and generally narrower than the small-winged utricle, which is $2 \mathrm{~mm}$. long. In poor soil, Neb. and Kans. to Tex. and Ariz. Also in Europe and Asia. July-Sept. [C. hyssopifolium var. microcarpum Wats.]

\section{ı. SALICÒRNIA L.}

Fleshy glabrous herbs, with opposite terete branches, the leaves reduced to mere opposite scales, the flowers sunken 3-7 together in the axils of the upper ones, forming narrow terminal spikes, perfect or the lateral ones staminate. Calyx obpyramidal or rhomboid, fleshy, 3-4-toothed or truncate, becoming spongy in fruit deciduous. Stamens 2, or sometimes solitary, exserted; filaments cylindric, short anthers oblong, large; ovary ovoid; styles or stigmas 2. Utricles enclosed by th spongy fruiting calyx, the pericarp membranous. Seed erect, compressed; embryo conduplicate; endosperm none. [Name Greek, salt-horn; from the saline habitat, and horn-like branches.] About ro species, natives of saline soil, widely distributed in both the Old World and the New. Only the following are known to inhabit N. Am.

Annuals; stem erect.

Scales very short, acute or blunt ; spikes $2-3 \mathrm{~mm}$. in diameter.

Scales mucronate-tipped; spikes $4-6 \mathrm{~mm}$. in diameter. Perennial by a woody rootstock; stems trailing or decumbent.

I. S. herbacea.

2. S. Bigelorii.

3. S. ambigua.

r. Salicornia herbàcea L. Slender Glasswort. (I. F. f. 1389.) Annual, I.5-6 dm. tall; stem much bianched, the branches slender, ascending or nearly upright, their joints $2-4$ times as long as thick. Scales $2 \mathrm{~mm}$. long or less, broadly ovate or wider than long; fruiting spikes $2-8 \mathrm{~cm}$. long; middle flower of the 3 at each joint twice as high as the la:eral ones, reaching nearly to the top of the joint; utricle pubescent. In salt marshes, Anticosti to Ga.; about salt springs in central N. Y.; in saline scil from Manitoba to Br. Col., Kans. and Utah. Also in Europe and Asia. The plant often turns bright red in autumn, forming vividly colored areas in the salt marshes, hence called Marsh Samphire. July-Sept.

2. Salicornia Bigelòvii Torr. Bigelow's Glasswort. (I. F. f. 1390.) Annual, stout, erect or nearly so, 5-30 cm. tall. Scales ovate or triangular-ovate, sharply mucronate, $2-3 \mathrm{~mm}$. long, at length spreading; fruiting spikes $1-6 \mathrm{~cm}$. long, their joints not longer than thick; middle flower slightly higher than the lateral ones, reaching very nearly to the end of the joint; utricle pubescent. In salt marshes, N. S. to Fla. and Tex. Plant bright red in autumn. July-Sept.

3. Salicornia ambígua Michx. Woody Glasswort. (I. F. f. I39I.) Perennial by a woody rootstock; stem trailing or decumbent, 1.5-6 dm. long, the branches ascending or erect, slender, nearly or quite simple, rather long-jointed. Scales broadly ovate or wider than high, appressed or slightly divergent; fruiting spikes $x-4 \mathrm{~cm}$. long, their joints not longer than thick; flowers all about equally high and about equalling the joints. On sea beaches and salt meadows, Mass. to Fla. and Tex., and on the Pacific Coast. Aug.-Sept.

\section{SARCÓBATUS Nees.}

An erect much branched shrub, with spiny branches and alternate linear fleshy entire sessile leaves. Flowers monœcious or diœcious, the staminate in terminal 
ament-like spikes, the pistillate solitary in the axils, or rarely several together. Staminate flowers without a calyx; stamens 2-5 together under peltate rhombicovate acute spirally arranged scales; filaments short. Pistillate flowers sessile or very nearly so; calyx compressed, ovoid or oblong, slightly 2 .lipped, adnate to the bases of the 2 subulate exserted papillose stigmas, appendaged by a narrow border which expands into a membranous horizontal wing in fruit. Seed vertical, the testa translucent, double; embryo coiled into a flat spiral, green; endosperm none. [Name Greek, flesh-thorn, from the fleslıy leaves and thorny stems.] A monotypic genus of western N. Am.

I. Sarcobatus vermiculàtus (Hook.) Torr. Grease wood. (I. F. f. 1392.) Glabrous or the young foliage somewhat pubescent, o.6-3 m. high, the branches nearly white. Stem $2-8 \mathrm{~cm}$. in diameter; wood yelkw, very hard; leaves obtuse or subacute, I-4 cm. long, 2-3 $\mathrm{mm}$. wide; spikes of staminate flowers $6-25 \mathrm{~mm}$. long, cylindric, short-peduncled or sessile: wing of the calyx $8-12 \mathrm{~mm}$. broad when mature, conspicuously veined. In dry alkaline and saline soil, western Neb. and Mont. to Nev. and N. Mex. June-July.

\section{DÓNDIA Adans. [SUAEDA Forsk.]}

Fleshy herbs, or low shrubs, with alternate narrowly linear thick or nearly terete entire sessile leaves, and perfect or polygamous bracteolate flowers, solitary or clustered in the upper axils. Calyx 5-parted or 5-cleft, the segments in fruit enclosing the utricle. S amens 5. Styles usually 2, short. Pericarp separating from the seed. Embryo coiled into a flat spiral. Endosperm wanting or very little. [In honor of Jacopodi Dondi, Italian naturalist of the fourteenth century.] About 50 species, of wide geographic distribution. Besides the following, some 6 others occur in the western and southern parts of N. Am.

Calyx-lobes not appendaged; Atlantic coast species.

Dark green, not glaucous : sepals acutely keeled; seed black.

Light green, glaucous : sepals scarcely keeled; seed dark red. One or more of the calyx-lobes crested or winged; western species.

I. D. Americana.

2. D. maritima.

3. D. depressa.

I. Dondia Americàna (Pers.) Britton. TAll Sea-Blite. (I. F. f. 1393.) Stem erect. strict, 3-10 $\mathrm{dm}$. tall, pale green or nearly white, the branches slender, very leafy, erect-ascending or sometimes recurved. Leaves of the stem linearsubulate, 1-4 cm. long, those of the branches much shorter, somewhat 3-angled, lanceolate-subulate, widest just above the base, the upper surface flat; sepals glancous, acutely keeled or almost winged; seed orbicular, black, shining, $1 \mathrm{~mm}$. broad On salt marshes and along salt-water ditches, N. S. to N. J. Aug.-Sept.

2. Dondia marítima (L.) Druce. Low SEA-Blite. (I. F. f. I394.) Pale green and somewhat glaucous; stem bushy-branched, 1-4 dm. high, becoming brownish, the branches ascending. Leaves $10-25 \mathrm{~mm}$. long, those of the branches not conspicuously shorter than the upper ones of the stem, 3-angled, broadest at the base; sepals pale green, rounded or obtusely keeled, somewhat roughened; seed orbicular, dark brownish red, shining, about $2 \mathrm{~mm}$. in diameter. On sea beaches, stony and muddy shores, and in salt marshes, Me. to S. N. Y. Also on the coasts of Europe. July-Sept.

3. Dondia depréssa (Pursh) Britton. Western Blite. (I. F. f. 1395.) Branched, I.5-6 dm. tall, the branches usually very leafy. Leaves narrowly linear, $\mathbf{1 - 2 . 5} \mathrm{cm}$. long, broadest at or just above the base, or the upper lanceolate or ovate. lanceolate and commonly much shorter; sepals acute, one or more of them strongly keeled or crested in fruit; seed about $\mathbf{I} \mathrm{mm}$. in diameter, rather dull, minutely reticulated. In saline soil, Minn. to the N. W. Terr.,' south to Kans., Colo. and Nev. June-Aug.

\section{SÁLSOLA L.}

Bushy-branched herbs, with rigid subulate prickle-pointed leaves, and sessile perfect 2 -bracteolate flowers in the axils. Calyx 5-parted, its segments appendaged by a broad membranous horizontal wing in fruit and enclosing the utricle. Stamens 5. Ovary depressed; styles 2. Utricle flattened. Seed horizontal; embryo coiled into a conic spiral; endosperm none. [Name Latin, a diminutive of salsus, 
salty.] About 50 species, of wide geographic distribution on seashores and in saline districts, occasionally pernicious weeds in cultivated grounds.

Calyx coriaceous, not conspicuously veined; plant maritime.

Calyx membranous, very strongly veined; plant an inland weed. r. S. Kali:

2. S. Tragus.

I. Salsola Kàli L. SAltwort. (I. F. f. 1396.) Annual, loosely much branched, 3-6 dm. high, the branches ascending or spreading, mostly stout. Leaves dull green or grayish, 6-20 mm. long, succulent, lanceolate-subulate, swollen at the base, the midvein excurrent into a stout yellowish green prickle; flowers solitary in the axils ; wing of the persistent calyx nearly orbicular, lobed, becoming lacerate, not conspicuously veined, $4-8 \mathrm{~mm}$. in diameter; calyx coriaceous, not conspicuously veined, its wing not longer than the ascending lobe. On sea beaches, Cape Breton Island to Florida. Also in Europe and Asia. July-Sept.

2. Salsola Tràgus L. Russian Thistle. (I. F. f. 1397.) Similar to the preceding, but bushy branched, the branches usually slender. Leaves and outer branches usually bright red at maturity; leaves not noticeably swollen at the base, linear, prickle-tipped, less fleshy; calyx membranous, conspicuously veiny, its wing longer than the ascending lobe. In cultivated fields and waste places, N. J. to Ont., the N. W. Terr. and Kans. A very troublesome weed in many parts of the Central and Western States. Naturalized from northern Europe or Asia. July-Sept.

\section{Family 2. AMARANTHÀCEAE J. St. Hil.}

\section{Amaranth Family.}

Herbs, some exotic genera low shrubs, with simple mostly entire thin leaves. Flowers small, green or white, bracteolate, variously clustered, usually in terminal spikes or axillary heads. Petals none. Calyx herbaceous or membranous, 2-5-parted, the segments distinct, or united at the base, equal, or the inner ones smaller. Stamens I-5, mostly opposite the calyx-segments, hypogynous; filaments distinct, united at the base, or into a tube. Ovary I-celled; ovule solitary in the following genera, amphitropous (several in some tropical genera); stigmas I-3. Fruit a utricle, circumscissile, bursting irregularly, or indehiscent, I-seeded in our genera. Seed mostly smooth; embryo annular; endosperm mealy, usually copious. About 40 genera and 425 species, widely distributed, most abundant in warm regions.

Anthers 2-celled; leaves alternate.

Caly 5 -parted or of 5 sepals.

Calyx of the pistillate flowers wanting.

1. Amaranthus.

2. Acnida.

Anthers I-celled; leaves opposite.

Flowers in small axilliary clusters.

Flowers variously spicate or paniculate.

Calyx 5 -cleft ; filaments united into a tube.

Caly x 5-parted; filaments united at the base.

3. Cladothrix.

4. Froelichia.

5. Iresine.

\section{AMARÁNTHUS L.}

Annual branched erect or diffusely spreading glabrous or pubescent herbs, with petioled pinnately veined leaves and small monœecious polygamous or diøecious green or purplish mostly 3 -bracteolate flowers in dense terminal spikes or axillary clusters. Calyx of $2-5$ distinct sepals. Stamens 2-5; anthers longitudinally dehiscent. Styles or stigmas 2 or 3. Fruit an ovoid or oblong utricle, 2-3-beaked by the persistent styles. Embryo annular. [Greek, unfading flower, from the dry, unwithering bracts.] About 50 species of wide geographic distribution. Besides the following some 22 others occur in the southern and western U. S.

Utricle circumscissile, the top falling away as a lid.

Flowers, at least the upper, in dense terminal spikes.

Axils not spine-bearing.

Spikes stout, 8-14 mm. thick.

Spikes slender, $4-6 \mathrm{~mm}$. thick.

A pair of stout spines in each axil. 
Flowers all in small axilliary clusters, mostly shorter than the leaves.

Plant prostrate: sepals 4 or 5 .

Plant erect, bushy branched; sepals 3 .

4. A. blitoides.

5. A. graecizans.

Utricle indehiscent, membranous, coriaceous or fleshy.

Upper flowers in terminal, more or less elongated spikes.

Sepals 5, clawed; flowers diøecious ; southwestern species.

Bracts cuspidate-tipped, short.

Bracts subulate, long and sharp.

6. A. Torreyi.

7. A. Palmeri.

Sepals 2 or 3 , oblong or spatulate ; flowers monœcious or polygamous; in waste places.

Utricle smooth, dry, scarious. $\quad$ 8. A. lividus.

Utricle fleshy, 3-5-nerved.

Flowers all in small axillary clusters shorter than the leaves.

Plant not fleshy; stem prostrate ; leaves crisped.

Seacoast fleshy plant; stem short, erect; leaves not crisped.

9. A. deflexus.

10. A. crispus.

Ir. A. pumilus.

I. Amaranthus retrofléxus L. Rough Pigweed. (I. F. f. I398.) Roughishpuberulent, rather light green; stem stout, $0.3-3 \mathrm{~m}$. tall. Leaves ovate, rhombicovate or the upper lanceolate, acute or acuminate at the apex, narrowed or cuneate at the base, the larger 7-15 cm. long, their margins undulate or entire; flowers green, densely aggregated in spikes, which are sessile, stout, ovoid-cylindric, I-6 $\mathrm{cm}$. long; bracts subulate, twice as long as the 5 scarious mucronate-tipped and often emarginate sepals; stamens 5; utricle slightly wrinkled, rather shorter than the sepals. A weed, throughout N. Am. except the extreme north. Also in Eu. rope. Naturalized from tropical America. Aug.-Oct.

2. Amaranthus hybridus L. Slender Pigweed. (I. F. f. I399.) Similar to the preceding but darker green, or purple; stem usually slender, erect, $0.3-2.5 \mathrm{~m}$. tall. Leaves usually smaller; spikes linear-cylindric, axillary and forming dense terminal panicles, ascending, somewhat spreading or drocping; bracts subulate, twice as long as the 5 oblong acute or cuspidate sepals; stamens 5 ; utricle scarcely wrinkled. A weed, in waste grounds, range of the preceding species, but locally rare or absent. Naturalized from tropical America. Aug.-Oct.

Amaranthus hýbridus paniculatus (L.) Uline \& Bray. Flowers and foliage more or less deeply tinged with red or purple; leaves sometimes lanceolate and bracts shorter. Range of the type, but less abundant.

3. Amaranthus spinòsus L. Spiny Amaranth. (I. F. f. r400.) Stem stout, ridged, usually much branched, sometimes red, 3-12 dm. high. Leaves ovate, rhombic-ovate or the upper lanceolate, acute at both ends, $2-8 \mathrm{~cm}$. long, with a pair of rigid stipular spines at each node, the midvein excurrent; flowers in numerous capitate axillary clusters, and in dense terminal spreading or drooping spikes 2-15 $\mathrm{cm}$. long; bracts lanceolate-subulate about as long as the 5 scarious oblong mucronate-tipped I -nerved sepals, and the thin imperfectly circumscissile utricle; stamens 5. In waste and cultivated soil, Mass. to Penn., Ohio, Kans., Fla. and Mex. Naturalized from tropical America. June-Sept.

4. Amaranthus blitoides S. Wats. Prostrate Amaranth. (I. F. f. I401.) Stem diffusely branched, prostrate and spreading on the ground, 1.5-6 dm. long, often forming mats. Leaves obovate or spatulate, 6-25 $\mathrm{mm}$. long, narrowed into slender petioles; flowers in small axillary clusters; bracts lanceolate-subulate, little longer than the 4 or 5 oblong-lanceolate acute or cuspidate sepals; stamens 3 ; utricle nearly smooth, equalling or slightly longer than the sepals. In waste places, espe. cially along the principal routes of travel, Me. to S. Ont., Minn., N. J., Mo. and Kans. Naturalized from west of the Rocky Mts., where it appears to be indigenous from Utah and Colo. to Mex. June-Oct.

5. Amaranthus graecizans L. Tumble-WeEd. (I. F.f. I402.) Glabrous, pale green; stem erect, bushy-branched, whitish, I.5-7 dm. tall, the branches slender, ascending. Leaves oblong, spatulate or obovate, $1-4 \mathrm{~cm}$. long, papillose, the midvein excurrent; flowers polygamous, several together in small axillary clusters; bracts subulate, pungent-pointed, spreading, much longer than the 3 membranous sepals; stamens 3 ; utricle wrinkled, longer than the sepals. In waste and cultivated soil throughout N. Am. Naturalized from tropical America. The leaves fall away in autumn, and on the western plains the plant, thus denuded, is freely uprooted and blown before the wind, whence the popular name. June-Sept. [A. albus L.] 
6. Amaranthus Tórreyi (A. Gray) Benth. TORREY's Amaranth. (I. F. f. 1403.) Glabrous or nearly so; stem erect, grooved, 6-1o dm. tall. Leaves lanceolate or rhombic-lanceolate, thin, narrowed above to a rather blunt apex, mostly cuneate at the base, 4-10 cm. long, slender-petioled; flowers diœcious, in terminal slender spikes and in axillary clusters; bracts shorter than or about equalling the 5 sepals, cuspidate; sepals of the pistillate flowers obovate or broadly spatulate, clawed, obtuse or emarginate, those of the staminate flowers narrower and subacute. In dry soil, W. Neb. to Nev., south to Mex. Plant with the aspect of Acnida. June-Aug.

7. Amaranthus Pàlmeri S. Wats. Palmer's Amaranth. (I. F. f. I404.) Somewhat similar to the preceding; stem slender, branched, 6-10 dm. tall, usually pubescent above. Leaves ovate, rhombic-ovate or the upper lanceolate, blunt, narrowed at the base, slender-petioled; flowers dicecious, in elongated spikes often $2 \mathrm{~cm}$. long or more, and some of them commonly in clusters in the upper axils; bracts subulate, spiny-awned, spreading, twice as long as the sepals; sepals 5, spatulate, clawed. In dry soil, Kans. to Tex. and Mex., west to Cal. June-Sept.

8. Amaranthus lividus L. Purplish Amaranth. (I. F. f. 1405.) Glabrous, rather succulent, purplish-green; stem slender, 3-9 dm. tall. Leaves ovate, entire, 2-8 cm. long, strongly emarginate, narrowed at the base, slender-petioled; flowers monœcious or polygamous, in dense terminal spikes and in capitate axillary clusters; bracts shorter than the 2 or 3 oblong or spatulate sepals; utricle smooth, longer than the sepals. In waste places, E. Mass. to S. N. Y. Adventive from tropical America. July-Sept.

9. Amaranthus defléxus L. Low Amaranth. (I. F. f. 1406.) Glabrous, vurplish-green: stem usually much branched, 3-10 dm. tall. Leaves ovate or oval, obtuse retuse or emarginate, mostly narrowed at the base, $\mathbf{I}-4 \mathrm{~cm}$. wide, slender-petioled; flowers polygamous in dense, thick terminal spikes and capitate in the axils; bracts shorter than the 2 or 3 oblong or spatulate sepals; utricle fleshy, 3-5-nerved, smooth, rather shorter than the sepals. In waste places and ballast along the coast, Mass. to S. N. Y. Also in Cal. Probably adventive from tropical America. July-Sept.

10. Amaranthus críspus (Lesp. \& Thev.) Braun. CRisp-Leaved Amaranth. (I. F. f. 1407.) Pubescent; stem copiously branched, slender, spreading, forming mats 2-7 dm. in diameter. Leaves oblong or lanceolate, mostly acute at the apex and narrowed at the base, petioled, $8-25 \mathrm{~mm}$. long, their margins remarkably crisped; flowers in small axillary clusters; bracts lanceolate, cuspidate, shorter than the 5 spatulate spreading sepals; stamens (always?) 3; utricle wrinkled, about as long as the sepals. In waste places, N. Y. City, and Albany, N. Y. Also in France. Native region unknown. June-Sept.

II. Amaranthus pùmilus Raf. Coast Amarantri. (I. F. f. 1408.) Glabrous, fleshy, branched, the branches 0.5-2 dm. long. Leaves ovate, rhombicovate or suborbicular, most of them clustered toward the ends of the branches, obtuse or emarginate, narrowed or rounded at the base, prominently veined; 6-20 $\mathrm{mm}$. long, the veins often purple; flowers few in small axillary clusters; bracts lanceolate, subacute, shorter than the 5 oblong obtuse sepals; stamens 5 ; anthers yellow; utricle fleshy, faintly 5-ribbed, slightly wrinkled, nearly twice as long as the sepals when mature; seed very large for the genus. On sea beaches, R. I. to N. Car. June-Sept.

\section{ACNIDA L.}

Annual, glabrous herbs, similar to the diœcious Amaranths, with alternate petioled pinnately veined leaves. Flowers small, green, I-3-bracted, in terminal and axillary spikes, or clustered in the axils. Staminate flowers consisting of 5 scarious erect I-nerved mucronate sepals longer than the bracts, and as many stamens; filaments subulate, distinct; anthers 2-celled. Pistillate flowers without a calyx; stigmas 2-5, papillose or plumose. Seed erect, smooth and shining. [Greek, without nettle.] About 4 species, natives of eastern North America and the West Indies. 
I. Acnida cannábina L. Salt-marsh Water-hemp. (I. F. f. 1409.) Succulent, stem usually much branched, $0.3-3 \mathrm{~m}$. tall. Leaves lanceolate, acuminate but generally blunt-pointed and apiculate, $5-15 \mathrm{~cm}$. long, narrowed at the base, entire or slightly undulate; staminate spikes $2-13 \mathrm{~cm}$. long, usually dense; sepals oblonglanceolate or ovate-oblong, cuspidate or mucronate; stigmas slender, papillose. hispid, I $\mathrm{mm}$. long; utricle 3-5-angled, 2-4 $\mathrm{mm}$. long when mature, becoming black, much longer than the bracts. In salt and brackish marshes, and up the rivers to fresh water, Mass. to Fla. July-Aug.

Açida Floridàna S. Wats., a more slender plant, of the southern Atlantic coast, with narrower slender-petioled leaves, the flowers in elongated interrupted spikes, and a smaller utricle, may occur in southern Va.

2. Acnida tamaríscina (Nutt.) Wood. Western Water-hemp. (I. F. f. 1410.) Similar to the preceding, the branches usually slender. Leaves lanceolate or ovate-lanceolate, mostly long-acuminate, but sometimes obtuse, narrowed at the base; spikes mostly loose or interrupted; sepals lanceolate, subulate-acuminate; stigmas plumose, rather short; utricle not angled, I-2 mm. long, circumscissile; bractlets lanceolate, cuspidate. In swamps, Ill. to S. Dak., La. and N. Mex. July-Sept.

Acnida tamaríscina tuberculàta (Moq.) Uline \& Bray. Tall, erect, sometimes $3 \mathrm{~m}$. high, with flexuous branches; inflorescence spicate; utricle ovoid, tubercled, indehiscent. Vt. to Manitoba, Tenn. and Neb. This and the following varieties perhaps constitute a distinct species.

Acnida tamaríscina concatenàta (Mog.) Uline and Bray. Stems of ten pecumbent ; flowers larger, in separate glomerules. Range of preceding variety.

Acnida tamariscina prostràta Uline \& Bray. Stems diffuse and prostrate or sometimes ascending; leaves rarely over $2.5 \mathrm{~cm}$. long, spatulate; flowers in axillary clusters or ill separated glomerules. Mich. to S. Dak. and Mo.

\section{CLÁDOTHRIX Nutt.}

Diffusely branched stellate-pubescent herbs, with opposite entire or slightly undulate petioled leaves, and very small perfect 3 -bracted flowers in the axils. Calyx of 5 equal pilose erect dry oblong I-nerved sepals. Stamens 5, hypogynous, their filaments united at the base, their anthers I-celled. Ovary subglobose; style short; stigma capitate or 2-lobed. Utricle globose, indehiscent. [Greek, branchhair, from the stellate pubescence.] About 4 species, natives of southwestern $\mathrm{N}$. Am. and Mex.

I. Cladothrix lanuginòsa Nutt. (I. F. f. 14II.) Perennial, somewhat woody at the base, or sometimes annual; stem much branched, the branches I-3 $\mathrm{dm}$. long. Leaves orbicular, broadly ovate or rhombic-ovate, usually narrowed at the base, entire, inconspicuously veined, 4-25 $\mathrm{mm}$. wide; flowers I $\mathrm{mm}$. broad or less, mostly clustered in the axils of small upper leaves. In dry soil, Kans. to Tex., Ariz. and Mex. June-Sept.

\section{FROELÍCHIA Moench.}

Annual erect woolly or silky herbs, with opposite sessile entire or slightly undulate narrow leaves, or the lower and basal ones contracted into petioles. Flowers perfect, 3-bracted, often bracteolate, in panicled dense spikes. Calyx tubular, nearly terete, 5.cleft or 5-tootlied, very woolly, its tube longitudinally crested and sometimes tubercled in fruit. Stamens 5 , their filaments united into a tube, which is 5 -cleft at the summit and bears the I-celled anthers between its lobes. Ovary ovoid; stigma capitate or penicillate. Utricle indehiscent, enclosed by the tube of united filaments. [Name in honor of J. A. Froelich, a German botanist.] About 12 species, all American. Besides the following, 2 others occur in the Suuthwestern States.

Stout, 6-12 dm. tall; crests of fruiting calyx continuous, dentate. Slender, 2-5 dm. tall ; crests of fruiting calyx interrupted.

1. F. campestris.

2. F. gracalis.

1. Froelichia campéstris Small. Prairie Froelichia. (I. F. f. 1412.) Stem stout, the branches leafless above. Upper leaves linear or linearoblong, acute or acuminate at both ends, 2-8 cm. long, the lower spatulate or oblanceolate, $8-15 \mathrm{~cm}$. long, narrowed into margined petioles; spikes mostly 
opposite, narrowly ovoid or oblong, I-2.5 cm. long. In dry soil, Ill. and Minn. to Neb., Colo., Tenn., and Tex. June-Sept. [F. Floridana Moq., in part.]

2. Froelichia grácilis Moq. Slender Froelichia. (I. F. f. I4I3.) Similar to the preceding, but the stem slender, sometimes simple, $2 \cdot 5-5 \mathrm{dm}$. tall. Leaves all linear or linear-ublong, acute at both ends, 2-5 cm. long: spikes altcrnate or opposite, oblong, mostly obtuse, 6-25 mm. long. In dry soil, W. Neb. and Colo. to Tex. June-Sept.

\section{IRESINE P. Br.}

Tall herbs, with opposite broad petioled leaves and small 3-bracted white flowers, in large terminal panicles or panicled spikes. Calyx 5-parted, the pistillate usually woolly. Stamens 5, rarely fewer; filaments united by their bases, filiform; anthers x-celled. Utricle very small, subglobose, indehiscent. [Greek, in allusion to the woolly pubescence.] About 20 species, natives of warm and temperate regions. Besides the following another occurs in the southwestern U.S.

I. Iresine paniculàta (L.) Kuntze. Blood-leaf. JubA's Bush. (I. F. f. 1414.) Annual; stem erect, 0.6-1.5 m. tall, glabrous or nearly so. Leaves ovate, ovate-lanceolate or the upper lanceolate, $0.5-1.5 \mathrm{dm}$. long; flowers very numerous, $2 \mathrm{~mm}$. broad or less, calyx and bracts silvery; pistillate flowers white-villous at the base, about twice as long as the bracts. In dry soil, Ohio to Kans., Md., Fla. and Tex. Widely distributed in tropical America. Aug.-Sept. [I. celosioides L.]

\section{Family 3. PHYTOL.ACCÀCEAE Lindl.}

\section{Pokeweed Family.}

Herbs (some tropical species shrubs or trees) with alternate entire mostly exstipulate leaves, and perfect regular polygamous or monœcious flowers. Calyx 4-5-parted or of 4 or 5 sepals, its segments or sepals imbricated in the bud. Petals wanting. Stamens as many as the calyx-segments or sepals and alternate with them, or more numerous, hypogynous; filaments distinct, or united at the base; anthers 2-celled, the sacs longitudinally dehiscent, ofter nearly separated. Ovary superior, several-celled in most of the genera; ovules solitary in the cavities, amphitropous. Styles as many as the carpels, short or none; stigmas linear or filıform. Fruit a berry in the following genus. Endosperm of the seed mealy or fleshy. About 22 genera and 85 species, mostly in the tropics.

\section{x. PHYTOLÁCCA L.}

Tall perennial herbs, with petioled exstipulate leaves, and small flowers in terminal racemes, which by the further growth of the stem become opposite the leaves. Pedicels bracted at the base and often 1-3-bracted above. Calyx of 4 or 5 persistent rounded sepals. Stamens 5-15, inserted at the base of the calyx. Ovary composed of 5-15 distinct or somewhat united carpels. Fruit a depressed. globose 5-I5-celled fleshy berry. Seeds I in each cavity, erect, compressed; embryo annular in the mealy endosperm. [Name Greek and French, referring to the crimson juice of the berries.] About 10 species, the following of castern N. Am., the others tropical.

r. Phytolacca decándra L. Poke. Scoke. Pigeon-rerry. Garget. (I. F. f. I4I5.) A glabrous strong-smelling succulent erect herb, I-4 m. tall, the root large, poisonous, the stem stout, its pith divided into disks. Leaves oblonglanceolate or ovate-lanceolate, acute or acuminate at both ends, 2-3 dm. long; racemes $0.5^{-2} \mathrm{dm}$. long; pedicels 4-12 mm. long; flowers perfect; calyx white, 4-6 mm. broad; stamens 10, slightly shorter than the sepals; ovary green, 10. celled; styles recurved; berry dark purple, 10-12 $\mathrm{mm}$. in diameter, very juicy, its 10 carpels conspicuous when dry. In various situations, Me. and Ont. to Minn., Fla. and Tex. Naturalized in Europe. June-Sept. Berries ripe Aug.-Oct. 


\section{Family 4. NYCTAGINÀCEAE Lindl.}

\section{Four-o'clock Family.}

Herbs (some tropical genera trees or shrubs) with simple entire leaves, and regular flowers in clusters, in the following genera subtended by involucres. Petals none. Calyx inferior, usually corolla-like, its limb 4-5-lobed or 4-5-toothed. Stamens hypogynous; filaments filiform; anthers 2-celled, dehiscent by lateral slits. Ovary enclosed by the tube of the perianth, I-celled, I-ovuled; ovule campylotropous; stigma capitate. Fruit a ribbed, grooved or winged anthocarp. About 17 genera and 250 species, of wide geographic distribution, most abundant in America.

Involucre of united bracts; pairs of leaves equal.

Involucre of separate bracts; pairs of leaves mostly unequal.

I. Allionia.

\section{ALLIónIA'Loefi. [OXYBAPHUS L'Her.] (See Appendix.)}

Forking herbs, with opposite equal leaves, and involucres in loose terminal panicles. Involucre 5 lobed (of 5 partially united bracts), 3-5-flowered, becoming enlarged and reticulate-veined after flowering. Perianth campanulate, its tube constricted above the ovary, its limb deciduous. Stamens 3-5, generally 3 , un. equal, hypogynous. Fruit obovoid or clavate, strongly ribbed, pubescent in our species. [Name in honor of Chas. Allioni, 1725-1804, a botanist of Turin. About 20 species, natives of N. and S. Am., one Asiatic.

Leaves broadly ovate, cordate or oblong-ovate, all petioled.

Leaves oblong or lanceolate, only the lower petioled.

Plant glabrous or nearly so except the inflorescence.

Plant densely pubescent all over.

Leaves linear, sessile.

Plant tall, $59 \mathrm{dm}$. high; branches erect-ascending.

Plants low, I-2.5 dm. high, diffusely branched; branches divergent.

Involucres axillary, their lobes ovate-oblong, acute.

Involucres clustered at the ends of branches, lobes simicircular, obtuse.

1. A. nyctaginea.

2. A. lanceolata.

3. A. hirsuta.

4. A. linearis.

5. A. Bodini.

6. A. Bushi.

I. Allionia nyctagínea Michx. Heart-leaved Umbrella-wort. (I. F. f. 1416.) Stem often 4-sided below, glabrous or slightly pubescent, 3-9 dm. tall. Leaves broadly ovate, $5-10 \mathrm{~cm}$. long, acute at the apex, cordate, rounded or trun. cate at the base, all petioled except the bract-like uppermost ones, glabrous or nearly so; peduncles and pedicles commonly somewhat pubescent; involucre shorter than the flowers; perianth red; stamens 3-5, exserted; style exserted; fruit oblong or narrowly obovoid, very pubescent. In dry soil, Minn. to the N. W. Terr., Ill., La. and N. Mex. May-Aug.

2. Allionia lanceolata Rydb. PAle UMbrella-wort. (I. F. f. I417.) Stem 4-sided below, 3-9 dm. tall, the peduncles and branches commonly glandular and viscous. Leaves lanceolate or oblong-lanceolate, 3-veined, the upper sessile, the lower short-petioled; involucre much enlarged in fruit, pubescent, ciliate, becoming whitish and purpled-veined; perianth pink or lilac; fruit with 5 or 6 obtuse hispid ribs, roughened in the furrows. Minn. to Mont., Colo., Ala., Mo. and Tex. May-Aug. (A. albida Rydb., in part, not Walt.)

2a. Allionia floribùnda (Choisy) Kuntze. Ovate-Leaved Umbrel.AWORT. Similar to the preceding, but the leaves ovate or the upper ovate-lanceo. late, not cordate. Dry soil, S. D. to Mo., Wyo. and N. Mex.

3. Allionia hirsùta Pursh. HaIry Umbrella-wort. (I. F. f. I4I8.) Stem 3-9 dm. tall, erect. anoled. olandular-pubescent, especially at the nodes, occi. sionally glabrate toward the base. Leaves lanceolate or linear-lanceolate, obtuse, sessile or the lowest sometimes short-petioled, pubescent, $2-8 \mathrm{~cm}$. long; branches and petioles very pubescenc; inflorescence usually contracted; stamens often $\mathbf{5 i}$ fruit narrowly obovoid, the ribs obtuse. In dry soil, Minn. to the N. W. Terr., Wis., Colo. and Tex. July-Aug.

4. Allionia lineàris Pursh.

NARROW-LEAVED UMBRELla-WORT.

(I. F. $\mathbf{f}$ 1419.) Stem glabrous, glaucous, $3^{-13} \mathrm{dm}$. tall, the branches and peduncles some. 
times puberulent. Leaves linear, thick, I-nerved, 2-6 cm. long, sessile or the lower occasionally short-petioled; involucre about 3 -flowered; perianth purple, longer than the involucre; stamens and style exserted; fruit commonly roughened in the furrows between the 5 prominent ribs. In dry soil, Minn. to Mont., Utah, Tex. and Mex. June-Aug.

5. Allionia Bòdini (Holzinger) Morong. (Bodin's Umbrella-wort. (I. F. f. 1420.) Low, glabrous or minutely pubescent, stem whitish, diffusely branched, $0.5^{-1.3 ~ d m}$. high. Leaves narrowly linear, sessile, I-3 cm. long, $2 \mathrm{~mm}$. wide or less, fleshy; involucres solitary and short-peduncled in the upper axils, finely pubescent, about $6 \mathrm{~mm}$. broad when mature, 5-lobed to about the middle, the lobes ovate-oblong, acute; fruit narrowly obovoid, obtusely 5 -ribbed, very pubescent, 5 mm. high. In dry soil, E. Colo. and W. Kans. June-July.

6. Allionia Búshi Britton. Bush's Umbrella-wort. (I. F. f. I42I.) Low, glabrous, somewhat fleshy, stem nearly white, diffusely branched, about $2 \mathrm{dm}$. high, the branches widely divergent. Leaves narrowly linear, sessile, $2-8 \mathrm{~cm}$. long, 2-3 $\mathrm{mm}$. wide, blunt, their width almost uniform from base to apex; involucres clustered at the ends of the branches, at first campanulate and longer than the flowers, at length rotate and becoming $2 \mathrm{~cm}$. broad, membranous, pubescent, finely reticulate-veined, their lobes semicircular, rounded, the midveins prominent. In dry ground; Jackson Co., Mo. Aug.

\section{ABRÒNIA Juss.}

Herbs, with opposite petioled thick entire leaves, one of each pair somewhat larger than the other. Stems branching, mostly glandular-pubescent, with clus. tered or solitary numerous-flowered involucres on long axillary peduncles. Flowers sessile, usually conspicuous. Perianth-tube elongated, tubular or funnelform, the limb spreading, 5-lobed, the lobes obcordate or emarginate. Stamens 3-5, unequal, inserted on the tube of the perianth; anthers linear-oblong, included. Style filiform. Fruit dry, I-5-winged, the wings reticulate-veined. Seed cylindric, smooth, shining. [Name from the Greek, graceful,] About 15 species, all American. Besides the following, some 10 others occur in western N. Am.

Perennial ; flowers white; wings of the fruit $2 \mathrm{~mm}$. broad or less. I. A. fragrans. Annual ; flowers pink ; wings thin, 8-14 mm. broad, very conspicuous.

2. A. micrantha.

I. Abronia fràgrans Nutt. White AbroniA. (I. F.f. I422.) Viscid-pubescent; stem erect or ascending, usually much branched, 3-6 dm. high. Leaves oval, ovate, or oblong-elliptic, petioled, obtuse at the apex, 2-6 cm. long; bracts of the involucre 5 or 6 , large, ovate or obovate, white; flowers white, very numerous in the involucres, $1-2 \mathrm{~cm}$. long, fragrant, opening at night; fruit 8 - Io $\mathrm{mm}$. high, coriaceous with 5 or sometimes fewer, undulate coarsely reticulated wings which do not close over its summit. In dey soil, Iowa to Neb., Mont., Tex. and Mex. June-Aug.

2. Abronia micrántha (Torr.) Chois. Pink Abronia. (I. F. f. 1423.) Glabrous below, more or less glandular-pubescent above; stem ascending, branched, 3-6 dm. high. Leaves similar to those of the preceding; involucral bracts ovate or ovate-lanceolate, acute or acuminate; flowers several or numerous, about $18 \mathrm{~mm}$. long, bright pink; calyx-limb 8-16 $\mathrm{mm}$. hroad; fruit nearly $2.5 \mathrm{~cm}$. high, its $2-4$ membranous wings entire-margined, shining, glabrous, united over the body of the fruit, beautifully reticulate-veined. In dry soil. W. Neb. to Mont., Nev., Tex. and N. Mex. June-Aug.

\section{Family 5. AIZOÀCEAE A. Br.}

\section{Carpet-weed Family.}

Herbs, rarely somewhat woody, mostly prostrate and branching, with (in our species) opposite or verticillate leaves and perfect, small regular flowers. Stipules none or scarious, or the petiole-bases dilated. Calyx 4-5-cleft or 4-5-parted. Petals small or none in our species. Stamens perigynous. Ovary usually free from the calyx, 3-5-celled, and ovules numerous in each cell in our species. Fruit a capsule with loculicidal 
or circumscissile dehiscence. Seeds amphitropous; endosperm scanty or copious; embryo slender, curved. About 22 genera and 500 species, mostly of warm regions, a few in the temperate zones.

Fleshy seacoast herbs ; leaves opposite ; capsule circumscissile.

Not fleshy ; leaves in our species verticillate; capsule 3 -valved.

r. Sesuvitum.

2. Mollugo.

\section{SESÙVIUM L. (See Appendix.)}

Fleshy decumbent or prostrate herbs, with opposite leaves and axillary pink or purplish flowers. Stipules none, but the petioles often dilated and connate at the base. Calyx-tube top-shaped, 5-lobed, the lobes oblong, obtuse. Petals none. Stamens 5-6o, inserted on the calyx-tube. Filaments filiform, sometimes united at the base. Ovary 3-5-celled. Styles 3-5, papillose along the inner side. Capsule membranous, oblong, 3-5-celled, circumscissile. Seeds round-reniform, smooth; embryo annular. About 4 species, natives of seacoasts and saline regions. Besides the following, another occurs in the Southern States and in the alkaline areas of the Far West.

I. Sesuvium marítimum (Walt.) B. S. P. Sea Purslane. (I. F. f. I424.) Annual, glabrous; branches 0.5-3 dm. long. Leaves obovate or spatulate, entire, rounded or slightly emarginate at the apex, narrowed into a petiole or the upper sessile, 8-25 mm. long; flowers sessile or nearly so, about $2 \mathrm{~mm}$. broad, mostly solitary; stamens 5 , alternate with the calyx-lobes; capsule ovoid, about $4 \mathrm{~mm}$. high, scarcely longer than the calyx. Sands of the seashore, Long Island, N. Y., to Fla. July-Sept. [S. pentandrum Ell. $]$

\section{MOLLÙGO L.}

Herbs, mostly annual, much branched, witl verticillate, or in some species basal or alternate leaves, and small cymose or axillary whitish flowers. Stipules scarious, deciduous. Calyx 5-parted. Sepals persistent, scarious-margined. Petals none. Stamens 3-5, when 3 alternate with the cavities of the ovary, when 5 alternate with the sepals. Ovary usually 3-celled. Capsule usually 3-celled, 3-valved, loculicidally dehiscent. Seeds small, the testa smooth, granular or sculptured. About I 2 species, most of them tropical. Besides the following, another occurs in the Southwest.

I. Mollugo verticillàta L. CARPET-WEed. (I. F. f. I425.) Prostrate, glabrous, not fleshy, spreading and forming patches sometimes $5 \mathrm{dm}$. in diameter. Leaves verticillate, in 5's or 6's, spatulate, obovate or linear, entire, obtuse, I-2.5 $\mathrm{cm}$. long, narrowed into a petiole; flowers axillary, less than $2 \mathrm{~mm}$. broad; pedicels filiform; sepals oblong, slightly shorter than the ovoid capsule, which appears roughened by the projecting seeds; seeds reniform, usually smooth and shining. In waste and cultivated grounds, N. B. and Ont. to Minn., Fla., Tex. and Mex. Native of the warmer parts of America. May-Sept.

\section{Family 6. PORTULACÀCEAE Reichenb.}

\section{Purslane Family.}

Herbs, rarely somewhat woody, with regular perfect but unsymmetrical flowers. Sepals commonly 2 (rarely 5). Petals 4 or 5, rarely more, hypogynous, imbricated. Stamens hypogynous, equal in number to the petals or fewer, rarely more; filaments filiform; anthers 2-celled, longitudinally dehiscent. Ovary I-celled; style 2-3-cleft or 2-3-divided, the divisions stigmatic on the inner side; ovules $2-\infty$, amphitropous. Capsule circumscissile, or dehiscent by 3 valves. Seeds $2-\infty$, reniform-globose or compressed; embryo curved. About 150 species, mostly natives of America.

Calyx free from the ovary; capsule 3 -valved.

Seeds numerous; stamens $5-\infty$.

Seeds not more than 6 ; stamens $2-5$.

Petals distinct or very nearly so, and stamens 5 in our species.

Petals united into a short tube at the base; stamens 2 or 3 .

x. Talinum.

2. Claytonia.

3. Montia.

Calyx partly adnate to the orary; capsule circumscissile.

4. Portulaca. 


\section{TALİNUM Adans. (See Appendix.)}

Fleshy glabrous erect or ascending herbs, with alternate terete or flat exstipulate leaves (terete and clustered near the base in the following species). Sepals z, ovate. Petals 5, hypogynous, fugacious. Stamens adherent to the bases of the petals. Ovary many-ovuled; style 3-lobed or 3-cleft. Capsule ovoid, oval or globose. Seeds numerous, borne on a central globose placenta. [Aboriginal name of a Senegal species.] A genus of about 12 species, all but 1 or 2 natives of America. In addition to the following, about 4 others occur in the western and southwestern U. S.

Flowers 10-16 nm. broad; sepals deciduous.

Stamens ro-30; capsule globose.

Stamens only 5: capsule oval.

Flowers 20-30 mn. broad; şepals persistent.

I. T. teretifolium.

2. T. parviflorum.

3. 7. calycinum.

I. Talinum teretifòlium Pursh. FAME-FLower. (I. F. f. I426.) Perennial, erect, I-3 dm. high, leafy at the base. Leaves linear, terete, $\mathbf{I}-5 \mathrm{~cm}$. long, about $2 \mathrm{~mm}$. wide, the base broadened and prolor ged posteriorly; scape-like peduncles I-5, terminal, branched. leafless, o.7-I.5 dm. long; cymes terminal, loose; flowers pink, I2-16 mm. broad, opening for a day; sepals membranous, deciduous, ovate, obtuse, $4 \mathrm{~mm}$. long, about half the length of the petals; style as long as the stamens; capsule globose. $4 \mathrm{~mm}$. in diameter; bracts of the cyme ovate or ovate-lanceolate. On dry rocks, Penn. to Minn., Ga. and Tex. May-Aug.

2. Talinum parvifiòrum Nutt. SMall-Flowered Talinum. (I. F. f. 1427.) Perennial, similar to the preceding. Leaves terete or nearly so, rather more slender, broadened at the base; scape-like peduncles slender, $0.7-2 \mathrm{dm}$. tall; cymes loose; flowers pink, 8-Io mm. broad; sepals ovate, deciduous, acute or subacute; stamens 5 (or sometimes fewer ?); capsule $4 \mathrm{~mm}$. high, about $2 \mathrm{~mm}$. in diameter; bracts slightly prolonged posteriorly. In dry soil, Minn. to S. Dak., Ark., N. Mex. and Tex. Miy-Sept.

3. Talinum caly cinum Engelm. LARGE-FLOWEREd TALiNum. (I. F. f. I428.) Peremnial, erect from a thick root, $1.5-2.5 \mathrm{dm}$. high. Leaves nearly terete, $3-5 \mathrm{~cm}$. long, the base triangular-broadened, slightly prolonged posteriorly; •cyme somewhat compound, scarious-bracted; flowers pink, 2-3 cm. broad; sepals broadly ovate, persistent, cuspidate; petals twice as long as the calyx; stamens I2-30; style twice as long as the stamens; capsule globose-ovoid, about $6 \mathrm{~mm}$. in diameter. In dry soil, Neb. and Kans. to Tex. June.

\section{CLAYTÒNIA L.}

Succulent glabrous herbs, with petioled basal leaves, and opposite or alternate cauline ones. Flowers terminal, racemose or cymose. Sepals 2, ovate, persistent. Petals 5, hypogynous, distinct, or slightly united by their bases. Stamens 5, inserted on the bases of the petals. Ovary few-ovuled; style 3-lobed or 3-cleft. Capsule 3-valved, 3-6-seeded. Seeds compressed, orbicular or reniform. [In honor of John Clayton, I686?-I773, American botanist.] About 25 species, mainly natives of northern N. Am.

Upper leaves not connate.

Perennials : leaves linear, lanceolate, oval or ovate. Leaves linear lanceolate, $8-17 \mathrm{~cm}$. long.

Leaves ovate-lanceolate or ovate, $5-8 \mathrm{~cm}$. long.

Annual, diffuse ; leaves spatulate or oblanceolate. Upper leaves connate, forming an orbicular disk.

r. C. Virginica.

2. C. Caroliniana.

3. C. Chamissoi.

4. C. perfoliata.

I. Claytonia Virgínica L. Spring Beauty. (I. F. f. I429.) Ascending or decumbent, perennial from a deep tuberous root; stem I.5-3 dm. long, simple or rarely with a few branches. Leaves elongated, linear, or linear-lanceolate, the bisal 2-12 cm. wide, the cauline shorter and opposite; raceme lonse, somewhat secund; flowers white or pink, with darker pink veins, I-2 cm. broad; pedicles slender, at length recurved; petals emarginate; capsules shorter than the sepals. In moist woods, N. S. to the N. W. Terr., Ga. and Tex. March-May.

2. Claytonia Caroliniàna Michx. Carolina Spring Beauty. (I. F. f. 1430.) Similar to the preceding species but sometimes more nearly erect. Basal 
leaves ovate-lanceolate or oblong, $\mathbf{I}-2 \mathrm{~cm}$. wide, obtust, tsem-leaves on petio'es 6-12 mm. long; flowers fewer. In damp woods, N. S. to the N. W. Terr., Conn., N. Car., Ohio and Mo. March-May.

3. Claytonia Chamíssoi Ledeb. Chamisso's Claytonia. (I. F. f. I43I.) Annual, glabrous, stoloniferous; stems weak, ascending or procumbent, $0.7-2.5 \mathrm{dm}$. long. Leaves spatulate or oblanceolate, obtuse, 6-10 mm. wide; flowers few, pink, racemose, 6-8 $\mathrm{mm}$. broad; pedicels slender, recurved in fruit; capsule very small. In wet places, Minn. to Br. Col., Alaska, south in the Rocky Mts. to N. Mex. and to Cal. May-June.

4. Claytonia perfoliàta Donn. Spanish Letruce. (I. F. f. I432.) Annual; stems several, simple, $0.7-3 \mathrm{dm}$. ligh, bearing a pair of connate-perfoliate leaves near the summit. Basal leaves rhomboid-ovate, long-petioled; petioles shorter than the stems; raceme usually peduncled, several flowered; bracts broad, deciduous ; flowers white or pink, 6-10 mm. broad; petals and stamens 5 ; capsule globose, 2-4 $\mathrm{mm}$. in diameter, 2-5-seeded. Established near Painesville, Ohio. Native from Br. Col. to Mex. April-May.

\section{MÓNTIA L.}

Small annual glabrous herbs, with opposite fleshy leaves and minute nodding white flowers. Sepals 2 (rarely 3), broadly ovate, persistent. Petals 5, hypogynous, more or less united. Stamens 3 (very rarely 5), inserted on the corolla. Ovary 3-ovuled; style short, 3-parted. Capsule 3-valved, 3-seeded. Seeds nearly ribicular, compressed, minutely tuberculate ; embryo peripheral. [In honor of Guiseppe Monti, Italian botanist and author of the eighteenth century.] About 4 species, widely distributed in the colder parts of both hemispheres. In addition to the following, another occurs in Oregon.

r. Montia fontana L. Water or Blinking Chickweed. (I. F. f. 1433.) Tufted, weak, diffuse or ascending, 2-15 cm. long, inanching. Leaves opposite, spatulate or obovate, mainly obtuse, 6-12 mm. long, $2 \mathrm{~mm}$. broad or less; flowers nodding, solitary and terminal or in a small loose leafy-bracted raceme; sepals obtuse, slightly shorter than the ovate-oblong petals; capsule globose, nearly $2 \mathrm{~mm}$. in diameter. In springs and wet places, Quebec and Me. to Lab., Newf. and across arctic America, south in the mountains to Calif. Also in the Andes of S. Am., in Australasia and in northern Europe and Asia. Summer.

\section{PORTULÀcA L. (See Appendix.)}

Diffuse or ascending, glabrous or pubescent fleshy herbs, with terminal flowers. Sepals 2, united at the base and partly adnate to the ovary. Petals 4-6 (mainly 5), inserted on the calyx, fugacious. Stamens $7-\infty$, also on the calyx. Ovary manyovuled; style deeply 3-9-cleft or parted. Capsule membranous, dehiscent by a lid, many-seeded. [Latin, in allusion to the purging qualities of some species.] A genus of about 20 species, all but 2 or 3 natives of America. In addition to the following, some 7 others occur in the southern U. S.

Glabrous thiroughout; flowers small, yellow.

Leaves mainly rounded at the apex; seeds minutely rugose.

Leaves mainly retuse; seeds prominently tuberculate.

Pilose pubescent, especially in the axils.

Flowers red or pink, 8-12 mm. broad.

Flowers variously colored, $2-5 \mathrm{~cm}$. broad.

I. P. oleracea.

2. $P$. retusa.

3. P. pilosa.

4. P. grandiflora.

r. Portulaca oleràcea L. Purslane. Pussley. (I. F. f. r434.) Annual, prostrate, branching from a deep central root; branches $\mathbf{I}-2.5 \mathrm{dm}$. long. Leaves alternate and clustered at the ends of the branches, obovate or cuneate, 6-20 $\mathrm{mm}$. long, rounded at the apex, very fleshy; flower-buds flat; flowers solitary, sessile, 4-6 mm. broad, yellow, opening in bright sunshine; sepals broad, keeled, acutish; style 4-6-parted; capsule 6-10 mm. long: seeds finely rugose. In fields and waste places, common throughout our area, and in warm and tropical America. Native in the southwest, but naturalized northward. Summer. 
2. Portulaca retùsa Engelm. Notched Pursi.ane. (I. F. f. I435.) Closely resembles the preceding. Leaves cuneate, generally broader, mostly retuse or emarginate; sepals broad, obtusish, carinate-winged; style larger, 3-4-cleft; capsule 4-6 mm. long; seeds distinctly tuberculate; petals smaller and the flowers opening earlier in the morning than those of that species, where the two grow together. Minn. (?), Mo. and Ark. to Tex., west to Nev. Growing in large patches. Summer.

3. Portulaca pilòsa L. Hairy Portulaca. (I. F. f. I436.) Annual, from a deep root, pilose-pubescent, with small tufts of light-colored hairs in the axils. Branches 5-I5 cm. long; leaves linear, terete, obtuse, $8-16 \mathrm{~mm}$. long, about $2 \mathrm{~mm}$. wide, alternate, and clustered at the ends of the branches; sepals oblong, acute, menibranous, not carinate, deciduous with the operculum of the capsule: stamens numerous; style 5-6-parted; seeds minutely tuberculate. In dry soil, N. Car. to Fla., Kans., Tex., Mex. and Cal. Also throughout tropical America. Summer.

4. Portulaca grandifiòra Hook. Garden Portulaca. Sun-plant. (I. F. f. 1437.) Ascending or spreading. Branches 1.5-3 dm. long; leaves alternate, and clustered at the ends of the branches, terete, about $2 \mathrm{~mm}$. wide; flowers pink, yellow, red, or white, open in sunshine; sepals broad, obtuse, scarious-margined; petals obovate; capsule ovoid; seeds gray, shining. In waste places, occasionally escaped from gardens. Introduced from S. Am. Summer.

\section{Family 7. CARYOPHYLLÀCEAE Reichenb.}

\section{Pink Family.}

Herbs often swollen at the nodes, with opposite entire leaves, and perfect or rarely diøcious regular flowers. Sepals 4 or 5, persistent, separate or united into a calyx-tube. Petals equal in number to the sepals or none. Stamens twice as many as the sepals or fewer, hypogynous or perigynous; anthers longitudinally dehiscent. Ovary mainly I-celled (rarely 3-5-celled); styles 2-5; ovules and seeds attached to a central column. Fruit generally membranous, a capsule, dehiscent by valves or teeth, or an indehiscent achene or utricle. Seeds mainly amphitropous; embryo curved and peripheral to the endosperm, rarely straight; cotyledons mainly incumbent. About 70 genera and 1500 species, widely distributed, most abundant in the northern hemisphere.

* Calyx of united sepals, tubular or ovoid.

Calyx-ribs at least twice as many as the teeth, running both into the teeth and into the sinuses.

Styles 5 , alternate with the foliaceous calyx-teeth.

Styles 3-5, when 5, opposite the short calyx-teeth.

Styles 5 , capsule several-celled at the base.

Styles 3, rarely 4 .

Styles 5, capsule I-celled to the base.

Calyx 5-ribbed, 5-nerved, or nerveless, or striate-nerved.

I. Agrostemma.

2. I iscaria.

3. Silene.

4. Lychnis.

Calyx conspicuously scarious between its green nerves.

Calyx not bracteolate at the base.

Calyx bracteolate at the base.

5. Gypsophila.

6. Tunica.

Calyx not at all scarious.

Petals appendaged at the base of the blade.

Petals not appendaged at the base of the blade. Calyx strongly 5-angled, not bracteolate. Calyx terete or nearly so, subtended by bractlets.

7. Saponaria.

8. Vaccaria.

Q. Dianthus.

** Calyx of distinct sepals, or the sepals united only at the base.

Fruit a capsule, dehiscent by apical teeth or by valves.

Styles separate to the base; stipules wanting.

Plants not fleshy; disk of the flower inconspicuous or none.

Yetals deeply 2-cleft or 2-parted (rarely none).

Capsule ovoid or oblong, dehiscent by valves.

Capsule cylindric, commonly curved, dehiscent by teeth.

ro. Alsine.

I1. Cerastium. 
Petals entire or emarginate (rarely none).

Capsule cylindric.

Capsule ovoid or oblong.

Styles as many as the sepals.

Styles opposite the sepals.

Styles alternate with the sepals.

Styles fewer than the sepals.

Seeds not appendaged by a strophiole.

Seeds strophiolate.

Plants fleshy, maritime; disk conspicuous, 8-10-lobed.

Styles separate to the base; stipules present, scarious.

Styles and capsule-valves 5 .

Styles and capsule-valves 3 .

Styles united below; southwestern herbs with subulate leaves.

Fruit an indehiscent or irregularly bursting utricle or achene.

Leaves stipulate.

Sepals awn-tipped.

Sepals awnless.

Leaves not stipulate.

12. Holosteum.

13. Moenchia.

14. Sagina.

15. Arenaria.

16. Moehringia.

17. Ammodenia.

18. Spergula.

19. Tissa.

20. Loefingia.

21. Paronychia.

22. Anychia.

23. Scleranthus.

\section{AGROSTÉMMA L.}

Annual pubescent herbs, with linear or linear-lanceolate acute or acuminate sessile leaves, and large red or white erect flowers, solitary at the ends of long axillary peduncles. Calyx oblong, not inflated, narrowed at the throat, ro-ribbed, 5-lobed, the lobes linear, elongated and foliaceous. Petals 5, shorter than the calyx lobes, their blades obovate or cuneate, emarginate, not appendaged; stamens ro. Styles 5, opposite the petals. Capsule r-celled. Seeds numerous, black. [Greek, a field-garland.] Two known species, natives of Europe and Asia.

r. Agrostemma Githàgo L. Corn Cockle. Corn Rose. Corn Campion. (I. F. f. I438.) Erect, 3-10 dm. high, densely pubescent with whitish appressed hairs. Leaves linear-lanceolate, acute or long-acuminate, erect, 5-10 cm. long, 4-6 mm. wide; flowers red, 2-8 $\mathrm{cm}$. broad; calyx ovoid, its lobes 3 or 4 times the length of the tube and much exceeding the petals, deciduous in fruit; petals usually slightly emarginate, the blade obovate-cuneate. In grain fields and waste places, frequent or occasional throughout our area. Adventive from Europe, occurring also in northern Asia. July-Sept.

\section{VISCÀRIA Roehl.}

Perennial or biennial glabrous herbs, with erect stems and narrow leaves, the basal densely tufted, those of the stem sessile, and small red or rarely white flowers in clustered terminal cymes, the inflorescence in our species almost capitate. Calyx oblong-campanulate, not inflated, 4-5-toothed, 8-10-ribbed. Petals 4 or 5, much exceeding the calyx, each with a 2 -cleft appendage at the base of the obovate emarginate blade. Stamens 10, exserted. Styles alternate with the petals. Capsule several-celled at the base, its teeth as many as the styles. [Latin, glutinous.] About 5 species, the following of arctic and subarctic regions; the others European and Asiatic.

r. Viscaria alpina (L.) Roehl. Red Alpine CAmpion. (I. F. f. 1439.) Tufted, o.7-3 dm. high, rather stout, somewhat glaucous. Basal leaves narrowly oblanceolate or linear, 2-4 mm. wide; stem-leaves distant, linear-lanceolate, about $2 \mathrm{~cm}$. long; inflorescence $\mathbf{I}-2.5 \mathrm{~cm}$. broad; bracts small, membranous; flowers pink, 6-8 $\mathrm{mm}$. wide; calyx campanulate, $4 \mathrm{~mm}$. long, its teeth short, rounded; petals obovate, 2-lobed; appendages minute. Quebec to Lab., Newf., Hudson Bay, Greenland, and in arctic and alpine Europe and Asia. Summer.

\section{SILENNE L.}

Herbs, with mainly pink red or white flowers. Calyx more or less inflated, 5-toothed or 5-cleft, ro-many-nerved, not bracted at the base. Petals 5, narrow, clawed. Stamens 10. Styles 3 (rarely 4 or 5); ovary 1-celled, or incompletely 2-4-celled. Pod dehiscent by 6 or rarely 3 apical teeth. Seeds mainly spiny or tubercled. [Greek, saliva, in allusion to the viscid secretions of many species.] About 250 species of wide geographic distribution. In addition to the following, some 35 others occur in the southern and western U. S. 
Dwarf, arctic-alpine; flowers solitary.

I. S. acaulis.

Erect or ascending herbs; flowers clustered (sometimes solitary in nos. $3-7$ ).

Leaves or some of then verticillate in 4 's.

2. S. stellata.

Leaves all opposite.

Caly $x$ much inflated and bladdery.

Flowers few, leafy-bracted.

3. S. alba.

Flowers numerous, in leafless cymes.

Calyx merely expanded by the ripening pod.

4. $S$. vulgaris.

Flowers cymose or paniculate.

Day-blooming; flowers rarely white, mostly pink or red.

Perennials, more or less viscid-pubescent.

Petals 2-cleft, 2-lobed, or irregularly incised, scarlet or crimson.

Leaves lanceolate or spatulate; flowers numerous.

Flowers in slender panicles, nodding.

5. S. nutans.

Flowers in terminal cymes, erect. 6. S. Virginica.

Leaves broadly oval ; flowers few or solitary.

Petals erose, entire, or emarginate.

7. S. rotundifolia.

Petals scarlet ; plant 9-12 dm. tall.

Petals pink; plant $\mathrm{I}-2.5 \mathrm{dm}$. high.

8. S. regia.

9. S. Caroliniana.

Annuals, glutinous at or below the nodes.

Calyx ovoid.

Flowers small, panicled; calyx-teeth ovate.

ro. S. antirrhina.

Flowers large, cymose; calyx-teeth subulate.

II. S. conica.

Calyx club-shaped; flowers large, cymose.

Night-blooming ; flowers large, white.

Flowers spicate or racemose, short-pedicelled.

Spike-like raceme simple; flowers small.

Raceme forked; flowers $12-16 \mathrm{~mm}$. broad. I $5 . S$.
Flowers axillary and terminal, slender-pedicelled; western.
12. S. Armeria.

13. S. noctiflora.

14. S. Anglica.

5. S. dichotoma.

16. S. Menziesii.

I. Silene acàulis L. Moss Campron. (I. F. f. 1440.) Perennial, branched, densely tufted, 2-8 cm. high. Leaves sessile, crowded, linear, 8-12 mm. long, about $\mathbf{I} \mathrm{mm}$. wide, the margins ciliate-serrulate; flowers sessile or slender-peduncled, 8-12 mm. broad, purple or purplish; calyx campanulate, glabrous, $8 \mathrm{~mm}$. high; petals with a scale at the base of the blade; pod oblong. White Mountains, N. H., to Quebec; Lab. and throughout arctic America, south in the higher Rocky Mts. to Ariz. Also in arctic and alpine Europe and Asia. Summer.

2. Silene stellàta (L.) Ait. Starry Campion. (I. F. f. I44I.) Perennial, erect, 6-10 dm. high, densely and minutely rough-pubescent. Leaves ovatelanceolate, acuminate, 5-IO cm. long, $1-2.5 \mathrm{~cm}$. wide, verticillate in 4's or the lowest opposite, their margins finely ciliate; flowers white, $\mathbf{I - 2} \mathrm{cm}$. broad, in panicled cymes; calyx campanulate, inflated, 14-16 mm. high, its teeth triangular, acute; petals crownless, fimbriate, about equalling the stamens; pod globose-ovoid. In woods, R. I. to Niagara, Minn., Ga., Neb. and Ark. June-Aug.

3. Silene álba Muli. Western White Campion. (I. F. f. I442.) Perennial, rather weak, minutely puberulent or glabrate. Leaves lanceolate or oblonglanceolate, 8-13 cm. long, I-1.6 cm. wide, acuminate, the upper gradually smaller; pedicels divaricate; flowers white, about $2 \mathrm{~cm}$. broad; calyx inflated, elongatedcampanulate, pubescent, its teeth ovate, obtuse; petals cuneate, 2 -cleft, or 2 -lobed, minutely crowned. In shaded or moist places, Penn. to D. C., Minn. and Neb. June-July.

4. Silene vulgàris (Moench) Garcke. Bladder Campion. (I. F. f. I443.) Perennial, branched from the base, glaucous and glabrous, or rarely pubescent, I.5-4.5 dm. high. Leaves ovate-lanceolate or oblong, acute, or the lower often spatulate; flowers white, $\mathbf{I}-\mathbf{2} \mathrm{cm}$. broad, in loose cymose panicles, often drooping; calyx at length inflated and globose, $8-12 \mathrm{~mm}$. long, strongly veined; petals 2-cleft. In meadows and waste places, N. B. to Ont., N. J. and Ill. Naturalized from Europe. Summer.

5. Silene nùtans L. Nodding Catchfly. (I. F. f. I444.) Perennial; stem erect, 3-6 dm. tall. Lower and basal leaves spatulate, subacute, 6-16 mm. wide, 
tapering into slender petioles; stem-leaves few, distant, oblong or lanceolate, acute or acuminate, sessile; flowers $12-16 \mathrm{~mm}$. broad, white or pink, nodding or spreading in a loose panicle; pedicels slender; calyx oblong-cylindric in flower, 8-10 $\mathrm{mm}$. long, glandular, its teeth triangular, acute; petals 2-cleft or sometimes 4-cleft; capsule ovoid, IO-12 mm. high, distending the calyx. Mt. Desert Island, Me., and Staten Island, N. Y. Fugitive from Europe. June-Sept.

6. Silene Virgínica L. Fire PINk. (I. F. f. I445.) Perennial, viscidpubescent, 3-6 dm. high. Leaves thin, those of the lower part of the stem spatulate or oblanceolate, 8-13 cm. long; upper leaves oblong-lanceolate, acute, sessile ; inforescence loosely cymose-paniculate ; flowers crimson, 2-3 cm. broad; pedicels slender, $\mathrm{r}-5 \mathrm{~cm}$. long; calyx tubular-campanulate, $1.5-2.5 \mathrm{~cm}$. long, enlarged by the ripening pod, its teeth ovate, acute; petals 2-cleft, 2-lobed, or irregularly incised, crowned. In dry woods, S. N. J., W. N. Y. and Ont. to Minn., Ga. and Mo. May-Sept.

7. Silene rotundifòlia Nutt. Round-Leaved Catchfly. (I. F. f. I446.) Perennial; stem ascending or reclining, viscid-pubescent, 4-6 dm. long. Leaves thin, the lower and basal ones obovate ; $5-10 \mathrm{~cm}$. long, narrowed into a winged petiole, the cauline obovate, broadly oblong or orbicular-ovate, acute, the uppermost sessile; flowers few or solitary, scarlet, 2-5 cm. broad; pedicels slender ; calyx tubular-campanulate, $2-3 \mathrm{~cm}$. long, somewhat enlarged by the ripening pod, its teeth ovate, acute: petals 2-cleft, lobed, or laciniate, crowned. In shaded places, S. Ohio and Ky. to Ga. Summer.

8. Silene régia Sims. Royal Catchfly. (I. F. f. 1447.) Perennial; stem erect, stout, I-I.2 m. high, minutely rough-pubescent, slightly viscid. Leaves all but the lowest sessile, thick, ovate-lanceolate, acute or acuminate, $5-8 \mathrm{~cm}$. long ; inflorescence a narrow panicle of few-flowered cymose clusters ; flowers numerous, deep scarlet, about $2.5 \mathrm{~cm}$. broad; calyx oblong-tubular, $2 \mathrm{~cm}$. long, slightly enlarged by the ripening pod, its teeth ovate, acute; petals emarginate or laciniate, crowned. Prairies, Ohio to Ala., Temn. and Mo. July.

9. Silene Caroliniàna Walt. WrLd PrNk. (I. F. f. I448.) Perennial, tufted, I-2.5 dm. high, viscid-pubescent, especially above. Basal leaves spatulate, or oblanceolate, 5-10 $\mathrm{cm}$. long, narrowed into a broad petiole; stem-leaves shorter, sessile, oblong or lanceolate; flowers pink, about $2.5 \mathrm{~cm}$. broad, in terminal cymes; calyx narrow, much enlarged by the ripening pod, its teeth ovate, acute; petals cuneate, emarginate, eroded, crowned. In dry, sandy or rocky soil, Me. to Ga., west to central N. Y., Penn. and Ky. April-June.

ro. Silene antirrhina L. Sleepy CATChFly. (I. F. f. I449.) Annual, puberulent or glabrous, glutinous about the nodes, 2-7 dm. high. Basal and lower leaves spatulate or oblanceolate, $2-5 \mathrm{~cm}$. long, narrowed into a petiole; upper leaves linear to subulate; inflorescence a loose cymose panicle; pedicels slender, erect; flowers pink, 2-4 mm. broad; calyx narrowly ovoid, 4-6 mm. long, much expanded by the ripening pod, its teeth ovate, acute; petals obcordate, minutely 'crowned. In waste places and woods, N. Eng. to S. Ont., Br. Col., Fla. and Mex. Summer.

Silene antirrhina divaricata Robinson. More slender than the species and with narrower leaves; branches spreading, filiform; calyx 4-5 $\mathrm{mm}$. long; petals none. III. and N. Y.

Ir. Silene cónica L. Striate, or Corn Catchfly. (I. F. f. 1450a.) Canescent or puberulent; stems erect, commonly forked above, 1.5-6 dm. high. Leaves linear-lanceolate, acute, sessile, about $3 \mathrm{~mm}$. wide ; inflorescence cymose ; flowers I-several; calyx ovoid, rounded or truncate at the base, densely about 3o-nerved, its teeth triangular-subulate; petals rose, obcordate; capsule oblongovoid, distending the calyx. Clyde, Ohio. Adventive or naturalized from Europe. June-July.

I2. Silene Armèria L. Sweet William or Lobel's Catchfly. (I. F. f. I450.) Annual, glabrous and glaucous, or minutely puberulent, about $3 \mathrm{dm}$. high, glutinous below each node. Basal leaves oblanceolate, 5-8 cm. long, obtuse; stem-leaves ovate or ovate-lanceolate: inflorescence a terminal compact compound cyme; flowers purple or pink, 12-16 mm. broad; calyx club-shaped, Io-16 mm. 
long, slightly enlarged by the ripening pod; petals emarginate, crowned with narrow scales. In waste places and spontaneous in gardens, N. B. and Ont. to Mich., E. Mass., N. J. and Penn. Introduced from Europe. June-July.

I3. Silene noctifiòra L. Night-Flowering Catchfly. (I. F. f. I45I.) Annual, viscid-pubescent, 3-10 dm. high. Lower and basal leaves obovate or oblanceolate, $5^{-13} \mathrm{~cm}$. long, obtuse, narrowed into a broad petiole; upper leaves sessile, ovate-lanceolate, acute or acuminate; flowers few, white or pinkish, 1.5$2.5 \mathrm{~cm}$. broad, in a loose panicle; calyx 2-3 cm. long, tubular, Io-nerved and beautifully veined, much enlarged by the ripening pod, its teeth linear, acute; petals 2-cleft. In waste places, N. S. and N. B. to Manitoba, Fla. and Mo. Adventive from Europe. Flowers opening at dusk and remaining so until the morning of the next day, fragrant. July-Sept.

14. Silene Ánglica 1. ENGlish or Small-Flowered Catchfly. (I. F. f. 1452.) Annual, hirsute-pubescent; stem 3-6 dm. high. Leaves spatulate or oblanceolate, I-5 cm. long, obtuse, sometimes mucronate, or the upper narrower and acute; flowers in a terminal simple I-sided raceme, nearly sessile or the lower ones distant and longer-pedicelled, sometimes all distinctly pedicelled; calyx IOnerved, villous, $8-10 \mathrm{~mm}$. long, much enlarged by the ripening pod, its teeth lanceolate, spreading; petals white, somewhat longer than the calyx. In waste places, Me. to Ont., N. Y. and Penn. Adventive from Europe. Naturalized as a weed on the Pacific Coast. April-July.

15. Silene dichótoma Elirh. Forked Catchfly. (I. F. f. 1453.) Annual, pubescent, 3-6 dm. high. Lower and basal leaves lanceolate or oblanceolate, 5-8 $\mathrm{cm}$. long, acuminate or acute, tapering into a petiole; upper leaves sessile, lanceolate or linear; flowers white, distant in forking I-sided spikes; calyx cylindric, 12-16 mm. long, hirsute, much enlarged by the ripening pod, its teeth ovatelanceolate, acute; petals white, bifid, with a short obtuse crown. In fields and waste places, Me. to N. J. and Penn. Also in Cal. Adventive from southern Europe. Summer.

I6. Silene Menzièsii Hook. Menzies' Pink. (I. F. f. 1454.) Perennial, ascending or decumbent, leafy, widely branching, minutely glandular-pubescent, 1.5-4.5 dm. high. Leaves sessile, or the lowest petioled, oval, ovate-lanceolate or slightly oblanceolate, acute or acuminate at each end, minutely ciliate, 2-6 cm. long: flowers axillary and terminal, numerous, slender-peduncled, white (or pink?), 8-10 mm. long; petals 2-cleft, crownless, longer than the 5 -toothed calyx; capsule about the length of the calyx. In damp soil, Neb. to the N. W. Terr., Br. Col, Cal. and N. Mex. June-Aug.

\section{LÝCHNIS L.}

Herbs, mainly erect. Calyx ovoid, tubular, or inflated, 5-toothed, ro-nerved. Petals 5, narrowly clawed, the blade entire, 2-cleft, or laciniate, generally crowned. Stamens I0. Ovary. I-celled or incompletely several-celled at the base, manyovuled; styles 5, opposite the calyx-teeth (occasionally 4 or rarely 3). Capsule dehiscent by apical teeth or valves. [From the Greek for lamp, in allusion to the flame-colored flowers of some species.] A genus of about 35 species, natives of the north temperate and arctic zones. In addition to the following, about 9 others occur in northern and western N. Am.

Calyx-teeth not twisted; plants pubescent, glandular or glabrate.

Flowers cymose or panicled; calyx enlarged by the ripening pod.

Fruiting calyx much enlarged, ovoid, obovoid or globose.

Plants viscid-pubescent; flowers usually diœcious.

Flowers white or pink, opening in the evening.

Flowers red, opening in the morning.

Plant roughish-pubescent; flowers perfect, scarlet.

Fruiting calyx campanulate or tubular.

Petals deeply laciniate; introduced species.

Petals entire or emarginate; native western species.

Flowers solitary: calyx inflated; plants arctic-alpine.

Flower nodding; pod erect.

Flower and pod erect or nearly so.

Calyx-teeth twisted; plant densely white-wnolly all over.

I. L. alba.

2. L. dioica.

3. L. Chalcedonica

4. L. Fl;s-cuculi.

5. L. Drummondi.

6. L. apetala.

7. L. affinis.

8. L. Coronaria. 
I. Lychnis álba Mill. White Campion. Evening Lychnis. (I. F. f. 1455.) Biennial, freely branching, 3-6 dm. high. Leaves ovate-oblong or ovate-lanceolate, acute, $2-8 \mathrm{~cm}$. long, the lower petioled, the upper sessile; flowers few, loosely paniculate, $1.5-2.5 \mathrm{~cm}$. broad, white or pinkish, opening at dusk and remaining open into the morning of the next day; calyx at first tubular, swelling with the ripening pod so as to become ovoid and $12-14 \mathrm{~mm}$. in diameter, its teeth short, lanceolate; petals obovate, 2 -cleft, crowned; teeth of the capsule 2 -cleft, nearly $\in$ rect. In waste places and on ballast, occasional in the maritime provinces of Canada, Ont. and in the Eastern and Middle States. Adventive or naturalized from Europe. Summer.

2. Lychnis diòica L. Red Campion. (I. F. f. I456.) Biennial, 3-6 dm. high. Basal leaves long-petioled, oblong, the blade 5-8 cm. long; stem-leaves sessile or the lower short-petioled, ovate, acute, 2-5 cm. long; flowers red or nearly white, opening in the morning; calyx at first tubular, swollen in fruit to nearly globular by the ripening pod, its teeth ovate-lanceolate, acute; petals obovate, 2 -cleft, crowned; teeth of the capsule 2 -cleft, recurved. In waste places and ballast, N. S., Ont., N. Eng. and the Middle States. Adventive from Europe. Summer.

3. Lychnis Chalcedónica L. Scarlet Lychnis. (I. F. f. I457.) Perennial; stem pubescent or hirsute, 3-7 dm. tall. Leaves ovate, ovate-lanceolate or the upper lanceolate, acute or acuminate at the apex, rounded or subcordate at the base, sessile or somewhat clasping, I-2 cm. wide ; flowers perfect, about $2.5 \mathrm{~cm}$. broad, scarlet, in one or more dense terminal cymes; calyx becoming obovoid, its teeth triangular, acute; petals 2-cleft or laciniate; capsule borne on a stipe of nearly its own length, its teeth entire. Escaped from gardens to roadsides, Mass. to S. N. Y. Native of eastern Europe and western Asia. June-Sept.

4. Lychnis Flós-cùculi L. Cuckoo Flower. Ragged Robin. (I. F. f. I458.) Perennial, 3-6 dm. high, freely branching, downy-pubescent below, slightly viscid above. Lower and basal leaves oblanceolate or spatulate, 5-8 cm. long, tapering into a broad petiole ; upper leaves sessile, lanceolate or linear-lanceolate, distant ; inflorescence paniculate; flowers pink, blue or white, $1.5-2.5 \mathrm{~cm}$. broad; calyx Io-nerved, becoming campanulate in fruit, its teeth triangular, acute; petals cleft into 4 linear lobes, the middle pair of lobes longer; capsule globose. In moist waste places, N. B. to N. J. and Penn. Fugitive from Europe. June-Sept.

5. Lychnis Drúmmondi (Hook.) S. Wats. Drummond's PINK. (I. F. f. I459.) Erect from a perennial root, finely glandular-pubescent and viscid, $3-9 \mathrm{dm}$. high. Leaves oblanceolate or linear, acute, petioled or the upper sessile, $2-8 \mathrm{~cm}$. long; flowers few, slender-pedicelled, white or purplish, $1-2 \mathrm{~cm}$. long; petals scarcely longer than the tubular calyx; capsule oblong-cylindric, I2-16 $\mathrm{mm}$. long; seeds tuberculate. In dry soil, Minn. to Manitoba, Neb., Ariz. and Ore. June-July.

6. Lychnis ápétala L. Nodding Lychis. (I. F. f. I460.) Tufted, perennial, 0.7-2 dm. high, glandular-pubescent at least ab נve. Stems I-flowered; leaves linear or oblanceolate, I-6 cm. long, sessile, or the lower petioled; flower nodding, 12-16 mm. long; petals narrow, 2-cleft, included in the calyx; calyx inflated, strongly purple-veined, its teeth triangular-ovate, acute; petals narrow, about $2 \mathrm{~mm}$. wide, minutely appendaged, equalling or shorter than the calyx, deeply 2-cleft; capsule erect, ovoid. Labrador and throughout arctic America. Also in arctic and alpine Europe and Asia. Summer.

7. Lychnis affinis Vahl. ARCTIC Lycinis. (I. F. f. 146r.) Tufted, perennial, 5-10 cm. high, glandular-pubescent. Basal leaves spatulate, obtuse, about I cm. long, ciliatr: stem-leaves linear, I-5 cm. long. obtuse; flower erect, 8-I2 $\mathrm{cm}$. long; calyx oblong or ovate-campanulate, slightly inflated, its teeth short, acute; petals somewhat exserted, the blade narrowed below, emarginate and eroded, the appendages minute. Lab. and arctic America and Europe. Summer.

8 Lychnis Coronària (L.) Desr. Mullein Pink. Rose Campion. (I. F. f. r462.) Perennial, densely white-woolly; stem 3-10 dm. tall. Lower leaves spatulate, 5-10 cm. long, narrowed into margined petioles; upper leaves oblong or lanceolate, sessile, acute or acuminate; flowers few, $2 \mathrm{~cm}$. broad or more, longpedicelled in open terminal panicles; calyx oblong-campanulate, its teeth filiformsubulate, twisted, shorter than tise tube; petals crimson. Escaped from gardens to roadsides and waste places, Mass. to S. N. Y. Native of Europe. June-Aug. 


\section{GYPSÓPHILA L.}

Mostly glabrous and glaucous herbs, with narrow leaves, and small numerous axillary or paniculate flowers. Calyx 5-toothed, 5-nerved, bractless. Petals 5, their claws narrow. Stamens 10; styles 2. Capsule dehiscent by 4 valves. Seeds reniform, laterally attached; embryo coiled. [Greek, in allusion to the supposed preference of some species for gypsum soils.] About 60 species, natives of Europe, Asia and northern Africa.

Annual, diffuse; leaves narrowly linear; flowers axillary on filiform peduncles.

Erect perennial; leaves lanceolate; flowers paniculate.

I. G. muralis.

2. G. paniculata.

I. Gypsophila muràlis L. Low Gypsophyl.. (I. F. f. I463.) Annual, diffuse, slender, much branched, smooth, or slightly rough at the base, I-2 dm. high. Leaves narrowly linear or subulate, attenuate at each end, 6-20 $\mathrm{mm}$. long, 0.5-1 mm. wide; peduncles 6-20 mm. long; flowers purplish, 3-4 mm. broad; calyx turbinate, the teeth rounded; petals crenate or emarginate, much exceeding the calyx; pod about $4 \mathrm{~mm}$. long, slightly longer than the calyx. In waste places, Me. and Ont. to Mich., Mass., N. Y. and N. J. Adventive or naturalized from Europe. June-Sept.

2. Gypsophila paniculàta L. Tall Gypsophyll. (I. F. f. I464.) Perennial; glabrous, or sometimes pubescent below, 3-6 dm. tall. Leaves lanceolate, those of the $s, 3 \mathrm{~m} 2 \mathrm{~cm}$. long or more, $4-8 \mathrm{~mm}$. wide, acuminate at the apex, narrowed at the base, those of the branches much smaller; flowers 3-4 mm. broad, in panicled cymes; calyx campanulate, $2 \mathrm{~mm}$. high, deeply 5-lobed, the segments with scarious margins; petals white or pink, slightly emarginate, longer than the calyx. Manitoba and Neb. Fugitive from northern Europe or Asia. Summer.

\section{TÙNICA Adans.}

Rigid and slender mainly perennial herbs, with small glomerate panicled or solitary flowers, bracted at the base. Calyx top-shaped or campanulate, 5-toothed, 5-15-nerved. Petals 5, long-clawed, the limb emarginate or bifid. Stamens ro. Styles 2. Capsule deliscent by 4 apical teeth or valves. Seeds compressed, laterally attached; embryo excentric. [Latin, a cloak, in allusion to the bracts at the base of the calyx.] About 20 species, natives of southern Europe and western Asia.

I. Tunica Saxífraga (L.) Scop. Saxifrage Pink. (I. F. f. I465.) Perennial, tufted, sparsely pubescent or glabrous; stems $\mathbf{I}-2 \mathrm{~cm}$. long, terete. Leaves linear-subulate, erect, acute, 6-8 $\mathrm{mm}$. long, less than I $\mathrm{mm}$. wide, connate at the base, the lower imbricated, the upper distant; flowers panicled, about $6 \mathrm{~mm}$. broad, pink or purple; calyx 5-ribbed, twice the length of the scarious-margined acute bracts. Roadsides, Flushing, Long Island, N. Y., and London, Ont. Adventive from Europe. Summer.

\section{SAPONÀRIA L.}

Herbs. mostly with broad leaves and large flowers. Calyx 5-toothed, obscurely nerved. Petals 5, long-clawed. Stamens Io. Ovary I-celled or incompletely 2-4-celled; styles 2. Capsule dehiscent by 4 short apical teeth or valves. [Latin, soap; the juices abound in saponin.] About 35 species, natives of Europe, Asia and northern Africa.

I. Saporaria officinàlis L. Soapwort. Bouncing Bet. (I. F. f. r 466.) Perennial, glabrous, erect, leafy, 3-6 dm. high. Leaves ovate or oval, $5-8 \mathrm{~cm}$. long, 3-5-ribbed, acute, narrowed into a broad short petiole; flowers pink or whitish, aboint $2.5 \mathrm{~cm}$. broad, in dense terminal corymbs, with numerous small lanceolate floral leaves; calyx tubular, $1.5-2 \mathrm{~cm}$. long; petals obcordate with a scale at the base of the blade; pod narrowly oblong, shorter than the calyx. Roadsides and waste places, common in most districts, spreading by underground stolons. Natu. ralized from Europe. Flowers sometimes double. Summer.

8. VACCÀrIA Medic.

Annual glabrous and glaucous erect branching herbs, with clasping ovate or ovate lanceolate acute leaves, and rather small red or pink slender-pedicelled 
flowers in terminal cymes. Calyx cylindric in flower, becoming sharply 5-angled and inflated in fruit, 5-toothed, not bracted at the base. Petals much longer than the calyx, not appendaged. Stamens ro. Styles 2. Capsule 4-toothcd. Seeds laterally attached; embryo curved. [Latin, cow, in allusion to its value for fodder.] About 3 species, natives of Europe and Asia.

I. Vaccaria Vaccària (L.) Britton. Cow-Herb. (I. F. f. I467.) Plant 3-6 $\mathrm{dm}$. high. Leaves $2-8 \mathrm{~cm}$. long, connate at the base; flowers pale red, $6-8 \mathrm{~mm}$. broad; calyx 10-15 mm. long, 5-ribbed: petals crenulate. In waste places, Ont. to Br. Col., Fla. and La. Also in the Rocky Mt. region. Naturalized or adven. tive from Europe. June-Aug.

\section{DIÁNTHUS L.}

Stiff herbs, mainly with narrow leaves. Flowers terminal, solitary or cymosepaniculate, generally purple. Calyx 5-toothed, finely and equally many-striate, tubular, several-bracted at the base. Petals 5, long-clawed, dentate or crenate. Stamens IO. Styles 2. Ovary I-celled, stipitate. Capsule cylindric or oblong, stalked, dehiscent by 4 or 5 short teeth at the summit. Seeds compressed, laterally attached. Embryo straight, excentric. [Greek, the flower of Jove.] Species about 200, natives of the Old World; one of Siberia extending into arctic America.

Annuals ; flowers clustered.

Bracts broad, scarious.

Bracts narrow, hes baceous, long-pointed.

1. D. prolifer. Perennials.

Flowers solitary ; leaves linear, short.

Flowers clustered; leaves lanceolate.

2. D. Armeria.

3. D. deltoides.

4. D. barbatus.

I. Dianthus prólifer L. Proliferous Pink. (I. F. f. I468.) Glabrous, 1.5-4 dm. high, simple, or with few erect branches. Leaves distant, linear, acute, I-2 mm. wide; flowers small, pink, in terminal oblong or obovoid heads, and appearing successively from behind the bracts, which are broad, ovate, imbricated, shining, obtuse or mucronate, concealing the calyx. In waste places and ballast, Mass. to Del. and Ohio. Fugitive from Europe. Summer.

2. Dianthus Armèria L. Deptford Pink. (I. F. f. I469.) Finely pubescent, 1.5-4.5 dm. high; branches few, nearly erect. Leaves linear, erect, $2-3 \mathrm{~mm}$. wide; flowers small, pink with whitish dots, in terminal often dense clusters; bracts lanceolate-subulate, erect, mostly longer than the sharply-toothed calyx. In fields and along roadsides, Me. to $\mathrm{S}$. Ont. Mich. and Va. Naturalized from Europe. Summer.

3. Dianthus deltoides L. Maiden Pink. (I. F. f. I470.) Tufted, glabrous or somewhat hoary; stems ascending, 1.5-4 dm. long. Leaves linear-lanceolate, $2 \mathrm{~mm}$. wide, those of the flowering stems erect, acutish, the lower obtuse; flowers pink or whitish, solitary; petals dentate; bracts ovate, pointed, about half as long as the calyx or less. In waste places, Conn. and eastern Mass. to northern N. Y. and Mich. Adventive from Europe. Summer.

4. Dianthus barbàtus L. Sweet William. (I. F. f. 1471.) Tufted, glabrous, erect, 3-6 dm. high. Leaves lanceolate or ovate-lanceolate, $8-18 \mathrm{~mm}$. wide, acute; bracts linear-filiform, about equalling the long-toothed calyx; flowers pink or whitish, in large terminal clusters. In waste places, occasional in the Eastern and Middle States. Introduced from Europe. Summer.

\section{ALSINE L. [Including STELLARIA L.] (See Appendix.)}

Tufted herbs, with cymose white flowers. Sepals 5, rarely 4. Petals of the same number, 2-cleft, 2-parted, or emarginate, white in our species, rarely none. Stamens Io or fewer, hypogynous. Ovary I-celled; styles commonly 3 , rarely 4 or 5 , usually opposite the sepals. Capsule dehiscent by twice as many valves as there are styles. [Greek, grove, the habitat of some species.] Species about 75, widely distributed, most abundant in temperate or cold climates.

Styles 5 ; leaves ovate, $2-5 \mathrm{~cm}$. long.

I. A. aquatica.

Styles 3 , rarely 4 .

Leaves broad, ovate, ovate-oblong or oblong.

Plants glabrous, or with a few scattered hairs.

Flowers few, terminal; leaves ovate, $4-6 \mathrm{~mm}$. long.

2. A. humifusa. 
Cymes lateral; leaves oblong, $\mathrm{I}-2 \mathrm{~cm}$. long.

Stems with 1 or 2 pubescent lines; petioles often ciliate.

Petals shorter than the calyx; lower leaves petioled.

3. A. uliginosa.

Petals longer than the calyx; lower leaves rarely petioled. 5

Leaves narrow, linear, oblong, oblanceolate or spatulate.

Flowers $1.4^{-2} \mathrm{~cm}$. broad.

Flowers only $4^{-12} \mathrm{~mm}$. broad.

Bracts of the cyme small, scarious.

Pedicels widely spreading; cyme diffuse.

Leaves linear, acute at each end; seeds smooth. 7. A. longifolia.

Leaves lanceolate, broadest below; seeds rough. 8. A. graminea.

Pedicels erect ; flowers few or solitary.

Bracts of the cyme foliaceous, resembling the upper leaves.

9. A. longipes.

Capsule $11 / 2-2$ times as long as the calyx; leaves lanceolate or oblong. lanceolate.

Seeds rough; petals equalling or longer than the calyx.

Io. $H$. crassifolia.

Seeds smooth; petals much shorter than the calyx or none. II. A. borealis.

Capsule not longer than the calyx ; leaves linear or linear-spatulate; petals none.

12. A. foutinalis.

I. Alsine aquática (L.) Britton. Water Mouse-Ear Chickweed. (I. F. f. 1472.) Perennial; stem angled, mostly glandular-pubescent above, ascending or decumbent, 3-7 dm. long. Leaves ovate or ovate-lanceolate, acute, the upper sessile and subcordate, the lower petioled, rounded at the base, 2-5 cm. long; flowers about $1.2 \mathrm{~cm}$. broad, solitary in the forks of the stem and in terminal cymes; pedicels slender, glandular, deflexed and much longer than the calyx in fruit; calyx campanulate; sepals ovate, acute, about one-halt as long as the 2 -cleft petals; stamens I0; capsule ovoid-ob'ong, slightly longer than the calyx; seeds rough. In wet and waste places, Ont. to Penn. Also in Br. Col. Adventive from Europe. May-Aug.

2. Alsine humifàs a (Rottb.) Britton. Low Chickweed. (I. F. f. 1473.) Glabrous; stems spreading and ascending, 2-8 $\mathrm{cm}$. long, purplish. Leaves ovate or oblung, fleshy, 4-6 mm. long, sessile; bracts foliaceous; flowers few or solitary, 6-10 $\mathrm{mm}$. broad; sepals ovate-lanceolate, acute or acutish, $4 \mathrm{~mm}$. long; petals 2-parted; capsule ovoid, as long as the sepals; seeds smooth, brown. In moist or wet places, Lab. to N. B. and Me., west to Ore and Alaska. Also in northern Europe and Asia. Summer.

3. Alsine uliginòsa (Murr.) Britton. Bog Starwort. Marsh ChickWEED. (I. F. f. I474.) Weak, slender, generally growing in masses; stems nearly simple, I-4 dm. long. Leaves oblong, 16-25 mm. long, 4-10 mm. wide, narrowed at the base, the lower slightly petioled and sometimes ciliate, the upper sessile; flowers $6 \mathrm{~mm}$. broad, in lateral sessile cymes, rarely terminal; sepals lanceolate, acute; petals 2-parted, about the length of the caly $x$ and the ovoid pod: seeds rough. In cold brooks and springs, Md. and Penn. to Newf. Also in Br. Col. and the N. W. Terr., Europe and Asia. Summer.

4. Alsine mèdia L. Common Chickweed. (I. F. f. 1475.) Annual, tufted, much branched, decumbent or ascending, I-4 dm. long, glabrous except a line of hairs along the stem and branches, the pubescent sepals and the sometimes ciliate petioles. Leaves ovate or oval, 4-35 mm. long, acute or rarely obtuse, the lower often cordate; flowers $4-8 \mathrm{~mm}$. broad, in terminal leafy cymes or also solitary in :he axils; sepals oblong, longer than the 2-parted petals; stamens 2-10; capsule ovoid, longer than the calyx; seeds rough. A weed in waste places, meadows and woods, common throughout N. Am. Naturalized from Europe, though possibly native northward. Jan.-Dec.

5. Alsine pùbera (Michx.) Britton. Great Chickweed. (I. F. f. I476.) Perennial, I-3 dm. high, branching, the stems and branches with two hairy lines. Leaves oblong or ovate-oblong, $\mathbf{I}-6 \mathrm{~cm}$. long, their margins ciliate, the upper generally sessile, the lower sometimes narrowed at the base or on broad petioles, those of sterile shoots sometimes all petioled; flowers 8-12 mm. broad, in terminal leafy cymes; sepals lanceolate, shorter than the 2-cleft or 2-parted petals; capsule subglobose, or ovoid, its teeth revolute after splitting; seeds rough. In moist rocky places, N. F. and Penn. to Ind., Ky., Ga. and Ala. May-June. 
6. Alsine Holóstea (L.) Biaton. Greater Stitchwort or Starwort. ADDER's MEAT. (I. F. f. I477.) Erect from a creeping rootstock, glabrous or slightly downy, 4-6 dm. high, Leaves sessile, lanceolate, 2-8 cm. long, tapering to a long slender tip : flowers showy, $1.4-3 \mathrm{~cm}$. broad, in terminal leafy cymose panicles; pedicels downy ; sepals lanceolate, acute, one-half to two-thirds the length of the 2 cleft petals; capsule globose ovoid. Along Train's Meadow Road, Long Island, N. Y.; Poland, Me. Fugitive or adventive from Europe. Native also of northern Asia. Also called Allbone, from its brittle nodes. AprilJune.

7. Alsine longifòlia (Muhl.) Britton. Long-Leaved Stitchwort. (I. F. f. I478.) Weak, glabrous, or the stem rough-angled, freely branching, 2-5 dm. high. Leaves linear, spreading, acute or acutish at each end, 2-6 cm. long, 2-6 mm. wide, the lower smaller; bracts lanceolate ; pedicels slender, divaricate; cymes terminal or lateral ; flowers numerous, 6-1o min. broad; sepals lanceolate, acute, 3-nerved, equalling or somewhat shorter than the 2-parted petals; capsule ovoid-oblong, nearly twice as long as the calyx ; seeds smooth, shining. In low meadows and swamps, Newf. to Alaska, Ky. and La., and in the Rocky Mountain region, Br. Col., northern Europe and Asia. May-July.

8. Alsine gramínea (L.) Britton. Lesser Stitchwort. Lesser Starwort. (I. F. f. r 479.) Weak, glabrous, ascending from creeping rootstocks, 3-5 dm. high or long; stem 4-angled. Leaves sessile, lanceolate or oblong-lanceolate, $2-3 \mathrm{~cm}$. long, 4-6 mm. wide, broadest just above the base, acute, the lower smaller; cymes diffuse; pedicels spreading; bracts scarious, often ciliate, lanceolate, 4-6 $\mathrm{mm}$. long; flowers 6-10 mm. broad; sepals lanceolate, acute; petals 2-cleft, about the length of the sepals; capsule oblong, exceeding the sepals; seeds finely roughened. In fields and along roadsides, Newf. to Ont. and Md. Adventive from Europe. May-July.

9. Alsine lóngipes (Goldie) Coville. Long-Stalked Stitchwort. (I. F.f. 1480.) Tufted, simple, or sparingly branched, o.7-3 dm. high, glabrous, shining, rarely glaucous or pubescent. Leaves lanceolate or linear-lanceolate, I-3.5 cm. long, 2-6 $\mathrm{mm}$. wide at the base, rigid, ascending or erect; flowers few, 6-10 $\mathrm{mm}$. broad, terminal, on long erect pedicels; bracts lanceolate; sepals ovate or lanceolate, acute or acutish; petals 2-cleft, exceeding the calyx; capsule ovoid, longer than the sepals; seeds smooth. In moist places, Lab. and N. S. to northern New England, Alaska and Minn., south in the Rocky Mts. to Colo., and in Cal. Also in northern Asia. Summer.

Alsine lóngipes Edwárdsii (R. Br.) Britton. Leaves lanceolate or ovate-lanceolate, sparingly ciliate at the base; stems 2-3-flowered, 5-8 cm. tall. Lab. and Quebec, through arctic America to Siberia.

Alsine lóngipes peduncularis (Bunge) Britton. Stem $5^{-15} \mathrm{~cm}$. high, bearing $\mathrm{I}-3$ larger flowers on longer pedicels; stem more or less pubescent, especially at the nodes. Lab. to Alaska and Siberia.

ro. Alsine crassifòlia Ehrh. Fleshy Stitchwort. (I. F. f. r48r.) Diffuse or ascending, weak, slender, simple or branched, glabrous, 5-25 cm. long. Leaves somewhat fleshy, oblong-lanceolate to linear-oblong, acute or obtuse, narrowed at the base, 6-16 mm. long, 2-5 $\mathrm{mm}$. wide; cymes terminal, few-flowered, or flowers axillary and solitary: bracts foliaceous, small; peduncles slender, ascending; flowers $46 \mathrm{~mm}$. broad; sepals lanceolate-oblong, acute; petals longer than the calyx; capsu'e ovoid, longer than the sepals; seeds rough. In springs and moist places, Lab. to N. H., Minn., Ill. and Manitoba, and in arctic America, south in the Rocky Mts. to Colo. Also in northern Europe and Asia. Summer.

I I. Alsine boreàlis (Bigel.) Britton. Northern Stitchwort. (I. F. f. 1482.) Erect or ascending, weak, much branched, glabrous, or pubescent above, 1.5-4.5 dm. long. Leaves membranous, lanceolate or oblong-lanceolate, I-4 cm. long, 4-10 mm. wide, acute, sessile, their margins ciliate or naked; inflorescence a leafly terminal compound cyme; pedicels slender, ascending or spreading; flowers 4-8 $\mathrm{mm}$. broad; sepals ovate-lanceolate, acute; petals - 5 , shorter than the sepals, or none; capsule oblong, much exceeding the sepals; seeds smonth. In wet places, Lab. to R. I., northern N. J., Minn. and Br. Col., south in the Rocky Mts. to Colo. Also in north. ern Europe and Asia. Summer. 
nisıne boreàlis alpéstris (Fries) Britton. Larger, leaves broader, cyme more diffuse; upper bracts scarious or scarious-margined; seeds obscurely roughened. Lake Superior, the Saskatchewan region, Br. Col. and the Rocky Mts. Also in northern Asia.

I2. Alsine fontinàlis (Short \& Peter) Britton. Water Stitchwort. (I. F. f. 1483.) Annual, glabrous; stems weak, very slender, branched, ascending or diffuse, I-3 dm. long. Leaves linear-spatulate, $8-25 \mathrm{~mm}$. long, about $2 \mathrm{~mm}$. wide, the upper sessile, acute or subacute at the apex, the lower obtuse and narrowed into short petioles; pedicels filiform, 6-30 mm. long, erect or ascending, solitary or 2-3 together in the forks of the stem and branches and axils; calyx oblong-campanulate, $2 \mathrm{~mm}$. long; sepals 4 or 5 , oblong or linear, obtuse, about equalling the ovoid-oblong obtuse capsule; stamens $4-8$; petals wanting; styles very short; seeds densely tuberculate-roughened. In wet places, Ky. and Tenn. April-May.

\section{x. CERÁSTIUM L.}

Generally pubescent or hirsute herbs, with terminal cymes of white flowers. Sepals 5, rarely 4. Petals of the same number, emarginate or bifid (rarely wanting). Stamens ro, rarely fewer. Styles equal in number to the sepals and opposite them. or in some species fewer. Capsule cylindric, I-celled, many-ovuled, often curved. dehiscent by 10 , rarely 8 , apical teeth. Seeds rough, more or less flattened, attached by their edges. [Greek, horny, referring to the horn-like capsule of many species.] About 50 species, of wide distribution, most abundant in the temperate zones.

Petals equalling the sepals, or shorter.

Pedicels not longer than the sepals; flowers glomerate. I. C. viscosum.

Pedicels at length longer than the sepals; flowers cymose.

Leaves $4-8 \mathrm{~mm}$. long; capsule nearly straight.

Leaves 8-25 mm. long; capsule curved upward.

Petals manifestly longer than the sepals (rarely wanting).

(2.) C. semidecandrum.

3. C. vulgatum.

Annuals, viscid-pubescent ; flowers $4-6 \mathrm{~mm}$. broad.

Pedicels much longer than the calyx.

Pedicels shorter than or but little exceeding the calyx.

4. C. longipedunculatum.

5. C. brachypodum.

Perernials, glabrous or pubescent ; flowers $12-20 \mathrm{~mm}$. broad.

Styles always 5 .

Leaves linear or lanceolate-oblong, mainly acute. 6. C. arvense.

Leaves oblong-ovate, obtuse.

Styles 3 (very rarely 4 or 5 ): leaves linear-oblong.

7. C. alpinum.

8. C. cerastioides.

I. Cerastium viscòsum I. Mouse-Ear Chickweed. (I. F. f. 1484.) Annual, tufted, densely viscid-pubescent, I-3 dm. high. Leaves ovate, obovate, or the lower spatulate, 8-25 $\mathrm{mm}$. long, obtuse; bracts small, herbaceous; flowers 4-6 mm. broad, in glomerate cymes; pedicels shorter than or equalling the acute sepals; petals shorter than the calyx, 2-cleft. In waste places and meadows, N. B. and Ont. to Fla. and Mex. Naturalized from Europe. Naturalized also in the W. I., Cent. Am. and on the Pacific Coast. April-July.

2. Cerastium semidecándrum L. Small Mouse-ear Chickwefd. (I. F. f. 1485.) Low, tufted, annual, 5-15 cm. high, finely viscid-pubescent. Leaves ovate, or the lower spatulate, obtuse; bracts scarious; pedicels at length longer than the calyx; flowers 2-3 mm. broad; sepals lanceolate, acute, slightly exceeding the emarginate petals; capsule narrow, nearly straight; stamens often 5 . In dry, sterile soil, N. J. to Va. Naturalized from Europe. April-May.

3. Cerastium vulgàtum L. Larger Mouse-ear Chickweed. (I. F. f. 1486.) Biennial or perennial, viscid-pubescent, tufted, 1.5-4.5 dm. long. Lower and basal leaves spatulate-oblong, obtuse ; upper leaves oblong, $\mathbf{I}-\mathbf{2 . 5} \mathrm{cm}$. long ; inflorescence loose, the pedicels at length much longer than the calyx; sepals about equalling the 2 -cleft petals, $4-6 \mathrm{~mm}$. long; capsule curved upward. In fields and woods, common throughout our area. May-Sept.

4. Cerastium longipedunculàtum Muhl. Nodning Chickweed. PowderHORN. (I. F. f. 1487.) Annual; stem weak, reclining or ascending, 1.5-6 dm. long, striate, finely clammy-pubescent to glabrate. Lower and basal leaves spatulate, obtuse, petioled, I-2.5 dm. long, the upper lanceolate or oblong, acute, sessile; inflorescence lons?: prdicels in fruit several times the length of the calyx; flowers 4-6 mm. broad; sepals lanceulate, abuut one-half the length of the 2 -cleft 
petals (petals sometimes wanting); pods nodding, I-2 $\mathrm{cm}$. long, curved upward, much exceeding the calyx. In moist, shaded places, N. S. and Hudson Bay to N. Car., Br. Col., Nev. and northern Mexico. April-June.

5. Cerastium brachypodum (Engelm.) Robinson. Short-stalked ChickWEED. (I. F. f. I488.) Annual, light green, viscid-pubescent or puberulent : stems tufted, erect, 0.7-2.5 dm. tall. Lower and basal leaves oblanceolate or spatulate, 6-25 $\mathrm{mm}$. long, narrowed into short petioles, the upper linear or linearoblong, acute, sessile, sometimes erect-appressed; flowers about $4 \mathrm{~mm}$. broad; fruiting pedicels, or some of them, deflexed, not more than twice as long as the calyx; capsule straight or slightly curved upward, 2-3 times as long as the calyx. In dry soil, Ill. and Mo. to Neb., S. Dak., Mont., Nev., Ariz. and Mex. March-July.

Cerastium brachýpodum compáctum Robinson. slender. Neb, to Tex.

6. Cerastium arvénse L. Field Chickweed. (I. F. f. I489.) Perennial, densely tufted, erect or ascending, flowering stems I-2.5 dm. high. Basal leaves and those of the sterile shoots linear-oblong, close; stem-leaves distant, linear or narrowly lanceolate. $1-3 \mathrm{~cm}$. long, 2-4 $\mathrm{mm}$. wide, acute; flowers $12-16 \mathrm{~mm}$. broad; petals obzordate, much exceeding the lanceolate acute sepals which equal or are a little shorter than the slightly oblique capsule. In dry, rocky places, Lab. to Alaska, Ga., Mo., Nev. and Cal. Also in Europe and Asia, April-July.

Cerastium arvénse oblongifollium (Torr.) Holl. \& Britt. Larger, pubescent; leaves oblong or lanceolate, broader, mainly obtuse; capsules about twice the length of the calyx. Mainly on magnesian rocks, N. S. to Va., S. Ont., Minn. and in the Rocky Mts. and Sierra Nevada.

Cerastium arvénse velutinum (Raf.) Britton. Depressed, villous-pubescent; stemleaves lanceolate or ovate-lanceolate; capsule 2 or 2.5 times the length of the calyx. On serpentine rocks, Lancaster and Chester counties, $\mathrm{Pa}$.

7. Cerastium alpinum L. Alpine Chickweed. (I. F. f. 1490.) Perennial, generally silky-hairy; sterile stems prostrate; flowering stems erect, $5-\mathbf{I} 5 \mathrm{~cm}$. high. Lower leaves oblanceolate or spatulate, 4-8 $\mathrm{mm}$. long, obtuse; upper leaves distant, ovate-oblong, obtusish, 8-16 mm. long; flowers solitary or 2-3, 12-1 $8 \mathrm{~mm}$. broad; petals 2 -lobed, twice the length of the lanceolate acute scarious-tipped sepals; pod longer than the calyx, nearly straight. In moist, rocky places, Quebec, Lab. and in arctic America. Also in arctic and alpine Europe and Asia. Sum. mer.

Cerastium alpinum Fischeriancm (Ser.) T. \& G. Taller; pubescence more rigid. Lab. and through arctic America to Siberia.

8. Cerastium cerastioides (L.) Britton. Starwort Chickweed. (I. F. f. 149I.) Perennial, glabrous except a line of minute hairs along one side of the stem and branches, rarely pubescent throughout. Flowering branches ascending, 0.7-I.5 dm. long; leaves linear-oblong, 8-16 mm. long, about $2 \mathrm{~mm}$. wide, obtuse; flowers solitary or few, IO-12 mm. broad, long-pedicelled; petals 2-lobed, twice the length of the sepals; capsule nearly straight, twice the length of the calyx; styles 3 , rarely 4 or 5 ; sepals and petals 5 or 4 . Quebec and arctic America. Also in arctic and alpine Europe and Asia. Summer.

\section{HOLÓSTEUM L.}

Annual erect herbs, often viscid-pubescent above, with cymose-umbellate, whitc flowers on long terminal peduncles. Sepals 5. Petals 5, emarginate or eroded. Stamens 3-5, hypogynous. Styles 3. Ovary I-celled, many-ovuled. Capsule ovoid-cylindric, dehiscent by 6 short valves or teeth. Seeds compressed, attached by the inner face, rough. GGreek, signifying all bone, an antiphrase, the herbs being tender.] About 3 species, natives of Europe and temperate Asia.

I. Holosteum umbellàtum L. JAGGED Chickweed, (I. F. f. 1492.) Glabrous or slightly downy below, tufted, I-3 dm. high. Basal leaves spreading, oblanceolate or oblong; stem-leaves oblong, sessile, I-5 cm. long; umbel 3-8. flowered; pedicels slender, about $2.5 \mathrm{~cm}$. long, erect or ascending in flower, sub. sequentiy reflexed and again erect when the fruit is mature; flowers white, 4-6 
mm. broad; sepals obtuse, somewhat shorter than the petals; capsule nearly twice the length of the sepals, its teeth recurved. Penn. and Del. Naturalized from Europe. April-May.

\section{MOÈNCHIA Ehrh.}

Low annual glabrous herbs, with small narrow sessile leaves. Flowers terminal, solitary or cymose, 4-parted or sometimes 5-parted, white. Sepals lanceolate. Petals entire. Stamens 4-IO. Styles as many as the sepals and opposite them. Capsule cylindric, 8 toothed or rarely Io-toothed, the teeth somewhat revolute at maturity. [In honor of Konrad Moench, Professor in Marburg.] Two or three species, natives of the Mediterranean region.

I. Moenchia erécta (L.) Gaertn. Upright Pearlwort. (I. F. f. I493.) Glaucous, tufted, 5-15 cm. high. Basal leaves spatulate, narrowed into a short petiole; stem-leaves sessile, linear or linear-lanceolate, $8-16 \mathrm{~mm}$. long, about $2 \mathrm{~mm}$. wide; flowers few or solitary, 4-8 $\mathrm{mm}$. broad, on slender erect pedicels; sepals 4 , lanceolate, acute, 4-6 mm. long, scarious-margined; petals 4, slightly shorter than the sepals, entire; stamens 4 , rarely 8 ; styles 4 . In waste grounds, near Philadelphia and Baltimore. Fugitive or adventive from Europe. Not recently collected. May-July.

\section{SAGINA L.}

Tufted matted low herbs, with subulate leaves, and small pedicelled whitish flowers. Sepals 4 or 5 . Petals of the same number, entire, emarginate or none. Stamens of the same number, or fewer, or twice as many. Ovary I celled, manyovuled. Styles as many as the sepals and alternate with them. Capsule 4-5. valved, at length dehiscent to the base, the valves opposite the sepals. [Ancient name of the spurry.] About ro species, natives of the northern hemisphere.

Farts of the flower in 4's (or some flowers in 5's).

Plant depressed-spreading; petals present.

Plant erect; petals very minute or none.

I. S. procumbens.

2. S. apetala.

Parts of the flower in 5 's.

Leaves opposite, not fascicled.

Petals equalling or shorter than the sepals.

Petals and pods longer than the sepals.

Leaves fascicled in the axils; petals exceeding the sepals.

3. S. decumbens.

4. S. saginoides.

5. S. nodosa.

I. Sagina procúmbens L. Procumbent Pearliwort. (I. F. f. I494.) Annual or perennial, branching, decumbent, or spreading, glabrous or minutely downy, matted, 2-8 cm. high. Leaves linear, subulate, 2-6 cm. long, connate at the base; flowers about $2 \mathrm{~mm}$. broad, numerous; peduncles capillary, longer than the leaves, often recurved at the end after flowering; sepals 4 , sometimes 5, ovateoblong, generally longer than the petals, which are occasionally wanting; capsule about equalling the calyx; stamens 4 , rarely 5 . In moist places, Newf. and Greenland to N. J., Penn., Kans. and Mich. Native of Europe and Asia. Probably in part naturalized from Europe. May-Sept.

2. Sagina apétala Ard. Small-flowered Pearlwort. (I. F. f. r495.) Erect or ascending, annual, glabrous, filiform, 2-10 cm. high. Leaves linear-subulate, glabrous or sparingly ciliate, $2-8 \mathrm{~mm}$. long; flowers $2 \mathrm{~mm}$. broad or less; peduncles elongated, capillary, erect; sepals 4, ovate or oval, obtuse; petals none, or 4 and very minute; pod ovoid, nearly twice the length of the calyx. In dry soil in woods and fields, Mass. to N. J. and Penn. Apparently introduced. Native of Europe. June.

3. Sagina decúmbens (Ell.) T. \& G. Decumbent Pearlwort. (I. F. f. 1496.) Annual, tufted; stems 5-10 cm. long, glabrous or minutely glandularpubescent. Leaves narrowly linear, sometimes bristle-tipped, 6-10 mm. long; peduncles filiform; flowers $2-3 \mathrm{~mm}$. broad; sepals, petals and styles 5 : stamens 5 or Io; pod ovoid-oblong, nearly twice as long as the calyx. In dry soil, eastern Mass. to Ill., Fla., Mo. and La. March-May.

Sagina decúmbens Smíthii (A. Gray) S. Wats. Slender; stems erect or nearly so ; flowers apetalous. Plant with the aspect of $S$. apetala, but the parts of the flower in s's. Southeastern Penn, and southern N. J. 
4. Sagina saginoides (L.) Britton. Arctic Pearlwort. (I. F. f. 1497.) Perennial, glabrous, tufted, $2-10 \mathrm{~cm}$. high, few-flowered or the flowers solitary at the ends of the stems. Leaves linear-subulate, or filiform, 4-10 mm. long, acuminate or mucronate; flowers 3-5 mm. broad; sepals, petals and styles 5 ; stamens 10 ; sepals oval, obtuse, half the length of the ovoid-oblong capsule. On rocks, Ldb., Anticosti and in arctic America. Also in the higher Rocky Mts., south to Colo. and Utah, in Cal., and in alpine and arctic Europe and Asia. Summer.

5. Sagina nodòsa (L.) Fenzl. KNotted Pearlwort. (I. F. f. I498.) Perennial, tufted, $5^{-15} \mathrm{~cm}$. high; stems glabrous, or slightly glandular-pubescent above. Lower leaves linear, teretish, 8-16 $\mathrm{mm}$. long, mucronulate, the upper shorter and with clusters of minute ones in their axils; flowers few, about $6 \mathrm{~mm}$. broad; sepals, petals and styles 5; stamens Io; sepals ovate-oblong; obtuse; petals obovate, longer than the calyx, as is also the ovoid pod. In wet, sandy places, coast of Mass. to Greenland; shores of Lake Superior, Lake Winnipeg and of the Arctic Sea. Also in northern Europe and Asia. Summer.

\section{ARENÀria L. (See Appendix.)}

Mainly tufted herbs, with sessile leaves, and terminal cymose or capitate, rarely solitary, white flowers. Sepals 5. Petals 5, entire or scarcely emarginate, rarely none. Stamens IO. Styles generally 3 (rarely 2-5). Ovary I-celled, many ovuled. Capsule dehiscent at the apex by as many valves or teeth as there are styles, or twice as many. Seeds reniform-globose or compressed. [Latin, sand, in allusion to the habitat of many species.] About 150 species, of wide distribution.

Valves of the capsule 2-cleft or 2-toothed, sometimes appearing as if double the number of the styles.

Leaves ovate or oblong.

Sepals acute or acuminate; annual herb of waste places.

Sepals obtuse or scarcely acute; perennial; arctic.

Leaves subulate or setaceous.

Cymes very dense; stems 2-ro cm. tall.

Cymes loose; stems I-4 dm. tall.

Valves of the capsule entire (Genus Alsine Wahl).

1. A. serpyllifolia.

2. A. ciliata.

3. A. Hookeri.

4. A. Fendleri.

Leaves rigid, subulate or setaceous.

Arctic or alpine, densely tufted, $2-8 \mathrm{~cm}$. high.

Flowers $10-16 \mathrm{~mm}$. broad.

Flowers $4-6 \mathrm{~mm}$. broad.

Neither arctic nor alpine, tufted but diffuse, I-4 dm. high.

Leaves densely imbricated ; pine barren species.

Leaves fascicled in the axils.

Sepals ovate or ovate-lanceolate, $4 \mathrm{~mm}$. long; plant bright green.

8. A. Michauxii.

Sepals narrowly lanceolate, long-acuminate, $5 \mathrm{~mm}$. long; plant pale green.

Leaves soft, herbaceous, narrowly linear or filiform.

Sepals prominently ribbed; southern.

Sepals not ribbed; alpine and northern.

5. A. biflora.

6. A. verna.

\section{A. Caroliniana.}

ro. A. patula.

11. A. Groenlandica.

I. Arenaria serpyllifòlia L. Thyme-Leaved Sandiort. (I. F. f. I 499.) Annual, slender, slightly downy-pubescent, widely branched, 0.5-2 dm. high. Leaves ovate, 4-8 $\mathrm{mm}$. long, acute; pedicels 4-12 $\mathrm{mm}$. long; bracts ovate, resembling the leaves; flowers $4 \mathrm{~mm}$. broad or less, very numerous in cymose panicles; sepals ovate, acute or mucronate, 3-5-nerved; petals obovate or oblong, usually shorter; capsule ovoid, dehiscent by 6 short apical valves; seeds rough. In dry or rocky places, throughout eastern N. Am. Naturalized from Europe. May-Aug.

2. Arenaria ciliàta L. FRINGe1) SANDwort. (I. F. f. I500.) Perennial, tufted, glandular-puberulent; stems very slender, creeping or ascending, pubescent in lines, $2-13 \mathrm{~cm}$. long, or the flowering branches erect. Leaves ovate or oblong, sessile or very nearly so, 2-6 min. long, ciliate or glabrous; peduncles filiform, erect, mostly I-flowered; flowers about $6 \mathrm{~mm}$. broad; sepals ovate or oblong, ob. tuse, nerveless or faintly I-nerved, about as long as the petals; capsule oblong, twice as long as the calyx, its 3 valves deeply 2 -cleft; seeds slightly roughened. Quebec to Greenland. Also in arctic and alpine Europe. Summer.

3 Arenaria Hoókeri Nutt. HoOKer's SAndwort. (I. F. f. I5OI.) Tufted from a deep woody root, 2-10 $\mathrm{cm}$. high. Leaves linear-subulate, rigid, very 
sharp-pointed, densely imbricated, glabrous, $\mathbf{I}-2.5 \mathrm{~cm}$. long ; flowering stems finely pubescent; bracts lanceolate-subulate, the margins ciliolate; cyme $1.5-3.5 \mathrm{~cm}$. broad, its rays short and pubescent ; sepals lanceolate-subulate, pubescent, shorter than the similar bracts and about one-half the length of the petals. In dry or rocky soil, Neb. and Colo. to Mont. and Idaho. June-Aug.

4. Arenaria Féndleri A. Gray. Fendler's Sandwort. (I. F. f. 1502.) Perennial by a woody root, pale green, glandular-pubescent above; stems tufted, erect, very slender, $1-4 \mathrm{dm}$. tall, the internodes $2-5 \mathrm{~cm}$. long. Lower leaves subulate or setaceous, glabrous or minutely ciliate, $2-10 \mathrm{~cm}$. long, about $0.5 \mathrm{~mm}$. wide, the upper somewhat connate at the base; cyme loose, its rays filiform, several-flowered; pedicels very glandular; flowers $8-12 \mathrm{~mm}$. broad; sepals linear: lanceolate, acuminate, nearly as long as the obovate petals ; capsule rather shorter than the sepals. In dry, usually rocky soil, Neb., and Wyo. to Utah, N. Mex. and C.al. June-Aug.

5. Arenaria bifiòra (L.) S. Wats. ARCtic SAndwort. (I. F. f. 1503.) Perennial, tufted, glandular-pubescent, 2-5 cm. high. Leaves linear or linear-lanceolate, sessile and sheathing, densely imbricated, $6-8 \mathrm{~mm}$. long, semiterete, obtuse, glabrous, ciliate or glandular-pubescent; peduncles I-2-flowered; flowers 10-16 mm. broad; sepals linear-oblong, 3-nerved, obtusish : petals obovate, twice as long as the calyx ; capsule slightly longer than the sepals : seeds smooth. Greenland and Lab. to Quebec and Alaska, south in the Rocky Mts. to Ariz. Also in Asia. Summer.

6. Arenaria vérna L. Vernal Sandwort. (I. F. f. I504.) Perennial, tufted; flowering stems $2-13 \mathrm{~cm}$. higl. Leaves subulate-linear, rather rigid, imbricated below, more distant above, 4-8 mm. long; the uppcr a little shorter and broader than the lower; flowers $4-6 \mathrm{~mm}$. broad, numerous in loose cymes; sepals lanceolate, acuminate, 3-ribbed; capsule 3-valved, exceeding the sepals; seeds rugose. In rocky places, Smuggler's Notch, Vt.; Mt. Albert, Quebec; Lab. and arctic America. Also in northern and alpine Europe and Asia. Summer.

7. Arenaria Caro.iniàna Walt. PINe-BarRen SAndworT. (I. F. f. 1505.) Perennial froin a deep root, tufted, glandular-pubescent; flowering stems I-2.5 dm. high. Lower leaves subulate, rigid, 4-6 mm. long, keeled by the prominent midrib, densely imbricated; upper leaves similar, distant; cymes few-flowered; flowers Io-16 mm. broad; sepals ovate-oblong, obtuse, nerveless; petals oblanceolate, 3-4 times as long as the calyx; pod short-ovoid, twice as long as the calyx, 3-valved; seeds nearly smooth. In dry sand, southeastern N. Y., pine barrens of N. J., south near the coast to Fla. and Ga. May-July.

8. Arenaria Michauxii (Fenzl.) Hook. f. Rock SAndworT. (I. F. f. I 506.) Perennial, tufted, slender, glabrous, dark green, I.5-4 dm. high. Leaves slender, rigid, subulate or filitorm, broadest at the sessile base, $8-20 \mathrm{~mm}$. long, distinctly 1 -ribbed, spreading, with numerous others fascicled in the axils; flowers 8-10 mm. broad; calyx ovoid-oblong in fruit; sepals lanceolate or ovate-lanceolate, acute, 3 -ribbed, about half the length of the petals and slightly shorter than the ovoid pod: seeds minutely rugose. In dry, rocky places, Ont. and Vt. to Va., Minn., S. Dak. and Mo. [A. stricta Michx. ; not A. stricta (Sw.) S. Wats.] June-July.

9. Arenaria Texàna (Robinson) Britton. Texas SandworT. (I. F. f. 1507.) Similar to the preceding, but lower, stiffer, pale green : stems erect, I-2 dm. tall, thickened at the nodes, the internodes mostly short. Leaves subulate, stiff, 6-12 mm. long, connate, with numsrous minute or similar ones fascicled in their axils; cymes small, rather few-flowered; calyx narrowly conic in fruit; sepals narrowly lanceolate, strongly 3 -ribbed, long-acuminate, $4 \mathrm{~mm}$. long, longer than the capsule. In dry rocky soil, Kans. and Mo. to Tex. June-July.

I o. Arenaria pátula Michx. Pitcher's Sannwort. (I. F. f. I508.) Annual, branched from the base, slender or even filiform, I-2.5 dm. high. Leaves soft, linear-filiform, 8-25 mm. long, I mm. wide or less : cyme several-flowered, diffuse; sepals lanceolate, acuminate, 3-5-nerved, about half the length of the emarginate petals and equalling the pod; seeds rough. In open dry places, Ky. to Ill., Minn., Kans., Ala., Tenn. and Tex. April-May.

I I. A renaria Groenlándica (Retz) Spreng. Mountain Sandwort or StarWORT. (I. F. f. I509.) Perennial from a slender rootstock, tufted, glabrous ; flowering stems stender, $5^{-13} \mathrm{~cm}$. liigl): leaves linear-filiform, the upper distant, 
the lower matted, 6-12 mm. long: cyme terminal, several-flowered; pedicels filiform; flowers $8_{-12} \mathrm{~mm}$. broad; sepals oblong, obtuse, nerveless, half the length of the petals and shorter than the oblong pod; petals rarely wanting; seeds com. pressed, smooth. On dry rocks, Lab. and Greenland to N. N. Y., Conn., the mountains of S. N. Y. and Penn., and on the higher Alleghanies of Va. and N. Car. June-Sept.

\section{MOEHRÍNGIA L.}

Low herbs, our species perennials, with oblong ovate-lanceolate or linear soft leaves, sessile or very short-petioled, and small white flowers solitary or in cymes. Sepals and petals 4 or 5 . Stamens 8 or Io. Capsule oblong or ellipsoid, fewseeded. Seeds mostly smooth and shining, appendaged at the hilum by membranous broad strophiole. [In honor of P. H. G. Moehring, naturalist of Danzig.] About 20 species, natives of the northern hemisphere. Only the following are known to occur in N. Am.

Leaves oblong or oval, usually obtuse; sepals obtuse or acute, much shorter than the petals.

Leaves lanceolate, usually acute; sepals acuminate, longer than the petals.

2. M. macrophylla.

I. Moehringia lateriflòra (L.) Fenzl. Blunt-Leaved Moehringia or SANDWORT. (I. F. f. I5 IO) Stems finely pubescent, I-3 dm. high. Leaves thin, oval or oblong, $1-5 \mathrm{~cm}$. long, obtuse, the margins and nerves ciliate ; cymes few-flowered or flowers sometimes solitary ; flowers $6-8 \mathrm{~mm}$. broad; sepals half as long as the petals; ovary at first 3-celled ; capsule ovoid, nearly twice as long as the calyx, dehiscent by three 2 -cleft valves. In moist places and on shores, $\mathrm{S}$. N. Y. and N. J. to Mo., N. S. and Alaska, extenling in the Rocky Mts. to Utah. Also in Ore., Br. Col., Europe and Asia. May-July. [Arenaria lateriflora L.]

2. Moehringia macrophýlla (Hook.) Torr. Large-Leaved MoenRingia oR SANDWOR'T. (I. F. f. I5II.) Stems decumbent, puberulent, 1.5-4 dm. long. Leaves lanceolate, acute or acuminate (rarely obtusish) at the apex, narrowed at the base, 2-8 cm. long, 4-10 $\mathrm{mm}$. wide; cymes $\mathbf{I}-5$-flowered; flowers about $6 \mathrm{~mm}$. broad; sepals lanceolate or ovate-lanceolate, long-acuminate, longer than the small petals; capsule rather shorter than the calyx, 3-valved, the valves 2-cleft. Isle St. Ignace, Lake Superior, to Br. Col., south to Cal. May-Aug.

\section{I7. AMMODÈnIA J. G. Gmel.}

Perennial fleshy maritime herbs, with ovate, obovate, oblong, or oblanceolate leaves, and rather small flowers, solitary in the axils and in the forks of the stem or branches. Sepals 5 (rarely 4). Petals the same number, entire. Stamens 8 or 10. Disk prominent, 8-10-lobed, glandular. Styles 3-5. Capsule subglobose, fleshy, 3-5-valved when mature, the valves entire. Seeds numerous, obovate, not strophiolate. [Greek, referring to the growth of these plants in sand.] Two species, of sea beaches in the north temperate zone.

I. Ammodenia peploìdes (L.) Rupr. Sea-BEACH Sandwort. (I. F. f. I5I2.) Perennial by long rootstocks, glabrous; stems stout, tufted, $0.7-2.5 \mathrm{dm}$. long. Leaves sessile, clasping, ovate or oval, acute or mucronate, $\mathbf{x - 2} \mathrm{cm}$. long : flowers 6-8 mm. broad ; peduncles stout ; ovary 3-celled (rarely 4-5-celled) ; sepals ovate, obtusish, about equalling the petals, shorter than the pod; seeds smooth, shortbeaked at the hilum. On sands of the seashore, Va. to arctic America. Also on the shores of Europe and Asia. June-July. [Arenaria peploides L.]

\section{SPÉRGULA L.}

Annual branched herbs. with subulate stipulate leaves, much fascicled in the axils, and terminal cymes of white flowers. Sepals and petals 5. Stamens ro or 5. Styles 5, alternate with the sepals. Capsule 5-valved, the valves opposite the sepals. Seeds compressed, acute-margined or winged. [latin, from spergo, to scatter.] Two or three species, natives of the Old World.

1. Spergula arvénsis L. Spurry. Corn Spurry. (I. F. f. 1513.) Slender, glabrous or sparingly pubescent, 1.5-4.5 dm. high. Leaves narrowly linear or subulate, $2-5 \mathrm{~cm}$. long, clustered at the nolles in two opposite sets.of 6-8 together, appearing verticillate; stipules small, connate; flowers $4-6 \mathrm{~mm}$. broad, numerous 
in loose terminal cymes; pedicels slender, divaricate; sepals ovate, slightly longer than the petals; stamens ro or 5 ; capsule ovoid, longer than the calyx. In fields and waste places, frequent as a weed throughout eastern Canada and the Eastern and Middle States, and locally westward. Adventive or naturalized from Europe. Summer.

\section{TísSA Adans. [SPERGULARIA Pers.]}

Low herbs, mostly with fleshy linear or setaceous leaves, often with others clustered in the axils, and small pink or whitish flowers in terminal cymes. Stipules scarious. Sepals 5. Petals the same number, rarely fewer, or none, entire. Stamens 2-10. Ovary I-celled, many-ovuled; styles 3. Pod 3-valved to the base. Seeds reniform-globose or compressed, smooth, winged or tuberculate. [Name unexplained.] About 20 species, of wide distribution, most of them on saline shores or salt marshes.

Species of salt marshes or sea beaches; leaves vcry fleshy.

Pedicels $\mathrm{r} 1 / 2-2$ times the length $\mathrm{r}$ the sepals; flowers pink. I. T. marina.

Pedicels 2-4 times the length of the sepals; flowers pale or white.

Species mostly of dry sandy soil ; leaves scarcely fieshy.

2. T. Canadensis,

3. 7. rubra.

I. Tissa marina (L.) Britton. Salt-marsh Sand Spurry. (I. F. f. I5 I4.) Annual to perennial, erect, ascending or nearly prostrate, I-2 dm. high, branching. Stipules ovate; leaves linear, terete, fleshy, I-4 cm. long, I-2 mm. wide, often much fascicled in the axils; pedicels $4-10 \mathrm{~mm}$. long; sepals ovate, $2-6 \mathrm{~mm}$. long; capsule equalling or longer than the calyx; seeds smooth, or roughened with projecting processes, wingless, or winged. In salt marshes, N. B. to Fla. Also in those of Salina, N. Y., the Pacific Coast, and of Europe and northern Asia. Summer.

Tissa marìna mínor (Wats. \& Coult.) Britton. Rarely over $6 \mathrm{~cm}$. high; flowers smaller; pedicels $1-4 \mathrm{~mm}$. long. Coast of New England. [Buda marina minor Wats. \& Coult.].

2. Tissa Canadénsis (Pers.) Britton. Northern Sand Spurry. (I. F. f. 1515.) Annual, diffuse and spreading, glabrous, 5-13 cm. high. Leaves linear, fleshy, teretish, 10-16 mm. long, mainly obtuse, generally not fascicled; stipules broadly ovate; pedicels slender, at length much exceeding the calyx; sepals $2 \mathrm{~mm}$. long: flowers pale or white; capsule twice the length of the calyx; seeds smooth or papillose, usually wingless. On muddy shores, R. I. and Mass. to Lab. Summer.

3. Tissa rubra (L.) Britton. Sand Spurry. Purple Sandwort. (I. F. f. 15I6.) Annual to perennial, depressed or ascending, very leafy, glabrous, or glandular-pubescent above, 5-15 cm. high. Leaves linear, flat, scarcely fleshy, 4-8 mm. long; flowers bright pink, 2-3 mm. broad; stipules ovate-lanceolate, acuminate; sepals ovate-lanceolate, acutish; pedicels slender, spreading, 4-8 mm. long; pods about equalling the calyx; seeds wingless, rough with projecting points. In waste places and along roadsides, or sometimes maritime, Newf. to Penn., western N. Y., Ohio and Va. Apparently adventive from Europe. Also in Cal. and Ore., Europe and Asia. Summer.

\section{LOEFLÍNGIA L.}

Low annual glandular-puberulent diffusely branched herbs, with small subulate or setaceous stipulate leaves, and very small sessile flowers in the axils. Sepals 5 , rigid, keeled, acuminate or awn-tipped, the outer ones commonly with a tooth on each side. Petals 3-5, minute, or wanting. Stamens 3-5, perigynous. Ovary triangular-pyramidal, I-celled, many-ovuled. Capsule 3-valved. Seeđis attached near their bases; cotyledons accumbent. [In honor of Peter Loefling, 1 729-1756, Swedish traveler.] About 5 species, natives of N. Am., Europe, and central Asia. Besides the following, 2 others occur in the southwestern U. S.

I. Loeflingia Texàna Hook. Texan Loeflingia. (I. F. f. I5I7.) Bushy, 7-15 cm. high, the branches slender, terete, ascending or those bearing flowers secund and recurved. Leaves 4-6 $\mathrm{mm}$. long; flowers less than $2 \mathrm{~mm}$. broad; sepals nearly or quite straight: stamens usually 3 ; capsule shorter than the calyx; seẹds obovate. In dry soil, Neb, to Tex. April-June, 


\section{2x. PARONÝchia Adans. (See Appendix.)}

Perennial tufted herbs, often woody at the base, with opposite leaves, scarious stipules, and small clustered scarious-bracted apetalous flowers. Calyx 5-parted, the segments bristle-pointed. Stamens 5, inserted at the base of the calyx, sometimes alternate with as many staminodia. Ovary narrowed upward into the style; style 2 -cleft at the apex; ovule solitary, amphitropous Utricle membranous, included in the calyx, I-seeded. [Greek, for a disease of the fingers and a plant supposed to cure it.] About 40 species, natives of warm and temperate regions. Besides the following about 5 others occur in the Southern States, one in the Rocky Its., and one in Cal.

Awns of the calyx-segments erect.

Awns of the calyx-segments divergent.

Stipules 2-cleft.

Stipules entire.

I. P. argyrocoma.

Lowest leaves obtuse, uppermost mucronate or bristle-pointed.

Leaves all acute, mucronate or bristle-pointed.

3. P. Jamesii.

4. P. dichotoma.

r. Paronychia argyrócoma (Michx.) Nutt. Silver Whitlow-wort. (I. F. f. I5 18.) Stem much branched, 0.7-2 dm. high, clothed with silvery appressed scale-like hairs. Leaves linear, I-nerved, acute or mucronate; stipules silvery-white, entire; flowers in forking cymes, subtended by the large silvery bracts; calyx-segments 4-5 mm. long, their awns erect, nearly as long; style filiform; staminodia minute and much shorter than the filaments or wanting. In rocky places, Me. and N. H. to Tenn. and Ga. July-Sept.

2. Paronychia sessiliflìra Nutt. Low Whitlow-Wor'r. (I. F. f. 1519.) Densely tufted from thick roots, low, the internodes very short and hidden by the imbricated leaves and stipules. Lraves lineir-subulate, the lowest erect and obtuse, the uppermost recurved-spreading, mucronate or bristle-pointed; stipules 2-cleft; bracts entire; flowers sessile, solitary or several together; calyx 2-3 mm. long, its segments hooded at the apex, tipped with divergent awns of nearly their own length; staminodia about as long as the filaments. In dry soil, N. W. Terr. to Neb. and Wyo. Aug-Sept.

3. Paronychia Jàmesii T. \& G. James' Whitlow-worT. (I. F. f. I520.) Scabrous-pubescent; stems 0.7-2 dm. high, much branched. Leaves linear-subulate, the lowest obtuse, the uppermost mucronate or bristle-pointed; stipules entire; flowers in small cymes; bracts shorter than the calyx; calyx 2-3 mm. long, the segments hooled at the apex, tipped with divergent awns of about one-fourth their length; staminodia about as long as the filaments. In dry soil, Neb. and Colo. to Tex. July-Oit.

Paronychia Jàmesii depréssa Nutt. Lower, rarely over $0.7 \mathrm{dm}$. high, densely tufted; internodes very short; leaves imbricated. Neb. to 'Tex.

4. Paronychia dichótoma (L.) Nutt. Forking Whitlow-wort. Nailwort. (I. F. f. I52I.) Much branched from the thick woody base, I-4 dm. tall. Leaves subulate, acute, mucronate or bristle-tipped; stipules entire, often 10-12 mm. long; caly $\times$ 2-4 mm. long, the awns of its segments divergent, short; staminodia hardly one-fourth as long as the filaments; styles nearly as long as the perianth-segments. In dry soil, Md. to N. Car., Ark. and Tex. July-Oct.

\section{ANÝCHIA Michx.}

Annual herbs, with forking stems, elliptic oval or oblanceolate opposite, mostly punctate, short-petioled leaves, small scarious stipules, and minute green apetalnus flowers. Calyx 5-parted, its segments oblong, concave, not awned. Stamens 2-5, inserted on the base of the calyx; filaments filiform. Staminodia wanting. Ovary subglobose, compressed; styles 2, distinct, or united at the base; ovule solitary, amphitropous. Utricle subglobose, as long as the calyx or longer. [Derivation same as the preceding genus.] Only the following species, natives of eastern $\mathbf{N}$. Am. 
I. Anychia polygonòides Raf. Forked ChICKwEed. (I. F. f. 1522.) Pubescent; stems mostly prostrate or ascending, much forked, o.7-2 dm. high, the internodes often shorter than the leaves. Leaves narrowly elliptic, 4-8 mm. long, I-2 $\mathrm{mm}$. wide, mucronate or acute, sessile, or the base tapering into a very short petiole, usually numerous and crowded; flowers sessile in the forks, more or less clustered, scarcely I mm. high. In dry woods, thickets and in open places, Me. to Minn., Fla., Ala. and Ark. June-Sept.

2. Anychia Canadénsis (L.) B. S. P. Slender Forked Chickweed. (I. F. f. 1523.) Glabrous or nearly so; stem very slender or filiform, usually erect, I.5-3 dm. tall, the internodes sometimes $2.5 \mathrm{~cm}$. long, much longer than those of the preceding. Leaves elliptic, oval or sometimes oblanceolate, 6-16 mm. long, 2-8 $\mathrm{mm}$. wide, narrowed into petioles about $2 \mathrm{~mm}$. long, not crowded; flowers more or less pedicelled. In dry woods, Ont. to Mass., Ga., Minn. and Ark. June-Sept.

\section{SCLERÁNTHUS L.}

Low annual herbs, with forking stems, opposite subulate leaves connate at the base, no stipules and minute green clustered apetalous flowers. Calyx not bracted deeply 5-lobed (rarely 4-lobed), the lobes awnless, the cup-like tube hardened. Stamens I-IO, inserted on the calyx-tube. Ovary ovoid; styles 2, distinct; ovule solitary, pendulous, amphitropous. Utricle I-seeded, enclosed by the calyx. [Greek, referring to the hard calyx-tube.] About ro species, of wide distribution in the Old World, the following nat. from Europe as a weed.

I. Scleranthus ánnuus L. KNawel. German Knotgrass. (I. F. f. I524.) Much branched, the branches prostrate or spreading, 7-13 cm. long. Leaves subulate, 4-25 $\mathrm{mm}$. long, ciliate, light green, often recurved; tube of the calyx roangled, rather longer than the lobes, the lobes somewhat angled on the back and their margins incurved. In fields and waste places or on dry rocks, Quebec and Ont. to Penn. and Fla. Nat. from Europe. March-Oct.

\section{Order I5. RANÀLES.}

Herbs, shrubs or trees. Calyx present, usually of separate sepals. Corolla usually present and of separate petals. Ovary or ovaries superior, free from the calyx; carpels I to many, usually separate. Stamens mostly hypogynous and more numerous than the sepals.

* Aquatic herbs; floating leaves peltate, or with a basal sinus.

Carpels 3 or more; petals large; floating leaves not dissected. Fam. I. Nymphaeaceae. Pistil I; petals none; leaves whorled, all submersed and dissected.

\section{* * Land or marsh plants (some Ranunculaceae aquatic.)}

Fam. 2. Ceratophyllaceae.

Etamens numerous; sepals distinct ; petals present (except in some Ranunculaceae and in Calycocarpum of the Menispermaceae).

Receptacle not hollow; leaves alternate (except in Clematis).

Flowers perfect (except in some species of Clematis and Thalictrum).

Fruit aggregate, cone-like; trees; sepals and petals in 3 series, or more, of 3.

Fam. 3. Magnoliaceae.

Fruit not aggregate; the carpels separate, at least when mature. Anthers not opening by valves; pistils usually more than $\mathrm{I}$.

Sepals 3; petals 6; shrubs or trees. Fam. 4. Anonaceae.

Sepals $3^{-1} 5$; petals (when present) about as many ; our species herbs or vines (Xanthorrhiza shrubby). Fam. 5. Ranunculaceae. Anthers opening by valves (except in Podophyllum): pistil $\mathrm{I}$.

Fam. 6. Berberidaceae.

Diœcious climbing vines with simple leaves; fruit drupaceous.

Fam. 7. Menispermaceae.

Receptacle hollow, enclosing the numerous pistils and achenes; opposite-leaved shrubs.

Fam. 8. Calycanthaceae.

Stamens 9 or 12 , in 3 or 4 series of 3 ; anthers opening by valves; aromatic trees or shrubs with no petals, more or less united sepals, and 1 pistil. $\quad$ Fam. 9. Lauraceae. 


\section{Family I. NYMPHAEÀCEAE DC.}

Water Lily Family.

Aquatic perennial herbs, with horizontal rootstocks, floating, immersed or rarely emersed leaves, and solitary axillary flowers. Sepals

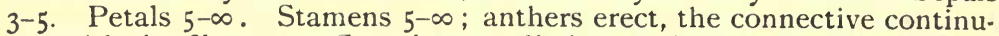
ous with the filament. Carpels $3^{-\infty}$, distinct, united, or immersed in the receptacle. Stigmas distinct, or united into a radiate or annular disk; ovules $\mathrm{I}-\infty$, orthotropous. Fruit indehiscent. Seeds enclosed in pulpy arils, or rarely naked; cotyledons fleshy; hypocotyl very short. streams.

Eight genera and about 33 species, of wide distribution in fresh-water lakes and

Sepals and petals 3 ; stamens 6, hypogynous ; carpels distinct ; ovules few.

Leaves dissected, excepting the small floating ones.

Leaves peltate, entire, floating.

I. Cabomba.

2. Brasenia.

Sepals 4-6; petals numerous or several; carpels united; ovules numerous.

Petals small or minute; stamens hypogynous.

Petals large, numerous; stamens epigynous.

3. Nymphaea.

4. Castalia.

Sepals 4-5; petals numerous; carpels distinct, immersed in the receptacle ; ovule I.

\section{I. САBÓMBA Aubl.}

5. Nelumbo.

Stems slender, coated with gelatinous matter, branching. Leaves petioled, peltate, the floating ones small, entire; submerged ones opposite, palmately dissected into capillary segments. Flowers small, white or yellow. Sepals and petals 3. Stamens 6; filaments slender; anthers extrorse. Carpels 2-4. Stigmas small, terminal; ovules commonly 3, pendulous. Fruit coriaceous, indehiscent, about 3seeded. [Guiana name.] A genus of 2 or 3 species, natives of the warmer parts of America.

I. Cabomiba Caroliniàna A. Gray. Cabomba. Carolina Water-shield. (I. F. f. 1525.) Stem several feet long. Submerged leaves opposite or sometimes verticillate, $2-5 \mathrm{~cm}$. broad, repeatedly divided; floating ones linear-oblong, $\mathbf{I}-2 \mathrm{~cm}$. long; flowers long-peduncled from the upper axils, $1-1.5 \mathrm{~cm}$. wide, white, or yellow at base within; petals obovate; ripened carpels 3, separate, flask-shaped. In ponds and slow streams, Mo. and S. Ill. to N. Car., Fla. and Tex. May-Aug.

\section{BRASENIA Schreb.}

Plant covered with gelatinous matter. Leaves alternate, oval, entire, $5-10 \mathrm{~cm}$. long, long-petioled, floating. Flowers axillary, purple. Sepals and linear petals 3 . Stamens 12-18; filaments filiform. Carpels 4-18, separate. Ovules 2 or 3, pendulous from the dorsal suture. Ripe carpels indehiscent, coriaceous, I-2-seeded. [Name unexplained.] A monotypic genus of N. Am., Cuba, eastern and tropical Asia, west tropical Africa, and Australia.

I. Brasenia purpùrea (Michx.) Casp. WATER-SH1Eld or -TARGet. (I. F. f. I526.) Rootstock slender. Leaves thick, rounded at each end; flowers $\mathbf{I}-\mathbf{I} .6 \mathrm{~cm}$. in diameter, on long stout peduncles; fruit oblong, $68 \mathrm{~mm}$. long. In ponds and slow streams, N. S. to Fla., Man., Tex., Mex., and at a few stations on the Pacific Coast from Cal. to Wash. Summer.

\section{NYMPHAÈA L. [NUPHAR Sibth. \& Sm.]}

Herbs, with cylindric thick horizontal rootstocks, and large cordate leaves with a deep sinus. Flowers showy, yellow, or sometimes purplish. Sepals 5 or 6 , concave, thick. Petals $\infty$, small, stamen-like, hypogynous. Stamens $\infty$, hy pogynous. Carpels $\infty$, many-ovuled, united into a compound pistil. Stigmas disciform, 7-24radiate. Fruit ovoid, naked. Seeds with endosperm. [Greek, water-nymph.] About 8 species, natives of the north temperate zone.

Leaves broadly ovate or oval.

Leaves I-3 dm. long; stigma 12-24-rayed; petals truncate, fleshy. I. N. advena.

Leaves $0.7^{--2.5} \mathrm{dm}$. long; stigma 9-12-rayed; petals spatulate, fleshy.

Leaveș 0.5-1 dm. long; stigma 7-10-rayed; petals spatulate, thin. 3. N. Kalmiana. 
I. Nymphaea ádvena Soland. Large Yellow Pond Lily. (I. F. f. I527.) Floating and emersed leaves $\mathbf{I}-2.5 \mathrm{dm}$. broad, ovate or orbicular-oval, thick, the sinus generally open; submerged leaves, when present, thin-membranous, nearly orbicular; petioles, peduncles ${ }^{\circ}$ and lower surfaces of the leaves often pubescent; flowers 3-9 $\mathrm{cm}$. in diameter, depressed-globose, yellow or tinged with purple; sepals 6 , oblong, about $3 \mathrm{~mm}$. long; petals oblong, 8-10 $\mathrm{mm}$. long; stamens in 5-7 rows; anthers about the length of the filaments; stigmatic disk undulate, yellow, or pale red; fruit ovoid, not deeply constricted into a neck, 3-5 cm. long. In ponds and slow streams, Labrador to the Rocky Mts., Fla., Tex. and Utah. April-Sept. Rev. Thos. Morong (Bot. Gaz. I I: I67) describes a var. (?) minor having smaller flowers, the margins of the stigmatic disk more crenate, rays $\mathbf{1 0}$, and fruit only $\mathbf{2 . 5}$ $\mathrm{cm}$. long. Called also Cow-lily and Spatter-dock.

2. Nymphaea hýbrida Peck. Red-disked Pond Lily. (I. F. f. I528.) Floating leaves $0.5-1.5 \mathrm{dm}$. long, sometimes pubescent beneath; submerged leaves generally present, membranous, orbicular; flowers $2.5-4 \mathrm{~cm}$. broad, yellow; sepals 5 or 6 ; petals $6-8 \mathrm{~mm}$. long, less fleshy than those of the last; anthers nearly the length of the filaments; stigmatic disk crenate, bright red or crimson; stamens in about 5 rows; fruit about $2.5 \mathrm{~cm}$. long, contracted below into a neck. In ponds and slow streams, Vt. to Ont., N. Y., Penn. and Mich. May-Sept.

3. Nymphaea Kalmiàna (Michx.) Sims. Small Yellow Pond Lily. (I. F. f. I 529.) Leaves $0.5-1 \mathrm{dm}$. long, commonly pubescent beneath; submerged ones always present, membranous, orbicular, larger; flowers $2.5 \mathrm{~cm}$. in diameter or less, yellow; sepals 5 ; petals $4 \mathrm{~mm}$. long; stamens in 3 or 4 rows, narrowly linear, the anther one-fourth the length of the filament; stigmatic disk crenate or stellate, 4-6 $\mathrm{mm}$. broad, dark red; fruit ovoid, with a short neck. In ponds and slow streams, Newf. to N. Y., Penn., Minn. and Saskatch. Summer, flowering later than the two preceding.

4. Nymphaea sagittaefolia Walt. Arrow-Leaved Pond Lily. (I. F. f. I530.) Floating leaves glabrous, obtuse, 2-4 dm. long; submerged ones numerous, similar, but membranous and commonly larger; flowers yellow, about $2.5 \mathrm{~cm}$. broad; sepals 5 ; petals broadened above, $6 \mathrm{~mm}$. long; stamens in 4 or 5 rows, the filaments about equalling the anthers; stigmatic disk crenate, II-I5-rayed; fruit ovoid, not constricted into a neck. In ponds, S. Ind. and Ill., and in the Atlantic States from N. Car. to Fla. Summer.

\section{CASTÀLIA'Salisb.}

Herbs with horizontal perennial rootstocks, floating leaves and showy flowers. Sepals 4. Petals imbricated in several rows, inserted on the ovary, gradually pass. ing into stamens; stamens $\infty$, the exterior with large petaloid filaments and short anthers, the interior with linear filaments and elongated anthers. Carpels $\infty$, united into a compound pistil with radiating linear projecting stigmas. Fruit globose, covered with the bases of the petals, ripening under water. [A spring of Parnassus.] About 25 species, of wide geographic distribution.

Flowers $0.7-1.5 \mathrm{dm}$. broad, fragrant ; leaves orbicular, purplish beneath. I. C. odorata. Flowers $1-2.5 \mathrm{dm}$. broad, not fragrant ; leaves orbicular, green both sides.

Flowers $2.5-4 \mathrm{~cm}$. broad, not fragrant ; leaves oval or oblong.

2. C. tuberosa.

3. C. tetragona.

I. Castalia odoràta (Dryand.) Woodv. \& Wood. Sweet-Scented White Water Lily. Pond Lily. (I. F. f. I53I.) Rootstock thick. Leaves I-3 dm. in diameter, glabrous above, more or less pubescent beneath, cordate-cleft or reniform: petioles and peduncles with 4 main air-channels; flowers white, or tinged with pink; petals narrowly oblong, obtuse; fruit globose, or slightly depressed; seeds stipitate, oblong, shorter than the aril. In ponds and slow streams, Newf. to Manitoba, Fla. and Tex. June-Sept.

Castalia odoràta ròsea (Pursh) Britton. Flowers large, deep pink or red. E. Mass. to N. J., near the coast.

2. Castalia tuberòsa (Paine) Greene. Tuberous White Water Lily. (I. F. f. I532.) Rootstock with numerous lateral tuberous-thickened branches. 
Leaves green both sides; the veins very prominent on the lower surface; flowers pure white, inodorous or very slightly scented; petals oblong, broader than those of $C$. odorata, obtuse; fruit depressed-globose; seeds globose-ovoid, sessile, longer than or about equalling the aril. Lake Champlain,• west through the Great Lakes to Mich., south to Del., Penn. and Ark. Summer.

3. Castalia tetragòna (Georgi) Lawson. Small White Water Lily. (I. F. f 1533.) Leaves oval or oblong, 0.5-I dm. long, green above, green or purplish beneath, the sinus narrow; petioles and peduncles nearly or quite glabrous; flowers white, inodorous; petals in about 2 rows, faintly striped with purple, oblong or obovate, thin, about the length of the sepals. In the Misinaibi River, Ont.; in ponds along the Severn River, Keewatin; near Granite Station, northern Idaho. Also in Siberia, Japan and the Himalayas. Summer.

\section{NELÚMBO Adans.}

Large herbs, with thick rootstocks, long-petioled concave leaves, and small and scale-like submerged ones borne sessile on the rootstock. Flowers large, yellow, pink or white. Sepals imbricate. Petals and stamens $\infty$, inserted on the calyx, caducous. Filaments more or less petaloid; anthers introrse. Carpels distinct, contained in pits in the large convex receptacle. Style short; ovules I or 2; endosperm none; cotyledons thick, fleshy. Nuts globose, ovoid or oblong. [Ceylon name for $N$. Nelumbo.] A genus of 2 species, one North American, the other Asiatic and Australasian.

Flowers pale yellow; plant native.

Flowers pink or white; plant introduced.

1. N. lutea.

2. N. Nelumio.

1. Nelumbo lùtea (Willd.) Pers. American Nelumbo or Lotus. (I. F. f. 1534.) Rootstock tuberiferous. Emersed leaves 3-6 dm. broad, nearly orbicular but often somewhat constricted in the middle, centrally peltate, prominently ribbed, glabrous above, more or less pubescent and lepidote beneath, the lower surface marked with an oblong, transverse area; petioles and peduncles thick, 0.9-2.2 m. long, with several large air-canals; flowers $\mathbf{I}-2.5 \mathrm{dm}$. broad; petals concave, obovate, obtuse; anthers appendaged; fruit obconic or somewhat hemispheric, 7-10 $\mathrm{cm}$. long; seeds nearly globular. Ont. to Mass., Fla., Minn. and Tex. July-Aug.

2. Nelumbo Nelúmbo (L.) Karst. Indian Lotus. (I. F. f. I535.) Leaves 6-9 $\mathrm{dm}$. in diameter, concave, glaucous; petioles and peduncles 9-18 dm. long, glabrous or with scattered minute prickles; flowers $1-2.5 \mathrm{dm}$. broad, pink or sometimes white; petals oblong or elliptic, obtuse; fruit obconic, 10-13 cm. long; seeds oblong or ovoid. Nat. in ponds about Bordentown, N. J. July-Aug.

\section{Family 2. CERATOPHYLLÀCEAE A. Gray. Hornwort Family.}

Submerged aquatics, with slender branching stems, and verticillate leaves, the monœcious or diøcious flowers solitary and sessile in the axils. Perianth many-parted, the segments entire or toothed. Stamens numerous, crowded on a flat or convex receptazle; anthers sessile or nearly so, linear-oblong, extrorse, the connective prolonged into a thick appendage beyond the sacs. Pistillate flowers with a superior 1-celled ovary; ovule 1, orthotropous, pendulous; style filiform, stigmatic at the summit. Fruit an indehiscent nut or achene. Endosperm none; embryo composed of 4 verticillate cotyledons, with a short hypocotyl and a plumule of several nodes and leaves. The family contains only the following genus:

\section{CERATOPHÝLLUM L.}

Leaves crowded, linear or filiform, spinulose-serrulate, forked. Sterile flowers with ro-20 stamens, the anthers ahout as long as the perianth. Fertile and sterile flowers generally at different nodes. Ovary and fruit somewhat longer than the perianth, the fruit beaked with the long persistent style. One species or possibly two, widely distributed in fresh water. 
I. Ceratophyllum demérsum L. Hornwort. (I. F. f. I536.) Stems 0.5-2.5 $\mathrm{m}$. long. Leaves $8-25 \mathrm{~mm}$. long; ripe fruit oval, 4-6 mm. long with a spine-like beak 4-8 mm. long, sinooth and spurless or with a long basal spur on each side, or tuberculate and with narrowly winged spiny margins or broadly winged without spines. In ponds and slow streams, throughout N. Am., except the extreme north. June-July.

\title{
Family 3. MAGNOLIÀCEAE J. St. Hil.
}

\author{
Magnolia Family.
}

Trees or shrubs, with alternate leaves, large solitary flowers, and bitter aromatic bark. Sepals and petals hypogynous, deciduous. Stamens $\infty$; anthers adnate. Carpels $\infty$, separate or coherent, borne on the surface of the elongated receptacle, ripening into an aggregate fruit composed of I-2-seeded follicles or achenes. About 10 genera and 70 species, of wide distribution.

Anthers introrse; leaves entire, or with 2 basal lobes. Anthers extrorse; leaves lobed or truncate.

1. Magnolia.

2. Liriodendron.

\section{MAGNÒLIA L.}

Leaves large and generally thick, entire. Buds covered with conduplicate sheathing stipules. Flowers fragrant. Sepals petaloid. Petals 6-12, imbricated in 2-4 series. Anthers linear, introrse. Carpels spiked or capitate on the elevated or elongated receptacle, 2 -ovuled, forming follicles at maturity. Seeds fleshy, suspended from the ripe pink or rose cones by slender filamentous threads. [In honor of Pierre Magnol, 1638-1715, Professor of Botany in Montpellier.] A genus of about 15 species, natives of eastern N. Am., eastern Asia and the Himalayas.

Leaves auriculate, glabrous.

Leaves cordate, white-pubescent beneath.

Leaves acute at the base.

Leaves 2-5 dm. long, light green beneath; corolla higher than broad.

Leaves $0.7-\mathrm{r} .5 \mathrm{dm}$. long, glaucous beneath; corolla broader than high.

I. M. Fraseri.

2. M. macrophylla.

Leaves rounded or truncate at the base, thin.

4. M. Virginiana.

5. M. acuminata.

I. Magnolia Fràseri Walt. Fraser's Magnolia. Long- or Ear-Leaved UMBRELLA-TREE. (I. F. f. 1537.) A tree 8-16 m. high, the branches spreading. Leaf-buds glabrous; leaves clustered at the ends of the branches, auriculate, 1.5-4 $\mathrm{dm}$. long, elongated-obovate or oblong, contracted below, the lower surface light green, the upper darker; petioles $2-8 \mathrm{~cm}$. long; flowers white, I-2 dm. broad; petals spatulate or obovate, obtuse, much longer than the sepals; cone of fruit 0.7-I dm. long. In mountain woods, Va. and Ky. to Fla. and Miss. May-June.

2. Magnolia macrophylla Michx. Great-leaved Magnolia. LargeLEAVED UMBRELla-TREe, OR CUCUMBER-TREe. (I. F. f. 1538.) A tree 6-20 m. high; bark gray. Leaf-buds silky-pubescent: leaves oblong or obovate, blunt, cordate, 3-1 I dm. long, I-3.5 dm. broad, glaucous-white and pubescent beneath; petioles stout, 5-10 $\mathrm{cm}$. long; flowers $2-4 \mathrm{dm}$. in diameter, white with a large purple centre; petals ovate-oblong, obtuse, thrice the length of the rounded sepals; cone of fruit ovoid-cylindric, I-I.5 dm. long. In woods, Ky. to N. Car., Fla., Ark. and La. May-June.

3. Magnolia tripétala L. Umbrella-tree. Elk-wood. (I. F. f. I539.) A tree 6-13 m. high. Leaf-buds glabrous; leaves clustered at the summits of the branches, 3-5 dm. long, I-2 dm. wide, obovate, acute, cuneate at the base, more or less pubescent beneath; petioles stout; flowers $2-2.5 \mathrm{dm}$. in diameter, white, slightly odorous; sepals broad, reflexed, early deciduous; petals oblong-lanceolate or obovate-lanceolate, acutish; cone of fruit I-I.5 dm. long. In woods, Penn. to Ga., Ark. and Miss. May.

4. Magnolia Virginiàna L. Laurel Magnolia. Siveet Bay. (I. F. f. 1540.) A tree 5-23 m. high. Leaf-buds pubescent; leaves scattered, 0.7-I.5 dm. 
long, 2-5 cm. broad, oval or oblong, obtuse or blunt-acuminate, acute at the base, coriaceous, dark green above, glaucous and more or less pubescent beneath; flowers white, depressed-globose, deliciously fragrant, 5-8 cm. in diameter; sepals spreading, obtuse, nearly as large as the obovate rounded petals; cone of fruit oblong, 4-5 cm. high. In swamps and swampy woods, eastern Mass. to Penn., Fla. and Tex. May-June. [M. gliuca L.]

5. Magnolia acuminàta L. Cucumber-Tree. Mountain Magnolia. (I. F. f. 1541.) A tree 20-30 m. high. Leaf-buds silky-pubescent; leaves scattered, I.5$2.5 \mathrm{dm}$. long, thin, oval, acute or somewhat acuminate, rounded or truncate at the base. light green and more or less pubescent on the lower surface; flowers oblongcampanulate, greenish-yellow, $5 \mathrm{~cm}$. high; petals obovate or oblong, much longer than the spreading deciduous sepals; cone of fruit cylindric, usually curved, 0.7-I dim. long. In woods, N. Y. to Ill., Ga., Ala. and Ark. May-June.

\section{LIRIODÉNDRON L.}

Leaves alternate, truncate or broadly emarginate, 4-6-lobed or rarely entire, recurved on the petiole in the laterally compressed obtuse buds. Stipules united at the base. Flowers large, slightly fragrant. Sepals 3, petaloid, reflexed. Petals 6, connivent. Anthers linear, extrorse. Carpels spiked on the elongated receptacle, 2-ovuled, samaroid, I-2-seeded; seeds pendulous by a short slender funiculus at maturity. [Greek, a tree bearing lilies.] One or possibly two species, natives of eastern N. Am. and China.

I. Liriodendron Tulipífera L. Tulip-tree. Winte-woon. Yeliow Poplar. (I. F. f. I 542.) A magnificent tree 20-65 m. high, with diverging curved branches. Leaves glabrous, very broadly ovate or nearly orbicular in outline, truncate, rounded or cordate at the base, 0.7-I.5 dm. long with 2 apical and 2-4 basal lobes with rounded sinuses; flowers about $5 \mathrm{~cm}$. high, erect, greenishyellow, orange-colored within; petals obovate, obtuse, about equalling the sepals; cone of fruit dry, oblong, acute, 7-8 cm. long. In woods, Vt. and R. I. to Fla., Mich. and Ark. May-June.

\section{Family 4. ANONÀCEAE DC.}

\section{Custard-apple Family.}

Trees or shrubs, generally aromatic, with alternate entire leaves. Stipules none. Sepals 3 (rarely 2), valvate or rarely imbricate. Petals about 6, arranged in 2 series. Stamens $\infty$; anthers adnate, extrorse. Carpels $\infty$, separate or coherent, mainly fleshy in fruit. Seeds large, anatropous; embryo minute ; endosperm copious, wrinkled. About 46 genera and 550 species, mostly in the tropics, a few in the temperate zones.

\section{ASÍMiNA Adans.}

Small trees, or shrubs, with lateral or axillary nodding flowers. Buds naked. Sepals ovate, valvate. Petals 6, imbricated in the bud, those of the outer series the larger when mature. Receptacle subglobose. Stamens and carpels 3-15. Style oblong, stigmatic along the inner side: ovules numerous, in 2 rows. Fruit, large fleshy oblong berries. Seeds large, flat, horizontally placed, enclosed in fleshy arils. [From the aboriginal name Assimin.] A genus of about 7 species, natives of eastern N. Am.

I. Asimina tríloba (L.) Dunal. North American Papaw. (I. F. f. 1543.) A shrub or small tree I-I5 m. high. Shoots and young leaves dark-pubescent, becoming glabrous; leaves obovate or cuneate, acute, 1.5-3 dm. long; petioles 8-12 mm. long: flowers axillary, on shoots of the preceding year, appearing with the leaves, $2-4 \mathrm{~cm}$. in diameter, dark purple; sepals olsovate, densely darkpubescent; outer petals spreading, nearly orbicular, slightly exceeding the ovate inner ones; fruit $0.7-2 \mathrm{dm}$. long, 2-7 cm. thick, sweet and edible when ripe, pendulous, several together on a thick peduncle. Along streams, Ont. and N. Y. to Mich., Neb., Fla. and Tex. March-April. 


\section{Family 5. RANUNCULÀCEAE Juss.* \\ Crowfoot Family.}

Herbs, or rarely climbing shrubs, with acrid sap. Leaves alternate (except in Clematis and Atragene). Stipules usually none, but the base of the petiole often sheathing. Pubescence, when present, composed of simple hairs. Sepals 3-15, generally caducous, often petal-like, imbricate, except in Clematis and Atragene. Petals about the same number (occasionally more), or wanting. Stamens $\infty$, hypogynous, their anthers innate. Carpels $\infty$ or rarely solitary, I-celled, I-many-ovuled. Ovules anatropous. Fruit achenes, follicles or berries. Seeds with endosperm. About 35 genera and 1050 species, distributed throughout the world, not abundant in the tropics.

* Carpels several-ovuled (I-2 ovuled in nos. I and 8 ); fruit a follicle or berry.

Flowers regular; leaves palmately nerved or palmately compound.

Petals wanting.

Carpels ripening into a head of red berries.

Carpels ripening into a head of dry follicles.

Petals present, narrow or small, linear, flat.

Fetals present, narrow or small, tubular, at least at the base.

Sepals persistent ; stem tall, leafy.

Sepals deciduous; stem scape-like, bearing one leaf.

Flowers regular; leaves ternately or pinnately compound or decompound.

Petals not spurred.

Low herbs with solitary or panicled flowers.

Carpels and follicles stalked.

Carpels and follicles sessile.

Low shrub with racemose flowers.

Tall erect herbs with racemose flowers.

Fruit berries.

Fruit follicles.

Petals prolonged backward into hollow spurs.

Flowers irregular.

Posterior sepal spurred.

Posterior sepal hooded, helmet-like.

\section{** Carpels I-ovuled; fruit an achene.}

I. Hydrastis.

2. Caltha.

3. Trollius.

4. Helleborus.

5. Cammarum.

Flowers subtended by involucres remote from the calyx or close under it; sepals petallike.

Styles short, glabrous or pubescent, or none.

Involucre remote from the calyx; styles short, subulate. 14. Anemone.

Involucre of 3 simple sessile leaves close under the flower. I5. Hepatica.

Involucre of 3 compound sessile leaves; leaflets stalked; stigma sessile.

Styles elongated, densely plumose.

16. Syndesmon.

17. Pulsatilla.

Flowers not subtended by involucres.

Leaves opposite; sepals petal-like.

Petals wanting.

Petals present, small, spatulate.

Leaves alternate or basal.

Small annual herbs; leaves basal, linear; sepals spurred. 20. Myosurus.

Low or tall herbs, mostly with both basal and stem leaves; sepals spurless.

Petals none; leaves palmately lobed.

21. Trautvetteria.

Petals present, bearing a nectariferous pit at the base of the blade.

Achenes compressed, smooth, papillose or spiny ; flowers yellow.

22. Rarunculus.

Achenes transversely wrinkled; flowers white.

Achenes swollen, smooth; sepals 3 ; petals mostly 8 .

23. Batrachium.

Achenes compressed or terete; longitudinally nerved.

24. Ficaria.

Achenes terete : leaves pinnately compound.

Achenes compressed; leaves crenate or lobed.

Petals none; leaves ternately decompound.

25. Cyrtorhyncha.

26. Oxygraphis.

27. Thalictrum.

Petals present, with no nectar-bearing pit ; leaves dissected.

28. Adonis.

* Revised by Dr. P. A. RYDBERG. 


\section{x. HYDRÁSTIS Ellis.}

Erect perennial pubescent herbs, with palmately lobed reniform leaves, and small solitary greenish-white flowers. Sepals 3, petaloid, falling away at anthesis. Petals none. Stamens numerous. Carpels $\infty$, each bearing two ovules near the middle, and in fruit forming a head of $\mathbf{1 - 2}$-seeded crimson berries. [Greek, wateracting, from its supposed drastic properties.] Two known species, one of eastern N. Am., the other Japanese.

I. Hydrastis Canadénsis L. ORAnGe-Root Golden-SEAL. Rootstock thick, yellow; stem erect, about $3 \mathrm{dm}$. high. Basal leaf l. F. f. I544.) . 12-20 cm. broad, 5-9-lobed, the lobes broad, acute, sharply serrate; cauline leaves 2 , borne at the summit of the stem, the upper one subtending the greenish white flower, which is 8 -10 $\mathrm{mm}$. broad when expanded; filaments widened, about $4 \mathrm{~mm}$. long; anthers oblong, obtuse; head of fruit ovoid, blunt, about $16 \mathrm{~mm}$. long, the fleshy carpels tipped with a short curved beak. In woods, Conn. and southern N. Y. to Ont., Minn., Ga. and Ark. April.

\section{CÁLTHA L.}

Succulent herbs, with simple mostly basal cordate or auriculate leaves. Flowers yellow, white or pink. Sepals large, deciduous, petal-like. Petals none. Sta. mens numerous, obovoid. Carpels numerous or few, sessile, bearing ovules in 2 rows along the ventral suture, in fruit forming follicles. [Latin name of the Marigold.] A genus of marsh plants, comprising a hout io species, of temperate and arctic regions. In addition to those here described, three others are found on the western side of the continent.

Stems erect or ascending, not rooting at the nodes; flowers yellow.

Leaves cordate, generally with a narrow sinus; flowers $2.5-4 \mathrm{~cm}$. wide.

Leaves flabelliform with a broad sinus; flowers $\mathbf{x}-2.5 \mathrm{~cm}$. wide. Stems floating or creeping, of ten rooting at the nodes.

Flowers yellow, $1-2.5 \mathrm{~cm}$. broad; upper leaves more or less triangular-cordate, dentate.

I. C. palustris.

2. C. fabellifolia.

Flowers white or pinkish, 8-16 $\mathrm{mm}$. broad; all the leaves reniform, wavy or entire. 4. C. natans.

I. Caltha palústris L. Marsh-marigold. Meadow-gowan. (I. F. f. 1545.) Stout, glabrous; stem hollow, 3-6 dm. high. Basal leaves on long and broad petioles, cordate or reniform, 5-18 cm. wide, the upper shorter-petioled or sessile, with nearly truncate bases; sepals oval, obtuse; follicles 3-12 or even more, compressed, Io-1 $2 \mathrm{~mm}$. long, many-seeded. In swamps and meadows, Newf. to S. Car. and Neb. April-June.

2. Caltha flabellifolia Pursh. Mountain Marsh-marigold. (I. F.f. I546.) Weak, slender, 3-4 dm. long, glabrous. Basal leaves 5-10 cm. broad, longpetioled; the upper sessile or short-petioled, similar or with truncate bases, all crenate or dentate; flowers solitary or 2-3 together; sepals oval; achenes 4-ro, about $8 \mathrm{~mm}$. long, compressed. In cold shaded mountain springs, Penn. and northern N. J. to Md. June-July.

3. Caltha radicans Forst. Rooting Marsh-Marigold. Slender, prostrate or reclining, $\mathbf{I}-4 \mathrm{dm}$. long. Basal leaves $4-8 \mathrm{~cm}$. broad, reniform with a broad sinus, long-petioled; upper short-petioled, all dentate, thin and lighter-colored than in the preceding; sepals rounded, oval; follicles about $8 \mathrm{~mm}$. long. In swamps, Woodlawn, N. Y., and West Hampton, Long Island. (Circumboreal).

4. Caltha nàtans Pall. Floating Marsh-Marigold. (I. F. f. I547.) Stems slender, 1.5-3 dm. bong, branching. Lower and basal leaves slender-petioled, 3-5 cm. wide, wavy or entire, thin, with a narrow sinus; upper leaves shortpetioled, smaller; sepals oval, obtusish ; follicles several or numerous, rather densely capitate, about $4 \mathrm{~mm}$. long. the beak short and straight. In pools and streams, Tower, Mich.; Athabasca; arctic Am. and northern Asia. Summer.

\section{TRÓLLIUS L.}

Perennial herbs, with palmately divided or lobed leaves, thickened fibrous roots, and large usually solitary yellowish or purplish flowers. Sepals $5-\infty$, petaloid, deciduous. Petals $5-\infty$, small, unguiculate, linear, with a nectariferous

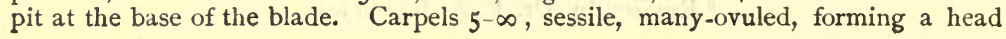


of follicles in fruit. Stamens numerous. [Old German, trol, something round.] About 10 species, natives of the north temperate zone. Only the following and one from the Rocky Mts. are N. American.

I. Trollius láxus Salisb. American Globe-flower. (I. F. f. I548.) Stems slender, ascending, 3-6 dm. long. Leaves all but the upper petioled, palmately 5-7-parted, 5-10 cm. wide, the segments obovate, cuneate, lobed, cleft or toothed; flowers $2.5-3.5 \mathrm{~cm}$. broad; sepals 5-7, ovate or obovate, obtuse, spreading; petals 15-25, minute, much shorter than the stamens; head of fruit about $2 \mathrm{~cm}$. hroad, the follicles ro $\mathrm{mm}$. long, each tipped with a straight subulate beak of one-fourth its length. In swamps, N. H. to Del., west to Mich. May-July.

\section{HELLÉBORUS L.}

Erect perennial herbs, with large palmately divided leaves, the basal longpetioled, the upper sessile and sometimes reduced to bracts. Flowers large, white, greenish or yellowish. Sepals 5, broad, petaloid, mainly persistent. Petals small, unguiculate, tubular. Stamens $\infty$. Carpels generally few, sessile, in fruit forming several-seeded capsules, which are dehiscent at the apex at maturity. [The classical name for $H$. orientalis; derivation unknown.] About 10 species, natives of Europe and western Asia.

I. Helleborus víridis L. Green Hellebore. (I. F. f. I549.) Stout, 3-6 dm. high, glabrous. Basal leaves 2-3 dm. broad, on petioles 15-25 cm. long, divided into 7-11 oblong acute sharply serrate segments; stem hardly exceeding the basal leaves, and bearing several sessile similar leaves near the top subtending the large flowers; sepals broadly oblong, obtuse, spreading, about $2.5 \mathrm{~cm}$. long; petals 2-lipped, $4 \mathrm{~mm}$. long; pods $16 \mathrm{~mm}$. long, tipped with a slender beak one-third their length or longer. In waste places, locally adventive from Europe in N. Y., N. J., Penn., N. Car. and W. Va. May.

\section{CÁMMARUM Hill. (Eranthis Salisb.)}

Low herbs, with perennial tuberiferous rootstocks. Basal leaves palmately dissected. Cauline leaf one, borne near the summit of the stem, sessile or amplexicaul, immediately subtending the large yellow flower. Sepals narrow, petaloid, deciduous. Petals, small two-lipped nectaries. Stamens numerous. Carpels commonly few, stipitate, many-ovuled, in fruit forming a head of follicles. [Greek, for aconite.] About 5 species, natives of Europe and the mountains of Asia.

I. Cammarum hyemàle (L.) Greene. Winter Aconite or Hellebore. (I. F. f. I550.) Erect, simple, 12-20 cm. high. Basal leaves long-petioled, 3 $\mathrm{dm}$. broad, divided and cleft into numerous linear or oblong lobes; cauline leaf similar, involucrate, sessile, clasping; flower solitary, 3-4 dm. wide, sessile; sepals 5-9, membranous, obovate, obtuse; stamens numerous; anthers obtuse; follicles compressed, I cm. long, tipped with a sharp beak. Nat. from Europe at Bartram's Garden, Philadelphia, and at Media, Penn. February. [Eranthis hyemalis Salisb.]

\section{6. cóPTIS Salisi.}

Low herbs, with slender perennial rootstocks, basal compound or divided leaves, and scapose white flowers. Sepals 5-7, petaloid, deciduous; petals 5-6, small, linear, cucullate. Stamens numerous. Carpels stipitate, few, in fruit forming an umbel of follicles. [Name from the Greek, referring to the cut or divided leaves.] About 9 species, of the north temperate zone. In addition to the following, three others are found on the Pacific Coast.

1. Coptis trifòlia (L.) Salisb. Gold-Thread. (I. F. f. 1551.) Tufted, glabrous, 7-15 cm. high from a slender yellow rootstock. Leaves evergreen, longpetioled, the blade reniform, 3-5 cm. broad, 3-divided : segments broadly obovate, cuneate, obtuse, prominently veined, crenate or slightly lobed, dark green and shining above, the teeth mucronate; scape I-flowered; sepals oblong, obtuse; follicles 3-7, about $6 \mathrm{~mm}$. long, borne on stipes of about their own length, spreading, tipped with a beak $2-3 \mathrm{~mm}$. long. In damp mossy woods and bogs, Newf. to Md., E. Tenn., Minn., Br. Col. and Alaska. May-Aug.

\section{ISOPỲRUM L.}

Slender glabrous herbs, with ternately decompound leaves, and white flowers. Sepals 5-9, petaloid, deciduous. . Petals 5, nectariform, or none. Stamens numer- 
ous. Carpels 2-20, sessile (stalked in a western species), several-ovuled, forming a head of follicles in fruit. [Old Greek name for some Fumaria.] About $\mathbf{I}_{5}$ species, natives of the north temperate zone. Besides the following, 3 others occur in western N. Am.

I. Isopyrum biternàtum (Raf.) T. \& G. False Rue Anemone. (I. F. f. 1552.) Erect, paniculately branching above; roots fibrous and sometimes tuberiferous. Basal leaves lung-petioled, thin, the ultimate segments broadly obovate, obtuse, lobed or divided; upper ones similar but sessile or short-petioled; flowers several, terminal and axillary, 10-18 mm. broad; sepals 5, oblong or somewhat obovate, obtuse; petals none; follicles widely spreading, ovate, $4 \mathrm{~mm}$. long, several. seeded, tipped with a beak nearly one-half their length. In moist woods and thickets, Ont. to Minn., south to Fla. and Tex. May.

\section{XANTHORRHİZA L'Her.}

Low shrubby plants, with pinnate or bipinnate leaves, and small compoundly racemose flowers. Sepals 5, petaloid, deciduous. Petals 5, smaller than the sepals, unguiculate, concave, 2-lobed. Stamens 5 or 10. Carpels 4-10, sessile, 2-ovuled, forming I-seeded follicles at maturity by the suppression of one of the ovules. [Greek, yellow root.] A monotypic genus of eastern N. Am.

I. Xanthorrhiza apiifòlia L'Her. Shrub Yellow-root.

(I. F. f. I553.) Glabrate, 3-6 dm. high, the bark and rootstocks yellow and bitter. Leaves clustered at the summit of the short stem, the blade $12-15 \mathrm{~cm}$. long, slender petioled; leaflets 5, thin, 3-7 cm. long, incisely toothed, cleft or divided, sessile, ovate or oblong, acute, shining; branches of the raceme slender, drosping, 5-7 cm. long; flowers about $4 \mathrm{~mm}$. broad, pedicelled, solitary or 2-3 together, brownish purple; sepals ovate, acute; follicles 4-8, inflated, light yellow, r-seeded, diverging, curved at the apex, minutely beaked. In woods, southwestern N. Y. to Ky. and Fla. April-May.

\section{ACTAÈA L.}

Erect perennial herbs, with large ternately compound leaves, and small white flowers in terminal racemes. Sepals $3-5$, petaloid. Petals 4 -10. small, spatulate or narrow, clawed. Stamens numerous. Ovary I, many-ovuled, forming in fruit a large somewhat poisonous berry; stigma broad, sessile. [An ancient name of the elder.] About 6 known species, natives of the north temperate zone. Besides the following, another occurs in the western United States.

Pedicels slender.

Berries red, spherical.

Berries red, ellipsoid

Berries white, ellipsoid.

Pedicels stout ; berries white, ellipsoid.

x. A. arguta.

2. A. rubra.

3. A. eburnea.

4. A. alba.

I. Actaea argùta Nutt. Western Red Baneberry. Erect, 6-8 dm. high, glabrous except the inflorescence. Basal leaf long-petioled, ternate, the divisions long petioled, pinnate; leaflets ovate, 4-I4 cm. long, generally more incised and thinner than those of the next; teeth mostly sharp; raceme ovoid, in fruit often elongated; petals spatulate; berry 5-7 $\mathrm{mm}$. long. In rich woods, from $\mathrm{Br}$. Col. to Mont., Black Hills of S. Dak., W. Neb., N. Mex. and Cal. [A. rubra arguta (Nutt.) Greene.]

2. Actaea rùbra (Ait.) Willd. Red BAneberRy. (I. F. f. 1554.) Erect, bushy, 3-6 dm. high, pubescent or glabrate. Leaves petioled, or the upper sessile; leaflets ovate, or the terminal one obovate, tonthed or somewhat cleft, the teeth mainly rounded or mucronate, or acutish; raceme ovoid; petals spatulate, shorter than the stamens; berries red, oval, 10-12 $\mathrm{mm}$. long and $6 \mathrm{~mm}$. in diameter. In woods, N. S. to N. J. and Penn., west to S. Dak. and Neb. Most abundant northward. April-June.

Actaea rùbra dissécta Britton. Leaflets all deeply incised, the lower compound or decompound. Lincoln Co., Ont. Perhaps not properly referable to this species.

3. Actaea ebúrnea Rydb. Ivory Baneberry. Stout, 6-ro dm. high from a very thick knotted rootstock, with the habit and leaves of $A$. arguta; sepals rhom. bic-spatulate; fruit 9-12 $\mathrm{mm}$. long and about $6 \mathrm{~mm}$. in diameter, about 12-seeded. 
In rich woods from Idaho and Utah to the Black Hills of S. Dak. Also collected on Mt. Mackay, Ont., and Willoughby Mountains, Vt.

4. Actaea álba (L.) Mill. White Baneierry. (I. F. f. 1555.) Closely resembles $A$. rubra. Leaflets generally more cut and the teeth and lobes acute or acuminate; raceme oblong, petals truncate; fruiting pedicels as thick as the peduncle and often red; berries white, often purplish at the end. In woods, N. S. and Anticosti to Ga., west to Minn. and La. April-June.

\section{CIMICÍFUGA L.}

Tall erect perennial herbs, with large decompound leaves, and white racemose flowers. Sepals 2-5, petaloid, deciduous. Petals I-8, small, clawed, 2-lobed or none. Stamens numerous. Carpels 1-8, many-ovuled, sessile or stipitate, forming follicles at maturity. Stigma broad or minute. [Latin, to drive away bugs.] A genus of about ro species, natives of N. Am., Asia and eastern Europe. Besides the following, there are 3 on the western side of the continent.

Carpels $\mathrm{r}$ or 2 , sessile; seeds in 2 rows, smooth.

Leaflets ovate, oblong or obovate, narrowed, truncate or subcordate at the base.

Leaflets broadly ovate or suborbicular, deeply cordate. Carpels 2-8, stalked; seeds in I row, chaffy.

I. C. racemosa.

2. C. cordifolia.

3. C. Americana.

I. Cimicifuga racemòsa (L.) Nutt. Black Snakeroot. Black Cohosh. (I. F. f. I 556.) Stem slender, I-2.5 m. high, leafy above. Leaves ternate, the divisions pinnate and the ultimate leaflets often again compound; leaflets ovate or oblong, or the terminal one obovate, incisely-toothed, cleft or divided, thickish, nearly glabrous; racemes compound, terminal, 1.5-6 dm. long; flowers $12-14 \mathrm{~mm}$. broad, foetid; petals 4-8, 2-cleft; follicles oval, 6-8 min. long, minutely beaked. In woods, Me. and Ont to Wis., south to Ga. and Mo. June-Aug.

Cimicifuga racemòsa dissécta A. Gray. Leaves pinnately compound, the leaflets all incised. Conn., S. Penn. and Del.

2. Cimicifuga cordifòlia Pursh. Heart-leaved Snakeroot. (I. F. f. 1557.) Tall, similar to the preceding species. Leaflets very broadly ovate or orbicular, acute, obtuse or acuminate at the apex, deeply cordate at the base, sometimes $15 \mathrm{~cm}$. wide; pistil I, sessile; follicles apparently very similar to those of C. racemosa. In woods, S. W. Va. to N. Car. and Tenn. June-July.

3. Cimicifuga Americàna Michx. American Bugbane. (I. F. f. I558.) Sten slender, I-I.5 m. high, leafy. Leaves ternate, the divisions pinnate, with many of the ultimate leaflets again compound; leaflets ovate or oblong, the terminal one generally cuneate, acute, thin, glabrate, all incisely toothed, cleft or divided, 3-7 $\mathrm{cm}$. long; racemes slender, compound, densely and finely pubescent, 3-6 dm. long; flowers pedicelled, 8-12 mm. broad; pedicels minutely bracted; pistils $3-8$, stipitate; stigma minute; follicles inflated, membranous, $10 \mathrm{~mm}$. long, narrowed beluw; beak short, oblique, subulate. Watkins, N. Y., to Blair Co., Penn., and Ga. Aug.-Sept.

\section{AQUILÈGIA L.}

Erect branching perennial herbs, with ternately decompound leaves, and large showy flowers. Sepals 5, regular, petaloid, deciduous. Petals concave, produced backward between the sepals into a hollow spur; stamens numerous, the inner ones reduced to staminodia. Carpels 5, sessile, many ovuled, forming heads of follicles in fruit. [Latin eagle. from the fancied resemblance of the spurs to the eagle's claws.] About 15 species, distributed throughout the north temperate zone and extending into the mountains of Mexico. Besides the following, some $\mathbf{2} 2$ others occur in the western part of $\mathrm{N}$. Am.

Spur of petals nearly straight: flowers scarlet, white or in a variety yellow.

Spur stout, abruptly narrowed near the apex; sepals ovate-lanceolate.

Spur slender, gradually narrowed from near the base, sepals broadly ovate.

Spur incurved; flowers blue, white or purple.

Flowers $15-18 \mathrm{~mm}$ : style in fruit $2-4 \mathrm{~mm}$.

Flowers $2-4 \mathrm{~cm}$.; style in fruit $6-8 \mathrm{~mm}$.

2. A. Canadensis.

3. A. brevistyla.

4. A. vulgaris. 
1. Aquilegia coccínea Small. Large Red Columbine. Tall, 3-8 dm. high, sparingly pubsecent at the nodes. Leaves larger than in the next; leaflets with 3 main lobes, glaucous beneath, nearly orbicular in outline; sepals acute or acuminate, 17-2x mm. long; spur, 30-33 mm. long; follicles straight, $20 \mathrm{~mm}$. long, tipped by a style shorter than the body. On clifts and in rocky woods, Va. to Mo., Neb. and Ala. May-July.

2. Aquilegia Canadénsis L. Wild Columbine. (I. F. f. 1559.) Glabrous or somewhat pubescent, 2-6 dm. high. Lower leaves slender-petioled, biternate, the ultimate leaflets cuneate, obtusely lobed and toothed, pale beneath; leaves of the upper part of the stem lobed or divided; flowers nodding, 3-4 cm. long, the spurs $12 \mathrm{~mm}$. long, thickened at the end; stamens and styles long exserted; follicles with spreading tips, about $16 \mathrm{~mm}$. long, tipped with a filiform beak of about the same length. In rocky woods, N. S. to the N. W. Terr., south to N. Car. and Kans. April-July.

Aquilegia Canadénsis flaviflòra (Tenney) Britton. Flowers yellow; foliage lighter green than in the type. Mass., N. Y. and N. J. Rare.

3. Aquilegia brevístyla Hook. Small-flowered Columbine. (I. F. f. 1560.) Slender, erect, sparingly pubescent, brancling, 3-5 dm. high. Basal leaves long-petioled, biternate, the ultimate leaflets nearly sessile, broadly obovate, lobed and crenate; leaves of the stem few, nearly sessile, lobed or divided; flowers small, nodding; spurs about $4 \mathrm{~mm}$. long; stamens and short styles barely exserted; follicles slightly spreading, $16 \mathrm{~mm}$. long, pubescent. N. W. Terr. to S. Dak. and Alb. June-July.

4. Aquilegia vulgàris L. European Columbine. (I. F. f. I56r.) Stout, erect, 3-6 dm. high. Basal and lower leaves petioled, 2-3-ternate, the lateral divisions broadly obovate, obtuse, lobed and crenate, glaucous beneath; the upper few, lobed or divided; spurs 6-8 mm. long, stout, strongly hooked; sepals spreading; stamens and styles hardly exserted. Escaped from gardens in the Eastern and Middle States, in N. S. and N. B. Adventive or nat. from Europe. May-July.

\section{DELPhínium L. (See Appendix.)}

Erect branching herbs, with racemose or paniculate showy flowers. Leaves palmately lobed or divided. Sepals. 5, the posterior one prolonged into a spur. Petals 2 or 4, small, the two posterior ones spurred, the lateral, when present, small. Carpels few, sessile, many-ovuled, forming follicles at maturity. [Latin, from the supposed resemblance of the flowers to a dolphin.] A genus comprising some 60 species, natives of the north temperate zone. Besides the following, some 20 others in western N. Atm.

Annuals; pistil I.

Follicle glabrous.

Follicle pubescent.

I. D. Consolida.

2. D. Ajacis.

Perennials; pistils 3 .

Follicles erect.

Leaf-segments narrow, ultimate divisions linear or oblong linear.

Raceme elongated, pedicels almost erect.

Bractlets close under the usually bright blue flower.

3. D. Carolinianum.

Bractlets 2-4 $\mathrm{mm}$. (in fruit even to $\mathrm{mm}$.) below the almost white flower.

Raceme short; pedicels spreading.

Leaf-segments broad, ultimate divisions lanceolate. $\quad$ 6. D. urceolatum.

Follicles in fruit widely spreading.

4. D. albescens.

5. D. Nelsonii.

6. D. urceolatum

I. Delphínium Consólida L. Field Larkspur. Knight's-spur. LarkHEEL. (I. F. f. I562.) Erect, 3-5 dm. high, divaricately branched. Leaves short-petioled or sessile, all divided into narrowly linear cleft or toothed segments; racemes terminating the branches, rather loose and few-flowered; flowers blue or white, 3-4 cm. long; spur slender, bent near the middle; petals 2, united; follicles 8-10, tipped with a short slender beak. In waste places, nat. from Europe in southern N. J. and Penn. to Va. and Kans., locally adventive or fugitive northward. Summer.

2. Delphinium Ajàcis L. GARDEN LARKSPUR. Like the preceding, gen. erally taller, 3-7 dm. high. Leaves with shorter and more diverging divisions; 
racemes longer, I-3 dm. long, more densely flowered; follicle I2-15 mm., tipped with a short stout beak. Often escaped from gardens, from N. Y. to Va., Tenn. and Mo.

3. Delphinium Caroliniànum Walt. Carolina Larkspur. (I. F. f. I564.) Stem slender, more or less glandular pubescent, 3-6 dm. high, from a cluster of thickened roots. Leaves deeply cleft into narrowly linear toothed or cleft segments; flowers blue or the petals light brown, 2-3 cm. long, the spur curved upward, $16 \mathrm{~mm}$. long; follicles downy, I4-18 mm. long, tipped with a subulate beak; seedcoat rugose. Sandy soil, from N. Car. to Ark., La. and Fla.; probably also in southern Va. May-June. [D. azureum Michx.]

4. Delphinium albéscens Rydb. Prairie Larkspur. Stem stout and tall, 5-10 dm. high, strigose below, more or less glandular above, from a thick, woody root. Leaves as those of the preceding, but generally larger and with broader segments, more or less puberulent; flowers white, slightly tinged with blue and bluish spots on the sepals; spur generally horizontal, I2-15 $\mathrm{mm}$. long, straight or slightly curved upward; follicle $12-18 \mathrm{~mm}$. long, puberulent. It has hitherto been confused with the preceding. Open prairies, from 11l. to Manitoba, Kans. and Ark. May-July.

5. Delphinium Nélsoni Greene. Nelson's Larkspur. (I. F. f. 1564a.) Finely puberulent, at least above; stem slender, simple, 2-4 dm. high from a cluster of tuberous roots near the surface of the ground. Leaves firm, divided into linear segments; flowers blue, slightly villous, slender-pedicelled; sepals oblong, shorter than the slender spur; lower petal 2-cleft, with a tuft of hairs about the middle; appressed-pubescent; seeds wing-angled above. Wyo., western Neb. and Colo. May-June.

6. Delphinium urceolàtum Jacq. TAll LARkspur. (I. F. f. 1563.) Slender, 6- I $8 \mathrm{dm}$. high, glabrous below, densely and finely pubescent above. Leaves large, all but the upper petioled, deeply 3-5-cleft, the divisions acuminate, upper ones reduced to small linear bracts; racemes dense, elongated; flowers purple or blue, I6-20 mm. long, downy-pubescent, the lower pedicels about $2 \mathrm{~cm}$. long; spur nearly straight, $4 \mathrm{~mm}$. long; follicles $8-10 \mathrm{~mm}$. long, pubescent, tipped with a subulate beak. In woods, Penu. to Minn., south to N. Car., Ala. and Neb. July-Aug. [D. exaltatum Ait.]

7. Delphinium tricórne Michx. Dwarf Larkspur. (I. F. f. 1565.) Stout, simple, 3-1o dm. high. Leaves slender-petioled, deeply 5-7-cleft or divided, the divisions linear or obovate, obtuse, entire, or again cleft and toothed; raceme loose, IO-I $2 \mathrm{~cm}$. long, mostly several-flowered; flowers $2.5-3 \mathrm{~cm}$. long, blue or white; spur generally slightly bent, ascending, 2-2.5 cm. long; follicles 10-12 $\mathrm{mm}$. long, tipped with a short beak; seed-coat smooth, dark. Western Penn. to Ga., west to Minn. and Ark. Roots tuberous. April-June.

\section{ACONITUM L.}

Erect ascending or trailing perennial herbs, with palmately lobed or divided leaves, and large irregular showy flowers. Sepals 5, the posterior (upper) one larger, hooded or helmet-shaped. Petals $2-5$, small, the two superior ones hooded, clawed, concealed in the helmet, the three posterior ones, when present, minute. Stamens numerous. Carpels 3-5, sessile, many-ovuled, forming follicles at maturity. [Ancient Greek name for these plants.] A genus of some 18 species, mostly natives of the north temperate zone. Besides the following, 4 others are found in the Rocky Mts. and on the Pacific Coast.

Flowers blue.

Helmet arched, tipped with a descending beak.

Helmet conic, slightly beaked.

Flowers white; stem trailing; helmet elongated-conic.

I. A. Noveboracense.

2. A. uncinatum.

3. A. reclinatum.

I. Aconitum Noveboracénse A. Gray. New York Monkshood. (I. F. f. 1566.) Slender, erect, about $6 \mathrm{dm}$. high, leafy. Lower leaves all petioled, 7-IO cm. broad, nearly orbicular, deeply 5-7-cleft, the divisions obovate, cuneate, toothed and cut, acute or acuminate, glabrous, rather thin; upper leaves nearly sessile, 3-5-cleft, otherwise similar; flowers $15 \mathrm{~mm}$. broad; follicles erect, $6 \mathrm{~mm}$. long, subulate-beaked. Orange, Ulister and Chenango Counties, N. Y. Reported from Ohio. June - Aug. 
2. Aconitum uncinàtum L. WILd Monkshood. (I. F. f. 1567.) Slender, weak, 6-12 $\mathrm{dm}$. long, ascending or climbing, leafy. Leaves thick, broader than long, 7-10 cm. wide, deeply 3-5-lobed or cleft; lobes oblong or ovate-lanceulate, cleft or toothed, acute, glabrous or nearly so; panicle few-flowered, pubescent: flowers $20 \mathrm{~mm}$. broad or more; follicles $3,12-14 \mathrm{~mm}$. long, subulate-beaked. In woods, southern Penn. and Wis., to Ga. and Ky. June-Sept.

3. Aconitum reclinàtum A. Gray. Trailing Wolfsbane. (I. F.f. I568.) Trailing, 6-25 dm. long. Leaves 3-7-cleft, all but the upper petioled, thin, the lower $15-20 \mathrm{~cm}$. broad, mainly obovate, acute, toothed and cleft toward the apex; simple panicle or raceme loose, pubescent; flowers $16-20 \mathrm{~mm}$. long; follicles 3 , Ic $\mathrm{mm}$. long, with slender divergent beaks. In woods, Cheat Mountain, Va., south along the Alleghanies to Ga. July-Aug.

\section{ANEMÒNE L.}

Erect perennial herbs. Basal leaves lobed, divided or dissected, those of the stem forming an involucre near to or remote from the flower. Sepals 4-20, petaloid. Petals none. Stamens $\infty$, shorter than the sepals. Carpels $\infty$. Achenes compressed, r-seeded. [From the Greek, a flower shaken by the wind.] About 75 species, widely distributed through the temperate and subarctic regions of both hemispheres. About 18 species are natives of N. Am.

\section{* Achenes densely woolly.}

Stem simple, slender, I-flowered.

Root tuberous; sepals 6-20, narrow.

Radical leaves or some of them simply ternate.

Radical leaves repeatedly ternately divided.

Rootstock slender; sepals 5 , oval.

Stem commonly branching above, tall, generally 2-several-flowered.

Leaves of the involucre sessile or short-petioled; sepals red or green; head of fruit

globose or oval. 4 4. Hudsoniana.

I. A. decapetala.

2. A. Caroliniana.

3. A. parvifiora. Leaves of the involucre slender-petioled; sepals white or green; head cylindric, oval, or oblong.

Beak of fruit I mm. long; divisions of the leaves wedge-shaped, narrow.

Beak of fruit $2 \mathrm{~mm}$. long; divisions of the leaves ovate, broad.

5. A. cylindrica.

Flower greenish white, $1.5-3 \mathrm{~cm}$. wide; head of fruit oblong.

6. A. Virginiana.

Flower pure white, $3-5 \mathrm{~cm}$. wide; head of fruit short-cylindric.

7. A. riparia.

Leaves of the involucre sessile.

** Achenes pabescent, or nearly glabrous.

Stout, 3-6 dm. high, branching and bearing several flowers; carpels nearly orbicular.

Slender, .5-3 dm. high, I-flowered; carpels narrow.

8. A. Canadensis.

9. A. Richardsonii

Leaves of the involucre petioled.

Involucral leaf-divisions lobed and incised; plant $\mathrm{I}-2 \mathrm{dm}$. high.

Involucral leaf-divisions dentate; plant 1.5-4 dm. high.

ro. A. quinquefolia.

I1. A. trifolia.

I. Anemone decapétala Ard. Ten-petaled Anemone. Appressed-pubescent or glabrate, 1-3 dm. high from a globose or cylindric tuber. Basal leaves slender-petioled, ternate, divisions broad, ovate to olovvate, thick, crenate; those of the involucre on short, broid petioles, cleft into linear lobes; sepals 10-20, blue, oblong, linear; head of fruit cylindric, 5-20 mm. long. Ala. to Kans. and Tex. Also in Mex. and southern S. Am.

2. Anemone Caroliniàna Walt. Carolina Anemone. (I. F. f. I569.) Sparsely hairy, 10-25 $\mathrm{cm}$. high, arising from a tuber $8-12 \mathrm{~mm}$. in diameter. Basal leaves slender-petioled, 3-divided, the divisions variously lobed and parted, those of the involucre sessile and 3-cleft; flower erect, $10-35 \mathrm{~mm}$. broad; sepals 6-20, linear-oblong, purple, varying to white; head of fruit oblong. Open places, Ill. to Wis., S. Dak., Ga. and Tex. April-May.

3. Anemone parviflòra Michx. Northern Anemone. (I. F. f. 1570.) Sparingly hairy, 1-2 dm. high from slender rootstocks. Basal leaves longpetioled, 3-parted, the broadly wedge-shaped divisions obtusely lobed or crenate, those of the involucre nearly sessile. similarly loled; flower $1-4 \mathrm{~cm}$. in diameter or 
less; sepals oval, very obtuse, white; head of fruit short-oval or globose. Lab. and Newf. to Minn., and in arctic America, south in the Rocky Mts. to Colo. Also in northern Asia. May-June.

4. Anemone Hudsoniàna Richards. Cut-leaved Anemone. Red WindFLOWER. (I. F. f. I57 I.) Silky-hairy, I.5-4.5 dm. high, sparingly branched, the lateral peduncles involucrate. Basal leaves long-petioled, reniform, 3-5-parted, the divisions cleft into narrowly linear acute lobes, those of the invclucres shortpetioled and more or less cuneate, otherwise similar; sepals 5-9, greenish or red, oblong, forming a flower $10-15 \mathrm{~mm}$. broad; head of fruit $1-2 \mathrm{~cm}$. long. Anticosti, Hudson Bay and N. B. to northern N. Eng. and Minn. Has been confused with A. multifida Poir., a South American species. Summer.

5. Anemone cylindrica A. Gray. Long-fruited Anemone. (I. F. f. 1572.) Silky-hairy throughout, 3-6 dm. high, branched at the involucre. Basal leaves long-petioled, 3-5-parted; those of the involucre similar, their petioles about $2 \mathrm{~cm}$. long; sepals 5-6, greenish-white, oblong, generally obtuse; flowers $15-18 \mathrm{~mm}$. broad, on elongated generally naked peduncles; head of fruit cylindric, $2-4 \mathrm{~cm}$. long. Open places, N. B. and Ont. to Conn., N. J., N. Mex. and in Br. Col. June-Aug.

6. Anemone Virginiàna L. Tall Anemone. (I. F. f. I573.) Hairy, 6-1o $\mathrm{dm}$. high, stout, branching at the involucre, the lateral peduncles bearing secondary involucres. Basal leaves long-petioled, 3-parted, cleft into acute serrate lobes, those of the involucres similar, on petioles $2-5 \mathrm{~cm}$. long; sepals generally 5 , acute or obtuse; head of fruit $\mathbf{I}-2.5 \mathrm{~cm}$. long and $12-15 \mathrm{~mm}$. thick. In woods, N. S. to S. Car., Kans., Manitoba and the Canadian Rocky Mts. June-Aug.

7. Anemone ripária Fernald. River-bank Anemone. Like the last but generally more slender; petals large and pure white, obtuse; head of fruit more cylindric, $2-3 \mathrm{~cm}$. long and $\mathbf{I} \mathrm{cm}$. wide. On river banks, Me. and Ont. to Va. June-July.

8. Anemone Canadénsis L. Canada Anemone. (I. F. f. 1574.) Somewhat hairy, especially on the lower surfaces of the leaves, branching at the involucre. Basal leaves long-petioled, 3-5-parted, the divisions broad, acute, variously cleft and toothed, those of both primary and secondary involucres similar, sessile; sepals white, oblong, obtuse; flower $2.5-4 \mathrm{~cm}$. broad; head of fruit globose; achenes flat, tipped with the stout style of their own length. Low grounds, Lab. to the N. W. Terr., E. Mass., Md., Ill. and Colo. May--Aug.

9. Anemone Richardsònii Hook. Richardson's ANemone. (I. F. f. I 575.) Low, slender, pubescent, from slender rootstocks. Basai leaves reniform, slenderpetioled, 3-5-parted, the lobes acute, broadly oblong, dentate or crenate; those of the involucre similar, sessile: flower solitary, $18 \mathrm{~mm}$. broad, white (?); sepals about 6, oblong; head of fruit depressed-spherical; achenes nearly glabrous, compressed, ovate-oblong, reflexed, tipped with a long hooked persistent style. Lab., Hudson Bay and in Arctic America. Also in Siberia. Summer.

I0. Anemone quinquefòlia L. Wind-Flower. (I. F. 1. I576.) Low, simple, nearly glabrous, from thick rootstocks. Basal leaves long-petioled, appearing later than the flowering stem, 5-parted, the divisions oblong, cuneate, dentate; those of the involucre 3-5.parted; flower solitary, $2.5 \mathrm{~cm}$. broad; sepals 4-9, obovate or oval, white, or purplish without: head of fruit globose, inclined; achenes pubescent, oblong, tipped with the hooked styles. In low woods, N. S. to Ga., west to the Rocky Mts. April-June. [A. nemorosa Michx., not L.]

I I. Anemone trifolia L. Mountain Anemone. (I. F. f. I577.) Stout, nearly glabrous. Basal leaves mostly 3-divided (sometimes 4-5-divided), longpetioled, dentate, often somewhat lobed; involucral leaves stout-petioled, 3-parted, the divisions oblong-lanceolate, 3-7 cm. long; flower solitary, white, $2.5-4 \mathrm{~cm}$. broad when expanded; sepals oblong; head of fruit globose, 10-12 $\mathrm{mm}$. in diameter; achenes 10-20, oblong, finely pubescent, tipped with the hooked style. Southern Penn., Va., N. Car. and Ga. Also in Europe. May.

\section{HEPÁTICA Scop.}

Perennial scapose herbs, with long-petioled thick 3-lobed evergreen basal leaves, and large white or purple flowers, solitary on slender scapes. Involucre of 3 small sessile leaves close under the flowers, simulating a calyx. Sepals membranous, 
petal-like. Stamens all anther-bearing. Achenes short-beaked, pubescent. [Name ancient, from the supposed resemblance of the leaves to the liver.] About 4 species, natives of the north temperate zone. Only the following are known from N. Am.

Lobes of the leaves rounded or obtuse. Lobes of the leaves acute.

x. H. Hepatica.

2. H. acuta.

I. Hepatica Hepática (L.) Karst. Round-Lobed oR Kidney Liver leaf, NOBLE LIVERWORT. (I. F. f. 1578 .) Scapes 10-15 cm. high, villous; roots fibrous. Leaves long-petioled, reniform, 5-6 $\mathrm{cm}$. broad when mature, spreading on the ground, 3-lobed, and the lobes sometimes toothed or again lobed, obtuse; involucral leaves obtuse; flowers blue, purple or white, 12-20 mm. broad; sepals oval or oblong, obtuse, longer than the stamens; achenes several, $4 \mathrm{~mm}$. long, oblong, acute, hairy. In woods, N. S. to northern Fla., west to Manitoba, Iowa and Mo. Also in Europe and Asia. Dec.-May. [Hepatica triloba Chaix.]

2. Hepatica acùta (Pursh) Britton. Sharp-Lobed or Heart Liver-leaf. (I. F. f. I579.) Scapes I-2 dm. high, villous. Plant closely resembling the preceding, differing in that the leaf-lobes and those of the involucre are acute or acutish. In woods, Quebec and throughout Ont., south to Ga., west to Iowa and Minn. Puzzling forms occur which are referable with about equai certainty to the preceding species. March-April.

\section{SYNDÉSMON Hoffmg. [ANEMONELLA Spach.]}

A glabrous perennial herb from a cluster of tuberous-thickened roots, with basal 2-3-ternately compound leaves, those of the involucre similar but sessile, and large terminal umbellate slender-pedicelled white flowers. Sepals thin, petaloid. Petals none. Stamens all anther-bearing. Achenes terete, deeply grooved; stigma sessile, truncate. [Greek, bound together, the plant uniting many of the characters of Anemone and Thalictrum.] A monotypic genus of eastern N. Am.

I. Syndesmon thalictroides (L.) Hoffmg. RUE-AnEmONE. (I. F. f. 1580.) Low, glabrous, 10-35 $\mathrm{cm}$. high, the flowering stem arising in early spring, the ternately-compound basal leaves appearing later and resembling those of Thalictrum; sepals 5-IO, white or pinkish, longer than the stamens; flower I-2 cm. broad; achenes sessile, pointed, $8-12 \mathrm{~mm}$. long. In woods throughout the eastern U. S., west to Kans. and Minn., sparingly in Ont. March-June.

\section{PULSATílla Adans.}

Peremnial scapose herbs, with thick rootstocks, basal long-petioled digitately divided leaves, and large purple or white solitary flowers. Involucre remote from the flower, 3-leaved. Sepals petaloid. Petals none. Inner stamens anther-bearing, the outer ones often sterile. Achenes with long persistent plumose styles. [Latin name, unexplained.] About 18 species, of the north temperate and subarctic zones. Besides the following, 2 others occur in northwestern N. Am.

I. Pulsatilla hirsutíssima (Pursh) Britton. American or NutTall's PASQUe Flower. (I. F. f. I581.) Villous, I.5-4 dm. high. Leaves much divided into narrow linear acute lobes, the basal on slender petioles, those of the involucre sessile and erect or ascending; sepals ovate-oblong, light bluish-purple; fruit a head of silky achenes like those of some Clematis. In dry soil, prairips of Ill. to the N. W. Terr., Br. Col., Neb. and Tex. March-April.

\section{CLÉMATIS L.}

Climbing vines, or perennial herbs, more or less woody. Leaves opposite, slender-petioled, pinnately compound, lobed, or in some species entire. Sepals 4 or 5 , valvate in the bud, petaloid. Petals none. Stamens $\infty$. Pistils $\infty$. Achenes I-seeded. Style long, persistent, plumose, silky or naked. [Greek name for some climbing plant.] About 100 species of very wide geographic distribution, most abundant in temperate regions. Besides the following, some 12 others occur in the southern and western parts of North America.

\section{* Climbing vines; leaves pinnate or 3 -foliolate.}

Flowers panicled, numerous: filaments glabrous.

Leaves glabrate or nearly so; achenes with a thick obtuse margin 
Flowers solitary; filaments pubescent.

Fruiting styles silky, not plumose; sepals thin.

Sepals conspicuously dilated; leaflets thin, pinnately veined. 4. C. crispa.

Sepals with recurved tips; venation strongly reticulated. 5. C. Simsii.

Fruiting styles plumose.

Leaflets thick, strongly reticulated, glaucous beneath.

6. $C$. versicolor.

Leaflets thin, not strongly reticulated.

Leaflets all simple, pubescent beneath.

Lower leaflets ternate or 3 -lobed, glabrate, or nearly so.

Leaflets or their lobes rounded, ovate or subcordate.

Leaflets or their lobes ovate or ovate-lanceolate.

8. C. glaucophylla.

9. C. Viorna.

\section{* * Erect or ascending perennial herbs; leaves simple or pinnate.}

Glabrous, glaucous; leaves simple, or pinnate and tendril-bearing. 1o. C. Addisoniz.

Pubescent; leaves simple or pinnate, not tendril-bearing.

Leaves simple, entire or rarely lobed.

Fruiting styles long, plumose; eastern species.

Flowers yellowish-green; style-plumes brown, achenes straight.

Flowers purple; style-plumes white; achenes distinctly oblique.

12. C. ovata.

Fruiting styles short, I cm., silky below, naked above; western species.

Leaves pinnate, or the lowest entire.

13. C. Fremontii.

14. C. Scottii.

I. Clematis Virginiána L. VIRGinia Virgin's Bower. (I. F. f. I582.) Leaflets mostly broadly ovate, acute at the apex, toothed or lobed, sometimes slightly cordate; flowers white, in leafy panicles, polygamo-diœcious, $16-30 \mathrm{~mm}$. broad when expanded; persistent styles plumose, 2-4 cm. long or more. In low woodlands and along fences and watercourses. Ga. to Kans., north ward to N. S. and Manitoba. Leaves rarely 5 -foliolate. July-Sept.

2. Clematis ligusticifòlia Nutt. Western Virgin's Bower. (I. F. f. 1583.) Leaves pinnately 5 -folioliate; leaflets oblong or ovate-lanceolate, acute and sometimes acuminate at the apex, rounded or cuneate at the base, toothed, lobed or divided; flowers white, in leafy panicles; persistent styles plumose throughout, nearly white, 3-5 cm. long. Neb., Mo. and throughout the Rocky Mts., west to the Pacific Coast. June-Aug.

3. Clematis Missouriénsis Rydb. n. sp. Missouri Virgin's Bower. Stem obtusely angled, silky-puberulent. Leaves pinnately 3-5-foliolate; leaflets ovate or cordate, often 3-lobed and incised; flowers dull white, polygamo-diœcious in rather small panicles, the branches often subumbellate; achenes lanceolate-ovate, pubescent, $4 \mathrm{~mm}$. long, with a plumose style $3 \mathrm{~cm}$. long. Rich woods in the Missouri Valley from Mo. to Kans. and Neb. Type from Lincoln, Neb. July-Sept. Has been confused with $C$. Virginiana and $C$. Catesbyana.

4. Clematis crispa L. Marsh Clematis. (I F. f. I584.) Leaves pinnate; leaflets mostly trifoliolate, the ultimate divisions entire or occasionally lobed, glabrous and thin; flowers nodding, bluish-purple, 20-35 mm. long; calyx cylindric below, but the sepals thin and widely spreading above, their margins undulate; persistent styles silky, not plumose. In marshes, S. E. Va. to Fla. and Tex. May-June.

5. Clematis Simsii Sweet. Sims' Clematis. (I. F. f. I585.) High climbing, the branches more or less pubescent. Leaves pinnate; leaflets entire, lobed or trifoliolate, thick, reticulated, generally mucronate; calyx campanulate, less than $2.5 \mathrm{~cm}$. long, purplish, pubescent; persistent styles more or less pubescent. Southern Ind. to Mo., Neb. and Tex. May-Aug.

6. Clematis versícolor Small, n. sp. Pale Clematis. A branching vine, glabrous or slightly pubescent below the nodes. Leaves pinnate; leaflets firm, oblong to ovate-lanceolate, 2-7 cm. long, conspicuously reticulate, very glaucous beneath; sepals thin, lanceolate, about $2 \mathrm{~cm}$. long, glabrous, slightly recurved at the tip. Rocky ledges, Mo. and Ark. July. Type from McDonald Co., Mo.

7. Clematis fláccida Small, n. sp. Thin-leaved Clematis. Stem climbing over bushes, angled; pubescent or glandular. Leaves pinnate; leaflets oblong or ovate-lanceolate, $2-10 \mathrm{~cm}$. long, slender-stalked, apiculate or rarely acuminate; calyx greenish to light lavender, $1.5 \mathrm{~cm}$. long, nodding; sepals acutish, pubescent 
without; achenes rhomboid, 6-7 mm. long; style of fruit $2.5-3 \mathrm{~mm}$. long. In thickets, Ky. and Tenn. May. Type from Warren Co., Ky.

8. Clematis giaucophýlla Small. Glaucous Clematis. Stem 2-5 mm., climbing over bushes, glabrous. Leaves pinnate; leaflets simple, 3-lobed or 3foliolate, uvate, $3^{-10} \mathrm{~cm}$., prominently veined and glaucous beneath; sepals glossy purple, lanceolate-acummate, not very thick; styles in fruit 5-6 cm. long, tawny. River valleys, N. Car. and Ky., south to Fla. June-July.

9. Clematis Viórna L. Leather-Flower. (1. F. f. 1586.) A vine, climbing to the height of $3 \mathrm{~m}$. or more over bushes. Leaves mostly pinnate; leaflets glabrous, entire, lobed or trifoliolate; uppermost and lowest leaves often entire; calyx ovoid-campanulate, purple; persistent styles plumose throughout, $2 \mathrm{~cm}$. long or more, brownish. In rich soil, S. Penn. to Ind. Mo., Ga. and Tenn. MayJuly.

io. Clematis Addisònii Britton. Addison Brown's Clematis. (I. F. f. 1587.) Ascending or erect, 3-10 dm. long, tufted. Lower leaves simple, entire or I-4-lobed, obtuse, deep bluish-green above, glaucous beneath, sessile, clasping, 5-10 cm. long; upper leaves pinnate, or sometimes simple; leaflets 2-4, ovate, sessile; flowers solitary, purplish, nodding; calyx ovoid, I8-30 mm. long, contracted near the summit; sepals thick, lanceolate, acute, their tips recurved; achenes flat, nearly orbicular, silky pubescent; persistent styles, brown-plumose throughout. Banks near Roanoke, Va., and N. Car. May-June.

\section{Clematis viornioìdes Britton is a hybrid between this and $C$. Viorna. Roanoke, Va.}

I r. Clematis ochroleùca Ait. Erect Silky Clematis. (I. F. f. I588.) An erect silky-hairy plant, 3-6 dm. high, somewhat woody at the base. Leaves sessile, ovate, obtuse, glabrous and reticulated above, silky beneath, entire or occasionally lobed, mucronate; flower terminal, nodding, $2 \mathrm{~cm}$. long; calyx cylindraceous, green; sepals thick, very silky without, their tips recurved; head of fruit erect; achenes scarcely oblique; styles yellowish-brown, 3-4 cm. long. S. N. Y. and Penn. to Ga. May-June.

12. Clematis ovàta Pursh. Erect Mountain Clematis. (I. F. f. 1589.) Similar to the preceding species; stems stiff, 3-6 dm. tall, pubescent when young, becoming nearly glabrous when old. Leaves ovate, entire, 4-5 dm. long, strongly reticulate-veined and nearly glabrous when mature; flowers solitary at the ends of the stem or branches, nodding, about $2 \mathrm{~cm}$. long; styles $3-4 \mathrm{~cm}$. long. Kate's Mountain, White Sulphur Springs, W. Va., and Negro's Head in S. Car., or Ga. May-June.

I3. Clematis Fremóntii S. Wats. Fremont's Clematis. (I. F. f. I590.) Stout, erect, I.5-4 dm. high, the stem villous-pubescent, especially at the nodes, simple or branched. Leaves sessile, coriaceous, conspicuously reticulaterl, glabrous except on the veins beneath, broadly ovate, entire or sparingly toothed; flowers terminal, nodding; calyx purple, $2.5 \mathrm{~cm}$. long; sepals thick, tomentose on the margins, their tips recurved. Prairies, Kans., S. Neb. and Mo. Rare and local. AprilMay.

14. Clematis Scóttii Porter. Scotr's Clematis. (I. F. f. I59I.) Somewhat villous when young, nearly glabrous when old; stems erect, 2-6 dm. tall. Leaves petioled, the upper pinnate or bipinnate, their segments entire or fewtoothed, stalked, acuminate or acute at the apex, narrowed at the base, $12-36 \mathrm{~mm}$. long: lower leaves sometimes entire; flowers solitary. long-peduncled, nodding, about $2 \mathrm{~cm}$. long, purple; sepals ovate-lanceolate, thick; persistent styles plumose throughout, $2.5 \mathrm{~cm}$. long or more, the plumes brown. In dry soil, S. Dak. to Neb., Colo. and Idaho. May-July.

\section{ATRÁGENE L.}

Perennial climbing vines, with opposite petioled compound leaves, and large showy peduncled flowers, solitary in the axils, or at the ends of the branches. Sepals very large, petaloid, mostly membranous and prominently veined. Petais small, spatulate. Stamens very numerous, the outer ones usually with broalened filaments. Styles long, persistent, plumose. [Ancient Greek name for some vine.] About 5 species, natives of the north temperate zone: In addition to the following, two occur in the Rocky Mts. and one in northwestern N. Am. 
I. Atragene Americàna Sims. PURple Virgin's Bower. (I. F. f. I592.) Leaves trifuliolate; leaflets thin, uvate, acute, toothed or entire; petioles slender; flowers purplish blue, 5-10 $\mathrm{cm}$. broad; sepals 4, thin and translucent, strongly veined, silky along the margins and the vems; petals spatulate, $12-18 \mathrm{~mm}$. long; persistent styles, plumose throughout. Hudson Bay to Manitoba, Conn., Va. and Minn. May-June. [Clematis verticillaris DC.]

\section{MYOSÜRUS L}

Diminutive annual herbs, with fibrous roots, basal linear entire leaves and Iflowered scapes; sepals 5 (rarely 6-7), long-spurred at the base. Petals the same number or nune, when present greenish-yellow, narrow, the claw bearing a nectariferous pit at the sumnit, the limb spreading. Stamens 5-25, about equalling the sepals. Pistils numerous, borne on a central axis, which becomes greatly elongated in fruit. Ovule I, suspended. Achenes a piculate or aristate. [Greek, mouse-tail.] A genus of insignificant plants of local but wide geographic distribution, consisting of the species here described and 4 others found in western America and Australia.

I. Myosurus mínimus L. Mouse-TAIL. (I. F. f. I593.) Low, glabrous, 2-15 cm. high, the scape at length surpassing the leaves and the elongated receptacle attaining the length of $3 \mathrm{~cm}$. or more. Leaves $5-10 \mathrm{~cm}$. long, blunt; petals small; achenes glabrous, apiculate. In moist places, southern Ont. to Neb., Kans. and Fla. Reported from the Pacific Coast. Also in central Europe. April-July.

2I. TRAUTVETTÉRIA F. \& M.

Tall erect perennial herbs, with large palmately-lobed leaves, those of the stem distant. Sepals $3-5$, concave, caducuus. Petals none. Carpels $\infty$, I-ovuled. Achenes capitate, sharply angular, inflated, tipped with the minute styles. Embryo large. Flowers small, white, corymbosely paniculate. [In honor of Prof. Trautvetter, a Russian botanist.] A genus of two species in N. Am. and one in eastern Asia.

I. Trautvetteria Carolinénsis (Walt.) Vail. False Bugbane. (I. F. f. 1594.) Stout, 6-ro dm. high, branching, nearly glabrous, except the lower surfaces of the leaves. Basal leaves long-petioled, $15-20 \mathrm{~cm}$. broad, 10-12 cm. long, deeply lobed, the lobes acute and sharply dentate; panicle ample, the flowers 6-12 mm. broad, borne in cymose clusters at the ends of its branches; filaments slender, slightly widened; anthers oblong. Southwestern Penı., south to Fla., west to Ind. and Mo. June-July. [T. palmata F. \& M.]

\section{RANÚNCULUS L.}

Herbs, with alternate simple entire-lobed or divided or dissected leaves, and yellow white or red flowers. Sepals mostly 5 , deciduous. Petals equal in number or more, conspicuous or minute, provided with a nectariferous pit and a scale at the base of the blade. Carpels $\infty$, r-ovuled. Achenes capitate or spicate, generally flattened, tipped with a minute or an elongated style. [Latin for a small frog, in allusion to the marsh habitat of many species.] Some 200 species, widely distributed in the temperate and cool regions of both hemispheres and on mountain tops in the tropics. In addition to those here described, about $5^{\circ}$ others inhabit the western and northwestern parts of the continent.

+ Aquatic or creeping mud plants with palmately lobed, divided or dissected leaves.

Leaves orbicular, palmately divided.

Achenes marginless, flowers 7-14 mm. broad.

Achenes callous-margined.

Flowers $15-30 \mathrm{~mm}$. broad; leaves mostly finely dissected. 2. $R$. delphinifolius.

Flowers 6-10 mm. broad; leaves mostly thrice 3-cleft. $\quad 3 . R$. Missouriensis.

Leaves 3 -lobed or 3 -cleft, cuneate at the base.

4. $R$. hyperboreus.

t+Scapose plant from a filiform rootstock; leaves reniform, 3-parted.

5. R. Lapponicus.

$+\dagger+$ Plants of swamps or muddy shores; leaves entire or denticulate.

Annuals; achenes beakless; tipped with the persistent style-base.

Petals 2-4 mm. long; stamens few, I-ro.

Petals $4-6 \mathrm{~mm}$. long; stamens numerous.

6. $R$. pusillus.

Perennials, rooting from the nodes; achenes beaked.

Stems trailing; achenes minutely beaked.

Stems ascending or erect; achenes subulate-beaked.

7. R. oblongifolius.

8. $R$. reptans.

9. R. obtusiusculus. 
t+t+ Terrestrial species with some or all the leaves lobed or divided. Calyx conspicuously black-pubescent ; arctic ; flowers white or light yellow.

Calyx glabrous or pubescent ; flowers yellow. 10. $R$. nivalis.

1. Achenes smooth, neither papillose, muricate nor spiny.

Plants low, arctic-alpine; leaves small, palmately lobed.

Flowers $4^{-6} \mathrm{mn}$. in diameter ; sepals glabrous or slightly hairy.

Flowers about $1 \mathrm{~cm}$. in diameter; sepals densely hairy. I I. R. pygmaeus.

Plants neither arctic nor alpine.

12. R. Sabini.

Basal leaves, some or all of them, merely crenate.

Head of fruit oblong, 2-3 times as long as thick.

Flowers 4-12 mm. in diameter; sepals glabrate or slightly hairy.

Flowers $1.5^{-2} \mathrm{~cm}$. in diameter; sepals densely villous.

I3. $R$. pedatifidus.

Head of fruit globose or subglobose.

14. R. cardiophyllus.

Petals large, oblong, longer than the sepals.

Basal leaves oval or ovate, not cordate. 15. R. ovalis.

Basal leaves reniform or orbicular, cordate.

16. R. Harveyi.

Petals small, oblong, shorter than or equalling the sepals.

Styles very short, curved.

Basal leaves cordate; plant glabrous or nearly so.

Basal leaves not cordate; plant villous.

17. R. abortivus.

18. R. micranthus.

Styles subulate, hooked, nearly one-half as long as the achene.

Leaves all lobed or divided.

19. R. Alleghaniensis.

Plant glabrous; stem hollow ; flowers very small. 20. R. sceleratus.

Plants more or less pubescent.

Beak of the achene strongly hooked; flowers 8-1o mm. wide.

Beak of the achene short.

2I. $R$. recurvatus.

Erect plants, naturalized in fields ; flowers $25 \mathrm{~mm}$. broad.

Calyx spreading; roots fibrous. 22. $R$. acris.

Calyx reflexed; stem bulbous-thickened at base.

23. $R$. bulbosus.

Erect or ascending plants of moist soil ; flowers 6-12 mm. broad.

Petals not longer than the reflexed sepals; head of fruit oblong to cylindric. 24. R. Pennsylzanicus.

Petals longer than the sepels; head of fruit sphericalovoid.

25. R. Macounii.

Ascending and creeping by stolons; flowers $2.5 \mathrm{~cm}$. broad.

26. $R$. repens.

Beak of the achene long, stout or slender; flowers $12-36 \mathrm{~mm}$. broad.

Beak stout, sword-shaped; roots slender; leaflets cuneate at base.

27. $R$. septentrionalis.

Beak of achene slender, subulate; roots thickened.

Leaf-segments broad, oblong or obovate.

Leaf-segments narrow, linear-oblong.

2S. R. hispidus.

29. R. fascicularis.

2. Achenes with a few scattered papillae near the margins.

3. Achenes rough-papillosed all over.

3o. $R$. parvulus.

31. R. parviflorus.

4. Achenes muricate or spiny.

Leaf-lobes broad, obtuse.

Leaf-lobes narrow, subacute.

32. R. muricatus.

33. R. arvensis.

I. Ranunculus Púrshii Richards. Pursh's Buttercup. (I. F. f. I596.) Aquatic or creeping, pubescent at least on the younger parts. Leaves slenderpetioled, 6-24 mm. wlle. palmately divided nearly to the base into obtuse lobes or segments; petals about 5 ; head of fruit subglobose or ovoid oblong, 4-6 mm. long, In moist soil, N. S. to Mich., Minn., western Ont. and Arctic Am., west to Br. Col., Colo. and Utah. July-Aug. 
2. Ranunculus delphinifòlius Torr. Yellow W'Ater-Crowfoot. (I. F. f. 1595.) Aquatic or partly emersed. Immersed leaves repeatedly divided into capillary segments, short-petioled, 3-7 cm. long: emersed leaves $1-5 \mathrm{~cm}$. broad, petioled or the upper nearly sessile, 3-5-divided, the divisions cleft into linear or cuneate segments; petals 5-8, much longer than the sepals; head of fruit globose or oblong, 6-1o $\mathrm{mm}$. long. In ponds, Me. and Ont. to Mich., south to N. Car., Mo. and Kans. The so-called var. terrestris, appears to be an emersed form. June-Aug. [R. multifidus Pursh, not Forsk.]

3. Ranunculus Missouriénsis Greene. Missouri Buttercup. (I. F. f. 1597.) Perennial, sparingly pubescent; stems slender, decumbent, leafy, $3 \mathrm{dm}$. long or more, rooting at the lower nodes. Leaves usually wider than long, thin, $3-7 \mathrm{~cm}$. wide, palmately divided into 3 obovate-cuneate incised and lobed segments, the lobes obtuse; petals about 5 ; head of fruit oblong, about $8 \mathrm{~mm}$. long; achenes compressed, somewhat wrinkled. In ditches and on borders of lakes, Mo. to N. Mex. July-Aug.

4. Ranunculus hyperbòreus Rottb. Arctic Buttercup. (I. F. f. I598.) Stem slender, glabrous, filiform, creeping, 5-15 cm. long. Leaves petioled, 3-lobed or cleft, 4-8 mm. long, obtuse, the base cuneate or rounded, the lobes oblong, obtuse, the lateral ones sometimes toothed; flowers few, 4-6 mm. broad; petals slightly shorter than the reflexed sepals; head of fruit globose, $4 \mathrm{~mm}$. broad; achenes slightly compressed, with a minute blunt tip. Lab., Arctic Am., Iceland, northern Europe and Siberia. Summer.

5. Ranunculus Lappónicus L. Lapland Buttercup. (I. F. f. I599.) Scapose from running rootstocks, $7-15 \mathrm{~cm}$. high. Basal leaves long-petioled, the blade 3-4 cm. broad, reniform, 3-parted, the divisions broadly obovate, cuneate, obtuse, crenate or lobed; scape I-flowered, slender, longer than the leaves; flower 6-10 mm. broad; petals 5-6; sepals generally fewer and reflexed; head of fruit globose, $12 \mathrm{~mm}$. broad; achenes flattened, ovate, with a slender hooked beak. Lab., Lake Nipigon and Thunder Bay, Lake Superior, northern Minn., Arctic Am. and in northern Europe and Siberia. Summer.

6. Ranunculus pusíllus Poir. LOW SPEARwOrt. (I. F. f. I600.) Slender, weak, glabrous, branching, 15-30 cm. high. Lower leaves oblong or ovate, on long petioles, the upper narrower, lanceolate or linear, short-petioled or sessile ; flowers 4-6 $\mathrm{mm}$. broad, the petals few, often barely exceeding the sepals; head of fruit globose, $4 \mathrm{~mm}$. broad. Marshes, southern N. Y. and N. J., Penn., south to Fla., and west through the Gulf States to Tex. and Mo. April-July.

7. Ranunculus oblongifolius Ell. OBLong-Leaved SPEARwort. (I. F. f. I60I.) Branched above, erect or ascending, 3-5 dm. high, glabrous or pubescent. Leaves oblong, or oblong-lanceolate, the lower on long petioles, the blade sometimes $7 \mathrm{~cm}$. long, the upper narrower. lanceolate or linear; flowers IO- $12 \mathrm{~mm}$. broad, the 5 petals much exceeding the sepals; head of fruit $4 \mathrm{~mm}$. broad. In swamps, southern Va., southern Ill. and Mo., south to Fla. and Tex. April-Sept.

8. Ranunculus réptans L. Creeping Spearwort. (I. F. f. I6o2.) The flowering stems and peduncles ascending. Leaves linear, lanceolate or spatulate, $2-5 \mathrm{~cm}$. long, mainly entire, gradually narrowed into the petiole; flowers 8-IO $\mathrm{mm}$. broad, solitary on peduncles $2-7 \mathrm{~cm}$. long; petals $4-7$, much exceeding the calyx; achenes flattish; stamens numerous. On shores, Newf. and Arctic Am., south to N. J., Penn. and Mich., and in the Rocky Mts. to Colo. Also in Europe and Asia. Summer.

Ranunculus rêptans intermèdius (Hook.) T. \& G. Larger; leaves longer and wider, $7^{-13} \mathrm{~cm}$. long, $4^{-6} \mathrm{~mm}$. wide. Newf. to the shores of the Great Lakes, and Ore.

9. Ranunculus obtusiúsculus Raf. Water Plantain Spearwort. (I. F. f. I603.) Stout, 3-10 dm. high, ascending, glabrous; stem hollow, sometimes nearly $2 \mathrm{~cm}$. thick at the base. Leaves lanceolate or oblong-lanceolate, 7-12 cm. long, 10-1 $2 \mathrm{~mm}$. wide, denticulate or entire, all but the uppermost on broad petioles; fiowers $12-16 \mathrm{~mm}$. broad: petals $5-7$, much exceeding the sepals; head of fruit glohose or slightly elongated, IO-12 mm. in diameter; achenes I $\mathrm{mm}$. long. Marshes, Me. and Ont. to Ga., west to Minn. and Mo. June-Aug. [R. ambigens S. Wats.]

Io. Ranunculus nivàlis I. SNOW BuTtercup. (1. F. f. I604.) Stem simple, I-2 dm. high. Basal leaves long-petioled, 3-7-lobed, or crenate, thick, glabrous, the blade about $2 \mathrm{~cm}$. broad, those of the stem short-petioled or sessile, 
deeply lowed; flowers solitary, 12-18 mm. broad; head of fruit oblong, $12 \mathrm{~m}$. long; achenes tipped with the subulate style. Lab. and Arctic America; also in northern Europe and Asia. Summer.

I I. Ranunculus pygmaèus Wahl. Pigmy Butrercup. (I. F. f. I605.) Small, 2-5 cm. high, glabrous or sparsely pubescent. Basal leaves slenderpetioled, deeply 3-5-lobed or divided, the blade 6-12 mm. wide; those of the stem similar and nearly sessile; the petals slightly exceeding the sepals; head of fruit short-oblong, $4 \mathrm{~mm}$. long; achenes $1 \mathrm{~mm}$. long, lenticular, tipped with a slender beak. Lab., Arctic Am., and in the Rocky Mts. Also in Europe and Asia.

12. Ranunculus Sábini R. Br. Sabine's Buttercup. Small, 6-io cm. high, glabrous, and upper portion hairy. Basal leaves petioled, orbicular-reniform, deeply 5 -cleft, about $15 \mathrm{~mm}$. wide, lobes obovate-cuneate 3 -lobed; stem leaves ses. sile, deeply 3-divided into oblong segments; petals 5-8, about hali longer than the orbicular sepals. Melville Island and Lab. Also in the northern Rccky Mts.

I3. Ranunculus pedatífidus J. E. Smith. Northern Buttercup. (I. F. f. 1606.). Erect, I-3 dm. high, branching. Basal leaves petioled, broadly ovate or nearly orbicular, about $2 \mathrm{~cm}$. broad, obtuse, crenate or often lobed, those of the stem deeply lobed, nearly sessile, the lobes narrow, obtuse; the petals slightly exceeding the spreading sepals; head of fruit oblong, 5-10 m. long, 4-5 mm. in diameter; achenes oval, tipped with a short beak, often hairy. Lab. and Quebec to Alaska, south in the Rocky Mts. to Ariz. Also in northern Asia. Summer.

14. Ranunculus cardiophyllus Hook. Heart-Leaved Buttercup. Stout, I-3 dm. high, more or less villous. Basal leaves broadly ovate or orbicular, often subcordate at the base, and upper portion crenate or lobed; stem leaves ses. sile, pedately 3-7 divided into oblong divisions; petals one-half or more longer than the sepals; head of fruit 10-15 $\mathrm{mm}$. long, 6-8 $\mathrm{mm}$. in diameter; achenes oval, tipped with a short curved beak. Lab. to Br. Col., south to Quebec, S. Dak. and Colo. June.

I5. Ranunculus ovàlis Raf. Prairie Crowfoot. (I. F. f. I607.) Pubescent, branching, 1.5-4 dm. high. Lower and basal leaves oval, oblong, or ovateoblong, long petioled, the blade $2-3 \mathrm{~cm}$. in length or more, crenate or slightly lobed, obtuse, the base more or less cuneate; upper cauline leaves sessile or short petioled, deeply divided into 3-7 linear or oblong obtuse lobes; flowers 18-24 mm. broad; carpels and achenes oval or orbicular, minutely beaked. In fields and on prairies, Lab. and Ont. to the N. W. Terr., Ill. and Neb. March-May.

I6. Ranunculus Hàrveyi (A. Gray) Britton. Harvey's Buttercup. (I. F. f. I608.) Glabrous; stem erect, slender, branched, 2-4 dm. tall. Leaves thin, the basal and lower ones long-petioled, obtusely crenate or somewhat lobed, $1-3.5 \mathrm{~cm}$. wide, cordate, truncate at the base, the upper sessile or nearly so, deeply 3.cleft or 3-parted into linear or narrowly oblong segments; flowers bright yellcw, 12-18 $\mathrm{mm}$. broad; petals $4-8,4$ or 5 times as long as the reflexed sepals; head of fruit globose, $4 \mathrm{~mm}$. in diameter: achenes oblique, compressed, tipped with a minute straight style. On dry hillsides, Mo. and Ark. April-May.

I7. Ranunculus abortivus L. KinNEY-LEAVED CROWfoot. (I. F. f. I6og.) Glabrous, or but sparingly pubescent, I.5-6 dm. high, branched. Basal leaves long-petioled, bright green, thick, crenate or sometimes lobed, broadly ovate, obtuse, and generally cordate or reniform, the cauline sessile or nearly so, divided into oblong or linear somewhat cuneate lobes; receptacle short, pubescent; flowers 4-6 mm. broad. In woods and moist grounds, Newf., Lab. and N. S. to Manitoba, Fla., Ark. and Colo. April-June.

Ranunculus abortivus eucyclus Fernald. Stem and branches more slender, the latter flexuous: leaves thin, shining, some of the basal ones orbicular: flowers and achenes smaller. Me. and Quebec to Mass.

I8. Ranunculus micránthus Nutt. Rock CRowfoot. (I. F. f. I6ro.) Similar to the preceding species but usually smaller, villous with spreading hairs, flowering when very young, I.5-4 dm. tall. Leaves thin, dull green, the basal ones ovate or suborbicular, 3-lobed or crenate, narrowed, rounded or subcordate at the base; segments of the upper leaves narrow; flowers about $6 \mathrm{~mm}$. broad; sepals narrowed into a short claw; head of fruit rather longer than thick, the receptacle linear, glabrous or very nearly so. In rich woods, often on rocks, range apparently nearly that of $R$. abortivus. Roots tuberous. April-May. 
I9. Ranunculus Alleghaniénsis Britton. Mountain CRowfoot. (I. F. f. I6r1.) Similar in aspect to $R$. abortivus and $R$. micranthus, glabrous; stem widely branched, 3-6 dm. tall. Basal leaves reniform or suborbicular, $1.5-5 \mathrm{~cm}$. wide, long-petioled, crenate or some of them lobed, the teeth and lobes subacute; stem leaves sessile or the l,wer petioled, divided into linear acute segments; flowers about $6 \mathrm{~mm}$. broad; petals glandular; head of fruit $4 \mathrm{~mm}$. in diameter; achenes slightly compressed and margined; styles of about one-half their length. Mountains of Va. and N. Car. to Penn., the Catskills, and eastern Mass. April May.

20. Ranunculus scelerà'us L. Celery-leaved or Ditch Cruwfoot. (I. F. f. I6I2.) Stout, I.5-6 dm. high, freely branching. Basal leaves thick 3-5lobed, on long and broad petioles, the blade $3-5 \mathrm{~cm}$. broad, reniform or corclate, those of the stem petioled or the upper sessile, deeply lobed or divided; flcwers 6-8 $\mathrm{mm}$. broad, the petals about equalling the calyx; head of fruit oblong or cylindric, 8-12 mm. long; achenes I $\mathrm{mm}$. long, very numerous, inerely apiculate. In swamps and wet ditches, N. B. to Fla., Kans. and Minn. Also in Europe and Asia. April-Aug.

21. Ranunculus recurvàtus Poir. Hooked CRowfoor. (I. F. f. I613.) Erect, I.5-6 dm. high, usually hirsute, branching. Leaves all petioled, broadly reniform, 5-7 cm. wide, deeply 3 -cleft, the divisions broadly cuneate, acute, toothed and lobed; flowers light yellow, the petals not exceeding the reflexed calyx; head of fruit globose, $12 \mathrm{~mm}$. wide; achenes compressed, margined. In woods, N. S. to Manitoba, south to Fla. and Mo. April-June.

22. Ranunculus àcris L. TALL OR MEADOW BUTTERCUP. (I. F. f. I614.) Hairy, branched above, 6-9 dm. high. Basal leaves tufted, petioled, 3-7-divided, the divisions sessile and cleft into numerous narrow mainly acute lobes; upper leaves short-petioled and merely 3-parted; flowers about $2 \mathrm{~cm}$. broad; petals twice or thrice the length of the calyx, obovate; head of fruit globose, 12-14 mm. broad. In fields and meadows, common, especially in the Northern States and Canada. Nat. from Europe. May-Sept.

23. Ranunculus bulbòsus L. Bulbous Butrercup. (I. F. f. 16I5.) Erect, hairy, 1.5-4 dm. high. Leaves petioled, 3 divided, the terminal division stalked, the lateral ones sessile or nearly so, all variously lobed and cleft, flowers about $2 \mathrm{~cm}$. broad; petals much longer than sepals, obovate, rounded; head of fruit globose, I0-12 mm. broad; achenes compressed, very short-beaked. In fields and along roadsides, in the Eastern States. Nat. from Europe. May-July.

24. Ranunculus Pennsylvánicus L. f. Bristly Buttercup. (I. F. f. 16r6.) Erect, branching, pilose-hispid, 3-6 dm. high, leafy. Leaves thin, 3divided; divisions deeply 3-cleft, the lobes lanceolate, cuneate, acute, incised; flowers $6-8 \mathrm{~mm}$. wide; head of fruit $6 \mathrm{~mm}$. thick, sometimes $12 \mathrm{~mm}$. long; achenes smooth, pointed with a sharp beak one-third their length; receptacle hairy. In wet, open places, N. S. to Ga. and west to the Rocky Mts. and Br. Col. June-Aug.

25. Ranunculus Macòunii Britton. Macoun's Buttercup. (I. F. f. I6I7.) Erect or diffuse, hairy, branching, 3-6 dm. high. Leaves 3-divided, the blade 5-8 cm. long, the divisions broadly oblong. acute, cuneate, variously cleft and lobed; flowers 10-12 mm. broad; head of fruit oblong, $8 \mathrm{~mm}$. thick; achenes smooth, pointed with a sharp beak about one-fourth their length. Western Ont., Iowa and west to the Pacific Coast, extending south in the Rocky. Mts. to Ariz. Summer.

26. Ranunculus rèpens L. CReeping Buttercup. (I. F. f. 1618.) Generally hairy, sometimes only slightly so. Leaves petioled, 3-divided, the terminal division, or all three stalked, all ovate, cuneate or truncate, acute, cleft and lobed, often blotched; petals obovate, much exceeding the spreading sepals; head of fruit globose, $8 \mathrm{~mm}$. in diameter; achenes margined, tipped with a stout short slightly bent beak. Fields and roadsides, Newf. to Va. and locally in the interior. Mainly introduced from Europe. May-July.

27. Ranunculus septentrionalis Poir. Swamp or Marsh Buttercup. (I. F. f. I6r9.) Roots fibrous; plant branching, 3-9 dm. high, glabrous, or sometimes pubescent, the later branches procumbent and sometimes rooting at the nodes. Leaves large, petioled, 3-divided; divisions mostly cuneate cleft into broad lobes; petals obovate, twice the length of the spreading sepals; head of fruit globose or oval, $8 \mathrm{~mm}$. in diameter; achenes flat, strongly margined. 
Mainly in swamps and low grounds, N. B. to Manitoba, Ga., Ky. and Kans., April-July.

28. Ranunculus híspidus Michx. Hispid Buttercup. (I. F. f. 1620.) Densely villous when young, sometimes merely appressed-pubescent or glabrate when old; stems ascending or spreading, 2-6 dm. long. Leaves pinnately 3-5divided, the divisions sharply cleft or lobed, usually thin, flowers I $2-35 \mathrm{~mm}$. broad; petals about twice as long as the spreading sepals; head of fruit globoseoval or globose; achenes broadly oval, lenticular, narrowly margined. In dry woods and thickets, Ont. to the N. W. Terr., Ga. and Ark. March-May.

29. Ranunculus fasciculàris Muhl. EARLY OR TUFTED BUTTERCUP. (I. F. f. I621.) Pubescent; plant generally low, I.5-3 dm. high, tufted. Leaves petioled, 3-5-divided; divisions stalked (especially the terminal one), deeply lobed and cleft, the lubes oblong or linear; petals obovate, much longer than the spreading sepals, rounded, truncate or even emarginate; head of fruit globose, about $8 \mathrm{~mm}$. in diameter; achenes flat, slightly margined. Woods, Ont. and N. Eng. to N. Car., west to Manitoba, Kans. and Tex. April-May.

30. Ranunculus párvulus L. Hairy Buttercup. (I. F. f. 1622.) Erect, hairy, I.5-3.5 dm. high, branching. Basal and lower leaves broad-petioled, the blade about $5 \mathrm{~cm}$. broad and long, 3-divided or cleft, the divisions broadly ovate, cuneate, stalked, cleft and lobed, the upper sessile or nearly so, deeply cleft into linear-oblong obtuse segments; flowers yellow, 10-15 $\mathrm{mm}$. broad; petals much exceeding the reflexed calyx; head of fruit oblong, 4-6 $\mathrm{mm}$. thick; achenes flat, strongly margined, short-beaked. In ballast grounds and waste places, N. B. to Va. and Fla. Fugitive from Europe. Sunmer.

31. Ranunculus parvifiòrus L. Small flowered Crowfoot. (I. F. f. 1623.) Hairy, slender, diffuse, branching from the base, $15-25 \mathrm{~cm}$. high. Basal leaves long-petioled, the blade reniform or cordate-orbicular, $2.5 \mathrm{~cm}$. broad or less, 3-cleft, the lobes broadly oval, obtuse, cut and toothed; upper leaves short-petioled or nearly sessile, 3-5-parted into linear-oblong lobes; flowers yellow, 2-4 mim. wide, the petals not longer than the calyx; head of fruit globose, $4 \mathrm{~mm}$. broad; achenes flat, margined, densely papillose, $3 \mathrm{~mm}$. long, tipped with a sharp beak of about one-fourth their length. In waste places, Md. and eastern Va. to Fla., Ark. and Tex., and in ballast grounds about the northern seaports. Nat. or fugitive from Europe. Summer.

32. Ranunculus muricàtus L. Spiny-fruited Crowfoot. (I. F. f. 1624.) Glabrous or sparingly pubescent, branched from the base, 3-6 dm. high. Lower and basal leaves on long broad petioles, the blade reniform or cordate-orbicular, 3$5 \mathrm{~cm}$. wide, 3-lobed, cleft, or crenate; the upper 3-divided, cuneate, short-petioled or sessile; flowers light yellow, 6-10 $\mathrm{mm}$. wide, the petals exceeding the calyx; head of truit globular, $10-12 \mathrm{~mm}$. wide; achenes flat, $4 \mathrm{~m}$. long, tipped with a stout slightly curved beak. Waste places, eastern Va. and southward, naturalized or fugitive from Europe. Also on the Pacific Coast. Native also in Asia and natu. r.lized in tropical America. Summer.

33. Ranunculus arvénsis L. CORN Crowfoot. Hunger-weed. (I. F. f. 1625.) Erect, glabrous or sparingly pubescent, branched above, $3 \mathrm{dm}$. or more high. Lower leaves petioled, the upper sessile, all deeply cleft or divided into linear-oblong, obtuse cuneate, lobed or toothed segments or the lowest entire; flowers 12-16 mm. broad, pale yellow, the petals exceeding the sepals; achenes 8$16 \mathrm{~mm}$., flattened, margined, $4 \mathrm{~mm}$. long, tipped with a subulate beak. In waste grounds, Tom's River and Passaic, N. J., and in ballast about the northern seaports. Fugitive from Europe. Summer.

\section{BATRÀCHIUM S. F. Gray.}

Perennial aquatic or ditch herbs, with alternate dissected or palmately lobed leaves, the segments of the submerged ones often filiform, and solitary rather small white flowers, borne on peduncles opposite the leaves: sepals and petals usually 5 . Petals oblong or oval, the base sometimes yellowish, the claw bearing a small pit. Stamens several or numerous. Achenes oblique, compressed, not margined, nearly or quite beakless, transversely wrinkled. [Greek, referring to the aquatic habitat.] About 20 species of very wide geographic distribution. Besides the following, 3 others occur in northwestern N. Am. 
Leaves all reniform, 3-5-lobed, about $\mathbf{I} \mathrm{cm}$. wide; receptacle glabrous.

Leaves all dissected into filiform segments; receptacle hairy.

1. B. hederaceum.

1.eaves sessile, circinate, the segments short, spreading around the stem nearly in one plane; beak of achene minute.

Leaves more or less petioled, not circinate.

Beak of achene nearly $1 \mathrm{~mm}$. long.

2. B. divaricatum.

Beak of achene minute or none.

Petals 5-7 nim. long, broadly obovate; stamens many.

Segments of the leaves $10-15 \mathrm{~mm}$. long, rather rigid, scarcely collapsing when withdrawn from water. 4 . B. trichophyllum.

Segments of the leaves $15-30 \mathrm{~mm}$. long, flaccid, collapsing when withdrawn from waier.

Petals less than $5 \mathrm{~mm}$. long, oblong-obovate, stamens $5^{-12}$.

Stem slender; leaves not very flaccid.

Stem filiform; leaves very flaccid.

5. b'. fiaccidum.

6. $B$, Drouetii.

7. B. confervoides.

I. Batrachium hederàceum (L.) S. F. Gray. Ivy-LEAvei Crowfoot. (I. F f. 1628.) Semi-aquatic, rooting extensively at the joints, branching, entirely glabrous. Leaves floating, or spreading on the mud, the lobes obtuse; flowers white, 4-6 mm. broad; head of fruit globose, $4 \mathrm{~mm}$. wide; achenes rugose, minutely beaked. In ponds and pools, Newf. and southeastern Va. Nat. from Europe. June-Aug. [Ranunculus hederaceus L.]

2. Bat,achium divaricàtum (Schrank) Wimm. Circinate White WaterCrowfoot. (I. F. f. 1627.) Submerged, $3 \mathrm{dm}$. or more. Leaves distant, I-2 $\mathrm{cm}$. broad, with very short lobes; stipules membranaceous, very short and broad, glabrate; peduncles 4-10 $\mathrm{cm}$. long; petals broadly obovate, about $5 \mathrm{~mm}$. long; head of fruit globose. Very rare; most specimens referred here belong to the next. Lakes and ponds, N. Eng. to Minn. Also in Europe. June-Aug.

3. Batrachium longiróstris (Godr.) F. Schultz. LoNG-BEAKED White WATER-CRowfoot. Stem very leafy, submerged. Petioles short; stipules broad and hairy; segments very numerous, about $15 \mathrm{~mm}$. long, not flaccid; peduncles 2-4 cm. long; petals broadly ovate, 5-7 $\mathrm{mm}$. long; head globose. Has been confused with the preceding. In ponds and streams, Ont. and N. Eng. to Minn.,

N. Mex. and Mo. June-Aug.

4. Batrachium trichophýllum (Chaix) Bossch. White Water-Crowfoot. (I. F. f. I626.) Submerged; stems usually $3 \mathrm{dm}$. long or more. Leaves petioled, 3-5 cm. long, stipules broad and short, hairy: flowers white, 12-18 mm. broad, on stout peduncles $2-5 \mathrm{~cm}$. long, blooming at the surface of the water; head of fruit globose, $4 \mathrm{~mm}$. broad; receptacle hairy; achenes apiculate but beakless. In ponds and streams, N. S. to Br. Col., south to N. Car. and Cal. Also in Europe and Asia. The so-called var. caespitosus is a small mud form with rather fleshy leaf-segments. June-Sept. [Ranunculus trichophyllus Chaix.]

5. Batrachium fáccidum (Pers.) Rupr. Flaccid White Water-Crowfoot. Like the next preceding except the leaves, which have longer, more slender petioles and very long flaccid leaf-segments, collapsing when withdrawn from water. In streams, Mass. to Wash, south to N. Car. and Lower Cal. Also in Europe, Asia and South Africa. May-Sept

6. Batrachium Drouètii (F. Schultz) Nym. Drouet's White Water-CrowFoот. Like B.trichophyllum. but more slender and with smaller flowers, fewer and more slender leaf-segments, narrower and glabrous stipules and fewer stamens. In streams, Vt. and R. I. to Alaska, south to Lower Cal. Also in Europe, Asia, Africa, and Bolivia.

7. Batrachium confervoides Fries. Filiform White Water-Crowfoot. Resembling the last, but stem filiform, I-2 dm. long; leaves very flaccid and the receptacles conic, not ovoid. In cold pools, from Lake Winnipeg (according to Hiern) to Alaska, and south to the Yellowstone Park. Also northern Europe.

\section{FICÀrIA Huds.}

Glabrous slightly fleshy perennial herbs, with thickened tuberous roots, branched or simple spreading or erect stems, petioled entire or toothed cordate leaves, and large solitary yellow terminal or axillary flowers. Sepals 3 or sometimes 5, deciduous. Petals 7-12 (commonly 8 , yellow, or red at the base, bearing 
a small pit at the base of the blade. Stamens and pistils numerous. Achenes slightly compressed, blunt, not wrinkled nor ribbed. Cotyledon only one. [Latin, fig, from the fig.like thickened roots.] About 4 species, natives of the Old World.

I. Ficaria Ficària (L.) Karst. Lesser Celandine. (I. F. f. 1629.) Glabrous: flowering stems scapose, 10-12 $\mathrm{cm}$. high, bearing I or 2 leaves or naked. Leaves uvate, obtuse, crenate, somewhat fleshy, on broad petioles, the blade 3-5 cm. lony; flowers yellow, $2.5 \mathrm{~cm}$. broad; head of fruit globose, I cm. broad; carpels beakless, truncate. College Point, Long Island; Staten Island; Philadelphia and D. C. Fugitive from Europe; also in western Asia. April-May.

\section{CYRTORHYNCHA Nutt.}

A glabrous perennial herb, with fibrous roots, slender erect stems, crenate or lobed leaves, and small yellow flowers. Sepals 5, spreading, deciduous. Petals 5, narrowly spatulate or oblong, bearing a small pit near the base. Stamens and pistils numerous. Head of fruit globose. Achenes terete, longitudinally ribbed or nerved, tipped with the inflexed style. [Greek, curved-beak.] The genus as here recognized consists of the following species only.

I. Cyrtorhyncha ranuncùlina Nutt. Nutrall's Buttercup. (I. F. f. 1630.) Slender, glabrous, erect, branched above, 1.5-2.5 dm. high. Basal leaves on long slender petioles, bipinnate, parted into oblong or linear, acutish lobes; stem leaves few, ternately or pinnately parted into linear lobes; flowers few, corymbose, about $12 \mathrm{~mm}$. broad; sepals yellow, petaloid, spreading; petals spatulate; achenes 2-3 mm. long, in a globose head, glabrous, oblong-cylindric. In gravelly soil, Wyo. and Colo. Reported from Neb. June.

\section{OXÝGRAPHIS Bunge.}

Perennial herbs, with crenate dentate or lobed long-petioled leaves, and small yellow flowers, solitary or 2-7 together on scapes or scape-like peduncles. Sepals usually 5, spreading. tardily deciduous. Petals 5-12, each bearing a small nectarpit near the base. Stamens and pistils numerous. Head of fruit oblong, oval or subglobose. Achenes compressed, sometimes swollen, longitudinally striate, without a hard coat. [Greek, sharp-style.] About 10 species, the following of North America, Asia and southern Suuth America, the others Asiatic.

I. Oxygraphis Cymbalària (Pursh) Prantl. Seaside Crowfoot. (I. F. f. 1631.) Low, glabrous, spreading by runners. Leaves mostly basal, slenderpetioled, the blade cordate-oval or reniform, crenate, 4-18 mm. long; flowers $1-7$, about 6-8 $\mathrm{mm}$. broad, borne on scapes $2-12 \mathrm{~cm}$. long, these sometimes bearing one or more leaves toward the base; head of fruit oblong, 6-16 $\mathrm{mm}$. long; achenes compressed, somewhat swollen, distinctly striate, minutely sharp-pointed. On sandy shores, N. J. to Lab., west to Alaska, Cal., Mex. and Kans. Also in Asia and S. Am. Summer. [R'anuncuius cymbalaria L.]

\section{THALÍCTRUM L. (See Appendix)}

Erect perennial herbs. Lfaves ternately decompound, basal and cauline, the latter alternate. Flowers perfect, polygamous or diœcious, generally small, greenish.white, panicled or racemed. Sepals 4 or 5. Petals none. Carpels commonly few, one-seeded, ribbed or nerved, stipitate or nearly sessile. Stamens $\infty$, exserted. [Derivation doubtful.] A genus of about 75 species, most abundant in the north temperate zone, a few in the Andes of South America, India and South Africa. In addition to the species described below, about 8 others occur in southern and western N. Am.

Flowers perfect.

Stem simple, scape-like; achenes sessile; filaments slender. I. T. alpinum.

Sten branched, leafy; achenes long-stipitate; filaments spatulate, petal-like.

Flowers diøecious or polygamous.

2. $T$. clavatum.

Flaments filiform or slender, not wider than the anthers.

Flowers strictly diœcious : lower stem leaves distinctly petioled.

Achenes terete; eastern species.

Leaflets thin, orbicular or broader ; roots not yellow.

3. T. dioicum.

Leaflets thick, obovate or reniform; roots bright yellow.

4. 7 , corraceum. 
Achenes 2-edged; western species.

5. . venulosum.

Flowers polygamous; leaflets usually glandular, or waxy stem leaves almost sessile.

Filaments spatulate, often wider than the anthers; plant not glandular.

6. 7: purpurascens.

7. 1. polygamum.

1. Thalictrum alpinum L. Arctic or Dwarf Meadow-Rue. (I. F. f. 1632.) Smooth or slightly glandular, $3-10 \mathrm{~cm}$. high. Leaves small, tufted at the summits of scaly rootstocks, biternate; leaflets cuneate-obovate or orbicular, firm, 3-5-lobed at the apex, margins revolute; panicle very simple, often racemose; stamens about IO; anthers oblong-linear, mucronate; stigma linear; achenes $3 \mathrm{~mm}$. long, obliquely obovoid. Anticosti, Newf. and Arctic Am. Also in the Rocky Mts., Cal. and in Europe and Asia. Summer.

2. Thalictrum clavatum DC. Muuntain Meadow-Rue. (I. F. f. I633.) Glabrous, branching, 1.5-6 dm. high. Leaves oval, ovate, or the terminal obovatecuneate, basal and cauline, large, biternate; leaflets thin, stalked, with 3 main lobes and a few secondary ones, their margins not revolute; inflorescence cymose; anthers oblong, blunt; achenes spreading, equalling their stipes or longer, obliquely ovoid, narrowed at each end, flattened; stigma minute. Mountains of Va. and W. Va. to Ga., Ala. and Tenn. May-June.

3. Thalictrum diòicum L. EARLy Meadow-Rue. (I. F.f. 1634.) Glabrous, erect, 3-6 dm. high, slender, leafy; leaves 3-4-ternate; leaflets pale beneath, often cordate and the terminal one somewhat cuneate, 5-9-lobed; flowers greenish; panicle elongated, of numerous lateral corymbs or umbels; filaments longer than the sepals; achenes ovoid, sessile or minutely stipitate, deeply grooved, much longer than the style. In woods, Lab. and Anticosti to Ala., west to Saskatch. and Mo. April-May.

4. Thalictrum coriàceum (Britton) Small. Thick-Leaved Meadow-Rue. (I. F. f. I635.) Tall, I-I.5 m. high. Stem striate, paniculately branched above; leaves 3-4-ternate, short-petioled, the lower petioles expanded at the base into stipule-like appendages; leaflets nearly white beneath, usually deeply and sharply incised, the veins prominent on the lower surface; staminate flowers nearly white; pistillate flowers purple; achenes oblong-ovoid, subacute, stalked, sharply ribbed, longer than the persistent style. In open places, mountains of Va., N. Car. and Ky. May-June.

5. Thalictrum venulòsum Trelease. Veiny Meadow-Rue. (I. F. f. I636.) Glabrous, pale green and glaucous, stem purplish, erect, or assurgent at the base, I. 5-6 dm. tall. Leaves 3-4-ternate, long-petioled; leaflets firm, obovate or suborbicular, rounded at the apex, cuneate, obtuse or subcordate at the base, 8-16 $\mathrm{mm}$. long, 3-5-lobed, the lower surface rather prominently rugose-veined; anthers linear, slender-pointed; achenes ovoid, nearly sessile, tapering into a short beak, thickwalled, 2-edged. In dry soil, Manitoba and S. Dak. to the N. W. Terr. and Wash., south to Colo. May-June.

6. Thalictrum purpuráscens L. Purplish Meadow-Rue. (I. F. f. I637.) Stout, erect, I-2 m. high, leafy, branching above, glandular, pubescent or even glabrous; leaves 3-4-ternate; leaflets thick, oblong or obovate, dark green above, commonly waxy beneath, with revolute margins; anthers linear or linear-oblong, cuspidate; stigma linear, persistent; achenes ovoid, glabrous or pubescent, shortstipitate, with 6-8 longitudinal wings. In copses and woodlands, N. S. and Anticosti to Fla., west to Saskatch. and Ariz. Stems often purplish. June-Aug.

7. Thalictrum polfgamum Muhl. TAll MEADOW-RUE. (I. F. f. 1638.) Stout, $\mathbf{I}-\mathbf{2 . 5} \mathrm{m}$. high, branching, leafy, smooth or pubescent but not glandular nor waxy. Leaves 3-4-ternate; leaflets moderately thick, light green above and paler beneath, oblong, obovate or orbicular, with 3 main apical pointed or obtuse lobes; flowers polygamous, white; anthers oblong, short; achenes ovoid, stipitate, 6-8winged, glabrous or pubescent. Lab. and Quebec to Fla., west to Ohio.

\section{ADÒNIS L.}

Leaves alternate, pinnately dissected into numerous linear segments. Flowers yellow or red, solitary, terminal. Petals 5-16, conspicuous. Carpels $\infty, 1$-ovuled. Achenes capitate or spicate, tipped with the persistent styles. [Mythological name 
for a favorite of Venus, changed into a flower.] A genus of Europe and Asia, consisting of the following and about five other species.

1. Adonis ánnua L. Pheasant's Eye. (I. F. f. 1639.) Annual, erect, 3-6 dm. high, glabrous. Leaves fincly dissected, the lower petioled, the upper sessile, the segments acute; sepals smooth, deciduous ; flowers $1.5-3.5 \mathrm{~cm}$. broad, nearly globular, the petals obovate, and darker colored at the base; achenes spicate, rugose or angular. Occasional in waste places, especially southward. Fugitive from Europe. Summer.

\section{Family 6. BERBERIDÀCEAE T. \& G.}

\section{Barberry Fimily.}

Shrubs or herbs, with alternate or basal leaves, with or without stipules, and solitary or racemed mostly terminal flowers. Sepals and petals generally imbricated in several series. Stamens as many as the petals and opposite them, hypogynous. Flowers perfect and pistil one in our species. Anthers extrorse, opening by valves (except in Podophyllum). Style short; ovules $2-\infty$, anatropous. Fruit a berry or capsule. A bout 20 genera and 105 species, widely distributed in the north temperate zone, the Andes and temperate S. Am., a few in tropical regions.

Shrubs ; fruit baccate.

Herbs.

I. Berberis.

Anthers opening by valves.

Pericarp early bursting, leaving two large naked stalked seeds, resembling berries.

Fruit baccate; stamens 6 .

Fruit capsular, half circumscissile.

Anthers longitudinally dehiscent ; fruit baccate ; stamens 6-18

2. Caulophyllum.

3. Diphylleia.

4. Jeffersonia.

x. BÉRBERIS L.

5. Podophyllum.

Shrubs with yellow wood, simple or compound often spiny leaves, and yellow racemose (rarely solitary) flowers. Sepals 6-9. petaloid, bracted. Petals 6, imbricated in 2 series, each with 2 basal glands. Stamens 6, irritable, closing around the stigma when shocked; anthers dehiscent by valves opening from the apex. Pistil I ; stigma peltate. Berry I-few-seeded. [From the Arabic name.] A genus of about 75 species, natives of N. Am., Europe, northern Asia and S. Am. Besides the following, about ro others are found in the western parts of N. Am.

Leaves simple : racemes drooping; berries scarlet.

Twigs ash-colored; racemes many-flowered; petals entire.

Twigs dark brown; racemes few-flowered; petals notched. Leaves pinnate; racemes erect ; berries blue or purple.

I. B. vulgaris.

2. B. Canadensis.

3. B. Aquifolium.

T. Berberis vulgàris L. European BARberRy. (I. F. f. 1640.) A glabrous shrub, 2-3 m. high, the branches arched, the twigs gray. Leaves alternate or fascicled, obovate or spatulate, unifoliolate, obtuse, $2-5 \mathrm{~cm}$. long, bristly serrate, many of those on shoots reduced to 3 -pronged spines; racemes lateral, manyflowered, 2-10 cm. long ; flowers yellow, 6-8 mm. broad; petals entire ; berries oblong. scarlet when ripe, acid. In thickets, nat. from Europe in the Eastern and Middle States, adventive in Canada and the West. May-June.

2. Berberis Canadénsis Mill. American Barberry. (I. F f. I64I.) A shrub, $0.3^{-2} \mathrm{~m}$. high, with slender, reddish brown branchlets. Leaves similar to those of $B$. vulgaris, but with more divergent and distant tecth, or sometimes nearly entire : racemes few-flowered; petals notched or emarginate at the apex ; berries scarlet, oval or subglobose. In woods, mountains of Va. to Ga., and in Mo. June.

3. Berberis Aquifolium Pursh. Trailing Mahonia.

(I. F. f. I642.) A trailing glabrous shrub. Leaves petioled, pinnate: leaflets 3-7, ovate, oval, or nearly orbicular, oblique, obtuse, truncate or siightly cordate at the base, sessile, thick, persistent, finely reticulated, dentate with spine-bearing teeti, $2-5 \mathrm{~cm}$. long; racemes several, erect, dense, terminal, many-flowered; flowers yellow, 6-8 $\mathrm{mm}$. broad, short-pedicelled ; bracts ovate, persistent; herry glubose, blue or purple, about $6 \mathrm{~mm}$. in diameter. W. Neb., Ariz. and Br. Col. April-May. 


\section{CAULOPHÝLLUM Michx.}

Erect herbs, with thickened rootstocks, and ternately compound leaves. Sepals 6, the calyx 3-4-bracted. Petals 6, smaller, cucullate, opposite the sepals. Stamens 6; anthers oblong, dehiscent by valves. Pistil $\mathrm{I}$ : style short; stigma lateral; ovu!es 2, ripening into large globose stipitate seeds, resembling berries, which in growth soon rupture the membranous caducous pericarp. [Greek, stem leaf.]

I. Caulophyllum thalictroides (L.) Michx. BlúE CoHosh. (I. F. f. 1643.) Glabrous, glaucous when young, 3-9 dm. high, with 2 or 3 large sheathing scales at the base, a large triternate nearly sessile leaf near the summit, and generally a smaller similar one near the base of the inflorescence. Divisions of the leaves long petioled. the ultimate segments thin, $2-8 \mathrm{~cm}$. long, oval, oblong or obovate, 3-5lobed near the apex; panicle terminal, $5-8 \mathrm{~cm}$. long; flowers greenish purple, 8-I2 $\mathrm{mm}$. broad; seeds $8 \mathrm{~mm}$. in diameter, blue, glaucous, borne on stout stalks about $6 \mathrm{~mm}$. long. In woods, N. B. to S. Car., Minn., Neb. and Mo. April-May.

\section{DIPHYLLEIA Michx.}

Herbs with horizontal rootstocks, large peltate leaves, and cymose white flowers. Sepals 6, petaloid. Petals 6, flat. Stamens 6; anthers dehiscent by valves. Pis. til I; ovules few, arranged in 2 rows. Fruit a berry. Seeds oblong, curved. [Greek, double-leaf.] Two species, one of eastern N. Am., the other of Japan.

I. Diphylleia cymòsa Michx. Umbrella-Leaf. (I. F. f. I644.) Erect, stout, 3-6 dm. high, glabrous or nearly so. Basal leaves solitary, long-petioled, 3-6 dm. in diameter, peltate, deeply 2-cleft, many-lobed, the lobes acute or acuminate, sharply dentate; cauline leaves 2, similar. smaller, petioled, constricted in the middle and generally peltate near the margin; cyme many-flowered, $5-8 \mathrm{~cm}$. hroad; petals oblong, obtuse; fruiting pedicels slender, $2 \mathrm{~cm}$. long or more; berries bue, oblong, $\mathbf{I}-\mathbf{I} .5 \mathrm{~cm}$. long. In woods, Va. to Tenn. and Ga. along the mountains. May-June.

\section{JEFFERSÒNIA Bart.}

Glabrous herbs, with basal palmately-veined or palmately-lobed leaves, and solitary white flowers on slender scapes. Sepals 4, petaloid, caducous. Petals 8, flat, longer than the sepals. Stamens 8; anthers dehiscent by valves. Pistil I, many-ovuled. Capsule leathery, pyriform, half-circumscissile near the summit. Seed; oblong, arillate. [In honor of Thomas Jeflerson.]. 'Two species, one of eastern N. Am., the other of Mantchuria.

I. Jeffersonia diphýlla (L.) Pers. Twin-leaf. (I. F. f. r645.) Scape erect, I. 5-2 dm. high when in flower, attaining 4-4.5 dm. in fruit. Leaves glaucous beneath, long-petioled, cordate or reniform, 7-15 cm. long, 5-1o cm. wide, parted longitudinally into 2 obliquely ovate obtuse lobed or entire divisions; flowers about $2.5 \mathrm{~cm}$. broad; petals oblong; stigma peltate, undulate; capsule about 2.5 cm. long, short-stipitate. In woods, Ont. to Wis., Va. and Tenn. May.

\section{PODOPHÝLLUM L.}

Erect herbs, with horizontal poisonous rootstocks, large peltate palmately lobed leaves, and solitary white flowers. Sepals 6, petaloid, fugacious. Petals 9-6, flat, obovate, longer than the sepals. Stamens as many or twice as many as the patals; anthers linear, longitudinally dehiscent. Pistil I (rarely several, many-ovuled, forming a large fleshy berry in fruit. Seeds numerous, obovate, enclosed in fleshy arils. [Greek, duck-foot leaf.] About 4 species, one of eastern. N. Am., the others Asiatic.

r. Połophyllum peltàtum I. May Apple. Wild Mandrake. (I. F. f. 1646.) Erect, 3-4 dm. high. Basal leaves centrally peltate, nearly $3 \mathrm{dm}$. in diameter, long petioled, deeply 5-7-lobed, glabrous, or pubescent on the lower surface; lobes 2 -cleft and dentate at the apex; flowering stems bearing I-3 similar leaves, or occasionally leafless; flower stout-peduncled. nodding, $5 \mathrm{~cm}$. broad, appearing from the base of the upper leaf and generally from immediately between the two leaves: fruit ovoid, yellowish $5 \mathrm{~cm}$. long, edible. In low woods, Quebec and Ont, to Minn., Fla., La. and Tẹx. May, 


\section{Family 7. MENISPERMÀCEAE DC.}

\section{Moonseed Family.}

Vines with alternate entire or lobed leaves, no stipules, and small diœcious panicled racemose or cymose flowers. Sepals 4-12. Petals 6, imbricaled in 2 rows, sometimes fewer, or none. Stamens about the same number as the petals. Carpels $3-\infty$ (generally 6), I-ovuled separatı; styles commonly recurved. Fruit drupaceous. Embryo long, curved. About 55 genera and I 50 species, mainly of tropical distribution, a few extending into the temperate zones.

Petals none.

Petals present.

Stamens 6; drupe red.

Stamens 12-many; drupe black.
I. Calycocarpum.

2. Cebatha.

3. Menispermum.

\section{CALYCOCÀrPUM Nutt.}

Leaves large, petioled, palmately lobed. Flowers greenish in long narrow drooping panicles. Sepals 6, oblong, obtuse. Stamens about 12, nearly equalling the sepals; anthers 2-celled. Pistils 3: stigma laciniate. Drupe oval, the stone flattened and hollowed out on one side. [Greek, cup-fruit, in allusion to the cuplike stone.] A monotypic genus of eastern N. Am.

I. Calycocarpum Lỳoni (Pursh) Nutt. Cup-Seed. (I. F. f. I647.) Climbing to the tops of trees, glabrous or slightly pubescent. Leaves thin, broadly ovate or nearly orbicular in outline, $\mathrm{I}-2 \mathrm{dm}$. long, cordate with a broad sinus, 5-7-lobed, glabrous above, more or less pubescent on the veins beneath; lobes ovate or oblong, acute or acuminate, repand, dentate or entire; panicles axillary, I-2.5 dm. long; flowers $4 \mathrm{~mm}$. broad; cirupe nearly $2.5 \mathrm{~cm}$. long, black, the stone toothed or erose along the margin of its lateral cavity; pistillate flowers sometimes containing abortive stamens. In rich woods, Ill. to Mo., Kans., Fla. and Tex. May-June, the fruit ripe in August.

\section{CÉBATHA Forsk. [COCCULUS DC.]}

Flowers small, diœcious, panicled. Sepals 6, in two series. Petals 6, shorter than the sepals, concave. Stamens 6; anthers 4-celled or 4-lobed. Pistils 3-6, sometimes accompanied by sterile filaments; styles erect; stigma entire. Drupe globose or ovoid, the stone flattened, curved. [Name Arabic.] About 10 species, mairly of tropical regions, two or three in the temperate zones.

I. Cebatha Carolina (L.) Britton. Carolina Moonseed. (I. F. f. 1648.) Trailing or climbing, the stem glabrous or pubescent. Leaves broadly ovate, 5-10 $\mathrm{cm}$. long, cordate or rounded at the base, entire or lobed, sometimes densely pubescent beneath, mainly glabrous above; petioles $2-10 \mathrm{~cm}$. long; panicles loose, $2-13 \mathrm{~cm}$. long; flowers about $2 \mathrm{~mm}$. broad; drupe red, laterally flattened, 4-6 mm. in diameter, the stone curved into a closed spiral, crested on the sides and back. A 'ong streams, Va. to Ill., Kans., Fla. and Tex. June-Aug.

\section{MENISPÉRMUM L.}

Flowers small, panicled. Sepals $4-8$, in two series, longer than the $6-8$ petals. Stamens 12-24. Anthers 4-celled. Pistils 2-4, on a slightly elevated receptacle, generally accompanied by 6 sterile filaments. Drupe nearly globular, or ovoid, laterally flattened, the stone curved into a spiral and crested on the sides and back. [Greek, moonseed.] Two species, one of eastern N. Am., the other of eastern Asia.

I. Menispermum Canadénse L. Canada Moonseed, (I. F. f. I649.) Stem slender, slightly pubescent, or glabrous. Leaves slender-petioled, broadly ovate, I-2 dm. wide, cordate or sometimes nearly truncate at base, entire, or with 3-7 lobes, pale beneath, peltate near the base; flowers greenish white, $4 \mathrm{~mm}$. wide: panicles loose, bracteolate; drupe bluish black, globose-oblong, 6-8 $\mathrm{mm}$. in diameter. In woods, Quebec to Manitoba, Ga, and Ark. June-July. 


\section{Family 8. CALYCANTHÀCEAE Lindl.}

\section{Strawberry-shrub Family.}

Shrubs, with op usite entire short-petioled leaves, no stipules, and terminal solitary large flowers on leafy uranches. Sepals and petals imbricated in many series. Stamens $\infty$, the inner sterile, short, inserted on the receptacle; anthers innate. Pistils $\infty$, nearly enclosed in the hollow receptacle; ovules I or 2 , anatropous. Fruit accessory, consisting of the enlarged ovoid oblong or pyriform receptacle, to which the bases of petals, sepals and bracts are adnate, enclosing few to many smooth shining achenes. Seed erect; cotyledons foliaceous, convolute. A family of 2 genera and about 5 species, natives of N. Am. and eastern Asia.

\section{BUTNERIA Duham. [CALYCANTHUS L.]}

Stamens inserted in several rows. Flowers purple or red. Otherwise as in the family. [Name in honor of Butner or Buettner.] The genus comprises 3 species, one additional to those here described occurring on the Pacific Coast. Chimonanthus Lindl. of Japan and China comprises 2 species.

Leaves pubescent beneath; flowers fragrant.

Leaves green, often glaucous beneath, smooth or rough above; flowers not fragrant.

2. B. fertilis.

I. Butneria flórida (L.) Kearney. Hairy Strawberry-Shrub. (I. F. f. 1650.) A branching slirub, I-3 m. high, tlie branclilets and petioles pubescent. Leaves ovate or oval, rough above; flowers dark purple, about $2.5 \mathrm{~cm}$. broad, with a strong odor of strawberries when crushed; sepals and petals linear or oblong, 12-16 mm. long. In rich soil, Va. (?), N. Car. to Ga., Ala. and Miss. April-Aug.

2. Butneria fértilis (Walt.) Kearney. SMooth StraWberRY-Shrub. (I. F.f. I65I.) Branchlets and petioles glabrous or nearly so. Leaves ovate, ovate-lanceolate or oblong-lanceolate, acute or acuminate, rough and dark green above, glaucous and sometimes slightly pubescent beneath or bright green and smooth on both sides; sepals and petals linear or linear-lanceolate, acute; flowers greenishpurple, inodorous. In rich woods, Penn. to N. Car., Tenn. and Ga. March-Aug.

\section{Family 9. LAURÀCEAE Lindl.}

\section{Laurel Family.}

Aromatic trees and shrubs, with alternate (very rarely opposite) mostly thick, punctate exstipulate leaves. Flowers small, perfect, polygamous, diœcious, or sometimes monœecious, usualiy fragrant, yellow or greenish, in panicles, corymbs, racemes or umbles. Calyx 4-6-parted, the segments imbricated in 2 series in the bud. Corolla none. Siamens inserted in 3 or 4 series of 3 on the calyx, distinct, some of them commonly imperfect or reduced to staminodia; anthers opening by valves. Ovary superior, free from the calyx, I-celled; ovule solitary, anatropous, nendulous; stigma discoid or capitate. Fruit a I-seeded drupe or berry. Endosperm none. Cotyledons plano-convex, accumbent. About 40 genera and 900 species, widely distributed in tropical regions; a few in the temperate zones.

Flowers perfect, panicled, not involucrate : leaves evergreen.

Flowers perfect, panicled, not involucrate: leaves evergreen. Persea.

I. Persea.

Anthers 4-celled.

Flowers in umbelled racemes: leaves, or some of them, lobed. 2. Sassafras.

Flowers in capitate umbels; leaves all entire. 3 . Malapoenna.

Anthers 2-celled; leaves entire.

4. Benzoin.

\section{x. PÉRSEA Gaertn. f.}

I eaves alternate, coriacenus, persistent, entire. Calyx 6-parted, persistent. Stamens 12 , in 4 series of 3 , the inner series reduced to gland-like staminodia, the 
3 other series anther-bearing, their anthers 4-celled, 4-valved, those of the third series extrorse and the others introrse in our species. Staminodia large, cordate, stalked. Fruit a berry. [Ancient name of some oriental tree.] About 50 species, natives of America. Besides the following another occurs in Fla.

Twigs and petioles puberulent or nearly glabrous.

1. P. Borbonia.

Twigs and petioles densely tomentose.

2. F. pubescens.

I. Persea Borbònia (L.) Spreng. Red BAy. IsAbella-wood. (I. F. f. I652.) A tree, with dark red bark. Leaves lanceolate, oblong or oblong-lanceolate, bright green above, paler beneath, glabrous when mature, 2-5 cm. wide, obscurely veined, narrowed at the base; petioles $\mathbf{I}-2.5 \mathrm{~cm}$. long; peduncles short, axillary, often little longer than the petioles, bearing few-flowered panicles; calyx puberulent, spreading in fruit, its inner segments longer than the outer; berries dark blue; about 12 $\mathrm{mm}$. in diameter, their pedicels thick, red. Along streams and borders of swamps, Del. (?), Va. to Fla., Tex, and Ark. April-June. Fruit ripe Aug.-Sept.

2. Persea pubéscens (Pursh) Sarg. Swamp Bay. (I. F. f. I653.) Bark brown; leaves oval, oblong or lanceolate, glabrous and shining above when mature, pubescent beneath or also tomentose on the veins, strongly veined, $1-4 \mathrm{~cm}$. wide; petioles $0.8-1.6 \mathrm{~cm}$. long; peduncles tomentose, mostly longer than the petioles, sometimes 5-8 cm. long; calyx tomentose, its inner segments longer than the outer; berry dark blue, 12-18 $\mathrm{mm}$. in diameter. In swamps and along streams, S. Va. to Fla. and Miss. May-July. Fruit ripe Sept.

\section{SÁSSAFRAS Nees \& Eberm.}

A rough-barked tree, with broad entire or 2-6-lobed leaves, and yellow diœcious flowers in involucrate umbelled racemes at the ends of twigs of the preceding season, unfolding with or before the leaves, the involucre composed of the persistent bud-scales. Calyx 6-parted, that of the pistillate flowers persistent, its segments equal. Staminate flowers with 3 series of 3 stamens, the 2 outer series with glandless filaments, those of the inner series with a pair of stalked glands at the base. Anthers introrse, 4 valved. Pistillate flowers with about 6 staminodia and an ovoid ovary. Fruit an oblong-globose blue drupe. [The popular Spanish name.] A monotypic genus of eastern N. Am.

I. Sassafras Sássafras (L.) Karst. Sassafras or Ague Tree. (I. F. f. 1654.) A tree sometimes $4^{\circ} \mathrm{m}$. high, the twigs and leaves mucilaginous, pubescent when young but becoming glabrous. Leaves oval or often as wide as long, membranous, pinnately veined, petioled; racemes several or numerous in the umbels, peduncled; flowers about $6 \mathrm{~mm}$. broad; stamens about equalling the calyx-segments; fruiting pedicels red, much thickened below the calyx; drupe nearly $1.2 \mathrm{~cm}$. high. In dry soil, Me. to Ont., Mich., Fla, and Tex. April-May. Fruit ripe July-Aug.

\section{MALAPOENNA Adans. [TETRANTHERA Jacq.]}

Leaves entire, deciduous in our species. Flowers small. greenish or yellow, in umbels or almost capitate, involucrate by the bud-scales, axillary, or in the following species unfolding before the leaves at the nodes of twigs of the previous season. Calyx 6-parted, deciduous. Staminate flowers much as in Sassafras, bearing 3 series of 3 stamens, their anthers all 4 -celled, 4 -valved and introrse. Pistillate flowers with 9 or 12 staminodia and a globose or oval ovary. Fruit a small drupe. [Malabar name.] Alout 100 species, natives of tropical and warm regions of both the Old World and the New, only the following known in N Am.

1. Malapoenna gericulàta (Walt.) Coulter. POND SPICE (I F. f. I655) A much-branched shrub, with terete smooth zigzag twigs. Leaves oblong. firm. I-5 cm. long, 6-I $3 \mathrm{~mm}$. wide, narrowed at the base, glabrous above, paler and puberulent, at least on the veins, beneath, or quite glabrous when mature: umbels 2-4-flowered, sessile; involucres of 2-4 scales; flowers yellow, less than $4 \mathrm{~mm}$. broad; drupe globose, red, about $6 \mathrm{~mm}$. in diameter. In swamps and wet soil, S. Va. to Fla, March-April.

4. BÉNZOIN Fabric. [LINDERA Thunb.]

Leaves alternate, pinnately veined and in our species deciduous. Flowers diœcious or polygamous, yellow, in lateral sessile involucrate clusters unfolding 
before the leaves, the involucre of 4 deciduous scales. Calyx-segments 6 , equal, deciduous. Staminate flowers with 3 series of 3 stamens, the filaments of the inner series lobed and gland-bearing at the base, those of the two outer series glandless; anthers introrse, 2 valved. Pistillate flowers with 12-15 staminodia and a globose ovary. Fruit a red drupe. [Named from Benzoin gum, from its similar fragrance.] About 7 species, of eastern N. Am. and Asia. Only the following are North American.

Shrub glabrous or nearly so throughout; leaves narrowed at the base.

Twigs and lower surfaces of the leaves pubescent; leaves rounded or subcordate at the base.

2. B. melissaefolium.

r. Benzoin Bénzoin (L.) Coulter. Spice-Bush. Benjamin-Bush. (I. F. f. 1656.) A shrub, I-7 m. high, with smooth bark. Leaves obovate, oval or elliptic, 5-13 cm. long, 2-6 cm. wide, or those of shoots much larger, acute: short-acuminate or some of them rounded at the apex, narrowed at the base; petioles 6-12 $\mathrm{mm}$. long; flowers about $3 \mathrm{~mm}$. broad, fragrant; pedicels about equalling the calyxsegments; ovary about as long as the style; drupe 8 -10 $\mathrm{mm}$. long, about $6 \mathrm{~mm}$. in diameter. In moist woods, thickets and along streams, Me. to Ont., Mich., N. Car., Tenn. and Kans. March-May. Fruit ripe Aug.-Sept.

2. Benzoin melissaefolium (Walt.) Nees. HaIRY SpICE-Bush. (I. F. f. 1657.) Similar to the preceding, but the young twigs, buds and lower surfaces of the leaves densely pubescent. Leaves ovate-lanceolate or oblong, acute or acuminate at the apex, rounded or subcordate at the base, 5-10 cm. long, 1.5-3.6 $\mathrm{cm}$. wide; petioles $2-6 \mathrm{~mm}$. long; pedicels equalling or slightly longer than the calyx segments; drupe 6-10 nm. high. In swamps and wet soil, Ill. and Mo. to N. Car., Ala. and Fla. Feb.-March.

\section{Order I5. PAPAVERÀLES.}

Mostly herbs, with clustered, regular and perfect flowers. Petals, with very rare exceptions, present, separate. Sepals usually separate. Stamens hypogynous. Ovary superior, free from the calyx, compound, composed of two united carpels, or more.

Sepals 2 (very rarely 3 or 4 ); endosperm fleshy.

Sepals or calyx-segments 4-8; endosperm none.

Fam. 1. Papaveraceae.

Capsule 2-celled by a longitudinal partition, usually 2-valved, rarely indehiscent ; sepals and petals 4 .

Capsule 1 -celled, of 2-6 carpels.

Sepals and petals 4 , regular, or petals irregular ; capsule of 2 carpels, 2 -valved.

Fam. 3. Capparidaceae.

Sepals and petals $4-8$, irregular; capsule of $3-6$ carpels, $3-6$ valved at the top ; disk large.

Fam. 4. Resedaceae.

\section{Family I. PAPAVERÀCEAE B. Juss.}

\section{Poppy Family.}

Herbs, with milky or colored sap, and alternate leaves or the upper rarely opposite. Stipules none. Flowers perfect, regulat or irregular. Sepals 2 (rarely 3 or 4 ), caducous. Petals $4-6$ or rarely more, imbricated, often wrinkled, deciduous. Stamens hypogynous, distinct; filaments filiform; anthers longitudinally dehiscent. Ovary I, many-ovuled, mainly I-celled; style short; ovules anatropous. Fruit a capsule, generally dehiscent by a pore, or by valves, rarely indehiscent. About 26 genera and 200 species, widely distributed, most abundant in the north temperate zone. 
* Flowers regular.

Pod dehiscent at the top, or only to the middle.

Leaves not spiny-toothed.

Leaves spiny-toothed.

Pod dehiscent to the base.

Flowers white; juice red.

Flowers and juice yellow.

Capsule oblong or short-linear, bristly.

Capsule long-linear, rough, tipped with a dilated stigma.
Capsule linear, smooth, tipped with a subulate style and minute stigma.

I. Papaver.

2. Argemone.

3. Sanguinaria,

4. Stylophorum.

5. Glaucium.

6. Chelidonium.

\section{** Flowers irregular. Family FumariaCEAE DC.}

Each of the 2 outer petals spurred at the base.

Corolla deeply cordate at base; petals slightly coherent.

Corolla deeply cordate at base; petals slightly coherent. 7. Bicuculla.

One of the outer petals spurred at base.

Capsule 2-valved, few-several-seeded.

Fruit globose, indeliscent, $\mathrm{r}$-seeded.

8. Adlumia.

9. Capnoides. 10. Fumaria.

\section{PAPÀVER L.}

Sap milky. Leaves lobed or dissected, alternate. Flowers and flower-buds nodding. Sepals 2 or occasionally 3. Petals 4-6. Stamens $\infty$. Anthers extrorse. Ovules $\infty$, borne on numerous internally-projecting placentae. Stigmas united into a radiate persistent disk. Capsule globose, obovoid, or oblong, dehiscent near the summit. Seeds marked with minute depressions. [Classic Latin name of the poppy.] About 25 species, mostly natives of the Old World, but 2 or 3 indigenous in western America.

Glabrate and glaucous; leaves lobed, clasping; capsule subglobose. Green, hirsute; leaves pinnately divided.

1. P. somniferum.

Stems branching, leafy; weeds of waste or cultivated ground.

Capsule glabrous.

Capsule subglobose or top-shaped.

Capsule oblong, narrowed below.

Capsule oblong, hispid with a few er ect hairs.
Leaves all basal ; capsule obovoid, densely hispid with erect hairs; arctic. Ar

2. P. Rhoeas.

3. P. dubium.

4. P. Argemone.

5. $P$. radicatum.

I. Papaver somníferum L. OPIUM OR GARDEN POPPY. (I. F. f. 1658.) Erect, glaucous, 3-9 dm. high. Leaves clasping by a cordate base, I-2 dm. long, oblong, wavy, lobed or toothed; flowers 7-10 $\mathrm{cm}$. broad, bluish-white with a purple centre; filaments somewhat dilated upward; capsule glabrous. Occasional in waste grounds and on ballast. Fugitive from Europe. Summer.

2. Papaver Rhoèas L. FIELd, RED OR CORN PoPPy. (I. F. f. I659.) Erect, 3-9 dm. high, hispid with spreading bristly hairs. Lower leaves petioled, I-I.5 dm. long, the upper smaller, sessile, all pinnatifid; lobes lanceolate, acute, serrate; flowers 5-10 cm. broad, scarlet with a darker centre; filaments not dilated; capsule glabrous, the disk with Io or more stigmatic rays. In waste places and on ballast, Me. to Va. Fugitive from Europe. Summer.

3. Papaver dùbium L. Long Smooth-Fruited Poppy. (I. F. f. r660.) Slender, 3-6 dm. high, hirsute with spreading hairs. Lower leaves petioled, I-I.5 dm. long, the upper smaller, nearly sessile, all deeply pinnately clivided; lobes oblong, pinnatifid, cleft or sometimes entire; flowers $5 \mathrm{~cm}$. broad, scarlet, sometimes darker in the centre; filaments not dilated; capsule oblong, klitbrous, J. 5-2 cm. long, narrowed below; stigmatic rays 6-10. In waste and cultivated grounds, Penn. to Va. and southward. Adventive from Europè. Summer.

4. Papaver Argemòne L. PALE, OR LONG Rough-Fruited Poppy. (I. F. f. 166r.) Slender, 3-6 dm. high. Leaves all but the upper petioled, lanceolate in outline, pinnately divided, the divisions pinnatifid and toothed; flowers $2-5 \mathrm{~cm}$. broad, pale red, often with a darker centre; filaments not dilated; capsule oblong, $1.6-2 \mathrm{~cm}$. long, narrowed at the base, bristly.hairy. Waste grounds, Philadelphia, and in ballast about the seaports. Fugitive from Europe. Sunmer. Old name Wind-rose. 
5. Papaver radicâtum Rottb. ARctic Poppy. (I. F. f. I662.) More or less hirsute. Leaves all basal, pinnately lobed or cleft, the lobes linear-oblong; scape erect, slender, 0.5-3 dm. tall, much exceeding the leaves; flower solitary, 2-8 $\mathrm{cm}$. broad, yellow or red; filainents filiform; capsule narrowly obovoid, 1-1.6 $\mathrm{cm}$. high, about $8 \mathrm{~mm}$. in greatest diameter, densely beset with erect bristly hairs. Greenland and Lab. ts Alaska and Br. Col. Also in Europe and Asia. Summer.

\section{ARGEMONNE L.}

Glaucous herbs, with yellow sap, spiny-toothed leaves and large flowers. Sepals 2 or 3 . Petals $4-6$. Stamens $\infty$. Placentae 4-6, many-ovuled. Style very short. Stigma dilated, 3-6-radiate. Capsule prickly, oblong, dehiscent at the apex by valves. Seeds numerous, cancellate. [Greek, an eye disease, supposed to be relieved by the plant so called.] A genus of about 10 species, natives of the warmer parts of America.

Petals yellow or ochroleucous.

1. A. Mexicana.

Yetals white or pinkish.

Stem spiny or unarmed, not hispid-pubescent.

Horns of the sepals nearly erect, the terminal spine $1-1.5 \mathrm{~mm}$. long; flowers peduncled.

2. A. alba.

Horns of the sepals diverging, the terminal spine $2-4 \mathrm{~mm}$. long; flowers usually sessile.

Stem spiny and also hispid-pubescent.

3. A. intermedia.

4. A. hispida.

I. Argemone Mexicàna L. Mexican or Prickly Poppy. (I. F. f. I663.) Stem 3-6 dm. high, spiny or sometimes nearly unarmed. Leaves sessile, clasping by a narrowed base, $\mathbf{I}-\mathbf{2 . 5} \mathrm{dm}$. long, glaucous, runcinate-pinnatifid, spiny-toothed and more or less spiny on the veins; flowers orange or yellow, sessile or subsessile, 2-8 cm. broad; sepals acuminate, bristly-pointed; capsule $2.5 \mathrm{~cm}$. long or more; stigma sessile. In waste places, N. J. and Penn, to Fla. and Tex. Also in ballast about the northern seaports. Adventive from tropical America. June-Sept.

Argemone Mexicana ochroleùca Lindl. Flowers ochroleucous ; style distinct. Occasional with the type.

2. Argemone álba Lestib. White Prickly Poppy. (I. F. f. 1664.) Similar to the preceding species, but commonly stouter and taller. Leaves pinnatifid or pinnately lobed, sometimes whitish along the veins; flowers white, usually larger, 7-10 $\mathrm{cm}$. broad, distinctly peduncled; petals generally cuneate-obovate; terminal spine of the nearly erect, flattened sepal-tips, I-1.5 mm. long; capsules oval-ellipsoid, 2.5-4 cm. long. Fla. to Mo. and Tex. May-Aug.

3. Argemone intermédia Sweet. Leafy, the flowers usually sessile or nearly so. Petals broadly obovate, often as wide as long; horns of the sepals pyramidal, not much flattened, diverging, the terminal spine $2-4 \mathrm{~mm}$. long: capsule cylindricellipsoid. Plains, S. Dak. to Idaho, Tex. and Mex. May-Aug.

4. Argemone híspida A. Gray. Plant spiny, and also densely hispid-pubescent. Petals obovate; horns of the sepals triangular-lanceolate, more or less spiny and hispid. Kans. to N. Mex. and Cal.

\section{SANGUINÀRIA L.}

Rootstock horizontal, thick ; juice red. Leaves basal, palmately veined and lobed, cordate or reniform. Scape I-flowered (rarely 2). Flower white. Sepals 2, fugacious. Petals 8-12, arranged in 2 or 3 rows. Stamens $\infty$. Stigmas grooved. Placentae 2. Capsule oblong, dehiscent to the base, the valves persistent. Seeds smooth, crested. [Name from the red juice.] A monotypic genus of eastern N. Am.

I. San ruinaria Canadénsis L. Bloodroot. (I. F. f. I665.) Glabrous, glaucous, especially when young. Rootstock several inches long, clothed with thick fibrous roots; petioles 1.5-3.5 dm. long; leaves 1.5-3 dm. broad, I-2 dm. long, palmately 5-9-lobed, the lobes repand, or cleft at the apex; flower $2.5-4 \mathrm{~cm}$. broad; petals oblong or obovate, early deciduous; capsule oblong, narrow, I-celled, 2-valved, 2-3 cm. long. In rich woods, N. S. to Manitoba, Neb., Fla. and Ark. April-May. 


\section{STYLÓPHORUM Nutt.}

Herbs, with stout rootstocks, yellow sap, pinnatifid leaves and clustered or solitary flowers. Sepals 2. Petals 4. Stamens. $\infty$. Placentae 2-4; stigma 2-4lobed, radiate. Capsule dehiscent to the base. Seeds cancellate, crested. [Name Greek, style-bearing.] About 4 species, natives of eastern N. Am. and Asia.

I. Stylophor um diphyllum (Michx.) Nutt. Yellow or Celandine Poppy. (I. F. f. 1666.) Glaucous, especially the lower surfaces of the leaves, sparingly pubescent, 3-4.5 dm. high. Leaves I-2.5 dm. long, slender-petioled, I-2-pinnatifid, the divisions obovate, obtuse, lobed or irregularly crenate, those of the stem 2-4, the upper opposite; flowers 2-4, terminal, about $2.5 \mathrm{~cm}$. broad, deep yellow; sepals hirsute, caducous; petals obovate, rounded; capsule $2.5 \mathrm{~cm}$. long, ovoid, acute at each end, hirsute, tipped with the persistent style. In low woods, western Penn. (?), Ohio to Tenn., Wis. and Mo. March-May.

\section{GLAÙCIUM Juss.}

Glaucous herbs, with alternate lobed or dissected leaves, and saffron-colored sap. Sepals 2. Petals 4. Stamens $\infty$. Placentae 2, rarely 3; stigma sessile, dilated, 2-lobed, the lobes convex. Capsule long-linear, 2-celled, dehiscent to the base. Seeds cancellate, crestless. [Name Greek, from the glaucous foliage.] About 6 species, natives of the Uld World.

1. Glaucium Glaùcium (L.) Karst. Yellow Horned or Sea Poppy. (I. F. f. 1667.) Stout, 6-9 dm. high. Leaves thick, ovate or oblong, 0.7-2 dm. long, scurfy, the lower petioled, the upper sessile, clasping, all pinnatifid, the divisions toothed; flowers axillary and terminal, yellow, 2-5 cm. broad; capsule narrcwly linear, 1.5-3 dm. long, tipped with the persistent stigma. In waste places, R. I. to Va. Adventive from Europe. Summer.

\section{CHELIDÒNIUM L.}

Erect branching herbs, with alternate, deeply pinnatifid leaves, yellow sap and yellow flowers. Sepals 2. Petals 4. Stamens $\infty$. Placentae 2. Styles distinct; stigma not dilated, 2-lobed. Capsule linear, dehiscent to the base. Seeds smooth, shining, crested. [Name Greek for the swallow.] A monotypic genus of Europe and Asia.

1. Chelidonium màjus L. Celandine. (I. F. f. 1668.) Weak, 3-6 dm. high, sparingly pubescent. Leaves thin, I-2 dm. long, glaucous beneath, I-2pinnatifid, the segments ovate or obovate, crenate or lobed; petioles often dilated at the base; flowers $12-16 \mathrm{~mm}$. broad, in axillary pedunculate umbels; petals rounded; pedicels slender, elongating in fruit; capsule glabrous, 2-5 cm. long, tipped with the persistent style and stigma. Was:e places, roadsides and woods, common in the East. Nat. or adventive from Europe. Summer. April-Sept.

\section{BICUCÚlLA Adans. [DICENTRA Bernh.]}

Herbs, with dissected leaves, and clustered irregular flowers. Pedicels 2 bracted. Sepals 2, scale-like. Corolla cordate at base ; petals 4, in 2 pairs, connivent, slightly coherent, the exterior pair oblong, concave. spurred at the base, spreading at the apex, the inner narrow, clawed, coherent above, crested or winged on the back. Stamens 6 , in two sets placed opposite the outer petals ; filaments more or less diadelphous. Placentae 2; style slender; stigma 2-4 lobed. Capsule oblong or linear, dehiscent to the base by 2 valves. Seeds crested. [Name from the Latin, double-hooded.] About 14 species, natives of N. Am. and western Asia.

Racerne simple; flowers white or whitish.

Spurs divergent ; inner petals minutely crested.

Spurs short, rounded; in ner petals conspicuously crested. Raceme compound: flowers deep pink.

I. B. Cucullaria.

2. B. Canadensis.

3. B. eximia.

I. Bicuculla Cucullària (L.) Millsp. Dúrchman's Breeches. Soldier's CAP. (I. F. f. 1669.) Delicate, glabrous, I-2.5 dm. high, from a bulbous base. Leaves basal, pale beneath, slender-petioled, ternately compound, the divisions stalked and dissected into linear or oblanceolate segments; scape slender; raceme secund, 4-10-flowered; flowers nodding, pedicelled, 12-16 mm. long, 6-20 mm. 
broad at the base, white, or faintly pink, yellow at the summit; spurs widely divergent. In woods, N. S. to Minn., Wash., N. Car., Neb. and Mo. April-May.

2. Bicuculla Canadénsis (Goldie) Millsp. Squirrel Corn. (I. F.f. r67o.) Similar, the rootstock bearing numerous small tubers. Leaves decidedly glaucous beneath; flowers nodding, short-pedicelled, 14-18 $\mathrm{mm}$. long, Io $\mathrm{mm}$. broad at the base, greenish white, purplish tinged, slightly fragrant; spurs short, rounded. In rich woods, N. S. to Minn., Va., Ky., Neb. and Mo. May-June.

3. Bicuculla exímia (Ker) Millsp. Wild Bleeding-heart. (I. F. f. I671.) Glabrous, somewhat glaucous, 3-6 dm. high; rootstock scaly. Leaves larger than those of the preceding species, ternately parted, the divisions stalked, finely pinnatifid into oblong or ovate segments; scape slender, about equalling the leaves; raceme compound; flowers clustered in cymes, slender-pedicelled, pink, nodding, r6-20 mm. long, 6-8 mm. broad at the base; spurs short, rounded, incurved; outer petals spreading at the apex. In rocky places, W. N. Y. to Ga. and Tenn. May-Sept.

\section{ADLÙMIA Raf.}

A glabrous climbing vine, with decompound leaves. Sepals 2, scale-like. Petals 4, permanently united into a narrowly ovate cordate persistent spongy corolla 4-lobed at the apex. Stamens 6, monadelphous below, diadelphous above, adherent to the petals. Capsule oblong, included in the persistent corolla. Seeds crestless. Closely related to certain Asiatic species of Bicuculla. [In honor of John Adlum, a gardener of Washington.] A monotypic genus of eastern N. Am.

I. Adlumia fungòsa (Ait.) Greene. Climbing Fumitory. Alleghany VINE. (I. F. f. I672.) Weak, slender, climbing by slender petioles. Leaves bipinnate, the divisions slender-stalked; ultimate segments lobed or entire, very thin, ovate or cuneate, pale beneath; flowers numerous in axillary drooping cymes, 10-I4 mm. long, $6 \mathrm{~mm}$. broad at the base, greenish purple; capsule 2-valved, fewseeded. In moist woods and thickets, N. B. to Ont., N. Car. and Tenn. June-Oct.

\section{CAPNOİDES Adan. [CORYDALIS Vent.] (See Appendix.)}

Herbs, with decompound leaves, and racemose flowers. Sepals 2, small. Corolla irregular, deciduous; petals 4 , erect-connivent, one of the outer pair spurred at the base, the interior ones narrow, keeled on the back. Stamens 6, in 2 sets, opposite the outer petals. Placentae 2 ; style entire, dilated or lobed, persistent. Capsule linear or oblong, 2-valved. [Greek, smoke-like. in allusion to the smokelike odor of some species, as in Fumaria.] About I Io species, natives of the north temperate zone and South Africa.

Stems tall; flowers pink with yellow tips.

I. C. sempervirens.

Stems low, diffuse or ascending; flowers yellow.

Flowers 6-8 mn. long; suur short.

Seeds sharp-margined, wrinkled; pods drooping or spreading.

Seeds blunt-margined, smooth, shining: pods ascending. 3. C. micranthum.

Flowers 8-16 mm. long: spur conspicuous.

Pods smooth.

Seeds smoorh or obscurely reticulated.

Capsules spreading or drooping, distinctly tcrulose; eastern.

Capsules ascending, terete or slightly torulose; western.

4. C. aureum.

5. C. montanum.

Seeds finely muriculate; pods ascending.

Pods densely covered with transparent vesicles.

6. C. curvisiliquum.

7. C. crystallinum.

I. Capnoides sempérvirens (L.) Borck. Pink Corvdalis. (I. F. f. I673.) Glabrous, glaucous, 3-6 dm. high. Lower leaves $2-10 \mathrm{~cm}$. long, short-petioled, the upper nearly sessile, pinnately decompound, the ultimate segments obovate or cuneate, toothed or entire, obtuse, often mucronulate; flowers numerous, 1o-16 $\mathrm{mm}$. long, pink with a yellow tip; spur rounded, about $2 \mathrm{~mm}$. long; capsules narrowly linear, erect, 2-5 cm. long, nodose when mature ; seeds shining, minutely reticulated. In rocky places, N. S. to Alaska, N. Car. and Minn. April-Sept. 
2. Capnoides flávulum (Raf.) Kuntze. Pale Corvdalis. (I. F. f. 1674.) Slen. der, glabrous, diffuse or ascending, 1.5-3.5 $\mathrm{dm}$. high. Lower leaves petioled, the upper nearly sessile, all finely dissected into linear or oblong, sometimes cuneate, segments ; pedicels very slender; bracts conspicuous, broadly oblong, acute or acumi. nate, 4-8 $\mathrm{mm}$. long; spur I $\mathrm{mm}$. long, rounded; outer petals sharp.pointed; crest dentate; pods torulose; seeds sharp-margined, finely reticulated. In rocky woods, S. N. Y. to S. W. Ont., Minn., Va., Kans. and La. May-June.

3. Capnoides micránthum (Engelm.) Britton. Small-Flowered Corydalis. (I. F. f. 1675.) Habit and foliage nearly as in the preceding, the ultimate leafsegments generally slightly broader. Flowers similar, the crest entire; or some. times cleistogamous and minute, spurless; pods ascending, short-pedicelled, torulose; seeds obtuse-margined, smooth, shining. In woods, Minn. to Mo., Kans., Tex., Va. and Fla. Feb.-April.

4. Capnoides àureum (Willd.) Kuntze. Golden Corydalis. (I. F. f. I676.) Glabrous, 1-3.5 dm. high, diffuse. Leaves all but the uppermost petioled, finely dissected into oblong obovate or cuneate segments ; flowers $12 \mathrm{~mm}$. long ; spur onehalf the length of the body of the corolla, or more, rounded; outer petals keeled, not crested ; pedicels short, slender; pods spreading or pendulous, torulose : seeds obtuse-margined, shining, obscurely reticulated. In woods, N. S. to Ảlask., Penn. and Wis., south in the Rocky Mountains to Ariz. March-May.

5. Capnoides montànum (Engelm.) Britton. Mountain Corydalis. (I. F. f. I677.) Closely resembles $C$ aureum, but lighter green, and the leaves often more finely divided. Flower-clusters spicate-racemose, the pedicels usually very short; flowers $12-16 \mathrm{~mm}$. long; spur of the corolla as long as its body, or less; capsules spreading or somewhat ascending; seeds sharp margined, shining or obscurely reticulated. In dry soil, S. Dak. to Kans., Tex., Ore. (?), Utah and Mex. April-Aug.

6. Capnoides curvisıliquum (Engelm.) Kuntze. Curved-fruited CoryDALIS. Usually stout, similar to the two preceding species, often rather taller than either. Flowers spicate or spicate-racemose, about $16 \mathrm{~mm}$. long, conspicuous: spur of the corolla conspicuous; pods curved upward, very short-pedicelled, stout, somewhat 4-sided; seeds sharp-margined, finely muriculate. Apparently restricted in distribution to Texas, though reported from much farther north. April June.

7. Capnoides crystállinum (Engelm.) Kuntze. Vesicular Corydalis. (I. F. f. I679.) Erect or ascending, glabrous, 2-5 dm. high. Lower leaves slender petioled, the upper sessile, all finely dissected into oblong or cuneate segments; pedicels stout, short, diverging; flowers spicate, 12-16 mm. long; spur 6-8 $\mathrm{mm}$. long; crest large, dentate; capsules $18 \mathrm{~mm}$. long, ascending or erect, densely covered with transparent vesicles; seeds acute-margined, reticulated. Prairies, Mo., Kans. and Ark. April-June.

\section{I0. FUMÀRIA L.}

Herbs, with finely dissected leaves, and small racemose flowers. Sepals 2, scale-like. Petals 4, erect-connivent, the outer pair larger, I of them spurred, the inner narrow, coherent at the apex, keeled or crested on the back. Stamens 6, diadelphous, opposite the outer petals. Ovule I; style slender; stigma entire or lobed. Fruit I-seeded, nearly globose, indehiscent. [Name from the Latin, smoke, from the smoke-like smell of some species.] About 15 species, all natives of the Old World.

I. Fumaria officinàlis L. Fumitory. HedGe Fumitory. (I. F. f. i68o.) Glabrous; stems diffuse or ascending, 1.5-9 dm. long. Leaves petioled, finely dissected into entire or lobed linear oblong or cuneate segments; racemes $2-8 \mathrm{~cm}$. long, narrow; pedicels $2-4 \mathrm{~mm}$. long, axillary to small bracts; flowers purplish, 4-6 $\mathrm{mm}$. long, darker at the summit; spur rounded, I $\mathrm{mm}$. long; nut $2 \mathrm{~mm}$. in diameter, depressed-globose. In waste places and on ballast, N. S. to Fla. and the Gulf States, and locally in the interior. Fugitive or adventive from Europe.

Summer. 


\section{Family 2. CRUCÍFERAE B. Juss.}

\section{Mustard Family.}

Herbs, rarely somewhat woody, with watery acrid sap, alternate leaves, and racemose or corymbose flowers. Sepals 4 , deciduous, or rarely persistent, the 2 outer narrow, the inner similar, or concave, or saccate at the base. Petals 4, hypogynous, cruciate, nearly equal, generally clawed. Stamens 6, hypogynous, tetradynamous, rarely fewer. Pistil 1, compound, consisting of 2 united carpels, the parietal placentae united by a dissepiment; style generally persistent, sometimes none; stigma discoid or usually more or less 2 -lobed. Fruit a silique or silicle, generally 2 -celled, rarely $\mathbf{I}$-celled, in a few genera indehiscent. Seeds attached to both sides of the septum; endosperm none; cotyledons incumbent, accumbent or conduplicate. About 185 genera and 1500 species, of wide geographic distribution.

The following wholly artificial key is designed to apply only to the species and genera of our Flora. The natural alliances of the genera are largely based on minute characters. The family is also known as BrassicaceaE.

* Pod a silique or silicle, dehiscent into two valves to the base.

$\dagger$ Pod an elongated-linear silique, or at least twice as long as wide. (See also species of No. 29.)

I. Silique borne on a long stipe.

I. Stanleya.

2. Silique terete, 4-sided, or compressed, very slıort-stipitate, or sessile on the receptacle.

a. Silique tipped with the short sler.der style, or style none.

Seeds globose or oblong, wingless.

Seeds in 2 rows in each cell of the pod.

Pubescence, when present, of simple hairs.

Pubescence of forked hairs; leaves finely dissected.

Seeds in only 1 row in each cell.

Leaves auricled at the base; flowers violet.

Leaves reniform or cordate, undulate or repand; flowers white.

17. Roripa.

30. Sophia.

8. Alliaria.

Leaves dentate or pinnatifid; hairs simple; flowers yellow.

9. Sisymbrium.

Leaves finely dissected; pubescence of forked hairs; flowers yellow.

Leaves entire, or slightly toothed.

31. Sophia.

Stigma nearly entire, discoid; plant glabrous. 2. Thelypodium.

Stigma 2-lobed; plants more or less pubescent.

Flowers white or pink.

Valves of the silique nerved.
Leaves dentate to pinnatifid.
9. Sisymbrium.

Leaves entire, cordate.
Valves of the silique nerveless, rounded.

39. Conringia.

Flowers yellow.

Flowers large, purple, purplish or white. 38. Hesperis.

Seeds flat, wingless or winged.

32. Stenophragma.

34. Erysimum.

Siliques 4-angled, the valves keeled; flowers yellow.

Siliques flat or flattish.

Valves of the silique nerveless.

r6. Barbarea.

Seeds winged; stem scape-like; flowers few. 23. Leavenworthia.

Seeds wingless; valves of the silique elastically dehiscent.

Stems leafy below or throughout. r. Cardamine.

Stems leafless below, 2-4-leaved above. 20. Dentaria.

Valves of the silique I-nerved or veiny, not elastically dehiscent.

b. Silique produced into a beak beyond the valves.

33. Arabis.

Beak conic, very short in no. 13 .

Silique terete; seeds in 1 row.

Silique flat: seeds in 2 rows.

13. Brassica.

Beak flat, sword-shaped.

14. Diplotaxis.

12. Sinapis. 
3. Silique elliptic or oblong, very flat, 2-3 times as long as broad, clearly stipitate.

Flowers violet; funiculus of the seed adnate to the septum of the pod.

Flowers yellow; funiculus of the seed free from the septum. 21. Lunaria. 22. Selenia.

†† Pod an orbicular globose or oblong silicle, or but little more than twice as long as wide (except in some species of no. 29).

I. Silicle globose, or flattened parallel with the septum.

a. Plants terrestrial, or not strictly aquatic.

+ Silicle globose, or terete-oblong, little or not at all compressed.

Plants not maritime.

Petals not 2-cleft.

Seeds minute, round, not flattened, in 2 rows in each cell.

Seeds flat; silicle inflated; plants stellate-pubescent.

Petals 2-cleft.

Plants maritime, fleshy, northern.

++ Silicle didymous, its cells globose-inflated.

+++ Silicle compressed or flat, many-seeded.

$$
\text { 2-8-seeded. }
$$

Flowers yellow.

Flowers white.

++++ Silicle pear-shaped, or obovoid, many-seeded.

b. Wholly submersed small aquatic; silicle globose or oblong.

2. Silicle fiattened at right angles to the narrow septum.

Seeds several in each cell of the silicle.

Silicle triangular, obcuneate.

Silicle elliptic, wingless, its valves with a strong nidvein.

Silicle oblong or orbicular, winged all around.

Seeds solitary in each cell, compressed.

\section{** Pod indehiscent, short or elongated.}

Pod broader than long. more or less didymous.

Pod globose, reticulated.

Pod elongated.

Pod of 2 joints, separating at maturity; plants maritime.

Pod constricted between the seeds, not jointed, beaked.

Pod obcuneate to spatulate, flattened.

\section{STÁNLEYA Nutt.}

Glabrous and glaucous, perennial tall herbs, with large yellow bractless flowers in elongated terminal racemes. Sepals linear, narrow. Petals narrow, long. clawed. Stamens 6, very nearly equal; anthers twisted. Ovary short-stipitate; style short or none. Siliques linear, long-stipitate, spreading or recurving, somewhat compressed, dehiscent, the valves with a strong midnerve. Seeds in I row in each cell, numerous, pendulous. Cotyledons straight, incumbent. [Named for Lord Edward Stanley, President of the Linnaean Society.] About 3 species, of western N. Am.

I. Stanleya pinnàta (Pursh) Britton. Stanleya. (I. F. f. r681.) Stems 0.6-1.5 m. tall, sometimes decumbent. Lower leaves pinnatifid or pinnately divided, or entire, I-2 dm. long, long-petioled; upper leaves similar, or less divided, or narrowly oblong or lanceolate, entire, short-petioled; petals $1.5-2.5 \mathrm{~cm}$. long; filaments filiform, exserted; siliques 5-8 cm. long, about $2 \mathrm{~mm}$. thick, 2-3 times as long as their stipes, downwardly curved, somewhat constricted between the seeds when dry. In dry soil, S. Dak. and Neb. to Cal., N. Mex. and Ariz. May-July. [S. pinnatifida. Nutt.]

\section{THELYPÒDIUM Endl.}

Erect biennial or perennial herbs, with entire toothed or pinnatifid leaves, and racemose flowers. Siliques nearly terete, linear, with a short stipe in some species; valves I-nerved, dehiscent; stigma nearly entire. Seeds in I row in each cell of the pod, oblong, marginless ; cotyledons obliquely incumbent. [Greek, femalestalk, from the stiped ovary.] About I8 species, natives of N. Am.

1. Thelypodium integrifolium (Nutt.) Endl. ENTIRE-Leaved Thelypodium. (I. F. f. I682.) Glabrous, 0.9-1.8 m. high. Leaves entire, thickish, 
the basal and lower ones petioled. narrowly oval or oblong, 5-10 $\mathrm{cm}$. long, the upper sessile, linear, lanceolate or oblong-lanceolate, acute or acuminate; flowers pink, in short racemes; pedicels siender, 4-8 mm. long; petals obovate or spatulate, long-clawed; pods about $2.5 \mathrm{~cm}$. long and $\mathrm{I} \mathrm{mm}$. wide; stipe very short; style slender, nearly $2 \mathrm{~mm}$. long. Neb. and Wyo. to Ore., Utah and N. Mex. JulySept.

\section{SUBULÀRIA L.}

Small annual aquatic submersed herbs, with basal linear subulate leaves, and minute racemose white flowers. Silicles short-stipitate, oblong or elliptic, the valves convex, ribbed on the back. Stigma sessile, entire. Seeds few, in 2 rows in each cell, marginless. Cotyledons incumbent, curved above their base. [Latin awl, from the awl-shaped leaves.] A monotypic genus of the northern hemisphere.

I. Subularia aquática L. Water Awlwort. (I. F. f. 1683.) Tufted, glabrous, 2-10 cm. high, growing in shallow water. Flowering scape simple, lateral; leaves nearly cylindric, $\mathbf{r}-3 \mathrm{~cm}$. long: flowers few, distant; pedicels slender, 2-6 mm. long in fruit; pods $2-3 \mathrm{~mm}$. long. In clear, cold lakes, Newf. to Br. Col., Me., Vt. and Ont., south in the Rocky Mts. to Wyo., and to Cal. Also in Europe and Siberia. June-Sept.

\section{LEPÍDIUM L. (See Appendix.)}

Erect or rarely diffuse herbs, with pinnatifid lobed or entire leaves and racemose white or whitish flowers. Stamens often fewer than 6 . Petals short, sometimes none. Silicles oblong or obovate, flattened contrary to the partition, winged or wingless; valves keeled, dehiscent. Seeds solitary in each cell, flattened; cotyledons incumbent or rarely accumbent. [Greek, a little scale, from the flat scale. like pods.] About $6_{5}$ species, widely distributed. In addition to the following, about $\mathbf{I} 6$ others occur in western N. Am.

Stem-leaves clasping by an auriculate base.

Pods broadly ovate, winged.

Pods wingless, broader than long.

Stem-leaves petioled or sessile, not clasping.

Pods and seeds entirely wingless; petals none.
Pods slightly winged above, orbicular or oval, about $2 \mathrm{~mm}$. broad; petals present or none.

Cotyledons accumbent; petals generally present, Cotyledons incumbent; petals minute or wanting.

Pods oblong, winged all around, longer than wide, about $4 \mathrm{~mm}$. high.

1. L. campestre.

2. L. Draba.

3. L. ruderale.

6. L. sativum.
.

I. Lepidium campéstre (L.) R. Br. Field or Cow CRess. (I. F. f. I684.) Annual or biennial, erect, $2-4.5 \mathrm{dm}$. high, branching above, hoary-pubescent with scale-like hairs or rarely nearly glabrous. Basal leaves entire, or pinnatifid in the lower part, obtuse, petioled, 5-8 cm. long; stem-leaves oblong or lanceolate, entire or slightly dentate, sessile, clasping ; flowers white or yellowish ; pedicels rather stout, spreading, $48 \mathrm{~mm}$. long in fruit; pods forming dense elongated racemes, broadly ovate, slightly curved upward, broadly winged at the apex, notched, tipped with a minute style. In fields and waste places, N. S. and Ont. to Va.. Kans., and on the Pacific Coast, a bad weed in the Middle States. Nat. from Europe. May-July.

2. Lepidium Dràbz L. HoARy CRess. (I. F. f. 1685.) Perennial, erect or ascending, $2-4.5 \mathrm{dm}$. high, hoary-pubescent. Leaves oblong or lanceolate-oblong, obtuse, slightly dentate or entire, $3-5 \mathrm{~cm}$. long. the lower petioled, the upper sessile and clasping; pedicels 6-12 mm. long in fruit; flowers white, about $4 \mathrm{~mm}$. broad; pods broadly ovate, or cordate, $3 \mathrm{~mm}$. long, in short racemes; valves papillose, keeled, tipped with a style $\mathbf{I}-2 \mathrm{~mm}$. long. Near Astoria and Syracuse, N. Y., and on ballast about the seaports. Also in Colo. and Cal. Fugitive from Europe. April-June.

3. Lepidium ruderàle L. Roadsine Pepper-grass. (I. F. f. 1686.) Annual, 1.5-4 dm. high, glabrous, wiry. Basal and lower leaves oblong in outline, 2-10 cm. long, I-2-pinnatifid into linear or oblong obtuse segments; upper leaves 
smaller, entire or with a few lobes; flowers I mm. broad or less, greenish ; petals none ; stamens 2 ; pods flat, not margined, about $2 \mathrm{~mm}$. in length, short-oval or suborbicular; pedicels slender, 3-4 mm. long in fruit; valves sharply keeled, barely winged; cotyledons incumbent. In waste places, on ballast and along roadsides, N. S. to Tex. Nat. from Europe. Summer.

4. Lepidium Virgínicum L. Wild Pepper-grass. (I. F. f. I687.) Similar to $L$. ruderale. Basal leaves obovate or spatulate in outline, less pinnatifid, generally with a large terminal lobe and numerous small lateral ones, all dentate, glabrous or slightly pubescent; stem-leaves lanceolate or oblong-linear, sessile, or the lower sta!ked; flowers I-2 mm. broad, white; petals generally present, sometimes wanting in the later flowers; pedicels slender, spreading, 4-6 $\mathrm{mm}$. long in fruit; pod flat, short-oval or orbicular, minutely winged above; cotyledons accumbent. In fields and along roadsides, Quebec to Minn., Colo., Fla., Tex. and Mex. Also in the West Indies. May-Nov.

5. Lepidium apétalum Willd. Apetalous Pepper-grass. (I. F. f. I688.) Much like L. ruderale and L. Virginicum. Basal leaves pinnatificl. Pods nearly orbicular, slightly wing-margined above, about $2 \mathrm{~mm}$. in diameter; flowering pedicels ascending, forming narrow racemes, or in fruit spreading; petals minute or wanting: cotyledons incumbent. In dry soil, Me. and Ont. to Cal., D. C. and Tex. Apparently nat. trom Asia. May-Aug.

Lepidium mèdıum Greene, with rather large white petals, orbicular pods, $3 \mathrm{~mm}$. broad, and incumbent cotyledons, is found by Mr. Bicknell near New York city, and on Mt. Desert Island, Me. It is native of Western N. Am.

6. Lepidium sativum L. Garden, TOWn, OR Golden Pepper-grass. (I. F. f. I689.) Glabrous, bright green ; stem about $3 \mathrm{dm}$. high. Lower leaves 2pinnate, or pinnate with the segments lobed or pinnatifid, 0.7-2 dm. long; upper leaves sessile or nearly so, much smaller; flowers in loose elongated racemes, about $2 \mathrm{~mm}$. broad; petals present. often pinkish; silicles oval, about $2 \mathrm{~mm}$. wide, equalling or longer than their pedicels, emarginate, winged all around; style very short. In waste places, Quebec to N. Y. and Br. Col. Escaped from gardens. Native of Europe. May-Aug.

\section{CORÓNOPUS Gaertn. [SENEBIERA DC.]}

Annual or biennial, diffuse herbs, with mostly pinnatifid leaves, and small whit. ish flowers. Silicles small, didymous, laterally compressed, sessile. Stamens often only 2 or 4 . Valves of the capsule oblong or subglobose, obtuse at each end, indehiscent, falling away from the septum at maturity. Seeds I in each cell; cotyledons narrow, incumbent or conduplicate. [Greek, crow-foot, from the shape of the leaves.] About 6 species, of wide distribution..

Pod rugose, not crested.

Pod coarsely wrinkled, crested.

I. Coronopus didymus r69o.) Tufted, spreading on the ground, sparingly pubescent. Stems 0.5-4 dm. long; leaves deeply I-2-pinnatifid ; flowers white, racemose ; pedicels slender, 2-3 $\mathrm{mm}$. long in fruit; pod about $2 \mathrm{~mm}$. broad and slightly more than $\mathrm{I} \mathrm{mm}$. high ; valves obtuse at each end and readily separating into 2 ovoid nutlets. In waste places, Newf. to Fla., Mo. and Tex., west to Cal. Summer. Nat. from the south.

2. Coronopus Corónopus (I.) Karst. WART or Swine's Cress. (I. F. f. I69I.) Tufted, spreading on the ground, succulent, glabrous and glaucous, or.with a few spreading hairs. Leaves similar to those of the last species, generally larger, sometimes less divided; flowers similar; pedicels stout, $2 \mathrm{~mm}$. long or less; pod $4 \mathrm{~mm}$. broad and about $3 \mathrm{~mm}$. high, flattish, rounded, apiculate at the summit, marked with coarse wrinkles which form a crest around the margin; valves not distinctly separate. In waste places and on ballast, N. B. to Fla. and Tex., and on the Pacific Coast. Fugitive or adventive from Europe. Summer.

\section{THLÁSPI L.}

Erect glabrous herbs, with entire or dentate leaves, those of the stem, or at least the upper ones, auriculate and clasping. Flowers white or purplish. Siliques obcuneate, obcordate, or oblong-orbicular, mostly emarginate, flattened at right angles to the narrow septum, crested or winged. Valves dehiscent. Seeds 2 or 
several in each cell, wingless. Cotyledons accumbent. [Greek, to flatten, from the flat pod.] A genus of about 25 species, natives of temperate, arctic and alpine regions. In addition to the following, 2 others occur in western $\mathrm{N}$. Am.

Lower stem-leaves not clasping; seeds rugose.

All the stem-leaves cordate-clasping; seeds smooth.
1. $T$. arvense.

2. T. perfoliatum.

I. Thlaspi arvénse L. Field Penny-Cress. (I. F. f. 1692.) Annual, glabrous, 1.5-4.5 dm. high. Basal leaves petioled, oblanceolate, early deciduous; stem-leaves oblong or lanceolate, sparingly dentate, the upper clasping the stem by an auricled base; flowers white, about $1 \mathrm{~mm}$. broad; pedicels spreading or curved upward, slender, $1-2 \mathrm{~cm}$. long in fruit; pods nearly orbicular, 8-12 mm. broad, very flat, broadly winged all around, notched at the apex, in long racemes; style minute, or none; seeds about 6 in each cell. In waste places and on ballast, Quebec to Man., the N. W. Terr., N. Y. and Kans. June-Aug.

2. Thlaspi perfoliàtum L. Perfoliate Penny-Cress. (I. F. f. I693.) Annual, glabrous; stems $0.5^{-2} \mathrm{dm}$. tall. Basal leaves ovate or suborbicular; stemleaves oblong or oblong-lanceolate, sessile, clasping, I-2.5 cm. long; pedicels filiform, spreading: silicle obovate-orbicular, 4-6 $\mathrm{mm}$. broad, rather rarrowly winged, broadly notched at the summit; style short but manifest; seeds usually 4 in each cell. Near Hamilton, Ont. Fugitive or adventive from Europe. May-Aug.

\section{COCHLEÀRIA L.}

Maritime herbs, with simple mostly fleshy leaves, and white or rarely purplish or yellowish racemose flowers. Silicle inflated, oblong or globose. Valves very convex, dehiscent. Stigma nearly simple, or capitate. Seeds several in each cell of the pod, usually in 2 rows, marginless. Cotyledons mainly accumbent. [Greek, spoon, from the shape of the leaves.] About 25 species, natives of the colder parts of the north temperate zone. Besides the following, about three others are found on the arctic and northern Pacific coasts of N. Am.

Stem-leaves oval or oblong, subsessile or with a broad-winged petiole. 1. C.officinalis. Stem-leaves deltoid to hastate, all except the uppermost slender petioled.

2. C. Danica.

r. Cochlearia officinàlis L. ScuRvy-GRASS. (I. F. f. I694.) Annual to perennial, diffuse, branching, glabrous, some what fleshy, the branches $15-30 \mathrm{~cm}$. long. Lower leaves long-petioled, oblong, orbicular or reniform, obtuse, $1-3 \mathrm{~cm}$. loing, dentate or entire; flowers white, 4-5 mm. broad; petals emarginate, or entire; pods globose or ovoid, 4-6 mm. long, smooth or reticulated. Along seacoasts and rivers, Anticosti to Greenland and arctic America. Also in arctic Europe and Asia. Summer.

2. Cochlearia Dánica L. Danish Scurvy-grass. Annual with slender $\mathrm{d}$ ffuse branches, $\mathbf{1}-2 \mathrm{dm}$. long. Lower leaves rounded, reniform, 3-6 mm. in diam-

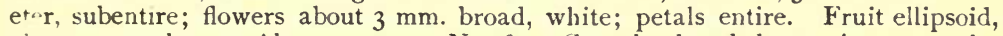
ahout $4 \mathrm{~mm}$. long. Along seacoast, Newf. to Greenland and the arctic coast; also in Europe. Summer.

\section{ALLIÀRIA Adans.}

Biennial or perennial, sparingly pubescent or glabrous herbs, with broad dentate cordate or reniform leaves, and rather large racemose white flowers. Sepals short. Petals oblong. clawed. Stamens 6. Style short, conic. Siliques linear, slightly constricted between the seeds when dry, the valves with a strong mid. nerve, dehiscent from the base. Seeds oblong, striate, in I row in each cell; cotyledons flat, incumbent. [Fro'n Allium. garlic, on account of its similar odor.] About 5 species, natives of Furpe and Asia.

T. Alliaria Alliària (L.) Britton. Hedge-garlic. Garlic Mustard. (I. F. f. I695.) Erect. 3.9 dm. high, glabrous, or with a few hairs on the petioles and leaf-margins. Leaves cr'nate or undulate, the lower $0.5^{-2} \mathrm{dm}$. broad on long petioles, the upper smaller, sessile or nearly so; pedicels $4-6 \mathrm{~mm}$. long, spreading an 1 very stout in fruit; flowers $6.8 \mathrm{~mm}$. broad; pods glabrous, stiff, $2-5 \mathrm{~cm}$. long, 2 mm. thick. pointed, 4-sided when dry. Waste places, woods and along roadsides, Ont., N. Y., N. J. and Va. May-June. [.Sisymbrium Alliaria L.] 


\section{SISÝMBRIUM L.}

Annual or biennial, mostly tall herbs, with simple entire lobed or pinnatifid leaves, and yellow white or rarely pink flowers. Petals generally elongated. Siliques elongated, linear, many-seeded. Valves mostly 3-nerved, dehiscent. Stigma nearly simple, or with 2 short lobes. Seeds in 1 row in each cell of the pod, marginless. Cotyledons incumbent. [Ancient Greek name of some crucifer.] A genus of about 50 species, of wide distribution. In addition to the following, about 8 others are found in western N. Am.

\section{Leaves runcinate-pinnatifid.}

Flowers yellow; pods $\mathbf{I}-\mathbf{I} .5 \mathrm{~cm}$. long, appressed.

Flowers cream-color; pods 5-10 cm. long, divergent. Leaves oblong or spatulate, dentate; flowers white or pink.

1. S. officinale.

2. $S$. altissimum. 3. S. humile.

I. Sisymbrium officinàle (L.) Scop. Hedge Mustard. (I. F. f. 1696.) Erect, 3-9 dm. high, with rigid spreading branches. Leaves runcinate-pinnatifid, the lower petioled, the upper nearly sessile; lobes oblong, ovate or lanceolate, the lower ones often recurved ; pedicels $2 \mathrm{~mm}$. long, erect in fruit; flowers yellow, 3 $\mathrm{mm}$. broad, pods linear, acuminate, glabrous or slightly hairy, closely appressed; valves with a strong prominent midrib. In waste places, common throughout our area, except the extreme north. Nat. from Europe. May-Nov.

2. Sisymbrium altıssimum L. TAll Sisymbrium. (I. F. f. I697.) Erect, 6-12 dm. high, freely branching, glabrous or nearly so. Lowest leaves runcinatepinnatifid, petioled, the lobes often auriculate; upper leaves shorter petioled, deeply pinnatifid, the lobes linear or lanceolate, often with a narrow projection on the lower side near the base ; uppermost leaves often reduced to linear bracts ; flowers yellowish, about $6 \mathrm{~mm}$. broad; pedicels $6-8 \mathrm{~mm}$. long, spreading or ascending, thickened in fruit; pods narrowly linear, divergent, I $\mathrm{mm}$. wide; valves with a prominent midrib. In waste places, Quebec and Ont. to Alberta, D. C. and Mo. Adventive from Europe. Summer.

3. Sisymbrium hùmile Meyer. Low or Northern Rock-Cress. (I. F. f. I698.) Perennial, erect, I-2.5 dm. high, sparingly pubescent, with branched hairs. Leaves spatulate, or oblanceolate, the lower obtuse, $2-5 \mathrm{~cm}$. long, narrowed into a petiole, sharply dentate or rarely entire, the upper smaller, often acute; flowers white or pink, 3-4 mm. broad; pedicels 4-6 mm. long in fruit; pods nearly terete, narrowly linear, $\mathbf{I}-2 \mathrm{~cm}$. long. I $\mathrm{mm}$. wide; valves finely nerved; style I $\mathrm{mm}$. long. In rocky places, Anticosti, Willoughby Mountain, Vt., Lake Superior, to Alaska and Oregon. July.

\section{CAKÌLE Gaertn:}

Annual, glabrous fleshy branching herbs, with purplish flowers. Siliques elongated, sessile, flattened or ridged, indehiscent, 2 -jointed, the joints I-celled and I-seeded. Style none; cotyledons accumbent. [Old Arabic name.] A genus of about 3 species, natives of sea and lake shores of Europe and N. Am.

I. Cakile edéntula (Bigel.) Hook. Amfrican SEA Rocket. (I. F. f. I699.) Bushy-branched from a deep root, the lower branches spreading or ascending, the central ones erect, $3 \mathrm{dm}$. in height or less. Leaves oblanceolate, or obovate, obtuse, sinuate-dentate or lobed, narrowed at the base, the lower 7-13 cm. long ; flowers light purple, 4-6 $\mathrm{mm}$. broad; petals long-clawed, more than twice the length of the sepals; pod I-2 cm. long, upper joint slightly longer than the lower, ovoid, flattened, narrowed into a beak above; lower joint obovoid, not flattened. In sands of the seashore, Newf. to Fla., and along the Great Lakes, N. Y. to Minn. Also on the California coast. Summer.

\section{MỲAGRUM L.}

An annual glabrous glaucous branching herb, with entire or undulate oblong to lanceolate leaves, the lower petioled, the upper sessile and deeply auricled at the base. Flowers small, yellow, in elongating racemes; pedicels short, erect-ascending, bractless. Sepals nearly erect. Petals short : longer stamens somewhat connate in pairs. Silicle obcuneate to spatulate, flattened, indehiscent, falsely 3 -celled, I-seeded, tipped by the short style. Seed pendulous; cotyledons incumbent. [Greek, a fly-trap.] A monotypic genus of Europe and Asia. 
I. Myagrum perfoliàtum L. Myagrum. (I. F. f. 1699a.) Lower leaves narrowed into petioles; upper leaves $5-13 \mathrm{~cm}$. long, the basal auricles mostly rounded : pedicels $2-4 \mathrm{~mm}$. long, 2-3 times shorter than the pods ; longer stamens about equalling the petals. In waste places about Quebec. Fugitive or adventive from Europe. Summer.

\section{SINÁPIS L.}

Annual or biennial, usually erect, branching more or less hispid herbs, with pinnatifid or lobed leaves, and rather large, mostly yellow flowers in terminal racemes. Siliques linear, nearly terete, constricted between the seeds, sessile in the caly $x$, densely hispid in our species, tipped with a very long flat sword-like beak which sometimes contains a seed near its base. Seeds obiong or subglobose, not winged nor margined. Cutyledons conduplicate. [Name Greek, said to come from the Celtic for turnip.] About 5 species, natives of southern Europe. Only the following is known from N. Am.

I. Sinapis álba L. White Mustard. (I. F. f. I700.) Erect, 3-6 dm. high, more or less pubescent with stiff spreading hairs. Lower leaves $1.5-2 \mathrm{dm}$. long, obovate in outline, deeply pinnatifid or pinnate, with a large terminal leaflet or lobe and several pairs of smaller lateral ones, dentate all around; uppermost leaves lanceolate or cblong, merely dentate, short-petioled ; flowers yellow, I4 I 8 $\mathrm{m} \mathrm{m}$. broad; pedicels rather stout, spreading, 10-14 $\mathrm{mm}$. long in fruit; pods spreading or ascending, terete, constricted between the seeds; beak flat, equalling or sometimes longer than the pod; seeds light brown. In waste places and fields, occasional, mostly escaped from cultivation. Adventive from Europe. Native also of western Asia. Summer.

\section{BRÁSSICA L.}

Erect branching herbs, with pinnatifid basal leaves, and showy yellow flowers in elongated racemes. Siliques elongated, sessile, terete or 4-sided, tipped with an indehiscent conic usually $\mathbf{I}$-seeded beak. Valves convex, I-3-nerved. Seeds in I row in each cell, oblong, marginless: cotyledons conduplicate. [Latin name of the Cabbage.] About So species, natives of Europe, Asia and northern Africa.

None of the leaves clasping the stem, the upper sessile.

Pods slender, $1-2.5 \mathrm{~cm}$. long, appressed.

1. B. nigra.

Pods rather slender, $2-5 \mathrm{~cm}$. long, erect, not appressed, on slender pedicels 6-10 $\mathrm{mm}$. long.

Leaves merely toothed or lyrate-pinnatifid.

Leaves laciniate, at least marginally.
Pods spreading or ascending at maturity, on stout pedicels $4-6 \mathrm{~mm}$. long.

Upper leaves clasping by an auricled base.

2. B. juncea.

3. B. Japonica.

4. B. arvensis.

5. B. campestris.

I. Brassica nigra (L.) Koch. Black Mustard. (I. F. f. I7or.) Erect. $0.5^{-2.1} \mathrm{~m}$. high, freely branching. Lower leaves slender-petioled, with I terminal large lobe and 2-4 smaller lateral cnes, dentate all around, the uppermost reduced to lanceolate or oblong entire blades; flowers bright yellow, 6-Io mm. broad; pedicels slender, appressed, $4 \mathrm{~mm}$. long in fruit; pods narrowly linear, 4-sided, I-I.5 $\mathrm{cm}$. long, I mm. wide, appressed; beak slender, 2-4 $\mathrm{mm}$. long: seeds dark brown In fields and waste places, common throughout our area. Nat. from Europe June-Nov.

2. Brassica iúncea (L.) Cosson. Indian Mustarn. (I. F. f. I702.) Pale, glabrous, or slightly pubescent, somewhat glaucrus; stem erect, 3-12 dm. tall. Lower leaves long-petioled, I-I.5 dm. long, the uppermost sessile or nearly so, lanceolate or linear, commonly entire, much smaller; flowers $1.2-1.8 \mathrm{~cm}$. wide; pedicels 6 - $10 \mathrm{~mm}$. long, not appressed; pods $2-5 \mathrm{~cm}$. long, rather more than $2 \mathrm{~mm}$. wide, the conic-subulate empty beak one-fourth to one-third the length of the body. In waste places, N. H. to Penn., Mich., Va. and Kans. Adventive or nat. from Asia. May-July.

3. Brassica Japoninica Siebold. Similar to the preceding, but the leaves laciniate, sometimes deeply so, often much crisped. In waste places, Me. to Ga. Adventive from Asia. 
4. Brassica arvénsis (L.) B. S. P. Charlock. Wild Mustard. (I. F. f. I 703.) Erect, 3-6 dm. high, hispid with scattered stiff hairs, or glabrate. Leaves similar to those of $B$. nigra but generally not so much pinnatifid; flowers I-I.6 cm. broad; pedicels stout; pods glabrous, spreading or ascending, somewhat constricted between the seeds, $\mathbf{I}-\mathbf{1} .6 \mathrm{~cm}$. long, $2 \mathrm{~mm}$. wide, tipped with a flattened elongated-conic often I-seeded beak IO-12 mm. long, the valves strongly nerved. In fields and waste places, frequent or occasional. Adventive from Europe. MayNov. [B. Sinapistrum Boiss.]

5. Brassica campéstris L. Turnip. Wild Navew. (I. F. f. 1704.) Stem 3-9 dm. high, glabrous and glaucous, or sometimes slightly pubescent. Lower leaves petioled, pubescent, more or less lobed or pinnatifid; upper leaves lanceolate or oblong, sessile and clasping by an auricled base; glabrous; flowers bright yellow, 8-10 mm. broad; pedicels spreading or ascending, often $2.5 \mathrm{~cm}$. long in fruit; pods $3-5 \mathrm{~cm}$. long, tipped with a beak 8 -10 $\mathrm{mm}$. long. In cultivated grounds, sometimes persisting for a year or two, and occasional in waste places. Fugitive from Europe. April-Oct.

Brassica Nàpus L. (RAPE) has all the leaves glabrous, and is sometimes found in waste places.

Brassica olerdcea L. (CABBAGE) is occasionally found in waste places.

\section{DIPLOTÁXIS DC.}

Herbs similar to the Mustards, with pimatifid or lobed leaves, and rather large yellow flowers in terminal racemes. Silique elongated, linear, flat or flattish, short-beaked or beakless, the valves mostly I-nerved. Style usually slender. Seeds in two complete or incomplete rows in each cavity of the silique, marginless; cotyledons conduplicate. [Greek, referring to the double rows of seeds.] About 20 species, natives of the Old World, the following fugitive or adventive in our territory.

Perennial; stem leafy nearly to the inflorescence.

Annual; leaves mostly basal, oblanceolate.

I. D. tenuifolia.

I. Diplotaxis tenuifòlia (L.) DC. Wall Rocket. (I. F. f. I705.) Glabrous or nearly so, somcwhat glaucous: stem bushy, 3-12 dm. high. Leaves pinnatifid, thin, the lower 7-15 cm. long, the lobes mostly narrow; flowers $1.5^{-2}$ $\mathrm{cm}$. broad; pods $2-3 \mathrm{~cm}$. long, about $2.5 \mathrm{~mm}$. wide, nearly erect; pedicels slender, 2-4 cm. long in fruit. In waste places and ballast, N. S. to N. J. and Penn. Adventive from Europe. June-Aug.

2. Diplotaxis muràlis (L.) DC. SAnd Rocket. (I. F. f. I706.) Branched from the base, sparingly hispid or glabrous, leafy only below. Leaves oblanceolate, sinuate-lobed or pinnatifid, 5-10 $\mathrm{cm}$. long, narrowed at the base, mostly slender-petioled; flowers $12-16 \mathrm{~mm}$. broad; pod about $2.5 \mathrm{~cm}$. long and $2 \mathrm{~mm}$. wide, erect, flattish; fruiting pedicels $8-16 \mathrm{~mm}$. long. In waste places and ballast, range of the preceding. Adventive from Europe. June-Aug.

\section{RÁPHANUS L.}

Mainly biennial herbs, with lyrate leaves and showy flowers. Silique elongated. linear, coriaceous, fleshy or corky, constricted or continuous and spongy between the seeds, indehiscent. Style slender. Seeds subglobose; cotyledons conduplicate. [Greek, quick-appearing, from its rapid germination.] A genus of about 6 species, natives of Europe and temperate Asia.

Flowers yellow, fading white; pod longitudinally grooved, 4-ro-seeded.

Flowers pink or white; pod not longitudinally grooved, 2-3-seeded.

I. R. Raphanistrum.

2. R. sativus.

I. Raphanus Raphanístrum L. Wild RAdish. Jointed oR White Charlock. (I. F. f. I707.) Biennial or annual from a slender root, 3-7.5 dm. high, sparsely pubescent or rarely glabrous. Basal and lower leaves lyrate-pinnatifid, I-2 dm. long, with a large terminal lobe and 4- 6 pairs of successively sinaller lateral ones, all crenate or dentate; upper leaves small, oblong; flowers I-2 cm. broad, yellow, fading to white, purp'islı-veined; pedicels 6-16 $\mathrm{mm}$. long 
in fruit; pods $2.5-4 \mathrm{~cm}$. long, 6-10-seeded, nearly cylindric when fresh, constricted between the seeds when dry, tipped with a conic beak $\mathbf{I - 2} \mathrm{cm}$. long. In fields and waste places, Penn. to Ont. and N. B. Introduced also in Br. Col. Nat. from Europe. Summer.

2. Raphanus sativus L. GaRden Radish. (I. F. f. I708.) Similar to the last, but flowers pink or white. Root deep, fusiform or napiform, fleshy. Pods fleshy, 2-3-seeded, not longitudinally grooved, often equalled or exceeded by the long conic beak. Cultivated and occasionally spontaneous for a year or two in gardens or fields, rarely in waste places. Natives of Asia. June-Oct.

\section{เ6. BARBARÈA R. Br.}

Erect glabrous biennial or perennial branching herbs, with angled stems, pinnatifid leaves, and racemose yellow flowers. Stamens 6. Silique elongated, linear, 4-angled. Valves keeled or ribbed. Style short. Seeds in I row in each cell, flat, oblong, marginless; cotyledons accumbent. [Name from St. Barbara.] About 6 species, natives of the temperate zones.

Pods obtusely 4-angled, slender-pedicelled; leaf-segments $1-4$ pairs.

Pods divergent or ascending.

Pods erect, appressed.

Pods sharply 4-angled, stout-pedicelled; leaf-segments 4-8 pairs.

r. B. Barbarea.

2. B. stricta.

3. B. praecox.

I. Barbarea Barbarèa (L.) MacM. Yellow Rocket oR CRess. (I. F. f. I 709.) Tufted; stems 3-6 dm. high. Lower leaves petioled, $5-13 \mathrm{~cm}$. long, pinnatifid; terminal division much larger than the I-4 pairs of lateral ones, all oval or obovate : upper leaves sessile or nearly so; flowers $6-8 \mathrm{~mm}$. broad ; pods spreading or ascending, about $2.5 \mathrm{~cm}$. long, obscurely 4 -angled; pedicels about $4 \mathrm{~mm}$. long. In fields and waste places, $\mathrm{L} a \mathrm{~b}$. to $\mathrm{Va}$. and locally in the interior. Also on the Pacific coast. Nat. from Europe. April-June. [B. vulgaris R. Br.]

2. Barbarea stricta Andrz. EReCT-Fruited Winter Cress. (I. F. f. 17I0.) Similar to the preceding. Lateral segments of the leaves comparatively larger; pods obtusely or obscurely 4 -angled, about $2.5 \mathrm{~cm}$. long, erect and appressed against the rachis of the raceme on erect or ascending slender pedicels. In fields, and waste places, Quebec to Minn., the N. W. Terr., Fla. and Neb. Nat. from Europe. April-June.

3. Barbarea praecox (J. E. Smith) R. Br. Early Winter or Belle Isle CRESS. (I. F. f. I 7II.) Closely resembles the last species. Divisions of the leaves more numerous; pods sharply 4-sided, slightly compressed, $3-8 \mathrm{~cm}$. long, on stout pedicels. In waste places, S. N. Y. to Fla. Adventive from Europe. April-June.

\section{IODÁNTHUS T. \& (;.}

A glabrous erect perennial herb, with dentate leaves auricled at the base, or the lower and basal ones lyrate-pinnatifid, and violet or white flowers in panicled racemes. Sepals much shorter than the petals, the inner ones slightly gibbous at the base. Petals long-clawed. Style stout; stigma subcapitate. Silique linear-cylindric, somewhat constricted between the seeds. Seeds oblong, rounded, in I row in each cell. Cotyledons accumbent. [Greek, violet-colored flower.] A monotypic genus of S. N. Am.

I. Iodanthus pinnatífidus (Michx.) Steud. Purple or False Rocket. (I. F. f. I7 I2.) Stem slender, 3-ro dm. high. Lower leaves ovate or oblong (occasionally cordate), $0.5^{-2} \mathrm{dm}$. long, dentate, tapering into a margined petiole which is clasping and auriculate at the base, the lower part of the blade often pinnatifid into 2-6 pairs of small segments; stem-leaves similar or merely dentate, narrower, sometimes ovate lanceolate, the upper nearly sessile; flowers numerous, $6-8 \mathrm{~mm}$. broad; pedicels spreading, 2-4 $\mathrm{cm}$. long in fruit; pods linear, 4-6 mm. long, I $\mathrm{mm}$. wide, spreading or ascending; style $2 \mathrm{~mm}$. long. On river banks, W. Penn. to Minn., Tenn., Kans., La. and Tex. May-June.

\section{RORİPA Scop. [NASTURTIUM R. Br.]}

Branching herbs, with simple or pinnate lobed dissected or rarely entire leaves. Sepr's preading. Stamens I-6. Pods short or elongated, terete or nearly so. Stipe nule. Valves generally I-nerved. Style short or slender. Stigma 2-lobed 
or nearly entire. Seeds turgid, minute, in 2 rows in each cell (very rarcly in $\mathbf{I}$ row). Cotyledons accumbent. [Name unexplained.] About 25 species, of wide geographic distribution. Besides the following, there are about 5 other North American species, natives of the soutliern and western parts of the continent. 'The white-flowered species perhaps represent different generic types.

Flowers yellow.

Flowers and pods distinctly pedicelled.

Plants perennial by creeping or subterranean branches.

Leaves pinnately divided; style very short; naturalized European species.

Leaves pinnatifid; style slender; native western species.

Pedicels and pods glabrous or nearly so.

Pedicels and pods scurfy-puberulent.

Plants annual or perennial, with fibrous roots.

I. R. sylvestris.

Pods 2-1o mm. long, straight.

Fruiting pedicels $2-4 \mathrm{~mm}$. long: stem diffuse.

Pods linear to oblong, 6-10 $\mathrm{mm}$. long.

Puds subglobose, about $2 \mathrm{~mm}$. in diameter.

Fruiting pedicels $4-8 \mathrm{~mm}$. long; stem erect.

2. R. sinuata.

3. R. calycina.

Stem nearly or quite glabrous; pods linear or linear-oblong.

6. R. palustris.

Stem hispid-pubescent; pods globose or oval. 7. R. hispida.

Pods 8-14 mm. long, strongly curved upward.

Flowers and pods very nearly sessile.

8. R. curvisiliqua.

9. $R$. sessilifiora.

Flowers white.

Leaves pinnately divided; pods linear.

Leaves simple or the lower pinnatifid; pods oblong or globose.

Terrestrial, tall; leaves crenate, or the lower lobed or pinnatifid.

Aquatic; immersed leaves finely dissected.

I1. $R$. Armoracia.

12. R. Americana.

I. Roripa sylvéstris (L.) Bess. Creeping Yellow Water-Cress. (I. F. f• I713.) Perennial, glabrous; stems creeping, branches ascending. Leaves pinnatery divided or deeply pinnatifid, petioled, 7-13 $\mathrm{cm}$. long, 2-5 cm. broad, the divisions obovate, or oblong, toothed or lobed; pedicels slender, about $6 \mathrm{~mm}$. long; flowers yellow, 6-10 $\mathrm{mm}$. broad; pod linear, 8-12 mm. long; style very short. In low grounds and waste places, Newf. to Mass., Va. and Mich. Adventive or nat. from Europe. Summer.

2. Roripa sinuàta (Nutt.) A. S. Hitchcock. Spreading Yellow-cress. (I. F. f. I7 14.) Perennial, diffuse, glabrous, the branches ascending. Leaves ob. long, lanceolate, or oblanceolate, 5-8 cm. long, $\mathrm{I}-2.5 \mathrm{~cm}$. wide, pinnatifid, the lobes linear or oblong, obtuse; pedicels slender, $6 \mathrm{~mm}$. long; flowers yellow, 6-8 $\mathrm{mm}$. broad; pods linear-oblong, often curved, 8-15 mm. long; style slender, 2-4 mm. long. Minn. to S. Dak., Mo., west to the Sierra Nevada. June-Sept.

3. Roripa calycína (Engelm.) Rydb. Scurfy Yellow-Cress. Similar to $R$. simuata, the leaves rather more deeply pinnatifid; flowers about one-half the size, and pods and pedicels scurfy-puberulent. W. Neb., Wyo. and Mont. Has been referred to $R$. curvisiliqua. June-Aug.

4. Roripa obtùsa (Nutt.) Britton. Blunt-leaved Yfllow-Cress. (I. F. f. I 7 15.) Annual or biennial, diffuse. Leaves oblong or oblanceolate, 5-10 cm. long, pinnately divided, or pinnatifid, the lobes obtuse, repand-toothed, or sometimes en. tire; pedicels 2-4 mm. long; flowers yellow, 2-3 mm. broad or less; pods narrowly oblong, or linear, 6-1o $\mathrm{mm}$. long, ascending; style $1 \mathrm{~mm}$. long. In low grounds, Mich. to Tex., west to the Pacific coast. April-Aug.

5. Roripa sphaerocàrpa (A. Gray) Britton. Round fruited CRess. (I. F. f. I7 I6.) Glabrous, I-3 dm. high. Leaves oblong, obtuse, the lower lyrate-pinnatifid or incised, the upper sometimes nearly entire, petioled or the upper sub. sessi'e; petioles narrowly margined, somewhat clasping; flowers $2 \mathrm{~mm}$. broad or less; petals yellow, about equalling the sepals; silicle globose, about $2 \mathrm{~mm}$. in diameter, about as long as its pedicel; style very short. Ill. to Kans., Tex. and Cal. June-July.

6. Roripa pàlústris (L.) Bess. MARSH or Yellow Water-cress. (I. F. f. 17 17.) Annual or biennial, erect, glabrous or slightly pubescent, 3-10 dm. high. Lower leaves petioled, $7-17 \mathrm{~cm}$. long, oblong or oblanceolate, pinnatifid, the lobes repand or toothed; upper leaves nearly sessile, dentate or somewhat lobed; pedi- 
cels slender, $6 \mathrm{~mm}$. long in fruit; flowers yellow, 4-6 mm. broad; pods linear, or linear-oblong, 2-6 times as long as thick, about equalling the pedicels, spreading or curved; style I mm. long or less. In wet places, nearly throughout $\mathrm{N}$. Am. except the extreme north. Apparently nat. from Europe. May-Aug.

7. Roripa híspida (Desv.) Britton. Hispid Yellow-CRess. (I. F. f. I718.) Resembling the preceding, but often stouter, sometimes $12 \mathrm{dm}$. high, the stem, branches, petioles and veins of the lower surfaces of the leaves hirsute. Leaves lyrate-pinnatifid; pedicels slender, spreading, about $6 \mathrm{~mm}$. long, longer than the globose or ovoid pod, which is I-2 times as long as thick. In wet places, N. B. to Br. Col., Fla. and N. Mex. Summer.

8. Roripa curvisíliqua (Hook.) Bessey. Curved-fruited Cress. (I. F. f. I719.) Annual or biennial, sparingly pubescent or glabrous; stems $\mathbf{1 . 5}-\mathbf{4 . 5} \mathrm{dm}$. high. Leaves oval or oblanceolate, pinnatifid, pinnately lobed or toothed, the lower 2-8 cm. long; flowers light yellow, $4 \mathrm{~mm}$. broad in short racemes; petals rather longer than the sepals: style short; pods linear, 8-16 $\mathrm{mm}$. long, less than $2 \mathrm{~mm}$. wide, strongly curved upward; pedicels spreading or ascending, 2-4 $\mathrm{mm}$. long. In moist soil, Mont. to Br. Col. and Cal. Not certainly known within our range. May-Aug.

9. Roripa sessilifiòra (Nutt.) A. S. Hitchcock. Sessille-flowered Cress. (I. F. f. I720.) Annual or biennial, erect, glabrous, 2-5 dm. high. Leaves petioled, the lower 7-10 cm. long, obovate or oblong, obtuse, crenate, lobed or pinnatifid, with obtuse lobes; flowers yellow, $2 \mathrm{~mm}$. broad, nearly sessile; pods very slightly pedicelled, 6-12 $\mathrm{mm}$. long, $2 \mathrm{~mm}$. broad, narrowly oblong; style very short. In low grounds, Tenn., Ill. and Iowa to Kans., Fla. and Tex. April-June.

ro. Roripa Nastúrtium(L.) Rusby. Water-CRESs. (I. F. f. I721.) Aquatic, glabrous, rooting from the nodes. Leaves odd-pinnate, of 3-9 segments, the terminal one larger than the lateral, all obtuse, ovate or oval, or the terminal one nearly orbicular; flowers white, $4-5 \mathrm{~mm}$. broad; pods $\mathbf{I}-3.5 \mathrm{~cm}$. long, $2 \mathrm{~mm}$. wide, slightly curved upward, on pedicels of about their length; seeds in 2 rows. In brooks and streams, N. S. to Manitoba, Ore., Va. and Neb. and Ariz. Nat. from Europe. April-Nov. [Nasturtium officinale R. Br.]

I I. Roripa Armoracia (L.) A. S. Hitchcock. Horseradish. (I. F. f. I722.) Erect, 6-10 dm. high, from deep thick roots. Basal leaves on thick petioles 1.5-3 dm. long, the blade oblong, often nearly as long, crenate, sinuate or even pinnatifid, rough but glabrous; upper leaves sessile, narrowly oblong or lanceolate, crenate or dentate; racemes paniculate; pedicels slender, ascending, 4-6 mm. long; flowers white, 4-8 mm. broad; pods oblong or nearly globose; style very short. Escaped from gardens into moist grounds, especially along streams. Adventive from Europe. Summer.

I2. Roripa Americàna (A. Gray) Britton. LAke Water-Cress. (I. F. f. 1723.) Aquatic, branching, 3-6 dm. long. Immersed leaves $5^{-8} \mathrm{~cm}$. long, pinnately dissected into numerous filiform divisions; emersed leaves oblong, 2-8 $\mathrm{cm}$. long; pedicels 6-8 $\mathrm{mm}$. long, slender, spreading; flowers white; style slender, about $2 \mathrm{~mm}$. long; pods ovoid, $4 \mathrm{~mm}$. long, 1 -celled. In lakes and slow streams, Vt. and Quebec to Ont., Minn., Fla., La. and Ark. Summer. [ $N$. lacustre A. Gray.]

\section{CARDÁMINE L.}

Erect or ascending herbs, with scaly or tuberiferous rootstocks or fibrous roots, entire lobed or divided leaves, and racemose or corymbose white or purple flowers. Stamens 6, rarely 4. Siliques elongated, flat; valves nerveless or faintly nerved, elastically dehiscent at maturity. Stipe none. Seeds in I row in each cell, compressed, marginless; cotyledons accumbent. [Greek, heart-strengthening.] About 75 species, natives of temperate regions.

* Leaves pinnately divided, or some of them of but a single terminal segment. Flowers $\mathrm{I}-2 \mathrm{~cm}$. broad, white or purplish. I. C.pratensis. Flowers 2-8 $\mathrm{mm}$. broad, white.

Leaf-segments numerous, small, the terminal one 4-20 $\mathrm{mm}$. wide, narrowed, rounded or subcordate at the base.

Leaves nearly all basal, pubescent.

2. C. hirsuta.

Stem leafy; - leaves glabrous or very nearly so. 
Mature pods erect, $0.5^{-1} \mathrm{~mm}$. wide.

Flowers 4-5 mm. wide; plants of swamps, streams, or wet grounds. Segments of basal leaves 4-25 $\mathrm{mm}$. wide; plant $2-9 \mathrm{dm}$. tall.

3. C. Pennsylvanica.

Segments of basal leaves $1-3 \mathrm{~mm}$. wide; plant $1-3 \mathrm{dm}$. tall.

4. C. arenicola.

Flowers 2-3 mm. wide; plant of dry rocky situations.

Mature pods divergent or ascending, more than $1 \mathrm{~mm}$. wide.

5. C. parviflora.

6. C. Aexuosa.

Leaf-segments few, large, the terminal one $2-5 \mathrm{~cm}$. wide, deeply cordate.

7. C. Clematitis.

** Leaves entire, toothed, or rarely with $\mathrm{I}$ or 2 lateral segments.

Dwarf, alpine; leaves nearly entire, long-petioled.

8. C. bellidifolra.

Erect o: decumbent; leaves more or less toothed or lobed.

Flowers purple; stem erect.

Flowers white.

Stem erect from a tuberous base.

Stem decumbent, stoloniferous; roots fibrous.

9. C. purpurea.

10. C. bulbosa.

11. C. rotundifolia.

1. Cardamine praténsis L. Meadow Bitter-cress. Cuckoo-flower. (I. F. f. 1724.) Glabrous, 2-5 dm. high; roots fibrous. Leaves pinnately divided, lanceolate or oblong in outline, the lower petioled, the upper sessile; divisions 3-7 pairs and an odd one; petals three times the length of the calyx; pedicels slender, 8-12 mm. long in fruit; pods $1.5-3 \mathrm{~cm}$. long, $2 \mathrm{~mm}$. wide; style $\mathbf{I}-2 \mathrm{~mm}$. long, thick. In wet meadows and swamps, Lab. to N. J., Br. Col. and Minn. Also in Europe and northern Asia. April-May.

2. Cardamine hirsùta L. Hairy BitTer-Cress. (I. F. f. I725.) More or less pubescent; stem usually little branched, I-2.5 dm. tall. Leaves nearly all basal, 2-10 $\mathrm{cm}$. long, pinnate, the terminal segment orbicular or broader than long, entire or few-toothed, the lateral ones 2-5 pairs; stem leaves few, their segments linear, or linear-oblong; flowers $4 \mathrm{~mm}$. broad, white; pods linear, about $2.5 \mathrm{~cm}$. long and I $\mathrm{mm}$. wide, erect on ascending pedicels $4-8 \mathrm{~mm}$. long when mature; style almost none. In moist places, Penn. to Mich., Neb. and N. Car. Also in Europe and Asia. March-May.

3. Cardamine Pennsylvánica Muhl. Pennsylvania Bitter-cress. (I. F. f. I726.) Glabrous or rarely with a few hairs; stem erect, 2-9 dm. tall, usually much branched, leafy. Basal leaves $0.5-1.5 \mathrm{dm}$. long, the terminal segment obovate, oval or suborbicular, the lateral 4-8 pairs oblong, oval, or obovate; flowers about $4 \mathrm{~mm}$. broad, white; pods narrowly linear, $1.5-3 \mathrm{~cm}$. long, less than $\mathrm{I} \mathrm{mm}$. wide, erect when mature on ascending or divergent pedicels 4-6 $\mathrm{mm}$. long; style about I mm. long. In swamps and wet places, Newf. to Minn., Mont., Fla., Tenn. and Kans. April-June.

4. Cardamine arenícola Britton. Sand Bitter-cress. (I. F. f. I727.) Glabrous, usually branched from the base, leafy, erect, 1.5-3 dm. high. Segments of the leaves numerous, linear or linear oblong, I-3 mm. wide, obtusish, entire, or with I-3 small teetl; flowers about $4 \mathrm{~mm}$. broad, white; mature pods erect, about $2 \mathrm{~cm}$. long. $0.5^{-1} \mathrm{~mm}$. wide, their pedicels ascending; style almost wanting. In moist or wet sandy soil, Conn. to Fla., Ky. and Tenn, March-April.

5. Cardamine parviflòra L. Small-flowered Bitter Cress. (I. F. $f$. 1728.) Glabrous or sparingly pubescent ; stem weak, erect or ascending, very slender or almost filiform, 0.5-4 dm. long, usually leafy up to the racemes, the leaves scattered. Segments of the leaves numerous, oblong or linear, or the terminal one sometimes orbicular, $1-4 \mathrm{~mm}$. wide; mature pods $2-5 \mathrm{~cm}$. long or less, rather less than $1 \mathrm{~mm}$. wide, erect on ascending pedicels, 4-10 $\mathrm{mm}$. long, the axis of the racemes commonly zigzag ; flowers scarcely more than $\mathbf{I} \mathbf{m m}$. broad, white; style almost wanting. On rocks, Quebec to W. Ont., Ore., south to Mass. and Ga. Also in northern Europe and Asia. April-May.

6. Cardamine flexuòsa With. Wood BitTer-Cress. (I. F. f. I729.) Gla. brous; stem leafy, 1.5-4 dm. tall. Leaf segments obovate, oval, oblong or linear, the terminal one sometimes orbicular. narrowed rounded or subcordate at the base, I-2 cm. wide, the lateral ones usually much narrower; flowers white, $4 \mathrm{~mm}$. broad; pods ascending or divergent, on spreading or ascending pedicels, $1.5-3 \mathrm{~cm}$. long, I $\mathrm{mm}$. wide or rather more; style minute or none. In wet woods, streams and 
mountain swamps, Me. to Mich. and N. Car. Also in Europe and Asia MayAug.

7. Cardamine Clematitis Shuttlw. Mountain Bitrer-Cress. (I. F. f. I730.) Glabrous, dark green; stem weak, slender, I-4 dm. long. Leaves various, some of them of a single orbicular or reniform, deeply cordate terminal segment, some of them with two additional ovate oblong or rounded lateral segments, the uppermost occasionally linear-oblong and entire; flowers in short racemes, white, 6-8 $\mathrm{mm}$. wide; pedicels ascending, 6-12 $\mathrm{mm}$. long; pods ascending or divergent, $2-4 \mathrm{~cm}$. long, less than $2 \mathrm{~mm}$. wide; style $2-4 \mathrm{~mm}$. long, subulate. In wet woods, high mountains of Va. and N. Car. to Ala. May-July.

8. Cardamine bellidifòlia L. Alpine Cress. (I. F. f. I73I.) Tufted, glabrous, 5-13 cm. high; roots fibrous. Lower leaves long-petioled, ovate, obtuse, the blade 8-12 $\mathrm{mm}$. long, abruptly contracted into the petiole, entire, or with a few rounded teeth; upper leaves similar, shorter-petioled; flowers I-5, white; petals about twice the length of the calyx; pods erect, linear, $2.5 \mathrm{~cm}$. long, $2 \mathrm{~mm}$. wide, narrowed at each end; pedicels $2-6 \mathrm{~mm}$. long; style stout, less than $2 \mathrm{~mm}$. long. Alpine summits of the White Mountains, N. H.; Mt. Katahdin, Me.; Greenland and arctic Am. : the Canadian Rocky Mts.; Cal. Also in Europe. July.

9. Cardamine purpùrea (Torr.) Britton. Purple Cress. (I. F. f. 1732.) Glabrous, 1.5-7 dm. high from tuberiferous rootstocks. Basal leaves slenderpetioled, $2-3 \mathrm{~cm}$. broad, ovate or orbicular, cordate, thickish, the upper sessile, dentate or entire; pedicels $8-25 \mathrm{~mm}$. long; flowers purple, I-2 $\mathrm{cm}$. broad; pods nearly erect, $2.5 \mathrm{~cm}$. long, $2 \mathrm{~mm}$. broad, pointed at each end; style $4 \mathrm{~mm}$. long. In cold, springy places, Quebec and arctic Am. to the Canadian Rocky Mts., Md. and Wis. April-May.

Io. Cardamine bulbòsa (Schreb.) B.S.P. Bulbous Cress. (I. F. f r733.) Glabrous, erect from a tuberiferous base, 2-4.5 dm. high. Basal leaves oval, or nearly orbicular, 2-4 cm. long, sometimes cordate, angled or entire, long-petioled; stem-leaves sessile or the lower petioled, oblong or lanceolate, dentate or entire; pedicels $8-25 \mathrm{~nm}$. long; flowers white, $\mathbf{I}-\mathbf{1 . 5} \mathrm{cm}$. broad; petals three or four times the length of the calyx; pods $2.5 \mathrm{~cm}$. long, erect, linear-lanceolate, narrowed at each end; style 2-4 $\mathrm{mm}$. long; stigma prominent; seeds short-oval. In wet meadows and thickets, N. S. to Ont. and Minn., Fla. and Tex. April-June.

II. Cardamine rotundifòlia Michx. Round-Leaved or AMerican WaterCRESS. (I. F. f. 1734.) Weak, ascending or decumbent, forming long stolons; rots fibrous. Basal leaves and stem-leaves similar, the lower petioled, the upper sessile, ovate, oval, or orbicular, obtuse, undulate angled or entire, thin; pedicels $\mathbf{I}-2.5 \mathrm{~cm}$. long in fruit; flowers white, 4-6 $\mathrm{mm}$. broad; pods linear, I4-16 $\mathrm{mm}$. long, I mm. wide, pointed; style $2 \mathrm{~mm}$. long; stigma minute; seeds oblong. In cold springs, N. J. to Ohio, N. Car. and Ky. May-June.

\section{DENTÀriA L. (See Appendix.)}

Perennial herbs, with horizontal scaly or toothed rootstocks, erect, mostly unbranched stems leafless below, 3-divided or palmately laciniate petioled leaves, and corymbose or short racemose white rose-colored or purple flowers. Petals much longer than the sepals. Stamens 6. Style slender. Silique linear, flat, elastic. ally dehiscent from the base, its valves nerveless or with a faint midnerve; stipe none. Seeds in I row in each cell, thick, oval, flattened, wingless; cotyledons thick, accumbent. [Greek, tooth, from the toothlike divisions of the rootstock.] About 15 species, natives of the northern hemisphere. Besides the following, some 7 others occur in western N. Am.

Basal leaves and stem-leaves similar.

Leaf-divisions lanceolate or oblong, lobed or cleft.

Leaf-divisions ovate or ovate-oblong, crenate or lobed.

Stem-leaves 2 , opposite, or close together; rootstock continuous:

Stem-leaves 2-5, alternate; rootstock jointed.

2. D. diphylla.

3. D. maxima.

Divisions of the stem-leaves linear or lanceolate; those of the basal leaves ovate, much broader.

4. D. heterophylla.

I. Dentaria laciniàta Muhl. Cut-leaved Toothwort or Pepper-Root. (I. F. f. I735.) Pubescent or glabrous, scapose, 2-4 dm. high; rootstock deep, 
tubercled, jointed. Leaves $5-13 \mathrm{~cm}$. broad, those of the stem generally 3 and ap. proximate or verticillate, 3-parted nearly to the base; divisions lanceolate, linear or oblong, the lateral ones often deeply 2-cleft, all incisely toothed or lobed; basal leaves similar, rarely developed at flowering time; pedicels ascending, stout, I.5-2 $\mathrm{cm}$. long in fruit; flowers $1.4-2 \mathrm{~cm}$. broad, white or pink; pods linear, ascending, 2-4 cm. long; style 6-8 mm. long. In moist or rich woods, Quebec to Fla., Minn., Kans. and La. April-June.

2. Dentaria diphylla Michx. Two-leaved Toothwort. (I. F. f. I736.) Stout, scapose, glabrous, $2-4 \mathrm{dm}$. high; rootstock continuous, toothed. Basal leaves long-petioled, I-I.3 dm. broad, ternate, the divisions short-stakked, broadly ovate, dentate, or somewhat lobed, about $5 \mathrm{~cm}$. long; stem-leaves generally 2, opposite or nearly so; pedicels 2-4 cm. long; flowers white, $1.4-1.6 \mathrm{~cm}$. broad; pods $2.5 \mathrm{~cm}$. long or more. In rich woods and meadows, N. S. to Minn., S. Car, and Ky. May.

3. Dentaria máxima Nutt. LARGE Toothwort. (I. F. f. I737.) Similar to the preceding but larger; rootstock jointed, tubercled. Stem-leaves 2-7 (generally 3), alternate, similar to the basal ones; flowers pale purple, $1.5-2 \mathrm{~cm}$. broad. Vt. to N. Y. and Penn. May.

4. Dentaria heterophylla Nutt. Slender Toothwort. (I. F. f. I738.) Slender, glabrous or somewhat pubescent, 2.5-3.5 dm. high; rootstock jointed. Basal leaves long-petioled, ternate; divisions ovate, the terminal one cuneate or rounded at the base, the lateral ones inequilateral, the lobes or teeth mucronate; stem-leaves generally 2 , opposite or nearly so, ternate, the divisions linear or lanceolate; pedicels $2.5 \mathrm{~cm}$. long in fruit; flowers light purple, $1.6-1.8 \mathrm{~cm}$. broad; pods ascending, $2.5 \mathrm{~cm}$. long. In woods, N. J. and Penn. to Ga. and Tenn. AprilMay.

\section{I. LUNARIA I.}

Pubescent erect herbs, with broad dentate or denticulate mostly cordate leaves, and large violet flowers in terminal racemes. Lateral sepals saccate at the base. Petals obovate, clawed. Siliques long-stipitate, very flat, oblong or elliptic, dehiscent, the papery valves reticulate-veined. Style filiform; septum hyaline, translucent, shining. Seeds circular or reniform, very large, winged, borme on long funiculi, which are adnate to the septum: cotyledons large, accumbent. [Latin, moon, in allusion to the shining partition of the pod.] Two known species, natives of Europe and Asia.

Siliques oblong, pointed at both ends; perennial.

Siliques elliptic, rounded at both ends; annual or biennial.

x. L. rediviva.

2. L. annua.

I. Lunaria rediviva L. Perennial Satin-Pod or Satin-flower. (I. F. f. I739.) Pubescent with short simple hairs; stem 3-12 dm. tall. Leaves broadly ovate, acuminate at the apex, cordate or rounded at the base, thin, the lower long. petioled, 0.7-1.5 dm. long; flowers $\mathbf{1} .5-2.5 \mathrm{~cm}$. broad, slender-pedicelled; pods oblong, 5-8 mm. long, drooping, borne on slender stipes of about one-half their length; seeds reniform, broader than long. In thickets, Canadian side of Niagara Falls. Escaped from gardens or fugitive from Europe. May-July.

2 Lunaria annua L. Honesty. (I. F. f. 1740.) Resembles the preceding species when in flower, but the root is annual or biennial. Siliques elliptic or broadly oval, $3-5 \mathrm{~cm}$. long, $2.5 \mathrm{~cm}$. wide or rather more, rounded at both ends; seeds suborbicular, cordate, about as long as wide. Escaped from gardens to roadsides in southwestern Connecticut. Both this species and the preceding are occasionally cultivated for their remarkably large pods, which are gathered for dry bouquets, the valves falling away at maturity and leaving the septum as a shining membrane. May-June.

\section{SELENIA Nutt.}

Annual tufted glabrous herbs, with pinnatisect leaves, and racemose leafybracted yellow flowers. Sepals spreading. Petals narrow, erect, with ro hypogynous glands at their bases. Silique stalked, very flat, oblong, narrowed at each end, dehiscent; valves nerveless, thin, finely veined. Style long, slender. Seeds 
few, in 2 rows in each cell of the pod, orbicular, flat, broadly winged, free from the septum. Cotyledons accumbent. [Greek, moon, from the resemblance of this genus to Lunaria.] Two or three species, natives of the south-central United States and northern Mexico.

I. Selenia aùrea Nutt. Selenia. (I. F. f. I74I.) Stems simple, numerous, $0.5^{-2} \mathrm{dm}$. high. Basal leaves $2-5 \mathrm{~cm}$. long, narrow, I-2 pinnatifid into numerous oblong dentate segments; stem-leaves similar, smaller; bracts of the raceme pinnatifid, resembling the upper leaves; flowers $6-8 \mathrm{~mm}$. high, numerous; pedicels $\mathbf{I}-\mathbf{I} .5 \mathrm{~cm}$. long in fruit, spreading or ascending; pod $\mathbf{I}-2 \mathrm{~cm}$. long, 4-6 cm. broad; style $4 \mathrm{~mm}$. long, very slender. In open places, Mo. and Kans. to Tex. MarchApril.

\section{LEAVENWÓRTHIA Torr.}

Low annual glabrous scapose herbs, with lyrate-pinnatifid persistent basal leaves, and few or solitary terminal flowers. Petals wedge-shaped. Siliques flat, broadly linear or oblong, short-stipitate, dehiscent ; valves nerveless, finely reticulate-veined. Seeds in I row in each cell of the pod, flat, winged or margined; radicle short, slightly bent toward the cotyledons. [In honor of Dr. M. C. Leavenworth, U. S. A.] A genus of about 4 species, natives of southeastern North Am.

Pods not constricted between the seeds.

Pods constricted between the seeds.

I. L. uniflora.

2. L. torulosa.

I. Leavenworthia uniflòra (Michx.) Britton. Michaux's Leavenworthia. (I. F. f, 1742.) Tufted, 7-15 cm. high. Basal leaves rosulate, 2-10 $\mathrm{cm}$. long, the segments 5-17, dentate or angled, 4-6 mm. long, the terminal one somewhat larger, all narrowed near the base; stem-leaves none, or $1-3$, smaller; flowers about $6 \mathrm{~mm}$. broad; petals white or purplish with a yellow base, about twice the length of the sepals; pods oblong or linear, I-3 cm. long, $4 \mathrm{~min}$. wide when mature ; seeds winged; style about I $\mathrm{mm}$. long. In open, dry places, S. Ind. to Tenn. and Mo. April. L. Michauxii Torr.]

2. Leavenworthia torulòsa A. Gray. Necklace Leavenworthia. (I. F. f. I743.) Closely resembles the preceding, but the pods are narrower and constricted between the seeds. Style 3-4 mm. long; seeds sharp-margined, barely winged; terminal segment of the basal leaves decidedly broader than the lateral ones. Barrens of $\mathrm{Ky}$. and Tenn. April.

\section{PHYSÀriA A. Gray. (See Appendix.)}

Low perennial stellate-canescent herbs, with usually simple stems, spatulate mostly entire leaves, the basal ones tufted, and yellow flowers in terminal racemes. Petals longer than the sepals. Style filiform. Silicles membranous, stellate pubescent, their cavities inflated, subglobose, the septum narrow. Seeds not margined; cotyledons accumbent. [Greek, bellows, from the resemblance of the inflated fruit.] About 4 species, natives of western N. Am.

I. Physaria didymocàrpa (Hook.) A. Gray. Double Bladder-Pod. (I. F. f. I 744.) Root long and deep. Stems slender, 0.7-3 dm. long; leaves spatulate, the basal ones obtuse, entire, or few-lobed, narrowed into margined petioles; blade, or terminal segment, $2-\mathbf{I} 3 \mathrm{~cm}$. long; stem-leaves nearly sessile, acute or subacute, much smaller; flowers $\mathbf{I}-\mathbf{I} .3 \mathrm{~cm}$. broad; pods didymous, variable, often $\mathbf{I} \mathrm{cm}$. thick through the strongly inflated cavities, emarginate at base and summit, commonly broader than high; seeds numerous. In dry soil, N. W. Terr. to Br. Col., Neb., Colo. and Nev. May-Aug.

\section{LESQUERÉLLA S. Wats.}

Low herbs, with stellate pubescence, simple leaves, and racemose mainly yellow flowers. Petals entire. Anthers sagittate. Pod generally inflated, globose or oblong; valves nerveless; septum translucent, nerved from the apex to the middle. Seeds several or many in each cell of the pod, flattened, marginless or narrow. margined; cotyledons accumbent. [Dedicated to Leo Lesquereux, 1805-1889, Swiss and American botanist.] About 35 species, natives of America, and mainly of the western parts of the U.S. 
Pods densely stellate-pubescent.

Pods oblong to globose, acute, $4 \mathrm{~mm}$. long ; low perennial.

Pods globose, $2 \mathrm{~mm}$. in diameter; tall annual.

1. L. spathulata.

Pods oval or globose, $4-5 \mathrm{~mm}$. long; tall biennial or perennial. Pods glabrous or very nearly so.

2. L. globosa.

3. L. argentea.

Annual, sparingly pubescent; stem slender, 3-6 dm. tall, much branched; southwestern.

4. L. gracilis.

Perennial, densely stellate; stem rather stout, I.5-3 dm. tall, simple; western.

Perennial, 2-r $5 \mathrm{~cm}$. tall ; stem simple ; arctic.

5. L. ovalifolia.

6. L. arctica.

I. Lesquerella spathulàta Rydberg. Low Bladder-Pod. (I. F. f. I 745.) Perennial, I-I.3 dm. high; stems slender, simple. Lower leaves oblanceolate or spatulate, $\mathbf{I}-2.5 \mathrm{~cm}$. long, acutish, narrowed into a petiole; the upper linear; flowers about $4 \mathrm{~mm}$. broad; pedicels 6-12 $\mathrm{mm}$. long, recurved in fruit; pods oblong or nearly globose, finely canescent, about $4 \mathrm{~mm}$. long, few-seeded, tipped with a style of about their own length. Dry hills, Neb. and S. Dak. to Mont. and the N. W. Terr. June.

2. Lesquerella globòsa (Desv.) S. Wats. Short's Bladder-Pod. (I. F. f. 1746.) Slender, sparingly branched, 1.5-5 dm. high. Basal leaves obovate, 2-4 cm. long, obtuse; stem-leaves narrower, linear or oblong, smaller, sessile; petals 4-6 mm. long; pedicels slender, spreading, 8-10 $\mathrm{mm}$. long in fruit; pod nearly globular, $2 \mathrm{~mm}$. in diameter, glabrous when mature; seeds I or 2 in each cavity; style slender, $4 \mathrm{~mm}$. long. In open places, $\mathrm{Ky}$. and Tenn. to Mo. April.

3. Lesquerella argéntea (Pursh) MacM. Silvery Bladder-Pod. (I. F. f. I747.) Tufted, nearly simple, I.5-4.5 dm. high. Leaves linear, oblong or oblanceolate, the lower 5-8 cm. long, blunt, entire or sparingly repand-toothed; petals $6 \mathrm{~mm}$. long; pedicels slender, $1.5-2.5 \mathrm{~cm}$. long in fruit, spreading or recurved; pod slightly stipitate, stellate-pubescent, globose to oval, 4-5 $\mathrm{mm}$. long; style about equalling the pod. On plains, Minn. to Neb., Kans., Dak. and Ariz. May-June. [L. Ludoviciana S. Wats.]

4. Lesquerella grácilis (Hook.) S. Wats. Si.ender Bladder-Pod. (I. F. f. I748.) Weak; stem slender, 2.5-6 dm. high, freely branching, sparsely stellatepubescent. Leaves linear or oblanceolate, $1.5-5 \mathrm{~cm}$. long, their margins often undulate; petals about $6 \mathrm{~mm}$. long; pedicels spreading, sometimes $2.5 \mathrm{~cm}$. long in fruit, ascending or upwardly curved; pod globose, glabrous, $4 \mathrm{~mm}$. in diameter, stipitate; style $4 \mathrm{~mm}$. long. Prairies, Neb. to Tex. March-May.

5. Lesquerella ovalifòlia Rydberg. Oval-Leaved Bladder-pon. (I. F. f. 1749.) Basal leaves tufted, broadly oval to nearly orbicular, entire, pale, 2-5 cm. long, narrowed into petioles; stem-leaves distant, linear-oblanceolate or narrowly spatulate; fruiting pedicels comparatively stout, ascending, $\mathbf{I}-2 \mathrm{~cm}$. long; pods very short-stipitate, subglobose, 5-6 $\mathrm{mm}$. in diameter, glabrous; style about $6 \mathrm{~mm}$. long. In dry soil, Neb. and Kans.

6. Lesquerella àrctica (DC.) S. Wats. ArCtic Bladder-Pod. (I. F. f. 1750.) Tufted; stem nearly or quite simple, 2-15 cm. tall. Leaves oblanceolate, spatulate, or oblong, $2.5 \mathrm{~cm}$. long or less, obtuse, entire, the basal ones narrowed into broad petioles, the upper sessile; petals about $4 \mathrm{~mm}$. long; pods oval or subglobose, 4-6 $\mathrm{mm}$. high; septum perforated; style $2 \mathrm{~mm}$. long or less. Greenland and arctic Am. Summer.

Lesquerella àrctica Púrshii S. Wats. Taller, sometimes $1.5 \mathrm{dm}$. high; septum of the sparsely stellate-pubescent pod unperforated. Anticosti.

\section{HUTChínSIA R. Br.}

Low mostly diffuse herbs, more or less pubescent with forked hairs, our species annual, the small white flowers in terminal racemes, the axis elongating in fruit. Stamens 6. Style wanting or very short. Silicles oval, compressed at right angles to the partition, the valves with a strong midvein. Seeds numerous; cotyledons incumbent or accumbent. [Name in honor of Miss Hutchins, of Bantry, Ireland, an eminent botanist.] About 8 species, natives of the northern hemisphere, only the following known in N. Am.

I. Hutchinsia procúmbens (L.) Desv. Prostrate Hutchinsia. (I. F. f. 175I.) Tufted. branching near the base, the branches slender, 5-15 cm. long 
Lower leaves short-petioled, pinnatifid, lobed, dentate or sometimes entire, I -2.5 cin. long; upper leaves sessile or very nearly so; flowers about I $\mathrm{mm}$. broad; pedicels slender, ascending or spreading, 6-12 $\mathrm{mm}$. long in fruit; pods elliptic or oval, mostly obtuse or emarginate, 3-4 $\mathrm{mm}$. long. In moist ground, often in saline situations, Lab. to $\mathrm{Br}$. Col., and widely distributed in the Pacific States. Also in Europe, Asia and Australia. June-Aug.

\section{BÚRSA Weber. [CAFSELLA Medic.]}

Annual or winter-annual erect herbs, pubescent with forked hairs, the basal leaves tufted. Flowers racemose, small, white. Silicles cuneate, obcordate or triangular, compressed at right angles with the septum, their valves boat-slajed, keeled. Style short. Seeds numerous, marginless; cotyledons accunile'rt. [Middle Latin, purse, from the shape of the pod.] About 4 species, natives of the northern hemisphere. In addition to the following, another occurs in wesiern N. Am.

I. Bursa Bursa-pastòris (L.) Britton. Shepherd's Purse. (I. F. f. 1752.) Branching, 1.5-5 dm. high from a deep root, pubescent below, mainly glabious above. Basal leaves lobed, pinnatifid, or rarely entire, 5-15 cm. long; steni-leaves few, lanceolate, auricled; flowers about $2 \mathrm{~mm}$. long; pedicels $1-1.5 \mathrm{~cm}$. long in fruit; pods triangular, cuneate at the base, truncate or emarginate, 4- $8 \mathrm{~mm}$. long; seeds 10 or 12 in each cell. In fields and waste places, very comimon. Nat. from Europe. Jan.-Dec.

\section{CAMÉLINA Crantz.}

Erect annual herbs, with entire tcothed or pinnatifid leaves, and small yellowish flowers. Silicles olovoid or pear-shaped, slightiy flatter,ed; valves very convex, I-nerved. Sceds oblong, maiginless, in 2 rcws. Stigma entire; style slender. Cotyledons incumbent. [Greek, low flax.] Atout 5 species, natives of Europe and Asia.

Glabrous or nearly so : pod 6-8 mm. long.

Pubescent, at least below ; pod 4-6 mm. long.
I. C. sativa.

2. C. microcalpa.

T. Camelina sativa (L.) Crantz. Gold-of-Pleasure. False Flax. (I. F. f. I753.) Glabrous, or nearly so, 3-6 dm. high. Lowest leaves petioled, 5-8 cm. long, lanceolate, acutish; upper leaves sessile, smaller, clasping by a sagittate base, mostly entire; pedicels slender, spreading or ascending, $1-2 \mathrm{~cm}$. long in fruit; flowers numerous, about $6 \mathrm{~mm}$. long; pod obovoid or pyriform, margined, slightly flattened, $6-8 \mathrm{~mm}$. long; style slender, $3 \mathrm{~mm}$. long. In fields and waste places, frequent or occasional throughout our area. Adventive or nat. from Europe. June-July.

2. Camelina microcàrpa Andrz. Small-Fruited False-flax. (I. F. f. I753a.) Stem pubescent, at least below. Leaves lanceolate, sessile, auricled, or the lower narrowed at the base; fruiting racemes much elongated, often $3 \mathrm{dm}$. long or more; pedicels relatively somewhat shorter than those of $C$. sativa; pcd rather more flattened, 4-6 $\mathrm{mm}$. long, strongly margined. In waste places, R. I. to W. Va., Idaho, Br. Col. and Kans. Nat. or adventive from Europe. May-July.

\section{NÉSliA Desv.}

Annual erect branching herbs, hispid with branched hairs, with entire leaves, and small yellow racemose flowers. Silicles small, globose, wingless, reticulated, indehiscent, I-celled, I-seeded or rarely 2-seeded. Style filiform. Seeds horizontal; cotyledons incumbent. [Dedicated to J. A. N. De Nesle, a French botanist.] A monotypic genus of Europe and eastern Asia.

I. Neslia paniculàta (L.) Desv. Ball. Mustard. (I. F. f. I754.) Slender, rather densely rough-hispid, 3-6 dm. high. Leaves lanceolate, sagittate-clasping at the base, 2-6 cm. long, 4-16 mm. wide; racemes elongated; flowers yellow, nearly $2 \mathrm{~mm}$. broad; pedicels filiform, ascending. $6-10 \mathrm{~mm}$. long in fruit; silicles about $2 \mathrm{~mm}$. in diameter. In waste places, Ont., Manitoba and Br. Col., and in ballast about the eastern seaports. Adventive or fugitive from Europe. May-Sept. 
Rapistrum rugosum (L.) All., a plant with 2-jointed indehiscent pods, erect on appressed pedicels, in long racemes, has been found as a waif at Easton, Penn., and plentifully in ballast about the seaports. It is nearly related to Raphanus.

\section{DRÄBA L.}

Low tufted mostly stellate-pubescent herbs, with simple leaves, and mainly racemose flowers. Silicles elliptic, oblong or linear, flat, few to many-seeded. Stigma nearly entire. Seeds wingless, in 2 rows in each cell of the pod, numer. ous; valves dehiscent, nerveless; cotyledons accumbent. [Greek name for some plant of this family.] Species about 150, mainly natives of temperate and arctic regions. Besides the following, some 25 others occur in western N. Am.

Flowers white or whitish.

Petals deeply 2-cleft.

Petals entire, toothed, or emarginate.

1. D. verna.

Flowering stems scapose, leafy only below.

Plants annual, not arctic.

Leaves entire, obovate or oblong.

Leaves dentate, cuneate to spatulate.

Low arctic perennials.

Leaves pilose-ciliate or glabrous.

Leaves stellate canescent.

Flowering stems leafy throughout up to the inflorescence.

Leaves entire or sparingly dentate.

Leaves sharply dentate.

Flowers yellow; (white in No. 8); stems leafy.

Pods oblong, $2-4 \mathrm{~mm}$. long.

Pods linear or lanceolate, 6-14 mm. long.

2. D. Caroliniana.
3. D. cuneifolia.

4. D. Fladnizensis.

5. D. nivalis.

6. D. incana.

7. D. ramosissima.

8. D. brachycarpa.

Annual; pods $6-8 \mathrm{~mm}$. long; pedicels divaricately spreading.

Perennial ; pods 8-14 $\mathrm{mm}$. long; pedicels erect. Flowers yellow; stems scapose.
9. D. nemorosa.
Io. D. aurea.
II. D. alpina.

I. Draba vérna L. Vernal Whitlow-grass. (I. F. f. I755.) Annual, the leafless scapes numerous, $2-13 \mathrm{~cm}$. high, arising from a tuft of basal leaves, which are oblong or spatulate-oblanceolate, $\mathbf{I}-2.5 \mathrm{~cm}$. long, acutish and pubescent with stellate hairs; flowers $3-4 \mathrm{~mm}$. broad; pedicels $\mathbf{I}-2.5 \mathrm{~cm}$. long in fruit; pods oblong, glabrous, 6-8 mm. long, $2 \mathrm{~mm}$. broad, obtuse, shorter than their pedicels; style minute; seeds numerous. In fields, common except in the extreme north. Nat. from Europe. Feb.-May.

2. Draba Caroliniàna Walt. Carolina Whitlow-grass. (I. F. f. I756.) Annual; scapes 2-13 cm. high from a short leafy stem. Leaves tufted, obovate, 8-20 mm. long, obtuse, entire or rarely with 3 or 4 teeth, pubescent with stellate hairs; scapes nearly glabrous ; flowers $3-4 \mathrm{~mm}$. broad; petals entire, sometimes wanting in the later flowers; pedicels 2-4 mm. long in fruit; pods linear, 8-12 mm. long, nearly $2 \mathrm{~mm}$. broad, glabrous; style none. In sandy fields, Mass. to Ont., Minn., Neb., Ga. and Ark. Marcli-June.

Draba Caroliniàna micrántha (Nutt.) A. Gray. Differs from the type in the appressed-hispid pods. Petals often wanting. Prairies, Ill. to Tex., N. Mex. and Wash.

3. Draba cuneifjlia Nutt. Wedge leaved Whitlow-grass. (I. F. f. I757.) Annual, stellate-pubescent, I-2 dm. high, branching and leafy below. Leaves obsvate, cuneate, or the lowest spatulate, $\mathbf{I}-4 \mathrm{~cm}$. long, obtuse, dentate toward the apex ; flowers $4 \mathrm{~mm}$. broad ; petals emarginate, twice or thrice the length of the calyx; pedicels ascending or spreading, 4-8 $\mathrm{mm}$. long in fruit; pods linear-oblong, ob use, 8-Io $\mathrm{mm}$. long, $2 \mathrm{~mm}$. wide, minutely hairy; style none. In fields, $\mathrm{Ky}$. to Kans., Fla. and Cal. Feb.-April.

4. Draba Fladnizénsis Wulf. White Arctic Whitlow-grass. (I. F. f. 175.) Tufted. Leaves oblanceolate, basal, rosulate, acutish, entire, stellateca iescent or with some simple hairs, ciliate or rarely nearly glabrous, 8-16 mm. long; flowers whitish; scapes glabrous; pedicels ascending, 2-4 mm. long in fruit; pods oblong, glabrous, 4-6 $\mathrm{mm}$. long, nearly $2 \mathrm{~mm}$. wide; style almost wanting. Gaspé, Quebec, and through arctic America, south in the Rocky Mts. to Colo. Also in arctic and alpine Europe and Asia. Summer. 
5. Draba nivàlis Lilj. Yellow Arctic Whitlow-grass. (I. F. f. 1759.) Perennial by a short caudex; scapes tufted, pubescent, slender, $2-10 \mathrm{~cm}$. high, sometimes hearing a small sessile leaf. Basal leaves oblanceolate or spatulate, 4-I4 mm. long, entire, acutish or acute at the apex, narrowed into a short petiole, stellate-canescent; flowers about $4 \mathrm{~mm}$. broad; calyx pubescent; style short; pods oblong or linear-oblong, narrowed at both ends, glabrous or but little pubescent, on ascending pedicels 2-6 mm. long. Lab. through arctic America to Alaska, south in the Rocky Mts. to Colo., and in the Sierra Nevada to Nev. Also in northern Europe and Asia. Summer.

6. Draba incàna L. HOARY OR Twisted Whitlow-grass. (I. F. f. 1760.) Perennial or biennial, leafy, stellate-pubescent, 1.5-3 dm. high. Leaves lanceolate, oblanceolate or ovate, $8-25 \mathrm{~mm}$. long, acutish or obtuse, dentate or nearly entire; flowers 2-3 $\mathrm{mm}$. broad; petals notched, twice as long as the calyx; pods oblong or lanceolate, acute, twisted when ripe, on short pedicels, densely pubescent or nearly glabrous; style minute. In rocky places, Vt., Qucbec to arctic America, Br. Col., south in the Rocky Mts. to Colo. Also in arctic and alpine Europe and Asia. Summer.

Draba incàna arábisans (Michx.) S. Wats. Stem branched below, bearing tufts of spatulate narrow leaves: pods glabrous, twisted; style $1 \mathrm{~mm}$. long. Me., Vt., ind N. Y. to Lab., west along the Great Lakes to Minn. and Manitoba.

7. Draba ramosíssima Desv. Branching Whitlow-grass. (I. F. f. 176I.) Erect, much branched below, 1.5-3.5 dm. high, stellate-pubescent, the branches bearing tufts of leaves, the irflorescence ccrymbose-paniculate. Lower leaves spatulate or oblanceolate, $2-5 \mathrm{~cm}$. long, acute, dentate with spreading teeth; upper leaves oblong or ovate, similarly dentate; flc wers white, 4-6 $\mathrm{mm}$. broad; petals entire or erose, twice or thrice the length of the sepals; pedicels $6-8 \mathrm{~mm}$. long in fruit; pods oblong or lanceolate, hairy, 6-8 mm. long, twisted; style slender, 2-4 mm. long. Mountains of Va., Ky., N. Car. and Tenn. April-May.

8. Draba brachycàrpa Nutt. ShORT-Fruited Whirlow-Grass. (I. F. f. I762.) Annual, tufted, 4-I $3 \mathrm{~cm}$. high, loosely stellate-pubescent, leafy. Basal leaves ovate or obovate, 8-12 mm. long, abtuse, sparingly dentate or entire; stemleaves smaller, sessile, oblong, entire; pedicels 2-4 $\mathrm{mm}$. long in fruit; flowers white, $2 \mathrm{~mm}$. broad; petals somewhat longer than the calyx, sometimes wanting; pods oblong, acute, $2-4 \mathrm{~mm}$. long, I $\mathrm{mm}$. broad; style minute. Dry hills and fields, Va. to Ill., Kans., Ga. and La. March-May.

9. Draba nemcròsa L. Wood Whitlow-grass. (I. F. f. I $76_{3}$ ) Anrual, lonsely stellate-pubescent, $1.5-3 \mathrm{~cm}$. high, branching telow, leafy. Leaves oblongovate, or lanceolate, obtuse, sessile, dentate, the lcwer $I-2.5 \mathrm{~cm}$. long, $I-1.5 \mathrm{~cm}$. wide, the upper smaller; flowers yellow, fading to whitish, $2 \mathrm{~mm}$. broad; petals notched, slightly exceeding the calyx : pedicels spreading in fruit, glabrous, 6-20 $\mathrm{mm}$. long; pods pubescent, or nearly glabrous, oblong, obtuse, 6-8 mm. long; style none. W. Ont., Mich. and Minn. to Ore, arctic Am. and in the Rocky Mts. Also in northern Europe and Asia. Summer.

ro. Draba àurea Vahl. Golden Whitlow-grass. (I. F. f. I764.) Perennial, pubescent with stellate and simple hairs; stem 1.5-2.5 dm. high, leafy. Basal leaves oblanceolate or spatulate, $\mathbf{I - 2 . 5} \mathrm{cm}$. long, slightly dentate or entire, often ciliate at the base ; stem-leaves oblong or lanceolate, acute; pods lanceolate or oblong-lanceolate, $8-12 \mathrm{~mm}$. long ; flowers yellow, $4 \mathrm{~mm}$. broad; petals twice the length of the calyx ; pods acute, pubescent or rarely glabrous, at length slightly twisted, 8-14 mm. long, on erect pedicels; style $1 \mathrm{~mm}$. long. Mignon Island, Gulf of St. Lawrence, to Greenland; arctic Am. and in the Rocky Mts. south to Ariz. Summer.

I I. Draba alpina L. Alpine Whitlow-grass. (I. F.f. I765.) Perennial by a branched caudex, densely tufted; scapes pubescent, I-I $5 \mathrm{~cm}$. high. Leaves basal, entire or few-toothed, oblong, or oblong-lanceolate, mostly narrowed at the base, ciliate, or villous-pubescent, sometimes with some stellate hairs, 4-12 mm. long, sessile or short-petioled; flowers about $6 \mathrm{~mm}$. broad; calyx pubescent or villous; style I mm. long or less; pod oval or ovate, narrowed at both ends, 5-8 $\mathrm{mm}$. long: pedicels 2-10 mm. long. Hudson Bay to Br. Col. and Alaska. Also in northern Europe and Asia, Summer. 


\section{SOPHIA Adans.}

Herbs (some exotic species shrubby), canescent or pubescent with short forked hairs, with slender stems, 2-pinnatifid or finely dissected leaves, and small yellow flowers in terminal racemes. Calyx early deciduous. Style very short. Siliques linear or linear-ob!ong, the valves I-nerved. Seeds small, oblong, wingless; cotyledons incumbent. [Name in allusion to reputed medicinal properties.] About if species, natives of the north temperate zone, the Canary Islands, and the Andes of S. Am. Besides the following, a nother occurs in the southwestern U. S.

Pods narrowly linear, $1.5^{-2.5} \mathrm{~cm}$. long, $1 \mathrm{~mm}$. wide, curved upward ; pedicels ascending.

Pods linear-oblong, 5-14 mm. long, I-2 mm. wide, straight or nearly so.

$$
\text { I. S. Sophia. }
$$

Densely and finely canescent; pecicels horizontal; pods ascending. 2. S. pinnata.

Glabrate or somewhat canescent.

Pedicels and pods horizontal.

Pedicels ascending or erect; pods almost erect.

3. S. millefolia.

Pedicels mostly longer than the pods.

Leaves oblong or oblanceolate in outline; terminal segment of the pinnae not very broad; style evident but short.

4. S. intermedia.

Lower leaves obovate in outline; terminal segment of the pinnae much broader than the others; style obsolete. 5 5. S. brachycarpa.

Pedicels shorter than or equalling the pods. $\quad$ 6. S. Hartwegiana.

I. Sophia Sòphia (L.) Britton. Flixweed. Herb-Sophia. (I. F. f. 1766.) Minutely hoary-canescent; stem usually much branched, 3-7.5 dm. tall. Leaves 2-3-pinnatifil into narrowly linear or linear-oblong segments; flowers numerous, about $6 \mathrm{~mm}$. long; pedicels ascending, slender, 12-16 $\mathrm{mm}$. long, glabrous or nearly so; seeds in 1 row in each cell of the pod. In waste places, N. B. to Ont., N. Y., IIl. and Neb. Nat. from Europe. June-Aug. [Sisymbrium Soplizi L.]

2. Sophia pianàta (Walt.) Britton. TAnsy-Mustard. (I. F. f. 1767.) Densely canescent; stem $2.6 \mathrm{dm}$. tall, the branches ascending. Leaves $5-10 \mathrm{~cm}$. long, oblong in outline, 2 pinnatifid into numerous small obtuse segments; pedicels slender, spreading nearly or quite at right angles to the axis, 10-14 mm. long, usually longer than the pols; flowers $2-3 \mathrm{~mm}$. broad; pods ascending, oblong or linear-oblong, 6-8 $\mathrm{mm}$. long, $2 \mathrm{~mm}$. wide; style minute; seeds in 2 rows in each cell. In dry soil, Va. to Fla and Tex. May-July. [Sisymbrium canescens Nutt.]

3 S phia millefolıa Rydberg. SouThern TAnsy-Mustard. Generally taller and less leafy than the preceding, with broader leaves, oval in outline, less dissected, very thin; wloole plant almost perfectly glabrous; pedicels $15-20$ $\mathrm{mm}$. lon $r$; pods club-shaped, less than $1 \mathrm{~cm}$. long; style short; seeds in 2 rows. [Sisymbrium myriophyllum Meisner, not DC.] Ky. to Tex. May-June.

4. Sophia intermédia Rydb. Western Tansy-Mustard. (I. F. f. I768.) Resembles S.pinnata, but is greener, nearly glabrous, or the pubescence mixed with short glandular hairs. Leaves pinnately divided, and the pinnae I 2-pinnatifid into line:rr-oblong entire or toothed segments; fruiting pedicels widely ascending, I-2 cm. long, usually longer than the pods; pods 8-14 mm. long, about $2 \mathrm{~mm}$. thick, almost erect, seeds in I row. In dry soil, N. Y. to the N. W. Terr., Br. Col., Tenn., Kans., Tex. and Cal. Has been mistaken for S. pinnata aud S. incisa. May-Aug.

5. Sophia brachycàrpa (Richards.) Rydb. Northern Tansy-Mustari). In general habit and form of the leaves closely resembling $S$. Sophia, but the leaf segments are shorter, broader and more obtuse: pods short, clavate, $58 \mathrm{~mm}$. long, with an obsolete style [Sisymbrium brachycarpon Richardson]. Camada (Pursh and Presque Isle, Mich. (Houghton), to Assiniboia and Arkansis. May-July.

6. Sophia Hartwegiàna (Fourn.) Greene. HarTwEG's TANSY-Mustard. (I. F. f. I 769.) Minutely canescent or puberulent; stem 3-6 dm. tall. Leaves pinnately divided into 5-7 pinnae, which are pinnatifid, with obtuse segments and lobes: fruiting pedicels erect appressed, 3-8 $\mathrm{mm}$. long, shorter than or equalling the pods: pods erect or nearly so, linear, $8-10 \mathrm{~mm}$. long, about $1 \mathrm{~mm}$. thick; seeds in I row. In dry soil, Minn. to the N. W. Terr., Ore., Utah, Mex. and Cal. May-July. 


\section{STENOPHRÀGMA Celak.}

Herbs with the aspect of some species of Arabis, pubescent with forked hairs, with slender stems, and small white flowers in terminal racemes. Style very short; stigma 2 -lobed. Siliques narrowly linear, dehiscent, the valves rounded, nerveless. Seeds in I row in each cell in the following species, in some European species in 2 rows; cotyledons incumbent. [Greek, narrow septum.] About Io species, natives of Europe and Asia, the following are annual weed.

I. Stenophragma T. àliana (L.) Celak. Mouse-EAR Cress. (I. F. f. I770.) Stem erect, 2-40 cm. high, freely branching, pubescent, especially below. Basal leaves 2-5 cm. long, obtuse, oblanceolate or oblong, narrowed into a petiole, entire or slightly toothed; stem-leaves smaller, sessile, often entire; pedicels slender, spreading or ascending, $4-8 \mathrm{~mm}$. long in fruit; flowers white, about $3 \mathrm{~mm}$. long; petals about twice the length of the sepals; pods $8-20 \mathrm{~mm}$. long, acute; often curved upward, glabrous. In sandy fields and rocky places, Mass. and S. Ont. to Minn., Ga. and Mo. Nat. from Europe. April-May. [Arabis Thaliana L.]

\section{3. ÁRABIS L.}

Glabrous or pubescent herbs, with white or purple flowers. Siliques linear, elongated, flat; valves smooth, keeled or ribbed, mostly I-nerved, not elastically dehiscent. Seeds in $\mathbf{I}$ or 2 rows in each cell, flattened. winged; cotyledons accumbent. [Name from Arabia.] About 80 species, mainly natives of the northern hemisphere. In addition to the following, about 26 others occur in the northern and western parts of the continent.

Seeds in 1 row, or in 2 incomplete rows in each cavity of the pod.

Basal leaves pinnatifid; pods ascending.

Seeds about $2 \mathrm{~mm}$. broad, orbicular, wing-margined; stem-leaves pinnatifid.

Seeds minute, oblong, wingless ; stem-leaves entire, or dentate.

1. A. Virginica.

2. A. lyrata.

Leaves small, mostly entire; pods drooping; seeds oblong, wingless; arctic.

Basal leaves merely dentate or lyrate.

Seeds minute, oblong, wingless.

Seeds larger, oblong, winged or margined.

Pods curved upward, nearly $2 \mathrm{~mm}$. broad. 5. A. alpina.

Pods nearly erect, $1 \mathrm{~mm}$. broad.

3. A. arenicola.

Flowers white, $8 \mathrm{~mm}$. broad; pods not appressed; style I mm. long.

6. A. patens.

Flowers white or greenish-white, $4-6 \mathrm{~mm}$. broad ; pods appressed; style none.

Pods recurved-spreading.

Plant glabrous throughout.

Leaves and lower part of stem hairy.
ct rows in each cavity of the pod.

7. A. hirsuta.

Seeds in 2 distinct rows in each cavity of the pod.
Pods spreading or ascending; seeds winged.

Pods erect, appressed ; seeds wingless or narrowly winged.

Pods reflexed; seeds winged.

8. A. laevigata.

9. A. Canadensis.

I. Arabis Virgínica (L.) Trelease. Virginia Rock-CREss. (I. F. f. I77I.) Annual or biennial, diftuse, glabrate; stems ascending, I.5-3 dm. high. Leaves oblong, narrow, deeply pinnatifid, $2-8 \mathrm{~cm}$. long, the lower petioled, the upper nearly sessile, sometimes reduced to lobed or entire bracts; pedicels $4 \mathrm{~mm}$. long in fruit; flowers very small, white; pods linear, ascending, $1.5-2.5 \mathrm{~cm}$. long. about $2 \mathrm{~mm}$. broad; seeds nearly as broad as the pod. In open places, Va. and $\mathrm{Ky}$. to Kans., Fla. Tex. and Lower Cal. March-May. [A. Ludoviciana Meyer.]

2. Arabis lyràta L. LYRE-LEAVED ROCK-CKESS. (1. F. f. I772.) Tufted, perennial or biennial, erect; I-3 dm. high, glabrous, or pubescent below. Basal leaves lyrate-pinnatifid, $2-5 \mathrm{~cm}$. long, spatulate or oblanceolate; stem-leaves spatulate or linear, $1-2.5 \mathrm{~cm}$. long; pedicels $6.8 \mathrm{~mm}$. long in flower; flowers white, $6-8$ $\mathrm{mm}$. broad; petals much exceeding the calyx; pods $1.5-3 \mathrm{~cm}$. long, linear, less than $2 \mathrm{~mm}$. broad. their valves firm, nerved; style I $\mathrm{mm}$. long; seeds $0.5 \mathrm{~mm}$. long. Rocky and sandy places, Qut, to Va., Tenn., Manitoba and Mo. April- 
A rabis lyràta occidentzlis S. Wats. Valves of the pod thin, faintly nerved; stigma sessile or very nearly so. Lake Erie; $\mathrm{Br}$. Col. to Alaska.

3. Arabis arenícola (Richards.) Gelert. ArCtic Rock CRESS. (I. F. f. I773.) Perennial, pubescent below, or glabrous; stems diffuse or ascending, $0.7-1.5 \mathrm{dm}$. long. Leaves spatulate or oblong, nearly entire, 8-16 mm. long, the lower petioled; flowers purplish or white, about $6 \mathrm{~mm}$. broad; style very short; pods linear, flat, at length drooping, $1.5-2.5 \mathrm{~cm}$. long, rather more than I $\mathrm{mm}$. wide, the valves very faintly nerved; seeds in 2 incomplete rows in each cell; cotyledons imperfectly accumbent. Greenland and Lab. to Hudson Bay and the N. W. Terr. Summer. [A. humifusa S. Wats.]

4. Arabis dentàta T. \& G. Toothen Rock-Cress. (I. F. f. I774.) Slender, 3-6 dm. high, finely rough-pubescent. Basal leaves with margined petioles, obovate, dentate, 5-10 cm. long, obtuse ; stem-leaves sessile, clasping by an auricled base, dentate ; pedicels 2-4 mm. long; flowers greenish white, 2-4 mm. broad, the petals hardly exceeding the calyx : pods narrowly linear, 2-3 cm. long, spreading; style almost none. W. N. Y. to Minn., Tenn., Mo. and Kans. April-June.

5. Arabis alpina L. Alpine Rock CRess. (I. F. f. I775.) Densely and finely pubescent, $1-3 \mathrm{dm}$. high. Basal leaves 2-5 cm. long, obovate or spatulate, obtuse, dentate, on margined petioles ; stem-leaves ovate, sessile, clasping by an auricled base, dentate; flowers white, 4-6 mm. broad; petals much exceeding the calyx; pedicels $8 \mathrm{~mm}$. long in fruit; pods $2-4 \mathrm{~cm}$. long, curved upward, narrowly linear, $2 \mathrm{~mm}$. broad. Quebec to Lab. and Alaska. Europe and Asia. Summer.

6. Arabis patens Sulliv. Spreading Rock-Cress. (I. F. f. I776.) Erect, 3-6 dm. high, pubescent at least below. Basal leaves dentate, $2-8 \mathrm{~cm}$. long, on margined petioles; stem-leaves $2-5 \mathrm{~cm}$. long, ovate or oblong, acute or acutish, sessile, dentate or nearly entire, partly clasping; pedicels $12-16 \mathrm{~mm}$. long in fruit; pods $2-4 \mathrm{~cm}$. long, $1 \mathrm{~mm}$. broad, not appressed. E. Penn. to Minn., Ala. and Mo. Summer.

7. Arabis hirsùta (l.) Scop. HAIRy Rock-Cress. (I. F. f. I777.) Stem erect, 3-6 dm. high. Basal leaves with margined petioles, obovate or spatulate, obtuse, dentate or repand, 2-5 cm. long: stem-leaves sessile, clasping, lanceolate or oblong; pedicels nearly erect, 6-12 mm. long in fruit ; pods narrowly linear, erect, $2-5 \mathrm{~cm}$. long, about I $\mathrm{mm}$. wide; seeds I-rowed, or when young obscurely 2-rowed, oblong or nearly orbicular. In rocky places, N. B. to Br. Col., Ga., Ariz. and Cal. Also in Europe and Asia. May-Sept.

8. Arabis laevigàta (Muhl.) PoIr. SMOоTh Rock.cress. (I. F. f. I778.) Glaucous, glabrous, 3-9 dm. high. Basal leaves petioled, spatulate or obovate, sharply dentate, $5-8 \mathrm{~cm}$. long ; stem-leaves sessile, lanceolate, or the upper linear, acute, clasping by an auricled or sagittate base ; pedicels 8 - $10 \mathrm{~mm}$. long in fruit ; petals nearly twice the length of the calyx; pods $7-10 \mathrm{~cm}$. long, $2 \mathrm{~mm}$. wide, re. curved-spreading; seeds broadly winged; style almost none. In rocky woods, Quebec to Minn., Kans., Ga. and Ark. April-May.

\section{Ky.}

Arabis laevígata laciniàta T. \& G. Stem-leaves deeply and narrowly laciniate-toothed

Arabis laevigàta Búrkii Porter. Leaves linear or lanceolate, elongated, entire or sparingly toothed, not auricled at the base; flowers one-half the size of the type; petals equalling the sepals. Penn. to N. Car.

9. Arabis Canadénsis L. Sickle-pod. (I. F. f. I779.) Stem 3-9 dm. high, pubescent below. Basal leaves narrowed into a petiole, dentate or lyrately lobed, 7-16 cm. long; stem-leaves sessile, lanceolate or oblong, narrowed at each end, toothed, or the upper entire, pubescent : pedicels spreading or recurved and 8-12 mm. long in fruit; petals twice as long as the calyx; pods $5-9 \mathrm{~cm}$. long, $3 \mathrm{~mm}$. broad, scythe-shaped, pendulous; style almost none. In woods, Ont. to N. H., Ga., Minn., Kans. and Tex. June-Aug.

10. Arabis brachycàrpa (T. \& G.) Britton. Purple Rock-cress. (I. F. f. I78o.) Glaucous, generally purplish, glabrous except at the base, 3-9 dm. high. Basal leaves stellate-pubescent, obovate or spatulate, $2-8 \mathrm{~cm}$. long, dentate, nurrowed into a petiole; stem-leaves sessile, auricled, lanceolate or oblong-linear, entire or with a few teeth; pedicels 6 -10 $\mathrm{mm}$. long in fruit; flowers white or pink, $8 \mathrm{~mm}$. broad; petals twice the length of the calyx; pods narrowly linear, nearly 
straight, $2-8 \mathrm{~cm}$. long, $2 \mathrm{~mm}$. wide, spreading or ascending. Quebec to Manitoba, the N. W. Terr., Mass., N. Y., Ill. and Minn. June-July. [A. confinis S. Wats.]

I I. Arabis glàora (L.) Bernh. Tower Mustard. (I. F. f. I781.) Gla. brous, glaucous above, pubescent at the base, 6-12 dm. high. Basal leaves petioied, $0.5^{-2.5} \mathrm{dm}$. long, oblanceolate or oblong, dentate or sometimes lyrate, hairy; stem-leaves sessile, with a sagittate base, glabrous, lanceolate or oblong, acutish; pedicels 4-12 mm. long, erect; flowers yellowish-white, $4 \mathrm{~mm}$. broad; petals slightly exceeding the calyx; pods narrowly linear, $5^{-8} \mathrm{~cm}$. long, $1 \mathrm{~mm}$. wide, erect and appressed; style none. In fields and rocky places, Quebec to S. N. Y., Penn., west to the Pacific Coast. Also in Europe and Asia. May-Aug.

I 2. Arabis Holboèllii Hornem. Holboell's Rock-Cress. (I. F. f. I782.) Erect, 2-6 dm. high. Lower leaves spatulate or oblanceolate, tufted, petioled, I $-5 \mathrm{~cm}$. long, obtuse, entire or sparingly toothed; stem-leaves sessile, erect, clasping; pedicels reflexed or the upper ascending, 6-10 $\mathrm{mm}$. long in fruit; flowers purple or whitish, $6-8 \mathrm{~mm}$. long; petals twice the length of the calyx; pods linear, 2-5 cm. long, slightly more than $1 \mathrm{~mm}$. wide, reflexed; style very short or none. Manitoba and Arctic Am. to Neb., N. Mex. and Cal. Summer.

\section{ERÝSIMUM L. (See Appendix.)}

Annual or biennial herbs, more or less pubescent or hoary, with simple leaves. Flowers mostly yellow. Siliques elongated, linear, 4-angled or rarely terete; valves strongly keeled by a prominent midvein. Stigma lobed. Seeds oblong, in I row in each cell, marginless or narrowly margined at the top; cotyledons incumbent. [Greek, name of a garden plant, meaning, perhaps, blister-drawing.] About 85 species, natives of the north temperate zone. In addition to the following, 2 others are found in the Rocky Mts. and one on the Californian coast.

Flowers 4-8 mm. high.

Pedicels slender, spreading; pods very narrow, $1-2.5 \mathrm{~cm}$. long.

Pedicels stout, short; pods $1.5-5 \mathrm{~cm}$. long.

I. E. cheiranthoides.

Pods 2-5 cm. long, less than $2 \mathrm{~mm}$. thick; plant green, appressed-pubescent.

2. E. inconspicuum.

Pods $1.5-3.5 \mathrm{~cm}$. long, about $2 \mathrm{~mm}$. thick ; plant pale, appressed-canescent.

Flowers $16-25 \mathrm{~mm}$. high, conspicuous.

3. E. syrticolum.

Stem-leaves linear, grayish strigose ; pods widely spreading. 4. E. asperum.

Stem-leaves lanceolate, green; pods less spreading.

5. E. Arkansanum.

I. Erysimum cheiranthoides L. WORM-SEed or Treacle Mustard. (I. F. f. I783.) Minutely rough-pubescent, 2-6 dm. high. Leaves lanceolate or oblong-lanceolate, 2-10 cm. long, entire or slightly dentate, tapering into a short petiole or the upper sessile; pedicels spreading or somewhat ascending, 6-8 $\mathrm{mm}$. long in fruit; flowers about $5 \mathrm{~mm}$. high; pods linear, obtusely 4-angled, glabrous, I-2.5 cm. long, less than $2 \mathrm{~mm}$. broad, nearly erect on spreading pedicels; style I mm. long. Along streams and in fields, Newf. to Br. Col., Tenn. Also in northern Europe. June-Aug.

2. Erysimum inconspícuum (S. Wats.) MacM. Small Erysimum. (I. F. f. 1784.; Roughish puberulent; stem 3-6 dm. tall. Leaves oblanceolate or linear, 2-8 cm. long, obtuse, entire or dentate, the upper sessile, the lower slenderpetioled; flowers about $8 \mathrm{~mm}$. high; pedicels stout, about $4 \mathrm{~mm}$. long in fruit, ascending; pods narrowly linear, minutely rough-puberulent, ascending or erect; style very stout, I-2 mm. long. In dry soil, Ont. and Minn. to Manitoba, Alaska, Kans., Colo. and Nev. July-Aug. [E. parviflorum Nutt., not Pers.]

3. Erysimum syrtí:olum Sheldon. SAND ERysimum. (I. F. f. 1785.) Similar to the preceding, but pale and finely appressed-canescent, the stems 3-8 $\mathrm{dm}$. tall. Lezves firm, linear-lanceolate, entire or denticulate, early falling away; stigma conspicuously 2 -lobed; style less than $2 \mathrm{~mm}$. long; pods linear, erect or nearly so on ascending pedicels; seeds oblong, I $\mathrm{mm}$. long. On dry sandy banks, Minn. to the N. W. Terr. July-Aug.

4. Erysimum ásperum DC. Western WALl-Flower. (I. F. f. 1786.) Rough-pubescent or hoary, 2-5 dm. high. Lower leaves lanceolate or oblanceolate, tapering into a petiole, dentate or sometimes entire; upper leaves sessile or nearly 
so, entire or rarely toothed; flowers orange-yellow, $12-20 \mathrm{~mm}$. high and nearly as broad; pedicels stout, spreading, 4-6 mm. long in fruit; pods linear, rough, $5-8 \mathrm{~cm}$. long, nearly $2 \mathrm{~mm}$. wide, 4-sided; style short, thick. Dry plains, Ark. to Minn., Cal. and the N. W. Terr. May-July.

5. Erysimum Arkansanum Nutt. Yellow Phlox. Taller and greener than the preceding, 6-Io $\mathrm{dm}$. high, with a more leafy and branched stem, slightly strigose with branched hairs; flowers $20-25 \mathrm{~mm}$. high ; pod linear, tapering at the summit, about I dm. long. Open places, Ohio and Ill. to Tex. May-June.

\section{ALÝSSUM L.}

Low stellate pubescent herbs, with small racemose yellow or yellowish flowers. Petals entire. Filaments often dilated and toothed or appendaged. Silicle ovate, oblong or orbicular, compressed, its valves nerveless, the septum thin. Stigma nearly entire. Seeds I-8 in each cell, wingless; cotyledons accumbent. [Greek, curing madness.] About Ioo species, natives of the Old World.

I. Alyssum alyssoides (L.) Gouan. Yellow or Small Alyssum. (I. F. f. I787.) Densely stellate-pubescent, tufted, 0.7-2.5 dm. high. Leaves linearoblong or spatulate, narrowed at the base, obtuse, entire, $0.6-3 \mathrm{~cm}$. long; flowers $2 \mathrm{~mm}$. broad; pedicels $4 \mathrm{~mm}$. long in fruit; pods orbicular, $3 \mathrm{~mm}$. in diameter, margined, minutely pubescent, notched, tipped with the minute style; sepals persisting around the base of the pod; seeds 2 in each cell. In fields, Ont. to N. H., N. Y., N. J. and lowa, and in ballast about the seaports. Also in the Far West Nat. or adventive from Europe. Summer. [A. calycinum L.]

\section{KòNIGA Adans.}

Perennial herbs or shrubs, pubescent or canescent with forked hairs, with entire leaves, and small white flowers in terminal racemes. Petals obovate, entire. Filaments slender, not toothed, but with two small glands at the base. Silicle compressed, oval or orbicular. Seeds I in each cell. Cotyledons accumbent. [Name in honor of Charles Konig, a curator of the British Museum.] About 4 species, natives of the Mediterranean region.

I. Koniga maritima (L.) R. Br. Sweet Alyssum. Seaside Koniga. (I. F. f. I788.) Procumbent or ascending, I-3 dm. high, minutely pubescent. Stem-leaves nearly sessile, lanceolate or linear, I-5 cm. long; basal leaves oblanceolate, narrowed into a petiole; flowers fragrant, about $4 \mathrm{~mm}$. broad; pedicels 6 $8 \mathrm{~mm}$. long in fruit; pods glabrous, pointed, $2-3 \mathrm{~mm}$. long; calyx deciduous: stamens not appendaged. In waste places, occasional. Escaped from gardens. Adventive from Europe. Summer. [Alyssum maritimum L.]

\section{BERTERÒA DC.}

Herbs, pubescent or canescent with forked hairs, the leaves mostly narrow and entire, and the flowers white or yellow in terminal racemes. Petals 2-cleft. Filaments 2 -toothed at the base. Silicles oblong or subglobose, little compressed. Seeds several in each cell; cotyledons accumbent. [In honor of C. G. Bertero, a botanist of Piedmont, 1739-183I.] About 5 species, natives of Europe and Asia.

ז. Berteroa incàna (L.) DC. HoARy Alyssum. (I. F. f. I789.) Erect or ascending, 3-6 dm. high, hoary-pubescent. Leaves lanceolate or oblong, $1-4 \mathrm{~cm}$. long, obtuse, entire or slightly undulate; flowers white, $2-3 \mathrm{~mm}$. broad; pedicels 4-6 mm. long in fruit; pod pubescent, oblong, 6-8 mm. long; cells several-seeded; style 2-3 mm. long. In waste places, Me. to Ont., Minn., N. J., and Mo. Adventive or nat. from Europe. Racemes elongating, the flowers and pods very numerous. June-Sept. [Alyssum incanum L.]

\section{HÉSPERIS L.}

Erect perennial or biennial herbs, pubescent with forked hairs, with simple leaves and large racemose purple or white flowers. Stigma with 2 erect lobes. Siliques elongated, nearly cylindric, the valves keeled, dehiscent. I-nerved. Seeds in I row in each cell, globose, wingless; cotyledons incumbent. [Name from Hesperus, evening, when the flowers are most fragrant.] About 20 species, natives of Europe and Asia. 
¿. Hesperis matronàlis L. DAME's Rocket or DAine's V̂LLET. (I. F. f. 7790.) Erect, $69 \mathrm{dm}$. high, pubescent. Lower leaves I-2 dm. long, tapering into a petiole, ovate or ovate-lanceolate, acute, dentate with minute teeth, pubes. cent on both sides; upper leaves smaller, sessile or short-petioled; flowers 1.5-2.5 $\mathrm{cm}$. broad; blade of the petals spreading; pods 5-10 $\mathrm{cm}$. long, spreading or ascending, contracted between the seeds when ripe. In fields and along roadsides, Me. to Penn. and Iowa. Native of Europe and Asia. May-Aug.

39. CONRÍNGIA Link.

An erect glabrous annual herb, with elliptic or ovate entire leaves, sessile and cordate at the base, and middle-sized yellowish white flowers in terminal racemes. Sepals and petals narrow, Style 2-lobed or entire. Siliques elongated-linear, angled, the valves firm, I-3-nerved. Seeds in I row in each cell, oblong, marginless, cotyledons incumbent. [In honor of Hermann Conring, 1606-1681, Professor at Helmstädt.]

I. Conringia orientàlis (L.) Dumort. Hare's-ear. Treacle Mustard. (I. F. f. r790a.) Stem 3-9 dm. high. Leaves light green, obtuse, $5^{-1} 3 \mathrm{~cm}$. long; racemes elongating in fruit; pedicels $8-16 \mathrm{~mm}$. long; petals about $1.2 \mathrm{~cm}$. long, nearly twice as long as the sepals; pods 7-13 cm. long, about $2 \mathrm{~mm}$. wide, 4-angled, spreading. In waste places, Mich. and Minn. to the N. W. Terr., and from N. B. to N. Y. and Penn. Naturalized from Europe.

\section{Family 3. CAPPARIDÀCEAE Lindl.}

\section{Caper Family.}

Herbs or shrubs (rarely trees), with alternate or very rarely opposite leaves, and regular or irregular, mostly perfect flowers. Sepals 4-8.

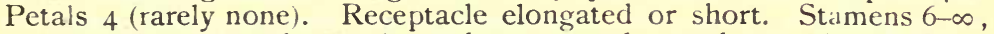
not tetradynamous, inserted on the receptacle; anthers oblong. Style generally short, ovules $\infty$, on parietal placentae. Fruit a capsule or berry. Seeds mainly reniform in our species; endosperm none; embryo generally coiled. About 35 genera and 400 species, mostly of warm regions.

Pod long-stipitate on its pedicel.

Pod linear-elongated; petals generally clawed.

Petals entire.

Petals laciniate.

Pod short, rhomboid; petals sessile.

Pod nearly or quite sessile on its pedicel.

I. Cleome.

2. Cristatella.

3. Cleomella.

4. Polanisia.

\section{CLEOME L.}

Herbs or low shrubs. Leaves digitately 3-5-foliolate, or simple. Flowers mostly racemose. Calyx 4-divided or of 4 sepals, often persistent. Petals 4 , cruciate, nearly equal, entire, more or less clawed. Receptacle short, slightly prolonged above the petal-bases. Stamens 6 (rarely 4), inserted on the receptacle. Ovary stalked, with a gland at its base. Capsule elongated, many-seeded. [Derivation uncertain.] About 75 species, mainly natives of tropical regions, especially American and African. In addition to the following, 4 others occur in the western part of the United States.

Leaves 3 -foliolate; flowers pink, or white.

Leaves, at least the lower, 5-7-foliolate.

Flowers pink, or white.

Flowers yellow.

I. Cleome serrulàta Pursh. Pink Cleome. (I. F. f. 179I.) Erect, gla. brous, 6-9 dm. high. Leaves 3-foliolate, the lower slender-petioled, the upper sessile or nearly so; leaflets lanceolate or oblong, acute, entire or distantly serrulate, 2-8 cm. long; bracts lanceolate or linear; pedicels spreading or recurved, $\mathbf{r}-2$ $\mathrm{cm}$. long in fruit; stipe of the pod about equalling the pedicel; petals oblong, slightly clawed, 50-12 $\mathrm{mm}$. long, obtuse; pods linear, acute, 2-5 cm. long. 
Prairies, Ill. to Minn., the Canadian Rocky Mts., Kans., N. Mex. and Ariz. Nat. from the west in its eastern range. July-Sept. [C: incegrifolia T. \& G.]

2. Cleome spinòsa L. SPIDER-Flower. (I. F. f. I792.) Erect, 6-12 dm. high, clammy-pubescent. Leaves 5-7-foliolate, the lower long-petioled, I-2 dm. in diameter, the upper passing into the simple bracts of the raceme; petioles spiny at the base; leaflets lanceolate, acute, serrulate; flowers long-pedicelled, purple or whitish, 2-3 cm. broad; petals obovate, long-clawed; stipe of the linear glabrous pod at length $5-15 \mathrm{~cm}$. long; stamens often long-exserted. In waste places, $\mathrm{S}$. N. Y. to Fla., Ill. and La. Adventive from tropical America. Summer.

3. Cleome lùtea Hook. Yellow Cleome. (I. F. f. I793.) Erect, glabrous, 4-ro dm. high. Leaves 5-foliolate, slender-petioled, or the upper 3-foliolate and nearly sessile; leaflets oblong or oblong-lanceolate, entire, short-stalked or sessile, 1-5 cm. long; bracts linear-oblong. mucronate; pedicels slender, 10-12 mm. long; flowe- s yellow; petals about I cm. long; pod linear, $3-8 \mathrm{~cm}$. long, acute, borne on a stipe becoming longer than the pedicel. In dry soil, Neb. to Wash. and Ariz. June-Sept.

\section{CRISTATÉLla Nutt.}

Annual viscid glandular-pubescent herbs, with digitately 3 -foliolate leaves, and small white or yellowish flowers in terminal bracted racemes. Sepals spreading, slightly united at the base. Petals 4, laciniate or fimbriate at the summit. borne on long slender claws, the two lower smaller than the two upper. Receptacle short, with a short petaloid nectary between the ovary and the upper sepal. Stamens 6-14; filaments slender, declined. Ovary stalked, also declined. Capsule linear, nearly terete, many-seeded. [Diminutive of cristatus, crested.] Two species, natives of the south-central U. S.

I. Cristatella Jàmesii T. \& G. James' CRistatella. (I. F. f. I794.) Erect, I.5-4 dm. high. Leaves slender-petioled; leaflets nearly sessile, linear or linear-oblong, entire, obtuse, 8-25 mm. long; flowers slender-pedicelled; bracts mostly 3-foliolate; claws of the larger petals 3-5 mm. long; pod much longer than its stipe and somewhat longer than the pedicel. In dry soil, Neb. to La. and Tex. June-Dec.

\section{CLEOMÉLLA DC.}

Annual glabrous herbs, with small yellow flowers and 3 foliolate leaves. Calyx of 4 sepals. Petals 4 , sessile, not clawed. Receptacle short, glandless. Stamens 6 , inserted on the receptacle. Ovary short, long-stalked. Capsule short, rhomboid or trapezoid, often broader than long, 4-10-seeded. [Diminutive of Cleome.] About 8 species, natives of southwestern N. Am. and Mex.

I. Cleomella angustifolia Torr. Nurthern Cleomella. (I. F. f. I795.) Branching above, 3-5 dm. high. Leaflets linear-lanceolate or linear-oblong : bracts linear, simple: flowers $4-6 \mathrm{~mm}$. broad; pedicels $\mathbf{I}-\mathbf{I} .5 \mathrm{~cm}$. long in fruit; pod rhomboil. $4.6 \mathrm{~mm}$. broad, pointed, raised on a slender stipe 4-8 $\mathrm{mm}$. long, its valves almost conic; placentae persistent after the valves fall away, each bearing about 3 seeds. Prairies, Neb. and Colo. to Tex. and N. Mex. Summer.

\section{POlanísia Raf.}

Annual herbs, mainly glandular-pubescent, with whitish or yellowish flowers, and palmately compound or rarely simple leaves. Sepals 4, lanceolate, deciduous. Petals slender or clawed. Receptacle depressed, bearing a gland at the base of the ovary. Stamens $8-\infty$, unequal. Pod nearly or quite sessile, elongated, cylindric or compressed, its valves dehiscent from the summit. Seeds rugose or reticulated. [Greek, very unequal, referring to the stamens.] About I4 species, of temperate and tropical regions.

Stamens equalling or slightly exceeding the petals; flowers $4^{-6} \mathrm{~mm}$. long.

Stamens much exceeding the petals; flowers 8-12 $\mathrm{mm}$. long.

1. P. graveolens.

2. P. trachysperma.

I. Polanisia gravèolens Raf. CLAMmy-WEed. (I. F. f. I796.) Viscid, I-4.5 dm. high. Leaves 3 . fol:olate, slender-petioled; leaflets oblong, obtuse, entire, I-2.5 cm. long; sepals purplish, slightly unequal; petals cuneate, emarginate or obcordate; stamens 9-12, purplish, equalling or slightly exceeding the petals; 
style about $2 \mathrm{~mm}$. long; pod lanceolate-oblong, slightly compressed, 2-4 cm. long, $6-8 \mathrm{~mm}$. wide, slightly stipitate, rough, reticulated; seeds rough. Sandy and gravelly shores, Quebec to Manitoba, the N. W. Terr., N. Y., Penn., Kans. and Colo. Summer.

2. Polanisia trachyspérma T. \& G. LARge-Flowered Clammy-weed. (I. F. f. I797.) Similar to the last, but flowers twice the size; style 4-6 mm. long; stamens much exserted; filaments purple, conspicuous; pod slightly larger, nearly or quite sessile. Prairies, Iowa to Tex., Br. Col., Nev. and Ariz. Summer.

\section{Family 4. RESEDÀCEAE S. F. Gray. Mignonette Family.}

Herbs, rarely woody, with alternate or fascicled leaves, gland-like stipules and racemose or spicate, bracted flowers. Flowers unsymmetrical. Calyx 4-7-parted, inequilateral. Petals generally 4-7, hypogynous. Disk fleshy, hypogynous, I-sided. Stamens 3-40; filaments generally unequal. Ovary I, compound, of 3-6 carpels ; styles or sessile stigmas 3-6; ovules $\infty$. Fruit capsular in all but I genus. Seeds reniform, without endosperm; cotyledons incumbent. Six genera and about 65 species, natives of the Old World.

\section{\. RESEDA L.}

Herbs, with small spicate or narrowly racemose flowers. Petals $4-7$, toothed or cleft. Disk cup-shaped, glandular. Stamens 8-30, inserted on one side of the flower and on the inner surface of the disk. Capsule 3-6-lobed, horned, opening at the top. [Ancient Latin name.] About 55 species, natives of the Old World.

Leaves entire; upper petals lobed, the lower entire.

I. R. Luteola. Leaves lobed or pinnatifid.

Petals greenish-yellow, 3 or 4 of them divided.

Petals white, all of them cleft or divided.

2. R. lutea.

3. R. alba.

I. Reseda Lutèola L. Dyen's Rocket. Yellow-weed. (I. F. f. I798.) Glabrous, erect, 3-8 dm. high. Leaves lanceolate or linear, entire, obtuse, sessile or the lower narrowed into petioles; flowers greenish-yellow, 2-4 mm. broad, in long narrow spikes; sepals 4 ; petals 4 or 5 , very unequal; capsule globose, 4-6 $\mathrm{mm}$. in diameter, with 3 or 4 apical teeth and 6-8 lateral ridges. In waste places, N. Y., and in ballast about the seaports. Adventive from Europe. Summer.

2. Reseda lùtea L. Yeliow Cut-Leaved Mignonette. (I. F. f. I799.) Ascending or decumbent. Leaves $5^{-10} \mathrm{~cm}$. long, broadly ovate or oblong in outline, deeply lobrd or divided; sometimes pinnatifid, their segments linear or oblong, obtuse; flowers greenish-yellow, 4-6 mm. broad; pedicels about $4 \mathrm{~mm}$. long in fruit; petals 6 or 5 , all but the lowest irregularly cleft; capsule oblong, about $8 \mathrm{~mm}$. long, 3-4 mm. wide, with 3 or rarely 4 short teeth. In waste places, Mass. to N. J. and Mich., and in ballast about the seaports. Adventive from Europe. Summer.

3. Reseda álba L. White Cut-leaved Mignonette. (I. F. f. I8oo.) Erect, somewhat glaucous, 3-9 dm. high. Leaves pinnate or deeply pinnatifid, the segments 9-12, linear or lanceolate, obtusish, 8-25 mm. long; flowers nearly or quite white, 4-6 mm. broad, in dense spike-like racemes; petals 6 or 5, 3-cleft at the summit; capsule ovoid-oolong, usually 4-toothed, ro-12 $\mathrm{mm}$. long. In waste places, Conn., N. Y., Ohio, in ballast about the eastern seaports and in $\mathrm{Br}$. Col. Adventive from S. Europe. July-Aug.

\section{Order I7. SARRACENIÀLES.}

Insectivorous plants secreting a viscid liquid, with basal leaves and perfect scapose flowers. Corolla choripetalous. Sepals mostly distinct. Stamens usually hypogynous. Ovary compound, superior. 


\section{Family I. SARRACENIÀCEAE La Pyl.}

\section{Pitcher-Plant Family.}

Marsh herbs, with tubular or pitcher-shaped leaves, and large scapose nodding flowers. Sepals 4 or 5, hypogynous, imbricated, persistent. Petals 5, imbricated, hypogynous, deciduous or none. Stamens $\infty$; anthers versatile. Ovary I, 3-5-celled; ovules $\infty$, in many rows. Capsule 3-5-celled, loculicidally dehiscent; style terminal, peltate, lobed, or in one genus simple. Seeds small, the testa reticulated; embryo small; enclosperm fleshy. Three genera and about to species, all natives of America.

\section{SARRACÉNIA L.}

Leaves hollow, with a lateral wing and a terminal lid or lamina. Sepals 5, with 3 or 4 bracts at the base. Petals ovate or oblong. Ovary 5 -celled. Style dilated into a peltate umbrella-like structure with 5 rays which terminate under its angles in hooked stigmas. Capsule 5-celled, granular, rugose. Seeds anatropous. [Named in honor of Dr. Jean Antoine Sarracin, a botanist of Quebec.] About 8 species, natives of N. Am.

Leaves pitcher-shaped, curved; flower purple or greenish (rarely yellow).

Leaves tubular-trumpet-shaped; flower yellow.

I. S. purpurea.

2. S. fava.

I. Sarracenia purpùrea L. Pitcher-Plant. Side-Saddle Flower. (I. F. f. 18or.) Glabrous, except the inner side of the lamina and inner surface of the pitchers, which are clothed with reflexed hairs. Leaves tufted, ascending, $\mathrm{r}-3 \mathrm{dm}$. long, inflated, narrowed into a petiole, broadly winged, persistent; scapes 3-6 dm. high, bearing a nodding nearly globose flower $5 \mathrm{~cm}$. in diameter or more; petals obovate, narrowed in the middle, incurved over the style. In peat-bogs, Lab. to the Canadian Rocky Mts., Fla., Ky. and Minn. May-June.

Sarracenia purpùrea heterophylla (Eaton) Torr. Flowers yellow ; leaves slightly or not at all purple-veined, light green or yellowish. Mass. and N. Y. to N. J.

2. Sarracenia flàva L. TRumpets. TRumpet-leaf. (I. F. f. 1802.) Glabrous throughout. Leaves trumpet-shaped, 3-9 $\mathrm{dm}$. long, 2-5 $\mathrm{cm}$. wide at the orifice, narrowly winged, prominently ribbed, the lid $2-10 \mathrm{~cm}$. wide, erect, contracted at the base; scape 3-6 dm. high, slender; flower 5-8 cm. broad; petals oblanceolate or obovate, drooping, slightly contracted at the middle. In bogs, Va. to Fla. and La. April.

\section{Family 2. DROSERÀCEAE S. F. Gray.}

\section{Sunder Family.}

Perennial or biennial glandular-pubescent herbs, exuding a viscid secretion, mostly with basal leaves, circinate in the bud, and fugacious perfect flowers, racemose in our species. Calyx persistent, 4-8-parted or the sepals distinct and imbricated. Petals 5, hypogynous, convolute, marcescent, distinct or slightly united at the base. Stamens 4-20; filaments subulate or filiform; anthers usually versatile. Disk none. Ovary free, or its base adnate to the calyx, I-3-celled; styles I-5, simple, 2-cleft or multifid; ovules numerous. Capsule I-5-celled, lorulicidally dehiscent. Endosperm fleshy; embryo straight, cylindric. Six genera and about 125 species, of wide geographic distribution.

\section{DRÓSERA L.}

Bog herbs, with leaves clothed with glandular hairs which secrete a fluid that entraps insects, and scapose racemose flowers. Calyx-tube short, free from the ovary, deeply 4-8-parted (commonly 5-parted). Petals usually 5, spatulate. Stamens as many as the petals; anthers short, extrorse. Ovary I-celled; styles 2-5, usually 3, distinct or united at the base, often 2-parted so as to appear twice 
as many, or fimbriate. Capsule 3 valved (rarely 5-valved), many-seeded, generally stipitate in the calyx. [Name from the Greek, dew.] About I ro species, most abundant in Australia. Besides the following, 2 others occur in the southeastern States.

Blacie of the leaf orbicular, or wider than long; petals white.

1. D. rotundifolia.

Blade of the leaf linear, or longer than wide.

Leaves linear or spatulate with a cistinct petiole; petals white.

Blade of the leaf spatulate.

Blade 2-3 times as long as wide.

Blade 6-8 times as long as wide.

Blade linear, ro-15 times as long as wide.

Leaves filiform, much elongated, with no distinct petiole; petals purple.

2. D. intermedia.

3. D. longifolia.

4. D. linearis.

5. D. filiformis.

I. Drosera rotundfòlia L. Round-LeAved Sundew or Dew-Plant. (I. F. f. I803.) Scape glabrous, I-2.5 dm. high. Leaves orbicular or broader, spreading, the blade 6-12 mm. long, abruptly narrowed into a flat pubescent petiole; raceme I-sided; pedicels $2-4 \mathrm{~mm}$. long; flowers white, about $4 \mathrm{~mm}$. broad; petals oblong; seeds fusiform, pointed at both ends, the testa loose. In bogs or wet sand, Lab. to Alaska, Fla. and Ala., and in the Sierra Nevada to Cal. July-Aug.

2. Drosera intermèdia Hayne. Spatulate-leaved Sundew. (I. F. f. I804.) Rootstock elongated; scape glabrous, 0.7-2 dm. high. Blades of the leaves ascending, spatulate, obtuse, $6-14 \mathrm{~mm}$. long, 3-4 $\mathrm{mm}$. wide, gradually narrowed into a glabrous petiole; raceme I-sided; pedicels about $3 \mathrm{~mm}$. long; petals white; seeds oblong, the testa close, roughened. In bogs, N. B. to Sask., Fla. and La. Also in the W. I. and Europe. July-Aug.

3. Drosera loigifjlia L. Oblong-leaved Sundew (I. F. f. I805.) Similar to the preceding, but the leaf-blade erect, longer (1.5-3 cm. long, 3-4 mm. wide), elongated-spatulate ; pedicels I-6 mm. long; flowers white, 4-5 mm. broad; seeds oblong, obtuse at buth ends, the testa loose. In bogs, Newf. and arctic America to Br. Col., Ont. and Cal. Also in northern Europe and Asia. Summer.

4. Drosera lineàris Goldie. Slender-leaved Sundew. (I. F. f. I 806.) Scape low but sometimes exceeding the leaves, glabrous. Petioles erect, glabrous, 5-IO cm. long; blade linear, 2-8 cm. long, about $2 \mathrm{~mm}$. wide, obtuse ; flowers few, or solitary, white; seeds oblong, the testa close. smooth and somewhat shining. In bogs, shores of Lake Superior and Lake Huron, west to the Canadian Rocky Mts.

5. Drosera filif ̈rmis Raf. Thread-Leaved Sundew. (I. F. f. I8o7.) Scape glabrous, 2-5 dm. high. Early leaves lanceolate, the apex glandular; later leaves filiform, glandular-pubescent, I.5-4 dm. long, about $2 \mathrm{~mm}$. wide, woolly with brown hairs at the base; racemes I-sided, Io 30 flowered; pedicels 4-8 mm. long; flowers purple, $8-25 \mathrm{~mm}$. broad; petals obovate; seeds fusiform, the testa minutely punctate. In wet sand, E. Mass. to Fla. July-Sept.

\section{Order I8. ROSÀLES.}

Herbs, shrubs or trees, the flowers usually petaliferous and the petals distinct. Stamens mostly perigynous or epigynous. Sepals mainly united or confluent with the concave receptacle. Carpels one or more, distinct or sometimes united into a compound ovary.

\footnotetext{
* Small aquatic fleshy herbs, with a spathe-like involucre, and a 2-3-celled capsule : perianth none.

** Land or rarely swamp plants withont an involucre.

+ Endosperm present, usually copious and fleshy; leaves mostly without stipules.
} Herbs.

Carpels as many as the calyx-segments; stamens as many or twice as many.

Plants succulent; carpels distinct or united at the base, in ours dehiscent lengthwise.

Fam. 2. Crassulaceae.

Plants not succulent; carpels united to the middle, circumscissile. 
Carpels fewer than the calyx-segments.

Staminodia present; carpels 3 or 4 , wholly united into a one-celled ovary.

Fam. 4. Parnassiaceae.

Staminodia none; carpels mostly 2, their upper part at least distinct.

Shrubs or trees.

Leaves opposite.

Fam. 5. Saxifragaceae.

Leaves alternate.

Fam. 6. Hydrangeaceae.

Fruit a 2-celled, thin-walled capsule; its base adnate to the calyx.

Fruit a 1 celled berry.

Fam. 7. Iteaceae.

Fruit a 2-celled woody or hard capsule.

Fam. 8. Grossulariaceae.

$t+$ Endosperm none, or very little (copious in Opulaster, shrub of the Rosa ceae); leaves mostly with stipules.

† Trees with broad leaves and small monœcious densely capitate flowers.

Fam. ro. Platanaceae.

$\ddagger \ddagger$ Flowers perfect, or if diœecious or monœcious not densely capitate.

a. Flowers regular.

Pistils usually several or numerous; if one only (as in Cercocarpus and sometimes in species of Alchemilla and Sanguisorba) it becomes a dry r-seeded achene.

Carpels distinct, rarely adnate to the calyx, ripening into follicles or achenes.

Fam. II. Rosaceae.

Carpels united, enclosed by the calyx-tube and adnate to it, the fruit a pome.

Pistil only $\mathrm{I}^{\circ}$

Fam. 12. Pomaceue.

Ovary 2-ovuled; fruit a drupe; leaves simple.

Ovary several-ovuled; fruit a legume; leaves 2-3-pinnate.

Petals valvate in the bud.

Fam. 13. Drupaceae.

(Petals imbricated in the bud: Gleditsia and Gymnocladus in the Caesalpiniaceae.)

b. Flowers irregular (nearly or quite regular in Gleditsia and Gymnocladus, trees of the Caesalpiniaceae).

Fruit a legume; upper petal enclosed by the lateral ones in the bud; leaves compound, mostly stipulate.

Fruit spiny, indehiscent; leaves simple, estipulate.

Fam. 15. Caesalpiniaceue.

Fruit a legume or loment; upper petal enclosing the lateral ones in the bud; leaves compound (sometimes I-foliolate), stipulate.

Fam. 17. Papilionaceae.

\section{Family I. PODOSTEMÀCEAE Lindl.}

\section{liver-weed Family}

Small aquatic herbs, the leaves usually poorly differentiated from the stem, the whole structure commonly resembling the thallus of an alga or hepatic, the small usually perfect flowers devoid of any perianth and subtended by a spathe-like involucre, or in some genera with a 3-5-cleft membranous calyx. Stamens hypogynous, only 2 in the following genus, numerous in some others; anthers 2-celled, the sacs longitudinally dehiscent. Ovary 2-3-celled; ovules, usually numerous in each cavity, anatropous; styles 2 or 3, short. Capsules 2-3-celled, ribbed. Seeds numerous, minute, without endosperm; embryo straight. About 2 I genera and 175 species, mostly in the tropics.

\section{PODOSTÈMON Michx.}

Flowers sessile or very nearly so in the spathe-like involucre. Perianth none. Stamens 2, their filaments united to near the summit; anthers 2, oblong or oval. Staminodia 2, filiform. Ovary ovoid, 2-celled : stigmas 2, short, subulate. Cap. sule ovoid, 6-1O-ribbed, 2-valved. [Greek, stalked-stamens.] About 12 species of wide gergraphic distribution.

I. Podostemon Ceratophýllum Michx. River-weed. Thread-foot. (I. F. f. I8c8.) Plant dark green, rather stiff, firmly attached to stones in running water, densely tufted, $2-25 \mathrm{~cm}$. long, the leaves sheathing at the base, commonly split above into almost filiform segments. Flowers less than $2 \mathrm{~mm}$. broad, at length bursting from the spathes; capsule oblong-oval, rather more than $2 \mathrm{~mm}$. long, obtuse, borne on a stipe of about its own length, 8-ribbed. In shallow streams, Mass. to N. Y., Ont., Minn., Ga., Ala. and Ky. July-Sept. 


\section{Family 2. CRASSULÀCEAE DC.}

\section{Orpine Family.}

Herbs, or somewh shrubby plants, mostly fleshy or succulent, with cymose or rarely solitary regular or symmetrical flowers. Stipules none. Calyx persistent, free from the ovary or ovaries, 4-5-cleft or 4-5-parted in our species. Petals equal in number to the calyx-lobes, distinct, or slightly united at the base, usually persistent, rarely wanting. Stamens of the same number or twice as many as the petals; anthers longitudinally dehiscent. Receptacle with a scale at the base of each carpel. Carpels equal in number to the sepals, distinct, or united below ; styles subulate or filiform; ovules numerous, arranged in 2 rows along the ventral suture. Follicles I-celled, dehiscent along the ventral suture. Seeds minute; endosperm fleshy; embryo terete; cotyledons short, obtuse. About 15 genera and 500 species, of wide geographic distribution.

Stamens of the same number as the sepals; minute herbs.

Stamens twice as many as the sepals; succulent herbs.

Flowers 4-5-parted.

Flowers 6-20-parted.
1. Tillaea.

2. Sedum.

3. Sempervivum.

\section{TILLAEA L.}

Minute aquatic or mud-loving herbs, with opposite entire leaves and very small flowers. Calyx 3-5-parted. Petals 3-5, distinct, or united at the base. Carpels 3-5, distinct. Styles short, subulate. Ovules usually few. [Named after Michael Angelo Tilli, 1653-1740, an Italian botanist.] About 20 species of wide distribution. Besides the following, about 4 others occur in the western States.

I. Tillaea aquática L. Pigmy-weed. (I. F. f. I 809.$)$ Stem I-8 cm. high, glabrous. Leaves linear.oblong, entire, connate at the base, 4-6 mm. long; flowers solitary, axillary, sessile or short-peduncled, I $\mathrm{mm}$. broad; calyx-lobes, petals, stamens and carpels 4 , rarely 3 ; petals greenish, about twice the length of the calyx-lobes; follicles ovoid, longer than the calyx-lobes, 8-Io-seeded. Muddy banks of streams, N. S. to Mass. and Md. Also in Europe. July-Sept.

\section{SÈDUM L.}

Fleshy mostly glabrous herbs, mainly with alternate, often imbricated leaves, and perfect or diøecious flowers in terminal often I-sided cymes. Calyx 4-5-lobed. Petals 4-5, distinct. Stamens perigynous, the alternate ones usually attached to the petals. Carpels 4-5, distinct. or united at the base; styles usually short: ovules $\infty$. [Latin, to sit, from the lowly habit of these plants.] About 150 species, mostly natives of temperate and cold regions of the northern hemisphere. Besides the following, about 20 others occur in western N. Am.

Cyme regular, compound, the flowers not secund; leaves broad, flat.

Flowers diœecious, mostly 4-parted.

I. S. roseum.

Flowers perfect, 5-parted.

Petals purple; plant somewhat glaucous; petals twice as long as the sepals.

2. S. Telephium.

Petals pink; plant very glaucous; petals 3-4 times as long as the sepals.

Flowers secund along the branches of the cyme.

Petals yellow.

Leaves short, thick, ovate, densely imbricated.

Leaves linear or terete, scattered on the stems.

Annual; petals little longer than the sepals.

Perennial; petals twice as long as the sepals.

Plant $0.7-1.5 \mathrm{dm}$. high; native, western.

Plant $2-3 \mathrm{dm}$. high, introduced in a few places.

Petals purple or white.

Leaves terete; petals purple, pink, or white.

Leaves flat, spatulate nr obovate; petals white.

Lower leaves verticillate in 3 's.

Leaves all alternate.

3. S. telephioides.

4. S. acre.

5. S. Torreyi.

6. S. stenopetalum.

7. S. reflexum.

8. S. pulchellum.

9. S. ternatum.

10. S. Nevii. 
I. Sedum ròseum (L.) Scop. Roseroot. Rosewort. (I. F. f. I8Io.1 Perennial, glabrous and somewhat glaucous, I-3 dm. high. Leaves sessile, oval or obovate, dentate or entire, I-2.5 cm. long, the lower ones smaller: cyme dense, I-5 cm. broad; flowers yellowish-green or purplish, 5-8 mm. broad; sepals oblong, narrower and shorter than the petals; follicles about $4 \mathrm{~mm}$. long, their tips spreading. In rocky places, Lab. and arctic Am. to Me., L. Penn. and on the southern Alleghanies. Also in the Rocky Mts. south to Colo., and in Europe and Asia. May-July.

2. Sedum Telèphium L. Orpine. Live-forever. (I. F. f. I8II.) Peren. nial; stems stout, tufted, glabrous and slightly glaucous, 3-5 dm. bigh. Leaves alternate, ovate to obovate, obtuse, $2-5 \mathrm{~cm}$. long, coarsely dentate, the upper sessile, the lower larger; cyme dense, compound, 5-8 cm. broad; flowers 5-8 mm. broad; petals purple, twice as long as the ovate acute sepals; follicles about $4 \mathrm{~mm}$. long, tipped with a short style. In fields and along roadsides, Quebec to Ont., Md. and Micin. N.tt. from Europe. Blooms sparingly, but spreads freely by its joints. June-Sept.

3. Sedum telephioides Michx. American Orpine. (I. F. f. I812.) Similar to the preceding, but more slender, seldom over $2.5 \mathrm{dm}$. high, glaucous and purplish. Leaves oval or obovate, obtuse, coarsely dentate or entire, 2-5 cm. long, narrowed at the base; cyme dense, 5-10 $\mathrm{cm}$. broad; flowers $6-8 \mathrm{~mm}$. broad; petals pale pink, much longer than the lanceolate sepals; follicles about $4 \mathrm{~mm}$. long, tipped with a slender style. On dry rocks, S. Penn. to W. N. Y., S. Ind., N. Car. and Ga. Aug.-Sept.

4. Sedum àcre L. Wall-pepper. Mossy Stonecrop. (I. F. f. I8I3.) Perennial, densely tufted, matted, glabrous; sterile branches prostrate, the flowering ones 2-8 cm. high. Leaves sessile, alternate, ovate, thick, imbricated, yellowish green, entire, about $3 \mathrm{~mm}$. long; cyme 2-3-forked, its branches $\mathrm{I}-2.5 \mathrm{~cm}$. long ; flowers sessile, about $8 \mathrm{~mm}$. broad; petals yellow, linear-lanceolate, acute, 3 or 4 times as long as the ovate sepals; follicles spreading, 3-4 mm. long, tipped with a slender style. On rocks and along roadsides, N. B. to Ont., N. Y. and Penn. Adventive from Europe. June-Aug.

5. Sedum Tórreyi Don. Torrey's Stonecrop. (I. F. f. I8I4.) Annual, low, tufted, glabrous, 5-8 cm. high. Leaves alternate, linear-oblong, teretish, sessile, entire, 4-8 mm. long; cyme 2-5-forked, its branches $1-5 \mathrm{~cm}$. long; flowers sessile or very short-pedicelled, about $7 \mathrm{~mm}$. broad; petals yellow, lanceolate, acute; follicles divergent, tipped with the short subulate style. In dry, open places, Mo., Kans. and Ark. to Tex. May.

6. Sedum stenopétalum Pursh. Narrow-petaled Stonecrop. (I. F. f. I8I5.) Perennial, tufted, glabrous; fluwering branches 8-I8 cm. high. Leaves alternate, crowded but scarcely imbricated, except on the sterile shoots, sessile, linear, 6-16 mm. long, entire ; cyme 3-7-forked, compact ; flowers mostly shortpedicelled, 8-10 $\mathrm{mm}$. broad; petals narrowly lanceolate, very acute, yellow ; follicles about $4 \mathrm{~mm}$. long, the subulate style-tip at length somewhat divergent. In dry, rocky piaces, Neb. and Colo. to Dak., the N. W. Terr., Utah, Ore. and Br. Col. May-June.

7. Sedum refléxum L. Crooked Yellow or Reflexed Stonecrop. Divarf Houseleek. (I. F. f. I8I6.) Perennial by a creeping stem producing numerous short barren shoots ; flowering branches erect; leaves alternate, sessile, imbricated on the sterile shoots, terete, somewhat spurred at the base, 6-1 $8 \mathrm{~mm}$. long; cyme 4 8-forked, its branches recurved in flower; flowers 8-12 mm. broad; petals linear, yellow, two to three times as long as the short ovate sepals; follicles about $3 \mathrm{~mm}$. long, tipperl with a slender somewhat divergent style. E. Mass. and IV. N. Y., escaped from gardens. Native of Europe. Summer.

8. Sedum pulchéllum Michx. Winow's Cross. (I. F. f. I8I7.) Glabrous, ascending or trailing, branched, I-3 dm. long. Leaves crowded, terete or linear, sessile, obtuse, slightly auriculate at the base, 6-25 $\mathrm{mm}$. long, about $2 \mathrm{~mm}$. wide; cyme 4-7-forked, its branches spreading or recurved in flower; flowers sessile, close together, $8-12 \mathrm{~mm}$. broad; petals linear-lanceolate, acute, about twice the length of the lanceolate obtusish sepals; follicles $4-6 \mathrm{~mm}$. long, tipped with a slender style. On rocks, Va. to Ga.. Ind., Kans. and Tex. May-July.

9. Sedum ternàtum Michx. Wild Stonecrop. (I. F. f. 18I8.) Perennial, 
glabrous, tufted; stems creeping, flowering branches, 0.7-2 dm. high. Lower leaves and those of sterile shoots flat, obovate, entire, $\mathbf{I - 2 . 5} \mathrm{cm}$. long, sometimes $2 \mathrm{~cm}$. wide, rounded at the apex, cuneate at the base or narrowed into a petiole, verticillate in 3's; upper leaves oblanceolate or oblong, alternate, sessile ; cyme 2-4-forked, its branches spreading or recurved in flower; flowers rather distant, often leafy-bracted, about $\mathbf{I} \mathrm{cm}$. broad; petals linear.lanceolate, acute, nearly twice the length of the oblong obtuse sepals; follicles $5 \mathrm{~mm}$. long, tipped with the slender style. On rocks, N. Y. and N. J. to Ga., Ind. and Tenn. Also escaped from gardens to roadsides in the Middle and Eastern States. April-June.

Io. Sedum Nèvii A. Gray. Nevius' Stonecrop. (I. F. f. I819.) Tufted, glabrous; stems spreading or decumbent, flowering branches ascending, $8-13 \mathrm{~cm}$. high. Leaves of the sterile shoots densely imbricated, spatulate or obovate, narrowed or cuneate at the base, mostly sessile, rounded at the apex, entire, 6-12 mm. long; leaves of the flowering branches spatulate or linear-oblong, alternate; cyme about 3-forked; flowers close together, $6-8 \mathrm{~mm}$. broad; petals linear, acuminate, longer than the sepals; follicles about $4 \mathrm{~mm}$. long, divergent, tipped with the short style. On rocks, Va. to Ala. May-June.

\section{SEMPERVIVUM L.}

Perennial herbs, the succulent leaves imbricated on the short sterile shoots and scattered on the erect flowering stems, with compound cymes of showy flowers. Flowers 6-20-parted. Petals distinct, oblong or lanceolate, acute or acuminate. Stamens twice as many as the petals. Styles filiform; ovules $\infty$. Follicles manyseeded. [Latin, always living.] About 40 species, natives of the Old World.

I. Sempervivum tectòrum L. HouseleEk. (I. F. f. I820.) Flowering stems about $3 \mathrm{dm}$. high, the barren shwots forming lateral nearly globular tufts. Leaves oval or ovate, the lower $2.5-4 \mathrm{~cm}$. long, thick, short-pointed, bordered by a line of stiff short hairs; cyme large, dense; flowers sometimes $2.5 \mathrm{~cm}$. broad, pink, sessile along its branches; petals lanceolate, acute, 2 to 3 times as long as the ob. tuse ciliate sepals. Essex Co., Mass. ; Somerset Co., N. J. Native of continental Europe. Summer.

\section{Family 3. PENTHORACEAE Rydb.}

Erect perennial scarcely succulent herbs, with alternate sessile serrate thin leaves, and greenish perfect flowers in forked sec: 1 cymes. Calyx 5-parted. Petals usually wanting, if present 5. Stamens Io, hypogynous; filaments filiform. Carpels 5 , united to the middle, ovules $\infty$. Capsule depressed, 5-lobed, 5-beaked, the lobes tipped with divergent styles, many-seeded. Only the following genus.

\section{x. PÉNTHORUM I.}

[Greek, five, from the symmetrical flower.] About 3 species, natives of eastern N. Am., Japan and China.

I. Penthorum sedoides L. Ditch or Virginia Stonecrop. (I. F. f. I82 I.) Glabrous, erect; stem 1.5-6 dm. high. Leaves lanceolate or narrowly elliptic, acuminate at each end, finely serrate, 5-IO $\mathrm{cm}$. long; cymes 2-3-forked; flowers short-pedicelled, about $4 \mathrm{~mm}$. broad; sepals triangular-ovate, acute, shorter than the flattish capsule; petals often or generally wanting. In ditches and swamps, N. B. to Fla., Minn., Neb. and Tex. July-Sept.

\section{Family 4. PARNASSIACEAE Dumort. Grass-of-Parnassus Family.}

Glabrous bog herbs with a rosette of basal leaves and generally one or a few alternate stem-leaves, and solitary terminal flowers. Flowers perfect. Calyx generally 5-lobed to near the base, free from or adnate to the ovary. Petals 5. Fertile stamens 5 ; staminodia (imperfect stamens) in clusters at the base of each petal. Ovary I-celled with 4 parietal 
placentae: style one; stigmas 4. Seeds numerous. Seed-coat winged. Only the following genus.

\section{PARNÁSSIA L}

[From the Greek mount ; the plant called Grass of -Parnassus by Dioscorides.] About 12 species, natives of the north temperate and arctic zones. Besides the following, another occurs in northwestern America.

Petals sessile; leaves ovate, oval, urbicular or cordate.

Staminodia 3-5 at the base of each petal

Flower 2-4 cm. broad; petals much exceeding the caly $x$-lobes.

Staminodia not longer than the stamens, stout.

Staminodia longer than the stamens, slender.

1. F. Caro'znzana.

Flower 8-10 $\mathrm{mm}$. broad; petals equalling the calyx-lobes.

Staminodia $5^{-15}$ at the base of each petal, slender.

Flower 8-10 mm. broad; leaves narrowed at base.

Flower $25 \mathrm{~mm}$. broad; leaves cordate at base.

Petals clawed; leaves reniform; staminodia 3 at each petal.

2. P. grandifolia.

3. P. Kotzebuei.

4. P. parviflora.

5. P. palustris.

6. P. asarifolia.

I. Parnassia Caroliniàna Michx. Carolina Grass of.Parnassus. (I. F. f. I852.) Scape 2-3 dm. high, with a nearly sessile ovate clasping leaf below the middle. Basal leaves long-petioled, ovate, oval or orbicular, obtuse, rounded or sometimes cordate at the base, or decurrent into the petiole, $2-5 \mathrm{~cm}$. long; calyxlobes ovate-oblong, obtuse; petals broadly oval, white, greenish-veined; staminodia generally 3 in each set; capsule 8-10 mm. long. In swamps and low meadows, N. B. to Manitoba, N. Car. and Iowa. June-Sept.

2. Parnassia grandiròlia DC. LARge-leaved Grass-of.Parnassus. (I. F. f. 1853.) Similar to the preceding, the scape bearing an ovate clasping leaf at the middle or below. Basal leaves often larger and narrowed at the base; petals white; staminodia 3-5 in each set, slender or almost filiform, exceeding the antherbearing stamens. In moist soil, Va. to Fla., Mo. and La. July-Sept.

3. Parnassia Kotzebuei C. \& S. Kotzebue's Grass-of-Parnassus. (I. F. f. I854.) Scape slender, 7-15 cm. high, leafless, or sometimes with a single sessile oval leaf near the base. Basal leaves short-petioled, membranous, ovate or oval, narrowed or sometimes cordate at the base, 6-24 $\mathrm{mm}$. long; calyx-lobes oblong; petals white, 3-5-veined, sessile; staminodia 3-5 at the hase of each petal. Quebec, Lab., arctic Am. to Alaska and in the Canadian Rocky Mts. Summer.

4. Parnassia parviflòra DC. Small-flowered Grass-of-Parnassus. (I. F. f. I856.) Scape I-3 dm. high, slender, usually bearing a clasping oval leaf at the middle. Basal leaves petioled, oval or ovate, narrowed at the base, not cordate, 12-25 mm. long; sepals equalling or somewhat shorter than the elliptic sessile petals; staminodia 5-7 at the base of each petal. In wet places, Quebec to Lab. and the Pacific Coast, south to Mich. and Utah. July-Sept.

5. Parnassia palústris L. MARSH OR NORThern Grass-of-Parnassus. (I. F. f 1855.) Scape slender, I-3 dm. high, bearing a clasping ovate leaf below the middle, or rarely leafless. Basal leaves slender-petioled, ovate, obtuse at the apex, usually cordate at the base, 18-35 mm. long; calyx $\frac{1}{4}-\frac{1}{2}$ shorter than the elliptic few-verned sessile petals; staminodia 9-I5 at the base or each petal. In wet places, Newt. and Lab. to Alaska, Mich. and Wyo. Also in Europe and Asia. July-Sept.

6. Parnassia asarifòlia Vent. Kidney-leaved Grass of-Parnassus. (I. F. f. 1857.) Scape $2.5-5 \mathrm{dm}$. high, bearing a clasping nearly orbicular leaf at about the middle. Basal leaves long-petioled, rounded, kidney-shaped, often $5-8 \mathrm{~cm}$. wide; flower 25-35 mm. broad; calyx-lobes oval, much shorter than the strongly veined elliptic petals; staminodia 3 in each set, slender, about the length of the stamens. In wet places, mountains of Va., Tenn., Ga., and N. Car. July-Oct.

\section{Family 5. SAXIFRAGÀCEAE Dumort.*}

\section{Saxifrage Family.}

Herbs. Flowers perfect or polygamo-diœecious. Calyx 5-lobed or 5-parted (rarel 12-lobed or parted), free, or adnate to the ovary, 
usually persistent. Petals usually 4 or 5 , rarely none. Stamens equal in number to or twice as many as the petals, in apetalous species as many or twice as many as the calyx-lobes, perigynous or epigynous; filaments distinct. Disk generally present. Carpels usually 2, distinct or united, but upper portion free, mostly fewer than the stamens. Seeds commonly numerous; endosperm generally copious, fleshy; embryo small, terete. About 70 genera and 600 species, of wide geographic distribution.

Large herbs; leaves 3 -ternate; flowers polygamous.

1. Astzlbe.

Leaves simple, cleft, lobed or 3 -foliolate; flowers perfect.

Placentae axial.

Ovary superior or nearly so; stamens Io.

Ovary more or less adnate to the calyx-tube.

2. Saxifraga.

Stamens 5, in our species.

Petals deciduous.

Petals persistent.

Stamens I0.

Placentae almost basal.

3. Therofon.

4. Sullivantia.

2. Saxifraga.

5. Tiarella

Placentae parietal.

Petals present (in our species); terrestrial plants.

Petals entire.

Petals lobed or pinnatifid.

Petals none; small aquatic plants.

6. Heuchera.

7. Mitella.

8. Chrysosplenium.

I. ASTÍLBE Hamilt.

Erect perennial herbs, with small spicate flowers in terminal panicles. Calyx campanulate, 4-5-lobed. Petals 4 or 5 (in our species), linear-spatulate, inserted at the base of the calyx. Stamens 8-ro; filaments elongated. Ovary superior or nearly so, 2-3-celled, deeply 2-3-lobed at the apex; styles 2-3; ovules $\infty$. Capsule 2-3-lobed, separating into 2 or 3 follicle-like carpels, each usually few-seeded. Seeds small, the testa loose, tapering at each end. [Greek without brightness.] About 7 species, natives of e.ustern N. Am., eastern Asia and the Himalayas.

I. Astilbe biternàta (Vent.) Britton. False Goat's Beard. Astilbe. (I. F. f. 1822.) Erect. I-2 m. high, more or less pubescent. Leaves petioled, often $6 \mathrm{dm}$. broad: leaflets thin, stalked, ovate, the lateral ones usually oblique, acuminate, sharply serrate or incised, $5-12 \mathrm{~cm}$. long; panicles often $3 \mathrm{dm}$. long; flowers sessile or nearly so, about $4 \mathrm{~mm}$. broad, yellowish white; petals of the staminate flowers spatulate, those of the perfect ones much smaller or none; stamens 10; follicles 2, acute, glabrous, about $3 \mathrm{~mm}$. long. In woods, mountains of Va. to Ga. and Tenn. Plant with the aspect of Aruncus. June.

\section{SAXIFRAGA L.}

Perennial herbs, with entire toothed or pinnatifid leaves, and perfect flowers. Calyx-tube free, or adnate to the base of the ovary, 5-lobed. Petals 5, perigynous. Stamens 10, inserted with the petals: anthers didymous. Ovary superior or partly inferior, usually 2 -celled, 2 -lobed at the summit; styles short: ovules $\infty$, on axial placentae. Capsule 2-beaked, many-seeded. Seeds small, the testa smooth or roughened. [Greek, stone-breaking, from reputed medicinal qualities.] About 2 ro species, nearly all natives of the north temperate zone. Besides the following, about 50 others occur in western N. Am.

* Stems prostrate ; leaves rounded, opposite; petals purple.

I. S. oppositifolia.

* * Stems erect or ascending; leaves alternate; petals white or yellow.

Flowers yellow; leaves entire.

Stems several-flowered; leaves linear.

Stens I-flowered; leaves oblong.

Flowers white: leaves 3-7-lobed, mostly wider than long.

Stems $10-25 \mathrm{~cm}$. tall; flower commonly solitary, nodding. 4. S. cernua.

Stems weak, 5-12 cm. long; flowers $1-5$, erect.

2. S. autumnalis.

3. S. Hirculus.

5. S. rivularis.

*** Stems scapose, naked or bracted, the leaves clustered at the base.

† Leaves stiff, oblong or oblanceolate; petals yellow or yellowish. 
Leaves sharply 3 -toothed at the apex.

Leaves with white denticulate margins.

$t+$ Leaves deeply 3 -5-cleft; petals white.

6. S. tricuspidata.

7. S. Aizoon.

8. S. caespitosa.

$++t$ Leaves soft, obovate or oval with narrowed or spatulace base.

Flowers regular; petals all nearly alike.

Plants large, $3^{-10} \mathrm{dm}$. tall, growing in wet places.

Leaves merely denticulate or repand; follicles ovoid.

Leaves coarsely and sharply dentate; follicles lanceolate.

Plants low, 5-45 cm. tall, growing in dry or rocky places.

Petals sessile, not clawed.

Flowers in cymose or at length panicled clusters. 11. S. Virginiensis.

Flowers capitate; arctic and alpine species.

Petals narrowed into a claw.

Flowers few, most or all of them replaced by tufts of leaves.

Inflorescence loose, cymose-paniculate.

13. S. comosa.

Follicles erect, united to near their summits; styles short.

14. S. stellaris.

Follicles divergent, united only at base; styles filiform.

Flowers irregular, 3 petals large, 2 smaller.

$t+t+$ Leaves soft, orbicular, cordate, dentate all around.

15. S. Grayana.

16. S. Michauxu.

17. S. Geum.

I. Saxifraga oppositifòlia I. Purple or Mountain Saxifrage. (I. F. f. 1823.) Tufted, stems densely leafy, 5-25 cm. long. Leaves sessile, persistent, keeled, fleshy, obtuse, punctate with I-3 pores, 2-5 mm. long, the margins ciliate; flowers solitary, peduncled or nearly sessile, $8-12 \mathrm{~mm}$. brcad; calyx-lobes obtuse, much shorter than the obovate purple petals; calyx free from the ovary and capsule; follicles abruptly short-pointed; seeds rugose. On wet rocks, Vt., Anticosti, and Newf. to Alaska, south in the Rocky Mts. to Wyo. and Ore. Also in Europe and Asia. Summer.

2. Saxifraga autumnàlis L. Yellow Mountain Saxifrage. (I. F. f. 1824.) Tufted, glabrous; stems $5-15 \mathrm{~cm}$. high. Leaves linear, fleshy, mucronate. tipped, sessile, $8-18 \mathrm{~mm}$. long, 2-5 $\mathrm{mm}$. wide, the margins often sparingly ciliate; flowers cory mbose, $814 \mathrm{~mm}$. broad; petals oblong, sometimes spotted with orange, exceeding the ovate-oblong calyx-lotes; carpels ahruptly acuminate; base of the capsule adnate to the calyx; seeds minutely rugose. On wet rocks, Newf. and Lab. to Vt., western N. Y., arctic Am. and Mich. Also in alpene and arctic Europe and Asia. Summer. [S. aizoides L.]

3. Saxifraga Hírculus L. Yellow Marsh Saxifrage. (I. F. f. 1825.) Erect, $10-25 \mathrm{~cm}$. high. Leaves I-4 cm. long, the lower petioled, the upper sessile; flower terminal, with scarlet spots; calyx-lobes obtuse, reflexed; petals obovate or oblong, about 3 times as long as the calyx-lobes; capsule free from the calyx or nearly so, about $8 \mathrm{~mm}$. long, its beaks at length diverging. In bogs, Lab. and arctic America. Also in northern and alpine Europe and Asia. Summer.

4. Saxifraga cérnua L. NoDding OR Drooping Bulbous Saxifrage. (I. F. f. I826.) Stem weak, ascending, pubescent but scarcely glutinous, I-3 dm. long. Basal and lower leaves petioled, broadly reniform, palmately 5-7-lobed, usually less than $25 \mathrm{~mm}$. wide: upper leaves smaller, sessile. 3-lobed or entire and bract-like, often bearing bulblets in their axils; flcwers $1-3$, terminal, 8-10 $\mathrm{mm}$. broad; petals obovate, 3-4 times as long as the ovate calyx-lobes. Newf., Lab. and arctic America to Alaska. Also in arctic and alpine Europe and Asia. Summer.

5. Saxifraga rivulàris L. Alpine Brook SAxifrage. (I. F. f. 1827.) Tufted, matted, 2-7 cm. high. Basal and lower leaves slender petioled, reniform, 3-5-lobed, seldom more than $6 \mathrm{~mm}$. wide; petioles dilated at the base; upper leaves lanceolate or ovate, sessile; flowers 1-5, terminal, white, 6-10 $\mathrm{mm}$. broad; calyxlobes ovate, obtuse, slightly shorter than the ovate-oblong petals; base of the cap. sule adnate to the calyx. White Mts., Iab., arctic Am. and south in the Rocky Mts. to Colo. Also in arctic and alpine Europe and Asia. Summer.

6. Saxifraga tricuspidàta Retz. Three-Toothed Saxifrage. (1. F. f. 1828.) Tufted; flowering stems $5-20 \mathrm{~cm}$. high, the leaves oblong or oblong- 
spatulate, parchment-like, 8 I $4 \mathrm{~mm}$. long, narrowed at the base, sessile, the margins ciliate; flowers corymbose, 8-10 $\mathrm{mm}$. broad; sepals ovate, coriaceous, much shorter than the petals; lower part of capsule adnate to the calyx. In rocky places, Newf. and Lab. to Alaska, south to Lake Superior and in the Canadian Rocky Mts. Also in arctic Europe. Summer.

7. Saxifraga Aizòon Jacq. Livelong Saxifrage. (I. F. f. 1829.) Leaves in a rosette; plant spreading by offsets. Leaves $8-24 \mathrm{~mm}$. long, spatulate, thick, obtuse; scape viscid-pubescent, I-2.5 dm. ligh; flowers corymbose, about $6 \mathrm{~mm}$. broad; calyx-lobes ovate-oblong, oltuse, viscid, shorter than the obovate, often spotted petals; base of capsule alnate to the calyx. On dry rocks, Vt.; Quebec to Lab., Lake Superior and Manitoba. Also in Europe. Summer.

8. Saxifraga caespitòsa L. Tufred SAXIFrage. (I. F. f. I8zo.) Tufted; leaves spatulate or fan-shaped, 6-18 mm. long, glabrous; flowering stem $5-20 \mathrm{~cm}$. high, viscid-pubescent, at least above, linear-bracted or with several 3-lobed leaves; flowers $\mathbf{I}-8$, corymbose, 8-14 mm. broad; calyx-lobes ovate-oblong, obtuse or $6 \mathrm{~b}$ tusish, much shorter than the petals; base of the capsule adnate to the calyx. On rocks, Quebec, Lab. and Newf. to Alaska, Ore. and Colo. Also in Europe and Siberia. Summer.

9. Saxifraga Peansylvánica L. Pennsylvania or Swami Saxifrage. (I. F. f. 1831.) Scape stout, terete, viscid-pubescent. Leaves oval to oblanceolate, 10-25 cm. long, 3-7 cm. wide, obtuse at the apex, narrowed at the base into a broad petiole; cymes in an elongated panicle; flowers greenish, regular, 3-5 mm. broad; calyx-tube nearly free from the ovary, its lobes ovate, obtusish, reflexed, one-halt shorter than the linear-lanceolate petals; filaments subulate or filiform. In swamps and on wet banks, Me. to Ont., Minn., Va.. Iowa and Mo. May.

I0. Saxifraga micranthidifòlia (Haw.) B. S. P. Lettuce Saxifrage. (I. F. f. 1832.) Scape slender, viscid. Leaves oblanceolate or oval, sometimes 3 dm. long, obtuse, tapering downward into a long margined petiole; panicle loose, elongated; flowers white, regular, 4-6 mm. broad; calyx-lobes reflexed, slightiy shorter than the oval or oblong obtuse petals; calyx-tube free from the ovary; filaments club-shaped. In cold brooks, Penn. to N. Car. May-June.

II. Saxifraga Virginiénsis Michx. Farly Saxifrage. (I. F. f. 1833.) Scape viscid-pubescent, $\mathbf{I}-3 \mathrm{dm}$. high. Leaves obovate or oval, narrowed into a margined petiole, dentate or crenate, $2-7 \mathrm{~cm}$. long or longer; flowers white, regular, 4-6 mm. broad; calyx-lobes erect, triangular-ovate, much shorter than the obtuse petals; ovary nearly free from the calyx; carpels nearly separate. In dry or rocky woodlands, N. B. to Minn., Ga. and Tenn. March-May.

12. Saxifraga nivàlis L. Clustered Alpine Saxifrage. (I. F. f. 1834.) Resembling the preceding, but seldom over $15 \mathrm{~cm}$. high. Scape viscid, naked, or bracted at the base of the capitate inflorescence; leaves ovate or oval, narrowed into a margined petiole, thicker; flowers white, 6-10 nm. broad; calyx-lobes ovate or oblong, obtuse, about one-half the length of the petals; ovary half-inferior; folicles deep purple, divergent. Lab. and arctic Am., south in the Rocky Mts. to Ariz. Also in Europe and Siberia. Summer.

13. Saxifraga comòsa (Poir.) Britton. Foliose Saxifrage (I. F. f. 1835.) Scape slightly viscid, 5-15 cm. high. Leaves oblanceolate, cuneate, dentate and mostly obtuse, $8-18 \mathrm{~mm}$. long; flowers white, regular; calyx nearly free from the ovary, its lobes reflexed. much shorter than the sagittate petals. Me.; Lab. and arctic America; Mt. Evans, Colo. Also in Asia and Europe. Summer.

14. Saxifraga stellàris L. STAR OR STARRY SAXIfrage. (I. F.f. 1836.) Scape bracted at the inflorescence, I-3 dm. high. Leaves oblong, oblanceolate or obovate, sharply dentate, tapering into a broad petiole, $\mathbf{I}-5 \mathrm{~cm}$. long; flowers about I $\mathrm{cm}$. broad; petals white, yellow-spotted at the base; calyx nearly free from the ovary, its lobes reflexed, lanceolite, obtusish, about one-half the length of the oblong petals ; capsule 4-6 mm. long. In rocky places, reported from Lab. and Greenland. Also in Europe and Asia. Summer.

I5. Saxifraga Grayàna Britton. Gray's Saxifrage. (I. F. f. 1837.) Glandular-pilose, scapose from a corm-like rootstock; scape 1.5-4.5 dm. tall. Basal leaves oblong to nearly orbicular, $2-12 \mathrm{~cm}$. long, crenate-dentate, narrowed into margined petioles, mostly shorter than the blıde; flowers white, 8-Io mm. broad; calix-tube adnate to the ovary, its segments uvate-oblong, reflexed, obtuse; petals 
ovate, obtuse, 2-spotted; filaments club-shaped; follicles oblong, 4-6 $\mathrm{mm}$. long. In rocky situations, mountains of Va. and N. Car. June-July.

16. Saxifraga Michaùxii Britton. Michaux's Saxifrage. (I. F. f. 1838.) Erect, viscid pubescent, $15-50 \mathrm{~cm}$. high. Basal leaves oblanceolate or oblong, 7-17 cm. long, narrowed into a margined petiole, coarsely dentate; scape leafy. bracted above; inflorescence paniculate; flowers 4-6 $\mathrm{mm}$. broad, irregular; petals clawed, white, the 3 larger ones sagittate or truncate and usually with a pair of yellowish spots at the base, the other 2 spatulate and unspotted; calyx-tube free from the ovary, its lobes reflexed; follicles lanceolate, about $5 \mathrm{~mm}$. long. In dry rocky places, Va. and W. Va. to Ga. May-Sept. [S. leucanthemifolia Michx.]

I7. Saxifraga Gèm L. Kidney-leaved Saxifrage. (I. F. f. 1839.) Glandular-pubescent, scapose ; scape 7-25 cm. high. Leaves clustered at the base, I-2.5 cm. wide; petioles stout, densely pubescent, $2-6 \mathrm{~cm}$. long; inflorescence paniculate; bracts small, linear; flowers 4-6 $\mathrm{mm}$. broad; petals white, oblong or ovate-oblong, with a yellow spot at the base and several smaller purp'ish spots at the middle; calyx-lobes lanceolate or reflexed; capsule oblong. Newf. and in Europe. June-July.

\section{THÉROFON Raf. [BOYKINIA Nutt.]}

Glandular pubescent perennial herbs, with alternate petioled orbicular or reniform leaves, and small white perfect flowers in panicles. Calyx-tube topshaped or subglobose, adnate to the ovary, its limb 5-lobed. Petals 5, deciduous, inserted on the calyx-tube. Filaments short. Ovary 2-celled (rarely 3-celled); styles 2, rarely 3. Capsule 2-celled, the beaks of the carpels divergent. Seeds numerous, the testa shining, minutely punctate. [Greek, beast-killing; an old name of aconite.] About 5 species, natives of N. Am.

I. Therofon aconitifolium (Nutt.) Millsp. Aconite Saxifrage. (I. F. f. 1840.) Stem 3-6 dm. high. Lower and basal leaves long-petioled, reniform-orbicular, cordate or truncate at the base, palmately 5-7-lobed, sharply incised-serrate; upper leaves short-petioled; cymes panicled; pedicels and calyx viscid; flowers white, about $4 \mathrm{~mm}$. broad; calyx-lobes lanceolate, erect; petals oblanceolate; capsule adnate to the calyx-tube, only its divergent beaks free. In woods, southwestern Va. to N. Car., Tenn. and Ga. July.

\section{SULlivántia T. \& G.}

Slender perennial herbs, with mainly basal long-petioled reniform-orbicular crenate or slightly lobed leaves, and small white cymose-paniculate flowers. Calyxtube campanulate, adnate to the base of the ovary, its limb 5 -lobed, the lobes erect. Petals 5, spatulate, marcescent. Stamens 5, inserted at the base of the calyx-lobes. Filaments short. Ovary 2-celled, 2-beaked, ripening into a 2 -beaked capsule. Styles 2. Ovules $\infty$. Seeds winged. [In honor of William Starling Sullivant, 1803-1873, American botanist.] Three known species, of North America.

I. Sullivantia Sullivántii (T. \& G.) Britton. Sullivantia. (I. F. f. I841.) Stem scapose, nearly leafless, reclined, slightly glandular-pubescent, 15$35 \mathrm{~cm}$. long. Ieaves long-petioled, $2-7 \mathrm{~cm}$. wide, reniform, sparingly pubescent or glabrous; panicle ample, sometimes leafy-bracted, glandular; pedicels recurved in fruit; flowers about $+\mathrm{mm}$. broad; calyx-lobes ovate, acutish; petals entire, exceeding the stamens. On cliffs, Ohio to Minn. and lowa. June.

\section{TIARÉLLA I.}

Perennial erect herbs, with the leaves mainly basal, long-petioled, lobed or 3foliolate, small stipules adnate to the petiole, and white pedicelled racemose or paniculate flowers. Calyx-tube campanulate, nearly or quite free from the base of the ovary, its limb 5-lobed. Petals 5, clawed. Stamens 10; filaments elongated. Ovary I-celled; styles 2; ovules $\infty$. Capsule membranous, I-celled, 2-valved, the valves usually unequal. Seeds usually few, smooth, not winged. [Diminutive of tiara, from the form of capsule.] About 6 species, natives of N. Am., Japan and the Himalayas. Besides the following, 3 others occur in western N. Am.

I Tiarella cordifòlia L. COOLwORT. FALSE Mitrewort. (I. F. f. 1842.) Scape 15-30 cm. high, slender, pubescent; plant producing runners later in the 
season. Leaves long petioled, broadly cordate, 3-7-loberl, obtuse or acutish at the apex, 5-Io $\mathrm{cm}$. long, crenate or dentate all around, pubescent with scattered hairs above, glabrate or downy along the veins beneath; inflorescence racem'sse, glandular-puberulent; flowers white, about $6 \mathrm{~mm}$. broad; petals oblong, entire or slightly dentate, clawed, somewhat exceeding the white calyx-lohes; capsule reflexed, about $6 \mathrm{~mm}$. long, its valves very unequal. In rich, moist woods, N. S. to Ont. and Minn., south to Ga. and lnd. April-May.

\section{HEÙCHERA L. (See Appendix.)}

Erect or ascending perennial herbs, with mainly basal long-petioled ovate or orbicular leaves, and small, paniculate or racemose, white green or purple flowers, on naked or leafy-bracted scapes. Calyx-tube campanulate, often oblique, adnate to the base of the ovary, 5-lobed. Petals small, spatulate, often shorter than the calyx-lobes, entire, inserted on the throat of the calyx. Stamens 5, inserted with the petals. Ovary I-celled; styles 2, slender. Ovules $\infty$. Capsule 2-valved, 2beaked. Seeds minutely hispid or muricate. [Named for Johann Heinrich von Heucher, I677-I747, a German botanist.] About 34 species, natives of N. Am. and Mex. Besides the following, about 20 others occur in western and southern N. Am.

Stem with $1-3$ leaves (seldom 4 or 5 ).

Stamens slightly if at all exceeding the petals; calyx in flower $5-8 \mathrm{~mm}$. long, decidedly turbinate at the base.

1. H. pubescens.

Stamens about twice as long as the petals; calyx in flower campanulate or slightly turbinate.

Stem and petioles glabrous or puberulent.

Calyx 5-7 $\mathrm{mm}$. long, cylindric-campanulate.

Calyx 3-4 mm. long, open-campanulate.

Stem and petioles villous; calyx in flower about $2 \mathrm{~mm}$.

Stem strictly scapose.

Flowers small ; calyx in flower $2-5 \mathrm{~mm}$. long, only slightly oblique.

Petioles and scape hirsute or villous, seldom glabrate.

Lobing of the leaves rather deep; lobes acute; calyx in flower about $\mathbf{2} \mathbf{m m}$.

Leaves cordate; lobes and teeth triangular. 4. H. villosa.

Leaves mostly reniform; lobes broadly ovate; teeth rounded, nucronate.

5. H. crinita.

Lobing of the leaves shallow; lobes obtuse : teeth rounded, mucronate. Caly $\mathrm{x}$ in flower about $2 \mathrm{~mm}$. long, petals white. 6. H. parviflora. Calyx in flower 4-5 mm.; petals greenish or purplish.

7. H. hirsuticaulis.

Petioles glabrous or puberulent ; scape rarely slightly hirsute.

Petals spatulate, scarcely exreeding the calyx-lobes. 8. H. Americana.

Petals oblanceolate, twice as long as the calyx-lobes. 9. H. lancipetala.

Flowers large; calyx in flower 6-10 $\mathrm{mm}$. long, decidedly oblique.

Leaves sinuately lobed, crenate with very shallow and broad mucronate teeth.

Leaves more deeply lobed; teeth broadly ovate.

10. H. longiflora.

I. H. hispida.

I. Heuchera pubéscens Pursh. Downy Heuchera. (I. F. f. 1846.) Stems rather stout, 3-9 dm. high, densely glandular-pubescent, at least above. Basal leaves slender-petioled, broadly cordate, 5-10 $\mathrm{cm}$. wide, 5-7 lobed, the lobes rounded or acute, crenate or dentate; panicle loose; calyx minutely glandular, its lobes usually unequal: petals broadly spatulate, purplish, slightly exceeding the calyx-lobes. In rich woods, mountains of Penn. to Ky. and N. Car. May-June.

2. Heuchera roseòla Rydb. Pink Hevchera. St $\in$ m 5-6 dm. high, glandular-puberulent, or glabrate below. Basal leaves round-cordate, 4-6 cm. wide, 5-7-lobed with rounded lobes, crenate with inucronate teeth, minutely hispid above, hirsute on the veins beneath and ciliate on the margin; stem-leaves small, broadly ovate, with sharp acuminate teeth; panicle loose, simple; calyx glandular puberulent, its lobes oblong, obtuse, slightly unequal: petals light pink, oblanceolate, about $\frac{1}{4}$ longer than the calyx-lobes. In woods, York Furnace, Penn. May.

3. Heuchera Cúrtisii T. \& G. Curtis' Heuchera. Stem 5-10 dm. high, glabrous below, puberulent above. Basal leaves round-cordate or reniform, 3.8 
$\mathrm{cm}$. broad, rounded-lobed and crenate, glabrous or slightly hispidulous above, ciliate on the margins; stem-leaves orbicular or broadly ovate, sharply toothed with acuminate teeth; panicle lax, open, with divergent branches; calyx puberulent, its lobes oblong, obtuse ; petals purple, puberulent, spatulate, scarcely exceeding the calyx-lobes. Rich woods of Va. and N. Car. June.

Heuchera Curtisii crenàta Rydb. Stem more leafy, with 3-5 rounded cordate or orbicular, crenate leaves; panicle narrower and petals ninute. Va. to N. Car. Type from Peaks of Otter, Va.

4. Heuchera villòsa Michx. Hairy Hevchera. (I. F. f. I844.) Stem erect, 2-6 dm. high, leafless, or bearing a few small bracts, generally villous-pubescent with brownish hairs, as are also the long petioles and the veins on the lower surfaces of the leaves. Basal leaves 7-12 cm. wide, orbicular or sometimes longer than broad; fowering calyx campanulate, regular; petals linear-spatulate, white or nearly so, about twice as long as the calyx-lobes; stamens much exserted. In rocky places, Va. and W. Va. to Ga. and Tenn. June-Sept. Called also American Sanicle.

5. Heuchera crinita Rydb. Large Halry Heuchera. Stem 5-7 dm. high, stout, bearing some bracts or often $\mathbf{I}-3$ leaves, villous, as well as the petioles, with brownish hairs. Basal leaves rounded, reniform, $10-22 \mathrm{~cm}$. in diameter, glabrous or slightly hispidulous above, more or less hairy beneath, especially on the veins; flowering calyx campanulate, almost regular, strigose-villous; petals spatulate, pinkish, slightly longer than the calyx-lobes; stamens about twice as long. In the form of the leaves it is intermediate between the preceding and the next, but it is much larger than either. In rocky places, from $\mathrm{Ky}$. and Ill. to $\mathrm{Va}$. Type from $\mathrm{Ky}$.

6. Heuchera parviflòra Bartl. Rugel's Hecchera. (I. F. f. 1843.) Stems slender, I.5-6 dm. long, weak, glandular-hirsute or villous, leafless, often bearing a few bracts. Basal leaves with long slender glandular-villous petioles, broadly reniform, $5-13 \mathrm{~cm}$. wide, with 7 - 9 broad lobes; inflorescence very loosely paniculate; flowering calyx regular, campanulate; petals linear-spatulate, 2-3 times as long as the calyx-lobes; stamens somewhat exserted. Shaded cliffs, Mo. and Ill. to western N. Car. July-Sept. The name H. Rugelii Shuttlw., of $\mathbf{1 8 4 7}$, must give place to the older $H$. parviflora Bartl., of 1839 .

7. Heuchera hirsuticaùlis (Wheelock) Rydb. Hirsute IIeuchera. Stem stout, 5-6 dm. high, leaflets long-hirsute. Leaves reniform, 5-10 cm. broad, glabrate or sometimes hirsute above, hirsute on the veins beneath; flowering calyx campanulate, glandular-puberulent, somewhat oblique; petals spatulate, greenish or purplish, generally shorter than the oblong obtuse calyx segments; stamens fully twice as long. Rocky banks, Mo., Ill. and Ind. May-June. [H, hispida hirsuticaulis Wheelock.]

8. Heuchera Americana L. Alum-root. (I. F. f. 1845.) Stem 6-y dm. high, leafless, more or less glandular-hirsute. Basal leaves long-petioled, 7-IO $\mathrm{cm}$. wide, with 7-9 rounded crenate-dentate lobes, the older ones glabrous, or with scattered hairs on the upper surface; flowering calyx broadly campanulate, nearly regular, 3-5 mm. long; petals small, greenish; stamens much exserted; anthers orange. In dry or rocky woods, Ont. to Conn., Minn., Ala. and La. May-Aug.

9. Heuchera lancipétala Rydb. Long-Petaled Alum-Root. Stem stout, about $6 \mathrm{dm}$. high, naked, sparingly glandular-hirsute. Leaves round-reniform, resembling those of the preceding, rather firm, glabrous except the ciliate margins and the veins beneath; panicle narrower and more simple than in the preceding; flowering calyx open campanulate, but decidedly turbinate at the base, nearly regular; petals whitish or pinkish: stamens about twice as long. Type from Ky.

I0. Heuchera longifiòra Rydb. Long-fioweren Heuchera. Stem about $5 \mathrm{dm}$. high, glandular-puberulent above, naked or with a few small bracts. Leaves firm, glabrous, except the ciliate margins, reniform, $5^{-8} \mathrm{~cm}$. in diameter; flowering calyx deeply campanulate, oblique, gibbous at the base on the shorter side, glandular.puberulent, its lobes oblong, very obtuse; petals spatulate with a slender claw, yellow at the base, purple-tipped, about equalling the calyx-segments; stamens and style included. Hills bordering Mudlick Bath, Ky. May. 
I1. Heuchera híspida Pursh. Rough Heuchera. (I. F. i. I847.) Stem 6-I $2 \mathrm{dm}$. tall, hirsutely-pubescent, glandular-puberulent, usually leafless. Leaves 4-7 cm. wide, with long petioles, broadly ovate-orbicular, 5-9 lobed; panicle narrow; flowering calyx deeply campanulate, very oblique, its lobes unequal; petals spatulate, slightly exceeding the calyx-lobes; stamens slightly exserted. In woods, Va. to W. Ont., Kans. and the N. W. Terr. May-June.

Heuchera hispida Richardsònii (R. Br.) Rydb. Very sparingly hairy ; leaves smaller, about $4 \mathrm{~cm}$. in diameter; flowering calyx longer, fully $10 \mathrm{~mm}$. long; stamens scarcely at all exserted. Manitoba, N. W. Terr. and Br. Col.

\section{MiTÉLLA L.}

Erect perennial herbs, with long petioled ovate to reniform basal leaves, naked or 2-leaved scapes, and small white or greenish flowers in elongated spiciform racemes. Calyx-tube adnate to the base of the ovary, its limb 5-lobed. Petals 5, 3-cleft or pinnatifid. Stamens Io (sometimes 5); filaments short. Ovary globose, I-celled; styles 2, short; ovules $\infty$. Capsule I-celled, 2-valved at the apex, many-seeded. Seeds sinooth, slining. [Diminutive of milra, a cap, from the form of the young pod.] About 12 species, natives of N. Am. and E. Asia. Besides the following, about 7 others occur on the Pacific Coast.

Basal leaves ovate, cordate; scape with 2 opposite leaves.

Basal leaves reniform; scape naked or $\mathrm{x}$-leaved near the base.

I. M. diphylla.

2. M. nuda.

I. Mitella diphylla L. Two-Leaved Bishop's Cap, or Mitrewort. (I. F. f. I 848 .) Scape $\mathbf{2} \cdot \mathbf{5}-\mathbf{4} .5 \mathrm{dm}$. high, pubescent, bearing a pair of opposite leaves near its middle. Basal leaves acute or acuminate, 3-5-lobed, dentate, scabrous and with scattered hairs on both sides, $2.5-5 \mathrm{~cm}$. long; leaves of the scape similar, usually smaller; raceme 0.7-2 dm. long; calyx-lobes and petals white; capsule flattish, broad, dehiscent above. In rich woods, Quebec to Minn., N. H., N. Car. and Mo. April-May.

2. Mitella nuda L. Stoloniferous or NAKed Bishop's CAP OR MITREWORT. (I. F. f. I849.) Usually stoloniferous; scape erect, slender, pubescent, 7-15 cm. ligh. Basal leaves crenate or duubly crenate, $2-4 \mathrm{~cm}$. wide, pubescent with scattered hairs; stem-leaves usually none; flowers pedicelled, greenish, about $4 \mathrm{~mm}$. broad. In cold woods and peat-bogs, Newf. and Lab. to the Pacific coast, N. Eng., Penn., Mich. and Mont. Also in Asia. Aprıl-June.

\section{CHRYSOSPLÉNIUM L.}

Low somewhat succulent mainly semi aquatic herbs, with petioled crenate leaves with no stipules. Flowers minute, greenish, perfect. Calyx-tube urn-shaped or obconic, adnate to the ovary, its limb 4-5-lobed. Petals none. Stamens 8-1o (rarely 4 or 5), inserted on the margin of a disk; filaments short. Ovary I-celled, flattish, 2.lubed; styles 2, short, recurved; ovules $\infty$. Capsule membranous, short, inversely cordate or 2 -lobed, 2 -valved above. Seed-coat muricate or pilose. [Greek, golden spleen, from some reputed inedicinal quality.] About 15 species, natives of the north temperate zone and southern S. Am. Besides the following, 2 others occur in northwestern America.

Lower leaves opposite: flowers mostly solitary. Leaves all alternate; flowers corymbose.
I. C. Americanum.

2. C. Iowensis.

I. Chrysosplenium Americànum Schwein. Golden Saxifrage. Water Carpet. (I. F. f. I850.) Stems decumbent, forked above, glabrous or very nearly so, 7-20 cm. long. Low r leaves opposite, the upper often alternate, broadly ovate, orbicular or somewhat reniform, obtuse or trurcate at the base, rounded at the apex, 4-20 mm. wide; flowers sessile, axillary, about $2 \mathrm{~mm}$. broad; calyxlobes commonly 4, yellowish, or purplish within; stamens commonly 8; anthers orange-red. In wet, shaded places, N. S. to the Sask. region, south to Ga., and to Ohio and Minn. March-June.

2. Chrysosplenium Iowénsis Rydb. Iowa Golden Saxifrage. (I. F. f. I85I.) Flowering stems, I-7 cm. ligh, branched above. Leaves reniform, thin, shining above, pale beneath, 4-10 $\mathrm{mm}$. wide, or crenate with 5-7 rather broad lobes; upper stem-leaves larger than the lower; calyx-lobes commonly 
4, orange-yellow within; stamens usually 8, rarely 4-6. Decorah, Iowa. MayJune. It has been confused with $C$. alternifolium $\mathrm{L}$. with dull punctate leaves with truncate lobes and $C$. tetrandrum Fries, with thick 3-5-lobed leaves and 4 stamens.

\section{Family 6. HYDRANGEÀCEAE Dumort. Hydrangea Family.}

Shrubs or trees with simple opposite leaves and no stipules. Flowers perfect or the exterior ones of the clusters sterile and conspicuous. Petals and sepals generally 5. Stamens twice as many or numerous, epigynous. Carpels 2-10, wholly united or the apex free, the lower half at least enclosed by and adnate to the calyx. Seeds numerous; endosperm generally copious ; embryo small. About 16 genera and 80 species, of temperate and tropical regions.

Stamens 8-10; exterior flowers of the corymb usually neutral.

Stamens 2040 ; all flowers perfect.

Vines; style $\mathrm{I}$; petals small.

Shrubs ; styles $3-5$; petals large.

1. Hydrangea.

2. Decumaria.

3. Philadelphus.

\section{HYDRÁNGEA L.}

Shrubs, or some Asiatic species small trees, with opposite simple petioled leaves and terminal corymbose flowers. Exterior flowers of the cory mb often apetalous, slender-pedicelled, sterile, but with enlarged and very conspicuous calyx-lobes; fertile flowers small. Calyx-tube hemispheric or obconic, 4-5-lobed. Petals 4 or 5 . Stamens inserted on the disk. Filaments filiform. Ovary 2- (seldom 3-4-) celled; styles 2-4, distinct, or united at the base; ovules $\infty$. Capsule membranous, usually 2 -celled, ribbed, many-seeded, dehiscent at the bases of the styles. [Greek, watervessel, from the shape of the capsule.] About 35 species, natives of eastern $\mathrm{N}$. Am., Asia and S. Am. Besides the following, 2 others occur in the southeastern States.

Leaves glabrous or somewhat pubescent beneath.

Leaves grayish-tomentose beneath.

1. H. arborscens. 2. H. cinerea.

I. Hydrangea arboréscens L. WiLd Hydrangea. (I. F. f. I858.) A acute or often acuminate at the apex, rounded, cordate or rarely broadly cuneate at the base, sharply dentate, green both sides, sometimes pubescent beneath; cymes 5-13 cm. broad; marginal sterile flowers usually few or none, but sometimes numerous. On rocky stream or river banks, southern N. Y. and N. J. to Iowa, Fla. and Mo. June-July.

Hydrangea arboréscens Kanawhàna Millsp. Leaves pale or somewhat glaucous beneath. W. Va.

2. Hydrangea cinérea Small. Gray Hydrangea. ((I. F. f. I859.) A shrub 2-3 m. high. Leaves slender-petioled, ovate, rounded or cordate at the base, acute or acuminate at the apex, 7-15 cm. long, green and nearly glabrous above; marginal flowers, or at least some of them, sterile and conspicuous. Has been confused with $H$. radiata. Mo. to Tenn. and Ga. June-July.

\section{DECUMÀRIA L.}

Woody climbing vines, with opposite petioled leaves, and terminal corymbose flowers. Stipules none. Calyx-tube top-shaped, adnate to the ovary, its limb 7-ro-toothed. Petals 7-10, narrow. Stamens inserted on the disk; filaments subulate. Ovary 5-10-celled, 10-15-ribbed, its apex conic; style thick; stigma capitate, 5-10-lobed; ovules $\infty$. Capsule fragile, ribbed, opening between the ribs. Seeds numerous, the testa membranouc, reticulated, produced into a clubshaped appendage. [Latin, decem, ten; the parts being often in Io's.] A mono. typic genus of southeastern N. Am.

I. Decumaria bàrbara L. Decumaria. (I. F. f. 1860.) Climbing by aerial rootlets. Petioles $1-3 \mathrm{~cm}$. long ; leaves ovate, 5-10 $\mathrm{cm}$. long, entire or 
repand-denticulate, glabrous and shining above : corymbs $5-8 \mathrm{~cm}$. broad; flowers white, fragrant, 6-8 mm. broad; calyx-teeth deciduous; capsule top-shaped, 4-6 mm. high, tipped with the conic persistent style. In swamps, Va. to Fla. and La. May-June.

\section{PHILADÉLPHUS L.}

Shrubs, with petioled simple deciduous leaves. Flowers large, terminal or axillary, corymbose, racemose or solitary, white or cream-colored. Calyx-tube top-shaped, adnate to the ovary, 4-5-lobed. Petals 4 or 5, convolute, rounded or obovate. Stamens inserted on the disk. Ovary 3-5-celled; styles filiform, distinct, or united at the base; ovules $\infty$. Capsule top-shaped, 3-5-celled, at length loculicidally dehiscent by $3-5$ valves, many-seeded. Seeds oblong, the testa membranous, produced at each end. [Named after King Ptolemy Philadelphus.] About 15 species, natives of N. Am., Mex., Asia and Europe. Besides the following, about 5 others occur in southern and western N. Am.

Flowers inodorous, solitary or few.

Calyx-lobes about equalling the tube, acute.

Calyx-lobes about twice as long as the tube, acuminate. Flowers racemose, numerous, fragrant.

1. P. inodorus.

2. P. grandiflorus.

3. P. coronarius.

I. Philadelphus inodòrus L. Scentless Syringa. (I. F. f. I86r.) A shrub, 2-3 m. high, glabrous or very nearly so. Leaves ovate or oval, acute or acuminate at the apex, rounded or sometimes narrowed at the base, 5-12 cm. long, strongly 3 -nerved, serrate with small distant teeth, or entire; flowers about $3 \mathrm{~cm}$. broad. In thickets, Va. to Ala. and Ga. Escaped from cultivation in Penn. May.

2. Philadelphus grandifiòrus Willd. LARGE-FLOWERED Syringa. (I. F. f. 1862.) A shrub, 2-3 m. high, resembling the preceding. Leaves broadly ovate or oval, more or less pubescent, especially beneath, 7-12 cm. long, acuminate at the apex, rounded or narrowed at the base, sharply dentate, 3-nerved; flowers 4$5 \mathrm{~cm}$. broad. In low grounds, Va. to Tenn. and Fla. April-May.

3. Philadelphus coronàrius L. Garien Syringa. Mock Orange. (I. F. f. I863.) A shrub $0.5-3 \mathrm{~m}$. high. Leaves short-petioled, oval, elliptic or ovateelliptic, 5-10 cm. long, glabrous above, pubescent beneath, acute or acuminate at the apex, denticulate with distant teeth, 3-nerved; flowers $2.5-4 \mathrm{~cm}$. broad, creamy white; calyx-lolses ovate, acute, longer than the tube. Escaped from gardens in Vit. and Ohio, and sparingly in the Middle and Eastern States. Native of Europe. May-June

\section{Family 7. ITEÀCEAE Agardh. Virginia Willowe Family.}

Shrubs or small trees with simple alternate leaves, no stipules and racemose flowers. Calyx 5-lobed, adnate to the base of the ovary. Petals 5. Stamens 5, inserted on the disk. Carpels 2, united to or near the apex. Capsule membranaceous, 2-celled, mostly superior, only the base enclosed in the calyx. Seeds several with a copious endosperm.

\section{ITEA L.}

Shrubs or small trees, with petioled deciduous leaves, and small white flowers. Calyx-tube obconic or campanulate. Petals linear, their apices inflexed. Stigma 2 -grooved in our species; ovules few or numerous. Capsule oblong or narrowly conic, 2-valved. Seeds narrow, flattish, the testa produced at each end. [Greek for willow, which its leaves resemble.] About 5 species, natives of the eastern U. S. and Asia. The following is the only one known to occur in N. Am.

I. Itea Virgínica L. Itea. Virginia Willow. (I. F. f. I864.) A shrub Io-25 cm. high, the twigs and inflorescence finally pubescent. Leaves short-petioled, narrowly oval, oblanceolate or rarely obovate, 3-7 cm. long, acute or acuminate at the apex, narrowed at the base, sharply serrulate, glabrous, or with a few hairs along the veins beneath; racemes terminal, dense, 5-15 cm. long; flowers 
short pedicelled; petals linear, erect or slightly spreading, about $5 \mathrm{~mm}$. long; capsule $4.6 \mathrm{~mm}$. long, pubescent, narrow. In wet places, pine barrens of N. J., and eastern Penn. to Fla., western N. Car. and La. May-June.

\section{Family 8. GROSSULARIÀCEAE Dumort.}

\section{Gooseberry Family.}

Shrubs, with often fascicled usually lobed petioled leaves, and race。 mose or subsolitary axillary or lateral flowers, the pedicels bracteolate. Calyx-tube adnate to the ovary, the limb 4-5-1obed, often colored. Petals 4 or 5 , inserted on the throat of the calyx, small, scale-like, often included. Stamens 4 or 5, inserted with the petals. Ovary I-celled; styles 2, distinct or united. Berry globose or ovoid, pulpy, the calyx persistent on its summit. Seeds obscurely angled, their outer coat gelatinous, the inner crustaceous. Only the following genus, having the characters of the family.

\section{RİBES L.}

About 60 species, natives of the north temperate zone and the Andes of S. Am. besides the following some 40 others occur in western N. Am.

Leaves plicate in vernation.

Racemes I-4-flowered; stems generally with subaxillary spines (Gooseberries).

Calyx-lobes oblong, shorter than the tube; berry often spiny or bristly; stamens not exserted.

Calyx-tube ovoid-campanulate, green; berry spiny. I. R. Cynosbati. Calyx-tube tubular; berry bristly or glabrous.

Flowers purplish; spines slender; plant very hairy.

Flowers whitish; spines stout; plant slightly pubescent.

2. R. Huronense.

3. $R$. setosum.

Calyx-lobes equalling or exceeding the tube; berry glabrous.

Caly $x$-lobes shorter than the tube and ovary; peduncles short.

Stanens scarcely exceeding the oblong caly $x$-lobes.

Spines stout, usually 3 together; raceme usually r-flowered.

Spines small, slender or none; raceme 2 -flowered.

4. R. Uva-crispa.

5. R. oxyacanthoides.

Stamens somewhat exceeding the linear calyx-lobes.

6. $R$. rotundifolium.

Calyx-lobes much longer than the tube and ovary; peduncle slender; stamens long-exserted.

Spines slender; bark purplish. $\quad$ 7. R. gracile.

Spines stout; bark light gray.

8. R. Missouriensis.

Racemes many-flowered; stem with spines and bristles, calyx saucer-shaped, glandular-bristly.

9. $R$. lacustre.

Racemes many-flowered; stem unarmed; calyx campanulate to tubular. (Currants.)

Calyx-tube campanulate.

Rerry glandular-bristly, red.

Berry glabrous.

Calyx-tube open-campanulate.

Raceme erect or ascending; berry black. II. R. Hudsonianum.

Raceme pendulous; berry red.

12. R. rubrum.

Calyx-tube cylindric-campanulate; berry black, 13. R. floridum.

Calyx-tube tubular, glandular; berry red, more or less glandular.

14. $R$. cereum,

Leaves convolute in bud; stem unarmed; calyx-tube tubular, bright yellow.

15. R. aureum.

I. Ribes Cynósbati L. Wild Gooseberry. Dogberry. (I. F. f. I865.) Infra-axillary spines slender, solitary or sometimes 2-3 together, erect or spreading, 6-1o $\mathrm{mm}$. long, or often wanting. Prickles few and weak or none; petioles 12-35 mm. long, slender, generally pubescent; leaf-blade nearly orbicular, 3-5 cm. broad, somewhat pubescent, at least when young, truncate or cordate at the base, deeply 3-5-lobed, the lobes crenate-dentate or incised; peduncles and pedicels 
slender; verry 8-12 mm. in diameter, with subulate prickles. In rocky woods, N. B., south to N. Car., west to Manitoba and Mo. April-June.

2. Ribes Huronénse Rydb. LAKE HURON GOOSEBERRy. Infra-stipular spines slender, solitary, 8-10 mm. long, ascending; prickles few and weak; stem finely pubescent; petioles slender, I-2 cm. long, very pubescent; leaf-blade rounded, obtuse at the base, deeply 5 -lobed, incised, densely and rather coarsely pubescent; peduncles slender but short, about $15 \mathrm{~mm}$. long, generally 3-flowered; calyx very pubescent; petals broadly cuneate, white; styles distinct to the middle; berry bristly or weakly spiny. Intermediate between the preceding and the following, but more pubescent than either. Type from Lake Huron $[R$. Cynosbati $\gamma$ Hook].

3. Ribes setòsum lindl. Bristly Gooseberry. (I. F. f. I866.) Infraaxillary spines $\mathrm{I}-3$ together, slender or rather stout, 5-10 $\mathrm{mm}$. long, spreading. Bristles usually numerous and stout; leaves slender-petioled, more or less finely pubescent, at least when young, $\mathbf{I}-3 \mathrm{~cm}$. in width, broadly ovate or orbicular, 3-5lobed, the lobes incised-dentate; flowers I-4, 6-10 mm. long; fruit sparingly bristly, or often glabrous, dark blue, very sour. On lake shores and in thickets, Manitoba to Mont., Neb. and Wyo. May.

4. Ribes Ùva-críspa L. Garden Gooseberry. (I. F. f. 187o.) Spines stout, spreading or reflexed, usually 3 together. Prickles scattered or none; leaves short-petioled, orbicular or broader, pubescent, at least when young, seldom over $2.5 \mathrm{~cm}$. wide, 3-5-lobed, the lobes obtuse and crenate-dentate; peduncles short, I-2-flowered, usually pubescent; flowers green, about $6 \mathrm{~mm}$. long. Along roadsides in N. J. and N. Y., escaped from gardens. Native of Europe and Asia. May.

5. Ribes oxyacanthoides L. Hawthorn or Northern Gooseberry. (I. F. f. I868.) Spines generally solitary, light colored, 4-10 $\mathrm{mm}$. long, often short. Prickles commonly wanting; leaves petioled; petioles and lower leafsurfaces commonly pubescent; flowers greenish-purple or white, 6-8 mm. long; berry 8-12 $\mathrm{mm}$. in diameter, reddish purple when ripe. In wet woods and low grounds, Lab. and Newf. to the N. W. Terr., N. J. and Neb. May-July.

6. Ribes rotundifòlium Michx. EASTern Wild GooseberRy. (I. F. f. L869.) Closely resembling the preceding, the spines comnionly shorter, or often altogether wanting, and the prickles none. Leaves similar, but more shining beneath when young; flowers greerish-purple, 6-8 mm. long; stamens exserted for about $\frac{1}{4}$ their length; berry usually not more than $8 \mathrm{~mm}$. in diameter. In rocky woods, Mass. and N. Y. to N. Car. May-July.

7. Ribes grácile Michx. Slender Gooseberry. (I. F.f. 1867.) Branches slender and generally purplish. Spines slender, solitary, or 2 or 3 together, purplish, 6-10 mm. long or more. Prickles none; leaves slender-petioled, somewhat pubescent when young, orbicular, $2-30.5 \mathrm{~cm}$. wide, truncate or obtuse at the base, 3-5-lobed, the lobes rather blunt, dentate; pedicels very slender, $1-2 \mathrm{~cm}$. long; flowers white, drooping, 10-12 $\mathrm{mm}$. long: calyx-tube narrow, very short; berry reddish purple, 8 -Io $\mathrm{mm}$. in diameter. In dry or rocky soil, Ill. and Kans. to La. and Tex. May.

8. Ribes Missouriénsis Nutt. Missouri Gooseberry. Branches stout, gray or whitish with shreddy bark; spines usually 3 together, stout, $8-15 \mathrm{~mm}$. long; bristles numerous on the young shoots, rather stout, usually none on the older stems and their branches; leaves with stouter petioles, pubescent especially when young, 2-6 cm. in diameter; flowers white, 10-15 mm. long; fruit purple, Io-15 mm. in diameter. It has been confused with the preceding. River banks and plain thickets, from Ill. and Penn. to Minn., Black Hills of S. Dak., and Kane. March-May.

9. Ribes lacústre (Pers.) Poir. Swamp Gooseberry. (I. F. f. I87i.) S in slender, weak, generally clustered. Branches usually densely $b_{1}$ istly; pe iol slender, pubescent : leaves nearly orbicular, thin, pubescent along he vein: $b$ neath, deeply 5-7-lobed, 3-5 cm. wide, the lobes acutish, incised-de : iate; flowe. green; pedicels slender, bracted at the base, about $4 \mathrm{~mm}$. long; caly s-lobes shor broad, spreading; stamens very short, $n$ t exserted; berry about $4 \mathrm{~mm}$. in dian

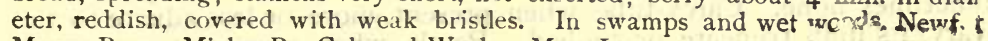
Mass., Penn., Mich., Br. Col. and Wash. May -June. 
I0. Ribes prostràtum L'Her. Fetid Currant. (I. F. f. I872.) Branches decumbent or spreading. Petioles slender, $37 \mathrm{~cm}$. long, the dilated base sometimes ciliate; leaves nearly orbicular, sharply and deeply $5-7$-lobed, 3-7 cm. wide, usually somewhat pubescent along the veins beneath, the lobes acute or acutish, dentate-serrate ; flowers racemose, about $5 \mathrm{~mm}$. broad ; pedicels $4-5 \mathrm{~mm}$. long, glandular, bracted at the base; stamens short, not exserted. In cold wet places, Lab. to the N. W. Terr. and Br. Col., south to N. Car., Mich. and Colo. Plant with a disagreeable odor. May-June.

II. Ribes Hudsoniànum Richards. Northern Black Currant. (I. F. f. I873.) Branches erect. Petioles slender, 3-10 $\mathrm{cm}$. long; leaves broader than long, 3-Io cm. wide, more or less pubescent and resinous-dotted beneath, 3-5lobed, the lobes obtuse or acutish, coarsely dentate; pedicels $4 \mathrm{~mm}$. long or less; flowers white, 4-6 mm. broad; calyx-lobes oval, obtuse; stamens short, not exserted; bracts setaceous, deciduous; fruit black, glabrous, 4-6 mm. in diameter. Hudson Bay and western Ont. to N. W. Terr. May-June.

Ribes nigrum L., the Black Currant of the gardens, with similar leaves, but loosely flowered drooping racemes, is beginning to escape from cultivation.

12. Ribes rùbrum L. Red Currant. (I. F. f. 1875.) Petioles slender, glabrous or sparingly pubescent, $3.8 \mathrm{~cm}$. long; leaves pubescent beneath, at least when young, orbicular or broader, cordate at the base, 3-5-lobed, the lobes acutish, sharply dentate; pedicels longer than the ovate bractlets; flowers greenish or purplish, about $4 \mathrm{~mm}$. broad; calyx flat-campanulate: stamens short; fruit 4-8 mm. in diameter. In cold woods, Lab. to Alaska, northern N. Eng, N. J., Ind. and Minn., and escaped from cultivation in the Middle and Eastern States. Also in Europe and Asia. May-June.

13. Ribes flóridum L'Her. Wild Black Currant. (I. F. f. I874.) Branches erect. Petioles slender; leaves nearly orbicular, glabrous above, somewhat pubescent and resinous-dotted beneath, 3-8 cm. wide, sharply 3-5-lobed, the lobes dentate-serrate, acutish; bractlets linear, much exceeding the pedicels, or shorter; flowers greenish-white, 8-10 mm. long; calyx-lobes short, broad, obtuse; stamens not exserted; fruit globose-ovoid, about $6 \mathrm{~mm}$. in diameter. In woods, N. S. to Va., Manitoba, and Neb. April-May.

14. Ribes cèreu n Dougl. White-flowered Currant. SQuaw Currant. (I. F. f. 1876.) Petioles more or less glandular-pubescent, 6-20 mm. long; leaves reniform-orbicular, cordate at the base, $1-4 \mathrm{~cm}$. wide, sparingly glandular pubescent, or glabrate on both sides, 3-5-lobed, the lobes obtuse, crenate or crenulate; racemes short, pubescent, pendulous; bractlets persistent; flowers sessile or short-pedicelled, pink or greenish-white; petals minute, nearly orbicular; stamens short; fruit insipid, about $6 \mathrm{~mm}$. in diameter. Dry hills, from S. Dak. and Neb., to Br. Col., Ariz. and Cal. May-June.

15. Ribes aùreum Pursh. Golden, Buffalo or Missouri Currant. (I. F. f. I877.) Petioles slender, pubescent, at least when young; leaves pubescent and ciliate, or at length glabrous ard shining, often broader than long, thick, 3lobed or sometimes 5-lobed, broadly cuneate or truncate at the base, the lobes obtuse; racemes leafy-bracted, few-flowered; flowers spicy-scented, 12-25 mm. long; calyx-tube cylindric, glabrous, 3-4 times as long as the oval spreading lobes; stamens slightly exserted; fruit black, glabrous, 6-10 $\mathrm{mm}$. in diameter. Along streams, Minn. to Mo., Tex., Cal., Ore. and the N. W. Terr. April-May.

Ribes aùreum chrysocòccum Rydb. Fruit yellow when mature, more acid. Western Neb. to Mont.

Family 9. HAMAMELIDÀCEAE Lindl. Witch Hazel Family.

Trees or shrubs, with alternate petioled simple leaves, and perfect or polygamous flowers, variously clustered. Perianth often imperfect, or sometimes none. Calyx-tube, when present, more or less adnate to the ovary, its limb truncate or 5-lobed. Petals, when present, $4^{-\infty}$, perigy- 
nous. Stamens $4-\infty$, perigynous; filaments distinct. Disk circular or none. Ovary compound, of 2 carpels united below, 2-celled; styles 2 , subulate, erect or recurved; ovules 1- $\infty$. Fruit a 2-celled 2-beaked woody or cartilaginous capsule, dehiscent at the summit. Seeds I-several, anatropous; embryo large; endosperm scanty. About 15 genera and 35 species, natives of N. Am., Asia and South Africa.

Ovules $\mathrm{I}$ in each cavity; flowers perfect or polygamous; shrubs or small trees; fruit not spiny.

Flowers white, in catkin-like spikes; petals none.

Flowers yellow, in axillary clusters; petals long.

r. Fothergilla.

2. Hamamelis.

Ovules several in each cavity; flowers monœcious; large trees; fruit globular, spiny.

3. Liquidambar.

\section{FOTHERGÍlLA Murr.}

Shrubs, the foliage somewhat stellate-pubescent. Leaves alternate, obovate. Flowers in catkin-like bracted terminal spikes, appearing a little before the leaves. Calyx campanulate, slightly 5-7-lobed. Petals none. Stamens about 24 , inserted on the edge of the calyx; anthers subglobose. Ovary 2-celled; styles slender. Capsule cartilaginous, 2 -celled, 2 -seeded. Seeds bony, pendulous. [Named for Dr. John Fothergill, 1712-1780, an English naturalist.] Two or three species of eastern N. Am.

I. Fothergilla Carolina (L.) Britton. Fothergilla. (I. F. f. 1878.) A shrub, 6-15 dm. high, the young twigs densely stellate-pubescent. Leaves shortpetioled, $5-8 \mathrm{~cm}$. long, obovate or broadly oval, obtuse or short-pointed at the apex, usually inequilateral, coarsely dentate-crenate above the middle, or entire; spikes erect, 3-5 cm. long; bracts densely pubescent, the lower ones sometimes lobed; stamens white or pinkish, 4-8 mm. long; capsule very pubescent. In wet grounds, Va. to Ga. April.

\section{HAMAMÈLIS L.}

Shrubs, with alternate leaves, and clustered lateral yellow bracted flowers, appearing in late summer or autuinn. Calyx 4-parted, persistent, adnate to the lower part of the ovary. Petals 4 , elongated, linear, persistent, or in the staminate flowers sometimes wanting. Stamens 4 , alternating with 4 scale-like staminodia; filaments very short; anthers dehiscent by a valve. Ovary 2 -celled; styles 2 , short; ovules I in each cell, pendulous. Capsule woody, at length 2 -valved at the summit. Seed oblong, its testa shining. [Greek, with the apple, flower and fruit being borne together.] Three known species, one native of eastern N. Am., the others of Japan.

I. Hamamelis Virginiàna L. Witch-HAzel (I. F. f. I879.) A shrub, or rarely a small tree. Leaves short-petioled, obovate or broadly oval, somewhat cordate and inequilatera! at the base, stellate-pubescent, at least when young, 5-12 $\mathrm{cm}$. long, thick, repand-dentate: flowers in axillary clusters, nearly sessile: petals about $1 \mathrm{~mm}$. wide, $12-18 \mathrm{~mm}$. long; capsule maturing the next season, $6-8 \mathrm{~mm}$. high, at length bursting elastically; seeds large, bony. In low woods, N. B. and N. S. to Minn., Mo., Fla. and Tex. Aug.-Dec.

\section{LIQUIDÁMBAR L.}

Large trees with resinous sap, simple alternate lobed petioled leaves, and small moncecious flowers in lheads, the staminate clusters racemose, the pistillate ones usually solitary. Calyx and corolla of the staminate flowers none; stamens numerous; filaments short; anthers longitudinally dehiscent. Calyces of the pistillate flowers confluent; petals none; anthers rudimentary, borne on the edge of the calyx; ovary partly inferior, 2-celled; ovules several or numerous; styles 2. Capsules 2beaked, 2 -valved at the summit, dry, hard, forming a dense spinose globular head. [Name Latin-Arabic referring to the fragrant sap.]

I. Liquidambar Styracíflua L. Sweet Gum. Star-leaved or Red Gum. Bilsted. Alligator-Tree. (I. F. f. I880.) A forest tree, maximum height about $45 \mathrm{~m}$. ; bark very rough, branches usually winged with corky ridges. Leaves broader than long, 7-20 cm. wide, subcordate at base, deeply 3-7-lobed, 
often pubescent in the axils of the veins beneath, the lobes triangular-ovate, acuie, sharply and finely serrate; sterile flower-clusters erect, of numerous small heads, greenish; fertile heads long-peduncled, at length drooping, borne near the base of the sterile; head of fruit about $3-4 \mathrm{~cm}$. in diameter, the fertile seeds few, with nu. merous minute sterile ones. In low woods, Conn. and southern N. Y. to Fla., IIl., Mo. and Mex. April-May.

\section{Family 10. PLATANÀCEAE Lindl.}

\section{Plane-tree Family.}

Large trees, with alternate petioled palmately lobed and veined leaves, the hollowed petiole bases enclosing the buds for the following season, and small green monœcious flowers in dense globular heads. Receptacle somewhat fleshy. Calyx of 3-8 externally pubescent minute sepals. Corolla of as many thin glabrous petals. Staminate flowers with stamens as many as the sepals and opposite them; filaments short; anthers oblong or linear, longitudinally dehiscent. Pistillate flowers with 2-8 distinct pistils; ovary linear, I-celled; style elongated ; stigma lateral. Ripened head of fruit composed of very numerous narrowly obpyramidal nutlets which are densely pubescent below with long nearly erect hairs. Seed pendulous; endosperm thin; cotyledons linear. Only the following genus, comprising some 7 species, natives of the north temperate zone.

\section{PLÁtANUS L.}

Characters of the family. [Name ancient.] Besides the following species, 2 others occur in the western U. S. and $I$ or 2 in Mex.

I. Platanus occidentàlis L. Button-wood. Button-ball. Plane-tree. (I. F. f. I88I.) A large tree; maximum height about $40 \mathrm{~m}$.; outer bark freely peeling off in thin plates, uncovering the bright white inner layers. Leaves orbicular, or wider than long, IO-25 cm. wide, cordate or truncate at the base, 3-5-lobed, densely floccose pubescent with whitish branched hairs when young, hecoming nearly glabrous when old, the lobes sharply serrate, or rarely entire ; stipules with broad spreading toothed borders, conspicuous on young shoots; fruit. ing heads $2 \mathrm{~cm}$. in diameter, usually solitary, hanging on a long peduncle, persist. ent through the winter. Along streams and in wet woods, Me. to Ont. and Minn., Fla., Kans. and Tex. May.

\section{Family 11. ROSÀCEAE* B. Juss. Rose Family.}

Herbs, shrubs, or trees, with alternate (in some exotic genera opposite) leaves, and regular perfect or rarely polygamo-dioecious flowers. Stipules commonly present, sometimes large. Calyx freê from or adnate to the ovary, 5-lobed (rarely,4-9-lobed), often bracteolate. Disk adnate to the base of the calyx. Petals equal in number to the calyx-lobes, distinct, or none. Stamens usually numerous, distinct; anthers small, 2 -celled. Carpels $1-\infty$, distinct, or adnate to the calyx. Ovary $i$-celled or rarely imperfectly 2 -celled; style terminal or lateral. Ovules I, 2, or several, anatropous. Fruit mostly follicles or achenes; endosperm none, or rarely copious. About 65 genera and 1200 species, of wide geographic distribution.

I. Fruit not enclosed in a hollow receptacle, the so-called calyx.

Pistils few, seldom more than 5 , ripening into $2-4$-seeded follicles.

Follicles dehiscent along both sutures; seeds shining.

Follicles dehiscent along one suture; seeds dull.

1. Opulaster.

Pistils alternate with the calyx-lobes.

Flowers perfect; leaves simple; shrubs.

Flowers diœcious; leaves 2-3-pinnate; tall herbs. 
Pistils opposite the calyx-lobes; petals white.

Follicles united at the base; petals obova or oblong; leaves pinnate.

Follicles free; petals strap-shaped; leaves trifoliolate.

4. Sorbaria.

5. Porteranthus.

Pistils numerous or rarely few, ripening into $1-2$-seeded drupelets or achenes.

Pistils ripening into drupelets crowded on the receptacle.

Drupelets very pulpy.

Drupelets nearly dry, enclosed by the calyx.

6. Rubus.

7. Dalibarda.

Pistils ripening into achenes.

Style deciduous.

Style nearly basal; ovules ascending or nearly erect, orthotropous ;

leaves pinnate.

8. Drymocallis.

Style lateral; ovules ascending and amphitropous.

Achenes hairy; low shrubs.

Leaves pinnate; style club-shaped; flowers yellow.

Leaves trifoliolate; style filiform; flowers white.

9. Dasiphora.

Achenes glabrous; herbs.

10. Sibbaldiopsis.

Achenes 10-15; stamens 5; leaves trifoliolate.

Achenes numerous; stamens about 20.

11. Sibbaldia.

Receptacle much enlarged and red in fruit; leaves trifuliolate.

Receptacle pulpy, edible; petals white.

Receptacle not pulpy; petals yellow.

12. Fragaria.

13. Duchesnea.

Receptacle in fruit somew hat enlarged, spongy; leaves pinnate; petals red.

I4. Comarum.

Receptacle not enlarged in fruit; leaves interruptedly pin-

nate; petals yellow. 15 . Argentina.

Style terminal or nearly so.

Pistils numerous; ovules pendulous and anatropous.

Pistils 2-6: ovules basal, erect.

16. Potentilla.

17. Waldsteinia.

Style persistent on the achene.

Pistils numerous: herbs.

Calyx-lobes and petals 5; leaves interruptedly pinnate.

Style jointed above, the upper portion deciduous.

Style not jointed.

18. Geum.

19. Sieversia.

Calyx lobes and petals 8 or 9; leaves simple; styles plumose

Pistil solitary; achene with a long plumose style; shrubs. 2o. Dryas.

21. Cercocarpus.

I'istils 5-15; fruit resembling a follicle, but indehiscent and I-seeded ; style not plumose; herbs.

2. Fruit, I-4 achenes, enclosed in the persistent dry receptacle; herbs. 22. Llmaria.

Calyx with 4 or 5 bractlets; petals none.

Calyx not bracteolate.

Calyx bearing hooked prickles; petals 5 .

Calyx not prickly; petals none. 3. Fruit, numerous achenes, enclosed in the fleshy receptacle; shrubs with pinnate
leaves.

\section{OPULÁSTER Medic.}

Branching shrubs, with petioled simple palmately lobed leaves, and white flowers in terminal corymbs. Calyx campanulate, 5-lobed. Petals 5, rounded, inserted in the throat of the calyx, Stamens 20-40, inserted with the petals. Pistils $\mathbf{I}-5$, short-stipitate, when 5 alternate with the calyx-lobes. Stigma terminal, capitate. Pods I-5, inflated, 2-4-seeded. Seeds ovoid or globose, crustaceous, shining; endosperm copious. [Greek, a wild Opulus, or cranberry-tree.] Species about 8, 3 of eastern N. Am., 4 of the Rocky Mts. and Pacific Coast, $I$ in Mantchuria. 
1. Opulaster opulifòlius (L.) Kuntze. Eastern Ninebark. (I. F. f. I882.) A shrub, I-3 m. high, with recurved branches, glabrous twigs and foliage, the bark peeling off in thin strips. Stipules caducous; leaves ovate-orbicular, generally acutely 3-lobed, cordate, truncate or broadly cuneate at the base, 3-5 cm. long, crenate-dentate; pedicels slender, 10-16 mm. long; flowers white or purplish; calyx glabrous or nearly so; follicles 5, glabrous, shining, 8-10 $\mathrm{mm}$. long, acute, obliquely subulate-tipped, twice as long as the calyx. River-banks and in rocky places, Quebec to Ky. and Ga. June. [Spiraea opulifolia L.]

2. Opulaster intermédius Rydb. Prairie Ninebark. Like the preceding, but generally lower, I-I.5 m. high; leaves orbicular in outline, with rounded lobes, 2-6 cm. long, obtuse or subcordate at the base, crenate: pedicels and calyx finely pubescent; ovaries 3 or 4 , rarely 2 , pubescent, united below, follicles $6-7 \mathrm{~mm}$. long, rounded or obtuse at the apex, tipped with a subulate style. River banks from IIl. and Mo. to Colo. and S. Dak.

\section{SPIRAÈA L.}

Shrubs. Flowers racemose, cymose, corymbose or paniculate, white or pink, perfect. Calyx persistent, its tube 4-5-lobed. Petals 4-5, inserted on the calyx, short-clawed. Stamens 20-60, distinct, inserted on the calyx; filaments filiform. Disk adnate to the calyx-tube. Pistils commonly 5 (rarely I-8), superior, alternate with the calyx-lobes. Stigmas capitate or discoid; ovules $2-\infty$. Follicles usually 5, not inflated. Seeds linear, pendulous, the testa dull. [Greek, twisting, the pods twisted in some species.] About 60 species, natives of the north temperate zone. Besides the following, about 5 others occur in western N. Am.

Flowers in dense terminal panicles.

Glabrous or nearly so throughout.

Twigs and lower surfaces of the leaves woolly-pubescent. Flowers in terminal corymbs.

Leaves broadly oval or ovate, thick, serrate.

Leaves oblong, thin, nearly entire.

1. S. salicifolia.

2. S. tomentosa.

3. S. corymbosa.

4. S. Virginiana.

I. Spiraea salicifòlia L. Willow-leaved or AMERican MEadow-Sweet. QUAKER LAdy. (I. F.f. I883.) An erect shrub, 6-12 dm. high. Leaves petioled, oblanceolate, obovate, lanceolate or oval, sharply serrate, especially above the middle, 3-5 cm. long, 8-24 $\mathrm{mm}$. wide, or on young shoots much larger, mainly cuneate at the base, pale beneath; flowers white or pinkish-tinged, 4-6 mm. broad; follicles glabrous. In swamps or moist ground, Newf. to the Rocky Mts., Ga. and Mo. Also in northern Europe and Asia. June-Aug.

2. Spiraea tomentòsa L. Hardhack. Steeple-bush. (I. F. f. r884.) Erect, shrubby, usually simple, the stems floccose-pubescent. Leaves shortpetioled, ovate or oval, 3-5 cm. long, 12-25 mm. wide, unequally serrate, glabrous and dark-green above, woolly-pubescent with whitish hairs beneath; flowers pink or purple, rarely white, about $4 \mathrm{~mm}$. broad; follicles pubescent. In swamps and low grounds, N. S. to Manitoba, Ga. and Kans. July-Sept.

3. Spiraea corymbòsa Raf. Corymbe1) Spiraea. (I. F. f. I885.) A shrub, 3-10 dm. high, nearly glabrous throughout. Leaves petioled, rounded or slightly cordate at the base, serrate, especially above the middle, green above, paler and sometimes minutely pubescent beneath, 4-7 cm. long, 3-5 cm. wide; flowers white, about $4 \mathrm{~mm}$. broad; follicles glabrous. On banks or in rocky places, mountains of Ga. to N. J., Ky. May-June.

4. Spiraea Virginiàna Britton. Virginia Spiraea. (I. F. f. I886.) A glabrous much-branched shrub, the branches forming wands 3-12 dm. long. Leaves petioled, cuneate or rounded at the base, 4-5 cm. long, 10-16 mm. wide, green above. pale or slightly glaucous beneath, entire, or with a few low teeth above the mildle: flowers white, about $6 \mathrm{~mm}$. wide; pedicels and calyx glaucous; follicles glabrous. On rocks, W. Va., to the mountains of N. Car. and Tenn. June.

Spiraea Japónica L. f., with oblong-lanceolate acuminate cut-toothed leaves, the branches and corymbose inflorescence finely pubescent, occurs as an escape from cultivation in E. Penn.

\section{ARÚNCUS Adans.}

Tall perennial herbs, with large 2-3-pinnate leaves, stipules minute or wanting, and very numerous white diøcious flowers in panicled spikes. Calyx mostly 
5-lobed. Petals as many as the calyx-lobes. Stamens numerous, inserted on the calyx; filaments filiform. Pistils usually 3, alternate with the calyx-lobes. Follicles glabrous, at length reflexed, usually 2 -seeded. Seeds minute, not shining. Two known species, the following of the north temperate zone, the other Japanese.

I. Aruncus Arúncus (L.) Karst. Goat's-BEARD. (I. F. f. I887.) Glabrous throughout, stem erect, somewhat branched, 1-2 m. high. Leaves long-petioled, the lower $3 \mathrm{dm}$. long or more; leaflets ovate, lanceolate or oval, thin, acumiriate or acute at the apex, rounded or slightly cordate, sharply doubly serrate or incised, 3-7 cm. long: inflorescence compound, branches spike-like, elongated; flowers 2-4 mm. wide; follicles short. In rich woods, Penn. to Iowa. Ga. and Mo. Also from Ore. to Alaska, and in Eur. and Asia. May-July. [Spiraea Aruncus L.

\section{SORBÁRIA A. Br.}

Shrubs with stipules, odd-pinnate leaves and white flowers in terminal panicles. Calyx openly campanulate, 5-lobed. Petals 5, obovate or oblong. Stamens 2040; pistils mostly 5, united at the base. Carpels not inflated. Seeds several, pendulous, with endosperm. About 4 Asiatic closely related species.

I. Sorbaria sorbifolia (L.) A. Br. Mountain-ASh SpIRAeA. Large shruh, pubescent when young, glabrate in age. Leaflets I3-2I, lanceolate, acuminate, sharply and doubly serrate, dark green. Native of Siberia, often cultivated f:r ornament and escaped in the Middle States. June-Sept.

\section{PORTERÁNThus Brition. [GILLENIA Moench.]}

Frect perennial herbs, with nearly sessile stipulate 3-foliolate or 3-parted leaves, and white or pinkish perfect flowers in loose terminal panicles. Calyx cylindric, persistent, narrowed at the throat, Io-nerved, 5-toothed, the teeth im. bricated, slightly glandular. Petals 5, linear-lanceolate, spreading, convolute in the bud, somewhat unequal, inserted on the calyx. Stamens 10-20, included; filaments short; anthers large. Carpels 5, villous-pubescent, opposite the calyxlobes. Ovules ascending; style filiform. Follicles 5, 2-4-seeded. Seeds with endosperm. [In honor of Thomas Conrad Porter, Professor in Lafayette College.] Only the following species.

Leaflets serrate; stipules subulate, mainly entire.

Leaflets incised; stipules broad, foliaceous, incised.

1. P. trifoliatus.

2. P. stipulatus.

I. Porteranthus trifoliàtus (L.) Britton. Indian Physic. Bowman'sRooT. (I. F. f. I888.) Herbaceous from a perennial root, erect, branching, 6-12 dm. high, glabrous or somewhat pubescent ; leaflets short-stalked, oval, ovate, lanceolate or slightly obovate, acuminate at the apex, narrowed at the base, 5-7 cm. long, irregularly serrate; upper leaves often 3 -lobed, or sometimes merely serrate; pedicels slender : petals white or pinkish, IO-12 mm. long; pods pubescent, subulate-tipped, little exceeding the calyx. Woodlands, N. Y. to Mich., Ga. and Mo. May-July.

2. Porteranthus stipulatus (Muhl.) Britton. AMERICAN IPECAC. (I. F. f. I889.) Resembling the preceding species, but generally more pubescent. Stipules foliaceous, broad, ovate, acuminate or acute, $8-25 \mathrm{~mm}$. long, sharply incised-serrate; leaflets commonly narrower than those of the preceding, incised-serrate, or those of the lower leaves deeply pinnatifid; pods less pubescent or sometimes quite glabrous. In woods, western N. Y. to Ind. and Kans., south to Ala., La. and the Ind. Terr. June-July.

\section{RÙBUS L.}

Perennial herbs, shrubs or trailing vines, often prickly, with alternate simple lobed or 3-7-foliolate leaves, the stipules adnate to the petiole. Flowers terminal or axillary, solitary, racemose or panicled, white, pink or purple, perfect or sometimes diœcious. Calyx persistent, not bracted, deeply 5-parted, its tube short and broad. Petals 5, deciduous. Stamens $\infty$, usually numerous, inserted on the calyx, distinct. Carpels $\infty$, rarely few, inserted on a convex or elongated receptacle, ripening into drupelets and forming an aggregate fruit. Ovules 2, one abortive, Style nearly terminal, slender, seed pendulous. [The ancient name of the 
bramble. from ruber, red.] About 250 species, of wide geographic distribution, most abundant in the north temperate zone. Besides the folluwing, some ro others occur in N. Am. beyond our area. The stems of many species are biennial.

\section{A. Leaves simple, crenate or palmately lobed.}

Shrubby, 6-15 dm. high, branched; flowers corymbose.

Flowers numerous, red-purple.

Lobes of the leaves broadly triangular, dentate.

Lobes of the leaves lanceolate, incised-dentate.

Flowers few, white; western.

Herbaceous, 8-25 cm. high, simple; flowers solitary, white.

1. R. odoratus.

2. $R$. Columbianus.

3. $R$. parviflorus.

4. R. Chamaemorus.

\section{B. Leaves 3-7-foliolate.}

1. Fruit falling away from the dry receptacle. RASPBERRIES.

Herbaceous, usually unarmed, I-3-flowered; leaves not white beneath.
Petals pink, spreading.
Petals white, erect.
5. $R$. arcticus.
6. R. Americanus.
Shrubby; many-flowered; leaves white-pubescent beneath.
St $\mathrm{ms}$ bristly, not glaucous; fruit light red.
Stoms prickly, slightly glaucous; fruit dark red.
Stems prickly, very glaucous; fruit purple-black.
7. R. strigosus.
8. R. neglectus.
9. R. occidentalis.

2. Fruit persistent on the ficshy receptacle. BLACKBERries and DEWBERRIEs.

* Erect, recurved or ascending ; fruit black.

Leaflets laciniate or deeply incised.

Leaflets serrate or slightly incised.

Leaves white-woolly beneath.

Leaves not white-woolly beneath.

10. R. laciniatus.

II. R. cuneifolius.

Inflorescence distinctly glandular.

Fruit broadly oval or nearly spherical, very pulpy.

Fruit narrowly oblong or thimble-shaped.

12. R. nigrobaccus.

13. R. Allegheniensis.

Inflorescence and leaves decidedly villous, scarcely glandular.

Terminal leaflet one-half longer than the lateral ones, oblong or oblongovate.

14. $R$. ostryifolius.

Terminal leaflet slightly larger than the lateral ones, obovate or rhombicobovate.

Inflorescence slightly villous.

Plant low, alnost herbaceous, weakly prickly. $\quad$ 16. R. Randii.

Plants tall and slirubby.
Plant strongly prickly.
17. R. argutus.

* * Trailing or decumbent.

Plant unarmed or with a few weak prickles. 18. $R$. Canadensi

† Stem prickly (no. 19 also bristly); fruit black.

Leaves thick, coriaceous, persistent.

Flowers corymbose; stem very bristly; leaves, except those of the flowering branchlets, 5 -foliolate.

Flowers I-3; stem scarcely bristly; leaves mostly 3-foliolate.

Leaves thin, deciduous. I9. $R$, rubrisetus.

20. R. trivialis.

Inflorescence usually many-flowered.

Flowers generally over $3 \mathrm{~cm}$. in diameter; inflorescence generally glandular; terminal leafiet of sterile shoots rounded or cordate at the base. Leaflets simply serrate.

Leaflets sharply doubly serrate.

21. R. invisus.

22. $R$. roribaccus.

Flowers generally less than $3 \mathrm{~cm}$. in diameter; inflorescence nut glandular; terminal leaflet of the sterile shoots cuneate or obtuse at the base.

Terminal leaflet one-half longer than the lateral ones, oblong or oblong-ovate, acute.

14. $R$. ostryifolius.

Terminal leaflet only slightly longer than the lateral ones, ovate, acuminate.

Inflorescence usually I-2-flowered.

23. $R$. procumbens.

Leaflets cuneate at the base; glabrous.

Leafets sharply serrate with triangular teeth.

Leaflets crenate serrate with ovate teeth. $25 . R$. Ensleni.

Leaflets rounded or cordate at the base, pubescent beneath. 
$\uparrow+$ Stem bristly or weakly prickly; fruit red or, when ripe, alruust black.

Leaflets thick; inflorescence stout, strongly bristly or weakly prickly.

Leaflets thin; inflorescence sparingly and weakly bristly.

27. $R$. nigricans.

Some of the leaves quinate; leaflets of the flowering shoots oblanceolate or narrowly cuneate.

28. R. setosus.

All leaves ternate; leaflets of the flowering shoots broadly obovate. 29. R. hispidus.

$+\uparrow+$ Stem unarmed; fruit red.

6. R. Americanus.

I. Rubus odoràtus L. Purple-Flowering Raspberry. (I. F. f. I89o.) Lrect, branched, shrubby, glandular-pubescent and somewhat bristly, not prickly, I-I.5 m. high. Stipules small, lanceolate, acuminate; leaves simple, petioled, sometimes nearly $3 \mathrm{dm}$. broad, 3-5-lobed, cordate at the base, pubescent, the lobes acuminate, finely serrate; flowers $3-5 \mathrm{~cm}$. broad; bracts membranous; calyx-lobes tipped with a slender appendage; fruit red when ripe, depressed-hemisplieric, scarcely edible. In rocky woods, N. S. to Ont., Mich., Ga. and Tenn. A form with white flowers has been found at Pine Hill, Ulster Co., N. Y. June-Aug.

2. Rubus Columbiànus (Millsp.) Rydb. Maple-LeAved Raspberry. Erect, shrubby, glandular-pubescent, rarely bristly. Leaves simple, slender-petioled, 5-7-lobed to near the middle, cordate at the base; lobes lanceolate, acuminate, doubly and sharply dentate; flowers smaller than in the preceding, 2-3 cm. broad; calyx-lobes ovate, with almost subulate tips; fruit red, small, depressed, of a very musky taste. Mountains of W. Va. July. [R. odoratus var. Columbianus Millsp.]

3. Rubus parviflòrus Nutt. Salmon-berry. White-Flowering RaspBERRY. (I. F. f. I89I.) Similar to $R$. odoratus but usually less glandular and scarcely bristly. Leaves petioled, simple, cordate at the base, 3-5-lobed, the lobes acute or obtusish, rarely acuminate, coarsely and unequally serrate; flowers few, corymbose, white, terminal, $3-5 \mathrm{~cm}$. broad; calyx lobes tipped with a long, slender appendage ; fruit depressed hemispheric, scarcely edible, red when ripe. In woods, Mich., Minn. and western Ont. to Alaska, Cal., Utah and Colo. MayJuly.

4. Rubus Chamaemòrus L. Cloudberry. Knotberry. Mountain Bramble. Mountain Raspberry. (I. F. f. I892.) Herbaceous; rootstock creeping; branches erect, 4-25 cm. high, finely pubescent or nearly glabrous, scaly below; leaves orbicular or broader, 5-9-lobed, cordate or reniform at the base, pubescent or glabrous, 3-7 cm. broad, the lobes usually short, broad, dentate; flowers diœecious, solitary, terminal, white, $12-25 \mathrm{~mm}$. broad: sepals ovate, shorter than the petals, sometimes toothed toward the apex; fruit red at first, yellow when ripe, composed of few drupelets, edible and pleasant. In peat-bogs and swamps, Me. and N. H. to Arctic Am., Alaska and Br. Col. Also in northern Europe and Asia. June-July.

5. Rubus árcticus L. Arctic Raspberry or Branble. (I. F. f. I893.) Stems erect, herbaceous, 7-25 cm. high, unarmed, finely pubescent, sometimes leafless below. Leaves 3 -foliolate (rarely 5 -foliolate); leaflets sessile or shortstalked, rhombic-ovate or obovate, coarsely and unequally serrate or slightly lobed, 18-25 mm. long; flowers solitary, or occasionally 2, slender-peduncled, pink, 12-25 mm. broad, sometimes diœcious; sepals acute, equalling or shorter than the obovate petals; fruit light red, of several or numerous drupelets, edilble, fragrant. In peat-bogs and damp woods, Quebec to Manitoba and Br. Col., and throughout Arctic Am. Also in Europe and Asia. Summer.

6. Rubus Americànus (Pers.) Britton. Divarf Raspberry. (I. F. f. I897.) Stem trailing or ascending, unarmed, annual, herbaceous, or slightly woody, I 5-45 cm. long, somewhat pubescent. Leaves petioled, 3-foliolate, rarely 5-foliolate; leaflets rhombic-ovate, glabrous or nearly so, acute, the lateral ones mostly rounded, the terminal one cuneate at the base, all sharply serrate; peduncles slender, 1-3-flowered, glandular-pubescent; flowers $8-12 \mathrm{~mm}$. broad; jetals 5-7, white, spatulate-oblong, erect, rather longer than the acuminate r flexed sepals; fruit red-purple, about $12 \mathrm{~mm}$. long. In swamps, Newf. to $\mathrm{M}$ Initoba, N. J. and Neb. Intermediate between Blackberries and Raspberries. May-July. 
7. Rubus strigòsus Michx. Wild Red RAspberRy. (I. F. f. I894.) Stems shrubby, biennial, branched, 5-20 dm. high, usually densely clothed with veak glandular bristles, or the older stems with small hooked prickles. Leaves pinnately 3-5-foliolate; leaflets ovate or ovate-oblong, acuminate, sharply and rregularly serrate or slightly lobed, rounded at the base, 3-7 cm. long; inflorescence racemose or paniculate, loose; pedicels slender, curving in fruit; flowers 8-12 mm. broad; petals white, ascending, about equalling the spreading acuminate sepals; fruit elongated-hemispheric, light red, white in a cultivated form. In dry or rocky situations, Newf. and Lab. to Manitoba, Br. Col., N. Car., and N. Mex. May-July.

8. Rubus negléctus Peck. Purple Wil. Rasprerry. (I. F. f. I895.) Intermediate between the preceding species and the next. Stems recurved and rooting at the tip, glaucous, sparingly lristly and prickly; leaflets ovate, sharply and irregularly incised-serrate, $2-8 \mathrm{~cm}$. long; inforescence corymbose, rather compact; pedicels erect or ascending even in fruit; flowers $8-10 \mathrm{~mm}$. broad; petals white, erect; fruit nearly hemispheric, dark-red or purple (yellowish in a cultivated form). In dry or rocky soil, N. Eng. to Penn. June-July. Fruit ripe July-Aug.

9. Rubus occidentàlis L. Black Raspberry. Thimble-berry. BlackCAP. (I. F. f. I896.) Very glaucous; stems cane-like, recurved, often rooting at the tip, sometimes 3-4 m. long, sparingly armed with hooked prickles, rarely slightly glandular-bristly above. Leaves pinnately 3 -foliolate (rarely 5 -foliolate); leaflets ovate, acuminate, coarsely incised-serrate; flowers as in the preceding species; inflorescence corymbose, compact, usually only terminal; pedicels short, ascending or erect in fruit; fruit purple-black, depressed-hemispheric. Quebec and Ont., to Ga. and Kans. May-June.

ro. Rubus laciniàtus Willd. Cut-leaved Blackberry. Stem ascending, 2-3 m. high, pale green or purplish, angled, with stout flat recurved prickles; the young shoots villous. Leaves pedately $3-5$-foliolate; leaflets often again pinnately 3-5-foliolate, laciniate or deeply incised and serrate, villous beneath; inflorescence cymose-paniculate; flowers $2-3 \mathrm{~cm}$. wide ; petals white, obovate-cuneate, often lobed at the apex; sepals more or less foliaceous and lobed; fruit large, black, hemispheric. Escaped from cultivation in S. N. Y. and Penn.; also in Ore. and Wash. Supposed to be a native of Europe. June-Aug.

II. Rubus cuneifòlius Pursh. Sand Blackberry. Knee-high BlackBERRY. (I. F. f. I9OI.) Shrubby, 3-10 $\mathrm{dm}$. high, much branched, armed with stout straight or recurved prickles. Leaves 3-5-foliolate; leaflets thick, rugose above, $2-5 \mathrm{~cm}$. long, obovate or rarely oval, obtuse, dentate, especially above the middle, the terminal one cuneate; peduncles mainly terminal, 2-5-flowered; flowers white or pinkish, nearly $2.5 \mathrm{~cm}$. broad; petals exceeding the sepals: fruit brownish-black, often $2.5 \mathrm{~cm}$. long, delicious. In sandy soil, Conn. to Fla., Mo. and La. May-July.

12. Rubus nigrobáccus Bailey. High Bush Blackberry. (I. F. f. 1898.) Shrubby, branched, glandular-pubescent ; stems erect or recurved, I-3 m. long, armed with stout recurved prickles. Leaves 3-5-foliolate; leaflets ovate or ovateoblong, acute or acuminate, coarsely and unequally serrate, pubescent beneath, the terminal one stalked; inflorescence mainly terminal, racemose-paniculate; bracts small; fowers $18-25 \mathrm{~mm}$. broad; petals white, obovate, much exceeding the sepals; fruit black, pulpy, $12-25 \mathrm{~mm}$. long. In dry soil, N. Eng. to Fla. and Ark., mostly at low altitudes. May-June. Fruit ripe July-Aug. A form with small white fruit occurs in Michigan. [R. villosus Gray and of Ill. Fl.; not Ait.]

R. nigrobaccus sativus Bailey is a form with short flower clusters and fewer and larger drupelets.

13. Rubus Allegheniénsis Porter. Mountain Blackberry. (I. F. f. 1899.) Glandular, resembling the preceding species. Stems rather more slender, red or purple, very prickly, erect or ascending, 6-25 dm. high. Leaflets usually narrower, ovate-lanceolate; fruit $16-28 \mathrm{~mm}$. long, 6-8 $\mathrm{mm}$. in diameter, much less pulpy and of a peculiar flavor; racemes sometimes very long, and pubescent; drupelets oblong when dry. In lry soil. Ont. and northern N, Y. to Penn, and Va., mostly at high altitudes. May-July. 
14. Rubus ostryifòlius Rydb. COAst Blackberry. Ascending or depressed, 6-12 dm. high. Stems brownish purple; prickles stout, broad, flat at the base, recurved; younger parts finely villous; leaves 3 -foliolate; leaflets oblong or oblong-ovate, rather simply serrate, finely villous below, slightly pubescent or glabrate above; corymb small, I-5-flowered, villous pubescent and somewhat prickly; flowers $\mathbf{I}-2 \mathrm{~cm}$. in diameter; sepals ovate, with a short subulate tip; fruit hemispherical, black, rather dry, less than $1 \mathrm{~cm}$. high. Near the seash re from N. J. to N. Car. Type from Atlantic Highlands, N. J. May-Aug. In habit intermediate between a blackberry and a dewberry.

15. Rubus frondòsus Bigel. IEAFY-BRACTED BlackberRy. Erect, about I $\mathrm{m}$. high, decidedly villous, especially when young. Stems stout, angled, with rather stout, straight prickles; leaves mostly 3 -foliolate, especially on the fluwering branches, leaflets short-obovate, doubly aus sharply serrate; terminal one generally short-petioled; inflorescence dense, generally leafy-bracted and subtended by unifoliolate leaves; flowers about $3 \mathrm{~cm}$. broad; petals broadly obovate. N. Eng. to Ohio and Va. [ $R$. villosus var. frondosus Torr.]

16. Rubus Rándii (Bailey) Rydb. Rand's Blackmerry. Low and diffuse, almost glabrous, 3-5 dm. high, with very few and weak pricklss, not rarely unarmed and only slightly shrubby. Leaves very thin, those of the sterile shoots 5 -foliolate, those of the flowering stems mostly 3 -foliolate, ovate or lance-ovate, longacuminate, sharply and doubly serrate, the terminal one slender-petioled; inflorescence elongated, many-flowered, bristly but not glandular; flowers $15-25 \mathrm{~mm}$. broad; fruit hemispheric, small, less than $1 \mathrm{~cm}$. long. Me. to Lake Superior and Va. June-Aug. [R. villosus var. R'andii Bailey.]

I7. Rubus argùtus Link. TALL BLACKBERRy. Resembling the last, but stems tall, r-2 m. high, stout, angled, purple, with streng and slightly recurved prickles; inflorescence corymbose, many-flowered, shcrt; leaves of the flowering branclies often small and the uppermost unifoliolate; flcwers $2-3 \mathrm{~cm}$. bread; petals oval or narrowly obovate; fruit hemispheric, at out $\mathbf{I} \mathrm{cm}$. high. It has been confused with $R$. frondosis, but is glabrate, its sterile shoots have larger, longacuminate leaflets, and the petals are narrower. Prince Edwaid Island to Ga., Ala. and Penn. May-July.

i8. Rubus Canadénsis L. Millspaugh's Elackbrrry. (I. F. f. rgco.) Ascending, wand-like, entirely unarmed, or with a few weak prickles, glabious or the younger shoots scurfy-pubescent; stems I 5 - $35 \mathrm{dm}$. long. Leaves long.petioled, pedately 5 -foliolate, or some 3 -foliolate; leaflets c val, thin, glabrcus on both sides, long-acuminate or acute, rounded or narrewed at the tase, often $15 \mathrm{~cm}$. long and $5 \mathrm{~cm}$. wide, sharoly but not very deeply serrate; stalk of tle terminal leafet $4-10$ $\mathrm{cm}$. long; inflorescence loosely racemose; pedicels slender, ascerding; fruit black, very pulpy, $15^{-25} \mathrm{~mm}$. long. In thickets and rich woods, mountairs of N. Eng., the Adirondacks, and in the higher southern Alleghanies. Jui:e-Aug. [R.Millspaughii Britt.]

i9. Rubus rubrisétus Rydb. Red-bristled DFWyerry. Stems 6-12 dm. long, trailing, weakly prickly and densely clothed with $r \in d$ or purplish bristles. Leaves 5-foliolate, or some of the flowering 1 ranches 3 -foliolate, thick, evergre $\mathrm{n}$, glabrous and shining; leaflets all petiolate, obovate or oval, acute or acuminate, dentate with broad teeth; inflorescence corymlose, 3-7-flowered, prickly and bristly; flowers $15^{-25} \mathrm{~mm}$. wide; sepals ovate, with a short subulate tip. In the Mississippi Valley from Mo. to La. Feb.-June. Ty pe from New Orleans.

20. Rubus triviàlis Michx. Southern IEwberry. (I. F. f. 1904.) Stem trailing or procumbent, $\mathrm{x}$. long or more, beset with stout hooked prickles, and sometimes slightly bristly. Branches erect, $3-15 \mathrm{~cm}$. high, prickly; leaves petioled, 3 -foliolate (rarely 5 -foliolate); leaflets oval or sometimes ovate lanceolate, coriaceous, evergreen, glabrous or very nearly so, acute or ol tusish at the apex, serratedentate; peduncles terminal, prickly, I-3 flowered; flowers often $25 \mathrm{~mm}$. broad, white; petals much exceeding the reflexed sepals; fruit black, often $25 \mathrm{~mm}$. long, well flavored. In dry sandy soil, Va. to Fla.. west to Tex. March-May.

2r. Rubus invísus Bailey. Itriaca Dewberry. Stems stout and partly ascending, terete, armed with straight, slightly reflexed prickles. Leaves of the sterile shoots 5 -foliolate, those of the flowering shonts generally 3 -foliolate, glabrous or nearly so; leaflets broadly ovate, more or less acuminate, especially those of tlee 
sterile shoots; corymbs few-flowered, with rather elongated pedicels; sepas with long tips; fruit globular-oblong. N. Y. to Ala. and Kans. June-July. [R. Cana. densis var. invisus Bailey.]

22. Rubus roribáccus (Bailey) Rydb. Lucretia Blackberry. Stem very stout, terete, with weak straight prickles. Young shoots and inflorescence decidedly villous-glandular; leav:s as those of the preceding, but less acuminate, sharply doubly serrate, thinner and greener; inflorescence many-flowered, leafy-bracted; flowers large, 3-5 cm. in diameter; petals generally broadly obovate; sepals nearly always foliaceous with a lanceolate base; fruit oblong-globose. Va., W. Va. and Penn. May-July. [R. Canadensis var. roribaccus Bailey.]

23. Rubus pro_únbens Mulil. Low Running Blackberry. Dewberry. (I. F. f. r906.) Trailing, shrubby; stem armed with scattered prickles or nearly naked. Branches erect or ascending, I-3 dm. long, more or less pubescent, sometimes slightly glandular; leaves petioled, 3-7-foliolate; leaflets ovate, oval or thin, obovate, acute or sometimes obtusish at the apex, rounded or narrowed at the bise. sharply dentate-serrate, usually sparingly pubescent; white, about $25 \mathrm{~mm}$. broarl; fruit black, delicious, often $25 \mathrm{~mm}$. long. In dry soil, Newf. and Ont. to Lake Superior, Va., La. and the Ind. Terr. April-May. Fruit ripe June-July. [R.Canadensis T. \& G., not L.]

24. Rubus subuniforus Rydb. One-flowered Dewberry. Like the preceding, but soon glabrate throughout; branches very slender; flowers $3-4 \mathrm{~cm}$. broad, mostly solitary, on long axillary peduncles in fruit fully as long as the leaves; prickles very weak; fruit small, hemispheric, I $\mathrm{cm}$. long or less, of few large grains. In habit intermediate between the preceding and the following, but the flowers larger than in either. Sandy or dry soil, near the coast from Me. to S. Car. May-July; fruit July-Sept. [R. villosus Ait. I789; not Thunb. I 784.$]$

25. Rubus Énsleni Tratt. Enslen's Dewberry. Slender, trailing, glabrous throughout, sparingly armed with reflexed prickles. Leaves small, 2-4 cm. long, obovate-cuneate or the terminal one rhombic-cuneate, entire at the base, crenatedentate or crenate-serrate above, acute; flowers small, about $15 \mathrm{~mm}$. broad; sepals narrowly ovite, mucronate: fruit small, of few drupelets. Woods in the South from Kans. (?) to Miss. and Ala. March-April.

26. Rubus Baileyànus Britton. Barley's Blackberry. (I. F. f. 1905.) Stem trailing or ascending, sparingly prickly, I-2 m. long. Leaflets broadly ovate or oval, pubsscent, at least on the lower surface, mostly rounded or cordate at the base, acute or obtuse, the uppermost leaves almost invariably unifoliolate; flowers few, rather large, $2-3 \mathrm{~cm}$. broad; fruit small. In dry woods and thickets, M. to N. Y. and Va. May-June.

27. Rubus nígricans Rydb. Peck's Dewberry. (I. F. f. I903.) Decumbent, with stout bristles. Shoots suberect, often $3 \mathrm{dm}$. high, the sterile ones very bristly, with stout reflexed bristles or slender prickles; leaves of the sterile shoots and the lower ones of the fertile 5-foliolate: leaflets petioled or the lower subsessile, obovate or oval, acuminate, sharply serrate, dark green; inflorescence racemose, leafy.. bracted; flowers about $15 \mathrm{~mm}$. broad; sepals lanceolate; fruit hemispheric, about I cm., at first red, but nearly black when fully ripe. Open grounds, Newf. to Mich., south to Penn. [R. hispidus var. suberectus Peck; not $R$. suberectus Anders.; $R$. setosus of Ill. Fl., in part.]

28. Rubus setòsus Bigel. Bristly Blackberry. Similar to the next following species but stouter: stems ascending or decumbent, the older parts densely clothed with slender slightly reflexed bristles. Lower leaflets generally 5, 3 in those of the flowering branches, oblanceolate, mostly acute or short-acuminate sometimes $5 \mathrm{~cm}$. long, short-stalked or sessile; flowers $12-18 \mathrm{~mm}$. broad, race mose; fruit small, sour. E. Mass. July-Aug.

29. Rubus híspidus L. Hispin or Running Swamp Blackberry. (I. F. f. 1902.) Stems slender, slightly woody, creeping, more or less densely beset with weak bristles. Branches erect or ascending, I-3 dm. long, naked; leaves petioled, 3-foliolate; leaflets obovate, obtuse, thick, persistent, narrowed at the loase, $\mathbf{1}-4$ $\mathrm{cm}$. long, sharply serrate above the middle; peduncles terminal or axillary, nearly or quite leafless; flowers corymbose, white, Io $14 \mathrm{~mm}$. broad; petals exceeding the sepals; fruit red, nearly black when ripe, sour, usually less than I $\mathrm{cm}$. long, 
composed of few drupelets. In swamps or low grounds, rarely in dry soil, N. S. to Ont., Minn., Ga. and Kans. June-July.

\section{DALIBÀRDA L.}

A low tufted perent al downy-pubescent herb, with simple long-petioled ovateorbicular cordate and crenate leaves, and scape-like peduncles bearing $\mathbf{I}$ or 2 white flowers. Calyx deeply 5-6-parted, its divisions somewhat unequal, the 3 larger ones commonly toothed. Petals 5, sessile, soon deciduous. Stamens numerous. Pistils 5-10; style terminal. Drupelets 5-IO, nearly dry, enclosed at length in the comnivent calyx-segments. [Named in lonor of Thos. Fran. Dalibard, a French botanist of the eighteenth century. $]$ A monotypic genus of northeastern North America.

I. Dalibarda rèpens I. DALibarDA. (I. F. f. I907.) Plant commonly bearing cleistogamous flowers. Stems slender, unarmed, much tufted, several inches long; leaves pubescent on both sides, $2-5 \mathrm{~cm}$. in diameter, the crenations low, obtuse or sometimes mucronulate; stipules setaceous; flowers 8 -ro mm. broad; peduncles slender, 4-12 cm. long; drupelets oblong, pointed, slightly curved, minutely roughened. In woors, N. S. to Minn., south to southern N. J., Ohio and Mich. June-Sept.

\section{DRYMOCÁLLIS Fourr.}

Perennial, more or less glandular or viscid, erect herbs with pinnate leaves. Flowers irregularly cymose; calyx 5 -bracteate; sepals 5 ; petals 5 , obovate, elliptic or orbicular, not emarginate, yellow or white. Stamens 20-30, in five festoons on the nuch thickened margins of the pentagonal disk around the receptacle; anthers flattened. Receptacle hemispheric with numerous pistils; style nearly basal and generally thickened near the middle; seed attached near the base of the style, ascending, orthotropous. A genus of 18 or 20 species of the north temperate zone; of these 13 are found in America.

I. Drymocallis argùia (Pursh) Rydb. Tall, or Glandular CingueFoIL. (I. F. f. I9I3.) Erect, stout, glandular and villous-pubescent, 3-Io dm. high. Basal leaves pinnately 7-I I-foliolate; leaflets ovate, oval or rhomboid, obtuse at the apex, the terminal one cuneate, the others rounded at the base and commonly oblique, all sharply incised-serrate; stem-leaves short-petioled or sessile, with fewer leaflets; flowers white, densely cymose, IO-18 $\mathrm{mm}$. broad; calyx-lobes ovate, acute, shorter than the obovate petals; stamens 25-30. [Potentilla arguta Pursh.] On dry or rocky hills, N. B. to the Rocky Mts., south to Tenn. and Kans. June-July.

\section{DASÍPHORA Raf.}

Shrubs with scarious sheathing stipules and pinnate leaves. Flowers solitary or in small cymes; bractlets, sepals and petals 5 . Petals orbicular, not emarginate, in ours yellow. Stamens about 25 , in 5 festoons on a disk as in Drymocallis; style lateral, club-shaped, thick and glandular above; stigma four-lobed. Achenes numerous, densely covered with long straight hairs; seed ascending and amphitropous. A genus of 8 or 9 species, all Asiatic, but the following also natives of North America and Western Europe.

T. Dasiphora fruticòsa (L.) Rydb. Shrubby Cinquefoll. (I. F. f. I932.) Shrubby, much branched; stems erect or ascending, very leafy, I.5-12 dm. high, the bark shreddy. Leaflets 5-7, oblong, entire, acute or acutish at each end, I-2 cm. long, silky-pubescent, the margins revolute; flowers bright yellow, $1.5-3 \mathrm{~cm}$. broad; calyx-lobes ovate: bractlets oblong. [Potentilla fruticosa L.] In swamps or moist rocky places, Lab. and Greenland to Alaska, N. J., Ariz. and Cal. Also in Europe and Asia. June-Sept.

Dasiphora fruticosa tenuifolia (Willd.) Rydb. Leaflets linear-oblong, more revolute; shrub lower and more hairy. On high mountains among exposed rocks. Range of the species.

Io. SIBBALDIÓPSIS Rydb.

A low undershrub, with trifoliolate subcoriaceous leaves and white cymose flowers. Bractlets and sepals 5. Petals 5, obovate or broadly oval, not emargi. 
nate. Style lateral, filitorm; achenes turgid, villous; seed ascending and amphitropous; otherwise as in Potentilla. A monotypic genus.

I. Sibbaldiopsis trident àta (Soland.) Rydb. Three-Toothed Cinquefoll. (I. F. f. 1933.) Caudex woody, creeping; branches of the year erect, 3-30 cm. high, pubescent. Stipules lanceolate, entire; leaflets cuneate, 3 -toothed or some. times 2-5-toothed at the truncate apex, dark green and shining above, pale and minutely pubescent beneath; flowers $1-6$, in a terminal cyme, about $1 \mathrm{~cm}$. broad; bractlets shorter and narrower than the ovate acute calyx-lobes; stamens abcut 20. [Potentilla tridentata Soland.] In rocky places, especially on mountains, Greenland to N. J., on the southern Alleghanies, shores of Lake Superior, and west to the Canadian Rocky Mts. June-Aug.

\section{SIBBÀLDIA L.}

Depressed alpine or arctic plants, with alternate mainly 3 -foliolate stipulate leaves, and cymose flowers. Calyx slightly concave, 5-lobed, 5-bracteolate, persistent. Petals 5, oblong or spatulate, much smaller than the calyx-lobes, yellow. Stamens 5 , opposite the calyx-lobes, inserted on the margin of the villous-pubescent disk. Carpels 5-10, on short pubescent stipes; style lateral, filiform. Aclicnos 5-10, glabrous. [Named in honor of Robt. Sibbald, a Scotch naturalist.] About 5 species, natives of the colder parts of the north teniperate zone.

I. Sibbaldia procúmbens L. Sibbaldia. (I. F. f. I938.) Densely tufted; stem decumbent or creeping, less than I dm. long. Stipules membranous, lanceolate or ovate-lanceolate, adnate; leaves 3 -foliolate; leaflets cuneate, 3 -5-toothed at the apex, pubescent with scattered hairs on both sides, resembling in outline those of Sibbaldiopsis tridentata; flowers yellow, 3-5 mm. broad, numerous; petals spatulate, very small; calyx-lobes oblong-ovate, acute, longer and broader than the bractlets. White Mts.; Mt. Albert, Quebec; Lab., Greenland to Alaska, south in the Rocky Mts. to Utah and Colo. Also in Europe and Asia. Summer.

\section{FRAGÀRIA L.}

Perennial acaulescent herbs ru pagating by runners, with basal tufted peticled 3-foliolate leaves, and sheathing membranous stipules. Flowers white, corymbese or racemose on erect scapes, polygamo-diøecious, the pedicels often recurved. Calyx persistent, its tube obconic or turbinate, 5-bracteolate, deeply 5-lobed. Petals 5, obovate, short-clawed. Stamens $\infty$; filaments slender. Carpels $\infty$, inserted on a glabrous convex or elongated receptacle, which becomes fleshy or pulpy in fruit; styles lateral. Achenes $\infty$, minute, dry, crustaceous. Seed ascending and amphitropous. [Latin, fragum, strawberry, signifying fragrance.] About 25 species, natives of the north temperate zone and the Andes of S. Am. Besides the following, 15 others occur in western N. Am.

Achenes imbedded in pits on the fruit.

Hairs of the scape and petioles nostly divaricate; leaflets generally petiolate.

Leaflets broadly oval or obovate; fruit globose or ovoid.

Leaflets oblong or narrowly obovate: fruit oblong-conic.

Hairs of the scape and petioles appressed; leaflets subsessile.

Achenes borne on the surface of the fruit; leaflets subsessile.

Stout ; leaflets thickish; plant naturalized; fruit ovoid to hemispheric.

Slender; leaflets thin; native plant; fruit ovoid to conic.

1. F. Virginiana.

2. F. Canadensis.

3. F. Terrae-noia?.

\section{F. vesca.}

5. F. Americana.

I. Fragaria Virginiàna Duchesne. Virginia or Scarlet Strawberry. (I. F. f. I908.) Rither stout, tufted, dark green, villous-pubescent. Leaflets thick, obtuse, dentate-serrate, the terminal one generally cuneate, the lateral inequilateral at the base; scape equalling or shorter than the leaves; hairs of the pedicels mostly appressed; calyx-lobes, at least of the sterile flowers, erect at maturity. In dry soil, Prince Edward Island to Minn., Ind. Terr. and Ga. April-June.

Fragaria Virginiana Grayłna (Vilm.) Rydb. Plant coarse and hairy; hairs of pedicels divaricate. Ohio to Kans. [F. I'irginiana Illinoensis Gray.]

Fragaria Virginiana austrdlis Rydb. Smaller and more hairy, $3-8 \mathrm{~cm}$. high ; leaflets only 2-4 cul. long, almost sessile; sepals broau, acuminate, Va, to N, C. and La, 
2. Fragaria Canadénsis Michx. Northern Wild Strawberry. (I. F.f. 1909.) Petioles slender, loosely villous. Leaves thin but firm; leaflets oblong or the middle one narrowly obovate, obtuse, rather few-toothed, 2-4 cm. long, glabrous or nearly so above, even when young, more or less appressed-pubescent beneath; flowers few, slender-pedicelled, 10-15 mm. broad; fruit 12-16 mm. long. In fields and meadows, Newf. to Mich., south to the Catskills. May-July.

3. Fragaria Terrae-nòvae Rydb. Newfoundland Strawberry. Leaves thin, glabrate above, slightly silky beneath; leaflets $2-5 \mathrm{~cm}$. long, obovate, serrate, the lateral ones slightly oblique at the base; scape slender, silky strigose at first, glabrate in age, few flowered; flowers $1.5-2 \mathrm{~cm}$. in diameter; petals often nearly twice as long as the sepals; fruit hemispheric, about $\mathbf{I ~ c m}$. broad. Newf. and Lab. to Me. and Ont.

4. Fragaria vésca L. European Wood Strawberry. (I. F. f. Igro.) Stout, tufted, dark green, silky. Leaflets ovate or broadly oval, obtuse, dentate, rather thin, the terminal one cuneate, the others inequilateral at the base; scape commonly exceeding the leaves so that the fruit is borne above them, sometimes $3 \mathrm{dm}$. high, its hairs mostly spreading; calyx-lobes remaining spreading or sometimes reflexed. In fields and along roadsides. Nat. from Europe in the Eastern and Middle States. April-June.

5. Fragaria Americàna (Porter) Britton. American Wood Strawberry. (I. F. f. I9II.) Slender, light green, silky-pubescent or glabrate, producing runners more freely than any of the preceding species. Leaflets very thin, ovate or oval, sharply incised.dentate, the terminal one commonly cuneate, the others inequilateral at the base, pubescent with silvery appressed hairs beneath; calyx-lobes reflexed in fruit; fruit often with a short neck. In rocky woods, Newf. to Va. and N. Mex. ,May-June.

\section{DUCHÈSNEA J. E. Smith.}

Perennial herbs, with leafy runners, 3-foliolate long-petioled leaves and axillary slender-peduncled yellow perfect flowers. Calyx 5-parted, 5-bracteolate, the bractlets larger than the calyx-segments and alternating with them, dentate or incised. Petals 5, obovate. Stamens numerous. Pistils numerous, borne on a hemispheric receptacle which greatly enlarges but does not become pulpy in fruit. Achenes superficial on the receptacle. [In honor of A. N. Duchesne, French botanist.] 'Two species, natives of southern Asia.

r. Duchesnez Índica (Andr.) Focke. Yellow or Indian Strawberry. (I. F. f. 1912.) Silky-pubescent, tufted and forming leafy runners, dark green. Leaflets rhombic obovate, rather thin, crenate or dentate, obtuse at the apex; peduncles equalling or longer than the leaves; flowers $1.5^{-2} \mathrm{~cm}$. broad; bractlets of the calyx dentate or incised, exceeding the ovate or lanceolate acuminate spreading calyx-lobes. In waste places, southern N. Y. and Penn. to Fla. and Ga. Naturalized or adventive from India. April-July.

\section{CÓMARUM L.}

A stout dark green nearly glabrous herb, with alternate pinnate large-stipuled leaves, the large purple flowers cymose or solitary, terminal or also axillary. Calyx deeply 5-lobed, 5-bracteolate, the bractlets narrow. Petals shorter than the calyx-lobes, acute, purple. Stamens numerous, inserted on the large pubescent disk. Pistils numerous, inserted on the pubescent receptacle which becomes spongy in fruit. Style lateral. Achenes glabrous, I-seeded. Seed pendulous. [Greek name of the Arbutus, from the similar fruits.] A monotypic genus of the north temperate zone.

I. Comarum palústre L. Purple or Marsh Cinquefoll. Purple MARShlocks. CoWBERry. (I. F. f. 1937.) Decumbent at the base. Leaves pinnate, the lower long-petioled, 5-7-foliolate; leaflets oblong or oblanceolate, sharply serrate, obtuse or acutish at the apex, narrowed at the base, $3-8 \mathrm{~cm}$. long; stipules membranous, sometimes adnate to the petiole for half its length; upper leaves nearly sessile, 3-5-foliolate; flowers showy, I cm. broad, in fruit. $2 \mathrm{~cm}$. ; calyx-lobes purple within, ovate, acuminate, much exceeding the ovate- 
lanceolate petals; bractlets much shorter than the calyx-lobes. In swamps and peat-bogs, Greenland to Alaska, N. J., Mont., northern Cal. and Iowa. Also in northern Europe and Asia. June-Aug.

\section{ARGENTINA Lam.}

Perennial herbs, with interruptedly pinnate leaves and long runners. Flowers yellow, solitary on long pedicels from the axils of the basal leaves; petals broadly oval or almost orbicular, not emarginate; stamens 20-25; style filiform, lateral, tardily deciduous; mature achenes with a thick, corky pericarp; seed ascending, amphitropous; otherwise as in Potentilla. A genus consisting of three species, one from New Zealand and the following.

Achenes thick, generally grooved at the upper end; leaves I-2 dm. long; leaflets sharply serrate.

Achenes lenticular; leaves $3-5 \mathrm{~cm}$. long; leaflets with rounded teeth.

I. A. Anserina.

2. A. Egedii.

I. Argentina Anserina (L.) Rydb. Silver-weed. Wild or GooseTANSY. (I. F. f. I934.) Herbaceous; runners 3-Io dm. long. Stipules membranous; leaflets $\mathbf{I}-3 \mathrm{~cm}$. long, oblong, oblanceolate or obovate, obtuse, the lower generally smaller, nearly glabrous above, white and silky-pubescent beneath; peduncles about equalling the leaves; flower yellow, IO-25 $\mathrm{mm}$. broad; petals exceeding the ovate acute calyx-lobes and oval bractlets; receptacle villous; achenes glabrous [Potentilla Anserina L.]. On shores and salt meadows, N. J. to Greenland, west to Cal. and Alaska, south in the Rocky Mts. to N. Mex. Also in Europe and Asia. May-Sept.

Argentina Anserina grándis (Torr. \& Gray) Rydb. Leaves often 3-4 dm. long, erect; leaflets oblong, $4-7 \mathrm{~cm}$. long. In grassy places, from Greenland and Newf. to Alaska, south to Mont. and Cal.

2. Argentina Egèdii (Wormsk.) Rydb. Egedis Silver-Weed. Much smaller than the preceding; leaflets 5-15, glabrous above, sometimes white-tomentose beneath, but never silky, broadly obovate or suborbicular, 5-1o mm. long; pedicels I-3 cm. long. [Potentilla Egedii (Wormsk.) T. \& G.] Greernland to Alaska, south to Mass. and Ore., along the coast. Also in Iceland.

\section{POTENTÍlLA L.}

Herbs or shrubs, with alternate stipulate digitately or pinnately compound leaves, and cymose or solitary, yellow white or purple perfect flowers. Calyx persistent, its tube concave or hemispheric, 5-bracteolate (rarely 4-bracteolate), 5-lobed (rarely 4-lobed). Petals 5 or rarely 4, mostly obovate or orbicular, usually emarginate. Stamens 20-30, seldom 5 or IO; filaments slender; anthers small. Carpels usually in 3 series, numerous, inserted on a dry, usually pubescent receptacle; style terminal, deciduous. Seed pendulous and anatropous. [Diminutive of potens, powerful, from the medicinal properties of some species.] About I5O species, nearly all natives of the north temperate zone. Besides the following about 30 others occur in western N. Am. All species of our range have yellow flowers and glabrous achenes.

I. Flowers cymose; erect or ascending herbs.

Leaves digitately 3-7-foliolate; leaflets dentate or incised.

Leaflets 5-7.

Leaves white-pubescent beneath.

Leaves green beneath.

I. P. argentea.

Plant 7-20 cm. high; leaflets obovate, $12-16 \mathrm{~mm}$. long; arctic.

2. P. maculata.

Plants 3-8 dm. high; leaflets $2-8 \mathrm{~cm}$. long; introduced species.

Leaflets obovate; flowers $6-8 \mathrm{~mm}$. broad. 3. $P$. intermedia.

Leaflets oblanceolate; flowers $12-20 \mathrm{~mm}$. broad. 4. P. sulphur \&a.

Leaflets 3 (or apparently 5 in no. 11 ).

Styles filiform; plants arctic or alpine.

Leaves white-pubescent beneath.

Leaves green belleath, of ten villous.

5. P. nivea.

Flowers ro-14 mim. broad. 
Teeth of the leaflets acute; bractlets oblong.

6. P. emarginata.

Teeth of the leaflets obtuse; bractlets oval. 7. $P$. nana. Flowers only $6 \mathrm{~mm}$. broad.

8. P. Robbinsiana.

Styles glandular-thickened below.

Plants stout, erect, rough-pubescent.

Stamens about 20.

$\begin{array}{ll}\text { Stamens 5-8; prairie species. } & \text { 10. } P \text {. pentandra. } \\ \text { Plant slender, of ten diffuse, villous or glabrate. } & \text { II. P. leucocarpa. }\end{array}$

Leaves pinnately $3-11$-foliolate.

Leaves villous, or softly pubescent, rarely glabrate.

All the leaves $7-11$-foliolate; inflorescence cymose.

Upper leaves 3 -foliolate; inflorescence falsely racemose.

Leaves white-tomentose on both sides.

12. P. paradoxa.

13. P. Nicolletii.

Leaves mostly regularly pinnate; pubescence silky and tomentose.

14. P. Hippiana.

Leaves mostly interruptedly pinnate; pubescence simply tomentose.

Leaves green above, white-tomentose beneath; leaflets pinnatifid.

15. P. effusa.

Styles thickened at the base.

Pubescence silvery-white.

Pubescence not silvery-white.

16. P. bipinnatifida.

Plants erect; leaves $7^{-1} 5^{- \text {foliolate. }}$

Plant dark green; leaves scarcely paler beneath.

17. P. atrovirens.

Plant not dark green; leaves decidedly paler beneath.

18. P. Pennsylvanica.

Plant ascending or decumbent; leaves 5-7-foliolate; leaflets approximate or almost digitate.

Styles not thickened; plänt low, spreading; leaves 5-9-foliolate.

19. P. litoralis.

20. P. multifida.

2. Flowers solitary, axillary; creeping or ascending plants.

Leaflets 5 , rarely 3 ; petals and sepals 5 .

Stem long-assurgent; first flower from the axil of the second stem-leaf or some subsequent leaf. 21 . P. Canadensis.

Plant low, less than I dm. high; first flower from the axil of the first stem-leaf.

Leaflets 3 , rarely 5 ; petals and sepals 4 , rarely 5 .

22. P. pumila.

23. P. procumbens.

I. Potentilla argéntea L. Silvery or HoARy Cinquefoll. (I. F. f. 1914.) Stems ascending, tufted, branched, slightly woody at the base, I-5 dm. long, white woolly-pubescent. Leaves all but the uppermost petioled, digitately 5foliolate; leaflets oblanceolate or obovate, green and glabrous above, white-pubescent beneath, laciniate or incised and with revolute margins; flowers 4-8 mm. broad; calyx-lobes ovate, acutish, a little shorter than the obovate retuse petals; stamens about 20; style filiform. In dry soil, N. S. and Ont. to Dak., south to D. C. and Kans. Also in Europe and Asia. May-Sept.

Potentilla collina Wibel, of Europe, collected at Winona, Minn., and Cambridge, Mass., differs in its more prostrate habit, broader, not revolute leaflets, and larger calyx.

2. Potentilla maculata Pourr. Northern Cinquefoil.

(I. F. f. I9I5.) Rootstock prostrate; stems ascending, simple, pubescent, 7-20 dm. high. Basal leaves slender petioled, digitately 5 -foliolate (rarely 3 -foliolate); leaflets obovate, glabrous above, pubescent along the margins and on the veins beneath, green both sides, deeply toothed ; flowers few, terminal, loosely cymose; petals obovate, ob. cordate, cuneate, orange-spotted at the base, longer than the ovate acutish calyxlobes; stamens about 2O; style filiform. Lab. and Greenland to James Bay. Also in Europe. Summer. [P. rubens Rydb., not Vill.]

3. Potentilla intermèdia L. Downy Cinquefoil. (I. F. f. 1916.) Perennial; stem 3-8 dm. high, leafy, much branched, finely pubescent with long hairs. Leaves green and finely hirsute on both sides, somewhat tomentose beneath, all but the uppermost 5-foliolate; leaflets obovate or oblong, the teeth rather obtuse; flowers numerous, cymose, leafy-bracted; petals obcordate, equalling the triangularovate acute sepals and oblong bractlets; stamens about 20 ; style short. Mass, N. 
Y. and N. J. Adventive from Europe. Resembles P. Monspeliensis, differing in its 5 -foliolate leaves, and perennial root.

Potentilla inclinàta Vill, a European species, has been collected by J. Fowler in Ontario. It resembles the last, but the leaves are grayish and slightly silky beneath.

4. Potentilla sulphùrea Lam. Rough-Fruited Cinquefoll. (I. F. f. 1917.) Erect, rather stout, branched above, villous-pubescent, 4-7 dm. high. Stipules ovate-lanceolate, the lower foliaceous and laciniate; leaves digitately 5-7-foliolate, all but the uppermost petioled; leaflets oblanceolate or oblonglanceolate, green both sides, sparingly pubescent, deeply toothed, with triangular divergent teeth; flowers light yellow, numerous, about $2 \mathrm{~cm}$. broad; stamens about 2o; style slender, terminal; carpels rugose. This has been confused with $P$. recta L., which is also cultivated and sometimes escapes from gardens. The latter has smaller, dark yellow petals. In waste places, Ont., N. Y., Va. and Mich. Adventive from Europe. June-Sept.

5. Potentilla nívea L. Snowy Cinquefoll. (I. F. f. I9I8.) Stems I-2 dm. high, woody at the base, silky-villous; leaves 3 -foliolate (very rarely 5 -foliolate), the lower petioled; leaflets oblong or obovate, usually deeply crenate, densely white-pubescent beneath, green and loosely villous above, $2-3 \mathrm{~cm}$. long, the terminal one generally cuneate; flowers I-5, I2-15 mm. broad; sepals silky, lanceolate, acute, shorter than the broadly obovate emarginate petals, longer than the bractlets; stamens about 20. Lab., Greenland and arctic Am. to $\mathrm{Br}$. Col., south in the Rocky Mts. to Utah and Colo. Also in Europe and Asia. Summer.

6. Potentilla emarginàta Pursh. Arctic Cinquefoll. (I. F. f. I9I9.) Stems villous-pubescent, tufted, about I dm. higl. Leaves 3 -foliclate; leaflets obovate, 4-I $2 \mathrm{~mm}$. long, coarsely serrate toward the apex with acute teeth, the terminal one of which is generally the largest, villous on both siles; flower solitary, rarely 2, I0-14 $\mathrm{mm}$. broad; calyx-lobes ovate, obtuse, pilose, equalling the oblong bractlets, shorter than the obcordate petals; stamens about 20. Lab., Greenland and arctic Am. to Alaska. Also in Siberia and Spitzbergen. Summer.

7. Potentilla nàna Willd. Low Cinquefoll. (I. F. f. Ig o.) Villouspubescent; stems $2-5 \mathrm{~cm}$. high, tufted, generally I-flowered. Leaves 3-fuliolate; leaflets broadly obovate or orbicular, toothed, the teeth short, rounded, the terminal one often the smallest; petals broadly obcordate, exceeding the ovate acute sepals and the oval obtuse bractlets. Lab., Hudson Bay and arctic Am. to Alaska, and the Canadian Rocky Mountains. Also in Siberia. Summer.

8. Potentilla Robbinsiàna Oakes. Robbins' Cinquefoil. (I. F. f. I921.) Depressed, $2-4 \mathrm{~cm}$. high, tufted from a woody base, villous-pubescent. Basal leaves petioled, 3-foliolate, those of the flowering stem sessile, small and 3-lobed; leaflets obovate, villous, 4-8 mm. long, deeply 3-7-toothed above, cuneate or narrowed at the base, obtuse at the apex; flowers solitary, terminal, 5-6 mm. broad; sepals and bractlets nearly equal, obtuse, slightly shorter than the obcordate petals. White Mountains. Summer.

9. Potentilla Monspeliénsis L. Rovgh Cinqueforl. (I. F. f. 1922.) Erect, annual or biennial, hirsutely rough-pubescent, 3-8 dm. high. Leaves 3foliolate, the lower and basal ones petioled, the upper sessile or nearly so; leaflets obovate, green both sides, obtuse, pubescent with spreading hairs, $3-5 \mathrm{~cm}$. long; flowers densely cymose and leafy-bracted, about $\mathbf{I} \mathrm{cm}$. broad; calyx-lohes ovate, acute, pubescent, slightly longer than the obovate retuse petals; stamens I5-20; style glandular-thickened below. In dry soil, Lab. to S. Car., Alaska, Kans. and Ariz. Also in Mexico and Asia. June-Sept.

Potentilla Monspeliénsis Norvégica (L.) Rydb., with oblong leaflets and fine pubescence, a native of Europe and Western Asia is introduced in the Eastern States.

Io. Potentilla pentándra Engelm. Five-STamened Cinquefoll. (I. F. f. 1923.) Similar to the preceding, erect, hirsute, 3-7 dm. high, much branched above. Basal and lower leaves slender-petioled, 3-foliolate, with the lower pair of leaflets parted nearly to the base, so as to appear 5 -foliolate; leaflets oblanceolate or oblong, obtuse, incised-dentate, more or less pubescent, $3-5 \mathrm{~cm}$. long; flowers in a more or less flat-topped cyme, pale yellow, less than $5 \mathrm{~mm}$. broad; calyx-lobes ovate, acute, much exceeding the small spatulate petals; stamens $5-8$; style thickened below. Prairies, Manitoba to Kans., Mo. and Ark. June-Sept. 
I I. Potentilla leucocàrpa Rydb. Diffuse Cinqueforl. (I. F. ᄃ. I924.) Decumbent or ascending, annual, usually diffusely branched, 4-8 dm. high, softly villous-pubescent, or glabrate. Leaves all but the uppermost petioled, 3-foliolate; leaflets oblong, cuneate, thin, flaccid, pubescent, deeply serrate, 2-4 cm. long; flowers loosely cymose, 3-4 mm. broad; calyx-lobes ovate, acute, exceeding the obovate petals: stamens about ro; style slightly thickened below. In damp soil, Ill. to Minn., N. Mex., Cal. and Wash. May-Sept.

Potentilla rivalis Nutt., a western species which may reach our limits, is distinguished from this by its usually pinnately 5 -foliolate lower leaves, viscid pubescence, stricter erect habit, and more numerous stamens. It has been collected at the stockyards of Chicago.

I2 Potentilla paradóxa Nutt. Bushy Cinquefoll. (I. F. f. I925.) Softly pubescent, annual or biennial, rather stout, bushy, 3-8 dm. high. Leaves all but the uppermost petioled, pinnately 7-II-foliolate; leaflets obovate or oval, obtuse, I5 $-25 \mathrm{~mm}$. long, sparingly pubescent, crenate, the upper ones commonly confluent or decurrent on the rachis; flowers terminal, loosely cymose, leafybracted, $7 \mathrm{~mm}$. broad; petals obovate, cuneate, about equalling the ovate calyxloles; stamens about 20; style terminal, thickened below. Shores and river banks, N. Y. and Ont. to Ore, and N. Mex. Also in Mex. and Mantchuria. June-Sept.

13. Potentilla Nicollétii (S. Wats.) Sheldon. Nicollet's Cinquefoil. (I. F. f. 1926.) Similar to $P$. paradoxa, but more spreading and more branched; lower ieaves only pinnate, with few leaflets; upper leaves 3 -foliolate; teeth of the leaflets acute; inflorescence elongated, falsely racemose; stamens 10-15. N. Dak., Iowa and Mo.

I4. Potentilla Hippiàna Lehm. Woolly Cinqueforl. (I. F. f. 1927.) Perennial, 3-5 dm. high, densely floccose as well as silky. Lower and basal leaves petioled, pinnately 5-II-foliolate; leaflets oblancevlate or oblong, obtuse, $2-5 \mathrm{~cm}$. long, deeply toothed, very white beneath, the lcwer ones smaller than the upper; flowers loosely cymose, 7-10 $\mathrm{mm}$. broad; petals obovate, retuse, a little exceeding the lanceolate acute calyx-lobes; stamens about 20 . Dry soil, Minn. and Assin. to Br. Col., Neb. and N. Mex. June-Aug.

15. Potentilla effìsa Dougl. Branched Cinquefoll. (I. F. f. 1928.) Closely related to $P$. Hippiana. Plant 2-4 dm high, diffusely branched above; leaves sometimes interruptedly pinnate, tomer.tose-car escent, but not silky; leaflets 5-II, cuneate-oblong, obtuse; flowers $6-8 \mathrm{~mm}$. broad, loosely cymose; bractlets shorter than the lanceolate acute calyx-lubes; petals obovate, emarginate, exceeding the calyx-lobes; stamens about 20. Prairies, Minn. (according to Upham) to Mont. and Colo. Summer.

I6. Potentilla bipinnatífida Dougl. Cut-leaved Cinqueforl. Stems erect or ascending, simple, white silky-villous, 3-5 dm. high. Basal leaves pinnately 7-9-foliolate; stem-leaves subsessile and often subdigitate; leaflets approximate, obovate in outline, pectinately divided into linear ubtuse segments, silvery white; flowers densely cymose; sepals ovate, longer than the lanceolate bractlets and about equalling the obovate-cuneate, truncate petals. Prairies, Hudson Bay to Sask., Alb. and Colo. [P. Pennsylvanica bipinnatifida T. \& G.]

I7. Potentilla atróvirens Rydb. DARK-GREeN Cinqueforl. Stem stout, 2-3 dm. high, branched, with erect branches, dark green, densely pilose. Leaves sinilar to those of P. Pennsylvanica, but dark green, densely pilose and strongly veined; cyme many-flowered, narrow, with erect branches; bractlets and sepals ovate, subequal, exceeding the cuneate-obovate bright yellow petals. Prities, Minn., S. Dak. and Wyo.

18. Potentilla Pennsylvanica L. Prairie Cinquefoll. (I. F. f. I929.) Stem 4-8 dm. high, tomentose. Leaves pinnately 5-15-foliolate, grayish-tomentose beneath, glabrous above ; leaflets oblong or oblanceolate, cleft halfway to the midrib into oblong lobes, margins scarcely revolute; cymes dense; petals yellow, obovate, truncate or slightly emarginate, about equalling the ovate triangular acute sepals and the lanceolate bractlets; style thickened below. On prairies, Hudson Bay to the Canadian Rocky Mountains, south to N. Mex. Summer.

Potentilla Pennsylvánica strigòsa Pursh. Stem usually lower: pubescent with long villous hairs: leaflets with deep narrow divisions, margins revolute. Manitoba and the N. W. Terr. to Kans. and N. Mex. Also in Siberia. 
19. Potentilla littoràlis Rydb. Const Cinqueforl. (I. F. f. 1930.) Per ennial, tufted; stems ascending or decumbent, 2-4 dm. high, appressed-silky or glabrate. Leaflets oblanceolate or obovate, incised-pinnatifid into oblong obtuse segments, grayish pubescent beneath, green and glabrate above, I-6 cm. long ; flowers yellow, cymose, 8 -Io mm. broad; petals obovate. equalling or slightly exceeding the ovate acute veined sepals and the lanceolate bractlets; stamens 20-25; style thickened below. Coast of Newf. and Lab. to Quebec and N. H. June-July.

20. Potentilla multífida L. Cut-leaved Cinquefoil. (I. F. f. I931.) Perennial ; stems several or many from the caudex, low, ascending or spreading, appressed-silky. Leaves pinnately 5-9-foliolate, grayish-tomentose beneath, glabrate above; leaflets finely divided to near the midrib into linear acule segments, with more or less revolute margins; petals a little exceeding the ovatelanceolate acute sepals; style short, not thickened at the base. Hudson Bay and the N. W. Terr. Also in Europe and Asia. Summer.

21. Potentilla Canadénsis L. Five-Finger. (I. F. f. 1935.) Stem slender, at first erect, later decumbent or prostrate, 4-6 dm. long, silky-villous; leaves petioled, digitately 5 -foliolate (rarely 3-4-foliolate); leaflets oblanceolate or oblong, 2-4 cm. long, incisely serrate, at least above; flowers $10-12 \mathrm{~mm}$. broad; petals 5, broadly oval, slightly. longer than the acute calyx-lobes and linear-lanceolate bractlets. In dry soil, Me. and Quebec to Ga., Minn. and the Ind. Terr. AprilAug. Called also Wild Strawberry.

Potentilla Canadénsis símplex (Michx.) T. \& G. Stem elongated, 5-10 dm. long, the pubescence more appressed; leaves larger, more glabrate and green; leaflets often 5-6 cm. long.

Potentilla réptans L., a European species, collected on ballast at Camden, N. J., differs in its more closely creeping habit, smaller leaves, and very broad elliptic bractlets.

22. Potentilla pùmila Poir. DWarf Five-finger. (I. F. f. I935a.) Low perennial herb, seldom more than a few inches high; flowering stems at first very short and upright, later in the season producing some slender prostrate runners; whole plant densely silky-strigose; basal leaves digitately 5 -foliolate, on slender petioles; stem-leaves few and often only 3 -foliolate; leaflets obovate, sharply serrate, usually about $2 \mathrm{~cm}$. long; otherwise as the preceding. In poor soil, N. Eng. to Penn.

23. Potentilla procúmbens Sibth. Wood Cinquefoll. (I. F. f. 1936.) Diffusely branched, trailing or ascending, very slender, somewhat pubescent, I-6 $\mathrm{dm}$. long. Leaflets oblanceolate or obovate, sharply dentate above; peduncles usually much exceeding the leaves; flowers $6-8 \mathrm{~mm}$. broad; petals obovate, emar. ginate, or rounded, exceeding the acute calyx-lobes and bractlets. Lab. (according to Hooker). Common in Europe. Summer. [P. nemoralis Nestl.]

\section{WALDSTEINIA Will.}

Perennial herbs with the aspect of Strawberries, with alternate mainly basal long-petioled 3-5-foliolate or lobed leaves, membranous stipules, and yellow corymbose flowers on bracted scapes. Calyx persistent, the tube topshaped, minutely 5-bracteolate or bractless at the summit, 5-lobed. Petals 5 . Stamens $c^{\circ}$, inserted on the throat of the calyx; filaments rigid, persistent. Carpels 2-6, inserted on a short villous receptacle; style nearly terminal, deciduous, filiform. Achenes 2-6, obliquely obovoid, pubescent. Seed erect. [Named in honor of Franz Adam von Waldstein-IVartenburg, 1759-1823, a German botanist.] Five known species, natives of the north temperate zone. Besides the following, another occurs in Ga.

Petals obovate, longer than the sepals.

Petals linear-oblong or narrowly elliptic, shorter than the sepals.

I. W. fragarioides.

2. W. parviflora.

I. Waldsteinia fragarioides (Michx.) Tratt. BARREN OR DRY STRAwrerry. (I. F. f. I939.) Pubescent, or nearly glabrous; rootstock creeping, rather stout. Leaves tufted, long-petioled, 3-foliolate (rarely 5-foliolate); leaflets obovate, obtuse at the apex, broadly "cuneate at the lase, dentate or crenate and sometimes 
incised, 3-5 cm. long ; flowers yellow, 6-10 $\mathrm{mm}$. broad; calyx-lobes ovatelanceolate, acute. Woods and shaded hillsides, N. Eng. and Ont. to Minn., Mich., Ind., and along the Alleghanies to Ga. May-June.

2. Waldsteinia parvifiòra Small. SOUTHERn Dry Strawberry. (I. F. f. I939 a.) Villous-hirsute, or glabrous in age. Leaflets cuneate-obovate or broadly rhomboidal, 4-7 cm. long, coarsely and irregularly crenate or lobed; tube of the calyx broadly turbinate, the segments triangular-lanceolate, or lanceolate-acuminate. In woods and shaded soil, Va. to N. Car., Tenn. and Ga. March-May.

\section{GÈUM L.}

Perennial herbs, with odd-pinnate, or deeply pinnatifid, stipulate leaves. Flowers cymose-corymbose or solitary. Calyx persistent, its tube obconic or hemispheric, usually 5-bracteolate, 5-lobed. Petals 5, orbicular, oblong or obovate, obtuse or emarginate. Stamens $\infty$, inserted on a disk at the base of the calyx; filaments filiform. Carpels $\infty$, aggregated on a short receptacle. Style filiform, terminal, jointed, the lower portion persistent, sometimes plumose in fruit. Seed erect, its testa membranous. [The ancient Latin name.] About 40 species, most abundant in the north temperate zone. Besides the following about 3 others occur in southern and western N. Am.

Calyx-lobes strongly reflexed; style not plumose, sometimes hispid at the base.

Flowers yellow, $4 \mathrm{~mm}$. broad; head of fruit stalked; calyx bractless.

Flowers 6-20 mm. broad; head of fruit sessile; calyx bracteolate.

I. G. vernum.

Petals white, or very nearly so, obovate.

Plant softly-pubescent or glabrate; receptacle bristly. 2. G. Canadense.

Plant rough-pubescent; receptacle glabrous or downy.

Petals cream-yellow, narrowly oblong, scarcely exceeding the sepals.

Petals yellow, broadly obovate or orbicular.

4. G. flavum.

Segments or lobes of upper stem-leaves broadly rhombic-obovate; petals 4-6 mm. long.

Basal leaves simple, or pinnately $3-7$-foliolate; plant pubescent, divaricately branched; petals about equalling the sepals.

5. G. urbanum.

Basal leaves interruptedly pinnate; plant hispid; petals exceeding the $\begin{array}{ll}\text { sepals. } & \text { 6. G. macrophyllum. }\end{array}$ Segments or lobes of upper stem leaves oblanceolate; petals 6-8 mm. long.

7. G. strictum.

Calyx-lobes erect or spreading; style plumose below ; flowers purple, nodding. 8. G. rivale.

I. Geum vérnum (Raf.) T. \& G. Spring Avens. (I. F. f. I943.) Erect or ascending, slender. simple or nearly so, 2-6 dm. high. Basal leaves tufted, petioled, with a single orbicular-reniform dentate $3-5$-lobed leaflet, or pinnate with 3-7 obovate or oval more or less dentate and lobed ones; stem-leaves few, sessile or short-petioled, pinnate or pinnatifid; flowers few, erect; calyx-lobes ovate, acute, reflexed; petals spreading: style glabrous, about $4 \mathrm{~mm}$. long ; receptacle glabrous. Shaded places, Ont. to W. Va., Tenn, Kans. and Tex. Nat. in N. J. and S. N. Y. April-June.

2. Geum Canadénse Jacq. White Avens. (I. F. f. I944.) Erect, branched above, 2-7 dm. high. Stipules small, dentate; basal leaves petioled, 3-foliolate or pinnately divided, their segments $3-5$, the terminal one broadly ovate or obovate, the lateral ones narrower, all dentate and more or less lobed, sometimes with smaller ones borne on the petiole; stem-leaves short petioled or sessile, 3-5-lobed or divided; peduncles slender; petals obovate, equalling or shorter than the sepals; head of fruit 8-12 $\mathrm{mm}$. long; style 6-8 mm. long. In shaded places, N. S. to Ga., Minn., Kans. and Mo. June-Aug.

3. Geum Virginiànum L. Rough Avens. (I. F. f. I945.) Resembling the preceding species but much stouter, the stem and petioles bristly-pubescent, the stout short peduncles pubescent with reflexed hairs. Basal leaves becoming very large, the terminal leaflet sometimes $15 \mathrm{~cm}$. wide; sepals exceeding the spreading revolute creamy-white petals; head of fruit very dense, 12-16 $\mathrm{mm}$. in diameter; 
style 8-ro mm. long. Low grounds, N. B. to Penn. and southward in the Alleghanies, west to Minn. and to Kans. Blooms earlier than G. Canadense. May-July.

4. Geum flàvum (Porter) Bicknell. Cream-Colored Avens. (I. F. f. I 946.) Stem bristly-hairy below, erect, 4-10 dm. tall. Stipules large, often $2.5 \mathrm{~cm}$. long, foliaceous, dentate or lobed. Basal leaves mostly pinnately divided, sometimes only lobed; lower stem-leaves usually also pinnately divided, the terminal segment often elongated; upper stem-leaves sometimes entire; peduncles slender: head of fruit about $1 \mathrm{~cm}$. in diameter; receptacle bristly-villous; style $6-8 \mathrm{~mm}$. long. In woods, Conn. and N. Y. to Va. and E. Tenn. June-Aug.

5. Geum urbànum L. European Yellow Avens. . Stem 3-6 dm. high, finely pubescent, divaricately branched. Basal leaves simple, reniform and 3-lobed or pinnately 3-7-foliolate, with rhomboid-cuneate leaflets, very rarely with smaller ones interposed; stem-leaves mostly 3 -foliolate, with rhombic leaflets or the uppermost simple; head of fruit $12-15 \mathrm{~mm}$. in diameter; receptacle pubescent; style 5-7 mm. long, purplish. Introduced from Europe and established at Cambridge, Mass.

6. Geum macrophýllum Willd. Large Leaved Avens. (I. F. f. I947.) Stout, erect, bristly-pubescent, 3-10 dm. high. Stipules broad, foliaceous; basal leaves petioled, lyrate-pinnate, the terminal segment much the largest, reniform, orbicular or cordate, dentate, 3-7-lobed; lateral leaflets 3-6, oval or obovate, with smaller ones interspersed or borne on the petiole; stem-leaves short-petioled or sessile; flowers several, short-peduncled; receptacle nearly glabrous; style $6-8 \mathrm{~mm}$. long; upper internode pubescent below. In low grounds, N. S. to Alaska, Br. Col., N. Y. and Ore. May-July.

7. Geum stríctum Ait. Yellow Avens. (I. F. f. 1948.) Pubescent, branched above, 6-15 dm. high. Stipules broad, foliaceous; basal leaves lyratepinnate; leaflets $5-7$, obovate, cuneate, dentate or lobed, with a few smaller ones interspersed, the terminal one largest, broadly cvate or cuneate, or rarely orbicular or reniform; stem-leaves sessile or short-petioled, with 3-5 ovate or oblong acute segments ; receptacle dow ny-pubescent; style 6-10 $\mathrm{mm}$. long, the upper internode hispid. In swamps or low grounds, Newf. to Br. Col., N. J., Penn., Mo. and Ariz. Also in Asia. June-Aug. A hybrid with G. Canadense has been found in eastern Penn.

8. Geum rivàle L. Purple or Water Avens. (I. F. f. 1940.) Erect, simple or nearly so, pubescent, 3-10 dm. high. Basal leaves lyrately and interruptedly pinnate, petioled, the later al segments generally few and small, the terminal I-3, much larger, all sharply and irregularly lobed and dentate; stem-leaves distant, short-petioled or sessile, simple, or 3-foliolate ; flowers few, $20-25 \mathrm{~mm}$. broad; petals obovate, emarginate, abruptly narrowed into a claw; head of fruit stalked in the calyx; style $6-8 \mathrm{~mm}$. long. In swamps and low grounds, Newf. to Br. Col., N. J., Penn., Mo. and Colo. Also in Europe and Asia. May-July.

\section{SIEVíRSIA R. Br.}

Generally low perennial herbs with odd-pinnate leaves, mostly clustered at the base. Flowers in cymes, or solitary, yellow or purplish. Calyx obconic or hemispheric, 5-lobed and generally 5-bracteolate. Petals 5. Stamens numerous; filaments filiform. Carpels many, on a short hemispheric receptacle. Style terminal, persistent, filiform, not jointed, pubescent or plumose, generally elongating in fruit. Seeds erect, basal. [Named in honor of Sievers]. About 15 species of temperate, alpine or arctic regions; besides the following five or six others occur in western and arctic North America.

Leaflets I-9; terminal one of the basal leaves orbicular-reniform; style plumose below ; flowers yellow. Leaflets numerous, cuneate; style plumose throughout ; flowers light purple.

1. S. Peckii.

2. S. ciliata.

I. Sieversia Péckii (Pursh) Rydb. Yellow Mountain Avens. (I. F f. 194I.) Pubescent with spreading hairs, or glabrate; stem I-6 dm. high, erect, simple, I-8-flowered at the summit. Basal leaves petioled, lyrately pinnate, the terminal segment very large, reniform-orbicular, sharply and irregularly dentate and slightly $3-5$-lobed, $7-15 \mathrm{~cm}$. broad; lateral leaflets small, few or none; flowers 
yciow, 12-20 mm. broad; bractlets much shorter than the erect lanceolate calyxlobes; petals obovate or orbicular, often slightly emarginate, spreading ; style plumose below, naked above, 12-16 $\mathrm{mm}$. long, not jointed. White Mountains of N. H.; Mt. Kineo, Me. July-Aug. [Geum Peckii Pursh.] S. radiàta (Michx.) Greene, of N. Car. and Tenn., with which this has been confused, is stouter and more hairy and has broadly and deeply obcordate petals.

2. Sieversia ciliàta (Pursh) Rydb. Long-Plumed Purple Avens. (I. F. f. 1942.) Softly pubescent, scapose ; scape I-4.5 dm. high, simple, 3-8 flowered at the summit. Basal leaves petioled, interruptedly pinnate with many small leaflets interspersed among the obovate or oval laciniate numerous larger ones; leaves of the scape 2 opposite small sesile pairs, the elongated peduncles commonly bearing a nother similar pair; flowers $12-18 \mathrm{~mm}$. broad; style $3-5 \mathrm{~cm}$. long. In dry or rocky soil, Lab. and northern N. Eng. to N. Y., Br. Col., Mo. and Ariz. [Geum ciliatum Pursh.] May-July.

\section{DRỲAS L:}

Low tufted herbaceous shrubs, with simple petioled stipulate leaves, white. canescent beneath, and white or yellow, perfect solitary flowers on slender scapes. Calyx persistent, not bracted, its tube concave, glandular-hirsute, 8 9-lobed. Petals 8 or 9 , obovate. larger than the calyx-lobes. Stamens $\infty$, inserted on the throat of the calyx; filaments subulate. Carpels $\infty$, sessile, inserted on the dry receptacle; style terminal, persistent, elongated and plumose in fruit. Seed ascending, its.testa membranous. [Name Latin, a wood-nymph.] Three species, natives of the cold-temperate and arctic parts of the north temperate zone.

Flowers white; sepals linear-lanceolate.

Leaves oval or ovate, coarsely crenate.

Leaves ovate, or ovate-lanceolate, subcordate, entire or nearly so.

I. octopetala.

Flowers yellow; sepals ovate ; leaves crenate.

2. D. integrifolia.

3. D. Drummondii.

I. Dryas octopétala L. White Mountain Avens. (I. F. f. 1949.) Stems prostrate, branched, $7-15 \mathrm{~cm}$. long. Stipules linear, adnate to the petiole; leaves green and glabrous above, generally obtuse at each end, I-2.5 cm. long; scape terminal, erect, $3-12 \mathrm{~cm}$. long, pubescent; petals spreading: sepals glandular-pubescent, persistent : style about $2.5 \mathrm{~cm}$. long, plumose and conspicuous in fruit. Lab., Greenland and arctic Am., south in the Rocky Mts. to Utall and Colo. Also in arctic and alpine Europe and Asia. June-Aug.

2. Dryas integrifòlia Vahl. Entire-Leaved Mountain Avens. (I. F. f. 1950.) Similar to the preceding, but the leaves are ovate or ovate-lanceolate, obtuse and often subcordate at the base, obtusish at the apex, entire or with $\mathbf{I}$ or 2 teeth near the base, the margins strongly revolute; flowers generally slightly smaller. "White Hills of N. H.," according to Pursh; Anticosti, Lab., west through arctic Am. to Alaska, and in Greenland. June-Aug.

3. Dryas Drummóndii Richards. Drummond's Mountain Avens. (I. F.f. I95 I.) Similar to $D$. octopetala, the leaves crenate-dentate, but generally narrowed at the base. Scape floccose-pubescent, often taller; petals generally erect; sepals ovate, acutish, black glandular-pubescent. On gravel, Gaspé, Quebec; Anticosti and Lab., throughout arctic America and south to Mont. June-Aug.

\section{CERCOCÀRPUS H. B. K.}

Shrubs or small trees, with alternate simple petioled coriaceous stipulate straight-veined leaves, and short-pedicelled or sessile, axillary or terminal, perfect flowers. Calyx narrowly tubular, persistent, contracted at the throat, 5-lobed. Petals none. Stamens. 15-25, inserted in 2 or 3 rows on the limb of the calyx; filaments very short. Ovary $\mathbf{I}$, terete, slender, included in the caly $\mathbf{x}$-tube, ripening into a villous achene; style filiform, villous, persistent, plumose and elongated in fruit; stigma obtuse; ovule nearly erect. Seed linear, its testa membranous. [Greek, tailed-1ruit.] About 6 species, natives of western N. Am. and Mexico.
I. Cercocarpus
parvifòlius
H. \& A.
SMALl-leaved Cercocarpus.

(I. F. f. 1952.) A low branching shrub. Leaves obovate or oval, coriaceous, 
obtuse, short-petioled, dentate, silky-pubescent or canescent below, $1.5-3 \mathrm{~cm}$. long, 6-15 $\mathrm{mm}$. broad; flowers axillary, solitary or in pairs, short-peduncled, recurved, about $6 \mathrm{~mm}$. broad; style becoming 5-10 $\mathrm{cm}$. long and very plumose in fruit. In dry or rocky soil, S. Dak. and W. Kans: to northern Mex., west to Cal. AprilJune.

\section{ULMÀRIA Hill.}

Tall perennial herbs, with alternate petioled pinnately divided stipulate leaves, and small perfect flowers in large cymose panicles. Calyx 5-lobed. Petals 5, clawed. Stamens numerous, inserted on the flat or slightly concave receptacle; filaments narrowed at the base. Pistils about Io (5-15), distinct; ovary 2-ovuled. Ripe carpels resembling follicles but indehiscent, $\mathbf{I}$-seeded. Seed pendulous. [Named from the fancied resemblance of the leaf-segments to those of Ulmus.] About 9 species, natives of the north temperate zone.

Lateral leaflets palmately 3-5-lobed; flowers pink or purple. I. U. rubra. Lateral leaflets merely serrate, or slightly lobed; flowers yellowish white. 2. U.Ulmaria.

1. Ulmaria rùbra Hill. QUeEN-OF-THE-PRairie. (I. F. f. I953.) Glabrous; stem branched, 6-25 dm. tall. Leaves large, the lower sometimes I m. long, pinnately 3-7-foliolate, commonly with smaller leaf-segments interposed or borne on the petiole; the lobes acute, unequally serrate or incised; terminal leaflet larger, 7-9-parted; flowers fragrant, about $8 \mathrm{~mm}$. broad; fruit glabrous. In moist grounds and on prairies, Penn. to Ill., Mich., Ga., Ky. and Iowa. Escaped from gardens farther east. June-July. [Spiraea lobata Gronov.]

2. Ulmaria Ulmària (L.) Barnhart. Meadow-Sweet or Meadow-QueEn. HONEY-SWEET. (I. F. f. 1954.) Stem 6-12 dm. tall. Leaves pinnately 3-9foliolate, densely and finely white-downy beneath, green above, or in some forms green on both sides; lateral leaflets sessile, opposite, ovate or ovate-lanceolate, acute or acuminate, the terminal one larger and deeply 3-5-lobed, the lobes acute and serrate. Escaped from gardens, Quebec to Mass. Native of Europe and Asia. June-Aug. [Spiraea Ulmaria L.]

\section{ALCHEMÍLLA L.}

Herbs, with alternate lobed or digitately compound leaves, adnate stipules, and small perfect greenish corymbose or capitate flowers. Calyx persistent, cup-shaped, contracted at the throat, 4-5-lobed, 4-5-bracteolate. Petals none. Stamens I-4; filaments short. Carpels I-4; style basal or lateral, slender. Achenes I-4, enclosed in the calyx-tube. Seed ascending, its testa membranous. [Name from its fancied value in alchemy.] About 35 species, natives of the Old World and of western America from Br. Col. to Chile.

Annual; flowers in sessile axillary clusters; leaves small.

Perennial; flowers in compound terminal corymbs; leaves large.

1. A. arvensis.

2. A. vulgaris.

I. Alchemilla arvénsis (L.) Scop. Parsley-Piert, or Field Lady's Mantle. ARgentill. (I. F. f. I955.) Annual, softly pubescent, the branches usually slender, ascending, $2-15 \mathrm{~cm}$. high. Stipules toothed or rarely entire; leaves very short-petioled, pubescent, fan-shaped, 4-10 mm. long, deeply 3-parted, the lobes cuneate, 2-4-cleft; flowers $2-3 \mathrm{~mm}$. broad, in sessile axillary clusters partly enclosed by the stipules. In dry fields, D. C., Va., Tenn., N. Car., and in N. S. Also on the Pacific coast. Nat. or adventive from Europe. April-Sept.

2. Alchemilla vulgàris L. LADY's MANTLE. DEW-CUP. (I. F. f. I956.) Perennial from a woody rootstock. Stipules mostly toothed: leaves orbicularreniform, 5-9-lobed, pubescent, the lower slender-petioled, the upper sessile or nearly so; lobes broad, not deep, serrate; flowers about $4 \mathrm{~mm}$. broad, very numerous in peduncled often leafy corymbs. In grassy places near the coast, N. S., Cape Breton, Lab. and Greenland. Nat. from Europe. May-Sept.

Alchemilla alpina L., reported by Pursh from the White and the Green Mountains, a native of alpine and northern Europe and Asia, is distinguished from the preceding by its 5 oblong silky entire leaflets. 


\section{AGRIMÒNIA L.*}

For's. .al erect herbs. Leaves alternate, petioled, odd.pinnate, with smaller leaf-segments interposed between the larger ones, and conspicuous stipules. Flowers small, regular, - perfect, yellow, in narrow racemes. Calyx-tube often grooved, uncinate-bristly above, the 5 lobes connivent. Petals 5, small. Stamens 5-15, slender. Carpels 2, included; style terminal; stigma 2-lobed; ovules pendulous. Fruit dry, mostly reflexed; achenes I-2, oblong. Seed suspended, its testa membranous. [Ancient Latin name.] About 15 species, natives of the north temperate zone and the Andes of S. Am. Besides the following, another occurs in the Southern States.

Racemes and leaves beneath with loose spreading liairs or glabrous.

Roots not tuberous; fruit large, turbinate, with numerous radiating bristles.

I. A. hirsuta. .

Ronts tuberous: fruit very small, hemispheric, with few ascending or erect bristles.

Racemes and leaves beneath closely and softly pubescent.

2. A. striata.

Roots tuberous; stems pubescent; leaves not glandular-dotted beneath.

Small, often simple, with elongated terminal raceme; leaflets $3-5$.

Larger, paniculate-branched; leaflets $5-11$.
Roots not tuberous; stems hirsute; leaves glandular-dotted beneath.

Leaflets mostly 7-9; fruit large, the bristles connivent.

Leaflets mostly $11-17$; fruit small, the bristles radiate.

3. A. pumila.

4. A. mollis.

5. A. Brittoniana.

6. A. parziflora.

I. Agrimonia hirsùta (Muhl.) Bicknell. Tall Hairy Agrimony. (I. F.f. 1957.) Tall, 3-I8 dm. high, minutely glandular, villous. Leaflets thin, bright green, mostly 7, spreading, elliptic to broadly oblong, or the odd one obovate, acute, base often subcordate, coarsely serrate, the margins and nerves beneath ciliate, the lower surface rarely pubescent; flowers $8-12 \mathrm{~mm}$. broad, the buds ovoid, acute; fruit reflexed. $6 \mathrm{~mm}$. long, short-turbinate. Woods and thickets, N. B. to Minn., N. Car., Kans. and Cal. June-Aug.

2. Agrimonia striàta Michx. Woodland Agrimony. (I. F. f. I958.) Mostly about $6 \mathrm{dm}$. high, minutely glandular; racemes filiform, loosely flowered. Leaflets thin, commonly 5, mostly oblong or obovate-oblong and obtuse, crenate or dentate, scarcely ciliate; flowers 4-5 mm. broad, the buds subglobose, truncate or nearly so; fruit $4 \mathrm{~mm}$. ligh or less, spreading or nodding, hemispheric, the furrows shallow or obsolete. In dry woods, Conn. to Va., Kans. and Mo. July-Sept.

3. Agrimonia pùmila Muhl. Small-fruited Agrimony. (I. F. f. I959.) Small and slender, $3^{-6} \mathrm{dm}$. high, erect or assurgent, simple, or with a few branclies above. Stem villous with spreading hairs below, appressed-pubescent above; leaves often crowded toward the base of the stem, frequently 3-foliolate; leaflets small, elliptic to obovate or cuneate, obtuse or acute at the apex, often pale beneath; fl: wers small; fruit $4 \mathrm{~mm}$. long or less, minutely glandular, hemispheric to turbirate; disk flat; bristles few, ascending or erect. In dry soil, Penn. and Md. to Fla., Ky. and La. Aug.

4. Agrimonia móllis (T. \& G.) Britton. Soft Agrimony. (I. F. f. I96o.) Virgately branched, 4-18 dm. tall. Stem pubescent, or villous below, finely pubescent above. Leaves thickish, dull green, veiny, pale and velvety-pubescent leneath; leaflets narrowly oblong to obovate, obtuse or acutish at the apex, crenate to dentate ; flowers 6-8 $\mathrm{mm}$. broad, the buds subglobose, obtuse; fruit $4 \mathrm{~mm}$. long or more, oblong to broadly turbinate. the ascending slender bristles nearly ir. a single row. Dry woods and thickets, Conn. to Mich., N. Car. and Kans. July-Oct.

5. Agrimonia Brittoniana Bicknell. Britton's Agrimony. (I. F. f. I96i.) Robust, $6.12 \mathrm{dm}$. tall, virgately branched. Stem hirsute-pubescent with short spreading brownish hairs, sub appressed above ; leaflets elliptic to rhomboid-lanceolate, deeply and closely serrate, dull green, thickish, rugose, their margins finely. scabrous-ciliolate; racemes long, erect or ascending; flowers crowded, 6-10 mm. wide; fruit 6-8 mm. long, long-turbinate, deeply grooved; bristles often purplish, short, crowded, inflexed and connivent over the sepals. Along thickets and road. sides, Quebec to northern N. Y. and W. Va. Also in the Rocky Mts. June-Sept. 
6. Agrimonia parvifiòra Soland. Many-Flowered Agrimony. (I. F. f. 1962.) Virgately branched, 6-12 dm. high, with long racemes. Stem densely hirsute with coarse brownish hairs, villous above; leaflets lanceolate or linear-lanceolate, acuminate, sharply serrate, rather thin, glabrous above, pubescent beneath, especially on the veins, very glandular ; flowers very numerous, 6-10 $\mathrm{mm}$. broad ; the buds rounded-truncate; fruit small, glandular, dilated-turbinate; bristles reflexed, spreading and erect. In moist or dry soil, N. Y. to Mich., Kans., Ga。 and Miss. July.-Oct.

\section{SANGUISÓRBA L.}

Erect, mostly perennial herbs, sometimes decumbent at the base, with alternate odd-pinnate stipulate leaves and small perfect or polygamo-diœcious flowers in dense terminal peduncled spikes or heads. Calyx-tube turbinate, constricted at the throat, persistent, 4-lobed, the lobes petaloid, deciduous. Petals none. Stamens $4-\infty$, inserted on the throat of the calyx; filaments filiform, elongated, exserted; anthers short; carpels $\mathbf{I}-3$, enclosed in the calyx-tube. Style filiform, terminal. Achene usually I, enclosed in the dry angled calyx. Seed pendulous. [Latin, blood-staunching, from its supposed properties.] About 20 species, natives of the north temperate zone. In addition to the following, 2 or 3 others occur in the western parts of North America.

Flowers capitate, greenish; stamens numerous; leaflets $\mathbf{1 2 - 2 0} \mathrm{mm}_{*}$ long.

Flowers spicate, white; stamens 4 ; leaflets $25-75 \mathrm{~mm}$. long.

I. S. Sanguisorba. 2. S. Canadensis.

I. Sanguisorba Sanguisórba (L.) Britton. Salad Burnet. (I. F. f. 1963.) Glabrous or pubescent, erect, slender, perennial, branched, 2.5-5 dm. high. Stipules usually small, laciniate; leaflets 7-19, ovate or broadly oval, deeply incised, short-stalked or sessile; flowers 6-12 $\mathrm{mm}$. long, the lower ones staminate, the upper perfect; stigma tufted, purple; calyx-lobes ovate, acute or acutish; fruit 2-4 mm. lorig. In dry or rocky soil and in ballast, southern Ont., N. Y. and Penn. to Md. Naturalized from Europe and native also of Asia. Summer.

2. Sanguisorba Canadéissis L. American Great Burnet. [I. F. f. 1964.] Glabrous or slightly pubescent toward the base, erect, branched above, 3-18 dm. high, the branches erect. Stipules often foliaceous and dentate; basal leaves long-petioled, sometimes $6 \mathrm{dm}$. long: leaflets 7-15, ovate, oblong or oval, serrate with acute teeth, stalked ; flowers perfect, bracteolate at the base; filaments long-exserted, white; achene enclosed in the 4-angled calyx. In swamps and low meadows, Newf. to Mich., south to Ga. July-Oct.

\section{RòsA L. (See Appendix.)}

Erect or climbing shrubs, generally with subterranean rootstocks. Stems com. monly prickly. Leaves alternate, odd-pinnate. Stipules adnate to the petiole. Flowers corymbose or solitary, red, pink or white (in our species). Calyx-tube cup-shaped or urn-shaped, constricted at the throat, becoming fleshy in fruit, 5(rarely 4-) lobed, the lobes imbricated, spreading, deciduous or persistent. Petals 5 (rarely 4), spreading. Stamens $\infty$, inserted on the hollow annular disk. Carpels $\infty$, sessile at the bottom of the calyx; ovaries commonly pubescent ; styles distinct or united. Achenes numerous, enclosed in the berry-like fruiting calyx-tube. Seed pendulous. [The ancient Latin name of the rose.]

A large genus, natives of the northern hemisphere. Besides the following, about 6 others occur in southern and western N. Am.

* Styles cohering in a column : leaflets mostly 3 ; stem climbing. ** Styles all distinct; leaflets 5-II.

Sepals persistent, erect on the fruit, or spreading.

Infrastipular spines generally none.

Stems unarmed or nearly so; sepals erect on the fruit.

Stems armed with numerous prickles.

I. R. setigera. 
Leaflets $3-9$, often resinous, obtuse at base; flowers solitary; sepals erect. Fruit globose or nearly so, $12-15 \mathrm{~mm}$. in diameter. 3. $\mathrm{K}$. Sayi. Fruit ellipsoid or obuvoid, 8-10 $\mathrm{mm}$. broad and $15^{-18} \mathrm{~mm}$. long.

4. K. Engelmanni.

Leaflets $7^{-11}$, not resinous, narrowed at base; fluwers curymbed; sepals spreading.

Infrastipular spines commonly present ; stems prickly.

5. R. Arkansana.

6. R. Woodsii.

Sepals deciduous, spreading.

Leaflets finely serrate; spines stout, recurved.

Leaflets coarsely serrate.

Infrastipular spines nearly straight ; native bushy species.

Stems with scattered prickles or naked.

Leaflets $7-9$, shining above; flowers corymbose; spines stout.

8. R. lucida.

Leatlets 5-7; flowers solitary or few ; spines slender. 9. $R$. humilis.

Stems very densely prickly; flowers usually solitary. $\quad$ o. $R$. nitida.

Infrastipular spines stout, hooked; introduced wand-like or climbing species.

Leaflets somewhat pubescent beneath, serrate.

Leaflets very glandular beneath, doubly serrate.

I1. R. canina.

12. R. rubiginosa.

I. Rosa setígera Michx. Prairie Rose. Climbing Rose. Michigan Rose. (I. F. f. I 965.1 Stems several meters long, armed with scattered curved prickles, not bristly. Petioles, twigs and peduncles often glandular-pubescent; stipules very narrow; leaflets mostly ovate, acute or obtusish at the apex, rounded at the base, 3-7 cm. long, sharply serrate; flowers corymbose, about $6 \mathrm{~cm}$. broad; sepals ovate, acute, at length reflexed and deciduous, glandular; petals rose-color or white: fruit globose, 8-10 mm. in diameter, more or less glandu'ar. In thickets and on prairies, Ont. to Wis., Kans., W. Va., Fla. and Tex. Escaped from cultivation in N. J. and Va. June-July.

2. Kos i blánda Ait. Smuoth or Meadow Rose. (I. F. f. 1966.) Erect, 6-12 dm. high, entirely unarmed or with a few straight slender prickles. Leaflets $5-7$, short-stalked, usually pale beneath, oval or obovate, commonly narrowed at the base $2-4 \mathrm{~cm}$. long, simply and sharply serrate; flowers pink, sometimes 7 $\mathrm{cm}$. bro.t, curymbose or solitary; sepals lanceolate, acuminate, entire, hispid puhescent; fruit globose or pyriform, glabrous or nearly so, about $\mathrm{I} \mathrm{cm}$. in diameter. In moist, rocky places, Newf. to Vt., N. J., Ont. and Ill. June-July.

3. Rosa Săyi Schwein. Prickly Rose. (I. F. f. I967.) Bushy, 3-10 $\mathrm{dm}$. high, the stems and often the branches densely armed with straight prickles. Stipules mostly bruad; leaflets 5-9 (rarely 3), oval or oval-lanceolate, obtuse at the apex, rounded at the base, simply or doubly serrate, often more or less resinouspubescent, 3-5 cm. long; flowers asually solitary, 6-7 cm. broad; sepals lanceolate, acuminate or sometimes dilated above, entire or few toothed, hispid or glabrous. Anticosti to Minn., the N. W. Terr. and Colo. June-July.

4. Rosa Engelmánni Wats. Engelmann's Rose. Like the preceding but low, $2-5 \mathrm{dm}$. high, very slender and with few branches; leaflets very thin, pale beneath; fruit small, elongated, with an evident neck and more or less conical at the base. In open woods from Mich. to S. Dak., Colo. and Tex.

5. Rosa Arkansàna Porter. Arkansas Rose. (I. F. f. I968.) Erect, $3.6 \mathrm{dm}$. high. Stems densely prickly with slender bristles; stipules rather narrow; leaflets 7-II, oval or obovate, sessile or nearly so, obtuse at the apex, narrowad at the base, seldom over $2.5 \mathrm{~cm}$. long, simply and sharply serrate, glabrous, or finely puherulent beneath; flowers corymbose or rarely solitary, about $5 \mathrm{~cm}$. broad; sepals lanceolate, acuminate, sparingly glandular-hispid or glabrous; fruit globose or nearly so, 10-12 mm. in diameter, glabrous. Prairies, Minn. and Iowa to Mont., Tex. and N. Mex. June-July.

6. Rosa Woòdsii Lindl. Woons' Rose. (I. F. f. I969.) Low, bushy, 3-1o $\mathrm{dm}$. high, armed with slender mostly straight spines, or unarmed above. Stipules rather broad, entire; leaflets 5-9, oval or obovate, short-stalked or sessile, obtusish at the apex, narrowed or cuneate at the base, IO-I $8 \mathrm{~mm}$. long, simply and sharply serrate, somewhat glaucous beneath; flowers $3-5 \mathrm{~cm}$. broad; sepals erect on the fruit; fruit globose or globose-ovoid, $8-10 \mathrm{~mm}$. in liameter, glabrous, sometimes glaucous. Prairies, Minn. to Mo.. the N. W. Terr. and N. Mex. June-July.

7. Rosa Carolina L. Swamp Rose. (I. F. f. I97o.) Bushy, 3-25 dm. high, 
with stout commonly recurved prickles or sometimes unarmed; leaflets 5-9 (usually 7), oval, oblong, ovate-lanceolate or even obovate, 3-7 cm. long, acute or acutish, pale or pubescent beneath: flowers corymbose or rarely solitary, 5-7 cm. broad; calyx-lobes lanceolate, acuminate or dilated above, hispid-pubescent, spreading, deciduous; fruit globose or depressed-globose, about $8 \mathrm{~mm}$. high, glandular-hispid. In swamps and low grounds, Quebec and Ont. to Minn., Fla. and Miss. June-Aug.

8. Rosa lùcida Ehrh. Glossy Rose. Like $R$. humilis but larger, $\mathrm{I}-2 \mathrm{~m}$. high; leaflets mostly 7, 2-4 cm. long, thick, shining above; stipules broad, often glandular-toothed; prickles rather stout and flat, straight or slightly curved; fruit about $\mathbf{I} \mathrm{dm}$. high. N. J. and Penn. to Ont. and Newf. [R. humilis lucida Best].

9. Rosa hùmilis Marsh. Low or Pasture Rose. (I. F. f. 1971.) Busliy, I-IO dm. high, usually armed with slender straight infrastipular spines, and more or less prickly. Stipules narrow, entire; leaflets usually 5 (sometimes 7), rather thin, ovate, oval or obovate, somewhat shining, 12-25 mm. long, mostly acute at each end, short-stalked or sessile, glabrous or pubescent beneath; flowers usually few or solitary, 5-7 cm. broad; pedicels and calyx usually glandular; sepals lanceolate. acuminate, or dilated above, commonly lobed; fruit globose or depressed. globose, glandular-hispid, about $8 \mathrm{~mm}$. high. In dry or rocky soil, Me. and Ont. to Wis., Ga., Kans. and La. May-July.

Rosa hùmilis villòsa Best. Low, very prickly; leaflets thickish, villous-pubescent beneath. N. J. and N. Y.

ro. Rosa nítida Willd. Northeastern Rose. (I. F. f. 1972.) Bushy, seldom over $6 \mathrm{dm}$. high, the stems and branches densely covered with slender straight prickles nearly as long as the slender infrastipular spines. Stipules usually broad; leaflets 5-9, oblong or oval, generally acute at each end, the terminal one sometimes slightly obovate and obtuse at the apex, all sharply serrate, shining above, glabrous or very nearly so, $12-30 \mathrm{~mm}$. long; flowers $3-6 \mathrm{~cm}$. broad; sepals lanceolate, acuminate, entire, hispid or glandular; fruit glandular-hispid, globose, about $8 \mathrm{~mm}$. high. In low grounds, Mass. to Newf. June-July.

I I. Rosa canina L. Dog Rose. CANker Rose. Wild Brier. (I. F. f. 1973.) Branches erect or straggling, sometimes $3.5 \mathrm{~m}$. long, armed with short hooked spines, not bristly but sometimes glandular. Stipules broad, glandular; leaflets 5-7, ovate or oval, rather thick, generally obtuse at each end, usually simply and sharply serrate, $2-4 \mathrm{~cm}$. long; flowers solitary or few, pink varying to white; sepals much lobed, lanceolate, reflexed, deciduous; truit long-ovoid, I-2 $\mathrm{cm}$. long, usually glabrous. In waste places, N. S. to N. J., Va., Tenn. and Kans. Nat. from Europe. June-July.

12. Rosa rubiginòsa L. Sweetbrier. (I. F. f. I974) Slender, I-2 m. high, or forming longer wands, armed with stout recurved spines. Stipules rather broad; leaflets $5-7$, similar to those of the preceding, but generally doubly serrate and densely glandular-pubescent and resinous beneath, very aromatic; flowers pink varying to white; sepals lanceolate, usually much lobed, spreading, deciduous, glandular-hispid; fruit oval or ovoid, I-2 cm. long. In waste places, N. S. to Ont., Kans., Tenn. and Va. Nat. from Europe. June-July.

Rosa cinnamomea L., the Cinnamon Rose, with small double reddish flovers, and leaves downy-pubescent beneath, is occasionally found along roadsides in the Middle and Eastern States.

\section{Family 12. POMÀCEAE L.}

\section{Apple Family.}

Trees or shrubs, with alternate leaves, the small deciduous stipules free from the petiole. Flowers regular, perfect. Calyx superior, mostly 5-toothed or 5-lobed, its tube adnate to the ovary. Petals mostly 5, usually clawed. Stamens numerous or rarely few, distinct; anthers small, 2-celled, the sacs longitudinally dehiscent. Ovary composed of I-5 wholly or partly united carpels; ovules 1-2 (rarely several) in each carpel, anatropous, ascending; styles $1-5$; stigma small. Fruit a more 
or less fleshy pome, consisting of the thickened calyx-tube enclosing the bony papery or leathery carpels. Endosperm none; cotyledons fleshy. About 20 genera and 225 species, of wide geographic distribution.

Ripe carpels papery or leathery.

Leaves pinnate.

Leaves simple, entire, toothed, or lobed.

I. Sorbus.

Cavities of the ovary (carpels) as many as the styles.

Flesh of the pome with grit-cells.

Flesh of the pome without grit-cells.

Cymes simple ; trees.

Cymes compound; shrubs.

Cavities of the ovary becoming twice as many as the styles.

Ripe carpels bony.

Ovule $\mathbf{I}$ in each carpel, or if 2 , dissimilar.

Ovules 2 in each carpel, alike.

2. Pyrus.

3. Malus.

4. Aronia.

5. Amelanchier.

6. Crataegus.

7. Cotoneaster

\section{r. SÓRBUS L.}

Trees or shrubs, with pinnate leaves, serrate leaflets, deciduous stipules, and white flowers, in compound cymes. Calyx-tube urn-shaped, 5-lobed, not bracteolate. Petals 5, spreading, short clawed. Stamens $\infty$. Ovary inferior; styles usually 3 , distinct; stigma truncate; ovules 2 in each cavity. Fruit a small red berry like pome. [The ancient Latin name of the Pear or Service-tree.] About 7 species, natives of the north temperate zone. Besides the following, another occurs in western N. Am.

\section{Leaflets glabrous above.}

Leaflets long-acuminate; fruit $4-6 \mathrm{~mm}$. in diameter.

Leaflets obtuse or short-pointed; fruit about $8 \mathrm{~mm}$. in diameter.

Leaflets pubescent on both sides.

1. S. Americana.

2. S. scopulina.

3. S. Aucuparia.

r. Sorbus Americàna Marsh. American Mountain Ash. Dogberry. (I. F. f. I975.) A small tree, with smooth bark. Leaves petioled; leaflets II-I7, lanceolate, long-acuminate, glabrous, or slightly pubescent, bright green above, generally paler beneath, 3-ro $\mathrm{cm}$. long; cymes dense, 7-15 cm. broad; flowers 4-6 mm. broad. In moist ground, Newf., Manitoba, N. Car. and Mich. May-June.

2. Sorbus scopulina Greene. Large-fruited Mountain Ash. (I. F. f. 1976.) Resembles the preceding. Leaflets 7-15, proportionately. broader and shorter, oval or ovate-lanceolate, obtuse or short pointed at the apex, glabrous and dark green above, pale and usually more or less pubescent beneath, especially along the veins, seldom over $7 \mathrm{~cm}$. long; flowers $6-7 \mathrm{~mm}$. broad; calyx and pedicels generally pubescent: cymes 5-ro cm. broad. In moist ground, Lab. to Alberta, northern N. Eng., Penn., Mich., and in the Rocky Mts. to N. M. and Itah. JuneJuly. [Pyrus sambucifolia A. Gray, not C. \& S.]

3. Sorbus Aucuparia L. European Mountain AsH. Leaves pubescent on both sides, especially when young, the calyx and pedicels usually woolly. Escaped from cultivation, N. S. to N. H. Native of Europe.

\section{PỲRUS L.}

Trees, or some species shrubs, with simple leaves. Flowers large, white or pink, in simple cymes. Calyx urn-shaped, 5-lobed, the lobes acute. Petals 5, rounded, short-clawed. Stamens usually numerous; styles mostly 5, distinct, or united only at the very base; ovules 2 in each cavity; carpels cartilaginous or leathery. Fruit a pome, usually pear-shaped, its flesh abounding in grit-cells. [Latin name of the Pear.] About 12 species, satives of the Old World.

1. Pyrus commùnis L. Pear. Choke Pear. (I. F. f. 1977.) A tree, sometimes $20 \mathrm{~m}$. high; branches usually thorny. Leaves ovate, elliptic or obovate, finely serrulate or entire, petioled, 3-8 cm. long, downy and ciliate when young, becoming glabrous or nearly so, the apex acute or acuminate: petioles sometimes as long as the blades or longer; cymes few-several-flowered, borne at the ends of short twigs of the preceding year; pedicels $1.5-5 \mathrm{~cm}$. long; flowers wl.i.; - $5 \mathrm{~cm}$. broad; calyx-lobes about as long as the tube; styles distinct to the 
base. In thickets and woods, Me. to N. J. and Penn., escaped from cultivation. Native of Europe and Asia. April-May.

\section{MÀLUS Hill.}

Trees or shrubs, with toothed or lobed leaves, and pink or white flowers in simple terminal cymes. Calyx-tube urn-shaped or campanulate, 5-lobed. Petals 5 , rounded, clawed. Styles 2-5 (usually 5), united at the base; ovules 2 in each cavity; carpels papery or leathery. Fruit a pome, usually depressed-globose, mostly hollowed at the base. [Greek, apple.] About 15 species, natives of the north temperate zone. Besides the following, another occurs in northwestern Am.

Leaves glabrous, at least when mature.

Leaves oblong, lanceolate or oval, narrowed at the base.

Leaves ovate, cordate or rounded at the base.

Leaves persistently pubescent or tomentose beneath.

Leaves mostly narrowed at the base; pome $2-4 \mathrm{~cm}$. in diameter.

Pedicels slender, $2-4 \mathrm{~cm}$. long.

Pedicels stout, $\mathrm{I}-2.5 \mathrm{~cm}$. long.

Leaves rounded or subcordate at the base; pome $5-10 \mathrm{~cm}$. in diameter.

I. $M$. angustifolia.

2. M. coronaria.

\section{M. Malus.}

I. Malus angustifòlia (Ait.) Michx. Narrow-Leaved Crab Apple. (I. F. f. 1978.) A small tree. Leaves oblong, oblong-lanceolate or oval, thick, shining and dark green above, sometimes pubescent beneath when young, dentate or often entire, 2-5 cm. long; cymes tew-flowered; pedicels $2-4 \mathrm{~cm}$. long, slender; flowers pink, fragrant, mostly less than $2.5 \mathrm{~cm}$. broad; pome about $2.5 \mathrm{~cm}$. in diameter. In thickets, N. J. to Ill., Kans., Fla. and La. March-May.

2. Malus coronària (L.) Mill. American Crab Apple. (I. F. f. I979.) A small tree. Leaves petioled, ovate to trangular-ovate, sparingly pubescent beneath when young, sharply serrate and often somewhat lobed, ovate, acute or acutish at the apex, $2-8 \mathrm{~cm}$. long; flowers rose-colored, very fragrant, $2-5 \mathrm{~cm}$. broad; pedicels I-4 cm. long, glabrous; calyx slightly pubescent; pome fleshy, globose or depressed, $2-4 \mathrm{~cm}$. in diameter, greenish-yellow, fragrant, acid. In thickets, Ont. to Mich. and S. Car. April-May. Fruit ripe Sept.

3. Malus Ioźasis (Wuod) Britton. Western Crab Apple. (I. F. f. I980.) A small tree, much resembliny Malus coronaria. Leaves firm, white-pubescent beneath, at length glabrous above, obtuse at the apex, mostly narrowed at the base, ovate, oval or oblong, dentate, crente or with a few rounded lobes, 2-5 cm. lorig, or on young shoots much larger; petioles, pedicels and calyx pubescent. Minn., Wis. and Ill. to Neb., Ky., La. and the Ind. Terr. April-May.

4. Malus Soulàrdi (Bailey) Britton. Soulard Crab Apple. (I. F.f. I98I.) A small tree, resembling the two preceding. Leaves ovate, elliptic or obovate, mostly obtuse or truncate at the apex, rugose and densely tomentose beneath, irregularly crenate-dentate or sometimes few-lobed; petioles $2.5 \mathrm{~cm}$. or less, tomentose; flowers smaller than those of $M$. coronaria, the cymes dense; pedicels stout, whitetomentose; pome 2.5-6 cm. in diameter. Minn. to Mo. and Tex. April-May.

5. Malus Màlus (L.) Britton. Apple. (I. F. f. I982.) A large tree with spreading branches. Leaves ovate or oval, rounded or slightly cordate at the base, glabrous or nearly so above, pubescent and often woolly beneath ; pedicels generally tomentose, $2-5 \mathrm{~cm}$. long ; flowers pink, or white, $3-8 \mathrm{~cm}$. broad; calyx tomentose. In woods and thickets, Me. to N. Y., N. J., Penn. and Ga. Introduced from Europe and escaped from cultivation. April-May.

\section{ARÓNIA Medic.}

Low shrubs, with simple petioled finely serrate leaves, the upper side of the midrib glandular, the narrow stipules early deciduous. Flowers small, white or pink, in compound cymes: Calyx urn-shaped, 5-lobed. Petals 5, concave, spreading. Stamens numerous, Styles 3-5, united at the base. Ovary woolly. Pome small, globose, oval, or somewhat top-shaped, its carpels rather leathery. [Name modified from Aria, the Beam-tree of Europe.] Only the following species:

Cyme and lower surfaces of the leaves woolly.

Fruit short-pyriform, bright red.

Fruit oval to globose, purple-black.

Cymes and leaves glabrous or nearly so; fruit black or purplish.

1. A. arbutifolia.

2. A. atropurpurea.

3. A. nigra. 
I. Aronia arbutifòlia (L.) Medic. Red Choke-Berry. (I. F. f. 1983.) Leaves oval, oblong or obovate, obtuse or short-pointed at the apex, narrowed or somewhat cuneate at the base, 2-8 cm. long, glabrous above, densely tomentose beneath; flowers white or purplish-tinged, 8-12 min. broad; calyx and pedicels tomentose; pome 4-6 mm. in diameter, short-pyriform, and bright red when mature, long-persistent. In swamps and wet woods, N. Y. to Fla. March-May.

2. Aronia atropurpùrea Britton.

Purple-Fruited Chokeberry. A shrub, sometimes $4 \mathrm{~m}$. high, usually taller than the other species. Calyx, pedicels and lower leaf-surfaces tomentose; flowers similar to those of the preceding ; fruit oval to globose, purple-black, 6-1o mm. high. In wet soil, N. S. to Fla. April-June. Type from Arlington, Staten Island.

3. Aronia nigra (Willd.) Britton. Black Chokeberry. (I. F. f. I984.) Leaves obovate or oval, short-petioled, crenulate, dark green above, paler beneath, glabrous or nearly so on both surfaces; calyx and pedicels nearly glabrous; fruit globose or oval, nearly black, 6-8 $\mathrm{mm}$. in diameter, early deciduous. In swamps or low woods, or sometimes in drier soil, N. S. to Ont., Fla. and Mich. MarchJune.

\section{AMELÁNCHIER Medic. (See Appendix.)}

Shrubs or trees, with simple petioled leaves, unarmed branches, and racemose or rarely solitary white flowers. Calyx-tube campanulate, adnate to the ovary, 5-lobed, the lobes narrow, reflexed, persistent. Petals 5: Stamens $\infty$, inserted on the throat of the calyx; filaments subulate; styles $2-5$, connate, pubescent at the base. Ovary inferior, its cavities becoming twice as many as the styles; ovule I in each cavity, erect. Pome small, berry-like, 4-ro-celled. Testa of the seed cartilaginous. [The Savoy name of the Medlar.] About 12 species, natives of the north temperate zone. Besides the following, some 3 others occur in western N. Am. and I in Mex.

Flowers several or numerous in the racemes; pome globose.

Glabrous or pubescent trees and shrubs; leaves usually serrate nearly all around.

Leaves acute or acuminate at the apex; top of the ovary glabrous or nearly so.

Leaves ovate, oval or ovate-lanceolate, glabrous when mature; base cordate or rounded.

1. A. Canadensis.

Leaves oblong, oval, ovate or obovate, rarely subcordate at base, densely white-woolly beneath, at least when young.

Leaves rounded, obtuse or subacute at the apex; top of the ovary woolly.

Low shrub of rocky places, 3-6 dm. high ; petals $4-8 \mathrm{~mm}$. long.

Tree or small shrub; petals Io-16 $\mathrm{mm}$. long.

Glabrous western shrub; leaves dentate above the middle only. Flowers only $1-4$ in the clusters; pome oblong or obovoid.

3. A. spicata.

4. A. rotundifolia.

5. A. alnifolia.

6. A. oligocarpa.

r. Amelanchier Canadénsis (L.) Medic. June-berry. Service-berry. MAY-CHERRY. (I. F. f. I985) A tree, sometimes reaching the height of $20 \mathrm{~m}$. Leaves ovate or oval, sharply and finely serrate, soon entirely glabrous, $2-10 \mathrm{~cm}$. long; racemes spreading or drooping; pedicels long, slender; bracts silky, purplish, deciduous; petals linear, linear-spatulate, or linear-oblong, $\mathbf{I}-2 \mathrm{~cm}$. long, 3-4 times the length of the nearly or quite glabrous calyx; pome red or purple, sweet, about $6 \mathrm{~mm}$. high. In dry woodlands, Newf. to Ont., Fla. and La. MarchMay. Fruit ripe June-July.

2. Amelanchier Botryàpium (L. f) DC. Shad-Bush. Swamp SugarPEAR. (I. F. f. 1986.) A shrub or small tree, sometimes Io m. high, the foliage and inflorescence densely white-woolly when young, often nearly or quite glabrous when old. Leaves acute at the apex, finely and sharply serrate nearly all around; racemes short, rather dense; pedicels short, seldom over $2.5 \mathrm{~cm}$. long; petals spatulate or linear-spatulate, $6-14 \mathrm{~mm}$. long, 2-3 times as long as the calyx-lobes: caly $\mathbf{x}$ usually densely white-woolly; pome $6.8 \mathrm{~mm}$. in diameter. In swamps and moist soil, N. B. to Manitoba, Fla. and La. April-May.

3. Amelanchier spicata (Lam.) Dec. Low June-berry. (I. F. f. I987.) Stems 3-6 dm. high from a long root creeping among rocks. Leaves elliptic or oval, 2-4 cm. long, rounded at both ends, or sometimes subacute at the apex, sometimes subcordate at the base, serrulate or dentate-serrate, or sometimes entire below the middle, dark green and quite glabrous when mature, woolly when young; 
racemes 4-IO-flowered; pedicels $1-2.5 \mathrm{~cm}$. long in fruit; calyx-lobes nearly triangular; pome about $6 \mathrm{~mm}$. in diameter. N. Y., N. J. and Penn. May.

4. Amelanchier rotundifòlia (Michx.) Roem. Round-Leaved June-Berry. (I. F. f. I988.) A tall shrub or small tree. Leaves broadly oval, ovate or nearly orbicular, $2.8 \mathrm{~cm}$. long, obtuse or rounded at both ends, or rarely subacute, often cordate at the base, serrate with large teeth, or entire near the base, glabrous from the time of unfolding or more or less woolly when very young; pedicels $2-4 \mathrm{~cm}$. long in fruit; calyx-lobes lanceolate; petals spatulate or oblanceolate, $\mathbf{I}-\mathbf{I} .6 \mathrm{~cm}$. long; pome $6-8 \mathrm{~mm}$. in diameter. In woods and thickets, N. B. to Minn., N. Y. and Mich. May.

5. Amelanchier alnifollia Nutt. Northwestern June or Service-Berry. (I. F. f. I989.) A shrub, tomentose-pubescent when young, at length glabrate and somewhat glaucous. Leaves thick, broadly elliptic or almost orbicular, very obtuse and often truncate at the apex, rounded or subcordate at the base, coarsely dentate above the middle, $\mathbf{r}-5 \mathrm{~cm}$. long; racemes short, rather dense; pedice s short; petals oblanceolate, cuneate, 6-18 mm. long, 2-4 times the length of the calyx; pome purple, with a bloom, $6.8 \mathrm{~mm}$. high, sweet. Dry soil, western Ont. to Br. Col., Micn., Neb., N. Mex. and Cal. April.

6. Amelanchier oligocàrpa (Michx.) Roem. OBLong-Fruited June-Berry. (I. F. f. I990.) A shrub, glabrous or very nearly so, except the early deciduous bracts, which are sometimes tomentose. Leaves thin; narrowly oval or oblong, generally about 3 times as long as broad, narrowed at each end, finely and sharply serrate, $2-8 \mathrm{~cm}$. long; racemes $\mathbf{I}-4$-flowered; pedicels slender; petals obovate or oblanceolate, $6-8 \mathrm{~mm}$. long, about twice as long as the calyx; pome pear-shaped, purple, with a bloom, 6-8 mm. long. In cold swamps or wet rocky places, Lab. to Ont., Penn. and Mich. May.

\section{CRATAÈGUS L. (See Appendix.)}

Shrubs or small trees, usually spiny, with petioled leaves and white or pink corymbose flowers. Calyx-tube cup-shaped or campanulate, adnate to the carpels, its limb 5-lobed. Petals 5, rounded, inserted on the throat of the calyx. Stamens $\infty$, usually numerous; filaments filiform. Ovary inferior, or its summit free, I-5-celled; styles I-5, separate; ovule $\mathbf{I}$ in each carpel, or if $\mathbf{2}$, dissimilar. Pome rather small, drupe-like, containing I-5 bony carpels, each I-seeded or rarely 2-seeded. Seed erect, flattish. [Greek, strong, from the toughness of the wood.] About 75 species, natives of the north temperate zone, Mexico and the Andes. Besides the following, 8 or Io others occur in southern and western N. Am.

\section{* Corymbs many-flowered.}

1. Leaves obovate, spatulate, oblanceolate or flabellate.

Foliage, pedicels and calyx glabrous.

Leaves obovate or oblanceolate, sharply serrate.

Spines long, slender; leaves shining.

Spines short, stout; leaves dull.

Leaves obovate or spatulate, crenate.

Leaves narrowly spatulate; flowers $8 \mathrm{~mm}$. wide. $\quad 3$. C. spathulata.

Leaves obovate; flowers $15 \mathrm{~mm}$. wide. 4 . C. Brownii.

Lower leaf-surfaces, pedicels and calyx more or less pubescent, at least when young.

Leaves short-petioled; fruit smaîl.

Leaves oblanceolate, very obtuse. $\quad 5$. C. berberifolia.

$\begin{array}{ll}\text { Leaves obovate-oval, acutish. } & \text { 6. C. prunifolia. }\end{array}$

Leaves obovate, acutish, dull. 7. C. collina.

Leaves slender-petioled; fruit large.

Leaves obovate, dull, irregularly serrate. $\quad$ 8. C. punctata.

Leaves flabellate, shining, incised-serrate. $\quad$ 9. C. flabellata.

2. Leaves ovate, oval, orbicular-obovate or nearly orbicular.

a. Foliage, pedicels and calyx glabrous, or nearly so.

Leaves mainly truncate or cordate at the base.

Leaves lobed; fruit 4-6 mm. high.

Leaves irregularly serrate; fruit ro-12 mm. high, glaucous.

Leaves narrowed or wedge-shaped at the base.

Leaves deeply cleft; styles $1-3$.

Leaves serrate or incised; styles mostly 5 .

Fruit about $6 \mathrm{~mm}$. in diameter.

I0. C. cordata.

I1. C. Eggerti.

12. C. Oxyacantha.

13. C. viridis. 
Fruit ro-12 mm. in diameter, glaucous or pruinose.

Leaves firm, shining.

Fruit globose; western. $\quad$ 14. C. nitida.

Fruit pyriform; eastern. $\quad$ 15. C. Porteri.

Leaves thin, dull.

16. C. pruinosa.

-ower surfaces or teeth of the leaves, pedicels and calyx pubescent or glandular.

Leaves deeply pinnately incised; fruit $4-6 \mathrm{~mm}$. long. 17 . C. afiifolia.

Leaves serrate or lobed; fruit 6-25 $\mathrm{mm}$. long.

Leaves glabrous, or nearly so.

Leaves, or most of them, truncate or cordate at the base.

Leaves, or most of them, narrowed at the base.

18. C. coccinea.

Fruit 8-r.4 $\mathrm{mm}$. in diameter.

Fruit globose to oval; leaves firm in texture.

Bractlets and calyx very glandular. 19. C. rotundifolia.

Bractlets and calyx pubescent. 20 . C. occidentalis.

Fruit pyriform; leaves thin. 2 2. C. tenuifolia.

Fruit only 6-8 mm. in diameter. 22. C. macracantha.

Leaves pubescent, especially along the veins beneath.

Leaves ovate-orbicular, mostly truncate or cordate at base. Fruit r.5-
$2.5 \mathrm{~cm}$. in diameter; red.
23. C. mollis.

Leaves ovate to oval, mostly cuneate or narrowed at the base.

Fruit globose or depressed-globose.

Veins not prominent on the lower leaf-surfaces.

Veins very straight and prominent.

24. C. Biltmoreana.

25. C. campestris.

Fruit oval to oblong.

Fruit dull red, over I $\mathrm{cm}$. long.

Fruit bright red, I cm. long or less.

Fruit pyriform.

26. C. tomentosa.

27. C. Chapmani.

28. C. pyriformis.

\section{** Corymbs I-7-flowered.}

Calyx-lobes not incised; petioles and leaf-serrations very glandular.

29. C. Aavá.

Calyx-lobes deeply incised; petioles and leaf-serrations little or not at all glandular.

Leaves obovate or spatulate, obtuse.

Leaves oval, mostly acute at both ends.

3o. C. uniflora.

31. C. Vailiae.

r. Crataegus Crús-gálli L. Cockspur Thorn. Newcastle Thorn. (I. F. f. I 991.) A shrub or small tree, the branches spreading. Thorns numerous, slender, 5-10 cm. long; leaves coriaceous, shining above, obuvate or oblanceolate, obtuse or abruptly acuminate at the apex, cuneate at the base, $2-5 \mathrm{~cm}$. long, sharply serrate; flowers about $12 \mathrm{~mm}$. broad; calyx-lobes linear-lanceulate; styles usually I-3: fruit globose or slightly pear-shaped, about $12 \mathrm{~mm}$. long. In thickets, Quebec to Manitoba, N. H., Fla. and Tex. May-June.

2. Crataegus brevíspina (Dougl.) Farwell. Douglas Thorn. A small tree. Foliage glabrous or nearly so. Leaves obovate, unequally serrate or somewhat lobed, cuneate or narrowed at the base, 4-8 cm. long, the petiole about one. fourth the length of the blade; thorns $1.5-3 \mathrm{~cm}$. long; flowers about $2 \mathrm{~cm}$. wide; calyx-lobes ovate, obtuse, rarely glandular; fruit globose, purple-black, $\mathbf{I}-\mathbf{1} .5 \mathrm{~cm}$. in diameter. Mich. to Br. Col., Colo. and Ore. May-June. [C. Douglasii Lindl.]

3. Crataegus spathulàta Michx. Small-Fruited Haw. (I. F. f. I992.) A shrub or small tree. Spines $2-5 \mathrm{~cm}$. long; leaves fascicled, coriaceous, shining above, rather dull beneath, spatulate, obtuse and crenate or with 2-3 lobes at the summit, entire and cuneate at base, almost sessile, $2-4 \mathrm{~cm}$. long: flowers alout 8 mm. broal ; calyx-lobes ovate; styles commonly 5 ; fruit red, glubose, $46 \mathrm{~mm}$. hng. In thickets, Va. to Fla., Mo. and Tex. May-June.

4. Crataegus Bròwnii Britton. ADdison BRown's Thokn. Glabrcus throughout. Leaves obovate or oval-obovate, obtuse, or obtusish at the afex, cuneate-narrowed at the base, irregularly crenate, with distinctly rounded teeth, slender-petioled, 4-6 cm. long: pedicels slender; bracts linear, very glandular; flowers about $1.5 \mathrm{~cm}$. broad; calyx-segments linear-lanceolate. Va. and W. Va. May. Type from Buchanan, Va.

5. Crataegus berberifjlia T. \& G. Barberry-leaved Thorn. Similar to $C$. Crus-galli, but the young leaves, pedicels and calyx densely pubescent. Thorns slender, 2-5 cm. long; mature leaves nubescent with scattered hairs, rather 
dull, oblanceolate to broadly obovate, 4-8 cm. long; fruit oval, about $\mathbf{x} \mathrm{cm}$. long. Mo. to La. April-May.

6. Crataegus prunifjlia (Marsh.) Pers. Plum-leaved 'Thorn. Similar to broad-leaved forms of C. Crus-galli, the leaves oval to obovate, acutish, serrate nearly to the base; 5-7 cm. long, 3-5 cm. wide, pubescent beneath, at least when young; pedicels and calyx pubescent; flowers and globose pome about $\mathbf{I ~} \mathrm{cm}$. broad. Mo. Perhaps not the original Mespilus prunifolia Marsh.

7. Crataegus collina Chapm. ROUnD-Fruited Thorn. A small tree, the young foliage and the inflorescence pubescent. Leaves obovate, mostly acute, finely serrate, tapering into the short petiole; flowers 8-10 mm. broad; styles 5; fruit hard, globular, about $\mathbf{I} \mathrm{cm}$. in diameter. Va. to Ga. and Mo. April-May.

8. Crataegus punctàta Jacq. LARGe-fruited Thorn. (I. F. f. 1993.) A shrub or small tree, with horizontal, thorny branches. Thorns $2-5 \mathrm{~cm}$. long, often branched; leaves slender-petioled, obovate, obtuse or short pointed at the apex and irregularly serrate or serrulate, cuneate at the base, nearly glabrous above, pubescent or at length glabrous beneath. $5-8 \mathrm{~cm}$. long, rarely lobed, veins straight, conspicuous; flowers $\mathbf{I}-\mathbf{2} \mathrm{cm}$. broad; calyx.lobes linear, entire ; styles mostly 3 ; fruit globose or oval, red or yellow, $1.5-2.5 \mathrm{~cm}$. in diameter. In thickets, Quebec and Ont. to N. H., Ga., west to Iowa. May.

Crataegus punctàta canéscens Britton. Lower leaf-surfaces, petioles, peduncles and pedicels densely whitish-tomentose. Vt. to Ont., Penn. and Ohio.

9. Crataegus fiabellàta (Spach) Rydb. FAN-Leaved THORn. Leaves flabellate, broadest above the middle, cuneate at the base, thin and usually with a few scattered hairs beneath when young, sharply and irregularly incised serrate, glabrous, firm and shining above when old, $6-10 \mathrm{~cm}$. long, sler.der-petioled; thorns $5 \mathrm{~cm}$. long or more; fruit globose, I-I.5 cm. in diameter. Quebec to Me., R. I., the N. W. Terr. and Munt.

Io. Crataegus cordàta (Mill.) Ait. Washington Thorn. (I. F. f. I994.) A tree, 5-15 m. high. Spines slender, 2-5 cm. long ; leaves slender-petioled, broadly ovate, generally sharply $3-7$-lobed and serrate, acute or acuminate at the apex, truncate or cordate at the base, $2-8 \mathrm{~cm}$. long; flowers $8-12 \mathrm{~mm}$. broad; styles 5; fruit bright red, depressed-globose, $4-6 \mathrm{~mm}$. high. In woods and thickets, Va. to Ga., Ill. and Tenn.; escaped from cultivation in southern N. J. and Penn. March-May.

II. Crataegus Éggerti Britton. ÉGgerT's Thorn. Foliage sparingly pubescent when young, glabrous when mature. Thorns $3-6 \mathrm{~cm}$. long; leaves ovateorbicular, dull green above, pale beneath, sharply and irregularly serrate, or somewhat lobed, mostly truncate or subcordate at the base, acute or acutish at the apex, slender-petioled, 5-12 cm. long, and about as wide; flowers $2-2.5 \mathrm{~cm}$. broad; bracts large, very glandular; fruit subglobose, large, sometimes nearly $2 \mathrm{~cm}$. in diameter, glaucous. In dry soil, Iowa to Mo. and Kans. April-Mav.

12. Crataegus Oxyacántha L. HAwTHORn. White OR MAY Thorn. (I. F. f. 1995.) A shrub or tree. Thorns stout, numerons; leaves slender-petioled, glabrous on both sides or pubescent when young, sharply 3-7-lobed, broadly ovate or slightly obovate, broadly cuneate at the base, $2-5 \mathrm{~cm}$. long; flowers $\mathbf{I}-\mathbf{I} .5 \mathrm{~cm}$. broad, white or pink; calyx-lobes ovate; styles I-3; fruit globose or globose ovoid. about $6 \mathrm{~mm}$. high. Along roadsides and in thickets, sparingly escaped from cultivation. May-June.

I 3. Crataegus víridis L. Southern Thorn. (I. F. f. 1996.) A small tree, often without spines. Leaves slender-petioled, ovate to lanceolate or somewhat obovate, glabrous, or pubescent in the axils of the veins beneath, sharply serrate and usually somewhat lobed, mostly acute at each end, $2.8 \mathrm{~cm}$. long; flowers I-I. $5 \mathrm{~cm}$. broad; calyx-lobes lanceolate; styles commonly 5 ; fruit globose or oval, about $6 \mathrm{~mm}$. high, persistent into the winter, 6-8-seeded. Mo. and Kans. to La., Tex., S. Car. and Fla. March-April.

I4. Crataegus nítida Engelm. SHINING Thorn. Similar to $C$. viridis, but often a larger tree, the leaves thicker, larger, ovate to oval, and more shining above. Flowers about $2 \mathrm{~cm}$. broad; fruit globose, $1 \mathrm{~cm}$. in diameter, or a little more, 4-5-seeded, glaucous. Ill., Mo. and Ark. May. [C. viridis nitida Engelm.]

15. Crataegus Pórteri Britton. PORTER's THORN. A shrub, wholly gla. 
brous. Leaves ovate to oval, dark green and shining above, paler beneath, 6-Io $\mathrm{cm}$. long, $3-5 \mathrm{~cm}$. wide, sharply irregularly serrate and slightly lobed, the slender petiole about one third the length of the-blade; pedicels slender; fruit pyriform, about $1.4 \mathrm{~cm}$. long and $\mathbf{I} \mathrm{cm}$. in diameter, pruinose. Calyx-lobes entire. Tannersville, Penn., July 4, I 896.

i6. Crataegus pruinòsa (Wendl.) Beadle. Pruinose Thorn. A shrub or small tree. Spines long and slender. Leaves ovate, acute, incised-serrate and somewliat lobed, thin, slender petioled, $6-8 \mathrm{~cm}$. long, glabrous or nearly so; fruit globose, pruinose, about $10 \mathrm{~mm}$. in diameter. Va. to N. Car. and Mo. [Mespilus pruinosa Wendl.]

I7. Crataegus apiifòlia (Marsh.) Michx. Parsley Haw. Parsley-leaved THORN. (I. F. f. I997.) A shrub or small tree. Spines stout, 2-5 cm. long; leaves slender-petioled, broadly ovate or nearly orbicular in outline, pubescent on both sides at least when young, truncate or slightly cordate at the base, $\mathbf{I}-3 \mathrm{~cm}$. long, thin, pinnately and deeply 5-7-cleft, the lobes sharply serrate; flowers 8-12 $\mathrm{mm}$. broad ; calyx-lobes linear, glandular; styles I-3 ; fruit red, oval, 4-6 mm. long. In thickets, Va. to Fla., Mo. and Tex. March-April.

I8. Crataegus coccínea L. Scarlet Thorn or Haw. Red Haw. (I. F. f. I998.) A shrub or sometimes a small tree. Spines stout, 3-5 cm. long; leaves slender-petioled, broadly ovate or orbicular, acute or acuminate at the apex. mostly truncate or subcordate at the base, thin, or becoming firm, sharply incised and serrate, the teeth glandular-tipped; pedicels, bractlets and calyx somewhat glandular-pubescent ; flowers $1.5-3 \mathrm{~cm}$. broad; calyx-lobes lanceolate; styles 3-5; fruit red, globose or oval, Io-16 mm. in diameter, rarely hairy. Thickets, Newf. to Manitoba, Fla. and Tex. April-May.

19. Crataegus rotundifòlia (Ehrh.) Borck. Glandular Thorn. (I. F.f. 1999.) A shrub, similar to the preceding, the spines slender. Leaves mostly smaller, slender-petioled, glabrous or very nearly so, oval, ovate, obovate, or some of them nearly orbicular, incised-serrate with gland-tipped teeth, or sometimes lobed, acute, most of them narrowed or cuneate at the base; bractlets and calyxlobes very glandular; flowers $\mathbf{1} .5-2.5 \mathrm{~cm}$. broad; fruit globose to oval, red, 8-16 mm. long. Conn. to Ind., Fla. and Ala. April-June.

20. Crataegus occidentàlis Britton. RIVER-BANK ThORN. Pedicels, calyx and lower leaf-surfaces pubescent. Thorns stout, $3 \mathrm{~cm}$. long or more. Leaves oval or slightly olovate, irregularly serrate and sometimes slightly lobed, mostly obtuse at the apex, and narrowed or subcuneate at the base, 4-7 cm. long, 3 or 4 cm. wide, slender-petioled; flowers about $1.5 \mathrm{~cm}$. wide; fruit oval-globose, about I cm. long. River banks, Neb., Colo., Wyo. and Mont.

21. Crataegus tenuifòlia Britton. Thin-leaved Thorn. A shrub, the thorns' slender, slightly curved, 5-6 cm. long. Leaves very thin, even when mature, ovate, acute or short-acuminate at the apex, narrowed, or some of them subtruncate at the base, incised-serrate and lobed, with short hairs on the upper surface, 6-10 $\mathrm{cm}$. long, the very slender petiole half the length of the blade or longer; pedicels slender; fruit pyriform, over I cm. long, 8-9 mm. thick, the calyx-lobes glandular-serrate. S. W. Va. Type from South Fork of the Holston River, June I5, I892.

22. Crataegus macracántha Lodd. Long-Spined Thorn. (I. F. f. 2000.) A shrub or small tree, the bright brown thorns 5-13 cm. long. Leaves dull, 3-9 $\mathrm{cm}$. long, usually with a few hairs on the prominent veins beneath, sharply and often doubly serrate with gland-tipped teeth, narrowed or cuneate at the base; pedicels often pubescent; calyx and bractlets glandular; flowers numerous, 12-16 $\mathrm{mm}$. broad : fruit globose or oval, 6-8 mm. in diameter. Quebec to Dak., Va. and Mo. May-June.

23. Crataegus móllis (T. \& G.) Scheele. Red-Fruited Thorn. (I. F. f. 200I.) A shrub or small tree. Leaves generally broadly ovate, truncate at the base, sometimes $13 \mathrm{~cm}$. long, incised and sharply serrate witl gland-tipped teeth, roughish above, pubescent beneath, especially when young; twigs, petioles and calyx densely pubescent; calyx-lobes usually incised and glandular; flowers $1.5-2.5$ $\mathrm{cm}$. broad; fruit bright red, 2-3 cm. in diameter, hairy. Thickets, Quebec to Mich., Neb., Kans., Penn., La. and Tex. April-May.

24. Crataegus Biltmoreàna Beadle. Biltmore Thorn. Lower leaf- 
surfaces, especially along the veins, calyx and pedicels pubescent. Leaves broadly ovate, or nearly orbicular, narrowed, or some of them somewhat truncate at the base, sharply and unequally serrate, subacute, 6-10 cm. long; petioles $2-3 \mathrm{~cm}$. lolig, mostly a little shorter than the pedicels; young fruit very pubescent; mature fruit subglobose, green to yellow, I cm. or rather more in diameter, green. Pa. to N. Car., Ala. and Mo. May.

25. Crataegus campestris Britton. Mature leaves firm, densely and finely pubescent and prominently straight-veined beneath, dull and with short scattered hairs above, 6-9 cm. long and nearly as wide, sharply and somewhat irregulariy serrate. Thorns stout, 4-6 cm. long; pedicels slender, pubescent ; fruit globose, $\mathbf{I}-\mathbf{I} .5 \mathrm{~cm}$. in diameter, pubescent when young. Mo. and Kans.

26. Crataegus tomentòsa L. PEAR-THORn. PEAR Haw. (I. F. f. 2002.) A shrub or small tree. Spines stout, $2-6 \mathrm{~cm}$. long; leaves petioled, broadly oval or ovate-oval, acute or acutish at the apex, narrowed or cuneate at the base, sharply dentate or somewhat lobed, not glandular, slightly scabrous above, pubescent, especially along the veins beneath, 5-13 cm. long: twigs, petioles and calyx tomentose-pubescent; flowers about $12 \mathrm{~mm}$. broad; calyx-lobes lanceolate, usually incised; styles 3-5; fruit dull red, oval to oval pyriform, over $\mathbf{I} \mathrm{cm}$. long. In thickets, Ont. to N. J., Ga., Mich. and Mo. May-June.

27. Crataegus Chápmani (Beadle) Ashe. Chapman's Thorn. A small tree, similar to $C$. tomentosa, but the leaves smaller and thicker in texture; flowers about $1.5 \mathrm{~cm}$. wide; fruit smaller, short-oval, $1 \mathrm{~cm}$. high or less, bright red. Va. to Ga. and Mo. May-June.

28. Crataegus pyrifòmis Britton. Pear-fruiten Thorn. Twigs light gray. Leaves broadly oval or obovate-oval, dull, $6-8 \mathrm{~cm}$. long, when mature glabrous above, pubescent, especially on the veins beneath, rather firely serrate nearly all around, not lobed, the blade decurrent into the petiole; pedicels slender: fruit pyriform, about I cm. long. Monteer, Mo., B. F. Bush, 1899.

29. Crataegus flàva Ait. Summer or Yellow Haw. (I. F. f. 2003.) A tree, with maximum height of about $7 \mathrm{~m}$., usually very thorny. Leaves obovate, petioled, irregularly glandular-dentate at the apex, narrowed or cuneate and often entire at the base, I-4 cm. long, pubescent on both sides or at length glabrate; pedicels and calyx pubescent; flowers $\mathbf{I}-2 \mathrm{~cm}$. broad; styles commonly 5 ; fruit globuse or somewhat pyriform, I-I.5 cm. in diameter. In sandy thickets, Va. to Fla., Mo. and Tex. April-May.

30. Crataegus unifiòra Muench. Dwarf Thorn. (I. F. f. 2004.) A slırub, or sometimes a small tree. Spines numerous, slender, $2-5 \mathrm{~cm}$. long; leaves obo. vate, coriaceous, nearly sessile, obtuse and crenate at the apex, cuneate and entire at the base, $\mathbf{r}-4 \mathrm{~cm}$. long, more or less pubescent, or glabrate and at length shining above; twigs, pedicels and calyx pubescent; flowers 8 -10 $\mathrm{mm}$. broad; calyx-lol es lanceolate, deeply incised, glandular; styles commonly 5 ; fruit globose or pyriform. I-1. $6 \mathrm{~cm}$. in diameter, yellow. In sandy soil, S. N. Y. to Fla., W. Va., Mo. and La. April-May.

3I. Crataegus Vàiliae Britton. VAIL's Haw. (I. F. f. 2005.) A slirub, the branches stout, light gray; thorns slender. Leaves oval, $2-8 \mathrm{~cm}$. long, shortpetioled, pubescent on both sides, but becoming glabrate and slightly shining abcve, sharply serrate, sometimes slightly 3-lohed; stipules narrow, glandular; corymbs 2-6-flowered; pedicels and calyx densely pubescent; calyx-lobes lanceolate, 8$12 \mathrm{~mm}$. long, dceply incised, glandular, reflexed in fruit; pome globose, ycllowish green, 8-10 mm. in diameter. In thickets, Va. and N. Car. to Mo. May-June.

\section{COTONEÁSTER Medic.}

Shrubs, with stipulate coriaceous leaves, and small white cymose or rarely soli. tary flowers. Calyx-tube adnate to the ovary, the limb 5-lobed, persistent. Petals 5, scarcely clawed. Stamens numerous. Ovary 2-5-celled or of 2-5 carpels, separate at the summit; styles $2-5$; ovules 2 in each cavity or carpel, alike, erect. Pome ovoid, globose or top-shaped, the carpels bony when mature. [Name neoLatin, Quince-star or Star-quince.] About 20 species, natives of the Old World.

I. Cotoneaster Pyracántha (L.) Spach. Evergreen or Fire TiIorn. Pyracanth. (I. F. f. 2006.) A shrub. Spines slender, I-2.5 cm. long; leaves evergreen, glabrous, oval or slightly oblanceolate, crenulate, obtuse at the apex, 
usually narrowed at the base, 2-5 cm. long, short-petioled: cymes many-flowered; pedicels and calyx pubescent; calyx-lobes ovate; flowers about $6 \mathrm{~mm}$. broad; styles 5; fruit scarlet, depressed-globose, about $4 \mathrm{~mm}$. high, bitter. In thickets, escaped from cultivation, S. Penn. to Ala. and Tenn. Native of Europe and Asia. May.

\section{Family 13. DRUPÀCEAE DC.}

\section{Plum Family.}

Trees or shrubs, the bark exuding gum, the foliage, bark and seeds containing prussic acid, bitter. Leaves alternate, petioled, serrate, the small stipules early deciduous, the teeth and petiole often glandular. Flowers regular, mostly perfect. Calyx inferior, deciduous, free from the ovary, 5-lobed. Disk annular. Calyx-lobes imbricated in the bud. Petals 5. inserted on the calyx. Stamens numerous, inserted with the petals. Pistil 1 in our genera; ovary I-celled, 2-ovuled; style simple; stigma mostly small and capitate. Fruit a drupe. Seed I, suspended; endosperm none; cotyledons fleshy. About 6 genera and I 10 species, widely distributed, most abuindant in the north temperate zone.

Drupe glabrous.

Drupe velvety.

\section{PRÙNUS L.}

I. Prunus.

2. Amygdalus.

Shrubs or trees, mostly with edible fruits, the white or pink flowers variously clustered, the leaves conduplicate or convolute in vernation. Petals spreading. Stamens 15-20, distinct; filaments filiform. Style terminal; stigma peltate or truncate. Exocarp of the drupe fleshy, the endocarp bony, smooth or a little rough . ened, globose or oval, or oblong and compressed. [Ancient Latin name of the Plum-tree.] About 9o species, natives of the north temperate zone, tropical America and Asia. Besides the following, some $\mathbf{1} 2$ others occur in southern and western N. A.

* Flowers in lateral scaly umbels or fascicles, expanding with or before the leaves.

† Inflorescence umbellate, the clusters sessile or nearly so.

Leaves convolute in vernation; fruit mostly large; pit more or less flattened.

Umbels several-flowered.

Leaves abruptly acuminate : drupe red or yellow.

Calyx-lobes entire, pubescent within; fruit globose. I. P. Americana.

Calyx-lobes glandular-serrate; fruit subglobose or oval.

Calyx-lobes glabrous within; leaves oval or obovate.

Calyx-lobes pubescent on both sides; leaves ovate-lanceolate. 3. P. hortulana.

Leaves acute, gradually acuminate, or obtusish ; drupe red or purple.

Leaves glabrous when mature.

Fruit red, with little bloom or none.

Leaves lanceolate; drupe thin-skinned. 4. P. angustifolia.

Leaves ovate-lanceolate or oblong; drupe thick-skinned; western shrub.

5. P. Watsoni.

Fruit dark purple, with a bloom; leaves ovate. 6. P. Alleghaniensis.

Leaves pubescent, at least on the lower surface, when mature.

Drupe $1.5-2.5 \mathrm{~cm}$. in diameter; coast plants.

Leaves ovate or oval, acute; stone pointed at both ends.

Leaves orbicular, very obtuse; stone pointed at base.

7. P. maritima.

8. P. Gravesii.

Drupe $0.6-\mathrm{r} \mathrm{cm}$. in diameter ; prairie plant.

Umbels only $\mathrm{I}-2$ flowered.

9. $P$. gracilis.

Io. P. spinosa.

Leaves conduplicate in vernation ; fruit mostly small ; pit mostly globose.

Flowers 6-12 mm. broad; low shrubs.

Leaves oblanceolate or spatulate; northern.

Leaves oval, oblong, or slightly obovate.

II. P. pumila.

Petioles 8-20 mm. long; drupe 8-ro $\mathrm{mm}$. in diameter ; eastern.

Petioles 4-6 mm. long; fruit 12-16 mm. in diameter; western.

12. P. cuncata. 
Flowers $15-30 \mathrm{~mm}$. broad ; trees.

Leaves glabrous; pedicels short ; fruit sour.

Leaves pubescent beneath, at least on veins; pedicels long; fruit sweet.

$\dagger+$ Inflorescence more or less corymbose : leaves shining.

15. P. Avium.

16. P. Pennsylvanica,

* * Flowers corymbose, terminating twigs of the season. 17. P. Mahaleb.

$* * *$ Flowers racemed, terminating branches of the season.

Fruit red to purple, astringent ; leaves obovate or oval.

Fruit purple or purplish-black, sweet or bitter.

Leaves oval or obovate; shrub or small tree.

Leaves oval-lanceolate to ovate; large tree.

18. P. Virginiana.

19. $P$. demissa.

20. P. serotina.

I. Prunus Americàna Marsh. Wild Yellow or Red Plum. (I. F. f. 2007.) A shrub or small tree; branches more or less thorny; bark thick. Leaves ovate or obovate, nearly or quite glabrous when mature, usually pubescent when young, sharply and often doubly serrate, rounded at the base, slender-petioled; petioles usually glandless; flowers 'white, $1.5-2.5 \mathrm{~cm}$. broad; pedicels $\mathbf{r}-2 \mathrm{~cm}$. long; drupe I.8-2.5 cm. in diameter, the skin tough, bloom little or none, the stone somewhat flattened, its ventral edge acute or margined, the dursal faintly grooved. N. Y. to Mont., Fla. and Colo. April-May. Fruit ripe Aug.-Oct.

2. Prunus nigra Ait. Canada Plum. Horse Plum. (I. F. f. 2008.) A tree, 6-10 m. high; bark thin. Leaves oval, ovate or obovate, long-acuminate, pubescent when young, crenulate-serrate ; petioles stout, $1-2.5 \mathrm{~cm}$. long, bearing I or 2 red glands near the blade ; flowers $2.5-3 \mathrm{~cm}$. broad; pedicels $1-2 \mathrm{~cm}$. long, glabrous; calyx-lobes glandular-serrate; drupe oval, $2.5-3 \mathrm{~cm}$. long, orange-red, thick-skinned, bloom little or none, the flesh adherent to the oval compressed stone, which is sharply ridged on the ventral edge, somewhat grooved on the dorsal. Newf. to Man., Mass. and Wis. May. Fruit Aug. Petals pink in age.

3. Prunus hortulàna Bailey. Wili) Goose Plum. (I. F. f. 2009.) A small tree, similar to the two preceding; branches spreading; bark thin. Leaves ovatelanceolate to ovate, long-acuminate, closely glandular-serrate, $10-15 \mathrm{~cm}$. long; petioles not $2.5 \mathrm{~cm}$. long, usually bearing two glands near the blade; pedicels $\mathrm{I}-2$ $\mathrm{cm}$. long; calyx-lobes glandular-serrate; drupe subglobose or short-oval, bright red, thin-skinned, bloom little or none, stone swollen, roughish, not margined. Ill. to Tenn., Kans. and Tex. April-May.

Prunus hortulàna Mìneri Bailey. Leaves dull, thick, irregularly coarsely serrulate, conspicuously veiny beneath; stone nearly smooth; leaves varying to oblanceolate. Ill. to Tenn. and Mo.

4. Prunus angustifòlia Michx. Chickasaw Plum. Hog Plum. (I. F. f. 2010.) A small tree, the branches somewhat thorny. Leaves acute, serrulate, often rounded at the base, 7-13 cm. long; flowers smaller than those of the preceding, in lateral umbels, expanding before the leaves; drupe red, globose, $12-18 \mathrm{~mm}$. in diameter, nearly destitute of bloom, its stone ovoid, hardly flattened, both edges rounded, one of them slightly grooved. In dry soil, N. J. to Fla., west to the Rocky Mts. April. Fruit ripe May-July.

5. Prusus Wàtsoni Sargent. Watson's Plum. Sand Plum. (I. F. f. 20Ir.) A shrub, 2-3.5 m. high, somewhat spiny. Leaves firm, acute or acuminate at the apex, finely crenulate-serrulate, $2-5 \mathrm{~cm}$. long, shining above, the petioles about I cm. long; flowers IO-12 mm. broad; pedicels 8-12 mm. long, red, glabrous; fruit globose or somewhat elongated, about $18 \mathrm{~mm}$. in diameter, orangered, without a bloom, the flesh yellow; stone oval, pitted, mostly rounded on both margins, abruptly flattened at the summit. Sandy soil, Neb. to Ark. April-May.

6. Prunus Alleghaniénsis Porter. Porter's Plum. (I. F. f. 20I2.) A low, straggling shrub or small tree; seldom thorny. Leaves acute or acuminate, finely serrate, rounded at the base, pubescent when young; flowers about $\mathrm{I} 4 \mathrm{~mm}$. broad; drupe globose-ovoid, about $\mathbf{I} \mathrm{cm}$. in greatest diameter, with a conspicuous bloom; pulp pleasantly acid; stone slightly flattened, a shallow groove on one margin, a slight expansion on the other. E. Conn.; Huntingdon Co., across the Alleghany Mts. to Clearfield Co., Pa. April.

7. Prunus marítima Wang. Beach Plum. (I. F. f. 2013.) A muchbranched shrub, $0.3^{-2} \mathrm{~m}$. high, not thorny. Leaves oval, ovate or obovate, finely 
and sharply serrate, rounded at the base, pubescent beneath even when old; flowers white, numerous, in lateral umbels, expanding before the leaves, $10-16 \mathrm{~mm}$. broad; petals obovate; drupe globose, purple, $1.5-2.5 \mathrm{~cm}$. in diameter, sweet, covered with a bloom; stone little flattened, acute on one margin, slightly grooved on the other. On seabeaches and in sandy soil near the coast, Va. to N. B. April-May. Fruit ripe in Sept. or Oct.

8. Prunus Gràvesii Small. Graves' Brach Plum. (I. F. f. 2014.) A low shrub, reaching a maximum height of about $\mathrm{r} .3 \mathrm{~m}$., not thoruy, the twigs of the season mostly puberulent. Leaves orbicular, oval-urbicular, or slightly obovate, I.6-3 cm. long. romnded, retuse or apiculate at the apex, obtuse or truncate at the base, pubescent, at least on the nerves beneath ; flowers about $12 \mathrm{~mm}$. broad, solitary or 2-3 tingether in lateral umbels, expanding with the leaves; petals suborbicular; drup: glubose, ro $16 \mathrm{~mm}$. in diameter, nearly black, with a light blue bloom; stone nearly as thick as wide, pointed only at the base. On a gravelly ridge, Groton, Conn. May-June. Fruit ripe in Sept.

9. Prunus gracilis Fingelm. \& Gray. Low Plum. (I. F. f. zOI5.) A shrub, 3-12 dm. high, the foliage and young twigs densely soft-pubescent. Leaves shortpetioled, ovate-lanceolate or ovil, acute or acutish at loth ends, sharply serrate, glabrate on the upper surface at maturity; flowers $6-8 \mathrm{~mm}$. broad, in lateral umbels, appearing before the leaves; pedicels slender, pubescent; drupe oval-globose, 8-ro $\mathrm{mm}$. in diameter; stone little flattened, nearly orbicular. In sandy or dry soil, Tenn. to Kans. and Tex.

io. Prunus spià̀sa L. Sloe. Blackthorn. Buckthorn. (I. F. f. 2016.) A shrub with thorny branches, $0.6-5 \mathrm{~m}$. high. Leaves ovate or oblong, obtuse at the apex, serrate, nearly glabrous when mature; flowers white, $8-12 \mathrm{~mm}$. broad, appearing before the leaves, the lateral clusters only 1-2-flowered; drupe ovoid-globose, nearly black with a bloom, about $12 \mathrm{~mm}$. in diameter; stone little flittened, acute on one elge. Along roadsides, etc., Penn. and N. J. to Mass. Nit. or adv. from Europe. April-May. [Prumus spinisa insititia A. Gray.]

I I. Prunus pùmila L. Sand Cherry. Dwarf Cherry. (I. F. f. zor7.) Much branched from the base, sometimes bushy, 0.2-2 m. high. Leaves inostly ob!anceolate or spatulate, acute or a utish, narrowed at the base, serrate, especially toward the apex, usually pale beneath and deep green above, glabrous or very nearly so on both sides when mature; flowers 8 -10 $\mathrm{mm}$. broad, appearing with the leaves in sessile lateral umbels; drupe $8-12 \mathrm{~mm}$. in diameter, dark red or nearly black when mature without bloom; flesh thin, acid. On sandy or gravelly shores, N. B. to Manitoba, N. J. and Mich. April-May. Fruit ripe in August.

12 Prunus cuneata Raf. Appalachian Cherry. (I. F. f. 2018.) An erect shrub, 3-12 dm. high, the branches light-colored. Leaves oval, oblong or obovate, obtuse or sometimes acute at the apex, narrowed or wedge-shaped at the base, serrate with rather appressed teeth, rather thin, $2-8 \mathrm{~cm}$. long; flowers in umbels, appearing with the leaves, about $1 \mathrm{~cm}$. broad; drupe globose, 8-10 $\mathrm{mm}$. in diameter. In wet soil, or a mong rocks, N. H. to Minn., N. Car. and Wis.

13. Prunus Bésseyi Bailey. Western Sand Cherry. Bessey's Cherry. (I. F. f. 2019.) A shrub, 3-12 dm. high, the branches spreading or prostrate. Leaves elliptic, oblong or oval, the teeth appressed, the apex and base mostly acute; flowers in sessile umbels, expanding with the leaves, 8 -ro mm. broad; fruit $12-16 \mathrm{~mm}$. in diameter, on stout pedicels; bitterish and astringent, black, mottled or yellowish. Prairies, Manitoba and Minn. to Kans. and Utah. April-May.

I4. Prunus Cérasus L. Sour Cherry. Egriot. (I. F. f. 2020.) A tree. Leaves ovate or ovate-lanceolate, variously dentate, abruptly acute or acuminate, rounded at the base, very resinous when young; flowers white, $1.5-2.5 \mathrm{~cm}$. broad, in sessile, lateral, very scaly umbels, expanding with the leaves or before them; pedicels little over $3 \mathrm{~cm}$. long in flower; drupe glotose, 8-10 $\mathrm{mm}$. in diameter larger in cultivation), black or red, sour, without bloom; stone globose. In woods and thickets, N. H. and Mass. to N. Y. and Pern., escaped from cultivation. Native of Europe. April-May. Fruit June-July.

15. Prunus Àvium L. Whld or Crab Cherry. Mazard. Gean. Sweet Cherry. (I. F. f. 202 I.) A large tree. Leaves ovate, oval, or slightly obovate, abruptly short-acuminate, irregularly serate pubescent on the veins beneath, or over the entire lower surface when young; fl wers white, about $2.5 \mathrm{~cm}$. broad, in 
scaly lateral umbels, expanding with the leaves; pedicels slender, 2.5-6 cm. long in flower; drupe globose, black or dark red, sweet. In thickets and woodlands, escaped from cultivation, Ont. to Mass. and Va. Native of Europe. April-May.

r6. Prunus Pennsylvánica L. f. Wild Red Cherry. Pin or Pigeon Cherry. (I. F. f. 20 2.) A small tree. Leaves oval or lanceolate, acute or acuminate, mainly rounded at the base, glabrous, serrulate, rather slender-petioled; flowers in lateral, peduncled or sessile leafless clusters, unfolding with the leaves; pedicels slender, glabrous, $\mathbf{I}-2.5 \mathrm{~cm}$. long; drupe globose, red, 4-6 mm. in diameter, without bloom, its flesh thin and sour, its stone globular. In rocky woods, and clearings, Newf. to Ga., west to the Rocky Mts. April-June. Fruit ripe in August.

17. Prunus Mahàleb L. Mahaleb. Perfumed Cherry. (1. F. f. 2023.) A small tree or shrub. Bark pale, smooth; leaves petioled, ovate, abruptly acute at the apex, rounded or slightly cordate at the base, glabrous, denticulate, fragrant; flowers about I cm. broad, in corymbs borne on short branches of the season, unfolding with the leaves; drupe reddish-black, globose or globose-ovoid, about $8 \mathrm{~mm}$. long, the flesh thin, the stone slightly flattened. Roadsides and waste places, Conn. to Ont., N. Y., E. Penn, and Kans. Adv. from Europe. AprilMay. Fruit ripe July.

I8. Prunus Virginiàna L. Choke Cherry. (I. F. f. 2024.) A shrub, or rarely a small tree, with gray bark. Leaves thin, obovate or broadly oval, abruptly acute or acuminate at the apex, rounded at the base, glabrous, or slightly pubescent along the veins beneath, serrulate with slender teeth; flowers 8-10 $\mathrm{mm}$. broad, in mainly loosely-flowered racemes, terminating leafy branches of the season; petals suborbicular; drupe red to nearly black, rarely yellow, globose, 8ro $\mathrm{mm}$. in diameter, very ascringent; stone globular. Along river banks and in rocky situations, Newf. to Manituba, Br. Col., Ga., Neb., Tex. and Colo. AprilMay. Fruit ripe in July or August.

i9. Prunus demíssa (Nutt.) Walp. Western Wild Cherry. (I. F. f. 2025.) A shrub or small tree. Leaves similar to those of the preceding, thicker, acute or often obtusish at the apex, and with shorter teeth; flowers 8 -10 mm. broad; racemes generally dense, terminating leafy branches; drupe dark purple or black, sweet or but slightly astringent, globose, $68 \mathrm{~mm}$. in diameter; stone globular. Prairies and dry soil, Dak. to Kans., N. Mex., Br. Col. and Cal. May July.

20. Prunus serótina Ehrh. Wild Black Cherry. Cabinet or Rum Cherry. (I. F. f. 2026.) A large tree, with maximum height of about $30 \mathrm{~m}$., the bark rough and black. Leaves thick, oval, oval-lanceolate or ovate, acuminate or acute, glabrous, or pubescent along the veins beneath, serrate with appressed callous teeth; flowers similar to those of the two preceding, the racemes elongated, spreading or drooping; petals obovate; drupe globose, 8-10 $\mathrm{mm}$. in diameter; dark purple or black, sweet but slightly astringent. In woods or open places, S. Ont. to Fla., Dak., Kans. and Tex. May. Fruit ripe Aug.-Sept.

Prunus serótina Smallii Britton. I eaves firm, coriaceous, coarsely serrate, pale beneath; racemes thick, divergent, rather few-flowered; calyx and filaments pubescent. Summit of White Top Mountain, Va.

\section{AMÝGDALUS L.}

Trees or shrubs, with mostly lanceolate serrulate short-petioled leaves, and pink or white flowers solitary or clustered at the nodes of the twigs of the preceding season. Petals spreading. Stamens 20-30, distinct, the filaments filiform. Style and stigma as in Prunus. Exocarp of the fruit mostly fleshy, velvety in the following species ; endocarp (stone) bony. deeply pitted or nearly smooth, oval or oblong, pointed, more or less compressed. [Name said to be Syrian.] About 5 species, natives of Asia.

1. A mygdalus Pérsica L. PeAch. (I. F. f. 2027.) A small tree. Leaves lanceolate or oblong-lanceolate, 7-14 cm. long, glabrous, long-acuminate, usually narrowed at the base, finely serrate; petioles $2-6 \mathrm{~mm}$. long; flowers pink, $1-5 \mathrm{~cm}$. broad, scaly-bracted; drupe subglobose, grooved, softly velvety, $3-8 \mathrm{~cm}$. in diameter. Escaped from cultivation, S. N. Y. to Ga. April-May. 
Family 14. MIMOSÁCEAE Reichenb.

\section{Mimosa Family.}

Herbs, shrubs or trees, with alternate, commonly 2-3-pinnate leaves, the stipules various, and small regular mostly perfect flowers in heads, spikes or racemes. Calyx 3-6-toothed or 3-6-lobed, the teeth or lobes mostly valvate in the bud. Corolla of as many distinct or united petals, also valvate. Stamens distinct, or monadelphous. Ovary I-celled ; style simple. Fruit a legume. Seeds without endosperm; cotyledons fleshy. About 30 genera and I 350 species, mostly tropical.

Stamens numerous, at least more than 10.

I. Acacia.

Stamens only as many as the petals, or twice as many.

Petals separate; pod smooth.

Pod separating into 2 valves.

Pod leathery, indehiscent.

Petals united to about the middle; pod spiny.

2. Acuan.

3. Prosopis.

4. Morongia.

\section{x. ACÀCIA Adans.}

Shrubs or trees, with bipinnate leaves, the ultimate leaflets usually small and numerous, or the leaves in many exotic species modified into flat simple phyllodes. Flowers small, in heads or spikes. Calyx campanulate, usually 4-5-toothed, or of 4 or 5 distinct sepals. Petals mostly 4 or 5 or wanting. Stamens exserted: filaments filiform; pollen-grains cohering in 2's-6's. Pod linear, oblong or oval, flat or swollen, often constricted between the seeds. [Greek, point, or thorn, many species being thorny.] About 450 species, chiefly in subtropical regions. Besides the following, some 15 others occur in the southern U. S.

I. Acacia filicoides (Cav.) Trelease. PraIRIE AcAcia. (I. F. f. 2028.) A thornless shrub. Pinnæ of the leaves 2-I5 pairs, oblong in outline, $2-5 \mathrm{~cm}$. long; leaflets 10-15 pairs, oblong or linear-oblong, about $4 \mathrm{~mm}$. long, less than 2 $\mathrm{mm}$. wide, slightly inequilateral, I-veined; heads globose, many-flowered, axillary, slender-peduncled, $\mathbf{I}-2 \mathrm{~cm}$. in diameter; sepals distinct or nearly so; filaments yellow; pod linear, acute, stipitate, mostly stright, 2-5 cm. long, about $6 \mathrm{~mm}$. wide, flat, its valves thin, reticulated, impressed between the seeds. Prairies Mo. and Kans. to Tex., Ariz. and Mex. May-July.

\section{2. ÁCUAN Medic. [DESMANTHUS Willd.]}

Perennial herbs or shrubs, with bipinnate leaves, small stipules, and greenish or whitish small regular flowers in axillary peduncled heads or spikes. Flowers perfect, sessile, or the lowest sometimes staminate, neutral or apetalous. Calyx cam. panulate, its teeth short. Petals valvate, distinct, or slightly united or coherent below. Stamens-10 or 5, distinct, mainly exserted; anthers all alike. Ovary nearly sessile; ovules $\infty$. Pod linear, straight or curved, acute, flat, several-seeded, 2 -valved. the valves coriaceous or membranous. About ro species, natives of warm and tropical America, one widely distributed in tropical regions of the Old World.

Pods few, linear, erect, straight.

Pods numerous in globose heads, oblong, curved.
I. A. lettoloba.

2. A. Illinoensis.

I. Acuan leptóloba (T. \& G.) Kuntze. Prairie Mimosa. (I. F. f. 2029.) Stems ascending, rough-angled, 6-9 dm. long. Leaves short-petioled. bipinnate; pinnæ 5-10 pairs, sessile : leaflets $10-24$ pairs, sessile, linear-lanceolate, acute, inequilateral, rounded at the base, usually glabrous, 3-4 $\mathrm{mm}$. long, I mm. wide or less; peduncles $\mathbf{I}-2.5 \mathrm{~cm}$. long, few-flowered; stamens (always ?) 5 ; pods $3-8$, narrowly linear, acuminate, about 3 times the length of the peduncle, 6-8-seeded. Prairies, Kans. to Tex. Summer.

2 Acuan Illinoónsis (Michx.) Kuntze. Il.tnois Mriosa. (I. F. f. 20zo.) Glabrous or nearly so; stems angled, 3-9 dm. high. Foliage resembling that of the preceding. but the pinnæ and obtusish leaflets are sometimes more numerous; perluncles $2-8 \mathrm{~cm}$. long; pods numerous, densely capitate. oblong or lanceolate, strongly curved, I.5-2.5 cm. long, acute, slightly impressed between the 2-5 seeds. Prairies and river-banks, Ind, to Ky., Fla., S. Dak. and Tex, May-Sept. 


\section{PRÒSOPIS L.}

Trees or shrubs often with spines in the axils, with 2-pinnate leaves and small spicate or capitate flowers. Calyx with 5 short teeth. Petals 5 , valvate, distinct, or connate below. Stamens 10, distinct; filaments long. Ovary often stalked, many-ovuled; style slender or filiform; stigma very small. Pod linear, compressed, leathery, indehiscent, the mesocarp spongy or dry. Seeds flattened. [Ancient name for some very different plant.] About 15 species, natives of warm and tropical regions. Besides the following, 2 or 3 others occur in the southwestern U. S.

I. Prosopis glandulòsa Torr. Praikie Mesquite. (I. F. f. 2032a.) A shrub, the axils usually with a pair of sharp spines. Leaves petioled, with 2 spreading short-stalked pinnæ, each of numerous sessile pinnules; pinnules linear or linear-oblong, entire, mostly mucronulate, firm, veiny, $1-5 \mathrm{~cm}$. long, 2-4 mm. wide ; spikes axillary, peduncled, densely many-flowered, $5-13 \mathrm{~cm}$. long; calyx campanulate; petals $2-4$ times as long as the calyx; ovary villous; pods linear, stipitate, I-2 dm. long, 8-12 mm. wide, constricted between the seeds. Kans. to Tex., Ariz. and Mex. April-June.

\section{MORÓNGIA Britton. [SCHRANKIA Willd., not Medic.]}

Perennial herbs, or shrubs, mainly prostrate or procumbent, armed with recurved prickles. Leaves bipinnate, usually sensitive; leaflets numerous, small; stipules setaceous. Flowers regular, small, 4-5-parted, pink or purple, perfect or polygamous, in axillary peduncled heads or spikes. Stamens usually 8-12, distinct or united at the base; arthers all alike. Ovary nearly sessile; ovules $\infty$. Pod linear, acute or acuminate, spiny all over, at length 4-valved, several-seeded. [Named in honor of the late Rev. Thos. Morong, a contributor to this work.] About Io species, natives of warm and tropical America, 1 in tropical Africa.

Leaflets elliptic, strongly veined.

Leaflets linear-oblong, scarcely veined.

I. M. uncinata.

2. M. angustata.

I. Morongia uncinàta (Willd.) Britton. Sensitive-Brier. (I. F. f. zO3I.) Iecumbent, 6-12 dm. long. Stem, branches, petioles and peduncles thickly armed with hooked prickles I-2 mm. long; stem grooved and angled; leaves petioled; pinnæ 4-8 pairs, distant; leaflets 8 I5 pairs, obliquely elliptic, thick, obtusish and mucronate at the apex, inequilateral and rounded at the base, slightly ciliate on the margins, 4-8 mm. long; heads globose, very dense, $1.5-2.5 \mathrm{~cm}$. in diameter; flowers pink; pods terete, very densely spiny, about $5 \mathrm{~cm}$. long. In dry soil, Va. to Ill., S. Dak., Fla. and Tex. May-July.

2. Morongia angustàta (T. \& G.) Britton. Narrow-Leaved SensitiveBRIER. (I. F. f. 2032.) Similar to the preceding species. Pinnæ 3-6 pairs: leaflets numerous, thin, acutish or obtuse, not mucronate or but very slightly so, not at all reticulated, 3-6 mm. long; peduncles shorter than the leaves; heads densely flowered, $1-1.6 \mathrm{~cm}$. in diameter; flowers pink; pods linear, sparingly or densely spiny, $5^{-1} 3 \mathrm{~cm}$. long. In dry soil, Va. to Fla., Tenn. and Tex. [Mimosa microphylla Dryand. ?].

\section{Family 15. CAESALPINIÀCEAE Kl. \& Garcke.}

\section{Senna Family.}

Trees, herbs or shrubs, with alternate simple or compound mostly stipulate leaves. Flowers mostly clustered and perfect, sometimes monœcious, diœcious or polygamous, nearly regular, or irregular. Calyx mostly of 5 sepals or 5-toothed. Petals usually 5 , imbricated, and the upper (unpaired) one enclosed by the lateral ones in the bud. Stamens Io or fewer in our genera, the filaments distinct, or more or less united. Ovary I-celled, I-many-ovuled. Fruit a legume, mostly dehiscent into 2 valves. Seeds with or without endosperm. About 90 genera and 1000 species, mostly of tropical distribution.

Trees or shrubs; leaves simple; corolla irregular, apparently papilionaceous, but the lateral petals enclosing the upper one, I. Cercis, 
Herbs (all our species); flowers perfect; leaves piunate or bipinnate; corolla nearly regular.

Leaves pinnate, not punctate.

Leaves bipinnate, glandular-punctate.

Trees; leaves pinnate or bipinnate; flowers diœcious or polygamous.

Receptacle short; stamens 3-5; pod flat.

Receptacle elongated; stamens 10; pod oblong, woody.

2. Cassia.

3. Hoffmanseggia

4. Gleditsia.

5. Gymnocladus.

\section{. CÉRCIS L.}

Small trees or shrubs, with broad leaves, and pink flowers in short lateral fascicles borne on the twigs of preceding season. Calyx somewhat oblique, broadly campanulate, 5-toothed. Corolla irregular: petals 5; standard enclosed by the wings in the bud; keel larger than the wings. Stamens 10, distinct, declined; anthers all alike, versatile, longitudinally dehiscent. Ovary short-stipitate; ovules $\infty$. Pod linear-oblong or oblong, flat, margined along the upper suture, 2 -valvde at maturity, the valves thin, reticulate-veined. [Ancient name of the Old World Judas-tree]. Abrout 5 species, natives of N. A., Europe and temperate Asia.

I. Cercis Canadénsis L. RED-Bud. AMerican Judas-tree. (I. F. f. 2033.) A tree, with greatest height of about 18 m., or often shrubby. Stipules membranous, small, caducous ; leaves petioled, cordate-orbicular, blunt-pointed, rather thick, glabrous, or pubescent along the veins beneath, 5-15 cm. broad; flowers several together in sessile umbellate clusters, appearing before the leaves; pedicels slender, $8-25 \mathrm{~mm}$. long; corolla pink-purple, about $8 \mathrm{~mm}$. long; pod shortstalked in the calyx, linear-oblong, acute at each end. glabrous, 5-8 cm. long, several-seeded. In rich soil, S. Ont. to Minn., Neb., N. J., Fla. and Tex. April.

\section{CÁSSIA L.}

Herbs, shrubs, or in tropical regions trees, with evenly pinnate leaves, and mainly (in all our species) yellow flowers. Calyx-teeth nearly equal, generally longer than the tube. Corolla nearly regular; petals 5 , spreading, nearly equal, imbricated, clawed. Stamens usually ro, sometimes 5 , often unequal and some of them imperfect; anthers all alike, or those of the lower stamens larger, opening by 2 pores at the summit. Ovules $\infty$. Pod often curved. Seeds numerous. [Ancient name.] About 275 species, of wide distribution in warm and temperate regions. Besides the following, about 20 others occur in the Southern States.

Leaflets linear to oblong, numerous, 6-20 mm. long ; plants $1.5-6.5 \mathrm{dm}$. high.

Flowers 4-8 mm. broad, short-pedicelled; anthers 5 .

Flowers $2.5-4 \mathrm{~cm}$. broad, slender-pedicelled; anthers 10.22.
Leaflets ovate, oblong or obovate, $2-5 \mathrm{~cm}$. long ; plants $3-15 \mathrm{dm}$. high.

Leaflets 6 or 4 , broadly obovate.
Leaflets 8-18, oblong or ovate-lanceolate.

Perennial ; leaflets oblong, obtuse.

Annual; leaflets ovate-lanceolate, acute or acuminate.

1. C. nictitans.

2. C. Chamaecrista.

3. C. Tora.

4. C. Marylandica.

5. C. occidentalis.

I. Cassia nictitans L. Sensitive Pea. Wild Sensitive-plant. (I. F. f. 2034.) Annual, more or less pubescent, 1.5-4 dm. high. Stipules subulatelinear, persistent; leaves petioled, sensitive, bearing a small gland near the base of the petiole; leaflets $12-44$, linear-oblong, obtuse and mucronate at the apex, rounded and oblique at the base, $6-16 \mathrm{~mm}$. long, 2-3 mm. wide; flowers 2-3 together in the axils; calyx-lobes acute or acuminate: stamens 5 , all perfect; pod linear, 2.5-4 $\mathrm{cm}$. long. In dry soil, Me. to Ga., Ind., Kans. and Tex. July-Oct.

2. Cassia Chamaecrista L. Partridge Pea. Large-flowered Sensitive PEA. (I. F. f. 2035.) Annual, widely branched. Stipules subulate-linear, persistent ; leaves petioled, with a sessile gland on the petiole, sensitive; flowers $2-4$ together in the axils, showy, some of the petals often purple-spotted ; leaflets 20-30, linear-oblong or the upper lanceolate, obtuse, mucronate, oblique at the base, 8-20 mm. long, 3-4 mm. wide: calyx-lobes long-acuminate; stamens 1o, all perfect; pod linear, pubescent or glabrate, 3-6 cm. long, 4-6 mm. wide. In dry soil, Me. to S. Dak., Fla. and Tex. July-Sept.

Cassia Chamaecrista robústa Pollard. Taller; stems stouter, densely pubescent; flowers larger. Ky. to Ala. and Miss.

3. Cassia Tòra L. Low Senna. (I. F. f. 2036.) Annual, glabrous, 4-6 dm. high. Stipules linear-subulate, at length deciduous; leaves petioled, the gland 
borne between or above the lowest pair of leaflets; leatlets 2-4 parrs, thin, obovate, obtuse and mucronulate at the apex, $2-4 \mathrm{~cm}$. long; flowers $\mathrm{I}-2.5 \mathrm{~cm}$. broad, few, in short axillary racemes; calyx-lobes oblong, obtuse; stamens ro, the anthers of the upper 3 imperfect; pod linear, very slender, strongly curved, I-I. $5 \mathrm{dm}$. long, about $3 \mathrm{~mm}$. wide. Along rivers, S. Tenn. to Ind., Kans., Fla. and Mex., and throughout tropical America and the warmer parts of the Oid World. July-Oct.

4. Cassia Marylándica L. Wili) or American Senna. (I. F. f. 2037.) Perennial, glabrous or pubscent with a few scattered hairs, $0.9-2.4 \mathrm{~m}$. high, little branched. Stipules subulate-linear, caducous; leaves petioled, the gland borne near the base of the petiole; leaflets $\mathbf{1 2 - 2 0}$, oblong or linceolate-oblong, obtuse or obtusish, mucronate, rounded at the base, 2-5 cm. long; flowers $14-18 \mathrm{~mm}$. broad, numerous in axillary racemes; calyx-lobes oblong, obtuse; stamens Io, the upper 3 imperfect; porl linear, pubescent or becoming glabrous, 7-10 $\mathrm{cm}$. long, $6 \mathrm{~mm}$. wide, curved. In swamps and wet soil, N. E. to Fla., Mich., Neb. and La. July-Aug.

5. Cassia occidentàlis L. Coffee Senna. (I. F. f. 2038.) Glabrous, much branched, I. 3-2 m. high. Stipules caducous; gland borne near the base of the petiole; leaflets $8-12$, rounded at the base, 2-5 cm. long, $8-18 \mathrm{~mm}$. wide; flowers 14-18 $\mathrm{mm}$. broad, in short axillary racemes; stamens Io, the upper 3 imperfect; calyx-lobes oblong, obtuse; pod linear, glabrous, I-I.5 dm. long, about $6 \mathrm{~mm}$. wide, somewhat curved, its margins thickened. In waste places, Va. to Ind., Kans., Fla. and Mex., and throughout tropical Am. Also in the Old World. July-Aug.

\section{HOFFMANSÉGgIA Cav.}

Herbs, or low shrubs, with glandular-punctate bipinnate leaves, small stipules, and yellow flowers in racemes. Calyx deeply 5-parted, the lobes nearly equal. Petals 5, oval or oblong, imbricated. Stamens 10, distinct, slightly declined; filaments often glandular at the base; anthers all alike, longitudinally dehiscent. Ovary nearly sessile; ovules $\infty$. Pod flat, linear, oblong or ovate, curved or straight, 2-valved, several-seeded. [In honor of Joh. Centurius, Giraf Hoffmansegge, a writer on Portuguese botany.] About 20 species, natives of western Am. and S. Africa. Besides the following, some 9 others occur in the south western U. S.

Leaflets black-puntate; pod obliquely oblong.

Leaflets not punctate; pod linear-oblong.
1. H. Jamesii.

2. H. Falcaria.

I. Hoffmanseggia Jàmesii T. \& G. James' Hoffmanseggia. (I. F. f. 2039.) Herbaceous, finely pubescent, branching from a deep woody root; stems 1.5-3 dm. high. Stipules subulate; leaves petioled, bipinnate; pinnæ 5-7; leaflets 9-19, oval or oblong, obtuse at each end, inequilateral, 3-6 $\mathrm{mm}$. long; racemes elongated; flowers yellow, distant, deflexed, 6-8 $\mathrm{mm}$. long, the upper petal spotted with red; pod flat, black-punctate, about $2.5 \mathrm{~cm}$. long and $1 \mathrm{~cm}$. wide, $2-3$-seeded, tipped with the base of the style. Prairies, Kans. to Tex. and N. Mex. June-July.

2. Hoffmanseggia Falcària Cav. Sickle-fruited HoffmansegGia. (I. F. f. 2040.) Herbaceous, puberulent, the glands of the peduncles and petioles stalked; stems $3 \mathrm{dm}$. high or less. Stipules ovate; leaves slender-petioled, bipinnate; pinnæ 7-II ; leaflets $12-2 \mathrm{I}$, oblong, obtuse, 3-6 $\mathrm{mm}$. long ; racemes fewseveral-flowered; pod flat, curved or nearly straight, $2.5-4 \mathrm{~cm}$. long, about $6 \mathrm{~mm}$. wide, blunt, 8-12-seeded, the fruiting pedicels recurved. Kans. (according to Fisher) to Tex. and Cal. Also in Central and South America. April-June.

\section{GLEDITSIA L.}

Large trees, with evenly once or twice pinnate leaves, small stipules, and small greenish polygamous flowers in axillary spicate racemes. Calyx campanulate,3-5cleft. Petals 3-5, equal, sessile, inserted at the summit of the calyx-tube. Stamens 6-Io, distinct; anthers all alike, longitudinally dehiscent. Ovary rudimentary or

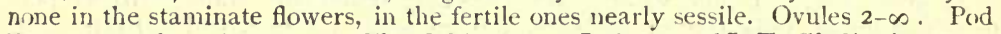
linear or oval, coriaceous, tardily dehiscent. [In honor of J. T. Gleditsch, I7 I41786, German botanist, the name often spelled Gleditschia.] About 6 species, natives of eastern N. A. and Asia. 
I. Gleditsia triacánthos L. Honey or Sweet Locust. Three-thorned ACACIA. (I. F. f. 204I.) A large tree, with rough bark, usually armed with stout branching or simple thorns. Leaves petioled, I-2-pinnate; leaflets shortstalked, oblong-lanceolate or oval, obtuse at each end, inequilateral at the base, often pubescent on the veins beneath, crenulate, $1.5-3 \mathrm{~cm}$. long; racemes droop. ing, dense, 7-13 cm. long; flowers greenish, about $4 \mathrm{~mm}$. broad; pod 3-5 dm. long, $2.5-4 \mathrm{~cm}$. wide, stalked, shining, twisted, pulpy within. In woods, W. N. Y. and Ont. to S. Dak., Ga., Kans. and Tex. Nat. and extensively planted further east. May-July.

2. Gleditsia aquática Marsh. Water or Swamp Locest. (I. F. f. 2042.) A tree, with maximum height of about $20 \mathrm{~m}$. Foliage similar to that of the preceding, but the leaflets thicker, darker green, usually larger, ovate-lanceolate or lanceolate in outline, the margins more crenulate; racemes drooping, elongated; pid glabrous, narrowed at each end, slender-stalked, $2.5-4 \mathrm{~cm}$. long, $1.8-2.5 \mathrm{~cm}$. wide, not pulpy within. In swamps, Ind. to Mo., S. Car., Fla. and La. July.

\section{GYMNÓCLADUS Lam.}

Trees, with bipinnate leaves, and showy white diœcious or polygamous flowers in terminal racemes. Calyx tubular, 5-lobed, the lobes narrow, nearly equal. Petals 5 (rarely 4), oblong or oval, nearly equal, imbricated, inserted at the top of the calyx-tube. Stamens ro, distinct, shorter than the petals and inserted with them: filaments pubescent; anthers all alike, longitudinally dehiscent. Ovary rudimentary, or none in the staminate flowers, sessile and many-ovuled in the pistillate and polygamous ones; style straight. Pod oblong, thick, large, coriaceous, flat, pulpy between the seeds, 2-valved. [Greek, naked-branch.] A monotypic genus of eastern N. A.

I. Gymnocladus dioica (L.) Koch. Kentucky Coffee-tree. (I. F. f. 2043.) A large forest tree, with rough bark. Leaves large, petioled; pinnæ 5-9; leaflets 7-I5 (or the lowest pair of pinnæ of but a single leaflet), ovate, acute or acuminate at the apex, rounded at the base, glabrous or pubescent on the veins beneath, ciliate, $2-8 \mathrm{~cm}$. long; racemes many-flowered, elongated; flowers slenderpedicelled, 16-18 mm. long; pod 1.2-2.5 dm. long, about $5 \mathrm{~cm}$. wide, the valves thick and coriaceous. Rich woods, S. Ont. to Penn., Tenn., S. Dak. and the Ind. Terr. May-June.

\section{Family 16. KRAMERIÀCEAE Dumort. Krameria Family.}

Pubescent herbs, or low shrubs, with alternate simple or digitately 3-foliolate leaves, and purple or purplish, irregular perfect flowers. Peduncles 2-bracted at or above the middle. Stipules wanting. Sepals 4 or 5, usually large, the outer one commonly wider than the others. Petals usually 5, smaller than the sepals, the 3 upper ones long-clawed, often united by their claws, or the middle one of the 3 wanting, the 2 lower ones reduced to suborbicular fleshy glands. Stamens 3 or 4 , monadelphous, at least at the base; anther-sacs opening by a terminal pore. Ovary I-celled, or partly 2-celled; ovules 2, collateral, anatropous, pendulous; style slender, acute or truncate. Fruit spiny, indehiscent, I-seeded. Seed without endosperm ; cotyledons fleshy. Only one genus, with about i 5 species, distributed from the southern. U. S. to Chile.

\section{KRAMÈRIA Loefl.}

[In honor of Johann Georg Heinrich Kramer, an Austrian physician of the last century.]

I. Krameria secundiflòra DC. Linear-leaved Krameria. (I. F. f. 2044.) A perennial herb from a thick woody root, the stems often $3 \mathrm{dm}$. long or more. Leaves linear, linear-lanceolate or linear-oblong, sessile, simple, entire, about $2.5 \mathrm{~cm}$. long, acute, tipped with a minute prickle; peduncles solitary, axil. lary, I-flowered, sometimes secund, bearing 2 leaf-like bracts just below the 
flower; flowers about $2.5 \mathrm{~cm}$. broad, the sepals purple within, pubescent without; claws of the 3 upper petals united; stamens 4; fruit globose, pubescent, very spiny, about $1.2 \mathrm{~cm}$. in diameter. Fla. to Kans., N, Mex. and Mex. April-June.

\section{Family 17. PAPILIONÀCEAE L. Pea Family.}

Herbs, shrubs, vines or trees, with alternate mostly compound stipulate leaves, and irregular (papilionaceous) perfect or sometimes polygamodiœcious flowers, mainly in spikes, heads, racemes or panicles. Calyx 4-5-toothed, or 4-5-cleft, sometimes 2-lipped. Petals more or less united, or separate, perigynous or hypogynous, usually consisting of a broad upper one (standard, banner), two lateral ones (wings), and two front ones more or less united (forming the keel); the standard encloses the wings in the bud. Stamens monadelphous, diadelphous, or sometimes separate, 10 in most of the genera, sometimes 9, rarely 5. Pistil simple, superior; ovary mainly 1 -celled, sometimes 2 -celled by the intrusion of the sutures, or several-celled by cross-partitions; style simple; ovules 1-many, anatropous or amphitropous. Fruit a legume, I-many-seeded, dehiscent into 2 valves, or indehiscent, in one tribe a loment. Seeds mostly without endosperm; cotyledons thick. About 320 genera and 5000 species, most abundant in temperate and warm regions.

\section{* The I0 stamens distinct.}

Leaves pinnate.

Leaves digitate (in ours 3 -foliolate), or simple.

Tribe I. SOPHOREAE.

Tribe 2. PODALYRIEAE.

\section{* * The stamens monadelphous or diadelphous.}

Herbs, shrubs, woody vines or trees, the leaves not tendril-bearing.

Pod not a loment, 2-valved or indehiscent.

Foliage not glandular-dotted (except in Glycyrrhiza, which has many-seeded pods).

Stanens monadelphous; anthers of 2 kinds.

Tribe 3. Genisteae.

Stamens diadelphous (except in Ononis); anthers all alike.

Leaves, in our species, 3 -foliolate, rarely 1 -foliolate.

Leaflets denticulate.

leaflets entire.

Tribe 4. TRIFOLIEAE.

Tribe 5. LOTEAE.

Leaves pinnately several-many-foliolate ( 3 -foliolate in Orophaca), very rarely $\mathrm{I}$-foliolate.

Tribe 7. GPLEGEAE.

Foliage glandular-dotted; pod indehiscent, I-2-seeded; herbs.

Pod a loment; herbs.

Tribe 6. I'SORALEAE.

Tribe 8. HEDYSAREAE.

Herbaceous vines, or herbs; leaves evenly pinnate, with tendrils.

Tribe 9. VICIEAE.

Vines, ours herbaceous, or erect herbs; leaves odd-pinnate, mostly 3 -foliolate, without tendrils.

Tribe 10. PhaseoleaE.

\section{Tribe I. SOPHOREAE.}

Our species herbs; flowers racemed.

Trees; flowers panicled.

\section{Tribe 2. PodalyrieaE.}

Ovary sessile, or nearly so; pod flat in our species.

Ovary distinctly stipitate; pod inflated.

3. Thermopsis.

4. Baptisia.

\section{Tribe 3. Genisteae.}

Herbs, with simple or $5^{-I I-f o l i o l a t e ~ l e a v e s . ~}$

Leaves simple: pod inflated.

Leaves $5^{-1} \mathrm{r}$-foliolate; pod flattened.

Shrubs, with I-3-foliolate leaves.

Calyx divided into 2 lips; leaves very prickly.

Calyx cleft into 2 lips to about the middle.

Calyx-teeth long.

Calyx-teeth short.
1. Sophora.

2. Cladrastis. 


\section{Tribe 4. TRIFOLIEAE.}

Flowers spiked, or capitate; pods curved, or coiled. Flowers in long racemes; pods coriaceous.

Flowers capitate or umbelled; pods straight, membranous.

10. Medicago.

II. Melilotus.

12. Trifolium.

\section{Tribe 5. LOTEAE.}

A single genus in our area.

\section{Tribe 6. PSORALEAE.}

Leaves digitately $3-5$-foliolate, or pinnately 3 -foliolate.

Leaves pinnately 5 -many-foliolate.

Stamens ro or 9, monadelphous, at least at the base.

Corolla of only r petal (the standard).

Corolla of 5 petals, the wings and keel united to the flament-tube.

Stamens only 5 , monadelphous.

13. Lotus.

14. Psoralea.

15. Amorpha.

16. Parosela.

17. Kuhnistera.

\section{Tribe 7. GalegeaE.}

Standard very broad, ovate or orbicular.

Herbs; leaves odd-pinnate.

Pod 4 -angled in our species.

Pod flat.

High-climbing woody vines.

Trees or shrubs.

Herbs; leaves evenly pinnate.

Standard narrow; our species all herbs.

Pod not prickly; foliage not glandular-punctate.

Keel of the corolla blunt.

Leaves pinnate, rarely $\mathrm{I}$-foliolate.

Pod not flattened, swollen, or one or both sutures intruded. Pod not much swollen, fleshy, leathery or papery.

Pod much inflated, membranous.

Pod flat, both sutures prominent externally.

Leaves 3 -foliolate.

Keel of the corolla acute.

Pod prickly; foliage glandular-punctate.
18. Indigofera.

19. Cracca.

20. Bradleya.

21. Robinia.

22. Sesban.

\section{Tribe 8. HeDysareaE.}

Leaves odd-pinnate.

Flowers purplish, umbellate.

Flowers purple or white, racemose

Flowers yellow, small.

Leaves 4 -foliolate or 2 -foliolate.

Leaves 3 -foliolate, the terminal leafiet stalked.

Flowers yellow.

Flowers purple, blue or white.

Pod of several joints; leaflets stipellate.

Pod of 1 or 2 joints; leaflets not stipellate.

23. Astragalus.

24. Phaca.

25. Homalobus.

26. Orophaca.

27. Aragallus.

28. Glycyrrhiza.

\section{Tribe 9. VicieaE.}

Style slender, with a tuft of hairs at the summit.

Style flattened, bearded along the inner side.

29. Coronilla.

30. Hedysarum.

31. Aschynomene.

33. Zornia.

32. Stylosanthes.

34. Meibomia.

35. Lespedeza.

\section{Tribe io. PhaseoleaE.}

36. Vicia.

37. Lathyrus.

Style bearded along the inner side; rachis not thickened at the insertion of the flowers ; keel of corolla not curved nor coiled. 39 . Clitoria.

Style glabrous, or slightly pubescent below; keel of corolla not curved nor coiled.

Standard spurred at the base.

Standard not spurred.

38. Bradburya.

Flowers blue, purple, purplish, or white.

Leaves odd-pinnate; leaflets 5-7.

Leaves 3 -foliolate, rarely $\mathrm{I}$-foliolate.

Calyx tubular, not bracteolate.

Caly $x$ short, bracteolate.

Flowers yellow.

41. Apios.

40. Falcata.

42. Galactia.

43. Dolicholus.

Style bearded along the inner side; rachis thickened at the insertion of the flowers.

Keel of the corolla spirally coiled; flowers racemed.

Keel strongly incurved; flowers purple, capitate.

Keel short, slightly incurved; flowers yeilowish, capitate.

44. Phaseolus.

45. Strophostyles.

46. Vigna. 


\section{ז. SOPHÒRA L.}

Leaves odd-pinnate. Flowers white, yellow or violet, in terminal racemes or panicles. Calyx generally campmulate, its teeth short. Standard obovate or orbicular; wings obliquely oblong; keel oblong, nearly straight. Stamens all dis. tinct or very nearly so; anthers versatile. Uvary short-stalked; style incurved. Pod stalked, coriaceous or fleshy, terete, constricted between the seeds, mainly indehiscent. [Name Arabic, yellow.] About 25 species, natives of warm and tropi. cal regions. Besides the following, about 5 others occur in the Southern States.

I. Sophora serícea Nutt. Silky SOPHORA. (I. F. f. 2045.) Herbaceous, woody at the base, silky or silvery pubescent, 15-30 cm. high. Stipules subulate, deciduous; leaves short petioled; leaflets 7-25, short-stalked, obovate or elliptic, obtuse or emarginate at the apex, narrowed or cuneate at the base, 6-13 mm. long; raceme peduncled, 5-10 $\mathrm{cm}$. long; flowers white, about $16 \mathrm{~mm}$. long, nearly sessile; pol dry, coriaceous, 3-5 cm. long, about $4 \mathrm{~mm}$. thick, finely pubescent, few. seeded. Prairies, Neb. and Colo. to Tex. and Ariz. April-June.

\section{CLADRÁSIIS Raf.}

Trees, with odd-pinnate leaves, no stipules nor stipels. Flowers showy, white, fragrant. in terminal panicles. Calyx-teeth 5, short, broad. Standard orbicularobovate, reflexed; wings oblong; keel incurved, obtuse, its petals distinct. Stamens Io, all distinct; filaments slender; anthers all alike, versatile. Ovary sessile or nearly so ; ovules few ; style incurved ; pod linear or lanceolate, short-stalked, flat, at length 2-valved, few-seeded. [Greek, brittle-branch.] Two known species, the following and one in Mantchuria.

I. Cladrastis lùtea (Michx.) Koch. American or Kentucky Yellow. wood. (I. F. f. 2046.) A smooth-barked tree. Foliage nearly glabrous: leaves petioled; leaflets 5-II, ovate, oval or obovate. stalked, 4-8 $\mathrm{mm}$. long, pointed or blunt-acuminate at the apex, obtuse or the terminal one cuneate at the base; panicles many-flowered, drooping, 2-5 dm. long; pedicels $1-2 \mathrm{~cm}$. long; calyx tubular-campanulate; corolla about $2 \mathrm{~mm}$ long; pod short-stalked, glabrous, $4-8 \mathrm{~mm}$. long, 8-ro mm. wide. In rich soil, Ky., Mo., Tenn. and N. Car. June.

\section{THERMÓPSIS R. Br.}

Perennial herbs, with sheathing scales at the base, alternate 3 -foliolate leaves, and large yellow or purple flowers in racemes. Stipules usually foliaceous. Calyx campanulate or short-turbinate, its lobes equal and separate, or the two upper ones united. Standard nearly orbicular, equalling the oblong wings and about equalling the keel. Stamens ro, incurved, separate. Ovary sessile or short-stipitate; ovules $\infty$; style slightly incurved; stigma terminal, small; pod sessile or shortstalked, fl it (in our species), linear or oblong, straight or curved. [Greek, Lupinelike.] About 15 species, of N. Am. and Asia. Besides the following, 5 others occur in the southern and western N. Am.

Leaflets $2.5-5 \mathrm{~cm}$. long; panicle elongated, usually long-peduncled; eastern.

Leaflets $\mathrm{I}-2.5 \mathrm{~cm}$. long; panicle short, short-peduncled; western.

I. T. mollis.

2. T. rhombifolia.

I. Thermopsis móllis (Michx.) M. A. Curtis. Alleghany Thermopsis. (I. F. f. 2047.) Erect, 6-9 dm. high, finely appressed-pubescent. Leaves petioled; leaflets oval, rhombic-elliptic or obovate, entire, nearly sessile: stipules ovate or lanceolate, shorter than the petiole; racemes mainly terminal; pedicels 4-12 mm. long, bracted at the base; flowers yellow, about $2 \mathrm{~cm}$. long: pod short-stalked, linear, slightly curved, about $10 \mathrm{~cm}$. long. Va., N. Car. and Tenn., in the mountains. July-Aug.

2. Thermopsis rhombifolia (Nutt.) Richards. Prairie Thermopsis. (I. F. f. 2048.) Erect, 2-5 dm. high, appressed silky-pubescent. Leaves petioled; leaflets oval or obovate or rhombic-elliptic, obtuse, sessile: stipules broad; racemes rather dense, few-flowered; pedicels 4-8 mm. long, bracted; flowers yellow, about $2 \mathrm{~cm}$. long; pod linear, recurved-spreading, several.seeded, stalked, $7-10 \mathrm{~cm}$. long. In sandy soil, on prairies, Kans., Neb., S. Dak. and Manitoba, west to the Rocky Mts. June-July 


\section{BAptísia Vent.}

rerennial herbs, with sheathing basal scales, 3-foliolate or sometimes sinple perfoliate leaves, and yellow, white or blue flowers in racemes. Calyx campanulate, obtuse at base, or slightly turbinate, the teeth equal and separate, or the two upper ones united. Corolla and stamens as in Thermopsis. Ovary stipitate ; pod stalked, tipped with the subulate style, inflated, the valves often coriaceous. [Greek, dyeing.] About 16 species, natives of eastern N. Am.

Flowers blue; plant glabrous.

Flowers yellow; leaves turning black in drying.

Racemes numerous, terminal ; plant glabrous.

Racemes few, lateral ; plant more or less pubescent.

I. B. australis.

wers white or cream color.

Very pubescent.

Glabrous or nearly so.

Leaflets oblong or lanceolate, green in drying.

Leaflets obovate-cuneate, black in drying.

2. B. tinctoria.

3. B. villosa.

4. B. bracteata.

5. B. alba.

6. B. leucantha.

I. Baptisia austràlis (L.) R. Br. Blue Wild or Blue False Indigo. (I. F. f. 2049.) Stout, 1-3 mm. high. Leaves short-petioled; leaflets oblanceolate or oval, obtuse, cuneate at the base, entire, $2-6 \mathrm{~cm}$. long, sessile or nearly so; stipules lanceolate, equalling the petioles, or longer, persistent; racemes terminal, erect, loosely flowered, elongated; bracts narrow, caducous; pedicels $3-5 \mathrm{~mm}$. long; flowers $2-2.5 \mathrm{~cm}$. long; pod oblong, stalked, $2-3 \mathrm{~cm}$. long. In rich soil. W. Penn. to Kans., Ga. and Ark. June--Aug. A hybrid of this with B. bracteata has been observed by Prof. A. S. Hitchcock in Kans.

2. Baptisia tinctòria (L.) R. Br. Wild Indigo. Yellow or Indigo BRoom. Horsefly-iveed. (I. F. f. 2050.) Erect, succulent, 6-I 2 dm. high. Leaves petioled; leaflets obovate or oblanceolate, $2-4 \mathrm{~cm}$. long, sessile or nearly so, obtuse, cuneate at the base, entire; stipules minute, caducous ; racemes few-flowered; bracts minute, deciduous; pedicels $2-4 \mathrm{~mm}$. long; flowers about $12 \mathrm{~mm}$. long; pods ovoid or nearly globose, 5-10 $\mathrm{mm}$. long. In dry soil, Me. to S. Ont., Minn., Fla. and La. June-Sept.

3. Baptisia villòsa (Walt.) Nutt. Hairy Wild INdigo. (I. F. f. 205I.) Erect, 6-12 dm. high. Leaves short-petioled or sessile; leaflets oblong, oval or obovate, obtusish at the apex, narrowed or cuneate at the base, 5-10 $\mathrm{cm}$. long, entire; stipules lanceolate or subulate, longer than the petioles; racemes sometimes $2.5 \mathrm{dm}$. long, many-flowered; pedicels $5-8 \mathrm{~cm}$. long; flowers about $2.5 \mathrm{~cm}$. long; bracts caducous or deciduous; pods oblong-ovoid, about $4 \mathrm{~cm}$. long, finely appressed-pubescent. In dry soil, Va. and N. Car. to Ark. June-July.

4. Baptisia bracteàta Ell. LARGE BRACTED WILD INDIGO. (I. F. f. 2052.) Bushy-branched. Leaves sessile or short-petioled; leaflets oblanceolate or spatulate, narrowed or cuneate at the base, $4-8 \mathrm{~cm}$. long, thick, reticulate-veined; stipules lanceolate or ovate, persistent ; racemes usually few, mainly lateral, sometimes $3 \mathrm{dm}$. long, reclining, many-flowered; flowers about $2.5 \mathrm{~cm}$. long, showy; pedicels slender, $\mathbf{I}-3 \mathrm{~cm}$. long, spreading, somewhat secund ; bracts large, persistent; pods ovoid, $2-5 \mathrm{~cm}$. long, pubescent, tipped with a long, at length deciduous, style. Prairies, Ill., Mich. and Minn. to La. and Tex. April-May.

5. Baptisia álba (L ) R. Br. White Wild Indigo. (I. F. f. 2053.) Divergently branching, 3-6 dm. high. Leaves petioled; petioles 5-20 mm. long; leaflets narrowed at the base, obtuse at the apex, 2-4 cm. long, 8-12 mm. wide, rather thin; stipules and bracts minute, subulate, deciduous; racemes erect, $15-25$ $\mathrm{cm}$. long, lateral, long-peduncled; pedicels 6-20 mm. long; flowers $12-14 \mathrm{~mm}$. long: pod linear-oblong, about $4 \mathrm{~cm}$. long, $7 \mathrm{~mm}$. thick, abruptly tipped with an almost filiform deciduous style. In dry soil, Mo. to S. Ind., La., N. Car. and Fla. May-June.

6. Baptisia leucántha T. \& G. Large White Wild Indigo. (I. F. f. 2054.) Succulent, 6-12 dm. high, the branches ascending. Leaves petioled; leaflets 2-5 $\mathrm{cm}$. long, $1-2 \mathrm{~cm}$. wide, very obtuse, rounded and sometimes slightly emarginate at the apex, narrowed or cuneate at the base; stipules lanceolate or linear, deciduous; racemes lateral, sometímes $3 \mathrm{dm}$. long, loosely flowered; flowers $1.5-2 \mathrm{~cm}$. long; pedicels 3-5 mm. long; pod ellipsoid, long-stalked in the calyx, about $2 \mathrm{~cm}$. long. In rich soil, Lake Erie to Minn., Ky., N. Car., Fla, and Tex. June-July. 


\section{CROTALARIA L.}

Herbs, sometimes slightly woody, with simple (or in some tropical species 3-7foliolate) leaves and racemose yellow flowers. Calyx 5-toothed, slightly 2-lipped; standard orbicular or ovate, often cordate : wings oblong or obovate; keel curved. Stamens monadelphous, their sheath deeply cleft; anthers of 2 forms, alternating with each other, the one small, versatile, the other larger; style more or less curved; pod oblong or globose, inflated, many-seeded, the seeds loose at maturity. [Greek, a rattle.] About 250 species, mainly of tropical regions. Besides the following some 7 others occur in the southern U. S.

Stem and branches erect or ascending ; leaves, at least the upper, lanceolate or oblong.

Stems prostrate, from a deep root ; leaves broadly oval.

I. C. sagittalis.

2. C. rotundifolia.

I. Crotalaria sagittàlis I. Rattre-Box. (I. F. f. 2055.) Annual, or perennial (?), villous-pubescent, rarely over $3 \mathrm{dm}$. high. Leaves simple, oval, lanceolate or oblong, rounded at the base, nearly sessile, $2-6 \mathrm{~cm}$. long, stipules persistent and united, decurrent on the stem, sagittate above, or the lower wanting ; peduncles 2-10 cm. long, 2-4-fluwered; pedicels 3-6 mm. long; flowers $8-12 \mathrm{~mm}$. long, the corolla about equalling the calyx ; pod oblong, glabrous, nearly sessile, $2.5 \mathrm{~cm}$. long, 8 -10 mm. in thickness, much inflated, nearly black at maturity; seeds shining. In dry, open places, northern N. Eng. to Fla., S. Dak., Ark. and Mex. June-Sept.

2. Crotalaria rotundifòlia (Walt.) Poir. Prostrate Rattle-box. (I. F. f. 2056.) Perennial by a deep rout, the slender branches usually prostrate. Pubescence mostly dense, brownish, appressed; leaves broadly oblong or oval, obtuse, paler beneath, I-4 cm. long; petioles 2-4 $\mathrm{mm}$. long; upper stipules sagittate : peduncles lateral, 5-15 cm. long, slender, 2-6 flowered; flowers $12-15 \mathrm{~mm}$. long; corolla little longer than the calyx; pod nearly as in the preceding. Mostly in dry soil, S. Va. to Fla. and Miss. May-Aug.

\section{LUPINUS L.}

Herbs, rarely shrubs, with digitately-compound 7-I5-foliolate (rarely simple or 3-5-foliolate) leaves, and showy flowers in terminal spikes or racemes. Calyx deeply toothed and 2-lipped. Standard orbicular or ovate, its-margins reflexed ; wings oblong or obovate; keel incurved, sometimes beaked. Stamens monadelphous, their sheath not cleft; anthers of two forms as in Crotalaria. Ovary sessile; style incurved: pot flattened, generally constricted between the seeds, the valves coriaceous. [Latin name of some pulse, from lupus, wolf.] Over roo species, mainly natives of temperate and warm regions. About 70 occur in N. Am., mainly on the western side of the continent.

Perennial ; flowers 14-18 mm. long; leaflets oblanceolate.

Corolla blue, pink or white, the standard not spotted.

Corolla blue, with a conspicuous dark spot on the standard.

Perennial : flowers 8-12 mm. long; leaflets oblong-linear.

Annual; leaflets mainly oblong ; pod 2 -seeded.

1. L. perennis.

2. L. Plattensis.

3. L. argenteus.

4. L. pusillus.

I. Lupinus perénnis L. Wild Lupine. (I. F. f. 2057.) Erect, more or less pubescent, 3-6 dm. high. Leaves slender-petioled, $5-8 \mathrm{~cm}$. broad, leaflets 7-I I (commonly about 8), sessile or nearly so, obtuse and mucronate, 2-4 cm. long, appressed-pubescent or glabrate ; raceme terminal, peduncled, $15-25 \mathrm{~cm}$. long, loosely flowered; flowers 12-15 mm. long; pod linear-oblong, pubescent, $4 \mathrm{~cm}$. long, usually 4-5-seeded, the valves coiling at dehiscence: style subulate. In dry, sandy soil, Me. and Ont. to Minn., Fla., Mo. and La. May-June. Wis.

Lupinus perénnıs occidentàlis S. Wats. Villous-pubescent all over. Mich. and

2. Lupinus Platténsis S. Wats. Nebraska Lupine. (I. F. f. 2058.) Resembles the preceding, 3-5 dm. high, villous or appressed-pubescent, the living plant with a glaucous appearance ; leaflets 7 -10, oblanceolate, spatulate or narrowly oval, $1.5-4 \mathrm{~cm}$. long, 5-10 $\mathrm{mm}$. wide; raceme terminal, I-2 dm. long, loosely flowered; corolla $12-15 \mathrm{~mm}$. long. Plaius, Neb., Wyo. and Dak. JuneJuly. 
3. Lupinus argénteus Pursh. Silvery LupiNe. (I. F. f. 2059.) Rather slirubby, bushy-branched, 3-6 dm. high, densely silky-pubescent with appressed hairs. Petioles equalling or the lower exceeding the leaves; stipules minute, subulate; leaflets sessile, narrowed at the base, $2-4 \mathrm{~cm}$. long; racemes terminal, rather dense, 5-12 cm. long; flowers purple, 7-10 $\mathrm{mm}$. dong; pod silky-pubescent, about $2.5 \mathrm{~cm}$. long, mostly 3-5-seeded. Prairies, W. Neb. and S. Dak. to Mont., N. Mex. and Ariz. July-Aug.

4. Lupinus pusíllus Pursh. Low Lupine. (I. F. f. 2060.) Annual, villouspubescent, I-2 dm. high, from a deep root, much branched near the base. Leaves petioled, 2-5 cm. wide; leaflets 5-7 (commonly 5), narrowed at the base, glabrous or nearly so above, pubescent with long scattered hairs beneath; racemes shortpeduncled or sessile, $3-8 \mathrm{~cm}$. long, densely few-flowered; pedicels $2-5 \mathrm{~cm}$. long; flowers blue, 5-7 mm. long; pod oblong, very pubescent, I2-18 mm. long; style subulate. Dry plains, Kans. to S. Dak., west to the Sierra Nevada, south to Ariz. and N. Mex. March-July.

\section{7. ÙLEX L.}

Shrubs, with stiff spine-like branches, simple, linear stiff, very prickly leaves, and large yellow solitary or racemed flowers. Calyx membranous, mostly yellow, divided nearly to its base into 2 concave lips; upper lip mostly 2 -toothed, and lower 3 -toothed; teeth short; standard ovate; wings and keel oblong, obtuse ; anthers alternately longer and shorter, the shorter versatile ; ovary sessile, several-manyovuled; style somewhat incurved, smooth ; pod ovoid, oblong or linear ; seeds strophiolate. [The ancient Latin name.] About 20 species, natives of eastern Europe.

I. Ulex Europaèus L. Furze. Gorse. Whin. (I. F. f. 206I.) Much branched, $3 \mathrm{dm} .-2 \mathrm{~m}$. ligh, more or less pubescent. Branchlets very leafy; leaves 4-I5 mm. long, the lowest sometimes lanceolate and foliaceous; flowers solitary in the axils, I2-I5 mm. long, the twigs appearing like racemes; pedicels short, bracted at the base; calyx a little shorter than the petals, minutely 2 -bracteolate; pod few-seeded, compressed, scarcely longer than the calyx. In waste places, southern N. Y. to Va. Also on Vancouver Island. Fugitive from Europe. May-July.

\section{GENISTA L.}

Low shrubs, mainly with $\mathbf{I}$-foliolate leaves, and clustered yellow flowers. Calyx 2-lipped; teeth long; standard oval or ovate; wings oblong; keel oblong, deflexed, the claws of its petals adnate to the uncleft sheath of the stamens; anthers alternately long and short; ovary sessile, several-ovuled; style incurved at the apex: pod various, flat in our species, several-seeded; seeds not strophiolate. [Celtic, gen, a small bush.] About 80 species, natives of Europe, N. Africa and W. Asia.

I. Genista tinctòria L. Dyeweed or Greenweed. Woad-waxen. Base BRoom. (I. F. f. 2062.) Sterile shoots decumbent, the flowering ones erect, stiff, 3-6 dm. high, slightly pubescent. Ieitves I-foliolate, sessile, lanceolate or ellipticlanceolate, I-4 cm. long, glabrous or with scattered hairs, acute, narrowed at the base, entire, shining; stipules none; racemes terminal, $3-5 \mathrm{~cm}$. long, few-flowered; bracts ovate-lanceolate, acute; flowers yellow, nearly sessile, about $\mathbf{I} \mathrm{cm}$. long ; calyx bracteolate at the base, its 3 lower teeth narrower than the 2 upper; pod about $2.5 \mathrm{~cm}$. long, glabrous. On dry hills, Me., Mass. and eastern N. Y. Naturalized from Europe. Summer.

\section{CÝTISUS I.}

Shrubs, with 3 -foliolate or I-foliolate leaves, and showy, clustered flowers, mainly in terminal racemes. Calyx 2-lipped, the teeth short; standard ovate or orbicular; wings oblong or obovate : keel straight or curved; anthers alternately larger and smaller; ovary sessile, many-ovuled; style incurved; pod flat, oblong or linear, several-seeded; seeds strophiolate. [From Cythrus, one of the Cyclades. About 45 species, natives of Europe, western Asia and northern Africa.

I. Cytisus scopàrius (L.) Link. Broom. (I. F. f. 2063.) Stiff, wiry, \$-1.5 m. high, nearly glabrous. Branches elongated, straight, angled; lower 
leaves petioled, 3-foliolate, the leaflets obovate, acute, or mucronate-tipped, 5-15 mm. long, entire; upper leaves sessile, often I foliolate; stipules none : flowers bright yellow, nearly $2.5 \mathrm{~cm}$. long, in elongated leafy racemes; pedicels solitary or $2-3$ together, 5-15 mm. long: pod flat, glabrous on the sides, ciliate on the margins, 3-5 cm. long; style slender. at length spirally curved. In waste places, N. S. to Va. Adv. or naturalized from Europe. Summer.

\section{Io. MEDICÀGO L.}

Herbs, with 3 -foliolate leaves, and small yellow or violet flowers in axillary heads or racemes. Leaflets commonly dentate, the veins terminating in the teeth. Calyx-teeth short, nearly equal; standard obovate or oblong; wings oblong ; keel obtuse; stamens diadelphous, the I opposite the standard separate from the other 9; anthers all alike; ovary I-several-ovuled; style subulate; pod curved or spirally twisted, reticulated or spiny, indebiscent, I-few-seeded. [Greek, Medike, from Medea, whence the Medic, or Lucerne, was derived.] About 50 species, natives of Europe, Asia and Africa.

Perennial; flowers violet, conspicuous.

Annual; flowers bright yellow, small.

Pod I-seeded, curved, not spiny.

Pod several-seeded, spiny on the edges, spirally twisted.

Pod loosely coiled, not furrowed on the edge.

Pod densely coiled, its edge furrowed.

\section{M. sativa.}

\section{M. lupulina.}

3. M. denticulata. 4. M. Arabica.

I. Medicago sativa L. Purple Medic. Alfalfa. Lucerne. (I. F. f. 2064.) Decumbent or ascending, 3-5 $\mathrm{dm}$. high, the young shoots and leaves with some scattered hairs. Leaflets oblanceolate or obovate, 4-25 $\mathrm{mm}$. long, dentate, obtuse, truncate or emarginate and often mucronate, narrowed or cuneate at the base; stipules entire; peduncles $\mathbf{I}-5 \mathrm{~cm}$. long, bearing a short raceme; petals about $5 \mathrm{~mm}$. long; pod pubescent, twisted into 2 or 3 spires. In fields and waste places, N. Eng. and Ont. to Minn., Va. and Kans. Much cultivated for fodder in the Southern and Western States. Introduced from Europe. Summer.

2. Medicago lupulina L. Black or Hop Medic. Blackseed Hop Clover. Nonesuch. (I. F. f. 2065.) Pubescent, the branches decumbent and spreading, often 3-6 dm. long; leaflets obovate, oval or nearly orbicular, sometimes 10-15 $\mathrm{mm}$. long, denticulate or crenulate, obtuse, mucronate or emarginate; stipules ovate or lanceolate, dentate; peduncles $3-8 \mathrm{~cm}$. long; head oblong or cylindric, dense, 4-20 $\mathrm{mm}$. long; flowers about $2 \mathrm{~mm}$. long; pods black when ripe, curved, strongly veined. In fields and waste places, common nearly throughout our area. Native of Europe and Asia. March-Dec.

3. Medicago denticulàta Willd. Toothed Medic. (I. F. f. 2066.) Branches spreading or ascending, glabrous or with a few appressed hairs. Leaflets obovate, rounded, emarginate or obcordate, cuneate, crenulate, $\mathbf{I}-2 \mathrm{~cm}$. long: stipules dentate; flowers few, in small, peduncled heads; pod spirally twisted, the 2 or 3 coils flat and rather loose, reticulated with elevated veins, the edges armed with $\mathbf{I}$ or 2 rows of curved prickles. In waste places and in ballast, N. S. to Penn. Also in the Southern and Western States and on the Pacific Coast. Fugitive or adventive from Europe. Summer.

4. Medicago Arábica All. Spotted Medic. (I. F. f. 2067.) Resembling the preceding species, but generally stouter. Leaflets often nearly $2.5 \mathrm{~cm}$. long, and with a dark spot or spots near the centre: pod globose, of 3 or 4 compactly wound coils, reticulate-veined on the sides, the edge thicker and furrowed between the marginal rows of curved prickles. In waste places and ballast. N. B. to Penn. Also on the Pacific Coast. Fugitive or adventive from Europe. Summer.

\section{MELILÒTUS Juss.}

Herbs, with 3 -foliolate leaves, dentate leaflets, their veins commonly ending in the teeth, and small white or yellow flowers in slender racemes. Calyx-teeth short, nearly equal; standard obovate or oblong; keel obtuse; ovary sessile or stipitate, few-ovuled; style filiform; pod ovoid or globose, straight, indehiscent or finally 2-valved: seeds solitary or few. [Greek, Honey-lotus.] About 20 species, na- 
Flowers white; standard a little longer than the wings.

Flowers yellow ; standard about equalling the wings.

r. M. alba.

2. M. officinalis.

¡. Melilotus álba Desv. White Melilot. White Sweet-clover. (I F. f. 2068.) Erect or ascending, I-3 m. high. Leaves rather distant; leaflets oblong or slightly oblanceolate, serrate, narrowed at the base, truncate, emarginate or rounded at the apex, I-2 cm. long; stipules subulate; racemes slender, $5-10 \mathrm{~cm}$. long, often I-sided; pedicels $2 \mathrm{~mm}$. long or less; pod ovoid, slightly reticulated, glabrous, $2-3.5 \mathrm{~cm}$. long. In waste places, frequent throughout our area and in the Southern States. Adventive or nat. from Europe. Leaves fragrant in drying, as in other species of the genus. June-Nov.

2. Melilotus officinàlis (L.) Lam. Yellow Melilot. Yellow SweetCLOVER. (I. F. f. 2069.) Resembling the preceding species. Leaflets oblong, oblanceolate or oval, serrate, the apex rounded, not truncate; pod about 4 $\mathrm{mm}$. long, with irregularly reticulated veins, often slightly pubescent with appressed hairs. In waste places, frequent throughout our area and in the Southern States. Adventive or nat. from Europe. Summer, blooming later than M. alba.

Melilotus Indica (L.) All, introduced on ballast about the seaports, and an exceedingly abundant weed in the Far West, may be readily distinguished from this by its much smaller yellow flowers.

Ononis rèpens L., an herb of the tribe TRIFOLIEAE, with axillary flowers, forming terminal leafy racemes, has been found as a waif in central New York. The genus is distinguished from others of the tribe by its monadelphous stamens.

\section{TRIFÒLIUM L.}

Herbs, with mostly 3-foliolate (occasionally 4-1I-foliolate) denticulate leaves, the flowers in dense heads or spikes. Stipules adnate to the petiole. Calyx-teeth nearly equal. Petals commonly persistent, their claws adnate to the stamen-tube. Stamens diadelphous, or the tenth one separate for only a portion of its length. Ovary few-ovuled. Pod often included in the calyx, membranous, indehiscent or tardily dehiscent by I suture, I-6-seeded. [Latin, referring to the 3 leaflets.] About 250 species, most abundant in the north temperate zone. Besides the following, about 50 others occur in the southern and western states.

Flowers yellow.

Head 12-18 mm. long; stipules linear; leaflets all sessile.

Head 8-12 mm. long, nearly globose; stipules ovate; termi

Head 3-20-flowered; standard scarcely striate.

Flowers red, purple, pink or white.

I. T. aureum.

al leaflet stalked.

2. T. procumbens.

3. T: dubium.

Head or spike much longer than thick; calyx silky, its teeth plumose.

Corolla crimson, equalling or exceeding the calyx-teeth. 4. 7. incarnat

Corolla whitish, shorter than the calyx-teeth.

Head globese, oval or ovoid ; calyx nearly glabrous.

Flowers sessile, or very nearly so ; heads dense, ovoid, oval or globose.

Heads sessile, or nearly so.

Heads always distinctly peduncied.

Calyx-teeth pubescent.

Plant glabrous throughout.

5. T. arvense.

6. 7. pratense.

7. T. medium.

8. T. Beckwithii.

Flowers pedicelled; heads unibel-like, globose.

Heads $2.5 \mathrm{~cm}$. in diameter or more; peduncles $2-8 \mathrm{~cm}$. long.

Prostrate; pubescent; perennial.

Ascending ; pubescent; annual or biennial.

Stonoliferous ; glabrous ; perennial.

9. 7. Virginicum.

1o. 7 . reflexum.

iा. $T$. stoloniferum.

Heads $12-18 \mathrm{~mm}$. in diameter; lower peduncles $5-20 \mathrm{~cm}$. long.

Ascending or procumbent : flowers pink, pinkish or purple.

Ascending ; calyx much shorter than the pink or nearly white corolla. 12. T. hybridum.

Procumbent ; tufted; calyx nearly equalling the purple corolla.

Creeping ; flowers white or pinkish.

13. T: Carolinianum.

I4. 7 . repens.

I. Trifolium aùreum Poll. Yellow or Hop-clover. (I. F. f. 207o.) Glabrous or slightly pubescent, annual, I.5-5 dm. high. Leaves petioled; stipules acuminate, 7-15 mm. long, adnate to the petiole for about one-half their length; leaflets all from the same point, obovate or oblong, finely denticulate, narrowed at 
the base, rounded, truncate or emarginate at the apex, 12-18 $\mathrm{mm}$. long; peduncles I-5 cm. lung; head oblong, or oval, densely many-flowered; flowers 4-6 mm. long, at length reflexed; pedicels shorter than the calyx; standard slightly emarginate, exceeding tine pod, conspicuously striate, and brown, especially when dry. Along roadsides and in waste places, N. S. to Va., Ont. and Iowa. Nat. from Eurcpe. May-Sept. [T. agrarium L., in part.] This species and the two following are sometimes referred to the genus Chrysaspis Desv.

2. Trifolium procúmbens L. Low, OR SMaller Hop-clover or HopTREFOIL. (I. F. f. 207I.) Similar to the preceding, but lower, more spreading and more pubescent. Leaflets obovate, cuneate at the base, rounded, truncate or emarginate at the apex, finely denticulate, 7-I5 mm. long, the lateral ones nearly sessile, the terminal stalked; stipules ovate, adnate to the lower part of the petiole, about $4 \mathrm{~mm}$. long; peduncles $525 \mathrm{~mm}$. long; heads $20-40$-flowered; flowers at length reflexed, about $4 \mathrm{~mm}$. long; standard dilated, not folded, exceeding the pod, brown when dry. In fields and along roadsides, frequent or occasional throughout our area and in the Southern States. Nat. from Europe. May-Sept.

3. Trifolium dùbium Sibth. LeAST HOP-ClOVER OR HOP-TREFoll. (l. F. f. 2072 .) Straggling or ascending, nearly glabrous; stems $5 \mathrm{~cm} .-5 \mathrm{dm}$. long, branch ing. Leaflets obovate, truncate or emarginate at the apex, or even obcordate, denticulate, cuneate at the base, the lateral ones nearly sessile, the terminal stalked; stipules ovate or lanceolate, adnate to the lower part of the petiole; peduncles 5-25 $\mathrm{mm}$. long; heads nearly globose, 4-6 mm. in diameter; flowers about $3 \mathrm{~mm}$. long, turning brown, at length reflexed; standard exceeding and folded over the pod. In fields and waste places, N. Eng., N. J. and in the Southern States. Also in Br. Col. Nat. from Europe. Summer. Said to be the true Shamrock.

4. Trifolium incarnàtum L. CRIMSON, OR Italian Clover. (I. F. f. 2073.) Annual, softly pubescent, little branched, 2-9 dm. high. Leaves longpetioled; stipules broad, membranous, dentate, 7-25 mm. wide; leaflets nearly sessile, obovate or obcordate, narrowed or cuneate at the base, denticulate, $12-25 \mathrm{~mm}$. long; heads terminal, oblong or ovoid, $2.5^{-6} \mathrm{~cm}$. long; flowers sessile, 7-12 mm. long; calyx hairy, calyx-lobes plumose. In fields, waste places and ballast, Me. to N. Y., N. J. and Penn. Introduced from Europe. Summer.

5. Trifolium arvénse L. RabBiT-Foot, Old-Field or Stone Clover. (I. F. f. 2074.) Annual, erect, silky-pubescent, I.5-5 dm. high. Leaves short. petioled; stipules narrow, 5-ro mm. long, subulate-tipped, entire or nearly so; leaflets linear or oblanceolate, denticulate above, obtuse and often emarginate, narrowed or cuneate at the base, 12-25 $\mathrm{mm}$. long: heads terminal, peduncled, oblong or cylindric, 12-25 mm. long, very dense; calyx very silky. In fields and waste places, common in most sections throughout our area and in the Southern States. Nat. from Europe. May-Sept.

6. Trifolium praténse L. Ren, Purple or Meadow Clover. (I. F. f. 2075.) Perennial, pubescent, I.5-6 dm. high. Leaves long-petioled; stipules ovate, strongly veined, subulate-tipped, 12-20 mm. long; leaflets short-stalked, oval, oblong or obovate, narrowed at base, hardly cuneate, obtuse and sometimes emarginate at the apex, often dark-spotted near the middle, finely denticulate, $\mathbf{I}-$ $3.5 \mathrm{~cm}$. long; heads globose or ovoid, rarely slightly peduncled, about $2.5 \mathrm{~cm}$. long; flowers red (rarely white), about $12 \mathrm{~mm}$. long, remaining erect in fruit; calyx sparingly hairy, its subulate teeth shorter than the corolla. In fields and meadows, throughout our area and in the Southern States. Nat. from Europe. April-Nov.

7. Trif lium mèdium L. Zig-zag Cloter. Cow-or Marl-grass. (I. F. f. 2076.) Resembling the preceding. Stem sometimes conspicuously zigzag. Stipules lanceolate; leaflets lanceolate or oblong, not spotted, frequently entire except for the projecting tips of the veins; corolla $12-14 \mathrm{~mm}$. long, bright purple; calyxtube nearly glabrous, the teeth slightly pubescent. In fields and waste places, Salem, Mass. Reported from N. S. and Quebec to N. Y. Adventive or nat. from Eirrope. Summer.

8. Trifolium Beckwithii Brewer. Beckwith's Clover. (I. F. f. 2077.) Perennial; stems rather stout, straight, $1.5 .5 \mathrm{dm}$. high. Basal leaves long-petioled; stipules narrow, acute, $2.5 \mathrm{~cm}$. long or less; leaflets oblong, or somewhat oblanceolate, obtuse, denticulate, 2-5 cm. long; heads long-peduncled, globose; flowers purple or purplish, 12-16 mm. long, very short-pedicelled, the lower at length re- 
flexed; calyx-teeth linear-subulate, the longer nearly equalling the tube; pod 2-6. seeded. Eastern S. Dak. to Mont. and Cal. May-June.

9. Trifolium Virgínicum Small. Prostrate Mountain Clover. (I. F. f. 2078.) Perennial by a long root, diffusely branched at the base. Leaflets linear, narrowly lanceolate or oblanceolate, $1-4 \mathrm{~cm}$. long, obtuse or cuspidate, serrate-dentate, glabrous above, more or less silky beneath, conspicuously veined; flowers whitish, crowded, the slender pediceis $2-5 \mathrm{~mm}$. long; standard emarginatemucronate, striate; calyx silky, the teeth long, subulate. W. Va. June.

Io. Trifolium refléxum L. Buffalo Clover. (I. F. f. 2079.) Annual or biennial, 2-5 dm. high. Leaves long petioled; stipules ovate-lanceolate, acuminate, foliaceous, few-toothed or entire, 1 7-25 mm. long; leaflets short-stalked, oval or obovate, cuneate at the base, obtuse or emarginate at the apex, denticulate, 12-25 mm. long; heads dense; flowers 11-13 mm. long, on slender pedicels, at length 7-1I mm. long and reflexed; standard red; wings and keel nearly white; calyx-teeth linear, shorter than the corolla; pods 3-6-seeded. In meadows, Ont., N. Y. and Penn. to Iowa, Neb., Fla. and Tex. April-Aug.

I I. Trifolium stoloníferum Muhl. Running Buffalo Clover. (I. F. f. 2080.) Branching, I.5-3 dm. long, forming 1 unners at the base. Leaves longpetioled; stipules ovate-lanceolate, acute, membranous, often $2.5 \mathrm{~cm}$. long; leaflets short-stalked, obovate or obcordate, cuneate at the base, denticulate, $2-3 \mathrm{~cm}$. long; heads nearly $2.5 \mathrm{~cm}$. in diameter; flowers white, purplish-tinged, $8-14 \mathrm{~mm}$. long; pedicels 7-9 mm. long, at length reflexed; calyx-teeth subulate, longer than the tube; pod commonly 2 -seeded. Prairies and dry woods, Ohio to Neb., Ky. and Mo. Introduced into S. Dak. May-Aug.

12. Trifolium hýbridum L. Alsike or Alsatian Clover. (I. F. f. 208r.) Perennial, 3-6 dm. high, glabrous or nearly so. Leaves long-petioled; stipules ovate-lanceolate, acuminate, membranous, 12-25 mm. long; leaflets short-stalked, obovate, sometimes emarginate but not obcordate, narrowed or cuneate at the base, serrulate, 12-25 mm. long; heads long-peduncled; flowers pink or nearly white, 7-9 mm. long; pedicels 2-5 mm. long, reflexed when old; corolla 3-4 times as long as the calyx; calyx-teeth subulate, about equalling the tube; pod 2-4-seeded. In meadows and waste places, N. S. to Idaho, Ga. and Kans. May-Oct.

I3. Trifolium Caroliniànum Michx. Carolina Clover. (I. F. f. 2082.) Perennial, pubescent, much branched, $7-20 \mathrm{~cm}$. high. Leaves slender-petioled; stipules ovate or ovate-lanceolate, foliaceous, $4-8 \mathrm{~mm}$. long, acute, few-toothed toward the apex, or entire; leaflets short-stalked, obovate, emarginate or obcordate, cuneate at the base, denticulate, 4-15 mm. long; peduncles elongated; flowers purplish, 4-7 mm. long; standard apiculate; pedicels $2-5 \mathrm{~mm}$. long. reflexed in fruit; corolla scarcely longer than the calyx; calyx-teeth subulate, longer than the tube; pod about 4-seeded. In waste places about Phila., and in fields and open places, Va. to Fla., Kans. and Tex. March-Oct.

14. Trifolium rèpens L. White, Dutch OR Honeysuckle Clover. (I. F. f. 2083.) Perennial, glabrous or with a few scattered hairs, the branches often rooting at the nodes, I-3 dm. long. Leaves long-petioled; stipules ovatelanceolate, membranous, acute, 4-12 mm. long; leaflets short-stalked, obovate, emarginate or obcordate, broadly cuneate at the base, denticulate, $8-20 \mathrm{~mm}$. long; heads long peduncled; flowers 7-12 $\mathrm{mm}$. long; pedicels $2-5 \mathrm{~mm}$. long, finally reflexed; corolla $2-3$ times as long as the calyx; calyx-teeth acuminate, somewhat shorter than the tube; pod about 4 -seeded. In fields and waste ground, common throughout our area and in the Southern States. Also in the Northwest. MayDec.

\section{LÒTUS L.}

Herbs or shrubs, with I-3-foliolate, simple or pinnate leaves, and solitary or clustered reddish yellow or white flowers. Calyx-teeth nearly equal. Petals free from the stamen-tube: standard ovate or orbicular; wings oblong or obovate; keel incurved, obtuse or beaked. Stamens diadelphous (I and 9). Ovary sessile, Iseveral-ovuled. Pod linear or oblong, 2-valved, I-several-seeded. [The Greek name of several different plants.] About 120 species, of wide distribution. Besides the following, some 40 others occur in the western U. S. 
I. Lotus corniculàtus L. Bird's-foot Trefoil. Ground Honeysuckle. BLOOM-FELL (I. F. f. 2084.) Perennial, appressed-pubescent or glabrate. Stems decumbent or ascending, $7 \mathrm{~cm} .-6 \mathrm{dm}$. long; leaves 3-foliolate, short-petioled; leaflets obovate, oblanceolate or oblong, 7-17 mm. long; stipules similar to the leaflets, often as large; peduncles sometimes $10-13 \mathrm{~cm}$. long, 3-12-flowered; calyxlobes acute, as long as the tube, or shorter; corolla bright yellow, 12-20 mm. long, or the standard reddish; pods linear, spreading, several-seeded. In waste places and on ballast, N. B. and about the seaports of the Eastern and Middle States. Adventive from Europe. June-Sept.

2. Lotus Americànus (Nutt.) Bisch. Prairie Bird's-foot Trefoll. (I. F. f. 2085.) Annual, erect, 2.5-5 dm. high. Leaves 3-foliolate, or the upper sometimes I-foliolate, sessile or the lower on petioles about $3 \mathrm{~mm}$. long: stipules minute or none; middle leaflet longer-stalked than the lateral ones, oblong, the lateral lanceolate, rounded at the base, $12-17 \mathrm{~mm}$. long; peduncles leafy-bracted at the summit, $2-2.5 \mathrm{~cm}$. long in fruit; flowers about $5 \mathrm{~mm}$. long. the standard darkerveined; keel acute; calyx-lobes linear, about twice the length of the tube; pods linear, straight, acute, glabrous, 4-7-seeded, deflexed at maturity. In dry soil, Minn. and S. Dak. to Mo., Ark., Kans., N. Mex. and Sonora. Summer.

\section{r4. PSORÀLEA L.}

Herbs or shrubs, with dark glands or pellucid dots, I-5-foliolate leaves, and purple, blue, pink or white flowers, mainly in spikes or racemes; stipules broad; calyx-lobes equal or the lower longest, or the two upper ones sometimes united; standard ovate or orbicular, clawed; wings oblong or falcate; keel incurved, obtuse; stamens monadelphous or diadelphous; ovary I-ovuled; pod ovoid, short, indehiscent, I-seeded. [Greek, scurfy, from the glandular dots, whence the name Scurfy-pea.] About I Io species, of wide distribution. In addition to the following, about 20 others occur in the western U. S.

Leaves digitately $3-5$-foliolate (leaflets all from the same point).

Plants leafy-stemmed.

Flowers small, $4-9 \mathrm{~mm}$. long.

Pods subglobose.

Leaflets narrowly oblong.

Leaflets, except those of basal leaves, filiform-linear.

Pods ovoid, or ovate.

Pods with a short, mostly abrupt beak.

Flowers few, scattered in slender elongated racemes.

Flowers numerous clustered or crowded in racemes.

3. P. tenuiflora.

Leaflets oblong-obovate.

Leaflets oblong.

Pods with slender sharp or elongated beak.

4. P. obtusiloba.

5. P. floribunda.

Leaflets linear; flowers in loose elongated racemes.

6. P. linearifolia.

Leaflets linear-lanceolate, oblong, oblanceolate or obovate; flowers spiked.

Leaflets oblanceolate or obovate; pubescence gray.

7. P. collina.

Leaflets linear-lanceolate to obovate ; pubescence silvery.

Leaflets linear to oblanceolate; caly $\mathrm{x}$ inflated in fruit.

8. P. digitata.

Leaflets oblong to obovate; calyx not inflated in fruit.

Flowers large, 13-17 mm. long, densely spicate.

9. P. argopliylla.

9. P. argopliylla.

Plants acaulescent, or nearly so, low, spreading; roots tuberous.

Leaflets oblong-cuneate.

Leaflets linear-oblong.

Leaves pinnately 3 -foliolate (the terminal leaflet stalked).

Racemes short, on peduncles about equalling the leaves.

Racemes spicate, elongated, much exceeding the leaves.

II. P. esculenta.

12. P. hypogaea.

13. P. stipulata.

Leaflets oblong-lanceolate, obtuse; pods $4 \mathrm{~mm}$. long, nearly orbicular.

14. P. pedunculata.

Leaflets ovate-lanceolate, acuminate ; pods 9-1 r mm. long, obliquely ovoid.

15. P. Onobrychis. 
I. Psoralea lanceolàta Pursh. Lance-Leaved Psoralea. (I. F. f. 2086.) Nearly glabrous, much branched, light green, 3-6 dm. high. Root not tuberous; stipules linear, 6-9 mm. long, early deciduous; leaflets 3, sessile, sometimes with a few scattered hairs, linear-oblong or oblanceolate, entire, narrowed or cuneate at the base, I 7-30 $\mathrm{mm}$. long; peduncles slender; spikes dense, short, 9-13 mm. thick, 6-Io flowered, bracts membranous, caducous; flowers bluish white, $6 \mathrm{~mm}$. long; corolla 2-3 times as long as the calyx; pod about $4 \mathrm{~mm}$. long, sparingly pubescent or glabrous, punctate; seed globose, brown. In dry soil, Kans. to S. Dak., the N. WV. Terr., Ariz., Wash. and Br. Col. June-July.

2. Psoralea micrántha A. Gray. Siall-flowered Psoralea. (I. F. f. 2087.) Assurgent, $3 \mathrm{dm}$. high or more; stems glabrous, with scattered brown glands, and often with scales at the base. Stipules setaceous; leaves crowded; leaflets 3 , linear or filiform-linear, I-5 cm. long, the basal ones oblong or cuneateoblong; peduncles about the length of the leaves; flowers about $4 \mathrm{~mm}$. long. white or bluish, in small heads or scattered in short spikes; bracts minute; calyx somewhat pubescent, glandular, the lobes about equal; pod over $6 \mathrm{~cm}$. long, glabrous, brownish with raiseil darker glands and a slender beak. Neb. to Ariz. June-Aug.

3. Psoralea te auiflòr Pursh. Few-Flowered Psoralea. (I. F. f. 2088.) Erect, finely appressed-canescent, especially when young, 6-12 dm. high. Ruot not tuberous; leaves short-petioled, 3-5-foliolate; stipules subulate, 2-4 mm. long; leaflets short-stalked, entire, oval, oblong or elliptic, I-2 cm. long, obtuse and mucronulate at the apex, narrowed or cuneate at the base; peduncles longer than the leaves; racemes 6-14 flowered; bracts scale-like, persistent; flowers purplish. $4 \mathrm{~mm}$. long; corolla about twice the length of the calyx; pod ovate, glabrous, punctate, 4-6 mm. long; seed ovoid, brown. Prairies, Ill. to S. Dak., Tex., Sonora, Colo. and Mont. May-Oct.

4. Psoralea obtusíloba T. \& G. Black-Dotted Psoralea. (I. F. f. 2089.) Erect, 3-6 dm. high; stems canescent with appressed silky white hairs. Stipules small, setaceous; petioles much shorter than the leaflets; leaves 3 -foliolate, or the basal often 4-5-foliolate; leaflets 5-35 mm. long, oblong-obovate, retuse or mucronulate, glabrous above, minutely canescent beneath; bracts small, ovate, cuspidate; calyx canescent with white silky hairs; pod ovate, about $9 \mathrm{~mm}$. long; seed compressed, obliquely ovoid. Kans. (?), Tex. to Ariz. and Mex.

5. Psoralea floribúnda Nutt. Many-flowered Psoralea. (I. F. f. 209o.) Stem 3-12 dm. high, branching, canescent, not glandular. Petioles mostly shorter than the leaflets; stipules 3-7 mm. long, subulate; leaves 3-5-(sometimes 7-) foliolate; leaflets $1-4 \mathrm{~cm}$. long, oblong, rugose, glabrous or with a few scattered hairs above, canescent with appressed white hairs beneath; peduncles $5-18 \mathrm{~cm}$. long ; spikes oblong or cylindric, the flowers about $9 \mathrm{~mm}$. long, at length interrupted and appearing as if whorled; bracts $2-3 \mathrm{~mm}$. long, lanceolate, hirsute; calyx canescent, tl:e lobes triangular, acute; pod ovoid, glabrous, light brown, covered with darker glands, its beak short, stout; seed $5 \mathrm{~mm}$. long, compressed. Ill. to Mont., Tex., Ariz. and Mex. May-Oct.

6. Psoralea linearifòlia T. \& G. NArrow-Leaved Psoralea. (I. F. f. 209r.) Erect, 3-6 dm. high. Stipules 3-7 mm. long, lanceolate or setaceous; leaves sessile or short-petioled, I-3-foliolate; leaflets II-3 I mm. long, linear, rugose, glabrous or with a few. appressed hairs; peduncles $2.5-22 \mathrm{~cm}$. long; flowers blue, loosely scattered, I-4 together on slender pedicels, 4-9 mm. long; bracts $2 \mathrm{~mm}$. long, ovate, acuminate; mature calyx $4 \mathrm{~mm}$. long, glandular, slightly pubescent; pod $9 \mathrm{~mm}$. long, narrowly ovoid or oblong, glandular, with a short stout straightish beak; seed flat, oblique, brown. Prairies, Neb. to Tex. May-Aug.

7. Psoralea collina Rydberg. Nebraska Psoralea (I. F. f. 2092.) Somewhat grayish-pubescent, 3-6 dm. high. Stipules narrow, 2-9 mm. long; leaves 3 foliolate, or sometimes 5 -folinlate; leaflets obovate or oblanceolate, mucronate, mostly glabrous above; brarts printed, $34 \mathrm{~mm}$. long; peduncles $\mathbf{I} .5-10 \mathrm{~cm}$. long; flowers about $6 \mathrm{~mm}$. long: calyx-segments linear-lanceolate, shorter than the ovate pod, the lower one a little longer than the others; pod 5-6 mm. long, tipped with a flat straight beak about $3 \mathrm{~mm}$. long. Hillsides, W. Neb. July-Aug.

8 Psoralea digitàta Nutt. Iigrtate Psoralea. (I. F. f. 2093.) Canescent with appressed hairs. 3-6 $\mathrm{lm}$. high. Petioles shorter than or sometimes a littic exceeding the leaves; stipules linear, 3-4 mm. long; peduncles often 3-5 
times as long as the leaves; leaflets 5 , or of the upper leaves 3 , short-stalked, oblong-linear or oblanceolate, 2-4 cm. long, mostly obtuse or mucronulate at the apex, narrowed or cuneate at the base; inflorescence spicate, interrupted, the blue flowers short-pedicelled or sessile in clusters of 3-5; corolla 9-II mm. long, exceeding the broad mucronate bracts; calyx lobes acute; pod ovoid, flattish, pubes. cent. Plains, S. Dak. to Kans. and Tex. June-July.

9. Psoralea argophýlla Pursh. Silver-leaf Psoralea. (I. F. f. 2094.) Densely silvery pubescent with white appressed hairs. Stem often zigzag, 3-9 dm. high; stipules narrowly linear, 6-9 $\mathrm{mm}$. long; leaflets 3-5, short-stalked, oval, oblong or obovate, obtuse and mucronate or acutish, $1.5-3 \mathrm{~cm}$. long; peduncles ex. ceeding the leaves; inflorescence spicate, interrupted, the blue flowers sessile, about $9 \mathrm{~mm}$. long, in clusters of 2-4; bracts lanceolate, slightly longer than the corolla, persistent; calyx-lobes lanceolate; pod ovate, straight-beaked. Wis. and Minn. to the N. W. Terr., Kans. and N. Mex. June-Aug.

ro. Psoralea cuspidàta Pursh. Large-Bracted Psoralea. (I. F. f. 2095.) Finely appressed-pubescent, at least above, 3-9 dm. high, from a deep tuberous thickened root. Petioles $3.5-5 \mathrm{~cm}$. long; stipules linear, acuminate, 13-17 mm. long; leaflets 5, short-stalked, broadly oblanceolate or oval, obtuse and commonly mucronate at the apex, narrowed or cuneate at the base, $2.5-5 \mathrm{~cm}$. long; spikes oblong, $3 \cdot 5-8 \mathrm{~cm}$. long; peduncles longer than the petioles; bracts lanceolate, long-cuspidate, equalling or exceeding the bluish corolla; pod oval. membranous, enclosed in the calyx. Plains, N. W. Terr. to S. Dak., Kans., Colo. and Tex. May-June.

I I. Psoralea esculénta Pursl. Pomme Blanche. Prairie Apple or TURNip. (I. F. f. 2096.) Rather stout, erect from a large farinaceous root or cluster of roots, $\mathbf{r}-5 \mathrm{dm}$. high, densely villous pubescent with whitish hairs. Lower petioles 2-4 times longer than the leaves: stipules lanceolate, $17-25 \mathrm{~mm}$. long; leaflets 5 , short-stalked, obtuse, narrowed at base, 2.5-5 cm. long; peduncles equalling or longer than the petioles; spikes oblong, dense, $3.5-8 \mathrm{~cm}$. long; bracts lanceolate or ovate, acute, II-17 mm. long, nearly equalling the bluish corolla; pod oblong, glabrous, about $5 \mathrm{~mm}$. long, slightly wrinkled, enclosed in the calyxtube. Plains, Manitoba and Dak. to Neb. and Tex. June.

12. Psoralea hypogaèa Nutt. Small Indian Bread-Root. (I. F. f. 2097.) Similar to the preceding, but smaller, nearly acaulescent, the stem hardly rising above the ground, densely pubescent with appressed whitish hairs. Petioles 2-in times as long as the leaves; stipules oblong, acutish, about $13 \mathrm{~mm}$. long; leaflets 5 sessile or nearly so, $2-3 \mathrm{~cm}$. long, often mucronate-tipped, narrowed at the base peduncles $\mathbf{I}-8 \mathrm{~cm}$. long; spikes dense, I3-25 $\mathrm{mm}$. long; bracts ovate, acute shorter than or nearly equalling the dull blue corolla; pod II $\mathrm{mm}$. long or more somewhat hirsute, slender-beaked. Plains, Neb. and Colo. to Tex. and N. Mex May-June.

13. Psoralea stipulàta T. \& G. Large-Stipuled Psoralea. (I. F. f 2098.) Sparingly pubescent or glabrous, nearly glandless ; stems 3-6 dm. long. Petioles shorter than the leaves; stipules ovate or lanceolate, about $\mathbf{I} 3 \mathrm{~mm}$. long; leaves 3-foliolate; leaflets oval or elliptic, $2-5 \mathrm{~cm}$. long, narrowed at the base, obtusish at the apex, the terminal one on a stalk 6-1 $3 \mathrm{~mm}$. long; racemes dense, $2.5 \mathrm{~cm}$. long or less; flowers purple, 9-II mm. long; bracts ovate, acute or acuminate, deciduous. In rocky places, Ohio, Ind. and Ky. June-July.

14. Psoralea pedunculàta (Mill.) Vail. Samson's Snakeroot. (I. F. f. 2099.) Erect, 3-5 dm. high, more or less pubescent and rough. Glands small and inconspicuous; leaves petioled, 3-foliolate; petioles shorter than or equalling the leaflets; stipules subulate; leaflets oblong-lanceolate, $3-8 \mathrm{~cm}$. long, entire, obtuse at each end, the apex mucronulate, the terminal one on a stalk 4-I $3 \mathrm{~mm}$. long: racemes rather loosely flowered, $5-13 \mathrm{~cm}$. long; bracts ovate-lanceolate, acuminate, deciduous, glandular; flowers purplish, about $4 \mathrm{~mm}$. long : pod wrinkled transversely. In dry soil, Kans. to Ind., N. Car., Tex. and Fla. March-July.

15. Psoralea Onóbrychis Nutt. Sainfoln Psoralea. (I. F. f. 2 Ioo.) Glabrous or slightly pubescent, I-2 m. high. Glands few and small; stipules subulate; petioles about equalling the 3 -foliolate leaves; leaflets ovate-lanceolate, 5-10 cm. long, entire, rounded or truncate at the base, acuminate at the apex, the terminal one on a stalk about $2.5 \mathrm{~cm}$. long; racemes numerous, loosely flowered, 
7-15 cm. long; peduncles equalling or shorter than the leaves ; flowers purplish ; pod 9-12 mm. long, transversely wrinkled and roughened with points. Along rivers, Mo. to Ohio, S. Ont., Ky. and S. Car. June-July.

\section{AMÓRPHA L.}

Glandular-punctate shrubs, with odd-pinnate leaves, and small violet blue or white flowers, in terminal spike-like racemes. Calyx-teeth nearly equal, or the lower ones longer; standard obovate, erect, clawed, folded around the stamens and style; wings and keel none; stamens monadelphous below; ovary 2-celled; style curved; stigma terminal; pod short, oblong, curved, nearly indehiscent, I-2 seeded. [Greek, deformed, four petals being absent.] About ro species, natives of N. Am. and Mex.

Tall shrub ; leaflets $2.5-5 \mathrm{~cm}$. long ; pod usually 2 -seeded.

Low shrubs: leaflets 9-15 mm. long; pod i-seeded.

Glabrous or nearly so ; spikes commonly solitary.

Densely canescent ; spikes commonly clustered.

I. A. fruticosa.

2. A. nana.

3. A. canescens.

I. Amorpha fruticòsa L. False or Bastard Indigo. (I. F. f. 2 Ior.) A shrub I.5-6 m. high. Leaves petioled, I.5-4 dm. long; leaflets I I-2 I, distant, short-stalked, oval or elliptic, obtuse and mucronulate, or sometimes slightly emarginate, entire; racemes dense, 7-15 cm. long; flowers 6-9 mm. long; standard violet-purple, 2-3 times as long as the calyx, emarginate; stamens exserted; pod glandular, thick-stalked, 6-9 mm. long, acute. Along streams, Ohio to Minn., Manitoba, Fla., Colo. and Chihuahua. Also escaped from cultivation in the Middle and Eastern States. May-July.

2. Amorpha nàna Nutt. Fragrant False Indigo. (I. F. f. 2102.) A low bushy shrub, seldom more than $3 \mathrm{dm}$. high. Leaves short-petioled, numerous, 3$8 \mathrm{~cm}$. long; leaflets 13-19, rigid, short-stalked, oval or oblong, rounded or emarginate and mucronate at the apex; flowers fragrant; standard purplish, about $4 \mathrm{~mm}$. long; calyx-teeth acuminate; pod short. Prairies, Iowa to Minn., Dak. and the N. WV. Terr. May.

3. Amorpha canéscens Pursh. Lead-plant. Shoe-strings. (I. F. f. 2103.) A bushy, white-canescent shrub, 3-9 dm. high. Leaves sessile or very nearly so, numerous, 5-10 $\mathrm{cm}$. long; leaflets $2 \mathrm{I}-49$, approximate, almost sessile, oval or short lanceolate, rounded or truncate at the base, less pubescent above than beneath; spikes 5-1 $8 \mathrm{~cm}$. long; calyx-teeth lanceolate; standard bright blue, nearly orbicular or obcordate, about $4 \mathrm{~mm}$. long; pod slightly exceeding the calyx. Prairies, Ind. to Minn., Manitoba, La. and Tex. Named from its leaden hue, not as indicative of lead. July-Aug.

\section{PAROSÈla Cav. [DALEA Willd, not P. Br.]}

Herbs, or sometimes shrubs, with usually glandular-punctate foliage, odd-pinnate leaves, minute stipules, and small flowers in terminal or lateral spikes. Calyxteeth nearly equal; standard cordate or auriculate, clawed; wings and keel mainly exceeding the standard, adnate by their claws to the lower part of the stamen tube; stamens 10 or 9, monadelphous; ovules 2 or 3 ; style subulate; pod included in the calyx, membranous, mostly indehiscent and I-seeded. [Anagram of Psoralea.] About 110 species, natives of America. In addition to the following some 42 others occur in the western U. S.

Spikes elongated, narrow, loosely flowered.

Foliage glabrous; corolla white ; leaflets linear.

Foliage pubescent; corolla purple or red; leaflets obovate.

Spikes oblong to ovoid, thick, densely flowered.

Foliage glabrous : corolla pink or white; leaflets $15^{-4} \mathrm{I}$.

Foliage pubescent; corolla yellow to red; leaflets 3-9.

Plant 3-6 dm. high ; calyx-teeth acuminate.

Plant not over $2.5 \mathrm{dm}$. high ; calyx-teeth aristate.

I. P. enneandra.

2. P. lanata.

3. P. Dalea.

4. P. aurea.

Spikes $1-3 \mathrm{~cm}$. long; bracts shorter than the calyx, mucronate.

5. P. nana.

Spikes $3-9 \mathrm{~cm}$. long; bracts as long as the calyx, or longer, acuminate. 
I. Parosela enneándra (Nutt.) Britton. Slender Parosela. (I. F. f. 2104.) Erect, 3-I2 dm. high, with numerous slender ascending branches. Leaflets 5-I I, linear or linear-oblong, obtusish, 2-II mm. long, narrowed at the base, nearly sessile; spikes $5^{-1} 3 \mathrm{~cm}$. long; bracts obtuse, nearly orbicular, punctate, 3 $\mathrm{mm}$. long, often mucronate; flowers 9-13 mm. long; calyx-teeth subulate, beauti. fully plumose, shorter than the corolla; standard small, cordate; keel exceeding the wings; stamens 9. Iowa to S. Dak., Colo., Miss. and Tex. June-Aug.

2. Parosela lanàta (Spreng.) Britton. Wooly Parosela. (I. F. f. 2105.) Decumbent, branching, softly and densely pubescent, 3-6 dm. long. Leaflets 9-13, obovate, obtuse, truncate or emarginate at the apex, narrowed or cuneate at the base, 9-13 mm. long. about $4 \mathrm{~mm}$. wide above; spikes short-peduncled, 2.5-10 cm. long; bracts oval or obovate, long-acuminate or mucronate, about $3 \mathrm{~mm}$. long; flowers $6 \mathrm{~mm}$. long; calyx teeth subulate, plumose; standard cordate, slightly exceeding the wings and keel; stamens 10. Plains, Kans. to Tex., Utah and N. Mex. Summer.

3. Parosela Dàlea (L.) Britton. Pink Parosela. (I. F. f. 2106.) Erect, 3-6 $\mathrm{dm}$. high. Leaflets oblanceolate or linear-oblong, obtuse at the apex, narrowed at the base, 4-6 mm. long; spikes oblong, dense, 2.5-5 cm. long, about II mm. thick, peduncled; bracts ovate or lanceolate, acuminate, deciduous, about equalling the calyx ; calyx silky-pubescent, its teeth linear-lanceolate, acuminate, plumose; corolla about $4 \mathrm{~mm}$. long; keel about equalling the wings. Prairies, Ill. to Minn., S. Dak., Tex. and Mex. Aug.-Sept.

4. Parosela aùiea (Nutt.) Britton. Golden Parosela. (I. F. f. 2107.) Erect, pubescent, 3-6 dm. high. Leaflets sessile, obovate, oblong or oblanceolate, obtuse, narrowed at the base, 9-13 mm. long: spikes solitary, short-peduncled, ovoid or oblong, dense, $2.5^{-8} \mathrm{~cm}$. long, $13-17 \mathrm{~mm}$. thick; bracts ovate, mucronate, shorter than the plumose and pubescent calyx-teeth; corolla 9-II mm. long; standard shorter than the wings and keel. Plains, S. Dak. and Neb. to Tex. Summer.

5. Parosela nàna (Torr.) Heller. Low Parosela. (I. F. f. 2107a.) Suffrutescent, silky-villous. Stems $\mathbf{I}-\mathbf{2 . 5} \mathrm{dm}$. high; leaflets 5, rarely 3,6-10 $\mathrm{mm}$. long, obovate to linear-oblong, usually minutely glandular beneath; spikes oblongovoid, I-3 cm. long, short peduncled; bracts ovate, mucronate or short-aristate, caducous; corolla somewhat longer than the setaceous aristate and plumose calyxteeth. Sand hills and prairies, Kans. to Tex. and Cal.

6. Parosela Jámesii (Torr.) Vail. James' PARosela. Prostrate or ascend. ing from a woody base, I-2 dm. high. Leaves 3-foliolate; leaflets $7 \mathbf{1} 8 \mathrm{~mm}$. long, obovate, obtuse, mucronulate, narrowed at the base, densely silky-pubescent; spikes thick, ovoid to oblong, sessile or nearly so; calyx-teeth plumose, aristate; bracts ovate-lanceolate, long-acuminate, usually longer than the calyx; standard reddish-purple; keel yellowish, exceeding the wings. Kans. and Colo. to N. Mex. May-June. [Dalea Jamesii Torr.]

\section{KUHNISTERA Lam. [PETALOSTEMON Michx.]}

Perennial glandular-punctate herbs, with long or deep roots, odd-pinnate leaves, and pink purple or white spicate or capitate flowers. Calyx-teeth nearly equal. Petals with long slender claws; standard oblong or cordate : wings and kecl-petals similar to each other. their claws adnate to the sheath of the stamen tube almost to its summit. Stamens 5, alternate with the petals. Ovary sessile, 2-ovuled; style subulate. Pod membanous, included in the calyx, I-2-seeded. [Named from the resemblance of these plants to the genus Kuhnia.] About 35 species, natives of N. Am. and Mex.

Foliage glabrous or very slightly pubescent.

Flowers white; leaflets 3-9.

Leaflets oblong, linear-oblong or oblanceolate; spikes cylindric or oblong.

Calyx villous-pubescent.

Calyx glabrous or nearly so.

r. $K$. compacta.

Stem little branched; spikes cylindric; leaflets $13^{-25} \mathrm{~mm}$. long, thin. 2. $K$. candida.

Stem much branched; spikes oblong; leaflets smaller, firm. 
Flowers pink or purple.

Leaflets 3-5 ; calyx silky-pubescent.

Bracts glabrous; leaflets mucronulate.

Bracts silky pubescent; leaflets obtuse.

Leaflets $13-31$; caly $x$ glabrous.

Foliage silky-pubescent; leaflets $9-17$.

5. $K$. purpurea.

6. $K$. tenuifolia.

7. $K$. foliosa.

8. $K$. villosa.

I. Kuhnistera compácta (Spreng.) Kuntze. Dense-flowered PrairieClover. (I. F. f. 2ro8.) Erect, 3-8 dm. high. Leaflets 5-7, short-stalked, oblong-lanceolate or linear-oblong, $13-25 \mathrm{~mm}$. long; peduncles elongated, not bracted; spikes 4-15 cm. long, about $13 \mathrm{~mm}$. thick, the rachis pubescent ; flowers about $4 \mathrm{~mm}$. long; bracts awn-pointed, longer than the calyx; wings and keel-petals oblong; standard cordate; pod pubescent, enclosed by the calyx. In dry soil, S. Dak. to Kans., Colo. and Wyo. July-Aug.

2. Kuhnistera cándida (Willd.) Kuntze. White Prairie-clover. (I. F. f. 2 ro9.) Stems 3-6 dm. high. Leaves petioled; leaflets 5-9, oblong or oblanceolate, 17-25 mm. long, often mucronulate, narrowed at the base, very short-stalked; peduncles elongated, bracted; spikes $2.5-10 \mathrm{~cm}$. long, II-I3 mm. thick; bracts awn-pointed, longer than the calyx; corolla 4-6 mm. long; wings and keel-petals oval; standard cordate; calyx-teeth and pod slightly pubescent. Prairies, Ind. to Minn., the N. W. Terr., La., Tex. and Colo. July-Aug.

3. Kuhnistera oligophýlla (Torr.) Heller. Slender White PrairieCLOVER. (I. F. f. 2 I IO.) Slender, 3-7 dm. tall, the branches ascending. Leaves short-petioled; leaflets about 7 (5-9), linear, linear-oblong or somewhat oblanceolate, firm, $2-4 \mathrm{~mm}$. wide, mostly less than $2 \mathrm{~cm}$. long, or those of the lower leaves larger; spikes oblong or short cylindric, blunt, less densely flowered than those of the preceding; bracts lanceolate, acuminate, equalling the calyx, or longer, early deciduous; calyx-teeth usually pubescent. Plains, S. Dak. to Wyo., Tex., Ariz. and Mex. June-Sept.

4. Kuhnistera multiflòra (Nutt.) Heller. Round-headed Prairie-Clover. (I. F. f. 21 II.) Erect, 3-6 dm. high. Leaves short petioled; leaflets 3-9, linear or oblanceolate, obtuse or obtusish at the apex, cuneate or narrowed at the base, shortstalked, 9-13 mm. long, 0.5-1 mm. wide, peduncles elongated; heads globose, 9-13 $\mathrm{mm}$. in diameter; bracts subulate, shorter than the calyx; calyx-teeth slightly pubescent; corolla about $4 \mathrm{~mm}$. long; wings and keel-petals ovate, oval or slightly cordate. Plains, Kans. to Tex. Summer.

5. Kuhnistera purpùrea (Vent.) MacM. Violet Prairie-clover. (I. F. f. 2112.) Glabrous or slightly pubescent, 4-9 dm. high. Leaves short-petioled; leaflets 3-5, narrowly linear, 6-19 $\mathrm{mm}$. long, narrowed at the base, very shortstalked; spikes peduncled, oblong or cylindric, $1.3-5 \mathrm{~cm}$. long, about I cm. thick; bracts obovate, mucronate, nearly glabrous, equalling the silky-pubescent•calyx, or shorter; corolla about $4 \mathrm{~mm}$. long: standard cordate; wings and keel-petals oblong. Prairies, Ind. to the N. W. Terr., Tex. and Coio. July-Aug.

6. Kuhnistera tenuifòlia (A. Gray) Kuntze. Silky Prairie-clover. (I. F. f. 2113.) More or less puhescent, erect, branching, 3-6 dm. high. Leaves short-petioled; leaflets 3-5, linear, somewhat involute, dotted with sessile glands, 6-25 mm. long, very short-stalked or sessile; peduncles terminal, elongated, bracted; spikes oblong or cylindric, $1.2-4 \mathrm{~cm}$. long, about II $\mathrm{mm}$. thick, the rachis pubescent; flowers rose-purple, about $5 \mathrm{~mm}$. long; bracts ovate, aristate, silkypubescent, slightly exceeding the very silky-pubescent calyx: standard nearly orbicular, cordate, cucullate. In dry soil, Kans. and Ark. to N. Mex. July-Aug.

7. Kuhnistera foliòsa (A. Gray) Kuntze. LeAfy Prairie-clover. (I. F. f. 2114.) Erect, branching, or sometimes simple, glabrous, 3-9 dm. high. Leaves numerous, petioled; leaflets I3-3I, close together, short-stalked, linear-oblong or slightly oblanceolate, 9-15 mm. long, acute or obtuse, mucronate at the apex, narrowed at the base; spikes terminal, long-ovoid or cylindric, $2.5-5 \mathrm{~cm}$. long, II-I3 mm. thick, densely flowered; peduncles short; bracts lanceolate, awnpointed, longer than the calyx; flowers rose purple, about $4 \mathrm{~mm}$. long; standard broad, nearly orbicular; wings and keel-petals oval; calyx-teeth finely ciliate. Along rivers, Ill. and $\mathrm{Ky}$. July-Aug.

8 Kuhnistera villòsa (Nutt.) Kuntze. Hairy Prairie-Clover. (I. F. f. 2115$.$) Ascending or decumbent, 3-6 dm. high. Leaves short-petioled or nearly$ 
sessile; leaflets 9-I7, approximate, linear-oblong or slightly oblanceolate, narrowed at the base, 6-II mm. long; spikes terminal, short-peduncled, cylindric, $2.5-8 \mathrm{~cm}$. long, II $\mathbf{I} 3 \mathrm{~mm}$. thick, dense; bracts lanceolate, acuminate, exceeding the densely villous calyx; corolla rose-purple or rarely white; standard oblong; wings and keel-petals oblong-obovate. Prairies, Wis. to Sask., Mo., Kans., and Mont. Aug.

\section{INDIGÓFERA L.}

Herbs, or rarely shrubs, often canescent with hairs affixed by the middle, with odd-pinnate leaves, small stipules, and pink or purple spicate or racemose flowers. Calyx-teeth oblique, nearly equal, or the lower longer; standard ovate or orbicular, sessile or clawed; wings oblong; keel erect, somewhat gibbous, or spurred; stamens mainly monadelphous; ovary I- $\infty$-ovuled; style slender; pod linear, 4-angled (in our species), septate between the seeds. [Name from the yield of indigo by some species.] About 250 species, natives of warm and temperate regions. In addition to the following, some 5 others occur in the southern U.S.

I. Indigofera leptosépala Nutt. WILD oR WESTERn INDIgo-Plant. (I. F. f. 2 I I6.) Perennial, decumbent, cinereous-pubescent, slender, 1.5-6 dm. long. Leaves short-petioled; leaflets 5-9, oblanceolate or oblong-linear, 6-25 $\mathrm{mm}$. long, obtuse and often mucronulate at the apex, narrowed or cuneate at the base. shortstalked; spikes peduncled, loosely few-flowered; flowers about $6 \mathrm{~mm}$. long; calyx-teeth subulate, equal; pods linear, acute, sessile, 17-25 mm. long, $2 \mathrm{~mm}$. thick, reflexed at maturity. Kans. to Tex. and Mex., east to Fla. May-Nov.

\section{Ig. CRÁCCA L. [TEPHROSIA Pers.]}

Herbs, sometimes slightly shrubby, with odd-pinnate not punctate leaves, and purple red or white flowers in racemes or short clusters. Stipules small; leaflets entire; calyx-teeth usually nearly equal ; petals all clawed; standard orbicular or broadly ovate; wings obliquely obovate or oblong; keel curved; stamens monadelphous or diadelphous; ovules several or many; pod linear, flat, 2-valved, several-seeded. [Latin, vetch.] About 120 species, mainly natives of warm and tropical regions. Besides the following, II species occur in the southern U. S.

Raceme terminal, dense, nearly sessile, many-flowered.

Peduncles lateral and terminal, elongated, few-flowered.

Villous ; flowers in an interrupted spike or raceme.

Pubescent; peduncles few-flowered near the summit.

I. C. Virginiana.

I. Cracca Virginiàna L. CAT-Gut. Goat's Rue. (I. F. f. 2117. ) Vil. lous or silky with whitish hairs, 3-6 dm. high. Roots long, fibrous, tough; leaves short-petioled; leaflets 7-25, oblong, linear-oblong or the terminal one oblanceolate, narrowed or cuneate at the base, rounded, mucronate or emarginate at the apex, 18-25 mm. long; flowers yellowish-purple, I3-19 mm. long; pedicels 4-9 mm. long; pod linear, densely pubescent, $2.5-5 \mathrm{~cm}$. long. In dry sandy soil, Me. to Minn., Fla., La. and Mex. June-July.

Cracca Virginiàna holoserícea (Nutt.) Vail. Densely woolly-pubescent; leaflets acutish. Ill. to Wis., I.a. and Ark.

2. Cracca spicàta (Walt.) Kuntze Loosely-Flowered Goat's Rue. (I. F. f. 2 I 18.) Villous-pubescent with long brown hairs, decumbent or straggling, much branched, 3-6 dm. long. Leaves few and distant, short-petioled; leaflets 9I5, short-stalked, oval, oblanceolate or narrowly obovate, obtuse and mucronate, 18-30 mm. long; peduncles slender, I-2.5 dm. long; inflorescence very loose, 5-12 cm. long; flowers purplish, I2-17 mm. long; pod linear, finely pubescent, about 5 $\mathrm{cm}$. long. In dry soil, Del. to Fla., Ala. and Miss. June-Aug.

3. Cracca hispídula (Michx.) Kuntze. Few-Flowered Goat's Rue. (I. F. f. 2I19.) More or less pubescent, procumbent or straggling, much branched, slender, 3-6 dm. long. Leaves petioled; leaflets 5-19, short stalked, oval, oblong, oblanceolate or obovate: peduncles slender, $5^{-10} \mathrm{~cm}$. long; flowers red-purple, few, about $12 \mathrm{~mm}$. long; pod linear, 2.5-4 cm. long, minutely pubescent. Dry sandy soil, Va. to Fla., west to Ala. May-Aug.

\section{BRÁ DLEYA Adans.}

High-climbing woody vines, with odd pinnate leaves, and showy blue or purplish flowers in large terminal racemes. Calyx somewhat 2-lipped, the 2 upper 
teeth slightly suurter than the 3 lower; standard large, reflexed, clawed, with 2 small appendages at the base of the blade; wings oblong, falcate, auriculate at the base; keel incurved, obtuse; stamens diadelphous; ovary stalked; ovules $\infty$; pod elongated, torulose, 2-valved, coriaceous. [Named for Richard Bradley, 16751732 Professor at Cambridge.] Five known species, the following of southeastern N. Am., the others Asiatic.

Racemes 4-ro cm. long; caly $x$-segments shorter than the tube.

I. B. frutescens. Racemes $20-30 \mathrm{~cm}$. long; caly $\mathrm{x}$-segments as long as the tube, or the lower one longer.

2. B. macrostachys.

I. Bradleya frutéscens (L.) Britton. American Wistaria. (I. F. f. 2i20.) A slender vine becoming Io m. long Leaves I-2 dm. long; leaflets 9-15, oblong to ovate or lanceolate, $\mathbf{I} \cdot 5-4 \mathrm{~cm}$. long, acute or slightly acuminate at the apex, acute or rounded at the base; racemes ovoid or oblong, 4-10 cm. long, with lanuginous rachis and pedicels; calyx pubescent with appressed hairs, 5-6 mm. long; corolla 15-18 mm. long. In low grounds, Va. to Fla. April-June. [Kraunhia frutescens Greene.]

2. Bradleya macróstachys (T. \& G.) Small. Long-Clustered Wistaria. (I. F. f. 2I20a.) A stout vine with stems often becoming $2-3 \mathrm{~cm}$. thick and $8 \mathrm{~m}$. long. Leaves 2-3 dm. long: leaflets usually 9, oval, oval-ovate to elliptic or elliptic-lanceolate, 3-7 cm. long, acuminate at the apex, rounded or cordate at the base; racemes 2-3 dm. long, narrowly conic, with densely hirsute and glandular rachis and pedicels; calyx pubescent like the pedicels, 10-12 $\mathrm{mm}$. long; corolla I 8-2 I mm. long. In and about swamps, Ind. to Kans. and La. Spring. [Kraunhia macrostachys Small.]

\section{ROBÍNIA L.}

Trees or shrubs, with odd-pinnate leaves, and axillary or terminal racemes of showy flowers. Stipules small, often spiny. Petioles slightly dilated at the base, enclosing the buds of the next year. Calyx-teeth short, broad, the 2 upper somewhat united. Standard large, reflexed, not appendaged; wings oblong, curved; keel curved, obtuse. Stamens diadelphous; anthers uniform, or the alternate ones smaller. Ovary stalked: ovules $\infty$. Pod flat, linear, not septate between the seeds, margined along the upper suture, 2-valved. [Named in honor of John and Vespasian Robin, who first cultivated the Locust-tree in Europe, I550-1629.] About 6 species, natives of N. Am. and Mex.

Twigs, petioles and pods glabrous; flowers white; a tree. Twigs and petioles glandular; pods hispid; flowers pinkish; a tree. 2. $R$. viscosa. Twigs and petioles bristly; pods hispid ; flowers pink or purple; a shrub.

3. R. hispida.

I. Robinia Pseudacàcia L. Locust-Tree. FAlse or BASTARd Acacia. Sildver-CHAIN. (I. F. f. 2I2I.) A large tree with very rough bark. Stipules often spiny; leaflets 9-19, stalked, ovate or oval, mainly rounded at the base, obtuse or emarginate and mucronulate at the apex, entire, $2.5-5 \mathrm{~cm}$. long; stipels small. setaceous; racemes loose, drooping; pedicels slender, 6-13 mm. long; flowers fragrant, 15-20 mm. long, the standard yellowish at base; pod 5-10 $\mathrm{cm}$. long. 4-7 seeded. Penn. to Ga.. Iowa and the Ind. Terr. Extensively naturalized in the Middle and Eastern States and eastern Canada. May-June.

2. Robinia viscòsa Vent. Clammy Locust. (I. F. f. 2122.) A small tree with rough bark. Stipules short, sometimes spiny; leaflets II-25, stalked, obtuse and mucronate, ovate or oval, nearly glabrous, $2.5-5 \mathrm{~cm}$. long, thicker than those of the preceding; stipels small, subulate; racemes rather dense; pedicels $4-9 \mathrm{~cm}$. long; flowers $18-25 \mathrm{~mm}$. long, not fragrant; pod 5-10 $\mathrm{cm}$. long, glandular-hispid. $\mathrm{s}$ uthwestern Va. to Ga. Occasionally escaped from cultivation in the Middle and Eastern States and in Canada. June.

3. Robinia híspida I. Rose Acacia Bristly or Moss Locust. (I. F. f. 2123.) A much-branched shrub, I-2.5 m. high. Stipules very small, or none; leaflets 9-13, stalked, broadly ovate or oblong, entire, mainly obtuse or rounded at each end, mucronate, $2.5-5 \mathrm{~cm}$. long; stipels subulate or none; racemes loose; pedicels 6-12 mm. long; flowers $17-30 \mathrm{~mm}$. long, not fragrant; pods linear, bristlyhispid Mountains of Va. and Tenn. to Ga. May-June. 
22. SÉSBAN Adans.

Herbs or shrubs, with evenly pinnate leaves, the leaflets numerous, entire, not stipcilate, or the stipels minute. Flowers in axillary racemes, the slender pedicels with 2 deciduous bractlets under the calyx. Calyx campanulate, nearly equally 5-toothed. Standard broad, ovate or orbicular; wings oblong, falcate; keel blunt. Stamens diadelphous (9 and 1). Ovary mostly stipitate, many-ovuled; style glabrous; stigma small. Pol elongated-linear, wingless, compressed, partitioned between the oblong seeds. [Name Arabic.] About I5 species, natives of warm and tropical regions, only the following known in N. Am.

1. Sesban macrocàrpa Mulıl. Long-Podded SEsban. (I. F. f. 2124.) Annual, glabrous, I-3.5 m. tall. Leaflets $10-35$ pairs, ohlong, obtuse, mucronate, thin, $2.5 \mathrm{~cm}$. long or less, pale beneath; racemes shorter than the leaves, I-5flowered; calyx-teeth subulate; corolla yellowish, purple-spotted, the standard I 7-2 I mm. long; pod $15-25 \mathrm{~mm}$. long, about $4 \mathrm{~mm}$. wide, somewhat curved, drooping. In wet or moist soil, Mo. to Tex., S. Car. and Fla., south to Central Am. Collected also in S. Penn. June-Sept.

Colutèa arboréscens L. A European shrub, with odd-pinnate leaves, yellow flowers in short racemes, and greatly inflated membranous pods, is reported escaped from cultivation in E. Mass.

\section{AStrágalus L. (See Appendix.)}

Herbs, sometimes woody, mostly with odd-pinnate or sometimes simple leaves, the flowers in spikes or racemes, or rarely umbellate or solitary. Stipules present. Calyx tubular, its teeth nearly equal. Petals clawed; standard erect, ovate or ob. long: wings oblong; keel obtuse, about equalling the wings. Stamens diadelphous; anthers all alike. Ovules $\infty$. Pod dehiscent or indehiscent, I-2-celled, very different in different species and affording the best characters in classification. [Greek name of some leguminous plant.] About rooo species, of wide geographic distribution. In addition to the following, at least 175 others occur in the western and southern U. S.

\section{* Pod 2-celled.}

Pod fleshy, thick-walled, indehiscent.

Pod glabrous, globose or oval.

Corolla purple; pod pointed.

Corolla yellowish-white; pod obtuse.

Pod pubescent, ovoid or oblong.

Pod ovoid, about $12 \mathrm{~mm}$. long, not wrinkled.

Pod oblong, curved, $2.5 \mathrm{~cm}$. long or more, wrinkled.

Pod dry, leathery, cartilaginous or papery, dehiscent.

Plant densely villous-pubescent all over.

Plants glabrous or grayish-pubescent.

Flowers yellowish; pod terete, glabrous.

Flowers purple; pod with a deep furrow, pubescent.

Pod finely appressed-pubescent.

Pod densely villous with white hairs.

I. A. crassicarpus.

2. A. Mexicanus.

3. A. Plattensis.

4. A. Tennesseensis.

5. A. mollissinus.

6. A. Carolinianus.

7. A. adsurgens.

8. A."Hypoglottis

* * Pod I-celled, but one or both sutures sometimes intruded.

Pod triangular or heart-shaped in section, membranous; flowers mostly yellowish-white.

Pod heart-shaped in section; plant woolly-pubescent.

Pod triangular in section; plant a ppressed-pubescent.

Pod 2-grooved on the upper side; flowers purple.

Pod nearly circular, or 8-shaped, in section, mostly coriaceous.

Leaflets narrowly linear, elongated, persistent; flowers yellow.

Leaflets oblong, lanceolate, oblanceolate, oval or linear, deciduous.

10. A. racemosus.

Ix. A. bisulcatus.

12. A. pectinatus.

Plants scapose, or short-stemmed, villous or silvery-pubescent.

I'lant gray-villous; flowers yellow.

Plants silvery-pubescent; flowers blue, violet or purple.

Pod nearly circular in section, straight.

Pod 8-shaped in section, its summit curved.

13. A. lotiflorus.

14. A. Missouriensis. 15. A. Shortianus.

Plants leafy-stemmed, appressed-pubescent or glabrate; flowers purple.

Pod 6-12 mm. long, wrinkled; flowers $6 \mathrm{~mm}$. long or less.

Plant erect; leaflets obtuse, very narrow.

Plant diffuse: leaflets emarginate, short-linear. 17. A. microlobus.

- d more than $12 \mathrm{~mm}$. long, smooth ; flowers $12 \mathrm{~mm}$. long. Pod not grooved, puberulent.

18. A. fiexuosus. 
Pod grooved on the lower side, glabrous.

Pod obovate in section, membranous, sessile in the calyx ; flowers purple.

Erect; raceme elongated; peduncles much exceeding the leaves.

19. A. distortus.

20. A. elegans.

Decumbent ; raceme short ; peduncles only slightly exceeding the leaves.

21. A. Bodini.

Pod flattened, grooved on the lower side, membranous, stalked.

Pod pubescent, slightly grooved, $19 \mathrm{~mm}$. long ; flowers white or purple.

22. A. Robbinsii.

Pod pubescent, deeply grooved on lower side, $12 \mathrm{~mm}$. long ; flowers violet.

23. A. alpinus.

I. Astragalus crassicàrpus Nutt. Ground Plum. (I. F. f. 2125.) Appressed-pubescent; branches decumbent or ascending, I.5-4.5 dm. long. Stipules ovate, acute, 4-6 mm. long; leaflets 15-25, oblong, elliptic or sometimes obovate, obtuse, narrowed at the base, 6-12 $\mathrm{mm}$. long; flowers violet-purple, $16-18 \mathrm{~mm}$. long, in short racemes; pods sessile, thick. shurt-pointed, 17-25 mm. in diameter. Prairies, Minn. to Manitoba, the N. W. Terr., Iowa, Colo. and Tex. Fruit edible, collected by prairie-dcgs for their winter store. April-June.

2. Astragalus Mexicànus A. IC. Larger Ground Plum. (I. F.f. 21 26.) Similar to the preceding, but less pubescent and with the hairs somewhat spreading. Leaflets $17-33$, oblong to obovate, obtuse or emarginate, narrowed at the base; flowers yellowish-white, or purplish at the tip, 18-25 $\mathrm{mm}$. long, in short racemes; pod sessile, thick, globose, $2.5-3 \mathrm{~cm}$. in diameter. Prairies, Ill. to S. Dak., Ark. and Tex. Fri it edible. May.

3. Astragalus Platténsis Nutt. Plat'te Milk Vetch. (I. F. f. 2127.) Villous-pubescent, prostrate or ascending, $1.5-2.5 \mathrm{~cm}$. high or long. Leaflets 13-29, oblong to obovate, obtuse, narrcwed at the base, 9-18 mm. long; stipules broad, ovate, pointed, 6-9 mm. long: flowers yellowish-white or tipped with purple, about $18 \mathrm{~mm}$. long, in short heads; pod sessile, pointed, smooth, loosely pubescent, nearly straight. Prairies, Ind. to Minn., S. Dak., Ala. and Tex. May.

4. Astragalus Tennesseénsis A. Gray. Tennessee Milk Vetch. (I. F. f. 2 I 28.) Villous with long whitish hairs. Leaflets I5-3I, oblong or linear-oblong, obtuse or emarginate, nearly glabrous above, 12-21 mm. long; stipules lanceolate, oval or ovate-lanceolate; racemes short, several-many flowered ; flowers about $2 \mathrm{~cm}$. long; pod strongly wrinkled, at least when dry, its summit curved. On hillsides, Tenn. to Ala. and Mo. March-May.

5. Astragalus mollíssimus Torr. Woolly Loco-weed or CRAzy-Weed. (I. F. f. 2129.) Bushy, 3-6 dm. high. Stem very short; stipules membranous, ovate, pointed, 6-1 I mm. long, adnate to the petiole; leaflets 19-27, oval, obtuse, but pointed at the apex, 9-13 mm. long; flowers violet-purple, I8-25 mm. long, in dense spikes; pod oblong. glabrous, somewhat compressed, sessile, 10-21 mm. long, about $6 \mathrm{~mm}$. thick, furrowed at both sutures, slightly curved at maturity. Plains, Neb. and Colo. to Tex. and N. Mex. June. The popular name of tle plant is from its poisonous effects on cattle.

6. Astragalus Caroliniànus L. Carolina Milk Vetch. (I. F. f. 2130.) Glabrous or slightly pubescent, 3-12 dm. high. Stipules membranous, broadly lanceolate, acuminate, 4-9 mm. long; leaflets I5-3I, elliptic or oval, obtuse or slightly emarginate at the apex, rounded at the base, $2.5-5 \mathrm{~cm}$. long; flowers $12-17$ $\mathrm{mm}$. long in dense spikes; pod sessile, coriaceous, erect, or sometimes slightly furrowed at the dorsal suture, pointed, nearly straight, 10-17 $\mathrm{mm}$. long. Along streams, Hudson Bay and Quebec to the Rocky Mts., south to Vt. W. N. Y., Ga., La. and Colo. July-Aug.

7. Astralagus adsúrgens Pall. Ascending Mrlk Vetch. (I. F. f. 213i.) Minutely cinereous-pubescent or glabrate, ascending or decumbent, I-2 dm. long. Stipules membranous, ovate, acuminate, 6-II mm. long: leaflets I5-25, oval to linear oblong, obtuse and sometimes emarginate, narrowed at the base, $16-25 \mathrm{~mm}$. long; peduncles exceeding the leaves; flowers purplish, I2-17 mm. long, in dense short spikes; pod sessile, oblong, pointed, coriaceous, erect, cordate-triangular in section, 9-I3 mm. long. Plains. Minn. to the N. W. Terr., Br. Col., Kans. and Colo. Also in northern Asia. June-July. 
8. Astragalus Hypoglóttis L. Purple Mil.K Vetch or Cock's-head. (I. F. f. 2132.) Slender, branched at the base, I.5-6 dm. long. Stipules ovate. lanceolate, acute, 4-6 mm. long; leaflets 1 7-25, oblong or elliptic, obtusish and generally emarginate at the apex, rounded at the base, $6-15 \mathrm{~mm}$. long; flowers violet-purple, I2-21 mm. long, in dense heads; pods membranous, sessile, ovoidoblong, 9-I I mm. long. Kans. to Minn., Hudson Bay, Nev. and Alaska. Also in northern Europe and Asia. May-Aug.

9. Astragalus Drummóndii Dougl. Drummond's Milk Vetch. (I. F. f. 2133.) Erect, 3-6 dm. high, rather stout. Stipules ovate, long-acuminate, 6-I I $\mathrm{mm}$. long; leaflets 19-33, oblong or sometimes oblanceolate, obtuse, narrowed at the base, II-2I mm. long; flowers yellowish-white or the keel purplish tinged, I7$19 \mathrm{~mm}$. long, in loose spikes; pod distinctly stipitate, cartilaginous, linear, pendent, glabrous, grooved, about $5 \mathrm{~cm}$. long ; calyx dark-pubescent above. Plains, Neb. to Manitoba, Wyo. and the N. W. Terr. June-July.

ro. Astragalus racemòsus Pursh. RaCemose Milk Vetch. (I. F. f. 2134.) Stem somewhat zigzag, 3-6 dm. high. Stipules ovate-lanceolate, mem-

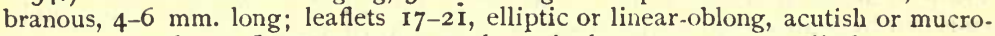
nate, $2-3 \mathrm{~cm}$. long; flowers $17-19 \mathrm{~mm}$. long, in loose racemes; pedicels $2-4 \mathrm{~mm}$. long; pods linear-oblong, imperfectly 2-celled by the intrusion of the dorsal suture, acute at cich end, glabrous, stipitate, broadly sulcate, pendent, about $2.5 \mathrm{~cm}$. long. Plains, Neb. and Kans, to the N. W. Terr. June-July.

II. Astragalus bisulcàtus (Hook.) A. Gray. Two-grooved Milk Vetch. (I. F. f. 2135.) Rather stout, 3-9 dm. high. Stipules membranous, ovate-lanceolate, acute, $9-13 \mathrm{~mm}$. long; leaflets $\mathbf{1 7 - 2 7}$, oval or oblong, obtuse, narrowed at the base, 1 7-25 $\mathrm{mm}$. long; flowers $15^{-1}$ - $\mathrm{mm}$. long, in elongated narrow racemes; peduncles longer than the leaves; pod linear, stipitate, deflexed, pointed, glabrous at maturity, membranous, $\mathrm{r}^{-21} \mathrm{~mm}$. long. Neb. and Colo. to Mont. and the N. W. Terr. June-Aug.

12. Astragalus pectinâtus (Hook.) Dougl. Narrow-Leaved Mil.k Vetch. (I. F. f. 2136.) Ascending, 3-6 dm. high, finely canescent or glabrate. Stipules membranous, ovate-lanceolate, acute or acuminate, 9-II mm. long; leaflets II-2I, narrowly linear, acute, $1.5-8 \mathrm{~cm}$. long; flowers $16-25 \mathrm{~mm}$. long, in loose spikes; standard much longer than the wings and keel; pod nearly terete, sessile, oblong, pointed, glabrous, not furrowed, keeled along the upper suture, 12-17 $\mathrm{mm}$. long. Plains, Neb. and Kans. to the N. W. Terr. June-Aug

13. Astragalus lotiflòrus Hook. Low MiLK VeTch. (I. F. f. 2137.) Silky-pubescent with white hairs; stems $\cdot 2-8 \mathrm{~cm}$. high. Stipules ovate, acuminate, 3-4 mm. long: leaflets 7-15, oval or oblong, obtuse and sometimes mucronulate, narrowed at the base, II-I7 mm. long; flowers $9-13 \mathrm{~mm}$. long, in rather dense short spikes; peduncles sometimes very short; pod sessile, villous-pubescent, ovoid-oblong, somewhat inflated, pointed, dehiscent, keeled along the straight dorsal suture. Plains, Manitoba to Neb., 'Tex., Colo. and the N. W. Terr. JuneJuly. Neb.

Astragalus lotiforus Nebraskénsis Bates. Whole plant densely hirsute. Central

14. Astragalus Missouriénsis Nutt. Missouri MiLk Vetch. (I. F. f. 2138.) Densely silky-canescent, tufted, $5-13 \mathrm{~cm}$. long. Stipules ovate-lanceolate, acute, 4-9 mm. long; leaflets 7-21, elliptic or obovate, obtuse but sometimes mucronate, 6-I I mm. long; flowers few, violet-purple, II-I9 $\mathrm{mm}$. long in loose heads or short spikes; pod sessile, acute, oblong. pubescent, dehiscent, slightly keeled along the ventral suture, transversely wrinkled, about $2.5 \mathrm{~cm}$. long. Plains, Neb. to the N. W. Terr., south to N. Mex. May-July.

15. Astragalus Shortiànus Nutt. SHORT's Milk Vetch. (I. F. f. 2139.) Silvery canescent. Stipules ovate, acutish, about $4 \mathrm{~mm}$. long: leaflets 9-15, elliptic or obovate, acutish, II-I9 mm. long: flowers blue or violet, $15^{-19} \mathrm{~mm}$. long; pod sessile, dehiscent at maturity, lanceolate-ovoid, puberulent, transversely wrinkled, strongly curved at the summit, $2.5-4 \mathrm{~cm}$. long. Plains, Neb. and Colo. to N. Mex. May-July.

16. Astragalus grácilis Nutt. Slender Milk Vetch. (I. F. f. 2140. Slender, finely pubescent, 3-6 dm. high. Stipules ovate. acute or acuminate, 
4-6 mm. long; leaflets II-2 I, narrowly linear, distant, obtuse; flowers purple, 6-8 $\mathrm{mm}$. long, in narrow elongated racemes; pods sessile, pendent, straight, ellipsoid, appressed-pubescent with white hairs, especially on the ventral side, transversely veined, 4-6 mm. long. Prairies, Minn. to S. Dak., Mo., Colo. and Wyo. May-June.

I7. Astragalus micrólobus A. Gray. Notched-leaved Milk Vetch. (I. F. f. 214I.) Finely canescent, about 3 dm. high. Stipules ovate-lanceolate, acute, 3-4 mm. long; leaflets 7-17, linear or linear-oblong, truncate or emarginate, narrowed at the base, 9-15 mm. long; flowers in loose spikes; peduncles often longer than the leaves; pod sessile, ovoid or ellipsoid, reflexed, finely pubescent, transversely veined, flattened on the back, keeled along the ventral suture, 4-6 mm. long. Plains, Neb. to Mo. and Colo. Similar to A. gracilis. Summer.

18. Astragalus flexuòsus (Hook.) Dougl. Flexile Milk Vetch. . (I. F. f. 2142.) Finely pubescent, 3-5 dm. high. Stipules ovate or ovate-lanceolate, 4-6 mm. long; leaflets 9-2 I, linear, oblong or oblanceolate, obtuse or emarginate, narrowed or cuneate at the base, 6-12 mm. long; peduncles exceeding the leaves; flowers purplish, 9-I I mm. long; pod sessile, cylindric, linear or linear-oblong, dehis.ent, pointed, I6-25 mm. long. Plains, Minn. and Neb. to Colo. and the N. W. Terr. June-Aug.

I (1. Astragalus distórtus T. \& G. Bent Milk Vetch. (I. F. f. 2I 43.) Sparingly pubescent or glabrate, diffuse or ascending; stems 2-4 dm. long. Leaflets II-25, obovate or oval, emarginate or rounded at the apex, narrowed at the base, . -I I mm. long; flowers in loose short spikes; pod sessile, slightly inflated, linear oblong, coriaceous, strongly curved, $2.5-4 \mathrm{~cm}$. long. In dry soil, Ill. to Iowa, Kans., IV. Va., Miss. and Tex. March-July.

20. Astragalus élegans (Hook.) Britton. Pretry Milk Vetch. (I. F. f. 2 I44.) Glabrous or finely strigose, erect or ascending, 2.5-5 dm. high. Stipules ovate, acute, about $4 \mathrm{~mm}$. long; flowers $6-8 \mathrm{~mm}$. long, in elongated racemes; leaflets 917 , oblong or linear-oblong, r6-20 mm. long; pod ellipsoid, pendent, slightly inflated, obtuse at each end, apiculate, black-pubescent all over, $5-8 \mathrm{~mm}$. long. Quebec, Lab., the Saskatch. region and in the higher and northern Rocky Mts. June-Aug.

21. Astragalus Bódini Sheldon. Bodin's Milk Veтch. Finely strigose ; stems 3-IO dm. long. Stipules ovate, acute; flowers 8-10 mm. long in dense racemes; calyx sparingly black-strigose; leaflets II -15 , oval, $8-15 \mathrm{~mm}$. long, acute at both ends; pod ellipsoid, somewhat flattened on the dorsal side, finely black-strigose, obtuse, 7-10 mm. long. River valleys, from W. Neb. to Wyo. and Colo. JuneAug.

22. Astragalus Robbínsii (Oakes) A. Gray. Robbins' Milk Vetch. (I. F. f. 2146.) Glabrous or nearly so, erect, slender, 2.5-4.5 dm. high. Stipules ovateoblong, membranous, 4-6 mm. long; leaflets 9-25, oblong, obtuse or slightly emarginate, 9-17 mm. long; flowers 6-II $\mathrm{mm}$. long in loose racemes; pod much flattened, oblong, short-stipitate, rather abruptly pointed at each end, membranous, finely blackish-pubescent, dehiscent, nearly straight, $18-25 \mathrm{~mm}$. long. In rocky places, Vt. and N. H. June-July.

23. Astragalus alpinus L. Alpine Milk Vetch. (I. F. f. 2147.) Ascending or decumbent, $\mathbf{1 . 5}-4 \mathrm{dm}$. high, slightly pubescent, or glabrous. Stipules ovate, foliaceous, 4-6 mm. long; leaflets $13-25$, oval or elliptic, obtuse or retuse, 6-12 min. long; flowers violet, the keel commonly darker, in short racemes; peduncles mostly exceeding the leaves; pod membranous, stipitate, pendent, dehis. cent. rather densely black-pubescent, oblong, acute, somewhat inflated, about I3 mm. long; calyx dark-pubescent. On rocks, N. N. Eng. to Newf. and Lab., west to Alaska and Br. Col., south in the Rocky Mts. to Colo. Also in northern Europe and Asia. June.

\section{PHÀCA L.}

Perennial herbs, similar to Astragalus, mostly with pinnate leaves, and racemed or spicate purplish or purple flowers. Pod much inflated, membranous in texture, strictly I-celled, neither of the sutures intruded. [Greek, Lentils.] A large genus, mainly of the north temperate zone. Besides the following, numerous other species occur in the western parts of N. Am. 
Leaflets 7-21, oblong, elliptic or ovate ; flowers white.

Pod stalked; flowers slender-pedicelled.

Pod sessile; flowers short-pedicelled.

Leaflet only $\mathrm{I}$, or sometimes $3-5$, very narrowly linear; flowers pink. 3. P. longifolia.

I. Phaca Americàna (Hook.) Rydberg. ArCtic Milk Vetch. (I. F. f. 2 I48.) Erect, nearly simple, glabrous, 3-6 dm. high. Stipules foliaceous, ovateoblong, 4-12 mm. long; leaflets 7-I 7, 2-4 cm. long; peduncles generally exceeding the leaves; flowers $16-19 \mathrm{~mm}$. long, in loose racemes; pedicels filiform, $13 \mathrm{~mm}$. long in fruit; pod stipitate, 2 I-25 mm. long, acute at each end, oblong, dehiscent at maturity, glabrous, shining. In wet rocky places, Quebec and arctic Am. to Br. Col. and Alaska, south in the Rocky Mts. to Colo. Junt-July.

2. Phaca neglécta T. \& G. Cooper's Milk Vetch. (I. F. f. 2149.) Glabrous or nearly so, 3-6 dm. high. Stipules ovate, acute, 2-4 mm. long; leaflets 9-21, thin, oblong or elliptic, often minutely pubescent beneath, $16-25 \mathrm{~mm}$. long, obtuse or emarginate, narrowed at the base; flowers II-15 mm. long, in loose spikes; calyx pubescent with blackish hairs, its teeth subulate; pod sessile, the ventral suture somewhat intruded, ovoid, acute, glabrous, slightly furrowed along both sutures, 13-20 mm. long. On banks and shores, Quebec to Minn. and Iowa. June-July.

3. Phaca longifòlia (Pursh) Nutt. Long Leaved Milk Vetch. (I. F. f. 2 150.) Erect, slender, finely canescent, 1.5-4.5 dm. high. Stipules subulate, rigid, those of the lower part of the stem connate; leaflet usually I, nearly terete, 2.5 -IO $\mathrm{cm}$. long, sometimes 3 or 5 ; flowers few, 6-I I mm. long, in short loose racemes; peduncles shorter than the leaves; pod short-stalked, spotted, glabrous, ovoid, short-pointed, not furrowed, about $2.5 \mathrm{~cm}$. long. In sandy soil, Neb. to Kans. and N. Mex. Leaves persistent. May-June.

\section{HOMÁLOBUS Nutt.}

Perennial herbs, with pinnate simple or pinnately 3-5 foliolate leaves, and racemose mostly small flowers, the peduncles short or elongated. Keel of the corolla obtuse; pod flat, glabrous or pubescent, completely I celled, few-several-seeded, the sutures both prominent externally. [Greek, regular-lobes.] Besides the following species, some 30 others occur in western N. Am.

Plants leafy-stemmed.

Leaves pinnate; leaflets 9-23, thin.

Finely pubescent, blackening in drying; pod straight.

Canescent, not blackening: pod slightly curved.

Leaves pinnate ; leaflets $3-7$, rigid, very narrow, spiny. 3 . H. mon
Plant scapose ; leaves simple or pinnately $3-5$-foliolate, the leaflets very narrow.

4. H. caespitosus.

I. Homalobus tenéllus (Pursh) Britton. Loose-flowered Milk Vetch. (I. F. f. 2 I5I.) Finely pubescent or glabrate, 2.5-4.5 dm. high. Stipules broadly ovate, 3-6 mm. long, the upper ones connate; leaflets oblong, linear.oblong or ob. lanceolate, obtuse, narrowed at the base, $13-21 \mathrm{~mm}$. long: flowers yellowish-white, 6-9 mm. long, in loose spike-like racemes; pod stalked, straight, oblong, acute at each end, papery, glabrous, I3-17 mm. long. Iry soil, S. Dak., Neb. and Colo. to Cal., the N. W. Terr. and Br. Col. May-Aug.

2. Homalobus aboriginum (Richards.) Rydberg. Indian Milk Vetch. (I. F. f. 2I 45.) Finely canescent, 2-5 dm. high. Stipules ovate, acute, 4-6 mm. long; leaflets 9-13, linear or oblong, I 2-2 I mm. long: flowers 9-I I $\mathrm{mm}$. long, in rather loose racemes; peduncles longer than the leaves; pod compressed, oval in section, half-elliptic, long-stipitate, acute at each end; calyx blackish-pubescent, its teeth subulate. S. Dak. to Manitoba, the N. W. Terr. and Colo. [Astragalus aboriginum Richards.] May-June.

3. Homalobus montànus (Nutt.) Britton. Prickly Milk Vetch. (I. F. f. 2152.) Densely tufted, intricately branched, $5-25 \mathrm{~cm}$. high, finely canescent. Stipules linear-lanceolate, spiny-tipped, 4-I I $\mathrm{mm}$. long; leaflets linear, widely spreading, 6-13 mm. long: flowers I-4 together in the axils, nearly sessile, yellowish white or bluish-tinged, 4-6 mm. long; pod sessile or short-stalked, I-3-seeded, ovoid-oblong, acute, coriaceous, dehiscent, pubescent, 6-9 mm. long. In dry, rocky places, Neb. to N. Mex., Nev. and the N. W. Terr. June-Sept. 
7. Homalobus caespitòsus Nutt. Tufted MrLk Vetch. (I. F. f. 2153.) silvery-canescent, tufted from a deep root, 7-15 cm. high. Stipules scarious, imbricated, lanceolate, acuminate, 8-12 $\mathrm{mm}$. long: leaves simple, spatulate-linear, 2.5-5 cm. long, or some of them 3-5-foliolate, with oblong-linear leaflets; peduncles scapiform; flowers purple, 9-II $\mathrm{mm}$. long, in short spike-like racemes; pod erect, sessile, few-seeded, oblong, acute, coriaceous, slightly curved, pubescent, 9-I I mm. long; calyx-teeth subulate. In dry rocky soil, Neb. and Colo. to the N. W. Terr. May-July. [Astragalus caespitosus A. Gray.]

26. ORÓPHACA Britton. (See Appendix.)

Perennial, silvery or villous-pubescent low tufted herbs, with branched woody caudices, deep roots, membranous scarious stipules, sheathing and united be'ow, and digitately 3 -foliolate (rarely 5 -foliolate) leaves, resembling those of Lupines. Flowers few, capitate or racemose, the clusters sessile or peduncled. Keel of the corolla blunt. Pod coriaceous, completely $\mathrm{x}$-celled, ovoid or oval, few seeded, villous, partly or wholly enclosed by the calyx. [Greek, mountain vetch ] Three known species, the following, and one in Colo. and Wyo.

Flowers yellowish, 1-3 together in the axils.

Flowers blue-purple, in peduncled racemes.

I. O. caespitosa.

2. O. sericea.

r. Orophaca caespitòsa (Nutt.) Britton. Sessile-flowered Milk Vetch. (I. F. f. 2 I 54.) Silvery-canescent, 5-10 cm. high. Stipu'es imbricated, glabrous, ovate-lanceolate, 6-9 $\mathrm{mm}$. long; leaves digitately 3-5 fuliolate, slender-petioled; leaflets oblong or oblanceolate, narrowed or cuneate at the base, 13-17 mm. long; flowers $13-17 \mathrm{~mm}$. long, sessile; pod sessile, ovoid, acute or acuminate, coriaceous, dehiscent, enclosed by the calyx, 4-6 mm. long. Plains, Kans to S. Dak., Mont. and the N. W. Terr. May-July. [A stragalus triphyllus Pursh.)

2. Orophaca serícea (Nutt.) Britton. HOARy Milk VeTch. (I. F. f. 2155.) Villous-pubescent, spreading on the ground, the stems 8-10 $\mathrm{cm}$. long. Leaves short-petioled, 3-foliolate; leaflets oblong or oblanceolate, narrowed or cuneate at the base, 4-II mm. long: peduncles 2-6-flowered; flowers about $6 \mathrm{~mm}$. long; pod sessile, ovoid-oblong, coriaceous, acute, about $6 \mathrm{~mm}$. long, partly enclosed by the calyx. In dry, sandy or rocky places, Neb. and Colo. May-July.

\section{ARAGÁllus Neck. [SPiesia Neck.]}

Herbs, sometimes shrubby, and mostly acaulescent, with odd-pinnate leaves, and racemose or spicate flowers. Calyx-teeth nearly equal. Petals clawed; standard erect, ovate or oblong; wings oblong; keel erect, shorter than or equalling the wings, its apex mucronate, acuminate or appendaged; stamens diadelphous; style filiform. Pod sessile or stipitate, 2-valved, I-celled, or more or less 2-celled by the intrusion of the ventral suture. About 120 species of the north temperate zone. In addition to the following, some II others occur in western N. Am.

Leaves simply pinnate.

Plants 2.5-10 cm. high; heads few-flowered.

Pods membranous, pubescent, much inflated, r-celled.

Pod coriaceous, ovoid, little inflated, pubescent, partly 2-celled.

Calyx gray-pubescent ; leaflets $7-9$, oblong.

Calyx dark-pubescent; leaflets $7-2 \mathrm{I}$, linear.
Plants r.5-4.5 dm. high; heads or spike-like racemes many-flowered.

Flowers 1 7-19 mm. long; pods papery.

Calyx black-hirsute; pod about $1 \mathrm{~cm}$. long.

Calyx finely pubescent; pod $15-20 \mathrm{~mm}$. long.

Flowers 19-30 mm. long; pods coriaceous.

Leaflets linear or linear-lanceolate, slightly silky.

Leaflets oblong or broadly lanceolate, densely silky.

Leaves pinnate, the leaflets verticillate.

Pod scarcely longer than the calyx, its tip spreading.

Pod 2-3 times as long as the calyx, its tip erect.

r. A. inflatus.

2. A. multiceps.

3. A. arcticus.

r. Aragallus inflàtus (Hook.) A. Nelson. Inflated Oxytrope. (I. F. f. 2I56.) Acaulescent or nearly so, villous pubescent, much tufted, 2-10 cm. high. Stipules membranous, imbricated, adnate to the petiole, lanceolate, about $4 \mathrm{~mm}$. long; leaflets 9-2I, linear, 4-8 $\mathrm{mm}$. long, about I $\mathrm{mm}$. wide, obtuse or obtusish; 
peduncles 1-2-flowered, scarcely exceeding the leaves: flowers violet, 14-17 $\mathrm{mm}$. long; calyx densely dark-pubescent; pod I-celled, ovoid, short-stalked or sessile, about $18 \mathrm{~mm}$. long, pointed; ventral-suture slightly intruded. Lab. and arctic Am., south in the Rocky Mts. to Colo. Summer. [Spiesia infata (Hook.) Britton.]

2. Aragallus múlticeps (Nutt.) Heller. Tufted Oxytrope. (I. F. f. 2157.) Nearly acaulescent, tufted and matted, silky.canescent, $8 \mathrm{~cm}$. high or less. Stipules membranous, acute, adnate to the petiole; leaflets oblong, 6-12 mm. long, 2-4 mm. wide; scape I-3.flowered; flowers purple, nearly $2.5 \mathrm{~cm}$. long; calyx slightly pubescent, its teeth short; pod short-stalked, coriaceous, about I $3 \mathrm{~mm}$. long, acute, enclosed by the swollen calyx. W. Neb., Wyo. and Colo. Summer. [Spiesia multiceps (Nutt.) Kuntze.]

3. Aragallus àrcticus (R. Br.) Greene. Arctic Oxytrope. (I. F.f. 21 58. ) Acaulescent, tufted, villous-pubescent, $2-\mathbf{I} \mathrm{cm}$. high. Stipules membranous, lanceolate, imbricated, pubescent: leaflets linear or linear-oblong, obtusish, 4-6 mm. long; peduncles exceeding the leaves, 2-5-flowered; flowers violet (?), I3-2I mm. long; pod coriaceous, little inflated, oblong or ovoid-oblong, sessile, pubescent. Shores of the Gulf of St. Lawrence, Hudson Strait, and along the Arctic seacoast. Summer. [Spiesia arctica (R. Br.) Kuntze.]

4. Aragallus campéstris (L.) Greene. Yellow Oxytrope. (I. F. f. 2159.) Acaulescent or nearly so, much tufted, sparingly pubescent or glabrate, I-3 dm. high. Stipules membranous, lanceolate, acuminate, imbricated, 6-9 mm. long; leaves 8-15 cm. long; leaflets $13-23$, linear-lanceolate or oblong, rounded at the base, sessile, 8-13 mm. long; peduncles generally exceeding the leaves ; flowers several or numerous in short spikes, white, yellowish-white or blue; pods sessile, ovoid or oblong, blackish-pubescent, acuminate with the subulate style. In rocky places, Lab. and Hudson Strait. Also in Europe. Summer. All American specimens belong to the var. carulea, with bluish flowers. [Spiesia campestris (L.) Kuntze.]

5: Aragallus Johannénsis (Fernald) Rydberg. St. John's Oxytrope. Like the preceding, but larger, I.5-3.5 dm. high, sparingly silky, especially the large scarious stipules; leaves 2-3 dm. long; leaflets $17-27$, oblong or lanceolate, $2-3 \mathrm{~cm}$. long; spike of about 12 rose-colored flowers, elongated, especially in fruit; pod sessile, cylindric, acute, sparingly white-silky; dorsal suture less intruded than in A. campestris. Gravelly beaches of St. John and other rivers of Me., N. B. and Quebec. June-July. [Oxytropis campestris var. Fohannensis Fernald.]

6. Aragallus Lámbertii (Pursh) Greene. STemless Loco-weed or CRAzYwEED. Colorado Loco-vetch. (I. F. f. 2160.) Sparingly silky-pubescent, acaulescent or nearly so. Stipules imbricated, membranous, pubescent, lanceolate, acute or acuminate, 9-15 mm. long: leaves 10-23 cm. long; leaflets 9-19, 17-19 mm. long; peduncles longer than the leaves; flowers purple or purplish, seldom yellowish, in dense heads; pod incompletely 2-celled, sessile, erect, ovoidcylindric, densely pubescent, long-acuminate, I $3-2 \mathbf{I} \mathrm{mm}$. long, exceeding the calyx. Plains, Minn. to the N. W. Terr., Br. Col., Tex. and N. Mex. AprilAug. [Spiesia Lambertii (Pursh) Kuntze.]

7. Aragallus seríceus (Nutt.) Greene. Silvery Loco-weEd. Densely silky throughout, stout, acaulescent. Stipules membranous, very silky, broadly ov.ue, I-2 cm. long; leaflets 9-17, 15-30 mm. long and 5-10 mm. wide; peduncles sturt; bracts ovate, acuminate; flowers pink purple; pod as in A. Lambertii, but larger and densely silky. W. Neb. to Utah, Ore. and Saskatch. June-Aug. [Spiesia Lambertii sericea (Nutt.) Rydberg.]

8. Aragallus spléndens (Dougl.) Greene. Showy Oxytrope. (I. F. f. 2I6r.) Densely silvery and silky-villous, acaulescent. Stipules imbricated, membranous, villous-pubescent, lanceolate, acute, 9-13 mm. long ; leaves I-2.5 dm. long, erect; leaflets numerous, in verticils of 3-6, oblong or oblong-lanceolate, acute or acutish, 13-21 mm. long: peduncles exceeding the leaves, sometimes $3 \mathrm{dm}$. long; flowers deєp purple, about $12 \mathrm{~mm}$. long, in dense spikes; pods ovoid, erect, 2-celled or nearly so, long acuminate with a spreading or oblique tip, villouspubescent, I3-19 mm. long. Plains, Minn. and Manitoba to the N. W. Terr., Colo. and N. Mex. June-Aug. [Spiesia splendens (Dougl.) Kuntze.)

9. Aragallus Béllii (Britton) Greene. (I. F. f. 2162.) Acaulescent, loosely 
villous with white hairs. Stipules membranous, ovate or oblong, acute or acuminate, imbricated, I I-I5 mm. long; leaves 7-I5 cm. long; leaflets oblong or oblong. lanceolate, subacute, rounded at the base, 6-9 $\mathrm{mm}$. long, in verticils of 3 or 4; peduncles about equalling the leaves; inforescence capitate; calyx black-pubescent; pod oblong, erect-spreading, densely pubescent with black hairs or some longer whitish ones intermixed, about $19 \mathrm{~mm}$. long, very nearly or quite 2-celled by the intrusion of the ventral suture, the tip erect. Hudson Bay. Summer. [Spiesia Bellii Britton.]

\section{GLYCYRRHìZA L.}

Perennial herbs, with thick sweet roots, odd pinnate leaves, and spicate or capitate flowers. Calyx-teeth nearly equal. Standard narrowly ovate or oblong, short.clawed; wings oblong, acutish; keel acute or obtuse, shorter than the wings. Stamens mainly diadelphous; anthers alternately smaller and larger. Pod sessile, covered with prickles or glands, nearly indehiscent, continuous between the seeds. [Greek, sweet-root.] About 15 species, natives of the north temperate zone, southern S. Am. and Australia. The following is the only N. Am. species.

I. Giycyrrhiza lepidòta Pursh. WILd Liquorice. (I. F. f. 2i63.) Erect, 3-9 dm. high, the foliage with minute scales or dots. Stipules lanceolate or ovatelanceolate, acute, $2-3 \mathrm{~mm}$. long, deciduous; leaves petioled; leaflets II-I9, lanceolate or oblong, entire, very short-stalked, $2-3.5 \mathrm{~cm}$. long; peduncles axillary, shorter than the leaves; spikes many-flowered $2.5-5 \mathrm{~cm}$. long; flowers yellowishwhite, $13 \mathrm{~mm}$. long; calyx-teeth slender, longer than the tube; pod about $13 \mathrm{~mm}$. long, few-seeded, oblong. Fort Erie, Ont.; Hudson Bay to Manitoba and Minn., Wash., Iowa, Mo., Chihuahua and Cal. May-Aug.

\section{CORONÍLLA L.}

Herbs, with odd.pinnate leaves, and purple purplish or yellow flowers, in peduncled heads or umbels. Calyx-teeth nearly equal, the 2 upper more or less united. Petals clawed: standard nearly orbicular; wings oblong or obliquely obovate; keel incurved, beaked. Stamens diadelphous (9 and I); anthers all alike. Pod jointed. [Diminutive of corona, crown.] About 25 species, natives of Europe, Asia and northern Africa.

I. Coronilla vària L. Coronilla. Axseed. Axwort. (I. F. f. 2i64.) Perennial, straggling or ascending, glabrous, 3-6 din. long. Leaves sessile; leaflets II-25, oblong or obovate, obtuse and mucronate at the apex, I3-I9 mm. long; peduncles longer than the leaves: flowers 9-13 $\mathrm{mm}$. long, in dense umbels; standard pink; wings white or purple-tipped; pod coriaceous, linear, 4-angled, the joints 6-9 mm. long. Roadsides and waste places, Mass. to N. Y. and N. J. Adventive or nat. from Europe. June-Aug.

\section{HEDÝSARUM L.}

Perennial herbs, with odd-pinnate leaves, and showy flowers in axillary peduncled racemes. Calyx bracteolate, its teeth nearly equal. Standard ovate or obcordate, narrowed at the base; wings oblong, shorter than the standard; keel longer than the wings, obtuse, obliquely truncate. Stamens diadelphous ( 9 and $\mathbf{I})$. Pod flat, linear, its joints oval, orbicular or quadrate. [Greek, sweet-broom.] About 60 species, natives of the north temperate zone and northern Africa. Besides the following, another occurs in northwestern N. Am.

Calyx-teeth ovate, acute, shorter than the tube.

Calyx-teeth subulate, acuminate, longer than the tube.

1. H. Americanum.

2. H. Mackenzii.

I. Hedysarum Americànum (Michx.) Britton. Hedysarum. (I. F. f. 2165.) Stem glabrous or nearly so, I.5-7.5 dm. high. Leaves short-petioled; stipules lanceolate, long-acuminate, 4-17 mm. long ; leaflets II-2I, oblong or oblanceolate, obtuse and often mucronulate, mostly rounded at the base, $13-20 \mathrm{~mm}$. long; racemes longer than the leaves; fowers violet-purple, or sometimes white, numerous, deflexed, I5-20 mm. long, in loose elongated racemes; pod $1.3-4 \mathrm{~cm}$. long, drooping, of 3-5 oval or orbicular nearly glabrous strongly reticulated joints. In rocky places, northern N. Eng. to Newf., Alaska and Br. Col., south in the Rocky Mts, to Utah and in the Black Hills, June-July. [H. boreale Nutt.] 
2. Hedysarum Mackénzii Richards. Mackenzie's Hedysarum. (I. F. f. 2 I66.) Sinilar to the preceding, but usually minutely pubescent; stem 3-7.5 dm. high. Leaflets II-19; flowers slightly larger, violet-purple, deflexed; calyx-teeth longer than the tube, or equalling it; pod minutely pubescent, 3-8-jointed. Hud. son Bay (according to Macoun); N. W. Terr. to Alaska, south to Colo. Summer.

\section{I. AESCHYNÓMENE L.}

Herbs, or in tropical regions shrubs, mainly with odd-pinnate leaves, and yellow flowers in axillary clusters. Calyx-teeth nearly equal, more or less united into 2 lips. Standard orbicular, short-clawed; wings oblong or obliquely obovate, about as long as the standard; keel curved. Stamens diadelphous (5 and 5); anthers all alike. Ovary stipitate; ovules $2-\infty$. Pod stalked, flat, jointed. [Greek, to be ashamed, referring to the sensitive leaves.] About 55 species, in warm and tropical regions. Besides the following, $\mathbf{I}$ occurs in the Southern States.

I Aeschynomene Virginica (L.) B. S. P. Sensitive Joint Vetch. .(I. F. f. 2 167.) Annual, rough-pubescent or glabrate, 6-15 dm. high. Stipules membranous, ovate, acuminate, 4-9 $\mathrm{mm}$. long, deciduous; leaves short-petioled; leaflets 25-55, oblong, linear-oblong or oblanceolate, obtuse, 6-18 mm. long, somewhat sensitive; flowers few, reddish-yellow, about II $\mathrm{mm}$. long; petals veined; pod linear, $2.5-6 \mathrm{~cm}$. long, sparingly tuberculate or glabrous, of 5-10 nearly square easily separable joints. River banks, Penn. and N. J. to Fla., west to La. Aug.-Sept. [A. hispida Willd.]

\section{STYLOSÁNTHES Sw.}

Perennial herbs, mainly with villous or viscid pubescence, 3 -foliolate leaves, and yellow terminal or axillary spicate or capitate flowers. Calyx-tube campanulate, its teeth membranous, the 4 upper ones more or less united. Petals and stamens inserted at or near the summit of the tube; standard orbicular; wings oblong; keel curved, beaked. Stamens monadelphous; anthers alternately longer and shorter. Ovary nearly sessile; ovules 2 or 3; style filiform. Pod sessile, flattened, I-2-jointed, reticulate, dehiscent at the summit. [Greek, column flower, alluding to the column-like calyx-tube.] About 25 species, of warm and temperate regions. Besides the following, another occurs in the Southern States,

Leaves oblong-iinear to oblanceolate; floral bracts entire.

Leaves elliptic to obovate; floral bracts deeply cleft.

I. S. biflora.

2. S. riparia.

I. Stylosanthes biflòra (L.) B. S. P. Pencil-Flower. (I. F. f. 2168.) Stems wiry, villous pubescent or glabrate, 1.5-6 dm. long. Stipules sheathing, linear-filiform above; leaves short-petioled; leaflets acute or acutish and mucronate, $12-36 \mathrm{~mm}$. long, strongly veined, the terminal one stalked; flowers few, mainly terminal, sessile or nearly so, ciliate-bracted, 6-9 $\mathrm{mm}$. long; pod obovate or suborbicular, pubescent, about $4 \mathrm{~mm}$. long, of I perfect and I abortive joint. In dry soil, N. Y. to Fla., Ind., Kans. and La. June-Sept. [S. elatior Sw.]

2. Stylosanthes ripària Kearney. Decumbent P'ENCIL-FLower. (I. F. f. 2I68a.) Stems $\mathrm{I}-3 \mathrm{~cm}$. long, usually with a tomentose line on the elongated internodes. Stipules subulate above: petioles pubescent; leaflets elliptic to obovatecuneate, the terminal one Io-I $8 \mathrm{~mm}$. long, the lateral ones somewhat smaller; spikes terminal, about 6-flowered, with only I or 2 perfect flowers: calyx-tube conspicuously veined; vexillum proportionately longer than in S. hiflora; upper segment of the pod nearly twice as broad as in S. biflora. In dry woods, Va. and W. Va. to Ala. and Tenn. May-Aug.

\section{ZÓRNIA Gmel.}

Herbs, with digitately 4 -foliolate or 2 -foliolate petioled leaves, the leaflets not stipellate, the stipules sagittate. Flowers yellow in our species, small, interruptedly spicate, large-bracted, sessile, rarely solitary, the spikes peduncled. Bracts 2 together, nearly enclosing the flower: Calyx 2-lipped, 5-lobed. Standard nearly orbicular, clawed; wings oblique; keel incurved. Stamens monadelphous; anthers alternately longer and shorter. Ovary sessile; ovules several; style very slender. Loment flat, several-jointed. [In honor of Johann Zorn, a German apothecary.7 Ab ut I? spe ies, all natives of America. Besides the following, another occurs in the Soutl.western States. 
I. Zornia bracteàta (Walt.) Gmel. Zornia. (I. F. f. 2r69.) Perennial by a long woody root, glabrous or sparingly finely pubescent; stems wiry, prostrate, 3-6 din. long. Stipules about $6 \mathrm{~mm}$. long; petioles $12-25 \mathrm{~mm}$. long; leaflets 4, oblong, lanceolate or oblong-obovate, acute at both ends, 12-25 $\mathrm{mm}$. long, or those of the lower leaves obtuse and shorter; peduncles longer than the petioles; spikes several-flowered, much interrupted in fruit, 5-10 cm. long; bracts ovate or broadly oval, acute or acutish: pod 3-5-jointed, the joints oval, 3-5 cm. long, densely spinulose. In dry sandy soil, Va. to Fla., Tex. and Mex. May-Aug.

Arachis hypogaèa L., the Pea-nut is occasionally seen as a waif, not permanently established.

\section{MEIBÒMIA Heist. [DESMODIUM Desv.]}

Perennial herbs, sometimes woody at the base, with stipellate 3 -foliolate or in some species I- or 5 -foliolate leaves, and usually small flowers in racemes or panicles. Calyx-tube short, its teeth more or less united into 2 lips, the upper one 2-toothed, the 3 lower teeth acute or attenuate. Standard oblong, ovate or orbicular, narrowed or rarely clawed at the base; wings obliquely oblong; keel nearly straight, obtuse. Stamens monadelphous or diadelphous (9 and I); anthers all alike. Ovules $2-\infty$. Loment flat, several-jointed, the joints mainly coriaceous and pubescent or muricate, indehiscent or rarely partially dehiscent, readily separable. [Named for Dr. Brandus Meibom; died at Helmstadt, I740.] About 160 species, natives of warm and temperate regions. Besides the following, about 20 others occur in the Southern and Southwestern States.

* Loment not constricted above, deeply constricted below, long-stalked; leafiets broad. Panicle arising from the base of the plant; peduncle usually leafless. 1. M. nudiflora. Yanicle terminal; leaves crowded at its base.

leaves scattered along the stem.

2. M. grandifiora.

3. M. paucifiora.

** Loment constricted on both margins, more deeply below than above.

+ Stems trailing or reclining.

Leaflets orbicular or nearly so.

Leaflets $2.5 \mathrm{~cm}$. long or less, glabrate, coriaceous.

Leaflets $2.5-6 \mathrm{~cm}$. long, thinnish, usually quite pubescent.

4. M. arenicola.

5. M. Michauxii.

Leaflets ovate or oval.

Corolla whitish; leaves yellowish-green; stipules broadly ovate.

Corolla purple; leaves dull green; stipules subulate.

6. M. ochroleuca.

++ Stems erect or ascending.

Leaves sessile or nearly so; leaflets linear or lanceolate.

7. M. glabella.

8. M. sessilifolia.

Leaves petioled.

Leaflets narrowly linear; joints of the loment usually concave on the back.

Leaflets broad (except in $M$. paniculata Chapmani).

9. M. stricta.

1. Joints of the loment notably longer than broad.

Leaflets obtuse, rough-pubescent, yellowish green. 10. M. canescens.

Leaflets long-acuminate, scabrate above, slightly villous beneath.

II. M. longifolia.

Leaflets long-acuminate, glabrous, glaucous beneath. 12. M. bracteosa.

2. Joints of the loment little longer than broad.

(a) Loment distinctly long-stalked in the calyx.

Plants glabrous or nearly so (except in $M$. paniculata pubens).

Leaflets lanceolate or oblong.

Leaflets broadly ovate or oval, glaucous beneath.

13. M. paniculata.

14. M. laevigata.

Plants pubescent or scabrous.

Leaflets thick, coriaceous, villous and reticulated beneath.

15. M. rhombifolia. velvety-pubescent beneath.

16. M. viridiflora.

Leaflets scarcely coriaceous, appressed-pubescent or villous beneath. 17. M. Dillenii.

(b) Loment sessile in the calyx or nearly so.

Loment-joints $4-7$; flowers numerous, showy.

Leaflets coriaceous, strongly reticulated beneath.

I8, M. Illinoensis. 
Leaflets not coriaceous, scarcely reticulated beneath; loments numerous.

Loment-joints 1-3.

Leaflets scabrous, $2-5 \mathrm{~cm}$. long.

Leaflets not scabrous, $1-2 \mathrm{~cm}$. long.

Plant nearly glabrous throughout.

Stem pubescent; leaflets and petioles ciliate.

19. M. Canadensis.

20. M. rigida.

21. M. Marylandica.

22. M. obtusa.

I Meibomia nudiflòra (L.) Kuntze. Naked-flowered TiCk-Trefoll, I. F. f. 2170.) Slender, the leaves clustered at the summit of the sterile stems: peduncle leafless or rarely with I or 2 leaves; stipules subulate, deciduous; petioles $2.5^{-10} \mathrm{~cm}$. long; leaflets oval or ovate, glabrous or slightly pubescent, pale beneath, $2.5-8 \mathrm{~cm}$. long, the terminal one rhomboid, the others inequilateral; panicle narrow, few-flowered; flowers rose-purple, 6-I I mm. long; caly x-teeth obtuse, the lowest one largest; loment 2-3-jointed, the joints longer than wide, straight or concave on the back, obliquely semi-rhomboidal, pubescent with uncinate hairs, the sutures glabrous. In dry woods, Quebec to Minn., Fla. and La. July-Aug.

2. Meibomia grandiflòra (Walt.) Kuntze. Pointed-Leaved TICK-TREFoil. (I. F. f. 217I.) Erect, glabrous or somewhat pubescent, 3-I5 dm. high. Petioles 6-12 mm. long; stipules subulate, generally persistent; leaflets ovate acuminate, 5-15 cm. long, pubescent with scattered hairs; panicle ample; flowers large, rosepurple; loment 2-3-jointed; joints longer than wide, concave above, obliquely rounded below, uncinate-pubescent. In dry or rocky woods, Quebec to S. Dak., Fla., Neb. and the Ind. 'Terr. June-Sept.

3. Meibomia pauciflora (Nutt.) Kuntze. Few-Floweren Tick-Trefoil. (I. F. f. 2172.) Decumbent or ascending, pubescent with scattered hairs, 3-9 dm. long. Stipules subulate, deciduous; leaves alternate, distant, petioled; leaflets ovate, pubescent, $2.5-8 \mathrm{~cm}$. long, the terminal one rhomboid; racemes simple, fewflowered; calyx-lobes acute, ciliate; corolla white (?), about $6 \mathrm{~mm}$. long; loment I4-jointed, the joints concave or straight on the back, obliquely rounded below, uncinate-pubescent. In woods, Ont.?; W. N. Y. to Fla., Ohio, Ark. and La. July-Aug.

4. Meibomia arenícola Vail. SAND Tick-Treroll (I. F. f. 2I73.) Decumbent or prostrate, pubescent or glabrate, slender, 3-6 dm. long. Stipules subulate, persistent; petioles about $12 \mathrm{~mm}$. long; leaflets ovate-orbicular, glabrous or nearly so, coriaceous, reticulate-veined; racemes elongated, usually pubescent; flowers purple, 4. $6 \mathrm{~mm}$. long; pedicels slender; loment small, 2-4-jointed, the joints uncinate-pubescent, less convex above than below, 3-5 $\mathrm{mm}$. long; stipe about equalling the calyx-lobes. In dry woods, Md. to Fla., west to La. July-Sept.

5. Meibomia Michàuxii Vail. Prostrate Tick trefoll. (I F. f. 2174.) Prostrate, 6-18 dm long, softly pubescent or densely villous. Stipules ovate or triangular-ovate, persistent, acuminate, somewhat cordate, ciliate; leaflets nearly orbicular; panicles loose; flowers purple, 6-11 mm. long; calyx-lobes ciliate; lo. ment $2.5 \mathrm{~cm}$ long or more, 3-5-jointed; joints obliquely rhomboid below. slightly convex above, uncinate-pubescent; stipe equalling or longer than the calyx-lobes. Dry woods, Me. and Ont. to Minn., Fla. and La. July-Sept.

6. Meibomia ochroleùca (M. A. Curtis) Kuntze. Cream flowered TickTREFoIL. (I. F. f. 2 I 75.) Procumbent or decumbent, hirsute, 3-9 dm. long. Stipules persistent, cordate; petioles $\mathbf{I} .3-3.5 \mathrm{~cm}$. long; leaflets recticulate-veined and somewhat scabrous beneath, $\mathbf{r} .7-5 \mathrm{~cm}$. long, the terminal one rhomboid, the lateral obliquely ovate, smaller or sometimes wanting; racemes simple; loment 2-3.jointed, the joints slightly more convex below than above. twisted, oval, pale green, glabrous except the uncinate pubescent sutures; stipe about as long as the calyx-lobes. In woodlands, N. J. to Ga. and Mo. Aug,-Sept.

7. Meibomia glabélla (Michx.) Kuntze. Trailing TiCk-Trefoil. (I. F. f. 2176.) Procumbent, glabrous or nearly so; stem sometimes $2.4 \mathrm{~m}$. long. Leaflets obtuse, glabrous or sparingly pubescent above, pale beneath, 2.5-6 cm. long, the terminal one slightly rhomboid; racemes panicled; loment 3-5-jointed, the joints obliquely semi-rhomboid, less convex above than below; stipe about $4 \mathrm{~mm}$. long. In dry sandy woods, E. Mass. to N. Y., Penn. and S. Car. Aug.-Sept.

8. Meibomia sessilifòlia (Torr.) Kuntze. SESSILE-LEAVED T'ICK-TREFolla 
(I. F. f. 2177.) Erect, 6-12 dm. high, uncinate-pubescent. Stipules small, deciduous; leaflets obtuse at each end, nearly glabrous above, reticulate-veined and pubescent beneath, $2-8 \mathrm{~cm}$. long; flowers $4-6 \mathrm{~mm}$. long; loment 1-3-jointed, the joints about $4 \mathrm{~mm}$. long, obliquely obovate, hispid, somewhat twisted, less convex above than below; stipe not exceeding the calyx-lobes. In dry soil, Mass., R. I. and Conn. to Mich., Ky., Ark. and Tex. July-Sept.

9. Meibomia stricta (Pursh) Kuntze. Stiff Tick-trefoll. (I. F. f. 2178.) Erect, slender, finely pubescent, 6-12 dm. high. Stipules subulate, deciduous; leaves petioled; leaflets obtuse, glabrous, thick, reticulate-veined, $2.5-6 \mathrm{~cm}$. long, about $6 \mathrm{~mm}$. wide; flowers 2-4 mm. long; loment small, I-3-jointed; joints semiobovate or semi-rhomboid, uncinate-pubescent, about $4 \mathrm{~mm}$. long; stipe about equalling the calyx-lobes. Pine barrens of N. J. to Fla., west to La. July-Sept.

ro. Meibomia canéscens (L.) Kuntze. Hoary Tick-trefoll. (I. F. f. 2179.) Erect, densely pubescent, I-1.7 m. high. Stipules ovate, acuminate, somewhat cordate, persistent; leaflets ovate, $1.5-10 \mathrm{~cm}$. long, scabrous above, pubescent beneath, ciliate, the terminal one commonly rhomboid and larger than the lateral ones; racemes compound; flowers 4-5 mm. long; loment 4-6-jointed, joints longer than wide, unequally rhomboid, 9-13 mm. long; stipe about equalling the upper lobe of the calyx. In rich soil, Ont. to Mass., Fla., Minn. and Tex. July-Sept.

Meibomia canéscens hirsùta (Hook.) Vail. Stem and branches more densely villous-pubescent; leaffets narrower. Mo.

II. Meibomia longifòlia (T. \& G.) Vail. Long-Leaved Tick-Trefoll. (I. F. f. 2180 .) Erect, $6-15 \mathrm{dm}$. high, the angled stems and panicle minutely pubescent. Stipules lanceolate-setaceous; leaflets 5-12 cm. long, lanceolate-ovate or ovate, scabrate above, lighter, appressed-pubescent or villous beneath; flowers slowy, purple; loment $2.5^{-8} \mathrm{~cm}$. long, 4-6-jointed, the joints triangular-oblong or lozenge-shaped, unicinate pubescent throughout; stipe about the length of the calyx-lobes. In rich soil and low woods, Ill. to La. and Ala. June-Sept.

12. Meibomia bracteòsa (Michx.) Kuntze. LARge-Bracten Tick-Trefoil. (I. F. f. 218I.) Erect, 9-18 dm. high, glabrous or nearly so below, the panicle finely pubescent. Stipules lanceolate, cuspidate, somewliat cordate; leaflets 5-20 cm. long, ovate or ovate-lanceolate; flowers purple, 9-II mm. long; bracts cuspidate, striate, deciduous; loment $2.5-8 \mathrm{~cm}$. long, 3-7-jointed, the joints obliquely oblong, about twice as long as wide, uncinate pubescent; stipe about the length of the lower calyx lobes. In thickets, Me. to Ont., Fla., Mo. and Tex. Aug.-Sept.

13. Meibomia paniculàta (L.) Kuntze. PAniclen TiCK-Trefoil. (I. F. f. 2182.) Erect, slender, 6-12 dm. high. Stipules small, subulate; leaflets oblong. lanceolate or linear-lanceolate, obtuse, $2.5-5 \mathrm{~cm}$. long; racemes compound; flowers purple, 6-9 mm. long ; loment $2.5 \mathrm{~cm}$. long or more, 4-6 jointed, the joints obliquely triangular or rhomboid, minutely uncinate-pubescent; stipe nearly equalling the lower lobes of the calyx. In dry soil, Ont. to Minn., Mass., Fla. and Tex. Juiy-Sept.

Meibomia paniculàta Chápmaní Britton. More slender; leaflets linear. Intermediate forms also occur. In dry, sandy soil, Va. to Fla., Ky. and Tex.

Meibomia paniculata pùbens (T. \& G.) Vail. Stems puberulent ; leaflets coriaceous when old, oblong-lanceolate, sometimes scabrous above, pubescent beneath; lomentjoints strongly angled on the back. In sandy soil, Va. to Fla., the Ind. Terr. and Tex.

I4. Meibomia laevigàta (Nutt.) Kuntze. Smooth Tick-Trefoll. (I. F. f. 2183 .) Stem terete, glaucous, erect or ascending, 6-12 dm. high, glabrous; stipules subulate, deciduous; petioles $2.5-5 \mathrm{~cm}$. long, leaflets ovate, acutish, the terminal one more or less rhomboid; racemes compound, slightly pubescent; bracts deciduous; calyx scabrous; flowers pink, II-I $3 \mathrm{~mm}$. long; loment 3-4-jointed, the joints triangular, angled on the back, uncinate-pubescent; stipe 4-6 mm. long. In dry woods, S. N. Y. to Fla., Mo. and Tex. Aug.-Sept.

I5. Meibomia rhombifjlia (Ell.) Vail. RHomb-LEAVED TICK-TREFoIL. (I. F. f. 2184.) Erect or ascending, 6-9 dm. high or more, uncinate pubescent. Stipules subulate, taper-pointed; leaflets ovate, often mucronulate, scabrous above, villous and reticulated beneath, 5-9 $\mathrm{cm}$. long, the terminal rbomboid, the lateral 
ones often wanting; racemes elongated, usually leafless; bracts minuie; loment 25 -jointed, the joints obliquely semi rhomboid, rounded on the back, uncinate pubes. cent; stipe often as long as the lowest juint. In sandy soil and pine lands, Va. to Fla., Ala. and La. May-Sept.

16. Meibomia viridiflòra (L.) Kuntze. Velvet-leaved Tick-trefoil. (I. F. f. 2185.) Erect, downy pubescent, 6-I2 dm. high. Stipules lanceolate, mainly deciduous; petioles $1-4 \mathrm{~cm}$. long; leaflets broadly ovate, rough above, velvety-pubescent beneath, 3-9 $\mathrm{cm}$. long, the terminal one somc what rhomboid; ra. cemes compound, elongated, uncinate-pubescent; flowers purple, 6-9 $\mathrm{mm}$. long, loment 2-4-jointed, the joints semi-rhomboid, uncinate, about $4 \mathrm{~mm}$. long; stipe about equalling the lower lobes of the calyx. Dry woods, E. Penn. and S. N. Y. to Fla., Mich., Mo. and Tex. Aug.-Oct.

17. Meibomia Dillènii (Darl.) Kuntze. Dillen's Tick-trefoll. (I. F. f. 2 I86.) Erect, 6-9 dm. high, pubescent or nearly glabrous. Stipules subulate, mainly deciduous; leaflets usually thin, oval or oblong-ovate, obtuse, 3-10 cm. long, sparingly pubescent or glabrous above, softly pubescent or villous beneath; racemes compound, loose : bracts small, deciduous; flowers 6-9 mm. long; loment 2-4jointed, the joints nearly triangular, about $6 \mathrm{~mm}$. long, somewhat convex on the back, uncinate-pubescent. Woods, Me. and Ont. to Minn., Va., Ky., Mo. and Tex. June-Sept.

18. Mesbomia Illinoénsis (A. Gray) Kuntze. Illinors Tick-Treforl. (I. F. f. 2187.) Erect, stout, 6-12 dm. high, uncinate-pubescent. Stipules ovate, acute, cordate, ciliate, pubescent, persistent; leaflets lanceolate or ovate-lanceolate, obtusish, scabrous above, reticulate veined and cinereous beneath, 2.5-9 cm. long; bracts ovate-lanceolate; flowers 6-9 mm. long; loments $1-2.5 \mathrm{~cm}$ long, often in pairs, 3-6-jointed, the joints oval or crbicular, densely uncinate-pubescent. Prairies, Ill. to S. Dak, Iowa and Kans. June-Sept

r9. Meibomia Canadénsis (L.) Kuntze. Canadian oR Showy TickTREFoIL. (I. F. f. 2188.) Erect, stout, pubescent, 6-24 dm. high. Stipules linear-lanceolate, mostly persistent; lower petioles $\mathbf{I}-\mathbf{2 . 5} \mathrm{cm}$. long, the upper leaves nearly sessile; leaflets cbiong or lanceolate-oblong, obtuse, appressedpubescent beneath; racemes densely panicled; flowers II-17 mm. long, conspicuous, purple or bluish-purple; bracts ovate-lanceolate, acute, ciliate; calyxlobes attenuate; loment about $2.5 \mathrm{~cm}$. long, 3-5 jointed; joints triangular, straight or convex on back, uncinate pubescent. Thickets and river-banks, N. B. to Manitoba, N. Car., Mo. and the Ind. Terr. July-Sept.

20. Meibomia rígida (Ell.) Kuntze. Rigid TICK-Trefoll. (I. F. f. 2I89.) Erect, rather rigid, finely uncinate-pubescent, 6-9 dm. high. Stipules small, lanceolate. deciduous; leaflets ovate or oval, obtuse, thickish, scabrous above, pubescent, especially along the veins beneath, $2.5-5 \mathrm{~cm}$. long; racemes compound; flowers 2-4 mm. long, purplish; loment joints obliquely ovate, rounded on the back, uncinate-pubescent, about $3 \mathrm{~mm}$. long. In dry soil, N. H. to Fla., Mich., Kans. and La. July-Oct.

21. Meibomia Marylándica (L.) Kuntze. Smooth Small-leaven Tick TREFOIL. (I. F. f. 2 IgO.) Erect or ascending, rarely with a few scattered hairs, 6-9 dm. high. Stipules subulate; leaves crowded; leaflets 12-25 mm. long, ovate or nearly orbicular; obtuse, glabrous, the lateral often subcordate; racemes panicled; corolla purplish, $2-4 \mathrm{~mm}$. long; loment-joints small, obliquely oval or semiorbicular. In dry soil, Ont. to Mass., Fla., Mich. and La. July-Sept.

22. Meibomia obtùsa (Muhl.) Vail. HaIRy Small-LEaved TICK-TREfoil. (I. F. f. 2I9I.) Erect, 6-9 dm. high, pubescent. Stipules subulate, deciduous: leaves crowded; petioles ciliate, shorter than the leaflets; leaflets bruadly ovate or oval, obtuse, somewhat coriaceous, more or less pubescent on both sides, ciliate, 12-25 mm. long; racemes uncinate-pubescent. flowers 2-4 mm. long: loment-joints obliquely oval; stipe not exceeding the calyx-lobes. Dry soil, Ont. to Mass., Fla., Mich. and Tex. July-Oct.

\section{LESPEDìzA Michx. (See Appendix.)}

Herbs, often somewhat woody, with pinnately 3 foliolate leaves, small stipules, and small purple or whitish flowers in axillary clusters, heads or panicles. Flowers often of 2 kinds intermixed, the one petaliferous and mainly sterile, the 
other minute, apetalous, abundantly fertile. Calyx lobes nearly equal. Standard in the petaliferous flowers obovate or oblong, clawed; wings oblong; keel incurved. Stamens more or less diadelphous (9 and I); anthers all alike. Ovary sessile or stipitate, I-ovuled. Prol ovate, oblong, oval or suborbicular, flat, indehiscent, reticulated, composed i a single joint, or rarely with a second stalk like joint at the base. [Named for Lespedez, governor of Florida, patron of Michaux.] A genus of about 35 species, natives of eastern N. Am., Asia and Australia.

\section{x. Perennials; stipules and bracts subulate; Calyx-lobes nakrow.}

* Both petaliferous and apetalous flowers present; corolla purple or purplish; pod exserted.

Peduncles slender and mostly exceeding the leaves.

Petaliferous flowers capitate or spicate.

Plants trailing or diffusely procumbent.

Glabrous or appressed-pubescent.

Woolly or downy-pubescent.

Plants erect, rather stout, pubescent.

Petaliferous flowers loosely paniculate; stem erect or ascending.

Flower-clusters of both kinds sessile or nearly so.

I. L. repens.

2. L. procumbens.

3. L. Nuttallii.

4. L. violacea.

Leaflets oval, oblong or orbicular.

Foliage densely downy-pubescent.

Foliage glabrate or appressed-pubescent.

Leaflets linear or linear-oblong.
5. L. Stuvei.

6. L. frutescens.

7. L. Virginica.

* * Flowers all complete; corolla whitish or yellowish; pod included or scarcely exserted.

Leaves oblong, ovate-oblong or nearly orbicular.

Peduncles' exceeding the leaves.

Peduncles shorter than the leaves.

Leaves linear or linear-oblong; peduncles elongated.

Spikes densely flowered.

Spikes interrupted, loosely-flowered.

2. ANNUAL; STIPULES OVATE; CALYX-LOBES BROAD.
8. L. hirta.
9. L. capitata.
10. L. angustifolia.
1x. L. leptostachya.
12. L. striata.

I. Lespedeza rèpens (L.) Bart. Creeping Bush-clover. (I. F. f. 2192.) Glabrate or appressed-pubescent, tufted; stems slender, 1.5-6 dm. long. Petioles shorter than the leaves; stipules about $2 \mathrm{~mm}$. long; leaflets oval or obovate, obtuse or retuse at the apex, 6-I7 mm. long; inflorescence rather loose; corolla violetpurple, 4-6 mm. long; pod oval orbicular, acute, finely pubescent, $3 \mathrm{~mm}$. long. In dry or sandy soil, L. I. to Fla., Minn., Kans. and Tex. Aug.-Sept.

2. Lespedeza procúmbens Miclix. Trailing Bush-clover. (I. F. f. 2 I93.) Woolly or downy-pubescent, sometimes ascending, stouter than the preceding species; stems $3-7.5 \mathrm{dm}$. long. Petioles commonly much shorter than the leaves; leaflets oval or elliptic, rarely slightly obovate, obtuse or retuse at the apex, rounded at the base, II -25 mm. long; peduncles longer than the leaves, or the flowers sometimes all apetalous and nearly sessile; corolla violet-purple or pinkishpurple; pod oval-orbicular, acute, pubescent, $3 \mathrm{~mm}$. long. In dry soil, N. H. to Fla., the Ind. Terr, and La. Aug.-Sept.

3. Lespedeza Nuttàllii Darl. Nutrall's Bush-Clover. (I. F. f. 2 I94.) Mre or less villous-pubescent, 6-9 dm. high. Petioles shorter than the leaves; leaflets oval, obovate or suborbicular, thickish, obtuse or emarginate, dark green and glabrous or nearly so above, villous-pubescent beneath, $9 \mathrm{~mm} .-4 \mathrm{~cm}$. long; inflorescence capitate or spicate, dense; flowers violet-purple, about $6 \mathrm{~mm}$. long; pod oblong or oval, acuminate or acute at each end, very pubescent, 5-6 $\mathrm{mm}$. long. Dry soil, southern N. Eng. and N. Y. to Mich., Fla. and Kans. Aug.-Sept.

4. Lespedeza violacea (L.) Pers. Bush.clover. (I. F. f. 2195.) Sparingly pubescent, usually much branched, 3-9 dm. high. Stipules 4-6 mm. long; leaflets oval, elliptic or elliptic-oblong, thin, obtuse or retuse, rounded at the base, $13 \mathrm{~mm} .-5 \mathrm{~cm}$. long, appressed-pubescent beneath; peduncles, at least the upper ones, longer than the leaves; inflorescence loose, paniculate; corolla violet-purple, 6 I I $\mathrm{mm}$. long; pod ovate or oval, acute, finely and sparingly pubescent or gla- 
brate, 4-6 mm. long. In dry soil, N. Eng. to Fla., Minn., Kans., La. and northern Mex. Aug.-Sept.

5. Lespedeza Stùvei Nutt. Stuve's Bush-clover. (I. F. f. 2196.) Wandlike, velvety or downy pubescent, 6-12 dm. high. Stipules 4-6 mm. long; petioles commonly much shorter than the leaves; leaflets oval, oblong or suborbicular, ob. tuse or retuse, I2-30 $\mathrm{mm}$. long; flowers in nearly sessile axillary clusters: corolla violet-purple, 4-6 $\mathrm{mm}$. long; pod ovate-oblong to orbicular, 4-6 $\mathrm{mm}$. long, downypubescent. Dry soil, Conn. to Va., Mich. and the Ind. Terr. Aug.-Sept.

Lespedeza Stùvei neglécta Britton. Leaflets linear or linear-oblong, obtuse, mucronulate. N. J. and Penn. to N. Car., Ga., Mo. and Tex.

6. Lespedeza frutéscens IL.) Britton. WAND-LIKE BuSH-CLover. (I. F. f. 2 I97.) Finely appressed-pubescent or glabrate, 3-9 dm. high. Stipules 4-6 mm. long; petioles equalling or shorter than the leaves; leaflets oval, oblong or elliptic, obtuse, truncate or retuse, 12-38 mm. long, glabrous and dark green above, paler and pubescent beneath; flowers in short-stalked or nearly sessile axillary clusters, generally crowded toward the summit of the stem; corolla violetpurple, 4-6 mm. long; pod ovate-oblong, acute, pubescent, about $4 \mathrm{~mm}$. long. Dry soil, Me. to Ont., Mich., Fla., Ill. and Tex. Aug.-Sept.

7. Lespedeza Virgínica (L.) Britton. Slender Bush clover. (I. F. f. 2 I98.) Slender, resembling the preceding. Leaflets linear or oblong-linear, I 2-38 mm. long, 2-5 $\mathrm{mm}$. wide, truncate, finely pubescent beneath, or glabrate on both surfaces; clusters crowded in the upper axils; flowers violet-purple, 4-6 mm. long: pod ovate or oval-orbicular, $4 \mathrm{~mm}$. long, pubescent, or nearly glabrous. Dry soil, Mass. to Ont., Minn., Kans., Fla. and Tex. Aug.-Sept.

8. Lespedeza hírta (L.) Ell. Hairy Bush-Clover. (I. F. f. 2 I99.) Erect or ascending, villous or silky pubescent, 6-12 dm. high. Stipules 2-5 mm. long; petioles shorter than the leaves; leaflets oval, or suborbicular, obtuse at each end, sometimes emarginate, $12 \mathrm{~mm} .-5 \mathrm{~cm}$. long; peduncles elongated; heads oblongcylindric, rather dense, $12-35 \mathrm{~mm}$. long; flowers all complete, corolla yellowishwhite or the standard purple-spotted, about $6 \mathrm{~mm}$. long; pod oval, acute, very pubescent, about equalling the calyx-lobes. Dry soil, Me. and Ont. to Fla., Ill., Minn. and La. Aug.-Oct.

Lespedeza hìrta oblongifolia Britton. Leaflets oblong, obtuse at each end, r.8-3 $\mathrm{cm}$. long, 4-6 mm. wide, glabrate above, appressed-pubescent beneath ; peduncles slender ; spikes looser, 2.5-3.8 cm. long; calyx very pubescent. Pine barrens, Egg Harbor, N. J., and in the Southern States.

9 Lespedeza capitàta Michx. Round-headen Bush-Clover. (I. F. f. 2200.) Stiff, mainly simple and wand-like, silky or silvery pubescent, $6-16 \mathrm{dm}$. high. Leaves nearly sessile; leaflets oblong or oval, $2.5-3.8 \mathrm{~cm}$. long; peduncles shorter than the leaves, or the dense globose-oblong heads sessile in the upper axils: flowers all complete; corolla yellowish-white, with a purple spot on the standard, $6 \mathrm{mn}$. long; pod ovate-oblong, pubescent. about half as long as the calyxlobes. Dry fields, Ont. and Me. to Fla., S. Dak., Kans. and La. Aug.-Sept.

Lespedeza capitàta longifòlia (DC.) T. \& G. Leaflets linear-lanceolate or linearoblong, sometimes $\mathrm{I} \mathrm{dm}$. long. Ill. and Mo.

Io. Lespedeza angustifòlia (Pursh) Ell. NARrow-leaved Bush Clover. (I. F. f. 220I.) Erect, appressed-pubescent, 6-9 dm. high. Leaves nearly sessile; leaflets linear or oblong-linear, rarely some of the lower ones lance-linear, 2.5-3 $\mathrm{cm}$. long, obtuse, truncate or acutish; peduncles usually exceeding the leaves; flowers nearly as in the preceding; pod ovate-orbicular, shorter than the calyx. lobes. Dry sandy soil, E. Mass. to Fla., Mich. and La. Aug.-Sept.

I I. Lespedeza leptostàchya Engelm. Prairie Bush-clover. (I. F. f. 2202.) Erect, 3-9 dm. high, silvery-pubescent with appressed hairs. Petioles shorter than the leaves; leaflets linear, 2.5-3 cm. long; spikes slender, on peduncles equalling or exceeding the leaves; corolla as in the preceding; pod ovate, pubescent, about $3 \mathrm{~mm}$. long, nearly equalling the calyx. Prairies, Ill. to Iowa, Wis. and Minn. Aug.-Sept.

12. Lespedeza striàta (Thunb.) H. \& A. JAPAN Clover. (I. F. f. 2203.) Diffuse or ascending, sparingly appressed-pubescent, $1.5-3 \mathrm{dm}$. long. Stipules 
ovate, acute or acuminate, 2-4 $\mathrm{mm}$. long; petioles much shorter than the leaves; leaflets oblong or oblong-obovate, 9-20 $\mathrm{mm}$. long, obtuse, narrowed at the base; flowers I-3 together, sessile or nearly so in the axils; corolla pink or purple, about $12 \mathrm{~mm}$. long; calyx-lobes ovate; pod oval, acute, exceeding the calyx-lobes. In fields, Va. to Ill., Mo., Kans. and very common in the Southern States. Nat. from eastern Asia. July-Aug.

\section{Vícia L.}

Climbing or trailing, herbaceous vines, with pinnate tendril-bearing leaves, half-sagittate or entire stipules, and axillary, mostly racemose, flowers. Calyx-tube somewhat oblique, obtuse at the base, its teeth about equal. Standard obovate or oblong, emarginate, clawed; wings obliquely oblong, adherent to the shorter oblong curved keel. Stamens diadelphous (9 and I), or monadelphous below. Ovules $\infty$; style very slender, with a tuft or ring of hairs at its summit. Pod flat, dehiscent, 2 valved, continuous between the seeds. [The classical Latin name of the Vetch.] About 120 species of wide distribution. In addition to the following, about I2 others occur in southern and western N. Am.

Flowers racemed or spicate; peduncles elongated.

Indigenous perennials.

Spike-like racemes dense, I-sided, 15-40-flowered.

Racemes loose, $\mathrm{I}-2 \mathrm{O}$-flowered.

Flowers $1.5^{-2} \mathrm{~cm}$. long.

Leaflets elliptic, or ovate-oblong.

Leaflets narrowly linear; western.

Flowers 4-ro $\mathrm{mm}$. long.

Racemes 8-20-flowered; flowers 9-1 I mm. long.

Racemes I-6-flowered; flowers 4-9 $\mathrm{nm}$. long.

1. V. Cracca.

Leaflets 2-5 pairs, linear, or those of the lower leaves oval or obovate.

Leaflets 4 or 5 pairs, all oval, elliptic or obovate.

2. V. Americana.

3. $V$. linearis.

4. V. Caroliniana.

5. V. micrantha.

6. V. Ludoviciana.

Introduced annuals ; flowers few, 4-6 mm. long.

Pod glabrous, 3-6-seeded.

Pod pubescent, 2-seeded.

7. V. tetrasperma.

8. V. hirsuta.

Flowers sessile or very nearly so, few, axillary.

Flowers 1 or 2 in the axils; annuals.

Leaflets oblong, oval or obovate.

Leaflets, except those of lower leaves, linear or linear-oblong.

Flowers 2-6 in a short nearly sessile raceme; perennial.

9. V. sativa.

10. $V$. angustifolia.

II. V. Sepium.

I. Vicia Crácca L. Tufted or Cow Vetch. Blue Vetch. (I. F. f. 2204.) Finely pubescent or sometimes glabrate: stems weak, 6-12 dm. long. Stipules linear, acute, entire, 2-9 $\mathrm{mm}$. long; leaves nearly sessile; leaflets $18-24$, thin, linear or linear-oblong, mucronate, $1.7-2 \mathrm{~cm}$. long; peduncles axillary, shorter than or equalling the leaves; racemes $2.5^{-10} \mathrm{~cm}$. long; flowers bluish-purple, II$13 \mathrm{~mm}$. long, reflexed; claw of the vexillum about equalling its blade; pod shortstalked, glabrous, $\mathbf{1} .8-2.5 \mathrm{~cm}$. long, 5-8-seeded. In dry soil, Newf. to Br. Col., N. J., Ky. and Kans. Also in Europe and Asia. June-Aug.

Vicia villosa Roth, a European species found by Dr. C. D. Fretz in eastern Pennsylvania, differs from the above in having the claw of the standard half the length of its blade.

2. Vicia Americàna Muhl. American Vetch. Pea Vine. (I. F. f. 2205.) Glitbrous, or with some appressed pubescence, 6-9 dm. long. Leaves nearly sessile: stipules broad, foliaceous, triangular-ovate, sharply toothed, 4-I I mm. long; leaflets 8-14, elliptic, ovate or oblong, obtuse or sometimes emarginate and mucronulite, rounded at the base, $\mathbf{1} .7-3.8 \mathrm{~cm}$. long: peduncles usually shorter than the leaves: racemes 3-9 flowered; flowers bluish purple, I7-2I mm. long, spreading; pod short-stalked, glabrous, $2.5-3 \mathrm{~cm}$. long, 4-7-seeded. In moist ground, N. B. to Manitoba, Br. Col., Va., Ky. and Nev. May-Aug.

2a. Vicia Oregàna (Nutt.). OREgon Vetch. Leaflets smaller and thicker, oblong, mostly obtuse or subtruncate. Kans. to S. Dak., Cal. and Br. Col.

3. Vicia lineàris (Nutt.) Greene. NARROW-LEAVED AMERICAN VETCH. (I. F. f. 2206.) Glabrous or nearly so; stems often zigzag, 3-6 dm. long. Leaf- 
lets 4-7 pairs, narrowly linear to linear oblong, I.8-3.5 cm. long, rather thick, the apex not toothed, mucronate; stipules 4-9 mm. long, half-sagittate, acuminate, their bases prolonged, sometimes dentate; racemes 2-6-flowered; flowers purple or purplish, about $18 \mathrm{~mm}$. long; pod about $2.5 \mathrm{~cm}$. long, glabrous, short-stalked. In dry soil, N. W. Terr. to Br. Col., S. Dak., Kans., N. Mex. and Cal. May-Aug.

$\begin{array}{llll}\text { 4. Vicia Caroliniàna Walt. Carolina Verch } & \text { (I. F. f. 2207.) Glabrous }\end{array}$ or nearly so, slender, 6-9 dm. long. Stipules linear or oblong, entire, 4-6 mm. long: leaves short-petioled; leaflets 8-18, oblong or linear-oblong, entire, obtuse or emarginate, or sometimes acutish and mucronate, I-2 cm. long; peduncles equalling or shorter than the leaves; racemes 8-20-flowered; flowers nearly white, 9-I I $\mathrm{mm}$. long, the keel bluish-tipped; pod glabrous, $\mathbf{I} .7-3 \mathrm{~cm}$. long, short-stalked, 5-8-seeded. Banks and cliffs, Ont. to Minn., Ga., Ky. and Kans. May-July.

5. Vicia micrantha Nutt. SMall-flowered VeTch. (I. F. f. 2:08.) P(rennial (or sometimes annual?), glabrous; stems slender, $3-6 \mathrm{dm}$. long. Leaflets 2-5 pairs, narrowly linear to linear-oblong, thin, $\mathbf{I}-4 \mathrm{~cm}$. long, obtuse, acutish or emarginate, or those of the lower leaves obovate, oval or even obcordate, usually shorter; peduncles 8-30 mm. long, I-2-flowered; flowers 4- $6 \mathrm{~mm}$. long, purplish; pod slightly pubescent or glabrous, about $2.5 \mathrm{cn}$. long, 6-12-seeded; seeds ccmpressed. On prairies and in thickets, Mo. to Tenn., Ala. and Tex. April-May.

6. Vicia Ludoviciàna Nutt. LouisianA VeTCH. (I. F. f. 22c9.) Glabrcus, or the young parts pubescent; stem rather stout, angled, 4-9 dm. long. Leaflets elliptic, oval or obovate, thin, $1.2-2 \mathrm{~cm}$. long, obtuse or emarginate; stipules very narrow, rarely over $6 \mathrm{~mm}$. long, linear or half-sagittate; pedurcles shorter than the leaves, or about equalling them, I-6-flowered; flowers 6-9 mm. long, bluish; pod $2.5 \mathrm{~cm}$. long, or rather more, glabrous, 4-6 seeded, the seeds compressed. Kans. (?), Tex. and Li. to Fla. April-May.

7. Vicia tetraspérma (L.) Moench. Slender Vetch. Smooth or Lentil TARE. (I. F. f. 22 IO.) Glabrous or nearly so, weak, slender, 1.5-6 dm. long. Stipules linear, long auriculate; leaves short petioled; leaflets 6 I 2 , thin, linear or linear-oblong, commonly mucroaulate, I2-17 mm. long; peduncles filiform, equalling or shorter than the leaves, I-6-flowered; flowers pale, liue or purplish, 4-6 $\mathrm{mm}$. long; pod 8-13 mm. long. In meadows and waste places, N. S. and Ont. to Va. Nat. from Europe. June-Sept.

8. Vicia hirsùta (L.) Koch. HAIRY Vetch or TARE. (I. F. f. 22II.) Sparingly pubescent or glabrous, much resembling the preceding. Stipules linear, long-auriculate and sometimes toothed; leaves iearly sessile; leaflets 12-14, oblong or linear, obtuse, emarginate or truncate, mucrcnulate, $8-17 \mathrm{~mm}$. long, narrcwed at the base; peduncles slender, mainly shorter than the leaves, 2-6-flowered; flowers pale purplish-blue, about $3 \mathrm{~mm}$. long; pod $8-\mathrm{I} 3 \mathrm{~mm}$. long. In fields and waste places, Va. to Ohio, N. B. and Alberta. Nat from Europe. May-Sept.

9. Vicia sativa L. COMMON Vetch oR TARE. PeBbie-vetch. (I. F. f. 221 2.) Pubescent or glabrate, spreading, 3-9 dm. long. Stipules brcad, ger.erally sharply toothed; leaves short-petioled; leaflets 8-14, olovate, oblong cr oblanceolate, obtuse, truncate or retuse and mucronate at the apex, rarrowed at the base, I.8-3 cm. long; flowers bluish-purple, $1.8-2.5 \mathrm{~cm}$. long; calyx-teeth about as long as the tube; pod linear.oblong, glabrous, 4-8 cm. long, 5-10-sceded. In fielc's a1.d waste places, frrequent or occasional throughout our area, in the Southern States and on the Pacific Coast. Adventive from Europe. May-Aug.

ro. Vicia angustifòlia Roth. SMaller Common VeTCH. (I. F. f. 2213.) Glabrous or puberulent; stem slender, 3-6 dm. long. Stipules mostly half-sagittate, toothed or entire; leaves short-petioled, or nearly sessile; leaflets 8-16, lintar, lanceolate or oblanceolate, 9-35 $\mathrm{mm}$. long, mucronulate, those of the lower leaves commonly obovate, broader and shorter; flowers 1 or 2 in the upper axils, purple, 12-17 mm. long; calyx-teeth as long as the tube or shorfer; pod linear, glabrous, $2.5-5 \mathrm{~cm}$. long. In fields and waste places, N. S. to Fla. Nat. from Europe. AprilJuly.

I I. Vicia Sèpium L. Bush Vetch. Wild TARE. (I. F. f. 2214.) Perennial by stolons, minutely pubescent; stem slender, $69 \mathrm{dm}$. long. Leaves shortpetioled. 5-15 cm. long: leaflets 10-18, ovate or oval, $1.2-2.5 \mathrm{~cm}$. long, emarginate or truncate at the apex, mucronulate, thin; stipules half-sagittate, I cm. long or less; racemes $\mathbf{I}-2.5 \mathrm{~cm}$. long; flowers very short-pedicelled, pale purple, $\mathbf{I}-2 \mathrm{~cm}$. 
long; calyx-teeth unequal, shorter than the tube; pod 2-3 cm. long, glabrous. Near Hamilton, Ont. Adventive or fugitive from Europe. May-July.

Ervum Léns 1.., the Lentil, distinguished from all our species of Vicia by its elongated caly $\mathrm{x}$-lobes and oval, I-2-seeded pod, is collected occasionally as a waif.

\section{LÁTHYRUS L.}

Herbaceous vines, rarely erect herbs, with pinnate mostly tendril-bearing leaves, and racemose or sometimes solitary flowers. Calyx oblique or gibbous at the base, its teeth nearly equal or the upper ones somewhat shorter than the lower; corolla rearly as in Vicia, but commonly larger; stamens diadelphous (9 and I), or monadelphous below. Ovary sessile or stalked; ovules generally numerous; style curved, flattened, hairy along its inner side; pod flat, or sometimes terete, 2-valved, dehiscent, continuous between the seeds. [Ancient Greek name of some leguminous plant. About Iro species, natives of the northern hemisphere and of S. Am. Besides the following, about 25 others occur in southern and western N. Am.

\section{Leaflets $3-7$ pairs ; flowers purple.}

Stipules foliaceous; plant of the seashore and the Great Lakes.

Stipules half-sagittate or small, or wanting ; inland plants.

Plants climbing or trailing ; stipules present ; pod sessile.

Leaflets ovate or oval, large; flowers ro-zo.

Leaflets linear, oblong or oval, smaller ; flowers 2-6. Leaflets linear or linear-oblong ; stem winged.

Leaflets oblong or oval; sten wingless.

Plants mainly erect ; stipules often wanting; pod stipitate.

Leaflets lanceolate or oblong.

Leaflets linear.

Leaflets 3-5 pairs; stipules foliaceous ; flowers yellowish-white.

Leaflets I pair ; stipules foliaceous.

Perennial; introduced; flowers yellow.

Annual; native western species; flowers purple.

I. L. maritimus.

2. L. venosus.

3. L. palustris.

4. L. myrtifolius.

5. L. decaphyllus.

6. L. ornatus.

7. L. ochroleucus.

8. L. pratensis.

9. L. pusillus.

I. Lathyrus marítimus (L.) Bigel. BEACH PEA. (I. F. f. 2215.) Perennial, glabrous or nearly so. slightly glaucous; stems angled, decumbent, 3-6 din. long. Stipules ovate, half-hastate, acute, 2.5-5 cm. long; leaves nearly sessile; leaflets 3-6 pairs, oblong, oval or obovate, obtusish and mucronulate at the apex, mainly narrowed at the base, soméwhat larger than the stipules; tendrils branched; peduncles shorter than the leaves; flowers 6-IO, 18-25 mm. long; pod sessile, linear. oblong, nearly glabrous, veined, $4-8 \mathrm{~cm}$. long. Beaches, N. J. to arctic Am., the Great Lakes, and on the Pacific coast. Also in Europe and Asia. May-Aug.

2. Lathyrus venòsus Mulı. Verny PEA. (I. F. f. 2216.) Finely pubescent or glabrous, perennial, 6-9 dm. long. Stems 4-angled; stipules lanceolate, halfsagittate, acute or acuminate, 8-25 mm. long; leaves petioled; leaflets 4-7 pairs, ovate or oval, mucronulate, often reticulated, mostly rounded at the base, $2.5-5 \mathrm{~cm}$. long; tendrils branched; peduncles shorter than the leaves; flowers 12-16 $\mathrm{mm}$. long; pod linear, sessile, glabrous, veined, $4-8 \mathrm{~cm}$. long. River shores and banks, N. J. and Penn. to Ind., Assiniboia, Ga., La. and Kans. May-July.

3. Lathyrus palústris I.. Marsh Vetchling. (I. F. f. 2217.) Perennial, glabrous or sparingly pubescent; stems slender, 3-6 dm. long; stipules half-sagittate, I-2 cm. long; leaflets 2-4 pairs, lanceolate, oblong or linear-oblong, acute or obtusish and mucronate, $2.5-6 \mathrm{~cm}$. long; tendrils branched; peduncles generally about equalling the leaves; flowers I-1.5 cm. long; pod linear, sessile, slightly pubescent or glabrous, $4-6 \mathrm{~cm}$. long. In moist or wet grounds, Lab. to Alaska, Mass., N. Y., S. Dak. and Br. Col. Also in Europe and Asia. May-Aug.

4. Lathyrus myrtifòlius Muhl. Myrtle-leaved Marsh Pea. (I. F. f. 2218.) Perennial, usually glabrous; stems angled, 3-9 dm. long, weak. Stipules obliquely ovate or half-sagittate, 12-25 mm. long, toothed; leaflets 2-4 pairs, mostly 3 pairs, oval, oval-oblong or ovate, mucronate, narrowed at the base, I.8-5 cm. long, rather thin; tendrils branched; peduncles equalling the leaves or shorter, 3-9-flowered; flowers similar to those of the preceding; pod linear, glabrous, sessile, $2.5-5 \mathrm{~cm}$. long. In moist or wet grounds, N. B. to Manitoba, N. Car. and Tenn. May-July.

Lathyrus myrtifolius macránthus White. Pubescent; stipules larger, often half as large as the leaflets; flowers $2-2.5 \mathrm{~cm}$. long. Me. 
5. Lathyrus decaphýllus Pursh. Prairie Vetchling (I. F. f. 2219.) Perennial, erect or ascending, glabrous or finely pubescent, I.5-4.5 dm. high. Stems angled; stipules hilf-sagittate, acuminate, $8-25 \mathrm{~mm}$. long; leaflets 3-7 pairs, mucronulate, narrowed at the base, thick, reticulated, $2.5^{-6} \mathrm{~cm}$. long; stipules often wanting; peduncles usually shorter than the leaves; flowers $2.5-4 \mathrm{~cm}$. long; pod linear, seeds with a narrow stalk and short hilum. Kans. (?); Idaho and Colo. to Ariz. and N. Mex. March-July.

6. Lathyrus ornàtus Nutt. Showy Vetchling. (I. F. f. 2220.) Closely resembling the preceding, but generally lower, often less than $3 \mathrm{dm}$. high. Stipules lanceolate or linear, 4-20 mm. long; leaflets narrow, acute and mucronate, 9-25 $\mathrm{mm}$. long: tendrils commonly wanting; flowers $2.5-4 \mathrm{~cm}$. long; pod linear; seeds with abroad stalk and long hilum. Ind. Terr. to Kans., S. Dak., Colo. and Utah. May-June.

Lathyrus ornàtus incinus Snith and Rydb. Plant densely villous-canescent. Neb. and Colo.

7. Lathyrus ochroleùcus Hook. CReam-Colored Vetchling. (I. F. f. 222I.) Perennial, glabrous, slightly glaucous; stem somewhat angled, climbing or trailing, 3-8 dm. long; stipules broad, half-ovate and half-cordate, $1.7-2.5 \mathrm{~cm}$. long; leaves petioled; leaflets thin, pale beneath, ovate or broadly oval, rounded at the base, 2.5-5 cm. long; tendrils branched; peduncles shorter than the leaves; flowers 5-10, I5-18 mm. long; pod oblong-linear, sessile, glabrous, $2.5-5 \mathrm{~cm}$. long. On river banks and hillsides, N. J. to Quebec and arctic Am., Iowa, Wyo. and Br. Col. May-July.

8. Lathyrus praténsis L. Meadow Pea. Yellow Vetchling. (I. F. f. 2222.) Perennial, glabrous or sparingly pubescent, climbing or straggling, 3-9 $\mathrm{dm}$. long. Stems angled: stipules lanceolate, half-sagittate, acuminate, I.3-2.5 $\mathrm{cm}$. long; leaflets oblong or linear-oblong, acute or acutish, mucronulate, 2.5-4 $\mathrm{cm}$. long; racemes exceeding the leaves; flowers 6-12, I2-17 mm. long; pods linear, glabrous, 2.5-4 $\mathrm{cm}$. long. In waste places, Me., N. Y., Mass. and Ont. Nat. from Europe. June-Aug.

9. Lathyrus pusíllus Ell. Low Vetchling. Annual, glabrous; stem winged, 3-6 dm. long. Leaflets I pair, linear-lanceolate. 2-5 cm. long. acute; stipules sagittate, $2 \mathrm{~cm}$. long or more; peduncles'elongated, $\mathbf{1}$-3-flowered; flowers purple, snall; pod IO-I5-seeded. S. Car. to Miss., Kans. and Tex. Apr.-May.

\section{BRADBÙRYA Rat. [CENTROSEMA Benth.]}

Slender vines, with pinnately 3 -foliolate leaves (rarely 5-7-foliolate), persistent stipules, and large axillary flowers. Calyx campanulate, its teeth or lobes nearly equal; standard orbicular. nearly flat, spurred on the back near its base; clawed; wings obovate, curved; keel curved; stamens more or less diadelphous ( 9 and I); style incurved, bearded at the apex around the stigma; pod linear, flattened, nearly sessile, partially septate between the seeds, 2-valved, the valves thick-edged, longitudinally finely nerved along their margins. [In honor of John Bradbury, who travelled in America early in the century.] About 30 species, natives of America. Besides the following, another occurs in the Southern States.

I. Bradburya Virginiàna (L.) Kuntze. SpUrred Butterfly-pea. (I. F. f. 2223.) Perennial, finely rough-pubescent, 6-12 dm. long. Stipules linear, acute; leaflets 3 , ovate, or oblong-lanceolate, stipellate, rounded at the base, reticulate-veined, $2.5-5 \mathrm{~cm}$. long; peduncles about equalling the petioles, I-4-flowered; bracts ovate, acute, finely striate; flowers $2.5-4 \mathrm{~cm}$. long: corolla violet; calyxlobes linear; pod IO-I3 cm. long, long-acuminate, its margins much thickened. Dry sandy soil, N. J. to Fla., Ark., Tex. and tropical Am. July-Aug.

\section{CLITÒRIA I.}

Woody vines, or erect or climbing herbs, with pinnately 3 -foliolate (sometimes 5-9-foliolate) leaves, persistent stipules, and large axillary flowers. Calyx tubular, 5 -toothed, the 2 upper teeth more or less united; standard large, erect, retuse, nar. rowed at the base, not spurred; wings oblong, curved; keel acute, shorter than the wings; stamens more or less monadelplous; anthers all alike; ovary stipitate; style 
elongated, incurved, hairy along the inner side; pod stalked in the calyx, linear or linear-oblong, flattened, 2.valved, partly septate between the seeds. About 30 species, natives of warm and temperate regions. The following is the only one known to inhabit N. Am.

I. Clitoria Mariana L. Butterfly-PeA. (I. F. f. 2224.) Erect or ascending, sometimes twining, glabrous or nearly so, 3-9 dm. high. Stipules ovate-lanceolate, acute; leaflets stipellate, ovate-lanceolate or oblong-lanceolate, obtuse, mu. cronate, 2.5-5 cm. long; peduncles short, I-3-flowered; bracts lanceolate, striate, leciduous; flowers about $5 \mathrm{~cm}$. long, very showy; calyx tubular, 12-17 mm. long, its teeth ovate, acute; corolla pale blue; pods acute, about $2.5 \mathrm{~cm}$. long. Dry soil, N. J., to Fla., Mo. and Tex. June-July.

\section{FALCÀTA Gmel. [AMPHICARPA Ell.]}

Twining perennial vines, with pinnately 3 -foliolate leaves, small white or violet flowers in axillary racemes, and also solitary apetalous fertile flowers in the lower axils or on the slender creeping branches from the base. Calyx of the petaliferous flowers tubular, 4-5-toothed; standard obovate, erect, folded around the other petals; wings oblong, curved. adherent to the incurved obtuse keel; stamens diadelphous ( 9 and $\mathrm{I}$ ); style filiform, not bearded; pods from the upper flowers linearoblong, several-seeded, 2-valved, those from the lower obovoid, fleshy, mainly I-seeded. [Latin, referring to the curved keel of the corolla.] About 7 species, natives of N. Am., eastern Asia and the Himalayas. Only the following in N. Am.

Leaves thin; bracts small; plant pubescent or glabrate.

Leaves firm; bracts large; plant villous-brown-pubescent.

\section{Falcata comòsa (L.) Kuntze. Wild or Hog PEA-Nut.} Slender, 3-24 dm. long. Stipules oblong or ovate, $4 \mathrm{~mm}$ long, (I. F. f. 2225.) Slender, 3-24 dm. long. Stipules oblong or ovate, 4 mm. long, striate; leaflets broadly ovate or rhombic-ovate, acute, rounded at the base, $2.5-8 \mathrm{~cm}$. long; racemes of petaliferous flowers mainly simple; bracts ovate, obtuse; flowers purplish or white, $12-15 \mathrm{~mm}$. long; pedicels equalling or exceeding the bracts; pods of the petaliferous flowers about $2.5 \mathrm{~cm}$. long, $6 \mathrm{~mm}$. wide, pubescent, especially along the margins. Moist thickets, N. B. to Fla., Manitoba, Neb. and La. Aug.-Sept.

2. Falcata Pítcheri (T. \& G.) Kuntze. Pitcher's Hog Pea-nut. (I. F. f. 2226.) Similar to the preceding, but generally stouter, villous-pubescent with reflexed brown hairs. Leaflets larger and thicker, scmetimes I dm. long; pedicels mostly shorter than the nearly orbicular car:escent bracts; ovary and pods of the petaliferous flowers pubescent throughout; subterranean fruit less abundantly produced than in $F$. comosa; calyx larger. Moist thickets, Mass. to western N. Y., S. Dak., Neb., Kans. and Tex. Aug.-Sept.

\section{1. ÀPIOS Moench.}

Twining perennial vines, with pinnately 3-7-foliolate leaves, small stipules and rather large brownish-purple or red flowers, mainly in axillary racemes or panicles. Caly $x$ campanulate, somewhat 2 -lipped, the 2 lateral teeth very small, the 2 upper united and short, the lower one long and acute. Standard ovate or orbicular, reflexed. Wings obliquely obovate, adherent to the elongated incurved at length twisted keel. Stamens diadelphous (9 and r). Ovary nearly sessile, ovules $\infty$; style slender. Pod linear, straight or slightly curved, compressed, 2 -valved, manyseeded. Rootstocks usually tuberous. [Greek, pear, from the shape of the tubers.] Five known species, 2 of eastern N. Am., 2 of China and 1 of the IIimalayas.

Standard suborbicular, rounded or retuse at the apex.

Standard produced at apex into a thickened appendage.

1. A. Apios.

2. A. Priceana.

I. Apios Àpios (L.) MacM. Ground-nut. bescent or glabrate. Stipu'es subulate, 2-4 mm. long, deciduous; leaves petioled; leaflets 5-7 (rarely 3 ), ovate or ovate-lanceolate, acute or acutish, rounded at the base, $2.5-8 \mathrm{~cm}$. long; racemes often compound; peduncles shorter than the leaves; flowers numerous, odorous, about $12 \mathrm{~mm}$. long; rachis of the inflorescence knobby; pod pointed, $2.5^{-10} \mathrm{~cm}$. long, about $5 \mathrm{~mm}$. wide. In moist ground, N. B. to Fla., Ont., Minn., Kans. and La. Stem with milky juice; tubers edible. July-Sept. 
2. Apios Priceàna Robinson. PrICE's Ground-nut. Stem soon glabrous. Stipules $6 \mathrm{~mm}$. long. Leaflets 3-9: racemes dense, mostly 2 or 3 together in the axils; standard $2.5 \mathrm{~cm}$. long; pods $12-15 \mathrm{~cm}$. long. Root solitary. Ky.

\section{GALÁCTIA P. Br.}

Perennial vines (sometimes erect and shrubby), mainly with pinnately 3 -foliolate leaves, small and deciduous stipules, and purple or violet axillary racemose flowers. Calyx 4-lobed, bracteolate, the lobes acute, often as long as the tube. Standard orbicular or obovate. Wings narrow, obovate, adherent to the narrow, nearly straight keel. Stamens diadelphous or nearly so (9 and I). Ovary nearly sessile; ovules $\infty$; style filiform, not bearded. Pod linear, straight or slightly curved, usually flattened, 2-valved, several-seeded. Fleshy few-seeded pods are sometimes produced from subterranean apetalous flowers. [Greek, milk-yielding, many of the species having milky sap.] About 50 species, natives of warm and temperate regions, most abundant in America. Besides the following about I5 others occur in the Southern and Southwestern States.

Nearly glabrous throughout; pods slightly pubescent.

Finely downy-pubescent; pods very downy.

1. G. regularis.

2. G. volubilis.

I. Galactia regulàris (L.) B. S. P. Milk PEA. (I. F. f. 2228.) Prostrate; stems matted, 3-6 dm. long. Leaflets elliptic or ovate-oblong, obtuse and often emarginate, rounded or slightly cordate at the base, 2-4 cm. long, $8-18 \mathrm{~mm}$. wide; peduncles longer than the petioles and generally exceeding the leaves, erect, 4-10. flowered; flowers reddish purple, I2-17 mm. long; pods 2.5-4 cm. long, 4-7. seeded. In dry sandy soil, N. Y. and Penn. to Fla., Kans. and Miss. July-Aug.

2. Galactia volúbilis (L.) Britton. Downy MiLk PEa. (I. F. f. 2229.) Similar to the preceding. Leaflets ovate, elliptic or oval, sometimes emarginate, rounded or slightly cordate at the base, $2-4 \mathrm{~cm}$. long, I I-25 mm. wide; racemes rather loose; flowers purplish, about $12 \mathrm{~mm}$. long; pod $2.5-4 \mathrm{~cm}$. long. In dry soil, N. Y. to Fla., Penn., Ky., Kans. and Tex. June-July.

\section{DOLÍCHOLUS Medik.}

\section{[RHYNCHOSIA Lour.]}

Perennial twining trailing or erect herbs, with pinnately I-3-foliolate leaves, and yellow mostly axillary and racemose flowers. Leaflets generally punctate with resinous dots, not stipellate; calyx 4-5-lobed, somewhat 2-lipped; standard obovate or orbicular, spreading or reflexed; wings narrow; keel incurved at the apex or falcate; stamens diadelphous (9 and I); ovary nearly sessile; ovules 2, rarely I; style filiform; pod flat, oblong or obliquely orbicular, 2-valved, I-2-seeded. [Greek, diminutive of Dolichos.] About roo species, natives of warm and temperate regions. In addition to the following, some 9 others occur in the Southern States.

Leaflets 3 .

Stem twining or trailing.

Racemes shorter than the leaves; flowers $6-8 \mathrm{~mm}$. long. I. D. tomentosus.

Kacemes longer than the leaves; flowers about $12 \mathrm{~mm}$. long.

Stem erect, 3-7.5 dm. high.

Leaflet solitary, very broad; plant low, erect, $8-23 \mathrm{~cm}$. high.
2. D. latifolius.

3. D. erectus.

4. D. simplicifolius.

I. Dolicholus tomentòsus (L.) Vail. Twrning Dolicholus. (I. F. f. 2230.) Pubescent with spreading hairs, 3-9 dm. long. Stipules ovate, acute, sometimes wanting: petioles shorter than the leaves; leaflets 3 , or the lowest leaves I-foliolate, ovate, orbicular or broader than long, obtuse but generally pointed, 2.5$5 \mathrm{~cm}$. long; racemes short-peduncled or sessile, 2-8-flowered; flowers 6-8 mm. long; calyx deeply 4-parted, the upper lobe 2-cleft; pod oblong, acute, pubescent, 16-19 mm. long. In dry sandy soil, Va. to Fla., west to Tex. May-July.

2. Dolicholus latifölius (Nutt.) Vail. Prairie Dolicholus. (I. F. f. 2231.) Softly pubescent; stem angled, sometimes $1.5 \mathrm{~m}$. long. Stipules lanceolate or wanting; petioles $2.5-8 \mathrm{~cm}$. long; leaflets broadly ovate or somewhat rhomboid, or the end one orbicular, $2.5-8 \mathrm{~cm}$. long, mostly obtuse; racemes elongated, sometimes $3 \mathrm{dm}$. long in fruit, many flowered; calyx about $12 \mathrm{~mm}$. long, deeply parted, 
the segments narrowly lanceolate, acuminate; corolla little longer than the calyx; pod oblong, acute, very pubescent, about $2.5 \mathrm{~cm}$. long. In dry soil, Mo. to La. and Tex. May-June.

3. Dolicholus eréctus (Walt.) Vail. ERect Dolicholus. (I. F. f. 2232.) Erect, velvety-pubescent or tomentose, 3-8 dm. high. Stipules linear-lanceolate, acuminate; petioles shorter than or equalling the leaves; leaflets oval, ovate or slightly obovate, thick, densely tomentose, especially beneath, $2.5-5 \mathrm{~cm}$. long; racemes 5-15-flowered, sessile or short-peduncled; flowers 6-10 $\mathrm{mm}$. long; pod oblong, I 2-17 mm. long. In dry soil, Del. to Fla., Tenn. and La. May-Sept.

4. Dolicholus simplicifòlius (Walt.) Vail. Round-LEaved Dolicholus. (I. F. f. 2233.) Simple, pubescent. Stipules lanceolate, acuminate; petioles shorter than or exceeding the leaves; leaflet orbicular or broader, thick, obtuse, slightly cordate at the base, $2.5-3 \mathrm{~cm}$. long (leaflets rarely 3 , the lateral ones ovate); racemes rather densely flowered, peduncled; flowers 6-10 $\mathrm{mm}$. long; pod as in the preceding. In dry soil, Va. to Fla., west to La. May-July.

\section{PHASÈOLUS L.}

Vines, rarely erect herbs, with pinnately 3 -foliolate leaves, and axillary racemose flowers. Calyx 5-toothed or 5-lobed, or the 2 upper teeth more or less united. Standard orbicular, recurved, spreading or somewhat contorted; wings mainly obovate; keel spirally coiled, linear or obovoid. Stamens diadelphous (9 and 1). Style longitudinally bearded; stigma oblique or lateral; ovary sessile or nearly so; ovules $\infty$. Pod linear, 2-valved, several-seeded, tipped with the persistent style. Seeds mostly with rounded ends. Rachis thickened at the bases of the pedicels. [Ancient name of the Kidney Bean.] About I7o species, of warm and temperate regions. Besides the following, about 12 others occur in the Southern States.

I. Phaseolus polystàchyus (L.) B.S.P. WILD BEAN OR BEAN VINE. (I. F. f. 2234.) Perennial, finely pubescent, 1.2-4 m. long. Stipules lanceolate, deciduous; leaflets broadly ovate or nearly orbicular, acute or acuminate, rounded at the base, 5-10 cm. long, the terminal one often slightly cordate; racemes peduncled, $1-3 \mathrm{dm}$. long, narrow, loosely flowered; pedicels minutely bracted at the base; corolla purple, about $8 \mathrm{~mm}$. long: pods stalked, drooping, somewhat curved, flat, 4-6 cm. long, 4-6-seeded, glabrous or nearly so; seeds chocolate-brown, 6-8 mm. long. In thickets, Canada (Torrey and Gray); Conn. to Fla., Minn., Neb. and La. July-Sept.

\section{STROPHOSTỲLES Ell.}

Herbaceous vines, rarely erect, with pinnately 3 -foliolate stipellate leaves, and pink-purple or nearly white flowers capitate at the ends of long axillary peduncles. Calyx as in Phaseolus. Standard nearly orbicular; wings mostly obovate; keel strongly curved. Stamens diadelphous (9 and I). Style longitudinally bearded, bent. Pod linear, usually straight, few-several-seeded, tipped by the persistent style. Seeds truncate at the ends, more or less pubescent or mealy. [Greek, bent style.] An American genus, of about 6 species.

Leaflets mainly lobed, $2-5 \mathrm{~cm}$. long; pod 5-8 cm. long. Leaflets mainly entire, $1-4 \mathrm{~cm}$. long; pod $2-5 \mathrm{~cm}$. long.

Flowers several, about $12 \mathrm{~mm}$. long; root perennial.

Flowers few, about $6 \mathrm{~mm}$. long; root annual.

1. S. helvola.

2. S. umbellata.

3. S. pauciflora.

I. Strophostyles hélvola (L.) Britton. Trailing Wild BEAN. (I. F. f. 2235.) Prostrate or low-twining, rather rough-pubescent, 6-16 dm. long, rarely erect, and 2.5-5 dm. high. Stipules narrowly lanceolate, 2-4 mm. long; leaflets broadly ovate, rounded at the base, thickish; peduncles axillary, exceeding the petioles; flowers 3-10, sessile; corolla greenish purple, 9-12 mm. long; keel slender, curved; pod slightly pubescent; seeds oblong, pubescent. In sandy soil, Quebec to Fla., S. Dak., Neb. and Tex. July-Oct.

Strophostyles hélvola Missouriénsis ( $\mathrm{S}$. Wats.) Britton. Climbing in trees to a height of 6-10 m. Leaflets larger, usually entire; seeds larger. Said to bloom later. Mo. and Kans.

2. Strophostyles umbellàta (Muhl.) Britton. Pink WiLd Bean. (I. F. f. 2236.) Stems trailing, more or less pubescent with retrorse hairs, $3-15 \mathrm{dm}$. long. 
Stipules ovate-lanceolate, 2-4 mm. long; leaflets ovate, lanceolate or oblong, sparingly pubescent, entire, or rarely with $\mathbf{I}$ or 2 shallow lobes; peduncles generally much longer than the leaves; flowers several, pink, fading yellowish, similar to those of the preceding; pod straight, little compressed, sparingly pubescent; seeds mealy-pubescent. In sandy soil, L. I. to Fla., Ind. and La. July-Sept.

3 Strophostyles pauciflòra (Benth.) S. Wats. SMall Wild Bean. (I. F. f. 2237.) Stems finely retrorsely hirsute, low climbing or trailing, 3-7 dm. long. Stipules ovate-lanceolate, I-3 mm. long; leaflets lanceolate or linear-oblong, ob. tuse, entire; peduncles exceeding the leaves; flowers 2-6, purplish; pod flat, about $2.5 \mathrm{~cm}$. long and $4 \mathrm{~mm}$. wide, pubescent; seeds purple, glabrous and shining at maturity. Along rivers, Ind. to S. Dak., Miss., Kans. and Tex. July-Sept.

\section{VÍGNA Savi.}

Herbaceous vines, or sometimes erect herbs, with pinnately 3 -foliolate stipulate leaves, the leaflets broad. Flowers clustered at the ends of long axillary peduncles, yellowish or purplish, the rachis of the head or raceme knotty, the bracts and bractlets early deciduous. Calyx 5 -toothed, or the 2 upper teeth united. Standard nearly orbicular, auricled at the base; wings shorter than the standard; keel about equalling the standard, slightly incurved. Stamens diadelphous (9 and I). Ovary sessile; ovules numerous; style bearded along the inner side. Pod linear, nearly terete, 2-valved. [In honor of Domenic Vigni, a commentator on Theophrastus.] About 30 species, natives of warm and tropical regions. Besides the following another occurs in the southern U. S.

I. Vigna Sinénsis (L.) Endl. Cow Pea. China Bean. Black-eyed Bean. (I.F.f. 2238.) Annual; stem striate. Stipules ovate or ovate lanceolate, acuminate, prolonged backward, 6-20 mm. long: terminal leaflet rhombic-ovate, 5-15 cm. long, often about as wide, long-stalked; lateral leaflets very obliquely ovate and inequilateral, short-stalked; flowers few, yellowish, 1.6-2 cm. long; pod fleshy, I-2 dm. long, 6-8 mm. thick, nearly straight. Escaped from cultivation. Mo. to Tex. and Ga. Native of Asia. July -Sept.

\section{Order I9. GERANIÀLES.}

Dicotyledonous herbs, shrubs or trees, usually with petals, and these separate (more or less united in Polygalaceae, wanting in most Euphorbiaceae, in Callitrichaceae, and in some species of Xanthoxylum in Rutaceae); sepals mostly distinct; stamens few, rarely more than twice as many as the sepals, opposite them when as many ; ovary superior, compound; ovules pendulous, the raphe toward the axis of the ovary.

Stamens more than one; land plants.

Flowers regular or nearly so; petals present, usually as many as the sepals.

Herbs, the leaves not punctate; flowers perfect.

Leaves not pinnately compound.

Capsule at length splitting into its 5 carpels; leaves lobed or dissected.

Capsule 2-5-celled, not splitting into its carpels.

Stamens $2-3$ times as many as the petals; leaves 3 -foliolate in our species.

Stamens as many as the petals; leaves entire. Fanı. 3. Linaceae. Leaves pinnately compound.

Fam. 4. Zygophyllaceae.

Our species trees or shrubs with compound leaves, often punctate; flowers diøecious or polygamous.

Leaves punctate.

Fam. 5. Rutaceae.

Leaves not punctate, the bitter bark with oil-sacs. Fam. 6. Simarubaceae. Flowers very irregular; petals 3 ; stamens usually 8 ; herbs. Fam. 7. Polygalaceae. Flowers regular, of ten apetalous, small, monœecious; carpels mostly 3; herbs or low shrubs, mostly with milky juice.

Stamen only I; perianth none; styles 2; small aquatic or rarely terrestrial plants with opposite entire leaves.

Fam. 9. Callitrichaceae 


\section{Family 1. GERANIÀCEAE J. St. Hil.}

\section{Geranium Family.}

Herbs with alternate or opposite leaves, and axillary solıtary or clustered perfect regular flowers. Stipules commonly present. Sepals 5 (rarely fewer), mostly persistent. Petals of the same number, hypogynous. Stamens as many as the sepals, or $2-3$ times as many, distinct; anthers 2-celled, versatile. Ovary I, usually 5-lobed and 3-celled, ovules I or 2 in each cavity. Fruit capsular. Embryo straight or curved : cotyledons flat or plicate. About ro genera and 450 species, natives of temperate regions, most abundant in South Africa.

Anthers Io, rarely 5 ; carpel-tails not hairy inside.

Anthers 5 ; carpel-tails bearded inside.

1. Geranium.

2. Erodium.

\section{GERÀNIUM L.}

Herbs with stipulate, palmately lobed, cleft or divided leaves, and axillary $\mathbf{I}-\mathbf{2}$. flowered peduncles. Flowers regular, 5-merous. Sepals 5, imbricated. Petals 5. hypogynous, imbricated. Stamens ro (rarely 5 ), generally 5 longer and 5 shorter. Ovary 5-lobed, 5-celled, beaked with the compound style. Ovules 2 in each cavity. Capsule elastically dehiscent, the 5 cavities $\mathrm{I}$-seeded and long tailed by the persistent style-divisions which are naked on the inner side. [Greek, a crane, from the long beak of the fruit.] About $r 70$ species, widely distributed in temper. ate regions. Besides the following, some 6 others occur in western N. Am.

Perennial ; flowers $2.5 \mathrm{~cm}$. broad or more.

Annuals or biennials ; flowers 4-12 mm. broad.

Leaves 3-divided; segments pinnatifid, thin.

Leaves pedately lobed or dissected.

Peduncles I-flowered.

Peduncles 2-flowered.

Peduncles longer than the leaves; carpels smooth.

Peduncles short; carpels rugose or hairy.

Seeds reticulated or pitted.

Glandular-pubescent with long white hairs. 5. G. rotundıfolium. Pubescent with short hairs; leaves deeply lobed.

Flowers pale purple : seeds minutely reticulated.

Beak short-pointed; inflorescence compact.

Beak long-pointed; infloresence loose.

6. G. Carolinianum.

Flowers deep purple seeds pitted. 7 . Bicknelli.

Seeds smooth or nearly so.

8. G. dissectum.

Stamens 5 ; carpels hairy, not rugose.

Stamens Io; carpels glabrate, rugose.

9. G. pusillum.

10. G. molle.

I. Geranium maculàtum L. WILd OR Spotted CRANE'S-BILl. AlunRoot. (I. F. f. 2239.) Pubescent with spreading or retrorse hairs, 3-6 dm. high. Basal leaves 7.5-15 cm. wide, deeply 3-5-parted, the divisions obovate, cuneate, variously toothed and cleft; stem-leaves 2, similar to the basal ones; peduncles I-5, elongated; ultimate pedicels $2.5-5 \mathrm{~cm}$. long; flowers rose-purple; sepals awn. pointed, villous, ciliate; petals woolly at the base: beak of the fruit $2.5-3.75 \mathrm{~cm}$. long; carpels pubescent; seed reticulate. In woods, Newf. to Manitoba, Neb., Ga., Ala. and Kans. April-July.

Geranium praténse L., the meadow geranium of Europe, is reported as escaped from cultivation in Quebec and N. B. It differs from the preceding by its blue-purple flowers and narrower lobes of the leaf-segments.

2. Geranium Robertiànum L. Herb Robert. Red Robin. (I. F. f. 2240.) Glandular-villous, weak, extensively branching, 1.5 -4.5 dm. high, heavyscented. Leaves ovate orbicular; peduncles slender, 2 -flowered, $2.5-7.5 \mathrm{~cm}$. long; pedicels divaricate, $1.25 \mathrm{~cm}$. long; sepals acuminate and awn-pointed; flowers red-purple, about $12 \mathrm{~mm}$. broad; petals narrow-clawed; beak of the fruit about 
$2.5 \mathrm{~cm}$. long, awn-pointed, nearly glabrous; carpels nearly glabrous, slightly wrinkled; seed smooth. In rocky woods, rarely in sandy places, N. S. to Manitoba, N. J., Pa. and Mo. Also in Europe, Asia and Africa. May-Oct.

3. Geranium Sibíricum L. Siberian Crane's-bill. (I. F. f. 224I.) Vil. lous pubescent, freely branched, 3-I3 dm. high. Leaves deeply 3-5-parted, 5-6 cm. broad, nearly orbicular, or cordate-reniform, the divisions oval lanceolate, cleft or toothed; peduncles slender, $5-7.5 \mathrm{~cm}$. long, 2-bracted near the middle; flowers nearly white, $6-8 \mathrm{~mm}$. broad; sepals oval, awned; beak of the fruit canescent, I. $4-\mathbf{I} .8 \mathrm{~cm}$. long, tipped with a short prolongation; lobes of the capsule puberulent or hairy; seed minutely reticulate. Along roadsides in the northern part of N. Y. City; also found at Cambridge, Mass., and in III. Adventive from Asia. Some of the pedicels are rarely 2-flowered. June-Sept.

4. Geranium columbinum L. Long-STalked Crane's-bill. (I. F. f. 2242.) Slender, slightly hispid.pubescent with whitish appressed hairs. Leaves 2.5-3.75 cm. in diameter, deeply 5-9-divided into narrow, variously cleft segments; petioles very slender; pedluncles slender, longer than the upper leaves; pedicels $2.5-7.5 \mathrm{~cm}$. long; flowers purple, about $8 \mathrm{~mm}$. broad; sepals ovate, awnpointed, enlarging in fruit; petals notched; capsule-lobes nearly glabrous, keeled, not rugose; beak $1.2-2 \mathrm{~cm}$. long, hispid; seeds deeply pitted. In fields and along roadsides, N. J., Penn., Md. and Va. Also in S. Dak. Nat. or adventive from Europe. May-July.

5. Geranium rotundifòlium L. Round-Leaved Crane's-Bill. (I. F. f. 2243.) Often tufted, I.5-4 dm. high, much branched, softly pubescent with spreading white purple-tipped hairs. Leaves reniform-orbicular, $3-4 \mathrm{~cm}$. wide, cleft about to the middle into 5-9 obtuse broad lobes, which are 3-5 toothed; petioles slender; flowers purple, 4-6 $\mathrm{mm}$. broad; sepals ovate, or oval, short-pointed, some. what shorter than the entire obovate petals; ovary and capsule-lobes hairy, not wrinkled; beak pubescent, about $\mathbf{I} .2 \mathrm{~cm}$. long, tipped by a short awn. In waste places, Micl., and in ballast about N. Y. Fugitive from Europe. Summer.

6. Geranium Caroliniànum L. Carolina Crane's bILl. (I. F. f. 2244.) Erect, generally branched, stout, I.5-4 dm. high, loosely pubescent with spreading often glandular gray hairs. Leaves reniform-orbicular, $2.5-7.5 \mathrm{~cm}$. wide, deeply cleft into 5-9 oblong or olovate cuneate toothed or lobed segments; peduncles rather short and stout; fowers in compact clusters, pale pink or whitish, 8-14 mm. broad; sepals ovate, ciliate, about equalling the obovate emarginate petals; ovarylobes hispid-pubescent; persistent filaments not longer than the carpels; beak nearly $2.5 \mathrm{~cm}$. long. In barren soil, N. Eng. and Ont. to Br. Col., Fla. and Mex. Also in Bermuda. April-Aug.

7. Geranium Bicknéllii Britton. Bicknell's Crane's-bill. (I. F. f. 2245.) Similar to the preceding, but taller, the stems usually more slender, loosely pubescent. Leaves somewhat angulate, the segments oblong or linear oblong, mostly narrower; peduncles slender, the inflorescence loose; sepals lanceolate; ovary-lobes pubescent; persistent filaments longer than the carpels; beak about $2.5 \mathrm{~cm}$. long, its tip 4-6 mm. long. N. S. to W. Ont., Br. Col., Mont. and S. N. Y. May-Sept.

8. Geranium disséctum L. Cut-leaved Crane's-Bill. (I. F. f. 2246.) Closely related to the two preceding species, but smaller in every way, more slender, the branches decumbent or ascending; leaves seldom more than $3.75 \mathrm{~cm}$. wide, deeply cleft into narrower segments; inflorescence loose; peduncles short; flowers purple, about $6 \mathrm{~mm}$. broad; sepals ovate, awned, equalling or slightly longer than the notched petals; capsule-lobes and beak pubescent. In waste places and in ballast, N. Y. and N. J. Also in the North west. Fugitive from Europe. June-Sept.

9. Geranium pusíllum Burm. f. SMall-Flowered Crane's-Bili. (I. F. f. 2247.) Widely branching, slender, pubescent or villous, $1-4.5 \mathrm{dm}$. long. Leaves petioled, reniform orbicular, 1.25-3.75 cm. wide, deeply divided into 7-9 oblong, or sometimes linear-oblong, entire or 3-toothed, cuneate lobes; peduncles short, 6I $8 \mathrm{~mm}$. long; pedicels $6-24 \mathrm{~mm}$. long; sepals acute, awnless; flowers pale purple, 6-10 mm. broad; petals notched; capsule -lobes hairy, keeled, not wrinkled; beak about I cm. long, canescent. In waste places, S. N. Eng. to N. J., Ohio, Ont., Neb., Wyo. and Br. Col. Adventive from Europe. May-Sept.

Io. Geranium mólle L. Dove's-Foot C'RANE'S-BILl. (I. F. f. 2248.) Resembling the preceding species, but more villous, the leaves nearly orbicular 
and not as deeply cleft, generally only to just below the middle, into 7-II obovate or cuneate lobes, which are 3-5-toothed at the apex; flowers dark-purple, 6-10 $\mathrm{mm}$. broad; sepals obtusish, not awned; capsule-lobes distinctly marked with transverse wrinkles; beak about $\mathbf{I} \mathrm{cm}$. long, sparingly pubescent. In waste places, Me. to Penn., N. Y., Ohio and Ont. Also in Wash. and Vancouver. Fugitive from Europe. May-Sept.

\section{ERÒDIUM L'Her.}

Herbs, generally with jointed nodes, opposite or alternate stipulate leaves, and axillary umbellate nearly regular flowers. Sepals 5, imbricated. Petals, 5, liypogynous, imbricated, the 2 upper slightly smaller. Glands 5. Anther-bearing stamens 5, alternating with as many sterile filaments. Ovary 5-lobed, 5-celled, beaked by the united styles, the beak terminating in 5 stigmas; ovules 2 in each cavity. Capsule-lobes $\mathbf{I}$-seeded, the styles elastically dehiscent and coiled spirally at maturity, villous-bearded on the inner side. Seeds not reticulate. [Greek, a heron, from the reremblance of the truit to its beak and bill.] About 6o species, widely distributed in temperate and warm regions. There are three native species in the southwest; several exotic ones have been collected on ballast at the seaports.

I. Erodium cicutàrium (L.) L'Her. Hemlock STORK'S-B1L. or Heron'sBILl. Alfilaria. (I. F. f. 2249.) Annual, tufted, villous-pubescent, somewhat viscid, 1.5-3 dm. high. Basal and lower leaves $7.5-18 \mathrm{~cm}$. long, $1.25-2.5 \mathrm{~cm}$. wide, pinnate, the segments finely pinnatifid; peduncles generally longer than the leaves, umbellately 2-12-flowered; flowers purple or pink, 8-10 mm. broad; sepals acute, villous, about equalling the entire petals; carpels hairy; beak $\mathbf{1} .25-3.75 \mathrm{~cm}$. long, its divisions spirally coiled when ripe. Waste places and fields, N. S., Ont., N. J., N. Eng., Penn. and Mich., and very abundant from Tex. to Ore. Adventive from Europe, in our area. A common weed in the Old World. April-Sept.

Erodium moschàtum Willd., reported from Ont., Mass. and Me., has much broader serrate or incised leaf-segments.

\section{Family 2. OXALIDÀCEAE Lindl.*}

\section{Wood-sorrel Family.}

Leafy-stemmed or acaulescent herbs, or rarely shrubs, often with rootstocks or scaly bulbs, the sap sour. Leaves mostly palmately 3foliolate, in some exotic species pinnate, or entire and peltate; stipules commonly present as scarious expansions of the petiole-bases; leaflets miostly obcordate. Flowers perfect, in umbel-like or forking cymes, or sometimes solitary; peduncles mostly long. Sepals 5, often unequal. Petals 5, white, pink, purple or yellow. Stamens 10-1 5. Ovary 5-celled, 5-lobed; styles united, or distinct; ovules 2-many in each cavity; fruit a loculicidal globose or columnar capsule, rarely baccate. Embryo straight, in fleshy endosperm. About 7 genera and 280 species, chiefly of tropical distribution.

\section{x. ÓXALIS L.}

Annual or perennial, caulescent or acaulescent, often bulbous herbs, with alternate, mostly digitately compound leaves (3-foliolate in our species) and axillary, I-several-flowered peduncles. F'owers regular, often heterogonous. Sepals 5, imbricated. Petals 5. Stamens Io, monale phous at base, 5 longer and 5 shorter, all anther-bearing. Ovary 5-celled; ovules several in each cavity; styles 5, separate, persistent, stigmas terminal. Capsule loculicidally dehiscent. Seeds 2 or more in each cavity, anatropous, with a loose aril-like dehiscent outer coat. [Greek. sour, from the acid juice.] About 250 species, mostly natives of warm or tropical regions. Besides the following, some ro others occur in the Southern and Western States. 
Acaulescent; flowers white, pink or rose-purple.

Scape I-flowered; flower pink, rarely white; capsule subglobose. I. O. Acetosella.

Scape several-flowered; flowers rose-purple, or rarely white; capsule ovoid.

Caulescent; flowers yellow.

2. O. violacea.

Cymes umbel-like; pedicels reflexed or deflexed at maturity.

Pedicels pubescent with appressed hairs.

Stens or branches creeping; introduced species.

Stems erect, or if decumbent, not creeping; native species.

Stems pubescent with appressed hairs.

Stems pubescent with spreading hairs or glabrous.

Cymes maturing several or all the flowers at about the same time, not accompanied by drooping buds.

Leaflets, or most of them, less than $1 \mathrm{~cm}$. wide; stems copiously leafy.

5. O. filipes.

Leaflets, or most of them, over $\mathrm{r} \mathrm{cm}$. wide; stems sparingly leafy.

6. O. Brittoniat.

Cymes maturing 1 or 2 flowers at a time, these accompanied by several drooping buds.

Pedicels pubescent with spreading hairs.

7. O. Bushii.

Foliage, especially the leaves, bright green.

Styles recurved; petals not ciliate.

Styles erect ; petals ciliate.

Foliage, especially the leaves, reddish purple.

Cymes dichotomous; pedicels erect or spreading.

Leaflets not discolored, green or reddish purple; petals 8-10 mm. long.

Foliage, especially the leaves, reddish purple; stems often glabrous.

Foliage, especially the leaves, green; stems pubescent.

Pedicels pubescent with appressed hairs.

Pedicels pubescent with spreading hairs.

Leaflets discolored, the margins brownish; petals $12-16 \mathrm{~mm}$. long.

Io. O, rufa.

8. O. recurva.

9. O. Priceae.

10. O.rufa.

6. O. Brittoniae. II. O. cymosa.

r2. O. grandis.

I. Oxalis Acetosélla L. White or True Wood-Sorrel. Alleidia. (I. F. f. 2250.) Rootstock scaly, elongated. Foliage pubescent with scattered brownish hairs; petioles jointed and dilated at the base; leaflets obcordate, wider than long; scapes 5-15 cm. high; flowers broadly campanulate, about $1.25 \mathrm{~cm}$. long; sepals obtusish; petals veined with deep pink, 3-4 times as long as the calyx; capsule subglobose, 2-4 mm. in diameter, glabrous; seeds ovoid, longitudinally grooved. In cold damp woods, N. S. to Manitoba, the mountains of N. Car. and the shore of Lake Superior. Also in Europe, Asia, and N. Africa. Cleistogene flowers are borne on recurved scapes at the base of the plant. May-July.

2. Oxalis violàcea L. VIOLET WOOD-SORREL. (I. F. f. 225 I.) Bulb brownish, with ciliate scales. Foliage nearly or quite glabrous; leaves about $2.5-3 \mathrm{~cm}$. wide; leaflets obcordate, minutely reticulated, the midrib sometimes sparingly hairy; scapes I-3 dm. high; pedicels slender; flowers $1.6-2 \mathrm{~cm}$. long, heterogonous; sepals obtuse; petals lighter toward the base, obtuse or truncate, 3 times as long as the sepals; capsule ovoid, $4 \mathrm{~mm}$. long: seeds flattened, rugose-tuberculate. In woods, northern N. Eng. to Minn. and the Rocky Mts., south to Fla. and N. Mex. Also apparently the same plant in the Andes of Bolivia. May-Jume.

3. Oxalis corniculàta L. Yellow Procumbent Woon-sorrel. (I. F. f. 2252.) Pubescent with appressed hairs or nearly glabrous, deep green, freely branching from the base; stem $2.5-3.5 \mathrm{~cm}$. long, the branches diffuse, mainly procumbent and often creeping. Leaflets about 8-12 mm. wide; petioles dilated at the base into oblong rounded or truncate stipules; peduncles I-3-flowered; flowers 5-IO $\mathrm{mm}$. wide; pedicels strigillose, more or less reflexed; capsule oblong, $\mathbf{I}-\mathbf{I} .5 \mathrm{~cm}$. long; appressed-pubescent; seeds compressed, transversely ridged. In ballast about the Eastern seaports, and frequently growing on the ground in greenhouses. Tex. and throughout tropical Am. Recently found in Ont. Occurs also in warm and tropical regions of the Old World. Feb.-Nov.

4. Oxalis stricta L. Upright Yellow WoOd-Sorrel. (I. F. f. 2254.) Foliage pale green. Stem commonly branched at the base, the branches spreading, I-3 dm. long; leaves $\mathbf{1} .8-3.7 \mathrm{~cm}$. broad; leaflets coarsely cellular, sensitive, drooping when touched; petiole-bases narrowly dilated; flowers fragrant; peduncles 
3-15 cm. long; sepals linear or lanceolate, about $5 \mathrm{~mm}$. long, ciliolate, erect or ascending; petals 8-10 $\mathrm{mm}$. long, commenly reddish at the base; capsule columnar, 16-30 mm. long; seeds fully I mm. long, with interrupted transverse ridges. In woods and fields, N. S. to N. Dak. and Colo., south to Fla. and Tex. Introduced into Europe as a weed. April-Oit.

5. Oxalis filıpes Small. Sirender Yellow Wood-sorrel. (I. F. f. 2253.) Foliage deep green. Stem wiry, usually very leafy, 0.5-2 dm. high; leaves 6-12 $\mathrm{mm}$. wide. not stipulate, or the stipules very narrow; leaflets with unequal sides; ped. uncles filiform, 2-3-flowered; pedicels very slender, recurved when mature; scpa!s oblong-lanceolate. 3-4 mm. long, obtuse, with a tuft of hairs at the apex; petals 4 \& $\mathrm{mm}$. long, emarginate; capsule 8-12 mm. long, gradually narrowed, often curved; seeds I $\mathrm{mm}$. long, with continuous ridges. In woods, L. I. to Va. and Tenn., south to Ga. Plant smaller than the next preceding species. May-Aug.

6. Oxalis Brittòniae Small, n. sp. Foliage bright green. Stem slender, sparingly leafy, I-4 din. tall, oftem branclied; leaves mostly $\mathbf{I}-2 \mathrm{~cm}$. broad; petioles filiform, sparingly villuus; leaflets broader than long, nearly glabrous; peduncles about twice as long as their subtending petioles; cymes dichotomous or the primary branches suppressed, thus more umbel-like; sepals elliptic to narrowly oblong, about $3 \mathrm{~mm}$. long; corolla light yellow, $\mathbf{I}-\mathbf{1 .} 5 \mathrm{~cm}$. wide; fila ments glabrous; styles glabrous; capsules columnar, acuminate, I.5-2 cm. long; seeds I mm. long, sharply ridged. In woods and fields, N. Y. to N. Car. and Tenn. Type from Staten Island, N. Y. May-July.

7. Oxalis Búshii Small. Bush's Wood-sorrel. Foliage bright green. Stems erect, $0.5^{-2} \mathrm{dm}$. tall, often simple; leaves few; petioles especially pubescent near the base; leaflets with rounded lobes, strigillose; peduncles slender, nearly erect, usually solitary, conspicuously overtopping the leaves, glabrous or nearly so except near the base; cymes umbel-like; sepals oblong, 3.5-4 $\mathrm{mm}$. long, obtuse; corolla light yellow, 9-I2 $\mathrm{mm}$. broad; filaments much dilated at the base; styles slightly pubescent. In dry soil, Penn., Mo. and Ark. May-June.

8. Oxalis recúrva Ell. LARGE-Flowered WOOD-SORREl. (I. F. f. 2255.) Foliage villous. Stems I-3 dm. tall, often woody at the base; leaves $\mathbf{I} 2 \mathrm{~cm}$. broad; leaflets often glaucescent; petioles filiform, slightly dilated at the base: flowers bright yellow, I or 2 opening at a time; sepais oblong, about 4.5-6 mm. long, obtuse, nearly erect; corolla $\mathbf{I} .5-2 \mathrm{~cm}$. broad; petals slightly notched; capsule columnir, IO-15 $\mathrm{mm}$. long, slender; seeds fully $1 \mathrm{~mm}$. long, with broken transverse ridges. In rocky or sandy places, Mo. to N. Car. and Alil. April Aug.

9. Oxalis Priceae Small. Price's Wood-Sorrel. Foliage deep green. Stems early decumbent, I-3 dm. long; leaves often numerous; leaflets pale or glaucescent beneath, ciliate; peduncles sometimes slightly longer than the petioles; sepals linear or nearly so, $6.8 \mathrm{~mm}$. long, pubescent at the base and tip; corolla deep chrome-yellow, I.4-2 $\mathrm{cm}$. broad; petals pubescent without; styles copiously villous; capsules stuut, columnar, 10-15 mm. long. On rocky hillsides and in open woods, Ky. Summer and fall.

10. Oxalis rùfa Small, n. sp. RE.D WOOD-SORREL. Foliage reddish-purple. Stems early branched at the base ard decumbent, I-3 dm. long, sometimes glaucescent; leaves numerous, commonly clustered: leaflets sometimes pale along the midrib; peduncles glabrous or villous, usually surpassing the leaves; cymes dichotomous or the primary branches suppressed. thus umbel-like; sepals oblong or oblong-lanceolate, $2-2.5 \mathrm{~mm}$. long; corolla light yellow, 6-10 cm. broad; petals glabrous, sometimes erose at the apex: capsules gradually narrowed. 8-12 $\mathrm{mm}$. long, usually pubescent with glandular hairs. In woods, Mass. to N. Y, Ga, and Tenn. Type from New York Botanical Garden. April-Sept.

I I. Oxalis crmosa Small. Tall Yellow Wood-Sorrel. (I. F. f. 2256.) Foliage bright green. Stem I.5-II dm. high, branched above, often villous; leaves $1.8-3 \mathrm{~cm}$. broat; leaflets broader than long, sharply notched; petiole-bases scarcely dilated; pedicels $6-8 \mathrm{~mm}$. long, more or less villous; sepals lanceolate or narrowly elliptic, 4-6 mm. long; corolla bright yellow, $8-10 \mathrm{~mm}$. broad; petals obtuse or emarginate: capsule columnar, Io-16 $\mathrm{mm}$. long. gradually narrowed to the summit: seeds almost $1.5 \mathrm{~mm}$. long, with nearly continuous ridges. In woods and fields, Ont. to Mich., Fla., Neb. and Tex. May-Oct.

I2. Oxalis graidis Small. Great Yellow WOOD-SORREL. (I. F. f. 
2257.) Foliage bright green. Stem 3-12 dm. tall, simple or nearly so; leaves $3.5-8 \mathrm{~cm}$. broad; leaflets with brown margins more or less ciliate; petioles villous, hardly dilated at the base; pedicels I-I.4 long; sepals ovate or oblong, 4-6 min. long, often ciliate at the apex; corolla deep yellow, $1.5^{-2.5} \mathrm{~cm}$. broad; petals rounded at the apex; capsule ovoid or ovoid-oblong; seeds $2 \mathrm{~mm}$. long, with prominent broken transverse ridges. On river banks, Peun. to Ill., N. Car. and Ala. May-Aug.

\section{Family 3. LINÀCEAE Dumort.}

\section{Flax Family.}

Herbs, or shrubs, with perfect regular nearly symmetrical flowers. Stipules mostly small or none. Sepals 5, rarely 4, imbricated, persistent. Petals of the same number and alternate with the sepals, imbricated, generally contorted. Stamens of the same number, alternate with the petals; filaments monadelphous at the base; anthers versatile, 2-celled. Ovary 1, 2-5-celled, or by false septa 4-10-celled. Ovules anatropous. Styles 2-5. Fruit mainly capsular. Seeds $1-2$ in each cavity, oily; endosperm little or none; embryo straight; cotyledons flat. Four known genera and about 150 species of wide distribution.

\section{LINUM L.}

Herbs, sometimes woody at the base, with sessile leaves, and perfect flowers. Inflorescence cymose, racemose or paniculate. Stipules a pair of glands, or want ing. Sepals 5. Petals 5, fugacious. Stamens 5, sometimes with interspersed staminodia. Ovary 4-5-celled, or 8-ro-celled by false partitions, the real cavities 2-ovuled. Capsule 5-IO-valved. [The classical Latin name.] About 90 species, natives of temperate or warm regions. In addition to the following some 17 others occur in the southern and western U.S.

\section{* Flowers blue.}

Annual; introduced; capsule about as long as the calyx. Perennial; western; capsule much exceeding the calyx.

1. L. usitatissimum.

2. L. Lewisii.

Capsules 2-3 mm. long.

$$
\text { ** Flowers yellow. }
$$

Leaves and bracts entire.

Stem nearly terete, corymbosely branched; usually only the lowest leaves opposite.

Leaves thin, oblong or oblanceolate, spreading. 3. L. Virginianum.

Leaves firm, appressed-ascending.

Capsule depressed-globose, $2 \mathrm{~mm}$. high.

Capsule ovoid, $3 \mathrm{~mm}$. high.

Stem angled, racemosely branched; leaves below the branches mostly opposite.

Upper leaves and bracts glandular-ciliate.

Capsules 4-5 mm. long.

*** Flowers white, small, long-pedicelled.

4. L. medium.

5. L. Floridanum.

6. L. striatum.

7. L. sulcatum.

8. L. rigidum.

\section{L. catharticum.}

I. Linum usitatíssimum L. Flax. Linseed. (I. F. f. 2258.) Often tufted, branching above, 3-5 dm. high; leaves alternate, 3-nerved, lanceolate, 1.25-3.75 cm. long, 2-6 mm. wide; inflorescence a terminal cymose leafy panicle; flowers 1.2-1.6 cm. broad; pedicels slender; sepals oval, acuminate, the interior ones ciliate and 3-ribbed; petals obcuneate, crenulate, twice the length of the sepals; capsule ovoid-conic, 6-8 $\mathrm{mm}$. long, indehiscent, the septa not ciliate. Along roadsides, and in waste places, fugitive from cultivation. Summer.

Linum humile Mill., variously regarded by authors as a distinct species or a variety or form of the Common Flax, may be distinguished by its dehiscent capsule with ciliate septa. It is rarely met with in our area in similar situations. Both have been cultivated since prehistoric times for their fibre and oil. Their origin is unknown.

2. Linum Lewísii Pursh. Lewis' Wild Flax. (I. F. f. 2259.) Perennial, 3-6 dm. high, glaucous, densely tufted, simple up to the cymose inflorescence. 
Leaves crowded, oblong or linear, 6-40 $\mathrm{mm}$. long, I-4 $\mathrm{mm}$. wide, acute or acutish, 3-5-nerved; flowers $2.5-3.75 \mathrm{~cm}$. broad; sepals oval, mainly obtuse, one-third or one-fourth the length of the petals; stigmas shorter than the styles; capsule broadly ovoid, obtuse. dehiscent, the septa ciliate. Plains, Manitoba to S. Dak., Kans., Tex., Ariz., Utah and Alaska. Suminer.

3 Linum Virginiànum L. Wild or Slender Yellow Flax. (I. F. f. 2260.) Perennial by suckers, rather dark green, corymbose-paniculate above, 3-6 dm. high. Stem and branches slender, not stiff; flowering branches ascending or sometimes weak and recurved; leaves oblong or oblanceolate, r-nerved, I.2-2.6 cm. long, 4-6 mm. wide, acute, or the lower opposite and spatulate, obtuse; pedicels filiform, the lower 4-12 mm. long, longer than the calyx; flowers 6-8 mm. broad; sepals ovate, acute, not ciliate, about equalling the depressed. globose IO-celled capsule. In shaded situations, N. Eng. to Ga. June-Aug.

4. Linum mèdium (Planch.) Britton. Stiff Yellow Flax. (I. F. f. 226r.) Perennial by suckers; stems erect, striate, stiff, corymbosely branched above, the branches erect-ascending both in flower and in fruit; leaves appressed-ascending, the lowest commonly spatulate and opposite, the others lanceolate to linear-lanceolate, acute, 8-24 mm. long, I-4 mm. wide; pedicels I $-6 \mathrm{~mm}$. long, the lower rarely longer than the calyx: sepals ovate, or ovate-lanceolate, acute, about equalling the capsule. In dry soil, Ont. to Mass., Fla., Mo. and Tex. June-Aug.

5. Linum Floridànum (Planch.) Trel. Florida Yellow Flax. (I. F. f. 2262.) Perennial; stem stiff, 4.5-7.5 dm. higl, cory mbosely branched above, the branches erect-ascending, slightly angled. Leaves acute, the lowest mostly opposite, narrowly oblong or oblanceolate, the others linear-lanceolate, appressed-ascending, alternate, $1-2 \mathrm{~cm}$. long, $\mathrm{I}-4 \mathrm{~mm}$. wide; fruiting branches erect-ascending; fruiting pedicels shorter than or little exceeding the calyx, or the lowest ones slightly longer; sepals ovate, acute or acuminate, about equalling the capsule; capsule ovoid, alout $3 \mathrm{~mm}$. long; petals twice as long as the calyx. Ill. (according to Trelease); Fla. to La. June-Aug.

6. Linum striàtum Walt. Ridged Yellow Flax. (I. F. f. 2263.) Perennial, racemosely branched, light green and somewhat viscid. Leaves usually opposite nearly up to the inflorescence, oblong; branches of the panicle short and divergent; flowers small, often clustered; capsule subglobose, usually rather longer than the sepals. In bogs and swamps, rarely in drier ground, Ont. to Conn., Fla., Ky., Ark. and Tex. Summer.

7. Linum sulcàtum Riddell. Grooved Yellow Flax. (I. F. f. 2264.) Annual, 3-6 dın. high. Stem wing-angled and grooved, at least above; leaves alternate, lanceolate or linear. 1.6-2.4 cm. long, 2-3 mm. wide, 3 -nerved, the lower glabrous; sepals glandular-ciliate; stipules a pair of small globose darkcolored glands; flowers racemose or corymbose, about $1.2 \mathrm{~cm}$. broad; pedicels 2-8 $\mathrm{mm}$. long; sepals lanceolate, acute, slightly longer than the ovoid, acute, incompletely Io-celled pod; styles separate above the middle; septa of the capsule ciliate. In dry soil, Ont. to Manitoba, Conn., Ga., Kans. and Texas. Summer.

8. Linum rígidum Pursh. Large-flowered Yellow Flax. (I. F. f. 2265.) Perennial(?), r.5-4 dm. high, glaucous, glabrous or puberulent. Branches stiff, angular; leaves erect, linear or linear.lanceolate, $8-24 \mathrm{~mm}$. long, $1-2 \mathrm{~mm}$. wide, acute or mucronate, the upper ones glandular-serrulate or ciliate; stipular glands minute, globose, sometimes wanting; flowers yellow, r.8-3 cm. broad; sepals lanceolate, acute or awn-pointed, glandular-serrulate; petals cuneate-cbovate, twice the length of the sepals; styles separate only at the summit; capsule ovoid, 5-valved, shorter than the sepals. Prairies, S. Dak. to Manitoba, Mo., Tex., N. Mex., Ariz. and Mex. Summer.

9. Linuin cathàrticum L. Dwarf or Cathartic Flax. (I. F. f. 2266.) Annual, slender, $7 \cdot 5^{-20} \mathrm{~cm}$. high. Leaves opposite, sessile, oval or somewhat obovate, entire, 4-8 mm. long; flowers 4-6 mm. broad, on long slender erect or ascending pedicels; sepals lanceolate, açute or acuminate; petals obovate; pod small, globose. Along a low sandy seashore, Pictou, N. S. Apparently nat. from Europe. July-Aug. 


\section{Family 4. ZYGOPHYLLÀCEAE Lindl.}

\section{Caltrop Family.}

Herbs, shrubs, or some tropical species trees, the branches often jointed to the nodes. Leaves mostly opposite, stipulate, pinnate, or 2-3foliolate, the leaflets entire. Stipules persistent. Flowers perfect, axillary, peduncled. Sepals usually 5, distinct, or united by their bases. Petals the same number as the sepals, or none. Stamens as many as the petals, or 2-3 times as many, inserted on the base of the receptacle, the alternate ones sometimes longer ; anthers versatile, longitudinally dehiscent; filaments usually with a small scale at the base or near the middle. Ovary 4-I2-celled; style terminal; stigma usually simple; ovules I-numerous in each cavity, pendulous or ascending. Fruit various, dry in our species. About 20 genera and 150 species, widely distributed in warm and tropical regions.

Fruit spiny, splitting into 5 3-5-seeded segments.

1. Tribulus.

Fruit not spiny, often tubercled, splitting into ro-12 I-seeded segments. 2. Kallstroemia.

\section{TRÍBULUS L.}

Herbs, with evenly pinnate leaves and peduncled axillary yellow flowers. Sepals 5, persistent. Petals 5, deciduous. Stamens 10, the alternate ones some. what longer. Ovary sessile, 5-lobed, 5-celled, hairy, the hairs erect; style short; stigma 5-ridged; ovules 3-5 in each cavity, pendulous. Fruit 5-angled, spiny, splitting into 5 3-5-seeded segments. [Greek, three-pronged, Caltrop, from the resemblance of the fruit to that implement.] About 12 species, of warm and tropical regions. Besides the following, another occurs in the Southwestern States.

I. Tribulus terréstris L. Ground Bur-nut. Land Caltrop. (I. F. f. 2267.) Pubescent, the stem prostrate or ascending, sometimes $3 \mathrm{dm}$. long or more. Leaves petioled; stipules small; leaflets 4-8 pairs, oblong, inequilateral, opposite, short-stalked, 6-16 mm. long; flowers solitary, about $1.2 \mathrm{~cm}$. broad, peduncled; petals oblong, about as long as tlie sepals; segments of the fruit usually with 2 long spines, 2 shorter ones, and a row of very short ones forming a crest on the back, also commonly with some bristle-like hairs. In ballast and waste places about the Eastern seaports, and Ill., Ark., Neb. Fugitive from Europe. June-Sept.

\section{KALlSTROÈmiA Scop. (See Appendix.)}

Mostly annual pubescent herbs, with opposite stipules, evenly pinnate leaves, and solitary axillary peduncled yellow flowers. Sepals usually 5 . Petals the same number, obovate or oblanceolate, deciluous. Stamens twice as many as the petals. Ovary sessile, IO-I 2 celled; ovule I in each cavity, pendulous: style long, or short, IO-I2 grooved, persistent; stigma mostly IO-I2-ridged. Fruit IO-12lobed, not spiny, often tuberculed, splitting into IO-I 2 I-seeded segments. [In honor of Kallstroem.] About Io species, widely distributed in warm and tropical regions. Besides the following, 3 others occur in the Southern and Western States.

r. Kallstroemia maxima (L.) T. \& G. Greater Caltrop. (I. F. f. 2268.) Branches slender, prostrate, 1.5-4.5 dm. long. Leaves short-petioled; stipules subulate; leaflets 3-5 pairs, oval or oblong, inequilateral, rounded or subcordate at the base, $8-20 \mathrm{~mm}$. long; peduncles slender, $1.2-5 \mathrm{~cm}$. long in fruit; flowers $2.5 \mathrm{~cm}$. broad, or less; sepals linear-lanceolate, very pubescent, persistent, shorter than the petals; fruit ovoid-conic, about $6 \mathrm{~mm}$. in diameter, about as long as the stout persistent style, the segments tubercled. In dry soil, Kans. to Ga., Fla. and Tex. Also in tropical Am. April-Sept. 


\section{Family 5. RUTÀCEAE Juss.}

\section{liue Family.}

Trees or shrubs, rarely herbs, with heavy-scented and glandularpunctate foliage, mainly compound exstipulate leaves, and (in our species) polygamo-diœcious generally cymose flowers. Sepals 4 or 5 , or none. Petals 4 or 5 , hypogynous or perigynous. Stamens of the same number, or twice as many, distinct, inserted on the receptacle; anthers 2-celled, mostly versatile. Disk annular. Pistils 2-5, distinct, or I and compound of 2-5 carpels, inserted on the receptacle. Fruit (in our species) a capsule, or samara. Seeds oblong or reniform; endosperm generally fleshy, sometimes none. About I IO genera and 880 species, most abundant in South Africa and Australia.

Pistils 2-5, distinct; fruit fleshy, capsular.

Pistil I, 2-celled; fruit a samara.

r. Xanthoxylum.

2. Ptelea.

\section{XANTHÓXYLUM L.}

Trees or shrubs with alternate odd-pinnate leaves, the twigs and petioles conmonly prickly. Flowers axillary or terminal, cymose, whitish or greenish, mostly small. Sepals 4 or 5 , or none. Petals imbricated. Staminate flowers with 4 or 5 hypogynous stamens. Pistillate flowers with 2-5 distinct pistils, rarely with some stamens. Carpels 2-ovuled. Pods 2-valved, I-2-seeded. Seeds oblong, black and shining. [Greek, yellow-wood.] About r ro species, of temperate and tropical regions. In addition to the following, 2 others occur in the Southern States.

Flowers in small sessile axillary cymes; calyx none.

Flowers in large terminal compound cymes; caly $\mathrm{x}$ present.
I. X. Americanum.

2. X. Clava-Herculis.

I. Xanthoxylum Americànum Mill. Prickly Ash. Toothache-tree. (I. F. f. 2269.) A shrub, or small tree. Leaves pubescent when young. glabrous or nearly so when old; leaflets 5-II, ovate, opposite, dark green above, lighter beneath, 3-5 cm. long, crenulate or entire, acutish; flowers greenish, about $3 \mathrm{~mm}$. broad, borne on the wood of the previous season and appearing before the leaves; pistils 2-5; capsules black, ellipsoid, about $4 \mathrm{~mm}$. long, short stiped, I-2-seeded. In woods and thickets, Quebec to Va., S. Dak., Neb. and Kans. April-May.

2. Xanthoxylum Clàva-Hérculis L. Southern Prickly Ash. Sea Ash. PePper-wood. (I. F. f. 2270.) A small, very prickly tree, the prickles supported on cushions of cork sometimes $2 \mathrm{dm}$. broad. Leaves glabrous, shining above, dull beneath; leaflets 5-17, obliquely ovate, 3-7.5 cm. long, acute, crenulate; flowers greenish white, appearing before the leaves; pistils 2 or 3 ; capsules about $4 \mathrm{~mm}$. long, sessile. Along streams, Va. to Fla., Ark. and Tex. June.

\section{PTÉLEA L.}

Slırubs or small trees, without prickles, the bark bitter. Leaves 3-5-foliolate; flowers greenish white, polygamous, corymbose-paniculate; calyx 4-5-parted, the lobes imbricated; petals 4 or 5 , much longer than the calyx, also imbricated; stamens 4 or 5 , alternate with the petals; filaments hairy on the inner side, present in the pistillate flowers but the anthers abortive or wanting; ovary flattened, 2 -celled (rarely 3-celled); fruit nearly orbicular, 2-winged (rarely 3-winged), indehiscent: cells I-seeded; seed oblong-ovoid. [Greek, Elm.] About 6 species, natives of tl.e U. S. and Mex.

I. Ptelea trifoliàta L. Three-leaved Hop-tree. Shrubby Trefoil. (I. F. f. 227I.) A shrub or small tree. Leaves 3-foliolate, pubescent when young, glabrate when old; leaflets $5^{-12} \mathrm{~cm}$. long; crenulate: flowers about $1 \mathrm{~cm}$. broad: odor disagreeable; sepals I $\mathrm{mm}$. long, obtuse; petals about $6 \mathrm{~mm}$. long, oblong: amara $1.6-1.8 \mathrm{~cm}$. in diameter, the wing membranous and reticulated, emarginate. In woods, Conn. to Fla., S. Ont., Minn., Kans. and Tex. June. 


\section{Family б. SIMARUBÀCEAE DC.}

\section{Ailanthus Family.}

Trees or shrubs, with bitter bark, and mainly alternate and pinnate, not punctate leaves. Stipules minute or none. Inflorescence axillary, paniculate or racemose. Flowers regular, diøecious or polygamous. Calyx 3-5-lobed or divided. Petals 3-5. Disk annular or elongated, entire or lobed. Stamens of the same number as the petals, or twice as many; anthers 2-celled. Ovaries 2-5, or single and 2-5-lobed, $1-5$ celled; styles 1-5. Seeds generally solitary in the cavities. About 27 genera and 145 species, natives of warm or tropical regions.

\section{AILÁNTHUS Desf.}

Large trees, with odd-pinnate leaves, and terminal panicles of greenish white flowers. Calyx short, 5-cleft, the lobes imbricated: petals 5, spreading, valvate; disk Io-lobed; staminate flowers with 10 stamens inserted at the base of the disk; pistillate flowers with a deeply 2-5-cleft ovary, its lobes flat, cuneate, I-celled, and 2-3 stamens; ovules solitary in each cavity; samaras $2-5$, linear or oblong, membranous, veiny, I-seeded at the middle: seed compressed; cotyledons nearly orbicular. [From the Chinese name.] Three species, natives of China and the E. I.

I. Ailanthus glandulòsa Desf. Tree-Of-HEaven. Ailanthus. (I. F. f. 2272.) A tree, $12-27 \mathrm{~m}$. high. Leaves 3-9 dm. long, glabrous; leaflets $13-4 \mathrm{I}$, stalked, ovate or ovate-lanceolate, cordate or truncate and often oblique at the base; flowers greenish, about $6 \mathrm{~mm}$. broad, pedicelled, the staminate ones ill-scented; samaras twisted, nearly $5 \mathrm{~cm}$. long. Escaped from cultivation, along roadsides and in fields, spreading extensively by suckers, and seeding freely in some localities, S. Ont. to Mass., Va. and Kans. Nat. from China. June-July.

\section{Family 7. POLYGALÀCEAE Reichenb.}

\section{Milkwort Family.}

Herbs, rarely shrubs or small trees in tropical regions. Stipules none. Pedicels generally 2-bracted at the base. Flowers perfect, irregular. Sepals 5, the two lateral ones (wings) large, colored, the others smaller. Petals 3 (or 5), hypogynous, more or less united into a tube, the lower one often crested. Stamens generally 8, united in 1 or 2 sets. Ovary 2-celled; style simple; stigma curved, dilated or lobed; ovules I in each cavity, anatropous. Fruit mainly capsular. Seeds generally caruncled; embryo straight. About 10 genera and 750 species, widely distributed.

\section{x. POLÝGALA L.}

Herbs or shrubs. Flowers racemose, spicate or capitate, rarely solitary and axillary, sometimes also cleistogamous and subterranean. Sepals very unequal, the two lateral ones large and petaloid. Petals 3 , united into a tube which is split on the back, and more or less adnate to the stamens. Stamens 8 or 6 , monadelphous below, or diadelphous; capsule membranous, compressed, dehiscent along the margin. Seeds I in each cavity, generally hairy. [Greek, much milk.] A genus of about 260 species, of wide distribution. Besides the following, about 36 others occur in southern and western N. Am.

* Flowers in corymbed spike-like racemes at the summit of the stem, yellow. Basal leaves long, narrow, acuminate. Basal leaves spatulate or obovate.

I. P. cymosa.

2. P. ramosa.

* * Flowers in solitary spikes or spike-like racemes, terminating the stem and branches. Basal leaves spatulate or obovate: flowers orange-yellow.

Basal leaves inconspicuous or wanting; flowers not yellow.

3. P. lutea.

Leaves, at least the lower, verticillate; spikes $8-18 \mathrm{~mm}$. thick, blunt; flowers purple to greenish white. 
Leaves verticillate and alternate; spikes $4-6 \mathrm{~mm}$. thick, acute.

Verticillate leaves predominating; spikes dense; flowers green to purplish.

6. P. verticillata.

Alternate leaves predominating; spikes loose, long; flowers more purple.

Leaves all alternate.

7. P. ambigua.

Petals united into a cleft tube, 6-8 mm. long; flowers pink.

8. P. incarnata.

Petals not conspicuously united into a tube.

Spikes ovoid to globose.

Bracts persistent; flowers rose-purple to white.

Spikes blunt; wings broadly ovate.

Spikes acutish ; wings narrowly ovate or elliptic. 10. $P$. Curtissii.

Spikes cylindric.

Bracts deciduous; flowers rose-purple. I1. P. Mariana.

Leaves oblanceolate to linear, 4-12 mm. long; flowers greenish to purplish.

12. P. Nuttallii.

Leaves lanceolate, $2.5-5 \mathrm{~cm}$. long, flowers white or greenish. 13. $P$. Senega.

Spikes elongated-conic; flowers white.

14. P. alba.

$* * *$ Flowers distinctly racemose, rose or purple.

* * * Flowers I-4, large, ax:llary, but apparently terminal, rose-purple to white.

16. P. paucifolia.

I. Polygala cymòsa Walt. Tall Pine-barren Milkwort. (I. F. f. 2273.) Stem erect, 6-9 dm. high, slightly angular. Basal leaves 5-7.5 cm. long, 4-6 mm. wide, entire, densely tufted; stem-leaves linear-subulate, scale-like, I-I.6 cm. long; pedicels 2-4 mm. long; bracts persistent; flowers drying greenish black; seeds globose, minute, nearly glabrous; caruncle none. In wet pine barrens, Del. to Fla., west to La. May-July.

2. Polygala ramòsa Ell. Low Pine barren Milkwort. (I. F. f. 2274.) Stems tufted or single, I.5-4 dm. high. Stem-leaves linear-oblong, obtuse, r.2-2 cm. long, 2-4 mm. wide; basal leaves much broader and often larger; inflorescence $7.5^{-1} 5 \mathrm{~cm}$. broad; flowers $3 \mathrm{~mm}$. long, drying dark green; pedicels $2 \mathrm{~mm}$. long or less; wings oblong, acuminate; crest minute; seed hairy, twice or thrice as long as the caruncle. In low pine barrens, Del. to Fla., west to La. June-Sept.

3. Polygala lùtea L. Orange Milkwort. Wild Bachelor's Button. (I. F. f. 2275.) Stems tufted, at length divaricately branched, I.5-3 dm. high. Stemleaves oblong-lanceolate, acute or obtuse, $1.5-3 \mathrm{~cm}$. long, 4-8 $\mathrm{mm}$. wide, entire; spike-like racemes ovoid or oblong, very dense, $1.25-4 \mathrm{~cm}$. long, $1.2-1.8 \mathrm{~cm}$. thick, obtuse; flowers 4-6 mm. long; pedicels 2-4 mm. long; wings oblong-ovate, abruptly acuminate; crest of the corolla-tube minute; caruncle-lobes linear, about equalling the hairy seed, or shorter. In pine-barren swamps, L. I. to Fla., Pa. and La. June-Oct.

4. Polygala cruciàta L. Cross-Leaved or Marsh Milkwort. (I. F. f. 2276.) Erect, $\mathbf{I}-4 \mathrm{dm}$. high, at length freely branching above. Stem square or slightly wing-angled; leaves of the stem and branches in 4's, or a few of them scattered, linear or oblanceolate, $1.25-4 \mathrm{~cm}$. long, 2-4 mm. wide, entire, obtuse, mucronulate; spike-like racemes oval, 8-18 mm. thick, sessile or short-peduncled; pedicels slender, 3-4 mm. long; bracts persistent; wings sessile, somewhat cordate, 3-6 mm. long, much exceeding the pods; crest of the corolla minute; seed oblong, slightly hairy, about equalling the caruncle. In sandy swanıs, Me. to Fla., Minn. and La. July-Sept.

5. Polygala brevifòlia Nutt. Short-leaved Milkwort. (I. F. f. 2277.) Resembling the preceding species, but lower, more slender and weaker. Leaves shorter, often scattered on the branches and upper part of the stem; spikes smaller, 6-10 mm. thick, on slender peduncles; wings obtuse or mucronulate. In sandy swamps, R. I. to Fla. and Miss. Summer.

6. Polygala verticillàta L. Whorled Milkwort. (I. F. f. 2278.) Slender, I. 5-3 dm. high, usually branched. Stem-leaves linear, 6-30 mm. long, I-4 mm. wide, acute, entire, punctate, mucronulate, mostly in 4's or 5's, with some scattered ones on the stem or branches; spikes conic, long-peduncled, acute, $4 \mathrm{~mm}$. thick at the base, very dense, $8-20 \mathrm{~mm}$. long; perlicels about $1 \mathrm{~mm}$. long; wings broadly oval, distinctly clawed, shorter than the pod; crest of the corolla manifest; seed oblong, hairy, twice the length of the caruncle; bracts deciduous. In dry or moist soil, Quebec and Ont. to Minn., Saskatch., Fla., Colo. and Mex. June-Nov. 
7. Polygala ambígua Nutt. Loose-spiked Milkwort. (I. F. f. 2279.) Resembling the preceding species, but often taller, I-4 dm. high, slender. Lower stem leaves commonly verticillate, but the others all alternate; spikes long, loose, the lower flowers often quite distant; peduncles often several inches long; flowers rather larger: wings purple or purplish, nearly circular in outline; mature capsule hardly longer than the wings, which are appressed to it; seed hairy. In dry soil, Me. to Ga., Mo. and La.

8. Polygala incarnàta L. PINK MiLkworT. (I. F. f. 2280.) Erect, glaucous, very slender, 3-6 dm. high; stem-leaves distant, linear or subulate, sessile, 2-12 $\mathrm{mm}$. long, rarely wanting; spike dense, $2.5-3.75 \mathrm{~cm}$. long, 4-8 $\mathrm{mm}$. thick; pedicels I mm. long or less; bracts minute or none; flowers $\mathbf{I}-\mathbf{I} .2 \mathrm{~cm}$. long; corollatube slender, 2-5 times the length of the wings, its keel prominently crested; wings cuspidate; seed hairy, the caruncle-lobes enveloping its beaked extremity. In dry soil, Ont. to Wis., N. J., Fla., Kans. and Mex. Summer.

9. Polygala viridéscens L. FIELd OR PURPLe Mil.kworT. (I. F.f. 2281.) Erect, I.5-4 dm. high, at length branching above, leafy. Stem somewhat angled; stem-leaves oblong or linear-oblong, I. $6-3 \mathrm{~cm}$. long, $2-4 \mathrm{~mm}$. wide, mucronulate; heads becoming oval, 8-12 $\mathrm{mm}$. thick; pedicels about I $\mathrm{mm}$. long; flowers rose-purple, greenish or sometimes white; wings sessile, sometimes slightly cordate, exceeding the pod; seed obovoid, hairy, about the length of the caruncle; crest minute. In fields and meadows, N. S. to N. Car., Minn., Kans. and La. June-Sept. The contrast between the green-flowered and purple-flowered forms is striking where the two grow together. [P. sanguinea $\mathrm{L}$.]

ro. Polygala Curtíssii A. Gray. Curtiss'Milkwort. (I. F. f. 2282.) Erect, slender, $2-2.5 \mathrm{dm}$. high, much resembling the preceding species and the following; heads globose or rarely elongated, loosely flowered, $8-12 \mathrm{~mm}$. thick; wings clawed, nearly erect, twice the length of the pod; seed obovoid, very hairy, apiculate; caruncle minute, much shorter than the seed. In dry soil, Penn. to Ky. and Ga. Aug.-Sept.

I I. Polygala Mariàna Mill. MarylandMilkwort. (I. F. f. 2283.) Slender, 1.5-4 dm. high, at length much branched above; stem-leaves linear, 6-18 $\mathrm{mm}$. long. about $2 \mathrm{~mm}$. wide, entire, mostly acute, mucronulate; heads globose or slightly longer than thick, obtuse, $6-8 \mathrm{~mm}$. wide; pedicels slender, 3-4 $\mathrm{mm}$. long; flowers rose-purple; wings ovate-oblong or obovate, pointed, narrowed at the base, slightly longer than the pod; caruncle-lobes embracing the smaller extremity of the slightly hairy obovoid seed; corolla minutely crested. In dry soil, southern N. J. to Fla., Ky. and La. July-Sept.

12. Polygala Nuttàllii T. \& G. Nuttall's Milkwort. (I. F. f. 2284.) Erect, slender, I-2 dm. high, branching above; stem leaves numerous, I-2 mm. wide, entire; spikes about $4 \mathrm{~mm}$. thick, $6-12 \mathrm{~mm}$. long, the floral axis elongating as the fruits fall away from below; pedicels I mm. long or less; bracts subulate, persistent; flowers greenish or yellowish purple, $2 \mathrm{~mm}$. long; seed obovoid, very hairy, longer than the caruncle; wings oblong to oval, about equalling the pod; crest very small. In dry sandy soil, Eastern Mass. to N. Car., Mo. and Ala. Aug.Sept.

13. Polygala Sénega L. Seneca Snakeroot. Mountain Flax. (I. F. f. 2285.) Stems several, from woody rootstocks, erect or ascending, r.5-3 dm. high; leaves alternate, sessile, $6-8 \mathrm{~mm}$. wide, serrulate, the lowest much smaller and scale-like; spike short-peduncled, dense, acute, $2.5-5 \mathrm{~cm}$. long; flowers $3 \mathrm{~mm}$. long, white or tinged with green; pedicels less than $1 \mathrm{~mm}$. long; wings orbicularobovate, concave; crest of the corolla short, few-lobed; seed hairy, slightly longer than the lobes of the caruncle. In rocky woods, N. B. to Minn. and the Canadian Rocky Mts., N. Car. and Ark. May. June.

Polygala Sénega latifolia T. \& G. Sten taller, often branched; leaves ovate or ovate-oblong, 5-10 cm. long, acuminate, acute at the base. Ont. to S. Dak., Md. and Tenn.

14. Polygala álba Nutt. White Milkwort. (I. F. f. 2286.) Stems numerous, erect from hard woody rootstocks, slender, 1.5-4 dm. high. Leaves alternate, narrowly linear, acute, $6-24 \mathrm{~mm}$. long, $\mathrm{I}-2 \mathrm{~mm}$. wide, their margins entire and revolute, the lower somewhat broader and shorter, clustered; spike long-peduncled, dense, 2.5-5 cm. long; flowers 2-3 mm. long; pedicels less than 
I mm. long; wings oblong-ovate, slightly concave; crest of the corolla short; seeds silky, about twice the length of the caruncle-lobes. Plains, S. Dak. to Mex. and Arizona. May-July.

15. Polygala polýgama Walt. Racemed Milkwort. (I. F. f. 2287.) Stems simple, I-5 dm. high, from a deep biennial root. Stem-leaves crowded, oblong or oblanceolate, obtuse, mucronulate, $1.6-2.5 \mathrm{~cm}$. long, $2-4 \mathrm{~mm}$. wide, entire, the lower smaller; basal leaves spatulate; raceme $2.5^{-10} \mathrm{~cm}$. long; pedicels 2-4 $\mathrm{mm}$. long; flowers rarely white, showy, 4-6 $\mathrm{mm}$. long; wings broadly obovate; crest of the corolla large, laciniate; stamens 8; subterranean branches horizontal, bearing numerous, cleistogamous flowers: seeds hairy, longer than the carunclelobes. In dry soil, N. S. to Manitoba, to Fla. and Tex. June-July.

I6. Polygala paucifòlia Willd. Fringed Milkwort. Flowering WinTERGREEN. GAY-WINGS. (I. F. f. 2288.) Glabrous, perennial by slender prostrate stems. Flowering branches $\mathrm{I}-2 \mathrm{dm}$. high; leaves of the summits of the stems clustered, ovate or oblong, 2-4 cm. long, acute, rough-margined, with petioles 4-8 $\mathrm{mm}$. long; those of the lower part of the shoots successively smaller, distant, the lowest scale-like; flowers I-4, axillary to the upper leaves, $1.4-2 \mathrm{~cm}$. long, slenderpeduncled, rose-purple or rarely white, showy; wings obovate; crest of the corolla beautifully fimbriate; seed slightly shorter than the caruncle; cleistogamous subterranean flowers few, on short lateral branclies. In moist rich woods, N. B. and Anticosti to Saskatch., Ga. and Ill. May-July.

\section{Family 8. EUPHORBIÀCEAE J. St. Hil.*}

$$
\text { Spurge Family. }
$$

Monœcioub or diœcious herb5, shrubs or trees, with acrid often milky sap. Leaves opposite, alterrate or verticillate. Flowers sometimes much reduced and subtended by an involuere which resembles a calyx (Euphorbia), the number of parts in the floral whorls often different in the staminate and pistillate flowers. Ovary usually 3-celled; ovules 1 or 2 in each cavity, pendulous; styles mostly 3, simple, divided, or many-cleft. Fruit a mostly 3-lobed capstule, separating, often elastically, into 32 -valved carpels from a persistent axis. Seeds anatropous; embryo in fleshy or oily endosperm, the broad cotyledons almost filling the seed-coats. About 210 genera and 4000 species, of wide distribution.

Flowers not in an involucre, with a true calyx.

Ovules 2 in each cavity of the ovary.

Petals wanting; stamens usually 3 .

Petals present, at least in staminate flowers; stamens 5 or 6.

Ovule $I$ in each cavity of the ovary.

Plants clothed with stellate pubescence, or scales.

Ovary, and dehiscent capsule 2-4-celled, mostly 3-celled.

Ovary, and capsule I-celled, achene-like.

1. Phyllanthus.

2. Andrachne.

Inflorescence spicate, racemose or of axillary clusters.

Flowers with petals.

Flowers without petals.

Styles many-cleft.

Styles simple, somewhat united at the base.

Inflorescence cymose.

Plants glabrous or nearly so.

3. Croton.

4. Crotonopsis.
gland-tipped.

5. Ditaxis.

6. Acalypha.

7. Tragia.

9. Jatropha.

Inflorescence racemose, somewhat panicled; pistillate flowers above the 8. Ricinus.
8tanate.

Inflorescence spicate; pistillate flowers below the staminate. 10. Stillingia.

Flowers in an involucre, the calyx represented by a minute scale at the base of the filament-like pedicel.

\section{PHYLLÁNTHUS L.}

II. Euphorbia.

Annual or biennial herbs (some tropical species shrubs or trees). Leaves alternate, entire, often so arranged as to appear like the leaflets of a compound leaf. Flowers monœcious, apetalous, a staminate and a pistillate one together in the axils. 
Calyx mostly 5-6-parted, the lobes imbricated. Stamens usually 3 . Ovules 2 in each cavity; styles 3, each 2-cleft. [Greek. leaf-flower, the blossoms in some species heing seated on leaf-like flattened branches.] More than 400 species, natives of the tropical and temperate zones of both hemispheres.

I. Phyllanthus Carolinénsis Walt. Carolina Phyllantrius. (I. F. f. 2289.) Annual; glabrous. Stem slender, I-5 dm. high, the branches 2-ranked; leaves obovate or oblong, 6-20 mm. long, obtuse; flowers inconspicuous, nearly sessile in the axils; calyx 6-parted, its lobes linear or oblong; glands of the pistillate flower more or less united; capsule about $2 \mathrm{~mm}$. in diameter; seeds I $\mathrm{mm}$. long, marked with lires and minute black papillæ. In sandy or gravelly soil, eastern Pemn. to Ill., Kans., Fla., Tex. and Cent. Am. May-Oct.

\section{ANDRÁCHNE L.}

Herbs, or shrubby plants, with diffusely branching stems. Leaves alternate. Flowers monœcious, axillary, the staminate often clustered, with a 5-6-lobed calyx, 5 or 6 petals, and 5 or 6 stamens; pistillate flowers solitary, with a 5-6-lobed calyx, minute petals, or these wanting; styles 2. cleft or 2-parted; ovules 2 in each cavity. [From the Greek for Portulaca.] About to species, of wide distribution.

I. Andrachne phyllanthoides (Nutt.) Muell. Arg. Northern Andrachne. (I. F. f. 2289a.) A straggling much branched shrub, 3-10 dm. tall, with glabrous lustrous branches and minutely pubescent twigs. Leaves obovate or oval, o.8I. $8 \mathrm{~cm}$. long, retuse or obtuse, often mucronulate, paler beneath than above; pedicels filiform, $6-20 \mathrm{~cm}$. long, glabrous; calyx-segments oblong-obovate, $1.5-3 \mathrm{~mm}$. long; petals of two kinds, those of the staminate flowers narrowly obovate or oblong-obovate, 3-5-toothed, those of the pistillate flowers smaller, broadly obovate, entire; capsule subglobose. On rocky barrens, Mo. to Ark. and Tex. Summer.

\section{CRIOTON I.}

Herbs or shrubs, strong-scented, stellate-pubescent. Leaves mostly alternate, sometimes with 2 glands at the base of the blade. Flowers often spicate or racemose. Staminate flowers uppermost; calyx 4-6-parted (usually 5 parted); petals usually present, but small or rudimentary, alternating with glands; stamens 5 or more. Pistillate flowers below the staminate: calyx 5-ro-parted; petals usually wanting; ovary mostly 3 -celled; ovule $\mathrm{I}$ in each cavity; styles once. twice or many times 2-cleft. [The Greek name of the Castor-oil plant.] About 600 species, mostly of warm and tropical regions, a few in the temperate zones.

Plants monœcious.

Leaves toothed; staminate calyx 4-lobed, pistillate 5-lobed. I. C. glandulosus.

Leaves entire; staminate calyx 3-5-lobed, pistillate 5-12-lobed.

Capsules conspicuously clustered, not nodding.

Capsules solitary or never conspicuously clustered, nodding.

Foliage whitish; capsules 6-7 mm. long.

Plant diœcious.

Foliage silvery ; capsules 4-5 nim. long.

I. Croton glandulòsus L. Glandular Croton. (I. F. f. 2290.) Deep green, rough with stellate hairs, and somewhat glandular. Stem 2-7.5 dm. high, corymbosely branched; leaves oblong, linear-oblong or ovate, $1.2-7.5 \mathrm{~cm}$. long, bearing 2 glinds at the base of the blade; staminate flowers in spikes, with 4 petals, a 4 rayed glandular disk and 8 stamens; pistillate flowers several, with rudimentary petals; capsule subglobose, about $5 \mathrm{~mm}$. in length; sceds oblong, minutely wrinkled. In sandy soil, Va. to Ia. and Kans.. south to Fla. and Cent. Am. Also in the W. I. and S. Am. March-Dec.

2. Croton capitàtus Michx. Capitate Croton. Hogwort. (I. F. f. 229I.) Silvery green, densely stellate-pubescent. Stem usually corymbosely branched above; leaves lanceolate, oblong or rarely ovate, often undulate; flowers clustered at the $\epsilon$ ds of the branches, the staminate racemose, with a 5 -parted calyx, 5 petals, and IO-I4 stamens; pistillate flowers several, sessile, with 7-12 sepals, no petals: capsule depressed-glohose, 6-7 mm. in diameter; seeds gray or variegated, turtle-shaped. In dry soil, N. J. to Iowa, Ga. and Tex. May-Oct.

3 Croton Lindheimeriànus Scheele. Lindhemer's Croton. (I. F. f, 2292a.) Stems I-4 dm. tall, sometimes diffusely branched; leaves rather numer. 
ous, the blades ovate to oblong-ovate, $1.2-5 \mathrm{~cm}$. long, green above, undulate; pedicels 2-6 mm. long, recurving; calyx slightly accrescent, its segments oblong or elliptic-oblong, becoming $4 \mathrm{~mm}$. long, slightly keeled in age; capsules oval, 6 $7 \mathrm{~mm}$. long, tomentose, truncate-obtuse at both ends, drooping; seeds oblongelliptic, nearly $4 \mathrm{~mm}$. long. In dry soil, Kans. to Tex. and N. Mex. Summer.

4. Croton monanthógynus Michx. Single-fruited Cróton. II. F. f. 229?.) Main stem slender, I-2 dm. high, topped by a 3-5-rayed umbel with rays I-4 dm. long, forked or umbellately branched; leaves ovate or oblong, $\mathrm{I}-3 \mathrm{~cm}$. long; staminate flowers clustered at the ends of erect peduncles, with 3-5 ur:equal calyx-segments, the same number of petals and scale-like glands, and 3-8 stamens; pistillate flowers mostly solitary, on recurved pedicels, with 5 equal calyx segments, no petals, and 5 glands; capsule ovoid or oblong-ovoid, 4-5 mm. ling; seeds oval or orbicular, variegated, ninutely pitted, shining. In dry soil, $\mathrm{N}$. Car. to Ind. and Kans., south to Fla. and Mex. June-Oct.

5. Croton Texénsis (Klotzsch.) Muell. Arg. Texas Croton. (I. F. f. 2293.) Stem rather slender, 2-6 dm. high, paniculately or ccrymbosely brancl.ed; leaves ovate to linear-oblong or almost linear, 2-7.5 mm. loug; staminate flowers racemose; pistillate flowers sessile or nearly so, in stalked clusters: calyx equally 5-parted, the segments ovate; petals none; glands 5 , minute; stamens mostly Io; capsule subglobose, 5-6 mm. in diameter, somewhat muricate: seeds ovoid or oval, variegated, finely reticulated. In dry soil, S. Dak. to Mo., Ala. and IN. Mex. June-Sept.

\section{CROTONÓPSIS Michx.}

Annual slender silvery-scurfy monœcious herbs with narrow alternate or rarely opposite leaves. Staminate flowers uppermost in the clusters, with an equally 5parted calyx, 5 petals and 5 inflexed stamens opposite the petals enlarged at the suinmit. Pistillate flowers with 3-5 parted calyx, no petals, 5 petal-like glands opposite the calyx-segments, and a I-celled ovary; ovule I. Fruit a small scaly or spiny achene-like capsule. Seed longitudinally wrinkled. [Greek, Croton-like.]

Two known species, natives of the southeastern U. S.

I. Crotonopsis lineàris Michx. Crotonopsis. (I. F. f. 2294.) Foliage covered with peltate somewhat fringed scales, except on the green upper surfaces of the leaves. Stem wiry, 1-5 dm. high; leaves oblong-ovate to linear-lanceolate, I-3 cm. long, entire; staminate flowers with spatulate petals; achene-like capsule ovoid.elliptic; seed ovoid. $2-3 \mathrm{~mm}$. long. In dry sandy soil, N. J. to Kans., south to Fla. and Tex. July-Sept.

\section{DITÁxis Vahl.}

Monœcious perennial herbs, or shrubs. Leaves alternate, often strongly nerved. Flowers often racemed, usually bracted. Staminate flowers often crowded at the ends of the racemes; calyx 4-5-lobed, the lobes valvate; petals 4 or 5 , alternate with the calyx-lobes and with the lobes of the disk; stamens of the same number as the petals or two or three times as many, united into a column. Pistillate flc wers with the calyx-lobes imbricated and smailer petals, the ovary 3-celled. Capsule 3-lobed, depressed. Seeds sometimes crested. [Greek, double-ranked, in allusion to the stamens.] About 20 species, natives of temperate and tropical regicns.

Flowers in terminal and axillary racemes: leaves sessile. Flowers in axillary clusters; leaves short-petioled.
I. D. mercurialina. 2. D. humilis.

I. Ditaxis mercuriàlina (Nutt.) Coult. TAll Ditaxis. (I. F. f. 2295.) Stem strict, silky, I-6 dm. high. Leaves ovate to narrowly lanceolate, $2-5 \mathrm{crn}$. long, undulate, often strongly 3 nerved; staminate flowers with lanceolate or linear-lanceolate acute ciliate calyx-segments, and spatulate-oblong undulate petals; pistillate flowers with a 5-parted calyx, the segments lanceolate, spreading, 3 times as long as those of the staminate; capsules 6-9 $\mathrm{mm}$. in diameter, somewhat silky; seeds globose-ovoid, $4 \mathrm{~mm}$. long, pointed, wrinkled. In dry soil, Kans. and Ark. to Tex. Lower leaves somewhat oblanceolate. April-July.

2. Ditaxis hùmilis (Engelm. \& Gray) Pax. Low Diraxis. (I. F. f. 2296.) Stem much branched, the branches spreading, I-3 dm. long. Leaves ovate, oblong, obovate or oblanceolate, $\mathbf{I}-3 \mathrm{~cm}$. long: staminate flowers with petals a little 
longer than the 5 calyx-segments and longer than the lobes of the disk; pistillate flowers with a 5-parted calyx ; capsule short-pedicelled, 4-6 $\mathrm{mm}$. in diameter, 3-4lobed; seeds oval-globose, about $2 \mathrm{~mm}$. long, muricate. Plains, Kans. to La. and Tex. March-Sept.

\section{ACALỲPHA L.}

Herbs or shrubs. Stems mostly erect. Leaves alternate, stipulate. Flowers in spikes or spike-like racemes, the staminate cluster peduncled, each flower in the axil of a minute bractlet, with a 4-parted calyx and 8-I6 stamens united at their bases. Pistillate flowers subtended by a foliaceous bract, which often equals or overtops the staminate, the calyx 3-5-parted; petals wanting in both kinds of flowers; capsule usually of 3 2-valved carpels, each I-seeded. [Greek, nettle.] About 230 species, mostly tropical and subtropical.

Staninate and pistillate flowers in separate spikes or racemes; capsule spiny.

Staminate and pistillate flowers in the same spike or raceme; capsule smooth.

I. A. ostryaefolia.

Plant not glandular; bract palmately many-lobed, equalling or exceeding the staminate spike.

Plant glandular; bract many-cleft, shorter than the spike.

2. 4. Virginica.

3. A. gracilens.

r. Acalypha ostryaefolia Ridd. Hornbeam Three seeded Mercury. (I. F. f. 2297.) Dark green, minutely pubescent. Stem erect, 3-8 dm. tall. Leaves thin, ovate, $6-10 \mathrm{~cm}$. long, short-acuminate, serrate, obtuse or cordate at the base, the petioles often as long as the blades; bractlets of the staminate flowers minute, those of the pistillate conspicuous, lobed; capsule much depressed, 3 -lobed, 3-4 mm. in diameter; seeds ovoid, $2 \mathrm{~mm}$. long, wrinkled. N. J. to Kans., Fla. and Mex. June-Nov.

2. Acalypha Virgínica L. Virginia Three-seeded Mercury. (I F. f. 2298.) Dark green, or becoming purplish. Stem I-6 dm. tall; leaves ovate or elliptic, 2-10 cm. long, thin, coarsely serrate except near the base; pistillate flowers I-3 at the base of the staminate peduncle; capsule 3-lobed, subglobose, about 3 mm. in diameter; seeds ovoid, reddish, striate. In woods and thickets, N. S. to Minn., Kans., Fla. and Tex. June--Oct.

3. Acalypha grácilens A. Gray. Slender Three-Seeded Mercury. (I. F. f. 2299.) Pale green. Stem slender, I-8 dm. tall, the branches often nearly filiform; leaves lanceolate to linear-oblong, I-5 cm. long, usually firm, acutish, serrate, narrowed to a short petiole; staminate spike very slender; pistillate flowers I or several; capsule subglobose, about $3 \mathrm{~mm}$. in diameter; seeds globose-ovoid, dark red, or gray mottled with red, striate-pitted. In dry woods and thickets, Mass. to Kans., Fla. and Tex. June-Sept.

\section{TRÀGIA L.}

Monœcious herbs or shrubs, sometimes climbing, usually armed with stiff stinging hairs. Leaves alternate, mostly cordate; fiowers in racemes, bracteolate, apetalous; staminate flowers with a 3-5-parted calyx and I-3 or rarely numerous stamens; pistillate flowers with a 3-8-lobed calyx, the segments entire or pinnatifid, and 3 styles, often united to above the middle; capsule 3 -lobed, separating into 3 2-valved carpels. [From Tragus, the Latin name of Hieronymus Bock, I498I553, a German botanist.] About 50 species, mostly natives of tropical regions.

Stems not twining.

Staminate calyx 4 -lobed; stamens 2.

Staminate calyx 3 -lobed; stamens 3 .

Staminate calyx $4-5$-lobed; stamens 4 or 5 . Stems twining.

I. Tragia ùrens L. Eastern Tragia. (I. F. f. 2300.) Dull green, pilose or hirsute. Stem erect, I-4 dm. tall, branched; leaves obovate or ovate to linear, entire or repand, short-petioled or sessile, $1.5 \mathrm{~cm}$. long; spike-like racemes often I dm. long; pistillate flowers several at the base of the racemes, with a 5-6-lobed calyx; capsule short-pedicelled, much depressed, 8-10 $\mathrm{mm}$. in diameter, sparingly pubescent; seeds subglobose, $4 \mathrm{~mm}$. long, smooth. In sandy soil, Va. to Fla. and Tex. May-Aug. 
2. Tragia nepetaefòlia Cav. Catnep Tragia. (I. F. f. 2301.) Hispid with stinging hairs. Stem erect or reclining, 1.5-4 dm. long; leaves triangularovate or lanceolate, $1-5 \mathrm{~cm}$. long, dentate-serrate, cordate, short-petioled, the lower sometimes orbicular; racemes $\mathbf{I}-4 \mathrm{~cm}$. long, many-flowered; pistillate flowers with a 5 -lobed calyx; capsule much depressed, $6 \mathrm{~mm}$. in diameter, hirsute; seeds globose, chestnut biown, smooth, $4 \mathrm{~mm}$. in diameter. In sandy soil, Kans. to Mex. and.N. Mex. May-Oct.

3. Tragia ramòsa Torr. BRAnching TRAGIA. (I. F. f. 2302.) Light green, bristly with stinging hairs. Stem usually much branched, $0.5-3 \mathrm{dm}$. long; leaves lanceolate, ovate-lanceolate or triangular-lanceolate, I.2-5 cm. long, acute at the apex, coarsely and sharply serrate, truncate or cordate at the base, shortpetioled; racemes $1-5 \mathrm{~cm}$. long; pistillate flowers solitary, with a 5-lobed calyx subtended by a 3 -lobed bract; capsule much depressed, $6-8 \mathrm{~mm}$. in diameter, bristly; seeds globose, $4 \mathrm{~mm}$. in diameter, orange, more or less variegated. In dry soil, Mo. to Tex., Colo. and Ariz. July-Aug.

4. Tragia macrocàrpa Willd. Twining OR Large-fruited Tragia. (I. F. f. 2303.) Slightly hirsute. Stem 2.5-14 dm. long, twining; leaves ovate, 5-12 cm. long, deeply cordate, coarsely dentate-serrate, acuminate; petioles mostly shorter than the blades; staminate flowers with a 3 -lobed calyx and 3 stamens; pistillate flowers with a 5-lobed calyx; capsule depressed, 12-16 $\mathrm{mm}$. in diameter; seeds subglobose, $5 \mathrm{~mm}$. long, smooth, variegated. In dry or rocky soil, $\mathrm{Ky}$. to Mo., Fla. and Mex. June-Sept.

\section{RÍCINUS L.}

A tall stout monœcious herb, glabrous and glaucous, with alternate large peltate palmately lobed leaves, and numerous small apetalous greenisli flowers in terminal racemes, the pistillate above the staminate. Staminate flowers with a 3-5-parted calyx, the segments valvate, and numerous crowded stamens; filaments repeatedly branched. Pistillate flowers with a caducous calyx. Capsule subglobose, or oval, separating into 3 2-valved carpels. Endosperm fleshy and oily. [The Latin name of the plant.] A monotypic genus of the warmer parts of Africa and Asia.

r. Ricinus commùnis L. CASTOR-OIL Plant. Castor-bean. Palma Christr. (I. F. f. 2304.) Stem erect, I-5 m. tall, more or less branched, becoming tree-like in warm regions. Leaves nearly orbicular in outline, $\mathbf{I}-6 \mathrm{dm}$. broad, 6-II-palmately lobed and peltate, the lobes toothed, acute or acuminate; capsule $12-16 \mathrm{~mm}$. in diameter, usually spiny; seeds shining, smooth, black, variegated with white, or mottled with gray and brown markings. In waste places, escaped from cultivation, N. J. to Fla. and Tex. An imposing ornamental plant, and also of medicinal value.

\section{JÁTROPHA L.}

Monœcious or rarely diœcious perennial bristly herbs, or shrubs, with entire, lobed or divided leaves, the flowers in cymes. Staminate flowers on the, upper parts of the cymes, with a corolla-like 5-lobed calyx, 5 petals distinct or united, or none, the stamens usually numerous (5-30). Pistillate flowers in the lower forks of the cymes: capsule ovoid or subglobose, easily separating into 2 valved carpels. [Greek, healing nutriment.] About 7o species, widely distributed in warm and temperate regions. Besides the following, some 4 others occur in the Southern States.

I. Jatropha stimulòsa Michx. Spurge Nettle. Trean-softly. (I. F. f. 2305.) Perennial by a stout root, herbaceous, bright green, stinging. Stem erect, x-I $\mathbf{d m}$. tall; leaves nearly orbicular in outline, $6-30 \mathrm{~cm}$. broad, truncate or cordate at the base, deeply 3-5-lobed, the lobes entire, toothed or pinnatifid; calyx of the staminate flowers salverform, white or pink, 2-4 cm. broad; capsule oblong, r2-16 mm. long, papillose, wrinkled; seeds oblong-obovoid, 10-12 mm. long, smooth, mottled. In dry sandy soil, Va. to Fla. and Tex. March-Aug.

Monœcious glabrous herbs or shrubs, with alternate or rarely opposite leaves, of en with 2 glands at the base, the flowers bracteolate, in terminal spikes, apetalons, the bractlets 2-glandular. Staminate llowers several together in the axils of 
the bractlets, the calyx slightly $2-3$-lobed; stamens 2 or 3 , exserted. Pistillate nowers solitary in the axils of the lower bractlets; calyx 3-lobed. Capsule 2-lobed or 3lobed, separating into 2 or 3 two-valved carpels. [In honor of Dr. B. Stellingfleet, an English botanist.] About 5 species, mostly of tropical America and the islands of the Pacific Ocean.

I. Stillingia sylvática L. Queen's Delight. Queen-Root. (I. F. f. 2306.) A bright green slightly fleshy herb. Stem usually branched from the base, 3-II dm. tall. Leaves obovate, oblong or elliptic, I-IO $\mathrm{cm}$. long, serrate with appressed teeth, often narrowed at the 2-glandular base, sessile; flowers lemon-colored, subtended by small bracts furnished with saucer-shaped glands; calyx cup-shaped; glandular disk none; capsule depressed, I-I.5 cm. in diameter, 3-lobed; seeds ovoid, $6 \mathrm{~mm}$. long, light gray, minutely pitted and papillose, the base flattened. In dry soil, Va. to Fla., Kans. and Tex. March-Oct.

\section{EUPHÓRBIA L.}

Monœcious herbs (many tropical species shrubs), with alternate, opposite or verticillate Jeaves. Flowers borne in involucres. Sinuses of the involucres usually bearing glands, naked or appendaged. Staminate flowers scattered over the inner surface of the involucre, consisting of a stamen jointed on a filament-like pedicel, which is subtended by a minute bractlet supposed to represent a calyx. Pistillate flower solitary, at the bottom of the involucre, at length usually exserted on a stalk. Capsule 3 -lobed, separating into 32 -valved carpels. Seeds sometimes caruncled, variously pitted, ridged or wrinkled. [Named in honor of Euphorbus, King Juba's physician.] Species about 700, most abundant in the warmer parts of the temperate zones. Besides the following, some 95 others occur in the southern and western parts of N. Am.

\section{* Glands of the involucre with petal-like appendages.}

$\nmid$ Leaves opposite, inequilateral, their bases more or less oblique.

¥ Leaves entire; seeds smooth.

Plants branched at the base, the branches prostrate.

Seeds about $3 \mathrm{~mm}$. long.

Seeds $\mathrm{I}-2 \mathrm{~mm}$. long.

Leaves usually more than twice as long as broad; seeds nearly terete, I. $5 \mathrm{~mm}$. long.

I. E. polygonifolia.

Leaves usually less than twice as long as broad; seeds obtusely 4 -angled, I $\mathrm{mm}$. long.

Plants with an erect or ascending stem, branched above, the branches ascending.

Seeds nearly terete, $2 \mathrm{~mm}$. long; leaves usually flat and straight.

Seeds 4 -angled, $1.5 \mathrm{~mm}$. long; leaves often involute and curved.

2. E. petaloidea.

3. E. Nuttallii.

$\ddagger \ddagger$ Leaves entire; seeds variously roughened.

Plants glabrous.

Plants canescent.

$\ddagger \ddagger \ddagger$ Leaves serrate or dentate; plants prostrate or spreading.

Herbage glabrous.

Seeds faintly transversely ridged and pitted.

Leaves of main branches mostly less than $\mathrm{x} \mathrm{cm}$. long; seeds gray.

13. E. Fendleri.

14. E. lata.

6. E. serpyllifolia.

Leaves of main branches over $1 \mathrm{~cm}$. long; seeds brown. 7. E. albicaulis.

Seeds strongly transversely ridged, not pitted.

Herbage pubescent or puberulent.

Seeds gray or white.

Leaves toothed at the apex; involucres campanulate; seeds pitted.

12. E. stictospora.

Leaves toothed nearly to the base; involucres turbinate; seeds transversely wrinkled.

Seeds brown or black.

Involucres not split.

Involucres split on one side.

$\ddagger \ddagger \ddagger \ddagger$ Leaves serrate or dentate; plant erect or ascending.

++ Leaves opposite, equilateral, their bases not oblique.

9. E. hirsuta.

10. E. maculata.

II. E. humistratá.

15. E. nutuns.

I6. E. hexagona.

$t+t$ ieaves alternate or scattered on the stem, except a whorl subtending the umbel. 
Bracts and leaves of the umbel small and green; seeds ovoid, smooth, sparingly pitted.

Pale green; leaves all whorled or opposite.

Deep green; leaves below the unbel alternate.

17. E. Marylandica.

18. E. corollata.

Bracts and leaves of the umbel large, white-margined: seeds ovoid-globose, reticulatetuberculate.

** Glands of the involucre without petal-like appendages.

19. E. marginata.

$\dagger$ Leaves mostly opposite; herbage glabrous.

Plants slender; stems or branches forked.

Annual; stem branched at the base; leaves, or some of them, oblique at the base.

I. E. polygonifolia.

Perenuial; stems several from a stout root; leaves not oblique at the base.

22. E. Ipecacuanhae.

Plants stout; stem usually simple below, topped by an umbel.

24. E. Lathyris.

$\dagger+$ Leaves m stly opposite; herbage pubescent.

Leaves linear or linear-lanceolate; seeds narrowly ovoid, not prominently tuberculate.

20. E. cuphospernia.

Leaves ovate or ovate-lanceolate; seeds broadly ovoid, prominently tuberculate.

2I. E. dentata.

$t+t$ Leaves alternate or scattered.

Stem not topped by an umbel.

23. E. heterophylla.

Stems topped by a several-rayed umbel.

Leaves serrulate; glands of the involucre oblong, oval or orbicular.

Seeds smooth or faintly reticulated.

Glands stalked; warts on the capsules elongated; seeds faintly reticulated. 26. E. obtusata.

Glands sessile; warts on the capsules depressed; seeds smooth.

Seeds strongly and prominently reticulated.

27. E. platyphylla.

Glands nearly sessile; capsules warty.

Upper leaves merely sessile; upper bracts of the umbel manifestly longer than broad.

Upper leaves with small basal lobes; upper bracts of the umbel about as broad as long or broader.

Glands stalked; capsules smooth.

Leaves entire; glands of the involucres crescent-shaped or reniform.

29. E.Missuturiensis. 3o. E. Helioscopia.

Annual or biennial; seeds pitted.

Capsules with 2-crested lobes. , 31. E. Peplus.

Capsules with rounded lobes. 32. E. commutata.

Perennial.

Glands reniform or oblong, without horns.

25. E. Darlingtonii.

Glands cresc $\_n t$ shaped, with horns.

Seeds smooth; glands with long slender horns.

Stem-leaves 4-12 $\mathrm{mm}$. broad; capsules smooth.

Bracts subtending the umbel lanceolate to oblanceolate.

Bracts ovate, oval or obovate.

33. E. Esula.

34. E. lucida.

Stem-leaves $0.5-3$ mn. wide; capsules with granular lobes.

35. E. Cyparissias.

Seeds pitted; glands with short rather blunt horns. 36. E. robusta.

I. Euphorbia polygonifòlia L. Seaside or KNotweed Spurge. (I. F. f. 2307.) Pale green, glabrous. Branches radiately spreading, prostrate, forked, 5-20 cm. long; leaves opposite, oblong, linear-oblong or linear-lanceolate, 6-20 $\mathrm{mm}$. long, fleshy, obtuse, often mucronulate, entire; involucres turbinate-campanulate, less than $2 \mathrm{~mm}$. long, with 4 columnar nearly naked glands shorter than the lobes; capsule globose-ovoid, 3-4 mm. long, minutely wrinkled; seeds ovoid, somewhat flattened, ash-colored, very minutely pitted and spotted. In sand along the Atlantic coast, N. H. to Fla., and on the shores of the Great Lakes. July-Sept.

2. Euphorbia petaloidea Engelm. White-Flowered Spurge. (I. F. f. 2308.) Pale green, glabrous. Stem erect, branched above, I.5 $6 \mathrm{dm}$. high; leaves opposite, linear, oblong or linear-lanceolate, $\mathbf{I}-2.5 \mathrm{~cm}$. long, obtuse, usually flat, straight, entire: involucres oblong campanulate, $2 \mathrm{~mm}$. long, bearing 4 wineglasssh iped glands about as long as the lobes, each subtended by a white ovate or orbicular appendage, capsule globose-reniform, $2 \mathrm{~mm}$. long; seedsoblong-ovoid, nearly ash-colored, minutely pitted, nearly terete, Iowa to Wyo. and Tex. July-Sept. 
3. Euphorbia Nuttàllii (Engelm.) Small. Prairie Spurge. (I. F. f. 2309.) Bright green, glabrous. Stem slender, erect or ascending, I- $6 \mathrm{dm}$. high, the branches wiry; leaves mostly linear and mucronulate or truncate at the apex, often involute, obtuse or narrowed at the base, usually curved; involucres campanulate, less than $2 \mathrm{~mm}$. long, long-peduncled, bearing 4 saucer-shaped glands subtended by white oblong or ovate appendages; seeds ovoid, $1.5 \mathrm{~mm}$. long, gray, 4-angled. Prairies, Mo. to Tex. and Mex. June-Sept.

4. Euphorbia Geýeri Engelm. \& Gray. Geyer's Spurge. (I. F. f. 23ro.) Olive-green, glabrous. Branches prostrate, radiately spreading, wiry, 5-40 cm. long; leaves oblong or ovate, 4-12 $\mathrm{mm}$. long, obtuse, usually mucronulate, entire or nearly so, oblique, obtuse or subcordate at the base; involucres campanulate, about $\mathrm{r} \mathrm{mm}$. high, with 4 wineglass shaped glands shorter than the lobes, and inconspicuous white or red appendages; capsule globose-reniform, about $2 \mathrm{~mm}$. long; seeds narrowly ovoid, ash-colored, nearly terete. In sandy soil, Minn. to Ill., S. Dak. and Kans. July-Sept.

5. Euphorbia sérpens H.B.K. Round-Leaved Spreading Spurge. (I. F.f. 23II.) Pale green, glabrous, sometimes glaucescent. Branches slender or filiform, prostrate, 5-30 cm. long; leaves orbicular, orbicular-ovate or oval, 2-6 mm. long, obtuse or emarginate, entire, often slightly revolute, the base oblique, rounded or subcordate; involucres solitary in the axils, nearly $\mathrm{I} \mathrm{mm}$. high, bearing 4 sessile saucer-shaped glands shorter than the lobes, and minute irregular appendages; capsule nodding, depressed-globose, $2 \mathrm{~mm}$. in diameter; seeds oblong-ovoid, smooth, obtusely 4-angled, light gray. Ill. to Iowa and S. Dak., south to Mex. March-Oct.

6. Euphorbia serpyllifòlia Pers. Thyme-Leaved Spurge. (I. F. f. 23I2.) Deep green, or becoming reddish, glabrous. Branches slender, prostrate, $\mathbf{I}-3 \mathrm{dm}$. long; leaves oblong to oval, $3^{-15} \mathrm{~mm}$. long, obtuse or retuse, serrulate to below the middle, the base oblique, mostly truncate or obtuse; involucres solitary in the axils, sometimes clustered toward the ends of the branchlets, less than $2 \mathrm{~mm}$. long, bearing 4 disk-like glands and narrow lobed appendages; capsule $2 \mathrm{~mm}$. broad; seeds ovoid, 4-angled, the faces transversely wrinkled and pitted. In dry soil, Wis. to Cal., south to Mex. May-Sept.

7. Euphorbia albicaùlis Rydb. White-stemmed Spurge. Pale green or yellowish. Branches procumbent, $\mathbf{x}-3 \mathrm{dm}$. lorig, glabrous, shining; leaves linear or slightly broadened upward, $\mathbf{I}-\mathbf{I} .5 \mathrm{~cm}$. long, nearly entire or toothed at the apex; involucres turbinate, about I $\mathrm{mm}$. high; appendages minute, rather broad, white, truncate or crenulate; capsule about $2 \mathrm{~mm}$. long, smooth, acute-angled; seeds light brown, oblong, I.3-I.5 mm. long, acutely 4-angled, shallowly transversely wrinkled. In sandy soil, Neb. and Mont. June-Sept.

8. Euphorbia glyptospérma Engelm. Ridge-SeEded Spurge. (I. F. f. 2313.) Pale green, glabrous. Branches spreading or prostrate, 5-40 cm. long; leaves oblong, linear-oblong or rarely ovate, 2-12 mm. long, more or less falcate, obtuse at the apex, inequilateral, serrulate, very oblique and obtuse or subcordate at the base; involucres solitary in the axils, campanulate, $1 \mathrm{~mm}$. long, with 4 dark ribs and 4 saucer-shaped glands, their appendages narrow; capsule depressed-globose, less than $2 \mathrm{~mm}$. in diameter; seeds oblong, ash-colored, transversely wrinkled. In sandy soil, Ont. to Br. Col., Conn., Tex. and Mex. June-Oct.

9. Euphorbia hirsùta (Torr.) Wiegand. HAIRY SPURGE. (I. F. f. 2314a.) Bright green, more or less hirsute. Branches prostrate or decumbent, 5-25 cm. long, zigzag; leaves ovate-oblong, 8-I6 $\mathrm{mm}$. long, acutish, serrulate nearly to the oblique base, pale beneath; involucres funnelform, I mm. high, glabrous, bearing 4 stalked saucer-shaped dark brown glands, and white appendages; capsule about 2 $\mathrm{mm}$. in diameter, broader than long, glabrous, its angles obtuse; seed 4-angled, black beneath a white coating, its faces slightly wririkled. In sandy or gravelly soil, Quebec and Ont. to Conn., N. Y. and Penn. June-Sept.

Io. Euphorbia maculàta L. Milk Purslane. Spotted or Blotched SPURGE. (I. F. f. 2314.) Dark green, puberulent or pilose. Branches slender, radiately prostrate, $5-40 \mathrm{~cm}$. long, often dark red; leaves usually blotched, oblong or ovate-oblong, 4-16 mm. long, obtuse, more or less serrate, the base oblique, sub. cordate: involucres solitary in the axils, $2 \mathrm{~mm}$. long, with 4 cup-shaped glands, the appendages narrow, white or red; capsule ovoid-globose, about $2 \mathrm{~mm}$. in diameter, pubescent; seeds ovoid-oblong, obtusely angled, minutely pitted and transversely 
wrinkled. Throughout N. Am. except the extreme north. Apparently introduced west of the Rocky Mts. June-Nov.

I I. Euphorbia humistràta Engelm. Hairy Spreading Spurge. (I. F. f. 2315.) Light green, puberulent or sparingly pilose. Branches radiately prostrate, I-3 dm. long; leaves ovate-oblong or obovate-oblong, or sometimes narrower, 4-15 mm. long, serrulate, at least above the middle, oblique, obtuse or subcordate at the base; involucres in lateral clusters, split on one side, $2 \mathrm{~mm}$. long, faintly 1 erved, with 4 disk-like glands, and narrow irregular red or white appendages; capsule depressed-globose, less than $2 \mathrm{~mm}$. in diameter, its 3 lobes keeled; seeds oblong, papillose, obscurely transversely wrinkled. Quebec to N. Y., Kans. and Miss. Aug.-Oct.

I2. Euphorbia stictóspora Engelm. NARrow-Seeded Spurge. (I. F. f. 2316.) Yellowish green, pilose. Branches radiating, 5-30 cm. long; leaves oblong to suborbicular, 4-6 mm. long, obtuse, dentate-serrate at the apex, the bases truncate or subcordate; involucres clustered, campanulate, I $\mathrm{mm}$. high, with 4 cup-shaped glands, and inconspicuous appendages; capsule ovoid, I-2 $\mathrm{mm}$. in diameter; seeds narrowly ovoid, pointed, pitted, gray or ash-colored, sharply 4-angled. S. Dak., Neb. and Colo. to Mex. June-Oct.

13. Euphorbia Féndleri T. \& G. Fendler's Spurge. (I. F. f. 2317.) Pale green, glabrous. Branches wiry, I-2 dm. long, brittle; leaves suborbicular, oval or elliptic, $3-8 \mathrm{~mm}$. long, obtuse, entire, the base oblique, obtuse or subcordate; involucres campanulate, 2-5 $\mathrm{mm}$. high, with 4 or 5 saucer-shaped oval glands and irregular appendages; capsule deflexed, $3 \mathrm{~mm}$. in diameter, sharply 3-lobed; seeds ovoid, wrinkled. Neb. and Colo. to Tex., Mex. and Ariz. April-Oct.

I4. Euphorbia làta Engelm. Hoary Spurge. (I. F. f. 23I8.) Pale green, canescent. Base somewhat woody; branches 5-10 cm. long; leaves ovate to lanceolate, 5-10 mm. long, revolute, abruptly narrowed, truncate or cordate at the base; involucres solitary in the axils, I $\mathrm{mm}$. long, bearing 5 disk like glands and narrow appendages; capsule subglobose, $2 \mathrm{~mm}$. in diameter; seeds oblong, acutish at both ends, 4-angled, the faces inconspicuously transversely wrinkled. Kans. to Tex. and N. Mex.

15. Euphorbia nùtans Lag. Large or Upright Spotted Spurge. (I. F. f. 23I9.) Deep green. Stem 2-6 dm. high, the branches mostly spreading; leaves opposite, oblong, or linear-oblong, varying to ovate or obovate, often falcate, oblique, 3-nerved, unequally serrate, often with a red blotch and red margins; involucres narrowly obovoid, I $\mathrm{mm}$. long, bearing 4 glands subtended by orbicular or reniform white or red appendages; capsule glabrous, $2 \mathrm{~mm}$. in diameter; seeds oblong ovoid, 4-angled, with broken transverse ridges. In fields and thickets, throughout eastern N. Am. except the extreme north, extending west to the Rocky Mts. May-Oct.

I6. Euphorbia hexagòna Nutt. ANGled Spurge. (I. F. f. 2320.) Yel. lowish green. Stem striate angled, I-5 dm. tall, the branches ascending, often almost filiform; leaves opposite, linear, oblong or lanceolate, equilateral; involucres solitary in the axils, often clustered, 2-3 mm. long, ciliate, pubescent, with 5 glands subtended by triangular-ovate whitish or green appendages; capsule glabrous, $4 \mathrm{~mm}$. in diameter; seeds ovoid or oblong-ovoid, terete, papillose. Iowa to Mont., Tex. and Colo. Also at Wilmington, Del. June-Oct.

I7. Euphorbia Marylándica Greene. Maryland Spurge. Perennial, glabrous, pale green. glaucescent. Stems trichotomous near the base, thence bushy, 3-4 dm. tall, the branches dichotomous; leaves linear to linear-lanceolate, 2-3.5 cm. long, acute, opposite above the whorl of 3 at the first fork; involucres hemispheric, nearly $2 \mathrm{~mm}$. high; appendages white, suborbicular to reniform. On sand hills, Anne Arundel Co., Md. Summer.

I8. Euphorbia corollàta L. Blooming or Flowering Spurge. (I. F. f. 232r.) Perennial by a long stout rootstock. Stem erect, 2.5-9 dm. tall, umbellately branched above; leaves linear, oblong or oblong-spatulate, 2-4 cm. long, entire, short petioled or sessile, the lower scattered, those subtending the umbel verticillate; bracts ovate to linear, green; involucres mostly terminal, less than $2 \mathrm{~mm}$. long, bearing 4 or 5 yellowish green oblong glands subtended by white petal-like cuneate or orbicular-cuneate appendages; capsule erect, subglobose, 2-4 $\mathrm{mm}$. in 
diameter; seeds ovoid, smooth, sparingly pitted. In dry soil, Mass. and Ont. to Minn. and Kans., south to Fla. and Tex. April-Oct.

I9. Euphorbia marginàta Pursh. White-margined Spurge. (I. F. f. 2322.) Bright green. Stem 2.5-9 dm. tall, usually pilose, topped by a mostly 3-rayed umbel; leaves, except the whorl subtending the umbel, scattered, ovate to obovate, 2-8 cm. long, entire; bracts large, white-margined; involucres campanulate, often clustered, $4 \mathrm{~mm}$. long, bearing 3 glands subteided by white reniform appendages; capsule depressed globose, $6 \mathrm{~mm}$. in diameter; seeds ovoid-globose, terete, dark ash-colored, reticulate-tuberculate. In dry soil. Minn. to Colo. and Tex. Introduced into waste places in the Central and Atlantic States. May-Oct.

20. Euphorbia cuphospérma (Engelm.) Boiss. Warty Spurge. (I. F. f. 2323.) Dull green. Stem 2-4 dm. high; leaves opposite or alternate, linear, oblong, or linear-lanceolate, $2-8 \mathrm{~cm}$. long, entire, undulate, or denticulate; involucres crowded at the ends of the branches, glabrous, or nearly so, nearly $4 \mathrm{~mm}$. long, bearing about 4 unappendaged glands; capsule $5 \mathrm{~mm}$. in diameter; seeds narrowly ovoid, about $3 \mathrm{~mm}$. long, irregularly 4-angled, ridged and slightly tuberculate. S. Dak. to Colo. and Mex. Aug.-Sept.

21. Euphərbia dentàta Michx. Toothen Spurge. (I. F. f. 2324.) Dull green. Stem 2--4 dm. high, the branches mostly ascending; leaves opposite, or the lower alternate, ovate to nearly linear or orbicular-oblong, $\mathbf{r}-8 \mathrm{~cm}$. long, coarsely dentate, the nerves prominent beneath; involucres clustered at the ends of the branches, oblong campanulate, about $3 \mathrm{~mm}$. long, 3-5-lobed, bearing I-4 yellowish glands; capsule 4-5 mm. in diameter; seeds ovoid or ovoid-globose, ash-colored, irregularly tuberculate, inconspicuously 4-angled. In dry or moist soil, Penn. to S. Dak., Tenn., La. and Mex. July-Oct.

22. Euphorbia Ipecacuánhae L. Wild IPECAC. IPecac Spurge. (I. F. f. 2325.) Root deep. Stems several or many, slender, I-2.5 dm. long; leaves green or red, wonderfully variable in shape from linear to orbicular, $\mathrm{I}-7 \mathrm{~cm}$. long, mostly opposite, entire, short-petioled; involucres axillary, mostly hemispheric, nearly 2 $\mathrm{mm}$. long, slender-peduncled, bearing 5 transversely elliptic or oblong green glands; capsule $3 \mathrm{~mm}$. in diameter; seeds light gray, oblong-ovoid or ovoid, pitted, obscurely 4-sided. In dry sandy soil, Conn. to Fla., mostly near the coast. Also in southern Ind. An emetic. May-Oct.

23. Euphorbia heterophýlla L. Various-Leaved Spurge. (I. F. f. 2326.) Bright green. Stem 3-9 dm. tall, with the branches ascending, or the lower spreading, leafy at the ends; leaves alternate, very variable, linear to orbicular, entire, undulate, sinuate or dentate, the uppermost often fiddle-shaped and blotched with red; involucres clustered at the ends of branches, $3 \mathrm{~mm}$. long; lobes 5, ovate or oblong, laciniate, the sinuses bearing I or several sessile glands; capsule glabrous or minutely pubescent, $6 \mathrm{~mm}$. in diameter: seeds oblong-ovoid, tranversely wrinkled and tuberculate. Ill. to Mnt., Fla. and Trop. Am. April-Nov.

24. Euphorbia Láthyris L. Caper or Myrtle Spurge. (I. F.f. 2327.) Glaucous. Stem 2-10 dm. tall, mostly simple below. umbellately branched above; leaves numerous, the lower scattered, linear, reflexed, those subtending the umbel verticillate, the upper lanceolate or linear-lanceolate, entire, sessile, subcordate at the base; bracts ovate or ovate-lanceolate, truncate or subcordate; involucres 5 mm. long, bearing 4 crescent-shaped glands prolonged into short horns; capsule subglobose, IO-12 mm. in diameter; seeds oblong-ovoid, terete, usually wrinkled. In waste places, Conn. to N. Car. Also in Cal. Native of Europe. May-Aug.

25. Euphorbia Darlingtònii A. Gray. Darlington's Spurge. (I. F. f. 2328.) Dark green, often minutely pubescent. Stem stout, 4-15 dm. tall, topped by a 5-8-rayed umbel, branched above; leaves oblong or oblanceolate, $3 \cdot 5-10 \mathrm{~cm}$. long, mostly obtuse, sessile, often undulate, those of the stem scattered, those subtending the umbels verticillate; bracts ovate or nearly reniform; involucres campanulate, nearly $4 \mathrm{~mm}$. long, bearing 5 reniform crenulate glands; capsule depressed-globose, minutely warty; seeds ovoid-globose. N. Y., Penn. and N. J. to N. Car. May-Sept.

26. Euphorbia obtusàta Pursh. Biunt-leaved Spurge. (I. F. f. 2329.) Yellowish green. Stem 36 dm. high, topped by a 3 -rayed umbel; branches simple or forked; leaves scattered, spatulate-oblong, obtuse, serrulate to below the middle; involucres $1 \mathrm{~mm}$. long, bearing 4 stilked glands; capsule subglobose, 
nearly $4 \mathrm{~mm}$. in diameter, with elongated warts; seeds oblong, or orbicular-oblong, dark brown, faintly reticulated. In dry soil, Va. to Iowa, S. Car. and Tex. March-July.

27. Euphorbia platyphýlla L. Broad-leaved Spurge. (I. F. f. 233o.) Bright green. Stems 1-5 dm. high, often reddish, topped by a usually 5-rayed umbel; leaves scattered, oblong or spatulate-oblong, 2-3 cm. long, acute, serrulate, slightly auricled; bracts triangular-ovate or reniform, mucronate; involucres campanulate, nearly $2 \mathrm{~mm}$. long, bearing 4 glands; capsule subglobose, about $4 \mathrm{~mm}$. in diameter, with depressed warts; seeds oblong or nearly orljicular, smooth, brown. Along the shores of the St. Lawrence River and the Great Lakes. Nat. from Europe. June-Sept.

28. Euphorbia Arkansàna Engelm. Arkansas Spurge. Olive green. Stem slender, 2-5 dm. tall, with few spreading branches above, topped by an umbel with 3 copiously dichotomous rays $2-3 \mathrm{~cm}$. long; stem-leaves cuneate or spatu. late, I-3 cm. long, rather acute, serrulate above the middle; bracts ovate to triangular ovate, $0.5^{-2} \mathrm{~cm}$. long, truncate or subcordate at the base, mucronate at the apex; involucres about I $\mathrm{mm}$. high, with transversely elliptic glands less than I $\mathrm{mm}$. wide, the lobes usually ciliate; capsules $2.5-3 \mathrm{~mm}$. wide. warty; seeds ovoid, closely reticulated, brown. Dry soil, Mo. to Colo., Ala. and Mex. May-Aug.

29. Euphorbia Missouriénsis (Norton) Small. Reticulate - SEeded SPURGe. (I. F. f. 2331.) Olive green. Stem 3-6 dm. high, topped by a compound 3-rayed umbel; leaves scattered, spatulate, $2-3.5 \mathrm{~cm}$. long: obtuse, serrate to below the middle, the upper slightly auricled at the base; bracts oblong or ovate, inequilateral, acute, serrate; involucres less than $2 \mathrm{~mm}$. long, with 4 oblong glands, the lobes glabrous; capsule $3-3.5 \mathrm{~mm}$. in diameter, with elongated warts; seeds ovoid, purplish brown, distinctly reticulated. [E. Arkansana var. Missouriensis Norton. E. dictyosperma Ill. Fl., not F. \& M.] Minn. to Wash., south to Kans. and N. Mex. May-Aug.

30. Euphorbia Helioscòia L. Sun Spurge. IVArtiveed. (I. F. f. 2332.) Bright green. Stem $1-3 \mathrm{dm}$. tall, often branched from the base, topped like the branches by a more or less compound 3-5-rayed umbel; leaves scattered, spatulate, obovate, oblong, or sometimes nearly orbicular, I-I2 cm. long, obtuse or retuse, serrulate, short-petioled; bracts oblong or ovate, serrulate, inequilateral; involucres oblong-campanulate, $2.5 \mathrm{~mm}$. long, usually with 4 oblong stalked glands; capsule globose-ovoid, or somewhat depressed, $4 \mathrm{~mm}$. in diameter, smooth, the lobes rounded; seeds ovoid, nearly $3 \mathrm{~mm}$. long, reddish brown, strongly reticulate. In waste places in the Valley of the St. Lawrence and along the Great Lakes, extending south to N. H., N. Y. and Ohio. Nat. from Europe. June-Oct.

31. Euphorbia Péplus L. Petty Spurge. (I. F. f. 2333.) Olive green. Stem I-3 dm. high, topped by a 3-5-rayed umbel; stem-leaves scattered, oblong or obovate, I-3 cm. long, obtuse or retuse, entire, slender-petioled; bracts opposite, ovate or triangular-ovate, apiculate, sessile; involucres campanulate. less than $2 \mathrm{~mm}$. long, bearing 4 crescent-shaped glands prolonged into slender horns; capsule globose-ovoid, 2-3 $\mathrm{mm}$. in diameter, slightly nodding, smooth, the lobes 2.keeled; seeds oblong or oblong-ovoid, whitish, nearly terete, marked with I-4 series of pits. In waste places, western N. Y. to N. J. and Penn. Adv. from Europe. June-Sept.

32. Euphorbia commutàta Engelm. Tinted Spurge. (I. F. f. 2334) Yellowish green, often tinged with red. Stem usugally decumbent, I-4 dm. long, topped by a 3-rayed umbel; branches forked or umbellately branched; leaves scattered, spatulate to ovate, 1.2-3.5 cm. long, obtuse or mucronulate, entire, slender-petioled; bracts ovate-reniform; involucres campanulate, $2.5 \mathrm{~mm}$. long, bearing 3 or 4 crescent-shaped glands prolonged into slender horns; capsule globoseovoid, $3 \mathrm{~mm}$. in diameter, glabrous, the lobes rounded; seeds oblong, terete, irregularly pitted. On hillsides, Penn. to Minn., Fla. and Mo. March-July.

33. Euphorbia Ésula L. Leafy Spurge. Faitour's Grass. (I. F. f. 2335.) Bright green. Stems often clustered, mostly erect, 2-6 din. tall, topped by a many-rayed umbel; leaves few, all scattered, linear or oiniong, $1.4-4 \mathrm{~cm}$. long, 4 $12 \mathrm{~mm}$. broad, entire, those subtending the umbel lanceolate or oblanceolate; bracts subreniform, mucronate; involuçes çampanulate, $2.5-3 \mathrm{~mm}$. long, 
bearing 4 crescent-shaped glands; capsule nodding, smooth; seeds oblong, terete, smooth. In waste places, Mass. to N. Y. and Mich. Nat. from Europe. Summer.

34. Euphorbia lúcida L. Shining Spurge. (I. F. f. 2336.) Deep green. Stems stout, usually clustered, $2-5 \mathrm{dm}$. high, usually very leafy, topped by a 4-7-rayed umbel; branches simple or forked; leaves alternate, linear or linearoblong, 1.2-10 cm. long, 4-12 mm. broad, entire, mostly apiculate, those subtending the umbel ovate, oval or obovate; bracts reniform; involucres campanulate, $3 \mathrm{~mm}$. long, bearing 4 yellowish oblong crescent-shaped, 2-horned glands; capsi'? globose-ovoid, $4 \mathrm{~mm}$. in diameter, nodding, smooth, finely wrinkled; seeds obiong, 2.5-3 mm. long, nearly terete, whitish, smooth. In fields along the Susquelianna River, southern N. Y. and northern Penn. Nat. from Europe. [E. Nicaeensis Ill. Fl.] July-Sept.

35. Euphorbia Cyparíssias L. Cypress Spurge. (I. F. f. 2337.) Bright green. Stems clustered in large patches, $3 \mathrm{dm}$. high, or less, the branches topped by many-rayed umbels; leaves linear, or alnost filiform, 1.2-2.5 cm. long, 0.5-3 mm. broad; involucres turbinate-campanulate, $2 \mathrm{~mm}$. long, with 4 unappendaged crescent-shaped glands; capsule subglobose, $3 \mathrm{~mm}$. in diameter, granular on the rounded lobes; seeds oblong, $2 \mathrm{~mm}$. long, smooth. Escaped from gardens to waste places, N. E. to Kans. Nat. from Europe. May-Sept.

36. Euphorbia robústa (Engelm.) Small. Rocky Mountain Spurge. (I. F. f. 2338.) Glaucous. Stems clustered, I-3.5 dm. tall, topped by a 3-5-rayed umbel; leaves scattered, ovate or oblong-ovate, I-I.8 mm. long, obtuse or apiculate, entire, sessile; bracts opposite, triangular-ovate or subreniform; involucres campanulate, $3 \mathrm{~mm}$. long, bearing 4 somewhat crescent-shaped unappendaged buff crenulate glands: capsule globose-ovoid, $4-4.5 \mathrm{~mm}$. long, its lobes rounded; seeds oblong or obovoid-oblong, terete, $2.3-2.5 \mathrm{~mm}$. long, gray, minutely pitted. S. Dak., Mont. and Wyo. to Neb. and Ark. May-Oct.

\section{Family 9. CALLITRICHÀCEAE Lindl.*}

\section{$U$ 'ater-starwort Family.}

Herbaceous aquatic or rarely terrestrial plants, with slender or capillary stems, opposite exstipulate entire spatulate or linear leaves, and minute ferfect or moncecious axillary flowers. Perianth none. Bracts 2, sac-like, or none. Stamen 1 ; filament elongated, filiform ; anthers cordate, 2-celled, opening by lateral slits. Pistil 1 ; ovary 4-celled; ovules I in each cavity; styles 2, filiform, papillose nearly the whole length. Fruit compressed, lobed, the lobes more or less winged or keeled on the margins, separating at maturity into 4 flattish I-seeded carpels. Seed anatropous, pendulous ; endosperm fleshy; embryo straight or nearl $y$ ' so, almost as long as the endosperm. Consists of the following genus:

\section{CALLÍTRICHE L.}

Characters of the family. [Greek, beautiful hair, from the hair.like stems.] Abrut 20 species of wide distribution. Besides the following, about 7 others occur in southern and western N. Am.

Fruit short-peduncled; bracts wanting; terrestrial.

Fruit sessile; aquatic, or sone forms growing in mud.

Bracts present.

Fruit oval, flat on the face, longer than the styles.

Fruit obovate, plano-convex, shorter than the styles.

Bracts none; leaves all linear, submersed.

x. C. Austini.

2. C. palustris.

3. C. heterophylla.

4. C. bifida.

I. Callitriche Aùstini Engelm. Terrestrial Water-starwort. (I. F. f. 2339.) Tufted, the branches spreading on the ground or ascending, $\mathrm{I}-5 \mathrm{~cm}$. long. I eaves spatulate or obovate, 3 nerved, 3-4 mm. long, about $2 \mathrm{~mm}$. wide, obtuse, tapering into a short margined petiole, destitute of stellate scales: fruit about $0.5 \mathrm{~mm}$. long and nearly $1 \mathrm{~mm}$. broal, deeply notched at both ends, its lobes with 
a narrow marginal wing or raised border, with a deep groove between them; styles persistent, not longer than the fruit, spreading or reflexed. In damp, shaded places, Conn. to N. J., Ohio, Mo., Tenn., Tex. and Mex. July-Sept.

2. Callitriche palústris L. Vernal Water-starwort. Water Fennel. (I. F. f. 2340.) Aquatic or growing in the mud; stems 5-25 cm. long. Submerged leaves linear, I-nerved, retuse or bifid at the apex, $1-2 \mathrm{~cm}$. long; emersed or floating leaves obovate, obtuse, truncate or retuse at the apex, narrowed into a margined petiole, dotted with stellate scales; aquatic forms occur with the leaves all linear; fruit 2-bracted, I-2 mm. long, about one-half as broad, slightly notched at the apex, winged only toward the apex, or all around, separated by a deep groove Mostly in cold or running water, apparently occurring nearly throughout the U. S. and Canada. Also in S. Am., Eur. and Asia. July-Sept. (C.verna L.)

3. Callitriche heterophýlla Pursh. Larger Water-Starwort. (I. F. f. 2341.) Similar to the preceding. Fruit smaller, usually slightly less than I mm. long, and about the same breadth, broadly notched at the apex, thick, almost ventricose at the base; lobes obtusely angled with a small intervening groove, wingless, or with a narrow wing or raised border on the margins. In ponds and slow streams, N. Eng. to Fla., N. W. Terr., Colo. and La. July-Sept.

4. Callitriche bífida(L.) Morong. Autumnal or Northern Water-starWORT. (I. F. f. 2342.) Subinerged. Leaves linear or linear-lanceolate, clasping at the base, retuse or bifid at the apex, I-nerved, I-I. $6 \mathrm{~cm}$. long, without stellate scales; fruit sessile, or rarely minutely pedunculate, orbicular or slightly narrower than long; I-2 mm. in diameter, its lobes separated by a deep groove and broadly winged on the margins; styles as long as the fruit, or shorter, soon deciduous. In flowing water, Quebec to Manitoba and Ore., south in the Rocky Mts. to Colo. Also in Europe and Asia. July-Sept. (C. antumnalis L.)

\section{Order 20. SAPINDÁLES.}

Mostly trees or shrubs (Limnanthaceare and Balsaminaceae herbs). Petals usually present and separate. Sepals mostly distinct. Stamens rarely more than twice as many as the sepals, when as many or fewer, opposite them. Ovary superior, compound. Ovules pendulous, with the raphe away from the axis of the ovary, or erect or ascending.

a. Flowers regular, or nearly so (except in Hippocastanaceae, which are trees or shrubs with digitately compound leaves.

Petals none (or 3 in Empetrum); flowers monœcious or diœcious; leaves evergreen.

Stamens mostly 3 ; low heath-like shrubs.

Stamens 4-7; our species an herb with broad leaves and spiked flowers.

Fam. 2. Buxaceae.

Petals present; leaves deciduous, except in Cyrillaceae and some Ilicaceae.

Low annual herbs, with pinnately divided leaves, the stamens twice as many as the petals.

Trees or shrubs, or rarely herbaceous vines.

Ovary 1-celled (in ours); fruit a small drupe. Fam. 4. Anacardiaceae.

Ovary 2-several-celled.

Leaves simple, pinnately veined.

Seeds not arilled.

Fruit dry; flowers racemed, perfect. Fam. 5. Cyrillaceae.

Fruit a small drupe; flowers not racemed, mostly polygamo-diœcious; ovules pendulous.

Fam. 6. Ilicaceae.

Seeds arilled; ovules erect; capsule fleshy. Fam. 7. Celastraceae.

Leaves simple and palmately veined, or compound.

Leaves opposite.

Fruit a bladdery 3-lobed capsule. Fam. 8. Staphyleaceae.

Fruit of 2 winged samaras. Fam. 9. Aceraceae.

Fruit a leathery capsule; flowers irregular; leaves digitately compound.

Leaves alternate; fruit various.

Fam. 1o. Hippocastanaceae.

Fam. II. Sapindaceae.

b. Flowers very irregular, the posterior sepal large, saccate; succulent herbs, the capsule elastically dehiscent.

Fam. 12. Balsaminaceae. 


\section{Family r. EMPETRÀCEAE Dumort.}

\section{Crouberry Fianily.}

Low evergreen shrubs, with small narrow nearly sessile exstipulate leaves jointed to short pulvini, channeled on the lower side by the revolute margins, and small diøcious, monœcious, or rarely polygamous flowers. Calyx of 3 sepals. Corolla of 2 or 3 petals, or none. Staminate flowers with 2-4 stamens, the filaments filiform, the anthers 2-celled, longitudinally dehiscent, sometimes with a rudimentary pistil. Pistillate flowers with a 2-several-celled sessile ovary, the single style cleft into as many stigma-bearing segments as there are ovary-cavities; ovules I in each cavity, amphitropous. Fruit a berry-like drupe, containing 2-several I-seeded nutlets. Embryo straight, terete, in copious endosperm. Three known genera, the following, and the monotypic Ceratiola of the southeastern U.S.

Flowers axillary; petals 3 .

Flowers in terminal heads; petals none.

x. Empetrum.

2. Corema.

\section{1. ÉMPETRUM L.}

Depressed or spreading herbaceous shrubs, the branches usually densely leafy, the leaves linear-oblong. Flowers inconspicuous, solitary in the upper axils. Sepals and petals mostly 3. Staminate flowers with 3 stamens, the anthers introrse. Pistillate flowers with a globose 6-9-celled ovary, and a short thick style with 6-9-toothed segments. Drupe black, or red, containing 6-9 nutlets. [Greek, on rocks, referring to the growth of these plants in rocky places.] Two known species, the following, and C. rubrum of southern S. Am.

I. Empetrum nigrum L. Black Crowberry. Heathrerry. (I. F. f. 2343.) Glabrous, or the young shoots pubescent, the branches diffusely spreading, 5-25 cm. long. Leaves dark green, thick, obtuse, 4-7 $\mathrm{mm}$. long, about I $\mathrm{mm}$. wide, the revolute margins roughish; flowers very small, purplish ; stamens exserted; drupe black (red in an arctic form), 4-6 mm. in diameter. In rocky places, Greenland to Alaska, Me., N. Y., Mich. and Cal. Also in Europe and Asia. Summer.

\section{CORÈMA Don.}

Low, much-branched shrubs, with narrowly linear leaves crowded on the branches, and small diøecious or polygamous flowers in terminal heads. Corolla none. Staminate flowers with 3 or sometimes 4 long-exserted stamens, occasionally with a rudimentary or perfect pistil. Pistillate flowers with a 2-5-celled (mostly 3-celled) ovary and a slender 2-5-cleft style, the stigmatic branches very slender, sometimes toothed. Drupe globose, usually with 3 nutlets. [Greek, a broom, in allusion to the bushy habit.] Two species, the following of the eastern U. S., the other of southwestern Europe, the Azores and Canaries.

I. Corema Conràdii Torr. Conrad's Broom Crowberry. (I F. f. 2344.) Much branched, 1.5-6 dm. high, the young twigs puberulent and densely leafy, the branches minutely scarred by the persistent pulvini. Leaves 4-6 $\mathrm{mm}$. long, rather less than I mm. wide, obtuse, glabrous when mature; flowers numerous in the terminal şessile heads, the pistillate ones almost concealed by the upper leaves, the staminate conspicuous by the exserted purple stamens; drupes nearly dry, less than $2 \mathrm{~mm}$. in diameter. In rocky or sandy soil, Newf. to N. J., mostly near the coast, but occurring in one station on the Shawangunk Mountains in Ulste: Co., N. Y. April-May.

\section{Family 2. BUXACEAE Dumort.}

\section{Box Family.}

Monœecious or diœcious trees, shrubs or perennial herbs, with simple mostly evergreen leaves, the sap not milky. Flowers regular, bracted. Petals none. Staminate flowers with 4-7 distinct stamens, the anthers 2-celled; sometimes with a rudimentary pistil. Pistillate flowers with a 
2-4-celled (mostly 3-celled) ovary, with 2 or 1 anatropous ovules in each cavity; styles as many as the ovary-cavities, simple. Fruit a capsule or drupe, its carpels 1-2-seeded. Embryo straight; endosperm fleshy, or almost wanting. About 6 genera and 30 species, only the following and the Californian Simmondsia native in N. Am.

\section{PACHYSÁNDRA Michx.}

Monœcious perennial herbs, with matted rootstocks, the stems procumbent or ascending, leafy above. Leaves alternate, estipulate, petioled, persistent, broad, 3 -nerved. Flowers spicate, the pistillate and staminate in the same spike. Staminate flowers with 4 sepals; stamens 4 , opposite the sepals; filaments thick, longexserted. Pistillate flowers with 4 sepals or more; ovary 3 -celled, the cavities with a partition at the base; styles 3 , spreading; ovules 2 in each cavity. Capsule of 3 2-seeded carpels. [Greek, thick stamen.] Two species, the following of southeastern N. Am., the other Japanese.

I. Pachysandra procúmbens Michx. Alleghany Mountain Spurge. (I. F. f. 2345.) Somewhat pubescent; stems $3 \mathrm{dm}$. long or less. Leaves ovate, oval, or obovate, 5-10 cm. long, coarsely dentate or some of them entire, cuneate or abruptly narrowed at the base into a petiole; spikes in the axils of the lower scales, $5-7.5 \mathrm{~cm}$. long, the staminate flowers forming most of the spike, the pistillate few toward its base; filaments white, 8-Io mm. long. In woods, W. Va. to Fla. and La. Flowers fragrant. April-llay.

\section{Family 3. LIMNANTHÀCEAE Lindl.}

\section{False Mermaid Family.}

Annual herbs, with alternate petioled estipulate pinnately divided leaves. Flowers perfect, regular, axillary, long-peduncled. Sepals 2-5, valvate, persistent. Petals the same number as the sepals, alternating with as many small glands, the nearly perigynous stamens distinct. Filaments filiform ; anthers 2-celled, the sacs longitudinally dehiscent. Carpels as many as the sepals and opposite them, 1-ovuled, nearly distinct, the single slender style arising from the centre, cleft above into as many stigmas as there are carpels; ovule ascending. Fruit very deeply 2-5lobed, the carpels indehiscent. Embryo straight; endosperm none; cotyledons thick. Two North American genera, the following, and Limnanthes, of the Pacific States, with 5 or 6 species.

\section{FLOÉRKEA Willd.}

A diffuse glabrous herb, with small white solitary flowers. Sepals 2 or 3 . Petals 2 or 3 , oblong, entire. Stamens 4-6. Ovary $2-3$-lobed nearly to the base, 2-3-celled; stigmas 2 or 3. Mature carpels I-3, indehiscent, fleshy. Seed erect. [In honor of H. G. Floerke, I790 1835, a German hotanist.] A monotypic genus.

I. Floerkea proserpinacoìdes Willd. False Mermaid. (I. F. f. 2346.) Slender, I-4 dm. long. Leaves thin, slender-petioled, $1.25-7.5 \mathrm{~cm}$. long, the segments 5 or 3 , distant, lanceolate, oblong or linear-oblong, entire or cleft; peduncles slender; flowers about $3 \mathrm{~mm}$. broad; sepals ovate, acute, at length much exceeding the fruit; stamens about equalling the petals: ripe carpels nearly globular, about $3 \mathrm{~mm}$. in diameter, tuberculate above. In marshes and along rivers, Quebec to Ont., Ore., Penn., Tenn., Mo., Utah and Cal. April-June.

\section{Family 4. ANACARDIÀCEAE Lindl.}

\section{Sumac Family.}

Trees or shrubs, with acrid resinous or milky sap, alternate or rarely opposite leaves, and polygamo-dinecious or perfect, mainly regular flowers. Calyx 3-7-cleft. Petals of the same number, imbricated in the bud, or rarely none. Disk generally annular. Stamens as many or twice as many as the petals, rarely fewer, or more, inserted at the base of the disk; fila- 
ments separate; anthers commonly versatile. Ovary in the staminate flowers I-celled. Ovary in the pistillate flowers 1- or sometimes 4-5celled; styles I-3; ovules 1 in each cavity. Fruit generally a small drupe. Seed-coat bony or crustaceous; endosperm little or none; cotyledons fleshy. About 50 genera and 400 species, most abundant in warm or tropical regions, a few extending into the temperate zones.

Styles terminal; leaves compound in our species; fruit nearly symmetrical. I. Rhus. Styles lateral; leaves simple; fruit gibbous.

2. Cotinus.

\section{RHúS L.}

Leaves alternate, simple, 3-foliolate, or odd-pinnate, estipulate. Flowers small, polygamous, in punicles. Calyx 4-6-cleft or parted (commonly 5-cleft), persistent. Petals equal, imbricated, spreading. Disk annular. Stamens (in our species) 5. Pistil I, sessile; ovary I-ovuled; styles 3, terminal. Drupe small, Iseeded, mostly subglobose, pubescent or glabrous. Seed inverted on a stalk that rises from the base of the ovary; cotyledons nearly flat. [Ancient Greek and Latin name; Celtic, red.] About I 20 species, natives of warm and temperate regions, most abundant in South Africa. Besides the following, about 8 others occur in the southern and western parts of the U.S.

Fruit pubescent; stone smooth.

Leaflets 9-3I; flowers appearing after the leaves.

Rachis of the leaf wing-margined.

Rachis of the leaf nearly terete.

Foliage and twigs velvety-pubescent.

Foliage and twigs mostly glabrous and glaucous. $3 . R$. glabra.

Leaflets 3 ; flowers appearing before the leaves.

Leaflets $2-8 \mathrm{~cm}$. long, pubescent, crenate-dentate.

Leaflets $1.25^{-2.5} \mathrm{~cm}$. long, glabrate, with few rounded teeth.

I. $R$. copallina.

2. R. hirta.

4. R. aromalica.

5. R. trilobata.

6. R. Vernix.

Fruit glabrous; stone striate.

Leaflets 7-13, glabrous.

Leaflets 3, more or less pubescent beneath.

Vine climbing by aerial rootlets, or trailing, rarely suberect.

Low shrubs, mostly without aerial rootlets.

7. $R$. radicans.

Leaflets very pubescent, crenately lobed; southern.

8. R. Toxicodendron.

Leaflets sparingly pubescent, entire, sinuate, or acutely lobed.

Leaflets entire or acutely lobed; fruit 3-4 $\mathrm{mm}$. in diameter; northern.

Leaflets sinuate; fruit $5-6 \mathrm{~mm}$. in diameter; western.

9. R. microcarpa.

10. R. Rydbergii.

I. Rhus copallina L. Dwarf, Black or Mountain Sumac. Upland Sumac. (I. F. f. 2347.) A shrub, or sometimes a small tree. Leaves pinnate, I.5-3 dm. long, the petiole and rachis more or less pubescent; leaflets 9-2 I, ovatelinceolate or oblong-lanceolate, inequilateral, entire, or few-toothed toward the apex, dark green and glabrous above, paler and often pubescent beneath; flowers green, $3 \mathrm{~mm}$. broad, in dense terminal panicles; pedicels and calyx finely pubescent; di upe compressed, $4 \mathrm{~mm}$. in diameter, crimson, covered with short acid hairs. In dry soil, Me. and southern Ont. to Fla., Minn., Neb. and Tex. June-Aug.

2. Rhus hírta (L.) Sudw. Staghorn Sumac. (I. F. f. 2348.) A small tree, or often shrubby. Leaves pinnate, 2-4 dm. long; leaflets I I-3I, lanceolate or oblong-lanceolate, $7 \cdot 5-12 \mathrm{~cm}$. long, acuminate, rounded at the base, sharply serrate, dark green and nearly glabrous above, pale and more or less pubescent beneath; panicles terminal, dense; flowers green, $3 \mathrm{~mm}$. broad: drupe globose, 3-4 $\mathrm{mm}$. in diameter. In dry or rocky soil, N. S. to Ga., Ont., S. Dak., Mo. and Miss. A form with laciniate leaflets has been found in New Hampshire. June.

3. Rhus glàbra L. Smooth UPland OR Scarlet Sumac. (I. F. f. 2349.) A shrub or rarely a small tree, 6-6o dm. high, similar to the preceding species, but glabrous and somewhat glaucous. Leaflets I I-3I, lanceolate or oblong-lanceolate. 5-10 cm. long, acuminate, rounded and often oblique at the base, dark green above, whitish beneath, sharply serrate; pedicels sometimes slightly pubescent; 
inflorescence and fruit similar to those of the two preceding; drupe covered with short reddish acid hairs. In dry soil, N. S. to Br. Col., Fla., Miss. and Ariz. This species and the two preceding sometimes have the whole or a part of the flowerclusters changed into small leaves. A form with laciniate leaflets occurs in southern Penn. and Del. June-Aug.

Rhus glabra borealis Britton, $\boldsymbol{n}$. var. Inflorescence, and sometimes the foliage, softpubescent. Mich. and Minn.

4. Rhus aromática Ait. Fragrant or Sineet-scented Sumac. (I. F. f. 2350.) A shrub, 9-24 dm. high, ascending or diffuse. Leaves petioled, 5-10 cm. long, aromatic; leaflets ovate or rhomboid, $2-8 \mathrm{~cm}$. long, $1.8-3.6 \mathrm{~cm}$. wide, the lateral ones sessile, the terminal short-stalked, the lateral rounded or truncate, the terminal cuneate at the base; flowers yellowish green, about $2 \mathrm{~mm}$. broad, in clustered spikes appearing before the leaves; drupe globose, red. In rocky woods, Ont. and Vt. to Fla., Minn., Kans. and La. March-April.

5. Rhus trilobàta Nutt. Ill-Scented Sumac. Skunk-bush. (I. F. f. 2351.) A glabrous or nearly glabrous shrub, 6-1 $8 \mathrm{dm}$. high. Leaves petioled, unpleasantly odorous, $2.5-5 \mathrm{~cm}$. long; leaflets sessile or nearly so, puberulent when young, ovate or oval, obtuse, the terminal one cuneate at the base, all crenately few-lobed or toothed or sometimes entire; flowers as in the preceding species, and fruit similar. Ill. to S. Dak., Tex. and Cal. March.

6. Rhus Vérnix L. Poison Sumac. Poison Elder. (I. F. f. 2352.) A shrub or small tree. Leaves petioled, 1.5-4 dm. long, glabrous or somewhat puberulent; leaflets thin, obovate, oval, or the lowest ovate, 5-10 $\mathrm{cm}$. long, $2.5-3.75 \mathrm{~cm}$. wide, green both sides, entire, short-acuminate, short-stalked; rachis terete; flowers green, about $2 \mathrm{~mm}$. broad, in loose axillary panicles 7-20 cm. long; drupe globose-oblong, $4 \mathrm{~mm}$. in diameter, gray. In swamps, southern Ont. to R. I., Fla., Minn., Mo. and La. Very poisonous. June.

7. Rhus radicans L. Poison Ivy. Poison OAK. Clmath. (I. F. f. 2353.) A woody vine, climbing by numerous aerial rootlets, the stem sometimes 7-IO cm. in diameter. Leaves petioled; leaflets ovate or rhombic, 2.5-15 cm. long, entire or sparingly dentate or sinuate, acute or short-acuminate, the lateral sessile or short-stalked, inequilateral, the terminal ones stalked; flowers green, $3 \mathrm{~mm}$. broad, in loose axillary panicles $28 \mathrm{~cm}$. long; fruit similar to that of the preceding. Thickets and along fences, N. S. to Fla., Minn., Neb. and Ark. Very poisonous, as are the three fullowing species. May-June.

8. Rhus Toxicodéndron L. POISON OAK. Low, erect, densely and finely pubescent. Leaflets ovate, mostly obtuse, crenate or crenately lobed, often to the middle, so as to resemble the leaves of an oak, the sinuses sharp; petals about $2 \mathrm{~mm}$. long; fruit depressed-globose, 6-8 mm. in diameter. In dry soil, Va. to Ga. and western N. Car.

9. Rhus microcàrpa (Michx.) Steud. Northern Poison OAK. Low and slender, puberulent, seldom over $4 \mathrm{dm}$. high, erect, or the stem sometimes trailing and the branches erect. Leaflets lanceolate to ovate-lanceolate, thin, acuminate, the middle one cuneate at the base, sharply toothed, lobed, or entire; fruit globose, small. Mich. [R. Toxicodenitron microcarpa Michx.]

Io. Rhus Rydbergii Small. Rydberg's Poison OAK. A shrub, less than I m. high. Leaflets broadly ovate to rhombic-ovate, rather thick, slightly pubescent on the veins beneath, 3-10 cm. long, the margins sinuate-dentate; petals ovate, about $3 \mathrm{~mm}$. long; fruit $5-6 \mathrm{~mm}$. in diameter. Hillsides and open woods, S. Dak. to Br. Col., Kans. and Ariz. May-June.

\section{Cótinus Adans.}

Shrubs or small trees, with ovate oval or obovate entire leaves, and small polygamous slender-pedicelled flowers in large terminal panicles. Calyx 5-parted, the segments imbricated, obtuse. Petals longer than the calyx, imbricated. Stamens 5. Ovary obovoid; styles 3, lateral; stigmas very small. Drupe obliquely oblong or oval, compressed, gibbous, I-seeded. Seed nearly as in Rhus. [Greek name or the oleaster, or wild olive.] Two known species, the following of southeastern N. Am., the other of Europe and Asia. 
r. Cotinus cotinoides (Nutt.) Britton. Wild or American Smoke-tree. CintTAM-Woon. (I. F.f. 2354.) A small widely-branched tree, with maximum height of about $12 \mathrm{~m}$. and trunk diameter of $4 \mathrm{dm}$. Leaves oval or slightly obovate, thin, glabrous or sparingly pubescent beneath, $7-15 \mathrm{~cm}$. long, $3.5-5 \mathrm{~cm}$. wide, obtuse at the apex, the blade slightly decurrent on the petiole; flowers $2.3 \mathrm{~mm}$. broad, green; pedicels elongating to $2.5-3.75 \mathrm{~cm}$. and becoming very p.umose in fruit; drupe reticulate veined, $4 \mathrm{~mm}$. long. Mo. and Ind. Terr. to Tenn. and Ala. April-May. Nearly related to the European C. Cotimus, which differs in its smaller coriaceous leaves, more pubescent, mostly rounded and obtuse at base; it occasionally escapes from cultivation. [R. cotinoides Nutt.]

\section{Family 5. CYRILLÀCEAE Lindl. Cyrilla Family.}

Glabrous shrubs, or small trees, with simple entire alternate estipulate leaves, long-persistent or evergreen, and small regular perfect bracted racemose flowers. Sepals 4-8 (mostly 5 ), persistent. Petals the same number as the sepals, hypogynous, distinct, or slightly united by their bases, deciduous. Stamens 4-10, in I or 2 series, distinct, hypogynous; anthers introrse, 2 celled, the sacs longitudinally dehiscent. Ovary 2-5-celled; ovules I-4 in each cavity, anatropous, pendulous; style short or none; stigma very small, or 2-3-lobed. Fruit dry, small, 1-5 seeded. Seeds oblong or spindle-shaped; endosperm fleshy; embryo central, cylindric. Three genera and 6 known species, natives of America.

\section{CYRÍLLA Garden.}

Racemes clustered at the ends of twigs of the preceding season. Sepals 5 , firm, acute, shorter than the petals. Petals 5, white, acute, spreading. Stamens 5, opposite the sepals, the filaments subulate, the anthers oval. Ovary ovoid, sessile, nostly 2-celled, sometimes 3-celled; ovules 2-4 in each cavity; style short, thick, 2-3-lobed. Fruit ovoid, 2-3 seeded, the pericarp spongy. [In lionor of Domenica Cyrillo, professor of medicine at Naples.] Two species, of southeastern N. Am.

I. Cyrilla racemiflòra Walt. Southern LeatherwoOd OR IRonwoov. (I. F. f. 2355.) A shrub or small tree, the bark at the base spongy. Leaves oblancelate, obovate or oval, cuneate-narrowed at the base, 5-10 cm. long, 6-25 mm. wide; racemes narrow, $5-15 \mathrm{~cm}$. long, bearing the very numerous small white flowers nearly to the base; pedicels $2-4 \mathrm{~mm}$. long, somewhat longer than the bracts, or shorter; fruit about $2 \mathrm{~mm}$. long. Along streams and swamps, Va. to Fla. and Tex. Also in the West Indies and S. Am. May-July.

\section{Family 6. ILICÀCEAE Lowe.}

\section{Holly Family.}

Shrubs or trees, with watery sap, and alternate petioled simple leaves. Flowers axillary, small. white, mainly polygamo-diœecious, regular. Stipules minute and deciduous, or none. Calyx 3-6-parted, generally persistent. Petals 4-6 (rarely more), separate, or slightly united at the base, hypogynous, deciduous, imbricated. Stamens hypogynous, as many as the petals, or sometimes more; anthers oblong, cordate. Disk none. Ovary I, superior, 3-several-celled; stigma discoid or capitate; stvle short or none; ovules I or 2 in each cavity. Fruit a small berry-like drupe, enclosing several nutlets. Seed pendulous; endosperm fleshy; embryo straight. Five genera and about 170 species, of temperate and tropical regions. 


\section{I. İLEX L.}

Leaves minutely stipulate. Flowers cymose or solitary, perfect or polygamous. Calyx small, 4-5-cleft or toothed. Petals 4-9, somewhat united at the base, oblong, obtuse. Stamens of the same number, adnate to the base of the corolla. Berry-like drupe globose, with $4-8$ bony or crustaceous nutlets. [Ancient name of the Holly Oak.] About I6o species, mostly natives of America. In addition to the following, some 5 others occur in the sontheastern U. S.

Leaves, thick, evergreen, persistent.

Nutlets ribbed.

Leaves spiny-toothed.

Leaves toothed or entire, not spiny.

Leaves entire or few-toothed; calyx-lobes acute.

Leaves coarsely crenate; calyx-lobes obtuse.

Nutlets not ribbed; leaves dotted beneath.

1. I. opaca.

Leaves oblanceolate to elliptic, obtusish; drupe $4-6 \mathrm{~mm}$. in diameter.

2. I. Cassine.

3. I. vomitoria.

4. I. glabra.

Leaves thin, deciduous.

Nutlets ribbed; peduncles I-flowered.

Leaves small, obovate or spatulate, crenate.

Leaves large, ovate or lanceolate, sharply serrate.

Nutlets not ribbed.

Flowers all short-pedicelled.

Leaves oval to oblong; twigs brown; fruit scarlet.

Leaves obovate; twigs gray; fruit orange-red.

Staminate flowers on long and slender pedicels.

6. I. decidua.

7. I. monticola.

8. 1. verticillata.

9. I. Bronxensis.

10. I. laevigata.

r. Ilex opàca Ait. American Holly. (I. F. f. 2356.) A tree of slow growth, sometimes $15 \mathrm{~m}$. high. Young twigs sparingly pubescent; leaves elliptic or obovate, 5-10 cm. long, $2.5-4 \mathrm{~cm}$. wide, glabrous, spiny-tipped, rarely nearly or quite entire; petioles 4-8 mm. long; staminate cymes 3-10-flowered, 1.25-2.5 $\mathrm{cm}$. long; fertile flowers mostly solitary; calyx-lobes acute, ciliate; drupe globose or globose-oblong, red, rarely yellow, $8-10 \mathrm{~mm}$. in diameter. In moist woods, $\mathrm{S}$. Me. to Fla., Penn., Mo. and Tex. April-June.

2. Ilex Cassine L. Dahoon Holly. (I. F. f. 2357.) A shrub, or small tree. Twigs pubescent; leaves oblanceolate or oblong-obovate, 5-10 cm. long, $1.25-2.5 \mathrm{~cm}$. wide, acute at the base, glabrous and dark green above, pale and usually pubescent beneath; petioles $6-8 \mathrm{~mm}$. long; staminate cymes several- or many-flowered; peduncles and pedicels pubescent; fertile cymes commonly 3flowered; calyx-lobes ciliate; drupes red, globose, 4-6 mm. in diameter. In low woods, S. Va. to Fla., near the coast, west to La. May.

3. Ilex vomitòria Ait. Cassena. Yaupon. (I. F. f. 2358.) A shrub, or small tree. Petioles and young twigs puberulent; leaves ovate-oblong or elliptic, 1.25-3.75 cm. long, 8-18 mm. wide, obtuse at both ends, crenate, glabrous, pale beneath, dark green above; petioles $2-4 \mathrm{~mm}$. long; staminate cymes several. flowered, short-peduncled; fertile cymes sessile, I-3-flowered; drupe red, 4-6 mm. in diameter. In low woods, Va. to Fla., Ark. and Tex. Also in Bermuda. May.

4. Ilex glàbra (L.) A. Gray. INkberry. Evergreen Winter-berry. (I. F. f. 2359.) A shrub, 6-I8 dm. high. Young twigs and petioles puberulent; leaves dark green and shining above, paler beneath, oblanceolate or elliptic, 2.5-5 $\mathrm{cm}$. long, $1-1.8 \mathrm{~cm}$. wide, generally cuneate at the base, obtusish and few toothed at the apex, or sometimes entire; petioles $4-8 \mathrm{~mm}$. long; sterile cymes severalflowered, slender-peduncled; fertile flowers generally solitary: drupe black. In sandy soil, E. Mass. to Fla., west to La., mainly near the coast. Reported from N. S. June-July.

5. Ilex lùcida (Ait.) T. \& G. Shrning Inkberry. (I. F. f. 2359a.) A glabrous shrub, $5 \mathrm{~m}$. high or less. Leaves acute at both ends, entire, or with a few small sharp teeth, $2-8 \mathrm{~cm}$. long, dark green and shining above, paler beneath, short-petioled, somewhat viscid when young; flowers clustered in the axils or the staminate solitary, the cymes sessile; pedicels bractless, short; calyx-segments 6-9; drupe black; nutlets flat. Swamps, Va. to Fla. and La. April-May. 
6. Ilex. decídua Walt. Swamp or Meadow Holly. (I. F. f. 2360.) A shrub, or small tree. Twigs light gray, glabrous; leaves $4-8 \mathrm{~cm}$. long, $8-16 \mathrm{~mm}$. wide, dark green, glabrous on the upper surface, paler and pubescent beneath, acute or cuneate at the base, blunt at the apex or sometimes emarginate; calyxlobes ovate, obtuse; drupe red, depressed-globose, 4-6 $\mathrm{mm}$. in diameter. In swamps and low grounds, D. C. and Va. to Fla., Kans. and Tex. May.

7. Ilex montícola A. Gray. LARGE-Leaved Holly. (I. F. f. 236I.) A shrub, or occasionally forming a slender erect tree. Leaves $5-15 \mathrm{~cm}$. long, 1.25-6 cm. wide, acuminate or acute, glabrous on both sides or somewhat pubescent beneath, especially along the veins; petioles $8-16 \mathrm{~mm}$. long; calyx-lobes acute or acutish, ciliate, not hairy; drupes red, globose-ovoid, 4-6 mm. in diameter. Mountain woods, N. Y. and Penn. to N. Car. and Ala. May.

llex montícola móllis (A. Gray) Britton. Leaves proportionately broader, 2.75-3.25 $\mathrm{cm}$. long, $2.5-5 \mathrm{~cm}$. wide, broadly ovate or oval, short-acuminate, densely soft-pubescent beneath, becoming glabrate with age; calyx-lobes downy-pubescent. In mountain woods, Penn. to Ga.

8. Ilex verticillàta (L.) A. Gray. Virginia Winter Berry. Black ALDER. (I. F. f. 2362.) A shrub, 2-8 m. high. Twigs nearly or quite glabrous, brown; leaves oval, elliptic or oblong-lanceolate, $5-7.5 \mathrm{~cm}$. long, about $2.5 \mathrm{~cm}$. wide, acute or acuminate at the apex, acute or obtusish at the base, dark green an I nearly glabrous above, pubescent beneath, sharply serrate; staminate cymes clustered, 2-10 flowered, the fertile I-3-flowered; pedicels 2-bracted; calyx-lobes obtuse, ciliate; drupes bright red (rarely white), clustered so as to appear verticillate, about $6 \mathrm{~mm}$. in diameter. In swamps, N. S. to Fla., Ont., Wis. and Mo. June-July.

Ilex verticillàta cyclophỷlla Robinson. Leaves smaller, broadly oval or nearly orbicular, thick. Northern N. Y. to Penn.

9. Ilex Bronxénsis Britton. Bronx Winter-Berry. Similar to the preceding species, but with light gray twigs, obovate, abruptly acuminate, thinner and more glabrous leaves, and larger orange-red fruit. In swamps, Me. to Mich. and N. J. [I. verticillata tenuifolia Torr.; not $I$. tenuifolia Salisb.]

Io. Ilex laevigàta (Pursh) A. Gray. Smooth Winter.berry. (I. F. f. 2363.) A shrub, much resembling the preceding. Twigs glabrous; leaves oval or oblong, 2.5-5 cm. long, mainly acute or acutish at each end, glabrous on both sides, or sometimes villous on the veins beneath, turning yellow in autumn, finely serrulate; staminate flowers solitary or occasionally 2 together, on pedicels I-I. $8 \mathrm{~cm}$. long; fertile flowers solitary, much shorter-pedicelled; calyx-lobes acute, glabrous drupes larger than in $I$. verticillata, orange-red, ripening earlier. In swamps, Me. to Penn. and Va. Blooms earlier than the preceding. May-June.

\section{ILICIOIDDES Dumont.}

A glabrous shrub, with slender-petioled oblong deciduous leaves, and small flowers. Calyx of the staminate flowers none, that of the pistillate minute, 4-5-toothed. Petals 4-5. Stamens 4 or 5, free from the corolla; anthers ovoid-globose. Ovary 3-5-lobed, 3-5-celled; ovules I in each cavity; stigmas 3-5, sessile. Drupe subglobose. Nutlets 4 or 5. [Greek, resembling holly.] A monotypic genus of eastern N. Am.

I. Ilicioides mucronàta (L.) Britton. Wild or Mountain Hollv. (I. F. f. 2364.) A shrub, 2-2.5 m. high, with ash-colored bark. Leaves elliptic or obovate, $1.25-2.5 \mathrm{~cm}$. long, acutish or mucronate at the apex, entire, or with a few small teeth; petioles 6-12 $\mathrm{mm}$. long; flowers of both kinds solitary, or the staminate sometimes 2-4 together; pedicels very slender, often $3.75 \mathrm{~cm}$. long; drupe red, 6-8 $\mathrm{mm}$. in diameter, nutlets faintly ribbed. In swamps, N. S. to Ont., Wis., Ind and Va. May. 


\title{
Family 7. CELASTRÀCEAE Lindl.
}

\author{
Staff-tree Family.
}

Trees or shrubs, often climbing. Leaves simple. Stipules, when present, small and caducous. Flowers regular, generally perfect, small. Pedicels commonly jointed. Calyx 4-5-lobed or-parted, persistent, the lobes imbricated. Petals 4 or 5, spreading. Stamens inserted on the disk. Disk flat or lobed. Ovary sessile, mostly 3-5-celled; style short, thick; stigma entire or 3-5-lobed; ovules 2 in each cavity, anatropous. Fruit (in our species) a somewhat fleshy dehiscent 2 -celled pod. Seeds arilled; embryo large ; cotyledons foliaceous. About 40 genera, and 350 species, widely distributed.

Leaves opposite.

Large erect or decumbent shrubs; fruit 3-5-lobed; aril red.

Low spreading shrubs; fruit oblong; aril whitish.

Leaves alternate; woody vine.

1. Euonymus.

2. Pachystima.

3. Celastrus.

\section{EUÓNYMUS L.}

Shrubs, with petioled entire or serrate leaves, and perfect cymose axillary greenish or purple flowers. Calyx 4-5-cleft, the lobes spreading or recurved. Petals 4 or 5 , inserted beneath the $4-5$-lobed disk. Stamens 4 or 5 , inserted on the disk. Ovary 3-5-celled; style short or none; stigma 3-5-lobed. Capsule 3-5-celled, 3-5-lobed, angular, rounded or winged, the cavities $\mathbf{1 - 2}$-seeded, loculicidally dehiscent. Seeds enclosed in the red aril. About 65 species, of the north temperate zone. Besides the following, 2 others occur in Cal.

Pods tuberculate; low shrubs; flowers greenish pink.

Erect or ascending; leaves ovate-lanceolate, acuminate.

Decumbent, rooting at the nodes; leaves obovate, obtuse.

Pods smooth; high shrubs or small trees.

Flowers purple; cymes 6-15-flowered.

Flowers greenish yellow; cymes 3-7-flowered.

I. E. Americanus.

2. E. obovatus.

I. Euonymus Americànus L. Strrawberry Bush. (I. F. f. 2365.) A shrub, 6-24 dm. high, with 4-angled and ash-colored twigs, divaricately branching. Leaves thick, $4-8 \mathrm{~cm}$. long, $1.25-2.5 \mathrm{~cm}$. wide, nearly sessile, crenulate, glabrous, or sparingly hairy on the veins beneath; peduncles 1.2-2.4 $\mathrm{mm}$. long, very slender, I-3-flowered; flowers I-1.2 cm. broad; petals separated, the blade nearly orbicular, erose or undulate, the claw short; pod slightly $3-5$-lobed, not angular, depressed. In low woods, southern N. Y. to Fla., Neb. and Tex. June.

2. Euonymus obovàtus Nutt. Running Strawberry Busi. (I. F. f. 2366.) A low shrub, seldom rising over a foot from the ground. Branches 4angled or slightly winged; leaves rather thin, mostly acute or cuneate at the base, finely crenulate serrulate, $2.5-5 \mathrm{~cm}$. long, $1.25-4 \mathrm{~cm}$. wide, glabrous; petioles 2-4 $\mathrm{mm}$. long; peduncles I-4-flowered; flowers smaller than in the preceding, about 6 $\mathrm{mm}$. broad; petals generally 5 , nearly orbicular, crenulate or erose, with scarcely any claw; pod commonly 3-celled, slightly lobed, depressed. In low woods, southern Ont. to Penn., Ind. and Ky. April-May.

3. Euonymus atropurpùreus Jacq. BurNing Bush. WaHoo. (I. F. f. 2367.) A shrub or small tree, 2-8 m. high. Twigs obtusely 4-angled; leaves ovate-oblong or elliptic, 4-13 cm. long, 2.5-8 cm. wide, acuminate, puberulent, especially beneath, crenulate-serrulate, rather thin: petioles $8-16 \mathrm{~mm}$. long; peduncles slender, $2.5-5 \mathrm{~cm}$. long, bearing a trichotomous cyme; pedicels $6-12 \mathrm{~mm}$. long; flowers I-I.2 cm. broad; petals commonly 4, obovate, undulate; pod deeply 3-4-lobed, 1.2-1.6 cm. broad. Ont. to Fla., Mont. and the Ind. Terr. June.

4. Euonymus Europaèus L. SPindLe-TREF. (I. F. f. 2368.) A glabrous shrub, I-3 m. high, resembling the preceding. Leaves oblong, to ovate-lanceolate, acuminate, crenulate; pelluncles mostly less than $2.5 \mathrm{~cm}$. long, stouter; flowers about I $\mathrm{cm}$. broad; petals 4 (rarely 5 ), oblong or obovate; pod smooth, deeply 4-lobed. Escaped from cultivation, N. H., N. Y. and N. J. June. 


\section{PACHÝSTIMA Raf.}

Low glabrous shrubs, with corky branches, coriaceous evergreen leaves, and small axillary, perfect brownish flowers. Calyx-lobes 4 , broad. Petals 4 , spreading. Stamens 4, inserted beneath the disk; filaments longer than the anthers. Ovary immersed in the disk, 2-celled; ovules 2 in each cavity, erect; style short; stigma slightly 2 -lobed. Capsule oblong, compressed, 2-celled, at length loculicidally dehiscent, I-2-seeded. Seeds oblong with a white many-lobed aril at the base. Two species, natives of N. Am. P. Myrsinites occurs in the Rocky Mountains.

I. Pachystima Cánbyi A. Gray. Canby's Mountain Lover. (I. F. f. 2369.) A shrub I-3 dm. high, with decumbent rooting branches. Leaves oblong, or slightly obovate, $1.2-2 \mathrm{~cm}$. long, 3-4 $\mathrm{mm}$. wide, obtuse at each end, very shortpetioled, pale green, serrate, the margins revolute; peduncles I-3-flowered, 2bracted below the middle; pedicels slender and 2-bracted near the base; calyxlobes oval, about equalling the petals; capsule about $8 \mathrm{~mm}$. long and $4 \mathrm{~mm}$. in diameter. On dry exposed rocks, Va. and W. Va. April-May.

\section{CELÁstruS L.}

Shrubs, mainly climbing, with thin deciduous leaves, and racemose or paniculate, small diœcious or polygamous flowers. Calyx 5-lobed. Petals 5, inserted under the disk. Stamens in the sterile flowers 5, inserted at the sinuses of the 5lobed disk. Ovary 2-4-lobed, 2-4-celled; style thick; stigma 2-4-lobed; ovules 2 in each cavity, erect. Capsule 2-4-celled, loculicidally dehiscent into as many valves. Seeds enclosed in a scarlet aril; embryo straight; endosperm fleshy; cotyledons flat, coriaceous. [Greek name of some evergreen tree.] About 30 known species, only I in N. Am.

I. Celastrus scándens L. Shrubby or Climbing Bittersweet. WaxwORK. (I. F. f. 237o.) Ascending trees to a height of $8 \mathrm{~m}$. or more, or trailing. Leaves ovate, oval or obovate, 5-10 cm. long, 2.5-5 cm. wide, acuminate or acute at the a pex, crenulate; petioles 1.2-1.8 cm. long; flowers greenish, about $4 \mathrm{~mm}$. broad, in terminal compound racemes $5-10 \mathrm{~cm}$. in length; petals crenate, much longer than the calyx-lobes; capsule yellow, or orange, I-I.2 cm. in diameter, opening in autumn and exposing the showy red aril. In rich soil, Quebec to N. Car., Manitoba, Kans., the Ind. Terr. and N. Mex. June.

\section{Family 8. STAPHYLEÀCEAE DC.}

\section{Bladder-nut Family.}

Trees or shrubs, with mostly opposite odd-pinnate or 3 -foliolate stipulate leaves and regular perfect flowers in terminal or axillary clusters. Sepals, petals and stamens usually 5. Carpels mostly 3. Disk large, the stamens inserted at its base without. Anthers introrse, 2-celled. Fruit a dehiscent bladdery capsule in the following genus, indehiscent in some others. Seeds solitary or few in each carpel ; testa hard; endosperm: fleshy; embryo straight. About 5 genera, and 22 species, widely distributed.

\section{STAPHYLÈA L.}

Shrubs, with axillary drooping racemes or panicles of white flowers. Pedicels jointed. Sepals imbricated. Petals the same number as the sepals and about equalling them. Ovary 2-3-parted, the lohes I-celled; ovules numerous in each cavity, anatropous. Capsule 2-3-lobed, 2-3-celled. Seeds globose. [Greek, cluster.] About 6 species, of the north temperate zone; S. Bolanderi A. Gray, in Cal.

I. Staphylea trifòlia L. American Bladder-N('T. (I. F. f. 237I.) A shrub, 2-4 m. high, with smooth striped bark. Young leaves and petioles pubescent; mature foliage glabrate; stipules linear, 8-12 mm. long, caducous; leaflets ovate or oval, 4-7 cm. long, acuminate, finely serrate, the lateral ones sessile or nearly so, the terminal one stalked; stipels subulate; flowers campanulate, about $8 \mathrm{~mm}$. long; pedicels slightly longer than the flowers; capsule about $5 \mathrm{~cm}$. long, $2.5 \mathrm{~cm}$. wide, much inflated, the 3 (rarely 4) carpels separate at the summit and dehiscent along the inner side. In moist woods and thickets, Quebec and Ont. to Minn., S. Car. and Kans. April-May. 


\title{
Family 9. ACERÀCEAE St. Hil.
}

\author{
Maple Fanily.
}

Trees or shrubs, with watery often saccharine sap, opposite simple and palmately lobed (rarely entire) or pinnate leaves, and axillary or terminal cymose or racemose regular polygamous or diøecious flowers. Calyx generally 5-parted, the segments imbricated. Petals of the same number, or none. Disk thick, annular, lobed, sometimes obsolete. Stamens 4-12, often 8 ; filaments filiform. Ovary 2-lobed, 2 celled; styles 2, inserted between the lobes. Fruit of 2 long-winged samaras, joined at the base and 1 -seeded (rarely 2 -seeded). Seeds compressed, ascending; cotyledons thin, folded. The family consists of the following genus and Dipteronia Oliver, of central Asia. There are about roo species of Maples.

\section{I ÀCER L. (See Appendix.)}

[Ancient name of the maples.] Besides the following, some 5 others occur in southern and western Nortl America.

Leaves simple, palmately lobed.

Flowers in dense sessile lateral clusters, unfolding before the leaves.

Petals none; ovary tomentose; samaras divergent.

Petals present; ovary glabrous; samaras incurved.

I. A. saccharinum.

Leaves pale and glabrous or but slightly pubescent beneath.

Leaves densely whitish-pubescent beneath; southern.

$$
\text { 2. A. rubrum. }
$$

\section{A. Drummondii.}

Flowers corymbose, unfolding with the leaves.

Flowers long-pedicelled, drooping; large trees.

Leaves pale and nearly glabrous beneath.

Leaves green and pubescent, at least on the veins, beneath.

Flowers short-pedicelled, erect; shrub or small tree.

Flowers racemed, terminal, unfolding after the leaves.

Racemes drooping; leaves finely serrate.

Leaves pinnate.

Racemes erect ; leaves coarsely serrate.

I. Acer sacchárinum L. Silver Maple. Sóft or White Maple. (I. F. f. 2372.) A tree with flaky bark. Leaves I-I.5 dm. long, deeply 5-lobed, the lobes rather narrow, acuminate, coarsely and irregularly dentate, truncate or slightly cordate at the base, green above, silvery white and more or less pubescent beneath; fluwers greenish or red; fruiting pedicels elongating; samaras at length $5-7 \mathrm{~cm}$. long, the wing often $\mathbf{I} .2 \mathrm{~cm}$. wide. Along streams, N. B. to Fla., S. Ont., Dak., Neb. and the Ind. Terr. Yields maple sugar in small quantities. Feb.-April.

2. Acer rùbrum L. Red, Scarlet or Water Maple. Swamp Maple. (I. F. f. 2373.) A tree with flaky or smoothish bark. Twigs reddish: leaves 7-10 cm. long, cordate at the base, sharply 3-5-lobed, the lobes irregularly dentate, acute or acuminate, green above, generally whitish beneath; flowers reddish or yellowish; petals narrowly oblong; stamens $3-6$; fruiting pedicels elongating ; samaras $1.8-2.5 \mathrm{~cm}$. long, the wing 6-8 mm. wide. In swamps and low grounds, N. B. to Manitoba, Fla. and Tex. Foliage crimson in autumn. March-April.

3. Acer Drummóndii H. \& A. Drummonn's Maple. (I. F. f. 2374.) Similar to the preceding. Leaves 7-15 cm. long, thicker, 3 -lobed, or sometimes 5 -lobed, obtuse or cordate at the base, the lobes shorter, broader, acute or acuminate; young twigs and petioles more or less tomentose; fruiting pedicels $2.5-5 \mathrm{~cm}$. long; samaras $3.75^{-6.25} \mathrm{~cm}$. long, the wing $\mathbf{I}-2 \mathrm{~cm}$. broad at middle. In swamps, southern Mo. to Ga., Fla. and Tex. Fruit scarlet, ripening in March or April.

4. Acer Sáccharum Marsh. Sugar or Rock Maple. Sugar-tree. (I. F. f. 2375.) A large tree. Leaves $7 \cdot 5-15 \mathrm{~cm}$. long, dark green above, cordate or truncate at the base, 3-7-lobed, the lobes acuminate, irregularly sinuate, the sinuses rounded; flowers in sessile corymbs, greenish yellow; petals none; samaras glabrous, slightly diverging, $2.5-3.75 \mathrm{~cm}$. long, the wing 6-Io $\mathrm{mm}$. wide. In rich 
woods, Newf. to Manitoba, south to Fla. and Tex. Its sap is the main source of maple sugar. April-May. [A. saccharinum L., not Wang.]

5. Acer nigrum Michx. Black Sugar Maple. (I. F. f. 2376.) Nearly or quite as large as the Sugar Maple, with rough, blackish bark. Leaves similar, but green both sides, thicker and generally more or less pubescent beneath, especially along the veins; lobes much broader and shorter, with few undulations or frequently entire, the basal sinus often narrow; samaras slightly more divergent. Ont. and Vt. to Ga., Minn., La. and Ark. April-May.

6. Acer glàbrum. Torr. Dwarf oR Rocky Mountain Maple. (I. F. f. 2 377.) A shrub, or small tree. Leaves $2.5-7.5 \mathrm{~cm}$. long, often broader, glabrous on both sides, or puberulent when young, 3-5-lobed, the lobes sharply serrate; flowers yellowish green, in numerous small sessile corymb-like racemes; pedicels short, glabrous; samaras glabrous, shining, 1.8-3 cm. long, little diverging: wing 8-12 mm. wide. Borders of streams and hillsides, western Neb. to Ariz., Nev. and Br. Col. May.

7. Acer Pennsylvánicum L. Striped or Goosefoot Maple. Moose. wood. (I. F. f. 2378.) A small tree, the smoothish green bark striped with darker lines. Leaves often $1.5^{-2} \mathrm{dm}$. long, broadest above the middle, thin, glabrous above, sparingly pubescent beneath when young, slightly cordate or truncate at at the base, 3-lobed near the apex, the lobes short and acuminate; racemes $7 \cdot 5^{-10}$ $\mathrm{cm}$. long; flowers greenish yellow, $6-8 \mathrm{~mm}$. broad; petals obovate; samaras glabrous, $2.5 \mathrm{~cm}$. long, widely divergent, the wing 8-10 $\mathrm{mm}$. wide. In rocky woods, N. S. to Lake Superior, and along the mountains to Ga. and Tenn. May-June.

8. Acer spicàtum Lam. Mountain Maple. (I. F. f. 2379.) A shrub, or rarely a small tree, the bark green, not striped. Leaves $7 \cdot 5-12.5 \mathrm{~cm}$. long, glabrous above, pubescent beneath, at least when young, 3-5-lobed, the lobes acute or acuminate; racemes compound, rather dense; flowers 2-3 $\mathrm{mm}$. broad, greenish yellow; petals linear spatulate; samaras $1.8-2 \mathrm{~cm}$. long, somewhat divergent, the wing 6-8 mm. wide. Damp rocky woods, Newf. and James'Bay to Manitoba, south, especially along the mountains, to N. Car., Tenn. and Minn. May-June.

9. Acer Negúndo L. Box Elder. Ash-leaved Maple. (I. F. f. 238o.) A tree. Leaves petioled, 3-5-foliolate; leaflets ovate or oval, pubescent when young, nearly glabrous when old, $5-13 \mathrm{~cm}$. long, $2.5-7.5 \mathrm{~cm}$. wide, dentate, slightly lobed or sometimes entire, acute or acuminate; flowers diœcious, drooping, very small, appearing a little before the leaves; samaras glabrous, slightly incurved, 2.5-3.75 cm. long, the broad wing finely veined. Along streams, Vt. and Ont. to Manitoba, Fla. and N. Mex. Rare near the Atlantic Coast. April. Tex.

Acer Negúndo Texànum Pax. Branchlets and leaves densely pubescent. Kans. to

Acer Pseùdo-Plátanus L., the Sycamore Maple, with terminal drooping racemes of yellowish flowers with very woolly ovaries, and deeply 3-5-lobed leaves, and Acer platanoldes L., the Norway Maple, with terminal corymbs of greenish yellow flowers appearing with or before the sharply 5-7-lobed leaves, are commonly planted, and have occasionally escaped from cultivation in the east.

\section{Family 10. HIPPOCASTANÀCEAE T. \& G.}

\section{Buckeye Family.}

Trees or shrubs, with opposite petioled digitately $3-9$-foliciate leaves, and conspicuous polygamous irregular flowers in terminal panicles. Calyx 5-lobed or 5-cleft in the following genus, the lobes unequal. Petals 4-5, unequal, clawed. Disk entire, often 1-sided. Stamens 5-8; filaments elongated. Ovary sessile, 3 -celled; ovules 2 in each cavity; style slender. Capsule leathery, smooth or spiny, 3-celled or by abortion $1-2$-celled, and often only I-seeded. Seeds large, shining; cotyledons very thick. The family consists of the following genus, containing about i 5 species, natives of America and Asia, and Billia, of Mexico. 


\section{AÉsCULUS L.}

\section{Characters of the family. [Ancient name.]}

Capsule spiny, at least when young; stamens exserted.

Flowers white, mottled with yellow and purple; leaflets abruptly acuminate.

Flowers yellow.

A tree; leaflets 5-7.

A shrub; leaflets 7-9.

Capsule glabrous; stamens not exceeding the petals. Corolla yellow, or purplish; calyx oblong; a tree.

Corolla red; calyx tubular; a shrub.
I. AE. Hippocastanum.

2. AE. glabra.

3. $A E$. arguta.

4. AE. octandra.

5. AE. Pavia.

I. Aesculus Hippocástanum L. Horse-chestnut. (I. F. f. 238I.) A large tree, the buds very resinous. Leaves long-petioled, glabrate when mature, or with persistent tufts of hairs in the axils of the veins on the lower surface; leaflets 5-7 (occasionally only 3 on some leaves), obovate, I-2 dm. long, cuneatenarrowed to the base, irregularly crenulate-dentate; iniforescence rather dense, often $3 \mathrm{dm}$. long, the pedicels and calyx canescent; fruit globose. Escaped from cultivation, N. Eng. to southern N. Y. and N. j. Native of Asia. June-July.

2. Aesculus glàbra Willd. Fetid Buckeye. Ohio Buckeye. (I. F. f. 2382.) Bark rough and fetid. Leaves long-petioled; leaflets $7.5-15 \mathrm{~cm}$. long, oval, oblong or lanceolate, acuminate, narrowed at the base, glabrous or slightly pubescent on the veins beneath, finely serrate; inflorescence loose, pubescent, II. $5 \mathrm{dm}$. long; flowers pale yellow; calyx campanulate; petals $4,1-1.4 \mathrm{~cm}$. long, slightly unequal, their claws about equalling the calyx-lobes; stamens curved, exserted; fruit $2.5-3.7 \mathrm{~cm}$. in diameter, prickly when young, becoming smoothish. Woods, Penn. to Ala., Mich., Neb. and the Ind. Terr. April-May.

3. Aesculus argùta Buckl. Shrubby or Western Buckeye. (I. F. f. 2383.) A shrub, I-3 m. high, with smooth bark. Twigs, young petioles, leaves and inflorescence somewhat pubescent, becoming glabrate; leaflets narrow, 7-IO cm. long, about $2.5 \mathrm{~cm}$. wide, long-acuminate, unequally serrate; inflorescence dense, I-I.5 dm. long; flowers yellow, "the centre reddish;" calyx broadly campanulate, its lobes very obtuse; stamens exserted, curved; petals $\mathbf{I}-\mathbf{I} .2 \mathrm{~cm}$. long; fruit very spiny when young. Kans. and the Ind. Terr. to Tex. March-Aprit.

4. Aesculus octándra Marsh. Yellow, Sweet or BIg Buckeye. (I. F. f. 2384.) A large tree, rarely reduced to a shrub; bark dark brown, scaly. Leaflets 5 , rarely $7,1-2 \mathrm{dm}$. long, $5-7.5 \mathrm{~cm}$. wide, oval, more or less pubescent beneath, acuminate, the lower ones oblique, the others cuneate at the base, all finely serrate; inflorescence rather loose, puberulent; petals 4, long-clawed, connivent, the 2 upper narrower and longer than the lower. Woods, Penn. to Ga., Iowa and Tex. April-May.

Aesculus octándra hybrida (DC.) Sarg. Purplish BuCkeye. Flowers purplish or pink; leaflets pubescent beneath; bark light brown. W. Va. to Ga. and Tex.

5. Aesculus Pàvia L. Red Buckeye. (I. F. f. 2385.) A shrub, I-4 m. high. Ieaflets $5-7$, stalked, oblong, lanceolate, or obovate, $7 \cdot 5-13 \mathrm{~cm}$. long, $2.5-3.75 \mathrm{~cm}$. wide, acute or short-acuminate, narrowed at the base, finely serrate, nearly glabrous on both sides when mature, shining; inflorescence loose; peduncles I-3-flowered; flowers $2.5-4 \mathrm{~cm}$. long; calyx-lobes short; upper petals longer than the lower. In rich soil, Va. to Fla., Ky., Mo. and Ark. April-May.

Aesculus parvifiora Walt., a low shrub with 5 -foliolate puberulent leaves and long thyrses of yellowish flowers, the stamens long-exserted, has been found as an escape from cultivation in southeastern Penn. It is a native of the Southern States.

\section{Family,I1. SAPINDÁCEAE R. Br.}

\section{Soapberry Family.}

Trees or shrubs, with watery sap, rarely herbaceous vines. Leaves alternate (opposite in one exotic genus), mostly pinnate or palmate, without stipules. Flowers polygamo-diœcious, regular or slightly irregular. Sepals or calyx-lobes 4 or 5, mostly imbricated. Petals 3-5. Disk fleshy. 
Stamens 5-10 (rarely fewer or more), generally inserted on the disk. Ovary I, 2-4-lobed or entire, 2 -4-celled; ovules 1 or more in each cavity. Fruit various. Seeds globose or compressed; embryo mainly convolute ; endosperm none. About 120 genera, including over 1,000 species, widely distributed in tropical and warm regions.

Trees or shrubs ; fruit a berry.

Herbaceous vines; fruit an inflated pod.

1. Sapindus.

2. Cardiospermum.

\section{SAPÍNDUS $\mathbf{L}$.}

Leaves alternate, mostly odd-pinnate. Flowers regular, polygamo-diœecious, in racemes or panicles. Sepals $4-5$, imbricated in 2 rows. Petals of the same number, each with a scale at its base. Disk annular, hypogynous. Stamens 8-IO, inserted on the disk; anthers versatile. Ovary commonly 3 -lobed, with the same number of cavities; ovules I in each cavity, ascending; style slender; stigma 2-4-lobed. Fruit a globose or lobed berry with I-3 seeds. [Name, Sapo Indicus, Indian soap, from the soapy quality of the berries.] About Io species, natives of warm and tropical Asia and America.

I. Sapindus Drúmmondi H. \& A. Soapberry. Wild China-tree. (I. F. f. 2386.) A tree. Leaves glabrous, or sparingly pubescent beneath, $\mathrm{r}-4.5 \mathrm{~cm}$. long; leaflets 7-19, inequilateral, obliquely lanceolate, often falcate, entire, 3.5Io $\mathrm{cm}$. long, acuminate at the apex and commonly acute at the base; panicles terminal, I-2 dm. long, dense; flowers white, about $4 \mathrm{~mm}$. broad; berry globose, oval, 8-12 mm. in diameter, very saponaceous. Kans. to Tex., La., Ariz. and northern Mex. Has been confused with the Southeastern S. marginatus Willd.

\section{CARDIOSPÉRMUM L.}

Vines, with alternate bipinnate or decompound leaves, and small axillary tendril-bearing corymbs of slightly irregular polygamo-diøecious flowers. Tendrils 2 to each corymb, opposite. Pedicels jointed. Sepals 4, the 2 exterior smaller. Petals 4, 2 larger and 2 smaller. Disk I-sided, undulate. Stamens 8; filaments unequal. Ovary 3-celled; style short, 3-cleft; ovules I in each cavity. Capsule inflated, 3-lobed. Seeds arilled at the base; cotyledons conduplicate. [Greek, heart.seed.] About 15 species, of warm and temperate regions.

I. Cardiospermum Halicácabum L. Balloon Vine. Heart-seed. (I. F. f. 2387.) Slender, glabrous or slightly pubescent, 6-18 dm. long. Leaves petioled, 5-IO cm. long; segments stalked, ovate or oblong, acute or acuminate, sharply ser. rate: peduncles commonly longer than the leaves; flowers white, $6-8 \mathrm{~mm}$. broad; capsule about $2.5 \mathrm{~cm}$. long, globose-pyriform; seeds globose, nearly black. In waste places, N. J., D. C., Kans., and in ballast about the seaports; occasionally escaping from gardens. Native of tropical America. Summer.

\section{Family I2. BALSAMINÀCEAE Lindl.}

\section{Jewel-weed Family.}

Succulent herbs, with alternate thin simple dentate petioled leaves, and showy very irregular axillary flowers. Sepals 3, the 2 laterai ones small, green, nerved, the posterior one large, petaloid, saccate, spurred, Petals 5, or 3 with 2 of them 2-cleft into dissimilar lobes. Stamens 5. short; filaments appendaged by scales on their inner side and more or less united; anthers coherent or connivent Ovary oblong, 5-celled; style short, or none ; stigma 5 -toothed or 5-lobed; ovules several in each cavity. Fruit in the following genus an oblong or linear capsule, elastically dehiscent into 5 spirally coiled valves, expelling the oblong ridged seeds. Endosperm none; embryo nearly straight; cotyledoris flat. Later flowers small, cleistogamous, apetalous. About 220 species, mostly natives of tropical Asia. The family consists of the following genus and the monotypic Asiatic Hydrocera. 


\section{IMPÀTIENS L.}

Characters of family, as given above. [Name in allusion to the elastically bursting pods.]

Flowers orange or orange-yellow, mottled; spur incurved.

Flowers pale yellow; spur short, spreading.

1. I. biflora.

2. I. aurea.

I. Impatiens biflòra Walt. Spotted Touch-me-not. Silver-leaf. (I. F. f. 2388.) Annual, glabrous, 6-I5 dm. high. Leaves ovate or elliptic, pale and glaucous beneath, $3 \cdot 5^{-8 \mathrm{~cm}}$. long, generally obtuse, coarsely toothed; peduncles 2-4-flowered; bracts linear; flowers horizontal, 1. $8-2.4 \mathrm{~cm}$. long; saccate sepal conic, longer than broad, contracted into a slender spur of one half its lengtl), which is 2-toothed at the apex. In moist grounds, N. S. to Ore., Alaska, Fla. and Kans. Spurs are occasionally developed on the 2 small exterior sepals, and spurless flowers have been observed. July-Oct.

2. Impatiens aùrea Muhl. PALE TouCH-Me-Not. (I. F. f. 2389.) Similar to the preceding, but larger and stouter. Flowers pale yellow, sparingly dotted with reddish-brown, or sometimes dotless, $2.4-3 \mathrm{~cm}$. long; saccate sepal dilatedconic, about as broad as long. abruptly contracted into a scarcely incurved notched spur, less than one-third its length; bracts of the pedicels lanceolate to ovate, acute. In similar situations, Quebec to Ore., Ga. and Kans. July-Sept.

\section{Order 2I. RHAMNÀLES.}

Shrubs, vines, or small trees, with nearly always alternate leaves. Flowers small, regular. Sepals mostly more or less united. Petals distinct or wanting. Stamens as many as the sepals or calyx-lobes, and alternate with them, opposite the petals when these are present. Ovary compound, superior; ovules erect.

Shrubs, small trees, or vines; petals 4 or 5 , or none; fruit a drupe or capsule.

Vines, climbing by tendrils, rarely shrubs; petals caducous; fruit a berry.

Fam. I. Rhamnaceae.

Fam. 2. Vitaceae.

\section{Family I. RHAMNÀCEAE Dumort.}

\section{Buckthorn Fanily.}

Erect or climbing shrubs, or small trees, often thorny. Leaves simple, stipulate, mainly alternate, often 3-5-nerved. Stipules small, deciduous. Inflorescence commonly of cymes or panicles. Flowers small, regular, perfect or polygamous. Calyx-limb 4-5-toothed. Petals 4-5, inserted on the calyx, or none. Stamens 4-5, inserted with the petals and opposite them; anthers short, versatile. Disk fleshy. Ovary ses.ile, free from or immersed in the disk, 2-5-(often 3-) celled; ovules 1 in each cavity, anatropous. Fruit often 3-celled. Seeds solitary in the cavities, erect; endosperm fleshy, rarely none; embryo large; cotyledons flat. About 45 genera and 575 species, of temperate and warm regions.

Ovary free from the disk; fruit a drupe.

Petals sessile, entire; stone of the drupe 2 celled

Petals short-clawed or none; stones of the drupe 2-4.

Ovary adnate to the disk at its base; fruit dry.

1. Berchemia.

2. Rhamnus.

3. Ceanothus.

\section{r. BERCHÈMIA Neck.}

Climbing or erect shrubs, with alternate petioled ovate or oblong pinnatelyveined leaves, and small greenish white flowers in axillary or terminal clusters, or rarely solitary. Petals 5, sessile, concave or cucullate. Stamens 5; filaments filiform. Disk filling the calyx-tube, covering the ovary. Drupe oval, obtuse, compressed, its flesh thin and coriaceous, its stone 2-celled. Seeds linear-oblong; cotyledo's thin. [Name unexplained.] About ro species, the following in south. eastern N. Am., the others in Asia and Africa. 
I. Berchemia scándens (Hill) Trel. Supple-JAck. (I. F. f. 2390.) A glabrous high-climbing shrub, with tough terete branches. Leaves ovate or ovateoblong, 2.5-5 cm. long, 1.25-2.5 cm. wide, obtuse or somewhat truncate at the base, dark green above, paler beneath, their margins undulate; flowers about $3 \mathrm{~mm}$. broad, mainly in small terminal panicles; petals acute; styles short; drupe 6-8 mm. long, equalling or shorter than its slender pedicel, its stone crustaceous. In low woods, Va. to Fla., Ky., Mo. and Tex. March-June.

\section{RHÁMNUS L.}

Shrubs or small trees, with pinnately veined and (in our species) deciduous leaves, and small axillary cymose racemose or paniculate, perfect or polygamous flowers. Calyx-tube urceolate, its limb 4-5 toothed. Petals 4 or 5, mainly emarginate and hooded, or none. Disk free from the 3-4-celled ovary. Style 3-4-cleft. Drupe berry-like, containing 2-4 nutlet-like stones. Seeds mainly obovoid; endosperm fleshy. [The ancient Greek name.] About 75 species, of temperate and warm regions. Besides the following, some 6 others occur in western N. Am.

Flowers dicecious or polygamous; nutlets grooved.

Petals present; flowers mainly 4-merous.

Leaves broadly ovate; branches thorny; drupe with 3 or 4 nutlets.

Leaves ovate-lanceolate; drupe with 2 nutlets.

Petals none; flowers 5-merous; drupe with 3 nutlets.

Flowers perfect; nutlets smooth.

Umbels peduncled; leaves acute; calyx campanulate.

Umbels sessile; leaves obtuse; calyx hemispheric.
I. $R$. cathartica.

2. R. lanceolata.

3. $R$. alnifolia.

4. $R$. Caroliniana.

5. R. Frangula.

I. Rhamnus cathàrtica L. Buckthorn. (I. F. f. 239I.) A shrub, 2-6 m. high. Leaves glabrous, petioled, $4-8 \mathrm{~cm}$. long, about $2.5 \mathrm{~cm}$. wide, regularly crenate or crenulate, with 3 or 4 pairs of veins, the upper running nearly to the apex; flowers greenish, about $2 \mathrm{~mm}$. wide, clustered, unfolding a little later than the leaves; petals very narrow; drupe globose, black, about $8 \mathrm{~mm}$. in diameter. In dry soil, escaped from hedges, N. E., the Middle States and Ont. Introduced from Europe. May-June.

2. Rhamnus lanceolàta Pursh. LANCE-Leaved Buckthorn, (I. F. f. 2392.) A tall shrub, with grayish bark. Leaves short-petioled, $2.5-8 \mathrm{~cm}$. long, I.25 $2.5 \mathrm{~cm}$. wide, glabrous or nearly so above, more or less pubescent beneath, finely serrulate; veins 6 or 7 pairs; flowers 2 or 3 together, greenish, about $3 \mathrm{~mm}$. broad, appearing with the leaves; pedicels 2-4 $\mathrm{mm}$. long; drupe black, about $6 \mathrm{~mm}$. in diameter, obovoid-globose. In moist soil, Penn. to Iowa, Neb., Ala. and Tex. May.

3. Rhamnus alnifòlia L'Her. Alder-leaved Buckthorn. Dwarf Alder. (I. F. f. 2393.) A small shrub. Leaves oval to elliptic, 5-10 cm. long, $2.5-5 \mathrm{~cm}$. wide, mainly acute at the base, irregularly crenate-serrate; veins 6 or 7 pairs: petioles 6-1 $2 \mathrm{~mm}$. long; flowers solitary or 2-3 together, green, about $3 \mathrm{~mm}$. broad, appearing with the leaves; fruiting pedicels $6-8 \mathrm{~mm}$. long; drupe globose or somewhat obovoid, about $6 \mathrm{~mm}$. in diameter. In swamps, N. B. to Br. Col., N. J., Ill., Neb., Mont. and Cal. May-June.

4. Rhamnus Caroliniana Walt. Carolina Buckthorn. (I. F. f. 2394.) A tall shrub, or small tree. Leaves elliptic or broadly oblong, glabrous, or somewhat hairy on the veins beneath, $5-15 \mathrm{~cm}$. long, 2.5-6.5 cm. wide, obscurely serrulate or even entire; veins 6-Io pairs; petioles $1.2-1.8 \mathrm{~cm}$. long; flowers 5-merous, greenish, about $2 \mathrm{~mm}$. broad, in umbels or solitary, unfolding after the leaves; calyx-lobes lanceolate, acuminate; petals present; drupe globose, sweet, about $8 \mathrm{~mm}$. in diameter. In wet soil, Va. and Ky. to Kans., Fla. and Tex. May-June.

5. Rhamnus Frángula L. Alder Buckthorn. (I. F. f. 2395.) A shrub, the young twigs finely and sparsely puberulent. Leaves thin, elliptic or obovate, entire or very obscurely crenulate, glabrous on both surfaces, 4-7 cm. long, 2.5$4 \mathrm{~cm}$. wide; petioles 4-8 mm. long; umbels 1 -6-flowered; flowers 5-merous; caly $\mathrm{x}$ lobes ovate, acute; fruiting pedicels 4-10 $\mathrm{mm}$. long; fruit 6-8 $\mathrm{mm}$. in diameter. In bogs, L. I. and N. J. Reported from Ont. Nat. from Europe. May-June. 


\section{CEANÒTHUS L.}

Shrubs, with petioled leaves and cymose panicles of small perfect flowers. Calyx-limb 5-lobed. Petals 5, hooded, clawed, longer than the calyx-lobes, inserted under the disk. Stamens 5; filaments filiform, elongated. Ovary immersed in the disk and adnate to it at the base, 3-lobed. Disk adnate to the calyx. Style short, 3-cleft. Fruit dry, 3-lobed, separating at maturity into 3 nutlets. Seed-coat smooth; endosperm fleshy; cotyledons oval or obovate. [Name used by Theophrastus for some different plant.] About 35 species, of N. Am. and northern Mex. Leaves ovate or ovate-oblong, pubescent. Leaves oblong or oval-lanceolate.

I. C. Americanus. 2. C. ovatus.

r. Ceanothus Americànus L. New Jersey Tea. Red-root. (I. F. f. 2396.) Stems erect or ascending from a deep reddish root, puberulent, especially above. Leaves $2.5-7.5 \mathrm{~cm}$. long, $1.25-2.5 \mathrm{~cm}$. wide, acute or acuminate at the apex, obtuse or subcordate at the base, serrate all around, strongly 3 -nerved; peduncles elongated, often leafy, bearing dense oblong cymose panicles of small white flowers; fruit depressed, about $4 \mathrm{~mm}$. high, nearly black. In dry open woods. Me. and Ont. to Manitoba, Kans., Fla. and Tex. May-July.

2. Ceanothus ovàtus Desf. Smaller Red-Root. '(I. F. f. 2397.) Similar to the preceding, but generally smaller and nearly glabrous. Leaves $2.5-5 \mathrm{~cm}$. long, 6-18 mm. wide, mainly obtuse at each end, but sometimes acute at the apex, serrate with prominently gland-tipped teeth; peduncles short, nearly always terminal, bearing dense short cymose panicles of white flowers; fruit nearly as in C. Americanus. In rocky places and on prairies, Ont. to Minn., S. Dak., Mass., D. C., Ill. and Tex. May-June.

Ceanothus ovàtus pubéscens T. \& G. Leaves, petioles and peduncles densely pubescent. Iowa to Kans. and Tex.

\section{Family 2. VITÀCEAE Lindl.}

\section{Grape Family.}

Climbing or erect shrubs, with copious watery sap, nodose joints, alternate petioled leaves, and small regular greenish perfect or polygamodicecious flowers, in panicles, racemes or cymes. Calyx entire or 4-5toothed. Petals 4-5, separate or coherent, valvate, caducous. Filaments subulate, inserted at the base of the disk or between its lobes; disk sometimes obsolete or wanting; anthers 2-celled. Ovary 1, generally immersed in the disk, 2-6-celled; ovules $1-2$ in each cavity, ascending, anatropous. Fruit a I-6-celled berry (commonly 2-celled). Seeds erect; testa bony; raphe generally distinct ; endosperm cartilaginous; embryo short. About 10 genera and 450 species, widely distributed.

Hypogynous disk present, annular or cup-shaped, lobed or glandular; leaves not digitately compound in our species.

Petals united into a cap, falling away without separating. I. Vitis.

Petals separate, spreading.

Foliage not fleshy, flowers mostly 5 -parted.

Foliage fleshy; flowers mostly 4-parted.

2. Ampelopsis.

3. Cissus.

Hypogynous disk obsolete or wanting; leaves digitately compound in our species, the leaflets 5-7.

4. Parthenocissus.

\section{Viris $\mathbf{L}$.}

Woody vines, rarely shrubby, mostly with tendrils. Leaves simple, usually palmately lobed or dentate. Stipules mainly small, caducous. Flowers mostly diœcious, or polygamo-diœcious, rarely perfect. Petals hypogynous or perigynous, coherent in a cap and deciduous without expanding. Ovary 2-celled, rarely 3-4celled; style very short, conic; ovules 2 in each cavity. Berry globose or ovoid, few-seeded, pulpy, edible in most species. [The ancient Latin name.] About 40 species, natives of warm and temperate regions. In addition to the following, some Io or 15 others occur in the southern and western U. S. 
Leaves woolly beneath.

Leaves glabrate, sometimes slightly pubescent when young.

Leaves not glaucous beneath.

Pubescence rusty-brown; berries large, musky.

Pubescence at length whitish; berries small, black, not musky.

Berries with bloom; branches terete.

Barries without bloom; branches angular.

Leaves bluish-white glaucous beneath.

Leaves 3-7-lobed; lobes acute or acuminate.

Lobes and sinuses acute; berries with bloom.

Lobes long-acuminate; sinuses rounded; berries without bloom.

Leaves sharply dentate, scarcely lobed.

1. V. Labrusca.

2. $V$. aestivalis.

3. V. cinerea.

4. V. bicalor.

5. V. vulpina.

6. I. palmata.

Bark loose; pith interrupted by the solid nodes.

High-climbing; leaves large; berries sour.

Leaves somewhat shining above, the apex long-acuminate; inflorescence loose.

7. $V$. cordifolia.

Leaves dull, the apex short-acuminate or blunt; inflorescence compact.

Low; leaves small; berries sweet.

Bark close; pith continuous through the nodes.

8. V. Baileyana.

9. $V$. rupestris.

10. $V$. rotundifolia.

I. Vitis Labrúsca L. Northern Fox- or Plum grape. Wild Vine. (I. F. f. 2398.) Young twigs, forked tendrils and petioles densely pubescent, especially when young; nodes solid, interrupting the pith. Leaves large, each opposite a tendril or a flower cluster, varying from merely dentate to deeply lobed with rounded sinuses; berries few, brownish-purple, about $1.8 \mathrm{~cm}$. in diameter; seeds 3-6, about $8 \mathrm{~mm}$. long; raphe narrow. Thickets, N. Eng. to Ind., Ga. and Tenn. May-June. Fruit ripe Aug.-Sept.

2. Vitis aestivàlis Michx. Summer Grape. Small Grape. (I. F. f. 2399.) Twigs and petioles glabrous or pubescent. Leaves as large as those of $V$. Labrusca, dentate, or 3-5-lobed, sometimes becoming nearly glabrous; tendrils and flower-clusters intermittent (wanting opposite each third leaf); inflorescence generally long and loose; berries numerous, about $\mathbf{I} \mathrm{cm}$. in diameter, acid; seeds 2 or 3 , about $6 \mathrm{~mm}$. long: raphe narrow. In thickets, southern N. Eng. to Fla., southern Ont., Wis. and La. May-June. Fruit ripe Sept.-Oct.

3. Vitis cinèrea Engelm. Downy Grare. (I. F. f. 2400.) Young shorts and petioles mostly floccose-pubescent; tendrils intermittent. Leaves dentate, or somewhat 3-lobed, often longer than wide; inflorescence loose ; herries $6-8 \mathrm{~mm}$. in diameter, pleasantly acid, I-2-seeded; seeds about $4 \mathrm{~mm}$. long, the raphe narrow. IIl. to Neb., Kans. and Tex.

4. Vitis bícolor LeConte. Blue or Winter Grape. (I. F. f. 2401.) Tendrils intermittent; branches terete. Twigs bluish-glaucous, the bloom sometimes disappearing; internodes long; leaves usually 3 -lobed, cordate, sometimes $3 \mathrm{dm}$. long, the sinuses rounded, the lobes acute or acuminate; inflorescence compact; berries bluish-black with a bloom, sour, about $8 \mathrm{~mm}$. in diameter; seeds about 4 $\mathrm{mm}$. long, raphe narrow. Northern N. Y. to Mich. and N. Car.

5. Vitis vulpina L. Riverside or Sweet Scented Grape. (I. F. f. 2402.) Glabrous, or pubescent on the veins of the lower surfaces of the leaves; branches rounded or slightly angled, greenish; tendrils intermittent. Leaves thin, shining, the terminal lobe commonly long; stipules $4-6 \mathrm{~mm}$. long, often persistent until the fruit is formed; berries bluish-black, 8 -10 $\mathrm{mm}$. in diameter, rather sweet; seeds $2-4,4 \mathrm{~mm}$. long, the raphe narrow. Along rocky river-banks, N. S. to Manitoba, Md. and Ark. May-June. Fruit beginning to ripen in July.

Vitis Lóngii Prince, which differs from $V$. vulpina in its floccose pubescent shoots and lower leaf-surfaces, the leaves more circular in outline, is reported from Kansas, and extends through western Tex. to N. Mex.

6. Vitis palmàta Vahl. Missouri Grape. (I. F. f. 2403.) Glabrous or nearly so, or with slight pubescence on the veins of the lower surfaces of the leaves; twigs bright red; bark separating in large flakes; tendrils intermittent, forked. Leaves dull, darker green than in $V$. vulpina, deeply 3-5-lobed; stipules 3-4 mm. long; inflorescence loose; berries black, 8-10 $\mathrm{mm}$. in diameter; seeds I or 2, about $6 \mathrm{~mm}$. long; raphe indistinct. River-banks, Ill. and Mo. June-July. 
7. Vitis cordifolia Michx. Frost Grape. Chicken Grape. (I. F. f. 2404.) Twigs glabrous or slightly pubescent, terete or indistinctly angled; inter. nodes long; tendrils intermittent; stem sometimes $3 \mathrm{dm}$. in diameter or more. Leaves 7.5-10 cm. wide, thin, sometimes sl:ghtly 3-lobed; tendrils forked, intermittent; stipules about $4 \mathrm{~mm}$. long; berries black, shining, about $6 \mathrm{~mm}$. in diameter, ripening after frost; seeds I or 2, about $4 \mathrm{~mm}$. long; raphe narrow. Moist thickets and along streams, N. Eng. to Neb., Fla. and 'Tex. May-June. Fruit ripe Oct.-Nov.

8. Vitis Baileyàna Munson. BaIley's Grape. (I. F. f. 2405.) Branches angled, the young twigs tomentose, the tendrils intermittent; internodes short. Leaves crenate-dentate, sometimes slightly 3 -lobed, as a rule smaller than those of $I$. cordifolia, the teeth mucronate; berries black, 8 - $10 \mathrm{~mm}$. in diameter; seeds about $4 \mathrm{~mm}$. long, the raphe broad. In valleys, Va., W. Va. and N. Car.

9. Vitis rupéstris Scheele. Sand Grape. Sugar Grape. (I. F. f. 2406.) Bushy, sometimes climbing to a height of $\mathbf{I}$ or 2 metres, glabrous or somewhat floc. cose-pubescent on the younger parts; tendrils forked, intermittent or often wanting. Leaves pale green, shining, abruptly pointed, rarely slightly 3 -lobed, the sides often folded together; stipules 4-6 mm. long; inflorescence compact; berries black, with a bloom, 6-8 mm. in diameter, 2-4-seeded; seeds about $4 \mathrm{~mm}$. long; raphe very slender. Southern Penn. to Mo., D. C., Tenn. and Tex. April-June.

ro. Vitis rotundifolia Micix. Southern Fox-grape. Bullace Grape. (I. F. f. 2407.) Glabrous or nearly so; tendrils simple, intermittent, sometimes few. Leaves nearly orbicular, $5-7.5 \mathrm{~cm}$. wide, dark green, shining; inflorescence dense: berries few, purple, $\mathbf{I}-\mathbf{I} .8 \mathrm{~cm}$. in diameter, without bloom, tough, musky; seeds several, flat, wrinkled, notched at the apex; raphe indistinct. In moist soil, Md. to Kans., Fla., Tex. and Mex. May. Fruit ripe Aug.-Sept.

\section{AMPELÓPSIS Michx.}

Climbing woody vines, or some species bushy, the coiling tendrils not tipped by adhering expansions. Leaves simple, dentate or lobed, or pinnately or pal. mately compound. Flowers polygamo-diœecious or polygamo-monœcious. Disk adnate to the base of the ovary; ovary 2-celled; ovules 2 in each cavity; style subulate. Berry 2-4-seeded, the flesh usually thin and inedible. [Greek, Vinelike.] About 15 species, of temperate and warm regions, the following in N. Am.

Leaves coarsely serrate, or slightly 3 -lobed.

Leaves $2-3$-pinnately compound.

r. A. cordata.

2. A. arborea.

\section{Ampelopsis cordàta Michx. Simple-leaved Ampelopsis. (I. F. f. 2408.)} Glabrous, or the young twigs sparingly pubescent, climbing, the branches nearly terete: tendrils few or none. Leaves broadly ovate, 5-10 cm. long, glabrous or pubescent along the veins, acuminate; panicles small, loose; disk cupshaped; berries 4-6 mm. in diameter, bluish, I-2-seeded; seeds about $4 \mathrm{~mm}$. long. Swamps and river-banks, southern Va. to Fla., Ill., Kans. and Tex. May-June.

2. Ampelopsis arbòrea (L.) Rusby. Pepper-vine. (I. F. f. 2409.) Glabrous or nearly so, bushy; tendrils often wanting. Leaves sometimes $2 \mathrm{dm}$. in length or more; leaflets ovate or rhombic-ovate, 1.25-4 cm. long: sharply serrate, obtuse or slightly cordate, or the terminal one cuneate at the base, glabrous or somewhat pubescent on the veins beneath; panicles short-cymose; berries black, depressed-globose, about $6 \mathrm{~mm}$. in diameter, sometimes pubescent; seeds I-3. In rich moist soil, Va. to Mo., Fla. and Mex. Also in Cuba. June-July.

Ampelopsis heterophylla (Thunb.) Sieb. \& Zucc., a climbing eastern Asiatic vine, with deeply palmately $3-5$-lobed leaves and short peduncled compound cymes, was found as a waif from cultivation at Lancaster, $\mathrm{Pa}$., in 1890.

\section{3. císsus $\mathrm{L}$.}

Mostly climbing vines with fleshy foliage. Leaves compound or simple, when compound the leaflets commonly separating in drying. Flowers mostly perfect. Petals usually 4, spreading. Disk cup-shaped, adnate to the base of the ovary, mostly 4-lobed. [Greek, ivy.] A large genus, mostly tropical.

1. Cissus incísa (Nutt.) Desmoul. Usually a large vine, fleshy throughout. Leaves 3-foliolate or 3-parted; leaflets or segments ovate, cuneate at base, toothed, 
or the middle one lobed; inflorescence umbel-like, berries obovoid, nearly black, I-2-seeded, on recurved pedicels. Kans, and Mo. to Tex. and Fla.

\section{PARTHENOCÍSSUS Planch.}

Woody vines, the tendrils often tipped with adhering expansions (disks), or sometimes merely coiling, our species with digitately compound leaves. Flowers perfect, or polygamo-monocious, in compound cymes or panicles. Petals 5, spreading. Stamens 5. Ovary 2-celled; ovules 2 in each cavity; style short, thick. Berry I-4-seeded, the flesh thin, not edible. About Io species, natives of Eastern N. Am. and Asia. Besides the following, another occurs in Tex.

I. Parthenocissus quinquefòlia (L.) Planch. Virginia Creeper. False Grape. AMERICAN IVY. (I. F. f. 24IO.) Tendrils usually numerous, and provided with terminal adhering expansions, the vine sometimes supported also by aerial roots; leaflets oval, elliptic, or oblong-lanceolate, $5^{-15} \mathrm{~cm}$. long, narrowed at the base, coarsely toothed, at least above the middle, glabrous or somewhat pubescent; panicles ample, erect or spreading in fruit; berries blue, about $1.2 \mathrm{~cm}$. in diameter, usually 2-3-seeded; peduncles and pedicels red. In woods and thickets, Quebec to Manitoba, Cuba, Tex. and Mex. July. Fruit ripe in October.

Parthenocissus quinquefòlia laciniàta Planch. Tendrils mostly without terminal adhering disks, the vine not high-climbing ; leaves more deeply and sharply toothed; fruiting panicles drooping. Ohio to Iowa, Kans. and Colo.

Parthenocissus tricuspidata (Sieb. \& Zucc.) Planch., the Ampelopsis Veitchii of the gardeners, a Japanese vine, clinging to walls by its very numerous disk-tipped tendrils, has the leaves sharply 3 -lobed or sometimes 3 -divided; it is freely planted for ornament.

\section{Order 22. MALVÀLES.}

Herbs, shrubs or trees, with simple, mostly alternate leaves. Flowers regular, usually perfect. Sepals separate, or more or less united, valvate. Petals separate, very rarely wanting. Stamens usually very numerous. Ovary superior, compound, the placentae united in its axis. Disk inconspicuous or none.

Stamens in several sets; anthers 2-celled ; embryo straight.

Stamens monadelphous; anthers I-celled; embryo curved.

Fam. 1. Tiliaceae.

Fam. 2. Malvaceae.

\section{Family I. TILIÀCEAE Juss.}

\section{Linden Family.}

Trees, shrubs or rarely herbs, with alternate (rarely opposite) simple leaves, mostly small and deciduous stipules, and generally cymose or paniculate flowers. Sepals 5, rarely 3 or 4 , valvate, deciduous. Petals of the same number, or fewer, or none, mostly imbricated in the bud. Stamens $\infty$, mostly 5-10-adelphous. Ovary 1, sessile, 2-10-celled; ovules anatropous. Fruit I-10-celled, drupaceous or baccate. Cotyledons ovate or orbicular; endosperm fleshy, rarely wanting. About 35 genera and 245 species, widely distributed.

\section{TíliA L. (See Appendix.)}

Trees, with serrate cordate mainly inequilateral leaves, and cymose white or yellowish perfect flowers, the peduncles subtended by and partly adnate to broad membranous bracts. Sepals 5. Petals 5, spatulate, often with small scales at the base. Stamens $\infty$ : filaments cohering with the petal-scales or with each other in 5 sets. Ovary 5-celled; cells 2-ovuled; style simple; stigma 5-toothed. Fruit dry, drupaceous, globose or ovoid, indehiscent, 1-2-seeded. Seeds ascending; endosperm hard: cotyledons broad, 5-lobed, corrugated. [The ancient Latin name.] About 12 species, natives of the north temperate zone, $\mathbf{I}$ in the mountains of Mex. 
Leaves glabrous or nearly so on both surfaces. Leaves glabrous above, pubescent beneath.

1. T. Americana.

2. T. pubescens.

Leaves glabrous above, silvery white beneath.

3. T. heterophylla.

I. Tilia Americàna L. BAss-wood. American Linden. White-wood. (I. F. f. 24II.) A forest tree with spreading branches. Leaves ovate, $5-13 \mathrm{~cm}$. wide, coriaceous, sharply serrate with glandular teeth, abruptly acuminate or acute; floral bracts 5-IO cm. long, strongly veined; cymes drooping, 6-2O-flowered; flowers I-I. $4 \mathrm{~cm}$. broad, fragrant; petals yellowish white, crenate, slightly longer than the pubescent sepals; scales similar to the petals, but smaller; fruit globose-ovoid, 8-10 $\mathrm{mm}$. in diameter. In rich woods and along river-bottoms, N. B. to Ga., Manitoba, Neb. and Tex. May-June.

2. Tilia pubéscens Ait. Southern Bass-wood or White-wood. (I. F. f. 2412.) A small tree. Leaves generally smaller than those of $T$. Americana; floral bracts commonly broader and shorter; fruit globose, 5-6 $\mathrm{mm}$. in diameter. In moist woods, L. I. to Fla., west to Tex., mostly along the coast. May-June.

3. Tilia heterophýlla Vent. White BASS-wood. BeE-TREe. (I. F. f. 2413.) A forest tree. Leaves larger than in either of the preceding species (often 1.5 to $2 \mathrm{dm}$. long), dark green above, acute or acuminate; floral bracts $7.5-12.5$ $\mathrm{cm}$. long, zarrowed at the base ; flowers slightly larger and often fewer than those of $T$. Amerucisx; fruit globose, about $\mathbf{I} \mathrm{cm}$. in diameter. In woods N. Y. to Fla., Ala., Ill., Ky. aıı Tenn. June-July.

The European Linlen, or Lime Tree, Tilia Europaèa L., is planted as an ornamental tree in parks and ou lawns. It may be distinguished from any of our species by the absence of scales at the base of the petals. Its name, Lin, was the origin of the family name of Linnaeus.

\section{Family 2. MALVÀCEAE Neck.}

\section{Mallow Family.}

Herbs or shrubs (sometimes trees in tropical regions), with alternate leaves. Stipules small, deciduous. Flowers regular, usually perfect, often large: Sepals 5 (rarely 3 or 4 ), more or less united, usually valvate; calyx often bracted at the base. Petals 5, hypogynous, convolute. Stamens $\infty$, hypogynous, forming a central column around the pistil, united with the bases of the petals; anthers I-celled. Ovary severalcelled; styles united below, distinct above, and generally projecting beyond the stamen-column, mostly as many as the cavities of the ovary. Fruit capsular (rarely a berry), several-celled, the carpels falling away entire or else loculicidally dehiscent. Seeds reniform, globose or obovoid ; embryo curved; cotyledons large, plicate or conduplicate. About 40 genera and 800 species, widely distributed.

Stamen-column anther-bearing at the summit.

Carpels i-seeded.

Flowers perfect.

Involucels of $6 \rightarrow 9$ bractlets.

Involucels of $1-3$ bractlets, or none.

Stigmas linear, on the inner side of the style-branches. Carpels beakless; petals obcordate.

Carpels beaked; petals truncate.

Stigmas capitate, terminal.

Seed ascending.

Flowers diccious.

Seed pendulous.

Carpels 2-several-seeded.

Involucels none.

Involucels of 3 bractlets.

Carpels continuous.

Carpels septate between the seeds.

r. Althaea.

2. Malva.

3. Callirrhoë.

5. Malvastrum.

6. Sida.

4. Napaea.

7. Abutilon.

8. Sphaeralcea.

9. Modiola.

Stamen-column anther-bearıng below the entire or 5 -toothed summit.

Carpels I-seeded.

Carpels several-seeded.

Io. Kosteletrkya.

11. Hibiscus. 


\section{ALTHAÈA L.}

Tomentose or pilose herbs, with lobed or divided leaves and solitary or racemose flowers. Involucels of 6-9 bractlets united at the base. Caly x 5-cleft. Petals 5. Cavities of the ovary numerous, I ovuled; style-branches the same number as the ovary.cavities, stigmatic along the inner side; carpels numerous, indehiscent, arranged in a circle around the axis. Seed ascending. [Ancient Greek, signifying to cure.] About I5 species, natives of the Old World.

I. Althaea officinàlis L. Marsh-mallow. (I. F. f. 2414.) Perennial, herbacecus, erect, 6-12 dm. high, densely velvety.pubescent. Leaves broadly ovate, dentate and generally 3 -lobed, the lower ones often cordate; petioles $1-2.5$ $\mathrm{cm}$. long; flowers in narrow racemes, pink, $2-4 \mathrm{~cm}$. broad; bractlets linear, shorter than the 5 ovate-lanceolate acute calyx-segments; carpels $15-20$, tomentose. In salt marshes, coast of Mass. and N. Y., and in Penn. Nat. from Europe. Summer.

Althaea cannábina L., with digitately 5-parted leaves, has been found in waste places at Washington, D. C.

Althaea ròsea Cav., the Hollyhock, is occasionally found beyond the limits of cultivation in the Middle States.

\section{MÁLVA L.}

Pubescent or glabrate herbs, with dentate lobed or dissected leaves, and axillary or terminal solitary or clustered flowers. Calyx 5-cleft. Bractlets of the involucels 3 (rarely none). Petals 5. Cavities of the ovary several or numerous, I-ovuled; style-branches of the same number, linear, stigmatic along the isıner side. Carpels arranged in a circle, beakless, indehiscent. Seed ascending. [Greek, referring to the emollient leaves.] About 30 species, natives of the Old W.rld. In addition to the following, another is naturalized in Cal.

Leaves with 5-9 shallow angular lobes.

Petals 2-4 times the length of the calyx.

Petals $1-2$ times the length of the calyx. Procumbent, low.

Erect, tall.

Leaf-margins not crisped.

Leaf-margins crisped, wrinkled.

Leaves deeply 5-7-lobed or pinnatifid.

Stem-leaves I-3-pinnatifid; carpels downy.

Stem-leaves deeply lobed; carpels glabrous.

1. M. sylvesiris.

2. M. rotuneifolia.

3. $M$. verticillata. 4. M. crispicl.

I. Malva sylvéstris L. High Mallow. (I. F. f. 2415.) Biennial, erect or ascending, pubescent with spreading hairs, or glabrate. Leaves orwicular, or reniform, 3-10 $\mathrm{cm}$. wide, with 5-9 shallow angular or rounded lobes, crenate-dentate, truncate or cordate at the base; flowers reddish purple, $2-4 \mathrm{~cm}$. bivad, in axillary clusters; pedicels slender; carpels about io, flat on the back, rugose-reticulate. In waste places and along roadsides, sparingly adventive fruin Europe in the U. S., Can. and Mex. Summer.

2. Malva rotundifolia L. Low, Dwarf or Running Mallew. Cheeses. (I. F. f. 24l6.) Annual or biennial, procumbent and spreading; stems I-3 dm. long. Leaves orbicular-reniform, $2-8 \mathrm{~cm}$. wide, cordate, with s,allow dentatecrenate lobes; flowers clustered in the axils, pale blue, 8-15 mm. broad; calyxlobes ovate, acute; carpels about 15, rounded on the back, pubesuent. In waste places, common throughout our territory, and widely distributed $a_{\infty}$ a weed. Nat. from Europe. May-Nov.

3. Malva verticillàta L. Whorled Mallow. (I. F. f. źfi7.) Annual, glabrous or nearly so, I-2 m. high. Leaves nearly orbicular witls shallow, angular crenate lobes; flowers white or whitish, sessile, clustered in the axils, about the size of those of $M$. rotundifolia; carpels rugose-reticulated. In waste places, Vt. Fugitive or adventive from Europe. Summer.

4. Malva críspa L. CuRlen Mallow. Similar to the preceding, but the margins of the leaves wrinkled and crisped, crenulate. In waste places, sparingly escared from gardens, N. S. to S. Dak. and N. J. Introduced from southern Europe or western Asia. Summer. [M. verticillata crispa L.] 
5. Malva moschàta L. Musk Mallow. Musk Rose. (I. F. f. 24I8.) Perennial, 3-6 dm. high, pubescent with long hairs, or glabrate. Basal leaves orbicular, 7-10 cm. wide, with broad rounded dentate lobes; stem-leaves deeply divided into linear or cuneate, pinnatifid or cleft segments: flowers $3-5 \mathrm{~cm}$. broad, pink or white, racemosely clustered at the summits of the branches; pet. als obcordate or emarginate, 5-8 times as long as the triangulate-ovate acute calyx-lobes; carpels 15-20, densely hairy, rounded on the back. In waste places, occasional in the Middle, Southern and Eastern States and in Canada. Adventive from Europe. Plant with a faint odor of musk. Summer.

6. Malva Álcea L. European Mallow. (I. F. f. 24I9.) Similar to thie preceding, but the stem-leaves are only once 5-7-parted or cleft, the lobes dentate or incised; pubescence shorter and denser; flowers pink, purplish or wlite; petals obcordate; carpels glabrous, very finely rugose-reticulated. In waste places, occasionally escaped from gardens. Introduced from Europe. Summer.

\section{CALLIRRHÖ̈ Nutt.}

Herbs with lobed or divided leaves, and showy perfect flowers. Bractlets of of involucels $1-3$, separate, or none. Calyx deeply 5-parted. Petals cuneate, ofter toothed or fimbriate. Cavities of the ovary $\infty$, I-ovuled; style-branches of the same number as the cavities of the ovary, stigmatic along the inner side. Carpels Io-20, I-seeded, beaked, the beak separated from the cavity by a septum. Seed ascending. [A Greek mythological name.] A genus of about 7 species, natives of the central and southern U.S. and northern Mex.

Bractlets of the involucels none.

Flowers $2-3 \mathrm{~cm}$. broad: carpels very pubescent.

Flowers $3-5 \mathrm{cn}$. broad; carpels scarcely pubescent.

1. C. alceoides. Bractlets of the involucels 3 .

Leaves triangular, crenate; carpels not rugose.

Leaves orbicular, palmatifid; carpels rugose.

2. C. digitata.

3. C. triangulata.

4. C. involucrata.

I. Callirrhoë alceoìdes (Michx.) A. Gray. Light Poppy-Mallow. (I. F. f. 2420.) Perennial, 2-5 dm. high, strigose-pubescent. Basal leaves triangular, palmately lobed or incised, 5-9 cm. long, slender-petioled; stem-leaves palmatifid, the divisions linear or cuneate ; flowers corymbose or racemose at the summit, pink or white ; pedicels slender; calyx-lobes triangular, acuminate; petals dentate and somewhat fimbriate; carpels rugose-reticulate on the back. In dry soil, $\mathrm{Ky}$. to Neb., Kans. and Tex. May-Aug.

2. Callirrhoë digitàta Nutt. Fringed Poppy-Mallow. (I. F. f. 2421.) Similar to the preceding. Divisions of the stem-leaves longer, narrowly linear, sometimes quite entire, sometimes deeply incised; flowers long.peduncled, reddish purple or lighter; petals fimbriate; calyx-lobes triangular to lanceolate, acuminate; carpels rugose-rfticulate. In dry soil, Mo. and Kans. to Tex. April-July.

3. Callirrhoë triangulàta (Leavenw.) A. Gray. Clustered Poppy-Mal. Low. (I. F. f. 2422.) Perennial, 4-7 dm. high, pubescent with short hairs. Leaves triangular-hastate, the lower long-petioled, crenate or slightly lobed, 5-8 $\mathrm{cm}$. long, the upper short-petioled or nearly sessile, smaller, 3-5-cleft or divided, the lobes narrow, dentate or crenate; flowers $2-5 \mathrm{~cm}$. broad, deep purple, in terminal panicled clusters; involucels of 3 linear or spatulate bractlets, nearly as long as the 5-lobed calyx; carpels numerous, hairy, short-beaked. Prairies, Ind. to Minn., N. C. and Tex. June-Aug.

4. Callirrhoë involucràta (T. \& G.) A. Gray. Purple Poppy-Mlallow. (I. F. f. 2423.) Perennial, procumbent or ascending, 3-6 dm. long, pulsescent with long hispid hairs. Leaves cordate-orbicular, the lobes dentate or incised, those of the upper leaves commonly narrower than those of the lower; stipules ovate, conspicuous; penduncles slender, I-flowered; bractlets of the involucels 3 . linear, half the length of the lanceolate acute 3-5-nerved calyx-lobes: flowers red-purple, 2-6 cm. broad. In dry suil, Minn. and Iowa to Tex., Utah, N. Mex. and northern Mex. April-Aug.

\section{NAPAEA L.}

Erect perennial herbs, with palmately-lobed leaves, and small white diœcious fowers in ample terminal corymbose panicles. Involucels none. Caly 5 5-toothed. 
Staminate flowers with $\mathbf{I}_{5-20}$ anthers borne at the summit of the stamen-coiumn. Pistillate flowers with 8-Io styles, stigmatic along their inner surface, the stamencolumn present but destitute of anthers. Cavities of the ovary as many as the styles, I-ovuled. Carpels $8-\mathbf{I O}$, separating at maturity from the axis, beakless, but minutely tipped, imperfectly 2-valved. Seed ascending. [Greek, a dell.] A monotypic genus of the east-central U. S.

r. Napaea dioica L. Glade Mallow. (I. F. f. 2424.) Simple, or branching above, 1-3 m. high. Basal and lower leaves 1.5-3 dm. broad, long-petioled, orbicular, 7-I I-parted, the divisions acute, dentate and lobed; upper leaves smaller, short-petio!ed, 5-9-lobed, the lobes incisely cut, acute or acuminate; staminate flowers I2-I $8 \mathrm{~mm}$. broad, the pistillate somewhat smaller; petals obovate, 2-3 times the length of the calyx; carpels strongly I-nerved, slightly rugose-reticulate. In moist grounds, southern Penn. to Va., Tenn., Minn. and Iowa. July.

\section{MALVÁsTRUM A. Gray.}

Herbs, with entire cordate or divided leaves, and solitary or racemose, shortpedicelled perfect flowers. Calyx 5-cleft. Bractlets of the involucels small, I-3 or none. Cavities of the ovary $5-\infty$, I-ovuled. Style-branches of the same number, stigmatic at the summit only, forming capitate stigmas; carpels indehiscent or imperfectly 2-valved, falling away from the axis at maturity, their apices pointed or beaked. Seed ascending. [Greek, star mallow.] About 75 species, natives of America and S. Africa. In addition to the following, about I 2 others inhabit the southern and western U. S.

Leaves lanceolate-oblong or linear-oblong, dentate.

Leaves pedately 3-5. parted, the lobes incised.

1. M. angustum.

I. Malvastrum angústum A. Gray. Yellow False Mallow. (I. F.f. 2425.) Annual, pubescent with appressed hairs, I.5-3 dm. high. Leaves oblong lanceolate, or linear-oblong, petioled, acute, finely dentate, 1.5-4 cm. long; flowers yellow, 8-12 $\mathrm{mm}$. broad, mostly solitary in the axils of the upper leaves, shortpeduncled; bractlets of the involucre linear, shorter than the ovate-triangular pubescent acute calyx-lobes; petals about equalling the calyx; carpels 5 , somewhat pubescent, reniform, 2 -valved at maturity. In dry ground, Tenn. and Ill. to Iowa and Kans. Summer.

2. Malvastrum coccín zum (Pursh.) A. Gray. Red False Mallow. (I. F. f. 2426.) Perennial, I-2.5 dm. high, densely and silvery stellate-pubescent. Lower leaves $2-5 \mathrm{~cm}$. wide, ovate-orbicular, petioled, pedately 3-5-parted; lobes cuneate to linear, incised; flowers red, 12-18 mm. broad, in dense short terminal racemes; bractlets commonly none; petals much longer than the lanceolate calyx-lobes; carpels IO-I5, rugose-reticulated, indehiscent, I-seeded (rarely 2-seeded). Prairies, Manitoba to S. Dak., Neb., Tex., Br. Col. and N. Mex. May-Aug.

\section{SìDA $\mathrm{L}$.}

Herbs, with serrate crenate or lobed leaves, and perfect flowers. Bractlets of

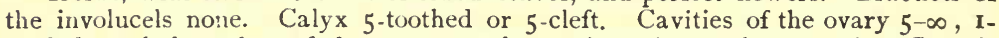
ovuled; style-branches of the same number, stigmatic at the summit. Carpels indehiscent, or at length 2-valved at the apex. Seed pendulous. [Greek, used by 'Theophrastus.] About 75 species, natives of the warmer parts of America, Asia, Africa and Australasia. Besides the following, some 17 others occur in the southern U. S.

Leaves linear, ovate or oblong, toothed.

Leaves ovate or oblong-lanceolate: flowers $4-8 \mathrm{~nm}$. broad.

Leaves linear or linear-oblong; flowers $12-25 \mathrm{~mm}$. broad.

Leaves palmately lobed, or palmately veined.

Glabrous or nearly so, tall; flowers in terminal panicles.

Densely stellate-cunescent: low; flowers axillary.

1. S. spinosa.

2. S. Elliottii.

3. S. hermaphrodita. 4. S. hederacea.

I. Sida spinòsa L. PrICKLy Sida. (I. F. f. 2427.) Annual, finely pubescent, 3-6 dm. high. Leaves ovate to oblong-lanceolate, $2-5 \mathrm{~cm}$. long, petioled, truncate or cordate at the base, crenate-dentate; flowers axillary, short-peduncled, yellow: peduncles shorter than the petioles; calyx-teeth triangular, acute; carpels 5 , dehiscent at the apex into 2 beaks; stipules linear; petioles of the larger 
leaves with a small spine-like tubercle at the base. In waste places, Me. to IN. J., Mich., Kans., Fla. and Tex., and in tropical Am. Summer.

2. Sida Ellióttii T. \& G. Elliotr's SidA. (I. F. f. 2428.) Perennial, gla. brous or nearly so, 3-12 dm. high. Leaves short-petioled, linear or linear oblong, 2-5 cm. long, 4-5 mm. wide, mostly obtuse, serrate-dentate; peduncles often longer than the petioles; flowers axillary, yellow; calyx-teeth broadly ovate, acute: carpels 8-ro, dehiscent at the apex, slightly and abruptly pointed. In dry soil, southern Va. to Fla., Mo. and Chihuahua. Summer.

3. Sida hermaphrodita (L.) Rusby. Virginia Mallow. (I. F. f. 2429.) Perennial, I-3 m. high. Leaves petioled, 7-15 cm. wide, ovate-orbicular, deeply 3-7-lobed or cleft, the lobes lanceolate or ovate, incised-dentate, acute or acuminate; flowers white, I $5-2.5 \mathrm{~cm}$. broad, numerous; pedicels, calyx, and petioles of the upper leaves finely pubescent; calyx-lobes acute; carpels about Io, acute, dehiscent at the top. Along rivers, in rocky places, southern Penn. to Ohio, Va. and Tenn. Sumner. [S. Napaea Cav.]

4. Sida hederácea Torr. Round-leaven Sina. Perennial, low, decumbent. Leaves reniform to broadly ovate, inequilateral, $\mathbf{I}-5 \mathrm{~cm}$. broad; flowers solitary or -few in the axils; peduncles recurved in fruit; petals white to yellowish; calyx 5 angled, the lobes ovate-lanceolate, acuminate; fruit short, conic, of 6-10 carpels. In moist, often saline, soil, Kans. to Tex., Mex., Cal., Utah and Wash.

\section{ABÙTILON Gaertn.}

Herbs or shrubs, sometimes trees in tropical countries, mostly soft-pubescent, with cordate angular or lob $\approx$ d leaves and axillary flowers. Involucels none. Calyx

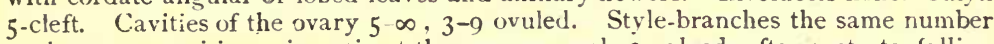
as the ovary-cavities, stigmatic at the apex; carpels 2 -valved, often rostrate, falling away from the axis at maturity. Seeds reniform, the upper ascending, the lower pendulous or horizontal. [Name given by the celebrated Arabian physician Avicenna (Ibn Sina), died I037.] About 90 species, natives of warm and tropical regions. In addition to the following, some 15 others inhabit the southern $U$. S.

I. Abutilon Abùtilon (L.) Rusby. Velvet Leaf. Indian Mallow. (I. F. f. 2430.) Annual, stout, I-2 m. high, densely velvety-pubescent. Leaves long petioled, cordate, ovate-orbicular, I-3 dm. wide, dentate, or nearly entire, acuminate, the point blunt; flowers yellow, I-2 $\mathrm{cm}$. broad; peduncles shorter than the petioles; head of fruit $2 \mathrm{~cm}$. in diameter or more; carpels $12-15$, pubescent, dehiscent at the apex, each valve beaked by a slender awn. In waste places, frequent or common throughout our area, except the extreme north. Nat. or adventive from southern Asia. Aug.-Oct.

\section{SPHAERÁLCEA St. Hil.}

Herbs or shrubs. Bractlets 3, distinct, or united at the base. Cavities of the ovary $5-\infty, 2-3$-ovuled. Style-branches the same number as the ovary-cavities, stigmatic at the apex; carpels 2-valved, not septate between the seeds, separating from the axis at maturity. Seeds reniform. [Greek, globe-mallow.| About 30 species, natives of America and S. Africa. In addition to the following, about I4 others occur in the southwestern U. S.

Leaves nearly orbicular, 5-7 lobed; flowers pink or white. Leaves lanceolate, crenulate; flowers red.

I. S. acerifolia.

2. S. cuspidata.

I. Sphaeralcea acerifòlia Nutt. Maple-Leaved Globe-mallow. (I. F. f. 2431.) Perennial, erect, 6-18 dm. high, finely stellate-pubescent and scabrous. Leaves palmately 5-7-lobed or cleft, cordate. the lobes ovate or lanceolate, dentate, acute; flowers $2.5-4 \mathrm{~cm}$. broad, short pedicelled, clustered in the upper axils or in terminal spike-like racemes; bractiets of the involucels linear, shorter than the calyx; calyx-lobes triangular, acute; carpels stellate-pubescent and hairy, not beaked. Kankakee Co., Ill.; Dak. to Nev. and Br. Col. Summer.

2. Sphaeralcea cuspidàta (A. Gray.) Britton. Sharp-Fruited Globe. mallow. (I. F. f. 243Ia.) Perennial, densely stellate-canescent; stems leafy, 3-12 dm. high. Leaves firm, crenulate, the lower with petioles as long as the blade, the others short-petioled, the larger $5^{-10} \mathrm{~cm}$. long. sometimes hastately lobed toward the base, flowers $1-2 \mathrm{~cm}$. L ruac, clustered in the axils, short-pedi- 
celled; carpels $\mathbf{r}$-3-seeded, cuspidate, the tip often deciduous, wrinkled on the sides. Kans. to Tex., Colo., Ariz. and Mex. April-Aug.

\section{MODIOLA Moench.}

Prostrate or ascending herbs, with palmately cleft or divided leaves, and small axillary peduncled red flowers. Bracts of the involucre 3, distinct. Calyx 5-cleft. Cavities of the ovary $\infty, 2-3$-ovuled. Style-branches stigmatic at the summit; carpels $5-20$, septate between the seeds, dehiscent into 2 valves with awn-pointed tips, and aristate on the back. [Iatin, from the likeness of the fruit to the small Roman measure, modiolus.] A monotypic genus.

I. Modiola Caroliniana (L.) Don. Bristry-fruited Mallow. (I. F. f. 2432.) Annual or biennial, more or less pubescent; stems 1.5-5 dm. long. Leaves nearly orbicular, I-6 cm. wide, petioled, 3-5-cleft, the lobes dentate or incised, or sometimes simply dentate; flowers $6-\mathrm{JO} \mathrm{mm}$. broad, red; peduncles at length elongated; fruit depressed-orbicular. In low grounds, Va. to Fla., west to Tex. and Cal., and in Cent. and S. Am. Summer.

\section{זo. KostelétzkyA Presl.}

Perennial, scabrous or pubescent herbs or shrubs, with hastate or angula $\dot{r}$ leaves, and showy, axillary or paniculate flowers. Bractlets several, linear. Calyx 5-toothed or 5-cleft. Stamen column anther-bearing below for nearly its entire length. Ovary 5-celled, the cavities I-ovuled; style-branches of the same number, stigmatic at the capitate summits. Capsule depressed, 5 angled. Seeds reniform, asceding. [Named in honor of V. F. Kosteletzky, a botanist of Bohemia.] About 6 species, natives of warm and temperate America. In addition to the following, 2 others occur in the southern U. S.

I. Kosteletzkya Virgínica (L.) A. Gray. Virginia Kosteletzkya. (I. F. f. 2433.) Erect, 6-12 dm. high, somewhat stellate-pubescent and scabrous. Leaves ovate, or hastate, truncate or cordate at the base, 5-13 cm. long, unequally dentate and often 3-lobed below, acute, not velvety-pubescent; flowers pink, 3-6 cm. broad, in loose terminal leafy panicles; bractlets 8 or 9 , linear, shorter than the lanceolate acute calyx-segments; carpels 5 , hispid-pubescent. In salt or brackish marshes, N. Y. to Fla. and La. A form approaching $K$. althaeifolia of the Southern States occurs in eastern Md. Aug.

\section{HiBíscus L. (See Appendix)}

Herbs, shrubs, or in tropical regions even small trees, with dentate or lobed leaves, and showy, mostly campanulate flowers. Bractlets numerous, narrow. Calyx 5-cleft or 5-toothed. Column of stamens anther-bearing below along much of its length. Ovary 5-celled, the cavities 3-several-ovuled; style branches 5. stigmatic at the capitate summit. Capsule 5-valved. Seeds reniform. [An ancient name, used by Dioscorides for the Marsh Mallow.] About I80 species, widely distributed. In addition to the following, about 14 others occur in the southern and western U. S.

Tall perennial herbs.

Leaves white-pubescent beneath; seeds glabrous, or nearly so.

Leaves glabrate, or stellate-hairy above; bractlets not ciliate. 1. H. Moscheutos. Leaves soft-hairy above; bractlets ciliate. $\quad$ 2. H. lasiocarpus.

Leaves glabrous on both sides; seeds hairy.

Low hairy annual of waste places.

Tall woody shrub, escaped from gardens.

3. H. militaris.

4. H. Trionum.

5. H. Syriacus.

I. Hibiscus Moscheùtos L. Swamp Rose-mallow. Mallow Ruse. (I. F. f. 2434.) Erect, I-2.5 m. high, forming numerous cane-like stems. Leaves ovate or ovate-lanceolate, $7-20 \mathrm{~cm}$. long, cordate or obtuse at the base, acute or acuminate at the apex, sometimes lubed at the middle, palmately veined, dentate or crenate; flowers $\mathbf{I}-\mathbf{2} \mathrm{dm}$. broad, pink, or white, sometimes with a crimson centre, clustered on stout pedicels at the summits of the stems; peduncles often adnate to the petioles; bractlets linear, not ciliate, shorter than the calyx; capsule ovoid, 2-3 cm. long, glabrous or sparingly pubescent; seeds glabrous. In brackish marshes, Mass. to Fla. and La., and on lake shores and in saline situations locally in the interior to W, Ont. $\Lambda$ ug-Sept. 
2. Hibiscus lasiocàrpus Cav. HaIRY-Fruited Rose-mallow. (I. F. f. 2435.) Resembles the preceding. Leaves broadly ovate, dentate or 3-7-lobed, mostly cordate or truncate at the base; pubescence of the lower surface white and densely stellate, that of the upper surface darker, with longer soft nearly simple hiirs; bractlets linear, equalling the calyx or shorter, ciliate; capsule ovoid, densely and finely hairy; seeds nearly glabrous. In swamps, southern Ind. to Mo., Fla. and Tex. Aug.

3. Hidiscus militàris Cav. Halberd-leaved Rose-mallow. SiveatingWEED. (I. F. f. 2436.) Erect, I-2 m. high, nearly glabrous. Leaves I-I.5 dm. long, ovate in outline, acute, or acuminate, cordate or truncate at the base, the lower, or sometimes all, hastately lobed, the margins dentate-crenate; flowers pink with a darker eye, 5-8 cm. long; peduncles jointed above the middle; bractlets linear, slightly shorter than the calyx, glabrous, or with a few scattered hairs; fruiting calyx inflated; capsule ovoid, enclosed by the calyx, glabrous: seeds silky. Along rivers, southern Penn. to Fla., Minn., Neb. and La. Aug.-Sept.

4. Hibiscus Triònum L. Bladder Ketmia. Flower-of-AN-hour. (I. F. f. 2437.) Pubescent with spreading hairs. Leaves ovate or orbicular in outline, pedately 3-7-lobed or divided, the lobes obtuse, dentate-crenate or cleft; flowers pale yellow with a purple eye, 2.5-6 cm. broad, axillary; petals tinged with purple on the outer edge; bracts linear, ciliate, much shorter than the membranous beautifully nerved hispid-pubescent 5 -angled inflated calyx; capsule globose-ovoid, hairy; seeds roughened with short processes. In waste places, N. S. to Fla., S. Dak. and Kans. Adventive from southern Europe. Aug.-Sept.

5. Hibiscus Syriacus L. Shrubby Althaea. Rose-of-Silaron. (I. F. f. 2438.) A shrub 3-7 m. high. Leaves short-petioled, ovate, 5-13 cm. long, 3-5lobed or the upper merely dentate; flowers axillary, short-peduncled, pink or white with a crimson centre, 5-10 $\mathrm{cm}$. broad; bractlets linear; peduncles, bractlets and calyx stellate-pubescent; capsule ovoid, nearly $2.5 \mathrm{~cm}$. long. Escaped from cultivation, N. J. to Ga. Introduced from W. Asia. Aug.-Sept.

\section{Order 23. PARIETÀLES.}

Herbs, shrubs, or some tropical types trees, the flowers mostly complete, perfect and regular (irregular in Violaceae). Sepals distinct, or more or less united, imbricated or convolute. Petals almost always present and distinct. Stamens usually numerous. Ovary compound, superior (inferior in Loasaceae); placentæ nıostly parietal.

Sepals distinct, mostly persistent.

Endosperm little or none.

Trees or shrubs with alternate leaves, and large solitary axillary flowers.

Herbs or low shrubs with opposite, rarely verticillate leaves.

Fam. 1. Theaceae.

Leaves punctate or black-dotted, estipulate.

Fam. 2. Hypericaceae.

Leaves stipulate; minute or small marsh or aquatic herbs with axillary flowers.

Endosperm copious.

Fam. 3. Elatinaceae.

Flowers regular, but the 2 outer sepals smaller; stamens numerous, oviles orthotropous.

Fam. 4. Cistaceae.

Flowers irregular, some often cleistogamous; stamens 5 ; ovules anatropous.

Sepals more or less united into a gamosepalous calyx.

Fam. 5. Violaceae.

A fringed crown in the throat of the calyx; our species vines; stamens 5 : ovary free from the calyx.

No crown; our species herbs; stamens numerous ; ovary adnate to the calyx.

Fam. 7. Loasaceide.

Family I. THEACEAE DC.

Tea Family.

Trees or shrubs with alternate or rarely opposite mainly estipulate leaves, and large, regular, mostly perfect flowers, Sepals 5 (rarely 4-7), imbricated. Calyx often 2-bracled at the base, Petals 5 (rarely 4-9), 
hypogynous, imbricated, crenulate. Stamens $\infty$, numerous, hypogynous, more or less united at their bases. Ovary sessile, 2-several-celled ; ovules 2 or more in each cavity. Fruit a 3-5-celled generally woody capsule. Endosperm little or none; embryo large, with conduplicate cotyledons. About 16 genera and 160 species, natives of tropical and warm regions.

Stamens monadelphous.

1. Stuartia.

Stamens 5-adelphous.

2. Gordonia.

\section{STUÁRTIA L.}

Shrubs, with deciduous membranous serrulate leaves, and large showy axillary solitary flowers on short peduncles. Sepals 5 , rarely 6, ovate or lanceolate. Petals of the same number, obovate. Ovary 5-celled; styles 1 or 5 ; ovules 2 in each cavity, anatropous; capsule ovoid, 5-celled, loculicidally dehiscent. Embryo straight. Cotyledons oval, longer than the inferior radicle. [Named in honor of John Stuart, Marquis of Bute.] Six species, natives of N. Am. and Japan.

Style I, compound; stigma 5-lobed; seeds marginless ; capsule subglobose.

Styles 5, distinct; seeds wing-margined; capsule ovoid, 5-angled. 2. S. pentagyna.

I. Stuartia Malachodéndron L. Round-Fruited Stuartia. (I. F. f. 2439.) A shrub, 2-4 m. high, the branches pubescent when young. Leaves oval, acute or acuminate at each end, $5-8 \mathrm{~cm}$. long, pubescent beneath, glabrous above; petioles 4-10 mm. long; flowers 7-10 cm. broad, solitary or occasionally in pairs ; sepals ovate or orbicular, obtuse, silky-pubescent, united at the base; petals white, minutely crenulate ; filaments purple ; anthers blue; capsule 12-16 mm. long, pubescent. In woods, Va. to Fla., west to La. April-May.

2. Stuartia pentagyna L'Her. Angled-fruited or Mountain Stuartia. (I. F. f. 2440.) A slirub resembling the preceding, Leaves oval, or ovate, larger, I-I. $5 \mathrm{dm}$. long, acuminate, pubescent beneath, mucronate-serrulate or rarely entire; flowers solitary, 5-8 cm. broad; peduncles 6-14 mm. long; sepals lanceolate, acutish, hairy; petals cream color, crenulate; capsule acute, nearly $2 \mathrm{~cm}$. long, densely pubescent. In woods, mountains of Ky. and N. Car. to Ga. and Ala. June.

\section{GORDònIA Ellis.}

Trees or shrubs, with coriaceous evergreen leaves, and large white solitary axillary flowers, often clustered at the ends of branches. Sepals 5 , imbricated, rounded, concave. Petals 5, imbricated, obovate. Stamens $\infty, 5$-adelphous, each cluster cohering with the base of a petal. Ovary I, 3-5 celled ; style I; stigma 5rayed. Capsule woody, ovoid, 5-valved, the axis persistent. Seeds compressed, with a short wing: cotyledons ovate, longitudinally plaited; hypocotyl short, su. perior. [Named for James Gordon, a London nurseryman.] About 16 species, natives of E. N. Am., Mex. and E. Asia.

I. Gordonia Lasianthus L. Loblolly BAy. TAN BAy. (I. F. f. 244I.) A tree. Leaves lanceolate, or oblong, acute and involute at the base, nearly sessile, 7-13 cm. long, 2-5 cm. wide, serrulate, glabrous, shining ; peduncles ascending ; flowers $3-5 \mathrm{~cm}$. broad; sepals orbicular, silky, ciliate; petals slightly pubescent without; capsule ovoid conic, pointed, 12-16 mm. long, sometimes 6-valved. In low woods, Va. to Fla. May-July.

\section{Family 2. HYPERICÀCEAE Lindl. \\ St. John's-wort Family.}

Herbs or shrubs, sometimes small trees in tropical regions, with opposite, or rarely verticillate, simple entire or rarely glandular-ciliate or dentate leaves, no stipules, and solitary or cymose-paniculate flowers. Foliage pellucid-punctate or black-dotted. Flowers regular and perfect. Sepals 5 or 4 , imbricated. Petals of the same number, hypogynous, generally oblique or contorted. Stamens $\infty$, hypogynous, of ten in sets of 3 or 5 ; anthers versatile or innate, 2-celled, longitudinally dehiscent. Ovary I-7-celled, composed of $1-7$ carpels; styles as many as the carpels; ovuies 
$\infty$, in 2 rows in each cavity, anatropous. Fruit mainly capsular with septicidal dehiscence; seeds mainly straight; endosperm none. About Io genera and 280 species, mainly of temperate and warm regions.

Sepals 4 , in unequal pairs; petals 4 .

I. Ascyrum.

Sepals and petals 5 .

Petals yellow.

Leaves normal, not reduced to scales.

Leaves reduced to minute appressed scales.

Flowers pink or greenish purple.

2. Hypericum.

3. Sarothra.

4. Triadenum.

\section{I. ÁSCYRUM L.}

Leafy glabrous low shrubs, with the aspect of Hypericum. Flowers bright yellow. Sepals 4, in 2 pairs, the exterior ones broad and round, the interior smaller and narrower. Petals 4, oblique or slightly contorted, deciduous. Stamens $\infty$, distinct, or united in clusters. Ovary I-celled, with 2-4 parietal placentae; styles 2-4. Capsule I-celled, 2-4-valved, dehiscent at the placentae. [Greek, not rough.] About 5 species, natives of eastern N. Am., the W. I. and Cent. Am.

Erect, 3-6 dm. high ; leaves clasping; styles 3 or 4 .

Diffusely branched, $\mathbf{I}-2.5 \mathrm{dm}$. high; leaves sessile; styles 2.

I. Ascyrum stáns Michx. St. Peter's-wort.

branches 2-edged or slightly winged; leaves erect or ascending, , oval, or broadly oblong, 1.5-3.5 cm. long, obtuse, thick; cyme terminal, few-flowered; pedicels 8$12 \mathrm{~mm}$. long, 2-bracted below the middle; flowers $1.5-2.5 \mathrm{~cm}$. broad; outer sepals 8-12 mm. long, curdate, the inner lanceolate, 6-12 $\mathrm{mm}$. long; petals obovate, longer than the sepals; capsule ovoid, about $6 \mathrm{~mm}$. long. In dry sandy soil, L. I. to eastern Penn., Fla., Tenn. and Tex. July-Aug.

2. Ascyrum hypericoides L. ST. ANdrew's Cross. (I. F. f. 2443.) Stems and branches flattened and 2-edged; leaves oblong or obovate, sessile, narrowed and 2-glandular at the base, I-4 cm. long, thin, obtuse; flowers terminal or also axillary; pedicels 2-6 mm. long, 2-bracted near the summit; flowers $12-18 \mathrm{~mm}$. broad; outer sepals oval or ovate, sometimes cordate, 8-12 $\mathrm{mm}$. long, obtuse, the inner narrower and mainly shorter; petals oblong-linear, about equalling the outer sepals; styles 2; capsule ovoid, about $4 \mathrm{~mm}$. long. In dry sandy soil, Mass. to Fla., Ill., Kans, and Tex. July-Aug. [A. Crux-Andreae L.]

\section{HYPÉRICUM I. (See Appendix.)}

Herbs or shrubs, with opposite punctate or black-dotted leaves, and mostly cymose yellow flowers. Sepals 5, equal or nearly so. Petals 5, mainly oblique or contorted, convolute or imbricated in the bud. Stamens $\infty$, distinct, or more or less united in clusters, sometimes with interposed hypogynous glands. Ovary I-celled, with 3-5 parietal placentae which sometimes project far into the cavity, or 3-5-celled (rarely 6-celled); ovules $\infty$, generally numerous: styles 3-6. Capsule I-5-celled (rarely 6-celled). [The Greek name.] About 2 Io species, of wide geographic distribution. In addition to the following, 12 others occur in the southern and western United States and British America.

* Styles 5 ; large perennials; pods 5 -celled.

Flowers 2-5 cm. broad; pods $1.8-2 \mathrm{~cm}$. long.

Flowers $\mathrm{I}-2.5 \mathrm{~cm}$. broad; pods 6-12 $\mathrm{mm}$. long.

I. H. Ascyron.

2. H. Kalmianum.

\section{* * Styles 3 (rarely 4).}

† Tall leafy shrubs; pods 3 -celled.

Flowers 12-16 $\mathrm{mm}$. broad; pods 8-12 $\mathrm{mm}$. long.

Flowers 8-12 mm. broad; pods 4-6 mm. long.

$t+$ Herbaceous, sometines woody at the base.

‡ Stamens numerous ( $15-40)$; flowers 6-25 mm. broad.

Capsules $\mathrm{x}$-celled or incompletely 3-4-celled.

Capsules incompletely $3-4$ celled by the projecting placentæ.

Leaves linear, $2-4 \mathrm{~mm}$. wide.

Leaves oblong, 6-1o mm. wide.

Capsules strictly I-celled; placentæ parietal.

Styles united into a beak, separate above; stigmas minute,
5. H. galioides.

6. H. adpressum. 


\section{Leaves linear or linear-oblong; seeds transversely rugose.}

Nearly simple, erect; pod globose.

Branched, decumbent ; pod 3-sided.

Leaves elliptic; seeds minutely pitted and striate.

Styles separate; stigmas capitate; cyme naked.

Capsules completely 3-celled; styles separate.

Leaves linear or oblong; sepals lanceolate.

Leaves broadly oblong, oval or ovate-lanceolate.

Sepals ovate.

Petals $4-6 \mathrm{~mm}$. long.

Petals $15-20 \mathrm{~mm}$. long.

Sepals lanceolate; petals 10-14 mm. long.
7. H. sphaerocarpum.

8. H. dolabriforme.

9. H. ellipticum.

1o. H. virgatum.

II. H. perforatum.

12. H. maculatum.

13. H. pseudomaculatum.

14. H. graveolens.

Leaves spreading or ascending, 3-7-nerved.

Cyme leafy-bracted.

Cymes subulate-bracted.

Leaves ovate, oval, oblong or lanceolate, 5-7-nerved.

Leaves ovate, oval or oblong; capsule 2-5 mm. long.

Leaves obtuse; sepals linear-oblong, acutish or obtuse.

16. H. mutilum.

Leaves acute, or only the lower obtuse; sepals long-acuminate. 1. H. gymnanthum.

Leaves lanceolate or oblong-lanceolate; capsule 8-10 mm. long.

Leaves linear, obtuse, 3-nerved.

I.eaves linear, erect, $\mathrm{x}$-nerved.

18. H. majus.

19. H. Canadense.

20. H. Drummondii.

I. Hypericum Áscyron L. Great or Giant St. John's-wort. (I. F. f. 2444.) Perennial, 6-I $8 \mathrm{dm}$. high, the branches angled. Leaves sessile, clasping, ovate-oblong or ovate-lanceolate, $5^{-13} \mathrm{~cm}$. long; cymes terminal, few-flowered; flowers bright yellow; pedicels $\mathbf{I}-5 \mathrm{~cm}$. long; sepals ovate-lanceolate, $8-\mathbf{I} 2 \mathrm{~mm}$. long, acute; petals obovate or oblanceolate; styles united below; stamens numerous, united in 5 sets; capsule ovoid, 5-celled. Banks of streams, Quebec and Vt. to Manitoba, Conn., N. J., Ill. and Kans. Also in Europe and Asia. July-Aug.

2. Hypericum Kalmiànum L. KaLm's ST. John's-wor'T. (I. F. f. 2445.) Shrubby, 3-6 dm. high, leafy; branches 4-angled; twigs flattened and 2-edged. Leaves oblong-linear or oblanceolate, sessile, or narrowed into a short petiole, obtuse, $2-6 \mathrm{~cm}$. long, more or less glaucous beneath, generally with smaller ones clustered in the axils; cymes terminal, few flowered; pedicels 4-20 mm. long; sepals foliaceous, oblong, acute, $6-8 \mathrm{~mm}$. long; stamens very numerous, distinct; styles 5 (4-6), united below; capsule ovoid, $6 \mathrm{~mm}$. long, 5 (4-6-) celled. Ont. and western N. Y. to Ill., Wis. and Mich. Aug.

3. Hypericum prolíficum L. SHRURBY ST. John's worT. (I. F. f. 2446.) Shrubby, 3-9 dm. high; branchlets 2-edged. Leaves linear-oblong or oblanceolate, narrowed at the base, or tapering into a short petiole, obtuse, often mucronulate, pale beneath, 2-8 cm. long, with tufts of smaller ones in the axils; cymes terminal and sometimes also axillary; pedicels $12 \mathrm{~mm}$. long or less; stamens numerous, distinct; capsules 3-celled. Sandy or rocky soil, N. J. to Ky. and Ga. July -Sept.

4. Hypericum densifiòrum Pursh. Bushy or Dense-flowered St. John'sWORT. (I. F. f. 2447.) Erect, I-2 dm. high, shrubby; branchlets 2-edged. Leaves crowded, 2-5 cm. long, with smaller ones clustered in the axils; cymes densely many-flowered, mainly terminal; pedicels $2-8 \mathrm{~mm}$. long; sepals narrow, not foliaceous; stamens numerous, distinct; capsule 3-celled. Pine-barrens of N. J. to Fla., Tenn., Ark. and Tex. July-Sept.

5. Hypericum galioídes Lam. Bed-Straw St. John's-wort. (I. F. f. 2448.) Perennial, somewhat woody, 3-8 dm. high, the branches nearly terete. Leaves linear, linear-oblong or oblanceolate, with smaller ones clustered in their axils, obtusish, thick, spreading, narrowed below, $\mathbf{I}-5 \mathrm{~cm}$. long, involute in drying; flowers short-pedicelled, 6-10 $\mathrm{mm}$. broad; sepals resembling the uppermost leaves; stamens numerous, distinct; capsule 4-6 mm. long. In low grounds, Del. to Fla., Tenn. and La. July-Sept.

6. Hypericum adpréssum Bart. Creeping ST. John's-wort. (I. F. f. 2449.) Stems nearly simple, 3-6 dm. high, 2-edged abnve. Leaves oblong or 
lanceolate, 2-5 cm. long, obtuse, ascending, often with smaller ones fascicled in the axils; cyme terminal, several-flowered; pedicels about $2 \mathrm{~mm}$. long; flowers I2-18 inm. broad; sepals lanceolate, acute; stamens numerous, distinct; capsule about $4 \mathrm{~mm}$. long. In low grounds, Mass. to Ga., La., Mo. and Ark. July-Aug.

7. Hypericum sp laerocàrpum Michx. Round-PODded ST. John's-WorT. (I. F. f. 2450.) Stems 4-angled, 3-8 dm. high. Leaves oblong or linear-oblong, obtuse, 3-8 cm. long, often with smaller ones in the axils; cymes terminal; flowers sessile or nearly so, 10-16 mm. broad; stamens numerous, distinct; capsule I-celled, 4-5 mm. long; seeds larger than in related species, rough-pitted. On rocky banks, Ohio to Iowa, Ala., Kans. and Ark. July-Sept.

8. Hypericum dolabrifórme Vent. Straggling St. John's-wort. (I. F. f. 245 I.) Straggling, I.5-5 dm. high; branchlets slightly angled. Leaves linear or linear-lanceolate, $1.5-4 \mathrm{~cm}$. long, with smaller ones clustered in the axils: cymes terminal, leafy; pedicels about I $\mathrm{mm}$. long; flowers $2-2.5 \mathrm{~cm}$. broad; sepals foliaceous, lanceolate or uvate, acute or acuminate, nearly or quite as long as the oblique pointed petals; stamens distinct; styles united below; capsule 6-8 $\mathrm{mm}$. long. On dry hills, barrens of $\mathrm{Ky}$. and Tenn. July-Aug.

9. Hypericum ellipticum Hook. Elliptic-leaved or Pale St. John'sWORT. (I. F. f. 2452.) Herbaceous, perennial; stem somewhat 4-angled, 2-5 dm. high. Leaves thin, spreading, elliptic or oval, obtuse, sessile, narrowed at the base or partly clasping, I.5-3 cm. long; cymes terminal, few-flowered, bracted; flowers pale yellow, nearly sessile, I-I. $5 \mathrm{~cm}$. broad; sepals oblong or oblanceolate, slightly shorter than the petals; styles united below; capsule ovoid-globose, about $4 \mathrm{~mm}$. long; sepals and petals sometimes 4. In swamps and along streams, N. S. to Manitoba, Conn., N. J., Penn. and Minn. July-Aug.

Io. Hypericum virgàtum Lam. Virgate or COPPER colored S'T. John'swORT. (I. F. f. 2453.) Herbaceous, 3-7 dm. ligh, the stem and branches 4-angled. Lower leaves ascending or erect, oblong lanceolate, acute or obtusish, I. $5-3 \mathrm{~cm}$. long, sessile; cyme terminal, compound, bracted; pedicels $\mathbf{I}-4 \mathrm{~mm}$. long; flowers numerous, copper-yellow, $8-12 \mathrm{~mm}$. broad; sepals foliaceous, ovate or lanceolate, keeled; styles distinct; stigmas capitate; capsule ovoid, $4 \mathrm{~mm}$. long, enclosed by the sepals. In low grounds, Del. to IIl. and Fla. July-Sept.

Hypericum virgàtum ovalifòlium Britton. Leaves oval or broadly elliptic, erect, appressed, very obtuse. Pine-barrens of N.J.

I1. Hypericum perforàtum L. Common St. John's-wort. (I. F. f. 2454.) Perennial, herbaceous, 3-7 dm. high. Stems erect, with numerous barren shoots at base; leaves sessile, oblong or linear, 1-2 cm. long, obtuse, more or less blackdotted; cymes terminal; flowers bright yellow, $1.5^{-2.5} \mathrm{~cm}$. broad; sepals acute, shorter than the copiously black-dotted petals: stamens united at their bases into 3 sets; styles 3; capsule ovoid, 4-6 mm. long, glandular. In fields and waste places, common throughout our area except the extreme north, and in the Southern States. Na , from Europe. June-Sept.

I2. Hypericuin maculàtum Walt. SPotTed ST. John's-wort. (I. F. f. 2455.) Herbaceous, perennial, 3-9 dm. high. Leaves sessile, partly clasping, oblong or ovate-lanceolate; obtuse, $2.8 \mathrm{~cm}$. long, copiously black-dotted; cymes terminal. many-flowered; pedicels about $2 \mathrm{~mm}$. long; flowers crowded, 8-I4 mm. broad; sepals ovate, acute, shorter than the conspicuously black dotted petals; stamens in 3 or 5 sets; styles 3 ; capsule ovoid, 4-6 mm. long. In moist soil, Me. and Ont. to Minn., Fla., Kans. and Tex. July-Sept.

Iypericum maculàtum subpetiolatum Bicknell. Leaves short-petioled, mostly narrowed at the base. Me. to Ga. and Ky.

I3. Hypericum pseudomaculàtum Bush. LARge Spotten St. John's. WORT. Similar to the preceding, but the flowers much larger, the petals $15-20$ mm. long. Mo.

I4. Hypericum gravèolens Buckley. Mountain St. John's-wort. (I. F. f. 2456.) Herbaceous, perennial. Stem 3-9 dm. high; leaves oval, ovate or ellipticoblong, sessile or clasping, obtuse, $2-8 \mathrm{~cm}$. long, sparingly black-dotted; cymes terminal; pedicels $2-8 \mathrm{~mm}$. long; flowers $2.5 \mathrm{~cm}$. in breadth or more; sepals lanceolate, acute, much shorter than the sparingly dotted or dotless petals; stamens united 
in sets; styles 3 ; capsule ovoid, somewhat 3-lobed, 8-12 mm. long. Mountains of Va., Tenn. and N. Car. June-Sept.

\section{Hypericum boreale (Britton) Bicknell. NORTHERn ST. John's-wort.} (I. F. f. 2457.) Annual, or sometimes stoloniferous, 3-45 cm. high. Leaves elliptic, oval, oblong, or linear-oblong, 6-32 $\mathrm{mm}$. long, sessile or slightly clasping, obtuse, mostly 3-nerved, those of the lower part of the stem commonly much smaller; cymes leafy-bracted; flowers about $5 \mathrm{~mm}$. broad; sepals obtuse; capsule oblong, obtuse or obtusish, apiculate, 4-5 mm. long, purple, cross.wrinkled, longer than the sepals; seeds $3-5$ times as long as wide, pale, longitudinally furrowed and finely cross-lined. Wet soil, Newf. to Vt., N. J. and Penn. July-Sept.

I6. Hypericum mùtilum L. DWARF OR SMALL-Flowered ST. JohN's. WORT. (I. F. f. 2458.) Annual, generally tufted, I.5-8 dm. high. Branchlets 4 angled; leaves oblong or ovate, sessile, clasping, obtuse, 8-32 $\mathrm{mm}$. long, 5-nerved at the base; cymes many-flowered, subulate-bracted; pedicels 2-12 mm. long; flowers I-4 mm. broad, light orange-yellow; sepals foliaceous, linear, lanceolate, or oblanceolate; stamens 5-12 ; styles 3 ; capsule ovoid, pointed. $2-4 \mathrm{~mm}$. long, somewhat longer than the sepals. In low grounds, N. S. to Man., Fla., Kans. and Tex. July-Sept.

I7. Hypericum gymnánthum Engelm. \& Gray. Ci.asping.leaved St. Joh N's-Wor'T. (I. F. f. 2459.) Annual, erect, 2-9 dm. high. Leaves ovate, or the lower oval, cordate-clasping, often distant, 8-20 $\mathrm{mm}$. long, acute, or the lower obtuse, 3-7-nerved at the base; cymes terminal, loose, subulate-bracted; flowers numerous, 2-4 mm. broad; sepals lanceolate, generally somewhat shorter than the ovoid capsule; styles 3; stamens IO-12; capsule about $4 \mathrm{~mm}$. long. In low grounds, N. J. and Del. to Minn., La. and Tex. July-Sept.

18. Hypericum màjus (A. Gray) Britton. LARger Canadian St. John's. wORT. (I. F. f. 2460.) Annual, erect, 3-9 dm. high, the branches nearly upright. Leaves lanceolate, or oblong-lanceolate, sessile or somewhat clasping, $2-6 \mathrm{~cm}$. long, 5-7-nerved; flowers 6. $10 \mathrm{~mm}$. broad; sepals lanceolate, acuminate; styles 3; capsule narrowly conic, acute, longer than the sepals; seeds minute, cross lined and faintly longitudinally striate. In moist soil, Me. to Mich., N. J. and Neb. June-Sept.

19. Hypericum Canadénse L. Canadian St. John's-wor't. (I. F. f. 2461.) Annual, I.5-5 dm. high. Branches angular; leaves linear, I-5 cm. long, obtuse, tapering to the base, 3-nerved; flowers 4-6 $\mathrm{mm}$. broad; sepals lanceolate, acute : stamens 5-10; styles 3; capsule narrowly conic, acute, 4-8 mm. long, longer than the sepals; seeds striate. In wet sandy soil, Newf. to Man., Ga., Ky., and Wis. July-Sept.

20. Hypericum Drummóndii (Grev. \& Hook.) T. \& G. DRummond's Sr. John's-wORT. (I. F. f. 2462.) Annual, bushy-branched, 2.5-8 dm. high, rigid. Leaves linear-subulate, 8-25 mm. long, erect or narrowly ascending, I mm. wide, I-nerved; flowers scattered along the upper part of leafy branches, $4 \mathrm{~mm}$. broad; sepals lance-linear, longer than the petals; stamens Io-20; styles 3 ; capsule ovoid, $4 \mathrm{~mm}$. long, equalling or shorter than the sepals; seeds large, rugose. In dry soil, Va. to Ga., Ill., Iowa, Kans. and Tex. July-Sept.

\section{SARÒTHRA L.}

A low annual much-branched herb, the opposite leaves reduced to subulate scales, the mostly opposite branches erect-ascending, the very small yellow flowers alternate, very short-pedicelled or sessile along them in the axils of still smaller scales. Sepals 5, equal. Petals 5. Stamens 5-10. Styles 3, separate. Capsule elongated-conic, I-celled, much longer than the sepals; seeds minutely striate and pitted. [Greek, a broom.] A monotypic genus of E. N. Am.

I. Sarothra gentianoides L. ORAnge-grass. Pine-weed. (I. F. f. 2463.) Erect, I-5 dm. high. Branches filiform, erect, wiry; leaves about $2 \mathrm{~mm}$. long, ap. pressed; flowers nearly sessile, 2-3 mm. long, open in sunlight; sepals linear, about equalling the petals and much shorter than the acute purple pod; seeds very small, In sandy soil, Me, to Fla.. Ont., Minn., Mo, and Tex. June-Oct. 


\section{TRIADÈnUM Raf. [ELODEA Pursh.]}

Perennial marsh herbs, with entire oblong oval or ovate leaves, and pink or greenish purple flowers in terminal cymes, or also axillary. Calyx of 5 equal persistent sepals. Petals 5, not contorted. Stamens 9, or sometimes more, in 3 sets, the sets alternating with 3 large hypogynous glands. Ovary 3-celled; styles 3 . Capsule oblong-conic, much longer than the sepals. [Greek, three glands.] Two species, natives of E. N. Am.

Leaves sessile; flower-clusters peduncled.

Leaves short-petioled; flower-clusters nearly sessile.

I. T. Virginicum.

2. T. petiolatum.

I. Triadenum Virgínicum (L.) Raf. Marsh ST. JoHN's-worT. (i. F. f. 2464.) Nearly simple, 3-5 dm. high. Leaves sessile or cordate-clasping, ovate or oblong, 2-6 cm. long, very obtuse, sometimes emarginate, glaucous beneath, blackdotted; flowers 12-16 mm. broad. in leafy clusters; sepals acute, shorter than the straight petals; stamens 9 or more, united in 3 sets; styles 3 , distinct; capsule oblong, 8-1o mm. long, acute, red-purple. In swamps, Lab. to Fla., Man., Neb. and La. July-Sept.

2. Triadenum petiolàtum (Walt.) Britton. LARGer Marsh ST. John'sWORT. (I. F. f. 2465.) Similar to the preceding, but often more branched and taller; leaves generally longer, petioled, or the upper sessile, not clasping, pale beneath: flower-clusters sessile or very short peduncled. In swamps, N: J. and Md. to Fla., Ark. and La. July-Aug.

\section{Family 3. ELATINÀCEAE Lindl.}

\section{Water-wort Family.}

Low herbs, sometimes woody in tropical regions, with opposite or verticillate stipulate leaves, and small axillary regular perfect flowers. Sepals 2-5, imbricated. Petals the same number, hypogynous. Stamens the same number or twice as many. Ovary 2-5-celled; styles 2-5, stigmatic at the apex; ovules $\infty$, anatropous. Capsule with septicidal dehiscence. Placentæ central. Seed-coat crustaceous, rugose or ribbed. About 25 species, of wide distribution.

Flowers 2-4-merous; glabrous aquatic or creeping herbs.

Flowers mainly 5 -merous; pubescent ascending or diffuse herbs.

I. Elatine.

\section{ELATINE L.}

Small glabrous or glabrate aquatic or creeping herbs, with minute mainly solitary flowers. Sepals 2-4, persistent, membranous, not ribbed. Styles or stigmas 2-4. Pod membranous, globose, 2-4-valved. Seeds $\infty$, straight, or slightly curved, striate longitudinally and transversely. [Greek, fir-like, with reference to the leaves.] About 9 species, of temperate and warm regions. In addition to the following, another occurs in Cal.

Petals and stamens 2 ; seeds distinctly sculptured.

Leaves obovate; seeds with 9-10 longitudinal and 20-30 transverse striae.

I. E. Americana.

Leaves oblong or oval ; seeds with 6-7 longitudinal and 1o-12 transverse striae.

Petals and stamens mostly 3 ; seeds little sculptured.

2. E. brachysperma.

3. E. triandra.

I. Elatine Americàna (Pursh) Arn. Water-wort. Mud-Purslane. (I. F. f. 2466.) Tufted, aquatic or terrestrial, 1-4 cm. long. Leaves obtuse, 2-6 mm. long, $2 \mathrm{~mm}$. wide or less; flowers sessile, minute, rarely opening in the submerged forms; sepals, petals, stamens and stigmas 2 (rarely 3 in the terrestrial forms); capsule globose, nearly $1 \mathrm{~mm}$. in diameter; seeds $0.5^{-1} \mathrm{~mm}$. long, slightly curved. Margins of ponds and slow streams, Me. and Ont. to Va., Mo. and Tex. Also in Colo. and Ore. Summer.

2. Elatine brachyspérma A. Gray. Short-Seeded WATER-wort. (I. F. f. 2467.) Terrestrial or sometimes submerged, spreading, tufted, $2-5 \mathrm{~cm}$. long. Leaves oblong, oval or lanceolate, narrowed at the base, 4-6 $\mathrm{mm}$. long, about 
$2 \mathrm{~mm}$. wide, obtuse; flowers sessile, minute; capsule nearly as in the preceding; seeds short-oblong, nearly straight, about $0.5 \mathrm{~mm}$. long. Margins of ponds, Ill. and Cal. Summer.

3. Elatine triándra Schk. Long-STemmed WATER-Wort. (I. F. f. 2468.) Flaccid, tufted, immersed or creeping; stems 5-10 cm. long. Leaves oblong or oblanceolate, very thin, obtuse, $4-8 \mathrm{~mm}$. long, narrowed at the base; flowers minute, sessile; sepals commonly 2 ; petals, stamens and stigmas 3 ; seeds slightly curved, about the size of those of E. Americana. Ponds, Ill., S. Dak. and Neb. Also in Europe. Summer.

\section{BÉRGIA L.}

Herbs, or somewhat shrubby plants, more or less pubescent, with opposite ieaves and small Towers. Parts of the flower in 5's (very rarely in 4's or 3's). Pod crustareous, 5-valved. Seeds numerous, striate longitudinally and transversely. [In honor of Dr. P. J. Bergius, I723-1790, professor of Natural History in Stockholm.] About I5 species, natives of warm and temperate regions.

I. Bergia Texàna (Hook.) Seub. Texas Bergia. (I. F. f. 2469.) Prostrate or ascending, diffusely branched; stems $1.5-2.5 \mathrm{dm}$. long. Leaves spatulate or obovate, 2-4 cm. long, serrate, narrowed into a short petiole; stipules about $2 \mathrm{~mm}$. long, ciliate-serrulate; flowers short-peduncled, about $3 \mathrm{~mm}$. broad, solitary or 2-3 together in the axils; sepals ovate, acuminate, denticulate, slightly longer than the obtuse petals; capsule globose, $2 \mathrm{~mm}$. in diameter, its dehiscence septifragal; seeds oblong, striate longitudinally and cross-barred. Southern Ill. to Tex., Nev. and Cal. Summer.

\section{Family 4. CISTÁAEAE Lindl.}

\section{liock-rose Family.}

Shrubs or low woody herbs, with simple leaves, and solitary racemose or paniculate flowers. Flowers regular, generally perfect. Sepals 3-5, persistent, when 5 the 2 exterior ones smaller, the 3 inner convolute. Petals 5 or 3 , or wanting, fugacious or persistent. Stamens $\infty$, hypogynous. Ovary I, sessile, I-several-celled; ovules orthotropous, stalked ; stı le simple. Capsule dehiscent by valves. Seeds several or numerous; embryo slender; endosperm starchy or fleshy. Four genera and about 160 species, all but I or 2 natives of the northern hemisphere.

I'etals 5, yellow, fugacious, or wanting.

Leaves broad, lanceolate or oblong.

Leaves subulate or scale-like, imbricated; style long.

Petals 3, not yellow, persistent; flowers minute; style none.

1. Helianthemum.

2. Hudsonia.

\section{HELIÁNTHEMUM Pers.}

Woody herbs or low shrubs, more or less branching, mostly with showy yellow flowers, and sometimes (in the following species) with other smaller apetalous ones. Petals in the larger flowers large, fugacious. Stamens numerous. Placentæ or false septa 3 . Ovules few or $\infty$; style jointed with the ovary; stigma capitate or 3-lobed. Embryo curved. [Greek, sun-flower.] About 125 species, of wide distribution. Besides the following, about 8 others occur in the Southern States and on the Pacific Coast.

Petaliferous flowers solitary, few or several: apetalous flowers in axillary sessile clusters.

Petaliferous flowers 5-12, in a short terminal cymose raceme, their capsules 3-4 $\mathrm{mm}$. long, little, if at all, overtopped by the short later axillary branches; capsules of the apetalous flowers about $1 \mathrm{~mm}$. in dianeter.

Petaliferous flowers solitary, rarely 2 , their capsules $6-8 \mathrm{~mm}$. long, nuch overtopped by the later elongated axillary branches; capsules of the apetalous flowers nearly $4 \mathrm{~mm}$. in diameter.

2. H. Canadense.

Flowers all cymose at the summit of the stem, the petaliferous ones slender-pedicelled.

3. H. corymbosum.

I. Helianthemum màjus (L.) B.S.P. HoAry Frostweed. (I. F. f. 2470.) Hoary-canescent, erect, 3-6 dm. high. Leaves oblong-lanceolate or oblanceolate, 
I.5-3.5 cm. long, stellate-canescent beneath, darker above, short-petioled; petaliferous flowers $5-12$ in a terminal cymose raceme, their corollas $1.5-2.5 \mathrm{~cm}$. broad, light yellow, their sepals densely canescent, the outer nearly as long as the inner, their capsules ovoid; apetalous flowers appearing later, minute, clustered, nearly sessile; seeds evenly reticulated. In dry soil, N. S. to S. Dak., Neb., N. Car. and Tex. June-July.

2. Helianthemum Canadénse (L.) Michx. Frost-wort. (I. F. f. 247I.) Puberulent canescent, erect, ascending, or sometimes diffuse, 0.7-6 dm. high. Leaves oblong, linear-oblong or oblanceolate, nearly sessile, $\mathbf{I - 3} \mathrm{cm}$. long, rough and dark green above, paler and canescent beneath, the margins commonly revolute in drying; petaliferous flowers solitary, or rarely 2, bright yellow, 2-3 cm. broad, their sepals pilose, the outer shorter than the ir ner, their capsules ovoid or obovoid, rounded above. In dry rocky or sandy soil, Me. to Ont., Wis., N. Car. and $\mathrm{Ky}$. Petaliferous flowers May-July.

3. Helianthemum corymbòsum Michx. Pine-barren Frostweed. (I. F. $t$. 2472.) Erect, $\mathbf{x} \cdot 5-3 \mathrm{dm}$. high, densely canescent. Leaves oblong, or the lowest obovate, 2-3 cm. long, entire, slightly revolute in drying, pale beneath, dark green above, short-petioled; flowers in nearly naked, fastigiate cymes, the petaliferous I-2 cm. broad, on pedicels $12-16 \mathrm{~mm}$. long; apetalous flowers clustered, nearly sessile; calyx of both kinds woolly-pubescent; outer sepals about equalling the inner; capsules of the larger flowers 4-6 mm. broad, many-seeded; those of the apetalous ones smaller, few-seeded. In sandy soil, Va. (?), N. Car. to Fla. and La.

\section{HUDSÒNIA L.}

Low diffusely branched shrubs, with small subulate or scale like, imbricated leaves, and numerous yellow flowers terminating short branches. Petals 5, obovateoblong. Stamens $\infty$. Style filiform, continuous with the ovary; placentæ 3; stigma minute. Capsule 3 -valved, included in the calyx. Seeds few; embryo slender, spirally curved. [Named for Wm. Hudson, I730-I793, an English botanist.] A genus of 3 species, natives of eastern N. Am.

Flowers slender-pedicelled; leaves subulate. Flowers nearly sessile; leaves scale-like.
1. H1. ericoides.

2. H. tomentosa.

I. Hudsonia ericoides L. Heath-Like Hudsonia. (I. F. f. 2473.) Bushybranched, greenish, softly-pubescent, I-2 dm. high. Leaves subulate, 6-8 mm. long, densely imbricated on the younger branches, more scattered on the older ones; pedicels Io-16 $\mathrm{mm}$. long; flowers about $8 \mathrm{~mm}$. broad; sepals acutish; stamens I2-I8; capsule oblong, slightly pubescent; seeds about 3 . In dry sandy soil, N. S. to Vt. and Va. May-June.

2. Hudsonia tomentòsa Nutt. Woolly Hunsonia. False Heather. Beach Heather. (I. F. f. 2474.) Densely tufted and intricately branched, hoary-pubescent, pale, I-2 dm. high. Leaves $2 \mathrm{~mm}$. long, oval or oblong, imbricated and appressed; flowers sessile, or on pedicels less than $2 \mathrm{~mm}$. long, slightly smaller than those of the preceding; sepals obtuse; stamens 9-I8; capsule ovoid, glabrous, usually r-seeded. Mostly in sands of the seashore and in pine-barrens, Va. to N. H., N. B., and on lake and river shores west to Slave Lake and the Lake of the Woods. May-July.

\section{LÈCHEA E.}

Perenniai herbs, often woody at the base, with small entire leaves and minute panicled greenish or purplish flowers. Sepals 5 , the 2 outer smaller and narrower. Petals 3, ovate to linear, inconspicuous, persistent. Stamens 3-12. Stigmas 3, nearly sessile, laciniate. Capsule 3-valved, 3-celled, or by obliteration of the dissepiments I-celled, about 6-seeded. Embryo curved or spiral. [Named for Johan Leche, a Swedish botanist, died I764.] About of I4 species, I I natives of eastern N. Am., I Texan, I Cuban and I Mexican. The characteristic basal shoots appear late in the season.

Leaves of the basal shoots oblong to ovate, not more than 3 times as long as broad.

Outer sepals longer than the inner; panicle very leafy.

Outer sepals equalling or shorter than the inner.

Pod oblong; pedicels slender, $2-4 \mathrm{~mm}$. long.

Pod globose; pedicels about $1 \mathrm{~mm}$. long.

2. L. racemulosa. 
Erect, villous-pubescent.

Ascending, bushy-branched, tomentose-canescent.

3. L. villosa.

4. L. maritima.

Leaves of the basal shoots lanceolate or linear, usually more than 3 times as long as broad.

Stem-leaves narrowly linear; inner sepals I-nerved.

Stem-leaves oblong-linear; inner sepals 3 -nerved.

5. L. tenuifolia.

Plants green, more or less pubescent.

Pod oblong to ovoid, $2 \mathrm{~mm}$. long; panicle dense; flowers secund, shortpedicelled.

6. L. moniliformis.

Pod obovoid, I mm. in diameter; panicle loose, the branches ascending or spreading; flowers short-pedicelled.

Pod globose, about $2 \mathrm{~mm}$. in diameter; panicle-branches nearly erect, loosely flowered; flowers slender-pedicelled.

8. L. intermedia.

Pod oval, about I mm. in diameter; panicle-branches erect-ascending, densely flowered; flowers short-pedicelled.

Plant pale, canescent; pod globose, $1 \mathrm{~mm}$. in diameter. ro. L. stricta.

I. Lechea minor L. Thyme-Leaved Pin-weed. (I. F. f. 2475.) " Pubescent with appressed hairs, 1.5-5 dm. Branches erect or ascending; stem-leaves oval or oblong, 8-14 mm. long, 4-6 mm. wide, ciliate; petioles $2 \mathrm{~mm}$. long; leaves of the basal shoots oval or oblong, obtuse, 6-10 $\mathrm{mm}$. long, 5-6 mm. wide; flowers close together, somewhat secund; outer sepals longer than the obovoid or globose pod. In dry open grounds, eastern Mass. to Mich., Fla. and La. Aug.-Sept.

2. Lechea racemulòsa Michx. Oblong-fruited Pin-weed. (I. F. f. 2476.) Pubescent with appressed hairs, r.5-5 dm. high. Branches divergent or ascending; leaves of the stem oblong or linear-oblong, narrowed at the base, 8-18 mm. long, 3-4 mm. wide; leaves of the basal shoots oval or oblong, 4-8 mm. long, 3-6 mm. wide, obtuse; flowers on divergent pedicels $2-4 \mathrm{~mm}$. long; pod oblong or ellipsoid. In dry sandy and rocky soil, E. Mass. (?); L. I. to Ind., Fla. and Tenn. July-Aug.

3. Lechea villòsa Ell. Large or HAIRy PIN-weed. (I. F. f. 2477.) Villous-pubescent, 3-8 dm. high, leafy. Branches ascending; leaves of the stem oblong-elliptic, obtuse, but pointed, 16-25 $\mathrm{mm}$. long, 6-10 $\mathrm{mm}$. wide; leaves of the basal shoots oval or oblong, obtuse, 6-8 mm. long, 4-6 mm. wide; branches of the panicle ascending, the ultimate branchlets often recurved; flowers more or less secund-scorpioid, close together; outer sepals about equalling the inner; pod depressed-globose, I mm. in diameter. In dry soil, Mass. and Vt. to southern Ont., Neb., Fla. and Tex. July-Aug.

4. Lechea marítima Leggett. Beach Pin-weed. (I. F. f. 2478.) Densely tufted, branching from the base, stout, rigid, 1.5-3 dm. high, tomentose-canescent with whitish hairs; leaves of the stem linear or linear-oblong, 8-20 mm. long, 2-4 $\mathrm{mm}$. wide; leaves of the basal shoots oblong or ovate-oblong, mainly acute, 6-8 $\mathrm{mm}$. long, 3-4 mm. wide, densely canescent; outer sepals shorter than the inner; pod globose, $1 \mathrm{~mm}$. in diameter. Sands of the seashore and in sandy pine-barrens, Me. to Ga. Also at the Crawford Notch, White Mts., N. H.

5. Lechea tenuifòlia Michx. Narrow-leaved Pin-weed. (I. F. f. 2479.) Densely tufted; stems slender, 1.2-5 dm. high, divaricately branched above, minutely strigose-pubescent. Branches slender; leaves of the stem narrowly linear, or sometimes nearly filiform, 4-14 $\mathrm{mm}$. lung, I mm. wide or less, acute, sessile, or very nearly so; leaves of the basal shoots linear, sessile, 6-8 $\mathrm{mm}$. long, about I $\mathrm{mm}$. wide; pedicels $2 \mathrm{~mm}$. long; flowers more or less secund, bracted by the upper leaves; outer sepals equalling or exceeding the inner; pod globose-oval, $\mathbf{~ m m}$. in diameter, or slightly more. In dry open places. eastern Mass. to Wis., Neb., Fla. and Tex. July-Aug.

6 Lechea monilifórmis Bicknell, n. sp. Necklace-like Pin-weed. Similar to L. Leggettii but with denser and more leafy and floriferous panicle of shorter branches and longer flowering branchlets; inflorescence more secund, the larger and more oblong fruiting calyx purplish; stem very pliant except when old, green, becoming purple and shining, glabrate below; leaves linear to oblong-linear, becoming $3.5 \mathrm{~cm}$. long, often subfalcate, acute, tapering into a petiole $1-2 \mathrm{~mm}$. long; pedicels 1.5-3 mm. long, appressed; fruiting calyx $2-2.5 \mathrm{~mm}$. long with shorter outer sepals, $1.5 \mathrm{~mm}$. broad ; capsule often exserted, substipitate. Nan. tucket Island, Mass., borders of salt marshes and low thickets. 
7. Lechea Leggéttii Britt. \& Holl. LeggetT's Pin-weed. (I. F. f. 2480.) Erect, rather slender, strigose-pubescent, 2-5 dm. high. Branches slender; leaves of the stem linear or linear-oblong, ro-25 mm. long, I-2 mm. wide, sessile or nearly so; leaves of the basal shoots oblong-linear, 4-6 $\mathrm{mm}$. long, I mm. wide, acute; panicle open; inflorescence somewhat secund; pedicels I-2 mm. long; outer sepals nearly equalling the inner. In open places, Mass. to Ind. and N. Car. July-Aug.

8. Lechea intermèdia Leggett. LARGE-PODded PIN-WEed. (I. F. f. 248r.) Erect, 2-6 dm. high, sparingly stribose-pubescent. Branches erect or nearly so, short; leaves of the stem oblong-linear, 12-28 mm. long, 2-5 mm. wide, acute, nearly sessile; leaves of the basal shoots oblong-linear, shorter; pedicels $2-4 \mathrm{~mm}$. long; outer sepals about equalling the inner; capsule subglobose or depressedglobose, about $2 \mathrm{~mm}$. in diameter. In dry open places, Penn. and N. J. to N. B., northern N. Y. and Ont. July-Aug.

9. Lechea junipérina Bicknell. Maine Pin-weed. (I. F. f. 2482.) Tufted, I-5 dm. high, finely hoary to canescent. Branches short, ascending or erect, leafy, forming a dense narrow panicle; stem-leaves ascending or appressed, glabrous, except the midrib and margins, linear-oblong to oblanceolate, 10-20 mm. long, 2-4 $\mathrm{mm}$. wide: flowers crowded; pedicels $\mathrm{r}-3 \mathrm{~mm}$. long; fruiting calyx ovoid-ellipsoid, 1. $5 \mathrm{~mm}$. long; inner sepals elliptic, nerveless or faintly 3 -nerved, often deep purple, the outer shorter, bright green; leaves of basal shoots oblong or elliptic, 4-6 mm. long. Me., N. H. and N. S. Aug.

Io. Lechea strícta Leggett. Bushy or Prairie Pin-weed. (I. F. f. 2483.) Erect, 3-4 dm. high, fastigiately branched, strigose-canescent, pale, bushy. Branches ascending or nearly erect; leaves of the stem linear-oblong, 12-25 mm. long, I-2 $\mathrm{mm}$. wide; leaves of the basal shoots linear-oblong, much smaller, I mm. wide or less, acute; pedicels slender, 2-3 mm. long; outer sepals shorter than or equalling the inner. In dry open places, Wis., Ill., Iowa and Minn. July-Aug.

\section{Family 5. VIOLÀCEAE DC.*}

\section{Violet Family.}

Herbs, shrubs, or rarely trees, with basal or alternate, simple, lobed or entire stipulate leaves and solitary or clustered, perfect, mostly irregular flowers. Sepals 5. Petals 5, hypogynous, imbricated in the bud, the lower one larger or with a posterior spur. Stamens 5 ; anthers erect, connivent or svngenesious. Ovary simple, I-celled, with 3 parietal placentæ. Fruit usually a loculicidal capsule. Seeds anatropous. About 15 genera and 325 species, of wide distribution.

Sepals more or less auricled at base.

Sepals not auricled at base.

Petals nearly equal: anthers syngenesious.

Petals unequal; anthers only connivent. r. Viola.

2. Cubelium.

3. Calceolaria.

\section{I. viola L. (See Appendix.)}

Acaulescent and scapose or leafy-stemmed herbs, the flowers solitary or rarely 2: early flowers petaliferous, often sterile, usually succeeded by apetalous or cleistogamous flowers which are abundantly fertile. Petals spreading, the lowermost one spurred or saccate; stamens 5, the two inferior ones spurred. Capsule 3-valved, elastically dehiscent. About 175 species, of wide distribution.

\section{*ACAULESCENT; FLOWERS SCAPOSE.}

\section{+ Plants NOT STOLONIFEROUS.}

\section{$\ddagger$ Leaves mostly lobed or parted (except in one variety of $V$. palmata.)}

Petals bearded; cleistogamous flowers produced freely.

Plants always more or less pubescent.

Plants comparatively glabrous, or with only slight pubescence.

I. V. palmata

* Contributed by Mr. Charles L. Pollard. 
Leaves pedately divided into linear lobes.

Eastern coastal plain species; leaves thin.

Western prairie species; leaves thick.

Leaves palmately lobed or cleft, the segments variously shaped.

2. V. Brittoniana.

Leaf-segments linear-lanceolate, obtuse; cleistogamous flowers on decumbent peduncles.

4. V. Bernardi.

Leaf-segments mostly ovate, coarsely incised; cleistogamous flowers on erect peduncles.

5. V. viarum.

Leaf-segments often falcate ; cleistogamous flowers on decumbent peduncles.

Petals not bearded; cleistogamous flowers wanting.

6. V. falcata.

7. V. pedata.

啔 Leaves merely crenate or dentate, or incised at base, none lobed.

Leaves ovate, reniform or orbicular, often broader than long, not incised at base.

Woodland species; peduncles of the cleistogamous flowers, horizontal or decumbent.

Plant densely hirsute or villous; keel petal cuspidate. 8. V. cuspidata.

Plants sparingly hirsute or glabrous; keel petal not cuspidate.

Leaves very thin, cordate-ovate, attenuate at apex. 9. V. obliqua.

Leaves thick, from ovate to reniform, obtuse or merely acute at apex.

Petals dark violet-purple, narrow, the upper reflexed.

Petals light blue, paler at base, broadly obovate.

10. V. papilionacea.

Petals reddish-purple, nearly orbicular.

II. $V$. pratincola.

12. $V$. villosa.

Meadow or swamp species; peduncles of the cleistogamous flowers erect (often horizontal in $V$. venustula).

Flowers pale violet-blue; leaves light green.

Capsule strongly 3 -angled; plant not northern. I3. $V$. cucullata.

Capsule very short, not angled; plant far northern. 14. $V$. septentrionalis.

Flowers deep purple, paler at base; leaves rather dark green.

Leaves attenuate at apex, crenate-serrate. 15.1 . venustula.

Leaves obtuse or merely acutish at apex, the margin crenulate.

I6. V. vagula.

Leaves lanceolate, oval or ovate-lanceolate, often incised at base.

Scapes shorter than the leaves.

Petals scarcely emarginate; leaf-blades sagittate-lanceolate.

I 7. $V$. $s a g i t$ etals usually emarginate; leaf-blades ovate or deltoid-triangular.
.

Petals not emarginate; leaf-blades oblong-triangular. Scapes longer than the leaves.

Introduced European species; leaf-blades lanceolate.

Native species; leaf-blades ovate-lanceolate or oblong.

Plants glabrous and succulent, densely tufted.

Plants pubescent, not succulent, mostly solitary.

r. $V$. emarginata.

I9. $V$. dentaia.

20. V. lancifolia.

21. $V$. conjugens.

22. V. fimbriatula.

†† Plants stoloniferous.

Introduced species; flowers deep violet-purple, sometimes white. 23. $V$. odorata.

Native species; flowers pale purple, violet-blue, yellow or white.

Flowers yellow.

Flowers pale blue or lilac.

Leaves glabrous, crenulate.

Leaves hirsute-pubescent, crenate.

24. $V$. rotundifolia.

25. V. palustris.

26. V. Selkirkii.

Flowers white.

Leaves from broadly ovate to orbicular; cleistogenes on deflexed peduncles.

Leaf-blades cordate-ovate, glabrate.

Upper and lateral petals twice as long as broad; petioles not spotted. 27. V. blanda.

Upper and lateral petals three times as long as broad; petioles usually red-spotted.

Leaf-blades reniform, pubescent.

28. V. alsophila.

29. V. renifolia.

Leaves from narrowly oval to linear; cleistogenes on erect peduncles.

Leaf-blades oval or ovate, sometimes pubescent. 30. $V$. primulaefolia.

Leaf-blades lanceolate linear-lanceolate, glabrous. 31. V. lanceolata.

** CAULESCENT, LEAFY-STEMMED; FLOWERS AXILLARY

Flowers yellow.

Leaves lanceolate, decurrent at base.

Leaves hastate, broadly ovate or reniform, not decurrent. 
Leaves hastate-lanceolate or hastate-ovate.

Leaves broadly ovate or reniform.

33. V. hastata.

Plant pubescent or villous; basal leaves early withering.

Plant sparsely pubescent or glabrate; basal leaves usually persistent.

35. V. scabriuscula.

Flowers blue, purple, white or cream-rolored.

Stipules entire.

Stipules incised or pinnatifid.

36. V. Canadensis.

Perennial; stipules much smaller than the blades.

Petals cream-colored, the lower one purple-veined.

Petals blue or purple, rarely white.

Spur of corolla shorter than the petals.

Stems spreading; plant glabrous; leaves acutish.

38. $V$. Labradorica.

Stems spreading; plant puberulent; leaves rounded.

39. V. arenaria.

Stems prostrate; plant puberulent; leaves orbicular, of ten mottled.

Spur of corolla longer than the petals.

40. $V$. multicaulis.

41. V. rostrata.

Annual; stipules nearly as large as the blades.

Flowers $16-25 \mathrm{~mm}$. broad; plant escaped from cultivation.

42. $V$. tricolor.

Flowers 8-16 mm. broad; plant native, growing in dry ground.

43. V. Rafinesquii.

I. Viola palmata L. Early Blue Violet. (I. F. f. 2484.) Pubescent, or rarely nearly glabrous; petioles greatly exceeding the blades, the latter cordateovate in outline, 5-13-lobed, $3^{-15} \mathrm{~cm}$. long when mature, the earliest merely crenate-dentate; lobes variously shaped, the middle one commonly broadest; scapes rarely exceeding the leaves; sepals lanceolate, acute or acuminate: petals deep blue, sometimes pale, $1-2.5 \mathrm{~cm}$. long; capsules $8-12 \mathrm{~mm}$. long, those from the cleistogamous flowers on horizontal or deflexed peduncles. In woodlands, Me. to Ont., Minn., Ga. and Ark. April-May.

Viola palmata dilatata Ell. Leaves with most of the blades 3 -lobed, the middle lobe ovate, the lateral subfalcate or semicircular. Range of the type, but more common southward.

Viola palmata sorória (Willd.) Pollard. (I. F. f. 2489.) Leaves villous, the blades from ovate to hastate-reniform, rarely lobed, the margins crenate. (V. sororia Willd.) Range of the type.

2. Viola Brittoniàna Pollard. Coast Violet. (I. F. f. 2485.) Nearly or quite glabrous; petioles much exceeding the blades, the latter pedately divided into linear or oblanceolate acute lobes; scapes exceeding the foliage, I-2 dm. high; sepals lanceolate, acuminate; flowers bright blue, $1.5-2.5 \mathrm{~cm}$. broad; capsules oblong, $12 \mathrm{~mm}$. long, those from the cleistogamous flowers on erect peduncles. Sandy soil near the coast, Mass. to N. Car. May-June. [ $V$. Atlantica Britton, not Pomel.

3. Viola pedatífida Don. Prairie Violet. (I. F. f. 2486.) Glabrous or glabrate, with a short ascending rootstock; leaves with blades $2-8 \mathrm{~cm}$. wide, pedately 5-9-parted into linear, obtuse lobes, their margins and midveins ciliate; scapes usually exceeding the leaves; flowers deep blue, $2.5 \mathrm{~cm}$. broad or more; sepals linear or lanceolate; capsules $10-12 \mathrm{~mm}$. long, those from the cleistogamous flowers on short erect peduncles. Prairies, Ill. to Br. Col. and Ariz. MarchMay. Forms occur in which the leaves are merely slightly lobed.

4. Viola Bérnardi Greene. Bernard's Violet. Pubescent or glabrate from a nearly vertical rootstock; leaf-blades broadly ovate, flabelliform, lobed, or more often palmately cleft into 5-II variously shaped segments, the middle usually the largest, these again lobed or incised, all obtuse; scapes equalling or exceeding the foliage; flowers $2.5-4 \mathrm{~cm}$. wide, bright blue; sepals lanceolate, ciliate; petals broadly oval; capsules oval, those from the cleistogamous flowers on decumbent peduncles. Dry woods, Ill. and Wis. to Mo. May.

5. Viola viàrum Pollard, n. sp. WAyside Violet. Glabrous, growing in large clumps from a stout rootstock which becomes greatly elongated in loose soil: leaves firm, thick-petioled, the blades rugose-veined, broadly ovate or reniform in 
outline, bccoming 7-13 cm. wide, some undivided, merely dentate or coarsely ser. rate, mostly cleft or divided to below the middle into 5 or 7 incised lobes, the base strongly decurrent; flowers blue; sepals lanceolate, acute; capsules abundant, those from the petaliferous flowers oval, prismatic, 8 - $16 \mathrm{~mm}$. long, on erect peduncles, those from the cleistogamous flowers oblong, smaller, ascending or erect. - Open ground along roads, Mo. to Kans. and Ind. Terr. Type collected by J. B. S. Norton at Valley Park, Mo., July I5, I899.

6. Viola falcàta Greene. Falcate-leaven Violet. Plants solitary, with a long perpendicular rootstock, leaves few, sparsely pubescent, the blades I -2.5 $\mathrm{cm}$. long when mature, broadly deltoid in outline, cleft or divided into several segments which are either simple or again lobed, the outer distinctly falcate; flowers similar to those of $V$. palmata; capsules from the apetalous flowers ovoid, usually hypogæous, on slender horizontal peduncles. In dry but rich woods, N. Car. to southern Ill. May-June.

7. Viola pedàta L. BikD's-Foot Violet. (I. F. f. 2492.) Glabrous, from a short vertical rootstock; leaves numerous, the blades nearly orbicular in outline, I. 5-5 cm. wide, pedately parted or divided into 5-I I linear, often toothed lobes, those of the earliest leaves broader and spatulate; flowers $1.5-3.5 \mathrm{~cm}$. broad, lilac, blue, or rarely white, one or both of the upper petals frequently dark purple; stigma beardless, not rostrate; capsules I-I.4 cm. long. Dry fields and hillsides, Me. and Ont. to Minn., Mo. and Fla. April-May.

8. Viola cuspidàta Greene. Cuspidate Violet. Low at flowering time, usually densely hirsute; leaves borne well above the flowering scapes, the blades from cordate-ovate to orbicular, crenate-serrate, rugose-veined, cucullate; flowers I6-I $8 \mathrm{~mm}$. broad, deep blue; sepals lanceolate, obtuse; upper petals obovate, acute, the lowermost one truncate and-cuspidate; capsules from the cleistogamous flowers on decumbent peduncles. Woods, Ind., Wis., Minn. to Br. Col. April-May.

9. Viola obliqua Hill. Thin-LeAved Wood Violet. Slender, often solitary, from a horizontal or ascending rootstock; leaves dark green, long petioled, the blades cordate-ovate, usually attenuate at apex, with a deep sinus at base, the margin irregularly crenate-dentiate, $2.5-7.5 \mathrm{~cm}$. broad; blade not at all cucullate, but spreading at right angles to the petiole; scapes nearly equalling the foliage; flowers pale blue; capsules oblong-oval, $6 \mathrm{~mm}$. long, those from the cleistogamous flowers on filiform deflexed peduncles. Rich soil in shade, N. Y. to Va. AprilMay. [ $V$. affinis LeConte. Not $V$. obliqua of Ill. Fl.].

ro. Viola papilionàcea Pursh. Meadow or Hooded Blue Violet. (I. F. f. 2487 .) Usually glabrous, the foliage bright green; leaves with blades $5-13 \mathrm{~cm}$. long, usually cucullate, reniform or ovate, crenate, cordate at base; scapes exceeding the leaves at flowering time; flowers $\mathbf{1} .5-2.5 \mathrm{~cm}$. broad, dark violet-purple, the two upper petals reflexed; keel petal narrow, this and the lateral ones copiously bearded with yellowish-white hairs: capsules oblong, those from the cleistogamous flowers on deflexed peduncles. [ $V$. obliqua of Ill. Fl., not of Hill.] Woodlands and meadows, N. S. to Minn., Ga. and Kan. April-June.

V. papilionàcea doméstica (Bicknell) Pollard. (I. F. App. f. 2487a.) Plant of much sţouter habit; blades of the leaves usually broadly reniform, somewhat decurrent at base, often $10-13 \mathrm{~cm}$. wide; cleistogamous flowers very numerous, mostly subterranean. [ $V$. domestica Bicknell.] Cultivated soil around dwellings, N. Y. to Va. April-May.

i I. Viola pratíncola Greene. Entrire-leaved Prairie Violet. Glabrous, from a stout ascending knotted rootstock; leaves light green, the blades cordatereniform, crenate, abruptly attenuate, becoming 6-Io cm. broad; scapes mostly exceeding the leaves; flowers I.5-2 cm. wide, light blue, the petals broad and rounded, paler at base, the lowermost purple-veined, the lateral conspicuously white-bearded; capsules from cleistogamous flowers oval, almost entirely subterranean. Prairies, Ind. to Minn. and Iowa. April-May.

12. Viola villosa Walt. SoutherN Wood Violet. (I. F. f. 2488.) Rootstock short, thick, oblique. Leaves commonly appressed to the ground, dark green, often purple-veined above, purplish beneath, silvery-hairy or glabrate, the blade reniform or orbicular, with a narrow sinus, usually obtuse, crenate, $2.5-6 \mathrm{~cm}$. wide; scapes exceeding the leaves; flowers reddish-purple, 12-16 mm. wide; sepals lanceolate, obtuse; spur blunt; capsules $6-8 \mathrm{~mm}$. long, those from the cleistogamous 
flowers on horizontal peduncles. Dry woods and hillsides, N. Y. and N. J. to Ga. and La. April-May.

13. Viola cucullàta Ait. Marsh Blue Violet. (I. F. App. f. 2487b.) Glabrous, the foliage pale green; leaves thin, trom reniform to broadly ovate, obtuse, cucullate, the margins irregularly crenate-dentate; scapes equalling or exceeding the leaves: flowers pale blue or sometimes white, $\mathbf{I} .5-2 \mathrm{~cm}$. wide; capsules oblong, trigonous, those from the cleistogamous flowers on elongated slender peduncles usually longer than the leaves. Bogs and wet meadows, Me. and Ont. to Ga. and Mo. April-June.

14. Viola septentrionàlis Greene. Northern Blue Violet. Tufted, low, the leaves and petioles sparsely hirsute; blades light green, paler beneath, from reniform to suborbicular, strongly cucullate, all obtuse, crenulate; scapes about equalling the foliage; flower pale violet-blue, $1.5-2 \mathrm{~cm}$. wide, the petals broad and mostly obcordate; sepals small, linear, ciliate; capsules oval, very short, those from the cleistogamous flowers on slender erect peduncles. Rich woods, Ont. to northern N. Eng. May.

i5 Viola venústula Greene. Small Blue Violet. Very small at flowering time, from a short oblique rootstock; leaves glabrous, rather dark green, deltoid-ovate or cordate-ovate, acute or attenuate, crenate-serrate, cucullate when young; scapes equalling or barely exceeding the leaves: flower 10-15 mm. broad, deep violet-blue; petals broad, obtuse, the lateral ones bearded with white hairs; capsules small, nearly globose, those from the later cleistogamous flowers subterranean. Wet meadows, Prince Edward Island and Ont. to northern N. Eng. May.

i6. Viola vágula Greene. Smal.l Mottled Blue Violet. Low, rather succulent, from an erect rootstock; leaves dark green with some scattered pubescence, the blades $2.5 \mathrm{~cm}$. broad, deltoid-cordate, the margin obscurely crenate; scapes surpassing the leaves; flowers $2.5 \mathrm{~cm}$. wide; petals deep violet, white at base with purple veinings, obovate, the lowermost often obcordate, the lateral densely bearded; sepals oblong, obtuse; capsules oblong, those from the cleistogamous flowers on short ascending peduncles. Meadows, Ont. and Vt. May.

I7. Viola sagittàta Ait. ARrow-leaven Violet. (I. F. f. 2490.) Glabrous or with traces of pubescence; rootstock stout, ascending or erect; leaves with elongated petioles, the blades sagittate, lanceolate or oblong-lanceolate, usually acute, obscurely crenate-dentatc above the middle, ise auricles of the cordate or truncate base commonly laciniately toothed or incised; flowers very dark purple, rarely white; capsules 8-14 $\mathrm{mm}$. long, those from the cleistogamous flowers on erect peduncles. Wet meadows and marshes, Me. to Mich., Ga. and Tex. April-May.

18. Viola emarginàta (Nutt.) LeConte. TRIANGle-Leaved Violet. (I. F. App. f. 2490a.) Glabrous; leaves with elongated petioles; blades broadly ovate or deltoid-triangular, merely dentate below the middle, or sometimes even deeply cleft or incised, the base subçordate, somewhat decurrent; flowers bright blue or purple, the oblong petals usually distinctly emarginate; capsules obscurely angled, those from the cleistogamous flowers on erect peduncles. Fields and hillsides, N. Y. to Va. April-May.

19. Viola dentàta Pursh. Upland Violet. Robust, from a stout branching rootstock; leaves long-petioled, dark green, the blade glabrous or pubescent along the veins, at first cordate-oblong, later oblong-triangular, 7-15 cm. long, the base subcordate, decurrent upon the petiole, the apex acute or obtuse, the margins irregularly crenate-dentate, ciliate, sometimes ir:sised below; scapes shorter than the leaves; flowers deep purple, $1.5^{-2} \mathrm{~cm}$. wide; capsules obscurely 3 -angled, those from the cleistogamous flowers on erect peduncles. Dry rich soil in hilly regions, Penn. to Va. May.

20. Viola lancifolia Thore. European LANCE-Leaved Violet. Tufted, glabrous, from a cluster of fibrous roots or a single thick root; lea ves short-petioled, lanceolate or oblong-lanceolate, obtuse, crenate, $2-8 \mathrm{~cm}$. long, tapering at base; flowers 2.5-4 cm. wide, purple; spur large and blunt, half the length of the petals; capsules small, those from the cleistogamous flowers on erect peduncles. Escaped from cultivation and established, Washington, D.C. Adventive from Europe. April-May.

21. Viola coniúoens Greene. Maryland Violet. Nearly glabrous, densely 
tufted, from short knotted rootstocks; leaves rather succulent, deep green, the blades narrowly ovate or subsagittate, subcordate at base, obtuse, crenulate; flowers bright blue; $1.5-2.5 \mathrm{~cm}$. broad; petals obovate, densely white-bearded; capsules as in $V$. emarginata. Grassy places, Md. to Va. May.

22. Viola fimbriàtula J. E Smith. Ovate-Leaved Violet. (I. F. f. 249I.) Densely pubescent or villous, tufted; leaves with petioles usually shorter than the blades; the latter ovate-lanceolate, oval or oblong, obscurely crenate, the base truncate or subcordate, sometimes dentate or incised; flowers blue, 8-14 mm. wide, the petals bearded; capsules oval, those from the cleistogamous flowers on erect peduncles. [ $V$. ovata Nutt. ] Dry soil, N. S. to Mo. and La. April-May.

23. Viola odoràta L. ENGlish oR Sweet Violet. (I. F. f. 2493.) Stolons rooting at the nodes; leaves pubescent or glabrate, the blades orbicular or broadly ovate, cordate, obtuse, crenate, $2-5 \mathrm{~cm}$. wide; scapes equalling the foliage; flowers fragrant, $\mathbf{I}-2 \mathrm{~cm}$. broad; sepals oblong, obtuse; petals beardless; capsules from cleistogamous flowers borne on short decumbent peduncles. Escaped from gardens, N. S. to southern N. Y. and N. J.; also in the South and on the Pacific Coast. Adventive from Europe. March-May.

24. Viola rotundifòlia Michx. Round-Leaved Violét. (I. F. f. 2494.) Stoloniferous in late summer; leaves glabrate, yellowish-green, paler beneath, the petioles somewhat pubescent; blades ovate or orbicular, cordate, crenate, $\mathbf{I}-5 \mathrm{~cm}$. wide at flowering-time, afterward becoming $10-13 \mathrm{~cm}$. wide and appressed to the ground; flowers yellow, 8-12 mm. broad; sepals linear-oblong, obtuse; lateral petals bearded and marked with brown veins; capsules ovoid, those from the cleistogamous flowers racemose on short deflexed peduncles. Woods and rocky hillsides, Lab. and Ont. to Minn., south in the mountains to N. Car.

25. Viola palústris L. Marsh Violet. (I. F. f. 2495.) Glabrous; rootstock slender, horizontal; blades of the leaves thin, reniform to nearly orbicular, 2.5-4 cm. wide, crenulate; scapes exceeding the foliage; flowers pale lilac or nearly white, marked with purple veins; petals $8-12 \mathrm{~mm}$. long, slightly bearded; spur short and blunt; capsule oblong, 6-8 mm. in length; cleistogamous flowers not produced. Wet soil, Lab. to Alaska and N. Eng., and in the Rocky Mts. Also in Europe and Asia. May-July.

26. Viola Selkírkii Pursh. Selkirk's Violet. (I. F. f. 2496.) Nearly glabrous; rootstock slender, creeping. Leaves dark green, the blades thin, $I-5 \mathrm{~cm}$. wide, broadly ovate or orbicular, deeply cordate, the margins crenate, the apex obtuse; basal sinus narrow, the auricles often overlapping; sepals lanceolate, acute; spur 5-8 $\mathrm{mm}$. long, obtuse; petals beardless, pale violet-blue; capsules oblong, 4-6 mm, long, those from the cleistogamous flowers on erect or ascending peduncles. Moist woods, N. S. to Mass., Penn. and Minn. Also in northern Europe and Asia. April-May.

27. Viola blánda Willd. Sweet White Vıolet. (I. F. f. 2497.) Glabrate, somewhat stoloniferous, from a very slender rootstock; blades of the leaves thin, light green, reniform to orbicular, $\mathbf{I}-7 \mathrm{~cm}$. wide, crenate, cordate at base, with a shallow sinus, the apex obtuse; sepals lanceolate, acute; flowers white, fragrant, 6-12 mm. broad; petals beardless, the lower and lateral ones marked with purple veins: capsules small, oval; cleistogamous flowers few. Swamps and wet meadows, Newf. to Br. Col. and N. Car. April-May.

28. Viola alsóphila Greene. Woodland White Violet. Strongly stoloniferous; leaves somewhat pubescent, bright green above, paler beneath. the petioles red-spotted; blades from ovate to orbicular, usually obtuse, with a deep narrow sinus; scapes mostly shorter than the leaves; flowers white, scarcely fragrant, I-2 cm. broad; petals very narrow, the two uppermost often twisted; capsules similar to those of $V$. blanda, but larger. [ $V$. blanda amoena (LeConte) B. S. P. Not $V$. amoena Symons.] Wet, hilly woods; N. Eng. to N. Car. and Ill. April-May.

29. Viola renifòlia A. Gray. Kidney-Leaved Violet. (I. F. f. 2498.) Densely pubescent or even villous, from a slender horizontal rootstock; leaves with broad reniform or orbicular blades, $2-8 \mathrm{~cm}$. wide, the margins obscurely crenate, the basal sinus deep; scapes about equalling the foliage; sepals linear-oblong, acute; flowers 8-10 $\mathrm{mm}$. wide, white, the petals beardless and marked with brownish veins; capsules oval, $8 \mathrm{~mm}$. long, those from the cleistogamous flowers on deflexed peduncles. Woods and thickets, N. S. to N. Y. and Minn. April-June. 
30. Viola primulæfollia L. Primrose-leaved Violet. (I. F. f. 2499.) Glabrous or somewhat pubescent, producing long stolons in late summer; leaves with oval or ovate-oblong blades, the base usually decurrent upon the petioles, sometimes truncate or subcordate, the margins entire or crenulate; sepals lanceolate, acuminate; flowers white, $8-12 \mathrm{~mm}$. wide, the petals purple-veined, scarcely bearded; capsules oval, 6-10 $\mathrm{mm}$. long, those from the cleistogamous flowers nodding on short erect peduncles. Moist or wet ground, N. B. to Fla. and La. April-June.

31. Viola lanceolàta L. LANCE-LeAved Violet. (I. F. f. 2500.) Glabrous, the stolons rooting freely at the nodes. Leaves lanceolate or linear-lanceolate, the blades $5^{-13} \mathrm{~cm}$. long, decurrent upon the petiole, the margins obscurely crenulate; scapes usually somewhat shorter than the leaves; sepals lanceolate, acuininate; flowers white, 8-10 $\mathrm{mm}$. wide, the petals beardless, the lower and lateral ones with purple veins; capsules oval, 6-10 $\mathrm{mm}$. long, those from the cleistogamous flowers nodding on short erect peduncles, frequently borne on the stolons. Wet meadows and along streams, N. S. to Minn., Fla. and Tex. April-June.

32. Viola Nuttàlii Pursh. NutTall's Violet. (I. F. f. 2501.) Subcaulescent, later with ascending tufted leafy stems from a thick rootstock; leaves firm, nearly glabrous, the blades lanceolate or ovate-lanceolate, entire or irregularly crenate, tapering below into margined petioles, the apex obtuse; peduncles shorter than the leaves; sepals lanceolate, acuminate; flowers yellow, $1-2 \mathrm{~cm}$. wide; petals beardless, the lower and lateral ones often purple-veined; stigma bearded; capsule oval, $6 \mathrm{~mm}$. long. Prairies, Manitoba to Mont., Kans. and Mo. May.

33. Viola hastàta Michx. Halberd-leaved Yellow Violet. (I. F. f. 2502.) Stem simple, erect, usually glabrous, I-3 dm. high; stem-leaves borne near the summit, short-petioled, hastate or hastate-ovate, $2-10 \mathrm{~cm}$. long, repand or denticulate, acute; basal leaves, when present, larger, more cordate; fluwers yellow, 8-16 mm. wide; lateral petals bearded; sepals linear-lanceolate, acute; spur short; capsule 8-10 mm. long. Woods, in hilly regions, Penn. and Ohio to Ga. and Ala. April-June.

34. Viola pubéscens Ait. Hairy Yellow Violet. (I. F. f. 2503.) Stem simple, erect, pubescent or villous, I-5 dm. high; basal leaves ovate-reniform, long-petioled, early withering; stem leaves borne near the summit, short-petioled, the blades ovate or reniform, $5^{-13} \mathrm{~cm}$. wide, acute or abruptly attenuate, crenatedentate; sepals oblong-lanceolate; flowers bright yellow, 12-16 mm. wide; petals obscurely purple-veined; spur short; capsule oblong, glabrous or tomentose, ro-16 $\mathrm{mm}$. long. Dry woods, Quebec to S. Dak., Ga. and Iowa. April-May.

35. Viola scabriúscula (T. \& G.) Schwein. Smoothish Yellow Violet. (I. F. f. 2504.) Stems clustered, glabrate or glabrous, decumbent or ascending, I-4 dm. high; basal leaves broadly ovate, long-petioled, more or less persistent; $s t \in m$ leaves with blades from reniform to cordate-ovate, acute, crenate, dentate, 2.5-6 cm. wide; sepals linear-lanceolate; flowers pale yellow, 10-16 mm. broad; petals purple-veined; spur short; capsule oval, glabrous or tomentose, 6-1o $\mathrm{mm}$. long. Moist woods and thickets, N. S. to Manitoba, Neb., Ga. and Tex. AprilMay. Blooms earlier than the preceding.

36. Viola Canadénsis L. Canada Violet. (I. F. f. 2505.) Stems tufted, leafy, $0.7-4 \mathrm{dm}$. high; leaves short-petioled, glabrous, the blades cordate-ovate, acute or acuminate, $2.5-6 \mathrm{~cm}$. long, serrate; stipules lanceolate, entire; flowers pale violet or white, $1-2 \mathrm{~cm}$. broad; lateral petals bearded, purple-veined; sepals linear, attenuate; capsule glabrous, oval, 6-8 $\mathrm{mm}$. long. Woods, in hilly districts, Newf. and Sask. to N. Car., Neb., N. Mex. and Ariz. May-July.

37. Viola striàta Ait. Pale or Striped Violet. (I. F. f. 2506.) Stems tufted, glabrous, becoming over $6 \mathrm{dm}$. long in late summer; leaves numerous, slender-petioled, the blades ovate or nearly orbicular, $2.5-6 \mathrm{~cm}$. wide, often slightly pubescent, the upper ones acute: stipules large, dentate or even laciniate; flowers long-peduncled, white or cream-colored, sometimes bluish, I-2 cm. broad; petals darker-veined, the lateral ones bearded; capsule ovoid, glabrous. Moist woods and thickets, N. Eng. and Ont. to Minn., Ga. and Mo. April-May.

38. Viola Labradórica Schrank. American Dog Violet. (I. F. f. 2507.) Stems tufted, glabrous, leafy; leaves slender-petioled, the blades reniform to orbicular, cordate, acutish or obtuse, I-4 cm. wide; stipules ovate-lanceolate, ciliate, entire or serrate; sepa!s linear-lanceolate, acuminate; flowers long-peduncled, light 
blue or purple, rarely white, $12-16 \mathrm{~mm}$. broad; petals twice as long as the slender spur, the lateral ones slightly bearded; capsule glabrous, 4-6 mm. long; cleistogamous flowers short-peduncled, produced late in the season. Moist soil, Lab. to Minn., N. Car. and Ky. March-May.

39. Viola arenària DC. SAND Violet. (I. F. f. 2508.) Stems slender, tufted, decumbent or ascending, their surface and that of the long-petioled leaves finely puberulent; blades ovate, usually obtuse at apex, truncate or subcordate at base, $\mathbf{I}-2.5 \mathrm{~cm}$. long, the margins crenulate; stipules laciniate; sepals linear, acuminąte; flowers violet-purple, IO-14 mm. wide; spur $6 \mathrm{~mm}$. long, blunt; capsule 6-8 mm. long. Sandy soil, Me. to Sask. and S. Dak. Also in Europe. May-June.

40. Viola multicaùlis (T. \& G.) Britton. Prostrate Blue Violet. (I. F.

I f. 2509 .) Stems slender, tufted, 5-20 cm. long; leaves numerous, slender-petioled, finely puberulent; blades orbicular, crenulate, cordate with a narrow sinus, often mottled or dark-veined, $2.5-4 \mathrm{~cm}$. wide; stipules laciniate; peduncles exceeding the leaves; flowers violet-blue, ro- $14 \mathrm{~mm}$. wide; petals bearded; sepals lanceolate, acuminate; capsule glabrous, 6-8 mm. long: cleistogamous flowers borne on the shoots of late summer. Woods, Ky. to Fla. and Tex. Feb.-July.

4I. Viola rostrata Pursh. Long-SPURRed Violet. (I. F. f. 2510.) Stems numerous, erect; leaves glabrous, slender-petioled, the blades cordate-ovate or the lower reniform, acuminate, serrate, I-4 cm. long; stipules laciniate, ciliate; flowers pale violet, darker veined, $\mathbf{1 . 5}-2 \mathrm{~cm}$. wide; sepals linear-lanceolate; petals beardless; capsule glabrous, $8 \mathrm{~mm}$. long. Rocky woods, Quebec to Mich., south in the mountains to Ga. June-July.

42. Viola tricolor L. Pansy. Heart's-ease. (I. F. f. 25 III.) Plant usually glabrous: stem branched, ascending, I-3 dm. high; upper leaves oval-lanceolate, crenate-dentate, $\mathbf{I}-2.5 \mathrm{~cm}$. long, the lower broader, often cordate; stipules large, foliaceous, laciniate or pinnatifid; flowers variously marked with yellow, purple or white, 1.6-2.5 cm. broad; petals veined, the lower one largest; capsule angled, 6. $10 \mathrm{~mm}$. long. Waste places, sparingly escaped from gardens. May-July.

43. Viola Rafinésquii Greene. FIELd PANSY. (I. F. f. 2512.) Stems very slender, glabrous, $7-23 \mathrm{~cm}$. high. Leaves ovate to oblong-lanceolate, obscurely crenate-dentate or entire, smaller than in the last; stipules similar; flowers yellowish-white or bluish-tinged, ro-I $6 \mathrm{~mm}$. wide; petals markedly exceeding the linear sepals; capsule 4-6 mm. long. [ $V$. tenella Muhl.; not Poir.] Woods and fields, N. Y. to Ga., Mich. and Tex. March-May.

\section{CUBELIUM Raf. [SOLEA Spreng.]}

A perennial erect leafy-stemmed herb, the alternate leaves entire or obscurely dentate, the small greenish flowers I-3 together in the axils. Sepals 5, equal, not auricled. Petals nearly equal, erect, imbricated, the lower one broadest and somewhat gibbous below. Stamens 5, syngenesious, the sheath glandular at base; anthers sessile. Style hooked at the apex. Capsule somewhat lobed, 3-valved. A monotypic genus of $\mathrm{N}$. Am.

I. Cubelium cóncolor (Forst.) Raf. Green Vrolet. (I. F. f. 2513.) Plant 3-9 dm. high, pubescent; leaves oblong-lanceolate, 7-I2 cm. long, acuminate, tapering to a short petiole; stipules linear, acute; flowers $8 \mathrm{~mm}$. long. on short recurved peduncles; seeds large. Moist woods, Ont. to Mich., N. Car. and Kans. May-June.

\section{CALCEOLÀRIA Loefl. [IONIDIUM Vent.]}

Herbs or rarely shrubs, with small axillary or racemose flowers. Sepals unequal, not auricled. Petals unequal, the lowermost one longest, gibbous or saccate at hase, the upper pair shorter than the lateral ones. Anthers connivent, on distinct filaments, the lower glandular or spurred. Capsule elastically dehiscent into 3 valves. About 45 chiefly tropical American species.

I. Calceolaria verticillàta (Ort.) Kuntze. NodDing Violet. (I. F. f. 25 I4.) Stems clustered, glabrate or somewhat pubescent, erect or ascending, I-4 dm. high, from a woody base; leaves alternate, linear, $1.5-4 \mathrm{~cm}$. long, often fascicled; stipules subulate: flowers white, solitary, nodding, $4-6 \mathrm{~mm}$. long. Dry ground, Kans. to Tex., Colo. and Mex. April-July. 


\section{Family 6. PASSIFLORÀCEAE Dumort. \\ Passion-flower Family.}

Woody vines, climbing by tendrils, or erect herbs, with petioled usually pa) nately-lobed leaves, and perfect regular flowers. Calyx-tube persistent. Petals usually 5, inserted on the throat of the calyx, distinct, or in some species united. Stamens 5. Throat of the calyx crowned with a double or triple fringe. Filaments subulate or filiform, monadelphous, or separate. Ovary free from the calyx, 1-celled; placentæ 3-5, parietal ; styles 1-5. Fruit a berry or capsule, usually many-seeded. About i 8 genera and 325 species, of warm and tropical regions, most abundant in S. Am.

\section{PASSIFLÒRA L.}

Climbing tendril-bearing vines, with alternate or rarely opposite leaves, and large axillary flowers, on jointed, often bracted, peduncles. Calyx-tube cupshaped or campanulate, 4-5-lobed, the lobes narrow, imbricated in the bud, its throat crowned with a fringe called the corona. Petals 4 or 5 (rarely none), inserted on the throat of the calyx. Ovary oblong, stalked. Filaments monadelphous in a tube around the stalk of the ovary, separate above; anthers narrow, versatile. Fruit a many-seeded berry. Seeds pulpy-arilled, flat, ovate; endosperm fleshy. [Flower of the Cross, or Passion, as emblematic of the crucifixion.] About $25^{\circ}$ species, mostly of tropical Am., a few in Asia and Australia. Besides the following, about 7 others occur in the southern and southwestern States.

Leaves deeply 3-5-lobed; lobes serrate; petals whitish; corona purple. 1. $P$. incarnata. Leaves obtusely 3 -lobed above the middle, the lobes entire; flower yellowish.

$$
\text { 2. P. iutea. }
$$

I. Passiflora incarnàta L. Passion-flower. Passion-vine. (I. F. f. 25 I5.) Stem glabrous, or slightly pubescent above. Petioles $1-5 \mathrm{~cm}$. long, with 2 glands near the summit; leaves nearly orbicular in outline, glabrous, or often somewhat pubescent, $7-13 \mathrm{~cm}$. broad, somewhat cordate at the base, the lobes ovate or oval, acute or acutish, finely serrate; flowers solitary, 3-5 cm. broad; peduncles usually 3 -bracted just below the flowers; calyx-lobes linear; berry ovoid, nearly $5 \mathrm{~cm}$. long, glabrous, yellow. In dry soil, Va. to Mo., Fla. and the Ind. Terr. Fruit edible, called Maypops. May-July.

2. Passiflora lùtea L. Yellow Passion-flower. (I. F. f. 25I6.) Glabrous or nearly so, climbing or trailing. Petioles $\mathbf{I}-3 \mathrm{~cm}$. long; leaves much broader than long, more or less cordate at base, with 3 wide obtuse rounded lobes, the lobes entire; stipules $2-3 \mathrm{~mm}$. long; peduncles usually in pairs from the upper axils; flowers greenish-yellow, $\mathbf{r}-2 \mathrm{~cm}$. broad; calyx-lobes linear; berry globoseovoid, Io-12 mm. in diameter, glabrous, deep purple. In thickets, Penn. to Kans., Fla. and La. May-July.

\section{Family 7. LOASÀCEAE Reichenb. Loasa Family.}

Herbs, often armed with hooked stinging or viscid hairs, with estipulate leaves, and regular, perfect, white yellow or reddish flowers. Calyxtube adnate to the ovary, its limb 4-5-lobed, persistent. Petals 4 or 5 , inserted on the throat of the calyx. Stamens $\infty$, inserted with the petals; filaments filiform, commonly arranged in clusters opposite the petals; anthers introrse. Ovary I-celled (rarely 2-3-celled), with 2-3 parietal placentæ; ovules anatropous. Capsule usually I-celled, crowned with the calyx-limb. Seeds mostly numerous; endosperm scanty. About I 3 genera and 200 species, all but I natives of America.

\section{MENTZÈLIA. L.}

Erect herbs, sometimes woody, with alternate leaves, and usually showy flowers. Calyx-tube cylindric, obconic, or club.shaped, its limb generally 5-lobed. 
Petals 5 or IO, spreading, convolute in the bud, deciduous. Stamens 20-300. Styles 3, more or less united; stigmas small, obtuse. Capsule dehiscent at the summit, few-many-seeded. Seeds flat and sometimes winged, roughened, or smooth. [In honor of C. Mentzel, a German botanist, died I701.] About 50 species, natives of America. Besides the following, some 25 others occur in west. ern N. Am.

Flowers $1-2 \mathrm{~cm}$. broad, yellow.

Leaves, at least the lower, petioled; stem very rough ; calyx-lobes $6 \mathrm{~mm}$. long.

Leaves sessile; stem little rough; calyx-lobes $4 \mathrm{~mm}$. long. I. $M$. oligospermc。 3. M. albicaulis. Flowers 3-10 $\mathrm{cm}$. broad.

Flowers yellowish white, opening in the evening.

Flowers $3-5 \mathrm{~cm}$. broad; calyx-tube usually bractless.

Flowers 7-10 cm. broad; calyx-tube usually bracted.

Flowers bright yellow, opening in sunshine.

2. M. nuda.

4. M. decapetala.

5. M. laevicaulis.

I. Mentzelia oligospérma Nutt. Few-Seeded Mentzelia. (I. F. f. 2517.) Rough and viscid-pubescent, 3-9 dm. high. Leaves ovate or oval, coarsely dentate or sinuate, $2-8 \mathrm{~cm}$. long, the upper rounded or truncate at the base and sessile, the lower narrowed at the base; flowers axillary or somewhat cymose, opening in sunshine; petals 5, oblong-cuneate, acute, about twice as long as the linear-lanceolate calyx-lobes; filaments 20-30, all filiform; capsule linear, 12-I6 mm. long, few-seeded; seeds oblong, wingless. Prairies, Ill. to S. Dak., Kans., Colo., La. and Mex. May-July.

2. Mentzelia nùda (Pursh) T. \& G. Bractless Mentzelia. (I. F. f 2518.) Rough with minute pubescence, slender, 3-15 dm. high, the stems light. colored. Leaves lanceolate or oblong-lanceolate, acute, usually sharply and deeply dentate, or the upper pinnatifid, $2-8 \mathrm{~cm}$. long; petals 10 , about twice as long as the lanceolate calyx-lobes; calyx-tube usually not bracteolate; stamens 100 or more, the outer ones somewhat petaloid; capsule oblong, $1.5-2.5 \mathrm{~cm}$. long, about $6 \mathrm{~mm}$. thick; seeds numerous, wing-margined. Plains, S. Dak. to Kans., Colo. and Tex. July-Aug.

3. Mentzelia albicaùlis Dougl. White-stemmed Mentzelia. (I. F. f. 2519.) Stem nearly white, shining, 1.5-5 dm. high. Leaves mostly lanceolate, sinuate-pinnatifid, sinuate-lobed, or the upper and lower sometimes entire, rough with short stiff hairs, $2-8 \mathrm{~cm}$. long; flowers few together at the ends of the branches, or also axillary, $\mathbf{I}-2 \mathrm{~cm}$. broad, short-pedicelled or sessile; calyx-lobes linear. lanceolate; capsule linear, $2.5 \mathrm{~cm}$. long or less, many-seeded; seeds angled, tuberculate, wingless. Neb. to Br. Col., Cal. and N. Mex. May-July.

4. Mentzelia decapétala (Pursh) Urban \& Gilg. Showy Mentzelia. (I. F. f. 2520.) Roughish-pubescent, stout, seldom over $6 \mathrm{dm}$. high. Leaves oval, lanceolate or oblong, acute or acuminate, sinuate-pinnatifid, $5-15 \mathrm{~cm}$. long, the upper sessile, the lower petioled; flowers mostly solitary, terminal; petals Io, about twice as long as the lanceolate calyx-lobes; filaments all filiform, very numerous (200-300); capsule oblong, 3-5 cm. long; seeds numerous, margined, not winged. Plains, Dak. and Mont. to Neb. and Tex. June-Sept.

5. Mentzelia laevicaùlis (Dougl.) T. \& G. Smooth-stemmen Mentzelia. (I. F. f. 252 r.) Stout, 6-I 2 dm. high, minutely pubescent, or the stems at length glabrate and whitish. Leaves sessile, lanceolate or ovate-lanceolate, sinuatepinnatifid, acute or acuminate, $2-8 \mathrm{~cm}$. long; flowers mostly solitary, terminal, 7-10 cm. broad; calyx-tube bractless; petals 5 , or with 5 additional narrower inner ones, 2-3 times as long as the calyx-lobes; stamens very numerous; capsule oblong, about $2.5 \mathrm{~cm}$. long; seeds numerous, winged, minutely tuberculate. Plains and dry soil, Neb., Mont. and Wyo. to Ore., Utah and Cal. June-July.

\section{Order 24. OPUNTIÀLES.}

Fleshy plants, with continuous or jointed stems, leafless, or with small leaves, generally abundantly spinv, the spines developed from cushions of minute bristles (areolæ). Flowers mostly solitary, sessile, perfect, 
regular, showy. Calyx-tube adnate to the ovary, its limb many-lobed. Petals numerous, imbricated in several rows, mostly distinct. Stamens numerous, inserted on the throat of the calyx. Filaments filiform; anthers small. Ovary I-celled; ovules numerous, anatropous, borne on several parietal placentæ. Style terminal, elongated; stigmas numerous. Fruit a berry, mostly fleshy, sometimes nearly dry. Seeds smooth, or tubercled, the testa usually crustaceous or bony; endosperm little, or copious. Only one family.

\section{Family 1. CACTÀCEAE Lindl.}

\section{Cactus Family.}

\section{About 20 genera, and 1000 species nearly all natives of America.}

Stems subglobose, oval, ovoid or cylindric, tubercled, ribbed or angled; no proper leaves. Flowers borne on the turbercles or ribs, at or near the areolæ.

Flowers borne close to fully developed clusters of spines.

Flowers borne close to areolæ, from which the spines subsequently develop.

Flowers borne between the tubercles, distant from the areolid.

2. Echinocactus.

3. Cactus.

Plants jointed, the joints flattened, or cylindric; leaves present, mostly subulate and deciduous.

4. Opuntia.

\section{ECHINOCÈREUS Engelm.}

Stems ovoid, cylindric or oval, ribbed, or tubercled, the ribs or rows of tubercles usually straight, vertical. Proper leaves none. Spine-bearing areolæ on the ribs or tubercles. Flowers borne on the ribs or tubercles, at or near the areolæ, close to fully developed clusters of spines. Calyx-tube with spine-bearing areolæ, or scaly, prolonged beyond the ovary. [Greek hedgehog-Cereus.] About 45 species, natives of America. Besides the following, some 20 others occur in the southwestern U. S.

Flowers greenish, about $2.5 \mathrm{~cm}$. broad; fruit 10-12 mm. long. Flowers rose-purple, $5-8 \mathrm{~cm}$. broad; fruit $18-20 \mathrm{~mm}$. long. r. E. viridiflorus, 2. E. caespitosus.

I. Echinocereus viridiflòrus Engelm. Green-Flowered Cereus. (I. F. f. 2522.) Stem subglobose to oval-cylindric, $2-20 \mathrm{~cm}$. high, simple, or sparingly branched, $2-5 \mathrm{~cm}$. in diameter. Ribs about 13 ; longer radial spines $12-18$, with 2-6 setaceous upper ones, the lateral unes reddish brown, the others white or rarely purple; central spine stout, or wanting, purple and white; flowers greenish brown without, yellowish green within; fruit ellipsoid, greenish; seeds tubercled. Kans. to Wyo., Tex. and N. Mex.

2. Echinocereus caespitòsus Engelm. \& Gray. Tufted Cereus, (I. F. f. 2523.) Stems ovoid-globose to ovoid-cylindric, usually tufted, $2-15 \mathrm{~cm}$. high, 2-10 $\mathrm{cm}$. in diameter; ribs 12 or 13 ; radial spines $20-30$, pectinate, white, the lateral ones the longer, 4-8 mm. long; central spines wanting, or sometimes 1 or 2 short ones; fruit ovoid, green; seeds tubercled, black. Western Kans. (?). Ind. Terr. to Tex. and Mex.

\section{ECHINOCÁCTUS Link \& Otto.}

Stems globose, oblong or cylindric, leafless, tubercled, the tubercles arranged in straight or spiral rows, bearing clusters of spines arising from areolae. Flowers borne on the tubercles, at or near areolæ from which spines are subsequently developed. Calyx-tube prolonged beyond the ovary, usually covered with scales, its lobes numerous, the outer scale-like, the inner elongated. Petals numerous, sim. ilar to the inner sepals. Stamens numerous. Ovary exserted; style columnar. Berry usually covered with scales and often with tufts of minute bristles. [Greek, hedgehog-cactus.] About 200 described species, natives of America. Besides the following, some 30 others occur in the Western States.

I. Echinocactus Símpsoni Engelm. Simpson's Cactus. HedgehogTHistle. (I. F. f. 2524.) Stems globose or with a narrowed base, 7-15 cm. high, 
7-10 $\mathrm{cm}$. in diameter. Tubercles ovoid, somewhat 4-sided at base, $12-16 \mathrm{~mm}$. long, arranged in spirals; central spines yellowish below, nearly black above, roI4 mm. long, the exterior ones slightly shorter, whitish; flowers greenish pink, $\mathrm{r} \cdot 5^{-2} \mathrm{~cm}$. broad, borne to one side at the ends of the tubercles; petals oblong, cre. nulate, cuspidate; berry dry, 6-7 $\mathrm{mm}$. in diameter, bearing 2 or 3 scales near its summit. Kans. (?), Colo. to Utah and Nev. Apri-May.

\section{CÁCTUS L.}

Stems globose or ovoid, tubercled. Tubercles conic or cylindric, woolly and with clusters of spines at the apex. Leaves none. Flowers borne from areolæ at the bases of the tubercles. Calyx-tube prolonged beyond the ovary, which is often hidden between the tubercles. Petals in several rows. Ovary smooth, ovoid; style filiform. Berry emersed, crowned by the withering corolla. [Greek name of some prickly plant.] About 300 described species, natives of warm and tropical America. Besides the following, 35 or more occur in the southwestern States.

Flowers yellow or reddish; central spine $\mathbf{r}$. Flowers purple; central spines several.

I. C. Missouriensis.

2. C. viviparus.

I. Cactus Missouriénsis (Sweet.) Kuntze. Missouri Cactus. (I.F.f. 2525.) Stems globose, 2-5 cm. high. Tubercles $12-16 \mathrm{~mm}$. long, arranged in about 8 spiral rows, slightly grooved; spines gray, 10-20 together, the stouter central one ro-12 mm. long, or wanting; flowers about $2.5 \mathrm{~cm}$. broad; petals abruptly mucronate; berry globose, scarlet, $6-8 \mathrm{~mm}$. in diameter, ripening the following spring; seeds black, globose, pitted, about $\mathbf{I} \mathrm{mm}$. in diameter. Plains and dry soil, S. Dak. to Kans., Tex. and Colo. May.

Cactus Missouriénsis símilis (Engelm.) Coult. Stems tufted; flowers 2-5 cm. long; seeds about $2 \mathrm{~mm}$. long. Kans. and Colo. to Tex.

2. Cactus vivíparus Nutt. Purple Cactus. (I. F. f. 2526.) Stems 2-I3 $\mathrm{cm}$. high, 3-5 cm. in diameter. Tubercles terete or nearly so, slightly grooved, bearing 3-8 slender reddish-brown spines, I-2 cm. long, surrounded by $12-25$ somewhat shorter, whitish or greenish ones in a single row; flowers nearly $5 \mathrm{~cm}$. long: petals lanceolate, narrow; sepals fringed; berry ovoid, 12-1 $8 \mathrm{~mm}$. long, green: seeds light brown, obovoid, curved, pitted, about $1.5 \mathrm{~mm}$. long. Prairies, Maritoba to Alberta, Kans. and Colo.

\section{OPÚNTIA Mill.}

Succulent plants, with jointed branching stems, the joints flat, or cylindric, and small mostly subulate deciduous leaves, the areolæ axillary, often spine-bearing. Flowers usually lateral. Calyx-tube not prolonged beyond the ovary, its lobes spreading. Petals numerous, slightly united at the base. Stamens very numerous. Ovary cylindric, exserted; style cylindric, longer than the stamens; stigma 2-7-rayed. Berry pear-shaped, often spiny. [Named from a town in Greece where some species grew.] About 150 species, natives of America. Besides the following, some 50 others occur in the western States.

Joints flattened, oval, oblong, obovate or orbicular: stems prostrate or ascending.

Fruit fleshy, juicy, spineless or sparingly spiny.

Joints spineless, or with solitary stout spines.

r. O. Opuntia.

Joints spiny (No. 2 sometimes unarmed), the spines $\mathbf{I - 1 5}$ at eacl areola.

Spines white, gray or yellowish.

Joints $7^{-13} \mathrm{~cm}$. long: longer spines $\mathrm{I}-4 \mathrm{~cm}$. long. 2. O. humifusa.

Joints $15^{-20} \mathrm{~cm}$. long; longer spines $2.5^{-6} \mathrm{~cm}$. long. 3. O. tortispina.

Spines reddish brown to black; joints $15^{-20} \mathrm{~cm}$. long. 4. O. Camanchica.

Fruit dry, with spine-bearing areolæ.

Joints orbicular or broadly obovate, flat.

Joints little flattened, ovoid, or subglobose.

Joints cylindric, or nearly so: stem erect.

5. O. polyacantha.

6. O. fragilis.

7. O. arborescens.

I. Opuntia Opúntia (L.) Coult. Eastern Prickly Pear. Indian Fig. (I. F. f. 2527.) Prostrate or ascending; joints obovate, oblong, oval or orbicular, $5^{-13} \mathrm{~cm}$. long. Leaves subulate, 4-8 $\mathrm{mm}$. long, usually early deciduous; bristles 
greenish or yellowish brown; spines, when present, solitary, stout, not deflexed, 6-35 mm. long; flowers yellow, sometimes with a reddish center, 5-8 cm. I road; fruit obovoid, edible, $2.5-4 \mathrm{~cm}$. long, red. In dry sandy soil, or on $10 . \mathrm{ks}, \mathrm{E}$. Mass. to Penn. and Fla. June-Aug. [O. vulgaris Mill.]

2. Opuntia humifùsa Raf. Western Prickly Pear. (I. F. f. 2528.) Prostrate, similar to the preceding; joints obovate, suborbicular, or ovil, usually leep green, 7-13 cm. long; leaves subulate, spreading, 6-10 mm. long; bristles reddish brown; spines few, mostly near the margins, $1-4$ together, deflexed, or the longer one spreading and $\mathbf{r}-2.5 \mathrm{~cm}$. long: flowers $6-10 \mathrm{~cm}$. broad; iruit clubshaped, not spiny, edible, 3-5 cin. long. In dry sindy or rocky soil, S. Dak. to Minn., Ky., Mo., Kans. and Tex. Summer.

3. Opuntia tortispina Engelm. Twisted-SpINed Cactus. (I. F. f. 2529.) Stems prostrate, the orbicular-obnvate flattened joints $15-20 \mathrm{~cm}$. long. Spanes 3-5, white, angled, the longer ones 3-6 cm. long, with 2-4 more slender and shorter ones: flowers sulphur-yellow, $6-8 \mathrm{~cm}$. broad; fruit ovoid, fleshy, unarmed, about $5 \mathrm{~cm}$. long; seeds orbicular, slightly notched at the hilum. Plains, Neb. to Tex.

4. Opuntia Camánchica Engelm. Comanche Cactus. (I. F. f. 2530.) Prostrate, with obovate-urbicular flattened joints $15-20 \mathrm{~cm}$. long. Spines I-3, flattened, reddish brown to blackish, 3-8 cm. long, or with 3-6 additional shorter ones, the upper one suberect, the cthers deflexed or spreading; fruit oval, deep red, 3-5 cm. long; seeds angular, margined, deeply notched at the hilum. W. Kans. (?), Colo. to Tex. and Ariz.

5. Opun iz polyacántha Haw. Many-Spined Opuntia. (I. F. f. 253I.) Prostrate; joints obovate to orbicular, tubercled, $5-15 \mathrm{~cm}$. long, about $1.2 \mathrm{~cm}$. thick, the tubercles $4 \mathrm{~mm}$. high, densely spiny and with cushions of fine bristles; spines 5-12, slender, I-5 cm. long, whitish; leaves minute; flowers light yellow, 5-8 cm. broad; fruit dry, ve:y prickly, 2-3 cm. long. Prairies and dry soil, S. Dak. to Br. Col., Neb., Mo. and N. Mex. May-June.

6. Opuntia frágilis (Nutt.) Haw. Brittle Opuntia. (I. F. f. 2532.) Decumbent or prostrate; joints ovate, $2-5 \mathrm{~cm}$. long, nearly terete. Leaves small, reddish; cushions composed of lew bristles; central spines I-4, I-4 cm. long, gray, darker at the apex, surrounded by 46 smaller ones; flowers yellow, smaller than those of the preceding; fruit nearly $2.5 \mathrm{~cm}$. long, becoming dry at maturity, provided with cushi ns of bristles usually bearing a few short spines. Prairies and dry soil, Wis. and Minu. to S. Dak., Utah, Kans. and N. Mex.

7. Opuntia arloréscens Engelm. Northern Tree-l.ike Cactus. (I. F. f. 2533.) Erect, tree-like, I $8 \mathrm{~m}$. high, I-2 dm. in diameter at the base, verticillately branched. Joints verticillate, mostly in 3's and 4's, cylindric, $5-15 \mathrm{~cm}$. long, the tubercles $1.5^{-2} \mathrm{~cm}$. long; leaves terete, I-2 cm. long; spines 8-30, terete, in yellowish sheaths, diverging, the interior ones often $2.5 \mathrm{~cm}$. long or more; flowers purple, 6-8 cm. broad; fruit subglobose, tuberculate, dry, or nearly so, yellow, unarmed, about $2.5 \mathrm{~cm}$. in diameter. W. Kans., Colo. to Tex., N. Mex. and Mex.

\section{Order 25. THYMELEÀLES.}

Mostly shrubs or trces, with simple leaves and incomplete flowers. Calyx inferior, 4-5-lobed or entire. Corolla mostly wanting. Stamens twice as many as the calyx-lobes, or fewer. Ovary 1-celled. Ovule I, anatropous.

Leaves green; seed pendulous.

Leaves silvery-scurfy; seed erect.

Fam. r. Thymeleaceae. Fam. 2. Elaeagnaceae.

\section{Family 1. THYMELEÀCEAE Reichenb.}

\section{Mezereon Family.}

Shrubs or trees (rarely herbaceous), with tough inner bark, and entire estipulate leaves. Flowers fascicled, capitate, racemose, or rarely solitary, regular, mostly perfect. Calyx-tube cylindric or urn-shaped. Petals 
none in our genera. Stamens borne on the calyx, often in two series, anthers erect, 2-celled, the sacs longitudinally dehiscent. Ovary 1-celled, I-ovuled (2-celled and 2-ovuled in some Asiatic and Australasian genera); ovule pendulous; stigma terminal, mostly capitate. Fruit a berry-like drupe in our plants. Seed coat mostly crustaceous; embryo straight ; cotyleduns fleshy; endosperm little or none, or copious in some exotic genera. About 37 genera and 425 species, widely distributed, most abundant in Australia and South Africa.

Calyx-lobes 4, large; stamens included; style very short.

Calyx-limb almost wanting; stamens and style long, exserted.

I. Daphne.

2. Dirca.

\section{x. DÁPHNE L.}

Shrubs, with alternate leaves, and small purple pink or white flowers in fascicles, heads or racemes, borne in the following species at the leafless nodes of twigs of the preceding season. Perianth tubular, its 4 lobes spreading. Stamens 8 , in 2 series on the perianth-tube, included, or the upper 4 slightly exserted; filaments very short. Disk none. Ovary sessile or nearly so, I-celled; stigma large, capitate. Drupe ovoid, or oblong, the calyx deciduous or persistent. About 40 species, natives of Europe and Asia.

I. Daphne Mezèreum L. Spurge Laurel. Lady Laurel. Mezereon. (I. F. f. 2534.) A shrub 3-12 dm. high, the young twigs somewhat pubescent. Leaves thin, deciduous, oblong-lanceolate or oblanceolate, $7-13 \mathrm{~cm}$. long, narrowed into short petioles; flowers in sessile fascicles of 2-5, very fragrant; perianth-tube appressed-pubescent, rose-purple or white, $12 \mathrm{~mm}$. long or less, the ovate acute lobes nearly as long; drupe red, oval-ovoid, 6-8 mm. long. Escaped from cultivation, Quebec to Mass. and N. Y. Native of Europe and Asia. April-May.

\section{DÍRCA L.}

Shrubs, with tough fibrous bark, alternate thin short-petioled deciduous leaves, and yellowish flowers in peduncled fascicles of 2-4 from scaly buds at the nodes of twigs of the preceding season. Perianth campanulate or funnelform, its limb undulately obscurely 4 -toothed. Stamens 8 , borne on the perianth, the alternate ones longer; filaments very slender. Disk obsolete. Ovary nearly sessile; stigma small, capitate. Drupe red, oval oblong. [Named from a fountain in Thebes.] Two known species, the following and D. occidentalis A. Gray, of Cal.

I. Dirca palústris L. Leather-wood. Moose-wood. (I. F. f. 2535.) A shrub, 6-18 dm. high, the twigs yellowish green, glabrous. Leaves oval, or obo. vate, obtuse, glabrous, or very nearly so, and $5-8 \mathrm{~cm}$. long when mature; budscales 3 or 4 , oval, or oblong, very pubescent with brown hairs, deciduous; peduncle about $5 \mathrm{~mm}$. long; flowers nearly sessile; perianth 4-6 $\mathrm{mm}$. long; style longer than the stamens; drupe about $\mathbf{I ~} \mathrm{cm}$. long. In woods and thickets, N. B. to Minn., Va., Tenn. and Mo., and Fla. (according to Chapman). April-May.

\section{Family 2. ELAEAGNÀCEAE Lindl.}

\section{Oleaster Family.}

Shrubs or trees, mostly silvery-scaly, or stellate-pubescent, with entire leaves, the flowers clustered in the axils or at the nodes of $t w i g s$ of the preceding season, rarely solitary. Lower part of the perianth of perfect or pistillate flowers enclosing the ovary and persistent, the upper part 4-lobed or 4-cleft, leciduous (obscurely 2-lobed in the Old World Hippophö̈); perianth of staminate flowers 4-parted (2-parted in Hippophö̈). Stamens 4 or 8 , those of perfect flowers borne on the throat of the perianth; filaments mostly short; anthers 2-celled, the sacs longitudinally dehiscent. Disk annular, or lobed. Ovary sessile; ovule 1, anatropous ; style slender. Fruit drupe-like, the perianth-base becoming thickened and enclosing the achene or nut. Seed erect; embryo straight; endosperm little or wanting. Three known genera and about 20 species, widely distributed. 
Stamens as many $2 \mathrm{~s}$ the perianth-parts; flowers perfect or polygamous; leaves alternate. I. Elaeagnus.

Stamens twice as many as the perianth-parts; flowers diøcious: leaves opposite.

2. Lepargyraea.

\section{ELAEÁGNUS L.}

Silver-scaly shrubs, some exotic species trees, with petioled leaves. Flowers solitary or 2-4 together in the axils, pedicelled, not bracted. Perianth tubular below, constricted over the top of the ovary, the upper part deciduous, the lobes valvate. Stamens 4, borne on the throat of the perianth. Ripened perianth-base fleshy or mealy. [Greek, sacred olive.] About 20 species; only the following is known in N. Am.

I. Elaeagnus argéntea Pursh. Silver Berry. (I. F. f. 2536.) Stoloniferous, sometimes $4 \mathrm{ml}$. high, the young twigs covered with brown scurf, becoming silvery. Leaves oblong, ovate or oval-lanceolate, densely silvery-scurfy on both sides, sliort petioled, $2-10 \mathrm{~cm}$. long; flowers usually numerous, $\mathbf{I}$ to 3 in the axils, fragrant, silvery, I2-16 mm. long: perianth silvery without, yellowish within, its lobes ovate, about $2 \mathrm{~mm}$. long: fruit oval, silvery, 8-12 mm. long, the stone 8-striate. James Bay to the N. W. Terr., Quebec, Minn., S. Dak. and Utah. May-July.

\section{LEPARGYRAEA Raf. [SHEPHERDIA Nutt.]}

Shrubs, brown- or silvery-scurfy or stellate-pubescent, with petioled leaves. Flowers small, diøecious, or sometimes polygamous, subspicate or fascicled at the nodes of the preceding season, or axillary, the pistillate few or sometimes solitary. Pistillate flowers with a 4-lobed perianth, bearing an 8-lubed disk at its mouth which nearly closes it; style sonewhat exserted. Staminate flowers with a 4 parted perianth and 8 stamens alterıating with as many lobes of the disk; filaments short. [Greek, silvery-scaly.] Only the following species, and L. rolundifolia of Utah.

Leaves ovate or oval, green above, silvery beneath; shrub thormless. I. L. Canadensis. Leaves oblong, silvery on both sides; shrub mostly thorny.

2. L. argentea.

I. Lepargyraea Canadénsis (L.) Greene. Canadian Buffalo-berry. (I. F. f. 2537.) A thornless shrub, $\mathbf{I}-2.8 \mathrm{~m}$. high, the young shoots brownscurfy. Leaves ovate or oval, obtuse, $2-4 \mathrm{~cm}$. long, green and sparingly stellatescurfy above, densely silvery stellate-scurfy beneath; petioles 4-6 $\mathrm{mm}$. long; flowers yellowish; perianth about $4 \mathrm{~mm}$. broad: fruit cval, red or yellowish, 4-6 mm. long, the flesh insipid, the nut smooth. On banks, Newf. to Alaska, Me., N. Y., Mich. and Utah. April-June.

2. Lepargyraea argéntea (Nutt.) Greene. Buffalo-berRy. RabBitBERRY. (I. F. f. 2538.) A shrub, 2-6 m. high, the twigs often terminating in thorns. Leaves oblong, or sometimes oblong-lanceolate, 2-5 cm. long, obtuse at the apex, usually cuneate-narrowed at the base; densely silvery-scurfy on both sides: petioles 4-12 mm. long; flowers fascicled at the nodes; fruit oval, or ovoid, scarlet, sour, 4-6 mm. long, edible. Manitoba and Minn. to Saskatch., Kans. and Nev. April-May.

\section{Order 26. MYRTÀLES.}

Our species mostly herbs, many tropical and subtropical ones shrubs or trees. Leaves simple, often lobed or dissected. Petals usually present, distinct (wanting in some Haloragidaceae). Calyx gamosepalous, mostly superior or adnate to the compound ovary. Ovules usually numero:

Land or marsh plants; or, if aquatic, submerged leaves not dissected.

Calyx-tube merely enclosing the ovary, but free from it, except at the base. Anthers longitudinally dehiscent. Anthers opening by terminal pores.

Fam. r. Lythraceae.

Fam. 2. Melastomaceae.

Caly x-tube almost wholly adnate to the ovary.

Fam. 3. Onagraceae.

Aquatic or amphibious herbs, the submerged leaves dissected (except in Hippuris, which has whorled narrow leaves and onlv I stamen). 
Petioles of the broad floating leaves inflated; flowers rather large, white.

Fam. 4. Irapaceae.

Leaves mostly sessile; petioles, if present, not inflated; flowers small, greenish; seeds with I coat.

Fan. 5. Haloragidaceae.

Family I. LYTHRÀCEAE Lindl.

Loosestrife Family.

Herbs, shrubs, or often trees in tropical regions, mostly with opposite leaves and perfect flowers. Stipules usually none. Calyx persistent, free from the ovary, the limb toothed. Petals as many as the primary calyx-teeth; inserted on the calyx, or none. Stamens inserted on the calyx. Anthers versatile. Ovary 2-6-celled or sometimes 1-celled; style I; ovules $\infty$, rarely few, anatropous. Capsule 1-several-celled. Seeds without endosperm; cotyledons flat, often auricled at the base. About 21 genera and 350 species, of wide distribution.

Calyx-tube campanulate or hemispheric; flowers regular.

Flowers small, axillary, solitary or few; low herbs.

Petals 4 in our species; capsule bursting irregularly.

Petals none; capsule indehiscent.

Petals 4 ; capsule septicidally dehiscent.

Flowers large, in axillary cymes; large aquatic shrub. Calyx-tube cylindric; flowers regular.

Calyx-tube tubular, oblique; flowers irregular.

1. Ammannia.

2. Didiplis.

3. Rotala.

4. Decodon.

5. Lythrum.

6. Parsonsia.

\section{AMMÁNNIA L.}

Annual glabrous or glabrate herbs, mostly with 4-angled stems, opposite sessile narrow leaves, and small axillary flowers. Calyx campanulate, globose or ovoid, 4-angled, 4-toothed, often with small accessory teeth in the sinuses. Petals 4 in our species, deciduous. Stamens $4-8$, inserted on the calyx-tube. Ovary neariy globular, 2-4-celled, bursting irregularly. [Named for Johann Ammann, r699-174I, a German botanist.] About 2 species, of wide distribution.

Flowers sessile, solitary, or 2-5 together.

Leaves linear-lanceolate, acuminate; style elongated.

Leaves obovate or oblanceolate, obtuse; style very short. Flowers pedicelled, in axillary cymes.

I. A. coccinea.

2. A. Koehnei.

3. A. auriculata.

I. Ammannia coccínea Rottb. Long-leaved Ammannia. (I. F. f. 2539.) Erect, $1.5-5 \mathrm{dm}$. high. Leaves obtusely cordate-auriculate and dilated at the somewhat clasping base, entire, 2-8 cm. long. 2-6 mm. wide; flowers I-5 in each axil, sessile or nearly so; petals purple, fugacious; style very slender, usually more than one-half the length of the capsule. In swamps, Ind. and Iowa to S. Dak., Fla., Mex. and Brazil. July-Sept.

2. Ammannia Koèhnei Britton. Koenne's Ammannia. (I. F. f. 2540.) Erect, 1.5-5 dm. high. Leaves obovate, oblanceolate, or somewhat spatulate, the upper ones clasping and more or less auriculate at the base, the lower narrowed and sessile or tapering into a short petiole; flowers $I-3$ together in the axils, sessile; petals fugacious: stamens very short, not exserted; style very short; capsule enclosed by the calyx. In swamps, N. J. to Fla. July-Sept.

3. Ammannia auriculàta Willd. Wright's Ammannia. (I. F. f. 2541.) Erect, 5-25 cm. high. Leaves sessile, linear-lanceolate or oblong, acute or acutish at the apex, auriculate at the base, I-4 cm. long; cymes peduncled; pedicels I-3 mm. long: petals purple; style slender; stamens exserted; capsule partly enclosed by the calyx. Neb. to Tex. and Brazil. Also in Asia and Africa. May-June.

\section{DIDIPLIS Raf.}

Aquatic or marsh plants, with 4-angled stems, opposite narrow entire leaves, and small axillary solitary green flowers. Calyx hemispheric or campanulate, 4-lobed, with no accessory teeth. Stamens $2-4$, usually 4 , inserted on the calyx- 
tube; filaments very short. Ovary globose, 2-celled; style scarcely any; stigma obscurely 2-lobed; ovules $\infty$. Capsule 2-celled. [Greek, twice double.] A monotypic genus of east-central N. Am.

1. Didiplis diándra (Nutt.) Wood. Water Purslane. (I. F. f. 2542.) Submersed or rooting in the mud, $0.7-3 \mathrm{dm}$. long. Submersed leaves thin, elongated-linear or lanceolate, acute or acuminate at the apex, broader at the base, I-2 cm. long; emersed leaves linear-oblong, narrowed at the base; flowers about I $\mathrm{mm}$. long; capsule about I mm. in diameter. Minn. and Wis. to Tex. and Mex., N. Car. and Fla. Resembling Callitriche in habit. June-Aug.

\section{ROTÀLA L.}

Low annual mainly glabrous herbs, usually with opposite leaves, 4-angled stems, and axillary mainly solitary small flowers. Calyx campanulate or globose, 4-lobed. Stamens 4, short. Ovary free from the calyx, globose, 4-celled. Capsule globose, 4-celled, the valves minutely and densely striate transversely. [Latin, wheel, from the whorled leaves of some species.] About 30 species, of wide distribution.

1. Rotala ramòsior (I.) Koehne. RotalA. (I. F. f. 2543.) Glabrous, $5-25 \mathrm{~cm}$. high. Leaves oblong or linear-oblong, I-3 cm. long, blunt at the apex, narrowed and sessile at the base or tapering into a short petiole, not auricled; flow. ers solitary or rarely 3 in the axils, very small; petals minute; style almost none. In swamps, Mass. to Fla., Ill., Neb., Tex. and Mex. Also in Cal., Ore., S. Am. and the W. Indies. July-Sept.

\section{DÉcODON J. F. Gmel.}

Herbaceous shrubs, with verticillate or opposite, short-petioled entire leaves, and showy purple trimorphous flowers, in nearly sessile axillary cymes. Calyx broadly campanulate, or hemispheric, nerved, 5-7-toothed, with as many slender elongated accessory teeth in the sinuses. Stamens I0, rarely 8, alternately longer and shorter, inserted on the calyx-tube, the longer exserted. Style filiform; stigma small. Capsule globose, 3-5 celled, included in the calyx, loculicidally dehiscent. [Greek, ten-inothed, referring to the calyx.] A monotypic genus of eastern N. Am.

I. Decodon verticillàtus (L.) Ell. Swamp Loosestrife OR WillowHERB. (I. F. f. 2544.) Aquatic, somewhat woody, with angular recurved glabrous or slightly pubescent stems, I-3 m. long, which root from the tip when they reach the water or mud. Leaves lanceolate, $5-13 \mathrm{~cm}$. long, glabrous above, somewhat pubescent beneath, acute at both ends; petioles $4-8 \mathrm{~mm}$. long; flowers nearly $2.5 \mathrm{~cm}$. broad; petals cuneate at the base; capsule about $5 \mathrm{~mm}$. in diameter. In swamps, Me. to Fla., Ont., Minn., Ky. and La. Stems clothed with ærenchyma at the base. July-Sept. [Nesaea verticillata H. B. K.]

\section{LỲTHRUM L.}

Herbs or shrubs, with 4-angled stems, entire leaves, and often dimorphous or trimorphous flowers. Calyx tube 8-12-ribbed, straight, with 4-6 primary teeth and an equal number of accessory ones in the sinuses. Petals 4-6, usually obovate, rarely wanting. Stamens 8-12, inserted on the calyx-tube. Ovary oblong, sessile, 2-celled; style filiform; stigma mostly capitate; ovules numerous. Capsules enclosed by the calyx, membranous, 2-celled, 2-valved, or bursting irregularly. [Greek, gore, from the purple flowers.] About 23 species, of wide distribution. Besides the following, about 4 others occur in the southern and western U. S.

Flowers axillary, solitary; stamens not more numerous than petals.

Leaves mostly alternate.

Leaves obtuse; stamens all included; annual.

Leaves acute; stamens of short-styled flowers exserted; perennial.

Leaves mostly opposite.

Leaves narrowly linear, narrowed at the base.

Leaves ovate or oval, rounded or cordate at the base.

Flowers in panicled spikes, terminal; stamens twice as many as petals.

\section{L. alatum.}

3. L. lineare.

4. L. Vulneraria.

5. L. Salicaria.

1. Lythrum Hyssopifòlia L. Hyssop Loosestrife. Grass Poly. (I. F. f. 2545.) Glabrous, pale green, 1.5-6 dm. high. Leaves sessile, mainly alter- 
nate, the lowest sometimes opposite, oblong wr linear-oblong, 8--20 mm. long; flowers not dimorphous, pink-purple, about $1 \mathrm{~mm}$. broad; stamens included; calyx 5-6 mm. long in fruit. Borders of salt marshes, Me. to N. J. Also in Cal. and S. Am. Nat. from Europe. June-Sept.

2. I.ythrum alàtum Pursh. Wing-ANGled Loosestrife. (I. F. f. 2546.) Perennial, glabrous, dark green, 3-I2 dm. high, the stem angled and often slightly winged. Leaves sessile, alternate or the lowest opposite, lanceolate or oblong, rounded or cordate at the base, $\mathrm{x}-3 \mathrm{~cm}$. long; flowers short-pedicelled, deep purple, 6-Io mm. broad, dimorphous; ovary nearly sessile; calyx 5-6 $\mathrm{mm}$. long in truit. In low grounds, southern Ont. to Mass., Ky., S. Dak. and Kans. June-Aug.

3. Lythrum lineàre L. LiNeAR-LeAved LoOSESTR1FE. (I. F. f. 2547.) Perennial, glabrous, rather pale green, 6-I2 dm. high. Leaves sessile, $1-2.5 \mathrm{~cm}$. long, 2-4 mm. wide, nearly all opposite; flowers light purple or nearly white, dimorphous, about $3 \mathrm{~mm}$. broad; stamens of the short-styled flowers exserted; ovary short stalked; fruiting calyx 3-4 mm. long. Borders of salt marshes, N. J. to Fla. and Tex. July-Sept.

4. Lythrum Vulnerària Ait. Kennedy's Loosestrife. (I. F. f. 2548.) Spreading or ascending, perennial, glabrous, 3-12 dm long. Leaves short-petioled, or sessile, $8-18 \mathrm{~mm}$. long, 4-8 mm. wide, rounded or cordate at the base, mostly obtuse; flowers usually short-peduncled, purple, about $8 \mathrm{~mm}$. broad; stamens of the short-styled flowers exserted; fruiting calyx 8 -10 mm. long. St. Louis, Mo. (according to Koehne); Fla. to Mex. May-Aug.

5. Lythrum Salicària L. Spiked or PUrple Loosestrife. (I. F. f. 2549.) Perennial, 0.5-3 m. high. Leaves opposite or sometimes verticillate in 3's, sessile, lanceolate, cordate or clasping at the base, $5^{-8 \mathrm{~cm}}$. long; flcwers purple, trimorphous, 12-16 mm. broad, in terminal spikes; stamens 8-IO, alternately longer and shorter, even the longer ones little exserted; ovary short-stalked; fruiting calyx about $6 \mathrm{~mm}$. long. In swamps and wet meadows, Cape Breton Island to Ont. and Del. Said to be naturalized from Europe. June-Aug.

\section{PARSÓNSIA P. Br. [CUPHEA P. Br.]}

Herbs (or shrubs in tropical regions), with opposite or verticillate leaves. Flowers axillary, irregular and unsymmetrical. Calyx-tube elongated, i2-ribbed, gibbous or spurred at the base, oblique at the mouth, with 6 primary tee th and usually as many accessory ones. Petal.s 6, unequal. Stamens II (sometimes I 2 in our species), inserted on the throat of the calyx, unequal; filaments short. Ovary with a curved gland at its base, unequally 2 -celled; style slender; stigma 2-lobed. Capsule oblong, I-celled, laterally dehiscent. Sieeds flattened. [In honor of James Parsons, M. D., a Scotch botanist.] About 180 species, natives of America. Besides the following 2 others occur in the Southern States.

I. Parsonsia petiolàta (L.) Rusby. Blue Wax-weed. Clammy Cuphea. TAR-WEed. (I. F. f. 2550.) Annual, very viscid-pubescent, 1.5-5 dm. high. Leaves slender-petioled, ovate lanceolate, scabrous, mostly rounded at the base and blunt-pointed at the apex, 2-4 cm. long: flowers short-peduncled, purple, 6-8 $\mathrm{mm}$. broad; petals ovate, clawed; stamens sometimes 12 ; fruiting calyx swollen, about $8 \mathrm{~mm}$. long; capsule deliscent before the seeds are ripe, the placenta projecting through the lateral orifice. In dry soil, R. I. to Ill., Kans., Ga. and La. Introduced into S. Ont. July-Oct.

\section{Family 2. MELASTOMÀCEAE R. Br.}

\section{Meadow-Beauty Family.}

Herbs (many shrubs or trees in tropical regions), with opposite 3-9nerved leaves, and regular perfect often showy but rarely odorous flowers. Stipules none. Calyx-tube usually 4-5-lobed, the lobes imbricated. Petals as many as the lobes of the calyx, and inserted on its throat, imbricated. Stamens twice as many, or equal in number to the petals, often inclined or declined, the alternate ones sometimes shorter. Ovary 2-several-celled (often 4-celled); style terminal, simple; ovules $\infty$, ana- 
tropous. Capsule included in the calyx-tube, irregularly or loculicidally dehiscent. Seeds mainly small, with no endosperm. About 150 genera and 2500 species, widely distributed in tropical regions, most abundant in $\mathrm{S}$. Am. ; represented in N. Am. only by the following genus.

\section{RHÉXIA L.}

Perennial herbs, often somewhat woody at the base, sometimes tuber-bearing, with mostly sessile opposite 3-5-nerved leaves, and terminal showy cymose or rarely solitary flowers. Calyx tube urn-shaped or campanulate, constricted at the neck, its limb 4-lobed, the lobes shorter than the tube. Petals 4, obovate, oblique. Stamens 8, equal; anthers incurved or inverted in the bud. Ovary free from the calyx, glabrous, 4-celled; style slender; stigma truncate. Capsule 4-celied, 4-valved. Placentæ 4, central. Seeds numerous, coiled or bent, rough. [Grcek. breaking, applied originally to a different plant.] Ten known species, of eastern N. Am.

Stem cylindric, very pubescent.

Stem square or angled, pubescent or glabrous.

Stem more or less pubescent; leaves ovate.

Stem glabrous.

I. R. Mariana.

Leaves oblong or lance-oblong; calyx with a few hairs above. 3. R. aristosa.

Leaves ovate, bristly-ciliate; calyx glabrous.

4. R. ciliosa.

I. Rhexia Mariàna L. Maryland Meanow-Beauty. (I. F. f. 255I.) Stem rather slender, 3-6 dm. high. Leaves spreading, short-petioled, oblong, or linear-oblong, narrowed at the base, $2-4 \mathrm{~cm}$. long, pubescent with scattered bristly hairs, 3-nerved, the margins ciliate-serrulate: flowers loosely cymose, pedicelled, pale purple, about $2.5 \mathrm{~cm}$. broad; pedicels and calyx-tube glandular-pubescent; petals rounded or short-aristate. In swamps, pine-barrens of L. I. to Fla., Ky., Mo. and Tex. June-Sept.

2. Rhexia Virgínica L. Meadow-Beauty. Deer-Grass. (I. F. f. 2552.) Stem more or less pubescent, 3-5 dm. high. Leaves mostly sessile, ovate or ovate-oval, acute or acutish, 2-5 cm. long. usually with a few scattered hairs on both surfaces, mostly 5-nerved, the margins ciliate-serrulate; flowers bright purple, cymose, short-pedicelled, $2.5-4 \mathrm{~cm}$. broad; calyx tube and pedicels glandularpubescent; petals rounded or slightly retuse. In sandy swamps, Me. to Fla., Ill., Mo. and La. July-Sept.

3. Rhexia aristòsa Britton. Awn-petaled Meadow. Beauty. (I. F. f. 2553.) Stem square, 4-6 dm. high. Leaves sessile, erect. obtusish at each end, I.5-3 cm. long, 3-6 $\mathrm{mm}$. wide. 3 nerved, serrate toward the apex with appressed subulate teeth, glabrous or nearly so beneath, but with a few scattered hairs above; flowers I-4 together, short pedicelled, magenta-red, 2.5-4 cm. broad; petals rounded, but obtusely pointed and aristate at the apex; anthers linear, minutely spurred on the back. In sandy swamps, pine-barrens of N. J., Del. and S. Car. Base of the stem coated with a spongy tissue when growing in water. July-Aug.

4 Rhexia ciliòsa Michx. Ciliate MEadow Besuty. (I. F. f. 2554.) Stem square, 3-6 dm. high. Leaves ascending, short-petioled, or sessile, acutish, I-2 $\mathrm{cm}$. long, 8-12 $\mathrm{mm}$. wide, 3 nerved, glabrous or nearly so beneath, pubescent with a few scattered hairs above; flowers very short-pedicelled, violet-purple, $2.5-4 \mathrm{~cm}$. broad; petals rounded, sometimes apiculate; anthers oblong, not spurred on the back. In swamps, Md. to Fla, west to La. June-Aug.

\section{Family 3. ONAGRÀCEAE Dumort.*}

\section{Evening-primrose Family.}

Herbs. or rarely shrubs, with alternate or opposite leaves, no stipules or mere glands in their places, and generally perfect flowers. Calyx-tube adnate to the ovary, the limb 2-6-lobed (usually 4-lobed). Petals 2-9 (usually 4), convolute in the bud, rarely none. Stamens usually as many or twice as many as the petals. Ovary I-6-celled (usually 4-celled); 
styles united; stigma capitate, discoid or 4-lobed; ovules generally anatropous. Fruit a capsule or small nut. Endosperm very little or none. Forty genera and about 350 species of wide geographic distribution, most abundant in America.

Floral whorls of 4 parts or more.

Fruit a many-seeded capsule, opening by valves or by a pore.

Calyx-tube not prolonged beyond the ovary.

Seeds naked.

Stamens 4 , in I row.

Leaves opposite; stems creeping or floating.

Flowers sessile; petals none, or very small ; leaves petioled ; capsules sessile, short, the top flat. $\quad$ 1. Isnardia.

Flowers long-stalked; petals conspicuous; leaves sessile; capsules elongated, curved, with a prominent 4-lobed stylopodium.

Leaves alternate; stems erect or ascending.

Stamens $8-12$, in 2 rows.

Seeds furnished with a tuft of silky hairs.

Calyx-tube prolonged beyond the ovary.

Seeds furnished with a tuft of silky hairs.

Seeds naked or sometimes tuberculate.

Stamens equal in length.

Stigma deeply 4-cleft, its segments linear.

Ovules and seeds horizontal, inserted in 2 or rarely more rows, prismatic-angled.

Ovules and seeds ascending, not angled.

2. Ludvigiantha.

3. Ludvigia.

4. Jussiaea.

5. Chamaenerion.

6. Epilobium.

Buds erect; petals yellow; ovules and seeds in 2 rows.

8. Oenothera.

Buds drooping; petals white or pink; ovules and seeds in I row.

Stigmas entire or slightly 4-toothed.

9. Anogra.

Calyx-tube longer than the ovary; stigma disk-like, entire.

16. Galpinsia.

Calyx-tube shorter than the ovary; stigma disk-like, slightly 4-toothed.

Stamens unequal in length, the alternate ones longer.

17. Meriolix.

Ovules and seeds many, clustered, on slender funiculi; capsules usually club-shaped.

Flowers yellow. $\quad$ Io. Kneiffia.

Flowers white, pink or reddish.

I1. Hartmannia.

Ovules or seeds few, sessile, in I or 2 row's.

Plants normally acaulescent.

Capsules obtusely or retusely 4-angled; seeds furrowed along the raphe. $\quad$ 12. Pachylophus.

Capsules sharply 4 -angled or winged; seeds with a tubercle at one end.

Plants caulescent.

13. Lavauxia.

Stems wiry, diffuse; capsules sharply 4-angled.

Stems stout, not diffuse; capsules 4 -winged. 14. Gaurella.

Fruit indehiscent, nut-like.

15. Megapterium.

Calyx-tube obconic; filaments with scales at the base; ovary 4-celled.

Calyx-tube filiform; filaments unappendaged; ovary $\mathrm{x}$-celled. 18. Gaura.

19. Stenosiphon.

Floral whorls of 2 parts.

20. Circaea.

\section{ISNÁRDIA L.}

Succulent herbs. Stems creeping or floating; leaves opposite, relatively few, petioled. Flowers axillary, sessile, not yellow. Calyx-segments 4, shorter than the tube or slightly longer. Filaments very short. Ovary very short; styles often almost wanting. Capsule obovoid or turbinate, straight. [In honor of Antoine Dante Isnard, a French botanist, and a member of the Academy of Sciences, died 1724.] About 4 species in N. Am. and Mex.

I. Isnardia palústris L. Marsh Purslane. (I. F. f. 2555.) Stems branching, I-5 dm. long; leaves oval, ovate or spatulate, I2-25 mm. long, nar- 
rowed into slender petioles; flowers solitary, about $2 \mathrm{~mm}$. broad; bractlets at base of the calyx usually none; calyx-lobes triangular, acute; petals small, reddish, or often wanting; capsule 4-sided, slightly longer than wide, about $3 \mathrm{~mm}$. high. slightly exceeding the calyx lobes. In muldy ditches and swamps, N. S. to Man. itoba, Ore., Fla., Cal. and Mex. Widely distributed in the Old World. June-Nov.

\section{LUDWIGIÁNTHA Small.}

Fleshy herbs. Stems prostrate, creeping; leaves opposite, sessile, numerous. Flowers yellow, on slender bracted peduncles. Calyx-segments narrow, longer than the tube. Petals conspicuous, surpassing the calyx-segments. Filaments elongated. Oviry relatively long; united styles filiform, elongated. Capsule clubshaped, curved at the base, about as long as the persistent calyx-segments. [Derivation as in the following genus.] A monotypic genus.

I. Ludwigian ha arcuata (Walt.) Small. Curved podded Ludwigiantha. (I. F. f. 2556.) Stems glabrous ur nearly so, 8-30 cm. long. Leaves oblanceolate, leathery, smooth, obtusish at the apex, narrowed at the base, 12-25 $\mathrm{mm}$. long; fowers axillary, solitary, bright yellow, 8-12 $\mathrm{mm}$. broad; calyx lobes linear. lanceolate, acuminate, shorter than the obovate petals; capsule club-shaped, somewhat curved, glabrous, 8-10 mm. long. In swamps, Va. to Fla. May-July.

\section{LUDWÍgia L.}

Perennial or annual herbs, with alternate usually entire leaves, and axillary or terminal flowers. Stems erect or ascending, sometimes angled, or winged. Calyx lobes generally persistent. Petals usually 4. Stamens usually 4. Ovary 4-5celled. Capsule terete, ribbed or winged, septicidally dehiscent, or opening by an apical pore. [Named in honor of C. G. Ludwig, 1 709-1773, Professor of Botany at Leipsic.] About 25 species, natives of warm and temperate regions, most abundant in N. Am. Besides the following about Io others occur in the southern and southwestern States.

Flowers inconspicuous; petals none, or small, yellowish or greenish; valves of the capsule separating from the terminal disk.

Capsules subglobose or top-shaped.

Bractlets at the base of the calyx minute, or none; capsule subglobose, finely pubescent. $\quad$ r. L. sphaerocarpa.

Bractlets at the base of the caly $x$ linear, about equalling the capsule; capsule topshaped, glabrous.

Capsules cylindric or obpyramidal.

Capsules cylindric.

Capsules obpyramidal.

2. L. polycarpa.

Capsules as long as broad, or broader, the angles winged.

Capsules several times longer than broad, the angles obtuse.

3. L. glandulosa.

4. L. alata.

5. L. linearis.

Flowers showy, peduncled; petals large, bright yellow; capsules opening by an apical pore.

Plants hirsute; capsules bristly pubescent.

Plants glabrous or nearly so; capsules glabrous.

6. L. hirtella.

7. L. alternifolia.

I. Ludwigia sphaerocàrpa Ell. Globe-fruited LUdwigia. (I. F. f. 2557.) Stem generally finely pubescent, 6-9 dm. high, the lower part clothed with arenchyma when growing in water. Leaves sessile, those of the stem and branches lanceolate, acute at both ends, 5-10 $\mathrm{cm}$. long, scabrous and minutely denticulate, those of the stolons obovate: flowers sessile, greenish, about $3 \mathrm{~mm}$. broad; calyx-lobes triangular-ovate, acute; petals commonly none; capsule about $4 \mathrm{~mm}$. high, scarcely longer than the calyx-lobes. In swamps, eastern Mass. and southern N. Y. to Fla., west to La. July-Sept.

2. Ludwigia polycàrpa Short \& Peter. Many-fruited Ludwigia. (I. F. f. 2558.) Stems glabrous, 3-9 dm. high. Leaves sessile, narrowly lanceoliate, acute at each end, 5-10 cm long, rough-margined, those of the stolons spatulate; flowers sessile, about $3 \mathrm{~mm}$. broad, greenish; calyx-lobes triangular-lancenla'e, acute, sometimes serrulate; petals minute, greenish: capsule glabrous, sli; htly 4sided, about $5 \mathrm{~mm}$. high, often twice the length of the calyx lobes. In swamps, Ont, to Minn, and Mass., south to Ky., Neb, and Kans. July-Oct. 
3. Ludwigia glandulòsa Walt. Cylindric-Fruited Ludwigia. (I. F. f. 2559.) Stems glabrous, much branched, 3-9 dm. high. Leaves sessile or narrowed into short petioles, oblong-lanceolate, acute at each end, 5-ro $\mathrm{mm}$. long; flowers axillary, rarely 2 together, greenish, about $2 \mathrm{~mm}$. broad; bractlets at base of calyx minute or none; calyx lobes triangular ovate, acute; petals none; capsule 4-grooved, $6.8 \mathrm{~mm}$. long, glabrous, 4-5. times as long as the calyx lobes. In swamps, southern Ill. and Mo. to Kans., Tex., east to Fla. and S. Car. July-Sept.

4. Ludwigia alàta Ell. Wing-STEMmed Ludwigia. (I. F. f. 2560.) Stems 3-9 dm. tall, winged, often stoloniferous; lea ves linear-oblanceolate to linearlanceolate, or sometimes nearly linear, $2.5-\mathrm{ro} \mathrm{cm}$. long, those of the stolons suborbicular or spatulate; flowers inconspicuous, about $4 \mathrm{~mm}$. broad, white or greenish; calyx glabrous, its segments triangular-ovate, acute or acuminate; petals none; cap. sules 3-4 mm. high, winged; seeds about $0.5 \mathrm{~mm}$. long, faintly pitted. In marshes, N. Car. to Mo., Fla. and La. June-Sept.

5. Ludwigia lineàris Walt. Linear-Leaved Ludwigia. (I. F. f. 256r.) Stems branching, glabrous, $3-7.5 \mathrm{dm}$. high, often stoloniferous, lower part clothed with ærenchyma. Leaves narrowly linear, sessile, acute at each end, $2.5-5 \mathrm{~cm}$. long, about $2 \mathrm{~mm}$. wide, the margins roughish, or those of the stolons obovate; flowers sessile, about $4 \mathrm{~mm}$. broad; calyx-lobes triangular.ovate, acute, slightly shorter than the yellowish petals; capsule narrowed at the base, 6-8 $\mathrm{mm}$. long, 3-5 times as long as the calyx-lobes. In swamps, soutliern N. Y. to Fla., west to La. July-Sept.

6. Ludwigia hirtélla Raf. Hairy Ludwigia. (I. F. f. 2562.) Stems branching, 3-6 dm. high. Leaves oblong-lanceolate or ovate-lanceolate, sessile, obtuse at the apex, rounded at the base, $2.5-3 \mathrm{~cm}$. long: flowers solitary, peduncled, 12-20 $\mathrm{mm}$. broad; calyx-lobes ovate-lanceolate, acute, somewhat shorter than the yellow petals; capsules cubic with a rounded base, about $5 \mathrm{~mm}$. high, shorter than the calyx-lobes, opening by an apical pore. In swamps, pine barrens of N. J. to Fla., west to Tex. June-Sept.

7. Ludwigia alternifòlia L. Seed-box. Rattre box. (I. F. f. 2563.) Stems branching, 6-12 dm. high. Leaves short petioled, lanceolate, acute or acuminate at the apex, 5-12 cm. long; flowers short-peduncled, solitary, 12-16 mm. broad; calyx-lobes ovate, acuminate. about equalling the yellow petals which fall away when the plant is shocked; capsules cubic with a rounded base, slightly wing-angled, about $5 \mathrm{~mm}$. high, opening by a pore. In swamps, N. H. to northern N. Y., Ont.(?), Mich., Fla., Kans. and Tex. Roots often tuberous. June-Sept.

Ludwigia alternifolia linearifolia Britton. Leaves linear, elongated; calyx-lobes linear-lanceolate; petals more persistent. W. Va.

\section{JUSSIAÈA L.}

Perennial herbs, with alternate, usually entire leaves, and white or yellow, axillary flowers. Calyx-lobes acute, persistent. Petals 4-6 (rarely more). Stamens 8-12, in 2 rows. Ovary 4-6 celled. Capsule linear, oblong or club shaped, angular or ribbed, septicidally dehiscent. [In honor of Bernard de Jussieu, r6991777, founder of the Natural System of Botany.] About 35 species, of warm and temperate regions. Besides the following 7 others occur in the Southern States.

Creeping or floating; petals 5 ; capsule cylindric.

Erect; petals 4; capsule club-shaped, 4-sided.

I. J. diffusa.

2. J. decurrens.

I. Jussiaea diffùsa Forskl. Floating oR CReeping Jussiaea or PRimROSE-WILLOW. (I. F. f. 2564.) Stem 3-9 dm. long. Leaves oval, oval-lanceolate or obovate, slender-petioled, veiny, obtuse or acute at the apex, $2.5-10 \mathrm{~cm}$. long; peduncles slender; flowers yellow, $12-25 \mathrm{~mm}$. broad; calyx-lobes 5 , lanceolate; stamens Io; capsule ridged, $2.5-4 \mathrm{~cm}$. long; seeds in $\mathrm{I}$ row in each cavity. In ponds, Ky. and Ill. to Kans., Fla. and Tex. Also in trop. Am. and Asia. JuneAug.

2. Jussiaea decúrrens (Walt.) DC. Upright Primrose-willow. (I. F. f. 2565.) Stem angled, branching, $36 \mathrm{dm}$. high. Leaves lanceolate, acute or acuminate at the apex, decurrent on the stem, $2.5-10 \mathrm{~cm}$. long; flowers short-peduncled, yellow, 8-12 mm. broad; calyx-lobes 4, ovate-lanceolate; stamens 8; cap- 
sule 2-3 times as long as the peduncle, 4 -sided, the angles somewhat winged; seeds in several rows in each cavity. In swamps, Md. to Ga., Fla., Ill., Ark. and Tex. July-Sept.

\section{CHAMAENÈRION Adans.}

Perennial herbs, with tufted stems, often woody at the base. Leaves mostly alternate, entire; flowers irregular, showy, in terminal racemes; calyx-tube not prolonged beyond the ovary; calyx-segments 4 , deciduous; petals 4 , entire; sta-1 mens 8, declined; filaments dilated at the base; stigmas 4-cleft. Capsule obtusely. 4-angled, elongated, opening loculicidally. Seeds with a tuft of hairs (coma) at the end. [Greek, ground rose-bay.] About 4 species, chiefly in the north temperate zone.

Bracts small; lateral nerves of the leaves confluent in marginal loops; style pubescent at the base.

I. C. angustifolium. Bracts leaf-like; lateral nerves of the leaves obsolete; style glabrous. 2. C: latifolium.

I. Chamaenerion angustifolium (L.) Scop. Great or SPIKED WillowHERB. FIRF-WEen. (I. F. f. 2566.) Erect, often finely pubescent above, $0.5^{-2.5} \mathrm{~m}$. high. Leaves lanceolate, $515 \mathrm{~cm}$. long, pale beneath, acute at the apex; flowers $1.5-3 \mathrm{~cm}$. broad, purple, or sometimes white, in elongated terminal spike-like racemes; capsules $5-7.5 \mathrm{~cm}$. long, finely canescent, at least when young; secds about I mm. long, the coma long, whitish. In dry soil, Lab. to Alaska, N. Car., Kans., Ariz. and Cal. Also in Europe and Asia. Junt-Sept.

2 Chamaenerion latifòlium (L.) Sweet. BRoAd-Leaved Willow-Herb. (I. F. f. 2567.) Erect, often quite canescent above, I.5-5 dm. high. Leaves $2.5-5 \mathrm{~cm}$. long, lanceolate or ovate-lanceolate, acutish at both ends, thick, those of the branches opposite, the veins inconspicuous; flowers purple, $2.5-5 \mathrm{~cm}$. broad, in mainly short leafy-bracted racemes; capsules $\mathbf{I}-3 \mathrm{~cm}$. long, canescent; seeds about $2 \mathrm{~mm}$. long; coma elongated. whitish. Moist ground, Newf. to Alaska, Quebec, Colo. and Ore. Also in Europe and Asia. June-Aug.

\section{EPILòBIUM I.}

Herbs, or sometimes shrubby plants, with alternate or opposite leaves, and solitary, spicate or racemose flowers. Calyx tube prolonged beyond the ovary, the limb 4-parted, deciduous. Petals 4, often notched. Stamens 8: stigma clubshaped or 4-lobed. Capsule narrow, elongated, 4-sided, loculicidally dehiscent by 4 valves. Seeds with a tuft of hairs (coma) at the summit. [Greek, upon a pod, flower and pod appearing together.] About 65 species, of wide geographic distribution, most abundant in temperate regions. Besides the following, about 30 others occur in the western and northwestern parts of $\mathrm{N}$. Am.

Stigma deeply 4-lobed; flowers large.

1. E. hirsutum.

Stigma entire, or merely notched.

Seeds smooth or nearly so; arctic or alpine species.

Flowers white; leaves usually denticulate.

Flowers violet; leaves mostly entire.

Seeds papillose.

Leaves linear or lanceolate, entire or nearly so.

Plants crisp-pubescent or canescent.

Leaves sessile, mostly obtuse. $\quad 4$. E. palustre.

Leaves petioled, very narrow, acute.

Plants glandular-pubescent throughout, or only above.

Densely glandular throughout; leaves sessile. 6. E. strictim.

Glandular-pubescent above; leaves petioled. 7. E. faniculatum.

Leaves lanceolate or ovate, serrate.

2. E. alpinum.

3. E. anagallidifolium.

Leaves lanceolate, acute or acuminate.

Seeds obconic, beakless; coma reddish.

Seeds ellipsoid, short-beaked; coma white.

Leaves ovate, thin, obtuse.

8. E. coloratum.

9. E. adenocaulon.

ro. E. Hornemanni.

I Epilobium hirsùtum L. Great Hairy Willow-herb. (I. F. f. 2568.) Strut, 5-I2 dm. high. softly hirsute-pubescent. Leaves lanceolate or oblong-lanceolate, usually opposite, often clasping at the base, acute at the apex, sharply ser. 
rulate, $2.5-7.5 \mathrm{~cm}$. long; flowers erect, rose-purple, about $2.5 \mathrm{~cm}$. broad; petals pubescent at the base within; capsule stalked, 5-7.5 cm. long. about $2 \mathrm{~mm}$. thick; seeds about I mm. long; coma whitish. In waste places, eastern N. Eng., N. Y., Ont. and in ballast about the seaports. Adventive from Europe. June-Sept.

2. Epilobium alpinum L. Alpine Willow-Herb. (I. F. f. 2569.) Slender, glabrous or nearly so, 8-30 $\mathrm{cm}$. high. Leaves pale, petioled, opposite, or the upper alternate, obtuse or obtusish at the apex, 12-20 mm. long; flowers few, nearly erect, 4-8 mm. broad; stigma nearly entire; capsules slender-stalked, 2.5-5 cm. long, about I mm. thick; seeds beaked. Lab. to Br. Col., N. H., Utah and Ore. Also in Europe. Summer.

3. Epilobium anagallidifòlium Lam. Pimpernel Willow-herb. (I. F. f. 2570.) Low, usually tufted, 5-15 $\mathrm{cm}$. high, resembling the next preceding species. Stems commonly pubescent in lines and nodding at the apex; leaves oblong or narrowly ovate, obtuse at the apex, short-petioled, IO-20 $\mathrm{mm}$. long; flowers few, clustered, nodding, about $5 \mathrm{~mm}$. broad; stigma entire; capsule slenderpedicelled, about $2.5 \mathrm{~cm}$. long, I $\mathrm{mm}$. wide: seeds smooth, short-beaked, about $\mathbf{I} \mathrm{mm}$. long. Lab. and through arctic Am. to Alaska, south in the Rocky Mts. to Nev. Also in Europe and Asia. Summer.

4. Epilobium palústre L. Marsh or Swamp Willow-herb, (I. F. f. 257 I.) Erect, usually simple, I.5-4 dm. high, canescent above with incurved hairs. Leaves mostly opposite, lanceolate-oblong, obtuse or subtruncate at the apex, 2.5-5 cm. long, erect or ascending, distinctly veined; flowers few, pink or whitish, usually nodding at first, 4-6 mm. broad; fruiting pedicels slender; cap. sules $2.5-5 \mathrm{~cm}$. long, slightly more than I mm. thick; seeds about I mm. long, a little papillose translucent, the apex scarcely narrowed. In bogs, N. B. to Alaska, the White Mts., Ont., Colo. and Wash. Also in Europe and Asia. Summer.

5. Epilobium lineàre Muhl. Linear-leaved Willow-herb. (I. F. f. 2572.) Slender, canescent throughout with incurved hairs, 3-6 dm. high, at length much branched. Leaves linear or linear-lanceolate, mostly short-petioled, opposite or alternate, acute at both ends, $2.5-5 \mathrm{~cm}$. long, the veins obscure; flowers erect, pink or whitish, 4-8 $\mathrm{mm}$. broad: stigma entire or slightly notched; pedicels mostly slender; capsules about $5 \mathrm{~cm}$. long; seeds less than $2 \mathrm{~mm}$. long, slightly papillose. In swamps, N. B. to Del., W. Va., Br. Col., the Ind. Terr. and Wyo. July-Sept. Sometimes produces bulblets near the base of the stem.

6. Epilobium stríctum Muhl. Downy OR SOFT Willow-Herb. (I. F. f. 2573:) Erect, usually much branched, 3-9 dm. high, glandular-pubescent with whitish somewhat spreading hairs. Leaves broader than those of the next preceding species, lanceolate, obtuse or obtusish, 1.8-4 cm. long, mostly entire, evidently veined; flowers pink or whitish, about $4-5 \mathrm{~mm}$. broad; capsules nearly $2 \mathrm{~mm}$. thick, short-pedicelled; seeds obconic, papillose. Bogs, Me. to W. Ont. and Minn., south to Va. and Ill. July-Sept.

7. Epilobium paniculàtum Nutt. Panicled Willow-Herb. (I. F. f. 2574.) Annual, slender, 3-6 dm. tall, loosely branched, glandular-pubescent above. Leaves alternate, varying from linear to linear-lanceolate, $2.5-7.5 \mathrm{~cm}$. long, denticulate or nearly entire, attenuate into slender winged petioles; calyx often purple, its tube funnelform, 2-3 mm. long, shorter than the lanceolate segments; petals cuneate, notched, $6-8 \mathrm{~mm}$. long, violet; capsules ascendirig, linear-fusiform, $2-3 \mathrm{~cm}$. long, curved; seeds obovoid, $2 \mathrm{~mm}$. long, bláck, slightly papillose. Lake Huron to Br. Col., Colo., Ariz. and Cal. Summer.

8. Epilobium coloràtum Muhl. Purple-leaven Willow-irerb. (I. F. f. 2575.) Erect, much branched, 3-9 dm. high, more or less canescent above with incurved hairs often arranged in lines. Stem and leaves often purplish; leaves generally slender petioled but sometimes sessile, lanceolate, acute or acuminate at the apex, sharply serrulate or denticulate, 5-15 cm. long: flowers numerous, pink or white, 4-6 mm. broad, generally nodding; capsules short-pedicelled, finely pubescent, 2.5-5 cm. long, about $2 \mathrm{~mm}$. thick; seeds papillose, less than $2 \mathrm{~mm}$. long. In low grounds, Me. to Ont., Wis., S. Dak., S. Car. and Kans. July-Sept.

9. Epilobium adenocaùlon Haussk. Northern Willow Herb. (I. F. f. 2570.) Closely resembling the next preceding species, but the inflorescence and capsules glandular pubescent. Leaves lanceolate or ovate-lanceolate, obtusish or sometimes acute, sparingly serrulate or denticulate, seldom over $6.5 \mathrm{~cm}$. long; 
flowers usually nodding at first; seeds abruj tly short-beaked, about $1 \mathrm{~mm}$. long, papillose. In moist grounds, N. B. to Ore., south to Mass., Penn., Iowa, Utah and Cal. July-Sept.

Io. Epilobium Hornemánni Reichenb. Hornemann's Willow-herb. (I. F. f. 2577.) Erect, I.5-3 dm. high, simple or nearly so, slightly pubescent above. Leaves short-petioled, ovate or elliptic, mostly broadly obtuse at the apex, rather remotely denticulate, $1.2-3 \mathrm{~cm}$. long; flowers tew, purple or violet, 6-7 $\mathrm{mm}$. broad; stigma entire; capsules $2.5-6 \mathrm{~cm}$. long, nearly glabrous, slender-pedicelled; seeds about I mm. long, papillose, nearly beakless. Moist places, White - Mts. to Lab., west to Wis. and Br. Col., south in the Rocky Mts. to Colo., and to Cal. Also in Europe. Summer.

\section{7. ÓNAGRA Adans. (See Appendix.)}

Annual or biennial herbs, with mostly erect stems. Leaves alternate, undulate or toothed; buds erect. Flowers yellow, nocturnal, in terminal spikes. Calyxtube elongated. Ovary 4-celled; ovules in 2 or more rows, horizontal. Capsule 4-angled, more or less tapering, opening loculicidally. Seeds prismatic-angled. [Greek, the wild ass, said to refer to the similarity of its leaves to the ears of that animal.] About 12 species, chiefly North American.

Flowers relatively small; petals narrow, $2-4 \mathrm{~mm}$. wide.

I. O. cruciata.

Flowers relatively large; petals broad, $12-50 \mathrm{~mm}$. wide.

Capsules $2-3 \mathrm{~cm}$. long or shorter, abruptly narrowed at the apex; pubescence not velvety.

Stems slightly hispid; capsules glabrous or sparingly pubescent.

Stems very strigose; capsules copiously pubescent.

2. O. biennis.

3. O. strigosa.

Capsules $3 \mathrm{~cm}$. long or longer, gradually narrowed to the apex; pubescence velvety.

4. O. Oakesiana.

r. Onagra cruciàta (Nutt.) Small. Sirall-flowered Evening-PRimrose. (I. F. f. 2578.) Glabrous or sparingly villous. Stem erect, 6-I2 dm. tall, usually simple; leaves narrowly oblung or oblanceolate (the upper ones often lanceolate), 4-10 cm. long, acute, serrate-denticulate, the lower ones slender-petioled, the uppermost nearly sessile; spikes I-3 dm. long, leafy-bracted; calyx-tube slender, 8-25 $\mathrm{mm}$. long, sparingly villous; petals linear, IO-12 $\mathrm{mm}$. long, acutish; capsules $2.5^{-2.8} \mathrm{~cm}$. long, gradually narrowed from the base. Me. to N. Y. and Mass. Aug.-Oct.

2. Onagra biénnis (L.) Scop. Common Evening-Primrose. Night WiLLOW-HERB. (I. F. f. 2579.) Erect, generally stout, 3-25 dm. high, more or less hirsute pubescent. Leaves lanceolate, acute or acuminate, sessile or the lower petioled, repand-denticulate, $2.5^{-15} \mathrm{~cm}$. long; flowers spicate, leafy bracted, bright yellow, 2.5-5 cm. broad; calyx-tube slender, much longer than the ovary; capsules oblong, narrowed above, erect, pubescent, 18-25 mm. long, nearly terete; seeds nearly $2 \mathrm{~mm}$. long. Usually in dry soil, Lab. to Fla., west to the Mississippi Valley. Nat. in the Old World. June-Oct.

Onagra biénnis grandiflòra (Ait.) Lindl. Stouter. Leaves larger, thicker and broader; flowers $5^{-10} \mathrm{~cm}$. broad. Range nearly that of the species; common southward.

3. Onagra strigòsa Fydb. Striguse Evenisg-primrose. Strigose and somewhat villous above with grayish hairs, 4-10 cm. high. Leaves various, the basal obovate or spatulate, obtuse; stem-leaves oblanceolate to lanceolate, $5-10 \mathrm{~cm}$. long or the upper shorter, acute, undulate; spike leafy-bracted, many-flowered; calyx-segments with short free tips; corollas pure yellow, $3-4.5 \mathrm{~cm}$. broad; capsules 2.5-3 cm. long. In rich soil, S. Dak. and Mont. to Neb. Summer. Nat. about eastern seaports.

4. Onagra Oakesiàna (A. Gray) Brittor. OAKes' Evening-PRimrose. (I. F.f. 2580.) Resembling the next preceding species, dull green, pubescent with appressed velvety hairs. Stem 3-12 dm. tall, often simple; leaves narrow, the basal narrowly oblanceolate, $7 \cdot 5^{-25} \mathrm{~cm}$. long, the cauline lanceolate or linear-lanceolate, all acute, distantly dentate; flowers $2.5-3.3 \mathrm{~cm}$. broad; calyx-tube about $2.5 \mathrm{~cm}$. long; capsule linear-pyramidal, gradually narrowed to the summit, 3- 
$3.7 \mathrm{~cm}$. long, 4-sided, curved; seeds about $2 \mathrm{~mm}$. long. Shores of the St. Law. rence and along the Great Lakes, to Mass., southern N. Y. and Neb. Summer.

\section{OENOTHÈRA L.}

Usually low annual biennial or perennial caulescent herbs. Leaves alternate, sinuate or pinnatifid. Flowers yellow, axillary, or sometimes in terminal spikes, nocturnal; buds erect. Calyx-tube sometimes filiform; calyx segments deciduous. Ovary 4-celled, elongated; ovules in 2 rows, ascending. Capsules usually narrowly cylindric, sometimes slightly tapering, spreading or ascending. Seeds terete, crowned by a tubercle. [Greek, wine-scenting, the roots being once used for that purpose.] About 20 species, in N. Am. and western S. Am.

Flowers axillary.

Silvery-pubescent with appressed or ascending hairs; seeds striate.

Glabrous or sparingly hirsute-pubescent; seeds pitted. Flowers in terminal bracted spikes.

r. $O E$. Inumifusa.

2. $O E$. laciniata.

3. $O E$. rhombipetala.

I. OEnothera humifùsa Nutt. Seaside Evening-Primrose. (I. F. f. 258I.) Spreading and decumbent, or ascending, branched from the base; stems 2-5 dm. long. Leaves acutish or sometimes obtuse at the apex, $1.2-5 \mathrm{~cm}$. long, repand-denticulate, the lower pinnatifid; flowers axillary, yellow, $12-20 \mathrm{~mm}$. broad; calyx-lobes somewhat spreading; capsule linear, 12-24 $\mathrm{mm}$. long, about $3 \mathrm{~mm}$. thick, very pubescent; seeds striate longitudinally. On sea-beaches, N. J. to Fla. June-Sept.

2. OEnothera laciniàta Hill. Sinuate-leaved Evening primrose. (I. F. f. 2582.) Decumbent or ascending, sometines branched, I-5 dm. high, glabrous or sparingly hirsute-pubescent. Leaves oval-lanceolate, oblong, or oblanceolate, acute or obtusish at the apex, sinuate-dentate or often pinnatifid, $2.5-5 \mathrm{~cm}$. long; flowers axillary (or on small plants sometimes solitary and terminal), I2 $36 \mathrm{~mm}$. broad; calyx-lobes reflexed; capsule linear, 2.5-3.5 cm. long, about $2 \mathrm{~mm}$. thick, more or less pubescent; seeds strongly pitted. In sandy dry soil, southern N. J. to Penn., Ill. and Neb., south to Fla., Tex. and Mex., extending into S. Am. MayJune. Naturalized in Vt.

o nothera laciniata grándis Britton. Similar to the species, but the leaves more prominently toothed and the flowers $5-7 \mathrm{~cm}$. broad. Mo. and Kans., south to Tex.

3. OEnothera rhombipétala Nutt. Rhombic Evening-Primrose. (I. F. f. 2583.) Erect, firely and densely appresserl-pubescent, 6-12 dm. high. Leaves linear. lanceolate, sessile and rounded at the base or the lower narrowed into petioles, acuminate at the apex, remotely denciculate, 5-10 $\mathrm{cm}$. long; flowers $2.5-5 \mathrm{~cm}$. broad; calyx-lobes canescent; petals rhombic obovate; capsule columnar, curved, pubescent, 12-16 mm. long, about $2 \mathrm{~mm}$. thick: seeds obovoid, tuberculate at the top. On prairies, Minn. to Ind., Neb. and the Ind. Terr. June-July.

\section{9. ÁNOGRA Spach. (See Appendix.)}

Low annual or perennial canescent herbs, often with a papery bark. Leaves alternate, usually pinnatifid. Buds drooping; flowers white or pink, usually axillary, diurnal. Calyx-tube elongated. Ovary elongated; ovules numerous, in $\mathrm{f}$ row, ascending. Capsules elongated, spreading or ascending, loculicidal. Seeds terete. [Anagram of Onagra.] About Io species, chiefly in southern N. Am.

Tips of the calyx-segments not free in the bud.

1. A. albicaulis.

Tips of the calyx-segments free in the bud.

Throat of the calyx-tube villous within.

Throat of the calyx-tube glabrous within.

2. A. coronopifolia. 3. A. pallida.

1. Anogra albicaùlis (Pursh) Britton. Prairie Evening-Primrose. (I. F. f. 2584.) Diffusely branched; branches decumbent or ascending, more or less hirsute or puberulent, whitish and often shreddy, I-3 dm. long. I.eaves ob. lanceolate or lanceolate, deeply pinnatifid or the lowest repand-dentate (rarely entire), 2.5-10 cm. long; flowers $3.5-7.5 \mathrm{~cm}$. broad, white, becoming rose-color; petals obcordate or emarginate; calyx-segments lançeolate, acuminate, hirsute; 
capsule linear, $2.5-3.5 \mathrm{~cm}$. long, about $2 \mathrm{~mm}$. thick; seeds finely pitted. Prairies, N. Dak. and Neb. to N. Mex. and Sonora. April-June.

2. Anogra coronopifolia (T. \& G.) Britton. Cut-leaved Evening-PrimROSE. (I. F. f. 2585.) Erect, branched, I.5-6 din. high, more or less hispid or canescent. Leaves lanceolate or oblanceolate in outline, $1.2-5 \mathrm{~cm}$. long, usually finely and deeply pinnatifid into linear-oblong lobes; flowers white, turning pink, r.8-3 cm. broad; calyx-segments linear; petals broadly obovate; capsule oblong, abruptly constricted at the top, straight, $8-20 \mathrm{~mm}$. long, alout $4 \mathrm{~mm}$. thick; seeds tuberculate. Prairies, S. Dak. to Colo., Utah, Kans. and N. Mex. Jume-Sept.

3. Anogra pállida (Liidl.) Britton. White-stemmed Evenis(y-1'Rimrosf. (I. F. f. 2586.) Erect, I.5-I2 dm. high; stems white or pale, rarely with scattered liairs, the bark often shreddy. Leaves linear or oblong-linear, entire, repand or somewhat pinnatifid, $2.5-8.5 \mathrm{~cm}$. long; flowers white, turning pink. $2.5-3.5 \mathrm{~cm}$. broad; segments of the calyx linear; petals nearly orbicular; capsule linear, curveil, 2.5-5 cm. long, about $3 \mathrm{~mm}$. thick; seeds smooth. Prairies, Minn. to Br. Col., Neb., Mex. and Cal. May-Aug.

\section{Io. KNEİFFIA Spach. (See Appendix.)}

Usually slender annual or perennial caulescent shrubby herbs. Leaves mostly narrow, entire or toothed. Buds mostly erect. Flowers yellow, diurnal, in terminal spikes or racemes. Calyx-tube slender. Uvary usually club-shaped, 4angled; ovules numerous, on slender stalks, in many rows. Capsules club-shaped, or oblong by the wings, 4-winged or rarely sharply 4 angled. Seeds not angled, without a tubercle. [In honor of Prof. C. Kneiff, of Strassburg, who wrote on cry ptogamic botany.] About ro species, mostly in temperate N. Am.

Stem-leaves filiform-linear; capsules 4 -angled or very slightly 4 -winged.

Stem-leaves never approaching filiform; capsules prominently winged.

I. $K$. linifolia.

Capsules club-shaped.

Pedicels and capsules pubescent.

Stems decumbent, spreading; body of the capsule becoming subglobose. 2. K. Alleni.

Stems erect or nearly so; body of the capsule more or less elongated.

Pedicel longer than the body of the capsule, the wings thick and pubescent.

3. $K$. longipedicellata.

Pedicel shorter than the body of the capsule, the wings thin and gla$\begin{array}{ll}\text { brous. } & \text { 4. K. linearis. }\end{array}$

Pedicels and capsules glabrous or glabrate. $\quad 5 . K$. pumila.

Capsules oblong or nearly so.

Plants not glaucous, usually pubescent; capsules less than $8 \mathrm{~mm}$. long.

6. K. fruticosa.

Plants somewhat glaucous, glabrous; capsules more than io mm. long.

7. K. glauca.

I. Kneiffia linifollia (Nutt.) Spach. Thread-Leaved Sundrops. (I. F. f. 2587.) Erect, very slender, I.5-4.5 dm. high, finely pubescent ahove. Stemeaves filiform linear, entire, $12-30 \mathrm{~cm}$. long; basal leaves tufted, oblanceolate or spatulate, about $2.5 \mathrm{~cm}$. long; flowers in loose spike-like racemes, $6-8 \mathrm{~mm}$. broad; calyx-tube rather shorter than the ovary; stigma-lobes very short; capsule obovoid, puberulent, sharply 4-sided, 4-6 mm. long. In dry soil, Ill. to Kans., Ga., Lil. and Tex. May-July.

2. Kneiffia Álleni (Britton) Small. Allex's Suxdrops. (I. F. f. 2588.) Low, appressed pubescent; stems decumbent, diffusely branched, 0.8 . $6 \mathrm{dm}$. long. zigzag. Leaves oblanceolate to lanceolate, $1.2-3 \mathrm{~cm}$. long, unclulate; flowers about $2.5 \mathrm{~cm}$. broad; calyx villous, its tube 4-6 mm. long. its segments linear-oblong, as long as the tube; petals orbicular-obovate; capsules club.shaped, 6-8 mm. long, the body winged, shorter than the pedicel; seeds obovoid to oblong, minutely pitted in rows. In sand, eastern L. I. June-Aug.

3. Kneiffia longipedicellàta Small. Long-Stemmed Sundrops. (I. F. f. 2589 .) Slender, puberulent; stems erect or assurgent, 3-8.5 dm. tall. Basal leaves spatulate or obovate-spatulate, $3 \cdot 5-7 \cdot 5 \mathrm{~cm}$. long; stem leaves few, linear-lanceolate, $2.5-6.5 \mathrm{~cm}$. long, entire, sometimes undulate; flowers yellow, $2.5-5 \mathrm{~cm}$. broad; calyx hirsute; petals emarginate; capsules narrowly obovoid, the body about io 
$\mathrm{mm}$. long, the angles with stout pubescent wings, the faces strongly ridged; seeas irregular, minutely papillose. N. Y. to W. Va. and Fla. May-Aug.

4. Kneiffia lineàris (Michx.) Spach. NARrow LEAVEd Sundrops. (I. F. f. 2590.) Slender, pilose or nearly glabrous. Stems erect or ascending. $1.5-5 \mathrm{dm}$. tall, finally angled; basal leaves spatulate or broadly oblanceolate, 5-8 cm. long, entire or nearly so; cauline leaves linear or linear lanceolate, $2.5-7.5 \mathrm{~cm}$. long, slightly toothed; flowers $1.8-3 \mathrm{~cm}$. broad; calyx slightly pubescent; petals shallowly notched at the apex and eroded; capsule, oblong-club-shaped, 8-14 mm. long, the angles with papery glabrous wings, its faces ridged; seeds irregular, angled. Cunn. to Tenn. and Ga. June Sept.

5. Kueiffia pùmila (L.) Spach. Small Sundrops. (I. F. f. 259r.) Erect, s)metimes finely puberulent, $2-6 \mathrm{dm}$. high. Leaves oblanceolate or oblong, nar$\mathrm{r}, \mathrm{w}$ ¿d at the base and often petioled, entire or very nearly so, 2-5 cm. long, the b.isal ones broader and shorter; flowers $8-25 \mathrm{~mm}$. broad; calyx-tube shorter than the ovary; petals obcordate; capsule sessile or short-stalked, glabrous or nearly so, 6-12 mm. long, the body obovoid, somewhat wing-angled. In dry soil, N. S. to Munitoba, N. J., Ga. and Kans. June-Aug.

6. Kneiffia fruticòsa (L.) Raimann. Common Sundrops. (I. F. f. 2592.) Erect, usually branched, 3-9 dm. high, rarely glabrous. Leaves lanceolate, ovate lanceolate or ovi-lanceolate, repand-denticulate, or rarely nearly entire, $2.5-10 \mathrm{~cm}$. long: flowers $2.5-5 \mathrm{~cm}$. broad; calyx-segments lanceolate; petals obcordate; capsule sessile or short-stalked, oblong, prominently winged, glabrous or pubescent, $68 \mathrm{~mm}$. long. In dry soil, N. S. to Ga., Minn. and La. June-Aug.

Kneiffia fruticòsa pilosélla (Raf.) Britton. Pubescent with long spreading hairs throughout. N. Y. to Ill., south to Ga.

7. Kneiffia glàuca (Michx.) Spach. Glaucous Sundrops. (I. F. f. 2593.) Erect, glabrous and glaucous, 4-9 dm. high. Leaves ovate or oval, repand-denticulate, 5-14 cm. long; flowers bright yellow, $3.5-7.5 \mathrm{~cm}$. broad, very showy; petals broadly obovate, emarginate; calyx-lobes ovate-lanceolate, acuminate; capsule oblong, broadly 4-winged, glabrous, IO-12 $\mathrm{mm}$. long, borne on a short stalk. In dry woods, mountains of Va. to Ga. and Ala. May-Sept.

\section{HARTMÁNNIA Spach.}

Annual or perennial herbs with branched stems. Leaves alternate, commonly pinnatifid or lyrate; buds drooping. Flowers white, red, or purple, diurnal, in terminal spikes or racemes. Calyx-tube funnelform. Ovary elongated; ovules numerous on slender stalks, in many rows. Capsules club-shaped, 4-winged. Seeds not tuberculate. [In honor of Emanuel Hartmann, a resident of Louisiana.] About ro species, in N. and S. Am.

r. Hartmannia speciòsa (Nutt.) Small. Showy Primrose. (I. F. f. 2594.) Erect, ascending or decumbent, branched, I.5-9 dm. high, puberulent or finely pubescent. Stem leaves lanceolate or linear-lanceolate, acutish, sinuate or pinnatifid, $5-7.5 \mathrm{~cm}$. long; basal leaves oval or oval-lanceolate, repand or pinnatifid at the base. flowers white or pink, $3.5-8 \mathrm{~cm}$. broad; petals emarginate; calyx lobes ovate-lanceolate, acuminate; capsule club-shaped. strongly 4-ribbed, 4-winged, pubescent, 12-18 mm. long. Prairies, Mo. and Kans. to La., Tex., Ariz. and northern Mex. May-July. Extensively naturalized in Ill., S. Car. and Ga.

\section{PACHÝLOPHUS Spach.}

Perennial acaulescent or nearly acaulescent herbs. Leaves basal, pinnatifid or pinnately-toothed. Flowers basal, tufted. Calyx-tube linear-funnelform, the segments shorter than the tube. Petals white or pink. Capsules basal, woody, pyramidal, their angles retuse or obtuse, transverseiy wrinkled. Seeds sessile, in I or 2 rows, deeply furrowed along the raphe. [Greek, referring to the tuberculate edges of the valves of the capsule.] A monotypic genus of western N. Am.

I. Pachylophus caespitòsa (Nutt.) Raimann. Scapose Primrose. (I. F. f. 2 j95.) Perennial or biennial from a woody root. Leaves clustered at the base, narrowed into slender petioles, lanceolate, oblanceolate or oval, densely pubescent, sinuate dentate, often densely ciliate with white hairs, repand or pinnatifid, $3.5^{-20} \mathrm{~cm}$. long; flowers few, white or rose, $3.5^{-8} \mathrm{~cm}$. broad; calyx pubescent, its 
tube 5-18 mm. long, dilated at the moith; capsule sessile, ovoid, strongly tuberculate on each side, the angles ribbed; seeds minutely tuberculate. Neb. and Mont. to the N. W. Terr., Nev., N. Mex. and Sonora. June-July.

13. LAVAÙXIA Spach.

Low usually perennial acaulescent herbs. Leaves mostly basal, pinnatifid. Flowers white, pink or pale yellow. Calyx-tube slender. Ovary short, 4-angled; ovules few. Capsules stout, their angles sometimes winged above. Seeds few. [In honor of Francois Delavaux, founder of the botanical garden at Nismes.] About 6 species, chiefly in southern N. Am.

Leaves membranous; capsules beaked, glabrate.

Leaves leathery; capsules hardly beaked, pubescent.

I. L. triloba.

2. L. brachycarpa.

I. Lavauxia tríloba (Nutt.) Spach. Three-Lobed Primrose. (I. F. f. 2596.) Nearly glabrous throughout. Leaves runcinate-pinnatifid, or sinuate, sometimes ciliate, oblong-lanceolate in outline, 7-30 cm. long; flowers white or pink, $2.5-6 \mathrm{~cm}$. broad; petals often 3-lobed; capsule ovoid, 4-wing-angled, reticulate-veined, 12-25 mm. long; seeds finely and densely tuberculate. In dry soil, Ky. and Tenn. to Kans., Cal., Miss., Tex. and northern Mex. May-July.

Lavauxia tríloba Wàtsonii Britton. Annual; flowers smaller; fruit densely crowded. Perhaps a distinct species. Kans.

2. Lavauxia brachycàrpa (A. Gray) Britton. Short-Ponded Primrose. (I. F. f. 2597.) Softly canescent. Leaves basal, ovate to narrowly oblong, 7.5$22 \mathrm{~cm}$. long, lyrate-pinnatifid or sometimes nearly entire; petioles sometimes as long as the blade; flowers yellow, basal; petals undulate; capsules elliptic, I6-1 8 $\mathrm{mm}$. long, leathery or corky, the angles very thin, the faces somewhat wrinkled. Mont. to Kans., Tex. and N. Mex. April-July.

\section{GAURÉLla Small.}

Low perennial herbs with wiry diffusely branched stems. Leaves nearly entire or distantly toothed. Flowers axillary, sessile. Calyx-tube slightly dilated at the throat, its segments slightly longer than the tube. Petals white or pink, spotted or striped with red. Ovary short; united styles stout, enlarged above. Capsules ses. sile, with a curved beak, the faces swollen. Seeds angled, delicately striate [Diminutive of Gaura.] A monotypic genus of the west-central U. S.

I. Gaurella guttulàta (Geyer) Small. SpotTed Primrose. (I. F. f. 2598.) Stems I-2 dm. high, canescent with appressed hairs, the branches decumbent or ascending. Leaves lanceolate or linear-lanceolate, obtusish at the apex, 8-16 mm. long, repand-denticulate or entire; flowers white or pink, I8-25 mm. wide; petals obovate, entire; capsule canescent, 8-10 $\mathrm{mm}$. long, angled, not winged; seeds angled, slipper-shaped. Prairies, Neb. to N. Mex. June-Sept.

\section{MEGAPTÈRIUM Spach.}

Spreading perennial herbs with stout stems. Leaves alternate, entire or slightly toothed. Flowers few, but large and showy, axillary, yellow. Calyx-tube much elongated. Ovary 4-angled or 4-winged; united styles filiform; ovules few, sessile. Capsules broadly 4.winged. Seeds crested. [Greek, broad-winged.] About 3 species, in N. Am. and Mex.

Corollas 7.5-15 cm. broad; capsules 5-7.5 cm. long, with suborbicular wings.

Corollas $2.5-5 \mathrm{~cm}$, broad; capsules $18-3 \mathrm{~cm}$ I. M. Missouriense.

Pubes $2.5 \mathrm{~cm}$. broad; capsules $1.8-3 \mathrm{~cm}$. long, with oblong wings.

Gubescent; capsules mostly less than $2.5 \mathrm{~cm}$.

2. $M$. Fremontii.

3. M. Oklahomense.

r. Megapterium Missouriénse (Sims) Spach. Missouri Primrose. (I. F. f. 2599.) Stems decumbent or ascending, densely canescent, 1.5-6 dm. long. Leaves thick, linear-lanceolate or oblong-lanceolate, acuminate or acute at the apex, entire or remotely denticulate, 5-I5 cm. long; flowers $7 \cdot 5-15 \mathrm{~cm}$. broad; calyxtube $5-15 \mathrm{~cm}$. long; capsule short-stalked, nearly orbicular, very broadly winged. In dry soil, Mo. and Neb. to Tex. May-July. 
2. Megapterium Fremóntii (S. Wats.) Britton. Fremont's Primrose. (I. F. f. 2600.) Stems ascending, 5-15 cm. high, appressed-pubescent. Leaves lanceolate to somewhat oblancolate, acuminate at the apex, entire or very nearly so, silvery canescent, $3 \cdot 5-7.5 \mathrm{~cm}$. long; flowers $2.5-5 \mathrm{~cm}$. broad; calyx-tube 4-5 times the length of the ovary; capsule oblong. broadly winged, rounded at the summit. Kans. to Tex. Summer.

3. Megapterium Oklahoménse Norton. Glabrous. Stems or branches I.5-3 dm. long; leaves rather numerous, lanceolate or almost oblong, 3-9 cm. long, remotely toothed or merely undulate; calyx-tube 8-10 $\mathrm{cm}$. long; calyx. segments purple-spotted; corollas 4-5 cm. broad; capsules oblong, $2.5-3 \mathrm{~cm}$. long, the wings less than I $\mathrm{cm}$. broad. On praịries and hillsides. Kans. and Oklán homa. Summer.

\section{GALPÍNSIA Britton. (See Appendix.)}

Perennial herbs or shrubby plants with much-branched stems. Leaves alter. nate. Flowers yellow, axillary. Calyx-tube slender, longer than the ovary. Ovary 4-celled, elongated; stigma disk.like, entire. Capsules elongated, narrowed at the base, more or less curved. Seeds sometimes tuberculate. [Anagram of Salpingia.] About 4 species, in the southern U. S. and Mex.

I. Galpinsia Hàrtwegi (Benth.) Britton. Hartweg's Primrose. (I. F. f. 260I.) Grlabrous or pubescent, much branched, I.5-4 dm. high. Leaves linearoblong or lanceolate, obtuse or ubtusish at the apex, $1.3-5 \mathrm{~cm}$. long, entire or slightly repand-denticulate; flowers $1.8-5 \mathrm{~cm}$. broad; calyx-lobes acuminate; petals rhombic-obovate, acutish; catpsule nearly sessile, narrowly cylindric, 12-25 mm. long, 2-4 mm. thick; sceds obscurely tuberculate. Prairies, Neb. and Colo. to Tex. and northern Mex. May-Sept.

\section{MERIOLIX Raf. (See Appendix.)}

Biennial or perennial herbs with branched stems or sometimes shrubby. Leaves alternate, naurow, entire or sharply serrite. Flowers regular, axillary, yellow. Calyx-tube funnelform, shorter than the ovary: calyx-segments keeled on the back. Petals often blotched at the base. Stigma disk-like, 4-toothed. Capsules linear, 4-angled, sessile. Seeds longitudinally grooved. A monotypic genus.

I. Meriolix serruláta (Nutt.) Walp. Tooth-leaved Primrose. (I. F. f. 2602.) Erect, canescent or glabrate, I-5 dm. high. Leaves linear-oblong, or lanceolate, sharply dentate or denticulate, $2.5-7.5 \mathrm{~cm}$. long; flowers $12-18 \mathrm{~mm}$. broad; calyx-lobes ovate, acuminate, the tube funnelform, silvery canescent: petals obovate, crenulate; capsule linear-cylindric, canescent, r.5-3 cm. long, about $2 \mathrm{~mm}$. thick, slightly grooved longitudinally. In dry soil, Manitoba and Minn. to Tex. and N. Mex. May-July. [OEnothera serrulata Nutt.]

Meriolix serrulata spinulòsa (T. \& G.) Small. More robust than the species. Leaves usually more spiny-toothed; flowers $2.5-5 \mathrm{~cm}$. broad; petals with a dark blotch at the base. Saskatch. to Mo. and Tex.

\section{GAÙ̃RA L. (See Appendix.)}

Annual biennial or perennial herbs, with alternate narrow leaves, and white, pink or red flowers in terminal spikes or racemes. Calyx-tube narıow, prolonged heyond the ovarv, the limb 4-lobed (rarely 3-lohed). Petals cliswed, unequal. Stamens usually 8 , declined, each with a small scale at the base. Ovary 4-celled, united styles declined; stigma 4 -lobed, surrounded by a cup-like border; ovules usually 4, pendulous. Fruit nut-like, ribbed or angled, indehiscent or nearly so, I-4-seeded. [Greek. proud, some species being showy.] About I8 species, natives of N. Am. and Mex.

Fruit sessile or very nearly so; flowers spicate.

Flowers 3-4 mm. broad; stigma little exserted beyond its cup.

Flowers 8-10 mm. broad; stigma exserted beyond its cup.

Flowers red, turning scarlet; fruit canescent.

Flowers white, turning pink; fruit villous.

1. G. parviflora.

2. G. coccinea.

3. G. biennis.

Fruit pedicelled; flowers racemose.

Fruit about $6 \mathrm{~mm}$. long, the body nearly as thick as long.

4. G. Michauxii. 
Fruit ro-14 mm. long, the body much longer than thick.

Leaves mostly glabrous; fruit $14 \mathrm{~mm}$. long, glabrous, its stout pedicel clubshaped.

5. G. sinuata.

Leaves densely villous; fruit ro $\mathrm{mm}$. long, pubescent, its slender pedicel nearly filiform.

6. G. zillosa.

I. Gaura parvifiòra Dougl. Smąl-flowered Gaura. (I. F. f. 2603.) Erect, villous-pubescent with whitish hairs, 6-I5 dm. high. Leaves lanceolate or ovate-lanceolate, acute or acuminate, repand-denticulate, softly pubescent, 3.5Io $\mathrm{cm}$. long; spikes elongated; flowers pink, the ovary and calyx-tube slender; fruit contracted at the base, 4 nerved, obtusely 4-angled, glabrous or nearly so, 6-8 mm. long. In dry soil, S. Dak. to Mo., La., Mex., Ore. and N. Mex. May-Aug.

2. Gaura coccínea Pursh. Scarlet Gaura. (I. F. f. 2604.) Erect or ascending, much branched, canescent or glabrate, 1.5-6 dm. high. Leaves oblong, lanceolate, or linear-oblong, denticulate, repand or entire, acute or obtuse at the apex, 1.2-3.5 cm. long; flowers red, turning scarlet; fruit terete below, 4-sided and narrowed above, canescent, 6-8 $\mathrm{mm}$. long. Prairies and dry soil, Manitoba and Minn. to Neb., Tex., Mont., Utah, Ariz. and in Mex. May-Aug.

3. Gaura biénnis L. Biennial Gaura. (I. F. f. 2605.) Erect, villous or downy-pubescent, 6-15 dm. high. Leaves lanceolate or oblong-lanceolate, acute or acuminate at each end, remotely denticulate, 5-10 $\mathrm{cm}$. long; spikes slender; flowers white, turning pink, 8-10 mm. broad; fruit narrowed at each end, 4-ribbed, villous, 6-8 mm. long. In dry soil, Quebec and Ont. to Minn., Ga., Tenn. and Miss. July-Sept.

4. Gaura Michauxii Spach. Michaux' Gaura. (I. F. f. 2606.) Erect, glabrous or nearly so, paniculately branched above, 6-18 dm. high. Leaves linear or linear-oblong, acute or acutish at both ends, or obtuse at the apex, sinuate or denticulate, $2.5-8 \mathrm{~cm}$. long; racemes loosely flowered, long-peduncled; flowers pedicelled, white, turning reddish, 6-8 mm. broad; fruit ovoid, 4-angled above, horne on a pedicel of rearly or quite its own length. In dry fields, Va. to Ill., Kans., Fla. and La. July-Aug.

5. Gaura sinuàta Nutt. Wavy-Leaved Gaura. (I. F. f. 2607.) Erect or decumbent, glabrous, or rarely sparingly villous. Stem branched at the base, 3-9 dm. tall, usually naked above; leaves oblanceolate to lanceolate, or nearly linear, sinuate-toothed, $2.5-8 \mathrm{~cm}$. long, acute; calyx slightly pubescent, its tube funnelform, 2-4 mm. long: petals 8-10 mm. long; fruit 4-ridged and 4-grooved above the club-shaped pedicel. In dry soil, Kans. to Ark. and Tex. May-July.

6. Gaura villòsa Torr. Woolly Gaura. (I. F. f. 2608.) Erect or nearly so, canescent or villous. Stems 3-9 dm. tall, often naked above; leaves varying from lanceolate to oblanceolate or sometimes nearly linear, $2.5-7.5 \mathrm{~cm}$. long, sinuate-toothed or pinnatifid, acute or acuminate; calyx canescent, its tube funnelform, 2-4 $\mathrm{mm}$. long; petals 10-14 $\mathrm{mm}$. long: body of the fruit sharply 4-angled, abruptly narrowed into a filiform pedicel. In dry soil, Kans. to Ark. and Tex. June-Sept.

\section{Ig. STENOSİPHON Spach.}

Erect perennial herbs, with alternate sessile narrow leaves, and white flowers in elongated terminal spikes. Calyx-tube filiform, much prolonged beyond the ovary. 4 lobed. Petals clawed. Stamens 8 , declined, not appendaged by scales at the base. Ovary I-celled; stigma as in Gaura. Fruit 8-ribbed, indehiscent, I-celled, I-seeded. Seed pendulous. [Greek, referring to the slender calyx-tube.] A monotypic genus of the south-central U. S.

T. Stenosiphon linifòlium (Nutt.) Britton. Flax-Leaved Stenosiphon. (I. F. f. 2609.) Slender, glabrous, 6-15 dm. high. Leaves lanceolate, linearlanceolate or linear, acuminate or acute at the apex, entire, 2.5-5 cm. long; spikes dense, narrow, sometimes $3 \mathrm{dm}$. long in fruit; flowers $8-12 \mathrm{~mm}$. broad; calyx-tube very slender, 8-Io $\mathrm{mm}$. long; fruit ovoid, pubescent, 2-3 $\mathrm{mm}$. long, very much shorter than the linear-subulate bracts. Prairies, Neb. and Colo. to the Ind. Terr. and Tex. June-July.

\section{CIRCAEA L.}

Low slender perennial herbs, with opposite petioled leaves, and small white flowers in racemes. Calyx-tube slightly prolonged beyond the ovary, its limb 
2-parted. Petals 2, notched. Stamens 2, alternate with the petals. Ovary 1-2celled; ovules usually $\mathbf{I}$ in each cavity. Fruit obovoid, indehiscent, bristly with hooked hairs. [Named for Circe, the enchantress.] Abuut 5 species, of the northern hemisphere. Besides the following, another occurs $\mathrm{n}$ the Pacific Coast.

Fruit 2-celled; leaves mainly of an ovate type:

Hairs of the fruit stiff, copious.

Hairs of the fruit weak, few.

Fruit I-celled; leaves mainly of a cordate type.

I. C. Lutetiana.

2. C. intermedia.

3. C. alpina.

I. Circaea Lutetiàna L. Enchanter's Nightshade. (I. F. f. 26io.) Finely pubescent, at least above; stem 3-6 dm. high. Leaves ovate, acuminate at the apex, rounded or rarely slightly cordate at the base, remotely denticulate, 5-10 cm. long; pedicels 4-8 mm. long, reflexed in fruit; bracts deciduous; flowers about $3 \mathrm{~mm}$. broad; fruit broadly obovoid, nearly $4 \mathrm{~mm}$. long, densely covered with stiff hooked hairs. In woods, N. S. to western Ont., S. Dak., Ga., Neb. and Kans. Also in Europe and Asia. June-Aug.

2. Circaea intermedia Ehrh. Resembling the preceding species in habit, glabrous or sparingly pubescent above; stems 2-5 dm. tall. Leaves ovate or ovatelanceolate, 4-8 cm. long, repand or sharply denticulate, cuneate or cordate at the base; fruit obovoid. 3-3.5 mm. long, with very slender, weak, hooked hairs or glabrate. In woods, Me. and Vt. Also in Europe. Summer.

3. Circaea alpina L. Smaller Enchanter's Nightshade. (I. F. f. 26I1.) Smaller, 7-20 cm. high, weak, glabrate or pubescent above. I eaves ovate, acute or acuminate at the apex, more or less cordate at the base, coarsely dentate, 2.5-5 $\mathrm{cm}$. long; flowers about $2 \mathrm{~mm}$. broad; pedicels 3-4 $\mathrm{mm}$. long, reflexed in fruit; fruit narrowly obovoid, about $2 \mathrm{~mm}$. long, covered with weak, soft, hooked hairs. In cold moist woods, Lab. to Alaska, Ga., Ind., Mich. and S. Dak. Also in Europe and Asia. July-Sept.

\section{Family 4. TRAPÀCEAE Dumort.}

\section{Water-nut Family.}

Aquatic herbs, with opposite pinnatifid submerged leaves, and clustered rhombic-ovate dentate floating ones with inflated petioles. Flowers perfect, axillary, solitary, short-peduncled. Calyx-tube short, the limb 4-parted, the lobes persistent. Petals 4, sessile, inserted on the perigynous disk. Stamens 4 , inserted with the petals; filaments subulate-filiform. Ovary 2-celled, conic above ; style subulate; ovule $I$ in each cavity. Fruit coriaceous or bony, large, 2-4-spinose or swollen at the middle, I-celled, 1 -seeded, indehiscent. Seed inverted. A single genus of 3 species, natives of Europe, tropical Asia and Africa.

\section{r. TRÀPA L.}

\section{Characters of the family. [Latin, from Calcitrapa, the Caltrop.]}

I. Trapa nàtans L. Swimming Water-nut. Water-chestnut. WaterCALTROP. (I. F. f. 26r2.) Rooting in the mud. Submerged leaves, pectinately dissected, 2-10 $\mathrm{cm}$. long, floating leaves in a rosette, their blades rhombic-ovate, sharply dentate above, broadly cuneate and entire below, about $2.5 \mathrm{~cm}$. wide, glabrous and shining above, the conspicuous veins of the lower surface beset with short stiff hairs; flowers white, about $6 \mathrm{~mm}$. broad; fruit $2-5 \mathrm{~cm}$. long, armed with 4 somewhat recurved spines. Nat. in ponds and streams, eastern Mass. and near Sclienectady, N. Y. Native of Europe. June-July.

Family 5. HALORAGIDÁCEAE Kl. \& Garcke.

$$
\text { Water-milfoil Family. }
$$

Perennial or rarely annual herbs, mainly aquatic, with alternate or verticillate leaves, the submerged ones often pectinate-pinnatifid. Flowers perfect, or monœcious, or diœecious, axillary, in interrupted spikes, solitary or clustered. Calyx-tube adnate to the ovary, its limb entire or 2-4- 
lobed. Perals small, $2-4$, or none. Stamens I-8. Ovary ovoid-oblong, or short-cylindric, 2-8-ribbed or winged, I-4-celled; styles I-4; stigmas papillose or plumose. Fruit a nutlet, or drupe, compressed, angular, ribbed or winged; indehiscent, of 2-4 I-seeded carpels. Endosperm fleshy; cotyledors minute. Eight genera and about Ioo species, of wide distribution.

Stamen I; ovary r-celle.t.

Stamens 2-8; ovary 3-4-celled.

Fruit 3 -angled or 4 -angled.

Fruit of 4 carpels.

I. Hippuris.

2. Proserpinaca.

3. Myriophyllum.

\section{HIPPÙRIS L.}

Aquatic herbs, with simple erect stems, and verticillate simple entire leares. Flowers small, axillary, perfect, or sometimes neutral or pistillate only. Limb of the calyx minute, entire. Petals none. Style filiform, stigmatic its whole length, lying in a groove of the anther. Fruit a small I-celled I-seeded drupe. [Greek, mare's-tail.] Three known species, natives of the north temperate and arctic zones and of southern S. Am. Besides the following, the third occurs in arctic America.

Leaves linear or lanceolate, in verticils of $5^{-12}$.

Leaves obovate, oblong, or oblanceolate, ir verticils of $4-6$. r. H. vulgaris.

2. H. tetraphylla.

I. Hippuris vulgàris L. Bottle Brush. Mare's-tail. Joint-weed. (I. F. f. 26I3.) Stem glabrous, 2-5 dm. high. Leaves acute, sessile, I-25 mm. long, more or less sphacelate at the apex; stamen with a short thick filament, and comparatively large 2-celled anther, dehiscent by lateral slits; seeds ovoid; stigma persistent. Swamps and bogs, Greenland to Alaska, Me., Lake Superior, N. Mex. and Cal. Also in Patagonia, and in Europe and Asia. Summer.

2. Hippuris tetraphýlla L.f. Four-Leavev MARE'S-TAIL. (I. F. f. 26r4.) Stem I-4 dm. high; leaves not sphacelate at the a pex or but slightly so, $8-\mathbf{I} 4 \mathrm{~mm}$. long. Lab. and Quebec to Hudson Bay and Al:ssa. Also in northern Europe and Asia. Summer.

\section{PROSERPINÀCA L.}

Aquatic herbs, with simple stems. Leaves alternate, lanceolate, dentate or pectinate-pinnatifid Flowers perfect. Tube of the calyx adnate to the triquetrous ovary, the limb 3-4-parted. Petals none. Stamens jor 4 . Styles 3 or 4, cylin. dric or conic-subulate, stigmatic above the middle. Fruit bony, 3-4-celled, with I seed in each cavity. [Middle Latin, forward-creeping.] Two known species, natives of eastern N. Am., extending to the W. I.

Emersed leaves linear-lanceolate to oblong, serrate; fruit sharp-angled. x. P. palustris. Leaves all pectinate-pinnatifid; fruit obtusely angled.

2. P. pectinata.

x. Proserpinaca palústris L. Mermaid-weed. (I. F. f. 26I5.) Glabrous, simple or sometimes branched, 2-5 dm. long. Emersed leaves, 2-5 cm. long, 2-I 2 $\mathrm{mm}$. wide, sharply serrate, the submerged ones pectinate-pinnatifid into stiff linear acute segments which are often serrulate, bearing a minate black spine in their axils; flowers solitary or several together, sessile in the axils of the emersed leaves; fruit abcut $4 \mathrm{~mm}$. long, the faces concave, smooth or rugose. In swamps, N. B. to Lake Huron, Fla., Iowa and Cent. Am. Also in Cuba. July.

2. Proserpinaca pectinàta Lam. Cut.leaven Mermaid weed. (I. F. f. 26r6.) Resembling the preceding, but usually smaller. Leaves all pectinate or pinnatifid, the segments shorter and rarely serrulate, more subulate, or capillary; calyx-lobes broader; fruit ahout $3 \mathrm{~mm}$. long, the faces flat or slightly convex, often wrinkled or somewhat tuberculate, the angles obtuse. In sandy swamps near the coast, eastern Mass. to Fla. and La. Summer.

\section{MYRIOPHÝLLUM L.}

Aquatic herbs, with verticillate or alternate leaves, the submerged ones pinnatifid into capillary segments, and axillary commonly monœecious 2 -bracted flowers, often interruptedly spicate. Upper flowers generally staminate with a very short calyx-tube, its limb 2-4-lobed, or none; petals 2-4; stamens 4-8. Interme- 
diate flowers often perfect. Lower flowers pistillate, the calyx 4-grooved and with 4 minute lobes, or none; ovary 2-4-celled; ovule I in each cavity, pendulous; styles 4 , short, often plumose. Fruit splitting into 4 boriy I-seeded indeliscent carpels. [Greek, myriad-leaved.] Abont 20 species, of wide distribution. In addition to the following, another occurs in the western U. S. The plants flower in summer.

Carpels smooth.

Flowers in emersed spikes.

Floral leaves shorter than the flowers.

Flowers in whorls.

Flowers alternate, or the lower sub-verticillate.

Floral leaves longer than the flowers, pinnatifid.

Floral leaves reduced to minute bracts.

Flowers on both emersed and submersed stems.

Flowers only on submersed stems.

Carpels rough or tuberculate.

Flowers on emersed spikes.

Floral leaves ovate or lanceolate, serrate.

Floral leaves linear, pectinate.

Flowers on submersed stems.

I. M. spicatum.

3. M. alterniflorum.

2. $M$. verticillatum.

4. M. tenellum.

5. M. humile.

9. M. proserpinacoides.

6. M. heterophyllum.

7. M. pinnatum.

8. M. Farwellii.

I. Myriophyllum spicàtum L. Spiked Water-milfoil. (I. F. f. 26I7.) Submerged leaves in whorls of 4's and 5's, dissected into capillary divisions. Floral leaves ovate, or sometimes none ; spike $2-8 \mathrm{~cm}$. long ; petals 4 , deciduous ; stamens 8 ; fruit about $2 \mathrm{~mm}$. long and $3 \mathrm{~mm}$. thick; carpels rounded on the back, with a deep wide groove between them. In deep water, Newf. to the N. W. Terr., Fla., Iowa, Kans. and Cal. Also in Europe and Asia.

2. Myriophyllum verticillàtum L. Whorled WATER-Milfoil. (I. F. f. 2618.) Submerged leaves in crowded whorls of 3's and 4's, the capillary divisions very slender, often minutely scabrate. Floral leaves much longer than the flowers: spike 5-15 cm. long; petals of the staminate flowers 4, purplish; stamens 8; fruit 2-3 mm. long, and about $2 \mathrm{~mm}$. thick, somewhat gibbous at the base. Quebec and Ont. to Fla., Minn. and Cal. Also in Europe arı Asia.

3. Myriophyllum alternifiòrum DC. LOOSE-Flowered WATER-Milfoil. (I. F. f. 2619.) Submerged leaves usually in whorls of 3's to 5's, occasionally scattered, the pinnate divisions capillary. Spikes short, $2-5 \mathrm{~cm}$. long; uppermost floral leaves ovate or linear, entire or minutely toothed, early deciduous; petals of the staminate flowers 4 , longer than the stamens, pale rose-color, deciduous; stamens 8; fruit nearly $2 \mathrm{~mm}$. long, slightly less than $2 \mathrm{~mm}$. thick; carpels rounded on the back, with a deep groove between them. In deep water, eastern Mass. to Newf. and Greenland. Common in Europe.

4. Myriophyllum tenéllum Bigel. Slender Water-Milforl. (I. F. $f$. 2620.) Stems slender, scape-like, nearly leafless, 4-30 cm. high. Rhizome creeping, sending up many sterile stems; flowers alternate, solitary; uppermost bracts obovate, often longer than the flowers, the lower oblong, often shorter, the lowest minute or none; petals 4, purplish; stamens 4; fruit I $\mathrm{mm}$. long and about as thick at the top, sometimes enlarged at the base; carpels rounded or obtusely angled on the back, separated by a shallow groove. Sandy bottoms of ponds and streams. Newf. to N. J., Penn. and Mich.

5. Myriophyllum hùmile (Raf.) Morong. Low Water-Milfoil. (I. F. f. 262I.) Typical form terrestrial, 2-4 cm. high, rooting in mud. Leaves entire or pectinate. Floating forms with stems often $3 \mathrm{dm}$. long, with all or most of the leaves pectinate; these produce the typical form if they take root; petals 4 , purplish; stamens 4; fruit usually less than $2 \mathrm{~mm}$. long and about as thick at base, its carpels separated by a shallow groove. In ponds, Me., R. I., to Md. and Ill.

6. Myriophyllum heterophýllum Michx. VARIous-Leaved Water-miLFoIL. (I. F. f. 2622.) Floral leaves in whorls of 3's to 5's, linear, ovate or lanceolate, serrate or rarely entire, much longer than the flowers. Submerged leaves subverticillate or scattered, crowded, pectinate-pinnatifid, about $2 \mathrm{~cm}$. long, the divisions capillary; flowering spike elongated; petals 4; stamens 4, rarely 6; fruit $2 \mathrm{~mm}$. long, and slightly longer than thick; carpels 2-keeled on the back. In ponds, Ont. and N. Y. to Fla., S. Dak., Tex. and Mex.

7. Myriophyllum pinnàtum (Walt.) B.S.P. Pinnate Water-milfoil. 
(I. F. f. 2623.) Leaves in whorls of 3's -5 's, or sometimes scattered, the floral ones linear, serrate or pectinate, 5-12 $\mathrm{mm}$. long, gradually passing into the submerged ones which are crowded, pinnately dissected, the divisions capillary; spikes I-2 $\mathrm{dm}$. long; petals purplish; stamens 4 . very rarely 6; carpels strongly 2 -keeled and scabrous on the back, separated by deep grooves; mature fruit about $2 \mathrm{~mm}$. long. In ponds, R. I. to Fla., Kans., La., Tex. and Panama.

8. Myriophyllum Farwéllii Morong. Farwell's Water-milfoll. (I. F.f. 2624.) Diœcious (?). Specimens with submerged leaves only, in whorls of 3's6 's, or scattered, narrow, pinnately parted, the divisions finely capillary in 5-7 opposite or subopposite pairs, with minute black spines in the axils; petals 4, purplish, oblong; pistillate flowers only seen; styles 4, short; stamens 4, minute, abortive; fruit about $2 \mathrm{~mm}$. long and I $\mathrm{mm}$. thick; carpels crossed longitudinally by 3 or 4 tuberculate or slightly toothed ridges, 2 on the back and commonly I on each margin; groove between the carpels shallow. In still water, Me. to Mich.

9. Myriophyllum proserpinacoides Gill. Chilian Water-Milfoil. (I.F. f. 2625.) Diøecious. Leaves all alike and submerged, somewhat glaucous, pectinate-pinnatifid in crowded whorls of 4's and 5's, I.5-2 cm. long; segments 20-25, capillary or sometimes linear-spatulate, about $5 \mathrm{~mm}$. long; pistillate flowers axillary, about I $\mathrm{mm}$. high, without petals; stigmas 4, white, plumose; young carpels glabrous: small white hair-like bracts are borne at the bases of the leaves and among the flowers. Haddonfield, N. J. Apparently established. Native of Chili.

\section{Order 27. UMBELLÀLES.}

Herbs, shrubs or trees, almost always with petaliferous flowers. Calyx-segments and petals usually 5. Stamens 4 or 5. Ovary inferior, adnate to the calyx, compound; ovule I in each cavity.

Stamens 5: styles 2-5, rarely united; flowers umbellate, capitate or panicled.

Fruit a fleshy berry or drupe.

Fruit dry when mature, splitting into two mericarps.

Fam. 1. Araliaceae.

Fam. 2. Umbelliferae.

Stamens 4; style I; stigma I; shrubs and trees; flowers not umbellate.

Fam. 3. Cornaceae.

\section{Family I. ARALIÀCEAE Vent.}

\section{Ginseng Family.}

Herbs, shrubs or trees, with alternate or verticillate (rarely opposite) leaves, and flowers in umbels, heads, or panicles. Calyx-tube adnate to the ovary. Petals usually 5, sometimes cohering together, inserted on the margin of the calyx. Stamens as many as the petals and alternate with them (rarely more). inserted on the epigynous disk; anthers introrse. Ovary inferior, I-several-celled; styles as many as the cavities of the ovary; ovules I in each cavity, pendulous, anatropous. Seeds flattened, or somewhat 3 angled, the testa thin; endosperm copious, fleshy; embryo small, near the hilum ; cotyledons ovate or oblong. About 52 genera and 450 species, widely distributed.

Herbs, shrubs or trees; leaves alternate, decompound; styles 5. Herbs; leaves verticillate, digitately compound; styles 2 or 3 .

1. Aralia.

2. Panax.

\section{ARÀlIA L.}

Leaves alternate, pinnately or ternately decompound. Flowers small, mostly perfect, in racemose corymbose or paniculate umbels. Flowers white or greenish. Petioles sheathing at the base. Stipules none or inconspicuous. Pedicels jointed below the flowers. Petals 5, spreading, obtuse, or with short inflexed points, val. vate or slightly imbricate. Stamens 5. Disk depressed. Ovary 5 celled; styles 5. Fruit a small berry enclosing about 5 seeds. About 27 species, natives of $\mathbf{N}$. Am. and Asia. Besides the following, 2 others occur in the western U. S.

Umbels numerous, panicled or racemose. 
Umbels 2-several, sometimes numerous, terminal or corymbose. Plant glabrate; leaf and peduncle arising from the rootstock. Plant bristly or hispid; stem leafy, erect.

3. A. nudicaulis. 4. A. hispida.

I. Aralia spinòsa L. Hercules' Club. Angelica or Spikenard Tree. (I. F. f. 2626.) A shrub or tree. Leaves long-petioled, bipinnate; leaflets acute or acuminate, stalked, serrate, dark green above, glaucous and sometimes slightly pubescent beneath, 2.5-10 cm. long; peduncles and pedicels pubescent; flowers white, $4 \mathrm{~mm}$. broad; fruit ovoid, black, 5 -lobed, about $6 \mathrm{~mm}$. long; styles distinct. In low grounds and along streams, Conn. to Fla., Ind., Mo. and Tex. June-Aug.

2. Aralia racemòsa L. American Spikenard. Indian-Root. (I. F. f. 2627.) Herbaceous, I-2 m. high, glabrous, or slightly pubescent. Roots large and thick, aromatic: leaves ternately or rarely quinately compound, the divisions pinnate; leaflets broadly ovate or orbicular, thin, acuminate, 5-15 cm. long, sharply serrate; peduncles and pedicels puberulent; flowers greenish, about $2 \mathrm{~mm}$. broad; fruit nearly globular, dark purple or reddish-brown, about $6 \mathrm{~mm}$. in diameter; styles united below. In rich woods, N. B. to Ga., S. Dak. and Kans. July-Aug.

3. Aralia nudicaùlis L. WILD OR Virginian Sarsaparilla. (I. F. f. 2628.) Acaulescent or nearly so. Rootstock long; petioles erect, 1.5-3 dm. long; primary divisions of the leaf ternate, slender-stalked, pinnately 3-5-foliolate; leaflets oval or ovate, acuminate, finely serrate, $5^{-13} \mathrm{~cm}$. long; umbels commonly 3 , simple; involucre none; pedicels slender; flowers greenish, $3 \mathrm{~mm}$. broad; fruit globose, purplish-black, about $6 \mathrm{~mm}$. long. 'In woods, Newf. to Manitoba, N. Car., Neb. and Mo. May-June.

Aralia nudicaùlis prolifera A. C. Apgar. Leaves more divided and umbels compound. Western N. J.

Aralia nudicaùlis elongàta Nash. Leaflets longer and narrower, gradually acuminate, coarsely serrate, paler beneath. Catskill Mountains.

4. Aralia híspida Vent. Bristly Sarsaparilla. Wild Elder. (I. F. f. 2629.) Erect, 3-9 dm. high, the stem and petioles more or less hispid with slender bristles. Leaves bipinnate; leaflets ovate or oval, acute, irregularly serrate, 2-5 $\mathrm{cm}$. long: umbels slender-peduncled, simple, cory mbo-racemose at the summit of the stem; flowers white, $2 \mathrm{~mm}$. broad; fruit dark purple, $6-8 \mathrm{~mm}$. in diameter, strongly 5 -lobed when dry. In rocky or sandy woods and clearings, Newf. to N. Car., Ont., Minn. and Ind. June-July.

\section{PÀNAX L.}

Erect perennial herbs, with aromatic roots, and a verticil of digitately com. pound leaves at the summit. Umbel terminal, simple. Flowers greenish or white, polygamous. Calyx-limb obscurely 5-toothed. Petals 5, spreading. Stamens 5. Fruit a small drupe-like somewhat flattened berry, enclosing 2 or 3 seeds. [Greek, all-healing.] About 7 species, natives of eastern N. Am. and Asia.

Leaflets 5 , ovate or obovate, stalked, acuminate.

Leaflets 3-5, oval to oblanceolate, sessile, obtuse.
I. $P$. quinquefolium.

2. P. trifolium.

I. Panax quinquefollium L. Ginseng. (I. F. f. 263o.) Glabrous, 2-4 dm. high. Ront fusiform, deep, simple or branched. Petioles 4-10 cm. long; leaflets 5 (rarely 6 or 7 ), thin, ovate or obovate, $5-13 \mathrm{~cm}$. long, irregularly dentate; peduncle slender, 2-5 cm. long; umbel 6-20.flowered; flowers greenish yellow, about $2 \mathrm{~mm}$. broad; styles usually 2 ; fruit flattened, somewhat didymous, bright crimson, $1 \mathrm{~cm}$. broad. In rich woods, Quebec to Ala., Minn., Neb. and Mo. July-Aug.

2. Panax trifòlium L. DWarf Ginseng or Ground-nut. (I. F. f. 263i.) Glabrous, 0.7-2 dm. high. Root globose, deep, about $1 \mathrm{~cm}$. in diameter, pungent to the taste; petioles $\mathrm{r}-5 \mathrm{~cm}$. long; leaflets $3-5$, oval to oblanceolate, sessile, obtuse, usually narrowed at the base, $2-4 \mathrm{~cm}$. long, dentate or serrate; peduncles $2.5^{-6}$ $\mathrm{cm}$. long; pedicels 2-3 $\mathrm{mm}$. long in fruit; flowers white, often monœcious, about $2 \mathrm{~mm}$. broad; styles usually 3 : fruit mostly 3 -angled (or when with 2 styles, didy. mous), yellow, about $4 \mathrm{~mm}$. broad. In moist woods and thickets, N. S. to Ga., Ont., Minn., Iowa and Ill. April-June. 


\title{
Family 2. UMBELLÍfERAE B. Juss.*
}

\author{
Carrot Family.
}

Herbs, with alternate decompound compound or sometimes simple leaves, the petioles often dilated at the base. Stipules none, or rarely present and minute. Flowers small, generally in compound or simple umbels, rarely in heads or capitate clusters, often polygamous. Umbels and umbellets commonly involucrate or involucellate. Calyx-tube adnate to the ovary, its margin truncate or 5-toothed, the teeth seldom conspicuous. Petals 5, inserted on the margin of the calyx, usually with an inflexed tip, often emarginate or 2-lobed, those of the outer flowers sometimes larger than those of the inner. Stamens 5, inserted on the epigynous disk ; filaments filiform; anthers versatile. Ovary inferior, 2celled; styles 2, filiform, persistent, often borne on a conic or depressed stylopodium; ovules 1 in each cavity, pendulous, anatropous. Fruit dry, composed of 2 carpels (mericarps), which generally separate from each other at maturity along the plane of their contiguous faces (the commissure). Fruit either flattened laterally (at right angles to the commissure), or dorsally (parallel to the commissure), or nearly terete (not flattened). Carpels after parting from each other supported on the summit of a slender axis (the carpophore), each with 5 primary ribs in their pericarps (rarely ribless), and in some genera with 4 additional secondary ones, the ribs or some of them often winged. Pericarp membranous or corky-thickened, usually containing oil-tubes between the ribs, or under the ribs and on the commissural sides, sometimes irregularly scattered, sometimes none. Seeds 1 in each carpel, usually adnate to the pericarp ; seed-coat thin; endosperm cartilaginous; embryo small, pla:ed near the hilum; cotyledons ovate, oblong or linear. About 170 genera and 1600 species, of wide distribution. The mature fruit is necessary for the certain determination of most of the genera and many of the species. The following key is wholly artificial.

* Leaves simple, undivided, sometimes slightly lobed.

Leaves narrow, mostly spiny-toothed; flowers in dense heads.

Leaves ovate and perfoliate in our species; flowers yellow.

๑. Eryngium.

Leaves orbicular or ovate, slender-petioled, often peltate.

Ribs of the fruit simple; leaves I at a node.

Ribs anastomosing; leaves tufted at the nodes.

Leaves reduced to hollow jointed petioles or phyllodes.

Umbels simple, few-flowered; plant low.

Umbels compound; plant tall.

i். Bupleurum.

1. Hydrocotyle.

2. Centella.

31. Liliaeopsis.

42. Oxypolis.

* * Leaves, or some of them, pinnate, ternate, digitate, decompound or deeply lobed.

Flowers in sessile or short-stalked capitate clusters opposite the leaves.

Flowers in simple umbels; leaves pedately lobed.

Flowers in dense peduncled heads; leaves sometimes bristly.

9. Torilis.

r. Hydrocotyle.

Flowers in more or less compound umbels.

1. Flowers white, greenish or pink.

a. Fruit, or its beak, bristly, papillose or tuberculate.

Leaves digitately 3-7-parted or lobed.

Leaves pinnately or ternately decompound or dissected.

Fruit linear, ribbed, long-attenuate at the base. 8 .

Fruit linear, with a beak much longer than the body.

Fruit ovoid, small, tuberculate or bristly.

4. Eryngium.

Carpels flattened dorsally.

Seed-face concave.

Seed-face flat.

II. Apiastrum.

17. Ammoselinum.

* Text prepared with the assistance of Dr. J. N. ROSE. 
Carpels terete, or slightly flattened laterally. 43. Spermolepis.

Fruit with 4 strong bristly wings.

Fruit dorsally flattened; calyx-teeth obsolete. 48. Daucus.

Fruit laterally flattened; calyx-teeth prominent.

b. Fruit smooth, ribbed or winged, rarely pubescent.

9. Torilis.

Fruit winged, at least on the lateral ribs, dorsally flattened.

Plants acaulescent, or nearly so; leaves bipinnate or dissected.

Plants tall, leafy-stemmed.

44. Peucedanum.

Leaves simply ternate or pinnate.

Leaf-segments ovate-lanceolate to oblong.

Leaf-segments very broad.

42. Oxypolis.

45. Imperatoria.

Leaves ternately or pinnately compound; segments broad. Segments ovate or oval, not cordate.

Bracts of the involucels setaceous or none.

Bracts of the involucels connate at base.

38. Angelica.

Segments large, cordate, pubescent. 47. Her
Leaves 2-3-pinnately decompound; segments narrow.

37. Conioselinum.

Fruit winged or wingless, not flattened either dorsally or laterally.

All its ribs winged.

Ribs distinct, but not winged.

Leaves finely dissected; segments narrow.

Leaf-segments broad.

40. Cymopterus.

Fruit with numerous oil-tubes between the ribs.

Fruit with solitary oil-tubes between the ribs.

34. Ligusticum.

35. Coelopleurum.

Leaves entire, or with a few narrow segments. 30. Cynosciadium.

Fruit laterally flattened.

Fruit broader than long, the carpels globose, at tached by a very narrow commissure.

Fruit linear or linear-oblong.

Leaves 3 -foliolate.

Leaves decompound or finely dissected.

Fruit long-beaked, smooth, ribless.

10. Bifora.

Fruit short beaked or beakless, ribbed.

Fruit ovoid or oval.

21. Deringa.

6. Anthriscus.

5. Chaerophyllum.

Umbels opposite the leaves.

Umbels terminal or axillary.

16. Apium.

Leaves finely dissected into filiform segments.

Ribs of the fruit equal, prominent. 29. Ptilimnium.

Lateral ribs much thickened. I6. Apium.

Ribs filiform, inconspicuous. 22. Carum.

Leaves pinnate or decompound; segments linear to ovate-oblong

Plants acaulescent, or nearly so.

Calyx-teeth obsolete; fruit nearly orbicular.

Calyx-teeth prominent ; fruit oblong.

12. Erigenia.

Plants leafy-stemmed.

14. Musineon.

Oil-tubes of the fruit none.

Leaves biternate with broad segments.

25. Agopodium.

Leaves decompound into small pinnatifid segments. 13. Conium.

Oil-tubes solitary between the ribs; leaves pinnate.

Oil-tubes numerous. 20. Cicuta.

Leaves pinnately compound; segments linear. 26. Eulophus.

Leaves pinnate; the segments sometimes pinnatifid. Tall native marsh perennials.

Oil-tubes $I-3$ in the intervals between the prominent ribs. 27. Sium. 
Oil-tubes numerous and close together along inner side of the pericarp; ribs filiform. 28. Berula.

Introduced plant of dry ground.

2. Flowers yellow or purple.

24. Pimpinella.

Fruit dorsally flattened.

Plants acaulescent; leaves finely dissected.

Plants leafy-stemmed.

44. Peucedanum.

Leaves pinnate; segments ovate; fruit with thin lateral wings. 46. Pastinaca.

Leaves pinnately compound; fruit-wings thick and corky.

Fruit not flattened; ribs or some of them winged.

Fruit laterally flattened; leaves decompound (except in $Z i z i a$ ).

Leaf-segments oval or ovate, entire.

Leaf-segments crenate, lobed or incised.

Leaf-segments broad, crenate or dentate. 19. Zizia.

Leaf-segments deeply incised.

Plant native, western; ribs of the fruit filiform.

41. Polytaenia.

36. Thaspium.

23. Taenidia.

I4. Musineon.

Plant sparingly escaped from cultivation; ribs prominent.

Leaf-segments filiform; fruit prominently ribbed.

I8. Petroselinum.

33. Foeniculum.

\section{r. HYDROCÓTYLE L. (See Appenđix.)}

Perennial herbs, prostrate and commonly rooting at the joints, with palmately lobed or veined, often peltate leaves, the bases of the petioles with 2 scale-likic stipules, and small white flowers in umbels opposite the leaves. Bracts of the involucre few, or none. Calyx-teeth minute. Petals entire. Disk flat. Fruit laterally compressed, orbicular or broader than high. Carpels with 5 primary ribs, the lateral ones usually curved; no large oil-tubes, but an oil-bearing layer of tissue beneath the epidermis. [Greek, water-cup.] About 75 species of wide distribution. Besides the following another occurs on the Pacific Coast.

Leaves nearly orbicular, peltate.

Umbels simple, rarely slightly proliferous; pedicels slender. I. H. umbellata.

Umbels, at least some of them, proliferous; pedicels, or some of them, short.

Fruit notched at each end.

Fruit not notched at either end.

Leaves nearly orbicular, cordate, or reniform, not peltate.

Leaves $5^{-1} 3^{-l o b e d}$; umbels nearly sessile.

Leaves 3-7-cleft; umbels long-peduncled.

2. H. Canbyi.

3. H. verticillata.

4. H. Americana.

5. H. ranunculoides.

1. Hydrocotyle umbellàta L. Umbellate or Many-flowered Marsh PENNYWORT. (I. F. f. 2703.) Glabrous; stem creeping, the subterranean branches tuberiferous. Petioles slender, 2-15 cm. long; leaves sometimes cordate at the base, I-4 cm. wide, crenately 7-II-lobed, the lobes mostly crenulate; pedicels slender, 4-12 mm. long; mature fruit notched at both ends, 2-3 mm. broad, not quite as long; intermediate ribs corky-thickened; dorsal rib obtuse. In swamps and low grounds, eastern Mass. to Fla. and the W. Indies, Minn., Tex. and Mex. Also in S. Am. June-Sept.

2. Hydrocotyle Canbyi C. \& R. Canby's Marsh-Pennywort. (I. F. t. 2704.) Stems creeping, sometimes $3 \mathrm{dm}$. long, the subterranean branches tuberiferous. Leaves $1-4 \mathrm{~cm}$. wide, with $7-1$ i shallow mostly crenulate lobes; peduncles elongated; inflorescence mostly proliferous; verticils 3-10-flowered; pedicels 2-8 $\mathrm{mm}$. long; fruit about $2 \mathrm{~mm}$. long and $4 \mathrm{~mm}$. broad, much flattened, the intermediate ribs corky-thickened, the dorsal one very obtuse. In moist ground, N. J. to Md. June-Sept.

3. Hydrocotyle verticillata Thunb. WhORLED MARSh-Pennywort. (I. F. f. 2705.) Similar to the two preceding. Inflorescence proliferous, $2-5 \mathrm{~cm}$. long; verticils 2-6-flowered; pedicels usually less than $1 \mathrm{~mm}$. long; fruit about $2 \mathrm{~mm}$. long. 3-4 mm. broad, rounded or truncate at each end; -intermediate ribs not corky. thickened, the dorsal one acute. In moist soil, Mass. to Fla., west to southern Cal., and in Central and S. Am. June-Sent. 
4. Hydrocotyle Americàna L. American Marsh-PE $\ldots$ r.. Wor ı. (i. F. f. 2706.) Stems creeping, often bearing small tubers; leaves reniform, $2-5 \mathrm{~cm}$. wide, with shallow lobes; umbels sessile or very nearly so, 1-5-flowered; pedicels les; than $2 \mathrm{~mm}$. long; fruit slightly more than $\mathbf{I} \mathrm{mm}$. broad and nearly as high, the ribs all filiform. In wet places, N. S. to Minn., Penn. and N. Car. June-Sept.

5. Hydrocotyle ranunculoides L. f. Floating Marsh-pennywort (I. F. f. 2707.) Stem usually floating, rooting from the nodes, 1.5-6 dm. long Petioles elongated, weak; leaves reniform, $2-5 \mathrm{~cm}$. wide, 3-7-cleft, the lobes cre nate; peduncles much shorter than the petioles, recurved in fruit; umbels 5-10. flowered; fruit nearly orbicular, about $3 \mathrm{~mm}$. broad, the ribs obscure and filiform. In ponds and swamps, Penn. to Fla., near the coast, west to Tex.; Ore. to L. Cal. Also in Cent. and S. Am., Abyssinia and Italy. June-Sept.

\section{CENTÉLLA L.}

Perennial herbs (some African species shrubby), ours with prostrate stems root. ing and sending up tufts of long-petioled leaves at the nodes, together with $1-3$ long-rayed umbellets of small white flowers, the true umbel sessile. Petiole-bases sheathing. Bracts of the involucels 2-4, mostly prominent. Calyx-teeth none. Disk flat, or slightly concave. Styles filiform. Fruit somewhat flattened laterally, rather prominently ribbed, the ribs mostly anastomosing; oil-tubes none. [Latin,

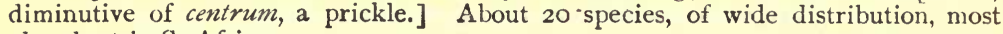
abundant in S. Africa.

I. Centella repànda (Pers.) Small. Ovate-Leaved Marsh-pennywort. (I. F. f. 2708.) Stem 2-I5 cm. long. Petioles 0.5-3 dm. long, sometimes pubescent; blades ovate, rather thick, rounded at the apex, bioadly cordate at the base, not peltate, 2-4 cm. long, repand-dentate; pedicels much shorter than the leaves, I $-5 \mathrm{~cm}$. long; umbellets capitate, 2-4 flowered, subtended by 2 ovate bracts; flowers nearly sessile; fruit $4-5 \mathrm{~mm}$. broad, about $3 \mathrm{~mm}$. high, prominently ribbed and reticulated. In wet grounds, Md. to Fla., west to Tex. Also in tropical Anı., Asia, Africa and Australia. June-Sept. [Hydrocotyle repanda Pers.]

\section{SANícula L. (See Appendix.)}

Perennial or biennial mostly glabrous herbs, with palmately 3-7-foliolate or pinnatifid leaves and small flowers in compound ganerally few-rayed umbels. Umbellets globose. Involucre foliaceous; involucels small. Calyx-lobes mostly persistent. Petals obovate, or narrower, emarginate. Disk flat. Fruit somewhat flattened laterally, subglobose, covered with hooked bristles in our species. Carpels not ribbed; oil-tubes usually 5. [From the Latin, to heal.] About 20 species, natives of the north temperate zone, S. Am. and S. Africa. Besides the following, about ro others occur in the southern and western U. S.

* Perennial; some staminate flowers in separate heads; styles longer than the bristles.

Petals and anthers greenish white; calyx-segments lanceolate, cuspidate; fruit $6 \mathrm{~mm}$. long. $\quad$ I. S. Marylandica. Petals and anthers yellow; calyx-lobes ovate, obtuse; fruit $3 \mathrm{~mm}$. long, or less.

2. S. gregaria.

* * Biennial; staminate flowers never in separate heads; styles shorter than the bristles.

Leaves 3-5-divided; pedicels of staminate flowers $2 \mathrm{~mm}$. long; fruit less than $4 \mathrm{~mm}$. long.

Leaves 3 foliolate; pedicels of staminate flowers $4 \mathrm{~mm}$. long; fruit $6 \mathrm{~mm}$. long, or more. 4. S. trifoliata.

I. Sanicula Marylándica L. Sanicle. Black Snake-Root. (I. F. f. 2664.) Rather stout, 4-12 dm. high, topped by a 2-4-rayed umbel. Leaves firm, bluish green, the basal long-petioled, the upper sessile, 5-7-parted; segments 4-15 cm. long, obovate to oblanceolate, serrate or dentate, often incised; involucral leaves much smaller, 3-cleft; involucel-bracts rarely $2 \mathrm{~mm}$. long; pedicels of staminate flowers $4 \mathrm{~mm}$. long; calyx $2 \mathrm{~mm}$. long, parted into subulate segments; petals little exceeding the calyx; fruit sessile, ovoid, the slender recurved styles longer than the stout bristles; oil-tubes 5, large: seed furrowed dorsally. In rich woods, Newf. to Alberta, Ga. and Co'o. May-July. 
2. Sanicula gregària Bicknell. Clustered SNake-Root. (I. F. f. 2665.) Stems erect, 3-9 dm. high, umbellate-branched, the branches slender. Leaves thin, bright green, 5-divided; segments stalked, obovate-cuneate to lanceolate, acute or acuminate, doubly serrate with bristle-tipped teeth, sharply incised, mostly less than $8 \mathrm{~cm}$. long; basal leaves numerous, those of the stem only I or 2, petioled; involucral leaves large, 3-parted; pedicels of staminate flowers, 2-3 mm. long, 3 or 4 times the length of the minute campanulate calyx; calyx-lobes ovate, obtuse; petals much surpassing the calyx; fruit stipitate, broadly obovoid, $3 \mathrm{~mm}$. long, the slender styles recurved; bristles very small; oil-tubes 5 ; seed not furrowed. In woods and thickets, Vt. and Ont. to Minn., Va., Kans. and Neb. May-June.

3. Sanicula Canadénsis L. ShORT-STyled SNAke-Root. (I. F. f. 2666.) Rather dull green, 3-12 dm. high, widely branched, the umbellate fruit-bearing rays only 2-10 $\mathrm{mm}$. long. Stem leafy; leaves petioled, 3-5-divided; segments cuneate-obovate to narrowly oblong, acute, mucronate-serrate, or incised, often small; involucral leaves small, those of the involucels bract-like; staminate flowers few; calyx I mm. long, parted into linear-lanceolate acute lobes which exceed the minute white petals; fruit short-stipitate, subglobose; the bristles slender; oil-tubes 5; seed dorsally furrowed. In woodlands, Vt. to Fla., S. Dak. and Tex. June-Aug.

4. Sanicula trifoliàta Bicknell. LARGE-FruIted SNAKE-ROOT. (I. F. f. 2667.) Stem slender, 3-8 dm. high. Umbels of 3-5 often irregular rays $8-25 \mathrm{~mm}$. long; leaves rather bright green, thin, slender-petioled, 3-divided; segments stalked, broadly ovate, or obovate, or the lateral ones rhomboid. acute, coarsely doubly serrate, or incised, the teeth spinulose-cuspidate; staminate flowers few; calyx I mm. long, its linear rigid lobes incurved, subulate; petals white, about half as long as the calyx; larger oil-tubes 2 , with numerous minute ones; seed not sulcate. In hilly woods, Vt, to Ont., N. Y. and Ind. June-July.

\section{ERÝNGIUM L.}

Herbs, with spiny-toothed lobed dentate or sometimes dissected, rarely entire leaves, and bracted heads or spikes of small white or blue flowers subtended by bractlets. Calyx-teeth rigid, pungent, or acute. Petals erect. Disk expanded. Fruit scaly or tuberculate, somewhat flattened laterally. Carpels nearly terete, their ribs obsolete or none, the oil-tubes usually 5. [Greek, a kind of thistle.] About 150 species, of wide distribution. Besides the following, about 18 others occur in southern and western N. Am.

Plants erect, tall ; stem-leaves spiny or bristly-margined.

Leaves elongated-linear, parallel-veined.

Leaves elongated-linear, reticulate-veined.

Stem-leaves palmately incised-pinnatifid.

Plants prostrate, slender; leaves unarmed.
I. E. aquaticum.
2. E. Virginianum.
3. E. Leavenworthii.
4. E. prostratum.

I. Eryngium aquáticum L. Rattlesnake-master. Button SNakeROOT. (I. F. f. 2660.) Stout, 6-I $8 \mathrm{dm}$. high, glabrous. Leaves acuminate, niostly clasping at the base, the lower sometimes I m. long and $4 \mathrm{~cm}$. wide; heads stoutpeduncled, globose-ovoid, I-2 cm. long, longer than the ovate or lanceolate cuspidate bracts: calyx-lobes ovate, acute; fruit scaly, about $2 \mathrm{~mm}$. long. In wet soil or upland, Conn. to S. Dak., Fla., Kans. and Tex. June-Sept.

2. Eryngium Virginiànum Lam. Virginian Eryngo. (I. F. f. 266r.) Stem glabrous, 3-9 dm. high. Upper stem-leaves linear, acuminate, sessile and clasping at the base, 5-20 cm. long, rarely laciniate; basal and lower leaves longpetioled, thc blade linear-oblong. entire, or remotely denticulate; heads subglobose, 8-14 $\mathrm{mm}$. long, equalling or shorter than the lanceolate reflexed bracts: bractlets usually 3-cuspidate; calyx-lobes lanceolate, cuspidate; fruit scaly. In marshes near the coast, N. J. to Fla., west to Tex. July-Sept.

3. Eryngium Leavenwórthii T. \& G. Leavenworth's ERyngo. (I. F. f. 2662.) Stout, glabrous, 3-9 dm. high. Stem-leaves sessile, palmately pinnatifid into spiny-toothed segments; basal and lowest leaves oblanceolate, mostly obtuse, spinose-denticulate; heads peduncled, ovoid-oblong, $2-5 \mathrm{~cm}$. long, equalling or longer than the spinose bracts; bractlets $3-7$-cuspidate, those of the upper part of the heads large and resembling the bracts; calyx-lobes pinnatifid. In dry soil, Kans. to Tex. July-Oct, 
4. Eryngium prostràtum Nutt. Prostrate Eryngo. (I. F. f. 26(3.) Prostrate, rooting from the nodes, the branches very slender. Lower and basal leaves slender-petioled, oval or oblong, mostly obtuse, entire, or crenate-dentate; stemleaves smaller, often clustered at the nodes, ovate, few-toothed, or entire, or some of them 3-parted; heads ovoid-oblong, dense, about $6 \mathrm{~mm}$. long, mostly shorter than the lanceolate reflexed bracts; bractlets very small; fruit about $\mathrm{I} \mathrm{mm}$. long, tuber. culate. In low grounds, Ky. to Mo., Fla. and Tex. Summer.

\section{CHAEROPHÝLLUM L. (See Appendix.)}

Herbs, our species annuals, with decompound leaves and small umbels of white flowers. Involucre none or rarely of $\mathbf{I}$ or 2 bracts. Involucels of numerous smail , bractlets. Stylopodium small, conic. Fruit oblong or linear-oblong, flattened laterally. Carpels 5-angled, slightly flattened dorsally, the ribs slender, obtuse; oil-tubes solitary in the intervals. Seed-face channeled. [Greek, pleasant leaf, from the fragrance.] About 30 species, only the following North American.

Fruit not beaked, its ribs slender, narrower than the intervals between them.

Fruit beaked, its prominent ribs mostly as broad as the intervals.

I. C. procumbens.

2. C. Teinturieri.

I. Chaerophyllum procúmbens (L.) Crantz. Spreading Chervil. (I. F. f. 2678.) More or less pubescent, slender, spreading, I.5-5 dm. high. Lower leaves ternately decompound, the divisions ovate, pinnatifid, the ultimate segments obtuse; umbels 2-6-rayed; rays $2-5 \mathrm{~cm}$. long in fruit; flowers few in the umbellets; bracts of the involucels ovate; fruit glabrous, $4-5 \mathrm{~mm}$. long. In moist ground, N. Y. and Ont. to Mich., N. Car. and Kans. April-June.

Chaerophyllum procúmbens Shórtii T. \& G. Fruit broader, ovate-oblong, pubescent, blunt, or scarcely narrowed at the summit. Penn. to Ky., La. and Ark.

2. Chaerophyllum Teinturièri Hook. Teinturier's Chervil. (I. F. f. 2679.) Similar to the preceding, much branched, often taller. Ultimate leafsegments acute or obtuse; rays of the umbels $2-8 \mathrm{~cm}$. long; fruit $6-8 \mathrm{~mm}$. long, less than $2 \mathrm{~mm}$. wide, glabrous, or pubescent. In dry soil, Va. to Tenn., Kans., Fla. and Tex. March-May.

\section{ANTHRISCUS Hoffm.}

Annual or biennial herbs, with decompound leaves, and compound umbels of white flowers. Involucre commonly none; involucels of numerous bracts. Calyxteeth obsolete or minute. Stylopodium conic or depressed. Fruit linear in our species, beaked, laterally compressed. Carpels nearly terete, ribless except at the beak; oil-tubes none. Seed-face channeled. [Greek name of this or some allied plant.] About ro species, natives of the Old World.

I. Anthriscus Cerefòlium (L.) Hoffm. Garden Chervil or BeakedpARSLEY. (I. F. f. 2676.) Annual, glabrous, or finely pubescent above, 4-6 dm. high. Basal and lower leaves slender-petioled, the upper nearly sessile, all ternately decompound into small segments; umbels 3-6-rayed, the rays divergent, I-4 cm. long in fruit; pedicels stout, 4-6 mm. long; bracts of the involucels linearlanceolate, acuminate, about $2 \mathrm{~mm}$. long; fruit $6 \mathrm{~mm}$. long, glabrous and ribless, tipped with a ribbed beak of one-third its length. Eastern and southern Penn, Nat. from Europe. May-June.

Anthriscus sylvéstris (L.) Hoffm. Wild Beaked-Parsley, a tall annual with glabrous beakless fruit, has been found as a waif on Staten Island, and in ballast about the seaports.

Anthriscus Anthríscus (L.) Karst. BUR-CHERVIL, readily recognized by its shortbeaked muricate fruit, has been found as a waif in N. S., according to Macoun.

\section{SCÁNDIX L.}

Annual herbs, with dissected leaves. Flowers white, in compound umbels. Involucre none, or rarely of $\mathrm{I}$ bract. Involucels of several bracts. Petals mostly unequal, the outer larger. Fruit linear, or linear-oblong, flattened laterally, prolonged into a beak mostly much longer than the body; primary ribs prominent; secondary ribs none: oil-tubes solitary, cr wanting. Seed-face sulcate. Stylopo dium short. [Greek name of the plant. I About Io species, of the Old World. 
I. Scandix Pécten-Véneris L. Venus'- or Lady's-comb. Shepherd'sNEEDLE. (I. F. f. 2683.) Pubescent; stem 1.5-5 dm. high. Leaves 2-3-pinnately dissected, the lobes acute, less than $1 \mathrm{~mm}$. wide; involucels of several lanceolate bracts sometimes 2-3-lobed at the apex; flowers nearly sessile; fruiting carpels 8-12 mm. long, terminated by a straight flat beak 4-6 cm. long, about $2 \mathrm{~mm}$. wide, its edges with stiff ascending hairs. In waste places, N. J., D. C., and in ballast about the seaports. Fugitive from Europe. May-July.

\section{WASHINGTÓNIA Raf. [OSMORRHIZA Raf.]}

Perennial herbs from fleshy clustered roots, with decompound leaves, and fewrayed umbels of white flowers. Involucre and involucels of few narrow bracts, or none. Stylopodium small, conic. Fruit narrow, linear or oblong-linear, short: beaked, compressed, bristly along the ribs, attenuated at the base, Carpels 5-angular, slightly flattened dorsally, the ribs acute, nearly equal; oil-tubes obsolete or none. [In honor of George Washington.] About I5 species, of N. Am., Asia and S. Am. Besides the following about 8 others occur in the western U. S. Pubescent; style and stylopodium I $\mathrm{mm}$. long or less.

Style with stylopodium I mm. long; involucel-bracts mostly present.

Stylopodium $0.5 \mathrm{~mm}$. long; involucel-bracts few or none. Glabrate; style and stylopodium $2 \mathrm{~mm}$. long.

I. W. Claytoni.

3. W. divaricata,

2. W. longistylis.

1. Washingtonia Clàytoni (Michx.) Britton. Woolly Sweet-cicely. (I. F. f. 2680.) Erect, 4-9 dm. high, villous-pubescent. Lower leaves sometimes $3 \mathrm{dm}$. wide, the segments ovate or oval, incised dentate; umbels long pedurcled, 2-6-rayed; rays divaricate, $2-5 \mathrm{~cm}$. long in fruit; involucels of several subulate bracts; fruit about $12 \mathrm{~mm}$. long, about $2 \mathrm{~mm}$. wide; stylopodium slender-conic. In woods, N. S. to S. Dak., Minn, N. Car., Ill. and Kans. May-June.

2. Washingtonia longístylis (Torr.) Britton. Smoother Sweet cicely. (I. F. f. 2681.) Similar to the preceding but only slightly pubescent, the stems and petioles at length quite glabrous; bracts of the involucels lanceolate, $6-8 \mathrm{~mm}$. long, persistent. In woods, N. S. to the N. W. Terr., Ala., Tenn. and Kans. Rcots more spicy than those of $W$. Claytoni. May-June.

3. Washingtonia divaricàta Britton. Western Sweet-Cicely. (I. F. f. 2682.) Stem 6-9 dm. high; leaf-segments thin, ovate, acute, or acuminate, coarsely toothed and usually incised, I- $6 \mathrm{~cm}$. long; umbels long-peduncled, 3-6rayed, the very slender divaricate rays $5-10 \mathrm{~cm}$. long in fruit; involucels of $\mathrm{I}-3$ subulate bracts, or none; pedicels very slender, 4-25 cm. long; fruit about $12 \mathrm{~mm}$. long, $2 \mathrm{~mm}$. wide or rather more, beaked. Manitoba to S. Dak., Br. Col. and Cal. May-June.

\section{TÓRILIS Adans.}

Annual, hispid or pubescent herbs, with pinnately decompound leaves, and compound umbels of white or reddish fowers. Calyx teeth prominent, acute. Bracts of the involucre few and small or none. Involucels of narrow bracts. Petals mostly 2-lobed. Stylopodium thick, conic. Fruit ovoid or oblong. Primary ribs 5, filiform. Secondary ribs 4, winged, each bearing a row of barbed or hooked bristles or tubercles. Oil-tubes solitary under the secondary ribs, 2 on the commissural side. [The Greek name.] About 20 species, of the northern hemisphere.

Umbels sessile or chort-stalked, capitate, opposite the leaves.

Umbels compound, peduncled; rays slender.

I. T. nodosa.

2. 7. Anthriscus.

1. Torilis nodòsa (L.) Gaertn. Knotted Hedge-Parsley. (I. F. f. 2633.) Decumbent and spreading. Leaves bipinnate, the segments linear-oblong, acute; rays $\mathbf{I}-3$, very short; fruit sessile, ovoid, about $3 \mathrm{~mm}$. long, the outer with barbed prickles on the secondary ribs, the inner with tubercles. In waste places, Pa., Md. and Iowa. Also in the Southern States, Cal., the W. Indies and S. Am. Adventive from Europe. May-Aug. [Cancalis nodosa (L.) Huds.]

2. Torilis Anthriscus (L.) Gmel. ERect Hedge-PARsLey. (I. F. f. 2634.) Erect, 6-9 dm. high. Leaves bipinnate, or the uppermost simply pinnate, the segments lanceolate, ubtuse, dentate or pinnatifid; umbels slender-peduncled; pedicels 2-4 $\mathrm{mm}$. long in fruit; rays $3-8$, about $1 \mathrm{~cm}$. long; fruit ovoid-oblong, densely bristly, 3-4 mm. long. In waste places, N. J. to D. C. and Ohio. Adventive from Europe. July-Sept. [Caucalis Anthriscus (L.) Huds.] 


\section{BIFORA Hoffm.}

Glabrous annuals, with dissected leaves and few-rayed umbels of white flowers. Involucre and involucels of few small bracts. Fruit didymous, laterally flattened, with globose glabrous hard carpels. Carpels with 4 filiform secondary ribs. Stylopodium conic. Styles recurved. Oil-tubes none. [Latin, referring to the didymous fruit.] About 4 species, natives of N. Am. and Europe.

I. Bifora Americàna (DC.) A. Gray. American Bifora. Slender, roughish above, 2-4 dm. high. Ultimate leaf-segments narrowly linear, acutish. R iys 5-8, $2.5 \mathrm{~cm}$. long or less; pedicels I-3 mm. long; carpels about $2 \mathrm{~mm}$. in diameter. Mo. (according to Drude); Ark. to Tex. and N. Mex. April-May.

Bifora rádians Bieb., has been collected in wast s places and ballast, in R. I. and Penn. It differs from the preceding in its larger wrinkled fruit.

\section{APIÁstrum Nutt.}

Annual glabrous much branched herbs, with petioled finely dissected leaves, the leaf segments linear or filiform. Flowers very small, white, in compound unequalrayed umbels. Involucre none; involucels of a few small bracts, or none. Calyxteeth obsolete. Fruit ovate, or suborbicular, laterally flattened, tubercled, not ribbed; pericarp thin; oil-tubes few, not clustered, 2 on the commissural side. Seed-face concave. Stylopodium small. [Greek, false celery.] Two species, the following, and one in Cal.

I. Apiastrum pàtens (Nutt.) Coult. \& Rose. Spreading Apiastrum. (I. F. f. 2672.) Erect, 3-6 dm. high, divergently branched above. Stem-leaves shortpetioled, biternately dissected; umbels terminal, or axillary, I-4 cm. broad; rays 6. $12 \mathrm{~mm}$. long; pedicels 3-4 $\mathrm{mm}$. long in fruit; fruit ovate, slightly more than I $\mathrm{mm}$. long, more or less tuberculate, usually densely so. Neb. and Mo. to Tex. and N. Mex. June.

\section{ERIGENIA Nutt.}

Low glabrous nearly acaulescent perennial herbs, arising from a deep tuber, with ternately decompound leaves, usually a single-leaved involucre, and small umbels of white flowers. Calyx-teeth obsolete. Petals flat, entire. Fruit nearly orbicular, notched at both ends, glabrous. Carpels incurved at top and bottom, with 5 slender ribs and I-3 small oil-tubes in the intervals. [Greek, springborn.] A monotypic genus.

I. Erigenia bulbòsa (Michx.) Nutt. Harbinger of Spring. (I. F. f. 2709.) Stem scapose, $0.7-2.5 \mathrm{dm}$. high. Basal leaves 2-4, ternately divided into thin oblong obtuse segments, the involucral one similar, smaller; petioles much dilated at the base; umbels mostly compound, of I-4 slender rays; involucels spatulate or sometimes foliaceous; pedicels $2-5 \mathrm{~mm}$. long in fruit; fruit about $2 \mathrm{~mm}$. long and $3 \mathrm{~mm}$. broad. Ont. to D. C., Ala., Minn. and Kans. Feb.-April.

\section{CONIUUM L.}

Tall biennial glabrous herbs, with spotted stems, pinnately decompound leaves, and small white flowers in compound many-rayed umbels. Involucre and involucels of ovate acuminate bracts. Calyx-teeth obsolete; petals obcordate, or entire with a short inflexed point; fruit broadly ovate, glabrous, somewhat flattened laterally. Carpels strongly wavy-ribbed; large oil.tubes none, but a layer of oilsecreting tissue next the deeply concave seed. [Greek, hemlock.] Two species, one of them native of Europe and Asia, the other of Africa.

I. Conium maculàtum L. Poison Hemlock. (I. F. f. 2684.) Erect, much-branched, 6-15 dm. high. Lower and basal leaves petioled, the upper sessile or nearly so, all pinnately dissected, the leaflets ovate in outline, thin, the ultimate segments dentate, or incised; petioles dilated and sheathing at the base; umbels 2-8 $\mathrm{cm}$. broad, the rays slender, 2-4 cm. long: pedicels filiform, 4-6 mm. long in fruit; flowers about $2 \mathrm{~mm}$. broad; fruit $3 \mathrm{~mm}$. long, about $2 \mathrm{~mm}$. wide, its ribs very prominent when dry. In waste places, Quebec and Ont. to Del., Ind. and Mich. Also in Cal. and Mex. Nat. from Eurone. june-July. 


\section{MUSínEON Raf. (See Appendix.)}

Low perennial resiniferous herbs, with pinnately decompound leaves, and compound umbels of yellow or white flowers. Involucre none. Bracts of the involucels few, narrow. Calyx-teeth ovate. Stylopodium small, depressed. Fruit ovatc or ovate-oblong, slightly compressed laterally. Carpels somewhat 5-angled, the ribs filiform, equal; oil-tubes usually 3 in the intervals. Seed-face concave. [A name of fennel.] Three known species, natires of N. Am.

Sten leafy, branching; fruit about $4 \mathrm{~min}$. long.

Plant acaulescent, tufted; fruit about $2 \mathrm{~mm}$. long.
I. M. divaricatum.

2. M. tenuifolium.

I. Musineon divaricàtum (Pursh) Nutt. Leafy Musineon. (I. F. f. 2673.) Branched, glabrous, I.5-3 dm. high. Leaves bipinnatifid, petioled, 5-15 cm. long, the rachis narrowly winged, the segments oblong or ovate, acutish, 3-5-dentate; umbels mostly long-peduncled, $2.5-6 \mathrm{~cm}$. broad, 8-25-rayed; rays 6-25 mm. long; flowers yellow; fruit smooth, or very nearly so. Prairies, S. Dak. to Manitoba, the N. W. Terr. and Ore. May-June.

2. Musineon tenuifòlium Nutt. Scapose Musineon。 (I. F. f. 2674.) Acaulescent from a woody root, tufted, glabrous, 5-15 cm. high. Leaves decompound into lincar acute incised segments; umbel $\mathbf{r}-2.5 \mathrm{~cm}$. broad, 5-18-rayed; rays 4-10 $\mathrm{mm}$. long; flowers greenish white (?); fruit oblong, nearly smooth, its ribs rather prominent when dry. In dry rocky places, S. Dak., Neb. and in the Rocky Mts. June-July.

\section{BUPLEUั่RUM L.}

Annual or perennial herbs, with simple entire clasping or perfoliate leaves, and compound umbels of yellow or greenish yellow flowers. Involucre none in our species. Involucels of 5 ovate mucronate bracts. Calyx-teeth obsolete. Stylopodium conic. Styles short. Fruit oblong or oval, somewhat compressed laterally. Carpels angled, with slender equal ribs; oil-tubes none in our species. Seed-face concave. [Greek, ox-ribbed, referring to the leaves.] About 65 species of wide distribution. Besides the following another occurs in northwestern Am.

I. Bupleurum rotundifollium L. Hare's Ear. ThoruUgh-Wax. (I. F. f. 2677.) Annual, rather stiff, glabrous, pale, 3-6 dm. high. Leaves broadly ovate, or oval, mostly obtuse, mucronate, $2-4 \mathrm{~cm}$. long, perfoliate, or the lowest narrowed into a petiole; umbels 3 -6-rayed, the rays seldom over $8 \mathrm{~mm}$. long; bracts of the involucels about as long as the rays, yellowish; fruit glabrous, about $3 \mathrm{~mm}$. long. In fields, N. H. to N. Car., S. Dak., Kans. and Ark. Also in the Southwest. Nat. from Europe. July-Aug.

Bupleùrum Odontites L., with narrowly linear leaves, also European, has been found in waste places in Mass.

\section{6. ÀPIUM L.}

Annual or perennial glabrous herbs, with pinnate or pinnately compound leaves, and white flowers in compound umbels. Calyx-teeth obsolete. Petals ovate, mostly inflexed at the apex. Stylopodium depressed, or short-conic. Fruit ovate, or broader than long, smooth, or tuberculate. Carpels mostly with prominent ribs, somewhat 5-angled: oil-tubes mostly solitary in the intervals, 2 on the commissural side. Seed terete. or nearlv so. [Latin name of these or some similar plants.] About 15 species. of wide distribution. Besides the following, 2 or 3 others occur in the southern and western U. S.

Leaf-segments broad.

Leaf-segments very narrow.

r. A. graveolens.

2. A. leptophyllum.

I. Apium gravèolens L. Celery. (I. F. f. 2688.) Glabrous; stem 3-9 $\mathrm{dm}$. high. Leaves pinnate; leaf-segments 3 or 5 , thin, broadly ovate to oval, coarsely toothed and often incised; umbels 3-7-rayed; involucre and involucels small, or none; flowers small, short-pedicelled; fruit oval, scarcely $1 \mathrm{~mm}$. long, the ribs somewhat winged; oil-tubes mostly solitary in the intervals and 2 on the commissural side. In waste places. escaped from cultivation in Va. and nat. in salt marshes on the coast of Cal. Native of Europe. May-July. 
2. Apium leptophýllum (DC.) F. Muell. Fine-Leaved Marsh Parsiey. (I. F. f. 2689.) Slender, much branched, 0.7-6 dm. high. Leaves ternately pinnatisected, the ultimate segments narrow, often incised; umbels $\mathrm{I}-4 \mathrm{~cm}$. broad, oppo. site the leaves; fruit ovate, glabrous, about $2 \mathrm{~mm}$. long, the ribs equal and prominent. In moist grounds, N. J.; " "St. Louis, Mo." (Nuttall). Common in the Southern States. Widely distributed in tropical Am. and the Old World. June-Aug.

\section{AMMOSELINNUM T. \& G.}

Low annuals, with ternately divided finely dissected leaves, and small white flowers in terminal slender-rayed umbels. Involucels of a few linear or dissected bracts. Calyx-teeth obsolete. Fruit laterally flattened, strongly ribbed, the ribs tuberculate or spinulose-tuberculate; pericarp thick and dense; oil-tubes solitary in the intervals, and 2 on the commissural side. Styles and conic stylopodium short. [Greek, sand-parsley.] 'Two known species, of the southwestern U. S. and Mex.

I. Ammoselinum Pòpei T. \& G. Pope's Sand-Parsley. (I. F. f. 2668.) Diffusely branched, I.5-4 dm. high, the branches, rays of the umbels and pedicels rough. Lower leaves slender-petioled, the upper sessile, or nearly so, all dissected into linear segments about I mm. wide; involucre usually of I dissected leaf or more; longer rays of the umbels $2.5 \mathrm{~cm}$. long in fruit, or less, the shorter ones often Iflowered; fruit ovate, 4-5 $\mathrm{mm}$. long, narrowed above, $2 \mathrm{~mm}$. wide, or a little more, the ribs rather strongly tubercled, or even spinulose. In sandy soil, Kans. to Tex., Mex. and Ariz. April-May.

\section{PETROSELINUM Hoffm.}

Annual or biennial herbs, with I-3-pinnate leaves, and yellow or yellowish flowers in compound umbels. Calyx.teeth obsolete. Stylopodium short-conic. Fruit ovate. Carpels with 5 filiform ribs. Oil-tubes solitary in the intervals, 2 on the commissural side. [Greek, rock-parsley.] A genus of 5 European species.

I. Petroselinum Petroselinum (L.) Karst. Parsley. (I. F. f. 2687.) Usually biennial, 3-9 $\mathrm{dm}$. high, glabrous. Leaves bipinnate, the segments ovate, dentate, or incised, or those of the upper leaves linear-oblong and entire; umbels peduncled, $2.5-6 \mathrm{~cm}$. broad, 15-20-rayed; pedicels about $3 \mathrm{~mm}$. long; involucre of 2-4 linear bracts; bractlets of the involucels subulate; fruit glabrous, about $4 \mathrm{~mm}$. long, the ribs rather prominent when dry. Md. to Ont., escaped from cultivation. Introduced from Europe. Summer. [Apium Petroselinum L.]

\section{ZízIA Koch.}

Perennial herbs, with ternate or ternately compound leaves, or the basal ones undivided, and compound umbels of yellow flowers. Involucre none; involucels of several small bracts. Calyx-teeth prominent. Stylopodium none. Styles elongated. Fruit ovoid, or oblong, glabrous, or nearly so, somewhat compressed, the rilss filiform, wingless; oil-tubes solitary in the intervals, with a small one under each rib. Seed-face flat. [In honor of I. B. Ziz, a Rhenish botanist.] 'Three species.

Basal leaves 2-3-ternately compound.

Rays of the umbel numerous, stout; fruit $4 \mathrm{~mm}$. long.

Ravs of the umbel 2-12, slender; fruit about $2 \mathrm{~mm}$. long.

Basal leaves cordate, undivided; fruit about $3 \mathrm{~mm}$. long.

I. Z. aurea.

2. Z. Bebbii.

3. Z. cordata.

I. Zizia aùrea (L.) Koch. Early or Golden Meadow-parsnip. (I. F. f. 269o.) Glabrous, 3-8 dm. high. Basal and lower leaves 2-3-ternately compound, the segments ovate, or ovate-lanceolate, $2-5 \mathrm{~cm}$. long, sharply serrate; upper leaves shorter-petioled, ternate; rays 9-25, stout, ascending, $2-5 \mathrm{~cm}$. long; fruit oblong. In fields, meadows and swamps, N. B. to Ont., S. Dak., Fla. and Tex. April-June.

2. Zizia Bébbii (Coult. \& Rose) Britton. Bebb’s Zrzıa. (I. F. f. 269r.) Slender, ascending, 3-6 dm. high. Basal and lower leaves 2-3-ternate, the segments ovate, oblong. or oval, mostly obtuse, $\mathbf{r}-2.5 \mathrm{~cm}$. long, sharply serrate; stemleaves ternate, or biternate, their segments lanceolate, generally narrower than 
those of the preceding; rays $2-\mathbf{I} 2$, slender, divergent, $2-8 \mathrm{~cm}$. long; fruit oval, or broader than long. Mountain woods, Va. and W. Va. to N. Car. and Ga. May. 3. Zizia cordata (Walt.) DC. Heart-leaved Alexanders. (I. F. f. 2692.) Glabrous, or somewhat fubescent, 6-9 dm. high. Basal and lower leaves broadly ovate, or orbicular, undivided, deeply cordate, sometimes $\mathbf{1 . 5} \mathrm{dm}$. long, crenate; stem-leaves ternate, or rarely quinate, the segments ovate, or oval, crenate, or lobed: rays $7-16$, ascending, $2-5 \mathrm{~cm}$. long; fruit ovate, or oval. In woods, Conn. to Minn., the N. W. Terr., Ga., Mo., Wyo. and Ore. May-June.

\section{2o. Cicùta L. (See Appendix.)}

Erect tall perennial glabrous herbs, with pinnate or pinnately compound leaves, and terminal umbels of white flowers. Involucre of few bracts, or none; involucels many-bracted. Calyx-teeth acute. Stylopodium short-conic; fruit ovate to oblong, glabrous, slightly flattened laterally. Ribs corky, the lateral ones strongest; oil-tubes solitary in the intervals, 2 on the commissural side. Seed nearly terete. [The ancient Latin name.] About 8 species, natives of the north temperate zone and Mex. Besides the following, about 4 others occur in western N. Am.

Leaf-segments lanceolate.

Leaf-segments narrowly linear.

I. C. maculata. 2. C. bulbifera.

I. Cicuta maculàta L. Water Hemlock. Musquash Root. (I. F. f. 2694.) Stout, 9-18 dm. high, the stem marked with purple lines. Roots several, tuberiform; leaves petioled, bipinnate, or tripinnate, the lower often $3 \mathrm{dm}$. long; leafsegments coarsely and sharply serrate, their veins apparently ending in the notches; umbellets many-flowered; pedicels unequal; fruit ovate, or oval, 2-3 mm. long. In swamps, N. B. to Manitoba. Fla. and N. Mex. Poisonous. June-Aug.

2. Cicuta bulbífera L. Bulb-Bearing Water Hemlock. (I. F. f. 2695.) Slender, 3-10 dm. high. Roots few, tuberiform. Leaves 2-3-pinnate, the upper ones less divided, smaller, and bearing clustered bulblets in their axils; leafsegments linear, sparingly serrate with distant teeth; fruit broadly ovate, slightly more than $2 \mathrm{~mm}$. long. In swamps, N. S. to Del., Manitoba, Ind. and Neb. JulySept.

\section{DÉRINGA Adans. [CRYPTOTAENIA DC.]}

A perennial glabrous herb, with 3-divided leaves, and irregular umbels of white flowers. Involucre and involucels none. Calyx-teeth obsolete. Stylopodium conic; fruit oblong, laterally compressed, glabrous. Carpels nearly terete, the ribs equal, obtuse; oil-tubes solitary in the intervals and also beneath each rib. Seedtace flat or nearly so. [Said to be named for Deering or Dering.] A monotypic genus of eastern N. Am. and Japan.

I. Deringa Canadénsis (L.) Kuntze. Honewort. (I. F. f. 2696.) Erect, 3-9 dm. high. Lower and basal leaves long-petioled, 3-divided, the segments thin, ovate, acute or acuminate, sharply and irregularly serrate, incised, or sometimes lobed, $2-$ Io $\mathrm{cm}$. long, the lateral ones nearly sessile, the terminal one abruptly narrowed into a margined incised stalk; umbels 4-IO-rayed; fruit narrowed at both ends, 4-6 mm. long, often curved. In woods, N. B. to S. Dak., Ga. and Tex. June-July.

\section{CÀRUM L.}

Glabrous herbs, with pinnate or pinnatifid leaves, and small white or yellowish flowers in terminal umbels. Calyx-teeth minute. Stylopodium conic; fruit ovate, or oblong, somewhat compressed, glabrous. Carpels somewhat 5-angled, the ribs filiform, or inconspicuous; oil-tubes solitary in the intervals and 2 on the com. missural side. Seed dorsally flattened, its face flat or slightly concave. [Greek, caraway.] About 50 species, natives of temperate and warm regions. Besides the following, about 4 others occur in western N. Am.

I. Carum Càrui L. Caraway. Carvies. (I. F. f. 2693.) Biennial or sometimes perennial, 3-6 dm. high. Leaves pinnatisected into linear or filiform segments; involucre of $\mathrm{I}-3$ linear bracts, or none; involucels commonly none; umbels 
7-10-rayed; rays I-5 cm. long in fruit; fruit oblong, usually slightly curved, about $4 \mathrm{~mm}$. long, the ribs conspicuous when mature. Occasional in waste places, Newf. to S. Dak., Penn. and Colo. Adventive from Europe. May-July.

\section{TAENÍDIA Drude.}

A glabrous perennial herb, with 2-3-ternate leaves and compound umbels of yellow flowers. Involucre and involucels none. Calyx-teeth obsolete. Stylopodium broadly conic. Fruit oval, more or less compressed. Carpels obscurely 5-angled with slender equal distant ribs; oil-tubes numerous, 2-6 in the intervals. Seed-face flat or slightly convex. A monotypic genus.

r. Taenidia integérrima (L.) Drude. Yellow Pimpernel. (I. F. f. 267o.) Erect, somewhat glaucous, 3-9 dm. high. Leaves 2-3-ternate, the upper with short dilated petioles, the lower long-petioled; segments ovate, oval, or lanceolate, obtuse, or acutish and often mucronulate at the apex, entire, $1-2.5 \mathrm{~cm}$. long; rays 10-2O; pedicels slender; fruit oval, about $4 \mathrm{~mm}$. long. In rocky or sandy soil, Quebec to N. Car., Ont., Minn., Kans. and Miss. May-June. [Pimpinella integerrima A. Gray.]

\section{PIMPINÉLLA L.}

Perennial herbs, mostly with ternately compound leaves and white flowers in compound umbels. Involucre and involucels none in our species. Stylopodium broadly conic. Fruit oval to ovate, compressed. Carpel-ribs slender. Oil-tubes 2-6 in the intervals. About 75 species, natives of the Old World.

I. Pimpinella Saxífraga L. Bennet. Pimpernel. (I. F.f. 267I.) Erect, 3-6 dm. high. Leaves pinnate; segments of the lower 9-19, sharply serrate, or incised, ovate, or nearly orbicular, 1.5-2.5 cm. long; umbels 7-20-rayed; rays $2-4 \mathrm{~cm}$. long in fruit; fruit oval. In waste places, N. Y., Penn., N. J. and Ohio. Adventive from Europe. June-Oct.

\section{AEGOPÒDIUM L.}

Perennial herbs, with I-2-ternate leaves, and compound umbels of white howers. Bracts of the involucre and involucels none, or rarely few and early deciduous. Calyx-teeth obsolete. Stylopodium thick, conic. Fruit ovate-oblong, glabrous, somewhat compressed. Carpels obscurely 5-angled, the ribs equal, distant; oil-tubes none. [Greek, goat-foot.] Two species, of Europe and Asia.

I. AEgopodium Podagrària L. Goutween. Goutwort. Herb-Gerard. (I. F. f. 2702.) Erect, glabrous, 4-7 dm. high. Basal and lower leaves biternate, the primary divisions stalked, the segments ovate, acute, or acuminate at the apex, rounded, or cordate at the base, sharply serrulate, $3-8 \mathrm{~cm}$. long: umbels long-peduncled, 9-25-rayed; rays $2.5 \mathrm{~cm}$. long in fruit or more; fruit about $4 \mathrm{~mm}$. long, scarcely $2 \mathrm{~mm}$. wide, the styles deflected. In waste places, Mass. to Penn. and Del. Adventive from Europe. June-Aug.

\section{EÙlOPHUS Nut*}

Perennial glabrous herbs, with deep tuber ${ }^{-}$Jots, ternately compound leaves, and long-peduncled compound umbels of 1 . ate or pinkish flowers. Involucre generally of $\mathbf{I}$ bract, sometimes none. Involucels of several bracts. Calyx-teeth usually prominent. Stylopodium conic. Styles recurved. Fruit glabrous, linear to oblong in our species; ribs filiform, with $\mathbf{I}-5$ oil-tubes in the intervals. Seedface concave. [Greek, well-plumed.] About 5 species, natives of N. Am.

I. Eulophus Americànus Nutt. EASTERN Eulophus. (I. F. f. 2675.) Erect, 9-15 dm. high. Basal and lower leaves large, long-petioled; segments linear; umbels 7-10 cm. broad, the rays 6-12, very slender. 5-10 $\mathrm{cm}$. long: involucels of narrowly lanceolate acuminate bracts; pedicels almost filiform, $8-16 \mathrm{~mm}$. long in fruit; flowers whitish (?); fruit oblong, 4-6 mm. long. In dry soil, Ohio to Kans., Tenn. and Ark. July.

\section{SìUM L.}

Perennial marsh herbs, with simply pinnate stem-leaves, the lower and basal ones often pinnatisected, and large umbels of white flowers. Involucre and 
involucels of numerous narrow bracts. Calyx-teeth minute. Styles short. Fruit cvate or oval, somewhat compressed. Carpels with prominent ribs; oil-tubes I- 3 in the intervals. Seed-face flat. [Greek name of a marsh plant.] About 8 species, natives of the north temperate zone and South Africa.

Plant stout, 6-18 dm. high; leaf-segments 7-1 7.

Plant weak, 3-9 dm. high; leaf-segments $3-7$.

1. S. cicutaefolium.

2. S. Carsuni.

I. Sium cicutaefòlium Gmel. Hemlock Water-Parsnip. (I. F. f. 2685.) Erect, stout. Lower leaves long-petioled, the uppermost nearly sessile; leaf-segments linear, or lanceolate, 3-13 cm. long, 3-25 mm. wide, acuminate, sharply serrate; or the lowermost pectinately dissected; umbels 8-20-rayed; rays $\mathrm{I}-4 \mathrm{~cm}$. long; fruit ovate, compressed, about $3 \mathrm{~mm}$. long. In swamps, N. S. to $\mathrm{Br}$. Col., Fla., La. and Cal. Very variable in leaf-form. July-Oct.

2. Sium Carsoni Durand. Carson's WATER-PARSNip. (I. F. f. 2686.) Stem slender, 3-6 dm. long. Leaf segments 3-7, those of the upper leaves linear, or lanceolate, acute, or acuminate, 2-5 cm. long, 3-6 $\mathrm{mm}$. wide, sharply serrate; lower leaves often floating and very thin, the segments broader and laciniate, or dissected; umbels $7-15$ rayed; rays $1-2.5 \mathrm{~cm}$. long in fruit. In streams, Me. to R. I. and Penn. July-Aug.

\section{BÉRULA Hoffm.}

A glabrous aquatic or marsh perennial, with pinnate leaves, serrate or sometimes incised leaf-segments, and terminal compound umbels of white flowers. Involucre and involucels of several narrow bracts. Calyx-teeth very small. Stylopodium conic; styles short. Fruit subglobose, slightly flattened laterally, glabrous, the ribs very slender, the pericarp thick and corky; oil-tubes numerous and close together along the inner side of the pericarp. Seed-face flat. [Latin name of the watercress.] A monotypic genus of the north temperate zone.

I. Berula erécta (Huds.) Coville. Cut-leaved Water-Parsnip. (I. F.f. 2701.) Erect, rather stout, much branched, I.5-9 dm. high. Leaflets 7-I9, ovate, oval, or linear-oblong, deeply serrate, laciniate, or lobed, r-3.5 cm. long, 4-Io $\mathrm{mm}$. wide, those of the upper leaves commonly more laciniate than those of the lower; umbels numerous, short-peduncled, IO-20-rayed; rays I- $6 \mathrm{~cm}$. long in fruit; pedicels 3-6 $\mathrm{mm}$. long; fruit less than $2 \mathrm{~mm}$. long, nearly orbicular, somewhat cordate at the base, the ribs inconspicuous. In swamps and streams, southern Ont. to Br. Col., south to Mass. (?), N. Y., Ill., Kans., in the Rocky Mts. to N. Mex, and to Cal. Also in Europe and Asia. July-Sept.

\section{PTILÍMNIUM Raf. [DISCOPLEURA DC.]}

Annual glabrous herbs, with dissected leaves, and compound umbels of white flowers. Bracts of the involucre filiform or dissected in our species. Calyx-teeth obsolete. Petals obovate, the apex inflexed. Stylopodium conic; fruit ovate, slightly compressed, glabrous. Carpels dorsally compressed, the dorsal and intermediate ribs prominent. slender, the lateral ones thick and corky; oil-tubes solitary in the intervals. Seed-face flat. [Greek, referring to the finely divided leaves.] Besides the following, another occurs in Texas and one in the East Indies.

Involucral bracts mostly pinnate; fruit $2-3 \mathrm{~mm}$. long. Involucral bracts short, entire; fruit $1-1.5 \mathrm{~mm}$. long.

x. P. capillaceum. 2. P. Nuttallii.

I. Ptilimnium capillàceum (Michx.) Raf. Mock BIshop-weEd. (I. F. f. 2699.) Slender, 3-6 dm. high. Leaves finely dissected into filiform segments; involucral bracts or some of them pinnately parted; involucels of several linear bracts; umbels 5-10 cm. broad, 5-20 rayed; fruit ovate, acute. In wet soil, especially brackish meadows, Mass. to Fla., west to Tex. June-Oct.

2. Ptilimnium Nuttàllii (DC.) Britton. Nuttall's Mock Bishop-weed. (I. F. f. 2700.) Similar to the preceding, but generally stouter, 6-9 dm. high, the branches nearly erect. Umbels 7-25-rayed; bracts of the involucre linear, entire, short, those of the involucels minute: fruit ovate-orbicular, obtusish. In s'wamps, 1ll. to Kans., La. and Tex. May-Sept. 


\section{CYNOSCIÀdIUM DC.}

Glabrous annuals, the lower and basal leaves mostly linear and entire, those of the stem mainly divided into few linear segnents. Involucres and involucels of several subulate or narrowly linear bracts. Flowers small, white, in compound umbels. Calyx-teeth short, persistent. Fruit ovoid, or oblong, nearly terete, strongly ribbed, the lateral ribs the larger; oil-tubes solitary in the intervals and 2 on the commissural side of each carpel. Seed-face flat. Stylopodiun conic. [Greek, dog-celery.] Two known species, natives of the southern U. S.

I. Cynosciadium pinnàtum DC: Pinnate Cynoscradium. (I. F.f. 2659.) Stem 3-6 dm. high. Lower and basal leaves petioled, the blade elongated-linear, entire, acuminate or acute at each end, $2-8 \mathrm{~cm}$. long; stem-leaves pinnately divided into 3-9 linear entire segments, the terminal segment much larger than the lateral ones, or some of them entire; bracts $4-6 \mathrm{~mm}$. long; umbels 4-IO-rayed; rays very slender; fruit about $4 \mathrm{~mm}$. long, less than $2 \mathrm{~mm}$. wide, crowned by the ovate calyx-teeth. In wet soil, Mo. to the Ind. Terr. and Tex. May-Aug.

OEnanthe aquática (L.) Poir., a tall usually aquatic herb with finely dissected leaves, the umbels mostly opposite them, the involucre wanting and the involucels of small bracts, has been found as a fugitive at Washington, D. C. [OE. Phellandrium Lan.]

\section{3r. LILAEÓPSIS Greene. [CRANTZIA Nutt.]}

Snall creeping glabrous perennial marsh herbs, the leaves reduced to linear terete septate hollow petioles, with simple umbels of white flowers. Bracts of the involucre several, small. Calyx-teeth acute. Stylopodium conic. Fruit glabrous, globular, somewhat flattened laterally. Carpels nearly terete, the dorsal and intermediate ribs filiform, the lateral ones much larger and corky-thickened, the commissural faces each with a corky longitudinal projection; oil-tubes solitary in the intervals. Seed terete. [Greek, resembling the genus Lilaea.] A small genus of wide distribution.

I. Lilaeopsis lineàta (Michx.) Greene. Lilaeopsis. (I. F. f. 2658.) Rooting in the mud, 5-13 cm. long. Petioles linear-spatulate, obtuse, generally 2-8 $\mathrm{cm}$. long, but sometimes longer, about $3 \mathrm{~mm}$. thick; peduncles somewhat exceeding the leaves; umbels 5 -Io-rayed, the rays $3-6 \mathrm{~mm}$. long; fruit about $2 \mathrm{~mm}$. long. Iu salt and brackish marshes, and on river-shores, N. H. to Fla., west to Miss. June-Aug.

\section{AETHÙSA L.}

Annual glabrous lerbs, with pinnately dissected leaves, and compound umbels, both terminal and opposite the leaves. Involucre none, or of a single bract. Bracts of the involucels $\mathbf{I}-5$, setaceous, turned to one side. Calyx-teeth obsolete. Stylopodium broad, thick. Fruit globose-ovoid, glabrous. Carpels dorsally compressed, the ribs prominent, corky, acute, nearly equal; oil.tubes solitary in the intervals. Seed-face flat. [Greek, burning, from the sharp taste.] A monotypic genus of Europe and Asia.

I. AEthusa Cynàpium L. Fool's Parsley. (I. F. f. 2656.) Erect, leafy, dichotomously branched, 3-8 dm. high. Leaves 2-3-pinnate; petiole-bases dilated; ultimate segments linear, acutish; umbels long-peduncled, $5-8 \mathrm{~cm}$. broad in fruit, 8-12-rayed; pedicels 2-8 mm. long; fruit about $3 \mathrm{~mm}$. long. In waste places, $\mathbf{N}$. S. to N. J. and Minn. Poisonous. Adventive from Europe. June-Sept.

\section{FOENÍCULUM Adans.}

Erect glabrous herbs, with pinnately decompound leaves, the segments linear or capillary, and compound umbels of yellow flowers. Involucre and involucels none. Calyx-teeth obsolete. Stylopodium large, conic. Fruit linear-oblong, glabrous, terete, or nearly so. Carpels half-terete, dorsally flattened, prominently ribbed; oil tubes solitary in the intervals. Seed-face flat, or slightly concave. [Latin, diminutive of foenum, hay, from its odor.] About 4 species, of the Old World.

I. Foeniculum Foenículum (L.) Karst. FenNel. (I. F. f. 2669.) Perennial, 6-12 dm. high. Leaves dissected into capillary segments; petioles broad, clasping; umbels large, 9-25-rayed, the rays rather stout, somewhat glaucous, $2-8 \mathrm{~cm}$. long in fruit; pedicels $2-8 \mathrm{~mm}$. long; fruit about $6 \mathrm{~mm}$. long. In waste 
places, N. J. and Penn. to Va. and La. Escaped from gardens. Adventive from Europe. July-Sept.

Anethum gravéolens L., DillweEd, sinilar to Fennel, but with the fruit somewhat flattened dorsally, and the root annual or biennial has been found in waste places at Wilnington, Del.

\section{LIGÚSTICUM L.}

Perennial glabrous herbs, with aromatic roots, ternately compound leaves, and large compound umbels of white flowers. Involucre of several narrow mostly deciduous bracts. Involucels of numerous linear bracts. Calyx-teeth obiolete. Stylopodium conic. Fruit oblong or ovoid, scarcely flattened. Carpels dorsaliy compressed, the ribs prominent, acute, separated by broad intervals; oil-tub.s 2-6 in the intervals. Seed-face flat or slightly concave. [Named from Liguria, wlere Lovage abounds.] About 20 species, natives of the northern hemisphere. Besides the following, some 7 others occur in western N. Am.

Leaves thin; fruit ovoid; southern species.

Leaves fleshy; fruit oblong; northern seacoast species.
I. L. Canadense.

2. L. Scoticum.

I. Ligusticum Canadénse (L.) Britton. Nondo. Angelico. (I. F. f. 2654.) Stout, 0.6-1.8 m. high. Leaves thin, the lower and basal petioled, often $3 \mathrm{dm}$. wide, their primary divisions ternate; segments ovate, or oval, $4^{-13} \mathrm{~cm}$. long, acute, rounded at the base, coarsely serrate, or those of the uppermost leaves linear-lanceolate and entire; umbels mostly twice compound, sometimes $2.5 \mathrm{dm}$. broad; bracts of the involucre 2-6, linear; pedicels $2-4 \mathrm{~mm}$. long in fruit; fruit ovoid, 4-6 mm. long, with prominent slightly winged ribs; ull-tubes 3 or 4 in the intervals; seed angled on the back. In rich woods, southern Penn. to Ga., Mo. and $\mathrm{Ky}$. June-Aug.

2. Ligusticum Scóticum L. Scotch Lovage. Sea Parsley. (I. F. f. 2655.) Stem 2.5-9 dm. high. Leaves mostly biternate, the segments broadly obovate or oval, $2-10 \mathrm{~cm}$. long, shining, dentate; umbels $5-10 \mathrm{~cm}$. broad in fruit; pedicels 4-10 $\mathrm{mm}$. long; fruit oblong, 6-10 $\mathrm{mm}$. long, the ribs prominent and somewhat winged; seed rounded on the back. Along salt marshes, Conn. to Lab. and the lower St. Lawrence River. Also on the Pacific coast and the shores of northern Europe and Asia. July-Aug.

\section{COELOPLEÙRUM Ledeb.}

Stout and tall maritime perennials, with large 2-3-ternate leaves, inflated petioles, and compound umbels of greenish white flowers. Involucre of a few linear deciduous bracts, or none. Involucels of numerous linear bracts. Calyxteeth obsolete. Stylopodium depressed. Fruit oblong, scarcely flattened; dorsal and intermediate ribs prominent, corky-thickened, the lateral ones slightly broader, acute, but not winged; oil-tubes solitary in the intervals, 1 or 2 under each rib and 2-4 on the commissural side. Seed loose in the pericarp, its face flat or slightly concave. [Greek, hollow-ribbed.] Two species, one widely distributed in the northern hemisphere, the other on our north western coast.

I. Coelopleurum Gmélini (DC.) Ledeb. Seacoast Angelica. (I. F. f. 2657.) Branching, 6-9 dm. high, the umbels and upper part of the stem puberulent. Lower leaves large, 2-3-ternate, the segments thin, ovate, acute or acuminate, sharply dentate and incised, 3-6 cm. long; umbels 7-13 cm. Lroad, ro-25-rayed; pedicels slender, 6-12 mm. long; fruit 5-7 mm. long. Seacoast, Greenland to Mass., on the lower St. Lawrence River and the Pacific cuast. Also on the coasts of eastern Asia. Summer.

\section{THÁSPIUM Nutt.}

Perennial herbs, with ternate or ternately compound leaves, or the basal ones sometimes undivided, and compound umbels of yellow or purple flowers. Involucre none, or of I-3 bracts. Involucels of several small bracts. Calyx-teeth prominent, acute. Stylopodium none. Style slender. Fruit ovoid or oblong, glabrous or nearly so, scarcely flattened. Carpels somewhat dorsally flattened, the ribs or at least some of them strongly winged; oil-tubes solitary in the intervals. Seed-face flat. [Name from the island Thapsus.] About 3 species, natives of eastern N. Am. 
Leaves mostly ternate; segments crenate, thickish.

Leaves mostly biternate; segments incised or lobed, rather thin.

Segments ovate, incised.

Segments pinnatifid into oblong lobes.

\section{T. trifoliatum.}

2. T. barbinode.

3. 7: pinnatifidum.

I. Thaspium trifoliàtum (L.) Britton. PURPle Meadow-Parsnip. (I. F. f. 2651.) Glabrous; stems 3-6 dm. liigh. Upper stem-leaves short-petioled, ternate, or rarely biternate, the segments ovate or ovate-lanceolate, $2-5 \mathrm{~cm}$. long: basal leaves long-petioled, sometimes undivided; umbels $2-5 \mathrm{~cm}$. broad; petals dark purple: fruit nearly $4 \mathrm{~mm}$. long, all the ribs usually winged. In woods, $R$. I. to N. J., Tenn. and Mo. June-July.

Thaspium trifoliatum aùreum (Nutt.) Britton. Flowers yellow. Range of the type.

2. Thaspium barbinòde (Michx.) Nutt. Hairy-Jointed MEadow-Parsnip. (I. F. f. 2652.) Erect, 6-12 dm. high, pubescent at the joints and sometimes also on, the shoots and rays of the umbels. Leaves petioled, mostly bipinnate; seg. ments acute, incised-serrate or cleft, 2-5 cm. long; umbels $2-5 \mathrm{~cm}$. broad; flowers light yellow; fruit nearly $6 \mathrm{~mm}$. long, usually glabrous, 7 of the ribs commonly broadly winged. Along streams, Ont. to Minn., Kans., Fla., Ky. and Ark. MayJune.

Thaspium barbinode angustifolium Coult. \& Rose. Leaf-segments more sharply cleft into narrower lobes; fruit puberulent. Penn. to W. Va. and lil.

3. Thaspium pinnatífidum (Buckl.) A. Gray. CuT-Leaved MeadowPARSNIP. (I. F. f. 2653.) Divergently branched, 6-12 dm. high, more pubescent than the preceding. Leaves ternately pinnatifid into numerous oblong or linearoblong lobes, the basal ones long-petioled and very large; flowers light yellow; fruit 3-5 $\mathrm{mm}$. long, puberulent, all the ribs winged, but 7 of the wings broader than the other 3. In woods and copses, Ky. to N. Car. and Tenn. June.

\section{CONIOSELINUM Hoffm.}

Perennial glabrous branching herbs, with decompound leaves, and compound umbels of white flowers. Involucre none, or of a few short bracts. Involucels of narrowly linear bracts. Calyx-teeth obsolete. Stylopodium depressed-conic. Fruit oval or oblong, dorsally flattened. Carpels with prominent approximate dorsal and intermediate ribs, the lateral ones broadly winged. Oil-tubes mostly 2 or 3 in the intervals, and 4-8 on the commissural side. Seed-face slightly concave, its back strongly convex. [Greek, hemlock-parsley.] Besides the following, some 3 others occur in western N. Am.

I. Conioselinum Chinénse (L.) B.S.P. Hemlock-Parsley. (I. F. f. 2638.) Stem terete, 6-I $5 \mathrm{dm}$. high. Leaves decompound into linear-oblong acutish segments; petioles sheathing; umbels $5-8 \mathrm{~cm}$. broad, 9-16-rayed; rays $3-6 \mathrm{~cm}$. long; pedicels slender, 4-6 mm. long; fruit broadly oval, about $4 \mathrm{~mm}$. long. In cold swamps, Lab. to Mass., N. Y., N. Car., Minn., Wis. and Ind. Aug.-Sept.

\section{ANGÉLICA L.}

Tall perennial herbs, with compound leaves and large umbels of white flowers (in our species). Involucre none, or of a few small bracts. Involucels of several small bracts, or sometimes wanting. Stylopodium depressed. Fruit ovate or oval, dorsally compressed. Dorsal and intermediate ribs prominent, the lateral ones broadly winged. Oil-tubes solitary or several in the intervals, 2-ro on the commissural side. [Named for its supposed healing virtues.] About 30 species, of the northern hemisphere and New Zealand. Besides the following, some $\mathbf{I}_{3}$ others occur in southern and western N. Am.

Umbels glabrous, or nearly so; leaf-segments acute or acutish.

Oil-tubes I (rarely 2-3) in the intervals; wings broader than the carpels

r. A. Curtisii.

Oil-tubes numerous and contiguous; wings narrower than the carpels.

Umbels densely tomentose; leaf-segments obtuse.

2. A. atropurpurea.

3. A. villosa.

I. Angelica Curtísii Buckl. Curtis' Angelica. (I. F. f. 2635.) Plant 6-10 dm. high. Leaves biternate, the lower long-stalked, the divisions pinnate, 
the upper mostly reduced to inflated petioles; segments sharply and irregularly dentate or incised, 5-10 $\mathrm{cm}$. long; umbels 7-15 cm. broad, 9-25-rayed; rays 4-8 cm. long; pedicels 8-12 $\mathrm{mm}$. long; fruit oval, glabrous, 4-6 mm. long, emarginate at the base. In woods, Penn. to N. Car. and Ga. Aug.-Sept.

2. Angelica atropurpùrea L. Great or Purple-stemmed Angelica. (I. F. f. 2636.) Stout, I-2 m. high, glabrous, or the umbel slightly rough-hairy. Lower leaves often $6 \mathrm{dm}$. wide, biternate and the divisions pinnate, the upper ones smaller, all with broad dilated petioles: segments oval or ovate, serrate and often incised, 3-5 cm. long; unbels sometimes $2.5 \mathrm{dm}$. broad, 9-25-rayed, the rays 5-10 cm. long; truit broadly oval, $6-8 \mathrm{~mm}$. long, slightly emarginate at the base. In swamps and moist ground, Litb. to Minn., Del. and Ill. June-July.

3 Angelica villis 3 (Walt.) B S.P. Pubescent Angelica. (I. F. f. 2637.) Rather slender, 6-12 dm. high, the umbels and upper part of the stem tomentosecanescent. Lower leaves ternate or biternate, the divisions pinnate, the segments thick, oval, rather finely dentate, obiuse or obtusish, $2-5 \mathrm{~cm}$. long; upper leaves mostly reduced to sheathing $\mathrm{p}$ :tioles; umbels $5-10 \mathrm{~cm}$. broad, 7-30-rayed; rays 2-4 cm. long; fruit broadly uval, emarginate at the base, $6 \mathrm{~mm}$. long, finely pubescent; lateral wings about as broad as the carpels; oil-tubes generally $3-6$ in the intervals. In dry soil, Conn. to Fla., Minn., Tenn. and Mo. July-Aug.

Angeliza sylvéstris L., of Europe, similar to the preceding, but with acute or acutish leaf-segments, their teeth acuminate, is reported as occurring on Cape Breton Island.

39. LEVÍsTicum Koch.

A perennial herb, with decompound leaves, the segments broad, cuneate, and large umbels of whitish yellow flowers. Involucre and involucels of numerous narrow bricts. Fruit ovite-oblong, somewhat flattened dorsally; primary ribs winged: oil-tubes solitary in the intervals. A monotypic genus.

1. Levisticum Levísticum (L.) Karst. Lovage. Glabrous, tall. Leaves I-3-pinnately divided, the segments 5- o cm. long, acute, deeply cleft or those of the upper leaves entire; umbels 7-10 $\mathrm{cm}$. broad. In waste places, Vt., Conn. and N. Y. [Ligusticum Levisticum L.]

\section{CYMÓPTERUS Raf. (See Appendix.)}

Perennial subscapose herbs, with thick roots, pinnately decompound leaves, and white flowers (in our species) in peduncled umbels. Involucels of $\mathbf{I}$ to numerous bracts. Calyx-teeth rather prominent. Stylopodium depressed or wanting. Carpels dorsally flattened, with 3-5 flat equal wings; oil-tubes several or solitary in the intervals. [Greek, wave-winged, referring to the fruit.] About 13 species, natives of western and central N. Am.

Involucre none.

Involucre prominent.

I. C. acaulis.

2. ${ }^{C}$. montanus.

I. Cymopterus acaùlis (Pursh) Rydberg. Plains Cymopterus. (I. F. f. 2649.) Stem seldom over $2.5 \mathrm{~cm}$. high. Leaves $0.7-2 \mathrm{dm}$. long, slender-petioled, pinnate or bipinnate into linear-oblong obtuse segments; umbels slender-peduncled, capitate, $2.5 \mathrm{~cm}$. broad or less; rays $2-5 \mathrm{~mm}$. long; involucre none; involucel of a single palmately-lobed bractlet; fruit broadly oval, about $6 \mathrm{~mm}$. in diameter; oil-tubes 4 or 5 in the intervals. In dry soil, Minn. and Wis. to Ark., the N. W. Terr., Br. Col. and Colo. April-May.

2. Cymopterus montànus T. \& G. Mountain Cymopterus. (I. F. f. 2650.) Similar to the preceding, somewhat glaucous, or very slightly pubescent. Leaves $2-15 \mathrm{~cm}$. high, pinnate, or bipinnate, the segments oblong, obtuse; peduncles stout, $2-15 \mathrm{~cm}$. high; involucre and involucels of broad membranou: somewhat united veined bracts: umbels $2-5 \mathrm{~cm}$. broad in fruit; rays several, 6-1 8 $\mathrm{mm}$. long: fruit ellipsoid, 6-12 mm. long, the carpels broadly 3-5-winged; oiltubes $1-3$ in the intervals. Dry soil, S. Dak. to Wyo. and Tex. March-April.

41. POLYTAENIA DC.

Perennial, nearly glabrous herbs, with pinnately decompound leaves, and com. pound umbels of yellow flowers. Involucre none, or rarely of $\mathrm{x}$ or 2 linear bracts. 
Involucels of a few subulate deciduous bracts. Calyx-teeth prominent, triangular. Petals obovate-cuneate, with a long incurved tip. Stylopodium none. Fruit oval or obovate, flattened dorsally, thick and corky; dorsal and intermediate ribs obscure, the lateral ones with thick wings which form a broad margin to the fruit, and are nerved toward the outer margin: oil-tubes 12-18, contiguous, with numer. ous smaller ones irregularly disposed in the thick pericarp. Seed flat. [Greek, many-fillets, or oil-tubes.] A monotypic genus.

I. Polytaenia Nuttallii DC. Polv'taenia. (I. F. f. 2644.) Stem slightly scabrous, leafy, 3-9 dm. high: roots fusiform. Leaves pinnate, the segments deeply pinnatifid or parted, $2-8 \mathrm{~cm}$. long, the lobes ovate, oblong or obovate; umbels 6-I--rayed, 2.5.6 cm. broad; rays scabrous, I-6 cm. long; pedicels finely pubescent, 2-4 $\mathrm{mm}$. long; fruit glabrous, 6-10 $\mathrm{mm}$. long, I $\mathrm{mm}$. thick, the margins obtuse, the central part of both carpels depressed when dry. Dry soil, Mich. and Wis. to Tenn., Kaus., Tex. and La. April-May.

\section{OXÝPOLIS Raf. [ARCHEMORA DC.]}

Perennial glabrous marsh herbs, from clustered tuberous roots, with pinnate or ternate leaves, or in one species the leaves reduced to hollow jointed phyllodes, and compound umbels of white flowers. Involucre none, or of a few linear bracts. Involucels of small bracts, or none. Calyx-teetl acute. Stylopodium thick, conic. Fruit glabrous, dorsally compressed, oval or obovate; dorsal and intermediate ribs slender, the lateral ones winged, strongly nerved along the inner margin of the wing, the carpels appearing as if equally 5-ribbed. Oil-tubes solitary in the inter vals, 2-6 on the commissural side. Seed-face nearly flat. Four known species, natives of $\mathrm{N}$. Am.

Leaves all reduced to hollow usually jointed phyllodes. Leaves pinnate; leaflets linear or lanceolate.

r. O. fliformis. 2. O. rigida.

I. Oxypolis filifórmis (Walt.) Britton. Oxypolis. (I. F. f. 2639.) Stem hollow, 6-12 dm. high. Leaves $2.5-45 \mathrm{~cm}$. long; involucre of several linearsubulate bracts; umbels 4-10 cm. br. ad, 6-15-rayed; rays $1-5 \mathrm{~cm}$. long; pedicels 4-8 mm. long; fruit oval, or slightly obovate, 4-6 mm. long; oil-tubes large. In ponds and swamps, southern Via. to Fla., west to La. Aug.-Sept. Plants collected in Delaware, leferred to this species, differ in liaving broadly oval corky-winged fruit, an inconspicuous disk, slender conic stylopodium and smaller oil-tubes.

2. Oxypolis rígidus (L.) Raf. Cowbane. Hemlock. (I. F. f. 2640.) Rather slender, 6-12 dm. high. Leaves petioled. simply pinnate, the lower often $3 \mathrm{dm}$. long or more; leaflets thick, ovate-lanceolate, lanceolate or oblong, entice, or remotely dentate, 3-8 cm. long; involucre of $\mathrm{I}-4$ bracts, or none; umbels 5-10 cm. broad, 7-25-rayed; rays slender, 2-10 cm. long; pedicels 4-18 mm. long; fruit oval. 5-6 $\mathrm{mm}$. long, 3-4 $\mathrm{nm}$. broad; oil-tubes small. In swamps, N. Y. to Fla., Minn., Mo. and La. Aug. - Sept.

Oxypolis rígidus longifollius (Pursh) Britton. Leaflets elongated-linear, entire, 2-3 $\mathrm{mm}$. wide; fruit smaller. N. J. to S. Car. and Tenn.

\section{SPERMÓLEPIS Raf. . [LEPTOCAULIS Nutt.]}

Glabrous slender annuals, the branches often nearly filiform, with dissected petioled leaves, the leaf-segments narrowly linear. Flowers small, white, in unequal-rayed umbels. Involucre none; involucels of a few narrow bracts, or none. Calyx teeth obsolete. Fruit ovate, laterally flattened, tuberculate or bristly; pericarp thick: oil tubes solitary in the intervals or also under the ribs, 2 on the com. missural side. Stylopodium short, conic. Two species, of the southern U. S.

Fruit tubercled.

Fruit covered with hooked bristles.

I. S. divaricatus. 2. S. echinalus.

x. Spermolevis divaricàtus (Walt.) Raf. Rough-Fruited SPERMolepis. (I. F. f. 2697.) Similar to Apiastrum patens, but more slender and more widely branching. Rays of the umbels almost filiform, I $-4 \mathrm{~cm}$. long, divaricate; pedicels 5-I $2 \mathrm{~mm}$. long; fruit cvate, densely tuberculate, $1 \mathrm{~mm}$. long; the ribs rather prominent. Neb. to Tex., N. Car. and Fla. Also in ballast at Philadelphia. April-May. 
2. Spermolepis echinàtus (Nutt.) Heller. Bristly-Fruited Spermolepis. (I. F. f. 2698.) Resembling the preceding, but lower, seldom over $3 \mathrm{dm}$. high, the branches ascending or sometimes spreading. Kays very slender; fruit about I $\mathrm{mm}$. long, covered with spreading hooked bristles the ribs obsolete, the commissure narrow. Ala. to Mo., Tex. and Cal. April-May.

\section{PEUCÉdanum L. (See Appendix.)}

Perennial herbs, acaulescent or nearly so, from thick roots, with ternate, pinnate, or in our species bipinnate or finely dissected leaves, and compound unbels of white or yellow flowers. Involucre none. Involucels of several or numerous bracts. Calyx-teeth mostly obsolete. Stylopodium depressed or none. Fruit oval, oblong, or orbicular, dorsally compressed. Carpels with filiform dorsal and intermediate ribs, the lateral ones broadly winged; oil tubes I-4 (rarely more) in the intervals, 2-IO on the commissural side. Seed-face flat or slightly concave. [Name Greek.] About I25 species, of wide distribution. In addition to the following, about 47 others occur in western N. Am.

Flowers white or pinkish.

I. P. nudicaule.

Flowers yellow.

Fruit glabrous; involucel-bracts united.

Plant pubescent.

Plant glabrous.

Fruit finely pubescent; involucel-bracts linear, distinct.

2. P. foeniculaceum.

3. P. K'ingii.

4. P. villosum.

I. Peucedanum nudicaùle (Pursh) Nutt. White-floweren Parsley. (I. F. f. 2645.) Leaves and peduncles 0.7-2 dm. high. Root e'ongated. Leaves bipinnate, the segments oblong or ovate, generally pinnatifid into linear or linearoblong obtusish lobes; bracts of the involucels lanceolate, scarious-margined; umbel 4-8-rayed, the rays unequal, I-4 cm. long in fruit; fruit oval or orbicular, glabrous, 4-6 $\mathrm{mm}$. long, the lateral wings narrower than the carpel, the dorsal and intermediate ones inconspicuous; oil-tubes generally solitary in the intervals. In dry soil, Minn. to Manitoba, Kans., the N. W. Terr. and N. Mex. March-May.

2. Peucedanum foeniculàceum Nutt. Fennel-leaved Parsley. (I. F. f. 2646.) Peduncles $I-2.5 \mathrm{dm}$. high, usually exceeding the leaves. Leaves finely dissected into short linear or filiform acute lobes and segments; umbels unequally 3-12-rayed, the rays $1-4 \mathrm{~cm}$. long; involucels tomentose; fruit broadly oval, about $6 \mathrm{~mm}$. long, the lateral wings narrower than the carpel, dorsal and intermediate ones rather prominent; oil-tubes $\mathrm{I}-3$ in the intervals. Prairies, N. W. Terr. to S. Dak., Kans., Mo. and Tex. March-April.

3. Peucedanum Kíngii S. Wats. King's Parsley. (I. F. f. 2647.) Scape I.5-5 dm. high. Leaves long-petioled, pinnately or 2 pinnately divided into narrowly linear segments I $\mathrm{mm}$. wide or less; umbel unequally 4-20-rayed; rays I$4 \mathrm{~cm}$. long; calyx teeth short; fruit oblong, glabrous, $8-12 \mathrm{~mm}$. long, nearly $4 \mathrm{~mm}$ wide, the carpels with narrow lateral wings, the dorsal and intermediate ribs also somewhat winged; oil-tubes 3-6 in the intervals, and 6-10 on the commissural side. Western Neb. to Utah. June-Aug.

4. Peucedanum villòsum Nutt. Hairy Parsley. (I. F. f. 2648.) Tomentose-pubescent ; peduncles $0.7-2 \mathrm{dm}$. long. Leaves finely dissected into narrowly oblong obtuse lobes and segments; umbel 4-IO-rayed, the rays 8-20 $\mathrm{mm}$. long in fruit; bracts of the involucels lanceolate, separate or nearly so: fruit oval, 6-7 $\mathrm{mm}$. long, about $5 \mathrm{~mm}$. broad, the lateral wings narrower than the carpel, the dorsal and intermediate ribs prominent; oil-tubes 3 or 4 in the intervals. Prairies and dry soil, Neb. and S. Dak. to the N. W. Terr., N. Mex. and Cal. April-May.

\section{IMPERATÒRIA L.}

Tall perennial herbs, with ternately divided or 2-pinnate leaves, and compound umbels of white flowers. Calyx-teeth obsolete. Fruit flattened dorsally, broadly oval, to nearly orbicular, the lateral ribs broadly winged all around, the intermediate and dorsal ribs slender, wingless; oil-tubes solitary in the intervals and 2 on the commissural side. Styles and stylopodium short. Seed-face flat. [Named for its supposed forçeful medicinal properties.] About ro species, of the Old World. 
I. Imperatoria Ostrùthium L. MAsterwort. (I. F. f. 2643.) Glabrous, or sparingly pubescent; stem stout, hollow, erect, 6-15 dm. tall. Leaves ternately divided into broad stalked segments which are often 3-parted to the base, sharply serrate and often incised, the segments of the long-petioled lower leaves often 1.3 $\mathrm{dm}$. broad; rays numerous, slender; involucre none, or of $\mathbf{I}$ or 2 lanceolate bracts; involucel-bracts few, narrow, deciduous; fruit about $4 \mathrm{~mm}$. long. In fields, Penn. and Mich. Reported from Newf. Nat. or adventive from Europe. May-July.

\section{PASTINÀCA L.}

Tall branching herbs, wilh thick roots, pinnate leaves, and compound umbels of yellow flowers. Involucre and involucels commonly none. Calyx-teeth obsolete. Stylopodium depressed. Fruit oval, glabrous, much flattened dorsally; dorsal and intermediate ribs filiform, the lateral winged, those of the two carpels contiguous and forming a broad margin to the fruit; oil tubes solitary in the intervals and 2-4 on the commissural side. Seed very flat. [Latin pastus, food.] About 7 species, natives of Europe and Asia.

I. Pastinaca sativa L. Wild Parsnip. (I. F. f. 2642.) Biennial or rarely annual, glabrous, or somewhat downy-pubescent, 6-15 dm. higl. Lower and basal leaves petioled, pinnate, often $4.5 \mathrm{dm}$. long, the segments rather thin, ovate or oval, obtuse, sessile, lobed or incised and sharply dentate, $2-8 \mathrm{~cm}$. long: umbels 5-15 $\mathrm{cm}$. broad, 7-15-rayed, the rays $1-5 \mathrm{~cm}$. long; pedicels $6-12 \mathrm{~mm}$. long in fruit; fruit broadly oval, 5-7 mm. long, the oil-tubes conspicuous. Roadsides and waste places, a common weed in nearly all parts of our area. Nat. from Europe. June-Sept.

\section{HERACLÈUM L.}

Erect perennial herbs, with ternately compound leaves, and compound umbels of white flowers. Bracts of the involucre few and deciduous, or none. Involucels of numerous linear bracts. Calyx-teeth obsolete or small. Petals cuneate, or clawed; those of the outer flowers dilated and obcordate or 2-lobed. Stylopodium thick, conic. Fruit flattened dorsally, broadly oval, obovate or orbicular; dorsal and intermediate ribs filiform, the lateral ones broadly winged and the wings nerved near the outer margin; oil-tubes extending only to about the middle of the carpels, conspicuous, I in each interval, 2-4 on the commissural side. [Greek, to Hercules]. About 60 species, of the northern hemisphere, only the following in N. Am.

I. Heracleum lanàtum Michx. Cow-PARSNIP. (I. F. f. 2641.) Verystout, tomentose-pubescent, I-3 m. high, the stem ridged, often $5 \mathrm{~cm}$. thick at the base. Leaves petioled, very pubescent beneath, the segments broadly ovate, or orbicular, cordate, stalked, lobed and sharply serrate, rather thin, 7-15 cm. broad; petioles much inflated; umbels $1.5-3 \mathrm{dm}$. broad, 8-30-rayed, the rays stout, 5-10 $\mathrm{cm}$. long; fruit 8-12 mm. long, 6-9 mm. broad, finely pubescent, emarginate at the summit. In moist ground, Newf. to Alaska, N. Car., Mo., Utah and Cal. June-July.

\section{DAÙCUS L.}

Biennial or annual, mostly hispid-pubescent herbs, with pinnately decompound leaves, and compound umbels of white or reddish flowers. Involucre of several foliaceous bracts in our species. Involucels of numerous entire or toothed bracts. Calyx-teeth obsolete. Petals obovate, the apex inflexed, those of the outer flowers often dilated and 2-lobed. Umbels concave in fruit. Fruit somewhat flattened dorsally. Primary ribs 5, slender. Secondary ribs 4, winged, each bearing a row of barbed prickles. Oil-tubes solitary under the secondary ribs, and 2 on the com. missural side of each carpel. [The ancient Greek name.] About 25 species, of wide distribution.

Stem retrorsely hispid; leaf-segments linear.

Stem bristly pubescent; leaf-segments lanceolate.

r. D. pusillus.

2. D. Carota.

I. Daucus pusillus Michx. American Carrot. Biennial, $3 \mathrm{~cm} .-6 \mathrm{dm}$. high, closely resembling the following species. Leaves finely dissected, the segments linear, acute; umbels $2-8 \mathrm{~cm}$. broad; pedicels very unequal. N. Car. to Fla., Mo., Mex. and Cal. April-June.

2. Daucus Caròta L. Wild Carrot. (I. F. f. 2632.) Usually biennial, 3-9 dm. high, the root fleshy, conic. Lower and basal leaves 2-3-pinnate, the 
segments dentate, lobed or pinnatifid; upper leaves less divided; bracts of the involucre parted into linear or filiform lobes; umbels 5-10 $\mathrm{cm}$ broad; rays numerous; flowers white, the central one of each umbel often purple, that of each umbellet occasionally so, all rarely pinkish; fruit 3-4 $\mathrm{mm}$. long. In fields and waste places, common throughout our area, often a pernicious weed. Nat. from Europe. The original of the cultivated Carrot. June-Sept.

\section{Family 3. CORNÀCEAE Link.}

\section{Dogwood Family.}

Shrubs or trees, with simple opposite, verticillate or alternate, usually entire leaves, and regular flowers in cymes, heads or rarely solitary. Calyx-tube adnate to the ovary, its limb 4-5-dentate, or none. Petals generally 4 or 5 , sometimes wanting, valvate or imbricate, spreading, inserted at the base of the epigynous disk. Stamens as many as the petals or more numerous, inserted with them ; filaments subulate or flat. Ovary inferior, I-2-celled in our species; style I, short or elongated; ovules I in each cavity, pendulous, anatropous. Fruit a drupe. Seeds oblong; embryo nearly as long as the endosperm; cotyledons foliaceous. About 16 genera and $S_{5}$ species, most abundant in the northern hemisphere.

Flowers perfect, 4-parted; ovary 2-celled.

I. Cornus. Flowers polygamous or diœecious; petals minute or none; ovary I-celled.

2. Nyssa.

\section{CóRnUS L. (See Appendix.)}

Flowers small, white, greenish or purple, in cymes, or heads, the latter involucrate with large white bracts in our species. Calyx tube top-shaped or campanulate, its limb 4-toothed. Petals 4, valvate. Stamens 4. Ovary 2-celled; stigma truncate or capitate; ovules 1 in each cavity. Drupe ovoid or globular, the stone 2-celled and 2-seeded. [Greek, horn, from the toughness of the wood.] About 25 species, natives of the north temperate zone, Mex. and Peru. Besides the fol. lowing, some 7 others occur in western N. Am.

* Flowers capitate, with an involucre of 4-6 large white bracts.

Low herbaceous shrubs; rootstocks slender.

Upper leaves verticillate; flowers greenish.

Leaves all opposite; flowers purple.

Tree or large shrub; flowers greenish yellow.

* Flowers cymose, white, not involucrate.

Leaves opposite.

Leaves downy-pubescent beneath, at least when young; (sometimes glabrate in No. 5)。

Leaves broadly ovate or orbicular; fruit blue.

Leaves ovate or ovate-lanceolate.

Fruit blue; stone pointed at the base.

Fruit white.

Stone globose, broader than high.

Stone compressed, much broader than high.

Leaves glabrate, or minutely pubescent beneath.

Leaves ovate, short-pointed; twigs purple.

Leaves ovate-lanceolate, acuminate.

Fruit white: twigs gray.

Fruit pale blue; twigs reddish.

Leaves alternate, clustered at the ends of the flowering branches.
I. C. Canadensis.

2. C. Suecica.

3. C. florida.

I. Cornus Canadénsis L. Low or Dwarf Cornel. Bunch-Berry. (I. F. f. 2710.) Flowering stems scaly, 7-30 cm. high. Rootstock nearly horizontal; leaves verticillate at the summit, or sometimes I or 2 pairs of opposite ones below, sessile, oval, ovate, or obovate, pinnately veined, glabrous or minutely appressed-pubescent, acute at each end, $2-8 \mathrm{~cm}$. long; peduncle $\mathrm{r}-4 \mathrm{~cm}$. long; involucral bracts ovate, 8-12 mm. long; flowers greenish, capitate; petals ovate, one of them with a subulate appendage; fruit globose, bright red, about $6 \mathrm{~mm}$. in diame. ter; stone smooth, globose. In low woods, Newf. to Alaska, N. J., Ind., Minn., Colo, and Cal. Rarely the upper leaves are opposite. May-July, 
2. Cornus Suècica L. Northern Dwarf Cornel. (I. F. f. 27xi.) Flowering stems 5-25 cm. high. Leaves 3-6 pairs, all opposite, sessile, ovate, or oval, entire, minutely appressed-pubescent above, the upper $1-4 \mathrm{~cm}$. long, the veins all arising from near the base; involucral bracts usually 4, ovate, 6-1 $2 \mathrm{~mm}$. long, obtusish; flowers dark purple, capitate; fruit globose, red, 6-8 mm. in diameter: stone flattened. In cold, wet woods, Newf. to Quebec and Alaska. Also in northern Europe and Asia. July-Aug.

3. Cornus flórida L. Flowering Dogwood. (I. F. f. 2712.) A small tree, or large shrub, with very rough bark and spreading branclies. Leaves petioled, ovate, or oval, rarely obovate, entire, pale and slightly pubescent on the veins beneath, dark green above, $7-15 \mathrm{~cm}$. long, acute at the apex, usually narrowed at the base; bracts of the involucre white or pinkish (rarely rose-red), very conspicuous, obovate, obcordate, or emarginate, strongly parallel-veined, $2.5 .6 \mathrm{~cm}$. long; flowers greenish yellow, capitate; fruit ovoid, scarlet, IO-12 mm. long, crowned with the persistent calyx; stone smooth, channeled. In woods, Me. and Ont. to Fla., Ky., Mo. and Tex. April June.

4. Cornus circinàta L'Her. Rouni-Leaved Cornel or Dogwood. (I. F. f. 2713.) A shrub, $0.8-3 \mathrm{~m}$. high, the twigs warty, green and glabrous. Leaves petioled, broadly ovate, or orbicular, acute, or short-acuminate, pale beneath, slightly pubescent above, 5-15 cm. long; flowers in rather dense cymes 3-7 cm. broad, the pedicels usually somewhat pubescent; petals ovate; fruit globose, light blue, about $5 \mathrm{~mm}$. in diameter; stone subglobose. In shady, often rocky situations, N. S. to Manitoba, Va., Ill. and I wa. May-June.

5. Cornus Amòmum Mill. Kinnikinnik. (I. F. f. 27I4.) A shrub, with purplish twigs, the youngest commonly pubescent. Leaves petioled, ovate, oval, or ovate-lanceolate, acuminate, usually finely pubescent with brownish hairs beneath, 2.5-13 cm. long; flowers in flat cymes; petals narrowly oblong; fruit globose, light blue, 6-7 mm. in diameter, stone oblique, ridged. In wet soil, N. B. to Ont., Fla., S. Dak. and Tex. May-July. [C. sericea L.]

6. Cornus asperifolia Michx. Rovgh-Leaved Cornel or Dogwood. (I. F. f. 27 I5.) A shrub, the twigs reddish brown, the youngest rough-pubescent. Leaves slender-petioled, ovate-oval, or elliptic, acuminate, pale and woollypubescent beneath, densely rough-pulescent above, $3-13 \mathrm{~cm}$. long; petioles and rays of the cyme rough-pubescent; cymes rather loosely-flowered, 5-8 cm. broad; petals oblong-lanceolate; fruit globuse, white, about $6 \mathrm{~mm}$. in diameter: stone slightly furrowed, little compressed. In wet ground, Ont. to Fla., Iowa, Kans. and Tex. May-June.

7. Cornus Bàileyi Coult. \& Evans. Barley's Cornel or Dogwoon. (I. F. f. 2716.) A shrub with reddish twigs. Leaves slender-petioled, ovate or ovatelanceolate, acute or acuminate, rather densely woolly-pubescent beneath, $2.5-13 \mathrm{~cm}$. long; petals ovate-oblong; cymes compact, the rays pubescent; fruit white, about $6 \mathrm{~mm}$. in diameter; stone flattened. slightly oblique. Lake sliores and in moist ground, Penn. to Minn. and the N. W. Terr., Wyo. and Neb. May-June.

8. Cornus stolonífera Michx. Red-osier Cornel or Dogwood. (I. F. f. 2717.) A shrub, I-5 m. high, usually stoloniferous, the twigs glabrous and bright reddish purple. Leaves slender-petioled, ovate, ovate-lanceolate or oval, acute or short-acuminate, white or whitish and sparingly pubescent or glabrous beneath; petals ovate-oblong; fruit white or whitish, globose, $6-8 \mathrm{~mm}$. in diameter. In moist soil, N. S. to Yukon Terr., Va., Ky., Neb., Ariz. and Cal. June-July.

9. Cornus candidíssima Marsh. PANicled Cornel or Dogwood. (I. F. f. 27 I8.) A shrub with gray smooth twigs. Leaves petioled, lanceolate or ovatelanceolate, long-acuminate at the apex, acute at the base, minutely appressedpubescent on both sides, pale beneath, 3-10 cm. long; cymes somewhat paniculate; petals lanceolate; fruit globose, white, about $6 \mathrm{~mm}$. in diameter; stone subglobose. In rich soil, Me. to N. Car., Minn. and Neb. May-June.

ro. Cornus strícta Lam. Stiff CoRnel or Dogwood. (I. F. f. 2719.) A shrub, $2.5-5 \mathrm{~m}$. high, resembling the preceding; twigs purplish or reddish brown. Leaves petioled, ovate, or ovate-lanceolate, acute or acuminate, sparingly appressed-pubescent on both sides, $3-8 \mathrm{~cm}$. long, the margins often minutely denticulate, green above and beneath; cymes rather loosely flowered, their rays 
nearly or quite glabrous; fruit pale blue, about $6 \mathrm{~mm}$. in diameter; stone globose, nearly smooth. In swamps, Va. to Ga. and Fla. April-May.

II. Cornus alternifolia L.f. Alternate leaved Cornel or Dogwood. (I. F. f. 27-O.) A shrub, or small tree, with smooth greenish bark. Leaves slender petioled, oval or o ate, acuminate, 5-10 $\mathrm{cm}$. long, pale and appressed-pubescent beneath, the maryins minutely denticulate; cymes pubescent; petals lanceolate; fruit globular, or slightly depressed, blue, about $8 \mathrm{~mm}$. in diameter; stone somewhat obovoid, channeled, scarcely flattened. In woods, N. S. to Ga., Ont., Minn., W. Va. and Ala. May-July.

\section{NÝSSA L.}

Trees or shrubs, with alternate petioled leaves. Flowers small, greenish, polygamo-diœcious, in capitate clusters, short racemes, or the fertile ones sometimes solitary, borne at the summit of slender axillary peduncles, appearing with the leaves. Staminate flowers numerous, the calyx 5-parted, the petals minute and fleshy, or none; stamens 5-15; filaments slender; disk entire or lobed; pistil none or rudimentary. Pistillate flowers 2-14, or solitary, bracted; calyx-limb 5-toothed, or truncate; petals minute and fleshy, or none; stamens several, or commonly abortive; ovary 1 -celled, with I pendulous ovule; style slender, recurved. Drupe ovoid or oval, the stone bony, compressed, I-seeded. [Name of a water nymph.] About 7 species, natives of N. Am., eastern and central Asia. Besides the following, another occurs in the Southern States.

Leaves usually entire; pistillate flowers $2-14$; fruit $6-14 \mathrm{~mm}$. long.

Leaves mostly acute or acuminate; stone little flattened.

Leaves mostly obtuse; stone much flattened.

I. N. sylvatica.

2. N. biflora.

Leaves usually dentate; pistillate flower solitary; fruit $16-30 \mathrm{~mm}$. long. 3. N. aquatica.

I. Nyssa sylvática Marsh. Pepperidge. Sour Gum. Tupelo. (I. F. f. 2721.) A large tree, with rough bark. Leaves obovate or oval, entire, glabrous and shining above, more or less pubescent beneath, 5-10 cm. long; staminate flowers capitate; pistillate flowers larger, 2-14 together; fruit ovoid, nearly black, 8-14 mm. long, acid; stone ovoid. In rich moist soil, Me. and Ont. to Fla., Mich. and Tex. Leaves rarely angulate toothed on young trees. April-June.

2. Nyssa biflòra Walt. Southern Tupelo. Water Tupelo. (I. F. f. 2722.) Similar to the preceding, the base swollen. Leaves mostly smaller and narrower, obtuse or sometimes acute, $2.5-13 \mathrm{~cm}$. long, glabrous when mature; pistillate flowers only I-3 together; fruit oval, or subglobose, 6-12 mm. long, acid; stone oval or oblong, distinctly flattened and furrowed. In swamps and along ponds, N. J. to Va., Fla. and Ala. April-May.

3. Nyssa aquática L. Large Tupelo. Cotton or Tupelo Gum. (I. F. f. 2723.) A large tree. Leaves slender petioled, ovate or oval, angular-dentate, or entire, acute, or acuminate, downy-pubescent beneath, especially when young, becoming glabrate on both sides, $0.7-2.5 \mathrm{dm}$. long; fruit oval, dark blue when ripe; stone narrowly obovate, flattened, spongy, with several sharp longitudinal ridges. In swamps, Va. to Fla., Mo. and Tex. April.

\section{Series 2. Gamopetalae。}

\section{Petals partly or wholly united, rarely separate or wanting.}

This series is also known as Sympetalae and has been called Monopetalae. The coherence of the petals is sometimes slight or they are quite separate, as in Clethraceae, Pyrolaceae, some Ericaceae, Primulaceae, Styracaceae, Asclepiadaceae, Oleaceae, Cucurbitaceae and Galax in Diapensiaceae. From this condition the coherence varies through all stages to the tubular or funnelform corollas of some Convolvulaceae, Caprifoliaceae and Compositae. In American species of Fraxinus (Oleaceae) and in Glaux (Primulaceae), there is no corolla.

\section{Order I. ERICÀLES.}

Flowers complete, regular. Calyx toothed, lobed, or divided, inferior, except in Vacciniaceae. Corolla mainly gamopetalous. Stamens free from the corolla, or adnate only to its base (except in Diapensia and 
Pyxidanthera of the Diapensiaceae), as many as its lobes and alternate with them, or twice as many. Ovary compound.

Stamens free from the corolla, or merely adnate to its base. not united into a tube.

Ovary superior; fruit a capsule, or rarely drupaceous.

Corolla essentially polypetalous.

Ovary 3-celled; shrubs; leaves deciduous.

Ovary 4-5-celled; low, mostly evergreen perennials.

Fam. 1. Clethraceae.

Fanı. 2. Pyrolaceae.

Corolla distinctly gamopetalous (except in Monotropa and Hypopitys of the Monotropaceae and Ledum of the Ericaceae).

Herbaceous saprophytes without green leaves. Fam. 3. Monotropaceae.

Shrubs with normal, often evergreen leaves. Fam. 4. Ericaceae.

Ovary inferior, adnate to the calyx, forming a many-seeded berry or drupe in fruit.

Fam. 5. Vacciniaceae.

Stamens borne at the sinuses of the corolla, or united in a ro-lobed tube.

Fam. 6. Diapensiaceae.

\section{Family I. CLETHRÀCEAE Klotsch.}

\section{White-alder Family.}

Shrubs or srees with alternate deciduous serrate or serrulate petioled leaves in our species, and small white fragrant flowers in terminal usually elongated racemes. Calyx 5-cleft, or 5-parted, persistent, the segments imbricated, Petals 5, slightly united at the base, imbricated, deciduous. Stamens 10; filaments slender; anthers sagittate, inverted in anthesis, the sacs opening by large apical pores; pollen-grains simple. Disk obsolete. Ovary 3-angled or 3-lobed, 3-celled, pubescent; ovules numerous; style slender; stigmas 3 in our species. Capsule 3-celled, loculicidally 3 -valved, the valves at length 2-cleft. Only the following genus, comprising about 30 species, of N. Am., Japan, Mex. and S. Am.

\section{x. CLÈTHRA L.}

Characters of the family. [Greek, alder, from the resemblance of the foliage.] Besides the following, another species occurs in the southern States.

Leaves obovate, acute or obtuse; filaments glabrous. Leaves oval or ovate, acuminate; filaments hirsute. r. C. alnifolia.

2. C. acuminata.

I. Clethra alnifòlia L. Sweet Pepperbush. White Alder. (I. F. f. 2724.) A shrub, I-3 m. high, the twigs minutely canescent. Leaves narrowed or cuneate at the base, sharply serrate, at least beyond the middle, glabrous or nearly so on both sides, 2.5-7.5 cm. long; petioles 2-12 mm. long; bracts short, deciduous; pedicels, calyx and capsule canescent; calyx lobes obtuse, nerved; flowers about $8 \mathrm{~mm}$. broad, of spicy fragrance; style longer than the stamens; capsule subglobose, about $3 \mathrm{~mm}$. in diameter, about the length of the calyx. In wet soil, Me. to northern N. J. and Fla., mostly near the coast. July-Aug.

2. Clethra acuminàta Michx. Mountain Sweet Pepperbush. (I. F. f. 2725.) A shrub or small tree, similar to the preceding. Leaves green above, pale and sometimes pubescent beneath, serrulate with sharp-pointed teeth, 5-18 cm. long, sometimes I $\mathrm{cm}$. wide; petioles $8-25 \mathrm{~mm}$. long; racemes spreading or recurved, 5-20 cm. long, the rachis, pedicels and calyx densely pubescent or canescent; bracts longer than the flowers, caducous. In mountain woods, Va. and W. $\mathrm{Va}$. to Ga. July-August.

\section{Family 2. PYROLÀCEAE Agardh.}

\section{Wintergreen Family.}

Low mostly evergreen perenniais, with branched rootstocks. Leav petioled. Flowers nearly regular, white or pink. Calyx 4-5-lobed. Corolla deeply 4-5-parted, or of 5 petals. Stamens twice as many as the divisions of the corolla, the anthers introrse in the bud, inverted at an- 
thesis, opening by pores or short slits; pollen-grains in 4's. Ovary 4-5celled; style often declined; stigma 5-lobed, or 5-crenate; ovules numerous, anatropous. Fruit a loculicidally dehiscent capsule. Seeds numerous, minute, the loose cellular coat much larger than the almost undifferentiated embryo. Three genera and about 20 species, natives of the northern hemisphere.

Flowers racemose; leaves basal.

Flowers solitary or corymbose; leaves opposite or whorled.

Stem leafy at base; flower solitary; style long.

Stem horizontal; branches erect, leafy; style very short.

1. Pyrola.

2. Moneses.

3. Chimaphila.

\section{PÝROLA L.}

Acaulescent or nearly so. Leaves basal, persistent (one northwestern species leafless). Flowers white, yellowish, pink, or purple, racemose, on erect scapes. Calyx 5-parted, persistent. Petals 5, concave, sessile. Stamens 10, declined, or straight and connivent; filaments subulate, glabrous; anthers erect in the bud, emar, ginate or 2-beaked at the base, mostly reversed at flowering, each sac opening by a basal but apparently apical pore. Ovary 5 celled; stigma 5-lobed. Disk usually. obsolete, rarely present and 10-lobed. Capsule subglobose, 5-lobed, 5-celled, loculi. cidally 5 -valved from the base, the valves cobwebby on the margins when opening, the apex and base intruded. [Latin, diminutive of Pyrus, pear, from the similar leaves.] About 15 species, natives of the northern hemisphere. Besides the following, 3 others occur in western N. Am.

Style and stamens declined (slightly so in No. 6).

Petals very obtuse: leaves rounded at the apex.

Leaves rounded, truncate or narrowed at the base.

Flowers white or greenish white; plants of dry woods.

Calyx-lobes oblong or lanceolate; leaves shining.

Calyx-lobes ovate or triangular, short; leaves dull. Blades orbicular, coriaceous, mostly shorter than petioles.

Blades oval, membranous, longer than their petioles.

2. P. chlorantha.

3. $P$. elliptica.
4. $P$. uliginosa.

Flowers pink or purple; bog plant.

Leaves reniform, cordate; flowers pink.

5. P. asarifolia.

Petals and leaves acute, the latter small.

6. P. oxypetala.

Style straight ; stamens connivent.

Style short; disk none; raceme regular.

Style elongated; disk Io-lobed; flowers in a I-sided raceme.

7. P. minor.

8. P. secunda

I. Pyrola rotundifòlia L. Round-Leaved Wintergreen. (I. F. f. 2726.) Scape 1.5-5 dm. high, 6-20-flowered. Blades orbicular or oval, spreading, coriaceous, crenulate, $4-8 \mathrm{~cm}$. long, often shorter than their petioles; flowers white, noddirg, very fragrant, $14-18 \mathrm{~mm}$. broad; pedicels 4-6 $\mathrm{mm}$. long, mostly longer than their bracts; calyx lobes about one third the length of the petals; capsule 4-6 mm. in diameter. In dry woods, N. S. to S. Dak., Ga. and Ohio. Also in Europe. June-July.

Pyrola rotundifolia pùmila Hornem. Scape 7-15 cm. high; leaves seldom $2.5 \mathrm{~cm}$. long; calyx-lobes oblong, mostly obtuse. Greenland and Lab. to the N. W. Terr.

2. Pyrola chlorántha Sw. Greenish flowered Wintergreen. (I. F. f. 2727.) Scape 1-3 dm. high, 3-10-flowered. Blades mostly obtuse at both ends, obscurely crenulate, or entire, I.2-2.5 cm. long; flowers nodding, slightly odorous, greenish white, $10-14 \mathrm{~mm}$. broad; pedicels $4-6 \mathrm{~mm}$. long, mostly longer than their bracts; calyx-lobes about one-fourth the length of the petals; anther-sacs shortbeaked; capsule about $6 \mathrm{~mm}$. in diameter. In dry woods, Iab. to Br. Col., D. C., Ill., Neb. and Colo. Also in Europe. June-July.

3. Pyrola elliptica Nutt. Shin-LEAF. (I. F. f. 2728.) Scape I-2.5 dm. high, 7-15-llowered. Blades dark green, obtuse at the apex, plicate-crenulate with very low teeth, $3 \cdot 5-4.5 \mathrm{~cm}$. long; flowers greenish white, nodding, $12-16 \mathrm{~mm}$. broad, very fragrant; calyx-lobes ovate-triangular, acute or acuminate, about onefourth as long as the petals; anther-sacs scarcely beaked; capsule about $6 \mathrm{~mm}$. in 
diameter. In rich, mostly dry woods, N. S. to Br. Col., D. C., Ill., Mich. and in the Rocky Mts. to N. Mex. June-Aug.

4. Pyrola uliginòsa Torr. Bog Wintergreen. (I. F. f. 2729.) Scape I.5-4 dm. high, 7-15-flowered. Blades broadly oval, or orbicular, dull, rather thick, obscurely crenulate, obtuse at both ends; flowers $10-16 \mathrm{~mm}$. broad; calyxlobes oblong or ovate-lanceolate, one fourth to one-third the length of the petals; anther-sacs beaked; capsule about $5 \mathrm{~mm}$. in diameter. In swamps and bogs, $\mathrm{N}$. S. to Br. Col., N. Eng., central N. Y., Mich. and in the Rocky Mts. to Colo. June.

5. Pyrola asarifòlia Michx. Liver-Leaf Wintergreen. (I. F. f. 2730.) Similar to the preceding. Blades usually wider than long, coriaceous, shining above Jbtuse, crenulate, $2.5-4 \mathrm{~cm}$. long, usually shorter than their narrowly margined petioles; flowers racemose, nodding, purple, or rose, $12-16 \mathrm{~mm}$. broad; calyx-lobes lanceolate, acute or acuminate, about cne-third the length of the petals; anther-sacs slightly beaked; capsule about $6 \mathrm{~mm}$. in diameter. In wet woods and swamps, N. B. to the N. W. Terr., Mass., N. Y., Mini. and Colo. June-July.

6. Pyrola oxypótala Austin. Sharp-Petaled Wintergreen. (I. F. f. 273I.) Scape slender, $2-2.5 \mathrm{dm}$. high, about 9-flowered. Blades ovate, coriaceous, dull, narrowed at the base, obscurely crenulate, 14-20 mm. long, shorter than their petioles; flowers racemose, ascending, greenish, 8-10 mm. broad; bracts shorter than the pedicels; calyx-lobes triangular-ovate, acute, about one-third the length of the elliptic-lanceolate acuminate connivent petals; anther-sacs slightly horned. Hills, Deposit, Delaware Co., N. Y. June.

7. Pyrola minor L. Lesser Wintergreen. (I. F. f. 2732.) Blades rather thin, broadly oval to orbicular, crenulate, obtuse, rounded, slightly narrowed, or subcordate at the base, I-2 cm. long; flowers racemose, nodding, white or pinkish, 6-8 $\mathrm{mm}$. broad; pedicels $2-5 \mathrm{~mm}$. long; calyx-lobes mostly triangular-ovate and acute; stamens not declined; petals oval or orbicular, obtuse; capsule about $5 \mathrm{~mm}$. in diameter. In woods, Greenland and Lab. to Alaska, N. Eng., Ont. and Ore., south in the Rocky Mts. to N. Mex. Also in Europe and Asia. June-Aug.

8. Pyrola secúnda L. Serrated or One-Sided Wintergreen. (I. F. f. 2733.) Scapes slender, I-2.5 dm. high. Blades ovate, or often oval, mostly thin, acute, or rarely obtuse, crenulate-serrulate, $2-5 \mathrm{~cm}$. long, longer than their petioies; flowers many, at first erect, soon drooping, greenish white, $6-8 \mathrm{~mm}$. broad; pedicels short; calyx lobes ovate, obtuse, or obtusish, very short; petals oval, obtuse, with a pair of tubercles at the base, campanulate-connivent; stamens not declined; capsule about $4 \mathrm{~mm}$. in diameter. In woods and thickets, Lab. to Alaska, D. C., Neb., along the Rocky Mts. to Mex. and to Cal. Also in Europe and Asia. June-July.

Pyrola secúnda pùmila Paine, is a low northern form, the scape 5-10 $\mathrm{cm}$. high. 3-8-flowered, the leaves orbicular or broadly oval, $1-2.5 \mathrm{~cm}$. long.

\section{MONÈSES Salisb.}

Leaves petioled, crenulate, opposite, or verticillate in 3's. Flower solitary, drooping, white or pink, at the summit of a slender scape. Calyx 4-5-parted, persistent. Petals 4 or 5 , broadly ovate or orbicular, sessile. Stamens 8 or Io, similar to those of Pyrola. Ovary globose, 4-5-celled; style straight; stigma 4-5-lobed; ovules numerous. Capsule subglobose, 4-5-lobed, 4-5-celled, loculicidally 4-5valve 1 from the summit, the valves glabrous on the margins. Seeds minute, the testa reticulated, produced at each end. [Greek, single-delight, from the single flower.] A monotypic genus.

I. Moneses uniflòra (L.) A. Gray. One-Flowered Wintergreen. (I. F. f. 2734.) Stem $5^{-15} \mathrm{~cm}$. high. Blades orbicular or ovate, obtuse, rather thin, 8-24 mm. long; flower $12-20 \mathrm{~mm}$. broad; calyx-lobes ovate, obtuse, about onefifth the length of the petals; capsule erect, $6.8 \mathrm{~mm}$. in diameter, about as long as the peristent style and stigma. In woods, Lab. to Alaska, Conn., Penn,, Mich., in the Rocky Mts. to Colo. and to Ore. Also in Europe and Asia. June-Aug.

3. CHIMÁPHILA Pursh.

Perennial herbs, with decumbent stems, ascending leafy branches, the leaves opposite, or verticillate, coriaceous, evergreen. short-petioled and serrate, and white: or purplish flowers in terminal corymbs. Pedicels mostly bracteolate. Calyx: 
5-cleft, or 5-parted, persistent. Petals 5, concave, nearly orbicular, sessile. Stamens 10, similar to those of Pyrola. Ovary globose, 5-lobed, 5-celled; ovules numerous; style short, obconic; stigma large, orbicular, 5-crenate. Capsule erect, globose, 5-lobed, 5-celled, loculicidally 5-valved from the top, the valves not woolly on the margins. Seeds numerous, minute, the testa reticulated, produced at each end. [Greek, winter-loving, from its evergreen leaves.] About 6 species, natives of N. Am., Mex. and Asia. Besides the following, another occurs on our Pacific Coast.

Leaves lanceolate, mottled with white.

Leaves spatulate or cuneate-oblanceolate, bright green.

1. C. maculata.

2. C. umbellata.

I. Chimaphila maculàta (L.) Pursh. Spotted Wintergreen. (I. F. f. 2735.) Stem sending up both sterile and flowering branches $8-25 \mathrm{~cm}$. high. Leaves acute or acuminate, sharply serrate, $2.5-7.5 \mathrm{~cm}$. long, 6-24 mm. wide below the middle; flowers few, white or pinkish, 12-20 $\mathrm{mm}$. broad; peduncle and pedicels puberulent; filaments villous at the middle; capsules erect, depressedglobose, about $8 \mathrm{~mm}$. in diameter. In dry woods, Me. and Ont. to Minn., Ga. and Miss. June-Aug.

2. Chimaphila umbellàta (L.) Nutt. Pipsissewa. Prince's Pine. (I. F. f. 2736.) Similar to the preceding, the branches commonly stouter, sometimes $3 \mathrm{dm}$. high, usually more leafly. Leaves obtuse or acutish, sharply serrate, shining, 2.5$6 \mathrm{~cm}$. long, 6-25 mm. wide above the middle; flowers several, white or pinkish, commonly smaller than those of the preceding, usually marked by a deep pink ring; filaments ciliate; capsule $6-8 \mathrm{~mm}$. in diameter. In dry woods, N. S. to $\mathrm{Br}$. Col., Ga., Mex. and Cal. Also in Europe and Asia. June-Aug.

\section{Family 3. MONOTROPÀCEAE Lindl.}

\section{Indian-pipe Family.}

Humus-plants or saprophytes, with mostly simple, leafless scaly scapes. Calyx 2-6-parted; sepals erect, imbricated, deciduous. Corolla gamopetalous or polypetalous (wanting in the California Allotropa); lobes or petals 3-6. Stamens 6-12, hypogynous; anthers 2-celled or confluently I-celled, attached to the filaments by their backs or bases; pollen-grains simple. Disk obsolete or 8-12-lobed. Ovary 4-6-lobed, I-6-celled; stigma capitate or peltate ; ovules numerous, anatropous. Capsule 4-6lobed, or terete, I-6-celled, loculicidally 4-6-valved, many-seeded. Seeds minute, the testa reticulated. About 9 genera and 12 species, mostly of the northern hemisphere.

Corolla gamopetalous, persistent.

Corolla globose-ovoid; anthers 2-awned.

Corolla campanulate; anthers awnless.

Corolla polypetalous, deciduous.

Flower solitary.

Flowers racenose.

1. Pterospora.

2. Monotropsis.

3. Monotropa.

4. Hypopitys.

\section{PTERÓSPORA Nutt.}

Scape slender, from a thick base of fibrous roots. Flowers and capsules racemose, pendulous. Calyx deeply 5 parted. Corolla globose-ovoid, with 5 reflexed lobes. Stamens 10, included; filaments subulate, glabrous; anthers introrse, horizontal in the bud, the sacs longitudinally dehiscent. Ovary 5-lobed, 5-celled; style short, columnar; stigma capitate, 5-lobed. Capsule depressed-globose, 5-lobed, 5-celled, 5-valved, the apex and base intruded. Seeds horizontal, globose-ovoid, with a terminal reticulated wing. [Greek, wing-seeded.] A monotypic genus.

I. Pterospora Andromedèa Nutt. Giant Bird's-nest. Pine-Drops. (I. F. f. 2737.) Roots astringent, forming a rounded mass sometimes $5 \mathrm{~cm}$. in diameter. Scape purplish or brown, 1.5-14 dm. high, grooved, covered with viscid hairs; scales lanceolate, or linear, numerous and crowded at the base; flowers white, 4-8 mm. broad; pedicels at first spreading, soon recurved, 6-20 mm. long, viscid; sepals oblong, about one-half the length of the corolla; capsule 8-12 mm. in diameter. In rich woods, Quebec and N. H. to Penn., Br. Col. and Cal., south in the Rocky Mts. to Ariz. June-Aug. 
2. MONOTRÓPSIS Schwein. [SCHWEINITZIA NuIt.]

Scape slender; plant glabrous. Sepals 5, oblong to linear. Corolla oblong. campanulate, persistent, 5-saccate at the base, 5-lobed, the lobes not reflexed. Stamens 10, included; filaments glabrous; anthers horizontal in the bud, introrse, the sacs confluent, opening by large terminal pores. Disk ro-crenate. Ovary globose, 5 -celled; style short, thick; stigma 5-angled. Capsule ovoid, 5-celled. Seeds numerous. [Greek, resembling Monotropa.] Two species, of southeastern N. Am.

I. Monotropsis odoràta Ell. Sweet Pine-sap. Carolina Beech-Drops. (I. F. f. 2738.) Plant light purplish brown; scapes usually several, 5-10 cm. high. Scales ovate-oblong, obtuse, appressed, 4-8 $\mathrm{mm}$. long; flowers few, pink, spicate, fragrant, 2-bracteolate at the base, spreading or erect, the spike at first recurved, becoming erect, 2.5-5 cm. long, sepals mostly oblong-lanceolate, acute, about ar long as the corolla and the bractlets. In woods, Md. to N. Car. Feb.-May.

\section{MONÓTROPA L.}

Scapose succulent white yellowish or red herbs, with a solitary nodding flower, the capsule becoming erect. Sepals 2-4, deciduous. Petals 5 or 6, not saccate at the base, tardily deciduous. Stamens 10-12; filaments subulate-filiform; anthers short, peltate, horizontal, opening at first by 2 transverse chinks, becoming trans. versely 2-valved. Disk 10-I2-toothed, confluent with the base of the ovary. Ovary 5-celled; style short, thick; stigma funnelform, its margin obscurely crenate. Capsule 5-celled, 5-valved, many-seeded. Seeds minute, the testa produced at each end. [Greek, once-turned.] Two species, of N. Am., Mex., Colombia and Asia.

I. Monotropa uniflòra L. InDIAN PIPE. (I. F. f. 2739.) Scapes white, glabrous, usually clustered, 1-2.5 dm. high from a mass of brittle roots, turning dark in drying. Flower inodorous, nodding, oblong-campanulate, $12-25 \mathrm{~mm}$. long; petals 4-6. puberulent within, white, rather longer than the usually io stamens; filaments pubescent; ovary ovoid, acute, narrowed into the short style; capsule obtusely angled, 10-16 $\mathrm{mm}$. high, 8-10 $\mathrm{mm}$. in diameter. In moist rich woods, Anticosti to Fla., Br. Col. and Cal. Also in Japan and the Himalayas. Whole plant occasionally pink or red. June-Aug.

\section{HYPÓPITYS Hill.}

Scapes pubescent, at least above, bearing white yel!cwish or red flowers in a nodding one-sided raceme which soon becomes erect. Roots a mass of fleshy fibres. Terminal flower usually 5-parted, the lateral ones 3-4-parted. Sepals commonly as many as the petals. Petals saccate at the base. Stamens 6-10; filaments subulate-filiform; anther-sacs becoming confluent, opening by 2 unequal valves, the larger one spreading or reflexed, the smaller erect. Disk 8-10-toothed. Ovary 3-5celled; stigma funnelform, its margin glandular-ciliate. Capsule 3-5-celled, 3-5valved, erect. [Greek, referring to its growth under firs.]

I. Hypopitys Americàna (DC.) Small. PINE-SAP. Plants tawny or deep pink, I-3 dm. tall, finely pubescent; scales crowded at the base of the stem, scattered above; sepals spatulate to oblanceolate, short-ciliate; petals sparingly pubes. cent and short-ciliate; stigma not bearded, capsule 7-10 mm. long. Woods, Newf. to Ont. and N. C. July-Sept.

2. Hypopitys lanuginosa (Michx.) Nutt. Woolly Pine-SaP. Similar to $H$. Americana, but the sepals and petals long-ciliate, the style very pubescent and the stigma retrorsely bearded; capsule 4-5 mm. long. Woods, N. S. to Fla, Br. Col., Tenn, and Ind. June-Aug.

\section{Family 4. ERICÀCEAE DC.}

\section{Heath Family.}

Shrubs, perennial herbs, or trees, with simple estipulate leaves, and mostly perfect flowers. Calyx free from the ovary, 4-5-parted or 4-5cleft, mostly persistent. Corolla regular, or rarely somewhat 2-lipped, usually 4-5-toothed, - lobed or -parted. Stamens hypogynous, usually as many or twice as many as the corolla-lobes, teeth or petals; anthers 2-celled, attached to the filaments by the back or base, the sacs often 
prolonged upwardiy into iubes. Ovary 2-5-celled; stigma peltate or capitate; ovules usually numerous, anatropous. Fruit a capsule, berry or drupe. Seeds usually numerous and minute, or sometimes only $\mathbf{I}$ in each cavity; endosperm fleshy; embryo central; cotyledons short; radicle terete. About 55 genera and I050 species of wide distribution.

* Fruit a septicidal capsule ; corolla deciduous ; anthers unappendaged.

Corolla of separate petals.

Corolla gamopetalous (polypetalous in No. 6).

r. Ledum.

Corolla somewhat irregular (except in No. 5); seeds flat, winged.

Corolla funnelform to campanulate; stamens exserted.

Corolla funnelform, slightly 2-lipped; leaves deciduous. 2. Azalea.

Corolla 2-lipped, lower lip divided to the base; leaves deciduous.

Corolla campanulate; leaves evergreen.

Corolla urn-shaped; stamens not exserted.

Corolla regular; seeds angled or rounded.

Corolla poly petalous.

Corolla gamopetalous.

Stamens 5; capsule 2-3-celled.

Stamens 10; capsule 5-celled.

Corolla saucer-shaped, Io-saccate. $\quad$ 8. Kalmia.

Corolla ovoid.

3. Rhodora.

4. Rhododendron.

5. Menziesia.

6. Dendrium.

7. Chamaecistus.

9. Phyllodoce.

* Fruit a loculicidal capsule, berry or drupe; corolla deciduous; anthers ofter awned.

† Fruit a dry capsule; calyx not accrescent, mostly small.

Low heath-like shrubs; leaves subulate, very small.

Shrubs, or trees; leaves linear to broadly oval.

ro. Cussiope.

Anther-sacs opening by a terminal pore or chink.

Sepals or calyx-lobes imbricated, at least in the bud.

Capsule dehiscent in to a single layer of 5 valves.

11. Leucothoë.

Capsule dehiscent into 2 layers, the outer 5-valved, the inner ro-valved.

Sepals or calyx-lobes valvate, or separate, in the bud.

15. Chamaedaphns.

Anthers 2-awned on the back.

Corolla urn-shaped or cylindric; leaves not glaucous.

13. Pieris.

Corolla globose; leaves narrow, glaucous beneath. 12. Andromeda.
Anthers awnless.
14. Xolisma.

Anther-sacs longitudinally dehiscent.

Corolla ovoid-cylindric, 5-toothed; tall shrub or tree.

Corolla salverform, 5-lobed; trailing shrub. Corolla salverform, 5-lobed; trailing shrub. $\quad$ 17. Epigaea.

Fruit consisting of the fleshy calyx surrounding the capsule.

Fruit a drupe with 4 or 5 nutlets.

16. Oxydendron.
Nutlets coalescent; leaves persistent.
Nutlets separate; leaves deciduous.
*** Fruit a septicidal capsule ; corolla withering-persistent ; anthers appendaged.

I. LÈDUM L.

Erect evergreen resinous shrubs, with scaly buds, the foliage fragrant when crushed. Leaves alternate, thick, short-petioled, oblong or linear, revolute-margined. Flowers white, in terminal umbels or corymbs. Pedicels bracted at the base, the bracts deciduous. Calyx 5-toothed, persistent. Petals 5, obtuse, spreading, imbricated. Stamens 5 or Io (rarely 5 to 7 ), exserted; filaments filiform; anthers small, attached by their backs to the filaments, globose-didymous, the sacs opening by terminal pores. Disk annular, 8-ro-lobed. Ovary ovoid, scaly, 5.celled: ovules numerous; style filiform; stigma 5-lobed. Capsule oblong, 5-celled, 5-valved from the base. [Greek, ledon, the plant now called Cistus Ledon.] Three species, natives of the north temperate and sub-arctic zones. Besides the following, another occurs on the Pacific coast.

Leaves linear, $2-4 \mathrm{~mm}$. wide; stamens ro.

Leaves oblong, 6-16 mm. wide; stamens 5-7.

I. L. palustre.

2. L. Groenlandicum.

I. Ledum palústre L. NARRow-Leaved LABRAdoR TEA. (I. F. f. 274r.) A shrub, 1.5-6 dm. high, the twigs rusty-tomentose. Leaves dark green and 
somewhat rugose above, densely tomentose with brown wool beneath, $12-40 \mathrm{mr}$. long; flowers 6-ro mm. broad; pedicels very pubescent, $\$ 2-25 \mathrm{~mm}$. long in fruit; capsule scurfy, about $4 \mathrm{~mm}$. high and $2 \mathrm{~mm}$. in diameter, nodding; calyx-teeth less than I mm. long, ovate, obtusish. In bogs, Newf. to Alaska. Also in northern Europe and Asia. Summer.

2. Ledum Groenlándicum OEder. LABrador TEA. (I. F. f. 2742.) A shrub, 3-12 dm. high, similar to the preceding. Leaves $2.5-5 \mathrm{~cm}$. long, slightly rugose above, densely brown-tomentose beneath; flowers 8 -10 $\mathrm{mm}$. broad; pedicels $2-2.5 \mathrm{~cm}$. long and recurved in fruit; capsule canescent, nodding, $6-7 \mathrm{~mm}$. long, 2-3 mm. in diameter. In bogs and swamps, Greenland to Br. Col., Mass., N. J. and Wis. May-June.

\section{AZÀLEA L.}

Mostly tall shrubs, with alternate leaves. Flowers large, in terminal umbels developed from cone-like scaly buds. Calyx 5-parted. Corolla funnelform, the tube mostly narrow, the limb nearly regularly 5-lobed or somewhat 2 -lipped. Stamens 5 (rarely 10), exserted, usually declined; anthers attached to the filaments by their backs, the sacs opening by terminal pores; style declined, exserted. Ovary 5-celled; ovules numerous. Capsule oblong or linear-oblong, 5-celled, 5valved from the summit, many-seeded. [Greek, dry, from its habitat.] About 40 species, natives of N. Am. and Asia. Besides the following, 2 others occur on the Pacific coast.

Flowers expanding before or with the leaves.

Flowers pink or white.

Leaves strigose on the midrib beneath; corolla-tube hirsute. 1. A. nudiflora.

Leaves canescent beneath; corolla-tube glandular.

Flowers orange, yellow or red; leaves canescent beneath.

Flowers expanding later than the leaves.

Leaves shining, glabrous beneath.

Leaves strigose on the midrib beneath.

2. A. canescens.

3. A. lutea.

4. A. arborescens,

5. A. viscosa.

I. Azalea nudifiòra L. Wild Honeysuckle. Pinkster-flower. Púr. Ple or Pink Azalea. (I. F. f. 2743.) A shrub, 0.6-2.8 m. high. Leaves oblong to obovate, acute at both ends, short-petioled, glabrous or with a few scattered hairs above when old, 5-10 cm. long, the margins ciliolate; pedicels strigose, 8 I $4 \mathrm{~mm}$. long; flowers faintly odorous, the limb somewhat 2-lipped, 3.5-5 cm. broad, shorter than the narrow tube, stamens much exserted; capsule strigose, I6-18 $\mathrm{mm}$. long, erect. In dry woods and thickets, Me. to Ill., Fla. and Tex. Reported from Canada. April-May.

2. Azalea canéscens Michx. Mountain Azalea. (I. F. f. 2744.) A shrub, 12-45 dm. high. Leaves oval, elliptic or sometimes obovate, wider and shorter than those of the preceding, pale beneath and stiff-hairy or pubescent on the veins, varying to nearly glabrous, the margins ciliolate serrulate; pedicels glandular; flowers very fragrant; corolla-limb often $5 \mathrm{~cm}$. broad, about equalling the rather stout, slightly viscid tube; stamens slightly exserted; capsule glandular, I2I6 mm. long. In woods, Mass. and N. Y. to Fla. and I.a. April-May.

3. Azalea lùtea L. Flame Azalea. (I. F. f. 2745.) Similar to the two preceding. Leaves obovate or oval, glabrous, or with some scattered hairs above, the inargins ciliolate-serrulate; pedicels short, pilose or glandular; flowers slightly fragrant; corolla-tube about the length of the nearly regular limb, glandular-pilose, the limb often $5 \mathrm{~cm}$. broad; stamens long-exserted; capsule about $16 \mathrm{~mm}$. high. In dry woods, N. Y. and Penn. to Ga. May-June.

4. Azalea arboréscens Pursh. Smooth or Tree Azalea. (I. F. f. 2746.) A shrub, 2-6 m. high, glabrous or nearly so. Leaves obovate, oblanceolate or oval, acute or sometimes abruptly acuminate, petioled, firm, bright green above, light green beneath, 5-Io cm. long, fragrant in drying, the margins ciliate; flowers white, or tinged with pink, fragrant, the limb nearly regular, $3.5-5 \mathrm{~cm}$. broad, about as long as the slender glandular tube; stamens and style red, long-exserted; capsule densely glandular, $12-16 \mathrm{~mm}$. long. In woods, Penn. to $\mathrm{N}^{\mathrm{T}}$. Car. and Tenn. June-July.

5. Azalea viscòsa L. Swamp Pink or Honeysuckle. White Azalea. (I. F. f. 2747.) A shrub, I-2 m. high, the twigs hairy. Leaves obovate-oblong 
to oblanceolate, 5-10 $\mathrm{cm}$. long, short-petioled, narrowed at the base, glabrous or with a few scattered hairs above, ciliolate, green on both sides; flowers white, fragrant; pedicels glandular; corolla 3.5-5 cm. long, the limb $2.5-5 \mathrm{~cm}$. broad, more or less 2-lipped, much shorter than the slender, very viscid, densely glandular tube; capsule 10-14 mm. high, glandular-bristly. In swamps, Me. to Ohio, Fla. and Tex. June-July.

Azalea viscòsa híspida (Pursh) Britton. Pedicels bristly-hispid; flowers, at least the limb, pink; leaves glaucescent beneath; shrub $2-5 \mathrm{~m}$. high. Borders of ponds, Shawanzunk Mts. to Penn. and Montauk Point, N. Y.

Azalea viscòsa glaùca Michx. Leaves white-glaucous beneath, $2.5-5 \mathrm{~cm}$. long, shrub 3-18 dm. high. Mass. to Va.

Azalea viscòsa nítida (Pursh.) Britton. Leaves about $2.5 \mathrm{~cm}$. long, bright green on both sides; low shrub. Mass. to Va.

\section{RHO.DÒRA L.}

A shrub, with oval or oblong short-petioled alternate leaves. Flowers umbellate or short-corymbose, short-pedicelied, rose-colored, purple, or nearly white, from terminal scaly buds. Calyx minute. Corolla 2-lipped, the upper lip unequally 2-3-lobed, the lower divided to the base, the segments recurved. Stamens Io, about equalling the corolla; anthers attached by their backs to the filaments. Ovary 5-celled; ovules numerous; style slightly exserted; stigma capitate. Cap. sule linear-oblong, 5-celled, 5-valved from the summit, many-seeded. [From the Greek, rhodon, a rose.] A monotypic genus.

I. Rhodora Canadénsis L. RhodorA. (I. F. f. 2748.) Stems 3-9 dm. high; twigs sparingly strigose. Leaves obtuse and mucronulate, entire, dark green and glabrous, or nearly so, above, pale, glaucous and slightly pubescent, at least on the veins, beneath, $2.5-5 \mathrm{~cm}$. long, 6-14 mm. wide; flowers expanding with or before the leaves; pedicels very short, hairy; corolla $2.5-4 \mathrm{~cm}$. broad; capsule puberulent, glaucous, IO-I4 mm. high. In bogs and on wet hillsides, Newf. to N. J., Quebec, central N. Y. and Penn. May.

\section{RHODODÉNDRON L.}

Leaves alternate, persistent, coriaceous. Flowers purple, rose-colored or white, corymbose or umbellate, from scaly cone-like buds. Calyx 5-lobed or 5-parted. Corolla campanulate, 5-lobed, nearly regular. Stamens 5-IO (usually 10), little exserted, declined or equally spreading. Anthers attached by their backs to the filaments, the sacs opening by terminal pores. Style slender; stigma capitate or 5-2O-lobed; ovules numerous. Capsule mostly woody, 5-2O-valved from the summit. Seeds numerous. [Greek, rose-tree.] About Ioo species, natives of the northern hemisphere. Resides the following, some 5 others occur in the southern and western parts of N. Am.

Arctic-alpine shrub, 5-30 cm. high; leaves small, lepidote. Tall shrubs or low trees; leaves large, glabrous.

Leaves usually acute at both ends; calyx-lobes oblong, obtuse.

Leaves mostly obtuse at both ends; calyx-lobes short, acute.

x. R. Lapponicum.

2. R. maximum.

3. R. Catawbiense.

I. Rhododendron Lappónicum (L.) Wahl. LApland Rose Bay. (I. F. f 2749.) Depressed-or prostrate. Leaves oval, elliptic or oblong, obtuse and mucronulate, 8-18 mm. long, 4-8 mm. wide, short-petioled; flowers few, on short pedicels with scurfy scales; calyx-lobes oblong, obtuse, pubescent; corolla purple, 5-lobed, 14-18 mm. broad, the lobes oblong, obtuse; capsule ovoid-oblong, 4-6 mm. high. Summits of the higher mountains of N. Eng. and the Adirondacks of N. Y.: Quebec to Greenland and Alaska. Delles of the Wisconsin River. Also in Europe and Asia. Summer.

2. Rhododendron máximum L. Great Laurel. Rose Bay. (I. F. f. 2750.) A tall shrub, or sometimes a tree. Leaves oblong, lanceolate-oblong or broadly oblanceolate, dark green on both sides, I-2 dm. long, $2.5-6.5 \mathrm{~cm}$. wide, drooping in winter; petioles stout, 12-25 $\mathrm{mm}$. long; pedicels viscid-pubescent, $2.5-5 \mathrm{~cm}$. long; corolla $3.5-5 \mathrm{~cm}$. broad, about $2.5 \mathrm{~cm}$. long, rather deeply 5 -cleft into oval obtuse lobes, rose-color, varying to white, sprinkled with yellowish or 
orange spots within; capsule oblong, puberulent, 10-14 mm. high. In woods and along streams, N. S. to Ont., Ohio and Ga. June-July.

3. Rhododendron Catawbiénse Michx. Moun'tain Rose Bay. Catawba or Carolina Rhododendron. (I. F. f. 275I.) A shrub, I-6 m. high. Leaves oval or broadly oblong, mucronate, $7 \cdot 5-13 \mathrm{~cm}$. long, $3.5-5 \mathrm{~cm}$. wide, dark green above, pale or glaucous beneath; petioles stout, 12-35 $\mathrm{mm}$. long; pedicels rather stout, becoming glabrous; corolla lilac-purple, $3.5-5 \mathrm{~cm}$. long, $5-6.5 \mathrm{~cm}$. broad, 5-lobed, the lobes rounded; capsule linear-oblong, puberulent, I6-20 mm. high. Mountain slopes and summits, Va. and W. Va. to Ga. May-June.

\section{MENZIÈSIA J. E. Smith.}

Shrubs, with alternate entire deciduous leaves, and small nodding greenish purple slender-pedicelled flowers, in terminal corymbs or umbels, developed from scaly buds. Calyx 4-toothed or 4-parted, persistent. Corolla urceolate-cylindric, or nearly globose, 4-toothed or 4-lobed. Stamens 8; filaments subulate, flattish, anthers linear-oblong, attached by their backs to the filaments, the sacs opening by terminal pores or chinks. Disk obscurely 8-crenate. Ovary mostly 4-celled; ovules numerous; style filiform; stigma 4-lobed or 4-toothed. Capsule 4-celled, 4-valved, many-seeded. Seeds slender, the testa membranous, prolonged at both ends. Parts of the flower rarely in 5's. [Named in honor of Archibald Menzies, surgeon and naturalist, died 1842.] About 7 species, natives of N. Am. and Japan.

Filaments glabrous; seeds pointed at each end.

Filaments pubescent below; seeds long-appendaged at each end.

r. M. pilosa.

2. M. glabella.

I. Menziesia pilòsa (Michx.) Pers. Alleghany Menziesia. (I. F. f. 2752.) Shrub 6-18 dm. high; twigs chaffy and with stiff hairs. Leaves oval, oblong or obovate, rough-hairy above, pale, glaucescent and sometimes chaffy on the veins beneath, 2.5-5 cm. long, the margins ciliate; petioles 4-10 $\mathrm{mm}$. long, pubescent; flowers few, drooping; pedicels filiform, glandular, $12-25 \mathrm{~mm}$. long; calyx-lobes short and broad, hirsute-ciliate; corolla 4-6 $\mathrm{mm}$. long; capsule ovoid, about $4 \mathrm{~mm}$. high, erect, glandular-bristly. In mountain woods, Penn. to Ga. May-June.

2. Menziesia glabélla A. Gray. Smoo'r M Menziesia. (I. F. f. 2753.) Similar to the preceding. Leaves obovate, obtuse and glandular-mucronulate at the apex, pale, glaucous and glabrous or nearly so beneath, sparingly pubescent above, $18-36 \mathrm{~mm}$. long, the margins ciliolate; flowers $\mathrm{I}-5$ in the umbels, becoming erect; pedicels $12-25 \mathrm{~mm}$. long, glandular; corolla about $4 \mathrm{~mm}$. long; capsule oblong or obovoid, erect, about $4 \mathrm{~mm}$. high, glabrous. Minnesota Point, Lake Superior, west to Ore. and Br. Col. May-June.

\section{DÉNDRIUM Desv. [LEIOPHYLLUM Pers.]}

A glabrous evergreen shrub, with coriaceous entire small mostly opposite leaves, and numerous small white or pinkish flowers, in terminal cory mbs. Bracts coriaceous, persistent. Calyx 5-parted, the segments rigid, acute, persistent. Petals 5, sessile, spreading. Stamens Io, exserted; filaments filiform, glabrous; anthers small, globose, didymous, attached by their backs to the filaments, the sacs opening longitudinally. Disk 10-lobed. Ovary 2-5-celled; ovules numerous; style slender, straight; stigma simple, truncate. Capsule ovoid, 2-5-valved from the top. [Greek, a tree.] A small genus of eastern N. Am.

I. Dendrium buxifòlium (Berg.) Desv. Sand Myrtle. (I. F. f. 2754.) A shrub with box-like foliage, widely branching, I-4.5 dm. high. Leaves crowded, oblong or oval, thick, obtuse, dark green and shining above, lighter and black. dotted beneath, short-petioled, somewhat revolute-margined, 6-14 $\mathrm{mm}$. long, the midrib prominent; flowers in short corymbs, about $4 \mathrm{~mm}$. broad; anthers purple; pedicels 6-10 $\mathrm{mm}$. long in fruit; capsule acute, slightly over $2 \mathrm{~mm}$. high. In dry, sandy pine-barrens, N. J. to Fla. April-June.

\section{CHAMAECÍSTUS OEder. [LOISELEURIA Desv,]}

A low giabrous straggling shrub, with small linear-oblong petioled obtuse entire evergreen leaves, and small flowers on terminal erect pedicels. Calyx 5-parted, the segments ovate-lanceolate, persistent. Corolla broadly campanulate, with 5 obtuse lobes. Stamens 5, included; filaments adnate to the corolla; anthers globose- 
didymous, dorsally attached to the filaments, longitudinally dehiscent. Disk obscurely 5 -lobed. Ovary globose; style short; stigma capitate; ovules numerous. Capsule subglobose, 2-3-valved, the valves 2-cleft. Seeds ovoid, the testa granular. [Greek, ground cistus.] A monotypic genus.

I. Chamaecistus procúmbens (L.) Kuntze. Alpine or Trailing Azalea. (I. F. f. 2755.) Tufted, diffuse; branches 5-IO $\mathrm{cm}$. long. Leaves mostly opposite, crowded, dark green above, paler beneath, $4-8 \mathrm{~mm}$. long, the midrib very prominent on the lower side, the margins strongly revolute; petioles $1 \mathrm{~mm}$. long or less; flowers $\mathrm{I}-5$ from terminal coriaceous buds; pedicels $6-8 \mathrm{~mm}$. long; corolla pink or white, about $4 \mathrm{~mm}$. high, longer than the purplish sepals; capsule about $2 \mathrm{~mm}$. in diameter. Summits of the White Mts.; Mt. Albert, Quebec; Lab. and Alaska. Also in northern Europe and Asia. July-August.

\section{KÁLMIA L.}

Erect shrubs, with entire evergreen coriaceous leaves. Flowers in umbels or corymbs, or solitary, or 2-3 together in the axils. Calyx 5-parted or 5-divided, the segments imbricated in the bud. Corolla saucer-shaped, the limb strongly ro-keeled in the bud, 5-lobed, with ro pouches below the limb, the keels extending from the pouches to the lobes and sinuses. Stamens 10, shorter than the corolla; anther-sacs opening by large terminal pores; nilaments erect in the bud, soon curving outward, placing the anthers in the pouches of the corolla, straightening elastically when the flower is fully expanded. Disk ro-crenate. Ovary 5 -celled; ovules numerous; stigma depressed-capitellate. Capsule subglobose, obscurely 5 -lobed, 5 -celled, 5 valved from the summit. Seeds small, subglobose. [Dedicated by Linnaeus to his pupil, Peter Kalm, I715-1779, who travelled in America.] Seven known species, 6 of N. Am., the other Cuban.

Flowers in mostly compound umbels or corymbs; twigs terete.

Leaves oblong, mostly obtuse; flowers 6-10 $\mathrm{mm}$. broad.

Leaves elliptic or oval, acute; flowers $16-25 \mathrm{~mm}$. broad.

Flowers in simple terminal umbels; twigs 2-edged.

Flowers mostly solitary in the axils; leaves and twigs hirsute.

I. $K$. angustifolia.

2. $K$. latifolia.

3. $K$. glauca.

4. K. hirsuta.

I. Kalmia angustifòlia L. Sheep-laurel. LAmbKILl.

(I. F. f. 2756.)

Leaves mostly opposite, or verticillate in 3 's, obtuse or sometimes acute, narrowed at the base, petioled, glabrous, dark green above, light green beneath, 2.5-6.5 $\mathrm{cm}$. long, 6-2.2 mm. wide; flowers purple or crimson, in lateral compound or simple corymbs; pedicels filiform, 12-24 $\mathrm{mm}$. long, recurved in fruit; sepals ovate, acute, canescent, persistent; capsule depressed-globose, 5-lobed, canescent, 3-4 mm. in diameter, the apex impressed; filiform style long-persistent. In moist soil, Newf. to Hudson Bay, south to Ga. and Mich. June-July.

2. Kalmia latifòlia L. American or Mountain Laurel. Calico-bush. (I. F. f. 2757.) Often forming dense thickets, becoming a tree; branches very stiff. Leaves alternate, or some of them opposite, or rarely verticillate in 3 's, petioled, glabrous, flat, green on both sides, persistent, 5-13 cm. long, 12-35 $\mathrm{mm}$. wide; flowers pink to white, numerous and showy in compound terminal corymbs; pedicels bracted and 2-bracteolate at the base, 12-35 $\mathrm{mm}$. long, glandular, erect, even in fruit; capsule depressed-globose, 5-lobed, glandular, 4-6 $\mathrm{mm}$. in diameter; calyx and style long persistent. In woods, N. B. to Ont., Ohio, Fla. and La. May-June.

Kalmia latifòlia myrtifolia Rand. Low, compactly much branched; leaves not over $4 \mathrm{~cm}$. long and 6-8 mm. wide. Mass.

3. Kalmia glaùca Ait. Pale or Swamp Laurel. (I. F. f. 2758.) Gla. brous, I.5-6 dm. high. Leaves opposite or sometimes in 3's, nearly sessile, oblong or linear-oblong, green above, white-glaucous beneath, 12-50 mm. long, 4-12 $\mathrm{mm}$. wide, the margins revolute; flowers few (I-I3), purple, IO-I $8 \mathrm{~mm}$. broad; pedicels filiform, 12-35 mm. long, erect, even in fruit; sepals ovate, scariousmargined, persistent; capsule depressed-globose. glabrous, about $5 \mathrm{~mm}$. in diameter. In bogs, Newf. to Alaska, Conn., N. J., Penn., Mich. and Cal. Summer.

4. Kalmia hirsùta Walt. Hairy LaUrel. (I. F. f. 2759.) Branching, 3-6 $\mathrm{dm}$. high, the branches ascending. Leaves oblong or oblong-lanceolate, nearly sessile, villous-hirsute, becoming glabrate in age, dark green above, lighter beneath, 6-12 mm. long; flowers rose-purple, 10-18 mm. broad; pedicels slender, nearly or 
quite glabrous; sepals acute, hirsute or ciliate, longer than the capsule, at length deciduous; capsule depressed, about $3 \mathrm{~mm}$. in diameter, glabrous. In moist pinebarrens, Va. to Fla. May-Aug.

\section{PHYLLQ́DOCE Salisb.}

Low branching shrubs, with small crowded linear obtuse evergreen leaves. Flowers long-pedicelled, nodding, mostly pink, blue or purple, in terminal umbels. Pedicels bracted at the base. Calyx 5-parted, persistent. Corolla contracted at the throat, 5-toothed. Stamens Io, included; anthers attached to the filaments by their backs, oblong, obtuse, the sacs dehiscent by oblique chinks. Disk obscurely lobed. Ovary 5-celled; ovules numerous; style included; stigma obscurely 5-lobed, or capitate. Capsule subglobose or globose-oblong, 5-valved to about the middle. Seeds minute, the testa coriaceous. [Greek, a sea nymph.] Three species, of arctic and alpine regions of the northern hemisphere.

I. Phyllodoce coerùlea (L.) Gren. \& Godr. Mountain Heath. (I. F. f. 2760.) A shrub, I-I.5 dm. high. Leaves yew-like, 6.10 mm. long, articulated with the branches, crowded above, the margins acutish, scabrous or serrulateciliolate; pedicels erect, very glandular, elongating in fruit; corolla 8-10 mm. long, about $4 \mathrm{~mm}$. in diameter, pink or purple; sepals acuminate, glandular; capsule erect, about $4 \mathrm{~mm}$. high. Summits of the higher mountains of Me. and N. H.; Mt. Albert, Quebec; Lab. to Alaska. Also in Europe and Asia. July-Aug.

\section{CASSIOPE D. Don.}

Low tufted heath-like evergreen shrubs, with small sessile imbricated or crowded, entire apparently veinless leaves, and solitary peduncled white or pink nodding flowers. Sepals 4 or 5 , not bracted at the base. Corolla campanulate, 4-5-lobed or 4-5-parted. Stamens 8-10, included; filaments glabrous; anthers attached to the filaments near the apex, the sacs opening by large terminal pores and tipped with a recurved awn. Disk 10-crenate. Ovary 4-5-celled; ovules numerous; stigma simple. Capsule globose or ovoid, 4-5-valved, each valve 2 -cleft at the apcx. Seeds minute, numerous. [Name from Cassiope, mother of Andromeda.] Ahout Io species, of the colder parts of the northern hemisphere. Besides the following, 3 others occur in northwestern N. Am.

Peduncle terminal; corolla 5-cleft; leaves subulate, crowded. Peduncles lateral; corolla 5-lobed; leaves thick, 4-ranked.

I. C. hypnoides.

2. C. tetragona.

I. Cassiope hypnoìdes (L.) D. Don. Moss-plant. Cassiope. (I. F. f. $276 \mathrm{I}$.) Glabrous, $2.5-7.5 \mathrm{~cm}$. high. Leaves imbricated, acute, flat above, convex beneath, 2-4 $\mathrm{mm}$. long; flowers $6-8 \mathrm{~mm}$. broad; peduncles erect, $8-24 \mathrm{~mm}$. long; corolla nearly white; style conic; capsule globose, about $3 \mathrm{~mm}$. in diameter, 2-3 times as long as the ovate calyx-lobes. Summits of the higher mountains of N. Eng. and the Adirondacks; Quebec and Lab. to arctic Am. Also in arctic Europe and Asia. Plant with the aspect of a moss. Summer.

2. Cassiope tetragòna (L.) D. Don. Four-Angled Cassiope. (I. F. f. 2762.) Tufted, I-3 dm. high. Leaves imbricated, thick, ovate or ovate oblong, closely appressed, channeled on the back, usually puberulent when young, 2-3 mm. long; peduncles slender, $10-24 \mathrm{~mm}$. long: flowers $6-8 \mathrm{~mm}$. broad; style slightly thickened below; capsule nearly globular, $2-3 \mathrm{~mm}$. in diameter. Lab., Greenland and Hudson Bay to Alaska and Ore. Also in Asia. Summer.

\section{LeUCóthoE D. Don. (See Appendix.)}

Shrubs, mostly tall, with alternate petioled leaves, and small usually white bracted flowers in racemes, jointed with their pedicels, or the pedicels jointed with the rachis. Sepals 5, distinct. Corolla cylindric or ovoid-urceolate, 5-toothed. Stamens Io, included: anthers attached to the filaments near their bases, oblong, the sacs opening by terminal pores, obtuse, 2-mucronate or 1-2-awned at the apex. Disk Io-lobed. Ovary 5-celled; stigma capitate or 5-lobed; ovules numerous. Capsule depressed-globose, often 5-lobed, 5-valved, the valves membranous, entire. Seeds numerous, minute. [Name mythological.] About 35 species, natives of N. and S. Am. and eastern Asia. 
Racemes in the axils of persistent leaves of the previous season.

Shoots puberulent; petioles 4-8 mm. long; sepals imbricated in flower.

Shoots glabrous; petioles $8-16 \mathrm{~mm}$. long; sepals not imbricated in flower.

1. L. axillaris.

2. L. Catesbaei.

\section{Racemes terminating the branches; flowers appearing with or before the leaves.}

Racemes mostly recurved; capsule 5-lobed.

Racemes erect or spreading; capsule not lobed.

3. L. recurva.

4. L. racemosa.

I. Leucothoë axillaris (Lam.) D. Don. Downy Leucothö. (I. F. f. 2763.) Leaves evergreen, oval to oblong-lanceolate, glabrous above, sparsely beset with minute hairs beneath, acute or acuminate, serrulate, $5-15 \mathrm{~cm}$. long, 12-35 mm. wide; racemes many-flowered, dense; bracts ovate, concave, borne near the bases of the short pedicels; anthers awnless; corolla about $6 \mathrm{~mm}$. long; stigma depressed, 5-rayed. In moist woods, Va. to Fla. and Ala. April.

2. Leucothoë Catesbaei (Walt.) A. Gray. CATEsby's Leucothö. (I. F. f. 2764.) Similar to the preceding. Leaves lanceolate or ovate-lanceolate, evergreen, acuminate, sharply serrulate with bristle-pointed teeth, $7 \cdot 5-15 \mathrm{~cm}$. leng, 18-35 mm. wide; racemes dense, many-flowered; hracts borne at the bases of the short petioles; corolla narrowly cylindric, about $5 \mathrm{~mm}$. long; capsule depressed, strongly 5-lobed, about $4 \mathrm{~mm}$. in diameter. Along streams, Va. to eastern Tenn. and Ga. April.

3. Leucothoë recurva (Buckl.) A. Gray. Mountain Levcothö̈. (I. F. f. 2765.) Widely branched, 6-30 dm. high, similar to the following species. Leaves deciduous, ovate or oval, often acuminate, pubescent on the veins beneath, $5-10 \mathrm{~cm}$. long; calyx 2-bracteolate, the bracts persistent; corolla about $6 \mathrm{~mm}$. long; anthersacs I-awned; capsule depressed, about $4 \mathrm{~mm}$. in diameter and $2 \mathrm{~mm}$. high; seeds winged. In dry woods, mountains of Va. to Ala. April-May.

4. Leucothoë racemòsa (L.) A. Gray. Swamp Leccothö̈. (I. F. f. 2766.) Leaves oblong to ovate, mostly acute at each end, deciduous, short-petioled, glabrous, or with some short hairs above, pubescent, at least on the veins beneath, serrulate, $2.5-7.5 \mathrm{~cm}$. long, $\mathbf{2} 2-25 \mathrm{~mm}$. wide; calyx 2 -bracteolate at the base, the bractlets firm, persistent; pedicels about $2 \mathrm{~mm}$. long, jointed with the rachis; corolla nearly cylindric, 6-8 mm. long; anther sacs 2 -awned; stigma capitate; capsule depressed-globose, slightly grooved, $3 \mathrm{~mm}$. in diameter; seeds smooth, wingless. In swamps and moist thickets, Mass. to Penn., Fla. and La. April-June.

\section{ANDRÓMEDA L.}

A glabrous shrub. Leaves coriaceous, linear or oblong, entire, revolute-margined, evergreen, short-petioled, white-glaucous beneath. Flowers white, drooping, in terninal umbels. Calyx 5-parted, persistent. Corolla globose-urceolate, 5 -toothed, the teeth recurved. Stamens Io, included; filaments bearded; anthers attached to the filaments at about the middle, ovate, obtuse, the sacs opening by large terminal pores, each with a reflexed awn. Disk Io-lobed. Ovary 5-celled; style columnar; ovules numerous. Capsule subglobose, 5-angled, 5-valved, manysceded. Seeds oval, the testa smooth, coriaceous, shining. [Named for Andro. meda of mythology.] A monotypic genus.

r. Andromeda Polifolia L. Wild Rosemary. Marsh Holy Rose. Moorwort. (I. F. f. 2767.) A shrub, 3-9 dm. high, the foliage acid. Leaves mucronulate, narrowed at the base, $2.5-6.5 \mathrm{~cm}$. long, $4-8 \mathrm{~mm}$. wide; petioles about $2 \mathrm{~mm}$. long; umbels few-flowered; bracts small, ovate, persistent; pedicels 8-12 mm. long; calyx-lobes triangular-ovate, acute; corolla $4-6 \mathrm{~mm}$. in diameter; cap. sule about $4 \mathrm{~mm}$. in diameter, about as long as the style. In bogs, Newf. to Alaska, N. J., Penn., Mich. and Br. Col. Also in Europe and Asia. May-June.

\section{PIERIS D. Don.}

Shrubs or small trees. Leaves alternate, persistent or tardily deciduous. Flowers mostly white, in bracted racemes or umbels, the pedicels commonly 1-3bracteolate. Calyx 5-parted, the segments ovate, acute, valvate in the bud, persistent. Corolla urceolate-cylindric, 5-toothed, the teeth recurved. Stamens 10, included; filaments often pubescent or ciliate; anthers oblong or ovoid, the sacs opening by large oval pores. Disk 10-lobed. Uvary 5-celled; ovules numerous; 
style columnar; stigma truncate. Capsule globose or ovoid, 5-angled, 5-celled, Seeds linear-oblong, not winged, clavate or falcate, the testa smooth, membranous. [Name from one of the Muses.] About 12 species, natives of eastern N. Am., Cuba, eastern Asia and the Himalayas.

Leaves coriaceous, evergreen, serrulate; flowers racemose.

Leaves coriaceous, evergreen, entire; flowers in axillary umbels.

Leaves membranous, deciduous, entire; flowers in lateral umbels.

I. P. floribunda。

2. P. nitida.

3. P. Mariana.

I. Pieris floribúnda (Pursh) Benth. \& Hook. Mountain Fetrer-Bush. (I. F. f. 2768.) Branches nearly erect, bristly or strigose-pubescent, leafy. Leaves oblong to ovate-lanceolate, glabrous above, black-dotted beneath, acute or acuminate, $3.5-7.5 \mathrm{~cm}$. long, $12-25 \mathrm{~mm}$. wide; petioles $4-8 \mathrm{~mm}$. long, very bristly, at least when young: flowers white, about $7 \mathrm{~mm}$. long; calyx-segments ovate-lanceolate, acute; corolla slightly 5-angled, 5-saccate at the base; filaments unappendaged; capsule globose-ovoid, about $4 \mathrm{~mm}$. high, longer than the slender style. Mountains of Va. to Ga. May.

2. Pieris nítida (Bartr.) Benth. \& Hook. FetTer-Bush. (I. F. f. 2769.) A glabrous shrub, 6-18 dm. high, the branches acutely angled. Leaves shortpetioled, oblong, oval, oblong-lanceolate, or obovate, acuminate or acute, somewhat black.dotted beneath, revolute, bordered by an intra-marginal nerve; flowers nodding or spreåding; pedicels $4-8 \mathrm{~mm}$. long; calyx-segments rigid, purplish, valvate in the bud; corolla white or red, ovoid-cylindric, narrowed at the throat, 6-8 mm. long; filaments 2-spurred; capsule globose, about as long as the calyxsegments. In wet woods, Va. to Fla., Cuba and La. April-May.

3. Pieris Mariàna (L.) Benth. \& Hook. Sragger-Bush. (I. F. f. 2770.) Branches nearly erect, glabrous or nearly so, black-dotted. Leaves oval or oblong, glabrous above, sparingly pubescent on the veins and black-dotted beneath; 5-7.5 cm. long; flowers nodding on the nearly leafless branches of the preceding season; calyx-segments acuminate, deciduous; corolla ovoid-cylindric, white, or faintly pink, IO-12 mm. long; filaments pubescent on the outer side, usually with 2 setose appendages; capsule ovoid-pyramidal, 3-4 mm. high, truncate, about as long as the sepals. In sandy soil, R. I. to Fla., Tenn. and Ark. May-July.

\section{XOLÍSMA Raf. (See Appendix.)}

Tall shrubs, or small trees, with terete twigs, alternate short-petioled leaves, and small mostly white flowers in clusters. Calyx 4-5-lobed or 4-5-cleft. Corolla globose, or urceolate, pubescent, 4-5-toothed, the teeth recurved. Stamens 8 or Io, included; filaments flat, incurved, pubescent; anthers attached to the filaments near their bases, truncate, the sacs opening by terminal pores. Disk 8-ro-lobed. Ovary 4-5-celled; style columnar; stigma truncate; ovules numerous, pendulous. Capsule 4-5 angled, 4-5-valved, its apex intruded. Seeds elongated, the testa membranous, loose, reticulated. [Name unexplained.] About Io species, natives of eastern N. Am., the W. Indies and Mex.

I. Xolisma ligústrina (L.) Britton. Privet Andromeda. (I. F. f. 2771.) A shrub I-4 m. high. Leaves obovate, oblong, oval or ovate, deciduous, minutely serrulate or entire, acute or abruptly acuminate, usually quite glabrous above, $2.5-6.5$ $\mathrm{cm}$. long; racemes mostly leafless, in terminal panicles; bracts sinall, caducous; pedicels $2-6 \mathrm{~mm}$. long, pubescent; calyx. lobes triangular-ovate, acute; corolla nearly globular, $3 \mathrm{~mm}$. in diameter; capsule depressed-globose, obtusely 5-angled, about 3 $\mathrm{mm}$. in diameter. In swamps and wet soil, Canada (?), Me to N. Y., Fla., Tenn. and Ark. May-July. [Andromeda liguistrina Muhl.]

\section{CHAMAEDÁPHNE Moench. [CASSANDRA D. Don.]}

An erect shrub, with stiff terete branches, alternate evergreen short-petioled narrow leaves, and white short-pedicelled secund flowers, solitary in the axils of the small upper leaves. Calyx of 5 distinct persistent sepals, bracted at the base. Corolla oblong-cylindric, narrowed at the throat, 5-toothed, the teetl recurved. Stamens IO, included; filaments subulate, glabrous; anther-sacs tapering upward into tubular beaks, opening by terminal pores. Disk 1o toothed. Ovary 5-celled, 5-grooved; stigma simple. Capsule depressed-globose, the epicarp 5-valved, sep- 
arating at length from the Io-valved endocarp. [Greek A monotypic genus.

I. Chamaedaphne calyculàta (L.) Moench. Leather-LeAf. DWARF CASSANDRA. (I. F. f. 2772.) Leaves oblong or oblanceolate, densely covered on both sides with minute scurfy scales, at least when young, $1.2-3.5 \mathrm{~cm}$. long, the margins obscurely denticulate; upper leaves gradually smaller, the uppermost reduced to floral bracts; pedicels $2 \mathrm{~mm}$. long or less; corolla about $6 \mathrm{~mm}$. long; capsule $4 \mathrm{~mm}$. in diameter, about twice as long as the ovate sepals. In bogs and swamps, Newf. to Alaska, N. J., Ga., Ill., Mich. and Br. Col. Also in Europe and Asia. April-June.

\section{OXYDÉNDRUM DC.}

A tree, with alternate petioled deciduous sour leaves, and numerous white flowers, in terminal panicled racemes. Pedicels 2-bracteolate. Sepals 5, slightly imbricated in the bud, persistent. Corolla ovoid-cylindric, minutely canescent, narrowed at the throat, tardily expanding, 5-toothed. Stamens Io; filaments wider than the linear anthers; anther-sacs opening by long chinks. Ovary ovoid, 5-celled, ovules numerous, near the base of the cavities; stigna simple. Disk ro-toothed. Capsule ovoid-pyramidal, 5-angled, 5-valved. Seeds ascending or erect, elongated, the testa reticulated, loose and extended at each end beyond the linear nucleus. [Greek, sour-tree.] A monotypic genus.

I. Oxydendrum arbòreum (L.) DC. Sour-wood. Sorrel-tree. (I. F. f. 2773). A smooth-barked tree. Leaves oblong, oval or oval-lanceolate, sharply serrulate, or entire, green and glabrous, finely reticulate-veined, acuminate, I-I.5 $\mathrm{dm}$. long, $2.5-7 \cdot 5 \mathrm{~cm}$. wide; racemes long and slender, erect or curving, panicled, the rachis and short pedicels canescent; flowers $6-8 \mathrm{~mm}$. long; capsule 4-6 mm. long, canescent, tipped by the persistent style, the pedicels curving. In woods, Ohio and Penn. to Va., Fla. and Miss. June-July.

\section{EPIGAÈA L.}

Prostrate slightly woody branching shrubs, with alternate evergreen entire leaves. Flowers rather large, perfect, heteromorphous or diœcious, bracted, sessile, white or pink, fragrant, clustered at the ends of the branches. Sepals 5, oblong, persistent, dry, much imbricated. Corolla salverform, the limb 5-lobed (rarely 4or 6-lobed). Stamens Io; filaments filiform; anthers attached to the filaments below the middle. Disk ro-lobed. Ovary ovoid, hirsute, 5-lobed, 5-celled; ovules numerous; style columnar; stigma 5-lobed. Capsule depressed globose, hirsute, slightly 5-lobed, at length loculicidally 5-valved. [Greek, on the earth.] Two species, the following of eastern N. Am., the other of Japan.

I. Epigaea rèpens L. Trailing Arbutus. Mayflower. Ground LauREL. (I. F. f. 2774.) Twigs hirsute; branches I.5-4 dm. long. Leaves oval or nearly orbicular, thick, cordate or rounded at the basc, mostly glabrous above, hirsute beneath, green both sides, $2.5-7.5 \mathrm{~cm}$. long, 12-35 mm. wide; petioles hirsute, $0.6-5 \mathrm{~cm}$. long; flowers 10-16 $\mathrm{mm}$. long and nearly as broad when expanded; corolla-tube somewhat longer than the sepals. In sandy or rocky woods, Newf. to the N. W. Terr., Fla., Ky. and Mich. Often forms patches. March-May.

\section{GAULTHÈRIA L.}

Shrubs, with alternate evergreen leaves, and small axillary, white, red or pink flowers. Calyx 5-parted or 5-cleft, persistent. Corolla urn-shaped or campanulate, 5 -toothed or 5 -lobed. Stamens ro, included, inserted at the base of the corolla; filaments dilated above the base; anther-sacs opening by a terminal pore, commonly awned. Stigma obtuse, entire. Disk ro-toothed. Ovary 5.celled, 5lobed. Calyx becoming fleshy and at length surrounding the capsule, forming a berry-like fruit. [Named after Dr. Gaultier, of Quebec.] About roo species. mostly of the Andes. Besides the following, 3 others occur on the Pacific Coast.

r. Gaultheria procúmbens L. SPRING OR CReEPIng Wintergreen. Checkerberry. (I. F. f. 2775.) Nearly glabrous, aromatic; stems slender, creeping or subterranean; branches erect, $5-15 \mathrm{~cm}$. high. Leaves mostly clustered at the ends of the branches, oval, ublong or obovate, narrowed at the base, short- 
petioled, the margins serrate with low bristle-tipped teeth, dark green and shining above, pale beneath, 2.5-5 cm. long; flowers usually solitary in the axils, on recurved peduncles 4-8 $\mathrm{mm}$. long, 2-bracteolate under the calyx; corolla ovoid. urceolate, white, 5-toothed, 4-6 mm. long; fruit depressed-globose, slightly 5-lobed, bright red, 8-12 $\mathrm{mm}$. in diameter, mealy, very spicy. In woods, Newf. to Manitoba, Ga. and Mich. June-Sept.

\section{ARCTOSTÁPHYLOS Adans.}

Shrubs, some western species small trees. Leaves alternate, petioled, firm ${ }^{-1}$ coriaceous, evergreen. Flowers small, nodding, pedicelled, white or pink, in ter. minal clusters. Calyx 4-5-parted, persistent. Corolla 4-5-lobed, the lobes recurved, imbricated in the bud. Stamens IO, rarely 8, included; filaments short; anthers short, erect, introrse, with 2 recurved awns on the back, the sacs opening by a terminal pore. Disk 8-Io-lobed. Ovary 4-10-celled; ovules solitary in the cavities; style slender. Fruit a drupe, with 4-10 seed-like nutlets coherent into a solid stons. [Greek, bear-berry.] About 20 species, the following of the northern hemisphere, the others of western N. Am.

I. Arctostaphylos U̇va-Úrsi (L.) Spreng. Red BEARbERry. KinnikiNIC. (I. F.f. 2776.) Trailing or spreading, branches $1.5-6 \mathrm{dm}$. long, the twigs puberulent. Leaves spatulate, obtuse, entire, glabrous or minutely puberulent toward the base, $12-25 \mathrm{~mm}$. long, 4-10 $\mathrm{mm}$. wide, finely reticulate-veined; petioles about $2 \mathrm{~mm}$. long; flowers few in short racemes; pedicels $2-4 \mathrm{~mm}$. long; corolla ovoid, constricted at the throat, white, about $4 \mathrm{~mm}$. long; drupe glubose, red, glabrous, insipid, rather dry, 6 Io $\mathrm{mm}$. in diameter, usually containing 5 coalescent nutlets. In dry, sandy or rocky soil, Lab. to Alaska, N. J., Penn., Ill., Neb., Colo. and Cal. Also in Europe and Asia. May-June.

\section{MAIRÀ NIA Neck.}

A low shrub, with shreddy bark, alternate thin deciduous leaves clustered toward the ends of the branches, and small white clustered pedicelled flowers. Calyx 4-5-parted. Corolla 4-5-toothed, the short teeth spreading or recurved. Stamens 8 or Io, included; anther sacs with 2 recurved dorsal awns. Ovary 4-5 celled; ovules $I$ in each cavity. Drupe globose, with 4 or 5 separate I-seeded nutlets. A monotypic genus.

I. Mairania alpina (L.) Desv. Alpine or Black Bearberry. (I. F. f. 2777.) Tufted or depressed-prostrate; branches 5-12 cm. high, the twigs glabrous or nearly so. Leaves obovate, crenulate, conspicuously reticulate-veined, ciliate at least when young, 12-25 $\mathrm{mm}$. long, 6-14 mm. wide; flowers few, appearing from scaly buds before or with the leaves; corolla white, ovoid, constricted at the throat; drupe black (or bright red, according to Macoun), juicy, 6-Io $\mathrm{mm}$. in diameter. Mountains of N. Eng.; Quebec to Newf., Alaska and Br. Col. Also in northern Europe and Asia. Summer. [Arctostaphylos alpina Sipreng.]

\section{CALLÙNA Salisb.}

A low evergreen shrub, with minute linear opposite imbricated leaves, and small white or pink flowers, in terminal one sided dense spilie-like racemes. Sepals 4, scarious, obtuse, longer than and concealing the corolla. Corolla campanulate, 4-parted, slightly twisted, persistent. Stamens 8; filaments short; anthers oblong, attached to the filaments by their backs, opening by a longitudinal slit, each sac with a dorsal reflexed appendage. Disk 8-lobed. Ovary depressed-globose, 8-angled; style slender. Capsule somewhat 4-sided, 4-celled, 4-valved, few-seeded. Seeds ovoid, pendulous, not winged. [Greek.] A monotypic genus.

I. Calluna vulgàris (L.) Salisb. Ling. Heather. Moor. Besom. (I. F. f. 2778.) Straggling, the branches ascending, I-4 dm. high. Leaves sessile, about $1 \mathrm{~mm}$. long, imbricated in 4 rows, usually 2 -auricled at the base, 3 -angled, grooved on the back; calyx with 4 bracts at the base; corolla about $3 \mathrm{~mm}$. long. Sandy or rocky soil, Newf. to N. J. Nat. or adventive from Europe. July-Sept. 


\section{Family 5. VACCINIÀCEAE Lindl.}

\section{Huckleberry Family.}

Shrubs, or small trees, with alternate leaves, and small perfect flowers, the pedicels commonly bracted. Calyx-tube adnate to the ovary, the limb 4-5-lobed or 4-5-cleft. Corolla 4-5-lobed, or rarely divided into separate petals, deciduous. Stamens twice as many as the corolla-lobes, epigynous, or inserted at the base of the corolla ; filaments mostly short; anthers dorsally attached, 2-celled, the connective entire or 2-awned. Ovary inferior, 2-10-celled, crowned by the epigynous disk; st;le filiform; ovules anatropous. Fruit a berry or drupe in our genera, globose ; cells 1-several-seeded, or the drupe containing several nutlets. Seeds compressed; testa bony; endosperm fleshy; embryo central; radicle near the hilum. About 20 genera and 300 species of wide distribution.

Ovary ro-celler: fruit a berry-like drupe with I seeded ro nutlets.

I. Gaylussacia.

Ovary 4-5-celled; fruit a many-seeded berry.

Corolla open campanulate, 4-5-lobed.

Flowers 4-parted; leaves small, coriaceous, persistent; low shrub.

Flowers 5-parted; leaves large, thin, deciduous; tall shrubs. Flower not jointed with its pedicel; anthers exserted. Flower jointed with its pedicel; anthers included; berry black.

2. Vitis-Idaea.

cylindric, subglobose or urceolate.

Corolla cylindric, subglobose or urceolate.
Erect shrubs; ovary entirely inferior; berries normally not white.

4. Batodendron.

Low trailing shrub; ovary half inferior; berry snow-white.

Corolla deeply 4 -cleft or 4 -divided, the lobes retlexed.

5. Vaccinium.

6. Cliogenes.

7. Uxycoicus.

\section{GAYLUSSÀCiA H.B.K.}

Branching slirubs, with alternate leaves, and small white or pink flowers in lateral bracted racemes. Pedicels mostly 2-bracteolate. Calyx-tube obconic, or turbinate, the limb 5-lobed or 5 toothed, persistent. Corolla urn-shaped, or tubslar-campanulate, the tube terete or 5-angled, the limb.5-lobed. Stamens Io, equal; filaments short; anther-sacs tapering upward into tubes, awnless, opening by terminal pores or chinks. [Named for the celebrated chemist, Gay-Lussac.] About 40 American species. Besides the following, 3 others occur in the Southern States.

Laaves pa!e and glaucous beneath, resinous; fruit blue with a bloom. r. G. frondosa. Leaves green both sides, resinous: fruit mostly black.

Bracts small, deciduous, mostly shorter than the pedicels.

Bracts oval, large, persistent, longer than the pedicels.

Leaves thick, evergreen, serrate, not resinous; bracts scale-like.

2. G. resinosa.

3. G. dumosa.

4. G. brachycera.

I. Gaylussacia frondòsa (L.) T. \& G. Blue Tangle. TAngleberry. DangleberRy. (I. F. f. 2779.) An erect shrub, 6-12 dm. high. Leaves oval to obovate, obtuse or retuse, entire, $3 \cdot 5-6.5 \mathrm{~cm}$. long, the upper surface green, glabrous; petioles about $2 \mathrm{~mm}$. long; flowers few, greenish pink; bracts linear-oblong, shorter than the filiform pedicels, deciduous; corolla globose-campanulate. $3 \mathrm{~mm}$. long; filaments glabrous; fruit globose. about $8 \mathrm{~mm}$. in diameter, sweet. In moist woods, N. H. to Fla., Ohio and La. May-June.

2. Gaylussacia resinòsa (Ait.) T. \& G. Bi.Ack or High-Bush HuckleBERRY. (I. F. f. 2780.) A shrub, 3-9 dm. high, the young shoots commonly pubescent. Leaves oval or oblong. rarely obovate, entire, mucronulate, glabrous or nearly so, firm, $2.5-5 \mathrm{~cm}$. long; petioles about $2 \mathrm{~mm}$. long; flowers few, pink or red, in one-sided racemes: corolla ovoid-conic. 5-angled, becoming campanulatecylindric, 4-5 mm. long; filaments ciliate; fruit (rarely white) about $6 \mathrm{~mm}$. in diameter, sweet but seedy. In woods and thickets, Newf. to Ga., Manitoba, Wis. and Ky, May-June. 
3. Gaylussacia dumòsa (Andr.) T. \& G. Dwarf or Bush Huckleberry. (I. F. f. 278I.) A shrub, 3-6 dm. high, the branches usually leafless below, the young twigs pubescent or hirsute, glandular. Leaves oblong-obovate or oblanceolate, obtuse, mucronate, entire, firm or coriaceous, shining when old, $2.5-3.5 \mathrm{~cm}$. long, sessile or nearly so; flowers white, pink or red, in rather loose racemes; bracts foliaceous, pubescent; corolla campanulate, $4-5 \mathrm{~mm}$. long; filaments pubescent; calyx puberulent; fruit 6-8 mm. in diameter, watery, rather insipid. In sandy swamps, Newf. to N. Y., Fla. and La. May-June.

Gaylussacia dumòsa hirtélla (Ait.) A. Gray. Pedicels and calyx hirsute. Va. to Fla. and La.

4. Gaylussacia brachycera (Michx.) A. Gray. Box-huckleberry. (I. F.f. 2782.) A low shrub, I.5-4 dm. high, the branches angular, the twigs glabrous or nearly so. Leaves coriaceous, glabrous, persistent, oval or oblong, I2-25 mm. long, with low teeth, the margins somewhat revolute; petioles $2 \mathrm{~mm}$. long or less; flowers few, white or pink, in short racemes; bracts and bractlets caducous; pedicels short; corolla cylindric-ovoid, about $4 \mathrm{~mm}$. long; filaments ciliate; fruit (according to A. Wood) light blue. In dry woods, Penn. to Va. May.

\section{VİTIS-IDAÈA Tourn.}

A low evergreen shrub, with creeping stems, alternate oval or obovate coriaceous leaves, and small white or pink nodding flowers, secund in small terminal clusters. Calyx 4-toothed. Corolla open-campanulate, 4-lobed. Stamens 8; arithers upwaidly prolonged into tubes. Ovary 4-celled, inferior. Fruit a dark red acid many-seeded berry. [Ancient name.] A monotypic genus.

I. Vitis-Idaea Vitis-Idaèa (L.) Britton. Mountain Cranberry. (I. F. f. 2795.) Branches erect, I-2 dm. ligh. Leaves thick, crowded, green and somewhat shining above, paler and black-dotted beneath, glabrous, or minutely ciliate toward the base, short-petioled, entire or sparingly serrulate, 6-16 $\mathrm{mm}$. long, the margins revolute; bracts reddish, short-oblong; bractlets 2; berries 8-10 $\mathrm{mm}$. in diameter. In rocky places, Essex Co., Mass., coast of Me., higher mountains of N. Eng. to Lab., west to Lake Superior, Br. Col. and Alaska. Also in northern Europe and Asia. [Vaccinium Vitis Iacea L.]

\section{POLYCòdIUM Raf. (See Appendix.)}

Shrubs with alternate deciduous leaves, and purplish or yellowish green flowers in leafy-bracted racemes. Calyx 5-toothed. Corolla open-campanulate, 5-lobed. Stamens IO; anthers upwardly prolonged into tubes. Ovary 5-celled, inferior. Berry green, nearly black, or yellow, globose to pyriform. Four or five species of eastern N. Am. [Greek, many belis.]

I. Polycodium stamíneum (L.) Greene. Deerberry. Buckberry. (I. F. f. 2796.) Divergently branched, 6-15 dm. high. Leaves oval, oblong or rarely obovate, acute or sometimes acuminate, petioled, entire, firm, green above, pale beneath, 2.5-10 $\mathrm{cm}$. long, I2-35 mm. wide; corolla purplish or yellowish green, deeply cleft, $46 \mathrm{~mm}$. long, 6-10 $\mathrm{mm}$. broad; berry globose or pear-shaped, green or yellow, 8 . $10 \mathrm{~mm}$. in diameter. inedible. In dry woods and thickets, Me. to Ont., Minn., Ark., Ky. and Ala. April-June. [Vaccinium stamineum L.]

\section{BATODÉND́RON Nutt. (See Appendix.)}

Shrubs or small trees, with firm deciduous leaves, and white flowers in leafybracted racemes. Calyx 5-toothed. Corolla campanulate, 5-lobed. Stamens IO; style exserted. Berry black, globose, many-seeded. Two or three N. Am. species. [Greek, blackberry tree.]

I. Batodendron arbòreum (Marsh.) Nutt. FARKLEberRY. (I. F. f. 2797.) Divergently branched, reaching a maximum height of about $9 \mathrm{~m}$. Leaves obovate or oval, short-petioled, shining and bright green above, duller, and sometimes sparingly pubescent beneath, entire or glandular-denticulate, $2.5-5 \mathrm{~cm}$. long, 12-25 $\mathrm{mm}$. wide; flowers slender-pedicelled: bracts persistent; berry about $6 \mathrm{~mm}$. in diameter, inedible. In dry sandy soil, N. Car. to Ky., Ill., Ind. Terr., Fla. and Tex. May-June. [Vaccinium arboreum Marsh.] 


\section{VACcíniUm L. (See Appendix.)}

Shrubs (some species small trees) with alternate leaves, and small white pink or red flowers, in racemes or clusters, or rarely solitary in the axils. Calyx-tube globose, hemispheric or turbinate, not angled, adnate to the ovary, the limb 4-5toothed or 4-5-lobed, persistent. Corolla gamopetalous, urn-shaped, or cylindric, rarely subglobose, its iimb 4-5-toothed or 4-5-lobed. Stamens twice as many as the lobes of the corolia; anthers upwardly prolonged into tubes, opening by terminal pores or chinks. Ovary 4-5-celled, or 8-10-celled by false partitions; ovules several or numerous; stigma small. Fruit a many-seeded berry. [Latin, blueberry.] About I25 species of wide distribution. Besides the following, some I I others occur in southern and western N. Am.

F lowers solitary. or $2-4$ together, on drooping pedicels; low shrubs.

Most or all the flowers 4-parted, and stamens 8.

Flowers all or nearly all 5-parted, and stamens ic.

Shrub 7-15 cm. high; leaves obovate or cuneate.

Shrubs $0.3-4 \mathrm{~m}$. high; leaves oval or oblong; northern species.

Leaves serrulate, green both sides; berries purple-black.

1. V. uliginosum.

Leaves entire or nearly so, pale beneath; berry blue with bloom.

Flowers fascicled or racemose, short-pedicelled; leaves deciduous.

4. V. ovalifolium.

Corolla cylindric or nearly so, 2-3 times as long as thick.

Flowers appearing before the leaves; berry black.

Flowers appearing with the leaves; berry blue with a bloom.

5. Virgatum.

6. V. corymbosum.

Corolla urn-shaped, oblong or oblong-cylindric, I-2 times as long as thick.

Leaves not glaucous; glabrous or pubescent beneath.

Leaves mostly entire, pubescent beneath.

Shrub I-5 m. high; leaves oval, large, fruit black.

Shrub 1.5-6 dm. high; leaves oblong, small; fruit blue.

8. V. Canadense.

Leaves serrulate, nearly or quite glabrous; low shrub; fruit blue.

9. I. Pennsylvanicum。

Leaves pale and glaucous beneath, mostly glabrous both sides.

Fruit black; shrub 1.5-5 dm. high; leaves oblong or oblanceolate.

10. V. nigrum.

Fruit blue; shrubs 3-18 dm. high; leaves oblong, oval, or obovate.

Leaves firm, mostly entire; berry about $6 \mathrm{~mm}$. in diameter.

II. V. vacillans.

Leaves thin, sharply serrulate; berry 8-12 mm. in diameter.

12. V. pallidum.

I. Vaccinium uliginòsum L. Great BilberRy. BOG Whortleberry. BleaberRy. (I. F. f. 2783.) Much branched, I.5-6 dm. high. Leaves thick, glabrous or nearly so, dull, pale or glaucous beneath, obovate, oblong, or oval, obtuse, or retuse, entire, nearly sessile, finely reticulate-veined, 10-25 mm. long; flowers mostly shorter than the pedicels; calyx sometimes 5-lobed; corolla pink, ovoid or urn-shaped, 4-5-toothed; berry blue with a bloom. about $6 \mathrm{~mm}$. in diameter, sweet. Mountains of N. Eng. and the Adirondacks; Lab. and Quebec to the shores of Lake Superior and Alaska. Also in Europe and Asia. June-July.

2. Vaccinium caespitòsum Michx. Dwarf Bilberry. (I. F. f. 2784.) Nearly glabrous throughout. Leaves $12-25 \mathrm{~mm}$. long, green and shining both sides, nearly sessile, serrulate: flowers longer than their pedicels: corolla obovoid or obovoid-oblong, pink or white, rarely 4-toothed: stamens rarely 8; berry blue with a bloom, sweet, about $6 \mathrm{~mm}$. in diameter. Me., N. H., N. B. to Lab., west to Alaska, south in the Rocky Mts. to Colo. June-July.

3. Vaccinium membranàceum Dougl. ThIN LEAved BILBERRy. (I. F. f. 2785.) Nearly glabrous, 3-15 dm. high, the twigs slightly angled. Leaves thin, not shining, acutish to acuminate, short-petioled. $2.5-5 \mathrm{~cm}$. long; flowers with their pedicels becoming erect in fruit; corolla depressed-globose or globoseurceolate, greenish or purplish, mostly 5-toothed; berry rather acid. In moist woods, Mich. to Mont., Ore. and Br. Col. June-July. 
4. Vaccinium ovalifòlium J. E. Smith. TAll or Oval-Leaved Bilberry. (I. F. f. 2786.) A straggling shrub, 9-36 dm. high; twigs glabrous, sharply angled. Leaves short-petioled, glabrous, green above, glaucous beneath, rounded at both ends, or somewhat narrowed at the base, thin, sometimes mucronulate, $2.5-5 \mathrm{~cm}$. long; flowers on rather short recurved pedicels; corolla globose-ovoid; berry 8-10 mm. in diameter. Woods, Quebec to Mich., Ore. and Alaska. June-July.

5. Vaccinium virgàtum Ait. SOUthern Black Huckleberry. (I. F. f. 2787.) A shrub, 9-36 dm. high, the branches slender, the young twigs puberulent. Leaves narrowly oval-oblong, broadest at the middle, mucronate, short. petioled, entire, green and glabrous above, pale or glaucous beneath, thick when old, $2.5-6.5 \mathrm{~cm}$. long, $12-25 \mathrm{~mm}$. wide, veins pubescent; flowers equalling or longer than their pedicels; calyx 5-lobed; corolla 6-8 $\mathrm{mm}$. long, 2-3 $\mathrm{mm}$. thick, white or light pink; stamens Io; berry with or without bloom, 4-6 mm. in diameter. In swamps, Va. to Fla. and La. April-May.

Vaccinium virgàtum tenéllum (Ait.) A. Gray. Low, mostly less than $6 \mathrm{dm}$. high; leaves smaller, narrower, $12-35 \mathrm{~mm}$. long; flowers white, or nearly so, 4-6 mm. long. Va. to Ark., Fla. and Ala.

6. Vaccinium corymbòsum L. HIGH-BUSH OR TALL BLUEBerRy. (I. F. f. 2788.) A shrub, 2-4.5 m. high; twigs terete, greenish brown. Leaves oval or oblong, mostly acute at each end, usually entire, sometimes ciliate, glabrous above, paler and often pubescent beneath, short-petioled, $2.5-7.5 \mathrm{~cm}$. long, 12-35 mm. wide; flowers equalling or longer than their pedicels; bracts deciduous; calyx 5lobed; corolla white or faintly pink, 6-12 mm. long, 3-6 mm. thick, 5-toothed (rarely 5-lobed); stamens 10; berry 6-8 $\mathrm{mm}$. in diameter, pleasintly acid. In swamps, thickets and woods, Newf. to Va., Minn. and La. May-June.

7. Vaccinium atrocóccum (A. Gray) Heller. Black BlueberRy. (I. F. f. 2789.) Similar to the two preceding; branches minutely warty, young twigs pubescent. Leaves dark green above, light green beneath, usually acute at both ends, mucronate, thick, $3 \cdot 5-7 \cdot 5 \mathrm{~cm}$. long, $12-35 \mathrm{~mm}$. wide; flowers appearing with the leaves, about the length of their pedicels; calyx 5-lobed; corolla short-cylindric or ovoid, pink or red, 4-6 $\mathrm{mm}$. long, about $3 \mathrm{~mm}$. thick, 5-toothed, constricted at throat; berry without bloom, sweet, 6-ro $\mathrm{mm}$. in diameter. In swamps and wet woods, N. B. and Ont. to N. J. and Penn. May-June.

8. Vaccinium Canadénse Richards. CanAda BlueberRy. (I. F. f. 279o.) Pubescent. Leaves acute, narrowed at the base, 2.5-3.5 cm. long, 8-12 mm wide; flowers few in the clusters, which are sometimes numerous on naked branches, appearing with the leaves; corolla oblong-campanulate, greenish white, about $4 \mathrm{~mm}$. long and $3 \mathrm{~mm}$. thick; berry with a bloom (rarely white), sweet, 5-6 mm. in diameter. In moist places, Lab. to the N. W. Terr., Va., Ill. and Mich. May-June.

9. Vaccinium Pennsylvánicum Lam. Dwarf, Sugar or Low-Busir BlueBERRY. (I. F. f. 279r.) Similar to the preceding species, but with green warty branches and nearly or quite glabrcus throughout. Leaves oblong or oblonglanceolate, slightly pubescent on the veins beneath, acute at both ends, $1.8-3.6 \mathrm{~cm}$. long, 6-12 $\mathrm{mm}$. wide; flowers few in the clusters, longer than the very short pedicels; corolla oblong-campanulate, slightly constricted at the throat, 4-5 mm. long, about $3 \mathrm{~mm}$. thick, white or pinkish; berry with a bloom, very sweet, 6-10 $\mathrm{mm}$. in diameter. In dry, rocky or sandy soil, Newf. to the N. W. Terr., N. J., Ill. and Mich. May-June.

Vaccinıum Pennsylvánicum angustifolium (Ait.) A. Gray. Leaves narrower, 2-3 mm. wide. Mts. of Me., N. H. and Adirondacks; Quebec to Lake Superior and arctic Am.

Io. Vaccinium nigrum (Wood) Britton. Low Black BlueberRy. (I. F. f. 2792.) Similar to $V$. Pennsylvanicum and often growing with it, the twigs glabrous. Leaves acute, finely serrulate, very nearly sessile, 12-25 $\mathrm{mm}$. long, 6-12 $\mathrm{mm}$. wide, green above; flowers few in the clusters, longer than their pedicels; corolla globose-ovoid, little constricted at the throat, white or cream color, about 4 $\mathrm{mm}$. long, $3 \mathrm{~mm}$. thick; berry without bloom, about $6 \mathrm{~mm}$. in diameter. In dry rocky soil, Me. to N. J., Penn. and Mich. Blooms earlier than $V$. Pennsylva. nicum. May.

I I. Vaccinium vacíllans Kalm. Low Bi.ueberry. Blue. Huckleberry. (I. F. f. 2793.) A stiff shrub, I.5-12 dm. high, with glabrous yellowish-green warty 
branches. Leaves usually mucronulate, finely reticulate-veined beneath, $2.3-0.5$ $\mathrm{cm}$. long, 12-30 $\mathrm{mm}$. wide; flowers several or few in the clusters which are sometimes racemose on nared branches; corolla oblong-cylindric, somewhat constricted at the throat, pink, 4-6 mm. long, 3-4 mm. thick; lerry with a bloom, sweet. In dry soil, Me. and N. H. to Ont., Mich., N. Car. and Mo. May-June.

12. Vaccinium pállidum Ait. Pale or Mountain BlueberRy. (I. F. f. 2794.) A shrub, 6-24 dm. high, with glabrous green warty twigs. Leaves oval, ovate or oblong, acute or acuminate, short-petioled, light green above, sometimes pubescent on the veins beneath, 2.5-3.5 cm. long; flowers about equalling their slender pedicels; corolla oblong-cylin.dric to urceolate, slightly constricted at the throat, greenish-pink, 4-5 mm. long, 3-4 $\mathrm{m}, \mathrm{m}$. thick; berry delicious. In woods, mountains of Va. to S. Car. May-June.

\section{CHI D́GENES Salisb.}

Creeping evergreen shrubs, with alternate 2-ranked oval or ovate small leaves, and solitary axillary small white flowers, on short recurved peduncles. Calyx. tube 2-bracted at the base, its limb 4-cleft. Corolla short-campanulate, 4-cleft, its lobes rounded. Stamens 8, inciuded; filaments short, nearly orbicular, roughish; anthers not awned nor prolonged into tubes, each sac 2 -cuspidate at the apex and opening by a slit down to the middle. Ovary 4-celled, surmounted by the 8 lobed disk; style short. Berry snow-white, many-seeded, rather mealy. [Greek, snow-born, in allusion to the berries.] A monotypic genus.

I. Chiogenes hispídula (L.) T. \& G. Creeping SNowberry. (I. F. f. 2798.) Branches strigose-pubescent, slender, I-3 dm. long. Leaves coriaceous, shortpetioled, acute, dark green, glabrous above, entire, with appressed stiff browıish hairs beneath and on the revolute margins, 4-10 mm. long; flowers about $4 \mathrm{~mm}$. long; berry aromatic, usually minutely bristly, crowned by the 4 calyx-teeth, becoming almost wholly inferior, about $6 \mathrm{~mm}$. in diameter. In cold wet wouds and bogs, Newf. to Br. Col., N. Car. and Mich. May-June.

\section{OXYcóccus Hill.}

Glabrous, or slightly pubescent shrubs, with alternate nearly sessile leaves, and pendulous or cernuous, slencer-peduncled red or pink flower-. Calyx-tube nearly hemispheric, adnate to the ovary, the limb 4-5-cleft, pers ${ }_{1}$ stent. Corolla long-conic in the bud, 4-5-divided into separate or nearly sepasate petals, these narrow and revolute. Stamens 8 or Io, the filaments distinct, anthers connivent into a cone, long-exserted when the flower is expanded, upwardly prolonged into hollow tuibes dehiscent by a pore at the apex. Ovary 4-5-celled; style slender or filiform. Fruit a many-seeded juicy red berry. [Greek, sour berry.] Four species, natives of the northern hemisphere.

Trailing bog shrubs; leaves evergreen, entire; flowers $1-6$ from terminal buds. Leaves ovate, acute, $4-8 \mathrm{~mm}$. long; berry globose.

Leaves oval or oblong, obtuse, $6.14 \mathrm{~mm}$. long; berry ovoid or oblong.

I. O. Oxycoccus.

2. O. macrocarpus.

Erect mountain shrub; leaves deciduous, serrulate; flowers solitary, axillary.

3. O. erythrocarpus.

r. Oxycoccus Oxycóccus (L.) MacM. Small or European Cranberry. (I. F. f. 2799.) Stems I.5-4.5 dm. long. Branches ascending or erect. $2.5^{-1} 5$ $\mathrm{cm}$. high: leaves thick, rounded or cordate at the base, dark green above, white beneath, 2-4 mm. wide, the margins revolute; flowers mostly umbellate, rarely racemose, from terminal scaly buds, on erect filiform pedicels; corolla pink, about $8 \mathrm{~mm}$. broad; filaments puberulent, about half the length of the anthers; berry 5-10 mm. in diameter, acid. In cold bogs, Lab. to Alaska, N. J., Mich. and Br. Col. Also in Europe and Asia. May-July.

2. Oxycoccus macrocàrpus (Ait.) Pers. LARge or American Cranberry. (I. F. f. 2800.) Similar to the preceding, but larger, the branches often $2 \mathrm{dm}$. long. Leaves 2-6 mm. wide, white or pale beneath, the margins revolute; flowers several, in somewhat racemose clusters, nodding on erect pedicels; corolla light pink, 8-10 mm. broad; filaments puberulent; berry acid, 8-18 $\mathrm{mm}$. long. In bogs, Newf. to the N. W. Terr., N. Car., W. Va., Mich. and Minn. June-Aug. 
3. Oxycoccus erythrocàrpus (Michx.) Pers. Southern Mountain Cran. BERRY. (I. F. f. 280I.) A slirub, 3-18 dm. high. Leaves thin, green both sides, paler beneath than above, reticulate-veined, ovate, ovate-lanceolate, or ovateoblong, acuminate, flat, $2.5-7.5 \mathrm{~cm}$. long, $12-25 \mathrm{~mm}$. wide; peduncles pendulous, filiform, less than half as long as the leaves; corolla red, about $\mathbf{I} \mathrm{cm}$. broad; fila. ments villous; berry globose, dark red when ripe, acid, 4-6 $\mathrm{mm}$. in diameter. In woods, mountains of Va. to Ga. June-July.

\section{Family 6. DIAPENSIÀCEAE Link.}

\section{Diapensia Family.}

Low tufted shrubs, or perennial scapose herbs, with alternate or basal simple estipulate leaves, and small, white pink or purple, perfect and regular flowers, solitary in the axils, or racemose at the summit of scapes. Calyx 5-parted, persistent; sepals imbricated in the bud. Corolla 5-lobed, 5-cleft, or 5-parted, deciduous. Stamens 5, inserted on the throat of the corolla and alternate with its lobes, or connate, sometimes with as many alternating staminodia; pollen-grains simple. Disk none. Ovary free from the calyx, superior, 3-celled; style persistent; stigma 3-lobed ; ovules anatropous or amphitropous. Capsule 3 -celled, loculicidally 3 -valved. Seeds minute, the testa loose or close; endosperm fleshy; embryo terete ; cotyledons short ; radicle elongated. Six genera and about 8 species, natives of the northern hemisphere.

Low tufted evergreen shrubs; corolla gamopetalous.

Tufted arctic-alpine shrub; flowers terminal, peduncled.

Trailing shrub; flowers solitary, sessile.

Tall scapose perennial'herb; flowers spicate-racemose; petals separate.

1. Diapensia.

2. Pyxidanthera.

3. Galax.

\section{DIAPÉNSIA L.}

Densely tufted glabrous low evergreen shrubs, with thick rather fleshy imbricated narrow leaves, and solitary terminal erect peduncled white or pink flowers. Calyx 2-4-bracted at the base, the sepals oval, obtuse, somewhat rigid. Corolla campanulate, tardily deciduous, 5-lobed, the lobes obtuse. Stamens 5, inserted at the sinuses of the corolla: filaments short and broad; anther-cells pointed, divergent, obliquely 2-valved; staminodia none. Style slender; ovules numerous in the cells, anatropous. Seeds oblong-cubic, the testa close, reticulated. [Greek, by fives, alluding to the stamens and corolla-lobes.] Two species, the following, the other Himalayan.

I. Diapensia Lappónica L. Diapensia. (I. F. f. 2802.) Glabrous, forming cushion-like tufts; stems $2-8 \mathrm{~cm}$. high. Leaves crowded below, thick, spatulate, sessile, often curved, entire, 6-12 $\mathrm{mm}$. long, about $2 \mathrm{~mm}$. wide; peduncles $2-5 \mathrm{~cm}$. long in fruit; sepals and bracts oval; corolla usually white, 6-8 $\mathrm{mm}$. long; capsule ovoid, 4-6 mm. high. Summits of the Adirondack Mts., and of the mountains of N. Eng.; Mt. Albert, Quebec; Lab. and arctic Am. Also in northern and alpine Europe and Asia. June-July.

\section{PYXIDANTHÈrA Michx.}

A rreeping tufted evergreen shrub, with small narrow alternate imbricated leaves, and numerous white or pinkish sessile flowers, solitary at the ends of the branches. Calyx bracted at the base, the sepals oblong, ciliate. Corolla shortcampanulate, 5-lobed, tardily deciduous. Stamens inserted at the sinuses of the corolla; filaments broad and thick: anthers 2-celled, the sacs globose, transversely 2 -valved, the lower valve cuspidate; staminodia none. Style columnar. Seeds globose-oblong, amphitropous, the testa black, cancellate. [Greek, box-anther.j A monotypic genus.

I. Pyxidanthera barbulata Michx. Prxie. Flowering Moss. (I. F. f. 2803.) Glabrous, or sparingly pubescent, growing in mats or large patches. Leaves sessile, linear, lanceolate or linear-oblong, acuminate or subulate tipped, 
entire. 4-8 mm. long; flowers 4-6 mm. broad; corolla-lobes cuneate-obovate, obtuse, retuse or eroded; capsule about $2 \mathrm{~mm}$. high, globose, surrounded by the upper leaves. In dry sandy pine-barrens, N. J. and N. Car. March-May.

\section{GÀLAX L.}

An acaulescent perennial herb, with orbicular cordate crenate-dentate longpetioled basal leaves, and numerous small white flowers, spicate-racemose at the ends of tall slender scapes. Calyx 2-bracteolate at the base, 5-parted, the sepals nerveless. Corolla 5 divided, the petals oblong, entire, adnate to the bases of the monadelphous stamens. Stamen-tube ro-lobed at the summit, the lobes which are opposite the petals petaloid (staminodia), those alternate with the petals antheriferous; anthers nearly sessile, granular on the back, I-celled, transversely 2 -valved. Style very short. Seeds ovoid, the testa loose. [Greek, milk; name not characteristic of this genus.] A monotypic genus.

I. Galax aphýlia L. Galax. Galaxy. Beetle-weed. (I. F. f. 2804.) Scape 3-5 dm. high, terete, with red scales at the base and many red fibrous roots. Leaves with a rather narrow sinus, persistent, shining, commonly shorter than their slender petioles, $2-8 \mathrm{~cm}$. in diameter; spike-like raceme dense, narrow, $5^{-13} \mathrm{~cm}$. long; flowers 3-4 mm. broad, spreading; capsule ovoid, acute, erect, short-pedicelled, $2 \mathrm{~mm}$. long, slightly exceeding the lanceolate acutish sepals. In dry waxde Va. to Ga. May-July.

\section{Order 2. PRIMULÀLES.}

Our species herbs. Corolla usually present, gamopetalous. Calyx mostly free from the ovary. Stamens borne on the corolla, as many as its lobes, or twice as many, or more.

Style 1; fruit a capsule.

Styles 5; fruit an achene or utricle.

Fam. I. Primulaceae.

Fam. 2. Plumbaginaceae.

\section{Family I. PRIMULÀCEAE Vent.}

\section{Primrose Frmily.}

Herbs, with perfect regular flowers. Calyx free from the ovary (adnate to its lower part in Samolus), usually 5-parted, persistent or rarely deciduous. Corolla gamopetalous in our species (wanting in Glaux), usually 5-cleft, deciduous. Stamens as many as the corolla-lobes and opposite them, hypogynous or rarely perigynous, inserted on the corolla; filaments distinct, or connate at the base; anthers introrse, 2-celled, the sacs longitudinally dehiscent. Disk obsolete, or none. Ovary superior (partly inferior in Samolus), I-celled; placenta central, free; ovules anatropous, or amphitropous ; style $\mathbf{r}$; stigma simple, capitate, entire. Capsule I-celled, 2-6-valved; rarely circumscissile or indehiscent. Seeds few or several, the testa adherent to the fleshy or horny copious endosperm; embryo small, straight; cotyledons obtuse. About 28 genera and 350 species of wide distribution.

* Lobes or segments of the corolla erect or spreading, not refiexed.

Lobes of the corolla imbricated, at least in the bud.

Ovary wholly superior.

Terrestrial scapose plants; leaves not pinnatifid.

Corolla-tube longer than the calyx; style slender.

Corolla-tube shorter than the calyx; style short.

Aquatic leafy-stemmed plant; ieaves finely pinnatifid.

Ovary adnate to the calyx ; marst herbs.

1. Primula.

2. Androsace.

3. Hottonia.

4. Samolus.

Lobes of the corolla convolute or valvate, at least in the bud (corolla wanting in No. 9). Capsule longitudinally dehiscent.

Corolla rotate, or rarely short-funnelform.

Stem leafy throughout; flowers yellow. 
Staminodia 5 ; each corolla-lobe curved around its stamen.

6. Steironerra.
Staminodia 5, tooth-like; flowers in axillary spike-like racemes or heads.

Leaves whorled at the top of the sten ; flowers white. Corolla none; flowers minute, solitary in the axils.

Capsule circumscissile; flowers axillary.

Corolla longer than the calyx; stamens borne on its base.

Corolla shorter than the calyx; stamens borne on its tube.

** Segments of the corolla reflexed; plants scapose.

7. Naumburgia.

8. Trientalis.

9. Glaux.

10. Anagallis.

II. Centunculus.

12. Dodecatheon。

\section{PRÍMULA L.}

Perennial scapose herbs, with basal leaves, and dimorphous flowers, umbellate, or in bracted racemose whorls. Calyx persistent, often angled, 5-lobed, the lobes imbricated. Corolla funnelform or salverform, the tube longer than the calyx in our species, the limb 5-cleft. Stamens 5, included; filaments short: anthers oblong, obtuse. Ovary globose or ovoid; ovules amplitropous; style filiform; stigma capitate. Capsule oblong, ovoid or globose, 5-valved at the summit, many seeded. Seeds peltate, the testa punctate. [Diminutive of the Latin primus, first, from the early blossoms.] About 150 species, mostly of the northern hemisphere. Besides the following, some ro others occur in western N. Am.

Leaves almost always white-mealy beneath; scape I-5 dm. high.

Leaves green both sides; scape $2-15 \mathrm{~cm}$. high.

Leaves spatulate or obovate, denticulate.

Leaves oval or lance-ovate, entire.

I. P. farinosa.

2. P. Mistissinica.

3. P. Egaliksensis.

I. Primula farinòsa L. Bird's-eye or Mealy Primrose. (I. F. f. 2805.) Leaves spatulate or oblong, obtuse, $2-10 \mathrm{~cm}$. long, the margins crenulate denticu. late; scape 3-20 flowered; flowers umbellate; bracts acute or acuminate; calyxlobes acute; corolla pink or lilac, usually with a yellowish eye, the tube slightly longer than the calyx, the lobes cuneate, retuse or obcordate, 4-6 mm. long; capsule narrowly oblong, erect, about I $\mathrm{cm}$. long, longer than the calyx. In moist places, Me. and Quebec to Greenland, the N. W. Terr. and Alaska. Also in Europe and Asia. Summer.

2. Primula Mistassínica Michx. Mistassini or Dwarf Canadian Primrose. (I. F. f. 2806.) Similar to the preceding, but smaller. Leaves spatulate or obovate, denticulate or repand, obtuse, I-4 cm. long; flowers $2-8$, umbellate; bracts acute or acuminate; corolla pink, or pale purple, with or without a yellow eye, the tube longer than the calyx: corolla-lobes obcordate, 3-5 mm. long; capsule narrowly oblong, erect, 5-8 mm. high. On wet banks, Me. to Greenland, N. Y., Mich. and the N. W. Terr. Occurs also in Europe. Summer.

3. Primula Egaliksénsis Hornem. Greenland Primrose. (I. F. f. 2807.) Leaves oval or lance-ovate, entire, or slightly undulate, obtuse or obtusish, I-2.5 cm. long, narrowed into petioles; scape slender, 5-I5 cm. high; umbels 2-6-flowered; bracts lanceolate, acuminate; calyx-lohes acute; corolla-lobes 2-4 mm. long, much shorter than the tube, obovate, sometimes cleft to the middle; capsule erect, about $6 \mathrm{~mm}$. high, longer than the calyx. Iab. and Greenland. Summer.

\section{ANDRÓSACE L.}

Low herbs, our species scapose, with tufted small basal leaves, and terminal umbellate involucrate small white or pink flowers. Calyx persistent, 5-lobed, the lobes erect in flower. Corolla salverform or funnelform, the tube not longer than the calyx, the limb 5-lobed. Stamens 5, included, inserted on the tube of the corolla; filaments short; anthers short, oblong, obtuse. Ovary turbinate or globose; ovules amphitropous; style short; stigma capitellate. Capsule 5-valved from the apex, few many-seeded. [Greek, man's shield, from the shape of the leaf in some species.] About 50 species, natives of the northern hemisphere. Besides the following, some 6 others occur in western and northwestern N. Am.

I. Androsace occidentàlis Pursh. Androsace. (I. F. f. 2808.) Annual, minutely pubescent, or glabrate; scapes filiform, $2-8 \mathrm{~cm}$. long. Leaves oblong or spatulate, obtuse, entire, sessile, 6-16 mm. long; bracts of the involucre similar to 
the leaves but much smaller: pedicels filiform; calyx-tube obpyramidal in fruit, the lobes acute, becoming foliaceous; corolla white, shorter than the calyx; calyx longer than the capsule. In dry soil, Minn. and Ill. to Kans., the N. W. Terr., Utah and N. Mex. April-June.

\section{HOTTÒNIA L.}

Aquatic glabrous herbs, with large pinnatifid submersed crowded leaves, and small white or purplish flowers, racemose-verticillate on bracted hollow ireit emersed peduncles. Calyx deeply 5-parted, the lobes linear, imbricated, persistent. Corolla salverform, the tube short, the limb 5-parted. Stamens 5, included; filaments short. Ovary ovoid; style filiform; stigma minute, capitate; ovules numerous, anatropous. Capsule subglobose, 5-valved. Seeds ellipsoid, numerous. [Dedicated to Peter Hotton, 1648-1709, professor at Leyden.] Two species, the following of eastern N. Am., the other of Europe and Asia.

I. Hottonia inflàta Ell. American Featherfoil. (I. F. f. 2809.) Stem submerged, spongy, sometimes $6 \mathrm{dm}$. long. Leaves sessile, or nearly so, ovate cr oblong in outline, divided very nearly to the rachis into narrowly linear entire segments I $-5 \mathrm{~cm}$. long, $0.5^{-2} \mathrm{~mm}$. wide; peduncles several in a cluster at the ends of the stem and branches, jointed, constricted at the joints, $0.7-2 \mathrm{dm}$. high; pedicels 4-25 mm. long; flowers 4-6 mm. long in verticils of 2-10 at the joints; corolla white, shorter than the calyx; capsule about $3 \mathrm{~mm}$. in diameter. In shallow stagnant ponds, N. H. and Mass. to central N. Y., Fla. and La. June-Aug.

\section{SÁMOLUS L.}

Perennial glabrous herbs, with alternate entire leaves, or the basal ones rosulate. Flowers small, white, in terminal racemes or panicles in our species. Calyx persistent, its tube adnate to the ovary below, its limb 5-cleft. Corolla perigynous, subcampanulate, 5-lobed or 5-parted, the lobes obtuse. Stamens 5, inserted on the tube of the corolla, opposite its lobes, alternating with as many staminodia (these wanting in $S$. ebracteatus), filaments short; anthers cordate. Ovary partly inferior; ovules amphitropous. Capsule 5-valved from the summit. Seeds minute. [Name Celtic.]. About Io species, of wide distribution. Besides the following another occurs in the southern U. S.

\section{Samolus floribúndus H. B. K. Water Pimpernel. Brookweer} (I. F. f. 28Io.) Erect or ascending, r.5-4.5 dm. high. Leaves $2-8 \mathrm{~cm}$. long, obovate, obtuse; flowers less than $2 \mathrm{~mm}$. broad, in elongated panicled racemes; pedicels filiform, spreading, 8-25 mm. long, bracteolate near the middle; calyx-lobes acute, shorter than the corolla; capsule $2-3 \mathrm{~mm}$. in diameter. In swamps and brooks, N. B. to Fla., Br. Col., Tex. and Cal. May-Sept.

\section{LYSIMÀCHIA L.}

Herbs, mostly perennial, with leafy stems. Leaves entire, often glandularpunctate; flowers in our species yellow, solitary in the axils, or clustered. Calyx 5-7-parted or 5-7-divided, persistent. Corolla rotate or campanulate, 5-7-parted, the tube very short. Stamens 5-7; anthers oblong or oval; staminodia none. Style filiform; stigma obtuse. Capsule 2-5-valved. [Greek, loose-strife.] About 70 species, mostly natives of the northern hemisphere. Besides the following, 2 others cccur in the southern U. S.

Leaves verticillate in 3 's- 7 's, or some of them rarely opposite.

Corolla rotate-campanulate, pure yellow, $\mathrm{I}-2.5 \mathrm{~cm}$. broad.

Flowers in terminal panicles; corolla-lobes glabrous.

Flowers axillary: corolla-lobes glandular-ciliolate.

Corolla rotate, $0.8-1.6 \mathrm{~cm}$. broad, its lobes dark-streaked. 3. L. quadrif
Leaves opposite. or some of them rarely alternate, sometimes verticillate in No. 5 .

Flowers in a terminal virgate raceme; stem erect.

Raceme leafy only at the base.

Raceme leafy to the middle or beyond.

Flowers axillary, solitary; stem creeping.

4. L. terrestris.

5. L. producta.

6. L. Iiummularia.

I. Lysimachia vulgàris L. Golden or Yellow LoOsestrife. (I. F. f. 28II.) Densely downy-pubescent; stem 6-1o dm. high. Leaves short-petioled, ovate-lanceolate or ovate, acute or acuminate, $5-10 \mathrm{~cm}$. long; flowers $\mathbf{I - 2} \mathrm{cm}$. 
broad; pedicels 4-12 $\mathrm{mm}$. long; sepals lanceolate, acute or a.cuminate: coro'il deeply parted; filaments monadelphous to about the middie, giandular; capsule about 3 $\mathrm{mm}$. in diameter, shorter than the sepals. In fielas and along roadsides, Me. to N. Y. and Penn. Nat. from Europe. June-Aug.

2. L.ysimachia punctàta L. SPOTTED LouseSTRIFE. (I. F. f. 28I2.) Re. sembles the preceding, but sometimes glabrate. Leaves oval or ovate-lanceolate, short-petioled, $2-8 \mathrm{~cm}$. long, usually proportionitely shorter and broader than those of L.vulgaris; flowers crowded in the upper axils, or racemose-verticillate, yellow, I. 5-2 cm. broad; pedicels 6-20 mm. long; sepals lanceolate or oblong-lanceolate; filaments monadelphous at the base. $I_{h_{1}}$ wasie places, N. S. to N. J. Adventive from Europe. June-July.

3. Lysimachia quadrifòlia L. C'Rosswort. Whorled Loosestrife. (I. F. f. 2813.) Stem slender, 3-9 dm. nigh. Leaves short-petioled or sessile, lanceo. late, oblong or ovate, acute or acuininate, $2-10 \mathrm{~cm}$. long, usually black-punctate; flowers axillary, 6-12 mm. broad, borne on filiform spreading peduncles; sepals narrowly lanceolate, acute or acuininate; corolla glabrous, dark-streaked or spotted; filaments monadelphous below; capsule nearly as long as the sepals. In thickets, N. B. to Minn., Ga. and Wis. June-Aug.

4. Lysimachia terréstris (L.) B.S.P. Bulb-Bearing Loosestrife. (I. F. f. 2814.) Glabrous; stem 2-6 dm. high, often bearing after flowering long bulblets in the axils. Leaves opposite or some of them rarely alternate, lanceolate or oblong-lanceolate, acute or acuminate at both ends, short petioled, or sessile, usually black-punctate, $2-8 \mathrm{~cm}$. long; flowers 6-10 $\mathrm{mm}$. broad, in terminal bracted racemes; pedicels 1-2 cm. long; sepals ovate to lanceolate, acute; corolla rotate, deeply parted, yellow with purple streaks or dots; filaments monadelphous below, glandular; capsule about $3 \mathrm{~mm}$. in diameter, nearly as long as sepals. In swamps and moist thickets, Newf., Manitoba, Ga. and Ark. July-Sept.

5. Lysimachia prodúcta A. Gray) Fernald. Intermediate between L. quadrifolia and $L$. terrestris, the leaves sometimes opposite, sometimes verticillate, pale green or glaucous and inconspicuously veined beneath; bracts of the usually loosely flowered raceme large. Me. to N. Y., Mass. and Mich. [L. polyantha Fernald.]

6. Lysimachia Nummulària L. Moneywort. Creeping Loosestrife. (I. F. f. 28I5.) Glabrous; stems creeping, sometimes $6 \mathrm{dm}$. long. Leaves opposite, orbicular or broadly oval, obtuse, sometimes cordate, petioled, I-2.5 cm. long, sparingly black-punctate; flowers solitary in the axils, $1.5-2.5 \mathrm{~cm}$. broad; sepals cordate-ovate to lanceolate, acute, half as long as the rotate, deeply 5 .lobed, yellow and dark-dotted corolla; filaments glandular, nonadelphous at the base; capsule shorter than the sepals. In moist places, Newf. to N. J., Penn. and Ind. Nat from Europe. June-Aug.

\section{STEIRONÈMA Raf.}

Perennial herbs, with opposite or verticillate entire leaves, and axillary slenderpeduncled yellow flowers. Calyx 5-parted, persistent, the segments valvate in the bud. Corolla rotate, deeply 5-parted, with no proper tube, the lobes cuspidate or erose-denticulate, each involute or convolute around its stamen. Stamens 5; filaments distinct, or united into a ring at the base, granulose-glandular; anthers linear, becoming curved; staminodia 5, subulate. Ovary globose. Capsule 5. valved. Seeds margined or angled. [Greek, sterile threads, from the abortive stamens.] About five species, natives of N. Am.

Leaves membranous, pinnately veined.

Leaves ovate to lanceolate.

Stem erect; flowers $12-25 \mathrm{~mm}$. broad.

Petioles strongly ciliate; capsule longer than the calyx.

I. $S$. ciliatum.
Petioles not ciliate, or slightly so at base; capsule not longer than the calyx. 2. S. tonsum.

Stem reclined; flowers 6-8 mm. broad; leaves not ciliate; petioles naked. 
I. Steironema ciliàtum (L.) Raf. Fringed Loosestrife. (I. F. f. 2816.) Stems mostly glabrous, 3-12 dm. high. Leaves acute or acuminate at the apex, obtuse, truncate or cordate at the base, 5-15 cm. long, the margins ciliolate; peduncles $1-5 \mathrm{~cm}$. long; calyx-segments lanceolate, shorter than the erose-denticulate commonly mucronate corolla-segments; flowers $1.5-2.5 \mathrm{~cm}$. broad. In moist thickets, N. S. to Br. Col., Ga., Ala., Kans. and Ariz. June-Aug.

2. Steironema tónsum (Wood) Bicknell. Southern Loosestrife. (I. F. f. 28r7.) Stem 3-6 dm. high, obtusely 4-angled, minutely glandular-puberulent above. Leaves 5-8 cm. long, acute at the apex, obtuse or subcordate at the base, ciliolate, the upper much smaller; panicle open, leafy; pedicels 2-6 times as long as the flowers; calyx-segments lanceolate, very acute; corolla $1.8-2 \mathrm{~cm}$. broad, its segments cuspidate. On dry rocks, Va. to Ky., Tenn. and Ala. June-July.

3. Steironema radicans (Hook.) A. Gray. Trailing Loosestrife. (I. F. f. 2818.) Stem soon decumbent or reclined, slender, glabrous, 3-9 dm. long. Leaves acute or acuminate, $2-10 \mathrm{~cm}$. long; peduncles $\mathbf{I}-5 \mathrm{~cm}$. long; calyx segments ovate or lanceolate, acuminate, about equalling the erose-denticulate corollasegments; capsule about one-half as long as the calyx. In swamps, Va. and W. Va. to Ark. and La. June-Aug.

4. Steironema lanceolàtum (Walt.) A. Gray. LANCE-LEAved Loosestrife. (I. F. f. 28 19.) Stem erect, glabrous, 1.5-9 dm. high. Leaves lanceolate, linear or oblong-lanceolate, petioled or nearly sessile, acute or acuminate, $2-13 \mathrm{~cm}$. long, the margins naked or ciliate; lower leaves shorter, often oblong or nearly orbicular; petioles naked or ciliate; peduncles I-4 cm. long; calyx segments lanceolate, acute or acuminate; flowers $\mathbf{I}-2 \mathrm{~cm}$. broad; capsule nearly as long as the calyx. segments. In moist soil, Me. to Minn., Fla., La. and Ariz. June-Aug.

5. Steironema quadrifòrum (Sims Hitchc. Prairie Moneywort. LinearLFAVED LoOSESTRIFE. (I. F. f. 2820.) Stem erect, strict, glabrous, 4-sided, 2.5.6 $\mathrm{dm}$. high. Stem-leaves all but the lowest sessile or very nearly so, I-nerved, acute or acuminate at both ends, 2-10 cm. long, 2-5 mm. wide, usually with smaller ones fascicled in the axils; basal leaves oblong or linear-oblong, shorter, slender-petioled; peduncles filiform; calyx-segments lanceolate, acute, shorter than the cuspidate and slightly erose corolla segments: flowers $1.5-2.5 \mathrm{~cm}$. broad, often somewhat clustered in 4's at the ends of the branclies. Along streams and lakes, W. Va. to western N. Y., Ont., Ky. and Manitoba. June-July.

\section{NAUMBÚRGIA Moench.}

An erect perennial leafy herb, with slender rootstocks, opposite sessile lanceolate entire leaves, the lower much smaller or reduced to scales, and small yellow flowers in axillary peduncled spike-like racemes or heads. Calyx 5-7-divided, the sepals linear, slightly imbricated. Corolla deeply 5-7-parted, the tube short, the segments narrow. Stamens 5-7, exserted; filaments slender, glabrous, slightly united at the base, alternating with as many small tooth-like staminodia. Ovary globose-ovoid; ovules few or several; style slender; stigma capitate. Capsule 5-7-valved, fewseeded. Seeds somewhat angled. A monotypic genus.

I. Naumburgia thyrsiflòra (L.) Duby. TUfTed Loosestrife. (I. F. f. 282 1.) Stems simple, erect, 3-8 dm. high. Leaves 5-10 cm. long, the upper lancolite or oblong lanceolate, acute or acuminate, the lower smaller; peduncles solitary in the axils: racemes $\mathbf{I}-\mathbf{2 . 5} \mathrm{cm}$. long, spike-like; pedicels very short; flowers 4- $\overline{\mathrm{\sigma}} \mathrm{mm}$. broad; corolla-segments yellow with black spots; anthers oblong; capsule globose, black-spotted, when mature slightly longer than the sepals. In swamps, N. S. to Alaska, N. Y., Penn., Mo. and Ore. Also in Europe and Asia. May-July.

\section{TRIENTÀLIS L.}

Glabrous low perennial herbs, with simple erect stems, and leaves mostly clustered in a verticil at the summit. Flowers few or solitary, terminal, slenderpeduncled, small, white or pink, deeply 5-9-(mostly 7-) parted. Sepals narrow, persistent, spreading. Corolla rotate, its tube almost none, its segments acute or acuminate, entire; filaments united into a narrow ring at the base; anthers linear, recurved after anthesis. Staminodia none. Ovary globose; ovules numerous; style filiform. Capsule globose, 5 valved. [Iatin, one-third of a foot, referring to the height of the plant.] About 4 species, of the northern hemisphere. 
r. Trientalis Americàna (Pers.) Pursh. Star-flower. Chickweer WinTERGREEN. (I. F. f. 2822.) Rootstock horizontal, sending up simple stem like branches $0.7-2.5 \mathrm{dm}$. high, the leaves in a verticil of 5-10 at the summit. Leaves membranous, lanceolate or oblong-lanceolate, acuminate at both ends, sessile or short-petioled, minutely crenulate, $3-10 \mathrm{~cm}$. long; pedicels filiform, erect, $2-5 \mathrm{~cm}$. long; sepals narrowly lanceolate or subulate, cuspidate; flowers $8-12 \mathrm{~mm}$. broad; capsule shorter than the sepals. In damp woods and thickets, Lab. to the N. W. Terr., Va., Ill. and Mich. May-June.

\section{GLAÙX L.}

A small succulent perennial leafy herb, with opposite entire obtuse fleshy leaves, and minute dimorphous nearly sessile axillary pink or white flowers. Calyx 5parted, the lobes petaloid. Corolla none. Stamens 5, inserted at the base of the calyx and alternate with its lobes; anthers cordate, attached by their backs to the filainents. Ovary ovoid, glandular; ovules few; style filiform; stigma capitellate. Capsule globose-ovoid, beaked, 5-valved at the top, few-seeded. Seeds ellipsoid. [Greek, sea-green.] A monotypic genus.

r. Glaux marítima L. SEa Milkwort. Black Saltwort. (I. F.f. 2823.) Glabrous, pale or glaucous, $0.5^{-2} \mathrm{dm}$. high. Leaves oval, oblong or linear-oblong, rarely somewhat spatulate, sessile, 4-12 mm. long; flowers about $3 \mathrm{~mm}$. broad, usually numerous; calyx-lobes oval; capsule nearly enclosed by tl e calyx. In salt marshes and on sea-beaches, N. J. to Newf. ; in saline soil from Minn. to the N. W. Terr., Neb. and Nev.; on the Pacific Coast. Also in Europe and Asia. June-Aug.

\section{ANAGÁLLIS L.}

Herbs, with opposite or verticillate (rarely alternate) sessile or short-petioled leaves, entire or nearly so, and small axillary peduncled flowers. Calyx 5-parted, the lobes lanceolate or subulate, persistent. Corolla deeply 5-parted, rotate, the segments entire or erose, convolute in the bud, longer than the calyx. Stamens 5; filaments puberulent, or pubescent, distinct, or united into a narrow ring at the base; anthers oblong, obtuse. Ovary globose; ovules numerous; stigma obtuse. Capsule globose, circumscissile, many.seeded. Seeds minute, flat on the back. [Greek, delightful.] About I5 species, mostly of the Old World.

I. Anagallis arvénsis L. Red or Scarlet Pimpernel. Poor Man's or Shepherd's Weather-Glass. (I. F. f. 2824.) Annual, diffuse; branches I--3 dm. long, 4-sided. Leaves ovate or oval, membranous, sessile or somewhat clasping, 6-20 mm. long, black-dotted beneath; peduncles filiform, $1-4 \mathrm{~cm}$. long, recurved in fruit; calyx-lobes keeled, slightly shorter than the crenate glandularciliate coro'la-segments; flowers scarlet, sometimes white, usually with a darker center, 4-6 mm. broad, opening only in bright weather; capsule glabrous, about 4 $\mathrm{mm}$. in diameter. In waste places, Newf. to Fla., Minn. and Mex., and on the Pacific Coast. Nat. from Europe. May-Aug.

Anagallis arvénsis coerùlea (Lam.) Ledeb. Flowers blue; corolla-segments glabrous. Reported as sparingly occurring in waste places.

\section{CENTÚNCULUS L.}

Low annual glabrous erect herbs, with alternate small entire sessile or shortpetioled leaves, or the lower opposite, and minute solitary axillary fowers. Calyx 4-5-parted, persistent, the lobes longer than the corolla. Corolla 4-5-cleft, marcescent, the tube subglobose, the lobes entire. Stamens 4 or 5 , inserted on the throat of the corolla; filaments short, distinct; anthers ovate or cordate, obtuse; stigma capitate. Ovules numerous, amphitropous. Capsule globose, circumscissile, many-seeded. Seeds minute, flat on the back. [Latin, diminutive of cento, a patch.] Three species, of wide distribution.

I. Centunculus mínimus L. Chaffiveed. Faise Pimpernel. (I. F. f. 2825.) Slender, $2-15 \mathrm{~cm}$. high. Leaves spatulate, obovate or oblong, $4-8 \mathrm{~mm}$. long; flowers sessile or nearly so, shorter than the leaves, mostly 4-parted, 2-4 mm. broad; calyx-lobes linear or linear-lanceolate, acuminate; corolla pink; capsule shorter than the calyx. In moist soil, Ill. and Minn. to Br. Col., Fla., Tex, and Mex. Also in Europe and S. Am. April-Sept. 


\section{DODECÀTHEON L. (See Appendix.)}

Glabrous scapose perennial herbs, with basal leaves. Flowers in involucrate umbels terminating scapes. Calyx deepiy 5-lubed, persistent, the lobes at first reflexed. Corolla 5-parted, the lobes reflexed, imbricated, the tube very short, thickened at the throat. Stamens 5, on the thioat of the corolla: filiments short, flat, monadelphous, connivent into a cone, exserted; anthers linear or lanceolate, connivent, attached by their bases to the filaments. Ovary superior; ovu'es amphitropous: style exserted; stigma simple. Capsule oblong or cylindric, erect, $5-6$ vilved at the apex or splitting to the base. Seeds numerous, minute; the testa punctate. [Greek, twelve gods: name used by Theophrastus for some different plant.] About I5 species, of N. Am. and nortlieastern Asia.

I. Dodecatheon Mèadia L. Shooting Star. American Cowslip. Pride-Of-OHIo. (I. F. f. 2826.) Perennial by a stout rootstock; scape erect, 2-5 dm. high. Leaves oblong or oblanceolate, obtuse or obtusish, narrowed into margined petioles, entire or toothed, $0.7-3 \mathrm{dm}$. long; flowers $2-3 \mathrm{~cm}$. long; bracts of the involucre lanceolate or linear, acute; pedicels unequal, the outer ones sometimes I dm. long; calyx-lobes acute; corolla purple, pink or white; capsule narrowly ovoid, erect, 5-valved above. On moist cliffs and prairies, Penn. to Manitoba, Ga. and Tex. April-May.

Dodecatheon Mèadia Frénchii Vasey. Leaves ovate or elliptic, base abruptly contracted or cordate. IIl. to Ark.; southern Penn.(?)

\section{Family 2. PLUMBAGINÀCEAE Lindl.}

\section{Plumbago Family.}

Perennial mostly acaulescent erect herbs, with basal tufted leaves, and small perfect and regular clustered flowers. Calyx inferior, gamosepalous, 5-toothed, plaited at the sinuses, the tube 5-15-ribbed. Corolla of 5 hypogynous clawed segments connate at the base, or united into a tube. Stamens 5, opposite the corolla-segments, hypogynous; anthers 2-celled, attached by their backs to the filaments, the sacs longitudinally dehiscent. Disk none. Ovary superior, 1-celled; ovule solitary, anatropous, pendulous; styles 5. Fruit a utricle or achene, enclosed by the calyx, rarely a dehiscent capsule. Seed solitary; testa membranous; endosperm mealy, or none ; embryo straight; cotyledons entire. About 10 genera and 350 species, of wide distribution, mostly in saline situations. Inflorescence cymose-paniculate; flowers in one-sided spikes. Flowers in a dense terminal head.

1. Limonium.

2. Statice.

\section{LIMÒNIUM Adans. [STATICE Willd.]}

Herbs, mostly with flat basal leaves, and numerous small flowers cymose-paniculate on bracted scapes, in 1-3-flowered bracteolate clusters, forming one-sided spikes. Calyx campanulate or tubular, the limb scarious, 5-toothed, the tube usually 10-ribbed. Petals 5, clawed. Stamens adnate to the bases of the petals. Styles 5, separate in our species, stigmatic along the inner side. Fruit a utricle. [Ancient name of the wild beet.] About 120 species. Besides the following, I occurs on the South Atlantic and $\mathbf{I}$ on the Pacific Coast and $\mathbf{I}$ in the Southwest.

I. Limonium Caroliniànum (Walt.) Britton. SEA Lavender. Marsh Rosemary. CANKer-Root. (I. F. f. 2827.) Glabrous, fleshy, rootstock thick; fusiform or branched; scape terete, striate, paniculately branched above, 3-6 dm. high. Leaves oblanceolate, narrowed into margined petioles, entire, or slightly undulate, $0.7-2.5 \mathrm{dm}$. long, shorter than the scapes, the midvein prominent, the lat. eral veins very obscure; flowers erect, about $4 \mathrm{~mm}$. high; calyx 5 -toothed, sometimes with as many minute intermediate teeth in the sinuses: corolla pale purple; petals spatulate; styles filiform. On salt meadows, Lab. to Fla. and Tex. July-Oct.

\section{STÁTICE I. [ARMERIA Willd.]}

Tufted acaulescent fleshy herbs, with mostly naked scapes, basal persistent rosulate narrow leaves with no differentiation into blade and petiole, and short. 
pedicelled or sessile flowers, in dcnse terminal glomerate heads, subtended by scarious bracts and bractlets, the lower bracts forming a kind of involucre to the head, the two lowest reflexed and more or less united into a sheath. Calyx 10ribbed, 5-toothed, oblique at the base or decurrent on the pedicel, scarious. Styles united at the base, pubescent below the middle. Utricle 5-pointed at the summit, rarely dehiscent. [Greek, standing.] About 20 species. The following is the only one native in N. Am.

I. Statice Armèria L. Thrift. Sea Pink. Ladies' Cushion. (I. F. f. 2828.) Scape I-4.5 dm. high. Leaves narrowly linear, obscurely $\mathrm{I}$-nerved, entire, 2-8 cm. long; bracts obtuse; head of flowers $1-2.5 \mathrm{~cm}$. in diameter; co. rolla pink, purple or white, $4-6 \mathrm{~mm}$. broad; petals obtuse or cuspidate. Along the sea-coast and on mountains, Lab. to Alaska, south on the Pacific Coast to Cal. Also in Europe, Asia and apparently at the Strait of Magellan. Summer.

\section{Order 3. EBENÀLES.}

Shrubs or trees, with alternate simple leaves, the flowers mostly regular. Calyx free from the ovary (inferior) or more or less adnate to it. Corolla gamopetalous or sometimes polypetalous. Stamens borne on the tube or base of the corolla, as many as its lobes, and opposite them, or more numerous.

Stamens as many as the coroila-lobes.

Stamens twice as many as the corolla-lobes, or more.

Styles 2-8; flowers mostly monœecious or diœcious. Fam. 2. Ebenaceae.

Style I, simple or lobed; flowers mostly perfect.

Stamens in several series.

Stamens in $\mathbf{x}$ series.

Fam. 3. Symplocaceae.

Fam. 4. Styracaceae.

\section{Family I. SAPOTÀCEAE Reichenb.}

\section{Sapodilla Family.}

Shrubs or trees, mostly with a milky juice. Leaves entire, mostly coriaceous and estipulate. Flowers small, regular and perfect, in axillary clusters. Calyx inferior, the sepals usually $4-7$, much imbricated. Corolla gamopetalous, the tube 4-7-lobed, the lobes imbricated in the bud, sometimes with as many or twice as many lobe-like appendages on the throat. Stamens as many as the proper lobes of the corolla and inserted on its tube; staminodia usually present, alternate with the corolla-lobes; anthers 2-celled, the sacs longitudinally dehiscent. Ovary 2-5-celled, or rarely many-celled; ovules solitary in each cavity, anatropous or amphitropous; stigma simple. Fruit a fleshy berry, commonly 1-celled and I-seeded. Seed large, the testa bony or crustaceous; embryo straight ; endosperm fleshy, or none. About 35 genera and 400 species, mostly of tropical regions.

\section{r. BUMÈLIA Sw.}

Wood very hard. Leaves sometimes clustered at the nodes. Flowers small, pedicelled, white, fascicled in the axils. Calyx deeply 5-parted, the segments un. equal. Corolla 5-lobed, with a pair of lobe-like appendages at each sinus, its tube short. Stamens 5, inserted near the base of the corolla-tube; anthers sagittate. Staminodia 5, petaloid. Ovary 5-celled; style filiform. Berry small, the pericarp fleshy, enclosing a single erect seed. Seed shining, the hilum at the base. [Greek, ox (large) ash.] About 30 species, natives of America. Besides the following, some ro others occur in the southern U. S. 
I. Bumelia Iycioides (L.) Pers. Southern Buckthorn. (I. F. f. 2829.) Bark gray, the twigs commonly spiny. Leaves rather firm, tardily deciduous, glabrous, finely reticulate-veined, oblong, elliptic, or oblanceolate, $5-13 \mathrm{~cm}$. long; petioles 4-12 mm. long; flowers about $3 \mathrm{~mm}$. broad, numerous; pedicels about the length of the petioles, glabrous; calyx-segments obtuse, glabrous; staminodia ovate, boat-shaped, entire; berry subglobose, black, 8-10 $\mathrm{mm}$. long. In moist thickets, Va. to Ill., Mo., Fla. and Tex. June-Aug.

2. Bumelia lanuginòsa (Michx.) Pers. Woolly Buckthorn. (I. F. f. 2830.1 Leaves persistent, rather coriaceous, glabrous above, densely tomentosepubescent beneath, oblanceolate, obovate or oblong, usually obtuse at the apex, narrowed or cuneate at the base, $3-8 \mathrm{~cm}$. long; flowers $3-18$ in the fascicles, about 3 $\mathrm{mm}$. broad: pedicels tomentose, longer than the petioles; calyx-segments ovate, tomentose, obtusish; staminodia ovate, obscurely toothed; berry oval, black, 8-10 mm. long. In woods and thickets, Ill. to Kans., Tex., Ga. and Fla. June-July.

\section{Family 2. EBENÀCEAE Vent.}

\section{Ebony Family.}

Trees or shrubs with very hard wood. entire estipulate leaves, and dicecious polygamous or rarely perfect regular flowers, solitary or cymose in the axils. Calyx inferior, 3-7-lobed, commonly accrescent and persistent. Corolla gamopetalous, deciduous, 3-7-lobed, the lobes usually convolute in the bud. Stamens $2-3$ times as many as the lobes of the corolla in the sterile flowers, and inserted on its tube, usually some imperfect ones in the pistillate flowers; anthers introrse, erect. Disk none. Ovary superior, several-celled; in the staminate flowers rudimentary or none; ovules I-3 in each cavity, suspended; styles $2-8$, distinct, or united below; stigmas terminal, scmetimes 2-parted. Fruit a berry. Seeds oblong, the testa bony; endosperm copious, cartilaginous ; embryo small ; cotyledons large, foliaceous. About 6 genera and 275 species, mostly tropical.

\section{DIOSPỲROS L.}

Flowers lateral, cymose, racemose or solitary, the pistillate commonly solitary, the staminate usually clustered. Calyx 4-6-cleft. Corolla urceolate in our species, 4-6-lobed. Stamens 8-20 in the sterile flowers. Styles 2-6 in the pistillate flowers; ovary globose or ovoid, its cavities twice as many as the styles. Berry large, pulpy, containing 4-12 flat hard seeds. [Greek, Zeus' wheat.] About r6o species, abundant in Asia. Besides the following, another occurs in the Southwest.

1. Diospyros Virginiàna L. Persimmon. Date plum. (I. F. f. 283I.) A tree; bark hard, dark, furrowed. Leaves ovate or oval, deciduous, pubescent when young, acute or acuminate, dark green above, pale beneath, $5^{-13} \mathrm{~cm}$. long; petioles loosely jointed with the twigs, the leaves falling away in drying; flowers mostly 4-parted; corolla greenish yellow; stamens of the sterile flowers about 16 , those of the pistillate 8 or fewer; fruit globose, about $2.5 \mathrm{~cm}$. long, reddish yellow and sweet when ripe, astringent when green. In fields and woods, R. I. to Kans, Fla. and Tex. May-June. Fruit ripe Sept.-Nov.

\section{Family 3. SYMPLOCÀCEAE Miers.}

\section{Swet-leaf Family.}

Trees or shrubs, with entire or dentate broad leaves, and regular mostly yellow and perfect flowers, in lateral or axillary clusters. Calyx-tube completely or partly adnate to the ovary, its limb 5-lobed. Corolla 5-parted, sometimes nearly to the base, the segments imbricated. Disk none. Stamens numerous in several series; filaments usually slightly united in clusters at the base of each corolla-segment; anthers innate, laterally dehiscent, Ovary 2-5-celled; ovules commonly 2 in each cavity, pendu- 
lous; style and stigma one. Fruit a small mostly nearly dry drupe, usually with I oblong seed; embryo straight; endosperm fleshy. Only the following genus, comprising about 175 spccies, most abundant in S. Am.

\section{SÝMPLOCOS L.}

Characters of the family. [Greek, connected, referring to the stamens.]

I. Symplocos tinctòria (L.) L'Her. Sweet-leaf. Horse-sugar. (I. F. f. 2832 .) A shrub or small tree. Leaves oblong or slightly obovate, acute or acu. minate at both ends, crenate-serrate or repand, short-petioled, glabrous or nearly so above and dark green when old, pale and pubescent beneath, 7-15 cm. long; fl w wrs bright yellow, fragrant, $8-12 \mathrm{~mm}$. broad, in sessile scaly-bracted clusters, appearing at the North before the leaves; corolla-segments oblong, obtuse, each bearing a cluster of stamens; drupe nut-like, oblong, 6-12 $\mathrm{mm}$. long, pubescent, crowned with the small calyx lobes. Woods and thickets, Del. to Fla. and La. March-April.

\section{Family 4. STYRACÀCEAE A. DC.}

\section{Storax Family.}

Flowers regular, perfect, or rarely polygamo-diœcious, clustered, pubescence mostly stellate. Calyx more or less adnate to the ovary. Corolla gamopetalous or polypetalous, the lobes or petals 4-8. Stamens twice as many as the lobes of the corolla or petals, or more, inserted on its tube or base, arranged in I series, the filaments monadelphous or 4-5adelphous. Disk none. Ovary partly superior, 2-5-celled; ovules anatropous; style slender; stigma simple or 2-5-lobed. Fruit a berry or drupe, or often nearly dry, winged in some genera, 1-seeded, or 2-5-celled with a seed in each cavity. Endosperm copious, fleshy; enbryo usually straight; cotyledons flat. About 7 genera and 75 species, mostly tropical.

Calyx superior, its tube obconic; fruit 2-4- winged.

Calyx nearly inferior, its tube campanulate; fruit globose or oblong. 2. Styrax.

I. Mohrodendron.

1. MOHRODÉNDRON Britton. [HALESIA Ellis, not P. Br.]

Small trees or shrubs, more or less stellate-pubescent, with denticulate or dentate leaves, and large white slender-pedicelled drooping bell-shaped flowers, in lateral fascicles or short racemes, appearing with or before the leaves. Calyx-tube obconic or obpyramidal, 4-5-ribbed, adnate to the ovary, the limb short, 4-toothed. Corolla campanulate, 4-5-cleft or 4-5 parted nearly to the base. Stamens 8-16; filaments flat, more or less monadelphous, slightly adnate to the corolla. Ovary 2-4celled; ovules about 4 in each cavity, the lower ascending, the upper pendulous. Fruit dry, oblong, 2-4 winged, I-4-celled, tipped with the style and the minute calyxterth. [In honor of Chas. Mohr, botanist of the Geological Survey of Alabama.] Aijut 3 species, natives of southeastern N. Am.

I. Mohrodendron Carolinum (L.) Britton. Silver-bell or SNow-drop TREE. (I. F. f. 2833.) A small tree. Leaves oval, ovate or ovate-oblong, denticulate, acuminate, dark green and glabrous above when old, pale green and stellatepubescent beneath, 5-15 cm. long; pedicels filiform, I-4 cm. long; corolla $\mathrm{I}-2 \mathrm{~cm}$. long; ovary 4-celled; fruit oblong-ellipsoid, 4-winged, 2-4 cm. long. In woods and along streams, Va. to Ill., Fla. and Ala. March-April. [H. tetraptera L.]

\section{STỲRAX L.}

Slirubs or small trees, with rather large mostly white drooping flowers, in fascicles or leafy racemes. Calyx persistent, nearly inferior, its tube campanulate, adnate to the lower part of the ovary, its limb minutely 5 -toothed. Corolla 5-parted or 5-divided. Stamens twice as many as the corolla-lobes or petals (rarely fewer); filaments flat, monadelphous below or rarely separate. Ovary nearly superior, mostly 3-celled at the base; ovules sever al in each cavity, ascending; stigma 3tonthed, 3-lobed or capitate. Fruit nearly dry, coriaceous or crustaceous, com- 
monly only I-seeded, 3-valved at the summit. [Greek name of Storax.] About 70 species, natives of America, Asia and southern Europe. Besides the following, 2 others occur in the southern and western U. S.

Foliage and inflorescence glabrous; calyx glandular-scurfy. Lower surfaces of the le. res and inflorescence canescent or tomentose.

Leaves oblong to oval, $2.5^{-6} \mathrm{~cm}$. long.

Leaves obovate to oval, $5^{-1} 5 \mathrm{~cm}$. long.

I. S. Americana.

2. S. pulverulenta.

3. S. grandifolia.

I. Styrax Americàna Lam. Sмоoтh Storax. (I. F. f. 2834.) A shrub, the foliage glabrous or nearly so. Leaves green on both sides, oblong, oval or obovate, 2-8 cm. long; flowers few or sometimes solitary, 8-14 mm. long, about the length of their pedicels; petals oblong-lanceolate, acute, valvate or but slightly overlapping in the bud; fruit subglobose, about $6 \mathrm{~mm}$. in diameter. In moist thickets and along streams, Va. to Fla., Ark. and La. March-April.

2. Styrax pulverulénta Michx. Downy Storax. (I. F. f. 2835.) Similar to the preceding; but the lower surfaces of the leaves, the caly $x$ and pedicels are stellate-pubescent or scurfy. Leaves oval or oblong, usually denticulate, pale beneath; flowers in short terminal racemes and often in pairs in the axils, usually longer than their pedicels; petals puberulent on both sides or only on the exterior, convolute or imbricated in the bud. In moist pine-barrens, Va. to Fla. and Tex. March-April.

3. Styrax grandifòlia Ait. Large-Leaven Storax. (I. F. f. 2836.) A shrub. Leaves obovate or oval, tomentose or canescent and pale beneath, $5-15 \mathrm{~cm}$. long, or on young shoots larger; flowers IO-16 $\mathrm{mm}$. long, longer than their pedicels, mostly several in loove sometimes elongated racemes; petals oblong, acutish, imbricated or convolute in the bud, puberulent without and often also within; fruit obovoid, about $8 \mathrm{~mm}$. long. In woods, Va. to Fla. and Ga. March-May.

\section{Order 4. GENTIANÀLES.}

Herbs, shrubs, vines or trees. Leaves opposite, or rarely alternate. Flowers regular. Corolla gamopetalous, rarely polypetalous, nerved, wanting in Adelia and in our species of Fraximus of the Oleaceae. Stamens mostly borne on the lower part of the corolla when this is present, as many as its lobes or fewer and alternate with them. Ovaries 2, distinct, or I with 2 cavities (rarely more), or 2 placentæ.

\section{a. Stamens (usually 2), fewer than the corolla-lobes, or corolla none; our species} trees or shrubs.

Fam. 1. Oleaceae.

b. Stamens as many as the corolla-lobes; mostly herbs.

Stigmas distinct ; juice not milky; ovary $\mathrm{r}$, compound.

Ovary 2 -celled; leaves stipulate, or their bases connected by a stipular line.

Ovary $\mathrm{I}$-celled, leaves not stipulate.

Fam. 2. Loganiaceae.

Leaves opposite or rarely verticillate; corolla-lobes convolute or imbricated in the bud.

Fam. 3. Gentianaceae.

Leaves basal or alternate; corolla-lobes induplicate-valvate in the bud; marsh or

aquatic herbs.
Stigmas united; juice milky; ovaries 2 n our species.

Fam. 4. Menyanthaceae.

Styles united; stamens distinct: pollen of simple grains. Fam. 5. Apocynaceae.

Styles distinct; stamens mostly monadelphous; pollen-grains united into waxy masses.

Fam. 6. Asclepiadaceae.

Family I. OLEÀCEAE Lindl.

Olive Family.

Trees or shrubs (a few genera almost herbaceous) with opposite or rarely alternate simple or pinnate estipulate leaves and regular 2-4-parted flowers in panicles, cymes or fascicles. Calyx inferior, usually small, sometimes none. Stamens 2-4; filaments separate; anthers ovate, oblong or linear, 2-celled, the sacs longitudinally dẹiscent. Ovary 
superior, 2-celled; ovules few in each cavity, anatropous or amphitropous: style usually short or none. Fruit a capsule, samara, berry or drupe. Endesperm fleshy, horny or wanting; embryo straight, rather large; radicle usually short. About 2 I genera and 500 species, of wide distribution in temperate and tropical regions.

Fruit a loculicidal capsule; leaves simple; flowers complete.

Fruit a samara; leaves pinnate; flowers mostly diœcious; corolla wanting.

Fruit a drupe or berry; leaves simple.

Flowers diœcious, mostly apetalous, from catkin-like scaly buds.

Flowers complete, poly petalous, paniculate: petals linear.

Flowers complete, gamopetalous, paniculate.

I. Syringa.

2. Fraxinus.

3. Adelia.

4. Chionanthus.

5. Ligustrum.

\section{SYRÍNGA L.}

Shrubs with opposite entire (rarely pinnatifid) leaves, and gamopetalous flowers, in terminal panicles or thyrses. Calyx campanulate, mostly 4-toothed, persistent. Corolla salverform, the tube cylindric, the limb 4-lobed, the lobes induplicate-valvate. Stamens 2, inserted near the summit of the corolla-tube. Ovary 2-celled; ovules 2 in each cavity, pendulous; style elongated; stigma 2-cleft. Capsule narrowly oblong, somewhat compressed, coriaceous, loculicidally 2 -valved from above. Seeds pendulous, compressed, obliquely winged. [Greek, a pipe or tube.] About 12 species, natives of Asia and eastern Europe.

I. Syringa vulgàris L. LIL.AC. (I. F. f. 2837.) Glabrous, 3-8 m. high. Leaves ovate, entire, deciduous, green on both sides, acuminate at the apex, truncate or subcordate at the base, $5^{-13} \mathrm{~cm}$. long; flowers lilac or white, very numerous, ro $15 \mathrm{~mm}$. long, in large terminal thyrses; ultimate pedicels short; capsule I.5-2.5 cm. long. Escaped from gardens to roadsides, Me. and N. H. to N. Y. and Penn. Native of eastern Europe. April-May.

\section{FRÁxinUS L. (See Appendix.)}

Trees, with opposite, and in our species, odd-pinnate leaves, and small diœcious or polygamous (rarely perfect) greenish fasciculate or racemose-fasciculate flowers, appearing before or with the leaves from the axils of those of the previous season. Calyx small, 4-cleft, irregularly toothed, entire or none. Stamens 2 (rarely 3 or 4). Ovules 2 in each cavity of the ovary, pendulous; stigma 2-cleft. Fruit a flat samara, usually I seeded. Seed oblong, pendulous. [The ancient Latin name.] About 40 species. Besides the following, some 7 others occur in the Southern and Western States.

Lateral leaflets stalked; calyx present in the fertile flowers.

Body of the samara terete or nearly so, the wing chiefly terminal.

Wing almost entirely terminal.

Foliage and twigs glabrous or nearly so. $\quad$ r. F. Americana.

Foliage and twigs pubescent.

Wing manifestly extending down on the sides of the body.

Wing of samara spatulate.

Foliage, twigs and pedicels glabrous or very nearly so.

Foliage, young twigs and pedicels velvety-pubescent.
Samara $3-5 \mathrm{~cm}$. long.
Samara $5-7 \mathrm{~cm}$. long.
4. F. Pennsylvanica.
5. F. profunda.
6. F. Darlingtònii.

Ving of samara long linear.

Body of the samara flat, the wing extending all around it.

Twigs terete; leaflets 5-7; samara elliptic or sfatulate.

Twigs 4-sided; leaflets 7-II ; samara oblong or cuneate.

Lateral leaflets sessile; calyx none; samara winged all around.

7. F. Carolinzana.

8. F. quadrangulata.

9. F. nigra.

I. Fraxinus Americàna L. White Ash. (I. F. f. 2838.) Twigs, petioles and rachis of the leaves glabrous: leaflets 5-9 (commonly 7), ovate, ovatelanceolate, oblong or rarely slightly obovate, entire or denticulate, pale or light green and often pubescent beneath, 7-15 cm. long, acuminate or acute; flowers diœecious (rarely monœcious); samara $2-5 \mathrm{~cm}$. long, its body terete, not margined, winged only from near the summit, one-fourth to one-half the length of the wing, Ins rich woods, N. S. to Minn., Fla., Kans. and Tex. April-June. 
2. Fraxinus Biltmoreàna Beadle. Biltmore Ash. Young twigs pubes. cent. Leaflets 7-9, ovate to lanceolate, acuminate, entire or obscurely denticulate, more or less pubescent beneath, especially along the veins; rachis pubescent; samaras $3.5-5 \mathrm{~cm}$. long, the wing linear, or somewhat broadened above, 2 to 3 times as long as the narrowly elliptic, nearly terete body. Woods, Penn. to Ga.

3. Fraxinus lanceolàta Borck. Green AsH. (I. F. f. 2839.) Glabrous or nearly so. Leaflets 5-9, entire or denticulate, ovate or oblong-lanceolate, acuminate or acute, green on both sides, $5-15 \mathrm{~cm}$. long; samara $2-5 \mathrm{~cm}$. long, very similar to that of the two preceding species, the usually spatulate and proportionately slightly longer wing usually decurrent on the sides of the body to below the middle. Moist soil, Vt. to the N. W. Terr., Fla. and Ariz. April-May.

4. Fraxinus Pennsylvánica Marsh. RED Ash. (I. F. f. 2840.) Twigs, petioles, rachis, petiolules and lower surfaces of the leaves velvety-pubescent; leaflets 5-9, ovate, ovate lanceolate or oblong, acuminate or acute, usually denticulate, 7-15 cm. long; samara 2.5-6 cm. long, its body linear, margined above by the decurrent linear or spatulate wing, and a bout equalling it. In moist soil, N. B. to S. Dak., Fla., Ala. and Kans. April-May.

5. Fraxinus profúnda Bush. Swamp AsH. Foliage and young twigs densely pubescent. Leaflets mostly 7, lanceolate to ovate-lanceolate, entire or very nearly so, 7-I5 cm. long; samaras $5-7 \mathrm{~cm}$. long, the wing obtuse, longer than the linear body and decurrent on its sides to the middle or beyond. In swamps, Mo. to Fla. [F. Americana profunda Bush.]

6. Fraxinus Darlingtònii Britton, n. sp. Darlington's Ash. Similar to $F$. lanceolata and $F$. Pennsylvanica, the foliage and twigs either quite pubescent or glabrate; samaras $5-7.5 \mathrm{~cm}$. long, the wing about $4 \mathrm{~mm}$. wide, longer than the narrowly linear body and decurrent on it for one-fourth to one-third of its length. N. Y. and Penn. Type from Westchester, Penn.

7. Fraxinus Caroliniàna Mill. WATER AsH. (I. F. f. 284I.) Foliage glabrous, or slightly pubescent. Leaflets 5-7 (rarely 9), ovate, ovate-lanceolate or oblong, acuminate or acute; samara $2-5 \mathrm{~cm}$. long, elliptic or spatulate, the body linear, flat, broadly winged all around, extending more than half-way to the apex of the fruit, the wing pinnately veined. In swamps and wet soil, Va. to Fla., Ark. and Tex. Also in Cuba. March-April.

8. Fraxinus quadrangulàta Michx. Blue Ash. (I. F. f. 2842.) Foliage glabrous, or sparingly pubescent when young. Leaflets 7-II, ovate, oblong or lanceolate, acuminate, green on both sides, sharply serrate or serrulate, $7-13 \mathrm{~cm}$. long; samara linear-oblong or cuneate, 2-5 cm. long, 6-14 $\mathrm{mm}$. wide, winged all around, parallel-nerved, the body extending more than half-way to the apex. In woods, Ont., Minn. and Mich. to Ala., Iowa and Ark. March-April.

9. Fraxinus nigra Marsh. Bl.ACK AsH. Hoop AsH. (I. F. f. 2843.) Foliage glabrous, except the midrib of the lower surfaces of the leaflets. Leaflets 7-II, sessile, green on both sides, oblong-lanceolate, long-acuminate, sharply serrate or serrulate, 7-15 cm. long: samara oblong or linear-oblong, parallel-nerved, $2.5-4 \mathrm{~cm}$. long, the body flat, winged all around, extending to or beyond the middle. In swamps and wet woods, Newf. to Manitoba, Va. and Ark. April-May.

\section{ADELLIA P. Br. [FORESTIERA Poir.]}

Shrubs with opposite leaves and small yellow or greenish diœcious or polygamous flowers, fascicled, short-racemose or paniculate from scaly buds produced at the axils of the preceding season, appearing before or with the leaves. Corolla wanting, or of I or 2 small deciduous petals. Stamens 2-4. Ovary ovoid, 2 celled; ovules 2 in each cavity, pendulous; style slender; stigma 2-lobed. Fruit a drupe with $\mathbf{I}$ or rarely 2 seeds. [Greek, inconspicuous, perhaps referring to the flowers.] About I5 species, natives of America. Besides the following, about 7 others occur in the southern U. S.

I. Adelia acuminàta Michx. Adelia. (I F. f. 2844.) A shrub or small tree, the branches somewhat spiny, the foliage glabrous. Leaves ovate, lanceolate or oblong, acuminate or acute at both ends, finely denticulate, $2.5-10 \mathrm{~cm}$. long; petioles slender; staminate flowers fascicled; pistillate flowers short-paniculate; calyx obsolete; drupe narrowly oblong, about $2 \mathrm{~cm}$. long, when young fusiform and often curved. River-banks, IIl. to Ga., Mo., Ark. and Tex. March-April. 


\section{CHIONÁNTHUS L.}

Shrubs or small trees, with opposite entire leaves, and complete conspicuous white flowers, in large loose panicles from the axils of the upper leaves of the preceding season. Calyx small, 4-cleft or 4-parted, inferior, persistent. Corolla of 4 linear petals, slightly united at the very base. Stamens 2 (rarely 3), inserted on the base of the corolla; filaments very short. Ovules 2 in each cavity of the ovary, pendulous; style short; stigma thick, emarginate or slightly 2 -lobed. Fruit a usually I-seeded drupe. [Greek, snow-blossom.] About 3 species, the following of southeastern N. Am., the others Chinese.

I. Chionanthus Virgínica L. Fringe-Tree. (I. F. f. 2845.) A shrub, or small tree, the young twigs, petioles and lower surfaces of the leaves pubescent, or sometimes glabrate. Leaves oval, oblong or some of them obovate, rather thick, narrowed at the base, 7-I5 cm. long; panic'es drooping, sometimes $2.5 \mathrm{dm}$. long, usually with some sessile leaflike bracts, its branches and the pedicels very slender; petals $2.5 \mathrm{~cm}$. long or more, $2 \mathrm{~mm}$. wide or less; drupe oblong or globoseoblong, nearly black, I-I. $6 \mathrm{~cm}$. long, the pulp thin. In moist thickets, Del. and southern Penn. to Fla. and Tex. May-June.

\section{LIGÚSTRUM L.}

Shrubs or small trees, with opposite entire leaves, and small white complete flowers in terminal thyrses or panicles. Calyx small, truncate or 4-toothed, inferior. Corolla gamopetalous, funnelform, its tube mostly short, the limb 4-lobed, the lobes induplicate-valvate in the bud. Stamens 2, inserted on the tube of the corolla; filaments short. Ovary 2-celled; ovules 2 in each cavity, pendulous; stigma thickened. Fruit a $\mathbf{I}-3$-seeded mostly globose berry. [The classical Latin name.] About 35 species, natives of the Old World.

I. Ligustrum vulgàre L. Privet. Prim. (I. F. f. 2846.) A shrub, the branches long and slender. Leaves firm, tardily deciduous, glabrous, lanceolate or oblong, short-petioled, I.5-5 cm. long, obscurely veined; panicles dense, short, minutely pubescent; flowers about $6 \mathrm{~mm}$. broad; pedicels very short; stamens included; berries black, 4-6 mm. in diameter. Escaped from cultivation, Me. and Ont. to Penn. and N. Car. Native of Europe and Asia. June-July.

\section{Family 2. LOGANIÀCEAE Dumort.}

\section{Logania Family.}

Herbs, shrubs, vines or some tropical genera trees, with opposite or verticillate simple stipulate leaves, or the leaf-bases connected by a stipular line or membrane, and regular perfect 4-5-parted flowers. Calyx inferior, the tube campanulate, sometimes short or none, the segments imbricated, at least in the bud. Corolla gamopetalous, funnelform, campanulate, or rarely rotate. Stamens inserted on the tube or throat of the corolla; anthers 2-celled, the sacs longitudinally dehiscent; pollen-grains simple. Disk usually none. Ovary superior, 2-celled (rarely 3-5-celled); ovules anatropous or amphitropous. Fruit a 2 -valved capsule in our species. Embryo small, usually straight; endosperm copious ; radicle terete or conic. About 30 genera and 400 species, widely distributed in warm and tropical regions.

Style 4-cleft; woody vine; flowers large yellow.

Style simple, 2-lobed or 2-divided with a common stigma; herbs.

Corolla-lobes valvate; capsule didymous or 2-lobed; leaves broad.

Style simple, jointed; spike simple.

Style 2-divided below; spikes cymose.

Corolla-lobes imbricate; capsule subglobose; leaves linear.

1. Gelsemium.

2. Spigelna.

3. Cynoctonum.

4. Polypremum.

\section{GELSEMIUM Juss.}

Glabrous vines; leaves opposite, or rarely whorled, their bases connected by a stipular line: flowers in axillary and terminal nearly sessile cymes, the pedicels scaly-bracteolate. Calyx deeply 5-parted, the segments imbricated. Corolla fun. 
nelform, with 5 broad lobes imbricated in the bud. Stamens 5, inserted on the tube of the corolla; anthers linear oblong. Ovary oblong, 2-celled; style slender or filiform, 4-cleft; ovules numerous on linear placentæ. Capsule elliptic, flattened contrary to the partition, septicidally dehiscent, the valves boat-shaped, 2-cleft at the summit; seeds flattened, winged. [From the Italian Gelsomino, the Jessamine.] Two known species, the following, the other of eastern Asia.

I. Gelsemium sempérvirens (L.) Ait. f. Yellow Jessamine. (I. F. f. 2847.) Stems sometimes $6 \mathrm{~m}$. long: Leaves lanceolate, oblong-lanceolate or ovatelanceolate, entire, short petioled, persistent, evergreen, $3-8 \mathrm{~cm}$. long; cymes I-6. flowered; pedicels short; bractlets several, dry, oblong or lanceolate; flowers dimorphous; corolla bright yellow, 2.5-4 cm. long; stigmas in one form short and anthers exserted, in the other form longer and anthers included; capsule flat, channeled on both sides, 8-14 $\mathrm{mm}$. long, cuspidate. In woods and thickets, Va. to Fla., Tex. and Guatemala. March-Oct.

\section{SPIGÈLIA L.}

Herbs, with opposite membranous entire pinnately veined leaves, small stipules, or the leaf-bases connected by a stipular line, and red, yellow or purple flowers in scorpioid cymes or unilateral spikes, or terminal and in the forks of the branches. Calyx deeply 5-parted. Corolla 5-lobed, the tube finely 15-nerved. Stamens 5, inserted on the corolla-tube; anthers 2-lobed at the base. Ovules numerous, on peltate placentæ; style filiform, jointed near the middle; stigma obtuse. Capsule didymous, 2-celled, somewhat flattened contrary to the dissepiment, circumscissile, the 2 carpels becoming 2-valved. Seeds peltate, not winged. [Named for Adrian von der Spigel, 1558-1625, physician.] About 35 species, all American. Besides the following, 4 others occur in the Southern States.

I. Spigelia Marylándica L. Indian or Carolina Pink. (I. F. f. 2848.) Perennial; stem 4-angled, glabrous or nearly so, 3-6 dm. higl. Leaves sessile, ovate, or ovate-lanceolate, acute or acuminate, 5-10 $\mathrm{cm}$. long, sparingly pubescent on the veins; flowers in a termis al I-sided peduncled spike; corolla scarlet outside, yellow within, 2-5 cm. long, its lobes lanceolate, about $6 \mathrm{~mm}$. long; calyx-segments subulate. In woods, N. J. (according to Gray) to Wis., Fla. and Tex. May-July.

\section{CYNÓCTONUM J. G. Gmel. [Mitreola R. Br.]}

Herbs, our species annual, with opposite entire leaves, and minute stipules, or the leaf-bases connected by a stipular line. Flowers small, whitish, in one-sided spikes forming cymes. Calyx 5-parted. Corolla urn-shaped, 5-lobed. Stamens 5 , included; filaments short: anthers cordate. Ovules numerous, on peltate placentæ; style short, 2 -divided below, united above by the common stigma, the divisions becoming separate. Capsule 2-lobed at the summit; carpels divaricate, dehiscent along the inner side. Seeds numerous, small, tuberculate. [Greek, dogkilling.] About 5 species, of warm and tropical regions.

I. Cynoctonum Mitrèola (I..) Britton. Mitrewort. (I. F. f. 2849.) Stem glabrous, erect, terete, 3-6 dm. high. Leaves lanceolate to ovate, petioled, $2.5-8 \mathrm{~cm}$. long, 6-25 $\mathrm{mm}$. wide, acute at both $\mathrm{ends}$, glabrous; cymes terminal and often also in the upper axils, slender-peduncled; flowers about $2 \mathrm{~mm}$. broad, numerous, sessile or nearly so; capsule deeply 2-lobed, compressed, the lobes at length widely diverging, acute. In wet or moist soil, Va. to Fla., Tex. and Mex. Also in the W. Indies. June-Sept. [Mitreola petiolata T. \& G.]

\section{POLYPREMUM L.}

A glabrous diffusely branched annual herb, with opposite linear-subulate leaves, their bases connected by a stipular nembrane, and small white flowers in terminal bracted cymes. Calyx deeply 4-parted (rarely 5 -parted), the segments subulate. Corolla campanulate, bearded in the throat, shorter than the calyx, 4 -lobed (rarely 5-lobed). Stamens 4 (rarely 5), inserted on the corolia, included; filaments short; anthers ovoid-globose. Ovules numerous, on oblong placentæ; style short; stigma capitate or obscurely 2 -lobed. Capsule slightly compressed, didymous, loculicidally 2 -valved, the carpels at length septicidal. Seeds minute, smooth. [Greek, many-stemmed.] A monotypic genus. 
I. Polypremum procúmbens L. Polypremum. (I. F. f. 2850.) Stems tufted, somewhat rigid, 4 -angled, 5-30 cm. long. Leaves I-4 cm. lor g, I-2 mm. wide, acute, sessile, ninutely rough-toothed on the margins, often with smaller ones fascicled in their axits; flowers solitary, sessile in the forks of the cymes and along their branches, leafy-bracted; corolla $2 \mathrm{~mm}$. long or less: capsule crustaceous, didymous, about $2 \mathrm{~mm}$. in diameter, slightly 2-lobed, the lobes obtuse. In dry sandy soil, N. J. and Penn. to Fla., Ky., the Ind. Terr. and Mex. Also in the W. Indies. May-Sept.

\section{Family 3. GENTIANÀCEAE Dumort.}

\section{Gentian Family.}

Bitter mostly glabrous herbs, with opposite (rarely verticillate) estipulate entire leaves, reduced to scales in Bartonia, and regular perfect flowers in clusters, or solitary at the ends of the stem or branches. Calyx inferior, persistent, 4-12-lobed, -toothed or -divided (of 2 sepals in Obolaria), the lobes imbricated or not meeting in the bud. Corolla gamopetalous, often marcescent, 4-12-lobed or -parted. Stamens as many as the lobes of the corolla, alternate with them, inserted on the tube or throat; anthers 2-celled, longitudinally dehiscent. Disk none, or inconspicuous. Ovary superior in our genera, I-celled or partly 2-celled; ovules numerous, anatropous or amphitropous; stigma entire, or 2 -lobed, or 2-cleft. Capsule mostly dehiscent by 2 valves. Endosperm fleshy, copious; embryo small, terete or conic. About 65 genera and 600 species, widely distributed.

Leaves normal; corolla-lobes convolute in the bud.

Style filiform; anthers usually twisting or recurving when old. Corolla salverform.

Corolla rotate.

Corolla campanulate-funnelform.

Style short, stout or none; anthers remaining straight.

Corolla without nectariferous pits, glands or scales.

Corolla funnelform, campanulate or clavate.

Corolla rotate.

1. Erythraea.

2. Sabbatia.

3. Eustoma.

I or 2 nectariferous pits, glands or scales at the base of each corolla-lobe.

Corolla rotate, a fringed gland at each lobe.

Corolla campanulate, spurred at the base.

6. Frasera.

7. Tetragonanthus.

Leaves, at least those of the stem, reduced to scales; corolla-lobes imbricated in the bud.

Calyx of 2 foliaceous spatulate sepals; upper leaves normal.

Calyx of 4 lanceolate sepals; leaves all reduced to scales.

8. Obolaria.

9. Bartonia.

\section{ERYTHRAÈ Neck.}

Herbs, mostly annual or biennial, with sessile or amplexicaul leaves, and pink white or yellow flowers in cymes or spikes. Calyx tubular, 5-4-lobed or -divided, the lobes or segments narrow, keeled. Corolla salverform, 5-4-lobed, the lobes spreading, contorted, convolute in the bud. Stamens 5 or 4 , inserted on the corolla. tube; filaments short-filiform; anthers becoming spirally twisted. Ovary I-celled, the placentæ sometimes intruded; style filiform; stigma 2-lobed. Capsule 2-valved. Seed-coat reticulated. [Greek, red, the color of the flowers in some species.] About 25 species, natives of the Old World and western N. and S. Am. Besides the following, about 8 others occur in the western U. S.

Flowers spicate-racemose.

Flowers cymose or cymose-paniculate.

Basal leaves tufted.

r. E. spicata.

No tuft of basal leaves.

Flowers cymose-paniculate, numerous.

Flowers few, cymose; western species.

2. E. Centaurium.

3. E. pulchella.

4. E. exaltata.

т. Erythraea spicàta (L.) Pers. Spiked Centaury. (I. F. f. 2851.) Glabrous, erect, I.5-4.5 dm. high. Leaves oblong or lanceolate-oblong, sessile, obtusish, clasping, 1-4 cm. long; flowers pink, sessile, about $16 \mathrm{~mm}$. long; tube 
of the corolla somewhat longer than the subulate calyx-segments, 2-3 times as long as the linear-oblong lobes; capsule 8-10 mm. long. Coast of Nantucket, and at Portsmouth, Va. Nat. from Europe. May-Sept.

2. Erythraea Centaùrium (L.) Pers. Lesser Centaury. Bitter-herb. BLoODWORT. (I. F. f. 2852.) Glabrous, I.5-4 cm. high. Leaves oblong, obtuse, the lower forming a basal tuft, 2.5-6 cm. long; stem leaves sessile or slightly clasp. ing; flowers $12-16 \mathrm{~mm}$. long, nearly sessile, in compound bracteolate cymes; corolla-lobes obtuse, 5-6 cm. long, about as long as the calyx-segments and onethird to one-half as long as the corolla-tube; stigmas oval. In waste places, N. S. and Quebec to Ill. Nat. from Europe. June-Sept.

3. Erythraea pulchélla (Sw.) Fries. Branching Centaury. (I. F. f. 2853.) Glabrous, much branched, 0.7-2 dm. high. Leaves oval, ovate or lanceolate, the lower mostly obtuse, 6-16 mm. long; no basal tuft of leaves; flowers pink, cymose-paniculate, all or nearly all of them pedicelled, $10-12 \mathrm{~mm}$. long; tube of the corolla $I_{\frac{1}{2}}-2$ times longer than the calyx-segments, its lobes oblung, obtuse, 3-4 mm. long; stigma oval. In fields and waste places, N. Y. to Penn. and Md.; also in the W. Indies. Nat. from Europe. June-Sept.

4. Erythraea exaltàta (Griseb.) Coville. TAll or Western Centaury. (I. F. f. 2854.) Glabrous, I.5-4.5 dm. high, the branches few, erect. Leaves ublong or linear-oblong, sessile, mostly acute at both ends, $1-2 \mathrm{~cm}$. long, the basal not tufted; flowers few, terminal and axillary, all slender-pedicelled, 12-16 mm. long; tube of the corolla about one-third longer than the calyx-segments, the lobes oblong, obtuse, 3-4 mm. long. In sandy soil, Neb. to Wyo., Wash., Ariz. and Cal. May-Sept.

Erythraea calycosa Buckl., a Texan species differing from this in its broader larger obtuse corolla lobes, has been found as a waif in Mo.

\section{SABBÀTIA Adans.}

Annual or biennial erect glabrous herbs, with opposite or sometimes verticillate sessile or rarely petioled or clasping leaves, and terminal pink rose or white flowers. Calyx 4-12-parted or-divided, the tube campanulate, sometimes very short, the lobes or segments usually narrow. Corolla rotate, deeply 4-12-parted. Stamens 4-12, inserted on the short tube of the corolla; filaments filiform, short; anthers curved, revolute or coiled in anthesis. Ovary I-celled, the placentæe intruded; style 2-cleft or 2 parted, its lobes filiform, stigmatic along their inner sides. Capsule 2-valved, many-seeded. Seeds small, reticulated. [In honor of L. Sab. bati, an Italian botanist.] About I4 species, natives of eastern N. Am. and Mex. Besides the following, some 5 others occur in the southern U. S.

Flowers normally 4-5-parted, sometimes 6-7-parted.

Branches opposite.

Style 2-parted to below the middle or nearly to the base; flowers white.

Leaves lanceolate or ovate, acute; flowers $16-25 \mathrm{~mm}$. broad.

r. S. lanceolata.

Leaves linear-oblong or lanceolate, obtuse; flowers $12-18 \mathrm{~mm}$. broad.

Style 2-cleft to about the middle; flowers normally pink.

2. S. paniculata.

Leaves linear-lanceolate, sessile; stem slightly 4-angled. 3. S. angustifolia.

Leaves ovate, cordate-clasping; stem strongly 4-angled. 4. S. angularis.

Branches alternate, the lower sometimes opposite in Nos. 5 and 6.

Calyx-segments foliaceous, longer than the corolla.

Calyx-segments linear or lanceolate, not longer than the corolla.

Caly x-tube strongly 5-ribbed; flowers $2.5-5 \mathrm{~cm}$. broad. 6. S. campestris.

Calyx-tube scarcely ribbed; flowers $2-4 \mathrm{~cm}$. broad.

Calyx shorter than the corolla; style 2-parted.

Flower pink with a yellow eye (rarely white); corolla-segments obovate.

7. S. stellaris.

Flowers white, very numerous; corolla-segments spatulate or oblanceolate. $\quad 8$. S. Elliottii.

Calyx-segments filiform, as lorg as the corolla; style 2-cleft.

Flowers normally 8-12-parted, 3.5-6 cm. broad.

9. S. campanulata.

Io. S. dodecandra.

I. Sabbatia lanceolàta (Walt.) T. \& G. LANCE-Leaved SABbatia. (I. F. f. 2855.) Stem somewhat 4-angled, 3-9 dm. high. Leaves 3-5-nerved, 2-5 cm. long, 
the uppermost reduced to narrow bracts; flowers in bracteolate corymbed cymes; pediceis 4-I4 mm. long; calyx-lobes filiform-linear, much shorter than the corolla; corolla-segments oblong or slightly obovate capsule ovoid, about $6 \mathrm{~mm}$. high. In pine-barren swamps, N. J. to Fla. May-Sept.

2. Sabbatia paniculata (Michx.) P'ursh. Branchivg Sabbatia. (I. F. f. 2856.) Stem 4-angled, 3-7.5 dm. high. Leaves $\mathrm{I}-4 \mathrm{~cm}$. long, the uppermost small and bract-like; flowers in corymbed cymes; central flowers of the cymes often nearly sessile; calyx-lobes linear, not more than one half the length of the corolla; corolla-segments spatulate-obiong; capsule oblong, about $6 \mathrm{~mm}$. high. In dry or moist soil, Va. to Fla. May-Sept.

3. Sabbatia angustif slia (Michx.) Britton. Narrow-leaven Sabratia. (I. F. f. 2857.) Stem 3-6 dm. high. Leaves linear to linear-lanceolate, sessile, 2-5 $\mathrm{cm}$. long, the uppermost small and bract-like; flowers pink with a yellowish or greenish eye, few in the cymes, or solitary, about $2.5 \mathrm{~cm}$. broad; calyx-lobes linear, usually more than one-half the length of the corolla; corolla-segments obovate oblong; capsule oblong, 6-8 mm. high. In dry or moist soil, Ind. to La., N. Car. and Fla. May-Sept. [S. brachicata Ell.]

4. Sabbatia angularis (L.) Pursh. Bitter-bloom. Rose-pink. Squarestemmed Sabbatia. (I. F. f. 2858.) Stem 6-9 dm. high. Leaves ovate, acute, cordate-clasping at the base, $1.5-3.5 \mathrm{~cm}$. long, or the lower oblong, those of the branches smaller; flowers rose-pink, with a central greenish star, occasionally white, $2.5-4 \mathrm{~cm}$. broad, usually solitary at the ends of the branches; calyx-lobes linear, one-lialf the length of the corolla, or less; corolla-segments obovate; capsule oblong, about $6 \mathrm{~mm}$. high. In rich soil, N. Y. and Penn. to Ont., Mich., Fla., the Ind. 'Terr. and La. July-Aug. Flowers fragrant.

5. Sabbatia calycina (Lam.) Heller. COAST Sabbatia. (I. F. f. 2859.) Stem I.5-3 dm. high. Leaves oblong or some of them slightly obovate, 3-nerved, $2-5 \mathrm{~cm}$. long, narrowed to the sessile base or the lower into petioles; flowers solitary at the ends of the branches or peduncles, $2.5-4 \mathrm{~cm}$. broad; calyx-lobes linear or spatulate, leaf-like, longer than the spatulate segments of the pink rose-purple or whitish corolla; capsule ovoid oblong, 6-8 mm. high. In moist soil, Va. to Fla. Also in Cuba. June-Aug.

6. Sabbatia campéstris Nutt. Prairie Sabbatia. (I. F. f. 2860.) Stem r.5-4 dm. high. Leaves ovate, oblong or lanceolate, mostly obtuse, sessile or slightly clasping and subcordate, $\mathbf{I}-2.5 \mathrm{~cm}$. long; flowers solitary at the ends of the branches and peduncles, $2-5 \mathrm{~cm}$. broad; calyx 5-ribbed or almost 5-winged, its lobes lanceolate, acute, $\mathbf{I - 2 . 5} \mathrm{cm}$. long, about as long as the obovate lilac corolla-segments; capsule oblong, 6-8 mm. high. On prairies, Mo. and Kans. to Tex.

7. Sabbatia stellàris Pursh. Sea or Marsh Pink. (I. F. f. 286I.) Stem I. 5-6 dm. high. Leaves lanceolate-oblong to linear, sessile, $1-2.5 \mathrm{~cm}$. long, or the lowest smaller, somewhat obovate, the uppermost narrowly linear and bract-like; flowers $1.5-3.5 \mathrm{~cm}$. broad, solitary at the ends of the branches or slender peduncles; calyx not ribbed, its lobes narrowly linear, shorter than or nearly equalling the oblong or obovate corolla-segments; corolla pink to white with a yellowish starry eye bordered with red; capsule about $5 \mathrm{~mm}$. high. In salt-meadows, Me. to Fla. July-Sept.

8. Sabbatia Ellióttii Steud. Elliott's Sabbatia. (I. F. f. 2862.) Stem 3-6 dm. high. Lower leaves obovate or lanceolate-oblong, obtuse, $1-2 \mathrm{~cm}$. long, the upper and those of the branches linear or subulate; flowers solitary at the ends of the branches, $2.5 \mathrm{~cm}$. broad or less; calyx not ribbed, its lobes subulate-linear, one-half as long as the spatulate or oblanceolate segments of the corolla, or less; capsule about $5 \mathrm{~mm}$. high. In pine barrens, Va. (?), N. Car. to Fla. July-Sept.

9. Sabbatia campanulàta (L.) Torr. Slfnner Marsh Pink. (I. F. f. 2863.) Similar to the preceding. Stem 3-6 dm. high. Leaves linear or linearlanceolate, $2-4 \mathrm{~cm}$. long, sessile, acute or the lowest much shorter, obtuse, oblong or oblanceolate, the uppermost almost filiform; flowers pink with a yellow eye, about $2.5 \mathrm{~cm}$. broad, mostly 5 parted; calyx-lobes filiform-linear, equalling the oblong-obovate corolla-segments, or somewhat shorter; capsule obovoid, about 5 $\mathrm{mm}$. high. In salt marshes and along brackish rivers, rarely in fresh-water swami $\Gamma$, eastern Mass, to Fla. and La. Also in Cuba. May-Aug. [S. gracilis Salisb.] 
10. Sabbatia dodecándra (L.) B.S.P. LARge Marsh Pink. (I. F. t. 2864.) Sten 3-6 dm. high, the branches alternate. Basal leaves spatulate, obtuse, 3-8 cm. long: stem-leaves lanceolate or oblong-lanceolate, acute, the uppermost usually narrowly linear: flowers few, pink, sometimes white, solitary at the ends of the branches or peduncles; calyx-lobes narrowly linear, about one-half as long as the 9-12 spatulate-obovate corolla-segments; anthers coiled; style deeply 2-cleft, its divisions clavate; capsule globose-oval, $6 \mathrm{~mm}$. high. Borders of ponds and along salt marshes, Mass. to Fla. and Ala. July-Sept. [S. chloroides Pursh.]

\section{EUSTÒMA Salisb.}

Glaucous annual herbs, with opposite sessile or clasping entire leaves. Flowers large blue, purple or white, long-peduncled, axillary and terminal. Calyx deeply 5-6.cleft, the lobes lanceolate, acuminate, keeled. Corolla deeply 5-6-lobed, the lobes oblong or obovate, convolute in the bud. Stamens 5-6, inserted on the throat of the corolla; filaments filiform; anthers oblong, versatile. Ovary I-celled; stigma 2-lamellate. Capsule 2-valved. Seeds small, numerous, foveolate. [Greek, open-mouth, referring to the corolla.] Two species, natives of the southern U. S., Mex. and the W. Indies.

I. Eustoma Russelliànum (L.) Griseb. Russell's Eustoma. (I. F. f. 2865.) Stem terete, 3-8 dm. high. Leaves oblong or ovate-oblong, 3-5-nerved, the upper usually acute at the apex, cordate-clasping at the base, $3-8 \mathrm{~cm}$. long, the lower usually obtuse and narrowed to a sessile or slightly auricled base; peduncles 2-10 cm. long; bracts lanceolate-subulate, small; flowers $5-8 \mathrm{~cm}$. broad; calyx-lobes shorter than the purple corolla; corolla lobes obovate, about 4 times as long as the tube; anthers remaining nearly straight. On plains, Neb. to La., Tex. and Mex. May-Aug.

\section{GENTIÀnA L. (See Appendix.)}

Mostly perennial and glabrous herbs, with opposite or rarely verticillate, entire sessile or short-petioled leaves. Flowers solitary or clustered. Calyx tubular, 4-7- (usually 5-) cleft. Corolla 4-7-lobed, often with membranous plits in the sinuses. Stamens as many as the lobes of the corolla and inserted on its tube, included; anthers connate into a tube, or separate. Ovary I-celled; ovules very numerous; stigma cleft into 2 lamellæ. Capsule 2-valved. Seeds numerous. [Named for King Gentius of Illyria.] About 300 species. Besides the following, some 30 others occur in the western parts of N. Am.

* Corolla without plaits or teeth in the sinuses; annuals.

Corolla-lobes fringed or serrate; flowers $2-8 \mathrm{~cm}$. long.

Corolla enclosed in the swollen wing-angled calyx.

I. G. ventricosa.

Corolla conspicuously longer than the wingless calyx.

Corolla-lobes fringed all around their sumnits; leaves lanceolate.

2. G. crinita.

Corolla-lobes fringed mainly on the margins; leaves linear.

3. G. procera.

Corolla-lobes with entire or rarely denticulate margins; flowers $1-2.5 \mathrm{~cm}$. long.

Corolla-lobes fimbriate crested at the base, acute.

4. G. acuta.

Corolla-lobes naked, subulate-acuminate.

Calyx-lobes unequal; flowers mostly 4-parted. 5 . G. propinqua.

Calyx-lobes equal; flowers 5-parted.

5. G. propinqua.
6. G. quinquefolia.

* * Corolla with membranous, toothed or lobed plaits in the sinuses; perennials.

Margins of leaves and calyx-lobes scabrous or ciliate; seeds winged.

Anthers separate, or merely connivent.

Stems usually clústered; ćalyx lobes unequal ; corolla narrowly funnelform.

7. G. affinis.

Stems mostly solitary; calyx-lobes equal; corolla campanulate-funnelform.

Anthers cohering in a ring or short tube.

8. G. puberula.

Corolla-lobes distinct, longer than or equalling $\star$ he plaits.

Flowers $\mathrm{I}-4$; corolla campanulate-funnelform, its lobes $2-3$ times as long as the plaits.

9. G. parvifolia.

Flowers several or numerous; corolla club-shaped, its lobes not nuch longer than the plaits.

Corolla-lobes none or minute, the plaits very broad.

Io. G. Saponaria.

I1. G. Andrewsii. 
Margins of leaves and calyx-lobes smooth or nearly so.

Flowers clustered, sessile, 2-bracteolate under the calyx.

Corolla-lobes ovate, twice as long as the plaits; leaves broad, acuminate; seeds winged.

Corolla-lobes rounded, little longer than the plaits; leaves narrow; seeds winged.

13. G. linearis.

Corolla-lobes ovate, acute, much longer than the broad plaits; leaves broad; seeds winged.

Corolla-lobes triangular-lanceolate; leaves obovate; seeds wingless.

Flowers solitary, peduncled, not bracteolate; leaves linear.

15. G. villosa.

16. G. Porphyrio.

I. Gentiana ventricòsa Griseb. Swollen Gentian. (I. F. f. 2866.) Stem terete, about $3 \mathrm{dm}$. high. Basal leaves obovate, small, those of the stem ovate-oblong, rounded or subcordate at the base, 2-5 cm. long; flowers few, solitary at the ends of stout peduncles, 4-parted; calyx inflated, ovoid, about $2 \mathrm{~cm}$. high; corolla-lobes oblong, obtuse; ovary elliptic-oblong. Grand Rapids of Saskatchewan, between Cumberland House and Hudson Bay.

2. Gentiana crinita Froel. Fringed Gentian. (I. F. f. 2867.) Stem 3-Io dm. high, the branches erect. Basal and lower leaves obovate, obtuse, the upper lanceolate or oblong-lanceolate, $2-5 \mathrm{~cm}$. long, acute or acuminate at the apex, sessile with a rounded or subcordate base; flowers mostly 4-parted, about $5 \mathrm{~cm}$. high, solitary at the ends of the usually elongated peduncles; calyx-lobes lanceolate. acuminate; corolla bright blue, rarely white, narrowly campanulate, its lobes obovate; capsule spindle-shaped, stipitate; seeds scaly-hispid. In moist woods and meadows, Quebec to Minn., Ga. and Iowa. Sept.-Oct.

3. Gentiana prócera Holm. Smaller Fringed Gentian. (I. F. f. 2868.) Similar to the preceding, but smaller; stem 0.7-4.5 dm. high. Basal and lower leaves spatulate, obtuse, the upper linear or linear-lanceolate, $2.5-6 \mathrm{~cm}$. long; flowers I-6, mostly 4 parted, about $3.5 \mathrm{~cm}$. high; calyx-lubes lanceolate, acuminate; corolla narrowly canpanulate, its lobes spatulate-oblong. In wet places, Newf. to Alaska, Anticosti, N. Y. Minn., S Dak. (G. serrata A. Gray, not Gunner; $G$. detonsa Torrey, not Rottb.) Aug.-Oct.

4. Gentiana acùta Michx. Northern Gentian. (I. F. f. 2869.) Stem 1.5-5 dm. high. Basal and lower leaves spatulate or obovate, obtuse, the upper lanceolate, acuminate or acute at the apex, rounded or subcordate at the base, sessile, I-5 cm. long: flowers racemose-spicate, I--1.6 cm. high; calyx-lobes lanceolate; corolla tubular-campanulate, blue, its lobes lanceolate, acute; capsule sessile. In moist or wet places, Lab. to Alaska, Quebec, Minn., south in the Rocky Mts. to Ariz. and Mex. Also in Europe and Asia. Summer.

5. Gentiana propínqua Richards. Four parted Gentian. (I. F. f. 2870.) Stems slender, usually branched from the base, 5-I $8 \mathrm{~cm}$. high. Basal leaves spatulate, obtuse, the upper distant, oblong, or lanceolate, $\mathrm{I}-4 \mathrm{~cm}$ long, rounded at the slightly clasping base; flowers $1.5-2 \mathrm{~cm}$. high; calyx 4 -cleft, 2 of the lobes oblong, the others linear-lanceolate; corolla blue or bluish, its lobes ovatelanceolate; capsule linear. Lab. to Alaska and $\mathrm{Br}$. Col. Summer.

6. Gentiana quinquefòlia L. Stiff Gentian. Ague-weed. (I. F. f. 287 I.) Stem ridged, $0.5-5 \mathrm{dm}$. high, quadrangular. Basal leaves spatulate, obtuse, those of the stem ovate, acute, clasping or rounded at the base, 3-7-nerved, $\mathbf{I}-5 \mathrm{~cm}$. long; flowers in clusters of $\mathbf{I}-7$ at the ends of the branches, or also axillary; calyx one fourth to one-third the length of the corolla; coralla tubular-funnelform, blue, its lobes triangular, entire; capsule stipitate; seeds globose. wingless. In dry or moist soil, Me. and Ont. to Mich., Fla. and Mo. Aug.-Oct.

Gentiana quinquefòlia occidentàlis (A. Gray) A. S. Hitchcock. Usually taller; corolla more broadly funnelform; calyx-lobes foliaceous, reaching to the middle of the corolla. Ohio to Minn., Tenn. and La.

7. Gentiana affinis Griseb. Oblong-leaved Gentian. (I. F. f. 2872.) Stems clustered from deep fuots, minutely puberulent, simple, 1.5-4.5 dm. high. Leaves linear-oblong to lanceolate oblong, firm, indistinctly nerved, $1-4 \mathrm{~cm}$. long, the floral smaller; flowers 5-parted, sessile in the axils of the upper leaves, about $2.5 \mathrm{~cm}$. high, not bracted under the calyx; calyx-lobes linear or subulate, unequal; corolla blue, its lobes ovate, acute or mucronate, entire, spreading, with laciniate 
appendages in the sinuses. In moist soil, Minn. to Br. Col., N. Mex. and Nev. Aug.-Oct.

8. Gentiana pubérula Michx. Downy Gentian. (I. F. f. 2873.) Stems usually solitary, $2-4.5 \mathrm{dm}$. high, puberulent, or glabrous. Leaves firm, lanceolate, or the lower oblong, indistinctly nerved, pale beneath, $2-8 \mathrm{~cm}$. long; flowers sessile or nearly so in the upper axils, rarely solitary and terminal, 2-bracteolate under the calyx, 3-5 cm. high; calyx-lobes linear-lanceolate, about as long as the tube; corolla campanulate-funnelform, 2-3 times as long as the calyx, its lobes ovate, entire, spreading, much longer than the cleft or laciniate appendages. On prairies, Ohio to the N. W. Terr., Ga. and Kans. Aug.-Oct.

9. Gentiana parvifòlia (Chapm.). Elliot I's Gentian. (I. F. f. 2874.) Roots a cluster of thick fibres; stems minutely rough-puberulent, $2-5 \mathrm{dm}$. high. Leaves ovate or ovate-lanceolate, acute or acutish, thin, $2-5 \mathrm{~cm}$. long, 3-nerved, or the lower much smaller and obtuse; flowers I-4, terminal, or rarely in the upper axils, about $5 \mathrm{~cm}$. long, sessile; calyx-lobes oblong or lanceolate, foliaceous, longer than the tube; corolla blue, its lobes ovate, entire, 6-8 $\mathrm{mm}$. long, about twice as long as the fimbriate or toothed appendages; seeds oblong, broadly winged. In moist soil, Va. to Fla. Sept.-Oct. [G. Elliottii Chapm., not Raf.]

Io. Gentiana Saponària L. SoAP-WorT Gentian. (I. F. f. 2875.) Stem glabrous, or minutely rough-puberulent, 3-8 dm. high. Leaves lanceolate, ovatelanceolate or oblong, usually acute at both ends, 3-5-nerved, 5-10 cm. long, the lowest obovate and smaller; flowers $2.5-5 \mathrm{~cm}$. high, in sessile terminal and usually also axillary clusters; calyx-lobes oblong or spatulate, ciliolate; corolla blue, its lobes erect, obtuse, equalling or longer than the appendages; seeds broadly winged. In wet soil, Ont. to Minn., Conn., Fla. and La. Aug.-Oct.

II. Gentiana Andréwsii Griseb. Closed or Blind Gentian. (I. F. f. 2876.) Similar to the preceding, stout, glabrous, 3-6 dm. high, simple. Leaves ovate to lanceolate, 3-7-nerved, acuminate, 5-10 cm. long; flowers $2.5-3.5 \mathrm{~cm}$. high in a terminal sessile cluster and commonly $\mathbf{I}$ or 2 in the upper axils: calyxlobes lanceolate or ovate, ciliolate; corolla oblong, club-shaped, blue, or occasionally white, nearly or quite closed, its lobes obsolete, the intervening appendages very broad; seeds oblong, winged. In noist soil, Quebec to the N. W. Terr., Ga. and Mo. Aug.-Oct.

I2. Gentiana flávida A. Gray. Yellowish Gentian. (I. F. f. 2877.) Stem stout, glabrous, simple, 3-9 dm. high. Leaves ovate-lanceolate or oblonglanceolate, acuminate, subcordate, clasping or rounded at the base, $5-13 \mathrm{~cm}$. long; flowers in a sessile terminal cluster and sometimes $\mathbf{I}$ or 2 in the upper axils, 3-5 cm. high; calyx-lohes ovate, acute; corolla campanulate-funnelform, open, greenish or yellowish white, its lobes ovate, twice as long as the erose-denticulate appendages. In moist soil, Ont. to Va., Minn. and Ky. Aug.-Oct.

13. Gentiana lineàris Froel. Narrow-Leaved Gentian. !I. F. f. 2878.) Glabrous; stem slender, terete, simple, 1.5-5 dm. high, leafy. Leaves linear or linear-lanceolate, acute at both ends, 3-nerved, 3-8 cm. long; flowers $2.5-4.5 \mathrm{~cm}$. high in a terminal cluster of $\mathbf{I}-5$ and sometimes also in the upper axils; calyxlobes linear or lanceolate; corolla erect, blue, oblong-funnelform, open, its lobes erect, rounded, 2-4 $\mathrm{mm}$. long, slightly longer than the entire or I-2-toothed appendages. In bogs and on mountains, N. B. and Ont. to Md. Aug.-Sept.

I4. Gentiana rubricaùlis Schwein. Red-Stemmed Gentian. (I. F. f. 2879.) Glabrous; stem terete, 3-6 dm. high. Leaves rather distant, lanceolate or ovatelanceolate, rounded at the base, $5-8 \mathrm{~cm}$. long, the lower narrower and obtuse; flowers $3-3.5 \mathrm{~cm}$. high in a sessile terminal cluster; calyx-lobes unequal; corolla greenish blue or bright blue, club-shaped, its lobes ovate, acute or acutish, much longer than the I-2-toothed appendages. In wet soil, N. B. to N. Y., Ont. and Minn. Aug.-Sept.

I5. Gentiana villòsa L. Striped Gentian. (I. F. f. 288o.) Glabrous or nearly so; stem simple, terete, I.5-5 dm. high. Leaves obovate, obtuse or the upper acute, faintly 5-nerved, $2-8 \mathrm{~cm}$. long, the lower much smaller; flowers in a terminal sessile cluster and sometimes also in the upper axils, nearly $5 \mathrm{~cm}$. long; calyx-lobes unequal, linear, longer than the tube; corolla greenish white, striped within, oblong funnelform, open, its lobes erect, much longer than the oblique 
entire or I-2-toothed appendages. In shaded places, N. J. and Penn. to Fla. and La. Sept.-Nov. [G. ochroleuca Froel.]

16. Gentiana Porphýrio J. F. Gmel. One-Flowered Gentian. (I. F. f. 288I.) Glabrous; stem r.5-4.5 dm. high. Leaves linear, firm, 2-5 cm. long, 2-4 $\mathrm{mm}$. wide, or the upper and lower shorter; flowers short-peduncled, about $5 \mathrm{~cm}$. high; calyx-lobes linear, longer than the tube; corolla funnelform, bright blue, sometimes brown-dotted within, its lobes ovate, spreading, r-r. $5 \mathrm{~cm}$. long, three times as long as the laciniate appendages, or more; seeds oblong, wingless. In moist pine barrens, southern N. J. to Fla. Aug.-Oct.[G. angustifolia Michx.]

\section{PLEURÓGYNE Eschol.}

Slender annual glabrous herbs, with opposite leaves, and rather large flowers in terminal racemes or panicles, or sulitary at the ends of the peduncles. Calyx deeply 4-5-parted; segments narrow. Corolla rotate, 4-5-parted; lobes ovate or lanceolate, convolute, acute, with a pair of narrow appendages at the base. Stamens 4 or 5 , inserted on the corolla-tube. Ovary $\mathbf{I}$-celled; ovules numerous; style none; stigma decurrent along the sutures of the ovary. Capsule 2 valved. Seeds small, numerous. [Greek, referring to the lateral stigmatic surfaces.] About 7 species, of the colder parts of the northern hemisphere.

Leaves linear or lanceolate; sepals linear.

Leaves spatulate or lanceolate; sepals ovate to lanceolate.

I. P. rotata.

2. P. Carinthiaca.

I. Pleurogyne rotàta (L.) Griseb. Pleurogyne. (I. F. f. 2882.) Stem erect, I-4 dm. high. Leaves $\mathrm{I}-5 \mathrm{~cm}$. long, 2-4 $\mathrm{mm}$. wide, the basal spatulate or oblong; sepals about the length of the lanceolate to oblong-lanceolate corolla-segments, which are 8-12 mm. long; capsule narrowly oblong. Greenland and Lab. to Alaska, south in the Rocky Mts. to Colo. Also in Europe and Asia. Summer.

2. Pleurogyne Carinthiaca (Wulf.) Griseb. Smaller Pleurogyne. (I. F.f. 2883. Similar to the preceding, but mostly snaller and more slender, rarely over I. $5 \mathrm{dm}$. high, the stems or branches I-few-flowered; leaves spatulate, ovate, oblong, or lanceolate, 6-12 $\mathrm{mm}$. long; sepals ovate to lanceolate, shorter than the corolla-segments or at length equalling them, these 6-12 mm. long, ovate, and acute; capules ovoid-oblong. Lab. and Quebec. The American plant was separated from the European by Dr. Gray as var. pusilla.

\section{FRÀSERA Walt.}

Perennial or biennial erect glabrous herbs, with opposite or verticillate leaves, and rather large flowers in terminal cymose panicles or thyrses. Calyx 4-parted. Corolla rotate, 4-parted, the lobes convolute in the bud, each bearing I or 2 fringed glands within. Stamens 4, inserted on the base of the corolla-tube; filaments sometimes united at the base; anthers versatile. Ovary ovoid, I-celled; style distinct; stigma 2-lobed or nearly entire. Capsule ovoid, coriaceous, compressed, 2-valved, few-seeded. Seeds flattened, smooth, margined or narrowly winged. [In honor of John Fraser, a botanical collector.] Eight species, natives of N.Am.

I. Frasera Carolinénsis Walt. American Columbo. (I. F. f. 2884.) Stem 9-12 dm. high, stout. Leaves mostly verticillate in 4's, those of the stem lanceolate or oblong, acute or acutish, 7-15 cm. long, the basal ones spatulate or oblanceolate, usually larger, the uppermost bract-like; inflorescence often $6 \mathrm{dm}$. long; flowers slender-pedicelled, about $2.5 \mathrm{~cm}$. broad; corolla yellowish white with brown-purple dots, its lobes broadly ob.ong, bearing a circular long-fringed gland; capsule much compressed, $\mathbf{r}-\mathbf{r} .6 \mathrm{~cm}$. high, longer than the calyx. In dry soil, western N. Y. and Ont. to Wis.. Ga. and Ky. June-Aug.

\section{TETRAGONÁNTHUS S. G. Gmel.}

[HALENIA Borck.]

Glabrous herbs, with opposite leaves, and middle-sized flowers in often panicled cymes. Calyx deeply 4 cleft or 4 parted. Corolla campanulate, 4-5-cleft, the lobes convolute in the bud, each with a hollow spur or projection below. Stamens 4 or 5 , inserted near the base of the corolla; anthers versatile. Ovary I-celled, the placentæ more or less intruded; ovules numerous; style short, or none; stigma 2-lobed. Capsule 2-valved. Seeds globose-ovoid, smooth. [Greek, allud- 
ing to the 4-parted flowers.] About 30 species, natives of N. Am., S. Am. and Asia. Besides the following, another occurs in the southwestern U. S.

I. Tetragonanthus defléxus (J. E. Simith) Kuntze. Spurred Gentian. (I. F. f. 2885.) Annual; stem I.5-5 dm. high. Basal leaves obovate or spatulate, obtuse, narrowed into petioles; stem-leaves ovate or lanceolate, acute, sessile, 3-5. nerved, $2-5 \mathrm{~cm}$. long, the uppermost smaller; calyx-segments acute or acuminate; corolla purplish or white, about $8 \mathrm{~mm}$. high, its lobes ovate, acute, the spurs deflexed or descending, one-fourth to one-half the length of the corolla; capsule 12I $4 \mathrm{~mm}$. long, about twice as long as the calyx. In moist woods and thickets, Lab. to Mass., N. Y., Mich. and the Ind. Terr. July-Aug.

Tetragonanthus defléxus Brentoniànus (Griseb.) Britton. Low, 0.7-2 dm. high; spurs shorter and thicker, perhaps specifically distinct. Newf. to Anticosti and Lab.

Tetragonanthus defléxus heteranthus (Griseb.) Britton. Corollas spurless, or oniy the earliest spur-bearing. the lower flowers mostly smaller than the upper. Newf. to Me. [Halenia heterantha Griseb.]

\section{OBOLÀRIA L.}

A low glabrous perennial herb, the lower leaves reduced to opposite scales, the upper foliaceous, subtending the racemose-spicate or thyrsoid. white or purplish flowers. Calyx of 2 spatulate sepals. Corolla oblong-campanulate, 4-cleft, the lobes imbricated, at least in the bud. Stamens 4, inserted in the sinuses of the corolla. Ovary I-celled, with 4 internal placental projcctions; ovules numerous; style distinct; stigma 2-lamellate. Capsule ovoid, 2-valved or irregularly bursting. Seeds minute, covering the whole interior of the capsule. [Greek, olbolus, a coin, alluding to the thick round leaves.] A monotypic genus.

I. Obolaria Virgínica L. Pennywort. (I. F. f. 2886.) Stems 7-15 cm. high from a perennial root of thick fibres, bearing 2-6 pairs of thick small obtuse scales. Floral leaves broadly obovate-cuneate, obtuse; purplish, 8-12 mm. long; flowers sessile or nearly so in the axils, in clusters of I-4, and terminal; corolla about I $\mathrm{cm}$. long, cleft to about the middle, the lobes oblong, obtuse; stamens included; capsule $5 \mathrm{~mm}$. long. In rich woods and thickets, N. J. to Ga., Ill. and Tex. April-May.

\section{BARTònia Muhl. (See Appendix.)}

Slender or filiform erect glabrous annual or biennial herbs, the leaves reduced to minute opposite scales, or these sometimes alternate, and small white or yel. lowish racemose or paniculate flowers, or these rarely solitary and terminal. Calyx deeply 4-parted, the segments acuminate, keeled. Corolla campanulate, deeply 4-cleft, the lobes imbricated in the bud. Stamens 4, inserted at the sinuses of the corolla. Ovary I-celled, the placentæ intruded; ovules numerous; style short or none; stigma 2-lobed. Capsule ovoid-oblong, acute, 2-valved. Seeds minute, covering the whole inner surface of the capsule. [In honor of Professor Benjamin Smith Barton, I766-1815, of Philadelphia.]

Corolla yeilowish, 3-4 mm. long, its lobes oblong.

Corolla purplish tinged, 4-5 mm. long, its lobes broadly oblong.

Corolla white, 6-8 mm. long, its lobes spatulate.

I. B. Virginica.

2. B. iodandra.

3. B. verna.

I. Bartonia Virgínica (L.) B.S.P. Yellow Bartonia. (I. F. f. 2887.) Stem almost filiform, I-4 dm. high, simple, or with few erect branches above, 5-angled, yellowish green. Subulate scales 2-4 mm. long, appressed; flowers mostly opposite, peduncled; peduncles ascending or erect, 4-12 mm. long; corolla somewhat exceeding the calyx; stamens included; stigma $2 \mathrm{~mm}$. long; ovary 4sided; capsule about $3 \mathrm{~mm}$. long. In moist soil, Newf. to Fla., Mich. and La. July-Sept. [B. tenella Willd.]

2. Bartonia iodindra Robinson. Purplish Bartonia. Stem 4-25 cm. high, simp!e or alternately branched above the middle. Scales alternate, $2-3 \mathrm{~mm}$. long; pedicels mostly I-flowered: corolla distinctly purplish, about twice as long as the calyx. its lobes obtusish, mucronate; stigma short, thick. In sphagnum, Newf. to N. J. [B. Moseri of Ill. Fl., in part.]

3. Bartonia vérna (Michx.) Muhl. Whire BıRtonia. (I. F. f. 2888.) Stem usually simple, 0.5-4 din. high, racemosely or corymbosely I-several-flowered. 
Scales appressed, some of them commonly alternate: flowers solitary at the ends of the elongated erect peduncles; peduncles sometimes $5 \mathrm{~cm}$. long; corolla about 3 times the length of the calyx; ovary compressed; capsule about $5 \mathrm{~mm}$. high. In swamps, southern Va. to Fla. and La. March-May.

\section{Family 4. MENYANTHÀCEAE G. Don.}

\section{Buckbean Family.}

Perennial aquatic or marsh herbs, with basal or alternate leaves, and clustered regular perfect flowers. Calyx inferior, deeply 5-parted, persistent. Corolla 5-lobed or 5-cleft, the lobes induplicate-valvate, at least in the bud. Stamens 5, borne on the corolla, and alternate with its lobes; anther-sacs longitudinally dehiscent; pollen-grains 3-angled. Ovary I-celled, the 2 placentæ sometimes intruded. Fruit a capsule, or indehiscent. Five genera and about 35 species, widely distributed.

Leaves 3 -foliolate; swamp plant.

Leaves simple, entire, cordate, floating. r. Menyanthes.

2. Limnanthemum.

\section{MENYÁNTHES L.}

A glabrous marsh herb, with creeping rootstocks, long-petioled 3-foliolate basal leaves, and white or purplish flowers, racemose or panicled on long lateral scapes. Calyx 5-parted. Corolla short-funnelform, 5-cleft, its lobes induplicate-valvate, fimbriate or bearded within. Stamens 5, on the tube of the corolla; anthers sagittate. Disk of 5 hypogynous glands. Ovary I-celled; style subulate; stigma 2-lamellate. Capsule oval, indehiscent or finally rupturing. Seeds few, compressed-globose, shining. [Greek, perhaps month-flower.] A monotypic genus.

I. Menyanthes trifoliàta L. Buckbean. MARsh OR BEAN Trefoil. BOG-BEAN. (I. F. f. 2889.) Rootstocks thick, scaly, sometimes $3 \mathrm{dm}$. long. Petioles sheathing at the base; leaflets oblong or obovate, entire, obtuse, narrowed to the sessile base, $3-8 \mathrm{~cm}$. long; raceme 10-20-flowered; pedicels $6-25 \mathrm{~mm}$. long, bracteolate at the base; flowers 10-1 $2 \mathrm{~mm}$. long; calyx shorter than the white or purplish corolla; capsule ovoid, obtuse, atout $8 \mathrm{~mm}$. long. In bogs, Greenland to Alaska, L. I., Penn., Neb. and Cal. Also in Europe and Asia. May-July.

\section{LIMNÁNTHEMUM S. G. Gmelin.}

Aquatic herbs, with slender rootstocks. Leaves petioled; ovate or orbicular, entire or repand, or the primary ones different; flowers yellow, or white, umbellate at the summit of filiform stems at the bases of the petioles, or axillary. Calyx 5parted. Corolla nearly rotate, deeply 5-cleft, the lobes induplicate valvate in the bud, sometimes fimbriate on the margins. Stamens 5, inserted on the base of the corolla; anthers sagittate, versatile. Ovary I-celled; style short or none; stigma 2-lamellate. Capsule indehiscent or irregularly bursting. [Greek, pool-blossom.] About 20 species, widely distributed.

Flowers accompanied by tufts of root-like tubers; native species.

Floating leaves 2-5 cm. long; flowers 6-12 mm. broad, yellow; seeds smooth.

I. L. lacunosum.

Floating leaves $5^{-15} \mathrm{~cm}$. long; flowers $12-20 \mathrm{~mm}$. broad, white; seeds rough.

2. L. aquaticum.

Flowers not accompanied by tufts of tubers; flowers bright yellow, $25 \mathrm{~mm}$. broad, or more; introduced species.

3. L. nymphaeoides.

I. Limnanthemum lacunòsum (Vent.) Griseb. Floating Heart. (I. F. f. 289o.) Primary leaves membranous, submerged, short-petioled; stems (stolons) filiform, sometimes $3 \mathrm{~m}$. long, bearing a short petioled floating leaf, an umbel of flowers and a cluster of narrow tubers at its summit, or some of the floating leaves on petioles as long as the stems; floating leaves ovate-orbicular, purplish beneath; pedicels slender; tubers linear-conic. $\mathbf{I}-2.5 \mathrm{~cm}$. long; capsule covered by the connivent calyx-segments. In ponds, N. S. to Fla., Ont., Minn. and La. July-Aug.

2. Limnanthemum aquáticum (Walt.) Britton. LARGer FloAting Heart. (I. F. f. 28gI.) Similar to the preceding but stouter and larger. Floating leaves 
cordate-orbicular, thick, entire or repand, spongy, and with the petioles and stolons densely covered with minute pits; primary leaves spatulate; tubers linear-oblong, thicker; seeds rough; capsule longer than the calyx. In ponds, N. J. and Del. to Fla. and Tex. May-Aug. [L. trachyspermum A. Gray.]

3. Limnanthenum nymphaeoides (L.) Hoffm. \& Link. Water LiLy Floating Heart. (I. F. f. 2892.) Stems long, branched, the upper nodes bearing a petioled leaf and a cluster of flowers, or the upper internodes very short and their leaves apparently opposite. Petioles stout, mostly longer than the ovateorbicular firm blades, which are $5-10 \mathrm{~cm}$. broad; pedicels stout, becoming 7-15 $\mathrm{cm}$. long; corolla-segments short-fringed. Nat. in ponds, D. C. Native of Europe and Asia. May-July.

\section{Family 5. APOCYNÀCEAE Lindl.}

\section{Dogbane Family.}

Perennial herbs, shrubs, vines, or some tropical genera trees, mostly with an acrid milky juice, with simple estipulate leaves, and perfect regular 5-parted flowers. Calyx inferior, persistent, the lobes imbricated in the bud. Corolla gamopetalous, its lobes convolute in the bud and often twisted. Stamens as many as the lobes of the corolla, alternate with them, inserted on the tube or throat; anthers 2-celled; pollen-grains simple. Ovary superior, or its base adherent to the calyx, of 2 distinct carpels, or I-celled, with 2 parietal placentæ, or 2-celled; ovules anatropous or amphitropous ; style simple. or 2-divided; stigma simple. Fruit usually of 2 follicles or drupes. Seeds often appendaged; endosperm fleshy; embryo straight; radicle terete, usually shorter than the cotyledons. About 130 genera and 1050 species, very widely distributed, mostly in tropical regions.

Leaves alternate; erect herbs.

Leaves opposite; vines or herbs.

Flowers large, axillary, solitary.

Flowers snall, cymose.

Erect or diffuse herbs; corolla campanulate to urceolate. High-climbing vines; corolla funnelform.
1. Amsonia.

2. Vinca.

3. Apocynum.

4. Trachelospermum.

\section{AMSÒNIA Walt.}

Perennial herbs, with alternate membranous leaves, and rather large blue or bluish flowers, in terminal thyrsoid or corymbose cymes. Calyx 5-parted, the segments acuminate. Corolla mostly salverform, the tube cylindric, but somewhat dilated at the summit, villous within. Stamens included; anthers ovate or oblong. Disk none. Ovary of 2 carpels, connected at the top by the filiform style; ovules in 2 rows in each cavity, numerous; stigm $x$ appendaged by a reflexed membrane. Fruit of 2 erect cylindric several-seeded follicles. Seeds obliquely truncate at each end, not appendaged. [Named for Charles Amson of South Carolina.] About I2 species, natives of N. Am. and eastern Asia. Besides the following, 5 others occur in the southern and western U. S.

Leaves ovate to ovate-lanceolate; pods divergent.

Leaves lanceolate to linear-lanceolate; pods ascending.
1. A. Amsonia.

2. A. salicifolia.

I. Amsonia Amsònia (L.) Britton. Broad-leaved Amsonia. Glabrous or nearly so, 6-12 dm. high. Leaves ovate or ovate-lanceolate, entire, acuminate, narrowed at the base, sometimes pubescent beneath, 5-10 $\mathrm{cm}$. long, 2-5 cm. wide; petioles 4-8 $\mathrm{mm}$. long; pedicels bracteolate at the base; calyx about $2 \mathrm{~mm}$. long, its segments subulate: corolla I2-1 $8 \mathrm{~mm}$. long, beaked by the convolute limb in the bud, its lobes linear and about as long as the tube; follicles $5^{-10} \mathrm{~cm}$. long, about $4 \mathrm{~mm}$. thick, attenuate at the apex, glabrous; seeds papillose. In moist soil, N. J. to Mo., Ky., Fla. and Tex. April-July. [A. Tabernaemontana Walt.]

2. Amsonia salicifolia Pursh. Willow. Leavied Amsonia. Similar to the preceding, but the leaves much narrower, lanceolate to linear-lanceolate, $8-15 \mathrm{~cm}$. 
long, IO-20 mm. wide; pods ascending, stem often much stouter. Tenn. to Kans. Fla. and La. April-June.

\section{VÍNCA L.}

Herbs, some species slightly woody, with opposite leaves, and large solitary axillary flowers. Calyx 5-parted, the segments acuminate. Corolla salverform, the tube pubescent within, the lobes oblique. Stamens included. Disk of 2 glands, alternate with the 2 carpels. Ovules several in each carpel; style filiform; stigma annular, its apex penicillate. Follicles 2, cylindric, several-seeded. Seeds oblongcylindric, truncate at each end. ['The Latin name.] About 12 species, one native of tropical Am., occurring in Fla., the others of the Old World.

I. Vinca minor L. Periwinkle. Myrtle. (I. F. f. 2894.) Perennial, trailing, glabrous; stems 1.5-6 dm. long. Leaves oblong to ovate, entire, firm, shining, green both sides, narrowed at the base, short-petioled, 2-6 cm. long; flowers blue, 1.8-3 cm. broad; peduncles I-4 cm. long; calyx-segments subulatelanceolate, glabrous; corolla-tube expanded above, as long as or slightly longer than the obovate, nearly truncate lobes; anther-sacs with a broad connective. Escaped from gardens, Ont. to Conn., N. Y., N. J. and Ga. Native of Europe. Feb.-May.

\section{APÓCYNUM L.}

Perennial herbs, with opposite entire leaves, and small white or pink flowers in corymbed cymes. Calyx 5-parted, the segments acute. Corolla campanulate, the tube bearing within 5 small triangular appendages alternate with the stamens, the limb 5-lobed. Stamens inserted $\mathrm{n}$ the base of the corolla; anthers sagittate, connivent around the stigma and slightly adherent to it. Disk 5-lobed. Uvary of 2 carpels; ovules numerous; stigma ovoid, obtuse, obscurely 2 -lobed. Follicles slender, elongated, terete. Seeds numerous, small, the apex tipped with a long coma. [Greek, dogbine.] About I5 species, of the north temperate zone.

Corolla 5-9 mm. long, its lobes spreading or recurved.

Corolla not angled, pink, its tube narrowed in the throat. r. A. androsaemifolium.

Corolla 5-angled, white or faintly pink, its tube not narrowed in the throat.

Corolla campanulate, $6-7 \mathrm{~mm}$. long.

2. A. medium.

Corolla urceolate to tubular, 4-6 mm. long.

Calyx-segnients triangular-ovate, much shorter than the corolla-tube. 3. A. Milleri.

Caly $\mathrm{x}$-segments lanceolate, about as long as the corolla-tube.

Corolla 3-4.5 mm. long, its lobes erect or nearly so.

4. A. urceolifer.

Leaves and cymes glabrous, or somewhat pubescent.

Leaves petioled, mostly narrowed at the base.

Leaves ovate-oblong to lanceolate, 2-4 times as long as wide: flowers green to whitish.

5. A. cannabinum.

Leaves oblong-lanceolate, 4-6 times as long as wide; flowers white.

6. A. album.

Leaves sessile or very nearly so, mostly cordate-clasping or obtuse at the base.

7. A. hypericifolium.

Whole plant, including the cymes, densely soft-pubescent. 8. A. pubescens.

I. Apocynum androsaemifòlium L. Spreading Dogbane. HoneyBLoom. (I. F. f. 2895.) Rootstock horizontal; stem 3-I5 dm. high; branches broadly spreading, mostly glabrous. Leaves ovate or oval, mucronate, glabrous above, pale and usually more or less pubescent beneath, 5-10 $\mathrm{cm}$. long; petiol $\mathrm{s}$ 4-8 mm. long; cymes loose, usually both terminal and axillary; pedicels 4- Io $\mathrm{mm}$. long, subulate-bracted at the base; flowers about $8 \mathrm{~mm}$. broad; calyx-segments shorter than the terete tube of the pinkish corolla; corolla-lobes revolute, rounded; follicles $10-17 \mathrm{~cm}$. long, narrowed at the apex. In fields and thickets, Anticosti to Br. Col., Ga., Neb. and Ariz. June-July.

2. Apocynum mèdium Greene. Intermediate Dogbane. Rootstock horizontal; stem stout, 7-13 dm. high, the branches ascending, glabrous. Leaves oblong to oval, mucronulate, ascending, 6-9 cm. long, somewliat pubescent beneath; petioles 4-8 mm. long; cymes compact, all terminal; pedicels $3-5 \mathrm{~mm}$. long: fowers erect; calyx-segments about half as lono as the 5-angled corolla-tube; corolla white, 
or faintly pink, 6-7 mm. long, its segments acutish, spreading; pods 7-12 cm. long. Fields and roadsides, Md. and D. C. June-Aug. [A. speciosum G. S. Miller.]

3. Apocynum Milleri Britton. Miller's Dogbane. Slender, seldom over ro dm. high, the branches widely spreading. Leaves oblong to ovate-lanceolate, 6-8 cm. long, mucronate, pubescent beneath; petioles $3-6 \mathrm{~mm}$. long, pubescent; cymes small, terminal, or also in the upper axils; pedicels $2-3 \mathrm{~mm}$. long. Flowers suberect; corolla pinkish, 5-6 mm. long, its rounded segments spreading; pods about $9 \mathrm{~cm}$. long. Dry soil, N. Y. to Md. June-July. [A. medium G. S. Miller, not Greene.]

4. A pocynum urceólifer G. S. Miller. Urn-flowered Dogbane. Similar to the preceding species, and about equally tall; flowers smaller; corolla 4-5 mm. long, white, or merely tinged with pink, its segments pointed, spreading; calyx ahout as long as the corolla-tube. Fields and roadsides, N. Y. to Md. and Mo. June-July.

5. Apocynum cannábinum I. Indian Hemp. Amy-Root. (I. F. f. 2896.) Root deep, vertical. Stem IO-I7 dm. high, the branches erect or ascending. Leaves oblong, lanceolate-oblong or ovate-oblong, mucronate, glabrous above, sometimes pubescent beneath, 5-10 cm. long; petioles 2-15 mm. long, or sometimes none; cymes dense; pedicels short, bracteolate at the base; calyx-segments nearly as long as the tube of the greenish white corolla: follicles $13-20 \mathrm{~cm}$. long. in fields and thickets, Anticosti to Br. Col., Fla. and Lower Cal. June-Aug.

6. Apocynum àlbum Greerie. River-BAnk DogBane. Glabrous; leaves sinaller, oblong-lanceolate, acute at each end, or sometimes rounded at the base, seldom over $7 \mathrm{~cm}$. long and $2 \mathrm{~cm}$. wide, distinctly petioled. On river-shores and similar situations, Me. and Ont. to Wisc., Va. and Mo. June-July.

7. Apocynum hypericifòlium Ait. Clasprng-leaved Dogbane. (I. F. f. 2897.) Glabrous, often glaucous; stem 3-6 dm. high, the branches ascending. Leaves oblong, oblong-lanceolate to oval, 2-8 cm. long, cordate-clasping, rounded, truncate, or the upper narrowed at the base, short-petioled, or sessile, the primary venation forming broad angles with the midvein; cymes many-flowered; pedicels mostly not longer than the flowers, bracteolate; calyx-segments about the length of the corolla-tube, lanceolate, acute; follicles 5-9 $\mathrm{cm}$. long. In dry soil, or along streams, Ont. to Br. Col.; L. I., Ill. and N. Mex. June-Aug.

8. Apocynum pubéscens R. Br. Velvet Dogbane. (I. F. f. 2898.) Whole plant, including the pedicels and calyx, densely velvety-pubescent. Branches ascending; leaves oval to elliptic, strongly mucronate, obtuse or obtusish at the base, the veins impressed in the pubescence of the lower surface; petioles 2-4 mm. long; cymes dense; calyx-segments about as long as the tube of the corolla, lanceolate, acute; corolla apparently purple, its lobes erect; follicles $6-7 \mathrm{~cm}$. long. Va. to Ill., Iowa and Mo.

\section{TRACHELOSPÉRMUM Lemaire.}

Twining woody vines (some exotic species nearly erect shrubs), with opposite entire leaves, and small flowers in compound cymes. Calyx small, deeply 5-parted, glandular within, the segments narrow. Corolla funnelform or salverform, the tube nearly cylindric, expanded above. Stamens included, or short-exserted; anthers sagittate, acuminate, connivent around the stigma. Disk of 5 glandular lobes. Ovary of 2 carpels; ovules numerous; style slender, its a pex thickened below the narrow ring of the ovoid stigma. Follicles much elongated, slender. Seeds linear, not beaked, long-comose at the apex. [Greek, neck-seed, but the seed is not beaked.] About 6 species, natives of eastern Asia and N. Am.

I. Trachelospermum diffórme (Walt.) A. Gray. Trachelospermum. (I. F. f. 2899.) Stems $\mathbf{I} \mathrm{cm}$. in diameter or more. Leaves thin. ovate, oval or lanceolate, acuminate or acute, $3-8 \mathrm{~cm}$. long; peduncles shorter than the leaves; flowers yellow or cream-color, 8-10 $\mathrm{mm}$. long; lobes of the corolla ovate, spread. ing, shorter than the tube; follicles 1.2-2.3 dm. long, scarcely $4 \mathrm{~mm}$. thick. In moist woods and along streams, Del. to Fla., Tex. and Mex., mostly near the coast. June-Aug. 


\section{Family 6. ASCLEPIADÀCEAE Lindl.*}

\section{Milkweed Family.}

Perennial herbs, vines or shrubs, mostly with milky juice, with estipulate leaves, and mostly umbellate perfect regular flowers. Calyx inferior, its tube very short, or none, its segments imbricated or separate in the bud. Corolla campanulate, urceolate, rotate or funnelform, 5-lobed or 5-cleft, the segments commonly reflexed. A 5-lobed or 5-parted crown (corona) between the corolla and the stamens and adnate to one or the other. Stamens 5, inserted on the corolla; filaments short, stout, mostly monadelphous, or distinct; anthers attached by their bases to the filaments, introrsely 2-celled, connivent around the stigma, or more or less united with each other; anther-sacs tipped with an inflexed or erect scarious membrane, or unappendaged at the top, sometimes appendaged at the base; pollen coherent into waxy or granular masses, one or rarely two such masses in each sac, connected with the stigma in pairs or fours, by 5 glandular corpuscles alternate with the anthers. Disk none. Ovary of 2 carpels; styles 2 , short, connected at the summit by the peltate discoid stigma; ovules numerous in each carpel, mostly anatropous, pendulous. Fruit of 2 follicles. Seeds compressed, usually appendaged by a long coma; endosperm cartilaginous; embryo nearly as long as the seed; cotyledons flat. About 220 genera and 1900 species of wide distribution.

Erect or decumbent herbs.

Corona-hoods each with an incurved horn within; leaves mostly opposite.

Corona-hoods prominently crested within; leaves alternate.

I. Asclepias.

Corona-hoods unappendaged or with a thickened crest-like keel; leaves opposite or alternate.

Twining vines.

Corolla-lobes erect; corona-lobes I-2-awned.

Corolla rotate.

3. Acerates.

Anthers tipped with a scarious membrane; pollen-masses pendulous.

Anthers merely tipped; pollen-masses horizontal.

\section{Cynanchum.}

6. Vincetoxicum.

\section{ASCLÉPIAS L. (See Appendix.)}

Perennial herbs, with entire leaves, and middle-sized or small flowers in umbels. Calyx 5-parted or 5-divided. usually small, the segments or sepals acute, often glandular within. Corolla deeply 5-parted, the segments mostly valvate, reflexed in anthesis. Corona-column generally present. Corona of 5 concave hoods, each bearing within a slender or subulate incurved horn. Filaments con. nate into a tube; anthers tipped with an inflexed membrane, winged, the wings broadened below the middle; pollen-masses solitary in each sac, pendulous on their caudicles. Stigma nearly flat, 5-angled or 5-lobed. Follicles usually thick, acuminate. Seeds comose in all but one species. [Dedicated to AEsculapius.] About 85 species, mostly natives of the New World; besides the following some 25 others occur in southern and western N. Am.

* Corolla and corona orange : leaves alternate or opposite.

Stem erect or ascending; leaves nearly all alternate.

Stems reclining; leaves, at least the upper, opposite, oblong or oval.

1. A. tuberosa.

2. A. decumbens.

* * Corolla bright red or purple; leaves opposite.

Flowers 2-4 mm. broad; corona-hoods $4-6 \mathrm{~mm}$. high.

Leaves lanceolate or linear; hoods oblong, obtuse

Leaves ovate or ovate-lanceolate; hoods lanceolate. $\quad$ 4. A. rubra.

3. A. lanceolata.

Leaves oblong, ovate or ovate-oblong; hoods oblong, acutish. 5. A. purpurascens. 
Flowers $1-6 \mathrm{~mm}$. broad; corona-hoods $2-3 \mathrm{~mm}$. ligh.

Plant nearly or quite glabrous; leaves lanceolate or oblong-lanceolate.

Plarit pubescent; leaves oblong.

6. A. incarnata.

7. A. pulchra.

*** Corolla greenish, purplish, yellowish or white; leaves opposite or verticillate.

Leaves ovate, oblong, ovate-lanceolate, obovate or orbicular.

Plants glabrous throughout, or minutely pubescent above.

Leaves sessile, clasping or very short-petioled.

Peduncles of the solitary or several umbels short.

Leaves ovate-oblong; hoods 2-auriculate at the base.

Leaves nearly orbicular; hoods truncate.

Peduncle of the usually solitary umbel elongated.

Leaves cordate-clasping, wavy-margined.

Leaves sessile, flat; horn not exceeding the hood.
8. A. Sullivantii.
9. A. latifolia.

o. A. ainplexicaulis.

II. A. Meadii.

Leaves manifestly petioled.

Corolla greenish; umbels loose; pedicels drooping. 12. A. exaltata.

Corolla white; umbels dense. $\quad$ 13. A. variegata.

Corolla pink; some of the leaves verticillate in 4's. I4. A. quadrifolia.

Plants, at least the lower surfaces of the leaves, canescent or tomentose.

Follicles tomentose, covered with soft spinose processes.
Corona-hoods obtuse, short.
Corona-hoods elongated, lanceolate.
15. A. Syriaca.
16. A. speciosa.

Follicles with no spinose processes, glabrous or pubescent.

Leaves wavy-margined; corolla-segments 9-1I mm. long.

Leaves flat; corolla-segments $4-6 \mathrm{~mm}$. long.

17. A. arenaria.

18. A. ovalifolia.

Leaves lanceolate, oblong-lanceolate or linear.

Leaves opposite, lanceolate or oblong-lanceolate.

Leaves thick, short-petioled; inflorescence woolly.

Leaves thin, slender-petioled; inflorescence downy.

Leaves mostly verticillate in 2 's -6 's, narrowly linear.

Hoods entire.

Hoods dorsally hastate-sagittate.

Leaves scattered, densely crowded, filiform-linear.

19. A. brachystephana.

20. A. perennis.

21. A. verticillata.

22. A. galioides.

23. A. pumila.

I. Asclepias tuberòsa L. Butterfly-weed. Pleurisy-root. (I. F. f. 2900.) Hirsute pubescent; stems stout above, very leafy, 3-6 dm. high, the milky sap scanty. Leaves usually all alternate, lanceolate or oblong, sessile or shortpetioled, 5-15 cm. long; umbels cymose, many-flowered; peduncles shorter than the leaves; pedicels pubescent; corolla-segments oblong, obtuse, about $6 \mathrm{~mm}$. long, greenish; hoods erect, oblong, bright orange, or rarely yellow, 2-3 times as long as the stamens, slightly longer than the filiform horns; fruiting pedicels decurved; follicles nearly erect, finely pubescent, $10-12 \mathrm{~cm}$. long. In dry fields, Me. and Ont. to Minn., Fla., Tex. and Ariz. June-Sept.

2. Asclepias decúmbens L. Decumben'r Butterfly-weed. (I. F. f. 2901.) Hirsute-pubescent; stems 6-9 dm. long, the ends ascending or erect. Leaves sessile or short-petioled, oblong or elliptic, obtuse at the apex, narrowed and often inequilateral at the base, 5-8 cm. long, the upper opposite, the lower commonly alternate, the uppermost very small; umbels racemose along the branches; peduncles stout; pedicels slender, somewhat pubescent; corolla segments oblong, acutish, about $6 \mathrm{~mm}$. long; the hoods erect, oblong, orange, slightly longer than the subulate horn; follicles more slender than in the preceding. In dry fields, Conn. to Ill., Ohio, N. Car. and Fla. June-Aug.

3. Asclepias lanceolàta Walt. Few-Flowered Milkweed. (I. F. f. 2902.) Nearly glabrous; stem usually simple, naked above, 6-12 dm. high. Leaves opposite, distant, elongated, acuminate, narrowed at the base, short-petioled, IO-25 $\mathrm{cm}$. long, roughish on the margins, the primary nerves widely spreading; umbels few-flowered, solitary or 2-4 at the summit; peduncles about equalling the slender puberulent pedicels; corolla-segments oblong, 9-I I mm. long, deep red; hoods obovate or oblong, 2-toothed near the base, nearly twice the length of the anthers and longer than the subulate incurved horn; anther-wings notched at the base; fruiting pedicels decurved; follicles erect, minutely puberulent, fusiform, about I dm. long. In swamps, N. J. to Fla. and Tex., mostly near the coast. June-Aug. 
4. Asclepias rùbra L. Red Milkweed. (I. F. f. 2903.) Nearly glabrous; stem usually simple, 3-I $2 \mathrm{dm}$. high. Leaves opposite, rather distant, short-petioled, rounded or subcordate at the base, gradually acuminate, rather firm, $I-2 \mathrm{dm}$. long, the primary nerves wide-spreading; umbels I-4, many-flowered; peduncles shorter than or equalling the upper leaves; pedicels slender, downy; corolla purplish red, or the hoods orange-red, 6-9 mm. long; horns of the hoods very slender, nearly straight; fruiting pedicels deflexed, the follicles erect, spindle-shaped, glabrous, about I dm. long. Moist soil, N. J. and Penn. to Fla., La. and Tex. June-July.

5. Asclepias purpuráscens L. Purple Milkweed. (I. F. f. 2904.) Stem stout, puberulent or glabrous, usually simple, 6-I2 dm. high, leafy to the top. Leaves petioled, mucronulate, nearly glabrous above, finely tomentose beneath, 8$20 \mathrm{~cm}$. long, the primary nerves wide-spreading: umbels many-flowered; peduncles stout; pedicels slender, puberulent; corolla deep purple, its segments oblong, about $6 \mathrm{~mm}$. long; hoods nearly twice as long as the anthers, pale red or purple, the horns broad at the insertion, short-subulate and incurved at the apex; fruiting pedicels deflexed, the downy follicles nearly erect $\mathbf{I O}-\mathbf{I} 3 \mathrm{~cm}$. long. In dry fields and thickets, Mass. to Va., Ont., Minn. and Kans. June-Aug.

6. Asclepias ing [. ?] slender, 6-12 dm. high, leafy to the top. Leaves acuminate, 8-15 cm. long, the primary nerves not wide-spreading; umbels usually numerous, many-flowered; pedicels pubescent; corolla re 1 or rose-purple, rarely white, its lobes oblong, about $4 \mathrm{~mm}$. long; horns incurved, longer than the hoods, obtuse, pink or purplish; anther-wings entire, or obscurely notched at the base; fruiting pedicels erect or incurved: follicles erect, 5-9 cm. long, sparingly puberulent. In swamps, N. B. to the N. W. Terr., Tem., La. and Kans. July-Sept.

7. Asclepias púlchra Ehrh. Hairy Milkweed. (I. F. f. 2906.) Similar to the preceding; stem stout, tomentose-pubescent, 6-10 dm. high, leafy to the top. Leaves acute, acuminate or some of them obtusish, pubescent, at least on the veins beneath, 7-I $3 \mathrm{~cm}$. long; petioles usually short; flowers similar to those of $A$. incarnata, but the corolla commonly lighter red or pink, rarely white; peduncles and pedicels tomentose; fruiting pedicels erect or incurved; follicles erect, finely and densely pubescent, $5-8 \mathrm{~cm}$. long. In moist fields and swamps, Me. to Minn. and Ga. July-Sept.

8. Asclepias Sullivántii Engelm. Sullivant's Milkweed. (I. F. f. 2907.) Stem stout, 6-I2 dm. high, leafy to the top. Leaves thick, oblong or ovateoblong, usually obtuse and mucronulate at the apex, subcordate, rounded or slightly clasping at the base, IO-I5 cm. long, the primary nerves very wide. spreading; umbels terminal and sometimes also in the upper axils, many-flowered; peduncles shorter than the leaves; corolla-segments oval-oblong, II-I3 mm. long, purplish; hoods oval, obtuse or truncate, longer than the anthers and the subulate incurved horn; follicles erect, glabrous, $8-10 \mathrm{~cm}$. long, usually with blunt processes near the apex. In moist soil, Ohio to Minn., Neb., Mo. and Kans. July-Sept.

9. Asclepias latifòlia (Torr.) Raf. BRoAd-Leaved Milkweed. (I. F. f. 2908.) Stem stout, usually simple, 3-7 dm. high, very leafy. Leaves very thick, oval to orbicular, commonly broadly emarginate and mucronulate at the apex and cordate or subcordate at the base, $10-15 \mathrm{~cm}$. long and nearly as wide, primary nerves very wide-spreading; umbels $2-4$, many-flowered, short-peduncled in the upper axils or rarely terminal; pedicels slender, canescent; corolla-segments ovate, acute, 9-I $3 \mathrm{~mm}$. long, greenish; hoods about equalling the anthers, the horn projecting from a short crest over the edge of the stigma; follicles erect on deflexed pedicels, ovoid, acutish, 5-8 cm. long, about $2.5 \mathrm{~mm}$. thick. On dry plains, Neb. to Colo., Tex. and Ariz. July-Sept.

ro. Asclepias amplexicaulis J. E. Smith. Blunt-leaved Milkweed (I. F. f. 2909.) Nearly glabrous, pale green, somewhat glaucous; stem erect or ascending, 6-9 dm. high. Leaves oblong or ovate oblong, obtuse and mucronu. late, $8-13 \mathrm{~cm}$. long; primary nerves wide-spreading; umbel many-flowered, rarely with a second shorter-peduncled one at its base; pedicels slender, downy, about $2.5 \mathrm{~cm}$. long; corolla-segments oblong, greenish purple, about $9 \mathrm{~mm}$. long; hoods pink, nearly truncate and toothed at the summit, shorter than the subulate incurved horn; follicles erect on the stout decurved fruiting pedicels, downy, 
ro-1 $5 \mathrm{~cm}$. long. In dry fields, mostly in sandy soil, Me. to Fla., Minn., Kans. and T'ex. May-Aug. [A. obtusifolia Michx.]

I I. Asclepias Mèadii Torr. Mead's Mrlkweed. (I. F. f. 29IO.) Nearly glabrous throughout, pale green or glaucous; stem simple, or rarely branched above, 3-6 dm. high. Leaves flat, mostly distant, ovate, ovate-lanceolate, lanceolate or the lower oblong, the margins scabrous; umbel several-flowered, borne on a peduncle 8-15 cm. long; corolla-segments greenish yellow, ovate, acute, 6-9 mm. long; hoods ovate, purplish, nearly twice as long as the anthers, rounded and truncate at the summit, longer than the subulate inflexed horn, with'a small tooth at each side on the inner infolded margin; follicles erect on decurved pedicels, puberulent, narrow, IO-I $2 \mathrm{~cm}$. long. Dry soil, Ill. to Iowa and Wisc. June-Aug.

r2. Asclepias exaltàta (L.) Muhl. Poke or TAll Milkiveed. (I. F. f. 29I1.) Nearly glabrous throughout, with two opposite lines of pubescence on the usually simple stem, I-2 m. high. Leaves thin or membranous, oval, ovate or oblong, acuminate at both ends, IO-23 cm. long, 3-10 $\mathrm{cm}$. wide, the lower some. times obovate, obtuse, shorter; peduncles $2.5^{-8} \mathrm{~cm}$. long; umbels usually several; pedicels slender, drooping or spreading, 2.5-5 cm. long, puberulent; corolla-segments ovate or oblong, obtusish, 6-9 mm. long; hoods white or pink, slightly shorter than the anthers, much shorter than the subulate horn, at the summit truncate and entire or erose, with I or 2 slender teeth on each of the inner margins; follicles erect on the deflexed pedicels, downy, long-acuminate, $10-15 \mathrm{~cm}$. long. In thickets and woods, Me. to Minn., Ga. and Mo. June-Aug.

I3. Asclepias variegàta L. White Milkweed. (I. F. f. 29I2.) Stem glabrous below, pubescent above when young, simple, 3-9 dm. high. Leaves thick, oval, ovate, oblong or the lower somewhat obovate, obtuse and cuspidate or acutish, dark green above, pale beneath, $6-15 \mathrm{~cm}$. long, the middle ones sometimes verticillate in 4's; petioles 6-25 mm. long; umbels I-4, terminal, or rarely 1 or 2 in the upper axils, densely many-flowered; pedicels erect or ascending, usually densely puberulent; corulla-segments ovate or oval, about $6 \mathrm{~mm}$. long, white, or purple near the base; column purplish; hoods globose-obovoid, obtuse, spreading, longer than the anthers, about equalling the semilunate horizontally pointed horn; follicles downy, erect on the deflexed fruiting pedicels, 10-13 cm. long. In dry woods and thickets, Conn. to Ill., Fla., Ark. and La. June-July.

14. Asclepias quadrifòlia Jacq. Four-Leaven Milkweed. (I. F. f. 2913.) Stem slender, simple, 3-6 dm. high, usually leafless below. Leaves thin, sparingly pubescent on the veins beneath, ovate to lanceolate, $5^{-15} \mathrm{~cm}$. long, acute or acuminate, or the lowest pair much smaller, obovate and obtuse; umbels I-4, terminal, or rarely in the upper axils; peduncles slender; corolla-lobes lanceolateoblong, 4-6 mm. long; hoods white, obtuse at the a pex, broadly 2 -toothed above the base, twice as long as the anthers and the incurved horn; follicles erect on the erect fruiting pedicels, $8-13 \mathrm{~cm}$. long, glabrous. Woods and thickets, Me. and Ont. to Minn., N. Car. and Ark. May-July.

I5. Asclepias Syriaca L. Comion Milkweed. Silkweed. (I. F. f. 2914.) Stem stout, usually simple, 9-I5 din. high, finely pubescent at least above. Leaves oblong, oval or ovate, densely pubescent beneath, soon glabrous above, Io$23 \mathrm{~cm}$. long, the primary nerves wide-spreading; petioles stout, 6-17 mm. long; umbels several or numerous; peduncles pubescent or tomentose, 3-9 cm. long; pedicels $2.5-5 \mathrm{~cm}$. long; corolla green-purple, its segments oblong-lanceolate, 6-9 $\mathrm{mm}$. long; hoods ovate-lanceolate with a tooth on each side, longer than the anthers and the incurved horn; follicles 6-13 cm. long, erect on recurved pedicels. In fields and waste places, N. B. to the N. IV. Terr., N. Car. and Kans. Leaves rarely lanceolate. June-Aug. [A. Cornuti Dec.]

I6. Asclepias speciòsa Torr. Showy Milkweed. (I. F. f. 29I5.) Whitetomentose or canescent all over, or glabrate below, pale; stem simple, stout, 3-7 $\mathrm{dm}$. high. Leaves thick, broadly ovate or oval, petioled, $8-20 \mathrm{~cm}$. long; peduncles $2.5-7 \mathrm{~cm}$. long; umbels several or rarely solitary, many-flowered; pedicels stout; corolla purple-green, its segments oblong or ovate-oblong, 9-13 mm. long, tomentose on the outer face; column very short or none; hoods lanceolate, II-I5 $\mathrm{mm}$. long, obtusish, expanded and with 2 blunt teeth below, the apex ligulate, 5-7 times as long as the anthers; horn short, inflexed; follicles erect or spreading on 
the recurved fruiting pedicels, 7-10 $\mathrm{cm}$. long. In moist soil, Minn. to $\mathrm{Br}$. Col. Kans., Utah and Cal. May-July.

I7. Asclepias arenària Torr. SAnd Milkweed. (I. F. f. 29I6.) Densely tomentose-canescent all over; stems simple, ascending or erect, stout, 3-6 dm. high. Leaves obovate or oval, thick, obtuse or retuse and cuspidate at the apex, truncate, subcordate, obtuse, or rarely some of them narrowed at the base, 5-10 $\mathrm{cm}$. long, the angle of the primary nervation broad; umbels densely many-flowered, short-peduncled or sessile; corolla yreenish white, its segments oval oblong: hoods oblong, truncate at each end, oblique at the apex, longer than the anthers, with a broad tooth on each side within; horn semi-lunate with an abruptly incurved subulate apex; follicles puberulent, 5-IO cm. long, erect on the decurved fruiting pedicels. On sand-bars and hills, Neb. and Colo. to Mex. and N. Mex. June-Sept.

18. Asclepias ovalifòlia Dec. Oval-leaved Milkwort. (I. F. f. 29I7.) Finely tomentose all over; stem simple, usually slender, erect, 3-6 dm. high. Leaves oval, ovate, oblong 'or ovate-lanceolate, $5-8 \mathrm{~cm}$. long, short-petioled, the upper surfaces becoming glabrate; umbels solitary or few, many-flowered; peduncles short; corolla greenish-white or purplish, its segments ovate-oblong, olstuse: hoods oval-oblong, nearly twice as long as the anthers, bearing a large acute tooth on each of the inner margins; horn subulate, incurved over the stigma; follicles ascending on the reflexed fruiting pedicels, pubescent. In woods and on prairies, Ill. to S. Dak., Manitoba and the N. W. Terr. June-July.

19. Asclepias brachystéphana Engelm. SHORT-Crowned Milkweed. (I. F. f. 29I8.) Puberulent when young, soon glabrate; stems clustered, often branched, spreading or ascending, $15-25 \mathrm{~cm}$. long. Leaves lanceolate or linearlanceolate, long-acuminate, 5-8 cm. long, or the lowest shorter; umbels several, terminal and axillary: few-flowered; peduncles short; pedicels equalling or longer than the peduncles; corolla greenish purple, its segments about $4 \mathrm{~mm}$. long; hoods ovate, obtuse, shorter than the anthers, the short erect-incurved horn slightly exserted; follicles erect on the spreading or decurved fruiting pedicels, downy or hoary, acuminate, 5-9 cm. long. In dry soil, Kans. (according to B. B. Smyth), Wyo. to Tex., Ariz. and Mex. June-Aug.

20. Asclepias perénnis Walt. Thin-Leaved Milkweed. (I. F. f. 2919.) Puberulent above, glabrous below ; stem slender, erect, sometimes slightly woody at the base, 3-9 dm. high. Leaves lanceolate, oblong or ovate-lanceolate, acuminate or acute at both erids, 5-I5 cm. long, glabrous or nearly so ; umbels solitary, or several and corymbose; peduncles $2.5-5 \mathrm{~cm}$. long; pedicels slender; flowers very small, white ; corolla-segments oblong, 2-4 mm. long; hoods oval, erect, entire, about as long as the anthers, shorter than the subulate-filiform incurved horn; follicles glabrous, erect on the erect fruiting pedicels; seeds II-I $3 \mathrm{~mm}$. long, very thin, destitute of coma. On river-shores and in wet places, N. Car. to Ill., Mo., Fla. and Tex. May-Aug.

21. Asclepias verticillàta L. Whorled Milkweed. (I. F. f. 2920.) Roots fascicled; stem slender, pubescent in lines at least above, very leafy, 3-8 dm. high. Leaves narrowly linear, sessile, verticillate in 3's-7's or some of them alternate, glabrous or nearly so, their margins narrowly revolute; umbels usually numerous, small ; peduncles slender; pedicels filiform; corolla greenish white, its segments oblong, 3-4 mm. long; hoods white, oblong, entire, about equalling the anthers, much shorter than the subulate incurved horn; follicles erect on the erect fruiting pedicels, narrowly spindle-shaped, glabrous, $5-7 \mathrm{~cm}$. long. Dry fields and hills, Me. and Ont. to the N. W. Terr., Fla., Mex. and N. Mex. July-Sept.

22. Asclepias galioides H. B. K. Bedstraw Milkweed. (I. F.f. 2920a.) Glabrous, except the minutely pubescent stems and pedicels. Stems erect, 3-5 dm. high from a horizontal rootstock; leaves erect or spreading, in whorls of 2-6, narrowly linear, 5-8 cm. long, the margins revolute; peduncles longer than the pedicels and shorter than the leaves; umbels $19-26 \mathrm{~mm}$. in diameter; flowers greenish-white; corolla-segments $4 \mathrm{~mm}$. long; hoods as high as the anthers, broadly rounded at the summit, dorsally hastate-sagittate, the ventral margins slightly involute, entire; horn arising from the base of the hood, long-exserted over the anthers; anther-wings minutely notched at the base; follicles erect on erect fruiting pedicels, attenuated, 5-7 cm. long, glabrous or nearly so. Kans. to Colo., Ariz. and Mex. May-July. 
23. Asclepias pùmila (A. Gray) Vail. Low Mrlkweed. (I. F. f. 2921.) Stems 4-25 cm. high, tufted from a woody root. Leaves numerous, crowded, sometimes obscurely whorled, filiform-linear, $2.5-5 \mathrm{~cm}$. long, smooth or minutely roughened, the margins revolute; umbels 2-several, short-peduncled, few-flowered; pedicels filiform, puberulent, 6-9 mm. long; corolla greenish white, its segments oblong, 3-4 mm. long; hoods white, erect, oblong, entire, equalling the anthers, shorter than the slender incurved horn; follicles erect on erect fruiting pedicels, narrowly spindle-shaped, $3-5 \mathrm{~cm}$. long, finely puberulent. Dry plains, S. Dak. to Ark., Colo. and N. Mex. July-Aug.

\section{ASCLEPIODÒRA A. Gray.}

Perennial herbs, similar to Asclepias, with entire leaves, and rather large flowers in terminal umbels. Sepals lanceolate. Corolla rotate, its segments spreading. Hoods oblong, inserted over the whole of the short corona-column, curved upward, obtuse, crested within, at least in the upper part, slightly longer than the anthers; at the sinuses between the hoods a small lobe or appendage, alternate with the anther-wings, simulating an inner crown. Anthers tipped with a scarious membrane, their wings horny, narrowed below, sometimes angled above the middle. Pollen-masses pendulous, pyriform, longer than their caudicles. Follicles ovoid or oblong, acuminate, with or without soft spinose processes, erect or ascend. ing on the decurved or twice bent fruiting pedicels. [Greek, gift of Asculapius.] Five or six species, natives of the southern U. S. and Mex.

Glabrous or nearly so; leaves oblong to ovate-lanceolate; umbels usually more than one, corymbose.

Stem rough-puberulent ; leaves lanceolate; or linear, acuminate ; umbels solitary.

2. A. decumbens.

\section{Asclepiodora víridis (Walt.) A. Gr. Oblong-Leaved Milkweed.} (I. F. f. 2922.) Stem erect, rather stout, simple, 3-6 dm. high. Leaves rather thin, short-petioled, 6-13 mm. long; pedicels slender; corolla globose-ovoid in the bud, greenish, its segments, when expanded, oblong, obtuse or acute, 9-13 $\mathrm{mm}$. long, 2-3 times as long as the purplish or violet entire-margined hoods; antherwings narrow, scarcely angled above; fruiting pedicels twice bent; follicles ascending, puberulent, 5-8 cm. long, sometimes with soft spinose projections. In dry soil, Ill. to Kans., Tex., S. Car. and Fla. May-July.

2. Asclepiodora decúmbens (Nutt.) A. Gray. Decumbent Milkweed. (I. F. f. 2923.) Stems decumbent or ascending, rather stout, 2-5 dm. long. Leaves firm, glabrous above, puberulent, at least on the veins beneath, narrowed at the base, 8-1 $8 \mathrm{~cm}$. long; umbel many-flowered; pedicels rather stout; corolla depressedglobose in the bud, greenish, its segments, when expanded, ovate or broadly oval, somewhat longer than the hoods: hoods purple, obtusely 3 -lobed on the ventral margins, about $6 \mathrm{~mm}$. long, their tips incurved ; anther-wings broad, angled above; follicles nearly erect on the recurved fruiting pedicels, $8-10 \mathrm{~cm}$. long, puberulent, at least when young, with or without soft projections. In dry soil, Kans. to Tex., Mex., Utah and N. Mex. April-June.

\section{ACERÀTES EII.}

Perennial herbs, similar to Asclepias, with thick leaves, and green or purplish fowers in short-peduncled or sessile umbels. Calyx 5-parted or 5-divided, the segments acute, glandular within. Corolla deeply 5-cleft, the segments valvate, retlexed in anthesis. Corona-column very short. Corona of 5 involute-concave or somewhat pitcher-shaped hoods, neither horned nor crested within or in one species having a small interior crest and usually a few small processes at the base of the antlier-wings, forming an obscure inner crown. Pollen-masses solitary in each sac, oblong. pendulous. Stigma 5-lobed. [Greek, without horn, referring to the crown.] About 7 species, natives of N. Am.

Umbels sessile, or very nearly so, mostly axillary.

Leaves oval to linear; hoods entire at the apex.

Leaves narrowly linear; hoods 3 -toothed.

Umbels, at least the lower, distinctly peduncled.

1. A. viridiflora.

2. A. angustifolia.

Plants glabrous, or nearly so; umbels usually several; leaves narrow. 
Hoods obtuse, entire; column I mm. long; stem roughish, puberulent.

Hoods emarginate; column very short; stem glabrous. 3. A. Floridana. 4. A. auriculata. Plant hirsute; umbel solitary, terninal; leaves ovate to oblong. 5 . A. lanuginosa.

I. Acerates viridifiòra (Raf.) Eaton. Green Milkweed. (I. F. f. 2924.) Puberulent or tomentulose, at least when young; stems simple, reclined or ascend. ing, rather stiff, 3-9 dm. high. Leaves slightly rough, alternate or opposite, thick, $2.5-8 \mathrm{~cm}$. long, I.5-5 cm. wide, short-petioled, the margins usually undulate; umbels several, or rarely solitary, densely many-flowered; pedicels very slen. der, tomentose; flowers green; corollia segments narrowly oblong, 4-6 mm. long; column very short or none; hoods lanceolate-oblong, obtuse, minutely 2-auricled at the base; mass of anthers longer than thick; anther-wings tapering below, semi. rhomboid above; follicles puberulent, 5-10 cm. long. In dry, sandy or rocky soil, Mass. to Ont., the N. W. Terr., Fla. and Tex. June-Sept.

Acerates viridiflòra Ívesii Britton. Leaves lanceolate or oblong-lanceolate, 5-12 $\mathrm{cm}$. long, 6-25 $\mathrm{mm}$. wide. Range of the type, often with it.

Acerates viridiflòra lineàris A. Gray. Leaves elongated-linear; stem low; umbels often solitary. Minn. and Manitoba to the N. W. Terr., La. and N. Mex.

2. Acerates angustifòlia (Nutt.) Dec. NARrow-LeAved Milkweed. (I. F. f. 2925.) Stems mostly several together, erect, 3-6 dm. high, puberulent above, glabrate below. Leaves opposite, or some of the lower alternate, sessile, $5^{-13} \mathrm{~cm}$. long, glabrous, the revolute margins and the thick midvein rough beneath; umbels IO-I5-flowered, usually numerous; pedicels puberulent! corolla-segments oblong, greenish; hoods white, not exceeding the anthers, the acute middle tooth merely a prolongation of the thickened crest-like midvein, shorter than the obtuse lateral ones; anther wings notched at about the middle; follicles slender, erect, about $8 \mathrm{~cm}$. long or more. On dry plains, Mo. to Neb., Colo. and Tex.

3. Acerates Floridàna (Lam.) Hitchc. Florida Milkweed. (I. F. f. 2926.) Stem slender, simple or little branched, 3-9 dm. high. Leaves linear or rarely linear-lanceolate, acute or acuminate, short-petioled, $5.20 \mathrm{~cm}$. long, $3^{-1} 3 \mathrm{~cm}$. wide, coinmonly rough ciliolate on the margins and midrib; umbels usually many-flowered; peduncles $6-20 \mathrm{~mm}$. long; pedicels slender, lirsute; corolla greenish-white, its segments narrowly oblong, about $4 \mathrm{~mm}$. long; column distinct; hoods oblong, shorter than the anthers; anther-wings narrowed to the base; follicles densely puberulent, $10-13 \mathrm{~cm}$. long. In moist soil, Chio to southerm Ont., Minn., N. Car., Fla. and Tex. June-Sept. [A. longifolia Ell.]

4. Acerates auriculàta Engelm. Auricled Mrlkweed. (I. F. f. 2927.) Stem often glaucous, sinuous above, usually stout, 3-9 dm. high. Leaves narrowly linear, glabrous, short-petioled, 8-zO $\mathrm{cm}$. long, I-5 $\mathrm{mm}$. wide, becoming leathery, the rough margins not revolute; umbels commonly several, densely manyflowered; peduncles 4-25 mm. long, pubescent; pedicels slender, pubescent; flowers greenish white, tinged with dull purple; corolla-segments oblong, 4-5 mm. long; column distinct; hoods yellow, often with a purplish keel, truncate at the apex, not exceeding the anthers, the involute margins spreading at the base into broad auricles; follicles 5-8 cm. long, curved. In dry soil, Neb. and Colo. to Tex. and N. Mex. June-Sept.

5. Acerates lanuginòsa (Nutt.) Dec. Woolly Milkweed. (I. F. f. 2928.) Stems erect, slender, simple, I.5-4 dm. high. Leaves obtuse at the apex, narrowed or rounded at the base, short-petioled, 3-10 $\mathrm{cm}$. long; umbel densely manyflowered; peduncle stout, densely hirsute, I.2-4 cm. long; pedicels slender, puberulent or hirsute; corolla greenish, its segments oblong, about $5 \mathrm{~mm}$. long; column none: hoods purplish, oblong, obtuse, entire, with a flat fold or auricle on the infolded lower ventral margins, shorter than the anthers; anther-wings broadest below the middle. On prairies, Ill. to Minn. and Wyo. June-Aug.

\section{GONÓlobus Michx.}

(Ampelanus Raf.)

Perennial herbaceous vines, with petioled opposite cordate thin leaves, and small whitish flowers in axillary cymes. Calyx 5-parted, minutely glandular 
within, the segments lanceolate. Corolla campanulate, deeply 5-cleft, the lobes slightly contorted, nearly erect. Crown nearly sessile, of 5 membranous truncate lobes, each appendaged by a simple or 2 -cleft awn. Stamens inserted at the base of the corolla, the filaments connate into a short tube; anthers terminated by an inflexed membrane; pollen-masses solitary in each sac, ellipsoid, pendulous. Stigma conic, slightly 2-lobed. Follicles thick, angled, acuninate. [Greek, angle-pod.] 'Two species, natives of America.

I. Gonolobus laevis Michx. SAND Vine. (I. F. f. 2929.) Stem sparingly puberulent, at least above, high-climbing, slender. Leaves ova:e, gradually acuminate, palmately veined, glabrous or very nearly so, entire, $8-18 \mathrm{~cm}$. long; cy mes usually numerous, rather densely flowered; peduncles stout, $6 \mathrm{~mm} .-5$ cul. long; flowers 4-6 mm. long; corolla-segments lanceolate, acute, about twice as long as those of the calyx and slightly exceeding the 2-cleft awns of the corona-lobes; follicles erect on the ascending fruiting pedicels, $10-15 \mathrm{~cm}$. long, glabrous when mature. Along river-banks and in thickets, Penn. to Ill., Kans, Fla. and Tex. June-Aug. [Ampelanus albidus (Nutt.) Britton.]

\section{CYNÁNCHUM L. [VINCETOXICUM Moench.]}

Perennial vines (some species erect herbs), with opposite or rarely verticillate or alternate leaves, and small yellowish green or purplish flowers in axillary cymes. Calyx 5-parted, minutely glandular within. Corolla rotate, deeply 5 cleft, the segments spreading, somewhat twisted. Crown cup-like, entire, 5-lobed or 5-parted, the lobes not appendaged. Stamens attached to the base of the corolla, their filaments connate into a tube; anthers appendaged by an inflexed membrane. Pollenmasses solitary in each sac, pendulous. Stigma flat or conic. Follicles acuminate, glabrous. [Greek, dog-strangling, alluding to its poisonous qualities.] About Ioo species, natives of warn and temperate regions. Besides the following, 2 native species occur in the southeastern U. S.

I. Cynanchum nigrum (L.) Pers. Black Sivallow-wort. (I. F.f. 2930.) Twining, or at first erect, stem slightly puberulent, slender, 6-I5 dm. high. Leaves ovate or ovate-lanceolate, entire, thin, acuminate at the apex, rounded at the base, pinnately veined, petioled, $5^{-1} 3 \mathrm{~cm}$. long, glabrous, or puberulent beneath; petioles 4-25 $\mathrm{mm}$. long; flowers purple, $5 \mathrm{~mm}$. broad; crown fleshy, 5 -lobed; follicles on nearly straight fruiting pedicels, about $4 \mathrm{~mm}$. long, glabrous. Waste places, escaped from gardens, Mass. to Penn. and Ohio. Introduced from Europe. June-Sept.

\section{VINCETÓXICUM Walt.}

Perennial vines, with opposite usually cordate leaves, and rather large flowers in axillary umbel-like cymes or fascicles. Calyx 5-parted or deeply 5-cleft, mostly 5 glandular within. Corolla rotate, very deeply 5-parted, the tube very short, the segments convolute in the bud. Corona (crown) annular or cup-shaped, adnate to the corolla. Stamens inserted on the base of the corolla, the filaments connate into a tube; anthers not appendaged, merely tipped, borne along or just under the margin of the flat-topped stigma, the sacs more or less transversely deliscent. Pollenmasses solitary in each sac, horizontal or nearly so. Follicles thick, acuminate, smooth, angled or tuberculate. [Greek, subduing poison.] About 75 species, natives of America. Besides the following, some Io others occur in the southern U. S.

Crown annular, Io-crenate; folicles angled, not warty.

Corolla about twice as long as the calyx.

Corolla $3-4$ times as long as the calyx.

Crown cup-shaped, about as high as the anthers; follicles warty.

Flowers purple to dull yellow.

Corolla-segments oblong, 6-9 mm. long.

Corolla-segments linear or linear-oblong, I I-15 mm. long.

Crown merely crenulate.

Crown toothed or lobed.

I. V. suberosum.

2. V. gonocarpos.

Crown 5-lobed, with a subulate 2-cleft tooth in each sinus.

Crown ro-toothed, the alternate teeth thinner and longer.

3. V. hirsutum.

4. V. obliquum.

5. V. Carolinen :

Flowers white.

6. V. Shortii.

7. V. Baldwinianum. 
I. Vincetoxicum suberòsum (L.) Britton. CoAst Vinceroxicum. (I. F. f. 293 I). Stem slender, twining. Leaves thin, 5-I3 cm. long, ovate or ovate. oval, acute or abruptly acuminate, the basal sinus shallow, open; petioles I-5 cin. long; cymes commonly few-flowered; peduncles 6-25 mm. long; pedicels 13-25 $\mathrm{mm}$. long, fleshy, nearly glabrous; corolla brown-purple, broadly conic in the bud, its segments lanceolate or ovate-lanceolate, acute, pubescent or granulose within, 6-9 mm. long, about twice as long as the calyx; follicles glabrous, 3-5-angled, when young fleshy, when mature dry and spongy, $10-15 \mathrm{~cm}$. long, $2.5 \mathrm{~cm}$. in diameter or more. In thickets, Va. to Fla. May-July.

2. Vincetoxicum gonocàrpos Walt. LARGE-LeAved ANGLE-POD. (I. F. f. 2932.) Stems slender, climbing high. Leaves broadly ovate, thin, I-2 dm. long, 5-15 cm. wide, acuminate, the basal sinus narrow or the rounded auricles overlapping; petioles 3-10 cm. long; cymes few-flowered; peduncles $3-8 \mathrm{~cm}$. long; pedicels rather stout, glabrous or nearly so; corolla conic in the bud, its segments lanceolate, 3-4 times as long as the calyx; follicles glabrous, similar to those of the preceding species but usually shorter. Along rivers and in moist thickets, Va. to S. Car., Ind., Mo. and Tex. May-July.

3. Vincetoxicum hirsùtum (Michx.) Britton. HaIRy Vince'toxicum. (I. F. f. 2933.) Stem downy, slender. Leaves ovate, acuminate, downy, 5-10 cm. long, 3-7 cm. wide, the basal sinus narrow, or the lobes sometimes overlapping; petioles slender, pubescent; peduncles usually about equalling the petioles, sometimes longer; umbels few-several-flowered ; corolla brown-purple to greenish yellow, ovoid in the bud, its segments oblong, very obtuse, 6-9 mm. long, minutely puberulent without, about 4 times as long as the densely pubescent calyx; crown fleshy, the margin ro-crenate; follicles lanceolate, $8-13 \mathrm{~cm}$. long, muricate, puberulent; seeds entire. In thickets, Md. to Fla. and Tenn. July-Aug.

4. Vincetoxicum obliquum (Jacq.) Britton. LARGE-FLOWERED VincetoxiCUM. (I. F. f. 2934.) Stein puberulent, or hirsute, slender. Leaves pubescent, broadly ovate, acuminate at the apex, 5-20 cm. long, 4-15 cm. wide; basal sinus open or closed; petioles rather stout, pubescent, 2.5-10 $\mathrm{cm}$. long; umbels slender-peduncled, few.flowered; pedicels very slender, $2.5-5 \mathrm{~cm}$. long; corolla narrowly conic in the bul, red-purple within, greenish and minutely pubescent without, its segments elongated-linear, obtuse; crown fleshy, its margin 10-crenulate, the intermediate crenulations sometimes 2-dentate; follicles ovoid-lanceolate, 5-8 $\mathrm{cm}$. long, muricate. In thickets, Penn. to Ohio, Va. and Ky. July-Aug.

5. Vincetoxicum Carolinénse (Jacq.) Britton. Carolina Vincetoxicum. (I. F. f. 2935.) Stem hirsute. Leaves broadly ovate, acute or shortacuminate, $8-18 \mathrm{~cm}$. long, 5-I4 cm. wide, pubescent, at least beneath; basal sinus narrow or closed; petioles hirsute; peduncles 5-10 $\mathrm{cm}$. long; pedicels very slender, $2.5 \mathrm{~cm}$. long or more; corolla brown-purple, oblong-conic in the bud, puberulent without, its segments linear-oblong or linear-lanceolate, obtusish, 5-6 times longer than the hirsute calyx; crown scarcely fleshy, 5-lobed, with a subulate longer 2-cleft erect tooth in each sinus; follicles muricate. In thickets, Va. to Mo., S. Car. and La. May-July.

6. Vincetoxicum Shórtii (A. Gray) Britton. Short's Vinceroxicum. (I. F. f. 2936.) Stem pubescent, or hirsute with spreading hairs. Leaves downy, broadly ovate, acute or short-acuminate at the apex, when old with a narrow or closed basal sinus, IO-I $2 \mathrm{~cm}$. long, 4-I $4 \mathrm{~cm}$. wide; petioles stout, pubescent; peduncles usually longer than the petioles; cymes several-flowered; pedicels 2.5 $\mathrm{cm}$. long or more; corolla oblong-conic in the bud, dark crimson-purple, its lobes linear, II-I5 mm. long; calyx hirsute; crown cup shaped, fleshy, as high as the anthers, its margin about ro-toothed, the alternate teeth thinner and longer, emarginate or 2-parted, the others broader, thicker, with an obscure internal crest or ridge below the summit; follicles warty. In thickets, Penn. to Ky. and Ga. Flowers with the odor of the Strawberry-shrub. June-Aug.

7. Vincetoxicum Baldwiniànum (Sweet) Britton. BALDwin's VinceToxIcum. (I. F. f. 2937.) Stem pulescent or hirsute. Leaves downy, broadly ovate, acute, or short-acuninate at the apex, $8-15 \mathrm{~cm}$. long, or more; petioles hirsute, 2.5-5 cm. long; peduncles usually longer than the pedicels; cymes several-many. flowered; corolla white, or cream-color, the lobes thin, oblong, or becoming spatulate, 9-II mm. long; crown thin, the 5 broader lobes quadrate, emarginate, or 
obscurely wothed; in their sinuses a pair o. "-ery slender linear-subulate teeth of more than double their length, much surpassing the stigma. Mo. and Ark. to Ga. May-June.

\section{Order 5. POLEMONIALES.}

Mostly herbs; rarely shrubs or trees. Corolla almost always gamo. petalous, regular or irregular. Stamens adnate to the corolla-tube usually to the middle or beyond, as many as the corolla-lobes, or fewer and alternate with them. Ovary 1, superior, compound (in Boraginaceae and Labiatæ deeply 4 lobed around the style).

a. Corolla regular (irregular in Echium of the Boraginaceae).

Ovary not 4-lobed, the carpels not separating as distinct nutlets at maturity.

Ovary 2 -celled, rarely 3 -4-celled; style $\mathrm{I}$, entire, 2 -cleft, or 2-parted; mostly twining vines.

Leaves normal.

Fam. I. Convolvul:xceae.

White or yellowish parasitic vines, the leaves reduced to minute scales.

Ovary 3 -celled; stigmas 3 , linear; herbs, not twining.

Fam. 2. Cuscutaceae.

Ovary I-celled (2-celled in $\Lambda$ ama); style I, 2-lobed, or 2-parted; herbs not twining.

Fam. 4. Hydrophyllaceae.

Ovary deeply 4-lobed around the style, or not lobed (Heliotropium); carpels separating as nutlets.

Fan1. 5. Boraginaceae.

b. Corolla irregular, more or less 2 lipped (regular in Solanaceae, in Mentha and Lycopus of the Labiatae, and nearly or quite so in Verbena and Callicarpa of the Verbenaceae).

\section{Carpels I-2-seeded.}

Ovary not lobed, 2-4-celled, the style apical; carpels separating into I-seeded nutlets.

Fam. 6. Verbenaceae.

Ovary 4 -lobed around the style, the lobes ripening into I-seeded nutlets.

Fam. 7. Labiatae.

2. Carpels several-many-seeded (2-seeded in some Acanthaceae).

$\ddagger$ Fruit a berry, or more commonly a capsule which is $1-2$-celled, 2 -valved, circumscissile, or irregularly burstíng, not elastically dehiscent.

Placentæa axile.

Ovary 2-celled, or rarely $3-5$-celled.

Flowers regular; fertile stamens 5 (4 in Petunia); fruit a berry or capsule.

Fam. 8. Solanaceae.

Flowers more or less irregular; fertile stamens 2 or 4 (5 in Verbascum); fruit a capsule.

Ovary I-celled; marsh or aquatic herbs with flowers on scapes.

Placentæ parietal.

Fam. Iо. Lentibulariaceae.

Herbs, parasitic on the roots of other plants, the leaves reduced to scales, not green ; ovary 1 -celled.

Fam. II. Orobanchaceae.

Trees, vines, shrubs, or herbs, the foliage normal.

Trees, shrubs, cr woody vines; capsule 2 -celled: seeds winged in our genera.

Fam. 12. Bignoniaceae.

Opposite-leaved herbs; capsule I-celled in our genus; seeds wingless.

Fam. 13. Martyniaceae.

$¥ \ddagger$ Capsule completely 2-celled, elastically loculicidally dehiscent; opposite-leaved herbs: placentæ axile.

Fam. I4. Acanthaceae

3. Ovary and fruit I-celled with I erect orthotropous ovule and seed; herb with spicate flowers and reflexed fruits. Fam. 15. Phrymaceae.

\section{Family I. CONVOLVULACEAE Vent.}

\section{Morning glory Family.}

Herbs or vines, some tropical species shrubs or trees, with alternate estipulate leaves, and regular perfect axillary cymose or solitary flowers. Calyx inferior. 5-parter or 5-divided. nsuallv persistent, the segments or sepals imbricated. Corolla gamopetil us, the limb 5-angled, 5-lobed or 
entire. Stamens 5 , inserted low down on the tube of the corolla ant? alternate with its lobes, all anther-bearing, the filaments firiform, or dilated at the base; anthers 2 celled, the sacs 1 ngitudinally dehiscent. Disk annular or none. Ovary superior, sessile, 2-3-celled, with 2 ovules in each cavity, or falsely 4-6-celled with a single ovule in each cavity, entire or 2-4-divided; styles $1-3$, terminal, or arising from between the ovary-divisions; ovules anatropous. Fruit a 2-4-valved capsule or of 2-4 distinct carpels, in our species. Seeds erect, the testa villous, pubescent or glabrous; embryo plaited or crumpled; cotyledons foliaceous ; endosperm fleshy or cartilaginous, usually scanty. About 40 genera and 900 species, of wide distribution.

Ovary 2-divided, the carpels 2-ovuled; creeping herbs.

Ovary entire, 2-4-celled; style simple, cleft or divided.

Style 2-cleft or 2-divided.

Style 2-cleft or 2-parted.

Style 2-divided to the ovary, each division 2-cleft.

Style entire up to the stigma.

Stigma or stigmas capitate or globose.

Corolla salverform; stamens and style exserted.

Corolla funnelform or campanulate; stamens and style included.

Stigmas 2, filiform to oblong.

x. Dichondra.

2. Breweria.

3. Evolvulus.

4. Quamoclit.

5. Itomosa.

6. Convolvulus.

\section{DICHÓNDRA Forst.}

Prostrate or creeping slender herbs, with nearly orbicular cordate or reniform petioled entire leaves, and small solitary axillary peduncled flowers. Sepals nearly equal. Corolla open-campanulate, deeply 5 -lobed. Stamens shorter than the corolla; filaments filiform. Ovary villous, deeply 2-parted, each lobe 2celled; styles 2, simple, arising from the bases of the ovary-lobes; stigmas capitate. Fruit of 2 pubescent 2 -valved or indehiscent I-2-seeded capsules. [Greek, wo-grained, referring to the capsules.] About 5 species, natives of warm and ropical regions.

I. Dichondra Carolinénsis Michx. Carolina Dichondra. (I. F. f. 2938 , as $D$. evolvulacea.) Somewhat pubescent, or glabrous; stems almost filiform, rooting at the nodes, I.5-6 dm. long. Leaves orbicular to reniform, deeply cordate, 6-30 mm. in diameter, palmately veined; petiole often much longer than the blade; flowers $2-4 \mathrm{~mm}$. broad; peduncles filiform; sepals obtuse, spatulate or obovate, villous; corolla yellow to white, shorter than the sepals, its lobes ovate to oblong; capsule $3 \mathrm{~mm}$. high or less. In moist or wet places, Va. to Tex. and Mex., near the coast. Widely distributed in Central and S. Am.

\section{BREWERIA R. Br.}

Herbs, mostly perennial and procumbent, with entire short-petioled or sessile leaves, and I-5-flowered axillary peduncles. Corolla campanulate or funnelformcampanulate: limb plaited, 5-angled or slightly 5-lobed. Stamens included. Ovary 2-celled; style 2-cleft or 2-parted; stigmas capitate. Capsule, 2-celled, $2-$ 4-valved. Seeds I-4. [Named for Samuel Brewer, a correspondent of Dillen.] About 30 species, widely distributed in warm-temperate and tropical regions.

Sepals acute or acuminate; leaves oblong, elliptic or linear.

Corolla white; filaments pubescent; plant pubescent.

Corolla purple; filaments glabrous; plant silky-tomentose. Sepals obtuse; leaves narrowly linear.

I. B. humistrata.

2. B. aquatica.

3. B. Pickeringii.

I. Breweria humistràta (Walt.) A. Gray. Southern Breweria. (I. F.f. 2939.) Pubescent or puberulent; stems slender, 3-6 dm. long, simple, or with a few long branches. Leaves elliptic, oblong-elliptic, or ovate-oblong, obtuse and mucronulate or some of them emarginate, $1-2.5 \mathrm{~cm}$. wide, $2-5 \mathrm{~cm}$. long; peduncles slender, longer than the leaves, I-7.fowered, minutely bracted at the summit; sepals oblong, $46 \mathrm{~mm}$. long; corolla white, I2-16 mm. long; filaments pubescent; "naule ovnid, acute, glabrous, about as long as the calyx. In dry pine barrens, Va. to Fla. and La, May-Aug. 
2. Breweria aquática (Walt.) A. Gray. Water BreWeh.A. (I. F. f. 29y4o.) Finely and densely silky-tomentose, the branches long and slender. Leaves oblong, elliptic, or oblong-lanceolate, obtuse at both ends, mucronate or emarginate, sometimes subcordate, I-4 cm. long, 4-16 mm. wide; peduncles I-3-flowered, longer than the leaves, minutely bracted at the summit; sepals tomentose, oblong; about $4 \mathrm{~mm}$. long; corolla I-I. $5 \mathrm{~cm}$. long: style 2-parted nearly to the base. In wet soil, Mo. to Tex., N. Car. and Fla. May-Aug.

3. Breweria Pickeríngii (M. A. Curtis) A. Gray. Pickering's Breweria. (I. F. f. 294I.) Stem pubescent or puberulent, very slender, 3- $6 \mathrm{dm}$. long. Leaves puberulent or glabrous, narrowly linear, narrowed at the base, $2.5^{-6} \mathrm{~cm}$. long, I-4 mm. wide; peduncles about as long as the leaves, with I or 2 linear bracts at the summit; sepals pubescent or hirsute, ovate to oval, about $4 \mathrm{~mm}$. long; corolla white, about $2.5 \mathrm{~cm}$. long; style 2-cleft; capsule ovoid, acute, pubescent. In dry pine barrens, N. J. to N. Car.; Ill. to La. and Tex. June-Aug.

\section{EVólVulus L.}

Mostly silky-pubescent or pilose herbs, with small leaves, and axillary smal flowers. Sepals nearly equal. Corolla funnelform, campanulate or rotate, the limb plaited, 5-angled or 5-lobed. Filaments filiform; anthers ovate or oblong. Ovary entire, 2-celled; style 2-divided to the base, or near it, each division deeply 2-cleft; stigmas linear-filiform. Capsule 2-4-valved, I-4-seeded. Seeds glabrous. [Latin, unrolling.] About 85 species, of warm and tropical regions. Besides the following, some 7 others occur in the southern U.S.

I. Evolvulus pilòsus Nutt. Evolvulus. (I. F. f. 2942.) Perennial, silkypubescent or villous; stems $0.7-2.4 \mathrm{dm}$. high, very leafy. Leaves sessile, oblong, lanceolate or spatulate, $6-18 \mathrm{~mm}$. long; flowers solitary in the axils; peduncles 2bracted at the base, recurved in fruit, $2-4 \mathrm{~mm}$. long; sepals acute or acuminate; corolla funnelform-campanulate, purple or blue, 6-12 mm. broad; capsule 3-4 mm. in diameter. On dry plains, Mo. to Kans., Mex. and Ariz. May-July.

\section{QUÁMOCLIT Moench.}

Twining herbaceous vines, with petioled leaves, and peduncled axillary flowers. Sepals 5, herbaceous, equal, acuminate, mucronate or appendaged. Corolla salverform (scarlet in the following species), the tube longer than the spreading 5-lobed limb. Stamens and style exserted; stigma capitate; ovary 2-celled or falsely 4-celied, 4-ovuled. Fruit usually 4 -celled and 4-seeded. [Greek, dwarf kidneybean.] About Io species, of warm and tropical regions; the following in N. Am.

Leaves pinnately parted into very narrow segments.

Leaves cordate, acuminate, entire or angulate-lobed.

I. Quamoclit Quámoclit (L.) Britton. Cypress Vine. Indian Pink. (I. F. f. 2943.) Annual, glabrous, Leaves ovate in outline, 5-I $8 \mathrm{~cm}$. long, pinnately parted into segments less than $2 \mathrm{~mm}$. wide; peduncles slender, I-6-flowered; pedicels thickening in fruit; sepals obtuse, usually mucronulate, 4-6 mm. long; corolla 2.5-4 cm. long, the tube expanded above, the limb nearly flat, the lobes ovate, acutish; ovary 4-celled; capsule ovoid, 4-valved, about I $\mathrm{cm}$. high, twice as long as the sepals. In waste and cultivated ground, Va. to Fla., Kans. and Tex. Sparingly escaped from gardens farther north. Nat. from tropical Am. July-Oct.

2. Quamoclit coccinea (L.) Moench. Small Red Morning-glory. (I. F. f. 2944.) Annual. Leaves ovate to orbicular, long-acuminate, 5-1 $5 \mathrm{~cm}$. long, entire or angulate-lobed, slender-petioled; peduncles few-several-flowered; sepals obtuse, about $4 \mathrm{~mm}$. long, subulate-appendaged; corolla 2-4 cm. long, the limb obscurely 5-lobed; ovary 4-celled; capsule globose, 4-valved, 6-8 mm. in diameter. Along river-banks and in waste places, Penn. to Fla., Ohio, Kans., Tex. and Ariz. Nat. from tropical America, or native in the Southwest. A hybrid with the preceding is sometimes cultivated. July-Oct.

\section{IPOMOÈA L.}

Twining trailing or rarely erect herbs, with large showy axillary flowers. Corolla funnelform or campanulate, the limb entire, 5-angled or 5-lobed, the tube 
plaited. Stamens included. Ovary entire, 2-4-celled, 4-6 ovuled; style filiform, included; stigmas I or 2, capitate or globose. Capsule usually septifragally 2-4valved, 2-4-seeded. [Greek, worm-like.] About $35^{\circ}$ species, of wide distribution. Besides the following, some 25 others occur in southern and western N. Am.

Ovary 2-celled (rarely 4-celled); stigma entire or 2-lobed.

Leaves cordate; stems trailing or twining.

Perennial from an enormous root; corolla $5-8 \mathrm{~cm}$. long.

Annual; roots fibrous; corolla 8-20 mm. long, white.

Annual; corolla $2.5-4 \mathrm{~cm}$. long, pink or purple.

Leaves linear; stems ascending or erect; perennial.

Ovary 3-celled; stigmas 3 ; leaves cordate ; annuals.

Leaves entire; corolla 5-7 cm. long.

Leaves deeply 3 -lobed, corolla $2.5-4 \mathrm{~cm}$. long.

1. I. pandurata.

2. I. lacunosa.

3. I. Carolina.

4. I. leptophylla.

5. I. purpurea.

6. I. hederacea.

I. Ipomoea panduràta (L.) Meyer. Wild Potato Vine. (I. F. f. 2945.) Glabrous or puberulent; stems $0.5-4 \mathrm{~m}$. long. Leaves acuminate, $5^{-1} 5 \mathrm{~cm}$. long, slender petioled, entire, sometimes contracted in the middle, or some of the later ones rarely dentate or 3 -lobed; peduncles $1-5$-flowered, much elongated in fruit; sepals oblong, I2-16 mm. long, glabrous; corolla funnelform, white, or with pinkish purple stripes in the throat, the limb 5-lobed; capsule ovoid, 2-valved, 2-4-seeded, the seeds woolly on the margins and pubescent on the sides. In dry soil, Ont. to Conn., Fla., Mich., Kans. and Tex. May-Sept.

2. Ipomoea lacunòsa L. SMall-flowered White Morning-glory. (I. F. f. 2946.) Pubescent or hirsute, rarely glabrous; stem $0.5-3.5 \mathrm{~m}$. long. Leaves slender-petioled, acute or acuminate, entire, angled or 3-lobed, 5-10 cm. long, the lobes acute; peduncles $\mathrm{r}$-3-flowered, shorter than the leaves; sepals oblong or lanceolate, acute or acuminate, pubescent or ciliate, about $1 \mathrm{~cm}$. long; corolla funnelform, white, or the limb purple; stigma capitate; capsule globose, 2 -valved. In moist soil, Penn. to S. Car., Ill., Kans. and Tex. July-Sept.

3. Ipomoea Carolina (L.) Pursh. Small-Flowered Pink MorningGLORY. (I. F. f. 2947.) Similar in habit to the preceding species, but the leaves usually more lobed; peduncles often longer than the leaves, I-3-flowered; sepals lanceolate or oblong-lanceolate, acuminate, pubescent or ciliate; capsule glabrous or pubescent. Kans. to Tex., east to S. Car. and Fla. [I. commutata R. \& S.]

4. Ipomoea leptophylla Torr. Bush Morning-Glory. (I. F. f. 2948.) Perennial from an enormous root, glabrous; stems rather stout, 6-12 $\mathrm{dm}$. long, much branched. Leaves narrowly linear, entire, acute, $5-8 \mathrm{~cm}$. long, 2-6 mm. wide; petioles very short; peduncles stout, nearly erect, usually shorter than the leaves, I-4-flowered; sepals broadly ovate, obtuse, $6-8 \mathrm{~mm}$. long, or the outer shorter; corolla funnelform, purple or pink, about $8 \mathrm{~cm}$. long, the limb scarcely lobed; capsule ovoid, acute, $1.5-2.5 \mathrm{~cm}$. long, 2-celled; seeds pubescent. In dry soil, S. Dak. to Wyo., Tex. and N. Mex. May-July.

5. Ipomoea purpùrea (L.) Roth. Morning-Glory. (I. F. f. 2949.) Stem retrorsely hairy, $1-3.5 \mathrm{~m}$. long. Leaves acute or acuminate, 5-10 cm. wide, slender-petioled; peduncles I-5-flowered; sepals lanceolate or oblong, acute, pubescent, or hirsute near the base, 12-16 mm. long; corolla funnelform, blue, purple, pink, variegated or white; ovary 3 -celled (rarely 2-celled); stigmas 3 (rarely 2 ); capsule depressed-globose, about $\mathbf{I} \mathrm{cm}$. in diameter, shorter than the sepals. In waste places, commonly escaped from gardens, N. S. to Fla., Ont., Neb. and Tex. Adventive or nat. from trop. Am. July Oct.

6. Ipomoea hederàcea Jacq. IVy-LEAved Morning-Glory. (I. F. f. 2950.) Stem 6-15 dm. long, slender, retrorsely hairy. Leaves ovate-orbicular in outline, long-petioled, deeply 3 -lobed, $5^{-1} 3 \mathrm{~cm}$. long, the lobes ovate, acuminate; peduncles $\mathbf{I}-3$-flowered, much shorter than the petioles; flowers opening in early morning, soon closing; sepals lanceolate with long linear often recurved tips. densely hirsute below, sparingly so above, $1.5-2.5 \mathrm{~cm}$. long; corolla funnelform, the tube usually nearly white, the limb light blue or purple; capsule depressedglobose, 3-valved, about as long as the lanceolate portion of the sepals. In fields and waste places, L. I. to Fla., Penn., S. Dak., Neb. and Mex. Nat, or adventive from trop. Am. July-Oct. 


\section{CONVÓlvulus L. (See Appendix.)}

Herbs (the following species perennials with slender roots or rootstocks) with trailing, twining or erect stems. Leaves mostly cordate or sagittate and petioled. Flowers axillary, large. Sepals nearly equal or the outer larger, the calyx bractless or with a pair of bracts at its base. Corolla funnelform or campanulate, the limb plaited, 5-angled, 5-lobed, or entire. Stamens inserted on the tube of the corolla, included. Ovary 1-2-celled, 4-ovuled; style filiform; stigmas 2, filiform, oblong, or ovoid. Capsule globose, I-4-celled, 2-4-valved. Seeds glabrous. [Latin, to roll together, or entwine.] About 175 species, of wide distribution. Besides the following, some 25 others occur in the southern and western U. S.

Calyx with 2 large bracts at the base, which enclose it. (Genus Volvulus Medic.)

Stems trailing or climbing.

Leaves hastate, the auricles often dentate.

Leaves sagittate, the auricles rounded, entire.

Stem erect or ascending; flowers white; bracts not cordate. Calyx not bracted; peduncle bracted at the summit.

Glabrous or nearly so; leaves entire, auriculate.

Canescent; leaves with 2-4 basal lobes.
I. C. sepium.

2. C. repens.

3. C. spithamaeus.

4. C. arvensis.

5. C. incanus.

I. Convolvulus sèpium L. Hedge or Great Bindiveed. Rutland Beauty. (I. F. f. 295 I.) Stems 1-3.5 m. long. Leaves slender-petioled, triangular in outline, hastate $5^{-13} \mathrm{~cm}$. long, acute or acuminate, the basal lobes divergent, usually acute, angulate dentate or entire; peduncles I-flowered, longer than the leaves; flowers pink with white stripes or white throughout, about $5 \mathrm{~cm}$. long; bracts at the base of the flower large, ovate, cordate; stigmas oblong. In fields and thickets, usually in moist soil, N. S. to N. Car., Mont., Utah and Kans. Also in Europe and Asia. June-Aug. The pink-flowered American plant ( $C$. sepium Americanus Sims; $\mathscr{C}$. Americanus Greene) 1s, perhaps, specifically distinct from the European.

Convolvulus Japónicus Thunb., a species with narrow hastate leaves and smaller pink flowers, cultivated in a double-flowered form, has in this form escaped from cultivation from N. H. to D. C. and Mo.

2. Convolvulus rèpens L. Trailing Bindweed. (I. F. f. 2952.) Pubescent or tomentose: stems 3-9 dm. long. Leaves ovate or oblong, 2-5 cm. long, sagittate or cordate at the base, entire, the basal lobes rounded, scarcely or not at all divergent: peduncles I-flowered, equalling or longer than the leaves; flowers white (sometimes pink?) about $5 \mathrm{~cm}$. long; calyx enclosed by 2 ovate slightly cordate bracts: stigmas oblong. In fields, Va. to Fla., Dak. and Tex. May-Aug.

3. Convolvulus spithamaèus L. Upright Bindweed. (I. F. f. 2953.) Pubescent or glabrate; stem erect or ascending, or the summit sometimes feebly twining, 1.5-3 dm. high. Leaves oval, short-petioled or the uppermost sessile, usually obtuse at both ends, 2-6 cm. long; peduncles I-flowered, longer than the leaves; flowers white, nearly $5 \mathrm{~cm}$. long; calyx enclosed by 2 large oval acutish bracts which are narrowed at both ends; stigmas oblong, thick. In dry sandy or rocky fields or on banks, N. S. to the N. W. Terr., Fla. and Ky. May-Aug.

4. Convolvulus arvénsis L. Small Bindweed. (I. F. f. 2954.) Glabrous, or nearly so; stems slender, 3-8 dm. long. Leaves slender-petioled, ovate or oblong, entire, sagittate or somewhat hastate, $2-5 \mathrm{~cm}$. long, the basal lobes spreading, acute: peduncles I-4 flowered, shorter than the leaves, I-3 bracted at the summit; sepals oblong, obtuse, $3 \mathrm{~mm}$. long; corolla pink or nearly white, 1.5-2.5 cm. broad; stigmas linear. In fields and waste places, N. S. to Ont., N. J., Neb. and Kans. Nat. from Europe. May-Sept.

5. Convolvulus incanus Vahl. HoAry Bindweed. (I. F. f. 2955.) Finely and densely canescent, 3-9 dm. long. Leaves short-petioled, lanceolate, ovate to linear in outline, 2-5 cm. long, usually with 2-4 divergent lobes at the base, or the lower pair of lobes reflexed, obtuse and mucronulate: peduncles $1-2$-flowered, as long as or longer than the leaves sepals oblong, about $6 \mathrm{~mm}$. long; corolla white to rose-color; stigmas narrowly linear; capsule globose. In dry soil, Neb., Kans, and Ark. to Ariz., Mex. and Tex. April-Aug. 


\section{Family 2. CUSCUTACEAE Dumort.}

\section{Dodder Family.}

White, red or yellow slender parasites, dextrorsely twining, the leaves reduced to minute alternate scales. Calyx inferior, 5-lobed or 5-parted (rarely 4-lobed or 4-parted), or of 5 distinct sepals. Corolla 5-lobed (rarely 4-lobed), the tube bearing as many fimbriate or crenulate scales as there are lobes and alternate with them, or these sometimes obsolete. Stamens as many as the corolla-lobes, inserted in the throat or sinuses above the scales; anthers short, ovate or oval, obtuse, 2-celled, the sacs longitudinally dehiscent. Ovary, 2-celled; ovules 2 in each cavity; styles 2, terminal, separate, or rarely united below; stigmas linear or capitate. Capsule globose or ovoid, circumscissile, irregularly bursting or indehiscent, I-4 seeded. Seeds glabrous; embryo linear, terete, curved or spiral, its apex bearing I-4 minute alternate scales, endosperm fleshy; cotyledons none.

\section{r. cúscuta L.}

Characters of the family. The filiform twining stems are parasitic on herbs and shrubs by numerous minute suckers. The seeds germinate in the soil and the plantlet attaches itself to its host, its root and lower portion soon perishing. The subsequent nutrition of the parasite is apparently wholly through its suckers. Indications of a small a mount of green coloring matter, possibly chlorophyll, have been observed in some species. [Name from the Arabic.] About roo species, of wide distribution. Besides the following, some $\mathbf{I}_{5}$ others occur in the southern and western parts of N. Am.

* Corolla-scales crenulate ; stigmas slender ; capsule circumscissile.

Scales crenulate above, not incurved.

Scales crenulate all around, strongly incurved.

** Corolla-scales fringed ; stigmas capitate ; capsule indehiscent.

1. C. Epilinum.

2. C. Epithymum.

Sepals united below into a gamosepalous calyx.

Flowers very nearly sessile; corolla persistent at the base of the capsule.

Corolla-scales ovate, fringed all around; calyx lobes obtuse. 3. C. arvensis.

Corolla-scales abortive, or of a few processes; calyx-lobes acutish.

4. C. Polygonorum.

Flowers distinctly pedicelled; corolla enclosing or capping the capsule, or at length deciduous.

Tips of the corolla lobes incurved or inflexed.

Scales ovate, fringed all around; capsule enclosed by the corolla.

5. C. indecora.

Scales abortive, or of a few slender processes; corolla capping the capsule.

Corolla lobes spreading or recurved.

6. C. Coryli.

Scales small, irregularly fringed; capsule depressed-globose.

Scales long, fringed mainly above; capsule pointed.

7. C. Cephalanthi.

Corolla $3 \mathrm{~mm}$. long; capsule globose, short-pointed or pnintless.

Flowers 4-6 mm. long; capsule oval, long-pointed.

8. C. Gronoviz.

9. C. rostrata.

Sepals separate, subtended by similar bracts.

Flowers cymose, pedicelled; scales short: bracts entire.

Flowers closely sessile in dense clusters; bracts serrulate.

10. C. cuspidata.

Bracts few, broad, appressed; styles as long as the ovary. II. C. compacta.

Bracts numerous, narrow, their tips recurved; styles longer than the ovary.

12. C. paradoxa.

I. Cuscuta Epílinum Weihe. Flax Dodder. (I. F. f. 2956.) Stems yellow or red; flowers sessile in dense clusters, yellowish white, about $3 \mathrm{~mm}$ : long. Calyx hemispheric, 5-lobed, the lobes ovate, acute; corolla short, becoming urceolate, 5-lobed, the lobes ovate, acutish, spreading, its scales short, erect, less 
than one-half the length of the tube, 2 cleft or emarginate, the crenulations not extending to the base; stigmas linear-filiform; capsule circumscissile, the withering corolla borne on its summit. On flax, N. S. to N. J. and Penn. Introduced from Europe. July-Aug.

2. Cuscuta Epítilymum Murr. Thyme Dodder. Clover Dodder. il. F. f. 2957.) Stems filiform, red; flowers sessile in small dense clusters, pinkish, about $2 \mathrm{~mm}$. long. Calyx 4-5-lobed, more than one half the length of the cylindric corolla-tube, the lobes acute; corolla 4-5-lobed, the lobes erect, about one-half as long as the tube, acute, its scales strongly incurved, crenulate nearly or quite to the base; stigmas filiform; capsule circumscissile, capped by the withering corolla. Usually on clover, Me. and Ont. to Conn., N. Y., Pa. and S. Dak. Introduced from Europe. July-Sept.

3. Cuscuta arvénsis Beyrich. Field Dodner. (I. F. f. 2958.) Plant pale yellow: stems filiform, the flowers nearly sessile in small clusters. Calyx broad, 5-lobed, the lobes obtuse; corolla nearly campanulate, 5-lobed, the lobes acute or acuminate, as long as the tube, their tips reflexed, its scales large, ovate, densely fringed all around with short irregular processes; stamens not exserted: style shorter than the ovary; stigmas capitate; capsule depressed glohose, indehiscent. On various herbs and low shrubs, Mass. to the N. W. Terr., Fla., Tex., Mex. and Cal. Also in S. Am. July-Aug.

4. Cuscuta Polygonòrum Engelm. Smart-weed Donder. (I. F. f. 2959.) Plant orange-yellow; stems rather coarse; flowers sessile or nearly so in dense clusters. Calyx short, 4-5-lobed, the lobes ovate-oblong, acute or acutish; lobes of the corolla 4 or 5, triangular-ovate, acute, the scales usually obsolete, wanting, or consisting of only 2 or 3 slender processes on each side of the attached lower portion of the filament; styles shorter than the ovary; stigmas capitate, capsule globose. On Polygonums and other herbs, Minn. and Wis. to Neb. and Ark. Also in Penn. and Del. Range probably more extensive. July-Sept.

5. Cuscuta indecòra Choisy. PretTy Dodder. (I. F. f. 2960.) Stems rather stout; flowers white, $3 \mathrm{~mm}$. long. pedicelled in loose cymes. Calyx 5-lobed, lobes ovate to lanceolate, acute; corolla camp.nulate, 5 -lobed, the lobes triangular, minutely crenulate, spreading, nearly as long as the tube; scales ovate, erect, irregularly fringed with short processes all around; stigmas capitate; capsule oblong, acute. On various herbs and low shrubs, Ill. to Neb., Fla., Tex., and Mex. Also in the W. Indies and S. Am. June-Aug.

6. Cuscuta Córyli Engelm. Hazel DoDDEr. (I. F. f. 296r.) Stems coarse: flowers about $2 \mathrm{~mm}$. long, pedicelled in cymes. Calyx 4-5-lobed, the lobes triangular or triangular-lanceolate, acutish; corolla campanulate, 4-5lobed, the lobes minutely crenulate, nearly erect, triangular, acute, about as long as the tube; scales small, oval, obtuse, often with only a few processes on each side; styles shorter than the ovary; stigmas capitate; capsule oblong, pointed. On hazels and other shrubs or herbs, Conn. to Va., S. Dak. and Ark. July-Aug.

7. Cuscuta Cephalánthi Engelm. Button-bush Dodder. (I. F. f. 2962.) Plant yellow; stems rather coarse; flowers about $2 \mathrm{~mm}$. long, short-pedicelled, clustered; calyx 5-lobed, the lobes ovate, obtuse; corolla cylindric-campanulate, its lobes ovate, obtuse, spreading, one-half the length of the tube or less; scales about as long as the lobes, fringed mainly toward the apex with irregular processes; styles slender, about as long as the ovary; stigmas capitate; capsule depressed-globose, $3 \mathrm{~mm}$. in diameter. On shrubs and tall herbs, Penn. to Minn., the N. W. Terr., Tex. and Ariz. July-Aug.

8. Cuscuta Gronòvii Willd. Gronovius' Donder. Love-vine. (I. F. f. 2963.) Stems yellow to orange, slender, flowers usually short-pedicelled, numerous in dense cymes. Calyx not bracted, its lobes ovate, obtuse, shorter than the corolla-tube; corclla campanulate, the lobes ovate, obtuse, spreading, nearly as long as the tube, the scales narrow, thickly fringed about the summit and sparingly along the sides with long slender processes; styles slender; stigmas capitate; capsule $3 \mathrm{~mm}$. in diameter, enveloped in or capped by the withering deciduous corolla. On herbs and low shrubs, N. S. to Manitoba, Fla. and Tex. July-Aug.

9. Cuscuta rostràta Shuttlw. Beaked Dodder. (I. F. f. 2964.) Stems coarse, yellowish white; flowers larger than in any of our other species, loosely 
cymose. Calyx 5-lobed, the lobes ovate-triangular, shorter than the corolla-tube; corolla campanulate, white, its lobes broadly ovate, obtuse, about as long as the calyx-lobes; scitles narrow, heavily fringed at the summit and sparingly along the sides with slender processes; styles slender; stigmas capitate. On herbs and shrubs, Md. to S. Car. and Ga. July-Sept.

Io. Cuscuta cuspidàta Engelm. Cuspidate Dodder. (I. F. f. 2965.) Plant yellowish; stems slender; flowers about $3 \mathrm{~mm}$. long in loose panicled cymes. Calyx shorter than the corolla-tube, with 2-4 similar bracts at its base; sepals cuspidate, mucronate or acuminate; corolla nearly salverform, its lobes triangularlanceolate or oblong, acute or cuspidate, spreading; scales narrow, usually less than one-half as long as the tube, fringed with short irregular processes; styles very slenuer; stigmas capitate; capsule bearing the withered corolla on its summit. On coarse herbs, Neb. to Mo. and Tex. July-Sept.

I I. Cuscuta compácta Juss. Compact DodDer. (I. F. f. 2966.) Plant yellowish white; stems rather stout; flowers about $4 \mathrm{~mm}$. long in dense clusters. Calyx of 5 (rarely 4 ) oval crenulate obtuse sepals, subtended by $3-5$ rhombicorbicular appressed serrulate bracts; corolla salverform, the tube zylindric, its 5 (rarely 4) lobes oblong or ovate, obtuse, spreading, much shorter than the tube, the scales narrow, fringed with numerous long processes; styles slender; capsule oblong, enveloped in or capped by the withering corolla. On shrubs, Ont. to N. Y., Ala., Kans. and Tex. July-Sept.

I2. Cuscuta paradóxa Raf. Glomerate Dornder. (I. F. f. 2967.) Plant yellowish white; stems slender; flowers sessile, $3 \mathrm{~mm}$. long, exceedingly numerous in dense confluent clusters covering portions of the stem of the host-plant. Calyx of 5 concave oblong obtuse serrulate sepals, subtended by $8-15$ narrower serrulate imbricated bracts with recurved tips; corolla-tube oblong.cylindric, its iobes obtuse, persistent; scales copiously fringed at the summit and sparingly along the sides with long processes; styles $2-4$ times as long as the ovary; capsule capped by the withering corolla. On tall herbs, mainly Compositae, Ohio to S. Dak., Neb and Tex. July-Sept. [C. aphylla Raf.?]

\section{Family 3. POLEMONIACEAE DC.}

\section{Phlox Family.}

Herbs. Flowers perfect, clustered, regular, or nearly so. Caly inferior, tubular or can panulate, 5-cleft, the lobes or teeth slightly im. bricated. Corolla gamopetalous, the limb 5-parted, the lobes contorted. Stamens 5 , inserted on the tube of the corolla and alternate with its lobes; anthers versatile, 2 celled, the sacs longitudinally dehiscent. Ovary superior, mostly 3 -celled; ovules $2-\infty$ in each cavity, amphitro. pous; style filiform; stigmas 3, linear. Capsule mostly leculicidally 3-valved. Seeds sometimes winged, sometimes enveloped in mucilage and emitting spiral tubes when wetted; endosperm present; embryo straight; cotyledons flat; radicle inferior. About 10 genera and 200 species, most abundant in western Am.

Calyx distended and at length ruptured by the ripening capsule.

Corolla salverform; leaves opposi:e, entire.

Corolla funnelform, tubular, salverform or campanulate; leaves alternate or opposite.

Calyx not distended nor ruptured by the capsule; leaves alternate.

2. Gilia.

Calyx-teeth herbaceous, not spinulose-tipped.

Stamens declined; leaves pinnate.

Stamens straight and leaves entire in our species.

Calyx-teeth spinulose-tipped; leaves pinnatifid.

3. Polemonium.

4. Collomia.

5. Naverretia.

\section{PHLÓX L.}

Perennial or rarely annual, herbs, with opposite entire leaves, or some of the upper ones alternate, and large flowers, in terminal cymes or cymose panicles. Calyx tubular or tubular-campanulate, 5-ribbed, 5-cleft, the lobes acute or acuminate, mostly scarious-margined. Corolla salverform, the tube narrow, the limb 
5-lobed; lobes obovate, orbicular or obcordate, spreading. Stamens straight, short, unequally inserted on the corolla tube. Ovary 3-celled; style usually. slender; ovules I-4 in each cavity. Capsule ovoid, 3 -valved at length distending and rupturing the calyx-tube. Seeds ovoid, not emitting spiral threads when wetted. [Greek, flame.] About 30 species, natives of N. Am. and Asia. Besides the following, some 24 others occur in southern and western N. Am.

Jeaves flat. ovate, oblong, lanceolate or linear.

Cymes panicled; flowers short-pedicelled or sessile.

Calyx-teeth subulate.

Stem glabrous or puberulent; leaves lanceolate to oblong.

Stem villous, very glandular above; leaves ovate to ovate-lanceolate.

Calyx-teeth lanceolate, acute; leaves lanceolate to ovate, acuminate.

2. P. amplifolia.

3. P. maculata.

Cymes corymbose, simple, or flowers scattered.

Flowering stems erect or ascending, simple.

Plants glabrous or nearly so.

Leaves ovate or oblong; calyx-teeth acute.

Leaves lanceolate or linear; calyx-teeth subulate-lanceolate.

Plants pubescent, hirsute or villous.

Stems erect or ascending; no prostrate sterile shoots.

Leaves linear or lanceolate, acuminate, spreading.

Leaves linear-oblong, acute or obtuse, nearly erect.

6. P. pilosa.

7. P. amoena.

Stems ascending or reclining; sterile shoots prostrate.

Lower leaves and those of the sterile shoots oblong or ovate.

Lower leaves and those of the sterile shoots obovate.

8. P. divaricata.

Stems diffusely branched, usually creeping; leaves narrow.

9. P. reptans.

Corolla-lobes cleft to or about the middle.

Corolla-lobes cleft only at the apex.

Corolla-lobes rounded; western.

10. P. bifida.

11. P. Stellaria.

12. P. Kelseyi.

Leaves subulate, fascicled or crowded; plants low.

Stems creeping or ascending ; flowers cymose ; eastern.

Corolla-lobes shallowly emarginate; plant not glandular. I3. P. subulata.

Corolla-lobes deeply emarginate; upper part of plant glandular.

Densely tufted: flowers mostly solitary; western.

Leaves densely white-woolly, $2 \mathrm{~mm}$. long; plant moss-like. 15. P. bryoides.

Leaves less woolly or merely ciliate, 4-12 mm. long.

Corolla-tube shorter than or equalling the calyx.

Corolla-tube longer than the calyx.

16. P. Hoodii.

1. P. Douglasii.

I. Phlox paniculàta L. Garden Phlox. (I. F. f. 2968.) Stem glabrous or puberulent, 6-18 dm. high. Leaves sessile or short-petioled, oblong to oblonglanceolate, acute or acuminate, $5^{-15} \mathrm{~cm}$. long; flowers in compact paniculate cymules, the inflorescence often $3 \mathrm{dm}$. long; calyx-teeth more than one-half as long as the tube; corolla pink, purple or white, its lobes broadly obovate, rounded, shorter than its tube; capsule oval, obtuse. In woods and thickets, Penn. to Fla., Ill., Kans. and La. Freely escaped from gardens in the north and east. July-Sept.

2. Phlox amplifolia Britton, $n$. $s p$. Large-leaved Phlox. Stem villous or glandular-villous, at least above, 6-12 $\mathrm{dm}$. tall. Leaves large and broad, 7-15 cm. long, 3-6 cm. wide, roughish above, the upper sessile, the lower or some of them narrowed, usually abruptly, into winged petioles, sometimes one-third the length of the blade; flowers similar to those of the preceding; calyx glandularvillous; corolla-tube glabrous. Tenn. to Mo. Aug.-Sept. Type from Knox Co., Tenn.

3. Phlox maculàta L. Wild Sweet-william. (I. F. f. 2969.) Stem glabrous or puberulent, usually flecked with purple, 3-9 dm. high. Leaves lanceolate or the upper ovate-lanceolate, glabrous, rather firm, long-acuminate, sessile, rounded or subcordate at the base, 5-12 cm. long; flowers short-pedicelled, the compact cymules forming an elongated narrow panicle; calyx-teeth acute, or acu. 
minate, about one-fourth the length of the tube; corolla-lobes roundid, shorter than the tube. In moist woods and along streams, Conn. to Fla., Minn. and Tenn. Occasionally escaped from gardens further north. June-Aug.

4. Phiox ovàta L. Mountain Phlox. (I. F. f. 297o.) Stems simple, ascending from a decumbent base, 3-6 dm. high. Leaves rather firm, the upper ovate or ovate-lanceolate, sessile by a rounded or subcordate base, acute, 2-5 cm. long, the lower and basal ones longer, oblong or ovate-oblong, acute, narrowed into slender petioles; flowers short-pedicelled; calyx-teeth one-third to one-half the length of the tube; corolla pink or red, its lobes obovate, rounded, entire. In woods, Penn. to N. Car. and Ala. May-Aug.

5. Phlox glabérrima L. Smooth Phlox. (I. F. f. 297x.) Stem simple. 3-6 dm. high. Leaves lanceolate or linear, mostly I-nerved, acuminate, narrowed at the base, 3-10 $\mathrm{cm}$. long, sessile, or the lowest linear or oblong, obtusish, and short-petioled; flowers short-pedicelled, the cymules corymbed; calyx-teeth onethird to one-half the length of the tube; corolla commonly pink, its lobes obovate, longer than the tube. In open woods and on prairies, Va. to Wis., Fla. and Ky. May-July.

6. Phlox pilòsa L. Downy Phlox. (I. F. f. 2972.) Soft-downy or liairy, often glandular; stem slender, 3-6 dm. high. Leaves linear or lanceolate, spreading, long-acuminate, $2-8 \mathrm{~cm}$. long, sessile; cymules corymbed; flowers shortpedicelled; calyx glandular, viscid, its teeth setaceous-subulate, longer than the tube; corolla-lobes obovate, entire, the tube usually pubescent; capsule shorter than the calyx. In dry soil, Ont. to Manitoba, N. J., Fla., Kans., Ark. and Tex. April-June.

7. Phlox amoèna Sims. HaIry Phlox, (I. F. f. 2973.) Usually quite hairy; stems $1.5-5 \mathrm{dm}$. high. Leaves linear-oblong, sessile, nearly erect, $\mathbf{r}-4 \mathrm{~cm}$. long, the lowest much shorter; flowers nearly sessile in a dense cyme, which is subtended by the uppermost pair of leaves; calyx hirsute, its teeth subulate; corolla pink or white, its lobes obovate, shorter than the glabrous tube. In dry soil, Va. to Tenn., Fla. and Ga. April-June.

8. Phlox divaricàta L. Wil. Blue Phlox. (I. F. f. 2974.) Finely viscidpubescent; stems ascending or diffuse, with creeping or ascending leafy shoots. Leaves of the sterile shoots obtuse, $2-5 \mathrm{~cm}$. long, those of the flowering stems lanceolate, ovate-lanceolate, or oblong, mostly acute; flowers in open corymbed cymules, faintly fragrant; calyx-teeth subulate, longer than the tube; corolla bluish, its lobes not much longer than the tube; capsule oblong-globose. In moist woods, Ont. to Minn., Penn., Fla., Kans., La. and Ark. April-June.

9. Phlox réptans Michx. Crawling Phlox. (I. F. f. 2975.) Stems slender, diffuse, producing sterile creeping leafy shoots. Leaves of the sterile shoots, obtuse, $2-8 \mathrm{~cm}$. long, narrowed into petioles; flowering stems $\mathbf{I}-2 \mathrm{dm}$. high, their leaves oblong or lanceolate; flowers slender-pedicelled; calyx-teeth linear subulate; corolla pink, purple, or violet, its lobes rounded, about one-half the length of the tube. In woods, Penn. to Ga. and Ky. April-June.

Io. Phlox bífida Beck. Cleft Phlox. (I. F. f. 2976.) Puberulent or pubescent; stems much branched, often $3 \mathrm{dm}$. long, the branches I-2 dm. high. Leaves of sterile shoots linear, sessile, $2-5 \mathrm{~cm}$. long, acute, those of flowering branches much shorter; flowers slender-pedicelled; calyx-teeth lanceolate-subulate; corolla pale purple, its lobes shorter than the tube, cuneate, 2-3-cleft to about the middle into obtuse diverging segments. In dry places, Ind. to Tenn. and Mich. April-June.

I I. Phlox Stellària A. Gray. Chickweed Phlox. (I. F. f. 2977.) Glabrous or puberulent; stems, much branched, the branches $0.7-2 \mathrm{dm}$. high. Leaves linear, or linear-lanceolate, sessile, acute, 2-5 cm. long: flowers slender-pedicelled; calyx.teeth subulate-lanceolate, shorter than the tube; corolla pale blue or nearly white, its lobes cuneate, 2-lobed, nearly as long as the tube. On cliffs, Ill. and $\mathrm{Ky}$. April-May.

12. Phlox Kélseyi Britton. Kelsey's PhLox. stemmed from a woody root, the stems sometimes $2 \mathrm{dm}$. (I. F. f. 2978.) Manystemmed from a woody root, the stems sometimes $2 \mathrm{dm}$. long, glabrous, or slightly
pubescent above. Leaves oblong, or linear-oblong, sessile, glabrous, or nearly so, 6-25 mm. long, 2-4 $\mathrm{mm}$. wide, or the upper longer and narrower, rigid, the apex spinose-mucronate, the revolute margins ciliate; flowers sessile, or short-peduncled 
calyx-teeth subulate, as long as the tube, or longer; corolla-tube somewhat exceed. ing the calyx, the limb about $16 \mathrm{~mm}$. broad, blue or lilac. N. Dak. to Neb. and Mont. May-June.

13. Phlox subulàta L. Ground or Moss Pink. (I. F. f. 2979.) Pubescent or becoming glabrate, forming mats, much branched, the branches $5^{-15} \mathrm{~cm}$. long. Leaves acute or acuminate, $8-20 \mathrm{~mm}$. long, I-3 $\mathrm{mm}$. wide, spreading, ciliate, commonly fascicled at the nodes; flowers slender-pedicelled; calyx 8-9 mm. long, its teeth subulate from a broader base, about as long as the tube; corolla pink, purple or white, its lobes shorter than the tube. In dry sandy or rocky soil, N. Y. to Fla., Mich. and Ky. Escaped from cultivation in N. Eng. April-June.

14. Phlox Brittònii Small. BRitTon's Phlox. Similar to the preceding. Leaves shorter and narrower; upper part of the plant glanduiar-pilose; calyx 5-7 $\mathrm{mm}$. long; corolla white, the tube longer than the calyx, the lobes cuneate-obovate with 2 pale magenta spots near the base. Mountain slopes, Va. and W. Va. to N. Car. April-May.

15. Phlox bryoides Nutt. Moss Phlox. (I. F. f. 2980.) Depressed, mosslike, densely branched from a deep woody root, forming compact tufts $5-8 \mathrm{~cm}$. high. Leaves about $2 \mathrm{~mm}$. long, closely imbricated in four ranks, copiously whitewoolly, triangular-lanceolate, pale, acute, the margins infolded; flowers solitary and sessile at the ends of the branches, about $5 \mathrm{~mm}$. long; tube of the corolla longer than the calyx, its lobes broadly cuneate, entire. On dry hills, western Neb. and Wyo. May-July.

16. Phlox Hoòdii Richards. Hoon's Phlox. (I. F. f. 2981.) Densely tufted and branched from a woody root, 5-10 cm. high. Leaves imbricated, erect, rigid, subulate, mucronate, somewhat woolly or ciliate, becoming glabrate, 4-I 2 $\mathrm{mm}$. long; flowers sessile at the ends of the branches, about $\mathrm{I} \mathrm{cm}$. long; calyx-teeth lanceolate, acuminate, rigid, longer than the tube; corolla-lobes obovate, entire. In dry sandy or rocky soil, Manitoba to the N. W. Terr., western Neb. and Wyo. May-July.

17. Phlox Douglásii Hook. Douglas' Phlox. (I. F. f. 2982.) Similar to the preceding species; leaves less imbricated, sometimes spreading, rigid, usually fascicled at the nodes, $8-14 \mathrm{~mm}$. long. Flowers sessile or short-pedicelled at the ends of the branches $\mathbf{I}-1.6 \mathrm{~cm}$. long; calyx-teeth narrowly lanceolate, acuminate, about equalling the tube; tube of the purple or white corolla longer than the calyx, its lobes obovate, entire. Dry soil, Neb. and Mont. to Utah, Cal. and Br. Col. May-July.

Phlox Douglásii andícola (Nutt.) Britton. Leaves longer, $16-25 \mathrm{~mm}$. long, less fascicled at the nodes. Range of the type. Perhaps specifically distinct.

\section{GilliA R. \& P.}

Calyx 5-toothed or 5-cleft, the sinuses usually scarious. Corolla funnelform, tubular, campanulate or rarely salverform, 5-lobed. Stamens equally or unequally inserted on the corolla. Ovary 3-celled. Capsule ovoid or oblong, 3-celled, at length distending and rupturing the calyx. Seed-coat commonly mucilaginous when wetted, in some species emitting spiral thread-like tubes. [Named for Philip Gil, a Spanish botanist.] About 75 species, natives of America. Besides the following, some 48 others occur in southern and western N. Am.

\section{Leaves entire.}

Flowers paniculate.

Flowers narrowly thyrsoid-spicate.

Leaves pinnately divided, pinnatifid or palmatifid.

Leaves palmatifid into 5-7 rigid subulate segments.

Leaves pinnatifid or pinnately divided, the segments linear, not rigid.

I. G. gracilis.
6. G. spicata.

Flowers thyrsoid-paniculate or corymbose-paniculate.

Corolla 2-5 cm. long; plants 3-12 dm. tall.

Flowers paniculate, white.

Flowers narrowly thyrsoid, red.

Corolla 6-1o $\mathrm{mm}$. long, violet or blue.

Flowers narrowly thyrsoid-spicate, purplish.

Flowers in dense or capitate cymes, or heads.

Flower-clusters leafy-bracted.

3. G. longiflora.

4. G. aggregata.

5. G. pinnatifida.

6. G. spicata. 
Perennial; corolla-tube not longer than the calyx.

Annual; corolla-tube $2-3$ times as long as the calyx. Clusters bractless; corolla campanulate.

Flowers axillary and terminal, scattered.

I. Gilia grácilis Hook. Entire-leaved Gilia. (I. F. f. 2983.) Annual, pubescent, at length much branched, $5^{-1} 5 \mathrm{~cm}$. high, the branches ascending. Lower and basal leaves oblong to spatulate, obtuse, commonly opposite and nearly sessile, the upper linear or lanceolate, sessile, $\mathbf{I}-2.5 \mathrm{~cm}$. long, opposite or alternate; cymes I-5-flowered; calyx-lobes linear-subulate; corolla 8-12 mm. long, the tube yellowish, narrow, the lobes purple or violet, short; ovules 2 or 3 in each cavity; capsule oblong, obtuse; seeds mucilaginous when wet. In dry or moist soil, western Neb., Colo. and N. Mex. to Br. Col. and Cal. April-Aug.

2. Gilia caespitòsa (Nutt.) A. Nelson. Tufted Gilia. Sharp-leaved Gilia. Shrubby, densely tufted, rigid, usually much branched, $0.5-1.5 \mathrm{dm}$. high. Leaves alternate, sessile, 5-7 mm. long, palmately divided into 3-5 subulate rigid awl-shaped segments, often with smaller ones fascicled in their axils, sometimes densely imbricated; flowers solitary, or 2-3 together, sessile at the ends of the branches, IO-I $5 \mathrm{~mm}$. long; calyx-lobes 4, subulate, as long as the tube, or shorter; corolla white to yellowish, salverform, the tube longer than the calyx, the limb 4-lobed; stamens 4; seeds not mucilaginous when wetted. In dry soil, Neb. and Wyo. May-July. [Gilia púngens caespitdsa (Nutt.) A. Gray.]

3. Gilia longiflòra (Torr.) Don. White-Flowered Gilia. (I. F. f. 2985.) Annual, glabrous, paniculately branched, 3-6 dm. high. Leaves all alternate, sessile, 2-6 cm. long, pinnately divided or the uppermost entire; flowers white, paniculate, about $5 \mathrm{~cm}$. long; calyx teeth triangular-lanceolate, acuminate; corolla salverform, its tube narrow, 4 or 5 times as long as the orbicular or ovate, spread. ing lobes; stamens unequally inserted; ovules 8-12 in each cell; capsule narrowly oblong: seed-coat mucilaginous and emitting spiral threads when wetted. In dry soil, Neb. and Colo. to Tex. and Ariz. May-Sept.

Gilia rúbra (L.) Heller (G. coronopifolia Pers.), a related species with less spreading corolla-lobes, is commonly cultivated, and rarely escapes from gardens.

4. Gilia aggregàta (Pursh) Spreng. Scarlet Gilia. (I. F. f. 2986.) Biennial, pubescent or puberulent; stem 6-12 dm. high. Leaves alternate, the basal often tufted, mostly petioled, $2-8 \mathrm{~cm}$. long, pinnately parted into narrowly linear segments; inflorescence often $3 \mathrm{dm}$. long; flowers sessile or nearly so in small peduncled clusters, scarlet or red; corolla tubular-funnelform, the tube $2-4 \mathrm{~cm}$. long, the limb cleft into ovate or lanceolate acute or acuminate spreading or recurved lobes; ovules numerous; seeds mucilaginous and emitting spiral threads when wetted. In dry soil, Neb. and Wyo. to Tex., Mex., Br. Col. and Cal June-Aug.

5. Gilia pinnatífida Nutt. Small-flowered Gilia. (I. F. f. 2987.) Biennial or perennial from a deep root, much branched, viscid-glandular, 1.5-6 dm. high. Leaves thick, pinnatifid, the basal tufted, $2-8 \mathrm{~cm}$. long, the segments linear-oblong, those of the stem alternate, the uppermost minute and entire; flowers numerous, paniculate; calyx 5-lobed, the lobes lanceolate to ovate; corolla salverform, 6-10 $\mathrm{mm}$. long, the limb violet or blue, its white tube longer than the calyx and its obovate lobes; stamens exserted; seeds not mucilaginous when wetted. In sandy soil, Neb. and Wyo. to N. Mex. June-Aug.

6. Gilia spicàta Nutt. SpICATE Gilia. (I. F. f. 2988.) Perennial, woollytomentose: stems stout, simple, r.5-5 dm. high. Leaves alternate, narrowly linear, entire, or pinnately parted into $3-5$ linear segments, $2-5 \mathrm{~cm}$. long; flowers in an elongated narrow thyrsus, sessile in small clusters, purplish, $8-12 \mathrm{~mm}$. long: tube of the corolla considerably longer than the ovate-oblong lobes; calyx-lobes acuminate; anthers equally inserted in the throat of the corolla. In dry soil, western Neb. and Kans. to Wyo. and Utah. May-Aug.

7. Gilia congésta Hook. Round-HeAded Gilia. (I. F. f. 2989.) Perennial, woolly-tomentose, at least when young, 0.7-4.5 dm. high. Leaves mostly petioled, $1-5 \mathrm{~cm}$. long, pinnately divided into 3-9 sharp-pointed segments, or the uppermost entire; flowers white, densely capitate-clustered, 4-6 mm. long; calyxlobes awn-like; corolla-tube about the length of the calyx; filaments equally 
inserted in or below the sinuses of the corolla; ovules I-4 in each cavity. In dry soil, Neb. and Colo. to Cal., Mont. and Ore. May-Aug.

8. Gilia pùmila Nutt. Low Gilia. (I. F. f. 2990.) Annual, woolly at least when young, $0.7-2 \mathrm{dm}$. high. Leaves thick, I-2.5 $\mathrm{mm}$. long, pinnately divided into mucronulate sometimes lobed segments, or the uppermost entire; flowers in dense cymes; corolla $6-8 \mathrm{~mm}$. long, its tube about 3 times the length of the lobes; calyx-lobes awn-like; stamens inserted in or below the sinuses of the corolla; ovules 5 or 6 in each cavity. In dry soil, Neb. to Tex., Nev. and N. Mex. April-June.

9. Gilia trìcolor Benth. Tricolored Gilia. (I. F. f. 299I.) Annual, viscid puberulent, at least above; stems 1.5-5 dm. high. Leaves slender-petioled, or the upper sessile, 2-3-pinnately divided into acute segments; flowers shortpedicelled, IO-I4 $4 \mathrm{~mm}$. long, in simple cymes; calyx-lobes triangular-lanceolate, acute or acuminate: corolla campanulate-funnelform, 2-3 times as long as the calyx, its tube yellowish, short, the throat brown-purple, the oval to orbicular lobes lilac or violet; ovules several in the cavities; seeds mucilaginous and emitting spiral threads when wetted. Escaped from girdens to roadsides at Lincoln, Neb. (according to Webber). Native of Cal. Aprik-May.

Io. Gilia acerósa (A. Gray) Britton. Nifedle-leaved Gilia. Perennial, glandular-puberulent, $8-15 \mathrm{~cm}$. high, bushy-branched. Leaves pinnately parted into 3-7 acicular segments; pedicels slender, $2 \mathrm{~cm}$. long or less; corolla nearly rotate, $2 \mathrm{~cm}$. in diameter, or less; filaments filiform; anthers oblong. Dry soil, Kans. to Tex., Mex. and N. Mex. [G. rigidula acerosa A. Gray.]

\section{POLEMÒNIUM L.}

Perennial or rarely annual herbs, with alternate pinnate leaves, and mostly large cymose-paniculate or thy rsoid flowers. Calyx herbaceous, campanulate, 5cleft, accrescent in fruit, the segments entire, erect, or connivent over the capsule. Corolla tubular-campanulate or tub'llar-funnelform, rarely rotate, the limb 5 -lobed. Stamens about equally inserted near the base of the corolla, declined. Ovary ovoid; ovules few or several in each cavity. Capsule ovoid, obtuse, 3-valved. Seeds mucilaginous and emitting spiral threads when wetted. About I 5 species, natives of the north temperate zone. Besides the following, some ro others occur in western N. Am.

Anthers exserted; flowers $15-20 \mathrm{~mm}$. broad; stem erect. Anthers included; flowers $10-12 \mathrm{~mm}$. broad; stem reclining.
I. P. Van Bruntiae. 2. P. reptans.

I. Polemonium Van Brúntiae Britton. American Jacob's Ladder. (I. F. f. 2992.) Rootstock stout, horizontal. Stems somewhat glandular-pubescent above, 3-7.5 dm. high, leafy to the top; leaflets of the lower leaves $15-19$, ovate or lanceolate, acute, $1-4 \mathrm{~cm}$. long, the uppermost leaves 3-5-foliolate or simple; cymose clusters rather loosely 3-5-flowered; flowers bluish purple; corolla-lobes rounded; calyx much enlarged in fruit. the lobes acute; ovules 3 or 4 in each cavity. In swamps and along streams, Vt. and northern N. Y. to Md. May-July.

2. Polemonium réptans L. Greek Valerian. (I. F. f. 2993 ) Glabrous or very nearly so, usually not more than $3 \mathrm{dm}$. high; stems weak, at length reclining or diffuse, the rootstock short. Leaflets oblong, ovate-oblong, or lanceolateoblong, the uppermost leaves 3-5-foliolate or simple; flowers blue; calyx 5-lobed; svules 3 or 4 in each cavity. Woods, N. Y. to Minn., Ga. and Kans. April-May.

\section{COLlòmia Nutt.}

Annual or rarely perennial herbs, with alternate leaves, and capitate or cymose flowers. Calyx obpyramidal or cup-shaped, 5-cleft, scarious in the sinuses, accrescent in fruit, not distended nor ruptured by the ripening capsule, its lobes entire, erect, the sinuses often at length enlarged into a revolute lobe. Corolla tubularfunnelform or salverform, the limb 5-lobed, the lobes obtuse. Stamens unequally inserted on the tube of the corolla. the filaments unequal. Seeds of most species mucilaginous and emitting spiral threads when wetted. [Greek, gluten, referring to the glutinous seeds when wetted.] About ro species, natives of western Am. Besides the following, some 6 others occur in the western U. S. and Br. Col. 
I. Collomia lineàris Nutt. Narrow-leaved Collomia. (I. F. f. 2994.) Annual, viscid-puberulent; stem $0.7-4.5 \mathrm{dm}$. high. Leaves linear-oblong. lanceolate or linear-lanceolate, entire, acuminate, sessile, or the lower sl:ortpetioled, 2-6 cm. long; flowers $10-15 \mathrm{~mm}$. long, in capitate leafy-bracted clusters; calyx.lobes triangular lanceolate, acute; corolla light purple or nearly white, the tube slender, longer than the calyx, the lobes 2-4 mm. long; capsule about as long as the calyx. In dry soil, Manitoba to Minn., Neb., Br. Col., Ariz. and Cal. Also in N. Y. and N. B. May-Aug. [Gilia linearis A. Gray.]

\section{NAVARRÈTIA R. \& P.}

Annual herbs, with alternate spinose-pinnatifid leaves, or the lowest entire, and small flowers in dense terminal bracted clusters. Calyx prismatic or obpyramidal, the tube 5-angled, 5-cleft, not accrescent, not distended by the ripening capsule, the sinuses scarious, the lobes spiny-tipped, often toothed. Corolla tubular-funnelform or salverform, 5-lobed. Stamens equally inserted in or below the throat of the corolla. Ovary 2-3-celled. Capsule I-3-celled. Seeds mostly mucilaginous and emitting spiral threads when wetted. [In honor of Navarrete, a Spanish physician.] About 24 species, natives of western Am. Besides the following, some 22 others occur in the western U. S.

I. Navarretia mínima Nutt. Small Navarretia. (I. F. f. 2995.) Depressed, tufted, somewhat pubescent; stem $2-8 \mathrm{~cm}$. high. Leaves sessile, I-2.5 $\mathrm{cm}$. long, I-2-pinnatifid into almost filiform acicular segments; flowers about $4 \mathrm{~mm}$. long, white (?); calyx-lobes awl-shaped, mostly toothed, about as long as the tube; the sinuses more or less white-pubescent; calyx-tube about equalling the indehiscent I-6-seeded capsule. In dry soil, Neb. and S. Dak. to Wash. and Ariz. Summer. [Gilia minima A. Gray.]

\section{Family 4. HYDROPHYLLACEAE Lindl.}

\section{Water-leaf Family.}

Herbs, mostly hirsute, pubescent or scabrous, with alternate or basal, rarely opposite leaves, and perfect regular 5-parted flowers, in scorpioid cymes, spikes or racemes, or rarely solitary. Calyx inferior, deepiy cleft or divided. Corolla gamopetalous. Stamens 5, inserted on the corolla, and alternate with its lobes; filaments filiforn; ; anthers mostly versatile, 2-celled, the sacs longitudinally dehiscent. Disk annular, or none. Ovary superior, 2-celled, or I-celled with 2 placentæ; styles 2, separate, or partly united; stigmas small, terminal; ovules anatropous or amphitropous. Capsule I-2-celled, mostly loculicidally 2-valved. Seeds usually pitted, rugose or reticulated; endosperm fleshy or cartilag. inous; embryo small; cotyledons half-terete or plano-convex. About I7 genera and I6o species, mostly natives of western N. Am.

Styles united below; ovary I-celled; leaves mostly lobed or dentate.

Corolla-lobes convolute in the bud; placentæ dilated.

Stamens exserted.

Stamens not exserted.

Sinuses of the calyx appendaged.

Caly $\mathrm{x}$ much enlarged in fruit, its sinuses not appendaged.

Corolla-lobes imbricated in the bud; placentæ narrow. Styles distinct to the base; ovary 2-celled; leaves əntire.

x. Hydrophyllum.

2. Nemophila.

3. Macrocalyx.

4. Phacelia.

5. Nama.

\section{HYDROPHÝLLUM L. (See Appendix.)}

Perennial or biennial herbs, with large lohed pinnatifid or pinnately divided leaves, and white, blue or purple flowers, in more or less scorpioid cymes. Calyx deeply 5-parted, the segments lanceolate or subulate. Corolla tubular-campanulate or campanulate, 5 -lobed, the lobes convolute in the bud, each with a linear appendage within, which extends to the base of the corolla and is incurved into a groove. Stamens 5, exserted; filaments pilose below or at the base: anthers versatile. Ovary I-celled, hispid-pubescent; placentrefleshy, dilated, free from the ovary-wall except at the top and bottom, each enclosing 2 ovules; styles united nearly to the 
summit. Capsule 2-valved. Seeds I-4, globose-obovoid. [Greek, water-leaf, referring to the supposed cavity for water in each leaf.] About 6 species, of N. Am. Leaves, at least the lower, pinnatified or pinnately divided.

Caly $\mathrm{x}$ not appendaged in the sinuses or scarcely so.

Plant sparingly pubescent; leaf-segments acute.

Plant villous-hirsute; leaf-segments blunt.

Calyx with a reflexed appendage in each sinus. Leaves palmately $5-9$-lobed.
1. Virginicum.
2. H. macrophyllum.
3. H1. appendiculatum.
4. H. Canadense.

I. Hydrophyllum Virgínicum L. Virginia Water-leaf. (I. F. f. 2996.) Perennial by scaly rootstocks; stems slender, glabrous or nearly so, rather weak, 3-9 dm. long. Lower and basal leaves $1.5-2.5 \mathrm{dm}$. long, pinnately divided into 5-7 acute or acutish sharply toothed or incised segments $2-5 \mathrm{~cm}$. long, glabrous or with few scattered hairs; upper leaves, short-petioled, smaller, with fewer segments; cymes slender-peduncled; flowers white to violet purple, short pedicelled; pedicels strigose-pubescent; calyx-segments hispid; corolla about $8 \mathrm{~mm}$. long. In woods, Quebec to Alaska, south to S. Car., Kans. and Wash. May-Aug.

2. Hydrophyllum macrophýllum Nutt. LARge-LeAved WATER-Leaf. (I. F. f. 2997.) Peremnial, villous-hirsute; stem 6-9 dm. high. Lower leaves 2-3 $\mathrm{Im}$. long, deeply pinnatifid or pinnately divided into $7-13$ obtuse dentate segments 2-8 cm. long; upper leaves smaller, shorter-petioled and with fewer segments; cymes long-peduncled, very dense; flowers nearly white; calyx cleft to below the middle, its lobes lanceolate, erect, white-hispid; corolla 10-12 mm. long; anthers oblong; capsule densely white-hispid, enclosed by the calyx. In rich woods, Ohio to Ala., Ill. and Tenn. April-June.

3. Hydrophyllum appendiculàtum Michx. Appendaged Water-LEAF. (I. F. f. 2998.) Biennial, rough-hairy: stems weak, 3-6 dm. long, somewhat viscid above. Lower and basal leaves pinnatifid or pinnately divided into 5-7 irregularly dentate or incised segments; upper leaves ovate to orbicular, variously lobed, the lobes acute and dentate; cymes loose, branched. the pedicels 8-20 mm. long; calyx parted to near the base, enlarging in fruit, the segments triangular-lanceolate, acuminate; corolla violet or purple, 12-14 $\mathrm{mm}$. long. In woods, Ont. to N. Car., Minn. and Kans. May-June.

4. Hydrophyllum Canadénse L. Broad-Leaved Water-leaf. (I. F. f. 2999.) Perennial; stems glabrous or nearly so, $3-\delta \mathrm{dm}$. high. Leaves nearly orbicular, cordate, sparingly pubescent, at least above, 5-9 lobed, the lower often $3 \mathrm{dm}$. broad; upper leaves smaller; lobes ovate, acuminate, dentate; cymes dense or becoming loose; pedicels short, nearly glabrous; calyx cleft nearly to the base, its segments linear lanceolate, acute, nearly or quite glabrous, sometimes with a minute tooth in each sinus: corolla campanulate-rotate, white to purplish. In woods, Mass. to N. Car., Ill. and Ky. June-Aug.

2. NEMÓPHILA Nutt.

Annual diffuse pubescent fragile herbs, with mostly pinnatifid or lobed leaves. Flowers white, blue, or variegated, solitary, peduncled. Calyx with an appendage in each sinus. Corolla campanulate or rotate-campanulate, usually with Io small appendages within at the base, the lobes convolute in the bud. Stamens included. Ovary I-celled with placentæ similar to those of Hydrophyllum; styles partly united. Capsule 2-valved. Seeds $\mathbf{I}-4$ in our species. [Greek, grove-loving.] About ro species, natives of $N$. Am.

I. Nemophila micrócalyx (Nutt.) F. \& M. Small-flowered Nemophila. (I. F. f. 3000.) Stems slender, 5-40 cm. long. Leaves membranous, petioled, 2-6 cm. long, pinnatifid or pinnately divided into 3-5 obovate cuneate or oblique obtuse 2-3-dentate or -lobed segments, the upper alternate, the lowest opposite; peduncles 8-25 $\mathrm{mm}$. long, opposite the leaves; flowers white or blue, 3-4 $\mathrm{mm}$. long; appendages of the calyx minute; calyx scarcely enlarged in fruit; ovules 2 on each placenta; corolla appendages obsolete or none; anthers oval; capsule about $3 \mathrm{~mm}$. in diameter, x-2-seeded. In woods, Va. to Fla., Ark. and Tex. April-June.

3. MACRÓCALYX Trew. [ELLISIA L.]

Annual hirsute or pubescent slender herbs, with pinnately divided or I-3-pinnatifid leaves, and small white or bluish flowers. Calyx 5-lobed or 5-parted, 
spreading, much enlarged in fruit, destitute of appendages. Corolla campanulate or nearly cylindric, shorter than or slightly exceeding the calyx, usually with 5 minute appendages on the tube within, its lobes convolute in the bud. Stamens included. Ovary I-celled; styles united below; ovules 24 on each of the placentæ. [Greek, large calyx.] About 3 species, natives of N. Am.

I. Macrocalyx Nyctèlea (L.) Kuntze. Nyctelea. (I. F. f. 300I.) Spar. ingly hirsute-pubescent; stem forked, I-3 dm. high. Leaves pinnately divided, petioled, 4-IO cm. long, ovate-oblong in outline, the upper alternate, the lower opposite, the segments oblong or lanceolate; peduncles I flowered, opposite the leaves; calyx in flower about $4 \mathrm{~mm}$. long, about equalling the corolla, enlarging, widely spreading and becoming $\mathbf{1 5 - 3 0} \mathrm{mm}$. broad in fruit, its lobes lanceolate or ovate. lanceolate, acuminate; fruit at length pendulous; capsule globose. In moist soil, N. J. to Minn., the N. W. Terr., Va., Neb. and Kans. April-July.

\section{PHACÈLIA Juss.}

Mostly hirsute hispid or scabrous herbs, with alternate leaves, the lowest rarely opposite, and blue, purple, violet or white flowers in terminal scorpioid cymes or racemes. Calyx 5 -lobed, somewhat enlarging in fruit; sinuses not appendaged. Corolla-tube sometimes appendaged within, opposite the lobes, the lobes imbricated in the bud. Stamens attached near the base of the corolla; anthers mostly ovate. Ovary I-celled, the 2 placentæ narrow, affixed to the walls; styles united below. Capsule I-celled, or falsely nearly 2 -celled, 2-valved. Seeds usually reticulated. [Greek, a cluster, referring to the clustered flowers.] About 8o species, natives of the New World. Besides the following, some 50 others occur in western N. Am.

Corolla-lobes entire.

Corolla manifestly appendaged within, between the stamens.

Leaves entire.

Leaves crenate-dentate.

Leaves pinnately divided, or pinnatifid, the segments incised.

Racemes loose; pedicels slender; ovules 2 on each placenta.

Racemes dense; pedicels short; ovules numerous.

Appendages of the corolla inconspicuous or none.

Filaments pubescent; calyx-lobes oblong.

Puberulent; flowers 8-10 mm. broad.

Hirsute; flowers $\mathrm{r2}-14 \mathrm{~mm}$. broad.

Filaments glabrous; calyx-lobes linear.

Corolla nearly rotate, its lobes fimbriate.

Lobes of the leaves and calyx acute.

Lobes of the leaves and calyx obtuse.

I. P. leucophylla.

2. P. integrifolia.

\section{P. bipinnatifida.}

4. P. Franklinii.

5. P. dubia.

6. P. hirsuta.

7. P. Covillei.

8. P. Purshii.

9. P. fimbriata.

I. Phacelia leucophýlla Torr. Silky Phacelia. (I. F. f. 3002.) Perennial by a stout rootstock, pale. densely silky-pubescent. Stem 3-5 dm. high; leaves lanceolate to oblong, 5-ro $\mathrm{cm}$. long, the lower long-petioled; spike-like branches of the scorpioid cymes dense, $2-8 \mathrm{~cm}$. long: flowers sessile, numerous, about $8 \mathrm{~mm}$. high; calyx-lobes hispid, oblong-lanceolate or linear, somewhat shorter than the white or bluish, 5-lobed corolla; corolla-appendages in pairs between the filaments; filaments exserted, glabrous or sparingly hairy; ovules 2 on each placenta. In dry soil, S. Dak. to Idaho and Neb. May-Aug.

2. Phacelia integrifòlia Torr. Crenate-leaved Phacelia. (I. F. $f$. 3003.) Annual or biennial; stem very leafy, I.5-5 dm. high. Leaves finely strigose-pubescent, ovate-oblong or oblong-lanceolate, irregularly crenate-dentate, obtuse at the apex, rounded or cordate at the base, $2-6 \mathrm{~cm}$, long, petioled or the uppermost sessile; spike-like branches of the scorpioid cymes dense, 5-10 $\mathrm{cm}$. long when expanded; flowers sessile, about $8 \mathrm{~mm}$. long; calyx-segments acute; corolla tubular-campanulate, white or blue, its tube longer than the calyx; filaments glabrous, exserted; ovules 2 on each placenta. In saline soil, Kans. and Colo. to Mex., Utah and Ariz. April-Sept.

3. Phacelia bipinnatífida Michx. Loose flowered Phacelia. (I. F. f. 3004.) Biennial, hirsnte-pubescent ; stem glandular-viscid above, 3-6 dm. high. Leaves slender.petıoled, $5^{-13} \mathrm{~cm}$. long, pinnately divided or deeply pinnatifid 
tato 3-7, dentate or incised segments, or these again pinnatifid; flowers blue or vrolet, I2-16 $\mathrm{mm}$. broad, in loose racemes, the inflorescence only slightly scorpioid; pedicels 8-20 mm. long, recurved in fruit; calyx-segments linear; appendages of the rotate-campanulate corolla in pairs between the stamens; filaments pilose, exserted. Moist thickets and along streams, Ohio to Mo., south to Ala. April-June.

4. Phacelia Franklínii (R. Br.) A. Gray. Franklin's Phacelia. (I. F. f. 3ou5.) Annual, villous pubescent; stem 1.5-4.5 dm. high. Leaves 3-8 cm. long, pinnately parted into 7-15 linear or linear-oblong acute segments; flowers blue or nearly white, in scorpioid racemes; calyx-segments linear-lanceolate, acute, longer than the tube of the rotate-campanulate corolla; appendages of the corolla free at the apex; filaments glabrous, or nearly so; styles united nearly to the summit. Ont. and Minn. to Br. Col., Wyo. and Idaho. Summer.

5. Phacelia dùbia (L.) Small. Small-flowered Phacelia. (I. F. f. 3006.) Annual, puberulent or glabrate, I-3 dm. high. Lower and basal leaves petioled, $2-5 \mathrm{~cm}$. long, pinnatifid or pinnately divided into $3-5$ obtuse segments or rarely merely dentate, or even entire; flowers light blue or white, racemose; racemes 5-15-flowered; corolla rotate-campanulate; anthers slightly exserted; capsule 6.I2-seeded; fruiting pedicels ascending. In moist soil, Penn. to Ga., Kans. and Tex. April-June. [P. parviflora Pursh.]

6. Phacelia hirsùta Nutt. Hairy Phacelia. (I. F. f. 3007.) Similar to the preceding but usually stouter, hirsute-pubescent. Leaves pinnatifid into 5-9 usually entire segments, or the upper 3-5-lobed, or entire, sessile; racemes rather dense; flowers blue; calyx segments hirsute; corolla rotate-campanulate; ovules 3 or 4 on each placenta; stamens scarcely exserted; capsule 4-8-seeded. In dry soil, Va. to Gra., Kans. and Tex. April-June.

7. Phacelia Covíllei S. Wats. Coville's Phacelia. (I. F. f. 3008.) Similar to the wwo preceding species, pubescent; branches weak, 1.5-3 dm. long. Leaf-segments $3-7$, obtuse; racemes I-5-flowered; pedicels filiform, $\mathrm{I}-3.5 \mathrm{~cm}$. long: calyx-segnents linear; corolla tubular-campanulate, about $6 \mathrm{~mm}$. long and broad; anthers not exserted; capsule 3-4 $\mathrm{mm}$. in diameter; fruiting pedicels recurved. Along the Potomac River above Washington, and in Ill. April-May.

8. Phacelia Prirshii Buckl. Pursh's Phacelia. (I. F. f. 3009.) Annual, pubescent; stem I.5-4.5 dm. high. Lower and basal leaves pinnately parted or pinnatifid into 9-15 oblong or lanceolate segments; upper leaves sessile, with fewer segments; racemes strongly $\mathbf{I}$-sided, IO-zo-flowered; pedicels 6-25 $\mathrm{mm}$. long; calyxsegments lanceolate or linear-lanceolate; corolla $10-12 \mathrm{~mm}$. broad, blue or white; filaments slightly exceeding the corolla; ovules 2 on each placenta. In moist woods or thickets, Penn. to Minn., N. Car., Ala. and Mo. April-June.

9. Phacelia fimbriàta Michx. Fringed or Mountain Phacelia. (I. F. f. 3010.) Annual, sparingly pubescent; stems 1.5-5 dm. long. Basal and lower leaves slender-petioled, pinnately divided into 5-9 obtuse segments; upper leaves sessile, their segments acute; clusters loose, 3-12-flowered; pedicels 8-30 $\mathrm{mm}$. long; flowers 8-IO mm. bruad, white; calyx segments linear to spatulate, obtuse; corolla rotate-campanulatc; filaments pilose, about equalling the corolla; ovules 2 on each placenta. In woods, mountains of Va. to Ala. May-June.

\section{NÀMA L. [HYDROLEA L.]}

Perennial herbs, with alternate entire leaves, sometimes with spines in their axils, and blue clustered flowers. Calyx-segments distinct to the base. Corolla rotate-campanulate, 5-cleft, the lobes imbricated in the bud. Stamens inserted on the base of the corolla; anthers sagittate. Ovary 2-celled (rarely 3-celled); ovules numerous on fleshy adherent placentæ; styles 2, rarely 3, distinct to the base; stigma capitellate. Capsule globose or ovoid, septicidally or irregularly dehiscent. [Greek, a stream, referring to the habitat.] About 15 species, natives of warm and tropical regions. Besides the following, another occurs in the southern $U$. S.

Leaves lanceolate; flowers mostly in axillary clusters.

Glabrous, or very nearly so, throughout ; sepals ovate to ovate-lanceolate.

Villous, at least above, and on the calyx; sepals lanceolate. Leaves ovate; flowers mostly in terminal clusters; sepals villous.
I. N. affinis.

2. N. quadrivalvis. 3. N. ovata. 
I. Nama affinis (A. Gray) Kuntze. Smooth Nama. (I. F. f. 3011.) Glabrous or nearly so; stems 3-8 dm. high. Leaves oblong-lanceolate, petioled, acute or acuminate at both ends, $5^{-1} 3 \mathrm{~cm}$. long; flowers $12-14 \mathrm{~mm}$. broad, shortpedicelled, in rather dense peduncled leafy-bracted axillary clusters; sepals about equalling the corolla; capsule $4 \mathrm{~mm}$. in diameter, shorter than the sepals. In wet places, southern Ill. to Mo., La. and Tex. June-Aug.

2. Nama quadriválvis (Walt.) Kuntze. HaIry Nama. (I. F. f. 30I2.) Similar to the preceding, but pubescent, at least above, with spreading hairs; stem ascending, 3-6 dm. high. Leaves lanceolate, acute or acuminate, glabrcius, or sparingly pubescent, petioled, 5-13 cm. long; sepals about as long as the corolla; capsule 4-6 mm. in diameter, about the length of the sepals. In wet soil, Va. to Fla. and La. June-Aug.

3. Nama ovàta (Nutt.) Britton. Ovate-Leaved Nama. (I. F. f. 30r3.) Stem 3-9 dm. high, puberulent, or hirsute, at least above. Leaves ovate, rarely ovate. lanceolate, puberulent, or glabrous, $2-7 \mathrm{~cm}$. long, acute; flowers terminal, often 2.5 $\mathrm{cm}$. broad, or more; sepals lanceolate, acuminate, very villous, shorter than the corolla, longer than the capsule. In wet soil, Ga. to Mo., La. and Tex. May-Sept.

\section{Family 5. BORAGINÀCEAE Lindl.}

\section{Borage Family.}

Herbs, shrubs, or some tropical species trees. Leaves alternate, rarely opposite or verticillate, estipulate, mostly entire and hispid, pubescent, scabrous or setose. Flowers perfect, usually regular, mostly blue, in onesided scorpioid spikes, racemes, cymes, or sometimes scattered. Calyx inferior, mostly 5-lobed, 5-cleft, or 5-parted, usually persistent. Corolla gamopetalous, mostly regular and 5-lobed, rarely irregular. Stamens as many as the corolla-lobes and alternate with them, inserted on the tube or throat ; anthers 2-celled, the sacs longitudinally dehiscent. Disk commonly inconspicuous. Ovary superior, of 2 2-ovuled carpels, entire, ol the carpels commonly deeply 2 -lobed, making it appear as of $4 \mathrm{I}$-ovuled carpels ; style simple, entire or 2-cleft in our genera; ovules anatropous or amphitropous. Fruit mostly of 4 i-seeded nutlets, or of 2 2-seeded carpels. Endosperm fleshy, copious, or none; cotyledons mostly flat or plano-convex; radicle short. About 85 genera and 1500 species, of wide distribution.

* Ovary entire or 2-4-grooved; style terminal. I. Heliotropium.

* * Ovary 4-divided or deeply 4-lobed, the style arising from the center.

Flowers regular.

Nutlets armed with barbed prickles.

Nutlets spreading or divergent, covered by the prickles. 2. Cynoglossum.

Nutlets erect or incurved, the prickles on their backs or margins.

Nutlets unarmed. 3. Lappula.

Nutlets attached laterally to the receptacle, sometimes just above their bases. Truiting calyx not greatly enlarged nor membranous.

Corolla small, usually white; receptacle conic or elongated.

Annuals; calyx nearly closẹd in fruit; inflorescence naked or bracteolate.

Lowest leaves mostly opposite; calyx persistent.

Leaves all alternate; caly $\mathrm{x}$ at length deciduous. 4. Allocarya.

5. Cryptanthe.

Perennials or biennials; calyx-segments more or less spreading in fruit; inflorescence leafy.

6. Oreocarya.

Corolla tubular-funnelform, mostly blue; receptacle flat or convex. Maritime: nutlets fleshy, smooth and shining. 7. Pneumaria. Not maritime; nutlets wrinkled and dry when mature. 
Nutlets attacled to the receptacle by their very bases.

Scar of attacliment small, flat.

Corolla salverform or funnelform, its lobes rounded, spreading.

Racemes not bracted; corolla-tube short. $\quad$ ro. Myosolis.

Racemes bracted; corolla-tube cylindric, usually slender.

Corolla tubular, its lobes erect, acute.

II. Lithospermum.

Scar of attachment large, concave.

Corolla tubular, 5-toothed.

Corolla rotate; anthers erect in a cone.

12. Onosmodium.

Flowers irregular.

Stamens included; throat of the corolla closed by scales.

Stamens exserted; throat of the corolla dilated, open.

13. Symphytum.

14. Borago.

15. Lycopsis.

16. Eichium.

\section{HELIOTRÒPIUM $\mathbf{L}$.}

Herbs or shrubs, with alternate mostly entire leaves, and small blue or white flowers, in scorpioid spikes, or scattered. Calyx lobes or -segments lanceolate or linear. Corolla salverform or funnelform, naked in the throat, its tube cylindric, its lobes imbricated, plicate or induplicate in the bud. Stamens included; fila. ments short, or none. Stigma conic or annular. Fruit 2-4-lobed, separating into 4 I-seeded nutlets, or into 2 2-seeded carpels. [Greek, sun-turning, i. e., turning to or with the sun.] About II5 species, widely distributed. Besides the follow. ing, some 9 others occur in southern and western N. Am.

Fruit 4-lobed, each lobe becoming a I-seeded nutlet.

Flowers in scorpioid spikes.

Plant rough-puberulent; leaves oval.

Glabrous, fleshy; leaves linear or spatulate.

Flowers solitary, terminating short branches.

Fruit 2-lobed, or of 2 carpels.

Style elongated; flowers large, scattered, white.

Style very short; flowers blue, in scorpioid spikes.

1. H. Europaeum.

2. H. Curassavicum.

3. H. tenellum.

4. H. convolvulaceum. 5. H. Indicum.

I. Heliotropium Europaèum L. European Heliotrope. (I. F. f. 3OI4.) Annual, much branched, rough puberulent, 1.5-5 dm. high. Leaves oval, 2-5 cm. long, obtuse, narrowed at the base, slender-petioled; flowers white, 2-4 mm. broad, in dense I-sided, bractless spikes; terminal spikes in pairs, the lateral ones commonly solitary; calyx-segments shorter than the corolla-tube; anthers distinct, obtuse; stigma-tip long-conic; fruit depressed-globose. pubescent. In waste places, N. Y. and Penn. to Fla. Adventive or nat. from Europe. June-Oct.

2. Heliotropium Curassávicum L. Sea-side Heliotrope. (I. F. f. 3015.) Annual (or southward perennial ?), fleshy, more or less glaucous, diffuse, the branches 1.5-4.5 dm. long. Leaves oblanceolate, linear, or spatulate. entire. in. conspicuously veined, $2-5 \mathrm{~cm}$. long. 3-6 $\mathrm{mm}$. wide, obtuse, narrowed into petioles, or the upper sessile; scorpioid spikes dense, bractless, mostly in pairs; flowers about $4 \mathrm{~mm}$. broad: calyx-segments acute; corolla white with a yellow eye or changing to blue; stigma umbrella-shaped; anthers acuminate; fruit globose. On sandy seashores, Va. to Tex. and Mex.

2a. Heliotropium spathulatum Rydb. Flowers much larger than in the preceding species, the corolla $6-8 \mathrm{~mm}$. broad; stem stout, ascending; leaves broadly spatulate. Saline soil, N. D. to Wash., Iowa, Nebr. and Utah.

3. Heliotropium tenéllum (Nutt.) Torr. Slender Heliotrope. (I. F. f. 3or6.) Annual, strigose-canescent; stem commonly leafless below, I.5-4.5 dm. high. Leaves linear, entire, I $4 \mathrm{~cm}$. long, narrowed at both ends, sessile, or the lower petioled; flowers white, about $5 \mathrm{~mm}$. long. bracted by $\mathrm{I}$ or 2 leaves; calyxsegments unequal; corolla-tube canescent, its lobes entire; anthers obtuse: stigma subulate-tipped; fruit depressed. strigose-pubescent. In dry soil, Ky. to Kans., Ala., Tex. and N. Mex. April-Aug.

4. Heliotropium convolvulàceum (Nutt.) A. Gray. Bindweed Heliotrope. (I. F. f. 3017.) Annual, strigose-canescent, I.5 4 dm. high. Leaves oblong, nvate, or lanceolate, entire, short-petioled, narrowed at the base, $\mathrm{r}-4 \mathrm{~cm}$. long; flwwers numerous, fragrant, short-peduncled, mostly solitary and opposite the leaves; calyx-segments acuminatc, equal; corolla white, strigose, $1.5-2 \mathrm{~cm}$. long, about $\mathbf{1 2}$ 
$\mathrm{mm}$. broad, its tube narrowed at the throat, longer than the angulate-lobed limb; anthers inserted on the tube of the corolla, slightly cohering by their tips; style filiform; stigma with a tuft of bristly hairs; fruit 2-lobed, pubescent. In dry sandy soil, Neb。 to Tex., Utah and Mex。 July-Sept.

5. Heliotropium Índicum L. Indian Heliotrope. (I. F. f. 3018.) Annual, hirsute or hispid; stem 3-9 dm. high. Leaves ovate or oval, obtuse, rounded or subcordate at the base, 5-15 cm. long, repand or undulate, margined-petioled; flowers blue, 4-6 $\mathrm{mm}$. broad, sessile in terminal dense bractless usually solitary scorpioid spikes; calyx-segments acute, shorter than the strigose corolla-tube; style very short, deciduous; fruit deeply 2-lobed, glabrous. In waste places, N. Car. to Ill., Fla. and Tex. Nat. from India. Also in ballast about the northern seaports. May-Nov.

\section{CYNOGLÓSSUM L.}

Hirsute or hispid (rarely glabrous) mostly tall herbs, with alternate entire leaves, the basal long-petioled, and purple blue or white flowers in panicled, more or less scorpioid racemes. Calyx 5-cleft or 5-parted, enlarged in fruit. Corolla funnelform or salverform, the tube short, the throat closed by 5 scales opposite the imbricated rounded lobes. Stamens included; filaments short. Ovary deeply 4-lobed. Nutlets oblique, attached laterally to the convex or conic recep. tacle, covered with short barbed prickles. [Greek, dog's tongue.] Abcut 75 species of wide distribution. Besides the following, some 3 others occur in western N. Am.

Stem leafy to the top: flowers reddish, purple or white; nutlets flat. 1. C. officinale. Stem leafless above; flowers blue; nutlets convex.

2. C. Virginicum.

I. Cynoglossum officinàle L. Hounn's-tongue. Girsy Flower. (I. F. f. 3org.) Biennial; stem stout, 4-9 dm. high. Basal and lower leaves oblong or oblong-lanceolate, sometimes obtuse, r.5-3 dm. long; upper leaves lanceolate, acute or acuminate, sessile; racemes much elongated in fruit; pedicels 6-12 mm. long; calyx-segments ovate-lanceolate, acute ; corolla abcut $8 \mathrm{~mm}$. broad; fruit pyramidal, about $\mathrm{I} \mathrm{cm}$. broad, each of the 4 nutlets forming a side of the pyramid, flat on their upper faces, margined, splitting away at maturity, but hanging attached to portions of the subulate style. In fields and waste places, Quebec and Ont. to Minn., Manitoba, N. Car. and Kans. May-Sept.

2 CynoglossumVirgínicum L. Wild Comfrey. (I. F. f. 3020.) Perennial, hirsute; stem usually simple, leafiess above, stout, 4-8 dm. high, Basal and lower leaves oval or oblong, $\mathbf{r}-3 \mathrm{dm}$. long, obtuse, narrowed into petioles; upper leaves oblong, or ovate-lanceolate, sessile and clasping by a cordate base, acute; racemes 2-6, bractless, long-peduncled; flowers about $1 \mathrm{~cm}$. broad; calyx-segments oblong-lanceolate, obtuse; fruit depressed, $8 \mathrm{~mm}$. broad, the nutlets convex on the upper face, not margined, separating and falling away at maturity. In woods, N. B. to western Ont., Fla., La. and Kans. April-May.

3. LÁPPULA Moench. [ECHINOSPERMUM Sw.] ]

Rough-pubescent or canescent herbs, with alternate narrow entire leaves, and small blue or white flowers, in terminal racemes. Calyx deeply 5-cleft or 5-parted, the segments narrow. Corolla salverform or funnelform, the tube very short, the throat closed by 5 scales, the lobes obtuse, spreading, imbricated in the lud. Stamens included: filaments very short. Ovary 4-lobed; style short. Nutlets 4, laterally attached to the receptacle, at length separating, the margins or backs armed with stout barbed prickles, the sides usually papillose or tuberculate. [Diminutive of the Latin lappa, a bur.] About 40 species, mostly of the north temperate zone. Besides the following, several others occur in western N. A.:

Racemes bracted; fruiting pedicels not deflexed.

Prickles in two rows on the margins of the nutlets, distinct.

Prickles in one row on the margins, more or less confluent.

1. L. Lappula.

2. L. Texana.

Racemes bracted only at the base; fruiting pedicels deflexed.

Stem leaves ovate-oblong, the basal cordate; fruit globose.

Leaves oblong, oblong-lanceolate or linear: fruit pyramidal. Flowers 6-1o $\mathrm{mm}$. broad; fruit about $6 \mathrm{~mm}$. broad.

Flowers $2-4 \mathrm{~mm}$. broad; fruit about $4 \mathrm{~mm}$. broad.

3. L. Virginiana.

4. L. floribunda.

5. L. Americana. 
7. Lappula Láppula (L.) Karst. European Stickseed. Burseed. (I. F. f 3021.) Annual, pale, leafy, hispid or appressed-pubescent, 3-6 dm. high, the br.nches erect. Leaves linear, lirear-oblong or the lowest spatulate, sessile or the lower narrowed into petioles, obtuse or obtusish, $1-4 \mathrm{~cm}$. long; racemes more or less I-sided; pedicels short, stout; calyx-segments lanceolate; corolla blie, about $2 \mathrm{~mm}$. broad; fruit globose-oval, $3 \mathrm{~mm}$. in diameter, the nutlets papillose on the b.ck, the margins with 2 rows of slender prickles. In waste places, N. S. to Br. Col., N. J. and Kans. Nat. from Europe. May-Sept.

2. Lappula Texàna (Scheele) Britton. HAIRy Stickseed. (I. F. f. 3022.) Annual, similar to the preceding. Leaves linear or linear-ob'ong, mostly obtuse, the lower narrowed into petioles; pedicels short, not deflexed in fruit; flowers about $2 \mathrm{~mm}$. broad; nutlets papillose-tuberculate on the back, the margins armed with a row of flat, usually confluent bristles, or these united into a cup. In dry soil, Manitoba and the N. W. Terr. to Br. Col., Neb., Tex. and Ariz. AprilAug.

3. Lappula Virginiàna (L.) Greene. Virginia Stickseed.

(I. F. f. 3023.) Biennial, pubescent; stem 6-12 $\mathbf{~ I m}$. high, the branches spreading. Basal leaves (seldom present at flowering time) ovate to orbicular, cordate, long-petic led; stem leaves ovate-oblong or oval, acute or acuminate, petioled, o.7-2 dm. long, the uppermost smaller, sessile; racemes slender, divergent; pedicels short, deflexed in truit; coro!la nearly white, about $2 \mathrm{~mm}$. broad; fruit nearly $4 \mathrm{~mm}$. in diameter; nutlets coverel on the margins and usually also on the back by the slender flattened barbed prickles, the backs commonly also more or less papillose. In dry woods and thickets, N. B. to Ont. and Minn., Ala., La. and Kans. June-Sept.

4 Lappula floribúnda (Lehm.) Greene. LARGE-FLowered Stickseed. (I. F. f. 3024.) Biennial or perennial, rough-pubescent; stem stout, 6-15 dm. high. Leaves oblong to linear-lanceolate, 5-10 cm. long, 4-20 mm. wide, sessile, or the lower narrowed into petioles; racenes erect or nearly so, densely flowered, many of them in pairs; pedicels 4-8 $\mathrm{mm}$. long, deflexed in fruit; flowers blue, 6-10 $\mathrm{mm}$. broad; fruit pyramidal, about $6 \mathrm{~mm}$. broad; nutlets keeled, papillose-tuberculate on the back, the margins armed wlth a row of flat prickles. Western Ont. and Minn. to Br. Col., N. Mex. and Cal. June-Aug.

5. Lappula Americàna (A. Gray) Rydberg. Nodding Stickseed. (I. F. f. 3025.) Annual, rough-puberulent; stem 3-9 dm. high. Leaves oblong or oblonglanceolate, mostly narrowed at both ends, 5-10 cm. long; racemes slender; pedicels slender, 4-8 mm. long, deflexed in fruit; corolla white or bluish, about $2 \mathrm{~nm}$. broad; fruit pyramidal; nutlets keeled, papillose-tuberculate on the back, rarely with a few prickles on the keel, the margins armed with a row of fiat prickles. In thickets, Manitoba and N. Dak. to Br. Col. May-Aug.

\section{ALLOCÀrYa Greene.}

Mostly annual low herbs, with linear entire leaves, the lowest often opposite, and small flowers in terminal spikes or racemes. Pedicels thickened at the summit, persistent. Calyx 5-divided, persistent, the segments narrow. Corolla salverform, white, yellow in the throat. Stamens included. Ovary 4-divided; style short. Nutlets crustaceous, attached at their base or below the middle to the receptacle. [Greek, different nuts.] About 25 species, of western N. Am.

r. Allocarya scopulòrum Greene. Mountain Allocarya. (I. F. f. 3026.) Pubescent, with scattered stiff appressed hairs, the slender spreading branches 2-20 cm. long. Leaves $1-3.5 \mathrm{~cm}$. long, 2-3 mm. wide, sessile or shortpetioled; flowers about $2 \mathrm{~mm}$. broad, distant, borne in most of the axils, shortpedicelled; floral bracts similar to the leaves; calyx-segments linear-lanceolate; nutlets reticulate on the back, lightly grooved on the ventral side. Western Neb. to Mont., Wyo. and Colo. June-Sept.

\section{CRYPTÄNTHE Lehm.}

Low annual setose or hispid herbs, with narrow alternate entire leaves, and small mostly white flowers, in scorpioid spikes. Calyx 5-parted or 5-cleft, at length deciduous, the lobes or segments erect, mostly connivent in fruit. Corolla small, funnelform, usually with 5 scales closing the throat, the lobes imbricated in 
the bud. Stamens included. Ovary 4-divided; style short; stigma capitellate. Nutlets erect, rounded on the back, not keeled, attached lateraily to the conic or elongated receptacle, the scar of attachment mostly longer than broad. [Greek, hidden-flowered.] About 50 species, natives of Am., mostly of the western U. S.

Nutlets, at least some of them, with short processes.

A!l four nutlets smooth and shining.

r. C. crassisepalac

2. C. Fendleri.

I. Cryptanthe crassisépala (T. \& G.) Greene. Thick-SEpaled CRYPTANTHE. (I. F. f. 3027.) Densely hispid, 7-15 cm. high. Leaves linear, or linear-spatulate, I-4 cm. long, sessile, or the lower narrowed into petioles; spikes densely flowered; flowers about $4 \mathrm{~mm}$. broad, sessile, bracteolate; fruiting calyx $6 \mathrm{~mm}$. long, closing over the fruit, its segments linear, obtusish, their midribs much thickened; fruit of 3 finely muricate nutlets, and I larger smooth and shining nutlet about $2 \mathrm{~mm}$. long. In dry soil, N. W. Terr. to Neb., Kans., Tex. and N. Mex. Junc-Aug.

2. Cryptanthe Féndleri (A. Gray) Greene. Fendlek's Cryptanthe. (I. F. f. 3028.) Erect, hispid; stem I.5-4 dm. high. Leaves linear, or the lowest linear-spatulate, 2-6 cm. long; spikes slender, bracteolate only at the base; flowers sessile, 2-4 cm. broad; fruiting calyx nearly closed, its segments linear, leaf-like, herbaceous; nutlets 4 , all alike, brown, less than $2 \mathrm{~mm}$. long. In dry soil, N. W. Terr. to Wash., Neb. and Ariz. June-Aug.

\section{OREOCÁRYA Greene.}

Hispid or strigose-pubescent herbs, mostly with thick woody roots, alternate or basal narrow leaves, and small white racemose-paniculate or densely thyrsoid flowers. Calyx deeply 5-parted or 5-divided, the segments lanceolate, more or less spreading or recurved in fruit. Corolla funnelform or salverform, mostly crested in the throat, 5-lobed. Stamens included. Ovary 4-divided; style mostly short. Nutlets 4, laterally attached to the receptacle, not keeled, their margins acute or winged. [Greek, mountain nut.] About 9 species, natives of western N. Am. and Mex.

Inflorescence racemose-paniculate; nutlets smooth.

Inflorescence thyrsoid or thyrsoid-glomerate; nutlets rough.

Corolla-tube not longer than the calyx, little longer than the lobes.

Densely rough-hairy, $1.5-4.5 \mathrm{dm}$. high.

Silvery appressed-pubescent, $0.7-1.5 \mathrm{dm}$. high.

Corolla-tube longer than the calyx, 2 or 3 times as long as the lobes.

1. O. suffruticosa.

\section{O. fulvocanescens.}

I. Oreocarya suffruticòsa (Torr.) Greene. Shrubby Oreocarya.

(I. F.

f. 3029.) Perennial, rather stout, strigose-pubescent or somewhat hirsute, $\mathbf{r}-3 \mathrm{dm}$. high. Upper leaves linear, I-2.5 cm. long, the lower oblanceolate, somewhat longer; pedicels about $2 \mathrm{~mm}$. long; calyx canescent and somewhat hispid; bractlets longer than the fruiting calyx; corolla $3-6 \mathrm{~mm}$. broad; nutlets nearly $2 \mathrm{~mm}$. long, shining, closely fitting together, triangular, acute-margined. In dry soil, western Neb. and Wyo. to Tex. and Ariz. May-Aug.

2. Oreocarya glomeràta (Pursh) Greene. Clustered Oreocarya. (I. F. f. 303o.) Perennial or biennial; stem I.5-4.5 dm. high. Leaves spatulate or the upper linear, obtuse, $2-6 \mathrm{~cm}$. long, the basal commonly tufted; inflorescence of thyrsoid clusters, the short dense lateral spike-like clusters mostly longer than the subtending bracts; calyx densely bristly; corolla 6-1o mm. broad; fruit pyramidal, the nutlets triangular-ovate, acute, acutely margined, papillose on the back. In dry soil, Manitoba to the N. W. Terr., Neb., N. Mex. and Utah. May-Sept.

3. Oreocarya serícea (A. Gray) Greene. Low Oreocarya. (I. F. f. 303I.) Perennial, low, tufteỏ; stems $7-15 \mathrm{~cm}$. high. Leaves linear-spatulate, $\mathbf{I}-2.5 \mathrm{~cm}$. long, imbricated on the short sterile shoots and at the bases of the flower. ing stems; inflorescence usually short; calyx densely hispid; corolla 4-6 mm. broad; style short; nutlets acutely margined, acute, papillose on the back. In dry soil, N. W. Terr. to Neb. and Utah. May-Sept.

4. Oreocarya fulvocanéscens (A. Gray) Greene. Tawny Oreocarya. (I. F. f. 3032.) Perennial, similar to the preceding, but densely strigose or hirsute. 
Leaves spatulate, or oblanceolate, obtuse, the lower and basal ones 2-4 cm. long; calyx densely setose with yellowish hairs, corolla about $4 \mathrm{~mm}$. broad; styie filiform: nutlets acutely margined, tuberculate on the back. In dry soil, western Neb. (according to Webber); Wyo. to Nev. and N. Mex. May-Aug.

\section{PNEUMÀRIA Hill.}

A perennial fleshy glabrous glaucous herb, with alternate entire leaves, and small blue pinkish or white flowers in loose terminal leafy-bracted racemes. Calyxlobes triangular-ovate or lanceolate, somewhat enlarging in fruit. Corolla tubularcampanulate, crested in the throat, 5-lobed, the lobes imbricated in the bud, slightly spreading. Ovary 4-divided; style slender. Nutlets erect, fleshy, attached just above their bases to the somewhat elevated receptacle, smooth, shining, acutish-margined, becoming utricle-like when mature. A monotypic genus.

I. Pneumaria marítima (L.) Hill. Sea Lungwort. Sea Bugloss. OysTER Plant. (I. F. f. 3033.) Pale green, the branches spreading or ascending, $0.7-4 \mathrm{dm}$. long. Leaves thick, ovate, obovate, or oblong, $2-10 \mathrm{~cm}$. long, the lower and basal ones contracted into margined petioles; flcwers blue or nearly white, about $6 \mathrm{~mm}$. long, pedicelled; pedicels slender, $\mathrm{I}-3.5 \mathrm{~cm}$. long; caly $\mathrm{x}$ shorter than the corolla-tube; nutlets about as long as the calyx-lobes when mature. On seabeaches, L. I. (?); Mass. to Newf. and Greenland; Ore. to Alaska. Also on the coasts of Europe and Asia. May-Sept.

\section{MERTÉNSIA Roth.}

Perennial herbs, with alternate leaves, and rather large clustered blue purple or white flowers. Calyx-lobes lanceolate or linear, little enlarged in fruit. Corolla tubular-funnelform or trumpet-shaped, its lobes obtuse, imbricated, little spreading. Stamens inserted on the tube of the corolla, included, or scarcely exserted; anthers obtuse. Ovary 4-divided; style filiform. Nutlets erect, coriaceous, wrinkled when mature, attached abcve their bases to the convex or nearly flat ieceptacie. [In honor of Prof. C. F. Mertens, a German botanist.] About 16 species, of the ncrthern hemisphere. Besides the following scme 9 others occur in western N. Am.

Corolla trumpet-shaped, not crested in the throat, the limb barely 5 -lobed.

I. M. Virginica.

Corolla funnelform-campanulate, crested in the throat, the limb manifestly 5-lobed.

Stem-leaves ovate or ovate-lanceolate, acuminate.

Stem-leaves oblong or lanceolate, obtuse or acute.

2. M. paniculata.

3. M. lanceolata.

I. Mertensia Virgínica (L.) DC. Virginia Cowslip. (I. F. f. 3034.) Crlabrous: stem 3-6 dm. high. Leaves oblong, oval, or obovate, obtuse, $5^{-13} \mathrm{~cm}$. long, the lower narrowed into margined petioles; racemes short, corymb-like; flowers blue-purple, showy, about $2.5 \mathrm{~cm}$. long; calyx-lobes oblong-lanceolate, obtusish; corolla-tube cylindric, a little expanded above, longer than the 5-lobed plaited limb, pubescent at the base within; disk with two opposite linear lubes; filaments filiform, much longer than the anthers. In loiv meaciows and along streams, Ont. to N. J., S. Car., Minn., Neb. and Kans. March-May.

2. Mertensia paniculàta (Ait.) G. Don. TALl. Lungwort. (I. F. f. 3035.) Roughish-pubescent, dark green; stem 4-9 dm. high. Leaves thin, pinnately veined, those of the stem $5^{-13} \mathrm{~cm}$. long, the lower narrowed into slender petioles; basal leaves ovate, rounded or cordate at the base; pedicels filiform, 8-20 $\mathrm{nm}$. long; flowers purple-blue, I2-I4 mm. long; calyx-lobes lanceolate, acute; corolla-tube about twice as long as the calyx and exceeding the 5-lched limb; filaments flattersed, slightly longer than the anthers; style filiform, usually somewhat exserted. In woods or thickets, HIudson Bay to Alaska, Mich., Neb., Colo. and Utah. JulyAug.

3. Mertensia lanceolàta (Pursh) DC. Lance-Leaved Lungwor'T. II. F. f. 3036.) Stem slender, I.5-4.5 dm. high. Leaves papillose, indistinctly veined, light green, the upper lanceolate, acute, sessile or slightly clasping at the base, the lower oblong or oblanceolate, obtuse, 7-10 cm. long, narrowed into margined petir $1 \cdots$; fowers blue, 10-12 $\mathrm{mm}$. long; pedicels $6-14 \mathrm{~mm}$. long; calyx-lobes lanceolate, tle tube longer than the calyx and longer than the 5-lobed limb. hairy at the 
base within; filaments a little longer than the anthers; style filiform, scarcely ex.. serted. In thickets, western Neb. to Manitoba, Wyo. and N. Mex. June-Aug.

\section{ASPERÙGO L.}

An annual rough-hispid procumbent herb, with alternate entire leaves, or the uppermost sometimes opposite, and small blue or nearly white flowers, short-pedicelled and I -3 together in the upper axils. Calyx campanulate, unequally 5-cleft, enlarged and folded together in fruit, the lobes incised-dentate. Corolla tubularcampanulate, 5-lobed, the lobes imbricated. Stamens 5, included, inserted on the corolla-tube; filaments short. Style short; stigma capitate. Nutlets 4, ovoid, erect, granular-tuberculate, keeled, laterally attached above the middle to the elongated-conic receptacle. [Latin, rough, referring to the leaves.] A monotypic genus of Europe and Asia.

I. Asperugo procúmbens L. German Madwort. Catchweed. (I. F. f. 3037.) Stems slender, I.5-4.5 dm. long. Leaves oblong, lanceolate, or the lower spatulate, I-4 cm. long, the lower narrowed into margined petioles; flowers short. pedicelled, about $2 \mathrm{~mm}$. broad, the pedicels recurved in fruit; fruiting calyx dry and membranous, strongly veined, 8-12 $\mathrm{mm}$. broad. In waste places and ballast, N. Y. to D. C. and Minn. Adventive from Europe. May-Aug.

\section{ı. MYOSÒTIS L.}

Low pubescent herbs, with alternate entire leaves, and small blue pink or white flowers in elongated more or less I-sided racemes. Calyx 5-cleft, the lobes narrow. Corolla salverform, the limb 5-lobed, the lobes convolute in the bud, rounded, the throat crested. Stamens 5, included, inserted on the corolla-tube; filaments filiform; anthers obtuse. Style filiform. Nutlets erect, attached by their bases to the receptacle, the scar of attachment small, flat. [Greek, nouse. ear.] About 35 species of wide distribution. Besides the following, I or 2 others occur in southern and western N. Am.

Hairs of the calyx all straight; perennial swamp or brook plants.

Calyx-lobes shorter than the tube; corolla $6-8 \mathrm{~mm}$. broad.

Calyx-lobes as long as the tube; corolla $4-6 \mathrm{~mm}$. broad.
Hairs of the calyx, or some of them, with hooked tips; annuals or biennials.

Fruiting pedicels longer than the calyx.

Fruiting pedicels not longer than the calyx.

3. $M$. arvensis.

Calyx-lobes equal.

Calyx closed after flowering; corolla yellow, changing to violet or blue.

Calyx open after flowering; corolla blue. 4. $M$. versicolor.

Calyx-lobes unequal; corolla white.

5. $M$. collina.

Caly $x$ not nodding in fruit, mostly less than $5 \mathrm{~mm}$. long; seeds r.5 mm. long.

6. $M$. Virginica.

Calyx nodding or spreading in fruit, 5-7 $\mathrm{mm}$. long; seeds $2 \mathrm{~mm}$. long.

7. M. macrosperma.

I. Myosotis palústris (L.) Lam. Forget-me-not. Mouse-ear ScorpionGRASS. (I. F. f. 3038.) Appressed-pubescent, with slender rootstocks or stolons: stems decumbent, I.5-5 dm. long. Leavcs oblong, oblanceolate or oblong-lanceolate, obtuse, narrowed at the base, $2-8 \mathrm{~cm}$. long; racemes loosely many-flowered; pedicels longer than the calyx; calyx-lobes equal, triangular-ovate, acute, spreading in fruit. corolla blue with a yellow eye; nutlets angled and keeled on the inner side. In brooks and marshes, N. S. to N. Y. and Tenn. Escaped from cultivation. Native of Europe and Asia. May-July.

2. Myosotis láxa Lehm. Smallek Forget-me-not. (I. F. f. 3039.) Similar to the preceding. Leaves oblong, oblong-lanceolate or spatulate, obtuse; racemes very loosely many-flowered; pedicels spreading, much longer than the fruiting calyx; calyx-lobes equal, ovate-lanceolate, acutish, spreading in fruit. quite as long as the tube; corolla blue with a yellow eye, its limb concave, about $4 \mathrm{~mm}$. broad; sutlets convex on both the inner and outer sides. In wet muddy places, Newf. to Ont., Va. and Tenn. Also in Europe. May-July.

3. Myosotis arvénsis (L.) Lam. Field Scorpion-grass, or Mouse-ear. (I. F. f. 3040.) Hirsute-pubescent; stem I.5-4.5 dm. long. Basal and lower 
leaves oblanceolate, obtuse; stem leaves mostly oblong or oblong-lanceolate, narrowed to the sessile base, I-4 cm. long; calyx-lobes equal, erect, or connivent in fruit, triangular-lanceolate, acute, about as long as the tube; coroila blue or white, the limb concave, 2-3 mm. broad; nutlets convex on the outer side, somewhat keeled on the inner. In fields, N. B. to Ont. and Minn., south to W. Va. Perhaps not indigenous. Also in Europe. June-Aug.

4. Myosotis versícolor (Pers.) Reichenb. Yellow and Blue ScorpionGRASS. (I. F. f. 304I.) Annual, hirsute-pubescent, often branched above; stems 1-3 dm. high. Leaves oblong, obtuse or obtusish, sessile, or the lower spatulate and narrowed into margined petioles; pedicels erect; calyx-lobes linear-lanceolate, erect or connivent in fruit, longer than or equalling the tube; corolla pale yellow changing to violet or blue, its limb about $2 \mathrm{~mm}$. broad; nutlets convex on the cuter, slightly keeled on the inner side. In fields and along roadsides, southern N. Y. to Del. Nat. from Europe. May-July.

5. Myosotis collina Hoffm. Early Myosote. Similar to the two preced. ing species, usually much branched from the base, rarely over $1.5 \mathrm{dm}$. high. Leaves oblong, or the lower spatulate, mostly obtuse; pedicels rarely over $2 \mathrm{~mm}$. long, the segments not closed over the fruit. Fields, Me. to Ont., Mass. and N. Y. Adventive from Europe. May-June.

6. Myosotis Virgínica (L.) B.S.P. Spring Scorpion-grass. (I. F. f. 3042.) Hirsute-pubescent or hispid, o.7-3 dm. high, the branches erect. Leaves oblong or linear-oblong, sessile, $0.6-2.5 \mathrm{cn}$. long, obtuse, or the lower spatulate and narrowed into short petioles; racemes strict, dense; pedicels ascending or erect, or slightly spreading at the apex, shorter than the fruiting calyx; calyx somewhat 2-lipped, unequally 5-cleft, the lobes lanceolate, acute, longer than the tube, connivent in fruit, very hispid; corolla limb $3 \mathrm{~mm}$. broad or less; nutlets convex on the back, slightly keeled and margined on the inner side. On dry hills and banks, Me. to Ont., Minn., Ga. and Tex. April-June. [M. verna Nutt.]

7. Myosotis macrospèrma Engelm. Southern Scorpion-Grass. Similar to $M$. Virginica, but usually larger, the slender branches ascending or spreading: racemes with comparatively few and distant fruiting calyces; pedicels ascending or recurved, about equalling the fruiting calyx. D. C. to Fla., Ky., Ark. and Tex. April-May.

\section{LITHOSPÉRMUM L.}

Pubescent hirsute or hispid herbs, with alternate entire leaves, the flowers in leafy-bracted spikes or racemes. Calvx 5-parted or 5-cleft, the segments or lobes narrow. Corolla funnelform or salverform, 5 -lobed, naked, pubescent or crested in the throat, the tube sometimes pubescent at the base within. Stamens 5 , included, inserted on the throat of the corolla; filaments short. Stigma capitate, or 2-lobed. Nutlets 4, or fewer, erect. white, smooth and shining, or brown and wrinkled, attached bv their bases to the nearly flat receptacle, the scar of attachment not con. cave. [Greek, stone seed, from the hard nutlets.] About 40 species, of the northern hemisphere, a few in S. Am. and Africa. Besides the following, some 7 others occur in the southern U. S.

Corolla white or yellowish, its tuhe shorter than or equalling the calyx ; flowers distant. Nutlets brown, wrinkled and pitted; annual or biennial.

Nutlets white, smooth and shining; perennials.

Leaves lanceolate, acute; nutlets ovoid.

Leaves ovate, acuminate; nutlets globose-ovoid.

I. L. arvense.

2. L. officinale.

Corolla dull yellow, its tube longer than the calyx; leaves lanceolate; flowers dense.

Corolla bright yellow, its tube much longer than the calyx; flowers dense.

Corolla-lobes entire; flowers all complete.

Hispid-pubescent: corolla-tube bearded at the base within. 5. L. Gmelini.

Hirsute, somewhat canescent; corolla tube not bearded at the base within.

Corolla-lobes erose-denticulate; later flowers cleistogamous.

6. L. canescens.

7. L. linearifolium.

I. Lithospermum arvénce L. Bastard Alkanet. Corn Gromweli. (i. F. f. 3043.) Appressed-pubescent, I.5-5 dm. high. Leaves bright green, lanceolate, linear or linear-oblong, sessile or the lowest short-petioled, mostly ap- 
pressed, narrowed at the base, indistinctly veined, I-4 cm. long, the uppermost smaller; flowers sessile or nearly so, white, about $6 \mathrm{~mm}$. long; calyx-segments linearlanceolate, longer than or equalling the corolla-tube; corolla funnelform, puberulent in the throat; nutlets glabrous, about $2 \mathrm{~mm}$. high, convex on the back, keeled on the inner side, one-third to one-half the length of the calyx-segments. In waste places and fields, Quebec to Ont., Mich., Ga. and Kans. Nat. from Europe.
May-Aug.

2. Lithospermum officinàle L. Gromwell. (I. F. f. 3044.) Finely puberulent; stem 6-12 dm. ligh, leafy. Leaves few-veined, sessile, 3-10 cm. long, the upper surface rough; flowers yellowish white, about $4 \mathrm{~mm}$. long, sessile; calyx-segments linear-lanceolate, about equalling the corolla-tube; corolla funnelform, crested in the throat; style about as long as the stamens; nutlets about $3 \mathrm{~mm}$. high, ovoid, obtuse, seldom all ripening. In fields and waste places, Ont. to N. Y., west to Minn. Nat. from Europe. May-Aug.

3. Lithospermum latifòlium Michx. American Gromwell. (I. F. f. 3045.) Rough-puberulent; stem 6-9 dm. high, the branches long and slender. Leaves pinnately veined, 5-13 cm. long, $2-5 \mathrm{~cm}$. wide, or the uppermost smaller; flowers yellowish white or pale yellow, 4-6 mm. long, few; calyx-segments linearlanceolate, about as long as the corolla; corolla funnelform, crested in the throat; style shorter than the stamens; nutlets globose-ovoid, about $4 \mathrm{~mm}$. long. In dry thickets and fields, Ont. and western N. Y. to Minn., Va., Kans. and Ark. May.

4. Lithospermum pilòsum Nutt. Woolly Gromwell. (I. F. f. 3046.) Perennial from thick roots, hirsute; stems usually clustered, very leafy, $2-4.5 \mathrm{dm}$. high. Leaves $5-10 \mathrm{~cm}$. long, 4-10 mm. wide, gradually acuminate, sessile, indistinctly veined; flowers crowded in a terminal leafy thyrsus; calyx-segments densely hirsute, shorter than the cylindric corolla-tube; corolla salverform, the throat puberulent below each lobe; style longer than the filaments; nutlets ovoid, acute, white, shining, about $4 \mathrm{mn}$. long. Western Neb. (according to Williams); Mont. to the N. W. Terr., Br. Col. and Cal. May-July.

5. Lithospermum Gmélini (Michx.) A. S. Hitchcock. HaIRy Puccoon. (I. F. f. 3047.) Perennial, hispid-pubescent, or scabrous; stems rather stout, 3-6 dm. high, very leafy. Leaves lanccolate, sessile, 5-8 cm. long, the lowest commonly reduced to appressed scales, the uppermost oblong; flowers 12-18 mp. long, in short terminal leafy racemes, dimorphous; calyx-segments linear-lanceolate; corolla salverform; corolla-lobes rounded, the throat crested, the tube bearded at the base within by 10 hirsute teeth; nutlets white, shining, about $4 \mathrm{~mm}$. high, ovoid, much shorter than the calyx-segments. In dry woods, N. Y. to Fla., Minn., Mont., Colo. and N. Mex. April-June.

6. Lithospermum canéscens (Michx.) Lehm. Hoary Puccoon. (I. F.f. 3048.) Perennial, hirsute, canescent at least when young; stems $1.5-4 \cdot 5 \mathrm{dm}$. high. Leaves oblong, linear oblong, or linear, sessile, I-4 cm. long, the lowest often reduced to appressed scales; flowers about $12 \mathrm{~mm}$. long, sessile, numerous in short 'eafy racemes, dimorphous; calyx-segments linear-lanceolate; corolla salverform, crested in the throat, its lobes rounded, entire, its tube glandular within; nutlets white, smooth, shining, acutish, much shorter than the calyx-segments. In dry soil, Orit. to N. J., Ala., the N. W. Terr., Kans. and Ariz. April-June.

7. Lithospermum linearifòlium Goldie. NARROW-LEAved PuCCOoN. (I. F. f. 3049.) Perennial by a deep root, strigose pubescent and scabrous; stem 1.5-6 dm. high. Leaves linear, sessile, acute or acutish, $1-5 \mathrm{~cm}$. long: flowers of two kinds, in terminal leafy racemes; corolla of the earlier ones salverform, about $2.5 \mathrm{~cm}$. long, bright yellow, the tube 3-5 times as long as the linear-lanceolate calyx segments, the lobes erose-denticulate, the throat crested; later flowers (sometimes all of them) much smaller, pale yellow, cleistogamous, abundantly fertile, their pedicels recurved in fruit; nutlets white, smooth, shining, ovoid, 3-4 mm. high, pitted, keeled on the inner side. In dry soil, Manitoba to Ill., Kans., Tex., Br. Col., Utah and Ariz. April-July. [L. angustifolium Michx., not Forsk.]

\section{ONOSMÒdIUM Michx. (See Appenđix.)}

Perennial stout hispid or hirsute herbs, with alternate entire strongly veined leaves, and rather small yellowish or greenish white proterogynous flowers, in 
terminal leafy-bracted scorpioid spikes or racemes. Calyx ueeply 5-parted. Corolla tubular or tubular-funnelform, 5-lobed, the lobes erect, the sinuses slightly inflexed, the tube with a glandular ro-lobed band within at the base. Stamens 5, inserted on the corolla, included; filaments short. Ovary 4-parted; style filiform, exserted. Nutlets 4, or commonly only I or 2 perfecting, ovoid, sometimes sparingly pitted, shining, smooth, white, attached by the base to the nearly flat receptacle, the scar of attacliment small, flat. [Greek, like onosma, or ass-smell.] About 6 species, of N. Am. and Mex. Besides the following, 2 others occur in the southwestern U. S.

\section{Leaves acute; stem hirsute.}

Plant green; hairs long and shaggy : nutlets ovoid, $3 \mathrm{~mm}$. long. 1. O. Carolinianum.

Plant pale; hairs shorter and soft; nutlets ovoid-globose, $4 \mathrm{~mm}$. long.

Leaves obtuse ; stem appressed-hispid.

2. O. molle.

3. O. Virginianum.

I. Onosmodium Caroliniànum (Lam.) DC. Shaggy False Gromwell. (I. F. f. 3050.) Spreading-hirsute with bristly hairs; stem 3-9 dm. high. Leaves lanceolate, ovate-lanceolate or oblong, sessile, 5-9 ribbed, 5-12 cm. long: flowers numerous and crowded; pedicels $2-4 \mathrm{~mm}$. long in fruit; calyx-segments linear, acute; corolla pubescent outsicle, about $\mathbf{I} \mathrm{cm}$. long, its lobes triangular-lanceolate, acute, about one-lialf as long as the tube; nutlets obtuse. In dry fields or thickets, or on banks, Ont. and western N. Y. to Minn., Kans., south to Ga. and Tex. May-July.

2. Onosmodium mólle Michx. Soft-hairy False Gromwell. (I. F. f. 305 I.) Similar to the preceding, but usually lower, 3-6 dm. high, canescent, at least when young, the pubescence soft and shorter, that of the leaves appressed. Leaves smaller, ovate-lanceolate; corolla-lobes usually less than one-half the length of the tube; nutlets larger. On plains, Manitoba and the N. W. Terr. to Ill., Kans., Tex. and Utah. May-July.

3. Onosmodium Virginiànum (L.) DC. Virginia False Gromwell.

F. f. 3052.) Appressed-hispid with stiff hairs; stem 3-8 dm. high. Leaves oblong, oval, or oblong-lanceolate, sessile, $2-8 \mathrm{~cm}$. long, or the lower oblanceolate, acutish and narrowed into petioles; calyx-segments linear-lanceolate, acuminate; corolla cylindric or nearly so, about $8 \mathrm{~mm}$. long, the lobes lanceolate, acuminate, nearly as long as the tube, strigose without; nutlets ovoid, obtuse or obtusish, 2-3 mm. long. In thickets or on hillsides, N. Eng. to Fla., Kans. and Tex. May-July.

\section{SÝMPHYTUM L.}

Erect rough hairy perennial herbs, with mucilaginous roots, alternate entire leaves, the uppermost tending to be opposite, the lower long-petioled. Flowers yellow, blue, or purple, in terminal scorpioid racemes. Calyx deeply 5-cleft. Corolla tubular to campanulate, slightly dilated above, 5-lobed, the lobes short, the throat with 5 crests below the lobes. Stamens 5, included, inserted on the corollatube. Style filiform. Nutlets 4, obliquely ovoid, wrinkled, inserted by their bases on the flat receptacle, the scar of the attachment broad, concave, dentate. [Greek, grow-together, from its supposed healing virtues.] About I5 species, of the Old World.

Pilose-pubescent.

Stem bristly-papillose. r. S. officinale.

2. S. asperimum.

I. Symphytum officinàle L. Comfrey. Healing-herb. (I. F. f. 3053.) Ronts thick, deep; stem 6-9 dm. high. Leaves lanceolate, ovate lancenlate, or the lower ovate, pinnately veined, $0.7-2.5 \mathrm{~lm}$. long, acute or acuminate; pedicels 4-8 mm. long: calyx segments ovate or ovate-lanceolate, acute or acuminate, much shorter than the corolla; corolla yellowish or purplish. I-2 $\mathrm{mm}$. long; nutlets brown, shining, $4 \mathrm{~mm}$. high. In waste places, Newf. to Minn., south to Md. Nat. or adventive from Europe. June-Aug.

2. Symphytum aspérimum Sims. Rough Comfrey. Similar to the preceding, but the stem and branches very rough-bristly. Leaves ovate to ovatelanceolate, rough; calyx-segments subulate. In waste places, N. Y. and Mass. Summer. Adventive from Europe. 


\section{BORÀGO L.}

Hirsute or hispid annual or biennial herbs, with alternate entire leaves, and showy blue flowers, in terminal loose leafy racemes. Calyx deeply 5-cleft or 5-parted. Corolla rotate, the tube short, the throat closed by scales, the limb 5-lobed, the lobes imbricated, acute. Stamens 5, on the corolla-tube; filaments diiated below, narrowed above into a slender appendage; anthers linear, erect, and connivent into a cone. Nutlets 4 , ovoid, erect, attached by their bases to the flat receptacle, the scar of attachment large, concave. [Middle Latin, burra, rough hair, alluding to the foliage.] Three species, natives of the Mediterranean region.

4. Borago officinàlis L. Borage. (I. F. f. 3054.) Stem 3-8 dm. high. Leaves oblong to obovate, $5-13 \mathrm{~cm}$. long, narrowed into margined petioles, or the upper smaller, ovate-lanceolate, sessile or partly clasping; flowers $1.5-2 \mathrm{~cm}$. broad; pedicels $3-5 \mathrm{~cm}$. long, spreading or recurving: calyx-segments lanceolate, nearly erect in fruit; corolla-lobes ovate-lanceolate, the cone of anthers darker, about $6 \mathrm{~mm}$. long; nutlets $4 \mathrm{~mm}$. high. In waste places. escaped from gardens, N. S. to Ont. and Penn. Native of Europe. June-Sept.

\section{LYCÓPSIS L.}

Annual bristly-hispid herbs, with alternate leaves, and small blue or bluish flowers, in leafy-bracted terminal spike-like scorpioid racemes. Calyx 5-parted. Corolla slightly irregular, salverform, the tube curved, the limb somewhat unequally 5 -lobed, the lobes obtuse, imbricated, the throat closed by hispid scales. Stamens 5, included, on the tube of the corolla; filaments short; anthers obtuse at each end. Nutlets 4 , wrinkled, erect, attached by their bases to the flat receptacle, the scar of attachment concave. [Greek, wolf-face.] About 4 species, natives of the Old World.

I. Lycopsis arvénsis L. Small Bugloss. (I. F. f. 3055.) Stem 3-6 dm. high, the branches becoming procumbent. Leaves lanceolate, narrowly oblong or the lower oblanceolate, obtuse, $2-5 \mathrm{~cm}$. long, undulate or dentate, sessile, or the lower narrowed into petioles, the upper much smaller and acute or acutish; flowers 4-6 min. broad; calyx-segments lanceolate, acute, nearly as long as the curved corolla-tube. In fields and waste places, N. S. to Ont., Penn. and Va. Nat. or adventive from Europe. June-Sept.

\section{6. ÉCHIUM L.}

iMostly bristly-liirsute herbs, with alternate leaves, and rather large blue violet or rarely white flowers, in leafy-bracted scorpioid spikes. Calyx 5-parted, the segments narrow. Corolla tubular-funnelform, the limb unequally 5-lobed, the lobes rounded, spreading. Stamens 5 , inserted low down on the tube of the corolla, unequal, at least the longer ones exserted; filaments dilated at the base; anthers ovate or oblong. Style filiform, 2-cleft at the summit. Nutlets 4, erect, ovoid, rugose. attached by their bases to the flat receptacle. [Greek, a viper.] About 30 species, natives of the Old World.

I. Echium vulgàre L. Viper's Bugloss. Blukween. (I. F. f. 3056.) Bristly-hairy, biennial; stem 3-8 $\mathrm{dm}$. high. Leaves oblong, linear-oblong, or linear-lanceolate, entire, 5-15 cm. long, sessile, or the lower and basal ones narrowed into petioles: flowers bright biue, varying to violet-purple, $1.5-2.5 \mathrm{~cm}$. long, numerous in short 1 . sided spikes, forming a narrow thyrsus. In fields and waste places, N. B. to Va., Ont. and Neb. Nat. from Europe. June-July.

\section{Family 6. VERBENÀCEAE J. St.Hil.}

\section{Vervain Family.}

Herbs, shrubs or some tropical genera trees, with opposite verticillate or rarely alternate leaves, and perfect irregular, or sometimes regular flowers, in spikes, racemes, cymes or panicles. Calyx inferior, mostly persistent, usually 4-5-lobed or 4-5-cleft. Corolla regular, or 2-lipped, the tube usually cylindric and the limb 4-5-cleft. Stamens 4 , didynamous, rarely only $z$, or as many as the corolla-lobes, inserted on the corolla and alternate with its lobes; anthers 2-celled, the sacs 
longitudinally dehiscent. Ovary superior, 2-4-celled (rarely 8-10-celled), composed of 2 carpels, each carpel with 2 anatropous or amphitropous ovules, thus in 4-celled ovaries 1 ovule in each cavity; style terminal; stigmas 1 or 2. Fruit dry, separating at maturity into 2-4 nutlets, or a drupe containing the $2-4$ nutlets. Endosperm little or none, or rarely fleshy; embryo straight. About 70 genera and 1200 species, of wic'e geographic distribution.

Flowers in heads or spikes; ovary $2-4$-celled; fruit of 2 or 4 erect nutlets; ours herbs.

Corolla-limb 5-lobed, regular or nearly so; nutlets 4 .

Corolla-limb 4-lobed, 2-lipped; nutlets 2.

Flowers in axillary cymes; shrubs; fruit drupaceous.

1. Verbena.

2. Lippia.

3. Callicarpa.

\section{r. VERBÈNA L. (See Appendix.)}

Herbs (some exotic species shrubby), mostly with opposite leaves, and bracted flowers, in terminal spikes. Calyx usually tubular, 5-angled, unequally 5 -toothed. Corolla salverform or funnelform, the limb spreading. Connective of the anthers unappendaged, or sometimes provided with a gland. Ovary 4-celled; ovule I in each cavity; style usually short, 2-lobed at the summit, one of the lobes stigmatic. Fruit mostly enclosed by the calyx, at length separating into 4 , I-seeded linear or linear-oblong crustaceous nutlets. [Latin name of a sacred herb.] About IOO species, natives of Am., or a single one indigenous in the Mediterranean region. Besides the following, some $\mathbf{I} 3$ others occur in the southern and western parts of N. Ain.

Flowers 4-1o $\mathrm{mm}$. long, in narrow spikes; anthers unappendaged.

Spikes filiform or slender; bracts shorter than the flowers.

Spikes filiform; fruit scattered; corolla usually white.

Leaves incised or pinnatifid; diffuse annual; fruit short.

Leaves serrate (rarely incised); erect perennial; fruit oblong.

I. V. officinalis.

2. V. urticifolia.

Spikes slender; fruits densely imbricated; corolla blue.

Plants glabrous or sparingly rough-pubescent; corolla 4-6 mm. long.

Leaves lanceolate, acuminate, petioled.

3. V. hastata.

Leaves linear to spatulate-lanceolate, mostly obtuse and sessile.

Plants densely soft-pubescent; corolla 8-10 $\mathrm{mm}$. long.

4. $V$. angustifolia.

5. $V$. stricta.

Spikes thick, dense; bracts longer than the flowers.

6. $V$. bracteosa.

Flowers $14^{-25} \mathrm{~mm}$. long, in short dense elongating spikes; connective of the longer stamens appendaged.

Corolla-limb $12-20 \mathrm{~mm}$. broad; bracts mostly shorter than the calyx.

Corolla-limb 8-10 $\mathrm{mm}$. broad; bracts equalling or exceeding the caly.

7. V. Canadensis.

8. V. bipinnatifida.

I. Verbena officinàlis L. European Vervain. Herb-of-The-Cross. BeRBINE. (I. F. f. 3057.) Stem 4-sided, glabrous or nearly so, diffusely branched, 3-9 dm. high. Leaves minutely pubescent, the lower deeply incised or I-2 pinnatifid, ovate, oblong, or obovate, $2-8 \mathrm{~cm}$. long, narrowed into margined petioles, the teeth acute; upper leaves linear or lanceolate, acute, entire, sessile; spikes filiform, at length $10-I_{3} \mathrm{~cm}$. long; fruits less than $2 \mathrm{~mm}$. high, scattered; bracts ovate, acuminate; corolla purplish or white, the limb $2-4 \mathrm{~mm}$. broad. In waste and culivated ground, Me. to Fla. and Tex. Also on the Pacific Coast. Nat. from the Old World. June-Sept.

2. Verbena urticifòlia L. White or NetTle-leaved Vervain. (I. F. f. 3058.) Usually pubescent; stem strict, 4-sided, 9-15 dm. high, the branches upright. Leaves ovate, oblong, or oblong-lanceolate, all petioled, or the uppermost sessile, serrate-dentate, thin, acute or acuminate, 3-13 cm. long; spikes filiform, at length I-I.5 dm. long; fruits oblong, about $2 \mathrm{~mm}$. high; bracts ovate, acuminate; corolla white or pale purple, its limb about $2 \mathrm{~mm}$. broad. In fields and waste places, N. B. to S. Dak., Kans., Fla. and Tex. Hybridizes with V. bracteosa, $V$. hastata and $V$. stricta. June-Sept. 
Verbena urticifolia ripària (Raf.) Britton. Leaves incised, sometimes 3-cleft near the base; flowers blue. River-banks, N. J. to N. Car.

3. Verbena hastàta L. Blue Vervain. Wild Hyssop. (I. F. f. 3059.) Perennial, roughish-puberulent; stem strict, 4-sided, 9-22 dm. high. Leaves oblonglanceolate or lanceolate, petioled, acute or acuminate, serrate or incised-dentate with acute teeth, $0.7-1.5 \mathrm{~cm}$. long, the lower sometimes hastately 3 -lobed at the base; spikes panicled, slender, usually peduncled, 5-15 cm. long; fruits 2-3 mm. high; bracts ovate, acuminate; corolla blue, its limb about $3 \mathrm{~mm}$. broad. In moist fields, meadows and in waste places, N. S. to Br. Col., Fla., Neb. and N. Mex. Hybridizes with $V$. stricta and $V$. bracteosa. June-Sept.

Verbena hastàta pinnatífida (Lam.) Britton. Leaves deeply incised or pinnatifid. Occasional in the range of the type.

4 Verbena angustifòlia Michx. Narrow-Leaved Vervain. (I. F. f. 3060.) Yerennial, roughish-puberulent or pubescent; stem slender, 4-sided above, 3-6 dm. high. Leaves linear, spatulate or lanceolate, cuneate at the base, serrate or serrulate, veiny, 3-8 cm. long, 4-10 mm. wide; spikes mostly solitary, slender, dense, $5-13 \mathrm{~cm}$. long; fruits $3 \mathrm{~mm}$. high; bracts lanceolate, acuminate, equalling or shorter than the calyx; corolla purple or blue, about $6 \mathrm{~mm}$. long. In dry fields, Mass. to Fla. to Minn., Kans. and Ark. Hybridizes with $V$. stricta and $V$. bracteosa. June-Aug.

5. Verbena stríctz Vent. Hoary or Mullen-leaved Vervain. (I. F. f. 306r.) Perennial, soft-pubescent; stem obtusely 4-angled, strict, very leafy, 3-8 dm. high. Leaves ovate, oval, or oblong, short-petioled, prominently veined, incised-serrate or laciniate, 2- ro cm. long; spikes mostly sessile, dense, becoming 1.5-3 dm. long in fruit; fruits 4-5 mm. high; bracts lanceolate-subulate, nearly as long as the calyx; corolla purplish blue. In dry soil, Ohio to Minn., S. Dak., Wyo., Tenn., Tex. and N. Mex. Nat. as a weed further east. Hybridizes with $V$. bracteosa. June-Sept.

6. Verbena bracteòsa Michx. LARGe-bracted Vervain. (I. F. f. 3062.) Perennial, hirsute-pubescent; stem 4-sided, the branches decumbent or ascending, slender, 1.5-4 dm. long. Leaves ovate, oval, or obovate in outline, pinnately incised or pinnatıfid, $2-8 \mathrm{~cm}$. long, the lobes mostly dentate; spikes sessile, stout, becoming $\mathbf{I}-\mathbf{I} .5 \mathrm{dm}$. long in fruit; bracts conspicuous, linear-lanceolate, rather rigid, the lower ones often incised; corolla purplish blue, about $4 \mathrm{~mm}$. long. On prairies and in waste places, Minn. and Ill. to Ala. and Fla., Br. Col., Ariz. and Cal. Hybridizes with $V$. Canadensis. May-Aug.

\%. Verbena Canadénsis (L.) Britton. Large-flowered Verbena. (I. F. f. 3063.) Perennial; stem slender, 2-4 dm. high, the branches ascending. Leaves ovate in outline, petioled, $2-8 \mathrm{~cm}$. long, truncate or broadly cuneate at the base, irregularly pinnately incised, often 3-cleft, the lobes dentate; spikes peduncled, solitary at the ends of the branches, becoming 5-10 cm. long in fruit; bracts linearsubulate; calyx-teeth filiform-subulate; corolla $2-2.5 \mathrm{~cm}$. long, blue, purple, white or in cultivation variegated; fruit 5-6 mm. high. In dry soil, Ill. to Tenn., Fla., Kans., Mex. and N. Mex. This and the next the source of many garden and other hybrids. May-Aug.

8. Verbena bipinnatífida Nutt. Small-flowered Verbena. (I. F. f. 3064.) Perennial, producing suckers, hirsute or hispid; stems erect, 1.5-4.5 dm. high. Leaves petioled or the uppermost sessile, broadly ovate in outline, deeply I-2-pinnatifid into linear or linear-oblong lobes and segments; spikes solitary at the ends of the branches, thick, dense, becoming 5-10 cm. long in fruit; calyxteeth filiform-subulate; corolla $12-18 \mathrm{~mm}$. long, purple or lilac; fruit 3-4 mm. high. On dry plains and prairies, S. Dak. to Tex., Chihuahua, Colo. and Ariz. May-Sept.

\section{LÍPPIA I.}

Perennial herbs, or shrubs, with opposite, or rarely alternate leaves, and small bracted flowers, in spikes or heads. Calyx small, ovoid, campanulate or compressed and 2-winged, 2-4-toothed or 2-4-cleft. Corolla-tube cylindric, the limb oblique, somewhat 2-lipped, 4-cleft. Stamens 4, didynamous; anthers ovate, not appendaged, the sacs nearly parallel. Ovary 2-celled; ovules I in each cavity; 
style short; stigma oblique or recurved. Fruit dry, with a membranous exocarp, at length separating into 4 nutlets. [Named in honor of Auguste Lippi, 1678I703, a French naturalist.] About Ioo species, most abundant in tropical Am. Besides the following, about 6 others occur in the southern U. S.

Leaves spatulate, 2-8-toothed above; peduncles little exceeding the leaves.

Leaves sharply serrate; peduncles much longer than the leaves.

I. L. cuneifolia.

Leaves oblong or lanceolate, mostly acute.

Leaves spatulate or obovate, mostly obtuse.

2. L. lanceolata.

3. L. nodiflora.

I. Lippia cuneifòlia (Torr.) Steud. Wedge-Leaved Fog-fruit. (I. F. f. 3065.) Pale, minutely puberulent, or glabrous, diffusely branched from the wo dy base; branches rigid, procumbent, somewhat zigzag. Leaves sessile, of ccurely veined, rigid, 2-4 cm. long, with 2-8 sharp teeth above the middle or rarciytire, acutish; head becoming cylindric and $12-16 \mathrm{~mm}$. long; bracts curiente, abruptly acuminate; calyx-lobes 2-toothed or emarginate; corolla-tube longer than the calyx; fruit oblong. On plains, S. Dak., Neb. and Colo. to Tex., Miex. and Ariz. May-Aug.

2. Lippia lanceolàta Michx. Fog-Fruit. (I. F. f. 3066.) Green, glabruus, or sparingly pubescent with forked hairs; stems slender, procumbent or ascending, sometimes rooting at the nodes, 3-6 dm. long. Leaves thin, oblong, ovate, or oblong-lanceolate, pinnately veined, short-petioled, acute or subacute, sharply serrate to below the middle, $2-8 \mathrm{~cm}$. long, $0.6-3 \mathrm{~cm}$. wide; heads beconing cylindric and about $12 \mathrm{~mm}$. long in fruit; bracts acute; corolla pale blue, scarcely longer than the calyx; fruit globose. In moist soil, N. J. to Ill., Kans., Fla., Tex. and Mex. Also in Cal. June-Aug.

3. Lippia nodiflora (L.) Michx Spatulate-Leaved Fog-Fruir. (I. F. f. 3067 .) Minutely and rather densely puberulent, creeping, or the branches ascend. ing, 3-9 dm. long. Leaves thickish, spatulate, oblanceolate, or obovate, $1-6 \mathrm{~cm}$. long, o.6-2.5 cm. wide, mostly obtuse, narrowed into a cuneate entire base, sharply serrate above the middle; heads at length cylindric and $\mathbf{I}-\mathbf{2 . 5} \mathrm{cm}$. long; corolla purple to white. In wet or moist soil, S. Car. to Mo., Fla. and Tex. Also in Cal., Cent. Am. and the W. Indies. May-Sept.

\section{CALLICÀRPAL.}

Shrubs or trees, with opposite leaves. and small blue purple or white flowers in axillary cymes. Calyx short, campanulate, 4-tootled (rarely 5-toothed), or truncate. Corolla-tube short, expanded above, the limb 4-cleft (rarely 5-cleft), the lobes equal. Stamens 4, equal, exserted; anther-sacs parallel. Ovary incompletely 2 -celled; ovules 2 in each cavity, laterally attached, amphitropous; style slender; stigma capitate, or 2-lobed. Fruit a berry-like drupe, much longer than the calyx, containing I-4 nutlets. [Greek, handsome fruit.] About 35 species, the following of southeastern N. Am., the others Asiatic, African and of tropical Am.

I. Callicarpa Americàna L. French Mulberry. (I. F. f. 3068.) A shrub, 6-15 dm. high, the twigs, petioles and young leaves stellate-scurfy, the mature leaves glabrous or nearly so, and glandular-dotted. Twigs terete; leaves thin, ovate, slender-petioled, acute or acuminate, crenate-dentate, 7-15 cm. long; cymes many-flowered, short-peduncled; pedicels very short; calyx-teeth much shorter than the tube; corolla pale blue, about $3 \mathrm{~mm}$. long; fruit violet-blue, globose, $3 \mathrm{~mm}$. in diameter. In moist thickets, Va. to Fla., Ala., Ark. and Tex. June-July.

\section{Family 7. LABIÀTAE B. Juss.}

\section{Mint Family.}

Aromatic punctate herbs, or shrubs (a few tropical species trees), mostly with 4-sided stems and simple opposite leaves; stipules none. Flowers irregular, perfect, clustered, the inflorescence typically cymose, usually bracteolate. Calyx inferior, persistent, 5-toothed or 5-lobed (rarely 4-toothed), mostly nerved. Corolla with a short or long tube, 
the limb 4-5-lobed, mostly 2-lipped, regular in a few genera; upper lip 2-lobed, or sometimes entire; lower lip mostly 3-lobed. Stamens borne on the corolla-tube, typically 4 and didynamous, sometimes 2 , rareiy equal; filaments separate, alternate with the corolla-lobes; anthers 2-celled, introrse, or confluently 1 -celled, or sometimes of a single sac. Disk usually present, fleshy. Ovary 4-lobed, or 4-parted, superior, each lobe or division with I mostly anatropous ovule; style arising from the centre of the lobed or parted ovary, 2.lobed at the summit. Fruit of 4 I-seeded nutlets. Seed erect (transverse in Scutellaria); endosperm scanty, or none; embryo mostly straight ; radicle short, inferior. About 160 genera and 3000 species, of wide distribution. The family is also known as LAMIACEAE.

\section{A. 0vary 4-lobed, the style not basal; nutlets laterally attached.}

Corolla-limb very irregular, apparently $\mathbf{I}$-lipped, or the other lip very short; stamens exserted.

Upper lip of corolla short, truncate.

Upper lip of corolla 2-lobed, or all the lobes united into the lower lip.

Corolla-limb nearly equally 5 -lobed.

2. Teucrium.

Corolla-lobes spreading; stamens short-exserted.

Corolla-lobes declined; stamens long-exserted.

B. Ovary 4-parted, the style basal; nutlets basally attached.

* Calyx with a protuberance on the upper side.

* * Calyx not gibbous on the upper side.

Stamens and style very short, includer in the corolla-tube.

Stamens longer, not included in the corolla tube.

3. Isanthus.

4. Irichostema.

+ Corolla strongly 2-lipped; lips unlike, the upper concave.

(a) Anther-bearing stamens 4 .

Posterior (upper) pair of stamens longer than the anterior.

Anther-sacs parallel or nearly so.

Tall erect herbs; posterior stamens declined, anterior ascending.

Trailing herb; stamens all ascending under upper lip of corolla.

5. Scutellaria.

6. Marrubium.

8. Meehania.

Anther-sacs divergent.

Calyx tubular, nearly equally 5 -toothed, not 2 -lipped; plant erect.

Calyx distinctly 2 -lipped, or unequally 5 -toothed.

Trailing herb; calyx unequally 5 -toothed.

Erect herbs; calyx 2-lipped.

9. Nepeta.

10. Glecoma.

I1. Dracocephalum.

Posterior pair of stamens shorter than the anterior.

Calyx distinctly 2-lipped, closed in fruit.

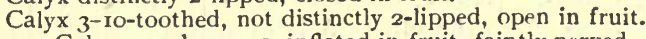

12. Prunella.

Calyx membranous, inflated in fruit, faintly nerved.

Calyx nearly equally 5-toothed, or 5-lobed. 13 . Physostegia.

Calyx 4 -lobed.

14. Synandra.

Calyx not membranous, not inflated in fruit, distinctly 5-10-nerved.

Style-branches very unequal.

Style-branches equal, or nearly so.

Anther-sacs transversely 2 -valved.

15. Phlomis.

Anther-sacs not transversely 2-valved, parallel or divergent. Nutlets 3 -sided, truncate.

Calyx-teeth not spiny-tipped.

Caly $x$-teeth spiny-tipped.

Nutlets ovoid, rounded above.

Calyx with a spreading 5-toothed limb. 19. Ballota.

Calyx-limb not spreading.

Corolla-tube not longer than the calyx; anther-sacs divergent.

18. Lamium.

17. Leonurus.

Corolla-tube exserted; lower petioles very long; anthersacs parallel.

21. Betonica.

(b) Anther-bearing stamens 2.

Connective of the anther very long, bearing a perfect sac at one end, and a rudimentary one, or none, at the other. 
connective very short, the anther-sacs confluent.

Calyx tubular, 15 -nerved, equally 5 -toothed.

Calyx ovoid-tubular, 13-nerved, 2-lipped.

23. Monarda.

24. Blephilia.

++ Corolla 2-lipped, or regular; upper lip, when present, flat, or only slightly concave.

(a) Flowers in axillary whorls or clusters, or these forming terminal spikes.

Corolla 2-lipped.

Stamens curved, often converging, or ascending under the upper lip of the corolla.

Anther-bearing stamens 2 .

25. Hedeoma.

Anther-bearing stamens 4 .

Corolla-tube upwardly curved, exserted.

26. Melissa.

Corolla-tube straight.

Calyx Io-nerved, campanulate, about equally 5 -toothed.

Calyx mostly 13 nerved, tubular, 2-lipped.

27. Satureia.

28. Clinopodium.

Stamens straight, often diverging.

Calyx 15-nerved.

Calyx so-r3-nerved.

29. Hyssopus.

Anther-bearing stamens 4 .

Anther-sacs divergent.

Calyx equally 5 -toothed; erect herbs.

Calyx 2-lipped, creeping herbs.

Anther-sacs parallel.

Anther-bearing stamens 2.

Corolla regular, 4-5-lobed.

Anther-bearing stamens 2; plants not aromatic.

Anther-bearing stamens 4 ; aromatic fragrant herbs.

30. Origanum.

32. Thymus.

3. Koellia.

33. Cunila.

(b) Flowers in terminal panicled racemes or spikes; corolla 2-lipped.

Anther-bearing stamens 2; lower lip of corolla long, fimbriate; native.

Anther-bearing stamens 4 ; lower lip of corolla not fimbriate; introduced.

36. Collinsonia.

Flowers racemose.

Flowers densely spiked.

37. Perilla.

38. Elsholtzia.

1. ÁJUGA L. (See Appendix.)

Herbs, mostly with dentate leaves, and rather large verticillate-clustered flowers in terminal spikes, or in the upper axils. Calyx Io-many-nerved, 5-toothed or 5-lobed, the teeth or lobes nearly equal. Corolla-limb 2-lipped, the upper lip short, the lower spreading, with 2 small lateral lobes and a much larger emarginate or 2-cleft middle one. Stamens 4, didynamous, the anterior pair the longer; anthersacs divergent, only slightly confluent at the base. Nutlets obovoid, rugose-reticulate. [Greek, without a yoke; from the seeming absence of the upper lip of the corolla.] About 40 species, natives of the Old World.

I. Ajuga réptans L. Bugle. (I. F. f. 3069.) Perennial, producing slender stolons; stem erect, I.5-4 dm. tall. Basal leaves tufted, obovate, rounded at the apex, crenate or undulate, $2-8 \mathrm{~cm}$. long, tapering into margined petioles; leaves of the stem oblong or oblanceolate, smaller, sessile or nearly so, those of the stolons mostly petioled; upper flower-clusters, often forming a short spike, the lower commonly distant and axillary; corolla blue or nearly white, about $12 \mathrm{~mm}$. long. In fields, Quebec and Me. to southern N. Y. Nat. from Europe. May-June.

\section{TEÙCRIUM L. (See Appendix.)}

Herbs or shrubs, with rather small pink white or purplish flowers, in terminal bracted spikes or heads, or verticillate in the upper axils. Calyx tubular-campanulate, Io-nerved, 5-toothed. Corolla-tube short, the limb irregularly 5-lobed, the 2 short upper lobes oblong, the lateral lobe declined, more or less united with the upper ones, the lower lobe broader, also declined. Stamens 4, didynamous, the anterior pair the longer; anther-sacs divergent, confluent at the base. Nutlets obovoid, rugose-reticulated. [Named from the Trojan king, Teucer.] Over Ioo species, of wide distribution. Besides the following, 3 others occur in the southern U. S.

Leaves dentate or serrate; flowers in terminal spikes. 


\section{Teucrium Canadénse J. American Germander or Wood Sagr.} (I. F. f. 307o.) Perennial, pubescent or canescent; stem stiff, 3-6 dm. tall. Leaves lanceolate to ovate-linceolate, acuminate, irregularly dentate, mostly narrowed at the base, short-petioled, 3-13 cm. long; spike becoming $\mathbf{1} .5-3 \mathrm{dm}$. long in fruit, its lower bracts sometimes foliaceous; upper bracts commonly not longer than the calyx; flowers $\mathbf{I}-2 \mathrm{~cm}$. long, short pedicelled; calyx about $6 \mathrm{~mm}$. long in fruit, its three upper teeth obtuse or subacute. In moist thickets or along marshes, N. E. to Manitoba, Fla., Kans., Tex. and Mex. June-Sept.

2. Teucrium occidentàle A. Gray. Hairy Germander. (I. F. f. 3071.) Perennial, villous or pubescent; stem 3-9 dm. high. Leaves lanceolate or ovatelanceolate, thin, acute or acuminate, sharply dentate, mostly rounded at the base, usually slender-petioled, 2-9 cm. long; spikes becoming $0.7-2 \mathrm{dm}$. long in fruit; bracts lanceolate-subulate or the lower sometimes larger; calyx and axis of the spike villous-pubescent, the 3 upper calyx-teeth acute or acutish; corolla 8-12 $\mathrm{mm}$. long. In moist soil, Ont. to Penn., Br. Col., Kans., N. Mex. and Cal. July-Sept.

3. Teucrium laciniàtum Torr. Cut-Leaven Germander. Diffusely branched from a woody perennial root, $1.5-3 \mathrm{dm}$. high. Leaves pinnately 3-7parted into linear segments; upper leaves about equalling the flowers; corolla I-2 cm. long, blue or lilac. Plains, Kans. and Colo. to Tex. and Ariz.

\section{ISÁNTHUUS Michx.}

An annual erect finely viscid-pubescent much-branched herb, with narrow entire or few-toothed leaves, and small blue flowers in loose axillary cymes. Calyx broadly campanulate, Io-nerved, nearly equally 5 -toothed, the teeth lanceolate. Corolla-tube not longer than the calyx, enlarged into the throat, the limb nearly equally 5-cleft into obovate somewhat spreading lobes. Stamens 4, didynamous, incurved-ascending, not longer than the corolla, the anterior pair slightly the longer; anther-sacs divergent at maturity. Ovary deeply 4 lobed; style minutely 2-cleft at the summit. Nutlets rugose-reticulated. [Greek, equal-flower, the corolla-lobes being nearly equal.] A monotypic genus.

1. Isan:hus biachiàtus (L.) B.S P. FAlse Pennyroyal. (I. F. f. 3072.) Stem slender, much branched, 1.5-5 dm. tall, the branches spreading. Leaves oblong or elliptic-lanceolate. acute at each end, entire, or with a few sharp teeth, 3-nerved, short-petioled, 2-5 cm. long, 4-12 mm. wide; axillary cymes I-3-flowered; pedicels very slender, some of them as long as the fruiting calyx; calyx lobes acute or acuminate, longer than or equalling the tube; corolla 4-6 $\mathrm{mm}$. long, the fruiting calyx $6 \mathrm{~mm}$. long. In sandy soil, especially along streams, Quebec and Ontario to Minn., Kans., Ga. and Tex. July-Sept. [I. cœrulcus Michx.]

\section{TRICHOSTÈMA L.}

Annual or perennial erect branching herbs, some western species shrubby, with lanceolate oblong or linear entire or slighly repand leaves. Flowers small, or middle-sized, pink, blue, purple, or white, paniculate, or in axillary loose or dense cymes. Calyx campanulate, very unequally 5-lobed in our species, the lobes ovate or lanceolate. Corolla-tube slender, exserted or included, the limb somewhat oblique and deeply 5-cleft into oblong more or less declined segments. Stamens 4, didynamous, ascending, curved, the anterior pair the longer, the filaments filiform, spirally coiled in the bud, long-exserted; anther-sacs divaricate, more or less confluent at the base. Ovary deeply 4-lobed; style 2-cleft at the summit. Nutlets obovoid, reticulated. [Greek, hair-stamen, referring to the slender filaments.] About 8 species, natives of North America.

Leaves oblong or lanceolate; plant minutely viscid-pubescent. Leaves linear; plant puberulent or glabrous.

1. T. dichotomum. 2. $T$. lineare.

I. Trichostema dichótomum L. Blue Curls. Bastarn Pennyroyal. (I. F. f. 3073.) Annual, minutely viscid-pubescent; stem slender, I.5-5 dm. high. Leaves oblong or oblong-lanceolate, membranous, narrowed into short petioles, 2-8 cm. long: the upper gradually smaller; flowers paniculate, $12-18 \mathrm{~mm}$. long, borne I-3 together on 2-bracteolate peluncles; calyx oblique, very unequally 5 -lobed, the 3 upper lobes much longer and more united than the 2 lower ones; corolla blue, pink or rarely nearly white, the limb longer than the tube; stamens 
blue or violet. In dry fields, Me. to Fla., Penn., Ky. and Tex. The lateral flowers become inverted by torsion of the pedicels. July-Oct.

2. Trichostema lineàre Nutt. Narrow-leaved Blue Curls. (I. F. f. 3074.) Puberulent or glabrous, not viscid or scarcely so. Leaves linear, sessile or short-petioled, I-5 cm. long, sometimes with smaller ones or short leafy branches in their axils; flowers similar to those of the preceding, sometimes larger. In sandy fields and dry pine barrens, R. I. to Ga. and La. July-Aug.

\section{SCUTELLÀRiA L. (See Appendix.)}

Bitter herbs, some species shrubby. Flowers blue to violet, in bracted mostly secund spike-like racemes, or solitary or 2-3 together in the axils. Calyx cam. panulate, gibbous, 2-lipped, the lips entire, the upper one with a crest or protuberance upon its back and often deciduous in fruit. Corolla recurved-ascending, dilated above into the throat, glabrous within, the limb 2-lipped; upper lip arched, entire or emarginate; lower lip spreading or deflexed, its lateral lobes small and somewhat connected with the upper, its middle lobe broad, the margins mostly recurved. Stamens 4, didynamous, all anther-bearing, ascending under the upper lip, the upper pair somewhat the shorter, their anthers 2-celled, ciliate; anthers of the lower pair of stamens I-celled, also ciliate. Nutlets papillose or tuberculate. [Latin, a dish, from the appendage to the fruiting calyx.] About roo species of wide distribution. Besides the following, some II others occur in southern and western N. Am.

\section{* Nutlets wingless, very slightly elevated on the short gynobase.}

Flowers 6-ro $\mathrm{mm}$. long, in axillary and sometimes terminal racemes.

Flowers 12-30 mm. long, in terminal often panicled racemes.

Plant glabrous or very nearly so; leaves broad.

x. S. lateriflora.

Plants pubescent, puberulent or pilose.

2. S. serrata.

Leaves, all except the floral, crenate or dentate, broad.

Canescent, not glandular; corolla canescent.

Densely glandular-pubescent; corolla puberulent. 4.5
Pubescent below, glandular above; corolla nearly glabrous.

3. S. incara.

4. $S$. cordifolia.

Leaves all except the lowest entire, narrow.

5. S. pilosa.

6. S. integrifolia.

Flowers solitary in the axils or sometimes also in terminal bracted racemes.

Annual, villous, branched from the base.

Perennial from a thick woody root.

7. S. Drummondii.

Fibrous-rooted; perennial by rootstocks or stolons.

Flowers 4-8 mm. long.

Plant glabrous, or slightly pubescent.

Plant densely pubescent all over.

8. S. resinosa.

Minutely and densely glandular-pubescent, resiniferous.

Densely cinereous-pubescent, pale.

Glabrous or merely slightly puberulent.

Leaves ovate, slender-petioled, cordate, obtuse. $\quad$ 13. S. saxatilis.

Leaves lanceolate or ovate-lanceolate, nearly sessile, acute.

9. S. parvula.

10. S. campestris.

* * Nutlets membranous-winged, elevated on the slender gynobase; flowers axillary. 15. S. nervosa.

I. Scutellaria lateriflòra L. MAd-dog Skullcap. (I. F. f. 3075.) Perennial by slender stolons, glabrous, or puberulent above; stem slender, leafy, 2-6 dm. high. Leaves ovate, ovate-oblong or ovate-lanceolate, thin, slenderpetioled, acute or acuminate, coarsely dentate-serrate, obtuse, rounded or subcordate at the base, $2-8 \mathrm{~cm}$. long, the upper gradually smaller, the uppermost sometimes entire; racemes narrow, secund; corolla blue, varying to nearly white, its lips about equal, one-fifth as long as the tube. In wet places, Newf. to Ont., Br. Col., Fla., N. Mex. and Wash. July-Sept.

2. Scutellaria serràta Andr. Showy Skullcap. (I. F. f. 3076.) Perennial; stem slender, 3-6 dm. high. Leaves ovate or elliptic, slender-petioled, acute, crenate or dentate, 5-10 cm. long, the uppermost reduced to small bracts; racemes almost always simple and terminal, the flowers opposite; corolla $2.5 \mathrm{~cm}$. 
long, blue, minutely puberulent, its tube narrow, gradually expanded above into the throat, its upper lip shorter than the lower. In woods, N. Y. and Penn. to N. Car., Ill. and Ky. Miay-June.

3. Scutellaria incàna Muhl. Downy Skullcap. (I. F. f. 3077.) Perennial, finely and densely whitish downy, or the upper surfaces of the leaves glabrous; stem 6-12 dm. high. Leaves ovate, oval, or oblong, rather firm, slenderpetioled, acute, crenate-dentate, 7-I I cm. long; racemes terminal, usually numerous and panicled; corolla $18-20 \mathrm{~mm}$. long; upper lip of the corolla slightly longer than the lower. In moist woods and thickets, Ont. to Ill., Kans., N. Car. and Ala. June-Aug.

4. Scutellaria cordifòlia Muhl. Heart-leaved Skullcap. (I. F. f. 3078.) Perennial, densely glandular-pubescent; stem 3-9 dm. high, often simple. Leaves slender-petioled, broadly ovate, crenate-dentate all around, 5-10 $\mathrm{cm}$. long, all but the uppermost cordate at the base; racemes terminal, narrow; hracts ovate, mostly entire, commonly longer than the pedicels; corolla puberulent, $2-2.5 \mathrm{~cm}$. long, blue with the lower side lighter or white, its tube narrow, its throat moderately dilated. In woods and thickets, Penn. to Fla., west to Wis., Kans. and Tex. June-Aug. S. venosa Kearney ( $S$. versicolor minor Chapm.) appears to differ from this only in size.

5. Scutellaria pilòsa Michx. Halry Skullcap. (I. F. f. 3079.) Perennial; stem slender, 3-8 dm. high. Leaves ovate, oval, or oblong, petioled, obtuse, or the upper subacute, crenate, $2-8 \mathrm{~cm}$. long; racemes terminal, sometimes also in the upper axils; bracts oblong or spatulate, entire, longer than the pedicels; corolla blue, 12-16 mm. long, its lower lip and lateral lobes somewhat shorter than the arched upper one. In dry sandy woods and thickets, N. Y. and Penn. to Mich., Mo., Fla. and Tex. May-July.

Scutellaria pilossa hirsùta (Short) A. Gray. Stouter, sometimes $9 \mathrm{dm}$. high, hirsute; leaves larger, coarsely crenate. Va. and $\mathrm{Ky}$.

6. Scutellaria integrifolia L. Larger or Hyssop Skullcap. (I. F. f. 308o.) Perennial, hoary with a minute down; stem 1.5-6 dm. high. Leaves thin, linear to oblong, petioled, or the upper sessile, obtuse, entire, $2-5 \mathrm{~cm}$. long, or the lower ovate, lanceolate or nearly orbicular, obtuse and sometimes subcordate at the base, often crenate-dentate or incised; racemes terminal; bracts linear-oblong, subacute, longer than the pedicels: corolla blue or whitish underneath, 2-3 cm. long, its large lips nearly equal. In fields, woods and thickets, Conn. and R. I. to W.Va., Fla., La. and Tex. May-Aug.

7. Scutellaria Drummóndii Benth. Drummond's Skullcap. (I. F. f. 3081.) Villous-puberulent or pubescent, the branches $0.7-2 \mathrm{dm}$. long. Leaves ovate, oblong, or obovate, entire, or the lower sparingly crenulate, 8-25 $\mathrm{mm}$. long, the upper sessile, the lower petioled, the uppermost gradually smaller: flowers solitary in the axils, short-peduncled; corolla blue, or the tube nearly white, $8-10 \mathrm{~mm}$. long, pubescent, the lower lip violet, spotted, longer than the upper. Kans. (according to Smyth), Tex. and Mex. April-June.

8. Scutellaria resinòsa Torr. Resinous Skullcap (I. F. f. 3082.) Minutely canescent or puberulent and usually resiniferous; stems rigid, tufted, ascending, 1.5-2.5 dm. high. Leaves ovate, oval, or oblong, sessile, or the lower short-petioled, entire, obtuse, 6-12 mm. long; flowers solitary in the axils; corolla violet or nearly white, very pubescent, 12-18 $\mathrm{mm}$. long, its tube narrow and lips nearly equal. On dry plains, Neb. to Tex. and Ariz. May-Aug.

9. Scutellaria parvula Michx. Small Skulicap. (I. F. f. 3083.) Glabrous, or sparingly puberulent, sometimes slightly glandular; stems $0.7-3 \mathrm{dm}$. tall. Leaves ovate, oval or lanceolate, or the lower nearly orbicular, entire and sessile, or the lower sparingly dentate and petioled, 6-25 $\mathrm{mm}$. long; flowers solitary in the axils; corolla $4-8 \mathrm{~mm}$. long, violet, pubescent. In moist sandy soil, Quebec to Ont., S. Dak., N. J., Fla., Neb. and Tex. April-July.

Io. Scutellaria campestris Britton. Prairie Skullcap. (I. F. f. 3084.) Pubescent; stems diffuse, or ascending, I-3 dm. long. Leaves ovate, or the lower almost orbicular, entire, or dentate, $\mathbf{I}-2 \mathrm{~cm}$. long, obtuse at the apex, rounded or or truncate at the base, the lower short-petioled, the upper sessile; flowers solitary 
in the axils; corolla 6-1o $\mathrm{cm}$. long, violet or purple, pubescent. In dry sandy or gravelly soil, N. Car. to Ill., Iowa, Kans. and the Ind. Terr. April-July.

I I. Scutellaria Brittònii Porter. BRitton's Skullcap. (I. F. f. 3085.) Viscidly glandular, pubescent or puberulent, branched from the base; stems I-2 dm. high, leafy. Leaves oblong or oval, sessile and entire or the lowest shortpetioled and slightly crenulate, obtuse, rather prominently veined on the lower surface, $1-2.5 \mathrm{~cm}$. long, the upper scarcely sinaller; flowers solitary in the axils; pedicels mostly shorter than the calyx; corolla pubescent, blue, $2-3 \mathrm{~cm}$. long. Neb. (according to Coulter); Colo. and Wyo. June-July.

I Scutellaria Búshii Britton, n. sp. BuSH'S Skullcap. Erect, rather stiff, 1.5-2.5 dm. high, finely ashy-pubescent. Leaves oblanceolate, obtuse, firm, entire, sessile, $2-3.5 \mathrm{~cm}$. long, 3-5 $\mathrm{mm}$. wide, the veins prominent; flowers axillary, shortpeduncled, $2.5 \mathrm{~cm}$. long; corolla pubescent. Rocky grounds, Shannon Co., Mo. (B. F. Bush, No. 54, June 3, 1890).

I3. Scutellaria saxátilis Riddell. Rock Skullcap. (I. F. f. 3086.) Perennial by filiform stolons, glabrate or sparingly puberulent; stem weak, ascending or reclining, 1.5-3 dm. long. Leaves ovate, slender-petioled, thin, coarsely crenate, obtuse, cordate, $2-5 \mathrm{~cm}$. long, or the lower nearly orbicular, and the upper lanceolate, subacute and entire; flowers solitary in the upper axils, or clustered in a terminal loose raceme; bracts longer than the pedicels; corolla light blue, very nearly glabrous, $1.5^{-2} \mathrm{~cm}$. long. On moist banks and in thickets, Del. to Va., Ohio and Tenn. May-July.

I 4 Scutellaria galericulàta L. Hooded Willow-herb. Marsh SkullCAP. (I. F. f. 3087.) Perennial by filiform stolons, puberulent or pubescent; stem 3-9 dm. high. Leaves oblong-lanceolate to ovate-oblong, thin, short-petioled, or the upper sessile, acute, dentate or the upper entire, subcordate or rounded at the base, 2-6 cm. long, the uppermost usually much smaller; flowers solitary in the axils; peduncles shorter than the calyx; corolla blue, puberulent, nearly or quite $2.5 \mathrm{~cm}$. long, with a slender tube and slightly enlarged throat. In swamps and along streams, Newf. to Alaska, N. Car., Ohio, Neb., Ariz. and Wash. Also in Europe and Asia. June-Sept.

I 5. Scutellaria nervosa Pursh. Veined Skullcap. (I. F. f. 3088). Perennial by filiform stolons; stem glabrous or sparingly pubescent, $2-6 \mathrm{~cm}$. high. Leaves thin, the lower slender-petioled, nearly orbicular, crenate, often subcordate, the middle ones larger, ovate, $2-5 \mathrm{~cm}$. long, sessile or nearly so, coarsely dentate or crenate, the upper lanceolate or ovate-lanceolate, acute, commonly entire; flowers solitary in the axils; corolla blue, $8-10 \mathrm{~mm}$. long, puberulent, the lower lip longer than the concave upper one. In moist woods and thickets, N. Y. and N. J. to Ill., N. Car., Tenn. and Mo. May-Aug.

\section{MARRÙBIUM L.}

Perennial herbs, with petioled dentate rugose leaves, and small white or purplish flowers in dense axillary clusters. Calyx tubular, 5-10-nerved, regularly 5-10toothed, the teeth nearly equal, or the alternate ones shorter, spreading or recurved in fruit. Corolla-limb 2 -lipped, the upper lip erect, the lower spreading, 3-cleft, its broader middle lobe commonly enarginate. Stamens 4 , didynamous, included, the posterior pair the shorter; anthers 2 -celled, the sacs divergent. Style 2-cleft at the summit, the lobes short. Nutlets ovoid, smooth. [Name Middle Latin, its meaning uncertain.] About 40 species, of the Old World.

I. Marrubium vulgare L. White HoARhound. (I. F. f. 3089.) Stem stout, woolly. 3-9 dm. high. Leaves oval, broadly ovate or nearly orbicular, rugose-veined, obtuse, crenate-dentate, $2-5 \mathrm{~cm}$. long, rough, whitish above; petioles I-2.5 cm. long, usually exceeding the flowers; clusters many-flowered; flowers whitish; calyx-teeth usually Io, subulate, glabrous above, woolly below. In waste places, Me. and Ont. to Minn., Br. Col., N. Car., Tex. and Mex. Nat. from Europe.

\section{AGÁstache Clayt. [LOPHANTHuS Benth.]}

Tall perennial herbs, with serrate, petioled leaves, and yellowish purplish or blue flowers, verticillate-clustered in thick bracted terminal spikes. Calyx narrowly campanulate, somewhat oblique, slightiy 2-lipped, 5-toothed. Corolla 
strongly 2-lipped, the tube as long as the calyx; upper lip erect, 2-lobed; lower lip spreading, 3-lobed; its middle lobe broader than the lateral ones and crenulate. Stamens 4, all anther-bearing, didynamous, the upper pair the longer; anthers 2-celled, their sacs nearly parallel. Nutlets ovoid, smooth. [Greek, many-spikes.] About 4 species, natives of N. Am. Besides the following, $\mathbf{I}$ or 2 others occur in the Western States.

Glabrous orr very nearly so, stout; corolla greenish yellow. Pubescent, stout; corolla purplish; leaves green both sides. Glabrous or slightly pubescent, slender; corolla blue; leaves pale beneath.

I. A. nepetoides.

2. A. scrophulariaefolia. 3. A. anethiodora.

I. Agastache nepetoides (L.) Kuntze. Catnep Giant-Hyssop. (I. F. f. 3090.) Stem 6-15 dm. high. Leaves ovate or ovate-oblong, acuminate or acute, mostly thin, coarsely dentate, 5-I5 cm. long; spikes $0.7-4.5 \mathrm{dm}$. long, usually very dense; petioles of the lowest leaves often $5 \mathrm{~cm}$. long; bracts ovate, acute or acuminate; calyx-teeth oblong or ovate-oblong, obtuse or subacute, sometimes purplish; corolla greenish-yellow, about $8 \mathrm{~mm}$. long, scarcely exceeding the calyx. In woods and thickets, Vt. and Ont. to S. Dak., Kans., Ga. and Ark. July-Sept.

2. Agastache scrophulariaefòlia (Willd.) Kuntze. Figwort. GiantHyssup. (I. F. f. 309I.) Similar to the preceding, but commonly taller, the stem, petioles and lower surfaces of the leaves more or less pubescent. Bracts broadly ovate, abruptly acuminate; calyx-teeth lanceolate or ovate-lanceolate, very acute or sometimes acuminate, whitish or purplish; corolla purplish, IO-I2 mm. long, considerably exceeding the calyx. In woods and thickets, Mass. to Wis., Kans., N. Car. and Ky. Plant strong-scented. -July-Oct.

Agastache scrophulariaefolius mollis (Fernald) Britton. Stem and lower leaf surfaces densely tomentose. Vt. and Conn. to lowa. (Lophanthus scrophulariaefolius mollis Fernald.)

3. Agastache anethiodòra (Nutt.) Britton. Fragrant Giant-hyssop. (I. F. f. 3092.) Stem rather slender, 6-12 dm. high. Leaves ovate or triangularovate, firm, mostly short-petioled, acute or acuminate at the apex, truncate, obtuse or sometimes subcordate at the base, sharply serrate, 5-9 cm. long, anise-scented; spikes seldom $\mathbf{1} .5 \mathrm{dm}$. long; bracts broadly ovate, abruptly acuminate; calyx-teeth ovate to lanceolate, acute, purple; corolla blue, 8-10 mm. long, somewhat exceeding the calyx. On prairies and plains, Minn. to the N. W. Terr., Ill., Neb. and Colo. July-Sept. [Lophanthus anisatus Benth.]

\section{MEEHÁNIA Britton.}

A low pubescent spreading or decumbent herb, with long-petioled cordate leaves, trailing leafy stolons, and large blue flowers in terminal secund bracted spikes. Calyx campanulate, 15 -nerved, slightly 2 -lipped, its teeth lanceolate, acute, the 3 upper longer than the 2 lower. Corolla much exserted, puberulent without, pubescent within, the tube narrow at the base, gradually widely ampliate into the throat, the limb 2-lipped; upper lip 2-lobed, arched, the lobes ovate, obtuse; lower lip about equalling the upper, spreading, 3-lobed, the middle lobe emarginate, broader than the lateral ones. Stamens 4, included, the upper pair longer than the lower; anthers 2-celled, the sacs nearly parallel. Nutlets oblong, smooth. [Named for 'Thomas Meehan, of Philadelphia, botanist and horticulturist.] A monotypic genus.

I. Meehania cordata (Nutt.) Britton. Meerania. (I. F. f. 3093.) Flowering stems $0.7-2 \mathrm{dm}$. high; stolons sometimes $6 \mathrm{dm}$. long. Leaves broadly ovate or ovate-orbicular, thin, obtuse or subacute, crenate all around, sparingly pubescent with srattered hairs on both surfaces, or nearly glabrous beneath, green on both sides, $2-5 \mathrm{~cm}$. long, the basal sinus broad; spikes 2-10 $\mathrm{cm}$. long; bracts ovate or oblong, acute, membranous, the lower sometimes crenulate and surpassing the calyx; bractlets small, lanceolate; calyx about $\mathbf{I ~} \mathrm{cm}$. long, puberulent, its longer teeth about one-half the length of the tube; corolla $2.5-3 \mathrm{~cm}$. long, showy. In rich moist woods and thickets, Penn. to Tenn. and N. Car. May-July.

\section{NÉPETA L.}

Herbs, with dentate or incised leaves, and mostly white or blue flowers in verticillate clusters, usually crowdẹ in terminal spikes. Calyx tubular, somewhat 
oblique, 15-nerved, 5-toothed, scarcely 2-lipped, but the upper teeth usually longer than the lower. Corolla-tube enlarged above, the limb strongly 2-lipped; upper lip erect, entire, emarginate or 2-lobed; lower lip spreading, 3-lobed. Anthers 2-celied, the sacs divaricate. Nutlets ovoid, compressed, smorth. [Ancient Latin name of catnep.] About I50 species, natives of Europe and Asia.

t. Nepeta Cataria L. Catmint. Catnep. Nep. (I. F. f. 3094.) Perennial, densely tomentulose-canescent, pale green; stem 6-9 dm. high. Leaves ovate to oblong, petioled, acute, coarsely crenate-dentate, mustly cordate at the base, $2-8 \mathrm{~cm}$. long; flower-clusters spiked, the spikes $2-13 \mathrm{~cm}$. long; bracts small; bractlets subulate; calyx densely puberulent, the upper teeth about one-half the length of the tube; corolla nearly white, or pale purple, dark-dotted, puberulent without, IO-I $2 \mathrm{~mm}$. long, the broad middle lobe of its lower lip crenulate. In waste places, N. B. and Quebec to S. Dak., Va. and Kans. Nat. from Europe. July-Nov.

\section{GLECòMA L.}

Low creeping herbs, with long-petioled nearly orbicular or reniform crenate leaves, and blue or violet flowers in small axillary verticillate clusters. Calyx oblong-tubular, 15-nerved, oblique, not 2-lipped, unequally 5-toothed. Corollatube exserted, enlarged above, the limb 2-lipped; upper lip erect, 2 -lobed or emarginate; the lower lip spreading, 3-lobed, the middle lobe broad, emarginate. Anther-sacs divergent. Nutlets ovoid, smooth. [Greek name for thyme, or pennyroyal.] About 6 species of Europe and Asia.

I. Glecoma hederàcea L. Ground Ivy. Gill-over-The-Ground. (I. F. f. 3095.) Perennial, pubescent, the creeping stems sometimes $4.5 \mathrm{dm}$. long. Lower petioles commonly longer than the leaves; leaves $\mathbf{I}-4 \mathrm{~cm}$. in diameter; clusters few-flowered, the flowers $1.4-2 \mathrm{~cm}$. long, short-pedicelled; bractlets subulate, shorter than the calyx; calyx puberulent, its teeth acute or lanceolate-acuminate; corolla tuke 2-3 times as long as the calyx; upper pair of stamens much longer than the lower. In waste places, woods and thickets, Newf. to Minn., Ga. and Kans. March-May.

\section{DRACOCÉPHALUM L.}

Herbs, with blue or purple flowers in axillary and terminal bracted clusters. Caly x tubular, 15-nerved, 5-toothed, or 2-lipped with the 3 upper teeth more or less united. Corolla expanded above, its limb 2 -lipped; upper lip erect, emarginate; lower lip spreading, 3-lobed, the middle lobe sometimes 2-cleft. Anthers 2-celled, the sacs divaricate. Nutlets ovoid, smootl. [Greek, dragon-head.] About 35 ipecies, of the northern hemisphere.

Corolla scarcely exceeding the calyx ; clusters mostly terminal, dense.

Corolla $2-3$ times as long as the calyx; clusters mostly axillary.

I. D. parviflorum.

2. D. Moldavica.

I. Dracocephalum parviflòrum Nutt. American Dragon-head. (I. F. f. 3096.) Annual or biennial; stem 1.5-5 dm. high. Leaves lanceolate, ovate, or oblong, slender-petioled, serrate, or the lower incised, thin, $2-8 \mathrm{~cm}$. long; clusters, many-flowered, in dense terminal spikes, and sometimes also in the upper axils; bracts ovate to oblong, pectinate with awn-pointed teeth; upper tooth of the calyx ovate-oblong, longer than the narrower lower and lateral ones, all acuminate; corolla light blue, scarcely longer than the calyx. In dry gravelly or rocky soil, $\mathrm{N}$. Y. and Ont. to Minn., Alaska, and in the Rocky Mts. to Ariz. and N. Mex. MayAug:

2. Dracocephalum Moldávica L. Moldavian Dragon-head. (I. F. f. 3097.) Annual, puberulent; stem 3-8 dm. high. Leaves oblong or linear-oblong, dentate or somewhat incised, obtuse, 2-5 cm. long, clusters loose, few-flowered, mostly axillar:r; bracts narrowly oblong, usually shorter than the calyx, deeply pectinate with aristate teeth; pedicels $4-8 \mathrm{~mm}$. long; calyx slightly curved, the 2 lower teeth somewhat shorter than the 3 broader equal upper ones; corolla 2-3 times as long as the calyx. In a cañon near Spring View, Neb. Also in northern Mex. Introduced from Europe. June-Aug. 


\section{PRUNÉLLA L.}

Perennial herbs, with petioled leaves, and rather small clustered purple or white flowers, in dense bracted spikes or heads. Calyx oblung, reticulate-veined, about Io-nerved, deeply 2 -lipped, closed in fruit; upper lip nearly truncate, or with 3 short teeth; lower lip 2-cleft. Corolla-tube inflated. slightly narrowed at the mouth, its limb strongly 2 -lipped; upper lip entire, arched; lcwer lip spreading, 3-lobed. Filaments of the longer stamens 2 -toothed at the summit, one of the teeth beuring the anther, the other sterile; anthess 2-celled, the sacs divergent or divaricate. Nutlets ovoid, smooth. [Origin of name doubtful; often spelled Brunella, the pre-Linnaean torm.] About 5 species, of wide geographic distridusion.

Leaves entire or crenate.

Leave, pinnatifid or deeply incised.

1. P. vulgaris.

2. P. laciniata.

I. Prunella vulgàris L. Self-heal. Heal-all. (I. F. f. 3098.) Stem slender, $0.5^{-6} \mathrm{dm}$. high. Leaves ovate, oblong or oblong-lanceolate, rather thin, 2-10 $\mathrm{cm}$. long, the lowest conmonly shorter and sonetimes subcordate; spikes terminal, sessile or short-peduncled, becoming $5-10 \mathrm{~cm}$. long in fruit; bracts broadly ovate-orbicular, cuspidate, ciliate; corolla violet, purple or sometimes white, 8-12 mm. long, about twice as long as the calyx. In fields, woods and waste places throughout nearly the whole of N. Am. Nat. from Europe. MayOct.

2. Prune'la laciniàta L. Cut-leaved Self-heal. (I. F. f. 3099.) Similar to the preceding, but the stem leaves pinnatifid, lobed, or incised, the basal ones often entire or merely crenulate. Vicinity of Washington, D. C. Adventive or fugitive from Europe. Summer.

\section{PHySOSTÈgia Benth. (See Appendix.)}

Erect perennial glabrous or puberulent herbs, with large or middle-sized bracted purple violet pink or white flowers in terminal spike-like racemes. Caly $\mathbf{x}$ membranous, swollen and remaiting open in fruit, faintly reticulate-veined and Io-nerved, equally 5-toxthed. Corolla much longer than the calyx, its tube gradually much enlarged upward, its limb strongly 2-lipped; upper lip concave, rounded, entire; lower lip spreading, 3-lobed, the middle lobe commonly emarginate. Filaments pubescent; anthers all alike, 2 -celled, the sacs nearly parallel, the margins of their valves commonly spinulose or denticulate. Nutlets ovoid triquetrous, smooth. [Greek, bellows-covering, from the inflated fruiting calyx.] About 8 species, natives of N. Am.

Flowers $2.5 \mathrm{~cm}$. long, or more; leaves firm.

Spike dense, many-flowered; leaf-serrations very acute.

Spike loose, few-flow'sed: leaf-serrations blunt.

Flowers $1-1.5 \mathrm{cin}$. long; te.tves thin.

Spike loose, $10-20 \mathrm{~cm}$. long; leaves few and distant.

Spike dense; 2-10 cm. long; stem leafy.

r. P. Virginiana,

2. P. denticulata.

3. P. intermedia. 4. P. parviflora.

I. Physostegia Virginiàna (L.) Benth. False. Dragon-head. Obedient Plant. Lion's Heart. (I. F. f. 3IOO.) Stem 3-12 dm. tall. Leaves lanceolate, oblong-lanceolate, or linear-lanceolate, acuminate, serrate or serrulate, the upper sessile $5^{-1} 3 \mathrm{~cm}$. long, the lowest petioled; bracts lanceolate, shorter than the calyx; spikes dense, becoming 1-2 dm. long in fruit; flowering calyx campanulate or somewhat turbinate, its teeth ovate, acute; fruiting calyx oblong, 8-10 $\mathrm{mm}$. long, the teeth much shorter than the tube; corolla pale purple or rose, often variegated with white, temporarily remaining in whatever position it is placed. In moist soil, Quebec to the N. W. Terr., Fla., La. and Tex. July-Sept.

2. Physostegia denticu!ata (Ait.) Britton. Few-flowered Lion's Heart. (I. F. f. 310r.) Stem slender, simple, or little branched, 3-6 dm. high. Leaves oblong, linear-oblong, or oblanceolate, crenulate, or entire, $2-8 \mathrm{~cm}$. long, the lower slender petioled; bracts lancer late, little longer than the fruiting pedicels; flowering calyx oval-campanulate, its teeth acute, about one-third as long as the tube: fruiting calyx oblong, 6-8 $\mathrm{mm}$. long; corolla rose-pink. In moist soil, Va. to Fla. and Tex. June-Aug. 
3. Physostegia intermèdia (Nutt.) A. Gray. Slender Lion's Heart. (I. F. f. 3 IO2.) Stem slender, usually simple, 3-9 dm. high. Leaves remote, narrowly lanceolate or linear, acute or acuminate, repand-denticulate, sessile, or the lowest petioled, $5-8 \mathrm{~cm}$. long; spikes slender; lower bracts often nearly as long as the campanulate calyx; calyx-teeth acute, shorter than the tube; fruiting calyx broadly oval, 4-5 $\mathrm{mm}$. long; corolla much dilated above. On prairies, western Ky. (according to Gray); La., Ark. and Tex. May-July.

4. Physostegia parvifiòra Nutt. PURPLE OR Western Lion's Heart. (I. F. f. 3IO3.) Stem usually simple, 3-9 dm. high. Leaves lanceolate, oblong. lanceolate, or ovate-lanceolate, acute, acuminate or the lower obtuse, sharply serrate or dentate, sessile or the lowest petioled, 7-10 $\mathrm{cm}$. long; spikes long; bracts ovate or ovate-lanceolate, acute, shorter than the calyx; fruiting calyx globose-oblong, 4-6 mm. long; corolla purple. In moist soil, Minn. to Neb., Br. Col. and Ore. June-Aug.

\section{SYNÁNDRA Nutt.}

An annual or biennial, somewhat hirsute herb, with long-petioled ovate cordate crenate leaves, and large white flowers in a terminal leafy-bracted spike. Calyx campanulate-oblong, membranous, deeply 4-cleft, inflated in fruit, faintly veined, the lobes narrowly lanceolate, the two upper shorter than the lower. Corolla much longer than the calyx, its tube narrow below, much expanded above, 2-lipped; upper lip concave, entire; lower lip spreading, 3-lobed. Filaments villous; anthers glabrous, 2-celled, the sacs divaricate, the contiguous ones of the upper pair of stamens sterile and connate. Nutlets ovoid, smooth, sharply angled. [Greek, stamens-together.] A monotypic genus.

I. Synandra hispídula (Michx.) Britton. Synandra. (I. F. f. 3 IO4.) Stem weak, 3-8 dm. long, striate. Leaves thin, palmately veined, the blade $5-10 \mathrm{~cm}$. long, and commonly shorter than the petiole; floral leaves sessile, ovate or ovatelanceolate, acute or acuminate; flowers solitary in their axils; uppermost leaves very small; calyx hirsute, its lobes about as long as the tube; corolla $2.5-4 \mathrm{~cm}$. long, the lower lip with purple lines. Along streams and in wet woods, Ohio and III. to Va. and Tern. May-June. [S. grandiflora Nutt.]

\section{PHLòmis L.}

Tall perennial herbs, or shrubs. Calyx tubular or tubular-campanulate, 5-10nerved, the iimb mostly equally 5-tootheci. Corona-tube usually with a woolly ring within, the limk strongly 2-lipped; upper sip erect, concave, arened or sometimes keeled, entıre or emarginate; lower lip spreading, 3-cleft. Anterıor pair of stamens the longer and their filaments with hooked appendages $a \pm$ the base: anther. sacs divergent. Nutlets ovoid, glabrous, or pubescent above. [Greek, mullen, in allusion to the thick woolly leaves of some species.] About 50 species, of the Old World.

I. Phlomis tuberòsa L. Jerusalem Sage. (I. F. f. 3105.) Herbaceous from a thick root; stem purplish, glabrous or loosely pubescent above, 9-18 dm. tall. Lower leaves triangular-ovate, long-petioled, acuminate or acute, coarsely dentate, deeply cordate, strongly veined, I-2.5 dm. long: upper leaves lanceolate, short-petioled or sessile, truncate or sometimes narrowed at the base; clusters densely many-flowered; bractlets subulate; calyx IO-1 $2 \mathrm{~mm}$. long, its teeth setaceous with a broader base, spreading; corolla $2-2.5 \mathrm{~cm}$. long, pale purple or white, twice as long as the calyx, densely pubescent, and the margins of its upper lip fringed with long hairs. In waste places, south shore of Lake Ontario. Nat. from Europe. June-Sept.

\section{GALEÓPSIS L.}

Erect annual herbs, with yellow red purple or mottled verticillate-clustered flowers in the upper axils, or forming terminal spikes. Calyx campanulate or tubular-campanulate, 5-10-nerved, 5-toothed, the teeth nearly equal, spinulose. Corolla-tube narrow, the throat expanded, the limb strongly 2-lipped; upper lip erect, concave, entire ; lower lip spreading, 3 -cleft, the middle lobe obcordate or emarginate. Anthers 2-celled, the sacs transversely 2-valved, the inner valve 
ciliate, the outer smooth, larger. Nutlets ovoid, slightly flattened, smooth. [Greek, weasel-like.] About 6 species, of Europe and Asia.

Plant puberulent; leaves linear to lanceolate.

Plant hispid; leaves ovate.

1. G. Ladanum.

2. G. Tetrahit.

I. Galeopsis Ládanum L. Red Hemp-Nettle. Ironwort. (I. F. f. 3 IO6.) Puberulent; stem 1.5-5 dm. high. Leaves linear, oblong, or lanceolate, mostly short-petioled, acute at both ends, dentate, or nearly entire, $2-5 \mathrm{~cm}$. long; flowerclusters mainly axillary; corolla $12-16 \mathrm{~mm}$. long, red or purple to white and variegated. In waste places, N. B. to Mich. and N. J. Adventive or nat. from Europe. July-Oct.

2. Galeopsis Tetràhit L. Hemp-nettle. Hemp Dead Nettle. (I. F. f. 3107.) A coarse rough-hairy herb, the stem 3-9 dm. high, swollen under the joints. Leaves ovate, membranous, slender-petioled, acuminate, coarsely dentate, $5^{-1} 3 \mathrm{~cm}$. long ; flower-clusters axillary, or in a short leafy-bracted spike ; corolla 16-25 $\mathrm{mm}$. long, pink or pale purple variegated with white. In waste places, Newf. to Alaska, N. Car. and Mich. Nat. from Europe. June-Sept.

\section{LEONÙRUS L.}

Tall herbs, with palmately cleft, parted or dentate leaves, and small white or pink flowers verticillate in dense axillary clusters. Calyx tubular-campanulate, 5-nerved, nearly regular and equally 5-toothed, the teeth rigid, subulate or aristate. Corolla-limb 2-lipped; upper lip erect, entıre; lower lip spreading or deflexed, 3-lobed, the middle lobe broad, obcordate or emarginate. Anthers 2-celled, the sacs mostly parallel. Nutlets 3 -sided, smooth. [Greek, lion's-tail.] About Io species, of Europe and Asia.

Lower leaves palmately 2-5-cleft, the upper 3-cleft. Leaves deeply 3-parted, the segments cleft and incised.

Leaves coarsely dentate or incised-dentate.

1. L. Cardiaca.

2. L. Sibiricus.

3. L. Marrubiastrum.

I. Leonurus Cardiaca L. Motherwort. (I. F. f. 3108.) Perennial, puberulent; stem $6-15 \mathrm{dm}$. tall, the branches straight and ascending. Leaves slender-petioled, the lower nearly orbicular, 5-10 cm. broad, the lobes acuminate, incised or dentate; upper leaves oblong-lanceolate or rhombic, 3-cleft, or the uppermost merely 3-toothed; flower-clusters exceeded by the petioles; corolla pink, purple or white, 6-10 $\mathrm{mm}$. long, its tube with an oblique ring of hairs within, its upper lip slightly concave, densely white-woolly without, the lower lip mottled; anther-sacs parallel.. In waste places, N. S. to N. Car., S. Dak. and Kans. Nat. from Europe. June-Sept.

2. Leonurus Sibíricus L. Siberian Motherwort or Lion's-tail. (I. F. f. 3IOg.) Biennial, puberulent or glabrate; stem 6-18 dm. high. Leaves longpetioled, 3-parted into ovate or lanceolate, acute or acuminate, cleft and incised segments, the lobes lanceolate or linear, acute; the uppermost linear or lanceolate; clusters dense, usually all axillary ; calyx campanulate, $6 \mathrm{~mm}$. long, glabrous or minutely puberulent; corolla purple or red, densely puberulent without, 8-12 $\mathrm{mm}$. long, its tube naked within; anther.sacs divergent. In waste and cultivated soil, Penn. and Del. Nat. from eastern Asia. May-Sept.

3. Leonurus Marrubiàstrum L. HoARHOUND MOtherwort or Lion'sTAIL. (I. F. f. 3 IIO.) Biennial, puberulent or pubescent; stem 6-I5 dm. high. Leaves petioled, ovate or ovate oblong, 2-8 dm. long, the upper narrower; flowerclusters axillary; calyx finely puberulent or glabrate; corolla nearly white, glabrate, about $8 \mathrm{~mm}$. long, its tube scarcely exceeding the calyx, naked within. In waste places, N. J. (according to S. Watson); Penn. and Del. Nat. from Europe. JuneSept.

\section{LÀMIUM L.}

Mostly diffuse herbs, with crenate dentate or incised, usually cordate leaves, and rather small flowers, verticillate in axillary and terminal clusters. Calyx tubularcampanulate, about 5-nerved, 5-toothed, the teeth equal or the upper ones. longer. Corolla-limb 2-lipped; upper lip concave, erect, usually entire; lower lip spread, ing, 3-cleft, the middle lobe emarginate, contracted at the base. Authers 2-celled, 
the sacs divaricate, often hirsute on the back. [Greek, throat, from the ringent corollia.] About 40 species, of the Old World.

Upper leaves sessile or clasping.

Leaves all petioled.

Flowers red or purple.

Corolla $12-18 \mathrm{~nm}$. long; leaves not blotched.

Corolla $20-25 \mathrm{~mm}$. long; leaves commonly blotched.

Flowers white.

1. L. amplexicaule.

2. L. purpureum.

3. L. maculatum.

4. L. album.

I. Lamium amplexicaùle L. Henbit. (I. F. f. 3 III.) Biennial or annual, sparingly pubescent; stems weak, slender, ascending or decumbent, $\mathbf{I} .5-5 \mathrm{dm}$. long. Ieaves orbicular or nearly so, coarsely crenate, $\mathbf{I}-4 \mathrm{~cm}$. wide, rounded at the apex, the lower slender-petioled; flowers in axillary and terminal clusters; calyx pubescent, its teeth erect, nearly as long as the tube; corolla purplish or red, 12-16 mm. long, its tube very slender, the lateral lobes of its lower lip very small. In waste and cultivated ground, N. B. to Ont., Br. Col., Fla. and Ark. Nat. from Europe. Feb.-Oct.

2. Lamium purpureum L. Red Dead Nettle. (I. F. f. 3112.) Annual, slightly pubescent, stems decumbent, I.5-4.5 dm. long. Leaves crenate or crenulate, the lower orbicular or broadly ovate, rounded at the apex, cordate at the base, the upper ovate, I-4 cm. long; flowers in axillary and terminal clusters; calyx-teeth narrowly lanceolate, acuminate; corolla purple-red, rarely exceeding $\mathbf{I} \mathbf{2 m m}$. long, the lateral lobes of its lower lip reduced to $\mathbf{I}$ or 2 short teeth. In waste and cultivated soil, R. I. to Penn. and D. C. Also in ballast about the northern seaports. Nat. or adventive from Europe. April-Oct.

3 Lamium maculàtum L. Spotted Dead Nettle. (I. F. f. 3113.) Perennial, somewhat pubescent; stems $2-5 \mathrm{dm}$. long. Leaves crenate or incised-crenate, usually blotched, broadly ovate or triangular-ovate, truncate or cordate at the base, 2-5 cm. long, or some of the lower ones much smaller and nearly orbicular; clusters mainly axillary; corolla purple-red, its tube contracted near the base, with a transverse ring of hairs within, the lateral lobes of its lower lip very small. Along roadsides, escaped from gardens, Me. to Va. Native of Europe and Asia. Miry-Oct.

4 Lamium álbum L. White Dead Nettle. (I. F. f. 3 II4.) Perennial, pubescent; stems 3-5 dm. long. Leaves ovate, crenate, dentate or incised, acute or acuminate, cordate or truncate at the base, $2.8 \mathrm{~cm}$. long, or the lower shorter and obtuse: clusters mostly axillary; corolla about $2.5 \mathrm{~cm}$. long, its tube short, stout, contracted near the base, with an oblique ring of hairs within, the lateral lobes of its lower lip each with a slender tooth. In waste places, Ont. to Va. Nat. or adventive from Europe. April-Oct.

\section{BALLòtA L.}

Perennial pubescen: or tomentose herbs, some species shrubby, with dentate or crenate leaves, and small bracted flowers in axillary clusters. Calyx tubular-funnelform, Io-nerved, 5-ro-toothed, the teeth dilated at the base, or connate into a spreading limb. Corolla-tube provided with a ring of hairs within, the limb strongly 2-lipped: upper lip erect. concave, emarginate. Anther sacs divergent at maturity. Nutlets ovoid, smooth. [The Greek name.] About 30 species, of the Old World.

I. Ballota nigra L. Black or Fetid HoArhound. (I. F. f. 3II5.) Herbaceous, puberulent or pubescent, ill-scented; stem 4-9 dm. high, its hairs mostly reflexed. Leaves slender petioled, ovate, or the lower'nearly orbicular, coarsely dentate, thin, $2-5 \mathrm{~cm}$. long, clusters several-flowered, dense; bractlets subulate; calyx about $8 \mathrm{~mm}$. long, its teeth lanceolate, bristle-pointed, spreading in fruit; corolla I2-18 mm. long, reddish purple to whitish, its upper lip pubescent on both sides; nutlets shining. In waste places, Mass. to Penn. Nat. from Europe. June-Sept.

\section{STÀCHYS L. (See Appendix.)}

Herbs, with purple yellow red or white flowers, loosely verticillate-clustered in terminal spikes, or also in the upper axils. Calyx mostly campanulate, 5-10. 
nerved, 5-toothed, the teeth nearly equal in our species. Corolla purple in our species, its tube narrow, the limb strongly 2-lipped; upper lip erect, concave, entire or emarginate; lower lip spreading, 3-cleft, the middle lobe broader than the lateral ones, sometimes 2-lobed. Anthers contiguous in pairs, 2-celled, the sacs mostly divergent. Nutlets ovoid or oblong. [Geeek, a spike, from the spicate inflorescence.] About 150 species, of wide distribution. Besides the following, some I2 others occur in the southern and westcrn U. S.

Leaves narrowed at the base, linear to lanceolate or oblong.

Stem glabrous; leaves entire, or nearly so.

Leaves linear, 2-5 $\mathrm{mm}$. wide.

Leaves oblong to linear-oblong, 4-10 $\mathrm{mm}$. wide.

Stem retrorsely hirsute; leaves serrate.

Leaves slightly pubescent; calyx-teeth lanceolate.

Whole plant densely clothed with stiff appressed hairs.

Leaves cordate or truncate at the base, lanceolate to ovate.

Stem glabrous or nearly so.

Calyx-teeth lanceolate-subulate, nearly as long as the tube.

Calyx-teeth triangular, about one-fourth as long as the tube.

r. S. hyssopifolia.

2. S. Atlantica.

Stem hirsute.

Leaves all very short-petioled, lanceolate to oblong.

Leaves, at least the lower, slender-petioled.

Leaves lanceolate or ovate, acute or acuminate.

Plant dark green ; leaves firm; petioles 6-36 mm. long.

Plant light green; leaves membranous; petioles $1-5 \mathrm{~cm}$. long.

3. S. ambigua.

4. $S$. arenicola.

5. S. tenuifolia.

6. S. latidens.

7. S. palustris.

Leaves ovate, obtuse ; diffuse annual.

Whole plant densely white-villous; introduced species.

9. S. cordata.

Io. S. arvensis.

11. S. Germanica.

I. Stachys hyssopifòlia Michx. Hyssop HedGe Nettle. (I. F. f. 3 I I6.) Perennial, glabrous or nearly so, sometimes slightly hirsute at the nodes; stem slender, erect, 3-5 dm. high. Leaves linear, acute at both ends, short-petioled or sessile, entire, or sparingly denticulate with low teeth, 2-5 cm. long, the uppermost reduced to short bracts; clusters forming an interrupted spike; fruiting calyx glabrous or slightly hirsute, $6 \mathrm{~mm}$. long, its teeth lanceolate-subulate, nearly as long as the tube: corolla about $1.5 \mathrm{~cm}$. long, light purple, glabrous. In fields and thickets, Mass. to Fla., Mich. and Va. July-Sept.

2. Stachys Atlántica Britton, n. sp. Coast Hedge Netrle. Perennial, glabrous, or with a few hairs at the nodes, weak, 2-4 dm. high. Leaves thin, mostly oblong and obtuse or obtusish, spreading, 2-5 cm. long, usually over $5 \mathrm{~mm}$. wide, remotely denticulate, the upper sometimes rounded at the base; corolla $\mathbf{I ~} \mathrm{cm}$. $1 \mathrm{nn} r \cdot$ fruiting calyx $5 \mathrm{~mm}$. long, its teeth triangular-ovate, acuminate. In marshy groun !, L. 1., to eastern Penn. Type from Southampton, L. I. Aug.-Sept.

Stachys annua I. An annual Euronean species with lanceolate to oblong leaves, at least the lower crenate-dentate, a siender puberulent stem, and villous calyx, has been found at one locality in Kansas, and in ballast about the seaports.

3. Stachys ambígua (A. Gray) Britton. Dense-flowered Hedge NetTle. (I. F. f. 3II7.) Perennial; stem retrorsely hispid, at least below, 3-6 dm. high. Leaves oblong, oblong-lanceolate, or linear, pubescent or glabrate, acuminate or acute, 4-20 mm. wide, $2-8 \mathrm{~cm}$. long, serrulate; clusters in a terminal rather dense spike, and usually also in the upper axils; calyx more or less hirsute, $5 \mathrm{~mm}$. long, its lanceolate-subulate teeth more than one-half as long as the tube. In moist soil, Penn. to Ga., Ill. and Ky. July-Aug.

4. Stachys arenícola Britton, n. sp. Sand Hedge Nettle. Perennial, very densely pubescent, 5-8 dm. high. Leaves lanceolate, narrowed at the base, sessile, finely crenate-dentate, acuminate, 6-10 $\mathrm{cm}$. long, the upper much smaller; upper bracts little longer than the flowers; calyx-teeth subulate-acicular, about as long as the tube; corolla about $\mathbf{I} \mathrm{cm}$. long. In sandy soil, southern N. Y. to Ill. and Mich. Type from New Dorp, Staten Island, N. Y.

5. Stachys tenuifòlia Willd. Smooth Hedge Nettle. (I. F. f. 3 II8.) Perennial; stem smooth, or slightly scabrous on the angles, slender, 3-8 dm. high. Leaves lanceolate, oblong, or ovate-lanceolate, slender-petioled, thin, acuminate at 
the apex, obtuse or subcordate at the base, sharply dentate or denticulate, dark green, 5-13 cm. long; clusters in terminal spikes, or also in the upper axils; calyx glabrous, or sparingly hirsute, $4 \mathrm{~mm}$. long, its teeth one-half as long as the tube or more; corolla I2-16 mm. long, pale red and purple. In moist fields and thickets, N. Y. to Ill., Kans., N. Car. and La. June-Aug.

\section{Stachys làtidens Small.}

Broad-toothed Hedge Nettle. Similar to $S$. tenuifolia, glabrous, or very nearly so throughout. Leaves thin, all shortpetioled, crenate-dentate, the lower ovate to oval, obtusish, the upper lanceolate to oblong-lanceolate, acuminate, 5-10 cm. long; spike interrupted; fruiting calyx broadly campanulate, about $5 \mathrm{~mm}$. long, its triangular sharp-pointed teeth $\mathbf{~} \mathrm{mm}$. long, I.5 mm. wide. White Top Mt., Va. (J. K. Small, I892).

7. Stachys palústris L. Hedge Netrle. Marsh or Clown's WoundWORT. (I. F. f. 3IIg.) Perennial, hirsute or pubescent; stem strict, retrorsehispid on the angles, 3-12 dm. high. Leaves lanceolate, oblong, or oblong-lanceolate, sessile, or very short-petioled, acuminate or acute, $5-13 \mathrm{~cm}$. long; crenulate or dentate; clusters forming an interrupted spike, sometimes also in the upper axils; calyx pubescent, its teeth subulate; corolla purplish to pale red, purple spotted, I2-16 mm. long, its upper lip pubescent. In moist soil, Newf. to the N. W. Terr., Mass., N. J., N. Y., Wisc. and Minn. Also in Europe and Asia. June-Sept.

8. Stachys áspera Michx. Rough Hedge NetTle or Woundwort. (I. F. f. 3120.) Perennial, rough hairy ; stem 6-I2 dm. high, commonly retrorsehispid on the angles. Leaves oblong, oblong-lanceolate, or ovate-oblong, crenatedentate, acute or acuminate, $5-15 \mathrm{~cm}$. long, the lower slender-petioled; spike mostly interrupted; clusters sometimes also in the upper axils; calyx about $6 \mathrm{~mm}$. long, its teeth triangular-lanceolate, acuminate; corolla red-purple, about $\mathbf{1} 2 \mathrm{~mm}$. long, its upper lip pubescent. In moist soil, Ont. to N. E., Fla., Minn. and I.a. June-Sept.

9. Stachys cordàta Riddell. Light-green Hedge Nettle. (I. F. f. 3r 21.) Perennial, hirsute, pale green; stem slender, weak, 6-9 dm. long. Leaves membranous, flaccid, ovate, oblong or ovate-lanceolate, acuminate, acute or the lowest obtuse, nearly all of them cordate at the base, dentate or crenate all around, long-petioled, 7-I5 cm. long, 2-8 cm. wide, the lowest petioles nearly as long as the blades; calyx-teeth subulate-lanceolate; corolla purplish, pubescent or puberulent, about $\mathbf{I} \mathrm{cm}$. long. In woods and thickets, Ohio to N. Car. and Tenn. JulyAug.

Io. Stachys arvénsis L. CORN OR FIELd WOundwort. (I. F. f. 3122.) Annual, hirsute; stem slender, diffusely branched, $0.5-6 \mathrm{dm}$. long. Leaves ovate or ovate-oblong, thin, long-petioled, obtuse, crenate, cordate or the upper rounded at the base, about $2.5 \mathrm{~cm}$. long; lower petioles commonly as long as the blades; clusters 4-6-flowered, in the upper axils and in short terminal spikes; calyx about $6 \mathrm{~mm}$. long, its teeth lanceolate, acuminate; corolla purplish, 6-10 mm. long. In waste places, Me., Mass., and in ballast about the eastern seaports. Nat. from Europe. July-Oct.

I I. Stachys Germánica L. Downy Woundwort. Mouse-ear. (I. F. f. 3I22a.) Annual; stem 3-9 dm. high. Leaves oval, ovate or lanceolate, crenate-dentate, villous, the lower rounded or subcordate at the base, long-petioled, mostly obtuse, the upper narrowed at both ends; clusters of flowers dense, borne in most of the axils; bracts lanceolate, half as long as the calyx; calyx-teeth ovate, acuminate, awned; corolla purple, its tube about as long as the calyx. Roadsides near Guelph, Ont. Adventive from Europe. July-Sept.

\section{2r. BETÓNICA L.}

Annual or perennial herbs, similar to Stachys. I ower leaves very long-petioled. Verticils many-flowered, in terminal spikes. Calyx nearly equally 5 -toothed, 5-Io-nerved. Corolla purple, the tube exceeding the calyx, the limb strongly 2-lipped; upper lip concave; lower 3-cleft, spreading. Stamerrs and pistil as in Stachys, but the anther-sacs parallel in some species. Nutlets ovoid, rounded above. [The classical Latin name of Wood Betony.] Ten species, or more, natives of Europe and Asia.

r. Betonica officinàlis L. Betony. Wood Betony. (I. F. f. 3123.) Perennial, deep green; stem erect, 3-9 dm. tall. Leaves oblong or ovate, obtuse, 
crenate, firm, cordate or truncate at the base, the basal and lower ones very long. petioled, the blades 7-I5 $\mathrm{cm}$. long. the upper short-petioled or nearly sessile; spike short, dense; bracts ovate, mucronate, about as long as the calyx : calyx-teeth acicular; corolla-tube exserted. In a thicket at Newton, Mass. Fugitive from Europe. July-Sept.

\section{SÁLVIA L.}

Herbs, or some species shrubs, with clustered flowers, the clusters mostly spiked, racemed, or panicled. Calyx mostly naked in the throat, 2-lipped; upper lip entire or 3-toothed; lower lip 2-cleft or 2-toothed. Corolla strongly 2-lipped; upper lip entire, emarginate or 2-lobed; lower lip spreading, 3-cleft or 3-lobed. Antherbearing stamens 2 (the posterior pair wanting or rudimentary); connective of the anthers transverse, linear or filiform, bearing a perfect anther-sac on its upper end, its lower end dilated, capitate or sometimes bearing a small or rudimentary one. Nutlets smooth, usually developing mucilage and spiral tubes when wetted. [Latin, salvus, safe, from its healing virtues.] About 500 species, of wide distribution. Besides the following, some 25 others occur in southern and western N. Am.

Leaves mostly basal, only $\mathrm{I}-3$ small pairs on the stem.

Leaves lyrate-pinnatifid or repand: upper corolla-lip short.

Leaves crenulate; upper lip arched, longer than the lower.

Stem leafy, bearing several pairs of leaves.

Leaves narrowly oblong, or lanceolate.

Corolla $2-3 \mathrm{~cm}$. long, its tube exserted.

Corolla 8-12 mm. long, its tube not exserted.

Leaves ovate, or broadly oval.

Upper corolla-lip short, not exceeding the lower.

Leaves merely crenate or crenulate; fruiting caly $x$ spreading.

Leaves pinnatifid, sinuate or incised; fruiting calyx deflexed.

I. S. lyrata.

2. S. pratensis.

3. S. Pitcheri.

4. S. lanceolata.

5. S. urticifolia.

Upper lip of corolla arched, longer than the lower.

6. S. verbenaca.

7. S. Sclora.

I. Salvia lyràta L. Lyre-leaved SAge. (I. F. f. 3124.) Perennial or biennial, hirsute or pubescent; stem 3-9 dm. high, bearing several whorls of large violet flowers. Basal leaves tufted, long-petioled, obovate or broadly oblong, thin. 0.7-2 dm. long; calyx campanulate, the teeth of its upper lip subulate, those of the lower longer, aristulate; corolla about $2.5 \mathrm{~cm}$. long, the upper lip much smaller than the lower; anther-sacs borne on both the upper and lower ends of the connective. In dry, mostly sandy woods and thickets, N. J. to Fla., Ill., Ark. and Tex. Corolla rarely undeveloped. May-July.

2. Salvia praténsis L. MEadow SAge. (I. F. f. 3125.) Perennial, pubescent or puberulent. Basal leaves long-petioled, ovate, oblong, or ovate-lanceolate, crenulate, obtuse at the apex, rounded or cordate at the base, thick, rugose, 5-18 cm. long; spike elongated, interrupted; calyx campanulate, glandular-pubes. cent, the teeth of the upper lip minute, those of the lower long, subulate; corolla purple, minutely glandular; lower end of the connective with a small or imperfect anther-sac. Atlantic Co., N. J. Fugitive or adventive from Europe. May-July.

3. Salvia Pítcheri Torr. PItcher's SAGE. (I. F. f. 3126.) Perennial, downy; stem 6-15 dm. high; branches nearly erect. Leaves linear or linearoblong. sessile, or narrowed at the base into short petioles, firm, 5-13 cm. long, the uppermost reduced to small bracts; clusters in long spikes; calyx oblong-campanulate, densely and finely woolly, about $6 \mathrm{~mm}$. long, its upper lip entire, obtuse, the lower with 2 ovate acute teeth; corolla blue, finely pubescent, its lower lip broad, sinuately 3 -lobed, longer than the concave upper one; lower ends of the connectives destitute of anther-sacs. On dry plains, Mo., Kans. and Colo. to Tex. Introduced into Ill. July-Sept.

4. Salvia lanceolàta Willd. LanCE-Leaved SAGE. (I. F. f. 3127.) Annual, puberulent or glabrous; stem 1.5-4.5 dm. high. Leaves petioled, mostly obtuse, $2-5 \mathrm{~cm}$. long, the upper reduced to lanceolate-subulate bracts; flowers in terminal spike-like racemes; pedicels shorter than the campanulate calyx; calyx 4-6 mm. long, its upper lip ovate, entire, the lower 2 -cleft, the teeth ovate, mucionate; corolla blue, its lower lip narrow, twice as long as the upper; lower ends of 
the connectives dilated. On plains, Neb. and Colo. to Tex., Ariz. and Mex. May-Sept.

5. Salvia urticifollia L. Nettle-leaved Sage. (I. F. f. 3128.) Perennial; stem glandular above, 3-6 dm. high. Leaves 5-ro $\mathrm{cm}$. long, irregularly crenate-dentate, usually acute, abruptly contracted into margined petioles; clusters in terminal interrupted spikes; bracts early deciduous; calyx oblong-campanulate, about $6 \mathrm{~mm}$. long, the upper lip minutely 3-toothed, the lower 2-cleft, its teeth triangular-lanceolate, acuninate; corolla puberulent, 12-16 mm. long, blue and white, the lower lip broad, 3-lobed, twice as long as the upper; lower ends of the connectives dilated. In woods and thickets, Md. to Ky., Ga. and La. AprilJune.

6. Salvia verbenàca L. Wild SAge. Wild Clary. (I. F. f. 3129.) Perennial; stem glandular-pubescent, 3-6 dm. high. Leaves coarsely and irregularly incised.dentate or pinnatifid, the lower $0.7^{-2} \mathrm{dm}$. long, obtuse, cordate, nearly glabrous, the upper acute, much smaller; floral bracts broadly ovate, short; clusters in terminal interrupted spikes; pedicels shorer than the calyx; calyx 6-8 mm. long, its upper lip recurved-spreading, witht 3 minute connivent teeth, the lower one with 2 lanceolate mucronate teeth; corolla blue, about $8 \mathrm{~mm}$. long, its upper lip scarcely longer than the lower: lower ends of the connectives dilated. In waste places, Ohio to S. Car. and Ga. Nat. from Europe. June-Aug.

7. Salvia Sclàrea L. Clary. Clear-eye. See-bright. (I. F. f. 3 I 3 o.) Biennial or annual, glandular-pubescent; stem 6-I I dm. high. Leaves broadly ovate, rugose, cordate, irregularly dentate-crenate or denticulate, the lower longpetioled, 1.5-2 dm. long, the upper small, short-petioled or sessile; clusters in terminal spikes; bracts broad, ovate, acuminate, pink or white; calyx campanulate; deflexed-spreading in fruit, 8-10 mm. long, its lips about equal, the teeth subulate, acicular; corolla blue and white, about $2.5 \mathrm{~cm}$. long; upper lip laterally compressedlower portions of the connectives dilated. In fields, Penn. to S. Car., escaped from gardens. Nat. from Europe. June-Aug.

\section{MONÀRDA L. (See Appendix.)}

Erect aromatic herbs, with dentate or serrate leaves, and white red purple yellowish or mottled flowers, in dense capitate clusters, terminal and sometimes also axillary. Calyx tubular, narrow, 15 nerved, nearly or quite equally 5toothed, mostly villous in the throat. Corolla usually puberulent or glandular, the limb 2-lipped; upper lip erect or arched; lower lip spreading, 3-lobed, the middle lobe larger or longer than the others. Anther-bearing stamens 2, ascending, usually exserted, the posterior pair (staminodia) rudinientary or wanting; anthers versatile, 2-celled, the sacs divaricate, more or less confluent at the base. Nutlets ovoid, smonth. [In honor of Nicolas Monardes, a Spanish physician and botanist.] About ro species, of N. Am. and Mex.

Flower-clusters solitary, terminal (rarely also in the uppermost axils).

Leaves manifestly petioled, the petioles commonly slender.

Corolla scarlet, $3-5 \mathrm{~cm}$. long; bracts red.

Corolla white, pink, or purple, $2-3 \mathrm{~cm}$. long.

I. M. didyma.

Leaves membranous; corolla slightly pubescent, $2-2.5 \mathrm{~cm}$. long.

Leaves thin or firm; corolla pubescent, $2.5-3 \mathrm{~cm}$. long.

2. M. Clinopodia.

Pubescence spreading: leaves thin.

Corolla cream-color, pink, or purplish.

3. M. fistulosa.

Corolla and bracts cieep purple or purple-red. 4. M. media.

Pubescence short, canescent; leaves firm, pale. 5. M. scabra.

Leaves sessile, or very short-petioled.

6. M. Bradburiana. Flower-clusters both axillary and terminal.

Caly $x$-teeth triangular-lanceolate; corolla yellowish, mottled.

Caly $x$-teeth subulate-aristate; corolla white or purple, not mottled.

7. M. punctata.

8. M. pectinata.

I. Monarda didyma L. Oswego Tea. American Bee Balm. (I. F. f. 3I3I.) Perennial; stem 6-9 dm. high. Leaves thin, ovate or ovate-lanceolate, petioled, dark green, usually with some villous pubescence beneath, acuminate, sharply serrate, 7-I5 cm. long; bracts commonly red; calyx incurved, slightly 
hirsute in the throat, its teeth subulate, nearly erect, about as long as the diameter of the tube; corolla sparingly puberulent. In moist soil, especially along streams, N. B. (?) to Ont., Mich. and Ga. July-Sept.

2. Monarda Clinopòdia L. Basal Balm. (I. F. f. 3132.) Perennial; stem glabrous or slightly villous, 3-9 dm. high. Leaves lanceolate, ovate or ovatelanceolate, bright green, mostly slender-petioled, villous on the veins beneath and puberulent above, acuminate, sharply serrate, 5-10 $\mathrm{cm}$. long; bracts pale or white; calyx curved, nearly glabrous without, somewhat hirsute in the throat, its teetk subulate, slightly spreading, about as long as the diameter of the tube; corolla yellowish pink, slightly pubescent. In woods and thickets, Ont. to Ga. and Ky. June-Aug.

3. Monarda fistulòsa L. Wild Bergamot. (I. F. f. 3133.) Perennial, villous-pubescent or glabrate ; stem 6-9 dm. high. Leaves thin but not membranous, usually slender-petioled, lanceolate, ovate or ovate-lanceolate, acuminate, serrate, 3-10 cm. long; bracts whitish or purplish; calyx puberulent or glabrous, densely villous in the throat, its subulate teeth rarely longer than the diameter of the tube; corolla yellowish-pink or purplish. On dry hills and in thickets, Me. and Ont. to Minn., Kans., Fla. and La. June-Sept.

4. Monarda mèdia Willd. Purple Bergamot. (I. F. f. 3I34.) Perennial, sparingly hairy or glabrate; stem stout, 6-I I dm. high. Leaves dark green, ovate, ovate-lanceolate, or the uppermost lanceolate, slender-petioled, acuminate, sharply toothed, usually rounded at the base, 7-13 cm. long; bracts deep purple, very conspicuous; calyx curved, glabrous, or nearly so, slightly villous in the throat, its teeth slightly spreading. In moist thickets, Me. to Ont., Penn. and Va. June-Aug.

5. Monarda scàbra Beck. Pale Wild Bergamot. (I. F. f. 3135.) Peren. nial; stem slender, puberulent at least above, 3-8 dm. high. Leaves usually shortpetioled, acuminate or acute, serrate, canescent or puberulent, rarely nearly glabrous, 2-10 $\mathrm{cm}$. long, $\mathbf{1}-\mathbf{2 . 5} \mathrm{cm}$. wide; bracts green or slightly pink; calyx puberulent, often hairy at the summit, densely villous in the throat, its short subulate teeth nearly erect; corolla yellowish or pink, pubescent, sometimes glandular. On prairies and plains, N. W. 'Terr. and Br. Col. to Mont., Neb., Mo. and Tex. June-Aug.

6. Monarda Bradburiana Beck. Bradbury's Monarda. (I. F. f. 3136.) Perennial, sparingly villous or glabrate; stem slender, 3-6 dm. high. Leaves bright green, ovate or ovate-lanceolate, sessile, or nearly so, or partly clasping by the cordate or subcordate base, acuminate, serrate, 5-9 cm. long; bracts green or purplish; calyx glabrous outside, hirsute within, narrowed at the throat, its teeth long, bristle-pointed, divergent, longer than the diameter of the tube; corolla pink or nearly white, about $2.5 \mathrm{~cm}$. long, its upper lip pubescent or puberulent, the lower commonly purple-spotted. On dry hills or in thickets, Ill. to Ala., Mo. and Kans. May-July.

7. Monarda punctàta L. Horse-mint. (I. F. f. 3 I37.) Perennial, usually rather densely downy; stem usually branched, 6-9 dm. high. Leaves lanceolate, linear-lanceolate or narrowly oblong, serrate, or nearly entire, usually acute at both ends, petioled, $2-8 \mathrm{~cm}$. long, often with smaller ones fascicled in their axils; bracts white or purplish, acute; calyx puberulent, villous in the throat, its teeth short, not longer than the diameter of the tube; corolla purple-spotted, about $2.5 \mathrm{~cm}$. long, the stamens equalling or slightly surpassing its pubescent upper lip. In dry fields, southern N. Y. to Fla., Wis., Kans. and Tex. July-Oct.

8. Monarda pectinata Nutt. Lemon Monarda. (I. F. f. 3138.) Annual, puberulent; stem 3-6 dm. high. Leaves lanceolate or oblong-lanceolate, mostly sharply serrate or serrulate, acute, narrowed at the base, $2-8 \mathrm{~cm}$. long; bracts white or purple, awned, the awns becoming recurved; calyx-tube nearly glabrous, the throat densely villous, the teeth bristle pointed, barbed, divergent or spreading, nearly half as long as the tube: corolla not spotted, nearly or quite glabrous, $2-2.5 \mathrm{~cm}$. long; stamens not exserted. On dry plains, Neb. and Colo. to Mo., Tex. and Ariz. June-Sept.

Monarda clinopodioldes A. Gray, a related Texan species, with a slender stem, green or greenish bracts, and hirsute calyx with erect broader teeth, is reported from Kiansas. 
24. BLEPHÍLIA Raf.

Perennial hirsute or pubescent erect herbs, with axillary and terminal dense glomerules of purplish or bluish flowers, or the glomerules in terminal interrupted spikes Calyx tubular, I3-nerved, not villous in the throat, 2 -lipped, the upper lip 3-toothed, the lower 2-toothed, the teeth all aristate or those of the lower lip subulate. Corolla glabrous within, the limb 2-lipped; upper lip erect, entire; lower lip 3 -lobed, the middle lobe narrower than the lateral ones. Anther-bearing (anterior) stamens 2, ascending; posterior stamens reduced to filiform staminodia, or none; anthers 2-celled, the sacs divaricate, somewhat confluent at the base. Nutlets ovoid, smooth. [Greek, eyelash, from the fringed calyx-teeth.] Two or three species, natives of eastern N. Am.

Pubescence short; upper leaves lanceolate or oblong, slightly serrate. Pubescence villous; leaves ovate or ovate-lanceolate, sharply serrate.

1. B. ciliata.

2. B. hirsuta.

I. Blephilia ciliàta (L.) Raf. Downy Blephilia. (I. F. f. 3139.) Stem puberulent, or with some short-villous pubescence above, commonly simple, 3-6 dm. high. Lower leaves and those of sterile shoots ovate or oval, crenatedenticulate, 2-5 cm. long, the upper short-petioled or sessile, longer and narrower; clusters in a terminal spike and in the uppermost axils; outer bracts ovate to lanceolate, acuminate, usually purplish, ciliate; calyx hirsute, the teeth of the upper lip about one third longer than those of the lower; corolla purple, villous-pubescent, Io-12 mm. long. In dry woods and thickets, Mass. to Mich., Wis., Ga. and Mo. June-Aug.

2. Blephilia hirsùta (Pursh) Tcrr. HaIRy Blephilia. (I. F. f. 3I40.) Stem villous-pubescent, usually branched, 3-9 dm. high. Leaves membranous, ovate or ovate-lanceolate, acuminate, 5-10 $\mathrm{cm}$. long, or the lower shorter and broader; clusters axillary, or in a short terminal spike; outer bracts lanceolate or linear-lanceolate, long-acuminate, hirsute; calyx-tube nearly glabrous, its teeth very villous, those of the upper lip much exceeding the lower; corolla pubescent, pale purple, darker-spotted, 8-10 $\mathrm{mm}$. long. In woods and thickets, Vt. to Wis., Kans., Ga. and Tex. June-Sept.

Blephilia hirsùta glabràta Fernald. Stem glabrous, or villous only above; head solitary, or with one or two additional lower ones. Vt.

\section{HEDEÒMA Pers.}

Aromatic and pungent herbs, with small leaves, and small blue or purple flowers in axillary clusters, these crowded into terminal spikes or racemes. Calyx tubular, 13-nerved, villous in the throat, the mouth mostly contracted in fruit, 2-lipped, or nearly equally 5 -toothed, the upper lip 3-toothed, the lower 2-cleft. Corolla-limb 2 -lipped, the upper lip erect, entire, emarginate or 2 -lobed, the lower spreading, 3-cleft. Perfect stamens 2, ascending under the upper lip, their anthers 2-celled, the sacs divergent or divaricate. Sterile stamens (staminodia) 2, minute, or none, very rarely anther-bearing. Nutlets ovoid, smooth. [Greek, sweet smell.] About 15 species, natives of Am. Besides the following, some 8 others occur in the Southern States.

Teeth of the upper lip of the calyx triangular; leaves serrate.

Teeth of both lips of the calyx subulate; leaves entire.

Calyx-teeth all nearly equal; annual.

Teeth of the lower lip nearly twice as long as the upper; perennial.

I. H. pulegioides.

2. H1. hispida.

3. H. Drummondii.

I. Hedeoma pulegioìdes (L.) Pers. American Pennyroyal. (I. F. f. 314I.) Annual; stem slender, much branched, finely soft-pubescent, I.5-4.5 dm. high. Leaves ovate to ovate-oblong, petioled, sparingly serrate, mostly obtuse, glabrous, or sparingly pubescent, thin, $1-4 \mathrm{~cm}$. long, the upper smaller; clusters few-flowered, rather loose; pedicels shorter than or equalling the calyx; calyx pubescent, gibbous, oblong-ovoid in fruit, its 3 upper teeth acute, not exceeding the 2 subulate hispid lower ones; corolla purple, about $6 \mathrm{~mm}$. long; rudimentary stamens manifest, rarely anther-bearing. In dry fields, N. S. to Ont. and Minn., Fla. and Kans. July-Sept.

2. Hedeoma híspida Pursh. Rough Pennyroyal. (I. F. f. 3i42.) Annual; stem 0.7-2 dm. high, pubescent. Leaves linear, firm, sessile, or the lower short. 
petioled, hispid-ciliate but otherwise mostly glabrous, $1-2.5 \mathrm{~cm}$. long, the lower much shorter and smaller; clusters numerous, crowded; pedicels pubescent, shorter than the calyx; bracts subulate, hispid; calyx oblong, gibbous, hispid, its teeth subulate, upwardly curved in fruit, about one-half as long as the tube, the 2 lower ones somewhat narrower and more hispid than the upper; corolla about $6 \mathrm{~mm}$. long, bluish-purple; sterile stamens rudimentary or none. On dry plains, Ill. to the N. W. Terr., La., Ark. and Colo. May-Aug. Also at Little Falls, N. Y.

3. Hedeoma Drummóndii Benth. Drummond's Pennyroyal. (i. $\dot{\mathrm{F}}$. $\mathbf{f}$. 3143.) Perennial from a woody base, with an ashy down nearly all over; stems 1.5-4.5 dm. high. Leaves oblong or linear, short-petioled or sessile, obtuse, I-2 cm. long, the lowest shorter; clusters loosely few-flowered; pedicels puberulent, about one-half as long as the calyx; calyx cylindric-oblong, hirsute, slightly gibbous, its teeth subulate, upwardly curved and connivent in fruit; corolla purple, 8-12 mm. long; sterile stamens rudimentary or none. In dry soil, Neb. and Colo. to Tex., Ariz. and Mex. April-Aug.

\section{MELÍSSA L.}

Leafy herbs, with broad dentate leaves, and rather small white or yellowish axillary clustered flowers. Calyx oblong-campanulate, deflexed in fruit, 13 -nerved, nearly naked in the throat, 2-lipped; upper lip flat, 3-toothed, the lower 2-parted. Corolla exserted, its tube curved-ascending, naked within, the limb 2-lipped; upper lip erect, emarginate; lower lip 3-cleft, spreading. Anthers 2 celled, their sacs divaricate. Nutlets ovoid, smooth. [Greek, bee.] About 4 species, of Europe and western Asia.

I. Melissa officinàlis L. Garden or Lemon Balm. BeE-BALM. (I. F. f. 3 144.) Perennial, pubescent; stem 3-8 dm. high. Leaves ovate, petioled, mostly obtuse at both ends, sometimes cordate, 2.5-6 cm. long; pedicel shorter than the calyx; calyx about $6 \mathrm{~mm}$. long, the teeth of its lower lip slightly exceeding those of the upper; corolla white, $\mathbf{r}-\mathbf{r} .5 \mathrm{~cm}$. long. In waste places, thickets and woods, Me. to Ga. and W. Va. Nat. from Europe. Plant lemon-scented. June-Aug.

\section{SATUREİA L.}

Herbs or shrubs, with small entire leaves, sometimes with smaller ones fascicled in their axils, and bracted purple flowers in dense terminal or axillary clusters. Calyx campanulate, mostly ro-nerved, 5-toothed, naked or rarely villous in the throat. Corolla-limb 2-lipped, the upper lip erect, flat, entire or emarginate, the lower spreading, 3-cleft. Anthers 2-celled, the sacs parallel or divaricate. Nutlets oblong or oval. [The classical Latin name.] About 18 species, the following introduced as a garden herb from Europe, one of doubtful affinity in Florida, the others of the Mediterranean region.

I. Satureia horténsis L. Savory. Summer Savory. (I. F. f. 3r45.) Annual, puberulent; stems much branched, 1.5-4.5 dm. high. Leaves linear or linear-oblong, short-petioled, acute, $1-4 \mathrm{~cm}$. long; clusters 6-1o $\mathrm{mm}$. in diameter, terminal and in many of the upper axils; calyx about equalling the corolla-tube, somewhat pubescent, its teeth subulate, about as long as the tube, ciliate; corolla little longer than the calyx: stamens scarcely exserted. In waste places, N. B. and Ont. to Penn., west to Nev. Nat. or adventive from Europe. July-Sept.

\section{CLINOPÒdIUM L. [CALAMINTHA Moench.]}

Herbs, or low shrubs, with entire or sparingly dentate leaves, and rather large flowers variously clustered. Calyx mostly gibbous at the base, about 13-nerved, 2-lipped, the upper lip 3-toothed, the lower 2-cleft. Corolla usually expanded at the throat, the tube straight, the limb 2-lipped; upper lip erect, entire or emarginate; lower lip spreading, 3-cleft. Stamens somewhat connivent in pairs, the longer mostly exserted; anthers 2-celled, the sacs divergent or divaricate. Nutlets ovoid, smooth. [Greek, bed-foot, the flowers likened to a bed-caster.] About 50 species, of the north temperate zone. Besides the following, 3 others occur in the southeastern U. S. and in Cal. 
* Flower-clusters dense, axillary and terminal, setaceous-bracted.

I. C. vulgare.

* Flower-clusters loose, axillary, or forming terminal thyrses; bracts small.

Plants pubescent; introduced species.

Clusters peduncled; caly $x$ not gibbous; upper leaves very small; perennials.

Leaves $0.6-2.5 \mathrm{~cm}$. long; corolla somewhat exceeding the calyx.

Leaves $2-5 \mathrm{~cm}$. long; corolla at least twice as long as the calyx.

2. C. Nepeta.

Clusters sessile; calyx very gibbous; plant leafy; annual.

3. C. Calamintha.

4. C. Acinos.

Plants glabrous; native species.

Leaves linear or the lower spatulate, entire; corolla $8 \mathrm{~mm}$. long. 5. C. glabrum.

Leaves oblong or oblong-lanceolate, serrate; corolla 12-14 $\mathrm{mm}$. long.

6. C. glabellum.

r. Clinopodium vulgàre L. Field or Wild Basil. Basil-Weed. (I. F. f. 3146.) Perennial by short stolons, hirsute; stem 3-6 dm. high. Leaves ovate or ovate-lanceolate, petioled, entire, undulate or crenate-dentate, thin, 2-6 cm. long; flowers in capitate clusters $2-3 \mathrm{~cm}$. in diameter; bracts hirsute-ciliate, usually as long as the calyx-tube; calyx pubescent, the setaceous teeth of its lower lip rather longer than the broader ones of the upper; corolla purple, pink, or white, little exceeding the calyx. In woods and thickets, N. S. to N. Car., Minn. and Manitoba, south in the Rocky Mts. to Colo. Also in Europe and Asia. June-Oct.

2. Clinopodium Népeta (L.) Kuntze. Field Balm. Lfsser Calamint. (I. F. f. 3147.) Villous or pubescent. Leaves broadly ovate, petioled, crenulate with few low teeth, the lower $1-2.5 \mathrm{~cm}$. long; flowers few in the numerous loose cymes, forming an almost naked elongated thyrsus; bracts very small, linear; calyx villous in the throat, about $3 \mathrm{~mm}$. long, the teeth of its lower lip twice as long as those of the upper; corolla light purple or almost white, about $8 \mathrm{~mm}$. long. In fields and waste places, Md. to S. Car., Ala., Ky. and Ark. Nat. from Europe. June-Sept.

3. Clinopodium Calamintha (L.) Kuntze. Calamint. Calamint Balm. (I. F. f. 3 I48.) Perennial by creeping rootstocks, 3-8 dm. high. Leaves broadly ovate, petioled, obtuse at both ends or subacute at the apex, dentate or crenatedentate, 2-5 cm. long and nearly as wide; inflorescence as in the preceding species, but commonly more leafy; calyx villous in the throat, 4-6 $\mathrm{mm}$. long; corolla purplish, 12-14 mm. long. "Inclined to escape from cultivation in a few places" (according to Gray). Native of Europe and Asia. June-Aug.

4. Clinopodium Ácınos (L.) Kuntze. Basil Thyme. Basil Balm. (I. F. f. 3 I 49.) Stems branched from the base, very slender, I.5-2 dm. high. Leaves oblong or ovate-oblong, petioled, acutish at both ends or the lower obtuse, crenulate or entire, 8-16 mm. long; flowers about 6 together in the axils; bracts shorter than the pedicels; calyx rough-hairy, longer than its pedicel, contracted at the throat, its subulate teeth somewhat unequal; corolla purplish, $11 / 2-2$ times as long as the calyx. In waste places, Ont. to Mass., N. Y. and N. J. Adventive from Europe. May-Aug.

5. Clinopodium glàbrum (Nutt.) Kuntze. Low Calamint. (I. F. f. 3150.) Perennial, stoloniferous, erect or ascending, $\mathrm{r}-3 \mathrm{dm}$. high. Leaves of the flowering branches linear, entire, short-petioled or sessile, mostly obtuse, obscurely veined, 8-18 mm. long, the margins slightly revolute; lower leaves and those of the stolons shorter and broader, distinctly petioled; flowers $1-4$ in the axils; pedicels filiform, mostly longer than the calyx; calyx not gibbous, its throat pubescent in a ring within, its lower teeth somewhat longer than the upper; corolla purple. On rocks and banks, N. Y. and Ont. to Ill., Minn., Mo. and Tex. May-Aug.

6. Clinopodium glabéllum (Michx.) Kuntze. Slender Calamint or BED'S-FOOT. (I. F. f. 315 I.) Perennial, stoloniferous; stems spreading or decumbent. at length freely branched, 2-6 dm. long. Leaves membranous, oblong, shortpetioled, obtuse or the uppermost subacute, narrowed to a cuneate base, serrate with low testh, 2-5 cm. long, 4-16 mm. wide, the lowest and those of the stolons sometimes shorter; axils 2-5-flowered; pedicels commonly twice as long as the calyx; calyx not gibbous, its throat pubescent in a ring within, its teeth nearly equal; corolla purplish. On river banks, Ky. and Tenn. Rare and local. MayTuly. 


\section{HYSSÒPUS L.}

A perennial erect herb, the stem somewhat woody at the base, with narrow, entire leaves, and small bracted purple or blue flowers, in dense clusters in the upper axils, and forming elongated terminal spikes. Calyx tubular, 15-nerved, about equally 5-toothed. Corolla-limb 2-lipped, the upper lip erect, emarginate, the lower spreading, 3-cleft. Anthers 2-celled, the sacs divaricate. Nutlets ovoid, somewhat 3-sided, nearly smooth. [Greek, an aromatic herb.] A monotypic genus.

I. Hyssopus officinàlis L. Hyssop. (I. F. f. 3152.) Stems usually several together, strict, puberulent, 3-9 dm. high. Leaves linear to oblong, sessile or nearly so, firm, acute at both ends or the lower obtuse, puberulent or glabrate, faintly veined, $3-5 \mathrm{~cm}$. long, sometimes with smaller ones or short leafy branches in their axils; spike dense; outer bracts as long as the calyx; calyx-teeth lanceolate, acute; corolla 8-10 $\mathrm{mm}$. long. Along roadsides and in waste places, Ont. to Me. and N. Car., and on the Pacific Coast. Nat. from Europe. June-Sept.

\section{3о. ORÍGANUM L.}

Perennial herbs, some species shrubby, with crenate-dentate or entire leaves, and small bracted pink or purple flowers, in dense terminal glomerules. Calyx villous in the throat, about I3-nerved, 5-toothed or 2-lipped. Corolla-limb 2-lipped, the upper lip erect, emarginate or 2-lobed, the lower longer, spreading, 3-cleft. Stamens didynamous, ascending; anthers 2-celled, the sacs divergent. Nutlets ovoid or oblong, smooth. [Greek, mountain joy.] About 30 species, of the Old World.

I. Origanum vulgàre L. Wild Marjoram. Organy. (I. F. f. 3153.) Perennial from nearly horizontal rootstocks, villous or hirsute; stem $3-8 \mathrm{dm}$. high. Leaves ovate, petioled, rounded or subcordate, crenate or entire, $2.5-4 \mathrm{~cm}$. long, often with smaller ones in their axils; flower-clusters often $5 \mathrm{~cm}$. broad; bracts purplish, ovate or oval, about equalling the 5-toothed calyx; corolla pink, purple or nearly white, the upper lobe broad; all four stamens, or the two longer, exserted. In fields and waste places, Ont. to N. J. and Penn. Nat. from Europe. July-Sept.

\section{KOÈLLIA Moench. [PYCNANTHEMUM Michx.]}

Perennial, mostly fragrant erect herbs, with small white or purple-dotted flowers, in terminal or sometimes also axillary capitate glomerules or cymose clusters. Calyx I0-13-nerved, 5-toothed, not villous in the throat, the 2 upper teeth sometimes united below. Corolla 2-lipped, the upper lip emarginate or entire, the lower 3-cleft. Stamens 4, didynamous, nearly equal, or the lower pair a little longer; anther-sacs parallel. Nutlets smooth, pubescent, or roughened. [Named for J. L. C. Koelle, a German botanist of the eighteenth century.] About I4 species, of N. Am. Besides the following, I occurs in California and $\mathbf{I}$ or 2 in the Southern States.

* Leaves prevailingly linear, linear-lanceolate or oblong-lanceolate.

Calyx-teeth ovate-triangular, acute, one-fourth as long as the tube.

Calyx-teeth subulate, lance-subulate or bristle-tipped.

2. $K$. Virginiana.

Leaves linear or lanceolate; calyx-teeth subulate or lanceolate.

Leaves linear or narrowly linear-lanceolate, entire.

I. $K$. flexuosa.

Leaves lanceolate, entire, or usually serrate.

Bracts appressed, erect; clusters dense.

Hirsute or pilose; leaves mainly entire.

Puberulent or glabrate; leaves mostly denticulate.

Bracts spreading; clusters loose.

3. $K$. pilosa.

4. $K$. verticillata.

5. $K$. clinopodioides.

Leaves oblong to linear-oblong, obtuse or subacute; calyx-teeth awn-like.

6. $K$. hyssopifolia.

* * Leaves prevailingly ovate, ovate-oblong or ovate-lanceolate.

Calyx-teeth bristle-tipped or subulate.

Bracts appressed; clusters dense; calyx-teeth bristle-pointed. 
Bracts spreading; clusters loose; calyx-teeth subulate.

Calyx-teeth about one-half as long as the tube.

Calyx-teeth as long as the tube.

Calyx-teeth triangular, triangular-lanceolate or lanceolate.

Bracts spreading; clusters loose; calyx-teeth short.

Bracts appressed; clusters dense.

Bracts canescent; leaves firm, acute.

Bracts ciliate or villous; leaves membrancus, acuminate.

8. $K$. incana.

9. $K$. pycnanthemoides.

Io. $K$, albescens.

Ir. $K$. mutica.

12. $K$. montana.

I. Koellia fiexuòsa (Walt.) MacM. Narrow-Leaved Mountain-mint. (I. F. f. 3154.) Stem stiff, nearly glabrous, 4-8 dm. high. Leaves entire, glabrous or the uppermost puberulent, sessile, or the lower very short-petioled, $2-5 \mathrm{~cm}$. long, I-3 nim. wide, often with short leafy branches in their axils; glomerules cymose, 6-ro mm. broad, canescent; bracts appressed, acuminate, or subulatetipped. not longer than the clusters; calyx cylindraceous, canescent, its teeth subulate and rigid, $\epsilon$ qual or nearly so, 3-4 times longer than broad, about one-third as long as the tube. In fields and thickets, Me. and N. H. to Fla., Ont., Kans., Minn. and Tex. Little fragrant. July-Sept.

2. Koellia Virginiàna (L.) MacM. Virginia Mountain-mint. (I. F. f. 3155.) Stem strict, glabrous or pubescent, 3-9 dm. high. Leaves lanceolate or linear-lanceolate, fragrant, short-petioled or sessile, firm, entire, acuminate, glabrous, or puberulent beneath, or the uppermost canescent, $2-5 \mathrm{~cm}$. long, 4-10 $\mathrm{mm}$. wide, often with short leafy branches in their axils; glomerules dense, 8-12 mm. in diameter, cymose, canescent; bracts appressed, rigid, acute, acuminate or subulate-tipped, not exceeding the clusters; calyx canescent, its teeth equal or nearly so, acute, little longer than wide; corolla pubescent, purple-spotted. In dry fields and thickets, Quebec and Ont. to Minn., Ga., Ala. and Kans. July-Sept.

3. Koellia pilòsa (Nutt.) Britton. HaIry Mountain-mint. (I. F. f. 3I56.) Pubescent, 3-8 dm. high. Leaves lanceolate, short-petioled or sessile, entire or sparingly denticulate, 2-5 cm. long, 6-I $2 \mathrm{~mm}$. wide, firm, acuminate, commonly with short leafy shoots in their axils; glomerules cymose, villous or hirsute-canescent, about $8 \mathrm{~mm}$. in diameter; bracts lanceolate, acuminate, equalling or exceeding the clusters; calyx narrow, canescent, its teeth equal, about 3 times as long as wide and one-fourth to one-third the length of the tube; corolla pubescent. On prairies and in dry woods, Ohio to Ga., Kans: and Ark. July-Sept.

4. Koellia verticillàta (Michx.) Kuntze. Torrey's Mountain-Mint. (I. F. f. $3 \mathrm{I} 57$.$) Stem slender, 3-8 dm. high. Leaves linear-lanceolate to ovate-lanceo-$ late, short-petioled or sessile, serrulate or entire, acute or acuminate, $2-8 \mathrm{~cm}$. long, 6-20 $\mathrm{mm}$. wide, the uppermost sometimes canescent; clusters dense, canescent, IO-1 $2 \mathrm{~mm}$. broad, cymose and commonly also in the upper axils; bracts appressed, lanceolate, acuminate, equalling or longer than the clusters; calyx canescent, its teeth subulate or lance-subulate, 2-3 times as long as wide, one-fourth to one-third as long as the tube; corolla pubescent. In dry fields and thickets, Vt. to R. I., N. Y., Va., Pa. and Mo. The narrower-leaved forms are Kocllia Torreyi (Benth.) Kuntze, and are possibly distinct. July-Sept.

5. Koellia clinopodioides (T. \& G.) Kuntze. Basil Mountain-Mint. (I. F. f. 3158 .) Pubescent or puberulent; stem 3-8 dm. high. Leaves rather thin, short-petioled, sharply serrate, or the upper entire, $3-8 \mathrm{~cm}$. long, I-2.5 cm. wide; flower-clusters terminal and axillary; bracts linear-acuminate or subulate-tipped, not exceeding the clusters; calyx canescent or glabrate, its teeth subulate, sometimes with a few long hairs, about one-fourth the length of the tube. In dry soil, N. Y. and Penn. to Tenn. Aug.-Sept.

6. Koellia hyssopifòlia (Benth.) Britton. Hyssop Mountain-Mint. (I. F. f. 3159.) Puberulent or glabrate; stem slender, stiff, 3-9 dm. high. Leaves linear-oblong to lanceolate-oblong, short-petioled, or the upper sessile, narrowed at the base, entire or denticulate, I-4 cm. long, 4-12 mm. wide, glabrous or minutely canescent; flower-clusters dense, minutely canescent, cymose, and usually also in the upper axils; bracts linear-oblong, terminated by an awn almost as long as the body; calyx glabrous or nearly so, nerved, its teeth bristle-pointed, nearly as long as the tube. In dry soil. Va. to Fla. June-Aug.

7. Koellia aristata (Michx.) Kuntze. Awned Mountain-Mint. (I. F. f. 3160.) Similar to the preceding; stem stiff, minutely canescent, 3-8 dm. high. 
Leaves ovate, or some of them ovate-lanceolate, short.petioled, sharply serrate, serrulate, or the upper entire, acute, rounded at the base, $2-5 \mathrm{~cm}$. long, $8-25 \mathrm{~mm}$. wide; bracts long-awned, appressed, the awn about one-third the length of the body; calyx canescent, its teeth equal, bristle-pointed, one-third to one-half as long as the tube. In dry pine barrens, N. J. to Fla. and La. July-Sept.

8. Koellia incàna (L.) Kuntze. Hoary Mountain-Mint. (I. F. f. 316r.) Stem pubescent, or glabrous below, 4-9 dm. high. Leaves thin, ovate to ovatelanceolate, petioled, acute, serrate or serrulate, white-canescent beneath, 3-8 cm. long, or the uppermost smaller and sometimes canescent on both sides; clusters loose, terminal and in the upper axils, canescent, bracts linear, or the outer broader, canescent or slightly villous; calyx canescent, its teeth subulate, some. what unequal. Dry thickets and hill-sides, Me. to Ont., Ohio and Fla. Aug-Oct.

9. Koellia pycnanthemoides (Leavenw.) Kuntze. Southern MountainMint. (I. F. f. 3162.) Stem pubescent nearly to the base, 6-9 dm. high. Leaves membranous, petioled, mostly ovate-lanceolate, acuminate or acute, serrate, pubescent beneath, puberulent or glabrate above, 3-ro $\mathrm{cm}$. long, the upper smaller and white-canescent on both sides; clusters loose, villous and canescent, terminal and axillary, $2-5 \mathrm{~cm}$. broad, the flowers often secund; bracts linear-oblong, acuminate or subulate-tipped; calyx-teeth very unequal, subulate, densely villous, the longer about equalling the tube. In dry woods and on hills, Va. to Ga. and Tenn. July-Sept.

ro. Koellia albéscens (T. \& G.) Kuntze. White-leaved Mountain. MinT. (I. F. f. 3I63.) Stem soft-pubescent nearly to the base, 3-6 dm. high. Leaves ovate to ovate-lanceolate, petioled, acute or subacuminate, serrate or nearly entire, 2-6 cm. long, white-canescent beneath, green above, or the upper canescent on both sides; clusters terminal and axillary, densely canescent; bracts linear, or the outer broader; calyx densely canescent, its teeth triangular, one-fifth to onefourth as long as the tube. In dry woods and thickets, Va. to Mo., Ark., Fla. and Tex. July-Sept.

II. Koellia mùtica (Michx.) Britton. Short-toothed Mountain.mint. (I. F. f. 3164.) Stem stiff, puberulent, or glabrous below, 3-8 dm. high. Leaves short-petioled or sessile, ovate or ovate-lanceolate, firm, acute at the apex, rounded or sometimes subcordate at the base, sharply serrate or serrulate, 3-8 $\mathrm{cm}$. long, the uppermost white-canescent on both sides, much smaller; flower-clusters capitate, cymose, often also in the upper axils, pubescent or canescent, 8-14 $\mathrm{nm}$. broad; bracts lanceolate-subulate or the outer broader; calyx pubescent, its teeth not much longer than wide, about one-fifth as long as the tube. In sandy soil, Me. to Va. and Fla., west to Mo. July-Sept.

12. Koellia montàna (Michx.) Kuntze. Thin-leaved Mountain-mint. (I. F. f. 3 I65.) Glabrous or nearly so, 6-9 dm. high. Leaves petioled, mem. branous, glabrous, ovate-lanceolate or the upper lanceolate, long-acuminate, sharply serrate, 5-13 cm. long, none canescent; flower-clusters terminal and in the upper axils, I-2.5 cm. broad; bracts lanceolate or linear-lanceolate, acuminate, bearded more or less with long hairs; calyx tubular, its teeth triangular-subulate, one-fifth to one-fourth as long as the tube. In woods, mountains of Va. to Ga., Tenn. and Ala. July-Sept.

\section{THYेMUS L.}

Perennial herbs, or low creeping shrubs, with small leaves, and small purple flowers in terminal glomerules, or in the axils of the leaves. Calyx ovoid, villous in the throat, 10-13-nerved, 2-lipped, the upper lip erect-spreading. 3-toothed, the lower 2-toothed, its teeth long and slender. Corolla-limb 2-lipped, the upper lip erect, emarginate, the lower spreading, 3-cleft. Stamens 4, mostly exserted; anthers 2-celled, the sacs parallel or divergent. Nutlets ovoid or oblong, smooth. [Greek, incense. $]$ About 50 species, of the Old World.

I. Thymus Serpyllum L. Wild or Creeping Thyme. Mother of Thyme. (I. F. f. 3166.) Stems more or less pubescent in lines, slender, procum. bent, tough, much branched, $\mathbf{I}-3 \mathrm{dm}$. long, commonly forming dense mats. Leaves oblong or ovate-oblong, petioled, obtuse, entire, glabrous, or ciliate, 4-10 $\mathrm{mm}$. long; bracts similar to the leaves, but smaller; calyx 2-lipped, the tube usually 
pubescent and the teeth ciliate; corolla longer than the calyx. In thickets, woods, and along roadsides, N. S. to Mass., N. Y., Penn. and N. Car. Nat. from Europe. June-Sept.

\section{CUNILA L.}

Perennial aromatic herbs, or low shrubs, with rather small purple or white flowers. Calyx tubular-ovoid, I0-13-nerved, villous in the throat, equally 5 -toothed. Corolla 2-lipped, longer than the calyx, the upper lip erect, emarginate, the lower spreading, 3-cleft. Anther-bearing stamens 2, long-exserted, straight, the posterior pair rudimentary, or wanting; anther sacs parallel. Nutlets smooth; scar of attachment basal and small. [Latin name of some plant.] About 15 species, natives of Am.

I, Cunila origanoides (L.) Britton. Stone Mint. American Dittany. (I. F. f. 3I67.) Stem slender, stiff, glabrous, or pubescent at the nodes, 2-5 dm. high. Leaves ovate, sessile, or short-petioled, acute, sharply serrate, rounded, truncate or subcordate at the base, I-4 cm. long, densely punctate; flowers 10-12 mm. long, in terminal loose cymose clusters; corolla purple-pink; posterior pair of stamens usually rudimentary. In dry woods and thickets, N. Y. to Fla., Ohio and Ga. Plant very aromatic. Aug.-Sept. [C.Mariana L.]

\section{LÝCOPUS L.}

Herbs, perennial by slender stolons or suckers, with small white or purple flowers, bracted and verticillate in dense axillary clusters. Calyx campanulate, regular or nearly so, 4-5-toothed, not bearded in the throat. Corolla funnelformcampanulate to cylindric, the limb nearly equally 4-cleft, or one of the lobes broader and emarginate. Perfect stamens 2, anterior, the posterior pair rudimentary, or altogether wanting; anther-sacs parallel. Nutlets truncate at the summit, narrowed below, trigonous, smooth. [Greek, wolf-foot.] About 15 species, of the north temperate zone. Besides the following, 3 or 4 others occur in western N. Am.

Calyx-teeth 4 or 5 , ovate, shorter than the nutlets.

Leaves mostly ovate, usually purple; base of stem not tuberous.

Leaves mostly lanceolate to oblong; base of stem tuberous.

I. L. Virginicus.

Leaves mostly firm, sessile or nearly so.

Leaves membranous, slender-petioled.
Calyx-teeth mostly 5 , lanceolate or subulate, longer than the nutlets.

Bracts minute; corolla twice as long as the calyx.

Leaves sessile.

Leaves narrowed into a manifest petiole.

Bracts lanceolate or subulate; corolla not twice as long as the calyx.

Leaves pinnatifid or deeply incised.

Leaves merely coarsely dentate or serrate (lower rarely incised).

Leaves oblong or oblong-lanceolate, serrate.

Leaves thin, narrowed at base.

Leaves firm, rounded at base.

Leaves ovate, coarsely dentate.

2. L. communis.

3. L. membranaceus.

4. L. sessilifolius.

5. L. rubellus.

6. L. Americanus.

7. L. lucidus.

8. L. asper.

9. L. Europaeus.

1. Lycopus Virgínicus L. Purple Bugle-weed. Purplish, rarely green, stouter than the following species and more puberulent, the stem obtusely angled, not tuberous at the base, but the stolons bearing terminal tubers. Leaves ovate to ovate-oblong, usually abruptly narrowed to both ends, acuminate, 6-15 cm. long, coarsely toothed, often slender-petioled; clusters dense, subglobose; calyx cylindraceous, the erect lobes oblong to oblong-lanceolate, acutish; corolla $2 \mathrm{~mm}$. long or less, not twice the length of the calyx, narrowly tubular, the short subequal lobes erect or nearly so; stamens and style included; sterile stamens evident; nutlets 1.5-2 mm. long, transversely notched and strongly denticulate. In moist soil, Conn. to Ala., Neb. and Kans. July-Sept.

2. Lycopus cómmunis Bicknell.

Common Bugle-weed. (I. F. f. 3168 , as L. Virginicus.) Green, or sometimes purplish, roughish-puberulent, or the leaves glabrate; stem tuberous at base, I-8 dm. high, subacutely angled with grnoved sides; stolons rarely tuber-bearing. Leaves 2.5-8 cm. long, oblong, narrowed to base and apex, serrate, very short-petioled; calyx campanulate, the lobes ovate to ovate-oblong, obtusish; corolla 2-3 mm. long, abruptly dilated at the 
throat, the lobes spreading; sterile stamens minute or obsolete; nutlets $\mathbf{I}-\mathbf{I} .5 \mathrm{~mm}$. long, oblique at the top. In moist soil, Newf. to Br. Col., Va., Neb. and Ore. Type from Van Cortlandt, N. Y. Aug-Sept.

3. Lycopus membranàceus Bicknell, n. sp. Thin-Leaved Bugle-weed. Puberulent to glabrate; stem slender from a tuberous base; stolons weakly developed, or wanting. Leaves very thin, lanceolate to oblong-lanceolate, mostly acuminate, narrowed into a slender petiole, coarsely toothed, 6-1I cm. long; clusters very small; calyx-lobes ovate, obtuse; corolla 3-4 $\mathrm{mm}$. long, with smaller and less spreading lobes than in L. communis; nutlets $1.5 \mathrm{~mm}$. long, or more, oblique at the top. In wet woods, Me. to N. Y. and Mich. Type from Mt. Desert, Me. Aug.-Sept.

4. Lycopus sessilifòlius A. Gray. Sessile-leaven Water Hoarhound. (I. F. f. 3I69.) Glabrous, or puberulent above, perennial by stolons and suckers; stem 3-6 dm. high. Leaves ovate-lanceolate or oblong-lanceolate, sessile, acute or acuminate, sharply serrate, somewhat narrowed at the base, $2-5 \mathrm{~cm}$. long: bracts very small, acute; calyx-teeth usually 5, subulate, rigid, nearly as long as the tube; rudimentary posterior stamens oval. In wet soil, eastern Mass. to Fla. Aug.-Oct.

5. Lycopus rubéllus Moench. Stalked Water Hoarhound. (I. F. f. 3170.) Glabrous or minutely puberulent, perennial by long leafy stolons, 3-10 $\mathrm{dm}$. high. Leaves ovate to oblong-lanceolate, or narrcwer, acuminate, sharply dentate, narrowed or cuneate at the base, $5^{-15} \mathrm{~cm}$. long; bracts minute, acute or acuminate; calyx-teeth triangular-subulate, herbaceous, one-half as long as the tube or more; rudimentary stamens small, oval to oblong, or obsolete. In wet soil, N. Y. to Fla., Ohio, Ark. and La. July-Oct.

6. Lycopus Americanus Muhl. Cut-leaved Water Hoarhound. (I. F. f. 3I7I.) Puberulent or glabrous, perennial by suckers; stem stiff, sharply angled, I-9 dm. high. Leaves lanceolate or ovate-lanceolate, petioled, acuminate, incised, pinnatifid or the uppermost merely serrate, $3-10 \mathrm{~cm}$. long; bracts subulate; calyxteeth triangular-subulate, cuspidate, rigid; corolla little exceeding the calyx, dilated at the throat; rudimentary stamens thickened at their tips. In wet soil, Newf. to Br. Col., Fla., Tex., Utah and Cal. June-Oct.

7. Lycopus lùcidus Turcz. Western WATER Hoarhound. (I. F. f. 3172.) Perennial by stolons; stem usually stout, strict, 3-9 dm. high. Leaves oblonglanceolate, acute, sessile, or short-petioled, 5-15 cm. long, sharply serrate with acute ascending teeth; bracts ovate or lanceolate, acuminate-subulate; calyx-teeth 5, subulate-lanceolate, nearly as long as the tube; corolla little longer than the calyx; rudimentary stamens thickened at the tips. In wet soil, Neb. to Kans., Br. Col., Cal. and Ariz. Also in Asia. The American plant perhaps distinct from the Asiatic. July-Sept.

8. Lycopus ásper Greene. Rough Bugle-weed. Stems simple, 3-6 dm. high, obtusely angled, leafy. Leaves firm, narrowly lanceolate to oblong-lanceolate, acute, sessile, scarcely narrowed at the base, strongly and nearly equally serrate with very sharp teeth, 4-6 cm. long, much longer than the internodes, conspicuously veiny, rough on both surfaces; calyx-teeth ovate-lanceolate, acuminate; nutlets very short, smooth. Minn. to the N. W. Terr. July-Aug.

9. Lycopus Europaèus L. WATER OR MARSH Hoarhound. Gipsy-wort. GIPSY-HERB. (I. F. f. 3173.) Puberulent or pubescent, perennial by suckers, 3-8 $\mathrm{dm}$. high. Leaves ovate, ovate-oblong, or oblong-lanceolate, short-petioled, or the upper sessile, coarsely dentate, or the lower incised at the base, $2-8 \mathrm{~cm}$. long, bracts subulate-lanceolate; calyx-teeth subulate-spinulose; corolla scarcely longer than the calyx; rudimentary posterior stamens obsolete. In waste places, N. Y. to Va. Nat. from Europe. July-Sept.

\section{MÉNTHA L.}

Odorous herbs, with simple mostly punctate leaves, and small whorled purple pink or white flowers, the whorls axillary or in terminal spikes. Calyx 1o-nerved, regular, or slightly 2 -lipped, 5-toothed. Corolla-tube shorter than the calyx, the limb 4-cleft, the posterior lobe usually somewhat broader than the others, entire or emarginate. Stamens 4, equal, erect, included or exserted, sometimes imperfect; filaments glabrous; anthers 2-celled, the sacs parallel. Nutlets ovoid, smooth. 
[Name used by Theophrastus; from the nymph Minthe.] About 30 species, of the north temperate zone.

* Whorls of flowers in terminal spikes, or some in the upper axils.

Plants glabrous or very nearly so.

Spikes slim, narrow, mostly interrupted; leaves sessile, or nearly so.

Spikes thick, mostly dense, at first short; leaves petioled.

Leaves lanceolate or oblong, acute.

Leaves ovate, obtuse, or the upper acute, subcordate.

I. M. spicata.

2. M. piperita.

3. M. citrata.

Plants villous, hirsute or canescent, at least at the nodes.

Spikes slim or narrow, often interrupted.

Leaves lanceolate or ovate-lanceolate, acute.

Leaves elliptic or ovate-oblong, obtuse, reticulated beneath.

Spikes IO-I2 mm. thick, dense, elongated or short.

Leaves sessile; spikes $2-8 \mathrm{~cm}$. long; plant canescent. $\quad 6$. M. alopecuroides.

Leaves distinctly petioled, or the uppernost sessile; spikes short.

Leaves simply serrate.

7. M. aquatica.

Leaves mostly incised, the margins crisped and wavy. 8. M. crispa.

* * Whorls of flowers all axillary.

Leaves crenate-dentate; calyx-teeth triangular, short.

Leaves sharply serrate; calyx-teeth subulate.

Calyx-teeth ciliate, the tube glabrous; leaves ovate.

Calyx densely or sparsely pubescent all over.

Leaves ovate, pubescent on both sides; hairs of the stem reflexed.

9. M. arvensis.

ro. M. gentilis.

11. M. sativa.

Leaves oblong or ovate-oblong, nearly or quite glabrous. 12. M. Canadensis.

I. Mentha spicàta L. Spearmin'r. (I. F. f. 3174.) Perennial by leafy stolons ; stem erect, 3-5 dm. high. Leaves lanceolate, sessile or short-petioled, sharply serrate, acute or acuminate, the largest about $7 \mathrm{~cm}$. long; whorls of flowers in spikes which become 5-10 cm. long in fruit, the one terminating the stem surpassing the lateral ones ; bracts subulate-lanceolate, ciliate; calyx campanulate, its teeth subulate, nearly as long as the tube ; corulla glabrous. In moist fields or waste places, N. S. to Out., Minn., Utah, Fla. and Kans. Nat. from Europe. July-Sept.

2. Mentha piperita L. Peppermint. (I. F. f. 3175.) Perennial by subterranean suckers, 3-9 dm. high. Leaves lanceolate, petioled, dark green, acute, sharply serrate, glabrous on both sides, or pubescent on the veins beneath, the larger 3-8 cm. long; whorls of flowers in spikes, which are obtuse, and become $2-8 \mathrm{~cm}$. long in fruit, the middle one at length overtopped by the lateral ones ; bracts lanceolate, acuminate ; calyx tubular.campanulate, glabrous below, its teeth subulate, usually ciliate, one-half as long as the tube or more ; corolla glabrous. In wet soil, N. S. to Minn., Fla. and Tenn. Nat. from Europe. July-Sept.

3. Mentha citràta Ehrh. Bergamot Mint. (I. F. f. 3176.) Perennial by leafy stolons; stem weak, decumbent or ascending, 3-6 dm. long. Leaves petioled, thin, ovate or ovate-orbicular, obtuse or the upper acute at the apex, sharply serrate, the larger about $5 \mathrm{~cm}$. long ; whorls of fowers in terminal short obtuse spikes, and commonly also in the uppernost axils; calyx glabrous, its teeth subulate, one-half as long as the tube, or longer; corolla glabrous. In wet soil, Staten Island, N. Y. and Ohio. Adventive from Europe. July-Sept.

4. Mentha longifòlia (L.) Huds. Horse Mint. (I. F. f. 3 I 77.) Perennial by suckers, canescent or puberulent, 3-8 dm. high. Leaves lanceolate, ovatelanceolate, or oblong-lanceolate, sessile or short-petioled, acute, sharply serrate, $2-8 \mathrm{~cm}$. long; whorls of flowers in narrow acute spikes, which become $5-13 \mathrm{~cm}$. long in fruit; bracts lanceolate-subulate; calyx tomentose or canescent, its teeth subulate, one-half as long as the tube ; corolla puberulent. In waste places, Conn. to Penn. and N. J. Nat. from Europe. July-Oct.

5. Mentha rotundifòlia (L.) Huds. Round-Leaved MrNT. (I. F. f. 3178 .) Perennial by leafy stolons, ranescent or tomentose-puberulent, somewhat viscid, 3-8 dm. high. Leaves elliptic, or ovate-oblong, short-petioled, or sessile and somewhat clasping by the subcordate or rounded base, obtuse, crenate-serrate, 2-5 cm. long, rugose-reticulated beneath; whorls of flowers in spikes which elon- 
gate to 5-ro cm. in fruit; bracts lanceolate, acuminate; calyx-teeth setaceous, usually about one-half as long as the tube; corolla puberulent. In waste places, Me. to N. Car., Tex. and Mex. July-Sept.

6. Mentha alopecuroides Hull. Woolly Mint. (I. F. f. 3I79.) Perennial by suckers, white-woolly, 3-9 dm. high. Leaves broadly oval, sessile, or partly clasping by a subcordate or rarely rounded base, obtuse, sharply and rather coarsely serrate, the lower 5-8 cm. long; spikes dense, stout, obtuse, $5-8 \mathrm{~cm}$. long in fruit; bracts lanceolate; calyx-teeth setaceous, one-half as long as the campanulate tube, or more; corolla pubescent. Along roadsides, Conn. to N. Y., N. J., Penn., and Mo. Nat. from Europe. July-Oct.

7. Mentha aquática L. Water Mint. Fish Mint. (I. F. f. 3i8o.) Perennial by suckers, hirsute or pubescent, rarely glabrate; stem $3-8 \mathrm{dm}$. high, its hairs reflexed. Leaves broadly ovate, petioled, acute, or the lower obtuse, rounded, subcordate or rarely narrowed at the base, sharply serrate, the larger $3-8 \mathrm{~cm}$. long and nearly as wide; whorls of flowers in dense short rounded spikes, and usually also in the upper axils: spikes seldom more than $2.5 \mathrm{~cm}$. long in fruit; bracts lanceolate, shorter than the flowers ; calyx hirsute, its teeth lanceolate-subulate or triangular-lanceolate, one-third to one-half as long as the nearly cylindric tube : corolla sparingly pubescent. In wet places, N. S. to Penn. and Ga. Nat. from Europe. Aug.-Oct.

8. Mentha críspa L. Crisped-leaved, Curled or Cross Mint. (I. F. f. 3181.) Sparingly pilose-pubescent, at least at the nodes, petioles and veins of the lower surfaces of the leaves : stem rather weak, 3-9 dm. long. Leaves petioled, or the uppermost sessile, ovate, mostly acute, rounded, truncate or subcordate at the base, their margins crisped, or the uppermost merely serrate ; whorls of flowers in thick rounded spikes, which become $2-4 \mathrm{~cm}$. long in fruit; caly $\mathbf{x}$ sparingly pubescent or glabrous, its teeth subulate, more than one half as long as the campanulate tube ; corolla glabrous. In swamps and roadside ditches, N. Y., N. J. and Penn. Aug.-Oct.

9. Mentha arvénsis L. Corn Mint. Field Min'r. (I. F. f. 3182.) Perennial by suckers, pubescent or glabrate ; stems I.5-6 dm. high, slender. Leaves oblong-lanceolate, oval or ovate, petioled, acute or the lower obtuse, crenate-serrate, mostly narrowed at the base, $2-6 \mathrm{~cm}$. long, the upper not much smaller than the lower; whorls of flowers all axillary, usually about equalling the petioles ; calyx pubescent, campanulate, its teeth triangular, about as long as the width of their base, acute or sometimes obtuse, one-third as long as the tube. In dry waste places, N. B. to N. Y., N. J., Penn. and Fla. Also in Cal. and Mex. Nat. JulySept.

ro. Mentha gentilis L. Creeping or Downy Whorled Mint. (I. F. f. 3183.) Perennial by suckers; stem puberulent with short reflexed hairs, 3-6 dm. high. Leaves ovate or oval, short-petioled, sparingly pubescent with scattered hairs, often blotched, acute at both ends, sharply serrate, the larger 3-5 cm. long, the upper sometimes much smaller than the lower; whorls axillary ; pedicels glabrous ; calyx campanulate, glabrous below, its teeth subulate, ciliate, one-half as long as the tube; corolla glabrous. In waste places and along streams, Me. to northern N. Y., N. J. and Penn. Nat. from Europe. Aug.-Oct.

Ir. Mentha sativa L. Marsh Whorled Mint. (I. F. f. 3184.) Perennial by suckers; stem ascending, usually widely branched, densely pubescent, 3-9 dm. long. Leaves ovate, short-petioled, pubescent on both sides, acute at the apex, mostly rounded at the base, sharply serrate, the larger $2-5 \mathrm{~cm}$. long, the upper sometimes much smaller; whorls axillary. commonly surpassing the petioles ; calyx campanulate, pubescent, its triangular-subulate teeth one-half as long as the tube. In waste places, N. S. to Penn. Nat. from Europe. July-Sept.

12. Mentha Canadénsis L. American Wild Mint. (I. F. f. 3185.) Perennial by suckers ; stem more or less pubescent with spreading or scarcely reflexed hairs, or glabrate, r.5-8 dm. high. Leaves oblong, ovate-oblong, or oblong-lanceolate, slender-petioled, acute, or the lower obtuse, sharply serrate, narrowed to a somewhat cuneate base, glabrous or sparingly pubescent, the larger 5-ro cm. long, whorls axillary, often shorter than the petioles ; calyx oblong-campanulate, pubescent, its teeth one-fourth to one-third as long as the tube. In moist soil, N. B. to the N. W. Terr., Br. Col., Va., Kans., N. Mex. and Nev. Variable. July-Oct. 


\section{COLLINSÒNIA L.}

Tall perennial aromatic herbs, with large membranous petioled leaves, and terminal loose panicled racemes of small yellowish mostly opposite flowers. Calyx campanulate, short, ro-nerved, 2-lipped, declined in fruit, usually pubescent in the throat; upper lip 3-toothed; lower 2-cleft. Corolla longer than the calyx, obliquely campanulate, 5 -lobed, 4 of the lobes nearly equal, the 5 th pendent or declined, fimbriate or lacerate, much larger, appearing like a lower lip. Antherbearing stamens 2, not declined, much exserted, coiled before anthesis ; bases of the filaments connected by a woolly ring; anthers 2 -celled, or the sacs at length partially confluent. Nutlets smooth, globose. [Named for Peter Collinson, I6931708, an English botanist, and correspondent of Linnaeus.] Two or 3 species of eastern N. Am.

1. Collinsonia Canadénsis L. Horse-balm. Citronella. Rich-weed. (I. F. f. 3186.) Stem 6-15 dm. high, glabrous, or glandular-pubescent above. Leaves ovate or ovate-oblong, acuminate, the lower slender-petioled, $1.5-2.5 \mathrm{dm}$. long, the upper nearly sessile, much smaller, all coarsely dentate; terminal panicles sometimes $3 \mathrm{dm}$. long; pedicels ascending, 6-12 $\mathrm{mm}$. long in fruit, subulatebracteolate at the base ; flowers lemon-scented; calyx-teeth subulate, those of the lower lip much longer than those of the upper; corolla light yellow, I-I. $5 \mathrm{~cm}$. long; fruiting calyx prominently ribbed, $6.8 \mathrm{~mm}$. long. In moist woods, Me. and Ont. to Wis., Fla. and Kans. Root large, thick, woody. July-Oct.

\section{PERÍlla Ard.}

Annual herbs, with petioled purple or discolored leaves, and small flowers in loose bracted racemes. Calyx campanulate, ro-nerved, 5-cleft, nearly regular in flower, enlarging, declined and becoming 2-lipped in fruit, the upper lip 3-toothed, the lower 2-cleft, the throat not bearded. Corolla-tube not longer than the calyx, the throat obliquely campanulate, the limb 5-cleft, the lower lobe slightly the larger. Stamens 4, nearly equal, or the posterior pair shorter, erect, divergent ; anthers 2-celled. Nutlets globose, reticulated. [The native name in India.] One or 2 species, natives of Asia.

r. Perilla frutéscens (L.) Britton. Perilla. (I. F. f. 3187.) Sparingly pubescent, 3-9 dm. high. Leaves long-petioled, broadly ovate, acuminate, coarsely dentate, $7-15 \mathrm{~cm}$. long and nearly as wide ; racemes terminal and axillary, manyflowered, 7- $15 \mathrm{~cm}$. long ; pedicels 3-6 mm. long in fruit ; calyx minute in flower, much enlarged, gibbous at the base and densely pilose-pubescent in fruit; corolla purple or white, $3 \mathrm{~mm}$. long, with a woolly ring within. In waste places, escaped from gardens, N. Y. to Ill. Native of India. July-Oct.

Perilla frutéscens Nankinénsis (Lour.) Britton. Leaves crisped and incised. Escaped from gardens, N. J. to W. Va.

\section{ELSHóltzia Willd.}

Herbs, with thin leaves, and small or minute clustered flowers, in terminal bracted spikes. Calyx campanulate or ovoid, Io-nerved, enlarging in fruit, not bearded in the throat, 5 -toothed, the teeth nearly equal. Corolla-tube little longer than the calyx, the limb oblique, or slightly 2-lipped, 4-lobed; upper lobe erect, concave, emarginate, the 3 others spreading. Anthers 2-celled, or the sacs more or less confluent. Nutlets ovoid or oblong. [Named in honor of J. S. Elsholtz, a Prussian botanist.] About 20 species, natives of Asia.

r. Elsholtzia Patrínii (Lepech.) Kuntze. Elsholtzia. (I. F. f. 3 r88.) Annual, glabrous or nearly so ; stems erect or ascending, 3-6 dm. high. Leaves long-petioled, ovate or oblong, acute or acuminate, crenate-dentate, $2-8 \mathrm{~cm}$. long ; spikes dense, about $12 \mathrm{~mm}$. thick; flowers several in the axils of each of the broadly ovate membranous reticulated mucronate bracts; calyx hirsute, shorter than the bract ; corolla $2 \mathrm{~mm}$. long, pale purple. Notre Dame du Lac, Temis. couata Co., Quebec. Nat. from Asia. July-Aug. 


\section{Family 8. SOLANÀCEAE Pers. \\ Potato Family.}

Herbs, shrubs, vines, or some tropical species trees, with alternate or rarely opposite estipulate leaves, and perfect regular or nearly regular cymose flowers. Calyx inferior, mostly 5 -lobed. Corolla gamopetalous, mostly 5 -lobed, the lobes induplicate-valvate or plicate in the bud. Stamens as many as the lobes of the corolla and alternate with them, inserted on the tube, all equal and perfect in the following genera, except in Petunia, where 4 are didynamous and the fifth smaller or obsolete; anthers 2-celled, apically or longitudinally dehiscent. Ovary superior, 2-celled (:arely 3-5-celled); ovules numerous on the axile placentæ, anatropous or amphitropous; style slender, simple; stigma terminal; fruit a berry or capsule. Seeds numerous; endosperm fleshy; cotyledons semiterete. About 70 genera and 1600 species, most abundant in tropical regions.

* Fruit a berry ; corolla plicate, its lobes generally induplicate.

Anthers unconnected, destitute of terminal pores, dihiscent.

Fruiting calyx bladdery-inflated.

Fruiting calyx 5-angled and deeply 5-parted; ovary 3-5-celled.

1. Physalodes.

Fruiting calyx 5-lobed, not parted, ro-ribbed, often 5-Io-angled, reticulated, wholly enclosing the berry; ovary 2 -celled.

Corolla open-campanulate, yellow or whitish, often with a dark center; seeds with a thin margin, finely pitted.

2. Physalis.

Corolla flat-rotate, violet or purple; seeds thick, rugose-tuberculate.

3. Quincula.

Fruiting calyx somewhat enlarged, but closely fitted to the fruit, thin, obscurely veiny, open at the nouth.

Corolla rotate, whitish; lobes of fruiting calyx much exceeding the berry. 4. Leucophysalis.

Corolla rotate, whitish, sometimes tinged with purple; fruiting caly $\mathbf{x}$ not exceeding the berry.

Anthers connivent or slightly connate; fruiting calyx not enlarged.

5. Chanaesaracha.

Anthers short or oblong, opening by terminal pores or short slits in our species.

Anthers long, tapering from base to summit, lorgitudinally dehiscent.

6. Solanum.

7. Lycopersicon.

* Fruit a nearly dry berry ; corolla campanulate, little or not at all plicate, its lobes imbricated.

8. Lycium.

*** Fruit a capsule; corolla funnelform.

Capsule circumscissile toward the top, which separates as a lid; corolla irregular.

Capsule opening by valves.

Capsule generally prickly.

9. Hyoscyainus,

Capsule not prickly.

Flowers paniculate or racemose; stamens nearly uniform in length.

Flowers solitary; stamens very unequal.

11. Nicotiana.

12. Petunia.

\section{PHYSALÒdES Boehm. [NICANDRA Adans.]}

An annual erect glabrous herb, with alternate petioled thin sinuate-dentate or lobed leaves, and large light blue peduncled nodding flowers, solitary in the axils. Calyx-segments ovate, connivent, cordate or sagittate at the base, strongly reticulated. Corolla broadly campanulate, slightly 5-lobed. Stamens 5, included, inserted on the corolla near its base; flaments filiform, dilated and pilose below; anther-sacs longitudinally dehiscent. Style slender; stigma 3-5-lobed. Berry globose, nearly dry, enclosed in the calyx. [Greek, Physalis-like.] A monotypic genus.

I. Physalodes physalòdes (L.) Britton. Apple-OF-Peru. (I. F. f. 3189.) Stem angled, 6-15 dm. high. Leaves ovate or oblong, acuminate but blunt, nar. 
rowed at the base, 0.7-2 dm. long; petioles longer than the peduncles; flowers $2.5-3.5 \mathrm{~cm}$. long and broad; corolla-limb almost entire; fruiting calyx $2.5-3.5 \mathrm{~cm}$. long and thick, its segments acute, their basal auricles acute or cuspidate; berry about $12 \mathrm{~mm}$. in diameter, loosely surrounded by the calyx. In waste places, escaped from gardens, N. S. to Ont., south to Fla. Adventive from Peru. JulySept.

\section{PHÝSALIS L.* (See Appendix.)}

Herbs, sometimes a little woody below, with entire or sinuately toothed leaves. Peduncles slender, in ours solitary from the axils. Calyx campanulate, 5-toothed, in fruit enlarged and bladdery-inflated, membranous, 5-angled, or prominently Ioribbed and reticulate, wholly enclosing the pulpy berry. Corolla often with a brownish or purplish center, open-campanulate, or rarely campanulate-rotate, plicate. Stamens inserted near the base of the corolla; anthers oblong, opening by longitudinal slits. Style slender, somewhat bent; stigna minutely 2-cleft. Seeds numerous, kidney-shaped, flattened. [Greek, bladder, referring to the inflated calyx.] The number of recognized species is about 50; 34 occur in the U. S.

\section{* Annuals with branched fibrous roots.}

+ Plants more or less pubescent (except P. Barbadensis obscura).

Fruiting calyx sharply 5-angled, more or less acuminate at the summit and sunken at the base; calyx-lobes (at flowering time) lanceolate or acuminate, as long as the tube or longer.

Leaves ovate, oblique, acute or acuminate, subentire at the base: upper part repand or subentire; fruiting calyx small and short; stem slender, diffuse, sharply angled.

$$
\text { I. P. pubescens. }
$$

-eaves cordate, oblique, strongly sinuate to the base; stem stout, obtusely angled; fruiting caly $x$ rounded.

2. P. pruinosa.

Leaves cordate, scarcely oblique, more or less abruptly acuminate, acutely repand dentate; stem tall, acutely angled; fruiting calyx larger, long-acuminate.

3. P. Barbadensis.

Fruiting calyx obtusely or indistinctly 5-10-angled; calyx-lobes (at flowering time) triangular, generally shorter than the tube.

4. P. Missouriensis.

$\dagger+$ Plants glabrous, or the upper part sparingly beset with short hairs, or a little puberulent when young; fruiting calyx obtusely 5-ro-angled, not sunken at the base.

Corolla yellow, sometimes with the center a little darker but never brown or purple.

Peduncles generally much longer than the fruiting calyx; leaves sinuately toothed or subentire.

Peduncles scarcely exceeding the fruiting calyx; leaves sharply dentate.

Corolla yellow, with a brown or purple center.

\section{P. angulata.}

Peduncles short, scarcely as long as the flowers, which are $10-20 \mathrm{~mm}$. in diameter: calyx-lobes broadly triangular.

7. P. ixocarpa.

Peduncles longer than the flowers, which are 16-25 mm. in diameter; calyx-lobes lanceolate-triangular.

\section{** Perennial by rootstocks and roots.}

+ Pubescence not stellate (although in P. pumila of branched hairs).

Pubescence on the leaves none, on the upper part of the stem and the calyx sparse and short, if any.

Fruiting calyx ovoid, nearly filled by the berry, scarcely sunken at the base.

Leaves ovate-lanceolate to broadly ovate, usually thin.

Leaves lanceolate, oblancenlate, or linear.

8a. P. subglabrata.

9. P. longifolia.

Fruiting calyx pyramidal, very much inflated and deeply sunken at the base: leaves broadly ovate, usually coarsely dentate. $\quad$ ro. P. macrophysa.

Pubescence sparse, consisting of flat, sometimes jointed, and in P. pumila branched hairs; in P. Virginzana sometimes a little viscid.

Fruiting calyx ovoid, scarcely angled and scarcely sunken at the base; leaves thick, obovate or spatulate to rhomboid, subentire.

Leaves obovate or spatulate; hairs all simple.

Leaves broader, of ten rhomboid; hairs on the lower surface branched.

12. P. pumila.

Fruiting calyx pyramidal, more or less 5 -angled and deeply sunken at the base; leaves ovate to lanceolate, generally more or less dentate. 13. P. Virginiana.

Pubescence dense, short, more or less viscid or glandular, often mixed with long flat jointed hairs. 
Leaves large; blade generally over $5 \mathrm{~cm}$. long and more or less cordate.

14. P. heterophylla.

Leaves less than $5 \mathrm{~cm}$. long, round-ovate or rhombic, scarcely at all cordate at the base; calyx, peduncles and younger branches with long white flat and jointed hairs. 15. P. comata.

Leaves sniall, $2.5-4 \mathrm{~cm}$. in diameter, nearly orbicular, sometimes a little cordate at the base, not coarsely toothed; stem diffuse or prostrate. 16. $P$. rotundata. ++ Pubescence dense, cinereous, beautifully stellate. 17. P. viscosa.

I. Physalis pubéscens L. Low Hairy Ground-cherry. (I. F. f. 3 Igo.) Stem generally diffuse or spreading, often a little swollen at the nodes, villouspubescent or nearly glabrous; leaves thin, 2.5-6 cm. long, ovate, acute or acuminate, slightly cordate, upward repand-denticulate or entire, pubescent, sometimes becoming nearly glabrous except along the veins; peduncles short; calyx-lobes narrow but not with a subulate tip; corolla 6-1o mm. in diameter, yellow with dark center; anthers usually purplish; fruiting calyx membranous, $2-3 \mathrm{~cm}$. long, py ramidal, ovoid-acuminate, retuse at the base. In sandy soil, Penn. to Fla. and Cal.; also in tropical Am. and India. July-Sept.

2. Physalis pruinòsa L. Tali. Hairy Ground-Cherry. (I. F. f. 3191.) Stout, generally erect, and more hairy than the preceding and the two following species; stem finely villous or somewhat viscid; leaves firm, 3-10 $\mathrm{cm}$. long, finely pubescent, ovate, cordate, and deeply sinuately toothed; calyx villous or viscid, its lobes as long as the tube, narrow but not subulate-tipped; corolia $4-8 \mathrm{~mm}$. in diameter; anthers yellow, or tinged with purple; fruiting caly $\mathbf{x}$ reticulate, $2-3$ $\mathrm{cm}$. long, ovoid, cordate; berry yellow or green. In cultivated soil, Mass. to Iowa, Mo. and Fla. July-Sept.

3. Physalis Barbadénsis Jacq. Barbadoes Ground-Cherry. (I. F. f. 3192.) Stem stout, acutely 3-4-angled, pubescent or viscid; leaves 3-6 cm. long, acute, or abruptly acuminate, sharply repand-dentate, pubescent with short hairs; peduncles short, but in fruit sometimes $2 \mathrm{~cm}$. long; calyx generally densely viscidhirsute, lobes lanceolate, acuminate; corolla 5-10 mm. in diameter; anthers generally purplish; fruiting calyx longer than in the two preceding speciés, reticulate. Sandy soil, N. Car., southern Ill. and Mex., the W. Ind. and S. Am. July-Sept.

Physalis Barbadénsis obscùra (Michx.) Rydberg. Greener, perfectly glabrous, or sometimes minutely pubescent. The distribution is about the same as that of the species.

4. Plysalis Missouriénsis Mack. \& Bush. Missouri Ground-Cherry. F. f. 3r93.) Stem spreading, often zigzag, striate, or slightly angled, villous with short hairs. Leaves $1-9 \mathrm{~cm}$. long, ovate, oblique and cuneate, obtuse, or cordate at the base, acute. repand or sinuately dentate, hairy, at least on the veins; peduncles in fruit 5-10 cm., reflexed, shorter than the fruiting calyx; calyx villous, corolla 3-8 mm. in diameter, yellow, generally with a dark center; anthers generally yellow: fruiting calyx 1.4-2 cm. long. round-ovoid, nearly filled by the berry, commonly rounded at the base. On rocky hillsides; Mo. and Kans. to Ark. and Ind. Terr. July-Sept. This species has been confused with the tropical P. Lagasca R \& S.

5. Physalis péndula Rydb. Lance-leaved Ground-Cherry. (I. F. f. 3194.) Erect, generally 4-5 dm. high; stem angled, glabrous; leaves in the typical form lanceolate; calyx cylindric-campanulate, its lobes broadly triangular, shorter than the tube; peduncles filiform, about $2.5 \mathrm{~cm}$. long, erect with nodding flower, in fruit reflexed; corolla $6-8 \mathrm{~mm}$. in diameter: campanulate, yellow, without at dark spot; anthers yellow, tinged with purple; fruiting calyx about $2 \mathrm{~cm}$. long, ovoid, indistinctly ro-angled, purple-veined, nearly filled by the berry. Ill. to Tex., and Kans. (P. lanceifolia Rydb., in part, not Nees.) July-Sept.

6. Physalis angulàta I. Cut-leaved Ground Cherry. (I. F. f. 3195.) Erect, 4-9 dm. high, glabrous; stem angled; leaves ovate, with cuneate base and long-acuminate teeth; blades $5-6.5 \mathrm{~cm}$. long, on slender petioles, thin, the veins not prominent: peduncles slender, $2-3 \mathrm{~cm}$. long, erect, in fruit often reflexed but seldom exceeding the fruiting calyx; calyx-lobes triangular to lanceolate, generally shorter than the tube; corolla 5-10 cm. in diameter; anthers purplish tunged; fruiting calyx about $3 \mathrm{~cm}$. long, ovoid, not prominently angled, it last nearly 
filled by the yellow berry. In rich soil, Va. and N. Car. to Ill., the Ind. Terr., Tex., Cent. Am., Brazil and the W. Ind. Also in India. July-Sept.

7. Physalis ixocàpa Brot. Tomatillo. Mexican Ground-Cherry. STRAWBERRY TOMATO. (I. F. f. 3196.) At first erect, later widely spreading; stem angled, glabrous, or the younger parts sparingly hairy, leaves from cordate to ovate, with a cuneate base, sinuately dentate or entire, 2.5-6.5 cm. long; pedun. cles $2-5 \mathrm{~mm}$. long; calyx sparingly hairy; its lobes shorter than the tube; corolla bright yellow with purple throat, I-2 cm. in diameter; fruiting calyx round-ovoid, obscurely Io-angled, often purple-veined, at last filled by the purple berry. Native of Mex. Cultivated for its fruit and frequently escapes from cultivition.

8. Physalis Philadélphica Lam. Philadelphia Ground-Cherry. (I. F. f. 3197.) Erect 7-15 dm. high; stem angled, dichotomously branched; blades ovate to ovate-lanceolate, often very oblique at the base and acuminate, entire or repand-denticulate, 6-10 $\mathrm{cm}$. long, often in pairs; peduncles slender, $1-2 \mathrm{~cm}$. long; calyx glabrous, or minutely ciliolate, lobes ovate-lanceolate or triangular, sometimes broadly ovate and unequal, generally equalling the tube; corolla yelkw or greenish yellow with purplish throat, $1.5-2.5 \mathrm{~cm}$. in diameter; anthers tinged with purple; fruiting calyx at first somewhat Io angled and sunken at the base, at last often filled with the large red or purple berry. R. I. to Ga., Ky. and Tex. July-Sept.

9. Physalis longifòlia Nutt. Long.Leaved Ground cherry. (I. F. f. 3I98.) Perennial by a thick rootstock; stem in the common form, stout, 4-9 dm. high, slightly angled. Leaves tapering into a petiole $\mathbf{I}-2 \mathrm{~cm}$. long, subentire or repand: pedun les $\mathbf{I}-2 \mathrm{~cm}$. long, in fruit often recurved; calyx generally glabrous, its lobes triangular-lanceolate, about the length of the tube; corolla $\mathbf{I - 2} \mathrm{cm}$. in diameter, yellow with a dark center; anthers tinged with purple; fruiting calyx about $3 \mathrm{~cm}$. long; berry yellow, the lower portion and the stipe glutinous. In rich soil, Iowa to Ark, Utah and Mex. July-Sept.

I0. Physalis macróphysa Rydb. LARge-bladder Ground.cherry. (I. F. f. 3199.) Perenuial; root so.newhat fleshy; stem erect, 4-9 dm. high, comparatively slender, angled. Leaves thin, 3-9 $\mathrm{cm}$. long, the lower obtuse, the upper acute or acuminate; petioles $2-4 \mathrm{~cm}$. long; peduncles in fruit reflexed; calyx smooth, its lobes ovate-trianzular or broadly lanceolate, generally a little shorter than the tube; corolla yellow with a dark center, about $2 \mathrm{~cm}$. in diameter; anthers generally yellow, sometimes tinged with purple; fruiting calyx $3-4 \mathrm{~cm}$. long, indistinctly ro-angled; berry small, in the center of the calyx. In rich soil, Tex. to Kans. and Ark. May-July. Rare.

II. Physalis lanceolata Michx. Prairie Ground-cherry. (I. F. f. 3200.) Rootstock apparently as a rule slender and creeping; stem 4-5 dm. high, first erect, later spreading or diffuse, slightly angled, sparingly hirsute with flat hairs. Leaves nearly always entire, rarely wavy, thickish, sparingly hairy with short hairs: peduncles $\mathbf{I}-2 \mathrm{~cm}$. long, in fruit reflexed; calyx-lobes triangular-lanceolate; corolla dullish yellow with a brownish center, about $1.6 \mathrm{~cm}$. in diameter; fruiting calyx round-ovoid, not sunken at the base, indistinctly Io-angled; berry yellow or greenish yellow. On dry prairies, common west of the Missouri River, extending eastward to Ill. and the Carolinas. July-Sept.

J2. Physalis pùmila Nutt. Low Ground.cherry. (I. F. f. 320I.) Perennial by a slender rootstock, 4-9 dm. high; stem obscurely angled. Leaves broadly ovate to oblong, acute at both ends, somewhat rhomboid, the lower often obtuse and obovate; blades 5-10 $\mathrm{cm}$. long, entire or seldom sinuate; peduncles in fruit reflexed and 3-5 cm. long: calyx densely hirsute, its lobes triangular, generally a little shorter than the tube; corolla yellow with brown center, $1.5^{-2} \mathrm{~cm}$. in diameter; fruiting calyx $3-5 \mathrm{~cm}$. long, indistinctly IO-angled. Plains, Mo. to Colo. and Tex. July-Sept.

I3 Physalis Virginiàna Mill. Virginia Ground-Cherry. (I. F. f. 3202. Perenni.al; rootstock thick; stem 4.9 dm. high, erect, dichotomously branched, somewhat angular, strigose hairy with flat hairs, in some forms nearly glabrous. Leaves ovate-lanceolate, tapering to both ends, 3-6 cm. long, generally sinuately dentate; peduncles in fruit curved but scarcely reflexed; calyx-lobes triangular or broadly lanceolate, nearly equalling the tube; corolla sulphur-yellow with pur. 
plish spots, 1.8-2.5 cm. in diameter; anthers yellow; berry reddish. Rich soil, especially in open places, N. Y. to Manitoba, Fla. and La. July-Sept.

Physalis Virginiàna intermèdia Rydberg. Leaves thin and subentire, gradually tapering into winged petioles; pubescence in the young plant somewhat viscid. Ind. to Ala. and Tex.

14. Physalis heterophýlla Nees. Clammy Ground-cherry. (I. F. f. 3203.) Perennial by a creeping rootstock, 4-9 dm. tall, viscid and glandular, and villous with long spreading jointed flat hairs; leaf blades often acute but very rarely with an acumination, thick, sinuately toothed, or sometimes subentire; calyx long-villous, its lobes triangular, generally shorter than the tube; corolla 1.6-2 cm. in diameter, greenish yellow with a brownish or purplish center; anthers mostly yellow; berry yellow. In rich soil, N. B. to Saskatch., Fla., Colo. and Tex.

Physalis heterophylla ambigua (A. Gray) Rydberg. Tall and generally upright, very long-villous, scarcely at ail viscid; flowers commonly larger; anthers mostly purplish. $\mathrm{Vt}$. to lowa and Tenn.

Physalis heterophýlla nyctagínea (Dunal) Rydberg. Leaves usually dark green and of a firm texture, nore or less acuminate at the apex, of ten subentire, and pubescent mainly on the veins of the lower surface. R. I. to Iowa and La.

Physalis Peruviana L. Strawberry Tomato. A native of South America; it is cultivated for its fruit in all warm and temperate regions, and often escapes. It resembles $P$. heterophylla, but differs in the leaves, which have a long distinct acumination, and in the pubescence, which is shorter, denser, and not at all viscid.

I5. Physalis comàta Rydberg. Hillside Ground-Cherry. (I. F.f. 3204.) Erect, 4-5 dm. high; pubescence fine and short, that on the calyx, peduncles and upper branches mixed with long white flat jointed hairs. Leaf-blades not over $5 \mathrm{~cm}$. long, round ovate, scarcely at all cordate, thin, somewhat repand-dentate, or nearly entire; peduncles as long as the fruiting calyx, or longer; corolla greenish yellow, with brown center, $\mathbf{1} .2-2 \mathrm{~cm}$. in diameter. Fruiting calyx thin, roundovoid, somewhat IO-angled, scarcely sunken at the base. Hillsides, Neb., Kans., Colo. and Tex.

I6. Physalis rotundàta Rydberg. Round-Leaved Ground-CherRy. (I. F. f. 3205.) Zigzag, generally dichotomously branched, from a perennial rootstock, densely and finely viscid pubescent, usually more glandular than the preceding. Leaves nearly orbicular, cordate, $2.5-4.5 \mathrm{~cm}$. in diameter, with small teeth; petioles short, more or less winged; peduncles short; corolla $1.6 \mathrm{~cm}$. in diameter, greenish yellow with a brownish center; fruiting calyx ovoid, slightly angled, scarcely sunken at the base. Dry plains, S. Dak. to Tex. and N. Mex. JulySept.

I7. Physalis viscòsa L. Stellate Ground-cherry. (I. F. f. 3206.) Perennial by a creeping rootstock; stems creeping, with a dense ashy stellate pubescence, or in age glabrate. Leaves elliptic, oval or ovate, obtuse, thinnish, entire or undulate, in the typical South American form often cordate at the base, but rarely so in our plant; peduncles $\mathrm{I}-2.5 \mathrm{~cm}$. long; calyx-lobes triangular, generally shorter than the tube; corolla greenisn yellow with a darker center, $1.5-2 \mathrm{~cm}$. in diameter; fruiting calyx 2-3 cm. long, round-ovoid, scarcely sunken at the base; berry orange or yellow. On sea beaches, or in sand near the coast, Va. and N. Car. to the Argentine Republic.

Physalis Alkekéngi L. Strawberry TOMato. Winter Cherry. A native of Europe and Asia, often cultivated for its fruit and sometimes escapes from cultivation. The flowers are whitish: corolla-limb more distinctly 5-lobed; leaves broadly deltoid, dcute at both ends, repand or angulately toothed.

\section{QUÍNCULA Raf.}

A low and diffuse somewhat scurfy herb, with a stout perennial root. Leaves sinuate to pinnatifid, somewhat fleshy. Peduncles commonly in pairs from the axils, sometimes solitary, or in fascicles of 3-5. Calyx campanulate, 5-toothed, in fruit inflated, sharply 5 -angular and reticulate, enclosing the fruit, the lobes connivent. Corolla pentagonal in outline, veiny. Anthers opening by longitudinal 
slits. seeas comparatively few, kidney-shaped, somewhat flattened, with thick margins. [Name unexplained.] A monotypic genus.

I. Quincula lobata (Torr.) Raf. Purple-flowered Ground-Cherry. (I. F. t. 3207.) Perennial, spreading or prostrate; stem obtusely angled and striate, much branched. Leaves oblanceolate or spatulate to oblong, sinuately toothed, or pinnatifid with rounded lobes, or rarely subentire, cuneate at the base, thickish and veiny, tapering into margined petioles; peduncles $2-5 \mathrm{~cm}$. long, in fruit reflexed; calyx-lobes triangular, acute, shorter than the tube; corolla $2-3 \mathrm{~cm}$. in diameter; anthers yellow, tinged with purple; fruiting calyx about as wide as long, sunken at the base. On high plains, Kans. to Cal. and Mex. May-Sept.

\section{LEUCOPHÝSALIS Rydberg.}

A tall erect viscid and villous annual, with entire leaves, the blade decurrent on the petiole. Peduncles generally in fascicles of 2-4 in the axils. Calyx campanulate, 5-lobed, at first a little inflated, but soun filled by and closely fitted to the berry, thin, neither angled nor ribbed, faintly veiny. Corolla rotate, white, sometimes tinged with purple and generally creamy or yellow in the center, the limb plicate. Stamens inserted near the base of the corolla; filaments long and slender; anthers oblong, opening by longitudinal slits. Style and stigma as in Physalis. Seeds kidney-shaped, flattened, punctate. [Greek, white Physalis.] A monotypic genus.

I. Leucophysalis grandifiòra (Hook.) Rydberg. LARge White-FLowered GROUND-CHERRY. (I. F. f. 3208.) Frect, $39 \mathrm{dm}$. high; stem more or less villous. Leaves I-2 dm. long, ovate to lanceolate-ovate, generally acute and entire, more or less villous and viscid; peduncles several from each axil, villous; calyxlobes lanceolate, equalling the tube; corolla 3-4 cm. in diameter, rotate; anthers short, yellow, often tinged with purple; fruiting calyx ovoid, early filled by the berry. Vt. to Saskatch. and Minn. May-July.

\section{CHAMAESÁRACHA A. Gray.}

Perennials, the leaf.blade decurrent on the petiole. Peduncles solitary, or in fascicles of 2-4 in the axils. Calyx campanulate, 5-lobed, in fruit somewhat enlarged, but not bladdery-inflated, close-fitting to the berry, thin, not angled nor ribbed, and faintly if at all veiny, open at the mouth, not exceeding the berry. Corolla rotate, white or crean-colored, often tinged with purple, the limb plicate. Stamens inserted near the base of the corolla; filaments long and slender; anthers oblong, opening by longitudinal slits; style and stigma as in Physalis. Seeds kidney-shaped, flattened, rugose-favose or punctate. [Ground-Saracha, the latter a genus named in honor of Isidore Saracha, a Spanish Benedictine botanist.] An American genus, of half a dozen species.

Pubescence dense, puberulent and hirsute.

Pubescence sparse, puberulent or stellate, hirsute (if at all) only on the calyx.

I. C. conioides.

2. C. Coronopus.

I. Chamaesaracha conioides (Moricand) Britton. HaIry ChamaesarACHA. (I. F.f. 3209.) Much branched, at first upright, at length spreading, cinereous-puberulent with short branched somewhat glutinous or viscid hairs, generally also viscidly hirsute or villous with long and branched hairs, especially on the calyx; leaves oblanceolate to obovate-rhombic, usually acutish, subentire to pinnatifid; calyx-lobes triangular, generally acutish; corolla about $12 \mathrm{~mm}$. in diameter, white or ochroleucous, or sometimes violet-purplish: berry 5-8 $\mathrm{mm}$. in diameter. In dry clayey soil, Kans. to Cal. and Mex. May-Sept.

2. Chamaesaracha Corónopus (Dunal) A. Gray. Smoothish ChamaeSARACHA. (I. F. f. 32 IO.) Branched and diffuse: stem obtusely angled; pubescence on the stem and leaves more or less roughish pruinose or stellate, often scarcely any; on the calyx stellate or sometimes hirsute. Leaves linear or lanceolate, sinuately lobed, occasionally subentire, sometimes pinnatifid; calyx-lobes triangular, acute; corolla white or ochroleucous, the appendages of the throat often protuberant; berry nearly white. In clayey soil, Kans. to Utah, Cal. and Mex. May-Sept. 


\section{SOLĀNUM L.}

Herbs or shrubs, often stellate-pubescent, sometimes climbing. Flowers cymose, umbelliform, paniculate, or racemose. Calyx campanulate or rotate, mostly 5 -toothed or 5 -cleft. Corolla rotate, the limb plaited, 5-angled or 5-lobed, the tube very short. Stamens inserted on the throat of the corolla; filaments short; anthers linear or oblong, acute or acuminate, connate or connivent into a cone, each sac dehiscent by a terminal pore, or sometimes by a short introse ierminal slit, or sometimes also longitudinally. Ovary usually 2-celled; stigna small. Berry mostly globose, the calyx either per:istent at its base or enclosing it. [Name, according to Wittstein, from solamen, quic ing.] About 900 species, of wide geographic distribution. Besides the following, some $\mathbf{1 5}$ others occur in the southern and western U.S.

* Glabrous or pubescent herbs, not prickly.

Plants green; pubescence simple, or some of it stellate; flowers white.

Leaves repand or entire: ripe berries black.

Leaves deeply pinnatifid; ripe berries green.

Plant silvery stellate-canescent; flowers violet.

I. S. nigrum.

2. S. triflor um.

4. S. elaeagnifolium.

* * Stellate-pubescent and prickly herbs.

Rerry not enclosed by the calyx; perennials.

Hirsute; leaves ovate or oblong, sinuate or pinnatifid.

Densely silvery canescent; leaves linear or oblong, repand or entire.

Pubescent; leaves ovate, 5-7-lobed.

Berry invested by the spiny calyx; annuals.

Plant densely stellate-pubescent; corolla yellow.

Plant glandular-pubescent, with few stellate hairs; corolla violet.

* * 7. S. heterodoxum.

4. S. elaeagnifolium.

5. S. Torreyi.

6. S. rostratum.

*** Climbing vine, not prickly; leaves hastate or 3-lobed. 8. S. Dulcamara.

I. Solanum n`grum L. Black or Garden Nightshade. (I. F. f. 32Ir.) Annual, glabrous, or somewhat pubescent with simple hairs, 3-8 dm. high. Leaves ovate, petioled, more or less inequilateral, $2-8 \mathrm{~cm}$. long, thin, acute, acuminate or acutish at the apex: peduncles lateral, umbellately 3-10-flowered; pedicels 6-14 mm. long; flowers 8-10 mm. broad; calyx-lobes oblong, obtuse, much shorter than the corolla, persistent at the base of the berry; filaments somewhat pubescent; anthers obtuse: berries glabrous, globose, 8-10 $\mathrm{mm}$. in diameter, on nodding peduncles. In waste places or cultivated soil, N. S. to the N. W. Terr., Fla. and Tex. Widely distı ibuted as a weed. July-Oct.

2. Solanum triflòrum Nutt. Cut-leaved Nightshade. (I. F. f. 3212:) Annual, sparingly pubescent with simple hairs, or glabrous, 3-9 dm. high. Leaves acute, petioled, 5-10 cm. long, the lobes triangular-lanceolate, entire or dentate, the sinuses rounded; peduncles lateral, I-3-flowered; pedicels reflexed in fruit; calyx-segments lanceolate, shorter than the corolla, persistent at the base of the berry; corolla 8-10 mm. broad; anthers obtuse; berries globose, glabrous, about $10 \mathrm{~mm}$. in diameter. On prairies and in waste places, western Ont. to the N. W. Terr., Kans. and Ariz. May-Oct.

3. Solanum Carolinénse L. Horse-nettle. (I. F. f. 32I3.) Stellatepubescent with 4 8-rayed hairs; stem erect, branched, 3-I2 dm. high, armed with straight subulate yellow prickles. Leaves oblong or ovate, repand, lobed, or pin. natifid, 5-15 cm. long; flowers cymose-racemose; pedicels 6-14 mm. long, recurved in fruit; calyx-lobes lanceolate, acuminate, about one-half the length of the corolla, persistent at the base of the berry; corolla-lobes ovate-lanceolate, acute; anthers elongated; berries orange-yellow, glabrous, $1.5-2 \mathrm{~cm}$. in diameter. In dry fields and in waste places, Ont. to Mass., Fla., Ill., Neb. and Tex. May-Sept.

4. Solanum elaeagnifòlium Cav. Silver-leaved Nightshade. (I. F. f. 32r4.) Perennial, finely stellate pubescent, silvery-canescent all over; stem 3$9 \mathrm{dm}$. high, armed with sharp prickles, or these wanting. Leaves lanceolate, oblong, or linear, petioled, 2-10 $\mathrm{cm}$. long, mostly obtuse, repand-rlentate or entire; flowers cymose, $1.5-2.5 \mathrm{~cm}$. broad; peduncles short and stout; calyx-lobes lanceolate or linear-lanceolate, acute; anthers linear; ovary white-tomentose; berries 
globose, yellow or darker, glabrous, $8-12 \mathrm{~mm}$. in diameter. On ary plains and prairies, Kans. to Tex. and Ariz. May-Sept.

5. Solanum Tórreyi A. Gray. Torrey's Nightshade. (I. F. f. 3215.) Perennial, hoary with a stellate pubescence of 8-12-rayed hairs, more or less armed with small subulate prickles. Leaves $7-15 \mathrm{~cm}$. long, the lobes entire or undulate, obtuse; cymes branched, loosely several-flowered; flowers showy; calyxlobes ovate, abruptly long-acuminate, persistent at the base of the berry; corolla violet, $2.5-4 \mathrm{~cm}$. broad, its lobes ovate, acute; berry globose, glabrous, $2.5 \mathrm{~cm}$. or more in diameter, yellow. On dry plains and prairies, Kans. to Tex.

6. Solanum rostràtum Dunal. Sand Bur. Beaked Nightshade. (I. F. f. 3216.) Densely pubescent with 5-8-rayed hairs, usually copiously armed with yellow subulate prickles, 3-8 din. high. Leaves ovate or oval in outline, irregularly pinnately 5-7-lobed or 1-2-pinnatifid, 5-13 cm. long, petioled, the lobes obtuse; flowers racemose, about $2.5 \mathrm{~cm}$. broad; racemes lateral; pedicels erect both in flower and fruit; calyx densely prickly, wholly enclosing the berry; calyxlobes lanceolate, acuminate; corolla about $2.5 \mathrm{~cm}$. broad, slightly irregular, its lobes ovate, acute; stamens and style declined, the lowest stamen longer with an incurved beak; fruit $2 \mathrm{~cm}$. in diameter or more. On prairies, S. Dak. to Tex. and Mex. Occasional in waste places as a weed, Ont. to N. H., Mass. and N. J., adventive from the West. May-Sept.

7. Solanum heterodóxum Dunal. Melon-leaved Nightshade. (I. F. f. 3217.) Glandular pubescent, or a few 4-5-rayed hairs on the leaves, copiously armed with slender yellow subulate prickles, diffusely branched, 3-9 dm. high. Leaves irregularly bipinnatifid, 5-I5 cm. long; racemes lateral, several-flowered; flowers $2.5-4 \mathrm{~cm}$. broad; stamens and style declined; lowest anther violet, larger than the four other yellow ones; corolla somewhat irregular, its lobes ovate, acuminate; fruit similar to that of the preceding. In dry soil, Kans. (according to Smyth) to Tex., Mex. and N. Mex. July-Sept.

8. Solanum Dulcamàra L. Nightshade. Blue Bindweed. Fellonwort. Bittersweet. (I. F. f. 32I8.) Perennial; stem climbing or straggling, somewhat woody below, 6-24 dm. long. Leaves petioled, ovate or hastate in outline, 5-10 cm. long, acute or acuminate, entire, 3-lobed, or 3-divided, with the terminal segment much the largest; cymes compound, lateral; pedicels slender, spreading or drooping; flowers blue, purple, or white, I-I.5 cm. broad; calyx-lobes short, oblong, obtuse, persistent at the base of the berry; corolla deeply 5-cleft, its lobes triangular-lanceolate, acuminate; berry oval or globose, red. In waste places or in thickets, N. B. to Minn. N. J., Penn. and Kans. Nat. from Europe. May-Sept.

\section{LYCOPÉRSICON Mill.}

Annual, or rarely perennial, coarse herbs, with I-2-pinnately divided leaves, and lateral irregular raceme-like cymes of small yellowish flowers opposite the leaves. Calyx 5-parted, or rarely 6-parted, the segments linear or lanceolate. Corolla rotate, the tube very short, the limb 5-cleft or rarely 6-cleft, plicate. Stamens 5 (rarely 6), inserted on the throat of the corolla; filaments short; anthers elongated, connate or connivent, introrsely longitudinally dehiscent. Ovary 2-3celled; style simple; stigma small, capitate. Berry in the wild plants globose or pyriform, much modified in cultivation, the calyx persistent at its base. [Greek, wolf-peach.] About 4 species, of S. Am.

I. Lycoper.icon Lycopérsicon (L.) Karst. Tomato. Love-APple. Cherry Tomato. (I. F. f. 32I9.) Viscid pubescent, much branched, 3-9 dm. high. Leaves petioled, I.5-5 dm. long, the segments stalked, the larger 7-9, ovate or ovate-lanceolate, mostly acute, dentate, lobed or again divided, with several or numerous smaller ones interspersed; flowers $10-16 \mathrm{~mm}$. broad; calyx-segments about equalling the corolla; berry the well-known tomato or love-apple. Escaped from cultivation, N. Y. and Penn. southward. June-Sept. [L. esculentum Mill.]

\section{LÝCIUM L.}

Shrubs, or woody vines, often spiny, with small alternate entire leaves, com. monly with smaller ones fascicled in their axils, and white greenish or purple, solitary or clustered flowers. Calyx campanulate, 3-5-lobed or -toothed, not enlarged in fruit, persistent. Corolla tube short or slender, the limb 5-lobed (rarely 4-lobed), 
the lobes obtuse. Stamens 5 (rarely 4); filaments filiform, sometimes dilated at the base; anther-sacs longitudinally lehiscent. Ovary 2-celled; style filiform; stigma capitate or 2-lobed. Berry globose, ovoid, or oblong. [Named from the country Lycia.] About 75 species, widely distributed. Besides the following, some I7 native species occur in southern and western N. Am.

I. Lycium vulgàre(Ait. f.) Dunal. Matrimony Vine. Box.thorn. (I. F. f. 3220.) Glabrous, spiny or unarmed; stems slender, climbing or trailing, 2-8 $\mathrm{m}$. long, the spines, when present, slender. Leaves lanceolate, oblong, or spatulate, narrowed into short petioles, firm, I-4 cm. long; peduncles filiform, $1-2.5 \mathrm{~cm}$. long; calyx-lobes ovate, $3 \mathrm{~mm}$. long; corolla funnelform, purplish changing to greenish, 8-12 mm. broad, its lobes ovate-oblong; stamens slightly exserted; berry oval, orange-red. In thickets and waste places, escaped from gardens, Ont. to Conn., Va., Minn. and Kans. Introduced from Europe. May-Aug.

\section{HYOSCỲAMUS L.}

Erect viscid-pubescent narcotic herbs, with alternate mostly lobed or pinnatifid leaves, and large nearly regular flowers, the lower solitary in the axils, the upper in a spike or raceme. Calyx urn-shaped or narrowly campanulate, 5-cleft, striate, enlarged and enclosing the capsule in fruit. Corolla funnelform, the limb somewhat oblique, 5-cleft, the lobes unequal, spreading. Stamens declined, mostly exserted; filaments filiform; anther sacs longitudinally dehiscent. Ovary 2-celled; style slender; stigma capitate. Capsule 2 -celled, circumscissile above the middle. [Greek, hog-lean.] About I5 species, of the Mediterranean region.

I. Hyoscyamus niger L. Black Henbane. Hog's-bean. (I. F.f. 3221.) Annual or biennial; stem stout, $3-8 \mathrm{dm}$. high. Leaves ovate, lanceolate, or oblong in outline, $7-\mathbf{I} \mathbf{c m}$. long, acute or acuminate, sessile, or the upper clasping, irregularly lobed, cleft or pinnatifid; flowers short-pedicelled, $2.5-5 \mathrm{~cm}$. broad; calyx-lobes triangular-ovate, acute; corolla greenish yellow, strongly reticulated with purple veins, its lobes ovate, obtusish; capsule globose-oblong, about $\mathbf{~} \mathrm{cm}$. high. Waste places, N. S. to Ont., N. Y. and Mich. Nat. from Europe. June-Sept.

\section{I0. DATÙRA L.}

Tall narcotic herbs, some tropical species shrubs or trees, with alternate petioled leaves, and large solitary erect short-peduncled white purple or violet flowers. Calyx elongated-tubular or prismatic, its apex 5-cleft or spathe-like, in the following species circumscissile near the base which is persistent and subtends the prickly capsule. Corolla funnelform, the limb plaited, 5-lobed, the lobes broad, acuminate. Stamens included or little exserted; filaments filiform, very long, inserted at or below the middle of the corolla-tube. Ovary 2-celled, or falsely 4-celled; style filiform; stigma slightly 2-lobed. Capsule 4 valved from the top, or bursting irregularly. [The Hindoo name, dhatura.] About 12 species, of wide distribution. The following are introduced weeds.

Glabrous or very sparingly pubescent; leaves lobed, calyx prismatic. Stem green; flowers white; lower prickles of the fruit shorter. Stem purple; flowers lavender or violet; prickles abnut equal. Finely glandular-pubescent; leaves entire; calyx tubular.
1. D. Stramonium.
2. D. Tatula.
3. D. Metel.

I. Datura Stramònium L. Stramonium. Jamestown or Jimson-Weed. Thorn-APple. (I. F. f. 3222.) Annual, glabrous or the young parts sparingly pubescent; stem stout, 3-15 dm. high. Leaves thin, ovate, acute or acuminate, mostly narrowed at the base, $0.7-2 \mathrm{dm}$. long, irregularly sinuate-lobed, the lobes acute; flowers white, about I dm. high: calyx prismatic, less than one-half the length of the corolla; capsule ovoid, dencely prickly, about $5 \mathrm{~cm}$. high. In fields and waste places, N. S. to Fla., Minn. and Tex. Nat. from tropical regions, probably from Asia. June-Sept.

2. Datura Tátula L. Purple Thorn-apple. Purple Stramonium. (I. F. f. 3223.) Similar to the preceding but usually a little more pubescent; stem commonly more slender, purple; leaves almost like those of D. Siramonium, but rather darker green or with a tinge of purple; flowers lavender colored or violet, or the tube nearly white. In fields and waste places, Ont. to Minn., N. Y., Fla. and Tex. Nat, from trop. Am. May-Sept. 
3. Datura Mètel L. Entire-leaved Thorn-Apple. (1. F. f. 3224.) Annual, finely glandular-pubescent, I-3 m. high. Leaves broadly ovate, acute, inequilateral, rounded or subcordate at the base, I-2.5 dm. long; flowers white, 1.5-1.8 dm. high; calyx about one-half as long as the corolla; capsule globose or ovoid-globose, obtuse, prickly and pubescent, $2.5-4 \mathrm{~cm}$. in diameter. In waste places, R. I. to Fla. Native of trop. Am. July-Sept.

\section{NICOTIÀNA L.}

Viscid-pubescent narcotic herbs or shrubs, with large alternate entire or slightly undulate leaves, and white yellow greenish or purplish flowers, in terminal racemes or panicles. Calyx tubular-campanulate or ovoid, 5-cleft. Corolla-tube usually longer than the limb, 5 lobed, the lobes spreading. Stamens 5, iriserted on the tube of the corolla; filaments filiform; anther.sacs longitudinally dehiscent. Ovary 2-celled (rarely 4-celled); style slender; stigma capitate. Capsule 2-valved, or sometimes 4-valved at the summit. Seeds numerous, small. [Named for John Nicot, French ambassador to Portugal, who sent some species to Catherine de Medici, about 1560.] About 50 species, mostly natives of America. Besides the following, some ro others occur in the southern and western U. S.

Corolla $2.5 \mathrm{~cm}$. long, the tube cylindric; calyx-lobes triangular. Corolla IO-I $5 \mathrm{~cm}$. long, the tube very slender; calyx-lobes linear.
I. N. rustica.

2. N. longifiora.

I. Nicotiana rústica L. Wild ToBacco.

(I. F. f. 3225.) Annual, 6-I2 dm. high. Ieaves broadly ovate, thin, entire, slender - petioled, $0.5^{-2} \mathrm{dm}$. long; flowers greenish yellow, piniclel; pedicels 6-12 mm. long; calyx-lobes acute, shorter than the tube; corolla-tube somewhat enlarged above, the lobes short, obtuse; capsule globose, glabrous, about $\mathbf{I} \mathrm{cm}$. in diameter, 2-valved. longer than the calvx. In fields anI waste places, Ont. to Minn., N. Y. and Fla. Cultivated by the Indians. June-Sept.

2. Nicotiana lo.1gifiòra Cav. Long-Floweren Tobacco. (I. F. f. 3226.) Annual, minutely rough-puberulent and viscid, 4-9 dm. high. Basal leaves obtuse, 1.5-2.5 dm. long, tapering into slender winged petioles; stem leaves linear or lanceolate, sessile: flowers short-pedicelled; calyx oblong, pubescent, its narrow lobes nearly as long as the tube; corolla white or purplish, viscid, the tube slender, 2-3 $\mathrm{mm}$. in diameter, expanding abuve, the lobes ovate lanceolate, acute; capsule oblong. Near Harrisburg and Easton, Pa. Escaped from gardens. Native of S. Am. Aug.-Oct.

\section{PETÙNIA Juss.}

Viscid pubescent herbs, with entire leaves, and white violet or purple flowers (in cultivation sometimes variegated). Calyx deeply 5 -cleft or 5 parted. Corolla funnelform or salverform, the limb plicate, spreading, slightly irregular. Stamens 5 , inserted on the throat of the corolla', 4 of them didynamous, perfect, the fifth smaller or obsolete; filaments slender; anthers 2-lobed. Disk fleshy. Ovary 2 celled; ovules numerous; style filiform: stigma 2 lamellate. Capsule 2-celled, 2valved, the valves entire. Seeds small, the testa rugose. [Petun, an Indian name of tobacco.] About 22 species, of S. Am.

Corolla white, its tube cylindric.

Corolla violet-purple, its tube campanulate.

1. P. axillaris.

2. P. violacea.

I. Petunia axillàris (Lam.) B.S.P. White Petunia. (I. F. f. 3227.) Very viscid, about $3 \mathrm{dm}$. high. Leaves ovate to obovate, obtuse or blunt-pointed, 7-10 $\mathrm{cm}$. long, sessile, or the lower narrowed into short margined petioles; peduncles slender, often longer than the leaves; calyx-segments linear-oblong, obtuse; corolla white, its tube slightly enlarged above, $2.5-4 \mathrm{~cm}$. long, 3-4 times as long as the calyx, its limb abruptly spreading, the lobes rounded. In waste places, escaped from gardens, N. Y. and Penn. Native of southern Brazil. July-Sept.

2. Petunia violàcea Lindl. Violet Petunia. (I. F. f. 3228.) Similar to the preceding, but usually lower, and the stem slender. Leaves ovate or obovate, all but the urpermost petioled, mostly obtuse, $2.5^{-6} \mathrm{~cm}$. long: peduncles slender; calyx-segments linear; corolla violet-purple, its tube campanulate, $1.8-3 \mathrm{~cm}$. long, 
the limb less abruptly spreading, the lob : subacute. In waste places, escaped from gardens, N. Y. and Penn. Native of southern Brazil and Paraguay. June-Sept.

Petunia parviflora Juss., a prostrate pubescent annual, with small linear to spatulate leaves, and a funnelform curolla 8-10 $\mathrm{mm}$. long, is abundant on ballast about the eastern seaports.

\section{Family 9. SCROPHULARIÀCEAE Lindl.}

\section{Figwort Family.}

Herbs, shrubs or trees, with estipulate leaves, and perfect mostly complete and irregular flowers (corolla wanting in one species of Sinthyris). Calyx inferior, persistent, 4-5-toothed, -cleft, or -divided, or sumetimes split on the lower side, or on both sides, the lobes or segments valvate, imbricate or distinct in the bud. Corolla gamcpetalous; the limb 2-lipped, or nearly regular. Stamens 2,4 or 5, didynamous, or rearly equal, inserted on the corolla and alternate with its lobes; anthers 2-celled; the sacs equal, or unequal, or sometimes confluent into one. Disk present or obsolete. Pistil I, entire or 2-lobed; ovary superior, 2-celled, or rarely I-celled; ovules anatropous or amphitropous, on axile placentæ; style slender, simple; stigma entire, 2-lobed or 2lamellate. Fruit mostly capsular and septicillally or loculicidally dehiscent. Seeds mostly numerous; endosperm fleshy; embryo small, straight or slightly curved; cotyledons little broader than the radicle. About 165 genera and 2500 species, widely distributed.

\section{Anther-bearing stamens 5 ; corolla rotate; leaves alternate. I. Verbascum.}

\section{Anther-bearing stamens 2 or 4 ; leaves opposite, verticillate or alternate.}

* Corolla spurred, saccate or gibbous on the lower side at the base.

Corolla spurred at the base.

Leaves palmately $3-5$-veined.

2. Cymbalaria.

Leaves pinnately veined.

Flowers solitary in the axils.

Flowers in terninal racemes.

3. Kickxia.

4. Linaria.

Corolla saccate or gibbous at the base.

5. Antirrhinum.

* * Corolla neither spurred, saccate nor gibbous on the lower side.

+ Anther-bearing stamens 4 , the fifth sterile or rudimentary.

Sterile stamen a scale adnate to the upper side of the corolla.

Sterile stamen elongated, longer or shorter than the others.

6. Scrophularia.

Corolla tubular, 2-lipped, the lobes of the lower lip flat.

Sterile stamen shorter than the others; seeds winged.

Sterile stamen about equalling the others; seeds wingless. 8. Pentstemon.

Corolla 2-cleft, declined; middle lobe of the lower lip conduplicate.

9. Collinsia.

++ Stamens 4, all anther-hearing, or 2 sterile, or 2 only.

a. Stamens 4, all anther-bearing; large Asiatic tree.

10. Paulounia.

b. Stamens 4, all anther-bearing; herbs; corolla 2-lipped; stamens not enclosed in upper

Calyx prismatic, 5 -angled, 5 -toothed. lip of corolla.

Calyx 5-parted, not prismatic.

Calyx-segments equal; leaves pinnatifid in our species.

Calyx-segments unequal, the upper one the largest.

I I. Mimulus.

12. Conolea.

13. Monniera.

c. Stamens 4, 2 anther-bearing and 2 sterile, or 2 only; corolla obviously 2 -lipped.

Calyx 5-parted; upper lip of corolla present.

Sterile filanents short or none.

Sterile filaments slender, 2 -lobed.

Calyx 4-toothed; upper lip of corolla obsolete; low mud plant.

14. Gratiola.

15. Jlysanthes.

16. Micranthemum.

d. Stamens 4, all anther-bearing; corolla nearly regular; flowers on scapes.

17. L.tinioselle, 
e. Stamens 2 only; corolla rotate, salverform, tubular, or none.

Leaves alternate; flowers spicate: corolla 2 -3-lobed or none.

Leaves, at least the lower, opposite or verticillate; corolla 4 -lobed.

Corolla rotate; capsule obcordate or emarginate, compressed.

Corolla tubular-funnelform; carsule ovoid, not compressed.

f. Staniens 4 , all anther-bearing; corolla campanulate, salverform or funnelform, scarcely 2 -lipped.

Leaves alternate: flowers in $\mathrm{I}$-sided racemes.

18. Synthyris.

19. Veronica.

20. Leptandra.

21. Digitalis.

Leaves, at least the lower, opposite.

Corolla salverform; flowers in a long spike.

Corolla campanulate or funnelform.

Stamens nearly equal: calyx-lobes as long as the tube.

22. Buchnera.

Stamens strongly didynamous, unequal; calyx-teeth shorter than the tube.

Anthers awned at the base; corolla yellow.

24. Dasystoma.

Anthers awnless; corolla purple, pink or rarely white. 25. Gerardia.

g. Stamens 4, all anther-bearing, ascending under the upper lip of the corolla.

Ovules several or numerous; capsule many-seeded.

Anther-sacs dissimilar, the inner one pendulous by its apex; leaves mostly alternate.

Upper lip of the corolla much longer than the lower.

Upper lip of the corolla scarcely longer than the lower.

Anther-sacs similar and sparaliel; ieaves mostly opposite.

Calyx 2-bracteolate at the base, 5 -toothed.

Calyx not bracteolate, 4-5-toothed, or cleft or split.

Upper lip of the corolla 2 lobed, its margins recurved; calyx 4-cleft.

Margins of the upper lip of the corolla not recurved.

26. Castilleja.

27. Orthocarpus.

28. Schwalbea.

29. Euphrasia.

Calyx scarcely or not at all inflated in fruit; galea entire.

Calyx 4 toothed or 4 -cleft; capsule straight.

Seeds spreading, numerous.

Seeds pendulous, few.

30. Bartsia.

3r. Odontites.

Calyx split on the lower side or on both sides; capsule oblique. Galea prolonged into a filiform curved beak.

Galea with a short beak or none.

Calyx ovoid, much inflated and veiny in fruit.

32. Elephantella.

33. Pedicularis.

34. Rhinanthus.

Ovules only $I$ or 2 in each cell of the ovary; capsule I-4-seeded; leaves opposite.

\section{VERBÁSCUM L.}

35. Melaimpyrum.

Biennial or rarely perennial, mostly tall herbs, with alternate leaves, and rather large flowers, in terminal spikes, racemes or panicles. Calyx deeply 5-cleft or 5-parted. Corolla flat rotate or slightly concave, 5-lobed, the lobes a little unequal, the upper exterior, at least in the bud. Stamens 5. inserted on the base of the corolla, unequal; filaments of the 3 upper stamens, or of all 5 , pilose; anther-sa $; 3$ confluent into one. Ovules numerous; style dilated and flattened at the summit. Capsule septicidally 2 -valved, the valves usually 2 -cleft at the apex. Seeds rugose. [The Latin name of the great mullen; used by Pliny.] About 125 species, of the Old World.

Plants densely woolly; flowers in dense terminal spikes, or spikelike racemes.

Leaves strongly decurrent on the stem.

Leaves not decurrent, or but slightly so.

Leaves white-tomentose beneath; flowers in large terminal panicles. Plant glabrous or sparingly glandular; flowers racemose.

I. Verbascum Thápsus L. Great Mullen. (I. F. f. 3229.) Simple or

I. V. Thapsus.

2. V. phlomoides.

3. V. Lychnitis.

4. V. Blattaria. with some erect branches, densely woolly with branched hairs, 6-25 dm. high. Leaves oblong, thick, acute, narrowed at the base, dentate or denticulate, I-3 dm. long, the hasal ones margined-petioled; flowers yellow, $1.5-2.5 \mathrm{~cm}$. broad, sessile, numerous in dense elongated spikes: stamens unequal, the three upper shorter with white hairy filaments and short anthers, the two lower glabrous or nearly so with larger anthers; capsule about $6 \mathrm{~mm}$. high. In fields and waste places, N. S. to S. Dak., Fla. and Kans. Nat. from Europe. June-Sept.

2 Verbascum phlomoides L. Crasping-Leaved Mullen. (I. F. f. 3230.) Stem usually simple, 3-12 dm. high. Leaves oblong to ovate-lanceolate, crenate, crenulate, or entire, woolly-tomentose, sessile or somewhat clasping, or slightly decurrent on the stem, or the lower often petioled with trunçate or subcordate bases; 
flowers yellow, or cream-color, $2.5 \mathrm{~cm}$. broad or more, usually in a tomentose spike-like raceme; pedicels clustered, shorter than the calyx; stamens as in $V$. Thapsus. Eastern Mass. Adventive or fugitive from Europe. June-Aug.

3. Verbascum Lychnitis L. White Mullen. (I. F. f. 3231.) Stem angled, branched above, 6-I4 dm. high, densely covered with a white nearly stellate pubescence. Leaves oblong, ovate or oblong-lanceolate, crenate-dentate, $5-17 \mathrm{~cm}$. long, the upper acute, sessile, the lower narrowed into margined petioles; flowers in a large terminal panicle, racemose on its branches, white or cream.color, I0-12 mm. broad, nearly sessile; pilose hairs of the 3 sho-ter filaments white; capsule about $4 \mathrm{~mm}$. high. In fields and waste places, Ont. to N. J. and Penn. Reported from Kans. Nat. from Europe. June-Sept.

4. Verbascum Blattària L. Moth Mullen. (I. F. f. 3232.) Stem terete, usually simple, 6-I8 dm. high. Leaves oblong, ovate or lanceolate, dentate, laciniate, or pinnatifid, acute or acuminate, the upper truncate or cordateclasping at the base, the basal ones seldom present at flowering time; raceme 3-6 dm. long, loose; pedicels spreading, $\mathbf{I}-2.5 \mathrm{~cm}$. long, bracted at the base; corolla yellow or white, about $2.5 \mathrm{~cm}$. broad, with brown marks on the back; fila. ments all pilose with violet hairs; capsule depressed-glohose, $6 \mathrm{~mm}$. in diameter. In fields and waste places, Quebec to Fla., Minn. and Kans. Nat. from Europe. June-Nov.

\section{CYMBALÁRIA Medic.}

Perennial creeping or spreading herbs, with long-petioled, mostly lobed, palmately veinerl leaves, and solitary axillary white to violet flowers. Calyx 5-parted. Corolla irregular, 2-lipped, short-spurred; upper lip 2-lobed, lower lip 3-lobed; throat nearly or quite closed by the palate. Stamens 4, didynamous, ascending, included, the filaments filiform. Style very slender. Capsule dehiscent by 2 terminal 3-toothed pores. Seeds numerous, small. [From the Greek for cymbal.] About 9 species, of the Old World.

I. Cymbalaria Cymbalària (L.) Wettst. Kenilworth or Coliseum Ivy. (I. F. f. 3233.) Glabrous; stem trailing, often rooting at the nodes, I-3 dm. long. Leaves reniform-orbicular, 3-5 lobed, $0.6-2.5 \mathrm{~cm}$. in diameter, the lobes broad and obtuse; flowers blue or lilac, 8-10 mm. long; peduncles slender, recurved, shorter than the petioles; calyx-segments lanceolate, acute; palate yellowish; capsule globose; seeds rugose. Waste places and roadsides, adventive from Europe, N. Y., N. J. and Penn., and in seaport ballast. June-Aug.

\section{KíckXIA Dumort.}

\section{[Elatinoides Wettst.]}

Mostly annual spreading or creeping horbs, with pinnately veined, short-petioled leaves, and solitary axillary white yellow or variegated flowers. Calyx 5. parted. Corolla irregular, spurred, 2-lipped, the throat closed by the palate. Stamens 4, didynamous, included; filaments filiform. Capsule opening by $\mathrm{I}$ or 2 tcrminal slits, pores, or valves. Seeds ovoid, mostly rough or tubercled. About 25 species, natives of the Old World. [In honor of Johann Kickx, professor in Ghent.]

Leaves ovate-orbicular, cordate or rounded at the base. Leaves triangular, mostly hastate.

x. E. spuria.

2. E. Elatine.

I. Kickxia spùria (L.) Dumort. Round-leaved Toad-flax. (I. F. f. 3234.) Annual, pubescent; stems prostrate, 0.7-6 dm. long. Leaves ovate-orbicular, entire, or sometimes dentate, mucronulate, cordate or rounded at the base, $0.6-2.5 \mathrm{~cm}$. in diameter; petioles 2-4 mm. long; flowers small; peduncles filiform, very pubescent, often much longer than the leaves; calyx-segments ovate, acute at the apex, cordate or rounded at the base, one-half as long as the corolla;. corolla yellowish with a purple upper lip, the spur curved; capsule subglobose. In waste places and ballast, N. Y. to N. Car. Adventive from Europe. June-Sept. [Elati. noides spuria Wettst.]

2. Kickxia Elatine (L.) Dumort. Sharp-pointed Fluellin or Toad-Flax. (I. - f 3235.) Annual, pubescent; stems prostrate, I.5-6 dm. long. Leaves 
I $-2.5 \mathrm{~cm}$. long, acute or acutish at the apex, triangular, hastate, truncate, or subcordate at the base, the basal auricles divergent, acute; flowers about $6 \mathrm{~mm}$. long; peduncles filiform; calyx-segments narrowly lanceolate, acute; corolla yellowish, purplish beneath, its spur slender, straight, declined; capsule subglobose. In sandy waste places, Canada; N. Y. to N. Car. and Ga. Nat. from Europe. JuneSept. [Elatinoides Elatine Wettst.]

\section{LINÀRIA Hill.}

Herbs, some exotic species shrubby, with alternate leaves, or the lower and those of sterile shoots opposite or verticillate, the flowers in terminal bracted racemes or spikes or axillary. Calyx 5-parted, the segments imbricated. Corolla irregular, spurred at the base, 2-lipped, the upper lip erect, 2 -lobed, covering the lower in the bud, the lower spreading, 3-lobed, its base produced into a palate often nearly closing the throat. Stamens 4, didynamous, ascending, included; filaments and style filiform. Capsule opening by I or more mostly 3 -toothed pores or slits below the summit. Seeds numerous, angled or rugose. [Latin, linum, flax, which some species resemble.] About 150 species, of wide distribution. Besides the following, another occurs in southern Florida. The corolla, especially the terminal one of the raceme, occasionally has 5 spurs and is regularly 5 -lobed, and is then said to be in the Peloria state.

Flowers yellow, $1.5-3 \mathrm{~cm}$. long.

Leaves linear; flowers $2.5-3 \mathrm{~cm}$. long; seeds winged.

Leaves lanceolate; flowers $1.5^{-2} \mathrm{~cm}$. long; seeds wingless.

Flowers blue to white, 6-12 $\mathrm{mm}$. long.

Spur of corolla filiform, curved; native species.

Spur of corolla short, conic; European adventive species.

r. L. Linaria.

2. L. genistaefolia.

3. L. Canadensis.

4. L. repens.

I. Linaria Linàriz (L.) Karst. Ranstead. Butter-And-Eggs. Yellow 'ToAD-FLAX. (I. F. f. 3236.) Perennial, pale green; stems erect, leafy, glabrous, or sparingly glandular-pulescent above, 3-9 dm. high. Leaves sessile, entire, mostly alternate, I-4 cm. long, 2-3 $\mathrm{mm}$. wide; flowers densely racemose, the palate orangecolored; pedicels 4-8 mm. long, nearly erect; calyx-segments oblong, acutish; spur subulate, nearly as long as the body of the corolla; middle lobe of the lower lip shorter than the other two: capsule ovoid. In fields and waste places, N. S. to Manitoba, Va. and Kans. Nat. from Europe. June-Oct. [L. vulgaris Mill.]

2. Linaria genistaefòlia (L.) Mill. Broom-Leaven Toad-Flax. (I. F. f. 3237.) Similar to the preceding but more glaucous, usually paniculately branched; leaves sessile, 2.5-9 cm. long, 4-12 mm. wide, acute or acuminate; flowers loosely racemose; pedicels short; spur of the corolla nearly as long as the tube. Sparingly established on the northern part of N. Y. Island; station now nearly or quite obliterated. Nat. or adventive from Europe. June-Aug.

3. Linaria Canadénsis (L.) Dumont. Blue or Wild Toad-flax. (I. F. f. 3238.) Biennial or annual, glabrous; flowering stems erect or ascending, very slender, I- $8 \mathrm{dm}$. high; sterile shoots procumbent, leafy. Leaves linear or linearoblong, 8-30 mm. long, entire, sessile, those of the sterile shoots, or some of them, usually opposite; flowers $6-8 \mathrm{~mm}$. long, in slender racemes; pedicels appressed in fruit; calyx-segments lanceolate, acute, or acuminate, about as long as the capsule; spur of the corolla as long as the tube or longer; palate a white convex 2 . ridged projection: seeds wingless. In dry soil, N. S. to Fla., Ore. and Cal. Also in Cent. and S. Am. A dwarf form with no corolla is frequent. May-Sept.

4. Linaria rèpens (L.) Mill. Pale-blue Toan-flax. (I. F. f. 3239.) Glabrous, perennial by a creeping rootstock, $2-8 \mathrm{dm}$. high. Leaves linear, entire, short-petioled or sessile, $\mathrm{I}-5 \mathrm{~cm}$. long, 2-4 $\mathrm{mm}$. wide, narrowed to both ends, the lower crowded, sometimes whorled; flowers in slender terminal racemes; pedicels 4-Io $\mathrm{mm}$. long; bracts narrowly linear, acute; corolla nearly white, but striped with blue or purple, about $12 \mathrm{~mm}$. long; spur short, conic; capsule subglobose; seeds wrinkled. Newf. and in ballast about the Atlantic seaports. Adventive from Europe. Summer.

Chaenurrhinum minus (L.) Lange (Linaria minor (L.) Desf), a low glandular branched annual, with solitary, axillary, long-peduncled, very small flowers, the palate not closing the throat of the corolla, the leaves linear, is reported from N. B. and Ont. Adventive from Europe. 


\section{ANTIRRHINUM L.}

Herbs, with alternate leaves, or the lower and those of sterile shoots opposite, and red purple yellow or white flowers, in terminal racemes, or solitary in the upper axils. Calyx 5-parted, the segments imbricated. Corolla irregular, gibbous, or saccate, but not spurred, 2-lipped, the upper lip erect, 2-lobed, the lower spreading, 3-lobed, its base produced into a palate nearly or quite closing the throat. Stamens 4, didynamous, included. Style filiform. Capsule opening by chinks or pores below the summit. Seeds numerous, not winged. [Greek, noselike., About 40 species, natives of Europe, Asia and western N. Am. Besides the foliuwng some 18 others inhabit the western U. S.

Flowers $2.5-4 \mathrm{~cm}$. long; calyx-segments ovate, much shorter than the corolla.

Flowers $\mathrm{I}-\mathrm{I} .5 \mathrm{~cm}$. long; calyx-segments linear, as long as the corolla. 2. A. Orontium.

I. Antirrhinum majus L. Great Snapdragon. Lion's-mouth. (I. F. f. 3240.) Perennial, usually glandular-pubescent above, 3-9 dm. high. Leaves lanceolate, linear or oblong-lanceolate, entire, short-petioled, acute, glabrous, $2-8 \mathrm{~cm}$. long; flowers racemose, purplish-red (of a variety of colors in cultivated forms); pedicels rather stout, erect in fruit; calyx-segments obtuse, 4-6 mm. long; capsule obliquely ovoid, $8-10 \mathrm{~mm}$. high, opening by 2 pores just below the summit or at length apically 2-valved, much longer than the calyx. In waste places, escaped from gardens in the Atlantic States. Adventive from Europe. June-Sept.

2. Antirrhinum Oróntium L. Lesser Snapdragon. (I. F. f. 324I.) Annual, about $3 \mathrm{dm}$. high. Leaves narrowly linear, or the lower linear-spatulate, almost sessile, narrowed at both ends, 2-5 cm. long; flowers solitary in the upper axils, purple, $\mathbf{I}-\mathbf{1} .5 \mathrm{~cm}$. long; peduncles shorter than the flowers; calyx-segments linear, unequal, as long as the corolla, elongated in fruit so as much to exceed the pubescent capsule. In fields and waste places, Ont., N. Eng. and N. Y. Also on Vancouver Island. Adventive from Europe. June-Aug.

\section{SCROPHULÁria L. (See Appendix.)}

Perennial strong-smelling herbs, some exotic species shrubby, with mostly opposite leaves, and small purple greenish or yellow proterogynous flowers, in terminal panicled cymes or thyrses. Calyx 5-parted or 5-cleft, the segments or lobes mostly obtuse. Corolla irregular. the tube globose to oblong, not gibbous nor spurred, the limb 5 -lobed, the 2 upper lobes longer, erect, the lateral ones ascending, the lower spreading or reflexed. Stamens 5,4 of them anther-bearing and didynamous, declined; their anther-sacs confluent into one, the fifth sterile, reduced to a scale on the roof of the corolla-tube. Style filiform; stigma capitate or truncate. Capsule ovoid, septicidally dehiscent. Seeds rugose, not winged. [Named for its repute as a remedy for scrofula.] About 120 species, of the northern hemisphere. Besides the following, 2 or 3 others occur in the western U. S.

Corolla dull outside; sterile stamen deep purple.

Corolla shining outside; sterile stamen greenish yellow.

I. S. Marylandica. 2. S. leporella.

r. Scrophularia Marylándica L. Maryland Figwort, Heal-all or Pilewor'T. (I. F. f. 3242.) Glabrous below, somewhat glandular-pubescent above; stem slender, 4-angled with grooved sides, 1-3 m. high. Leaves membranous, slender-petioled, usually puberulent beneath, ovate or ovate-lanceolate, acuminate, sharply serrate, 0.7-3 dm. long; flowers greenish purple, 6-8 mm. long, numerous in the nearly leafless thyrses; bractlets mostly opposite; pedicels 8-25 mm. long; calyx-lobes broadly ovate, obtuse, about the length of the tube; corolla brownish purple and shining within, little contracted at the throat, the two lateral lobes slightly spreading, the upper lip erect, its lobes short, rounded; capsule subglobose, with a slender tip. In woods and thickets, Me. to S. Dak., N. Car., Ga. and Tenn. July-Sept.

2. Scrophularia leporélla Bicknell. Hare Figwort. (I. F. f. 3243.) Stem viscid-glandular above, sharply 4 -angled with flat sides, $\mathrm{I}-2.8 \mathrm{~m}$. tall. Leaves short-petioled, ovate to lanceolate, acuminate, mostly narrowed at the base, glabrous on both sides when mature, usually incised-dentate, $5^{-25} \mathrm{~cm}$. long; flowers 8-10 $\mathrm{mm}$. long, in elongated narrow thyrses; bractlets mostly alternate; calyx. 
Iohes ovate; corolla contracted at the throat, green to purple and shining without, dull within, the two lateral lobes erect; lobes of the upper lip often narrowly oblong; capsule ovoid-conic. In woods and along roadsides, Vt. to Conn., Minn., Va. and Kans. May-July.

\section{CHLLÒNE L.}

Perennial, mostly glabrous herbs, with upposite serrate petioled leaves, and large white red or purple flowers, in terminal and axillary dense spikes. Calyx 5parted, bracted at the base, the segments ovate or lanceolate. Corolla irregular, the tube elongated, enlarged above, the limb 2-lipped; upper lip concave, emarginate or entire, exterior in the bud; lower lip spreading, w(x)lly within, 3-lobed. Stamens 5 , included, 4 of them antheriferous, didynamous, we fifth sterile, smaller; filaments slender, woolly; anthers woolly, cordate. Style filiform; stigma small, capitate. Capsule ovoid, speticidally dehiscent. Seeds numerous, compressed, winged. [Greek, tortoise, the head of which the corolla resembles.] Three species, of eastern N. Am.

Corolla white; bracts not ciliolate.

Corolla red or rose-purple; bracts ciliolate.

Leaves oblong or lanceolate.

Leaves ovate, acuminate; mountain plant.

I. C. glabra.

2. C. obliqua.

3. C. Lyoni.

1. Chelone glàbra L. SNake-head. Türtle-head. (I. F. f. 3244.) Stem obtusely 4-sided, simple or sometimes branched, 3-9 dm. high. Leaves lanceolate, sharply serrate with low appressed teeth, acuminate at the apex, narrowed at the base, short-petioled, 7-15 cm. long, the principal veins about 10 on each side of the midvein; flowers white or faintly pink, about $2.5 \mathrm{~cm}$. long; calyx-segments ovate-oblong, obtuse; capsule obtuse, about $12 \mathrm{~mm}$. high, twice as long as the calyx. In swamps and along streams, Newf. to Fla., Manitoba and Kans. Lower leaves sometimes broadiy oval. July-Sept.

2. Chelone obliqua L. RED TURTLE-Head. (I. F. f. 3245.) Stem slender, ascending, 3-6 dm. high, the branches mostly spreading or ascending. Leaves oblong, or broadly lanceolate, acuminate at the apex, narrowed at the base, petioled, sharply serrate with somewhat spreading teeth, or laciniate, $5-15 \mathrm{~cm}$. long; petioles 4-12 mm. long; principal veins about 1o on each side; flowers red or rosepurple, about $2.5 \mathrm{~cm}$. long; bracts and calyx-segments ciliolate and usually puberulent; capsule similar to that of the preceding. In wet thickets and along streams, Va. to III. and Fla. July-Sept.

3. Chelone Lỳoni Pursh. Lyon's Turtle-hrad. (I. F. f. 3246.) Stem erect or nearly so, 3-9 dm. high. Leaves ovate, acuminate at the apex, rounded, truncate or subcordate at the base, 7-18 cm. long, usually slender-petioled, sharply serrate with divergent teeth, the principal veins 8-10 on each side; flowers red or rose-purple, about $2.5 \mathrm{~cm}$. long; bracts and calyx-segments ciliolate and puber. lent. In swamps and wet thickets, mountains of Va. (?); N. Car. and Tenn. to Ga. July-Sept.

\section{PENTStÈmON Soland. (See Appendix.)}

Perennial herbs, mostly branched from the base only, with opposite or rarely verticillate leaves, or the upper occasionally alternate, and large, blue purple red or white flowers, in terminal thyrses, panicles, or racemes. Calyx 5-parted, the segments imbricated. Corolla irregular, the tube elongated, more or less enlarged above, the limb 2-lipped: upper lip 2-lobed: lower lip 3-lobed. Stamens 5, in. cluded, 4 of them antheriferous and didynamous, the $5^{\text {th }}$ sterile, as long as or shorter than the others; anther-sacs divergent or connivent. Style filiform; stigma capitate. Capsule ovoid, oblong, or globose, septicidally dehiscent. Seeds numer. ous, wingless. [Greek, five stamens.] About roo species, of N. Am. and Mex.

* More or less pubescent or glandular, at least the calyx and pedicels.

Coroila $2-3 \mathrm{~cm}$. long: leaves entire, serrate, or denticulate.

Stem pubescentt or puberulent nearly or quite to the base.

Thyrsus open, panicle-like.

Corolla densely bearded in the throat ; pubescence villous.

Corolla scarcely bearded in the throat; pubescence canescent.

I. P. hirsutus. 
Thyrsus narrow, raceme-like or spike-like.

Corolla-tube abruptly enlarged; sterile filament densely woolly.

3. P. cristatus.

Corolla-tube gradually enlarged; sterile filament slightly bearded.

4. P. albidus.

Only the inflorescence, or pedicels, or calyx pubescent, or puberulent.

Thyrsus open, panicle-like.

Stem leaves oblong, ovate, or lanceolate.

Calyx-segments merely acute.

Corulla white, abruptly enlarged, $2.5-3 \mathrm{~cm}$. long.

Corolla purplish, gradually enlarged, $1.5^{-2} \mathrm{~cm}$. long.

Calyx-segments with long acuminate tips.

6. P. Pentstemon

Stem leaves linear-lanceolate.

Thyrsus narrow, interrupted; calyx viscid.

7. P. calycosus.

8. P. gracilis.

9. P. tubiflorus.

Corolla $5 \mathrm{~cm}$. long, the tube much enlarged above; leaves dentate. Io. $P$. Cobaea.

** Completely glabrous throughout, mostly glaucous.

Leaves lanceolate, oblong, ovate, obovate, or orbicular.

Stem leaves rounded, clasping ; flowers $5 \mathrm{~cm}$. long.

- Stem leaves acute or acuminate; flowers r.8-3 cm. long.

Corolla $1.8-2 \mathrm{~cm}$. long; stem leaves lanceolate.

Corolla $2.5-3.5 \mathrm{~cm}$. long; stem leaves mostly oblong.

Leaves linear or linear-lanceolate ; flowers densely thyrsoid.

Bracts lanceolate, small ; flowers $12-20 \mathrm{~mm}$. long.

II. P. grandiflorus.

12. P. acuminatus.

13. P. glaber.

Bracts ovate, acuminate, large : flowers $25 \mathrm{~mm}$. long or more. 15. P. Haydeni.

I. Pentstemon hirsùtus (L.) Willd. HaIry Beard-tongue. (I. F. f. 3247.) Stem hairy nearly or quite to the base, 3-9 dm. high. Leaves puberulent or glabrous, denticulate or the uppermost entire, the basal oblong or ovate, obtusish, 5-12 cm. long, narrowed into petioles, the upper sessile, lanceolate, sessile or slightly clasping; inflorescence thyrsoid, rather loose, glandular-pubescent; pedicels mostly short; corolla purplish or violet, the tube gradually dilated above, 2 -grooved on the lower side, about $2 \mathrm{~cm}$. long, the throat nearly closed by the villous palate at the base of the lower lip; sterile filament densely bearded for about one-half its length. In dry woods and thickets, Me. to Ont., Manitoba, Fla., Minn. and Tex. May-July.

2. Pentstemon canéscens Britton. Gray Beard-tongue. (I. F. f. 3248.) Densely and finely canescent or puberulent, or the leaves sometimes rearly glabrous, 3-9 dm. high. Leaves denticulate, the lower and basal ones oval, obtuse, narrowed into long margined petioles, the next $\mathbf{I}$ or 2 pairs contracted belcw the middle and somewhat fiddle-shaped, 7-15 cm. long, the upper ovate or ovate. lanceolate, acuminate, clasping; thyrsus elongated, open, glandular pubescent. leafy-bracted below; pedicels very short; calyx-segments lanceolate, acuminate; corolla purple or nearly white, about $2.5 \mathrm{~cm}$. long, slightly or not at all bearded ir. the throat: sterile filament slightly t-aarded for about one-third its length; capsule ovoil, glabrous, longer than the calyx. In dry soil, western Va., W. Va., N. C. and T'enn. May-June.

3. Pentstemon cristàtus Nutt. Crested Beard-tongue. (I. F. f. 3249.) Puberulent below, glandular-villous and viscid above; stem leafy, 1.5-4.5 dm. high. Leaves firm, entire or repand, the lower and basal ones oblong or spatu. late, 5-ro $\mathrm{cm}$. long, narrowed into margined petioles, the upper sessile or some. what clasping, acute or acuminate; thyrsus dense, narrow, leafy-bracted; flowers almost sessile; calyx-segments linear-lanceolate, acuminate; corolla about $2.5 \mathrm{~cm}$. long, red or purple, its lower lip villous within. On plains, Manitsba and the N. W. Terr. to Neb. and Nev. May-July.

4. Pentstemon álbidus Nutt. White-flowered Beard-tongue. (I. F. f. 3250.) Stem puberulent below, densely glandular-pubescent above, 1.5-2.5 dm. high. Basal and lower leaves spatulate or oblong, obtusish, mostly entire, the upper lanceolate or oblong, sessile, denticulate, acute or acuminate, 3-7 cm. long; thyrsus narrow, raceme-like, leafy-bracted, interrupted; calyx-segments lanceolate, acuminate, viscid, one-half as long as the corolla-tube; corolla white or nearly so, I. 5-2 cm. long, the limb nearly equally 5-lobed, the lobes spreading. On dry plains, S. Dak, to Colo., Neb. and Tex. June-Aug. 
5. Pentstemon Digitàlis (Sweet) Nutt. Foxglove Beard-Tongue. (I. F. f. 325I.) Glabrous; except the glandular-pubescent inflorescence, 6-I5 dm. high. Lower and basal leaves ublong or oval, entire or repand, $5-17 \mathrm{~cm}$. long, narrowed into margined petioles; upper leaves ovate, lanceolate or ovate-lanceolate, sessile and more or less cordate-clasping at the base, acuminate, sharply denticulate; thyrsus many-flowered; pedicels 2-6 mm. long; calyx-segments lanceolate; corolla limb moderately 2 -lipped, the throat open; sterile filament bearded above. In fields and thickets, Me. to Ill., Kans., Va. and Ark. Escaped from cultivation in its northeastern range. May-July.

6 Pentstemon Pentstèmon (L.) Britton. Smooth Beard-tongue. (I. F. $f$. 3252.) Glabrous, except the glandular-pubescent inflorescence, 6-9 dm. high. Basal and lower leaves oblong or oval, obtuse, 7-15 cm. long, narrowed into margined petioles, denticulate; upper leaves sessile or slightly clasping, acute, oblong or lanceolate, denticulate; thyrsus usually many-flowered; flowers nearly sessile; calyx-segments lanceolate, acute, short; corolla purple or purplish, the throat wide open, scarcely or not at all bearded; sterile filament thinly bearded for about one. half its length, or more densely above. . In woods and thickets, Penn. to Fla., Ky. and La. May-July.

7. Pentstemon calycòsus Small. Long-Sepaled Beard-Tongue. Gíabrous except a few scattered hairs in the inflorescence and lines of puberulence on the internodes, deep green. Leaves various, the basal spatulate, 5-15 cm. long, entire or undulate, with winged petioles: lower stem-leaves similar to the basal, the upper lanceolate or ovate-lanceolate, acute or acuminate, finely repand or distinctly serrate, rounded at the base and clasping; calyx-segments with a lanceolate base and a slender tip, becoming I cm. long; corolla purple, $2.5-3 \mathrm{~cm}$. long; sterile filament sparingly bearded. On bluffs, Ky. to Mo. and Ala. May-June.

8. Pentstemon grácilis Nutt. Slender Beard-Tongue. (I. F. f. 3253.) Glabrous or nearly so up to the glandular-pubescent inflorescence; stem slender, r.5-4.5 dm. high. Basal and lower leaves linear-oblong or spatulate, denticulate, or entire, $2-8 \mathrm{~cm}$. long, narrowed into margined petioles; upper leaves sessile linear-lanceolate or the uppermost lanceolate, acuminate, denticulate; thyrsu: open, several-many-flowered; pedicels 4-8 $\mathrm{mm}$. long; calyx-segments lanceolate, acute or acuminate; corolla purple, $1.8-2.5 \mathrm{~cm}$. long, its tube gradually enlarged above, its throat wide open; sterile filament bearded for about one-half its length. On moist prairies, Manitoba to Minn., Miss., the N.W. Terr. and Colo. May-July.

9. Pentstemon tubiflòrus Nutt. Funnelform Beard-tongue. (I. F. f. 3254.) Glabrous, except the viscid-pubescent calyx and pedicels; stem 6-ro dm. high, leafless above. Leaves oblong, ovate, or lanceolate, 2-10 cm. long, the basal narrowed into broad margined petioles, the upper sessile or clasping, entire or merely undulate; thyrsus narrow, interrupted, the clusters several-flowered; pedicels 2-6 mm. long; calyx-segments ovate, acuminate, short, striate-nerved; corolla ne:arly funnelform, white or purplish, less than $2.5 \mathrm{~cm}$. long, nearly as broad when expanded, its tube gradually enlarged, the limb nearly equally five-lobed; sterile filument short bearded above; capsule acute, about twice as long as the calyx. In moist soil, Mo. and Kans. to Ark. May-July.

io. Pentstemon Cobaèa Nutt. Cobaea Beard-tongue. (I. F. f. 3255.) Densely and finely pubescent below, glandular-pubescent above, 3-6 dm. high. Leaves oblong to ovate, firm, 7-I $3 \mathrm{~cm}$. long, dentate, the lower mostly glabrous and narrowed into margined petioles, the upper sessile or cordate-clasping, usually pubescent; thyrsus short; calyx-segments lanceolate, acuminate, I-I.5 cm. long; corolla purple, puberulent without, its tube narrow up to the top of the calyx, then abruptly dilated, the lobes short, rounded; sterile filament sparingly bearded; capsule ovoid, acute, pubescent, reticulate-veined. On dry prairies, Mo. and Kans. to Tex. May-July.

Ir. Pentstemon grandiflòrus Nutt. I.ARge-flowered Beard-Tongue. (I. F. f. 3256.) Somewhat glaucous, stout, 6-I2 dm. high. Leaves entire, obtuse, the basal obovate, narrowed into broad petioles, those of the lower part of the stem sessile, oblong or oval, $2.5^{-6} \mathrm{~cm}$. long, the upper nearly orbicular, cordate-clasping, shurter; thyrsus open, leafy-bracted, the bracts orbicular, cordate; calyxsegments lanceolate, acute, 6-8 $\mathrm{mm}$. long; corolla lavender-blue, the tube dilated above the calyx, the limb somewhat 2 lipped; sterile filament incurved, villous 
and capitate at the summit: capsule acute, $1 \cdot 5^{-2} \mathrm{~cm}$. high, three times as long as the calyx. On prairies, Ill. to Minn., S. Dak. and Kins. June-Aug.

I2. Pentstemon acuminàtus Dougl. Sharp-Ifaved BeARD-Tongue. (I. F. f. 3257.) Glaucous, strict, I.5-6 dm. high, leafy. Leaves firm, entire, the lower and basal ones oblong or spatulate, narrowed into petioles, the upper sessile or clasping, lanceolate or ovate-lanceolate, 5-8 cm. long; thyrsus narrow, sometimes I-sided; calyx-segments lanceolate, acute, 4-6 cm. lony ; corolla blue, its tube rather gradually dilated, the limb 2-lipped; sterile filament bearded along the dilated summit; capsule acute, twice as long as the calyx. In dry soil, N.W. Terr. to Neb., Tex., Ore. and N. Mex. May-Aug.

13. Pentstemon glàber Pursh. Large Smooth Beard-tongue. (I. F. f. 3258.) Somewhat glaucous, leafy, 3-6 dm. high. Leaves entire, firm, the basal and lower ones narrowed into petioles, the upper oblong or oblong-lanceolate, acuminate; thyrsus narrow, elongated; pedicels $6-14 \mathrm{~mm}$. long in fruit; calyx. segments ovate-lanceolate, scarious margined, abruptly acuminate, 6-8 mm. long: corolla blue or purple, rather abruptly expanded above the calyx, the limb somewhat 2-lipped, the lobes rounded; sterile filament bearded at the slightly enlarged summit; capsule narrowly ovoid, acute, about twice as long as the calyx. In moist soil, S. Dak. to Neb., Ariz., Ore. and Cal. May-Aug.

14. Pentstemon angustifjlius Pursh. Pale-Blue Beard-tongue. (I. F. f. 3259.) Glaucous; stem slender, leafy, 1.5-4 dm. high. Leaves linear, or linearlanceolate, entire, the lower narrowed into petioles, obtusish, the upper sessile, acute, 3-6.5 cm. long, 3-4 mm. wide; thyrsus narrow, spike-like, mostly dense; bracts lanceolate, acuminate; pedicels very short; calyx-segments linear-lanceolate, acuminate, 4-6 mm. long; corolla blue or nearly white, the tube gradually ealarged, the limb somewhat 2-lipped; sterile filament bearded at the summit. In dry soil, Neb. to N. Dak. and Mont. May-July.

15. Pentstemon Hàydeni S. Wats. Hayden's Beard-Tongue. (I. F. f. 3260.) Not glaucous or slightly so; stem decumbent, leafy, 3-6 dm. high. Leaves linear or elongated-lanceolate, entire, sessile and slightly clasping, acute, acuminate, or the lowest obtusish, $5^{-1} 3 \mathrm{~cm}$. long, 2-Io mm. wide; thyrsus narrow, dense; bracts ovate or ovate-lanceolate, large, cordate-clasping, acute, or acuminate; calyxsegments lanceolate, striate-nerved, acuminate, 6-10 $\mathrm{mm}$. long; corolla blue, the tube broadly dilated above the calyx, the limb nearly equally 5 -lobed; capsule acute, twice as long as the calyx. In moist soil, Neb., Kans. and Wyo.

\section{COLlínsia Nutt.}

Winter-annual herbs, with opposite or verticillate leaves, and blue, pink, white or variegated flowers, verticillate, or solitary in the axils. Calyx campanulate, 5-cleft. Corolla irregular, the tube short, the limb 2-lipped; upper lip 2-cleft, the lobes erect or recurved; lower lip larger, 3-lobed, the lateral lobes spreading or drooping, flat, the middle one conduplicate, keel-like, enclosing the 4 declined stamens and the filiform style. Stamens dilynamous. Corolla with a gland on the upper side of the tube near the base. Filaments filiform; anther-sacs confluent at the apex. Stigma small, capitate or 2-lobed. Capsule ovoid or globose, septicidally 2 -valved, the valves 2 -cleft. Seeds few, large, peltate concave on the inner side. [Named for Zaccheus Collins, botanist, of Philadelphia, 1764-1831.] About 15 species, of N. Am.

Corolla ro- $16 \mathrm{~mm}$. long, the throat shorter than the limb.

Leaves, at least the lower, ovate or oblong; corolla-lobes notched. I. C. verna.

Leaves lanceolate; corolla-lobes obcordate.

Corolla 4-6 $\mathrm{mm}$. long, the throat longer than the limb.

I. Collinsia vérna Nutt. Blue-Eyed Mary. (I. F. f. 326r.) Glabrous or puberulent; stem weak, I.5-6 dm. long. Leaves thin, opposite, the lower broadly ovate or orbicular, obtuse, crenate or entire, slender-petioled; middle leaves sessile or cordate-clasping, ovate or oblong, obtuse, dentate, 2-5 cm. long, floral leaves ovate to spatulate, mostly acute; upper whorls 4-6-flowered; corolla $12-16 \mathrm{~mm}$. long, its lower lip blue, the upper purple or nearly white; capsule globose, 5-6 mm. in diameter. In moist woods and thickets, western N. Y. and Ont. to Wis., Penn., Ky. and the Ind. Terr. April-June. 
2. Collinsia violàcea Nutt. Violet Collinsia. (I. F. f. 3262.) Similar to the preceding, stem erect, $\mathbf{x} \cdot 5-4 \mathrm{dm}$. high. Leaves lanceolate or oblong-lanceolate, rather thick, entire or denticulate, obtuse or obtusish, the lower opposite, petioled, the middle similar, sessile, 2-5 cm. long, the floral linear or linear-lanceolate; upper whorls 2-5-Howered; corolla IO-12 mm. long, violet; capsule globose, about $4 \mathrm{~mm}$. in diameter. Kans, and Ark. April-June.

3. Collinsia parvifiòra Dougl. Small-flowered Collinsia. (I. F. f. 3263.) Diffusely branched, very slender, 0.7-4 dm. long. Leaves oblong or lanceolate, mostly obtuse, $\mathbf{1}-\mathbf{2 . 5} \mathrm{cm}$. long, entire, or sparingly toothed, the lower opposite, petioled, the floral sessile; upper whorls 2-6-flowered; corolla 4-6 mm. long, about twice as long. as the calyx, blue or whitish; capsule globose, 2-3 mm. in diameter. In moist places, Ont. to Br. Col., Mich., Colo., Ariz. and Utah. April-June.

\section{ro. PAULÒWNIA Sieb \& Zucc.}

A large tree, with the aspect of Catalpa, with broad opposite petioled pubescent leaves, and large violet flowers in terminal panicles. Calyx deeply 5 . cleft, the lobes short. Corolla irregular, the tube elongated, enlarged alove, the 5 lobes spreading, somewhat unequal. Stamens 4, didynamous, included; anther-sacs divaricate. Style slender, stigmatic on the inner side. Capsule coriaceous, ovoid, acute, loculicidally dehiscent. Seeds numerous, striate, whinged. Flowers expanding before the leaves appear. [Named for Anna Paulowna, daughter of the Czar Paul I.] A monotypic Japanese genus.

I. Paulownia tomentòsa (Thunb.) Baill. Paulownia. (I. F. f. 3264.) Leaves broadly ovate, $1.5-4 \mathrm{dm}$. long, long-petioled, canescent on both sides when young, glabrate above when old; flowers about $6 \mathrm{~cm}$. long, numerous in large erect terminal panicles; pedicels stout, densely tomentose; calyx 5-lobed, the lobes thick tomentose; corolla slightly irregular, puberulent without; capsule $5 \mathrm{~cm}$. higl. Escaped from cultivation N. Y. and N. J. to D. C. and Ga. May-July.

\section{MímuLus L.}

Herbs, with opposite leaves. Flowers axillary, solitary, peduncled, pink, violet, or yellow. Calyx prismatic, 5-angled, 5-toothed. Corolla irregular, its tube cylindric with a pair of ridges on the lower side within, its limb 2-lipped; upper lip 2-lobed; lower lip spreading, 3-lobed, the lobes rounded. Stamens 4, didynamous; anther-sacs divergent, or sometimes confluent at the summit. Style filiform; stigma 2-lamellate. Capsule loculicidally dehiscent, many-seeded, enclosed by the calyx. [Diminutive of mimus, a mimic actor.] About 30 species, natives of America. Besides the following, some 20 others occur in western N. Am.

Corolla violet, or rarely white; eastern species.

Leaves sessile, clasping; peduncles longer than the calyx.

Leaves petioled; peduncles shorter than the calyx.

1. M. ringens.

2. M. alatus.

Corolla yellow; western; two species adventive in the East.

Plants glabrous or glabrate.

Erect; branches spreading; leaves ovate; flowers $2.5 \mathrm{~cm}$. long.

Diffuse: leaves nearly orbicular; flowers about $1.2 \mathrm{~cm}$. long.

Plant villous and viscid, diffuse, musk-scented.

3. M. guttatus.

4. M. Jamesii.

5. M. moschatus.

I. Mimulus ríngens L. SQuare-Stemmed Monkey-flower. (I. F. f. 3265.) Glabrous, perennial by rootstocks; stem erect, 4 -sided or somewhat 4 winged, 3-9 din. high. Leaves oblong, lanceolate. or oblong-lanceolate, acuminate or acute, serrate, auriculate-clasping, or the lower merely sessile, 5-10 cm. long; peduncles $2-5 \mathrm{~cm}$. long in fruit, 2-4 times as long as the calyx; calyx-teeth lanceolate-subulate; corolla about $2.5 \mathrm{~cm}$. long, the throat narrow, exceeding the calyx, the lower lip puberulent within at the base; fruiting calyx oblong, 12-16 mm. long; seeds oblong, minute, slightly reticulated. In swamps and along streams, N. S. to Va., Tenn., Neb. and 'Tex. June-Sept.

2. Mimulus alàtus Soland. Sharp-iwinged Monkey-flower. (I. F. f. $3=66$.) Similar to the preceding, stem sharply 4 angled, the angles winged. Leaves ovate, ovate-lanceolate, or oblong, acute or acuminate, dentate-serrate, narrowed at the base, petioled, 5-13 cm. long; petioles 6-25 mm. long; peduncles stout; calyx-teeth 
short, broad, abruptly mucronulate; seeds smooth. In swamps, Ont. to Conn., Ill. Ga., Kans. and Tex. June-Sept.

3. Mimulus guttàtus IC. Yellow Monkey-Flower. (I. F. f. 3267 ) Peremial by stolons, glabrous or puberulent. Leaves ovate to obovate, dentate or denticulate, obtuse, $2-8 \mathrm{~cm}$. long, the lower short-petioled, the upper smaller, sessile or clasping; calyx oblique; corolla $2.5-5 \mathrm{~cm}$. long, the lower lip bearded at the base, often blotched with red or purple; fruiting calyx about $12 \mathrm{~mm}$. long; seeds longitudinally striate. In wet meadows, Norfolk, Conn. and southern N. Y. Introduced from Cal. Summer.

4. Mimulus Jàmesii T. \& G. James' Mimulus. (I. F. f。 3268.) Perennial by stolons, glabrous or nearly so; stems slender, creeping, rooting at the nodes, I.5-5 dm. long. Leaves broadly ovate, orbicular or broader, very obtuse, denticulate or entire, membranous, truncate, subcordate, or rarely narrowed at the base, palmately veined, short.petioled or the upper sessile, 6-25 $\mathrm{mm}$. in diameter; peduncles slender, longer than the calyx in fruit; calyx oblique, scarcely toothed; 6-8 mm. long at maturity; corolla $8-12 \mathrm{~mm}$. long, the lower lip bearded at the base within, the throat broad; seeds nearly smooth. In brooks and swansps, Ont. to Neb., Mex., Mont. and Ariz. June-Sept.

5. Mimulus moschàtus Dougl. Musk-flower. Musk-Pzant. (1. F. f. 3269.) Perennial, viscid; stems creeping and ascending, 1.5-3 dm. long. Lezves ovate or oblong, short-petioled, denticulate, rounded or subcordate at the base, 2-5 cm. long: peduncles slender, longer than the calyx; flowers $2.5 \mathrm{~cm}$. long or less; calyx-teeth lanceolate, acuminate; corolia 2-3 limes as long as the calyx. In wet places, N. S. and Ont. to N. Y. Adventive from the Pacific Coast. JuneSept.

\section{CONÒBEA Aubl.}

Herbs, with opposite pinnately parted pinnatifid incised or serrate leaves, and small blue or white peduncled flowers, solitary or two together in the axils. Calyx 5-parted, the segments narrow, equal. Corolla irregular, the tube cylindric, the limb 2-lipped; upper lip emarginate or 2-lobed; lower lip 3-lobed. Stamens 4, didynamous, ascending, included; filaments filiform; anther-sacs parallel. Style incurved at the summit; stigma 2-lamellate. Capsule septicidally dehiscent, the valves entire or 2-cleft. Seeds numerous, oblong, striate. [Guiana name.] About 8 species, natives of America. Besides the following, another occurs in the southwestern U. S.

I. Conobea multifida (Michx.) Benth. Conobea. (I. F. f. 3270.) Annual, finely viscid-pubescent, I-2 dm. high, very leafy. Leaves petioled, $1-2.5 \mathrm{~cm}$. long, pinnately parted into 3-7 linear or linear-oblong obtuse segments; flowers greenish white, 4-5 mm. long, about as long as their filiform peduncles; calyx. segments linear-subulate, slightly shorter than the corolla; capsule narrowly ovoid, glabrous, about equalling the calyx. Along streams and rivers, Oliio to Iowa, Kans., Ky. and Tex. Introduced along the Delaware below Phila. June-Sept.

\section{MONNIÈRA P. Br. [HERPESTIS Gaertn.]}

Herbs, with opposite leaves, and small peduncled flowers, mostly solitary in the axils. Calyx 5-parted, the upper segment the broadest. Corolla irregular or nearly regular, the tube cylindric or campanulate, the limb 2-lipped or 5-lobed; upper lip 2-lobed: lower lip 3-lobed. Stamens 4, didynamous, included. Style slender; stigma capitate, or 2-lobed. Seeds numerous. [Named for Louis Guillaume le Monnier, 1713-1799, professor of botany in the Jardin du Roi, Paris.] About 60 species, of warm and tropical regions. In addition to the following, 2 others occur in the southern U. S.

Corolla almost regular, 5-lobed; leaves spatulate.

Corolla manifestly 2-lipped; leaves oblong to lanceolate or ovate.

Stem erect: leaves serrate, not clasping, black in drying.

Stem creeping or ascending; leaves ovate, punctate, entire or crenulate, clasping.

Corolla almost regular; leaves obovate or orbicular.

\section{M. Monniera.}

2. M. acuminata.

3. M. Caroliniana.

4. M. rotundifolia.

I. Monniera Monnièra (L.) Britton. Monnier's Hedge hyssop. (I. F. f. 327r.) Perennial, glabrous, fleshy; stem creeping, rooting at the nodes, $1.5-5 \mathrm{dm}$. 
long. Leaves spatulate or cuneate-obcordate, sessile, rounded at the apex, entire, or sparingly denticulate, 6-20 mm. long; peduncles mainly in alternate axils, 2 -bracteolate at the summit, in fruit longer than the leaves; flowers pale blue, about I cm. long; upper calyx-segment ovate, acute; corolla obscurely 2-lipped; stamens nearly equal: capsule ovoid, acute, shorter than the calyx. On shores near the coast, Md. to Fla., Tex. and Mex. Widely distributed in tropical regions of both the Old World and the New. June-Oct.

2. Monniera acuminàta (Walt.) Kuntze. Purple Hedge-Hyssop. (I. F. f. 3272.) Perernial, glabrous; stem 3-6 dm. high, very leafy. Leaves oblong or oblong-lanceolate, serrate, short-petioled or sessile, narrowed or cuneate at the base, 2-5 cm. long, faintly veined; peduucles in alternate and opposite axils, in fruit longer than the leaves, not bracteolate at the summit; flowers 10-12 mm. long, purple; upper calyx-segment lanceolate, acute; corolla 2-lipped, the lower lip longer than the upper; stamens approximate in pairs; capsule oblong, 4 valved, 6-8 mm. high. In wet soil, Md. and D. C. to Fla. and Tex. Plant blackening in drying, June-Sept.

3. Monniera Caroliniàna (Walt.) Kuntze. Blue Hedge-Hyssop. (I. F. f. 3273.) Perennial, pubescent, fleshy; stems creeping and ascending, rooting at the lower nodes, 1.5-6 din. long. Leaves ovate to oval, clasping by a subcordate base, obtuse, parallel-veined, punctate, entire; peduncles usually shorter than the calyx; upper calyx-segment ovate, cordate; flowers blue, 8-10 $\mathrm{mm}$. long, ephemeral; disk IO-I2-toothed; stamens approximate in pairs. In wet pine barrens, N. J. to Fla. and La. March-July.

4. Monniera rotundifolia Miclix. Round-Leaved Hedge-Hyssop. (I. F. f. 3274.) Perennial by stolons, succulent, creeping and spreading, villous-pubescent, 3-6 dm. long. Leaves obovate or orbicular, palmately veined, entire, or slightly undulate, narrowed to a sessile or clasping base, $1-2.5 \mathrm{~cm}$. broad, glabrous; peduncles shorter than the leaves, longer than the flowers; flowers blue, $6-8 \mathrm{~mm}$. long; corolla scarcely 2 -lipped, longer than the calyx; stamens approximate in pairs; stigma 2-lobed; disk obsolete; capsule obtuse, $3 \mathrm{~mm}$. high, at length 4-valved, shorter than the calyx. On muddy shores. Ill. to S. Dak., Tenn. and Tex. Also in Cal. June-Sept.

\section{GRATİolA L.}

Low herbs, with opposite leaves, and yellow or whitish peduncled flowers solitary in the axils. Peduncles 2-bracteolate at the summit in the following species. Calyx 5-parted, the segments narrow, slightly unequal. Corolla 2-lipped; upper lip entire, emarginate, or 2-cleft; lower lip 3-lobed. Perfect stamens 2, the anterior pair wanting, or rudimentary; filaments filiform; anther sacs distinct. Style filiform; stigma dilated, slightly 2-lobed. Capsule 4-valved. Seeds numerous, striate. [Latin, grace or favor, from its reputed healing properties.] About 25 species, of wide distribution. Besides the following, some 7 others occur in southern and western N. Am.

Plants glabrous or glandular; anther-sacs transverse, separated.

Sterile filaments minute or none.

Glandular-puberulent ; flowers 8-10 $\mathrm{mm}$. long ; capsule ovoid.

Glabrous; flowers I4 mm. long; capsule globose.

Sterile filaments 2, slender, capitate at the summit.

Leaves lanceolate, entire or remotely denticulate.

Leaves ovate or oblong, sharply serrate.

Plant hirsute; anther-sacs parallel, contiguous.
1. G. Virginiana.
2. G. sphaerocarpa.
3. G. aurea.
4. G. viscosa.
5. G. pilosa.

I. Gratiola Virginiàna L. Clammy Hedge.hyssop. (I. F. f. 3275.) Annual; stem glandular.puberulent, at least above, $0.7-3 \mathrm{dm}$. high. Leaves oblong or oblong-lanceolate, sessile, narrowed to both ends, denticulate, 2-5 cm. long, glabrous or nearly so; peduncles slender, glandular; flowers 8-10 mm. long: bractlets as long as the calyx, or longer; calyx about one-half as long as the yellowish corolla-tube; limb of the corolla short, white: anther-sacs separated by a broad connective: capsule broadly ovoid, $4 \mathrm{~mm}$. high, as long as the calyx. In wet places, Quebec to Br. Col., Mass., Fla., Tex. and Cal. May-Oct. 
2. Gratiola sphaerocàrpa Ell. Round-Fruited HedGe-Hyssop. (I. F.f. 3276.) Annual, glabrous, $1.5-3 \mathrm{dm}$. high. Leaves oblong or obovate-oblong, sessile, dentate or denticulate, 3-5-nerved, narrowed at the base, 2-5 cm. long; peduncles little or not at all longer than the calyx; bract'ets about equalling the calyx: calyx-lobes linear; calyx nearly one-half as long as the corolla; flowers about $1.5 \mathrm{~cm}$. long; corolla-tube yellow, the limb palir; capsule $6 \mathrm{~mm}$, in diameter. In wet places, N. J. to Fla., Ill., Tex. and Mex. Juve-Sept.

3. Gratiola aùrea Muhl. Goldenpert. Golden Hedge-hyssop. (I. F. f. 3277.) Annual, glandular-puberulent above, or glabrate, decumbent, creeping or ascending, I-3 dm. long. Leaves lanceolate, I-2.5 cm. long, sparingly denticulate, scarcely narrowed to the sessile and somewhat clasping base: peduncles filiform, in fruit equalling or longer than the calyx; corolla bright yellow, 12-14 $\mathrm{mm}$. long, 3 times as long as the calyx: capsule globose-ovoid. In sandy wet places, Quebec and Ont. to N. J. and Fla. June-Sept.

4. Gratiola viscòsa Schwein. Viscin Hedge-Hyssop. (I. F. f. 3278.) An, nual; stem weak, finely viscid-pubescent, slender, commonly simple, $1.5-5 \mathrm{dm}$. long. Leaves ovate, ovate-oblong, or ovate-lanceolate; sharply serrate, acute, ses. sile, cordate-clasping, $\mathbf{r}-2.5 \mathrm{~cm}$. long; peduncles slender; brictlets and calyx-seg. ments foliaceous, one-third to one-half as long as the yellow or purplish corolla; flowers ro-12 mm. long; capsule subglobose. shorter than the calyx. In brooks and swamps, Del. to Ky. and Ga. May-Sept.

5. Gratiola pilòsa Michx. Hairy Hedge-hyssop. (I. F. f. 3279.) Perennial ?), hirsute; stems slender, erect, strict, I.5-6 dm. high. Leaves ovate or ovate-lanceolate, dentate or denticulate, sessile, rounded, truncate or subcordate at the base, $\mathbf{I}-2.5 \mathrm{~cm}$. long; flowers nearly or quite sessile, about $8 \mathrm{~mm}$. long; corolla purplish or white, slightly longer than the calyx and bractlets; capsule oblongconic, acuminate, about the length of the calyx, or shorter. In dry soil, southern N. J. to Ark. and Tex. May-Aug.

\section{ILYSÁNTHES Raf.}

Annual or biennial glabrous slender herbs. with opposite, mostly dentate and sessile leaves, and small purplish peduncled flowers solitary in the axils. Calyx 5 parted, the segments linear. Corolla irregular, the tube somewhat expanded above, the limb 2-lipped; upper lip 2-cleft, erect; lower lip larger, 3-lobed, spreading. Fertile stamens 2, included, their anther-sacs divergent; sterile stamens 2, 2-lobed, one of the lobes capitate, glandular, the other glabrous, shorter. Style slender: stigma slightly 2 -lobed. Capsule septicidally dehiscent. Seeds numerous, wrinkled. [Greek, mud-flower.] About ro species, of wide distribution. Besides the following, 2 or 3 others occur in the southeastern U. S.

Peduncles longer than the leaves; calyx-segments shorter than the capsule.

I. I. dubia.

Peduncles shorter than the leaves; calyx-segments mostly as long as the capsule, or longer.

2. I. attenuata.

I. Ilysanthes dùbia (L.) Barnhart. Long-Stalked False Pimpernel. (I. F. f. 3280.) At length diffusely branched, 0.7-2 dm. long. Leaves ovate, ovate-oblong, or the lower obovate, sessile, or slightly clasping at the base, remotely denticulate or entire, thickish, 3-7-nerved, $1-2.5 \mathrm{~cm}$. long, the upper ones commonly much smaller; peduncles slender; flower: 6-10 mm. long; calyx-segments linear, about one-half the length of the coro 11 ; capsule narrowly ovoid-oblong, bluntish, 4-6 mm. high; seeds $2 \mathrm{~mm}$. long, reddish, the ends usually truncate. In wet places, N. E. to Fla., Ont., S. Dak. and Tex. Also on the Pacific Coast. Lower leaves sometimes short-petioled. July-Sept. [I. gratioloides Benth.]

2. Ilysanthes attenuàta (Muhl.) Small. SHort-STALken False Pimpernel. (I. F. f. 328r.) Erect or ascending, 0.7-4 dm. long, the branches spreading. Leaves oblong to ovate, or sometimes obovate, $\mathbf{r}-4 \mathrm{~cm}$. long, thinnish, obtuse, serrate with a few low teeth, 3-5-nerved, narrowed into short petioles, or sessile; calyxsegments linear-subulate, as long as the capsule, or longer; corolla 4-12 mm. long; capsule narrowly ovoid, about $4 \mathrm{~mm}$. long, pointed; seeds slightly curved, $3-4 \mathrm{~mm}$. long, yellowish brown, the ends usually rounded. In wet places, Me. and Ont. to Wis., Ark., Fla., Mo. and Kans. May-Oct. 


\section{MICRÁNTHEMUM Michx.}

Creeping or ascending, small leafy annual glabrous herbs, with opposite obovate, oval or orbicular sessile entire leaves, and minute white or purplish short-peduncled flowers. solitary in the axils. Calyx 4-5-lobed or 4-5-parted. Corolla irregular, the tube short, the upper lip shorter than the lower, or wanting, the lower 3-lobed, the middle lobe the largest. Stamens 2, anterior; filaments short, somewhat dilated or appendaged at the base; anthers small, their sacs distinct, parallel, or slightly divergent. Style short; stigma 2 -lobed. Capsule globose, 2 -celled by a membranous partition or becoming I-celled. Seeds numerous, minute. [Greek, small flower.] About I6 species, natives of America. Besides the following, another occurs in the southern U. S.

I. Micranthemum micranthemoides (Nutt.) Wettst. NutTall's MicranTHEnum. (I. F. f. 3282.) Somewhat fleshy; stem filiform, creeping, the branches ascending, I-6 cm. high. Leaves obovate to oval, obtuse, $2-5 \mathrm{~mm}$. long; flowers about $1 \mathrm{~mm}$. long. on peduncles of about the same length; calyx campanulate in flower, obovoid in fruit, 4-lobed, usually split along one side; peduncles recurved in fruit; upper lip of the corolla nearly obsolete; middle lobe of the lower lip longer than the lateral ones; appendages at the bases of the stamens nearly as long as the filaments; stigma of 2 subulate lobes; capsule obovoid-globose, I $\mathbf{m m}$. in diameter, as long as the calyx. In tidal mud, N. J. to Fla. Also in Cuba. Aug-Oct.

\section{LIMOSÉLLA L.}

Low glabrous succulent floating or creeping, tufted annual herbs (or perenrial by stolons?), with filiform stems rooting at their nodes, basal slender-petioled entire leaves, and filiform I-flowered scape-like peduncles, the flowers small, white, pink, or purple. Calyx campanulate, 5-lobed. Corolla nearly regular, open-campanulate, the tube short, the limb 5-cleft. Stamens 4, inserted on the corolla-tube, scarcely exserted; filaments short; anther-sacs confluent. Style short; stigma capitate. Ovary 2 -celled at the base, I-celled above. Capsule globose or oblong, becoming r-celled, many-seeded. [Greek, mud-seated.] About 6 species, of wide distribution.

Leaves expanded above into an oblong or linear-oblong blade.

Leaves filiform-linear, with little or no distinction between blade and petiole.

I. L. aquatica.

2 L. tenuifolia.

I. Limosella aquática L. Mudweed. Mudwort. (I. F. f. 3283.) Leaves $2-13 \mathrm{~cm}$. long, the blade obtuse, one-fourth or one-third as long as the filiform petiole. Peduncles shorter than the leaves, arising from the base of the plant or from nodes of the stem; corolla pink or white, about $2 \mathrm{~mm}$. broad, scarcely longer than the calyx; calyx-lobes ovate, acute or acutish, about the length of the tube; stamens inserted on the corolla-tube; filaments somewhat longer than the anthers; capsule obtuse, $3 \mathrm{~mm}$. high, longer than the calyx. On muddy shores and in brooks, Lab. and Hudson Bay to the N. W. Terr., Colo. and Cal. Also in Europe, Australia and S. Am. June-Aug.

2. Limosella tenuifòlia Hoffm. Narrow-Leaved Mudwort. (I. F. f. 3284.) Similar to the preceding but usually smaller, the leaves seldom over $4 \mathrm{~cm}$. high, linear-filiform, with no distinction between blade and petiole, or sometimes slightly expanded toward the apex. In brackish mud, Lab. to N. J. Also in Europe, Australia and S. Am. Summer.

\section{SÝNTHYRIS Benth.}

Perennial herbs, with thick rootstocks, simple erect stems, large petioled basal leaves, those of the stem much smaller, alternate, sessile, or clasping, bract-like. Flowers small, pink or purple, in terminal dense spikes or racemes. Calyx 4-5parted. Corolla oblong or campanulate, 2-4-lobed, or parted, or wanting, the lateral lobes, when present, exterior in the bud. Stamens 2 (occasionally 4), posterior, inserted on the corolla, or on the outer side of the hypogynous disk, exserted; filaments slender. Ovary 2-celled or rarely 3-celled; style filiform; stigma capitate. Capsule compressed, obtuse, or emarginate, many-seeded, loculicidally dehiscent, its valves adhering to the axis of the placenta; seeds flat, oval, or orbicular. [Gireek, doors closed, aliuding to the ciapsule-valves] About ro species, 
of N. Am. and Europe. Our species have been erroneously referred to the Old World genus Wulfenia.

Corolla present, usually 2-lobed.

r. S. Bullii.

Corolla none.

2. S. rubra.

I. Synthyris Bùllii (Eaton) Barnhart. Bull's Synthyris. (I. F. f. 3285.) Pubescent, 3-8 dm. high. Basal leaves ovate or orbicular, rounded at the apex, truncate, cordate or reniform at the base, crenulate, $5^{-13} \mathrm{~cm}$. long, 5-7-nerved, petioled; stem leaves $\mathbf{I}-2.5 \mathrm{~cm}$. long, sessile or slightly clasping, crenulate, passing into the bracts of the dense spike; flowers greenish yellow, 4-6 $\mathrm{mm}$. long; corolla variously 2-4-lobed (commonly 2-lobed), somewhat longer than the calyx, its lobes obtuse: spike much elongated in fruit; capsule emarginate. On (Iry prairies, Ind. to Minn., Mich. and Iowa. May-July. [Wulfenia Houghtoniana (Benth.) Greene.]

2. Synthyris rubra (Hook.) Benth. Western Synthyris. (I. F.f. 3286.) Similar to the preceding but seldom over $3 \mathrm{dm}$. high. Basal leaves ovate or cblong, 3-8 cm. long, crenulate, petioled, indistinctly nerved; stem leaves ovate or lanceolate, acute, sessile, $0.6-2.5 \mathrm{~cm}$. long: spike $5^{-1} 3 \mathrm{~cm}$. long in fruit, its bracts purplish; corolla none; capsule little compressed, emarginate. In dry soil, N. W. Terr. to S. Dak., Neb., Br. Col. and Utah. May-June. [Wulfenia rubra (Hook.) Greene.]

\section{ig VERÓNICA I. (See Appendix.)}

Herbs (some exotic species shrubs or trees), with opposite and alternate, rarely verticillate leaves, and mostly small blue, purple, pink or white flowers, racemose, spicate, or solitary. Calyx mostly 4-parted, sometimes 5 parted. Corolla rotate, its tube very short, deeply and more or less unequally 4 -lobed (rarely 5-lobed), the lower lobe commonly the narrowest. Stamens 2, divergent; anthers obtuse, their sacs confluent at the summit. Ovary .2-celled; style slender; stigma capitate. Capsule compressed, sometimes very flat, emarginate, obcordate, or 2 -lobed, loculicidally dehiscent. Seeds flat, plano-convex, or excavated on the inner side. [Named for St. Veronica.] About 200 species, of wide distribution. Besides the following, 4 others occur in northwest Am.

* Flowers racemose in the axils of the leaves, bracteolate.

Glabrous, or minutely glandular above (No. 3 rarely hairy); brook or swamp plants.

Leaves ovate, oval, oblong, or oblong-lanceolate; capsule compressed.

Stem leaves sessile, partly clasping, serrulate or entire.

All the leaves petioled, serrate.

Leaves linear or linear-lanceolate; capsule very flat.

Pubescent, dry soil plants; leaves crenate or dentate.

Leaves oval or obovate, petioled; pedicels shorter than the calyx.

4. V. officinalis.

Leaves ovate, nearly or quite sessile; pedicels longer than the calyx.

5. V. Chamaedrys.

** Flowers in terminal spikes or racemes, or sclitary in the axils.

Flowers in terminal spikes.

Leaves all sessile; capsule elliptic, emarginate.

- Lower leaves petioled; capsule orbicular, obcordate.

Flowers solitary in most of the axils: peduncles shorter than the leaves.

Erect; glabrous or glandnlar: capsule emarginate.

Diffuse; pubescent; capsule obcordate.

r. Inagallis-aquatica.

2. I. Americana.

3. I. scutellata.

lowers solitary in the axils; peduncles as long as the leaves, or longer.

Leaves ovate or oblong, crenate or dentate.

Corolla not longer than the calyx ; capsule narrowly emarginate.

ro. V. agrestis.

Corolla longer than the calyx; capsule broadly emarginate.

II. $I$. Byzantina.

12. V. hederaefolia.

Leaves orbicular, or broader, 3-5-lobed or crenate

I. Veronica Anagállis aquática L. Water Speedwell. Water PimPERNEL. (I. F. f. 3287.) Perennial by stolons or leafy shoots; stem glabrous, or glandular-puberulent above, often rooting at the lower nodes, 3-9 dm. high. Leaves of sterile autumn shoots orbiculdr to oloovate. obtuse, serrulate, narrowed into margined petioles, those of the flowering stems ovate, oblong, or lanceolate, 
sessile and clasping or the lowest short-petioled, 3-10 $\mathrm{cm}$. long; racemes peduncled, 5-13 cm. long; flowers blue, or purplish striped, $4 \mathrm{~mm}$. broad: capsule com. pressed, nearly orbicular, 2-lobed, emarginate, $3 \mathrm{~mm}$. high; seeds flat. In brooks and swamps, N. S. to Br. Col., N. C., Tenn., Va., Neb. and N. Mex. Also in Europe and Asia. May-Sept.

2. Veronica Americana Schwein. American Brooklime. (I. F. f. 3288.) Similar to the preceding, glabrous; stem decumbent, rooting at the lower nodes, 1.5-9 dm. long. Leaves oblong, ovate or oblong-lanceolate, all petioled, sharply serrate, truncate, rounded, or subcordate at the base, $2-8 \mathrm{~cm}$. long; racemes peduncled, lo sse, sometimes $1.5 \mathrm{~cm}$. long; flowers blue or nearly white, usually striped with purple, $4 \mathrm{~mm}$. broad; capsule nearly orbicular, compressed, emarginate, 3 min. high; seeds flat. In brooks and swamps, Anticosti to Alaska, Penn., Neb., N. M.x. and Cal. April-Sept.

3. Veronica scutellàta L. Marsh or Skullcap Speedwell. (I. F. f. 3289.) Glabrous, or sparingly pubescent, rarely quite hairy, perennial by leafy shoots or stolons; stems slender, decumbent, or ascending, commonly rooting at the lower nodes, 1.5-6 dm. high. Leaves linear or linear-lanceolate, sessile and slightly clasping, remotely denticulate, acute, 2-8 cm. long, 2-6 mm. wide; racemes equalling or longer than the leaves; bractlets much shorter than the filiform spreading pedicels; flowers blue, 4-6 mm. broad; capsule broader than high, deeply emarginate at the summit, slightly so at the base, 4-5 $\mathrm{mm}$. broad; seeds flat. In sw.ımps, Lab. to Br. Col., N. Y., Minn. and Cal. Also in Europe and Asia. May-Sept.

4. Veronica officinàlis L. Common Speedwell. (I. F. f. 329o.) Perennial by stolons, pubescent; stem ascending, 0.7-2.5 dm. high. Leaves oblong, oval, or obovate, petiole $\mathrm{A}, \mathbf{I}-5 \mathrm{~cm}$. lo:ig, obtuse, serrate, narrowed into the petioles; racemes spike-like, narrow, much longer than the leaves; subulate bractlets and the calyx longer than the pedicels; flowers pale blue, 4-6 $\mathrm{mm}$. broad; capsule obovate-cuneate, compressed, broadly em.rginate, $4 \mathrm{~mm}$. high; seeds flat. In dry fields and woods, N. S. to Ont., S. Dak., N. Car. and Tenn. Also in Europe and Asia. Appears, in most places, as if introduced. May-Aug.

Veronica longifolia L., an erect European species with lanceolate petioled acuminate sharply serrate leaves, has been found in a meadow near Appalachin, N. Y.

5. Veronica Chamà̀drys L. Germander Speedwell. (I. F. f. 3291.) Perennial; stem ascending, slender, pubescent in two lines, I-3 dm. high. Leaves ovate, sessile, or nearly so, pubescent, truncate, rounded or ccidate at the base, incised-dentate, obtuse, I-3 cm. long; racemes peduncled, pubescent, loose, $5^{-1} 5 \mathrm{~cm}$. long; pedicels filiform; flowers light blue, 6-8 mm. broad; capsule obcordate, seeds numerous, flattish. In fields and waste places, N. S. and Quebec to N. Y. and Penn. Nat. from Europe. May-July.

Veronica Téucrium L., also European, similar to $V$. Chamaedrys, but with oblong to lanceolate crenate leaves, has been found in Ohio and Conn.

6 Veronica Wormskiòldii R. \& S. Alpine Speedwell. (I. F. f. 320? is $V$. alpina.) Perennial; stems slender, usually simple, $5-30 \mathrm{~cm}$. high. Leaves olong, ovate, or elliptic, sessile, mostly rounded at both ends, crenulate or entire, $-2.5 \mathrm{~cm}$. long; flowers in a short narrow raceme, light blue, $4-6 \mathrm{~mm}$. broad; pedishorter than the calyx in flower, 4-6 mm. long in fruit: capsule ellipsoid or sing obovoid, moderately compressed, emarginate, 4-6 mm. high; seeds numerous, fluttish. Lab., mountains of Quebec and N. Eng. to Alaska, south in the mountains to Colo. and Nev. Apparently distinct from $V$. alpina L. of Europe.

7. Veronica serpyllifòlia L. Thyme-Leaved Speedwell. (I. F. f. 3293.) Perennial, puberulent or glabrous; stems slender, decumbent, the branches ascend. ing or erect, 5-25 cm. high. Leaves opposite, petioled, or the uppermost sessile, oblong, oval, or ovate, 6-12 mm. long, crenulate or entire; flowers in racemes; pedicels usually shorter than the bractlets; corolla pale blue with darker stripes, sometimes white, about $4 \mathrm{~mm}$. broad; capsule broader than high, broadly obcordate or emarginate, about $2 \mathrm{~mm}$. long, about equalling the calyx; seeds flat. In fields and thickets, Lab. to Alaska, Ga., N. Mex. and Cal. Also in Europe, Asia and S. Am. April-Aug. 
8. Veronica peregrina L. Purslane Speedwell. Neckweed. (I. F. fo 3294.) Annual, glabrous, or glandular-puberulent; stem $0.7-3 \mathrm{dm}$. high. Leaves oblong, oval, linear or slightly spatulate, 6-:0 $\mathrm{mm}$. long, the lowest opposite, short-petioled, or sessile, broader than the upper and usually denticulate, the upper alternate, sessile, mostly entire, each with a short pedicelled flower in its axil; flowers nearly white, about $2 \mathrm{~mm}$. broad; pedicels much shorter than the calyx; capsule nearly orbicular, obcordate, usually a little shorter than the calyx. 2-3 mm. high, the seeds flat. In moist places, and common as a weed in cultivated soil, N. S. to Br. Col., Fla., Mex. and Cal. Also in Cent. and S. Am., and as a weed in the Old World. May-O.t.

9 Veronica arvénsis L. CORN OR Wall Speedwell. (I. F. f. 3295) Annual, pubescent; stem slender, at length much branched and diffuse, $0.7-2.5 \mathrm{dm}$. long. Lower leaves ovate or oval, opposite, obtuse at both ends, crenate or crenu late, 4-12 mm. long. the lowest petioled; upper leaves sessile, alternate, ovate or lanceolate, acute or acutish, commonly entire, each with a short-pedicelled flower in its axil; peduncles shorter than the calyx; corolla blue, or nearly white, $2 \mathrm{~mm}$. broad or less; capsule broadly obovate, obcordate, $2 \mathrm{~mm}$. high. In fields, woods and waste places and in cultivated soil, N. S. to Ont. and Wash., Fla., Kans. and Tex. Also in Bermuda. Nat. from Europe. March-Sept.

io Veronica agréstis L. Field or Garden Sipeedwell. (I. F. f. 3296.) Annual, pubescent; stems creeping or procumbent, very slender, $0.7-2 \mathrm{dm}$. long, the branches ascending or spreading. Leaves broadly ovate or oval, obtuse at the apex, rounded, truncate or subcordate at the base, crenate, short-petioled, or the uppermost sessile, the lower opposite, the upper alternate and each with a slenderpeduncled small blue flower in its axil; capsule broader than high, compressed, narrowly emarginate, $4 \mathrm{~mm}$. broad; seeds few, hollowed out on the inner side. In fields and waste places, N. S. to N. J. and La. Nat. from Europe. May-Sept.

I I. Veronica Byzantina (Sibth. \& Smith) B.S.P. Buxbaums Speedwell. (I. F. f. 3297.) Annual, pubescent; stems diffusely branched, 1.5-4 dm. long. Leaves ovate or oval, short-petioled, crenate-dentate or somewhat incised, 8-25 mm. long, the lowest opposite, the upper alternate and each with a slenderperluncled rather large blue flower in its axil; corolla $6-8 \mathrm{~mm}$. broad; capsule twice as broad as high, $6 \mathrm{~mm}$. broad, with a wide and shallow emargination at the summit; seeds few or several, hollowed out on the inner side. In waste places, N. S. to N. Y. and Ohio. Adventive or nat. from Europe. May-Sept.

12. Veronica hederaefò ia L. IVY-LEAVED SpEedwell. (I. F. f. 3298.) Annual, pubescent; stems slender, diffusely branched, $0.7-4.5 \mathrm{dm}$. long. Leaves orbicular or broader, truncate or subcordate at the base, 3-5-lobed or 3-5-crenate, petioled, $0.6-2.5 \mathrm{~cm}$. in diameter, the lower opposite, the upper alternate and with slender peduncled small blue flowers in their axils; corolla $4 \mathrm{~mm}$. broad, scarcely longer than the calyx; capsule little compressed, 2-lobed, broader than high, shorter than the densely ciliate sepals, 2-4-seeded; seeds excavated on the inner side. In thickets, fields and waste places, N. Y., Penn. and N. J. to S. C. Nat. from Europe. April-Oct.

\section{LEPTÁNDRA Nutt.}

Tall, erect perennial herbs, with verticillate or opposite leaves, and small minutely bracted white or blue flowers, in dense peduncled spike-like racemes, terminal, or in the upper axils. Calyx 4-parted, short. Corolla tubular, or salverform, nearly regular, 4-lobed, the tube cylindric, longer than the lobes. Stamens 2, exserted, inserted low down on the corolla-tube; filaments filiform; anthers obtuse. Style about as long as the stamens, stigma minute. Capsule narrowly ovoid, scarcely conpressed, not emarginate nor obcordate, 4-valved at the apex. Seeds numerous, oval, minutely reticulated. [Greek, slender stamens, referring to the filaments.] Two species, one native of eastern N. Am., the other of northeastern Asia.

1. Leptandra Virgínica (I.) Nutt. Culver's-Root. (I. F. f. 3299.) Stem glabrous, or nearly so, simple, strict, 6-2I dm. high. Leaves verticillate in 3 's 9 's or some of the upper ones opposite, lanceolate or oblong-lanceolate, shortpetioled, long-acuminate, sharply serrulate, narrowed at the base, glabrous troth sides, or pubescent beneath, 7-15 cm. long; racemes $7-23 \mathrm{~cm}$. long, very dense, 
the terminal one first developing; pedicels and bractlets about as long as the calyx; calyx-segments ovate-lanceolate, acute; corolla tubular, white or bluish, $4 \mathrm{~mm}$. long; capsule 2-3 mm. long, 2-3 times as long as the calyx. In meadows, moist woods and thickets, N. S. to Br. Col., Ala., Mo. and Kans. June-Sept.

\section{DIGITÀLIS L.}

Tall herbs, with alternate leaves, and large purple, yellowish or white flowers, in long terminal commonly I-sided racemes. Calyx 5-parted, the segments imbricated. Corolla declined, somewhat irregular, the tube contracted above the ovary, then rather abruptly expanded, longer than the 4-5-lobed slightly 2 -lipped limb; upper lip emarginate or 2-cleft; lower lip 3-lobed, the middle lobe largest, the lateral ones exterior in the bud. Stamens 4, didynamous, ascending, mostly included; anthers approximate in pairs. Style slender; stigma 2-lobed. Capsule ovoid, septicidally dehiscent. Seeds numerous, rugose. [Latin, digitale, the finger of a glove, which the flowers resemble.] About 20 species, of Europe and Asia.

1. Digitalis purpùrea L. PUrple Foxglove. (I. F. f. 3300.) Usually biennial, pubescent; stem stout, erect, 6-15 dm. high. Basal and lower leaves ovate or ovate-lanceolate, $1.5-2.5 \mathrm{dm}$. long, slender petioled, acute, narrowed at the base, dentate; upper leaves similar, smaller, sessile; racemes $3 \mathrm{dm}$. long o: more, dense, I-sided; flowers purple, 3-5 cm. long, drooping; upper calyx-segment narrower than the four other foliaceous ones; corolla spotted within. Cape Breton Island, apparently nat. from Europe (according to Macoun); sparingly escaped from cultivation. Also in the Northwest. June-Aug.

\section{BÜCHNERA L.}

Erect, perennial or biennial, strict hispid or scabrous herbs, blackening in drying, the lower leaves opposite, the upper sometimes alternate. Flowers rather large, white, blue, or purple, in terminal bracted spikes, the lower commonly distant. Calyx tubular, or oblong, 5-10-nerved, 5-toothed. Corolla salverform, its tube cylindric, somewhat curved, its limb nearly equally 5-cleft, spreading, the lateral lobes exterior in the bud. Stamens 4, didynamous; anther-sacs confluent into I. Style slender, thickened or club-shaped above; stigma small, entire or emarginate. Capsule loculicidally dehiscent. Seeds numerous, reticulated. [Named for J. G. Buchner.] About 30 species, of warm and temperate regions. Besides the following, another occurs in the southern U.S.

r. Buchnera Americàna L. Blue-hearts. (I. F. f. 330I.) Hispid and rough; stem slender, $3-8 \mathrm{dm}$. high. Leaves usually all opposite, prominently veined, the lowest obovate or oblong, obtuse, narrowed into very short petioles, the middle ones oblong or oblung-lanceolate, dentate, sessile, the upper lanceolate or linear-lanceolate, entire or nearly so; spike peduncled, 1.5-2.5 dm. long in fruit, the flowers mostly opposite, nearly $2.5 \mathrm{~cm}$. long; bractlets shorter than the ralyx; calyx strigose; corolla purple, its lobes obovate, obtuse; capsule ovoid, siightly oblique, $8 \mathrm{~mm}$. high, a little longer than the calyx. In sandy or gravelly soil, N. J. to western N. Y., Minn., Va., La., Kans. and Ark. June-Sept.

\section{AFZÈLIA J. G. Gmel. [SEYMERIA Pursh.]}

Erect branched herbs, mostly with opposite leaves, at least the lower 1-2 pinnately parted or dissected, and yellow flowers solitary in the axils, or in terminal bracted spikes or racemes. Calyx campanulate, 5-cleft or 5-parted. Corolla slightly irregular, campanulate or rotate, the tube short, the limb 5-lubed, the lower lobe exterior in the bud. Stamens 4, slightly unequal; filaments short, villous, at least near the base; anthers 2-celled, the sacs parallel, distinct. Capsule acute and more or less compressed at the summit. Seeds numerous, reticulated. [Named for Adam Afzelius, I750-I812, botanical professor at Upsala.] About Io species, of N. Am., Mex. and Madagascar. Besides the following, 4 others inhabit the southern U. S.

I. Afzelia macrophýlla (Nutt.) Kuntze. Mullen Foxglove. (I. F. f. 3302.) Annual (?), puberulent or glabrate; stem sparingly branched, or simple, $12-18 \mathrm{dm}$. high. Lower leaves long-petioled, pinnately parted, 1.5-4 dm. long, their seg- 
ments lanceolate, coarsely dentate, irregularly incised, or pinnatifid; upper leaves short-petioled or sessile, oblong or lanceolate, $2-8 \mathrm{~cm}$. long, entire, each with a sessile flower in its axil; flowers $\mathbf{I}-\mathbf{I} .5 \mathrm{~cm}$. long; calyx-lobes lanceolate or ovate, acute, about as long as the tube; corolla light yellow, 2-3 times as long as the calyx, woolly in the throat; style short, club-shaped; capsule globose-ovoid, 6-8 Inm. high, twice as long as the calyx. In moist thickets and along streams, Ohio to Iowa, Neb., Ky. and Tex. Aug-Oct.

\section{DASÝSTOMA Raf.}

Large herbs, partly parasitic on the roots of other plants, with opposite (rarely whorled) or some alternate leaves, and showy yellow flowers, in terminal mostly leafy-bracted racemes or panicles. Calyx campanulate or turbinate, 5-lobed, the lobes longer than or equalling the tube. Corolla slightly irregular, funnelform, or campanulate-funnelform, the tube villous or pubescent within, the limb spreading, 5-lobed. Stamens 4, didynamous, included, villous or pubescent; filaments slender; anthers all alike, their sacs distin t, parallel, awned at the base. Style filiform. Capsule oblong, acute, loculi il ıly dehiscent, many.seeded, longer than the calyx. [Greek, thick or hairy muth, referring to the corolla.] About 8 species, of eastern N. Am.

Plants glandular-pubescent; corolla pubescent without; leaves finely divided; annuals or biennials.

Glandular-pubescent above; leaves pinnatifid.

Glandular-pubescent throughout ; leaves 2-pinnatifid.

Puberulent, cinereous or glabrous; corolla glabrous without; perennials.

Cinereous-puberulent.

Leaves entire, dentate, or some of the lower pinnatifid.

Leaves entire, undulate, or the lower pinnatifid, with entire lobes.

3. D. fluva.

Upper leaves, or most of them, serrate, the lower pinnatifid with toothed lobes.

Leaves all pinnatifid, thin.

4. D. serrata.

5. D. grandiflora.

Glabrous or very nearly so throughout.

Leaves entire, or the lowest dentate or incised.

Leaves, at least all but the uppermost, pinnatifid.

6. D. laevigata.

7. D. Virginica.

I. Dasystoma Pediculària (L.) Benth. Fern-Leaved False Foxglove. (I. F. f. 3303.) Viscid above; stem much branched, leafy, 3-12 dm. high. Leaves sessile, or the lower petioled, pinnatifid, ovate or ovate-lanceolate, usually broadest at the base, $2-8 \mathrm{~cm}$. long, the segments incised-dentate; pedicels slender, ascending, 2-5 cm. long in fruit: calyx.lobes oblong, foliaceous, usually incised or pinnatifid, 6-8 mm. long; corolla $2.5-3.7 \mathrm{~cm}$. long, the limb about $2.5 \mathrm{~cm}$. broad; capsule pubescent, IO-I $2 \mathrm{~mm}$. long, its beak flat. In dry woods and thickets, Me. and Ont. to Minn., Fla. and Mo. Aug.-Sept.

2. Dasystoma pectinàta (Nutt.) Benth. Cut-leaved False Foxglove. Similar to the preceding, but densely glandular-pubescent nearly to the base, and the leaves 2-pinnatifid; caly $x$ densely glandular-pubescent, its lobes pinnatifid. In dry soil, Ga. to Ky., Mo., Fla. and Tenn. May-Sept.

3. Dasystoma flàva (L.) Wood. Downy False Foxglove. (I. F. f. 3304.) Downy, grayish; stem strict, simple, or with a few nearly erect branches, 6-I2 dm. high. Leaves oblong, lanceolate or ovate-lanceolate, firm, entire, or the lower sinuate-dentate or sometimes pinnatifid, 7-I5 $\mathrm{cm}$. Iong, short-petioled, the lobes obtuse; the upper sessile, passing into the bracts of the raceme; pedicels stout, usually shorter than the calyx even in fruit; calyx lobes lanceolate, entire, about as long as the tube; corolla $3-5 \mathrm{~cm}$. long, its tube much expanded above; capsule 16-20 mm. long, pubescent, twice as long as the calyx. In dry woods and thickets, Mass. to Ont., Wis., Ga. and Miss. July-Aug.

4. Dasystoma serràta (Torr.) Small. Serrate False Foxglove. Puberulent, similar to the preceding and the following species. Iower leaves pinnatifid, their lobes serrate or incised; upper leaves small, serrate or entire. Calyx-teeth as long as the tube, or longer. Mo. to Ark. and La. July-Sept.

5. Dasystoma grandiflòra (Benth.) Wood. WESTERN False Foxglove. (I. F. f. 3305.) Cinereous-puberulent and roughish; stem much branched, leafy to the top, 6-9 dm. high. Leaves short-petioled, thin, ovate or ovate-lanceolate in 
outline, all pinnatifid or deeply incised, 5-10 $\mathrm{cm}$. long; upper leaves smaller, ses. sile; pedicels, even in fruit, shorter than the calyx; calyx-lobes oblong or ovate, about as long as the tube; corolla $3-5 \mathrm{~cm}$. long, its tube much expanded above. In dry woods and thickets, Minn. and Wis. to Tenn., Kans. and Tex. July-Aug.

6. Dasystoma laevigàta Raf. Entire-leaved False Foxglove. (I. F. f. 3306.) Glabrous or nearly so, not glaucous; stem simple, or sparingly branched, 3-9 dm. high. Leaves usually all petioled, lanceolate or ovate-lanceolate, $3-10 \mathrm{~cm}$. long, entire, or the lowest dentate or incised; pedicels shorter than the calyx, or in fruit longer; calyx-lobes ovate-lanceolate, equalling or shorter than the tube; corolla $2.5-4 \mathrm{~cm}$. long, the limb fully as broad, the tube much expanded above; capsule glabrous, twice as long as the calyx. In dry thickets, Penn. to Mich., south to Ga. July-Aug.

7. Dasystoma Virgínica (L.) Britton. Smooth False Foxglove. (I. F. f. 3307.) Glabrous and glaucous; stem usually branched, 9-18 dm. high. Leaves usually all petioled, ovate or ovate-lanceolate in outline, the lower 1---pimmatifid, $10-15 \mathrm{~cm}$. long, the upper pinnatifid or deeply incised, the lobes lanceolate or oblong, acute; fruiting pedicels mostly longer than the calyx; calyx-lobes ovate or ovate-lanceolate, acute, entire, about equalling the tube; corolla $3 \cdot 5-5 \mathrm{~cm}$. long, its tube not widely expanded above; capsule glabrous, twice as long as the calyx. In dry or moist woods, Me. to Minn., Fla. and Ill. July-Sept.

\section{GERÀrdia ĩ. (See Appendix.)}

Erect herbs, some South American species shrubby, mainly with opposite and sessile leaves. Flowers showy, usually large. Calyx campanulate, 5 toothed, or 5-lobed. Corolla somewhat irregular, campanulate, or funnelform, the tube broad, the limb 5-lobed, slightly 2-lipped, the lower lobes exterior in the bud. Stamens 4, didynamous, included; filaments pubescent; anthers 2-celled, their sacs obtuse or mucronate at the base; style filiform. Capsule loculicidally dehiscent, manyseeded. Seeds mostly angled. [Named for John Gerarde, surgeon and botanist, author of the Herbal (1597), died 1612.] About 40 species, natives of America. Besides the following, some ro others occur in the southern U. S.

\section{* Flowers pedicelled; anthers all alike.}

Pedicels in flower shorter than the calyx, or but $1-2$ times as long.

Corolla $2-2.6 \mathrm{~cm}$. lonir.

Calyx-teeth minute; root perennial.

Calyx-teeth triangular, lanceolate or oblong, acute; annuals.

Leaves very scabrous, filiform; capsule oblong.

Leaves slightly scabrous, linear; capsule globose.

Corolla $1-1.6 \mathrm{~cm}$. long.

Caly $x$-teeth triangular-subulate, acute.

Caly $x$-teeth broad, short, obtuse.

Pedicels in flower $2-6$ times as long as the calyx.

Leaves linear, spreading or ascending; capsule globose.

Leaves $0.5^{-2.5} \mathrm{lnm}$. wide, $\mathrm{I}-4 \mathrm{~cm}$. long.

Lobes of the corolla entire, or barely emarginate.

Corolla 12-20 mm. long, pink to purple.

Leaves linear, $2.5 \mathrm{~mm}$. wide or less.

I.eaves filiform-linear, less than $\mathrm{x} \mathrm{mm}$. wide.

Corolla less than ro $\mathrm{mm}$. long, yellowish-pink.

I.obes of the corolla all obcordate.

Leaves $2-4 \mathrm{~mm}$ wide, $4-9 \mathrm{~cm}$. long. pedicels ascending

Io. G. Besseyana.

* * Flowers sessile; anthers of the shorter stamens smaller.

Leaves lanceolate or ovate-lanceolate, entire or nearly so.

Leaves pinnately divided into 3-7 linear-segments.

r. Gerardia linifjlia Nutt. Flax-leaved Gerardia. 12. G. auriculata. 13. G. densiflora.

(I. F. f. 3308.) Glabrous, 6-9 dm. high. Leaves narrowly linear, 2-5 cm. long, 2-3 mm. wide, erect, the upper much smaller and subulate; pedicels erect, in flower equalling or a little longer than the calyx, longer in fruit; caly $x$ campanulate, truncate; corolla purple, about $2.5 \mathrm{~cm}$. long, narrower than that of the two following species, villous within, the lobes ciliate; filaments and anthers densely villous; anther-sacs mucronate at the base; capsule globose, 4-6 mm. in diameter, but little longer than the calyx. In moist pine barrens, Del. to Fla. and Cuba. Aug.-Sept. 
2. Gerardia áspera Dougl. Rough Purple Gerardia. (I. F. f. 3309.) Annual, 3-6 dm. high, hispidulous scabrous with stiff short whitish hairs, the branches nearly erect. Leaves $2.5-4 \mathrm{~cm}$. long, less than $2 \mathrm{~mm}$. wide, erect or ascending: pedicels equalling or becoming longer than the turbinate calyx; calyxteeth triangular-ovate or triangular-lanceolate, acute, one-fourth to one-third as long as the tube; corolla deep purple, about $2.5 \mathrm{~cm}$. long, nearly or quite glabrous within, very pubescent without, the lobes ciliate; filaments villous; anthers obtuse at the base; capsule oblong, 6-8 $\mathrm{mm}$. high, considerably longer than the calyx. On dry plains and prairies, Ind. to S. Dak., Kans., Mo. and Ark. Aug.-Oct.

3. Gerardia purpùrea L. Large Purple Gerardia. (I. F. f. 3310.) Glabrous, 3-8 dm. high. Leaves narrowly linear, usually widely spreading, $2.5-4 \mathrm{~cm}$. long, about $2 \mathrm{~mm}$. wide, sometimes with smaller ones fascicled in their axils; flowers racemose on the branches, purple (rarely white), about $2.5 \mathrm{~cm}$. long and broad; pedicels shorter than or but little longer than the campanulate calyx; calyx-teeth triangular-lanceolate to ovate-oblong, acute, one-third to one-half the length of the tube; corolla much expanded above, the lobes ciliolate; anther-sacs mucronulate at the base; filaments villous; capsule 4-6 mm. in diameter. In moist fields and meadows, Me. and southern Ont. to Fla., mostly near the coast. Aug.-Oct.

4. Gerardia paupércula (A. Gray) Britton. Small-flowered Gerardia. (I. F. f. 33II.) Annual, sinooth or nearly so, 1.5-4.5 dm. high, the branches nearly erect. Leaves narrowly linear, $\mathbf{I}-2.5 \mathrm{~cm}$. long, I-2 $\mathrm{n} \cdot \mathrm{m}$. wide; pedicels equalling the calyx, or longer in fruit; calyx campanulate, its teeth about one-half the length of the tube, acute, or acuminate; corolla $1.2-2 \mathrm{~cm}$. long, rose purple, its limb about as broand, somewhat villous in the throat, the lobes ciliate; stamens villous; anther-sacs mucronulate at the base; capsule $6 \mathrm{~mm}$. high. In bogs and low meadows, Quebec to N. J., Manitoba and Wis. July-Sept.

5. Gerardia marítima Raf. Sea-Side or Salt-marsh Gerardia. (I. F. f. 3312.) Annual, fleshy, I-4 dm. high, the branches ascending. Leaves linear, I-2.5 cm. long, $2 \mathrm{~mm}$. wide or less, obtuse, spreading, the uppermost very small and subulate; pedicels in flower shorter than or equalling the calyx, about twice as long in fruit; calyx-teeth obtuse; corolla rose-purple, $1-2 \mathrm{~cm}$. long, glabrous, the limb about as broad; anther-sacs mucronu'ate at the base, capsule 4-6 mm. high. In salt marshes, Me. to Fla, and La. July-Aug.

6. Gerardia tenuifòlia Vahl. Slender Gerardia. (I. F. f. 3313.) Annual, glabrous; stem slender, paniculately branched, 1.5-6 dm. high, the branches spreading or ascending. Leaves linear, acute, I-4 cm. long; pedicels mostly equalling.or longer than the flowers; calyx campanulate, its teeth short, pointed; corolla light purple, spotted, rarely white, I $2-2 \mathrm{~cm}$. long, vertically compressed when fully expanded, minutely puberulent, or glabrous; anther-sacs mucronate at the base; capsule 4-5 mm. in diameter. In dry woods and thickets, Quebec to Ga., Ont., Kans. and La. Aug.-Oct.

Gerardia tenuifolia aspérula A. Gray. Leaves scabrous on the upper surface, linearfiliform; corolla not compressed. On dry hills and banks, Ont. to Ind. and Mo.

7. Gerardia Holmiàna Greene. Holm's Gerardia. Slender, smooth or nearly so, paniculately branched, 3-5 $\mathrm{dm}$. high. Leaves filiform-linear, spreading, about $2.5 \mathrm{~cm}$. long, acute, minutely roughened; pedicels filiform, about as long as the leaves, ascending; calyx campanulate, its teeth very short, acute; corolla rosepurple, I.5 cm. long, its lobes spreading, truncate or retuse, ciliate, its throat very villous within. In dry sandy woods, Long Island to D. C. Sept.-Oct.

8. Gerardia viridis Small. SMall-flowered Gerardia. Anmual, drying green. Stems 2-6 dm. tall, sharply angled; leaves mostly opposite, narrowly linear, I-2 cm. long, acute, revolute, sessile or nearly so; pedicels ascending, 8-15 $\mathrm{mm}$. long; calyx becoming 4-5 $\mathrm{mm}$. high, the tube turbinate or campanulate-turbinate, the segments acute, about one-thirl as long as the tube: corolla yellowishpink, less than I $\mathrm{cm}$. long, the lobes ciliate, truncate, or barely emarginate. In sandy soil, Mo., Ark. and La. Summer and fall.

9. Gerardia decemlòba Greene. Ten-loben Gerarnia. Slender, about $3 \mathrm{dm}$. high, with a few branches above the middle. Leaves setaceous, about $\mathrm{I} \mathrm{cm}$. long, acute, roughish, the lower ascending, the upper spreading; pedicels about I8 $\mathrm{mm}$. long, ascending, rather stiff; calyx-tube veiny, the teeth short; corolla 
bright pink, about $\mathrm{I} \mathrm{cm}$. long, its lobes all spreading, obcordate. In grassy places, Brookland, D. C. Oct.

ro. Gerardia Besseyàna Britton. Bessey's Gerardia. (I. F. f. 3314.) Annual, strict, 3-6 dm. high, the branches ascending or nearly erect. Leaves linear, 2-5 cm. long, 2-4 mm. wide, scabrous, acute, ascending; pedicels ascend. ing, longer than the flowers; calyx campanulate, its teeth triangular-subulate, onethird to one-half the length of the tube; corolla purple, 10-12 mm. long; capsule globose, 4-6 mm. in diameter. On dry hills and prairies, Iowa to S. Dak., Colo., La. and Kans. July-Sept.

I I. Gerardia Skinneriàna Wood. Skinner's Gerardia. (I. F. f. 3315.) Annual, roughish; stem strict, striate, I.5-4.5 dm. high, slender. Leaves ascending or commonly erect and appressed, $1-2.5 \mathrm{~cm}$. long, $\mathrm{I} \mathrm{mm}$. wide or less, the uppermost minute; pedicels longer than the calyx, scarcely longer than the flowers, 2-4 times the length of the capsule; calyx-teeth minute; corolla light purple, 10$12 \mathrm{~mm}$. long and about as broad, its lobes ciliolate; capsule oblong, 4-6 mm. high. In dry sandy woods and thickets, Mass. to Fla., Minn., Kans. and La. Aug.-Oct.

12. Gerardia auriculàta Michx. Auricled Gerardia. (I. F. f. 3316.) Annual, scabrous, hirsute, 3-6 dm. high. Leaves acuminate, sessile, mostly rounded and 2-lobed at the base, or entire, $2-5 \mathrm{~cm}$. long, the basal lobes obtusish, short; flowers solitary in the upper axils, sessile, purple, $1.5^{-2} \mathrm{~cm}$. long; calyx 5-cleft, its lobes lanceolate, acute, slightly unequal, as long as or longer than the tube; corolla densely puberulent outside, glabrous within; filaments glabrous; anthers of the shorter stamens smaller than those of the longer; anther-sacs obtuse at the base; capsule oval-oblong, about $\mathbf{r . 2} \mathrm{cm}$. high, a little shorter than the calyx. In moist open soil, Penn. to Minn., N. Car. and Kans. Adventive at Woodbridge, N. J. July-Sept.

13. Gerardia densifiòra Benth. Cut-Leaved Gerardia. (I. F. f. 3317.) Annual, scabrous and short-hispid, stiff, 3-8 dm. high, very leafy. Leaves sessile, ovate in outline, ascending, about $2.5 \mathrm{~cm}$. long, pinnately parted into $3-7$ acute rigid segments less than $2 \mathrm{~mm}$. wide; flowers $2.5-3 \mathrm{~cm}$. long, rose-purple, sessile in the upper axils; calyx 5-cleft, its lobes linear, acuminate, ciliate, about as long as the tube; corolla glabrous both outside and within; anthers of the shorter stamens smaller than those of the longer; capsule about $6 \mathrm{~mm}$. high, shorter than the calyx. On dry prairies, Kans. to Tex. Aug.-Oct.

\section{CASTILLÈJA Mutis.}

Herbs, parasitic on the roots of other plants, with alternate leaves; flowers in dense leafy-bracted spikes, the bracts often brightly colored and larger than the flowers. Calyx tubular, laterally compressed, cleft at the summit on the upper side, or also on the lower. Corolla very irregular, its tube not longer than the calyx, its limb 2-lipped; upper lip (galea) arched, elongated, laterally compressed, entire, enclosing the 4 didynamous stamens; lower lip short, 3 -lobed. Anther-sacs unequal, the outer one attached to the filament by its middle, the inner one pendulous from its apex. Style filiform. Capsule loculicidally dehiscent, many-seeded. Seeds reticulated. [Named for Castillejo, a Spanish botanist.] About 5o species, mostly of the New World. In addition to the following, about 40 others occur in western N. Am.

Bracts broad, dilated, lobed, or entire.

\section{* Plants villous-pubescent.}

Stem leaves deeply and irregularly cleft into narrow segments.

Leaves linear-lanceolate, entire, or rarely with a few lobes. Bracts linear or linear-lanceolate, entire.

I. C. coccinea.

2. C. indivisa.

3. C. minor.

* * Plants glabrous, woolly at the summit, or cinereous-puberulent. Glabrous, or tomentose at the summit; leaves lanceolate, mostly entire.

Cinereous-puberulent, pale; stem leaves cleft.

4. C. acuminata.

5. C. sessiliflora.

I. Castilleja coccínea (L.) Spreng. Scarlet Painted-cup. (I. F. f. 3318.) Annual or biennial; stem simple, or with few erect branches, 3-6 dm. high. Leaves sessile, parallel-veined, the basal oblong, obovate, or linear, tufted, mostly entire, 2-8 cr.. long, those of the stem 3-5-cleft into obtusish segments, the bracts broader and shorter, 3-5-'obed or cleft, bright red or scarlet, conspicuous; flowers sessile, 
$2-2.5 \mathrm{~cm}$. long, usually not exceeding the bracts; calyx cleft above and below into 2 entire or retuse oblong obtuse lobes, sometimes scarlet; corolla greenish yellow, its tube shorter than the calyx, its upper lip much longer than the lower; capsule oblong, acute, IO-12 mm. long. In meadows and thickets, Me. and Ont. to Manitoba, N. Car., Kans. and Tex. Bracts and calyx rarely yellow. May-July.

2. Castilleja indivisa Engelm. Entire-Leaved Painted-cup. (I. F. f. 33 I9.) Winter-annual; stem 2-4.5 dm. high. Leaves sessile, parallel-veined, lin. ear to linear lanceolate, 2.5-10 cm. long, entire, or rarely with 2-4 lateral lobes; no tuft of basal leaves; bracts obovate to spatulate, bright red; flowers sessile, 2.5 $\mathrm{cm}$. long or less, not longer than the bracts; calyx cleft as in the preceding species, and corolla similar. In sandy soil, Kans. to Tex. Spring.

3. Castilleja minor A. Gray. SMALl-Flowerki Yainted-cup. (I. F. f. 3320.) Annual, strict, simple, or with 1 or 2 erect branches, 3-8 dm. high. Leaves all linear-lanceolate and entire, parallel-veined, sessile, acuminate, $5-8 \mathrm{~cm}$. long, the bracts similar, smaller, red or red-tipped; narrow, equalling or longer than the short-pedicelled flowers; calyx green, cleft on both sides to about the middle, the lobes lanceolate, acute, entire, or 2-toothed; corolla yellow, I-2 cm. long, its upper lip much longer than the small lower one; capsule oblong, acute, 12-16 $\mathrm{mm}$. long. In moist soil, Neb. (according to Gray) to N. Mex., Nev. and Ariz. May-July.

4 Castilleja acuminàta (Pursh) Spreng. LANCE-Leaved Painted-cup. (I. F. f. 332I.) Perennial; stems slender, 1.5-6 dm. high. Leaves sessile, 3-5-nerved, mostly entire, the lower linear, the upper lanceolate, acuminate or acute, $5-10 \mathrm{~cm}$. long; bracts oblong, oval or obovate, obtuse, yellowish, greenish-white or purple, as long as the sessile flowers; calyx cleft on both sides to about the middle, the lobes lanceolate, usually again 2-cleft; corolla 12-16 mm. long, its upper lip 2-4 times as long as the lower; capsule oblong. In moist soil, Lab. to Alaska, the mountains of N. Eng., Ont., Minn., Colo. and Br. Col. June-Aug.

5. Castilleja sessilifiòra Pursh. Downy Painted-cup. (I. F. f. 3322.) Perennial, cinereous-puberulent; stems stout, 1.5-4 dm. high, densely leafy. Leaves sessile, 2-5 cm. long, the lowest commonly linear, obtuse and entire, the others laciniate into narrow segments; bracts green, similar to the upper leaves, shorter than the sessile flowers; calyx deeper cleft on the lower side than on the upper, its lobes linear-lanceolate, acute: corolla yellowish, $4 \mathrm{~cm}$. long, the upper lip about twice as long as the lower, the lobes of the latter linear; capsule oblong-lanceolate. On prairies, Manitoba to the N. W. Terr., Ill., Neb., Wyo. and Tex. May-July.

\section{ORTHOCÀrPUS Nutt.}

Herbs, mostly with alternate leaves, and yellow white or purplish flowers, in bracted spikes. Calyx tubular or tubular-campanulate, 4-cleft, or sometimes split down both sides. Corolla irregular, the tube slender, the limb 2-lipped; upper lip little if any longer than the 3 -lobed $\mathbf{I - 3}$-saccate lower one. Stamens 4, didynamous, ascending under the upper lip; anther-sacs dissimilar, the outer one affixed by its middle, the inner pendulous from its upper end, ccmmonly smaller. Style filiform; stigma entire. Capsule oblong, loculicidally dehiscent, many-seeded. Seeds reticulated. [Greek, erect-fruit.] About 30 species, natives of America, mostly of the western U. S.

I Orthocarpus lùteus Nutt. Yellow Orthocarpus. (I. F. f. 3323.) Annual, rough-pubescent or puberulent; stem strict, I.5-4.5 dm. high, densely leafy. Leaves erect or ascending, linear or lanceolate, entire, or sometimes 3-cleft, 2-4 cm. long; sessile, long-acuminate; bracts of the dense spike broader and shorter than the leaves, acute, green, mostly longer than the flowers; flowers bright yellow, 8-10 mm. long: calyx-teeth acute, shorter than the tube; corolla about twice as long as the calyx, puberulent without, its upper lip ovate, obtuse, about as long as the saccate 3 -toothed lower one; capsule about as long as the calyx-tube. On dry plains, Manitoba to Minn., Neb., Br. Col. and Cal. July-Sept.

\section{SCHWÀLBEA L.}

A perennial erect finely pubescent and minutely glandular leafy herb, with sessile entire 3-nerved leaves, and rather large yellowish-purple flowers in a bracted spike. Calyx tubular, somewhat oblique, ro-12-ribbed, 2-bracteolate at the base, 5 -toothed, the upper tooth much the smallest, the 2 lower ones partly connate; 
corolla very irregular, the tube cylindric, the limb 2-lipped; upper lip arched, concave, entire; lower lip somewhat shorter, 3-lobed, 2-plaited. Stamens 4, didynamous, ascending within the upper lip; anther-sacs equal. Style filiform. Capsule oblong, many-seeded. Seeds linear, with a loose reticulated testa. [Named for C. G. Schwalbe, of Holland, who wrote (1719) on Farther India.] A monotypic genus.

I. Schwalbea Americàna L. Chaff-SeEd. (I. F. f. 3324.) Stem strict, 3-6 dm. high. Leaves oblong, or ovate-oblong, entire, acute at both ends, 2.5-4 cm. long, the upper gradually passing into the bracts of the rather loose spike; flowers nearly sessile, $2.5-4 \mathrm{~cm}$. long, longer than the bracts; bractlets at the base of the calyx linear; corolla-tube slightly exceeding the lower lobes of the calyx, these connate to near their apices: capsule enclosed by the calyx. In wet sandy soil, eastern Mass. to Fla. and La., near the coast. May-July.

\section{EUPHRASIA L. (See Appendix.)}

Low herbs, parasitic on other plants, with opposite dentate or incised leaves, and small flowers in terminal leafy-bracted spikes. Caly $\mathrm{x}$ not bracteolate, 4-cleft (rarely 5-cleft, with one of the lobes much smaller than the others). Corolla very irregular, 2-lipped, the upper lip erect, 2-lobed, its margins recurved; lower lip larger, 3-lobed, spreading, its lobes emarginate or obtuse. Stamens 4, didynamous. ascending under the upper lip; anther-sacs equal, parallel, mucronate at the base. Capsule oblong, loculicidally dehiscent, many-seeded. Seeds oblong, longitudinally ribbed. [Greek, delight.] About I 10 species, of temperate and cold regions. Besides the following, another occurs in northwestern N. Am.

Bracts, and usually the leaves, glandular, at least beneath.

Spike short; teeth of the bracts merely acute.

Spike elongated, dense; lower teeth of the bracts aristate.

Neither bracts nor leaves glandular, but usually pubescent.

Spikes elongated; bracts sharply toothed; plant $10-25 \mathrm{~cm}$. high.

Spike short, capitate; bracts bluntly toothed; plant $2-5 \mathrm{~cm}$. high.

1. E. latifolia.

2. E. Canadensis.

3. E. Americana.

4. E. Oakesii.

I. Euphrasia latifòlia Pursh. Glandular Eyebright. (I. F. f. 3325.) Stem erect, simple, or with a few erect branches, pubescent with crisped hairs, 5-18 cm. high. Leaves ovate to obovate, obtuse, 2-5-toothed on each side, the teeth sharp or blunt; spike $2-4 \mathrm{~cm}$. long, the bracts broadly oval to orbicular, cuneate at the base, sharply toothed, glandular-pubescent beneath or also on the margins; calyx-teeth acute; corolla 6-8 mm. long, lilac, or variegated; capsule oblong-elliptic, ciliate on the margins, and more or less pubescent or pilose, about as long as the calyx. Greenland to Hudson Bay and Me. Also in Europe. Summer.

2. Euphrasia Canadénsis Townsend. Spinulose Eyebright. Branched from near the base, $8-15 \mathrm{~cm}$. high, the stem and branches with crisped hairs. Leaves ovate-oblong, the teeth of the upper aristate; bracts about 5 -toothed; spike 3-7 cm. long; calyx-teeth triangular-lanceolate, aristate; corolla about $7 \mathrm{~mm}$. long; capsule truncate or emarginate, mucronate. Fields, Quebec to N. H. Summer.

3. Euphrasia Americàna Wettst. HaIRY Eyebright. (I. F. f. 3326.) Pubescent with crisped hairs; stem often at length much branched, $10-25 \mathrm{~cm}$. high. Leaves sessile, ovate to oval, 3-5-toothed on each side; the teeth acute; bracts dentate, pubescent, slightly shorter than the flowers; calyx-teeth lanceolate, acuminate; corolla 6-8 mm. long, purplish or nearly white, its lobes emarginate; capsule narrow, cuneate, $4-6 \mathrm{~mm}$. high, about equalling the calyx. In fields and on hills, Me. and N. B. to Newf. Summer.

4. Euphrasia Òakesii Wettst. OAKes' Eyebright. (I. F.f. 3227.) Stem erect or ascending, very slender or filiform, simple, $2-5 \mathrm{~cm}$. high, somewhat pubescent. Stem leaves 2 or 3 pairs. Bracts and leaves orbicular or broadly oval, narrowed or nearly truncate at the base, 4-6 $\mathrm{mm}$. long, obtuse, pubescent, with 2-5 blunt teeth on each side; spike short, capitate, only 6-10 $\mathrm{mm}$. Inng, the bracts densely imbricated; calyx-teeth triangular-lanceolate, short; corolla $2-3 \mathrm{~mm}$. long, purplish; capsule oblong-elliptic, ciliate, longer than the calyx. White Mountains of N. H. 


\section{BÀRTSIA L.}

Herbs, partly parasitic on the roots of other plants, with opposite leaves, and purple, pink, red or yellow flowers, in terminal leafy-bracted spikes. Caly x 4-toothed or 4-cleft. Corolla very irregular, the tube straight or recurved, the limb 2-lipped; upper lip erect, concave, entire; lower lip spreading, 3-lobed. Stamens 4, didynamous, ascending under the upper lip; anther-sacs similar, parallel. Capsule loculicidally dehiscent, several-many-seeded. Seeds horizontal, striate, or ribbed. [Named for John Bartsch, a Prussian botanist, died 1738.] About 6 species of the northern hemisphere.

I. Bartsia alpina L. Alpine Bartsia. (I. F. f. 3328.) Perennial by short rootstocks, pubescent, leafy, simple, or rarely with I or 2 short branches, $\mathbf{I}-2.5 \mathrm{dm}$. high. Leaves sessile, ovate, or ovate-oblong, crenate-dentate, $\mathbf{I}-2.5 \mathrm{~cm}$. long; bracts similar, smaller, mostly shorter than the flowers; spike $2-5 \mathrm{~cm}$. long; flowers $1.5^{-2} \mathrm{~cm}$. long, sometimes borne also in the upper axils; calyx 4-cleft; corolla purple, its tube much longer than the calyx; anthers pubescent, at least on the back; capsule ovoid-oblong, equalling or longer than the calyx. Lab. to Greenland and the Arctic Sea. Also in Europe. Summer.

\section{3r. ODONTİTES Gmel.}

Annual herbs, half parasitic on the roots of other plants, with small opposite leaves, and yellow or red flowers in terminal spikes or racemes. Calyx 4-toothed. Corolla with a narrow tube and a strongly 2 -lipped limb, the upper lip concave, entire, or 2-lobed, the lower 3-lobed, spreading. Stamens 4, didynamous, ascending; anther-sacs similar. Capsule loculicidally dehiscent. Seeds few, pendulous. [Greek, referring to its supposed value as a cure for toothache.] About 20 species, mostly of the Mediterranean region.

I. Odontites Odontites (L.) Wettst. Red BARTsia. ReD Eyebright. (I. F. f. 3329.) Appressed-pubescent, roughish, slender, I.5-4 dm. high, the branches erect or ascending. Leaves sessile, lanceolate, or oblong-lanceolate, acute or acuminate, serrate with low distant teeth, I-4 cm. long; spikes becoming $5^{-1} 3 \mathrm{~cm}$. long in fruit, somewhat $\mathbf{I}$-sided; bracts similar to the leaves, but smaller; flowers numerous, 8-10 $\mathrm{mm}$. long; corolla red or pink, its tube somewhat longer than the calyx: anthers slightly pubescent; capsule oblong, shorter than the calyx. In fields and waste places, Me. to N. S. Nat. from Europe. June-Sept.

\section{ELEPHANTÉLLA Rydb.}

Herbs, blackening in drying, with pinnately divided leaves and toothed segments, and flowers in terminal many-flowered spikes. Calyx obliquely campanulate, 5-toothed. Corolla 2-lipped, tube almost included in the calyx, the upper lip strongly arcuate, produced into a long filiform upturned beak, enclosing the long style, the throat with a tooth on each side; lower lip very broad, 3 -lobed. Stamens and capsule as in Pedicularis. Three or four sub-arctic or sub-alpine species of the northern hemisphere. Another species is found in the Sierra Nevada.

I. Elephantella Groenlándica (Retz.) Rydb. Long-BEaked Elephantella. (I. F. f. 3330.) Perennial, glabrous; stem simple, 3-5 dm. high. Leaves alter. nate, lanceolate in outline, acute or acuminate, pinnately parted or the lower pinnately divided into lanceolate crenulate or incised segments, the upper sessile, the lower slender-petioled, $5^{-15} \mathrm{~cm}$. long; spike very dense; calyx $5_{\text {-toothed, nearly }}$ as long as the corolla-tube, the teeth short, acutish; corolla red or purple, the galea decurved against the lower lip and upwardly recurved beyond it; body of the corolla 5-6 $\mathrm{mm}$. long; capsule obliquely ovate, about $6 \mathrm{~mm}$. long. In wet soil, Lab., Greenland and Hudson Bay to the N. W. Terr., Br. Col., N. Mex. and Cal. Summer. [Pedicularis Groenlandica Retz.]

\section{PEDICULÀRIS L.}

Herbs, with pinnately lobed cleft.or pinnatifid leaves, the flowers in terminal spikes or spike-like racemes. Calyx tubular, cleft on the lower side or sometimes also on the upper, or 2-5-tonthed. Corolla strongly 2-lipped, the upper lip (galea) laterally compressed, concave or conduplicate, sometimes beaked; lower lip erect or ascending, 3-lobed, the lobes spreading or reflexed, the middle one the smallest. 
Stamens 4, didynamous, ascendi.ig within the upper lip; anthers approximate in pairs, their sacs transverse, equal, parallel, obtuse or rarely mucronate at the base. Capsule compressed, oblique or curved, beaked, many-seeded, loculicidally dehiscent. Seeds reticulate, pitted, striate or ribbed. [Latin, pertaining to lice, long supposed to breed lice in sheep that feed on these plants.] About I25 species, mostly natives of the northern hemisphere. In addition to the following, some 25 others inhabit western N. Am.

Beak of the galea conic, decurved, $2 \mathrm{~mm}$. long.

1. P. Lapponica.

Beak of the galea very short, or none.

Annuals or biennials; stems leafy, freely branching; northern.

Puberulent; upper leaves crenulate, lower pinnatifid.

Glabrous or very nearly so; leaves all pinnatifid.

Perennials; stems leafy, simple (rarely branched in No. 6).

2. P. euphrasioides.

3. P. parviflora.

Corolla yellow, or the galea red; plants I.5-9 dm. high; eastern species.

Leaves pinnately lobed; capsule ovate, scarcely longer than the caly $x$.

4. P. lanceolata.

Leaves pinnately parted; capsule lanceolate, 3 times as long as the calyx.

Lower leaves pinnately divided; capsule ovate.

Galea crimson or purple; plant $2.5-10 \mathrm{~cm}$. high ; arctic.

Perennial; stem scapose, or I-leaved; flowers capitate ; arctic.

5. P. Canadensis.

6. P. Furbishac.

7. P. flammea.

I. Pedicularis Lappónica L. Lapland Pedicularis.

(I. F. f. 333 r.) Perennial, puberulent, leafy, I-2 dm. high. Leaves sessile, or short-petioled, alternate or the lowest opposite, lanceolate or linear-lanceolate, obtuse or acutish, $\mathrm{r}-4 \mathrm{~cm}$. long, pinnately incised into numerous approximate oblong serrulate lobes: flowers almost capitate, light yellow, 12-14 mm. long; calyx cleft on the lower side, 2-toothed on the upper; galea erect, arched. In open places, Lab. and Greenland to the Arctic Sea. Also in Arctic Europe and Asia. Summer.

Pedicularis pedicellàta Bunge, an Alaskan species is recorded by Bunge from Labrador. It is distinguished from the above by its scapose stem, deeply pinnatifid leaves and pedicellate lower flowers.

2. Pedicularis euphrasioides Steph. Eyebright Pedicularis. (I. F. f. 3332.) Puberulent, I.5-4 dm. high, the branches ascending. Lower leaves petioled, lanceolate or oblong-lanceolate in outline, 5-10 $\mathrm{cm}$. long, pinnatifid into oblong obtuse crenate-dentate segments; upper leaves sessile, linear or linearoblong, smaller, crenulate; flowers in a short terminal spike and solitary in the upper axils; calyx cleft on the lower side, 2-3-toothed on the upper, shorter than the corolla-tube; corolla yellow, or the galea purplish, about $12 \mathrm{~mm}$. long; galea as long as the tube, tipped with a very short truncate beak, minutely 2 -toothed on the lower side at the apex. Lab. to Greenland, the Arctic Sea, Alaska and Br. Col. Also in northern Asia. Summer.

3. Pedicularis parvifiòra J. E. Smith. Purple Pedicularis. (I. F. f. 3333.) Glabrous, or the petiole-bases ciliate, 3-6 dm. high. Leaves $2-5 \mathrm{~cm}$. long, alternate, or some of them opposite, oblong-lanceolate in outline, pinnatifid into oblong crenate or incised segments; flowers in terminal rather loose spikes and solitary in the upper axils, 14-16 mm. long; calyx 2-cleft, the lobes with an incised crested border; corolla purple, its tube twice as long as the calyx, the lip much shorter, the galea arched at the top, not beaked, blunt, bearing a pair of minute teeth below its summit; capsule obliquely ovate, twice as long as the calyx. Lab. to Alaska, Quebec, the N. W. Terr. and Ore. Summer.

Pedicularis palústris L., which differs from this in its larger flowers and apiculate galea, is reported from Newf. and Lab.; it is widely distributed in Europe and Asia.

4. Pedicularis lanceolàta Michx. Swamp Lousewort. (I. F. f. 3334.) Glabrous or nearly so, 3-9 dm. high. Leaves alternate and opposite, lanceolate, or linear-lanceolate, $5^{-13} \mathrm{~cm}$. long, pinnately lobed, the lower petioled, the upper sessile, the lobes oblong, obtuse, short, crenate-dentate, the margins cartilaginous; spikes short; calyx 2 -lobed, the lobes with foliaceous margins; corolla yellow, $1.5^{-2} \mathrm{~cm}$. long, the galea arched, terminated by a very short truncate beak, the lower lip erect-ascending; capsule ovate, little exceeding the calyx. In swamps, Ont. to Conn., Va., Manitoba, Minn., Ohio, Mich. and Neb. (according to Williams). Aug.-Oct. 
5. Pedicularis Canadénsis L. Wuod Betony. Lousewort. (I. F. f. 3335.) Pubescent, or glabrate below; stems commonly tufted, I.5-4.5 dm. high, simple. Leaves alternate or some of them opposite, oblong-lanceolate, 7-13 cm. long, all but the uppermost slender-petioled, pinnately parted into obtuse incised or dentate lobes; spike I-2 dm. long in fruit, the lower bracts usually foliaceous, the others small; calyx cleft on the lower-side, 2-3-crenate on the upper, oblique; corolla yellow, or reddish (rarely white) $1.5-2 \mathrm{~cm}$. long, the tube much longer than the calyx, the galea arched, incurved, minutely 2-toothed below the apex; capsule oblique, 14-16 mm. long. In dry woods and thickets, N. S. to Manitoba, Fla., Miss., Colo. and Northern Mex. April-June.

6. Pedicularis Furbíshiae S. Wats. Miss Furbish's Pedicularis. (I. F. f. 3336.) Pubescent, at least above; stem strict, simple, 6-9 dm. high. Leaves lanceolate, alternate, or some of them opposite, the lower long-petioled, I-I.5 dm. long, pinnately divided into ovate or oblong, pinnatifid or incised segments, the upper sessile, pinnately parted or lobed; calyx 5 -lobed, the lobes entire or dentate, narrow, somewhat unequal; corolla yellow, 14-18 mm. long, the galea arched, truncate, not beaked, 2-cuspidate at the apex. In swamps and along streams, Me. and N. B. July-Sept.

7. Pedicularis flámmea L. Red-tipped Pedicularis. (I. F. f. 3337.) Glabrous or somewhat wooly; stem simple, 5-10 $\mathrm{cm}$. high with several linearoblong, pinnately parted leaves. Basal and lower leaves slender-vetioled, $2.5-4 \mathrm{~cm}$. long, the uppermost sessile, the lobes ovate or oblong, incised-serrate; flowers about $12 \mathrm{~mm}$. long, pedicelled in a short spike-like raceme, longer than the narrow bracts; calyx 5 -toothed, the teeth lanceolate, acute, unequal; corolla-tube and the lower lip greenish-yellow, the galea slightly arched, blunt, much longer than the lower lip; capsule lanceolate, I2-I6 mm. long, 2-3 times as long as the calyx; fruiting pedicels 6-10 $\mathrm{mm}$. long. Lab. to Greenland and Alaska. Also in arctic and alpine Europe. Summer.

8. Pedicularis capitàta Adams. Capitate Pedicularis. (I. F. f. 3338.) Stem scapose, leafless, or I-leaved, $2.5-13 \mathrm{~cm}$. high. Leaves slender-petioled, pinnately divided, the segments ovate or oblong, incised; flowers several in a capitate cluster, 2.5-4 cm. long; calyx 5-cleft, the lobes foliaceous, incised or crenate; corolla described as white; galea scarcely broadened above, slightly curved, obtuse, twice as long as the lower lip; capsule oblong, a little longer than the calyx beaked on the outer side near the summit. Hudson Bay to Alaska. Summer.

\section{RHINÁNTHUS L.}

Annual erect herbs, with opposite leaves, and yellow, blue, violet, or variegated flowers, in terminal I-sided leafy-bracted spikes, or solitary in the upper axils. Valyx compressed, 4-toothed, much inflated, membranous and conspicuously veiny in fruit. Corolla irregular, 2-lipped, the upper lip (gålea) compressed, arched, minutely 2-toothed below the entire apex, the lower lip 3-lobed, shorter, the lobes spreading. Stamens 4, didynamous, ascending under the galea; anthers pilose, the sacs obtuse at the base, transverse, distinct. Capsule orbicular, flat, loculicidally dehiscent, several-seeded. Seeds nearly orbicular, winged. [Greek, noseflower, from the beaked corolla.] About 3 species, of the northern hemisphere.

I. Rhinanthus Crísta-Gálli L. RatTle. RatTle-box. Yellow oR Penny RatTle. (I. F. f. 3339.) Glabrous, or pubescent above; stem usually branched, 1.5-4.5 dm. high. Leaves lanceolate or oblong-lanceolate, sessile, coarsely serrate-dentate, $2-5 \mathrm{~cm}$. long; bracts broader, ovate, or ovate-lanceolate, incised dentate, the teeth acuminate or subulate-tipped; flowers yellow, 12-16 mm. long; corolla-tube longer than the calyx, commonly with a purple spot on one or both lips; fruiting calyx 8-12 mm. in diameter; capsule nearly as broad as the calyx. Newf. and Lab. to Alaska, Ore., Quebec, Conn., N. Y,. Ont. and in the Rocky Mts. to N. Mex.; on the Atlantic Coast from R. I. to N. B. Common in northern Europe and Asia. June-Aug.

\section{MELAMPỲRUM L.}

Annual herbs with opposite leaves, and small flowers solitary in the upper axils, or in bracter spikes. Calyx 4-toothed, the 2 upper teeth somewhat the longer. 
Corolla irregular, 2-lipped, the tube gradu lly enlarged above, the upper lip compressed, obtuse or emarginate with a groova behind the margins, or these recurved or with a tooth on each side; lower lip 3-toothed, 2 grooved beneath. Stamens 4, didynamous, ascending under the upper lip; anther-sacs distinct, parallel, obtuse or mucronulate at the base. Capsule flat, oblique, loculicidally dehiscent, 2-4seeded. Seeds smooth, strophiolate. [Greek, black wheat.] About 10 species, of the northern hemisphere. Only the following are known in N. Am.

Leaves lanceolate or linear-lanceolate, the floral 2-4-toothed at the base.

Leaves ovate, all entire.

I. M. lineare.

2. M. latifolium.

I. Melampyrum lineàre Lam. Narrow-leaved Cow-wheat. (I. F. f. 3340.) Puberulent; stem obscurely 4-sided above, at length widely branched, I.5-5 dm. high. Leaves lanceolate to linear-lanceolate, short-petioled, acuminate or acute, $2.5-6.5 \mathrm{~cm}$. long, the lower all entire, the upper foral ones ovate or lanceolate, with 2-6 bristle-pointed teeth near the base; flowers short-peduncled, 8-12 mm. long: calyx about one-third the length of the corolla, its subulate teeth longer than its tube; corolla white or whitish, puberulent, the lower lip yellow; capsule 8-10 $\mathrm{mm}$. long, twice as long as the calyx. In dry woods and thickets, N. S. to Br. Col., N. Car., Ky. and Minn. Variable. May-Aug.

2. Melampyrum latifolium Muhl. BroAin-Leaved Cow-wheat. (I. F. f. 3341.) Similar to the preceding, 3-5 dm. high, but the leaves all entire, shortpetioled, the lowest small, spatulate, obtuse, the middle ones lanceolate or ovate, acuminate, narrowed at the base, $5-8 \mathrm{~cm}$. long, the floral ovate or ovate-lanceolate, shorter, acute, mostly rounded at the base; corolla purple, veiny. In dry woods, Del. (according to Muhlenberg); Va. to Ga. and Tenn. June-Aug.

\section{Family Io. LENTIBULARIÀCEAE Lindl.*}

\section{Bladderwort Family.}

Aquatic plants, or terrestrial on moist ground, with the leaves basal and tufted, or borne on branching stems, or reduced to minute scales. Scapes erect. Flowers perfect, irregular, the pedicels bracteolate. Calyx inferior, 2-5-parted. Corolla 2-lipped, the upper lip usually erect, concave, or the sides plicate, entire, or 2-lobed, interior in the bud; lower lip larger, spreading or reflexed, 3 -lobed, with a palate projecting into the throat and a nectariferous spur beneath, Stamens 2; anther-sacs confluent into 1 . Ovary superior, ovoid or globose, I-celled; ovules numerous; style short, or none; stigma 2-lamellate. Fruit a capsule, irregularly bursting, or dehiscent by valves. Seeds anatropous, rugose, reticulated, or bristle-bearing; endosperm none. About 4 genera and I 80 species, widely distributed.

Aquatic or bog plants : foliage often dissected and bladder-bearing. Terrestrial ; leaves basal, tufted, entire.

I. Utricularia. 2. Pinguicula.

\section{UTRICULÀRIA L.}

Herbs, floating, or rooting in the mud, the aquatic species with stems usually bearing finely divided leaves and covered with minute bladders; marsh species with a few bladder-bearing leaves or rootlets under ground. Bladders contracted at the mouth, closed by an operculum and furnished with a few projecting bristles. Flowers racemose or solitary at the summits of slender scapes, the pedicels 2-bracteolate. Calyx deeply 2 -lobed, the lobes equal or nearly so. Corolla 2 -lipped, the upper lip usually erect and entire, the lower larger, 3-lobed, spurred at the base and with a prominent palate, commonly bearded in the throat. Capsule manyseeded. [Latin, utriculus, a bag, or little bladder.] About 150 species, of wide distribution. Besides the following, some 4 others occur in the southern U.S. 
* Scapes rooting in the mud; leaves entire; bladders usually few or none.

Scapes stout, strict, I-Io-flowered; flowers yellow, 8-20 mm. broad.

Flowers $16-20 \mathrm{~mm}$. broad; spur $12 \mathrm{~mm}$. long.

Flowers 8-10 $\mathrm{mm}$. broad; spur $6 \mathrm{~mm}$. long.

Scape filiform, 2-bracted above; flower solitary, purple.

Scape filiform, the raceme zig-zagr; flowers I-Io, yellow.

Scape filiform; flowers minute, cleistoyamous.

I. $U$. cornuta.

2. U. juncea.

3. U. resupinata.

4. U. subulata.

5. U. cleistogama.

- * Branches and finely divided leaves floating, or creeping on the mud, bladderbearing.

† Scape bearing a whorl of leaves with inflated petioles.

6. U. inflata.

$+\uparrow$ Scape leafless, or with a few minute scales.

Leaves verticillate; corolla purple.

Leaves crowded, 2-3-pinnately divided; corolla yellow, large.

Leaves scattered, dichotomously divided.

Cleistogamous flowers among the leaves.

No cleistogamous flowers.

Bladders mainly or entirely on leafless branches.

Leaf-segments linear, flat

Leaf-segments capillary.

7. U. purpurea.

8. U. vulgaris.

9. U. clandestina.

Bladders among the leaves.

Flowers 2-8; spur usually reduced to a short protuberance.

Flowers I-2; spur shorter than the lower lip, conic, gibbous.

10. $U$. intermedia.

I1. U. fibrosa.

Flowers I-3; spur oblong, as long as the lower lip.

13. U. gibba.

14. U. biflora.

I. Utricularia cornùta Michx. Horned Bladderwort. (I. F. f. 3342.) Scape strict, 0.7-4 dm. high, with or without a few scattered scales, rooting in the mud. Stems and branches root-like, sometimes with a few entire leaves and few bladders, or several; flowers I-6, yellow, fragrant; pedicels 2-4 $\mathrm{mm}$. long; lower lip of the corolla large, somewhat galeate, the sicles strongly reflexed, with a prominent palate which projects inwardly and is pubescent at the throat; upper lip smaller, obovate; spur acute, curved; seeds black, rugosely pitted. On borders of ponds, or in bogs, Newf. to Ont., Minn., Fla. and Tex. June-Aug.

2. Utricularia júncea Vahl. Rush Bladderwort. (I. F. f. 3343.) Scape strict, I.5-4 dm. high, rooting in the mud, bearing few or several minute scales. Flowers 3 10, bright yellow; pedicels $2 \mathrm{~m}$. long, or less; lower lip of the corolla obovate, pointed, mainly composed of the palate, the upper little smaller, obovate, emarginate; spur linear-subulate, slightly curved, or straight. In bogs, Va. to Fla. and Tex., mostly near the coast. Also in the W. Ind. and S. Am. July-Aug.

3. Utricularia resupinàta B. D. Greene. Reversed Bladderiwort. (I. F.f. 3344.) Scape 5-18 cm. high, 2-bracted near the flower, arising from creeping rooting shoots which rise $2-5 \mathrm{~cm}$. above the ground and bear a few branc'ses and bladders. Flower resting transversely upon the summit of the scape and sc appearing resupinate; corolla 6-10 $\mathrm{mm}$. long, the limb deeply 2-parted, remote from the conic spur. In sandy bogs and borders of ponds, Me. to Fla., west to Mich. July-Aug.

4. Utricularia subulàta L. TINY OR ZIG-ZAG Bladderwort. (I. F. f. 3345.) Scape $2.5^{-20} \mathrm{~cm}$. high, the racemes zig-zag. Leaves few, entire, they and the bladders seldom found; pedicels 4-12 mm. long, slender; corolla 4-6 mm. broad, the lower lip 3-lobed, the upper smaller, ovate; spur conic, appressed to the lower lip and equalling it in length, or shorter. In wet, sandy soil, Mass. to Fla., west to Tex., Mex. and Ark. Also in Cuba. March-Aug.

5. Utricularia cleistógama (A. Gray) Britton. Closed Bladderwort. (I. F. f. 3346.) Scape hair-like, $2-8 \mathrm{~cm}$. high, I-2-flowered. Stems root-like, sparse, sending a few minute simple shoots above ground; bladders minute, seldom seen; flowers on short bracted pedicels: corolla $\mathrm{I}-2 \mathrm{~mm}$. broad, strictly cleistogamous, spurless, the lips nearly equal, the lower varying from purplish to yellow, the upper white; seeds rugosely pitted; capsule globose. In wet soil, eastern Mass. and in the pine-barrens of N. J. August.

6. Utricularia inflàta Walt. Swollen Bladderwort. (I. F. f. 3347.) Scapes stout, $0.7-5 \mathrm{dm}$. high, bearing a whorl of 5-9 leaves at about the middle. Branches long, floating, crowded with dichotomously divided leaves and covered 
with bladders; leaves of the scape finely dissected, their petioles cylindric, inflated, dilated upward; flowers 2-ro, yellow, about $2 \mathrm{~cm}$. broad; upper lip of the corolla broadly ovate, obscurely lobed or crenate, the lower 3-lobed; spur conic, emarginate, appressed to the lower lip and about one-half its length; capsule nodding in fruit. In ponds, Canada (according to Pursh; Me. to Fla. and Tex., near the coast. March-Aug.

7. Utricularia purpùrea Walt. Purple Bladdekwort. Scape 2.5-I5 cm. high, I-4-flowered. Branches floating, long, with numerous dichotomous capillary leaves in verticils of 4's and 5's, and many large bladders; corolla violet-purple, 6-I6 mm. broad, the lower lip 3-lobed, the lateral lobes saccate; upper lip truncate, emarginate; spur nearly conic, appressed to the lower lip and one-half its length, or more. In polids, Me. to Fla., near the coast; also in Ind. May-Aug.

8. Utricularia vulgàris L. Greater Bladderwort. Hooded WaterMilfoll. Pop-WeEd. (I. F. f. 3349.) Scapes stout, 0.7-3.5 dm, high. Leaves 2-3-pinnately divided, usually crowded, the segments setaceous; branches floating, sometimes $3 \mathrm{dm}$. long, the leaves sometimes I2-I4 $\mathrm{mm}$. long, with numerous bladders; flowers 3-20, racemose, yellow; pedicels $8-16 \mathrm{~mm}$. long, recurved in fruit; corolla $12 \mathrm{lnm}$. broad or more, the sides of the lips reflexed; palate prominent; upper lip nearly entire, the lower slightly 3-lobed and longer than the conic somewhat curved spur. In brooks and ponds, Newf. to Fla., Br. Col. and Cal. Also in Europe, Asia, Cuba and Mex. June-Aug.

9. Utricularia clandestina Nutt. HIDden-Fruited Bladderwort. (I. F. f. 3350.) Scape slender, 5-I3 cm. high, arising from long floating branches. Leaves scattered, repeatedly forked, the divisions capillary, bearing numerous bladders. Flowers of two kinds; those of the scape $3-5$, complete, those among the leaves cleistogamous, numerous, their pedicels reflexed in fruit; corolla of the upper com. plete flowers yellow, spreading, $8-10 \mathrm{~mm}$. broad when expanded, the lips nearly equal in length, the lower broader and 3-lobed; spur shorter than the lower lip, thick, obtuse, approximate to it. In shallow ponds, N. B. to N. J. July.

Io. Utricularia intermèdia Hayne. Flat-leaved Bladderwort. (I. F. f. 335 I.) Scape capillary, 5-25 cm. high. Branches floating, 5-I5 cm. long; leaves 6-12 mm. long, more or less scattered, 2-ranked, repeatedly dichotomous, the segments $0.25 \mathrm{~mm}$. wide or less, the margins bristly-serrulate. Bladders, with rare exceptions, borne on leafless branches; flowers I-5, yellow; corolla $12 \mathrm{~mm}$. broad, its lower lip broad with a large palate and exceeding the upper; spur conic, subacute, nearly as long as the lip, to which it is appressed. In shallow water, Cape Breton to Br. Col., N. J., Minn. and Cal. Also in Europe. June-Aug.

I I. Utricularia fibròsa Walt. Fibrous Bladderwort. (I. F. f. 3352.) Scape slender, $0.7-3 \mathrm{dm}$. high. Leaves scattered, small or sometimes scarcely any, bladders often on leafless branches, sometimes none; flowers I-6, yellow: corolla 8-12 mm. broad, the lips nearly equal, broad, the upper undulate or 3 -lobed, the middle lobe striate; spur nearly linear, obtuse, ascending, nearly equalling or sometimes exceeding the lower lip. In shallow ponds and swamps, L. I. to Fla. and La. June-July.

12. Utricularia minor L. Lesser Bladderwort. (I. F. f. 3353.) Scapes slender, 0.5-I.8 dm. high. Branches floating, short; leaf-divisions few and setaceous; bladders borne along the leaves, few, often none, the largest not over $2 \mathrm{~mm}$. long; flowers I-IO, pale yellow, racemose; corolla 4-6 $\mathrm{mm}$. broad, ringent, the upper lip smaller than the lower; spur usually reduced to a blunt broad protuber. ance, shorter than the lips; pedicels reflexed in fruit. In shallow ponds and in bogs, Greenland and Lab. to Br. Col., N. J., Ark., Utah and Cal. Also in Europe. June-July.

I3. Utricularia gibba L. Humped Blanderwort. (I. F. f. 3354.) Scapes filiform, $2.5-13 \mathrm{~cm}$. high, arising from sparingly leafy, floating or creeping branches. Leaves root-like, in the mud or just above it, usually delicate, the divisions often only I or 2, capillary; bladders few and minute, the largest about I $\mathrm{mm}$. long, or often none; flowers I or 2 , yellow; corolla $6-8 \mathrm{~mm}$. broad, its lips rounded, broad, entire, or undulate, about equal; spur thick, conic, ascending, gibbous at the base, obtuse. shorter than the 'ips. In shallow water, Ont. to Ie., Wich., Ala. and Ill. July-Aug. 
14. Utricularia bifiora La $a_{1 . .}$ Two-FLowered BladderworT. (I. F. f. 3355.) Scapes filiform, $5-13 \mathrm{~cm}$. high, arising from long floating branches. Leaves scattered, their divisions few, finely capillary, often copiously bladder-bearing; flowers I-3, yellow; corolla 8-12 $\mathrm{mm}$. broad, the lips rounded, nearly equal; spur narrowly oblong, blunt, curved upward, equalling the lower lip. In shallow water, eastern Mass. and R. I. to Ill., La. and Tex.

\section{PINGUÍCULA L.}

fscaulescent herbs, with fibrous roots, naked I-flowered circinate scapes, and basal tufted entire leaves, the upper surface covered, with a viscid secretion to which insects adhere, and are captured by the involution of the sensitive leaf-margins. Calyx 4-5-parted, or 2-lipped, the lower lip 3-parted, the upper 2-parted. Corolla 2-lipped, the upper lip 2-cleft, the lower 3-cleft; base of the corolla saccate and contracted into a nectariferous spur. Capsule 2-valved or 4-valved. Seeds oblong, wrinkled or reticulated. [Latin, pinguis, fat, the leaves seeming greasy to the touch.] About 30 species, of wide distribution. Besides the following, 4 others are found in the southern U.S.

Scapes villous, $2-5 \mathrm{~cm}$. high ; leaves oval, 6-12 $\mathrm{mm}$. long. Scapes glabrous or minutely downy; leaves ovate or elliptic, $2-5 \mathrm{~cm}$. long.

\section{P. vulgaris.}

I. Pinguicula villòsa L. Hairy Butterwort. (I. F. f. 3356.) Scapes slender. Leaves 3 or 4 , obtuse, 6-12 $\mathrm{mm}$. long, $4-6 \mathrm{~mm}$. wide; petioles short, villous; corolla pale violet with a yellowish-striped throat, 2-lipped, the upper lip 2parted, the lower larger, 3-parted, the tube abruptly contracted into a straight linear or oblong blunt spur 3-4 mm. long. Lab. and Hudson Bay to Alaska. Also in Greenland. Summer.

2. Pinguicula vulgàris L. Butterwort. Bog or Marsi Violet. (I. F. f. 3357.) Scapes 5-15 cm. high. Leaves 3-7, greasy to the touch on the upper surface, obtuse, $2-5 \mathrm{~cm}$. long, 6-20 mm. wide, short-petioled, or sessile; corolla violet-purple, $6-8 \mathrm{~mm}$. broad, the upper lip 2 -lobed, the lower 3-lobed, larger, the tube gradually contracted into a nearly straight spur 4-8 $\mathrm{mm}$. long; capsule globose-ovoid, longer than the calyx. On wet rocks or in gravelly rivulet beds, Greenland to Alaska, Vt., N. Y., Minn. and Br. Col. Also in Europe and Asia. July-Aug.

\section{Family II. OROBANCHÀCEAE Lindl.}

\section{Broom-rape Family.}

Erect root-parasites, the leaves reduced to alternate appressed scales, the flowers perfect, irregular (rarely cleistogamous,) sessile in terminal bracted spikes, or solitary and peduncled in the axils of the scales. Calyx inferior, gamosepalous, 4-5-toothed, 4-5-cleft, or split nearly or quite to the base on one or both sides. Corolla gamopetalous, oblique, the limb 2-lipped, 5-lobed. Stamens 4, didynamous, inserted on the tube of the corolla and alternate with its lobes, a fifth rudimentary one occasionally present; filaments slender; anthers 2-celled, the sacs parallel, equal. Ovary superior, I-celled, the four placentæ parietal; ovules numerous, anatropous; style slender; stigma discoid, 2-lobed, or sometimes 4-lobed. Capsule I-celled, 2-valved. Seeds numerous, reticulated, wrinkled or striate; embryo minute ; cotyledons scarcely differentiated. About I genera and 200 species of wide distribution.

Flowers all complete and perfect.

Calyx 2-5-toothed.

Calyx about equally 5-cleft; no bracts on pedicels nor calyx. I. Thalesia.

Calyx unequally toothed, or split on both sides; flowers bracted.

2. Orobanche.

Calyx spathe-like, split on the lower side, 3-4-toothed on the upper.

Lower flowers cleistogamous, fertile; upper conplete, mostly sterile. 4. Leptamnium. 


\section{THALÈSIA Raf. [APHYLLON A. Gray.]}

Glandular or viscid-pubescent simple-stemmed herbs, parasitic on the roots of various plants, with scattered scales, and long-peduncled flowers. Calyx campanulate or hemispheric, the lobes acute or acuminate. Corolla-tube elongated, curved, the limb slightly 2 -lipped, the upper lip erect.-spreading, 2-lobed, the lower spreading, 3-lobed, the lobes all nearly equal. Stamens included; anther-sacs mucronate at the base. Ovary ovoid; style slender, deciduous; stigma peltate, or transverse. ly 2-lamellate. [Dedicated to Thales.] About 3 species, of N. Am.

Stem very short ; peduncles I-4, erect; calyx-lobes lanceolate, acuminate. Stem erect, $5^{-13} \mathrm{~cm}$. high; peduncles several; calyx-lobes broad, acute.

r. T. unifora.

2. T. fasciculata.

I. Thalesia uniflòra (L.) Britton. Pale or Naked Broom-Rape. OneFlowered BROOM-RAPE. CANCER-ROOT. (I. F. f. 3358.) Stem usually less than $2.5 \mathrm{~cm}$. long, nearly subterranean, bearing several ovate-oblong scales and I-4 erect scape-like glandular-puberulent I-flowered peduncles, 7-20 cm. high. Caly x campanulate, pubescent, glandular, 8-10 $\mathrm{mm}$. high, less than one-half the length of the corolla, its lobes as long as the tube or longer, lanceolate, acuminate; corolla white or violet, puberulent without, $1.5-2.5 \mathrm{~cm}$. long, the tube about 3 times as long as the limb, the short lobes oval or obovate, obtuse: placentæ nearly equidistant; capsule ovoid, longer than the calyx. In woods and thickets, Newf. to Br. Col., Va., Ohio, Tex. and Cal. April-June.

2. Thalesia fasciculàta (Nutt.) Britton. Clustered or Yellow CancerRooT. (I. F. f. 3359.) Stem densely glandular-pubescent, bearing several scales and 3-15 naked I-flowered peduncles $2-8 \mathrm{~cm}$. long. Calyx glandular, broadly campanulate, 6-10 $\mathrm{mm}$. high, about one-third the length of the corolla, its lobes triangular-lanceolate or triangular-ovate, acute, equalling or shorter than the tube; corolla nearly $2.5 \mathrm{~cm}$. long, purplish yellow, puberulent without, the tube 3 times as long as the limb, the lobes oblong, obtuse, the limb more manifestly 2-lipped than in the preceding species; capsule ovoid to globose. In sandy soil, Ind. to the N. W. Terr., Br. Col., Neb., Ariz. and Cal. April-Aug.

Thalesia fasciculata lùtea (Parry) Britton. Whole plant light yellow. Western Neb. and Wyo.

\section{OROBÁNCHE L.}

Glandular-pubescent herbs, parasitic on the roots of various plants, with scattered scales, and spicate or racemose, bracted and sometimes bracteolate flowers. Calyx split both above and below, nearly or quite to the base, the divisions 2-cleft or rarely entire, or unequally 2-5-toothed. Corolla oblique, strongly 2-lipped; upper lip erect, emarginate or 2-lobed; lower lip spreading, 3-lobed. Stamens included; anther-sacs mostly mucronate at the base. Style slender, commonly persistent until after the dehiscence of the capsule; stigma peltate to funnelform, entire, or laterally 2-lamellate. [Greek, Choke-vetch.] About 90 species, of the Old World and western Am. Besides the following, some 6 others occur in western N. Am.

Calyx 4-toothed; stems mostly branched.

Calyx split on both sides; stem simple.

Calyx 5-cleft; stem simple.
I. O. ramosa.

2. O. minor.

3. O. Ludoviciana.

r. Orobanche ramòsa L. HeMP OR BRANCHED BROOM-RApe. (I. F. f. 3360.) Plant yellowish; stem branched, or rarely simple, $0.7-4 \mathrm{dm}$. high, the scales few and distant, 4-ro mm. long. Spike loosely many-flowered, denser above than below, the lowest flowers short-pedicelled; bracts usually 3 , the longest about equalling the calyx; calyx-teeth triangular-ovate, acute, or acuminate, about as long as the tube; corolla $\mathbf{I - 2} \mathrm{cm}$. long, the tube yellow, slightly constricted above the ovary, the limb bluish. Parasitic on the roots of hemp and tobacco, Ky. Adventive or nat. from Europe. Summer.

2. Orobanche minor J. E. Smith. Lesser or Clover Broom-Rape. Herb. BANE. (I. F. f. 336r.) Plant yellowish-brown; stem I-5 dm. high; lower scales numerous, ovate-oblong, the upper lanceolate, acute, scattered, $6-20 \mathrm{~mm}$. long. 
Spike dense, or the lower flowers separated, 0.7-2 dm. loun; bracts lanceolate, equalling or longer than the flowers; flowers $\mathrm{I}-2 \mathrm{~cm}$. long; calyx split both above and below, each of the lateral segments 2-cleft, the teeth lanceolate-subulate; corolla-tube yellowish, scarcely constricted above the ovary, the limb bluish. Parasitic on the roots of clover, N. J. to Va. Nat. from Europe. May-July.

3. Orobanche Ludoviciaña Nutt. Louisiana Broom-RAPE. (I. F. f. 3362.) Stems stout, simple, viscid-puberulent, I-3 dm. high, scaly. Flowers I2-16 mm. long, numerous in dense terminal spikes, I-2-bracted under the calyx; calyx-lobes somewhat unequal, linear-lanceolate, acuminate; corolla 2-lipped, pur. plish, it tube narrow, about twice as long as the limb; anthers woolly; capsule ovoid-oblong, shorter than the calyx. In sandy soil, Ill. to the N. W. Terr., Tex., Ariz. and Cal. June-Aug.

\section{CONÓPHOLIS Wallr.}

An erect stout simple glabrous, densely scaly, light-brown herb, parasitic on the roots of trees, with yellowish flowers 2-bracteolate under the calyx, in a thick dense bracted spike, the bracts similar to the scales of the stem. Corolla strongly 2-lipped, the tube slightly curved, the ur.per lip concave, nearly erect, emarginate, the lower spreading, 3 -lobed. Stamens exserted; anther-sacs bristly pubescent. Placentæ about equidistant; stigma capitate, obscurely 2-lamellate. Capsule ovoid-globose. [Greek, signifying a scaly cone.] Two known species, one of eastern N. Am., the other Mexican.

r. Conopholis Americàna (L. f.) Wallr. SQuaw-Root. (I. F. f. 3363). Plants 7-25 cm. high from a thickened base, light brown, usually clustered, covered with stiff imbricated scales. Upper scales lanceolate or ovate, acute, $\mathbf{I}-2 \mathrm{~cm}$. long, the lowest much shorter; flowers about $12 \mathrm{~mm}$. long, exceedingly numerous in the dense spike which is I-2 $\mathrm{cm}$. thick; corolla pale yellow, somewhat exceeding the calyx; anthers sagittate; capsule ovoid-globose, $8-10 \mathrm{~mm}$. high. In rich woods at bases of trees, Canada?; Me. to Mich. and Fla. April-Aug.

\section{LEPTÁmNiUm Raf. [EPIFAGUS Nutt.]}

An erect slender glabrous, purplish or yellowish, rather stiff branching herb, parasitic on the roots of the beech, with few small scattered scales, and sessile dimorphous flowers, distantly spicate on the branches, the lower cleistogamous, abundantly fertile, the upper complete but mostly sterile. Calyx short, 5 -toothed. Corolla of the upper flowers cylindric, slightly flattened laterally, the tube much longer than the 4-lobed limb, the upper lobe concave, larger than the three lower ones; stamens not exserted; anther-sacs mucronulate at the base; style filiform, 2-lobed; ovary with an adnate gland on the upper side near the base. Corolla of the lower flowers minute, not unfolding, borne like a hood on the summit of the ovary: style very short; placentr contiguous in pairs; capsule at length 2-valved at the summit. [Greek referring to the small calyx.] A monotypic genus.

1. Leptamnium Virginiànum (L.) Raf. BEECH-DROPS. (I. F. f. 3364.) Plant 1.5-6 dm. high from a thick scaly base, the roots brittle, fibrous. Branches straight, ascending; corolla of the upper flowers 8-10 $\mathrm{mm}$. long, striped with purple and white, the limb not spreading; stamens about as long as the corolla; style slightly exserted; lower flowers $3 \mathrm{~mm}$. long, the corolla resembling the calyptra of a moss; capsule $6 \mathrm{~mm}$. high, somewhat oblique and compressed, manyseeded. In beech woods, N. B. to Fla., Ont., Mich., Mo. and La. Aug-Oct.

\section{Family 12. BIGNONIÀCEAE Pers.}

\section{Trumpet-creeper Family.}

Trees, shrubs or woody vines, a few exotic species herbs, with opposite (rarely alternate) leaves, and mostly large and showy, clustered, more or less irregular flowers. Calvx inferior, gamosepalous. Corolla gamopetalous, 5-lobed, somewhat 2-lipped, at least in the bud. Antherbearing stamens 2 or 4 , inserted on the tube of the corolsa and alternate with its lobes; anthers 2 -celled, the sacs longitudinally dehiscent, Disk 
annular or cup-like. Ovary mostly 2-celled; placentæ parietal, or on the partition-wall of the ovary ; ovules numerous, horizontal, anatropous ; style slender; stigma terminal, 2-lobed. Capsule 2-valved. Seeds flat, transverse, winged in our genera; endosperm none; cotyledons broad and flat, emarginate or 2-lobed; radicle short, straight. About 60 genera and 500 species of wide distribution in tropical regions, a few in the temperate zones.

Leaves compound; anther-bearing stamens 4; our species vines.

Calyx-limb undulate; capsule flattened parallel with its partition-wall.

Calyx 5-toothed; capsule compressed at right angles to its partition-wall.

1. Bignonia.

2. Tecoma.

3. Catalpa.

Leaves simple; anther-bearing stamens mostly 2; trees.

\section{BIGNÒNIA L.}

Woody vines, with opposite 2-3-foliolate leaves, the terminal leaflet usually reduced to a tendril (some tropical species with deconpound or even simple leaves), and large flowers. Calyx campanulate, the limb undulate, truncate or slightly 5-toothed. Tube of the corolla much expanded above the calyx, the limb somewhat 2-lipped, 5-lobed, the lobes rounded. Anther-bearing stamens 4, didynamous, included; anther-sacs glabrous, divergent. Capsule linear, septifragally deliscent, the margins of the valves more or less thickened. Seeds in I or 2 rows on both margins of the partition, winged, much broader than high, the wing entire, or erose at the end. [Named after the Abbe Bignon, I662-1743, librarian to Louis XV.] About I50 species, natives of America. The following is the only one known in the U. S.

I. Bignonia crucígera L. Tendrillen Trumpet-flower. Cross-vine. (I. F. f. 3365.) Glabrous, climbing, the stems sometimes I dm. in diameter, exhibiting a cross in the transverse section. Leaves petioled, commonly with small simple stipule like ones in their axils, 2-foliulate, terminated by a branched tendril; leaflets stalked, oblong or ovate, entire, acute or acuminate at the apex, cordate at the base, 7-17 cm. long; cymes numerous, short peduncled, 2-5-flowered; pedicels 2-5 cm. long: caly $\mathbf{x}$ membranous; corolla $5 \mathrm{~cm}$. long, orange and puberulent without, yellow within; capsule $13-17 \mathrm{~cm}$. long, very flat, each valve longitudinally I-nerved; seeds broadly winged laterally, narrowly winged above and below. In moist woods, Va. to Fla., La., Ohio and Ill. April-June.

\section{TECÒMA Juss.}

Climbing woody vines with aerial rootlets, or erect shrubs, with opposite pin. nately compound or sometimes simple leaves, and large red or orange flowers, in terminal corymbs, racemes, or panicles. Calyx tubular-campanulate, unecually 5 toothed. Corolla-tube elongated, enlarged above the calyx, narrowly campanulate, the limb slightly 2-lipped, 5-lobed, the lubes spreading. Anther-bearing stamens 4, didynamous, ascending under the upper lip: anther-sacs divergent, glahrous or slightly pubescent. Capsule elongated, loculicidally and septicidally dehiscent. Seeds in 1,2 or several rows on each side of the margins of the partition, winged, the wing translucent. [From the Aztec name Tecomaxochitl.] About 80 species, of warm and temperate regions. Besides the following, another occurs in the southern U. S.

1. Tecoma radicans (L.) DC. Trumpet-Flower. Trumpet-creeper. (I. F. f. 3366.) Leaves petioled, odd-pinnate, not tendril-bearing, 2-4 dm. long; leaflets 7-II, ovate to lanceolate, short-stalked, sharply serrate, reticulate-veined, glabrous, or pubescent on the veins beneath, acute or acuminate, 3-7 cm. long; flowers corymbose, short-pedicelled; corymbs 2-9-flowered; calyx coriaceous, about $2.5 \mathrm{~cm}$. long; corolla scarlet, $6-7 \mathrm{~cm}$. long, the tube veined within, 3 times as long as the limb; anther-sacs glabrous; stigma spatulate; capsule stalked, ro-r 5 $\mathrm{cm}$. long, $2 \mathrm{~cm}$. in diameter, narrowed at both ends, little flattened, ridged above and below by the margins of the valves; seeds in several rows on each surface of the partition, broadly winged laterally, the wing eroded. In moist woods and 
thickets, N. J. and Penn. to Fla., Tex., Kans. and Ill. Escaped from cultivation further north. Aug.-Sept.

\section{CATÁLPA Scop.}

Trees, or some exotic species shrubs, with opposite or rarely verticillate simple petioled leaves, and large white or mottled flowers in terminal panicles, or corymbs. Calyx closed in the bud, splitting irregularly or into 2 lips in opening. Corollatube oblique, expanded above, 2 -lipped, 5-lobed, the lobes all spreading, their mar. gins crisped. Anther-bearing stamens 2, ascending under the upper lip of the corolla; anther-sacs glabrous, linear or oblong, divergent; sterile stamens (stami. nodia) 3, short (or occasionally 4 perfect didynamous stamens and I staminodium). Disk obsolete. Ovary sessile, 2-celled; ovules in 2-several rows on the sides of the partition. Capsule elongated-linear, terete, loculicidally dehiscent. Seeds flat, the large lateral wings dissected into capillary processes. [The American Indian name of the first species below.] About 7 species, the following in N. Am., 2 in eastern Asia, 2 or 3 in the W. Ind.

Corolla thickly spotted within, $2.5-4 \mathrm{~cm}$. long, the lower lobe entire. Corolla little spotted, $5 \mathrm{~cm}$. long, the lower lobe emarginate.

I. C. Catalpa.

2. C. speciosa.

r. Catalpa Catálpa (L.) Karst. Catalpa. Indian Bean. Candle-tree. BEAN-TREe. (I. F. f. 3367.) A tree, with thin flaky bark, the branches spreading. Leaves strong-scented, broadly ovate, entire, or 3-lobed, acute or acuminate, densely pubescent beneath, becoming glabrous above, obtuse at the base, 1.5-3 dm. long, the lobes, when present, acuminate; petioles.stout, nearly as long as the blade; flowers white, numerous, mottled with yellow and purple within, in large terminal erect panicles; corolla-tube campanulate, the lower lobe entire; capsules 2.5-3.3 dm. long, 8-10 mm. thick, thin-walled, drooping. In woods in the Gulf States. Escaped from cultivation northward as far as Penn. and southern N. Y. June-July. [C. bignonioides Walt.]

2. Catalpa speciòsa Warder. Catawba Tree. Larger Indian Bean. (I. F. f. 3368.) A tree, with thick rough bark, similar to the preceding. Leaves not unpleasantly scented, broadly ovate, commonly entire, long-acuminate; panicles few-flowered: corolla faintly mottled within, the tube obconic, the limb only slightly oblique, the lower lobe emarginate; capsule thick-walled, 2.5-5 dm. long, nearly $2 \mathrm{~cm}$. in diameter. In woods, Ill. to Tenn., Mo. and Ark. May-June.

\section{Family 13. MARTYNIÀCEAE Link. Unicorn-plant Family.}

Herbs, with opposite leaves, or the upper alternate, and perfect irregular flowers, racemose in our species. Calyx inferior, 4-5-cleft or 4-5 parted, or sometimes split to the base on the lower side. Corolla gamopetalous, irregular, the tube oblique, the limb slightly 2-lipped, 5 -lobed, the lobes nearly equal, the 2 upper ones exterior in the bud. Anther-bearing stamens 4, didynamous, or the posterior pair sterile; anthers 2-celled, the sacs longitudinally dehiscent. Ovary I-celled, with 2 parietal placentæ expanded into broad surfaces, or 2-4-celled by the intrusion of the placentæ or by false partitions; ovules, anatropous; style slender; stigma 2 -lobed or 2-lamellate. Seefs com pressed; endosperm none; embryo large; cotyledons fleshy, flat; ra dicle short, straight. Three genera and ro species, mainly tropical.

\section{MARTÝNIA L.}

Coarse glandular-pubescent and viscid strong-scented herbs, with long-petioled leaves, and large flowers in short terminal racemes. Calyx 1-2-bracteolate at the base. campanulate, inflated, deciduous. Corolla funnelform-campanulate. Anthers gland-tipped, their sacs divergent. Ovary I-celled, the 2 parietal placentæ intruded and expanded in the center of the cavity into broad surfaces bearing the ovules in 1 or 2 rows. Fruit an incurved beaked loculicidally 2 -valved capsule, 
the exocarp somewhat fleshy, the endocarp fibrous, woody, crested below or also above, 4-celled by the extension of the placentæ. Seeds numerous, tuberculate. [Named for John Martyn, 1693-1768, professor of botany at Cambridge, England.] About 8 species, natives of America. Besides the following, 2 others occur in the southwestern U. S.

I. Martynia Louisiàna Mill. Unicorn-plant. Elephant's Trunk. Dou. BI.E CLAW. (I. F. f. 3369.) Annual; stem stout, the branches prostrate or ascend. ing, 3-10 dm. long. Leaves broadly ovate to orbicular, rounded at the apex, cordate at the base, repand, undulate or entire, $0.7-3 \mathrm{dm}$. in diameter, the petiole stout; calyx somewhat cleft on the lower side; racemes several-flowered; pedicels slender; corolla whitish or yellowish, mottled with purple or yeilow within, 3-5 cm. long, the lobes obtuse; fruit curved, 1-1.5 dm. long, the beak longer than the body, splitting into 2 elastically diverging segments, the endocarp crested on the under side. In waste places, escaped from gardens, Me. to N. J. and N. Car. Native from Iowa, IIl. and Kans. southward. July-Sept. [M. proboscidea Gilox.]

\section{Family 14. ACANTHÀCEAE J. St. Hil.}

Acanthus Family.

Herbs, or some tropical genera shrubs or small trees, with opposite simple exstipulate leaves, and irregula: or nearly regular perfect flowers. Calyx inferior, persistent, 4-5-parted or 4-5-cleft, the sepals or segments imbricated. Corolla gamopetalous, nearly regularly 5-lobed, or 2-lipped. Anther-bearing stamens 4 , didynamous, or 2 only; anther-sacs longitudinally dehiscent. Disk annular, or cup-like. Ovary 2-celled; ovules 2-10 in each cavity, anatropous or amphitropous; style filiform, simple: stigmas I or 2. Capsule dry, 2-celled, loculicidally elastically 2-valved. Seeds not winged, borne on curved projections (retinacula) from the placentæ, the testa close, mostly roughened, often developing spiral threads and mucilage when wetted. Endosperm in the following genera none; cotyledons flat, commonly cordate. About 175 genera and 1800 species, natives of temperate and tropical regions.

Corolla convolute in the bud, nearly regular; stamens 4.

Ovules 2 in each cavity; capsule 2 -4-seeded.

Ovules 3-ro in each cavitv; capsule 6-20-seeded.

Corolla imbricated in the bud, strongly 2 -lipped: stamens 2.

Lower lip of the corolla 3-cleft; flowers bracted, not involucrate.

Lower lip of the corolla entire or 3 -toothed; flowers involucrate.

r. Calophanes.

2. Ruellia.

3. Dianthera.

4. Diapedium.

\section{§. CALÓPHANES D. Don.}

Perennial herbs or shrubs, with entire leaves (smaller ones sometimes fascicled in their axils), and blue or purple, rather large, axillary bracted flowers. Calyx deeply 5-cleft, the lobes setaceous. Corolla funnelform, the tube slightly curved, the limb spreading, 5-lobed, somewhat 2 -lipped, the lobes rounded. Stamens included; anther-sacs mucronate at the base. Summit of the style recurved; stigma simple, or of 2 unequal lobes. Capsule oblong, linear, narrowed at the base. Seeds flat, orbicular, attached by their edges to the retinacula. [Greek, beautiful appearance.] About 30 species, of wide distribution. Besides the following, 4 others occur in the southern U. S.

I. Calophanes oblongifòlia (Michx.) D. Don. Calophanes. (I. F. f. 3370.) Rootstocks horizontal, slender. Stems slender below, pubescent or puberulent, obtusely 4-angled, 1.5-4 dm. high. Leaves ascending or erect. oblong or oval, rounded at the apex, short-petioled, or sessile, r.5-3 cm. long; flowers commonly solitary in the axils; calyx-segments filiform, hirsute, exceeding the oblong obtuse bractlets; corolla blue, or mottled with purple, 1.5-2.5 $\mathrm{cm}$. long, its tube enlarged above; capsule oblong, about one-half the length of the calyx: anther-sacs mucronate. aristate at the base. In sandy pine barrens, Va. to Fla. June-Sept. 


\section{RUÉLLIA I.}

Perennial herbs, or shrubs, mostly pubescent, with entire or rarely dentate leaves and large flowers, solitary or clustered in the axils, or cymose in terminal panicles. Calyx 5-cleft, or 5-parted, the segments narrow. Corolla funnelform or salverform, the tube usually narrow, slightly enlarged above, the limb spreading, 5. lobed, the lobes obtuse. Anther-sacs not mucronate at the base. Apex of the style recurved; stigma simple, or of 2 unequal lobes. Capsule oblong or club shaped. Seeds compressed, ovate or orbicular, attached by their edges to the retinacula. [Named for I. De la Ruelle, I474-I537, an early French herbalist.] About 200 species, mainly of tropical America. Besides the following, some 5 others occur in the southern U. S.

Flowers sessile or nearly so.

Calyx-segments linear-lanceolate, scarcely exceeding the capsule. I. $R$. strepens.

Calyx-segments filiform-linear, exceeding the capsule.

Leaves sessile or very short-petioled.

Leaves slender-petioled.

Flowers peduncled; peduncle with two large bracts at the summit.

2. R. caliosa.

3. $R$. parviflora.

4. R. pedunculata.

I. Ruellia strèpens L. Smooth RUellia. somewhat pubescent; stem 4-sided, 3-12 dm. high. Leaves oblong, oval, or ovate, petioled, acute or subacute at the apex, narrowed at the base, 7-15 cm. long; flowers solitary or several together in the axils; calyx-segments linear-lanceolate, shorter than the corolla-tube, slightly pubescent or ciliate, $1.5-2.5 \mathrm{~cm}$. long, I-2 mm. wide; corolla blue, 3-5 cm. long, the limb nearly as broad, the tube about as long as the throat and limb; capsule club-shaped. In dry woods, Penn. to Wis., Fla. and Tex. May-July.

Ruellia strèpens micrántha (Engelm. \& Gray) Britton. Flowers mostly cleistogamous; leaves often narrower. Range of the type.

2. Ruellia ciliòsa Pursh. Hairy Ruellia. (I. F. f. 3372.) Hirsute or pubescent, 3-6 dm. high. Leaves hairy, ciliate, oblong, oval, or ovate, sessile or short-petioled, obtuse or subacute, 3-7 cm. long; flowers clustered or solitary in the axils, sometimes cleistogamous; calyx-segments filiform, hirsute, $2-2.5 \mathrm{~cm}$. long, $0.5 \mathrm{~mm}$. wide; corolla blue, $3.5-5 \mathrm{~cm}$. long, the tube equalling or longer than the obconic throat and nearly regular limb; capsule shorter than the calyx, In dry soil, N. J. and Penn. to Fla., Mich., Kans. and La. June-Sept.

3. Ruellia parvifiòra (Nees) Britton. Southern Ruellia. Less pubescent than the preceding, sometimes merely puberulent. Leaves ovate to lanceolate, 5-I2 cm. long, acute, or the lower obtuse : calyx-segments nearly filiform, ciliate. In woods and thickets Md. to W.Va., Fla. and Tex. May-Aug.

4. Ruellia pedunculàta Torr. Stalked Ruellia. (I. F. f. 3373.) Finely pubescent, 3-8 dm. tall. Leaves ovate to oblong-lanceolate, acute or acuminate at the apex, narrowed at the base, short-petioled, the larger 5-8 cm. long; peduncles $2-8 \mathrm{~cm}$. long, with 2 leaf-like bracts at the summit which subtend a solitary flower, or 2 or 3 slender-pedicelled ones with pedicels similarly bracted; calyx-segments awnlike, equalling the narrow corolla-tube, or shorter; corolla funnelform, $3-5 \mathrm{~cm}$. long; capsule about $2 \mathrm{~cm}$. long, puberulent, longer than the calyx. In dry soil, Mo. to Ark. and La. June-Sept.

\section{DIANTHÈRA L.}

Herbs, mostly perennial, with entire or rarely dentate leaves, and very irregular flowers, variously clustered or solitary in the axils. Calyx deeply 4-5-parted, the segments narrow. Corolla-tube slender; upper lip interior in the bud, erect or ascending, concave; lower lip spreading, 3-cleft. Stamens 2, inserted on the throat of the corolla, not exceeding the upper lip: anther-sacs slightly divergent, not mucronate, separated by a rather broad connective. Ovules 2 in each cavity of the ovary; style slender. Capsule contracted at the base into a long stipe, about 4seeded. Seeds flat, orbicular or ovate, the placentæ not separating from the walls of the capsule. [Greek, double anthers.] About roo species, mostly of tropical $\mathrm{Am}$. Besides the following, 4 others occur in the southern U.S. 
Flowers capitate, the heads dense, at length oblong.

Flowers in loose spikes.

Flowers in pairs in the spikes.

Flowers scattered singly along the spikes.

1. D. Americana.

2. D. ovata.

3. D. lanceolata.

I. Dianthera Americàna L. Dense-flowered Water Willow. (I. F. f. 3374.) Perennial, glabrous; stem erect, angled, slender, usually simple, 3-9 dm. high. Leaves lanceolate or linear-lanceolate, gradually acuminate, $7-\mathrm{r}_{5} \mathrm{~cm}$. long, entire, narrowed at the base into short petioles, or sessile; flowers violet, or nearly white, capitate-spicate at the ends of slender axillary peduncles; bractlets linearsubuilate, shorter than the flowers; corolla Io-12 mm. long, its tube shorter than the lips, the base of the lower lip rough and palate-like; capsule $12 \mathrm{~mm}$. long, exceeding the calyx, its stipe about the length of the slightly compressed body. In water and wet places, Ont. to Mich., Kans., Ga. and Tex. May-Aug.

2. Dianthera ovata Walt. Loose-Flowered WATER Willow. (I. F. f. 3375.) Perennial, glabrous; stem ascending or erect from a horizontal base, I.5-5 dm. high, simple, or sparingly branched. Leaves short-petioled, or sessile, ovate, oblong, oval to elliptic-obovate, 2-8 cm. long, 8-35 mm. wide; flowers in loose slender-peduncled axillary spikes; peduncles shorter than or little exceeding the leaves; calyx-segments narrowly linear, much longer than the bracts and bractlets; corolla pale purple. 8-10 $\mathrm{mm}$. long; capsule $10-12 \mathrm{~mm}$. long. In wet soil, Va. to Fla. and Tex. June-Aug.

3. Dianthera lanceolàra, (Chapm.) Small. NARrow-Leaved Water WiLLow. Perennial, often minutely puberulent: stems erect or spreading, I-3 dm. long. Leaves linear to linear-elliptic or elliptic-lanceolate, 3-ro cm. long, often acuminate, undulate, sessile, or nearly so; spikes slender, 3-10 cm. long, the flowers scattered singly and quite evenly along one side of the peduncle; calyxsegments narrowly linear, 5-7 $\mathrm{min}$. long; corolla about $1 \mathrm{~cm}$. long, the lips nearly as long as the tube, which is saccate at the bise; capsules about $1.5 \mathrm{~cm}$. long, the body as long as the stipe-like base or shorter. In swampy grounds, Mo. to Tenn., Fla. and Tex. May-Aug. (D. ovata var. lanceolata Chapm.)

\section{DIAPÈDIUM Konig. [DICLIPTERA Juss.]}

Herbs, with entire petioled leaves, and blue, red, or violet flowers, subtended by involucres of 2-4 bracts, the inflorescence mostly cymose or spicate, the involucres subtending I flower or several. Calyx 4-5-cleft, the lobes linear or subulate. Corolla-tube slender, slightly enlarged above; upper lip erect, concave, interior in the bud; lower lip spreading. entire or 3-toothed. Stamens 2; anther-sacs parallel, sometimes unequal, separated by a narrow connective. Style filiform; ovules 2 in each cavity of the ovary. Capsule flattened, ovate or suborbicular, 2-4-seeded. Placentæ separating elastically from the walls of the capsule. Seeds compressed, nearly orbicul.r. About 60 species, of warm and tropical regions. Besides the following, 4 others occur in the southern U.S.

I. Diapedium brachiàtum (Pursh) Kuntze. Diapedium. (I. F. f. 3376.) Annual (?), glabrate, or pubescent; siem slender, 6-grooved, erect, much branched, 3-6 dm. high. Leaves ovate, membranous, long-petioled, acuminate or acute, 7-15 cm. long; inflorescence paniculate, the involucres 1 -4-flowered, each of 2 oblong or obovate, opposite bracts; corolla $1.5-2.5 \mathrm{~cm}$. long, pink or purple, the lips about as long as the slender tube: upper lip 2-3-toothed, the lower entire; capsule oblong, $46 \mathrm{~mm}$. high, a little longer than the involucre, the valves slightly divergent in dehiscence, the placentæ curving upward and remaining attached to their summits. In moist thickets, Kans. and Ind. Terr. to Tex., Fla. and N. Car. July-Oct.

\section{Family 15. PHRYMÀCEAE Schauer.}

\section{Lopseed Family.}

An erect perennial herb with divaricate branches, opposite membranous simple leaves, and small irregular purplish flowers, distant in slender elongated spikes. Calyx cylindric, 2-lipped; upper lip 2-cleft, the teeth setaceous; lower lip much shorter, 3-toothed, the teeth subu- 
late. Corolla-tube cylindric, the limb 2-lipped; upper lip erect, concave, emarginate; lower lip larger, spreading, convex, 3-lobed, the lobes obtuse. Stamens 4, didynamous, included. Ovary oblique, I-celled; ovule $\mathrm{I}$, orthotropous, ascending; style slender; stigma 2-lobed. Calyx reflexed in fruit, enclosing the dry acliene, becoming prominently ribbed, closed and its teeth hooked at the ends. Cotyledons convolute; radicle superior. Consists of the following:

\section{PHRỲMA L.}

A monotypic genus of eastern N. Am., eastern and central Asia.

I. Phryma Leptostàchya L. LoPSEED. (I. F. f. 3377.) Puberulent; stem somewhat 4-sided, sometimes constricted above the nodes, branched above, the branches slender, elongated, divergent. Leaves ovate, acute or acuminate, coarsely dentate, 5- $15 \mathrm{~cm}$. long, the lower petioled, the upper often nearly sessile; spikes very narrow, 7-15 cm. long; flowers about $6 \mathrm{~mm}$. long, mostly opposite, distant, borne on very short minutely 2 -bracteolate pedicels, at first erect, soon spreading, the calyx, after flowering, abruptly reflexed against the axis of the spike. In woods and thickets, Can. to Minn., Fla. and Kans. June-Aug.

\section{Order 6. PLANTAGINÀLES.}

Only the following family:

\section{Family 1. PLANTAGINÀCEAE Lindl.*}

\section{Plantain Family.}

Herbs, with basal, or, in the caulescent species, opposite or alternate leaves, and small perfect polygamous or monœecious flowers, bracteolate in spikes or heads, or rarely solitary. Calyx 4-parted, inferior, peristent, the segments imbricated. Corolla hypogynous, scarious or membranous, mostly marcescent, 4-lobed. Stamens 4 or 2 (only $I$ in an Andean genus), inserted on the tube or throat of the corolla; filaments filiform, exserted or included; anthers versatile, 2-celled, the sacs logitudinally dehiscent. Ovary sessile, superior, 1-2-celled, or falsely 3-4-celled. Style filiform, simple, mostly longitudinally stigmatic. Ovules I-several in each cavity of the ovary, peltate, amphitropous. Fruit a pyxis, circunscissile at or below the middle, or an indehiscent nutlet. Seeds I-several in each cavity of the fruit; endosperm fleshy; cotyledons nar. row; radicle short, mostly straight. Three genera and over 200 species, of wide distribution.

Flowers in spikes or heads ; fruit a pyxis.

1. Plantago.

Flowers monœcious, the staminate solitary, peduncled, the pistillate sessile among the

linear leaves ; fruit indehiscent.

2. Littorella.

\section{Plantàgo L. (See Appendix.)}

Leafy-stemmed, short-stemmed or acaulescent herbs, with opposite, alternate or basal leaves, bearing axillary or terminal spikes or heads of small greenish or purplish flowers (flowers solitary in a few exotic species). Calyx-segments equal, or two of them larger. Corolla salverform, the tube cylindric, or constricted at the throat, the limb spreading in anthesis, erect, spreading or reflexed in fruit, 4-lobed or 4-parted. Stamens 4 or 2. Ovary 2-celled, or falsely 3-4-celled; ovules I-several in each cavity. Fruit a membranous pyxis, mostly 2-celled. Seeds various, sometimes hollowed out on the inner side. [The Latin name.] Over 200 species, of wide geographic distribution. Besides the following, some 28 others 
occur in the western and southwestern parts of N. Am. Known as Plantain, Ribwort or Road-weed.

* Stem acaulescent; flowers spicate or capitate at the ends of scapes.

Corolla-lobes spreading or reflexed in fruit, not closed over the top of the pyxis.

Leaves ovate, lanceolate or oblong.

Seeds several or many in each pyxis.

Pyxis ovoid, circumscissile at about the middle.

Pyxis oblong, circumscissile much below the middle.

Seeds $2-4$ in each pyxis.

Leaves all narrowed at the base, parallel-ribbed.

Seeds excavated on the inner side.

Seeds flat or but slightly concave on the inner side.

Capsule equalling or a little longer than the calyx.

Spike very dense; leaves pubescent. 4. P. media.

Lower flowers scattered; leaves glabrous or very nearly so.

Capsule twice as long as the calyx.

5. P. eriopoda.

6. P. sparsiflora.

Leaves, or some of them, cordate; veins starting from the midrib.

Leaves linear or filiform.

7. P. cordata.

Leaves fleshy; plant maritime.

Leaves not fleshy; plants not maritime.

8. P. maritima.

Spike densely tomentose; bracts usually not longer than flowers.

9. P. Purshii.

Plant light green and villous; bracts twice as long as the flowers.

10. P. spinulosa.

Plant dark green and pubescent ; bracts much longer than the flowers.

Ix. P. aristata.

Corolla-lobes erect and closed over the top of the pyxis.

Leaves spatulate to obovate; stamens 4.

Leaves linear-filiform; stamens 2.

Capsule about 4-seeded, slightly exceeding the calyx.

Capsule 8-20-seeded, twice as long as the calyx.

12. P. Virginica.

13. P. elongata.

14. P. heterophylla.

* * Stem erect, leafy; flowers capitate at the ends of axillary peduncles.

15. P. arenaria

I. Plantago màjor L. Common, or Greater Plantain. (I. F. f. 3378.) Perennial, glabrous or pubescent; rootstook short, thick, erect. Leaves longpetioled, mostly ovate, entire, or coarsely dentate, $2.5-25 \mathrm{~cm}$. long, 3-I I-ribbed; scapes $0.5-9 \mathrm{dm}$. high; spike linear-cylindric, usually dense, commonly błunt, 5-25 cm. long, 6-8 mm. thick; flowers perfect, proterogynous; sepals bróadly ovate to obovate, scarious margined, one-half to two-thirds as long as the obtuse or subacute, 5-16-seeded pyxis; stamens 4. In waste places, nearly throughout N. Am. Nat. from Europe, or perhaps indigenous in the far North and on salt meadows. May-Sept.

2. Plantago Rugèlii Dec. Rugel's Plantain. (I. F. f. 3379.) Similar to the preceding, the spikes less dense, at least toward the base, usually long-attenuate at the summit, sometimes $1 \mathrm{~cm}$. thick. Sepals oblong, prominently keeled on the back; pyxis 4-6 mm. long, twice as long as the sepals, circumscissile much below the middle and entirely within the calyx, 4-IO-seeded; corolla-lobes spreading or reflexed on the summit of the pyxis; stamens 4 . In fields, woods and waste places, Me. and Ont. to S. Dak., Fla., Neb. and Tex. Petioles commonly purple at the base. Usually brighter green and with thinner leaves than $P$. major. June-Sept.

3 Plantago lanceolàta L. Ribwort. Rib-grass. (I. F. f. 3380.) Perennial or biennial, pubescent; rootstock short, erect, with tufts of brown hairs at the bases of the leaves. Leaves narrowly oblong-lanceolate, shorter than the scapes, entire, acute or acuminate, gradually narrowed into petioles, 3-5-ribbed, 5-30 cm. long; scapes slender, channelled, sometimes $7.5 \mathrm{dm}$. tall; spikes dense, at first ovoid, becoming cylindric, blunt and I-IO $\mathrm{cm}$. long in fruit, 8-12 mm. thick; flowers perfect, proterogynous: sepals ovate, with a narrow green midrib and broad scarious margins, the two lower ones commonly united; corolla glabrous; filaments white; pyxis oblong, very obtuse, 2-seeded, slightly longer than the calyx, circumscissile at about the middle. In fields and waste places, N. B. to the $\mathbf{N}$ W. Terr., Br. Col., Fla. and Kans. Nat. from Europe. April-Nov. 
4. Plantago mèdia L. Hoary Plantain. (I. F. f. 338r.) Perennial, the short rootstock clothed with brown hairs. Leaves spreading, ovate, oblong or elliptic, entire, or repand-dentate, densely canescent, 5-7-ribbed, narrowed into margined petioles; scapes slender, much longer than the leaves, 3-6 dm. tall; spikes dense, cylindric, $2-8 \mathrm{~cm}$. long in fruit; flowers perfect; sepals all distinct, oblong, with a narrow green midrib and broad scarious margins; corolla glabrous; stamens pink or purple; pyxis oblong, obtuse, 2-4-seeded, the seeds concave on the face; stamens 4. In waste places, Me., R. I., Ont. and N. Y. Adventive from Europe. May-Sept.

5. Plantago eriópoda Torr. Saline Plantain. (I. F. f. 3382.) Perennial, succulent; rootstock usually covered with long brown hairs among the bases of the leaves. Leaves oblong, oblong-lanceolate, or oblanceolate, entire, or repand-dentate, acute, narrowed into petioles, 5-9-ribbed, $0.7-3 \mathrm{dm}$. long, glabrous or nearly so; scapes stout, pubescent, longer than the leaves, 1.5-4.5 dm. high; spikes $2-13 \mathrm{~cm}$. long, dense above, the lower Howers scattered; flowers perfect; sepals distinct, oblong-obovate with broad scarious margins; corolla glabrous, its lobes spreading or reflexed; pyxis ovoid-oblong, very obtuse, one-third longer than the calyx, 2-4-seeded, circumscissile below the middle. In maritime or saline soil, N. S. and Quebec to Minn., Cal. and the N. W. Terr. June-Sept.

6. Plantago sparsifiòra Michx. Southern Plantain. (I. F. f. 3383 .) Perennial, pubescent, or glabrate; scapes slender, sometimes $6 \mathrm{dm}$. tall. Leaves thin, oblong-lanceolate, $0.7-2.5 \mathrm{~cm}$. long, 5-7-ribbed, acute or acuminate, entire, narrowed into slightly margined petioles; spikes loosely flowered, sometimes $3 \mathrm{dm}$. long; flowers perfect; sepals oblong or oval, rather rigid, with narrow scarious margins; corolla glabrous, its lobes not erect over the fruit; pyxis oblong, $5 \mathrm{~mm}$. long, 2-seeded, circumscissile below the middle; seeds convex on the back, slightly concave on the face. In sandy dry soil, N. Car. to Fla. and in southern Ill.

7. Plantago cordáta Lam. Heart-leaved Plantain. Water Plantain. (I. F. f. 3384.) Perennial, glabrous, purple-green; rootstock short, stout. Leaves broadly ovate or nearly orbicular, pinnately veined, entire or dentate, rounded, abruptly narrowed, or cordate at the base, often $2.5 \mathrm{dm}$. long; petioles stout, margined above; scapes longer than the leaves; spikes loosely flowered, sometimes $3 \mathrm{dm}$. long, with interrupted clusters; flowers perfect; sepals ovate to obovate, obtuse, green; corolla-lobes spreading; pyxis ovoid-globose, obtuse, circumscissile at or slightly below the middle, I-4-seeded; seeds not excavated on the face. In swamps and along streams, N. Y. to Ala., Mo. and La. March-July.

8. Plantago marítima L. Sea or Senside Plantain. (I. F. f. 3385.) Annual, biennial, or perennial, fleshy; rootstock sometimes with tufts of whitish hairs among the bases of the leaves. Leaves linear, glabrous, obscurely nerved, sessile, or narrowed into short margined petioles, 5-25 cm. long, entire, or with a very few small teeth, 2-5 $\mathrm{mm}$. wide; scapes slender, more or less pubescent, longer than or equalling the leaves; spikes dense, linear-cylindric, blunt, $2.5-13 \mathrm{~cm}$. long; flowers perfect; sepals ovate-lanceolate to nearly orbicular, green, somewhat keeled; co. rolla pubescent without, its lobes spreading; pyxis ovoid-oblong, obtuse, 2-4-seeded, circumscissile at about the middle, nearly twice as long as the calyx; seeds nearly flat on the face. In salt marshes and on seashores, Lab. to N. J., and on the Pacific Coast from Alaska to Cal. Also on the coasts of Europe and Asia. JuneSept.

9. Plantago Púrshii R. \& S. PUrsh's Plantain. (I. F. f. 3386.) Annual, woolly or silky, pale green; scapes slender, $5-35 \mathrm{~cm}$. tall. Leaves ascending, linear, acute or acuminate, narrowed into margined petioles, 3-nerved, 3-8 mm. wide, entire, or rarely with a few small teeth; spikes usually dense, cylindric, obtuse, 2.5-13 cm. long, about $6 \mathrm{~mm}$. in diameter, exceedingly vilious; bracts rigid, equalling or slightly exceeding the flowers; flowers perfect but heterogonous, many of them cleistogamous; sepals oblong, obtuse, scarious-margined; corollalobes broadly ovate, spreading: stamens 4; pyxis oblong, obtuse, $2.5 \mathrm{~mm}$. long, little exceeding the calyx, 2 -seeded, circumscissile at about the middle; seeds convex on the back, deeply concave on the face. On dry plains and prairies, Ill. and western Ont. to Br. Col., Tex. and Mex. May-Aug.

I0. Plantago spinulòsa Dec. Spinulose Plantain. Intermediate in aspect between the preceding and the following species. Annual, pubescent, pale 
green, scapes 5-10 cm. high. Leaves nearly linear, acuminate, entire, 3-ribbed, 3-6 $\mathrm{mm}$. wide; spikes rather intcrrupted, cylindric, villous; bracts pubescent, linear, rather spreading, two to five times as long as the flowers; sepals spatulate. oblong, obtuse, scarious, with green midribs; corolla-lobes ovate, obtuse, reflexed; pyxis equalling the calyx, oval, obtuse, $2.5 \mathrm{~mm}$. long, circumscissile at the middle. Assiniboia to Mont. and S. Dak., southward to Tex.

I I. Plantago aristata Michx. Large-bracted Plantain. (I. F. f. 3387.) Annual, dark green, pubescent; scapes stout, erect, $7-30 \mathrm{~cm}$. tall, exceeding the leaves. Leaves linear, acuminate at the apex, entire, narrowed into slender petioles, sometimes prominently 3 -ribbed I $-5 \mathrm{~mm}$. wide; spikes very dense, cylindric, 3-12 cm. long, pubescent; bracts puberulent, linear, elongated, ascending, the lower often ro times as long as the flowers; pyxis 2-seeded; the seeds concave on the face. On dry plains and prairies, Ill. to La. and Tex., S. Dak., Br. Col. and N. Mex. Also widely adventive as a weed in the eastern States from Me. to Ga. May-Oct.

12. Plantago Virgínica L. Dwarf or White Dwarf Plantain. (I. F. f. 3388.) Annual or biennial, pubescent or villous; scapes erect, $2.5-45 \mathrm{~cm}$. high, much longer than the leaves. Leaves spatulate or obovate, thin, entire, or repanddenticulate, narrowed into margined petioles, or almost sessile, 3-5-nerved; spikes dense, or the lower flowers scattered, linear-cylindric, obtuse, 6-8 mm. thick, flowers imperfectly diœcious; corolla-lobes of the fertile plants erect and connivent on the top of the pyxis, those of the sterile spreading; stamens 4; pyxis oblong, about as long as the calyx, 2-4-seeded. In dry soil, Conn. to Fla., Ill., Mo., Ariz. and Mex. March-July.

Plantago occidentalis Decne. (P. Virginica var. longifolia A. Gray), of the Southwest, with larger leaves, longer spikes, and larger flowers may be specifically distinct. It is reported from Missouri.

13. Plantago elongàta Pursh. Slender Plantain. (I. F. f. 3389.) Annual, puberulent; scapes filiform, 5-18 cm. high, longer than the linear-filiform, mostly entire, blunt, obscurely $\mathrm{r}$-nerved leaves. Leaves about I mm. wide; spikes slender, linear, rather loosely flowered, $1-8 \mathrm{~cm}$. long, 3-4 mm. thick; flowers imperfectly diœcious, or polygamous; sepals oblong, obtuse, about as long as the bract, scarious-margined; corolla-lobes of the more fertile plants becoming erect over the pyxis; pyxis ovoid-oblong, obtuse, circumscissile at about the middle; seeds nearly flat on both sides. In dry sandy soil, Conn. to N. Y., Va., La., Ill., S. Dak. and Tex. April-Aug.

14. Plantago heterophýlla Nutt. Many-Seeden Plantain. (I. F. f. 3390.) Annual, similar to the prceding, but glabrous or slightly puberulent; scapes 5-25 $\mathrm{cm}$. long. Leaves narrowly linear or filiform, the larger about $4 \mathrm{~mm}$. wide, entire or often with distant small teeth or linear lobes; spikes loose, linear, $\mathrm{r}-\mathrm{r} 3 \mathrm{~cm}$. long; sepals oblong, obtuse, scarious-margined, mostly shorter than the bract; corollalobes in the more fertile plants becoming erect over the pyxis; pyxis oblong, subacute, circumscissile rather below the middle; seeds somewhat angled, scarcely concave on the face. In moist soil, N. J. to Fla., Tenn., Tex. and Cal. AprilJuly.

15. Plantago arenària IV. \& K. Sand Plantain. (I. F. f. 3391.) Annual, pubescent, somewhat viscid; stem commonly becoming much branched, leafy, 0.7-4 dm. high. Leaves opposite, or whorled, narrowly linear, entire, sessile, 2-8 cm. long, about $2 \mathrm{~mm}$. wide; peduncles axillary, often umbellate at the ends of the branches, slender; heads of flowers $1-2 \mathrm{~cm}$. long, about $1 \mathrm{~cm}$. thick: lower bracts acute or acuminate; calyx-lobes unequal: corolla-lobes acute; capsule 2-seeded. Dayton, Ohio. Adventive or fugitive from Europe. Summer.

\section{LITTORÉLLA I.}

A low perennial succulent herb, with linear entire basal leaves and monœcious flowers, the staminate solitary or two together at the summits of slender scapes, the pistillate sessile among the leaves. Sepals 4. Corolla of the staminate flowers with a somewhat urceolate tube, and a spreading 4-lobed limb. Corolla of the pistillate flowers urn-shaped, 3-4 toothed. Staminate flowers with 4 long-exserted stamens, their filaments filiform, the anthers ovate. Pistillate flowers with a single 
ovary and a long-exserted filiform style. Fruit an indehiscent I-seeded nutlet. [Latin, shore.] A monotypic genus of Europe and N. Am.

1. Littorella uniflòra (L.) Aschers. Plantain Shore-weed. Shore-grass. (1. F. f. 3392.) Tufted, usually growing in mats; leaves bright green, 2-8 cm. long, I-2 mm. wide, spreading or ascending, mostly longer than the scapes of the staminate flowers, which bear a small bract at about the middle; sepals lanceolate, mostly obtuse, sometimes only 3 in the fertile flowers; stamens conspicuous, 8-12 mm. long; corolla-lobes ovate, subacute; pistillate flowers very small; nutlet about $2 \mathrm{~mm}$. long. Borders of lakes and ponds, Me. and Vt. to N. S. and Ont. JulyAug. [L. lacustris L.]

\section{Order 7. RUBIÀLES.}

Corolla gamopetalous. Anthers separate, the stamens as many as the corolla-lobes and alternate with them (one fewer in Linnaa of the Caprifoliaceae) or twice as many. Ovary compound, inferior, adnate to the calyx-tube. Ovules I or more in each cavity of the ovary. Leaves opposite or verticillate.

Stamens as many as the corolla-lobes.

Leaves always stipulate. usually blackening in drying.

Leaves usually estipulate, not blackening in drying. Fam. 2. Caprifoliace
Stamens twice as many as the corolla-lobes; low herb with ternately divided leaves.

Fam. 1. Rubiaceae.

Fam. 3. Adoxaceae.

Family I. RUBIÀCEAE B. Juss.

Madder Family.

Herbs, shrubs, or trees, with simple, opposite or sometimes verticillate, mostly stipulate leaves, and perfect, often dimorphous or trimorphous, regular and nearly symmetrical flowers. Calyx-tube adnate to the ovary, its limb various. Corolla funnelform, club-shaped, campanulate, or rotate, 4-5 lobed. Stamens as many as the lobes of the corolla and alternate with them, inserted on its tube or throat. Ovary I-10-celled; style simple or lobed; ovules $1-\infty$ in each cavity. Fruit a capsule, berry, or drupe. Seeds various; seed-coat membranous or crustaceous; endosperm fleshy or horny (wanting in some exotic genera); cotyledons ovate, cordate, or fuliaceous.

About 355 genera and 5500 species of wide distribution.

* Leaves opposite, stipulate (sometimes verticillate in No. 3),

Ovules numerous in each cavity of the ovary; herbs.

Top of the capsule free from the ovary; seeds few, peltate.

Capsule wholly adnate to the ovary; seeds minute, angular.

I. Houstonia.

2. Oldenlandia.

Ovules $\mathrm{I}$ in each cavity of the ovary.

Shrubs or small trees; flowers in dense globular heads.

Low evergreen herbs; flowers 2 together, their ovaries united.

Herbs; flowers axillary, nearly sessile, distinct.

Capsule separating into 2 dehiscent carpels.

Capsule separating into 2 (or 3 ) indehiscent carpels.

3. Cephalanthus.

4. Mitchella.

5. Spermacoce.

6. Diodia.

** Leaves appearing verticillate; herbs (some of the leaves rarely opposite in No. 7.

Corolla rotate; calyx-teeth minute or none.

Corolla funnelform.

7. Galium.

Flowers in involucrate heads.

Flowers in panicles.

8. Sherardia.

9. Asperula.

\section{r. HOUSTònia L.}

Usually tufted herbs, with opposite entire often ciliate leaves, and small blue purple or white, mostly dimorphous flowers. Calyx-tube globose or ovoid, 4-lobed, the lobes distant. Corolla funnelform or salverform, 4-lobed, the lobes valvate. Stamens 4 , inserted on the tube or throat of the corolla. Ovary 2-celled. Style slender; ovules numerous; stigmas 2, linear. Capsule partly inferior, its summit 
free from the calyx, globose-didymous, or emarginate at the apex, loculicidally dehiscent above. Seeds peltate, concave, not angled. Seed-coat reticulate or roughened; endosperm horny; embryo club-shaped. [Named in honor of Dr. William Houston, botanist and collector in South America, died 1733.] About 25 species, of N. Am. and Mex.

\section{* Plants 2.5-18 cm. high; peduncles I-flowered.}

I'eduncles filiform, $2.5-6 \mathrm{~cm}$. long.

Erect; leaves obovate or spatulate, narrowed into petioles.

Diffuse or spreading; leaves nearly orbicular.

Peduncles $0.6-3.5 \mathrm{~cm}$. long, stouter.

Calyx-lobes narrow, about equalling the capsule.

Calyx-lobes broad, much exceeding the capsule.

** Plants 10-45 cm. high; flowers cymose.

Calyx-lobes lanceolate-subulate, 2 to 3 times as long as the capsule. Calyx-lobes linear-subulate, scarcely longer than the capsule.

Leaves broad, ovate, ovate-lanceolate, or lanceolate.

Leaves oblong or spatulate, ciliate.

Leaves linear-lanceolate or oblanceolate, not ciliate.

Leaves filiform or narrowly linear.

Flowers loosely cymose on filiform pedicels; leaves not fascicled.

9. H. tenuifolia.

Flowers densely cymose on very short pedicels; leaves usually fascicled.

10. H. angustifolia.

I. Houstonia coerùlea L. Bluets. Innocence. (I. F. f. 3393.) Erect, 7-18 cm. high, glabrous, or nearly so, perennial by slender rootstocks, forming dense tufts. Lower and basal leaves spatulate or oblanceolate, about $12 \mathrm{~mm}$. long, sometimes hirsute or ciliate, narrowed into a petiole, the upper oblong, sessile; flowers solitary on filiform peduncles; corolla salverform, violet, blue, or white, with a yellow center, 8-12 mm. broad, its tube slender and about the length of the lobes; capsule didymous, compressed, about $4 \mathrm{~mm}$. broad, broader than long, the upper half free from the calyx and shorter than its lobes. In open grassy places, or on wet rocks, N. S. to Quebec, Mich., Ga. and Ala. April-July, or producing a few flowers through the summer.

2. Houstonia serpyllifòlia Michx. Thyme-leaven Bluets. (I. F. f. 3394.) Perennial ; stems prostrate or diffuse, slender, glabrous, 1-2.5 dm. long. Leaves orbicular or broadly oval, abruptly petioled, 6-8 $\mathrm{mm}$. long, sometimes hispidulous, or those of the flowering stems narrower, distant; corolla usually deep blue, 8-12 mm. broad, its tube rather shorter than the lobes; capsule similar to that of the preceding, but usually slightly larger, nearly as long as the calyx. Mountains of Penn., Va. and W. Va. to S. Car. and Tenn. May.

3. Houstonia minor (Michx.) Britton. Small Bluets. (I. F. f. 3395.) Annual, glabrous or nearly so, branched from the base, $2-15 \mathrm{~cm}$. high. Iowerand basal leaves oval or ovate, IO-12 $\mathrm{mm}$. long, narrowed into petioles, the upper narrower and sessile; corolla violet-blue or purple, $6-8 \mathrm{~mm}$. broad, its tube about equalling the lobes; capsule compressed, didymous, 5-6 mm. broad, its upper part free from the calyx. In dry soil, Va. to Fla., Ark. and Tex. March-April.

4. Houstonia mínima Beck. Least Bluets. (I. F. f. 3396.) Annual, spreading or diffuse, $2.5-6.5 \mathrm{~cm}$. high, roughish. Lower and basal leaves oval or ovate, the upper oblong, sessile; flowers 8-10 $\mathrm{mm}$. broad; corolla violet or purple, the tube longer than the lobes; capsule didymous, compressed, about $6 \mathrm{~mm}$. broad, its upper part free from the calyx. In dry soil, Mo, and Ill. to Kans., Ark. and Tex. March-April.

5. Houstonia lanceolata (Poir.) Britten. CAlycose Houstonia. Glabrous, or pubescent, perennial, 1.5-3 dm. high. Leaves lanceolate to linear-lanceolate, sessile or the lowest spatulate and narrowed into petioles. Corolla little exceeding the calyx; capsule about $3 \mathrm{~mm}$. in diameter, much snorter than the lanceolate rigid calyx-lobes. N. C. to Ala., Ky., Tenn. and Mo. May-June. [H. purpurea calycosa. A. Gray.]

6. Houstonia purpùrea L. LARGe HoustonjA. (I. F. f. 3397.) Perennial, tufted, glabrous or somewhat pubescent, 1-4.5 dm. high. Leaves sessile. or the lower ones short-petioled, 3-5-nerved, $1-5 \mathrm{~cm}$. long, the margins often ciliate; pedicels 2-8 $\mathrm{mm}$. long; corolla purple or lilac, fuñuelform, 6-8 $\mathrm{mm}$. long, the tube 
at least twice as long as the lobes; capsule compressed-globose, $3 \mathrm{~mm}$. broad, some. what didymous, its upper half free, shorter than the subulate-linear calyx-lobes. In open places, Md. to Ky., Ga. and Ala. May-Sept.

Houstonia purpùrea pubéscens Brittun. Yubescent ; leaves lanceolate to oblonglanceolate. Va.

7. Houstonia ciliolàta Torr. FRINGED Houstonia. (I. F. f. 3398.) Perennial, tufted, I-2 dm. high. Lower and basal leaves petioled, thick, Inerved, obovate or oblanceolate, obtuse, $\mathbf{I - 2} \mathrm{cm}$. long, their margins conspicuously ciliate; stem leaves oblong or oblanceolate, sessile or nearly so; pedicels filiform, 2-8 $\mathrm{mm}$. long; corolla funnelform, lilac or pale purple, about $6 \mathrm{~mm}$. long, the lobes about one-third the length of the tube; capsule little compressed, obscurely didymous, $3 \mathrm{~mm}$ wide, overtopped by the linear-lanceolate calyx-lobes. On rocks and shores, Me (?), Ont. to Mich., Penn., W. Va., Ky. and Ark. May-Aug.

8. Houstonia longifolia Gaertn. Long-LEAved Hous'Tonia. (I. F. f. 3399.) Perennial, usually tufted, erect, glabrous, 1.2-2.5 dm. high. Basal leaves spatulate or oblanceolate, obtuse, not ciliate, short-petioled; stem leaves linear or linearoblong, I-nerved, I-2.5 cm. long, 2-5 min. wide; corolla pale purple or nearly white, $5^{-6} \mathrm{~mm}$. long, its lobes about one-third the length of the tube; capsule little coinpressed, globose-ovoid, about $2 \mathrm{~mm}$. in diameter, its upper half free and much exceeded by the subulate calyx-lobes. In dry open places, Me. and Ont. to Manitoba, Ga. and Mo. May-Sept.

9. Houstonia tenuifolia Nutt. Slender-leaved Houstonia. (I. F. f. 3400.) Perennial, somewhat tufted, slender, branching, erect, glabrous, $1.5-3 \mathrm{dm}$. high, sometimes pubescent below. Basal and lowest stem leaves ovate or oval, obtuse, petioled, 8-12 mm. long; upper leaves narrowly linear or filiform, blunt, I-3 cm. long, I-3 mm. wide; pedicels filiform, 4-12 mm. long: corolla purple, narrow, 4.6 mm. long, its lobes short; capsule compressed-globose, didynamous, about $2 \mathrm{~mm}$. in diameter, its upper half free and slightly exceeded by the subulate calyx lobes. In dry soil, Va. to Ohio, N. Car. and Tenn. May-July.

10. Houstonia angustifolia Michx. Narrow-leaved Houstonia. (I. F. f. 3401.) Perennial by a deep root, erect, stiff, glabrous, usually branched, 3-6 dm. high. Leaves linear, $1-3.5 \mathrm{~cm}$. long, 2-4 mm. wide, or the lowest narrowly spatulate, usually with smaller ones fascicled in the axils, or on short axillary branches; corolla white or purplish, between funnelform and salverform, about $4 \mathrm{~mm}$. long, its lobes shorter than the tube; capsule compressed-obovoid, $3 \mathrm{~mm}$. wide, its summit free and scarcely exceeded by the calyx-lobes. In dry open places, Ill. to Mo., Kans., Tex., Tenn. and Fla. May-July.

\section{OLDENLÁNDIA L.}

Herbs, with opposite leaves, and small white or pink flowers. Calyx:tube obovoid or subglobose, the limb 4-toothed. Corolla rotate or salverform, 4-lobed. Stamens 4, inserted on the throat of the corolla; anthers oblong. Ovary 2-celled; ovuies numerous in each cavity; style slender, 2 -lobed. Capsule small, ovoid, topshaped, or hemispheric, wholly adnate to the calyx-tube, loculicidally dehiscent at the summit. Seeds angular, not peltate; endosperm fleshy; embryo club-shaped. [Named for H. B. Oldenland, a Danish botanist.] About I75 species, mostly of tropical distribution. Besides the following 2 others occur in the Southern States and $x$ in $N$. Mex.

I. Oldenlandia uniflòra L. Clusteren Bluets. (I. F. f. 3402.) Annual, weak, usually tufted, more or less hirsute-pubescent, diffuse or ascending: stems 2.5-35 cm. long. Leaves short petioled or sessile, mostly thin, entire, 3-5-nerved, ovate, oblong, or oval, acute at the apex, narrowed at the base, $1-2.5 \mathrm{~cm}$. long; flowers sessile or nearly so, white, about $2 \mathrm{~mm}$. broad, terminal and axillary, clustered or solitary; calyx hirsute, hemispheric in fruit, the ovate or oval lobes erect and nearly equalling the tube. In low grounds, N. Y. to Fla. and Tex. Also in Cuba. June-Sept.

\section{CEPHALÁNTHUS L.}

Shrubs, or sometimes small trees, with opposite or verticillate entire deciduous leaves, and densely capitate, bracteolate small white or yellow flowers. Calyxtube obpyramidal, its limb with 4 obtuse lobes. Corolla tubular-funnelform, with 
4 short lober. Stamens 4, inserted on the throat of the corolla; filaments short; anthers civiong, 2-cuspidate at the base. Ovary 2-celled; ovules solitary in each cavity, pendulous; style filiform, exserted; stigma capitate. Fruit dry, obpyramidal, I-2-seeded. Endosperm cartilaginous; cotyledons linear-oblong. [Greek, head-flower.] About 7 species, natives of America and Asia.

I. Cephalanthus occidentàlis L. Butron-Bush. (I. F. f. 3403.) A shrub, or rarely a small tree, glabrous, or somewhat pubescent. Leaves petioled, ovate or oval, entire, acuminate or acute, $7-15 \mathrm{~cm}$. long, 2-6.5 cm. wide; peduncles $2-8 \mathrm{~cm}$. long; heads globose, about $2.5 \mathrm{~cm}$. in diameter, the receptacle pubescent; flowers sessile, white, 8-12 mm. long: style about twice the length of the corolla; calyx-tube prolonged beyond the ovary. In swamps and low grounds, N. B. to Ont., Wis., Neb., Fla. and Tex. Also in Cuba. June-Sept.

\section{MítChELLA L.}

Creeping herbs, with opposite petioled, entire or undulate, evergreen leaves, and white peduncled geminate dimorphous flowers, their ovaries united. Calyxtube ovoid, the limb 3-6-lobed (usually 4-lobed). Corolla funnelform, usually 4-lobed, the lobes recurved, bearded on the inner side. Stamens as many as the lobes of the corolla and inserted on its throat; filaments short and style exserted, or filaments exserted and style short. Ovary 4-celled; stigmas 4, short, filiform; ovules I in each cavity, erect, anatropous. Fruit composed of 2 united drupes usually containing 8 roundish nutlets. Seed erect; cotyledons short, obtuse: embryo minute. [Named after Dr. John Mitchell, botanist and correspondent of Linnaeus in Virginia.] Two species, one N. American, the other Japanese.

I. Mitchella rèpens L. PARTridge-Berry. Twin-Berry. (I. F. f. 3404.) Stems slender, rooting at the nodes, I.5-3 dm. long, branching, glabrous, or slightly pubescent. Leaves ovate-orbicular, petioled, obtuse at the apex, rounded or somewhat cordate at the base, 6-20 mm. long, dark green, shining; peduncles shorter than the leaves, bearing 2 sessile flowers at the summit; corolla $10-12 \mathrm{~mm}$. long; drupes red (rarely white), broader than high, 4-8 $\mathrm{mm}$. in diameter, persistent through the winter, edible. In woods, N. S. to Fla., Ont., Minn., Ark. and Tex. April-June, sometimes flowering a second time in the autumn.

\section{SPERMACÒCE L.}

Herbs, with 4-sided stems, opposite stipulate leaves, and small white flowers, in dense axillary and terminal clusters. Calyx-tube obovoid or obconic, its limb 4-toothed. Corolla funnelform, 4-lobed. Stamens 4, inserted on the tube of the corolla. Ovary 2-celled; ovules I in each cavity; style slender; stigma capitate, or slightly 2-lobed. Capsule coriaceous, didymous, of 2 dehiscent carpels, or one dehiscent, the other indehiscent. Seeds oblong, convex on the back; endosperm horny; embryo central; cotyledons foliaceous. [Greek, seed-point, from the sharp calyx teeth surmounting the carpels.] Two species, natives of America.

I. Spermacoce glàbra Michx. Smooth Butron-weed. (I. F. f. 3405.) Glabrous, decumbent or ascending, 2.5-5 dm. long. Leaves lanceolate or ellipticlanceolate, petioled, or the uppermost sessile, $2-8 \mathrm{~cm}$. long, $8-25 \mathrm{~mm}$. wide, acute at each end, the margins rough; corolla pubescent in the throat, about $3 \mathrm{~mm}$. long, scarcely exceeding the ovate-lanceolate acute calyx-teeth; stamens and style included; capsule obrvoid, about $4 \mathrm{~mm}$. long, glabrous; seeds black, punctate, On river-banks and in wet soil, southern Ohio and $\mathrm{Ky}$. to Fla., Kans. and Tex. Also in tropical Am. June-Sept.

\section{DIÒDIA L.}

Herbs, with opposite, mostly sessile, entire stipulate leaves, and small axillary white lilac or purple flowers. Citlyx-tube obconic or obovoid, the limb 2-4-lobed (sometimes I-6-lobed), often with minute teeth between the lobes. Corolla funnelform or salverform, mostly 4-lobed. Stamens usually 4, inserted on the throat of the corolla; filaments slender: anthers versatile, oblong-linear, exserted. Ovary 2-celled (rarely 3-4-celled); ovules 1 in each cavity; style filiform, simple, or 2-cleft; stigmas 2. Fruit 2 -celled, finally separating into 2 indehiscent carpels. Seed oblong, convex on the back; endosperm horny; cotyledons foliaceous; embryo 
straight. [Greek, thoroughfare, where the species are frequently found.] About 35 species, mostly American. Besides the following, another occurs in the Southern States:

Leaves linear-lanceolate; style entire; stigmas capitate.

Leaves lanceolate or oval; style 2-cleft; stigmas filiform.

r. D. teres.

2. D. Virginiana.

I. Diodia tères Walt. Rough Button-weed. (I. F. f. 3406.) Rigid, usually rough, much branched from near the base, the branches prostrate or ascend. ing, 4-sided above, I-7.5 dm. long. Leaves linear or linear-lanceolate, very rough, 1-4 cm. long, acute, the margins revolute when dry; flowers lilac or purple, 4-6 mm. long, usually solitary in the axils; style entire; stigmas capitate; fruit obovoid or top-shaped, hispid, about $4 \mathrm{~mm}$. high, the usually 4 persistent calyxlobes ovate to lanceolate. in dry or sandy soil, Conn. to Fla., Ill., Kans., Tex., N. Mex. and Sonora. July--Sept.

2. Diodia Virginiàna L. Larger Button-weed. (I. F. f. 3407.) Hispidpubescent or glabrate, much branched from near the base, the branches procum. bent or ascending, 3-6 dm. long. Leaves lanceolate to narrowly oval, narrowed at the base, acute, or the lowest obtuse, $2-8 \mathrm{~cm}$. long; flowers $\mathbf{I}$ or 2 in each axil, about $12 \mathrm{~mm}$. long, the corolla-tube very slender; fruit somewhat fleshy, but becoming dry, hirsute or glabrous, oval, $6-8 \mathrm{~mm}$. high, furrowed, crowned with the 2 or 3 persistent lanceolate calyx-lobes. In moist soil, southern N. J. to Fla., Ark. and Tex. June-Aug.

\section{GÀliUM L. (See Appendix.)}

Herbs, with 4-angled slender stems and branches, apparently verticillate leaves, and small flowers, mostly in axillary or terminal cymes or panicles, the pedicels usually jointed with the calyx. Flowers perfect, or in some species diœcious. Calyx-tube ovoid or globose, the limb minutely toothed, or none. Corolla rotate, 4-lobed (rarely 3-lobed). Stamens 4, rarely 3; filaments short; anthers exserted. Ovary 2-celled; ovules one in each cavity. Styles 2, short; stigmas capitate. Fruit didymous, separating into 2 indehiscent carpels, or sometimes only I of the carpels maturing. Seed convex on the back, concave on the face, o' spherical and hollow; endosperm horny; embryo curved; cotyledons foliaceous. [Greek, milk, from the use of $G$. verum for curdling.] About 225 species, of wid distribution. Besides the following, about 27 others occur in southern and wester N. Am. The leaves are really opposite, the intervening members of the verticils being stipules.

* Fruit dry, smooth, hispid, or roughened.

† Annuals (except Nos. $x$ and 2).

1. Flowers yellow; leaves narrowly linear. x. G. verum.

2. Flowers white or greenish white.
a. Fruit smooth and glabrous.
2. G. Mollugo.
b. Fruit bristly, tubercled, granular or papillose (or smooth in No. 3).

Flowers in axillary cymules, or panicled.

Fruit granular or tubercled, not bristly.

Fruit slightly granular, or smooth, I mm. broad; pedicels not recurved; stem very slender.

3. G. Parisiense.

Fruit granular-tubercled, $3 \mathrm{~mm}$. broad; fruiting pedicels recurved; stem stout.

Fruit densely bristly-hispid. 4. G. tricorne.

Cymes few-flowered; leaves $2-8 \mathrm{~cm}$. long; fruit fully $4 \mathrm{~mm}$. broad.

Cymes mostly several-flowered; leaves $\mathrm{I}-2.5 \mathrm{~cm}$. long; fruit smaller.

6. G. Vaillantii.

Flowers solitary in the axils, subtended by 2 foliaceous bracts; fruit bristly.

7. G. virgatum.

\section{t+ Perennials.}

1. Fruit bristly-hispid (or becoming glabrous in No. 12).
a. Leaves in 4 's, I-nerved.
b. Leaves in 4 's, 3 -nerved.
8. G. pilosum.

Leaves lanceolate, oval, or ovate ; flowers in open cymes:

Upper leaves lanceolate to ovate-lanceolate, acuminate. 
Upper leaves ovate, oblong, oval, ovate-lanceolate or obovate, obtuse.

Corolla usually hirsute; plant mostly pubescent; leaves oblong to ovate-lanceolate.

Corolla glabrous; plant little pubescent; some leaves obovate. 10. G. circaezans.

II. G. Kamtschaticum.

Leaves linear to lanceolate; flowers in terminal panicles.

c. Leaves in 6's.

12. G. boreale.

13. G. triflorum.

2. Fruit smooth and glabrous, or warty in No. 15 .

a. Flowers brown-purple.

Leaves lanceolate, 3-nerved; fruit smooth.

14. G. latifolium.

Leaves narruwly lanceolate, $x$-nerved; fruit warty.

I5. G. Arkansanum.

Endosperm of seed annular in cross-section.

b. Flowers white, yellowish, or greenisl.

Corolla 4-parted, its lobes acute; stems smooth, or nearly so.

I6. G. tinctor
Corolla mostly 3 -parted, its lobes obtuse; stems minutely retrorse-hispid.

Pedicels slender, rough: leaves mostly in 4 's.

Pedicels rather stout, smooth ; leaves mostly in 5 's and 6's.

17. G. trifidum.

18. G. Claytoni.

Endosperm of seed lunate in cross-section.

Leaves obtuse.

Leaves acute, or cuspidate.

Stem nearly or quite smooth.

Stem strongly retrorse-hispid.

19. G. palustre.

** Fruit fleshy, resembling a double berry. 22. G. hispidulum.

I. Galium vèrum L. Yellow Bedstraw. Lady's Bedstraw. (I. F. f. 3408.) Perennial from a somewhat woody base, erect or ascending, $\mathbf{1} \cdot \mathbf{5}-\mathbf{7 \cdot 5} \mathrm{dm}$. high. Stems smooth or minutely roughened; leaves in 6's or 8's, narrowly linear, 8-25 mm. long, about $\mathrm{I} \mathrm{mm}$. wide, rough on the margins, at length deflexed; flowers yellow, the cymes in dense narrow panicles; fruit usually glabrous, less than $2 \mathrm{~mm}$. broad. In waste places and fields, Ont. to Mass., N. Y. and N. J. Adv. or nat. from Europe. May-Sept.

2. Galium Mollùgo I. Wild Madder. White, OR Great HedGe BedSTRAW. (I. F. f. 3409.) Glabrous or nearly so, diffusely branched, 3-9 dm. long; leaves in 6's or 8's, oblanceolate or linear, cuspidate, 12-30 mm. long, 2-4 mm. wide, sometimes roughish on the margins; flowers small, white, very numerous in terminal panicled cymes; pedicels filiform; fruit smooth, glabrous, nearly $2 \mathrm{~mm}$. broad. In fields and waste places, Newf. to Vt., N. Y., Penn., N. J. and Del. Adv. or nat. from Europe. May-Sept.

3. Galium Parisiéuse L. Wall Bedstraw. (I. F. f. 3410.) Very slender, much branched; stem rough on the angles, 1.5-3 dm. high. Leaves in verticils of about $6(4-7)$. linear or linear-lanceolate, cuspidate, minutely scabrous on the margins and midrib, 4-8 $\mathrm{mm}$. long; cymes several-flowered, on filiform peduncles; flowers minute, greenish white; fruit glabrous, smooth or finely granular, less than $2 \mathrm{~mm}$. wide. Roadsides, Va. and Tenn. Adv. or nat. from Europe. June-Aug.

4. Galium tricóne Stokes. Rough-fruited Corn Benstraw. (I. F. f. 34II.) Rather stout, decumbent or ascending, I.5-3 dm. high, simple, or little branched. Stem rough with reflexed prickles; leaves in 6's or 8's, linear or narruwly oblinceolate, $2.5 \mathrm{~cm}$. long or less, $3^{-4} \mathrm{~mm}$. wide, rough on the margins and midrib: peduncles axillary, shorter than the leaves; pedicels thickened and curved downward in fruit; cymes axillary, usually 3- (I-3-) flowered; fruit tuberculate or granular, 8-10 mm, broad. In waste places or cultivated fields, eastward (according to Grayl; Ont., and in ballast about the eastern seaports. Introduced from Europe. May-Aug.

5. Galium A paríne L. Cleavers. Goosegrass. Cleaver wort. (I. F. f. 3412.) Weak, scrambling over bushes, 6 - $15 \mathrm{dm}$. long, the stems retrorsely hispid on the angles. Leaves in 6's or 8's, oblanceolate to linear, cuspidate, 2.5-8 $\mathrm{cm}$. long, 4-10 $\mathrm{mm}$. wide, the margins and midrib very rough; flowers in $1-3$ flowered cymes in the upper axils; peduncles $1-2.5 \mathrm{~cm}$. long; fruiting pedicels straight; fruit $4-6 \mathrm{~mm}$. broad, densely covered with hooked bristles. In various situations, N. B. to S. Dak., Fla., Mo. and Tex. Nat. from Europe. May-Sept.

6. Galium Vaillàntii DC. Lesser Goosegrass or Cleavers. (I. F. f. 3413 as $G$. spurium.) Similar to the preceding species but smaller, the stem equal- 
ly rough-angled. Leaves smaller, $2.5 \mathrm{~cm}$. in length or less, linear-oblong or slightly oblanceolate, cuspidate, rough on the margins and midrib; cymes 2-9-flowered; fruit 2-3 min. broad, usually less hispid. In low grounds, Ont. to Br. Col., south in the Rocky Mts. to Ariz. and to Cal. Also in Europe. G. spurium L., of Europe, appears to have uniformly smooth fruit. May-Aug.

7. Galium virgàtum Nutt. SouthwESTERN BEDSTRAw. (I. F. f. 3414.) Annual, I-3 dm. high, usually hispid, sometimes nearly glabrous; stem slender, 4-angled. Leaves in 4's, oblong or linear-oblong, 5-10 mm. long, $2 \mathrm{~mm}$. wide, or less; peduncles axillary, r-flowered, less than $2 \mathrm{~mm}$. long, recurved in fruit; flower white, subtended by 2 large oblong to lanceolate bracts which closely resemble the leaves; fruit about $2 \mathrm{~mm}$. in diameter, covered with slender barbed bristles. Tenn. and Mo. to Ark., La. and Tex. April-June.

8. Galium pilòsum Ait. Hairy Bedstraw. (I. F. f. 3415.) Perennial, hirsute-pubescent; stems ascending, branched, 3-7 dm. long. Leaves in 4's, oval or oval-ovate, punctate, I-nerved, obtuse, or obscurely 3-nerved at the base, mucronulate, $1-2.5 \mathrm{~cm}$. long, 6-10 $\mathrm{mm}$. wide, the lower usually smaller; peduncles axillary and terminal; cymes numerous, few-flowered; pedicels 2-12 $\mathrm{mm}$. long, flowers yellowish purple; fruit densely hispid, nearly $4 \mathrm{~mm}$. in diameter. In dry or sandy soil, Mass. to Ind., Kans., Fla. and Tex. June-Aug.

Galium pilòsum puncticulòsum (Michx.) T. \& G. Glabrous or nearly so ; leaves smaller, ciliate. Southern N. J. to Fla, and Tex.

9. Galium lanceolàtum Torr. TORREY's WiLd Liquorice. (I. F. f. 34I6.) Perennial, glabrous or nearly so, the stems minutely roughened, 3-6 dm. high. Leaves in 4's, lanceolate or ovate-lanceolate, acutish or acuminate, 3-nerved, ciliate on the margins and nerves, $2.5-6.5 \mathrm{~cm}$. long, $1-2.2 \mathrm{~cm}$. wide, the lower smaller and obtuse or obtusish; cymes rather few-flowered, loose, widely branched; flowers sessile or nearly so; corolla glabrous, yellowish green to purple, its lobes acuminate; fruit hispid with long hairs, $4-5 \mathrm{~mm}$. broad. In dry woods, Quebec and Ont. to Minn., N. J., Va., Penn. and Mich. June-Aug.

Io. Galium circaèzans Michx. Wild Liquorice. Cross-Cleavers. (I. F. f. 3417.) Perennial, more or less pubescent, branched, 3-6 dm. high. I.eaves in 4's, oval, oval-lanceolate or ovate, obtuse or obtusish, 3-nerved, $1-3.6 \mathrm{~cm}$. long, 8-16 mm. wide, usually somewhat pubescent on both surfaces, the lower smaller; cymes divaricately branched; flowers sessile or nearly so, greenish; corolla hirsute without, its lobes acute ; fruit hispid, similar to that of the freceding species, at length deflexed. In woods, Quebec and Ont. to Minn., Fla., Kans. and Tex. May-July.

Galium circaèzans glabèllum Britton. Foliage nearly or quite glabrous; corolla glabrous. N. Y.

II. Galium Kamtscháticum Steller. NORThern Wild Liquorice. (I. F. f. 3418.) Similar to the preceding species, but weak, smaller; stems I-4 dm. long. Leaves in 4's, broadly oval, orbicular or obovate, thin, 3-nerved, obtuse, mucronulate, $1-3.6 \mathrm{~cm}$. long, 8-25 mm. wide, glabrate, or pubescent with short scattered hairs on the upper surface and on the nerves beneath, sometimes ciliate; flowers few, all on pedicels 4-12 mm. long; corolla glabrous, yellowish green, its lobes acutish; fruit hispid, $4 \mathrm{~mm}$. broad. In mountainous regions, Quebec, northern N. E. and northern N. Y. Also in northeastern Asia. Summer.

12. Galium boreàle L. Northern Bedstraw. (I. F. f. 3419.) Erect, perennial, smooth and glabrous, strict, leafy, 3-7 dm. high. Leaves in 4 's, lanceolate or linear, 3-nerved, $2.5-6.5 \mathrm{~cm}$. long, 2-6 mm. wide, the margins sometimes ciliate; panicles terminal, dense, many-flowered, the flowers white in small compact cymes: fruit hispid, at least when young, sometimes becoming glabrate when mature, about $2 \mathrm{~mm}$. broad. In rocky soil or along streams, Quebec to Alaska, N. J., Penn., Mich., Mo., Neb., N. Mex. and Cal. Also in Europe and Asia. May-Aug.

13. Galium trifiòrum Michx. SweEt-scented or Fragrant Bedstraw. (I. F. f. 3420 .) Perennial, diffuse, procumbent or ascending, glabrous or nearly so, shining, fragrant in drying, the stems and margins of the leaves sometimes roughened. Leaves in 6's, narrowly oval or slightly oblanceolate, I-nerved, cuspidate, narrowed at the base, $2.5-9 \mathrm{~cm}$. long, 4-12 $\mathrm{mm}$. wide: peduncles slender, often exceeding the leaves, 3 -flowered or branched into 3 pedicels which are I-3flowered; flowers greenish; fruit 3-4 mm. broad, hispid with hooked hairs; seed 
almost spherical, the groove obsolete. In woods, N. S. to Alaska, Fla., La., the Ind. Terr., Colo. and Cal. Also in Europe and Asia. June-Aug.

14. Galium latifolium Michx. Purple Bedstraw. (I. F. f. 3421.) Perennial, erect, smooth and glabrous, branched, 3-6 dm. high. Leaves in 4's, lanceolate, 3-nerved, acuminate, $2-5 \mathrm{~cm}$. long, $8-16 \mathrm{~mm}$. wide, the midrib sometimes pubescent beneath, the margins minutely roughened, the lower smaller and sometimes opposite; peduncles slender, usually shorter than the leaves; flowers purple; cymes loosely many-flowered, the pedicels slender, 4-12 min. long, smooth or nearly so; fruit smooth, slightly fleshy, $4 \mathrm{~mm}$. broad, usually only one of the carpels developing. In dry woods, Penn. to Tenn. and Ga. May-Aug.

15. Galium Arkansànum A. Gray. Arkansas Bedstraw. (I. F. f. 3422.) Similar to the preceding, but usually lower, the leaves linear-lanceolate, $\mathbf{I}-2.5 \mathrm{~cm}$. long, 2-6 $\mathrm{mm}$. wide, the lateral nerves obscure or none, the midrib sometimes pubescent beneath, and the margins ciliate; fruiting pedicels roughish, 6-25 mm. long; flowers brown-purple, the numerous cymes loosely several-manyflowered; fruit glabrous, warty, somewhat fleshy, each carpel 2-3 $\mathrm{mm}$. in diameter. Southern Mo. and Ark. June-July.

16. Galium tinctòrium L. Stiff Marsh Bedstraw. Wild Madder. (I. F. f. 3423.) Perennial; stem erect, 1.5-4 dm. high, rather stiff, branched almost to the base, the branches commonly solitary, strict; stem 4 angled, nearly glabrous; leaves commonly in 4's, linear to lanceolate, $\mathbf{1}-2.5 \mathrm{~cm}$. long, broadest below the middle, obtuse, cuneate at the base, dark green and dull, I-nerved, the margins and midrib roughish; flowers terminal, in clusters of 2 or 3 ; pedicels slender, not much divaricate in fruit; corolla white, 2-3.5 mm. broad, 4-parted, its lobes oblong, acute; disk large; fruit smooth; seed spherical, hollow, annular in cross-section. Damp shady places, wet meadows and swamps, Can. to N. Car., Tenn., Mich., Neb. and Ariz. May-July.

Galium tinctòrium filifolium Wiegand. More slender than the type and often more diffuse; leaves almost filiform, $2 \mathrm{~mm}$. wide or less, not broader below the middle, strongly cellular-papillose; inflorescence more open; pedicels slender; bracts minute; flowers in 2's or 3's; corolla larger. Sandy places in swamps, Va. to Fla.

Galium tinctorium Labradòricum Wiegand. Low and strictly erect, 5-25 cm. high; branches few, ascending, mostly from the upper nodes; leaves small, 6-8 mm. long, linear, reflexed; flowers large. In sphagnous bogs, Conn., N. Y. and Wis. to Lab.

r7. Galium trífidum L. Small Bedstraw. Small Cleavers. (I. F. f. 3424.) Perennial, slender and weak; stem ascending, $4 \mathrm{dm}$. long or less, much branched and intertangled; stem sharply 4-angled, rough; branches commonly in 2's; leaves in 4's, linear-spatulate, 5-14 mm. long, obtuse, cuneate at the base, I-nerved, dark green and dull, scarcely papillose, the margins and midrib retrorsescabrous; flowers small, on pedicels which are capillary and much longer than the leaves, commonly two at each node, or three terminal; corolla very small, white, $0.5 \mathrm{~m}$. . long, trifid, its lobes broadly oval, very obtuse; fruit glabrous; seed spherical and hollow, annular in cross-section. Sphagnous bogs and cold swamps, Me. to N. Y., Ohio, Neb., Colo. and northward. Summer.

18. Galium Clàytoni Michx. Clayton's Bedstraw. (I. F. f. 3425.) Perennial; stem diffuse when old, I.5-6 dm. high; stem slender or sometimes quite stout, sharply 4-angled, rough, the diffuse branches in 2's; leaves $8-16 \mathrm{~mm}$. long, commonly in 5's or 6's, linear-spatulate or spatulate-oblong, obtuse, cuneately narrowed into a short petiole, rather firm in texture, scabrous on the margin and midrib, dark green and dull above, discolored in drving: flowers in clusters of 2 's or 3 's, terminal, provided with $\mathbf{I}$ or 2 minute bracts; pedicels straight. in fruit strongly divaricate, glabrous and rather stout; corolla minute, white, 3 -parted, the lobes broadly oval, obtuse; fruit glabrous; seed spherical and hollow. annular in crosssection. Swamps, Mass. and N. Y. to Fla., Mich., Mo. and Tex. May-July.

I9. Galium palústre L. Marsh Bedstraw. (I. F. f. 3426.) Perennial; stem erect, slender, about $4 \mathrm{dm}$. high; internodes very long; short branches mostly in 2's. Stem 4-angled, smooth or roughish; leaves in 2's to 6's, linear-elliptic to spatulate, cuneate at the base, obtuse, 6-16 $\mathrm{mm}$. long, 2-4 $\mathrm{mm}$. wide, the rather firm margins and the midrib slightly scabrous; flowers numerous in terminal and lateral cymes; bracteoles in the inflorescence minute; pedicels in flower ascending, 
3-5 mm. long, in frut strongly divaricate; corolla white, 2-3.5 mm. bread, 4-parted, the lobes oblong, acute; disk almost obsolete; fruit glabrous; endosperm of the seed grooved on the inner face, in cross-section lunate. In damp places, Newf. and Quebec to Mass., Conn. and N. Y. Also in Europe. Summer.

20. Galium concínnum Torr. \& Gray. Shining Benstraw. (I. F. f. 3427.) Perennial, glabrous, shining, usually much branched, the angles of the stem and edges of the leaves minutely scabrous. Leaves usually all in 6's, linear or sometimes broader above the middle, narrowed at the base, blunt-pointed, or minutely cuspidate, $8-\mathbf{1 2} \mathrm{mm}$. long, 2-3 mm. wide, green in drying; peduncles filiform; pedicels short; flowers minute, white, numerous in open cymes; fruit small, glabrous; endosperm deeply grooved. In dry woodlands, N. J. to Va., Minn., Kans. and Ark. June-Aug.

21. Galium aspréllum Michx. Rough Bedstraw. (I. F. f. 3428.) Perennial, weak, much branched and reclining on bushes, or sometimes erect; stem retrorsely hispid, 6-18 dm. long. Leaves in 6's or 5's, or those of the branches rarely in 4's, narrowly oval or slightly oblanceolate, cuspidate, narrowed at the base, 8-16 mm. long, 2-4 mm. wide, their margins and midribs rough ; cymes severalmany-flowered; flowers white; fruit smooth and glabrous, about $2 \mathrm{~mm}$. broad; endosperm with a shallow gronve. In moist soil, Newf. to Ont., N. Car., Ill., Wis. and Neb. June-Aug.

22. Galium hispídulum Michx. Coast Bedstraw. (I. F. f. 3429.) Perennial, much branched, hirsute, hispid or nearly glabrous, 3-6 dm. high. Leaves in 4's, I-nerved, oval, mucronate, rather thick, 6-20 $\mathrm{mm}$. long, 3-8 mm. wide, the margins more or less revolute in drying; flowers few, terminating the branchlets, white; pedicels 6-8 $\mathrm{mm}$. long, rather stout, becoming deflexed in fruit; fruit fleshy, minutely pubescent, -about $4 \mathrm{~mm}$. broad. In dry or sandy soil, southern N. J. to Fla. and Ga. May-Aug. This species has been referred, on account of its fleshy fruit, to the genus Relbunium Endl., but it lacks the characteristic involucre of the typical species.

\section{SHERÀRDIA L.}

Slender annual procumbent or diffuse herbs, with verticillate spiny-pointed leaves, and small nearly sessile pink or blue flowers, in involucrate heads. Calyxtube ovoid, its limb 4-6 lobed, the lobes lanceolate, persistent. Corolla funnelform, $4-5$-lobed, the tube as long as the lobes or longer. Stamens 4 or 5 , inserted on the tube of the corolla: filaments slender; anthers linear-oblong, exserted. Ovary 2celled; style 2-cleft at the summit; ovules $I$ in each cavity. Fruit didymous, the carpels indehiscent. Seed erect. [Named for Dr. Wm. Sherard, 1659-1728, patron of Dillenius.] A monotypic genus.

I. Sherardia arvénsis L. Blue Field-Madder. Herb Sherard. SpurWORT. (I. F. f. 3430.) Tufted, roughish; stems numerous, prostrate, ascending, or decumbent, $0.7-2.5 \mathrm{dm}$. long. Leaves in 4's, 5's or 6's, the upper linear or lanceolate, acute and sharp-pointed, rough-ciliate on the margins, 6 -16 $\mathrm{mm}$. long, $2 \sim 4 \mathrm{~mm}$. wide, the lower often obovate, mucronate; flowers in slenderpeduncled involucrate heads, the involucre deeply 6-8-lobed, the lobes lanceolate, sharp-pointed; corolla-lobes spreading; fruit crowned with the 4-6 lanceolate calyx-teeth. In waste places, Ont. and Mass. Also in Bermuda. Adv. from Europe. June-July.

\section{ASPÉRULA L. (See Appendix.)}

Perennial herbs, with 4-angled stems, verticillate leaves, and small white, pink or blue flowers in terminal or axillary, mostly cymose clusters. Calyx-tube somewhat didymous, the limb obsolete. Corolla funnelform, 4-lobed. Stamens 4, inserted on the tube or throat of the corolla; anthers linear or oblong. Ovary 2celled: ovules I in each cavity; style 2-cleft. Fruit globose-didymous, the carpels indehiscent. Seed adherent to the pericarp ; endosperm fleshy ; embryo curved. [Latin diminutive of asper, rough, referring to the leaves.] About 80 species, natives of the Old World.

I. Asperula odoràta L. SweEl WoonRuff. (I. F. f. 343I.) Stems erect, slender, smooth. Leaves usually in 8's (6's-9's), thin, oblong-lanceolate, mucronate, I-nerved, roughish on the margins, $1-3.5 \mathrm{~cm}$. long, the lower smaller, often 
obovate or oblanceolate; peduncles slender; cymes several-flowered; flowers white or pinkish, $3 \mathrm{~mm}$. long; pedicels $2-4 \mathrm{~mm}$. long; fruit hispid, about $2 \mathrm{~mm}$. broad. In waste places, New Brunswick, N. J. Fugitive from Europe. May-July.

Asperula arvénsis L., another European species, with terminal capitate flowers and linear obtuse leaves, has been found in waste places on Staten Island.

\section{Family 2. CAPRIF́OLIÀCEAE Vent.}

\section{Honeysuckle Family.}

Shrubs, trees, vines, or perennial herbs, with opposite leaves and perfect, mostly cymose flowers. Stipules none, or sometimes present. Calyxtube adnate to the ovary, its limb 3-5-toothed or 3-5-lobed. Corolla gamopetalous, the limb 5-lobed, sometimes 2-lipped. Stamens 5 (rarely 4 ), inserted on the tube of the corolla and alternate with its lobes; anthers versatile. Ovary inferior, 1-6-celled; style slender; stigma capitate, or 2-5-lobed, the lobes stigmatic at the summit; ovules anatropous. Fruit a I-6 celled berry, drupe, or capsule. Seeds oblong, globose, or angular ; seed-coat membranous or crustaceous, embryo usually small, placed near the hilum; radicle terete; cotyledons ovate. About ro genera and 260 species, mostly of the northern hemisphere.

Corolla rotate to urn-shaped; flowers in compound cymes; style deeply $2-5$-lobed; shrubs or trees

Leaves pinnate; drupe 3-5-seeded.

Leaves simple; drupe I-seeded.

Corolla tubular to campanulate, often 2 -lipped; style slender.

Erect perennial herbs; leaves connate.

Creeping, somewhat woody herb; flowers long-peduncled, geminate.

Shrubs or vines.

r. Sambucus.

2. Viburnum.

3. Triosteum.

4. Linnaea.

Fruit a few-seeded berry.

$\begin{array}{ll}\text { Corolla short, campanulate, regular, or nearly so. } & \text { 5. Symphoricar } \\ \text { Corolla more or less irregular, tubular or campanulate. 6. Lonicera. }\end{array}$

Fruit a 2-celled capsule; corolla funnelform.

7. Diervilla.

\section{SAMBÜCUS L.}

Shrubs or trees (or some exotic species perennial herbs), with opposite pinnate leaves, serrate or laciniate leaflets, and small white or pinkish flowers in compound depressed or thyrsoid cymes. Calyx-tube ovoid or turbinate, 3-5-toothed or 3-5lobed. Corolla rotate or slightly campanulate, regular, 3-5-lobed. Stamens 5, inserted at the base of the corolla; filaments slender; anthers oblong. Ovary 3-5celled; style short, 3-parted; ovules 1 in each cavity, pendulous. Drupe berrylike, containing 3-5, I-seeded nutlets. Endosperm fleshy; embryo nearly as long as the seed. [Latin name of the elder.] About 20 species, of wide geographic distribution. In addition to the following, 3 or 4 others occur in western N. Am.

Cyme convex; fruit purplish black.

Cyme thyrsoid-paniculate, longer than broad; fruit red.

I. S. Canadensis.

1. Sambucus Canadénsis L. American Elder. Sweet Elder. (I. F. f. 3432.) A shrub, I $-3.5 \mathrm{~m}$. high, glabrous or nearly so, the stems but little woody, the younger ones with large white pith. Leaflets 5-II, usually 7, ovate or oval, acuminate or acute, short-stalked, glabrous above, sometimes slightly pubescent on the veins beneath, 5-r $3 \mathrm{~cm}$. long, sharply serrate, sometimes stipellate: cymes broader than high; flowers white, about $3 \mathrm{~mm}$. broad: drupe nearly $6 \mathrm{~mm}$. in diameter: nutlets roughened. In moist soil, N. B. and N. S. to Fla., Manitoba, Kans. and Tex. June-July.

2. Sambucus pùbens Michx. Red-berried Elder. (I. F. f. 3433.) A shrub, o.6. $4 \mathrm{~m}$. high, the twigs and leaves commonly pubescent; stems woody, the younger with reddish-brown pith. Leaflets 5-7. ovate-lanceolate or oval, acuminate at the apex, often narrowed and usually inequilateral at the base, $5-13 \mathrm{~cm}$. long, not stipellate, sharply serrate ; cymes longer than broad; flowers whitish, turning 
brown in drying; drupe scarlet or red, 4-6 mm. in diameter; nutlets minutely roughened. In rocky places, N. B. to Alaska, Br. Col., Ga., Colo. and Cal. Fruit rarely white. April-May.

Sambucus pùbens dissécta Britton. Leaflets laciniate. Lake Superior and Penn.

Sambucus nigra laciniata (Mill.) DC., a cut-leaved variety of the related European species has been found at Cape May, N. J., perhaps escaped from cultivation.

\section{VIBÚRNUM L.}

Shrubs or trees, with entire dentate or lobed, sometimes stipulate leaves, anil white or rarely pink flowers in compound cymes, the outer flowers sometimes radiant and neutral. Calyx-tube ovoid or turbinate, its limb short, 5-toothed. Corolla ro. tate or short-campanulate in our species, regular, 5-lobed. Stamens 5, inserted on the tube of the corolla; anthers oblong, exserted. Ovary I-3-celled; style short, 3-lobed or 3-parted; ovules solitary in each cavity, pendulous. Drupe ovoid or globose, sometimes flattened, I-seeded. Seed compressed; endosperm fleshy; embryo minute. [The ancient Latin name.] About IOO species, of wide distribution. Besides the following, about 5 others occur in southern and western N. Am.

* Outer flowers of the cyme large, radiant; drupe red.

Leaves doubly serrate, pinnately veined.

Leaves 3-lobed, palmately veined.

I. $V$. alnifolium. 1. Leaves palmately veined, or 3-ribbed.

Cymes $\mathbf{x}-2.5 \mathrm{~cm}$. broad, the rays short; drupe red.

2. V. Opulus.

* * None of the flowers radiant; drupe blue or black (red in No. 3 ).

3. V. pauciflorum.

2. Leaves pinnately veined.

a. Leaves coarsly dentate, the veins prominent beneath.

Leaves very short-petioled, pubescent.

5. V.pubescens.

Petioles $0.6-4 \mathrm{~cm}$. long.

Leaves glabrous, or with tufts of hairs in the axils beneath. 6. V. dentatum.

Leaves pubescent beneath, the pubescence more or less stellate.

Drupe globose-ovoid; eastern and southern.

Veins of leaves not very prominent.

Veins very prominent on the under surfaces of the leaves.

Drupe oblong, twice as long as thick; western.

8. V. venosum.

b. Leaves entire, crenulate, or serrulate, the veins not prominent.

Cymes manifestly peduncled.

Peduncle shorter than the cyme; leaves crenulate.

Peduncle equalling or longer than the cyme.

ro. $V$. cassinoides.

II. V. nudum.

Cymes sessile, or nearly so.

Leaves slender-petioled, large.

Leaves prominently acuminate.

Leaves obtuse, or merely acute.

12: V. Lentago.

Leaves and scarcely winged petioles glabrous, or nearly so.

I3. V. prunifolium.

Veins of lower leaf-surfaces and winged petioles tomentose.

Leaves nearly sessile, obovate, small.

I4. V. rufotomentosum.

I5. $V$. obovatum

I. Viburnum alnifòlium Marsh. Hobble-bush. AMERICAN Warfaring TREe. (I. F. f. 3434.) A shrub, with smooth purplish bark, widely and irregularly branching, the branches often procumbent, the youngest twigs scurfy. Leaves orbicular, or very broadly ovate, short-acuminate or acute, usually cordate, finely stellate-pubescent, or at length glabrous above, scurfy with stellate pubescence on the veins beneath, finely serrate all around, $0.7-2 \mathrm{dm}$. broad, petioles $1-3 \mathrm{~cm}$. long; cymes sessile, 7-13 cm. broad, the exterior flowers usually about $2 \mathrm{~cm}$. broad; drupes red, becoming purple, ovoid-oblong, 10-12 $\mathrm{mm}$. long; stone 3-grooved on one side, I-grooved on the other. In low woods, N. B. to N. Car., western N. Y. and Mich. Leaves of shoots from cut stumps thin, ovate, coarsely toothed. May-June.

2. Viburnum Ópulus L. Cranberry-tree. Wild Guelder-rose. High BUSH.CRANBERRY. (I. F. f. 3435.) A shrub sometimes 4 m. high, with smooth branches. Leaves broadly ovate, sometimes broader than long, glabrous, or with scattered hairs above, more or less pubescent on the veins beneath, rather deeply 3 -lobed, rounded or truncate and 3 -ribbed at the base, the lobes acuminate, coarsely dentate; petioles $1-2.5 \mathrm{~cm}$. long; cymes peduncled, 7-10 cm. in diameter, 
the exterior flowers radiant, neutral; drupes globose, or oval, 8-1o mm. in diameter, red, very acid, translucent; stone orbicular, flat, not grooved. In low grounds, N. B. to Br. Col., N. J., Mich., S. Dak. and Ore. Also in Europe and Asia. June-July.

3. Viburnum paucifiòrum Pylaie. Few-Flowered Cranberry-tree. (I. F. f. 3436.) A straggling shrub, 6-18 dm. high, with twigs and petioles glabrous or nearly so. Leaves broadly oval, obovate, or broader than long, 5-ribbed, truncate or somewhat cordate at the base, mostly with 3 rather shallow lobes, coarsely and unequally dentate, glabrous above, pubescent on the veins beneath, 3-8 cm. broad; cymes peduncled, short-rayed, $1-2.5 \mathrm{~cm}$. broad; flowers all perfect and small; drupes globose to ovoid, light red, acid, 8-ro $\mathrm{mm}$. long; stone flat, orbicular, scarcely grooved. In cold mountain woods, Newf. to Alaska, Me., N. H., Vt., Penn., Colo. and Wash. June-July.

4. Viburnum acerifòlium L. Maple-Leaved Arrow-wood. Dockmakie. (I. F. f. 3437.) A shrub, I-2 m. high, with smooth gray branches, and somewhat pubescent twigs and petioles. Leaves ovate, orbicular, or broader than long, cordate or truncate at the base, pubescent on both sides, or becoming glabrate, 5-13 $\mathrm{cm}$. broad, mostly rather deeply 3-lobed, coarsely dentate, the lobes acute or acuminate; petioles $\mathbf{I}-2.5 \mathrm{~cm}$. long; cymes long-peduncled, $3-8 \mathrm{~cm}$. broad; flowers all perfect, 4-6 $\mathrm{mm}$. broad ; drupe nearly black, 6-8 $\mathrm{mm}$. long, the stone lenticular, faintly 2 -ridged on one side and 2 -grooved on the other. In dry woods, N. B. to N. Car., Ont., Mich. and Minn. May-June.

5. Viburnum pubéscens (Ait.) Pursh. Downy-leaved Arrow-wood。 (I. F. f. 3438.) A shrub, 6-I 5 dm. high, with straight gray branches. Leaves sessile, or with petioles less than $6 \mathrm{~mm}$. long, ovate or oval, rounded or slightly cordate at the base, acute or acuminate, coarsely dentate, $3-8 \mathrm{~cm}$. long, densely velvetypubescent beneath, glabrous, or with scattered hairs above, or rarely glabrate on both surfaces; cymes peduncled, $3-7 \mathrm{~cm}$. broad, the flowers all perfect; drupes oval, nearly black, about $8 \mathrm{~mm}$. long; stone slightly 2-grooved on both faces. In rocky woods, Quebec and Ont. to Manitoba, Ga., Ill., Iowa and Mich. June-July.

6. Viburnum dentàtum L. ARROw-wood. (I. F. f. 3439.) A shrub with glabrous gray branches, sometimes $5 \mathrm{~m}$. high. Petioles 6-25 mm. long ; leaves ovate, broadly oval or orbicular, rounded or slightly cordate at the base, acute or short-acuminate, prominently veined, coarsely dentate, $3-8 \mathrm{~cm}$. broad, glabrous on both sides, or pubescent with simple hairs in the axils of the veins beneath; cymes long-peduncled, 5-8 cm. broad; drupe globose-ovoid, about $6 \mathrm{~mm}$. in diameter, blue, becoming nearly black; stone rather deeply grooved on one side, rounded on the other. In moist soil, N. B. to Ont., Ga., Mich. and Minn. May-June.

7. Viburnum semitomentòsum (Michx.) Rehder. (I. F. f. 3440.) Similar to the preceding species, but the twigs, petioles, rays of the cyme and lower surfaces of the leaves more or less stellate-pubescent; petioles short and stouter; leaves usually larger, crenate or dentate, commonly somewhat pubescent above; drupe globose-ovoid, blue, $8 \mathrm{~mm}$. in diameter, its stone similar to that of $V$. dentatum. S. Penn. ?: Ky. to Fla. and Tex. ( $V$. molle A. Gray not Michx.)

8. Viburnum venòsum Britton.

CoAst ARrow-wood. A shrub, similar to the two preceding species. Twigs and lower surfaces of the leaves very densely steliate-tomentose; petioles stout, I-2 cm. long; blades broadly ovate to orbicular, 5-10 cm. long, coarsely toothed, glabrous or with a few scattered hairs on the upper surface; cymes $6-8 \mathrm{~cm}$. broad; drupe orbicular or short-oval, about 7 $\mathrm{mm}$. in diameter, the veins very prominent on the lower surfaces. E. Mass. to N. J. Type collected by E. P. Bicknell on Nantucket Island.

9. Viburnum molle Michaux. Soft-leaved Arrow-wood. (I. F. f. 344I.) A shrub about $4 \mathrm{~m}$. high, the older twigs ash-gray, or length grayish black, the bark exfoliating. Bud-scales acutish, ciliolate; leaves broadly ovate or nearly orbicular, short-acuminate, cordate or truncate at the base, 8-I3 $\mathrm{cm}$. long, coarsely dentate, glabrous and bright green above, soft-pubescent and p.ler beneath, some of the pubescence stellate; petioles $1.5^{-2} \mathrm{~cm}$. long, channeled; stipules linear-filiform; cymes peduncled, 4-7-rayed, glandular-puberulent; calyxteeth ciliate; drupe oblong, obtuse at both ends, about $1 \mathrm{~cm}$. long and $0.5 \mathrm{~cm}$. broad, much flattened, with 2 grooves when dry. Bluffs, and rocky woods. Ky., Mo, and Lowa.

( $V$. Demetrionis Deane and Robinson. 
.10. Viburnum cassinoides L. Withe-Rod. Appalachian Tea. (I. F. f. 3442.) A shrub, $0.6-4 \mathrm{~m}$. high, with ascending gray branches, the twigs somewhat scurfy, or glabrous. Leaves ovate or oval, thick, narrowed or sometimes rounded at the base, acute, $2-8 \mathrm{~cm}$. long, generally crenulate, glabrous or very nearly so; peduncle shorter than or equalling the cyme; drupe pink, becoming dark blue, globose to ovoid, 6-10 $\mathrm{mm}$. long; stone round or oval, flattened. In swamps and wet soil, Newf. to Manitoba, N. J., Ga. and Ala. June-July.

II. Viburnum nùdum L. LARGer Withe-ROD. (I. F. f. 3443.) Similar to the preceding, but usually larger. sometimes $5 \mathrm{~m}$. high. Leaves oval, ovallanceolate, or obovate, entire or obscurely crenulate, mostly larger (sometimes 2.2 $\mathrm{dm}$. long), narrowed at the base, acute or obtuse, more prominently veined, sometimes scurfy on the upper surface; peduncle equalling or exceeding the cyme. In swamps, Conn.to Fla., Ky. and La. Blooms a little later than the preceding species.

12. Viburnum Lentàgo L. NAnny-Berry. Sheep-berry. (I. F. f. 3444.) A shrub, or often a small tree. Winter buds acuminate, glabrous; leaves slenderpetioled, ovate, mostly rounded at the base, acuminate, 5-10 $\mathrm{cm}$. long, glabrous on both sides, or rarely a little pubescent beneath, sharply serrulate; petioles often broadened and wavy-margined, $1.8-2.5 \mathrm{~cm}$. long; cyme several-rayed, $5-13 \mathrm{~cm}$. broad ; drupes oval, bluish-black with a bloom, 10-12 $\mathrm{mm}$. long; stone very flat, circular or oval. In rich soil, Hudson Bay to Manitoba, N. J., Ga., Kans., Ind. and Mo. Fruit sweet, edible. May.

13. Viburnum prunifòlium L. Black Haw. Stag-bush. Sloe. (I. F. f. 3445.) A shrub or small tree, similar to the preceding; but the winter buds smaller, less acute, often reddish-pubescent. Leaves ovate or broadly oval, obtuse or acutish, $2-8 \mathrm{~cm}$. long, finely serrulate, glabrous or nearly so; petioles rarely margined; cyme several-rayed, $5-10 \mathrm{~cm}$. broad; drupe oval, bluish black and glaucous, 8-10 mm. long; stone very flat on one side, slightly convex on the other, oval. In dry soil, Conn. to S. Car., Mich., Kans. and Tex. April-June. Fruit ripe in September, sweet and edible.

Viburnum prunifolium globòsum Nash. Drupe globose, about $6 \mathrm{~mm}$. in diameter; cymes smaller; flowers expanding before the leaves. N. J. and Penn.

I4. Viburnum rufotomentòsum Small. Southern BLACK HAw. (I. F. f. 3446.) A small tree. Leaves elliptic to obovate, mostly obtuse, finely and sharply serrate or serrulate, the veins brown-tomentose beneath; petioles $6-16 \mathrm{~mm}$. long, winged, brown-tomentose: cymes large, the principal rays mostly 4 ; flowers 6-7 mm. broad; drupe oval, 10-14 mm. long, blue with a bloom: seed nearly orbicular. In woods and thickets, Va. to Ill., Mo., Fla. and Tex. April-May.

15. Viburnum obovàtum Walt. Small Viburnum. (I. F. f. 3447.) A shrub, $0.6-2.5 \mathrm{~m}$. high, the twigs, petioles and rays of the cyme slightly pubescent, or at length glabrate. Leaves obovate, oblanceolate or spatulate, obtuse or retuse, short-petioled, glabrous or very nearly so, entire, or obscurely crenate toward the apex, I-4 cm. long; cymes 3-5-rayed, $2-5 \mathrm{~cm}$. broad; drupe oval, black, 6-8 $\mathrm{mm}$. long; stone lenticular, slightly furrowed on both sides. In swamps and along streams, Va. (according to Gray) to Fla. April-May.

3. TRIÓSTEUM L.

Perennial herbs, with simple terete stems and opposite connate-perfoliate or sessile leaves narrowed below the middle. Flowers axillary, perfect, sessile, yellowish, green or purplish; 2-bracted. Calyx-tube ovoid, its limb 5-lobed, the lobes elongated, persistent and sometimes foliaceous in our species. Corolla-tube narrow or campanulate, gibbous at the base, the limb oblique, unequally lobed. Stamens 5. inserted on the corolla-tube; filaments very short; anthers linear. included. Ovary 3-5-celled; ovules I in each cavity; style filiform; stigma 3-5-lobed. Drupe coriaceous, orange or red, enclosing 2 or 3 (rarely 4-5) I-seeded nutlets. Endosperm fleshy; embryo minute. [Greek, three-bone, from the 3 bony nutlets.] Five known species, the following of eastern N. Am., two Japanese, one HimaLayan.

Leaves ovate or oval; flowers purplish or dull red.

Leaves, or some of them, connate-perfoliate; fruit orange-yellow. I. $T$. perfoliatum.

Leaves narrowed to a sessile base; fruit orange-red.

Leaves lanceolate or oval-lanceolate; flowers yellowish.

2. T. aurantiacum.

3. T. angustifolium. 
I. Triosteum perfoliàtum L. FEVER-Wort. Horse-Gentian. Stem erect, stout, finely glandular-pubescent, 6-1o dm. high. Leaves ovate to broadly oval, I-2.2 cm. long, acute or acuminate at the apex, abruptly narrowed at the base, soft-pubescent and rugose beneath, sometimes puberulent above, the margins entire; bracts linear; corolla purplish, 12-15 mm. long, viscid-pubescent, about the length of the calyx-lobes; filaments bearded; drupe 8-12 mm. long, obovoid to globose, densely and finely pubescent In rich soil, Conn. to Minn., Ala., Ky. and Kans. May-July.

2. Triosteum aurantiàcum Bicknell. Scarlet-fruited Horse-Gentian. (I. F. f. 3448 , as $T$. perfoliatum.) Stem 5-12 dm. tall, glandular-puberulent to subhirsute; leaves thin, I.5-2.5 dm. long, broadly ovate-oblong to oblong-lanceolate, acuminate, contracted below the middle into a narrow base, sometimes slightly connate but never broadly perfoliate, minutely soft-pubescent beneath, thinly appressed-hirsutulous to glabrate above; corolla dull red, I4-20 mm. long, with larger, more spreading lobes than in $T$. perfoliatum, the stamens shorter and style less exserted; calyx-lobes linear, obtuse, 10-20 $\mathrm{mm}$. long; fruit 12-14 $\mathrm{mm}$. long, larger and more obovoid-oblong than in $T$. perfoliatum, and bright orange-red in. stead of orange-yellow. Quebec to Minn., Mass., N. Car., Ky. and Iowa. Type from Van Cortlandt, N. Y. Similar to $T$. perfoliatum, but less finely pubescent and less leafy, the larger leaves greener, thinner and not rugose; the flowers and fruit markedly different. Flowers 2-3 weeks earlier than $T$. perfoliatum.

3. Triosteum angustifòlium L. Yellow OR NARROW-Leaved HORSEGentian. (I. F. f. 3449.) Stem slender, hirsute-pubescent, 3-9 dm. high. Leaves lanceolate or oval-lanceolate, acute or acuminate, 7-13 cm. long, I-4 cm. wide, rough-pubescent, tapering to the sessile base, or the lower smaller, obtuse and spatulate; corolla yellowish, 12-14 $\mathrm{mm}$. long; flowers commonly solitary in the axils. In rich soil, Conn. and L. I., to N. J., Penn., Ala., Ill. and La. May-Aug.

\section{LINNAÈA L.}

Creeping, somewhat woody herbs, with opposite evergreen petioled obovate or orbicular leaves, and perfect pink or purplish flowers borne in pairs at the summit of elongated terminal peduncles. Calyx-tube ovoid, the limb 5-lobed. Corolla campanulate to funnelform, regular, 5-lobed, the lobes imbricate. Stamens 4, inserted near the base of the corolla-tube, didynamous, included. Ovary 3-celled, 2 of the cavities with several abortive ovules, the other with I perfect pendulous ovule. Fruit nearly globose, 3 -celled, 2 of the cells empty, the other with a single oblong seed. Endosperm fieshy; embryo cylindric. [Named by Gronovius for Linnæus, with whom the plant was a favorite.] About 4 species of the north temperate zone.

I. Linnaea Americàna Forbes. American Twin-flower. GroundviNe. Branches slender, slightly pubescent, trailing, I.5-6 dm. long; petioles 2-4 $\mathrm{mm}$. long; leaves obscurely crenate, thick, 6-15 mm. wide, sometimes wider than long: peduncles slender, erect, 2 -bracted at the summit, 2-flowered (or rarely proliferously 4-flowered); pedicels filiform, 6-20 mm. long, 2-bracteolate at the summit; flowers nodding, 8-12 mm. long, fragrant; corolla funnelform; calyx-segments $2 \mathrm{~mm}$. long; ovary subtended by a pair of ovate glandular scales which are connivent over the fruit or adnate to it. In cold woods, Newf. to Alaska, S. Dak., Colo. Md., Penn., Mich., and Utah. The European and Asiatic L. borealis has an almost campanulate corolla, and calyx-segments $3 \mathrm{~mm}$. long. June-Aug.

\section{SYMPHORICÀRPOS Juss.}

Shrubs, with opposite deciduous short-petioled simple leaves, and small, white or pink, perfect flowers, in axillary or terminal clusters. Calyx-tube nearly globular, the limb 4-5-toothed. Corolla campanulate or salverform, sometimes gibbous at the base, 4-5-lobed; stamens 4 or 5, inserted on the corolla. Ovary 4-celled, 2 of the cavities containing several abortive ovules, the other two each with a single suspended ovule; style filiform; stigma capitate, or 2-lohed. Fruit a 4-celled 2 seeded berry. Seeds oblong; endosperm fleshy; embryo minute. [Greek, fruit borne together, from the clustered berries.] About ro species, of N. Am. and Mex. 
Fruit white ; style glabrous.

Stamens and style included; clusters usually few-flowered.

Erect shrub; leaves $2.5-5 \mathrm{~cm}$. long; clusters several-flowered.

I. S. racemosus.

Diffuse shrub; leaves $1-2.5 \mathrm{~cm}$. long; clusters I-2-flowered. 2. $S$. pauciflorus.

Stamens and style sonewhat exserted; clusters many-flowered. 3. S. occidentalis. Fruit red, style bearded.

4. S. Symphoricarpos.

I. Symphoricarpos racemòsus Michx. SNowberry. (I. F. f. 345I.) An erect shrub, glabrous or nearly so. Petioles about $4 \mathrm{~mm}$. long; leaves oval, obtuse at each end, sometimes a little pubescent beneath, entire, undulate, or those of young shoots sometimes dentate; axillary clusters few-flowered, the terminal one mostly interruptedly spicate; corolla campanulate, about $6 \mathrm{~mm}$. long. slightly gib. bous at the base, bearded within; style glabrous; berry snow-white, globose, loosely cellular, 6-10 $\mathrm{mm}$. in diameter. In rocky places and on river shores, N. S. to Br. Col., Penn., Ky., S. Dak. and in Cal. Commonly planted and sometimes escaped from cultivation. June-Sept.

2. Symphoricarpos paucifiòrus (Robbins) Britton. Low SNowberRy. (I. F. f. 3452.) A low spreading diffusely branched shrub, 1.5-2.5 dm. high. Leaves broadly oval to orbiculate, entire, softly pubescent, especially along the veins beneath; flowers 4-6 mm. long, solitary in the upper axils and 2 or 3 in the terminal spike; corolla campanulate, 5 -lobed, bearded within; berry oval when young, becoming globose, white, 4-6 $\mathrm{mm}$. in diameter. In rocky places, Ont. and Vt. to N. Y., Penn., S. Dak., Br. Col., Neb. and Colo. June-July.

3. Symphoricarpos occidentàlis Hook. WolfBerRY. (I. F. f. 3453.) Similar to $S$. racemosus but stouter, with larger paler leaves $2-8 \mathrm{~cm}$. long, more or less pubescent beneath, entire, or often undulate-crenate; axillary clusters spicate, many-flowered; corolla campanulate, $6 \mathrm{~mm}$. long, lobed to beyond the middle; berry nearly globular, white, $8-10 \mathrm{~mm}$. in diameter. Mich. and Minn. to Br. Col., Kans. and Colo. June-July.

4. Symphoricarpos Symphoricàrpos (L.) MacM. Coral-Berry. (I. F. f. 3454.) A shrub, 6-I5 dm. high, the branches, purplish, usually pubescent. Petioles 2-4 mm. long; leaves oval or ovate, entire or undulate, mostly obtuse at each end, glabrous or nearly so above, usually soft-pubescent beneath, $2-4 \mathrm{~cm}$. long; clusters dense, many-flowered, at length spicate, shorter than the leaves; corolla campanulate, sparingly pubescent within, pinkish, about $4 \mathrm{~mm}$. long; stamens included; berry purplish red, ovoid-globose, 3-4 mm. long. Along rivers and in rocky places, N. J. and Penn. to western N. Y., Dak., Neb., Ga. and Tex. Also sparingly escaped from cultivation farther east. July. [S. vulgaris Michx.]

\section{LONICERA L.}

Erect or climbing shrubs, with opposite mostly entire leaves; flowers spicate, capitate or geminate, usually somewhat irregular. Calyx-tube ovoid or nearly globular, the limb slightly 5 -tonthed. Corolla often gibbous at the base, the limb 5 -lobed, more or less oblique, or 2-lipped. Stamens 5, inserted on the tube of the corolla. Ovary 2-3-celled; ovules numerous, pendulous; style slender, stigma capitate. Berry fleshy, 2-3-celled or rarely I-celled, few-seeded. Seeds with fleshy endosperm and a terete embryo. [Named for Adam Lonitzer, 1528-1586, a German botanist.] About Ioo species, of the north temperate zone, a few in tropical regions. Besides the following, some 8 others occur in western N. Am. * Climbing or trailing vines; flowers in heads, or interrupted spikes; upper leaves

Corolla 2-lipped, the upper lip 4-lobed, the lower entire.

Corolla glabrous within.

Corolla pubescent within.

r. L. Caprifolium.

Leaves pubescent, at least beneath ; corolla yellow.

Leaves pubescent on both sides, at least when young, ciliate ; corolla slightly gibbous at base.

2. L. hirsuta.

Leaves glabrous above, pubescent beneath; corolla tube strongly gibbous at the base.

Leaves glabrous on both sides, very glaucous beneath.

3. L. glaucescens.

Corolla greenish yellow, the tube somewhat gibbous.

Corolla-tube 6-1o mm. long; filaments hirsute at the base.

4. L. dioica. 
Corolla-tube ro-14 mm. long; filaments nearly glabrous.

5. L. Sullivantii.

Corolla bright yellow or orange, its slender tube not gibbous.

Corolla tubular, the short limb nearly equally 5 -lobed.

6. L. flava.

- * Climbing vines; flowers in pairs on short axillary peduncles.

8. L. Japonica.

*** Shrubs; flowers in pairs on axillary bracted peduncles (Genus Xylosteum).

Bracts of the peduncle subulate, linear, minute, or none.

Leaves rarely cordate, more or less pubescent, or ciliate.

Leaves pale or glaucous, thick, strongly reticulate-veined.

Peduncles shorter than the flowers; fruit blue; leaves ciliate.

Peduncles equalling the flowers ; fruit red ; leaves not ciliate.

1o. L. oblongifolia.

Leaves bright green, thin, ciliate, not strongly reticulate; fruit red.

Leaves pale, densely pubescent beneath, even when old.

Leaves cordate, glabrous.

Bracts of the peduncle broad, foliaceous.

12. L. Xylosteum.

13. L. Tatalica.

14. L. involucrata.

I. Lonicera Caprifolium L. Italian or Perfoliate Honeysuckle. (I. F. f. 3455.) Climbing high, glabrous, somewhat glaucous. Upper pairs of leaves connate-perfoliate, glaucous beneath, the others sessile or short-petioled, oval or obovate, rounded at the base, entire; flowers in terminal capitate sessile clusters; corolla $2.5-3.7 \mathrm{~cm}$. long, purple without, the limb white within; upper lip 4-lobed, the lower one narrow, reflexed; tube slightly curved, not gibbous; stamens and style much exserted; berries red. Thickets, N. Y., N. J. and Penn. to Mich., and in the Southern States. Nat. from Europe. May-June.

2. Lonicera hirsùta Eaton. Hairy IIoneysuckle. (I. F. f. 3456.) Twining; branches hirsute-pubescent. Upper one or two pairs of leaves connate-perfoliate, the others oval or ovate, short-petioled or sessile, softly pubescent beneath, dark green and appressed-pubescent a bove, ciliate, obtuse or obtusish, 5-9 cm. long; flowers verticillate in short terminal interrupted spikes; corolla about $2.5 \mathrm{~cm}$. long, viscid-pubescent without, orange-yellow, the tube slender, somewhat gibbous at the base, the limb strongly 2-lipped, about as long as the tube; stamens and style exserted; filaments hirsute below. In woodlands, Vt. and Ont. to Manitoba, Penn., Ohio and Mich. June--July.

3. Lonicera glaucéscens Rydb. Douglas' Honeysuckle. (I. F. f. 3457.) Similar to the preceding, the branches glabrous. Leaves glabrous above, pubescent, at least on the veins, beneath, 3-9 cm. long, chartaceous-margined, not ciliate, usually only the upper pair connate-perfoliate; flowers verticillate in a short interrupted spike: corolla yellow, changing to reddish, pubescent or puberulent without, pubescent within, $2.5 \mathrm{~cm}$. long, or less, the 2-lipped limb shorter than the tube; stamens nearly glabrous, or somewhat pubescent; style hirsute; both exserted. Ont. to Saskatchewan, Penn., N. Car., Ohio and Kans. May-June.

4. Lonicera diòica L. Smooth-leaved OR Glaucous Honeysuckle. (I. F. f. 3458.) Glabrous, twining or shrubby, I-3 m. long. Leaves glaucous beneath, 3-8 cm. long, the upper connate-perfoliate, oval, obtuse; the lower sessile or short-petioled, narrower; flowers several in a terminal cluster, yellowish green and tinged with purple, pubescent within, the tube gibbous at the base, scarcely longer than the 2-lipped limb; stamens exserted with the style; berries red, 6-8 $\mathrm{mm}$. in diameter. In rocky and usually dry situations, Quebec to Manitoba, N. Car., Ohio and Mich. May-June. [L. glazea Hill.]

5. Lonicera Sullivántii A. Gray. Sullivant's Honeysuckle. (I. F. f. 3459.) Similar to the preceding, very glaucous. Leaves oval or obovate, glaucous and commonly pubescent beneath, obtuse; flowers larger than those of the preceding species, the tube slightly exceeding the limb, pale yellow; fruit yellow, $6 \mathrm{~mm}$. in diameter. In woodlands, Tenn., Ohio and western Ont. (?) to Wis. and Manitoba. May-June.

6. Lonicera flàva Sims. Yellow Honeysuckle. (I. F. f. 3460.) Twining or trailing, glabrous. Leaves broadly oval, or elliptic, entire, obtuse, shortpetioled, or the upper sessile, green above, glaucous beneath, the pairs subtending 
flowers connate-perfoliate; flowers fragrant, in a terminal interrupted spike; corolla $2.5-3.7 \mathrm{~cm}$. long, the slender tube pubescent above within, the limb strongly 2 lipped, about half as long as the tube; filaments and style glabrous, exserted; fruit about $6 \mathrm{~mm}$. in diameter. N. Car. to Ky., Ga. and Ala. April-May.

7. Lonicera sempérvirens L. TRUMPET OR CORAL HONeysuckle. (I. F. f. 346r.) Glabrous, high climbing, evergreen in the South. Leaves oval, obtuse, 5-8 $\mathrm{cm}$. long, or the lower ones smaller, narrower and acutish, the upper pairs connate-perfoliate, all glaucous and sometimes slightly pubescent beneath, dark green above; flowers verticillate in terminal interrupted spikes; corolla scarlet or yellow, $2-3.7 \mathrm{~cm}$. long, glabrous, the tube narrow, slightly expanded above; stamens and style scarcely exserted; berries scarlet, about $6 \mathrm{~mm}$. in diameter. In low grounds, or on hillsides, Conn. to Fla., Neb. and Tex. Escaped from cultivation farther north. April-Sept.

8. Lonicera Japónica Thumb. Japanese or Chinese Honeysuckle. (I. F. f. 3462.) Pubescent, climbing or trailing. Leaves short-petioled, ovate, entire, $2.5-8 \mathrm{~cm}$. long, acute at the apex, rounded at the base, dark green and glabrous above, pale and usually sparingly pubescent beneath; flowers leafy-bracted at the base, white or pink, fading to yellow, pubescent without, the tube longer than the strongly 2-lipped limb; stamens and style exserted; berries black, 6-8 $\mathrm{mm}$. in diameter. Freely escaped from cultivation, Conn, to Penn., Ill., N. Car., Fla. and W. Va. Nat. from eastern Asia. June-Aug.

9. Lonicera coerùlea L. BlUE OR MOUntain Fly-Honeysuckle. (I. F. f. 3463.) Shrubby, 3-9 dm. high, the twigs sometimes slightly pubescent. ieaves oval or obovate, $2.5-4 \mathrm{~cm}$. long, obtuse, thick, pale and pubescent beneath, glabrous above, at least when mature, ciliate; flowers short-peduncled, subulate-bracted, yellow, $12-16 \mathrm{~mm}$. long; corolla-tube gibbous at the base, the limb nearly regular, its lobes oblong, equalling or slightly exceeding the tube; ovaries of the two flowers becoming united and forming a bluish-black 2-eyed berry about $5 \mathrm{~mm}$. in diameter. In low grounds, Newf. to Alaska, R. I., Penn., Wis. and Cal. Also in Europe and Asia. June.

I0. Lonicera oblongifòlia (Goldie) Hook. Swamp Fly-Honeysuckle. (I. F. f. 3464.) Leaves oval-oblong, 2-5 cm. long, glabrous or nearly so when mature, downy-pubescent when young; flowers in pairs on long slender peduncles; corolla yellow, or purplish within, $16-18 \mathrm{~mm}$. long, gibbous at the base, deeply 2lipped; bracts of the peduncle minute or none; ovaries remaining distinct, or becoming united, the berries red or crimson. In swamps, Quebec to Manitoba, Vt., N. Y., Penn. and Mich. May-June.

II. Lonicera Canadénsis Marsh. American Fly Honeysuckle. (I. F. f. 3465.) Shrubby, 9- $15 \mathrm{dm}$. high, the twigs glabrous. Petioles $4-6 \mathrm{~mm}$. long very slender; leaves ovate or sometimes oval, acute or acutish, rounded or cordate at the base, villous-pubescent beneath when young, glabrous or nearly so when mature, but the margins strongly ciliate; flowers about $16 \mathrm{~mm}$. long; peduncles long-filiform: bracts very small, subulate; corolla-limb nearly regular, its lobes short; berries separate, ovoid, light red, about $6 \mathrm{~mm}$. in diameter. In moist woods, N. S. to Manitoba, Conn., Penn. and Mich. May. [L. ciliata Muhl.]

12. Lonicera Xylósteum L. Fly Honeysucki.e. (I. F. f. 3466.) A shrub, 9-2I dm. high, the foliage densely appressed-pubescent when young. Leaves ovite, oval, or obuvate, entire, short petioled, rather pale green, obtuse, or the upper acute, persistently pubescent beneath, $2.5-8 \mathrm{~cm}$. long; peduncles about as long as the flowers, or longer; flowers yellowish white; bracts linear-subulate; berries scarlet. Escaped from cult. R. I. and N. Y. Native of Eur. and Asia. May-June.

13. Lonicera Tatárica L. Tartarian Bush-Honeysuckle. (I. F. f. 3467.) A glabrous shrub, I.5-3 m. high. Leaves ovate, rather thin, cordate, not ciliate; flowers in pairs on slender axillary peduncles; corolla pink to white, I4-16 mm. long, the tube gibbous at the base, the limb irregularly and deeply 5-lobed, somewhat' 2-lipped: peduncles $2.5 \mathrm{~cm}$. long: bracts linear, sometimes as long as the corolla-tube; stamens and style scarcely exserted; herries separate, red. Escaped from cultivation, Ont. and Vt. to N. Y., N. J. and Ky. Native of Asia. May.

14. Lonicera involucràta (Richards.) Banks. Involucred Fiy-HoneySUCKLE. (I. F. f. 3468.) A glabrate or pubescent shrub, I-3 m. high. Leaves short-petioled, ovate, oval, or obovate, 5-15 cm. long, acute or acuminate, pubes- 
cent, at least when young; peduncles axillary, 2-5 cm. long, 2-3-flowered; bracts ovate or oval, often cordate; bractlets large, at length surrounding the fruit; flowers yellow; corolla pubescent, funnelform, the limb nearly equally 5-lobed; berries separate, globose, or oval, nearly black, about $8 \mathrm{~mm}$. in diameter. In woodlands, Quebec to Ont., Mich., Alaska, Ariz., Utah and Cal. June-July.

\section{DIERVÍLla Moench.}

Shrubs, with opposite leaves, and yellow cymose or solitary flowers. Calyxtube slender, narrowed below, the limb with 5 linear persistent lobes. Corolla narrowly funnelform, the tube slightly gibbous at the base, the limb nearly regular, 5lobed. Stamens 5; anthers linear. Ovary 2-celled; ovules numerous: style fiiform; stigma capitate. Fruit a linear-oblong capsule, narrowed or beaked at the summit, septicidally 2-valved, many-seeded. Seed-coat minutely reticulated; endosperm fleshy; embryo minute. [Named for Dr. Dierville, who brought the plant to Tournefort.] Three species, the following and two in the mountains of the Southern States.

I. Diervilla Diervílla (L.) MacM. Bush Honeysuckle. (I. F. f. 3469.) A shrub, 6-12 dm. high, glabrous or nearly so, with terete branches. Leaves short-petioled, ovate or oval, acuminate usually rounded at the base, 5-14 cm. long, irregularly crenulate and often slightly ciliate; peduncles terminal, or in the upper axils, slender, I-5 flowered; flowers about $18 \mathrm{~mm}$. long; corolla more or less pubescent both without and within, 3 of its lobes somewhat united; capsule glabrous, slender, beaked. In dry or rocky woodlands, Newf. to the N. W. Terr., N. Car. and Mich. May-June.

\section{Family 3. ADOXÀCEAE Fritsch.}

\section{Moschatel Family.}

Glabrous slender herbs, with scaly or tuberiferous rootstocks, basal and opposite ternately compound leaves, and small green flowers in terminal capitate clusters. Calyx-tube hemispheric, adnate to the ovary, the limb 2-3-toothed. Corolla rotate, regular 4-6-lobed. Stamens twice as many as the lobes of the corolla, inserted in pairs on its tube; filaments short; anthers peltate, I-celled. Ovary 3-5-celled; style 3-5parted; ovules I in each cavity, pendulous. Fruit a small drupe with 3-5-nutlets. Endosperm cartilaginous. The family contains only the following monotypic genus.

\section{ADóXA L.}

Characters of the family. [Greek, without glory, i.e., insignificant.]

I. Adoxa Moschatéllina L. Musk-Root. Hollow-root. Moschatel. (I. F. f. 3470.) Stems simple, weak, erect, $7-15 \mathrm{~cm}$. high, bearing a pair of opposite ternate leaves usually above the middle. Basal leaves I-4, long-petioled, ter. nately compound, the segments broadly ovate or orbicular, obtuse, thin, 3-cleft or 3. parted, the lobes obtuse and mucronulate; head $6-8 \mathrm{~mm}$. in dia meter, of $3-6$ flowers: corolla of the terminal flower 4-5-lobed, those of the others usually 5-6-lobed; drupe green, bearing the persistent calyx-lobes above the middle. In shaded rocky places, Arctic Am. to Iowa, Wis., S. Dak. and Colo. Also in Europe and Asia. Odor musky. May.

\section{Order 8. VALERIANÀLES.}

Herbs, the corolla gamopetalous. Stamens mostly fewer than the corolla-lobes; anthers separate. Ovary inferior, I-celled with I pendulous ovule, or 3 -celled with 2 of the cavities without ovules. 


\section{Family r. VALERIANÀCEAE Batsch.}

\section{Valerian Family.}

Herbs, with opposite leaves, no stipules, and usually small flowers, in corymbed panicled or capitate cymes. Calyx-tube adnate to the ovary, its limb inconspicuous or none in flower, often becoming prominent in fruit. Corolla epigynous, somewhat irregular, its tube narrowed, and sometimes gibbous or spurred at the base, its limb spreading, mostly 5lobed. Stamens 1-4, inserted on the corolla and alternate with its lobes. Ovary inferior, 1-3-celled, one of the cavities containing a single anatropous ovule, the others empty. Fruit indehiscent, dry, containing a single suspended seed. Endosperm little or none; embryo straight; cotyledons oblong. About 9 genera and 275 species, of wide distribution. Fruit I-celled; persistent calyx lobes becoming awn-like; tall herbs. I. Valeriana. Fruit 3-celled; calyx lobes minute or none; low herbs.

2. Valerianella.

\section{VALERIÀNA L.}

Perennial strong-smelling herbs, the leaves mainly basal and the cymose flowers paniculate in our species. Calyx-limb of 5-15 plumose teeth, short and inrolled in flower, but elongated, rolled outward and conspicuous in fruit. Corolla funnelform or tubular, usually more or less gibbous at the base, the limb nearly equally 5lobed. Stamens commonly 3. Style entire, or minutely $2-3$-lobed at the summit. Fruit compressed, $\mathrm{I}$-nerved on the back, 3-nerved on the front. [Name Middle Latin, from valere, to be strong.] About 185 species, mostly in the north temperate zone and the Andes. Besides the following, 6 or 7 others occur in southern and western N. Am.

Corolla-tube very slender, $\mathrm{I}-2 \mathrm{~cm}$. long; basal leaves cordate. Corolla-tube 2-6 mm. long; basal leaves not cordate.

Leaves thick, parallel-veined, entire, or the segments not dentate.

Leaves thin, reticulate-veined, the segments dentate.

$$
\text { 2. } V \text {. edulis. }
$$

Lower leaves spatulate, often entire; plant glabrous.

Segments of middle stem-leaves 9-13, usually sinuate-dentate; corolla $3 \cdot 5-5$ mm. wide.

3. V. uliginosa.

Segments of middle stem-leaves 5-7, entire ; corolla $2.5-3 \mathrm{~mm}$. wide.

All the leaves pinnately divided; plant pubescent, especially at the nodes.

4. $V$ septentrionalis. 5. V. officinalis.

I. Valeriana pauciflòra Michx. Large-flowered Valerian. (I. F. f. 347 I.) Rootstocks slender, usually horizontal. Stem glabrous, 3-9 dm. high, often sending out runners; leaves thin, the basal ones slender-petioled, simple, or sometimes with a pair of small segments on the petiole, broadly ovate, cordate, acute, crenate or dentate; stem leaves pinnately 3-7-divided, the terminal segment larger than the others; cymes terminal, clustered; corolla pink; bracts linear: fruit ob. long or oblong-lanceolate, about $6 \mathrm{~mm}$. long, glabrous or puberulent; bristles of the calyx at length elongated and plumose. In moist soil, Penn. to W. Va., III., Ky. and Mo. May-June.

2. Valeriana édulis Nutt. Edible Valerian. Tobacco-Root. (I. F. f. 3472.) Erect, 3-12 dm. high, from a deep carrot-shaped root. Stem glabrous, or nearly so, the young leaves commonly pubescent and the older ones ciliate, sometimes glabrous; basal leaves spatulate or oblanceolate, $0.7-3 \mathrm{dm}$. long, obtuse, narrowed into margined petioles, parallel veined, entire or with a few obtuse entire lohes; stem leaves few, sessile, pinnately parted into linear or lanceolate segments: flowers yellowish white, $4 \mathrm{~mm}$. long, polygamo-diœcious, paniculate; bracts lanceolate, short: fruit narrowly ovate, glabrous or nearly so, $4 \mathrm{~mm}$. long, at length exceeded by the plumose calyx-teeth. In wet open places, Ont. to Br. Col., Ohio, Wis., Ariz. and N. Mex. May-Aug.

3. Valeriana uliơinòsa (T. \& G.) Rydb. Wogd or Swamp Valerian. (I. F. f. 3473.) Erect, glabrous or nearly so, 3-7.5 $\mathrm{lm}$. high. Rontstocks creeping or ascending; basal leaves petioled, oblong or spatulate, obtuse, entire, or with a few 
obtuse lobes, reticulate-veined, $5-25 \mathrm{~cm}$. long: stem leaves 3 or 4 pairs, petioled, sparingly hairy when young, pinnately parted into $3-\mathbf{I} 3$ ovate to lanceolate, dentate or rarely entire segments; inflorescence cymose-paniculate; flowers pink or nearly white, 6-8 mm. long; bracts linear-lanceolate; fruit ovate, glabrous, 4-5 mm. long. In wet soil, Me. to N. Y., Ont. and Mich. May-Aug. [ $V$. sylvatica uliginosa T. \& G.: $V$. sylvatica Beck, not Banks.]

4. Valeriana septentrionàlis Rydb. NORTHekn VALERIan. Erect, perfectly glabrous throughout or the inflorescence minutely puberulent, 2-4 dm. high. Basal leaves petioled, spatulate or oval, 2-10 $\mathrm{cm}$. long, entire; stem-leaves usually 3 pairs, the lower petioled, the upper sessile; segments $5-7$; oval to linear-lanceolate, entire or merely undulate on the margins; inflorescence cymose-paniculate, in flower usually congested, flowers white, alout $5 \mathrm{~mm}$. long: fruit glabrous, 3-4 inm. long. In wet soil on hillsides, Newf., subarctic America to Br. Col. and south in the Rockies to N. Mex. [ $V$. sylvatica Banks; not F. W. Scmidt.]

5. Valeriana officinàlis L. GARDEN VALERIAN. (I. F. f. 3474.) Erect, 6-15 dm. high. Leaves pinnately parted into 7-25 thin reticulate-veined lanceolate acute or acuminate segments, sharply dentate, or those of the upper leaves entire, usually with some scattered hairs beneath; flowers pink or nearly white, about $4 \mathrm{~mm}$. long; inflorescence of several rather compact corymbed cymes; bracts linearlanceolate; fruit glabrous, ovate, about $3 \mathrm{~mm}$. long. Escaped from gardens to roadsides, N. Y. and N. J. Native of Europe and Asia. June-Aug.

\section{VALERIANÉLla Poll.}

Annual dichotomously branched herbs, the basal leaves tufted, entire, those of the stem sessile, often dentate, the flowers in compact or capitate cymes, in our species corymbed or panicled. Corolla small, white, blue, or pink, nearly regular. Calyx-limb short or obsolete in flower, often none. Corolla-tube narrowed at the base, the limb spreading, 5-lobed. Stamens 3: style minutely 3-lobed at the summit. Fruit 3 -celled, 2 of the cells empty, and in our species about as large as the fertile one. [Name a diminutive of Valerian.] About 50 species, of the northern hemisphere. Besides the following, some 8 others occur in western N. Am.

Corolla funnelform, the short tube not longer than the limb or about equalling it.

Fruit flattened, twice as broad as thick.

Fruit triangular-pyramidal.

Fruit oblong-tetragonal or ovoid-tetragonal, grooved.

Groove of the fruit broad and shallow.

Groove of the fruit narrow.

Fruit globose or saucer-shaped.

Corolla salverform, the slender tube much longer than the limb. r. $V$. Locusta.

2. $V$. chenopodifolia.

3. V. radiata.

4. $V$. stenocarpa.

5. V. Woodsiana.

6. V. longiflora.

I. Valerianella Locústa (L.) Bettke. European Corn Salad. (I. F. f. 3475.) Glabrous, or pubescent at the nodes, 1.5-3 dm. high, usually repeated. ly forked. Basal leaves spatulate or oblanceolate, rounded and obtuse at the apex, 3-5 cm. long, entire; upper stem leaves oblong.lanceolate, usually dentate; peduncles short; cymes 6-12 mm. broad, almost capitate; bracts linear or linear-oblong; corolla blue, about $2 \mathrm{~mm}$. long; fruit flattened, rounded on the edges, $2 \mathrm{~mm}$. long, glabrous, depressed.orbicular in outline, the two empty cavities smaller than the fertile one, which has a corky mass at its back. In waste places, N. Y., N. J. and Penn. to Va. and La. Nat. from Europe. April-July. [V. olitoria Poll.]

2. Valerianella chenopoditòlia (Pursh) DC. Goose-foot CORN SAlad. (I. F. f. 3476.) Glabrous, 3-6 dm. high. Leaves entire, or the basal and lower ones repand, spatulate, obtuse; upper stem leaves oblong or lanceolate, $2.5-8 \mathrm{~cm}$. long; cymes dense, $12-18 \mathrm{~mm}$. broad, at length slender-peduncled; bracts lanceolate or oblong-lanceolate; corolla white, about $2 \mathrm{~mm}$. long; fruit triangular-pyramidal, $4 \mathrm{~mm}$. long, $2 \mathrm{~mm}$. thick, glabrous or minutely pubescent, the two empty cavities narrower than the fertile one but about as deep. In moist soil, western N. Y. to Va., Wis. and Ky. May-July.

3. Valerianella radiàta (L.) Dufr. BEaked Conn SALAD. (I. F. f. 3477.) Glabrous, or minutely pubescent below, I.5-4.5 dm. high. Basal and lower leaves spatulate, obtuse, entire, the upper lanceolate, usually dentate; cymes 8-12 mm. broad, dense: bracts small, lanceslate or oblong-lanceolate; corolla white, $2 \mathrm{~mm}$. long; fruit finely pubescent or sometimes glabrous, $2 \mathrm{~mm}$. long, I mm. thick, the 
empty cavities as thick as or thicker than the beaked fertile one and separated from each other by a broad shallow groove. In moist soil, N. Y. to Fla., Mich., Mo. and Tex. May-July.

4. Valerianella stenocàrpa (Engelm.) Krok. NARrow-CELled CORN Salad. (I. F. f. 3478.) Similar to the preceding. Fruit oblong-tetragonal, slightly smaller, glabrous or sometimes pubescent; sterile cavities not as thick as the oblong seed-bearing one, and separated from each other by a narrow groove. Kans. and Mo. to Tex. March-June.

5. Valerianella Woodsiàna (T. \& G.) Walp. Woods' CoRn SALAd. (I. F. f. 3479.) Usually larger than any of the preceding species, sometimes $9 \mathrm{dm}$. high, glabrous or nearly so. Basal and lower leaves spatulate, obtuse, entire; upper leaves lanceolate to linear-oblong, usually dentate; cymes 6-12 mm. broad, few-flowered; bracts comparatively large, lanceolate; corolla white, about $2 \mathrm{~mm}$. long; fruit glabrous, nearly globular, about $2 \mathrm{~mm}$. in diameter, the empty cavities inflated, introrse with a depression or concavity between them, as broad as the fertile one. In moist soil, N. Y., Penn. and Ohio to Tenn. and Tex. May-July.

Valerianella Woodsiàna umbilicàta (Sulliv.) A. Gray. Empty cells of the fruit bladdery-inflated, curved together at the ends, forming a deep concavity. Same range.

Valerianella Woodsiàna patellària (Sulliv.) A. Gray. Empty cells divergent, the fruit beconing saucer-shaped. Ohio and Penn.

6. Valerianella longiflòra (T. \& G.) Walp. Long-FLowered Corn SAlad. (I. F. f. 3480.) Glabrous, 1.5-3 dm. high. Leaves very obtuse, the basal ones spatulate, $2.5-7 \mathrm{~cm}$. long, those of the stem oblong or spatulate-oblong, smaller, somewhat clasping; cymes dense, corymbed; corolla salverform, pink or purplish, about $12 \mathrm{~mm}$. long, the almost filiform tube 3-4 times as long as the limb, the lobes linear-oblong; bracts with small gland-tipped teeth; fruit broadly ovate or nearly orbicular, the empty cavities divergent, larger than the oblong seed-bearing one. In moist rocky situations, Mo. and Ark. April-May.

\section{Family 2. DIPSACÀCEAE Lindl. Teasel Family.}

Herbs, with opposite or rarely verticillate leaves, and perfect flowers in dense involucrate heads. Stipules none. Flowers borne on an elongated or globose receptacle, bracted and involucellate. Calyx-tube adnate to the ovary, its limb cup-shaped, disk-shaped, or divided into spreading bristles. Corolla epigynous, the limb 2-5-lobed. Stamens $2-4$, inserted on the tube of the corolla and alternate with its lobes; filaments distinct; anthers versatile. Ovary inferior, I-celled; style filiform; stigma undivided, terminal, or oblique and lateral; ovule $\mathrm{r}$, anatropous. Fruit an achene, its apex crowned with the persistent calyx-lobes. Seedcoat membranous; endosperm fleshy; embryo straight. About 7 genera and 140 species, of the Old World.

Scales of the elongated receptacle prickly pointed.

Scales of the receptacle not prickly, herbaceous, capillary, or none.

x. Dipsacus

\section{Dípsacus $\mathbf{L}$.}

Rough-hairy or prickly tall biennial or perennial herbs, with usually large leaves, and blue or lilac flowers in dense terminal peduncled oblong heads in our species. Bracts of the involucre and scales of the receptacle rigid or spiny pointed. Involucels 4-8-ribbed, with a somewhat spreading border. Limb of the calyx cup-shaped, 4-toothed or 4-lobed. Corolla oblique or 2-lipped, 4-lobed. Stamens 4. Stigma oblique or lateral. [Greek, to thirst, the leaves of some species holding water.] About 15 species, of the Old World.

Scales of the receptacle straight-pointed.

Scales of the receptacle hooked at the apex.

I. D. sylvestris.

2. D. fullonum.

I. Dipsacus sylvéstris Huds. Wild Teasel. (I. F. f. 348I.) Biennial, stout, with numerous prickles, otherwise glabrous or nearly so, I-2 m. high. Leaves sessile, or the upper connate-perfoliate, lanceolate or oblong, the upper acuminate and generally entire, the lower crenate or sometimes pinnatifid, often $3 \mathrm{dm}$. long; heads becoming cylindric, at length 7-10 $\mathrm{cm}$. long; flowers lilac, 
8-12 $\mathrm{mm}$. long; leaves of the involucre linear, curved upward, as long as the head or longer; scales of the receptacle ovate, tipped with a straight subulate barbed awn, usually exceeding the flowers. In waste places, Me. and Ont. to Va., west to Mich. Nat. from Europe. July-Sept.

2. Dipsacus fullònum L. Fuller's Teasel. (I. F. f. 3482.) Similar to the preceding species. Leaves of the involucre, or some of them, shorter than the heads, spreading or at length reflexed; scales of the receptacle with hooked tips, about equalling the flowers, which are usually paler than in $D$. sylvestris. About wool mills, Eastern and Middle States. Fugitive from Europe.

\section{SCABIÒSA L.}

Herbs, with opposite leaves, no prickles, and blue, pink, or white flowers in peduncled involucrate heads. Bracts of the involucre herbaceous. Scales of the receptacle small, capillary, or none. Involucels 2-8-ribbed, the margins 4-toothed or expanded. Calyx-limb 5-toothed. Limb of the corolla 4-5-cleft, oblique or 2.lipped. Stamens 4 (rarely 2). Stigma oblique or lateral. Achene adnate to the involucel, crowned with the persistent calyx. [Latin, scale, from its repute as a remedy for scaly eruptions.] About 100 species, natives of the Old World.

Leaves, or some of them, pinnatifid; receptacle hairy, not scaly.

Leaves entire, or toothed ; receptacle scaly.

I. S. arvensis.

2. S. australis.

I. Scabiosa arvénsis L. Field Scabious. (I. F. f. 3483.) Perennial, pubescent, simple or little branched, 3-9 dm. high. Basal and lower leaves petioled, lanceolate, acute or acuminate, entire, lobed, or pinnatifid, $0.7-2 \mathrm{dm}$. long; upper leaves sessile, often deeply pinnatifid; heads long-peduncled, depressedglobose, $2.5-3.7 \mathrm{~cm}$. broad; flowers lilac-purple, about $12 \mathrm{~mm}$. long; receptacle depressed-hemispheric; achene angled, crowned with the 8 or ro linear-subulate calyx-teeth. In cultivated fields and waste places, Mass., Vt., N. Y. and Penn. Adventive from Europe. June-Sept.

2. Scabiosa austràlis Wulf. Southern Scabious. (I. F. f. 3484.) Perennial, puberulent, at least above, slender, 4-9 dm. high. Basal leaves oblanceolate to oblong. mostly obtuse, I-3 dm. long, the petiole often as long as the blade, or longer; stem leaves distant, lanceolate or oblong-lanceolate, entire, or toothed, short-petioled, or the upper sessile, acute or acuminate; heads of purple flowers long-peduncled, rather less than $2.5 \mathrm{~cm}$. in diameter, oblong-ovoid in fruit; bracts of the involucre glabrous; receptacle scaly; achene crowned with 5 calyx-teeth. Nat. from Europe in N. Y. and Mass. Summer.

Scabiosa succisa L., similar to the preceding species, but with globose fruiting heads and hirsute involucre, is reported from Cape Breton Island.

\section{Order 9. CAMPANULÀLES.}

Herbs, rarely shrubs, the corolla gamopetalous, or petals sometimes separate in Cucurbitaceae. Stamens as many as the corolla-lobes (fewer in the Cucurbitaceae) ; anthers united except in Campanula and Specularia of the Campanulaceae, in Ambrosiaceae, and in Kuhnia of the Compositae. Ovary inferior.

Flowers not in involucrate heads; juice mostly milky.

Endosperm none; flowers monœcious or diœcious; our species vines.

Encosperm present, fleshy; flowers perfect.

Fam. I, Cucurbitaceae.

Flowers in involucrate heads.

Flowers all expanded into rays (ligulate); juice milky. Fam. 3. Cichoriacease.

Flowers all tubular, or the outer expanded into rays; juice very rarely milky.

Stamens distinct, or nearly so.

Fam. 4. Ambrosiaceae.

Stamens united by their anthers into a tube around the style (except in Kuhnia).

Fam. 5. Compositae.

\section{Family I. CUCURBITÀCEAE B. Juss.}

Gourd Family.

Herbacenus vines, usually with tendrils. Leaves alternate, petioled, generally palmately lobed or dissected, Flowers monocious or diœ- 
cious. Calyx-tube adnate to the ovary, its linb usually 5-lobed, the lobes imbricated. Petals usually 5, inserted on the limb of the calyx, separate, or united into a gamopetalous corolla. Stamens mostly 3 (sometimes I), 2 of them with 2 -celled anthers, the other with a I-celled anther; filaments short, often somewhat monadelphous. Ovary 1-3celled; style terminal, simple, or lobed; ovules anatropous. Fruit a pepo, indehiscent, or rarely dehiscent at the summit, or bursting irregularly; or sumetimes dry and membranous. Seeds usually flat; endosperm none. About 90 genera and 650 species, mainly of tropical regions.

Flowers large, yellow; prostrate vine.

Flowers small, white or greenish; climbing vines.

Fruit glabrous; seeds numerous, horizontal.

r. Cucurbita.

Fruit prickly ; seeds I or few, erect or pendulous.

2. Melothria.

Fruit dehiscent at the apex or bursting irregularly; several-seeded.

Leaves 3-7-lobed; anthers 3 .

Leaves digitately compound; anther $\mathbf{r}$.

Fruit indehiscent, 1-seeded.

3. Micrampelis.

4. Cyclanthera.

5. Sicyos.

\section{x. CUCÚRBITA L.}

Rough prostrate vines, rooting at the nodes, with branched tendrils, usually lobed leaves mostly cordate at the base, and large yellow axillary monœcious flowers. Calyx-tube campanulate, usually 5 -lobed. Corolla campanulate, 5-lobed to about the middle, the lobes recurving. Staminate flowers with three stamens, the anthers linear, more or less united, and no pistil. Pistillate flowers with I pistil; ovary oblong with 3-5 many-ovuled placentæ; style short, thick; stigmas 3-5, each 2-lobed, papillose; staminodia 3. Fruit large, fleshy, with a thick rind, many-seeded, indehiscent. [The Latin name of the gourd.] About ro species, natives of America, Asia, and Africa. Besides the following, some 6 others occur in the southern U. S.

I. Cucurbita foetidíssima H. B. K. Missouri Gourd. (I. F. f. 3485.) Stem stout, rough, hirsute. Root large, carrot-shaped. Petioles stout, very rough; leaves ovate-triangular, thick, somewhat fleshy, cordate or truncate at the base, acute, I-3 dm. long, usually slightly 3-5-lobed, denticulate, rough above, canescent beneath; peduncles $2-5 \mathrm{~cm}$. long; flowers mostly solitary; corolla 6-10 cm. long; pepo globose or globose-ovoid, 5-8 cm. in diameter, smooth, its pulp fibrous and bitter. Dry soil, Neb. to Tex. and Mex., west to southernCal. May-Sept.

- Cucurbito Pèpo L., the PUMPKIn, is found occasionally in waste places.

Citrullus Citrúllus (L.) Karst., the WATERMELON, is found escaped from cultivation along river shores in Va. and W. Va. and in the Southern States.

\section{MELÒTHRIA L.}

Slender vines, with simple or rarely bifid tendrils, thin leaves, and small white or yellow monœecious flowers, the staminate clustered, the pistillate often solitary. Calyx campanulate, 5-toothed. Corolla campanulate, deeply 5-parted. Stamens 3 in the staminate flowers, the anthers distinct or slightly united, the pistil want ing or rudimentary. Fertile flowers with I pistil; ovary ovoid, constricted below the corolla; placentæ 3; ovules numerous; style short: stigmas 3, linear. Fruit small, berry-like, pulpy. [From the Greek for some vine, probably Bryonia Cretica.] About 64 species, natives of warm and tropical regions. Besides the following 2 or 3 others occur in the southern U. S.

r. Melothria péndula L. Creeping Cucumber. (I. F. f. 3486.) - Root perennial. Stem slender, branched, glabrous, grooved; leaves nearly orbicular in outline, finely pubescent or scabrous on both sides, cordate at the base, 5-lobed or 5-angled, denticulate or dentate; tendrils puberulent; staminate flowers 4-7, racemose, borne on a peduncle $\mathbf{I}-2.5 \mathrm{~cm}$. long; fertile flowers solitary, slender-peduncled: corolla greenish white, about $4 \mathrm{~mm}$. broad; fruit ovoid, green, 8-12 mm. long. In thickets, Penn. (Schweinitz, according to Cogniaux), Va. to Fla., Ind., Ky., La. and Mex. June-Sept.

3. MICRÁMPELIS Raf. [ECHINOCYSTIS T. \& G.]

Mostly annual climbing herbs, with branched tendrils, lobed or arigled leaves, and small white monœecious flowers. Calyx-tube campanulate, 5-6-lobed, Corolla 
deeply 5-6-parted. Stamens 3 in the staminate flowers, the anmers more or less coherent. Pistillate flowers with a 2 -celled ovary; ovules 2 in each cavity; style very short; stigma hemispheric or lobed. Fruit fleshy or dry at maturity, densely spiny, 1-2-celled, usually with 2 seeds in each cavity, dehiscent at the summit. Testa of the seed roughened. [Greek, small-vine.] About 25 species, natives of America. Besides the following, about ro others occur in the western U. S.

I. Micrampelis lobàta (Michx.) Greene. Will Balsam Apple. Mock Apple. (I. F. f. 3487.) Stem nearly glabrous, angular and grooved, clin.bing to a height of $4.5-7.5 \mathrm{~m}$., sometimes villous-pubescent at the rodes. Leaves thin, roughish on both sides, deeply cordate, 3-7-lobed to about the middle, the loles triangular-lanceolate, acute or acuminate, remotely serrulate; staminate flowers very numero:s in narrow compound racemes; pistillate flowers solitary, or rasely 2 together; fruit ovoid, green, about $5 \mathrm{~cm}$. long, armed with slender spines. Alcng rivers, and in waste places, Me. to Ont., Mont., Va., Ky. and Tex. July-Sept.

\section{CYCLANTHÈRA Schrad.}

Climbing, mostly glabrous vines, with usually digitately compound leaves and small white or greenish monœcious flowers. Calyx cup-shaped, 5-toothed. Corolla rotate, deeply 5-parted. Staminate flowers racenose or panicled, the stamens united into a central column; anther I, annular in our species. Pistillate flcwers solitary; ovary obliquely ovoid, beaked, I-3-celled, with 2 ovules in each cavity; style short; stigma large, lemispheric. Fruit spiny, obliquely ovoid, beaked, at length irregularly dehiscent, few-seeded. [Greek, circle-anther.] Alout 40 species, natives of America.

I. Cyclanthera dissécta (T. \& G.) Arn. Cut-leaved Cyclanthera. (I. F. f. 3488.) Annual; stem grooved and angular, glabrous, tranching, climbing to a height of 9-12 dm., or straggling. Leaves digitately 3-7 foliolate, the leaflets oval or oblong, acute at each end, I-5 cm. long, rough on both sides, dentate, or somewhat lobed; staminate flowers racemose, borne on a peduncle $\mathbf{I}-5 \mathrm{~cm}$. long; pistillate flowers solitary, very short-peduncled; fruit narrowed at the base, slightly oblique, about $2.5 \mathrm{~cm}$. long, armed with slender spines. Thickets, Kans. to Tex., La. and northern Mex. July-Sept.

\section{Sícyos L.}

Annual climbing vines, with branched tendrils, angled or lobed leaves, and small white or green monœcious flowers. Calyx-tube campanulate or cup-shaped, 5-toothed. Corolla campanulate or rotate, 5 parted nearly to the base. Staminate flowers corymbose or racemose, with 3 stamens, the filaments united into a short column, the anthers coherent. Pistillate fiowers several together in capitate longpeduncled clusters; ovary oblong or fusiform, I-celled; ovule i, pendulous; style short, slender; stigmas usually 3. Fruit spiny, indehiscent, I-seeded. [Greek, a cucumber or gourd.] About 35 species, of America and Australasia. Besides the following, 2 others occur in the southwestern States.

I. Sicyos angulàtus L. ONe-Seeded Bur-Cucumber. Star Cucumber. Nimble Kate. (I. F. f. 3489.) Stem angled, more or less viscid-pubescent, climbing to a height of $4.5-7.5 \mathrm{~m}$., or trailing. Leaves nearly orbicular, rough on both sides, rather thin, deeply cordate at the base, 5-angled or 5-lobed, the lobes acute or acuminate, denticulate;-staminate flowers loosely corymbose or racemose, borne on elongated peduncles; fertile flowers capitate, their peduncles shorter; fruits sessile, 3-1o together, yellowish, about $\mathbf{I} .3 \mathrm{~cm}$. long, pubescent, armed with slender rough spines. Along river banks and in moist places, Quebec and Ont. to Fla., S. Dak., Kans. and Tex. Nat. in eastern Europe. June-Sept.

\section{Family 2. CAMPANULACEAE Juss. Bell-flower Family.}

Herbs (some tropical species shrubs or even trees), with alternate exstipulate simple leaves, acrid and usually milky juice, and perfect flowers. Calyx-tube adnate to the ovary, its limb mostly 5-lobed or 5-parted, the lobes equal or slightly unequal, valvate or imbricate in the bud, commonly persistent. Corolla gamopetalous, regular or irregular, inserted at the line where the calyx becomes free from the ovary, its 
tube entire, or deeply cleft on one side, its limb 5-lobed, regular, or more or less 2-lipped, or corolla rarely divided into separate petals. Stamens 5 , alternate with the corolla-lobes, inserted with the corclla; filaments separate or connate; anthers 2 -celled, introrse, separate, or united into a ring or tube. Ovary 2-5-celled (rarely 6-10-celled), with the placentæ projecting from the axis, or 1 -celled with two parietal placentæ; style simple; stigma mostly $2-5-1$ obed, pilose by a tuft or ring of hairs, or glabrous; ovules anatropous. Fruit a capsule or berry. Seeds numerous, small; embryo minute, straight; endosperm fleshy. About $6 \mathrm{c}$ genera and 1500 species, of wide distribution.

Corolla regular, campanulate or rotate; anthers separate.

Capsule opening by lateral pores or valves.

Corolla campanulate, rarely rotate; flowers all complete.

Corolla rotate; earlier flowers cleistogamous.

Capsule opening by terminal pores or valves.

Corolla irregular; anthers connate around the style.

1. Campanula.

2. Specularia.

3. Jasione.

4. Lobelia.

\section{CAMPÁNULA L.}

Perennial or annual herbs, with alternate or basal leaves. Flowers regular, complete, blue, violet, or white. Calyx-tube hemispheric, turbinate, obovoid, or prismatic, adnate to the ovary, the limb deeply 5-lobed or 5-parted (rarely 3-4parted). Corolla campanulate or rotate, 5-lobed or 5-parted. Stamens 5, free from the corolla; filaments usually dilated at the base. Uvary inferior, 3-5-celled; stigma 3-5-lobed. Capsule wholly or partly inferior, crowned by the persistent calyx-lobes, opening on the sides, either near the top, middle or bottom by 3-5 small valves or perforations, or tending to be indehiscent in some species. [Diminutive of the Latin campana. a bell.] About 250 species, natives of the northern hemisphere. Besides the following, some 12 others occur in southern and western N. Am.

* Corolla campanulate; flowers solitary, racemose, glomerate, or panicled.

Flower solitary at the end of the stem; arctic and alpine plants.

Corolla 8-12 mm. long; capsule-openings near the summit.

Corolla $12-25 \mathrm{~mm}$. long: capsule-openings near the base.

I. C. uniflora.

2. C. rotundifolia.

Flowers racemose, glomerate, or paniculate.

Corolla $\mathrm{r} 4-30 \mathrm{~mm}$. long.

Stem leaves linear, the basal orbicular, mostly cordate.

Leaves all ovate to lanceolate; plants pubescent or scabrous.

Flowers pedicelled in $\mathbf{I}$-sided racemes.

Flowers sessile in terminal and axillary clusters.

Corolla 4-12 mm. long.

Plant rough; style not exserted.

Flowers white, sometimes tinged with blue, 5-8 $\mathrm{mm}$. long; leaves mostly

linear-lanceolate, crenulate.
Flowers blue, 10-12 $\mathrm{mm}$. long; leaves linear, denticulate with minute

2. C. rotundifo'ia.

3. C. rapunculoides.

4. C. glomerata. callous teeth.

Plant smooth, glabrous, slightly viscid; style long-exserted.

6. C. uliginosa.

\section{** Corolla rotate; flowers spicate. \\ 7. C. divaricata. \\ 8. C. Americana.}

I. Campanula uniflòra L. Arctic Harebell or Bellflower. (I. F. f. 3490.) Perennial, glabrous or nearly so; stem simple, I-flowered, $3-15 \mathrm{~cm}$. high. Leaves linear or linear-oblong, acute, sessile, thickish, entire or sparingly dentate, $18-35 \mathrm{~cm}$. long, or the lower and basal ones spatulate, obtuse and narrowed into petioles; flower erect; calyx-tube turbinate, glabrous or pubescent, shorter than or equalling the lobes; corolla campanulate, 8-12 $\mathrm{mm}$. long, blue; capsulr cylindric or club-shaped, about $12 \mathrm{~mm}$. long, erect, opening by valves near the summit. Lab. and Arctic Am. to Alaska, south in the Rocky Mountains to Colo. Also in northern Europe and Asia. Summer.

2. Campanula rotundif lia L. Harebell. Blue Bells of Scotland. (I. F. f. 3491.) Perennial by slender rootstocks, glabrous or nearly so; stems erect or diffuse, often several from the same root, r.5-9 dm. high. Basal leaves nearly orbicular or broadly ovate, usually cordate, slender petioled, 6-25 mm. wide, den- 
tite or entire, often wanting at flowering time; stem leaves linear or linear-oblong, ac ute, mostly entire, sessile, or the lower narrowed into short petioles and somewhat spatulate; flowers, racemose (rarely solitary), drooping or spreading; calyxlobes subulate, spreading, longer than the short-turbinate tube; corolla blue, campanulate; capsule obconic or ovoid, pendulous, ribbed, opening by short clefts near the base. On moist rocks and in meadows, Lab. to Alaska, south to N. J., Neb., Ariz. and Cal. Also in Europe and Asia. June-Sept.

2a. Campanula dúbia D. C. Northern Bell-flower. Stems ascending, I-3 dm. high, glabrous, or slightly pubescent on the angles. Basal leaves reniform to ovate, long-petioled, those of the stem linear-lanceolate, wider than those of the preceding species; flowers usually solitary, sometimes $2-4$, erect, 2-2.5 $\mathrm{cm}$. long; calyx-lobes lanceolate to linear-lanceolate. On wet rocks, mountains of Me. and N. H.; Que. to Lab. and Newf. (C. rotundifolia Langsdorfiana Britton, not $C$. Langsdorfiana Fisch.)

3. Campanula rapunculoides E. Creeping or European Bellflower. (I. F. f. 3492.) Perennial by slender rootstocks; stem glabrous or pubescent, simple or rarely branched, leafy, erect, rather stout, 3-9 dm. high. Leaves pubescent or puberulent, crenate-denticulate, ovate or ovate-lanceolate, acute or acuminate, the lower and basal ones mostly cordate, 7-15 cm. long, 3-5 cm. wide, slenderpetioled, the upper short-petioled or sessile, smaller; flowers short-pedicelled, drooping, 25-35 mm. long; corolla deeply 5-lobed, much longer than the linear spreading calyx-lobes; capsule globose, nodding, about $8 \mathrm{~mm}$. in diameter, opening near the base. In fields and along roadsides, N. B. to Ont., southern N. Y. and Ohio. Nat. from Europe. July-Sept.

4. Campanula glomeraita L. Clustered Bellflower. Dane's Blood. (I. F. f. 3493.) Perennial by short rootstocks; stem stout, simple, erect, pubescent, leafy, 3-6 dm. high. Leaves pubescent on both sides, crenulate, the lower and basal ones oblong or ovate, mostly obtuse, sometimes cordate, 5-10 cm. long, the upper lanceolate or ovate-lanceolate, acute, sessile or clasping, smaller; flowers about 25 $\mathrm{mm}$. long, sessile, erect and spreading; corolla deeply 5-lobed; calyx-lobes lanceolate, acuminate; capsule ovoid or oblong, erect, about $6 \mathrm{~mm}$. high, opening near the base. In fields and along roadsides, eastern Mass. Nat. from Europe. June-Aug.

5. Campanula aparinoides Pursh. Marsh or Bedstraw Bellflower. (I. F. f. 3494.) Perennial; stems very slender or filiform, weak, reclining or diffuse, rough with short retrorse bristles, leafy, paniculately branched, 1.5-6 dm. long. Leaves lanceolate, or linear-lanceolate, sessile, sparingly crenulate with low teeth, or entire, rough on the margins and midrib, acute at both ends, 12-35 mm. long, 2-6 mm. wide; flowers paniculate, 5-8 $\mathrm{mm}$. long; corolla deeply 5-cleft, its tube equalling or longer than the triangular-lanceolate acute calyx-lobes; capsule subglobose, opening near the base. In grassy swamps, N. B. to the N. W. Terr., south to Ga., Ky. and Colo. June-Aug.

6. Campanula uliginòsa Rydb. n. sp. Blue Marsh Bellflower. Perennial; similar to the preceding but branches less spreading; stem 3-6 dm. high, retrorsely hispidulous on the angles. Leaves linear, $2.5-6 \mathrm{~cm}$. long, I-4 mm. wide, retrorsely hispidulous on the margins and midribs, acute, minutely denticulate with callous teeth or entire; corolla blue with darker veins, cleft to below the middle into lanceolate lobes; capsule subglobose, about $5 \mathrm{~mm}$. long and nearly as broad, opening near the base. In wet meadows, Me. and northern N. Y. to Minn. and Iowa; type collected by B. C. Taylor at Chisago City, Minn.

7. Campanula divaricàta Michx. Panicled Bellflower. (I. F. f. 3495.) Perennial, glabrous but somewhat viscid; stem erect, paniculately branched, slent der, 3-9 dm. high. Leaves lanceolate, ovate or oblong-lanceolate, the uppermossometimes linear, sharply serrate, acuminate at the apex, narrowed to the base, the upper sessile, the lower petioled, 5-7 cm. long, 6-25 $\mathrm{mm}$. wide; flowers in compound panicles, drooping; corolla light blue, about $6 \mathrm{~mm}$. long; calyx-lobes lanceolate, acute, often dentate; capsule turbinate, about $5 \mathrm{~mm}$. long, opening near the middle. On rocky banks, Va. and W. Va. to Ga. and Terın. June-Sept.

8. Campanula Americàna L. Tall Bellflower. (I. F. f. 3496.) Annual or biennial, more or less pubescent; stem erect or nearly so, simple or rarely with a few long branches, 6-18 dm. high. Leaves thin, ovate, oblong or lanceolate, serrate, acuminate at the apex, narrowed at the base, petioled, or the upper sessile, 
7-15 cm. long, the lowest sometimes cordate; flowers in a sometimes leafy spike, which is often 3-6 dm. long; lower bracts foliaceous, the upper subulate; corclla blue, or rarely white, about $25 \mathrm{~mm}$. broad, deeply 5-cleft; calyx-lobes linear-subulate, spreading; style declined and curved upward, long-exserted; capsule narrowly turbinate, ribbed, erect, 8-10 $\mathrm{mm}$. long, opening near the summit. In moist thickets and woods, N. B. to Ont., S. Dak., Fla., Ky., Ark. and Kans. July-Sept.

\section{SPECULÀRIA Heist.}

\section{[Legouzia Durand.]}

Annual herbs, with alternate toothed or entire leaves, the stem and branches long, slender. Flowers axillary, sessile or nearly so, 2-bracted, or the upper panicled in some exotic species, the earlier (lower) ones small, cleistogamous, the later with a blue or purple nearly rotate corolla. Calyx-tube narrow, the lobes in the earlier flowers 3 or 4 , in the later 4 or 5 . Corolla 5 -lobed or 5 -parted, the lobes imbricated in the bud. Filaments flat; anthers separate; linear. Ovary 3 -celled (rarely 2-or 4-celled); ovules numerous; stigma usually 3-lobed. Capsule prismatic, cylindric, or narrowly obconic, opening by lateral valves. Seeds ovoid, oblong, or lenticular. About Io species, natives of the northern hemisphere, one extending into South America. NName derived from Speculum Veneris, the ancient name of the European Venus' Looking-glass.] The generic name Specularia Heist., used by Fabricius in 1759, antedates Legouzia Durand, 1782.

Capsule narrowly oblong or turbinate.

Leaves sessile; capsule-valves near the top.

Leaves cordate-clasping; capsule-valves at about the middle. Capsule linear-cylindric; leaves sessile; western.

I. S. bifiora.

2. S. perfoliata. 3. S. leptocarpa.

I. Specularia bifiòra (R. \& P.) A. Gray. Small Venus' Looking-Glass. (I. F. f. 3497.) Glabrous, or nearly so; stem simple or branched, very slender, roughish on the angles, 1.5-3 dm. high. Leaves ovate, oblong, or the upper lanceolate, sessile, acute or obtuse at the apex, crenate with a few teeth, or entire, 8-20 mm. long, or the upper smaller; earlier flowers with 3 or 4 ovate to lanceolate calyx-lobes, those of the later flowers 4 or 5 , lanceolate-subulate, longer; capsule oblong-cylindric, 6-10 mm. long, opening by valves close under the calyxteeth. In dry soil, Va. to Mo., Kans., Fla. and Texas. Also in Cal. and S. Am. April-July.

2. Specularia perfoliàta (L.) A. DC. Venus' Looking-Glass. (I. F. f. 3498.) More or less pubescent; stem densely leafy, slender, sometimes prostrate, retrorse-hispid on the angles, or nearly smooth, 1.5-6 dm. long. Leaves orbicular or broadly ovate, crenate-dentate or sometimes entire, 6-25 mm. wide; flowers solitary or 2-3 together in the axils, the later (upper) ones with 5 (rarely 4) triangular-lanceolate acuminate rigid calyx-lobes, and a rotate blue or violet corolla 1-2 $\mathrm{cm}$. broad, the earlier ones with 3 or 4 shorter calyx-lobes longer than the rudimentary corolla; capsule oblong, or narrowly turbinate, 4-6 mm. long; seeds lenticular. In dry woods, Me. and Ont. to Br. Col., Fla., La., Mex., Utah and Ore. May-Sept.

3. Specularia leptocàrpa (Nutt.) A. Gray. Western Venus'Looking-Glass. (I. F. f. 3499.) Hirsute, or nearly glabrous; stem slender, I.5-4.5 dm. high. Leaves linear-lanceolate to oblong, not clasping, acute at both ends, or the lowest obtuse at the apex, entire or sparingly denticulate, $\mathbf{I}-2.5 \mathrm{~cm}$. long, 2-4 mm. wide; flowers usually solitary in the axils, the later ones with 4 or 5 subulate calyx-lobes and a rotate corolla $10-18 \mathrm{~mm}$. broad, the earlier ones with 3 shorter calyx-lobes and rudimentary corolla; capsule 8-16 $\mathrm{mm}$. long, less than $2 \mathrm{~mm}$. thick, the upper at length opening near the summit; seeds oblong. In dry soil, western Mo. to Mont. and Tex. May-Aug.

\section{JASIÒNE L.}

Herbs, the flowers in terminal heads subtended by a many-leaved involucre. Calyx tube campanulate, adnate to the ovary, the limb 5-divided. Corolla at first tubular, splitting later to the base into 5 linear or linear-oblanceolate segments. Filaments subulate. Anthers united at the base, free above. Ovary inferior, 2-celled; stigma club-shaped. Capsule 2-celled, dehiscent by two terminal pores. [Greek name of some medicinal plant.] Five species of central Europe and the Mediterranean Region. 
I. Jasione montàna L. Sheep's-BIT. Annual or biennial, with several stems from a simple root. Stems 1.5-2.5 dm. high, branched above, leafy below; leaves linear, rough-hairy, sessile; flowers in hemispherical heads; corolla blue, seldom white or pink. In waste places, R. I. and Conn. Adventive from Europe. JuneSept.

\section{LOBÈlı L. (See Appendix.)}

Herbs (some tropical species shrubs), with alternate or basal leaves, and race. mose spicate or paniculate, often leafy-bracted, red, yellow, blue, or white flowers. Calyx-tube turbinate, hemispheric or ovoid, adnate to the ovary. Corolla-tube straight, oblique, or incurved, divided to the base on one side, 2 -lipped in our species, the lobe on each side of the cleft erect or recurved, turnea away from the other 3 which are somewhat united. Stamens free from the corolla-tube, monadelphous, at least above, 2 or all the 5 anthers with a tuft of hairs at the tips, 3 of them usually larger than the other 2, all united into a tube or ring around the style. Ovary 2-celled, the 2 placentæ many-ovuled; stigma 2-lobed or 2-cleft. Capsule loculicidally 2-valved. [Named after Matthias de L'Obel, 1538-1616, a Flemish botanist.] About 225 species of wide geographic distribution. Besides the following, some 12 others occur in the southern and western U. S.

* Aquatic; stems simple, nearly naked; flowers light blue.

Leaves terete, hollow, obtuse, all tufted at the base.

Leaves flat, linear-oblong or spatulate, entire or glandular-denticulate.

I. L. Dortmanna.

2. L. paindosa.

* * Terrestrial plants of wet or dry soil; stems leafy.

1. Corolla-tube ro- $25 \mathrm{~mm}$. long.

Flowers bright scarlet (rarely white); corolla-tube $20-25 \mathrm{~mm}$. long.

Flowers blue, white, or blue and white; corolla-tube ro-r $5 \mathrm{~mm}$. long.

Leaves ovate, lanceolate, or the lower ones obovate.

Leaves glabrous or sparingly pubescent.

Calyx-lobes hirsute; sinuses with large deflexed auricles.

Calyx-lobes glabrous or glandular, usually without auricles.

3. L. cardinalis. 
mm. long, its lower lip pubescent at the base. In swamps and ponds, Del. to Fla. and La., mostly near the coast. May-July.

3. Lobelia cardinàlis L. CARDinal-Flower. Red Lobelia. (I. F. f. 3502.) Perennial by offsets; stem slightly pubescent, or glabrous, leafy, 6-13 dm. nigh. Leaves oblong, oval, ovate-lanceolate, or lanceolate, thin, glabrous or sparingly pubescent, $5-15 \mathrm{~cm}$. long, 6-35 $\mathrm{mm}$. wide, acuminate or acute at both ends, crenulate or denticulate, the upper sessile, the lower petioled; flowers racemose, commonly numerous, bright scarlet or red (rarely white), 25-37 mm. long; bracts usually glandular; calyx-lobes linear, elongated, acute; larger anthers glabrous. In moist soil, N. B. to Fla., the N. W. Terr., Kans. and Tex. July-Sept.

4. Lobelia syphilítica L. Great Lobelia. Blue Cardinal-flower. (I. F. f. 3503.) Perennial by short offsets; stem sparingly pubescent, rather stout, very leafy, usually simple, 3-9 dm. high. Leaves thin, green, 5-15 cm. long, $1-5 \mathrm{~cm}$. wide, acute or acuminate at the apex, narrowed at the base, repand-denticulate, or irregularly crenate-dentate, sessile or the lower petioled; flowers densely racemose, leafy-bracted; calyx-lobes lanceolate, acuminate, pubescent or ciliate; corolia bright blue, or occasionally white, 20-25 $\mathrm{mm}$. long, the lobes of its larger lip oblong-oval, obtuse, glabrous; larger anthers glabrous. In moist soil, Me. and Ont. to S. Dak., Ga., La. and Kans. July-Oct.

Lobelia syphilítica Ludoviciàna A. DC. Glabrous or very nearly so ; leaves thick, pale green, oblong or lanceolate, nearly entire, the lower obtuse and spatulate; calyxlobes sparingly pubescent; lobes of the larger lip of the corolla acutish. Neb. to La.

5. Lobelia amoèna Michx. Southern Lobelia. (I. F. f. 3504.) Nearly glabrous throughout, perennial; stem simple, slender, leafy, 3-I2 dm. high. Leaves thin, oblong-lanceolate to oval, repand-dentate or denticulate, the lower petioled and mostly obtuse, 5-15 cm. long, the upper sessile, acute or acutish, smaller; flowers blue, racemose, nearly $25 \mathrm{~mm}$. long; bracts narrow and small, or the lower foliaceous, glandular; calyx-lobes linear-subulate, acuminate, glabrous, elongated; corolla-tube Io-I4 $\mathrm{mm}$. long, 3-4 $\mathrm{mm}$. thick; larger anthers glabrous, or puberulent at the tip; lobes of the larger lip of the corolla broadly ovate to oval, obtuse, glabrous. In swamps, N. Car. to Fla.; probably within our area, though not reported. July-Sept.

Lobelia amoina glandulffera A. Gray. Smaller; stem very slender; leaves $2-5 \mathrm{~cm}$. long, mostly obtuse, glandular-dentate; bracts small, very glandular; raceme somewhat secund; sinuses of the calyx sometimes slightly auricled, the lobes commonly glandular. Del, and Va. to Fla. and Ala.

6. Lobelia pubérula Michx. Downy Lobelia. (I. F. f. 3505.) Perennial, densely and finely puberulent all over, slightly viscid; stem mostly simple, leafy, $3.9 \mathrm{dm}$. ligh. Leaves oval, oblong, ovate, or obovate, rather thick, the lower petioled, all obtuse or the uppermost acute, denticulate or crenate-dentate, the teeth often glandular; flowers blue, $16-20 \mathrm{~mm}$. long, in long spike-like racemes: lower bracts, or sometimes all of them, foliaceous, glandular; calyx hirsute or pubescent, its lobes narrowly lanceolate, elongated, usually with small short rounded auricles at the sinuses; corolla-tube about $\mathbf{I} \mathrm{cm}$. long, 2-3 $\mathrm{mm}$. thick, the lobes of its larger lip broadly ovate, glabrous; larger anthers minutely bearded. In moist sandy soil, southern N. J. to Fla., west to Ill., Kans. and Tex. Aug.-Oct.

7. Lobelia glandulòsa Walt. Glandular Lobelia. (I. F. f. 3506.) Perennial; stem slender, leafy below, nearly naked above, simple, glabrous, or sparingly pubescent, 3-12 dm. high. Leaves thick, glabrous, the lower petioled, obtuse, often $17 \mathrm{~cm}$. long and $8 \mathrm{~mm}$. wide, the upper sessile, acutish, shorter; flowers racemose-spicate, secund, often few and distant, blue, nearly $25 \mathrm{~mm}$. long; bracts narrow, glandular; calyx tube often densely hirsute, its lobes subulate, the sinuses not appendaged; corolla-tube 10-12 mm. long, 2-3 mm. thick, about twice as long as the calyx-lobes; larger lip of the corolla pubescent within at the base, its lobes ovate, acutish; anthers all bearded at the tip. In swamps near the coast, Va. to Fla. July-Sept.

8. Lobelia spicàta Lam. Pale Spiked Lobelia. (I. F. f. 3507.) Perennial or biennial, puberulent; stem strict, simple, leafy, 3-I $2 \mathrm{dm}$. high. Leaves thickish, pale green, repand-dentate, crenulate, or entire, the basal ones broadly oblong. oval, or obovate, very abtuse, narrowed into short petioles, $3-7 \mathrm{~cm}$. long, 
3-5 cm. wide; stem leaves sessile, oblong, lanceolate, or spatulate, obtuse, the uppermost gradually smaller and acutish; flowers pale blue, 8-10 $\mathrm{mm}$. Iong, racemose-spicate, bracts linear, entire; calyx-tube turbinate, usually glabrous, shorter than its subulate spreading lobes; corolla-tube abnut $5 \mathrm{~mm}$. long and $2 \mathrm{~mm}$. thick. In dry, mostly sandy soil, or in meadows, N. S. and Ont. to the N. W. Terr., N. C., La. and Ark. June-Aug.

Lobelia spicàta hirtélla A. Gray. Rough or roughish; bracts and calyx-lobes hirsute or ciliate. Manitoba to the N. W. Terr., south to Mich. and Kans.

Lobelia spicata parviflora A. Gray. Glabrous or nearly so; stem low, very slender; flowers only about $6 \mathrm{~mm}$. long; calyx-lobes broadly subulate. In swamps, Lancaster, Pa.

9. Lobelia leptóstachys A. DC. Sprcked Lobelia. (I. F. f. 3508.) Similar to the preceding species; stem usually stouter, puberulent or glabrous, 6-12 $\mathrm{dm}$. high. Basal leaves oval or obovate, obtuse; stem leaves spatulate, oblong, or lanceolate, obtuse, sometimes slightly scabrous, denticulate or entire, or the uppermost narrower and acute; bracts linear, glabrous; pedicels very short; calyx-lobes linear-subulate, nearly as long as the corolla-tube; flowers blue, 8-10 mm. long. In dry soil, Va. to Ohio and Ill., Ga. and Kans. June-Aug.

Io. Lobelia inflàta L. Indian Tobacco. Wild Tobacco. Annual, pubescent or hirsute, very acrid; stem leafy commonly paniculately branclied, 3-9 dm. high. Leaves thin, repand-dentate or denticulate, the lower oval or obovate, obtuse, 3-6 $\mathrm{cm}$. long, narrowed into short petioles, the upper sessile, oval, oblong, ovate, or ovate-lanceolate, obtuse, or the uppermost acute; flowers light blue, 4-6 mm. long, lower bracts foliaceous, the upper subulate; calyx glabrous or nearly so, its subulate lobes about as long as the corolla; capsule inflated, 6-8 $\mathrm{mm}$. long, finely transversely veined between the ribs. In fields and thickets, Lab. to the N. W. Terr., Ga., Neb., Ark. and Kans. July-Nov.

I I. Lobelia Kàlmii L. BRoOK OR Kalm's Lobelia. (I. F. f. 35 Io.) Perennial by short offsets, glabrous throughout, or sparingly pubescert below; stem leafy, erect, slender, $15^{-25} \mathrm{~cm}$. high. Lower and basal leaves spatulate, obtuse, short-petioled, sparingly repand-denticulate, or entire, 12-25 mm. long, 3-5 mm. wide; upper leaves sessile, linear, linear-oblong, or narrowly spatulate, the uppermost acute; flowers light blue, 8-Io $\mathrm{mm}$. long; lower bracts linear-lanceolate, the upper subulate; pedicels nearly filiform; calyx-lobes lanceolate-subulate, longer than the turbinate tube, the sinuses not appendaged; capsule wholly inferior, not inflated, campanulate or subglobose, about $4 \mathrm{~mm}$. long. On wet banks, and in wet meadows, N. S. to N. J., west to Ont., the N. W. Terr., Ohio and Mich. July-Sept.

I2. Lobelia Nuttàllii R. \& S. Nuttall's Lobelia. (I. F. f. 35II.) Annual, or perhaps biennial, glabrous throughout, or puberulent below; stem weak, usually reclining, very slender, loosely branched, at least when old, 3-9 dm. long. Basal leaves spatulate to oval, obtuse, mostly petioled, $12-25 \mathrm{~mm}$. long, slightly re. pand, or entire; stem leaves distant, linear, linear-oblong, or slightly spatulate, entire or sparingly glandular-denticulate; flowers pale blue, loosely racemose; bracts linear or the upper subulate; calyx-lobes subulate, longer than the depressed-hemispheric strongly ribbed tube, the sinuses unappendaged; capsule depressed-globose, halfinferior, about $2 \mathrm{~mm}$. long. Sandy soil, L. I. to Penn., Fla. and Ga. June-Sept.

I3. Lobelia Cánbyi A. Gray. Canby's Lobelia. (I. F. f. 35 I2.) Annual, slightly puberulent, usually glabrous; stem erect, slender, 6-9 dm. high. Stem leaves linear or linear-oblong, I-4 cm. long, I-3 mm. wide, the lower obtuse, sometimes slightly repand-denticulate, the upper acute, narrower, entire; flowers racemose, blue; lower bracts linear, the upper subulate; calyx-lobes linear-subulate, glandular-denticulate, equalling or somewhat ionger than the narrowly turbinate tube, mostly shorter than the tube of the corolla; capsule oblong-turbinate, $4 \mathrm{~mm}$. long, shorter than the calyx-tube. Swamps, N. J. to S. Car. July-Sept.

\section{Family 3. CICHORIÀCEAE Reichenb.}

\section{Chicory Family.}

Herbs (two Pacific Island genera trees), almost always with milky, acrid or bitter juice, alternate or basal leaves, and yellow, rarely pink, blue, purple, or 
white flowers in involucrate heads (anthodia). Bracts of the involucre in $\mathbf{I}$ to sev. eral series. Receptacle of the head flat or flattish, naked, scaly (paleaceous), smooth, pitted, or honeycombed. Flowers all alike (heads homogamous), perfect, Calyx-tube completely adnate to the ovary, its linb (pappus) of scales, or simple or plumose bristles, or both, or wanting. Corolla gamopetalous, will a short or long tube, and a strap-shaped (ligulate) usually 5-toothed limb (ray). Anthers connate into a tube around the style, the sacs sagittate or auricled at the base, not tailed, usually appendaged at the summit, the simple pollen-grains usually 12 -sided. Ovary I-celled; ovule I, anatropous; style very slender, 2-cleft, or'2-lobed, the lobes minutely papillose. Fruit an achene. Seed erect; endosperm none; radicle narrower than the cotyledons. About 65 genera and 1400 species, of wide geographic distribution. The family is also known as LigulifloraE, and is often regarded as a tribe of the COMPOSITAE.

* Pappus of scales, or of scales and bristles, or none (see No. 18).

Flowers blue or white; pappus of blunt scales.

1. Cichorium.

Flowers yellow.

Bracts of the involucre membranous, or herbaceous.

Pappus none; achenes 20-30-nerved.

Pappus none; achenes 8-10-ribbed.

Pappus of rounded scales, with or without an inner series of bristles.

2. Lapsana.

3. Serinea.

4. Adopogon.

Bracts of the involucre thickened and keeled after flowering; pappus none.

Receptacle chaffy.

* Pappus, at least some of it, of plumose bristles.

Receptacle naked.

Plume-branches of the pappus not interwebbed.

Flowers yellow; plants scapose, the leaves basal.

Flowers yellow; plants leafy-stemmed.

Flowers pink.

Plume-branches of the pappus interwebbed.

5. Arnoseris.

6. Hypochaeris.

* * Pappus of simple bristles (of soft white scales with or without bristles in No. 18.)

$\uparrow$ Receptacle with a few deciduous bristles; flowers yellow.

t† Receptacle naked.

I1. Malacothrix.

1. Achenes spinulose, or with short processes near the summit.

Heads few- (6-15-) flowered, yellow; stem branching.

Heads many-flowered, yellow, solitary on scapes.

7. Leontodon.

8. Picris.

9. Ptiloria.

Io. Tragopogon.

2. Achenes smooth, or papillose, not spinulose toward the summit.

(a) Achenes flattened.

Achenes truncate, not beaked; flowers yellow.

Achenes narrowed at the summit, or beaked; flowers blue or yellow.

(b) Achenes cylindric, or prismatic.

Achenes terete, not narrowed at the base; flowers pink or purple.

14. Sonchus.

15. Lactuca.

12. Chondrilla.

13. Taraxacum.

16. Lygodesmia.

Achenes narrowed at the base, narrowed or beaked at the summit ; flowers yellow.

Achenes slender-beaked.

Pappus-bristles not surrounded by a villous ring at base.

Pappus of slender simple bristles.

Pappus of narrow soft scales, with or without some slender bristles.

17. Agoseris.

18. Nothocalais.

Pappus-bristles surrounded by a villous whits ring at base. 19. Sitilias.

Achenes merely narrowed above, not beaked.

20. Crepis.

Achenes narrowed at the base, otherwise columnar, truncate (except in two species of Hieracium).

Flowers yellow, orange, or red.

Flowers white, cream-colored, or purple.

21. Hieracium.

22. Nabalus.

\section{CICHÒRIUM L.}

Erect branching herbs, with alternate and basal leaves, those of the stem and branches usually very small and bract-like, and large heads of blue, purple, pink, or white flowers, peduncled, or in sessile clusters along the branches. Involucre of 2 series of herbaceous bracts, the outer somewhat spreading, the inner erect and subtending, or partly enclosing. the outer achenes. Receptacle flat, naked, or slightly fimbrillate. Rays truncate and 5-toothed at the apex. Anthers sagittate 
at the base. Style-branches slender, obtushish. Achenes 5-angled or 5-ribbed, truncate, not beaked. Pappus of 2 or 3 series of short blunt scales. [From the Arabic name.] About 8 species, natives of the Old World.

I. Cichorium Intybus L. Chicory. Wild Succory. Blue Sallors. Bunk. (I. F. f. 35 I3.) Perennial from a long deep tap-root; stems slightly hispid, stiff, much branched, 3-9 dm. high. Basal leaves spreading on the ground, runcinate-pinnatifid, spatulate in outline, 7-15 cm. long, narrowed into long petioles; upper leaves much smaller, lanceolate or oblong, lobed or entire, clasping and auricled at the base; heads numerous, 25-37 mm. broad, I-4 together in sessile clusters on the nearly naked or bracted branches; inner bracts of the involucre about 8. Roadsides, fields and waste places, N. S. to Minn., N. Car., Neb. and Kans. The ground-up root is used as a substitute or adulterant for coffee. July-Oct.

Cichorium Intybus divaricàtum DC. Some or all the heads on stout spreading peduncles 2-ro $\mathrm{cm}$. long. Frequent with the type.

\section{LÁPSANA L.}

Annual erect branching herbs, with alternate dentate or pinnatifid leaves, and small panicled slender-peduncled heads of yellow flowers. Involucre nearly cylindric, its principal bracts in I series, nearly equal, with a few exterior small ones at the base. Receptacle flat, naked. Rays truncate and 5-toothed at the apex. Anthers sagittate at the base. Style-branches slender. Achenes obovate-oblong, 20-30-nerved, somewhat flattened, narrowed below, rounded at the summit. Pappus none. [Greek, lampsana, the name of a crucifer.] About 9 species, natives of the Old World.

I. Lapsana commùnis L. Nipplewort. SuCCory Dock-Cress. (I. F. f. 3514.) Stem paniculately branched, glabrous above, more or less hispid-pubescent below, 3-ro dm. high. Lower leaves ovate, repand-dentate, obtuse, thin, pubescent, or glabrate, petioled, 5-10 $\mathrm{cm}$. long, often with 2-6 lobes on the petiole, the uppermost oblong or lanceolate, sessile, acute, much smaller, mostly entire; heads very numerous, 6-12 $\mathrm{mm}$. broad; involucre oblong-cylindric, 4-6 mm. high, of about 8 linear glaucous principal bricts and several very small outer ones. Along roadsides and in waste places, Quebec and Ont. to N. J. and Penn. Also on the Pacific Coast. Nat. from Europe. June-Sept.

\section{SERÍNIA Raf.}

Low glaucescent branching annual herbs, with alternate clasping entire or lobed leaves, or those of the stem sometimes appearing as if opposite, and few small long-peduncled heads of yellow flowers. Involucre broadly campanulate, its bracts about 8 , equal, membranous, becoming concave after flowering. Receptacle flat, naked. Rays truncate and 5-toothed at the apex. Anthers sagittate at the base. Style-branches slender. Achenes obovoid, 8-ro-ribbed, contracted at the base, rounded at the summit. Pappus none, or a mere vestige. [Greek, small chicory.] Three known species of the southern U. S.

I. Serinia oppositifolia (Raf.) Kuntze. Serinia. (I. F. f. 3515.) Glabrous throughout, or slightly glandular-pubescent along the ends of the peduncles, branched from the base, 10-25 cm. high. Basal and lower leaves petioled, oblonglanceolate or spatulate in outline, acute or obtuse, entire, lobed or pinnatifid, 7-12 $\mathrm{cm}$. long, 4-12 mm. wide; upper leaves mainly sessile, clasping. alternate, or appearing as if opposite, usually entire, smaller; peduncles very slender, sometimes I dm. long; heads 3-4 mm. broad; bracts of the involucre acute or acuminate, about the length of the rays. In fields, Kans. to Tex., N. Car. and Fla. March-May.

\section{ADOPÒgON. Neck. [KRIGIA Schreb.]}

Herbs, with scapose or leafy stems, basal or alternate leaves, and small or middle-sized heads of yellow or orange flowers, solitary at the end of the scape or its branches. Involucre campanulate, its herbaceous bracts in 1 or 2 series, with no exterior shorter ones. Receptacle flat, naked. Rays truncate and 5-toothed at the apex. Anthers sagittate at the base. Style branches slender, obtusish. Achenes turbinate or oblong, 15-20-ribbed, truncate. Pappus in I or 2 series, the 
outer of thin broad rounded scales, the inner of slender naked bristles, or these sometimes wanting in the southwestern $A$. occidentale. [Greek, a pleasing beard.] Five known species, natives of N. Am.

Stem I-leaved and branched above, bearing 2-6 heads. Scape naked, monocephalous.

1. A. Virginicum.

Head about $25 \mathrm{~nm}$. broad; pappus-bristles I2-20; perennial. 2. A. Dandelion.

Head 6-r4 mm. broad; pappus-bristles 5-7; annuals.

Practs of the involucre $5-8$, remaining erect, firm, keeled. 3. A. occidentale. Bracts of the involucre 8-r 8, at length reflexed, thin.

I. Adopogon Virgínicum (L.) Kuntze. Cynthia. Virginia GoatsBEARD. (I. F. f. 35 r6.) Perennial, glabrous and glaucous ; stem 3-6 dm. high, I-leaved and branched above. Basal leaves tufted, runcinate, sinuate, denticulate, or entire, 5-17 cm. long, narrowed into margined petioles; heads about $4 \mathrm{~cm}$. broad; involucre of 9-15 lanceolate nerveless bracts $6-8 \mathrm{~mm}$. long; achenes nearly oblong; pappus of IO-I5 oblong scales and an equal or greater number of capil. lary bristles; flowers orange to reddish orange. In moist woods and meadows, Mass. to southern Ont. and Manitoba, Ga., Ky., Mo. and Kans. May-Oct.

2. Adopogon Dandèlion (L.) Kuntze. Dwarf Dandelion or Goatsbeard. (I. F. f. 35 I7.) Perennial, acaulescent, glabrous and somewhat glaucous; scape 15-45 cm. high, slender. Stolons filiform, bearing globose tubers; leaves all basal, tuft ad, linear-lanceolate to spatulate, entire, denticulate, sinuate, or pinnatifid, narrowed at the base, 7-15 cm. long, 4-10 mm. wide; head about $25 \mathrm{~mm}$. broad; involucre about $\mathbf{I} \mathrm{cm}$. high; pappus similar to that of the preceding species. In moist soil, Md. to Fla., west to Kans. and Tex. April-June.

3. Adopogon occidentàle (Nutt.) Kuntze. Western Dwarf Dandelion. (I. F. f. 35 18.) Annual, acaulescent; scapes tufted, 5-20 cm. high, usually glandular, at least above, bearing a single head $10-20 \mathrm{~mm}$. broad. Leaves basal, lanceolate co obovate, entire to pinnatifid, mostly shorter than the scapes; involucre 4-6 mm. high, its bracts 5-8, lanceolate, becoming ovate-lanceolate to ovate, firm and keeled at maturity, remaining erect; pappus of 5 obovate scales and usually 5 alternating bristles. Prairies, southern Mo. to Tex.

4. Adopogon Caroliniànum (Walt.) Britton. Carolinia Dwarf DanDELION. KRIGIA. (I. F. f. 3519.) Annual, acaulescent; scapes usually several from the same root, very slender, glabrous or hispidulous, monocephalous, $3-40 \mathrm{~cm}$. high. Leaves commonly all basal, tufted, spatulate, lanceolate or linear, pinnatifid, sinuate, lobed, dentate or rarely entire, 3-15 cm. long, narrowed into margined petioles; head 6-14 mm. broad; involucre of 9-18 linear-lanceolate bracts; pappus usually of 5 round short scales and 5-1o long capillary bristles. In dry, sandy soil, Me. to Ont., Minn, Fla. and Tex. April-Aug.

\section{ARNÓSERIS Gaertn.}

A low annual scapose herb, glabrous, or nearly so, with tufted basal dentate or nearly entire leaves. Scapes several or numerous, simple or branched, upwardly thickened below the solitary heads of yellow flowers. Involucre campanulate, its bracts in I series, narrow, equal, thickened and keeled on the back after flowering, rarely with a few outer minute ones. Receptacle flat, pitted, not chaffy. Anthers sagittate. Style-branches obtuse. Achenes oval, 8-ro-ribbed, narrowed below, truncate, or with a denticulate margin. Pappus none. [Greek, lamb-succory.] A monotypic genus of western Europe.

I Arnoseris mínima (I..) Dumort. Lamb Succory. (I. F. f. 3520.) Scapes slender, 7-30 cm. high, leafless, simple, or with I-4 branches mostly above the middle. gradually thickened and hollow upward. Leaves oblanceolate, obovate, or oblong, 3-7 cm. long, 6-20 mm. wide, usually coarsely and sharply toothed, narrowed into margined petioles; heads $16 \mathrm{~mm}$. broad, or less; bracts of the involucre linear-lanceolate, acuminate, strongly keeled after flowering, 4-8 $\mathrm{mm}$. long, curving over the achenes. Mount Desert Island, Me. Fugitive from Europe. Summer.

\section{HYPOCHAÈRIS L.}

Mostly perennial herbs, with scapose, often branched stems and mostly basal tufted leaves, pinnatifid to entire, those of the scapes few, scale-like, very small, or none. Heads mostly large, long-peduncled. Flowers yellow. Involucre oblong- 
cylindric to campanulate, its bracts herbaceous, imbricated in several series, ap. pressed, the outer smaller. Receptacle flat, chaffy. Anthers sagittate. Stylebranches slender, obtusish. Achenes oblong to linear, ro-ribbed, somewhat narrowed below, contracted above into a long or short beak, or the outer truncate. Pappus of I row of plumose bristles, sometime: with some shorter simple ones. [Greek, for pigs, which are fond of its roots.] About 50 species, natives of Europe, Asia, and S. Am.

I. Hypochaeris radicàta L. Long-Rooted CAT'S-EAR. Gosmore. (I. F. f. 3521.) Perennial; stems several together, glabrous, slender, 3-6 dm.high, bracted, or rarely simple, bearing a few scales. Ieaves spreading on the ground, oblanceolate to obovate in outline, pinnatifid-lobed to dentate, $5^{-15} \mathrm{~cm}$. long, hirsute on both sides; involucre oblong-cylindric, about $25 \mathrm{~mm}$. high, its bracts glabrous, or sparingly pubescent; heads $25 \mathrm{~mm}$. broad or more: achenes rough, all with very slender beaks longer than the body: flowers longer than the involucre. In waste places, L. I. to N. J. Also in Cal. and Wash. Adventive or nat. from Europe. Native also of Asia. May-Oct.

Hypochaeris glàbra L., the smooth Cat's-ear, a smaller species, with nearly or quite glabrous leaves, flowers scarcely longer than the involucre, and the outer achenes truncate, has been found as a waif in Me., and is nat. or adventive on the Pacific Coast.

\section{LEÓNTODON L.}

Perennial scapose herbs, with tufted basal mostly pinnatifid leaves, branched and scaly, or simple and naked scapes, and large heads of yellow flowers, solitary at the end of the scape or of its branches. Involucre ovoid or oblong, its principal bracts in $I$ or 2 series, nearly equal, with several series of short outer ones. Receptacle flat, fimbrillate, villous, or somewhat honeycombed. Rays truncate and 5-toothed at the apex. Anthers sagittate at the base. Style-branches slender. Achenes oblong or linear, finely striate, contracted or beaked at the summit. Pappus of 1 or 2 series of plumose persistent brownish bristles, somewhat broadened at the base, or the outer scale-like and simple. [Greek, lion's tooth.] About 45 species, natives of the Old World.

Plant nearly glabrous; scape commonly branched; pappus-bristles all plumose.

I. L. autumnale.

Plant somewhat hirsute; scape simple; outer pappus of outer achenes simple.

2. L. nudicaule.

r. Leontodon autumnàle L. Fall Dandelion. Autumnal Hawkiti. Lion's-тоотн. (I. F. f. 3522.) Scape slender, usually branched and scaly, 1.5-6 dm. high. Leaves narrowly oblong to linear-lanceolate, pinnatifid into narrow lobes, or some of them coarsely dentate, 7-20 cm. long, 6-25 mm. wide, acuminate at the apex, short-petioled; heads several, rarely solitary, about 25-30 mm. broad: involucre oblong, glabrous or slightly pubescent. In fields and along roadsides, Newf. and Ont. to N. J., Penn. and Ohio. Nat. from Europe. Native also of Asia. June-Nov.

2. Leontodon nudicaùle (L.) Porter. Rough or Hairy Hawkbit. (I. F. f. 3523.) Scape simple, slender, r-3 dm. high, minutely scaly, or naked. Leaves linear-oblong to narrowly spatulate, acute or obtuse, not acuminate, nearly entire, coarsely sinuate-dentate or sometimes pinnatifid, 5-12 cm. long, 6-16 mm. wide, narrowed into petioles: head solitary at the end of the scape, $\mathbf{I}-2 \mathrm{~cm}$. broad; involucre canescent or pubescent; outer achenes with an outer pappus of simple narrow scales and an inner one of plumose bristles. In ballast and waste places about the eastern seaports. Also at Seidersville, Penn., and on Vancouver Island. Adventive from Europe. June-Oct.

\section{PİCRIS L.}

Erect hispid, mostly branching, leafy herbs, with alternate leaves (in our species), and rather large, usually corymbose or paniculate heads of yellow flowers. Involucre campanulate or cup-shaped, its principal bracts in one series, nearly equal, with 2-3 series of small or large exterior spreading ones. Receptacle flat, short-fimbrillate. Rays truncate and 5-toothed at the apex. Anthers sagittate at the base. Style-branches slender. Achenes linear or oblong, somewhat incurved, terete or angled, 5-10.ribbed and transversely wrinkled, narrowed at the base and 
summit, or beaked in some species. Pappus of $\mathbf{I}$ or 2 series of slender plumose bristles. [Greek, bitter.] About 35 species, natives of the Old World, one perhaps indigenous in Alaska.

Outer involucral bracts linear; achenes not beaked.

Outer involucral bracts ovate, foliaceous; achenes short-beaked.

I. $P$. hieracioides.

2. P. echioides.

I. Picris hieracioides L. Hawkweed Picris. (I. F. f. 3524.) Biennial, more or less hispid, much branched, 3-9 dm. high, Leaves lanceolate or oblonglanceolate, dentate, or nearly entire, the basal narrowed into petioles, acute, often $15 \mathrm{~cm}$. long, those of the stem mostly sessile and smaller; heads numerous, $1-2.5 \mathrm{~cm}$. broad; involucre 8-12 mm. high, its outer bracts linear, subulate, spreading, the inner linear-lanceolate, acuminate; pappus copious, nearly white. In waste places, Ill., Penn., N. J., and in ballașt about the seaports. Adventive from Europe. Nat. also of Asia. Very bitter. June-Sept.

2. Picris echioides L. Bristry Ox-tongue. Bugloss and Bugloss PicRIS. (I. F. f. 3525.) Annual or biennial, branched, hispid; stem about $7 \mathrm{dm}$. high. Basal and lower leaves spatulate or oblong, obtuse, repand-dentate, $5-15 \mathrm{~cm}$. long, narrowed into petioles; upper leaves sessile and clasping, oblong or lanceolate, smaller, the uppermost mainly acute and entire; heads numerous, short-peduncled, about $12 \mathrm{~mm}$. broad; outer bracts of the involucre 4 or 5 , foliaceous, ovate, acute, hispid-ciliate, the inner ones lanceolate, membranous. In waste places, N. S. and Ont., and in ballast about the seaports. Fugitive from Europe. July-Sept.

\section{PTILÒRIA Raf. [STEPHANOMERIA Nutt.]}

Annual or perennial, mostly glabrous, often glaucous herbs, with erect, simple or branched, usually rigid stems, alternate or basal, entire dentate or runcinatepinnatifid leaves, those of the stem and branches often reduced to subulate scales, and small erect heads of pink flowers, paniculate, or solitary at the ends of the branches, opening in the morning. Involucre cylindric or oblong, its principal bracts few, equal, scarious-margined, slightly united at the base, with numerous short exterior ones and sometimes a few of intermediate length. Receptacle flat, naked. Anthers sagittate at the base. Style-branches slender. Achenes oblong or linear, terete or columnar, 5-ribbed, truncate or beaked at the summit, the ribs smooth or rugose. Pappus of $\mathrm{I}$ series of rather rigid plumose bristles. [Greek, referring to the feathery pappus.? About 16 species, natives of western and central N. Am.

Pappus brownish, plumose except at the base. Pappus white, plumose to the base.

x. P. pauciflora. 2. P. ramosa.

I. Ptiloria pauciflòra (Torr.) Raf. Brown-plumed Ptiloria. (I. F. f. 3526.) Perennial; stem rather stout, striate, rigid, divergently branched, 3-6 dm. high. Basal and lower leaves runcinate-pinnatifid, 3-6 cm. long, 6-12 mm. wide, the upper all short and narrowly linear or reduced to scales; heads somewhat racemose-paniculate along the branches, usually about 5-flowered; involucre 8-10 $\mathrm{mm}$. high; rays 2-4 $\mathrm{mm}$. long: pappus brownish, plumose to near the base. Plains, Neb. (?), Kans. and Wyo. to Tex. and Cal. Summer.

2. Ptiloria ramòsa Rydb. White-Plumed Ptiloria. (I. F. f. 3527.) Similar to the preceding species, but commonly lower, bushy-branched. Basal leaves runcinate-pinnatifid, those of the stem linear, entire, or sometimes runcinatedentate, the uppermost reduced to small scales; heads numerous, usually solitary at the ends of the branchlets; pappus bright white, very plumose to the base. Plains and dry, rocky soil, western Neb. to Mont. and Colo. May-Aug. It has been confused with $P$. tenuifolia (Torr.) Raf.

\section{xo. TRAGOPÒGON L.}

Biennial or perennial, erect, usually branched, somewhat succulent herbs, with slender fleshy tap-roots, alternate entire linear-lanceolate long-acuminate leaves, clasping at the base, and long-peduncled large heads of yellow or purple flowers, opening in the early morning, usually closed by noon. Involucre cylindric or narrowly campanulate, its bracts in I series, nearly equal, acuminate, united at the base. Rays truncate and 5-toothed at the apex. Anthers sagittate at the base. 
Style-branches slender. Achenes linear, terete, or 5-angled, 5-ro-ribbed, terminated by slender beaks, or the outermost beakless. Pappus-bristles in I series, plumose, connate at the base, the plume-branches interwebbed. [Greek, goats. beard.] About 35 species, natives of the Old World.

Flowers yellow; involucral bracts equalling or shorter than the rays. 1. $T$. pratensis. Flowers purple; involucral bracts much longer than the rays.

2. $T$. porrifolius.

I. Tragopogon praténsis L. Yellow Goat's-Beard. Meadow Salsify. (I. F. f. 3528.) Stem branched, 4-9 dm. high. Leaves keeled, tapering from the broad, more or less clasping base to a very long acuminate tip, the lower sometimes $25 \mathrm{~cm}$. long and $25 \mathrm{~mm}$. wide; peduncles thickened at the top; heads $3-6 \mathrm{~cm}$. broad; bracts of the involucre about 8 , lanceolate, acuminate, shorter than or equalling (rarely exceeding) the yellow rays; marginal achenes striate, smonth or roughened. In fields and waste places, N. B. to N. J., Ont., Ohio and Manitoba. Nat. from Europe. June-Oct.

2. Tragopogon porrifòlius L. Oyster Plant. Salsify. Purple Goat'sBEARD. (I. F. f. 3529.) Taller, sometimes $1.5 \mathrm{~m}$. high. Peduncles very much thickened and hollow for $3-7 \mathrm{~cm}$. below the heads; heads 5-10 cm. broad, very showy; bracts of the involucre linear-lanceolate, acuminate, usually much longer than the purple rays; achenes sometimes $5 \mathrm{~cm}$. long, the outer ones covered with scale-like tubercles, especially on the ribs below. In fields and waste places, Ont. to N. J., N. Car., Minn. and Colo., mostly escaped from gardens, where it is common. Native of Europe. June-Oct.

\section{MALÁCOTHRIX DC.}

Annual or perennial, branching or scapose herbs. with alternate or basal, mostly pinnatifid leaves, and long-peduncled panicled or solitary heads of yellow or rarely white flowers. Involucre campanulate, its principal bracts in $\mathbf{I}$ or 2 series, equal or nearly so, with several series of shorter exterior ones. Receptacle flat, naked or bristly. Rays truncate and 5-toothed at the apex. Anthers sagittate at the base. Style-branches slender. Achenes oblong or linear, glabrous, 10-15 ribbed, 4 or 5 of the ribs usually more prominent than the others, truncate, or margined and 4-5-toothed at the summit. Pappus-bristles in 2 series, the inner naked or minutely serrulate, slender, coherent at the base and deciduous in a ring, the outer few (1-8), more persistent, or all deciduous in our species. [Greek, soft-hair, in allusion to the soft pappus.] About I5 species, natives of the western and south. western U. S. and lower Cal.

I. Malacothrix sonchoides (Nutt.) T. \& G. Malacothrix. (I. F. f. 3530.) Annual, glabrous throughout, or slightly glandular; stem branched, 15-30 cm. high. Leaves somewhat fleshy, oblong or linear-oblong in outline, pinnatifid and the lobes dentate with muccronate-pointed teeth, the basal ones $4-7 \mathrm{~cm}$. long, narrowed into short broad petioles, those of the stem smaller, sessile; heads several or numerous, $16-25 \mathrm{~mm}$. broad; principal bracts of the involucre linear, acute, scarious-margined, the outer short, oblong; achenes linear-oblong, margined at the summit by a 15-denticulate white border; pappus-bristles all deciduous. On dry plains, western Neb. and Kans. to Cal. and N. Mex. May-Aug.

\section{CHONDRÍLLA L.}

Perennial herbs, with stiff divaricately branched stems, the basal leaves large and mostly pinnatifid, those of the stem small, narrow, alternate, and few middle sized heads of yellow flowers mostly solitary at the ends of the branches. Involucre cylindric, several-flowered, its inner bracts in I or 2 series, nearly equal, with several series of small or minute outer ones. Receptacle flat, naked. Rays truncate and 5-toothed at the summit. Anthers saigittate at the base. Style-branches slender. Achenes oblong or linear, 4-5-angled, many-ribbed, more or less spiny near the summit. abruptly contracted into a beak. Pappus of copious soft white simple bristles. [Greek, lump, from the gummy matter borne on the stems of some species.] About I 8 species, of the Old Wrorld.

I. Chondrilla júncea L. Gum Succory. (I. F. f. 35.3I.) Stem rush-like, hirstite at the base, glabrous above, much branched, 3-9 din. high. Basal leaves runcinate-pinnatifid, those of the stem linear or linear-lanceolate, acute, dentate or 
entire, sessile, I-4 cm. long, I-3 mm. wide; heads termınal asa lateral on the branches, short-peduncled or sessile, $8-12 \mathrm{~mm}$. broad; involucre glabrous or nearly so, about $8 \mathrm{~mm}$. high, its inner bracts narrowly linear; achenes slightly shorter than the filiform beak. In dry fields and waste places, Del. to Md. and Va. Nat. from Europe. July-Aug.

\section{TARÁXACUM Hall.}

Perennial acaulescent herbs, with basal tufted pinnatifid or sinuate-dentate leaves, and large heads of yellow flowers, solitary, or very rarely 2 or 3 together at the ends of naked hollow scapes. Involucre oblo:ig or campanulate, its inner bracts in I series, nearly equal, slightly united at the base, the outer of several series of shorter somewhat spreading ones, often reflexed at maturity. Receptacle flat, naked. Rays truncate and 5-toothed at the summit. Anthers sagittate at the base. Style-branches slender, obtusish. Achenes oblong or linear-fusiform, 4-5angled, 5-10.nerved, roughened or spinulose, at least above, tapering into a very slender beak. Pappus of numerous filiform unequal simple persistent bristles. [Name of some wild succory, probably of Arabic or Persian origin.] About 20 species, natives of the northern hemisphere and southern S. Am.

Outer involucral bracts reflexed; achenes greenish brown, the beak 2-3 times their length.

Outer involucral bracts spreading or ascending.

Achenes greenish, the beak 2-3 times their length.

Achenes red, the beak not more than twice their length.

1. T. Taraxacum.

2. T. latilobum.

3. $T$. erythrospermum.

I. Taraxacum Taráxacum (L.) Karst. DANDelion. Blowball. (I. F. f. 3532.) Root thick, deep, often 2-3 dm. long, bitter. Leaves oblong to spatulate in outline, usually pubescent, at least when young, acute or obtuse, pinnatifid or sinuate-lobed, rather succulent, 7-25 cm. long, I-6 cm. wide, narrowed into petioles; scape erect, 5-45 cm. high; head 3-5 cm. broad; flowers 150-200; inner bracts of the involucre linear or linear-lanceolate, the outer similar, shorter, not glaucous, reflexed, all acute; achenes greenish-brown, fusiform, spinulose above. In fields and waste places. Perhaps indigenous northward, southward naturalized as a weed from Europe. Also in Asia and distributed as a weed in all civilized parts of the world. Jan-Dec.

2. Taraxacum latilobum DC. Mountain Dandelion. Similar to the preceding but scape lower, $5-15 \mathrm{~cm}$. high. Leaves sinuately lobed with broadly triangular lobes, but less deeply so than in $T$. Taraxacum and rarely as far as halif way to the midrib, or often merely dentate or subentire; heads smaller, about $3 \mathrm{~cm}$. wide; bracts fewer, the outer broadly ovate, appressed or merely spreading. In moist places in subalpine or subarctic regions, Lab, to Br. Col., south in the mountains to Colo. and Cal. (T. Taraxacum alpinum Porter; not T. alpinum Koch of Europe.)

3. Taraxacum erythrospérmum Andrz. RED-SEEded DANDELion. (I. F. f. 3533.) Similar to the two preceding species, the leaves glabrous, very deeply runcinate-pinnatifid or pinnately divided into narrower triangular-lanceolate usually long-pointed segments; heads rarely more than $25 \mathrm{~mm}$. broad, 70-9o flowered; bracts of the involucre glaucous, the outer lanceolate, spreading or ascending, the inner linear, longer, each usually with an appendage just leelow the tip; achenes narrower, bright red, or red-brown, spinulose above; pappus dirty white. In fields and woods, Me. to Vt., southern N. Y. and Penn. Nat. from Europe? April-June.

\section{SÓNCHUS $\mathbf{L}$.}

Annual or perennial succulent herbs, with alternate, mostly auriculate-clasping, entire dentate lobed or pinnatifid, prickly-margined leaves, and large or middle-sized, peduncled corymbose or paniculate heads of yellow flowers. Involucre ovoid or campanulate, usually becoming thickened and more or less conic at the base when old, its bracts herbaceous or membranous, imbricated in several series, the outer successively smaller. Receptacle flat, naked. Rays truncate and 5 toothed at the apex. Anthers sagittate at the base. Style-branches slender. Achenes oval, oblong, or linear, more or less flattened, 10-20-ribbed, somewhat 
narrowed at the base, truncate. Pappus of very copious soft white simple capillary bristles, usually falling away connected, sometimes with I or 2 stouter ones which fall separately. [The Greek name of the Sow-thistle.] About 45 species, of the Old World. Besides the following, another occurs on the Pacific Coast.

Involucre glandular-pubescent; heads nearly $25 \mathrm{~mm}$. high.

I. S. arvensis.

Involucre glabrous; heads $12-16 \mathrm{~mm}$. high.

Auricles of the leaves acute; achenes striate and transversely wrinkled. 2. S. oleraceus.

Auricles rounded; achenes ribbed, not transversely wrinkled.

3. S. asper.

I. Sonchus arvénsis L. Corn Sow-Thistle. Milk Thistle. (I. F. f. 3534.) Perennial by deep roots and creeping rootstocks, glabrous; stem leafy below, paniculately branched and nearly naked above, 6-12 dm. high. Lower and basal leaves runcinate-pinnatifid, spinulose-dentate, narrowed into short petioles, the upper pinnatifid or entire, lanceolate, clasping; heads several or numerous, corymbose-paniculate, $3-5 \mathrm{~cm}$. broad, bright yellow, very showy; bracts as also the peduncles glandular-bristly; achenes oblong, with about 10 rugose longitudinal ribs. In low grounds along salt meadows and streams, N. J. to Que. and at Great Salt Lake, Utah, and in fields and along roadsides, Newf. to Minn. Nat. from Europe. July-Oct.

2. Sonchus oleràceus L. Annual Sow-Thistle. Hare's Lettuce. (I. F. f. 3535.) Annual, with fibrous roots; stem leafy below, nearly simple, 3-30 dm. high. Basal and lower leives petioled, lyrate-pinnatifid, Io-25 cm. long, the terminal segment commonly large and triangular, the margins denticulate with mucronate or scarcely spiny teeth; upper leaves pinnatifid, clasping by an auricled or sagittate base; uppermost leaves uften lanceclate and entire; heads several or numerous, pale yellow, $18-30 \mathrm{~mm}$. broad. In fields and waste places, a comnon weed in nost cultivated parts of N. Am. except the extreme north. Also in Cent. and S. Am. Nat. from Europe. May-Nov.

3. Sonchus ásper (L.) All. Spiny or Sharp-fringen Sow-Thistrle. (I. F. f. 3536.) Annual, similar to tle preceding species: leaves undivided, lobed or sometimes pinnatifid, spinulose-dentate to spinulose-denticulate, the lower and basal ones obovate or spatulate, petioled, the upper oblong or lanceolate, clasping by an auricled basc; heads several or numerous, $25 \mathrm{~mm}$. broad or less; flowers paie yellow. In waste places throughout most of our area and in tropical and S. Am. Widely distributed as a weed in nearly all cultivated parts of the earth. Nat. from Europe. May-Nov.

\section{LAC'TùCA L. (See Appendix.)}

Tall leafy herbs, with small panicled heads of yellow, white or blue flowers, and alternate leaves. Involucre cylindric, its bracts imbricated in several series, the outer shorter, or of I or 2 series of principal nearly equal inner bracts, and several rows of short outer ones. Receptacle flat, naked. Rays truncate and 5. toothed at the summit. Anthers sagittate at the base. Style-branclies mostly slender. Achenes oval. oblong or linear, flat, 3-5-ribbed on each face, narrowed above or contracted into a narrow beak, which is som what expanded at the sum. mit into a small disk bearing the copious soft capillary white or brown pappus. bristles. [The ancient Latin name, from lac, milk, referring to the milky juice.] About 95 species, natives of the northern hemisphere.

\section{* Pappus bright white.}

1. Leaves spiny-margined and often with spiny or hispid midribs; flowers yellow. Heads $6-12$-flowered; involucre very narrow, $8-12 \mathrm{~mm}$. high Heads 12-20-flowered; involucre broader.

Involucre 16-18 mm. high; achene about as long as its beak.

Involucre 8-12 mm. high: achene longer than its beak.

2. I.. Ludoriciana.

6. L. sagittifolia.

2 Leaves neither spiny-margined nor with spiny nijdribs (rarely spinulose in No. 4).

(a) Achenes very thin, flat, contracted into filiform or tapering beaks.

Outer involucral bracts abruptly shorter than the inner; heads 8-14 mm. high; flowers yellow to red (blue in No. 5).

Leaves, or some of them, pinnatifid.

Plant glabrous throughout, $x-3 \mathrm{~m}$. high.

Leaves, at least their midribs, hirsute.

3. L. Canadensis.

Beak of the achene as long as its body; flowers yellow. 4. L. hirsuta.

Beak of the achene less than half as long as its body; flowers blue. 
Leaves entire or dentate, none of them pinnatific.

Stem glabrous, or hirsute only toward the base.

Leaves oblong or oblong-lanceolate; achene longer than the beak.

Leaves lanceolate; achene about equalling the beak.

6. L. sagittifolia.

3. L. Canadensis.

Stem hirsute up into the branches of the inflorescence.

7. L. Steelei.

Outer bracts gradually shorter; heads $16-20 \mathrm{~mm}$. high; flowers blue. 8. L. pulchella.

(b) Achenes beakless or with short necks, thickish; flowers blue.

Leaves oblong to ovate, acuminate, dentate.

Leaves pinnatifid, the terminal segment commonly triangular.

* * Pappus brown; flowers blue to white.

9. L. villosa.

10. L. Fioridana.

Ir. L. spicala.

I. Lactuca Scariola L. Prickly Lettuce. (I. F. f. 35.37.) Biennial, green and glaucous; stem stiff, leafy, usually paniculately branched, glabious throughout, or hirsute at the base, 6-20 dm. high. Leaves oblong, or oblonglanceolate, denticulate or pinnatifid, sessile or auriculate-clasping, the lowest sometimes $25 \mathrm{~cm}$. lorg and $7 \mathrm{~cm}$. wide, the npper much smaller; heads $4-8 \mathrm{~mm}$. bruad, very numerous in an open panicle; involucre cylindric, its outer bracts about onethird the length of the inner; rays yellow; achenes obovate-oblong. about as long as the filiform beak. In fields and waste places, Me. to S. Dak., N. J., Ga., Net., Colo. and Kans. Nat. from Europe. Aug-Sept.

Lactuca salígna L., the Willow LeTTUCE of Europe, similar to L. Scuriola, but with runcinate-pinnatifid lower leaves, either spinulose on the midvein $y^{*}$ unarmed, l.as been found in Ohio.

2. Lactuca Ludoviciàna (Nutt.) DC. Western LetTuce. (I. F. f. 3538 ). Biennial, glabrous throughout, leafy up to inflorescence, paniculately brincliec, 6-15 dm. high. Leaves oblong to ovate-oblong, acute or acutish, 5-10 cm. long, auriculate-clasping, spinulose-denticulate to pinnatifid with spinulose segments; heads 6-10 mm. broad, numerous in an open panicle; involucre cylindric cr ovoid-cylindric, glabrous, its bracts successively shorter and broader, the lower ones ovate; rays yellow: achenes oval to.obovate, flat. Plains and banks, Iowa, Minn. and S. Dak. to Kans. and Tex. July-Sept.

3 Lactuca Canadénsis L. Wild oR Tall Lettuce. Wild Opium. (I. F. f. 3539.) Biennial or annual, glabrous throughout, somewhat glaucous; stem leafy up to the inflorescence, I-3 m. high, branching above into a narrow panicle. Stem-leaves sessile or auriculate-clasping, 5-20 cm. long, the uppermost smaller, often lanceolate, acuminate and entire, the basal often $3 \mathrm{dm}$. long, narrowed into petioles; heads numerous, 4-6 $\mathrm{mm}$. broad; involucre cylindric; rays yellow; achenes oval. In moist, open places, N. S. to the N. W. Terr. south to Ga., Ala., La. and Ark. June-Nov.

Lactuca Canadénsis montana Britton. Plant $3^{-12} \mathrm{dm}$. high; leaves all lanceolate and entire; bracts of the involucre purple or purplish. Mountains, Penn. and N. Y.

4. Lactuca hirsùta Muhl. Hairy or Red Wood-Lettuce. (I. F. f. 3540.) Similar to the preceding species, but commonly smiller and less leafy; stem 3-I $8 \mathrm{dm}$. high, naked and paniculately branched above. usually hirsute, at least below. Stem-leaves mostly sessile or auriculate-clasping, 7-17 cm. long, the uppermost sometimes lanceolate and entire, the basal petioled; midvein rarely spinulose; heads numerous, 4-6 $\mathrm{mm}$. broad; involucre glabrous, $10-18 \mathrm{~mm}$. high; outer bracts shorter than the inner; rays reddish-yellow or paler; achenes oblong. oval, flat, about the length of the beak. In dry soil, Me. to Ont., Mimm., Ala. and Tex. July - Sept.

5. Lactuca Mórssii Robinson. Morss Wild Letruce. Similar to the preceding species; stem strict, leafy, I-3 m. tall, somewhat hirsute at the base. Lcaves runcinate-pinnatifid, the lower sparingly hirsute beneath along the midrib and cordate-clasping narrowed base, the upper glabrous; involucre shorter than in L. hirsuta; rays blue; achenes oval lanceolate, 3-ribled on each face, $4.5 \mathrm{~mm}$. long, 3-4 times as long as the filiform beak. Along salt meadows, Me. and eastern Mass. to N. Y.

6. Lactuca sagittifj̀lia Ell. Arrow-Leaven Lettuce. (I. F. f. 354r.) Biennial; stem glabrous throughout, or hirsute helow, leafy nearly up to the usually paniculate inforescence. 6-18 $\mathrm{dm}$. high. Leaves entire or denticulate, the lower rarely pinnatifid, sometimes spinulose on the margins, those of the stem 
sessile or sagittate-clasping, 7-15 cm. long, $1-3 \mathrm{~cm}$. wide, the basal and lower ones petioled; heads commonly very numerous, $4-8 \mathrm{~mm}$. broad; involucre cylindric, Io-14 mm. high, the outer bracts shorter than the inner; rays yellow or reddish. In dry, open soil, N. B. and Ont. to Idaho, Ga. and Kans. July-Sept.

7. Lactuca Steèlei Britton, n. sp. Streele's Wild Letruce. Stem and branches hirsute. Leaves obovate to oval, the larger $2 \mathrm{dm}$. long and $\mathbf{I} \mathrm{dm}$. wide, sessile, irregularly dentate, not lobed, hispid on the veins beneath, short-acuminate; involucre about $12 \mathrm{~mm}$. high; rays not seen; achenes oval, 3-ribbed, about $3 \mathrm{~mm}$. long, the filiform beak slightly shorter; pappus bright white. Near Washington, D. C., E. S. Steele, July ro, 1897.

8. Lactuca pulchélla (Pursh) DC. Large-flowered Blue LetTuce. (I. F. f. 3542.) Perennial, glabrous throughout, somewhat glaucous; stem rather slender, leafy up to the cory mbose-paniculate inflorescence, 3-9 dm. high. Leaves linear-lanceolate, lanceolate or oblong, acute, entire, dentate, lobed or pinnatifid, those of the stem sessile or partly clasping, 5-20 $\mathrm{cm}$. long, 4-35 mm. wide, the lowest and basal ones sometimes petioled; heads mostly numerous, 12-20 mm. broad; involucre well imbricated, $16-20 \mathrm{~mm}$. high; achenes oblong-lanceolate, flat, twice as long as their tapering beaks. In moist soil, western Ont. to the N. W. Terr. and Br. Col., south to Mich., Kans., N. Mex. and Cal. June-Sept. 9. Lactuca villòsa Jacq. Hairy-veined Blue Lettuce. (I. F. f. 3543.) Annual or biennial; stem glabrous, leafy up to the paniculate inflorescence, 6-18 dm. high. Leaves acuminate, acutely dentate or the teeth mucronate-tipped, glabrous above, pubescent with short, stiff hairs on the veins beneath, sessile and slightly clasping at the base, or petioled, 10-15 cm. long, 3-6 cm. wide, the lowest sometimes lobed at the base; heads numerous, 6-10 $\mathrm{mm}$. broad; involucre about $1 \mathrm{~cm}$. high, some or all of the bracts obtuse; achenes thick, oblong, little flattened, narrowed above. In thickets, N. Y. to Ill., south to Fla., Ga. and Ky. July-Sept.

ro. Lactuca Floridàna (L.) Gaertn, FAlSE OR FloRIdA LeTtuce. (I. F. f. 3544.) Annual or biennial; stem glabrous, rather stout, leafy up to the large, paniculate inflorescence, $\mathbf{I}-2 \mathrm{~m}$. high. Leaves sessile or petioled, $\mathbf{r}-3 \mathrm{dm}$. long, glabrous above, pubescent on the veins beneath, the lateral segments lanceolate to oval, acute, all usually dentate, or the leaves irregularly lobed; heads numerous, 5-10 $\mathrm{mm}$. broad; rays blue; involucre about $12 \mathrm{~mm}$. high. In moist, open places, southern N. Y. and Penn. to Ill., Neb., Fla., La. and Kans. July-Sept.

II. Lactuca spicàta (Lam.) Hitchc. TAll Blue Lettuce. (I. F. f. 3545.) Annual or biennial; stem usually stout, glabrous, I $-3.5 \mathrm{~m}$. high, leafy up to the large, rather dense panicle. Leaves deeply pinnatifid or lobed, sharply dentate with mucronate-pointed teeth, sessile, or the lower narrowed into margined petioles, glabrous on both sides, or pubescent on the veins beneath, $12-30 \mathrm{~cm}$. long, 5-15 cm. wide: heads very numerous, about $4 \mathrm{~mm}$. broad; rays blue to nearly white; achenes oblong, compressed, narrowed above into a short neck. In moist soil, Newf. to Manitoba, south to N. Car., Tenn., Iowa and S. Dak. July-Oct.

Lactuca spicàta integrifolia (A. Gray) Britton. Leaves oblong, sharply denticulate, undivided, or some of the lower ones pinnatifid. N. Car. to Mich.

\section{LYGODÉSMIA D. Don.}

Glabrous rigid branching herbs, with linear leaves, or the basal and lower ones sometimes broader and pinnatifid, those of the stem very narrow and entire or reduced to linear scales, and middle-sized 3-12-flowered heads of pink or purple flowers, solitary and erect at the ends of the stem and branches, or sometimes racemose. Involucre cylindric, its principal bracts $5-8$, linear, scarious-margined, equal, slightly united at the base, with several very short outer ones. Receptacle flat, naked. Rays truncate and 5-toothed at the apex. Anthers sagittate at the base. Style-branches slender. Achenes linear, smooth or striate. Pappus of copious somewhat unequal simple bristles. [Greek, twig-bundle, from the numer. ous branches.] About 6 species, natives of western and southern N. A.

Heads solitary at the ends of the branches; leaves linear or subulate. Heads racemose along the branches; leaves elongated-linear.

1. L. juncea.

2. L. rostrata.

I. Lygodesmia júncea (Pursh) D. Don. Rush-like Lygodesmia. (I. F. f. 3546.) Perennial by a thick woody root; stems stiff, striate, much branched, 
20-45 cm. high, the branches erect. Lower leaves linear-lanceolate, rigia, entire, acute, or acuminate, $\mathbf{I}-2.5 \mathrm{~cm}$. long, I-3 mm. wide, the upper similar but smaller, or reduced to subulate scales; heads $12-16 \mathrm{~mm}$. broad, mostly 5-flowered; involucre 12-16 mm. high; achenes narrowly columnar or slightly tapering, truncate at the summit, about 8-nerved or ribbed; pappus light brown. Plains, Minn. to Mont., Mo., Kans. and N. Mex. June-Aug.

2. Lygodesmia rostràıa A. Gray. Beaked Lygodesmia. 2. Lygodesmia rostraıa A. Gray. BEAKED LYGoDESMiA. (1. F. f. 3547.)
Annual, less rigid; stem striate, leafy, paniculately branched, 3-9 dm. high. Leaves elongated-linear, acuminate, entire, 3-nerved, the lower 7-17 cm. long, 2-3 mm. wide, the uppermost very small and subulate; heads numerous, 7-10. flowered, about I cm. broad; involucre IO-14 $\mathrm{mm}$. high; achenes narrowly fusiform, narrowed or somewhat beaked at the summit, 5-8-ribbed or -striate, 8 -Io mm. long, longer than the whitish pappus. Kans. and Neb. to the N. W. Terr., Colo. and Wyo. Aug.-Sept.

\section{AGÓSERIS Raf.}

Herbs, mostly acaulescent, with tufted usually sessile basal leaves, and solitary heads of yellow or rarely purple flowers at the end of a naked or bracted scape. Involucre campanulate or oblong, its bracts imbricated in several rows, appressed, or with spreading tips, membranous or herbaceous, not thickened after flowering, the outer ones gradually shorter and broader. Receptacle flat, naked or foveolate. Rays truncate and 5-toothed at the apex. Anthers sagittate at the base. Stylebranches slender. Achenes oblong, obovate, or linear, Io-ribbed, not flattened, beaked at the summit. Pappus of copious slender simple white bristles. [Greek, head-or chief-succory.] About 25 species, natives of western and southern N. A. and southern S. A. Besides the following, some 20 others occur in the western parts of the U. S.

Head $3-5 \mathrm{~cm}$. broad; achenes ro-12 mm. long.

Head $2.5 \mathrm{~cm}$. broad or less; achenes about $6 \mathrm{~mm}$. long.
1. A. glauca.

2. A. parvifiora.

I. Agoseris glàuca (Pursh) Greene. LARge-Flowered Agoseris. (I. F. f. 3548.) Perennial, pale or glaucous, glabrous throughout or a little woolly below. Leaves linear, lanceolate, or oblong, entire, dentate or pinnatifid, 5-25 cm. ling. 4-20 mm. wide, acuminate at the apex, narrowed at the base, sometimes into margined petioles; scapes stout, glabrous or slightly pubescent, longer than the leaves, often $4 \mathrm{dm}$. high; involucre oblong-campasulate, or broader in fruit, commonly quite glabrous, its bracts lanceolate, acuminate: achenes conspicuously beaked; pappus of rather rigid scabrous or denticulate bristles. S. Dak. to the N. W. Terr., Kans, Colo., and Utah. May-July. [Troximon glaucum Pursh.]

2. Agoseris parvifiòra (Nutt.) Greene. Small-Flowered Agoseris. 11. $2:$ f. 3549.) Perennial, glabrous throughout; scape slender, much longer than ti.s leaves, $12-40 \mathrm{~cm}$. high. Leaves nirrowly linear, acuminate, entire, 7-20 cm. long, 2-5 $\mathrm{mm}$. wide; involucre oblong-ovoid, becoming nearly hemispheric in fruit, I2-16 mm. high, glabrous, its bracts lanceolate, acuminate; achenes conspicuously beaked; pappus of numerous unequal very slender bristles. Plains, western Neb. to Manitoba, Idaho and N. Mex. May-July.[T. farviforum Nutt]

\section{NOTHOCÁlAIS Greene.}

Perennial herbs, with basal tufted narrow undulate or crisped, tomentose-margined leaves, and large heads of yellow flowers solitary at the ends of simple naked scapes. Involucre oblong-campanulate, its bracts in 2-4 series, lanceolate, acute, or acuminate, appressed, nearly equal, the margins hyaline. Receptacle flat, alveolate. Rays truncate and 5-toothed at the apex. Anthers sagittate at the base. Achenes fusiform, contracted or beaked at the summit, IO-ribbed or IOstriate. Pappus of 10-30 white soft unequal narrow scabrous scales, with or without some capillary bristles. [Greek, false Calais.] Three known species, of western and central N. A.

I. Nothocalais cuspidàta (Pursh) Greene. False Calais. (I. F. f. $355^{\circ}$.) Leaves linear, long-acuminate, thick, pubescent or glabrate, I-2 dm. long, 4-IO mm. wide, somewhat conduplicate, their margins conspicuously white-tomentose and crisped, or entire. Scape stout, tomentose, at least above, shorter than or equalling 
the leaves; head 3-5 cm. broad; involucre usually quite glabrous, nearly $25 \mathrm{~mm}$. high; achenes slightly contracted at the summit, about $6 \mathrm{~mm}$. long; pappus of 40-50 unequal scales and bristles. In dry soil, on prairies and rocky hills, Ill. to the N. W. Terr., south to Neb. and Kans. April-June.

\section{SITÍLIAS Raf. [PYRRHOPAPPUS DC.]}

Perennial herbs (some species annual ?), with alternate or basal leaves, and mostly large, solitary or few heads of yellow flowers, borne on long, usually bracted peduncles. Involucre oblong or campanulate, its principal bracts in I series, nearly equal, slightly united at the base, with several series of smaller outer ones. Rays truncate and 5-toothed at the summit. Anthers sagittate at the base. Style-branches short, obtusish. Achenes oblong or fusiform, mostly 5-ribbed, roughened or hirsute, abruptly narrowed into a long filiform beak. Pappus of numerous soft simple brownish semewhat unequal bristles, surrounded at the base by a villous white ring. [Name unexplained.] Six known species, of N. Am. and Mex.

Stem leafy, usually branched; plant glabrous, or nearly so.

Scape naked, monocephalous; plant hirsute, or pubescent.

I. S. Caroliniana.

2. S. grandiflora.

1. Sitilias Caroliniàna (Walt.) Raf. Leafy Stemmed False Dandelion. (I. F. f. 355 I.) Glabrous or nearly so; stem leafy, usually branched, 6-r $5 \mathrm{dm}$. high. Basal leaves oblong or oblong-lanceolate, pinnatitid, lobed, coarsely dentate or some of them entire, acute, acuminate, or obtusish, 7-20 cm. long, $1-3 \mathrm{~cm}$. wide, narrowed into margined petioles; stem leaves sessile or partly clasping, the upper usually lanceolate, entire and acuminate; heads I or several, 25-35 mm. broad; involucre commonly puberulent or pubescent, its outer bracts setaceous or subulate, spreading, the inner corniculate at the apex. In dry fields, Del. to Fla., Mo., La. and Tex. April-July.

\section{Sitilias grandifiòra (Nutt.) Greene. Rough False Dandelion.} F. f. 3552.) Hirsute or pubescent. Root tuberous-thickened; leaves all basal, oblong or spatulate in outline, deeply pinnatifid, $7-17 \mathrm{~cm}$. long, $2.5-3.5 \mathrm{~cm}$. wide, narrowed into margined petioles; scape naked or sometimes with a small leaf near its base; head solitary, 3-5 cm. broad; suter bracts of the involucre small, short, subulate, the inner ones obscurely corniculate at the tip. On prairies, Kans. to Tex. April-June.

\section{CRÈPIS L.}

Perennial or annual herbs, with alternate or basal, mostly toothed or pinnatifid leaves, and small or middle-sized heads, usually paniculate or corymbose, of yel. low or orange flowers. Involucre cylindric, campanulate or swollen at the base, its principal bracts in I series, equal, with a number of exterior smaller ones. Receptacle mostly flat, naked or short-fimbrillate. Rays truncate and 5-tonthed at the apex. Anthers sagittate at the base. Style-branches slender. Achenes linearoblong, 10-20-ribbed or nerved, not transversely rugose, narrowed at the base and apex, be:kless in our species. Pappus copious, of very slender white bristles. [Greek, sandal; application not explained.] About 180 species, of the northern hemisphere. Besides the following, about Io others occur in western N. Am.

Involucre glabrous.

Involucre cylindric; plant pubescent below: introduced.

Involucre campanulate; plant glaucous; native, western.

Involucre pubescent, glandular, or canescent.

Foliage not canescent nor scurfy, sometimes hirsute.

Stem naked, or with $\mathrm{r}$ or 2 small leaves; western, native.

Stems leafy; introduced annuals or biennials.

Stem leaves narrow, revolute-margined, sessile.

Stem leaves lanceolate, clasping, not revolute-margined.

Involucre 6-8 $\mathrm{mm}$. higl,; achenes ro-striate.

Involucre 8-12 mm. high; achenes 13 -striate.

Foliage cinereous, canescent. or scurfy, sometimes also hirsute.

Inner bracts of the involucre $5-8$; flowers $5-8$.

Inner bracts of the involucre 9-24; flowers 10-30.

I. C. pulchra.

2. C. glauca.

I. Crepis púlchra I. Small-Flowered Hawksbeard. (I. F. f. 3553.)

3. C. runcinata.

4. C. tectorum.

5. C. virens.

6. C. biennis.

7. C. intermedia.

8. C.occidentalis. Annual; stem 6-13 dm. high, leafy and pubescent below, mostly glabrous, naked and paniculately branched above. Stem leaves oblong or oblong-lanceolate, den. 
tate, clasping by an auricled base or truncate, pubescent, 7-10 $\mathrm{cm}$. long, acute or obtuse; basal leaves runcinate, narrowed into petioles; heads very numerous, about $6 \mathrm{~mm}$. broad, in a large naked panicle; involucre narrow, cylindric, glabrous, about I $\mathrm{cm}$. high, its principal bracts 12-15, linear, acuminate, the outer ones very short, ovate, appressed; achenes linear, faintly Io-nerved. Along railruad near Culpepper, Va. Nat. or adventive from Europe. May-July.

2. Crepis glàca (Nutt.) T. \& G. Glaucous Hawksbeard. (I. F. f: 3554.) Perennial; scapose, or rarely with $I$ or 2 leaves on the stem, 3-7 dm. high, glabrous and glaucous throughout. Basal leaves spatulate, oblanecolate, or obovate, gradually narrowed into margined petioles, entire, dentate, or pinnatifid, 5-15 cm. long, I-2 cm. wide; heads not numerous, long-peduncled, 12-25 mm. broad; peduncles glabrous; involucre campanulate, its principal bracts lanceolate, acute, the outer ones very short, ovate, appressed; achenes oblong-cylindr.c, strongly ro-ribbed. In moist and saline soil, Neb. to the N. W. Terr., Nev. and Utah. July-Aug.

3. Crepis runcinàta (James) T. \& G. Naked-stemmed Hawksbeard. (I. F. f. 3555.) Perennial, similar to the preceding species but not glaucous or scarcely so, often pubescent below; stem leafless or with I or 2 small leaves, 3-9 dm. high. Basal leaves spatulate, obovate, or oblong, obtuse or acute, entire, repand, dentate, or rarely runcinate-pinnatifid, 5-r5 cm. long, $2-3 \mathrm{~cm}$. wide; heads several, long-peduncled, nearly $25 \mathrm{~mm}$. broad; involucre campanulate, its principal bracts linear-lanceolate, acute, outer ones short, lanceolate, appressed; achenes linear-oblong, Io-ribbed. In moist soil, Iowa to Manitoba, west to Utah and Mont. June-July.

4. Crepis tectoorum L. Narrow-leaved Hawksbeard. (I. F. f. 3556.) Annual; stem slender, puberulent or pubescent, leafy, branclied, 3-6 dm. high. Basal leaves lanceolate, dentate, or runcinate-pinnatifid, $10-15 \mathrm{~cm}$. long; stem leaves sessile, sometimes slightly sagittate at the base, linear, entire, dentate, or lobed; heads numerous, corymbose, $12-20 \mathrm{~mm}$. broad; involucre narrowly campanulate, canescent or pubescent, 6-IO mm. high, its principal bracts lanceolate, acuminate, downy within, the exterior ones linear, spreading; achenes Io-ribibed, the ribs minutely scabrous. In waste places and in ballast, N. J. to Conn., Ont., Mich. and Neb. June-July.

5. Crepis virens L. Smooth Hawksbeard. (I. F. f. 3557.) Annual; stem corymbosely branched aloove, glabrous or somewhat hirsute below, 3-7 $\mathrm{dm}$. high. Basal leaves spatulate, pinnatifid, or dentate, sometimes $2 \mathrm{dm}$. long and $5 \mathrm{~cm}$. wide, narrowed into petioles; stcm leaves lanceolate or oblong, clasping by a sagittate base, flat, the upper mostly very small and usually entire; heads numerous, ro-r $6 \mathrm{~mm}$. broad, slender-peduncled; involucre oblong, 6-8 $\mathrm{mm}$. high, its principal bracts lanceolate, glabrous within, the outer mostly appressed; achenes Io-ribbed, smooth. In fields and waste places, Conn., N. Y., N. J. and Penn., and in ballast about the seaports. Also on the Pacific Coast. Adventive from Europe. Very variable. July-Sept.

6. Crepis biénnis L. Rough Hawksbeard. (I. F. f. 3558.) Biennial, or sometimes annual; stem pubescent or hirsute, leafy, at least below, branched above, 6-9 dm. high. Leaves runcinate-pinnatifid, usually hirsute, $5-15 \mathrm{~cm}$. long, oblong or spatulate, the lower and basal ones narrowed into petioles and sometime $s$ merely dentate; heads several, subcorymbose, 2-4 cm. broad; involucre canescent or pubescent, 8-12 mm. high, its principal bracts linear-lanceolate, downy within, the outer ones linear-oblong or lanceolate, spreading; achenes oblong, I3 striate, glabrous. In waste places, Vt., Penn., and in ballast about the seaports. - Nat. or adventive from Europe. June-Aug.

7. Crepis intermèdia $A$. Gray. Small-flowered Gray Hawksbeard. (I. F. f. 3559.) Perennial, cinereous puberulent or scurfy; stem rather slender, I-3-leaved, 3-6 dm. high, naked and branched above. Basal leaves lanceolate or oblong-lanceolate, laciniate-pinnatifid, long-acuminate at the apex, narrowed at the base, IO-15 cm. long; stem leaves lanceolate, sessile, less divided; heads several, I2-I8 mm. broad; involucre oblong-campanulate, its principal bracts 5-8, lanceolate or linear-oblong, canescent, acutish, the outer ones few and short; achenes oblong, strongly ro-ribbed. In dry soil, western Neb. and Colo. to Cal. and $\mathrm{Br}$. Col. May-Sept. 
8. Crepis occidentalis Nutt. Large-flowered Gray Hawksbeard. (1. F. f. 356o.) Perennial, scurfy and canescent, sometimes also hirsute; stem ratlier stout, leafy, branched, 15-45 high. Leaves oblong-lanceolate or oblong in outline, laciniate-pinnatifid, acute or acuminate, the lower and basal ones $\mathbf{1 5 - 2 5} \mathrm{cm}$. long, narrowed into petioles, the upper sessile and slightly clasping; heads few or several, corymbose, stout-peduncled, about $25 \mathrm{~mm}$. broad; involucre oblong-campanulate, canescent, its principal bracts 9-24, linear, acute; achenes oblong, sliarply Io-ribbed, glabrous. Plains, western Neb. (according to Gray) and Colo. to Cal., north to the N. W. Terr. and Br. Col. May-July.

\section{HIERÀCIUM L.}

lerennial hispid scabrous glandular or glabrous herbs, with alternate or basal leaves, and small middle sized or large, solitary corymbose or paniculate heads of y tiow orange or red flowers. Involucre cylindric, campanulate, or nearly hemispheric, its principal bracts in $\mathbf{I}-3$ series, the outer either regularly and gradually smaller or abruptly much smaller, none of them much thickened at the base after flowering. Receptacle flat, naked or short-fimbrillate. Rays truncate and 5-toothed at the apex. Anthers sagittate at the base. Style-branches slender. Achenes oblong, columnar, or fusiform, not beaked, ro-15-ribbed, terete or 4-5-angled. Pappus copious, or I-2 rows of simple rather stiff persistent brown or brownish bristles. [Greek, hawk.] Not fewer than 300 species, natives of the north temperate zone and the Andes of S. Am. Besides the following, some 15 others occur in western N. Am.

* Flowering stem leafless, or with I-5 leaves; achenes columnar or oblong, truncate.

(a) Stem scapose, with a single head only; introduced; principal bracts in 1 or 2 series. 1. H. Pilosella.

(b) Heads corymbose or paniculate; principal bracts in $1-3$ series.

Leaves coarsely dentate; introduced species.

Leaves cordate or subcordate.

Leaves narrowed at both ends.

2. H. murorum.

3. H. vulgatum.

Leaves denticulate or entire.

Leaves mostly entire, spatulate to oblong; heads corymbose; introduced species; principal bracts of the involucre in $2-3$ series.

Heads $16-25 \mathrm{~mm}$. broad; flowers red or orange.

Heads ro-r $8 \mathrm{~mm}$. broad; flowers yellow.

Glaucous, slightly hispid.

Densely hirsute.

4. H. aurantiacum.

5. H. praealtum.

6. H. pratense.

Leaves, at least some of them, denticulate, mostly obovate or oval; heads corymbosepaniculate; natives; principal bracts in I series.

Principal bracts of the involucre glabrous, or nearly so.

Stem glabrous, or nearly so; leaves usually purple-veined.

Stem pilose below; leaves green.

Involucre and peduncles densely hirsute and glandular.

* * Flowering stem abundantly leafy, at least below.

(a) Principal bracts of the involucre in 2-4 series; heads corymbose.

I.eaves sessile, not clasping; involucre glabrous.

Leaves, at least the upper, clasping; involucre pubescent.

10. H1. umbellatum.

(b) Principal bracts in I series; heads small, paniculate or racemose.

1. Achenes columnar at maturity, truncate.

Plant nearly or quite glabrous except towards the base; heads $15^{-20-f l o w e r e d . ~}$

Plants scabrous or glandular; heads 15-50-flowered.

Peduncles stout, spreading.

Peduncles slender, ascending.

No tuft of basal leaves at flowering time.

- Basal leaves present at flowering time.

7. H. venosum.

8. H. Marianum.

9. H. Greenii.

2. Achenes spindle-shaped, or with a tapering summit at maturity.

Leaves and lower part of the stem pilose.
Leaves and stem densely clothed with very long brown hairs.

12. H. paniculatum.

13. H. scabrum.

8. H. Marianum.

14. H. Alleghaniense.

15. H. Gronovii.

16. H. longipilum.

I. Hieracium Pilosélla L. Mouse-ear Hawkweed. (I. F. f. 356r.) Sto. loniferous, pilose-pubescent throughout; stolons leafy, rooting, slender, $7-30 \mathrm{~cm}$. long. Scape slender, erect, IO-25 cm. high, leafless, with a single head: leaves oblong or spatulate, entire, obtuse or acutish at the apex, narrowed into petioles, 
often white-tomentc.se beneath, 4-7 cm. long, 8-16 mm. wide; head $25 \mathrm{~mm}$. broad or more; flowers yellow; bracts linear, acuminate, pubescent, usually with $\mathbf{I}$ or 2 exterior ones. Dooryards and fields, Ont., N. Y., Penn. and Mich. Adventive from Europe. May-Sept.

- Hieracium Pilosélla Peleteriànum Mer. Stolons shorter, thick; plant silky-pubescent. Fields and roadsides, Prince Edward Island. Nat. from Europe.

2. Hieracium muròrum L. Wall HawkweEd. (I. F. f. 3562.) Stem pubescent or glabrate, simple, or with I or 2 branches, 3-7 dm. high. Basal leaves thin, ovate or oblong, obtuse or acute, cordate or truncate at the base, or abruptly narrowed in to petioles, coarsely dentate or laciniate, at least near the base, $5-10 \mathrm{~cm}$. long, 3-5 cm. wide, the petioles villous; stem leaves $I$ or 2 (sometimes none), shortpetioled or sessile; heads about $25 \mathrm{~mm}$. broad; peduncles ascending, usually glandular; involucre 8-10 mm. high, its bracts linear-lanceolate, acute, glandular. pubescent; pappus nearly white. Woodlands near Brooklyn, N. Y.; about Quebec. Adventive or fugitive from Europe. June-Aug.

3. Hieracium vulgàtum Fries. HAwkweEd. (I. F. f. 3563.) Similar to the preceding species, sometimes taller and slightly glaucous; stem 2-5-leaved, pubescent or glabrate. Basal leaves oblong or lanceolate, coarsely dentate or denticulate, petioled, 5-12 cm. long, I-3 mm. wide, stem leaves similar, short-petioled or sessile; petioles more or less pubescent; peduncles mostly glandular, straight; bracts linear, acuminate, mostly glandular. Lab. and Newf. to Quebec and in southern N. Y. and N. J. Probably introduced. Also in Greenland, northern Europe and Asia. July-Sept.

4. Hieracium aurantiacum L. ORAnge or TAwny Hawkweed. Golden Mouse-EAR HAWKWEed. (I. F. f. 3564.) Stoloniferous, or stolons wanting; stem leafless or rarely with I or 2 small sessile leaves, hirsute, slender, 1.5-5 dm. high. Basal leaves hirsute, tufted, spatulate or oblong, obtuse, narrowed at the base, entire, or sometimes slightly denticulate, 5-12 $\mathrm{cm}$. long, $\cdot 5^{-2} \mathrm{~cm}$. wide: heads 14-25 $\mathrm{mm}$. broad; peduncles glandular-pubescent; involucre 8-10 mm. hign, its bracts linear-lanceolate, acuminate, hirsute and sometimes glandular. In fields, woods and along roadsides, N. B. and Ont. to N. Y., N. J. and Penn. Nat. from Europe. June-Sept.

5. Hieracium praeáltum Vill. KING-Devil. (I. F. f. 3565.) Stoloniferous or stolons wanting; stem glabrous, or somewhat hispid, glaucous, slender, 4-9 dm. high, bearing I-3 leaves near the base. Basal leaves tufted, narrowly oblong, lanceolate, or spatulate, entire, obtuse or acute at the apex, narrowed below into margined petioles, hirsute with stiff hairs, 5-10 cm. long, 6-14 mm. wide; heads 8-12 mm. broad; peduncles mostly short, pilose and glandular; involucre about $6 \mathrm{~mm}$. high, its bracts linear, acute or acuminate, pilose and somewhat glandular. In fields, meadows and along roadsides, Me. and Ont. to N. Y. Nat. from Eurcpe. June-Sept.

6. Hieracium praténse Tausch. Field HAwkweEd. (I. F. f. 3566.) Stoloniferous, hirsute or pilose with long hairs, those of the stem blackish. Stem scapose, simple, 3-6 dm. high, bearing 1 or 2 leaves below the middle; basal leaves numerous, tufted, light green, oblanceolate to oblong, obtuse, 5-12 cm. long, 1-2 $\mathrm{cm}$. wide, narrowed into margined petioles, or to a sessile base, entire, or with few distant minute glandular teeth; heads $2 \mathrm{~cm}$. wide, or less; peduncles glandular and often tomentose; bracts of the involucre linear-lanceolate, acuminate, glandular and pilose. Dongan Hills, Staten Island, N. Y. Nat. or adventive from Europe.

7. Hieracium venòsum L. Rattlesnake-Weed. Poor Robin's PlanTAIN. (I. F. f. 3567.) Stems solitary or several from the same root, slender, glabrous, or with a few hispid hairs, leafless or with I-3 leaves, 3-9 dm. high. Basal leaves tufted, spreading on the ground, obovate, oval or oblong-spatulate, mostly obtuse, narrowed at the base, sessile or petioled, 3-10 $\mathrm{cm}$. long, $1-3 \mathrm{~cm}$. wide, usually purple-veined, more or less hirsute, sorne or all of them glandulardenticulate; heads 10--16 mm. broad, 15-40-flowered, slender-peduncled; peduncles glabrous, or slightly glandular; involucre about $6 \mathrm{~mm}$. high. Dry woods and thickets, Me. to Ont. and Manitoba south to Ga., Ky. and Neb. May-Oct.

8. Hieracium Mariànum Willd. Maryland Hawkweed. (I. F. f. 3568.) Stems usually solitary, slender, 3-9 dm. high, bearing 2-7 leaves. Basal leaves 
obovate or oblong, ascending or erect, obtuse, narrowed at the base, sessile or petioled, villous or hirsute, glandular-denticulate, 5-20 cm. long, 3-5 cm. wide, those of the stem similar, smaller; heads $12-20 \mathrm{~mm}$. broad, I5-40-flowered, slenderpeduncled; peduncles more or less glandular and sometimes canescent; involucre about $8 \mathrm{~mm}$. ligh, bracts linear-las ceolate, acute, or acuminate, glabrous or nearly so, with a few short outer ones. In dry woods and thickets, R. I. to southern N. Y., Penn., Ky., Ala. and Fla. May-July.

9. Hieracium Greènii Porter and Britton. Green's Hawkweed. (I. F. f. 3569.) Stem glabrous up to the branclies, rather slender, leafless or rarely with I or 2 leaves, 4-7 dm. high. Basal leaves tufted, ascending, spatulate, oblong, or obovate, obtuse, narrowed at the base, mostly petioled, glandular-denticulate or entire, villous-pubescent or somewhat hispid, IO-I $7 \mathrm{~cm}$. long, I-5 cm. wide; heads 30-40-flowered, slender-peduncled, $16-20 \mathrm{~mm}$. broad; involucre $10 \mathrm{~mm}$. high, bracts linear, acute, densely pilose-glandular. In dry soil, mountains of Penn. to Va. and W. Va. May-June.

I0. Hieracium umbellàtum L. NaRRow-Leaved HawkweEd. (I. F. f. 3570.) Stem rather slender, glabrous or puberulent, 3-7 dm. high. Leaves lanceolate or linear-lanceolate or the lowest spatulate, entire, denticulate or sometimes laciniate-dentate, acute or acuminate, narrowed to a sessile base, 3-7 cm. long, 4-12 $\mathrm{mm}$. wide, glabrous above, mostly somewhat pubescent beneath, the margins commonly ciliolate; heads about $25 \mathrm{~mm}$. broad; peduncles rather stout, canescent; involucre IO-I $4 \mathrm{~mm}$. high, the outer bracts spreading. Lower St. Lawrence River to Ont., Minn., Neb., Br. Col. and Ore. Also in northern Europe and Asia. June-Aug.

I I. Hieracium Canadénse Michx. Canada Hawnweed. (I. F. f. 3571.) Stem erect, firm, glabrate or pubescent, 3-15 dm. high. Leaves numerous, oblonglanceolate, ovate-oblong, or lanceolate, acute or acuminate at the apex, rounded, sessile, and, at least the upper ones, clasping at the base, 3-7 cm. long, $6-25 \mathrm{~mm}$. wide, serrate or incised, the margins sometimes ciliolate, glabrous or pubescent beneath, the lowest somewhat spatulate and petioled; heads about $25 \mathrm{~mm}$. broad; involucre about $12 \mathrm{~mm}$. high, outer bracts spreading. In dry woods and thickets, N. S. to Ont. and the N. W. Terr., south to N. J. and Mich. July-Sept.

I 2. Hieracium paniculàtum L. Panicled Hawkweed. (I. F. f. 3572.) Glabrous throughout, or somewhat pilose-pubescent below, stem paniculately branched above, leafy, slender, 3-9 dm. high. Leaves thin, lanceolate or oblonglanceolate, acute or acuminate at the a pex, narrowed to a sessile base, or the lowest into petioles, denticulate or dentate, 5-15 cm. long, 6-25 $\mathrm{mm}$. wide; heads 10-14 $\mathrm{mm}$. broad; peduncles filiform, often drooping, glabrous or sometimes glandular; involucre about $6 \mathrm{~mm}$. high, glabrous or nearly so, bracts linear, acute, with a few very small outer ones at the base. In dry woods, Me., Quebec and Ont. to Ga., Ala. and Ky. July-Sept.

13. Hieracium scàbrum Michx. Rough Hawnweed. (I. F. f. 3573.) Stem stout, leafy, densely hirsute or hispid below and glandular-pubescent above, strict, 3-12 dm. high. Leaves hirsute, obovate, oblong, or broadly spatulate, 5-10 $\mathrm{cm}$. long, 2-4 cm. wide, obtuse at the apex, narrowed to the sessile base or the lowest into margined petioles, denticulate; heads $12-16 \mathrm{~mm}$. broad; peduncles stout, densely glandular; involucre 8-10 mm. high, glandular; bracts linear, acute, with a few very small outer ones. In dry woods and clearings, N. S. to Minn., Ga., Neb. and Kans. July-Sept.

14. Hieracium Alleghaniénse Britton n. sp. Alleghany Hawkweed. Stem rough-hairy below, glabrous or nearly so above, about $6.5 \mathrm{dm}$. tall. Lower and middle stem-leaves oblanceolate, I-I.5 dm. long, $3 \mathrm{~cm}$. wide or more, obtuse, cuspidate, tapering into narrowly margined pubescent petioles, thin, pale and pubescent along the midvein beneath, green above, with a few very distant minute glandular teeth; upper leaves oblong to oblong-lanceolate, acute, narrowed to a sessile base; inflorescense paniculate, its branches filiform, glandular; heads rather numerous: involucre about $7 \mathrm{~mm}$. high, its bracts linear-lanceolate, sparingly glandular, a little shorter than the brown pappus; young achenes truncate. Aurora, Alleghany Mountains of W. Va., E. S. Steele, Aug. 29, I898.

I5. Hieracium Gronòvii L. Gronovius' Hawkweed. Hairy Hawkweed. (I. F. f. 3574.) Stem stiff, mostly slender, leafy and villous or hirsute, sometimes 
nearly leafless, 3-9 cm. high. Leaves villous or hirsute, the basal and lower ones obovate or spatulate, denticulate, or entire, obtuse, $5^{-15} \mathrm{~cm}$. long, usually narrowed into petioles; stem leaves mostly sessile, oblong or oval, obtuse or acute, the upper gradually smaller; heads IO-I8 $\mathrm{mm}$. broad; peduncles glandular and canescent, slender; involucre about $8 \mathrm{~mm}$. high, somewhat canescent, bracts linear lanceolate, acute, with several very small outer ones. In dry soil, Mass. to Ont., Ill., Fla. and Tex. July-Sept.

I6. Hieracium longípilum Torr. Long-BEARDEd Hawnweed. (I. F. f. 3575.) Stem, at least its lower portion, and leaves densely covered with long brown rather rigid bristly hairs $\mathbf{I}-2.5 \mathrm{~cm}$. long, arising from papillæ. Stem very leafy below, stiff, simple, 6-Io dm. higin; basal and lower leaves spatulate or oblong, obtuse, mostly entire, 8-16 $\mathrm{cm}$. long, narrowed into margined petioles, the upper lanceolate or spatulate, mostly sessile; heads $16-20 \mathrm{~mm}$. broad; peduncles tomentose and glandular; involucre 8-Io $\mathrm{mm}$. high, bracts linear-lanceolate, acuminate, with several short subulate outer ones. Prairies and dry woods, Ont. to Minn., Ill., Kans. and Tex. July-Sept.

\section{NÁBALUS Cass. (See Appendix.)}

Perennial, herbs with alternate, mostly petioled, dentate lobed or pinnatifid leaves, or the upper auriculate and clasping, and numerous small heads of ligulate white yellowish or purplish flowers in open or spike-like terminal panicles, or also in axillary clusters, usually drooping. Involucre cylindric, usually narrow, its principal bracts in I or 2 series, nearly equal, with a few smaller exterior ones at the base. Receptacle flat, naked. Rays truncate and 5-toothed at the summit. Style-branches slender. Achenes oblong or narrowly columnar, truncate, terete or 4-5-angled, mostly ro-ribbed. Pappus of copious rather rigid simple white to reddish-brown bristles. [Modern Latin, from an Indian name for Rattlesnake-root.] About 20 species, natives of America and Asia. Besides the following, another occurs in northwestern Am.

* Bracts of the involucre glabrous, or with a few scattered hairs.

Heads 5-7 flowered; involucre very narrow, light green, $2 \mathrm{~mm}$. thick; pappus light straw-color.

I. N. altissimus.

Heads 8-16 flowered; involucre broader, green, purple or glaucous, 3-6 mm. thick.

Leaves, or some of them, lobed, divided, or pinnatifid; involucre about $3 \mathrm{~mm}$. thick.

Pappus deep cinnamon-brown.

Pappus straw-color or light brown.

2. $N$. albus.

Inflorescence paniculate.

Involucral bracts with some stiff hairs, obviously shorter than the pappus; panicle-branches divergent.

Involucral bracts glabrous, equalling the pappus; panicle-branches ascending, or erect.

Inflorescence thyrsoid or glomerate.

Leaves palmately lobed or divided; northern. $5 . N$. nanus.

Leaves pinnately lobed or pinnatifid; southern.

Leaves irregularly dentate or denticulate, oblong ; plant tall.

Leaves entire or denticulate ; plant low, alpine; involucre $5-6 \mathrm{~mm}$. thick.

6. N. virgatus.

3. $N$. serpentarius.

7. N. Boottii.

** Bracts of the involucre hirsute-pubescent.

Inflorescence narrowly thyrsoid; heads 8-r6-flowered.

Leaves and stem rough-puberulent or scabrous.

Leaves and sten glabrous, glaucous.

Inflorescence corymbose-paniculate; heads 20-25-flowered.

8. N. asper.

9. N. racemosus.

ro. $N$. crepidineus.

I. Nabalus altíssimus (L.) Hook. Tall White Lettuce. (I. F. f. 3576.) Glabrous, or sparingly hispidulous, not glaucous; stem slender, I-2 m. high, green, or sometimes purplish. Leaves thin, hastate, cordate, ovate, or the uppermost lanceolate, entire, denticulate, dentate or palmately lobed or divided, most of them long-petioled, the larger sometimes $15 \mathrm{~cm}$. long: heads very numerous, in a narrow panicle, and often in axillary clusters, 5-7-flowered, pendulous, about $4 \mathrm{~mm}$. broad; inflorescence often narrow; involucre narrowly cylindric, 10-18 mm. long, about $2 \mathrm{~mm}$. thick, green, glabrous, its principal bracts about 5 ; flowers greenish or yellowish white. In woods and thickets, Newf. to Manitoba, south to Ga. and Tenn. July-Oct. [Prenanthes altissima L.] 
2. Nabalus álbus (L.) Hook. Rattlesnake-Roo'r. White Lettuce. (I. F. f. 3577.) Glabrous and glaucous; stem conmonly purple, 6-15 dm. high. L.eaves hastate, ovate, cordate, denticulate, dentate, lobed, or palmately divided, or the upper lanceolate, entire; heads numerous, pendulous, about $6 \mathrm{~mm}$. broad, paniculate, or thyrsoid, and often in axillary clusters; involucre glabrous, or with a few scattered hairs, glaucous, IO-I $4 \mathrm{~mm}$. high, its principal bracts about 8 , purplish; flowers greenish or yellowish white, fragrant. In woods, Me. and Ont. to Manitoba, south to Ga. and Ky. Aug.-Sept. [Prenanthes alba L.]

$\therefore$ Nabalus serpentàrius (Pursh) Hook. Lron's-Foot. GALL-OF-THE-EARTH. (I. F. f. 3578.) Glabrous or sparingly pubescent, green; stem stout or sleuder, not glaucous, 3-12 dm. high. Leaves rather firm, similar to those of the preceding species, equaily variable in outline, often pinnatifid or pinnately lobed, or p.lmately divided; inflorescence paniculate, the branches divaricate, upcurved; heads numerous, about $6 \mathrm{~mm}$. broad, pendulous; involucre nore or less bristlyhispid, rarely glabrous, Io- $14 \mathrm{~mm}$. long, its principal bracts about 8 , shorter than the pappus; flowers whitish or cream-color, rarely yellow. In fields and thickets, Ont. to southern N. Y., Fla., Ala. and Ky. July-Oct.

Nabalus serpentarius integrifolius (Cass.) Britton. Leaves oblong to oval, irregulurly dentate, denticulate or entire. L. I. to N. Car.

4. Nabalus trifoliolàtus Cass. TAll Rattlesnake-Root. (I. F. f. 3579.) Glabrous throughout; stem usually stout, $10-27 \mathrm{~d} ! n$. high. Leaves thinnish, the lower long-petioled, usually 3-divided with the divisio..s stalked or sessile, the upper short petioled or sessile, all commonly lubed or dentate, but the upper sometimes lanceolate, acuminate and entire; panicle-braurhes ascending, or nearly erect; heads few in the clusters, drooping: involucre glabrous, $12 \mathrm{~mm}$. long, its principal bracts 6-8, equalling the pappus; flowers whitish or pale yellow. In woods and thickets, Me. to Vt., Pern., Tenn. and Mo. Aug.-Oct.

5. Nabalus nànus (Pigel.) DC. LOW KAT1LESNAKE-ROOT, or Lron`S-FOOT. (I. F. f. 3580.) Glabrous throughout; stem simple, erect, I-4 dm. high. Basal and lower leaves slender petioled, 3 -divided, or sometimes broadly hastate, the divisions variously lobed, toothed, or entire; upper leaves much smaller, entire, toothed, or lobed, sessile, or short-petioled; inflorescence rarely with $\mathbf{I}$ or 2 short ascending branches; involucre dark purple-brown or nearly black, glabrous, 8-12 mm. long, its inner bracts 6-8, slightly ciliate at the apex, about as long as the pappus. Alpine summits of the Adirondacks and the mountains of N. Eng.; N. S. to Lab. and Newf. Aug.-Sept.

6. Nabalus virgàtus (Michx.) DC. Slender Rattlesnake-root. De WITT'S SNAKEROOT. (I. F. f. 358 I.) Glabrous, somewhat glaucous; stem strict, mostly simple, 6-12 dm. high. Leaves lanceolate or oblong-lanceolate, the basal and lower ones sinuate-pinnatifid or pinnately parted, petioled, often $25 \mathrm{~cm}$. long, the lobes entire or dentate, distant; upper leaves all sessile, pinnately lobed, or the uppermost entire, very small and bract-like; heads very numerous, pendulous, about $4 \mathrm{~mm}$. broad, in a narrow, simple or branched, terminal thyrsus, often unilateral; involucre ro $\mathrm{mm}$. long, its prineipal bracts about 8 ; flowers white or pinkish. In moist sandy soil, N. J. to Fla., near the coast. Sept-Oct.

7. Nabalus Boottii DC. Boott's Rattlesnake-Root. (I. F. f. 3582.) Glabrous below, commonly pubescent above; stem simple, I-3.5 dm. high. Leaves thickish, the basal and lower ones ovate, hastate, or deltoid, petioled, mostly obtuse, entire, or denticulate, 3-5 cm. long, the upper ovate or oblong, usually entire, short-petioled or sessile, much smaller; heads erect, spreading, or some of them pendulous, racemose or somewhat thyrsoid, 8-10 $\mathrm{mm}$. broad; involucre campanulate-oblong, 8-14 mm. long, dark purplish green, its principal bracts 8 -10, obtuse or obtusish; flowers whitish, odorous. Alpine summits of the mountains of northern N. Eng. and N. Y. July-Aug.

8. Nabalus ásper (Michx.) T. \& G. Rough White-LetTuce. (I. F. f. 3583.) Stem virgate, 6-12 dm. high. Leaves firm, oval, oblong, or oblanceolate, those of the stem all closely sessile, acute or acutish, dentate, denticulate, or the uppermost entire, the lower sometimes clasping, 5-7 cm. long, $1-2.5 \mathrm{~cm}$. wide, the basal tapering into winged petioles, commonly obtuse; heads numerous, erect, spread. ing, or slightly drooping, $6-8 \mathrm{~mm}$. broad, 12-16-flowered, in a long narrow thyrsus; 
involucre oblong, 4-5 mm. thick, I0-14 $\mathrm{mm}$. high, very hirsute, its piincipa bracts 8-ro; flowers light yellow; pappus straw-color. On dry prairies, Ohio u, Minn. and Neb., south to Ky., La. and Kans. Aug.-Sept.

9. Nabalus racemòsus (Michx. DC. Glaucous White-LetTuce. (I. F. f. 3584.) Stem virgate, striate, 3-18 dm. high. Leaves thickish, glabrous and glaucous, the lower and basal ones oval, oblong, oblanceolate, or obovate, dentate or denticulate, $\mathbf{I - 2} \mathrm{cm}$. long, mustly obtuse, tapering into long margined petioles; upper leaves sessile, smaller and partly clasping, lanceolate to ovate-lanceolate, denticulate or entire, mostly acute; heads numerous, erect, spreading, or slightly drooping, 12-16-flowered, 4-6 mm. broad; involucre oblung-cylindric, hirsute, 10-12 $\mathrm{mm}$. long, 3-5 mm. thick, longer than the hirsute peduncle, its princip.1 bracts 8-10, with several small outer ones; flowers purplish. In moist open places, N. B. and Anticosti to the N. W. Terr., south to southern N. Y., N. J., Mo. and Colo. Aug.-Sept.

Nabalus racemòsus pinnatífidus (A. Gray) Britton. Leaves pinnatifid or pinnately lobed. Hackensack nuarshes, N. J.; near Mt. Vernun, N. Y.

Prenanthes Mainénsis A. Gray, from northern Me., is probably a hybrid between $\lambda$. racemosus and $N$. trifoliolatus.

ro. Nabalus crepidíneus (Michx.) DC. CoRymbed Rattlesnake-Root. (I. F. f. 3585. ) Stem glabrous or nearly so below, sometimes puberulent above, stout, 1.5-2.7 m. high. Leaves thin, the basal and lower ones hastate, ovate, oblong, or deltoid, sharply dentate, lobed, or incised, sometimes $25 \mathrm{~cm}$. long, usually with broadly winged petioles; the upper much smaller, sessile or short-petioled, narrowed at the base, not clasping, ovate, deltoid, or lanceolate, acute; heads numer. ous, pendulous, short-peduncled, 8-12 mm. broad; involucre oblong or oblongcampanulate, hirsute, IO-I $5 \mathrm{~mm}$. long, about $6 \mathrm{~mm}$. thick, dark green or purplish, its principal bracts 12-15; flowers cream-color; pappus brown. In fields and thickets, western Penn. and N. Y. to Ky., Minn. and Kans. Aug.-Oct.

\section{Family 4. AMBROSIÀCEAE Reichenb.}

\section{Ragweed Family.}

Herbs, monœcious, or sometimes diœcious, many of them weeds. rarely shrubby, with alternate leaves, or the lower opposite, and small heads of greenish or white flowers subtended by an involucre of few, separate or united bracts, the pistillate heads sometimes larger and nut-like or bur-like. Staminate and pistillate flowers in the same, or in separate heads. Receptacle chaffy. Pistillate fowers with no corolla, or this reduced to a short tube or ring; calyx acinate to the I-celled ovary, its limb none, or a mere border; style 2-cleft. Staminate flowers with a funnelform tubular or obconic 4-5-lobed corolla; stamens mostly 5. separate, or their anthers merely connivent, not truly syngenesious, with short inflexed appendages; ovary rudimentary; summit of the style often hairy or penicillate. Eight genera and about 55 species, mostly natives of America.

Staminate and pistillate flowers in the same heads; involucre of a few rounded bracts.

x. Iva.

Staminate and pistillate flowers in separate heads, the staminate mostly uppermost; involucre of the pistillate heads bur-like or nut-like.

Involucral bracts of the staminate heads united.

Involucre of the pistillate heads with several tubercles or prickles in a single series.

2. Ambrosia.

Involucre of the pistillate heads with numerous prickles in several series.

3. Gaertneria.

Involucral bracts of the staminate heads separate; involucre of pistillate heads an oblong bur.

4. Xanthium.

\section{I. iv A $\mathbf{L}$.}

Puberulent or scabrous herbs, with thick opposite leaves, or the upper alternate, and small nodding, axillary and solitary, spicate racemose or paniculate heads of greenish flowers. Involucre hemispheric or cup-shaped, its bracts few, rounded. 
Receptacle chaffy, the linear or spatulate chaff enveloping the flowers. Marginal flowers I-6, pistillate, fertile, their c rollas short, tubular or none. Disk-flowers perfect, sterile, their corollas funnelform, 5-lobed, their styles undivided, dilated at the apex. Anthers entire at the base, yellow, scarcely coherent with each other, tipped with mucronate appendages. Achenes compressed, obovoid, glabrous. Pappus none. [Nam d after Ajuga Iva, from its similar smell.] About 12 spe(ies, natives of America. Besides the following, 6 others occur in the southern and western U. S.

Heads spicate or racemose, solitary-axillary, each subtended by a linear or oblong leaf.

Heads solitary, pedicelled.

Bracts of the involucre 4-5; heads $3-5 \mathrm{~mm}$. high.

Leaves serrate, oval or oblong; eastern.

Leaves entire or nearly so, obovate or oblong; western.

1. I. frutescens.

Bracts of the involucre 6-9; heads 6-8 mm. high; southeastern,

Heads spicate; leaves dentate.

3. I. imbricata.

4. I. ciliata.

Heads spicate-paniculate, not subtended by leaves.

5. I. xanthiifolia.

I. Iva frutéscens L. Marsh Elder. High-water Shrub. (I. F. f. 3586 .) Perennial, shrubby or herbaceous, somewhat fleshy; stem minutely pubescent, or sometimes glabrous below, 9-35 dm. high. Leaves oval, oblong, or oblong-lanceolate, all the lower ones opposite, short-petioled, 3-nerved, acute or obtusish, serrate, narrowed at the base, the lower 10-15 cm. long, 3-5 cm. wide, the upper smaller and narrower, passing gradually into those of the racemose inflorescence, which are much longer than the short-pedicelled heads ; involucre depressed-hemispheric, its bracts orbicular-obovate, separate; fertile flowers about 5, their corollas tubular. Along salt marshes and on muddy seashores, N. H. to Fla. and Tex. July-Sept.

2. Iva axillàris Pursh. Small-flowered Marsh Elder. (I. F. f. 3587.) Perennial by woody roots; stems herbaceous, ascending, glabrous or sparingly pubescent, simple or branched, 3-6 dm. high. Leaves sessile, entire or very nearly so, obtuse, faintly 3 nerved, obovate, oblong, or linear-oblong, $1-4 \mathrm{~cm}$. long, thick, somewhat fleshy, glabrous or pubescent, the lower opposite, the upper alternate and smaller, passing gradually into those of the inflorescence; lieads mostly solitary in the axils of the leaves, 4-6 $\mathrm{mm}$. broad, short-peduncled; involucre hemispheric, about $3 \mathrm{~mm}$. high, its bracts about 5 , connate at the base; pistillate flowers 4 or 5 , their corollas tubular. In saline or alkaline soil, N. W. Terr. to S. Dak., Neb., N. Mex., Br. Col. and Cal. May-Sept.

3. Iva imbricàta Walt. Seacoast Marsh Elder. (I. F. f. 3588.) Perennial by woody roots, glabrous or nearly so throughout, fleshy; stem 3-6 dm. high, simple, or sparingly branched. Leaves all but the lowest alternate, sessile, oblongspatulate, or lanceolate, obtusish, mucronulate, entire, or rarely serrate, obscurely 3-nerved, the larger $3-5 \mathrm{~cm}$. long, 6-10 $\mathrm{mm}$. wide; heads short peduncled or nearly sessile, the upper ones longer than their subtending leaves; involucre broadly campanulate, its bracts 6-9, not united, somewhat imbricated in 2 series; fertile flowers 2-4, their corollas tubular, the staminate ones much more numerous. On sandy seashores, Va. and N. Car. to Fla. and La. July-Oct.

4. Iva ciliàta Willd. Rough Marsh Elder. (I. F. f. 3589.) Annual, hispid-pubescent; stem simple, or branched, 6-20 dm. high. Leaves nearly all opposite, ovate, petioled, scarcely fleshy, puberulent beneath, acuminate at the apex, abruptly or gradually narrowed at the base, coarsely and irregularly dentate, 3 nerved, the lower 10-12 cm. long; upper leaves linear-lanceolate, hispid, squarrose, much longer than the heads; heads about $2 \mathrm{~mm}$. broad; bracts of the involucre 3-5, distinct or united below; hispid; fertile flowers 3-5, their corollas slender; staminate flowers 10-15. In moist soil. Ill. to Neb., La. and N. Mex. Aug.-Oct.

5. Iva xanthiifòlia (Fresen.) Nutt. BURWEed MARsh EldDer. (I. F. f. 3590.) Annual; stem much branched, pubescent or puberulent above, glabrous below, I-2 m. high. Leaves nearly all opposite, broadly ovate, long-petioled, acuminate at the apex, abruptly or gradually contracted at the base, coarsely and irregularly dentate, pale and canescent or puberulent beneath, roughish above, 3ribbed; inflorescence spicate-paniculate, terminal and axillary, ample, naked; heads sessile or minutely peduncled, less than $2 \mathrm{~mm}$. broad; bracts of the involucre in 2 
series of 5 , the outer ovate, the inner obovate or truncate, concave, subtending the usually 5 achenes; corollas of the fertile flowers rudimentary or none; staminate flowers ro-I5, their corollas obconic. In moist soil, or waste places, Ont. to N. W. Terr., south to Wis., Neb., N. Mex. and Utah. July-Sept.

\section{AMBRÒSIA L.}

Monœcious (rarely diœcious) branching herbs, with alternate or opposite, mostly lobed or divided leaves, and small heads of green flowers, the staminate spicate or racemose, the pistillate solitary or clustered in the upper axils. Involucre of the pistillate heads globose, ovoid or top-shaped, closed, $\mathbf{r}$-flowered, usually armed with 4-8 tubercles or spines; corolla none; stamens none; style-branclies filiform; achenes ovoid or obovoid; pappus none. Involucre of the staminate heads mostly hemispheric or saucer-shaped, 5-12-lobed, open, many-flowered; receptacle nearly flat, naked, or with filiform chaff; corolla funnelform, 5-toothed; anthers scarcely coherent, mucronate-tipped; st $/$ le undivided, penicillate at the summit. [Tlee incient classical name.] About 12 species, mostly natives of America. Besides the following, some 5 others occur in the southern and western U.S.

Sterile heads sessile; a lanceolate hispid lobe on inner border of involucre.

Sterile heads short-pedicelled; involucre depressed-hemisp heric.

$$
\text { I. A. bidentata. }
$$

Leaves opposite, palnately 3-5-lobed, or uncivided; receptacle naked.

Leaves opposite and alternate, I-2-pinnatif:d; receptacle chaffy. 2. A. trifida.

Annual; leaves thin; fruiting involucre spiny.

Perennial; leaves thick ; fruiting involucre naked or tubercled.

3. A. artemisiafolia.

4. A. psilostackya.

I. Ambrosia bidentàta Michx. Lance-Leaved Ragweed. (I. F. f. 359r.) Annual, hirsute, usually much branched, very leafy, 3-9 dm. high. Leaves lanceolate, mainly alternate, sessile and somewhat cordate-clasping at tlie base, acuminate at the apex, I-nerved, $3-7 \mathrm{~cm}$. long, 4-8 mm. wide, usually with $\mathbf{I}$ or 2 sharp lobes at the base and a few minute sharp teeth above, or the upper ones quite entire; spikes of staminate heads dense, their receptacles chaffy; fertile heads solitary, or clustere 1 , oblong, 4-angled, 6-8 $\mathrm{mm}$. long, bearing 4 sharp spines. Prairies, Ill. to Kans., La. and Tex. July-Sept.

2 Amjosia trífil l L. Horse-Cane. Bitter-weed. Great Ragweed. (I. F. f. 3592.) Annual, scabrous or hispid, or nearly glabrous. branclied, I-5 m. high. Lazves all oppsite, patioled, 3-nerved, deeply 3-5-lobed, the lobes lanceo. late or ovite, sharply serrate, acute or acuminate; the upper sometimes ovate and undivid $\approx$ d racemes of steril 3 heads $7-25 \mathrm{~cm}$. long, their involucres saucer-shaped, 3 -ribbed on the outer side; fertile heads usually clustered in the axils of the upper bract like leaves, turbilate to obovoid, 5-7-ribbed, conic-beaked, 6-8 mm. long, each rib bearing a tubercle near the summit. In moist soil, Quebec to Fla., the N. W. Terr., Neb., Colo. and Ark. July-Oct.

Ambrosia trífida integrifolia (Muhl.) T. \& G. Leaves ovate or oblong-lanceolate, not lobed; plant usually lower. Frequent with the type.

3. Ambrosia artemisiæfollia L. Ragweed. Roman Wormwond. HogWeEd. Wild Tansy. (I. F. f. 3593.) Annual, pubescent, puberulent or hirsute, paniculately branched, 3-r $8 \mathrm{dm}$. high. Leaves thin, I-2-pinnatifid, petioled, 5-ro cm. long, the upper alternate, the lower mostly opposite, pale or canescent beneath, the lobes oblong or lanceolate, obtuse or acute; racemes of sterile heads very numerous, $2-15 \mathrm{~cm}$. long, the involucres hemispheric, crenate; fertile heads obovoid or subglobose, mostly clustered, 3-4 mm. long, short-beaked, 4-6-spined near the summit, sparingly pubescent. In dry soil, often a pernicious weed in cultivated fields. N. S. to Fla., west to $\mathrm{Br}$. Col. and Mex. Also in the W. Ind. and S. Am., and introduced into Europe as a weed. July-Oct.

4. Ambrosiz psilostàchya DC. Western Ragweed. (I. F. f. 3594.) Similar to the preceding species, but perennial by running roots, the leaves thick, t're pubescence strigose or hispid. Stems usually much branched, 6-12 dm. high, rat'ler stout; leaves $\mathbf{I}-2$ pinnatifid. 5-12 $\mathrm{cm}$. long. the lohes acutish; racemes of sterite heads several or numerous, $5-15 \mathrm{~cm}$. long, the involucres campanulate, the 
receptacles chaffy; fertile heads mostly solitary, ovoid or obovoid, reticulated, short-pointed, unarmed, or with about 4 short tubercles, pubescent, 3-4 mm. long. In moist open soil, Ill. to the N. W. Terr., Tex., Mex. and Cal. July-Oct.

\section{GAERTNERIA Med. [FRANSERIA Cav.]}

Hispid or tomentose branching herbs, with the aspect of Ambrosias, sometimes woody at the base, with mostly alternate lobed or divided leaves, and small monœcious greenish heads of discoid flowers, the staminate in terminal spikes or racemes, the pistillate solitary or clustered in the upper axils. Involucre of the pistillate heads ovoid or globose, closed, I-4-celled, I-4-beaked, armed with several rows of spines and forming a bur in fruit; corolla none or rudimentary; style deeply bifid, its branches exserted; stamens none; achenes obovoid, thick, solitary in the cells; pappus none. Staminate heads sessile, or short-peduncled, their involucres broadly hemispheric, open, 5-12-lobed; receptacle chaffy; corolla regular, the tube short, the limb 5-lobed; style undivided; anthers scarcely coherent; mucronate-tipped. [In honor of Joseph Gaertner, I732-179I, German botanist.] About 15 species, natives of America. In addition to the following, some 8 others occur in the western and southwestern United States.

Plant hirsute; annual: spines of the fruiting involucre long, flat. I. G. acanthicarpa. Leaves densely white-tomentose beneath; spines short, conic; perennials.

Leaves bipinnatifid.

Leaves pinnately divided, the terminal segment large.

I. Gaertneria acanthicàrpa (Hook.) Britton.

2. G. discolor.

3. G. tomentosa.

(I. F. f 3595.) Annual, erect or diffuse, paniculately branched stem hirsute or hispid. Lower and basal leaves slender-petioled, bipinnatifid, 5-10 $\mathrm{cm}$. long, the upper short-petioled or sessile, once pinnatifid, or merely lobed; racemes of sterile heads usually numerous, $3-7 \mathrm{~cm}$. long; fruiting involucres clustered in the axils, $6-8 \mathrm{~mm}$. long, commonly I-flowered, armed with numerous long flat straight spines. N. W. 'Terr. to Kans., Tex., Br. Col. and Cal. July-Sept.

2. Gaertneria discolor (Nutt.) Kuntze. White-Leaved Gaertneria. (I. F. f. 3596.) Erect or ascending from perennial rootstocks, branched, about $3 \mathrm{dm}$. high. Leaves nearly all bipinnatifid, petioled, densely white-tomentose beneath, green and pubescent or glabrate above, 5-12 cm. long: sterile racemes narrow, commonly solitary, 3-5 cm. long; fruiting involucres clustered in the axils, finely canescent, about $4 \mathrm{~mm}$. long, mostly 2 -flowered, armed with short, sharp, conic spines. In dry soil, S. Dak. to Wyo., Colo. and N. Mex. Aug.-Sept.

3. Gaertneria tomentòsa (A. Gray) Kuntze. Woolly Gaertneria. (I. F. f. 3597.) Erect from a deep perennial root, usually branched at the base, 3-9 dm. high. Leaves pinnately lobed or divided, finely and densely tomentose on both sides, or ashy above, the terminal segment lanceolate or oblong-lanceolate, acuminate, serrulate or entire, very much larger than the 2-6 rather distant narrow lat. eral ones; sterile racemes solitary, 5-10 cm. long; fruiting involucres solitary, or 2-3 together in the upper axils, ovoid, finely canescent or glabrate, 2 -flowered, about $6 \mathrm{~mm}$. long, armed with subulate-conic, very acute, sometimes curved spines. On rich prairies and along rivers, western Neb., Kans. and Colo. Aug.-Sept.

\section{XÁNTHIUM L.}

Monœcious annual branching coarse rough or spiny herbs, with alternate lobed or dentate leaves, and rather small heads of greenish discoid flowers, the staminate ones capitate-clustered at the ends of the branches, the pistillate axillary. Staminate heads with a short involucre of $\mathbf{I}$ to 3 series of distinct bracts; receptacle cylindric, chaffy; corollas tubular, 5-toothed; anthers not coherent, mucronate at the apex; filaments monadelphous; style slender, undivided. Pistillate heads of an ovoid or oblong, closed involucre, covered with hooked spines, I-2-beaked, 2-celled, each cavity containing one obovoid or oblong achene; corolla none; pappus none; style 2-cleft, its branclies exserted. [Greek, yellow, from its yielding a yellow hair-dye.] About I5 species, of wide geographic distribution.

Leaves lanceolate, not cordate; axils bearing 3-divided spines. $\quad$ r. X. spinosum. Leaves orbicular or broadly ovate, cordate, or truncate; axils not spiny.

Bur 12-20 mm. long, usually nearly glabrous; beaks straight or nearly so. 
Bur $1.5-30 \mathrm{~mm}$. long; beaks hooked or incurved.

Body of the bur oblong, twice as long as thick or more.

Bur and its spines merely puberulent and glandular or with a few hispid hairs. Prickles very dense, slender; leaves thin, sharply toothed.

Prickles scattered, stout; leaves firm, bluntly toothed. 3. X. Pennsylvanicum.

Bur or its prickles very hispid.

4. $X$. Canadense.

Prickles as long as the diameter of the bur or longer.

Prickles not longer than the diameter of the bur. ${ }^{5}$. speciosum.

5. $X$. spec.
he middle.

Prickles slender, loosely hispid to about the middle.
6. X. commune.

Prickles stout, very densely long-hispid nearly to the stronglyhooked tip. $\quad$ 7. X. Macounii.

Bouy of the bur oval to ovoid, not twice as long as thick.

Prickles of the bur dense; pubescence of the bur and its prickles brown. 8. X. echinatum.

Prickles of the bur scattered; pubescence of the bur and its prickles yellow. 9. X. glanduliferum.

I. Xanthium spinòsum L. SPINy or Thorny Clotbur or Burweed. (I. F. f. 3598 .) Stem pubescent or puberulent, much branched, 3-6 dm. high. Leaves lanceolate or ovate-lanceolate, acute or acuminate, lobed, or the upper entire, narrowed at the base, short-petioled, white canescent beneath and on the whitish yeins of the upper surface, $5-12 \mathrm{~cm}$. long; ripe fertile involucre (bur) oblong-cylindric, $8 \mathrm{r} 2 \mathrm{~mm}$. long; about $4 \mathrm{~mm}$. in diameter, pubescent, armed with short subulate rather inconspicuous beaks, and numerous glabrous prickles about $2 \mathrm{~mm}$. long. In waste grounds, Ont. to Fla., west to W. Va., Mo. and Tex. Widely distributed as a weed. Nat. from Europe or Asia. Aug.-Nov.

2. Xanthium glabràtum (DC.) Britton. SMoothish Cocklebur or BuRWEeD. (I. F. f. 3599.) Rough, 3-ro dm. high. Leaves slender-petioled, broadly ovate to orbicular, 3-ribbed and cordate or cordate-reniform at the base, the lower often $25 \mathrm{~cm}$. wide, the margins dentate, or more or less 3-5-lobed, both surfaces roughish and green; bur oblong, glabrous or nearly so, $12-18 \mathrm{~cm}$. long, about $6 \mathrm{~mm}$. in diameter, its 2 sharp subulate 2 -toothed beaks straight or nearly so, equalling or slightly longer than the numerous, nearly glabrous or pubescent prickles. In waste places, N. Eng. and N. Y. to Neb., south to Fla. and Mex. [X. macrocarpon, var. glabratum DC.; X. pungens Wallr.; has generally been referred to the Old World $X$. strumarium L., which has smaller, puberulent burs, with stouter shorter beaks.] Aug.-Oct.

3. Xanthium Pennsylvànicum Wallr. Pennsylvania Clotbur. Stem comparatively slender, smooth below, roughish above, 2-6 dm. high. Leaves thin, long-petioled, sharply toothed and some of them 3-5-lobed, smoothish, or the upper surface scabrate, glandular; burs clustered in the axils, $15-18 \mathrm{~mm}$. long, about one-third as thick, puberulent and resinous glandular, and commonly with a few longer hairs; prickles very numerous, subulate, hooked, the longer ones nearly as long as the diameter of the bur; beaks slender, but stouter than the prickles, incurved and hooked. D. C. to Penn., Ont. and Minn.

4. Xanthium Canadénse Mill. American Cocklebur. Hedgehog BurwEED. (I. F. f. 3600 .) Similar to the preceding species. Leaves roughish and thicker, bluntly toothed and lobed; bur puberulent and glandular, oblong, 15-20 $\mathrm{mm}$. long, 5-8 mm. in diameter, the two stout beaks hooked or incurved at the apex, longer than or equalling the scattered rather slender hooked prickles. Northern N. Y. to Mass. and Quebec. Aug.-Oct.

5. Xanthium speciòsum Kearney. Great Clotbur. Very stout, I-I.5 m. high. Stem sharply angled above; lower petioles Io-15 $\mathrm{cm}$. long; leaf-blades broadly triangular-ovate, the larger $15-22 \mathrm{~cm}$. wide, 3-5-lobed, dentate, scabrous on both surfaces; burs commonly clustered, oblong to ovoid-oblong, $2.5 \mathrm{~cm}$. long or more, the stout beaks 10-12 mm. long, somewhat incurved, strongly hooked at the apex, equalling or a little longer than the dense subulate uncinate prickles, which are hispid to above the middle. Tenn. and Mo. to N. Dak.. Kans. and Tex.

6. Xanthium commùne Britton, n. sp. Common Clotbur. Stem rather slender, 3-6 din. high, roughish. Leaves broadly ovate, more or less lobed, sca. 
brous, especially above; burs commonly solitary in the axils, oblong, $1.5-2.5 \mathrm{~cm}$. long, half as thick, or less, the subulate-conic beaks slightly incurved, hooked at the apex, about as long as the subulate uncinate prickles, which are hispid to about the middle with brown hairs. Quebec to N. Y., Kans., Mo. and Ariz. Type collected by N. L. Britton at Westport, N. Y.

7. Xanthium Macoùnil Britton, n. sp. Macoun's Clotbur. Stem purplish or purple-blotched, about $2.5 \mathrm{dm}$. high. Leaves slender petioled, triangularovate, acute, irregularly dentate, firm, scabrous on both surfaces; burs mostly 2 in each axil, oblong, the body about $2 \mathrm{~cm}$. long and $8 \mathrm{~mm}$. thick, the stout prickles very densely hispid, excepting their strongly incurved, glabrous lips, shorter than the stouter, hispid incurved beaks, and than the diameter of the bur. Goose Island, Lake Winnipeg, Manitoba, J. M. Macoun, Aug. 16, I884. Specimen in the herbarium of the Geological and Natural History Survey of Canada.

8. Xanthium echinàtum Murr. BEACH Clotbur. Stem rough, purplish or purple-blotched, 3-6 dm. high. Leaves firm, scabrous, with scattered short papillose hairs, ubtusely toothed and lobed, somewhat resinous-glandular beneath; burs commonly clustered in the axils, ovoid to oval, 15-20 $\mathrm{mm}$. long, 8-12 $\mathrm{min}$. thick, glandular; prickles very dense, densely hispid from the base to the middle or beyond, subulate, hooked, the longer about $5 \mathrm{~mm}$. long, and about equalling the stout hispid beaks. Sea, lake and river beaches, N. C. to Mass., Que., northern N. Y. and Minn. (X. maculatum Raf.; X. oriforme Wallr., ex descr.)

9. Xanthium glandulíferum Greene. Glandular Clotbur. Similar to $X$. echinatum. Leaves very thick and scabrous with short stout papillæ; burs oval, IO-15 mm. long, 6-9 mm. thick, yellow, the prickles scattered, bristly-hispid nearly to the hooked apex, scarcely as long as the conic-subulate short-bristly beaks. Neb. to N. Dak. and Assiniboia.

\section{Fami.y 5. COMPÓSITAE Adans.}

\section{Thistle Family.}

Herbs, rarely shrubs (some tropical forms trees), with watery or resinous (rarely milky) sap, and opposite alternate or basal exstipulate leaves. Flowers perfect, pistillate, or neutral, or sonetines monœcious or diœcious, borne on a common receptacle, forming heads, subtended by an involucre of few to many bracts arranged in one or more series. Receptacle naked, or with chaffy scales subtending the flowers, snooth, or variously pitted or honeycombed. Calyx-tube completely adnate to the ovary, the limb (pappus) of bristles, awns, teeth, scales, or crownlike, or cup-like, or wanting. Coralla tubular, usually 5-lobed or 5-cleft, the lobes valvate, or that of the marginal flowers of the head expanded into a ligule (ray); when the ray-flowers are absent the head is said to be discoid; when present, radiate; the tubular flowers form the disk. Stamens usually 5, borne on the corolla and alternate with its lobes, their anthers united into a tube (syngenesious), often appendiged at the apex, sometimes sagittate or tailed at the base; pollen-grains globose, often rough or prickly. Ovary 1-celled; ovu'e 1, anatropous; style of fertile flowers 2-cleft; stigmas marginal; style of sterile flowers commonly undivided. Fruit an achene. Seed erect; endosperm none; embryo straiglit; hypocotyl inferior. About 760 genera and not less than 10,000 species, of wide geographic distribution. In Kuhnia, the anthers are distinct, or nearly so.

* Anthers not tailed at the base; stigmatic lines of the style-branches only at the base, or not extending beyond the middle ; flowers all tubular and perfect, never yellow; rays none.

Style-branches filiform or subulate, hispidulous; receptacle naked.

Tribe I. VERNONIEAE.

Style branches thickened upward, obtuse, papillose.

Tribe 2. EUPATORIEAE.

* * Anthers tailed at the base, unappendaged at the tip; heads small; rays none (except in Inula, where they are large and yellow).

Tribe 4. INUleaE. 
*** Anthers not tailed at the base; stigmatic lines of the style-branches in the perfect flowers extending to the summit; flowers tubular only, or tubular and radiate, often yellow.

1. Receptacle naked (see also Nos. $79,80,81$ and 82 of Tribe 7.)

a. Bracts of the involucre usually well imbricated.

Style-branches of the perfect flowers flattened, with terminal appendages.

Style-branches truncate, or with hairy tips.

Tribe 3. AstereaE.

Tribe 6. HELENIEAE.

b. Bracts little imbricated, or not at all; pappus of soft bristles.

2. Receptacle chaffy (except in Nos. $79,80,8 \mathrm{r}$ and 82 ).

Bracts of the involucre herbaceous or foliaceous; not scarious. Tribe 5. HELIANTHEAE. Bracts of the involucre dry, scarious.

Tribe 7. ANTHEMIDEAE.

**** Anthers long-tailed at the base, with elongated appendages at the tip; heads large; rays none. (In Centaurea often with enlarged marginal flowers; bracts imbricated.

Tribe 9. CYNAREAE.

\section{Tribe I. VERNONIEAE.}

Pappus double, the inner of rough capillary bristles, the outer of scales, or short bristles ; heads not glomerate.

1. Vernonia.

Pappus a single series of bristles; heads glomerate, subtended by sessile bracts.

2. Elephantopus.

\section{Tribe 2. EupatorieaE.}

* Achenes 3-5-angled, not ribbed.

Pappus of 5 broad obtuse scales; aquatic herb with linear whorled leaves.

Pappus of numerous capillary bristles.

Involucre of more than 4 bracts; erect herbs.

Involucre of 4 bracts: twining herbaceous vines. * Achenes 8-ro-ribbed, or 8-ro-striate.
3. Sclerolepis.

4. Eupatorium.

5. Willugbaeya.

1. Bracts of the involucre in several series, the outer successively shorter.

Bracts of the involucre strongly striate-nerved; heads panicled or corymbed in our species.

Pappus-bristles rough or serrate; involucral bracts numerous.

Pappus-bristles plumose; involucral bracts few.

Bracts of the involucre faintly striate, if at all; heads spiked or racemed.

6. Coleosanthus.

7. Kuhnia.

8. Lacinaria.

2. Bracts of the involucre in only 2 or 3 series; all nearly equal.

9. Trilisa.

\section{Tribe 3. Astereae.}

\section{A. Ray-flowers yellow (white in one species of Solidago), or wanting; plants not dicecious.}

* Pappus of scales, or awns, or wanting, never of numerous capillary bristles.

Heads small, nor over $4 \mathrm{~mm}$. high ; leaves narrowly linear, entire.

Perennial herbs, or shrubs; all the flowers fertile.

Annual herb; disk-flowers sterile.

Heads large, showy; leaves oblong to lanceolate, spinulose-dentate.

10. Gutierrezia.

Ir. Amphiachyris.

12. Grindelia.

* Pappus of either the radiate or tubular flowers, or both, of numerous capillary bristles, with or without an outer series of shorter ones, or of scales.

+ Pappus, at least of the disk-flowers, double, an inner series of capillary bristles, and an outer one of scales or short bristles; heads large.

Achenes of the ray-flowers thick, the pappus obsolete, or of a few caducous bristles; achenes of the disk-flowers flat.

Achenes of both ray-flowers and disk-flowers flattened.

++ Pappus wholly of capillary bristles.

I. Heads wholly of disk-flowers (in our species): ravs none; leaves narrowly linear.

a. Perennial herbs: style-tips not exserted; eastern. 15. Chondrophora.

b. Shrubs; style-tips mostly exserted; western.

Involucral bracts gradually narrowed to the tip, keeled, chartaceous.

Involucral bracts cuspidate, flat, herbaceous.

16. Chrysothamnus.

17. Oonopsis.

2. Heads with both ray-flowers and disk-flowers (in our species).

a. None of the leaves cordate; pappus mostly as long as the achene, or longer.

Leaves bristly-serrate or pinnatifid.

Achenes glabrous; pappus-bristles deciduous.

Achenes white-tomentose ; pappus-brisțles persistent.

18. Prionopsis.

19. Sideranthus, 
Leaves entire, or toothed, not bristly-serrate.

Leaves narrow, coriaceous, evergreen, entire: low western undershrubs.

Annual or perennial herbs: leaves not evergreen.

20. Stenotus.

Pappus-bristies unequal; heads loosely panicled; annual.

Pappus-bristles equal; heads variously clustered; perennial herbs.

2r. Isopappus.

Receptacle alveolate; rays mostly not more numerous than the disk-flowers. 22. Solidago.

Receptacle fimbrillate; rays more numerous than the disk-flowers; heads corymbose-paniculate. 23. Euthamia.

b. Lower and basal leaves cordate; pappus-bristles shorter than the achene.

24. Brachychaeta.

\section{B. Ray-flowers present, not yellow in any of our species.}

* Pappus a mere crown, or of a few awns or bristles, or wanting, never of numerous capillary bristles

1. Receptacle conic.

Outer bracts of the involucre shorter than the inner; achenes prismatic.

Bracts of the involucre all about equal; achenes flattened.

25. Aphanostephus.

2. Receptacle flat, or somewhat convex.

Achenes of the disk-flowers compressed, of the ray-flowers 3 -angled; perennial herbs with large heads.

Achenes fusiform, terete; annual herbs with small heads.

Achenes obovate, flattened, with thickened or winged margins; perennials.

27. Tozunsendia.

28. Chaetopappa.

29. Boltonia.

* * Pappus of numerous capillary bristles.

I. Pappus a single series of capillary bristles; sometimes with an outer series of shorter ones.

a. Bracts of the involucre in 2 to many series.

Bracts mostly in 2-5 series; teeth or lobes of the leaves not bristle-tipped.

Involucre narrow, its bracts firm; rays few, white. 30. Sericocarpus.

Involucre turbinate to hemispheric, bracts mostly thin; rays usually numerous, white to purple.

Disk-flowers turning red, purple, or brown. 3r. Aster.

Disk-flowers permanently white; leaves subulate to spatulate, crowded, rigid.

32. Leucelene.

Involucre turbinate; rays not exceeding the mature pappus, or none.

33. Brachyactis.

Bracts in many series; teeth or lobes of the leaves bristle-tipped in our species.

34. Machaeranthera.

b. Bracts of the involucre in only $\mathrm{x}$ or 2 series, very narrow; heads mostly long-peduncled.

Rays longer than the diameter of the disk.

Rays not longer than the diameter of the disk; heads very small, panicled.

36. Leptilon.

2. Pappus distinctly double, the inner bristles long, the outer shorter.

Leaves lanceolate, ovate, or obovate; rays white.

Leaves narrowly linear; rays violet.

C. Ray-flowers none; diœcious shrubs; pappus capillary.

37. Doellingeria.

38. Ianactis.

39. Baccharis.

\section{Tribe 4. InUleae.}

* Heads small, rays none; flowers white or whitish.

1. Receptacle chaffy.

Receptacle convex; pappus none.

Receptacle subulate; pappus of the inner flowers of rough capillary bristles.

2. Receptacle naked.

4I. Gifola.

a. Pappus, at least that of pistillate flowers, of capillary bristles.

Bracts of the involucre not scarious; plants pubescent or glabrous, not woolly.

Bracts of the involucre scarious, mostly white or pink; plants woolly.

42. Pluchea.

Plants diœcious, or polygamo-diœcinus.

Pappus-bristles of staminate flowers thickened above.

Pappus-bristles not thickened; stem leafy.

43. Antennaria.

44. Anaphalis. 
Plants not diœcious; flowers all fertile.

45. Graphalium.

b. Pappus none; leaves broad, alternate, woolly beneath. 46. Adenocaulon.

$$
\text { * * Heads large; ray-flowers yellow. 47. Inula. }
$$

\section{Tribe 5. Heliantheae.}

\section{A. Disk-flowers perfect, but sterile.}

Achenes thick, short, not flattened; pappus none.

Achenes merely subtended by the inner involucral bracts.

Achenes embraced and enclosed by the inner involucral bracts.

Achenes flattened.

Ray-flowers in 2 or 3 series; achenes falling away free. 50. Silphium.

Ray-flowers in I series; achenes adnate to 2 or 3 scales of the receptacle, falling away with them.

Rays large, yellow.

Leaves opposite and basal.

Leaves alternate.

Pappus none, or of 2 caducous awns.

Pappus a persistent irregularly-cleft crown.

Rays small, the heads appearing discoid.

51. Chrysogonum.

52. Berlandiera.

53. Engelmannia.

54. Parthenium.

\section{B. Disk-flowers fertile.}

* Ray-flowers persistent upon the achenes.

Achenes compressed, or 3-angled; leaves entire.

Achenes short, thick; leaves toothed.

55. Crassina.

* * Ray-flowers deciduous, or none.

$\uparrow$ Pappus a cup, or crown, or of a few teeth, awns, or bristles.

1. Achenes, at least those of disk-flowers, not compressed (except in Ratibida and Verbesina); scales of the receptacle mostly concave, or clasping.

Scales of the receptacle small, awn-like or bristle-like; rays white, short.

Scales of the receptacle broad, larger.

57. Eclipta.

Involucre of 4 large somewhat united bracts.

58. Tetragonotheca.

Involucre of several or numerous separate bracts.

Receptacle conic, or columnar.

Ray-flowers fertile, or wanting; leaves opposite. 59. Spilanthes.

Ray-flowers sterile, or neutral; leaves mostly alternate.

Rays yellow.

Achenes 4-angled.

Achenes compressed, winged.

Rays rose-purple.

6o. Rudbeckia.

6r. Ratibida.

62. Brauneria.

Receptacle flat, or convex (low-conic in species of Nos. 64 and 65).

Low, fleshy seacoast shrubs.

Tall herbs, not fleshy.

63. Borrichia.

Achenes not much flattened, not winged, nor nuargined.

Achenes of disk-flowers flattened and margined, or winged.

64. Helianthus.

65. Verbesina.

2. Achenes very flat; scales of the receptacle flat, or but slightly concave.

a. Bracts of the involucre all separate.

Pappus of 2 short teeth or awns, or a mere border, or none.

66. Coreopsis.

Pappus of $2-6$ awns or teeth, upwardly or downwardly barbed or hispid.

67. Bidens.

b. Inner bracts of the involucre united to about the middle.

68. Thelesperma.

\section{$+\dagger$ Pappus of numerous scales.}

Leaves opposite, toothed; ray-flowers fertile; rays small.

Leaves alternate, entire.

69. Galinsoga.

Rays large, neutral ; receptacle deeply honeycombed.

Rays none; scales of the receptacle narrow, rigid. 


\section{Tribe 6. Helenieae.}

\section{A. Rny-flowers persistent on the achenes, falling away with them, papery.} 72. Psilostrophe.

\section{B. Ray-flowers deciduous, or wanting.}

* Plants not dotted with oil-glands.
a. Pappus none.
73. Flaveria.

b. Pappus present (in all our species), of separate scales or bristles.

I. Bracts of the involucre petal-like, colored, their margins and apices scarious.

Leaves, at least the lower, pinnately parted, or pinuatifid; rays none; corolla-lobes of disk-flowers ovate.

Leaves entire; rays present, or none; corolla-lobes of disk-flowers linear.

74. Hymenopappus.
75. Polypteris.

2. Bra

Bracts of

Receptacle naked.

Bracts of the involucre appressed.

Achenes 4-angled, linear or oblong.

Achenes 5-10-ribbed or 5-ro-angled, top-shaped.

Outer involucral bracts separate.

Outer involucral bracts connate at base.

Bracts of the involucre spreading, or reflexed at maturity.

Receptacle with bristle-like chaff.

* * Plants dotted with oil-glands, especially the leaves and involucre.

Involucral bracts more or less united; style-branches of the disk-flowers elongated.

Involucral bracts united at the base.

81. Boebera.

Involucral bracts united high up into a cup.

Involucral bracts separate; style-branches of the disk-flowers very short.
76. Picradeniopsis.
77. Tetraneuris.
78. Picradenia.
79. Helenium.
8. Galliardia.

83. Pectis.

\section{Tribe 7. Anthemideae.}

* Receptacle chaffy.

Achenes flattened; involucre obovoid to campanulate; heads small.

Achenes terete; involucre hemispheric; heads large.

84. Achillea.

85. Anthemis.

* * Receptacle not chaffy, naked, or sometimes hairy.

I. Ray-flowers usually present, sometimes wanting; rays large.

Receptacle flat to hemispheric; bracts of the involucre in several series.

Receptacle conic to ovoid; bracts in few series; rays white or none.

86. Chrysanthemum.

2. Ray-flowers none; heads small.

Heads corymbed; pappus a short crown; flowers yellow.

Heads racemose, spicate or panicled; pappus none.

\section{Tribe 8. Senecioneae.}

Leaves all basal; heads on scapes.

Head solitary; flowers yellow.

Heads corymbed; flowers white or purple.

Leaves opposite; rays yellow.

Leaves alternate.

Flowers white, whitish or pinkish: rays none.

Marginal flowers pistillate; disk-flowers perfect.

Flowers all perfect.

Involucre of about 5 bracts; sap milky.
Involucre of about 12 bracts and several smaller outer ones.

Flowers yellow; ray-flowers mostly present.

87. Matricaria.

88. Tanacetum.

89. Artemisia.

\begin{abstract}
90. Tussilago.
91. Petasites.

92. Arnica.
\end{abstract}

93. Erechtites.

94. Mesadenia.

95. Synosma.

96. Senecio.

\section{Tribe 9. Cynareae.}

Receptacle densely bristly.

Filaments separate.

Involucral bracts hooked at the tip; leaves not bristly.

Involucral bracts not hooked; leaves bristly. 
Filaments united below.

Receptacle fleshy, not bristly.

99. Mariana.

Ioo. Onopordon.

* * Achenes obliquely inserted on the receptacle.

Heads not subtended by bristly leaves; involucral bracts often bristly.

Heads sessile, subtended by bristly leaves.

I01. Centaurea.

102. Cnicus.

\section{x. VERNÒNIA Schreb.}

Erect branching perennial herbs, or some tropical species shrubby, with alternate (very rarely opposite), in our species sessile leaves, and discoid cymose-paniculate heads of purple, pink, or white tubular flowers. Involucre hemispheric, campanulate or oblong-cylindric, its bracts imbricated in several or many series. Receptacle flat, naked. Corolla regular, 5-cleft. Anthers sagittate at the base, not caudate. Style-branches subulate, hispidulous their whole length. Achenes 8-Io-ribbed, truncate. Pappus of our species in 2 series, the inner of numerous roughened capillary bristles, the outer of much shorter small scales or stout bristles. [Named after William Vernon, English botanist.] About 475 species, of wide distribution in warm-temperate regions, most abundant in $\mathrm{S}$. Am. Besides the following, 2 or 3 others occur in the southern and southwestern U. S.

Bracts of the hemispheric involucre, or some of them, with subulate or filiform tips.

Involucre 6-1o $\mathrm{mm}$. broad, its bracts shorter than the head. I. V. Noveboracensis.

Involucre $18-25 \mathrm{~mm}$. broad, its bracts as long as the head. 2. $V$. crinita.

Bracts of the involucre merely acute, obtuse or truncate.

Leaves lanceolate to oval, pinnately veined.

Bracts of the involucre with squarrose tips.

Bracts of the involucre appressed or their tips slightly spreading.

Leaves glabrous or very nearly so on both surfaces.

Leaves thin, pale beneath, the lower oval, coarsely serrate.

Leaves thin, green beneath, lanceolate, finely serrate.

4. $V$. glauca.

Leaves thick, narrowly lanceolate, sharply serrate.

5. $V$. gigantea.

6. V. fasciculata.

Leaves densely pubescent beneath, lanceolate.

Involucre 8-12 $\mathrm{mm}$. high; plant tomentose.

Involucre 6-7 $\mathrm{mm}$. high; plant pubescent.

7. V. Drummondii.

8. V. interior.

9. V. marginata.

Leaves narrowly linear, $x$-nerved, $4-6 \mathrm{~mm}$. wide, dentate.

I. Vernonia Noveboracénsis (L.) Willd. New York Iron-weed. Flat Top. (I. F. f. 360I.) Roughish-pubescent or glabrate, 9-27 dm. high. Leaves lanceolate or narrowly oblong, serrulate, $7-25 \mathrm{~cm}$. long, I0-25 mm. wide, acuminate or acute at the apex; heads peduncled; involucre 20-30-flowered; bracts brownish-purple, ovate or ovate-lanceolate, tipped with subulate spreading awns usually of twice or three times their own length, or some of the lower linear subulate, the upper sometimes merely acute; flowers deep purple, rarely white; achenes hispidulous on the ribs. In moist soil, Mass. to Minn., Ga. and Kans. July-Sept.

Vernonia Noveboracénsis tomentòsa (Walt.) Britton. Leaves densely puberulent beneath, broader; involucre purple, some scales sometimes merely acute. In dry soil, Va. to N. Car.

2. Vernonia crinita Raf. Great Iron-weed. (I. F. f. 3602.) Stout, glabrate or finely rough-pubescent, 25-35 dm. high. Leaves narrowly lanceolate, finely denticulate, acuminate. IO-30 cm. long, 6-25 $\mathrm{mm}$. wide; heads stoutpeduncled, the peduncles thickened above; involucre 50-70 flowered; bracts green. or the upper reddish, very squarrose, all filiform-subulate from a broader base and equalling the head, the inner ones somewliat wider below; achenes hispidulous on the ribs. On prairies and along streams, Mo. and Kans. to Tex. Aug.-Oct.

3. Vernonia Baldwinii Torr. Baldwin's Iron-weEd. (I. F. f. 3603.) Stout, 6-16 dm. high, finely and densely tomentose-pubescent. Leaves lanceolate or oblong-lanceolate, acuminate or acute at the apex, sharply serrate, ro-20 $\mathrm{cm}$. long, $1-2.5 \mathrm{~cm}$. wide, scabrate above, densely tomentulose beneath; heads stout. peduncled, I5-30-flowered; involicre hemispheric, $6-8 \mathrm{~mm}$ broad; bracts ovate, the acute tips recurved or spreading. In dry soil, Mo. and Neb. to Tex. July- 
4. Vernonia glàuca (L.) Britton. BROAd-LEAved IRON-weed. (I. F. f. 3604.) Slender, glabrous or finely puberulent, 6-I $5 \mathrm{dm}$. high. Leaves tiin, the lower broadly oval or slightly obovate, sharply serrate, acute or acuminate, 10-17 $\mathrm{cm}$. long, 3-6 cm. wide, the upper narrower and more finely toothed; inflorescence loosely branched; heads 10-20-flowered; involucre campanulate, 4-7 mm. broad; bracts ovate, acute, or mucronate, or the upper ones obtuse; achenes minutely hispidulous. In woods, Penn. and Md. to Ohio, south to Fla. and La. Aug.-Sept.

5. Vernonia maxima Small. TALL IroN-WeEd. (I. F. f. 3605.) Glabrous or nearly su, $\mathbf{1} \cdot 5-3 \mathrm{~m}$. high. Leaves tlin, lanceolate, sometimes broadly so, usually long-acuminate, fineıy serrate, I-3 dm. long, I-4 cm. wide, usually glabrous on buth surfaces; inflorescence at length loosely branched and open; involucre campanulate, rounded at the base, 4-5 $\mathrm{mm}$. broad, I5-30-flcwered; bracts obtuse or inucronate, more or less ciliate; achenes slightly hispidulous; pappus purple. In moist soil, Peun. to Ala., Mo., Ky. and La. July-Sept. [ $V$. gigantea (Walt.) Britton, in part.]

Vernonia maxima pubéscens E. L. Morris. Mostly over $3 \mathrm{~m}$. tall, pubescent, especially on the lower surfaces of the leaves, the peduncles bracted below the heads. W. Va.

6. Vernonia fasciculàta Michx. Western Iron-weed. (I. F. f. 3606.) Glabrous, or puberulent above, 6-12 dm. high. Leaves firm, lanceolate or linearlanceolate, long-acuminate, 7-15 cm. long, 4-30 mm. wide, glabrous or nearly so on both surfaces; inflorescence usually compict; heads short-peduncled, or some of them sessile; involucre campanulate, 4-6 mm. broad, 20 30. flowered; bracts ovate or oval, acute, ciliate, or sometimes pubescent; achenes glabrous, or a little pubescent. In moist soil or on prairies, Ohio to Minn. and N. Dak., south to Ky. and Tex. July-Sept.

7. Vernonia Drummóndii Shuttlw Drummond's Iron-weed. (I. F. f. 3607.) Stout, densely tomentose, 9-2I dm. high. Leaves lanceolate to narrowly oblong, acuminate, finely serrate, 7-15 $\mathrm{cm}$. long, I-4 cm. wide, scabrous above, densely pubescent beneath; heads short peduncled; involucre hemispheric or shortcylindric, I5-50 flowered; bracts purplish, ovate, acute, or mucronate, more or less floccose-pubescent or ciliate; achenes glabrous. Prairies, Ill. and Ky. to Mo., Ala. and Tex. Autumn.

8. Vernonia intérior Small. INLAND IRON-weEd. Stem I-2 m. tall, leafy. Leaves lanceolate to elliptic-lanceolate, $6-20 \mathrm{~cm}$. long, acuminate, finely and sharply serrate; involucre 4-7 mm. high, its bracts pubescent, acute or acuminate, the tips erect or slightly spreading; achenes pubescent; pappus purple. Prairies and plains, Mo. to Kans. and Tex. Autumn.

9. Vernonia marginàta (Torr.) Britton. James' Iron-weed. (I. F. f. 3608.) Gilabrous or very nearly so, 3-9 dn. high. Leaves minutely denticulate, I-nerved, firm, punctate, 5-I $2 \mathrm{~cm}$. long, 3-9 $\mathrm{mm}$. wide, acuminate; inflorescence rather loose; involucre campanulate or turbinate, $15-30$-flowered, 8-12 mm. broad; bricts ovate to ovate-lanceolate, acute, to short-acuminate, purplish, somewhat pubescent, appressed; achenes nearly glabrous, or somewliat pubescent. Prairies, Neb. to Tex. and N. Mex. Autumn.

\section{ELEPHÁNTOPUS L.}

Perennial rigid pubescent herbs, with alternate or basal, simple pinnately-veined leaves. and in our species glomerate bracted heads of blue or purple flowers in branching corymbs. Heads discoid, 2-5 flowered. Involucre compressed, oblong, its chaffy bracts imbricated in about 2 series, the 4 outer bracts shorter. Bracts of the glomerules large, foliaceous. Receptacle small, naked. Corolla nearly regular, 5 -lobed, but a little deeper cleft on the inner side. Achenes Io-ribbed, truncate. Pappus of rigid persistent awn-like scales or bristles in I or 2 rows. [Greek, ivory, or Elephant's foot.] About I4 species. natives of tropical or warm regions. Besides the following another occurs in the southern U.S.

Stem and branches usually leafy.

x. E. Carolinianus.

Stem scapiform, naked, or with $\mathrm{r}$ or 2 leaves.

Leaves oblong or oblanceolate, $1.8-5 \mathrm{~cm}$. wide; heads $8 \mathrm{~mm}$. long.

2. E. nudatus.

Leaves ovate, oval, or obovate, 5-10 $\mathrm{cm}$. wide; heads $12 \mathrm{~mm}$. long. 
I. Elephantopus Caroliniànus Willd. CARolina Elephant's-Foot. (I. F. f. 3609.) Erect, hirsute-pubescent, or glabrate above, branched above, 3-9 dm. high. Leaves oval, ovate, or obovate, thin, the lower rather abruptly narrowed into margined petioles, obtuse, crenate-dentate, 7-20 cm. long, 5-10 cm. wide, the upper snialler, narrower and sessile; glomerules, including the bracts, nearly 25 mım. broad; scales of the pappus lanceolate-subulate, gradually narrowed into a long slender awn. In dry woods, southern N. J. and Penn. to Fla., Kans. and Tex. Aug.-Sept.

2. Elephantopus nudàtus A. Gray. Smoothish Elephant's-Foot. (I. F. f. 36ro.) Erect, rathe: stout, appressed-pubescent, or glabrate, 3-6 dm. high. Leaves obtuse at the apex, gradually narrowed at the base, crenate or repand, 5-25 cm. long, the basal ones usually much larger than those of the stem and branches, or these usually few and hract like; glomerules $12-18 \mathrm{~mm}$. broad; scales of the pappus ovate-triangular, abruptly narrowed into the awn. In sandy woods, Del. to Fla., west to Ark. and La. Aug.-Sept.

3. Elephantopus tomentòsus L. Woolly Elephant's-foot. TobaccoWEED. (I. F. f. 36II.) Erect, villous-pubescent, or sometimes glabrate, 3-6 dm. high, the stem branching above, leafless or with I or 2 leaves Basal leaves narrowed at the base, usually silky-pubescent beneath, crenate-dentate, $10-22 \mathrm{~cm}$. long; glomerules $2.5-4 \mathrm{~cm}$. bruad; scales of the pappus triangular-subulate, gradually narrowed into the awn. In moist soil, Va. to Fla., west to Ky., Ark. and La. Aug.-Sept.

\section{SCLERÓLEPIS Cass.}

Slender aquatic herbs, with linear entire verticillate leaves, and solitary (rarely 2-4) discoid peduncled terminal heads of small purplish flowers. Involucre broadly campanulate or hemispheric. Bracts imbricated in about 2 series. Receptacle conic, naked. Corolla regular, its tube short, its limb campanulate, 5-lobed. Anthers obtuse at the base. Style-branches slender, obtuse. Pappus of 5 broad cartilaginous obtuse scales. Achenes 5-angled. [Greek, hard scale, referring to the pappus.] A monotypic genus.

I. Sclerolepis uniflòra (Walt.) Porter. Sclerolepis. (I. F. f. 3612.) Per. ennial; stem simple, decumbent at the base, erect or ascending, glabrous or slightly pubescent, 3-6 dm. long, leafy. Leaves sessile, verticillate in 4's-6's, linear, I-nerved, 8-25 mm. long, I-2 $\mathrm{mm}$. wide, or the submerged ones filiform; head about I cm. broad; bracts of the involucre linear-oblong, acutish, usually puberulent. In shallow ponds and streams, pine barrens of N. J. to Fla. July-Sept.

\section{EUPATÒRIUM L.}

Erect, perennial herbs, with opposite or verticillate, or sometimes alternate, often punctate leaves, and in our species cymose-paniculate discoid heads of white, blue or purple flowers. Involucre oblong, ovoid, campanulate, or hemispheric, the bracts imbricated in 2-several series. Receptacle naked. Corolla regular, its tube slender, its limb 5-lobed or 5-toothed. Anthers obtuse and entire at the base, appendiculate at the apex. Style-branches elongated, flattened, or thickened above, stigmatic at the base. Achenes 5-angled, truncate. Pappus of numerous capillary usually scabrous bristles arranged in I row. [Named for Mithridates Eupator, i.e., of a noble father.] About 475 species, mostly of warm or tropical regions. Besides the following, some 35 others occur in southern and western N. A.

* Leaves alternate, pinnatifid into filiform segments. I. E. capillifolium. ** Leaves petioled, verticillate in 3's -6 's, or the upper opposite.

Leaves rugose, pubescent; inflorescence depressed.

Leaves ovate, acute.

Leaves lanceolate, long-acuminate.

Leaves nearly glabrous; inflorescence pyramidal.

Leaves sharply serrate.

Leaves crenate, the teeth apiculate.

*** Leaves opposite (rarely in 3's), or the uppermost alternate.

2. E. maculatum.

3. E. Rydbergi.

4. E. purpureum.

5. E. trifoliatum.

+ Involucral bracts imbricated in 2 or more series, the outer shorter.

I. Leaves, at least the lower, slender-petioled.

6. E. serotinum.

2. Leaves all sessile, short-petioled or connate-perfoliate.

a. Leaves not clasping nor connate-perfoliate. $\S$ Leaves narrowed at the base. 
Bracts of the involucre acute or cuspidate.

Leaves linear-lanceolate, sparingly toothed, 4-12 mm. wide. 7. E. leucolepis.

Leaves oblong or lanceolate, coarsely toothed, $\mathrm{I}-4 \mathrm{~cm}$. wide. 8. E. album. Bracts of the involucre obtuse.

Leaves linear, crowded, usually entire, obtuse.

Leaves lanceolate, oval or oblong, usually serrate.

Leaves linear-lanceolate, acute, dentate.

9. E. hyssopifolium.

Leaves oblong to oval, sharply serrate, obtusish or acute. Io. Eorreyanum.

Leaves lanceolate, sparingly dentate, long-acuminate. 12. E. altissimum. $\S \S$ Leaves rounded, obtuse or truncate at the base.

Plant glabrous; leaves lanceolate, long-acuminate.

Plants pubescent; leaves ovate or oblong, acute or obtuse.

13. E. sessilifolium.

Leaves ovate-oblong, to lanceolate, mostly rounded at the base, usually obtuse. 14. E. verbenaefolium.

Leaves broadly ovate, crenate-dentate, mostly truncate at the base, obtusish.

Leaves ovate, dentate, acute.

b. I.eaves clasping or connate-perfoliate at the base.

15. E. rotundifolium.

I6. E. pubescens.

Leaves connate-perfoliate; involucral bracts acute.

Leaves merely clasping; involucral bracts obtuse.

17. $E$. perfoliatum.

$+\dagger$ Involucral bracts in 1 or 2 series, all equal or nearly so.

Receptacle flat; flowers white.

Leaves thin, 5-12 cm. long, sharply dentate, acuminate.

Leaves thickish, $25 \mathrm{~cm}$. long, blunt-toothed, acute or obtusish.

Receptacle conic; flowers blue or violet.

19. E. ageratoides.

20. E. aromaticum.

21. E. coelestinum.

I. Eupatorium capillifòlium (Lam.) Small. Dog-Fennel. Hog-weed. (I. F. f. 36I3.) Erect, paniculately much branched, with the aspect of an Artemisia, the stem finely pubescent, I-3 m. high. Leaves crowded, glabrous or nearly so, alternate, the lower petioled, the upper sessile; heads very numerous, about $3 \mathrm{~mm}$. high, short-peduncled, racemose-paniculate, 3-6 flowered; bracts of the involucre in about 2 series, linear, cuspidate, narrowly scarious-margined, glabrous; flowers greenish white. In fields, Va. to Fla. Also in the W. Ind. Sept.

2. Eupatorium maculàtum L. SPotTed JoE-PYE WEed. (I. F. f. 36I4.) Scabrous or pubescent, 6-18 dm. high. Stem usually striate, often rough and spotted with purple; leaves thick, ovate or ovate-lanceolate, coarsely dentate, verticillate in $3^{\prime} \mathrm{s}-5$ 's, or the upper ones opposite; peduncles and outer scales of the involucre pubescent; flowers pink or purple. In moist soil, N. Y. to Ky., Minn., Br. Col., Kans. and N. Mex. Aug.-Sept.

Eupatorium maculàtum amoènum (Pursh) Britton. Leaves opposite, or in 3's or 4's, ovate or oblong; heads smaller, fewer; plant low. In dryer places, Va. to N. Y. and Me.

3. Eupatorium Rýdbergi Britton, n. sp. Rydberg's Joe-pye Weed. Stem tall, pubescent, often densely so, at least above. Leaves verticillate in 3's--5's, rather slender-petioled, lanceolate, serrate, acuminate at the apex, narrowed at the base, scabrous above, finely densely pubescent and reticulate-veined beneath, I-I.5 $\mathrm{dm}$. long, 2-3.5 cm. wide; inflorescence depressed or subpyramidal; outer bracts of the cylindric involucre pubescent; flowers pink or purple. In moist soil. Iowa to Neb. and Colo. Type Rydberg, No. 1682, from South Fork of Dismal River, Neb. July-Sept.

4. Eupatorium purpùreum L. JOE-PYE OR TRUMPET-WEED. (I. F. f. 36I5.) Glabrous or sparingly pubescent, $\mathbf{I}-3 \mathrm{~cm}$. high. Stem green or purple, usually simooth; leaves thin, verticillate in 3's-6's, ovate, oval, or ovate-lanceolate, petioled, acuminate, serrate, sometimes incised, $\mathbf{I}-3 \mathrm{dm}$. long, $3-7 \mathrm{~cm}$. wide; heads numerous; involucre cylindric, its bracts pink, oblong, obtuse, imbricated in 4 or 5 series, the outer shorter: flowers pink or purple, occasionally white. In moist soil, N. B. to Man., Fla. and Tex. Aug.-Sept.

Eupatorium purpùreum falcàtum (Michx.) Britton. Leaves narrower, linear-lanceolate, or linear-oblong, 12-30 mm. wide. With the type.

5. Eupatorium trifoliàtum L. Crenate-leaved Joe-pye Weed. Stem tall, stout, often purple, glabrous, or very nearly so. Leaves rather firm, lanceolate to oblong-lanceolate, verticillate, acute or acuminate at the apex, 1.5-2 dm. long, smooth and glabrous on both sides or very nearly so, crenate ; inflorescence ample, 
its branches puberulent; bracts ( $f$ the cylindric involucre all obtuse, the outer short, puberulent. In moist soil, N. Y. and N. J. to eastern Tenn. and Wis. July-Sept.

6. Eupatorium serótinum Michx. LATE-Flowering Thoroughwort. (I. F. f. 3616.) Much-branched, finely and densely pubescent, or glabrate below, I2-25 dm. high. Leaves lanceolate or ovate-lanceolate, acuminate, sharply serrate, 7-15 cm. long, I-5 cm. wide, 5-nerved at the base, the lower opposite, the upper alternate; heads very numerous, the inflorescence broadly cymose; heads 7-15-flowered, 4-6 mm. high; involucre campanulate, its bracts pubescent, linear. oblong, obtuse or truncate; flowers white. In moist soil, Md. to Fla., Iowa, Kans. and Tex. Sept.-Nov.

7. Eupatorium leucólepis T. \& G. White-Bracted Thoroughwort. JUSTICE-WEED. (I. F. f. 36I7.) Slender, puberulent, branched above, 3-6 dm. high. Leaves linear, oblong or ollong-lanceolate, glaucous green, rough, thick, blunt-pointed, sparingly serrate, or the upper entire, $3-7 \mathrm{~cm}$. long, 4-10 $\mathrm{mm}$. wide, obscurely 3-nerved; inflorescence cymose-paniculate; heads 6-8 mm. high, about 5 -flowered; bracts of the narrow involucre white, lanceolate, densely canescent, the outer shorter; flowers white. In moist places, pine barrens of N. J. to Fla., Ga. and La. Aug.-Sept.

8. Eupatorium álbum L. WiIte Thoroughwort. (I. F. f. 3618.) Pubescent with spreading hairs, branched above, 3-9 dm. high. Leaves obtuse, obtusish or the upper acute at the apex, $3-10 \mathrm{~cm}$. long, $\mathbf{I}-2.5 \mathrm{~cm}$. wide, rather thick, minutely scabrous above, more or less pubescent beneath; inflorescence cy. mose-paniculate; heads numerous, 8-10 mm. long, 5-7-flowered; involucre narrow, its bracts bright white, linear, cuspidate, the outer short and usually pubescent, the inner much longer, glabrous and shining; flowers white. In sandy soil, L. I. to Fla., west to La. Aug.-Sept.

Eupatorium àlbum subvenòsum A. Gray. Leaves $2-5 \mathrm{~cm}$. long, acute, less coarsely serrate, prominently 3 -nerved at the base; bracts of the involucre greenish. Eastern L. I. and N. J.

9. Eupatorium hyssopifòlium L. Hyssop-leaved Thoroughwort. JusTICE-WEED. (I. F. f. 3619.) Roughish-puberulent, densely cory mbosely branched above, bushy, 3-6 dm. high. Leaves opposite, and fascicled in the axils, $1-5 \mathrm{~cm}$. long, 2-4 mm. wide, firm, narrowed at the base, margins usually revolute; inflorescence densely cymose-paniculate; heads $6-8 \mathrm{~mm}$. long, about 5 -flowered; involucre campanulate, its bracts linear or linear-oblong, sometimes apiculate, puberulent; flowers white. In dry fields, Mass. to Fla. and Tex. Aug.-Sept. A plant from the coast of Maryland with very narrow leaves, closely approaches Eupatorizm lecheaefolium Greene, from Florida.

Io. Eupatorium Torreyànum Short. Torrey's Thoroughwort. (I. F. f. 3620.) Rootstock tuberous-thickened; stem usually densely puberulent, mostly branched above, 4-9 dm. high. Leaves commonly with short leafy branches in their axils, often drooping, acute, $2-7 \mathrm{~cm}$. long, 4-12 mm. wide, usually distinctly 3-nerved, the upper and those of the branches much smaller, linear, entire; heads about $6 \mathrm{~mm}$. high, generally 5 -flowered; bracts of the campanulate involucre linearoblong, pubescent, or puberulent; flowers white. In dry soil, Penn. to N. Car., Ky., Fla. and Tex. July-Sept.

II. Eupatorium semiserràtun DC. SMall-Flowered ThORoughwort, (I. F. f. 3621.) Pubescent or puberulent, loosely branched above, 6-9 dm. high. Leaves rather thin, short-petioled, narrowed at the base, 5-10 cm. long, 10-25 $\mathrm{mm}$. wide, 3-nerved, usually with short branches in their axils; heads 4-6 $\mathrm{mm}$. high, about 5 -flowered; involucre campanulate, its bracts linear-oblong, canescent; flow. ers white. In dry soil, Va. to Fla., Tex. and Ark. Aug.-Sept.

12. Eupatorium altíssimum L. TALI. THOROUGHWORT. (I. F. f. 3622.) Densely and finely pubescent, corymbosely much-branched above, 12-25 dm. high. Leaves tapering below into a short petiole, roughish, rather thick, some of them entire, strongly 3-ribbed, $5-12 \mathrm{~cm}$. long, 10-25 mm. wide; heads about 5-fowered, 6-8 mm. high; involucre campanulate, its bracts oblong, densely pubescent; flowers white. In dry open places, Penn. to N. Car., Ala., S. Dak., Neb. and Tex. Sept.-Oct.

I3. Eupatorium sessilifòlium L. UPLAND OR BASTARD BONESTT. 3623) Glabrous throughout, or pubescent above, branched near the summit, 
6-18 dm. high. Leaves closely sessile, thin, sharply serrate, 7-15 cm. long, I-3 mm. wide; heads 8-Io mm. high, about 5-flowered; involucre campanulate, its bracts linear-oblong, the inner obtuse, the outer acutish; flowers white. In dry woods, Mass. to Penn., Ill. and Ala. Aug.-Oct.

Eupatorium sessilifolium Brittoniànum Porter. Leaves ovate or oblong-ovate, sparingly and finely serrate, firm, rounded at the base, acute, the upper $2-5 \mathrm{~cm}$. long, 12-18 mm. wide, pinnately veined, dark green; cymes dense, their branches puberulent. Budd's Lake, N. J.

14. Eupatorium verbenaefolium Michx. Rough or Vervain ThoroughworT. (I. F. f. 3624.) Rough-pubescent, slender, 9-25 dm. high, branched at the summit. Leaves obtuse or blunt-pointed, rounded at the base, more or less crenate-dentate, 5-10 cm. long, $\mathbf{r}-2.5 \mathrm{~cm}$. wide, the upper pairs distant and small; heads 5 -flowered, about $6 \mathrm{~mm}$. high; involucre campanulate, its bracts linearlanceolate, acute, densely pubescent; flowers white. In moist soil, Mass. to Penn., south to Fla. and La. July-Sept.

Eupatorium verbenaefolium Saùndersii Porter. Leaves of the stem lanceolate or lance-ovate, acuminate, not rounded at the base, strongly incised-dentate, with the teeth mostly acute; those of the inflorescence smaller and entire. Collected in a sphagnum. bog near Willow Grove, Montgomery Co., Penn., by Mr. C. F. Saunders, for whom it is named, and later in Tinicum, Delaware Co., by Mr. B. H. Smith.

I5. Eupatorium rotundifolium L. Round-Leaved Thoroughwort. Wiln HoARhound. (I. F. f. 3625.) Rough-pubescent, branched at the summit, 3-6 dm. high. Leaves broadly ovate, often as wide as long, acutish or obtuse, truncate to subcordate at the base, coarsely dentate crenate, $2-5 \mathrm{~cm}$. long, ascending; heads about 5-flowered, 4-6 cm. high; involucre campanulate, its bracts linear-oblong, acute, dersely pubescent; flowers white. In dry soil, southern N. Y. to Fla., Ky. and Tex. Grily-Sept.

I6. Eupatoriım pubéscens Muhl. Hairy Thoroughwort. (I. F. f. 3626.) Puberulent or pubescent, branched above, usually taller than the preceding species. Leaves often twice as long as wide, rounded or truncate at the base, coarsely dentate with acute or acutish teeth, or the lower inciserl-dentate; heads 5-8-flowered, 4-6 mm. high; involucre campanulate, its linear-oblong bracts in 2 or 3 series, the outer shorter; flowers white. In dry soil, N. H. and Mass. to Penn., W. Va. and Fla. July-Sept.

I7. Eupatorium perfoliàtum L. Common Thoroughwort. Boneset. INDIAN SAGE. (I. F. f. 3627.) Pubescent, stout, branched above, 6-I5 dm. high. Leaves opposite, or rarely in 3 's, divaricate, lanceolate, long-acuminate with a slender apex, finely crenate-serrate, rugose and pubescent beneath, $1-2 \mathrm{dm}$. long, 2-4 cm. wide; heads crowded, 10-16-flowered, 4-6 mm. high; involucre campanulate, its bracts lanceolate, pubescent; flowers white, rarely blue. In wet places, N. B. to Man., Fla., Neb. and Tex. July-Sept.

Eupatorium perfolia tum truncàtum (Muhl.) A. Gray. Leaves separated and truncate, or somewhat rounded at the base. Occasional with the type.

Eupatorium perfoliatum cuneatum (Engelm.) A. Gray. With leaves smaller, narrowed and separated at the base, occurring in Ark. and Mo., is regarded by collectors as a hybrid with $E$. serotinum.

I 8. Eupłatorium resinòsum Torr. Resin Boneset. (I. F. f. 3628.) Slen. der, resinous-pubescent, 6-9 dm. high, branched at the summit, the inflorescence comparatively small, 7-10 cm. broad. Leaves closely sessile, clasping, or slightly connate perfoliate at the base, linear-lanceolate, long-acuminate, sharply serrate, 7-15 cm. long, 6-12 mm. wide, roughish above, canescent beneath: heads 10-15flowered; involucre campanulate, about $4 \mathrm{~mm}$. high, its bracts oblong; flowers white. In wet places, pine-barrens of N. J. Aug.-Sept.

I9 Eupatorium ageratoides L. f. White SNAKE-Root. White Sanicle. (I. F. f. 3629.) Glabrous or nearly so, much branched, 3-12 dm. high. Leaves oppo. site, thin, rounded, truncate or cordate at the hase, or abruptly narrowed into the slender petiole, coarsely dentate or crenate, 2-7 cm. wide, 3 -nerved and veiny inflorescence rather loose, ample; heads 10-30-flowered; involucre narrowly car. panulate, about $4 \mathrm{~mm}$. high; its brącts linear, acute or acuminate. In rich woods, N. B. to Ga., Ont., S. Dak., Neb., the Ind. Terr. and La. July-Nov. 
20 Eupatorium aromàticum L. SMALleR White SNAKe-Root. (I. F. f. 3630.) Puberulent or glabrate, slender, branched at the summit, 3-7 $\mathrm{dm}$. high.
Leaves opposite, petioled, firm, sometimes narrowed at the base, crenate-dentate, at the apex, rounded, cordate or 3-nerved and veiny; petioles 4-16 mm. long; inflorescence usually compact; heads obtuse; flowers white. In dry soil,

2r. Eupatorium coelestinum Aug... Oct.

cent or puberulent, branched, 3-9 dm. hisT-FLOWER. (I. F. f. 363I). Pubesobtuse or acute at the apex, truncate at . Leaves opposite, petioled, ovate, the petiole, crenate-dentate, 4-7 cm. long. I 8 base, or abruptly contracted into involucre broadly campanulate, its bracts $18-35 \mathrm{~mm}$. wide; heads $4-6 \mathrm{~mm}$. high; blue or violet. In moist soil, N. J. to Fls linear-lanceolate, acuminate; flowers Cuba. Aug.-Oct.

\section{WILLUGBAÈA Neck. [MIKANIA Willd.]}

Herbaceous twining vines, or some tropical species shrubs, with opposite, peti. oled leaves, and discoid, mostly cymose-paniculate heads of white or pink flowers. Heads 4-flowered. Involucre oblong, of 4 slightly unequal narrow bracts. Receptacle small, naked. Corolla regular, its tube slender, the limb campanulate, 5-cleft. Anthers entire and obtuse at the base. Style-branches elongated, acutish. Achenes truncate, 5. angled. Pappus of numerous capillary rouglish bristles in $\mathbf{I}$
or 2 series. lish naturalist, but the name spelled by Necker as above. Am. Besides the following another occurs in the southern U. S. 150 species, of

I. Willugbaeya scá a

(I. F. f. 3632.) Glabrous or nearly so I tate, deeply cordate, acuminate, repand, $1.5-4.5 \mathrm{~m}$. long. Leaves ovate or has. wide; petioles slender, shorter than or obtusely dentate, 5-10 cm. long, $2-5 \mathrm{~cm}$. at the ends of the branches; acuminate or apiculate; flowers moist soil, N. H. and Mass. to western or pink; achenes resinous. In swans and W. Ind. and S. Am. July-Sept.

\section{COLEOSÀnthus Cass.}

Herbs or shrubs, with discoid heads of white, yellowish or pink flowers, in panicles or cymes, or rarely solitary. Involucre campanulate or oblong, its bracts striate, imbricated in several series, the exterior ones successively smaller. Recepbranches long, obtuse. numerous rough or serrate Besides the following some

I. Coleosanthus occur in the southern and western U. S. oughworT. (I. F. f. 6-9 dm. high. Leaves 3633.) Erect, glabrous or puberulent, much branched, nate at the a pex, coarsely short-peduncled, I2-14 mm crenate-dentate, 5-10 cm. long, 2-5 cm. wide; heads 30-45-flowered, the outer subulate tipped, the inner linear, ovate, pubescent, tisually abruptly acuminate or to Ore. and Ariz. Aug.-Sept.

\section{KÜHNIA L.}

Perennial herbs, with alternate punctate resinous-dotted leaves, and discoid heads of white or purplish flowers in terminal cymose corymbs. "Involucre turbinate-campanulate, its bracts striate, imbricated in several series, the outer shorter. Corolla regular, the tube slender, the limb 5-lobed. Anthers obtuse and entire at the base, nearly or quite separate. Style-branches slender, obtusish. Achenes Io striate. Pappus a single row of numerous very plumose bristles. [Named for Dr. Adam Kuhn, of Philadelphia, a pupil. of Linnæus.] About 8 species, of
N. Am. and Mex. 
Puberulent; leaves sparingly dentate, or entire; heads loosely clusterea, 8-1o mm. high. Pubescent or tomentulose; 1 . K. eupatorioides. high.

clustered, 12-16 mm. 2. $K$. glutinosa.

I. Kuhnia eupatorioides L. FALSE Boneset. (I. F. f. 3634.) Erect, puberulent and resinous, 3-9 dm. high, branched above. Leaves lanceolate or linear-lanceolate, acute or obtusish at the apex, narrowed at the base, the upper sessile, the lower usually short-petioled: heads several or numerous, peduncled, 8-Io mm. high; outer bracts of the involucre lanceolate or ovate-lanceolate, acuminate, the inner much longer, linear, cuspidate; pappus tawny, or sometimes nearly white. In dry soil, N. J. to Ga., Ohio, W. Va. and Tex. Aug.-Sept.

2. Kuhnia glutinòsa Ell. Prairie False Boneset. (I. F. f. 3635.) Stouter and often taller than the preceding species, corymbosely or paniculately branched, somewhat viscid. Leaves all sessile, lanceolate to ovate-lanceolate, usually sharply serrate with distinct teeth, veiny, 3-7 cm. long, 6-20 $\mathrm{mm}$. wide; or those of the branches linear-lanceolate and entire; heads numerous, $12-16 \mathrm{~mm}$. high, their peduncles mostly short; inner bracts of the involucre lanceolate, acuminate; pappus tawny or brown. In dry soil, Ill. to S. Dak., Ala. and Tex. Aug.-Oct.

\section{LACINÀRIA Hill. [LIATRIS Schreb]}

Erect perennial herbs, usually from a globular tuber, simple or little branched, with alternate entire narrow I-5-nerved leaves, and spicate or racemose discoid heads of rose purple or white flowers. Involucre oblong, ovoid or subhemispheric, its bracts imbricated in several series, the outer shorter. Receptacle Hat, or slightly convex, naked. Corolla regular, its tube slender, its limb 5-lobed or 5-cleft. Anthers obtuse at the base. Style branches elongated, obtuse or flattened at the apex. Achenes ro-ribbed, slender, tapering to the base. Pappus of I or 2 series of slender barbellate or plumose bristles. [Latin, fringed, from the appearance of the heads.] About 25 species of eastern and central N. Am.

* Bracts of the involucre acute, acuminate or mucronate.

Involucre cylindric, or turbinate, $15-60$-flowered, its base rounded.

Bracts with lanceolate spreading rigid tips.

Bracts mucronate, closely appressed.

Involucre oblong, or narrowly campanulate, 3-6-flowered.

Inner bracts with prolonged petaloid tips.

Bracts all acute, mucronate or acuminate.

Bracts appressed; pappus-bristles very plumose.

Leaves 2-4 $\mathrm{mim}$. wide: spike usually leafy below.

Leaves less than 2 mm. wide; spike mostly naked.
Tips of the bracts spreading; pappus-bristles barbellate.

I. L. squarrosa.

2. L. cylindracea.

3. L. elegans.

4. L. punctata.

5. L. acidota.

6. L. pycnostachya.

Bracts of the involucre very obtuse.

Involucre hemispheric, 10-25 mm. broad, 15-45-flowered; heads peduncled.

Involucre oblong, 4-8 mm. broad, 5-15-flowered.

7. L. scariosa.

Involucre rounded at base; bracts usually not punctate; heads mostly sessile.

Spike elongated, not very dense, often $3 \mathrm{dm}$. long. 8 . I.. spicata.

Spike short, exceedingly dense.
Involucre narrowed at base; brarts usually very punctate; heads peduncled.

9. L. Kansana.

10. L. graminifolia.

Bracts of the involucre acutish, punctate; involucre oblong-campanulate.
Io.

II. L. Smallii.

I. Lacinaria squarròsa (L.) Hill. Scaly Bi.azing Star. (I. F. f. 3636.) Usually stout, 2-6 dm. high, pubescent or glabrous. Leaves narrowly linear, rigid, sparingly punctate, $7-15 \mathrm{~cm}$. long, $2-5 \mathrm{~mm}$. wide: heads sessile or shortpeduncled, usually few, or sometimes solitary, 2-4 cm. long, 8-15 mm. thick; bracts of the involucre imbricated in 5-7 series, lanceolate, rigid, acuminate, glabrous or pubescent; flowers bright purple; pappus very plumose. In dry soil, western Ont. to Ky.. Fla., S. Dak., Neb. and Tex. June-Sept.

Lacinaria squarròsa intermèdia (Lindl.) Porter. Heads narrower; tips of the bracts 
2. Lacinaria cylindràcea (Michx.) Kuntze. Cylindric Blazing'Star. (I. F. f. 3637.) Glabrous or nearly so, stout, 3-5 dm. high, sometimes branched above. Leaves narrowly linear, rigid, scarcely punctate, $7-17 \mathrm{~cm}$. long, $2-4 \mathrm{~mm}$. wide; heads several or numerous, peduncled, or the lower sessile, turbinate-cylindric, $\mathbf{I}-2.5 \mathrm{~cm}$. high, 8-12 mm. thick; bracts of the involucre imbricated in 5 or 6 series, broadly oval, abruptly acuminate at the apex; flowers purple; pappus very plumose. In dry soil, western Ont. to Minn. south to Ill. and Mo. July-Sept.

3. Lacinaria élegans (Walt.) Kuntze. Handsome Blazing S'rar. (I. F. f. 3638.) Densely and finely pubescent, rarely glabrate, 6-9 dm. higl. Leaves linear, very punctate, $3^{-12} \mathrm{~cm}$. long, $2-6 \mathrm{~mm}$. wide, the upper much smaller than the lower and soon reflexed; heads 4-5-flowered, 12-14 mm. high, narrowly campanulate, very numerous in a dense spike or raceme; bracts of the involucre in 2 or 3 series, the inner ones linear, with rose colored petaloid or sometimes white tips; pappus very plumose; flowers purple. In dry soil, Va. to Fla., Ala. and Tex. Aug.-Oct.

4. Lacinaria punctàta (Hook.) Kuntze. Dotred Butron-SNakeroot. (I. F. f. 3639.) Glabrous, or sparingly pubescent, $1.5-7.5 \mathrm{dm}$. high; rootstock stout, branching, or globose. Leaves linear, rigid, very punctate, $5^{-1} 5 \mathrm{~cm}$. long, about $2 \mathrm{~mm}$. wide, or the lower $4 \mathrm{~mm}$., the upper gradually shorter, all erect or ascending: heads 3-6-flowered, 12-16 mm. long, sessile, crowded into a dense spike; spike commonly leafy below; involucral bracts oblong, cuspidate or acuminate, often ciliate on the margins, imbricated in 4 or 5 series; flowers purple. In dry soil, Minn. and Manitoba to Mont., Mo., Tex., N. Mex. and Sonora. Aug.-Oct.

5. Lacinaria acidjta (Engelm. \& Gray) Kuntze. Slender Butron-SNake. RоOT. (I. F.f. 3640 .) Similar to the preceding species, but usually glabrous through, out. Stem $6 \mathrm{dm}$. high, or less, slender. Leaves narrowly linear, .5-I mm. wide, or the lower wider, slightly punctate, 2-ro $\mathrm{cm}$. long, the upper gradually shorter. spike slender, naked, or sparingly leafy at the base; heacls 3.flowered, 12-18 mm, long; involucre narrowly oblong-campanulate, its biacts oblong to c vate-lanceolatc more or less punctate, abruptly or gradually acuminate, glabrous or sparingly ciliate; flowers purple. Prairies, Kans. and Mo. to 'Tex. Aug.-Oct.

6. Lacinaria pycnostàchya (Michx.) Kuntze. Prairie or HaIR y hutToriSNAKEROOT. (I. F. f 364I.) Hirsute-pubescent above, usually glabrous below, 6-I5 dm. high, very leafy. Lower leaves linear-lanceolate, narrowed below the middle into a slender margined petiole, acumiriate at the apex, often $3 \dot{\alpha} r_{\text {s. }}$ long and I $\mathrm{mm}$. wide, the upper much smaller, linear-subulate, rigid, punctate; heads 8-I2 $\mathrm{mm}$. long, 3-6-flowered; involucre oblong or cylindric, its bracts ubiong, pubescent and ciliate, with acute, slightly spreading, colored tips; flower's fas p. On prairies, Ill. and Minn. to Neb., Ky., La., and Tex. Aug.-Sept.

7. Lacinaria scariòsa (L.) Hill. LARGE ButTon-SNAKEre.Jr. (I. F. f. 3642.) Finely pubescent, at least above, 3-18 dm. high. Lower leaves oblanceolate, spatulate or oblong-lanceolate, narrowed into a margined petiole, uften $3 \mathrm{dm}$. long and

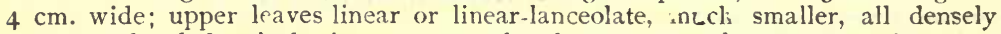
punctate; heads hemispheric, on stout pedur.cles 4-50 $\mathrm{r} . \mathrm{m}$. lcng, or sometimes ses sile; bracts of the involucre imbricated ir: 5 or 6 series, spatulate-linear, oblanceo late or obovate, their tips dry and scarious, of el. culored; flowers bluish purple pappus barbellate. In dry soil, Me. to Fla., Ji.c., Manitoba, Neb. and Tex. Aug Sept.

Lacinaria scariosa squarrulosa (Michx.) Sr.sall. Heads smaller, Io- $14 \mathrm{~mm}$. broad turbinate-hemispheric. Dry wcods, Va. to rla. and Tex. Perbaps a distinct species.

8. Lacinaria soicàtz (L.) Kuntze. Dense Button-snakeroot. Gai Feather. Devil's Bit. (I. F. f. 364.3.) Glabrous or nearly so, 6-I $8 \mathrm{dm}$. high. Lower leaves linear-lanceolate or tinear-oblong, usually blunt pointed, sometimes is $\mathrm{dm}$. long and $\mathbf{I ~} \mathrm{cm}$. wide, the upper inear or even subulate, somewhat or obscurely punctate: spike general!y aense. I-4 dm. long: bracts appressed, oblong, obtuse and scarious-marginerl at the apex, imbricated in 4-6 series; flowers blue-purple, occasionally white. In moist soil, Mass. to Fla., Ont., S. Dak., Ky., La. and Ark. Aug.-Oct.

Lacinaria stricàta nùmila (Lodd.) Porter. Low, stout, 3-6 dm. high. Lower leaves broader asd shorter, obtuse; spike shorter; heads larger. 
9. Lacinaria Kansàna Britton, n. sp. KANSAS BUTTON-SNAKERoo'T. Very leafy, glabrous, about $6 \mathrm{dm}$. high. Base of the stem clothed with the fibrous remnants of old leaves, as in L. spicata; leaves similar to those of that species, linear, blunt-tipped; heads confluent into a very dense spike 5-7 cm. long, about $2.5 \mathrm{~cm}$. thick, with numerous undeveloped ones in the axils of linear-subulate bracts below; bracts of the oblung involucre oblong to oblong-spatulate, purple, rounded or ubtuse; pappus plumose. Dodge City, Kansas, on river bottorns, B. B. Smyth, No. 163, I890.

Io. Lacinaria graminifòlia (Walt.) Kuntze. LOOSE-FLOWERED ButToNSNAKEROOT. (I. F. f. 3644.) Glabrous, or sparingly pubescent, 3-9 dm. high. Leaves similar to those of the two preceding species, but more conspictiously punctate, usually somewhat ciliate near the base and acute or acutish at the apex; bracts distinctly punctate, appressed, rounded and scarcely margined at the apex, thick; flowers purple; pappus barbellate; achenes hairy. In dry soil, Va. to Fla. and Ga. Aug.-Sept.

Lacinaria graminifolia pilosa (Ait.) Britton. Leaves usually prominently ciliate; heads larger, spicate, racemose, or even paniculate; bracts of the involucre linear-oblong or spatulate, narrowly scarious-margined. In sandy soil, N. J. to Fla. and Ala.

II. Lacinaria Smàllii Britton, n. sp. Small's Button-snakeroot. Similar to L. graminifolia. Stem very slender, 3-5 dm. high. Leaves scattered, linear, 4-10 nm. wide, acute, pubescent on the midvein beneath, very punctate; heads scattered, sessile in the axils of the upper small leaves, the uppermost leaves not larger than the involucral bracts; involucre oblong-campanulate, about 8-flowered, about $\mathrm{I} \mathrm{cm}$. high, its innermost bracts linear, acute or acutish, the outermost obtusish, all punctate; flowers purple; pappus short-plumose. Iron Mountain, Smyth Co., Va., at 2900 ft., J. K. Small, Aug. 8, 1892.

\section{TRÍLISA Cass.}

Erect perennial herbs, with fibrous roots and alternate simple leaves; those of the stem sessile or clasping, the basal ones narrowed into petioles. Heads small, discoid, of 5-10 purple or white flowers, in terminal thyrsoid or corymbose panicles. Involucre campanulate, its bracts imbricated in 2 or 3 series, the outer scarcely shorter than the inner. Receptacle flat, naked. Corolla regular, its limb 5-lobed. Anthers obtuse and entire at the base. Achenes nearly terete, ro-ribbed. Stylebranches slender, obtuse. Pappus of $\mathbf{I}$ or 2 series of elongated, barbed bristles. [Anagram of Liatris.] Two known species.

Stem glabrous; heads corymbose-paniculate.

Stem viscid-pubescent; heads thyrsoid-paniculate.
1. T. odoratissima. 2. T. paniculata.

I. Trilisa odoratíssima (Walt.) Cass. VAnilla-leaf. Vanilla-Plant. (I. F. f. 3645.) Rather stout, glabrous, 6-9 dm. high. Leaves thick, entire, or sometimes dentate, the lower oblanceolate, oblong or spatulate, obtuse, ro-25 cm. long, $2.5-3.5 \mathrm{~cm}$. wide, those of the stem gradually smaller, oblong, ovate, or oval, the uppermost bract-like; heads corymbose-paniculate, about $6 \mathrm{~mm}$. high; bracts of the involucre oblong, obtusish; achenes glandular-pubescent. In pine-barrens, Va. to Fla. and La. Aug.-Sept.

2. Trilisa paniculàta (Walt.) Cass. Hairy Trilisa. (I. F. f. 3646.) Stem viscid-pubescent, 3-9 dm. high. Leaves entire, the basal ones lanceolate or narrowly oblong, acute, or obtusish, $7-25 \mathrm{~cm}$. long, $\mathrm{I}-3.5 \mathrm{~cm}$. wide, those of the stem much smaller, lanceolate, or oblong-lanceolate; heads thyrsoid-paniculate, about $6 \mathrm{~mm}$. high; bracts of the involucre oblong, obtusish; achenes finely pubescent. In pine-barrens, Va. to Fla. and Ga. Sept.-Oct.

\section{ro. GUTIERRÈzIA Lag.}

Erect branching, usually glabrous and often glutinous herbs, or shrubs, with linear entire alternate leaves, and small heads of both tubular and radiate yellow flowers, corymbosely paniculate in our species. Radiate flowers few, pistillate. Disk-flowers regular, mostly perfect, or some of them only staminate, the corollalimb 5-lobed. Involucre ovoid or narrowly campanulate, its bracts-coriaceous, imbricated in few series. Receptacle flat, convex, or conic, commonly foveolate. 
Anthers obtuse and entire at the base. Style-branches narrow, flattened, their appendages slender. Achenes terete, ribbed, or 5-angled. Pappus of several scales, those of the ray-flowers shorter than or equalling those of the disk. [Named from Gutierrez, a noble Spanish family.] About 20 species of western N. Am., Mex. and western S. Am. Besides the following some ro others occur in the southwestern U. S.

I. Gutierrezia Saròthrae (Pursh) Britt. and Rusby. Gutierrezia. (I. F. f. 3647.) Glabrous or minutely pubescent, bushy, I- $6 \mathrm{dm}$. high, the branches rigid, ascending. Leaves linear, I-3.5 cm. long, I-2 mm. wide, acute; heads oblong, 3-4 mm. high, few-flowered, usually in clusters of 2-5 at the ends of the numerous branches; rays I-6, scarcely $2 \mathrm{~mm}$. long; scales of the pappus linear-oblong, subulate or acuminate; achenes pubescent. In dry or rocky soil, Minn. and Manitoba to western Neb., Tex. and Sonora, west to Nev., Ariz. and Cal. Aug.-Sept.

\section{AMPHIÁCYYYIS DC.}

Erect, much branched, glabrous herbs, with small alternate entire leaves, and very numerous small heads of both tubular and radiate yellow flowers, solitary or clustered at the ends of the branches. Involucre ovoid or hemispheric, its bracts coriaceous, imbricated in few series. Receptacle naked. Ray-flowers pistillate. Disk-flowers perfect, but sterile, or staminate. Pappus of the ray-flowers obsolete or coroniform, that of the disk flowers of 5-20 subulate scales or bristles somewliat united at the base. Achenes pubescent. [Greek, chaff-around.] Two known species, natives of the south-central U. S.

r. Amphiachyris diacunculoides (DC.) Nuit. Amphiachyris. (I. F. f. 3648.) Annual, slender, much brancheJ, 15-45 $\mathrm{cm}$. high, the branches ascending. Leaves linear, I2-35 $\mathrm{mm}$. long, 2-4 $\mathrm{mm}$. wide, acurish, the uppermost almost filiform; heads solitary at the ends of short branches, ro-30-flowered, about $4 \mathrm{~mm}$. high; involucre hemispheric, its bracts oval, obtuse; rays 5-10, about as long as the involucre; disk-flowers mostly staminate, their ovaries abortive, their pappus of 5-8 subulate aristate scales, united into a short cup at the base. In dry soil, Mo. and Kans. to Tex. ; adventive at Easton, Penn. Sept.-Oct.

\section{GRINDÈLIA Wiild.}

Perennial or biennial herbs, sometimes woody at the base, with alternate sessile or clasping leaves, usually spinulose-dentate, and rather large heads of both discoid and radiate yellow flowers, solitary at the ends of the branches (rays rarely wanting). Involucre hemispheric or depressed, its bracts imbricated in several or many series, usually subulate-tipped. Receptacle flat or convex, naked, foveolate. Rayflowers fertile. Disk-flowers perfect, or sometimes only staminate. Anthers obtuse and entire at the base. Style-branches narrow, flattened, their appendages linear or lanceolate. Achenes short, thick, sometimes compressed, glabrous, 4-5-ribbed. Pappus of 2-8 soon deciduous awns or bristles. [Named for Prof. H. Grindel, of Riga, 1776-1836.] About 25 species, natives of western N. Am., Peru and Chili. Besides the following, some 15 others occur in western N. Am.

Leaves spatulate to oblong, obtuse or obtusish; achenes truncate. Leaves linear or linear-oblong, acute; achenes 2-toothed.

r. G. squarrosa.

2. G. lanceolata.

I. Grindelia squarròsa (Pursh) Dunal. Broad-leaved Gum Plant. (I. F. f. 3649.) Glabrous, erect or ascending, 2-6 dm. high. Leaves oblong or oblong-spatulate, obtuse, more or less clasping at the base, sharply dentate, sometimes laciniate, $1-3.5 \mathrm{~cm}$. long, 6-12 mm. wide; heads very glutinous; bracts of the involucre linear-lanceolate, subulate-tipped, strongly squarrose: achenes truncate, those of the outer flowers usually thicker than those of the inner; pappus of 2 or 3 awns. In dry soil, Ill. and Minn. to Manitoba, south to Mo., Tex., Nev. and Mex. Adventive in southern N. J. June-Sept.

Grindelia squarròsa nùda (Wood) A. Gray. Rays wanting. Mo. and westward with the type.

3. Grindelia lanceolàta Nutt. NarRow-leavei Gum.plant. 3650.) Slender, erect, glabrous, about $6 \mathrm{dm}$. high. Leaves lanceolate or linear, acute at the apex, sessile or clasping at the base, spinulose-dentate, laciniate, or 
the uppes entire, $2-5 \mathrm{~cm}$. long, 4-10 $\mathrm{mm}$. wide; bracts of the involucre linearsubulate, the immer erect, the outer spreading: pappus of 1 or 2 awns. In dry soil, Tenn. to Kans., 1.x. and Tex. July-Sept.

\section{r3. HETEROTHÈCA Cass.}

Erect, hirsute or pubescent herbs, with alternate, mostly dentate leaves, and. rather large heads of both discoid and radiate yellow flowers, generally solitary at the ends of the branches. Involucre hemispheric or broadly campanulate, its bracts imbricated in several series, the outer shorter. Receptacle flat, alveolate. Ray-flowers pistillate. Disk-flowers perfect, or some of them only staminate. Style-branches flat, their appendages lanceolate or triangular. Achenes pubescent, obtuse, those of the ray-flowers thick, those of the disk-flowers flattened. Pappus of the ray-flowers obsolete or of a few caducous bristles, that of the disk-flowers of an inner row of numerous capillary rough bristles, and an outer row of shorter stouter bristles or scales. [Greek, different-case, from the dissimilar achenes.] Five or 6 species of the southern U. S. and Mex.

1. Heterotheca subaxillàris (Lam.) Britt. \& Rusby. Héterotheca. (I. F. f. 3651.) Biennial or sometimes annual, 3-9 dm. high. Basal and lower leaves petioled, ovate or oblong, 5-7 cm. long, the upper ones oblong, sessile or clasping, smaller, all acutish or obtuse, dentate; heads rather numerous, 12-18 $\mathrm{mm}$. broad; involucre nearly hemispheric, 6-10 $\mathrm{mm}$. high, its bracts linear, or slightly dilated above, the inner with scarious margins; rays 10-25; inner bristles of the pappus of the disk-flowers about $4 \mathrm{~mm}$. long. In dry soil, Del. to Fla., La., Kans., Ariz. and Mex. July-Sept. [H. Lamarckii Cass.]

\section{CHRYSÓPSIs Nutt.}

Perennial herbs, with alternate sessile entire leaves, or the basal ones dentate, and large many-flowered heads of both tubular and radiate yellow flowers (rays wanting in some western species), loosely corymbose. or sclitary at the ends of the branches. Involucre campanulate to hemispheric, its bracts narrow, imbricated in several series, the outer shorter. Receptacle usually flat, foveolate. Ray-flowers pistillate. Disk flowers mostly all perfect. Pappus double in both the disk-and ray-flowers, the inner of numerous rough capillary bristles, tise outer of smaller or minute scales or bristles. Achenes flattened, oblong-linear or obovate. Stylebranches narrow, somewhat flattened, their appendages linear or subulate. [Greek, of golden aspect.] About 20 species, of N. Am. and Mex. Besides the following, about 8 others occur in the southern and western U. S.

Leaves elongated-linear, parallel-veined; achenes linear: involucre campanulate.

Plant 3-9 dm. high, silvery-pubescent; leaves grass-like, 7-30 cm. long.

Plant $\mathrm{r}-2.5 \mathrm{dm}$. high, woolly-pubescent; leaves rigid, 2-10 $\mathrm{cm}$. long.
2. C. falcata.

1. C. graminifolia.

Leaves oblong, lanceolate, or linear, pinnately veined; achenes obovate, or oval; involucre hemispheric.

Plant densely woolly-pubescent.

Plants hirsute, or villous-pubescent.

Heads numerous, corymbose-paniculate; eastern species. 4. C. Mariana.

Heads fewer, corymbose, or terminating the branches; western species.

Villous-pubescent; leaves oblanceolate, oblong, or lanceolate.
Leaves acute.
Leaves obtuse.
5. C. camporum.
6. C. villosa.

Hirsute-pubescent.

Leaves linear, acutish, short.

Leaves spatulate, obtuse.

Pilose-pubescent; leaves oblong-lanceolate.

7. C. stenophylla.

8. C. hispida.

9. C. Nuttallii.

I. Chrysopsis graminifòlia (Michx.) Nutt. Grass-leaved Golden Aster. (I. F. f. 3652.) Slender, corymbosely branched above. Leaves 3-5-nerved, shining, the basal ones 7-30 $\mathrm{cm}$. long, 4-10 $\mathrm{mm}$. wide, the upper much smaller, and the uppermost subalate and erect; heads several or numerous, about $1 \mathrm{~cm}$. broad, solitary at the ends of the branches; involucre campanulate. its bracts glabrate; achenes linear-fusiform. In dry soil, Del. to Fla., Ohio and Tex. Aug.-Oct. 
2. Chrysopsis falcàta (Pursh) Ell. Sickle-leaved Golden Aster. (I.F. f. 3653.$)$ Corymbosely branched above, rather stiff, leafy to the top. Leaves linear, rigid, spreading, sometimes slightly curved, 2-6 nim. wide, obscurely parallel-nerved; heads rather few, 6-10 $\mathrm{mm}$. broad, terminating the branches; involucre campanulate, its bracts slightly pubescent; achenes linear. In sandy soil, eastern Mass. to N. J. July-Aug.

3. Chrysopsis pilosa (Walt.) Britton. Cottony Golden Aster. (I. F. f. 3654.) Stout, 3-6 dm. high, branched above. Leaves spatulate or oblong, obtuse, the lower and basal ones 2-7 $\mathrm{cm}$. long, 6-10 $\mathrm{mm}$. wide, the upperinost much smaller; heads usually about $2 \mathrm{~cm}$. broad, terminating the branches, briglit yellow: involucre hemispheric, its bracts densely pubescent when young, becoming glalorate; achenes obovate. In pine-barrens, $\mathrm{Va}$. to Fla. and Ala. Autumn.

4. Chrysopsis Mariàna (L.) Nutt. Maryland Golden Aster. (I. F. f. 3655.) Stout, 3-7 dm. high, loosely villous-pubescent with silky hairs when young, at length nearly glabrous. Upper leaves oblong or lanceolate, acutish or obtuse, sessile, $2-5 \mathrm{~cm}$. long, the lower oblanceolate or spatulate and narrowed into a petiole, generally obtuse, 5-10 $\mathrm{cm}$. long and sometimes $25 \mathrm{~mm}$. wide; heads commonly numerous, 18-25 mm. broad, on glandular peduncles; involucre hemispheric, its bracts glandular, acute, viscid-pubescent: achenes obovate. In dry soil, southern N. Y. and Penn. to Fla. and La. Aug.-Sept.

5. Chrysopsis campòi um Greene. Prairie Golden Aster. (I. F. f. 3656.) Stem erect, 3-7 dm. high, leafy up to the inflorescence. Leaves lanceolate to oblong-lanceolate, entire, or with a few low distant teeth, acute, sessile, or the lower nar. rowed into petioles, appressed-pubescent with short hairs, ciliate, at least near the base, 2-7 cm. long, 4-10 mm. wide; heads 25-35 mm. broad, showy; involucre nearly hemispheric, I cm. high, its bracts lanceolate, acuminate, pubescent; outer pappus.bristles subulate. On prairies, Ill. and Ky. to Mo. July-Sept.

6. Chrysopsis villòsa (Pursh) Nutt. Hairy GoldDen Aster. (I. F. f. 3657.) Stem villous or strigose-pubescent, 3-6 dm. high. Leaves oblong, lanceolate, or oblanceolate, obtuse, $2-5 \mathrm{~cm}$. long, 4-IO $\mathrm{mm}$. wide, the upper sessile, the lowernarrowed into a petiole, pale, persistently canescent with appressed hairs; heads rather few, 25 $\mathrm{mm}$. broad or more; involucre lemispheric, 8-10 $\mathrm{mm}$. high, its bracts linear-subulate, pubescent and often ciliate: achenes obovate. In dry soil, Minn. and Ill. to Ala., Manitoba, Br. Col. and Neb. July-Aug.

7. Chrysopsis stenophýlla (A. Gray) Greene. Stiff-leaved Golden As. TER. (I. F. f. 3658.) Low, slender, I5-25 cm. high. Leaves linear or slightly broadened above, densely canescent and ciliate, acutish, $2-3 \mathrm{~cm}$. long, $2-4 \mathrm{~mm}$. wide, the margins revolute in drying; involucre hemispheric or broadly campanulate, its bracts pubescent or the outer densely ciliate; heads few, I2-20 mm. broad. In dry soil, Neb. to Ark. and Tex. Aug.-Sept.

8. Chrysopsis híspida (Hook.) Nutt. Hispid Golden Aster. (I. F. f. 3659.) Lower than C. villosa, stem rarely over $3 \mathrm{dm}$. high; with spreading hirsute or hispid pubescence. Leaves spatulate to oblong, entire, spreading, $18-35 \mathrm{~mm}$. long, obtuse at the apex, narrowed at the base, often into peticles half as long as the blade or more; heads smaller, often more numerous; involucre not over $8 \mathrm{~mm}$. high, its bract's lanceolate, hirsute. In dry soil, Manitoba to Idaho, Kans. and Tex. July-Sept.

9. Chrysopsis Nuttàllii Britton. Nuttall's Golden Aster. (I. F f. 3660.) Pilose-pubescent with soft hairs and minutely glandular, 3-6 dm. high, branched above. Leaves oblong-lanceolate, mostly acute, $2.5-6 \mathrm{~cm}$. long, 4-10 mm. wide, entire, or the lower serrate or even incised; heads few, I5-25 $\mathrm{mm}$. broad, terminating the branches; involucre hemispheric, its bracts glandular-viscid; achenes obovate. In dry soil, Kans. to La., Ark. and Tex. July-Sept.

\section{CHONDRÓPHORA Raf.}

Perennial stiff herbs, with alternate entire leaves, and corymbose-paniculate discoid heads of yellow flowers. Involucre oblong or campanulate, its bracts rigid and glutinous, imbricated in several series. Receptacle flat, generally foveolate, naked. Corolla regular, tubular, the limb 5-cleft. Anthers obtuse at the base. Style-branches flattened, their appendages lanceolate. Achenes oblong, 
somewhat compressed, I-2-ribbed on each side. Pappus of $\mathbf{I}$ or 2 series of numerous capillary unequal bristles. [Greek, cartilage-bearing.] One, or perhaps two species, of eastern N. Am.

I. Chondrophora nudàta (Michx.) Britton. Rayless Goldenrod. (I. F. f. 366r.) Glabrous, erect, simple, $3-7 \mathrm{dm}$. high. Lower and basal leaves spatulate, obtuse, or obtusish, 7-15 cm. long, 6-12 mm. wide, attenuate into a margined petiole; stem leaves distant, small, linear or subulate; heads numerous, $4-6 \mathrm{~mm}$. high, crowded in a compound terminal corymbose cyme; involucre narrowly campanulate, acute at the base, its bracts coriaceous, appressed, linear-oblong, imbricated in 3 or 4 series, the outer much smaller than the inner. In moist pine-barrens, N. J. to Fla. and Tex. Aug.-Oct. [Bigelovia nudata DC.]

Chondrophora nudata virgàta (Nutt.) Britton. Lower leaves linear, shorter, or the basal ones linear-spatulate. Perhaps specifically distinct. With the type, southward, not certainly known north of $\mathrm{N}$. Car.

\section{CHRYSOTHÁMNUS Nutt.}

Low shrubs, with equably leafy branches, hard wood, linear leaves, and discoid heads of yellow perfect flowers. Heads narrow, 5-7-flowered. Involucre oblong to narrowly campanulate, its bracts more or less keeled, thin, or papery, imbricated in several series, often so as to form 5 vertical rows. Corolla 5 -toothed. Anthers obtuse at the base. Style-branches exserted, their appendages subulate to filiform. Achenes narrow, mostly pubescent. Pappus of copious capillary roughened bristles. [Greek, golden-bush.] About 25 species, of western N. Am.

Heads about $12 \mathrm{~mm}$. high; involucral bracts obtuse or mucronulate. Heads 14-20 mm. high; involucral bracts subulate-tipped.

I. C. nauseosus. 2. C. Howardi.

I. Chrysothamnus nauseòsus (Pursh) Britton. Fetid Rayless GoldenRoD. (I. F. f. 3662.) Densely white-tomentose, at least when young, much branched, very leafy, 3-12 dm. high, odorous. Leaves linear, or slightly spatulate, 2-5 cm. long, 2-4 mm. wide; heads $10-15 \mathrm{~mm}$. high, very numerous and crowded in terminal compound corymbose cymes; rays none; involucre narrowly campanulate, acute at the base, its bracts oblong or linear-oblong, acutish, puberulent, imbricated in about 4 series; achenes linear; pappus-bristles soft, copious. In sterile soil, N. W. Terr. to Neb., N. Mex., Br. Col. and S. Cal. Aug.-Oct.

2. Chrysothamnus Hówardi (Parry) Greene. Howard's Rayless GoldenRoD. (I. F. f. 3663.) Densely white-tomentose when young, glabrous or nearly so when old, tufted, much branched, 1.5-2.5 dm. high. Leaves narrowly linear, entire, 2-5 cm. long, about $2 \mathrm{~mm}$. wide; heads narrow, 5-flowered, more or less glomerate, usually surpassed by the upper leaves; involucre slightly pubescent, or glabrous, its bracts lanceolate, thin, acuminate or subulate-tipped; achenes nearly linear, pubescent. In dry soil, western Neb., Colo. and Utah to N. Mex. July-Sept.

\section{OONÓPSIS Greene.}

Perennial herbs, the following species glabrous, mostly tufted, with woody roots, the stems leafy to the top. Leaves entire, linear to lanceolate. Heads cymose at the end of the stem or branches. Involucre campanulate to ovoid, its bracts flat, imbricated in several series, herbaceous, cuspidate, appressed and erect, or the outer spreading. Disk-flowers with a nearly cylindric 5-toothed corolla. Stamens and style included or scarcely exserted. Ray-flowers present or wanting, pistillate. Style-appendages ovate to subulate. Achenes glabrous, or somewhat pubescent. Pappus-bristles coarse, rigid. [Greek, resembling an egg, referring to the ovoid involucre.] Four known species, natives of central N. Am.

1. Oonopsis Engelmanni (A. Gray) Greene. Engemmann's Oonopsis. (I. F. f. 3664.) Perennial by a deep woody root, glabrous throughout; stems stiff, about $2 \mathrm{dm}$. high, lensely leafy. Leaves narrowly linear, sessile, $18-35 \mathrm{~mm}$. long, less than $2 \mathrm{~mm}$. wide, brittle when dry; heads clustered, or sometimes solitary at the ends of the branches, about I cm. wide, sessile anong the upper leaves; involucre oblong-campanulate, its bracts in about 4 series, oblong to spatulate, shortacu:ninte or mucronate, appressed; ray-flowers none; achenes linear-oblong, narrowed it the base, many-striate. Western Kans. and Neb. Sept.-Oct. 


\section{PRIONÓPSIS Nutt.}

A glabrous annual or biennial herb, leafy to the top, with sessile spinulose. dentate leaves, and large heads of yellow radiate and tubular flowers. Involucre broadly hemispheric, its bracts imbricated in several series, lanceolate, acuminate, the outer more or less spreading. Receptacle naked. Disk-flowers perfect, their corollas 5-toothed. Ray-flowers very numerous, pistillate. Achenes glabrous, those of the ray-flowers broader than those of the disk; pappus of a few deciduous rigid unequal bristles, the outer very short. [Greek, resembling a saw, referring to the leaf-margins.] A monotypic genus.

I. Prionopsis ciliata Nutt. Prionopsis. (I. F. f. 3665.) Stem erect, stout, branched, very leafy, $6-I_{5} \mathrm{dm}$. high. Leaves sessile, oval or the lower obovate, ohtuse, conspicuously veined, 2-7 cm. long, I-3 mm. wide, sharply serrate with bristle-pointed teeth; heads few, clustered, stalked or nearly sessile, 25-35 mm. broad; involucre depressed-hemispheric, its bracts glabrous; achenes of the rayflowers ellipsoid, those of the disk-flowers oblong, the central sterile; pappus-bristles rigid, the inner ones rough or ciliate. On hillsides and river-banks, Mo. and Kans. to Tex. Aug.-Sept. [Aplopappus ciliatus DC.]

\section{SIDERÁNTHUS Fraser.}

\section{[ERIOCARPUM Nutt.]}

Herbs or shrubs with alternate spinulose-dentate or lobed leaves and manyflowered heads of tubular or of both tubular and radiate yellow flowers (heads rarely without rays). Involucre hemispheric to campanulate, its bracts imbricated in several series, the outer ones gradually smaller. Receptacle flat or convex, generally foveolate, naked. Ray-flowers fertile. Disk-flowers usually perfect. Anthers obtuse and entire at the hase. Style-branches flattened, their appendages short, lanceolate. Achenes oblong or obovoid, obtuse, white-tomentose. or canescent, usually 8-ro-nerved, Pappus of I-3 series of numerous capillary persistent more or less unequal bristles. [Greek, iron-flower.] About 15 species, of America. Besides the following, about II others occur in the western U.S.

Rays none; leaves dentate.

Rays present.

Leaves dentate; annual.

Leaves pinnatifid; perennial.

Tomentose-canescent.

Glabrous or slightly puberulent.

1. S. grindelioides.

2. S. rubiginosus.

3. S. spinulosus.

4. S. glaberrimus.

I. Sideranthus grindelioides (Nutt.) Britton. Rayless Sideranthus. (I. F. f. 3666.$)$ Perennial by a deep woody root, finely pubescent; stems tufted, simple, erect, I-3 dm. high. Leaves oblong-lanceolate to spatulate, sessile, or the lower petioled, $1-2.5 \mathrm{~cm}$. long, firm, spinulose-dentate; heads terminating the stem or branches; involucre campanulate, its bracts linear, acute, puberulent, their tips somewhat spreading, the outer shorter than the inner; achenes densely silky tomentose. In dry soil. N. W. Terr. to S. Dak., Neb., Utah and Ariz. July-Aug. [Eriocarpum grindelioides Nutt.]

2. Sideranthus rubiginòsus (T. \& G.) Britton. Viscin Sideranthus. (I. F. f. 3667.) Viscid, glandular-pubescent, erect, annual, branched near the summit, 3-9 dm. high. Leaves sessile, or the lowest narrowed into short petioles, oblong, lanceolate, or oblanceolate, conspicuously dentate with distant awn-pointed teeth, 3-6 cm. long, 4-12 mm. wide; heads several, cymose paniculate, $16-30 \mathrm{~mm}$. broad; involucre hemispheric, its bracts linear-subulate with spreading tips; pappus-bristles rigid, very unequal; achenes villous-canescent, turbinate, not compressed. Neb. and Colo. to Tex. Autumn.

3. Sideranthus spinulòsus (Nutt.) Sweet. Cut-leaved Sineranthus. (I. F. f. 3668.) Canescent, much branched at the base, perennial from thick woody roots, I-4 dm. high. Leaves pinnatifid, sessile, linear to ovate in outline, $1-3.5 \mathrm{~cm}$. long, 2-5 $\mathrm{mm}$. wide, the lobes with bristle-pointed teeth; heads several or numerous (rarely solitary), 12-25 $\mathrm{mm}$. broad: involucre hemispheric, its bracts linear, acute, appressed; achenes pubescent, narrowed below; pappus soft and capillary. In dry soil, N. W. Terr. to Neb. and Tex., Mont., Ariz. and Mex. 
4. Sideranthus glabérrimus Rydb. Northern Sideranthus. Very similar to the preceding species, but wholly glabrous, or a little puberulent, wholly destitute of tomentum. S. Dak. to Wyo., Kans. and Oklahoma.

\section{STENÒTUS Nutt.}

Low undershrubs, with coriaceous narrow entire evergreen leaves, scapose or leafy stems, and rather large heads of both radiate and tubular yellow flowers. Involucre mostly hemispheric, its bracts imbricated in several series, appressed, ovate to lanceolate. Receptacle alveolate. Disk-flowers perfect, their corollas tubular, usually somewhat enlarged upward, deeply 5-toothed. Ray-flowers fertile. Anthers obtuse at the base. Appendages of the style-branches short, lanceolate. Achenes white-villous. Pappus of soft white capillary bristles. [Greek, narrow, referring to the leaves.] About 20 species, natives of western N. Am.

I. Stenotus armerioldes Nutt. NARRow-Leaved Stenotus. (I. F. f. 3669.) Perennial, tufted from a branched woody caudex, glabrous throughout; flowering stems slender, naked above, or quite leafless, I-2 dm. high. Basal leaves numerous, narrowly spatulate or linear, acute or acutish, firm, 2-7 cm. long, 2-4 $\mathrm{mm}$. wide, entire, narrowed below; stem leaves usually I-3, sessile, linear, sometimes none; head commonly solitary, about $2.5 \mathrm{~cm}$. broad; involucre campanulate, 8-12 $\mathrm{mm}$. high, its bracts broadly oval, green, appressed, obtuse or retuse, scarious-margined, rays 8-10. In dry, mostly rocky soil, western Neb. to Wyo., Utah and N. Mex. June-July. [Aplopappus armırioides A. Gray.]

\section{ISOPÁPPUS T. \& G.}

Rough-hairy annual or biennial herbs, loosely paniculately branched, with alternate linear to lanceolate $\mathbf{I}$-nerved entire or somewhat toothed leaves, and small slender peduncled heads of radiate and tubular yellow flowers. Involucre cam. panulate-cylindric, its appressed lanceolate or subulate bracts in 2 or 3 series. Receptacle alveolate. Ray-flowers 5-12, pistillate. Disk-flowers 10-20, perfect. Anthers not sagittate. Style-appendages narrow, hirsute. Achenes terete, narrowed below, silky-villous. Pappus a single series of rough capillary bristles, nearly equal in length. [Greek, equal pappus.] Two known species, of the southern U. S.

I. Isopappus divaricàtus (Nutt.) T. \& G. Isopappus. (I. F. f. 3670.) Annual or biennial, erect, paniculately much branched, slender, rough-pubescent or glandular, 3-9 dm. high. Lea ves linear, linear-lanceolate, or the lowest linearspatulate, acute or cuspidate, dentate with distant teeth, or sometimes entire, 2-7 $\mathrm{cm}$. long, 2-6 $\mathrm{mm}$. wide, the uppermost much smaller, subulate or bractlike; heads numerous, 6-10 $\mathrm{mm}$. broad: involucre campanulate, its bracts linearlanceolate, subulate-tipped, pubescent. In dry soil, Kan. to Tex. east to Ga. and Fla. Aug.-Oct.

\section{SOLIDÀGO L. (See Appendix.)}

Perennial erect herbs, sometimes woody at the base, simple, or little branched, with alternate simple, toothed or entire leaves, and small heads of both tubular and radiate yellow or rarely white flowers, in terminal or axillary panicles, thyrsi, or cymose-corymbose or capitate clusters. Involucre oblong or narrowly campanulate, its bracts imbricated in several series, the outer successively shorter. Receptacle small, flat, or somewhat convex, generally alveolate. Ray-flowers in one series, pistillate. Disk flowers mostly all perfect, their corollas tubular or narrowly campanulate, 5-cleft or 5-lobed. Anthers obtuse and entire at the base. Stylebranches flattened, their appendages lanceolate. Achenes terete or angled, usually ribbed. Pappus of numerous capillary rough neasly equal bristles in I or 2 series. [Greek, to make whole.] About 100 species, mostly of N. Am., several in Europe, a few in Mex. and S. Am.

\section{A. Tips of the involucral bracts, or some of them spreading or recurved.}


B. Tips of the involucral bracts all erect and appressed.

* Heads in axillary clusters, or also in a terminal spike-like, sometimes branched thyrsus.

1. Heads 4-6 mm. high, chiefly in axillary clusters; achenes pubescent. Stem and branches terete; leaves lanceolate to oblong. Stem and branches grooved or angled.

Leaves broadly oval, contracted into margined petioles.

Leaves lanceolate, sessile.

4. S. caesia.

2. Heads $4-6 \mathrm{~mm}$. high, chiefly in a terminal spike-like thyrsus; achenes glabrous, or

Rays white; stem pubescent. nearly so.

Rays yellow; stem densely pubescent.

iays yellow; stem glabrous, or sparingly pubescent.

i.eaves thick, not acuminate, dentate, or the upper entire.

Leaves thin, acuminate, sharply serrate.

7. S. bicolor.

8. S. hispida.

9. S. erecta.

10. S. monticola.

ir. S. macrophylla.

* * Heads in a terminal simple or branched thyrsus, not at all secund on its branches, or scarcely so.

Plants not glutinous.

I. Bracts of the involucre acute or acutish.

High northern; leaves spatulate, glabrous. $\quad 44$. S. multiradiata.

Eastern; stem minutely puberulent or glabrous; heads $5-6 \mathrm{~mm}$. high.

12. $S$. puberula.

Involucre and upper leaves glutinous.

13. S. Lindheimeriana.

14. S. Randii.

2. Bracts of the involucre obtuse (or the inner acutish in No. 15.)

a. Upper leaves abruptly smaller than the lower, appressed. 15. S. stricta.

b. Leaves gradually smaller upward, spreading or ascending.

+ Lower leaves large, oblong, or oval, acute or obtusish.

¥ At least the lowest leaves dentate; plants 6-r8 dm. high.

Lower leaves oblong-lanceolate; branches of the thyrsus appressed.

I6. S. uliginosa.

Lower leaves ovate or broadly oval; branches of the thyrsus ascending.

17. S. speciosa.

$\ddagger \ddagger$ Leaves lanceolate or oblong-lanceolate, entire, 2-12 cm. long. 18. S. rigidiuscula.

$\dagger+$ Basal leaves narrowly spatulate. rg. S. Purshii.

+++ Basal leaves obovate, oblanceolate, or broadly spatulate.

Plant 7-30 cm. high, on alpine summits: stem angular.

Plant 3-9 dm. high, not alpine; heads $6-8 \mathrm{~mm}$. high.

20. S. alpestris.

21. S. Virgaurea.

* * * Heads in a terminal, usually large panicle, secund on its spreading or recurved branches.

$\ddagger$ Plant maritime; leaves thick, fleshy, entire. 22. S. sempervirens.

$\ddagger \ddagger$ Plants not maritime; leaves not fleshy.

I. Leaves pinnately veined, not triple-nerved.

a. Leaves all entire, thin and glabrous. 23. S. odora.

(b) Leaves, at least the lower, more or less dentate or serrate.

+ Leaves linear or linear-cblong, 2.5-5 cm. long, scabrous. 24. S. tortifolia.

++ Leaves broader, lanceolate, oblong, or ovate, $5^{-25} \mathrm{~cm}$. long.

$\ddagger$ Stem densely pubescent; leaves more or less so.

Leaves rugose-veiny beneath, sharply serrate.

Leaves not rugose, sparingly dentate or entire.

25. S. rugosa.

$\ddagger \ddagger$ Stem glabrous, or puberulent, or pubescent only above.

Leaves very scabrous on the upper surface, serrulate.

27. S. patula.

Leaves smooth, or minutely roughened on the upper surface (pubescent in forms of No. 32.).

Racemes few, widely divergent, very slender.

Lower leaves oblong, coarsely serrate.

Lower leaves ovate or lanceolate, rather fincly serrate.

Racemes numerous, spreading, recurved or ascending.

Leaves all oblong or oblong-lanceolate, sessile.

At least the lower leaves petioled, lanceolate or ovate-lanceolate.

Leaves firm, ovate-lanceolate or oblong-lanceolate; heads about $4 \mathrm{~mm}$. high; racemes short; rays several.

28. S. ulmifolia.

29. S. Boottii.

3i. S. neglecta.

Leaves firm, narrowly lanceolate; heads about $4 \mathrm{~mm}$. high: racemes few, short; rays $\mathbf{I}-3$.

32. S. uniligulata.

Leaves firm, lanceolate or oval-lanceolate; heads $3-4 \mathrm{~mm}$. high; racemes numerous, slender.

33. S. juncex.

Leaves thin, the lower broadly ovate, short-acuminate; heads $5-7 \mathrm{~mm}$. high; racemes numerous.

34. S. arguta. 
2. Leaves triple-nerved, i.e., with a pair of lateral veins stronger than the others, these often obscure in No. 4I.

Stem glabrous: bracts of the involucre obtuse.

Leaves and bracts of the involucre thin.

Leaves linear-lanceolate, entire or sparingly serrate.

Leaves lanceolate, sharply serrate.

35. S. rupestris.

36. S. serotina.

Leaves and bracts of the involucre thick, somewhat rigid.

Leaves linear-lanceolate or lanceolate; achenes glabrous.

Leaves oblong-lanceolate; achenes silky-pubescent.

37. S. Missouriensis.

Basal leaves oblanceolate; upper bract-like.

38. S. Shortii.

39. S. Gattingeri.

Stem pubescent or scabrous.

Leaves lanceolate, sharply serrate or entire, rough above.

40. S. Canadensis.

Leaves oblanceolate, spatulate, oblong or ovate; the lower crenate.

Minutely rough-pubescent, grayish; lower leaves oblanceolate; heads $4 \mathbf{m m}_{\text {。 }}$ high.

41. S. nemoralis.

Canescent and pale; leaves oblong, or ovate; heads $6 \mathrm{~mm}$. high.

42. S. mollis.

Very scabrous, green, not grayish, nor canescent. 43. S. radula.

Leaves broadly ovate-oval, sharply serrate, finely pubescent.

44. S. Drummondii.

**** Heads in a terminal, corymbiform, sometimes thyrsoid cyme, forming a flate topped inflorescence.

Leaves ovate, oblong or oval, very rough on both sides. 45. S. rigida.

Leaves lanceolate, linear, oblong, or oblanceolate, glabrous or nearly so.

Leaves, at least the lower, oblauceolate; high northern.

Leaves not oblanceolate nor spatulate.

Lower leaves oblong-lanceolate, serrulate.

Leaves all lanceolate or linear, entire.

Stout; leaves lanceolate, the basal 2-3 dm. long.

Slender; leaves linear, the basal 10-12 cm. long.

46. S. multiradiata.

47. S. Ohioensis.

48. S. Riddellii.

49. S. Houghtoni.

I. Solidago squarròsa Muhl. Stout RagGed Goldenrod. (I. F. f. 367r.) Stem stout, simple, or rarely branched above, glabrous or puberulent, 6-15 dm. high. Upper leaves oblong, acute, entire or nearly so, sessile; lower and basal leaves obovate, oval, or broadly spatulate, acute or obtuse, sharply dentate, often narrowed into a margined petiole; heads 15-25-flowered, 8-10 $\mathrm{mm}$. high, numerous in a terminal narrow often leafy thyrsus sometimes $3 \mathrm{dm}$. in length; rays $10-15$, showy, 4-6 mm. long; tips of the involucral bracts green, acute or obtuse, all usually strongly recurved; achenes glabrous. In rocky soil, N. B. and Ont. south to Va. and Ohio. Aug.-Oct.

2. Solidago petiolàris Ait. Downy RagGed Goldenron. (I. F. f. 3672.) Stem rather slender, pubescent or puberulent, 3-9 dm. high, simple or branched above. Leaves sessile, or very short-petioled, oblong to oval, acute, obtuse or mucronate, entire or dentate, $\mathrm{I}-7 \mathrm{~cm}$. long, rough or ciliate on the margins; heads 6-8 $\mathrm{mm}$. high, in a terminal narrow more or less compound thyrsus; involucral bracts with green acute to acuminate tips, the outer spreading, the inner appressed; achenes glabrous or nearly so. In dry soil, Ill. to Kans. and Tex., east to N. Car. and Fla. Sept.-Oct.

3. Solidago Wàrdii Britton, n. sp. WARD's Goldenrod. Stem puberulent, 4-9 dm. high. Leaves lanceolate to ovate lanceolate, entire or with a few teeth, rather firm, 5-9 cm. long, pale and silvery shining on both sides, or only above, the margins ciliate; thyrsus I-2 dm. long, sometimes quite leafy; heads short-peduncled, about $8 \mathrm{~mm}$. high, the bracts linear-lanceolate to linear-oblong, acute, distinctly squarrose, canescent; rays large, bright yellow. Mo. and Kans. to Ark. and Ind. Terr. Sept.Oct. Type collected by L. F. Ward, in Clark Co., Kans., Oct. 2, I897.

4. Solidago caèsia L. Blue-stemmed or Wreath Goldenrod. WoodLAND GOLDENROD. (I. F. f. 3673.) Stem glabrous, slender, often glaucous, usually bluish or purple, branchè or simple, 3-9 dm. high. Leaves sessile, acuminate at the apex, narrowed at the base, glabrous, sharply serrate; 5-12 cm. long, 6-30 $\mathrm{mm}$. wide; heads 4-6 mm. high, in axillary clusters or racemes, or occasionally with some in a short terminal thyrsus; bracts of the involucre obtuse; achenes 
pubescent. In woods and thickets, Me. and Ont. to Minn., Fla., Ark. ałd Tex, Aug.-Oct.

Solidago caèsia axillàris (Pursh) A. Gray. Heads few, in deuse short axillary clusters, much exceeded by the long thin leaves; upper leaves of ten entire. N. S. to Ont. and N. J.

5. Solidago flexicàulis L. ZIG-ZAG or BROAD-LEAved GOLdenrod. (I. F. f. 3674.) Stem glabrous, angled, usually simple, zig-zag, 3-9 dm. high. Leaves thin, ovate, acuminate at the apex, somewhat pubescent, or glabrous beneath, sharply serrate, 5-17 cm. long, 2-10 $\mathrm{cm}$. wide, the uppermost sometimes lanceolate and entire or nearly so; heads about $6 \mathrm{~mm}$. high; bracts of the involucre obtuse to acutish; achenes hirsute-pubescent. In rich woods, N. B. to Ga., west to S. Dak. and Kans. July-Sept.

6. Solidago Curtísii T. \& G. Curtis' Goldenrod. (I. F. f. 3675.) Stem glabrous or sparingly pubescent, simple or branched, slender, 4-9 dm. high, angled and grooved. Leaves thir, sometimes broader above the middle, longacuminate, narrowed below into an entire base, sharply serrate, $7-15 \mathrm{~cm}$. long, $8-25 \mathrm{~mm}$. wide, glabrous or nearly so; heads $4-6 \mathrm{~mm}$. high; bracts of the invo. lucre few, obtuse. In mountain woods, Va. and W. Va. to Ga. Aug.-Sept.

7. Solidago bícolor L. White Goldenrod. Silver-Rod. (I. F. f. 3676.) Stem rather stout, hirsute-pubescent, or nearly glabrous, I.5-I2 dm. high, simple or branched. Basal and lower leaves obovate or broadly ablong, mostly obtuse, 5-10 $\mathrm{cm}$. long, 2-5 cm. wide, narrowed into long margined petioles, dentate or crenate-dentate, more or less pubescent; upper leaves smaller and narrower, oblong or sometimes lanceolate, subsessile, often entire; heads 4-6 mm. high; bracts of the involucre obtuse; rays white. In dry soil, N. B. to Ga., west to Ont., Minn. and Mo. July-Sept.

8. Solidago hispida Muhl. Hairy Goldenrod. (I. F. f. 3677.) Stout, stem densely pubescent or hirsute, simple, or sometimes branched, 4-9 dm. high. Lower leaves oval, acute, or obtuse, petioled, pubescent on both sides, usually dentate, 5-12 dm. long, 2-5 cm. wide; upper leaves oblong, sessile, acute, dentate or entire, smaller, sessile; heads about $6 \mathrm{~mm}$. high, crowded; involucral bracts obtuse; achenes with a few appressed hairs, or glabrous. In dry soil, N. S. to W. Ont. and Minn., south to Penn. and Wis. Aug.-Oct.

9. Solidago erécta Pursh. Slender Goldenrod. (I. F. f. 3678.) Stem slender, 6-9 dm. high, simple or rarely branched. Leaves firm, nearly glabrous on both sides, ciliolate on the margins, the lower and basal ones broadly oblong or oval, obtuse or obtusish, crenate-dentate, the upper lanceolate or oblong-lanceolate, acute, usually quite entire; heads $4-6 \mathrm{~mm}$. high; bracts of the involucre obtuse. In dry soil, N. J. and Penn. to Ga. and N. Car. Reported from Minn. and S. Dak. Aug.-Sept.

Io. Solidago montícola T. \& G. Mountain Goldenrod. (I. F. f. 3679.) Slender, glabrous or nearly so, 3-9 dm. high. Stem-leaves ovate-oblong, or oblonglanceolate, narrowed at the base, sharply and sparingly serrate, or the upper entire, 2-15 cm. long. 8-35 mm. wide, the upper sessile, the lower petioled; basal leaves broadly oblong, obtuse, with slender petioles; heads about $4 \mathrm{~mm}$. high: bracts of the involucre acutish or obtuse. In mountain woods, Penn. and Md. to Ga. and Ala. July-Sept.

Ir. Solidago macrophýlla Pursh. Large-leaved Goldenrod. (I. F. f. 3680.) Stem glabrous or sparingly pubescent, stout, 1.5-12 dm. high. Leaves thin, ovate, acuminate, or the basal ones obtuse, sharply serrate, glabrous, or sparingly pubescent beneath, 7-12 cm. long, 2-6 cm. wide, abruptly contracted into margined petioles, or the uppermost lanceolate, entire, sessile; heads in a terminal compact or loose thyrsus and usually also in axillary clusters; bracts of the involucre linear, acute; rays 8-ro, linear-oblong. conspicuous; achenes glabrous or nearly so. In rocky woods, Catskill Mts., N. Y. to Lab. and Hudson Bay, west to Lake Superior. July-Sept.

12. Solidago pubérula Nutt. Downy Goldenrod. (I. F. f. 368r.) Minutely puberulent, or glabrous, usually simple, rather slender, 4-9 dm. high, leafy. Stem-leaves oblong-lanceolate, acute, sparingly serrate or entire, 3-5 cm. long, sessile, or the lower petioled: basal leaves and sometimes the lowest ones of the stem spatulate, obtuse, sharply serrate, $5^{-10} \mathrm{~cm}$. long, narrowed into margined petioles; 
bracts of the involucre subulate; achenes glabrous; heads rarely a little secund. In sandy soil, N. B. to northern N. Y., Fla. and Miss. Aug.-Sept.

13. Solidago Lindheimeriàna Scheele. LindHeimen's Goldenrod. (I. F. f. 3682.) Scabrous, simple, 4-9 dm. high, leafy, rather stout and rigid. Leaves oblong, oblong-lanceolate or oval, acute or acutish at the apex, narrowed or rounded at the base, all entire, thickish, rough on both surfaces, sessile or the low. est petioled; heads about $6 \mathrm{~mm}$. high in a terminal, often short thyrsus; bracts of the involucre acute or the outer obtuse, puberulent; achenes nearly glabrous. Southern Kans. to Tex., Ariz. and northern Mex. Aug.-Nov.

Solidago Bigelòvii A. Gray, another southwestern species, which is rougher than this one, and with oval or oblong leaves obtuse or obtusish at both ends, is reported from Kans.

14. Solidago Ràndii (Porter) Britton. Rand's Goldenrod. Stem stout, often purple, glabrous, 3-7 dm. tall. Dasal leaves spatulate, mostly obtuse, dentate or crenate-dentate, narrowed into margined petioles; stem-leaves spatulate to lanceolate, the upper sessile, acute, entire; inflorescence and upper leaves distinctly glutinous, adhering to paper when drying; heads about $8 \mathrm{~mm}$. high; bracts of the involucre acute, or the outer obtuse. Me. to northern N. Y. [S. Virgaurea Kandii Porter; S. Virgaurea Redfieldii Porter.]

15. Solidago strícta Ait. WAND-LiKe or Willow-Leaf Goldenrod. (I. F. f. 3683.) Glabrous throughout, slender, erect, simple, 6-25 dm. high. Basal and lowest stem-leaves oblong, or somewhat spatulate, with few lateral veins, obtuse, entire, or very sparingly dentate, $4-20 \mathrm{~cm}$. long, $\mathbf{I}-2.5 \mathrm{~cm}$. wide, narrowed into long petioles; upper stem-leaves narrowly oblong, spatulate or linear, the uppermost very small and bract-like; heads about $6 \mathrm{~mm}$. high in a dense simple, or sometimes branched, naked thyrsus; bracts of the involucre oblong; achenes glabrous, or sparingly pubescent. In wet sandy pine-barrens, N. J. to Fla. and La. Also in Cuba. Aug.-Oct.

I6. Solidago uliginòsa Nutt. BoG Goldenrod. (I. F. f. 3684.) Stem glabrous, rather stout, simple, 6-12 dm. high. Leaves glabrous, firm, more or less ciliolate or scabrous on the margins, few-veined, acute or acuminate, the lower and basal ones IO- $22 \mathrm{~cm}$. long, I-2.5 cm. wide, more or less serrate and narrowed into petioles, the upper smaller, mostly sessile and entire; heads 4-6 mm. high; bracts of the involucre linear-oblong, oltuse; achenes glabrous. In swamps and bogs, Newf. to northern N. J. and Penn. west to W. Ont., Minn. and Wis. Aug.-Sept.

I7. Solidago speciòsa Nutt. Showy or Noble Goldenrod. (I. F.f. 3685.) Stem stout, glabrous below, often rough above, usually simple, I-2 m. high. Leaves glabrous, firm, the basal I-2.5 dm. long, 2-10 $\mathrm{cm}$. wide, dentate or crenate, pinnately veined, acute or obtuse at the apex, long-petioled; upper leaves smaller, oblong or oval, acute at each end, crenate dentate, or entire, sessile or short-petioled, rough-margined; heads $6-8 \mathrm{~mm}$. high, in a large terminal thyrsus, the branches of which are ascending and often leafy; bracts of the involucre oblong, very obtuse; achenes glabrous or nearly so. In rich soil, N. S. to N. Car. west to Minn., Ky., Kars. and Ark. Aug.-Oct.

Solidago speciòsa pállida Porter. Leaves ovate or oblong, coriaceous, prominently veined, pale green : stems stout, tufted, $3^{-6} \mathrm{dm}$. high, densely pubescent above. On the rocky summit of Mt. Mackay, W. Ont.

r8. Solidago rigidiúscula (T. \& G.) Porter. Slender Showy Goldenrod. (I. F. f. 3686.) Stem rather slender, usually glabrous below, rough-pubescent above, sirnple, 6-12 dm. high. Basal leaves sometimes crenate, strongly ciliolate on the margins, $2-7 \mathrm{~cm}$. long, 6-25 $\mathrm{mm}$. wide, the upper sessile, the lower sometimes narrowed into petioles; heads similar to those of the preceding species; thyrsus generally narrow, dense, simple or rarely branched. In dry soil, mostly on prairies, Ohio to Ala., S. Dak., Neb., Kans. and Tex. Aug.-Oct.

I9. Solidago Púrshii Porter. River-bank Goldenrod. (I. F. f. 3687.) Glabrous or nearly so; stems simple, usually somewhat glutinous, 1.5-4.5 dm. high. Lower and basal leaves oblanceolate, obtuse or acutish, dentate, or crenate, 5-15 $\mathrm{cm}$. long, $\mathbf{I}-2.5 \mathrm{~cm}$. wide, narrowed into slightly margined petioles; stem-leaves sessile, lanceolate, oblong or linear, numerous, crenate or entire, mostly acute, smaller; heads 6-8 mm. high, in a terminal simple or branched thyrsus; bracts of 
the involucre linear-oblong, obtuse, or the inner acutish; achenes striate, pubescent. On rocky river-banks, Newf. to northern N. Y., Vt. and Va. July-Sept.

20. Solidago alféstris Wald. \& Kit. Alpine Goldenrod. (I. F. f. 3688 .) Glabrous, or somewhat pubescent; stems simple, often tufted, 7-30 cm. high, ascending, or erect, angular. Basal leaves serrate, at least above the middle, obtuse, or acute, 5-10 cm. long, narrowed into petioles; stem-leaves oblanceolate, spatulate, or oblong, sessile, or the lower petioled, mostly distant; inflorescence a short raceme or thyrsus, with clusters of heads in the axils of the leaves; heads 6-8 $\mathrm{mm}$. high; bracts of the involucre obtuse or acute; achenes pubescent. Alpine summits of the mountains of Me., N. H. and northern N. Y., mostly above timber line. Also in Europe. Aug.-Sept.

3I. Solidago Virgàrea L. European Goldenrod. (I. F. f. 3689.; Somewhat pubescent, at least above; stem usually simple, rather stout, 3-6 din. high. Basal leaves 7-12 cm. long, $2.5 \mathrm{~cm}$. wide, or less, obtuse or acuta, mostly dentate, narrowed into margined petioles; stem-leaves sessile, or the lower petioled, oblong-lanceolate to spatulate, acute; heads $6-8 \mathrm{~mm}$. high, in a narrow, dense or interrupted, rarely branched thyrsus which is often $2 \mathrm{dm}$. long; bracts of the involucre obtuse or acute; achenes more or less pubescent. Me., N. H., Vt. and northern N. Y., mostly at middle altitudes. Also in Europe. Aug.-Sept.

Solidago Virgdurea Dèanei Porter. Stem only 0.7-3 dm. high, often slender; thyrsus short, 5-IO cm. long; heads 3-6 mm. high. Mountains, Me., Vt. and N. H.

Solidago Virgàrea Gillmani (A. Gray) Porter. Stout, 4-9 dm. high ; thyrsus paniculately branched; basal leaves very large, sometimes $25 \mathrm{~cm}$. long, sharply serrate. Sand hills, southern shore of Lake Superior. Perhaps not referable to this species.

22. Solidago sempérvirens L. SEa-side Goldenrod. Salt-marsh GoldENROD. (I. F. f. 369o.) Stem stout, leafy, usually simple, 6-25 dm. high, glabrous, or slightly puberulent above. Leaves with 2-5 pairs of lateral veins, the lower and basal ones oblong, spatulate or lanceolate, mostly obtuse, sometimes 3 $\mathrm{dm}$. long, narrowed into long petioles; upper leaves sessile, lanceolate to oblonglanceolate, acute; heads, 6-10 $\mathrm{mm}$. high; rays 8-10, showy; bracts of the involucre lanceolate, acute. On salt marshes, sea beaches, along tidal rivers and in sandy soil near the sea, N. B. to Fla. and Mex. Also in Bermuda. Aug.-Dec.

23. Solidago odòra Ait. Sweet or Anise-scented Goldenrod. Blue Mountain TEA. (I. F. f. 369r.) Slender; stem simple, glabrous, or minutely pubescent above, 6-12 dm. high. Leaves punctate, anise-scented when bruised, lanceolate, quite entire, acute or acuminate, 5-10 $\mathrm{cm}$. long, 6-16 mm. wide, sessile, or the lower ones petioled; heads 4-5 $\mathrm{mm}$. high, rays 3 or $4,4-6 \mathrm{~mm}$. long: bracts of the involucre oblong-lanceolate, acute. In dry soil, N. S. (?), Mass. to Fla., west to N. Y., Ky. and Tex. July-Sept.

Solidago odòra inodora A. Gray. Leaves not punctate, scentless when bruised. Probably a mere form.

24. Solidago tortifòlia Ell. Twisted-leaf Goldenrod. (I. F. f. 3692.) Stem slender, rough-pubescent or puberulent, 6-9 dm. high, simple. Leaves often twisted, scabrous, sessile, acute, 2.5-5 cm. long, 3-6 mm. wide, obscurely veined but with a distinct midrib, the lower serrate, the upper entire; heads about $4 \mathrm{~mm}$. high; rays 3-5, short; bracts of the involucre linear, obtuse or obtusish. In dry sandy soil, Va. to Fla. and Tex., mostly near the coast. Autumn.

25. Solidago rugòsa Mill. Wrinkle-leaved, or Tall Hairy Guldenrod. Bitter-Weed. (I. F. f. 3693.) Stem hirsute, usually stout, 3-22 dm. high, simple, or branched at the summit. Leaves rather thin, oval or oblong-lanceolate, acute or acuminate (rarely obtusish) at the apex, narrowed at the base, sharply serrate, 2-10 $\mathrm{cm}$. long, 8-35 mm. wide, sessile, or the lowest sometimes tapering into petioles; heads 3-4 mm. high; panicle usually large and compound; bracts of the involucre linear, obtuse or obtusish. Usually in dry soil, in field's and along roadsides, Newf. to IV. Ont., south to Fla. and Tex. July-Nov.

26. Solidago fistulòsa Mill. Pine-barren Goldenron.

(I. F. f. 3694.) Stem rather stout, simple, or branched above, I-2 m. high, hirsute. Leaves numerous, sessile, ovate-oblong, oblong-lanceolate, or sometimes lanceolate, thick. rough or hirsute on the margins and midrib beneath, the upper small, obtuse or obtusish, entire, the lower sparingly serrate, obtuse or acute, 3-10 cm. long, with a 
broad base; heads about $4 \mathrm{~mm}$. high; rays 7-10, small; bracts of the involucre, at least the outer, acute. In moist pine-barrens, N. J. to Fla. and La. Aug.-Oct.

27. Solidago pátula Muhl. Kough-leaved or Spreading Goldenrod. (I. F. f. 3695.) Stem stout, rather rigid, usually simple, 6-20 dm. high, strongly angled, at least below. Leaves thick, glabrous beneath, rough above, the lower and basal ones very large, 7-40 $\mathrm{cm}$. long, 4-12 cm. wide, oval or elliptic, narrowed into maryined petioles, the upper smaller, oval or oblong, sessile. acute, finely serrate, or the uppermost entire; heads $6-8 \mathrm{~mm}$. high; rays small; bracts of the involucre linear-oblong, obtuse. In swamps, Me. and Ont. to Minn., south to Ga., Mo. and Tex. Aug.-Oct.

28. Solidago ulmifòlia Muhl. Elm-leaved Goldenrod. (I. F. f. 3696.) Stem slender, 6-12 dm. high, simple, or branched above, the arched branches puberulent or pubescent. Leaves thin, oblong, acute, or acuminate at the apex and base, pinnately veined, glabrous or sparingly pubescent, the lower and basal ones 7-12 cm. long, 2-4 cm. wide, narrowed into margined petioles, the upper smaller, sessile; heads 4-6 $\mathrm{mm}$. high; rays small, deep yellow; bracts of the involucre oblong-lanceolate, obtusish. In woods and copses, Me. to Ga., west to Minn., Kans. and Tex. July-Sept.

29 Solidago Boòttii Hook. Bootr's Goldenrod. (I. F. f. 3697.) Stem slender, usually branched near the summit, 6-15 dm. high. Leaves firm, pinnately and finely reticulate-veined, the lower and basal ones ovate or oblong-lanceolate, narrowed into margined, sometimes ciliate petioles, acuminate at the apex, 7-15 cm. long, the upper smaller, entire, or finely serrate, sessile; heads 4-6 mm. high; rays few, small; bracts of the involucre linear-oblong, obtuse; acheres pubescent. In dry woods, Va. to Fla. and Tex. July-Sept.

30. Solidago Ellióttii T. \& G. Elliot'r's Goldenrod. (I. F. f. 3698.) Stem stout, 9-18 dm. high, simple, or branched at the inflorescence. Leaves firm, acute or acuminate, sessile by a broad base, or sometimes narrowed below, finely serrate, crenate-serrate. or the upper entire, rough on the margins, glabrous on both sides, or puberulent on the veius beneath, 3-12 cm. long, 8-25 mm. wide; heads about $6 \mathrm{~mm}$. high; bracts of the involucre linear-oblong, obtuse; rays 6-I2, short; achenes pubescent. In swamps, N. H. and Mass. to N. Car. and Ga., mainly near the coast. Sept.-Oct.

3I. Solidago neglécta T. \& G. Swamp Goldenrod. (I. F. f. 3699.) Stem simple, rather stout, 6-8 dm. high. Leaves firm, the basal and lower ones large, sometimes $3 \mathrm{dm}$. long, acute or obtusish, serrate or serrulate, tapering into margined petioles, rough on the margins; upper leaves smaller, lanceolate, acute, sessile, serrate or nearly entire; heads 5-6 mm. high; rays 3-8, small; bracts of the involucre linear-oblong, obtuse; achenes glabrous, or nearly so. In swamps, N. B. to Wis., Md. and Ill. Aug.-Sept.

32. Solidago uniligulàta (DC.) Porter. Few-RAyed Goldenrod. (I. F. f. 3700.) Stem simple, slender, 4-7 dm. high. Leaves firm, lanceolate or oblonglanceolate, finely and sharply serrate, acute or acuminate, the lower long-petioled, IO-22 $\mathrm{cm}$. long, 8-I $8 \mathrm{~mm}$. wide, the upper sessile, the uppermost very small and erect; rays I-4; bracts of the involucre linear-oblong, obtuse; achenes glabrous. In swamps, Me. to N. Y. and N. J. Aug.-Sept.

33. Solidago júncea Ait. EArly or Sharp-toothed Goldenrod. Yellow. TOP. Plume GoldenRod. (I. F. f. 370r.) Stem rigid, rather stout, simple, or branched at the inflorescence, 4-12 dm. high. Leaves firm, glabrous, acute or acuminate, serrate, serrulate, or nearly entire, the lower large, sometimes $3 \mathrm{dm}$. long and $5 \mathrm{~cm}$. wide, long-petioled; the upper smaller, sessile; rays 7-12, small; bracts of the involucre oblong or ovate-oblong. obtuse or acute; achenes glabrous or sparingly pubescent. In dry or rocky soil, N. B. to Hudson Bay and Manitoba, N. Car. and Mo. June-Nov.

Solidago júncea scabrélla (T. \& G.) A. Gray. Leaves rigid, scabrous, ciliate, pubescent on the upper surface or also beneath. Ind. to Wis., $\mathrm{Ky}$. and Mo.

Solidago júncea ramòsa Porter and Britton. Much branched at the summit, the branches slender, erect, slightly curved, the heads in short small racemes. Me. to western N. J., IV. Va. and Ohio.

34. Solidago argùta Ait. Cut-leaved Goldenrod. (I. F. f. 3702.) Stem simple, rather'stout, 6-12 dm. high. Leaves thin, the lower and basal ones broadly 
svate or oval, short-acuminate, $7-40 \mathrm{~cm}$. long, 2-12 cm. wide, narrowed into margined petioles, sharply and coarsely serrate; upper leaves sessile, ovate to oblong, acute or acuminate, more or less serrate, smaller; rays 5-7, large; bracts of the involucre oblong, obtuse; achenes glabrous or nearly so. In rich woods, Me. and Ont. to Ohio, south to Va. July-Uct.

35. Solidago rupéstris Raf. Rock Goldenrod. (I. F. f. 3703.) Stem slender, 6-9 dm. high. Leaves thin, 5-12 cm. long. 6-ro mm. wide, acuminate at the apex, narrowed at the base, sessile, or the lowest petioled, glabrous; heads small, $3 \mathrm{~mm}$. high, secund on the short spreading branches of the small panicle; rays $4-6$, short; bracts of the involucre thin, linear; achenes small, 1:early glabrous. Rocky banks of streams, Penn. to D. C., IV. Va., Tenn. and Ind. Aug.-Sept.

36. Solidago serótina Ait. I.ATE Goldenrod. (I. F. f. 3704.) Stem stout, 9-25 dm. high, glabrous, sometimes glaucous. Leaves thin, sessile, or the lowest petioled, glabrous on both sides but more or less rough-margined, $7-15 \mathrm{~cm}$. long, 4-25 mm. wide, acuminate at the apex, narrowed at the base; heads $5-7 \mathrm{~mm}$. high; bracts of the involucre oblong, thin, obtuse; rays 7-I5, rather large; achenes finely pubescent. In moist soil, Newf. to Br. Col., south to Ga., Tex., Nev. and Ore. Aug.-Oct.

Solidago serótina gigantèa (Ait.) A. Gray. Leaves hispid or pubescent on the lower surface, at least on its prominent veins. With the type, at least in the East.

37. Solidago Missouriénsis Nutt. Missouri Goldenron. (I F. f. 3705.) Stem rather slender, 9-15 dm. high. Leaves firm or thick, those of the stem ses. sile, acuminate at the apex, narrowed at the base, 5-10 $\mathrm{cm}$. long, very roughmargined, entire, or sparingly serrate with low sharp teeth, the basal and lowest ones larger, spatulate, petioled; heads 5-6 $\mathrm{mm}$. high; bracts of the involucre oblong, greenish-tipped, obtuse, or the inner acute, trick; rays 6-13, short. On dry prairies, Manitoba and Minn. to Tenn., Wash., Neb. and Tex. Autumn.

38. Solidago Shórtii T. \& G. Short's Goldenrod. (I. F. f. 3706.) Stem slender, 6-I2 dm. high. Leaves sessile (the lowest petioled ?), acute or acuminate at the apex, glabrous on both sides, the larger 5-10 $\mathrm{cm}$. long, ro- $12 \mathrm{~mm}$. wide, sharply serrate with rather small and distant teeth, the upper gradually smaller, sparingly serrate, or entire; heads about $6 \mathrm{~mm}$. high; involucre narrowly campanulate, its bracts linear-oblong, obtuse; rays 5-7, rather small. On rocks at the Falls of the Ohio River and in northwestern Ark. July-Aug.

39. Solidago Gattıngeri Chapm. Gatringer's Goldenrod. (I. F. f. 3707.) Stem slender, 6-9 dm. high, branched at the inflorescence. Leaves firm, glabrous beneath, rough above, ciliolate, the lower and basal ones acutish, $7-15 \mathrm{~cm}$. long, $12-20 \mathrm{~mm}$. wide, serrate with low distant teeth, narrowed into margined petioles, entire, sessile; heads 4-5 $\mathrm{mm}$. high; bracts of the involucre oblong, very obtuse; rays 6-Io; achenes puberulent, or glabrous below. In dry soil, Tenn. and Mo. July-Aug.

40. Solidago Canadénsis L. Canada Goldenrod. (I. F. f. 3708.) Stem stout, puberulent-pubescent, or hirsute, $625 \mathrm{dm}$. high. Leaves acute at each end, the lower ones sharply serrate and petioled, 7-15 cm. long, 8-25 mm. wide, the upper smaller, entire, sessile; heads $3-4 \mathrm{~mm}$. high, very numerous; bracts of the involucre linear, obtuse or acutish; rays 9-I5; achenes glabrous or somewhat pubescent. Usually in dry soil, N. B. to the N. W. Terr. and Br. Col., south to Fla. and Ariz. Aưg.-Nov.

Solidago Canadénsis prócera (Ait.) T. \& G. Leaves less serrate, sometimes all entire, cinereous-pubescent with short appressed hairs. With the type.

Solidago Canadénsis glabràta Porter. Stems 6-12 dm. high, glabrous or nearly so below, puberulent above; leaves narrowly lanceolate, smooth above, pubescent on the veins beneath; panicles and heads smaller than in the type. Me. to northern N. Y. and Penn.

Solidago Canadénsis scabriúscula Porter. Leaves shorter, sparingly serrate or entire, rough above, rugose beneath; heads mostly larger than in the type. N. Y. and Penn. to Fla. and Tex.

Solidago iCanadénsis gilvocanéscens Rydberg. A foot high, or less, leafy, canescent, yellowish: leaves remotely serrate above the middle, or entire; inflorescence dense; heads smaller than in the type. Minn. to Mont. and Kans.

4r. Solidago nemoràlis Ait. Gray or Field Goldenrod. Dyer's WEED. (I. F. f. 3709.) Slender, I-6 dm. high, finely and densely pubescent. 
Leaves thick, roughish; basal and the lower stem-leaves petioled, obscurely triple-nerved, obtuse or acutish, crenate-dentate, 7-I5 cm. long, 8-25 mm. wide; upper leaves gradually sinalier, oblanceolate or linear-oblong, acute or acutish, entire; heads 4-6 mm. high; panicle usually one-sided; bracts of the involucre linear-oblong; rays 5-9; achenes pubescent. In dry soil, Quebec to the N. W. Terr., Fla. and Tex. July-Nov.

Solidago nemoràlis arenícolla Burgess. Depressed, or prostrate, about $15 \mathrm{~cm}$. high, inflorescence dense, flattened, composing most of the plant. Sand hills, Cape Cod tn I I.

Solidago pulcherrima A. Nelson, is the western representative of this species, f.. tending east into Kans. and Neb. It differs in its pale color and narrower basal leaves, but 1 have not been able to separate it specifically.

42. Solidago móllis Bartl. Velvety Goldenrod. (I. F. f. 37 Io.) Stem. rigid, stout, low, canescent or slightly scabrous, I.5-3 dm. high. Leaves pale canescent or rough, entire or dentate, strongly 3-nerved, oblong, ovate or oblanceo= late, the lower petioled, 5-7 cm. long, 6-25 $\mathrm{mm}$. wide, very obtuse, the upper sessile, smaller; heads 4-6 mm. high, somewhat or scarcely secund on the short branches of the erect, dense panicle; bracts of the involucre oblong; rays 5-9; aclienes pubescent. Dry plains, Minn. to the N. IV. Terr., south to Tex. and Mex. July-Sept.

43. Solidago Radula Nutt. Western Rough Goldenrod. (I. F. f. 37II.) Stem rough-pulsescent, rather slender, 3-9 dm. high. Leaves thick, green, rough on both sides, the lower oblanceolate or spatulate, dentate-crenate, obtuse or acutish, petioled, 7-20 cm. long, 12-40 mm. wide, obscurely 3-12erved, the upper smaller, oblanccolate, entire or nearly so, sessile, distinctly 3-nerved; heads 4-6 mm. high; bracts of the involucre oblong or linear-oblong, obtuse; rays 3-7, very short; achenes minutely pubescent. In dry soil, Ill. to Mo., La. and Tex. Aug.-Sept.

44. Solidago Drummóndii T. \& G. Drummond's Goldenrod. (I. F. f. 3712.) Stem rather slender, 3-9 dm. high, finely soft-pubescent. Leaves rather thin, glabrous or nearly so above, finely, but sumetimes sparingly pubescent, or roughish Leneath, sharply serrate, acute at the apex. narrowed at the base, petioled, or the upper sessile, the larger 7-10 cm. long, 4-5 cm. wide; heads 4-5 mm. high; bract-like upper leaves obtuse, or acute, entire; rays 4-6, conspicuous; bracts of the involucre oblong-lanceolate, obtuse; achenes pubescent. In rocky soil, Ill. to La. and Mo. Sept -Oct.

45. Solidago rigida L. Stiff or Hard-leaved Goldenrod. (I. F. $f$. 3713.) Stem stout, simple, or branched above, densely and finely rough-pubescent, hoary, 3-15 din. high. Leaves thick, rigid, often obtuse, rough on both sides, the upper sessile, clasping, and rounded or sometimes narrowed at the base, 3-5 cm. long, mostly entire; lower and basal leaves long-petioled, sometimes $3 \mathrm{dm}$. long and $7 \mathrm{~cm}$. wide, entire or serrulate; heads 8-10 $\mathrm{mm}$. high, many-flowered, in a terminal dense corymbuse cyme; involucre broadly campanulate, its bracts oblong, obtuse, the outer pubescent; rays 6-10, large; achenes glabrous, IO-I5-nerved. In dry sandy, gravelly, or rocky soil, Ont. to the N. W. Terr., south to Ga., Tex. and Colo. Aug.-Oct.

46. Solidago multiradiàta Ait. Northern Goldenrod. (I. F. f. 3714.) Ste:n glabrous or somewhat pubescent above, rather slender, I.5-4 dm. high. Leaves firm, the basal and lower ones spatulate or oblanceolate, entire, or sparingly serrate, obtuse, finely reticulate-veined, 7-12 $\mathrm{cm}$. long, 6-18 $\mathrm{mm}$. wide, the upper smaller, narrower, sessile, entire; heads about $8 \mathrm{~mm}$. high, usually few in a terminal rather compact, corymbose cyme; bracts of the involucre thin, linear-lanceolate. acute, glabrous; rays 8-15, prominent, linear; achenes pubescent. Lab. to Br. Col., south in the Rocky Mts. to Colo. July-Aug.

47. Solidago Ohioénsis Riddell. Ohro Goldenron. (I. F. f. 37I5.) Very smooth throughout: stem rather slender, simple, 6-9 dm. kigh. Leaves firm, the basal and lower ones obtuse, long-petioled, serrulate toward the end, or sometimes entire, often $3 \mathrm{dm}$. long: upper leaves sessile, lanceolate, entire, gradually smaller; heads 5-6 mm. high, numerous in a terminal compound cyme, 15-25flowered: rays 6-9, small: bracts of the narrowly campanulate involucre oblong, obtuse, glabrous; achenes glabrous, 5-nerved. In moist soil, western N. Y. to Ill. Aug.-Sept, 
48. Solidago Riddéllii Frank. Riddell's Goldenrod. (I. F. f. 3716.) Stem stout, glabrous, or slightly pubescent above, 3-9 dm. high. Leaves numerous, thick, glabrous on both sides, entire, acute at each end, the lower and basal ones long-petioled, elongated, often $3 \mathrm{dm}$. long, 8-20 mm. wide, the upper smaller, similar, sessile and clasping at the base, conduplicate, somewhat falcate; heads $6-8 \mathrm{~mm}$. high, 20-30-flowered, very numerous in a dense corymbose cyme, involucre oblong. campanulate, its bracts broadly oblong, obtuse; rays 7-9, narrow; achenes 5. nerved, glabrous. On moist prairies, Ohio to Minn. and Mo. Also at Fortress Monroe, Va. Aug-Sept.

49. Solidago Hoùghtonii T. \& G. Houghton's Goldenrod. (I. F. f. 3717.) Stem glabrous below, sparingly pubescent above, 3-6 dm. high. Leaves linear, the basal and lower ones petioled, 4-8 $\mathrm{mm}$. wide, 3-nerved, entire, acute at each end, the upper sessile, slightly conduplicate, otherwise similar, the uppermost small and bract-like; heads about $6 \mathrm{~mm}$. high, few, in a small corymbose cyme, 20-30-flowered; involucre broadly campanulate, its bracts oblong, obtuse; achenes glabrous, 4-5-nerved. In swamps, north shores of Lakes Superior and Huron, and in Genesee Co., N. Y. Autumn.

\section{EUTHÀMIA Nutt.}

Erect, paniculately branched herbs, perennial by $\cdot$ long rootstocks, with linear or linear-lanceolate entire sessile $\mathbf{r}-5$-nerved punctate leaves, and numerous small heads of both tubular and radiate yellow flowers, clustered in the large cymose, convex or nearly flat-topped inflorescence. Bracts of the involucre ubtuse, appressed, somewhat glutinous. Receptacle flattish, fimbrillate, or pilose. Rayflowers pistillate, usually more numerous than the disk-flowers, the rays small. Disk-flowers perfect. Anthers cbtuse at the base. Style branches with lanceolate appendages. Achenes top-shaped or oblong, villous-pubescent. [Greek, referring to the clustered heads.] Four known species, the following, and one of western N. Am.

Leaves distinctly 3-5-nerved; ray-flowers 12-20.

Leaves I-nerved, or with a pair of indistinct lateral nerves; ray-flowers 5-10.

Stem-leaves $4-6 \mathrm{~mm}$. wide ; disk-flowers 3 or 4 .

Leaves $1-4 \mathrm{~mm}$. wide; disk-flowers 5 or 6 .

2. E. leptocephala.

3. E. Caroliniana.

I. Euthamia graminifòlia (L.) Nutt. Bushy or Fragrant Gol.denrod. (I. F. f. 37 18.) Stem glabrous, sometimes slightly rough above, 6-12 dm. high. Leaves numerous, linear-lanceolate, acuminate or acute at each end, $2-12 \mathrm{~cm}$. long, 4-8 mm. wide, minutely rough. pubescent on the margins and nerves of the lower surface; resinous dots few; heads 4-6 mm. high, sessile in capitate clusters arranged in a flat-topped corymbose cyme; involucre ovoid-campanulate, its bracts oblong or oblong-lanceolate, slightly viscid; disk-flowers 8-12. In moist soil, fields and roadsides, N. B. to the N. W. Terr., Fla., Neb. and Kans. July-Sept.

2. Euthamia leptocéphala (T. \& G.) Greene. Western Bushy GoldenROD. (I. F. f. $37 \mathrm{Ig}$.) Stem much branched, smooth, 4-7 dm. high. Leaves linear to linear-lanceolate, acuminate or acute at each end, rough-margined, those of the stem usually 5-7 cm. long, 4-6 mm. wide; heads 4-6 mm. high, rather narrower than those of the preceding species, sessile in the clusters of the flat-topped inflorescence; bracts of the involucre linear-oblong. In moist soil, Mo. to La. and Tex. Aug.-Oct.

3 Euthamia Caroliniàna (L.) Greene. Slender Fragrant Goldenrod: (I. F. f. 3720.) Resembles the preceding species but is smaller, glabrous, and somewhat resinous, seldom over $4 \mathrm{dm}$. high. Leaves narrowly linear, entire, acuminate, sessile, narrowed at the base, 2-7 cm. long, 2-4 $\mathrm{mm}$. wide, punctate, often with smaller ones clustered in the axils; heads about $3 \mathrm{~mm}$. high, very numerous and crowded in the dense corymbose cyme; involucre oblong-campanulate, its bracts oblong. In dry sandy soil, eastern Mass. to Ill., Fla., La. and Tex., mainly near the coast. Aug.-Oct. [Solidago tenuifolia Pursh.]

24. BRACHYCHAÈTA T. \& G.

An erect, perennial herh. with the aspect of a Goldenrod. Leaves alternate, the lower and basal ones large, cordate, long petioled, the upper ovate, short. 
petioled or sessile. Heads composed of both tubular and radiate flowers, in a terminal narrow spike-like thyrsus. Involucre narrowly campanulate, its bracts coriaceous, imbricated in few series, the outer successively smaller. Receptacle small, naked. Rays small, yellow, pistillate. Disk-flowers perfect, their corollas tubular, somewhat expanded above, 5-cleft. Anthers obtuse and entire at the base. Style-branches flattened, their appendages lanceolate. Achenes 8-ro-ribbed. Pappus a single row of scale-like bristles, shorter than the achene. [Greek, shortbristle, referring to the pappus.] A monotypic genus.

I. Brachychaeta sphacelata (Raf.) Britton. False Goldenrod. (I. F. f. 372I.) Stem pubescent, 6-12 dm. high. Basal and lower leaves broadly ovate, cordate or truncate at the base, acute at the apex, sharply serrate, 7-15 cm. long, the slender petioles 7-22 cm. long; stem-leaves gradually smaller and shorter-petioled, the uppermost very small and sessile; heads about $5 \mathrm{~mm}$. high, racemosesecund or densely clustered on the short branches of the narrow elongated terminal thyrsus; bracts of the involucre oblong or linear-oblong, obtuse or acutish; rays and disk-flowers each about 5. In dry woods, western Va. to Ind., south to N. Car. and Gr. Aug.-Sept. [B. cordata T. \& G.]

\section{APHANÓSTEPHUS DC.}

Erect or ascending canescent branching herbs, with alternate leaves, and rather large heads of both tubular and radiate flowers, solitary at the ends of the branches. Involucre hemispheric, its bracts lanceolate or linear, scarious-margined, imbricated in a few series, the outer smaller. Receptacle convex or conic, naked. Rayflowers pistillate, white or purplish. Disk-flowers perfect, yellow, their corollas tubular, the limb expanded above, 5-dentate. Anthers obtuse and entire at the base. Style-branches flattened, their appendages short, obtuse. Achenes manyribbed. Pappus a short dentate crown. [Greek, faint-crown.] About 5 species, of the southwestern U. S. and Mex.

I. Aphanostephus skirróbasis (DC.) Trelease. Aphanostephus. (I. F. f. 3722.) Erect, or diffusely branched, densely canescent, 1.5-6 dm. high. Basal and lower leaves spatulate, obtuse, 2-10 cm. long, somewhat dentate, laciniate or entire, narrowed into margined petioles; upper leaves lanceolate, oblong or oblanceolate, obtuse or acute, mostly sessile, smaller; heads $16-25 \mathrm{~mm}$. broad, 6-10 $\mathrm{mm}$. high; rays numerous, narrow, entire. In dry soil, Kans. to Tex. Also in Fla. May-Aug.

\section{BÉLLIS L.}

Tufted herbs, with branching or scapose stems, alternate or basal leaves, and rather large heads of both tubular and radiate flowers, solitary at the ends of the branches, or of the monocephalous scape. Involucre hemispheric or broadly campanulate, its bracts herbaceous, imbricated in I or 2 series, nearly equal. Receptacle convex or conic, naked. Ray-flowers white or pink, pistillate. Disk-flowers yellow, perfect, their corollas tubular, the limb 4-5-toothed. Anthers obtuse and entire at the base. Style-branches flattened, their appendages short, triangular. Achenes flattened, nerved near the margins. Pappus none, or a ring of minute bristles. [Latin, pretty.] About 9 species, of the northern hemisphere. Only the following are known to occur in N. Am., but 2 others are found in Mex.

Stem branched, $15-40 \mathrm{~cm}$. high; involucral bracts acute. Scapes monocephalous, $3^{-1} 7 \mathrm{~cm}$. high; involucral bracts obtuse.
1. B. integrifolia.

2. B. perennis.

I. Bellis integrifòlia Michx. Western DAisy. (I. F. f. 3723.) Slender, diffusely branched, pubescent. Leaves thin, entire, obtuse, the lower and basal ones spatulate, $2-7 \mathrm{~cm}$. long, narrowed into margined petioles, the upper smaller, oblong, oblanceolate or linear; heads $12-30 \mathrm{~mm}$. broad; bracts of the involucre acute or acuminate, scarious-margined, glabrous or nearly so; ravs usually violet, oblong-linear. In moist soil, Ky. and Tenn. to Ark. and Tex. May-July.

2. Bellis perénnis L. European or Garden Daisy. (I. F. f. 3724.) Perennial, tufted. Leaves all basal, obovate, obtuse, slightly dentate, $2-5 \mathrm{~cm}$. long, narrowed into margined petioles, pubescent and ciliate: heads $12-25 \mathrm{~mm}$. broad; rays numerous, linear, white, pink. or purple; bracts of the involucre oblong, obtuse, usually purple. In waste places, or occasionally spontaneous on lawns. 
Southern N. Y. and eastern Penn. to N. S. and Ont. Fugitive from Europe. Native also of Asia. Nat. in Cal. and Br. Col. April-Nov.

\section{TOWNSÉNDIA Hook.}

Tufted scapose or branching herbs, with alternate entire linear or spatulate leaves and large heads of both tubular and radiate flowers. Involucre hemispheric or broadly campanulate; bracts imbricated in several series, the outer shorter. $\mathrm{Re}$ ceptacle nearly flat. Ray-flowers pink or white, pistillate. Disk-flowers tubular, mostly perfect, their corollas regular, 5-lobed. Anthers obtuse and entire at the base. Style-branches flattened, their appendages lanceolate. Achenes of the diskflowers ccmpressed, those of the rays commonly 3-angled. Pappus a single series of rigid bristles or short scales. [Named for David Townsend, botanist of Philadelphia.] About 20 species, natives of western N. Am.

Branching from the base; heads terminal.

Acaulescent, or nearly so; heads sessile among the leaves.

I. T. grandiflora.

Leaves narrowly oblanceolate or spatulate, green, $2.5-5 \mathrm{~mm}$. wide.

2. T: intermedia.

Leaves narrowly linear or nearly so, canescent, $\mathrm{I}-2 \mathrm{~mm}$. wide.

3. T. exscapa.

I. Townsendia grandiflòra Nutt. LARge-Flowered Townsendia. (I. F. f. 3725.) Perennial from a long woody root, branching at the base and sometimes also above, pubescent, or at length glabrate, 5-20 cm. high. Leaves linear or linear-spatulate, 3-7 cm. long, 3-6 mm. wide, canescent; heads $3-4 \mathrm{~cm}$. broad, solitary at the ends of the branches; involucre hemispheric, its bracts scarious-margined, lanceolate, conspicuously acuminate; rays violet or purple; pappus of the rayfowers a crown of short scales, that of the disk-flowers of rigid bristles longer than the achene. In dry soil, Neb. to Wyo. and N. Mex. May-Aug.

2. Townsendia intermédia Rydb. n.sp. Intermediate Townsendia. A caulescent from a woody root but less branched than the next, 2-5 cm. high. Leaves oblanceolate or rarely spatulate, mostly acute, green, finely strigose, or in age glabrate; heads closely sessile, $1.5-3 \mathrm{~cm}$. broad, surpassed by the leaves; involucre broadly campanulate, its bracts broadly lanceolate, often tinged with purple, the inner scarious-margined; rays rose-color or white; pappus as in the next. In dry soil, Neb., Kans. and Colo. May-July. Type from Trego Co., Kans.

3. Townsendia exscàpa (Richards) Porter. Silky or Low Townsendia. (I. F. f. 3726.) Acaulescent, or nearly so, from a deep woody root, tufted, $2-3 \mathrm{~cm}$. high. Leaves all clustered at the base, narrowly linear or slightly broader upward, 2-5 cm. long, permanently strigose-canescent; heads closely sessile, $2-4 \mathrm{~cm}$. broad, equalled or surpassed by the leaves; involucre broadly campanulate, its bracts lanceolate, acute, the inner scarious-margined; rays white or purplish; pappus of both ray and disk-flowers a row of rigid bristles, that of the rays shorter and smaller. In dry soil, N. W. Terr. to Neb., Ariz. and N. Mex. April-July.

\section{CHAETOPÁPPA DC.}

Annual slender much-branched herbs, with small alternate entire leaves, and small long-peduncled heads of both tubular and radiate flowers. Involucre narrowly campanulate, its bracts lanceolate, acute or acuminate, imbricated in few series, the outer slightly shorter. Receptacle small, naked. Ray-flowers in one row, pistillate. Disk-flowers perfect, or the central ones staminate, their corollas 5-lobed. Anthers obtuse and entire at the base. Style-branches narrow, flattened, their appendages short, obtuse. Achenes nearly terete, fusiform, or linear, 5-ribbed. Pappus usually of 5 rigid awn-like scabrous bristles, alternating with as many short scales or more. [Greek, bristle-pappus.] Two known species, natives of the central and southwestern U. S.

I. Chaetopappa asteroides DC. ChaetopaṕpA. (I. F. f. 3727.) Annual, pubescent, erect, 5-30 cm. high, the branches filiform. Lower and basal leaves spatulate, obtuse, $\mathbf{I}-2.5 \mathrm{~cm}$. long, petioled, the upper linear, much smaller and bract. like, sessile; heads about $6 \mathrm{~mm}$. broad; involucre about $4 \mathrm{~mm}$. high, its bracts scarious-margined, glabrous or nearly so; rays $5^{-12}$, raised on slender tubes; central sterile flowers usually awnless; shorter scales of the pappus of the fertile flowers hyaline, sometimes lacerate. Dry soil, Mo, to Tex. and northern Mex. April-July. 


\section{RQL,TÒNIA i'Her.}

Perennial glabrous herbs, with striate or angled stems, alternate entire sessile, or clasping leaves, and numerous rather large heads of both tubular and radiate flowers, paniculate, or solitary at the ends of the branches. Involucre hemispheric or broadly campanulate, its bracts scarious-margined, imbricated in few series, the outer slightly shorter. Receptacle convex or conic, foveolate. Ray-fowers pistillate. Disk-flowers perfect, their corollas elongated, 5-lobed. Anthers obtuse and entire at the base. Style-branches flattened, their appendages short, lancsolate. Achenes flattened, obovate, their margins thickened or narrowly winged, glabrous or nearly so. Pappus a series of short scales, usually with 2-4 slepder rigid bristles. [Named for James Bolton, an English botanist of the I8th century.] As here limited, the genus consists of the 4 following species, with perhaps a fifth in Oregon.

Disk about $4 \mathrm{~mm}$. broad; leaves linear.

I. B. diffusa.

Disk 6-12 $\mathrm{mm}$. broad; leaves lanceolate.

Leaves narrowed at the base, sessile, not decurrent on the stem.

Involucre-bracts lanceolate, acute.

Involucre-bracts spatulate, obtuse, or mucronate.

Stem-leaves, and sometimes those of the branches, decurrent, sagittate.

2. B. asteroides.

3. B. latisquama.

4. B. decurrens.

I. Boltonia diffùsa Ell. Panicled Boltonia. (I. F. f. 3728.) Paniculately much branched, 6-20 cm. high, the branches very slender or filiform. Leaves acutish, the larger 3-5 cm. long, $4 \mathrm{~mm}$. wide, those of the branches very small and subulate; heads about $4 \mathrm{~mm}$. high; rays usually white, $2-4 \mathrm{~mm}$. long; involucre broadly campanulate, its bracts oblong or oblong-lanceolate, acutish or obtuse; achenes obovate, narrowly winged; pappus of several short scales and 2 subulate bristles shorter than the achene. In dry soil, southern Ill. to Tex., east to S. Car. and Fla. Aug.-Oct.

2. Boltonia asteroides (L.) L'Her. Aster-Like Boltonia. (I. F. f. 3729.) Rather stout, 6-24 dm. high, somewhat cymosely paniculate. Leaves lanceolate to oblanceolate, sessile, 5-12 cm. long, 6-25 $\mathrm{mm}$. wide, the upper linear-lanceolate, sualler; rays white, pink or purple, 6-12 mm. long; involucre hemispheric, its bracts lanceolate or oblong lanceolate, acute or acuminate; pappus of setose scales, with or without 2-4 slender bristles nearly as long as the obovate or oval achene. In moist soil, N. J. to Fla., west to Minn., Neb. and La. July-Sept.

3. Boltonia latisquàma A. Gray. BroAd-SCAled Boltonia. (1. F. f. 3730.) Similar to the preceding species and perhaps a variety or form of it. Leaves lan. ceolate, acute, sessile; heads rather larger; rays blue-violet; bracts of the involucre oblong-spatulate, obtuse or mucronate; pappus of numerous small short broad scales and 2 long bristles. Western Mo., eastern Kans. and Ark. Autumn.

4. Boltonia decúrrens (T. \& G.) Wood. Clasping-Leaved Boltonia. (I. F. f. 373r.) Stout, 9-18 dm. high, branched above. Leaves oblong-lanceolate or elongated lanceolate, mucronate at the apex, those of the stem decurrent and sagittate at the base, 7-15 cm. long, 12-16 mm. wide, those of the branches smaller and merely sessile or some of them also decurrent; heads 5-6 mm. high; involucre hemispheric; rays about $6 \mathrm{~mm}$. long, violet or purple; pappus of several or numerous short scales and 2 very slender bristles. In wet prairies, Ill. and Mo. Aug.-Sept.

\section{SERICOCÀRPUS Nees.}

Erect perennial herbs, with alternate leaves, and middle-sized heads of boih tubular and radiate flowers, in terminal cymose panicles. Involucre ovoid, oblong, or campanulate, its bracts coriaceous, with herbaceous or squarrose tips, imbricated in several series, the outer shorter. Receptacle small, foveolate. Ray.tlowers white, pistillate. Disk-flowers mostly perfect, their corollas tubular, narrow, yellowish or purplish, 5-lobed. Anthers obtuse and entire at the base. Stylebranches with lanceolate-subulate appendages. Acbenes slightly compressed, linear-oblong, I-nerved on each side, pubescent. Pappus of numerotis capillary scabrous bristles, the outer usually shorter. [Greek, silky fruit, referdng to the açhenes.] Four known species, natives of N. Am, 
Leaves entire, linear, spatulate, or obovate, rigıd.

Glabrous, or nearly so; leaves linear or linear-spatulate.

Puberulent or scabrous; leaves obovate.

Leaves dentate, ob!ong, or obovate, thin.

1. S. linifolius.

2. S. bifoliatus.

3. S. asteroides.

I. Sericocarpus linifòlius (L.) B.S.P. NARRow-Leaved White-Topped As'rER. (I. F. f. 3732.) Glabrous or very nearly so throughout; stem rather slender, striate, 3-5 dm. high. Leaves spreading, faintly 3-nerved, thick, obtuse at the apex, narruwed at the base, 3-5 cm. long, 3-6 $\mathrm{mm}$. wide, sessile, or the lowest with short margined petioles, their margins scabrous; heads about $6-8 \mathrm{~mm}$. high, clustered in 2's-6's at the ends of the cymose branches; involucre oblong-campanulaic, its bracts oblong, obtuse, the outer with somewhat spreading or reflexed grcen tips, the inner scarious and often lacerate or ciliate at the apex; rays 4 or 5 , 8-ro mm. long; pappus white. In dry, usually sandy soil, Canada, Vt. to Ohio, Ga. and La. June-Sept. [S. solidagineus Nees.]

2. Sericocarpus bifoliätus (Walt.) Porter. Rough White-Topped Aster. Rattlesnake Master. (I. F. f. 3733.) About $6 \mathrm{dm}$. high, the stem terete, or slightly angled. Leaves sessile, obscurely veined, thick, obtuse, ascending or erect by a twist at the base, $\mathbf{I}-2.5 \mathrm{~cm}$. long, 8-16 mm. wide, mucronulate, densely appressed-puberulent on both sides, the upper mostly oblong, much smaller; heads 8-10 $\mathrm{mm}$. high, cymose-paniculate; involucre narrowly campanulate, its bracts oblong or the inner linear, pubescent, their tips somewhat spreading; rays short; pitppus white. In dry soil, Va. to Fla. and La., mainly near the coast. JulySept.

3. Sericocarpus asteròides (L.) B.S.P. Toothed White-Topped Aster. (I. F. f. 3734.) Stem pubescent, or glabrate, slightly angled, 3-6 dm. high. Leaves pubescent or glabrous, ciliate, the basal and lower ones obovate or spatulate, dentate or rarely entire, 5-10 $\mathrm{cm}$. long, 5-35 $\mathrm{mm}$. wide, narrowed into margined petioles; upper leaves oblong or oblong-lanceolate, entire or dentate, acute or obtuse, smaller: heads 10-12 mm. high, densely clustered; involucre campanulate, its bracts oblong, ciliate or pubescent, the outer with green reflexed tips; pappus brown or white. In dry woods, Me. to Fla., Ohio, Ky. and Ala. July-Sept.

\section{1. ÁSTER L.* (See Appendix.)}

Perennial or rarely annual, mostly branching herbs, with alternate leaves, and corymbose or paniculate (rarely racemose or solitary) heads of both tubular and radiate flowers. Involucre hemispheric, campanulate or turbinate, its bracts various, imbricated in several series, the exterior ones usually smaller and shorter. Receptacle flat or convex, generally foveolate. Ray-flowers white, pink, purple, blue, or violet, pistillate. Disk-flowers tubular, perfect, their corollas 5-lobed, usually yellow and changing to red, brown, or purple. Anthers obtuse and entire at the base. Style-branches flattened, their appendages subulate, lanceolate or ovate, acute. Pappus-bristles slender, numerous, scabrous or denticulate, usually in I series, sometimes in 2 series. Achenes mostly flattened and nerved. [Greek, star.] A genus of not less than 250 species, most abundant in N. Am. where, in addition to the following, about 70 others occur beyond our limits. The species are very variable, as is expressed in the large number of subspecies here admitted.

A. Basal and lower leaves, or some of them, cordate and slender-petioled. (See No. 52.)

1. None of the stem-leaves cordate-clasping.

* Rays white, violet or rose.

$\S$ Rays white, or rarely rose, usually 2 -toothed; plants not glandular.

+ Involucre ovoid, campanulate or turbinate, its bracts mostly obtuse or rounded; basal leaves few and small, or commonly none (except in No. 6).

(a) Leaves membranous or thin, smooth, or nearly so.

Heads $18 \mathrm{~mm}$. broad or less, the disk turning crimson; leaves acute or short-acuminate, chiefly crenate-serrate.

I. A. carmesinus.

Heads $18 \mathrm{~mm}$. broad or more, the disk turning brown or reddish brown; leaves longacuminate, sharply serrate.

Heads $18-25 \mathrm{~mm}$. broad; leaves of the branches small, obtuse, or acute.

2. A. divaricatus. 
Heads $25 \mathrm{~mm}$. broad or more; leaves of the branches large, long, lanceolate, acuminate.

Involucral bracts mainly acute; teeth of leaves salient. 3. A. tenebrosus.

Involucral bracts, all but the lowert, obtuse; leaves low-serrate, the teeth chiefly appressed.

(b) Leaves thick, firm, rough, at least when dry.

4. A. leptocaulis.

Heads 12-16 mm. high ; inflorescence forking.

Heads 8-ro mm. high; inflorescence paniculate or glomerate.

5. A. furcatus.

Leaves acute, or short-acuminate, pilose beneath; inflorescence glomerate.

6. A. glomeratus.

Leaves long-acuminate, not pilose beneath; inflorescence open-paniculate.

7. A. Claytoni.

$f+$ Involucre cylindric, its bracts tapering to an obtuse apex ; basal leaves large, tufted. Bracts of the involucre pale, scarious, usually without herbaceous tips.

Bracts of the involucre broader, with herbaceous tips.

8. A. curzescens.

9. A. Schreberi.

$\S \S$ Rays violet, usually 3 -toothed; plants glandular.

† Predominant glands large, capitate; leaves thick, coarse, heavy.

Sinus broad; glands chiefly on the inflorescence; plant usually harsh.

Io. A. macrophyllus.

Sinus narrow; glands abundant on the leaves and stem; growing plant clammy.

II. $A$. roscidus.

$\dagger+$ Predominant glands minute, scarcely capitate; leaves usually thin.

(a) Inforescence rather regular, flat, or convex-topped; plants usually less than $8 \mathrm{dm}$. tall. Sinus broad, shallow.

Broader leaves orbicular-cordate, their teeth and the inflorescence-leaves inconspicuous.

12. A. ianthinus.

Broader leaves reniform, sharply incised; some inflorescence-leaves conspicuous. 3. A. violaris.

Sinus rather deep and narrow; broader leaves ovate-cordate, sharply serrate.

14. A. multiformis.

(b) Inflorescence very irregular, paniculate-corymbose; plants often 1.2-1.6 m. high; broader leaves large, cordate, acute. I5. A. nobilis.

* * Rays blue or purple; plants not glandular.

$\dagger$ Bracts of the involucre spreading or recurved; rays $30-45$.

I6. A. anomalus.

++ Bracts of the involucre appressed, or erect; rays 8-20.

(a) Leaves all entire, or nearly so, thick, or firm.

Leaves nearly or quite glabrous above.

17. A. Shortii.

Leaves rough-puberulent on both sides, the tupper bract-like. I8. A. azureus.

(b) Leaves nearly all sharply serrate, thin.

Heads 4-6 mm. high, numerous; bracts obtuse or obtusish.

Leaves rough; petioles not wing-margined; bracts appressed.

Leaves smonth, or nearly so ; petioles, or some of them, wing-margined.

19. A. cordifolius.

20. A. Lowrieanus.

21. A. Lindleyanus.

Heads 8-1o mm. high, usually few ; bracts acute or acuminate.

Heads 6-1o mm. high, numerous; bracts acute or acuminate.

Stem densely and finely pubescent.

Stem glabrous or nearly so ; bract-tips spreading.

Inflorescence racemose-paniculate.

Inflorescence cory mbose-paniculate.

22. A. Drummondii.

23. A. sagittifolius.

24. A. Saundersii.

2. Stem-leaves, or some of them, cordate-clasping; plant rough when dry.

25. A. undulatus.

\section{B. No cordate and petioled leaves; those of the stem, or some of them, with more or less cordate or auricled clasping bases.}

1. Stem rough, or hirsute-pubescent.

* Leaves entire, oblong, linear, or lanceolate.

\& Heads $2.5-5 \mathrm{~cm}$. broad; leaves sessile, strongly cordate-clasping.

+ Sten rough ; leaves oblong to lanceolate; involucre turbinate.

Leaves thick, firm, very rough, oblong to oval.

Leaves thin, roughish, oblong-lanceolate.

+ + Stem hirsute; leaves lanceolate; involucre hemispheric.

26. patens.

27. A. phlogifolius.

\& Heads $\mathrm{I}-2.5 \mathrm{~cm}$. broad; leaves but slightly clasping.

28. A. Novae-Angliae.

Involucre hemispheric, its bracts glandular.

Involucre turbinate, its bracts hispid.

29. A. oblongifolius.

30. A. amethystinus. 
* Leaves, at least the lower, serrate.

Stems usually pilose; bracts very glandular.

Stems hispid-pubescent; bracts glabrous, or ciliate.

31. A. major.

32. A. puniceus.

2. Stem glabrous, or only sparingly pubescent above (villous in forms of No. 33 ).

* Leaves sharply serrate.

$\S$ Leaves tapering to the base.

Outer bracts of the involucre foliaceous.

Bracts of the involucre narrow, not foliaceous.

Leaves lanceolate to oblong-lanceolate, sessile.

Leaves oval to ovate, the lower often petioled.

33. A. tardiflorus

32. A. puniceus.

3.. 1. patulus.

$\S \S$ Leaves abruptly contracted into margined petioles, often enlarged neir the base.

35. A. prenanlhoides.

$\S \S$ Leaves strongly cordate-clasping; bracts green-tipjed. - 36. H. laevis.

* Leaves entire, or very nearly so.

$\S$ Involucre campanulate, its bracts appressed, green-tipped.

$\dagger$ Bracts of the involucre with rhomboid green tips.

Stem-leaves oblong, lanceolate or oval-lanceolate.

Stem-leaves elongated-lanceolate to linear.

35. A. laevis.

37. 1. concinnus.

$f+$ Bracts of the involucre linear, the tips narrower, lanceolate: stem-leaves linear or narrowly lanceolate.

§ Involucre hemispheric.

38. A. purpuratus.

+ Bracts of the involucre narrow, not foliaceous.

(a) Bracts in several series, unequal.

Bracts linear-subulate; leaves narrowly linear.

Bracts lanceolate, linear, or spatulate: leaves lanceolate to linear.

Western dry-soil plant, 3-6 dm. tall; leaves $2.57 .5 \mathrm{~cm}$ long. $40 . A$. adscendens.

Eastern swamp plant, 6-1 5 dm. tall; leaves $5^{-1} 5 \mathrm{~cm}$. long. 41 . A. Novi-Belgii.

(b) Bracts in only 1 or 2 series; leaves linear to lanceolate.

$t+$ Bracts of the involucre green, foliaceous; 42. ivesterm. longifolius.

43. A. foliaceus.

C. Leaves sesslle, or petioled, not at all clasping, or scarcely so.

1. Leaves silky, silvery or canesient on bolih sides, enlire.

Heads cory mbose-paniculate; bracts oblong; achenes labrous. 44. A. sericeus.

Heads in a narrow racems; bracts linear; achenes silky.

45. 1. concolor.

2. Leaves nenther silky, silvery nor canescent, often toothed.

* Rays normally purple, blue, pink, or violet; not white.

$\S$ Leaves bristly ciliate, linear, rigid; western species. 46. 4. Fendleri. $\S \S$ Leaves not bristly ciliate.

+ Tips of the involucral bracts stron

Leaves linear to linear-oblong, rigid, obtuse, entire; heads $2.5 \mathrm{~cm}$. broad.

Leaves lancenlate to oblong, at least the lower dentate.

47. A. grandifiorus.

Involucre liemispheric, or nearly so; heads $2.5 \mathrm{~cm}$. broad or more.

Bracts of the involucre glandular.

Bracts of the involucre ciliate, or glabrous.

Involucre turbinate; heads $12-18 \mathrm{~mm}$. broad.

48. A. sfectabilis.

49. 1. surcubosus.

50. 4. gracilis.

$\dagger+$ Tips of the involucral bracts appressed, or erect (except in furms of No. 52 )

(a) Bracts of the involucre coriaceous or herbaceous, oblong, linear, lanceolate, o1 spatulate.

Bracts of the involucre coriaceous, obtuse.

Involucre hemispheric; leaves oblong, sharply serrate; stem smooth.

Involucre turbinate.

51. A. Radula.

Leaves ovate-oblong, the lower dentate; stem rough.

Leaves linear-oblong, entire, ciliolate.

Bracts of the involucre herbaceo'ss, acute.

Involucral bracts foliaceous; leaves oblong, very rough. 54. A. Nebraskensis.

Involucral bracts not foliaceous: leaves linear or the lower spatulate, not rough.

Pubescent; inner involucral bracts abruptly acuminate or obtusish.

55. A. Priceae.

Glabrous ; involucral bracts all narrowly linear, gradually acuminate.

56. A. Kentuckiensis.

Bracts of the involucre rigid, lanceolate, large, acute; leaves linear.

(b) Bracts of the involucre linear-subulate, membranous, acute.

57. A. paludosus.

58. A, nemoralis. 
* * Rays mostly white or nearly so (often pink or purple in Nos. 59, 6r, 63, 64, and 73).

$\S$ Heads corymbose, $20-40 \mathrm{~mm}$. broad.

Leaves ovate-oblong, acuminate, sharply serrate; bracts linear-subulate.

Leaves linear, entire or nearly so; bracts oblong, obtuse.

59. A. acuminatus. 60. A. ptarmicoides.

$\$$ Heads solitary at the ends of slender branchlets.

I.eaves linear or linear-lanceolate, acute or obtuse.

1,eaves oblong-lanceolate, acuminate at both ends.

6r. A. dumosus.

62. A. Gravesii.

$\S \S \S$ Heads paniculate, or racemose, $8-20 \mathrm{~mm}$. broad

+ Bracts of the involucre acute to obtusish; plants glabrous or pubescent.

(a) Heads paniculate, not in $\mathrm{I}$-sided racemes.

Stem leaves lanceolate, serrate or entire.

Heads $16-20 \mathrm{~mm}$. broad.

Plaints glabrous, or sparingly pubescent above.

Leaves firn, roughish or rough; rays often bluish.

Leaves thin, smoothish; rays chiefly white.

Plant puberulent all over.

Heads 12-16 mm. broad; stem-leaves narrowly lanceolate.

Stem-leaves linear-lanceolate to subulate, mostly entire.

Heads scattered, I2-I8 nm. broad; upper leaves linear.

Heads numerous, 8-I $4 \mathrm{~mm}$. broad; upper leaves subulate.

Paniculately branched, busliy.

Simple, or with ascending slender branches; northern.

(b) Heads racemose and I-sided on the branches.

Stem-leaves oval, oblong, or lanceolate, serrate, or chiefly so.

Stem pubescent or glabrate.

Stem villous; leaves narrowly lanceolate, thin.

Sten-leaves linear-lanceolate to linear, nearly entire ; stem glabrate.

63. A. salicifolius.

64. A. paniculatus.

65. A. Missouriensis.

66. A. Iradescanti.

67. A. Faxoni.

68. A. cricoides.

69. A. Pringlei.

70. A. lateriflorus.

71. A. hirsuticaulis.

72. A. vimineus.

++ Bracts of the involucre, at least the outer, obtuse; flants very rougl.

Heads 6-8 $\mathrm{mm}$. broad, very numerous, densely clustered.

Pubescence appressed; leaves nearly glabrous.

Pubescence spreading; leaves pubescent and ciliate.

Heads I2-16 mm. broad, rather loosely clustered; western.

73. A. multiflorus.

74. A. exiguus.

75. A. commutatus.

\section{Leaves fleshy, narrow, entire; plants of salt marshes or saline soil (No. 77 some- times in non-saline situations).}

Perennial; hexds $12-25 \mathrm{~mm}$. broad; involucral bracts lanceolate, acuminate.

Annuals ; heads 6-1o $\mathrm{mm}$. broad; involucral bracts linear-subulate.

76. A. tenuifolius.

Involucre campanulate; disk-flowers more numerous than the rays; rays about $4 \mathbf{m m}$. long.

Involucre cylindraceous; disk-flowers fewer than the very short rays.

77. A. exilis.

78. A. subulatus.

I. Aster carmesinus Burgess. Crimson-Disk Aster. (I. F. f. 3735.) Stems erect, delicate, 3-6 dm. high, glabrous, reddish brown, terete. Leaves all petioled, glabrate, very thin, but firm and crisp, the lower and basal ones somewhat oval, rounded into a small deep sinus at the base, bluntly acute or short-acuminate at the apex, crenate-serrate, the upper ones sometimes ovate-lanceolate, the uppermost short-elliptic; petioles slender; inflorescence $12.5 \mathrm{~cm}$. broad, or less; rays chiefly 6, white; disk at first golden yellow, finally deep purplish crimson; florets broadly bell-shaped; outer bracts obtuse, ciliate, pale, witlı a green tip. On shaded rocks in the lower Hudson valley. Sept.

2. Aster divaricàtus L. White Wood Aster. (I. F. f. 3737.) Stems tufted, assurgent, flexuous, brittle, terete, 4-6 dm. high, glabrate at maturity. Leaves thin, smoothish, slender-petioled, ovate, lanceolate, closely dentate with sharp teeth, or the small basal ones coarsely serrate, acute to acuminate, the basal sinus moderate; leaves of the inflorescence small, short. ovate and acute to orbicular, subentire; corymb broad, flattish, repeatedly forked, the slender branches long, divergent; heads I $8-25 \mathrm{~mm}$. broad; rays chiefly 6-9, white; disk turning reddish brown; bracts of the involucre broad, ciliate, the rounded tip with an inconspicuous green spot. In open woodlands and thickets, in rather dry soil, Canada to Man., Ga. and Tenn. Variable; rays rarely rose-purple. Sept.-Oct.

Aster divaricàtus cymulosus Burgess. Smaller, bearing a single dense corymb about I dm. broad, or several smaller ones; the branches short, suberect; rays short, broad, 
chiefly 6-8 mm. long. In grassy openings in woods, often in dense patches, N. Eng. and N. Y. to Va.

Aster divaricàtus curtifolius Burgess. Stem erect, reddish, smooth, sometimes glaucous; leaves small, dull green, firm, ovate to orbicular, the sinus broad, rounded, the apex obtuse or apiculate; inflorescence loose, flattish; disks turning purple; rays about I cm. long; green tips of the involucral bracts conspicuous. In moist woods, N, Y. to Va.

Aster divaricatus deltoideus Burgess. Delicate, $4.5 \mathrm{dm}$. high or less; lower leaves triangular, cordate with a broad sinus or subtruncate, the apex incurved-acuminate; the teeth large, sharp; petioles often all filiform; veins directed forward; heads nearly as in the preceding variety. In moist shaded places, N. Eng. to N. Y., Va. and Tenn.

Aster divaricatus persaliens Burgess. Stems virgate, $7.5 \mathrm{dm}$. high, or less; leaves extremely thin, firm, chiefly lanceolate-acuminate, long and narrow, the teeth very slender, salient or recurved, the lowest ovate with a snall narrow sinus; disk maroon. In deep shade, N. Eng. and N. Y. to Va. and Ky.

Aster divaricàtus fontinalis Burgess. Plants solitary; basal leaves often numerous, tufted, thin, smoothish, sharply serrate or dentate, $15 \mathrm{~cm}$. long by $\mathrm{II}_{\mathrm{I}} \mathrm{cm}$. broad, or smaller, broadly oval, acute, the base subcordate or rounded; involucre turbinate, its bracts with definite green tips. In springy places and grassy ditches in open sunny situations, N. Eng. and N. Y, to Va.

3. Aster tenebròsus Burgess. Long-Leaven Wood Aster. (I. F. f. 3736.) Stems solitary or scattered, glabrate, striate, 6-9 dm. high. Leaves very thin and smooth, slender-petioled, broadly oblong, coarsely toothed with remote acuminate teeth, abruptly long-acuminate at the apex, the basal sinus broad, rounded, shallow, except in the lowest ones; leaves of the inflorescence lanceolate, subentire, sessile, sometimes I dm. long; inflorescence broadly corymbose, heads about $8 \mathrm{~mm}$. high, often $3 \mathrm{~cm}$. broad; rays usually 9-12; disk pale yellow, becoming purplish brown, the florets funnelform with a long slender tube; outer bracts chiefly elongated-triangular, acute, green, the others linear. obtusish, the green tips lancelinear. In moist dark woodlands, N. Y. to Va. Peculiar in its large dark leaves with coarser teeth than in the preceding species. Aug.-Sept.

4. Aster leptocaùlis Burgess, n.sp. Smooth-stemmed Aster. Stem slender, smooth, $4 \mathrm{dm}$. high or more, the branches puberulent, erect-ascending, leafy to the inflorescence. Stem-leaves lanceolate or the lower ovate-lanceolate, the larger $\mathbf{1} .5 \mathrm{dm}$. long, thin, slightly rough above, finely and densely pubescent beneath, long-acuminate, sharply serrate nearly or quite to the base, the upper sessile, or very nearly so, the lower petioled and cordate or subcordate at the base; inflorescence corymbose, leafy; peduncles slender, $1-2.5 \mathrm{~cm}$. long; involucre turbinate-campanulate, about $8 \mathrm{~mm}$. high, its bracts obtuse or obtusish, ciliate; heads about $2.5 \mathrm{~cm}$. broad. Milwaukee, Wis., collected by Dr. H. E. Hasse.

5. Aster furcàtus Burgess. Forking Aster. (I. F. f. 3738.) Stem leafy, 4.5 dm. high, or less, loosely forked above. Leaves hispid above, hispidulous beneath, firm, saliently cut-toothed, the lower ovate, short-petioled, with a small or shallow sinus, the upper sessile, often $12.5 \mathrm{~cm}$. long by $6 \mathrm{~cm}$. wide, the uppermost elliptic-oblong, often $8.5 \mathrm{~cm}$. long; heads few $(5-20)$, slender-peduncled; involucre with a truncate or rounded base; rays 3 -toothed; disk turning brown, the florets funnelform with rather broad lobes; pappus long, straight; achenes pubescent, subangular, not constricted at the summit. In woods, especially on shaded cliffs, Ill. and Mo. Aug.-Oct.

6. Aster glomeràtus (Nees) Bernh. Bernhardis Aster. (I. F. f. 3739.) Loosely clustered, dull green. Leaves not large, mostly short-pilose beneath, thickish, rough above; basal leaves present, these and the lower stem-leaves cordate with a deep narrow sinus, the teeth sharp, rather close and small; petioles slender, ciliate; upper leaves much smaller, ovate, truncate with a short broadly winged base, or the uppermost ovate to lanceolate, sessile, entire; inflorescence compact, of many glomerate clusters, round-topped; heads about $8 \mathrm{~mm}$. high; bracts pubescent, obtuse, green, the inner twice as long as the outer; rays about 6, cream-white, short, soon deciduous: disk turning brown. In moist thickets, swamps, or ravines, N. Y. and Penn. July.

7. Aster Clàytoni Burgess. Clayton's Aster. (I. F. f. 3740.) Similar to A. divaricatus; stems red, tough. Leaves chiefly ovate-lanceolate, not large, rough, thick, slender-petioled, coarsely serrate, pale, or dull, acuminate, the upper sessile by a broad base, lanceolate-triangular. serrulate; inflorescence high, with percurrent axis, the long suberect branches each bearing a small umbelliform clus. 
ter of heads; peduncles filiform, as long as the heads, 6-8 $\mathrm{mm}$. long; bracts pale; rays short, narrow, chiefly 6 , snow-white; disks at first golden yellow, finally sienna brown; florets about 20; achenes densely short-hairy. In sunny or slightly shaded rocky places, N. Y. to the mountains of Va. Sept.

Aster Clayytoni crispicans Burgess. Basal leaves often not cordate, deeply incised : those of the stem long-acuminate or even caudate, sharply serrate with large acute close teeth, some of which are suberect; chief bracts of the involucre acute. On rocky banks, solitary or in small clusters. Me. to N. Y. and N. J.

8. Aster curvéscens Burgess. Dome-Topped Astrk. (I. F. f. 374I.) Dark green, chiefly glabrous; stem pale green, striate, delicate, 4-6 dm. high. Basal leaves tufted, conspicuous, these and the lowest sten-leaves with a broad shallow sinus, abruptly incurved-acuminate; middle leaves ovate, short-petioled, rounded at the base, the upper lanceolate, slenderly acuminate, often falcate; leaves firm, smoothish, the teeth broad, curved; inflorescence small, convex, 7-12 cm. broad, its short filiform naked branches widely ascending; heads 8-10 mm. high; lower bracts short, obtuse, the others longer, nearly uniform, scarious, shining, linear, often acute, usually glabrous; rays about 8, cream-white, about Io mm. long; disk becoming purple-brown; pappus early reddening; achenes slender, glabrous. In loose moist shaded soil, N. Eng. and N. Y. to Va. Aug.-Sept.

Aster curvéscens umbellifórmis Burgess. Stem very smooth, deep red, robust, straight, sometimes I m. tall; leaves apple-green, smooth when dry, sparingly toothed; inflorescence symmetrically umbelliform, decompound; sinus of the lower leaves rather deep and narrow. In grassy woods and thickets, Conn. to Va. July.

Aster curvéscens oviformis Burgess. Stem about $7 \mathrm{dm}$. high, leafy; leaves dull green, not acuminate, very thin but rough, ovate, cordate with deep narrow sinus, $2 \mathrm{dm}$. long by $12 \mathrm{~cm}$. wide, or smaller; some of the bracts broader and green-tipped; inflorescence smaller and less branched. Range of the preceding.

9. Aster Schréberi Nees. Schreber's Aster. (I. F. f. 3742.) Stem stout, 6-9 dm. high, with long internodes. Basal leaves often in extensive colonies, thin, $c^{3}$ ull green, firm, rough above, with scattered slender appressed bristles, pubescent beneath on the veins, reniform-cordate or cordate-triangular, often $\mathbf{I} 7 \mathrm{~cm}$. long by $12 \mathrm{~cm}$. wide, the basal sinus, when well developed, rectangular, $5 \mathrm{~cm}$. across and $2.5 \mathrm{~cm}$. deep; upper leaves ovate-oblong to lanceolate, with a short broad basal wing, or sessile; lower petioles long, ciliate when young; inflorescence decompound, flattish, or irregularly convex, $15-30 \mathrm{~cm}$. broad; heads about I cm. high; bracts greenish, mostly obtuse, ciliate; rays usually Io. In borders of woods, and along fence rows in partial shade, N. Y. to Mich. and Va. July-Aug.

ro. Aster macrophýllus L. LARGE-LEAved Aster. (I. F. f. 3743.) Rough; rootstocks long, thick; stem reddish, angular, 6-9 dm. high. Basal leaves forming large colonies, 3 or 4 to each stem, broad, cordate with a large irregular sinus, rough above, harsh, thick, the teeth broad, curved; upper stem-leaves oblong with short broadly-winged petioles, the uppermost sessile, acute; inflorescence strigose and glandular, broadly corymbose, irregular; heads IO-12 mm. high: peduncles rigid, thickish; rays about 16 , 10-14 $\mathrm{mm}$. long, chiefly lavender, sometimes violet, rarely pale: bracts conspicuously green-tipped, the lower acute, the inner oblong, obtuse; disk turning reddish brown; florets short-lobed. In moderately dry soil, in shaded places, Canada to Minn. and N. Car. Aug.

Aster macrophýllus velùtinus Burgess. Smaller; leaves small, ovate-triangular, slender-petioled, often truncate at the base, about $6 \mathrm{~cm}$. long by $5 \mathrm{~cm}$. wide, sometimes none of them cordate ; glands fewer; pubescence subpilose or velvety ; bracts broad, flat, green; rays violet or blue. In grassy woods and thickets, especially in mountainous regions, Me. to Minn. and W. Va.

Aster macrophýllus sejúnctus Burgess. Strigose-pubescent; glands numerous; leaves apple-green above, pale beneath, chiefly cordate-orbicular, abruptly short-acuminate, thick, spongy, conmonly minutely wrinkled: basal leaves few; bracts narrow, obtuse; peduncles slender; inflorescence dense, convex, $1-2 \mathrm{dm}$. broad, not leafy; rays lilac. In open grassy places, Me. to Penn. and Wis.

Aster macrophýllus apricénsis Burgess. Glabrate, deeply branched, the branches numerous, often $45 \mathrm{~cm}$. high ; rays short, pinkish lavender; leaves broad, oval to ovate, the teeth and sinus little developed; petioles often expanded into a long wing, sometimes 
$7 \mathrm{~cm}$. long and $\mathrm{I} \mathrm{cm}$. wide ; uppermost leaves short-oblong with a narrowed sessile base. In clearings and open gravelly or sandy places, N. Y. and Penn.

Aster macrophýllus bifórmis Burgess. Small, stocky, with 3 or 4 small oval closely crenate spongy-thickened lower leaves with long slender petioles, the sinus deep, narrow, the teeth triangular to semicircular ; stem-leaves crowded, much reduced, subentire, ovateoblong, subsessile; inflorescence nearly naked, dense, convex, usually $\mathbf{I} \mathrm{dm}$. broad ; strigose pubescence little developed; rays lilac. In open grassy sunny situations, forming small patches, Me. to Ont. and Lake Erie.

Aster macrophýllus pinguifolius Burgess. Stems stout, leafy, glabrous, about 6 $\mathrm{dm}$. high; basal and lower leaves large, forming extensive patches, deep green above, very pale beneath, many of them appearing greasy, some roughening in drying; petioles fleshy, sometimes $23 \mathrm{~cm}$. long; inflorescence broad, flat-topped; heads large ; rays lavender to almost white; only the upper leaves sessile. Borders of woods, Conn. and L. I. to Minn.

Aster macrophýllus excélsior Burgess. Stem robust, glabrous, often $12 \mathrm{dm}$. tall, purple, or glaucous; leaves mostly very smooth, pale, numerous, narrower, cordateoblong to ovate-lanceolate, chiefly sessile; rays deep lilac to violet. Along paths and borders of rocky woods, Ont. and western N. Y. to Mich.

I I. Aster róscidus Burgess. Dewy-leaf Aster. (I. F. f. 3744.) Clammy-hairy, odorous, copiously glandular when young, somewhat so at maturity; stem $9 \mathrm{dm}$. high, or less. Basal leaves in close colonies, coriaceous, cordate-qua drate, lowserrate, the sinus deep, narrow; stem-leaves chiefly orbicular and not cordate, with short broadly winged petioles, rarely slender-petioled; involucre hemispheric, its bracts chiefly with rounded ciliate tips; rays 14-16, broad, clear violet; disks at first golden yellow, soon turning red. In slight shade and rich cleared woodlands, Me. to Penn. and Mich., Aug.--Sept.

I2. Aster iánthinus Burgess. Violet Wood Aster. (I. F. f. 3745.) Glandular, dark green, slightly strigose-pubescent. Stem erect, or decumbent, 6-9 $\mathrm{dm}$. tall ; leaves thinnish, rough, the lower and basal ones orbicular to oblong, $\mathbf{I} \mathbf{c m}$. long, or less, abruptly acuminate, low-serrate or crenate, the sinus broad, open, shallow; inflorescence open, nearly naked; peduncles slentler, divergent; heads large ; rays Io-13, long, very deep violet or sometimes pale, 8-12 mm. long, bracts green-tipped, little pubescent. On shaded banks and along woodland paths, Me. to Lake Erie and W. Va. July-Oct.

13. Aster violàris Burgess. Violet-leaf Aster. (I. F. f. 3746.) Caudex thick, fleshy; plant glabrate, bluish green, minutely glandular. Stem slender, erect, or assurgent, $6 \mathrm{dm}$. high, or less; basal and lower leaves broadly reniform, abruptly acuminate or apiculate, often $7 \mathrm{~cm}$. long and $10 \mathrm{~cm}$. wide, their slender petioles $15-20 \mathrm{~cm}$. long, the sinus very broad and shallow; middle stem-leaves similar, not cordate; the upper numerous, long-elliptic, chiefly with narrowed liases, all thin, firm; rough above; inflorescence leafy, small, loose, nearly levelt. ppod; i.eals $12 \mathrm{~mm}$. high, or more; rays $12-15$, pale violet, narrow. In shaded muist places, sometimes in leaf-mold among rocks, N. Y. from the IHudson to Lake Erie. Sept.-Oct.

14. Aster multifórmis Burgess. Various-Leaved Aster. (I. F. f. 374.7.) Deep green, minutely glandular. Stem erect, slender, 3-6 dm. high, angularstriate in drying. Basal leaves usually 2, large, cordate-oblong; stem-leaves very thin, sharply serrate, rough above, minutely puberulent beneath, the lower ovate, acuminate, usually with a narrow sinus, the upper oval to ovate-lanceolate, petioled, the uppermost elliptic-lanceolate, serrulate, sessile or nearly so; inflorescence small, its branches upwardly curved; heads about $14 \mathrm{~mm}$. high, rays about $\mathrm{I}_{3}$, rounded and retuse at the apex; bracts green, glands few, almost hidden by the minutely strigose pubescence of the peduncles. In moist shaded places, Me. to western N. Y., Penn. and Md. July-Aug.

15. Aster nóbilis Burgess. Stately Aster. (I. F. f. 3748.) Tall, minutely glandular above; stem shining, bright green, 12-15 dm. high. Leaves thin, but firm, smooth in growth, roughened in drying, minutely puberulent beneath, dark green, basal and lower leaves large, the blade often $22 \mathrm{~cm}$. long by $15 \mathrm{~cm}$. wide, about as long as the stout petiole, sharply toothed, the sinus deep, broad, or the lobes overlapping; stem.leaves similar, the upper oblonglanceolate, sessile: inflorescence irregularly cymose-paniculate: bracts long, acute, green; heads $12 \mathrm{~mm}$. high, or less: rays $13^{-15}$, violet-blue or pale violet. In leafmold, Lake Champlain to Lake Erie. Aug. 
I6. Aster anómalus Engelm. Many-Rayed Aster. (I. F. f. 3749.) Stem rough, rather stout, branched above, 3-9 dm. high. Leaves thin, the lower and basal ones deeply cordate, ovate, or ovate-lanceolate, entire or slightly repand, rough-pubescent on both surfaces, acute or acuminate, 7-10 $\mathrm{cm}$. long, $2-5 \mathrm{~cm}$. wide, with slender naked petioles; upper leaves short-petioled or sessile, lanceolate, oblong, or linear, much smaller; heads few, 8-12 mm. high, 25-30 mm. broad; receptacle hemispheric, its bracts lanceolate, acute, or acuminate, hirsute, imbricated in several series, their foliaceous tips spreading or reflexed; rays $30-45$, I0-1 $2 \mathrm{~mm}$. long, bright violet blue; pappus whitish. On limestone cliffs, Ill. to Mo. and Ark. Sept.

I7. Aster Shortii Hook. Short's Aster. (I. F. f. 3750.) Stem roughish or smooth, slender, paniculately branched above, $6-12 \mathrm{dm}$. high. Leaves thick, glabrous or nearly so above, finely and sparingly pubescent beneath, the lower and basal ones ovate or ovate-lanceolate, cordate at the base, acute or acuminate, often entire, 5-15 cm. long, $2-5 \mathrm{~cm}$. wide, borne on slender naked petioles; upper leaves lanceolate, entire, sessile or short-petioled, not cordate, those of the branches small and bract-like; heads numerous, Io- $14 \mathrm{~mm}$. high; involucre broadly campanulate, its bracts linear, acute, puberulent, imbricated, their green tips appressed; rays 10-15, linear, violet blue, 10-12 $\mathrm{mm}$. long; pappus tawny. On banks and along edges of woods, western Penn. to Va., Ga., Ill. and Tenn. Sept.-Oct.

18. Aster azùreus Lindl. Sky-Bluf. Aster. (I. F. f. 375 I.) Stem slender, stiff, rough, branched above, 3-I2 dm. high. Leaves thick, usually all entire, scabrous on both sides, the lower and basal ones cordate, ovate, ovate-lanceolate, or lanceolate, acute, acuminate, or obtusish, 5-15 cm. long, with slender often pubescent petioles; upper leaves short-petioled or sessile, lanceolate or linear, those of the branches reduced to small appressed bracts; heads numerous, 8-10 mm. high; involucre turbinate, its bracts glabrous, linear-oblong, abruptly acute, imbricated, their green tips appressed; rays IO-20, bright blue, 6-8 mm. long: pappus tawny. On prairies and along borders of woods, western N. Y. to Ga., Minn., Kans. and Tex. Aug.-Oct.

19. Aster cordifòlius L. Common Blue Wood Aster. (I. F. f. 3752.) Stem glabrous or nearly so, much branched, bushy, 3-I5 dm. high. Leaves thin, rough, more or less pubescent, sharply serrate, acuminate, the lower and basal ones slender-petioled, broadly ovate-cordate, 5-12 cm. long, the upper shortpetioled or sessile, ovate or lanceolate; heads very numerous, small, $4-6 \mathrm{~mm}$. high, I2-I $8 \mathrm{~mm}$. broad, handsome; involucre turbinate to cylindric, its bracts oblonglinear, obtuse or obtusish, green-tipped, appressed; rays 10-20, 6-8 mm. long, violet or blue, sometimes pale (rarely white); pappus whitish. Woods and thickets, N. B. to Minn., Ga. and Mo. Sept.-Dec.

Aster cordifolius Furbishiae Fernald. Similar; stem and petioles densely villous, the leaves somewhat so beneath. Northern Me.

Aster cordifolius polycéphalus Porter. More robust and more branched than the type, leaves smaller, often rough only when dry, the upper ones sessile, ovate; panicle large; heads usually smaller, very numerous. Me. and Mass. to eastern Penn. and Va.

Aster cordifolius alveàrius Burgess. Leaves thin, usually smoothish, cordate, triangular-lanceolate, or broader; inflorescence dense, thyrsoid, not leafy, in form resembling that of the lilac; bracts linear, acute; heads medium sized; rays blue. On shaded banks, Mass. to N. Car. and Tenn.

Aster cordifolius pedicellatus Burgess. Stem leafy, often $12 \mathrm{dm}$. high; leaves thin, the lower ovate, cordate, the upper ovate-lanceolate, or those of the branches elliptic and subentire; inflorescence loosely pyramidal, often $6 \mathrm{dm}$. high and $4 \mathrm{dm}$. broad, its ultimate branchlets long and often naked; heads large, $18 \mathrm{~mm}$. broad or more, of ten ro $\mathrm{mm}$. high: rays chiefly purple blue; bracts obtuse. In moist wood borders, Ont. to Va. and $\mathrm{Ky}$.

20. Aster Lowrieànus Porter. Lowrie's Aster. (I. F. f. 3753.) Glabrous, or very nearly so, throughout; stem branched, 3-12 dm. high. Leaves thickish, firm, a little succulent, the basal slender.petioled, ovate to ovate-lanceolate, cordate, acute or obtusish, serrate, $5-15 \mathrm{~cm}$. long, those of the stem ovate to oblong, often cordate, contracted into winged petioles, the uppermost lanceolate; heads usually not very numerous, 5-6 mm. high, loosely panicled; involucre turbinate, its bracts obtuse or obtusish, appressed; rays light blue, $6-8 \mathrm{~mm}$. long, but 
variable in length. In woods, Conn. and southern N. Y. to Penn., Iowa, N. Car. and $\mathrm{Ky}$. Sept.-Oct.

Aster Lowrieanus lancifolius Porter. Leaves lanceolate, appressed-serrate, only the basal ones cordate. Southern N. Y. and Penn. to W. Va. and Ala.

Aster Lowrieànus Bicknéllii Porter. Leaves all lanceolate. all sharply serrate, or the lowest incised, usually none of them cordate. Southern N. Y. and Penn.

2I. Aster Lindleyànus T. \& G. Lindley's Aster. (I. F. f. 3754.) Stem usually stout, glabrous. or sparingly pubescent, 3-10 dm. high, branched above. Leaves rather thick, glabrous, or slightly pubescent, especially on the veins, the lower and basal ones cordate at the base, sharply serrate, ovate, acute or acuminate, 5-10 cm. long, with slender naked petioles; upper leaves ovate, or lanceolate, less serrate, or entire, sessile, or with margined petioles, those of the branches lanceolate or linear-lanceolate, smaller; heads usually not numerous, 8-10 $\mathrm{mm}$. high; involucre broadly turbinate or nearly hemispheric, its bracts linear-lanceolate, acute, rather loosely imbricated, glabrous, or nearly so, their tips green; rays Io-20, blue or violet, 6-10 $\mathrm{mm}$. long; pappus nearly white. In open places, Lab. to the N. W. Terr. and Br. Col., south to Me. and Mich. Aug.-Oct.

Aster Lindleyanus exímius Burgess. Tall, sometimes $2 \mathrm{~m}$. high; leaves thick. usually rough and strigose-pubescent above, almost glabrous beneath; inflorescence widely branched, loosely paniculate, often over $6 \mathrm{dm}$. long; rays bluish purple; heads nearly $2.5 \mathrm{~cm}$. broad; bracts linear, abruptly acute. N. H. to Ohio and Va.

22. Aster Drummóndii Lindl. Drummond's Aster. (I. F. f. 3755.) Stem usually stout, finely and densely canescent, $6-15 \mathrm{dm}$. high. Leaves mostly thin, ovate or ovate-lanceolate, acuminate, rough above, canescent beneath, the lower and basal ones cordate, with slender naked petioles, sharply toothed, $5-10 \mathrm{~cm}$. long, the upper cordate or rounded at the base, usually on margined petioles, those of the branches sessile and entire or nearly so, much smaller; heads 6-8 mm. high, rather numerous on the racemose branches; involucre turbinate, its bracts linear, slightly pubescent, acute or acuminate, their green tips appressed; rays 8-15, blue, $0-8 \mathrm{~mm}$. long; pappus whitish. In dry soil, borders of woods and on prairies, Ohio to Minn., Kans., Ark. and Tex. Sept.-Oct.

23. Aster sagittifòlius Willd. Arrow-leaved Aster. (I. F. f. 3756.) Stem stout, or slender, strict, glabrous, or sparingly pubescent above, 6-15 dm. high, paniculately branched at the inflorescence, the branches ascending. Leaves thin, slightly roughened, or glabrous above, usually glabrate beneath, the lower and basal ones cordate or sagittate, ovate-lanceolate, sharply serrate, acuminate, 7-15 $\mathrm{cm}$. long, with slender naked or narrowly margined petioles; upper leaves lanceolate, sessile, or on short and usually margined petioles, serrate or entire, those of the branches very small; heads $5-8 \mathrm{~mm}$. high, $16-20 \mathrm{~mm}$. broad, numerous, crowded, racemose; involucre turbinate, its bracts linear-subulate, glabrous or nearly so, their tips green and slightly spreading; rays 10-15, light blue or purplish, 6-8 mm. long; pappus whitish. In dry soil, N. B. to N. Dak., N. J., Ky. and Kans. Aug.-Oct.

Aster sagittifolius dissitiflorus Burgess. Differs from the typical form of the species in its broader looser pyramidal inflorescence, the somewhat larger and longer peduncled heads, the leaves less serrate, often none cordate. N.Y. to Fla., Miss. and Oklahoma.

Aster sagittifolius urophýllus (Lindl.) Burgess. Leaves pilose beneath during growth, persistently so on the veins rough, above, lanceolate, acuminate, the lower, or all of them, cordate; stem often $15 \mathrm{dm}$. tall, the narrow inflorescence sometimes $9 \mathrm{dm}$. long; heads about $6 \mathrm{~mm}$. high; rays white. Grassy thickets and river-banks, N.Y. to Minn.

24. Aster Saún jersii Burgess, n. sp. Saunders' Aster. Puberulent on the branches of the inflorescence, otherwise glabrous, or the petioles sparingly ciliate; stem 3-6 dm. high. Basal leaves with narrowly margined or marginless petioles, longer than the blades, the latter ovate, rather deeply cordate, serrate, 6Io $\mathrm{cm}$. long; lower stem-leaves similar, but with margined petioles, often broadly so, the uppermost lanceolate, chiefly entire, much smaller, partly clasping: heads corymbose-paniculate $2.5 \mathrm{~cm}$. broad or less; rays apparently purple; involucre 
about $8 \mathrm{~mm}$. high, its bracts linear-lanceolate with acuminate green bracts. S. Dak. and lowa. Type from Roberts Co., S. Dak. (De Alton Saunders, No. 8067.) 25. Aster undulàtus L. Wavy-leaf Aster. Small Fleabane. Various. LEAVED ASTER. (I. F. f. 3757.) Stem stiff, very rough and pubescent, divaricately branched above, 3-10 $\mathrm{dm}$. high. Leaves usually thick, rough on both sides, pubescent beneath, dentate, undulate or entire, acute or acuminate, the lowest and basal ones ovate, cordate, 5-12 cm. long, with naked or margined petioles; middle ones ovate, lanceslate or oblong, with margined petioles dilated and clasping at the base, the upper sessile or clasping, those of the branches small and subulate; heads numerous, racemose and often secund on the spreading branches, about $8 \mathrm{~mm}$. high, 16-20 mm. broad; involucre broadly turbinate, its bracts linear-oblong, pubescent, acute or acutish, their green tips appressed; rays 8-15, pale blue to violet, 6-Io mm. long; pappus whitish. In dry soil, N. B. and Ont., south to Fla., Ala. and Ark. Sept.-Oct.

Aster undulàtus abruptifolius Burgess. Tall, I-1.5 m. high; leaves rougher, chiefly short-ovate, sessile, entire and about $5 \mathrm{~cm}$. long, $4 \mathrm{~cm}$. broad; inflorescence pyramidal; heads much darker, more crowded. N. Eng. to Va.

Aster undulatus lorifórmis Burgess. Predominant leaves greatly elongated, linearoblong to linear-lanceolate, often $15 \mathrm{~cm}$. long, with the clasping base narrowed or broadened, only a few of the lower ones contracted into winged petioles; plant little pubescent at maturity. Eastern Mass. to Va. and Penn.

Aster undulatus torquatus Burgess. Leafy, 2-3.5 dm. high, dark green, shortdowny; leaves small, very short and broad, close together, entire, their bases clasping the stem as a succession of collars, often $\mathbf{I ~ c m}$. in diameter; lowest leaves petioled; inflorescence much tranched, paniculate. Martha's Vineyard, Mass., to Long Island.

Aster undulatus triangularis Burgess. Tall, leafy, I-2 m. high, pale; pubescence slight; leaves hispid above, ovate-triangular, acuminate, chiefly $5-7 \mathrm{~cm}$. long, $18 \mathrm{~mm}$. broad and sessile. N.Y. to S. Car.

26. Aster pàtens Ait. Late Purple Aster. (I. F. f. 3758.) Stem slender, rough, 3-9 dm. high, divergently branched. Leaves ovate-oblong to oblonglanceolate, rough, pubescent, somewhat rigid, strongly cordate or auriculate-clasping at the broad base, entire, acute, or the lowest obtuse, $2.5-7.5 \mathrm{~cm}$. long, those of the branches much smaller and bract-like, the margins rough-ciliate; heads $25 \mathrm{~mm}$. broad or more, solitary at the ends of the branches; involucre broadly turbinate, its bracts linear-oblong, finely pubescent or scabrous and somewhat glandular, im. bricated, their green acute tips spreading; rays 20-30, purplish blue, or deep violet, 8-12 mm. long; pappus tawny; achenes pubescent. In dry, open places, Mass. to northern N. Y., Minn., Kans., Fla., La. and Tex. Reported from Canada. Aug.-Oct.

27. Aster phlogifòlius Muhl. Thin-leaved Purple Aster. (I. F. f. 3759.) Similar to the preceding species, usually taller. Leaves larger, lanceolate to oblong-lanceolate, entire, thin or membranous, acuminate at the apex, strongly auriculate-clasping at the base, roughish above, pubescent beneath, usually narrowed below the middle, sometimes $15 \mathrm{~cm}$. long; heads usually numerous, $3-5 \mathrm{~cm}$. broad, panicled, or somewhat racemose on the branches: bracts of the involucre lanceolate, glabrate, rather loose, with herbaceous tips; rays numerous, purple-blue. In woods and thickets, N. Y. to Ohio, N. Car. and Tenn. Aug.-Sept.

28. Aster Nòvae-Angliae L. New England Aster. (I. F. f. 3760.) Stem stout, hispid, pubescent, corymbosely branched above, 6-25 dm. high, very leafy. Leaves oblong-lanceolate, entire, acute, pubescent, 5-12 cm. long, I2-25 $\mathrm{mm}$. wide, clasping the stem by an auriculate or broadly cordate base; heads numerous, $3-5 \mathrm{~cm}$. broad, clustered at the ends of the branches; involucre hemispheric, its bracts linear-subulate, somewhat unequal, green, spreading, pubescent and more or less glandular-viscid; rays 40-50, linear, IO-I $6 \mathrm{~mm}$. long, violet- * purple, rarely pink or red, or white; achenes pubescent; pappus reddish white. In fields, and along swamps, Quebec to the N. W. Terr., south to S. Car., Mo., Kans. and Colo. Aug.-Oct.

29. Aster oblongifòlius Nutt. Aromatic Aster. (I. F. f. 376r.) Stem much branched, hirsute-pubescent; 3-7 dm. high, the branches divaricate or ascending. Leaves crowded, oblong, or oblong-lanceolate, sessile by a broad, partly clasping base, usually rigid, entire, acute or mucronulate at the apex, rough 
or hispidulous on both sides, rough-margined, those of the stem 3-5 cm. long, 4-8 $\mathrm{mm}$. wide, those of the branches gradually smaller; heads corymbose, nearly 25 $\mathrm{mm}$. broad; involucre hemispheric, its bracts much imbricated, glandular, aromatic, linear or linear.oblong, the acute green tips spreading; rays 20-30, violetpurple, rarely rose-pink, 6-10 $\mathrm{mm}$. long; pappus light brown; achenes canescent. On prairies and bluffs, central Penn. to Minn., Neb., Va., Tenn. and Tex. Aug.-Oct.

30. Aster amethýstinus Nutt. Amethyst Aster. (I. F. f. 3762.) Resembles the preceding species, but is often taller, sometimes $15 \mathrm{dm}$. high. Leaves often crowded, linear-lanceolate, entire, rough or hispidulous on both sides, partly clasping, sessile, acute, those of the stem 3-5 cm. long, 4-6 mm. wide; heads rather numerous, racemose or corymbose, $\mathbf{I}-2.5 \mathrm{~cm}$. broad; involucre broadly turbinate, its bracts much imbricated, linear, lispid, not glandular, the acutish green tips spreading; rays 20-30, blue-purple, about $6 \mathrm{~mm}$. long; pappus brown; achenes canescent. In moist soil, Mass. to southern N. Y., eastern Penn., Ill. and Iowa. Sept.-Oct.

31. Aster màjor (Hook.) Porter. Great Northern Aster. (I. F. f. 3763.) Stem stout, leafy to the summit, usually densely pilose-pubescent with many-celled hairs, rarely glabrate, branched above, 12-18 $\mathrm{dm}$. high. Leaves membranous, lanceolate, partly clasping by a narrowed base, acuminate, sharply serrate with low distant teeth, dark green and slightly pubescent above, villous-pubescent on the veins beneath, 7-12 cm. long, 10-20 mm. wide; heads mostly solitary at the ends of short branches, $3.5 \mathrm{~cm}$. broad; involucre hemispheric, its bracts imbricated, green, linear-subulate, densely glandular; rays 35-45, purple, Io-14 mm. long: achenes appressed-pubescent; pappus tawny. In n:oist soil, western Ont. to Dak., Ore. and Br. Col. Sept.-Oct.

32. Aster puníceus L. Red-Stalk or Purple-stem Aster. (I. F. f. 3764.) Stem usually stout, reddish, corymbosely or racemosely branched above, hispid with rigid hairs, 9-25 dm. high. Leaves lanceolate to oblong-lanceolate, acuminate, sessile and clasping by a broad or narrowed base, sharply serrate, or some of them entire, usually very rough above, pubescent on the midrib beneath, 7-15 cm. long, I-4 cm. wide; heads generally numerous, $2-4 \mathrm{~cm}$. broad; involucre nearly hemispheric, its bracts linear or oblong, attenuate, imbricated in about 2 series, glabrous or ciliate, green, loose, spreading, nearly equal, sometimes broadened; rays 2O-4O, violet purple or pale, IO-I4 mm. long, showy; pappus nearly white; achenes pubescent. In swamps, N. S. to western Ont. and Minn., south to N. Car., Ohio and Mich. July-Nov.

Aster puniceus firmus (Nees) T. \& G. Sten sparingly hispid, or glabrous, 6-15 dm. high; leaves sharply serrate. With the type.

Aster puníceus oligocéphalus Fernald. Stem seldom over $7 \mathrm{dm}$. high, glabrate below; branches of the inflorescence short; heads few or solitary, large, the outer involucral bracts commonly large and foliaceous. Newf. and Lab. to Ont., N. H. and northern N. Y.

Aster puniceus compáctus Fernald. Stem very hispid; leaves firm, large, the upper mostly longer than the short branches of the inflorescence; heads compactly clustered, large. Eastern Mass. to Penn.

Aster puníceus lucídulus A. Gray. Stem nearly or quite glabrous; leaves crowded, entire, or nearly so, thin, glabrous or slightly rough-pubescent. Quebec to N. Eng., Ont. and Mich.

Aster puníceus Cráwfordl Porter. Stems slender, in height 7.5-8 dm., somewhat hispid; lower and middle leaves linear and lance-linear, acuminiate, 5-10 cm. long and about $5 \mathrm{~mm}$. broad, becoming revolute, scantily denticulate, very scabrous above, pubescent on the midribs beneath: the upper ones on the panicle nuuch smaller and ovate. Collected at Tullytown, Bucks County, Pa., by Mr. Joseph Crawford.

33. Aster tardiflòrus L. Northeastern Aster. (I. F. f. 3765.) Stem glabrous, slightly pubescent above, or sometimes villous, corymbosely branched near the summit, 3-9 dm. high. Leaves lanceolate or oblong-lanceolate, serrate with low teeth, or some of them entire, acuminate, narrowed into a clasping base, glabrous or nearly so on both sides, roughish margined, 7-15 cm. long, 8-20 mm. wide; heads about $25 \mathrm{~mm}$. broad, not very numerous: involucre hemispheric, its outer bracts broad and foliaceous, often $12 \mathrm{~mm}$. long, acute, somewhat unequal; rays $20-30$, violet; pappus nearly white; achenes pubescent. Along streams, Mass. to Lab. Aug.-Oct. 
34. Aster pátulus Lam. Spreading Aster. (I. F. f. 3766.) Pubescent, or nearly glabrous; stem 3-12 dm. high. Leaves oval, ovate, or oblong-lanceolate, sharply and irregularly serrate, rather thin, acute, acuminate, or blunt, the lower 7-15 cm. long, $2.5-6 \mathrm{~cm}$. wide, narrowed into margined petioles, the upper sessile and somewhat clasping; heads numerous, panicled, about $25 \mathrm{~mm}$. broad; involucre campanulate, $6-8 \mathrm{~mm}$. high, its bracts linear to linear lanceolate, acuminate, not foliaceous, loosely imbricated in 3 or 4 series, the outer shorter; rays violet-purple or rarely white. N. B. to N. H. Sept.

35. Aster prenanthoìdes Muhl. Crooked-STem Aster. (I. F. f. 3767.) Stem glabrous, or pubescent in lines above, flexuous, much branched, 3-6 dm. high. Leaves thin, oblong to ovate-lanceolate, sharply and coarsely serrate, scabrous above, glabrous or nearly so beneath, 7-1 $5 \mathrm{~cm}$. long, $18-35 \mathrm{~mm}$. wide, acuminate, abruptly narrowed below into a broad-margined entire petiole, the base auriculate-clasping; heads usually numerous, $25 \mathrm{~mm}$. broad or more; involucre hemispheric, its bracts linear, acute, green, spreading, imbricated in 3 or 4 series, the outer shorter; rays 20-30, violet, 8-12 mm. long; pappus tawny; achenes pubescent. In moist soil, Mass. to Wis., south to W. Va., Ky. and Iowa. Aug.Oct.

Aster prenantholdes porrectifolius Porter. Leaves narrowly lanceolate, much elongated, sometimes $2 \mathrm{dm}$. long, gradually contracted into an entire clasping base. Penn.

36. Aster laèvis L. Smooth Astrer. (I. F. f. 3768.) Stem usually stout, glabrous often glaucous, 6-12 dm. high, branclied or simple. Leaves thick, entire, or serrate, glabrous, slightly rough-margined, the upper all sessile and strongly cordate-clasping, oblong-lanceolate, oblanceolate or ovate, acute or obtusish, 2-IO $\mathrm{cm}$. long, 8-50 mm. wide, the basal and lower gradually narrowed into winged petioles, those of the branches often small and bract-like; heads usually numerous, about $25 \mathrm{~mm}$. broad; involucre campanulate, its bracts rigid, acute, appressed, green-tipped, imbricated in several series; rays 15-30, blue or violet; pappus tawny; achenes glabrous or nearly so. Usually in dry soil, Me. and Ont. to Penn., La., the N. W. Terr. and Kans. Sept.-Oct.

Aster laèvis amplifolius Porter. Stout, somewhat fleshy; leaves broadly ovate, nare rowed toward the base, strongly clasping. Mass. to eastern Penn., Minn. and Mo.

Aster laèvis Potomacénsis Burgess. Lower stem-leaves abruptly contracted into winged petioles, sharply serrate; heads few, usually racemose; green tips of the bracts broad, conspicuous. Md. and Va.

37. Aster concínnus Willd. Narrow-leaved Smooth Aster. (I. F. f. 3769.) Similar to narrow-leaved forms of Aster laevis, glabrous or sparingly pubescent above; stem paniculately branched, 3-9 dm. high. Leaves light green, lanceolate to linear, entire, or sometimes serrulate, the upper sessile, somewhat clasping, 2-7 cm. long, the lower and basal ones spatulate, or oblong, narrowed into margined petioles, sometimes coarsely toothed; heads usually numerous, about $25 \mathrm{~mm}$. broad; bracts of the involucre with rhomboid acute herbaceous tips; rays violet to purple. Conn. to Penn., Va., N. Car.(?) and Ark.

38. Aster parpuràtus Nees. Southern Smooth Aster. (I. F. f. 3770.) Stem slender, glabrous, simple, or branched above, 4-12 dm. high, the branches some. times puberulent. Leaves firm, glabrous, dark green, entire, the upper sessile and clasping at the base, elongated-lanceolate or linear-lanceolate, acuminate, $5-12 \mathrm{~cm}$. long, 4-8 $\mathrm{mm}$. wide, the lower and basal ones petioled, oblong-lanceolate, obtusish, those of the branches very small; heads rather few, loosely paniculate, $16-25 \mathrm{~mm}$. broad; involucre campanulate to turbinate, its bracts coriaceous, linear, appressed, green-tipped, acute, imbricated in several series; rays 5-10, blue or violet, 6-10 mm. long; pappus tawny; achenes glabrous. Va. and W. Va. to Ga. and Tex. Aug.-Sept.

39. Aster júnceus Ait. Rush Aster. (I. F. f. 377r.) Stem very slender, glabrous, or minutely pubescent above, simple or little branched, 3-9 dm. high. Leaves firm, glabrous, narrowly linear, entire, or sometimes with a few distant teeth, acute or acuminate, sessile by a broad clasping and often slightly cordate base, 7-15 cm. long, 3-8 $\mathrm{mm}$. wide; heads paniculate, rather distant, about 25 $\mathrm{mm}$. broad; involucre hemispheric, about $6 \mathrm{~mm}$. high, its bracts glabrous, linear. subulate, very acute, imbricated in 3 or 4 series, the outer shorter; rays violet to. 
nearly white, o-10 $\mathrm{mm}$. long; pappus pale. In swamps and bogs, N. S. to the N. W. Terr., south to N. J., Ohio, Wis. and in the Rocky Mts. July-Sept.

40. Aster adscéndens Lindl. Western Aster. (I. F. f. 3772.) Stem slender, rigid, glabrous, or sparingly hirsute-pubescent, branched or simple, I.5-6 dm. high. Leaves firm, entire, rough-margined, sometimes ciliolate, those of the stem linear-lanceolate or linear-oblong, acute or obtusish, 2-7 cm. long, 4-10 $\mathrm{mm}$. wide, sessile by a more or less clasping base; basal leaves spatulate, narrowed into short petioles; heads not numerous, about $25 \mathrm{~mm}$. broad; involucre hemispheric, its bracts imbricated in 3-5 series, oblong-linear or spatulate, their tips obtuse or obtusish, slightly spreading, the inner often mucronulate; pappus nearly white: achenes pubescent. On prairies and moist banks, western Neb. to Wyo., Mont. and the N. W. Terr., west to Colo., N. Mex. and Nev. July-Sept.

41. Aster Nòvi-Bélgii L. New York Aster. (I. F. f. 3773.) Stem slender, usually much branched, glabrous, or slightly pubescent above, 3-9 dm. high. Leaves lanceolate, oblong-lanceolate, or linear-lanceolate, firm, entire, or slightly serrate, glabrous, or very nearly so, acuminate at the apex, narrowed, sessile and more or less clasping at the base, 5-12 cm. long, 6-16 $\mathrm{mm}$. wide, the lowest petioled; heads corymbose-paniculate, usually numerous, $2-3 \mathrm{~cm}$. broad; involucre hemispheric to campanulate, its bracts linear, acute, green, somewhat spreading, in 3-5 series, the outer shorter; rays $15-25$, violet, 8-10 $\mathrm{mm}$. long; pappus whitish; achenes glabrous or nearly so. In swamps, Newf. to Me. and Ga., mainly near the coast. Aug.-Oct.

Aster Nòvi-Bélgii litòreus A. Gray. Low and spreading, more or less fleshy, much branched; leaves shorter, broader, thickish, acute, $3-6 \mathrm{~cm}$. long; principal bracts of the involucre obtuse, loose, spatulate. Along salt-marshes, Pr. Edw. Isl. and Quebec to Ga.

Aster Nòvi-Bélgii elòdes (T. \& G.) A. Gray. Leaves narrowly linear-lanceolate, often elongated to ro-r $5 \mathrm{~cm}$; bracts of the involucre acute. In moist ground, southern N. Y. to N. Car.

Aster Nòvi-Bélgii Atlánticus Burgess. Leaves lanceolate, tapering from the middle to an acuminate base and apex, sometimes $25 \mathrm{~mm}$. wide; heads usually fewer; inflorescence racemose-corymbose. In shaded swamps, Mass. to N. Car.

Aster Nòvi-Bélgii Brittònıi Burgess. Leaves thick; heads short-peduncled, racemosespicate toward the ends of the branches; green tips of the bracts short. Mass. to southeastern N. Y. and Va., near the coast.

42. Aster longifòlius Lam. Long-leaved Aster. (I. F. f. 3774.) Stem gla. brous, or somewhat pubescent, leafy, paniculately branched, 3-9 dm. high. Leaves lanceolate to linear lanceolate, entire or nearly so, acuminate, narrowed into a sessile clasping usually slightly cordate base, 7-20 $\mathrm{cm}$. long, 4-12 $\mathrm{mm}$. wide; heads rather numerous, about $25 \mathrm{~mm}$. broad; involucre hemispheric, 8-10 $\mathrm{mm}$. high, its bracts glabrous, narrow, green, acute, imbricated in only 1 or 2 series, nearly equal; rays numerous, about $8 \mathrm{~mm}$. long, violet or pale purple; pappus pale. In swamps and moist ground, Lab. to the N. W. Terr., south to northern. N. Eng., Ont. and Mont. Summer.

Aster longifòlius villicaulis A. Gray. Stem densely white-villous; leaves narrowly linear-lanceolate, the midrib villous beneath; heads fewer, long-peduncled; rays dark violet. Northern Me. and N. B.

43. Aster foliàceus Lindl. Leafy-Bracted Aster. (I. F. f. 3775.) Stem usually stout, sparingly pubescent in lines, 6-9 dm. high, branched above, the branches ascending. Leaves rather thin, oblong-lanceolate, acute, entire, or with a few small distant teeth, glabrous on both sides, very rough-margined, 5-10 cm. long, $\mathbf{I}-2.5 \mathrm{~cm}$. wide, the upper all strongly clasping at the base, the lowest petioled: heads corymbose-paniculate, numerous, $25 \mathrm{~mm}$. broad or more; involucre hemispheric, its bracts green, foliaceous, oblong, mucronate, the inner mostly narrower and acute; rays about 30, violet, 8-10 mm. long; pappus nearly white; achenes pubescent. Neb. to Mont. and Cal. August.

44. Aster seríceus Vent. Western Silvery or Silky Aster. (I. F. f. 3776.) Stem slender, paniculately or corymbosely branched, stiff, glabrous, leafy, 3-6 dm. high. Stem-leaves sessile, with a broad base, oblong, entire, mucronate, I-4 cm. long, 4-10 $\mathrm{mm}$. wide, erect or ascending, with a dense silvery-white silky pubescence on both sides; basal and lowest leaves oblanceolate, narrowed into margired petioles; heads numerous, about $35 \mathrm{~mm}$. broad; involucre turbinate, its 
bracts oblong, or the inner lanceolate, canescent, imbricated in 3 or 4 series, their tips green, acute, spreading; rays 15-25, violet-blue, I2-16 mm. long; pappus tawny; achenes glabrous. In dry open soil, Ill. to Minn. and Man., south to Tenn., Kans. and Tex. Aug.-Sept.

45. Aster cóncolor L. Eastern Silvery Aster. Lilac-flowered Aster. (I. F. f. 3777.) Stem slender, glabrous, or pubescent above, 3-7 dm. high, leafy, single, or with few erect branches. Leaves oblong or linear-oblong, finely and densely canescent on both sides, or the lower glabrate, sessile, obtuse or mucronate, 4-5 cm. long; heads in an elongated narrow raceme resembling that of Lacinaria; involucre broadly turbinate, its bracts linear or linear-oblong, appressed, canescent, imbricated in 4 or 5 series, their tips green, acute, the outer shorter; rays IO-I 5 , lilac, $\overline{0}-8 \mathrm{~mm}$. long; pappus tawny; achenes villous. In dry, sandy soil, eastern Mass. and R. I. to Fla. and La., near the coast. Aug.-Oct.

46. Aster Féndleri A. Gray. Fendler's Aster. (I. F. f. 3778.) Stems several or solitary from thick woody roots, rigid, hirsute, I.5-3 dm. high. Leaves linear, rigid, I-nerved, acute or acuminate, $16-30 \mathrm{~mm}$. long, 2-3 $\mathrm{mm}$. wide, glabrous on both sides, but the margins bristly-ciliate; heads usually few and racemose, I-2.5 cm. broad; involucre turbinate, its bracts glandular, linear-oblong, imbricated in about 4 series, the inner acute, the outer shorter and obtuse; rays IO- I5, violet, 6-1o $\mathrm{mm}$. long. In dry soil on the plains, western Kans. to Colo. and N. Mex. Aug.-Sept.

47. Aster grandifiòrus L. LARge-flowered Aster. (I. F. f. 3779.) Stem rather stiff, divaricately much branched, hispid with short hairs, 3-7 dm. high. Leaves oblong, linear, or somewhat spatulate, rigid, sessile by a broad, sometimes slightly clasping base, reflexed, entire, obtusish, hispid, the larger $5 \mathrm{~cm}$. long and $8 \mathrm{~mm}$. wide, those of the branches very numerous, 4-10 $\mathrm{mm}$. long; heads about $5 \mathrm{~cm}$. broad, terminating the branches; involucre hemispheric, its bracts very squarrose and foliaceous, imbricated in 5-7 series, linear, or linear-oblong, glandular, the outer obtusish, the inner acute; rays very numerous, deep violet, nearly $25 \mathrm{~mm}$. long, $3 \mathrm{~mm}$. wide; pappus brownish; achenes ribbed, canescent. In dry soil, Va., east of the mountains, to Fla. Sept.

48. Aster spectábilis Ait. Low Showy Aster. Seaside Purple Aster. (I. F. f. 3780.) Stem stiff, simple, or corymbosely branched above, puberulent, or rough below, more or less glandular above, 3-6 dm. high. Leaves firm, thickish, the basal and lower ones oval, acute or acutish, 7-12 cm. long, 2-4 cm. wide, sparingly dentate with low teeth, narrowed at the base into slender petioles; upper leaves sessile, entire or very nearly so, acute, linear-oblong; heads several or numerous, about $35 \mathrm{~mm}$. broad, corymbose, very showy; involucre nearly hemispheric, its bracts linear-oblong or slightly spatulate, glandular, imbricated in about 5 series, the green obtusish tips spreading; rays $15-30$, bright violet, 12-20 mm. long; pappus whitish; achenes slightly pubescent. In dry sandy soil, Mass. to Del., mostly near the coast. Aug.-Oct.

49. Aster surculòsus Michx. Creeping Aster. (I. F. f. 378I.) Stem slender, from elongated-filiform rootstocks, minutely scabrous-pubescent, $25-45 \mathrm{~cm}$. high, corymbosely branched above. Leaves firm, lanceolate or linear, the lower petioled, 5-7 cm. long, 8-16 mm. wide, rough-margined, slightly scabrous above, sparingly dentate, the upper narrower, sessile, entire; heads few, or sometimes solitary, about $3 \mathrm{~cm}$. broad; involucre turbinate-hemispheric, its bracts coriaceous, imbricated in about 5 series, ciliate, but scarcely glandular, their green tips spreading; rays $\mathbf{1}_{5}$ 3o, violet; pappus whitish; achenes nearly glabrous. In sandy or gravelly soil, N. Car. and Ga. Reported from N. J. Sept.-Oct.

50. Aster grácilis Nutt. Slender or Tube Aster. (I. F. f. 3782.) Stem slender, finely puberulent and scabrous, cory mbosely branched above, 3-4 dm. high. Leaves minutely scabrous, the basal and lower ones oval, acute or obtusish, $5-7 \mathrm{~cm}$. long, 8-16 mm. wide, dentate, narrowed into slender petioles; upper leaves linear, linear-oblong, or slightly oblanceolate, acute, entire, sessile or a little clasping; heads usually numerous, $12-20 \mathrm{~mm}$. broad; involucre narrowly turbinate, its bracts coriaceous, glabrous or very nearly so, imbricated in about 5 series, their tips green and spreading, obtusish; rays 9-15, violet, 6-9 mm. long; pappus nearly white; achenes minutely pubescent. In dry sandy soil, N. J. to Ky., Tenn. and N. Car. Rootstock tuberous thickened. July-Sept. 
51. Aster Rádula Ait. Low Rough As'rer. File-blade Aster. 3783.) Stem glabrous, or puberulent above, corymbosely branched near the sum. mit, 3-6 dm. high. Leaves sessile, rough above, more or less pubescent beneath, oblong-lanceolate, acute, sharply serrate, strongly pinnately veined, 5-7 cm. long, 6-25 mm. wide; heads several, or sometimes numerous, $25-35 \mathrm{~mm}$. broad; involucre hemispheric, its bracts oblong or oblong-spatulate, coriaceous, appressed-pubescent, conspicuously ciliolate, their green obtuse tips appressed; rays 20-30, violet, 8-12 mm. long; achenes glabrous, striate; pappus nearly white. In swamps, Del. and southern Penn. to Newf. July-Sept.

Aster Rádula biflòrus (Michx.) Porter. Lower, very slender; heads I-3; leaves nar rower, less serrate or entire; involucral bracts, or some of them, acute. Mountains of N. Eng. to Labr. and Newf. Perhaps a distinct species.

52. Aster Hérveyi A. Gray. Hervey's Aster. (I. F. f. 3784.) Stem roughish, at least above, slender, simple or corymbosely branched, rarely panicu. late, 3-9 dm. high, the branches glandular-puberulent. Leaves firm, rough above, pubescent on the veins beneath, the basal and lower ones on slender naked petioles, ovate, with low usually distant teeth, acute, narrowed, rounded or rarely cordate at the base, 5-15 cm. long, 2-7 cm. wide; upper leaves sessile, or narrowed into winged petioles, smaller, entire or nearly so; heads $25-35 \mathrm{~mm}$. broad; involucre turbinate or campanulate, its bracts appressed, or sometimes spreading, densely glandular, oblong or spatulate, obtuse or mucronulate; rays $15-25$, violet, 10-14 $\mathrm{mm}$. long; achenes minutely pubescent, striate; pappus nearly white. In dry soil, eastern Mass., Conn. and R. I. Aug.-Oct.

53. Aster turbinéllus Lindl. Prairie Aster. slender, paniculately branched, glabrous below, puberulent above, 6-9 dm. high.
Leaves firm, lanceolate, or oblong-lanceolate, entire, ciliate, acute or acuminate, 5-7 cm. long, the lower and basal ones petioled, the upper sessile, those of the branches much smaller; heads about $25 \mathrm{~mm}$. broad, mostly solitary at the ends of the branches; involucre turbinate, its bracts oblong, coriaceous, obtuse, appressed, imbricated in 5 or 6 series, their tips green only at the apex; rays $10-20,6-10 \mathrm{~mm}$. long, violet; pappus tawny; achenes finely pubescent. In dry soil, especially on prairies, Ill. to Mo., Kans., La. and Ark. Sept-Oct.

54. Aster Nebraskénsis Britton. Nebraska Aster. (I. F. f. 3786.) Stem strictly erect, slender, stiff, rough to the base, simple, or with a few short nearly erect branches, very leafy, 4-7 dm. tall. Leaves thick, rather rigid, ascending, lanceolate to oblong-lanceolate, sessile by a subcordate base, acute or acuminate at the apex, 2-7 cm. long, 8-12 $\mathrm{mm}$. wide; very rough on both sides, the mid. vein prominent beneath, the lateral veins obscure; heads few, terminating short leafy branchlets, 25-30 mm. broad; involucre broadly campanulate or hemispheric, about $6 \mathrm{~mm}$. high, its bracts green, oblong, acute, imbricated in several series, the outer quite foliaceous; rays purple, about $12 \mathrm{~mm}$. long. Lake shores, central Neb. Sept.

55. Aster Priceae Britton, n. sp. Miss Price's Aster. Stem pubescent, widely branched, 3-7 dm. high. Basal leaves oblanceolate, obtuse or acutish, entire, petioled, 3-7 cm. long, the petioles ciliate, broad; stem-leaves linear-lance. olate, sessile, ciliate, acuminate, $2-5 \mathrm{~cm}$. long, those of the branches similar but smaller; involucre nearly hemispheric, about $6 \mathrm{~mm}$. high, its bracts linear, the outer gradually acuminate, green, the inner a little broader, abruptly acuminate, acute or obtusish; heads about $25 \mathrm{~cm}$. broad; rays bright purple or pink. $\mathrm{Ky}$. and N. C. Type collected by Sadie F. Price near Bowling Green, Ky. Oct. Similar to $A$. ericoides pilosus but with pink or purple rays.

56. Aster Kentuckiènsis Britton, n. sp. Kentucky Aster. Glabrous, over $3 \mathrm{dm}$. high, the numerous branches diverging. Upper leaves all linear-subulate, $1.5 \mathrm{~cm}$. long or less, ascending, sessile, revolute-margined; heads solitary at the ends of the branchlets, about $2.5 \mathrm{~cm}$. broad; rays pink or purple; involucre about $8 \mathrm{~mm}$. high, its linear-subulate bracts all gradually acuminate, much resembling the upper leaves. Near Bowling Green, Ky., Sadie F. Price, Oct., I898.

57. Aster paludòsus. Ait. Southern Swamp Aster. (I. F. f. 3787.) Stem roughish, or rough-pubescent, slender, simple, or somewhat branched above, 3-7 dm. high. Leaves linear, entire, glabrous, the margins rough or ciliate, rather 
rigid, 5-15 cm. long, 4-8 mm. wide, mostly I-nerved, acute, the lower part commonly sheathing the stem; heads few or several, racemose or paniculate, $3.5-5 \mathrm{~cm}$. broad; involucre broadly campanulate or hemispheric, its bracts imbricated in about 5 series, foliactous, ciliate, the outer lanceolate, acute, the inner oblong or spatulate; rays 20-30, deep violet, IO-I $4 \mathrm{~mm}$. long, pappus tawny; achenes 8-IO-nerved, glabrous or nearly so. Swamps, Kans. and Mo. to Tex., N. C. and Fla. Aug.-Oct.

58. Aster nemoràlis Ait. Bog Aster. (I. F. f. 3788.) Stem puberulent, siender, simple, or corymbosely branched above, 1.5-6 dm. high. Leaves sessile, membranous, oblong-lanceolate or linear-oblong, acute at each end, pubescent or puberulent on both sides, dentate or entire, 2-5 cm. long. 3-8 $\mathrm{mm}$. wide, margins vften revrlute; heads several, or solitary, 25-35 mm. broad, the peduncles slender; involucre hemispheric, its bracts appressed, linear-subulate, acute or acuminate, imbricaced in absut 3 series; rays $15-25$, light violet-ptirple to ruse-pink; achenes glandular-pubescent; pappus white. In sandy bogs, N. J. to northern N. Y., Ont., Newf. anä Hudson Bay. Aug.-Sept.

Aster nemnralıs Blakei Porter. Stems 3-7 dm. high, ascending, leafy from the base; leaves $5-10 \mathrm{~cm}$. long, 10-25 mm. wide, oblong-lanceolate, renutely and sharply dentate, or nedrly entire; heads rather few, sometines solitary. Me., N. H. and northern N. Y. Fornis resemble the following species.

59. Aster acamindtus Michx. Whorled or Mountain Aster. (I. F. f. 3789.) Stem pubescient or puberulent, zigzag, corymbosely branched, often leafless below, 3-9 dm. high. Leaves thin, broadly oblong, acuminate at the apex, narrowed to a somewhat cuneate sessile base, sharply and coarsely dentate, pinnately veined, glabrous or punescent above, pubescent at least on the veins beneath, 7-I 5 $\mathrm{cm}$. long, I-4 cm. wide, often approximate above, and appearing whorled; heads several or numerous, $25-37 \mathrm{~mm}$. broad; involucre nearly hemispheric, its bracts subulate-linear, acuminate, the outer much shorter; rays 12-18, narrow, 12-16 mm. long, white or purplish; pappus soft, fine, nearly white: achenes pubescent. Moist woods, Lab. to Ont., western N. Y., and in the mountains to Ga. July-Oct.

6o. Aster ptarmicoides (Nees) T. \& G. Upl.and White Aster. (I. F. f. 3790.) Stems tufted, slender, rigid, usually rough above, corymbosely branched near the summit, 3-6 dm. high. Leaves linear-lanceolate, 3-ribbed, entire, or with a few distant teeth, firm, shining, rough-margined or ciliate, sometimes scabrous, acute, narrowed to a sessile base, or the lower petioled, the lowest and basal ones 7-15 cm. long, 4-8 $\mathrm{mm}$. wide, the upper smaller, those of the branches linearsubulate; heads not numerous, $16-25 \mathrm{~mm}$. broad, terminating the branches of the corymb; involucre nearly hemispheric, 4-6 mm. high, its bracts linear-oblong, obtuse, appressed, tearly glabrous, green, imbricated in about 4 series; rays 10-20, snow-white, 6-8 $\mathrm{mm}$. long; pappus white; achenes glabrous. In dry or rocky soil, Mass., Vt. and Ont., to the N. W. Terr., Ill., Mo. and Colo. July-Sept.

Aster ptarmicoldes lutéscens (Hook.) A. Gray. Rays pale yellow, short; involucre narrower. Northern Ih, to the N. W. Terr.

6r. Aster dumòsus L. Bushy Aster. Rice zutton Aster. (I. F. f. 3791.) Glabrous or very nearly so throughout, paniculately much branched, 3-9 $\mathrm{dm}$. high. Leaves firm, those of the stem linear or linear-lanceolate, entire, acute, or obtusish, 2-7 cm. long, 3-9 nım. wide, roughish-margired, often reflexed, those of the branches very numerous, small and bract like, the basal ones spatulate, dentate: heads $\delta-14 \mathrm{~mm}$. broad, terminating the usually divergent slender branches and braiıchlets, usually numerous: involucre broadly campanulite, its bracts linearsubulate, obtuse or acutish, appressed, imbricated in about 4 series, green-tipped; rays $15-30$, white to pale violet, $4 \mathrm{~mm}$. long, pappus white; aclienes minutely pubescent. Sandy soil, Me. to western N. Y., Ont., Fla., La. and Mo. Aug.-Oct.

Aster dumòsus coridifolius (Michx.) T. \& G. More rigid and stouter; branchlets elongated; bracts of the involucre coriaceous: leaves of the branches small and numerous, very close, divergent. Pine-barrens, Martha's Vineyard to Fla.

Aster dumosus strictior T. \& G. Stem sparingly branched, thie branches ascending, terminated by rather laryer heads; leaves sessile by a broad base, acuninate, mostly quite entire. Swamps, Muss. to N. J., Penn. and Md.

62. Aster Grávesii Burgess, n.sp. Graves' Aster. Glabrous; stem slender, $6 \mathrm{dm}$. high or more, Stem-leaves oblong-lanceolate, entire, firm, sessile, or the 
lower petioled, acuminate at the apex, narrowed at the base, roughish-margined, the larger about $7.5 \mathrm{~cm}$. long; branches very slender, recurved, bearing few or solitary heads, clothed with leaves $\mathbf{I}-2 \mathrm{~cm}$. long, the uppermost leaves very small and bract-like; involucre about $6 \mathrm{~mm}$. high, its bracts linear, acute, greenish. tipped; heads nearly $2.5 \mathrm{~cm}$. broad, the rays purple. In dry woods, Waterford, Conn., C. B. Graves. Sept.

63. Aster salicifòlius Lam. Wilı.ow Aster. (I. F. f. 3792.) Stem rather slender, paniculately much branched, usually very leafy, 6-I5 dm. high, glabrous, or somewhat pubescent above. Leaves firm, lanceolate or linear-lanceolate, rougb. margined, acute or acuminate, narrowed and sessile or sliglitly clasping at the base, entire or sparingly dentate with low teeth, glabrous or nearly so, $5-\mathrm{Jo} \mathrm{cm}$. long: 4-12 mm. wide, the lowest sometimes petioled, those of the branches gradually smaller; heads numerous, $16-25 \mathrm{~mm}$. broad; involucre broadly turbinate, its bracts linear-oblong, appressed, imbricated in 4 or 5 series, their green tips acute or obtusish; rays numerous, violet, or violet-purple, or sometimes white, 6-8 $\mathrm{mm}$. long; pappus white; achenes minutely pubescent. In moist soil, Me. and Ont. to Mass. and Fla., west to Mont., Mo. and Tex. Intergrades with $A$. paniculatus. Aug.-Oct.

Aster salicifolius subásper (Lindl.) A. Gray. Stem scabrous; leaves more or less so، Ind. to Mo. and Tex.

Aster salicifòlius stenophýllus (Lindl.) Rurgess. Leaves narrowly linear-lanceolate, small, those of the branches liumerous and minute; bracts of the involucre linear-subu. late. Southern N. Y. and eastern Penn. to Va.

64. Aster paniculàtus Lam. Tall White or Panicled Aster. (I. F. f. 3793.) Stem glabrous or nearly so, paniculately much branched, $6-25 \mathrm{dm}$. high. Leaves lanceolate to oblong-lanceolate, acuminate at the apex, narrowed to a sessile or slightly clasping base, glabrous, usually thin, roughish-margined, those of the stem sparingly serrate in the middle, or sometimes very nearly entire, $7-15 \mathrm{~cm}$. long, 6-12 min. wide, the upper and those of the bra:aches gradually smaller, heads numerous, 16-20 $\mathrm{mm}$. broall: involucre nearly hemispheric, 6-8 $\mathrm{mm}$. high, it: bracts narrowly linear-lanceolate, acute or acuminate, appressed, green tipped, imbricated in 4 or 5 series; rays numerous, white, or faintly tinged with viole $i$, 6-8 mm. long; pappus white or nearly so; achenes minutely pubescent. In moist soil, N. B. to western Ont. and Mont., south to N. J., Va., Ky., La. and Kans. Aug. Oct.

Aster paniculatus bellidiflorus (Willd.) Burgess. Leaves narrowly linear, acuminate at both ends, entire, or remotely appressed serrate, chiefly $10 \mathrm{~cm}$. long and $7 \mathrm{~cm}$. wide, or less; heads numerous, rather densely clustered on the ascending branches of the large panicle. In moist or wet soil, in open situations, N. B. to western Ont., N. Car., Mo。 and $\mathrm{K}$ ans.

Aster paniculatus simplex (Willd.) Burgess. Leaves oblong-lanceolate or oblanceolate, thin, long-acuminate at both ends, the larger often $2 \mathrm{dm}$. long and $25 \mathrm{~mm}$. wide, sparingly serrate with low teeth; inflorescence leafy, the heads less showy than in the preceding. In shaded moist places, Mass. to Ohio, Va. and Ky.

Aster paniculatus acùtidens Burgess. Leaves oblong lanceolate, the larger often $15 \mathrm{~cm}$. long by $3 \mathrm{~cm}$. wide, very sharply serrate, at least above the middle; branches often very short, sometimes elongated. Along streams and ditches, Conn. to Va., Ohio and Kans.

Aster paniculàtus cineráscens Fernald. From Maine, is described as cinerous-hirsute, a churacter otherwise unknown in this species.

65. Aster Missouriénsis Britton. Missouri Aster. (I. F. f. 3794.) Stem densely puberulent or pubescent, at least above, much branched, $6 \mathrm{dm}$. high or more. Leaves thin, oblong-lanceolate to oblaı ceolate, acute or acuminate, sharply serrate above the middle, gradually tapering to an entire sessile or slightly clasping base, or the lower pctioled, puberulent above, finely pubescent beneath, the larger 7-10 cm. long, the upper much smaller, entire; heads I2-16 mm.-broad, panicled, short-perluncled, or terminating short leafy branchlets, sometimes somewhat secund; involucre $4-6 \mathrm{~mm}$. high, its linear acute bracts well imbricated, ciliate or pubescent; rays white. In moist soil. Kans. and Mo. Sept.-Oct.

66. Aster Trade-cánti L. Tradescan's Aster. Michaelmas Daisy. (I. F. f. 3795.) Stem slender, paniculately branched, 6-1 5 dm. high, the branches usually ascending and often pubescent in lines. Stem-leaves linear-lanceolate or 
lanceolate, acuminate, narrowed to a sessile base, 7-15 cm. long, 3-12 mm. wide, glabrous or nearly so on both sides, commonly thin, sharply serrate in the middle with low teeth, or sometimes entire; heads very numerous, racemose but not secund on the branches, 10-16 mm. broad; involucre hemispheric to broadly turbinate, 4-6 mm. high, its bracts linear, acute, appressed, green-tipped, imbricated in 4 or 5 series; rays white or nearly so, numerous, 4-6 mm. long; pappus white; achenes minutely pubescent. In fields and swamps, Ont. to Va., west to the N. W. Terr., Ill. and Minn. Extends to Fla. Aug.-Oct.

67. Aster Fáxoni Porter. Faxon's Aster. (I. F. f. 3796.) Glabrous throughout; stem paniculately or corymbosely branched, rather stout, 6-15 dm. high. Stem-leaves lanceolate or linear-lanceolate, acute or acuminate, narrowed to a sessile base, or the lower into margined petioles, entire or nearly so, firm, 5-12 cm. long, 4-8 $\mathrm{mm}$. wide, those of the branches gradually smaller; basal leaves oblong to spatulate, obtuse, dentate; heads not very numerous, $12-18 \mathrm{~mm}$. broad; involucre hemispheric, nearly $8 \mathrm{~mm}$. high, its bracts linear-lanceolate, acute or subulate, green-tipped or green on the back, imbricated in about 3 series, the outer shorter; rays bright white, 6-8 $\mathrm{mm}$. long, numerous; pappus white; achenes minutely pubescent. On moist cliffs, Vt. and Mass. to Penn., west to Wis.(?), south to N. Car. Aug.-Sept.

68. Aster ericoides L. White Heath Aster. Frost-weed Aster. (I. F. f. 3797.) Stem glabrous or very nearly so, paniculately branched, usually bushy, 3-9 dm. high, the branches racemose, and the branchlets often somewhat secund. Leaves firm or rigid, the basal ones spatulate, obtuse, dentate, narrowed into margined petioles, glabrous or ciliate; stem-leaves narrowly linear, acute, entire, 2-7 cm. long, 2-6 $\mathrm{mm}$. wide, those of the branches linear-subulate, numerous; heads usually very numerous, $8-12 \mathrm{~mm}$. broad; involucre campanulate to hemispheric, its bracts coriaceous, lanceolate or linear-lanceolate, abruptly acute or acuminate, green-tipped, imbricated in about 3 series; rays $15-25$, white, or tinged with rose; pappus white; achenes finely pubescent. In dry soil, Me. and Ont. to Fla., west to Wis. and Ky. Sept.-Dec.

Aster ericoides pilosus (Willd.) Porter. Stem, branches and often the leaves villoushirsute or hispid; leaves linear-lanceolate. W. Ont. to Penn. and Ga., west to Minn. and Mo.

Aster ericoldes platyphýllus T. \& G. Densely villous-hirsute: stem-leaves lanceolate or oblong-lanceolate, 2-5 cm. long, 8-25 $\mathrm{mm}$. wide. Ind. to N. Car. and Ga.

Aster ericoides depauperatus Porter. Glabrous, very slender, r5-30 cm. high; stemleaves and those of the branches linear or subulate. S. Penn. and W. Va.

Aster ericoldes Rándi Britton. Low, stout, glabrous, seldom over $3 \mathrm{dm}$. high, corymbosely or somewhat racemosely branched above, often bushy; stem-leaves elongated, sometimes $6 \mathrm{~mm}$. wide; basal leaves spatulate, petioled, entire; heads numerous, larger than in the type, sometimes over $25 \mathrm{~mm}$. broad; rays white to violet; bracts of the involucre greener than in the type. Perhaps a distinct species. Mt. Desert Island, Me.

Aster ericoldes pàrviceps Burgess. More or less pilose; stem strict, erect, about 3 $\mathrm{dm}$. high, usually bushy, branched above, the branches mostly short; leaves narrowly linear, ascending, with short leafy branches in their axils; heads numerous, crowded, 6-8 mm. broad, somewhat secund; involucre $\mathrm{r}-4 \mathrm{~mm}$, high; leaves of the branches reduced to small scales. Prairies, Ill. and Mo.

69. Aster Prínglei (A. Gray.) Britton. Pringle's Aster. (I. F. f. 3798.) Stem very slender, glabrous, simple, or with few or numerous slender ascending branches, not bushy, 1.5-6 dm. high. Basal leaves lanceolate, oblong or oblanceo. late, 5-15 cm. long, 4-12 mm. wide, entire, or slightly toothed, ciliate and sometimes a little pubescent, at least on the slender petioles, which are often as long as the blades; stem-leaves narrowly linear, those of the branches small and subulate; heads as large as those of $A$. ericoides, or commonly smaller, usually fewer, solitary at the ends of the branches and branchlets; bracts of the campanulate involucre with short green tips; rays white. On banks, especially in rocky places, Me. to Mass., Vt. and Wis. Aug.-Oct.

70. Aster lateriflòrus (L.) Britton. Starved Aster. Calico Aster. (I. F. f. 3799.) Stem puberulent or nearly glabrous, slender, divergently branched, 3-15 dm. high. Basal leaves ovate, slender-petioled; stem-leaves broadly lanceo. late or oblong-lanceolate, mostly acuminate, serrate, 5-12 cm. long, I2-25 mm. wide, those of the branches smaller, oblong or linear-oblong; heads 6-10 mm. broad, 
racemosely unilateral on the branches, short-peduncled or sessile, usually numerous and crowded; involucre turbinate, its bracts linear-oblong, obtuse or acutish, imbricated in about 4 series, their short green tips appressed or slightly spreading; rays numerous, short, white or pale purple; disk-flowers purple; pappus white; achenes minutely pubescent. In dry or moist soil, N. S. to western Ont., south to N. Car., La. and Tex. Called in Maryland Rosemary. Aug.-Oct.

Aster lateriflorus glomeréllus (T. \& G.) Burgess. Chiefly unbranched, with the habit of Solidago caesia; leaves hispidulous above, oblong-lanceolate, dull green, the teeth very sharp and straight; heads glomerate in the axils, of ten somewhat spicate toward the summit of the plant, sometimes also on short branches. In deep woods, N. Y. to Va.

Aster laterifiorus thyrsòideus (A. Gray) Sheldon. Ashy-pubescent; leaves ovate to lanceolate; branches ascending, rather stiff, mostly short; heads usually densely thyrsoidpaniculate, less markefly secund than in the type. Me. to N. Y., Ont. and Ill.

Aster lateriflòrus grándis Porter. Taller and larger-leaved than the type, the branches spreading; leaves lanceolate, sometimes $1_{5} \mathrm{~cm}$. long and nearly $25 \mathrm{~mm}$. wide; heads mostly larger, rather loosely paniculate. In shaded places, southern N. Y. to Ky. and Ill.

Aster laterifiòrus péndulus (Ait.) Burgess. Leaves linear-elliptic, conspicuously drooping, remotely appressed-serrulate, often with narrowly margined petioles, roughish when dry; branches long, slender, often pendulous; heads long-peduncled; rays and bracts of ten purple-tinged. In thickets, N. Y. to Va.

Aster laterifiorus horizontàlis (Desf.) Burgess. Branches long, slender, widely spread. ing; leaves firm, those of the branches very small, mostly entire; heads very numerous; rays rather large. Southern N. Y. to Va.

71. Aster hirsuticaùlis Lindl. HaIRy-stemmed Aster. (I. F. f. 3800.) Stem slender, erect, 4-9 dm. high, pubescent, nearly or quite to the base, the usually short branches spreading or ascending. Leaves thin, glabrous above, usually pubescent on the midvein beneath, serrate with a few appressed teeth, or entire, linearlanceolate to lanceolate, sometimes $15 \mathrm{~cm}$. long, 4-14 mm. wide, sessile, or the basal ones spatulate and petioled; heads more or less secund on the branches, densely or loosely clustered, often also solitary or few in the lower axils; bracts of the involucre in 3 or 4 series, linear-lanceolate, acuminate or acute; rays white, about $4 \mathrm{~mm}$. long. In woods and thickets, Me. to N. Y., Penn. and Ky.

72. Aster vimíneus Lam. SMall White Aster. (I. F. f. 3801.) Glabrous or nearly so; stem slender, divergently branched, 6-15 dm. high. Stemleaves linear-lanceolate, entire, or with a few low teeth, 7-12 cm. long, 4-8 $\mathrm{mm}$. wide, acuminate, narrowed to a sessile base, those of the branches much smaller; heads very numerous, 6-10 $\mathrm{mm}$. broad, 4-6 mm. high, generally densely racemosesecund, short-peduncled; involucre broadly turbinate, its bracts linear, acute or acutish, green-tipped, appressed; rays numerous, about $4 \mathrm{~mm}$. long, white; pappus white; achenes minutely pubescent. In moist soil, Ont. to Mass., Fla., Minn., Kans. and Ark. Aug.-Sept.

Aster vimineus foliolosus (Ait.) A. Gray. Branches ascending, very leafy; heads paniculate, scarcely secund, less densely clustered. Mass. to Va., Ill. and Mo.

Aster vimineus Columbianus Britton. Minutely pubescent, 6-12 dm. high, the slender branches ascending; leaves linear to linear-lanceolate, those of the sten deflexed; heads about $25 \mathrm{~mm}$. broad; rays red-purple. Perhaps a distinct species. D. C. to N. Y.

Aster vimíneus saxatilis Fernald. Low, $1.5-6 \mathrm{dm}$. high, the leafy-bracteate branches bearing few or solitary heads, $1-1.5 \mathrm{~cm}$. broad; stem-leaves sometimes slightly clasping at the base. Shores and banks, Me., Vt. and Quebec. Perhaps not properly referred to this species.

73. Aster multifòrus Ait. Dense-flowered Aster. White Wreath Aster. (I. F. f. 3802.) Stem strict, much branched and bushy, grayish-strigose, 3-20 dm. ligh, the branches ascending or spreading. Leaves rigid, linear or linear-oblong, entire, mostly obtuse, sessile or slightly clasping at the base, strigose or glabrate, those of the stem $\mathrm{I}-2.5 \mathrm{~cm}$. long, those of the brauches very small and crowded; heads 6-8 mm. broad, densely crowded, nearly sessile; involucre turbinate, 4-6 $\mathrm{mm}$. high, its bracts coriaceous, pubescent, in 3 or 4 series, their short green tips obtuse or mucronate, spreading; rays 10-20, white, 3-4 mm. long: pappus brownish white; achenes puberulent. In dry open places, Me. and Ont. to S. Dak., Ga., Tex., Ariz. and Mex. Aug.-Nov.

74. Aster exíguus (Fernald) Rydb. Ciliate-LeAved Aster. Stem much branched and bushy, 3-10 dm. high, rough-pubescent with short divaricate hairs; 
branches spreading, often secund; leaves as in the preceding, but more pubescent, with spreading hairs, ciliate; heads as in the preceding, but usually on shorter branchlets; bracts broader with a thick, broad, oval or obovate green portion, hispid and ciliate. On prairies, plains and other open places, Vt. and $\mathrm{Pa}$. to Wash., Tex. and Ariz. Rare in the East. Aug.-Nov. - $[A$. ciliatus Muhl., not Walt.; A. multiflorus var. exigunes Fernald.]

75. Aster commutàtus Torr. \& Gray. White Prairie Aster. (I. F. f. 3803.) Similar to the two preceding species, except in the inflorescence, the stem rough-pubescent, or sometimes nearly ylabrous, 4-7 dm. high, with ascending or divergent branches. Leaves linear or linear-oblong, obtuse, entire, sessile or slightly clasping at the base, those of the stem 2-7 cm. long; heads larger than those of $A$. multiflorus, 12-16 mm. broad; involucre 6-8 $\mathrm{mm}$. high, its bracts squarrose-tipped and sometimes foliaceous; rays $20-30$, about $6 \mathrm{~mm}$. long. On prairies and along rivers, N. W. Terr. to western Neb., Tex., Ore., Utalı and N. Mex. Aug.-Uct.

76. Aster tenuifòlius I. Perennial Salt-marsh Aster. (I. F. f. 3804.) Perennial, glabrous and fleshy; stem flexuous, striate, at least when dry, sparingly and loosely branched, 3-6 dm. high. Stem-leaves linear, entire, acute, sessile or partly clasping at the base, the lowest lanceolate-linear, 5-15 cm. long, 4-6 mm. wide, those of the branches minute, bract-like, appressed; heads rather few, I2$25 \mathrm{~mm}$. broad, terminating the branches; involucre turbinate, about $8 \mathrm{~mm}$. high, its bracts lanceolate, acuminate or mucronate, glabrous, green on the back or tip, appressed, imbricated in about 5 series, the outer shorter; rays numerous, longer than the pappus, pale purple or nearly white; pappus tawny; achenes hispid-pubescent, 5 -nerved. In salt marshes, coast of Mass. to Fla. Aug.-Oct.

77. Aster exilis Ell. SLIM AsTER. (I. F. f. 3805.) Annual, glabrous, fleshy; stem slender, usually much branched, the branches usually divergent. Leaves linear to linear-lanceolate, 2-1o $\mathrm{cm}$. long, 2-5 m.n. wide, entire, sessile, acute or acuminate, or the lowest narrowly oblong, 6-8 mm. wide and petioled, those of the branches subulate; heads num srous, panicled, about $1 \mathrm{~cm}$. broad; involucre campanulate, about $6 \mathrm{~mm}$. high, its bracts linear-subulate, appressed, imbricated in 3 or 4 series; rays purplish, about $4 \mathrm{~mm}$. long, mostly fewer than the disk flowers, longer than the pappus; achen:s sonzw.int pabesient. In moist or wet soil, especially in saline situations, Kins. to Tex., S. Car. and Fla. Aug.-Oct.

78. Aster subulàtus Michx. Anvual Salt-marsh Aster. (I. F. f. 3806.) Annual, glabrous and fleshy; ste.n paniculately branched, flexuous above, 3-18 dm. high, slightly angled, som times $25 \mathrm{~mm}$. in diameter at the base, but usually s naller. Stem-leaves linear-linceolate, acute, entire, sessile by a broad or slightly clasping base, 5-25 cm. lon \$, 2-16 mm. wide, those of the branches very small and subulate; heads numerous, 6-10 $\mathrm{mm}$. broad; involucre campanulate, or at length hemispheric, 4-6 mm. high, its bracts linear-subulate, green, imbricated in 3 or 4 series, the outer shorter; rays 20-30, purplish, scarcely exceeding the nearly white pappus, more numarous than the disk flowers; achenes compressed, minutely pubescent. In salt marshes, coast of N. H. to Fla. Aug.-Nov.

\section{LEUCELENE Greene.}

Low perennial herbs, with much branched leafy stems, sessile, rather rigid, narrow entire leaves and small heads of both tubular and radiate white flowers, solitary at the ends of the numerous slender branchlets. Involucre turbinate. its bracts well imbricated. Disk-flowers perfect, their corollas white, tubular-funnelform, 5-toothed. Ray-flowers numerous, white, or drying red to rose, pistillate. Style appendages acutish. Achenes elongated, flattened, hispirlulous. Pappus a single series of slender rough white bristles [Greek, referring to the white disk.] One species, or more, native of the southwestern States and Mexico.

I. Leucelene ericoides (Torr.) Greene. ROSE Heath Aster. (I. F. f. 3807.) Stems tufted from deep wondy roots, corymbosely much branched, 7-30 cm. high, hispid or scabrous, the branches erect or diffuse. Leaves hispid. ciliate, erect, or slightly spreading, obtusish or mucronulate, the lower and basal ones spatulate, 6-12. mm. long, tapering into short petioles, the upper sessile, linear or linear-spatulate; heads terminating the branches, Io-16 $\mathrm{mm}$. broad; bracts lanceolate, appressed, scarious-margined, imbricated in 3 or 4 series, rays 12-15, 
white to rose, 4-8 mm. long. In dry soil, western Neb. to Kans., Tex. and Mex., west to Cal. May-Aug.

\section{BRACHYÁCTIS Ledeb.}

Annual, nearly glabrous, somewhat fleshy herbs, with narrow chiefly entire leaves, and small racemose or racemose-paniculate heads of tubular, or also radiate purplish flowers. Involucre campanulate. Central flowers of the head few, perfect, their narrow corollas 4-5-toothed; outer flowers pistillate, usually in 2 series or more, and more numerous than the perfect ones: style-appendages lanceolate; rays very short, or none. Achenes 2-3-nerved, slender, appressed-pubescent. Pappus a single series of nearly white bristles. [Greek, short rays.] About 5 species, natives of western N. Am. and northern Asia.

r. Brachyactis angústus (Lindl.) Britton. Rayless Aster. (I. F. f. 3808.) Stem usually sparsely pubescent, at least above, $1.5-6 \mathrm{dm}$. high, striate, at least when dry. Leaves linear, fleshy, ciliate on the margins, acutish, entire, sessile by a rather broad base, the basal (when present) spatulate; heads 8-12 mm. broad; involucre campanulate or nearly hemispheric, $4-6 \mathrm{~mm}$. high, its bracts linear or linear-oblong, somewhat foliaceous, green, acute or obtuse, imbricated in 2 or 3 series, glabrous or slightly ciliate, nearly equal; rays none or rudimentary; pappus soft and copious. In wet saline soil, or sometimes in waste places, Minn. to the N. W. Terr., Utah and Colo. Found also about Chicago. July-Sept.

\section{MACHAERANTHÈRA Nees.}

Annual, biennial or perennial branched herbs, with leafy stems, alternate, mostly serrate or pinnatifid leaves, the teeth or lobes usually bristle-tipped, and large heads of both tubular and radiate flowers. Involucre of numerous series of imbricated canescent or glandular bracts with herbaceous or foliaceous spreading or appressed tips. Receptacle alveolate, the alveoli usually toothed or lacerate. Rayflowers numerous, violet to red or purple, pistillate. Disk flowers perfect, their corollas tubular, 5-lobed, yellow, changing to red or brown; anthers exserted, appendaged at the tip, rounded at the base; style-appendages subulate to lanceo-

late. Achenes turbinate, narrowed below, pubescent. Pappus of numerous stiff rough unequal bristles. [Greek, sickle-anther.] About 15 species, natives of western N. Am.

Annual or biennial; leaves pinnatifid.

Perennial or biennial; leaves sharply serrate.

r. M. tanacetifolia. 2. $M$. sessilifiora.

I. Machaeranthera tanacetifòlia (H. B. K.) Nees. TAnsy Aster. DAGGER-FLOWER. (I. F. f. 3809.) Annual or biennial; stem glandular-pubescent, often viscid, densely leafy, much branched and bushy, 3-6 dm. high. Leaves sessile or short petioled, pubescent, the lowest $2-7 \mathrm{~cm}$. long, 2-3-pinnatifid, their lobes linear or oblong, acute or mucronate, the upper pinnatifid, those of the branches sometimes entire: heads numerous, corymbose-paniculate, $3-5 \mathrm{~cm}$. broad; involucre hemispheric, $8-12 \mathrm{~mm}$. high, its bracts linear, glandular, imbricated in 5-7 series; rays $15-25$, Io-1 $6 \mathrm{~mm}$. long, achenes villous. In dry soil, Neb. to Tex. and Mex., west to Cal. June-Aug.

2. Machaeranthera sessilifiòra (Nutt.) Greene. Viscid Aster. (I. F. f. 38 ro. ) Stem usually stout, finely rough-pubescent or canescent, branched, and viscid-glandular above, 3-6 dm. high. Leaves lanceolate, linear, or the lowest spatulate, sessile, sharply incised-dentate, the larger $2-7 \mathrm{~cm}$. long, the teeth bristletipped; heads numerous, racemose, or corymbose above, $25-37 \mathrm{~mm}$. broad, the lower often nearly sessile: involucre broadly turbinate or hemispheric, 8-12 $\mathrm{mm}$. high, its bracts acute, imbricated in 6-10 series; rays 8-12 mm. lono: achenes narrow, appressed-pubescent. In dry soil, central and western Neb. July-Oct.

\section{ERIGERON L.}

Branching or scapose herbs, with alternate or basal leaves, and corymbose, paniculate or solitary, peduncled heads, of both tubular and radiate (rarely all tubular) flowers. Involucre hemispheric or campanulate, its bracts arrow, nearly equal, imbricated in but $\mathbf{I}$ or $\mathbf{2}$ series in our species. Receptacle nearly flat, usually naked. Ray-flowers, in our species, white, violet or purple, pistillate. Disk- 
flowers yellow, tubular, perfect, their corollas mostly 5-lobed. Anthers obtuse and entire at the base. Style-branches more or less flattened, their appendages short, mostly rounded or obtuse. Achenes flattened, usually 2-nerved. Pappus-bristles fragile, slender, scabrous or denticulate, in I series, or often an additional outer shorter series. [Greek, early-old, alluding to the early hoary pappus.] A genus of some 130 species, of wide distribution. In addition to the following, about 60 others occur in southern and western N. Am.

* Rays long, narrow, usually equalling or longer than the diameter of the disk.

+ Stem $2-25 \mathrm{~cm}$. high, simple, leafy; head solitary; involucre woolly.

I. E. unifiorus.

++ Stem $\mathrm{I} \rightarrow 9 \mathrm{dm}$. high, leafy, usually branched; involucre hirsute or glabrous. 1. Roots perennial, thick and woody.

Heads 25-50 mm. broad; leaves lanceolate, ovate, oblong, or spatulate.

Rays violet or purple; stem-leaves ovate, lanceolate, or oblong.

Stem-leaves linear-lanceolate, the upper much smaller.

Stem-leaves ovate-lanceolate, the upper little smaller.

Rays mostly white; stem-leaves linear or linear-oblong.

Heads I 2-25 $\mathrm{mm}$. broad; leaves linear.

Plants hirsute or canescent; pappus double; western species.

Stem hirsute; achenes pubescent ; flowers white.

2. E. asper

3. E. subtrinervis.

4. E. caespitosus.

5. E. pumilus.

Stem appressed-canescent; achenes glabrous; flowers purple or white.

Plant nearly glabrous; pappus simple; northern.

2. Perennial by decumbent rooting stems or stolons.

6. E. canus.

7. E. hyssopifolius.

8. E. Alagellaris.

3. Roots annual or biennial, fibrous; plants often perennial by offsets.

Heads 25-37 mm. broad, few; stem simple; eastern.

Heads 12-25 mm. broad, numerous; stem branched.

Rays $100-150$, narrow, mostly purple or violet.

Pappus simple; plant erect, corymbosely branched.

Pappus double; plant diffusely branched, western.

9. E. pulchellus.

Rays much less numerous, purplish or white.

Plants $1.5^{-3} \mathrm{dm}$. high, diffuse, western; pappus simple. r2. E. Bellidiastrum.

Plants 3-10 $\mathrm{dm}$. high, erect, corymbosely branched; pappus double.

Stem-leaves lanceolate, nearly all sharply serrate.

Stem-leaves linear-lanceolate or oblong, nearly all entire.

$\dagger \nmid t$ Stem leafless or nearly so; heads $12 \mathrm{~mm}$. broad, corymbose.

14. E. ramosus.

10. E. Philadelphicus.

II. E. divergens.

I5. E. vernus.

* * Rays inconspicuous or short; a row of tubular pistillate flowers inside the row of rays.

16. E. acris.

I. Erigeron uniflòrus L. Arctic ERIgeron. (I. F. f. 38 II.) Perennial by short branching rootstocks; stems slender, single or tufted, more or less pubescent, simple, erect. Basal leaves petioled, spatulate, obtuse, entire, 2-5 cm. long; stem-leaves sessile, lanceolate or linear-lanceolate, entire; head solitary, peduncled, 12-25 mm. broad; rays about 100, purple or purplish, 4-8 mm. long; bracts linear-lanceolate, acute, copiously woolly; pappus simple. Lab. and arctic Am. to Alaska. Rocky Mts. specimens referred to this species belong to $E$. simplex. Also in Europe. Summer.

2. Erigeron ásper Nutt. Rough Erigeron. (I. F. f. 3812.) Stem simple, or branched above, more or less pubescent, sometimes hirsute, I.5-6 dm. high. Leaves glabrous, pubescent or ciliate, entire, the basal ones spatulate, obtuse, 5-10 $\mathrm{cm}$. long, 6-25 $\mathrm{mm}$. wide, narrowed into margined petioles; sten-leaves oblong-lanceolite or linear-lanceolate, obtuse or acute, the upper smaller; heads several or solitary, slender peduncled, $2-5 \mathrm{~cm}$. broad; bracts linear, acute, hirsute or pubescent; rays $100-150$, very narrow, violet, purple, or nearly white, 8-14 $\mathrm{mm}$. long; pappus double, the outer row of bristles much shorter than the inner. In dry soil, Minn. to Neb., west to the N. W. Terr., Utah and N. Mex. June-Sept.

3. Erigeron subtrinérvis Rydberg. THREe-Nerved Fleabane. (I. F. f. 38r3.) Similar to the preceding species, finely pubescent. Stems leafy to the inflorescence; leaves entire, thin, the basal and lower ones oblanceolate to oblong, obtuse or acute, petioled, the upper lanceolate or ovate-lanceolate, sessile or somewhat clasping. acute, rather distinctly 3-nerved; heads $25-37 \mathrm{~mm}$. broad, corymbose, or rarely solitary; rays numerous, blue to pink; pappus double, the outer bristles very short. S. Dak. to Neb. and Utah. 
4. Erigeron caespitòsus Nutt. Tufted ERIGERON. (I. F.. f. 38I4.) stems tufted, canescent, simple, or branched above, r.5-3 dm. high. Leaves canescent or pubescent, entire, the lower and basal ones petioled, narrowly oblanceolate or spatulate, 2-7 cm. long; heads solitary or several, short-peduncled, 25-37 mm. broad; bracts lanceolate or linear-oblong, acute, canescent; rays 40-60, 6-12 mm. - long, white or pinkish; papr dry soil, Manitoba and the N. W. Terr. to Neb., N. Mex. and Cal. June-Aug.

5. Erigeron pùmilus Nutt. Low Erigeron. (I. F. f. 3815.$)$ Stems tufted, slender, simple, or branched, $\mathbf{I - 2 . 5} \mathrm{dm}$. high. Leaves entire, hirsute, the lower and basal ones narrowly spatulate or linear, petioled, 2-10 $\mathrm{cm}$. long, 2-4 $\mathrm{mm}$. wide; stem-leaves linear; heads 12-20 mm. broad, short-peduncled; bracts linear, acute, hirsute: rays $50-80$, white, $6-8 \mathrm{~mm}$. long, at length deflexed; pappus double, the outer row of bristles short and more or less intermixed with the inner; achenes pubescent. Dry plains, S. Dak. to N. W. Terr., western Kans., Br. Col. and Utah. May-Sept.

6. Erigeron cànus A. Gray. Hoary Erigeron. (I. F. f. 3816.) Stems slender, erect, tufted, 15-25 cm. high, simple, or branched above. Leaves narrow, entire, canescent, the basal and lower ones narrowly spatulate, petioled, 5-10 $\mathrm{cm}$. long, the upper linear, sessile, acute, gradually smaller; heads solitary, or 2 4, I 2-15 mm. broad; bracts linear, acute, densely canescent; rays 40-50, purple or white, 4-6 mm. long; pappus double, the outer row of bristles rather conspicuous. In dry soil, S. Dak. to western Neb., Wyo., Colo. and N. Mex. June-Aug.

7. Erigeron hyssopifolius Michx. Hyssop Leaved ERIGEkON. (I. F. f. $3^{817}$.) Perennial by slender rootstocks; stenıs tufted or single, very slender, simple or branched, glabrous or very nearly so, $10-35 \mathrm{~cm}$. high. Leaves narrow, thin, the basal and lower ones oblong or spatulate, short-petioled, 2-4 cm. long, 3-4 $\mathrm{mm}$. wide, the upper linear or linear-oblong, acute, heads solitary or several, slenderpeduncled, IO-I5 $\mathrm{mm}$. broad; bracts linear-lanceolate, sparingly pubescent; rays 20-30, white or purplish, 4-6 mm. long; pappus simple. On moist cliffs, Newf. to Vt., the N. W. Terr. and Lake Superior. July-Aug.

- 8. Erigeron flagellàris A. Gray. Running Fleabane. (I. F. f. 3818.) Appressed-pubescent, sometimes densely so. Stem slender, branched, the branches elongated; leaves entire, the basal and lower ones spatulate or oblong, obtuse or acute, 2-5 cm. long, narrowed into long petioles, the upper sessile, linear or linearspatulate, much smaller; peduncles solitary, elongated; heads about $25 \mathrm{~mm}$. broad and $6 \mathrm{~mm}$. high; rays very numerous, white to pink; pappus double, the outer series of subulate bristles. In moist soil, S. Dak. to Colo., Utah, Tex. and N. Mex. May-July.

9. Erigeron pulchéllus Michx. Robin's or Poor Robin's Plantain.

F. f. 3819.) Perennial by stolons and offsets, villous pubescent; stems simple, slender, 2.5-6 dm. high. Basal leaves tufted, spatulate or obovate, somewhat cuneate at the base, narrowed into short margined petioles, obtuse at the apex, 2$7 \mathrm{~cm}$ long, I-5 cm. wide, dentate or serrate; stem-leaves sessile, partly clasping, oblong, lanceolate to ovate, mostly acute, entire, or sparingly serrate: heads I-6, slender-peduncled, bracts linear, acuminate, villous; rays numerous, violet or purplish, 8-14 mm. long; achenes nearly glabrous; pappus simple. On hills and banks, N. S. to Ont., S. Dak., Fla. and La. April-June.

ro. Erigeron Philadélphicus L. Philadel.phia Fleabane. Skevish. (I. F. f. 3820.) Perennial by stolons and offsets, soft-pubescent or sometimes nearly glabrous; stems slender, mostly branched above, 3-9 dm. high. Basal and lower leaves spatulate or obovate, obtuse, dentate, $2-7 \mathrm{~cm}$. long, narrowed into short petioles; upper stem-leaves clasping and often cordate at the base; heads several or numerous, corymbose-paniculate, ro-25 mm. broad, slender-peduncled; bracts linear, usually scarious-margined; achenes puberulent. In fields and woods, throughout N. Am., except the extreme north, but locally rare. April-Aug.

I1. Erigeron divérgens T. \& G. Spreading Fleabane. (I. F. f. 3821.) Annual or biennial, diffusely branched, $15-37 \mathrm{~cm}$. high, densely cinereouspubescent or hirsute. Basal and lower leaves spatulate or oblanceolate, acute or obtuse, mostly petioled, entire, dentate or lobed, 2-5 cm. long, 4-1o mm. wide, the upper sessile, linear or narrowly spatulate, usually acute, gradually snaller; heads 16-25 mm. broad; bracts linear, acute, hirsute or canescent; rays about 100, 
purplish, violet or nearly white, 4-8 $\mathrm{mm}$. long; pappus double, the short outer row of bristles subulate. In moist soil, Mont. to Neb., Tex., Mex., Wash. and Cal. April-Sept.

12. Erigeron Bellidiástrum Nutt. Western Daisy Fleabane. (I. F. f. 3822.) Annual, much branclied, cinereous-pubescent throughout. Leaves entire, linear-spatulate, the lower and basal petioled, $2-4 \mathrm{~cm}$. long, the upper sessile and smaller; heads several, or numerous, $10-16 \mathrm{~mm}$. broad; involucre hemispheric, about $4 \mathrm{~mm}$. high, its bracts linear, hirsute, acute; rays 30-65, white or purplish, about $4 \mathrm{~mm}$. long; pappus a single series of capillary bristles. In moist soil, Neb. and Kans. to Tex. May-July.

I3 Erigeron ánnuus (L.) Pers. Sweet Scabious. Daisy Fleabane. (I. F. f. 3823.) Annual, sparingly pubescent, with spreading hairs; stem erect, corymbosely branched. Leaves thin, the lower and basal ones ovate or ovate-lanceolate, mostly obtuse, petioled, usually coarsely dentate, 5-15 cm. long, 2-7 cm. wide, the upper sessile or short-petioled, lanceolate, oblong, or linear-lanceolate; heads rather numerous, IO-I $4 \mathrm{mn}$. broad; bracts somewhat hispid; rays 40-70, linear, white, or commonly tinged with purple, 4-8 $\mathrm{mm}$. long; pappus double, the inner a series of slender fragile deciduous bristles, often wanting in the ray-flowers, the outer a persistent series of short, partly united, slender scales. In fields, N. S. to the N. W. Terr., soutl to Va., Ky., Kans. and Mo. Nat. in Europe. May-Nov.

14. Erigeron ramòsus (Walt.) B. S. P. DA LSY Fleabane. (I. F. f. 3824.) Resembles the preceding species, but is usually lower and the pubescence more appressed. Stem-leaves linear-oblong, or linear-lanceolate, nearly all of them entire; basal and iowest spatulate or oblong, usually serrate; bracts of the involucre glabrous or nearly so; pappus similar to that of the preceding; rays white, or sometimes purplish, occasionally minute or wanting. In fields, N. S. to the N. W. Terr, south to Fla., La. and Tex. May-Nov.

Erigeron ramòsus Beyríchii (F. \& M.) Smith \& Pound. Stem more slender; leaves narrower; heads smaller; pubescence minute. Ga. to Neb. and Tex.

15. Erigeron vérnus (L.) T. \& G. Early Fleabane. (I. F. f. 3825.) Perennial by stolons and offsets; stem slender, simple or branched above, glabrous, or the branches pubescent, 3-5 dm. high. Leaves mainly in a basal rosette, glabrous, obovate, oval or spa:ulate, obtuse, repand-denticulate or entire, 5-10 cm. long, narrowed into margine.l petioles; stem-leaves mostly reduced to subulatelanceolate scales; heads not nilmerous, corymbose, peduncled, about $1 \mathrm{~cm}$. broad; rays 20-30, white or pink, $4.6 \mathrm{~mm}$. long; pappus simple; achenes usually 4nerved. In marshes and moist soil, Va. to Fla. and La. April-May.

16. Erigeron àcris L. Bl Ue or Bitter Fleabane. (I. F. f. 3826.) Biennial or perennial; stem hirsute-pubescent, slender, simple, or branched above, I.5$4.5 \mathrm{dm}$. high. Leaves pubescent or glabrous, entire, the basal and lower ones spatulate, mostly obtuse, 2-7 cri. long, petioled, those of the stem mostly oblong or oblanceolate, obtuse or acutisi., sessile, shorter; heads several or numerous, racemose or paniculate, peduncled, $10-12 \mathrm{~mm}$. broad; bracts linear, hirsute; rays numerous, purple, equalling or slightly exceeding the brownish pappus; tubular pistillate Howers numerous; pappus simple or nearly so, copious. Lab. to Br. Col., south in the Rocky Mts. to Colo. and Utah. Also in Europe and Asia. July-Aug.

Erigeron acris Droebachianus (O F. Mueller) Blytt. Usually taller and less pubescent, or glabrate; involucre nearly glabrous. N. B. to western Ont., Alaska, Br. Col. and Colo. Also in Europe.

Erigeron deris débilis A. Gray. Slightly pilose-pubescent, very slender; heads few. Range of the last.

\section{LÉPTILON Raf.}

Annual or biennial herbs, with small racemose thyrsoid or panicled heads of white flowers, the rays small, usually shorter than the diameter of the disk or none. Involucre mostly campanulate, its narrow bracts in 2 or 3 series. Receptacle naked. Ray-flowers pistillate; disk-flowers perfect, their corollas usually 4-lobed or 4-toothed, the anthers obtuse at the base; style-branches somewhat flattened, their appendages short. Achenes flattened. Pappus of numerous simple fragile bristles in 1 series. [Greek, referring to the small heads.] About 20 species, 
natives of America and Asia. Besides the following, 2 or 3 others occur in the southwestern U. S. and one is nat. from Asia on the southern Atlantic and Pacific coasts.

Lower leaves spatulate, toothed; rays white.

Leaves all linear or subulate, entire; rays purplish.
1. L. Canadense.

2. L. divaricatum.

\section{Leptilon Canadénse (L.) Britton. Horse-weed. Canada Fleabane.} (I. F. f. 3827.) Stem hispid-pubescent, or glabrate, 7-30 dm. high, the larger plants paniculately much branched. Leaves usually pubescent or ciliate, the basal and lower spatulate, petioled, incised, dentate or entire, $2-10 \mathrm{~cm}$. long, obtuse or acutish, those of the stem linear and mainly entire; heads usually very numerous; about $4 \mathrm{~mm}$. broad; involucre, 2-3 $\mathrm{mm}$. high, its bracts linear, acute, glabrate; rays numerous, white, shorter than the pappus and mostly shorter than their tubes. In fields and waste places, a common weed throughout N. Am., except the extreme north. Widely distributed as a weed in the Old World and in S. Am. June Nov.

2. Leptilon divaricàtum (Michx.) Raf. Low Horse-Weed. Purple. HoRSE-WEED. (I. F.f. $3^{828}$.) Stem diffusely much branched, 7-30 cm. high, pubescent or hirsute. Leaves all linear or subulate, entire, 8-25 mm. long, about I mm. wide, the uppermost minute; heads numerous, about $4 \mathrm{~mm}$. broad; involucre $2 \mathrm{~mm}$. high, its bracts linear, acute, pubescent; rays purplish, shorter than their tubes. In sandy soil, especially along rivers, Ind. to Minn., S. Dak., Tenn., La., Neb. and Tex. June-Oct.

\section{DOELLINGÈRIA Nees.}

Perennial leafy herbs, the lower leaves reduced to scales or sheaths, the upper large, mostly entire, acute or acuminate in our species. Basal leaves none. Heads corymbose; involucre campanulate to hemispheric, its bracts imbricated in several series, appressed, thin, sometimes scarious-margined, their tips not herbaceous nor foliaceous. Receptacle foveolate. Ray-flowers white, pistillate, not very numerous. Disk-flowers perfect, the corolla with a sleıder tube abruptly expanded into a campanulate 5-lobed limb, white to greenish in our species. Anthers obtuse at the base; style-appendages ovate to subulate (rarely obtuse). Achenes obovoid. Pappus double, the outer series of numerous short bristles or scales, the inner of long capillary bristles, some or all of which have thickened tips. [In horor of Th. Dollinger, botanical explorer.] About 4 species, natives of eastern N. Am.

Leaves lanceolate to ovate; heads mostly numerous.

Leaves lanceolate to oblong-lanceolate, acuminate.

Leaves ovate to ovate-lanceolate, acute.

Leaves, at least the lower, obovate; heads commonly few.

I. D. umbellata.

2. D. humilis.

3. D. infirma.

r. Doellingeria umbellàta (Mill.) Nees. Tall Flat-top Whrte Aster. (I. F. f. 38 20.) Stem glabrous or pubescent above, striate, corymbosely branched at the summit, 6-25 dm. high. Leaves glabrous above, usually pubescent on the veins beneath, membranous, narrowed at the base into short petioles, or the uppermost sessile, hispid-margined, those of the stem 12-15 cm. long, $1-2.5 \mathrm{~cm}$. wide; heads $12-25 \mathrm{~mm}$. broad, in terminal compound corymbs; involucre $3-4 \mathrm{~mm}$. high, its bracts lanceolate, usually pubescent or ciliate, acutish or cbtuse: rays 10-15, white; style-appendages ovate, acute; achenes nerved, slightly pubescent. In moist soil, Newf. to Ga., west to the N. W. Terr., Mich. and Ark. July-Oct.

Doellingeria umbellata pùbens (A. Gray) Britton. Under leaf-surfaces pubescent. Mich. to the N. W. Terr.

2. Doellingeria hùmilis (Willd.) Britton. BroAd LEAved Flat-ToP White Aster. (I. F. f. $383^{\circ}$.) Similar to the preceding species, usually lower, seldom over $12 \mathrm{dm}$. high. Stem striate, corymbosely branched above, glabrous, or some. what pubescent. Leaves rather firm, sessile, or the lower very short-petioled, nar. rowed, or sometimes rounded at the base, rough-margined, those of the stem 2-7 $\mathrm{cm}$. long, 12-50 $\mathrm{mm}$. wide, inflorescence as in D. umbellata; achenes somewhat pubescent. In moist soil, southern N. J. and Penn. to Fla. and Tex. July-Sept.

3. Doellingeria infírma (Michx.) Greene. Cornel-leaved Aster. (I. F. f. $3^{8} 3$ 1.) Stem slender, glabrous, or roughish above, sparingly branched at the summit, terete, 4-9 dm. high. Leaves entire, hispid-margined, glabrous above, 
sparingly hispid on the veins beneath, the lower usually sessile, the upper larger, oblong-lanceolate, acute, 5-12 cm. long, 2-4 cm. wide; heads few, about $25 \mathrm{~mm}$. broad, in a divergently branched terminal corymbose cluster; involucre 4-6 mm. high, its bracts oblong-lanceolate, obtuse, sparingly pubescent; rays 8-I5, white; style appendages subulate; achenes nerved, glabrous. In dry, usually rocky soil Mass. to N. Y., Penn. and Tenn. Aug.-Sept.

\section{IONÁCTIS Greene.}

Low, mostly branching, perennial herbs with numerous narrow entire I-nerved leaves, and rather large and showy heads of tubular and radiate flowers terminating the stem and branches. Basal leaves none. Involucral bracts coriaceous, inbricated in several series, appressed, their tips not herbaceous. Ray-flowers nor. mally violet, pistillate. Disk-flowers perfect, the corolla with a campanula limb. Achenes villous. Pappus double, the inner series of long capillary bristic. the outer much shorter. [Greek, violet rays.] Three known species, of N. An.

I. Ionactis linariifólius (L.) Greene. Strff or Savory-Leaved Aster. (I. F. f. 3832.) Stems tufted, stiff, puberulent or scabrous, very leafy, corym. bosely branched above, r.5-6 dm. high. Leaves linear or spatulate, spreading, I-nerved, rigid, entire, rough, usually ciliolate on the margins, mucronulate, $18-35$ $\mathrm{mm}$. long, 2-4 $\mathrm{nm}$. wide, sessile, those of the branches much smaller and somewhat appressed; heads several, terminating the branchlets, about $25 \mathrm{~mm}$. broad; involucre broadly turbinate, its bracts linear-lanceolate, keeled, green on the back, the inner obtuse, the outer usually acute; rays IO-I5, violet, rarely white, 8-IO mm. long; pappus tawny; achenes silky. In dry or rocky soil, Newf. to Quebec and Fla., west to Minn., Mo. and Tex. July-Oct. [Aster linariifolius L.]

\section{BÁCCHARIS L.}

Diœcious shrubs, with alternate leaves, and small paniculate or corymbose heads of tubular flowers. Involucre campanulate in our species, its bracts imbricated in several series, the outer shorter. Receptacle flat, naked, commonly foveolate. Corolla of the pistillate flowers slender, that of the staminate tubular, 5-lobet. Anthers obtuse and entire at the base. Style-branches narrow or subulate, those of the fertile flowers smooth, exserted, those of the sterile flowers rudimentary, tipped with an ovate pubescent appendage. Achenes more or less compressed, ribbed. Pappus of the fertile flowers copious, capillary, that of the sterile flowers short. [Named for Bacchus; originally applied to some different shrubs.] About 275 species, all American, most abundant in S. Am. Besides the following, some 18 others occur in the southern and western U. S.

Shrubs; pappus of fertile flowers in $x$ or 2 series.

Leaves oblong, or lance-oblong, mostly obtuse, sparingly dentate.

Leaves deltoid-obovate, cuneate, $x$. B. salicina.

Heads in

Heads clustered in the axils of the leaves.
Leaves linear or linear-lanceolate, mostly acute, sparingly dentate.

2. B. halimifolia.

3. B. glomeruliflora.

Herbaceous from a woody base; pappus of fertile flowers in several series.

5. B. Wrightii.

I. Baccharis salícina T. \& G. Wrllow BACCHARIS. (I. F. f. 3833.) A glabrous glutinous much-branched shrub, I-2 m. high, the branches ascending. Leaves firm, more or less conspicuously 3 -nerved, narrowed into a cuneate subsessile base, $2-4 \mathrm{~cm}$. long, 4-12 mm. wide: heads in peduncled clusters of $\mathrm{I}-7$, the involucre of both sterile and fertile ones campanulate, 5-6 mm. high, its bracts ovate or ovate-lanceolate, acute or subacute: pappus usually but a single series of nearly white capillary bristles. Western Kans. and Colo. to Tex. May-July.

2. Baccharis halimifolia L. Groundsel-tree OR -BUSH. Pencil-Tree (I. F. f. 3834 .) A branching glabrous shrub, I-3 dm. high, the branchlets angled, sometimes minutely scurfy. Leaves thick, those of the stem and larger branches 2-7 cm. long, I-5 cm. wide, those of the branchlets oblanceolate. short-petioled or sessile, entire, or few toothed toward the apex: heads in terminal perluncled cluss ters of $1-5$, those of the sterile plant nearly globose when young, the bracts of the 
involucre oblong-ovate, obtuse, glutinous, appressed, the inner ones of the pistillate heads lanceolate, acute or acutish; fertile pappus bright white, 6-8 ma. long, of I-2 series of capillary bristles, much exceeding the involucre. Along salt marshes and tidal rivers, extending beyond saline influence, Mass. to Fla. and Tex. The white pappus is very conspicuous in autumn. Sept.-Nov.

3. Baccharis glomerulifiòra Pers. Axillary-flowered Baccharis. Similar to the preceding species but brighter green, the leaves often spatulate: heads in small sessile or short-peduncled clusters in the upper axils; involucral bracts obtuse. In swamps, Va. to Fla., near the coast. Sept.-Dec.

4. Baccharis neglécta Britton. Linear-Leaved Baccharis. (I. F. f. 3835.) A much-branched, glabrous or slightly glutinous shrub, $1 \mathrm{~m}$. high or more, the branches paniculate, slender, ascending. Leaves faintly 3 -nerved, grad. ually attenuate into a nearly sessile base, $2-7 \mathrm{~cm}$. long, 2-6 $\mathrm{mm}$. wide; heads in short-peduncled clusters; involucre of both kinds of heads campanulate, $4 \mathrm{~mm}$. high, its outer bracts ovate, acute or somewhat obtuse, the inner lanceolate, acu. minate; pappus of the fertile flowers a single series of capillary dull-white bristles. Neb. to Tex. and northern Mex. July-Sept.

5. Baccharis Wrightii A. Gray. Wright's Baccharis. (I. F. f. 3836 .) Much branched, glabrous, not glutincus, 3-9 $\mathrm{dm}$. high, the branches straight, nearly erect, slender, striate. Leaves linear, sessile, I-nerved, entire, 6-25 mm. long, I-2 mm. wide; heads solitary at the ends of the branches, $10-12 \mathrm{~mm}$. broad; involucre of the sterile heads hemispheric, about $6 \mathrm{~mm}$. high, that of the fertile ones somewhat campanulate and longer; bracts of both involucres lanceolate, acuminate, with scarious margins and a green back: pappus tawny or purplish, copious. W. Kans. and Colo. to Tex., Ariz. and Chihuahua. April-July.

\section{FILÀGO L.}

White-woolly annual herbs, with alternate entire leaves, and small discoid clustered heads, usually subtended by leafy bracts. Bracts of the involucre few and scarious. Receptacle convex or elongated, chaffy, each chaffy scale subtending an achene. Outer flowers of the heads in several series, pistillate, fertile, their corollas filiform, minutely 2-4-dentate. Central flcwers tew, perfect, mainly sterile, their corollas tubular, 4-5-toothed. Anthers sagitate at the base, the auricles acuminate. Achenes compressed or terte. Pappus none. [Latin, filum, a thread.] About 12 species, natives of both the New Wcrld and the Old. In addition to the following, 3 others occur in the western U. S.

I. Filago prolífera (Nutt.) Britton. Filago. (I. F. f. 3837.) Stem simple, or branched at the base, very leafy, 5-15 cm. high. Leaves spatulate, obtuse, sessile, ascending or appressed, 8-I6 $\mathrm{mm}$. long, 2-5 mm. wide; heads in a sessile leafy-bracted cluster, usually sultended by $\mathbf{I}$ or several slender, nearly leafless branches, each terminated by a similar cluster, or these again proliferous; heads oblong or fusiform; receptacle convex; chaff of the central sterile flowers woolly. tipped, that of the fertile flowers scarious, mostly glabrous. In dry soil, Tex. to Kans. and S. Dak., west to Colo. and N. Mex. April-July.

\section{Gífola Cass.}

White-woolly herhs, closelv resembling those of the preceding genus, with alternote entire leaves, and small discoid glomerate heads, often subtended by leafy brarts. the clusters proliferous in our species. Involucre small, its bracts scarious, imbricated in several series, the outer usually tomentose. Receptacle subulate, cvlindric or obconic, chaffy, each chaffy scale near its base enclosing an achene. Outermost flowers pistillate, fertile, with filiform corollas and no pappus, or the pappus a few rudimentary bristles: inner flowers also pistillate and fertile, but with a pappus of capillary scabrous bristles: central (uppermost) flowers few, perfect, their corollas tubular, their pappus capillary and scabrous. Anthers sagittate at the base. Achenes terete or slightly compressed. [Anagram of Filago.] About ro species, natives of warm and temperate regions.

I. Gifola Germánica (L.) Dumort. Cudweed. Cotton Rose. Herba ImpiA. (I. F. f. 3838 .) Annual, erect, cottony, I-4.5 dm. high, simple, or branched at the base, very leafy. Leaves sessile, lanceolate, linear, or slightly 
spatulate, erect or ascending, obtuse or acutish, 6-25 $\mathrm{mm}$. long, stem terminated by a sessile dense cluster of heads, usually subtended by several leafy branches terminated by similar clusters and these often again proliferous; heads 10-30 in each cluster, many-flowered; involucre ovoid, light yellow, its bracts mainly acute. In dry fields, southern N. Y. to Penn. and N. Car. May-Sept.

\section{PLÙCHEA Cass.}

Pubescent or glabrous herbs, or some tropical species shrubby, with alternate dentate leaves, and small heads of tubular flowers in termindl corymbose cymes. Involucre ovoid, campanulate, or nearly hemispheric, its bracts appressed, herbaceous, imbricated in several series. Receptacle flat, naked. Outer flowers of the head pistillate, their corollas filiform, 3-cleft or dentate at the apex. Central flow. ers perfect, but mainly sterile, their corollas 5-cleft. Anthers sagittate at the base, the auricles caudate. Style of the perfect flowers 2-cleft or undivided. Achenes 4-5 angled. Pappus a single series of capillary scabrous bristles. [Named for the Abbé N. A. Pluche, of Paris.] About 30 species, widely distributed in warm and temperate regions.

Perennial: leaves sessile, cordate, or clasping at the base.

Annual; leaves, at least those of the stem, petioled.

Leaves short-petioled; heads about $6 \mathrm{~mm}$. high; involucral bracts densely puberulent.

Leaves long-petioled; heads 4-5 mm. high; involucral bracts granulose, ciliate. 3. P. petiolata.

I. Pluchea foètida (L.) B.S.P. Viscid Marsh Fleabane. (I. F. f. $3^{839 .)}$ Stem simple or sparingly branched at the summit, puberulent and slightly viscid, 4-9 dm. high. Leaves oblong, ovate or ovate-lanceolate, sharply denticulate, pubescent or puberulent, $5-10 \mathrm{~cm}$. long, I-4 cm. wide, reticulate-veiny: clusters of heads compact, leafy-bracted; involucre 5-6 mm. high, its bracts lanceolate, acute, viscid-puberulent. In swamps, southern N. J. to Fla. and Tex., mainly near the coast. Also in the W. Ind. July-Sept. [Pluchea bifrons DC.]

2. Pluchea camphoràta (L.) DC. Spicy or Salt-marsh Fleabane. (I F. f. 3840.) Stem usually branched, finely viscid-puberulent, or nearly glabrous, 6-9 dm. high, somewhat channeled. Leaves ovate, oblong or lanceolate, puberulent or glabrous, acute or acuminate at the apex, narrowed at the base, the upper sessile but not clasping, 7-20 cm. long, 3-7 cm. wide, serrate or denticulate, not conspicuously reticulate-veined; bracts of the involucre ovate-lanceolate, or lanceolate, zcute: flowers purplish; achenes pubescent. In salt marshes, coast of N. H. to Fla., Tex. and Mex. Also in the W. Ind. Aug.-Oct.

3. Pluchea petiolàta Cass. Inland Marsh Fleabane. (I. F. f. 384 I.) Similar to the preceding species, but glabrate, usually taller, 7-1 $2 \mathrm{dm}$. high, the stem stout, rather strongly channeled. Leaves ovate-lanceolate to oval, thin, 10-25 $\mathrm{cm}$. long, 4-7 cm. wide, mostly acuminate at the apex, cuneate narrowed at the base, irregularly serrate; petioles of the larger leaves 15-25 $\mathrm{mm}$. long; acheries short-pubescent. In moist soil, often in woods, Va. to Fla., Ill., Mo. and the Ind. Terr. Aug.-Oct.

\section{ANTENNÀriA Gaertn. (See Appendix.)}

Perennial woolly diœcious or polygamo-diœcious herbs, with alternate and basal leaves, and small discoid many-flowered heads, glomerate, racemose, solitary, or cory mbose. Involucre oblong, ovoid or campanulate, its bracts scarious, imbricated in several series, the outer shorter, usually woolly. Receptacle convex, or nearly flat, foveolate, not chaffy. Staminate flowers with a truncate or minutely dentate corolla, usually undivided style and scanty pappus of club-shaped smooth or minutely barbed bristles. Pistillate or perfect flowers with tubular mostly 5 -toothed corollas, 2-cleft style, and copious pappus of capillary naked bristles, slightly united at the base. Achenes oblong, terete, or slightly compressed. [Iatin, in allusion to the fancied resemblance of the sterile pappus to insect antennæ.] About 50 species, natives of the north temperate zone and southern S. Am. In addition to the following, about a dozen others occur in the western parts of N. Am., and one or more in the Southern States. 
Several species and subspecies additional to those here recognized have been recently described, but I am unable at present to characterize them so that they may be distinguished from the following.

* Pappus-bristles of sterile flowers with club-shaped or dilated tips.

† Plant not stoloniferous; basal leaves oblanceolate.

$\dagger f$ Plants stoloniferous; growing in patches.

1. A. Carpathica.

$\ddagger$ Involucral bracts white, greenish brown, or yellowish; plants not arctic.

Basal leaves small, $0.7-2 \mathrm{~cm}$. long, 1-nerved, or indistinctly 3-nerved.

Basal leaves bright green and glabrous above from the first, or slightly woolly when unfolding.

2. A. Canadensis.

Basal leaves dull and more or less persistently woolly on the upper surface.

Basal leaves spatulate, usually abruptly mucronulate.

Inner involucral bracts of the fertile heads obtuse or acutish; western.

3. A. aprica.

Inner involucral bracts of the fertile heads acuminate; eastern.

Basal leaves obovate to oblanceolate, acute or obtuse.

4. A. neodioica.

Stem of fertile plant slender, $2-3 \mathrm{dm}$. high ; basal leaves mostly oblanceolate.

5. A. neglecta.

Basal leaves persitently

7. A. microphylla.

Basal leaves large, 2-12 cm. long, distinctly 3-nerved, sometimes 5 -nerved, the lateral nerves also often prominent.

Plants not glandular; leaves dull and woolly on the upper surface, at least when young.

Involucre of the fertile plants 6-8 $\mathrm{mm}$. high.

Basal leaf-blades obovate to spatulate-obovate.

Basal leaves with nearly orbicular or rhombic-obovate large blades.

Involucre 8-10.5 mm. high.

9. A. calophylla.

Bracts of the fertile involucre linear to linear-lanceolate, the inner long-acuminate.

Io, A. fallax.

Bracts of the fertile involucre oblong to lanceolate, the inner merely acute.

Plants glandular, at least above.

11. A. Farwellit.

Basal leaves and those of the ends of stolons glabrous and bright green on the upper surface from the first, or slightiy woolly when unfolding.

12. A. Parliniti.

Leaves all dull and more or less persistently woolly on the upper surface.

$\ddagger \ddagger$ Involucral bracts dark greenish brown, acute. 13. A. ambigens.

14. A. alpina.

* * Pappus-bristles of sterile flowers not dilated, barbellate; plant $2-3 \mathrm{~cm}$. high, tufted; head solitary.

15. A. dimorpha.

I. Antennaria Carpáthica (Wahl.) Hook. Carpathian Everlasting. (I. F. f. 3842.) Plant floccose-woolly throughout, not stoloniferous; stem $5-25 \mathrm{~cm}$. high, simple. Basal leaves oblanceolate or oblong, obtuse or acutish at the apex, narrowed at the base into short petioles, 3-5 cm. long, 4-8 $\mathrm{mm}$. wide; stem-leaves linear, acute or acutish, erect, the upper gradually smaller: heads in a terminal subcapitate cluster, or rarely solitary, 5-6 mm. broad; involucre 4-6 mm. high, woolly at the base, its bracts brownish purple, the inner ones of the fertile heads mostly acutish, those of the sterile heads mainly obtuse. In dry soil, Lab. and Anticosti to Hudson Bay. Also in Europe and northern Asia. May-Sept.

2. Antennaria Canadénsis Greene. Canadian Cat's-foot. Scape 2-3.5 $\mathrm{dm}$. high, slender. Basal leaves and those of the ends of stolons spatulate to oblanceolate, obtuse or apiculate, $2.5-3.5 \mathrm{~cm}$. long, $1 \mathrm{~cm}$. wide or less, gradually tapering from above the middle to a long narrow base, I-nerved or with two faint lateral nerves, bright green and glabrous above, lanate beneath; stolons short, leafy, assurgent; stem-leaves linear-lanceolate, distant, 1.5-2.5 mm. wide; inflorescence capitate to racemose-corymbose; fertile involucre about $9 \mathrm{~mm}$. high, its outer bracts oblong, obtuse, the inner lanceolate, acute to attenuate. Quebec and N. B, to Vt. and Mass, May-June. 
3. Antennaria áprica Greene. Rocky Mountain Cudweed. (I. F. f. 3844 is $A$. dioica.) Floccose-woolly or canescent, surculose, forming broad patches. Flowering stems 6-20 cm. high; basal leaves spatulate, obtuse, rather abruptly aarrowed from above the middle, white-canescent on both sides, or sometimes green above, $8-30 \mathrm{~mm}$. long, 4-8 $\mathrm{mm}$. wide; stem-leaves linear to spatulate, sessile; aeads $6-8 \mathrm{~mm}$. broad in a terminal capitate or corymbose cluster; involucre 8-10 $\mathrm{mm}$. high, the bracts of the $f_{\mathrm{c}}$ rtile heads oblong, white or pink, all obtuse, or the inner ones acute; those of the sterile heads oval or elliptical, obtuse; achenes glabrous, or minutely glandular. Manitoba to Br. Col., Neb. and Ariz. May-Aug. Plants previously referred to the European $A$. dioic ${ }_{l}$ are now divided among several species.

4. Antennaria neodioica Greene. Smaller CAt's-Foot. (I. F. f. 3845.) Floccose-woolly, with numerous stolons which are leafy throughout. Stem of fertile plants slender, about $3 \mathrm{dm}$. high; stolons mostly short; basal leaves about $2.5 \mathrm{~cm}$. long, 6-10 $\mathrm{mm}$. wide, narrowly to broadly spatulate, I-nerved, or indistinctly 3-nerved, white-tomentose beneath, dull and often glabrate above, abruptly nar. rowed from above the middle, distinctly apiculate; stem-leaves linear, acute; heads loosely corymbose, $6-8 \mathrm{~mm}$. broad; outermost bracts of the involucre obtuse, the rest lanceolate, acute or acuminate, greenish yellow or brownish below, with white tips; achenes obtusely 4-angled, granular-papillose; staminate plant lower, 7-20 cm. high; heads more densely clustered; bracts of the involucre oblong, obtuse. In dry shaded places, Quebec to Vt., Va. and S. Dak. April-July.

5. Antennaria neglécta Greene. Field CAT's-Foot. (I. F. f. 3846.) Stoloniferous, the stolons.mostly long and slender. Basal leaves oblanceolate to obovate oblanceolate, obtuse or acutish, gradually tapering to a sessile base, whitetom.entose beneath, dull and glabrate above, I-nerved, or with two faint additional lateral nerves; stem-leaves linear; fertile plant 2-4 dm. high; heads $6-8 \mathrm{~mm}$. broad, capitate, corymbose, or racemose; bracts brownish, with white tips, lanceolate, acute, acuminate, or the outer blunt; sterile plant I-2 dm. high, the heads densely clustered, the bracts oblong, obtuse. In fields and pastures, Me. to N. Y., Va. and Wis. April-June.

6. Antennaria campéstris Rydb. Prairie Cat's-Foot. (I. F. f. 3847.) Stolons short, leafy; flowering stems of both fertile and sterile plants $5-15 \mathrm{~cm}$. high; basal leaves obovate-cuneate, white-tomentose beneath, glabrate above, I-nerved, or indistinctly 3 nerved; stem-leaves small, linear; heads $6-8 \mathrm{~mm}$. broad, in subcapitate clusters; bracts of the fertile heads lanceolate, greenish below, brownish at the middle, the apex white, acute or acuminate; bracts of sterile heads elliptic, obtuse. On dry prairies, Neb., Kans. and S. Dak. to Saskatchewan. May-June.

7. Antennaria microphỳlla Rydb. Small-leaved Cat's foot. Stem slender, 2-3 dm. high. Stolons short, not over $5 \mathrm{~cm}$. long; basal leaves and those of the ends of the stolons spatulate, obtuse, or apiculate, $0.5-1.5 \mathrm{~cm}$. long. $2-4 \mathrm{~mm}$. wide, narrowed from above the middle; stem-leaves linear-oblong, or the leaves linear-spatulate, often longer than the basal ones; heads corymbose, rather numerous; involucre 5-7 mm. high; bracts of the fertile heads linear-oblong, acute or acutish, those of the sterile obtuse. In dry soil, Alberta and Saskatchewan to Mont., Neb. and Colo. July-Aug.

8. Antennaria plantaginifolia (L.) Richards. Plantain-leaf EverlastIng. Mouse-ear Everiasting. (I. F. f. 3848 .) Floccose-woolly, stoloniferous, forming broad patches. Flowering stems of fertile plant 1.5-3.5 dm. high; basal leaves obovate to broadly oval, obtuse, sometimes apiculate, distinctly 3 ribbed, petioled, becoming glabrate and dull green above, silvery beneath, 4-7 cm. long, I-3 cm. wide; stem leaves sessile, oblong or lanceolate; heads in corymbose or subcapitate clusters, 8-10 $\mathrm{mm}$. broad; involucre 6-8 $\mathrm{mm}$. high, its loracts greenish white, lanceolate, acute or acutish; achenes minutely glandular; sterile plant smaller, 7-20 cm. high; basal leaves somewhat smaller; stem-leaves mostly linear; heads smaller, 6-8 mm. broad; bracts oblong, obtuse. In dry soil, especially in open woods, Lab. (?), Ont. to Fla., Ill., Kans. and Tex. April-June.

9. Antennaria calophỳlla Greene. BroAd LEAved CAT'S-Foor. Stolons strut, sometimes I dm. long, their leaves mostly in a tuft at the end, broadly ovate to olovate, 8-10 $\mathrm{cm}$. long, 4-5 $\mathrm{cm}$. wide, olstuse, apiculate, narrowed abruptly into 
the long, very narrow base which is about as long as the expanded portion, strongly 3-nerved, and usually with an additional pair of lateral nerves, densely tomentose beneath, dull green and loosely floccose above: pistillate heads rather numerous, corymbose; involucre about $7 \mathrm{~mm}$. high, its bracts linear to linear. lanceolate, brown below, the inner acuminate; stem of staminate plant $\mathbf{I}-\mathbf{I} .5 \mathrm{dm}$. high, the heads small, glomerate. Ill. and Mo. to La. The basal leaves of a plant evidently closely related to this were collected by Mr. Bicknell at New York and by Mr. Pollard at Washington.

ro. Antennaria fallax Greene. TALL CAT's-Foot. Stolons rather stout, often I dm. long, leafy. Scape of fertile plant 3.5-4.5 dm. tall, stoutish; basal leaves oval to obovate, 6-10 $\mathrm{cm}$. long, 2-4 cm. wide, acute or obtuse, contracted gradually into a narrow base about as long as the expanded portion, dull green and loosely floccose, or at length glabrous above, densely white-tomentose beneath; stem-leaves lanceolate, rather distant, acuminate, $2.5-5 \mathrm{~cm}$. long; heads capitate to corymbose; involucre 8-10 $\mathrm{mm}$. high, its inner bracts attenuate-acuminate, the outer oblong, obtuse; staminate plant very much smaller. In dry soil, Me. to D. C., Wis. and Kans. April-May.

I I. Antennaria Fàrwellii Greene. FARwell's CAT'S-Foot. Closely resembling the preceding species, sometimes lower. Stolons rather stout, leafy; basal leaves spatulate to obovate-spatulate, obtuse, the expanded portion usually larger than the gradually narrowed base, dull green and floccose or becoming glabrous above, strongly 3 -nerved, $4-8 \mathrm{~cm}$. long, $2.5 \mathrm{~cm}$. wide or less; heads capitate to subcorymbose; involucre 8-10.5 mm. high, its inner bracts acute, obtusish, or a few of them acuminate. Me. to Mich. May-June.

12. Antennaria Pàrlinii Fernald. PARLIN's CAT'S foot. More or less glandular-pubescent; stems of fertile plant 3-4.5 dm. tall. Leaves bright green and devoid of tomentum on the upper surface froin the time of unfolding, or very slightly floccose when very young, the basal ones obovate or spatulate to elliptic, obtuse or acutish, gradually contracted into a narrow base about as long as the expanded part, 5-8.5 cm. long, 2-3.5 cm. wide; stem-leaves lanceolate or the lower narrowly oblong; heads corymbose; involucre about $8 \mathrm{~mm}$. high, its bracts all lanceolate-acuminate or the outer ones linear-oblong and obtusish. Me. and Vt. to N. J. and D. C. May-June

13. Antennaria ambigens (Greene) Fernald. Intermediate Cat's-Foot. Similar to $A$. fallax, and perhaps only a glandular form of that plant. Stem not so tall, its leaves rather closer together, usually glandular only above; basal leaves sometimes not over $2.5 \mathrm{~cm}$. long; inner involucral bracts of the fertile heads acuminate. Me. to D. C.

I4. Antennaria alpina (L.) Gaertn. Alpine Everlasting. (I. F. f. 3843.) Surculose by short stolons; stems floccose-woolly, 3-10 cm. high. Basal leaves usually numerous, spatulate or linear-oblong, obtuse, silvery-woolly on both sides, or glabrate and green above, 8-25 mm. long; stem-leaves linear and small, few; heads in a terminal capitate, or seldom somewhat corymbose cluster, rarely solitary, 4-5 $\mathrm{mm}$. broad; involucre about $5 \mathrm{~mm}$. high, the bracts of the fertile heads dark brownish green, the inner ones acute or acuminate; those of the sterile heads lighter, brownish, broader and obtuse; achenes glandular. Latb. and arctic Am. to Alaska. The Rocky Mountain plant referred to this species is $A$. media Greene.

15. Antennaria dimórpha (Nutt.) T. \& G. Low Everlasting. (I. F. f. 3849.) Tufted from a thick woody often branched caudex, 3-4 cm. high. Leaves all in a basal cluster, spatulate, white-canescent or tomentose on both sides, obtuse or acutish, I-2.5 cm. long, 2-4 mm. wide, narrowed into short petioles; heads of staminate flowers about $6 \mathrm{~mm}$. broad and high, solitary and sessile among the leaves, or raised on a very short sparingly leafy stem, with obtuse or obtusish brownish involucral bracts, those of pistillate flowers longer, their inner bracts linear-lanceolate, acuminate; pappus of the staminate flowers slender. scarcely thickened, but barbellate at the tips, that of the pistillate flowers of fine and smooth bris. tles. Dry soil, Neb. to Utah and Cal., north to Mont. and Br. Col. April-June. 
ers. Involucre oblong to campanulate, its bracts scarious, imbricated in several series, mostly white, the outer shorter. Receptacle mostly convex, not chaffy. Staminate flowers with a slender or filiform corolla, an undivided style, and a pappus of slender bristles, not thickened at the summit, or scarcely so; anthers tailed at the base. Pistillate flowers with a tubular 5-toothed corolla, 2-cleft style, and a copious pappus of capillary separate bristles. Achenes oblong. [Greek name of some similar plant.] About 30 species, natives of the north temperate zone. Only the following and one other in N. Am.

I. Anaphalis margaritàcea (L.) Benth. \& Hook. Pearly OR LargeFLOWERED EVERLASTiNG. (I. F. f. 3850 .) Stem floccose-woolly, corymbosely branched at the summit, leafy, 3-9 dm. high. Leaves linear-lanceolate, narrowed to a sessile base, revolute, green, but more or less pubescent above, woolly beneath 7-12 cm. long, 4-8 mm. wide, the lowest shorter, spatulate, usually obtuse; cory mb cumpound, 5-20 cm. broad; heads very numerous, short.peduncled or sessile, about $6 \mathrm{~min}$. high, $8 \mathrm{~mm}$. broad when expanded; involucre campanulate, its bracts ovate-lanceolate, obtuse, finely striate, pearly white, mostly glabrous; pappusbristles of the fertile flowers distinct and falling away separately. Dry soil, Newf. to Alaska, N. Car., Kans. and Cal. Also in northern Asia.

\section{GNAPHÀLIUM L.}

Woolly branched herbs, with alternate leaves, and discoid heads of pistillate and perfect flowers arranged in corymbs, spikes, racemes, or heads. Receptacle flat, convex or conic, not chaffy, usually foveolate. Pistillate flowers in several series, their corollas filiform, minutely dentate or 3-4-lobed. Central flowers perfect, tubular, few, their corollas 5-tonthed or 5-lobed. Anthers sagittate at the base, the auricles tailed. Achenes oblong or obovate, terete or slightly compressed, not ribbed. Pappus a single series of capillary bristles, sometimes thickened above, cohering at the base, or separately deciduous. [Greek, referring to the wool.] About 120 species, widely distributed.

Tall, erect ; inflorescence cory mbose, or paniculate; pappus-bristles distinct.

Leaves sessile; plant not viscid.

Leaves sessile; plant glandular-viscid.

Leaves decurrent; plant glandular-viscid.

I.ow, diffuse; inflorescence mostly capitate; pappus-bristles distinct.

Floccose-woolly; involucral bracts yellowish, or white.

Appressed-woolly; involucral bracts becoming dark brown.

r. G. obtusifolium.

2. G. Helleri.

3. G. decurrens.

Tufted low mountain herbs; heads few; bracts brown; pappus-bristles distinct.

6. G. supinum.

Slender, simple; heads spicate; pappus-bristles united at base, falling away in a ring.

Leaves linear or lanceolate-spatulate, acute : heads about $6 \mathrm{~mm}$. high; northeastern. Bracts dalk brown; stem-leaves lanceolate-spatulate. 7. G. Norvegicum. Bracts brownish tipped; stem-leaves linear.

8. G. sylvaticum.

Leaves spatulate, obtuse or obtusish; heads $4-5 \mathrm{~mm}$. high; eastern and southern.

9. G. purpureum.

I. Gnaphalium obtusifòlium L. SWeet or White Balsam. SWeEt or Fragrant Life Everlasting. (I. F. f. 385 I.) Annual or winter-annual, fragrant; stem erect, simple, or branched above, tomentose, 3-9 $\mathrm{dm}$. high. Leaves lanceolate or linear-lanceolate, sessile, acute or acutish, or the lower obtuse at the apex, narrowed at the base, densely white-woolly beneath, glabrate and commonly dark green above, $2-7 \mathrm{~cm}$. long, 4-8 $\mathrm{mm}$. wide, the margins undulate; heads numerous, about $6 \mathrm{~mm}$. high; bracts of the involucre white, or ting $\epsilon \mathrm{d}$ with brown, oblong, thin and scarious, obtuse, the outer woolly at the base; achenes glabrous. In dry, mostly open places, N. S. to Fla., Manitoba, Kans. and Tex. Leaves of winter rosettes oblong. Aug.-Sept.

2. Gnaphalium Hélleri Britton. Heller's Everlasting. (I. F. f. 3852.) Similar to the preceding species, 4-6 dm. high, the stem and branches densely glandular-pubescent, not tomentose. Leaves oblong-lanceolate, sessile, acuminate at both ends, green and hispidulous above, white-tomentose beneath, the larger about $5 \mathrm{~cm}$. long and $1 \mathrm{~cm}$. wide, the uppermost much smaller and narrower; heads very numerous, about $5 \mathrm{~mm}$. broad ; involucre oblong, or becoming campanulate, $6 \mathrm{~mm}$. high, its bracts bright white, tomentose, the outer oblong, the inner linearoblong, all obtuse; achenes glabrous, In fields, Va. to Ky. and Ga. Sept.-Oct. 
3. Gnaphalium decúrrens Ives. Ciammy Everlasting. Winged CudWEED. (I. F. f. $3^{853}$.) Annual or biennial, similar to the two preceding species, fragrant; stem very leafy, glandular-viscid, 6-9 dm. high. Leaves lanceolate or broadly linear, acutish at the apex, densely white-woolly beneath, glabrate or loosely woolly above, sessile and decurrent on the stem at the base, 3-7 cm. long, 4-6 mm. wide, or the lowest shorter and slightly spatulate; heads about $6 \mathrm{~mm}$. high; bracts of the involucre white or brownish, ovate, acutish or the inner lanceolate and acute, the outer woolly at the base; achenes glabrous. In open, moist or dry places, N. S. to Penn., west to western Ont., Mich. and Br. Col., south in the Rocky Mts. to Ariz. July-Sept.

4. Gnaphalium palústre Nutt. Western Marsh Cudweed. (I. F. f. 3854 .) Annual; diffusely branched from the base, densely but loosely floccose-woolly all over, 5-20 cm. high. Leaves sessile, oblong, linear-oblong, or the lower spatulate, obtuse or acutish, I2-25 mm. long, 3-6 mm. wide; heads about $4 \mathrm{~mm}$. high, several together in leafy-bracted glomerules; involucre more or less woolly, its bracts linear or lanceolate, acute, white or pale yellow. In moist wet soil, N. W. Terr. to western Neb. and N. Mex., west to Br. Col. and Cal. May-Aug.

5. Gnaphalium uliginòsum L. Low or Marsh Cudweed. Wartwort. Mouse-EAR. (I. F. f. $3^{855 .)}$ Annual; diffusely branched from the base, or the stems sometimes erect or ascending, 5-20 cm. high. Leaves sessile, spatulatelinear, linear, or the lower oblanceolate or spatulate and narrowed into petioles, all obtuse or obtusish, generally mucronulate, $2-4 \mathrm{~cm}$. long; heads about $4 \mathrm{~mm}$. high, numerous in dense leafy-bracted terminal glomerules; bracts of the involucre oblong or oblong-lanceolate, the outer obtuse or obtusish and more or less woolly, the inner acute. In damp soil, Newf. to Va. west to western Ont., Minn. and Ind. Apparently nat. from Europe, where it is common. Occurs also in the far Northwest, where it is probably indigenous. July-Sept.

6. Gnaphaliuin supinum L. DWarf Cudweed. (I. F. f. 3856.) Perennial, white-woolly, much tufted; stems simple, $2-8 \mathrm{~cm}$. high. Leaves mainly basal, linear, acute, narrowed at the base, sessile, 12-25 $\mathrm{mm}$. long, 2-4 mm. wide; heads few or several, capitate or short-spicate, about $6 \mathrm{~mm}$. high; flowers yellowish; bracts of the involucre brown, glabrous, lanceolate or oblong-lanceolate, acute. Alpine summits of the mountains of Me. and N. H.; Lab. and Greenland, and in Europe and Asia. July-Aug.

7. Gnaphalium Norvégicum Gunner. Norwegian Cudweed. (I. F. f. 3857.) Perennial; stem simple, 1.5-4.5 dm. high. Leaves lanceolate to spatulate, elongated, acute, narrowed at the base, woolly on both sides, or green and glabrate above, 7-15 cm. long, 4-10 $\mathrm{mm}$. wide, the lower and basal ones petioled; heads about $6 \mathrm{~mm}$. high, the lowest often distant, solitary or glomerate in the upper 2xils; bracts of the involucre ovate-oblong, dark brown, or brown-tipped, glabrous or slightly woolly, obtuse; achenes hispidulous. Mt. Albert, Gaspé, Quebec, north to Greenland and arctic Am. Also in Europe. July-Aug.

8. Gnaphalium sylváticum L. Wood Cunweed. Chafeweed. Owl's Crown. Golden Motherwort. (I. F. f. 3958.) Perennial; stem slender, simple, 1.5-4.5 dm. high. Leaves linear, acute, 3-5 cm. long, about $2 \mathrm{~mm}$. wide, or the lowest linear-spatulate, woolly beneath, glabrous or glabrate above; heads about $6 \mathrm{~mm}$. high; bracts of the involucre linear-oblong. obtuse, mostly glabrous, yellowish or greenish with a brown spot at or just below the apex; achenes hispidulous. N. H., N. B. and Cape Breton Island, perhaps introduced from Europe. Widely distributed in Europe and northern Asia. June-Aug.

9. Gnaphalium purpùreum L. Purplish Cunweed. (I. F. f. 3859.) An. nual or biennial, simple and erect, or branched from the base and the branches ascending, 5-6 dm. high. Leaves spatulate, or the uppermost linear, mostly obtuse, mucronulate, woolly beneath, usually green and glabrous or nearly so above when old, sessile, or the lowest narrowed into petioles, 3-5 cm. long, 4-6 mm. wide: heads $4-5 \mathrm{~mm}$. high; bracts of the involucre yellowish brown or purplish, lance. olate-oblong, acute or acutish, the outer woolly at the base; achenes roughish. In dry sandy soil, eastern Me. to Fla., west to Penn., W. Va., Ky., Kans., Tex. and Mex. Also on the Pacific Coast and in S, Am. May-Sept, 


\section{ADENOCAŨLON Hook.}

Perennial herbs, with broad alternate slender-petioled leaves, woolly beneath, and panicled small heads of tubular flowers. Involucre campanulate, composed of a few herbaceous bracts. Receptacle nearly flat, naked. Corollas all tubular, 4-5-lobed. Marginal flowers pistillate, fertile. Central flowers perfect, sterile, the style undivided; anthers slightly sagittate at the base. Pappus none. Achenes obovoid or clavate, very obtuse, faintly nerved, glandular above, longer than the bracts of the involucre. [Greek, gland-stem.] About 3 species, natives of $\mathrm{N}$. Am., Japan, the Himalayas and Chiie. Only the following in N. Am.

I. Adenocaulon bícolor Hook. Adenocaulon. (I. F. f. 3860.) Stem floccose-woolly, or at length glabrous, 3-9 dm. high, leafless and mostly paniculately branclied above. Leaves all basal or nearly so, deltoid-ovate, obtuse or acute at the apex, deeply cordate at the base, coarsely repand-toothed or lobed, thin, green and glabrous above, densely and persistently white-woolly beneath, 5$15 \mathrm{~cm}$. long and broad, with slender narrowly margined petioles; heads numerous, very slender-peduncled, small; bracts of the involucre 4 or 5 , ovate to lanceolate, reflexed in fruit, at length deciduous: achenes $6-8 \mathrm{~mm}$. long, $1 \mathrm{~mm}$. thick, the upper part beset with nail-shaped glands. In moist wonds, northern Mich. and Lake Superior to Br. Col. and Cal. May-July.

\section{INULA L.}

Perennial, mostly tomentose or woolly herbs, with alternate and basal leaves, and large heads of both tubular and radiate yellow flowers. Involucre hemispheric or campanulate, its bracts imbricated in several series, the outer often foliaceous. Receptacle flat or convex, areolate or foveolate, not chaffy. Ray-flowers pistillate, their ligules 3-toothed. Disk-flowers perfect, their corollas tubular, 5-toothed. Anthers sagittate at the base, the auricles caudate. Style-branches of the disk-flowers linear, obtuse. Achenes 4-5-ribbed; pappus of capillary rough bristles in our species. [The ancient Latin name.] About 90 species, natives of Europe, Asia and Africa.

I. Inula Helènium L. Elecampane. Horseheal. (I. F. f. 386r.) Stems tufted from large thick roots, simple or rarely somewhat branched, 6-r $8 \mathrm{dm}$. high, densely pubescent above. Leaves large, broadly oblong, rough above, densely pubescent beneath, denticulate, the basal ones acute at each end, long-petioled, 2.5-5 dm. long, I-2 dm. wide; stem-leaves sessile, or cordate-clasping at the base, acute at the apex, smaller; heads solitary, or few, terminal, stout-peduncled, 5-ro cm. broad; involucre hemispheric, nearly $25 \mathrm{~mm}$. high, its outer bracts ovate, foliaceous, pubescent; rays numerous, linear; achenes glabrous, 4-sided. Along roadsides and in fields, N. S. to Ont. and Minn., south to N. Car. and Mo. Nat. from Europe.

\section{POLÝMNIA L.}

Perennial herbs (some tropical species woody), with opposite membranous lobed or angled leaves, or the lower alternate, and mostly large corymbose-paniculate heads of both tubular and radiate yellow or whitish flowers, or rays sometimes obsolete. Involucre hemispheric or broader, of about 5 large outer bracts, and more numerous smaller inner ones. Receptacle chaffy. Ray-flowers pistillate, fertile, subtended by the inner involucral bracts, the ligules elongated, minute or none. Disk-flowers subtended by the chaffy scales of the receptacle, perfect, sterile, their corollas tubular, 5-toothed. Anthers 2-toothed at the base. Pappus none. Acheres thick, short, turgid, glabrous. [From the Muse Polhymnia.] About ro species, natives of America. Only the following and one other species are known in N. Am.

Rays commonly $12-25 \mathrm{~mm}$. long, yellow; achenes strongly striate. Rays commonly minute and whitish, or none; achenes 3 -ribbed.

\section{P. Uvedalia.}

2. P. Canadensis.

I. Polymnia Uvedàlia L. Yellow or LARGe-flowered Leaf-CUP. (I. F. $f$. 3862.) Rough-pubescent, stout, branched, $1-3 \mathrm{~m}$. high. Leaves broadly ovate or deltoid, 3-nerved, abruptly contracted above the base, minutely ciliate, more or less pubescent on both sides, angulate-lobed, the lower often $3 \mathrm{dm}$. long and broad, 
petioled, the upper sessile, somewhat clasping: heads few, 4-7 cm. broad; rays 10-15, linear-oblong, bright yellow; exterior bracts of the cup-like involucre ovateoblong, obtuse, ciliate, 8-20 mm. long; achenes slightly oblique and laterally compressed, nearly $6 \mathrm{~mm}$. long. In rich woods, N. Y. to Ind. and Mich., Fla., Mo. and Tex. July-Aug.

2. Polymnia Canadénsis L. Small-Flowered Leaf-Cup. (I. F. f. 3863 .) Rather slender, viscid-pubescent, at least above, 6-15 dm. high. Leaves deltoidovate to hastate, usually very thin, all petioled, deeply angulate-lobed and the lobes dentate, or the lower lyrate-pinuatifid, I-2.5 dm. long, the upper ones sometimes ovate and entire or merely denticulate; heads few, 8-12 mm. broad; outer bracts of the involucre ovate to lanceolate, obtuse or acutish, $4.6 \mathrm{~mm}$. long; achenes 3-angled, obovoid, obcompressed, 3-ribbed. In damp, rich shaded places, western Ont. to Minn., Ga., Mo. and Ark. June-Sept.

Polymnia Canadénsis radiàta A. Gray. Ligules larger, sometimes 12 nım. long, 3-lobed, nearly white. Occasional in the range of the type.

\section{MELAMPÒdIUM L.}

Herbs, some species woody, with opposite entire or dentate leaves, and terminal peduncled heads of both tubular and radiate, white or yellow flowers in our species. Involucre hemispheric, its bracts in 2 series, the 4 or 5 outer ones broad, often connate at the base, the inner hooded, embracing or permanently surrounding the pistillate fertile ray flowers. Receptacle convex or conic, chaffy. Ray-flowers in 1 series, the rays spreading, 2-3-lobed or $\epsilon$ ntire. Disk-flowers perfect, sterile, their corollas with a narrowly campanulate 5 -toothed limb, the anthers entire at the base, the style undivided. Achenes obovoid, more or less incurved. Pappus none. [Greek, black foot, without significance.] About 25 species, natives of the warmer parts of America. Besides the following, some 4 others occur in the southwestern U. S.

I. Melampodium leucànthum T. \& G. Pale Melampodium. (I. F. f. 3864 as $M$. cinercum.) Pereunial, canescent, $\mathbf{I}-3 \mathrm{~cm}$. high, the branches slender. Leaves linear, lanceolate, or the lower spatulate, sessile, entire, undulate or sinuate, 3-5 cm. long, 3-9 $\mathrm{mm}$. wide, obtuse or obtusish at the apex; heads $16-28 \mathrm{~mm}$. broad; peduncles slender, 2-7 cm. long ; outer bracts of the involucre ovate or oval, obtuse, united below; rays 5-9, cuneate-oblong, white; inner bracts turbinate or terete, hooded, muricate, the hood wider than the body. In dry soil, Kans. to Colo., Ariz., Tex. and Mex. June-Oct.

\section{SILPHIUM L.}

Tall perennial herbs, with resinous juice, and large corymbose or paniculate (rarely solitary) peduncled heads of both tubular and radiate yellow flowers. Involucre hemispheric or campanulate, its bracts imbricated in few series. Receptacle flat or nearly so, chaffy, the chaff subtending the disk-flowers. Ray-flowers in 2 or 3 series, pistillate, fertile, the ligules numerous, linear. Disk-flowers perfect but sterile, their corollas tubular, 5-toothed, the style undivided. Anthers minutely 2-toothed or entire at the base. Achenes broad, dorsally flattened, 2-winged, notched at the apex. Pappus none, or of 2 awns confluent with the wings of the achene. [Greek, from the resinous juice.] About 25 species, of N. Am.

Stem leafy, the leaves opposite, alternate, or verticillate.

Leaves, or their petiole-bases, connate-perfoliate: stem square.

Leaves not connate-perfoliate, sessile or petioled.

1. S. perfoliatum.

Leaves opposite, or the uppermost alternate; cauline sessile.

Leaves, or some of them, verticillate in 3 's or 4 's, petioled.

2. S. integrifolium

3. S. trifoliatum.

Most or all of the leaves alternate, entire or dentate.

Involucral bracts ovate to orbicular, mostly obtuse, glabrous or puberulent. 4. S. Asteriscus.

Involucral bracts triangular to lanceolate, acute, hirsute or pubescent.

Leaves all alternate, pinnatifid or bipinnatifid, large.

5. S. Gatesii.

6. S. laciniatum.

Stem leafless or nearly so, scaly above; leaves basal, large.

7. S, terebinthinaceum. 
1. Silphium perfoliàtum L. Cup-Plant. Indian-CuP. (I. F. f. 3865.) Stem square, glabrous, or rarely somewhat hispid, branched above, or sometimes simple, $1-2.4 \mathrm{~m}$. high. Leaves ovate or deltoid-ovate, opposite, the lower abruptly contracted into margined petioles, all thin, usually scabrous on both sides, or pubescent beneath, coarsely angulate-dentate, or the upper entire, the larger 12$25 \mathrm{~mm}$. long, 8-16 mm. wide; heads commonly numerous, 5-7 cm. broad; rays 20-30, about $25 \mathrm{~mm}$. long and $4 \mathrm{~mm}$. wide; involucre depressed-hemispheric, its outer bracts broad, ovate, ciliolate, spreading or erect; achenes obovate, emarginate, sometimes 2 -toothed. In moist soil, southern Ont. to S. Dak., south to Ga., Neb. and La. Naturalized near N. Y. City. July-Sept.

2. Silphium integrifòlium Michx. ENtire-Leaved Rosin-weed. (I. F. f. 3866 .) Stem glabrous, rough or sometimes hirsute, cory mbosely branched above, $0.6-1.5 \mathrm{~m}$. high. Leaves ovate to ovate-lanceolate, acute or acuminate, entire, denticulate or remotely dentate, rough above, pubescent or glabrous beneath, $7-12 \mathrm{~cm}$. long, 3-5 cm. wide; heads usually numerous, $2-5 \mathrm{~cm}$. broad; involucre nearly hemispheric, its outer bracts ovate or ovate-lanceolate, acute, spreading, ciliolate or pubescent; rays 15-25; achenes oval or obovate, 8-10 min. long, deeply emarginate. On prairies, Ohio to Minn., La., Neb., Ark. and Tex. Aug.-Sept.

3. Silphium trifoliàtum L. Whorled Rosin-weed. (I. F. f. 3867.) Stem glabrous, sometimes glaucous, corymbosely branched at the summit, $1-2 \mathrm{~m}$. high. Leaves lanceolate or oblong-lanceolate, acuminate at the apex, narrowed at the base, rough or roughish above, pubescent or nearly glabrous beneath, entire or denticulate, 7-17 cm. long, I-4 cm. wide; heads several or numerous, 4-5 cm. broad; involucre hemispheric, its outer bracts ovate or oval, acute or obtuse, glabrous, or slightly pubescent, ciliolate; rays I 5-20; achenes oval or obovate, narrowly winged, emarginate, sharply 2-toothed. In woods, Penn. to Ohio, Va. and Ala. JulyOct.

4. Silphium Asteríscus L. Starry Rosin-weed. (I. F. f. 3868.) Stem $0.6-1.2 \mathrm{~m}$. high, usually purple. Leaves ovate, ovate-oblong, or lanceolate, acute or obtusish, sessile, somewhat clasping, or the lower narrowed into short petioles, dentate, or the upper entire, 5-12 cm. long, $1-2.5 \mathrm{~cm}$. wide; heads commonly few, 3-5 $\mathrm{cm}$. broad; rays $12-15$; involucre hemispheric, its bracts mostly hispid, orbicular, ovate or oblong, obtuse; achenes oval or obovate, narrowly winged, 2 -toothed. In dry soil, Md. to Tenn. and Mo., south to Fla. and La. June-Sept.

5. Silphium Gátesii Mohr. Gates' Rosin-weed. Stems 0.6-1.5 m. tall, hispid, simple or sparingly branched above. Leaves alternate, broadly linear to oblong-lanceolate or lanceolate, $5^{-14} \mathrm{~cm}$. long, acute, remotely serrate, roughpubescent, the lower ones short-petioled; heads showy; involucre campanulate, barely $\mathrm{I} \mathrm{cm}$. high, the bracts mainly triangular to lanceolate, hirsute or pubescent, the outer acute or short-acuminate; ray-flowers several, the ligules yellow, 12-20 $\mathrm{mm}$. long: achenes suborbicular or broader than high, the teeth when present separated by a broad sinus. In dry soil, Mo. to Tenn. and Ala. May-Aug.

6. Silphium laciniàtum L. Compass-Plant. Pilot-Weed. (I. F. f. 3869.) Rough or hispid, very resinous; stem $2-5 \mathrm{~m}$. high; basal leaves pinnatifid or bipinnatifid, long-petioled, $3 \mathrm{dm}$. long or more, the lobes oblong or lanceolate ; stemleaves alternate, vertical, their edges tending to point north and south, sessile, or the lower short-petioled, the upper cordate-clasping at the base; heads 5-12 cm. broad, the peduncles bracted at the base ; rays $20-30,25-35 \mathrm{~mm}$. long ; involucre nearly hemispheric, its bracts large, rigid, lanceolate or ovate, very squarrose ; achenes oval, about $12 \mathrm{~mm}$. long, the wing broader above than below, notched at the apex, awnless. On prairies, Ohio to S. Dak., Ala., La., Kans. and Tex. July-Sept.

7. Silphium terebinthinàceum Jacq. Prairie Dock. (I. F. f. $3^{870 .) ~ S t e m ~}$ glabrous or nearly so, branched and scaly above, I-3 m. high. Leaves coriaceous, ovate, mostly long-petioled, acute at the apex, cordate at the base, rough on both sides, often $3 \mathrm{dm}$. long and $15 \mathrm{~cm}$. wide, sharply dentate; heads numerous, 4-7 cm. broad; involucre hemispheric, its bracts obovate-oblong, erect, glabrous or minutely pubescent ; rays 12-20 ; achenes obovate, narrowly winged, slightly 2-toothed and emarginate at the apex. On prairies and in dry woods, southern Ont. and Ohio to Minn., Iowa and La. July-Sept.

Silphium terebinthinàceum pinnatifidum (Ell.) A. Gray. Leaves laciniate or pinnatifid. Ohio to Tenn. and Ga. 


\section{CHRYSÓGONUM L.}

Pubescent perennial herbs, with opposite and basal petioled leaves, and slenderpeduncled axillary and terminal, rather large heads of both tubular and radiate yellow flowers. Involucre hemispheric, its bracts in 2 series of 5 , the outer large, obovate or spatulate, foliaceous, the inner oval, firm, each subtending a pistillate ray-flower. Receptacle chaffy, each scale subtending and partly enclosing a per. fect but sterile tubular flower with a 5-toothed corolla. Anthers nearly entire at the base. Achenes obovate, compressed, their margins acute, not winged, I-nerved on the back, I-2-ribbed on the inner side. Pappus a short half-cup-shaped crown. [Greek, golden-knee.] A monutypic genus.

1. Chrysogonum Virginànum L. Chrysogonum. (I. F. f. 3871 .) Perennial by rootstocks or rumners, pubescent or hirsute throughout, branched from the base, or at first acaulescent, 7-30 cm. high. Leaves ovate or oblong, obtuse or acutish at the apex, the upper sometimes subcordate at the base, crenate-dentate, rather thin, 3-7 cm. long, $1-2.5 \mathrm{~cm}$. vide, peduncles $3-10 \mathrm{~cm}$. long; heads $2.5-4$ $\mathrm{cm}$. broad; outer bracts of the involucre obtuse ; rays about $5,8-\mathrm{I} 4 \mathrm{~mm}$. long. In dry soil, southern Penn. to Fla. April-July.

Chrysogonum Virginianum dentatum A. Gray. Leaves dentate, the teeth and acutish apex mucronulate; outer bracts of the involucre acuce. High Island, Potomac River, near Washington.

\section{BERLANDIÈRA DC.}

Perennial canescent or pubescent herbs, with alternate leaves and rather large, peduncled heads of both tubular and radiate yellow flowers. Involucre depressed. hemispheric, its bracts imbricated in about 3 series, the outermost small, mostly oblong, the second series broader, oval or obovate, the inner membranous, similar, reticulated when mature, subtending the ray-flowers and exceeding the disk. Receptacle nearly flat, chaffy, the chaff subtending the disk-flowers. Ray-flowers 5-12, pistillate, fertile. Disk-flowers perfect, tubular, sterile, their corollas 5toothed. Anthers entire, or minutely 2-tonthed at the base. Style of the tubular flowers undivided, hirsute. Achenes obovate, compressed, not winged, I-ribbed on the inner side, the pappus obsolete, early deciduous or of 2 caducous awns. [Named after J. L. Berlandier, a Swiss botanical collector in Texas and Mexico.] About 5 species, natives of the southern U. S. and Mex.

Stem leafy ; leaves ovate to oblong, crenate.

Plant acaulescent, or nearly so; leaves lyrate-pinnatifid.

1. B. Texana. 2. B. lyrata.

I. Berlandiera Texàna DC. Texan Berlandiera. (I. F. f. 3872.) Hirsute-pubescent throughout; stem erect, branched above, or simple, 6-9 dm. high, leafy. Leaves acutish or obtuse at the apex, rounded or cordate at the base, 5-10 $\mathrm{cm}$. long, 3-5 cm. wide, the upper sessile, the lower petioled; heads few or several, 3-4 cm. broad, in a terninal cory mbose-cymose cluster ; inner bracts of the involucre twice as large as the outer. In dry soil, Mo. and Kans. to Ark. and La. July-Aug.

2. Berlandiera lyràta Benth. Lyre-Leaved Berlandiera. (I. F. f. 3873.) Finely whitish-canescent; scapes or peduncles slender, $7-20 \mathrm{~cm}$. long, bearing a solitary head, or rarely 2. Leaves lyrate-pinnatifid, obtuse, petioled, the terminal segment usually larger than the lateral ones, the lower ones very small, all obtuse, mostly crenate, sometimes becoming green and glabrate above; head about $25 \mathrm{~mm}$. broad; inner bracts of the involucre much broader than the outer, orbicular, or wider than long. In dry soil, Kans. to Tex., Ariz. and Mex.

\section{ENGELMÁNNIA T.\& G.}

Perennial hirsute herbs, with alternate pinnatifid leaves, and corymbose slenderpeduncled rather large heads of both tubular and radiate yellow flowers. Involucre hemispheric, its bracts imbricated in 2 or 3 series, the outer linear, loose, hirsute, ciliate, the inner oval or obovate, concave, appressed, subtending the rayflowers. Receptacle flat, chaffy, the chaff subtending and partly enclosing the diskflowers. Rays 8-10, pistillate, fertile. Disk-flowers about as many, tubular, perfect,- sterile, the corolla 5-toothed. Anthers minutely 2-dentate at the base. 
of the rubular flowers undivided. Achenes obovate, compressed, not winged, I-ribbed on each face. Pappus a persistent irregularly cleft crown. [Named for Dr. Geo. Engelmann, botanist, of St. Louis.] A monotypic genus.

I. Engelmannia pinnalíida T.\&G. ENGelmanNia. (I. F. f. 3874 ) Stem usually branched above, 3-9 dm. high. Basal leaves slender-petioled, I-2 din. long, their lobes lanceolate or oblong, dentate or entire, ubtuse or acutish; upper leaves sinaller, sessile, less divided, the uppermost sometimes entire, or with a pair of basal lobes; heads usuilly uumerous, about $25 \mathrm{~mm}$. broad; outer bracts of the involucre somewhat in 2 series, the first linear, the second broadened at the base. In dry suil, Kans. to La., Ariz. and N. Mex. May-Aug。

\section{PARTHẼNIUM L.}

Perennial, mostly pubescent or canescent herbs, or shrubs, with alternate leaves, and small corymbose or paniculate heads of both tuluular and radiate white or yellow flowers. Involucre broadly campanulate or hemispheric, its bracts imbricated in 2 or 3 series, ubtuse, appressed, nearly equal. Receptacle convex or conic, chaffy, the chaff membranous, surrounding the disk-flowers. Ray-flowers about 5: pistillate, fertile, their ligules short, broad, 2-toothed or obcordate. Diskflowers perfect, sterile, their corollas 5-toothed, the style undivided. Anthers entire at the base. Achenes compressed, keeled on the inner face, margined, bearing the persistent rays on the summit. Pappus of 2-3 scales or awns. [Greek, virgin.] About ro species, natives of N. An., Mex., the IV. Ind. and northern S. Am. Besides the following, some 5 others occur in the southern and southwestern U. S.

Leaf-bases not auricled.

Stem minutely pubescent, or glabrous below; rootstocks thickened.

Stem pilose or hispid; rootstocks slender, creeping, forming runners.

I. P. integrifolium.

2. P. repens.

Upper leaves with sessile auricled bases.

3. P. auriculatum.

I. Parthenium integrifolium L. American Fever-few. Prairie Dock. (I. F. f. 3875.) Stem stout, striate, corymbosely branched above, 3-12 din. high. Rootstocks tuberous-thickened; leaves firm, ovate or ovate-oblong, acute or acuminate, crenate-dentate or somewhat ly rate at the base, hispidulous and roughish on both sides, the lower and basal ones petioled, often $3 \mathrm{dm}$. long and $12 \mathrm{~cm}$. wide, the upper smaller, sessile and partly clasping; involucre nearly hemispheric, about $6 \mathrm{~mm}$. high, its bracts firm, the outer oblong, densely appressed-pubescent, the inner broader, glabrous, or ciliate on the margins; rays white or whitish. In dry soil, Md. to Minn., Ga., Mo. and Tex. May-Sept.

2. Parthenium rèpens Eggert. CReEPING or HAIRY PARThenium. (I. F. f. 3876 .) Similar to $P$. integrifolium, but lower, seldom over $6 \mathrm{dm}$. high. Rootstocks slender. forming runners; stem pilose or hispid with spreading hairs: leaves hispid on both sides, irregularly crenate, sometimes lyrate at the base, the teeth rounded and obtuse : heads fewer, slightly larger, in a smaller looser corymb; outer bracts of the involucre proportionately broarler. Mo. and Kans. April-July.

3. Parthenium auriculatum Britton. Auriclfo Parthenium. (I. F.f. 3875 a.) Rootstock an oval erect tuber twice as long as thick; stem villous-pubescent, 4-7 $\mathrm{dm}$. high. Leaves rough above, villous, especially on the veins beneath, oval, ovate or oblong, irregularly crenate-dentate, some or all of them laciniate or pinnatifid at the base, the basal and lower slender-petioled with petiole as long as the blade, or longer, the upper with a sessile clasping auricled base, or with margined clasping petioles: inflorescence densely corymbose, its branches villous-tomentose; bracts of the involucre densely canescent. Near Clarksville, Va.; Alleghany Mts.

\section{CRASSINA Scepin. [ZINNIA L.]}

Annual or perennial herbs, some species shrubby, with opposite entire, or sparingly serrate, mostly narrow and sessile leaves, and large or middle sized heads of both tubular and radiate flowers. Ray-flowers pistillate, yellow or variegated, persistent on the achene. Disk-flowers perfect, fertile; corolla cylindraceous, its lobes villous. Involucre campanulate to nearly cylindric, its bracts obtuse, dry, 
firm, appressed, imbricated in 3 series or more, the outer gradually shorter. Re. ceptacle conic or cylindric, chaffy, the chaff subtending and enwrapping the disk. flowers. Style-branches elongated, not appendaged. Achenes of the ray-flowers somewhat 3-angled, those of the disk flattened. Pappus of few awns or teeth. [In honor of Paul Crassus, an Italian botanist of the 16th century.] About 12 species, natives of the U. S. and Mex.

I. Crassina grandiflòra (Nutt.) Kuntze. Prairie Zinnia. (I. F. f. 3877.) Perennial, woody at the base, tufted, much branched, rough, 1-1.5 dm. high. Leaves rather rigid, linear to linear-lanceolate, entire, $1-3 \mathrm{~cm}$. long, $3 \mathrm{~mm}$. wide or less, connate at the base, acute or acutish, crowded; heads numerous, peduncled, terminating the branches, $20-35 \mathrm{~mm}$. broad; rays 4 or 5 , broad, yellow rounded or emaryinate, their achenes with a pappus of 2 or 4 awns; involucre campanulate-cylindric, 6- $8 \mathrm{~mm}$. high ; style-branches of the disk-flowers subulate. In dry soil, Kans. and Colo. to Tex., Mex. and Ariz. June-Sept.

\section{HELIÓPSIS Pers.}

Perennial herbs (a tropical species annual), with opposite petioled 3 -ribbed leaves, and large peduncled terminal and axillary heads of tubular and radiate yellow flowers. Involucre hemispheric or broadly campanulate, its bracts oblong or lanceolate, imbricated in 2 or 3 series. Receptacle convex or conic, chaffy, the chaff enveloping the disk-flowers. Ray-flowers pistillate, fertile, the rays spread. ing, the tube very short, conmonly persistent on the achene. Disk-flowers perfect, the tube short, the limb elongated, 5 -toothed. Anthers entire, or minutely 2 -toothed at the base. Style-branches tipped with small hirsute appendages. Achenes thick, obtusely 3-4-angled, the summit truncate. Pappus none, or of 2-4 teeth, or a coroniform border. [Greek, sun-like.] About 6 species, natives of America. Besides the following, two others occur in the southern and southwestern U. S.

Leaves smooth, or nearly so; pappus none, or of 2-4 short teeth. Leaves rough; pappus crown-like, or of $1-3$ sharp teeth.
1. H. helianthoides. 2. H. scabra.

I. Heliopsis helianthòides (I.) B.S.P. Ox-eye. False Sunflower. (I. F. f. 3878.) Stem glabrous, branched above, 9-15 dm. high. Leaves opposite, or rarely in 3's, ovate or ovate-lanceolate, rather thin, acuminate at the apex, usually abruptly narrowed at the base, sharply and nearly equally dentate, 7-15 cm. long, $2.5-6 \mathrm{~cm}$. wide ; heads long-peduncled, somewhat corymbose, $3 \cdot 5-6 \mathrm{~cm}$. broad; rays 18-25 mm. long; bracts of the involucre oblong or linear-oblong, obtuse or acutish; achenes glabrous, the summit truncate. In open places, Ont. to Fla., west to Ill. and $\mathrm{Ky}$. July-Sept. [Heliopsis lavis Pers.]

2. Heliopsis scàbra Dunal. Rough Ox-EYe. (I. F. f. 3879.) Similar to the preceding species, but stem rough, at least above, simple or branched, 6-12 dm. high. Leaves ovate or ovate-lanceolate, acute or acuminate, sharply dentate, firm, 5-12 cm. long, 4-5 cm. wide, abruptly narrowed at the base, short petioled; heads few, or solitary, long-peduncled, 5-6 cm. broad; rays usually $25 \mathrm{~mm}$. long, or more ; bracts of the involucre canescent, oblong or linear-oblong ; achenes pubes. cent on the margins when young. Usually in dry soil, Me. to N. Y., N. J., Ill., Br. Col., Kans. and Ark. June-Sept.

\section{ECLÍPTA L.}

Erect or diffuse branching pubescent or hirsute herbs, with opposite leaves, and small peduncled terminal and axillary heads of tubular and radiate whitish flowers. Involucre hemispheric or broadly campanulate, its bracts imbricated in about 2 series, nearly equal, or the outer longer. Receptacle flat or convex, chaffy, the chaff awn-like, subtending the achenes. Ray-flowers pistillate, fertile. Diskflowers perfect, mostly fertile, their corollas tubular, 4-toothed or rarely 5-toothed. Anthers entire or minutely 2-toothed at the base. Style-branches of the diskflowers with obtuse or triangular tips. Achenes thick, those of the rays 3 -sided, those of the disk compressed. Pappus none, or of a few short teeth. [Greek, wanting, referring to the absence of pappus.] About 4 species, mostly of tropical distribution.

r. Eclipta álba (L.) Hassk. Eclipta. (I. F. f. 3880.) Annual, rough with appressed pubescence, erect or diffuse, 1.5-9 dm. high. Leaves lanceolate, 
oblong-lanceolate or linear-lanceolate, acute or acuminate, denticulate or entire, narrowed to a sessile base, or the lower petioled, $2-12 \mathrm{~cm}$. long, 4-20 $\mathrm{mm}$. wide; heads commonly numerous, 6-12 mm. broad, nearly sessile, or slender-peduncled; rays short, nearly white; anthers brown; achenes 4-toothed, or at length truncate. Along streams, and in waste places, southern N. Y. to Ill. and Neb., south to Fla., Tex. and Mex. Naturalized from tropical Am. and widely distributed in warm regions as a weed. July-Oct.

\section{TETRAGONOTHÈCA L.}

Erect perennial mostly branched herbs, with opposite sessile or connate-perfoliate, broad dentate leaves, and large peduncled heads of tubular and radiate yellow flowers. Involucre depressed-hemispheric, its principal bracts 4, large and foliaceous, inserted in I series; inner bracts 6-15, small, subtending the pistillate ray-flowers. Receptacle conic, chaffy, the chaff concave, enwrapping the perfect fertile disk-flowers, the corollas of which are slender and 5-toothed. Anthers entire or minutely 2-toothed at the base. Style-branches of the disk-flowers hispid, tipped with elongated appendages. Achenes thick, 4-sided, truncate at the summit. Pappus none, or of several short scales. [Greek, 4-angled case, referring to the involucre.] Three known species, of the southern U. S. and northern Mex.

I. Tetragonotheca helianthoides L. Tetragonotheca. (I. F. f. 388I.) Viscidly pubescent; stem branched or simple, 3-7 dm. high. Leaves ovate, ovateoblong, or somewhat rhomboid, thin, coarsely and unequally dentate, acute at the apex, narrowed at the base, sessile, or connate-perfoliate, 5-15 cm. long, 2-7 cm. wide; heads usually few, $3-7.5 \mathrm{~cm}$. broad; principal bracts broadly ovate, acute; rays 6-Io, strongly nerved, 2-3-toothed; achenes 4-sided, or nearly terete; pappus none. In dry soil, Va. to Fla. and Ala. May-June. Sometimes flowering again in the autumn.

\section{SPILÁNTHES Jacq.}

Annual branching herbs, or some species perennial, with opposite, usually toothed leaves and rather small, long-peduncled discoid and radiate heads, terminal, or in the upper axils, or rays wanting in some species. Involucre campanulate, its bracts in about 2 series, herbaceous, loosely appressed. Receptacle convex or elongated, chaffy, its chaff embracing the disk-achenes and at length falling away with them. Riy-flowers yellow, or white, pistillate. Disk-flowers yellow, perfect, their corollas tubular with an expanded 4-5-cleft limb. Anthers truncate at the base. Style-branches of the disk-flowers long, sometimes penicillate at the summit. Ray-achenes 3 sided, or compressed, those of the disk-flowers compressed, margined. Pappus of $\mathbf{I - 3}$ awns, or more. [Greek, spot- or stain-flower, not significant.] About 30 species, of warm and tropical regions.

I. Spilanthes rèpens (Walt.) Michx. Spilanthes. (I. F. f. 3882.) Perennial, usually rooting at the lower nodes; stem slender, spreading or ascending, 2-6 $\mathrm{dm}$. long. Leaves ovate to lanceolate, petioled, acute, acuminate, or the lower obtuse, coarsely toothed, or nearly entire, 3-7 cm. long; heads solitary at the ends of the stem and branches, $12-20 \mathrm{~mm}$. broad; bracts of the involucre oblong to oblonglanceolate; rays 8-12, yellow; receptacle narrowly conic; achenes oblong, most of them roughened when mature and hispidulous. In moist or wet soil, Mo. to Tex., east to S. Car. and Fla. June-Sept.

\section{6o. RUDBÉCKIA L. (See Appendix.)}

Perennial or biennial (rarely annual), mostly rigid, usually rough or hispid herbs, with alternate undivided lobed or pinnatifid leaves, and large long-peduncled heads of tubular (mostly purple) and radiate (yellow) flowers. Involucre hemispheric, its bracts imbricated in $2-4$ series. Receptacle conic or convex, with chaffy concave scales subtending or enveloping the disk-flowers. Ray-flowers neutral, the rays entire or toothed. Disk-flowers perfect, fertile, their corollas 5-lobed, Anthers entire or minutely 2-mucronate at the base. Style-branches tipped with hirsute appendages. Achenes 4-angled, obtuse or truncate at the apex. Pappus coroniform, sometimes of 2-4 short teeth, or none. [In honor of Claus Rudbeck, 1630-1702, Swedish anatomist and botanist.] About 27 species, of N. Am. and 
Mex. In addition to the following, some 25 others occur in the southern and west. ern U. S.

\section{* Stem-leaves not cordate-clasping ; achenes 4-angled.}

Disk globose or ovoid and purple or dark brown in fruit; lower leaves entire or lobed. Lower leaves deeply 3-lobed or 3-divided.

Plant more or less hirsute; leaves thin; chaff awned.

Plant scabrous; leaves thick; chaff blunt, pubescent at apex.

Leaves neither 3 -lobed nor 3 -divided.

I. R. triloba.

2. R. subtomentosa.

Plants hispid; chaff acute or acutish, hirsute at summit; style-tips subulate.

Stem-leaves lanceolate, ovate to oblong; involucre shorter than the rays.

Upper stem-leaves narrowly lanceolate, entire or nearly so.

3. R. hirta.

Upper stem-leaves ovate to ovate-lanceolate, mostly toothed.

4. R. monticola.

Stem-leaves oval to obovate ; involucral bracts foliaceous, nearly as long as the rays.

Plants pubescent, hirsute or glabrate; style-tips obtuse.

5. $R$. Brittonii.

Leaves denticulate or entire; rays $1.8-2.5 \mathrm{~cm}$. long.

Stem-leaves oblong, ovate or oblong-lanceolate ; disk 10-16 mm. broad, subglobose.

Basal leaves oval, acute or acutish, sparingly pubescent.

Basal leaves narrowly oblong, obtuse, hirsute.

6. R. fulgida.

7. R. Missouriensis.

Basal leaves broadly ovate to orbicular, cordate, obtuse, slightly pubescent.

8. R. palustris.

Stem-leaves obovate or spatulate ; disk 8-10 mm. broad, depressed.

Leaves dentate or laciniate ; rays about $3.5 \mathrm{~cm}$. long.

Stem-leaves elongated-lanceolate.

Stem-leaves ovate-lanceolate.

9. R. spathulata.

Io. $R$. speciosa.

II. R. Sullivantii.

Disk elongated or cylindric in fruit, yellowish or gray; lower leaves pinnately divided or pinnatifid.

12. R. laciniata.

** Stem-leaves cordate-clasping; achenes nearly terete, striate. 13. R. amplexicaulis.

I. Rudbeckia tríloba L. Thin-Leaved Cone-Flower. (I. F. f. 3883.) Stem somewhat pubescent and rough, rarely glabrate, branched, 6-15 dm. high. Leaves rough on both sides, bright green, the basal and lower ones petioled, the lobes lanceolate or oblong, acuminate, sharply serrate; upper leaves ovate, ovatelanceolate, or lanceolate, acuminate or acute, narrowed to a sessile base or into short margined petioles, serrate or entire, 5-10 $\mathrm{cm}$. long, $1-2.5 \mathrm{~cm}$. wide; heads nearly $5 \mathrm{~cm}$. broad, corymbed; bracts of the involucre linear. acute, pubescent, soon reflexed; rays 8-12, yellow, or the base orange or brownish purple; disk dark purple, ovoid, about $12 \mathrm{~mm}$. broad; pappus a minute crown. In moist soil, N. J. to Ga., west to Mich., Kans. and La. June-Oct.

2. Rudbeckia subtomentòsa Pursh. Sweet Cone-Flower. (I. F. f. 3884 .) Densely and finely cinereous-pubescent and scabrous; stem branched above, 6-18 dm. high. Leaves thick, the lower ones petioled, 7-12 cm. long, the lobes oblong or lanceolate, acute or acuminate, dentate; upper leaves, or some of them, lanceolate or ovate, acuminate, sessile or nearly so; heads numerous, $5-7 \mathrm{~cm}$. broad; rays I 5-20, yellow, or with a darker base; disk subglobose, rounded, purple, 12-16 mm. broad; bracts of the involucre linear-lanceolate, acuminate, squarrose, sweetscented; pappus a short crenate crown. On prairies and along rivers, Ill. to La., Kans. and Tex. July-Sept.

3. Rudbeckia hírta L. Black-eyed Susan. Yellow Daisy. (I. F. f. 3885.) Biennial or sometimes annual; stems simple or sparingly branched, often tufted, 3-9 dm. high. Leaves thick, sparingly serrate with low teeth, or entire, the lower and basal ones petioled, mostly obtuse, 3-5-nerved, 5-17 cm. long, $1-5 \mathrm{~cm}$. wide, the upper sessile, narrower, acute or acutish; heads commonly few or solitary, 5-10 $\mathrm{cm}$. broad; rays $10-20$, orange, rarely darker at the base; bracts of the involucre very hirsute, spreading or reflexed; disk globose-ovoid, purple-brown; pappus none. In fields, Quebec to western Ont. and the N. W. Terr., south to Fla., Colo. and Tex. Widely distributed in the east as a weed. May-Sept. 
4. Rudbeckia montícola Small. Mountain Cone-flower. Perennial by a woody root; stem hirsute, simple or with long, slender branches, 4-7 dm. high. Leaves thin, rough-pubescent on both sides, the basal and lower ones with oval to oblong, obtuse or obtusish blades tapering into margined petioles, the upper ovate to ovate-lanceolate, serrate, acute to acuminate, 6-12 cm. long, sessile and partly clasping, or narrowed into broad clasping petioles; heads very long-peduncled, 8-10 $\mathrm{cm}$. broad; involucral bracts narrowly lanceolate to linear, half as long as the rays, or less. Mountainous regions, W. Va. to Tenn., N. Car., Ala. and Ga. June-Aug.

5. Rudbeckia Brittònii Small. Britton's Cone-flower. (I. F. f. 3886.) Stem stout, erect, 4-7 dm. high, simple, grooved, leafy, at least below. Leaves serrate or crenate-serrate, strigose-pubescent, the basal ones ovate to ovate-lanceolate, 7-10 cm. long, obtuse, long-petioled; stem-leaves often with a lateral lobe, the petioles wing-margined; uppermost leaves often ovate-lanceolate, sessile, cordate; bracts of the involucre often $25 \mathrm{~mm}$. long or more; head 5-7 cm. broad; rays about 12, 2-lobed; style-tips slender, acute. In woods, mountains of Penn. to Va. and Tenn. May-July.

6. Rudbeckia fúlgida Ait. Orange Cone-flower. (I. F. f. 3887.) Perennial; stem hirsute or strigose-pubescent, slender, sparingly branched or simple, 3-9 dm. high. Leaves firm, more or less hirsute or pubescent on both sides, the basal and lower ones oblong or spatulate, obtuse, 5-10 cm. long, 3-nerved, narrowed into margined petioles, the upper sessile, or slightly clasping at the base; heads few, 2-4 cm. broad; bracts of the involucre oblong or lanceolate, 6-16 $\mathrm{mm}$. long; rays 10-15, linear, bright yellow, or with an orange base; disk brownpurple; chaff of the receptacle linear-oblong. obtuse, glabrous, or nearly so at the summit; pappus a minute crown. In dry soil, N. J. and Penn, to Ga., west to Mo. and Tex. Aug.-Oct.

7. Rudbeckia Missouriensis Engelm. Missouri Cone-flower. Stem more or less hirsute, 4-7 dm. high, simple or branched. Leaves firm, entire, or with an occasional minute callous tooth, the basal ones narrowly oblong, acutish or obtuse, 6-20 cm. long, 8-12 mm. wide, 3-nerved, hirsute, narrowed into petioles, those of the stem sessile or the lower petioled. linear-lanceolate to linear, acute or obtusish; heads 7-9 cm. broad; rays mostly 12-14, 2-3-toothed; involucral bracts oblong to lanceolate, obtuse to acute, much shorter than the rays; disk hemispheric, purple-brown; chaff pointed; style-tips obtuse; pappus a very short crown. Missouri and Arkansas.

8. Rudbeckia palústris Eggert. Swamp Cone-flower. Perennial; stem grooved, smooth and glabrous, or nearly so, branched, 4-9 dm. high, the branches slender, erect. Leaves rather thin, the basal ones with broadly ovate to orbicular blades 5-8 cm. long, palmately veined, remotely denticulate, cordate or obtuse at the base, their slender pubescent petioles $10-15 \mathrm{~cm}$. long; stem-leaves ovate to ovate-lanceolate, sparingly serrate, acute or acuminate at the apex, narrowed at the base, 3-5-nerved, the lower petioled, the upper sessile; peduncles long, slender, pubescent; heads $3 \mathrm{~cm}$. wide or more; involucral bracts oblong, obtuse, appressedpubescent, half the length of the rays or less. In wet soil, $\mathrm{Ky}$. to Tenn. and Mo.

9. Rudbeckia spathulàta Michx. Spatulate-leaved or Flat-headed Cone-Flower. (I. F. f. 3888 .) Perennial; stem slender, simple, or little branched, finely strigose-pubescent, 3-9 dm. high. Leaves appressed-pubescent on both sides, the lower 5-10 cm. long, 2-4 cm. wide, the basal ones sometimes nearly orbicular, obtuse or obtusish, denticulate, narrowed into margined petioles: heads few, or solitary, 2.5-4 cm. broad; bracts of the involucre short, at length reflexed; disk depressed-globose or ovoid, about $1 \mathrm{~cm}$. broad; rays 8-12, oblong, yellow, mostly orange at the base; chaff of the receptacle obtuse; pappus a short-toothed crown. In dry woods, Va. to Tenn. and Fla. Aug.-Sept.

Io. Rudbeckia speciòsa Wenderoth. SHowy Cone-Flower. (I. F. f. 3889.) Perennial, more or less hirsute or hispid; stem branched above, 3-12 dm. high. Leaves firm, slender-petioled, 5-12 cm. long, 3-5 cm. wide, dentate with low teeth, acute or sometimes acuminate, 3-5-nerved; stem-leaves sessile or partly clasping. or narrowed into broad margined petioles, laciniate or sharply serrate, lanceolate, acuminate, often $\mathbf{I} 5 \mathrm{~cm}$. long, the uppermost smaller and sometimes entire; heads several, $5-7 \mathrm{~cm}$. broad; bracts of the involucre linear-lanceolate, 
acute; rays 12-20, bright yellow, usually orange at the base; disk depressedglobose, IO-16 mm. broad, brown-purple; chaff of the receptacle acute, ciliate or naked; florets 5.5-6.5 $\mathrm{mm}$. long; achenes 2.5-3 mm. high; pappus a short crown. In moist soil, N. J. to Mich., south to Ala. and Ark. Aug.-Oct.

II. Rudbeckia Sullivàntii Boynton \& Beadle. Sullivant's Cone-flower. Perennial, 5-12 dm. high. Stem-leaves ovate to ovate-lanceolate, the lower 15-20 $\mathrm{cm}$. long, 4-8 cm. wide, their petioles 3-7 cm. long, the blade coarsely and irregularly serrate, more or less pube'scent; heads several, 5-9 cm. broad; rays $10-15$; chaff acute, smooth or nearly so; florets $6.5-7.5 \mathrm{~mm}$. long; achenes 3-4 mm. high. Ohio and Michigan.

I2. Rudbeckia laciniàta L. TALL OR GREen-HEAdED CoNE-FLower. (I. F. f. 3890.) Perennial; much branched, glabrous, or nearly so, I-3.5 mm. high. Leaves rather thin, minutely pubescent on the margins and upper surface, broad, the basal and lower ones long-petioled, often $3 \mathrm{dm}$. wide, the segments variously toothed and lobed; stem-leaves shorter-petioled, 3-5-parted or divided, the upper ones much smaller, 3-lobed, dentate or entire; heads several or numerous, 6-10 $\mathrm{cm}$. broad; rays 6-10, bright yellow, drooping; bracts of the involucre unequal; chaff of the receptacle truncate and canescent at the apex; pappus a short crown. In moist thickets, Quebec to Manitoba and Mont., south to Fla., Kans. and N. Mex. July-Sept.

Rudbeckia laciniàta hùmilis A. Gray. Simple or branched, glabrous or nearly so, 3-6 dm. high: some or all of the basal leaves orbicular and undivided; heads $4-6 \mathrm{~cm}$. broad; disk globose $\mathrm{D}_{\mathrm{i}}$ ovoid. Va. and N. C. to Tenn. and Ga., mostly in the mountains.

\section{Ruoibeckia amplexicaùlis Vahl. Clasping Leaved Cone-Flower.} (I. F.f. 38 I. ) Annual; glabrous throughout, somewhat glaucous; stem branched, grooved, 3-6 dm. high, the branches ascending. Leaves entire, or sparingly toothed, I-ribbed, reticulate-veined, the lower oblong to spatulate, sessile, the upper ovate, ovate-oblong, o: lanceolate, acute ; heads solitary at the ends of the branches, long-peduncled, about $5 \mathrm{~cm}$. broad; bracts of the involucre few, lanceolate, acuminate; rays yellow, or sometimes brown at the base; disk ovoid.oblong, often becoming $25 \mathrm{~mm}$. high; achenes striate and transversely wrinkled, obliquely attached to the elongated receptacle; chaff at length deciauous; pappus none. In wet soil, Kans. and Mo. to La. and Tex. June-Aug.

\section{6r RATIBIDA Raf. [LEPACHYS Raf.]}

Mostly perennial herbs, with alternate pinnately divided or parted leaves, and long-peduncled terminal heads of tubular and radiate flowers, the disk-flowers gray or yellow, becoming brown, the rays yellow, or with brown bases, drooping or spreading. Involucral bracts in 2 or 3 series. Disk globose, oblong, or cylindric. Receptacle columnar to subulate, the concave chaff subtending or enveloping the disk-flowers, truncate, the tips inflexed, canescent. Ray-flowers neutral. Diskflowers perfect, fertile, their corollas with scarcely any tube. Achenes short, flattened, sharp-margined, or winged, at length deciduous with the chaff. Pappus with 1 or 2 teeth, or none. [Name unexplained.] About 4 species, of N. Am.

Style-tips lanceolate-subulate; leaf-segments lanceolate; rays $25-75 \mathrm{~mm}$. long.

Style-tips short, blunt; leaf-segments linear ; rays 6-30 mm. long.

I. R. pinnata.

Disk cylindric, at length $2.5 \mathrm{~cm}$. long or more; rays mostly equalling it, or longer.

Disk globose to short-oval, about $\mathrm{I} \mathrm{cm}$. high; rays mostly short. $\begin{aligned} & \text { 2. R. R. Tagetes. } \\ & \text { 3. Tamnaris }\end{aligned}$

r. Ratibida pinnàta (Vent.) Barnhart. Gray-Headed Cone-flower. (I. F.f. 3892 .) Perennial; rough and strigose-pul;escent throughout; stem branched or simple, 9-15 dm. high. Leaves pinnately 3-7 divided, the basal ones sometimes $2.5 \mathrm{dm}$. long, petioled, the segments cleft or entire, acute or acuminate; upper leaves sessile or nearly so, the uppermost commonly small and entire: bracts of the involucre linear or linear-oblong, short, reflexed; rays 4-10, bright yellow, drooping; disk oblong, gray or becoming brown, rounded, at length twice as long as thick; the inner margin of achenes produced into a short tooth. On dry prairies, western N. Y. to Fla., west to S. Dak., Neb. and La. June-Sept. 
2. Ratibida columnàris (Sims) D. Don. Long-headed or Prairie ConeFLOWER. (I. F. f. 3893.) Perennial, strigose-pubescent and scabrous; stem slender, usually branched, 3-7 $\mathrm{dm}$. high. Leaves pinnately divided into acute or obtuse, entire dentate or cleft segments, the cauline short-petioled or sessile, 5-IO $\mathrm{cm}$. long, the basal ones sometimes oblong, obtuse and undivided, slender-petioled; bracts of the involucre short, linear-lanceolate or subulate, reflexed, rays 4-Io, yellow, brown at the base, or brown all over, drooping; pappus of $\mathbf{I}$ or 2 subulate teeth usually with several short intermediate scales. On dry prairies, N. W. Terr. to Minn., Tenn., Neb., Tex. and Ariz. May-Aug.

3. Ratibida Tagètes (James) Barnhart. Short-RAYed Cone-Flower. (I. F. f. 3894.) Perennial, rough-canescent; stem 3-4 cm. high, usually much branched, leafy. Leaves firm, pinnately divided into 3-7 mostly entire segments; peduncles terminal, $\mathbf{I}-5 \mathrm{~cm}$. long: heads $25 \mathrm{~mm}$. broad, or less; bracts of the receptacle narrow, deflexed; rays few, mostly shorter than the globose to short-oval disk; pappus of 1 or 2 subulate deciduous teeth, with no short intermediate teeth. On dry plains and rocky hills, Kans. to Tex., Chihuahua, N. Mex. and Ariz. July-Sept.

\section{BRAUNĖRIA Neck. [ECHINACEA Moench.]}

Perennial erect branched or simple herbs, with thick black roots, thick rough alternate or opposite 3-5-nerved entire or dentate undivided leaves, and large longpeduncled heads of tubular and radiate flowers, the rays purple, purplish red or white, the disk green or purple, at length ovoidior conic. Involucre depressed-hemispheric, its bracts lanceolate, spreading or appressed, imbricated in 2-4 series. Receptacle conic, chaffy, the chaff carinate and cuspidate. Ray-flowers neutral, or with a rudimentary pistil. Disk-flowers perfect, the corolla cylindric, 5-toothed. Achenes 4-sided, obpyramidal, thick. Pappus a short dentate crown. [Named for Jacob Brauner, a German botanist of the I8th century.] Five known species, natives of N. Am.

Rays purple to white.

Leaves ovate or ovate-lanceolate, mostly dentate.

Leaves lanceolate, oblong-lanceolate, or linear, entire.

Rays purplish to white, $2-3 \mathrm{~cm}$. long, spreading.

Rays rose-purple, 3-7 cm. long, narrow, drooping.

Rays yellow to red.

I. B. purpurea.

2. B. angustifolia.

3. B. pallida.

4. B. atrorubens.

I. Brauneria purpùrea (L.) Britton. Purple Cone-flower. Black SampsoN. ReD Sunflower. (I. F. f. 3895.) Stem glabrous or sparingly hispid. usually stout, 6-15 dm. high. Lower and basal leaves slender-petioled, ovate mostly 5-11erved, acute or acuminate at the apex, abruptly narrowed or rarely cordate at the base, commonly sharply dentate, 7-20 cm. long, 4-7 cm. wide ; petioles mostly winged at the summit; uppermost leaves lanceolate or ovate-lanceolate, 3-nerved, sessile or nearly so, often entire : rays 12-20, purple, crimson, or rarely pale, 4-7 cm. long, spreading or drooping. In moist, rich soil, Va. to Ala., west to Ill., Ky. and La. July-Oct.

2. Brauneria angustifolia (DC.) Heller. Narrow-leaved Purple ConeFLoWER. (I. F. f. 3896 as B. pallida.) Stem hispid, slender, often simple, 3-6 $\mathrm{dm}$. high. Leaves lanceolate, oblong-lanceolate or linear-lanceolate, acute and about equally narrowed at each end, strongly 3-nerved and sometimes with an additional pair of marginal less distinct nerves, entire, 7-20 $\mathrm{cm}$. long, 8-25 mm. wide, the lower and basal ones slender-petioled, the upper short-petioled or sessile; rays short, 2-3 cm., spreading, or rarely deflexed, often pale. In dry soil, especially on prairies, Minn. to the N. W. Terr., Wyo. and Tex. June-Oct.

3. Brauneria pállida (Nutt.) Britton. Pale Purple Cone-flower. Similar to the preceding species, but usually taller, sometimes I m. high. Stem-leaves elongated-lanceolate, entire; rays narrow and elongated, drooping, 4-7 cm. long, 3-6 mm. wide, rose-purple or sometimes nearly white. In dry soil, Ill. to Mich., Ark., Ala., La. and Tex. May-July.

4. Brauneria atrórubens (Nutt.) Boynton \& Beadle. Red Cone-Flower. Glabrous, or with a few scattered stiff hairs; stem stout, simple, 6-7.5 dm. tall. Leaves elongated-lanceolate, entire, strongly 3-nerved, the lower $1.5^{-2} \mathrm{dm}$. long, the petioles often as long as the blades, $1.2-2 \mathrm{~cm}$. wide, the upper sessile, all 
rough-ciliate on the margins and with some appressed hairs on both surfaces; peduncle long, stout: rays 3-5 $\mathrm{cm}$. long, 6-8 $\mathrm{mm}$. wide, narrowed below, drooping, "very dark red" according to Nuttall, apparently yellow in Missouri speci. mens. Ark. and Mo.

\section{BORRÍCHIA Adans.}

Fleshy, more or less canescent, branching shrubs of the seacoast, with opposite entire or denticulate, cuneate, oblong, spatulate or obovate, I-3-nerved leaves, and terminal large long peduncled heads of both tubular and radiate yellow flowers. Involucre hemispheric, its bracts slightly unequal, imbricated in 2 or 3 series, tl.e inner ones coriaceous. Receptacle convex, chaffy, the chaff rigid, concave. subtending or enwrapping the disk-flowers. Ray-flowers pistillate, fertile. Diskflowers perfect, the corolla tubular, 5-tocthed, the style-brancles elongated, hispid. Anthers dark culored, entire at the base, or minutely sagittate. Achenes of the ray-flower; 3 sided, those of the disk-flowers 4 -sided. Pappus a slort dentate crown. [Named for Olaf Borrick, a Danish hotanist.] Alout 5 species, natives of America. In addition to the following, another occurs in South Fla.

r. Borrichia fru.éscens (L.) DC. ShiA Ox-EyE. (I. F. f. 3897.) Finely canescent, even when old; stems terete. sparingly branched, 3-12 dm. high. Leaves mostly erect or ascending, spatulate or obovate, fleshy, tapering to the sessile base, somewhat connate, 3-7 cm. long, 4-14 mn. wide ; heads solitary or few, about $25 \mathrm{~mm}$. broad; rays .15-25, rither short; exterior bracts of the involucre ovate and somewhit spreiding, the inner ones and the chaff of the receptacle cuspidate. Seacoast, Va. to Fict. and Tex. Also on the coasts of Mex. and W. Ind. April- Oct.

\section{HELIÁNTHUS L.}

Erect, annual or perennial, mostly hranched herbs, with opposite or alternate simple leaves, and large peduncled corymbose or solitary lieads of both tubular and radiate flowers, the rays yellow, the disk yellow, brown or purple. Involucre hemispheric or depressed, its bracts in:bricated in several series. Receptacle flat, convex or conic, chaffy, the chaff subtending the disk-flowers. Ray-flowers aeutral (in our species), the rays spreading, mostly entire. I)isk flowers perfect, furtile, the corolla tubular, the tube short, the limb 5 lcbed. Anthers entire, or minutely 2-toothed at the base. Style-branches tipped with hirsute appendages. Achenes thick, oblong or obovate, compressed, or somewhat 4.angled. I'appus of 2 scales or awns, or sometimes with 2-4 additional slorter ones, Geciduous. [Grcek, sunflower.] About 60 species, natives of the New World. Besides the following, about 25 others occur in the southern and western parts of N. Am.

\section{* Disk purple, purplish or brcwn; receptacle flat or convex.}

1. I.eaves mostly alternate, the lower opposite.

Leaves narrow, linear or lanceolate; perennials.

Stem rough: leaves linear or linear-lanceolate; eastern.

Stem glabrous; leaves elongated-linear; western.

Leaves broad, ovate; annuals.

Leaves dentate; bracts orate, acuminate, ciliate, hispid.

Leaves entire or nearly so; bracts lanceolate, canescent.

1. H. angustifolius.

2. H. orgyalis.

3. H. aunuus.

4. H. petiolaris.

2. I.eav's mostly opposite, the upper alternate.

Leaves hispid, abruptly contracted into winged petioles. $5 . \mathrm{H}$. atrorubers.

Leaves gradually narrowed into petioles.

Stem-leaves lanceolate: involucral bracts acuminate.

Stem-leaves rhombic-ovate to lanceolate; involucral bracts acute.

7. H. subrhomboideus.

* * Disk yellow or yellowish; receptacle convex or conic.

+ Leaves nearly all basul or near the base of the stem; ufper bract-like.

8. H. occidentalis.

\section{++ Stems leafy; leaves alternate or opposite.}

1. Leaves prevailingly lanceolate and 3-8 times as long as wide.

a. Leaves glabrous on both sides; heads $2 \cdot 5-4 \mathrm{~cm}$. broad.

b. Leaves scabrous, at least on the upper surface.

9. H. Laevigatus.

Heads I $-3.5 \mathrm{~cm}$. broad; leaves thin, stem glabrous.

Io. H. microcephalus. 
Heads $3.5-8 \mathrm{~cm}$. broad; leaves firm, many of them often alternate.

Stem scabrous, scabrate or hispid, at least above; leaves sessile or nearly so.

Leaves lanceolate, scabrous above, hirsute beneath, flat.

Leaves mostly alternate, narrowed at the base. II. H. giganteus.

Leaves all but the uppermost opposite, obtuse at base.

Leaves very scabrous on both sides.

12. H. ambiguus.

Leaves elongated-lanceolate, conduplicate, pinnately veined.

Plant I-4 m. high; heads numerous ; leaves mostly alternate.

13. H. Maximiliani.

Plant 4-7 dm. high; heads I or 2; leaves all but the upper opposite.

Leaves lanceolate to ovate-lanceolate, flat, 3-nerved. 14. H. Dalyi.

Leaves narrowly lanceolate, gradually narrowed at the base.

15. H. subtuberosus.

Leaves ovate-lanceolate, abruptly narrowed at the base.

Stem glabrous; leaves sessile by a truncate base.

16. H. Rydbergi.

Stem glabrous; leaves petioled.

Stem glaucous; leaves lanceolate, firm.

Stem not glaucous; leaves elongated, linear-lanceolate, thin.

19. H. divaricatus.

17. H. grosseserratus.

18. H. Kellermani.

2. Leaves prevailingly ovate, ovate-lanceolate, or oblong.

a. Leaves sessile, or very nearly so.

Stem glabrous; leaves divaricate.

Stem hirsute or hispid; leaves ascending.

Leaves cordate-clasping at the base.

Leaves narrowed from below the middle.

b. Leaves manifestly petioled.

Stem puberulent or glabrous.

19. H. divaricatus.

20. H. mollis.

21. H. doronicoides.

Leaves membranous, slender-petioled, sharply serrate.

Leaves regularly serrate.

Leaves irregularly serrate-laciniate.

Leaves firmer, shorter-petioled, less serrate or entire.

Bracts of the involucre much longer than the disk.

Bracts of the involucre about equalling the disk.

Stem hirsute, hispid, or scabrous.

Leaves rounded or truncate at the base, short-petioled.

Leaves, at least the upper, narrowed at the base.

Bracts of the involucre ovate-lanceolate, appressed.

Bracts of the involucre lanceolate-acuminate, spreading.

Leaves villous-pubescent beneath.

Leaves scabrous or puberulent beneath.

22. H. decapetalus.

23. H. scrophularifolius.

24. H. tracheliifolius.

25. H. strumosus.

26. H. hirsutus.

27. H. laetiflorus

28. H. tomentosus.

29. H. tuberosus.

r. Helianthus angustifolius L. Narrow-Leaved or Swamp Sunflower. (I. F. f. 3898 .) Perennial by slender rootstocks: stem branched above, or simple, slender, often hirsute below, 6-20 dm. high. Leaves firm, entire, sessile, slightly scabrous, rarely somewhat canescent beneath, 5-17 cm. long, 4-6 mm. wide, the margins revolute when dry; heads usually few, sometimes solitary, $5-7 \mathrm{~cm}$. broad; involucre hemispheric, its bracts linear-lanceolate, acute or acuminate, scarcely squarrose, pubescent; receptacle slightly convex; chaff entire or 3-toothed; rays I2-20; achenes truncate, glabrous; pappus usually of 2 short awns. In swamps, Long Island, N. Y., to Fla, Ky. and Tex., mainly near the coast. Aug.-Oct.

2. Helianthus orgyàlis DC. Linear-Leaved Sunflower. (I. F. f. $3^{899}$.) Perennial by slender rootstocks; stem branched near the summit, very leafy to the top, 2-3 m. high. Leaves sessile, entire, remotely dentate and short-petioled, rough with mucronate-tipped papillae, especially on the lower surface, acuminate, I $-4 \mathrm{dm}$. long, 2-8 $\mathrm{mm}$. wide; heads usually numerous, about $5 \mathrm{~cm}$. broad, terminating slender branches; involucre nearly hemispheric, its bracts linear-subulate to lanceolate, acuminate, squarrose, ciliate; receptacle convex, its chaff entire, or toothed, slightly ciliate; rays 10-20: achenes oblong-obovate, glabrous, 2-4-awned. On dry plains, Neb. and Colo. to Tex. Sept.-Oct.

3. Helianthus ánnuus L. Common Sunflower. (I. F. f. 3900.) Stem hispid or scabrous, stout, branched above, I-2 m. high, or in cultivated forms sometimes $4.5 \mathrm{~m}$. high. - Leaves broadly ovate, petioled, 3-nerved, dentate or denticulate, acute at the apex, rough on both sides, sometimes pubescent beneath, the lower cordate at the base, 7-30 cm. long; heads in the wild plant 7-15 cm. broad; invo. 
lucre depressed, its bracts ovate or oblong, usually long-acuminate or aristate; chaff of the receptacle 3-cleft; achenes obovate-oblong, appressed-pubescent, or nearly glabrous. On prairies, etc., Minn. to the N. W. Terr., Mo. and Tex. Much larger in cultivation: an occasional escape in the east. July-Sept.

4. Helianthus petiolàris Nutt. Prairie Sunflower. (I. F. f. 390r.) Annual, similar to the preceding species, but smaller and with smaller heads; stem strigose-hispid or hirsute, 3-10 dm. high. Leaves petioled, oblong, ovate, or ovatelanceolate, rough on both sides, usually paler beneath than above, 3-7 cm. long, entire, or denticulate, obtuse or acutish at the apex, mostly narrowed at the base; heads 4-7 cm. broad; involucre depressed-hemispheric, its bracts not hispid-ciliate, acute, or short-acuminate; achenes villous-pubescent, at least when young. On dry prairies, Minn. to the N. W. Terr. and Ore., south to Mo., Tex. and Ariz. Found rarely in waste places farther east. June-Sept.

Helianthus petiolàris cànus Britton. Leaves ovate, white-canescent beneath. Neb. to Tex. and N. Mex.

Helianthus petiviaris patens (Lehm.) Rydb. Heads larger, long-peduncled, the peduncles fleshy toward the top; leaves large, long-petioled. Neb. and Mo.

5. Helianthus atrórubens L. Hairy Wood Sunflower. Purple-disk Sunflower. (I. F. f. 3902.) Perennial; stems hirsute below, often minutely pubescent above, branched at the sumnit, 6-15 dm. high. Leaves hirsute on both sides, or canescent beneath, mostly thin, ovate or ovate-lanceolate, acutish, dentate or crenate-dentate, $10-25 \mathrm{~cm}$. long, 3-10 $\mathrm{cm}$. wide; heads not numerous, slenderpeduncled, about $5 \mathrm{~cm}$. broad; involucre hemispheric, its bracts oblong to obovate, obtuse, ciliolate, appressed; receptacle convex, its chaff acute, entire, or 3-toothed; rays Io-20; achenes obovate, truncate, finely pubescent, about $4 \mathrm{~mm}$. long; pappus usually of 2 lanceolate awns. In dry woods, Va. to Fla., west to Ohio, Minn., Mo., Ark. and La. Aug.-Oct.

6. Helianthus scabérrimus Ell. Stiff Sunflower. (I. F. f. 3903.) Perennial; stems simple or little branched, hispid or scabrate, 5-25 dm. high. Leaves thick, coriaceous, serrate or serrulate, very scabrous on both sides, $1-5 \mathrm{~cm}$. long, 5-1 $7 \mathrm{~cm}$. wide, acute at the apex, narrowed at the base, the lower ovate or ovateoblong, petioled, the upper lanceolate or oblong-lanceolate, sessile or short-petioled; heads solitary or few, $5-7 \mathrm{~cm}$. broad; involucre hemispheric, its bracts ovate, acute, ciliate; receptacle--convex, its chaff obtuse; rays 15-25. light yellow; achenes more or less pubescent, oblong-obovate; pappus of 2 broad scales or of 2-4 stout awns. Prairies, Minn. to Ill., Ga. and Tex. Aug. -Sept.

7. Helianthus subrhomboìdeus Rydb. Rhombic-Leaved Sunflower. Stem simple, sparingly hirsute, usually tinged with red. Leaves opposite, firm, very scabrous, 3-nerved, slightly serrate, the basal ones broadly ovate to obovatespatulate, those of the stem rhomboid-ovate to rhomboid-lanceolate, short-petioled, 5-10 $\mathrm{cm}$. long, the uppermost very small; heads $\mathrm{I}-3,2.5-4 \mathrm{~cm}$. in diameter; bracts of the involucre oblong, acutish, densely white-ciliate. Plains, S. Dak. to Saskatch., Neb. and Mont. July-Sept.

8. Helianthus occidentàlis Riddell. Few-Leaved Sunflower. (I. F. f. 3904.) Perennial; stems appressed-pubescent or sometimes nearly glabrous, slender, mostly simple, 6-9 dm. high. Leaves mainly basal, firm, ovate or oblonglanceolate, obtuse or obtusish at the apex, narrowed at the base, 3-5-nerved, serrulate or entire, mostly scabrous above, pubescent beneath, with slender petioles ; heads several or solitary, 4-6 cm. broad; involucre hemispheric, its bracts lanceolate or ovate-lanceolate, acute or acuminate, generally ciliate, appressed; receptacle convex, its chaff acute; rays 12-15; achenes truncate and pubescent at the summit; pappus of 2 lanceolate-subulate awns. In dry soil, Ohio to Minn., south to Fla. and Mo. Aug.-Sept.

Helianthus occidentalis Dowellianus (Curtis) T. \& G. Leaves broader and more numerous, smooth or nearly so on both sides. D. C. to N. Car. and Ga.

9. Helianthus laevigàtus T. \& G. Sмоoтh Sunflower. (I. F. f. 3905.) Stems slender, from a perennial root, simple or little branched, glabrous, or somewhat glaucous, 6-12 dm. high. Leaves nearly all opposite, firm, glabrous, lanceolate, short-petioled, or the upper sessile, serrulate or entire, pale beneath, acuminate, narrowed at the base, $7-15 \mathrm{~cm}$. long, $\mathrm{r}-4 \mathrm{~cm}$. wide, the margins sometimes 
roughish; heads few or solitary; involucre campanulate, its bracts lanceolate or ovate-lanceolate, firm, ciliolate, the tips of the outer ones spreading; rays 5-10; chaff linear; achenes slightly pubescent at the summit; pappus of 2 lanceolate or ovate awns, with or without 2 intermediate scales. In dry soil, mountains of Va. and N. Car. Aug.-Oct.

Io. Helianthus microcéphalus T. \& G. Small Wood Sunflower. (I. F. f. 3906.) Stems slender, glabrous, branched above, or rarely simple, I-2 m. high. Leaves thin or thinnish, petioled, most of them opposite, lanceolate, or the lower ovate lanceolate, rough above, canescent or puberulent beneath, long-acuminate at the apex, narrowed at the base, serrulate, or the lower serrate, $7-17 \mathrm{~cm}$. long, I-4 $\mathrm{cm}$. wide; heads commonly several or numerous, borne on slender, sometines roughish peduncles; involucre campanulate, its bracts lanceolate or ovate, acute or acuminate, ciliol te, the tips of the outer ones spreading; cliaff of the receptacle oblong, entire, or 3-toothed; rays 5-10; disk yellow; achenes nearly glabrous: pappus usually of 2 subulate awns. In moist woods and along streams, Penn. to Ga., west to Ohio, Mo. and La. July-Sept.

Ir. Helianthus gigantèus L. Tal, or Giant Sunflower. (I. F. f. 3907.) Perennial by fleshy roots and creeping rootstocks; stems hispid or scabrous, at least above, $\mathbf{I}-3.5 \mathrm{~m}$. ligh. Leaves sessile or short-petioled, firm, serrate or denticulate, acuminate at the apex, narrowed at the base, $5-15 \mathrm{~cm}$. long, $I-2.5 \mathrm{~cm}$. wide; heads usually several, mostly long-peduncled, $4-6 \mathrm{~cm}$. broad; involucre hemispheric, its bracts squarrose, lanceolate-subulate, hirsute or ciliate, commonly as long as the diameter of the disk; chaff of the receptacle oblong-linear, acute; achenes oblong, glabrous; rays 10-20; pappus of 2 subulate awns. In swamps and wet meadows, Me. and Ont. to the N. W. Terr., south to Fla., Neb. and La. Stem commonly purple. Aug.-Oct.

12. Helianthus ambíguus (T. \& G.) Britton. Amriguous Sunflower. Stem slender, rough-hispid above, $5-8 \mathrm{dm}$. high, simple or little branched. Leaves thin, lanceolate, sharply serrate, long-acuminate, 6-10 $\mathrm{cm}$. long, finely roughpubescent on both sides, broadest just above the obtuse or subacute base, the upper sessile, the lower short-petioled; heads few, 7-8 cm. broad; bracts of the involucre lanceolate, acuminate, densely ciliate. In moist soil, L. I. and Ga. July-Sept. [H. giganteus ambiguus T. \& G.]

13. Helianthus Maximiliani Sclirad. Maximilian's Sunflower. (I. F. f. 3908.) Perennial by fleshy routs and thickened rootstocks; stems stout, scabrous or hispid below, I-4 m. high. Leaves folding in drying, rigid, acuminate or acute at both ends, denticulate or entire, 7-17 cm. long, I-4 cm. wide; heads few or numerous, 5-7 cm. broad, on stout densely rough-pubescent peduncles; involucre hemispheric, its bracts lanceolate, acuminate, squarrose, densely strigose-pubescent, often $18 \mathrm{~mm}$. long; rays 15-30; chaff linear, acute, pubescent above; achenes linear-oblong, glabrous or nearly so; pappus commonly of 2 lanceolate awns. On dry prairies, Minn. and Manitoba to the N. W. Terr., Neb. and Tex. Aug.-Oct.

14. Helianthus Dàlyi Britton. Judge Daly's Sunflower. Perennial by a fusiform tuber, 3-4 cm. long. Stem slender, simple, roughish, appressed-pubescent, about $6 \mathrm{dm}$. high: leaves firm, conduplicate, drooping, finely rough pubescent on buth sides, narrowly lanceolate, acuminate at both ends, distantly serrate with low teeth, the larger about I dm. long and $\mathbf{I} .4 \mathrm{~cm}$. wide, all opposite or the uppermost alternate: heads usually solitary and long-peduncled, rarely 2, about $8 \mathrm{~cm}$. broad; involucral bracts narrowly lanceolate with long subulate tips: rays acute; pappus 2 subulate awns; chaff of the receptacle pubescent at the acute apex. Sag Harbor, N. Y.

I5. Helianthus subtuberòsus Bourgeau. Indian Potato. Fleshy roots thick and edible. Leaves thick, more or less serrate, all or all but the upper distinctly petioled, sometimes all opposite, $6-12 \mathrm{~cm}$. long, acuminate at the apex, mostly narrowed at the base, the petioles ciliate; heads not very numerous; bracts of the involucre lanceolate, acuminate, densely pubescent and white-ciliate, about $1.5 \mathrm{~cm}$. long; rays 3-4 cm. long. Mich. and Minn. to the N. W. Terr., Wyo. and Mont. Aug.-Sept. [H. giganteus subtuberosus Britton.]

I6. Helianthus Rydbergi Britton, n. sp. Rydberg's Sunflower. Perennial by a narrowly fusiform tuberous rout with several stout branches. Stem 0.7$1.5 \mathrm{~m}$. high, somewhat branched near the summit; leaves ovate-lanceolate or the 
upper ones lanceolate, thick, pale green, scabrous on both sides, 3-nerved, sparingly serrate, acuminate at the apex, abruptly narrowed at the base into short petioles, the larger about I dm. long and $3 \mathrm{~cm}$. wide; heads several, stout-peduncled, 8-9 $\mathrm{cm}$. broad; bracts of the involucre lanceolate, acuminate, long-ciliate. Sand hill region of central Neb.; type, Rydberg No. I767, from Middle Loup River, Hooker Co.

I7. Helianthus grosseserràtus Martens. SAw-Tooth Sunflower. (I. F. t. 3909.) Perennial by fleshy roots and slender rootstocks; stems glabrous, glaucous, branched above, 2-3 m. high, the branches usually strigose-pubescent; leaves long-lanceolate, slender-petioled, long-acuminate, narrowed at the base, sharply serrate, or merely denticulate, the uppermost entire, rough above, densely puberulent or canescent beneath, I-2 dm. long, I-2.5 cm. wide; heads several or numerous, 4-7 cm. broad; involucre hemispheric, its bracts squarrose, narrowly lanceolate, acuminate, hirsute; chaff linear-oblong, pubescent at the summit, acute. often 3-toothed; disk yellowish; rays 10-20, deep yellow; achenes nearly glabrous; pappus of 2 lanceolate awns. In open places, eastern L. I. to Penn., S. Dak., Mo. and Tex. May contain more than one species as here characterized.

18. Helianthus Kéllermani Britton, n. sp. Kellerman's Sunflower. Stem 2-3 m. high, very smooth, much branched above, the branches slender. Leaves narrowly elongated-lanceolate to linear-lanceolate, drooping, rather thin, distantly serrate with very small teeth, long-acuminate at the apex, attenuate at the base into short petioles or the upper sessile, scabrate and sparingly pubescent on both surfaces, pinnately veined, the lower about $2 \mathrm{dm}$. long and $1.5 \mathrm{~cm}$. wide; branches of the inflorescence pubescent; bracts of the involucre linear-lanceolate, about $\mathbf{1} .5$ $\mathrm{cm}$. long, and $\mathbf{1} .5 \mathrm{~mm}$. wide at the base, ciliate, long-acuminate; rays goldenyellow, 3-4 cm. long; chaff of the receptacle linear. Columbus, Ohio. W. A. Kellerman, Sept. 5 , 1898 .

I9. Helianthus divaricàtus L. Rough OR Woodland Sunflower. (I. F. f. 39 IO.) Perennial by slender rootstocks; stem glabrous throughout, or pubescent at the summit, slender, 6-20 dm. high. Leaves usually all opposite, divaricate, lanceolate or ovate-lanceolate, firm, dentate or denticulate, 3-nerved, rough above, pubescent beneath, gradually long-acuminate, $7-20 \mathrm{~cm}$. long, $6-36 \mathrm{~mm}$. wide; heads few or solitary, about $25 \mathrm{~mm}$. broad, borne on strigose-pubescent peduncles; involucre hemispheric, its bracts lanceolate or ovate-lanceolate, strigose or hirsute, the outer ones spreading; rays 8-15; chaff of the receptacle apiculate; achenes glabrous; pappus of 2 short subulate awns. In dry woodlands, Me. and Ont. to the N. W. Terr., south to Fla., Neb. and La. July-Sept.

20. Helianthus móllis Lam. Hairy Sunflower. (I. F. f. 39 rr.) Perennial, stem stout, simple, or sparingly branched above, 6-12 dm. high. Leaves pinnately veined, 3-nerved above the base, all opposite, or the upper alternate, acute or acuminate, scabrous or cinereous pubescent above, densely and finely pubescent beneath, serrulate, 5-12 cm. long, 2-6 cm. wide; heads solitary or few, 5-7 cm. broad; involucre hemispheric, its bracts lanceolate, acuminate, densely villous. canescent, somewhat spreading; rays 15-25; chaff canescent at the summit; mature achenes nearly glabrous; pappus of 2 lanceolate scales. In dry barren soil, Ohio to Ga., west to Iowa, Kans., and Tex.; also on L. I. Aug.-Sept.

21. Halianthus doronicoides Lam. OBlong-Leaved Sunflower. (I. F. f. 3912.) Perennial by slender rootstocks; stems stout, rough, or finely roughpubescent, branched above, I $-2 \mathrm{~m}$. high. Leaves oblong, ovate-oblong, or ovate, thick, ascending, serrate or serrulate, acute or acuminate at the apex, rough on both sides, or finely pubescent beneath, somewhat 3-nerved, I-2 dm. long, 2-6 $\mathrm{cm}$. wide; heads commonly numerous, $6-10 \mathrm{~cm}$. broad; involucre hemispheric, its bracts lanceolate, acuminate, pubescent or hirsute, somewhat spreading; rays 12-20, 8-12 mm. wide; achenes glabrous; pappus of 2 subulate awns. In dry soil, Ohio to Mich., Mo. and Ark. Aug.-Sept.

22. Helianthus decapétalus L. Thin-leaved or Wild Sunflower. (I. F. f. 3913.) Perennial by branched, sometimes thickened rootstocks; stem slender, glabrous or nearly so, branched above, 3-15 dm. high; branches puberulent. Leaves 7-20 cm. long, 4-7 cm. wide, ovate or ovate-lanceolate, the upper commonly alternate, roughish above, finely but often sparingly pubescent beneath, acuminate, the rounded or truncate base decurrent on the petiole; heads numer- 
ous, 5-7 cm. Droad; involucre hemispheric; its bracts linear-lanceolate, acuminate, hirsute, ciliate, spreading, often longer than the disk; rays 8-15, light yellow; chaff entire or 3-toothed, pubescent at the apex; achenes glabrous; pappus of 2 subulate awns. In moist woods and along streams, Quebec to Mich., Ga. and Ky. Aug.Sept.

23. Helianthus scrophulariifolius Britton, n. sp. Figwort Sunflower. Root $3 \mathrm{dm}$. long, or more, slender. Stem simple, glabrous, and smooth, striate, about $1 \mathrm{~m}$. high. Leaves rather thin, ovate to ovate-lanceolate, 7-12 cm. long, roughish on both sides, 3-nerved, sharply, deeply, and very irregularly toothed, the apex long-acuminate, the base rather gradually narrowed into a ciliate margined petiole 2-4 cm. long, or the uppermost leaves nearly sessile; heads few, on slender scabrous peduncles, $6-8 \mathrm{~cm}$. broad; involucral bracts linear to linear-lanceolate, acute, about equalling the disk, not conspicuously ciliate. Hillside thicket northwest of Woodlawn, N. Y. City, E. P. Bicknell.

24. Helianthus tracheliifòlius Mill. Throatwort Sunflower. (I. F. f. 39I4.) Similar to the following species, but the stem usually roughish-pubescent. Leaves short-petioled, ovate-lanceolate, 3-nerved near the base, green both sides, but darker above, generally rougher on the upper surface, the lower ones sharply serrate; branches and peduncles scabrous; heads several, $6-8 \mathrm{~cm}$. broad; bracts of the hemispheric involucre linear-lanceolate, long-acuminate, ciliate and puberulent, sometimes foliaceous, and 3 times the length of the disk. In dry soil, Penn. and Ohio to Wis. Aug.-Sept.

25. Helianthus strumòsus L. Pale-leaved Wood Sunflower. (I. F. f. 3915.) Perennial by branched, sometimes tuberous-thickened rootstocks; stem glasbous below, sometimes glaucous, I-2 m. high, branched above, the branches usually pubescent. Leaves ovate or ovate-lanceolate, not membranous, rough above, pale and somewhat puberulent or canescent beneath, acuminate, contracted much below the middle and decurrent on the petiole, 3-nerved above the base, 7-20 $\mathrm{cm}$. long, 2-4 cm. wide, mostly opposite, the upper often alternate; heads commonly several, 6-10 cm. broad; involucre hemispheric, its bracts lanceolate or ovate-lanceolate, acuminate, ciliate; rays 5-15; chaff pubescent; achenes nearly glabrous. In dry woods and on banks, Me. and Ont. to Minn., Ga. and Ark. July-Sept.

Helianthus strumòsus macrophýllus (Willd.) Britton. Leaves finely and densely canescent beneath. Mass. to Penn., Iowa and Miss.

26. Helianthus hirsùtus Raf. Stiff-haired Sunflower. (I. F. f. 3916.) Perennial; stem usually branched, stout, rigid, 6-12 cm. high. Leaves ovatelanceolate or the upper lanceolate, acuminate at the apex, thick, very rough above, rough-pubescent beneath, 3-nerved, serrate or serrulate, 7-15 cm. long, I-2.5 cm. wide, nearly all opposite; heads usually several, 5-7 cm. broad; involucre hemispheric, its bracts lanceolate, or ovate-lanceolate, acuminate, ciliate, mostly puberulent, erect or but slightly spreading, equalling or shorter than the disk; rays 12-15; chaff obtusish, pubescent at the summit; achenes oval, rounded at the summit, glabrous: pappus of $\mathbf{I}$ or 2 subulate awns. In dry soil, Penn. and Ohio to Wis., south to W. Va., Ga., Kans. and Tex. July-Oct.

Helianthus hirsùtus trachyphyllus T. \& G. Leaves thick, very rough on both sides; heads larger; involucral bracts more spreading. Neb. to Ark.

27. Helianthus laetiflòrus Pers. Showy Sunflower. (I. F. f. 3917.) Perennial; stem scabrous or hispid, leafy, I-2.8 m. high. Leaves oval-lanceolate or ovate-lanceolate, short-petioled, 3 -nerved, rough on both sides, long-acuminate at the apex, serrate or serrulate, $10-25 \mathrm{~cm}$. long, I-6 cm. wide, the upper often alternate; heads usually several, 5-10 cm. broad, mostly short-peduncled; bracts of the hemispheric involucre ovate-lanceolate, or oblong-lanceolate, imbricated in only 2 or 3 series, ciliate, otherwise nearly glabrous, appressed or but little spreading, shorter than or equalling the disk; rays $\mathbf{1 5}^{-25}$, showy; chaff of the receptacle entire, or sometimes 3-toothed. On prairies and barrens, Penn. and Ohio to Minn. Aug.-Sept.

28. Helianthus tomentòsus Michx. Woolly Sunflower. (I. F. f. 3918.) Perennial; stem stout, hirsute or hispid, especially above, branched, I-3 m. high. Leaves rather thin, ovate, or the lower oblong, mostly alternate, 3 -ribbed 
above the base, gradually or abruptly contracted into margined petioles, rough above, sparingly serrate, the lower often $3 \mathrm{dm}$. long and $\mathrm{I} \mathrm{dm}$. wide; heads commonly several or numerous, 7-10 $\mathrm{cm}$. broad; involucre hemispheric, its bracts imbricated in many series, densely hirsute and ciliate, usually longer than the disk; chaff of the receptacle and lobes of the disk-corollas pubescent; pappus of 2 subulate awns. In dry soil, Va. to Gr.. and Ala. Reported fron Ill. Aug.-Oct.

29. Helianthus tuberòsus L. JERUSAlem ARTichoke. Earth Apple. (I. F. f. 3919.) Perennial by fleshy thickened rootstocks bearing tubers; stems branched above, $2-3.5 \mathrm{~m}$. high. Leaves ovate or ovate oblong, firm, 3-nerved near the base, narrowed, or the lower rounded, truncate or subcordate at the base, acuminate at the apex, rather long-petioled, serrate, I-2 dm. long, 4-7 cm. wide, the upper alternate, the lower opposite; heads several or numerous, $5-8 \mathrm{~cm}$. broad; involucre hemispheric; rays 12-20; chaff of the receptacle acute and pubescent at the summit; achenes pubescent. In moist soil, N. B. and Ont. to the N. W. Terr., south to Ga., Kans. and Ark. Often occurs along roadsides in the east, a relic of cultivation by the aborigines. Now extensively grown for its edible tubers. Sept.Oct.

Helianthus tuberòsus subcanéscens A. Gray. Lower; leaves densely white canescent beneath. Prairies, Minn. to the N. W. Terr., south to Mo.

\section{VERBESINA L.}

Pubescent or scabrous herbs (some tropical species shrubby), with leaves often decurrent on the stem and branches, and corymbose or solitary heads of both tubu. lar and radiaie yellow or white flowers, or the rays sometimes wanting. Involucre campanulate or hemispheric, its bracts imbricated in few series. Receptacle chaffy, the chaff embracing the disk-flowers. Ray-flowers pistillate or neutral. Diskflowers perfect, mostly fertile, their corollas with an expanded 5-lobed limb, usually longer than the tube. Style branches of the disk-fowers with acute papillose appendages. Achenes flattened, or those of the ray-flowers 3 -sided, their margins winged or wingless. Pappus of 2 (I-3) subulate awns, sometimes with 2 or 3 intermediate scales. [Name altered from Verbena.] A large genus, variously restricted by authors, mainly natives of the New World. Besides the following, about 6 others occur in the southern and southwestern U. S.

Involủcre campanulate, 4-6 $\mathrm{mm}$. broad; heads small, numerous.

Leaves alternate; rays white.

Leaves opposite; rays yellow.

Involucre hemispheric, $12-20 \mathrm{~mm}$. broad; heads few, large.

Leaves ovate, sessile, serrate.

Leaves deltoid, petioled, coarsely dentate.

Involucre of a few, at length deflexed bracts; disk globose.

1. V. Virginica.

2. V. occidentalis.

3. V. helianthoides.

4. $V$. encelioides.

5. V. alternifolia.

I. Verbesina Virgínica L. Small White or Virginia Crownbeard. (I. F. f. 3920.) Perennial; stem densely puberulent, terete or winged, I-2 m. high. Leaves usually thin, ovate, roughish above, puberulent, canescent or gla. brate beneath, acute or acuminate, 10-25 cm. long, $2-7 \mathrm{~cm}$. wide, contracted at the base into winged petioles, the uppermost sessile, lanceolate, smaller, often entire; heads corymbose-paniculate, $12-20 \mathrm{~mm}$. broad; bracts narrowly lanceolate, erect, obtuse, pubescent; rays $3-5$, obovate, white, pistillate; achenes minutely pubescent, winged or wingless. In dry soil, Penn. to Va., Ill. and Kans., south to Fla. and Tex. Aug.-Sept.

2. Verbesina occidentàlis (L.) Walt. Small Yellow Crownbeard. (I. F. f. 3921.) Perennial; stem glabrous, or puberulent above, usually much branched, narrowly 4-winged, $1-2 \mathrm{dm}$. high, the branches also winged and pubescent. Leaves thin, ovate, or the upper oblong, minutely rough-pubescent on both sides, or glabrate, acuminate at the apex, narrowed or contracted below into slender petioles, serrate, 10-25 cm. long, $2-8 \mathrm{~cm}$. wide; heads $12-25 \mathrm{~mm}$. broad, corymbose; bracts lanceolate, obtuse, erect, or the tips slightly spreading, pubescent; rays $\mathbf{I}-5$, usually pistillate, rarely none; achenes wingless. In dry thickets and on hillsides, Md. and southern Penn. to IIl., Fla. and Ga. Aug.-Oct.

3. Verbesina helianthoides Michx. Sunflower Crownbeard. (I. F. f. 3922.) Perennial; stem hispid or hirsute, 4-winged, usually simple, 6-12 dm. 
high. Leaves acute, acuminate or obtuse at the apex, narrowed at the base, rough or appressed-hispid above, densely pubescent or canescent beneath, 5-10 cm. long, $2-4 \mathrm{~cm}$. wide, all alternate, or the lower opposite; heads solitary or few, 5-7 cm. broad; bracts lanceolate, acutish, canescent, appressed; rays 8-15, pistillate or neutral, linear-oblong, yellow; achenes scabrous or pubescent, broadly winged. On dry prairies and in thickets, Ohio to Ga., Iowa, Kans. and Tex. June-July.

4. Verbesina encelioìdes (Cav.) A. Gray. Golden Crownbeard. (I. F. f. 3923.) Annual; stem densely puberulent, much branched, 3-6 dm. high. Leaves thin, 5-10 $\mathrm{cm}$. long, acuminate; acute or blunt at the apex, green and minutely pubescent above, pale and densely canescent beneath, all alternate, or the lowest opposite, narrowed at the base into naked or wing-margined petioles, which are often provided with dilated appendages at the base; heads $3-5 \mathrm{~cm}$. broad; involucre hemispheric, about $12 \mathrm{~mm}$. high, its bracts lanceolate, canescent; rays 12-15, bright golden yellow, 3-toothed; achenes of the disk-flowers obovate, winged, pubescent: those of the ray-flowers rugose, thickened, often wingless. In moist soil, Kans. to Tex., Ariz. and Mex. Also in Fla., and widely distributed in warm regions as a weed. Summer.

5. Verbe ina alternifolia (L.) Britton. Actinomeris. (I. F. f. 3924.) Perennial; stem puberulent or glabrous, narrowly winged, or wingless, simple or branched near the summit, leafy, I.2-3 m. high. Leaves oblong-lanceolate or lanceolate, acuminate, serrate, serrulate or entire, rough or roughish on both sides, gradually nurrowed to the sessile base, or the lower short-petioled, I-3 dm. long, I-7 cm. wile, sessile, short-petioled, alternate, or the lower opposite and slenderpetioled; heads numerous, $3-5 \mathrm{~cm}$. broad, corymbose-paniculate; rays 2-10, yellow; achenes broadly winged or nearly wingless, sparingly pubescent. In rich soil, N. J. to western N. Y., Iowa, Fla., Kans. and La. Aug.-Sept.

\section{COREÓPSIS L.}

Herbs, with opposite leaves, or the upper alternate, and large long-peduncled heads of both tubular and radiate flowers, the rays yellow, or brown at the base, or brown throughout, or pink. Involucre usually hemispheric, its bracts in 2 distinct series, all united at the base, those of the outer series commonly narrower and shorter than the inner. Receptacle flat or slightly convex, chaffy, the chaff flat or concave. Ray.flowers neutral. Disk-flowers perfect, fertile, their corollas with slender tube and broader 5 -toothed limb. Anthers mostly entire at the base. Achenes flat, orbicular to oblong. Pappus of 2 short teeth; or a mere coroniform border, or none. [Greek, bug-like, referring to the achenes.] About 50 species, natives of America, S. Africa and Australasia. In addition to the following, some Io others occur in the southern and western U. S.

* Rays pink, or occasionally white; leaves linear, entire.

I. C. rosea.

* * Rays yellow with a brown base, or brown; lower leaves pinnately divided. Lobes of the lower leaves oblong or oval; achenes winged.

Leaf-lobes all linear-lanceolate; achenes wingless.

2. C. cardaminefolia.

3. C.tinctoria.

** Rays yellow throughout.

1. Leaves sessile, rigid, palmately 3 -lobed below the middle.

4. C.palmata.

2. Leaves sessile, some or all 3 -divided to the base, appearing verticillate.

Leaf-segments oblong or lanceolate, entire.

Leaf-segments I-2-pinnately parted.

Divisions of the segments linear-lanceolate.

Divisions of the segments very narrowly linear.
3. Stem-leaves sessile or petioled, entire, or the lower $3-5$-lobed; achenes often with a

5. C. major. callus at each end on the inner side.

Glabrous or nearly so; stem-leaves lanceolate; achenes winged.

Plants hirsute, hispid or pubescent, at least below.

8. C. lanceolata.

Plant leafy, 6-12 dm. high; stem-leaves oblong to ovate, acutish.

Leaves few ; plants 3-6 dm. high ; stem-leaves mostly obtuse.

9. $C$. pubescens.

Achenes broadly winged; basal leaves oblong.

Achenes narrowly winged; basal leaves nearly orbicular. 
4. Leaves, or most of them, I-2-parted into linear segnients; rays lobed.

12. C. grandiflora.

5. Leaves petioled, all but the upper pinnately 3-5-divided; rays entire.

13. C. tripteris.

I. Coreopsis ròsea Nutt. Small Rose or Pink Tickseed. (I. F. f. 3925.) Perennial by slender rootstocks; stems at length much branched, slender, strict, glabrous, 1.5-6 dm. high. Leaves opposite, glabrous, obscurely I-nerved, 3-6 cm. long, $1-3 \mathrm{~cm}$. wide, sessile, or the lower petioled; heads slender-peduncled, several or numerous, $12-25 \mathrm{~mm}$. broad; disk yellow; rays $4-8$, oblong to obovate, slightly 3 toothed or sometimes entire; inner bracts of the hemispheric involucre ovateoblong, glabrous, much longer than the lanceolate outer ones; style-tips truncate; achenes oblong or linear-oblong, thin, not winged, slightly ribbed on the inner face; pappus a very short truncate crown. In open swamps, eastern Mass. to Ga., near the coast. July-Aug.

2. Coreopsis cardaminefòlia (DC.) T. \& G. Cress-leaved Tickseed. (I. F. f. 3926.) Annual; stem glabrous, branched, 3-8 dm. high. Basal leaves petioled, 5-10 cm. long; stem-leaves distant, sessile or nearly so, pinnately parted into linear segments, or the uppermost entire; heads r6-25 $\mathrm{mm}$. broad, slenderpeduncled; involucre hemispheric, its inner bracts brown, ovate or ovate-lanceolate, obtuse or obtusish, scarious-margined, much longer than the lanceolate obtusish outer ones; rays 4-8, 3 toothed; achenes oval, 2-3 mm. long, winged, smooth, or slightly papillose; pappus of 2 minute awns, or none. In moist soil, Kans. to N. Mex., La. and northern Mex. May-Oct.

3. Coreopsis tinctòria Nutt. Garden Tickseed. (I. F. f. 3927.) Annual; stem glabrous, branched, 3-10 $\mathrm{dm}$. high; heads slender-peduncled, 20-25 mm. broad, or in cultivation much broader; involucre hemispheric, its inner bracts brown, ovate or oblong, obtuse or acute, scarious-margined, 3-5 times as long as the obtuse outer ones; rays 6-10, cuneate, yellow with a brown base or brown all over; style-tips truncate; achenes linear or linear-oblong, about $2 \mathrm{~m}$. long; pappus a mere border, or none. In moist soil, Minn. to the N. W. Terr., south to Neb., La. and Ariz. Escaped from gardens to roadsides and waste places eastward. May-Sept.

4. Coreopsis palmàta Nutt. Stiff Tickseed. (I. F. f. 3928.) Perennial, stems rigid, glabrous, simple or little branched, very leafy, 3-9 dm. high. Leaves sessile, 5-7 cm. long, the uppermost entire, thick, rigid, the lobes linear-oblong, obtusish, entire, or with $\mathrm{I}-3$ lateral lobes, their margins rough; heads few or solitary, short-peduncled, 3-5 cm. broad; involucre hemisplieric, its bracts somewhat united at the base, those of the outer series narrower and nearly as long as the inner ones; rays 6-10, bright yellow, oblong or obovate, mostly 3-toothed; achenes oblong, narrowly winged, slightly incurved; pappus of 2 short tips, or none. On dry prairies and in thickets, Ill. to La., west to Minn., Manitoba, Neb. and Tex. June-July.

5. Coreopsis major Walt. Wood, or Greater Tickseed. (I. F. f. 3929.) Perennial; stem pubescent, branched above, 6-9 dm. high. Leaves more or less pubescent, or glabrous, divided into 3, segments 5-10 $\mathrm{cm}$. long, 8-25 mm. wide, which appear as if in verticils of 6 ; the upper and lower leaves (rarely all of them) undivided and entire; heads several or numerous, slender-peduncled, 3-5 cm. broad; bracts of the hemispheric involucre all united at the base, the outer ones linear-oblong, obtuse, equalling or shorter than the broader inner ones, all pubescent; rays 6-10, oblong, entire; disk yellow; achenes oblong to elliptic, winged, I-4 cm. long : pappus of 2 short deciduous teeth. In dry sandy woods, Va. and N. Car. to Fla. and Miss. July-Aug.

Coreopsis major Oèmleri (Fll.) Britton. Plant glabrous throughout; leaf-segments often narrower. Va, and W. Va. to Ga.

6. Coreopsis delphinifolia Lam. Larkspur TiCkseed. (I. F. f. 3930.) Perennial, stem glabrous, branched above, rather slender, 3-9 dm. high. Segments 3-5 cm. long, 2-6 mm. wide; heads several or numerous, 4-6 cm. broad; involucre hemispheric, its bracts glabrous, the outer linear-oblong, obtuse, shorter than or equalling, the ovate-oblong inner ones; rays 6-ro, entire; disk brown; achenes 
oblong to oval, narrowed at the base, narrowly winged; pappus of 2 short teeth. In dry woods, Va., N. Car. to Ga. and Ala. Aug.-Sept.

7. Coreopsis verticillàta L. Whorled Tickseed. (I. F. f. 393I.) Perennial; stem stiff, much branched, slender, leafy, 3-6 dm. high. Heads numerous, 3-4 cm. broad; involucre hemispheric, or short.cylindric in fruit, glabrous, its outer bracts linear, obtuse, commonly somewhat shorter and much narrower than the ovate-oblong inner ones; rays 6-IO, spatulate-oblong, obtuse; disk dull yellow; achenes oblong, narrowly winged, $4 \mathrm{~mm}$. long; pappus of 2 short teeth. In dry soil, western Ont. to northern Mich., Md., N. Car., Ky., Neb. and Ark. JuneSept.

8. Coreopsis lanceolàta L. Lance-Leaved Tickseed. (I. F. f. 3932.) Perennial; stem slender, 3-6 dm. high. Leaves glabrous, the lower and basal ones slender-petioled, spatulate or narrowly oblong, very obtuse, $5^{-15} \mathrm{~cm}$. long, entire, or with $\mathbf{I}-3$ lateral obtuse entire lobes; heads few or solitary on elongated slender peduncles, 4-6 cm. broad, showy; peduncles often $3 \mathrm{dm}$. long; involucre depressed-hemispheric, its bracts glabrous or ciliate, lanceolate or ovate-lanceolate, the outer narrower than the inner, but nearly as long; rays 6-10, cuneate, 3-7lobed; achenes oblong, about $2 \mathrm{~mm}$. long; pappus of 2 short teeth. In dry or moist soil, western Ont. to Va., Fla., La. and Mo. May-Aug.

9. Coreopsis pubéscens Ell. Star Tickseed. (I. F. f. 3933.) Perennial; stem leafy, little branched, or simple, erect. Leaves pubescent or glabrous, entire, or some of them 3-5-lobed or divided, the basal and lower ones slenderpetioled, obovate oval, obtuse, the upper short-petioled or sessile, 5-7 cm. long; heads few, 2.5-3.5 cm. broad, long-peduncled; involucre depressed-hemispheric, glabrous, star-like, its lanceolate obtuse or acute outer bracts nearly as long as but much narrower than the ovate inner ones: rays 8-10, cuneate, lobed at the apex; achenes similar to those of the preceding species or broader. In dry woods, Va. to Ill. and Mo., south to Fla. and La. June-Aug.

Io. Coreopsis crassifollia Ait. Thick-Leaved or Hairy Tickseed. (I. F. f. 3934.) Perennial; stem ascending, little branched, 2-5 dm. high. Leaves rather thick, hirsute or pubescent, all entire, the lower and basal ones petioled, 4-7 $\mathrm{cm}$. long, 8-20 mm. wide; stem-leaves few, short petioled or sessile, obtuse or acutish, narrower; heads few, 3-5 cm. broad, borne on slender, puberulent peduncles of ten $3 \mathrm{dm}$. long, similar to those of $C$. lanceolata, as are the rays, involucral bracts and achenes. Dry soil, Ill. to La., east to S. Car. and Fla. May-Aug.

II. Coreopsis auriculàta L. Running or Lobed Tickseed. (I. F. f. 3935.) Perennial; stoloniferous; stems weak, very slender, decumbent or ascending, I.5-4 dm. long, little branched, or simple. Leaves thin, entire or pinnately 3-5-lobed or 3-5-divided, the terminal segment entire and much' larger than the lateral ones, the lower and basal more or less pubescent, with slender pubescent petioles: stem-leaves few, petioled or sessile, mostly obtuse; heads $2-4 \mathrm{~cm}$. broad, slender-peduncled; outer bracts of the involucre oblong, narrower than the mostly ovate and acute inner ones; rays 6-1o, cuneate, about 4-toothed, yellow; achenes oval, the wings involute and thick. In woods, Va. to Ky., south to Fla. and La. May-Aug.

I2. Coreopsis grandiflòra Hogg. Large-flowered Tickseed. (I. F. f. 3936.) Perennial (or sometimes annual ?); stem glabrous, usually branched above, 3-9 dm. high. Leaves, or most of them, I-2-pinnately parted, or the lower entire and slender-petioled; segments of the lower stem-leaves oblong, obtuse, the terminal one larger than the lateral; segments of most of the stem-leaves linear or even filiform; petioles ciliate; heads commonly several, 3-5 cm. broad, long.peduncled; outer bracts of the involucre lanceolate, narrower and mostly shorter than the oval or ovate-lanceolate inner ones; rays 6-10, achenes oblong, broadly winged when mature, the projections on the inner face usually large; pappus of 2 short scales. In moist soil, Kans. and Mo. to Tex., east to Ga. May-Aug.

13. Coreopsis tripteris L. TAll Tickseed. (I. F. f. 3937.) Perennial; stem glabrous, much branched above, 12-25 dm. high. Leaves petioled, glabrous, or very nearly so, firm, the lower all divided into lanceolate entire acute rough-margined segments, which are 5-12 $\mathrm{cm}$. long, 6-25 $\mathrm{mm}$. wide and pinnately veined; uppermost leaves lanceolate, entire; heads numerous, slender-peduncled, $3-4 \mathrm{~cm}$. 
broad; outer bracts of the invoiucre linear, obtusish, much narrower than the ovateoval or ovate-lanceolate, acute inner ones; rays 6-10, yellow, obtuse, achenes oblong to obovate, narrowly winged, emarginate; pappus none. In moist woods and thickets, Penn. to Wis., Kans., Va., Fla. and La. July_Oct.

\section{BìDENS L. (See Appendix.)}

Annual or perennial herbs, with opposite, serrate, lobed, divided or dissected leaves, or the uppermost alternate, and mostly large heads of both tubular and radiate flowers, or the rays none, or rudimentary. Involucre campanulate or hemispheric, its bracts in 2 series, distinct or slightly united at the base; the outer often foliaceous and much larger than the inner. Receptacle flat or nearly so, chaffy, the chaff subtending the disk-flowers. Rays, when present, neutral, mostly entire, yellow in our species. Disk-flowers perfect, fertile, their corollas tubular, 5-toothed. Anthers entire, or minutely sagittate at the base. Style-branches with short or subulate tips. Achenes flat, quadrangular or nearly terete, cuneate, oblong, or linear. Pappus of 2-6 teeth or subulate awns, upwardly or downwardly barbed or hispid. [Latin, two-toothed, referring to the achenes.] About 75 species of wide geographic distribution. Besides the following, several others occur in the southern and western U. S.

Plants terrestrial, erect; leaves simple, or divided.

Leaves lanceolate, serrate, undivided, rarely lobed (pinnately divided in B. connata pinnata.

Rays present, large and conspicuous, twice as long as the disk or longer.

Heads usually erect; rays oval; leaves lanceolate, many-toothed.

I. B. laevis.

Heads nodding; rays linear-oblong; leaves narrowly lanceolate, fine toothed. 2. B. elegans.

Rays small, not more than twice as long as the disk, sometimes very short or wanting.

Heads nodding after flowering.

3. B. cernua.

Heads persistently erect.

Pappus-awns downwardly barbed.

Involucral bracts not foliaceous; stem purple;

flowers orange.

4. B. connata.

Involucral bracts foliaceous; stem straw-color; flowers greenish yellow.

Outer involucral bracts erect or nearly so ; lower leaves petioled.

5. B. comosa.

Outer involucral bracts spreading; leaves sessile.

Pappus-awns upwardly barbed.

6. B. acuta.

7. $B$. bidentoides.

Leaves, some or all of them, pinnately 1-3-parted or dissected.

Rays rudimentary, none, or very short.

Achenes flat ; leaves, some or all of them, 1-3-divided.

Outer involucral bracts, 4-8; achenes nearly black.

Achenes 4-4.5 mm. long; awns very short ; outer bracts 4 .

8. B. discoidea.

Achenes $6 \mathrm{~mm}$. long; awns half as long as the achene; outer

bracts $6-8$.

Outer involucral bracts 10-16; achenes brown.

Achenes linear; leaves dissected.

9. $B$. frondosa.

10. B. vulgata.

II. B. bipinnata.

Rays large and conspicuous.

Achenes sparingly pubescent, not ciliate; pappus of 2 short teeth.

Achenes ciliate; pappus 2-4 subulate teeth or awns.

Achenes cuneate, or linear-cuneate.

Achenes obovate, very flat.

12. B. coronata.

13. B. trichosperma.

Bracts of the involucre glabrous or ciliate, short.

14. B. aristosa.

Outer bracts densely hispid, much longer than the inner.

15. B. involucrata.

Plant aquatic; submersed leaves filiformly dissected.

16. B. Beckii.

I. Bidens laèvis (L.) B.S.P. LARger or SMooth Bur-Marigold. BRook Sunflower. (I. F. f. 3938.) Annual; glabrous throughout; stems branched, erect or ascending, 3-6 dm. high. Leaves sessile, acuminate at the apex, narrowed to the sometimes connate-perfoliate base, 7-20 $\mathrm{cm}$. long, 6-25 mm. wide; heads 
numerous, short-peduncled, erect, 4-6 cia. bruad; rays very showy, golden yellow ; involucre hemispheric, its outer bracts linear-oblong or spatulate, equalling or exceeding the broader, ovate or oblong, membranous inner ones; rays 8-10, oval to oblong, obtuse; achenes cuneate, truncate, $2 \mathrm{~mm}$. long, retrorsely hispid on the margins; pappus of 2-5 (usually 2), rigid downwardly barbed awns. In swamps and wet meadows, Mass. to N. Car. and western N. Y. Aug.-Oct.

2. Bidens élezans Greene. NARrow-RAYED Bur-Marigold. Glabrous; stem slender, sparingly branched, terete, red-purple. Leaves narrowly lanceolate, $6-8 \mathrm{~cm}$. long, with few short salient teeth; heads nodding, on long slender peduncles; outer bracts of the involucre shorter than the inner; rays 6-8, about 3 times as long as the involucre; outer achenes 4-awned, the inner 3-awned; awns and margins of the achenes retrorsely barbed. Southeastern Va.

3. Bidens cérnua L. Smaller or Nodding Bur-Marigold. (I. F. f. 3939.) Annual; stems glabrous, or hispid, usually erect, branched, 5-9 dm. high. Leaves sessile and commonly somewhat connate-perfoliate at the base, glabrous, acuminate, 7-15 cm. long, 6-25 mm. wide; heads numerous, globose, short-peduncled, $\mathbf{I}-\mathbf{2 . 5} \mathrm{cm}$. broad, nodding after or during flowering; rays 6-10, short (6-12 $\mathrm{mm}$.), or none; involucre depressed-liemispheric, its outer bracts commonly ciliate, often large, foliaceous and much exceeding the broad, yellowish-margined membranous inner ones; achenes cuneate, about $4 \mathrm{~mm}$. long, retrorsely hispid on the margins; pappus of 2-4 (usually 4) downwardly barbed awns. In wet soil, N.S. to Hudson Bay and Br. Col., south to N. Car., Mo. and Cal. Also in Europe and Asia. July-Oct. It has recently been proposed by Professor E. L. Greene to separate this into several species, and $\mathrm{Mr}$. Wiegand has suggested two subspecies.

4. Bidens connàta Muhl. Purple-STemmed Swamp Beggar-Ticks. (I. F. f. 3940.) Annual; glabrous throughout; stem erect, usually much branched, I.5$25 \mathrm{dm}$. high. Leaves petioled, thin, apex acuminate, base tapering, blade $5-12 \mathrm{~cm}$. long, 6-25 mm. wide, decurrent on the petiole, the lower sometimes with a pair of lateral basal lobes; heads several or numerous, peduncled, I-4 cm. broad; involu. cre campanulate or hemispheric, its outer bracts ciliate or naked, somewhat exceed. ing the ovate-oblong inner ones; rays none, or I-5 and inconspicuous; stamens often exserted; achenes cuneate or obovate, hairy and tubercled, or nearly glabrous, often keeled, the margins with either erect or retrorse hairs, or both; pappus-awns 3 or 4: corolla 5 -toothed. In swamps or moist soil, N. S. to the N. W. Terr., south to Del., Ga., Ky. and Mo. Aug.-Oct.

Bidens connàta pinnàta $S$. Wats. Leaves pinnately divided into $4-6$ pairs of acute, entire to incised segments. Minn.

5. Bidens comòsa (A. Gray) Wiegand. Leafy-Bracted Tickseed. (I. F. f. 394I.) Annual, glabrous; stem erect, branched, I.5-10 dm. high. Leaves shortpetioled, with mostly smaller teeth than in $B$. connata, tapering to each end, the petioles broadly margined; heads several or numerous, $\mathbf{I} \mathrm{cm}$. broad or more; outer bracts of the involucre spatulate or lanceolate, foliaceous, often toothed, 2-4 times as long as the head; corollas mostly 4-lobed, stamens and style included ; achenes larger, 7-II mm. long, evenly cuneate, very flat, retrorsely hairy; pappus-awns commonly 3, downwardly barbed. In wet soil, southern N. Y. and Mass. to Ill. Aug.-Oct.

6. Bidens acuta (Wiegand) Britton. Prairie Beggar-ticks. Similar to $B$. comosa. Leaves lanceolate to oblong-lanceolate, sessile by a narrowed base, 4-8 cm. long, sharply serrate, the margins sparingly ciliate; involucre broader than high, 1. 5-3 cm. broad; outer bracts foliaceous, ciliate, acutish, longer than the achenes, spreading; inner bracts narrowly triangular-lanceolate, acute; achenes cuneate, sparingly retrorsely hairy; awns 3 , retrorsely barbed, the longer more than half as long as the achene. In wet soil, Kans. and Mo. Aug.-Sept. [ $B$. comosa acuta Wiegand; $B$. riparia Greene.]

7. Bidens bidentoides (Nutt.) Britton. Swamp BEgGar-TICKs. (I. F. f. 3942.) Closely resembles $B$. connata, glabrous throughout; stem branched, 3-12 dm. high. Leaves petioled, or the upper sessile and entire, acuminate at the apex, narrowed at the base; involucre narrowly or becoming somewhat broadly campanulate, its outer loracts linear, foliaceous, not ciliate, usually much exceeding the oblong inner ones; rays none, or rarely present and very short; achenes linear. 
cuneate, 8-10 $\mathrm{mm}$. long, their sides and the 2 slender pappus-awns (rarely with a short intiermediate awns) upwardly barbed or hispid. Muddy shores, Penn., 1N. J., Del. and Md. Aug.-Oct.

8. Bidens discoidea ('T. \& G.) Britton. Small Beggar-'Ticks. (I. F. f. 3943.) Annual, glabrous, slender, brancling, erect, 5-18 dm. high. Leaves membranous, very slender-petioled, all the lower ones divided into 3 lanceolate or oblong-lanceolate, dentate, acuminate segments which are $2-7 \mathrm{~cm}$. long; uppermost leaves commonly rhombic-lanceolate and undivided; heads usually numerous, slenderpeduncled, 5-10 $\mathrm{mm}$. broad; involucre broadly campanulate or hemispleric, its outer bracts mostly foliaceous and obtuse, usually much surpassing the inner ones; rays apparently always wanting; achenes flat, na rrowly cuneate, upwardly strigose, abcut $4 \mathrm{~mm}$. long; pappus of 2 short, upwardly hispid, rarely downwardly barbed awns. In swamps and wet places, Conn. to Va., Ohio, Mich., La. and Tex. July-Sept.

9. Bidens frondòsa L. BLACK BEgGar-Ticks. Annual; stem erect, branched, sparingiy pubescent or glabrous, 5-IO dm. high. Leaves - slenderpetioled, pinnately 3-5-divided or the uppermost undivided, the segments lanceolate or oblong-lanceolate, sharply serrate, acuminate at the apex, narrowed at the base, usually slightly pubescent beneath, stalked, 5-10 $\mathrm{cm}$. long, I-2 cm. wide; heads usually numerous, slender-peduncled, 9-15 mm. broad; involucre campanulate, becoming hemispheric, its outer bracts foliaceous, often exceeding the oblong inner ones; achenes flat, cuneate, nearly black, the margins upwardly hairy; the two slender awns downwardly barbed, or sometimes upwardly hispid. In moist soil, often a weed in fields, N. B, to Fla., Neb. and Tex. July-Oct.

I0. Bidens vulgàta Greene. TAll BEGGAR-TiCKs. (I. F. f. 3944, as B. frondosa.) Taller, sometimes $3 \mathrm{~m}$. high, glabrous or nearly so. Leaves pinnately 3-5. divided, the veins straight and prominent; heads larger, I.5-2.5 cm. broad, stoutpeduncled; outer involucral bracts linear to linear-spatulate, ciliate, the inner mostly ovate or narrowly triangular, pubescent at the apex; ray-flowers usually present, pale yellow; achenes very flat, 7-9 $\mathrm{mm}$. long, 4-5 $\mathrm{mm}$. wide, bre wn or greenish brown; the margins downwardly barbed above, upwardly hairy bele w; awns 2 , half as long as the achene or more, downwardly barbed. In moist soil, I'nt. to N. Car., Br. Col., Mo. and Cal.

Bidens vulgàta pubérula (Wiegand) Greene. Crisp-pubescent above, especially on the involucre; inner bracts pubescent on the back. Wis. to Saskatch., Jow N, Neb. and Mo.

I I. Bidens bipinnàta L. Spanish Needles. (I. F. f. 3945.) Aunual: stem quadrangular, erect, freely branched, rather slender, 3-15 dm. high. Leaves thin, acuminate, petioled, 1-3-pinnately dissected into ovate or oblong, toothed or wbed segments; lower leaves often $2 \mathrm{~cm}$. long; heads usually numerous, long-peduncled, 4-8 mm. broad; involucre narrow, its outer bracts linear, ascending, nearly a: long as the broader erect inner ones; rays 3-4, yellow, short, sometimes none; achenes linear, 4-angled, slightly pubescent, narrowed upward into a beak, io-I $\delta$ $\mathrm{mm}$. long, the outer ones commonly shorter and thicker than the inner; pappus of 2-4 (usually 4), downwardly barbed, slightly spreading awns, much shurter than the achene. In various situations, often a weed in cultivated fields, R. I. to Fla., west to Ohio, Neb. and Ariz. Also in Mex. and tropical Am., and introduced as a weed into southern Europe and Asia. July-Oct.

I2. Bidens coronàta (L.) Fisch. Southern Tickseed-Sunflower. (I. F. f. 3946.) Annual, glabrous or nearly so throughout; stem branched, 3-9 dm. high. Lower leaves petioled, 7-12 cm. long, 3-divided, the terminal segment lanceolate. acute or acuminate, serrate, much larger than the serrate or entire lateral ones; upper leaves much smaller, 3-parted, 3-lobed or undivided, sessile or short-petioled, entire or serrate; heads numerous, slender-peduncled, $3-5 \mathrm{~cm}$. broad; involucre hemispheric, its outer bracts linear-oblong, obtuse, equalling or slightly exceeding the broader inner ones; rays 6-10, obtuse; aclienes broadly cuneate, 2-4 mm. long; pappus of 2 chaffy, divergent, somewhat laciniate teeth, rarely with 2 shorter intermediate ones. In wet places, Va. to Fla. and Ala. July-Sept.

I3. Bidens trichospérma (Michx.) Britton. Tall Tickseed-Sunflower. (I. F. f. 3947.) Annual or biennial, glabrous; stem tall, obscurely quadrangular, much branched, 6-15 dm. high. Lower leaves petioled, I-2 cm. long, pinnately 
divided into 5-7 lanceolate, acuminate, sharply serrate, incised or nearly entire, sessile or short-stalked segments; upper leaves sessile or nearly so, 3-lobed, 3divided, or entire and linear-lanceolate; heads numerous, 4-6 cm. broad, longpeduncled; involucre hemispheric, its outer bracts linear or spatulate, sometimes ciliate, about the length of the broader inner ones; rays 6-19, obtuse, golden yellow, 14-25 mm. long; achenes 6-8 mm. long: pappus of 2 upwardly hispid teeth or short awns. In swamps and wet meadows, Mass. to Ga., Ill. and Ky. Aug.-Oct.

Bidens trichospérma tenuiloba (A. Gray) Britton. Segments of the leaves linearlanceolate, serrate or entire; achenes sometimes smaller. In bogs, Ill., Ind., Minn., lowa and southern Ont. A similar form occurs in southern N. J.

14. Bidens aristòsa (Michx.) Britton. Western Tickseed-Sunflower. (I. F. f. 3948.) Annual or biennial; stem much branched, 3-9 dm. high. Leaves thin, slender-petioled, pubescent beneath, the lower ones pinnately 5-7-divided, 7-I $5 \mathrm{~cm}$. long, the segments lanceolate, serrate, incised or pinnatifid, acuminate, narrowed at the base; upper leaves less divided, lanceolate, or merely lobed, sessile or short-petioled; heads numerous, slender-peduncled, 2-5 cm. broad; onter bracts of the hemispheric involucre linear or spatulate; rays 6-9, obtuse; achenes upwarlly ciliate and strigose-pubescent; pappus of 2 slender upwardly or downwardly barbed awns, nearly as long as the achene, rarely wanting. In swamps and wet prairies, Del. to Mich., La. and Mo. Auy.-Oct.

15. Bidens involucràta (Nutt.) Britton. Long-Bracted Tickseed-SunFLOWER. (I. F. f. 3949.) Similar to the two preceding species, minutely pubescent, 3-9 dm. high, much branched. Segments of the leaves narrower, linearlanceolate, incised or pinnatifid, long-acuminate; heads numerous, $3-5 \mathrm{~cm}$. broad, on slender, usually hispid peduncles; outer bracts of the hemispheric involucre linearlanceolate, acuminate; rays orange at the base; achenes flat, ciliate and strigose; pappus of 2 short teeth. In swamps, Ill. to Kans., Ark. and Tex. July-Sept.

16. Bidens Béckii Torr. Water Marigold. (I. F. f. 3950.) Perennial, aquatic; stems simple, or little branched, 6-25 dm. long. Submersed leaves sessile, 3-5 cm. long; emersed leaves few, sessile, opposite, or sometimes in 3's, lanceolate or oblong, acute, serrate or laciniate, I-4 cm. long; heads solitary or few, shortpeduncled, $2.5-3.5 \mathrm{~cm}$. broad; involucre hemispheric, its bracts oval or oblong, obtusish, glabrous, the outer somewhat shorter than the inner; rays 6-10, obovate, or oblong, obtuse, golden yellow; achenes nearly terete, each end truncate; pappus of 3-6 slender awns, downwardly barbed above, smooth below, divergent, 12-25 $\mathrm{mm}$. long. In ponds and streams, Quebec to N. J., west to Manitoba and Mo. Aug-Sept. Emersed leaves sometimes wanting. This and a northwestern species constitute the recently-described genus Megalodonta Greene.

\section{THELESPÉRMA Less.}

Glabrous herbs, with opposite linear and undivided, or finely dissected leaves, and long-peduncled heads of both tubular and radiate flowers, or the rays wanting. Involucre of 2 distinct series of bracts, the outer short, narrow and somewhat spreading, the inner united into a cup, their tips scarious-margined. Receptacle flat, chaffy, the 2-nerved broad white scarious chaff subtending the disk-flowers and achenes. Ray-flowers, when present, neutral, the rays yellow, entire or toothed. Disk.flowers perfect, fertile, their corolla with a slender tube and 5-toothed limb. Anthers obtuse and entire at the base. Style-tips acute. Achenes, some or all of them, papillose on the back, oblong or linear, slightly compressed or terete, wingless. Pappus of 2 retrorsely hispid awns or scales, or sometimes none. [Greek, nipple-seed.] About 7 species, natives of the south central U. S., Mex. and south. ern S. Am.

Rays large; pappus-awns shorter than the width of the achene.

Leaves not rigid, their segments filiform-linear; annual or biennial.

Leaves rigid, their segments linear; perennial. Rays inconspicuous, or none; awns longer than the width of the achene.

1. T. trifidum.

2. $T$. intermedium.

3. $T$. gracile.

I. Thelesperma trífidum (Poir.) Britton. 
bipinnately divided; heads $2.5-3 \mathrm{~cm}$. broad; outer bracts of the involucre about 8 , subulate-linear, equalling or more than half as long as the inner, which are united not higher than the middle; rays 6-10, somewhat spatulate, 3-lobed; disk purple or brown; achenes linear-oblong, straight, or slightly curved, the outer ones strongly papillose. In dry soil, Neb. to Tex. June-Aug.

2. Thelesperma intermèdium Rydb. Intermediate Thelesperma. (I. F. f. 3952.) Perennial from a deep woody root; stem rigid, usually much branched, 3-4 dm. high. Leaves usually numerous, $4-5 \mathrm{dm}$. long, less compound than those of the preceding species; outer bracts of the involucre lanceolate-subulate, usually much shorter than the inner ones, which are united to about the middle; rays and achenes similar to those of the preceding. In dry soil, Wyo., Colo. and Neb. June-Aug. It has been confused with the southwestern T. ambiguum, which is less leafy and has a slender rootstock.

3. Thelesperma grácile (Torr.) A. Gray. Rayless Thelesperma. (I. F. f. 3953.) Perennial from a deep root; stem rigid, 3-9 dm. high, the branches nearly erect. Leaves rigid, erect or ascending, 5-7 cm. long, pinnately or bipinnately divided into linear segments, or the upper linear and entire; heads $1.2-2 \mathrm{~cm}$. broad; rays usually none, sometimes present and 4-6 $\mathrm{mm}$. long; outer bracts of the involucre 4-6, oblong or ovate, mostly obtuse, very much shorter than the inner ones which are united to the middle or beyond; disk yellow, or brownish; outer achenes slightly papillose. On dry plains, Neb. and Wyo. to Tex., northern Mex. and Ariz. May-Aug.

\section{GALINSÒGA R. \& P.}

Annual branching herbs, with opposite, mostly petioled leaves, and small reduncled heads of both tubular and radiate flowers, terminal and in the upper .xils. Involucre hemispheric or broadly campanulate, its bracts in 2 series, ovate, obtuse, membranous, striate, nearly equal, or the outer shorter. Receptacle conic or elongated, its thin chaff subtending the disk-flowers. Ray-flowers white, pistillate, fertile, the rays 4 or 5, short. Disk-flowers yellow, perfect, the corolla 5-toothed. Anthers minutely sagittate at the base. Style-branches tipped with acute appendages. Achenes angled, or the outer ones flat. Pappus of the diskflowers of several short laciniate or fimbriate scales, that of the ray-flowers of several or few short slender bristles, or none. [Named in honor of M. M. Galinsoga, superintendent of the Botanic Gardens at Madrid.] About 5 species, natives of tropical and warm temperate America.

I. Galinsoga parvifiòra Cav. GalinsogA. (I. F. f. 3954.) Slightiy appressed-pubescent, 3-9 dm. high. Leaves thin, ovate or deltoid-ovate, 3-nerved, 2-8 cm. long, acute at the apex, mostly obtuse at the base, dentate, the lower slender-petioled, the upper short-petioled or sessile, and sometimes nearly or quite entire; heads usually numerous, $4-6 \mathrm{~mm}$. broad, slender-peduncled; bracts of the involucre glabrous or nearly so, the outer shorter; pappus of the disk flowers 4-16, oblong to spatulate, fimbriate obtusish scales, shorter than the finely pubescent obpyramidal achene. In door-yards and waste places, eastern Mass. to Ore., N. Car., Kans. and Mex. Nat. from tropical Am. June-Nov.

Galınsoga parvifiora hispida DC. Pubescence more abundant, especially above, spreading; pappus of the disk-flowers attenuate, bristle-tipped. In waste places, R. I. to Penn., N. Car. and Wis.

\section{ACTINOSPÉRMUM Ell.}

Erect herbs, with alternate entire narrow punctate leaves, and large terminal heads of both tubular and radiate yellow flowers, or those of the disk purplish. Involucre hemispheric, its small bracts imbricated in several series, appressed, or with spreading tips, the outer shorter. Receptacle convex, deeply honey-combed, chaffy, the persistent chaff coriaceous or cartilaginous, laterally united, subtending the disk-flowers. Rays large, neutral, toothed. Disk-flowers perfect, fertile, the corolla 5-toothed. Anthers sagittate at the base. Style-branches with truncate subulate tips. Achenes turbinate, silky-villous. Pappus of 7-12 scarious nearly -qual scales. [Greek ray-seed.] Two known species, natives of the south- 
1. nctıuuspermum uniflòrum (Nutt.) Barnhart. ONE-Headed Actino. SPERMUM. (I. F. f. 3955.) Stem stout, puberulent, simple, or with a few erect branches, 3-9 dm. high. Leaves thick, spatulate-linear or the upper linear, ses. sile, erect or ascending, 2-5 cm. long, the lower 4-6 $\mathrm{mm}$. wide; heads long. peduncled, solitary, $5-6 \mathrm{~cm}$. broad; bracts of the involucre ovate, acuminate, thick, their tips at length spreading; rays 20-30, cuneate, 3-4-toothed at the truncate apex; disk I6-25 mn. broad; chaff of the receptacle cuneate, truncate, very cartilaginous, more or less united laterally, the summit eroded; achenes obconic; pappus of 7-9 oblong scales about as long as the achene. In wet pinebarrens, Va. to Fla. and La. July-Sept.

\section{7r. MARSHÁLlia Schreb.}

Perennial, often tufted, nearly glabrous herbs, with basal or alternate, entire leaves, and large long-peduncled discoid heads of purple, pink or white, glandularpubescent flowers. Involucre hemispheric or broadly campanulate, its bracts in I or 2 series, herbaceous, narrow, nearly equal. Receptacle convex or at length conic, chaffy, the scales narrow, rigid, distinct. Rays none. Flowers all perfect and fertile, their corollas with a deeply 5-lobed or 5-parted campanulate limb and a slender tube. Anthers minutely sagittate at the base. Style-branches long, truncate. Achenes turbinate, 5-ribbed and 5-angled. Pappus of 5 or 6 acute or acuminate, ovate or lanceolate-deltoid, nearly entire scales. [Named for Humphrey Marshall, of Pennsylvania, botanical author.] About 8 species, of the southern and central U. S.

Leaves ovate or oval, or oval-lanceolate, 3-5-nerved ; corolla-tube swollen at the throat.

Stem-leaves ovate to ovate-lanceolate, acuminate.

Stem-leaves lanceolate to oblong-lanceolate, acute or obtuse.

I. M. trinervia. Leaves linear, or the basal spatulate, thick; corolla-tube not swollen at the throat.

3. M. caespitosa.

1. Marshallia trinérvia (Walt.) Porter. Broad-leaved Marshallia. (I. F. f. 3956.) Stem simple, or little branched, leafy to or beyond the middle, 3-6 dm. high. Leaves acute or acuminate at the apex, narrowed to a sessile base, 5-7 cm. long, 18-35 $\mathrm{mm}$. wide; heads $\mathrm{I}-2 \mathrm{~cm}$. broad; corolla purplish; bracts of the involucre linear-lanceolate, acute, rigid; chaff of the receptacle subulatefiliform; pappus-scales lanceolate-acuminate from a triangular base; achenes glabrous when mature. In dry soil, Va. to Ala. and Miss. May-June.

2. Marshallia grandiflòra Beadle \& Boynton. Large-flowered MarSHALlia. Similar to the preceding species, leafy to above the middle. Lower and basal leaves oblong to oblong-lanceolate, tapering into petioles often as long as the blade, obtuse or obtusish ; upper leaves lanceolate, sessile; florets slightly larger than those of $M$. trinerita, I.5-2 cm. long; achenes larger, 4-5 mm. long: pubescent. In moist soil, Penn. to VV. Va. and N. Car. July-Aug.

3. Marshallia caespitòsa Nutt. Narrow-leaved Marshaliala. (I. F. f. 3957.) Stems usually tufted and simple, sometimes sparingly branched, leafy either only near the base or to beyond the middle, 2-4 dim. high. Leaves near the base usually much longer and linear, sometimes $\mathrm{I} \mathrm{dm}$. long and $6 \mathrm{~mm}$. wide, the upper ones linear, acutish, shorter; head about $25 \mathrm{~mm}$. broad, borne on a peduncle often $2.5 \mathrm{dm}$. long; corollas pale rose or white; bracts of the involucre linear. lanceolate, acute or acutish; chaff of the receptacle linear, or slightly dilated above; achenes villous on the angles; scales of the pappus ovate, acutish, equalling or longer than the achene. In dry soil, Kans. to Tex. May-June.

\section{PSILÓSTROPHE DC.}

Branched woolly herbs, often nearly glabrous when old, with alternate leaves, and middle-sized heads of both tubular and radiate yellow flowers, corymbose, or clustered at the ends of the branches. Involucre cylindraceous, its 4-Io bracts in I series, narrow, equal, densely white-woolly, separate, but erect and connivant, commonly with I-4 scarious ones within, and occasionally a narrow outer one. Rays broad, becoming papery and whitish. persistent, 5-7-nerved, 2-3-toothed, pistillate. Receptacle small, naked. Disk flowers perfect, fertile; their corollas with a short proper tube and elongated cylindraceous limb, 5-toothed, the teeth 
glandular-bearded. Anthers obtuse and entire at the base. Style-branches of the disk-flowers capitellate. Achenes linear, striate. Pappus of 4-6 nerveless acute scales, glabrous or villous. Four species, natives of the southwestern U. S. and northern Mex.

I. Psilostrophe villòsa Rydb.

Northern Psilostrophe. (I. F. f. 3958.) Perennial, branched, I.5-6 dm. high, loosely white-woolly. Basal and lower leaves oblanceolate, entire, dentate or rarely pinnatifid, mostly obtuse, 5-Io cm. long; upper leaves sessile, or nearly so, smaller, oblanceolate or spatulate, entire; heads several together in the clusters, $8-10 \mathrm{~mm}$. broad, short-peduncled, or subsessile; rays few, lemon yellow, $4 \mathrm{~mm}$. long, commonly wider, with 2 or 3 broad teeth or lobes at the summit; achenes glabrous, or sparingly pubescent; pappus scales linear-lanceolate, glabrous, shorter than the disk corollas. In dry sandy soil, Kans. to Tex. and Ariz. June-Sept. It has been confused with P. Tagetinae with orange persistent rays $5-10 \mathrm{~mm}$. long.

\section{FLAVÉRIA Juss.}

Glabrous or minutely puberulent, light green, mostly annual herbs, with opposite sessile leaves, and small, I-several-flowered, usually sessile, oblong and densely cymose-capitate heads of tubular, on both tubular and radiate. yellow or yellowish Howers. Involucre of 2-5 narrow, nearly equal, appressed bracts, sometimes with I or 2 additional small exterior ones. Receptacle small, naked. Ray-flower commonly one, pistillate, fertile, sometimes wanting. Disk-flowers 1-15, perfect, fertile, their corollas 5-toothed. Anthers entire at the base. Style-branches of the disk-flowers truncate. Achenes oblong or linear-oblong, 8-ro-ribbed. Pappus none. [Latin, flavus, yellow, from its dyeing properties.] About 7 species, natives of America. In addition to the following, 3 others occur in the southern U. S.

I. Flaveıia campéstris Johuston. NARrow.leaved Flaveria. (I. F. f.'3959.) Annual, glabrous or very nearly so, erect, 3-6 dm. high, little branched. Leaves linear or lanceolate, serrulate or entire, 3-nerved, acuminate or acute at the apex, sessile by a broad and somewhat clasping base, $3-6 \mathrm{~cm}$. long, 4-8 $\mathrm{mm}$. wide; heads about $6 \mathrm{~mm}$. high, closely sessile in terminal glomerules or these pedunculate from the upper axils; involucre usually of 3 oblong-lanceolate bracts, 2-5 flowered; ray equalling or longer than the breadth of the disk; achenes linear, glabrous, about $3 \mathrm{~mm}$. long. In alkaline soil, Kans. and Colo. to Tex., Mex. and N. Mex. Aug.-Oct.

\section{HYMENOPÁPPUS L'Her.}

Perennial or biennial, erect herbs, with angled stems, alternate or basal, mostl, pinnatifid or dissected leaves, and small or rather large discoid heads of white or yellow flowers. Involucre hemispheric or broadly campanulate, its bracts 6-12, in $\mathbf{I}$ or 2 series, nearly equal, mostly appressed, colored, petal-like, the margins and apices scarious. Receptacle small, naked. Rays none. Disk-flowers all perfect and fertile, their corollas with slender tubes and reflexed or spreading cam panulate 5 lobed limbs, the lobes ovate. Anthers entire at the base. Stylebranches with short conic appendages. Achenes obovoid or obpyramidal, 4-5angled, the faces usually prominently I-3-nerved. Pappus of IO-20 thin obtuse scales, sometimes very short or none. [Greek, membrane-pappus.] About 8 species, natives of N. Am. and Mex.

Bracts of the involucre broadly ovate or oval, bright white.

Bracts of the involucre obovate or oblong, green with whitish or yellow tips.

Achenes puberulent or sparingly pubescent on the angles.

Colored portion of the bracts broad, whitish to sulphur-yellow; corolla whitish.

Segments of the leaves, at least of the lower, oblong or broadly linear.

Segments of all the leaves narrowly linear.

Colored portion of the bracts narrow, yellow; corolla yellow.

2. H. sulphureus.

3. H. corymbosus.

4. H. favescens.

Achenes densely villous or hirsute.

Pappus over I mm. long, equalling the corolla-tube or nearly so, not hidden by the hairs of the achenes; heads numerous.

5. H. tenuifolius.

Pappus less then I mm. long, shorter than the corclla-tube and hidden by the hairs of the achenes; heads few.

6. H. filifolius. 
1. Hymenopappus Carolinénsis (Lam.) Porter. White-Bracted HyaenoPAPpUS. (I. F. f. 3960.) Biennial ; stem leafy below, corymbosely branched and nearly naked above, 6-9 dm. high. Basal and lower leaves petioled, I-1.5 dm. long, I-2. pinnately parted or deeply pinnatifid into linear or oblong, obtuse or obtusish lobes, more or less white-tomentose beneath; heads commonly numerous, corymbose, 12-20 $\mathrm{mm}$. broad; bracts of involucre broadly ovate or oval, thin, bright white; corolla lobes about as long as the throat, white; achenes puberulent or pubescent; pappus of very small nerveless scales, shorter than the width of the top of the achene. In dry sandy soil, Ill. to Tex., S. Car. and Fla. March-June.

2. Hymenopappus sulphureus Rydb. Sulphur-Bracted Hymenopappus. Biemnial; stem more or less permanently white-tomentose, branched above, 3-6 $\mathrm{dm}$. high. Lower leaves pinnately divided into oblong or linear toothed often obtuse lobes, white-tomentose beneath, glabrate above; upper leaves twice pinnate with narrower lobes; heads corymbose, about $\mathbf{I} \mathrm{cm}$. broad; bracts obovate, their tips light sulphur or almost white; corolla whitish; its lobes as long as the throat; achenes puberulent, short-hairy on the angles; pappus scales obovate, shorter than the width of the achene. Prairies, Kans. to Tex. Apr.-July. [Type from Riley Co., Kans., J. B. Norton, No. 285.]

3. Hymenopappus corymbòsus T. \& G. Corymbed, or Smooth White Hymenopappus. (1. F. f. 396I.) Biennial; stem glabrous or nearly so, corymbosely branched and nearly naked above, 3-6 dm. high. Lower and basal leaves petioled, I-2-pinnately parted into linear or nearly filiform, acute or acutish glabrous lobes, or somewhat tomentose beneath; upper leaves few, much smaller and less divided; heads corymbose, numerous, $8-12 \mathrm{dm}$. broad; bracts of the involucre obovate to oblong, puberulent, their tips greenish white; corolla white, its lobes about as long as the throat; achenes puberulent; pappus-scales small, nerveless, shorter than the width of the achene. On dry prairies, Neb. to Tex. Summer.

4. Hymenopappus flavéscens A. Gray. Woolly Yellow Hymenopap. PUs. (I. F. f. 3963.) Biennial; stem densely white-woolly, at least when young, 3-7 dm. high, leafy, branched above. Leaves I-3-pinnately parted or divided into linear segments; heads numerous, usually larger than those of the following species; involucral bracts obovate to ovate with greenish-white margins; corolla yellow or yellowish, the lobes about equalling the throat; achenes sparingly shortvillous; pappus-scales spatulate, shorter than the slender corolla-tube. In sandy soil, Kans. to Tex., Ariz. and northern Mex.

5. Hymenopappus tenuifòlius Pursh. Woolly White Hymenopappus. (I. F. f. 3962.) Biennial; stem lightly tomentose, or at length glabrate, 3-6 dm. high, slender, leafy below, corymbosely branched and nearly naked above. Lower and basal leaves petioled, I-3-pinnately parted into linear or filiform lobes, woollypubescent beneath, at least when young; heads numerous, corymbose, 8-12 mm. broad; bracts of the involucre obovate-oblong, usually densely tomentose; corolla white, its lobes slightly shorter than the throat; achenes densely villous-pubescent; pappus of several oblong to ovate ribbed or nerved scales, which are about as long as the widtl of the top of the achene. On dry prairies, S. Dak. to Tex. June-Sept.

6. Hymenopappus filifòlius Hook. Low Tufted Hymenopappus. (I. F. f. 3964.) Perennial from a deep woody root; stems usually tufted, woolly when young, sometimes glabrate when old, densely leafy toward the base, usually naked or nearly so above, I.5-4.5 dm. high. Leaves tomentose when young, the lower and basal ones petioled, I-3-pinnately parted or pinnatifid into narrowly linear, somewhat rigid lobes; heads commonly few, $12-25 \mathrm{~mm}$. broad; bracts of the involucre obovate-oblong, usually densely woolly, their tips whitish; corolla yellow or yellowish, its lobes much shorter than the throat; achenes densely villous; pappus-scales costate, short. On prairies and in dry rocky soil, N. W. Terr. to S. Dak., Neb. and Ariz. June-Sept.

\section{POLÝPTERIS Nutt.}

Erect rough, glandular or cinereous herbs, with alternate, mostly entire leaves, or the lower opposite, and corymbose heads of tubular or both tubular and radiate pink or purple flowers. Involucre campanulate or obconic, its bracts in I or 2 series, narrow, herbaceous, nearly equal, or with a few exterior shorter ones, appresssd, usually colored. Receptacle small, flat, naked. Ray-flowers, when 
present, pistillate, fertile, the rays 3-cleft. Disk-flowers perfect, fertile, their corollas with slender tubes and deeply 5-parted campanulate limbs. Style-branches filiform, acutish, glandular-pubescent throughout. Achenes linear or obpyramidal, quadrangular. Pappus of 8-12 lanceolate strongly costate scales, that of the outer achenes often much shorter than that of the inner. [Greek, many-winged.] About 6 species, natives of the southern and south-central U. S. and Mex.

Rays purple, deeply 3-lobed; leaves lanceolate.

Rays none; leaves linear or linear-lanceolate.

I. P. Hookeriana。

2. P. callosa.

I. Polypteris Hookeriàna (T. \& G.) A. Gray. HookeR's Polypteris。 (I. F. f. 3965.) Annual; stem rather stout, glandular-pubescent and viscid above, 3-9 dm. high. Leaves lanceolate, entire, acute or acuminate, narrowed at the base, rough on both sides, the upper alternate, the lower opposite and slender-petioled, 5-10 cm. long, 6-10 mm. wide; bracts of the involucre 10-16, linear-lanceolate or spatulate, glandular-hispid, the inner with purplish tips; ray-flowers 8-IO; achenes about $8 \mathrm{~mm}$. long and $1 \mathrm{~mm}$. thick; pappus-scales of the disk-flowers $6-8$, lanceolate, awned, those of the ray-flowers as many, spatulate, obtuse, shorter. In dry soil, Neb. to Tex. and Mex. July-Sept.

2. Polypteris callòsa (Nutt.) A. Gray. Rayless Polyp'teris. (I. F. f. 3966.) Annual; glandular, at least above; stem slender, paniculately branched, 3-6 $\mathrm{dm}$. high. Leaves 3-6 cm. long, 2-5 mm. wide, entire, short-petioled, mustly alternate; bracts of the top-shaped involucre 8-ro, lincar or narrowly oblong, herbaceous, pubescent, about $6 \mathrm{~mm}$. long; corollas purple, deeply 5-parted; achenes narrowly obpyramidal, pubescent or glabrous, nearly as long as the involucre; pappus-scales obovate or nearly orbicular, rounded or retuse, or sometimes minute, or none. In dry soil, Mo. to Tex. and N. Mex. June-Oct.

\section{PICRADENIÒPSIS Rydb.}

[BAHIA Nutt., not Lag.]

Herbs or shrubs, more or less woolly, with opposite or alternate leaves, and small or rather large corymbose or solitary heads, of both tubular and radiate yellow flowers. Involucre campanulate or hemispheric, its bracts in $\mathbf{I}$ or 2 series herbaceous, obtuse, appressed, nearly equal. Receptacle small, nearly flat, naked, foveolate. Ray-flowers in I series, pistillate, fertile. Disk-flowers perfect, fertile, their corollas with campanulate or cylindric 5-cleft limb. Anthers entire or emarginate at the base. Style-tips mostly truncate and obtuse. Achenes quadrangular; linear or oblong. Pappus of several nerveless or costate scales, rarely none. [Name referring to resemblance of this genus to Picradenia.]

I. Picradeniopsis oppositifòlia (Nutt.) Rydb. FALSE BaHia. (I. F. f. 3967.) Perennial, herbaceous; stem densely cinereous, much branched, I-3 dm. high, very leafy. Leaves opposite, or the uppermost alternate, 1-4 cm. long, palmately 2-5parted into linear, obtuse or obtusish, entire segments, finely cinereous on both sides; heads short-peduncled, 12-18 mm. broad; involucre campanulate, or becoming hemispheric, its bracts oblong, obtuse, densely tomentose; rays 5-7, short; achenes linear-oblong, glandular-pubescent; pappus of 4-8 spatulate to lanceolate scales with thickened bases. On plains, S. Dak., Neb. and Mont. to Kans. and N. Mex. June-Sept. [Bahia oppositifolia Nutt.]

\section{TETRANEÙRIS Greene.}

Branched or scapose, villous-pubescent or glabrous, bitter and aromatic herbs, with alternate or basal, often punctate entire leaves, and small or rather large, peduncled heads of both tubular and radiate yellow flowers, or rays rarely wanting. Involucre hemispheric, campanulate or depressed, its bracts imbricated in 2-3 series, appressed. Receptacle convex or conic, naked. Ray-flowers pistillate and fertile, the rays 3-toothed, 3-lobed. Disk-flowers perfect, fertile, their corollas with 4-5-toothed limbs. Anthers entire or minutely sagittate at the base. Style. branches truncate and penicillate at the summit. Achenes turbinate, 5-ro-ribbed or angled, villous or pubescent. Pappus of 5-12 thin aristate acuminate or truncate scales. [Greek, four-nerved.] About 20 species, natives of western N. Am. and Mex. Besides the following, some Io others occur in the western U. S. 
Annual, or perhaps biennial, with a branching stem.

Cespitose scapigerous perennials with all the leaves basal.

I. T. linearifolia.

Branches of the caudex comparatively slender and elongated; leaves narrowly linear, the blade much narrower than the dilated base.

Bases of the leaves and involucre sparingly silky-villous. 2. T. stenophylla.

Bases of the leaves conspicuously arachnoid hairy; involucre densely villous.

3. 7. fastigiata.

Branches of the caudex very short and thick; leaves from linear to spatulate, but the blade not much narrower than the base if at all.

Bracts of the involucre acutish, densely silky; leaves decidedly silky.

Leaves linear or narrowly oblanceolate, $4-7 \mathrm{~cm}$. long.

Leaves oblanceolate or spatulate, $2-4 \mathrm{~cm}$. long.

4. T. simplex.

5. T. acaulis.

Bracts of the involucre rounded, obtuse, sparingly silky; leaves nearly glabrous.

6. T: herbacea.

I. Tetraneuris linearifòlia (Hook.) Greene. Fine-leaved Tetraneuris* (I. F. f. 3968.) Annual or perhaps biennial; stem usually diffusely branched, finely hirsute, or glabruus, or woolly at the base, slender, $15-35 \mathrm{~cm}$. high. Stemleaves narrowly linear, sessile, I-4 cm. long, I-2 mm. wide; basal leaves spatulate, often villous, much broader, obtuse, narrowed into margined petioles; heads numerous, slender-peduncled, 12-16 $\mathrm{mm}$. broad; involucre broadly campanulate, its bracts oblong, obtuse, pubescent, imbricated in about 2 series; receptacle conic; rays 6 -10, oblong; achenes pubescent; pappus of 5 or 6 ovate awned scales. In dry soil, Kans. to La., Tex. and N. Mex. May-Sept. [Picradenia linearifolia (Hook.) Britton.

2. Tetraneuris stenophỳlla Rydb. Narrow-Leaved Tetraneuris. Perennial with a branched caudex; branches often $5-8 \mathrm{~cm}$. long, upper portion covered with the scarious bases of old leaves; bases of the leaves dilated, sparingly silkyvillous; blades narrowly linear, 3-4 cm. long, I-2 mm. wide, glabrous, conspicuously punctate; scape $6-10 \mathrm{~cm}$. high, minutely strigose: involucre $10-13 \mathrm{~mm}$. wide; bracts oval or oblong-acutish; rays about $10 \mathrm{~mm}$. long and $4 \mathrm{~mm}$. wide. In dry soil, Kans. to Colo. and Mex. [Actinella glabra T. \& G., not Nutt.; Picradenia scaposa Britton, Ill., Fl., in part.]

3. Tetraneuris fastigiàta Cireene. Fastigiate Tetraneuris. Like the preceding, but leaves still narrower, about $\mathbf{I} \mathrm{mm}$. wide, the bases conspicuously arachnoid villous; involucre about $8 \mathrm{~mm}$. wide; bracts ovate, densely villous. Only known from the imperfect type material from dry hills near Coolidge, Kans.

4. Tetraneuris símplex A. Nelson. Simple Tetraneuris. Cespitose perennial; caudex with very short thick erect branches; scapes few, I-2 dm. high, silkystrigose; leaves linear or linear-oblanceolate, silky but less so than in the next, 4-7 $\mathrm{cm}$. long, 2-5 $\mathrm{mm}$. wide; involucre $15-18 \mathrm{~mm}$. wide, its bracts oblong-lanceolate, acute, densely silky-villous; rays about I cm. long. On dry hills, Black Hills of S. Dak., western Neb., Wyo. and Mont. June-July.

5. Tetraneuris acaùlis (Nutt.) Greene. Stemless Tetraneuris. (I. F. f. 3970.) Similar to the preceding species, perennial by thick roots and a stout branched caudex; scapes tufted, densely silky or tomentose, $5-15 \mathrm{~cm}$. high. Ieaves all borne on the ends of the branches of the caudex, spatulate, entire, obtuse or obtusish, 3-5 cm. long, 3-6 mm. wide, densely silky or villous; heads $18-35 \mathrm{~mm}$. broad; involucre hemispheric, its bracts densely villous; rays 10-15; pappus of 5 or 6 ovate or oblong awned scales. In dry or rocky soil, N. W. Terr. to Mont., Neb., Ariz. and N. Mex. May-Aug. [Picradenia acaulis (Nutt.) Britton.]

6. Tetraneuris herbàcea Greene. Green Tetraneuris. Perennial, with a rather simple caudex; scape stout, IO-15 cm. high, strigose-silky; leaves narrowly oblanceolate, 5-8 cm. long, 4-8 mm. wide, at first sparingly long-silky, soon glabrous and green; involucre about $16 \mathrm{~mm}$. wide, its bracts oblong, rounded, obtuse, sparingly silky; rays $15 \mathrm{~mm}$. or more long, 20-25 in number. Hills, Ohio and Ill. May-June.

\section{PICRADÈNIA Hook.}

Branched, more or less pubescent plants with alternate, pinnately divided leaves with linear segments and peduncled radiate heads with yellow flowers. Involucre hemispheric, its bracts in 2 series, the outer ones united at the base. Receptacle convex or conic, naked. Ray-flowers pistillate and fertile, usually 3-toothed. 
Disk-flowers perfect, fertile. Style-branches truncate and penicillate at the summit. Achenes turbinate, pubescent. Pappus scales acuminate or awned. [Greek, bitter glands.]

I. Picradenia odoràta (DC.) Britton. Fragrant Picradenia. Limonillo. (I. F. f. 397I.) Annual; stem much branched, puberulent, sparingly hirsute or glabrous, 3-6 dm. high, leafy. Leaves $3-5 \mathrm{~cm}$. long, I-3 parted into filiform entire somewhat pubescent segments about $\mathbf{I} \mathrm{mm}$. wide; heads commonly numerous, $12-20 \mathrm{nmm}$. broad. Involucre campanulate, puberulent, its outer bracts 6-9, lanceolate, keeled, acute, united at the base; rays 7-Io, cuneate; pappus-scales lanceolate, acuminate. In dry soil, Kans. to Tex., Mex. and Cal. April-July.

\section{HELENIUM L.}

Erect, mostly branching herbs, with alternate, mainly decurrent, punctate bitter entire or dentate leaves, and large peduncled heads of both tubular and radiate, yellow or brownish-yellow flowers, or rays sometimes wanting. Involucre broad and short, its bracts in I or 2 series, linear or subulate, reflexed or spreading. Receptacle convex, sub-globose or obl-ng, naked. Ray-flowers pistillate and fertile, or neutral, the rays cuneate, 3-5 iobed. Disk-flowers perfect, fertile, their corollas 4-5-toothed, the teeth glandular-pubescent. Anthers 2-toothed or sagittate at the base. Style-branches of the disk-flowers dilated and truncate at the apex. Achenes turbinate, ribbed. Pappus of 5-8 entire, dentate or incised, acuminate or aristate scales. [The Greek name of some plant, from Helenus or Helena.] About 24 species, natives of North and Central America. In addition to the following, some 18 others occur in the southern and southwestern U. S.

Stem-leaves oblong-lanceolate or ovate-lanceolate, dentate rays fertile, disk yellow.

Leaves glabrous or nearly so.

Leaves grayish, scabrous, puberulent.

I. H. autumnale.

2. H. montanum.

Stem-leaves lanceolate or linear-lanceolate, mainly entire; rays neutral; disk purple.

Leaves all linear-filiform, entire; rays fertile.

3. H. nudiflorum.

4. H. tenuifolium.

I. Helenium autumnàle L. False or Swamp Sunflower. Sneezeweed. VFllow-STAR. OX-EYe. (I. F. f. 3972.) Perennial; stem puberulent or glabrous, rather stout, narrowly winged by the decurrent bases of the leaves, corymbosely branched above, 6-18 dm. high. Leaves firm, acuminate or acute at apex, narrowed to the sessile base, pinnately few-veined, $5^{-12} \mathrm{~cm}$. long, $.5-5 \mathrm{~cm}$. wide, bright green; headsnumerous, $3-5 \mathrm{~cm}$. broad, borne on long puberulent peduncles; bracts of the flattish involucre densely canescent, linear-lanceolate; rays 10-18, drooping, bright yellow, 3-cleft; achenes pubescent on the angles; pappus-scales ovate, acuninate or aristate, often lacerate or toothed. In swamps and wet meadows, Que. to Conn., Fla., S. Dak., Kans. and Ala. Aug.-Oct.

2. Helenium montánum Nutt. Western Sneezeweed. Like the last but lower, 3-8 dm. high. Leaves narrower with smaller and closer teeth, grayish, scabrous on both sides, especially heneath; stem also very scabrous; rays short, about $8 \mathrm{~mm}$. long, reflexed; bracts lanceolate. Meadows, Manitoba to Br. Col., south to Miss. and Ariz. July-Sept. [H. autumnale pubescens Britton.]

3. Helenium nudiflorum Nutt. PUR rle-head SNeEzeweed. (I. F. f. 3973.) Perennial; stem mostly slender, puberulent at least above, corymbosely branched, 3-9 dm. high, narrowly winged by the decurrent leaf bases. Stem leaves 4-7 cm. nng, 4-12 mm. wide, sessile; basal and lower leaves spatulate, obtuse, dentate, apering into margined petioles; heads $3-4 \mathrm{~cm}$. broad, on slender or short puberulent peduncles; rays IO-I5 (sometimes wanting), drooping, yellow, yellow with a brown base, or brown throughout, 3-toothed; pappus-scales ovate, aristate. In moist soil, Kans. to Ill., Tex., east to N. Car. and Fla. Also near Philadelphia. June-Oct.

4. Helenium tenuifolium Nutt. Fine-Leaved SNEeZeWEen. (I. F. f. 3974.) Annual; glabrous or minutely pubescent above; stem slender, very leafy and usually much branched, 2-6 dm. high. Leaves sessile, often fascicled, $\mathrm{I}-4 \mathrm{~cm}$. long, I mm. or less wide; heads several or numerous, cory mbose, I 8 -30 mm. broad, borne on slender or filiform peduncles; bracts of the involucre few, linear or subulate, sometimes pubescent, soon reflexed; rays 4-8, at length drooping; achenes villous; pappus-scales ovate, tipped with slender awns. In moist soil, S, E. Va. to Fla., Mo., Kans., Ark. and Tex. Aug.-Oct. 


\section{GAILLARDIA Foug.}

Branching or scapose, pubescent herbs, with alternate or basal leaves, and large peduncled heads of both tubular and radiate flowers, or rays wanting. Involucre depressed-hemispheric, or flatter, its bracts imbricated in 2 or 3 series, their tips spreading or reflexed. Receptacle convex or globose, bristly, fimbrillate or nearly naked. Rays cuneate, yellow, purple, or parti-colored, neutral or rarely pistillate, 3-toothed or 3-lobed. Disk-flowers perfect, fertile, their corollas with slender tubes and 5-toothed limbs, the teeth pubescent with jointed hairs. Anthers minutely sagittate or auricled at the base. Style-branches tipped with filiform or short appendages. Achenes turbinate, 5-ribbed, densely villous, at least at the base. Pappus of 6-12 I-nerved awned scales, longer than the achene. [Named for M. Gaillard de Marentonneau, a French botanist.] About 12 species, natives of the U. S. and Mex., I in southern S. Am.

Stem leafy; style-tips with filiform hispid appendages.

Fimbrillæ of the receptacle obsolete, or short; southern.

Fimbrillæ subulate or bristle-like, mostly longer than the achenes. Rays yellow; fimbrillæ exceeding the achenes.

Rays purple, or red at base; fimbrillæ about equalling the achenes.

I. G. lanceolata.

2. G. aristata.

Leaves basal; style-tips with short naked appendages; rays none, or few.

3. G. pulchella.

I. Gaillardia lanceolàta Michx. Sweet Gaillardia.

4. G. suavis.

(I. F. f. 3975.) Annual, or perhaps perennial; stem puberulent with jointed hairs, or cinereous, usually branched, 4-9 dm. high, the branches straight, nearly erect. Stem-leaves sessile, spatulate or linear, entire or sparingly serrate, puberulent, ciliolate, acute or obtusish and mucronulate at the apex, narrowed to the base, 3-7 cm. long, 4-8 mm. wide; basal leaves broader, very obtuse, sometimes short-petioled; heads 3-5 $\mathrm{cm}$. broad, long-peduncled; flowers sweet-scented; bracts of the involucre about equalling the violet disk; rays 8-12, yellow or reddish with darker veins, rarely none; achenes villous at the base, or to beyond the middle; awns of the pappus slender. In dry woods, Kans. to Tex., east to S. Car. and F.a. May-Sept.

2. Gaillardia aristàta Pursh. Great-flowered Gatllardia. (I. F. f. 3976.) Perennial; stem simple, or little branched, hirsute, or densely pubescent with jointed hairs, 3-9 dm. high. Leaves firm, densely and finely pubescent, the lower and basal ones petioled, oblong or spatulate, laciniate, pinratifid or entire, mostly obtuse, 5-12 cm. long; upper leaves sessile, lanceolate or oblong, or slightly spatulate, smaller, entire or dentate, rarely pinnatifid; heads $4-10 \mathrm{~cm}$. broad, long-peduncled; bracts of the involucre lanceolate, acuminate, birsute; achenes villous, at least at the base. On plains and prairies, Minn. to the N. W. Terr., Br. Col., Kans., Colo. and N. Mex. I.eaves sometimes all basal. May-Sept.

3. Gaillardia pulchélla Foug. Showy Gaillardia. (I. F. f. 3977.) Annual; diffusely branched at the base, the branches ascending, 15-35 cm. high, or larger in cultivation, more or less hirsute or pubescent with jointed hairs. Leaves lanceolate, oblong, or the lower spatulate, $3-7 \mathrm{~cm}$. long, entire, dentate or sinuate. pinnatifid, all but the lowest sessile; heads $3-7 \mathrm{~cm}$. broad, long-peduncled, bracts of the involucre lanceolate, acuminate, hirsute or pubescent; achenes more or less villous, or glabrous. In dry soil, Neb. and Kans. to La., Mex. and Ariz. MaySept.

4. Gaillardia suàvis (A. Gray) Britt. \& Rusby. Rayless Gaillardia. (I. F. f. 3978.) Annual or biennial. Leaves in a basal tuft, or a few near the base of the slender pubescent scape, spatulate or obovate in outline, 5-15 cm. long, pinnatifid, dentate, or some of them entire: scape 3-6 dm. high, monocephalous; head about $25 \mathrm{~mm}$. broad, with the odor of heliotrope, globose in fruit; rays none, or short and pistillate, or a few of them longer and neutral: bracts of the involucre oblong or lanceolate, sparingly pubescent; fimbrillae of the receptacle obsolete; achenes densely villous; pappus-scales broad, their awns very slender. In dry rocky soil, Kans. to Tex. April-June. [G. simplex Schecle.] 


\section{8x. BOEBÈrA Willd.}

[Dysòdia Lag., not Cav.]

Erect or diffuse, branching, mostly annual, strong-scented more or less glandu. lar herbs, with opposite or alternate, mostly finely dissected leaves, and small peduncled heads of both tubular and radiate yellow flowers. Involucre cylindric, campanulate or nearly hemispheric, its bracts in I series, united into a cup, usually with a few small additional outer ones. Receptacle flat, pubescent, or covered with short bristles. Ray-flowers pistillate, the rays short. Disk flowers perfect, their corollas 5-toothed. Anthers entire or minutely 2-toothed at the base. Stylebr.inches of the disk-flowers elongated, hirsute, sometimes apiculate. Achenes narrowly obpyramidal, 3-5-angled, striate. Pappus of about ro scales, parted to beyond the middle into numerous capillary, rather stiff, bristle-like segments. [Nam.cd for J. von Boeber, a Russian botanist.]

I. Boebera pappòsa (Vent.) Rydb. Fetid Marigold. False DogFENNEL. (I. F. f. 3979.) Annual, very leafy, glabrous or finely pubescent, glanddotted, much branched, $15-45 \mathrm{~cm}$. high, the branches diffuse or erect. Leaves opposite, sessile, or short-petioled, $\mathbf{I}-4 \mathrm{~cm}$. long, pinnately parted into linear or slightly spatulate, sharply serrate or incised segments; heads numerous, shortpeduncled, 6-10 $\mathrm{mm}$. broad: involucre campanulate, of 8-10 appressed, oblong, btuse, green or purplish, glabrous or ciliate bracts, with several narrow shorter outer ones; rays few, not longer than the width of the disk: receptacle and aclienes pubescent. Along streams and roadsides, Ohio to Minn. and Neb., south to La., Mex. and Ariz. Occasionally found as a weed in waste places in the Eastern and Middle States; and in Ont. July-Oct. [Dysodia papposa (Vent.) A. S. Hitchc.

\section{THYMOPHÝLLA Lag.}

Annuai or perennial herbs, some species low undershrubs, with gland-dotted foliage and involucre, alternate or opposite leaves, and small heads of both tubular and radiate, mostly yellow flowers. Involucre campanulate, its principal bracts united into a cup, sometimes with smaller outer ones. Receptacle naked, or fimbrillate, not chaffy. Ray-flowers pistillate, fertile, Disk-flowers perfect, fertile. Style-branches truncate or blunt. Achenes striate. Pappus of several or numerous scales or bristles. [Greek, thyme-leaf, not applicable to the following species.] About ${ }_{5}$ species, natives of America. Besides the following, some 4 others occur in the western parts of the U. S.

I. Thymophylla àurea (A. Gray) Greene. Thym -Leaf. (I. F. f. 3980.) Annual, glabrous, I-3 dm. high, much branched; the leaves and involucre with large oval oil-glands. Leaves alternate, or the lower opposite sessile or nearly so, very deeply parted into 5-9 linear filiform, mostly entire, blunt segments; heads numerous, corymbose, 12-20 $\mathrm{mm}$. broad, terminating the brinches; involucre about $6 \mathrm{~mm}$. high, its bracts acute: rays about I2, 5-6 min. long; pappus of 6-8 erose trincite scales, somewhat longer than the thickness of the achene. Kans. and Colo. to Tex. June-Sept.

\section{PÉCTIS L.}

Annual or perennial, diffuse prostrate or erect, mostly glabrous herbs, glanddotted and strong-scented, with opposite narrow sometimes ciliate leaves, and small usually cymose heads of both tubular and radiate yellow flowers. Involucre cylindric, oblong or campanulate, its bracts in I series, narrow, keeled, distinct. Receptacle small, naked. Ray-flowers pistiliate, the rays small, entire or 3-lobed. Disk-flowers perfect, their corollas with expanded, somewhat irregularly 5-cleft limbs. Anthers entire at the base. Style-branches of the disk-flowers very short, obtuse. Achenes linear, slightly angled, striate. Pappus of several or numerous scales, slender bristles or awns, sometimes with a few outer smaller additional ones. [Latin, pecten, comb, referring to the pappus.] About 50 species, natives of the warmer parts of America. Besides the following, about ro others occur in the southern and western U.S.

I. Pectis angust ifòlia Torr. Lemon-scented Pectis. (I. F. f. 3981.) Annual, much branched, I-3 dm. high, the branches diffuse or ascending. Leaves 
narrowly linear, sessile, obtusish, $\mathrm{r}-5 \mathrm{~cm}$. long, $2 \mathrm{~mm}$. wide or less, often ciliate with a few bristles near the base; heads several or numerous, short-peduncled, about $6 \mathrm{~mm}$. broad; involucre short-cylindric or narrowly campanulate, its bracts about 8 , linear, acutish, partly enclosing the outer achenes; rays few, 3-toothed, or entire; pappus a crown of 4-6 somewhat united short scales, with or without 2 slender short awns. In dry soil, Neb. and Colo. to Mex. and Ariz. Plant with the odor of lemons. May-Oct.

\section{ACHILLÈA L.}

Herbs, mostly perennial, with erect, leafy stems, finely dissected, pinnatifid or serrate alternate leaves, and small heads of both tubular and radiate flowers, corymbose at the ends of the stem and branches. Involucre obovoid, or campanulate, its bracts appressed, imbricated in few series, the outer shorter. Receptacle nearly flat, or convex, chaffy, the membranous chaff subtending the disk-flowers. Rayflowers pistillate, fertile, the rays white or pink. Disk-flowers perfect, fertile, their corollas yellow, 5-lobed. Anthers obtuse and entire at the base. Style branches of the disk-flowers truncate. Achenes oblong or obovate, slightly compressed. Pappus none. [Named for Achilles.] About 75 species, natives of the northern hemisphere, mostly of the Old World. Besides the following, several others occur in northwestern N. Am.

Leaves serrate.

r. A. Ptarmica.

Leaves finely dissected.

Involucre broadly campanulate; bracts fuscous-margined; rays 1o-20.

2. A. borealis.

Involucre oblong; bracts scarcely fuscous-margined; rays 5-ro.

Rays 3-6 mm. broad; plant villous; achenes broadly margined.

3. A. lanulosa.

Rays 2-3 mm. broad; plant sparsely villous or glabrate; achenes scarcely margined.

4. A. Millefolium.

I. Achillea Ptàrmica L. Sneezewort. White TAnsy. (I. F. f. 3982.) Perennial by horizontal or creeping rootstocks ; stem glabrous, or slightly pubescent, nearly or quite simple, 3-6 dm. high. Lea ves linear or linear-lanceolate, sessile and sli yhtly clasping at the base, acute at the apex, regularly and closely serrate, sonetimes pubisient on the veins beneath, 3-6 $\mathrm{cm}$. long, 3-6 $\mathrm{mm}$. wide; heads not very numerous, 10-18 mm. broad; peduncles puberulent; bracts ovate-oblong, obtuse or obtusish, slightly tomentose; rays 5-15, white, rather large. In moist soil, Newf. to Quebec, Mass. and Mich. Nat. from Europe. July-Sept.

2. Achillez boreàlis Bong. Northern Yarrow. Perennial, 2-4 dm. high; stem more or less lanate. Leaves bipinnate, with numerous crowded segments, sparingly lanate; cory mb dense; heads 4-8 $\mathrm{mm}$. high; involucral bracts somewhat scarious with broad fuscous margins; rays large, white or pink, 3-5 mm. broad; achenes prominently winged. Lab. to Alaska, south in the mountains of the Pacific Coast to Mex. June-Sept.

3. Achillea lanulòsa Nutt. Western Yarrow. Perennial, 3-5 dm. high; stem lanate. Leaves finely bipinnatifid, with approximate segments; cyme rather dense in age, becoming flat-topped; involucral bracts stramineous, with greenish keel and brown margins; achenes elliptical, broadly margined. Plains and mountains, S. Dak. to Br. Col., south to Mex. and Kans. Also introduced further east. June-Sept.

4. Achillea M:llefòlium L. Yarrow. Milfoll. (I. F. f. 3983.) Perennial from horizontal rootstocks; flowering stems sparsely pubescent, or nearly glabrous, simple, or corymbosely branched above, 3-6 dm. high. Basal leaves and those of the numerous short sterile shoots, mostly petioled, sometimes $25 \mathrm{~cm}$. long and $\mathrm{I} \mathrm{cm}$. wide, those of the stem sessile, all somewhat pubescent or nearly glabrous; heads numerous, 4-6 mm. broad, in terminal compound dense, somewhat convex corymbs; involucre ovoid, its bracts oblong, stramineous with greenish keel, obtusish, pubescent; rays 4-6, white, or often pink or purple. In various situations in the east occurring as a naturalized weed. Native of Europe and Asia. June-Nov.

Achillea ligustica All., a native of Europe, has been collected in N. Y. and Mass. It differs from $A$. Millefolium in the open loose panicle and broad and short leaf-seg. ments. 


\section{5. ÁNTHEMIS L.}

Annual or perennial herbs, with pinnatifid or dissected, alternate leaves, and usually large peduncled heads of both tubular and radiate flowers, terminating the branches. Involucre hemispheric, its bracts imbricated in several series, scariousmargined, appressed, the outer shorter. Receptacle convex, conic or oblong, chaffy at least toward the summit, the chaff subtending the disk-flowers. Rayflowers pistillate and fertile, or neutral, the tube terete or 2-winged, the ray white or yellow, entire or 2-3-toothed. Disk-flowers perfect, fertile, yellow, their corollas with 5-cleft limbs. Anthers obtuse and entire at the base. Style-branches of the disk-flowers truncate. Achenes oblong, angled, ribbed or striate. Pappus none, or a short coroniform border. [Greek name of Camomile.] About 60 species, natives of Europe, Asia and Africa.

Rays white.

Rays neutral; plant glabrous, or nearly so, fetid.

Rays pistillate ; plants pubescent.

Annual; chaff of the receptacle acute.

Perennial: chaff of the receptacle obtuse.

Rays yellow; plant pubescent, or tomentose.

I. A. Cotula.

2. A. arvensis.

3. A. nobilis.

4. A. tenctoria.

I. Anthemis Cótula L. Mayweed. Dog's, or Fétid Camomile. DillwEED. (I. F. f. 3984.) Annual, glandular and with a fetid odor and acrid taste, much branched, 3-6 dm. high. Leaves mostly sessile, 3-5 cm. long, finely $\mathbf{I}-3^{-}$ pinnately dissected into narrow, or almost filiform, acute lobes; heads commonly numerous, about $25 \mathrm{~mm}$. broad; bracts of the involucre oblong, obtuse or obtusish, usually somewhat tomentose; rays 10-18, mostly 3 toothed; receptacle convex, becoming oblong, its chaff bristly, subtending the central flowers; achenes roribbed, rugose or glandular-tuberculate; pappus none. In fields, waste places and along roadsides, all over $\mathrm{N}$. Am., except the extreme north. Nat. from Europe. June-Nov.

2. Anthemis arvénsis L. Corn or Field Camomile. (I. F. f. 3985.) Annual or sometimes biennial, not fetid; stem finely pubescent, usually much branched, about $3 \mathrm{dm}$. high, the branches decumbent or ascending. Lea ves sessile, 3-9 cm. long, I-2 pinnately parted into linear or lanceolate acute lobes, less divided than those of the preceding species and with broader segments; heads commonly numerous, 3-4 cm. broad; bracts of the involucre oblong, obtuse, usually somewhat pubescent, with broad scarious margins; rays 10-18, mostly 2-toothed; chaff of the obtuse receptacle lanceolate; achenes oblong, obtusely 4 angled; pappus a mere border. In fields and waste places, N. S. to Va., west to Mich., Mo., and on the Pacific coast. Nat. from Europe. May-Aug.

3. Anthemis nóbilis L. Garden, Scotch, White or Low Camomile. (I. F. f. 3986.) Perennial, pubescent, aromatic, much branched, 1.5-4.5 dm. high, the branches procumbent. Leaves numerous, $3-5 \mathrm{~cm}$. long, finely and compactly dissected into nearly filiform lobes and segments; heads about $25 \mathrm{~mm}$. broad; bracts of the involucre obtuse, pubescent, their scarious margins broad; rays 12-18, 2-3-toothed; chaff of the conic receptacle broad, membranous; achenes oblong, obtusely 3-angled; pappus none. Sparingly escaped from gardens, R. I. to Del. and Mich. Adventive from Europe. June-Aug.

4. Anthemis tinctória L. Yellow or OX-eye Camomile. (I. F. f. 3987.) Perennial; stem erect, branched, 3-9 dm. high, with nearly erect branches. Leaves sessile, 3-7 cm. long, pinnately divided, the oblong segments pinnatifid into narrow acutelobes; heads few or several, $3-4 \mathrm{~cm}$. broad; bracts of the involucre oblong, obtuse, densely tomentose; rays 20-30, ristillate, usually 2-toothed; chaff of the nearly hemispheric receptacle lanceolat, : cumiıate, rather rigid; achenes 4-angled, somewhat compressed; pappus a cr(:N-i-1ike border. In fields and waste places, Me. to N. J., and locally escaped fro.n gurde:as. Adventive from Europe. JuneSept.

\section{CHRYSANTHEMUM L.}

Perennial or annual, mostly erect and branching herbs, with alternate dentate incised or dissected leaves, and large, usually long-peduncled heads of both tubular and radiate flowers, or rays rarely wanting. Involucre hemispheric or depressed, 
its bracts appresised, imbricated in several series, the outer shorter. Receptacle flat, convex or hemispheric, naked. Ray-flowers pistillate, fertile, the rays white, yellow or rose-colored, entire or toothed. Disk-flowers perfect, fertile, their corol. las with terete or 2-winged tubes and 4-5-cleft limbs. Anthers obtuse and entire at the base. Style-branches of the disk-flowers truncate, penicillate. Achenes angled or terete, 5-10 ribbed, those of the ray-flowers commonly 3-angled. Pappus none or a scaly cup. [Greek, golden-flower.] About roo species, of wide distribution in the northern hemisphere. Besides the following, 2 others occur in northwestern arctic America. Our species have white ray-flowers.

Heads large, few or solitary at the ends of the stem or branches.

Stem-leaves linear-spatulate, pinnately incised; weed.

Stem-leaves cuneate-spatulate, toothed or lobed above; arctic.

Heads numerous, small, corymbose; plants escaped from gardens.

Leaves pinnatifid, segments incised.

Leaves oblong, serrate.

I. C. Leucanthemum.

2. C. arcticum.

3. C. Parthenium.

4. C. Balsamita.

I. Chrysanthemum Leucánthemum L. White-weed. White or OX-eye DAIsy. (I. F. f. 3988.) Perennial; stem glabrous, or sparingly puberulent, simple or little branched, 3-9 dm. high, often tufted, the branches nearly erect. Basal leaves obovate, oblong, or spatulate, coarsely dentate or incised, narrowed into long slender petioles; stem-leaves mostly sessile and partly clasping, $3-7 \mathrm{~cm}$. long, the uppermost very small and nearly entire; heads $3-5 \mathrm{~cm}$. broad, on long naked peduncles; rays 20-30, white, spreading, slightly $2-3$-toothed; bracts of the involucre oblong-lanceolate, obtuse, mostly glabrous, with scarious margins and a brown line within the margins; pappus none. In pastures, meadows and waste places, common as a weed. Nat. from Europe. Rays rarely short and tubular. Disk bright yellow. May-Nov.

2. Chrysanthemum àrcticum L. Arctic Daisy. (I. F. f. 3989.) Similar to the preceding species, but somewhat fleshy, lower, seldom over $3 \mathrm{dm}$. high. Leaves cuneate-spatulate, $3 \cdot 5-7 \cdot 5 \mathrm{~cm}$. long, crenate or cleft at the apex, narrowed into a long tapering entire base, or the lower into slender petioles, slightly clasping at the base, the uppermost few, small, linear and nearly entire; heads solitary or few, long-peduncled, 3-4 cm. broad; rays 20-30, white; bracts of the involucre oblong, obtuse, brown or with broad brown scarious margins, usually pubescent; pappus none. Coast of Hudson Bay to Alaska. Also in arctic Europe and Asia. Summer.

3. Chrysanthemum Parthènium (L.) Pers. Common Feverfew. FeathERFEW. (I. F. f. 3990.) Perennial; stem puberulent or glabrate, much branched, 3-7 dm. high. Leaves thin, the lower often $15 \mathrm{~cm}$. long, petioled, or the upper sessile, pinnately parted into ovate or oblong, pinnatifid or incised segments; heads numerous, corymbose, slender-peduncled, 12-20 $\mathrm{mm}$. broad; bracts of the depressed involucre lanceolate, rather rigid, keeled, pubescent, acute or acutish; rays 10-20, white, oval or ohovate, spreading, mostly toothed, long-persistent; pappus a short toothed crown. In waste places, N. B. and Ont. to N. J., and locally in the interior, mostly escaped from gardens. Nat. or adventive from Europe. Summer.

4. Chrysanthemum Balsámita L. Costmary. Cost. Alecost. Alecoast. (I. F. f. 399I.) Perennial, puberulent or canescent; stem much branched, 6-12 dm. high. Leaves 3-5 cm. long, those of the stem mostly sessile, and often with a pair of lateral lobes at the base: heads numerous, corymbose, slender-peduncled, Io- $5 \mathrm{~mm}$. broad, or when rayless only $6 \mathrm{~mm}$. broad; bracts of the involucre narrow, obtuse, pubescent; rays IO-I5, white, spreading; pappus a short crown. Sparingly escaped from gardens, Ohio to Ont. and N. S. Native of the Old World. Summer.

\section{MATRICÀRIA L.}

Mostly erect herbs, similar to some species of the preceding genus, with alternate leaves, dissected into filiform or narrowly linear segments and lobes, and pe. duncled heads of both tubular and radiate flowers, or rays wanting in some species. Involucre hemispheric, its bracts appressed, imbricated in few series, the outer shorter. Receptacle conic, elongated or hemispheric, naked. Rays, when present, white, pistillate and fertile. Disk-flowers yellow, perfect, fertile, their corollas 4-5-toothed. Anthers obtuse and entire at the base. Style-branches of the disk. 
flowers truncate, penicillate. Achenes 3-5-ribbed. Pappus none, or a coroniform border. [Latin, matrix, from its medicinal virtues.] About 20 species, natives of the norchern hemisphere and South Africa.

Ray's present, white.

Achenes obpyramidal, strongly 3 -ribbed.

Plant tall, much branched; bracts of the involucre green. 1. M. inodora.

Plant low, nearly simple, arctic; bracts dark brown or black.

Achenes nearly terete, oblong, faintly 3-5-ribbed. Rays none; achenes oblong, faintly nerved.

2. M. grandiflora.

3. M. Chamomilla.

4. M. matricarioides.

I. Matrirariz inodòra L. Scentless Camomile. Corn Mayweed. (I. F. f. 3992.) Annual; stem glabrous, or very nearly so throughout, 3-6 dm. high. Leaves numerous, sessile, 2-3 pinnately dissected into filiform lobes, the rachis somewhat dilated at the base. Heads several or numerous, terminating the branches, 1.5-4 cm. broad; bracts of the involucre lanceolate-oblong, obtuse, green with brown scarious margins; receptacle hemispheric or ovoid; pappus a short entire or 4-toothed crown. In fields and waste places, Newf. to N. J., and locally in the interior. Nat. or adventive from Europe. June-Sept.

2. Matricaria grandiflòra (Hook.) Britton. ARctic CAmomile. (I. F. f. 3993.) Perennial; stem usually simple and monocephalous, glabrous, I-3 dm. high. Leaves sessile, or the lowest short-petioled, 1-2-pinnately disseeted, 3-7 cm. long. Head not very long-peduncled, 3-5 cm. broad; bracts of the involucre ovate or ovate-oblong, obtuse, glabrous, brown or nearly black, or with broad, brown, scarious margins; receptacle hemispheric when mature. Coast of Hudson Bay to Alaska. Reported from Lake Huron. Summer.

3. Matricaria Chamomílla L. Wild or German Camomile. (I. F. f. 3994.) Annual, glabrous, much branched, 3-6 dm. high. Leaves aromatic, finely 2-3-pirmately dissected into numerous linear lobes: heads numerous, $16-25 \mathrm{~mm}$. broad, slender-peduncled at the ends of the branches; bracts of the involucre oblong, obtuse, green, or with brownish margins; receptacle ovoid. becoming conic and hollow; pappus none. In waste places and on ballast, southern N. Y. to Penn. Adventive or fugitive from Europe. Summer.

4. Matricaria matricarioides (Less.) Porter. Rayless Camomile. (I. F. f. 3995.) Annual, glabrous; stem very leafy, at length much branched, 15-45 $\mathrm{cm}$. high. Leaves 2-3.pinnately dissected into linear acute lobes; heads numerous, 6-8 mm. broad, peduncled; bracts of the involucre oval or oblong, green with broad white scarious margins, much shorter than the ovoid yellow disk; receptacle conic; pappus an obscure crown, sometimes produced into 2 coriaceous oblique auricles. In waste places, in ballast and along railroads, Mont. to Mo., Me. and M.tss Adventive from the Pacific coast. May-Aug. [M. discoidea DC.]

\section{TANACÈTUM L.}

Erect, strongly aromatic herbs, our species perennials, with alternate, I-3-pin. nately dissected or divided leaves, and numerous small cory mbose heads of tubular flowers, or with rays sometimes present and imperfectly developed. Involucre hemispheric, depressed, or campanulate, its bracts appressed, imbricated in several series. Receptacle flat or convex, naked. Marginal flowers pistillate, fertile, their corollas 2-5-toothed or lobed, sometimes produced into short rays. Disk-flowers perfect, fertile, the corollas 5-toothed. Anthers obtuse and entire at the base, their tips broad. Style-branches truncate and penicillate at the summit. Achenes 5-angled or 5-ribbed, truncate or obtuse. Pappus none, or a short crown. [From tanasie, old French for tansy; Greek, athanasia, immortality.] About 35 species, natives of the northern hemisphere. Besides the following, 6 others occur in western and northwestern N. Am.

Glabrous, or nearly so; heads numerous, 6-1o mm. broad. Villous-pubescent; heads few, 12-16 mm. broad.
1. T. vulgare.

2. T. Huronense.

I. Tanacetum vulgàre L. TANSY. (I. F. f. 3996.) Stem stout, usually simple up to the inflorescence, 4-9 dm. high. Leaves pinnately divided into linearoblong, pinnatifid or incised segments, the lobes acute, usually serrate; lower segments of the leaves oftens maller than the others; basal leaves often $3 \mathrm{dm}$. long: hears 
rather short-peduncled; involucre depressed-hemispheric, its bracts oblong-lanceolate, obtuse, or the outer acute, slightly pubescent or ciliate; receptacle flat; flowers yellow; marginal corollas with short oblique 3-toothed limbs; pappus a short crown. Along roadsides, mostly escaped from gardens, N. S. and Ont. to S. Dak., south to N. Car., Mo. and Kans. Nat. from Europe. July-Sept.

Tanacetum vulgàre crispum DC. Leaf-segments more incised and crisped. Occasional, in similar situations; in some places more plentiful than the type.

2. Tanacetum Huronénse Nutt. Lake Huron Tansy. (I. F. f. 3997.) Villous-pubescent throughout, at least when young, less so when mature, 3-6 dm. high. Leaves 2-pinnately divided, the lobes dentate or incised, acute, the lower segments commonly smaller than the others; heads I-8, on very stout pubescent peduncles; involucre depressed-hemispheric; marginal flowers with 3-5-lobed limbs, often expanded into short rays; pappus a short crown. In moist soil, N. B. to Hudson Bay, Me., Lake Superior, Alaska and Ore. July-Sept.

\section{ARTEMÍSIA I.}

Odorous herbs or shrubs, with alternate leaves, and small discoid, racemose, spicate, glomerate or paniculate heads of greenish or yellowish flowers. Involucre ovoid, oblong, or broadly hemispheric, its bracts imbricated in few series, the outer gradually shorter. Receptacle naked or pubescent, not chaffy. Central flowers perfect, sometimes sterile, with abortive ovaries and undivider styles, sometimes perfect and fertile, with truncate style-branches; marginal flowers usually pistillate and fertile, their corollas 2-3-toothed; or flowers all perfect and fertile in some species. Anthers obtuse and entire at the base, often tipped with subulate appendages. Achenes obovoid or oblong, 2-ribbed or striate, rounled at the summit, usually bearing a large epigynous disk. Pappus none. [Named for Artemisia, wife of Mausolus.] About 200 species, natives of the northern hemisphere and southern S. Am. Besides the following, some 30 others occur in western N. Am.

* Marginal flowers pistillate; central flowers perfect, sterile.

a. Biennial or perennial herbs.

Leaves pinnately dissected into narrowly linear lobes.

Heads very numerous, $2 \mathrm{~mm}$. broad; leaves mostly glabrous.

Heads $4 \mathrm{~mm}$. broad, in narrow panicles; leaves silky-pubescent.

Heads few; involucre brown, mostly pubescent.

Heads numerous; involucre green, mostly glabrous.

Leaves linear, the lower sometimes 3 -cleft or pinnately divided.

Leaves glabrous.

Leaves finely and densely pubescent.

b. Shrubby, silvery-canescent; heads small and numerous.

2. A. borealis.

3. A. Canadensis.

\section{A. filifolia.}

** Marginal flowers pistillate; central flowers perfect, fertile. .

a. Receptacle villous-pubescent.

Leaf-segments linear-filiform, short.

Leaf-segments oblong, or linear-oblong; introduced.

7. A. frigida.

8. A. Absinthium.

b. Receptacle glabrous, or sparingly pubescent.

Leaves dissected, glabrous or pubescent, green, not tomentose.

Heads about $4 \mathrm{~mm}$. broad, numerous in panicled racemes; perennial.

Heads about $2 \mathrm{~mm}$. broad, paniculate or spicate; annuals.

Leaves finely 2-3-pinnately divided; heads paniculate.

Leaves finely 2-3-pinnately divided; heads paniculate. Io. A. annua.
Leaves pinnately divided; segments pinnatifid; heads in leafy spikes.

9. A. Abrotanum.

Leaves densely white-canescent or tomentose, at least beneath.

Leaves pinnatifid or dissected.

I r. A. biennis.

Heads 6-8 mm. broad; racemose-glomerate; sea-beach plant.

Heads 2-4 mm. broad, spicate-paniculate or racemose.

Leaves deeply pinnatifid, the segments mostly incised.

Leaves finely dissected into short linear lobes.

13. A. vulgaris.

14. A. Pontica.

Leaves pinnately parted into 5-7 narrow entire segments.

15. A. Kansane. 
Leaves lanceolate, oblanceolate, or linear, serrate, somewhat lobed, or entire, not pinuatifid.

Leaves lanceolate, sharply serrate, glabrous above.

Leaves linear, oblong or lanceolate, entire or lobed. Leaves elongated, at length glabrous above.

16. A. serrata.

17. A. longifolia.

Leaves shorter, oblanceolate, oblong, or lanceolate, tomentose both sides.

Heads $4 \mathrm{~mm}$. high, $2.5-3 \mathrm{~mm}$. broad; leaves entire or some of the lower toothed, white-tomentose on both sides.

Heads $3 \mathrm{~mm}$. high, $2-2.5 \mathrm{~mm}$. broad; leaves, except the upper ones, deeply 3-7 lobed, greener above.

Leaves cuneate, $1 \mathrm{~cm}$. long, 3-toothed at the apex.

19. A. Ludoviciana. 20. A. Bigelovii.

*** Flowers all perfect and fertile; far western species.

Leaves cuneate, 3 -toothed or 3 -lobed.

Leaves linear, entire.

21. A. trideniata.

22. A. cana.

I. Artemisia caudàta Michx. TALL OR WILd Wormwood. (I. F. f. 3998.) Root biennial (sometimes perennial ?); stems slender, glabrous, tufted, strict, very leafy, 0.6-2 m. high, at length paniculately branched; branches glabrous, or rarely slightly pubescent, nearly erect. Lower and basal leaves and those of sterile shoots slender-petioled, sometimes a little pubescent, 7-I5 cm. long, 2-3-pinnately divided into lobes about I mm. wide; the uppermost entire and short; heads short peduncled, mostly nodding; bracts of the ovoid-campanulate involurere ovate, or the inner elliptic, glabrous; receptacle hemispheric, naked; central Howers sterile. In dry sandy soil, abundant on sea-beaches, Quebec to Fla., Manitoba, Neb. and Tex. July-Sept.

2. Artemisia boreàlis Pall. Northern Wormwood. (I. F f. 3999.) Perennial, $\mathbf{1 2}-35 \mathrm{~cm}$. high, densely silky-pubescent all over. Leaves less divided, the basal and lower ones petioled, 2-6 cm. long, the upper sessile, linear and entire or 3-parted; heads about $4 \mathrm{~mm}$. wide in a dense, terminal, rarely branched thyrsus; involucre nearly hemispheric, its bracts brown or brownish, pilose-pubescent or nearly glabrous; receptacle convex, naked; disk-flowers sterile. Me. (according to Fernald); Quebec to Greenland, west through arctic Am. to Alaska, south to Colo. Also in northern Asia. July-Aug.

3. Artemisia Canadénsis Michx. Canada Wormwood. (I. F. f. 4000.) Root perennial (or sometimes biennial); stem pubescent or glabrous, strict, 3-6 dm. high, the branches appressed and erect. Leaves usually pubescent, but sometimes sparingly so, the basal and lower ones petioled, $5-8 \mathrm{~cm}$. long, 2-pinnately divided into lobes which are shorter and broader than those of Artemisia caudata; upper leaves sessile, less divided; heads short-peduncled, mostly spreading or erect, in small forms the panicle reduced to a nearly or quite simple terminal raceme; involucre ovoid, its bracts ovate or oval; receptacle hemispheric; central flowers sterile. In rocky soil, Hudson Bay to northern Me. and Vt., west to Minn., Manitoba, the Canadian Pacific Coast, south to Ariz. and Neb. July-Aug.

4. Artemisia dracunculoides Pursh. Linear-leaved Wormwood. (I. F. f. 4001.) Perennial, glabrous; stem somewhat woody, usually much branched, 6-12 $\mathrm{dm}$. high, the branches nearly erect. Leaves 3-9 $\mathrm{cm}$. long, 2-4 $\mathrm{mm}$. wide, acute, entire, or the lower and basal ones sometimes 3-cleft or even more divided; heads very numerous, 2-3 mm. broad, nodding, very short-peduncled, racemose-paniculate; involucre nearly hemispheric, its bracts ovate or oblong, green, scariousmargined; receptacle hemispheric, naked. Dry plains and prairies, Manitoba to the N. W. Terr., Br. Col., Neb., Tex. and Cal. July-Nov.

5. Artemisia glaùca Pall. Silky Wormwood. (I. F. f. 4002.) Perennial, similar to the preceding species; stems strict, leafy, usually simple or little branched, 3-6 dm. bigh, pubescent, tomentose or canescent, or glabrous below. Leaves linear, I- $6 \mathrm{~cm}$. long, about $2 \mathrm{~mm}$. wide, entire, obtuse or obtusish, or the lower or sometimes nearly all of them 3-cleft into linear lobes 2-4 cm. long: panicle narrow, branched, its branches nearly erect; heads drooping, sessile, very numerous, scarcely more than $3 \mathrm{~mm}$. long; involucre hemispheric, its bracts scarious-margined, obtuse; receptacle naked. Minn. and Manitoba to the N. W. Terr.

6. Artemisia filifollia Torr. SIlvery Wormwood. (I. F. f. 4003.) Stem branched, 3-6 dm. high, the rigid branches nearly erect. Leaves $2-5 \mathrm{~cm}$. long, nearly all 3-parted into filiform entire segments less than $1 \mathrm{~mm}$. wide, or the uppermost undivided; heads exceedingly numerous, about I $\mathrm{mm}$. broad, racemose, 
paniculate, very short-peduncled, 3-5-flowered; involucre oblong, its bracts densely canescent; receptacle small, naked or slightly fimbrillate; central I-3 flowers sterile. On dry plains, S. Dak. to Utah, south to Tex., Mex. and N. Mex. JulyOct.

7. Artemisia frígida Willd. Pasture Sage-Prush. Wormwood Sage. (I. F. f. 4004.) Perennial, woody at the base, densely silky-canescent all over; stem 2.5-5 dm. high. Leaves I-4 cm. long, ternately or 5-nately divided into numerous short, acutish, mostly entire lobes less than $1 \mathrm{~mm}$. wide, the lower and basal ones petioled, and often with a pair of entire or 3-cleft divisions near the base of the petiole, the upper sessile and less divided; heads rather numerous, racemose or racemose-paniculate, short-peduncled, nodding, about $4 \mathrm{~mm}$. broad; involucre hemispheric, its bracts oblong, canescent or tomentose. On dry plains and in rocky soil, Minn. to the Yukon, Idaho, Neb., Tex. and N. Mex. July-Oct.

8. Artemisia Absínthium L. Common Wormwood. Absinth. (I. F. f. 4005.) Shrubby, finely crnescent; stem much branched, 6-12 dm. high. Leaves 5-12 cm. long, 1-3-pinnaiely divided, the lower long-petioled, the upper shortpetioled or sessile, the uppermost commonly linear and entire; heads numerous, yellow, racemose-paniculate, drooping, short peduncled, 4-5 $\mathrm{mm}$. broad; involucre hemispheric, its outer bracts linear, the inner much broader, scarious-margined; receptacle pilose-pubescent; central flowers fertile, the marginal ones fertile or sterile. In waste places, Newf. and Hudson Bay to Mass., western Ont., Mont. and N. C. Nat. or adventive from Europe. July-Oct.

9. Artemisia Abrótanum L. Solíthernwood. (I. F. f. 4006.) Perennial, somewhat shrubby; stem puberulent or glabrous, much branched, 6-12 dm. high, the bra.uches short, erect or ascending. Leaves glabrous or somewhat pubescent, I-7 cm. long, 1-3-pinnately parted into linear, obtuse, entire lobes alout $1 \mathrm{~mm}$. wide, or the uppermost linear and entire, the lowest petioled; heads severalflowered, yellow, very numerous, nodding, 4-5 mm. broad; involucre nearly hemis. pheric, pubescent, its outer bracts lanceolate, acute, the inner ones obovate. In waste places, Mass. to N. C., Ont., and Neb. Adventive from Europe.

Artemisia prócera Willd, a similar species, but with glabrous involucre, is stated by Dr. Gray to have escaped from gardens at Buffalo, N. Y.

ro. Artemisia ánnua L. AnNual Wormwood. (I. F. f. 4007.) Annual, glabrous throughout, much branched, 6-15 dm. high. Leaves $5^{-15} \mathrm{~cm}$. long; lobes very narrow, short, obtuse; lower and basal leaves slender-petioled, the upper sessile and less divided, but none of them entire; heads very numerous, drooping, borne on very slender peduncles of about their own length or less; involucre hemispheric, glabrous, its bracts few, ovate to oblong. In waste places Ont. to D. C., Tenn., Ark. and Kans.; a bad weed in some places. Adventive or nat. from Asia. Summer.

II. Artemisia biénnis Willd. Biennial Wormwood. (I. F. f. 4008.) Annual or biennial, glabrous throughout; stem very leafy, usually branched, $3^{-12}$ $\mathrm{dm}$. high, the branclies nearly erect. Leaves $2-8 \mathrm{~cm}$. long; lobes linear or linear. oblong, acutish, serrate or incised; lowest leaves petioled, the uppermost less divided or rarely quite entire; heads not drooping, sessile and exceedingly numerous ir axil. lary crowded glomerules; involucre nearly hemispheric, its bracts green, scarious. margined. Native in the N. W. Terr, and the northwestern U. S., now widely distributed as a weed from Manitoba to N. S., south to Kans., Ky. and Penn. Aug.-Oct.

12. Artemisia Stelleriàna Bess. Beach Wormwood. (I. F. f. 4009.) Perennial, densely white-tomentose; stem branched, 3-5 dm. high, bushy, the branches ascending. Leaves obovate to spatulate, $3-10 \mathrm{~cm}$. long: pinnatifid into oblong obtuse entire or few-toothed lobes, the lower petioled, the upper sessile, all densely tomentose beneath, but becoming green and glabrous above when old; heads not drooping; involucre oblong-campanulate, its bracts tomentose, lanceolate or oblong-lanceolate. Sandy sea-beaches, Me. and Mass. to N. J. Cultivated in gardens along the coast. Native of northeastern Asia. Occurs also on the coast of Sweden. July-Aug.

I3. Artemisia vulgàris L. Common Mugwort. (I. F. f. 4010.) Perennial: stem glabrous or nearly so, much branched, 3-10 dm. high. Leaves 3-12 cm. 
long, deeply pinnatifid, into linear, oblong or somewhat spatulate, pinnatifid, toothed or entire lobes, densely white-tomentose beneath, dark green and glabrous above, the lower petioled, the upper sessile, the uppermost sometimes linear and entire; heads numerous, erect, about $4 \mathrm{~mm}$. broad, in panicled simple or compound spikes; involucre oblong campanulate, its bracts oblong, obtusish, scarious-margined; tomentose or g'abrous. In waste places, N. S. to Ont., Mich., N. C. and Penn. Nat. from Eur pe. Native also of Asia. July-Oct.

14. Arte sisia Póntica L. Roman or Hungarian Wormwood. (I. F. f. 4011.) Per nnial; stem branched, glabrous or canescent, 3-10 dm. high. Leaves 3-6 cm. lo $x, 2-3$ pinnately dissected into short narrow lobes less than $2 \mathrm{~mm}$. wide, canescent un both sides, or tomentose beneath, the lower petioled and the petioles somewhat clasping or auricled at the base, the upper mostly linear and entire; heads numerous, 2-4 $\mathrm{mm}$. broad, drooping, slender-peduncled; involucre liemispheric, canescent, its bracts oblong or obovate, obtuse, the outer short, lanceolate. Railway embankment near Tumble Station, Hunterdon Co., N. J,; mountain-side near Lily Lake, Luzerne Co., Pa. Fugitive or adventive from central Europe. July-Aug.

I5. Artemisia Kansana Britton. Kansas Mugwort. (I. F. f. 4012.) Densely white-woolly all over; stem erect, much branched, the branches strict, bearing very numerous small heads forming a narrow dense panicle. Leaves numerous, crowded, the lower pinnately divided into 3-7 narrowly linear revolute. margined segments I $\mathrm{mm}$. wide or less, greenish above; upper leaves mostly narrowly linear and entire; heads oblong-oval, sessile, or very short-peduncled, erect, or somewhat spreading, $3 \mathrm{~mm}$. long; involucre very woolly, its bracts ovatelanceolate to oblong-lanceolate, acute. Plains, western Kans.

16. Artemisia serràta Nutt. SAW-LEAF Mugwort. (I. F. f. 4013.) Perennial; stem stout, tomentose or becoming glabrous, much branched, $1 \cdot 5-3 \mathrm{~m}$. high. Leaves lanceolate, 5-15 cm. long, 6-25 mm. wide, densely white-tomentose beneath, acuminate at the apex, narrowed to a sessile base, or the lowest petioled; heads very numerous, greenish, erect, about $3 \mathrm{~mm}$. broad, sessile or short-peduncled in panicled spikes or racemes; involucre canescent, its bracts oblong, obtuse, or the outer ones lanceolate. Prairies, Ill. to Minn. and S. Dak. Introduced on the Mohawk River, near Schenectady, N. Y. Aug.-Oct.

I7. Artemisia longifolia Nutt. Long-Leaved Mugwurt. (I. F. f. 40I4.) Perennial; stem densely white-tomentose, branched, 6-15 dm. high. Leaves linear or linear-lanceolate, 5-12 $\mathrm{cm}$. long, 2-10 $\mathrm{mm}$. wide, acuminate, tapering to a sessile base, or the lower petioled, densely white-tomentose on both sides, or becoming green and glabrate above; heads numerous, erect, spicate-paniculate; about $4 \mathrm{~mm}$. broad; involucre tomentose, its bracts oblong, obtuse. In dry rocky soil, western Neb. to Minn., Mont. and the N. W. Terr. Aug.-Sept.

18. Artemisia gnaphalòdes Nutt. Prairie, Western or Cud-weed Mugwort. (I. F. f. 40I5.) Perennial, similar to the preceding species; stem white-tomentose, usually much branched, 3-12 $\mathrm{dm}$. high. Leaves lanceolate or oblong, 3-7 cm. long, 4-12 mm. wide, entire, or the lower somewhat toothed, white-tomentose on both sides, acute or acuminate, sessile or the lower narrowed into short petioles; heads numerous, erect, spicate-paniculate, above $3 \mathrm{~mm}$. brcad, involucre oblong, tomentose. On prairies and ary banks, western Ont. and Ill. to Br. Col., south to Mo., Tex., Ariz., Mex. and Cal. Aug.-Oct.

19. Artemisia Ludoviciàna Nutt. Lobed Cud-Ween. Perennial, ascending or erect, lower than the preceding, 3-5 dm. high, branched; stem somewhat tomentose. Leaves oblanceolate or sumewhat cuneate in outline, $2-5 \mathrm{~cm}$. long, densely white-tomentose beneath, floccose but greener above, deeply 3-7-lobed with lanceolate lobes, or the upper entire; heads very small and numerous, somewhat nodäing; involucre oblong-campanulate, tomentose, but less so than in the preceding. Prairies and mountain-sides, Mo. to Col. Ang.-Oct.

20. Artemisia Bigelòvii A. Gray. Bigelow's SAGE-bUsh. (I. F. f. 40r6.) Perennial, shrubby, silvery-canescent throughout, 2-4 $\mathrm{dm}$. high, much branched, the branches erect. Leaves narrowly cuneate, or oblong, obtuse, truncate, or 3-5to thed at the apex, 10-18 mm. long, about $2 \mathrm{~mm}$. wide; heads very numerous, about $2 \mathrm{~mm}$. broad, densely glomerate-spicate in a narrow virgate panicle, 2-5flowered, 1 or 2 of the marginal ones pistillate, the others perfect and fertile; invo- 
lucre short-oblong, canescent or tomentose, its bracts oblong, obtuse. Kans. (ac. cording to Smyth), and Colo. to Ariz. Aug.-Oct.

2r. Artemisia tridentàta Nutt. Common SAge-bush. Sage-brush. SaGe-wood. Mountain Sage. (I. F. f. 40I7.) Shrubby, silvery-canescent; stem much branched, 3-35 dm. high. Leaves narrowly cuneate, I-4 cm. long, 2-6 mm. wide, sessile, 3-7-toothed at the truncate apex; heads very numerous, 5-8-flowered, about $3 \mathrm{~mm}$. broad, sessile, or very nearly so, in large dense panicles; involucre oblong, tomentose, its inner bracts oblong, the outer short, ovate, all obtuse or obtusish. On dry plains and in rocky soil, western Neb. to Colo., Utah and Cal., north to Mont. and Br. Col. July-Sept.

22. Artemisia càna Pursh. HoAry SAGe-Bush. (I. F. f. 40r8.) Shrubby, densely white-canescent; stem much branched, 3-7 dm. high. Leaves linear, linear-oblong or narrowly lanceolate, sessile, acute at both ends, 3-5 cm. long, 3-6 mm. wide, usually quite entire, rarely with 2 or 3 acute teeth or lobes; heads numerous, about $3 \mathrm{~mm}$. broad, glomerate or sometimes solitary in the axils of the leaves, or crowded into a naked thyrsus at the summit, 5-9 flowered; involucre oblong, canescent, its inner bracts oblong or lanceolate, obtuse, usually with I-3 shorter outer ones. Plains, Neb. and Colo. to N. Dak. and the N. W. Terr. JulySept.

\section{TUSSILÀGO L.}

An acaulescent herb, more or less white-tomentose, with slender perennial rootstocks, broad basal cordate, dentate or lobed, long-petioled leaves, and large soli. tary, monœcious heads of both tubular and radiate yellow flowers at the summit of a scaly scape, appearing before the leaves of the season. Involucre campanulate to cylindric, its principal bracts in a single series, equal, with or without a few shorter outer ones. Receptacle flat, naked. Ray-flowers in several series, pistillate, fertile. Disk-flowers perfect, sterile, the corolla 5-cleft, the style undi. vided and obtuse. Achenes of the ray-flowers linear, 5-10-ribbed. Pappus copious, of numerous slender roughish bristles, that of the sterile flowers shorter than that of the fertile. [Latin, tussis, cough, for which the plant was a reputed remedy.] A monotypic genus.

1. Tussilago Farfara L. Coltsfoot. Coughwort. (I. F. f. 40I9.) Scape slender, 7-45 cm. high, bearing a solitary large head at the summit. Leaves nearly orbicular, or broadly ovate-reniform, angulately lobed and dentate, 7-16 $\mathrm{cm}$. broad, green and glabrous above, persistently white-tomentose beneath; head about $25 \mathrm{~mm}$. broad; involucre campanulate: rays bright yellow, numerous, linear, pistillate, fertile. In moist soil, along roadsides, etc., N. S. and N. B. to Mass., N. Y. and Minn. Nat. from Europe. April-June.

\section{PETASİTES Gaertn.}

Herbs with perennial thick horizontal rootstocks, broad basal petioled leaves, and scaly scapes bearing racemose or corymbose heads of tubular or both tubular and radiate, white or purplish, often diœcious or subdiœcious flowers. Involucre campanulate to cylindric, its bracts in I series, equal. Receptacle flat, or nearly so, not chaffy. Corolla of pistillate flowers very slender, 2-5-toothed, truncate or sometimes with a ray, marginal, or composing most of the head; perfect but sterile flowers with a tubular 5-cleft corolla, the style undivided. Anthers entire or minutely sagittate at the base. Fertile achenes linear, the pappus of numerous capillary rough or barbellate bristles. [Greek, a broad-rimmed hat, referring to the broad leaves of these plants.] About 12 species, natives of the north temperate and subarctic zones.

Flowers whitish, the pistillate radiate; natives; northern.

Leaves orbicular, 7-1r-cleft nearly to the base.

Leaves hastate-reniform, sinuate-lobed or toothed.

Leaves deltoid-ovate, repand-denticulate.

Flowers all rayless, purple; introduced.

1. P. palmata.

2. $P$. frigida.

3. $P$. sagittata.

4. P. Petasites.

I. Petasites palmàta (Ait.) A. Gray. Palmate-leaf Sweet Coltsfoct. (I. F. f. 4020.) Scape very scaly, stout, 1.5-6 dm. high. Leaves 7-30 cm. broad, green and glabrous above, densely white-tomentose beneath, at least when young, 
sometimes becoming glabrate, the lobes oblong or obovate, acute, often somewhat cuneate, sharply dentate or incised; heads mostly diœcious, corymbose or racemose. corymbose, numerous, 7-12 mm. broad; flowers nearly white, fragrant. In swamps and along streams, Newf. to Alaska and Br. Col., south to Mass., N. Y., Wis. and Cal. April-June.

2. Petasites frígida (L.) Fries. Arctic Sweet Coltsfoot. (I. F. f. 402 I.) Scape very scaly, $7-30 \mathrm{~cm}$. high. Leaves $3-10 \mathrm{~cm}$. long, irregularly and angulately lobed and incised, green and glabrous above, persistently white-tomentose beneath, the lobes entire or few-toothed; heads usually fewer and larger than those of the preceding species; involucre short-campanulate; flowers nearly white, fragrant. Lake Winnipeg to the Arctic Sea, west to Alaska and the mountains of Br. Col. Also in northern Europe and Asia. June-Aug.

3. Petasites sagittàta (Pursh) A. Gray. ARrow-leaf Sweet Coltsfoot. (I. F. f. 4022.) Scape and racemose-corymbose inflorescence similar to those of the two preceding species. Leaves deltoid-ovate or reniform-ovate, persistently whitetomentose beneath, glabrous or rearly so above, $1-3 \mathrm{dm}$. long, their margins sinuate. denticulate, neither cleft nor lobed; involucre campanulate; flowers nearly white. In wet ground, Hudson Bay to Manitoba and Minn., Br. Col., S. Dak. and Colo. May-June.

4. Petasites Petasites (L.) Karst. Butter-Bur. Butterfly-dock. (I. F. f. 4023.). Scape very scaly, $15-45 \mathrm{~cm}$. high. Leaves orbicular or hastate-reniform, often $3 \mathrm{dm}$. broad when mature, rounded or pointed at the apex, repand. denticulate all around, persistently white-tomentose beneath, green and mostly glabrous above; heads 8-12 mm. broad, mostly diocious, in a dense raceme, the staminate ones smaller than the pistillate. In cultivated and waste ground, $\mathrm{Pa}$. Nat. from Europe. Native alsci Oa northern Asia. April.

\section{2. ÁRNICA L.}

Erect, simple or little branched herbs, with opposite leaves, or the upper rarely alternate, and large, long-peduncled heads of both tubular and radiate yellow flowers, or rays wanting in some species. Involucre turbinate or campanulate, its bracts in I or 2 series, narrow, nearly (yual. Receptacle flat, naked, fimbrillate or villous. Ray-flowers pistillate, fertile, the rays spreading, entire, or 2-3toothed. Disk-flowers perfect, fertile, the corolla 5-lobed, the style with slender branches. Anthers entire or minutely 2-auriculate at the base. Achenes linear, 5-Io-ribbed, more or less pubescent. Pappus a single series of rough or barbellate rigid slender bristles. [Derivation uncertain, perhaps from Ptarmica.] About 30 species, natives of the northern hemisphere. Resides the following, some 20 others occur in the western parts of North America.

Basal leaves ovate or oval, sessile; southern.

Basal leaves oblong, lanceolate, or cordate-ovate, petioled.

Basal leaves cordate-ovate.

Basal leaves not cordate, tapering to the peticle.

Stem-leaves 3-5 pairs, the upper somewhat snalier.

Stem-leaves $1-3$ pairs, the upper much smaller.

I. A. acaulis.

2. A. cordifolia.

3. A. lanceolata. 4. A. alpina.

I. Arnica acaùlis (Walt.) B.S.P. Leoparn's. BANE. (I. F. f. 4024.) Glandular-hirsute; stem 3-9 dm. high, bearing several slender.peduncled heads at the summit. Basal leaves tufted, ovate or oval, obtuse, narroved to a sessile base, denticulate or entire, 5-12 cm. long, 4-7 cm. wide; stem-leaves I-3 pairs, and some alternate, very small ones above; heads $25-35 \mathrm{~mm}$. broad; bracts of the involucre linear-lanceolate, acute or acutish; rays 12-15, commonly 3 toothed at the truncate apex; achenes pubescent when young, glabrous or nearly so when mature. In low woods, Del. and southern Penı. to Fla. April-May.

2. Arnica cordifolla Hook. HearT-Leaf Arnica. (I. F. $f$ 4025.) Hirsute, or pubescent; stem simple, or sparingly branched, 3-9 dm. ligh. Basal and lower leaves ovate to nearly orbicular, obtuse or acute, deeply cordate at the base, dentate, 3-7 cm. long, with slender sometimes margined petioles; stem.leaves $\mathrm{I}-3$ pairs, ovate to oblong, sessile or short-petioled, much smaller; heads $1-8,5-7 \mathrm{~cm}$. broad; bracts of the involucre acute or acuminate, $12-20 \mathrm{~mm}$. long; rays 12-16, 
toothed at the apex; achenes hirsute-pubescent, or glabrous at the base. Western Neb. to S. Dak., the N. W. Terr., Nev. and Br. Col. May-July.

2. Arnica lanceolata Nutt. Northern Arnica. (I. F. f. 4026.) Sparingly villous-pubescent; stem simple, or little branched, 3-7 dm. high, bearing I-6 heads at the summit. Leaves oblong or oblong-lanceolate, dentate or entıre, acute or obtuse, 5-12 cm. long, 6-18 $\mathrm{mm}$. wide, the lower and basal ones narrowed into petioles, the upper sessile, and usually somewhat connate by a broad or narrowed base, those of the stem 3-5 pairs, usually with some alternate small ones on the branches; heads $2-5 \mathrm{~cm}$. broad; bracts of the involucre acute; rays 10-15, 3-toothed: achenes hirsute-pubescent. Mountains of northern N. Y., N. H. and Me. to N. B., west to Lake Superior. June-Aug. It has been confused with the grayish pubescent $A$. Chamissonis of the west.

4. Arnica alpina (L.) Olin. Mountain Tobacco. Arctic Arnica. (I. F. f. 4027.) Similar to the preceding species, but smailer and more slender, 15-35 cm. high, villous or pubescent. Stem simple, usually bearing but a single head; leaves lanceolate, linear-oblong, or the lowest spatulate, thickish, entire or dentic ulate, 3-nerved, the basal ones petioled, those of the stem I-3 pairs, sessile or short-petioled, scarcely connate, the upper pair usually much smaller than the lower ones; heads about $5 \mathrm{~cm}$. broad; rays 10-15, toothed; achenes hirsute or glabrate. Labrador to Greenland and the Arctic Sea. Also in northern Europe. May-Sept.

\section{ERECHTITES Raf.}

Erect, usually branching herbs, with alternate leaves, and (in our species) rather large discoid many-flowered heads of whitish flowers, corymbose-paniculate at the ends of the stem and branches. Involucre cylindric, swollen at the base. its principal bracts in I series, linear, with or without some much smaller outer ones. Receptacle concave, naked. Marginal flowers in 2-several series, pistillate, fertile, their corollas filiform, the limb 2-4-toothed. Central flowers perfect, fertile; corolla narrowly tubular, the limb 4-5-toothed, the style-branches elongated, truncate or obtuse at the summit. Anthers obtuse and entire at the base. Achenes linearoblong, angled or striate. Pappus of copious caspillary soft smooth white bristles. [Ancient name of some groundsel.] About 12 species, natives of America and Australasia. The following is the only one known to occur in North America.

I. Erechtites hieracifòlia (L.) Raf. FIRE-WeEd. PILEwort. (I. F. f. 4028.) Annual, glabrous, or somewhat hirsute; stem striate, succulent, usually branched, 3-25 dm. high. Leaves thin, lanceolate or ovate-lanceolate, dentate and often deeply incised, 5-20 $\mathrm{cm}$. long, the upper sessile or auriculate-clasping, mostly acuminate, the lower usually narrowed into petioles; heads $12-20 \mathrm{~mm}$. long, about $6 \mathrm{~mm}$. in diameter, the involucre conspicuously swollen at the base before flowering, its bracts numerous, striate, green, with narrow scarious margins; pappus bright white. In woodlands, thickets and waste places, Newf. to Fla., west to the N. W. Terr., Neb., Kans. and La. Also in Mex. and S. Am. July-Sept.

\section{MESADÈNIA Raf.}

Tall perennial mostly glabrous herbs, with alternate petioled leaves and numerous, rather small, corymbose, discoid heads of white, yellowish or pinkish flowers, all tubular and perfect. Sap inilky (at least in some species). Involucre cylindric or nearly so, its principal bracts 5, in I series, equal, usually with a few short outer ones. Receptacle flat, not chaffy, with a fleshy projection in the center. Corollas with somewhat spreading 5 -cleft limbs, the lobes usually with a mid-nerve. Style-branches conic or obtuse at the apex. Achenes oblong, glabrous. Pappus of copious white scabrous bristles. [Greek, referring to the central projection of the receptacle.] About 12 species, natives of North and Central America. Besides the following, 4 others occur in the southern and southwestern U. S. 
1. Mesadenia renifórmis (Muhl.) Raf. Great Indian Plantain. Wild Collard. (I. F. f. 4029.) Glabrous; stem angled and grooved, I-3 m. high. Leaves green both sides, the basal and lower reniform, long-petioled, sometimes $6 \mathrm{dm}$. wide, the upper ovate or fan-shaped, mostly cuneate at the base, the uppermost small and oblong; heads numerous, mostly 5 -flowered, about $5 \mathrm{~mm}$. broad, in large compound corymbs: involucre $6-8 \mathrm{~mm}$. high. In woods, N. J. and Penn. to Minn., south to N. C. and Tenn. July-Sept. [Cacalia reniformis Muhl.]

2. Mesadenia atriplicifòlia (L.) Raf. Pale Indian Plantain. (I. F. f. 403o.) Stem terete, glabrous, glaucous, 9-18 dm. high. Leaves thin, the lower and basal ones slender-petioled, sometimes $15 \mathrm{~cm}$. wide, the upper reniform, fan-shaped, or triangular with a nearly truncate base, the uppermost commonly small, lanceolate or oblong and entire; heads very numerous, about $3 \mathrm{~mm}$. broad, in large loose compound corymbs; involucre $6-8 \mathrm{~mm}$. high. In woods, W. Ont. to Minn., south to Fla., Mo. and Kans. July-Sept. [Cacalia atriplicifolia L.]

3. Mesadenia tuberòsa (Nutt.) Britton. Tuberous Indian Planiain. (I. F. f. 403I.) Glabrous and green throughout; stem angled, stout, 6-18 dm. high. Leaves strongly 5-9-nerved, the lower and basal ones oval, ovate, or ovatelanceolate, obtuse or acutish, usually quite entire, but sometimes rapand, long petioled, narrowed at the base, or rarely subcordate, I-2 dm. long. $2-7 \mathrm{~cm}$. wide; upper leaves ovate to oblong or cuneate obovate, sessile or short-petioled, much smaller; heads very numerous in a compound corymb, mostly 5 -flowered, about $4 \mathrm{~mm}$. broad; involucre 6-8 mm. high. On wet prairies and in marshes, Ohio and W. Ont. to Minn., Ala., La., Ark. and Kans. June-Aug. [Cacalia tuberosa Nutt.]

\section{SYNÓSMA Raf.}

A perennial leafy herb, glabrous or very nearly so, with triangular or hastate, alternate leaves, the lower petioled, the upper sessile, and several or numerous, corymbose or corymbose-paniculate, discoid heads of white or pinkish flowers. Involucre nearly cylindric, its principal bracts I2-15, linear, acute, usually with some subulate outer ones. Receptacle flat, naked. Flowers perfect; corolla 5lobed. Style-branches not appendaged. Pappus of very numerous white soft capillary bristles. [Greek, perhaps signifying a fragrant composite.] A monotypic genus of eastern North America.

I. Synosma suavèolens (L.) Raf. Sweet-scented Indian Plantain. (I. F. f. 4032.) Glabrous or very nearly so throughout; stem striate, $\mathbf{I}-\mathbf{I . 5} \mathrm{m}$. high, leafy to the inflorescence. Leaves triangular-lanceolate or hastate, sharply and irregularly serrate, acuminate, $\mathbf{I}-2.5 \mathrm{dm}$. long, $5-15 \mathrm{~cm}$. wide at the base, the auricles sometimes with I or 2 lobes on the lower side; petioles margined, or those of the basal leaves naked and slender; uppermost leaves sometimes merely lanceolate and sessile; heads 4-6 $\mathrm{mm}$. broad in a usually large and compound corymb; involucre 8-12 mm. high. its principal bracts linear, acute; heads 20-30flowered. In woods, Conn. and N. J. to Ill. and Minn., south to Fla., W. Va. and Ky. Aug.-Oct. [Cacalia suaveolens L.]

\section{SENÈCIO L.}

Annual or perennial herbs (some tropical species shrubby or even arborescent), with alternate or basal leaves, and solitary corymbose or paniculate many-flowered heads, of both tubular and radiate, or only tubular flowers, in our species yellow. Involucre cylindric or campanulate, its principal bracts in I series, distinct, or united at the base, usually with some shorter outer ones. Receptacle flat or slightly convex, mostly naked, often honeycombed. Rays, when present, pistillate, fertile. Disk-flowers perfect, fertile, their corollas tubular, the limb 5-toothed or 5lobed. Anthers obtuse and entire at the base, or rarely slightly sagittate. Stylebranches of the disk-flowers usually recurving or spreading. Achenes terete, or those of the marginal flowers somewhat compressed, 5-10-ribbed, papillose, or canescent, at least after wetting, and then usually emitting a pair of spiral threads. Pappus of numerous slender or capillary, smooth or rough, mostly white bristles. [Latin, senex, an old man, referring to the hoary character of some species, or to the white pappus.] An inmense genus of probably at least rooo species, of very wide geographic distribution. In addition to the following, some 70 others occur 
in the southern and western parts of North America. Uur species known as Groundsel, Ragwort, or Squaw-weed.

* Heads conspicuously radiate (except in forms of Nos. 9, ro and $x 6$ ).

(a) Heads solitary or few, 12-25 $\mathrm{mm}$. high ; northern species.

Stout; leaves $\mathrm{I}-2 \mathrm{dm}$. long; heads 4-5 $\mathrm{cm}$. broad.

Low; leaves $3-5 \mathrm{~cm}$. long; heads $2-3 \mathrm{~cm}$. broad.

1. S: Pseudo-Arnica.

2. S. frigzdus.

(b) Heads several or numerous, corymbose, mostly smaller.

† At least the lowest leaves entire or dentate, not pinnatifid (or sometimes pinnatifid in Nos. 7 and 14 ).

$\ddagger$ None of the leaves cordate.

Heads 10-14 mm. higli; plants $3^{-1} 5 \mathrm{dm}$. tall; northwestern species.

Involucral bracts acuminate; leaves mostly entire. 3. S. iniegerrimus.

Bracts acute or obtuse, mostly black-tipped; leaves denticulate.

Heads 6-ro mm. high; plants $1.5-7 \mathrm{dm}$. tall.

4. S. atriapiculatus.

Leaves and stems persistently more or less tomentose or woolly.

Achenes glabrous.

Achenes hispidulous or glandular.

5. S. Purshianus.

Basal leaves long-pttioled, crenate-clentate or sometimes pinnatifid; plants tall.

Basal leaves crenate-dentate: eastern. $\quad 6 . S$. tomentosus.

Stem-leaves, and often also the basal, pinnatifid; western.

7. S. Plattensis.

Basal leaves short-petioled, much tufted, oval, few-toothed or entire; plant low.

Leaves glabrous or nearly so; sten often woolly, especially below.

Basal leaves obovate, spatulate, or oval; achenes giabrous.

Basal leaves obuvate or suborbicular, crenate or dentate; involucral bracts 4-5 mm. long.

9. S. obovatus.

Basal leaves ovate to oval; involucral bracts 6-1o mni. long.

Rays usuaily wanting, northern species. $\quad$ 10. S. discoideus.

Rays large and conspicuous.

Basal leaves oblong; achenes glabrous or hispidulous.

Heads few or several, 6-8 mm. high; basa! leaves $2-7 \mathrm{~cm}$. long.

Heads numerous, 4-5 $\mathrm{mm}$. higlı; basal leaves $7^{-15} \mathrm{~cm}$. long.

12. S. Balsamitae.

13. S. Sinallii.

Basal leaves linear-cuneate, entire or 3 -toothed at apex.

14. S. compactus.

+ + Basal leaves cordate or subcordate; plants mostly glabrous.

Basal leaves lanceolate or oblong-lanceolate.

Basal leaves orbicular or ovate-oval.

tt Leaves narrowly linear, entire.

15. S. Robbinsii.

16. S. aureus.

17. S. spartioides.

$t+\dagger$ Leaves all pinnatifid or coarsely sinuate-dentate; plants glabrous, or somewhat woolly when young.

Leaves sinuate-dentate, lanceolate; heads 8-Io mm. high. $\quad$ 19. S. palustris.

Leaves pinnatifid.

Segments narrowly linear, entire.

Segments not linear.

Leaves pinnately divided; segments dentate; heads $4-6 \mathrm{~mm}$. high.

Leaves 2-pinnatifid; heads $6 \mathrm{~mm}$. high ; introduced species.

20. S. lobatus.

21. S. Jacobaea.

* * Heads discoid, the rays none, or minute; introduced species.

Leaves pinnatifid; plants glabrous or puberulent; achenes canescent.

Heads 6-8 mur. high; involucre naked, or nearly so at the base.

Heads 8-12 mm. high; involucre with several short outer bracts.

22. S. syliaticus.

23. S. vulgaris.

Leaves pinnatifid; plant viscid-pubescent; achenes glabrous.

24. S. viscosus.

Basal leaves obovate, orbicular, or spatulate, merely dentate.

Nos. 9, 10 and 16.

I. Senecio Pseùdo-Árnica Less. SEA-BEACH Senecio. (I. F. f. 4033.) Perennial, somewhat fleshy: stem stout. mostly simple, very leafy, I.5-9 dm. high. I eaves oblong-obovate, or the lower spatulate, acute or obtuse at the apex, densely tomentose beneath, at least when young, repand-dentate or denticulate, narrowed to a sessile and partly clasping base. or the lowest into margined petioles; heads stuut-peduncled, nc: rly $=5 \mathrm{~mm}$. high; involucre broadly campanulate, its bracts 
lanceolate, acuminate, mostly tomentose, commonly with several subulate spread. ing ones at the base; rays 12-15, linear, conspicuous; disk-corollas 5 lobed; achenes glabrous; pappus dull. On sea-beaches and rocks near the sea, Me., N. B. and the lower St. Lawrence to Lab. and the Arctic Sea. Also in Alaska and northern Asia. July-Aug.

2. Senecio frígidus Less. Arcric Senecio. (I. F. f. 4034.) Perennial, more or less tomentose, or becoming glabrous when old; stem slender, 1.5-3 dm. high, bearing a solıtary head rarely 2 or 3 ). Basal and lower leaves spatulate or obovate, petioled, obtuse, repand-dentate or entire; stem-leaves oblong to linearlanceolate, obtuse or acute, sessile, mostly entire, smaller; involucre broadly cam. panulate, its bracts lanceolate, acute, with no exterior smaller ones; rays I0-16, 12-20 mm. long, 3-toothed, linear-oblong, or cuneate at the base; achenes glabrous or sparingly pubescent. Lab. and arctic Am. to Alaska. Also in northeastern Asia. Suminer.

3. Senecio integérrimus Nutt. Entire-Leaved GroundSEl. (I. F. f. 4035.) Perennial, more or less woolly when young, glabrous or nearly so when old. Leaves entire, or sparingly denticulate, somewhat fleshy, the lower and basal ones oval or oblong, obtuse or obtusish at the apex, 7-15 cm. long, 2-4 cm. wide, petioled, the upper linear or lanceolate, acute, the uppermost very small; heads numerous, corymbose, long-peduncled, $12-20 \mathrm{~mm}$. broad; involucre nearly cylindric, its principal bracts linear, green, usually with a few subulate outer ones; rays 8-12, linear-oblong; achenes nearly glabrous. Minn. and Manitoba to Wyo. and $\mathrm{Br}$. Col. June-July.

4. Senecio atriapiculàtus Rydb. Black-TIPPEd Groundsel. (I. F. f. 4036 as $S$. lugens.) Similar to the preceding species, more or less woolly when young, soon glabrous; stem stout, 3-9 $\mathrm{dm}$. high. Basal and lower leaves oblong, oval, or slightly spatulate, obtuse or acute, denticulate or dentate, 5-12 cm. long, 3-4 $\mathrm{cm}$. wide, narrowed into margined petioles; upper leaves few, sessile, snall and bract-like; heads several or numerous, corymbose, often short-peduncled, 12-20 $\mathrm{mm}$. broad; involucre campanulate, its bracts lanceolate or oblong-lanceolate; rays Io 12, ob!ong-linear; achenes glabrous. In moist soil, the N. W. Terr. to Minn., Iowa and Neb., west to Br. Col. and Cal. Juı.e-Aug. This has been confused with the smaller arctic $S$. lugens Richardson.

5. Senecio Purshianus Nutt. Pursh's Groundsel. (I. F. f. 4037 as $S$. camis.) Perennial, densely and persistently white-tomentose to the inflorescence; stems slender, usually tufted, I-2 dm. higl. Basal and lower leaves spatulate or oval, entire, very obtuse, 3-6 cm. long, narrowed into petioles; upper leaves oblong or spatulate, obtuse or acute, mostly sessile. smaller, entire; heads severál or numerous, 10-15 mm. broad, usually slender-peduncled; involucre campanulate, or at first short-cylindric, about $8 \mathrm{~mm}$. high, its bracts linear-lanceolate, acute sparingly tomentose, or glabrate, usually with no exterior smaller ones; rays 8-12; achenes glabrous, at least below. In clry soil, Manitoba to Minn. and Neb., west to Br. Col. and Utah. May-Aug. It has been confused with the larger S. canus of the Rockies.

6. Senecio tomentòsus Michx. Woolly Ragweed. Ashwort. (I. F. f. 4038.) Perennial, more or less densely and persister.tly tomentose or woolly-canes. cent; stems rather stout, solitary, or sometimes tufted, 3-7 dm. high. Basal and lower leaves ovate-lanceolate, oblong or rarely spatulate, erect, very obtuse, 5-15 $\mathrm{cm}$. long, $\mathrm{I}-5 \mathrm{~cm}$. wide, narrowed or truncate at the base; stem-leaves few and distant, small, linear-lanceolate or spatulate, crenate or rarely laciniate; heads mostly long-peduncled, $16-20 \mathrm{~mm}$. broad; involucre cylindric, or narrowly campanulate, its bracts linear-lanceolate, acute or acuminate, at length glabrate; rays IO-15; achenes hispidulous, at least on the angles. In moist soil, southern N. J. to Fla., west to La. April-June.

7. Senecio Platténsis Nutt. Prairie Ragwort. (I. F. f. 4039.) Perennial; similar to the preceding species, usually smaller-leaved, lower and less tomentose, or becoming glabrate in age, seldom over $4 \mathrm{dm}$. high. Basal leaves oval, ovate or oblong, some or all of them more or less pinnatifid, with the terminal segment much larger than the lateral ones, crenulate $\mathrm{c}_{\mathrm{s}}$ - dentate, long petioled; heads several or numerous, compactly or loosely corymbose, conspicuously radiate. IIl. to S. Dak., Wyo., Colo. and Ind. Terr. April-June. 
8. Senecio antennariifòlius Britton. CAT'S-PAw RAGwort. (I. F. f. 4040.) Perennial, tufted in mostly large clumps; stems slender, 2-4.5 dm. high, loosely white-woolly. Leaves nearly all basal, commonly numerous, oval to spatulate, angulately few-toothed or entire, mostly obtuse, narrowed into a petiole as long as the blade or longer, densely white-tomentose beneath, green and finally glabrous above, 2-4 cm. long; stem-leaves small, spatulate, laciniate, or the upper narrowly linear and entire; heads slender-peduncled, rather less than $25 \mathrm{~mm}$. broad; rays golden yellow, showy; involucre $6 \mathrm{~mm}$. high, white-woolly; achenes glandular-pubescent. White Sulphur Springs, W. Va., on a loose slate hillside; Blue Ridge, Va.

9. Senecio obovàtus Muhl. Round-Leaf Squaw-weed. (I. F. f. 404I.) Perennial; stems commonly several from the same root, glabrous, or a little woolly at the base, 2-6 dm. high. Leaves rather thick, the basal ones very obtuse and rounded at the apex, $2-7 \mathrm{~cm}$. long, $\mathbf{1 - 2 . 5} \mathrm{mm}$. wide, often purplish; usually with short, margined petioles, or the earliest sessile; stem-leaves coinmonly few and sessile, spatulate to oblong, often incised or pinnatifid; headr several, corymbose, $12-16 \mathrm{~mm}$. broad, about $6 \mathrm{~mm}$. high, slender-peduncled; inv 'ucre nearly cylindric, its principal bracts linear-lanceolate, 4-6 mm. long, acute; rays 8-12, usually conspicuous. In moist soil and on banks, N. S. to Fla., west to Ont., Mich., Ky. and Mo. April-June.

Senecio obovatus elongatus (Pursh) Britton. Stem slender, weak ; leaves, or some of them, with tufts of wool in their axils; heads few, rayless or short-rayed, often longpeduncled. On moist shaded banks, eastern Penn.

Senecio obovatus rotúndus Britton. Basal leaves orbicular, broadly oval, or ovateorbicular, rather abruptly narrowed into the petiole, the larger $6-7 \mathrm{~cm}$. broad. On wet banks, or rocks, Ky. to Mlo. and the Ind. Terr.

ro. Senecio discòideus (Hook) Britton. Northern Squaw-weed. (I. F. f. 4042.) Perennial, glabrous except for small tufts of wool in the axils of the lower leaves; stem rather stout, 3-6 dm. tall; basal leaves oval to ovate, obtuse, thin, sharply dentate, abruptly narrowed into petioles longer than the blade; stemleaves few, small, more or less laciniate; heads few or several, slender-peduncled, corymbose; bracts of the involucre narrowly linear, 6-10 $\mathrm{mm}$. long; rays usually very short, or none. In moist places, Mich. to the N. W. Terr. and Alaska. June-Aug.

II. Senecio Cráwfordii Britton. Crawford's Squaw-weed. Perennial, with slender thread-like roots, glabrous, or with sparse woolly pubescence below. Stem slender, about $4 \mathrm{dm}$. high; leaves thick, firm, the basal ones erect, the larger 2-2.5 dm. long, the blades oval, oblong, or some of them narrowly obovate, mostly not more than one-half as long as the slender petioles, sharply and nearly equally serrate from the apex to the entire cuneate base, or the lower teeth somewhat larger than the upper; stem-leaves lanceolate or narrower, mostly acuminate, incised-serrate, clasping, the upper sessile, the lower petioled, the uppermost very small; heads 3-7; peduncles I.5-10 cm. long, slender, bracted, rarely forked; involucre 7-9 $\mathrm{mm}$. high, its bracts linear-lanceolate, acuminate, I-I.5 mm. wide, shorter than the white barbellate pappus; rays 8-ro $\mathrm{mm}$. long; achenes linear, striate, $2.5 \mathrm{~mm}$. long, $0.5 \mathrm{~mm}$. thick. Tullytown, $\mathrm{Pa}$.

12. Senecio Balsámitae Muhl. Balsam Groundsel.

(I. F. f. 4043.) Perennial, often tufted; stems slender, 2.5-5 dm. high, woolly at the base and in the axils of the lower leaves. Basal leaves slender-petioled, very obtuse, narrowed at the base, mostly thick, crenate, often purplish, 3-7 cm. long, 6-12 $\mathrm{mm}$. wide, their petioles and sometimes their lower surfaces persistently tomentose or woolly, or glabrous throughout; lower stem-leaves petioled, laciniate or pinnatifid, the upper sessile, very small; heads few or several, slender-peduncled, 12-20 $\mathrm{mm}$. broad; rays 8-12. In dry or rocky soil, N. S. to N. Car., west to Wash., Br. Col., Tex. and Neb. May-July.

Senecio Balsamitae paupérculus (Michx.) Fernald. Lower; heads few, sometimes only one. Me. to Lab. Apparently merely a reduced form of the type.

Senecio Balsamitae praelongus Greenman. Tall ; lower leaves long-petioled, 1.5-6 $\mathrm{cm}$. long, ro-12 mm. broad; stem-leaves large, sometimes $2 \mathrm{~cm}$. wide, deeply pinnatifid with usually rounded lobes; achenes hispidulous. Vt. and Mont. to N. Y. and Penn. 
13. Senecio Smàllii Britton. Smalz's Squaw-weed. (I. F. f. 4044.) Similar to the preceding species but taller, growing in large clumps. Stem 4-7 dm. high, slender, densely and persistently floccose-woolly at the base and in the lower axils, or finally glabrate; basal leaves elongated-oblong or linear-oblong, obtuse or acute, long-petioled, crenate-dentate, at first tomentose, at length nearly glabrous; stem-leaves several, deeply pimnatifid, or the lower lyrate; heads very numerous, 8-10 $\mathrm{mm}$. broad, slender-peduncledl, forming large corymbs; rays 8-10. In meadows and thickets, Va. andN. Car. to Ga. and Ala. May-June.

14. Senecio compáctus (A. Gray) Rydb. Western SQuaw-weed. (I. F. f. 4045.) Perennial; stem usually tufted, low, rather stout, $15-30 \mathrm{~cm}$. high, woolly at the base and in the lower axils, or glabrous. Basal leaves linear( cuneate, entire, or 3-toothed at the apex, $2-7 \mathrm{~cm}$. long, 4-6 mm. wide, thick, slender-petioled, the petioles com...only woolly-margined; lower stem leaves often much larger and broader, usually laciniate or pinnatifid, but sometimes similar to the basal, the uppermost very sinall and sessile; heads several, $\mathbf{r} 6-20 \mathrm{~mm}$. broad, short-peduncled in a compact corymb; rays 10-15; achenes hispidulous. On dry plains, Neb. and Colo. to Tex. May-June.

15. Senecio Robbínsii Oakes. Robbins' Squaw-wred. (I. F. f. 4046) Perennial, glabrous or very nearly so throughout; stems slender, 3-7 dm. high. Basal leaves long-petioled, lanceolate, obtuse or acute at the apex, cordate, subcordate or truncate at the base, usually thin, 5-10 $\mathrm{cm}$. long, I-4 cm. wide, sharply dentate; heads several or numerous, slender-peduncled in an open corymb; I6-二o $\mathrm{mm}$. broad; rays 6-12; achenes glabrous. In swamps and mountain meadows, northern N. H., Me., Vt. and N. Y., and on the summit of Roan Mountain, N. Car. June-Sept.

I6. Senecio aùreus L. Golden Ragwort. Life-root. Swamp Squaw. WEED. (I. F. f. 4047.) Perennial, glabrous or very nearly so throughout; stems rather slender, solitary or tufted, 3-7 dm. high. Basal leaves cordate-ovate, cordate-orbicular or reniform, crenate-dentate, very obtuse and rounded, often purplish, 2-15 cm. long, with long slender petioles; lower stem-leaves lanceolate or oblong, usually laciniate, pinnatifid or lyrate, somewhat auriculate and clasping; heads several, 16-20 mm. broad, 8-10 mm. high, slender-peduncled in an open corymb; rays 8-I2, golden yellow; achenes glabrous. In swamps and wet meadows, Newf. to Fla., west to Ont., Mo. and Tex. May-July.

Senecio aùreus pauciflorus (Pursh) Britton. Glabrous or with a little wool in the axils of the lower leaves; stem rather stcut, $15-30 \mathrm{~cm}$. high; basal leaves ovate to orbicular, about $1 \mathrm{~cm}$. broad, cordate or subcordate at the base, crenate; stem-leaves few, pinnatifid; heads I-IO, short-peduncled, rather large, apparently always rayless; bracts very narrow, acuminate, tinged with purple. Newf. to the Canadian Rocky Mts. and Wyo.

Senecio aùreus grácilis (Pursh) Britton. Stem slender, 3-6 dm. high, the lowest axils sometimes woolly. Basal leaves smaller than those of the type, cordate or subcordate; heads numerous, rather small; rays conspicuous. In wet soil, R. I. to Mich., S. Dak., Va. and Mo.

17. Senecio spartioides Torr. \& Gray. Linear-Leaved Senecio. Like the next in habit, but slender from a woody base, glabrous; leaves entire, narrowly linear, 5-10 $\mathrm{cm}$. long, I-3 $\mathrm{mm}$. wide; heads numerous; involucre about $1 \mathrm{~cm}$. high, 6-8 $\mathrm{mm}$. broad, almost cylindraceous; rays about 7 , golden yellow. Dry plains, Neb. to Wyo., south to Tex. and Ariz. July-Sept. [S. Douglasii A. Gray in part.]

18. Senecio Fremòntii (T. \& G.) Rydb. Narrow-lobed Senecio. (I. F. f. 4048 as $S$. Douglasii.) Woody at the base, usually branched, sometimes shrubby, glabrous or nearly so, leafy, 3-18 $\mathrm{dm}$. high. Leaves sessile, or the lowest petioled, thick, 3-7 cm. long, pinnately parted into 3-9 linear or filiform entire segments, or the upper entire; heads corymbose at the ends of the branches, $1-2 \mathrm{~cm}$. broad, slender-peduncled; involucre cylindric or becoming campanulate, ro- $15 \mathrm{~mm}$. high, its bracts linear, acute or acuminate, usually with some subulate exterior ones; rays 8-15, achenes canescent. Plains, in dry soil, Neb. to Tex. and Mex. JuneSept. [S. filifolius var. Fremiontii, T. \& G.; S. Riddellii T. \& G.; S. Douglasii A. Gray, in part.]

19. Senecio palústris (L.) Hook. Marsh Fleawort. Pale Ragwort. MARSH GroundSEL. (I. F. f. 4049.) Annual or biennial, pubescent or glabrate; 
stem hollow, 15-60 cm. high. Leaves lanceolate, oblong or spatulate, entire, dentate, or laciniate, acute or obtuse, 5-18 cm. long, 6-30 $\mathrm{mm}$. wide, or the upper linear-lanceolate and small, those of the stem sessile and somewhat auriculateclasping, the basal petioled; heads numerous, $12-25 \mathrm{~mm}$. broad, mostly shortpeduncled in a large, rather dense, terminal corymb; involucre cylindric, becoming campanulate, 6-8 mm. high, its bracts linear, acute, more or less pubescent, with no shorter outer ones; rays 15-20, pale yellow; achenes glabrous; pappus white, elongated, at length twice the length of the involucre. In swamps, lowa and Wis. to Manitoba and arctic Am., west to Alaska. Reported from Lab. Also in Greenland, northern Europe and Asia. June-Aug.

20. Senecio lobàtus Pers. Butter weed. Cress-leaved Groundsel. (I. F. f. 4O50.) Annual, glabrous throughout, or slightly woolly when young, fleshy and tender; stem hollow, simple or branched, 3-9 dm. high. Leaves $5-25 \mathrm{~cm}$. long, the segments orbicular, oblong, obovate or cuneate, obtuse, sinuate-dentate, entire or lobed, the terminal segment usually larger than the others; lower and basal leaves slender-petioled; heads numerous, $14-20 \mathrm{~mm}$. broad, slender-peduncled in terminal corymbs; involucre nearly cylindric, $5 \mathrm{~mm}$. high, its bracts linear, acute, usually with no smaller outer ones; rays 6-12; achenes minutely hispidulous on some of the angles. In swamps, Mo. and southern Ill. to N. Car., N. Mex., Mex. and Fla. April-Sept.

21. Senecio Jacobaèa L. Tansy Ragwort. Staggerwort. (I. F. f. 405I.) Perennial by short thick rootstocks, somewhat woolly, or glabrous; stems stout, simple, or branched above, 6-12 dm. high, very leafy. Leaves 5-20 $\mathrm{cm}$. long, the lower petioled, the upper sessile, the lobes oblong-cuneate, dentate or incised; heads very numerous, $12-16 \mathrm{~mm}$. broad, short-peduncled in large compact corymbs; involucre narrowly campanulate, about $5 \mathrm{~mm}$. high, its bracts linearlanceolate, acute, green, or tipped with black; rays 12-15; achenes of the diskflowers pubescent, those of the rays glabrous. In waste places, N. S., N. B. and Ont., and in ballast about N. Y. and Philadelphia. Adventive from Europe. July-Sept.

22. Senecio sylváticus L. Wood Groundsel. (I. F. f. 4052.) Annual; stem usually much branched, 3-7 dm. high, leafy. Leaves oblong or lanceolate in outline, the segments oblong or spatulate, obtuse, dentate, lobed or entire, or the uppermost leaves linear and merely dentate; heads several or numerous in the cory mbs, slender-peduncled, about $4 \mathrm{~mm}$. broad; involucre usually swollen at the base; rays none, or very short and recurved; achenes canescent. In waste places, N. S. and Pr. Edw. Isl. to Me. Also on the coasts of Cal. and Br. Col. Nat. or adventive from Europe. April-Sept.

23. Senecio vulgàris L. Common Groundsel. (I. F. f. 4053.) Annual; stem hollow, usually much branched, 1.5-3.5 dm. high. Leaves 5-15 cm. long, the lower spatulate in outline, petioled, obtuse, the upper sessile or clasping at the base, more deeply lobed or incised, their segments oblong, dentate; heads several or numerous in the cory mbs, nearly $6 \mathrm{~mm}$. broad; bracts of the involucre linear, often blackish-tipped; rays none; achenes slightly canescent. In cultivated ground and waste places, Newf. and Hudson Bay to Va., west to Mich. and S. Dak. Also on the Pacific Coast. Nat. from Europe. April-Oct.

24. Senecio viscòsus L. Fetid or Viscous Groundsel. (I. F. f. 4054.) Annual, strong-scented; stem usually much branched, 3-6 dm. higl.. Leaves 1-2pinnatifid, 4-7 cm. long, oblong or somewhat spatulate in outline, the segments oblong or cuneate, dentate or incised; lower leaves petioled; heads few in the cory mbs, 6-8 mm. broad, mostly slender-peduncled; involucre nearly cylindric, 8-10 $\mathrm{mm}$. high, its bracts linear, acute, usually with I-3 shorter outer ones; rays commonly about 20, very short, recurved and inconspicuous; pappus about one-third longer than the involucre. In waste places and on ballast near the coast, N. B. to N. Car. July-Sept.

\section{7. ÀRCTIUM I.}

Large coarse branching, rough or canescent, mostly biennial herbs, with broad alternate petioled leaves, and rather large heads of purple or white perfect tubular flowers, racemose, corymbose or paniculate at the ends of the branches. Involucre subglobose, its bracts rigid, lanceolate, tipped with spreading or erect hooked bristles, 
imbricated in many series. Receptacle flat, densely bristly. Corollas tubular with 5-cleft limbs. Filaments glabrous. Anthers sagittate at the base. Achenes oblong, somewhat compressed and 3-angled, ribbed, truncate. Pappus of numerous short serrulate scales. [Greek, bear, from the rough involucre.] About 6 species, natives of Europe and Asia.

Bracts densely cottony ; heads corymbose.

Bracts of the involucre glabrous, or slightly woolly.

I. A. tomentosum.

Involucre $25 \mathrm{~mm}$. broad or more; inner bracts equalling or exceeding the flowers.

Involucre $12-20 \mathrm{~mm}$. broad; inner bracts not exceeding the flowers.

2. A. Lappa.

3. A. minus.

I. Arctium tomentòsum (Lam.) Schk. Wooli.y OR CoTtTony Burdock. (I. F. f. 4055.) Similar to the following species. Heads $16-20 \mathrm{~mm}$. broad, cory mbose at the ends of the branches, mostly long-peduncled; bracts of the involucre densely cottony, the inner ones erect and somewhat shorter than the flowers. In waste places, N. B. to Mass. and southern N. Y. Adventive from Europe. JulyAug.

2. Arctium Láppa L. Great Bur, Burdock, or Clotbur. (I. F. f. 4056.) Stem much branched, 12-27 din. high. Leaves thin, broadly ovate, pale and tomentose-canescent beneath, obtuse, entire, repand or dentate, mostly cordate, the lower often $4.5 \mathrm{dm}$. long; petioles solid, deeply furrowed; heads clustered or subcorymbose, sometimes long-peduncled, 3-4 cm. broad; bracts of the involucre glabrous or nearly so, their spines all spreading; corolla-tube longer than the limb. In waste places, N. B. and Ont. to southern N. Y., and locally in the interior. Nat. from Europe. July-Oct.

3. Arctium minus Schk. Common Burdock. (I. F. f. 4057) Smaller than the preceding species, seldom over $\mathbf{I}_{5} \mathrm{dm}$. high. Leaves similar, the lower deeply cordate; petioles hollow, not deeply furrowed; heads numerous, racemose on the branches, short-peduncled or sessile; bracts of the involucre glabrous or slightly cottony, the spines of the outer ones spreading, those of the inner erect and shorter than the flowers; corolla-tule about as long as the limb. In waste places, common throughout our area. Nat. from Europe. July-Nov.

\section{CÀRDUUS L.}

Erect, branched or simple, prickly herbs, some species acaulescent, with alternate or basal, sinuate-dentate lobed or pinnatifid, usually very spiny leaves, sometimes decurrent, and large many-flowered, solitary or clustered, discoid heads of purple, yellow or white, tubular, perfect and fertile, or rarely diœcious flowers. Involucre ovoid or globose, its bracts prickle-tipped or unarmed, imbricated in many series. Receptacle flat or convex, bristly. Corolla tube slender, the limb deeply 5-cleft. Filaments pilose, or rarely glabrous. Anthers sagittate at the base. Style-branches short or elongated, obtuse. Achenes obovate or oblong, compressed or obtusely 4-angled, glabrous, smooth or ribbed. Pappus of several series of slender, plumose, minutely serrulate, or simple bristles, connate at the base. [The ancient Latin name of these plants.] About 250 species, widely distributed in the northern hemisphere. Besides the following, some 35 others occur in the southern and western parts of N. Am.

- Pappus-bristles, at least those of the inner flowers, plumose. (Plumed Thistles.)

† Outer involucral bracts, or all of them, strongly prickly-pointed.

1. Leaves glabrous or hispid above, tomentose beneath (tomentose on both sides in No. 3).

All the bracts of the involucre tipped with prickles; naturalized weed.

I. C. lanceolatus.

Outer bracts prickle-tipped, the inner merely acuminate; native species.

Branches leafy up to the heads; involucral bracts firm or rigid.

Leaves undivided, lobed or dentate, rarely pinnatifid.

Leaves deeply pinnatifid into lanceolate or linear segments.

Leaves tomentose on both sides, strongly spiny ; stem white-tomentose.

Leaves glabrate above, weakly spiny; stem green, glabrous.

2. C. altissimus.

3. C. Flodmanii.

4. C. discolor.

Heads naked-peduncled, $25 \mathrm{~mm}$. high; involucral bracts thin.

5. C. Virginianus. 
2. Leaves tomentose on oth sides, or becoming glabrous above; western.

Leaves pinnately parted; segments linear, entire or lobed.

6. C. Pitcheri.

Leaves pinnatifid into triangular or lanceolate dentate segments.

Outer bracts with spines less than one-half their length.

Leaf-lobes triangular; flowers pink or purple.

Leaf-lobes linear-lanceolate to oblong; flowers cream-color.

Outer bracts with spines of nearly or quite their length. Leaves entire or undulate; outer pappus-bristles barbellate.

3. Leaves green both sides, somewhat pubescent beneath.

Leaf-lobes acute; bracts of the involucre faintly nerved.

Leaf-lobes blunt; bracts with a prominent glutinous midnerve.

$t+$ Bracts of theinvolucre not at all prickly-pointed, or s

7. C. undulatus.

8. C. Plattensis.

9. C. ochrocentrus.

ro. C. Nebraskensis.

Ir. C. odoratus.

12. C. Hillii.

Heads large, few, 3-ro $\mathrm{cm}$. broad; flowers all perfect and fertile.

Heads involucrate by the upper very spiny leaves; flowers usually yellow.

Heads peduncled, naked, or with $\mathbf{I}$ or 2 bracts at the base; flowers purple.

13. C. spinosissimus.

14. C. muticus.

Heads small, numerous, $2.5 \mathrm{~cm}$. broad or less; flowers imperfect, diœecious.

15. C. arvensis.

* * Pappus-bristles simple, or minutely serrulate.

Head solitary, nodding; bracts of the involucre lanceolate.

Heads clustered, erect or ascending; bracts linear

(Plumeless Thistles.)

16. C. nutans.

17. C. crispus.

I. Carduus lanceolàtus L. Common BUR or Spear Thistle. (I. F. f. 4058.) Biennial; stem stout, branched, more or less tomentose, I-1.5 m. high, leafy to the heads. Leaves dark green, lanceolate, acuminate, deeply pinnatifid, 7-15 cm. long, or the lowest larger, decurrent on the stem and branches, the lobes triangular-lanceolate, tipped with stout prickles, the margins and decurrent bases bristly, the lower surface brown-tomentose and midnerve pilose especially when young; heads mostly solitary at the ends of the branches, $4-5 \mathrm{~cm}$. broad, 4-5 cm. high; bracts of the involucre cottony, narrowly lanceolate, acuminate; flowers dark purple. In fields and waste places, Newf. to Ga., west to Minn., Neb. and Kans. Nat. from Europe. Natíve also of Asia.

2. Carduus altissimus L. TAll or RoAdside Thistle. (I. F. f. 4059.) Biennial or perennial; roots often thickened; stem pubescent, or tomentose, stout, branched, leafy to the heads, I-3 m. high. Leaves ovate-oblong or oblong-lanceolate, sessile, or slightly clasping, sparingly pubescent above, densely white-tomentose beneath, scarcely or not at all decurrent, acute, spinulose-margined, entire, dentate with bristle-pointed teeth or lobed, sometimes pinnatifid, the lowest sometimes $2 \mathrm{dm}$. long, narrowed into margined petioles, the uppermost linear or lanceolate, much smaller; heads about $5 \mathrm{~cm}$. broad, 4-5 cm. high, mostly solitary at the ends of the branches; outer bracts of the involucre ovate or ovate-lanceolate, firm, with a dark, slightly glandular spot at the apex, tipped with short prickles; flowers light purple. In fields and thickets, Mass. to S. Dak., Fla., Neb. and Tex. Aug.-Sept.

3. Carduus Flódmanii Rydb. Flodman's Thistle. Stem rather slender, .5-I m. high, more or less white cottony. Leaves deeply divided into linear-oblong or lanceolate, acute segments. floccose but green above, white-tomentose beneath; head campanulate, 3-4 $\mathrm{cm}$. broad; bracts like those of the preceding but narrower; flowers rose or reddish purple. In river-bottoms and meadows, Neb. to Mont. and Wyo. July-Sept.

4. Carduus discolor (Muhl.) Nutt, Field Thistle. (I. F. f. 406o.) Similar to Carduus altissimus. but lower and more leafy, seldom over $2 \mathrm{~m}$. high. Leaves deeply pinnatifid into linear, linear-lanceolate, or falcate, prickly-toothed segments, white-tomentose beneath, sessile, the basal ones sometimes $3 \mathrm{dm}$. long; heads 4-5 cm. broad, about $4 \mathrm{~cm}$. high, usually involucrate by the upper leaves, mostly solitary at the ends of the branches; outer bracts of the involucre coriaceous, ovate, slightly woolly, tipped with slender bristles, which are longer than those of C. altissimus; flowers light purple or pink, rarely white. In fields and along roadsides, Quelec and Ont. to Ga., S. Dak., Neb. and Mo. July-Nov.

5. Carduus Virginiànus L. Virginia Thistle. (I. F. f. 4061.) Biennial; stem slender, naked or scaly above, pubescent or somewhat tomentose, simple or branched, 6-12 dm. high. Leaves oblong, oblong-lanceolate, or the lowest slightly 
spatulate, sessile, or somewhat clasping, not decurrent, spinulose-margined, entire, lobed or pinnatifid into triangular-lanceolate lobes, the lower sometimes $2 \mathrm{dm}$. long and $5 \mathrm{~cm}$. wide, narrowed into margined petioles, all pubescent or glabrate above, and densely white-tomentose beneath; heads long peduncled; outer bracts of the involucre not coriaceous, lanceolate or ovate-lanceolate, tipped with weak short bristles; flowers purple. In dry woods and thickets, Va. to Ky., Ohio, Fla. and Tex. April-Sept.

6. Carduus Fítcheri (Torr.) Porter. Pitcher's Thistle. (I. F. f. 4062.) Biennial, persistently white-tomentose throughout; stem stout, leafy up to the heads, usually branched, 3-6 dm. high. Leaves sessile, partly clasping, or slightly decurrent, with sparingly prickly segments $4-6 \mathrm{~mm}$. wide, with revolute margins; basal leaves often $3 \mathrm{dm}$. long; heads solitary or several and racemose-spicate at the ends of the branches, about $4 \mathrm{~cm}$. broad; outer bracts of the involucre ovatelanceolate, sparingly pubescent and tomentose-ciliate, glutinous on the back, tipped with short spreading bristles, the inner narrowly lanceolate, acuminate or sometimes tipped with weak prickles; flowers cream color. Shores of Lakes Michigan, Huron and Superior. June-Aug.

7. Carduus undulàtus Nutt. Wavy-Leaved Thistle. (I. F. f. 4063.) Biennial, persistently and densely white-tomentose throughout, or the upper surfaces of the leaves at length green and glabrous; stem stout, leafy, usually branched, 3-10 dm. high. Leaves lanceolate or oblong-lanceolate in outline, acute, sessile or decurrent, or the lowest petioled, undulate, lobed or pinnatifid; heads about $5 \mathrm{~cm}$. broad, and nearly as high, solitary at the ends of the branches; outer bracts of the involucre ovate or ovate-lanceolate, firm, glutinous on the back, tipped with short spreading prickles, the inner ones lanceolate, acuminate. On plains and prairies, Lake Huron to the N. W. Terr. and Br. Col., south to Kans., N. Mex. and Ore. June-Sept.

Carduus undulatus megacéphalus (A. Gray) Porter. Heads larger than in the type, 5-7 dm. broad. Minn. to Idaho and Ariz.

8. Carduus Platténsis Rydb. Prairie Thistle. (I. F. f. 4064.) Perennial or biennial, the root thick and deep. Stem stout, simple, or little branched, 4-7 dm. tall, densely white-felted. Leaves deeply pinnatifid, whitetomentose beneath, green, loosely tomentose, or glabrate above, the lower 12-17 $\mathrm{cm}$. long, the lobes lanceolate to oblong, acute, prickly tipped and margined; heads $\mathrm{few}$, about $5 \mathrm{~cm}$. high and broad: outer bracts of the involucre lanceolate to ovate-lanceolate, firm, dark, tipped with short weak spreading prickles, the inner linear-lanceolate, unarmed, tipped with scarious reflexed erose appendages; pappus of outer flowers merely barbellate. Sand hills, Neb. and S. Dak. May-July.

9. Carduus ochrocéntrus (A. Gray) Gireene. Yellow-SPined Thistle. (I. F. f. 4065.) Similar to Carduus undulatus, but commonly taller and more leafy, often $2 \mathrm{~m}$. high, equally white-tomentose. Lcaves oblong-lanceolate in outline, usually very deeply pinnatifid into triangular-lanceolate, serrate or entire segments, armed with numerous long yellow prickles; lower leaves often 15-20 $\mathrm{cm}$. long; heads about $5 \mathrm{~cm}$. broad, $4-5 \mathrm{~cm}$. high, solitary at the ends of the branches; outer bracts of the involucre lanceolate, tipped with stout yellow prickles of nearly or quite their own length, the inner narrowly lanceolate, long-acuminate; flowers purple (rarely white?). On plains, Neb. to Tex., Nev, and Ariz. May-Sept.

10. Carduus Nebraskénsis Britton. Nebraska Thistle. (I. F. f. 4066.) Stem densely white-woolly. apparently over $3 \mathrm{dm}$. high. Leaves linear-oblong to lanceolate, white-woolly beneath, green and sparingly loosely woolly above, irregularly slightly toothed or entire, the upper 7-15 cm. long, 5-25 mm. wide, the margins prickly; heads solitary, or few. short-peduncled, about $4 \mathrm{~cm}$. high; outer bracts of the involucre lanceolate, prickle-tipped, the inner narrower, with reflexed acute scarious appendages; pappus-bristles of inner flowers plumose, of the outer barbellate. Scott's Bluff, western Neb. and Wyo. July-Aug.

II. Carduus odoràtus (Muhl.) Porter. Pasture Thistre. Fragrant Thistle. (I. F. f. 4067.) Biennial, more or less villous-pubescent; stem stout, simple or branched, leafy, 3-10 dm. high. Roots thick, branched, solid; stemleaves sessile and clasping, oblong or oblong-lanceolate in outline, acute, $7-17 \mathrm{~cm}$. 
long, 3-5 cm. wide, pinnatifid into triangular acute dentate prickly lobes; basal leaves petioled; heads solitary, terminal, $5-7 \mathrm{~cm}$. broad, about $5 \mathrm{~cm}$. high, often involucrate by the upper leaves; outer bracts lanceolate or ovate-lanceolate, with a slight glutinous strip on the back, glabrous or sparingly tomentose, tipped with slender prickles, the inner narrow, long-acuminate; flowers purple, rarely white, fragrant. In fields, Me. to Penn. and Del. July-Sept.

12. Carduus Hillii (Canby) Porter. Hill's Thistle. (I. F. f. 4068.) Biennial (?), low, villous-pubescent or somewhat woolly; stem leafy, simple or branched, 3-6 dm. high. Root perpendicular, fusiform, slender and hollow atove, enlarged below, $2.3 \mathrm{dm}$. long; leaf-lobes dentate, spinulose or with some rather stout prickles, upper leaves oblong, sessile and clasping, the lower spatulate-oblong, narrowed at the base or the lower petioled and $5 \mathrm{~cm}$. long; heads $1.5^{-2} \mathrm{dm}$. broad, 5-7 cm. high; outer bracts of the involucre ovate-lanceolate, tipped with short bristles, the inner narrowly lanceolate, long-acuminate; flowers purple. In fields, western Ont. to Minn., south to Penn., Ill. and Iowa. June-July.

13. Carduus spinosíssimus Walt. Yellow Thistie. (I. F. f. 4069.) Biennial or perennial, somewhat woolly when young, but becoming glabrate; stem branched, leafy, 6-10 dm. high. Leaves green both sides, lanceolate or oblong in outline, sessile and clasping or the basal ones short-petioled and somewhat spatulate, pinnatifid into triangular or broader spinulose-margined and prickle-tipped, entire or dentate lobes; heads 5-10 $\mathrm{cm}$. broad, 4-6 cm. high; bracts of the involucre narrowly lanceolate, roughish and ciliate. long-acuminate; flowers yellowish, or occasionally purple. In moist or dry sandy soil, Me. to Penn., Fla. and Tex. May-Aug., or earlier in the South.

I4. Carduus mùticus (Michx.) Pers. Swamp Thistle. (I. F. f. 4070.) Biennial; stem woolly or villous when young, becoming glabrate, slender, striate, leafy, paniculately branched above, $1-2.5 \mathrm{~m}$. high. Leaves densely white-tomentose beneath when young, sometimes becoming glabrous on both sides, deeply pinnatifid into lanceolate or oblong, entire, lobed or dentate, spiny segments usually tipped with slender prickles; basal leaves petioled, $1-2 \mathrm{dm}$. long, those of the stem sessile and smaller; heads about $4 \mathrm{~cm}$. broad and high; outer bracts viscid, appressed, more or less cottony, ovate or ovate-lanceolate, the inner linear-lanceolate, acute, all unarmed. In swamps and moist soil, Newf. to Fla., N. W. Terr. and Tex. July-Oct.

Carduus mùticus subpinnatifidus Britton. Leaves lobed, not deeply pinnatifid, green, and nearly glabrous on both sides. N. J. to W. Va.

I5. Carduus arvénsis (L.) Robs. Canada Thistle. Creeping Thistle. (I. F. f. 407 r.) Perennial by horizontal rootstocks, forming patches, nearly glabrous; stems striate, 3 -10 dm. high, branched above. Leaves sessile and slightly clasping, lanceolate or oblong-lanceolate deeply pinnatifid into very prickly, lobed or dentate segments; basal leaves somerimes petioled, $12-20 \mathrm{~cm}$. long; heads numerous, corymbose, purple or white; staminate heads globose, corollas projecting; pistillate heads oblong-campanulate, corollas shorter, the long pappus conspicuous; outer bracts ovate or ovate-lanceolate, appressed, tipped with short prickly points; inner bracts of the pistillate heads linear, elongated. In fields and waste places, Newf. to Va., S. Dak., Mont. and Kans. In many places a pernicious weed. Nat. from Europe. June-Sep.

16. Carduus nutans L. Musk Thistre. Plumeless Thistle. (I. F. f. 4072.) Biennial, branched, sparingly tomentose, 6-9 dm. high. Leaves lanceolate in outline, deeply pinnatifid, acuminate, 7-15 $\mathrm{dm}$. long, the lobes triangular, very prickly; heads long-peduncled, $4-6 \mathrm{~cm}$. broad, purple, rarely white, fragrant; bracts of the involucre in many series, long-acuminate, the prominent midnerve prolonged into a prickle, or the inner nerveless and awned; pappus-bristles 20-25 mm. long. In waste places, Penn. and N. J. to N. B., and in ballast about the seaports. Nat. or adventive from Europe. Native also of Asia. July-Oct.

I7. Carduus críspus L. Curled Thistle. Welted Thistle. (I. F. f. 4073.) Biennial, somewhat tomentose; stem much branched, densely prickly, 6-1 $2 \mathrm{dm}$. high. Leaves lanceolate in outline, with undulate and ciliate-spiny margins, all sinuate-pinnatifid into broad, 3 lobed, toothed segments, the teeth pricklepointed; heads several, usually crowded at the ends of the winged branches, $25 \mathrm{~mm}$. 
broad or less, purple or white, sessile or short-peduncled, or some of them rarely solitary and slender-peduncled: bracts of the involucre very numerous, linear, the outer prickle-tipped and rigid, the inner thinner and merely acuminate. In waste places, N. B. and N. S., and in ballast about the seaports. Adventive from Europe. Native also of Asia. July-Sept.

\section{MARIÁNA Hill.}

Annual or biennial, simple or branched, nearly glabrous herbs, with large alternate clasping, sinuate-lobed or pinnatifid, white-blotched leaves, and large discoid heads of purple tubular flowers, solitary at the end of the stem or branches. Involucre broad, subglobose, its bracts rigid, imbricated in many series, the lower ones fimbriate-spinulose at the broad triangular summit, the middle ones similar but armed with huge spreading or recurved spines. the inner lanceolate, acuminate. Receptacle flat, densely bristly. Corolla-tube slender, the limb expanded and deeply 5-cleft. Filaments monadelphous below, glabrous. Anthers sagittate at the base. Style nearly entire. Achenes ubovate-oblong, compressed, glabrous, surmounted by a papillose ring. Pappus-bristles in several series, flattish, barbellate or scabrous. A monotypic genus of the Mediterranean region.

I. Mariana Mariàna (L.) Hill. MiLk Thistle. (I. F. f. 4074.) Stem striate, glabrous or slightly woolly, little branched, 6-12 dm. high. Leaves oblunglanceolate, prickly, strongly clasping, the lower often $3 \mathrm{dm}$. long and $15 \mathrm{~cm}$. wide, the upper much smaller, scarcely lobed, acute; heads about $6 \mathrm{~cm}$. broad; spines of the middle involucral bracts often $4 \mathrm{~cm}$. long; pappus bristles white, barbellate. Escaped from gardens near Kingston, Ontario; in ballast about the eastern seaports, and on the Pacific Coast from Br. Col. to southern Cal., where it is naturalized. June-Aug. [Silybum Marianum Gaertn.]

\section{I0O. ONOPÓRDON L.}

Coarse, branching, or rarely acaulescent, tomentose herbs, with stout stems winged by the decurrent bases of the alternate dentate or pinnatifid, prickly leaves, and large discoid heads of purple, violet or white flowers, mostly solitary at the ends of the branches. Involucre nearly globular, its bracts imbricated in many series, all tipped with long spines in our species, the inner narrower than the outer. Receptacle flat, fleshy, honeycombed, not bristly. Corolla-tube slender, the limb expanded and deeply 5-cleft. Filaments pilose. Anthers sagittate at the base. Achenes obovate or oblong, 4-angled or compressed, smooth or corrugated. Pappusbristles in several series, filiform, barbellate or plumose, united at the base. [Greek, Asses' Thistle, the ancient name.] About 12 species, natives of the Old World.

I. Onopordon Acánthium L. Cotton Thistle. Scotch Thistle. (I. F. f. 4075.) Biennial, white-tomentose all over; stem usually much branched, leafy, I-3 m. high. Leaves oblong, lobed and dentate, acute, very spiny, the lower often $3 \mathrm{dm}$. long; heads $4-5 \mathrm{~cm}$. broad, about $4 \mathrm{~cm}$. high, solitary at the ends of the branches; outer bracts of the involucre ovate or oblong, minutely serrulate, tipped with long, stout, spreading spines; flowers pale purple; achenes slightly corrugated; pappus-bristles brownish, longer than the achene. In waste places, N. S. and Ont. to N. J. and Mich. Nat. from Europe. Native also of Asia. JulySept.

\section{ror. CENTAURÈA L.}

Perennial or annual herbs, with alternate entire, dentate, incised or pinnatifid leaves, and large or middle-sized heads of tubular purple-violet, white or rarely yellow flowers. Involucre ovoid or globose, its bracts imbricated in many series, appressed, fimbrillate, or dentate. Receptacle flat, densely bristiy. Marginal flowers usually neutral and larger than the central ores, which are perfect and fertile, or flowers all perfect and fertile in some species. Corolla tube slender, the limb regular or oblique, 5-cleft or 5-lobed, the segments sometimes appearing like rays. Anthers sagittate at the base. Style-branches short, somewhat connate, ob. tuse. Achenes ohlong or obovoid, compressed or obtusely 4-angled, usually smoth and shining, obliquely or laterally attached to the receptacle, surmounted by a disk with an elevated margin. Pappus of several series of bristes or scales, rarely 
none. [Greek, of the Centaurs, who -ere said to use it in healing.] About 350 species, mostly natives of the Old World. Besides the following, 2 others, introduced species, occur on the Pacific Coast, and are rarely found in ballast about the eastern seaports.

Bracts of the involucre lacerate or fimbriate, not spiny.

Heads $4 \mathrm{~cm}$. broad or less; achenes laterally attached; introduced species.

Annual; pappus about the length of the achene.

Perennials ; pappus obsolete, or short.

Flowers all perfect; marginal ones scarcely enlarged.

Marginal flowers neutral, with palmately cleft corollas.
Heads 5-10 cm. broad; acheues obliquely attached: native western

x. C. Cyanus.

2. C. nigra.

3. C. Jacea.

Heads 5-10 cm. broad; achenes obliquely attached; native western species.

Bracts of the involucre tipped with stout, nearly simple spines.

4. C. Americana.

5. C. Calcitratia.

I. Centaurea Cyanus L. Blue-bottle. Corn Blue-bottle. Corn. Flower. (I. F. f. 4076.) Annual, woolly or tomentose, at least when young; stem leafy, slender, branched, 3-7 dm. high, the branches ascending. Leaves linear or linear-lanceokate, mucronate, $7-15 \mathrm{~cm}$. long, the basal and lower ones mostly dentate or pinnatifid, the upper or sometimes all of them, entire; heads on long naked peduncles; involucre campanulate, its bracts greenish yellow or with darker tips and margins, appressed; flowers blue or purplish, varying to white, the marginal ones neutral with large radiant corolla-limbs; achenes slightly compressed, or 4angled; pappus bristles unequal, nearly as long as the achene. In waste places, escaped from gardens, and in ballast, Quebec to N. Y., Va., S. Dak. and Kans. July-Sept.

2. Centaurea nigra L. Black KNapweed. Horse-knops. Hardheads. Centaury. (I. F. f. 4077.) Perennial, scabrous or pubescent; stem stiff, branched, 3-6 dm. high. Lower and basal leaves spatulate or oblong, acutish, entire denticulate, dentate or lobed, not pinnatifid, 7-15 cm. long, narrowed into long petioles; upper leaves oblong or lanceolate, sessile, or partly clasping, entire or nearly so; heads rarely $2.5 \mathrm{~cm}$. broad, bracted by the small, uppermost leaves; involucre globose, its bracts lanceolate, or ovate-lanceolate, closely imbricated, tipped with brown fimbriate appendages, or the uppermost merely lacerate; flowers rose-purple; achenes slightly 4-sided; pappus none, or a ring of minute scales. In waste places and fields, Newf. to Ont. and N. J. Nat. from Europe. July-Sept.

3. Centaurea Jàcea I. Brown or RAyed KNapweed. (I. F. f. 4078.) Perennial, similar to the preceding species. Leaves entire or denticulate, rarely lobed; heads $2.5-4 \mathrm{~cm}$. broad; involucre globular to ovoid, its bracts closely im. bricated, brown or with brown bracts, tle outer oncs with fimbriate appendages, the middle ones lacerate, the inner entire or nearly so; achenes obscurely 4-sided; pappus none, or a minute crown. In waste places, N. Y. to Conn. and Vt. and in ballast about eastern seaports. Also in Br. Col. Fugitive from Europe. JuneSept.

4. Centaurea Americàna Nutt. American Star Thistle. (I. F. f. 4079.) Annual, roughish; stem stout, simple, or little branched, 6-18 dm. high. Leaves entire or denticulate, the lower and basal ones spatulate or oblong, 5-12 cm. long, narrowed into petioles, the upper oblong-lanceolate, sessile, mucronate; heads solitary at the ends of the leafy stem or branches: involucre nearly hemispheric, its bracts ovate or lanceolate with conspicuously pectinate appendages; flowers pink or purple, the marginal ones with enlarged and radiant corolla-limbs; achenes somewhat compressed: pappus of copious unequal bristles longer than the achene. Dry plains, Mo. and Arr. to La., Mex. and Ariz. May-Aug.

5. Centaurea Calcítrapa L. Star Thistre. (I. F. f. 408o.) Annual, pubescent or glabrous, green; stem much branched, 3-4 dm. high. Leaves I-2pinnatifid into oblong-lanceolate to linear, serrulate-pinulose, dentate or entire mostly acute lobes, the upper sessile and slightly clasping, the lower and basal short-petioled, I-2 dm. long, the uppermost somewhat involucrate at the bases of the sessile heads, which are about $25 \mathrm{~mm}$. broad; involucre ovoid, its outer bracts ovate-oblong, spiny; flowers purple, none of them radiant; achenes compressed or obscurely 4 -sided; pappus none. In waste places and ballast, Mass. to N. Y., N. J. and Va. Also in Br. Col. Adventive or nat. from Europe. June-Oct. 


\section{2. crilcus L.}

An annual herb, with alternate pinnatifid or sinuate-dentate leaves, the lobes or teeth spiny, and large sessile heads of yellow tubular flowers, solitary at the ends of the branches, subtended by the upper leaves. Bracts of the involucre im. bricated in several series, the outer ovate, the inner lanceolate, tipped by long pin. nately branched spines. Receptacle flat, bristly. Achenes terete, striate, laterally attached, the horny margin ro-toothed at the summit; pappus of 2 series of awns, the inner fimbriate, the outer longer, naked; anther-appendages elongated, united to their tips. [Latin name of Safflower, early applied to thistles.] A monotypic genus of the Old World.

I. Cnicus benedíctus L. Blessed Thistle. Our Lady's Thistle. (I. F. f. 408I.) Hirsute or pubescent, much branched, seldom over $7 \mathrm{dm}$. high. Leaves oblong-lanceolate in outline, rather thin, reticulate-veined, 7-15 cm. long, the upper clasping, the basal and lower ones narrowed at the base and petioled; heads about $25 \mathrm{~mm}$. broad, subtended by several large lanceolate to ovate-lanceolate leaves: bristles of the receptacle soft, long; outer awns of the pappus alternating with the inner. In waste places, N. S. to Md, Penn. and Ala. and on the Pacific Coast. Adventive from southern Europe. Mav-Aug. 


\title{
ANALYTICAL KEY TO THE GENERA OF THE COMPOSITAE.*
}

\author{
(AMBROSIACEAE, CICHORIACEAE, CARDUACEAE.)
}

PREPARED BY

DR. KARL M. WIEGAND.

$A$ Flowers of the head all ligulate.

PAGE

$b$ Pappus of scales, or of scales and bristles, or none.

$c$ Flowers, blue or white..................................

cc Flowers yellow.

$d$ Pappus of scales, often with bristles also.

$e$ Achenes truncate, $15-20$-ribbed; involucre in $\mathrm{I}-2$ series.

$e e$ Achenes contracted into a beak, ro-ribbed; involucre in $2-4$ series.

$d d$ Pappus none.

Lapsana $89 \mathrm{r}$

$e$ Achenes $20-30$-nerved. ...............
$e$ e Achenes 8-ro-nerved or ribbed.

f Scapose plants ...............................noseris

if Leafy-stemmed plants............................ Serinia

$b b$ Pappus of bristles.

$c$ Bristles plumose, at least some of them.

d Receptacle chaffy........................... Hypochaeris

$d d$ Receptacle not chaffy.

$e$ Leaves linear, grass-like, cauline.................. Tragopogon

ee Leaves not grass-like; plants often scapose.

f Flowers pink or purple......................... Ptiloria

if Flowers yellow.

g Plants scapose............................. Leontodon

gg Plants leafy-stemmed.............................

cc Bristles simple.

$d$ Achenes with spiny processes near the summit.

$e$ Stem branching, leafy; heads small.................Chondrilla

ee Stem scapose; heads large, solitary................. Taraxacum

$d d$ Achenes smooth or merely papillose.

$e$ Achenes flattened.

$f$ Achenes truncate at the summit..................... Sonchus

if Achenes narrowed into a beak or neck .................. Lactuca

$e e$ Achenes not distinctly flattened.

f Flowers white, cream-colored, or purple.

$g$ Leaves mostly linear or scale-like, often nearly wanting . Lygodesmia 899 gg Leaves broad, ovate to triangular or oblong.Nabalus (Prenanthes) 906 if Flowers yellow, orange, or flame-red.

$g$ Achenes truncate or merely narrowed at the summit.

$h$ Pappus bright white.

* The names in parentheses are those used in Gray's Manual for the corresponding genera, wholly or in part. 
$i$ Pappus in 2 series, the inner coherent at the base and deciduous

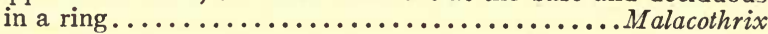

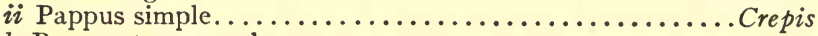

hh Pappus tawny or brown.

$i$ Involucre narrowly cylindrical, few-flowered; bracts ro or fewer. Nabalus (Prenanthes)

ii Involucre campanulate, many-flowered; bracts more than ro.

gg Achenes slender-beaked.

Hieracium

$h$ Pappus-bristles surrounded by a villous white ring at the base.

$h h$ Pappus naked at the base.

Sitilias (Pyrrhopappus)

906

$i$ Pappus entirely of bristles...............................

ii Pappus of both scales and bristles........ Nothocalais (Troximon)

\section{$A A$ Flowers of the head all, or all but the marginal, not ligulate.}

$b$ INVOLUCRE OF PISTILLATE FLOWERS CLOSED AND WOODY; FLOWERS GREENISH; MONECIOUS; HEADS UNISEXUAL. ..................... Family AMBRosIACEAE $c$ Involucral bracts of the staminate heads separate; pistillate heads forming an oblong bur............................. cc Involucral bracts of the staminate heads united.

d Pistillate involucres naked or with a single series of tubercles or prickles. . .............................mbrosia $d d$ Pistillate involucres with numerous prickles in several series.

Gacrtneria

$b b$ INVOLUCRE NOT CLOSED AND WOODY..Family COMPOSITAE $c$ HeAdS DISCOID.

$d$ Pappus composed of awns.

$e$ Involucral bracts with pinnate spines; inner pappus awns fimbriate.

ee Involucral bracts naked; pappus awns not fimbriate.

$f$ Bracts of the involucre distinct or nearly so............. Bidens rooo

If Bracts of the inner involucre united to the middle...Thelesperma 1003 $d d$ Pappus composed of scales.

$e$ Involucral bracts hooked at the tip Arctium 1029 $e e$ Involucral bracts naked.

$f$ Receptacle chaffy. . Marshallia 1005

If Receptacle not chaffy.

$g$ Heads white or yellow.

gg Heads pink or purple.

$h$ Aquatic herbs.

$h h$ Terrestrial herbs.

$i$ Heads glomerate, the glomerules also with an involucre.

ii Heads separate, not glomerate.

Elephantopus

$j$ Pappus scales awned at tip; leaves mostly basal....Gaillardia IoI r

ji Pappus scales rounded or retuse; leaves cauline.... Polypteris 1007 $d d d$ Pappus none or a mere crown.

$e$ Corolla large, deeply-lobed; flowers pink, purple, or white, showy.

ee Corolla small, dentate; flowers yellow or yellowish white.

Centaurea 1034

$f$ Receptacle chaffy.

$g$ White-woolly herbs.....

gg Puberulent or scabrous merbs.

Filago (Evax)

$h$ Heads 8- $5 \mathrm{~mm}$. broad; leaves very large, $\mathrm{I}-3 \mathrm{dm}$. broad, deltoidovate, irregularly lobed. .....................Polymnia

hh Heads 2-6 $\mathrm{mm}$. broad; leaves linear, ovate, or spatulate..Iva 
$g$ Receptacle conic.

$g g$ Receptacle flat or convex.

$h$ Heads corymbose; pappus a short crown.

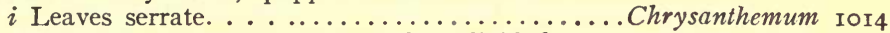

ii Leaves $\mathrm{r}-3$-pinnately dissected or divided.........Tanacetum ror6

$h h$ Heads paniculate-racemose or spicate; pappus none.

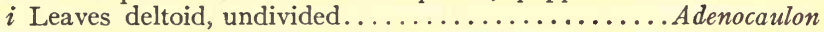

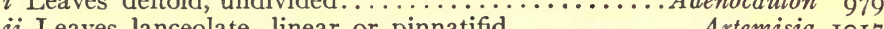
dddd Pappus capillary.

$e$ Receptacle chaffy; white-woolly herbs. ee Receptacle not chaffy, sometimes bristly.

$f$ Involucral bracts white-scarious, in several series; white-woolly herbs.

$g$ Basal leaves larger than, and differing from, the cauline; diœcious

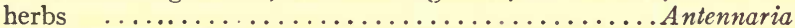

gg Basal leaves nearly similar to the cauiline or wanting.

$h$ Involucre papery-white, spreading; plants diœcious.... Anaphalis

$h h$ Involucre appressed, yellow, whitish, purple, or brown; plants not diœcious.

$i$ Heads narrow, 5-7-flowered; bright yellow; corolla large. Chrysothamnus (Bigelovia)

ii Heads broader, many-flowered, not bright yellow; corollas small. Gnaphalium

If Involucral bracts not scarious, or only at the tip, or if entirely so IOI 7

plant not white-woolly.

$g$ Flowers yellow or yellowish-cream color.

$h$ Involucral bracts in one series, often with minute ones at the base.

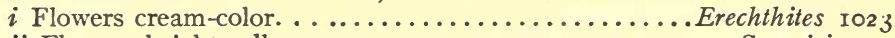

ii Flowers bright yellow.................................. 1024

$h h$ Involucral bracts imbricated in several series.

$i$ Leaves spiny or spinulose-dentate.

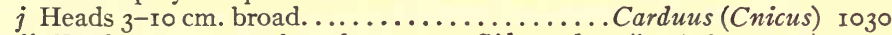

jj Heads r 2-30 mm. broad.......... Sideranthus (in Aplopappus) $93^{2}$

ii Leaves not spiny.

$j$ Shrubby at least at the base.

$k$ Diøecious; glabrous or glutinous........................

$k k$ Flowers perfect; plants white-woolly when young.

ji Herbaceous.

Chrysothamnus (in Bigelovia)

$k$ Involucre glutinous; eastern.......Chöndrophora (in Bigelovia)

$k k$ Involucre not glutinous; western.......Oonopsis (in Bigelovia)

gg Flowers purple, violet, or white.

$h$ Involucral bracts in I series, often with minute bracts at the base.

$i$ Climbing plants................Willugbaeya (Mikania)

ii Not climbing.

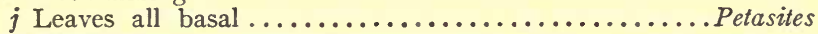

ji Leaves cauline.

$k$ Leaves lanceolate or ovate-lanceolate, tapering gradually toward

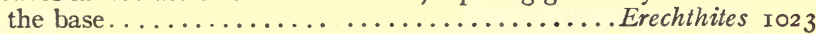

$k k$ Leaves oval, reniform or hastate-lanceolate.

$\zeta$ Involucre of about 5 bracts............Mesadenia (in Cacalia) 1023

ll Involucre of about 12 bracts ............Synosma (in Cacalia) I024

hh Involucral bracts in 2-many series.

$i$ Foliage spiny.

$j$ Receptacle densely bristly.

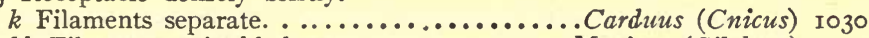

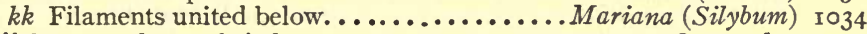

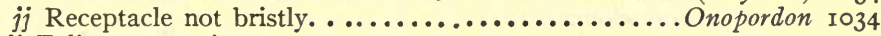

ii Foliage not spiny.

j Shrubby plants; diœcious...............................

ij Herbs; not diœcious. 
$k$ Receptacle densely brist $;$; corolla deeply lobed; involucral bracts fimbriate or den ate. .................... entaurea

$k k$ Receptacle naked; corolla dentate.

$l$ Bracts of involucre in 2 series, outer shorter; leaves large; heads in involucrate glomerules. ................ Elephantopus

$l l$ Bracts in $2-3$-series, all nearly equal.

$m$ Flowers $4-30$ in the head.

$n$ Achenes ro-ribbed.

Trilisa

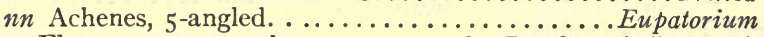

$\mathrm{mm}$ Flowers 50-100; achenes 2-3-nerved.. Brachyactis (in Aster)

IIl Bracts of involucre in several series, outer shorter.

$m$ Involucral bracts strongly striate-nerved; heads paniculate or corymbose.

n Pappus-bristles rough or serrate; involucral bracts numerous. Coleosanthus (Brickellit)

nn Pappus-bristles plumose; involucral bracts few..Kuhnia

$m m$ Involucral bracts faintly if at all striate.

$n$ Heads spiked or racemose...........Lacinaria (Liatris)

$n n$ Heads corymbose.

o Anthers tailed at the base.............................

oo Anthers not tailed.

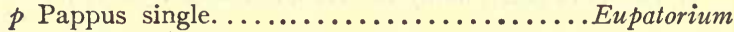

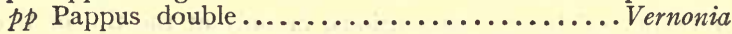

$c c$ HEADS WITH RAY AND DISK-FLOWERS.

$d$ Pappus composed of awns; rays yellow, white, or purple.

$e$ Receptacle not chaffy.

$f$ Heads 6 mm. broad...........................

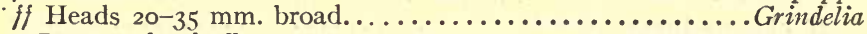

ee Receptacle chaffy.

$f$ Involucral bracts of 2 distinct sorts.

$\delta$ Bracts all separate or nearly so......................

$\mathrm{g} g$ Bracts of the inner series united to about the middle. Thelesperma 1003

ff Involucral bracts of one sort, the outer merely shorter.

$g$ Receptacle convex or low-conical...................... gg Receptacle narrow-conical or cylindrical.

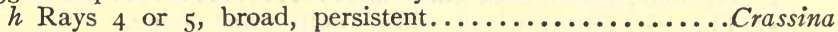

hh Rays 8-12, deciduous..........................................

dd Pappus composed of scales.

$e$ Receptacle chaffy.

$f$ Rays white or nearly so, pistillate.

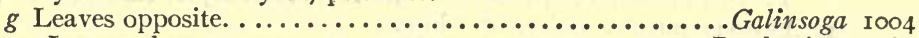

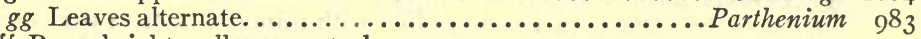

if Rays bright yellow, neutral.

$g$ Involucral bracts of 2 distinct sorts....................

$g g$ Involucral bracts of I sort, the outer merely shorter.

$h$ Leaves punctate, spatulate-linear. ...Actinospermum (Baldwinia) 1004

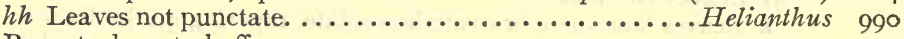

ee Receptacle not chaffy.

$f$ Rays purple, violet, or white.

$g$ Rays nearly entire, elliptical.

gg Rays cuneate, 3 -lobed, or cleft.

Boltonia 945

$h$ Involucral bracts petal-like, colored, scarious at the tip. .Polypteris 1007

$h h$ Involucral bracts not as above.................. Gaillardia Iо I

ff Rays yellow.

$g$ Plants dotted with oil-glands, especially the leaves and involucres.

$h$ Involucral bracts more or less united; style-branches of the diskflowers elongated.

$i$ Bracts united only at the base................ebera (Dysodia) Ior 2

ii Bracts united high up into a cup............. Thymophylla IOI2 
hh Involucral bracts separate; style-branches of the disk-flowers very short. ..............................

gg Plants not dotted with oil-glands.

$h$ Rays rounded and nearly or quite entire at the apex.

$i$ Perennial herbs or shrubs; disk-flowers all or nearly all fertile.

ii Annual herbs; disk-flowers sterile............. Amphiachyris 928

$h h$ Rays truncate and coarsely toothed or lobed at the apex.

$i$ Involucral bracts spreading or reflexed.

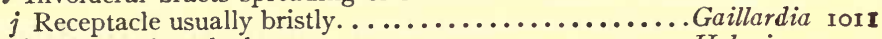

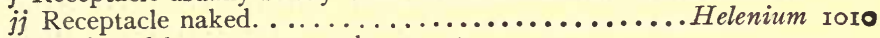

$i i$ Involucral bracts appressed or erect.

j Rays persistent; achenes linear, striate.

ji Rays deciduous.

Psilostrophe 1005

$k$ Achenes 4 -angled, linear or oblong..................

$k k$ Achenes 5-Io-ribbed or 5-ro-angled, top-shaped.

$l$ Outer involucre bracts separate.

Tetraneuris (Actinella, Picradenia) 1008

ll Outer involucre bracts connate at the base.

ddd Pappus none or a mere crown.

$e$ Receptacle not chaffy.

$f$ Rays yellow.

$g$ Leaves pinnately divided or compound...........................

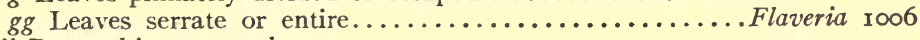

ff Rays white or purple.

$g$ Rays narrow-linear, numerous, 30 or more; leaves not divided.

$h$ Outer involucral bracts shorter than the inner; achenes prismatic.

Aphanostephus

hh Outer bracts all about equal; achenes flattened .......... Bellis 943

gg Rays broader, fewer than 30 ; leaves frequently divided.

943

$h$ Receptacle flat or convex; involucral bracts in several series.

hh Receptacle ovoid-conic; bracts in few series..........Matricaria ror 5 ee Receptacle chaffy.

$f$ Rays white or purple.

$g$ Involucral bracts of 2 sorts.

$h$ Inner bracts hooded, embracing the ray-achenes .... Melampodium

$h h$ Inner bracts flat, not embracing the ray-achenes........ Coreopsis

gg Involucral bracts similar.

$h$ Heads very large, $5^{-1} 5^{-\mathrm{cm}}$. broad........... Brauneria (Echinacea)

hh Heads smaller, $4 \mathrm{~cm}$. broad or less.

$i$ Leaves opposite...................................

ii. Leaves alternate.

$j$ Achenes flattened; heads small...........................

ji Achenes terete; heads large.................. Anthemis ror 4

if Rays yellow.

$\approx$ Ray-flowers neutral.

$h$ Involucral bracts of 2 sorts........................

hh Involucral bracts similar, the outer often shorter.

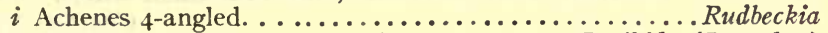

ii Achenes compressed, winged......................... (Lepachys)

gg Ray-flowers pistillate.

$h$ Achenes flattened.

$i$ Rays in $2-3$ series; achenes falling free............ Silphium

ii Rays in I series; achenes attached to 2 or 3 scales of the receptacle.

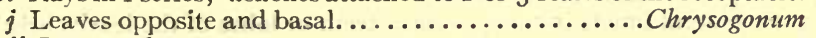

jj Leaves alternate.

$k$ Pappus none or of 2 caducous awns........... Berlandiera 
$k k$ Pappus a persistent irregularly cleft crown...... Engelmannia $h$ At least the disk achenes not flattened.

$i$ Disk-flowers sterile; leaves very large and thin........Polymnia

ii Disk-flowers fertile; leaves smaller.

$j$ Involucre of 4 large somewhat united outer bracts, and 6-I5 smaller inner ones.................... Tetragonotheca

jj Involucre of many ordinary bracts.

$k$ Fleshy seacoast plants; leaves spatulate, entire...... Borrichia

$k k$ Inland plants.

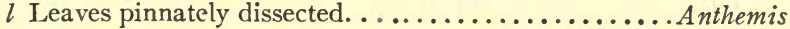

Il Leaves ovate, serrate........................... dddd Pappus capillary; receptacle not chaffy.

$\boldsymbol{e}$ Rays yellow.

$f$ Involucral bracts in one series, rarely in two.

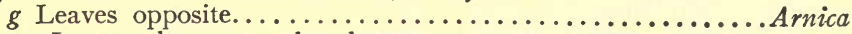
$g g$ Leaves alternate or basal.

$h$ Head solitary on a bracted scape, appearing before the large orbicu-

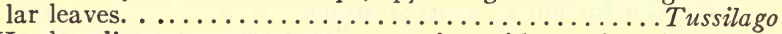

$h h$ Heads solitary or numerous, appearing with or after the leaves.

If Involucral bracts in 3 -several series.

Senecio 1024

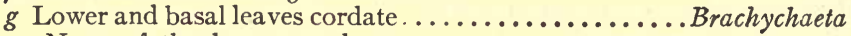

$g g$ None of the leaves cordate.

$h$ Leaves bristly-serrate or pinnatifid.

$i$ Achenes glabrous; pappus-bristles deciduous.

ii Achenes white-tomentose; pappus-bristles persistent.

Prionopsis (in Aplopappus) 93\%

hh Leaves entire or toothed, not bristly-serrate.

Sideranthus (in Aplopappus)

$i$ Leaves narrow, coriaceous, evergreen, entire; low western under-

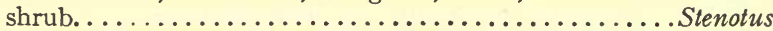

ii Leaves not evergreen.

$j$ Pappus double, the inner long,the outer of short scales or bristles.

. $k$ Achenes of disk flattened; ray-pappus obsolete.... Heterotheca

$k k$ Achenes of both disk and ray flattened; ray-pappus present.

ji Pappus single.

Chrysopsis

$k$ Heads very large, $5^{-10} \mathrm{~cm}$. broad.............. Inula

$k k$ Heads small, $0.5^{-2} \mathrm{~cm}$. broad.

$l$ Annuals; heads very loosely paniculate on long, slender pedicels.

¿l Perennials.

Isopappus (in Aplopappus)

$m$ Receptacles simply alveolate; rays few; panicles mostly

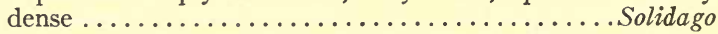

$m m$ Receptacle fimbrillate; rays several or many; inflorescence more open, corymbose.........Euthamia (in Solidago)

ee Rays violet, purple, or white.

$f$ Pappus-bristles very rigid and coarse.

$g$ Achenes of the disk-flowers compressed, of the ray-flowers 3 -angled; perennial herbs with large heads. .............. Townsendia gg Achenes fusiform, terete; annual herbs with small heads.

ggg Achenes obovate, flattened, with thickened or winged margins; perennials ....................................

gggg Achenes turbinate, narrowed below, not winged.

ff Pappus-bristles soft and fine.

$g$ Involucral bracts in many series; teeth or lobes of the leaves bristle-

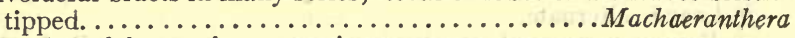


$h$ Leaves very large, reniform or orbicular, basal........Petasites IO2 I hh Leaves smaller, cauline, and basal.

$i$ Heads 6-35 mm. broad; rays mostly longer than the diameter of

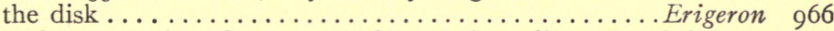
ii Heads $4 \mathrm{~mm}$. broad; rays not longer than diameter of disk.

ggg Involucral bracts in 3-5 series.

Leptilon (in Erigeron) 969

$h$ Involucral bracts firm; rays few, white; leaves spatulate, linear, or

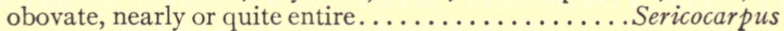
hh Involucral bracts membranous.

$i$ Pappus distinctly double; inner bristles long, outer shorter. $j$ Leaves lanceolate, ovate or obovate; rays white.

Doellingeria (in Aster) 970

ij Leaves narrowly linear; rays violet........ Ionactis (in Aster) $97 \mathbf{I}$ ii Pappus single.

$j$ Disk-flowers turning red, purple, or brown...........Aster 946

jj Disk-flowers permanently white; leaves subulate-spatulate, crowded, rigid. ........................ Lencelene 



\title{
ANALYTICAL KEY TO THE GENERA OF THE FAMILY GRAMINEÆ,
}

\author{
INCLUDING GENERA CULTIVATED WITHIN THE \\ RANGE OF THIS WORK. \\ PREPARED BY
}

\section{KARL M. WIEGAND.}

Note.-The scales borne on the primary axis of the spikelet are termed glumes; the one on each secondary axis is termed the palet. The two lowest glumes, termed empty glumes, inclose no flowers and frequently differ from the other glumes. Rarely there are more than two empty glumes, sometimes one, or none at all.

Make a careful dissection of the spikelet before using the key. Count the nerves by transmitted light if possible.

e.g. = spk. means, - at least one empty glume equal in length to the spikelet or longer. e.g. <spk. means,- - both empty glumes shorter than the spikelet.

The names in parenthesis represent genera in cultivation only.

$a$ An ivory-like ovoid capsule at base of each $\mathrm{fl}$. cluster, from an orifice in the top of which the stam. spikelets project.................. Corx.) $a a$ No such ivory-like capsule.

$b$ Pist. spikes axillary, grown together forming a cob, the whole inclosed in a leafy involucre; stam. inf. terminal; stout leafy grasses with broad leaves.

$b b$ Inflorescence not as above.

(ZEA.)

$c$ Glumes or glume-like involucre bearing on the surface hooked or straight spines or prickles.

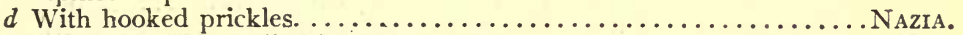

$d d$ With straight or slightly curved spines.

$e$ One recurved spine from middle of glume; spike dense, one-sided.

$e e$ Several spines on the globular involucre .............. CENCHRUS.

cc Glumes not spiny nor prickly.

$d$ Spikelets in distinctly one-sided spikes or spike-like panicles.

$e$ Spikelets laterally compressed; glumes keeled.

$f$ Sume of the glumes long-pointed or awned, or 3 -toothed.

$g$ Spikelets 3 -or more-fld., in panicles or spikes; glumes 5 or more; e.g. $<$ spk.

$h$ Spikelets regularly imbricated in 2 rows on one side of axis of solitary

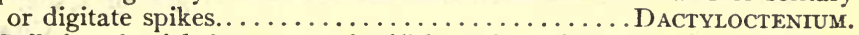

$h h$ Spikelets fascicled at apex of stiff branches of the interrupted, spikelike or open, one-sided panicle................. DACTYLIS.

$g g$ Spikelets $1-2$-fld., often with some rudimentary modified fls.; in true spikes only; normal glumes 3 or 4 .

$h$ Normal glumes 4 ; spikes somewhat whorled; fl. gl. much broader than e.g., usually with subapical awn; e.g. <spk.......... CHLORIs.

hh Normal glumes 3 ; sometimes also abnormal ones besides. 
$i$ Rudiment of $4^{\text {th }}$ or $5^{\text {th }}$ glume present; e.g. $=$ spk.

$j$ Spikes dense; lateral teeth of fl. gl. awn-pointed or awned.BoutelouA.

jj Spikes very slender, interrupted; lateral teeth of fl. gl. minute, not

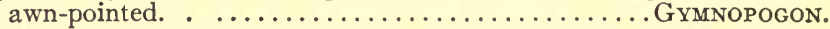
(Atheropogon sometimes has secund spikes.)

ii Rudiment of $4^{\text {th }}$ glume absent.

j Spikes very slender, almost filiform; spikelets distant; e.g.<spk. SCHEDONARDUS.

ij Spikes more dense; spikelets overlapping; e.g. $=$ spk...... SPARTINA. ff None of the glumes long-pointed or awned, nor distinctly 3-toothed.

$g$ Spikelets almost circular, i.e. very broad, strongly imbricated; e.g. $=$ spk.

gg Spikelets narrower; glumes narrow; e.g. $<$ spk.

BECKMANNIA.

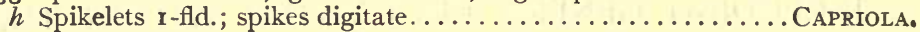

$h h$ Spikelets 2 - or more-fld.; spikes racemose.

$i$ Spikes filiform, alternately fld.

LEPTOCHLOA.

ii Spikes dense........................... Elusine.

ee Spikelets not laterally compressed; glumes rounded.

$f$ Glumes or some of them awn-pointed or awned; e.g. $=$ spk. or none.

$g$ Leaves setaceous; well-developed glumes only I; spikelets distant, in

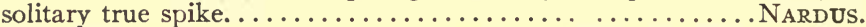

gg Leaves broad; glumes more than I; one glume indurated; spikelets in spikes or spike-like panicles, which are racemose.

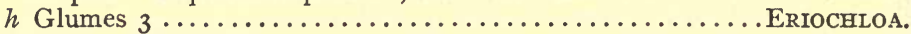

hh Glumes 4 .

$i$ First glume awned; creeping grasses............(Oplismenus.)

ii First glume usually awnless; glumes coarsely hairy; erect grasses.

ECHINOCHLOA.

ff Glumes not awn-pointed.

$g$ Peculiar extensively creeping grasses with monœcious inf., only the stam. secund; pist. very different, clustered in the upper sheaths; e.g. $<$ spk.

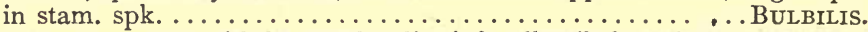

$g g$ Ordinary grasses with hermaphrodite inf., all spikelets alıke; one glume indurated.

$h$ Glumes 4 .

$i$ Second glume shorter than spk.; 3-nerved.......... SYNTHERISMA.

ii Second glume equaling the spk., or nearly so; 5-nerved. . BrachIARIA.

hh Glumes 3; e.g. $=$ spk.

$i$ First glume 3 -nerved, $2 \mathrm{~d} 7$-nerved..................

ii First and $2 \mathrm{~d}$ glume $3-5$-nerved.

$j$ Back of indurated glume turned toward rachis......... PAsPalum.

ji Back of indurated glume turned away from rachis. . . . . ANASTROPHUS.

dd Spikelets not in distinctly I-sided spikes.

$e$ Hairs or bristles forming a tuft or whorl at base of fl. gl., or on the rachis, or on sterile pedicels, or forming an involucre around the spikelet: hairs on the fl. gls., if present, are abruptly different (shorter or appressed) and do not grade gradually over into the others.

(The pedicels of the ordinary spikelets are very villous in Lamarckia.)

$f$ Glumes 4 , the 3 d gl. with stamens only or empty, and usually of thinner texture than the 4 th gl.; spikelets surrounded by an involucre of bristles or hairs.

$g$ Involucre of rigid barbed persistent bristles; e.g. $=$ or $<$ spk.

CHATOCHLOA.

gg Involucre of unequal softer bristles or hairs which are often plumose; $4^{\text {th }}$ gl. scarcely coriaceous; e.g. $=$ spk.............. (PENnISETUM.)

ff Glumes similar in texture or else the $3 \mathrm{~d}$ firmer than the Ist and $2 \mathrm{~d}$ or the outer gls. firmer.

$g$ Spikelets in pairs or threes, all but one often sterile and reduced; hairs outside of empty gls.; fl. gl. of perfect spikelet long-awned except sometimes in Sorghum; Ist e.g. larger than $2 \mathrm{~d}$ and $=$ spk. 
$h$ Both spikelets of the cluster perfect, one longer pediceled than the other; large ornamental grasses.

$i$ Axis of spike continuous; panicle somewhat fan-shaped.(MIsCANTHUs.)

ii Axis of spike articulate; panicle denser............. ERIANTHUs.

$h h$ Spikelets of the cluster unlike, one or two sterile and more slender or much reduced (often to a mere pedicel).

$i$ Clusters of spikelets in irregular panicles.

$j$ Lateral spikelets reduced to mere plumose pedicels, two with each fertile spikelet, all sessile at apex of a long common pedicel.

SORGHASTRUM.

ji Lateral spikelets with glumes; ultimate branches of inf. dichotomous'y sympodial, two branches at base of each fertile spikelet, one bearing a sterile spikelet, the other a continuation of the inf., terminal

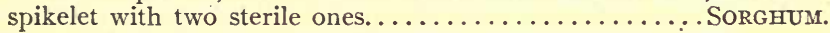

ii Clusters of spikelets in false spikes.

$j$ Spikes in pairs or digitate; rachilla-internodes and pedicels opaque. ANDROPOGON.

ji Spikes panicled; rachilla-internodes and pedicels thickened on margins, intervening portion thin and translucent.......... AMPHILOPHIS.

gg Spikelets not in small definite clusters as above; Ist e.g. smaller than or equaling the $2 \mathrm{~d}$ (rarely slightly longer in Calamagrostis).

$h$ Spikelets I-fld. or with rudiment of $2 \mathrm{~d} f \mathrm{fl}$

$i$ Empty glumes shorter than the fl. gls., nearly equal..... REDFIELdiA. ii Empty glumes as long as or longer than the fl. gls., or if shorter then very unequal.

$j$ Flowering glume awned; e.g. $=$ spk.

$k$ Fl. gl. with a terminal awn.

$l$ Awn twisted, very long; fl. gl. $4 \mathrm{~mm}$. or more long, firmer than

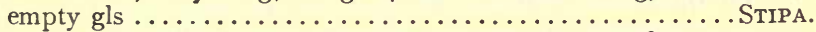

ll Awn straight; fl. gl. less than $4 \mathrm{~mm}$. long, about as firm as empty

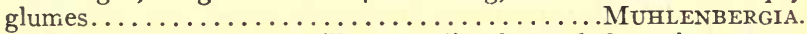

$k k \mathrm{Fl}$. gl awned on back; rachilla extending beyond the palet; empty

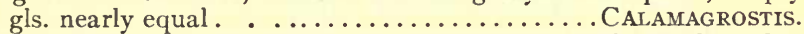

$k k k$ Fl. gls. awned between 2 teeth; spikelets spiked on slender branches

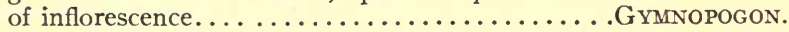

ij Flowering glume not awned.

$k$ A small tuft of hair on either side of base of $\mathrm{fl}$. gl., each borne on a minute scale representing the very udimentary $3 \mathrm{~d}$ and 4 th glumes;

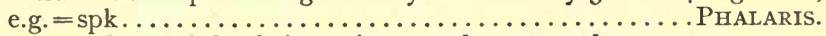

$k k$ Hairs at base of $\mathrm{f}$. gl. in a ring, not borne as above.

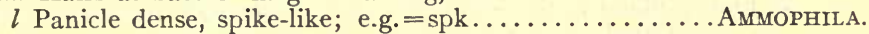

ll Panicle open; e.g. $=$ or $<$ spk. .......................

$h h$ Spikelets 2-many-flowered.

$i$ Very tall reed-like grasses (1.5-6 m. high); e.g. <spk.

ij Leaves $8-50 \mathrm{~mm}$. broad, evenly distri uted up the culm (see also Arundo $) . . . \ldots \ldots \ldots \ldots \ldots \ldots \ldots . \ldots \ldots$. . . . . . . . . . . .

jj Leaves very long and narrow, recurved, densely clustered at base of

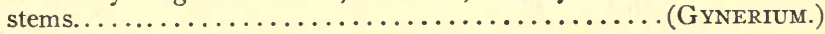

ii Lower ordinary grasses.

$j$ Flowering glume with a dorsal awn.

$k$ Spikelets more than $7 \mathrm{~mm}$. long; e.g. $=$ or $<\mathrm{spk} . \ldots \ldots \ldots$...... $k k$ Spikelets $7 \mathrm{~mm}$. or less long.

$l$ Fl. gl. acutely 2 -toothed at apex; e.g. $<$ spk.......... TRISETUM.

$l l \mathrm{Fl}$. glume blunt or bluntly 2 -lobed at apex; e.g. $=$ or $<$ spk.

ij Flowering glume awnless or 3 -toothed or mucronate.

DESCHAMPSIA.

$k$ Fl. glume 3 -toothed, broad, shorter than empty glumes; sheaths villous at summit; ligule a ring of hairs; e.g. = spk..... SieglingIA.

$k k \mathrm{Fl}$. glume not 3 -toothed, broad or narrow.

$l$ Ligule a ring of hairs; e.g. <spk. 
$m$ Panicle contracted; spikelets 4-5 mm. long, 7-II-fld.; fl. glumes

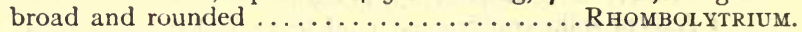
$m m$ Panicle diffuse; spikelets $6 \mathrm{~mm}$. long, I-3-fld.; fl. g1s. narrow,

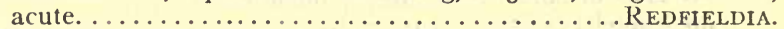

$l l$ Ligule scale-like.

$m$ Fl. glume rounded; rachis glabrous; e.g. $=$ spk. ...... ScolochLoA. inm Fl. glume keeled.

$n$ Rachis hirsute; e.g. $<$ spk............. GRAPHEPHORUM. $n_{i \imath}$ Rachis glabrous; e.g. $=$ spk. . . . . . . . . . Dupontia. (See also Poa )

ee Hairs or bristles at base of flowering glumes, if present, grading over into those on the flowering glumes.

$f$ Spikelets in little clusters (of $2-5$ ) of two very distinct sorts, one sterile of many glumes usually concealing the few-fld. fertile; e.g. $<$ spk.

$g$ Glumes of both kinds of spikelets obtuse; fertile spikelets I-fld.

(LAMARCKIA.)

$g g$ Glumes of the very flat sterile spikelets pointed or awned; fertile $2-3$-fld.

Cynosurus.

ff Spikelets not conspicuously dimorphic; or if so then the fertile and sterile not in the same little clusters, or the sterile with few glumes ( 4 or less) or zudimentary.

$g$ Blade articulated with the sheath and eventually deciduous at this point; branched plants with large lanceolate leaves; e.g. $<$ spk.

$h$ Internodes not flattened; sheaths persistent.

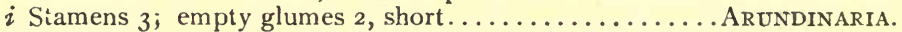
ii Stamens 6; empty glumes 2-6, gradually increasing in size upward.

(BAMBUSA.)

$h h$ Internodes flattened at least on one side; sheaths soon deciduous; stamens 3 ; the $\mathrm{I}-2$ spikelets surrounded by a large leaf at the

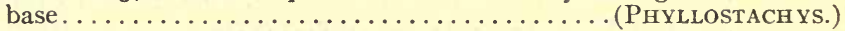

gg Leaves not articulated with the sheath, though sometimes with a different-colored zone at this point.

$h$ Flower-bearing glumes rugose with transverse and longitudinal cellular reticulations; palet similar, I-nerved; two much shorter empty glumes, and still two more fold-like ones at the base.............(ORYzA.)

$h$ Flower-bearing glumes and spikelets not as above.

$i$ Empty glumes at base of spikelet strongly transversely wrinkled or pitted, thick and coriaceous; spikelets imbedded in the thickened rachis and very closely appressed; e.g. $=$ spk......... MANISURUS.

ii Empty glumes at base of spikelet not strongly transversely wrinkled nor pitted as above.

$j$ Rachis of spike-like inf. very thick; pist. spikelets at its base and imbedded in it; stam. spikelets above, not imbedded; e.g. =spk.... TRIPSACUM.

ji Rachis slender and spikelets often paniculate.

$k$ Spikelets in pairs at each node of the spike-like branches of the inflorescence, one longer pediceled than the other; fl. gl. and rachis with long silky spreading hairs; e. gls. three; fl. gl. awned; e.g. =

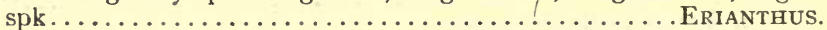

$k k$ Spikelets $2-3$ at each node of the simple spike-like inf., $5 \mathrm{~mm}$. or more long. (See also kkk.)

$l$ Empty glumes at base of spikelet absent or minute and awn-like; spike very open with spreading long-awned spikelets..... Hystrix.

ll Empty glumes present; spikelets usually ascending and approximate; e.g. $=$ or $<$ spk.

$m$ Spikelets I-fld., or with a mere rudiment of a second; lateral spike-

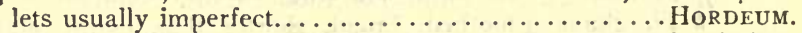

$m m$ Spikelets, at least most of them, 2-or more-fld., all usually similar.

$n$ Rachis of spike easily breaking up at maturity; western. SitANion.

$n n$ Rachis not breaking up into joints............. ELYMUS.

$k k k$ Spikelets solitary at each joint of the spike, or panicled. 
$l$ Empty glumes of pist. fls. indurated, with 3 green terminal ligulate lobes; extensively creeping grasses with pist. spikelets clustered in

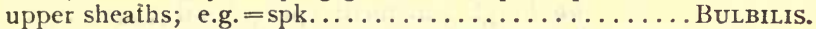

$l l$ Empty glumes and habit not as above.

$m$ Very tall corn-like grasses (2-10 m. high), with rather short and very broad, evenly distrubuted, spreading leaves; $\mathrm{f}$. gls. very long-

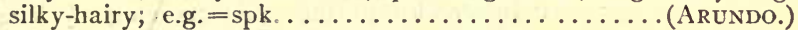

$m m$ Habit not as above.

$n$ Flowering glumes narrowed into a 3 -branched awn; e.g. $=$ spk. ARISTIDA.

$n n$ Flowering glumes awnless or with a simple awn (which may be borne between two awn-pointed teeth).

o Flowering glumes, at least one of them, bearing an awn on back, or between the terminal teeth, or strongly 3 -toothed.

$p$ Awn borne on the back below the apex or apical notch; e.g. $=$ spk. except in Avena, Trisetum, and Bromus.

$q$ Glumes 3.

$r$ Panicle spike-like, very dense.

$s$ Empty glumes densely covered with woolly hairs. .(LAGURUS.) ss Empty glumes not densely woolly, sometimes villous.

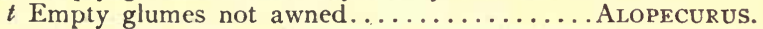

tt Empty glumes awned................. Polypogon.

rr Panicle open, branches long and slender.

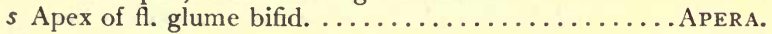

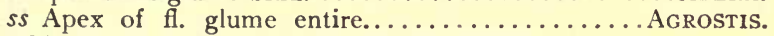

$q q$ Glumes 4 or more, the $3 \mathrm{~d}$ sometimes sterile.

$r$ One of the two flowers awnless, one flower staminate only. $s$ Plant glabrous; awn on lower flower only, long bent and

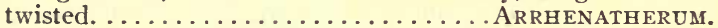
ss Plant soft-velvety; awn on upper flower only, usually hooked.

Holcus.

rr At least two, usually all, of the flowers with awns.

$s$ Rachilla produced beyond the insertion of the upper flower; stigmas terminal.

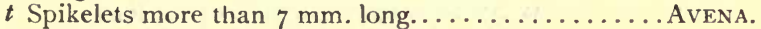

tt Spikelets $7 \mathrm{~mm}$. long or less............. Trisetum.

ss Rachilla not produced beyond the insertion of the upper flower.

$t$ Spikelets many-flowered; fl. gl. about $6-8 \mathrm{~mm}$. long; stigmas inserted below apex of ovary............. BROMUs.

$t t$ Spikelets 2-fld.; fl. gls. nearly glabrous.............. AIRA.

ttt Spikelets essentially 3 -fld., but the two lower fls. staminate or sterile; fl. glumes ciliate or silky, fragrant-aromatic grasses.

$u$ Fifth glume very acute, $3 \mathrm{~d}$ and $4^{\text {th }}$ staminate.. SAvastana. uи Fifth glume obtuse, $3 \mathrm{~d}$ and $4^{\text {th }}$ empty... Anthoxanthum.

$p p$ Awn borne between two terminal teeth, or the apex 3 -toothed.

$q$ Spikelets nearly sessile in the axils of the clustered rigid apical foliage leaves, low erect or prostrate grasses; wesiern; e.g. $<$ spk. ...........................

$q q$ Spikelets in ordinary spikes or panicles.

r Spikelets I-fld. (glumes 3), or with a rudiment of a second. $s$ Inflorescence spicate.

$t$ Spikelets reflexed; e.g. $<$ spk. ......................

$t t$ Spikelets ascending; e.g. $=$ spk........... Gy MNOPOGON

ss Inflorescence paniculate; e.g. $=$ spk........... CinNA.

rr Spikelets 2-many-fld. (glumes 4 or more).

$s$ Spikelets regularly spiked; e.g. <spk......... TRITICUM. ss Spikelets paniculate.

(Tricholana, with very long silky glumes, rarely has awns.) 
t Empty glumes nearly or quite equaling the spikelet.

$u \mathrm{Fl}$. gl. with long bent awn; spk. 2-fld....... DANTHONIA. uu Fl. gl. 3-toothed; spk. 3-5-Ad............ SiEgLingia. tt Empty glumes much shorter than the spikelet.

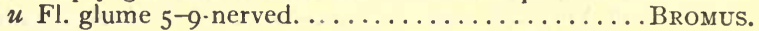
$u u$ Fl. glume 1-3-nerved, margin and nerves pilose.

$v$ Internodes in the spikelets long ( $\frac{1}{2}$ length of glume); callus long-pointed pilose............. TRIPLASIS.

$v v$ Internodes very short; callus short.

$w$ Spikelets irregularly paniculate.......... TRICUSPIS. ww Spikelets distantly spicate on branches of the open inflorescence.................

oo Flowering glume awnless, or sometimes narrowed into a terminal cusp or awn, the latter not borne between two teeth.

p Glume I (empty glumes absent); spikelets flattened laterally, I-fld.

(See also Muhlenbergia and Brachyelytrum.)

$q$ Lowest glume awned, at least in the pist. spikelets; spikelets unisexual, monœcious.

r Pistillate spikelets ovate, borne at the apex of each branch of

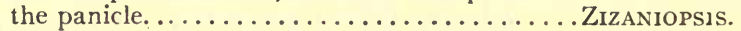

rr Pistillate spikelets linear, borne on the upper branches of

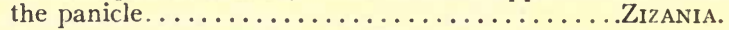

$q q$ Lowest glume not awned; spikelets hermaphrodite.

HOMALOCENCHRUS.

$p p$ Glumes 2 (ist empty glume absent)..... Abnormal conditions in Muhlenberga Brachyelytrum, and Phippsia.

$p p p$ Glumes more than 2.

$q$ Glumes 5 , the $3 \mathrm{~d}$ and 4 th reduced to minute, often hairy scales; outer glumes large and keeled, equaling the spikelet.

PhaLARIS.

$q q$ Glumes 3 ; spikelets I-fld. (See also qqq.)

$r$ Fl. gl. awned at tip (awn in one genus soon deciduous).

$s$ Awn twisted; glume $4 \mathrm{~mm}$. or more long; e.g. $=$ spk. .STIPA. ss Awn straight; glume short or long.

$t$ Fl.gl. broad, oval or elliptical, much firmer than empty glume; e.g. $=$ spk.

$u$ Fl. gl. short-hairy or glabrous ............ Oryzopsis. uu Fl. gl. silky, hairs longer than spikelet ........ ERIocoma. tt Fl. gl. narrow, elliptical to linear, not conspicuously firmer than empty glumes.

$u$ Leaves 6-18 mm. wide; e. gls. very minute.

$u$ Leaves less than $6 \mathrm{~mm}$. wide; e. gls. long or short.

$v$ Fl. gl. 3-nerved; grain inclosed by glume. MUHLENBERGIA.

vv Fl. gl. I-nerved; grain and seed free...... SPORoBoLIs.

r Fl. gl. awnless.

$s$ Fl. gls. distinctly coriaceous and firmer than the empty glumes; e.g. $=$ spk.

$\boldsymbol{t}$ Sheaths papillose-hirsute; both aerial and subterranean

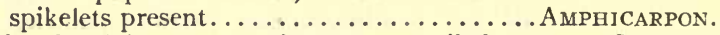

$t t$ Sheaths glabrous; no subterranean spikelets..... MiLIUm.

ss Fl. gls. not distinctly different in texture from the enspty glumes.

$\boldsymbol{t}$ Spikelets truly spiked, alternately arranged, appressed, acute; plant decumbent, much branched; e.g. =spk... LEPTURUs.

tt Spikelets paniculate, panicle contracted or open.

$u$ Empty glumes cuspidately awn-pointed, equaling the spikelet; panicle very densely spike-like; e.g. $=$ spk.. PhLEUM.

uи Empty glumes gradually acute, or obtuse. 
$v$ Empty glumes minute; low arctic grasses with dense inflorescence...................... PHippsia.

vv Empty glumes one-half length of fl. glumes or more.

$w$ Spikelets very densely spicate; upper sheaths inflated.

HELEOCHLOA.

ww Spikelets interruptedly spicate or open-paniculate.

$\boldsymbol{x}$ Third glume shorter than the 2 d, rarely equaling it,

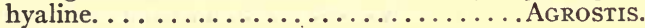

$x x$ Third glume equaling $2 \mathrm{~d}$ or longer, membranous, not hyaline.

y Arctic grasses; 3d glume obtuse, hispid on keel.

ArCtagrostis.

yy Not arctic; 3 d glume acute or obtuse, not distinctly hispid on keel.

z Rootstock densely scaly; 3d gl. usually 3-nerved; grain inclosed by glume........ MUHLENBERGIA.

$z z$ No densely scaly rootstocks; 3d glume usually I-nerved; grain and seed free........ SPOROBOLIS.

$q q q$ Glumes four or more, only the Ist and $2 \mathrm{~d}$ occasionally very dissimilar from other in size.

r Glumes 4, but the 3 d glume empty or containing stamens only, membranous; the $4^{\text {th }}$ coriaceous; e.g. $=$ spk.

$\boldsymbol{s}$ Second glume much enlarged, saccate at base; panicle con-

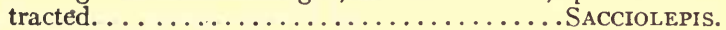

ss Second glume not enlarged nor saccate.

$t$ Empty glume densely covered with long silky hairs which equal or exceed the spikelet............. (TRICHOLANA $)$

tt Empty glume not long-silky . . . . . . . . . . . . PANicum.

rr Glumes 4 or more, all similar in texture, or the lower two firmer.

$s$ Very large grasses $2-6 \mathrm{~m}$. high, with the very long rigid recurved leaves densely clustered at base; not hardy north; e.g. <spk..........................(Gynerium.)

ss Smaller grasses not as above (Uniola $25 \mathrm{dm}$. tall, but leaves ordinary).

t Spikelets truly spicate, turned with their edges toward the axis and the empty glume in the axil regularly absent; e.g. $=$ or $<$ spk. ..................... Lolium.

$\boldsymbol{t}$ Spikelets paniculate, or if spicate then the side turned toward the axis and both empty glumes present.

$u$ Fl. glumes $\mathrm{I}-3$-nerved.

$v$ First empty glume linear, acute, second broad oblanceolate or obovate, truncate or abruptly acute; e.g. $<$ spk.

vv Empty glumes not very dissimilar except in size.

EATONIA.

$w$ Lateral nerves of fl. glumes pilose; e.g. <spk. TRrCUSPIS. ww Lateral nerves glabrous.

$x$ Spikelets alternate and distant, in a true spike, lanceolate acute; fl. glume I-nerved; e.g. $=$ spk.

LEPTURUS.

$x x$ Spikelets paniculate; e.g. $<$ spk.

$y$ Flowering glumes keeled.

$z$ Inflorescence contracted; spikelets very flat, $2-5$-fld.

KOEIERIA.

$z z$ Inflorescence open; spikelets 2-35-fd ERAGROSTIS.

yy Flowering glumes rounded on the back.

z Panicle narrow, more or less contracted.

$z^{1}$ Fl. glume coriaceous when mature; seed beaked. 
$z^{1} z^{1} \mathrm{Fl}$. glume membranous; seed not beaked.

Molinia.

zz Panicle open. .......................

uи Fl. glumes 5-many-nerved; e.g <spk. (excepting in Savastana).

$v$ Palet with the keels winged or appendaged; fl. glumes broad, truncate or erose at apex........ PLEUROPOGON.

$v v$ Palet without wings or appendages.

$w$ Fl. glumes more or less strongly compressed and keeled. $x$ Empty basal glumes 3-6; spikelets very flat and broad, ovate-oval, I 5-35 mm. long. . ........ Uniola. $x x$ Empty glumes only two.

y Ligule a ring of hairs; spikelets diœeious. Distichlis. yy Ligule scale-like.

z Spikelets regularly spiked; fl. gls. awned..(SECALE.) $z z$ Spikelets in an open or dense panicle.

$z^{1}$ Empty glumes equaling or exceeding the spikelet.

$z^{1} z^{1}$ Empty glumes shorter than the spikelet.

SAVASTANA.

$z^{2}$ Glumes short-awned, 5-6 mm. long; spikelets fascicled at ends of stiff rays of interrupted spikelike or open panicle; green or purple.Dactylis.

$z^{2} z^{2}$ Glumes awnless.

$z^{3}$ Silvery shining condensed panicle; no cobwebby hairs on keel of thin fl. glumes; spikelets 2-5-fld. ................. KoelERIA.

$z^{3} z^{3}$ Not silvery shining; panicle rarely condensed.

$z^{4}$ Hairs at base of 7-nerved $\mathrm{f}$. glume glandular.

DEMAZERIA.

$z^{4} z^{4}$ Hairs at base of 5 -nerved fl. glume cobwebby.

PoA.

(Some species of Bromus have glumes slightly keeled.)

ww Fl. glumes rounded on the back.

$x$ Spikelets regularly spiked, one spikelet at each node, placed with its side to the axis.

$y$ Fl. glume deciduous at maturity and with a distinct callus which is limited by a furrow at the base.

Agropyrum.

yy $\mathrm{Fl}$. glume persistent at maturity and without a callus.

$x x$ Spikelets paniculate.

(TRITICUM.)

$y$ Spikelets abruptly nodding on the pedicel; empty glume not much shorter than the spikelet; uppermost

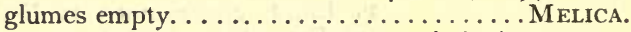
(See also Avena sativa, awnless varieties.)

yy Spikelets not abruptly nodding.

$z$ Palet exceeding the lanceolate, acute fl. glumes.

PANICULARIA.

$z z$ Palet shorter than the fl. glumes.

$z^{1}$ Nerves of the fl. glumes not converging above and usually not reaching the scarious blunt or truncate apex.

$z^{2} \mathrm{Fl}$. glumes cordate at the apex, margin very broadly scarious, outline nearly orbicular.

BRIZA.

$z^{2} z^{2}$ Fl. glumes not cordate at the base.

$z^{3} \quad$ Fl. glumes plainly 5-7-nerved; style present.

PANICULARIA. 
$z^{3} z^{3} \mathrm{Fl}$. glumes obscurely 5 -nerved; style wanting. Puccinellia. $z^{1} z^{1}$ Nerves of the fl. gumes converging above, almost or quite reaching the usually acute, often awned apex.

$z^{2}$ Stigmas subapical on ovary; nerves of fl. glum

$5-9 \ldots \ldots \ldots \ldots \ldots \ldots \ldots$. BROMUS. $z^{2} z^{2}$ Style apical; nerves of fl. glume $5 \ldots$. Festuca. 


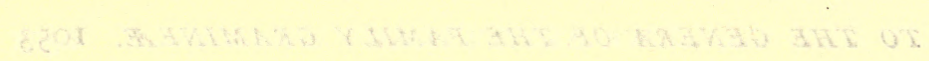




\section{APPENDIX.}

THE following appendix contains descriptions of additional species found within the area covered by this Manual, and of species made known from investigation, during the two years that the first edition of this book was in press and during the three years since it was published. Several species proposed by various students have not been admitted, as they appear to require further investigation before their status can be satisfactorily established. A few corrections are also noted.

P. 24, add:

ra. Lycopodium porophìlum Lloyd \& Underw. Rock Club-moss. Prostrate portion of stems short, abundantly rooting, curving upward, then dichotomously branching $\mathrm{I}-3$ times to form a rather dense tuft $(4-10 \mathrm{~cm}$. high) of vertical stems, densely clothed with spreading or reflexed leaves; leaves $(7-9 \mathrm{~mm}$. $\times$ I $\mathrm{mm}$.) very slightly broadened above the middle and similarly contracted toward the base, those between the strobilar regions shorter $(6-7 \mathrm{~mm}$.), broadest at the base but very gradually tapering, entire or very minutely denticulate; sporangia compressed-reniform; sporophylls minutely denticulate above the middle or entire, acuminate $(4-5 \mathrm{~mm}$. $\times$ I $\mathrm{mm}$. wide at base); plant often gemmiparous. Differs from $L$. lucidulum in its nearly linear entire leaves and smaller size, and from L. Selago in the bases of its leaves, which are flattened. On sandstone rocks, Wis., Ind. and Ala.

\section{P. 25, add:}

3a. Lycopodium Chapmànii Underw. Chapman's Club-moss. Stems prostrate and frequently rooting or slightly arching and rooting toward the end, $18-40 \mathrm{~cm}$. long, simple or occasionally pinnately branching, thick (about $3 \mathrm{~mm}$. in diameter); leaves $6-7 \mathrm{~mm}$. long by $2 \mathrm{~mm}$. broad, thick, rigid, lanceolate-acuminate, upwardly curving, the margin irregularly toothed, the teeth often compound below the middle of the leaf; peduncles I0-25 cm. long, slender, leafy with more or less appressed subulatetoothed leaves below and similar entire leaves above; strobiles about 3 $\mathrm{mm}$. in diameter and $\mathrm{I} .8-7 \mathrm{~cm}$. long; sporophylls I mm. $\times 5-6 \mathrm{~mm}$. with a broad base, suddenly contracted above into a narrow subulate apex, usually more or less toothed near the base; sporangia subglobose. Differs from $L$. inundatum by its much thicker stems, toothed leaves, tall peduncles, and long narrow strobiles. Mass. to Fla. and La., mostly near the coast.

P. 26, at end of description of Lycopodium complanàtum, strike out the last sentence commencing with "Forms with", and add:

12. Lycopodium tristâchyum Pursh. Creeping Christmas-Greers. Rhizomes extensively creeping $2-4 \mathrm{~cm}$. below the surface of the ground, white, terete, their whorled or loosely spirally arranged leaves lanceslate or ovate to broadly ovate; the terminal branchlets regularly producing innovations the second and sometimes the third season, the older foliage branches ultimately spreading and becoming lax; leaves of the primary 
axis in 6-8 rows, from ovate through lanceolate-acute to acuminate, those of the subterminal and terminal branchlets in four rows, glaucous, bluish green, acuminate, appressed, those of the under row differing scarcely at all from those of the other three rows, the leaves of the lateral rows somewhat incurved underneath; peduncles terete, glaucous, $50-60 \mathrm{~mm}$. long to the first forking, usually twice forked, the second 8-18 mm. distant from the first, spreading and curving upward; strobiles two, three or usually four, $20-28 \mathrm{~mm}$. long, the sporophylls broadly depressed-ovate, truncate at the base, the lateral margins variously toothed, suddenly contracted into a s'bulate scarious tip; sporangium reniform, opening by a transverse slit along the top; spores ripening early in August. (L. Chamaecyparissus A. Br.) Differs from L. complanatum, with which it has been confused, in its subterranean habit, its uniform leaves, its method of branching, and in its distant clusters of strobiles. Me. to Ga. and Minn.

P. 28, after Isoetes lacistris, insert:

ra. Isoetes heteróspora A. A. Eaton. Submerged with a bilobed trunk. Leaves $50-75,5^{-8} \mathrm{~cm}$. long, stiffly erect, tapering to a sharp point, without stomata; sporange spotted with dark cells, covered onethird to two-thirds by the velum; macrospores 540-675 $\mu$ in diameter or even much more densely covered with thick jagged convoluted crests, often reticulate-honeycombed below; microspores about $35 \times 27 \mu$, dark brown, papillose. In ponds, Mt. Desert Island, Me.

After Isoetes Tuckermáni, insert:

2a. Isoetes hieroglyphica A. A. Eaton. Submerged with a bilobed trunk. Leaves $10-20,6-7.5 \mathrm{~cm}$. long, blunt at the apex, without stomata; sporange unspotted, covered one-third by the velum; macrospores $486-590 \mu$ in diameter, polished, covered with bold vermiform, subconfluent and somewhat reticulated ridges, becoming naked near the equator; microspores $3 \mathrm{I}-44 \mu$ in diameter, distinctly verrucose. St. Francis, Moosehead and Rangeley lakes, Me.

After Isoetes echinospora Braùnii, insert:

3a. Isoetes Hárveyi A. A. Eaton. Submereged, the trunk 2-lobed

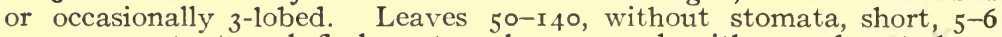
$\mathrm{cm}$, very stout and fleshy, strongly recurved, with an abrupt sharp point, purple-bronze or reddish in drying; sporange small, unspotted, covered one-fourth to one-third with the velum; macrospores 526-648 $\mu$ in diameter or rarely larger, with irregular parallel thickish crests above, and reticulate-honeycombed below; microspores $35-40 \mu$ long by $22-30 \mu$ broad, rough. Pushaw Pond, Oldtown, and Long Pond, Mt. Desert, Me.

\section{P. 29, after Isoetes Canadensis, insert:}

8a. Isoetes Grávesii A. A. Eaton. Diœcious or polygamous with submerged or emersed leaves. Leaves $50-75$, I $2-15 \mathrm{~cm}$. long, erect, sharp-pointed, dark green, with abundant stomata and four bast bundles; sporange oval, cinnamon-colored from the abundant vermiform cells, with only the margins covered by the velum; macrospores small, $35 \mathrm{I}-$ $405 \mu$ in diameter, the upper faces flat, covered with short truncate mostly single columns; microspores rare. Mud flats near outlet of Tyler Pond, Goshen, and gravelly tidal shore, Selden's Cove, Lyme, Conn.

P. 33, after Pinus rígida, add:

Ir. Pinus serótina Michx. Black Pine. Pond Pine. A tree. sometimes $25 \mathrm{~m}$. high, and with a trunk $9 \mathrm{dm}$. thick, the bark flaky. Leaves in 3's, glaucous, $15^{-25} \mathrm{~cm}$. long, the sheaths about $1.5 \mathrm{~cm}$. long; cones lateral, ovoid to globose-ovoid, $4-6 \mathrm{~cm}$. long; scales thickened at the apex, bearing a minute prickle; wing of the seed nearly $2 \mathrm{~cm}$. long. In swamps, S. E, Va. to Fla. Mar.-April. 
P. 37, after Juniperus Virgiànina, insert:

3a. Juniperus scopulòrum Sargent. Western Red Cedar. A tree, resembling the eastern Red Cedar, but with larger fruit, 7-8 $\mathrm{mm}$. in diameter, which ripens at the close of the second season and usually contains two seeds. Alberta to W. Tex., Br. Col., Ore., Nev. and Ariz.

\section{P. 40, before Sparganium símplex, insert:}

2a. Sparganium Americànum Nutt. Sim ple-stemmed Bur-reed. Similar to $S$. androcladum, but the stem simple, the lower heads of the inflorescence merely peduncled. Leaves drying green, the upper with more or less sac-like bases and broad hyaline-scarious margins; nutlets slightly angled, each gradually narrowed into a stout conspicuous style. In low grounds or ponds, Ont. to Br. Col., Penn. and the Ind. Terr. Summer.

\section{P. 40, after Sparganium mínimum, add:}

5. Sparganium hyperbòreum Laest. Northern Bur-reed. Stem 2-3 $\mathrm{dm}$. high; leaves shorter and narrower than those of $S$. minimum, I-3 $\mathrm{mm}$. wide; inflorescence $1.5-2.5 \mathrm{~cm}$. long; pistillate heads I or 2 , sessile, or the lower one short-peduncled; ripe fruiting heads $5^{-10} \mathrm{~mm}$. in diameter; nutlets oblong, obscurely triangular at the summit; stipe very short, stigma oval, oblique, minute, sessile, or nearly so. Lab. and Hudson Bay. Also in northern Europe. Summer.

P. 49. Additional species and subspecies of Potamogeton have been described by Arthur Bennett in recent papers published in the "Journal of Botany."

P. 68, after Erianthus brevibàrbis Michx., insert:

4a. Erianthus contórtus Ell. Twisted-AWned Plume-grass. Culms $\mathrm{I}-2 \mathrm{~m}$. tall, the summit and panicle-axis glabrous, or nearly so; leaves I.5-8 dm. long, 5-20 mm. wide; panicle I.5-3 dm. long, 3-5 cm. wide; spikelets crowded, exceeding the basal hairs and about one-half again as long as the internodes, the outer scales $7-7.5 \mathrm{~mm}$. long, the fourth scale 2-toothed at the apex, the awn $1.5-2 \mathrm{~cm}$. long, the included portion often a little spiral at the base, the remainder loosely spiral. In pine woods, Del. to Fla. and Miss. Sept. and Oct. Differs from E. brevibarbis in having the spikelets smaller and the exserted portion of the awn loosely spiral.

P. ;o, after Andropogon Virgínicus L., insert:

4a. Andropogon tetrastáchyus Ell. FoUR-SPIKED BEARD-Grass. Culms tufted, 8-I5 dm. tall; sheaths, at least the lower ones, densely villous, with dark hairs; leaves $4 \mathrm{dm}$. long or less, $2-4 \mathrm{~mm}$. wide, the lower ones villous on both surfaces toward the base; spathes usually $3-4 \mathrm{~cm}$. long, extending beyond the racemes; racemes usually in fours, $3-4 \mathrm{~cm}$. long; sessile spikelet 3-4 mm. long, the awn straight, I.5-2 cm. long. In dry or moist soil, Va. (according to T. H. Kearney, Jr.) to Fla. and Ala. Sept. and Oct. Differs from $A$. Virginicus in having the sheaths, at least the lower ones, densely villous all over, and the racemes usually in fours.

\section{P. 73, after Paspalum laève Michx., insert:}

5a. Paspalum angustifòlium Le Conte. Narrow-Leaved Paspalum. Culms tufted, 6-12 dm. tall; sheaths compressed, glabrous; leaves long, the larger 2-4 dm. long, less than I cm. wide, glabrous, or the upper surface sometimes sparingly hairy near the base; racemes $3-5$, spreading, usually ó-10 cm. long: spikelets singly disposed, $3-3.5 \mathrm{~mm}$. long and about $2.5 \mathrm{~mm}$. wide, glabrous. In fields, D. C. to Fla., La., Kans. and Mo. June-Sept. Differs from $P$. laeve in having the leaves elongated and in the more numerous racemes. 
5b. Paspalum australe Nash. Southern Paspalum. Culms tufted, 4-7 dm. tall; sheaths usually hirsute only on the margins; leaves erect, short, commonly I.5 dm. long or less, 5-10 mm. wide, strongly ribbed, rather thick, firm, glabrous beneath or nearly so, hirsute above; racemes 2-5, finally spreading, usually $5 \mathrm{~cm}$. long or less; spikelets singly disposed, oval, $2.7-3 \mathrm{~mm}$. long and about $2 \mathrm{~mm}$. wide, glabrous. On grassy flats and banks, Va. to Fla. and Ala. Aug. and Sept. Differs from $P$. laeve and $P$. angustifolium by its hairy sheaths, and from the latter also by its short leaves. Type collected by Dr. J. K. Small, at Stone Mt., Ga., Aug. I-6, I 895 .

P. 73, after Paspalum circulàre Nash, insert:

6a. Paspalum Bosciànum Fluegge. Bosc's Paspalum. Culms 5-12 dm. long, compressed, finally branched, often decumbent at the base and rooting at the lower nodes; sheaths compressed, glabrous, or the basal ones papillose-hirsute; leaves 4-30 $\mathrm{cm}$. long, 3-10 $\mathrm{mm}$. wide, hairy above near the base; racemes 2-I3, spreading or ascending, 4-9 $\mathrm{cm}$. long, the rachis broadly winged; spikelets in pairs, and often so crowded as to appear in 4 rows, frequently reddish brown, broadly obovate, $2-2.3 \mathrm{~mm}$. long, I.5-I.8 mm. broad, the flowering scale deep brown at maturity. In meadows and moist places, Va. (according to T. H. Kearney, Jr.) to Fla. and Miss. Aug.-Oct. Differs from $P$. laeve and its relatives in having the spikelets in pairs and the flowering scale a deep seal-brown at maturity.

P. 74, after Paspalum longipedunculàtum Le Conte, insert:

ira. Paspalum Kentuckiénse Nash. Kentucky Paspalum. Culms tufted, 2-5 dm. tall, slender; sheaths ciliate on the overlapping margin, otherwise glabrous; leaves erect, lanceolate, $6 \mathrm{~cm}$. long or less, 4-10 $\mathrm{mm}$. wide, glabrous on both surfaces, ciliate on the margin with hairs less than I $\mathrm{mm}$. long; racemes single or in pairs, $2-5 \mathrm{~cm}$. long; spikelets about I.6 $\mathrm{mm}$. long and about I. $3 \mathrm{~mm}$. wide, glabrous. In dry soil, Ky. and Tenn. June-Aug. The upper surfaces of the leaves in this species are glabrous, while in $P$. longipedunculatum they are pubescent; the marginal leaf-hairs in this are but $1 \mathrm{~mm}$. long, about one-half the length of those in $P$. longipedunculatum. Type collected near Poor Fork P. O., Ky., by T. H. Kearney, Jr., Aug. I893.

\section{P. 83, after Panicum amàrum, insert:}

Ioa. Panicum ámaroìdes Scribn. \& Merr. Solitary Sea-Beach PANICUM. A low grass with long rootstocks, from which at rather distant intervals culms arise singly, glaucous foliage, and a slender narrow panicle which bears but few spikelets. Culms $3^{-8} \mathrm{dm}$. tall; sheaths overlapping; blades thick and leathery, involute, at least at the apex, $\mathrm{I} \cdot 5^{-2.5} \mathrm{dm}$. long, less than I cm. wide; panicle $\mathrm{I}-2 \mathrm{dm}$. long, the branches appressed; spikelets $5^{-6} \mathrm{~mm}$. long, commonly broad and stout, the first scale much exceeding one-half the length of the spikelet, or often equalling it or nearly so, the second and third scales about equal, all the scales acute. In sands along the coast, Ct. to Fla. and Miss. Aug.-Oct. Differs from P. amarum E11. by its rootstocks, nearly simple panicle, and larger spikelets.

\section{P. 84, after Panicum angustifòlium, insert:}

2ra. Panicum Búshii Nash. Bush's Panicum. A tufted nearly glabrous perennial. Culms about $3 \mathrm{dm}$. tall, finally much branched; leaves about 3 ; blades erect, linear, acuminate, very rough on the margins, ciliate at the base with a few very long hairs, the larger primary blades 8-10 cm. long, 3-4 mm. wide; panicle much exserted, $6-7 \mathrm{~cm}$. long, its branches ascending; spikelets $2.5 \mathrm{~mm}$. long and about $1.2 \mathrm{~mm}$. 
wide, obovoid, glabrous. In dry ground, Mo. June and July. Related to $P$. angustifolium Ell, but has glabrous leaves and spikelets, the latter also differing in shape.

P. 84 , before No. 17 , insert:

r6a. Panicum perlóngum Nash. Elongated Panic-grass. A tufted pubescent perennial. Culms 2-4 dm. tall, simple; sheaths hirsute with long ascending hairs; leaves elongated, linear, erect, papillose-hispid beneath, $2-3 \mathrm{~mm}$. wide, the upper one commonly 8-14 $\mathrm{cm}$. long; panicle much exserted, generally extending beyond the apex of the upper leaf, 4-6 cm. long, its branches erect or nearly so; spikelets about $3.25 \mathrm{~mm}$. long and $1.5-1.75 \mathrm{~mm}$. wide, pubescent with a few scattered long hairs. On prairies and in dry soil, Ill. to S. Dak. and the Ind. Terr. May-Aug. Differs from $P$. Enslini in having larger spikelets which are neariy glabrous.

P. 84, afte Panicum Bicknéllii Nash, insert:

18a. Panicum ciliàtum Ell. Ciliate Panic-Grass. Culms tufted, I-2.5 $\mathrm{dm}$. tall, simple, glabrous, the axis of the panicle and its branches hirsute; sheaths glabrous; leaves spreading or ascending, glabrous on both surfaces, conspicuously ciliate on the margin, usually $2-6 \mathrm{~cm}$. long and $5^{-10}$ $\mathrm{mm}$. wide; panicle $3-5 \mathrm{~cm}$. long, its branches ascending; spikelets I.8-2 $\mathrm{mm}$. long and about I $\mathrm{mm}$. wide, elliptic, pubescent with short spreading hairs. In sandy soil, Va. (according to T. H. Kearney, Jr.) to Fla. and Miss. May-July. The short and broad strongly ciliate leaves distinguish this from $P$. Bicknellii Nash, and the glabrous sheaths separate it readily from P. laxiflorum Lam.

\section{P. 85 , before No. 24, insert:}

23a. Panicum Yadkinénse Ashe. Yadkin Panic-grass. A glabrous perennial. Culms single, 8-Io dm. tall, finally somewhat branched; sheaths white-spotted; leaves ascending, lanceolate, acuminate, the primary ones 8-I2 cm. long, 8-I2 $\mathrm{mm}$. wide; panicle 8-12 cm. long, its branches long, ascending; spikelets about $2.3 \mathrm{~mm}$. long and I $\mathrm{mm}$. wide, elliptic, acute, glabrous. In dry or sandy soil, Md. to Ga. June-Sept. Differs from Panicum dichotomum $\mathrm{L}$. in its taller culms, and larger leaves and spikelets.

No. 24, read "lùcidum Ashe" instead of "sphagnícola Nash"; length of spikelets should be $1.5-2 \mathrm{~mm}$.; omit in line 7 the words "or sparsely pubescent".

\section{After Panicum Èatoni Nash, insert:}

27a. Panicum octonòdum J. G. Smith. Eight-Jointed Panic-grass. Glabrous. Culms erect, 7-II dm. tall, finally branched; leaves erect, firm, 4-I I cm. long, 4-8 mm. wide, lanceolate; panicle 9-I3 cm. long, oblong, dense, $2-4 \mathrm{~cm}$. wide, its branches erect or nearly so; spikelets $1.3 \mathrm{~mm}$. long and about $0.8 \mathrm{~mm}$. wide, glabrous, oval or nearly globular. In wet places, N. J. to Ala. and Tex. May-Aug. Differs from Panicum Eatoni in its smaller, nearly globular glabrous spikelets.

\section{P. 85 , after Panicum Ėatoni, insert:}

27b. Panicum paucípilum Nash. Few-haired Panicum. A tufted nearly glabrous perennial. Culms $6-\mathrm{ro} \mathrm{dm}$. tall; leaves $5-8$; sheaths with the exterior margin ciliate toward the summit; blades erect or ascending, thickish, sometimes minutely puberulent on the lower surface, the lower and larger primary ones 6-9 $\mathrm{cm}$. long, 5-7 $\mathrm{mm}$. wide; panicle 5-10 cm. long, rather dense, its branches erect-ascending or erect; spikelets numerous, about r.4 mm. long and $0.8 \mathrm{~mm}$. wide, oval, pubescent with spreading hairs. In wet soil, southern N. J. to Fla. and Miss. July and Aug. 
27c. Panicum leucothrix Nash. Gray-haired Panicum. A villous densely tufted perennial. Culms 3-6 dm. tall; primary leaves 3-5; blades erect, rather firm, lanceolate, densely and softly pubescent on the lower surface with short spreading hairs, glabrous above, $3-5 \mathrm{~cm}$. long, 4-6 $\mathrm{mm}$. wide; primary panicle usually $3-5 \mathrm{~cm}$. long, broadly ovoid, its branches ascending; spikelets about I.2 $\mathrm{mm}$. long and about $0.6 \mathrm{~mm}$. wide, oval, pubescent. In usually dry sandy soil, southern N. J. to Fla. and Tex. July and Aug.

After Panicum boreale, insert:

28a. Panicum Clútei Nash. Clute's Panicum. A tufted nearly glabrous perennial. Culms rather stout, $6-8 \mathrm{dm}$. tall, at length branched; leaves 4 or 5 ; sheaths rather loose, minutely pubescent at the apex; blades firm, ascending, lanceolate, smooth on both surfaces, rough on the margins, the lower and larger $7-14 \mathrm{~cm}$. long, 7-I2 $\mathrm{mm}$. wide; panicle considerably exserted, broadly ovoid, 6-10 cm. long; spikelets oval, acutish, about $2.3 \mathrm{~mm}$. long and $1.3 \mathrm{~mm}$. wide, densely pubescent with short hairs. In the pine-barrens of southern N. J. July. Differs from $P$. boreale Nash by its stouter habit and larger spikelets.

P. 86, No. 35, read " unciphyllum Trin." instead of "pubéscens Lam.", and as a synonym add " $P$. pubescens A. Gray, not Lam."

After No. 35, insert:

35a. Panicum Tennesseénse Ashe. Tennessee Panic-grass. Culms tufted, 4-6 dm. tall, rather weak and ascending, papillose-hirsute with long spreading hairs; leaves ascending, lanceolate, the lower surface softly and densely pubescent with short hairs, the upper surface with scattered long hairs, the primary leaves 4-10 $\mathrm{cm}$. long, 5-10 $\mathrm{mm}$. wide, those on the branches much shorter and spreading and with the upper surface nearly glabrous; panicle 7-10 $\mathrm{cm}$. long, its branches ascending; spikelets 1.7-2 $\mathrm{mm}$. long, o.8-0.9 mm. wide, elliptic or obovoid, strongly pubescent with long spreading hairs. In woods, N. Y. and Ill. to Tenn. and Fla. JulySept. Differs from $P$. uncifhyllum Trin, in its lighter color, usually weak culms, and the glabrous upper surface of the leaves.

P. 87, No. 38, read " scopàrium Lam." instead of "víscidum Ell.", and refer the latter to synonymy, to which add also " $P$. pubescens Lam."

After No. 38, insert:

38a. Panicum scabriúsculum Ell. Rovghish Panic-Grass. Culms glabrous or pubescent, 8-14 dm. long, erect, finally branched; sheaths glabrous or pubescent; leaves erect or ascending, linear-lanceolate, glabrous, I-2 dm. long, 8-12 mm. wide; panicle I-2 dm. long, its branches spreading or ascending; spikelets lanceolate, glabrous, $2-2.3 \mathrm{~mm}$. long and I $\mathrm{mm}$. broad, ovate to ovate-lanceolate, acute, the nerves of the flowering scale very prominent. In swampy places and ponds, Va. to Fla. and Tex. May-Aug. Differs from $P$. scoparium Lam. in its longer and narrower glabrous leaves and glabrous spikelets.

P. 87, after Panicum Addisònii, insert:

39a. Panicum psammophilum Nash. SAND PANICUM. A tufted perennial. Culms $2-4 \mathrm{dm}$. tall, appressed-hirsute below, finally much branched; leaves of the main culm 3-5; sheaths appressed-pubescent; blades erect or nearly so, thick, firm, serrulate on the margins, puberulent beneath, occasionally with a few long scattered hairs on the upper surface, the primary blades $2-5 \mathrm{~cm}$. long and $2-5 \mathrm{~mm}$. wide; primary panicle usually $2-3 \mathrm{~cm}$. long, at least its axis puberulent; spikelets broadly obovate, I. 3-1.5 mm. long, $0.8-1 \mathrm{~mm}$. wide, obtuse, densely pubescent with spreading hairs. In sandy soil along the coast, Mass. to N. J. June to Aug. Differs from $P$. Addisonii Nash by its much smaller spikelets. 
After Panicum Commonsiànum, insert:

40a. Panicum scoparioìdes Ashe. A tufted pubescent perennial. Culms $3^{-8} \mathrm{dm}$. tall, rather slender, pubescent with ascending hairs; leaves about 4 ; sheaths strongly papillose, ascending stiff hairs arising from the papillæ; blades ascending, lanceolate, $5-10 \mathrm{~cm}$. long, $5^{-8} \mathrm{~mm}$. wide, glabrous on the upper surface, the lower surface more or less pubescent with scattered spreading hairs; panicle barely exserted, $5-8 \mathrm{~cm}$. long, its branches ascending; spikelets about $2.5 \mathrm{~mm}$. long and about I. $3 \mathrm{~mm}$. wide, elliptic, pubescent. In dry soil, Penn. and Del. July and Aug. Differs from $P$. Commonsianum Ashe in the barely exserted panicle, the broader leaf-blades, and the papillose sheaths with spreading shorter hairs.

After Panicum Scribneriànum Nash, insert:

43a. Panicum oligosánthes Schult. Culms tufted, erect, 3-8 dm. tall, villous, finally fasciculately branched; sheaths, at least the lower ones and those of the branches, papillose-hispid, ciliate on the margin; leaves erect or ascending, 5-IO $\mathrm{cm}$. long, 5-10 mm. wide, lanceolate, softly and densely pubescent on the lower surface, the upper surface glabrous or nearly so; primary panicle $6-8 \mathrm{~cm}$. long, its branches ascending; spikelets about 3.5 $\mathrm{mm}$. long and $1.7 \mathrm{~mm}$. wide, oval, pubescent. In dry soil, Va. to Ga. and Miss. June-Sept. Differs from P. Scribnerianum Nash by its usually fewer spikelets and the softly pubescent lower surface of the leaves.

43b. Panicum Ravenélii Scribn. \& Mer. Ravenel's Panic-Grass. Culms tufted, erect, $4-6 \mathrm{dm}$. tall, finally branched, papillose-hirsute below with ascending hairs, the pubescence above softer; sheaths densely papillosehirsute with ascending hairs; leaves erect or ascending, glabrous above, densely and softly pubescent beneath, broadly lanceolate, 8-I2 cm. long, I-2 $\mathrm{cm}$. wide, cordate at the clasping base; panicle 8-10 $\mathrm{cm}$. long, its branches ascending; spikelets about $4 \mathrm{~mm}$. long and $1.8 \mathrm{~mm}$. wide, obovoid, pubescent with rather weak hairs. In woods, D. C. to Fla. and La. July-Sept. (P. scoparium Ell., not Lam.) Differs from $P$. Scribnerianum in its broader leaves with the lower surface softly pubescent, and from $P$. oligosanthes in its larger leaves and more numerous spikelets.

P. 88, after Panicum Porteriànum Nash, insert:

5ra. Panicum pubifòlium Nash. Hairy-Leaved Panic-Grass. A tufted softly pubescent perennial. Culms 3-7 dm. tall, the nodes densely barbed; sheaths densely pubescent and ciliate on the margins; leaves spreading or ascending, ovate-lanceolate to ovate, cordate at the rounded clasping base, pubescent on both surfaces with short spreading hairs, the upper primary leaves 7-II cm. long and $2-3 \mathrm{~cm}$. broad, the lower smaller; primary panicle usually but little exserted, 7-I I cm. long, its axis, as well as the branches, densely pubescent with short soft spreading hairs; spikelets 4-5 $\mathrm{mm}$. long and about $1.6 \mathrm{~mm}$. broad, narrowly obovoid, the scales distant, strongly pubescent with long spreading hairs. In rocky woods, N. Y. to Fla., Mo. and Miss. June-Sept. Differs from Panicum Porterianum Nash in having the whole plant softly pubescent, especially the lower surface of the leaves and the panicle.

P. 88, after Panicum clandestìnum, add:

53. Panicum decoloratum Nash. Discolored Panicum. A more or less purplish tufted perennial, glabrous or nearly so. Culms $4^{-6} \mathrm{dm}$. tall, finally branched, the nodes barbed; leaves 5 or 6 ; sheaths loosely embracing the culm, the lower and basal ones papillose-hirsute between the nerves, the upper ones ciliate on the external margin; blades erect or ascending, variously colored with black-purple, broadly lanceolate, cordate-clasping at the base, $7-12 \mathrm{~cm}$. long, $\mathrm{I}-2 \mathrm{~cm}$. wide, very rough on the margins; panicle usually included at the base; spikelets $2.7 \mathrm{~mm}$. long and I.3 mm. wide, elliptic, sparingly pubescent. In sandy soil, Penn. May and June. Differs from its nearest relative, $P$. clandes- 
tinum L., in the softer pubescence, naked leaf-margins, and smaller spikelets.

P. 9o, before Chaetochloa occidentàlis Nash, insert:

2a. Chaetochloa imbérbis (Poir.) Scribn. Perennial Foxtail-grass. Perennial. Culms tufted, 3-7 dm. tall, from rootstocks, slender, compressed, rough below the raceme; sheaths glabrous, compressed; leaves I-3 dm. long, 3-7 mm. wide, the upper surface often with a few long hairs at the base; racemes dense, spikelike, $2-5 \mathrm{~cm}$. long, nearly $\mathrm{I} \mathrm{cm}$. in diameter, exclusive of the bristles, the rachis pubescent; bristles 5-IO mm. long; spikelets ovoid, acute, $2-2.5 \mathrm{~mm}$. long, the flowering scale acute, striate, finely transverse-rugose. In moist soil, N. J. to Fla. and Tex.; and in Kans. and Mo. Also in Tropical America. June-Aug. Differs from C. glauca in having the bristles green or purplish instead of tawny yellow, and in being perennial instead of annual. From $C$. versicolor Bicknell it is distinguished by the 5-7-nerved second scale of the spikelet.

P. 9०, after Cenchrus tribuloides L., insert:

ra. Cenchrus macrocèphalus (Doell) Scribn. Large Bur-grass. Culms at first erect or ascending, finally falling prostrate, becoming branched and forming mats, 3-6 dm. long; sheaths very loose, glabrous, compressed; leaves flat or complanate, smooth and glabrous, I dm. long or less, 4-8 $\mathrm{mm}$. wide; spikes stout, $3-5 \mathrm{~cm}$. long; involucres $5-12,6-8 \mathrm{~mm}$. broad, enclosing 2 spikelets, pubescent, the spines usually 5-8 $\mathrm{mm}$. long, the spikelets not exserted beyond the involucre. Along the seashore, N. J. to Miss. July-Sept. Differs from C. tribuloides L. in having the involucres much larger; in that species they are usually less than $5 \mathrm{~mm}$. broad.

P. 95, after Aristida grácilis Ell., insert:

roa. Aristida intermèdia Scribn. \& Ball. Intermediate Aristida. Culms slender, finally branching, 3-8 dm. tall; sheaths glabrous or sparsely hirsute; leaves $5^{-15} \mathrm{~cm}$. long, $2 \mathrm{~mm}$. wide or less, erect, involute; panicle 2-4 dm. long, slender, its branches appressed; spikelets 8-10 $\mathrm{mm}$. long, the empty scales manifestly awned, about equal, the flowering scale strongly hispidulous above the middle, equalling or exceeding the empty scales, the awns spreading, the middle one $15-25 \mathrm{~mm}$. long, the lateral ones shorter. In sandy soil, Ia. to Miss. and Tex. July-Sept. Intermediate between $A$. gracilis and $A$. purpurascens, having the large spikelets of the latter, and more the habit of the former.

P. 105, before Sporobolus longifòlius (Torr.) Wood, insert:

ra. Sporobolus canóvirens Nash. Southern Rush-Grass. Culms erect, 3-Io dm. tall; leaves $2.5 \mathrm{dm}$. long, or less, I-3 mm. wide, attenuate and filiform above; panicle $5^{-1} 3 \mathrm{~cm}$. long: spikelets $5^{-6} \mathrm{~mm}$. long, the scales acuminate, the empty ones unequal, the flowering scale appressed-pubescent below with long hairs, about equalling or a little exceeded by the acute palet. In dry sandy soil, Tenn. to Mo., Kans., Miss. and Tex. July-Sept. Resembles S. asper, but the spikelets are smaller, and the palet much shorter relatively, equalling or but little exceeding the flowering scale.

P. I30, after Eragrostis capillàris (L.) Nees, insert:

ra. Eragrostis hirsùta (Michx.) Nash. HaIry Eragrostis. Culms densely tufted, rather stout, $7-13 \mathrm{dm}$. tall; sheaths, at least the lower ones, strongly papillose-hispid, each with a tuft of hairs at the apex; leaves flat, the lower ones $4-6 \mathrm{dm}$. long, less than I cm. wide; panicle 5-8 dm. long, diffuse, its branches finally widely spreading; spikelets 3-5-flowered, 3-4 $\mathrm{mm}$. long, the flowering scales $2-2.5 \mathrm{~mm}$. long. In dry fields, thickets 
and woodlands, Va. (according to T. H. Kearney, Jr.) to Fla., the Ind. Terr. and Tex. Aug. and Sept. Differs from E. capillaris in its stouter and taller culms, strongly papillose-hispid sheaths, and elongated leaves.

\section{P. I3I, after Eragrostis secundiflòra Presl, insert:}

12a. Eragrostis capitàta (Nutt.) Nash. Culms branching and creeping, rooting at the nodes, which send up branches $6-10 \mathrm{~cm}$. long; sheaths, at least those on the branches, pubescent; leaves spreading or ascending, $\mathbf{I - 3} \mathrm{cm}$. long, I.5-3 $\mathrm{mm}$. wide, flat, lanceolate, pubescent; panicle $2-3 \mathrm{~cm}$. long, nearly or quite as broad, oval; spikelets crowded, clustered, 12-30flowered, 6-I4 mm. long. (Poa capitata Nutt.) In sandy, usually wet soil, Ark. and La. to Neb., N. Mex. and Tex. Also in Mexico. June-Aug. Differs most prominently from E. hypnoides (Lam.) B.S.P. by its longer pubescent flowering scales.

P. 132, in Eatonia obtusàta (Michx.) A. Gray, third line, omit the words "sometimes pubescent"; add:

ra. Eatonia pubéscens Scribn. \& Mer. Hairy Eatonia. A tufted perennial, with the sheaths, back of the ligule and lower part of the culm softly and densely pubescent. Culıns 3-8 dm. tall; leaves 5-I8. cm. long, 3-6 mm. wide, glabrous, or often softly pubescent; panicle $5-20 \mathrm{~cm}$. long; spikelets $2.5-3.5 \mathrm{~mm}$. long. In dry soil, Conn. to Penn., Ga. and Tex. May-Aug. Differs from E. obtusata in having the sheaths, and often also the leaves and culms, softly pubescent.

After Eatonia nítida (Spreng.) Nash, insert:

3a. Eatonia glàbra Nash. Sмоотн Eatonia. Clums densely tufted, slender, $3-7 \mathrm{dm}$. tall; sheaths glabrous; leaves rough, flat, $2-7 \mathrm{~cm}$. long, I.5-3 $\mathrm{mm}$. wide; panicle 7-I $5 \mathrm{~cm}$. long, slender, nodding at the summit; spikelets 3-4 mm. long. In woods, southern N. Y. to Tenn. MayJuly. The glabrous sheaths and leaves separate this from $E$. nitida. Type collected in Madison Co., Tenn., by S. M. Bain, Apr. I893, No. 507.

P. I35, after Uniola láxa (L.) B.S.P., insert:

ra. Uniola longifôlia Scribn. Hairy-Sheathed Uniola. Culms tufted, 8-12 dm. tall; sheaths, at least the lower ones, densely hirsute; leaves flat, $3 \mathrm{dm}$. long or less, narrowed at both ends, 6-12 $\mathrm{mm}$. wide; panicle $2-4.5$ $\mathrm{dm}$. long, its branches short and appressed, or the lower ones sometimes long and ascending; spikelets $3-4$-flowered, usually about $6 \mathrm{~mm}$. long, the flowering scales about $5 \mathrm{~mm}$. long. In dry, usually sandy soil, Tenn. to Fla. and La. Aug. and Sept. Distinguished by its larger size and strongly hirsute sheaths.

P. 156, in Elymus striàtus Willd., sixth line, omit the words "rough, hispid or"; add:

ra. Elymus Arkansànus Scribn. \& Ball. Arkansas Wild Rye. Culms slender, erect, 6-9 dm. tall; sheaths ciliate on the margin; leaves $\mathrm{I}-2 \mathrm{dm}$. long, $4-8 \mathrm{~mm}$. wide, erect or ascending, auricled at the base, rough on the lower surface, the upper surface finely and densely pubescent; spike longexserted, nodding, $6-9 \mathrm{~cm}$. long: spikelets 2 at each node, 2 -flowered; empty scales linear-subulate, hispidulous and 2-3-nerved above, 8-10 $\mathrm{mm}$. long and bearing a straight awn $\mathrm{I}-2 \mathrm{~cm}$. long; flowering scales minutely hispidulous, about $7 \mathrm{~mm}$. long, ending in a straight awn $2-4 \mathrm{~cm}$. long. In woods, Ia. to Ark. and Mo. July. Differs from E. striatus in having the empty and flowering scales merely hispidulous.

P. 157, after Elymus hirsutiglùmis Scribn. \& Sm., insert:

3a. Elymus austràlis Scribn. \& Ball. Southern Wild Rye. Culms stout, erect, 9-I5 dm. tall; sheaths rough-hairy; leaves ascending, 2-3 dm. long, I-I.5 $\mathrm{cm}$. wide, very rough on the lower surface, rough or rough- 
hairy above; spike I-I.5 dm. long; spikelets 2 at each node, 4-5-flowered; empty scales diverging, thickened, coriaceous and somewhat curved at the base, usually rough-hairy, about $1.5 \mathrm{~cm}$. long, bearing an awn of about the same length; flowering scales 8-10 $\mathrm{mm}$. long, hirsute, terminated by a straight awn $2.5-3 \mathrm{~cm}$. long. In moist woods and thickets, N. C. to Fla., west to Ark. and Mo. July and Aug. Intermediate between E. hirsutiglumis and E. Canadensis; separated from the former by its stouter spike and longer scales and awns, and from the latter by the thickened and hirsute empty scales.

3b. Elymus glabriflòrus (Vasey) Scribn. \& Ball. Smooth-FLowered Wild Rye. Culms erect, stout, 5-10 dm. tall; sheaths loose, smooth or rough-hairy; leaves numerous, I.5-3 dm. long, 6-1o mm. wide, erect or ascending, somewhat roughened on the lower surface, rough and sometimes a little hairy on the upper surface; spike stout, erect or nodding, I-I.5 dm. long, sometimes glaucous; spikelets 2 or 3 at each node, 3-5-flowered; empty scales thickened, strongly 3-5-nerved, hispidulous on the nerves, II-I5 mm. long, bearing an awn about $2 \mathrm{~cm}$. long; flowering scales 9-12 $\mathrm{mm}$. long, minutely hispidulous, terminated by a straight slender awn 2-3 $\mathrm{cm}$. long. In low rich woods or thickets, Penn. to Tenn. and $\mathrm{Ga}$., west to N. Mex. July and Aug. Related to E. hirsutiglumis, but distinguished by its merely hispidulous, not hirsute, flowering scales. add:

In Elymus Canadensis L., line 6, omit the words " nearly smooth to";

4a. Elymus brachystáchys Scribn. \& Ball. Short-spiked Wild Rye. Culms stout. 3-Io dn. tall, erect; sheaths glabrous; leavs $\mathrm{I}-2 \mathrm{dm}$. long, 6-10 $\mathrm{mm}$. wide, ascending, smooth or a little rough below, finely hispidulous above; spike rather dense, $8-16 \mathrm{~cm}$. long, much exserted; spikelets 2 at each node, 3-5-flowered; empty scales hispidulous, 8-10 $\mathrm{mm}$. long, bearing a straight awn $1.5-2.5 \mathrm{~cm}$. long; flowering scales smooth or minutely hispidulous, II-I3 mm. long, 5-nerved, the nerves next the midnerve oiien shortly excurrent, terminated by a straight or sometimes diverging awn 2-4 cm. long. In moist open or shaded places, Mich. and S. Dak. to N. Mex. and Tex. Also in Mexico. June-Aug. Distinguished from $E$. Canadensis by its smaller size and merely hispidulous, not hirsute, towering scales.

P. I6I, Cyperus microdóntus, read for range, Va. and N. C., and add:

5a. Cyperus Gátesii Torr. Gates's CyPERus. Annual; bright green. Leaves $0.5-4 \mathrm{~mm}$. wide; scapes tufted, I-4 dm. high, often longer than the leaves; bracts of the involucre surpassing the 3-8-rayed umbel; rays of the umbel I-5 cm. long; spikelets linear to linear-lanceolate, 6-15 $\mathrm{mm}$. long, acute; scales oblong-lanceolate, shining, striate; achene oblong, abruptly apiculate. In moist soil, Va. to Fla. and Tex. May-Sept. Differs from C. microdontus in the oblong, not ovate, scales, the 3-8-rayed, not capitate, umbel, and the abruptly apiculate achene.

P. 162. Cyperus Schweinitzii, strike Kans. from range and add:

9a. Cyperus Búshii Britton. Bush's Cyperus. Perennial by tuberlike corms. Leaves 3-4 $\mathrm{mm}$. wide, smooth; scapes smooth, 3-6 dm. high, longer than the leaves; longer involucral bracts much exceeding the umbel; umbel capitate, or with $1-5$ rays; spikelets loosely capitate, flat, linear, acute, 8-16 mm. long; scales firm, shining, oblong, mucronate, strongly about II-nerved; achene oblong, 3-angled, nearly twice as long as thick, apiculate, two-thirds as long as the scale. In sandy soil, Minn. to Wis., Neb. and the Ind. Terr. July-Sept. Type collected by B. F. Bush at Arkansas, Ind. Terr.

P. I69, Eleocharis ovàta, ranges southward cnly to Mass. and Mich.; 
8a. Eleocharis obtúsa Schultes, Blunt SPIKE-RUSH. Differs from Eleocharis ovata in the pale scales of the spike and in the tubercle, which is nearly or quite as broad and about one-third as high as the achene. In wet soil, N. S. to Fla., Br. Col., Kans. and Texas.

\section{P. I70, before Eleocharis aciculàris, insert:}

roa. Eleocharis Smállii Britton. Small's SPIKE-RUSH. Perennial; llms rather stout, about $6 \mathrm{dm}$. high and $2-3 \mathrm{~mm}$. thick. Summit of the basal sheath oblique; spikelet cylindric, acute, about $1.5 \mathrm{~cm}$. long, about as thick as the culm; scales narrowly lanceolate-oblong, acuminate; achene dark brown, obovate, turgid-lenticular, somewhat shining, I.5 mm. long, rounded at the top; tubercle bulb-like, constricted at the base, one-fourth as long as the achene and about one-half as wide; bristles about as long as the achene and tubercle. Valley of the Susquehanna River, Pa. Aug.-Oct.

\section{P. I7I, after Eleocharis intermèdia, insert:}

2ra. Eleocharis Macoùnii Fernald. Macoun's SpIKe-Rush. Annual, similar to E. intermedia, but with stouter culms, longer, narrower, ellipticlanceolate, densely flowered spikelets about I cm. long. Scales dark brown; achene compressed-trigonous, obovate, light brown, shining, tubercle deltoid-conic, about half as long as the achene; bristles downwardly barbed, about as long as the achene and tubercle. Borders of marshes, North Wakefield, Quebec.

\section{P. I78, after Scirpus válidus, insert:}

I5a. Scirpus heterochaètus Chase. Unequal-BRistled Bulrush. Similar to S. validus, but more slender, though about as tall. Umbel compound, of $9^{-1} 7$ ovoid-oblong acute spikelets $8-\mathrm{I} 2 \mathrm{~mm}$. long; scales reddish brown, ovate-oblong, emarginate, glabrous, the excurrent midvein scabrous; style 3 -cleft; bristles $2-4$, usually 2 , unequal, fragile shorter than the achene, retrorsely barbed; achene obovate, trigonous, $2.5-3$ $\mathrm{mm}$. long. Lakes and ponds, Vt. to N. Y., Ill., Minn., Nebr. and Ore.

\section{P. I79, after Scirpus robústus, insert:}

rga. Scirpus Férnaldi Bicknell. Fernald's Bulrush. Slender, rather pale green, the sharply three-angled culms $4-8 \mathrm{dm}$. high; leaves $2-6$ $\mathrm{mm}$. wide, slenderly attenuate, the longer ones often surpassing the culms; primary involucral leaf erect, mostly $1.5^{-2} \mathrm{dm}$. long; spikes rather pale, short-ovate or finally broadly ovate, I-I.5 cm. long, I-3 in a sessile cluster or stipitate, and I-5 borne on slender, stiffly flexuous or crinkled, wiry, diverging peduncles $2-7 \mathrm{~cm}$. long; scales finely close-puberulent, the lower ones often somewhat spreading, becoming bifid and finally lacerate, the midvein excurrent in a recurved awn 3-12 $\mathrm{mm}$. long; achene yellowish brown and shining, broadly truncated, obovoid-cuneate, $2.5-3 \mathrm{~mm}$. long and broad, almost equally trigonous or slightly depressed-trigonous with rounded angles or the dorsal swelling more or less umbonate, shortmucronulate; bristles fugacious, shorter than or equal to the achene. Mt. Desert, Me., shore of Somes Sound with S. paludosus, Aug. 20, I898.

sb. Scirpus paludòsus A. Nelson. Low Marsh Bulrush. Similar to $S$. robustus Pursh, but lower and more slender, with shorter, narrower leaves and more densely clustered, sessile, mostly ovate or ovate-oblong, dark brown spikes; culms I.5-6 dm. high, stiff and often very slender, usually growing in close colonies, the leaves I-4 mm. wide. Resembles $S$. interior Britton, of the prairie region, but the spikes are much darker, the achenes more truncate-obovate and more bluntly angled. From Can. and New Eng. to N. J. and at alkaline inland stations, flowering from 2-4 weeks earlier than $S$. robustus. 
No. 24, for "Scirpus microcàrpus Presl", read "Scirpus rubrntìnctus Fernald." S. microcarpus occurs only on the Pacific slope.

P. I8o, at end of Scirpus, add:

30. Scirpus atrocínctus Fernald. Blackish Wool-grass. Similar to $S$. cypcrinus L., S. Eriophorum Michx., but the culm slender, about $1.5 \mathrm{~mm}$. thick at the top, the bases of the involucral leaves black or nearly so; inflorescence loose and ample with the spikelets pedicelled, or these in a subcapitate cluster; scales greenish black; bristles light brown or olivebrown. In wet places, Newf. to Manitoba, Saskatchewan, Conn., Penn. and Iowa.

For "Scirpus çpérinus Erióphorum" read "Scirpus Erióphorum Michx." The plant proves to be specifically distinct from $S$. cyperis:us and from the foregoing.

P. I 86, after Rynchospora gracilenta, insert:

roa. Rynchospora Smállii Britton. Small's Beaked-Rusir. Culms rather stout, I.4 m. high or less, tufted. Leaves flat, $2-5 \mathrm{~mm}$. wide; spikelets numerous in several rather loose clusters, $3-4 \mathrm{~mm}$. long, fusiform, their scales brown; bristles upwardly barbed, as long as the achene and tubercle; achene narrowly obovate, brown, smooth, shining, I. $5 \mathrm{~mm}$. long, the smooth tubercle about one-half as long. Bogs and damp hillsides, Pa. and N. C. July-Aug.

P. 188, after Scleria pauciflòra, insert:

Scleria ciliàta Michx. HAIRY NuT-RUSH. Resembles Scleria pauciflora, but is usually stouter, $3-6 \mathrm{dm}$. high, pubescent; bracts of the flower-clusters ciliate; achenes subglobose to globose-ovoid, $3 \mathrm{~mm}$. long, acute, roughened by short ridges or projections; hypogynium a narrow obtusely 3 -angled border supporting 3 tubercles, these often 2-lobed. In pine lands, Va. to Fla., Mo. and Tex. Also in the W. I. June-Sept.

P. 189 , before Uncínia, insert:

2. Kobresia elachycarpa Fernald. Tufted; culms compressed, wiry, $5.5 \mathrm{dm}$. high or less, rough toward the top. Leaves $\mathrm{I}-2 \mathrm{~mm}$. wide, flat, much shorter than the culms; spike $\mathrm{r}-2.5 \mathrm{~cm}$. long; spikelets $2-7$, staminate, androgynous, or pistillate; scale ovate; glume ovate, connate at base, emarginate; stigmas 2, elongated; stamens 2 ; achene oblong, truncate, nerveless, about $\mathrm{x} .5 \mathrm{~mm}$. long. Me. June-July.

P. 223, after Carex interior capillacea, insert:

I76a. Carex seòrsa E. C. Howe. HowE's SEDGE. Loosely tufted; culms weak, $6.5 \mathrm{dm}$. high or less. Leaves pale green, soft, 2-4 mm. wide, shorter than the culms; spikes 2 to 6, subglobose to oblong, 6-20flowered, remote, or the upper approximate, $3 \cdot 5^{-7} \mathrm{~mm}$. long, the lowest one often subtended by a filiform tract, the uppermost with many staminate flowers at its base; scales membranous, ovate, acute, much shorter than the perigynia; perigynia ovate elliptic, widest near the middle, strongly nerved, tapering to both ends, substipitate, with a very short and smooth beak. In wet woods and swamps, Mass. to S. N. Y. and Del. May-June.

P. 226 , before Carex scopària, insert:

192a. Carex Crawfòrdii Fernald. Crawford Notch Sedge. Culms slender, tufted or solitary, $\mathrm{I}-3 \mathrm{dm}$. tall, rough above. Leaves $2.5 \mathrm{~mm}$. wide or less, often exceeding the culms; spikes oblong or ovoid, bluntish, greenish brown, clustered in an oblong head, the lower one often subtended by a filiform bract which sometimes surpasses the head; perigynia narrowly lanceolate, firm, about $4 \mathrm{~mm}$. long, $1.5 \mathrm{~mm}$. wide or less. Newf. to Assiniboia, Mass., N. Y., and Mich. June-Sept. 


\section{P. 227 , after Carex leporina, insert:}

194a. Carex Oronénsis Fernald. ORono SEDGe. Loosely cæespitose, $1 \mathrm{~m}$. high or less, the slender culms erect, rough above. Leaves $2.5-4$ nım. wide, shorter than the culms; spikes $3-9$, oval to obovoid, 5-1o mm. long, ascending, dark brown, acutish, clustered in an oblong-cylindric spike; scales scarious-margined, ovate, acutish, about equalling the perigynia; perigynia narrowly lanceolate, $3.5-4.5 \mathrm{~mm}$. long, narrowly winged above. Woods, thickets, and fields, Orono, Me. June-July.

\section{P. 227 , after Carex adùsta, insert:}

I96a. Carex aènea Fernald. Wiry Sedge. Culms wiry, smooth, I $2 \mathrm{dm}$. high or less, tufted, much longer than the leaves, the top nodding. Leaves flat, 2-4 mm. wide; spikes obovoid, light brown, the upper close together, the lower separated; perigynia ascending, lenticular, ovate, 4-5 $\mathrm{mm}$. long, about one-half as wide as long, brown, the inner face nerveless or few-nerved toward the base. Newf. to Alberta, Mass., N. Y. and Mich. June-Aug.

P. 228, after Carex tenera invìsa, insert:

200a. Carex suberécta (Olney) Britton. Prairie Sedge. Culms tufted, slender but stiff, erect, 6-9 dm. high, longer than the leaves, rough above. Leaves flat, 2-3.5 $\mathrm{mm}$. wide; spikes 2-6, clustered at the top of the culm, ovoid or oblong, acutish, 7-10 mm. long, ferruginous; scales ovate-lanceolate, acuminate or short-awned, appressed, shorter than the perigynia; perigynia ovate, about $5 \mathrm{~mm}$. long and one-half as wide as long, appressed or closely ascending, broadly winged, rather abruptly narrowed into the sharp beak (C. tenera var. suberecta Olney; $C$. foenea var. ferruginea A. Gray, not $C$. ferruginea Scop.). Ohio to Mich., Ill. and Iowa.

\section{P. 229, after Arisaema triphyllum, insert:}

ra. Arisaema Stewardsònii Britton. STEWARDSON BRown's INDIAN TURnIP. Dark green, 3-6 dm. high. Leaf-segments 3, lanceolate, acuminate, thin, narrowed at the base, shining on both sides, 4-20 $\mathrm{cm}$. long; spathe about as long as its peduncle, strongly fluted, green with white stripes, the dilated part acuminate; spadix slender, blunt; fruits 8-10 $\mathrm{mm}$. in diameter. In wet woods, growing among Sphagnum, Penn. to Vt. Differs from related species by its fluted spathe and shining leaves. Type from Tannersville, Penn., collected by Stewardson Brown, E. P. Bicknell and N. L. Britton, July $4^{\text {th, }}$ Igor.

P. 236, after Xyris Caroliniàna, insert:

4a. Xyris Cóngdoni Small, n. sp. Congdon's Yellow-eyed Grass. Scapes relatively stout, $4-6.5 \mathrm{dm}$. tall. Leaves linear from a broad base which is sometimes over I $\mathrm{cm}$. wide, the longer ones nearly as long as the scapes; head oval or nearly so, I 1-16 mm. long; bracts erose at the top, the larger ones 6-8 $\mathrm{mm}$. long; lateral sepals $6-7 \mathrm{~mm}$. long, the broad keel crested above the middle. Differs from $X$. Caroliniana in the greater size of the plant, the broader greatly elongated leaves, the more numerous bracts of the head, and the longer lateral sepals. Low grounds, Mass to N. J., near the coast. Type from Scuth Kingston, R. I. Aug.-Sept.

P. 237, after Eriocaulon septanguláre, insert:

Ia. Eriocaulon Párkeri Robinson. 'PARKER's PIPE-wort. Tufted, nearly glabrous, 6-I I cm. high. Leaves linear-lanceolate, $3-4 \mathrm{~mm}$. wide at the base, 3-5 cm. long, 7-9-fenestrate-nerved; scapes erect, subrigid; heads 3-4 $\mathrm{mm}$. in diameter, campanulate at the base in fruit (ellipsoid in E. septangulare); flowers erect (the outer ones spreading in 
E. septangulare); perianth-segments nearly glabrous. In tidal rud near Camden, N. J. Sept.-Oct.

P. 248, after Juncus ténuis, insert:

Ira. Juncus intèrior Wiegand. InLAND RUSH. Plants 5-10 dm. tall, light green. Leaves basal; blades about one-third the length of the scape, I-I.25 mm. wide, sometimes involute; scapes grooved; inflorescence 3-IO $\mathrm{cm}$. long, many-flowered, the branches ascending; flowers scattered, rather distant; perianth straw-colored, 3-4 $\mathrm{mm}$. long; sepals and petals nearly equal, lanceolate-subulate, slenderly acute or acuminate. appressed or erect; stamens 6, one-half as long as the perianth; anthers much shorter than the filaments; capsule oblong or rarely ovoid-oblong, about as long as the perianth, obtuse or barely apiculate; seeds oblong, $0.35-0.50 \mathrm{~mm}$. long. In dry woods or on prairies, I1l. to Wyo., Tenn., Miss. and Ariz. Spring and early summer. Differs from $J$. secundus in the longer bracts of the inflorescence, the larger perianth, the flowers scarcely or not at all secund.

r rb. Juncus Dúdleyi Wiegand. Dudley's Rush. Plants 3-Io dm. tall, pale green. Leaves basal; blades about one-half the length of the scape, or less, very narrowly linear, flat, frequently somewhat involute; scapes tufted, often relatively stout, but wiry, striate-grooved; inflorescence 2-5 $\mathrm{cm}$. high, or rarely slightly larger, usually rather congested, considerably exceeded by its bract, few-flowered; perianth green or pale straw-colored, 4-5 $\mathrm{mm}$. long; sepals and petals firm, nearly equal, lanceolate-subulate, acute, more or less spreading, scarious-margined; anthers slightly shorter than the filaments; capsules ovoid-oval, shorter than the perianth, somewhat apiculate; seeds oblong, $0.37-0.45 \mathrm{~mm}$. long, apiculate at each end. In damp soil and open places, Me. to Ont., Saskatchewan, Wash., Conn., Tenn. and Mex. Spring and summer. Differs from J. tenuis by the yellow-brown cartilaginous margins of the leaf-sheaths.

P. 248, after Juncus Váseyi, insert:

13a. Juncus Oronénsis Fernald. Orono Rush. Perennial, tufted, similar to J. Vaseyi, but the inflorescence elongated and much shorter than the filiform lower bract, which is sometimes $9 \mathrm{~cm}$. long; branches of the inflorescence nearly erect, the flowers secund; perianth $4-5 \mathrm{~mm}$. long; stamens 6 , half as long as the perianth, the anthers as long as the filaments; capsule oblong, triquetrous, shorter than the perianth; seeds larger than those of $\vec{J}$. Vaseyi, about 15 -ribbed, I $\mathrm{mm}$. long, short-tailed. In swamps, Me.

P. 252, béfore Juncus megacéphalus, insert:

34a. Juncus válidus Coville. STURdy Rush. Stout, $1 \mathrm{~m}$. high or less, the compressed stem I-3-leaved. Leaves $\mathrm{I}-2 \mathrm{dm}$. long, 2-4 $\mathrm{mm}$. wide, compressed, the septa complete; inflorescence $3.5 \mathrm{dm}$. long or less, its branches stiff, spreading; heads several or numerous, globose, 1 2 I $5 \mathrm{~mm}$. in diameter; perianth $4-5 \mathrm{~mm}$. long, its parts subulate, about twice as long as the 3 stamens; capsule subulate, often falcate, I-celled, exceeding the perianth, beakless, dehiscent to the base; seeds broadly oval, reticulate in about 20 longitudinal rows. In sandy soil, Mo. to Miss. and Texas.

P. 254, after Juncoides campéstre, adu':

8. Juncoides bulbòsum (Wood) Small. Bulbous Wood-Rush. Base of the plant accompanied by bulblets. Foliage almost glabrous or somewhat webby on the leaf-margins and at the tops of the sheaths; stems I-4 $\mathrm{dm}$. tall; inflorescence umbel-like, the peduncles very unequal at maturity; sepals and petals ovate-lanceclate or lanceolate, $2-2.5 \mathrm{~mm}$. long, brownish, acuminate, neither manifestly soft nor hyaline at the apex; capsule 
broadly obovoid, or globose-obovoid, often nearly as thick as long, surpassing the sepals or sometimes about equalling them. [Luzula campestris var. bulbosa Wood.] In woods, thickets and open sandy places, Va. to Kans., Ga. and Tex. Spring.

\section{P. 263, after Allìum vineàle, add:}

6a. Allium carinàtum $L$. KeELed Garlic. Similar to A. vineale. Bul's ovoid, its coats membranous; stem terete, leafy to about the middle, 2.5 $\mathrm{dm}$. tall or less; leaves linear, channeled below, flat toward the apex, $2-3$ $\mathrm{mm}$. wide, prominently 3-5-nerved; bracts of the umbel 2 , narrowly linear, one much longer than the other; umbel erect, bearing either bulbs or capsules; pedicels filiform, 2-4 cm. long, filaments simple, not tcothed. Bucks Co., Penn. Fugitive from Europe.

P. 263 , after Allium Nuttállii, insert:

9a. Allium Hélleri Small. Heller's Wild Onion. Bulbs ovoid, usually two together, fibrous-coated. Scape $2 \mathrm{dm}$. high or less, equalling or longer than the leaves; leaves basal, linear, about $2 \mathrm{~mm}$. wide; bracts ovate to ovate-lanceolate, acute; pedicels slender, 8-r $5 \mathrm{~mm}$. long; perianth white or rose, 6-7 $\mathrm{mm}$. long, its segments oblong-lanceolate to elliptic, obtuse; bases of the filaments broadened; capsule crestless, much shorter than the perianth. Dry soil, Neb. to Kans. and Texas. April-June.

\section{P. 266, insert:}

\section{7a. TÙLIPA L.}

Bulbous herbs with erect leaf-bearing stems and large solitary (rarely 2) erect flowers. Perianth campanulate, the segments distinct, erect or erect-spreading, deciduous, usually with a spot at the base, but without a nectar-gland; stamens 6, hypogynous, shorter than the perianth; anthers erect, basifixed; ovary nearly or quite sessile, 3-celled; ovules numerous; capsule oblong or globose; seeds numerous, flat. [Ancient name.] Fifty species or more, natives of Europe and Asia.

I. Tulipa sylvéstris L. WILD TUlip. Bulb ovoid, $2.5 \mathrm{~cm}$. long or less; stem about $3 \mathrm{dm}$. high, with I-3 linear-lanceolate acuminate leaves; flower yellow, 7-9 cm. broad; inner perianth-segments rather broader than the outer, acute; filaments pubescent at the base. In meadows, Bucks Co., Penn. Adventive from Europe.

\section{P. 274, after Trillium víride, insert:}

2a. Trillium viridéscens Nutt. Stem 4-6 dm. tall, slender, usually pubescent at the top; leaves ovate, orbicular-ovate or broadly elliptic, I O-I 5 $\mathrm{cm}$. lang, acuminate, sometimes abruptly so, 5 -nerved, sessile; flower sessile; sepals linear-lanceolate or almost linear, 4-5 cm. long, acute, green; petals conspicuously narrow, the claw-like base linear, $1.5-2 \mathrm{~cm}$. long, greenish, the blade narrowly linear-lanceolate or nearly linear, fully twice as long as the claw-like base, pale purple; filaments $2.5-5 \mathrm{~mm}$. long; anthers $12-15 \mathrm{~mm}$. long; stigmas $6-8 \mathrm{~mm}$. long, straight, or recurved only near the tip. On hillsides and rich woods, Kans. and Ark. Spring. Differs from $T$. viride in its acuminate leaves and pale purple narrower petals.

P. 283 , after Iris Caroliniàna, insert:

3a. Iris foliòsa Mackenzie \& Bush. Leafy Blue Flag. Stems rather stout, 6-Io dm. tall, flexuous. Leaves broadly linear, green, not glaucous, $1.5^{-2.5} \mathrm{~cm}$. wide, often $6 \mathrm{dm}$. long, exceeding the flowers, which are thus partly hidden among them; flowers about 3, their pedicels 2-3 cm. long; perianth-segments bluish, spreading, crestless, about $6 \mathrm{~cm}$. long; capsule strongly 6-angled. Meadows and borders of low woods, Mo. June. 
P. 294, after Limnorchis hyperbòrea, insert:

ra. Limnorchis major (Lange) Rydb. LARGe Green Orchid. Stem stout, 2-6 dm. high. Leaves lanceolate, mostly acute, $5-30 \mathrm{~cm}$. long, $1.5^{-4} \mathrm{~cm}$. wide; spike dense, $5^{-1} 5 \mathrm{~cm}$. long; bracts lanceolate, the lower slightly exceeding the flowers; flowers I2-14 $\mathrm{mm}$. long; upper sepal broadly ovate, obtuse, $5 \mathrm{~mm}$. long, the lateral ones ovate-lanceolate, obtuse, spreading; petals lanceolate, acute, oblique, a little shorter than the sepals; lip 5-6 mm. long, ovate-lanceolate, obtuse; spur almost equalling or somewhat exceeding the lip, distinctly clavate and curved. Greenland to N. Y. and Wis. May-Aug.

P. 294, after Limnorchis fràgrans, add:

6. Limnorchis graminifòlia Rydb. Grass-Leaved Orchid. Very slender, 3-4 dm. high. Leaves narrowly linear, 5-10 cm. long, 3-4 mm. wide; spike short; bracts lanceolate, shorter than the flowers; flowers white, I 2-I $5 \mathrm{~mm}$. long; upper sepal ovate, $4 \mathrm{~mm}$. long, the lateral ones lanceolate, slightly shorter than the upper one; lip lanceolate, obtuse dilated near the base, but not rhombic; spur one-third to one-half longer than the lip, clavate toward the apex, acute. Alaska; Rivière du Loup, Canada.

\section{P. 294 , add the genus:}

\section{7a. PIPÈRIA Rydb.}

Somewhat leafy-stemmed plants, but the leaves usually near the base and withering at or before anthesis, the stem-leaves reduced and bractlike. Tubers spherical or ellipsoid; flowers greenish or white; sepals and petals I-nerved or very obscurely 3-nerved; upper sepal ovate or lanceolate, erect, the lateral ones spreading, linear to lanceolate, their bases united with the claw of the lip; upper petals free, lanceolate or linear-lanceolate, oblique, but not cordate; blade of the lip linear-lanceolate to ovate, obtuse, truncate or hastate at the base, concave but with a longitudinal low ridge in the middle produced by the undulation of the lip, the claw united with the bases of the lower sepals, bordered with an erect margin which connects the lip with the column; anthercells unusually large for the size of the flower, parallel, opening nearly laterally; stigma a small beak in the angle between the anther-cells; ovary sessile, ellipsoid in fruit. About ro species, natives of North America. [In honor of Professor C. V. Piper.]

I. Piperia Unalaschénsis (Spreng.) Rydb. Alaska Piperia. Stem strict, slender, 3-5 dm. high, leafy only near the base; basal leaves oblanceolate, I-I.5 dm. long, $0.8-3 \mathrm{~cm}$. wide; stem-leaves linear-lanceolate to lanceolate, attenuate, $0.5^{-1} \mathrm{~cm}$. long; spike long and lax, $\mathrm{I}-3$ $\mathrm{dm}$. long; bracts lanceolate to ovate-lanceolate, one-half to two-thirds as long as the flowers; flowers greenish, distinctly in spirals, 8-10 $\mathrm{mm}$. long; petals and sepals $2-4 \mathrm{~mm}$. long; upper sepal ovate, acutish, the lateral ones oblong-lanceolate, obtusish; petals purplish green, somewhat fleshy, lanceolate, oblique at the base; lip oblong, obtuse, slightly hastately lobed near the base; spur filiform or slightly clavate, a little exceeding the lip, but shorter than the ovary. In damp woods from southern Alaska and Alberta to Cal. and Colo., and on Jupiter River, Anticosti.

P. 300, after Gyrostachys cérnua, insert:

4a. Gyrostachys parvifiòra (Chapm.) Small. SMall-flowered LADIES' TRESSES. Stem $2-4 \mathrm{dm}$. tall, leafy below, minutely pubescent above; blades of the basal and lower cauline leaves broadly linear to linear-oblong, 4-16 cm. long; spike compact, elongating in age, the bracts not surpassing the flowers; perianth white; lateral sepals lanceolate, sometimes broadly so, with the base often dilated, about $5 \mathrm{~mm}$, 
long; petals broadly linear or linear-lanceolate, about as long as the sepals; lip ovate or oblong-ovate, about $5 \mathrm{~mm}$. long, the callosities somewhat incurved. In woods and swamps, Ohio, Ala. and La. Oct.

P. 3I3, after Salix lùcida, insert:

4a. Salix seríssima (Bailey) Fernald. Late-fruiting Willow. A

rub sometimes $4 \mathrm{~m}$. high, with glabrous brown shining twigs. Leaves lanceolate to elliptic-lanceolate, $4-10 \mathrm{~cm}$. long, $1-3.5 \mathrm{~cm}$. Wide, finely glandular-serrate, acute or acuminate, firm, dark green and shining above with a light green midrib, pale green and dull beneath, glabrous; petioles $12 \mathrm{~mm}$. long or less, bearing large glands at the apex; aments borne at the ends of short leafy branches, the rachis, peduncles, and scales densely white-pilose, the staminate oblong, $2 \mathrm{~cm}$. long or less; pistillate aments loosely flowered, becoming $4 \mathrm{~cm}$. long or less; capsules glabrous, shining, larger than those of $S$. lucida, ripening from August to October. In bogs and wet meadows, Mass. to Ont., Minn., N. J., Ohio, and $\mathrm{Ky}$. May-June.

\section{P. 316, after Salix interior, insert:}

2ra. Salix Wheeleri (Rowlee) Rydb. Wheeler's Willow. A low shrub, related to $S$. interior, but in habit and pubescence more resembling the western $S$. argophylla Nutt. Young twigs appressedsilky with white hairs, becoming glabrous toward the end of the first season; bark of older twigs grayish brown; leaves linear-lanceolate to oblong-lanceolate or oblanceolate, $7-8 \mathrm{~cm}$. long, I-I.5 cm. wide, sessile, rather strongly veined, densely white-silky on both sides, evenly denticulate, rather abruptly short-acuminate; aments borne at the ends of short leafy branches, shorter and denser than those of S. interior, clustered; bracts oblong, light brown, villous; capsule pubescent. Sandy beaches, N. B. to Mich., N. Y. and Ill. June-July. (S. interior Wheeleri Rowlee.)

P. 328, after Betula populifòlia, insert:

Ia. Betula cœrùlea Blanchard. BlUE BIRCH. Similar to B. populifolia, but larger and stouter, the white bark freely separating in thin sheets. Foliage bluish green; young shoots warty; leaves ovate, or sometimes deltoid-ovate, long-petioled, irregularly sharply serrate, truncate to broadly cuneate at the base, the apex gradually acuminate to long-acuminate, both surfaces glabrous when mature; ripe pistillate aments stalked, cylindric or oblong-cylindric, $\mathrm{I}-3.5 \mathrm{~cm}$. long; bracts densely puberulent, their lateral lobes larger than the middle one; nut narrower than its wings. Woods, Vermont. May.

\section{P. 328 , after Betula nìgra, insert:}

4a. Betula Sándbergi Britton. SANDBERG's Birch. Young twigs loosely pubescent, green, becoming brown. Leaves rhombic-ovate, acute, rather evenly serrate, dark green and strongly netted-veined on the upper side, light green, very glandular and slightly pubescent on the veins beneath, $6 \mathrm{~cm}$. long or less, cuneate at the base; petioles glabrous, $1.5 \mathrm{~cm}$. long or less; staminate catkins $6 \mathrm{~cm}$. long or more; strobiles slender-stalked, cylindric, $2-2.5 \mathrm{~cm}$. long, about $6 \mathrm{~mm}$. thick, their scales about $4 \mathrm{~mm}$. long, pubescent, 3-lobed at the apex, the middle lobe a little longer than the blunt ascending lateral ones, all the lobes blunt; nut oval to obovate, $1.5 \mathrm{~mm}$. long, rather narrower than its wings. Swamps, Hennepin County, Minn., and Saskatchewan.

P. 329 , after Betula lùtea, insert:

5a. Betula Alleghaniénsis Britton. Southern Yellow Birch. Resembling $B$. lenta and $B$. lutea. Bark either close and furrowed, or peeling off in thin yellowish-gray layers; young twigs long-pubescent, becoming brown and shiny; leaves ovate to ovate-oblong, usually 
gradually acuminate, $12 \mathrm{~cm}$. long or less, rather coarsely and sharply serrate, mostly cordate at the base but sometimes rounded, dark gre $\mathrm{n}$ and glabrous above, yellow-green and more or less pubescent on the veins beneath when mature; petioles pubescent, about I $\mathrm{cm}$. long; staminate catkins $6 \mathrm{~cm}$. long or more, their scales broadly ovate and obtusish; strobiles oblong-cylindric, $2-3 \mathrm{~cm}$. long, very short-stalked or sessile, their scales $4^{-6} \mathrm{~mm}$. long, pubescent, nearly or quite as wide as long, 3-lobed above the middle, the wedge-shaped part below the lobes short, the margins ciliate; nut narrowly obovate to oblong, $2-3 \mathrm{~mm}$. long, mostly narrower than its wings. Mass. to Que. and Mich., south to southern N. Y., Penn., and in the mountains to Ga.

\section{P. 330, after Alnus Alnobetula, insert:}

ra. Alnus móllis Fernald. Hairy Green Alder. Similar to $A$. Alnobetula, but more pubescent, especially on the young twigs and the under leaf-surfaces, which are often quite densely hairy. Leaves finely unequally serrate, $10 \mathrm{~cm}$. long or less; fruiting pistillate aments, averaging larger, $\mathbf{I . 2 - 2} \mathrm{cm}$. long; nut oblong, its thin wing about as broad as the body. Rocky places and swampy soil, Newf. to Man., Mass., N. Y. and Mich. May-June.

rb. Alnus Mitchelliana M. A. Curtis. Mitchell's Alder. Resembles A. mollis, but the young twigs are glabrate, or only sparingly pubescent. Leaves broadly ovate or nearly orbicular, blunt or shortpointed at the apex, rounded or often quite deeply cordate at the base, the veins of the under side quite densely pubescent, otherwise glabrous or with a few scattered hairs; staminate aments stout; ripe pistillate aments as large as those of $A$. mollis, or larger, much larger than those of A. Alnobetula. High mountains of Va., N. C., and Eastern Tenn. May.

P. 330, after Alnus incàna, insert:

2a. Alnus Noveboracénsis Britton. New York Alder. A shrub or small tree, sometimes $8 \mathrm{~m}$. tall, with a trunk $1.5 \mathrm{dm}$. thick. Young twigs and petioles densely pubescent; leaves oblong to obovate, acute at both ends, $12 \mathrm{~cm}$. long or less, sharply irregularly serrate, very densely pubescent on the prominent veins beneath, otherwise glabrous or nearly so, dark green above, paler green but not at all glaucous on the under side; ripe pistillate aments numerous, oblong, $1.5 \mathrm{~cm}$. long, very short-stalked; nut oval, about one-half longer than wide, narrowly margined. Woods and thickets near the coast, southeastern N. Y. Type from Grant City, Staten Island.

P. 3.39, after Celtis occidentális, insert:

ra. Celtis canina Raf. Dog HAckBerry. Taller than $C$. occidentalis, the trunk sometimes nearly a meter thick. Leaves broadly lanceolate or ovate-lanceolate, light green, $8-16 \mathrm{~cm}$. long, thin, attenuateacuminate, smooth on the upper surface when mature, pubescent beneath, at least on the veins; petioles slender, $2 \mathrm{~cm}$. long or less, about half as long as the fruiting peduncles; drupe oblong to globular, purple, about I cm. long. In rich soil, N. Y. to Ill., S. Dak., Pa. and Mo. April-May.

P. 339, after Celtis crassifòlia, insert:

2a. Celtis Georgiàna Small. Georgia Hackberry. A shrub or small tree, with pinnately arranged branches, the young twigs puberulent. Leaves small, mostly less than $5 \mathrm{~cm}$. long, short-petioled, obliquely ovate, subcordate, acute or short-acuminate, sharply few-toothed or some of them entire, firm, rough or roughish above, prominently reticulate- 
veined beneath; peduncles short, $2-8 \mathrm{~mm}$. long, mostly not longer than the diameter of the globose fruit. In rocky places, Penn. to Fla., Mo. and Ala. April.

P. 339, after Celtis Mississippiénsis, add:

4. Celtis reticulata Torr. Net-veined Hackberry. A small tree. Leaves thick and coriaceous, strongly reticulate-veined beneath, the veins impressed in the upper surface; blades $7 \mathrm{~cm}$. long or less, bright green, and either very rough or nearly smooth, above, ovate, acute, serrate or entire; drupe red, globular, 8-12 mm. in diameter. Along streams, Kans. to Texas, Colo. and Cal.

P. 34I, after Humulus Lùpulus, add:

ra. Humulus Japònicus Sieb. \& Zucc. Japanese Hop. A twining vine, similar to the Common Hop, the leaves deeply pedately 5-7-cleft. Pistillate aments few-flowered, their bracts and bractlets deltoid, acuminate, hispid-pubescent at least on the margins, not glandular. In waste ground, Conn. to D.C. Introduced from Japan. Aug.-Sept.

P. 364 , after Polygonum Ráyi, insert:

24a. Polygonum Fówleri Robinson. Fowlen's KNotweed. Similar to $P$. Rayi in habit, but pale green. Leaves elliptic or oblong, often narrowly so, $1.5-3 \mathrm{~cm}$. long, mostly obtuse; flowers solitary or 2 together; calyx deeply 5-parted, whitish or reddish, the lobes oblong; achene narrowly ovoid, $4 \mathrm{~mm}$. long, the narrow tip exserted. Differs from $P$. Rayi chiefly in the more obtuse leaves, which do not become black in drying, the oblong calyx-lobes, and the smaller, more gradually narrowed achene. Sandy shores. N. B., Anticosti and Me. Aug. and Sept.

\section{P. 364 , after Polygonum exsértum, insert:}

26a. Polygonum leptocàrpum Robinson. NARROW-FrUited KNOTwEED. Resembling $P$. ramossissimum prolificum in habit but more slender; stem about $3 \mathrm{dm}$. tall, profusely branched, the branchlets angled. Leaves linear or linear-lanceolate, at least mainly so, pale green, the upper ones 6-8 $\mathrm{mm}$. long; ocreæ $3 \mathrm{~mm}$. long or longer on the lower part of the stem; calyx $2 \mathrm{~mm}$. long, 4-5-lobed, the lobes oblong, rounded at the apex, the margins pale or sometimes reddish; stamens 4 or 5; achene 3-angled, lanceolate in outline, about $2.8 \mathrm{~mm}$. long, brownish, nearly or quite twice as long as the calyx. Kans. Sept. and Oct.

\section{P. 369, after Chenopodium glaùcum, insert:}

2a. Chenopodium vulvària L. Stinking Goosefoot. Annual, muchbranched, white-mealy, the branches procumbent, $3 \mathrm{dm}$. long, or more; leaves ovate, entire, $2.5 \mathrm{~cm}$. long, or less, the slender petioles about as long as the blades; flowers in dense short axillary and terminal branched or simple spikes mostly shorter than the leaves; sepals ovate-lanceolate, obtusish. In waste places and ballast, Ont. to Del. July-Sept.

\section{P. 383 , before Allionia Bòdini, insert:}

4a. Allionia bracteàta Rydb. Bracted Umbrella-wort Stems I $2 \mathrm{dm}$. high or less, glabrous below, viscid-pubescent above, erect or ascending. Leaves of the stem linear to linear-oblong or linear-lanceolate, 3-9 cm. long, those of the branchlets small, less than $\mathbf{r} \mathrm{cm}$. long, viscid-pubescent; inflorescence of numerous panicled involucres; involucres ro-I $4 \mathrm{~mm}$. wide, their lobes obtuse; perianth white or pale, about ro $\mathrm{mm}$. broad; fruit oblong-obovate, about $5 \mathrm{~mm}$. long, 8-ribbed, apiculate, constricted near the base. In dry soil, Mo. July-Aug. 


\section{P. 384, after Sesuvium marítimum, add:}

ra. Sesuvium séssile Pers. Western Sea Purslane. Much-branched, glabrous, similar to $S$. maritimum, the stems often copiously verrucose; pedicels I-3 mm. long, or none; stamens numerous; flowers and capsules slightly larger than in $S$. maritimum. On beaches, shores and in saline soil, W. Kans. and Colo. to Tex., Cal. and Mex. Also in S. Am. MayNov.

P. 385, strike "Minn." from range of Talinum teretifòlium and insert:

ra. Talinum rugospèrmum Holzinger. Rough-SEeded Talinum. Similar to $T$. teretifolium and confused with that species. Stamens 12-25; filaments very slender, red; anthers nearly circular in outline, yellow; style 3-cleft nearly one-third its length into linear stigmatic lobes; seeds pale, roughened. T. teretifolium differs in having short, blunt style-lobes, oblong anthers, and smooth black seeds. In dry soil, Ind. to Wis. and Minn.

P. 387 , after Portulaca retùsa, insert:

2a. Portulaca neglécta Mackenzie and Bush. Stout Purslane. Stems long, thick, erect or ascending, bright reddish purple; leaves large, I $-5 \mathrm{~cm}$. long, obovate or oblanceolate, obtuse or retuse; flowers 6-1 $2 \mathrm{~mm}$. broad, pale yellow; petals deeply 2-cleft; style 3-4-parted; stamens 1 2-1 8 ; seeds blackish, tuberculate. Forming large patches, single plants sometimes a meter or more across in rich soil. Mo.

P. 395, after Alsine pùbera, insert:

5a. Alsine Tennesseénsis (C. Mohr) Small. Tennessee ChickWEED. Similar to $A$. pubera, the stem and branches pubescent in lines. Leaves oval, oblong, or the lower subcrbicular, the upper short-petioled, the lower often with petioles as long as the blades: flowers long-pedicelled; sepals lanceolate, acuminate, I $\mathrm{cm}$. long, the outer ones ciliate with long hairs; petals cleft to below the middle, about as long as the sepals; capsule $4-5 \mathrm{~mm}$. long; seeds rough. In woods and thickets, W. Va., Ky., Tenn. and Ala. April-June.

P. 400 , after Arenaria serpyllifòlia, insert:

Ia. Arenaria leptóclados Guss. Slender Thyme-leaved SandwORT. Usually more slender than $A$. serpyllifolia, the leaves smaller, ovate to lanceolate, the bracts of the inflorescence very small; flowers only about half as large; capsule oblong, papery (ovoid or flask-shaped and coriaceous in A. serpyllifolia). Waste places, Me. and Vt. to Va., and on the Pacific Coast. Nat. from Europe. May-Aug.

\section{P. 404, after Paronychia Jamesii depréssa, insert:}

3a. Paronychia diffùsa A. Nelson. Spreading Whitlow-wort. Low, densely tufted, less than I dm. high, the branches prostrate or ascending. Inflorescence rather loose, the bracts shorter than the flowers or equalling them (in $P$. Jamesii depressa, best regarded as a species, $P$. depressa Nutt., the inflorescence is compact and the bracts longer than the flowers). Dry soil, S. D. to Neb., Kans., Wyo. and Colo. June-Aug.

\section{P. 417, after Delphinium albéscens, insert:}

4a. Delphinium Treleàsei Bush. Trelease's Larkspur. Roots fascicled; stem erect, 6-12 dm. tall, glabrous, slightly glaucous, few-leaved; basal leaves long-petioled, deeply palmatifid into linear segments 1.5-3 nmm. wide; raceme often $3 \mathrm{dm}$. long or more, loose, the lower pedicels sometimes branched; pedicels very slender, ascending, the lower 5-10 cm. 
long, the upper shorter; flowers blue; sepals and spur about equal in length, puberulent; spur straight, nearly $2 \mathrm{~cm}$. long; sepals narrowly ovate; bractlets borne somewhat below the calyx; lower petal yellowbearded; follicles 3 , erect, slightly pubescent. In barrens, Mo. MayJune.

P. 43I, after Thalictrum dioìcum, insert:

3a. Thalictrum occidentàle A. Gray. Western Meadow-RUE. Rootstock slender. Stem glabrous, I m. high, or less, bearing 3-6 leaves; leaves glaucous beneath and sometimes minutely glandular, the upper short-petioled; leaflets thin, reniform to obovate, their lobes few, rounded; flowers diœcious or polygamo-diœcious, in panicles $1.5-3 \mathrm{dm}$. high; achenes 6-7 mm. long, 2-3 mm. wide, flattened, 2-edged, strongly 3-ribbed on each side, the ribs somewhat branching; persistent style filiform, half as long as the achene, or more; filaments yellowish-green to purplish, slightly clavate. Me., New Brunswick, and northern N. Y; Manitoba and Mont. to the Pacific Coast. May-July.

\section{P. 43r, after Thalictrum coriáceum, insert:}

4a. Thalictrum caulophylloìdes Small. Cohosh-Like MEAdow-Rue. Tall, diøecious, I.5 m. high or less, glabrous; stems slender, somewhat glaucous. Leaves 3-4-ternate; leaflets deep green above, orbicular or often broader than long, pale beneath and strongly veined, $4-9 \mathrm{~cm}$. broad, 3-5-lobed, the lobes blunt or apiculate; panicle large; pedicels filiform but stiff, $8-25 \mathrm{~mm}$. long; achenes oblong, 4-6 mm. long, stalked, sharply ridged; filaments nearly filiform; sepals of the staminate flowers 4.5-5.5 mm. long. Slopes and river-banks, Md. to Va., Ky., and Tenn. May.

P. 442, after Capnoides montánum, insert:

5a. Capnoides campéstre Britton, $n$. sp. Prairie Corydalis. (I. F. f. I678, as C. curvisiliquum.) Slender, pale green or somewhat glaucous, $3 \mathrm{dm}$. high or less. Leaves very finely dissected; flowers narrowly racemose, the pedicels $2-3 \mathrm{~mm}$. long; bracts ovate to lanceolate, longer than the pedicels; corolla yellow, I3-I6 $\mathrm{mm}$. long, the nearly straight blunt spur 4-5 mm. long; pods $2 \mathrm{~cm}$. long or less, about $2 \mathrm{~mm}$. broad, torulose when ripe, and ascending or upcurved; seeds shining, reticulated, sharp-margined. In fields and woods, IIl. to Nebr., Ark. and Texas. April-May. Type from Benton Co., Ark.

\section{P. 446, after Lepidium apétalum, insert:}

5a. Lepidium ramosíssimum A. Nelson. Much-Branched PepperGRASS. Biennial, branched from the base upward, finely puberulent. Basal leaves oblanceolate, $2-4 \mathrm{~cm}$. long, coarsely toothed, the petiole about as long as the blade; lower stem-leaves oblanceolate, few-toothed on the margin, 3-toothed at the apex, the upper ones linear, entire; racemes very numerous, dense, mostly short; sepals I mm. long; petals white, spatulate, about $0.5 \mathrm{~mm}$. long; pods broadly ovate to oval, $3 \mathrm{~m}$. long, notched; fruiting pedicels about $3 \mathrm{~mm}$. long; cotyledons incumbent Dry soil, along railroad, Kearney, Nebr., Wyo. and Colo. June-Aug.

P. 456 , after Dentaria laciniata, insert:

Ia. Dentaria furcàta Small. NarRow-leaved Tooth-wort. Differs from $D$. laciniata, of which it may be a form, by its narrowly linear leaf-segments, which vary from entire to coarsely toothed. In moist woods, Ohio to Iowa, Ark., Tenn. and Ala. March-May. Specimens from the Eastern and Middle States resemble this very closely. 
P. 456, after Dentaria máxima, insert:

3a. Dentaria incisifólia Eames. CUT-Leaved Tooth-wort. Much resembles $D$. maxima, the rootstock similar, with fusiform joints. Stemleaves 2, opposite or nearly so, similar to the long-petioled basal ones; leaf-divisions sessile (stalked in D. maxima), incised-dentate; pedicels $3 \mathrm{~cm}$. long or less; petals about 2.5 times as long as the sepals (about twice as long in D. maxima). Sherman, Conn. [D. incisa Eames, not Small.]

Dentaria anómala Eames, from Plainville, Conn., growing with $D$. diphylla and $L$. laciniata, may be a hybrid of these two species.

P. 457, after Physaria didymocárpa, add:

2. Physaria brassicoìdes Rydb. CABBAGE Bladder-Pod. Root thick and deep, the tufted leaves forming a large rosette often I $\mathrm{dm}$. in diameter and resembling a small head of cabbage. Basal leaves sinuatedentate, long-petioled, the blades obovate to nearly orbicular, obtuse, the petioles margined; flowering stems ascending, about I dm. high, their leaves small, spatulate; fruit nearly obcordate, acute at the base, deeply lobed above, grooved, 8-1 $0 \mathrm{~mm}$. long, densely stellate-canescent; style about $5 \mathrm{~mm}$. long. Rocky places, western Nebr. and N. Dak. June.

P. 465 , before Erysimum àsperum, insert:

3a. Erysimum repándum L. Repand-Leaved Erysimum. Annual or biennial, 2-4 dm. high, more or less rough-pubescent. Leaves lanceolate, the lower ones sinuate-pinnatifid or repand, short-petioled, the upper repand-dentate or entire; pedicels short, stout; flowers about $4 \mathrm{~mm}$. high, yellow; stigma slightly 2-lobed; pods narrowly linear, ascending, obtusely quadrangular, $3-7 \mathrm{~cm}$. long; style short. In waste places, Ohio, Mo. and Ariz. Adventive from Europe. May-July.

\section{P. 482, after Heuchera villòsa, insert:}

Heuchera macrorhìza Small. Big-Rooted Heuchera. Similar to $H$. villosa, but stouter, the rootstock thicker and woody; pubescence of the stem and petioles denser; leaf-lobes shorter and broader, their margins copiously villous-ciliate; pedicels more villous than the turbinate calyx; capsule longer, twice as long as the calyx. River-banks, Tenn. and Ky.

P. 5I3, after Rosa setígera, insert:

ra. Rosa bractèta Wendl. Evergreen Rose. A shrub with dark green evergreen leaves, the stems and branches diffuse or spreading, $6 \mathrm{~m}$. long or less, armed with recurved prickles. Leaflets $5-\mathrm{Ir}$, obovate to oval, $\mathrm{I}-2 \mathrm{~cm}$. long, often cuneate at the base, retuse, truncate or apiculate at the apex, serrate, shining above; flowers few together or solitary; sepals acuminate, reflexed when old, persistent on the fruit; petals white to yellow, retuse or notched at the apex; styles distinct; fruit $x \cdot 5^{-2} \mathrm{~cm}$. in diameter. In woods and waste places, Va. to Fla., Tenn. and Miss. Nat. from China. April-June.

P. 518. Additional species of Crataegus have been described by $\mathrm{Mr}$. W. W. Ashe in "Journal of the Elisha Mitchell Scientific Society" and in "Bulletin of the North Carolina Agricultural Experiment Station," and by Mr. C. D. Beadle and Prof. C. S. Sargent in the "Botanical Gazette," and elsewhere.

P. 5 18, after Amelanchier oligocárpa, insert:

7. Amelanchier argùta Nutt. Low JUNEBERRY. A shrub, r.3 m. high or less, the leaves glabrous, at least when mature, the caducous stipules long-hairy. Leaves ovate to ovate-oblong, sharply serrulate 
$6 \mathrm{~cm}$. long or less, acute or acutish at both ends; racemes 1 -3-flowered; pedicels $2 \mathrm{~cm}$. long or less; petals $5^{-6} \mathrm{~mm}$. long: pome subglobose or somewhat longer than thick, about $8 \mathrm{~mm}$. in diameter. In swamps, Vt. and Mass. to Mich. May.

\section{P. 553, after Astragalus Robbínsii, insert:}

22a. Astragalus Jésupi (Eggleston \& Sheldon) Britton. Jesup's MILK Veтch. Similar to $A$. Robbinsii, but with larger, darker purple flowers, the pod longer, acuminate, somewhat triangular in section, with a dorsal groove, and a stipe equalling or longer than the calyx. In rocky places, Me., N. H., Vt. (A. Robbinsii Jesupi Egg. and Sheld.)

\section{P. 555, after Orophaca caespitòsa, inser :}

Ia. Orophaca argophjlla (Nutt.) Rydb. Silvery Milk-vetch. Resembles $O$. caespitosa, but with relatively broader and shorter leaflets, the whole plant silvery-cottony. Stipules scarious; corolla smaller than in O. caespitosa, pubescent outside ((glabrous in O. caespitosa); calyx-tube a little longer than its teeth (more than twice as long as the teeth in $O$. caespitosa). Dry soil, Neb. to Wyo. May-July. (Phaca argophylla Nutt.; Astragalus hyalinus M. E. Jones.)

\section{P. 563, after Lespedeza Nuttàllii, insert:}

3a. Lespedeza Brittònii Bicknell. Britton's Bush-clover. Light green and densely cinereous-pubescent, especially above, the upper surface of the leaves glabrate; stems ascending, $0.5^{-1} \mathrm{~m}$. long, wand-like, bearing short flowering branches and reduced leaves above, often longer branched about the middle; leaves short-petioled; petioles 2-ro mm. long; leaflets oblong, rounded or contracted at base and apex, $20-45 \mathrm{~mm}$. long, 8-20 mm. wide; terminal flower-clusters short-spicate on slender pedunc!es 2-5 cm. long; lower peduncles short and few-flowered, or bearing clustered cleistoramous flowers; coralla pinkish-purple, much surpassing the attenuate calyx-lobes, 6-8 mm. long; pod ovate or ovate-oblong, 4.5$6.5 \mathrm{~mm}$. long, acute, canescent or short-pubescent, twice the length of the calyx-lobes or less. Dry soil, Bronxville, N. Y. City. Also eastern Mass. and N. J. Aug.-Sept.

3b. Lespedeza acuticàrpa Mackenzie \& Bush. Erect-ascending; stems finely pubescent to glabrate, 5-6 dm. long, slender. Leaflets oblong to oblong-elliptic, glabrate above, densely appressed-pubescent beneath, 8-30 $\mathrm{mm}$. long, 4-8 $\mathrm{mm}$. wide, obtuse or acutish, mucronulate; racemes peduncled, few-flowered, much longer than the subtending leaves; pedicels 2-I $4 \mathrm{~mm}$. long; flowers purplish, 6-8 mm. long; calyxteeth subulate, about $3 \mathrm{~mm}$. long; pod ovate-oval, $6 \mathrm{~mm}$. long, shortstipitate, sparingly pubescent, very acute. Mo. and Ark.

3c. Lespedeza Manniàna Mackenzie \& Bush. Erect, somewhat branched, the slender branches pubescent, ascending. Leaflets oblong, I-4 cm. long; 4-I $2 \mathrm{~mm}$. wide, obtuse and mucronulate at the apex, narrowed or subcuneate at the base, sparingly appressed-pubescent above, densely so beneath; peduncles much longer than the leaves, several-flowered; calyx about $8 \mathrm{~mm}$. long, the subulate teeth $5^{-6} \mathrm{~mm}$. long, equalling or a little longer than the purplish corolla and the oval acute pod. Dry open soil, Kans. and Mo. Aug.

\section{P. 564, before Lespedeza Stùvei, insert:}

4a. Lespedeza praìrea (Mackenzie \& Bush) Britton. Resembling $L$. violacea, but smaller. Leaflets oval to oblong or obovate, obtuse or often retuse at the apex, mucronulate, narrowed at the base, 6-r $8 \mathrm{~mm}$. long, 4-9 $\mathrm{mm}$. wide; peduncles very slender, longer than the leaves, 
2-6-flowered; pedicels very short; corolla purplish, 6-8 $\mathrm{mm}$. long; calyx much shorter than the corolla and the broadly oval acute pod. In dry soil, Mo., Kans., Ind. Terr. and Ark.

\section{P. 564 , after Lespedeza Virgínica, insert:}

7a. Lespedeza simulàta Mackenzie \& Bush. Similar to L. Vir. ginica, $9 \mathrm{dm}$. tall or less, erect or nearly so, the stem pubescent to nearly glabrous. Leaflets linear-oblong to linear-elliptic, $3 \mathrm{~cm}$. long or less, 4-10 $\mathrm{mm}$. wide, appressed pubescent on both sides, strongly so beneath; flower-clusters dense, on peduncles shorter than the leaves; corolla purple, 6-8 mm. long; calyx $5^{-6} \mathrm{~mm}$. long, its linear acuminate lobes twice as long as the tube; pod oval, acute, scarcely exceeding the calyxlobes. In dry soil, S. Penn., Mo. and Ind. Terr. Aug.-Sept.

\section{P. 564, before Lespedeza angustifòlia, insert:}

9a. Lespedeza velutina Bicknell. Velvety Bush-Clover. With the habit and appearance of $L$. capitata, but densely soft-velvety all over, with somewhat cinereous pubescence, the younger parts velvety-canescent, 0.5 $1.2 \mathrm{~mm}$. high, often bushy-branched above; leaves crowded, ascending, the petioles 3-7 $\mathrm{mm}$. long; leaflets oblong, narrowed to the base, rounded at the apex, 25-40 mm. long, 8-18 mm. wide, velvety on both surfaces, tomentose-ciliate; inflorescence very dense, of crowded short clusters; corolla $7-8.5 \mathrm{~mm}$. long, about equalling the calyx-lobes, the standard pure white, with purplish-streaked centre; pod narrowly rhomboid-oblong, narrowed to each end, 5-6 mm. long, $2.5 \mathrm{~mm}$. wide, canescently pubescent, much shorter than the calyx-lobes. Low thicket near Woodlawn, N. Y. City. Also in eastern Mass. Sept.

P. 580, after Kallstroemia máxima, add:

2. Kallstroemia hirsutíssima Vail. Hirsute Caltrop. Stout, hirsute, paler green than $K$. maxima, usually much branched. Sepals linear-subulate, bristly-hirsute, $3 \cdot 5-45 . \mathrm{mm}$. long; fruit $6-8 \mathrm{~mm}$. long, the stout persistent style about the same length. Plains and prairies, Kans. to Colo., Texas, N. Mex. and Mex.

\section{P. 607 , after Acer rùbrum, insert:}

2a. Acrr Carolinianum Walt. Southern Red Maple. Similar to Acer rubrum, but the leaves dark green above, pale beneath, the contrast between the colors of the two surfaces being quite striking; leaves, or many of them, 3-lobed, obovate, mostly narrowed at the base. The bark is lighter gray than that of $A$. rubrum. Moist soil, E. Penn. and N. J. to Fla., Texas and Mo. [A. rubrum tridens A. Wood.]

\section{P. 6r 7 after Tilia heterophýlla, add:}

4. Tilia Michaùxii Nutt. Michaux's Linden. A large forest tree, sometimes $30 \mathrm{~m}$. tall, with furrowed bark. Leaves firm in texture, 7-22 cm. long, acuminate, serrate, whitish-pubescent beneath, dark green and glabrous above, the base usually very oblique. Floral bracts spatulate, attenuate downward and decurrent in the peduncle to within $\mathrm{I}-3 \mathrm{~cm}$. of its base (in $T$. heterophylla decurrent on the peduncle to its base or very near it, and there rather abruptly narrowed); staminodia spatulate; fruit oval or globular, $7-1 \mathrm{rmm}$. long. In woods, $\mathrm{Pa}$. and Ohio to Ky., Ga. and Ala. June-July.

P. 622, after Hibiscus Moscheùtos, insert:

ra. Hibiscus oculiròseus Britton. Crimson-eye Rose-mallow. Similar to H. Moscheutos, attaining the same height, and leaves nearly iden- 
tical. Corolla white with a lark crimson center; capsule ovoid-conic, long-pointed (globose-ovoid in H. Moscheutos); calyx-segments triangular-lanceolate, nearly th e as long as broad (in H. Moscheutos triangular-ovate). N. J. Aug.-Sept.

\section{P. 623, after Hibiscus lasiocárpus, insert:}

2a. Hibiscus incànus Wendl. Velvety Rose-mallow. Erect, I-2 m. tall, perennial. Leaves ovate or broadly lanceolate, velvetypubescent on both sides, r.5 dm. long or less, acuminate at the apex, obtuse or subcordate at the base, serrate-dentate, long-petioled, very pale green beneath, darker above; bracts linear, $2 \mathrm{~cm}$. long or less, velvety, not ciliate, shorter than the calyx; calyx velvety, its ovate or ovate-lanceolate acuminate lobes equalling the tube or shorter; petals white, yellowish or pink, blotched at the base, $8-10 \mathrm{~cm}$. long; capsule ovoid, rather shorter than the calyx, hispid. In swamps, Md. to Fla. and Ala. June-Aug.

\section{P. 627, before Hypericum sphaerocàrpım, insert:}

6a. Hypericum Bisséllii Robinson. BISSELL's ST. JoHn's-wort. Perennial, 4-5 dm. high, erect, glabrous. Stems leafy, nearly or quite simple; leaves oblong, erect or ascending, sessile, $2-3.5 \mathrm{~cm}$. long, $3-5 \mathrm{~mm}$. wide, I-nerved; cyme about $8 \mathrm{~cm}$. wide, many-flowered; bracts ovate, acute, ro $\mathrm{mm}$. long or less; pedicels $4 \mathrm{~mm}$. long or less; flowers about r. $5 \mathrm{~cm}$. wide; sepals very unequal, the larger ones broadly ovate, $1.3 \mathrm{~cm}$. long; stamens numerous, not separable into phalanxes as they are in H. adpressum; capsule I-celled, ovoid, pointed, $7 \mathrm{~mm}$. long, the 3 placentæ not intruded. Southington, Conn. July-Aug.

\section{P. 63I, before Helianthemum Canadénse, insert:}

ra. Helianthemum propínquum Bicknell, $n$. $s p$. InTERmediate FrostweEd. Somewhat intermediate between $H$. Canadense and H. majus, but lower than either and growing in close masses, many stems rising separately along subterranean rootstocks. Plant pale bluishgreen and hoary-canescent; stems erect, at flowering time only Io-20 $\mathrm{cm}$. high; branches ascending, firm, closely leafy, finally crowded with apetalous flowers in axillary glomerules; leaves linear to narrowly oblanceolate, abruptly obtuse to subacute, tapering into petioles $2-5 \mathrm{~mm}$. long, densely canescent beneath, the larger stem-leaves $3 \mathrm{~cm}$. long and $7 \mathrm{~mm}$. wide; petaliferous flowers $2-6$, terminal, becoming loosely racemose and slender-pedicelled, finally much surpassed by the branches; calyx densely hoary-tomentulose, $5-8 \mathrm{~mm}$. high; capsules of the apetalous flowers ovoid or obovoid, $2-3 \mathrm{~mm}$. high. Southwestern Long Island in sandy soil, beginning to flower with H.Canadense. Type from Valley Stream, L. I.

\section{P. 635 , before Viola Brittoniàna, insert:}

ia. Viola Múlfordae Pollard. Miss Mulford's Violet. Finely pubescent, the short thick rootstock erect or nearly so. Leaf-blades oblong to ovate in outline, pinnately lobed, $8 \mathrm{~cm}$. long or less, longer than the petioles, the lateral lobes lanceolate, acute, the terminal lobe much larger, oblong to oblong-lanceolate, crenate; scapes shorter than the leaves, or at first exceeding them; flowers violet-purple, nearly $2 \mathrm{~cm}$. broad; sepals narrowly lanceolate, ciliate; petals obovate, bearded; cleistogamous flowers on erect peduncles. Dry, sandy soil, Hempstead Plains, L. I. May. 
P. 635 , after Viola Brittoniàna, insert:

2a. Viola notábilis Bicknell. Elegant Violet. Deep green and nearly glabrous. Leaves with some minute mostly marginal pubescence, long-petioled, broadly ovate to oblong-ovate, openly cordate tc nearly truncate at base, obtuse or rounded at apex, bearing below the middle several oblong, obtuse lobes cut about half-way to the midrib or less, the basal lobe broader and obtusely dentate or lobed; peduncles often much surpassing the leaves, becoming $20-33 \mathrm{~cm}$. high; flowers very large, deep purple, the petals $8-\mathrm{r}_{5} \mathrm{~mm}$. wide; sepals lanceolate, mostly apiculate-obtuse, ciliolate; cleistogamous flowers narrowly lanceolate-acuminate, on erect peduncles sometimes surpassing the leaves, their sepals produced backward into long auricles. Southwestern Long Island in low grounds. May. Type from Woodmere, L. I.

\section{P. 637 , after Viola cucullata, insert:}

r3a. Viola lavenduiàcea Bicknell.

Lavender Violet. Light green and essentially glabrous; petioles slender, becoming $15^{-2} 3 \mathrm{~cm}$. long; blades with some minute scattered hairs on upper surface, oval or ovate and obtuse to deltoid-ovate and acute, not cordate, obscurely crenate or crenate-dentate, $2.5-7 \mathrm{~cm}$. long, 2-5 cm. wide; peduncles surpassing the leaves, $10-30 \mathrm{~cm}$. long; flowers pale lilac-blue, the petals sharply dark-lined, only the lateral pair bearded, the lower one short; sepals lanceolate or linear-lanceolate, obtusely purplish-apiculate; cleistogamous flowers on erect peduncles; mature capsule not seen. Boggy meadows, southwestern Long Island. May. Type from Woodmere, L. I.

\section{P. 637 , after Viola marginàta, insert:}

18a. Viola pectinàta Bicknell. Pectinate Violet. Dark green and nearly glabrous; petioles slender, 10-30 $\mathrm{cm}$. long, often purplish, the blacies with some minute hispidulous pubescence, mostly widely deltoid, with truncate often decurrent base, abruptly acuminate, 4-6 cm. long, 6-10 $\mathrm{cm}$. wide, below the middle closely cut-pectinate with numerous linear entire lobes or sometimes sharp-dentate, dentate or crenate above; peduncles equalling the leaves or shorter; flowers deep purple or paler, the petals often undulate-dentate; sepals narrowly lanceolate, tapering acute, with posterior dentate auricles; cleistogamous flowers small, sharply acuminate, on slender erect peduncles; cansules oval to oblong, obtuse, 6-10 $\mathrm{mm}$. long. Near the borders of sait marshes, southwestern Long Island. May-June. Type from Woudmere, L. I.

\section{P. 638, for "Viola alsophìla Greene" read "Viola LeConteàna Don",} the older name.

P. 640 , after Viola Rafinésquii, add:

44. Viola arvénsis Murr. European Field Pansy. Similar to $V$. Rafinesquii, but usually stouter, the stipule-segments fewer. Flowers rather larger; petals pale yellow or the upper ones sometimes lavendertinged, scarcely if at all longer than the narrowly lanceolate sepals (in $V$. Rafinesquii manifestly longer than the sepals). In fields and waste places, Newf. to Mass. and Penn. May-Aug.

P. 640. Additional species of Viola have been described by Prof. E. L. Greene in "Pittonia."

P. 657 , after Onagra biénnis, insert:

2a. Onagra argillícola Mackenzie. Narrow-Leaved Evening PrimRose. Stems finely puberulent, $1.5 \mathrm{~m}$. high or less, several from the 
same root. Leaves of the first year oblanceolate, $6-15 \mathrm{~cm}$. long, $\mathrm{r} .5 \mathrm{~cm}$. wide or less, acute, sinuate, tapering into long petioles; stem-leaves linear-lanceolate, $6-8 \mathrm{~cm}$. long, $7 \mathrm{~mm}$. widc or less, acute, remotely sinuate, glabrous or slightly puberulent; calyx-tube very slender, $3-4 \mathrm{~cm}$. long, glabrous; petals bright yellow, obcordate, crenulate, $3-4 \mathrm{~cm}$. long; capsules glabrous, gradually tapering upward from the base, often curved, $2-3 \mathrm{~cm}$. long. In loose rocky soil, Va. and W. Va. July-Sept.

\section{P. 659, after Anogra pallida, add:}

4. Anogra latifòlia Rydb. Canescent Evening Primrose. Much branched, $6 \mathrm{dm}$. high or less, the branches stout ascending, canescent. Leaves oblong to lanceolate, thick, acute, $9 \mathrm{~cm}$. long or less, $1-3 \mathrm{~cm}$. wide, mostly sinuate-dentate, canescent on both sides; flowers white, turning pink, $5 \mathrm{~cm}$. wide or less; capsules divergent or upwardly curved. In dry soil, Nebr. to Kans., Utah and Wyo. June-Aug.

\section{P. 660, after Kneiffiia lineàris, insert:}

4a. Kneiffia praténsis Small. Western Sundrops. Stems erect or nearly so, I I dm. high or less, hirsute, simple or sparingly branched. Leaves elliptic to elliptic-lanceolate, $3^{-I I} \mathrm{~cm}$. long, sinuate, acute, hirsute; calyx more or less hirsute, its segments lanceolate, somewhat shorter than the tube; petals $2-3.5 \mathrm{~cm}$. long; capsules club-shaped, $\mathrm{x} \cdot 5^{-2} \mathrm{~cm}$. long, hirsute, the narrowly winged body much longer than its stout stalk. In wet places, Ohio to I1l., Mo. and Ark. May-July.

P. 662, after Galpinsia Hártwegi, add:

2. Galpinsia lavendulaefolia ( $T$. \& G.) Small. LAvender-LEAved Prinirose. Low, pale, finely pubescent; stems tufted, $1.5 \mathrm{dm}$. long or less. Leaves numerous, usually crowded, linear to linear-spatulate, mostly entire, acute. or the lower obtuse, I-4 cm. long; calyx finely pubescent, the tube gradually dilated above, its lobes $\mathrm{I}-\mathrm{I} .5 \mathrm{~cm}$. long, acute; petals $2 \mathrm{~cm}$. long or less; capsules $2-2.5 \mathrm{~cm}$. long. Plains and prairies, Nebr. to Wyo., Texas and Ariz. May-Aug.

3. Galpinsia intèrior Small. Oblong-Leaved Primrose. Hirsutepubescent or tomentose; stems somewhat tufted, 2-3 dm. high, erect or ascending. Leaves mostly oblong, entire, $2.5 \mathrm{~cm}$. long or less, sessile and partly clasping; calyx hirsute, at least near the base, its lobes $\mathrm{I}-\mathrm{x} .5 \mathrm{~cm}$. long, acuminate; petals $1.5^{-2.5} \mathrm{~cm}$. long; capsules $1.5^{-2} \mathrm{~cm}$. long. Pla:ns, Nek.r. and Kans. to Texas. June-Aug.

P. 662, after Meriolix serrulàta spinulòsa, add:

2. Meriolix intermédia Rydb. Canescent Primrose. Similar to $M$. se:rulata, but commonly larger, usually finely canescent. Leaves linear to spatulate, firm, 4-7 cm. long; flowers larger, the petals 2-2.5 $\mathrm{cm}$. long; capsules $2-2.5 \mathrm{~cm}$. long. Dry soil, Minn. and Man. to Kans. and Texas. June-July.

P. $66_{3}$, after Gaura coccínea, insert:

2a. Gaura glábra Lehm. Smoотн Gaura. Differs from G. coccinea in its glabrous shining stem, the leaves also glabrous or very sparingly pubescent. In dry soil, S. Dak. to Mont., Nebr., Wyo., Colo. and N. Mex. May-July.

P. 663 , after Gaura biénnis, insert:

3a. Gaura Pítcheri (T. \& G.) Small. Pitcher's Gaura. Resembles G. biennis, but is stouter, taller, often much branched. Stem puberulent or canescent, not villous; leaves thicker; fruit 6-10 mm. long, puberulent. In dry soil, Iowa to Nebr. and Ark. July-Sept. 
P. 668 , at bottom, add:

\section{ECHINOPÀNAX Dec. \& P1.}

A densely prickly shrub, with palmately lobed leaves and racemed or panicled umbels of small greenish-white flowers. Calyx-teeth obsolete; petals 5, valvate; stamens 5; filaments filiform; anthers oblong or ovate; ovary 2-3-celled; styles 2; stigma terminal; fruit laterally compressed. (Greek, prickly Panax.) A monotypic genus of northwestern North America and northeastern Asia.

r. Echinopanax hórridum (J. E. Smith) Dec. \& Pl. Devil's Club. Stems erect from a decumbent base, I-4 m. high, densely prickly, leafy above; leaves nearly orbicular in outline, 1.5-6 dm. broad, cordate at the base with a rather narrow sinus, 3-7-lobed, with scattered prickles on both sides and puberulent beneath, the lobes acute, sharply irregularly serrate; inflorescence wooly, terminal, I-3 dm. long; peduncles subtended by a narrow laciniate bract; pedicels filiform; stamens about twice as long as the ovate petals; fruit $4-5 \mathrm{~mm}$. long, scarlet. In rocky places, Isle Royale, Lake Superior (according to W. A. Wheeler); Mont. to Ore. and Alaska. June.

\section{P. 67I, after Hydrocotyle verticillàta, add:}

3a. Hydrocotyle austràlis C. \& R. Southern Marsh-PEnnywort. Like $H$. verticillata, the inflorescence proliferous; pedicels $2-4 \mathrm{~mm}$. long; fruit about $2 \mathrm{~mm}$. long and $3 \mathrm{~mm}$. broad, rounded at the base. In wet soil, $\mathrm{Va}$. to Fla. and Tex., near the coast. Differs from $H$. verticillata in the longer pedicels, and from $H$. Canbyi in the unnotched fruit.

\section{P. 673, before Sanicula Canadénsis, insert:}

2a. Sanicula Smàllii Bicknell. Small's Snakeroot. Stem $25-40 \mathrm{~cm}$. tall, usually simple, widely 2 -forked above; leaves slender-petioled, subcoriaceous, dull green, paler beneath, 3 -divided, the lateral segments cleft or parted; divisions obovate or broadly rhomboid, mostly obtuse, dentateserrate with aculeate teeth, often incised, 4-8 cm. long; stem-leaves 3-4, the opposite upper pair subsessile and 3-cleft; rays of umbel 2-6, spreading; pedicels $2-3 \mathrm{~mm}$. long; sepals finally spreading, linear, cuspidate; anthers little exserted; petals yellowish or greenish, obovate, shorter than the sepals; fruits 3-6, closely sessile, subglobose, 5-6 mm. long, the bristles slender; styles slender, spreading, about the length of the calyxsegments; oil-tubes 5. Rich or rocky woods, N. C. to Fla., Ga., Mo. and Miss. May-June.

P. 674, after Chaerophyllum Teinturiéri, add:

3. Chaerophyllum Texanum Coult \& Rose. Texan Chervil. Glabrous; stems erect, 3-7 dm. high. Leaves finely divided, the ultimate segments acutish; rays of the umbel several, each ro-17-flowered; fruits glabrous, short-pedicelled or sessile, beakless but narrowed above, the strong ribs much broader than the intervals between them. Moist places, Mo. and Kans. to Texas. Mar.-May.

P. 677 , after Musineon divaricàtum, insert:

ra. Musineon Hóokeri (T. \& G.) Nutt. Hooker's Musineon. Similar to $M$. divaricatum, but scabrous all over. Fruit scabrous, smaller, $2-3 \mathrm{~mm}$. long, the ribs prominent; oil-tubes mostly solitary in the intervals, often with smaller accessory ones. Plains, S. D. and Nebr. to Assin., Mont. and Colo. June-July. (M. trachyspermum Nutt.) 
P. 678, for "Apium leptophýllum" read "Apium Ammi (L.) Urban", the older name.

P. 679, after Cicuta maculàta, insert:

ra. Cicuta Curtíssii C. \& R. Curtiss' Water Hemlock. Similar to Cicuta maculata, but with thicker ovate-lanceolate leaf-segments, the veins prominent beneath; fruit orbicular, about $2 \mathrm{~mm}$. long, constricted at the commissure. In wet soil, Va. and Ky. to Fla. and La. June-Aug.

rb. Cicuta occidentàlis Greene. Western Water Hemlock. Similar to Cicuta maculata, the oval to oblong fruit constricted at the commissure, the ribs all projecting about equally, while in $C$. maculata the fruit is not constricted at the commissure, and the lateral ribs are much the largest; veins prominent on the lower surface of the leaflets. In wet soil, S. Dak. and Neb. to Idaho and N. Mex. June-Sept.

P. 685, for "Cymopterus montànus T. \& G." read "Phellopterus montànus Nutt." The genus. Phellopterus Nutt. differs from Cymoptèrus Nutt., as shown by Coulter and Rose.

\section{P. 686, before SPERMÓLEPIS, Raf., insert the genus:}

\section{2a. PSEUdOTAENÍDIA Mackenzie.}

An erect glabrous and glaucous perennial with stout rootstocks. Leaves ternately decompound, almost identical with those of Taenidia integerrima. Umbels compound. Involucre and involucels none, or rarely of $\mathrm{I}$ or 2 bractlets. Calyx-teeth short. Fruit glabrous, oval or obovate, strongly flattened dorsally, the dorsal and intermediate ribs filiform, much narrower than the intervals, the lateral ribs thick, broadly winged; oil-tubes I or 2 in the intervals; stylopodium very short or none. [Greek, false Taenidia.] A monotypic genus.

I. Pseudotaenidia montàna Mackenzie. Plant 4-8 dm. high, the stems striate. Leaf-blades 2-3-ternate, the segments entire, mucronate, ovate to oblong-lanceolate or oblanceolate, $\mathrm{I}-3 \mathrm{~cm}$. long, 6-20 $\mathrm{mm}$. wide, strongly veined beneath; petioles dilated and sheathing at the base; peduncles $6-20 \mathrm{~cm}$. long; rays of the umbels 8-12, varying from $\mathrm{x}$ to $3 \mathrm{~cm}$. long; rays of the umbellets $3-7 \mathrm{~mm}$. long; fruit $5^{-6} \mathrm{~mm}$. long, $4 \mathrm{~mm}$. wide. Mountains of Va. and W. Va.

P. 687. Substitute for genus 44. PEUCÉDANUM L., the name LOMÁTIUM Raf. As shown by Coulter and Rose, the Old World Peucedanums are generically distinct from the North American plants which have been so called. Our species, according to these authors, are as follows:

I. Peucedanum nudicaule = Lomatium orientàle C. \& R. $\& \mathrm{R}$.

2. Peucedanum foeniculàceum = Lomatium daucifôlium (Nutt.) C.

3. Peucedanum Kingii is referred to Cynomarathrum Nuttállii (A. Gray) C. \& $\mathrm{R}$.

4. Peucedanum villosum $=$ Lomatium foeniculàceum (Nutt.) C. \& R.

\section{P. 690, after Cornus Amòmum, insert:}

5a. Cornus obliqua Raf. Purpus' Cornel. Similar to C. Amomum, the leaves usually narrower, mostly ovate-lanceolate, narrowed or cuneate at the base, papillose on the under side, and appearing glaucous, the veins fewer (usually 4 or 5 pairs); flowers rather smaller; fruit light blue. Moist soil, Que. to Alberta, Conn., Ky., Mo. and Kans. (C.Purpusi Koehne.) 
P. 690 , after Cornus asperifòlia, insert:

6a. Cornus Príceae Small. Miss PRICE's CoRnel. A shrub, 2 m. high or less, the young twigs red, finely pubescent. Leaves ovate to ovate-elliptic, $5^{-I} 2 \mathrm{~cm}$. long, acuminate at the apex, rounded or narrowed at the base, roughish-puberulent above, paler and softly pubescent beneath; petioles $1-2 \mathrm{~cm}$. long, pubescent; fruit white, subglobose, only about $3 \mathrm{~mm}$. in diameter, the stem a little longer than thick, faintly ribbed. River-banks, Ky. and Tenn. May-June.

\section{P. 703, after Leucothoë racemòsa, add:}

5. Leucothoë elongàta Small. Long Swamp Leucotioë. A shrub, similar to $L$. racemosa in size, habit, and foliage, the racemes longer, $\mathrm{I}-2 \mathrm{dm}$. long; pedicels $\mathrm{I}-3 \mathrm{~mm}$. long; sepals narrower, linearlanceolate, about half as long as the corolla, longer than the capsule (in $L$. racemosa one-quarter to one-third as long as the corolla, and not longer than the capsule). Swamps, S, E. Va. to Fla. April-May.

P. 704, after Xolisma ligústrina, add:

2. Xollsma foliosiflora (Michx.) Small. Similar to $X$. ligustrinci, but leaves thicker, and usually more pubescent, somewhat shining on the upper surface; panicles leafy-bracted; sepals ovate; corolla $2-3 \mathrm{~mm}$. in diameter. In wet soil, Va. to Fla. and La. Apr.-June.

P. 708, after Polycodium stamíneum, add:

2. Polycodium negléctum Small. Smooth Deerberry. A shrub, I-I.5 $\mathrm{m}$. high, differing from $P$. stamineum in having leaves and inflorescence glabrous. Woods and thickets, Va. to Fla., Ky., Kans. and La.

3. Polycodium cándicans (C. Mohr) Small. Glaucous Deerberry. A shrub, $2 \mathrm{~m}$. high or less, differing from $P$. stamineum in having the leaves white-glaucous beneath and the fruit glaucous, and from $P$. neglectum in having finely pubescent leaves and inflorescence. Woods and thickets, N. Y. and Pa. to Ohio, Ga. and Ala. April-May.

P. 708, after Batodendron arbòreum, add:

2. Batodendron andrachnefórme Small. Missouri FARKLEBERRY. A much-branched shrub, the twigs finely pubescent. Leaves oval, I-2 cm. long, serrulate, obtuse, strongly reticulate-veined on both sides, dark green and shining above, pale, dull, and pubescent beneath; flowers solitary in the axils of the leaves, on short pedicels only $2-6 \mathrm{~mm}$. long; corolla globular-campanulate, its lobes only about one-fourth as long as the tube. On bluffs, Mo. and Ark. May-June.

P. 7 ro, after Vaccinium atrocóccum, insert:

7a. Vaćcinium simulàtum Small. Serrulate-leaved Blueberry. A shrub, $3 \mathrm{~m}$. high or less. Leaves elliptic to oblong-lanceolate, 2.5-7 $\mathrm{cm}$. long, acute or short-acuminate at the apex and usually acute at the base, bright green and glabrous above, pubescent, at least on the veins beneath, the margins serrulate; corolla urn-shaped, $3 \cdot 5-4.5 \mathrm{~mm}$. long; berries globular, about $7 \mathrm{~mm}$. in diameter, glaucous. In moist woods and thickets, N. Y. to Va., Ga. and Ala., mostly in the mountains. May-June.

\section{P. 7I9, after Dodecatheon Méadia Frénchii, add:}

2. Dodecatheon brachycàrpa Small. ShORT-Fruited SHootincstar. Similar to $D$. Meadia, the corolla pink-purple. Filaments united at the base into a very short tube, this much shorter than in D. Meadia; capsule ovoid, $x \mathrm{~cm}$. long, little longer than the calyx (that of $D$. Meadia narrowly ovoid or oblong, I.2-I.5 cm. long and much longer than the calyx). In fields, Md. to Mo., Ala. and Ark. May-June. 
P. 725, after Fraxinus Pennsylvánica, insert:

4a. Fraxinus Michaùxii Britton. Michaux's Ash. A large tree, with rough and fissured bark, the young twigs either velvety-pubescent or glabrate. Leaflets 5-9, long-stalked, oblong-lanceolate, thick, entire, $13 \mathrm{~cm}$. long or less, dark green above, paler and more or less pubescent beneath; sam.ras broadly spatulate, $3.5-5 \mathrm{~cm}$. long, $8-10$ $\mathrm{mm}$. wide, the thick obtuse or notched wing as long as or longer than the nearly terete body and decurrent on its sides to or above the middle. In swamps S. N. Y. to N. C. Type specimen from a wild tree in the New York Botanical Garden. [F. tomentosa Michx. f. Arb. For. 3: $p l$. 9 , but not as to the description there given, which applies to $F$. Pennsylvanica.]

P. 733, after Gentiana parvifòlia, insert:

9a. Gentiana latifolia (Chapm.) Britton. Chapman's Gentian. Stem puberulent, $3-5 \mathrm{dm}$. tall. Leaves oblong to elliptic, narrowed at both ends, acute, $2-8 \mathrm{~cm}$. long, ciliolate; flowers several in a terminal cluster, sometimes also in the upper axils; calyx-tube glabrous, its lobes linear to linear-lanceolate, spreading, about as long as the tube, ciliolate; corolla rose-purple, funnelform, $4-5 \mathrm{~cm}$. long, its lobes ovate, acute, much longer than the 2-cleft but otherwise nearly entire plaits; seeds broadly winged. In moist soil, Va. to Fla. and Ala. Oct.-Nov.

\section{P. 733, after Gentiana Saponària, insert:}

ioa. Gentiana décora Pollard. Mountain Gentian. Stems finely puberulent, $5 \mathrm{dm}$. high or less. Leaves thin, ciliolate, oblong to oblongelliptic, 5-8 cm. long, acute at both ends, sessile, or the lowest much smaller and obtuse; flowers usually several in a terminal cluster, sometimes also solitary in the upper axils; calyx $1.5 \mathrm{~cm}$. long or less, its lobes subulate, spreading, shorter than the pubescent tube; corolla purple, $2.5-3 \mathrm{~cm}$. long, its ovate lobes much longer than the cleft plaits; seeds winged. In mountain woods, Va. to Ga. Sept.-Oct.

P. 735, after Bartonia Virgínica, insert:

ra. Bartonia lanceolàta Small. Sharp-petalled Bartonia. Resembling $B$. Virginica, but with the branches spreading or upwardly curved; corolla-lobes lanceolate, acute or acuminate, entire (in B. Virginica oblong, abruptly tipped, more or less erose). Moist soil, N. Y. to Fla. and Ark. Aug.-Oct.

\section{P. 743, before Asclepias Mèadii, insert:}

roa. Asclepias intermedia Vail. Intermediate Milkweed. Stems erect, glabrous, purplish, not glaucous, $3 \mathrm{dm}$. high or more; leaves oblong-elliptic, yellow-green and glabrous above, paler and minutely pubescent beneath, 8-I4 cm. long, $3-7 \mathrm{~cm}$. wide, obtuse, or the upper ones subcordate at the base, obtuse and apiculate at the apex, the margins undulate: petioles $\mathrm{I}-3 \mathrm{~mm}$. long; umbels terminal, 2 or more, short-peduncled, 16-24-flowered; peduncles minutely and sparingly pubescent, $2-8 \mathrm{~cm}$. long; pedicels $2.5-3 \mathrm{~cm}$. long, slender, minutely pubescent; corolla green-purple, its segments oblong-lanceolate, 6-8 $\mathrm{mm}$. long; hoods erect, ovate-lanceolate, obtuse, 5-6 $\mathrm{mm}$. long, pinkish purple with a darker red or purplish stripe down the back, the lateral margins incurved, each with an erect tooth somewhat above the middle; horn slender, the tips incurved and meeting over the anthers, free from about the middle of the hood. Lawrence, Long Island. Appears to be intermediate between Asclepias Syriaca and $A$. amplexicaulis and may be a hybrid. 


\section{P. 743, after Asclepias Syriaca, insert:}

15a. Asclepias Kansàna Vail, n. sp. Kansas Milkweed. Stems erect, stout, canescently-tomentose, $2 \mathrm{dm}$. high or more. Leaves shortpetioled, the basal ones broadly oblong-ovate, truncate and rounded at the base, obtuse and mucronulate or emarginate at the apex, the upper ones elliptical-oblong, the lower ones I 3-16 cm. long; minutely tomentose or becoming glabrate above, densely canescently-tomentose beneath, the midvein very broad and conspicuous, the primary veins wide-spreading; umbels seve al, axillary, peduncled, many-flowered; peduncle $3-7 \mathrm{~cm}$. long; pedicles $2-3 \mathrm{~cm}$. long, tomentose; corolla-segments oblong, 7-8 mm. long, tomentose outside; hoods oblong, about $4 \mathrm{~mm}$. long, diverging at the obtu e apex, the lateral margins infolded with a broad obtuse tooth on each side at about the middle, the tips of which meet under the exserted incurving horn horn falcate, affixed near the base of the hood, and incu ving over the edge of the anthers; follicles erect, on recurved pedicels, 8-10 $\mathrm{cm}$. long, $3-3.5 \mathrm{~cm}$. wide, obtuse, densely white-tomentose, echinate with numerous soft spinose processes that vary in $1 \mathrm{ngth}$ from $3^{-10} \mathrm{~mm}$; seeds $8 \mathrm{~mm}$. long. Kansas. Type from Fort Riley.

\section{P. 749, at end of Asclepiadàceae, add:}

\section{PERIPLOCA L.}

Woody twining plants with entire opposite leaves and middle-sized flowers in umbels. Calyx 5-parted, glandular within; corolla deeply 5parted, the segments obtuse, dextrorsely rotate, villous on the inner surface; corona adnate to the base of the corolla, with io broad or 5 slender elongated, entire or lobed scales or appendages; filaments short, free, conniving at the short appendiculate apex; pollen granulose, loosely aggregated in two masses in each anther-cell; follicles slender, glabrous, generally united at the apex; seeds comose. (Greek, twining.)

I. Periploca Graèca L. Glabrous; leaves ovate-oblong, acute, paler beneath; umbels cymose; peduncles shorter than the leaves; corolla-segments dull brownish or greenish, with a darker line down the middle and a whitish spot at the base within; appendages of the corona slender, ligulate, 2-toothed at the apex. A handsome woody climber of the Old World, escaped from cultivation, Mass. to Kans. Native of Syria and the Grecian Islands. Called Silk Vine.

P. 753, after Convolvulus sè pium, insert:

r. Convolvulus fraterniflorus Mackenzie and Bush. Two-FLowered BINDWEED. Stem I $\mathrm{m}$. long or more, glabrous or sparingly hairy. Leaves hastate, 6-ro cm. long, dark green, rather thick, finely pubescent on both sides, the basal auricles divergent, entire or with one or two teeth; axils or most of them two-flowered, the peduncle of one of the flowers longer than the petiole, the other shorter; bracts $2.5-3 \mathrm{~cm}$. long; corolla 6 or $7 \mathrm{~cm}$. long, white. Prairies, Mo. July-Aug.

\section{P. 763, after Hydrophyllum Virgínicum, insert:}

ra. Hydrophyllum pàtens Britton. Purple Water-Leaf. Similar to $H$. Virginicum in habit and foliage, the petioles more strongly ciliate. Calyx-segments at flowering time appressed to the corolla (spreading in H. Virginicum); corolla purple, its segments with spreading tips (erect in $H$. Virginicum). Minn. June.

\section{P. 775, after Onosmodium molle, insert:}

2a. Onosmodium subsetòsum Mackenzie \& Bush. Sмоотнish FAlse Gromwell. Leaves, branches, and upper part of the stem appressed-strigose, the lower part of the stem smooth or with scattered 
stiff hairs. Leaves lanceolate to oblong-lanceolate, $8 \mathrm{~cm}$. long or less, dark green above, paler and with the veins conspicuous beneath, acute or acuminate at the apex, narrowed at the base; pedicels $\mathrm{I}-6 \mathrm{~mm}$. long, calyx-segments linear, obtuse; corolla greenish-white, 8-18 mm. long, its triangular acute lobes much shorter than the tube; nutlets $2-3 \mathrm{~mm}$. long. Dry soil, Mo. and Ark. May-June.

P. 778, Verbena Canadénsis, strike out range, "Mex. and N. Mex.," and add:

7a. Verbena Drummóndii (Lindl.) Baxter. Drummond's VerBENA. Perennial, hirsute, the branches $2-4 \mathrm{dm}$. long. Leaves pinnatifid or bipinnatifid into oblong-lanceolate or linear, mostly acute segments; calyx about ro $\mathrm{mm}$. long, longer than the bract, its lobes setaceous; corolla-tube about twice as long as the calyx, its limb i i to I $5 \mathrm{~mm}$. wide; nutlets $3-3.5 \mathrm{~mm}$. long, Differs from $V$. bipinnatifida in the larger corolla with a longer tube. Prairies and fields, Va. to Kans., La., Texas and N. Mex. March-July.

\section{P. 781, after Ajuga réptans, add:}

2. Ajuga Genevènsis L. ERECt Bugle. Similar to the Creeping Bugle, but devoid of runners, and the whole plant pubescent with long hairs. Basal leaves tufted; flowering stems solitary or several, 1.5-3 dm. high. In lawns and waste places, Penn. to N. Y., Me. and Conn. May-June. Adventive from Europe.

\section{P. 782, after Teucrium occidentàle, insert:}

2a. Teucrium littoràle Bicknell. CoAst Germander. Pale and canescent, 3-5 dm. high, erect or assurgent, often with ascending branches; leaves thickish and rugose-veiny, narrowly oblong or sometimes broader, narrowed into the petiole, closely fine-serrate or becoming unequally dentate-serrate, 6-II cm. long, I.5-4 cm. wide; petioles 5-10 $\mathrm{mm}$. long; spikes narrow, often interrupted; bracts about the length of the calyx; calyx small, 4-5 $\mathrm{mm}$. high, becoming somewhat gibbous-urceolate, the teeth short, the upper ones obtuse; corolla pale pink, about $15 \mathrm{~mm}$. long, loosely pilose without. On or near the coast, Me. to Fla. July-Aug.

2b. Teucrium róseum Bicknell. Maine Germander. Rather stout and deep green, 3-7 dm. high, the stem soft-pubescent or downwardly villous; leaves broadly oblong or oblong-ovate, cuneate at base, acute or acuminate at apex, irregularly dentate-serrate or somewhat cut-serrate, hoarytomentose beneath, softly pilose-pubescent above, 6-9 cm. long, $2.5-4.5$ $\mathrm{cm}$. wide, the slender petioles hoary-pubescent, IO-15 $\mathrm{mm}$. long; inflorescence hoary-villous; calyx often purplish, 5-7 $\mathrm{mm}$. long, the upper tooth acute, the lateral ones obtuse, the lower pair but little longer, triangularsubulate; pedicels very short; bracts usually longer than the calyx, ciliatefringed; corolla rose-purple, somewhat smaller than in $T$. littorale and less exserted, more or less pilose-bearded. Coast of Me. and Mass. Aug.Sept.

2c. Teucrium boreàle Bicknell. Northern Germander. Erect or ascending, rather slender, often widely branched from the base, $3-8 \mathrm{dm}$. tall, or more; stem loosely pubescent with recurved hairs to glabrate; inflorescerice somewhat villous-pubescent, scarcely if at all glandular; spikes short, or the terminal one elongated and somewhat flexuous; leaves thin or membranous, ovate-oblong to oblong-lanceolate, 5-10 $\mathrm{cm}$. long, 2-3.5 $\mathrm{cm}$. wide, acute, serrate to dentate-serrate, above minutely hispidulouspubert!ent, beneath thinly tomentulose, or sometimes glabrate throughout; petioles of the main leaves becoming I-2 cm. long; bracts mostly shorter than the calyx, ciliate; calvx thin, campanulate, 4-5 $\mathrm{mm}$. long, the subequal teeth short and broad, the lateral pair very obtuse; corolla purpiish-pink, I2-15 $\mathrm{mm}$. long, about three times the length of the calyx, 
loosely short-pubescent and dotted with minute glands, the terminal lobe broad. N. H. to northern N. Y. Aug.

2d. Teucrium menthifölium Bicknell. Mint-Leaved Germander. Hirsute-pubescent with recurved hairs to nearly glabrous except the inflorescence, smaller and less branched than $T$. occidentale, the denser spikes shorter, with the bracts often elongated and foliaceous, the pubescence not viscid nor glandular; leaves firm, pale green, minutely pubescent to glabrate above, white-veiny and thinly tomentulose beneath, lanceolate or narrowly oblong, narrowed at the base, $5-9 \mathrm{~cm}$. long, $2-3 \mathrm{~cm}$. wide, acute or acuminate, sharply serrate; calyx 5-6 mm. long, narrowly campanulate, the teeth shorter and less rigid than in $T$. occidentale, the lateral obtuse, the lower pair only slightly longer; corolla pink, short, sometimes not twice the length of the calyx, thinly pubescent and glandular, the terminal lobe small, often not broader than the lateral ones. Central Mich.

\section{P. 782, after Teucrium laciniátum, add:}

3a. Teucrium Bòtrys L. Annual, pubescent, branched, 3-4 dm. high. Leaves bipinnatifid, or the upper ones pinnately parted, the basal longpetioled; flowers purple, verticillate in all the upper axils, the whorls 2-6-flowered; pedicels equalling the calyx or shorter; calyx gibbous at the base, 5-toothed, the teeth triangular, acute. Adv. from Europe at Great Barrington, Mass.

\section{P. 783 , after Scutellaria lateriflòra, insert:}

ra. Scutellaria Churchilliána Fernald. Churchill's Skullcap. Intermediate in aspect between S. lateriflora and S. galericulata. Leaves thin, ovate, acuminate, long-petioled; bracts of the racemes similar to the leaves but smaller, as long as the flowers or longer; corolla $I-I .5 \mathrm{~cm}$. long, blue-violet, pilose, the lower lip somewhat longer than the upper. In wet soil, Me. Aug.-Sept.

P. 788, after Physostegia Virginiána, insert:

ra. Physostegia Digitalis Small. Foxglove; Lion's-Heart. Stems stout, erect, $7-\mathrm{I} 2 \mathrm{dm}$., tall, sharply angled. Leaves oblong-elliptic to oblong-obovate; the lower $1-2.5 \mathrm{dm}$. long, $7 \mathrm{~cm}$. wide or less, acute or acutish, repand-dentate above the middle or entire, sessile or part!y clasping, the upper much smaller, narrower, and entire; racemes simple or branched, puberulent; bracts lanceolate to ovate-lanceolate, $4^{-6} \mathrm{~mm}$. long; flowers very nearly sessile in dense spike-like racemes; calyx 8-ro $\mathrm{mm}$. long, its tube cylindric-turbinate, its teeth lanceolate, acuminate or acute, about half as long as the tube; corolla $2-2.5 \mathrm{~cm}$. long, the lower lip spreading, its middle lobe marginate, about twice as large as the lateral ones. Moist soil, Mo. to La. and Texas.

\section{P. 793, after Stachys palústris, insert:}

7a. Stachys Nuttallii Shuttlw. Nutrall's Hedge Netrle. Perennial, hirsute to the base; stems erect, simple, rather stout, 4-I I dm. tall. Leaves oblong-lanceolate to ovate-oblong, I2 cm. long or less, acute or acuminate, serrate-dentate all around, rounded, truncate or subcordate at the base; petioles only 5-10 $\mathrm{mm}$. long; spike interrupted, I dm. long or longer; calyx hirsute, its teeth triangular-lanceolate, acuminate, half as long as the tube; corolla purple, about I $\mathrm{cm}$. long, its tube saccate near the middle, longer than the calyx, the upper lip concave, hairy, the lower lip drooping, as long as the tube. Mountain slopes, Va., N. C., and Tenn. June-Aug.

7b. Sta-hys sopulorum Greene. Rocky Mountain Hedge Nettle. Stem simple or branched 3-6 dm. high, softly hirsute. Leaves very short-petioled or sessile, oblong-lanceolate, the lower mostly obtuse, 
the upper often acute, finely pubescent, rounded or truncate at the base, rather finely crenate-dentate all around, $7 \mathrm{~cm}$. long or less; calyxteeth lanceolate, subulate, a little shorter than the tube; corolla pink to red-purple, Io-I $2 \mathrm{~mm}$. long, pubescent. Meadows and moist soil, N. Dak. to Alberta, Wash., Wyom. and N. Mex. June-Sept.

P. 796, after Monarda scàbra, insert:

5a. Monarda móllis L. Canescent Wild Bergamot. Similar to $M$. fistulosa and $M$. scabra, differing from the former in its canescent, not spreading pubescence, and from the latter in its longer-petioled leaves mostly narrowed at the base. In dry soil, N. E. to Ga., S. Dak., Kans. and Tex. Summer.

P. 796, after Monarda pectináta, add:

9. Monarda tenuiaristàta (A. Gray) Small. Long-Awned Monarda. Annual, 6 d.n. high or less, simple or branched, puberulent. Leaves oblong or oblong-lanceolate, serrate, petioled, mostly narrowed at the base, the apex acute; bracts green or purplish, lanceolate or linearlanceolate, gradually tapering into a long terminal bristle; calyx-tube 7 or $8 \mathrm{~m} . \mathrm{n}$. long, puberulent, its setaceous teeth spreading, sparingly ciliate; corolla about $2 \mathrm{~cm}$. loing; nutlets about $\mathrm{I} .5 \mathrm{~mm}$. long. In dry soil, Kans. to Texas, Ariz. and northern Mex. May-Aug.

ro. Monarda dispersa Small. Oblong-Bracted Monarda. Similar to the preceding species, 2-8 $\mathrm{dm}$. high, usually branched. Leaves oblong to lanceolate or oblanceolate, serrate, petioled; bracts, at least the lower ones, oblong, $1.5-2.5 \mathrm{~cm}$. long, abruptly narrowed into the long terminal bristles, usually purple above; calyx-tube 8 or $9 \mathrm{~mm}$. long, puberulent, the setaceous teeth sparingly ciliate, spreading; corolla about $2.5 \mathrm{~cm}$. long. In dry soil, Kans. and Mo. to Texas and Mex. Nat. in Tenn., Ga., and Fla. May-Aug.

\section{P. 8II, after Physalis Philadélphica, insert:}

8a. Physalis subglabràta Mackenzie \& Bush. Glabrate GroundCHERRY. Perennial, $6 \mathrm{dm}$. high or less, nearly glabrous throughout. Leaves ovate, sinuate-dentate, very oblique at the base, similar to those of $P$. Philadelphica; corolla yellow with a dark center, about $2 \mathrm{~cm}$. broad; anthers purplish; fruiting calyx sunken at the base, acuminate. Fields and river bottoms, Ont. to Tenn., Neb. and Colo. June-Sept.

\section{P. 822, after Scrophular:a Marylándica, insert:}

ra. Scrophularia negiécta Rydb. HAlRY FIGWORT. Stems minutely pubescent, $2 \mathrm{~m}$. tall or less. Leaves ovate, lanceolate or oblong-lanceolate, serrate, rather densely pubescent beneath; calyx-lobes ovate to oblong-ovate, obtuse; corolla larger than that of $S$. Morylandica, about $9 \mathrm{~mm}$. long; capstles also larger, $6 \mathrm{~mm}$. long or more. Woods and thickets, 'Tenn. to Mo., Kans. and Ark. Aug.-Oct.

\section{P. 823 , after Scrophularia leporélla, add:}

3. Scrophularia occidentàlis (Rydb.) Bicknell. Western FigwoRT. Similar to S. leporella, but the upper lip of the corolla much shorter than the tube (as long as the tube in S. leporella), and the short ascending branches of the panicle densely glandular; leaves, at least the lower ones, hastate-incised at the base; capsules larger than those of S. Leporella. Thiclets and moist soil, S. Dak. to Kans., the Ind. Terr., Wash. and Cal. June-Aug. 
P. 824, after Pentstemon canéscens, insert:

2a. Pentstemon pállidus Small. Pale Beard-tongue. Stem canescent-puberulent to the base, $9 \mathrm{dm}$. tall or less. Basal leaves broadly oval, oblong or spatulate, entire or nearly so, narrowed into petioles; lower stem-leaves mostly spatulate, the others oblong to narrowly lanceolate, acute or acuminate, sessile or somewhat clasping, usually remotely dentate; panicle narrow, its branches erect-ascending; calyx-segments ovate, acute; corolla pale purple or nearly white, $2-2.5 \mathrm{~cm}$. long, the tube gradually dilated upward, the throat sparingly bearded; s'crile filament bearded with short hairs; capsules 5-6 mm. long, longer than the calyx. In sandy soil, Conn. and N. Y. to Fla., Mo, and the Ind. Terr. June- July.

\section{P. 833, after Veronica Americàna, insert:}

2a. Veronica Beccabùnģa L. European Brooklime. Similar to $V$. Americana, the leaves petioled, but low-serrate and obtuse. City of Quebec; ballast grounds at Brooklyn, N. Y., and Weehawken, N. J. Nat. or adv. from Europe.

\section{P. 838 , after Gerardia purpùrea, insert:}

3a. Gerardia fasciculata Ell. Fascicle-leaved Gerardia. Similar to $G$. purpurea, often larger, sometimes I $2 \mathrm{dm}$. high, puberulent or slightly hispidulous. Leaves linear, usually less than $2 \mathrm{~mm}$. wide, very rough, the larger with fascicles of smaller ones in their axils; pedicels shorter than the calyx; calyx-tube campanulate, 2.5-3.5 $\mathrm{mm}$. long, the lobes very small, acute; corolla rose-purple, $2-3 \mathrm{~cm}$. long; capsule about $5 \mathrm{~mm}$. in diameter. In moist soil, Va. to Fla. and Texas. Aug.Sept.

\section{P. 838 , after Gerardia Holmiàna, insert:}

7a. Gerardia Gattíngeri Small. Gattinger's Gerardia. Stems wiry, smooth, $5 \mathrm{dm}$, high or less, the branches very long and slender. Leaves almost filiform, I.5-3 cm. long, smooth or roughish, mostly without smaller ones in their axils; pedicels filiform, I-2.5 $\mathrm{cm}$. long; calyx-tube campanulate, $2.5-33.5 \mathrm{~mm}$. long, the acute teeth I $\mathrm{mm}$. lon' or less; corolla rose-purple, about I $\mathrm{cm}$. long, its lobes rounded; capsule longer than the calyx. In dry soil, Tenn. to Mo., Ala. and Texas. July-Sept.

\section{P. 84I, after Euphrasia Canadensis, insert:}

2a. Euphrasia hirtélla Jordan. Hairy Eyebright. Stem slender, pubescent, simple or branched, I.8 dm. high or less. Leaves glandularpubescent and also bearing simple hairs, ovate-oblong; bracts ovate, glandular-pubescent, sharply 5-8-toothed on each side; inflorescence becoming elongated; calyx very pubescent, about $5 \mathrm{~mm}$. long in fruit, its teeth acute; corolla about $7 \mathrm{~mm}$. long, purplish. N. Mich. to Iudson Bay, Minn. and the northern Rocky Mountains. Also in Europe.

\section{P. 84I, after Euphrasia Americàna, insert:}

3a. Euphrasia Rándii Robinson. Rand's Eyebright. Stem often much branched and decumbent, or at first erect, sometimes $6 \mathrm{dm}$. long. pubescent, the inflorescence short, or much elongated: Leaves mostly ovate-orbicular, 7-I $5 \mathrm{~mm}$. long, subcordate, ciliate, more or less pubescent above, setulose on the veins beneath, several-toothed, the teeth obtuse or acutish; flowers borne in most of the axils; calyx pubescent, $3.5 \mathrm{~mm}$. long in flower, becoming longer in fruit, its teeth triangularlanceolate, acute, straight; corolla 3-4 mm. long, cream-colored to purple; capsule elliptic-oblong, obcordate, ciliate above. Newf. to Me. July-Aug. 
P. 84I, after Euphrasia Òakesii, add:

5. Euphrasia Williamsii Robinson. Williams' Eyebright. Stem slender, simple, erect, $3-10 \mathrm{~cm}$. high, pubescent with crisped white hairs. Leaves $5^{-8} \mathrm{~mm}$. long, ciliolate near the margin, otherwise glabrous, the lower ovate-oblong, about 7 -toothed, the upper obovate to flabelliform or suborbicular, crowded; flowers in a terminal dense leafy spike, the bracts with 7 or 9 acutish teeth; calyx $4 \mathrm{~mm}$. long, its teeth lanceolate; corolla brownish purple with a yellow eye, about $4 \mathrm{~mm}$. long; capsule elliptic, obcordate, ciliate above. Mt. Washington, N. H. July-Aug.

\section{P. 857, after Plantago màjor, insert:}

ra. Plantago halophila Bicknell. Salt-Marsh Plantain. Very similar to $P$. major, often diminutive, but sometimes as large. More or less hirsutulous-tomentulose throughout, dull green, the spikes and scapes often bright purplish; leaves thick, undulate, often prostrate in a stiff rosette or ascending, the blades usually but not always longer than the petioles; scapes stiff and slender, commonly upcurved-assurgent, the naked lower part mostly longer than the leaves and often 2-4 times the length of the narrow spikes; bracts thinner and less concave than in $P$. major, mostly rather shorter and more ovate and acute; pyxis relatively narrower than in $P$. major, circumscissile mostly within the tips of the sepals and somewhat below the middle, lid longer and less conic than in P. major. Salt marshes and shores, Me. to N. J. Type from Van Cortlandt, N. Y. City, flowering in July, about two weeks later than $P$. major.

P. 859. Strike out note on Plantago occidentàlis, and substitute:

12a. Plantago rhodospérma Decne. Red-seeded Plantain. Annual or biennial, densely pubescent; scapes erect or decumbent, $2.5-20 \mathrm{~cm}$. long, usually much longer than the leaves. Leaves and spikes similar to those of $P$. Virginica; flowers diøecious; bracts and calyx-lobes acuminate; capsules oblong, about $3 \mathrm{~mm}$. long; seeds dark red (golden yellow in P. Virginica). Sandy soil, Mo. to La., Tex. and Ariz. April-July.

P. 865 , after Galium Mollùgo, inse t:

2a. Galium eréctum Huds. Upright Bedstraw. Resembles $G$. Mollugo, but has larger white flowers on ascending pedicels (pedicels divergent in G. Mollugo); branches erect or ascending. In fields, N. S. to N. J. Adv. from Europe. May-Sept.

P. 868, after Galium aspréllum insert:

2ra. Galium sylvátic'ım L Wood Bedstraw. Perennial, 5-8 dm. high, erect. Stem obtusely 4-angled, glabrous or somewhat pubescent, not rough; leaves oblong-lanceolate, mucronate, obtuse or acute, those of the stem whorled, in 6's or 8's, 3-4 cm. long, 5-8 mm. wide, those of the branches fewer in the whorls or often opposite; panicle usually large, the pedicels filiform, nodding before flowering, erect-spreading in fruit; flowers white; lobes of the corolla apiculate; fruit glabrous. Me. and Vt. Nat. from Continental Europe. June-July.

P. 869 , after Asperula odoráta, add:

2. Asperula galioìdes M. Bieb. Bedstraw Asperula. Leaves linear, rigid, usually in 8 's, involute-margined, mucronate, subterete, $3 \mathrm{~cm}$. long or less, $\mathrm{I}-2 \mathrm{~mm}$. wide; stems erect or ascending, glabrous or pubescent below, paniculately branched; fruit smooth. Southington, Conn. Adventive from Europe.

P. 885, after Campanula rapunculoìdes, insert:

3a. Campanula Trachèlium L. Nettle-leaved Bell-flower. Perennial, rough-hirsute, 5-8 dm. tall. Basal leaves broadly ovate, deeply 
cordate, acute, coarsely doubly toothed, the slender petiole longer than the blade; stem-leaves ovate to oblong-lanceolate, irregularly toothed, acute or acuminate at the apex, narrowed at the base, the upper sessile, the lower petioled; flowers solitary or 2 or 3 together in the upper axils; calyx hirsute, its broadly lanceolate lobes nearly half as long as the corolla; capsules nodding, dehiscent at the base. Vicinity of Montreal, Quebec. Nat. from Europe. July-Sept.

\section{P. 888, before Lobelia puberula, insert:}

5a. Lobelia elongàta Small. LoNG-Leaved Lobelia. Perennial, glabrous or nearly so throughout, simple, $3^{-I 2} \mathrm{dm}$. high. Leaves linear to linear-oblong, ro $\mathrm{cm}$. long or less, acute, serrate with gland-tippcd teeth, sessile or short-petioled, erect or ascending; raceme $\mathrm{I}-3 \mathrm{dm}$. long, the flowers secund; bracts linear to lanceolate, glandular-serrate, the lower ones sometimes longer than the flowers; sepals elongated-linear to linear-setaceous, entire, often as long as the deep blue corolla; capsules 6-8 $\mathrm{mm}$. broad. In swamps, Del. to Va., Fla. and La.

P. 898. Read for range of Lactuca Scariòla, "in waste places, N. J. to W. Va., Idaho and Mont., and in ballast about the eastern seaports; not common."

Before Lactuca Ludoviciàna, insert:

ra. Lactuca viròsa L. Strong-Scented Lettuce. Similar to the Prickly Lettuce (Lactuca Scariola) and confused with it. Leaves oblong to oblanceolate, finely irregularly denticulate, rarely slightly sinuate; achenes dark-colored. L. Scariola has sinuate-pinnatifid leaves and pale achenes. A common weed in waste and cultivated grounds, Me. to N. Dak., Ga., Kans.

\section{P. 907, before Nabalus trifoliolàtus, insert:}

3a. Nabalus cylíndricus Small. Mountain Rattlesnake-Root. Stem $3-9 \mathrm{dm}$. tall, glabrous. Leaves triangular or triangular-ovate, ro $\mathrm{cm}$. long or less, acute or acuminate, 3-lobed or 3-cleft, sinuately toothed, truncate or cordate at the base, the lower ones long-petioled; panicle narrow, long, contracted, the heads in clusters in the upper axils; involucre about $10 \mathrm{~mm}$. long, the principal bracts linear-lanceolate, bearing a few scattered hairs, slightly shorter than the light brown pappus. Mountains of Ky., Tenn. and N. C. Sept.

\section{P. 939, after Solidago ulmifòlia, insert:}

28a. Solidago microphýlla Engelm. Small-Leaved Goldenrod. Stem smooth, 8-r $3 \mathrm{dm}$. tall. Leaves numerous, somewhat pubescent, rough above, firm, the basal ones spatulate or oblanceolate, $6-$ I I cm. long, shallowly toothed, the upper elliptic to oblong, serrate or entire; heads numerous, $5-7 \mathrm{~mm}$. high, the involucre $4-4.5 \mathrm{~mm}$. high, $2 \mathrm{~mm}$. thick, its bracts linear to linear-lanceolate, acute; achenes pubescent. In dry soil, Kans. to Ark. and Tex. Aug.-Oct.

P. 940, after Solidago argùta, insert:

34a. Solidago Váseyi Heller. VASEY's Goldenrod. Similar to $S$. arguta, the basal leaves larger and relatively broader; heads larger, the involucre $5^{-6} \mathrm{~mm}$. high, $3^{-4} \mathrm{~mm}$. thick; achenes finely pubescent. Mountain woods, Va. to Ky., Ga. and Ala. Aug.-Oct.

\section{P. 94I, after Solidago nemoràlis, insert:}

4ra. Solidago longipetiolàta Mackenzie \& Bush. LONG-PETIOLED GolDENROD. Resembles $S$. nemoralis, but grayish green. Leaves firm in texture, usually with fascicles of smaller ones in their axils, 3-nerved, the basal and lower ones long-petioled; heads rather larger than those of S. nemoralis; bracts of the involucre oblong, obtuse, thick; achenes pubescent. Dry soil, Mich. to Wyo., Mo. and Tex. 
P. 94I, after Solidago rígida, insert:

45a. Solidago corymbòsa El1. Corymbose Goldenrod. Resembles S. rigida, differing in the smoother leaves and stem, the upper leaves lanceolate and acute, those of S. rigida being ovate or ovate-lanceolate and obtuse or obtusish; heads somewhat smaller than those of S. rigida and mostly fewer-flowered. In dry soil, Ohio to Tenn., Ga. and Ala. Aug.-Oct.

P. 946. Additional species of Aster have been described by Prof. E. S. Burgess in Dr. Small's "Flora of the Southeastern United States."

\section{P. 976, after Antennaria ámbigens, insert:}

\section{I3a. Antennaria Braìnerdii Fernald. BRAINERD's CAT's-Foot.} Stolons short, assurgent; stems slender, 2-3 dm. tall, the upper part bearing glandular hairs intermixed with the floccose pubescence. Basal leaves $5 \mathrm{~cm}$. long or less, obovate, apiculate, tapering into a petiole about as long as the blade, dull and more or less woolly above, or becoming glabrous, rather strongly 3-nerved; stem-leaves linear-lanceolate, acute; heads corymbose, short-peduncled; involucre 6 to $8 \mathrm{~mm}$. high, its outer bracts oblong, obtuse, yellowish brown, the inner white or white-tipped, acuminate. Woods and meadows, Me. and Vt. May-June.

P. 987 , before Rudbeckia speciòsa, insert:

9a. Rudbeckia grandifiora C. C. Gmelin. LARge-flowered ConeFLOWER. Perennial, rough-hispid, or scabrous; stem stout, strongly striate, 5 to ro $\mathrm{dm}$. tall. Leaves ovate-elliptic to ovate-lanceolate, rather thick, varying from sharply toothed to entire, strongly $3-5$-ribbed, narrowed at both ends, the lower $\mathrm{I}-2 \mathrm{dm}$. long, with long pubescent petioles; heads few, large; bracts of the involucre linear, acuminate, densely hispid; rays 20 or fewer, $3.5 \mathrm{~cm}$. long or less, yellow, drooping; disk I.5-2 cm. thick; chaff of the receptacle canescent or pubescent at the tip; style-branches obtuse; pappus toothed. In dry soil, Mo. (perhaps introduced); Ark. to La. and Tex. June-Aug.

P. 988, after Rudbeckia Sullivàntii, insert:

ira. Rudbeckia umbròsa Boynton \& Beadle. Woodland ConeFLOWER. Perennial; stem I m. high or less, striate, loosely pubescent, branched above. Basal and lower leaves long-petioled, ovate, acute, $5^{-8} \mathrm{~cm}$. long, cordate or truncate at the base, coarsely dentate, the upper smaller, short-petioled, ovate to lanceolate, often entire; heads several, 4-6 cm. broad; bracts of the involucre oblong or linear-oblong, $\mathrm{I}-\mathrm{r} .5 \mathrm{~cm}$. long; rays $8-\mathrm{r} 2$, yellow or orange-yellow, $\mathrm{I} .5^{-2} \mathrm{~cm}$. long; disk subglobose; chaff of the receptacle densely ciliate at the apex; styletips obtuse; pappus coroniform. Woodlands, Ky., Tenn. and Ga. July-Aug.

P. roor, after Bidens comòsa, insert:

5a. Bidens Eàtoni Fernald. Eaton's BegGar-ticks. Related to $B$. comosa and to B. connata. Leaves lanceolate, coarsely serrate, petioled, $5^{-\mathrm{r}} 5 \mathrm{~cm}$. long; heads cylindric to obovoid, longer than thick; outer bracts of the involucre 3 to 5, exceeding the disk; inner bracts about 5 , oblong, obtuse or mucronate, striate; ray-flowers none; corollas 4-lobed, pale yellow; achenes 7-9 mm. long, narrowly oblanceolate; awns 2-4, either upwardly or downwardly barbed, half as long as the achene or less. Brackish shores, E. Mass. Sept.

P. 1022, insert the genus

9ia. HAPLOÉSTHES A. Gray.

A low glabrous somewhat fleshy and woody bushy-branched perennial, with very narrowly linear opposite leaves, often with fascicles of similar 
ones in their axils, and numerous small cymose heads of yellow tubular and ligulate flowers. Ray-flowers few, the rays short; disk-corollas numerous, 5-toothed. Involucre campanulate, of 4 or 5 broadly oval bracts, the outer ones overlapping the inner; receptacle nearly flat. Achenes glabrous, striate, linear, terete; pappus a single series of rough and rather stiff whitish bristles. [Greek, refer-ing to the few-bracted involucre.] A monotypic genus of southwestern United States.

I. Haploésthes Gréggii A. Gray. Gregg's Haploesthes. Plant $6 \mathrm{dm}$. high or less, the branches erect or ascending. Leaves entire, 2-5 cm. long, about $\mathbf{1} .5 \mathrm{~mm}$. thick, sessile, the lower pairs connateclasping at the base; involucre $2.5-3.5 \mathrm{~mm}$. high, the outer bracts acutish, the inner blunt; rays mostly shorter than the involucre; achenes $2 \mathrm{~mm}$. long, about as long as the pappus. Saline and gypsum soil, Kans. and S. Col. to Texas and adjacent Mexico. April-Sept.

P. I035, after Centaurea Calcítrapa, add:

6. Centaurea Meliténsis L. Annual, I.3 m. high or less, gray-pubescent or slightly woolly, much branched. Basal leaves lyrate, sometimes $1.5 \mathrm{dm}$. long, their petioles margined, their lobes obtuse; lower stem-leaves few-lobed or entire, the upper narrowly lanceolate, entire, acute, $2 \mathrm{~cm}$. long or less; heads sessile or nearly so, the involucre $1-1.5 \mathrm{~cm}$. thick, its principal bracts tipped with a slender spine 6-1 $2 \mathrm{~mm}$. long, which bears several spinules at its base; corollas yellow, none of them enlarged; pappus-scales unequal. Waste and cultivated grounds, Ga. to Mo., Ariz., Cal. and Ore., and in ballast about eastern seaports. Nat. from Eu. April-Sept. 


\section{GLOSSARY OF SPECIAL TERMS}

Acaulescent. With stem subterranean, or nearly so.

Accumbent. Cotyledons with margins folded against the hypocotyl.

Achene. A dry one-steded indehiscent fruit with the pericarp tightly fitting around the seed.

Acicular. Needle-shaped.

Acuminate. Gradually tapering to the apex.

Acute. Sharp pointed.

Adnate. An organ adhering to a contiguous differing one; an anther attached longitudinally to the end of the filament.

Adventive. Not indigenous, but apparently becoming naturalized.

Albumen. See Endosperm.

Alliaceous. Onion-like, in aspect or odor.

Alternate. Not opposite; with a single leaf at each node.

Alveolate. Like honeycomb; closely pitted.

Ament. A spike of imperfect flowers subtended by scarious bracts, as in the willows.

Amphibious. At times inhabiting the water.

Amphitropous. Term applied to the partly inverted ovule.

Amplexicaul. Clasping the stem, or other axis.

Anastomosing. Connecting so as to form a well.defined network.

Anatropous. Applied to an inverted ovule with the micropyle very near the hilum.

Androgynous. Flower-clusters having staminate and pistillate flowers.

Angiospermous. Pertaining to the Angiospermae; bearing seeds within a pericarp.

Anther. The part of the stamen which contains the pollen.

intherid. The male organ of reproduction in Pteridophyta and Bryophyta.

Anthesis. Period of flowering.
Apetalous. Without a corolla.

Apical. At the top,or referring to the top. Apiculate. With a minute pointed tip. Appressed. Lying against another organ.

Arborescent. Tree-like, in size or shape. Archegone. The female reproductive organ in Pteridophyta and Bryophyta.

Areolate. Reticulated.

Areolation. The system of meshes in a network of veins.

Areole. A mesh in a network of veins. Aril. A fleshy organ growing about the hilum.

Arillate. Provided with an aril.

Aristate. Tipped by an awn or bristle. Aristulate. Diminutive of aristate.

Ascending. Growing obliquely upward, or upcurved.

Asexual. Without sex.

Assurgent. See Ascending.

Auricled. (Auriculate). With basal, ear-like lobes.

Awn. A slender bristle-like organ:-

Axil. The point on a stem immediately above the base of a leaf.

Axile. In the axis of an organ.

Axillary. Borne at, or pertaining to, an axil.

Baccate. Berry-like.

Barbellate. Furnished with minute barbs.

Basifixed. Attached by the base.

Berry. A fruit with pericarp wholly pulpy.

Bilabiate. With two lips.

Bipinnate. Twice pinnate.

Bipinnatifid. Twice pinnatifid.

Blade. The flat expanded part of a leaf.

Bract. A leaf, usually small, subtending a flower or flower-cluster, or a sporange.

Bracteate. With bracts.

Bracteolate. Having bractlets.

Bractlet. A secondary bract, borne on a pedicel, or immediately beneath a flower; sometimes applied to minute bracts. 
Bulb. A bud with fleshy scales, usually subterranean.

Bulblet. A small bulb, especially those borne on leaves, or in their axils.

Bulbous. Similar to a bulb; bearing bulbs.

Caducous. Falling away very soon after development.

Caespitose. Growing in tufts.

Callosity. A small, hard protuberance.

Callus. An extension of the inner scale of a grass spikelet; a protuberance.

Calyx. The outer of two series of floral leaves.

Campanulate. Bell-shaped.

Campylotropous. Term applied to the curved ovule.

Cancellate. Reticulated, with the meshes sunken.

Canescent. With gray or hoary fine pubescence.

Canaliculate. Channelled; longitudinally grooved.

Capitate. Arranged in a head; knob. like.

Capsular. Pertaining to or like a capsule.

Capsule. A dry fruit of two carpels or more, usually dehiscent by valves or teetl.

Carinate. Keeled; with a longitudinal ridge.

Carpel. The modified leaf forming the ovary, or a part of a compound niary.

Caruncle. An appendage to a seed at the hilum.

Carunculate. With a caruncle.

Caryopsis. The grain; fruit of grasses, with a thin pericarp adherent to the seed.

Caudate. With a slender tail.like appendage.

Caudex. The persistent base of perennial herbs, usually only the part above ground.

Caudicle. Stalk of a pollen-mass in the Orchid and Milkweed families.

Cauline. Pertaining to the stem.

Cell. A cavity, of an anther or ovary.

Chaff. Thin dry scales.

Chalaza. The base of the ovule.

Chartaceous. Papery in texture.

Chlorophyll. Green coloring matter of plants.

Chlorophyllous. Containing chlorophyll.

Ciliate. Provided with marginal hairs.

Ciliolate. Minutely ciliate.

Cilium. A hair.

Cinereous. Ashy; ashy-colored.
Circinnate. Coiled downward from the apex.

Circumscissile. Transversely dehiscent, the top falling a way as a lid.

Clavate. Club-shaped.

Cleistogamous. Flowers which do not open, but are pollinated from their own anthers.

Cleft. Cut about halfway to the mid. vein.

Clinandrium. Cavity between the anther-sacs in orchids.

Cochleate. Like a snail shell.

Coma. Tuft of hairs at the ends of some seeds.

Commissure. The contiguous surfaces of two carpels.

Conduplicate. Folded lengthwise.

Confuent. Blended together.

Connate. Similar organs more or less united.

Connective. The end of the filament, between the anther-sacs.

Connivent. Converging.

Convolute. Rolled around or rolled up longitudinally.

Coralloid. Resembling coral.

Cordate. Heart-shaped.

Coriaceous. Leathery in texture.

Corm. A swollen, fleshy base of a stem.

Corolla. The inner of two series of floral leaves.

Corona; Crown. An appendage of the corolla; a crown-like margin at the top of an organ.

Coroniform. Crown-like.

Corymb. A convex or flat-topped flowercluster of the racemose type, with pedicels of rays arising from different points on the axis.

Corymbose. Borne in corymbs; corymblike.

Costate. Ribbed.

Cotyledon. A rudimentary leaf of the embryo.

Crenate. Scalloped; with rounded teeth.

Crenulate. Diminutive of crenate.

Crustaceous. Hard and brittle.

Cucullate. Hooded, or resembling a hood.

Culm. The stem of grasses and sedges.

Cuneate. Wedge-shaped.

Cusp. A sharp stiff point.

Cuspidate. Sharp pointed; ending in a cusp.

Cyme. A convex or flat flower-cluster of the determinate type, the central flowers first unfolding.

Cymose. Arranged in cymes; cyme- 
Deciduous. Falling away at the close of the growing period.

Decompound. More than once divided.

Decumbent. Stems or branches in an inclined position, but the end ascending.

Decurrent. Applied to the prolongation of an organ, or part of an organ running along the sides of another.

Deflexed. Turned abruptly downward.

Dehiscence. The opening of an ovary, anther-sac or sporange to emit the contents.

Dehiscent. Opening to emit the contents.

Deltoid. Broadly triangular, like the. Greek letter delta.

Dentate. Toothed, especially with outwardly projecting teeth.

Denticulate. Diminutive of dentate.

Depauperate. Impoverished, small.

Depressed. Vertically flattened.

Dextrorse. Spirally ascending to the right.

Diadelphous. Stamens united into two sets.

Diandrous. Having two stamens.

Dichotomous. Forking regularly into two nearly equal branches or segments.

Licotyledonous. With two cotyledons.

Didymous. Twin-like; of two nearly equal segments.

Diffuse. Loosely spreading.

Digitate. Diverging, like the fingers spread.

Dimorphous. Of two forms.

Diacious. Bearing staminate flowers or antherids on one plant, and pistillate flowers or archegones on another of the same species.

Discoid. Heads of Compositae composed only of tubular flowers; rayless; like a disk.

Disk. An enlargement or prolongation of the receptacle of a flower around the base of the pistil; the head of tubular flowers in Compositae.

Dissected. Divided into many segments or lobes.

Dissepiment. A partition-wall of an ovary or fruit.

Distichous. Arranged in two rows.

Distinct. Separate from each other; evident.

Divaricate. Diverging at a wide angle.

Divided. Cleft to the base or to the mid-nerve.

Dorsal. On the back, pertaining to the back.

Drupaceous. Drupe-like.
Drupe. A simple fruit, usually indehiscent, with fleshy exocarp and bony endocarp.

Drupelet. Diminutive of drupe.

Echinate. Prickly.

Ellipsoid. A solid body, elliptic in section.

Elliptic. With the outline of an ellipse; oval.

Emarginate. Notched at the apex.

Embryo. A rudimentary plant in the seed.

Embryo-sac. The macrospore of the flowering plants, contained in the ovule.

Endocarp. The inner layer of the peri. carp.

Endogenous. Forming new tissue within.

Endosperm. The substance surrounding the embryo of a seed; albumen.

Ensiform. Shaped like a broadsword.

Entire. Without divisions, lobes, or teeth.

Ephemeral. Continuing for only a day or less.

Epigynous. Adnate to or borne on the upper part of the ovary.

Epiphytic. Growing on other plants, but not parasitic.

Equitant. Folded around each other; straddling.

Erose. Irregularly margined, as if gnawed.

Evanescent. Early disappearing.

Evergreen. Bearing green leaves throughout the year.

Excurrent. With a tip projecting beyond the main part of the organ.

Exfoliating. Peeling off in layers.

Exocarp. The outer layer of the pericarp.

Exogenous. Forming new tissue outside the older.

Exserted. Prolonged past surrounding organs.

Exstipulate. Without stipules.

Extrorse. Facing upward.

Faliate. Scythe-shaped.

Farinaceous. Starchy, or containing starch.

Fascicle. A dense cluster.

Fascicled. Borne in dense clusters.

Fastigiate. Stems or branches which are nearly erect and close together.

Fenestrate. With window-like markings.

Fertile. Bearing spores, or bearing seed.

Fertilization. The mingling of the contents of a male and female cell. 
Ferruginous. Color of iron-rust.

Fetid. Ill-smelling.

Fibrillose. With fibres or fibre-like organs.

Filament. The stalk of an anther; the two forming the stamen.

Filamentous. Composed of thread-like structures; thread-like.

Filiform. Thread-like.

Fimbriate. With fringed edges.

Fimbrillate. Minutely fringed.

Fistular. Hollow and cylindric.

Flabellate. Fan-shaped, or arranged like the sticks of a fan.

Flaccid. Lax; weak.

Flexuous. Alternately bent in different directions.

Floccose. With loose tufts of wool-like hairs.

Fcliaceous. Similar to leaves.

Foliolate. With separate leaflets.

Follicle. A simple fruit dehiscent along one suture.

Follicular. Similar to a follicle.

Fon'eate. Foveolate. More or less pitted.

Free. Separate from other organs; not adnate.

Frond. The leaves of ferns.

Frutescent. Fruticose. More or less shrub-like.

Fugacious. Falling soon after development.

Fugitive. Plants not native, but occurring here and there, without direct evidence of becoming established.

Funiculus. The stalk of an ovule or seed.

Fusiform. Spindle-shaped.

Galea. A hood-like part of a perianth or corolla.

Galeate. With a galea.

Gametophyte. The sexual generation of plants.

Gamopetalous. With petals more or less united.

Gemma. A bud-like propagative organ.

Gibbous. Enlarged or swollen on one side.

Glabrate. Nearly without hairs.

Glabrous. Devoid of hairs.

Gladiate. Like a sword-blade.

Gland. A secreting cell, or group of cells.

Glandular. With glands, or glandlike.

Glaucous. Covered with a fine bluish or white bloom; bluish-hoary.

Globose. Spherical or nearly so.

Glomerate. In a compact cluster.
Glomerule. A dense capitate cyme.

Glumaceous. Resembling glumes.

Glume. The scaly bracts of the spikelets of grasses and sedges.

Granulose. Composed of grains.

Gregarious. Growing in groups or colonies.

Gynobase. A prolongation or enlargement of the receptacle supporting the ovary.

Habit. General aspect.

Habitat. A plant's natural place of growth.

Hastate. Halberd-shaped; like sagittate; but with the basal lobes diverying.

Haustoria. The specialized roots cf parasites.

Head. A dense round cluster of sessile of nearly sessile flowers.

Herbaceous. Leaf-like in texture and color, pertaining to an herb.

Hilum. The scar or area of attachment of a seed or ovule.

Hirsute. With rather coarse stiff liairs. Hispid. With bristly stiff hairs.

Hispidulous. Diminutive of hispid.

Hyaline. Thin and translucent.

Hypocotyl. The rudimentary stem of the embryo; also termed radicle.

Hypogynium. Organ supporting the ovary in some sedges.

Hypogynous. Borne at the base of the ovary; or below.

Imbricated. Overlapping.

Imperfect. Flowers with either stamens or pistils, not with both.

Incised. Cut into sharp lobes.

Included. Not projecting beyond surrounding parts.

Incumbent. With the back against the hypocotyl.

Indehiscent. Not opening.

Indusium. The membrane covering a sorus.

Inequilateral. Unequal sided.

Inferior. Relating to an organ which arises or is situated below another.

Inflexed. Abruptly bent inward.

Inflorescence. The flowering part of plants; its mode of arrangement.

Integument. A coat or protecting layer.

Internode. Portion of a stem or branch between two successive nodes.

Introrse. Facing inward.

Involucil. A secondary involucre.

Involucrate. With an involucre, or like one.

Involucre. A whorl of bracts subtending a flower or flower-cluster.

Involute. Rolled inwardly. 
Irregular. A flower in which one or more of the organs of the same series are unlike.

Labiate. Provided with a lip-like organ; belonging to the family Labiatae.

Laciniate. Cut into narrow lobes or segments.

Lanceolate. Considerably longer than broad, tapering upward from the middle or below; lance-shaped.

Latex. The milky sap of certain plants.

Leaflet. One of the divisions of a compound leaf.

Legume. A simple dry fruit dehiscent along both sutures.

Lenticular. Lens-shaped.

Ligulate. Provided with or resembling a ligule.

Ligule. A strap-shaped organ, as the rays in Compositae.

Limb. The expanded part of a petal, sepal, or gamopetalous corolla.

Linear. Elongated and narrow with sides nearly parallel.

Lineolate. With fine or obscure lines.

Lobed. Divided to about the middle.

Loment. A jointed legume, usually constricted between the seeds.

Loculicidal. Applied to capsules which split longitudinally.

Lodicules. Minute hyaline scales subtending the flower in grasses.

Lunate. Crescent-shaped.

Lyrate. Pinnatifid, with the terminal lobe or segment considerably larger than the others.

Macrosporange. Sporange containing macrospores.

Macrospore. The larger of two kinds of spores borne by a plant, usually giving rise to a female prothallium.

Marcescent. Withering but remaining attached.

Medullary. Pertaining to the pith or medulla.

Mericarp. One of the carpels of the Umbelliferae.

Mesocarp. The middle layer of a pericarp.

Micropyle. Orifice of the ovule, and corresponding point on the seed.

Microsporange. Sporange containing microspores.

Microspore. The smaller of two kinds of spores borne by a plant, usually giving rise to a male prothallium; pollen-grain.

Midvern (Midrib). The central vein or rib of a leaf or other organ.

Monadelphous. Stamens united by their filaments.
Moniliform. Like a string of beads.

Monxcious. Bearing stamens and pistils on the same plant, but in different flowers.

Monstrous. Unusual or deformed.

Mucronate. With a short sharp abrupt tip.

Mucronulate. Diminutive of mucronate.

Muricate. Roughened with short hard processes.

Muticous. Pointless, or blunt.

Naked. Lacking organs or parts which are normally present in related species or genera.

Naturalized. Plants not indigenous to the region, but so firmly established as to have become part of the flora.

Nectary. A suyar-secreting organ.

Node. The junction of two internodes of a stem or branch, often hard or swollen, at which a leaf or leaves are usually borne.

Nodose. Similar to nodes or joints; knotty.

Nodulose. Diminutive of nodose.

Nut. An indehiscent one-seeded fruit with a hard or bony pericarp.

Nutlet. Diminutive of nut.

Obcordate. Inversely heart-shaped.

Oblanceolate. Inverse of lanceolate.

Oblong. Longer than broad, with the sides nearly parallel, or somewhat curving.

Obovate. Inversely ovate.

Obovoid. Inversely ovoid.

Obsolete. Not evident; gone, rudimentary, or vestigial.

Obtuse. Blunt, or rounded.

Ochreae. The sheathing united stipules of Polygonaceae.

Ochreolae. The ochreae subtending flowers in the Polygonaceae.

Ochroleucous. Yellowish white.

Ossphere. The cell of the archegone which is fertilized by spermatozoids.

Operculate. With an operculum.

Operculum. A lid.

Orbicular. Approximately circular in outline.

Orthotropoos. Term applied to the straight ovule, having the hilum at one end and the micropyle at the other.

Ovary. The ovule-bearing part of the pistil.

Ovate. In outline like a longitudinal section of a hen's egg.

Ovoid. Shaped like a hen's egg.

Ovule. The macrosporange of flowering plants, becoming the seed on maturing. 
Palate. The projection from the lower lip of two-lipped personate corollas.

Palet. A bract-like organ enclosing or subtending the flower in grasses.

Palmate. Diverging radiately like the fingers.

Panicle. A compound flower-cluster of the racemose type, or cluster of sporunges.

Paniculate. Borne in panicles or resembling a panicle.

Papilionaceous. Term applied to the irregular flower of the Pea Family.

Papillose. With minute blunt projections.

Pappus. The bristles, awns, teeth, etc., surmounting the achene in the Chicory and Thistle Families.

Parasitic. Growing upon other plants and absorbing their juices.

Parietal. Borne along the wall of the ovary, or pertaining to it.

Parted. Deeply cleft.

Pectinate. Comb like.

Pedicel. The stalk of a flower in a flowercluster, or of a sporange.

Peduncle. Stalk of a flower, or a flowercluster, or a sporocarp.

Pedunculate. With a peduncle.

Peltate. Shield shaped; a flat organ with a stalk on its lower surface.

Penicillate. With a tuft of hairs or hairlike branches.

Perfect. Flowers with both stamens and pistils.

Perfoliate. Leaves so clasping the stem as to appear as if pierced by it.

Perianth. The modified floral leaves (sepals or petals), regarded collectively.

Pericarp. The wall of the fruit, or seedvessel.

Perigynium. The utricle enclosing the ovary or achene in the genus Carex.

Perigynous. Borne on the perianth, around the ovary.

Peripheral. Pertaining to the peripliery.

Persistent. Organs remaining attached to those bearing them after the grow ing period.

Petal. One of the leaves of the corolla.

Petaloid. Similar to petals; petal-like.

Petiolate. With a petiole.

Petiolule. The stalk of a leaflet.

Petiole. The stalk of the leaf.

Phyllode. A bladeless petiole or rachis. Pilose. With long soft hairs.

Pinna. A primary division of a pinnately conipound leaf.
Pinnate. Leaves divided into leaflets or segments along a common axis.

Pinnatifid. Pinnately cleft to the middle or beyond.

Pinnule. A division of a pinna.

Pistil. The central organ of a flower containing the macrosporanges (ovules).

Pistillate. With pistils; and usually employed in the sense of without stamens.

Placenta. An ovule-bearing surface.

Plicate. Folded into plaits, like a fan.

Plumose. Resembling a plume or feather.

Plumule. The rudimentary terminal bud of the embryo.

Pollen. Pollen grain. See Microspore.

Follinia. The pollen-masses of the Orchid and Milkweed Families.

Polvgamons. Bearing both perfect and imperfect flowers.

Polypetalous. With separate petals.

Pome. The fleshy fruit of the Apple Family.

Procumbent. Trailing or lying on the ground.

Prophylla. Bractlets.

Prothallium. The sexual generaticn of Pteridophyta.

Puberulent. With very short hairs.

Pubescent. With hairs.

Punctate. With translucent dots or pits.

Pungent. With a sharp stiff tip.

Pyriform. Pear-shaped.

Raceme. An elongated determinate Hower cluster with each flower pedicelled.

Racemose. In racemes, or resembling a raceme.

Rachilla. The axis of the spikelet in grasses.

Rachis. The axis of a compound leaf, or of a spike or raceme.

Radiant. With the marginal flowers enlarged and ray-like.

Radiate. With ray-flowers; radiating.

Radicle. The rudimentary stem of the embryo; hypocotyl.

Radicular. Pertaining to the radicle or hypocotyl.

Raphe (Rhaphe). The ridge connecting the hilum and chalaza of an anatropous or amphitropous ovule; the ridge on the sporocarp of Marsilea.

Ray. One of the peduncles or branches of an umbel; the flat marginal flowers in Compositae.

Receptacle. The end of the flower stalk, bearin the floral organs; or, in Com. 
positae, bearing the flowers; also, in some ferns, an axis bearing sporanges. Recurved. Curved backward.

Reflexed. Bent backward abruptly.

Regular. Having the members of each part alike in size and shape.

Reniform. Kidney-shaped.

Repand. With a somewhat wavy margin. Reticulate. Arranged as a network.

Retrose. Turned backward or downward.

Retuse. With a shallow notch at the end.

Revolute. Rolled backward.

Rhachis. See Rachis.

Rhizome. See Rootstock.

Rootstock. A subterranean stem, or part of one.

Ringent. The gaping mouth of a twolipped corolla.

Rostellum. Beak of the style in Orchids. Rostrate. With a beak.

Rosulate. Like a rosette.

Rotate. With a flat round corollalimb. Rugose. Wrinkled.

Runcinate. Sharply pinnatifid, or in cised, the lobes or segments turned backward.

Sac. A pouch, especially the cavities of anthers.

Saciate. With a pouch or sac.

Sagittate. Like an arrow-head, with the lobes turned downward.

Samara. A simple indehiscent winged fruit.

Saprophyte. A plant which grows on dead organic matter.

Scabrous. Rough.

Scale. A minute, rudimentary or vestigial leaf.

Scape. A leafless or nearly leafless stem or peduncle, arising from a subterranean part of a plant, bearing a flower or flower cluster.

Scapose. Having scapes, or resembling a scape.

Scarious. Thin, dry, and translucent, not green.

Scorpioid. Coiled up in the bud, or in the beginning of growth, unrolling in expanding.

Secund. Borne along one side of an axis. Segment. A division of a leaf or fruit. Sepal. One of the leaves of a calyx. Septate. Provided with partitions.

Septicidal. A capsule which splits longitudinally into and through its dissepiments.

Serrate. With teeth projecting forward.

Serrulate. Diminutive of serrate; serrate with small teeth.

Sessile. Without a stalk.
Setaceous. Bristle-like.

Setose. Bristly.

Silicle. A silique much longer than wide.

Silique. An elongated two-valved capsular fruit, with two parietal placentae, usually dehiscent.

Sinuate. With strongly wavy margins.

Sinuous. In form like the path of a snake.

Sinus. The space between the lobes of a leaf.

Sorus (Sori). A group or cluster of sporanges.

Spadiceous. Like or pertaining to a spadix.

Spadix. A fleshy spike of flowers.

Spathaceous. Resembling a spathe.

Spathe. A bract, usually more or less concave, subtending a spadix.

Spatuiate. Shaped like a spatula; spoonshaped.

Spermatozoids. Cells developed in the antherid, for the fertilization of the oösphere.

Spicate. Arranged in a spike; like a spike.

Spike. An elongated flower-cluster or cluster of sporanges, with sessile or nearly sessile flowers or sporanges.

Spikelet. Diminutive of spike; especially applied to flower-clusters of grasses and sedges.

Spinose. With spines, or similar to spines.

Spinule. A small sharp projection.

Spinulose. With small sharp processes or spines.

Sporange. A sac containing spores.

Spore. An asexual vegetative cell.

Sporocarp. Organ containing sporanges or sori.

Sporophyle. The asexual generation of plants.

Spreading. Diverging nearly at right angles; nearly prostrate.

Spur. A hollow projection from a floral organ.

Squarrose. With spreading or projecting parts.

Stamen. The organ of a flower which bears the microspores (pollen-grains).

Staminodium. A sterile stamen, or other organ in the position of a stamen.

Standard. The upper, usually broad, petal of a papilionaceous corolla.

Stellate. Star-like.

Sterigmata. The projections from twigs, bearing the leaves, in some genera of Pinaceae.

$S$ erile. Without spores, or without seed. Stigma. The summit or side of the 
pistil to which pollen-grains become attached.

Stipe. The stalk of an organ.

Stipitate. Provided with a stipe.

Stipules. Appendages to the base of a petiole, often adnate to it.

Stipulate. With stipules.

Stolon. A basal branch rooting at the nodes.

Stolonifcrous. Producing or bearing stolons.

Stoma (Stomata). The transpiring orifices in the epidermis of plants.

Strict. Straight and erect.

Strigose. With appressed or ascending stiff hairs.

Strophiole. An appendage to a seed at the hilum.

Strophiolate. With a strophiole.

Style. The narrow top of the ovary.

stylopodium. The expanded base of a style.

Subacute. Somewhat acute.

Subcordate. Somewhat heart-shaped.

Subcoriaceous. Approaching leathery in texture.

Subfalcate. Somewhat scythe-shaped.

Subligneous. Somewhat woody in texture.

Subterete. Nearly terete.

Subulate. Awl-shaped.

Subversatile. Partly or imperfectly versatile.

Succulent. Soft and juicy.

Sulcate. Grooved longitudinally.

Superior. Applied to the ovary when free from the calyx; or to a calyx adnate to an ovary.

Suture. A line of splitting or opening. Symmetrical. Applied to a flower with its parts of equal numbers.

Syncarp. A fleshy multiple or aggregate fruit.

Tendril. A slender coiling organ.

Terete. Circular in cross section.

Ternate. Divided into three segments, or arranged in threes.

Tetradynamous. With four long stamens and two shorter ones.

Thallus. A usually flat vegetative organ.

Thyrsoid. Like a thyrsus.

Thyrsus. A compact panicle.

Tomentose. Covered with tomentum.

Tomentulose. Diminutive of tomentose.

Tomenlum. Dense matted wool-like hairs.

Torsion. Twisting of an organ.

Tortuous. Twisted or bent.

Tracheae. The canals or ducts in woody tissue.

Tracheids. Wood-cells.
Triandrous. With three stamens.

Tricarpous. Composed of three carpels.

Trimorphous. Flowers with stamens of three different lengths or kinds; in three forms.

Triquetrous. Three-sided, the sides channeled.

Truncate. Terminated by a nearly straight edge or surface.

Tuber. A thick short underground branch or part of a branch.

Tubercle. The persistent base of the style in some Cyperaceae; a small tuber.

Tuberculate. With rounded projections.

Turbinate. Top-shaped.

Uliginous. Inlabiting mud.

Umbel. A determinate, usually convex flower-cluster, with all the pedicels arising from the same point.

Umbcllate. Borne in umbels; resembling an umbel.

Umbellet. A secondary umbel.

Umbelloid. Similar to an umbel.

Uncinate. Hooked, or in form like a hook.

Undulate. With wavy margins.

Urceolate. Urn-shaped.

Utricle. A bladder-like organ; a oneseeded fruit with a loose pericarp.

Valvate. Meeting by the margins in the bud, not overlapping; dehiscent by valves.

Vascular. Relating to ducts or vessels.

Vein. One of the branches of the woody portion of leaves or other organs.

Veinlet. A branch of a vein.

Velum. A fold of the inner side of the leaf-base in Isoetes.

Velutinous. Velvety; with dense fine pubescence.

Venation. The arrangement of veins.

Vernation. The arrangement of leaves in the bud.

Versatile. An anther attaclied at or near its middle to the filament.

Verticil. See Whorl.

Verticillate. With three or more leaves or branches at a node; whorled.

Vestigial. In the nature of a vestige or remnant.

Villous. With long soft hairs, not matted together.

Virgate. Wand-like.

Whorl. A group of three similar organs or more, radiating from a node. Verticil.

Whorled. See Verticillate.

Winged. With a thin expansion or expansions. 


\section{ABBREVIATIONS OF THE NAMES OF AUTHORS.}

A. Benn. Bennett, Arthur. $A$. Br. Braun, Alexander. Adans. Adanson, Michel. Ait. Aiton, William.

Ait. f. Aiton, William Townsend.

All. Allioni, Carlo.

Anders. Andersson, Nils Johan.

Andr. Andrews, Henry C.

Andrz. Andrzejowski, Anton Lukianowicz.

Angs. Angström, Johan.

Ard. Arduino, Luigi.

Arn. Arnott, George Arnold Walker. Aschers. Ascherson, Paul Friedrich August.

Aubl. Aublet, Jean Baptiste Christophore Fusée.

Aust. Austin, Coe Finch,

Bab. Babington, Charles Cardale.

Bald. Baldwin, William.

Baill. Baillon, Henri.

Bartl. Bartling, Friedrich Gottlieb.

Bart. Barton, William P. C.

Bartr. Bartram, John.

Beauv. Palisot de Beauvois, A. M. F. J.

Benth. Bentham, George.

Benth. \& Hook. Bentham, George, and Hooker, Joseph Dalton.

Berch. Berchtold, Friedrich von.

Bernh. Bernhardi, Johann Jacob.

Bess. Besser, Wilhelm S. J. G. von.

Bieb. Beiberstein, F. A. M. von.

Bigel. Bigelow, Jacob.

Bisch. Bischoff, Gottlieb Wilhelm.

Biv. Bivona-Bernardi, Antonio.

Boeckl. Boeckeler, Otto.

Boehm. Boehmer, Georg Rudolf.

Boiss. Boissier, Edmond.

Borck. Borckhausen, Moritz Balthazar.

Brack. Brackinridge, William D.

Brezu. Brewer, William Henry.

B. S. P. Britton, N. L.; Sterns, Emerson Alexander; Poggenburg, Justus.

Brot. Brotero, Felix de Avellar.

Buch. Buchenau, Franz.

Buckl. Buckley, Samuel Botsford.
Burgsd. Burgsdorff, Friedrich August Ludwig von.

Carr. Carriere, Élie Abel.

Casp. Caspary, Robert.

Cass. Cassini, Henri.

Cav. Cavanilles, Antonio José.

Celak. Celakowsky, Ladislav.

Cerv. Cervantes, Vicente.

Chan. Chamisso, Adalbert von.

C. \& S., Cham. \&o Sch. Chamisso and Schlechtendahl.

Chapm. Chapman, Alvan Wentworth.

Chois. Choisy, Jacques Denis.

Clairv. Clairville, Joseph Philippe de.

Clayt. Clayton, John.

Cogn. Cogniaux, Alfred.

Coult. (Dips.) Coulter, Thomas.

Coult. Coulter, John Merle.

$C$. \& $R$. Coulter, J. M. and Rose, Joseph Nelson.

Darl. Darlington, William.

Davenp. Davenport, George Edward. $D C$. De Candolle, Augustin Pyramus. $A$. $D C$. De Candolle, Alphonse.

Dec. Decaisne, Joseph.

Desf. Desfontaine, René Louiche.

Desr. Desroussoux,

Tesv. Desvaux, Nicaise Augustin.

Dicks. Dickson, James.

Dietr. Dietrich, David Nathanael

Friedrich.

Dill. Dillen, John Jacob.

Dougl. Douglas, David.

Drej. Drejer, Saloman Thomas Nicolai.

Dryand. Dryander, Jonas.

Dufr. Dufresne, Pierre.

Dumort. Dumortier, B a r th élemy Charles.

Eat. Eaton, Amos.

Eat. E Wr. Eaton, Amos, and Wright, John.

Eberm. Ebermaier, Karl Heinrich.

Ehrh. Ehrhart, Friedrich.

Ell. Elliott, Stephen.

Endl. Endlicher, Stephen Ladislaus. Engelm. Engelmann, George.

Esch. Escholtz, Johann Friedrich

Fabr. Fabricius. Philipp Konrad 
Fisch. Fischer, Friedrich Ernst Ludwig von.

$F$. \& $M$. Fischer and Meyer, C. A.

Foug. Fougeroux, Auguste Denis.

Forsk. Forskal, Pehr.

Forst. Forster, Johann Reinhold and George.

Fresen. Fresenius, Johann Baptist Georg Wolfgang.

Froel. Froelich, Joseph Aloys.

Gaert. Gaertner, Joseph.

Gaerin. $f$. Gaertner, Carl Friedrich.

Gal. Galeotti, Henri.

Gaud. Gaudichaud-Beaupré, Charles.

Gey. Geyer, Carl Andreas.

Gill. Gillies, John.

Ging. Gingins de Lassaraz, Frédéric Charles Jean.

Glox. Gloxin, Benjamin Peter.

Gmel. Gmelin, Samuel Gottlieb.

Gmel. F. F. Gmelin, Johann Fried. rich.

Gooden. Goodenough, Samuel.

Gren. \& Godr. Grenier, Charles, and Godron, D. A.

Grev. Greville, Robert Kaye.

Griseb. Grisebach, Heinrich Rudolf August.

Gronov. Gronovius, Jan Frederik.

Guss. Gussone, Giovanni.

Hack. Hackel, Eduard.

Hall. Haller, Albert von.

Hamilt. Hamilton, William.

Hartm. Hartman, Carl Johann.

Hassk. Hasskarl, Justus Carl.

Hausskn. Haussknecht, Carl.

Haw. Haworth, Adrian Hardy.

$H B K$. Humboldt, Friedrich Alexander von ; Bonpland, Aimé and Kunth, Carl Siegesmund.

Hegelm. Hegelmaier, Friedrich.

Hell. Hellenius, Carl Niclas.

Heist. Heister, Lorenz.

Herb, Herbert, Willian.

Hitch. Hitchcock, Albert Spear.

Hochst. Hochstetter, Christian Friedrich.

Hoffm. Hoffman, Georg Franz.

Hoffmg. Hoffmansegg, Johann Centurius.

Holl. Hollick, Arthur.

Hook. Hooker, William Jackson.

$H$. \& $A$. Hooker, W. J., and Arnott, George A. Walker.

Hook. f. Hooker, Joseph Dalton.

Hornem. Hornemann, Jens Wilken.

Huds. Hudson, William.

Irm. Irmisch, Thilo.

facq. Jacquin, Nicholas Joseph.

Fuss. Jussieu, Antoine Laurent.

A. Fuss. Jussieu, Adrien de.
Karst. Karsten, $\mathrm{H}$.

Kl. Klotsch, Johann Friedrich.

Kuehl. Kühlwein.

L. Linnaeus, Carolus, or Carl von Linné.

L. f. Linné, Carl von (the son).

$L$ 'Her. L'Heritier de Brutelle, Charles Louis.

Laest. Laestadius, Lars Levi.

Lag. Lagasca, Mariano.

Lam. Lamarck, Jean Baptiste Antoine Pierre Monnet.

Lamb. Lambert, Aylmer Bourke.

Leavenz. Leavenworth, Melines C.

Ledeb. Ledebour, Carl Friederich von.

Lehm. Lehmann, Johann Georg Christian.

Le Peyr. Le Peyrouse, Philippe.

Lepeh. Lepechin, Iwan.

Lesp. \& Thev. Lespinasse, G., and

Theveneau, A.

Less. Lessing, Christian Friedrich.

Lestib. Lestiboudois, François Joseph.

Lightf. Lightfoot, John.

Lilj. Liljeblad, Samuel.

Lindl. Lindley. John.

Lodd. Loddiges, Conrad.

Loefl. Loefling, Pehr.

Lois. Loiseleur-Deslongchamps, Jean

Louis Auguste.

Loud. Loudon, John Claudius.

Lour. Loureiro, Juan.

MacM. MacMillan, Conway.

Marsh. Marshall, Humphrey.

Mars. Marsson, Theodor.

Mart, Martens, Martin.

Mart. \& Gal. Martens, Martin, and

Galeotti, Henri.

Maxim. Maximowicz, Carl Johann.

Med. Medicus, Friedrich Cassimir.

Meisn. Meisner, Carl Friedrich.

Mer. Merat, François Victor.

Mert. \& Koch. or $M$. \& $K$. Mertens,

Franz Karl, and Koch, Wilhelm

Daniel Joseph.

Mett. Mettenius, George Heinrich.

Mey. Meyer, Ernst Heinrich Friedrich.

Michx. Michaux, Andre.

Michx. $f$. Michaux, François André.

Mill. Miller, Philip.

Millsp. Millspaugh, Charles Frederic.

Mitch. Mitchell, John.

Mont. Montagne, Jean François Ca-

mille.

Moric. Moricand, Moise stienne.

Moq. Moquin-Tandon, Alfred.

Muell. Arg. Muiller, Jean, of Aargau.

Muench. Muenchhausen, Otto von.

Muhl. Muhlenberg, Heinrich Ludwig.

Murr. Murray, Johann Andreas. 
Neck. Necker, Noel Joseph de.

Nestl. Nestler, Christian Gottfried.

Nutt. Nuttall, Thomas.

Ort. Ortega, Casimiro Gomez.

Pall. Pallas, Peter Simon.

Parl. Parlatore, Filippo.

P. Br. Browne, Patrick,

Pers. Persoon, Christian Hendrik.

Planch.'Planchon, Jules Emile.

Poir. Poiret, Jean Louis Marie.

Poll. Pollich, Johann Adam.

Pourr. Pourret, Pierre André.

$R$. Br. Brown, Robert.

Raf. Rafinesque-Schmaltz, Constantino Samuel.

Redf. \&o Rand. Redfield, John H., and Rand, Edward S.

Reichenb. Reichenbach, Heinrich Gott-

lieb Ludwig.

Retz. Retzius, Anders Johan.

Richards. Richardson, John.

Roem. Roemer, Johann Jacob.

$R$. \& $S$. Roemer, J. J., and Schultes, Joseph August.

Roem. \& Ust. Roemer, J. J., and

Usteri, Paulus.

Rostk. Rostkovius, Friedrich Wilhelm

Gottlieb.

Rottb. Rottboell, Christen Fries.

Roxb. Roxburgh, William.

$R$. \& $P$. Ruiz, Lopez Hipolito, and

Pavon, Josef.

Rupr. Ruprecht, Franz J.

Rydb. Rydberg, Per Axel.

St. Hil. St. Hilaire, August de.

Salisb. Salisbury, Richard Anthony.

Sarg. Sargent, Charles Sprague.

Sartw. Sartwell, Henry P.

Sav. Savi, Gaetano.

Schk. Schkuhr, Christian.

Schlecht. Schlechtendal, Diedrich

Franz Leonhard von.

Schleich. Schleicher, J. C.

Schleid. Schleiden, Matthias Jacob.

Schrad. Schrader, Heinrich Adolph.

Schreb. Schreber, Johann Christian

Daniel von.

Schult. Schultes, Joseph August.

Sch. Bip. Schultz Bipontinus, Karl

$\mathrm{H}$ cinrich.

Schum. Schumacher, Christian Fried-

rich.

Schwein. Schweinitz,Lewis David von.

Scop. Scopoli, Johann Anton.

Scribn. Scribner, Frank Lamson.

Scribn. \& Ryd. Scribner, F. L., and

Rydberg, P. A.

Ser. Seringe, Nicolas Charles.

Seub. Seubert, Moritz.

Sheld. Sheldon, Edmund P.

Shuttlwe, Shuttleworth, Robert.
Sibth. Sibthorp, John.

Sieb. \& Zucc. Siebold, Philipp Franz

von, and Zuccarini, Joseph Gerhard.

Soland. Solander, Daniel.

Spreng. Sprengel, Kurt.

Steud. Steudel, Ernest Gottlieb.

Stev. Steven, Christian.

Sudw. Sudworth, George B.

Swe. Swartz, Olof.

S. Wats. Watson, Sereno.

Thuill. Thuillier, Jean Louis.

Thunb. Thunberg, Carl Peter.

Thurb. Thurber, George.

Torr. Torrey, John.

Torr. \& Schw. Torrey, J., and

Schweinitz, L. D.

Torr. \& Hook. Torrey, John, and

Hooker, William Jackson.

Tourn. Tournefort, Joseph Pitton de.

Tratt. Trattinnick, Leopold.

Trel. Trelease, William.

Traut. Trautvetter, Ernest Rudolph.

Trin. Trinius, Karl Bernhard.

Trin \& Rupr. Trinius, Karl, and

Ruprecht, F. J.

Tuckerm. Tuckerman, Edward.

Turcz. Turczaninow, Nicolaus.

Underw. Underwood, Lucien Marcus.

Vaill. Vaillant, Sébastien.

Vell. Velloso, José Marianno de Conceiçao.

Vent. Ventenat, Étienne Pierre.

Vill. Villars, Dominique.

Wahl. Wahlenberg, Georg.

Wahlb. Wahlenberg, Pehr Friedrick. $W$. \& $K$. Waldstein, Franz Adam von, and Kitalbal, Paul.

Wallr. Wallroth, Karl Friedrich Wi!-

helm.

Walp. Walpers, Wilhelm Gerhard.

Walt. Walter, Thomas.

Wang. Wangenheim, Friedrich Adam

Julius von.

Wats. \& Coult. Watson, Sereno, and

Coulter, John Merle.

Web. Weber, Friedrich.

Wedd. Weddell, H. A.

Weinm. Weinmann.

Wender. Wenderoth, George Wilhelm

Franz.

Wettst. Wettstein, R. von.

Wigg. Wiggers, Friedrich Heinrich.

Willd. Willdenow, Carl Ludwig.

Wimm. Wimmer, Friedrich.

Wisliz. Wislizenus, A.

With. Withering, William.

Wolfg. Wolfgang.

Woodv. Woodville, William.

Wormsk. Wormskiold, M. von.

Wr. Wright, John.

Wulf. Wulfen, Franz Xavier. 



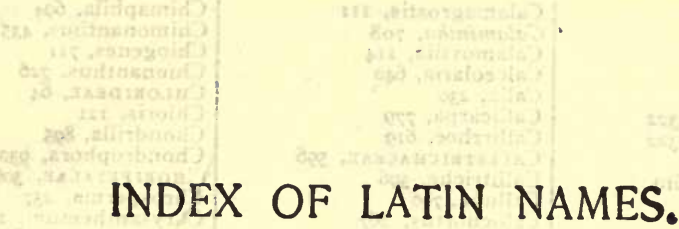

[Classes, Orders, Families and Tribes in Small Capitals; genera in roman; synonyms in italics.]

Abama, 255

Abies, 34

Abronia, 383

Abutilon, 621

Acacia, 527

Acalypha, 588

Acanthaceat, 853

Acer, 607, I068

Aceraceae, 607

Acerates, 745

Achillea, 1013

Achroanthes, 303

Acnida, 379

Aconitum, 417

Acorus, 23I

Actaea, 4I4

Actinospermum, I004

Acuan, 527

Adelia, 725

Adenocaulon, 979

Adiantum, 7

Adicea, 343

Adlumia, 44I

Adonis, 43I

Adopogon, 89I

Adoxa, 877

A doXACEAe, 877

AEgopodium, 680

A Eschynomene, $55^{8}$

AEsculus, 609

AEthusa, 682

Afzelia, 835

Agastache, 785

Agave, 280

Agoseris, 900

Agrimonia, 5Ir

Agropyron, 153

Agrostemma, 388

Agrostideae, 63

Agrostis, 109

Ailanthus, $5^{82}$

Aira, II5

Arzoncene, 383

Ajuga, 781, 1076

Alchemilla, 5 Io

Aletris, 268

Alisma, 54

Alisma, 54

Alism acear, 53

Alliaria, 447

Allionia, 382, I063

Allium, 262 , 1058

Allocarya, 769

Alnus, 329, 1062

Alopecurus, 102

Alsine, 394, ro64

Althaea, 618
Alyssum, 466

Alyssum 466

Amaranthaceae, 377

Amaranthus, 377

AMARYLLIDACEAE, 278

Ambrosia, 910

Ambrosi A CEAE, 908

Amelanchier, 51 7, 1066

Amianthium, 257

Ammannia, 648

Ammodenia, 402

Ammophila, II 4

Ammoselinum, 678

Amorpha, 545

Ampelanus, 746

Ampelopsis, 615

Amphiachyris, 928

Amphicarpa, 569

Amphicarpon, 75

Amphilophis, 7I

Amsonia, 737

Amygdalus, 526

ANACARDIACELE, 599

Anagallis, 718

Anaphalis, 976

Anastrophus, 75

Anchistea, Io

Andrachne, 586

Andromeda, 703

Andropogon, 68, 1046

Andropogon, 71

ANDROPOGONEAE, 62

Androsace, 714

Androstephium, 264

Anemone, 418

Anemonella, 420

Anethum, 683

Angelica, 684

ANGIOSPERMAE, 38

Anogra, 658, I07 I

Anonacene, 410

Antennaria, 973, 1083

ANTHEMIDEAE, 917

Anthemis, Ior 4

Anthoxanthum, 92

Anthriscus, 674

Antirrhinum, 822

Anychia, 404

Apera, 115

Aphanostephus, 943

Aphyllon, 849

Apiastrum, 676

Apios, 569

Apium, 677, 1072

Apium, 678

Aplectrum, 304

Aplopappus, 932, 933
A pocynaceae, 737

A pocynum, 738

Aquilegia, 415

Arabis, 463

ARACEAE, 229

Aragallus, 555

Arales, 228

Aralia, 667

Araliaceae, 667

Arceuthobium, 344

Archemora, 686

Archichlamideae, 306

Arctagrostis, 108

Arctium, 1029

Arctostaphylos, 706

Arenaria, 400, 1064

Arenaria, 402

Arethusa, 298

Argemone, 439

Argentina, 502

Arisaema, 229, 1057

Aristida, 93, 1052

Aristolochia, 349

ARISTOLOCHIACEAE, 347

Aristolochiales, 346

Armeria, 7 I 9

Arnica, 1022

Arnoseris, 892

Aronia, 516

Arrhenatherum, 118

Artemisia, 1017

Aruncus, 492

Arundinaria, 158

Asarum, 348

Asclepiadaceae, 740

Asclepias, 740, 1075, 1076

Asclepiodora, 745

Ascyrum, 625

Asimina, 410

Asparagus, 270

Asperugo, 772

Asperula, 868, 108I

Aspidium, 14

Asplenium, io

Asprella, 158

Aster, 946, 1083

Aster, 071

ASTEREAE, 914

Astilbe, 477

Astragalus, 550,1067

Astragalus, 555, 1067

Atamasco, 279

Atheropogon, 123

Atragene, 422

Atriplex, 372

Avena, II7

Aveneat, 64 
Azalea, 698

Azolla, 21

Baccharis, 971

Bahia, 1008

Balanops, 322

Balanopsidaceae, 322

BALANOPSI DALES, 322

Ballota, 79I

Balsaminaceae, 6ro

BAM BUSEAE, 67

Baptisia, 535

Barbarea, 45I

Bartonia, 735, I075

Bartsia, 842

Batodendron, 708, 1074

Batrachium, 428

Beckmannia, 123

Bellis, 943

Benzoin, 436

BERBERI DACEAE, 432

Berberis, 432

Berchemia, 6II

Bergia, 630

Berlandiera, 982

Berteroa, 466

Berula, 68I

Betonica, 793

Betula, 327, 106r

Betulaceae, 326

Bicuculla, 440

Bidens, 1000, 1083

Bifora, 676

Bigelovia, 93 r

Bignonia, 85I

Bignoniceat, 850

Billia, 608

Blephariglottis, 295

Blephilia, 797

Blitum, 37 I

Boebera, I0I2

Boehmeria, 343

Boltonia, 945

BorAginaCEAE, 766

Borago, 776

Borrichia, 990

Botrychium, 2, 1037

Bouteloua, 123

Bouteloua, 123

Boykinia, 480

Brachiaria, 77

Brachyactis, 966

Brachychaeta, 942

Brachyelytrum, IOr

Bradburya, 568

Bradleya, 548

Brasenia, 406

Brassica, 449

Brauneria, 989

Breweria, 750

Brickellia, 924

Briza, I35

Bromeliacene, 238

Bromus, 148

Broussonetia, 340

Brunnichia, 367

Buchloë, I 25

Buchnera, 835

Bulbilis, 125

Bumelia, 720

Bupleurum, 677

Burmannia, 289

BURMANNIACEAE, 289

Bursa, 459

Butneria, 435

BuXACEAE, 598

Cabomba, 406

Cacalia, I 024

Cactaceae, 643

Cactus, 644

Caesalpiniaceae, 528

Cakile, 448
Calamagrostis, III

Calamintha, 798

Calamovilfa, I14

Calceolaria, 640

Calla, 230

Callicarpa, 779

Callirrhoë, 619

Callitri chaceaz, 596

Callitriche, 596

Calluna, 706

Calochortus, 267

Calophanes, 853

Calopogon, 298

Caltha, 412

Calycanthaceae, 435

Calycanthus, 435

Calycocarpum, 434

Calypso, 304

Camassia, 267

Camelina, 459

Cammarum, 413

Campanula, 884, 108

CAM PAN UlaceaE, 883

Campanulales, 88 I

Camptosorus, I3

Campulosus, I2I

Cannabis, 341

Capnoides, 441, ro65

CAPPARIDACEAE, 467

CAPRIFoliaceae, 869

Capriola, II

Capsella, 459

Cardamine, 453

Cardiospermum, 6ıo

Carduus, 1030

Carex, I89, 1056

Carpinus, 326

Carum, 679

CARYOPHYLLACEAE, 387

Cassandra, 704

Cassia, 529

Cassiope, 702

Castalia, 407

Castanea, 33I

Castilleja, 839

Casuarinales, 307

Catabrosa, 133

Catalpa, 852

Caucalis, 675

Caulophyllum, 433

Ceanothus, 613

Cebatha, 434

Celastraceae, 605

Celastrus, 606

Celtis, 339, I062

Cenchrus, 90 1052

Centaurea, r 034, 1084

Centella, 672

Centrosema, 568

Centunculus, 718

Cephalanthus, 862

Cerastium, 397

Ceratophyllaceae, 408

Ceratophyllum, 408

Cercis, 529

Cercocarpus, 509

Chaerophyllum, 674, ro7a

Chaetochloa, 89, 1052

Chaetopappa, 944

Chamaecistus, 700

Chamaecyparis, 36

Chamaedaphne, 704

Chamaelirium, 256

Chamaenerion, 655

Chamaesaracha, 8 I3

Cheilanthes, 9

Chelidonium, 440

Chelone, 823

Chenopodi aceae, 368

CHENOPODIALES, 367

Chenopodium, 368, ז063
Chimaphila, 694

Chimonanthus, 435

Chiogenes, 7II

Chionanthus, 726

Chlorideae, 64

Chloris, 121

Chondrilla, 895

Chondrophora, 930

Choripetalae, 306

Chrosperma, 257

Chrysanthemum, ror4

Chrysogonum, 982

Chrysopogon, $7 \mathrm{I}$

Chrysopsis, 929

Chrysosplenium, 483

Chrysothamnus, 931

CICHORIACELE, 889

Cichorium, 890

Cicuta, 679, 1073

Cimicifuga, 415

Cinna, 108

Circaea, 663

Cissus, 615

Cistaceae, 630

Citrullus, 882

Cladium, 186

Cladothrix, 380

Cladrastis, 534

Claytonia, 385

Clematis, 420

Clematis, 423

Cleome, 467

Cleomella, 468

Clethra, 692

Ciethraceae, 692

Clinopodium, 798

Clintonia, 270

Clitoria, 568

Cnicus, 1036

Cocculus, 434

Cochlearia, 447

Coeloglossum, 292

Coelopleurum, 683

Coleosanthus, 924

Collinsia, 826

Collinsonia, 807

Collomia, 76I

Colutea, 550

Comandra, 345

Comarum, 501

Commelina, 239

COMMELINACEAE, 239

CoM POSITAE, 913

Comptonia, 321

Conioselinum, 684

Conium, 676

Conobea, 828

Conopholis, 850

Conringia, 467

Convallaria, 273

CONVALLARIACEAE, 269

Convolvulaceae, 749

Convolvulus, 753,1076

Convolvulus, 753

Cooperia, 279

Coptis, 413

Corallorhiza, 305

Corema, 598

Coreopsis, 997

Corispermum, 374

Cornaceae, 689

Cornus, 689, 1073, 1074

Coronilla, 557

Coronopus, 446

Corydalis, $44 \mathrm{I}$

Corylus, 327

Cotinus, 601

Cotoneaster, 522

Cracca, 548

Crantzia, 68

Crassina, 983 
Crassulaceae, 473

Crataegus, 518, 1066

Crepis, 901

Cristatella, 468

Crotalaria, 536

Croton, 586

Crotonopsis, 587

Cruciferae, 443

Cryptanthe, 769

Cryptogramma, 8

Cryptotaenia, 679

Cubelium, 640

Cucurbita, 882

Cucurbitaceae, 88 t

Cunila, 803

Cuphea, 650

Cuscuta, 754

Cuscutaceae, 754

Cycadales, 30

Cyclanthaceae, 228

Cyclanthera, 883

Cycloloma, 372

Cy mbalaria, 820

Cymopterus, 685, 1073

Cynanchum, 747

CYNAREAE, 9I7

Cynoctonum, 727

Cynodon, 110

Cynoglossum, 768

Cynomarathrum, 1073

Cynosciadium, 682

Cynosurus, 136

CYPERACEAE, $15 \delta$

Cyperus, I 59, 1054

Cypripedium, 290

Cyrilla, 602

Cyrillaceae, 602

Cyrtorhyncha, 430

Cystopteris, 17

Cytisus, 537

Dactylis, 136

I yloctenium, I24

D. L a, 545

Dalibarda, 499

Danthonia, I18

Daphne, 646

Dasiphora, 499

Dasystoma, 836

Datura, 816

Daucus, 688

Decodon, 649

Decumaria, 484

Delphinium, 416, I064

Dendrium, 700

Dennstaedtia, 19

Dentaria, 455, 1065, 1066

Deringa, 679

Deschampsia, 116

Desmanthus, $\mathbf{5 2 7}$

Desmodium, 559

Dianthera, 854

Dianthus, 394

Diapedium, $8_{55}$

Diapensia, 712

DIAPENSIACEAE, 712

Dicentra, 440

Dichondra, 750

Dichromena, 172

Dicksonia, 19

Dicliptera, 855

Di COTYLEDONES, 306

Didiplis, 648

Diervilla, 877

Digitalis, 835

Diodia, 863

Dioscorea, 28I

DiosCoREACEAE, 28t

Diospyros, 721

Diphylleia, 433

Diplachne, 128

Diplotaxis, 450
Di psaceae, 880

Dipsacus, 880

Dirca, 646

Discopleura, 68I

Disporum, 272

Distichlis, 135

Ditaxis, $5^{87}$

Dodecatheon, 710,1074

Doellingeria, 970

Dolicholus, 570

Dondia, 376

Draba, 460

Dracocephalum, 787

Drosera, 470

DROSERACEAE, 470

DRuPaCEaE, 523

Dryas, 509

Drymocallis, 499

Dryopteris, 14

Duchesnea, 501

Dulichium, 166

Dupatya, 237

Dupontia, 142

Dysodia, I012

Eatonia, I32, I053

EBENACEAE, 721

EBENALES, 720

Echinacea, 989

Echinocactus, 643

Echinocereus, 643

Echinochloa, 78

Echinodorus, 54

Echinodorus, 54

Echinopanax, I072

Echinospernum, 768

Echium, 776

Eclipta, 984

Elaengnaceae, 646

Elaeagnus, 647

Ezatinaceae, 629

Elatine, 629

Elatinoides, 820

Eleocharis, I 67, I 054

Elephantella, 842

Elephantopus, 919

Eleusine, 124

Ellisia, 763

Elodea, 60, 629

Elsholtzia, 807

Elymus, I 56, 1053

Elyna, 188

EMPETRACEAE, 598

Empetrum, 598

Engelmannia, 982

Epifagus, 850

Epigaea, 705

Epilobium, 655

Epipactis, 299

EQUISETACEAE, 2I

EQUISETALES, 2t

Equisetum, 2I

Eragrostis, I 29, 1052

Eranthis, 413

Erechtites, 1023

Erianthus 67,1047

ERICACEAE, 696

Ericales, 69I

Erigenia, 676

Erigeron, 966

Eriocarpum 932

Eriocaulaceae, 236

Eriocaulon, 237, 1057

Eriochloa, 76

Eriocoma, 98

Eriogonum, 35I

Eriophorum, I80

Erodium, 575

Ervum, 567

Eryngium, 673

Erysimum, 465, 1066

Erythraea, 729
Erythronium, 266

Eulophus, 680

Euonymus, 605

EUPATORIEAE, 914

Eupatorium, 920

Euphorbia, 590

EUPHORBI ACEAE, 585

Euphrasia, 84I I080, ro8I

Eurotia, 374

Eustoma, 731

Euthamia, 942

Evolvulus, 751

Fagaceae, 330

FAGales, 326

Fagopyrum, 357

Fagus, 331

Falcata, 569

Festuca, 145

Festuceae, 65

Ficaria, 429

Filago, 972

Filicales, I

Filix, 17

Fimbristylis, 173

Flaveria, 1006

Floerkea, 599

Foeniculum, 682

Forestiera, 725

Fothergilla, 489

Fragaria, 500

Franseria, 911

Frasera, 734

Fraxinus, 724, 1075

Fritillaria, 266

Froelichia, 380

Fuirena, I82

Fumaria, 442

FUMARIACEAE, 438

Gaertneria, 911

Gaillardia, I0II

Galactia, 570

Galax, 713

GalegeaE, 533

Galeopsis, 789

Galeorchis, 292

Galinsoga, 1004

Galium, 864, 1081

Galpinsia, 662 , 1071

GAM OPETALAE, 691

Gaultheria, 705

Gaura, 662, 107I

Gaurella, 66I

Gaylussacia, 707

Gelsemium, 726

Gemmingia, 284

Genista, 537

GENiSTEAE, 532

Gentiana, 731, 1075

Gentianaceae, 728

Gentianales, 723

GERANIACEAE, 573

GERANIALES, 572

Geranium, 573

Gerardia, 837, ro80

Geum, 507

Geum, 509

Gifola, 972

Gilia, 759

Gillenia, 493

Ginkgo, 37

Glaucium, 440

Glaux, 718

Glecoma, 787

Gleditsia, $53^{\circ}$

Glyceria, I42

Glycyrrhiza, 557

Gnaphalium, 977

GNetALES, 30

Gonolobus, 746

Goodyera, 302

Gordonia, 624 
Graminales, 6I

Gramineae, 6 I

Graphephorum, 142

Gratiola, 829

Grindelia, 928

GrossulariaceAE, 486

Gutierrezia, 927

Gymnandeniopsis, 293

Gymnocladus, 53 I

Gymnopogon, 122

GYMNOSPERMAE, 30

Gypsophila, 393

Gyrostachys 299, I060

Gyrotheca, 278

Habenaria, 293-296

HAEM ODORACEAE, 278

Halenia, 734

Halesia, 722

Halophila, 59

Halo Ragidaceae, 664

HAMAM ELI DACEAE, 488

Hamamelis, 489

Hartmannia, 660

Haploesthes, I083 $_{3}$

Hedeoma, 797

Hedysareae, 533

Hedysarum, 557

HELENIEAE, 9 I7

Helenium, I0IO

Heleochloa, ror

Helianthemum, 630,1069

HELIANTHEAE, 9 I 6

Helianthium, 54

Helianthus, 990

Heliopsis, 984

Heliotropium, 767

Helleborus, 413

Helonias, 256

Hemerocallis, 26r

Hemicarpha, 183

Hepatica, 4r9

Heracleum, 688

Herpestis, 828

Hesperis, 466

Heteranthera, 243

Heterotheca, 929

Heuchera, 481, 1066

Hexalectris, 306

Hexastylis, 347

Hibiscus, 622, 1068,1069

Hicoria, 323

Hieracium, 903

Hierochloë, 93

Hi procastanaceae, 608

Hippuris, 665

Hoffmanseggia, 530

Holcus, II 5

Holosteum, 398

Homalobus, 554

Homalocenchrus, 91

HordeaE, 66

Hordeum, 154

Hottonia, 715

Houstonia, 860

Hudsonia, 631

Humulus, 34I, I 1063

Hutchinsia, 458

Hydrangea, 484

HyDRANGEACEAE, 484

Hydrastis, 412

Hydrocotyle, 671 , 1072

Hydrocotyle, 672

Hydrolea, 765 .

HYDROPHYLLACEAE, 762

Hydrophyllum, 762 , 1075

Hymenocallis, 280

Hymenopappus, 1006

HYMENOPHYLLACEAE; 5

Hyoscyamus, 816

Hypericacene, 624

Нурегісum, 625, 1060
Hypochaeris, 892 .

Hypopitys, 696

Hypoxis, 280

Hyssopus, 800

Hystrix, $15^{8}$

Ilex, 603

ILICACEAE, 602

Ilicioides, 604

Ilysanthes, 830

Impatiens, 6 II

Imperatoria, 687

Indig ofera, 548

Inula, 979

INULEAE, 915

Iodanthus, $45^{I}$

Ionactis, $97 \mathrm{I}$

Ionidium, 640

Ipomoea, $75 \mathrm{I}$

Iresine, $38 \mathrm{I}$

IRIDACEAE, $28 \mathrm{I}$

Iris, 282, 1059

Isanthus, 782

Isnardia, 652

ISOETACEAE, 27

Isoetes, 27, 1046

Isopappus, 933

Isopyrum, 4I3

Isotria, 297

Itea, 485

ITEACEAE, 485

Iva, 908

Jasione, 886

Jatropha, 589

Jeffersonia, 433

JUGLAN DACEAE, 322

JUGLANDALES, 322

Juglans, 323

JUNCACEAE, 244

Juncoides, 253,1058

Juncus, 244, I058

Juniperus, 36, I047

Jussiaea, 654

Kallstroemia, 580, 1068

Kalmia, 70I

Kickxia, 820

Kneiffia, 659, 107I

Kobresia, 188, 1056

Kochia, 374

Koeleria, I32

Koellia, 800

Koniga, 466

Korycarpus, 134

Kosteletzkya, 622

Krameria, 53I

KRAMERIACEAE, 531

Kraunhia, 549

Krigia, 89 I

Kuhnia, 924

Kuhnistera, 546

Kyllinga, 166

LABIATAE, 779

Lachnocaulon, 238

Lacinaria, 925

Lactuca 897, 1082

Lamiaceae, 780

Lamium, 790

Laportea, 342

Lappula, 768

Lapsana, 89r

Larix, 33

Lathyrus, 567

LAURACEAE, 435

Lavauxia, 66I

Leavenworthia, 457

Lechea, 63I

Ledum, 697

Leersia, $9 \mathrm{I}$

Legouzia, 886

Leiophyllum, 700

Leitneria, 322

LEITNERIACEAE, 322
LeItNeRIALES, 321

Lemna, 232

LEMNACEAE, 232

LENTIBULACEAE, 845

Leontodon, 893

Leonurus, 790

Lepachys, 988

Lepargyraea, 647

Lepidium, 445, 1065

Leptamnium, 850

Leptandra, 834

Leptilon, 969

Leptocaulis, 686

Leptochloa, I 24

Leptorchis, 303

Lepturus, I52

Lespedeza, 562, 1067, 1068

Lesquerella, 457

Leucelene, 965

Leucocrin um, 261

Leucophysalis, 813

Leucothoë, 702, 1074

Levisticum, $68_{5}$

Liatris, 925

Ligusticum, 683

Ligusticum, 685

Ligustrum, 726

Lilaeopsis, 682

LILIACEAE, 260

LILIALES, 244

Lilium, 264

LIMNANTHACEAE, 599

Limnanthemum, 736

Limnobium, 60

Limnorchis, 293, 1060

Limodorum, 298

Limonium, 7 I9

Limosella, 831

LI NACEAE, 578

Linaria, 821

Linaria, 82I

Linnaea, 873

Linum, 578

Liparis, 303

Lipocarpha, I83

Lippia, 778

Liquidambar, 489

Liriodendron, 410

Listera, 301

Lithospermum, 773

Littorella, 859

LOASACEAE, $64 \mathrm{I}$

Lobelia, 887 , 1082

Loeflingia, 403

LOGANIACEAE, 726

Loiseleuria, 700

Lolium, 152

Lomatium, ro73

Lonicera, 874

Lophanthus, 786

Lophiola, 28I

Lophotocarpus, 55

LORANTHACEAE, 344

Lorinseria, 10

LOTEAE, 533

Lotus, 541

Ludwigia, 653

Ludwigiantha, 653

Lunaria, 456

Lupinus, 536

Luzula, 253

Lychnis, 39I

Lycium, 815

Lycopersicon, 815

LYCOPODIACEAE, 24

LYCOPODIALES, 23

Lycopodium, 24, I045

Lycopsis, 776

Lycopus, 803

Lygodesmia, 899 
Lysias, 294

Lysiella, 295

Lysimachia, 715

LYTHRACEAE, 648

Lythrum, 649

Machaeranthera, 966

Maclura, 340

Macounastrum, 35 I

Macrocalyx, 763

Magnolia, 409

MAGNOLIACEAE, 409

Maianthem um, 27 I

Mairania, 706

Malacothrix, 895

Malapoenna, 436

Malus, 5 I6

Malva, 6I8

Malvaceae, 6i7

Malvales, 616

Malvastrum, 620

Manisuris, 68

Marantacene, 288

Mariana, 1034

Marrubium, 785

Marshallia, 1005

Marsilea, 20

Marsileaceae, 20

Martynia, 852

MARtyniaceAe, 852

Mateuccia, I9

Matricaria, Iors

Mayaca, 235

MAYACACEAE, 234

MAYDEAE, 62

Medeola, 273

Medicago, 538

Meehania, 786

Megapterium, 66r

Meibomia, 559

Melampodium, 980

Melampyrum, 844

Melanthaceae, 254

Melanthium, 258

Melastomacene, 650

Melica, 133

Melilotus, 538

Melissa, 798

Melothria, 882

MenispermaceAe, 434

Menispermum, 434

Mentha, 804

Mentzelia, 64I

Menyanthaceae, 736

Menyanthes, 736

Menziesia, 700

Meriolix, 662, I07I

Mertensia, 771

Mesadenia, 1023

Micrampelis, 882

Micranthemum, 83 I

Microstylis, 303

Mikania, 924

Milium, 98

Mimosaceae, 527

Mimulus, 827

Mitchella, 863

Mitella, 483

Mitreola, 727

Modiola, 622

Moehringia, 402

Moenchia, 399

Mohrodendron, 722

Molinia, 128

Mollugo, 384

Monarda, 795, 1079

Moneses, 694

Monniera, 828

Monocotyledones, 38

Monolepis, 372

Monopetalae, 691

Mnnotropa, 696
MONOTROPACEAE, 695

Monotropsis, 696

Montia, 386

MoRACEAE, 339

Morongia, 528

Morus, 340

Muhlenbergia, 99

Munroa, 125

Muscari, 268

Musineon, 677, 1072

Myagrum, 448

Myosotis, 772

Myosurus, 423

Myrica, 32I

MYRICACEAE, 320

MYRICALES, 320

Myriophyllum, 665

Myrtales, 647

Nabalus, 906, 1082

NaIAdaceae, 40

NaIAdales, 40

Naias, 50

Nama, 765

Napaea, 6rg

Narcissus, 279

Nardus, I5I

Narthecium, 255

Nasturtium, 45I, 453

Naumbergia, 717

Navarretia, 762

Nazia, 7 I

Nelumbo, 408

Nemastylis, 284

Nemophila, 763

Nepeta, 786

Nesaea, 649

Neslia, 459

Nestronia, 346

Nicandra, 808

Nicotiana, 817

Nothocalais, 900

Notholaena, 7

Nothoscordum, 264

Nuphar, 406

Nyctaginaceae, 382

Nymphaea, 406

NYMPHAEACEAE, 406

Nyssa, 691

Obolaria, 735

Odontites, 842

OEnanthe, 682

OEnothera, 658

Oldenlandia, 862

Oleacea e, 723

Onagra, 657, 1070

ONAGRACEAE, 651

Onoclea, I9

Ononis, 539

Onopordon, 1034

Onosmodium, 774, го76

Oonopsis, 931

OPHIOGLOSSACEAE, I

Ophioglossum, I

Opulaster, 49I

Opuntia, 644

OPUNTIALES, 642

ORCHIDACEAE, 289

ORChidDALES, 288

Orchis, 29I

Orchis, 292

Oreocarya, 770

Origanum, 800

Ornithogalum, 267

OROBANCHACEAE, 848

Orobanche, 849

Orontium, 231

Orophaca, 555, 1067

Orthocarpus, 840

ORYZEAE, 63

Oryzopsis, 97

Oryzopsis, 98
Osmorrhiza, 675

Osmunda, 4

OSMUNDACEAE, 4

Ostrya, 327

Oxalidaceae, 575

Oxalis, 575

Oxybaphus, 382

Oxycoccus, 7 II

Oxydendrum, 705

Oxygraphis, 430

Oxypolis, 686

Oxyria, 357

Pachylophus, 660

Pachysandra, 599

Pachystima, 606

Paepalanthus 237

Palmaceae, 228

Panax, 668

Pandanales, 38

Paniceae, 62

Panicularia, 142

Panicum, 78 ro49

Panicum, 7778

Papaver, 438

Papaveraceae, 437

Papaverales, 437

Papilionaceae, 532

Pardanthus, 284

Parietales, 623

Parietaria, 343

Parnassia, 476

Parnassiaceae, 475

Paronychia, 404, 1065

Paroseh, 545

Parsonsia, 650

Parthenium, 983

Parthenocissus, 616

Paspalum, 72, 1048

Paspalum, 75

Passiflora, 641

Passifloraceae, 64 I

Pastinaca, 688

Paulownia, 827

Pectis. I012

Pedicularis, 842

Pedicularis, 842

Pellaea, 8

Peltandra, 230

Penthoraceae, 475

Penthorum, 475

Pentstemon, 823, I08I

Peramium, 302

Perilla, 807

Periploca, 1077

Persea, 435

Perularia, 292

Petalostemon, 546

Petasites, I02I

Petroselinum, 678

Petunia, 817

Peucedanum, 687

Peucedanum, 1074

Phaca, 553

Phacelia, 764

Phalarideae, 63

Phalaris, 92

Phaseoleae, 533

Phaseolus, 57I

Phegopteris, I6

Phellopteius ro73

Philadelphus, 485

Philotria, 60

Phippsia, I03

Phleum, I02

Phlomis, 789

Phlox, 756

Phoradendron, 345

Phragmites, I25

Phryma, 856

Phry maceae, 855

Phyllanthus, 585 
Phyllitis, 13

Phyllodoce, 702

Physalis, 809, 1080

Physalodes, 808

Physaria, 457, 1067

Physostegia, 788

Phytolacca, 381

Phytolaccaceae, 38I

Picea, 33

Picradenia, 1009

Picradeniopsis, 1008

Picris, 893

Pieris, 703

Pilea 343

Pimpinella, 680

Pimpinella, 680

Pinaceae, 30

Pinales, $3^{\circ}$

Pinguicula, 848

Pinus, 31,1046

PiPERALES, 307

Piperia, 1060

Planera, 338

Plantaginaceae, 856

Plantaginales, 856

Plantago, 856, $108 \mathrm{r}$

Platanaceae, 490

Platanus, 490

Pleurogyne, 734

Pleuropogon, 134

Pluchea, 973

Plumbaginaceae, 719

Pneumaria, 771

Poa, 136

Podaly Rieae, 532

Podophyllum, 433

Podostemaceae, 472

Podostemon, 472

Pogonia, 297

Pogonia, 297, 298

Polanisia, 468

Polemoniacene, 756

Polemoniales, 749

Polemonium, 761

Polycodium, 708, 1074

Polygala, 582

Polygalaceae, 582

Polygonaceae, 350

Polygonales, 350

Polygonatum, 273

Polygonella, 366

P-y rาnum, 358, 1063

lolymnia, 979

1 ULPODIACEAE, 6

Polypodium, 7

Polypogon, I07

Polypremum, 727

Polypteris, 1007

Polystichum, 13

Polytaenia, 685

Pomacene, 514

Pontederia, 242

Pontederiaceae, 242

Populus, 308

Porteranthus, 493

Portulaca, 386, 1064

Portulacacene, 384

Potamogeton, 4r, 1047

Potentilla, 502

Potentilla, 499, 502

Prenanthes, 906, 907

Primula, 714

Primulaceae, 713

Primulales, 713

Principes, 228

Prionopsis, 932

Proserpinaca, 665

Prosopis, 528

Proteaceae, 344

Proteales, 344

Prunella, $788^{\circ}$
Prunus, 523

Pseudotaenidia, ro73

Psilocarya, 172

Psilostrophe, 1005

Psoralea, 542

Psoralea 533

Ptelea, 581

Pteridophyta, I

Pteris, 8

Pterospora, 695

Ptilimnium, 68I

Ptiloria, 894

Puccinellia, I45

Pulsatilla, 420

Pycnanthemum, 800

Pyrola, 693

Pyrolaceae, 692

Pyrularia, 346

Pyrus, 5I5

Pyxidanthera, 712

Quamasia, 267

Quamoclit, 751

Quercus, $33^{2}$

Ouincula, 812

Ranales, 405

RANUNCULACEAE, 4 II

Ranunculus, 423

Ranunculus, 429,430

Raphanus, $45^{\circ}$

Rapistrum, 460

Ratibida, 988

Razoumofskya, 344

Redfieldia, 128

Reseda, 469

RESEDACEAE, 469

RHAMNACEAE, 6II

Rhamnales, 6II

Rhamnus, 612

Rhexia, 65I

Rhinanthus, 844

Rhododendron, 699

Rhodora, 699

Rhombolytrum, I29

Rhus, 600

Rhus, 602

Rhynchosia, 570

Ribes, 486

Ricinus, 589

Robinia, 549

Roripa, 45I

Rosa 5I2, 1066

ROSACEAE, 490

Rosales, 47 I

Rotala, 649

Rottbocllia, 68

Roubieva, 37 I

RubiaCEAE, 860

Rubiales, 860

Rubus, 493

Rudbeckia, 985, ro83

Ruellia, 854

Rumex, 354

Ruppia, 49

RUtACEAE, 58I

Rynchospora, 183,1056

Sabbatia, 729

Sacciolepis, 89

Sagina, 399

Sagittaria, 56

Sagittaria, 55

SAli Caceae, 307

Salicales, 307

Salicornia, 375

Salix 310, ro6r

Salomonia, 273

Salsola, 376

Salvia, 794

Salvinia, 20

SAlviniaceae, 20

Salviniales, 19

Sambucus, 869
Samolus, 715

Sanguinaria, 439

Sanguisorba, 512

Sanicula, 672, 1072

Santalaceae, 345

SANTALALES, 344

SAPINDACEAE, 609

SAPIN DALES, 597

Sapindus, 610

Saponaria, 393

SAPOTACEAE, 720

Sarcobatus, 375

Sarothra, 628

Sarracenia, 470

SARRACENIACEAE, 470

SARRACENIALES, 469

Sassafras, 436

Satureia, 798

SAURURACEAE, 307

Saururus, 307

Savastana, 93

Saxifraga, 477

SAXIFRAGACEAE, 476

Scabiosa, 88I

Scandix, 674

Schedonnardus, 122

Scheuchzeria, 53

SCHEUCHZERIACEAE, 52

Schizaea, 5

SchizaEACEAE, 5

Schrankia, 528

Schwalbea, 840

Schweinitzia, 696

Scirpus, I 74, ro55

SCI TAM I N ALES, 288

Scleranthus, 405

Scleria, I 87, 1056

Sclerolepis, 920

Scolochloa, 142

Scolopendrium, I3

Scrophularia, 822, ro79

SCROPHULARIACEAE, 818

Scutellaria, 783 , 1078

Sedum, 473

Selaginella, 26

SelaginellaceaE, 26

Selenia, 456

Sempervivum, 475

Senecio, 1024

SENECIONEAE, 917

Sericocarpus, 945

Serinia, 89r

Sesban, 550

Sesuvium, 384, I064

Setaria, 89

Seymeria, 835

Shepherdia, 647

Sherardia, 868

Sibbaldia, 500

Sibbaldiopsis, 499

Sicyos, 883

Sida, 620

Sideranthus, 932

Sieglingia, 126

Sieglingia, 126, 129

Sieversia, 508

Silene, 388

Silphium, 980

Silybum, 1035

SimARUBACEAE, 582

Simmondsia, 599

Sinapis, 449

Sisymbrium, 448

Sysymbrium, 447, 462

Sisyrinchium, 284

Sitanion, I55

Sitilias, 901

Sium, 680

SMilACEAE, 275

Smilacina, 271

Smilax, 275 
Solanaceae, 808

Solanum, 814

Solea, 640

Solidago, 933, 1082, 1083

Sonchus, 896

Sophia, 462

Sophora, 534

SOPHOREAE, 532

Sorbaria, 493

Sorbus, 515

Sorghastrum, 7I

Sorghum, 7I

SPARGANIACEAE, 39

Sparganium, 39, 1047

Spartina, 120

Spathyema, 231

Specularia, 886

Spergula, 402

Spergularia, $4 \circ 3$

Spermacoce, 863

SPERMATOPHYTA, 30

Spermolepis, 686

Sphaeralcea, 621

Spiesia, 555

Spigelia, 727

Spilanthes, 985

Spiraea, 492

Spiraea, 492, 493, 510

Spiranthes, 299

Spirodela, 232

Sporobolus, 104, 1052

Stachys, 791, 1078

Stanleya, 444

Staphylea, 606

StAPHyLEACEAE, 606

Statice, 719

Steironema, 716

Stellaria, 394

Stenanthium, 257

Stenophragma, 463

Stenophyllus, 173

Stenosiphon, 663

Stenotus, 933

Stephanomaria, 894

Stillingia, 589

Stipa, 96

Streptopus, 272

Strophostyles, 57 I

Struthiopteris, 19

Stuartia, 624

Stylophorum, 440

Stylosanthes, $55^{8}$

StYRACEAE, 722

Styrax, 722

Suaeda, 376

Subularia, 445

Sullivantia, 480

Sympetalae, 691

Symphoricarpos, 873

Symphytum, 775

SYM PLOCACEAE, $72 I$

Symplocarpus, $23 \mathrm{I}$

Symplocos, 722

Synandra, 780

SYNANTHAE, 228

Syndesmon, 420

Synosma, 1024

Syntherisma, 76

Synthyris, 831

Syringa, 724

Taenidia, 680

Talinum, 385, 1064
Tanacetum, 1016

Taraxacum, 896

TAXACEAE, 37

Taxodium, 35

Taxus, 37

Tecoma, 851

Tephrosia, 548

Tetragonanthus, 734

Tetragonotheca, 985

Tetraneuris, 1008

Tetranthera, 436

Teucrium, 781, 1077, 1078

Thalesia, 849

Thalia, 288

Thalictrum, 430, 1065

Thaspium, 683

Thenceae, 623

Thelesperma, 1003

Thelypodium, 444

Thermopsis, 534

Therofon, 480

Thlaspi, 446

Thuja, 35

ThyM ELEACEAE, 645

THYMELEALES, 645

Thymophylla, I0I2

Thymus, 802

Tiarella, 480

Tilia, 6I 6, 1068

Tiliaceae, 616

Tillaea, 473

Tillandsia, 238

Tipularia, 304

Tissa, 403

Tofieldia, 255

Totilis, 675

Townsendia, 944

Toxylon, 340

Trachelospermum, 739

Tradescantia, 240

Tragia, 588

Tragopogon, 894

Trapa, 664

Trapacene, 664

Trautyetteria, 423

Triadenum, 629

Tribulus, 580

Trichomanes, 5

Trichostema, 782

Tricuspis, I26

Trientalis, 717

TRIFOLIEAE, 533

Trifolium, 539

Triglochin, 52

Trilisa, 927

Trillium, 274, I059

Triosteum, 872

Triphora, 298

Triplasis, 127

Tripsacum, 67

Trisetum, 117

Trollius, 412

Troximon 900

Tsuga, 34

Tulipa, I059

Tunica, 393

Tussilago, 1021

Typha, 38

TyPhacene, 38

Ulex, 537

ULMACEAE, 337

Ulmaria, 5 I0
Ulmus, 337

UMBELLALES, 667

UMBELLIFERAE, 669

Uncinia, 189

Unifolium, 271

Uniola, 1 34, 1053

Urtica, 342

URTICACEAE, 34I

URTICALES, 337

Urticastrum, 342

Utricularia, 845

Uvularia, 260

Vaccaria, 393

VACCINIACEAE, 707

Vaccinium, 709, 1074

Vaccinium, 708

Vagnera, 271

Valeriana, 878

VALERIANACEAE, 878

VALERIANALES, 877

Valerianella, 879

Vallisneria, 60

VALLISNERIACEAE, 59

Veratrum, 259

Verbascum, 819

Verbena, 777, 1077

VERBENACEAE, 776

Verbesina, 996

Vernonia, 918

VERNONIEAE, 914

Veronica, 832 , 1080

Viburnum, 870

Vicia, 565

VICIEAE, 533

Vigna, 572

Vinca, 738

Vincetoxicum, 747

Vincetoxicum, 747

Viola, 633, ro69, ro7o

Violaceae, 633

Viscaria, 388

Vitaceae, 6r3

Vitis, $6 \pi_{3}$

Vitis-Idaea, 708

Waldsteinia, 506

Washingtonia, 675

Willugbaeya, 924

Wolffia, 233

Wolffiella, 234

Woodsia, 17

Woodwardia, 10

Wulfenia, 832

Xanthium, 9Ir

Xanthorrhiza, 4I4

Xanthoxylum, 58I

Xerophyllum, 256

Xolisma, 704, 1074

XYRIDACEAE, 235

XYRIDALES, 234

$\mathrm{X}$ yris, 235, 1057

Yucca, 269

Zannichellia, 50

Zephyranthes, 279

Zinnia, 983

Zizania, 9I

Zizaniopsis, 9r

Zizia, 678

Zornia, 558

Zostera, 51

ZoYsI EAE, 62

Zygadenus, 257

ZYGOPHYLIACEAE, 580 



\section{ENGLISH INDEX OF PLANT NAMES.}

Abele, 308

Absinth, 1019

Acacia, 549

Acanthus Family, 853

Aconite, 413

Actinomeris, 997

Adam-and-Eve, 305

Adder's-mouth, 303

ADDER'S-TONGUE FAMILY, I

Adder's-tongue, 2, 266

Agrimony, 5II

Ague-weed, 732

Aillanthus Family, 582

Ailanthus, $5^{82}$

Alder, 330, 1062

Black, 604

Dwarf, 6i 2

White, 692

Alecoast, Alecosto ror5

Alexanders, 679

Alfalfa, $53^{8}$

Alfilaria, 575

Alkanet, Bastard, 773

Alleluia, 576

Alligator-tree, 489

Aloe, False, 280

Althaea, Shrubby, 623

Alum-root, 482, 573

Alyssum, 466

AMARANTH FAMILY, 377

Amaranth, 378, 379

AmaryLlis FAMiLy, 278

Amy-root, 739

Andromeda, Privet, 704

Anemone, 418

False Rue, 4I4

Angelica, Sea-coast, 683

Angelico, 683

Angle-pod, 748

APPLE FAMILY, 514

Apple, 516

Balsam, 883

Crab, 516

Earth, 996

May, 433

Mock, 883

Prairie, 544

Apple of Peru, 808

Arbor-vitae, 36

Arbutus, Trailing, 705

Ark, Noah's, 29I

Arrow-arum, 230

ArRow-grass Family, 52

Arrow-grass, 52

Arrow-head, 57, 58

ARROW-ROOT FAMILY, 288

ARUM FAMILY, 229

Arrow-wood, 871

Artichoke, Jerusalem, 996

Arum, Water, 230

Ash, 724, 1075

Mountain, 515

Prickly, 58i

Sea, 58i

Ashwort, I026
Aspen, 310

Asphodel, 255

Aster, 949

Golden, 929

Heath, 965

Rayless, 966

Savory-leaved, 97I

Stiff, 971

Tansy, 966

Viscid, 966

White Flat-top, 970

White-topped, 946

Wood, 949, 952, 953

Avens, 507

Mountain, 508, 509

Purple, 500

Awlwort, Water, 445

Axeseed, 557

Axewort, 557

Azalea, Alpine, 701

Trailing, 70I

Bahia, False, 1008

Bald Cypress, 35

Bald-rush, 172

Balm, Basil, 796, 799

Bee, American, 795

Calamint, 799

Field, 799

Garden, 798

Lemon, 798

Balm-of-Gilead, 309

Balsam, 977

Baneberry, 414

BARBERRY FAMILY, 432

Barberry, 432

Barley, 155

Barnyard-grass, 78

Bartsia, Red, 842

Basil, Field, 799

Wild, 799

Basilweed, 799

Bass-wood, 6I7

Bay, Loblolly, 624

Red, 436

Rose, 699

Swamp, 436

Sweet, 409

Tan, 624

BAyberRy Family, 320

Bayberry, 321

Bayonet, Spanish, 269

Beaked-parsley, 674

Beaked-rush, 184, 1056

Bean, Black-eyed, 572

China, 572

Indian, 852

Wild, 571

Bean-tree, 852

Bear-berry, 706

Bear-grass, 269, 1038

Beard, Goat's, 477

Beard-grass, 69, 71, 108

Beard-tongue, 824 , ro80

Beauty, Rutland, 755

Spring, 385
Bed's-foot, 799

Bed-straw, 865, ro8s

Bee-balm, 798

Beech Family, 330

Beech, 326, 33I

Beech-drops, 850

Carolina, 696

False, 696

Beetle-weed, 713

Bee-tree, 617

Beggar-ticks, roor , 1083

Bellflower Family, 883

Bellflower, 884, ro8 I

Bellwort, 260

Benjamin-bush, 437

Bennet, 680

Bent-grass, I09, III, II5

Berbine, 777

Bergamot, 796, ro79

Bermuda-grass, I 9

Berry, Silver, 647

Besom, 706

Betony, 793

Wood, 793, 844

Bilberry, 709

Bilsted, 489

Bindweed, 365,753, ro 6

Blue, 815

BIRCH FAMILY, 326

Birch, 328, 106I

Bird's-nest, Giant, 695

BIRTHWORT Family, 347

Birthwort, 349

Bishop-weed, 68I

Bistort, 359

Bitter-bloom, 730

Bitter-cress, 454

Bitter-herb, 729

Bitter-nut, 324

Bitter-sweet, 8I5

Climbing, 606

Shrubby, 606

Bitter-weed, 910

Blackberry, 496, 498

Black-cap, 496

Black-eyed Susan, 986

Black-grass, 248

Black Sampson, 989

Black-thorn, 525

BLADDER-NUT FAMiLy, 606

Bladder-nut, 606

Bladder-pod, 457, 458, 1066

BLADDERWORT FAMILY, 845

Bladderwort, 846

Blazing Star, 257, 925

Bleeding-heart, Wild, 44I

Blite, 372, 376

Blood-leaf, 38ז

Blood-root, 439

Bloodwort, 720

BLOODWORT FAMILY, 278

P.lcomfell, 542

Plowball, 806

Blue Bells of Scotland, 884

Blueberry, 710, 1074 
Blue-bottle, I035

Blue-curls, 782

Blue-eyed Mary, 826

Blue-grass, 139, I4I

Blue-hearts, 835

Blue-tangle, 707

Blue-weed, 776

Bluets, $86 \mathrm{I}$

Clustered, 862

Bog-asphodel, 256

Bog-bean, 736

Boneset, 922, 923

Climbing, 924

False, 925

Borage Family, 766

Borage, 776

Bouncing-bet, 393

Bouteloua, 123

Bower, Virgin's, 421, 423

Bowman's-root, 493

Box FAmily, 598

Box-thorn, 816

Brake, 8

Bramble, 495

Bread-root, 544

Breeches, Dutchman's, 440

Brier, Wild, 514

Brome, I5I

Brome-grass, 149, I5I

Brooklime, 833, 1080

Brookweed, 7I5

Broom, 537

Base, 537

Indigo, 535

Yellow, 535

BROOM-RAPE FAMILY, 848

Broom-rape, 849

Brush, Bottle, $66_{5}$

BuCK-BEAN FAMILY, 736

Buck-bean, 736

Buckberry, 708

Buckeye FAmily, 608

Buckeye, 609

BUCK-THORN FAMILY, 6II

Buck-thorn, 525, 612, 721

BuckWhEAT FaMiLy, 350

Buckwheat, 358,365

False, 365

Buffalo-berry, 647

-grass, 125

-nut, 346

Bugbane, Amer., 4I5, 423

Bugle, 781, ro77

Bugle-weed, 803

Bugloss, 894

Sea, 771

Small, 776

Viper's, 776

Bug-seed, 375

Bulrush, I77 ro55

Bunchberry, 689

Bunk, 891

BUNCH-FLOWER FAMILY, 254

Bunch-flower, 259

Bur, Great, ro30

Sand, 8r5

Bur-chervil, 674

Bur-cucumber, $88_{3}$

Bur-grass, 1042

Bur-head, 54

Bur Marigold, I000

Bur-nut, 580

BUR-REED FAMILY, 39

Bur-reed 39 I047

Burdock, 1038

Sea, 912

Burmania FAMILY, 280

Burnet, 512

Burseed, 760

Burweed, 912

Bush, Burning, 605
Bush, Hobble, 870

Juba's, 38I

Strawberry, 605

Bush-clover, 563, 1067, 1068

Bush-cranberry, 870

Bush-honeysuckle, 876

Butter-and-eggs, 821

Butter-bur, 1022

Buttercup, 424, 430

Butterfly-dock, 1022 -pea, 568, 569

-weed, 741

Butternut, 323

Butterweed, ro29

Butterwort, 848

Button, Bachelor's, 583

Button-ball, 490 -bush, 863

Button-snakeroot, 926

Button-weed, 863

Button-wood, 490

Cabbage Skunk, 23I

Cactus Family, 643

Cactus, 645

Simpson's, 643

Calais, False, 900

Calamint, 799

Calamus-root, 231

Calico-bush, 70r

Calopogon, 298

Caltrop Family, 580

Caltrop, 580 I068

Camomile, ro14, I016

Campion, 388, 389, 392

Canary-grass, 92

Cancer-root, 849

Candle-tree, 852

Cane, I 58

Canker-root, 719

Cap, Bishop's, 483

Soldier's, $44^{\circ}$

Caper Family, 467

Caraway, 679

Cardinal-flower, 888

Carnation-grass, 212

Carpet, Water, 483

CARPET-WEed FAMILY, 383

Carpet-weed, 384

Carrion-flower, 276

CARrot Family, 669

Carrot, 688

Carvies, 679

Cassandra, Dwarf, 705

Cassena, 603

Castor-bean, 589

Catbrier, 277

Catchfly, 389

Catch-weed, 772

Cat-gut, 548

Cat-mint, 787

Catnep, 787

Cat-tail Family, 38

Cat-tail, 39

Cat's-ear, 893 -foot, 974, 975,1083

Cedar, $36,37,1047$

Celandine, 440

Lesser, $43^{\circ}$

Celery, 677

Centaury, 728, 1035

Cereus, 643

Chafe-weed, 978

Chaff-seed, 841

Chaff-weed, 718

Chain-fern, 10

Charlock, 450

Cheat, 150

Checkerberry, 705

Cheeses, 618

Cherry, 525

Winter, 812
Chervil, 674, 1072

Chess, 149, 150, I5I

Chestnut, 331

Chickweed, 386, 395, 397, 398, 405,1064

Chicory Family, 889

Chicory, 89I

China-tree, Wild, 610

Chinquapin, 332

Chittam-wood, 602

Choke-berry, 517

Christmas-green, 1037

Cinquefoil, 499, 500, 501, 503

Citronella, 807

Clammy-weed, 468

Clary, 795

Claytonia, 386

Cleareye, 795

Clearweed, 343

Cleavers, 865,867

Cleever-wort, 865

Cliff-brake, 8

Climath, 601

Clot-bur, 912, 1030

Cloud-berry, 495

Clover, 540 Hop, 538

Japan, 563

Club, Devil's, 1049

Hercules', 668

CLUB-moss Family, 24

Club-mosses, 24, 1045

Club-rush, i76

Cockle, 388

Cockle-bur, 912

Cock's-head, 552

Cockspur-grass, 78

Cohosh, Black, 4I5

Blue, 433

Coffee-tree, Kentucky, 538

Colic-root, 269

Collard, 1024

Collinsia, 827

Coltsfoot, ro2I

Sweet, 1021

Columbine, 416

Columbo, Amer., 734

Comfrey, 775

Wild, 768

Compass-plant, 981

Cone-flower, 986, 988, 989,

Conifers, 30

Coolwort, 480

Coral-berry, 874

Coral-root, 305, 306

Cord-grass, 120

CORK-WOOD FAMILY, 322

Cork-wood, 322

Corn, Squirrel, 44I

Corn-flower, 1035

Cornel, 689, I073, I074

Corydalis, 441, 1065

Cost, 1015

Costmary, ror 5

Cotton-grass, 181

Cottonwood, 309

Couch-grass, 154

Coughwort, I02I

Cowbane, 686

Cowberry, 50r

Cow-grass, 540

-herb, 394

- parsnip, 688

-wheat, 845

Cowslip, American, 7 I9

Virginia, 771

Crab-grass, 77, 124

Cranberry, 7 II

Mountain, 708

Cranberry-tree, $870,87 x$ 
Crane's-bill, 573

Crazy-weed, 551, 556

Creeper, Virginia, 616

Cress, 445, 451, 452, 453, 455 Alpine, 455

Mouse-ear, 463

Swine's, 446

Cross, St. Andrew's, 625

Cross-cleavers, 866

Cross Vine, 85I

Cross, Widow's, 474

Crosswort, 716

Crow BERRY FAMILY, 598

Crowberry, 598 Broom, 598

Crowfoot Family, 4II

Crowfoot, $426,428,429$

Seaside, 430

Crownbeard, 996

Cuckoo-flower, 454

Cucumber, Creeping, 882 Star, 883

Cucumber-root, 274

-tree, 409, 410

Cudweed, 972, 975, 978, 1020

Culver's-root, 834

Cuphea, Clammy, ${ }_{50}$

Cup-plant, 98I

Cupseed, 434

Curly-grass, 5

Currant, 488

Cushion, Ladies', 720

Custard-apple Family, 410

Cut-grass, 9I

Cynthia, 892

Cypress, Bald, 35

CyRILla FAMILY, 602

Daffodil, 279

Dagger-flower, 966

Daisy, 943, 1015

Michaelmas, 962

Yellow, 986

Dandelion, 896

Dwarf, 892

Fall, 893

False, 901

Danes' Blood, 885

Dangleberry, 707

Darnel, 152

Date Plum, 721

Day-flower, 239

Deerberry, 708, 1074

Deer-grass, 651

Dewberry, 497, 498

Devil's-club, I 072

Dew-cup, 5 Io

Dew-plant, $47 \mathrm{I}$

Diapensia Family, 712

Dillweed, 683 , Ior 4

Ditch-moss, 60

Dittany, Amer., 803

Dock, 355

Prairie, 981, 983

Dock-cress, Succory, 891

Dockmakie, 871

DodDER FAMiLY, 754

Dodder, 754

DOGBANE FAMILY, 737

Dogbane, 738

Dogberry, 486

Dog-fennel, 921

False, I012

Dogwood Family, 689

Dogwood, 690

Door-weed, 363

Double-claw, 853

Dragon, Green, 229

Dragon-head, 787

False, 788

Dragon-root, 229

Dropseed, 106
Dropseed-grass, 100, 106

DUCKWEED FAMILY, 232

Duckweed, 232, 234

Dyer's-weed, 940

Dye-weed, 537

Ear, Hare's, 677

EBONY FAMILY, 721

Eel-grass, 5I, 60

Egriot, 525

Elder, 869

Box, 608

Marsh, 909

Poison, 601

Wild, 668

Elecampane, 979

Elephant's-foot, 920

-trunk, 853

Elk-wood, 409

Elm Family, 337

Elm, 338

Eryngo, 673

Evening-Primrose Family,

Evening-primrose, 657, ro70

Everlasting, 974, 977

Large-flowered, 977

Life, 977

Pearly, 977

Eye, Pheasant's, 432

Eyebright, 841, 842, ro8o,

False-flax, 459

False Mermaid, 599

False Mermaid Family,

False-oat, II7

Fame-flower, $3^{85}$

Farkleberry, 708, 1074

Feather, Prince's, 363

Featherfew, I0I5

Featherfoil, 715

Fellonwort, 815

Fennel, 682

Water, 597

FERN FAMILY, 6

Fern, Bristle, 5

Brittle, I3

Christmas, 14

Cinnamon, 4

Clayton's, 4

Climbing, 6

Hartford, 6

Maiden-hair, 8

Male, I5

Ostrich, 19

Royal, 4

Sensitive, 19

Shield, I4

Sweet, 32I

Venus-hair, 7

Ferns and fern-allies, I

Fescue-grass, 146

Fetter-bush, 704

Feverfew, American, 983

Common, 1015

Fever-wort, 873

Field-madder, 868

Fig, Indian, 644

FigWORT FAMILY, 8I8

Figwort, 822 , 1079

Finger-grass, 76

Fiorin, 109

Fir, 34

Fire-weed, ro23

Five-finger, 506

Flag, 282

Blue, 282 , 1059

Red-brown, 283

Sweet, 231

Yellow, 283

FIAX FAMILY, 578
Flax, 578

Mountain, 584

Wild, 578

Fleabane, 967,970

Marsh, 973

Small, 955

Fleawort, Marsh, 1028

Fleur-de-lis, 283

Flixweed, 462

Flower, Cuckoo, 392 Gipsy, 768

Flower-of-an-hour, 623

Flower, Moccasin, 291

Pasque, 420

Side-saddle, 470

Fly-honeysuckle, 876

Fly-poison, 257

Fog-fruit, 779

Forget-me-not, 772

FOUR-O'CLOCK FAMILY, 382

Foxglove, 835

False, 836

Mullen, 835

Fox-grape, 614, 6I5

tail, 103

Fringe-tree, 726

Frog's-bit, 6I

Frost-weed, 630, 1069

Frostwort, 631

Fumitory, 442

Climbing, 44

Hedge, 442

Furze, 537

Galaxy, 713

, Sweet, 32I

Gall-of-the-earth, 907

Gama-grass, 67

Garget, 38I

Garlic, 263 , I059

False, 264

Gay-wings, 585

Gean, 525

Gentian FaMiLY, 728

Gentiar, 732, 1075

Spurred, 735

Geranium FAMILY, 573

Geranium, 37 I

Germander, 782, 1077, 1078

Giant Hyssop, 786

Gill-over-the-ground, 787

Ginger, Wild, 348

GINSENG FAMILY, 667

Ginseng, 668

Gipsy-herb, 804

Gipsywort, 804

Gladiole, Water, 887

Glasswort, 375

Globe-flower, 413

Globe-mallow, 621

Goat's-beard, 493, 892, 895

Gold-of-pleasure, 459

Golden-club, 231

Goldenpert, 830

Goldenrod, 935, 942, 1082 ,

False, 943

Rayless, 93I

Golden-seal, 412

Gold-thread, 4 I 3

Good King Henry, 371

GoOSEBERRY FAMILY, 486

Gooseberry, 486

Goosefoot Family, 368

Goosefoot. $369,371,1063$

Goose-grass, 145, 865

Goose-tansy, 502

Gorse, 537

Gosmore, 893

GoURd FAMILY, 88I

Gourd, Missouri, 882

Gout-weed, -wort, 680 
Grama-grass, 123

GRAPE FAMILY, 613

Grape, 614

False, 616

Grape-hyacinth, 268

Grass Family, 6I

Grass, Barnyard, 78

Beard 69 71 I08 1047

Bent, I09, 115

Blue, 139

Black-oat, 97

Blue-eyed, 285

Blue-joint, I12

Bottle-brush, I58

Brome, 148

Buffalo, 125

Bur, 90, 1052

Canary, 92

Catch-fly, 92

Cat's-tail, 102

Cockspur, 78

Cord, 120

Couch, 154

Crab, 77, 124

Cut, gi

Dog's-tail, 136

Dog's-tooth, I19

Drop-seed, 100, 106

Egyptian, I24

Faitour's, 595

Fescue, 146

Finger, 76

Fiorin, 109

Fowl, Meadow-, 139

Fox-tail, 89, 90, 1052

Gama, 67

Goose, 145

Hedgehog, 90

Holy, 93

Hungarian, 90

Indian, 7I

Johnson, 7I

Joint, 73

June, I39

Kentucky Blue, 139

Manna, I43

Meadow-fescue

Mesquite, 123

Millet, 98

Munro's, I25

Oat, 118

Orchard, 136

Pigeon, 89

Plume, 67, I047

Prickle, 72

Quake, Quaking, ${ }_{136}$

Rye, I52

Salt-meadow, r2o

Seneca, 93

Smut, ro6

Soft, II 5

Spear, 138

Squirrel-tail, 155

Sweet Vernal, 92

Terrell, 156

Texas Blue, I4I

Toothache, I2I

Vanilla, 93

Velvet, II5

Wheat, 153

White, or

Wrack, 5I

Yard, 124

Grass-of-Parnassus, 476

Grass-of-Parnassús ${ }^{47}$ FaILY, 475

Grass-pink, 298

Grass-poly, 649

Grease-wood, 376

Green-brier, 276

Green-weed, 537
Gromwell, 773

False, 775, 1076

Ground-cherry, 810,813, 1078

Ground-hemlock, 37

Ground-nut, 569, 668

Ground-pine, 25

Ground-vine, 873

Groundsel, 1026, 1027, 1029

Groundsel-bush, 971

-tree, 971

Guelder-rose, Wild, 870

Gum, Cotton, 691

Red, 489

Sour, 691

Star-leaved, 489

Sweet, 489

Tupelo, 691

Gum-plant, 928

Gypsophyll, 39.

Hackberry, 339, 1062

Hackmatack, 33

Hair-grass, 101, 110, I15, I16

Harbinger of Spring, 676

Hardgrass, 152

Hardhack, 492

Hardheads, 1035

Harebell, 884

Hare's-ear, 467

Hart's-tongue, I3

Haw, 519, 521

Black, 872

Hawkbit, 893

Hawk's-beard, 901

Hawkweed, 903

Mouse-ear, 904

Hawthorn, 520

Hazel-nut, 327

Heal-all, 788, 822

Healing-herb, 775

Heart, Floating, 736

Lion's, 788, 1078

Heartease, 640

Heart-seed, 610

Heath Family, 696

Heath, Mountain, 702

Heathberry, 598

Heather, 706

Beach, False, 63I

Heather-grass, 126

Hedge-garlic, 447

Hedgehog-thistle, 643

Hedge-hyssop, 828,829

Hedge-parsley, 675

Heliotrope, 767

Hellebore, 259, 413

Helleborine, 299

Hemlock, 34, 37, 686

Poison, 676

Water, 679, 1073

Hemlock-parsley, 684

Hemp, 34I

Indian, 739

Nettle, 790

Hempweed, Climbing, 924

Henbane, Black, 816

Henbit, 79I

Herb-bane, 849

- Gerard, 680

Herb-of-the-cross, 777

Herb-Robert, 573

-Sherard, 868

-Sophia, 462

Herba Impia, 972

Herd-grass, 102, 109

Heron's-bill, 575

Hickory, 324, 325

Hoarhound, Black, 79r

Fetid, 791

Marsh, 804

Water, 804, 923

White, 785
Hobble-bush, 870

Hog's-bean, 816

Hogweed, 910, 92r

Hog wort, 586

Hollow-root, 877

HoLly FAMILY, 602

Holly, 603

Mountain, 604

Holly-fern, I3

Wild, 604

Hollyhock, 618

Holy-grass, 93

Honesty, 456

Honewort, 679

Honey-bloom, 738

HoNEYSUCKLE FAMILY, 869

Honeysuckle, 875

Bush, 877

Ground, 542

Swamp, 698

Wild, 698

Honey-sweet, 510

Hop, 34I, ro6 3

Hop-clover, 539

-hornbeam, 327

Hop-tree, 58I

-trefoil, 540

Hornbeam, 326

HoRNWORT FAMILY, 408

Hornwort, 409

Horse-balm, 807

Horse-brier, 277 -cane, 910

Horse-chestnut, 609

Horsefly-weed, 535

Horse-gentian, 873

Horse-heal, 979

-knops, I035

Horse-mint, 796

Horse-nettle, 814

Horse-radish, 453

Horse-sugar, 722

HoRSE-TAIL FAMILY, 21

Horse-tails, 21

Horse-weed, 970

Hound's-tongue, 768

House-leek, 475

HUCKLEBERRY Family, 707

Huckleberry, 707, 710

Hunger-weed, 428

Hyacinth, Wild, 267

HydRANGEA FAMILY, 484

Hyssop, 800

Wild, 778

Indian-cup, $98 \mathrm{I}$

INDIAN-PIPE FAMILY, 695

Indian-root, 668

Indigo, Wild, 535

Bastard, 545

Blue False, 535

False, 545

Indigo-plant, 548

Inkberry, 603

Innocence, 86r

Ipecac, American, 493

Wild, 594

IRIS FAMILY, 28I

Iris, Dwarf, 283,284

Iron-weed, 918

Iron-wood, 327

Southern, 602

Ironwort, 790

Isabella-wood, 436

Ivray, 152

Ivy, American, 616

Coliseum, 820

Ground, 787

Kenilworth, 820

Poison, 601

Jack-in-the-pulpit, 229

Jamestown-weed, 816 
Jessamine, Yellow, 727

JEWEL-WEED FAMILY, 610

Jimson-weed, 816

Joe Pye Weed, 921

Johnson-grass, 7 I

Joint-grass, 73, 112

Joint-weed, 367,665

Judas-tree, 529

June-grass, 139

June-berry, 51 7, 1066

Juniper, 36

Ketmia, Bladder, 623

King-devil, 904 -nut, 324

Kinnikinnik, 690, 706

Knapweed, I035

Knawel. 405

Knight's-spur, 4I6

Knot-berry, 495

Knot-grass, 363, 405

Knotweed, 363, 366, 1063

Krameria Family, 531

Ladder, Jacob's, 761

Lady's-comb, 675

Lamb-kill, 701

Larch, 33

Lark-heel, 416

Larkspur, 4I 6, 1064

LAUREL FAMILY, 435

Laurel, 701

Great, 699

Ground, 705

Lady, 646

Spurge, 646

Lead-plant, 545

Leaf, Velvet, 62I

Leaf-cup, 979

Leather-flower, 422 -leaf, 705

Leather-wood, 646

Southern, 602

Leek, Wild, 262

Leopard's-bane, 1022

Lettuce, 386,898 , 1082 Blue, 899

Hare's, 897

White, 906

Licorice, Wild, 866

Life-root, 1028

Lilac, 724

LILY FAMILY, 260

Lily, 265

Atamasco, 279

Blackberry, 284

Day, 26I

Mariposa, 267

Pond, 407

Water, 407

LILY-OF-THE-VALLEY ILY, 260

Lily-of-the-valley, 273 False, 27I

Limonillo, го

LINDEN FAMILY, 6 I 6

Linden, 61 7, 1068

Ling, 706

Linseed, 578

Lion's-foot, 907 -heart, 788 , 107 8 -mouth, 822 -tail, 790

Iip-fern, 9

Liquorice, 557

Live-forever, 474

Liver-leaf, 420

IIZARD'S TAIL FAMILY, 307

Lizard's-tail, 307

I, OASA FAmily, 64I

Loco-vetch, 356

Loco-weed, 551, 556

Locust, 531, 549
Locust-tree, 549

Logania FAMiLy, 726

Loosestrife Family, 648

Loosestrife, 649, 715, 717

Swamp, 649

LOPSEED FAMILY, 855

Lopseed, 856

Lotus, 408

Lousewort, 843

Lovage, 685

Scotch, 683

Love-apple, 815

Lover, Mountain, 606

Love-vine, 755

Lucerne, 538

Lungwort, 771

Sea, 771

Lupine, 536

Lychnis, 392

Lyme-grass, I 57

MADDER FAMily, 860

Madder, Wild, 865,867

Madwort, German, 772

Magnolia Family, 409

Mahaleb, 526

Mahonia, Trailing, 432

Mallow FaMiLY, 6I7

Mallow, 618

Bristly-fruited, 622

False, 620

Glade, 620

Indian, 621

Virginia, 62I

Mandrake, Wild, 433

Manna-grass, I 43

Mantle, Lady's, 5 Io

Maple Family, 607

Maple, 607, 1068

Maram, II4

Mare's-tail, 665

Marigold, Fetid, ror2 Water, 1003

Marjoram, 800

Marl-grass, 540

Marsh-grass, 120, 121

-mallow, 618

-marigold, 412

-pennywort, 671, ro72.

Marshlocks, Purple, 5or

Masterwort, 688

Mat-grass, 151

Mat-rush, 178

Mat-weed, II4

May-cherry, 517

Mayflower, 705

Mayaca Family, 234

Mayaca, 235

Mayweed, Ior4

Corn, 1016

Mazard, 525

Meadow-beauty Family,

Meadow-beauty, $65 \mathrm{I}$ -gowan, 412

Meadow-grass, I38, 139, I40, $141,144,145$

Meadow-parsnip, 678, 684

Meadow-queen, 510

Meadow-rue, 43I, I065

Meadow-sweet, 492, 5 Io

Medic, 538

Melic-grass, 133

Melilot, 539

Mercury, Three-seeded, 588

Mermaid-weed, $66_{5}$

Mesquite, 123,528

Mesquite-grass, 123

MEZEREON FAMILY, 645

Mezereon, 646

Mignonette Family, 469

Mignonette, 469
Milfoil, Ior 3

Milk-vetch, 55 I, 554, 1067

MilKWEed FAMiLY, 740

Milkweed, 74I, 745, 746,

Milkwort Family, 582 1075,1076

Milkwort, 583, 744

Sea, 718

Millet, $76,82,90$

-grass, 98

Mimosa Family, 527

Mimosa, 527

Mint Family, 779

Mint, 805

Stone, 803

Mist-flower, 924

Mistletoe Family, 344

Mistletoe, 344, 345

Mitrewort, 483,727

False, 480

Mocker-nut, 325

Moneywort, 716

Prairie, 717

Monkey-flower, 827

Monk's-hood, 417

Moonseed FAmily, 434

Moonseed, 434

Moonwort, 3

Moor, 706

Moorwort, 703

Moose-wood, 608, 646

Morning-glory FaMiLy,

Morning-glory, 751, 752

Moschatel Family, 877

Moschatel, 877

Moss, Florida, 239

Flowering, 712

Long, 239

Moss-plant, 702

Mother-of-thyme, 802

Motherwort, 790

Golden, 978

Mountain-mint, $80 \mathrm{I}$

Mountain Rice, 97

Mouse-ear, 772, 793, 978

Mouse-tail, 423

Mud-plantain, 243

-purslane, 629

weed, or -wort, 831

Mugwort, Iorg

MulberRy Family, 339

Mulberry, $34^{\circ}$

French, 779

Mullen, 819

Musk-flower, 828 -plant, 828 -root, 877

Mustard Family, 443

Mustard, 449, 465, 467

Ball, 459

Garlic, 447

Hedge, 448

Tower, 465

White, 449

Myosote, 773

Myrtle, $73^{8}$

Sand, 700

Nailwort, 404

Nanny-berry, 872

Nard, I5I

Navew, Wild, 450

Neckweed, 834

Needle, Adam's, 269

Nep, 787

NetTle Family, 34!

Nettle, 342, 343

Dead, 790, 791

Hedge, 792, 1078

Spurge, 589

Nettle-tree, 339 
Nightshade, 814

Enchanter's, 664

Nimble Kate, 883

Will, 100

Ninebark, 492

Nipple-wort, 89 I

Nondo, 683

Nonesuch, 538

Nut-grass, 163

Nut-rush, I 87, 1056

Nyctelea, 764

Oak, 333, 37I

Poison, 601

Oak-fern, I7

Oat, II 8

Sea, or Seaside, 'I35

Water, 91

Oat-grass, 97, I18, II

Oats, Sea, 135

Oil-nut, 346

Oleaster Family, 646

Olive Family, 723

Onion, 263

Wild, 263 , I 59

Opium, Wild, 898

Orache, 373

Orange-grass, 628

Osage, 340

Orange, Mock, 485

OrCHID FAMILY, 289

Orchis, 292, 293, 294, 295.

Bog, 294, 295

Crane-fly, 304

Fen, 304

Wood, 293

Organy, 800

OrPINE FaMILY, 473

Orpine, 474

Oryzopsis, 98

Owl's Crown, 978

Ox-eye, 984

Ox-eye, Sea, 990

Ox-tongue, Bristly, 894

Oxytrope, 555

Painted Cup, 839

Palma Christi, 589

Palms, 288

Panic-grass, 1049

Panicum, 77,78

Pansy, 640

Papaw, North Amer., 4I0

Parsley, 678, 687

Fool's 682

Marsh, 678

Sea, $68_{3}$

Parsley-piert, 510

Parsnip, Wild, 688

Partridge-berry, 863

Passion-flower Family,

Passion-flower, 64I -vine, 641

Pea Family, 532

Pea, 567

Cow, 572

Marsh, 567

Milk, 570

Partridge, 529

Sensitive, 529

Pea-nut, 559

Hog, or Wild, 560

Peach, 526

Pear, 515

Choke, 515

Prickly, 644

Pearlwort, 399

Pear-thorn, 522

Pecan, 324

Pellitory, 343

Pencil-flower, $55^{8}$
Pencil-tree, 97I

Penny-cress, 447

Pennyroyal, 797

Bastard, 782

False, 782

Pennywort, 735

Pepper, Water, 362

Pepperbush, Sweet, 692

Pepper-grass, 445, 1065

Pepperidge, 69I

Peppermint, 805

Pepper-root, 455

-vine, 615

-wood, 58 I

Periwinkle, 738

Persicaria, 360

Persimmon, 721

Phlox Family, 756

Phlox, 757

Yellow, 466

Physic, Indian, 493

Pickerel-Weed FAMILY, 242

Pickerel-weed, 243

Pigeon-berry, 38 I

Pigmy-weed, 473

Pig-nut, 325

Pig-weed, 378

Pilewort, 822, 1023

Pilot-weed, 98

Pimpernel, 680, 7I8

False, 718, 830

Water, 715, 832

Pine Family, 30

Pine, 31, 1046

Ground, 25

Prince's, 695

Running, 25

Pine-apple Family, $23^{8}$

Pine-drops, 695

-sap, 696

-weed, 628

Pink Family, 387

Pink, 390, 391, 392, 393, 394

Carolina, 727

Ground, 759

Indian, 727,751

Marsh, 730

Moss, 759

Sea., 720, 730

Swamp, 256, 698

Pinkster-flower, 698

Pinweed, 632

Pipe, Dutchman's, 350 Indian, 696

Pipe-vine, 350

Pipewort Family, 236

Pipewort, 237, 238, 1057

Pipsissewa, 695

Pitcher-plant Family, 470

Pitcher-plant, 470

Pitch-pine, 33

Plane-tree Family, 490

Plane-tree, 490

Planer-tree, 338

Plant, Castor-oil, 589

Obedient, 788

Oyster, 771, 895

Plantain Family, 856

Plantain, 857, ro8I

Indian, 1024

Poor Robin's, 904, 968

Rattlesnake, 302

Robin's, 968

Water, 54

Pleurisy-root, 74I

Plum Family, 523

Plum, 524

Groind, $55 \mathrm{I}$

Plumbago Family, 719

Plum-grape, 6I4

Plume=grass, 67,1047
Pogonia, 297, 298

POKE-WEed FAMILY, 38r

Poke, 38 r

Poke, Indian, 259

Polypody, ?

Pomme Blanche, 544

Pondweed, 42

Poplar, 308, 309

Yellow, 410

PopPy Family, 437

Poppy, 438

Celandine, 440

Prickly, 439

Sea, 440

Yellow Horned, 440

Poppy-mallow, 6 ig

Pop-weed, 847

Porcupine-grass, 97

Portulaca, 387

Potato Family, 808

Potato, Indian, 993

Poverty-grass, 94

Powder-horn, 397

Prairie-clover, 547

Prickle-grass, 72

Pride-of-Ohio, 7 I9

Prim, 726

Primiose Family, 713

Primrose, 661, 714

Evening, 657, 1070, 1071

Lavender-leaved, I 107

Scapose, 660

Showy, 660

Primrose-willow, 654

Privet, 726

Puccoon, 774

Pumpkin, 882

Purse, Shepherd's, 459

Purslane Family, 384

Purslane, 384, 386, 387, 1064 Marsh, $65^{2}$

Milk, 592

Sea, 1064

Water, 649

Pussley, 386

Putty-root, 305

Pyracanth, 522

Pyxie, 712

Quake-grass, 136

Ouaker Lady, 492

Ouaking-grass, 136

Ouarters, Lamb's, 369

Queen-of-the-prairie, 510

Queen's-delight, 590

Queen-root, 590

Quercitron, 334

QUILLWORT FAMILY, 27

Ouillworts, 27

Quitch-grass, 154

Rabbit-berry, 647 -foot, 540

Radish, Garden, $45 \mathrm{I}$ Wild, 450

RAgWEed FAMILY, 908

Ragweed, 910

Woolly, 1026

Ragwort, 1026, 1028, 1029

Ranstead, 821

Raspberry, 495

Rattle, 844

Rattle-box, 536, 654, 844

Rattlesnake-grass, 143

-master, 673

-root, 907,908

-weed, 904

Rattlesnake-root, 907, I082

Ray-grass, 152

Red-bud, 529

Red-root, 278, 613

Red-top, 109, 126, 139

Reed, 91, I25 
Reed-grass, I12, I14, 120 Wood, I08

Rib-grass, -wort, 857

Rice, Indian, 91

Jungle, 78

Mountain, 97

Rice, Wild, 9 I

Richweed, 343, 807

River-Weed Family, 472

River-weed, 472

Robin, Ragged, 392

Red, 573

Rockbrake, 8

Rock-cress, 448, 463, 465

RoCK-ROSE FAMILY, 630

Rocket, 450

Dame's, 467

Dyer's, 409

False, 45I

Purple, 45I

Sea, American, 448

Root, Musquash, 679

Rose FAMILY, 490

Rose, 388, 513, 1066

Cotton, 972

Holy, 703

Mallow, 622, 1068, 1069

Musk, 619

Rose-mallow, 622

Rosemary, Marsh, 719

Wild, 703

Rose-of-Sharon, 623

Rose-pink, 730

Roseroot, 474

Rosewort, 474

Rcsin-weed, 98 r

Rue-anemone, 420

RUE FAMILY, 58I

Rue, Goat's, 548

Running-pine, 25

Rush Family, 244

Rush 246, 1058

Chair-maker's, 177

Horned, 184

Rushes, Scouring, 2I

Rush-grass, 104, 1052

Rye, Wild, I 56, 1053

Rye-grass, 152

Sage, 374, 794

Indian, 923

Jerusalem, 789

Wood, 782

Wormwood, rorg

Sage-brush, I02I

Pasture, 1019

Sage-bush, 1020

Sailors, Blue, 89 r

St. JoHN's-WORT FAMILY,

St. John's-wort, 626, ro69 Marsh, 629

St. Peter's Wort, 625

Salad, Corn, 879

Salmon-berry, 495

Salsify, 895

Saltwort, 377

Black, 718

Sand-grass, 127

-parsley, 678

-reed, II4

-star, 218

SANDALWOOD FAMILY, 345

Sandwort, $400402,403,1064$

Sanicle, 672

White, 923, 924

SAPODILLA FAMILY, 720

Sarsaparilla, 668

Satin-flower, 456

Satin-pod, 456

Savin, 37

Savory, 798
Saw-grass, 187

SAxifrage FAMILY, 476

Saxifrage, 478,480

Golden, 483

Scabious, 881

Sweet, 969

Scoke, $3^{8} \mathrm{I}$

Scorpion-grass, 772

Scouring-rush, 23

Scurvy-grass, 447

Scutch-grass, I19

Sea-blite, 376

Sea-lavender, 719

SEDGE FAMILY, I58

Sedge, 190, 1056

Coast, 179

See-bright, 795

Seed-bearing plants, 30

Seed-box, 654

Self-heal, 788

SENNA FAMILY, 528

Senna, 529

Sensitive-brier, 528

-plant, 529

Serpentary, 349

Service-berry, 517

Shad-bush, 517

Shag-bark, 324

Sheep-berry, 872

Sheep-laurel, 701

Sheep's-bit, 887

Shepherd's-needle, 675

Shield-fern, I4

Shin-leaf, 693

Shoe-strings, 545

Shooting Star, 7 I 9, 1074

Shore-grass, -weed, 860

Shrub, High-water, 909

Sickle-pod, 464

Silk-weed, 743

Silver-leaf, 6 II

-rod, 936

-weed, 502

Skevish, 968

Skull-cap, 783, 1078

Skunk-bush, 601

Slipper, Ladies', 291

Sloe, 525,872

Small-reed, 1 II

Smartweed, 362

Smilax FAmily, 275

Smoke-tree, 602

Smut-grass, 106

Snake-head, 823

Snake-mouth, 297

Snake-root, 349, 415, 544, 672,

Button, 673

Seneca, 584

White, 923

Snap-dragon, 822

Sneezeweed, roro

Sneezewort, sor3

Snowberry, 874

Creeping, 71

SoAPBERRY FAMILY, 609

Soapberry, 6ro

Soapwort, 393

Sofi-grass, II5

Sorrel, 354

Minuntain, 357

Sorrel-tree, 705

Sour-wood, 705

Southernwood, rorg

Sow-thistle, 897

Spanish Needles, 1002

Spear-grass, 138, 139, 140,

Spearmint, 805

Spearwcrt, 425

Speedwell, 832
Spice-bush, 437

Pond, 436

Spider-flower, 468

SPIDERWORT FAMILY, 239

Spiderwort, 24 I

Spike-grass, I35

Spikenard, 668

Wild, 271

Spike-rush, 1 68, 1055

Spindle-tree, 605

Spiraea, 492, 493

Spleenwort, ro

Spruce, 33

SPURGE FAMILY, 585

Spurge, 59I

Mountain, 599

Spurry, 402, 403

Spurwort, 868

Squaw-root, 850

Squaw-weed, 1027, 1028

STAFF-TREE FAMILY, 605

Stag-bush, 872

Stagger-bush, 704

-wort, 1029

Star-flower, 718

Star-grass, 243, 269, 280

Star-of-Bethlehem, 268

Starwort, 395, 401

Steeple-bush, 492

Stickseed, 769

Stitchwort, 396

Stonecrop, 474, 475

Storax FAMILX, 722

Storax, 723

Stork's-bill, 575

Stramonium, 816

Strawberry, 500

Barren, 506

Dry, 506

Indian, $50 \mathrm{I}$

Yellow, 5or

STRAWBERRY-SHRUB i A $\mathbf{M}$ ILX, 435

Strawberry-shrub, 435

Succory, Gum, 895

Lamb, 892

Wild, 891

Sugar-berry, 339

Sugar-pear, 517

Sugar-tree, 607

Sumac Family, 599

Sumac, 600

SUNDEW FAMILY, 470

Sundew, 47 I

Sundrops, 659, ro7x

Sunflower, 991

Brook, 1000

Fa!se, 984 , roro

Red, 989

Swamp, Ioro

Sun-plant, 387

Supplc-Jack, 612

Swallow-wort, 747

Sweating-weed, 623

Sweet-brier, 514

Sweet-cicely, 675

Sweet-clover, 539

SweET-LEAF FAMILY, 728

Sweet-leaf, 722

Sweet William, 394

Wild, 757

Syringa, 485

Tacamahac, 309

Tamarack, 33

Tangleberry, 707

Tansy, Ior6

White, ror3

Wild. 502, oro

Tansy Mustard, 462

TAPE-GRASS FAMILY, 59

Tape-grass, 60 
Tar-weed, 650

Tare, 566

TEA FAMILY, 623

Tea, Appalachian, 872 Blue Mountain, $93^{8}$ Labrador, 697

Tea, Mexican, 37 I New Jersey, 6r3 Oswego, 795

Tear-thumb, 366

Teasel Family, 880

Teasel, 880

Terrell-grass, 156

Thimble-berry, 496

Thin-grass, 110

Thistle Family, 913

Thistle, 377, 1031

Blessed, 1036

Cotton, 1034

Milk, 897, 1034

Our Lady's, 1036

Scotch, 1034

Star, 1035

Thorn, 519

Evergreen, 522

Fire, 522

Thorn-apple, 816

Thoroughwax, 677

Thoroughwort, 922

Large-flowered, 924

Thread-foot, 472

Three-square, 177

Thrift, 720

Thumb, Lady's, 36I

Thyme, 802

Basil, 799

Thyme-leaf, 1012

Tickseed, 998

Tickseed Sunflower, 1002

Tick-trefoil, 560

Timothy, 102

Toad-flax, 820,821

Bastard, 345

Tobacco, 817

Indian, 889

Mountain, 1023

Wild, 889

Tobacco-root, 878 -weed, 920

Tomatillo, 8I I

Tomato, 8I5

Cherry, 815

Strawberry, 812

Toothache-grass, I2I -tree, $58 \mathrm{I}$

Toothwort, 455, 1064

Top-flat, 918

Torch-pine, 33

Touch-me-not, 6rr

Tread-softly, 589

Tree, Ague, 436

Angelica, 668

Catawba, 852

Lime, 617

Spikenard, 668

Silver-bell, 722

Snowdrop, 722

Tree-of-heaven, 582

Trefoil, Bean, 736

Bird's-foot, 542

Marsh, 736

Shrubby, 58I

Tresses, Ladies', 299, ro6o

TRUM PET-CREEPER FAMILY,

Trumpet-creeper, $85 \mathrm{I}$

Trumpet-flower, 851

Trumpet-leaf, 470

Trumpet-weed, 921

Trumpets; 470

Tulip, 1059
Tulip-tree, 410

Tumble-weed, 81,378

Tupelo, 691

Turkey-beard, 256

Turnip, 450

Indian, 229, 1057

Prairie, 544

Turtle-head, 823

Twayblade, 301, 303

Twig-rush, 186

Twin-berry, 863

-flower, 873

-leaf, 433

Twisted Stalk, 272

Umbrella-leaf, 433

Umbrella-tree, 409

Umbrella-wort, 382, 1063

UNICORN-PLANT FAMILY, 852

Unicorn-plant, 853

VAlerian FamiLy, 878

Valerian, 878

Greek, 76I

Vanilla-grass, 93

-leaf, 927

-plant, 927

Velvet-grass, II5

Venus'-comb, 675

Venus'-looking-glass, 886

Verbena, 778, 1077

Vernal-grass, 92

Vervain Family, 776

Vervain, 777

Vetch, 565

Joint, 558

Milk, 551, 554, 555, 1048

Vetchling, 567

Vine, Alleghany, 44I

Balloon, 6ro

Bean, 571

Cypress, 75I

Matrimony, 816

Pea, 565

Potato, 752

Sand, 747

Wild, 614

Violet FAMILY, 633

Violet, 635, 1060, 1070

Bog, 848

Dame's, 467

Green, 640

Marsh, 848

Nodding, 640

Virginia Willow, 485

VIRGINIA WILLOW FamiLY,

Wahoo, 338, 605

485

Wake-robin, 274

Walking-fern, 13

Wall-flower, Western, 465

Wall-pepper, 474

WALNUT FAMIIY, 322

Walnut, 323

Wart-cress, 446

-weed, 595

-wort, 978

Water-caltrop, 664

-chestnut, 664

-cress, 452, 453, 455

-crowfoot, 425, 429

-hemp, 380

WATER-LEAF FAMILY, 762

Water-leaf, 763 , 1075

WATER-LILy FAMILY, 406

Watermelon, 882

850 WATER-MILFOIL FAMILY, 664

Water-milfoil, 666

Hooded, 817

WATER-NUT FAMILY, 664

Waternut, Swimming, 664

Water-parsnip, 68r

WATER-PLANTAIN FAMILY, 53
Water-plantain, 54

-shield, 406

WATER-STARWORT FAMILY,

Water-starwort, 596

-target, 406

-thyme, 60

-weed, 60

Waterwort FaMily, 629

Waterwort, 629

Waxberry, 32I

Wax-myrtle, 321

Wax-weed, 60, 650

Wax-work, 606

Wayfaring Tree, 870

Weather-glass, 718

Weed, Tumble, 8 r

Wheat-grass, 153

Whin, 537

White-ALder Family, 692

White-lettuce, 907

White-man's-weed, ror5

White-weed, 1015

White-wood, 410, 617

Whitlow-grass, 460

Whitlow-wort, 404, 1064

Whorl-grass, I33

Whortleberry, 709

Wild-rye, 157

Will, Nimble, 100

WiLlOW FAMILY, 307

Willow, 31 2, 1061

Water, 855

Willow Herb, 649, 655

Hooded, 785

Night, 657

Wind-flower, 419

Windlestraw, 115

Winterberry, 603,604

WINTERGREEN FAMILY, 692

Wintergreen, 693

Chickweed, 718

Creeping, 705

Flowering, 585

Spotted, 695

Spring, 705

Wirebent, $15 \mathrm{I}$

Wire-grass, 106, 124, 141

Wistaria, 549

Witch-grass, 8

WITCh-HAZEL FAMILY, 488

Witch-hazel, 489

Withe-rod, 872

Woad-waxen, 537

Wolfberry, 874

Wolf's-bane, Trailing, 418

Wood-lettuce, $8 \mathrm{~g} 8$

Woodruff, Sweet, 868

Wood-rush 253, ro58

WOOD-SORREL FAMILY, 575

Wood-sorrel, 576

Wool-grass, 180 , 1056

Worm-seed, 371

Wormwood, 1018

Roman, 9ro

Woundwort, 793

YAM FAMILY, 28I

Yam-root, Wild, 281

Yard-grass, 124

Yarrow, 1013

Yaupon, 603

Yellow-cress, 452, 453

YELLOW-EYED GRASS FAM. ILY, 235

Yellow-eyed Grass, 235, 1057

Yellow Root, 414

Yellow-top, 939

Yellow-weed, 460

Yellow-wood, 534

Yew, 37

Zinnia, Prairie, 984 









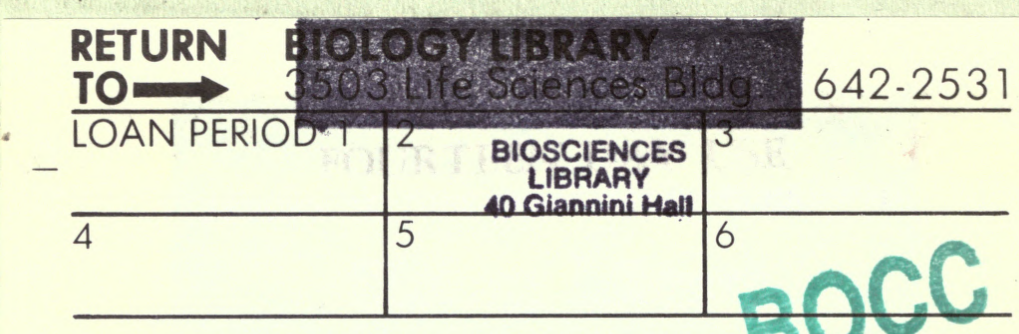

ALL BOOKS MAY BE RECALLED AFTER TDAYS

Renewed books are subject to immediate recall

\section{DUE AS STAMPED BELOW}

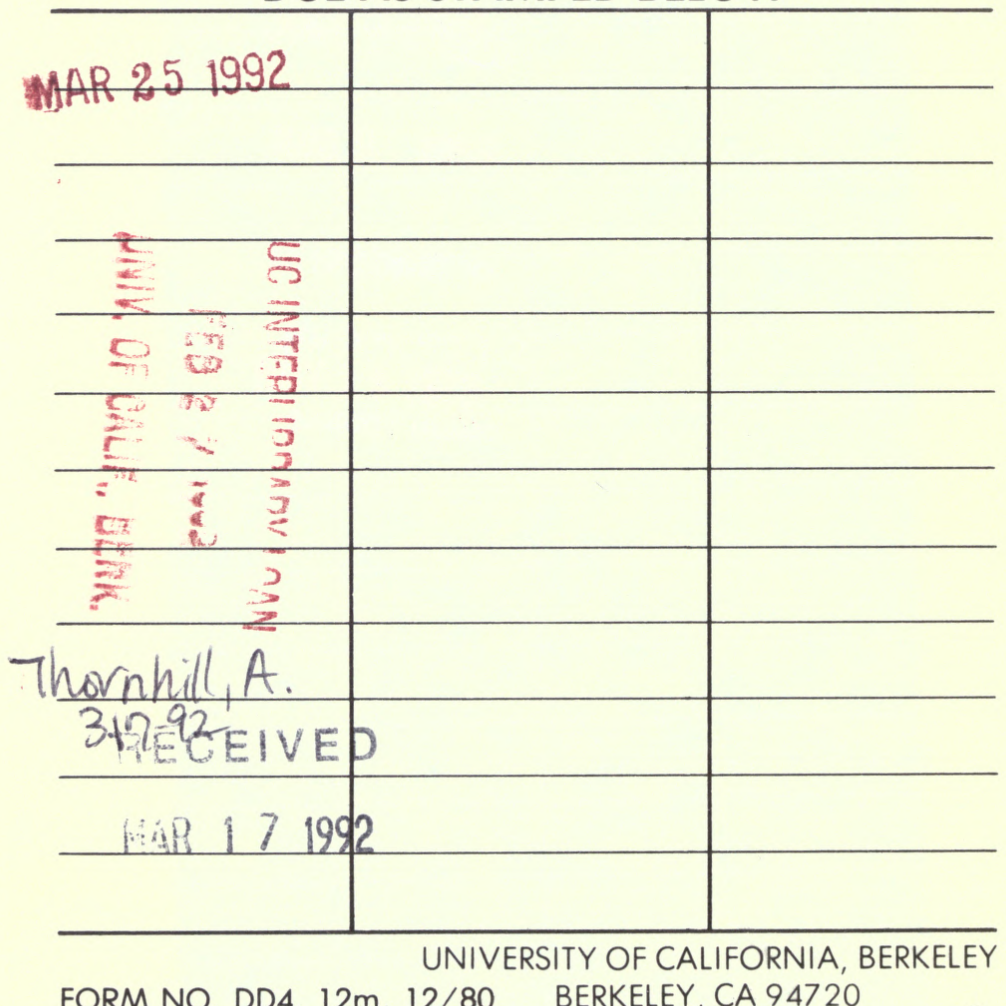

FORM NO. DD4, 12m, 12/80 BERKELEY, CA 94720 
U.C. BERKELEY LIBRARIES

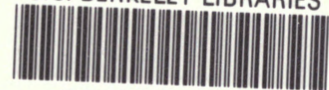

CO26266?6?

NEDWICK'S BOOK STORE

171 NO. MICHIGAN AVE.

CHICAGO 1, ILL.

"OUT-OF-PRINT BOOKS" 
